Natural History Museum Library 






\section{CATALOGUE}

\section{OF THE \\ FOSSIL FISHES}

«x $\mathrm{THB}$

\section{BRITISH MUSEUM}

(NATURAL HISTORY),

CROMWELL ROAD, S.W.

\section{PART IV.}

CONTAINING THE

ACTINOPTERYGIAN TELEOSTOMI OF THE SUBORDERS ISOSPONDYLI (IN PART), OSTARIOPHYSI, APODES, PERCESOCES, HEMIBRANCHII, ACANTHOPTERYGII, AND ANACANTHINI.

BY

ARTHUR SMITH WOODWARD, LL.D., F.R.S., F.G.S.

L ONDON:

PRINTED BY ORDER OF THE TRUSTEES.

SOLD BY

LONGMANS \& Co., 39 PATERNOSTER ROW, E.C. ;

B. QUARITCH, 15 PICCADILLY, W.; DULAU \& Co., 37 SOHO SQUARE, W. KEGAN PAUL, TRENCH, TRÜBNER \& Co., CHARING CROSS ROAD, W.C.;

BRITISH MUSEUM (NATURAI HISTORY), CROMWELI ROAD, S.W. 1901. 


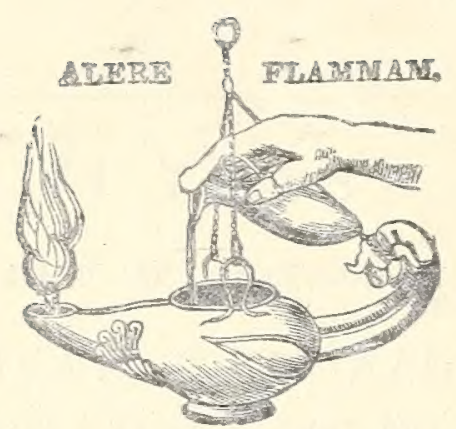

PRINTED BY TATLOR AND FRANCIS, BED LION COURT, FLERT STREET. 
From 1967 new species and references are entered on genera cards. 



\section{P R E F A C E.}

THE completion of the fourth rolume of the Catalogue of Fossil Fishes preserved in the Geological Department of the British Museum of Natural History will afford much satisfaction to palæontologists-more especially to those who are interested in the study of Ichthyology. Nor can it be deemed inappropriate to congratulate the author, Dr. Arthur Smith Woodward, F.R.S., upon the consummation of a task which has extended orer at least 17 years, during which time a very large amount of other scientific work has been accomplished by him. Indeed, the present volume would have appeared early in the Spring, but was delayed in consequence of the author's absence for three months in Greece, where he was engaged in carrying out for the Museum the exploration of the Tertiary Mammalian deposits at Pikermi near Athens.

Dr. Smith Woodward proposes to prepare, in 1902, a Supplement giving a list of additional important genera discovered and published since the earlier volumes appeared; also a Stratigraphical Table showing the appearance in time of families and genera of Fossil Fishes; together with a General Index to the four rolumes; the 4th volume being already larger than its predecessors, and the illustrations more numerous.

It is probable that the Collection of Fossil Fishes is the largest in the world, the English Cretaceous Fishes being particularly rich. 
This series comprises the private collections of Mantell, Dixon, Bowerbank, Capron, and others; whilst the Lebanon Chalk is represented by the fine series derived from the collection of the late Prof. E. R. Lewis, formerly of the Syrian Protestant College, Beyrout. The London Clay series is also enriched by the Dixon, Bowerbank, Enniskillen, Egerton, Gardner, and Shrubsole Collections.

The restorations of fishes have been prepared by Miss G. M. Woodward, who has also drawn the lithographed plates.

Geological Department,

$$
\text { HENRY WOODWARD. }
$$

October 7 th, 1901. 


\section{INTRODUCTION.}

As soon as fishes with a completely osseous endoskeleton began to predominate at the dawn of the Cretaceous period, specialisations of an entirely new kind were rapidly acquired. Until this time the skull of the Actinopterygii had always been remarkably uniform in type. The otic region of the cranium often remained incompletely ossified, and was never prominent or projecting beyond the roof-bones; the supra-occipital bone was always small and covered with the superficial plates; the maxilla invariably formed the greater part of the upper jaw; the cheek-plates were large and usually thick; while none of the head or opercular bones were provided with spines or ridges. The pelvic fins always retained their primitive remote situation, and the fin-rays never became spines. During the Cretaceous period the majority of the bony fishes began to exhibit modifications in all these characters, and the changes occurred so rapidly that, by the dawn of the Eocene period, the diversity observable in the dominant fish-fauna was much greater than it had ever been before. At this remote epoch, indeed, nearly all the great groups of bony fishes, as represented in the existing world, were already differentiated, and their subsequent modifications have been quite of a minor character.

It is the object of the present volume to enumerate and partially discuss the known Cretaceous and Tertiary bony fishes which illustrate these phenomena. The result, however, is much less satisfactory than might have been expected from the study of animals which lived under conditions most favourable for their preservation as fossils. The cireumstance that a very large proportion of the Tertiary fishes are known only from detached otoliths, suffices to indicate the extreme imperfection of the geological record in their case. 


\section{IsOSPONDYLI.}

The most important Cretaceous families of primitive bony fishes are the Elopidx and Chirocentridæ, which have a few Tertiary representatives, but are almost extinct at the present day. Their distribution in the seas of the Cretaceous period is known to have been very wide, and individuals of the various species were especially abundant.

The Elopidæ, represented in the existing fauna by Elops and Megalops, cannot be the direct descendants of the Jurassic Leptolepidæ, because all the satisfactorily-known genera still retain the gular plate. This plate, however, now appears for the last time in the class of fishes, being completely absent in all known representatives of the higher grades; and in some of the Elopines themselves, such as Thrissopater (p. 33, no. 9052) and Spaniodon (p. 51, no. P. 9190), it is quite a rudimentary structure. The skull still differs very little from that of the higher Jurassic fishes, and the otic region remains covered by the roof-bones. In the Elopidx, however, the supraoccipital bone begins for the first time to exhibit the forward and upward growth which characterises it in all the higher bony fishes. The parietal bones still meet in the middle line in several of the genera; but even in this case the supraoccipital may extend forwards beneath them to meet the frontals (e.g. Megalops, p. 24). In some early genera they are distinctly separated in the cranial roof by the exposure of the supraoccipital. In this family, therefore, the latter element exhibits the usual inconstancy of an incipient or developing structure.

The Albulidæ are merely Elopine fishes with a forwardly-inclined mandibular suspensorium, a small mouth, and reduced branchiostegal apparatus. Their primitive character is, indeed, shown by the presence of a muscular conus arteriosus with two rows of valves in the heart of the sole surviving species ${ }^{1}$. They seem to differ from the Elopidæ in exactly the same manner as the more generalised Pycnodontidæ differ from the Semionotidæ among Jurassic fishes. Now, however, the splenial bone has disappeared and is no longer available to bear a powerful dentition. A new modification therefore occurs for the first time, and is almost constantly repeated in later fishes which have teeth on the palate or

\footnotetext{
1 J. E. V. Boas, "Ueber den Conus arteriosus bei Butirinus und bei anderen Knochenfischen," Morphol. Jahrb. vol, vi. (1880), p. 528.
} 
the base of the skull. This upper dentition is henceforth usually opposed not to the mandible but to a dental arrangement on the tongue or hyoid apparatus.

One of the common Cretaceous fishes (Istieus, p 66), here placed in the Albulidx, is interesting as being essentially identical with an imperfectly-known fish still surviving in the deep sea (Bathythrissa). It is the most elongated type of this primitive group, with multiplied vertebræ and an extended dorsal fin.

The Osteoglossidæ, with a curiously-thickened skull, also seem to be closely related to the early Albulidx. The fragmentary fossils already discovered suggest that these families will need a new definition as soon as their extinct representatives are satisfactorily known.

The primitive nature of the Chirocentridæ has long been inferred from the presence of a rudimentary spiral valve in the intestine of the sole surviving species, Chirocentrus dorab ${ }^{1}$. This family of fishes is, indeed, now proved to be very old, dating back at least to the beginning of the Cretaceous period, during which it attained its maximum development. Early Cretaceous forms, such as Chirocentrites, cannot even be distinguished from the typical species of the Upper Jurassic Thrissops until the cranium be available for detailed study. It is still not definitely determined that Thrissops belongs to the lower division (family Leptolepidæ) in which it is usually placed.

The true Clupeoid fishes also date back to the beginning of the Cretaceous period, and their skeleton is so closely similar to that of the typical Jurassic Leptolepidæ that they may well be direct descendants of the latter. Their higher grade is definitely indicated by the prominence of the supraoccipital and otic bones in the skull. Most of the Cretaceous forms are typical Clupeidæ, and they have scarcely changed during subsequent epochs. A few, however, discorered only in Cretaceous rocks, are of special interest as exhibiting the precocious development of a character which was never permanently acquired by fishes with so primitive a skull, but soon became the common feature of the spiny-finned or acanthopterygian families. These are the Ctenothrissidæ, which have hitherto been mistaken for Berycoids because they display the character in question, namely, the forward displacement of their pelvic fins, which are situated more or less directly beneath the pectoral pair.

${ }^{1}$ Cuvier and Valenciennes, 'Histoire Naturelle des Poissons,' vol. xix. (1846), p. 160, pl. 565 . 
The few undivided rays in front of their fins, however, are always articulated distally and never form true spines.

Among the typical Cretaceous Clupeidæ the early acquisition of the ventral ridge-scutes, peculiar to Clupea and its allies, is specially noteworthy. Some small fishes from the Neocomian of Switzerland (p. 138) exhibit these scutes quite clearly. A widespread marine Cretaceous genus, Diplomystus, possessed dorsal ridge-scutes as well as the ventral series. It became a freshwater fish in the Eocene period, and now survives only in the rivers of New South Wales and Chili. Pectinated scales also characterised one Cretaceous genus (Pseudoberyx), which is proved to be a Clupeoid - and not a Berycoid as hitherto supposed-by the distinctly observabie structure of the head and fins.

Nothing is definitely known concerning the extinct Salmonoids; and Palæontology affords no information concerning the origin or relationships of this family.

Of all Cretaceous Isospondyli, three families of eel-shaped fishes are the most difficult to understand. They are all characterised by a primitive cranium of the Jurassic type; but they exhibit the new specialisation by which the extending premaxilla gradually excludes the maxilla from the upper border of the mouth. Their elongated shape is alone indicative of high specialisation; but no intermediate forms are yet known to afford a clue to their more normally shaped ancestors. Of these families the Halosauridæ and Notacanthidæ still survive in the deep sea. The existing Halosaurus itself, indeed, cannot be clearly distinguished from the Cretaceous Echidnocephalus; while Notacanthus of the present fauna only seems to differ from Pronotacanthus of the Cretaceous period in the possession of dorsal spines and fin-rays. The Dercetidæ, on the other hand, are only known by fossils from Cretaceous formations, in which they are widely distributed. They are interesting as being the earliest type of fish in which evidence of a distensible stomach has been observed (p. 177). Their fins are less specialised than those of the two families just mentioned; and their trunk is provided with paired longitudinal series of enlarged scutes.

Isospondyli exhibiting a definite tendency towards the development of acanthopterygian fishes seem to have been almost as abundant in Cretaceous seas as the Elopines and Clupeoids. In fact, in the absence of a complete knowledge of the skeleton, some of the Cretaceous fishes might be referred equally well to the 
Isospondylous Scopelidæ or to the Acanthopterygian Berycidæ. One very abundant family, that of the Enchodontidx, might perhaps furnish the ancestors of both. These exclusively Cretaceous fishes are Scopeloids, in which the premaxilla has not completely excluded the maxilla from the tooth-bearing margin of the jaw. They are variously specialised by the development of large teeth and dermal scutes; and two of them (Eurypholis and Prionolepis) are provided with a formidable spine at the angle of the preoperculum - a feature unknown among existing physostomous fishes. The stoutness of their bones indicates that they lived in shallow water or at the surface of the ocean during the Cretaceous period; while their nearest allies at the present day-the Odontostomidx and Alepisauridæ-are all denizens of the deep sea.

Of the family Scopelidæ many of the Cretaceous representatives scarcely differ from genera widely distributed in existing seas. The only remarkable Cretaceous forms-and those provisionally placed here-are two genera in which the stout premaxilla forms a pointed rostrum. These are Apateodus and Rhinellus; the former with a short snout, the latter with so slender a rostrum that a very superficial study of the fish has caused it hitherto to be erroneously classified with Belone and the Scombresocidæ.

The Gonorhynchidæ are only slightly modified Scopeloids, and are now shown to date back to the Cretaceous period, when all the characteristic features of Gonorhynchus, except the extension of scales over the head, seem to have been already acquired. The discovery of an early Tertiary freshwater genus (Notogoneus) both in North America and Europe, is one of considerable interest.

Other modified Scopeloids seem to be recognisable among Cretaceous fishes, but their osteology is as yet imperfectly known. The remarkable extinct "flying fishes" of the family Chirothricidæ may probably be thus interpreted.

The Esocidæ are essentially freshwater Scopeloids, and the Cyprinodontidæ are generally admitted to be closely allied to this family. Nothing of importance is known concerning their geological history.

\section{OSTARIOPHYSI.}

The past history of all freshwater fishes is very imperfectly known. Freshwater deposits are of such limited extent that they rarely escape denudation for long geological periods; and, except perhaps from a few sediments deposited at the mouths of rivers, 
geology has as yet revealed nothing definite concerning the freshwater life of the Cretaceous and Jurassic periods. In the case of the fishes of the suborder Ostariophysi this is especially unfortunate; because it is clear that in early Tertiary times they were already well differentiated, and it is probable that their peculiarly modified auditory apparatus was originally an adaptation to the circumstances of life in a confined area. Eren the highly specialised Siluroids were completely developed in the early part of the Eocene period (Bucklandium, p. 330); and one Eocene skull is identical with that of the existing genus Arius (p. 333). The Characinidæ have a cranium not much more advanced than that of Amia; and as these seem to be at the base of the series of Ostariophysi, the modification of the auditory apparatus must have begun in a very low type of physostomous fish.

\section{APODES.}

The eels are unique among the so-called teleostean fishes in possessing more than five basal bones in the pectoral fin-a feature characteristic of all the lower groups of Actinopterygii. Their skull is also of a comparatively primitive type. The elongate shape of their body, the loss of the upper part of their pectoral arch, and the complete loss of their pelvic and caudal fins, are marks of degenerate specialisation. Even before the end of the Cretaceous period they displayed all these characteristics except the lack of the caudal fin; for Urenchelys (p.337), from the Chalk of Mount Lebanon, is a typical generalised eel only differing from the generalised existing genera in the possession of a small separate caudal fin. It therefore seems probable that, although the Apodes are "Teleostei" in the sense in which these are defined by Müller and Guinther, they are not degenerate members of any group of these modern fishes, but are directly derived from some of the Mesozoic fishes which would be termed "Ganoidei" by the same authors. At least they cannot be regarded as degenerate members of any group of Cretaceous "Teleostei" hitherto discovered.

\section{Percesoces.}

Spinous fin-rays, except as mere basal fulcra, are unknown before the Cretaceous period; and the earliest type of fish in which they form a conspicuous feature of the dorsal fin is Crossognathus (p. 348), from the Neocomian of Switzerland and Germany. In its 
osteology, so far as known, this fish seems to agree very closely with the existing Atherines; but it differs in having one continuous dorsal fin, with the right and left halres of each spine not completely fused together. Another genus, Syllcemus, from the English and North American Chalk, is nearly similar. The Crossognathidæ are therefore probably the Cretaceous forerunners of the Percesoces, which were already completely differentiated into their surviving families before the close of the Eocene period. Atherina, Mugit, and Sphyrcena all date from the Cpper Eocene or Oligocene. The only noteworthy extinct genus, the European Oligocene Cobitopsis, belongs to the Ammodytidæ and retains the pelvic fins which have disappeared in the existing genera.

\section{HEMIBRANCHIr,}

Among extinct Tertiary fishes there are sereral so closely similar to existing Hemibranchs and Lophobranchs, that there need be no hesitation in associating them with the latter. As yet, howerer, they afford no clue to the origin of this group. The comparatively generalised Gasterosteidæ are not represented; but all the nther known families seem to date back to the Eocene period. Even the Centriscidæ and Syngnathidæ have scarcely changed since that time. The highly-specialised Amphisite seems to have persisted without any essential modification in its armour; while Hippocampus appears to have only lost its caudal fin in the interval.

\section{ACANTHOPTERYGII.}

The study of the existing fauna has already suggested that the oldest true acanthopterygian fishes are comprised among the Berycoids and Scombroids. It is therefore interesting to find that most, if not all, of the typical Cretaceous Acanthopterygii are referable to these two groups. The Upper Cretaceous genera are, indeed, very little specialised; and it seems probable that they actually originated at about the period of deposition of the Chalk in the northern hemisphere. All are characterised by a single dorsal fin, no distinct cleft having yet appeared between the spinous and persistently soft portions. Some undoubtedly Berycoid genera (e. g. Hoplopteryx, p. 396) exhibit an excessive development of mucus-carities on the head.

One genus (Prolates), from the uppermost Cretaceous horizon in France, is probably a true Percoid. It marks the dawn of the 
higher groups, and must have been contemporaneous with many unknown Acanthopterygii which rapidly became differentiated into various families in seas of which the sediments still remain undiscovered or unexplored. Palæontology has, indeed, hitherto revealed as little concerning the origin of the dominant Tertiary fishes as of the Tertiary mammals. According to present knowledge, all the principal types had already appeared early in the Eocene period; and among these fishes there are many which cannot be distinguished by their skeleton from genera which still survive.

The Eocene Acanthopterygii are best known by imperfect skulls and other uncrushed fossils from the Lower Eocene London Clay of Sheppey, and by compressed skeletons from the fissile Upper Eocene limestone of Northern Italy. Freshwater fishes, perhaps of the same age, are also represented by good skeletons in the Green River Shales of Wyoming, U.S.A. Among the Berycoids there are none particularly remarkable; but the Scombroid family of Carangidæ includes some of its most specialised and aberrant genera, such as Vomeropsis and Mene, of which the latter has survived unchanged until the present day. Among extinct fishes to be placed near the Scombroids, the most remarkable are the highly specialised Palæorhynchidæ, which range from the Lower Eocene to the Lower Miocene. Among Percoids the fragmentary fossils suggest that the families were less differentiated in the Eocene period than they are at the present day; but one curious specialisation, the fusion of the lower pharyngeal bones now so characteristic of the Labridæ and Chromidæ, had already been acquired by several genera. The Plectognathi were also less completely differentiated from the Chætodonts than they are in the existing fauna. The Scorpænoids are represented in the Lower Eocene by one imperfectly known genus (Ampheristus), which has a typically armoured skull and cheek. The Cottoids, Gobioids, and Blennioids also appear to be recognisable; and with the latter may possibly be associated the problematical genus Blochius, which does not range beyond Eocene formations.

Even after the Eocene period the history of the Acanthopterygii cannot be clearly traced. Most of the known fossils are too imperfect for satisfactory determination; for the constant distinctive characters of these highly specialised fishes are of a minor kind and often quite inconspicuous compared with those which permit the classification of the lower grades. Moreover, a very large proportion of the species are represented solely by the detached otoliths, 
which cannot always be identified with much certainty or precision. The Catalogue of the extinct Acanthopterygii is thus, for the most part, a bare list of names of fragmentary fossils, to which an approximate and provisional systematic position has been assigned. This circumstance is all the more regrettable, since no satisfactory classification of the surviving Acanthopterygii has hitherto been proposed, and the aid of Palæontology is much needed for its accomplishment.

\section{AnaCANTHTNi.}

Typical cod-fishes and flat-fishes date back to the Oligocene and Upper Eocene periods respectively. No generalised ancestors of either type have hitherto been recognised.

With fragmentary materials of this nature, it is impossible to attempt a very exact classification. It has, therefore, been deemed adrisable to adopt a broad conception of families and genera more in accordance with that of Dr. Günther than with that of later writers. This corresponds with the method of treatment followed in the earlier parts of the Catalogue, and still seems adequate for a synoptical work of which the results can only be provisional. Lists of the specimens in the Museum and the published names of fossils not represented in this collection have been arranged approximately in their natural order for convenience of reference, without any detailed discussion of their affinities. The incorporated new matter, indeed, relates rather to the facts of osteology than to premature essays in taxonomy. A detailed knowledge of the skeleton of the early bony fishes of the Cretaceous period is particularly important; and the writer has made special efforts to discover the essential facts by studying most of the available collections. He is indebted to the Rer. William Bird and Professor Alfred Ely Day for the opportunity of examining the fine series of Cretaceous fishes from Mount Lebanon in the Syrian Protestant College at Beyrout; to Professor Karl Busz for permission to study the unique collection of Westphalian Cretaceous fishes in the Academy of Münster; and to Professor S. W. Williston, for the privilege of making a detailed examination of the remarkable remains of fishes from the Kansas Chalk, now in the Museum of the State Unirersity of Kansas. A brief survey of the Cretaceous fishes from Northern Brazil in the 
National Museum at Rio de Janeiro, made with the kind help of Professor Orville A. Derby, has also yielded some new facts; while a study of the small series of Swiss Neocomian fishes and Lebanon Cretaceous fishes at Geneva, thanks to the kindness of Drs. Bedot and Weber, has elucidated several points left doubtful by Pictet's original descriptions. The Museums of the Universities of Munich and Naples have been re-visited; while the Woodwardian Museum at Cambridge, and the Willett Collection in the Brighton Museum, have proved as useful to the author now as in the preparation of the previous volumes of the Catalogue. Thanks are not only due to the many friends and colleagues in Palrontology who have facilitated these researches, but also to Mr. G. A. Boulenger, F.R.S., whose valuable advice and assistance have been continually at the writer's disposal, and whose opinions concerning the general relationships of the higher fishes ${ }^{1}$ correspond very closely with those suggested by this Catalogue.

ARTHUR SMITH WOODWARD.

Department of Geology,

October 1st, 1901.

\section{List of Collections.}

In addition to the Collections enumerated in Parts I. to III., the following are also referred to in the present volume :-

Bravard Collection.-Vertebrate fossils from the Tertiaries of France, purchased from M. Auguste Bravard, 1852.

Castelli Collection.-A miscellaneous collection of Italian fossils made by Cav. Federico Castelli, of Leghorn, purchased 1898.

Green Collection.-Vertebrata from the Forest Bed of Norfolk and from the Fenland, collected by the Rev. C. Green, of Bacton, purchased 1843.

Layton Collection.-Vertebrate remains dredged off the Eastern Coast, purchased from the Rev. John Layton, of Happisburgh, Norfolk, 1858.

Piestwich Collection.-A miscellaneous collection including vertebrate remains from the Pliocene Crags, purchased from Professor (afterwards Sir Joseph) Prestwich, 1894.

1 G. A. Boulenger, "Les Poissons du Bassin du Congo" (Musée du Congo, 1901). 
INTRODUCTION.

$X \nabla$

Soul Collection .-A miscellaneous collection presented by Mr. W. D. Saul to the Metropolitan Institute, and purchased from the Directors of the latter in 1863.

Sain Collection.-Vertebrata from the Forest Bed of Norfolk, collected by Mr. Alfred C. Saving, of Comer, and purchased from him in 1897.

Stater Collection .-A miscellaneous collection of fossils, chiefly from Gloucestershire, made by Mr. T. J. Slatter, F.G.S., of Evesham, purchased 1896.

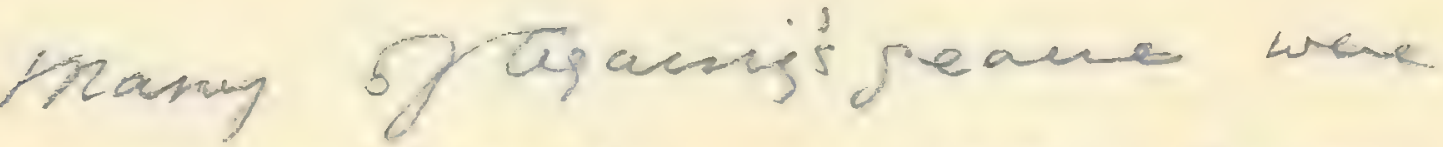

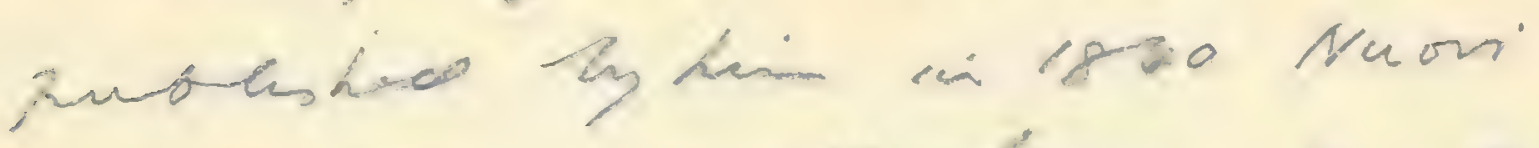
Rem. Fee Not, Bolo pun, Ln, P. 244. ( hit optrakian fisher). 


\title{
SYSTEMATIC INDEX
}

\author{
$O F$ \\ G E N R A A N D S P E C E S \\ DESCRIBED IN PART IV.
}

Order ACTINOPTERYGI (continued) . . . . Page 1

Suborder IV. ISOSPONDYLI (continued) . . . . 1

Family LEPTOLEPID $\mathrm{E}$ (continued) . . . . . 1

Lycoptera . . . . . . . . . . 1

—_ middendorffi . . . . . . 2

- sinensis . . . . . . . . 3

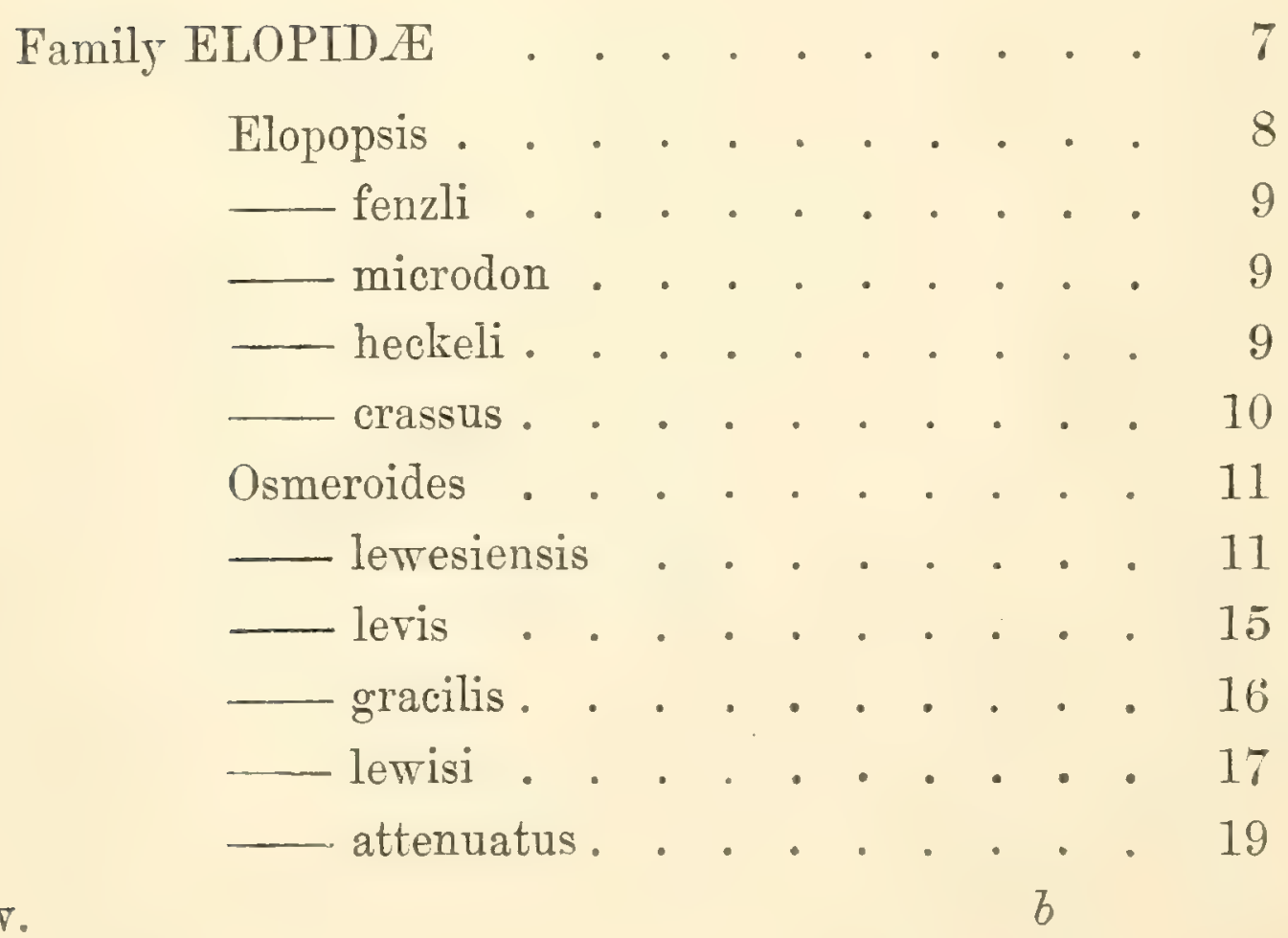


Family ELOPID E (continued).

Osmeroides sardinioides . . . . . 19

— cretaceus . . . . . . . 20

Elops . . . . . . . . . . 22

Megalops . . . . . . . . . . 24

— priscus . . . . . . . . 24

- oblongus : . . . . . . 26

Notelops . . . . . . . . 27

— brama . . . . . . : . . . 27

Rhacolepis . . . . . . . . 29

— buccalis . . . . . . . . 30

- latus . . . . . . . 32

Thrissopater . . . . . . . . 32

— salmoneus . . . . . . . . . 33

- magnus . . . . . . . 33

— (?) megalops . . . . . . . . 35

Pachyrhizodus . . . . . . . . 37

- basalis . . . . . . . . 37

— diblegi . . . . . . . . . 38

— gardneri . . . . . . . 40

- latimentum . . . . . . . . 42

— subulidens . . . . . . 43

Esocelops . . . . . . . . . . . 46

cavifrons . . . . . . . 46

Spaniodon . . . . . . . . 48

blondeli . . . . . . . 48

— elongatus . . . . . . . 51

— latus . . . . . . . . 53

Thrissopteroides . . . . . . 54

— elongatus . . . . . . . . 54

— latus . . . . . . . 54

— intermedius . . . . . . . 55

— tenuiceps . . . . . . . 55

— pulcher . . . . . . 56

Protelops . . . . . . . . . 56

— geinitzi . . . . . . . . 5 ร

— anglicus . . . . . . . . . 
Family ALBULIDA

Albula . . . . . . . . . 60

- oweni •. . . . . . . 60

Chanoides . . . . . . . . . . 63

-_ macropoma . . . . . . . 63

Chanos . . . . . . . . 64

Prochanos . . . . . . . . 65

— rectifrons . . . . . . . 65

Ancylostylos . . . . . . . . . 66

-

Istieus . . . . . . . . . . 66

grandis . . . . . . . . . 67

— macrocephalus . . . . . . 70

- lebanonensis . . . . . . . 71

Anogmius . . . . . . . . 71

- polymicrodus . . . . . . . 72

Family OSTEOGLOSSID $\AA$. . . . . . . . 73

Dapedoglossus . . . . . . . . 74

- testis . . . . . . . . 75

— æquipinnis . . . . . . . 75

Brychrtus . . . . . . . . 76

- muelleri . . . . . . . 76

Incertæ sedis . . . . . . . . 80

Plethodus . . . . . . . . 80

— expansus . . . . . . . . . 81

— pentagon . . . . . . . . 83

— oblongus . . . . . . . . . 83

Thryptodus . . . . . . . . . 85

Family NOTOPTERID王 . . . . . . . . 85

Notopterus . . . . . . . . . 86

primævus . . . . . . . . 86 
Family CHIROCENTRID $Æ$. . . . . . 86

Chirocentrus . . . . . . . . 88

— (?) polyodon . . . . . . . . 88

Platinx . . . . . . . . . . 89

Chiromystus . . . . . . . . 89

—— mawsoni . . . . . . . . . 90

Chirocentrites . . . . . . . . . 90

— coroninii . . . . . . . . . 91

Portheus . . . . . . . . . 92

- molossus . . . . . . . . . 92

— mantelli . . . . . . . . 95

— daviesi . . . . . . . . 95

— gaultinus . . . . . . . 95

Spathodactylus . . . . . . . 98

— neocomiensis . . . . . . . 98

Ichthyodectes . . . . . . . . . 99

— etenodon . . . . . . . 100

- anaides . . . . . . . . 100

—

— serridens . . . . . . . 101

- minor . . . . . . . . 102

— elegans . . . . . . . 103

— tenuidens . . . . . . . 104

— libanicus . . . . . . . 105

Cladocyclus . . . . . . . 107

— gardneri . . . . . . 108

— lewesiensis . . . . . . 109

Saurodon . . . . . . . . 111

— leanus . . . . . . . . . 111

— phlebotomus . . . . . . 112

— intermedius . . . . . . . . 112

Saurocephalus . . . . . . . 113

- lanciformis . . . . . . . 113

— woodwardi . . . . . . . 114

Incertæ sedis . . . . . . . . . 116

Tomognathus . . . . . . 116

mordax. . . . . . . 117 


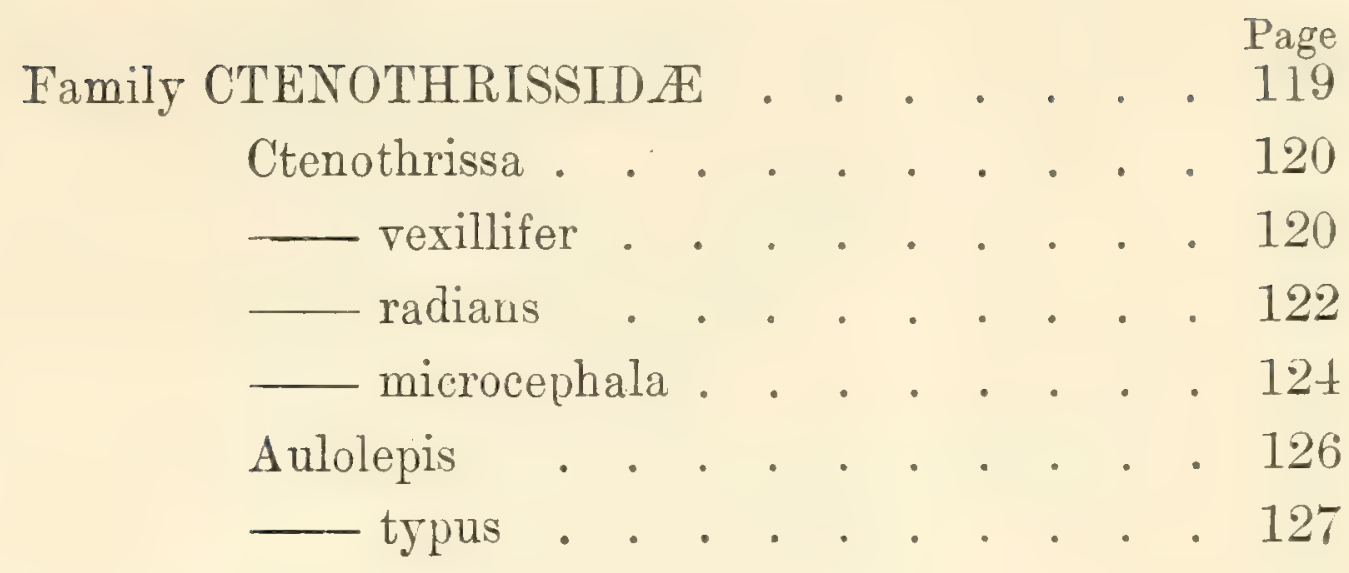

Family CLUPEIDE . . . . . . . . 128

Pseudoberyx . . . . . . . . . . 129

— syriacus . . . . . . . . . 129

— bottæ . . . . . . . 130

— grandis . . . . . . . . 130

Histiothrissa . . . . . . . . 131

macrodactyla . . . . . . . 131

— crassapinna . . . . . . . 132

Engraulis . . . . . . . . . 133

Halecopsis . . . . . . . . 133

—insignis . . . . . . . . . . 134

Scombroclupea . . . . . . . . . 135

— macrophthalma . . . . . . 135

- gaudryi . . . . . . . . 138

Diplomystus . . . . . . . . . . 139

- dentatus . . . . . . . . 139

- brevissimus . . . . . . . 140

- birdi . . . . . . . . 142

longicostatus . . . . . . . 143

— humilis . . . . . . . . . 144

- altus . . . . . . . . 145

— vectensis . . . . . . . . 146

Clupea . . . . . . . . . . 146

- scheuchzeri . . . . . . 147

- catopygoptera . . . . . . 148

humilis . . . . . . . . 150

— crenata . . . . . . . . 151

numidica . . . . . . . . . 151

— sardinites . . . . . . 152

- sprattus . . . . . . 153 
Family SALMONIDE $\mathrm{E} \quad$ • • . . . . . . 159

Salmo : . . . . . . . . 159

Mallotus . . . . . . . . . 160

— villosus. . . . . . . . . . 161

Family HALOSAURID正 . • . . . . . . 162

Echidnocephalus . . . . . . 163

- troscheli . . . . . . 163

Enchelurus . . . . . . . . 164 villosus. . . . . . . . . . 164

— syriacus : . . . . . . . . 165

- anglicus . . . . . . . 167

Family NOTACANTHIDA . . . . . . . 168

Pronotacanthus . . . . . . . 169

— sahel-almæ . . . . . . . 169

Family DERCETID $Æ$ ・ 。 . . . . 171

Dercetis . . . . . . . . 172

— scutatus . . . . . . . 172

Leptotrachelus . . . . . . . 173

— armatus . . . . . . . . 174

— triqueter . . . . . . . 174

— graciljs . . . . . . . 180

— hakelensis . . . . . . . . 184

— elongatus . . . . . . . 184

Pelargorhynchus . . . . . . 188

dercetiformis . . . . . 188

Family ENCHODONTID $\approx$. . . . . . 189

Enchodus . . . . . . . . 190

— lewesiensis . . . . . . . . 191

— pulchellus . . . . . . . . 193

— annectens . . . . . . . 195

— faujasi . . . . . . . . . 196

- lemonnieri . . . . . . . 198

— longidens . . . . . . . 199 
Family ENCHODONTID无 (continued).

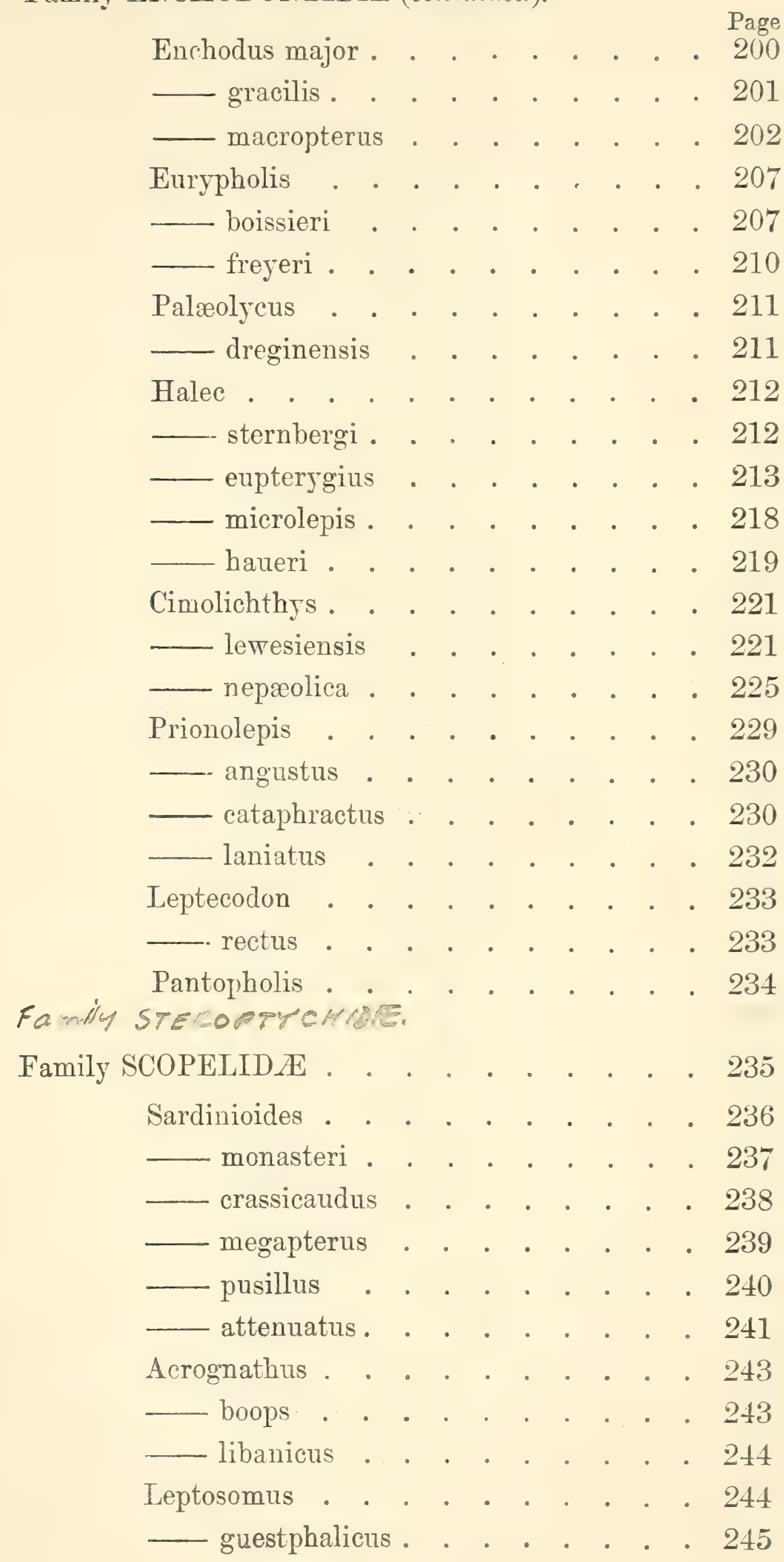


Family SCOPELID $Æ$ (continued).

Leptosomus elongatus

— macrourus . . . . . . . . . 245

- minimus . . . . . . . . 246

Sardinius . . . . . . . . 247

cordieri . . . . . . . 247

Dactylopogon . . . . . . . 248

grandis. . . . . . . . . 249

Nematonotus . . . . . . . 249

— bottæ . . . . . . . . 250

Nicrocoelia . . . . . . . 252

- granulata . . . . . . . . 252

- libanica . . . . . . . . . 252

Opisthopteryz . . . . . . . . 253

— gracilis . . . . . . . . 254

Scopeloides . . . . . . . . 254

— glarisianus . . . . . . . 255

Parascopelus . . . . . . . 256

- lacertosus . . . . . . . . 256

Anapterus . . . . . . . . . 257

— megistosoma . . . . . . 257

Apateodus . . . . . . . 258

glyphodus . . . . . . . . . 258

striatus. . . . . . . 260

lanceolatus . . . . . . . 264

Rhinellus . . . . . . . . . 265

- furcatus . . . . . . . . . 266

— ferox . . . . . . . 267

C damoni. . . . . . . . 268

Family GONORHYNCHID $\mathrm{E}$. . . . . . 271

Charitosomus . . . . . . . 271

- formosus . . . . . . . 272

- major . . . . . . . . 272

— lineolatus . . . . . . . 274

hakelensis . . . . . . 274

Notogoneus . . . . . . . 275 
Family GONORHYNCHIDE (continued).

Notogoneus osculus . . . . . . 275

— squamosseus . . . . . . 276

- cuvieri . . . . . . . . 277

- longiceps . . . . . . . . . 278

Family CHIROTHRICID $A$. . . . . . . . 279

Chirothrix . . . . . . . 280

- libanicus . . . . . . . 280

— lewisi . . . . . . . . . 283

—_ guestfalicus . . . . . . . 283

Telepholis . . . . . . . . 284

— acrocephalus . . . . . . 284

— (?) tenuis . . . . . . . . . 285

Exocœtoides . . . . . . . . 286

- minor . . . . . . . . . 286

Family ESOCID

Esox . . . . . . . . . . 287

— lepidotus . ... . . . . . 288

Family CYPRINODONTID $Æ$. . . . . . 289

Prolebias . . . . . . . . 290

— cephalotes. . . . . . . . 290

— furcatus . . . . . . 291

— gregatus . . . . . . . 292

—- stenoura . . . . . . . 292

— goreti . . . . . . . . . 293

— brongniarti . . . . . . . . 293

Pachylebias . . . . . . . . . 294

— crassicaudus . . . . . . 295

Suborder V. OSTARIOPHYSI . . . . . . 296

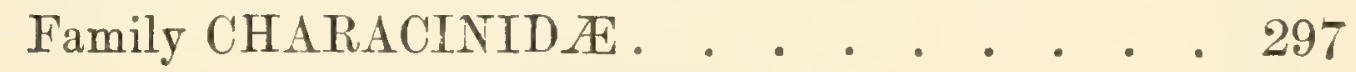

Tetragonopterus . . . . . . 298

— avus . . . . . . . . 298

— ligniticus . . . . . . . . 298 


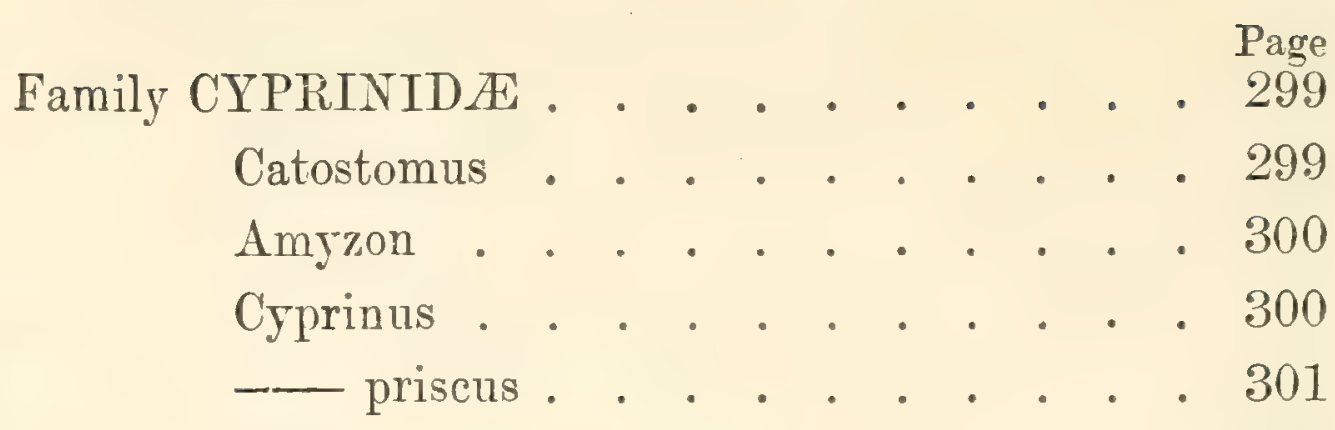

Barbus . . . . . . . . . 301

— megacephalus . . . . . . 302

Thynnichthys . . . . . . 303

— amblyostoma . . . . . . 303

Gobio . . . . . . . . 303

— analis . . . . . . . . 304

Amblypharyngodon . . . . . . 304

Leuciscus . . . . . . . . . 305

— oeningensis . . . . . . 305

— papyraceus . . . . . . 307

— colei . . . . . . . . 308

- macrurus . . . . . . . 308

— leptus . . . . . . . . 309

Tinca . . . . . . . . . . 312

— furcata . . . . . . . . . 312

— leptosoma . . . . . . . . . 313

— micropygoptera . . . . . . . 314

— tarsiger . . . . . . . 315

Rhodeus . . . . . . . . 316

— elongatus . . . . . . . 316

— latior . . . . . . . . 317

Aspius . . . . . . . . . 318

— gracilis . . . . . . . . . . 318

— minutus . . . . . . . 318

Cobitis . . . . . . . . 320

— centrochir . . . . . . . 320

— angustus . . . . . . . . 321

— cephalotes . . . . . . . . . 321

Hexapsephus . . . . . . . 322

- guentheri . . . . . . . 322 


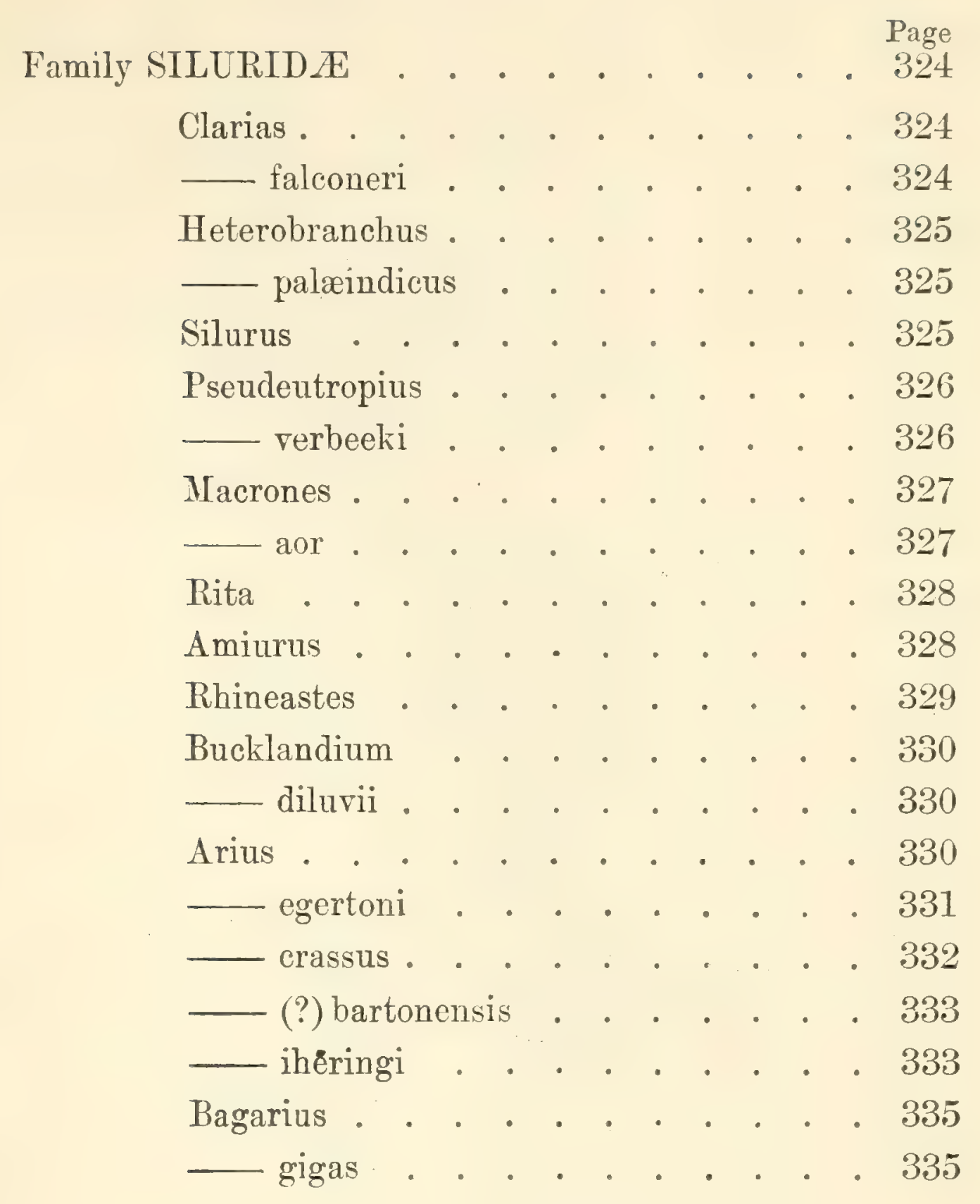

Suborder V1. APODES . . . . . . . 336

Family MUR ENID $\mathrm{E}$. . . . . . . . 336

Urenchelys . . . . . . . 337

$\longrightarrow$ avus . . . . . . . 337

— hakelensis . . . . . . 338

— anglicus . . . . . . . . . 339

Eomyrus . . . . . . . . 340

- dolloi . . . . . . . 340

— latispinus . . . . . . . 340

— ventralis . . . . . . . 341

Rhynchorhinus . . . . . . 342

- branchialis . . . . . . 342

- major . . . . . . . 343 
Family MURANIDA (continued).

\begin{tabular}{|c|c|c|c|c|c|}
\hline Paranguilla . & & & & & \\
\hline — tigrina . & & & & & • \\
\hline Anguilla. & & & & . & • \\
\hline L leptoptera & & & & & . \\
\hline _ elegans. & & & & . & . \\
\hline Nettastoma . & & & . & • & e \\
\hline
\end{tabular}

Suborder VII. PERCESOCES . . . . . . . 347

Family CROSSOGNATHID $Æ$. . . . . 348

Crossognathus . . . . . . . . 348

— sabaudianus . . . . . . . 349

Syllæmus . . . . . . . . . 350

— latifrons . . . . . . . 351

_ anglicus . . . . . . . 351

Family AMMODYTID A . . . . . . . . 354

Cobitopsis . . . . . . . . 354

- acutus . . . . . . . 355

Family SCOMBRESOCID $\mathrm{E}$. • . . . . 356

Belone . . . . . . . . 356

- tenuis . . . . . . . 357

Scombresox . . . . . . . 357

- obtusirostris . . . . . . . 357

Hemiramphus . . . . . . . 358

Family ATHERINID $\approx$. . . . . . . . 358

Atherina . . . . . . . . . 359

— macrocephala . . . . . . . 359

- sarmatica . . . . . . . 360

—

Rhamphognathus . . . . . . . 361

— paralepoides . . . . . . . 361

— sphyrænoides , . . . . . . 362 
Family MUGIITD $\quad$ Page

Mugil . . . . . . . . . . . 363

— - princeps . . . . . . . . 364

- radobojanus . . . . . . 365

Family SPHYRANID $\mathrm{E} . \quad . \quad . \quad . \quad . \quad .36$. .

Sphyræna . . . . . . . . . 366

- bolcensis . . . . . . . . . 366

_ intermedia . . . . . . . 367

—

Suborder VIIL. HEMIBRANCHII . . . . . . . 369

Family AULORHYNCHID 玉 • . . . . . . 371

Protaulopsis . . . . . . . . 371

— bolcensis . . . . . . . . 371

Aulorhynchus . . . . . . . . 372

- sumatrensis . . . . . . 373

Family FISTULARIID $\mathrm{E}$. . . . . . . . 373

Fistularia. . . . . . . . . 374

— koenigi . . . . . . . . 374

- longirostris . . . . . . . 375

Aulostoma . . . . . . . . . 375

— bolcense . . . . . . . . 375

Urosphen . . . . . . . . . 376

dubia . . . . . . . . 376

Family CENTRISCIDA . . . . . . . . 377

Rhamphosus . . . . . . . . . 377

— aculeatus . . . . . . . 377

— biserratus . . . . . . . . 378

Amphisile . . . . . . . . . . 378

- heinrichi . . . . . . . . . 379

Family SOLENOSTOMATID $\mathrm{E}$. . . . . . 379

Solenorhynchus . . . . . . . 380

elegans . . . . . . . 380 


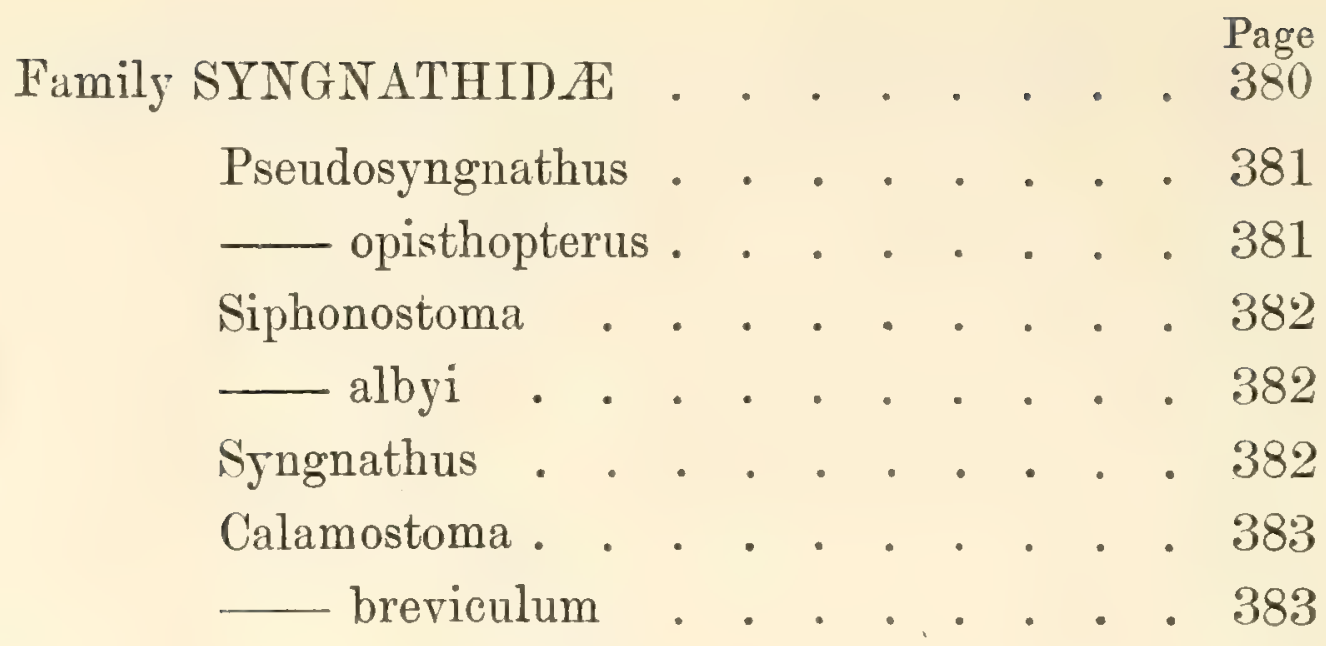

Suborder IX. ACANTHOPTERYGII . . . . . . 384

Division A. Beryciformes . . . . . . . 384

Family BERYCIDA . . . . . . . . . . 384

Beryx • . . . . . . . . . 385

Sphenocephalus . . . . . . . 387

— fissicaudus . . . . . . . . 387

- cataphractus . . . . . . . 388

Acrogaster . . . . . . . . . 388

— parvus . . . . . . . . . . 389

— brevicostatus . . . . . . . . 389

— heckeli . . . . . . . . . $₫ 90$

— daviesi . . . . . . . . 390

Pycnosterinx . . . . . . . . 391

russeggeri . . . . . . . . 392

— discoides . . . . . . . . . 393

- gracilis . . . . . . . . . 394

Lubius . . . . . . . . . 395

Hoplopteryx . . . . . . . . . . 396

— antiquus . . . . . . . . 396

— zippei . . . . . . . . . 397

— lewesiensis . . . . . . . 397

- superbus . . . . . . . 403

lundensis . . . . . . . . . 404

- lewisi . . . . . . . . . 404

- syriacus . . . . . . . 405

- stachei........ . 406 
Family BERYCID $\mathrm{E}$ (continued).

Dinopteryx . . . . . . . 406

- spinosus . . . . . . . 407

Homonotus . . . . . . . 407

- dorsalis . . . . . . . . 408

Myripristis . . . . . . . . 410

- leptacanthus . . . . . . . . 410

- homopterygius . . . . . . 411

Holocentrum . . . . . . . 412

— macrocephalum . . . . . 412

— melitense . . . . . . . . 413

Family APHREDODERID $Æ$. . . . . . 416

Family CYTTID $Æ$. . . . . . . . . . . 417

Division B. Scombriformes .. . . . . . . . 418

Family STRONATEID $\mathrm{E}$ 。 . . . . . . . . 419

Omosoma . . . . . . . . . . 419

— sahel-almæ . . . . . . 419

— intermedium . . . . . . 420

— pulchellum . . . . . . . . . 421

Platycormus . . . . . . . . . 421

— germanus . . . . . . . . . 421

Berycopsis . . . . . . . . 423

— elegans . . . . . . . . 423

Family CARANGID无 . . . . . . . 425

Aipichthys . . . . . . . . 427

— pretiosus . . . . . . . . . 427

— velifer . . . . . . . 427

minor . . . . . . . . 428

— nuchalis . . . . . . . . 429

Semiophorus . . . . . . . . . 430

- velifer . . . . . . . . 430

— relicans . . . . . . . 431

Platax . . . . . . . . . 432 
Family CARANGIDA (continued).

Platax woodwardi . . . . . . 432

Amphistium . . . . . . . . . 434

— paradoxum . . . . . . . 434

Vomeropsis . . . . . . . . . 435

— longispinus . . • . . . . . 436

— elongatus . . . . . . . . . 437

__ valenciennesi . . . . . . . 437

Mene . . . . . • . . . . . 437

_ rhombeus . . . . . . . 439

oblongus . . . . . . . . 440

Caranx . . . . . . . . . . 441

Archæus . . . . . . . . . . . 442

glarisianus . . . . . . . 442

Seriola. . . . . . . . . . 444

—_ prisca . . . . . . . . . 444

— lata . . . . . . . 445

— analis . . . . . . . . 445

Carangopsis . . . . . . . . 446

- breris . . . . . . . 446

- dorsalis . . . . . . . 447

Ductor . . . . . . . . . . 448 leptosomus . . . . . . . 448

Family SCOMBRID王 . . . . . . . . 451

Isurichthys . . . . . . . . . . 453

— macrurus . . . . . . . . 453

- orientalis . . . . . . . . 453

Thynnus . . . . . . . . . . 454

— thynnus . . . . . . . . 455

— scaldisi . . . . . . . . 455

— lanceolatus . . . . . . . 456

Eothynnus . . . . . . . . . 457 salmoneus . . . . . . . 457

Scomber . . . . . . . . . . . . 459

Palimphyes . . . . . . . . . 460 elongatus . . . . . . . . 460 
Family SCOMBRID $\mathrm{E}$ (continued).

Scombrinus

- uuchalis . . . . . . . . 461

- macropomus . . . . . . . 462

Auxis . . . . . . . . . . 463

(?) propterygius . . . . . . . 464

Cybium . . . . . . . . . 465

— speciosum . . . . . . . . 466

- bleekeri . . . . . . . . 466

- excelsum . . . . . . . . . 467

- bartonense . . . . . . . 46 i

— lingulatum . . . . . . . . 469

Eocoelopoma . . . . . . . . 470

— colei . . . . . . . . 470

- curvatum , . . . . . . . 472

Sphyrænodus . . . . . . . . . 473

— priscus . . . . . . . . . . 473

Scombramphodon . . . . . . . 474

-_ benedeni . . . . . . . . 474

— curvidens . . . . . . . . . 474

crassidens . . . . . . . 475

Thyrsitocephalus . . . . . . . . 476

- alpinus . . . . . . . . . 477

Lepidopus . . . . . . . . . . . 477

— glarisianus . . . . . . . 477

— brevicauda . . . . . . . 480

— albyi . . . . . . . . 480

Family PALÆORHYNCHID $Æ$. . . . . 482

Palæorhynchus . . . . . . . 483

— glarisianus . . . . . . . 483

longirostris . . . . . . . 486

— zitteli . . . . . . . . . 487

Hemirhynchus . . . . . . . . 488

— deshayesi . . . . . . . . 488

colei. . . . . . . . . 488 


$$
\begin{aligned}
& \text { Family XIPHIID } \mathrm{E} \text {. . . . . . . . } 490 \\
& \text { Xiphiorhynchus . . . . . . . . } 490 \\
& \text { — elegans . . . . . . . . } 491 \\
& \text { - priscus . . . . . . . . . . } 491 \\
& \text { Acestrus . . . . . . . . . } 494 \\
& \text { - ornatus . . . . . . . } 494 \\
& \text { Histiophorus . . . . . . . . } 495 \\
& \text { — eocænicus . . . . . . . . . } 495 \\
& \text { - rotundus . . . . . . . . } 495
\end{aligned}
$$

Division C. Perciformes . . . . . . . . . 497

Family PERCID $\mathbb{E}$. . . . . . . . . 498

Prolates . . . . . . . . . 499

- heberti . . . . . . . . 499

Acanus . . . . . . . . 500

— spinosus . . . . . . 500

— regleysianus . . . . . . 501

Lates . . . . . . . . . . 502

— gracilis . . . . . . . . 502

Cyclopoma . . . . . . . . . 504

— gigas . . . . . . . . 504

— (?) micracanthum . . . . . . 504

Smerdis . . . . . . . 506

— minutus . . . . . . . 506

formosus . . . . . . 507

— macrurus . . . . . . . 507

Labrax . . . . . . . . 509

ubinoi . . . . . . . 510

- schizurus . . . . . . . 510

— oeningensis . . . . . . 511

Percichthys . . . . . . . . . . 514

— antiquus . . . . . . . 514

Properca . . . . . . . . 514

— angusta . . . . . . . 515

— beaumonti. . . . . . . 515

—(?) prisea . . . . . . . . . 516 
Family PERCIDAE (continued).

Mioplosus. . . . . . . . $\frac{\text { Page }}{517}$

— labracoides . . . . . . . 517

Perca . . . . . . . 518

Family TEUTHIDID $\mathbb{A}$. . . . . . . . 523

Family SPARIJ $巴$. . . . . . . . . 524

Sparnodus . . . . . . . . 524

— macrophthalmus . . . . . . 525

— elongatus . . . . . . 526

- microstomus . . . . . . 527

- howerbanlí . . . . . 527

Sargus . . . . . . . . 529

- oranensis . . . . . . . 529

— laticonus . . . . . . . . 529

Trigonodon . . . . . . . . 531

— oweni . . . . . . . . 531

— serratus . . . . . . 531

Pagellus . . . . . . . . . 532

Pagrus . . . . . . . . 533

Chrysophrys . . . . . . . . 534

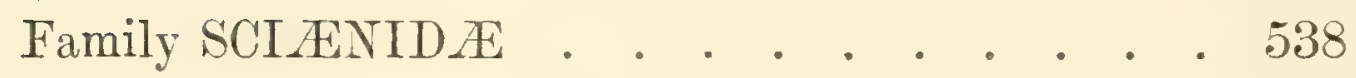

Family LABRID $Æ$. . . . . . . . . . . 539

Labrus . . . . . . . . . . 539

Julis . . . . . . . . . . 541

Labrodon . . . . . . . . 541

— superbus . . . . . . . 542

- canariensis . . . . . . 542

Phyllodus . . . . . . . . . 546

— toliapicus . . . . . . . 546

Egertonia . . . . . . . 550

Isodonta . . . . . . . 551

Platylæmus . . . . . . . . 551

— colei . . . . . . . . 551

Pseudosphærodon . . . . . . . . 552 hilgendorfi . . . . . 552 
Family CHROMTD

Priscacara . . . . . . . . 554

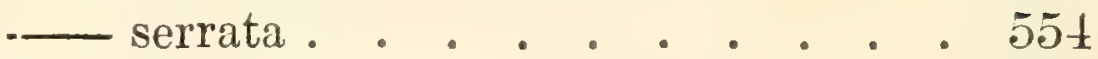

— cljvosa . . . . . . . . 554

Division D. Chætodontiformes . . . . . . 556

Family CHETODONTID $Æ$. . . . . . 556

Pygæus . . . . . . . . . 557

— coleanus . . . . . . . . 557

Proantigonia. . . . . . . . 558

Ephippus . . . . . . . . . 559

- rhombus . . . . . . . 559

Family ACRONURID $\mathrm{E}$. . . . . . . . 562

Aulorhamphus . . . . . . 562

Apostasis . . . . . . . . . 563

Acanthurus . . . . . . . 563

Naseus . . . . . . . . 564

— rectifrons . . . . . . 564

Family BALISTID $Æ$. . . . . . . 565

Spinacanthus . . . . . . 566

Acanthopleurus . . . . . . . . 566

—- serratus . . . . . . . 567

Acanthoderma . . . . . . 568

— spinusum . . . . . . 568

Ostracion . . . . . . . . . . 569

Family GYMNODONTIDE . . . . . . 570

Tetrodon . . . . . . . 571

Diodon. . . . . . . . . . 571

— erinaceus . . . . . . 572

— scillæ . . . . . . . . 572

— sigma . . . . . . . . 573

— vetus . . . . . . . 573

Orthagoriscus . . . . . . 576 
Dirion Page

Dirision E. Scorpæniformes . . . . . . . 576

Family SCORPANIDE . . . . . . . . 577

Ampheristus . . . . . . . . . 577

— toliapicus . . . . . . . 577

Family COTTID $\mathrm{E}$. . . . . . . . • . 580

Eocottus . . . . . . . . 580

- veronensis. . . . . . . 581

Lepidocottus . . . . . . . . . 581

- aries . . . . . . . . 582

- brevis . . . . . . . . . 582

— papyraceus . . . . . . . 583

— multipinnatus . . . . . . 584

Cottus . . . . . . . . 585

Eamily TRIGLID $\mathrm{E}$. . . . . . . . . . 585

Division F. Gobiiformes . . . . . . . . . 587

Family GOBIID $\mathrm{E}$. . . . . . . . . . . 587

Family TRACHINIDA • . • . . . • . 589

Callipteryx • . . . • . . . . . 589

$\longrightarrow$ speciosus . • . . . . . . . 589

- recticaudus . . . . . . . 589

Division G. Blenniiformes . . . . . . . . . 591

Family BLOCHIID仺 . . . . . . . . . . 591

Blochius . . . . . . . . . 593

— longirostris . . . . . . . . 593

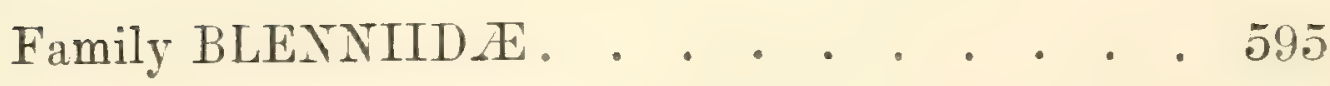

Pterygocephalus. . . . . . . , . 595̄

— paradoxus . . . . . . . . 59. 
Suborder X. ANACANTHINI . . . . . . . . 597

Family GADIDA. . . . . . . . . . 597

Nemopteryx • • • . . . . . . 598

— troscheli . . . . . . . 598

Gadus . . . . . . . . . . 599

Brosmius . . . . . . . . 602

Family PLEURONECTID $\mathrm{E}$ • . . . . . 606

Rhombus . . . . . . . . 606

— minimus . . . . . . . 607

Pleuronectes . . . . . . . . 608

Solea . . . • . • . . . . 609

kirchbergana . . . . . . . 609 


\section{LIST OF ILLUSTRATIONS.}

Page

Fig. 1. Lycoptera sinensis; restoration . . . . . . . 3

2. Osmeroides lewesiensis; restoration . . . . . 13

3. Pachyrhizodus dibleyi ; portions of upper jaw . . 39

4. Spaniodon blondeli ; restoration . . . . . . 50

5. Portheus gaultinus; partial restoration of head . . 96

6. Ctenothrissa vexillifer; restoration . . . . . 120

7. Eurypholis boissieri ; restoration . . . . . . 206

8. Cimolichthys nopæolica; remains of head and abilominal region . . . . . . . . . . . 224

9. Cimolichthy's nepæolica; head-bones, etc. . . . . 227

10. Chirothrix libanicus; restoration . . . . . . 281

11. Arius egertoni; dorsal fulcral spine and supraoccipital bone . . . . . . . . . . . 332

12. Cobitopsis acutus; restoration. . . . . . . 355

13. Hoplopteryx lewesiensis; restoration . . . . . 398

14. Mene rhombeus; restoration . . . . . . 4 4:38

15. Cybium excelsum; right premaxilla andleft dentury 468

16. Cybium bartonense; right premaxilla and left dentary . . . . . . . . . . . 468

17. Palæorhynchus glarisianus; restoration . . . . 484

18. Outlines of Rostra of Extinct Xiphiidæ . • . . 496

19. Phyllodus polyodus; upper pharyngeal dentition . 547

20. Diodon scillæ; inner dental plates . . . . . . 573

21. Ampheristus toliapicus; cranium and preoperculum . 578

22. Blochius longirostris; restoration of skeleton and portion of squamation . . . . . . . 592 


$$
\text { - }
$$

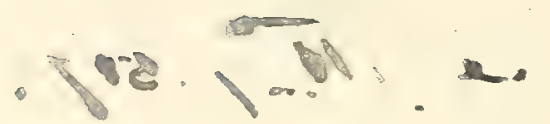


hy ooptemsale

$1 a$

Sungarichthys gen. nox. FTakai 1944 L. Fac-Sci.1.1.Tokyo II 6 p.262, typo Leplotepis longi cephalus s.m. Takai, 1942 said.p. $129 \mathrm{Li} \% \mathrm{z}$ III p.507.

$(6,2),-15$ 


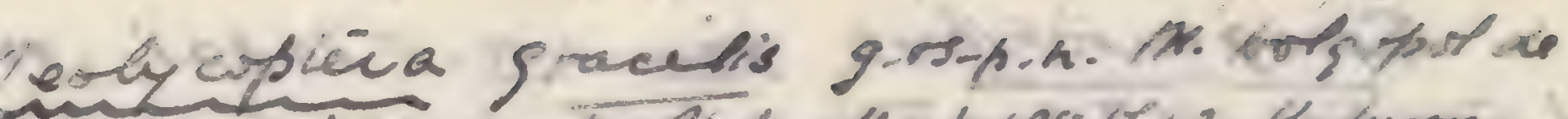

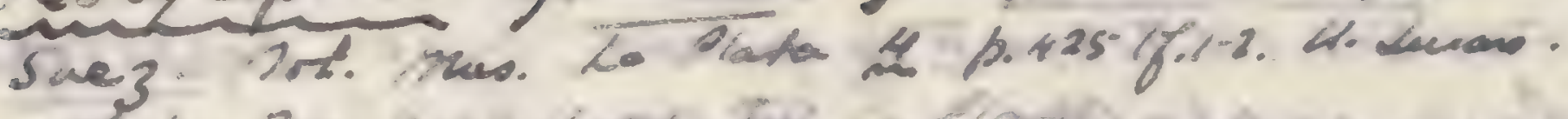
Let. itjoentine.

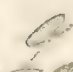
Lime: "The Find Bawna of the Califoriac Jertiary" ( Stanford Unis. Belle. Wniver Series, Bial Señ rdi ino. 4

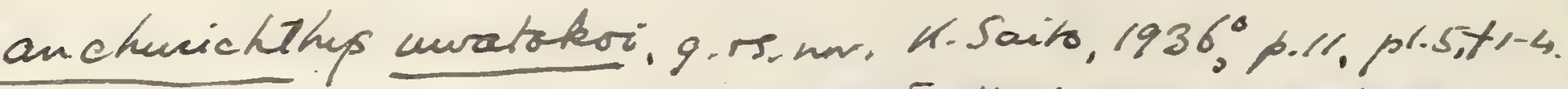

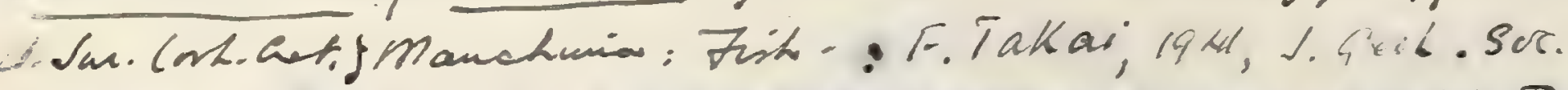

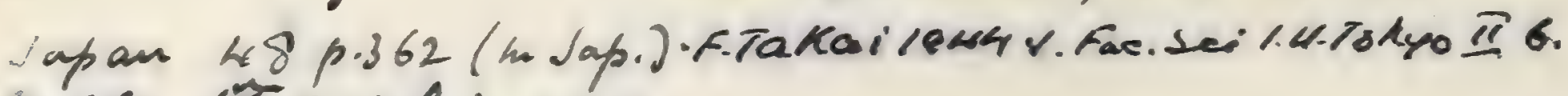
A. 260 4.8.12 plo ix $x / 4.4$.

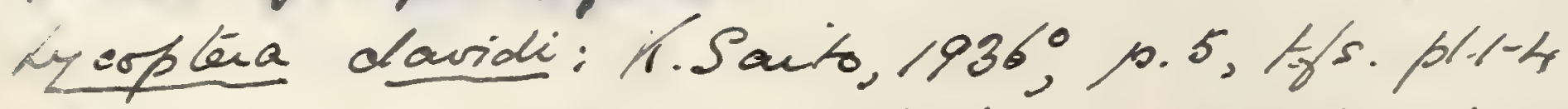

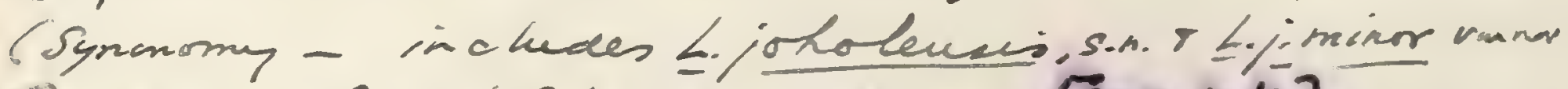
Gaban 01928. 1.672.). Manchuia [see p.42.

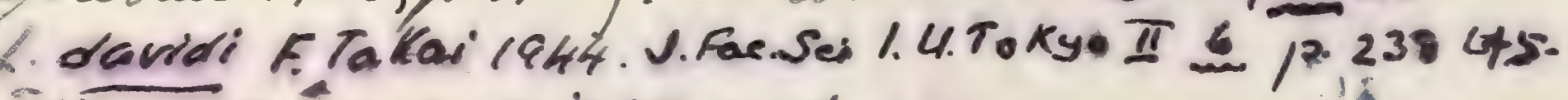

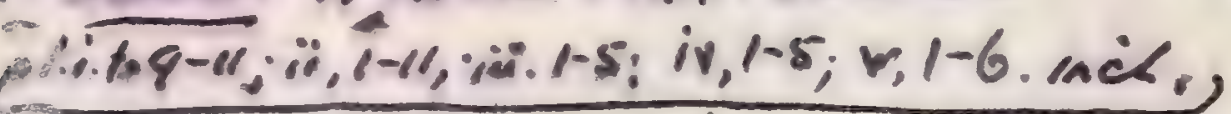

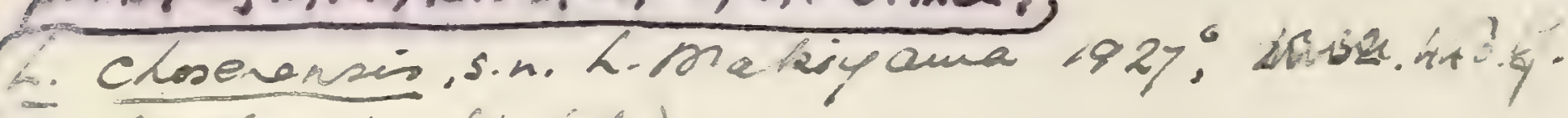
(v. Vurea). (herap.).

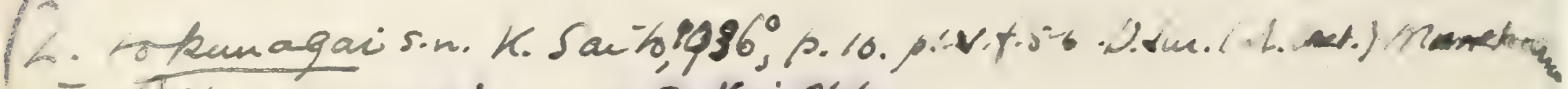

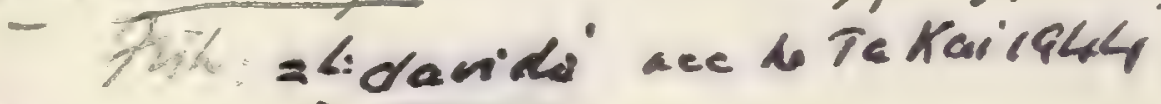

Lecoptera Kansuensis. Grabare Pe P.Takai 1944 J. Tar.Sei 1.4. Tokyo II 6 p. 246 pl.vii. 3-s: MrU.Sur. Chen"

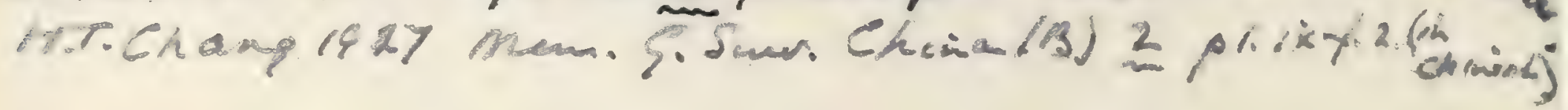





\title{
CA'T A L G U E
}

\author{
OF \\ FOSSIL FISHES.
}

PART IV.

\section{Order II. ACTINOP'TERYGII (continued).}

Suborder IV. ISOSPONDYLI (continued) ${ }^{1}$. LYCOPTEKIDE (ser Takar 1944 Family IEPTOLEPID

Genus LYCOPTERA, J. Müller. Univ. Tokyo (II) 6

[Middendorff's Sibirische Reise, vol. i. pt.i. 1848, p. 262.] / 235 .

Head large; maxilla arched, with a slightly convex dentigerous border; mandible prominent, the dentary gradually deepening from the symphysis backwards without any marked thickening; teeth minute and closely arranged. Opercular and branchiostegal apparatus apparently as in Leptolepis. Vertebral centra in form of delicate constricted cylinders. Pectoral fins much larger than the pelvic pair; dorsal fin small and short-based, opposite to the anal fin, which is not longer than deep ; caudal fin forked. Scales completely covering the trunk, none enlarged or thickened.

1 Recent researches seem to necessitate a modification of the definition of the Isospondyli given in Part III., p. 446, by the omission of the statements "symplectic bone present" and "precoracoid arch present." The suborder is thus made to include the so called Scyphophori and Haplomi of Cope. Conscut cerning the former (Mormyridæ and Gymnarchidæ) see G. A. Boulenger, Proc. Zool. Soc. 1898, pp. 775-821.

PART IV. 
The feeble development of the vertebral centra suggests the early Jurassic age of this fish. As observed by J. Muiller, the genus is closely related to Thrissops; but it is distinguished by the characters of the vertebræ and the considerably less extension of the anal fin.

\section{Lycoptera middendorffi, Müller.}

1846. Pholidophorus macrorhynchus, E. von Eichwald, Géogn. de Russie, p. 498 (in Russian, apparently undefined).

1848. Lycoptera middendorffi, J. Müller, in A. T. von Middendorff's Sibirische Reise, vol. i. pt. i. p. 262, pl. xi. figs. 1-5.

1868. Lycoptera macrorhyncha, E. von Eichwald, Lethæa Rossica, vol. ii. (Période moyenne), p. 1200, pl. xxxviii. figs. 1-4.

1868. Lycoptera middendorffi, E. von Eichwald, ibid. p. 1202, pl.

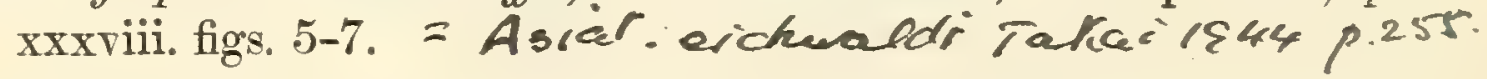

Type. Nearly complete fish; Imperial Academy of Sciences, St. Petersburg.

The type species, attaining a length of about $0 \cdot 1$. Length of head with opercular apparatus slightly exceeding the maximum depth of the trunk and occupying about one quarter of the total length to the base of the caudal fin. 'Pectoral fins, when adpressed, reaching considerably more than half way to the origin of the pelvic pair, which arise about midway between the pectorals and the anal; Jorsal fin with 10 rays, arising immediately behind the origin of the anal fin, which comprises 14 rays, the length of the longest about equal to the depth of the caudal region at its insertion.

This fish was erroneonsly supposed by Egerton to belong to the Cyprinoid genus Aspius (T. R. Jones, Mon. Foss. Estheriæ, Pal. Soc. 1862, p. 112).

Form.\& Loc. Lower Jurassic (?): Turgá, Nertchinsk, Transbaikal Province, Siberia.

P. 273. Six small pieces of shale exhibiting various remains of this fish associated with Estheria middendorffi, (T. R. Jones, Mon. Foss. Estheriæ, Pal. Soc. 1862, p. 112), collected at Turgá by C. G. A ustin. One specimen (numbered P. 273a) also displays remains of comparatively large fins which may belong to the genus Belonorhynchus.

Transferred from Mus. Practical Geology, 1880.

P. 1841. Two similar specimens. Egerton Coll.

P. 6728. Slab exhibiting two imperfect small fishes. Presented by Dr. Friedrich Schmidt, 1892. 

Atoliths in Ligeptera middendorffic moticea Iy T. Koken, Reitsch. dentuch geol. Ger. vol xxxvi ). p.563. Her by Reir, 1909.

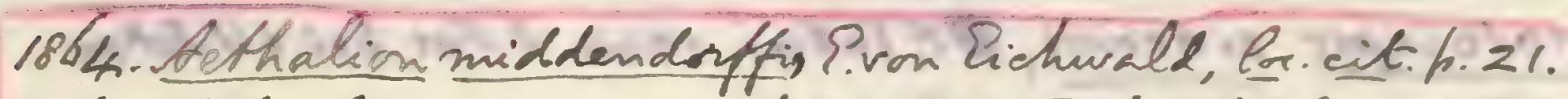

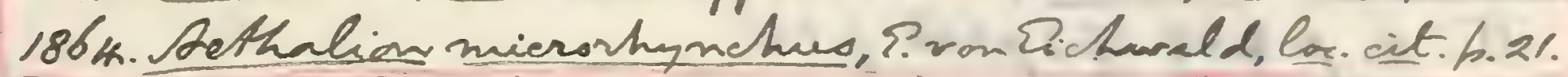
1864. Hethalion macrorhynchus, ?. vow Gichuvald, Bull. Sor. Géd. Arance [2] vol. xxi,h.21.

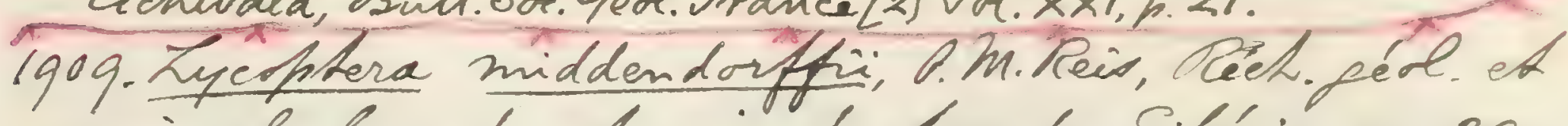
min. le lony der chemin de fer de Sibérie, no. 29, h.5. pl.i. fir. $1-3,11$.

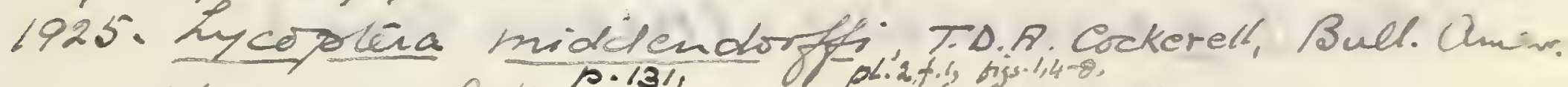

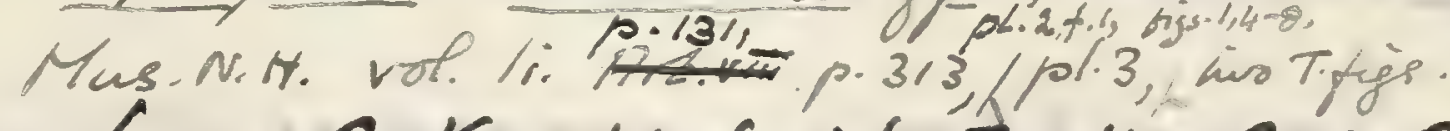

1933. I. m. A. Kryshtoforich, Ir. Un. Ges. Pmp. U.S.S.R. 2. 326 , pl. xiii. f. 9 -11.

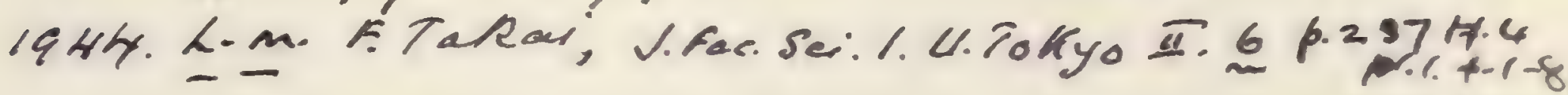

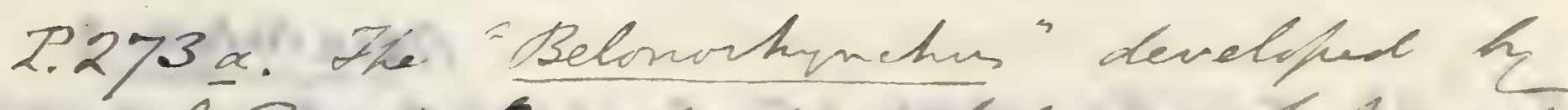

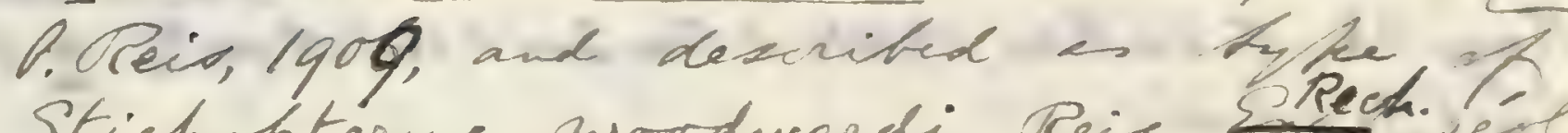
Stichopterus woodwardi, Reis, Pech. Éel.

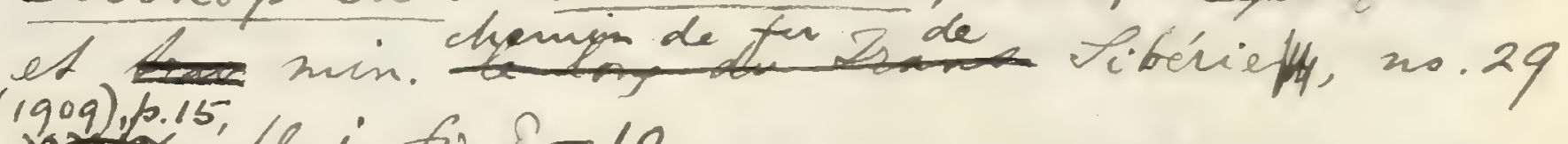

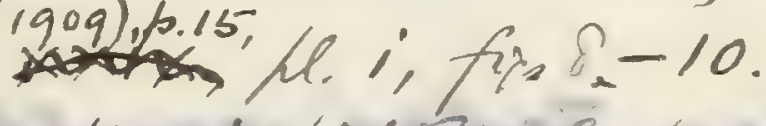

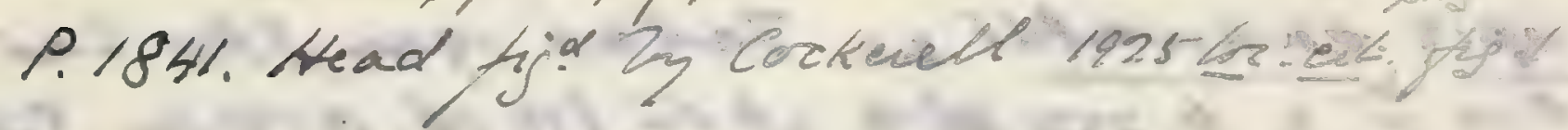





\section{Lyeoptera sinensis, sp. nor.}

[Restoration in text-figure 1.]

Type. Imperfect fish; British Museum.

A species attaining a length of about $0 \cdot 13$. Length of head with opercular apparatus slightly less than the maximum depth of the trunk and occupying scarcely more than one quarter of the total length to the base of the candal fin. Vertebræ about 45 in number, 20 being caudal. Pectoral fins, when adpressed, scarcely reaching more than half way to the origin of the pelvic pair; other fins apparently as in the type species. Fof Asiatolepis

Form. \& Loc. Lower Jurassic (?): Poh-tse, near Layang Nsien, Province of Shantung, China.

P. 7358. Type specimen, collected by H. M. Besher. Among the remains of the head, the small mouth is distinct, bounded above both by the premaxilla and the long arched maxilla Traces of small, bluntly conical teeth are also distinguishable. Indications of a few slender branchiostegal rays

Fig. 1.

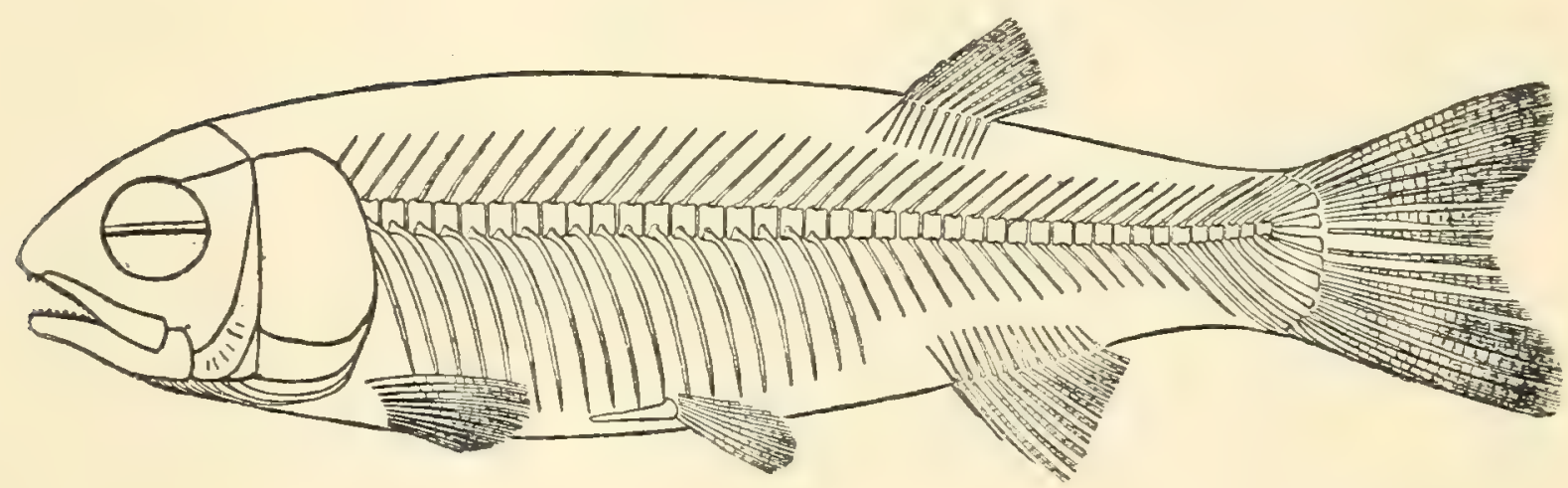

Lycopter'a sinensis; restoration, slightly less than nat. size.

occur below the hinder end of the mandible. The delicate vertebral centra are very imperfectly preserved, but 18 or 19 pairs of stout ribs can be counted, and these almost or completely encircle the abdominal cavity. The neura and hæmal spines in the caudal region are comparatively small, except at the base of the caudal fin. The fish is distorted in the anterior part of the caudal region, but all the fins are tolerably well preserved. Purchased, 1894.

P. 735\%. Contorted specimen in counterpart, collected by H. M. Becher. One of the slabs exhibits a second well-preserved fish on the obverse side. The characteristic jaws, dentition, 
and opercular apparatus are distinct; and the delicate cylinders forming the vertebral centra are well shown.

Purchased, 1894.

P. 7090. Imperfect impression of large fish, and greater portion of trunk of a smaller specimen. The latter displays the delicate vertebral centra and the thin scales marked with fine longitudinal striations.

Presented by Harry M. Becher, Esq., 1894.

P. 7095. Distorted specimen, artificially polished. Purchased, 1894.

To Lycopter a may also probably be referred the so-called Prolebias davidi (H. E. Sauvage, Bull. Soc. Géol. France, [3] vol. viii. 1880, p. 452, pl. xiii. figs. 5, 6). It is described as abundant in a whitish shaly limestone " belonging to the Tertiary formations of Northern China." It is not represented in the Collection.

rycopleira davidi - sup.l.

Synopsis of Cretaceous and Tertiary Families of Isospondyli.

All characterised by presence of intermuscular bones and absence of fulcra on fins.

I. Margin of upper jaw formed by maxilla and premaxilla. Precoracoid arch present.

(a) Parietal bones usually meeting in the middle line, and squamosal bones well developed.

Marginal dentition comparatively well-developed; opercular apparatus complete, and branchiostegal rays numerous, with gular plate ..............

Nouth small, and marginal dentition feeble or absent; opercular apparatus complete, but branchiostegal rays few, and no gular plate ..................

Opercular apparatus incomplete, with 10 to 20 branchiostegal rays, but no gular plate; scales thick, mosaic-like in structure .

(b) Supraoccipital usually more or less completely separating the parietal bones in the middle line; squamosal bones much reduced, and pterotic region prominent; nc gular plate.

ELOPIDEe (p. 7).

Albulide (p.59).

OSTEOGLOSSID A (p. 73). 



$$
\text { n }
$$


9Lotithus(hypiotepidancem) simptex, slicatis, ouscamis, cuncifemis, Elongarus, Bewangulatis

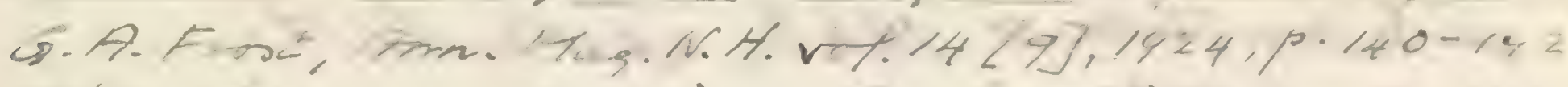

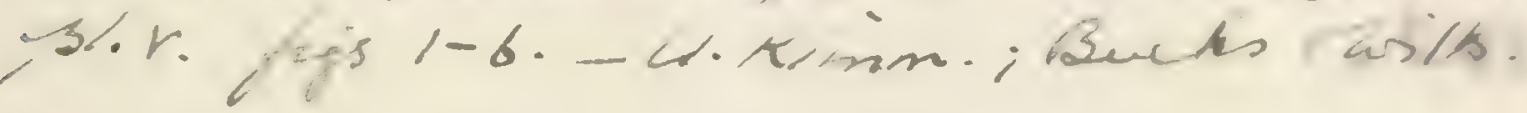

Haplospondylus clupeoides g.ets.n. A.Caunera, Rensita rueseo. Plota XXX (1927) pp.317-9. L.Cretag?: L.San montin, Sta Couz, Orgentaro. (9mp. Fish: Theses do la Plata?.

9. 9.9. Ntotto, 7.5.9., has a Zycoptere furm near Tong-shan, Pe-chi-le, h. Chima.

Atho, ha 812.190\%.

P.116\%. Well-huenved firh $\alpha$ assoviated portion. of firstes, of the phecied Zycoptena davidi, in a piece of light-colomed shale from China.

Resented if hus. Dotert Bruce, 1913.

Pthithus (Zycoftera) gnasicameratus, 0.M. Reis, Expl. geol. et trav min. le long du Trans-cibérien, no.xxix (1909), h. 12, hli. fip. bi, hliifip. 1-16. Juzga. Ptrlithur (?-) witimensio, O.M. Reir, lor. cit. (190q). f.14, hli.fip. 4. - Witim, Transtaikalia. 
Syin of Teleorleain ghthi Cs. Wrsticuo 1942. Gm. D.t. (ii) $q$ p. 202 .

Rigin Aloupew we Aramming

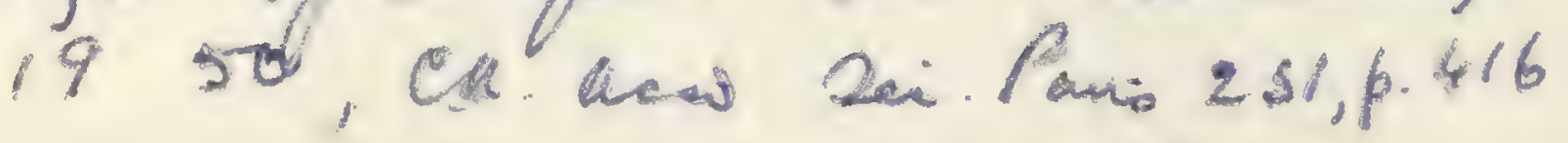


Parietal bones partly meeting in the middle line; opercular apparatus incomplete, with few branchiostegal rays; abdominal vertebræ with transverse processes.

Maxilla and premaxilla firmly fixed; opercular apparatus complete, with few branchiosteg'dl rays; abdominal vertebræ without transverse processes ....... Maxilla loosely attached, with two supramaxillaries ; opercular apparatus complete, with few branchiostegal rays; abdominal vertebræ without transverse processes; postclavicle overlapped by clavicle; pelvic fins enlarged and far forwards ....

Maxilla loosely attached, usually with two supramaxillaries; opercular apparatus complete, with few branchiostegal rays; abdominal vertebræ with short transverse processes; postclavicle overlapping clavicle; dorsal fin median, and no adipose dorsal .............

As Clupeida, but with adipose dorsal fin and postclavicle overlapped by clavicle .........

II. Premaxilla partly or completely excluding maxilla from margin of upper jaw; no gular plate. Precoracoid arch reduced or absent.

(a) Parietal bones meeting in the middle line, and squamosal bones well developed.

Maxilla partly entering gape; opercular apparatus incomplete; scapular arch supported by posttemporal bone; scales cycloid, regularly arranged; lateral line near ventral border of flank ..

Premaxilla completely excluding maxilla from margin of upper jaw ; opercular apparatus complete; scapular arch supported by igament, without post-
Notoptertì (p. 85).

Chirocentrid $\overline{\text { (p. 86), }}$

Ctenothrissina

$[($ p. 119).

Clupeid (p. 128).

Salmonid 2 (p. 159).

Halosauride (p. 162). 
temporal bone scales cycloid, regularly arranged ateral line above middle of flank.......

Premaxilla completely excluding maxilla from margin of upper jaw ; opercular apparatus complete; scapular arch supported by post-temporal bone; body with paired longitudinal series of scutes; lateral line piercing a series of scutes above middle of flank.

(b) Supraoccipital separating the parietal bones in the middle line; squamosal bones much reduced, and pterotic region prominent.

Maxilla partly entering gape; upper dentition chiefly on inner bones of mouth; abdominal vertebræ without transverse processes; an adipcse dorsal fin; scales minute or absent, but usually rows of scutes, the dorsal series, when present, being unpaired. . Premaxilla completely excluding maxilla from margin of upper jaw; dentition usually feeble, but upper enlarged teeth, when present, on the premaxilla; abdominal vertebræ without transverse processes; an adipose dorsal fin scales usually present, no scutes ............

Premaxilla delicate but completely excluding relatively large maxilla from margin of upper jaw ; dentition absent or on inner bones; abdominal vertebræ with transverse processes; no adipose dorsal fin ; dense regular squamation ................

Premaxilla completely excluding maxilla from margin of upper jaw ; dentition feeble or absent ; abdominal vertebræ with transverse processes; paired fins excessively enlarged .........

Premaxilla small, and maxilla form-
Notacanthidet (p. 168).

Dercetide (p. 171).
SCOPELIDE (p. 235).

\section{GONORHYNCHID A}

$[(\mathrm{p} .271)$.

ChIRothricid (p. 279), 
Reviers Af fossil + living elopiforms, P. Forry 1973, B.4L.BM Gerl, Suppt. 10.

Hit fin Getacerns Kansas Hw. miken usto Troun. Kansan Acare se GI p. 213 Itig.

see also Anoethalion, wh. III. 
ing greater part of margin of upper jaw ; dentition powerful ; abdominal vertebræ without transverse processes; no adipose dorsal fin; dense regular squamation .............

Premaxilla completely excluding Esocid (p. 287). maxilla from margin of upper jaw ; dentition absent on inner bones except rarely on vomer ; abdominal vertebræ with transverse processes; no adipose dorsal fin; regular squamation ............

Cyprinodontide

$[(\mathrm{p} .289)$.

\section{Family ELOPID Æ.}

Trunk fusiform, and caudal region relatively short. Supraoccipital bone not prominent, but extending forwards ieneath the united parietals or separating the latter in the mediau line; squamosals suturally united with parietals and completely covering the otic bones except behind; snout not produced; cheek almost or completely covered by the suborbital and circumorbital plates. Mandibular suspensorium vertical or inclined forwards and gape moderately wide; premaxilla small and maxilla relatively large, both entering the upper border of the mouth; one or two supramaxillaries; teeth acuminate, best developed on the premaxilla, maxilla, and dentary bones. Opercular apparatus complete, with numerous branchiostegal rays ( 20 to 30 ) and a gular plate. Vertebral centra well ossified, none with transverse processes; ribs nearly or completely encircling the abdominal cavity; hæmal arches scarcely if at all fused at the base of the tail. Intermuscular bones present. Fin-fulcra absent ; fin-rays divided and closely articulated distally; dorsal and anal fins small, the former short-based and nearly median; no adipose dorsal fin. Scales thin, cycloid, deeply imbricating.

\section{Synopsis of Genera.}

I. Parietal bones meeting in middle line.

Teeth large; gape extending beyond orbit; operculum simple ......

Teeth minute and clustered; gape

Elopopsis (p. 8). not extending beyond orbit; operculum simple; no enlarged scale at base of paired fins ....

Osmeroides (p.11) 
Teeth small; operculum simple; an enlarged scale at base of paired fins; lateral line simple ......

Teeth minute; operculum subdivided by transverse suture; lateral line radiating on each scale traversed; hindermost ray in dorsal and anal fins much elongated ..

Teeth small; operculum subdivided by transverse suture; lateral line simple ................

II. Parietal bones relatively small and not meeting in the middle line.

Teeth small; no deep depression in frontal region of skull; abdqmen rounded or flattened .........

Teeth small; deep depression in frontal region of skull; abdomen compressed to sharp edge.....

Teeth large and rounded; no deep depression in frontal region of skull.................

Teeth large, laterally compressed; no deep depression in frontal region of skull; gape rather small....

Enlarged pair of teeth at symphysis of mandible; gape wide; dorsal fin opposed to pelvic pair ......

As Spaniodon, but dorsal fin opposed to space between pelvic and anal fins ................

\section{Incertæ Sedis.}

Teeth of moderate size and slender, each tipped only with a cap of enamel; gape not much directed upwards ...............
Elops (p. 22).

Megalops (p. 24).

Notelops (p. 27).

Rhacolepis (p. 29).

Thrissopater (p. 32).

Pachyrhizodus (p. 37)

Esocelops (p. 46).

Spaniodon (p.48).

Thrissopteroides (p. 54).

Protelops (p. 56).

\section{Genus ELOPOPSIS, Heckel.}

[Denkschr. k. Akad. Wiss., math.-naturw. Cl. vol. xi. 1856, p. 251.]

Trunk somewhat laterally compressed, abdomen flattened. Mandible a little prominent, and gape extending behind the eje; one supramaxillary bone; margin of the jaws with a series of robust conical teeth. Operculum simple; branchiostegal rays between 25 and 30 in number. Vertebræ between 50 and 60 in number, the centra not longer than deep, all slightly constricted and marked 


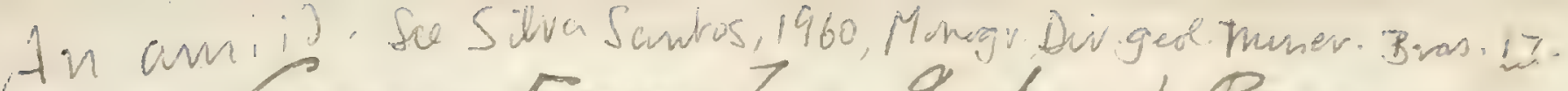
ge En Erretes. Iordan a Bummer.

[Snithsm. Wizcell. Coll. vol. 7ii. 1908, h. 23.]

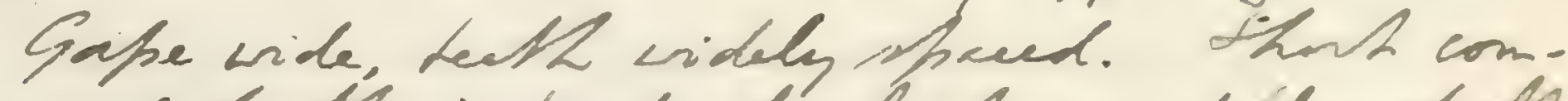

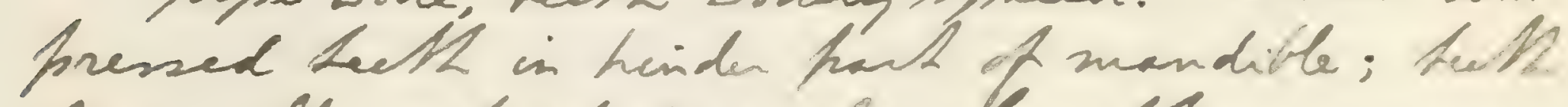

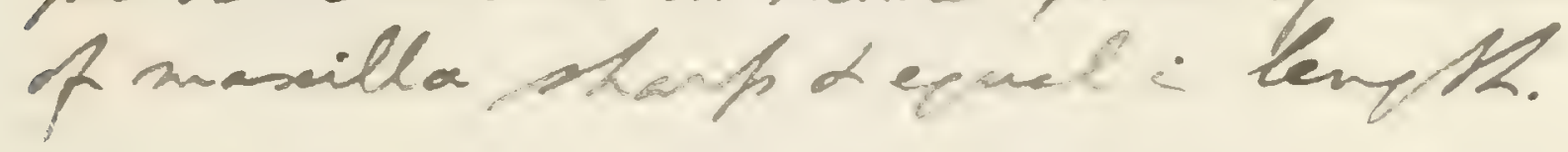

Enneler andaxe. Iordan L Brammen, Lor cit. p.23, fl.vii. Reat-fies. 14, 1s:- Crotaceons; Cearó, Brazil. KHead, Le; Muses Drethe and

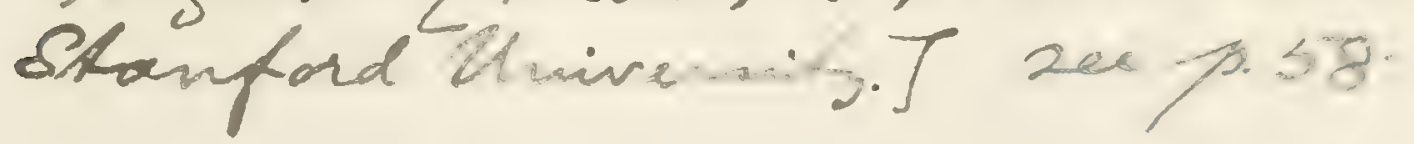

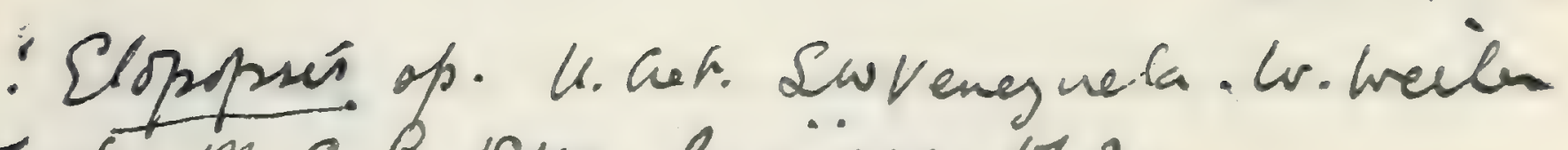

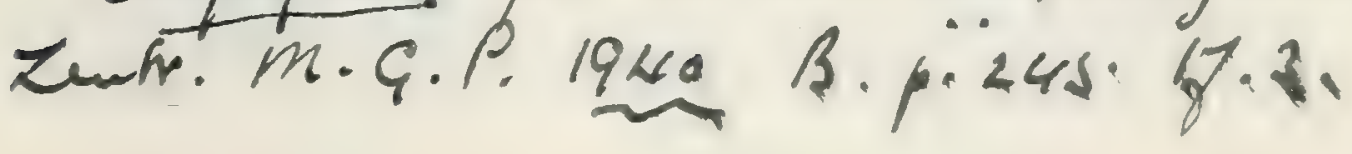


1912. Elopopsir fenzli, 7. Bassani d G. D'Srawn, hem. Sor.

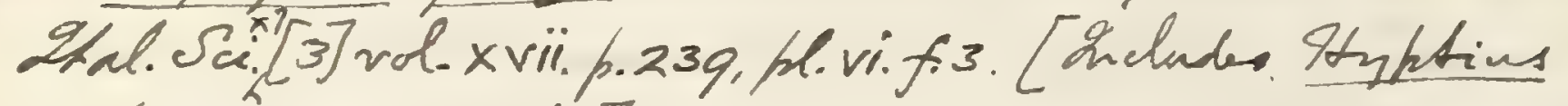
sebustiani, Costa.]

Cenomanian: Jorre d'Orlando, Castellamare.

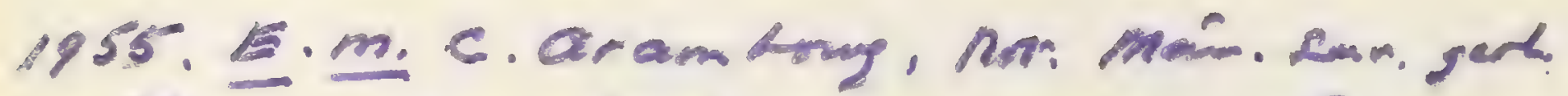
Meare. 118 p.62 $8.30-34$ pr. vii,. Gamman? 
with longitudinal ridges. Pelvic fins opposed to the dorsal; caudal fin forked; no fin-rays excessively elongated. Scales very delicate, the exposed portion deeper than broad.

\section{Elopopsis fenzli, Heckel.}

1856. Elopopsis fenzlii, J. J. Heckel, Denkschr. k. Akad. Wiss., math.naturw. Cl. vol. xi. p. 25 l, pl. xiii. fig. 1.

1867. Elopopsis fenzlii, R. Kner, Sitzungsb. k. Akad. Wiss., math.naturw. Cl. vol. lvi. pt. i. p. 197.

Type. Imperfect fish, wanting tail; Court Museum, Vierna.

The type species, attaining a length of about $0 \cdot 4$. Length of head with opercular apparatus much exceeding the maximum depth of the trunk and equalling the length of about 23 anterior vertebræ; depth of head at occiput much less than the length of the cranium. Cheek-plates ornamented with a few tuberculations; dentigerous border of maxilla almost straight; teeth with broad bases, those of the upper jaw increasing in size towards the hinder end of the maxilla, those of the mandible similarly increasing in size, and the largest. Operculum much deeper than broad. Dorsal fin arising about over the 26th vertebra, with four short undivided rays followed by about 18 rays divided and articulated distally; pelvic fins one-third shorter than the pectorals, each with 10 rays, arising opposite the hinder end of the dorsal fin.

Form. \& Loc. Cretaceous: Comen, Istria.

Not represented in the Collection.

\section{Elopopsis microdon, Heckel.}

1856. Elopopsis microdon, J. J. Heckel, Denkschr. k. Akad. Wiss., math.-naturw. Cl. vol. xi. p. 256, pl. xiv.

(?) 1863. Elopopsis microdon?, R. Kner, Sitzungsb. k. Akad. Wiss., math.-naturw. Cl. vol, xlviii. pt. i. p. 135.

Tippe. Imperfect fish; Court Museum, Vienna.

A species about as large as the type, with comparatirely slender teeth. Length of head with opercular apparatus much exceeding the maximum depth of the trunk and equalling the length of 24 anterior vertebræ; depth of head at occiput equalling the length of the cranium. Cheek-plates less conspicuously tuberculated than in E. fenzli; dentigerous border of maxilla slightly sinuous; teeth increasing in size towards the hinder end of each jaw, but none much expanded at the base.

Form.\& Loc. Cretaceous : Comen, Istria.

Not represented in the Collection. 


\section{Elopopsis heckeli, Reuss.}

1857. Elopopsis heckeli, A. E. Reuss, Denkschr. k. Akad. Wiss., math.naturw. Cl. vol. xiii. p. 39, pl. iii.

1878. Elopopsis heckeli, A. Fritsch, Rept. u. Fische böhm. Kreideform. p. 41 , fig. 61 .

Type. Head; Royal Bohemian Museum, Prague.

A species known only by the head and a fragment of the anterior abdominal region, the mandible measuring 0.13 in length. Length of head with opercular apparatus exceeding the maximum depth of the trunk; depth of head at occiput not quite equalling the length of the cranium. Dentigerous border of maxilla slightly convex; teeth increasing in size towards the hinder end of each jaw, all considerably expanded at the base.

Form. \& Loc. Cenomanian: Prague, Bohemia.

Not represented in the Collection.

\section{Elopopsis crassus (Dixon).}

1850. Osmeroides crassus, F. Dixon, Geol. Sussex, p. 376.

1888. Osmeroides crassus, A. S. Woodward, Proc. Geol. Assoc. vol. x. p. 322 .

1895. Elopopsis crassus, A. S. Woodward, Proc. Zool. Soc. 1894, p. 659, pl. xliii. fig. 1.

Type. Head; Brighton Museum.

An imperfectly known large species, the mandible measuring about 0.09 in length. Depth of head at occiput at least equalling the length of the cranium. Premaxilla elongate-triangular in shape, bearing a close series of small conical teeth on its oral border and two much-enlarged, laterally-compressed teeth within; dentigerous border of maxilla convex, with a regular series of small stout teeth, not increasing in size backwards; mandible rapidly tapering to an almost pointed symphysis, with relatively large, widely-spaced teeth, of which the largest seem to be in front.

Form. \& Loc. Turonian: S.E. England.

P. 1169. Imperfect head, with fragments of trunk; Chalk, Kent.

Egerton Coll.

The following species is known only by an imperfect head much resembling $E$. crassus:-

Elopopsis ziegleri, W. von der Marck, Palæontogr. vol. x₹. (1868), p. 293, pl. xli. figs. 2-4.-Cenomanian; Wessum, near Ahaus, Westphalia. [Head, ete.; otim Ziegler Coll., Ahaus.] 


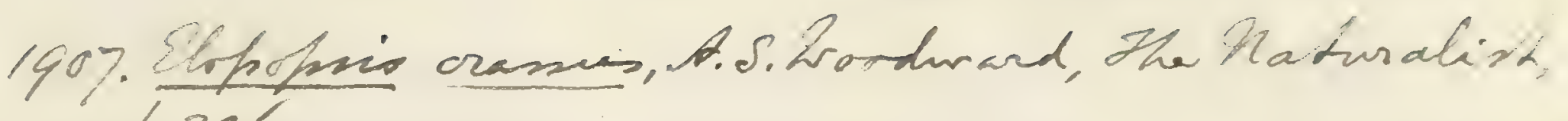
p.306.

1908. Slopopio crassuo, A. P. Loodward, Ans. Fish inglish Chalte (Nall th.), h. 133, hi. xxvili.fin. 2-4.

Probig. Teft dentary de? a fip? A.S.2. 1908, f.135, fll. $x \times$ viii. fij. 3.

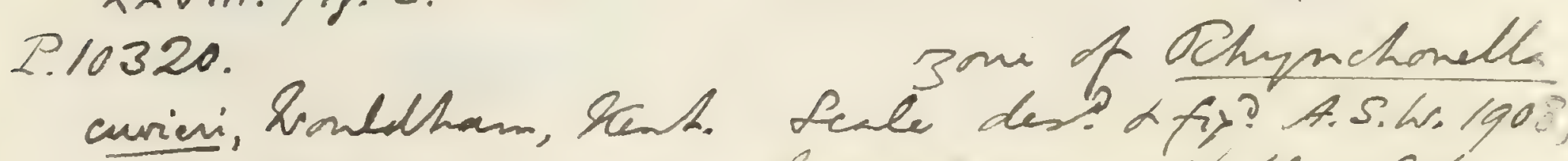
h. 135; pl. xxviii. fir. 4. Litiud pases. Briblez Colle

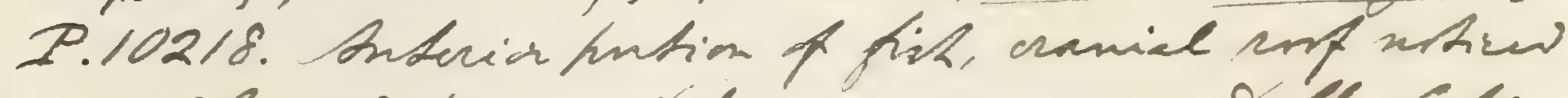
A.s.s.1908, b.134; itik.

oritley Colls. P.10217. 


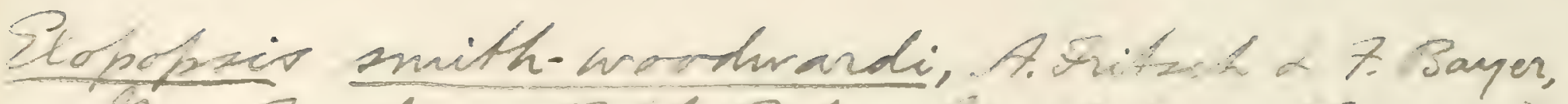

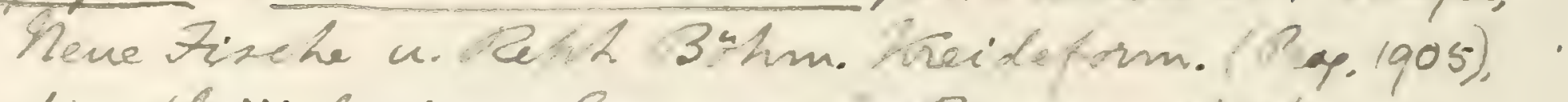

k.7. hl.iiifij.1. - Tenonian; Prizen, Brhernia.

Lowherior half of firk; Con. Bhem. Wus, Mavie.]

Parel as prazateii, A Fitsch I Bayen, f.cit.

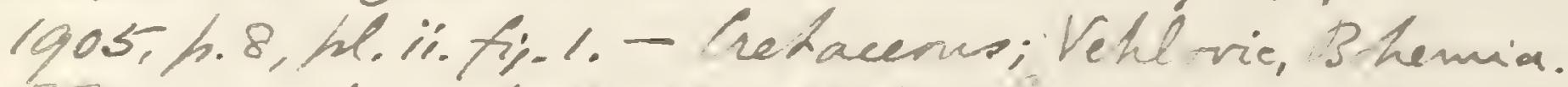
Erepmentary tirti; Roy. Bhem. mus, Pasue.J T. Parelob. Fo B., undefined.

Holcolepis delicalostrialüs, M.s, H.Yake o T. Obata, 1930, Jap. Joun. Geot Geogr. VIII. 2, pli plirf. r-2. Crelac. Tapan. (v.1mp. inuenk) 
Dsmaroides Lenvionaiss (Mantell)

32

Salns lewesiensis. Mantell 1822 Foss. S.Deuns, 1.235 .

SYNTYPES

(1) 4301 figs. pl. $x$ l, tig. 1 .

(2) 4293. deser. 1.236; figg. 1825, "Selmo lenesiensis.", London, fig. 3. (A folio shect published separately.)

(3)

A.S.W. also mentions "pl. $x \times x 12, f i g .3 "$ in the Cat. but though this spece. is a scale of Osmereides, Mantele calls it indeterminable 1 names "fig. 6" as O. lemeniensis.

(4) pl. xxx111, fig.12 appeans to be an impert. head of toploptergax, lent cannot be found 2.12.53. 



$$
\begin{aligned}
& \text { fanily Osmero id Fapid (Albuloidei) P. Fory, Bull. B/4 (gers.) } \\
& \text { Genus OSMeroIDES, Agassiz }{ }^{1} \text {. } \\
& \text { [Poiss. Foss. vol. v. pt. ii. 184t, p. 103.] } \\
& \text { suppl. } 00,0.94
\end{aligned}
$$

Syn. Rhabdolepis, W. von der Marck (non Troschel, 1857), Palæontugr. vol. xi. 1863, p. 26.

Holcolepis, W. von der Marck, ibid. rol. xv. 1868, p. 278.

Head and trunk not much laterally compressed, and abdomen flattened. Parietal bones in contact in the median line; mandible a little prominent, and gape not extending behind the eye; two supramaxillary bones; margin of the jaws and some inner bones with clusters of minute bluntly-pointed teeth, sometimes perhaps tritoral. Branchiostegal rays about 20 in number, about five of the uppermost and broadest supported by the epihyal. Vertebræ between 50 and 70 in number, about 20 being caudal; the centra not longer than deep, all slightly constricted and marked with small irregular longitudinal ridges. No enlarged scale at the base of the paired fins; dorsal fin never much longer than deep, opposite or nearly opposite the pelvic pair; anal smaller than the dorsal fin; caudal fin forked; no fin-rays excessirely elongated. Scales often ornamented in their exposed portion with delicate radiating lines of minute tubercles, marked in their covered portion with a few radiating grooves terminating in notches at the anterior truncated margin; hinder margin not serrated; course of lateral line indicated by a feeble ridge and a notch in the hinder border of most of the scales.

The generic name Osmeroides was originally giren by Agassiz to some fishes from the Cretaceous of Westphalia catalogued below in the family Scopelidæ (Sardinioides monasteri). When it was afterwards applied to fossils discovered by Dr. Mantell in the English Chalk, Agassiz expressly stated that the determination of generic identity was uncertain and provisional. In course of time, however, the name has become universally recognised as belonging to the English specimens, and least confusion will be caused in established nomenclature if Osmeroides lewesiensis be regarded as the type species.

\section{Osmeroides lewesiensis (Mantell).}

$$
\text { [Text-figure 2.] }
$$

1822. Salmo lewesiensis, G. A. Mantell, Foss. South Downs, p. 235, pl. xxxiii. fig. 12, pl. xxxiv. fig. 3, pl. xl. fig. 1 .

1 This name was first published, without definition, by Agassiz, Neues Jahrb. 1834, p. 305. 
1837-44. Osmeroides lewesiensis, L. Agassiz, Poiss, Foss. vol. v. pt. i. p. 14, pt. ii. p. 105, pl. lx b. figs. 1, 2, 5-7 (non figs. 3, 4), pl. lx $c$.

1838. Osmeroides mantellii, G. A. Mantell, Wonders Geol. vol. i.p. 307, fig. 1.

(?) 1878. Osmeroides lewesiensis, A. Fritsch, Rept. u. Fische böhm. Kreidefor'm. p. 32, pl. vii. fig's. 5, 6, pl. viii. fig. 1.

(?) 1885. Osmeroides lewesiensis, G. C. Laube, Denkschr. k. Akad. Wiss., math.-naturw. Cl. vol. 1. p. 292, pl. i. figs. 2, 3, \& woodc.

1888. Osmeroides levesiensis, A. S. Woodward, Proc. Geol. Assoc. vol. x. p. 322 .

1895. Osmeroides lewesiensis, A. S. Woodward, Proc. Zool. Soc. 1894, p. 656, pl. xlii.

Type. Imperfect fish; British Museum.

The type species, attaining a length of about $0 \cdot 45$. Form and proportions not definitely known, but length of head with opercular apparatus contained nearly three times in the length of the trunk from the pectoral arch to the base of the caudal fin. Length of cranium somewhat exceeding twice its maximum width at the occiput; bones of the hinder half of the cranial roof, cheek-plates, opercular bones, and upper branchiostegal rays ornamented with coarse radiating rugæ. Rays of each pelvic fin not less than 11 in number; the small anal nearer to the caudal than to the pelvic pair. Exposed area of scales narrow and deep, usually smooth, sometimes oruamented with rery fine closely-arranged radiating lines of tubercles.

The principal features of the collection from the English Chalk enumerated below are described in the Proc. Zool. Soc. 1894 (1895), pp. 656-659, pl. xlii., and include all the more important osteological characters of the genus. The lack of more precise information concerning the proportions of the fish and its fins, however, renders it impossible to determine at present whether the fragmentary specimens of Osmeroides from the Turonian and Senonian of Bohemia, described by Fritsch and Laube (loc. cit.), truly belong to the same species. In any case, Fritsch's outline-restoration of "Osmeroides lewesiensis, Ag.," is much too slender and has too small a head for this fish, while the anal fin is not sufficiently remote. As shown by the English fossils, the cranial osteology differs much from the tentative restorations both of Fritsch and Laube.

Form. \& Loc. Turonian and Senonian: Sussex and Surrey. (?) Turonian and Senonian: Bohemia.

4294. Type specimen, comprising head and abdominal region, figured by Agassiz, tom. cit. pl. lx b. figs. 1, 5 ; Lewes. 


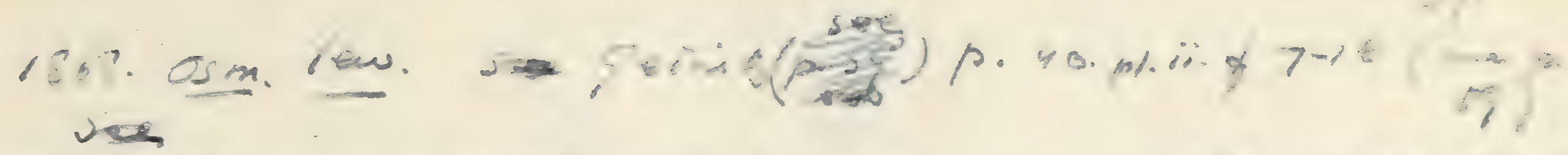

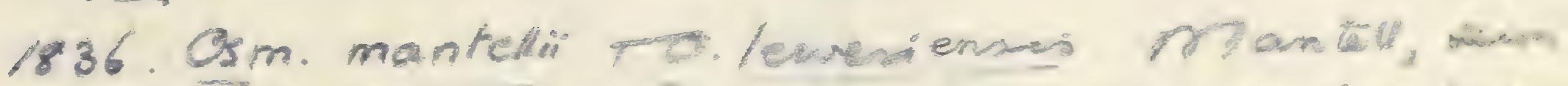

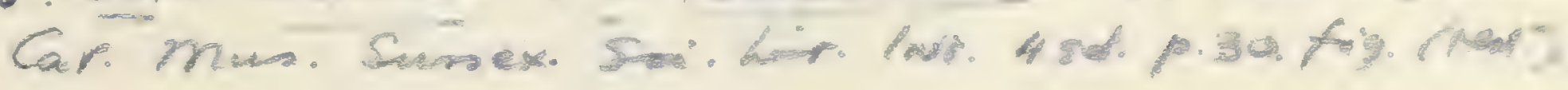

1907. Ameroider lewenienzir, A. P. Arodwand, Fon

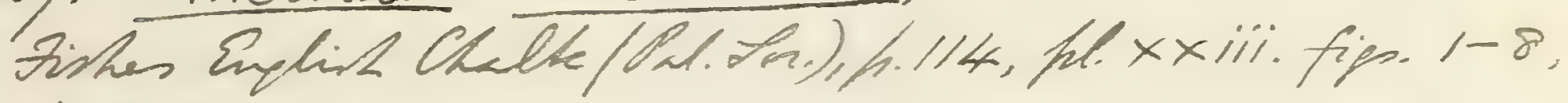
text-fis. 38.

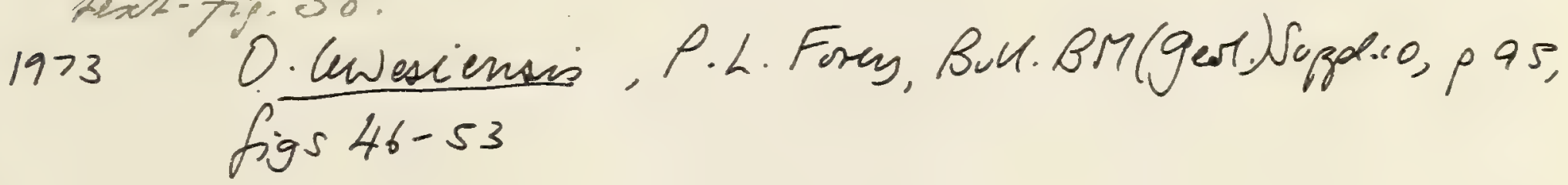

4294. Tencony conal of dentary motiod A.S.S.1907, h.116. 



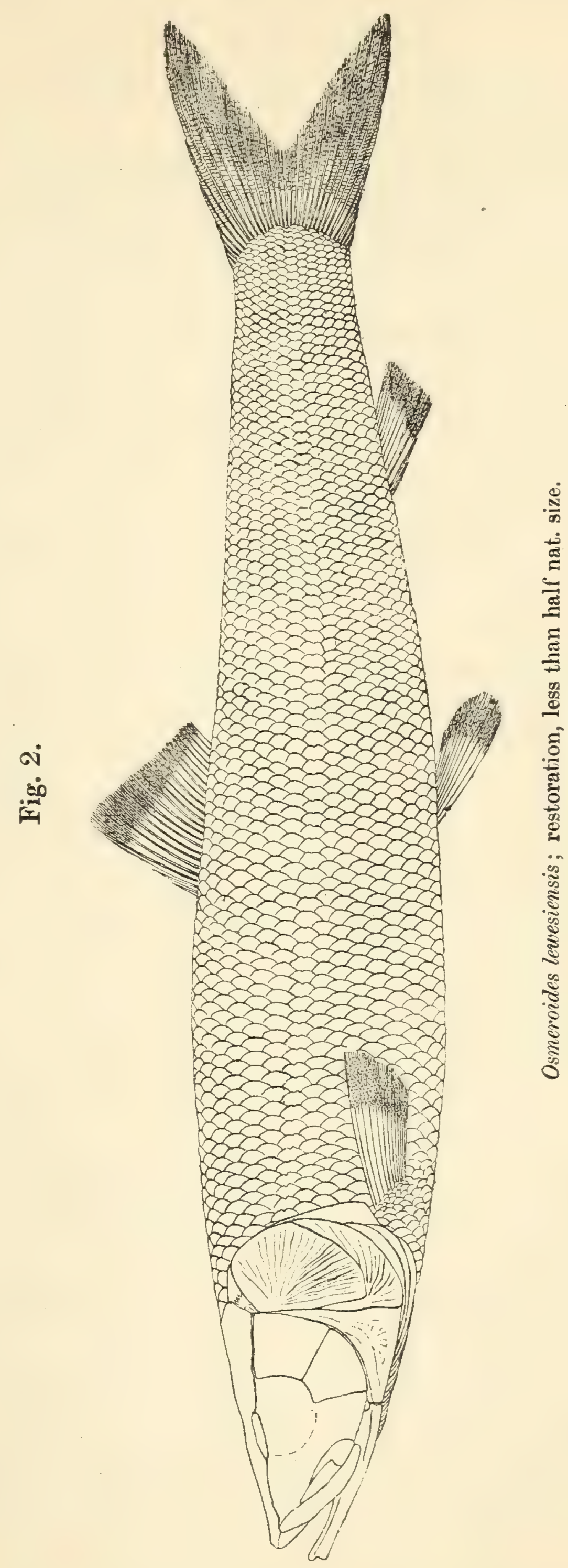


4293. Imperfect contorted fish of smaller size, figured ibid. pl. lx. $b$. fig. 2 ; Lewes.

Mantell Coll.

4295. Imperfect head and abdominal region, figured by Agassiz, tom. cit. pl. lx c. figs. 1, 2, 4; Lewes. Cranial roof also figured in Proc. Zool. Soc. 1894, pl. xlii. fig. 2.

Mantell Coll.

4296. Head and abdominal region, the right mandibular ramus figured by Agassiz, tom. cit. pl. lx $c$. fig. 3 ; Lewes. The same ramus and also the rostrum and left side of the head figured in Proc. Zool. Soc. 1894, pl. xlii. figs. $3,3 \alpha, 6$; the gular plate is noticed, ibid.p. 658. Mantell Coll.

4303. Fractured and contorted fish, with traces of vertebræ in the anterior abdominal region and at the base of the tail, these figured by Agassiz, tom. cit. pl. lx $c$. figs. 5, 6 ; Lewes.

Mantell Coll.

4207, 4292, 4299, 4300. Four imperfect fishes, the first and third exhibiting the gular plate, as noticed in Proc. Zool. Soc. 1894, p. 658 ; Lewes.

Mantell Coll.

49891. Nearly complete large fish, slightly lengthened by distortion and with imperfect fins; Lewes. Partly described in Proc. Zool. Soc. 1894, pp. 657, 658 ; the left maxilla with supramaxillaries and the oral aspect of the mandibular symphysis being figured, ibid. pl. xlii. figs. 5, 5a.

Capron Coll.

P. 6456. Another fine large specimen exhibiting the ornamentation of the external bones and the openings of the sensory canal on the mandible (noticed loc. cit. 1894, p. 658); probably from Lewes.

Beckles Coll.

P. 7188. Smaller distorted fish, described and figured loc. cit. 1894, p. 658, pl. xlii. fig. 1 ; Southover, Lewes.

Presented by J. S. Valentine, Esq., 1894.

49892. Imperfect specimen showing endoskeleton of trunk, described 7oc. cit. 1894, p. 658; Lower Chalk, Lewes. Capron Coll.

P. 5680. Fine head, obliquely crushed and fractured but displaying many osteological features; Kent. The parietal bones are broken away, thus exposing the supraoccipital, which extends forwards as far as the frontals. The right quadrate, metapterygoid, and symplectic are figured loc. 


429.5. Des? a fiy? A. S. 2. 1907, h. 115, hex xiii, for. 3.

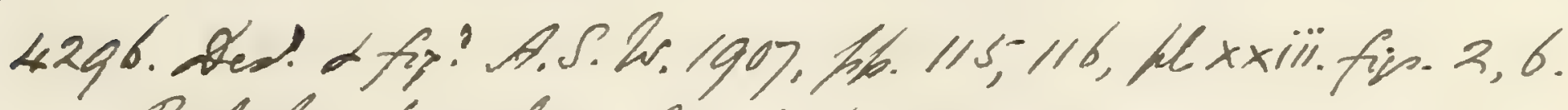
Prit. Lemporal noticed h. 117.

49891. Inscilla, mpramaxillde, a dentaries dest a fy: A.S.h. 1907, h. 116, hl. xxiii. fip.s.

P.opst. Serrong canal of dentary notired A. A. A. 1907, h.116.

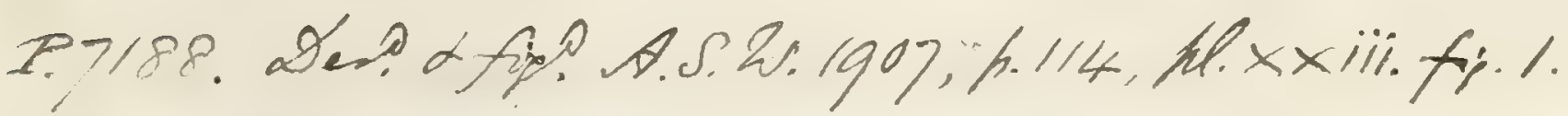

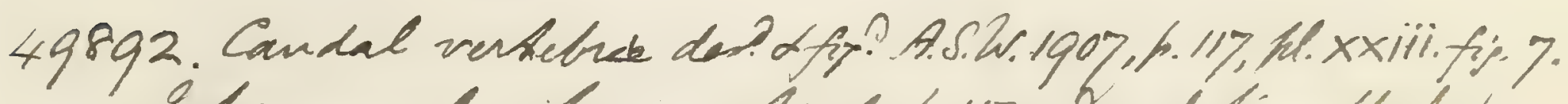

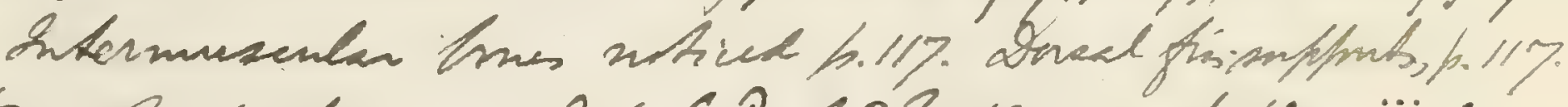

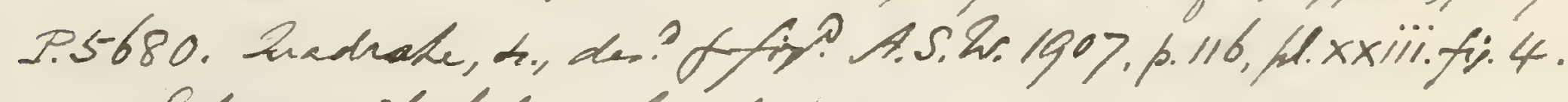
Aupraverifital noticed, b. IIS.- 


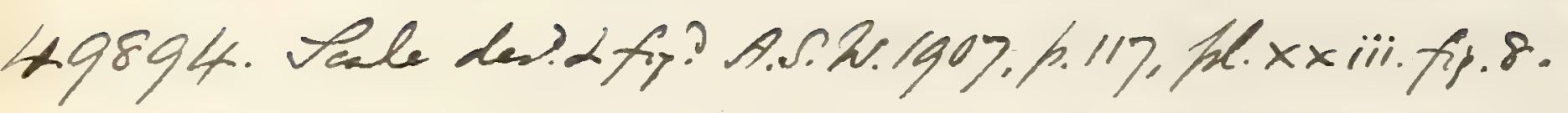

39433.

Thbtemporal frow noticed A.S.L. 1907. F.115.

W894. Anew st keetral fini-ray asticed A.S.L. 1907, h. 11 ?

1907. Omeroider Cevior, A.S. Lroodward, Ans. Finh

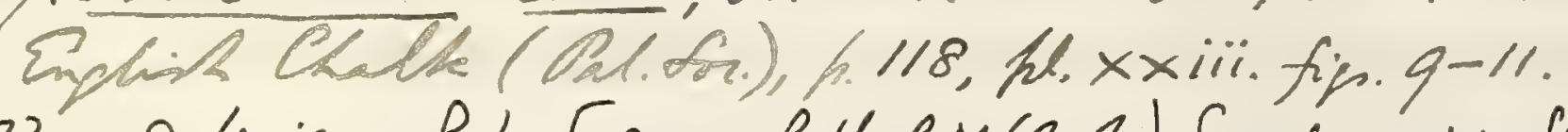
1973 O. Evis, P.L. Forry, Bul. BM (geol.) Suppl.co.p.III, fig. 54 
cit. 1894, pl. xlii. fig. 4 , and the branchiostegal rays, not less than 18 in number, are noticed ibid. p. 658.

Haiford Coll.

49893. Imperfect head and anterior scales, most of the bones destitute of the external layer; Upper Chalk, Shalford, near Guildford.

Capron Cont.

P. 9155. Two skulls; English Chalk.

History unkinown.

49894. Fragment of anterior abdominal region, displaying finely ornamented scales and part of the pectoral fins; Dorking, Surrey. Foremost pectoral fin-ray with proximal expansion noticed, Toc. cit. 1894, p. 658.

Caproir Coll.

4301. Portion of trunk, figured by Mantell, op. cit. 1822, pl. xl. fig. 1; Lewes.

Hantell Coll.

4290. Group of large scales; Lewes.

Mantell Coll.

P. 9156. Group of similar scales; St. Catherine's Pit, Guildford.

Egerton Coll.

P. 1858. Two groups of smaller scales, labelled "Osineroides Tewesiensis, Ag.", by Agassiz, and the locality given as Burham, Kent.

Egerton Coll.

4286. Scale figured by Nantell, op. cit. 1822, pl. xxxir. fig. 3 ; Lewes.

Mantell Coll.

Osmeroides levis, sp. nov.

1895. Aulolepis typus, A. S. Woodward, Proc. Zool. Soc. 1894, p. 660, pl. xliii. figs, 2, 3, 5 (errore).

1900. Osmeroides, A. S. Woodward, Ann. Mag. Nat. Hist. [ $\tau_{-}$rol. v. p. 325.

Type. Imperfect fish; British Museum.

An imperfectly known small species, attaining a length of about 0.2. Length of head with opercular apparatus exceeding the maximum depth of the trunk, and probably nearly equalling half the length from the pectoral arch to the base of the caudal fin. Length of cranium not exceeding twice its maximum width at the occiput; all external bones remarkably smooth, the rugose markings being rery coarse and feeble. Distance between occiput and origin of dorsal fin about equalling that between the end of this fin and the base of the caudal.

Form. \& Loc. Turonian: Kent and Sussex. 
P. 5681. Type specimen, described and figured from the superior aspect, Toc. cit. 1894, pl. xliii. fig. 2, and right mandibular ramus figured ibid. fig. $2 a$; Lower Chalk, Burham, Kent. Harford Coll.

P. 1854. Imperfect head and abdominal region, much fractured, labelled Aulolepis typus by Agassiz, and probably utilised by him in his description of that species; Burham. The right frontal bone is figured loc. cit. 1894, pl. xliii. fig. 3, and the right maxilla with supramaxillaries ibid. fig. $3 a$.

Egerton Coll.

49903. Head and opercular apparatus, with remains of pectoral fin and squamation, the former figured loc. cit. $1 \leqslant 94$, pl. xliii. fig. 5 ; Lower Chalk, Lewes.

Capron Coll.

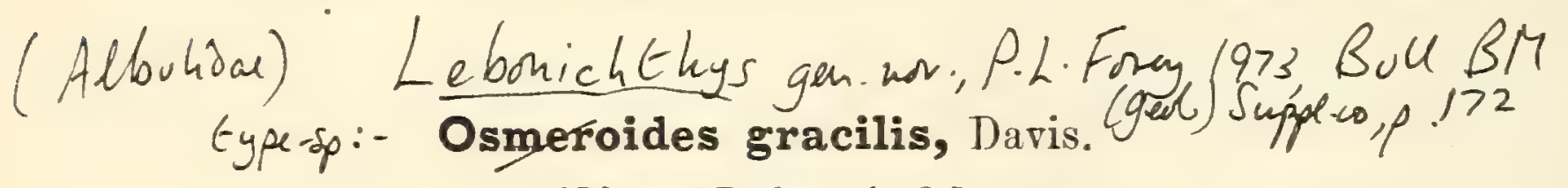

[Plate II. figs. 1, 2.]

1887. Osmeroides gracilis, J. W. Davis, Trans. Roy. Dublin Soc. [27 vol. iii. p. 559, pl. xxxi. figs. 2 , 3.

1887. Osmeroides latus, J. W. Davis, ibid. p. 561, pl. xxxi. fig. 1 [Imperfect distorted fish; Edinburgh Museum.]

(?) 1887. Osmeroides brevis. J. W. Davis, ibid. p. 560, pl. xxxii. fig. 1. [Ditto.]

(?) 1887. Osmeroides dubius, J. W. Davis, ibid. p. 565, p1. xxxi. fig. 4. [Ditto.]

Type. Imperfect fish; Edinburgh Museum of Science and Art.

Length of head with opereular apparatus nearly equalling half that of the trunk from the pectoral arch to the base of the caudal fin. Cranial roof, opercular bones, and upper branchiostegal rays smooth and unornamented; a few minute tritoral teeth within the mouth. About 40 abdominal and 20 caudal vertebræ. Dorsal fin comprising 20 rays, the distance between its origin and the occiput somewhat less than that between its termination and the base of the caudal fin; pelvic fins opposite the hinder half of the dorsal; anal fin small, with not more than 8 or 10 rays, arising nearer to the caudal than to the pelvic pair. Radiating grooves in orerlapped portion of scales especially conspicuous.

The type specimen of this species is evidently lengthened by crushing, and the rotund form of the fish causes the mode of distortion of the different specimens to be very varied. It is thus difficult to determine the original proportions of the species.

Form. \& Loc. Upper Cretaccous: Sahel Alra, Mount Lebanon. 


2.5681. Des? L fig: A.S.2. 1907. h. 118, he xxiii.fis. G.

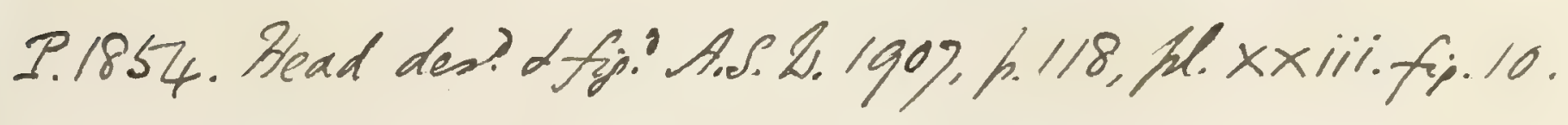

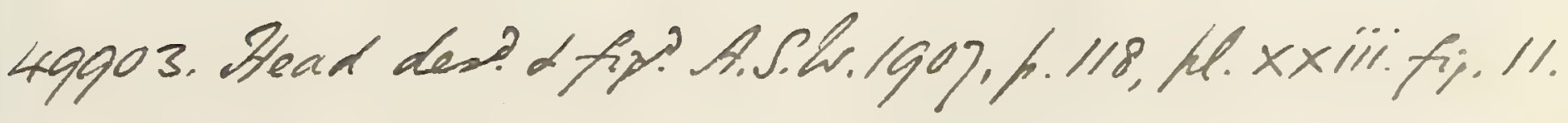

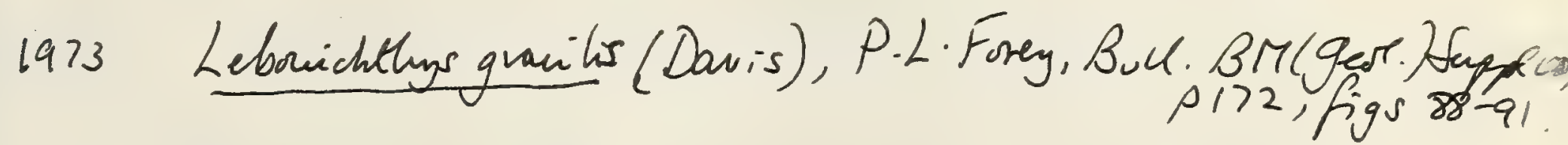

Asmervides Zazitrons. A.S.L.

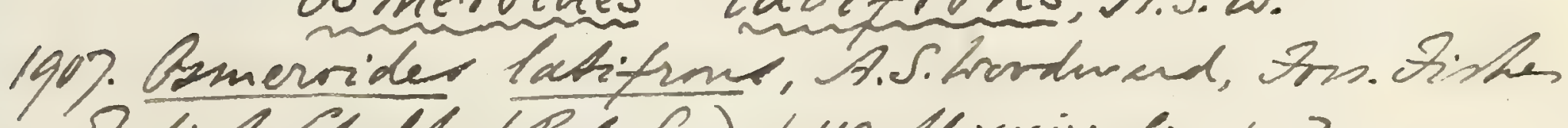

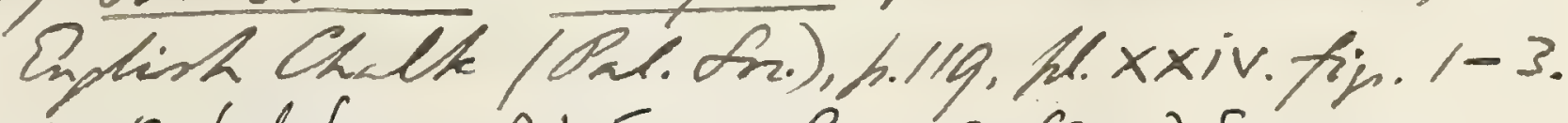

1973 0.Catifuns, P.L.Fory, Buu. Bri (gen.) Suppl.co, p. 114, figs $55-57$ oflu. Menll, che; shit. hum.

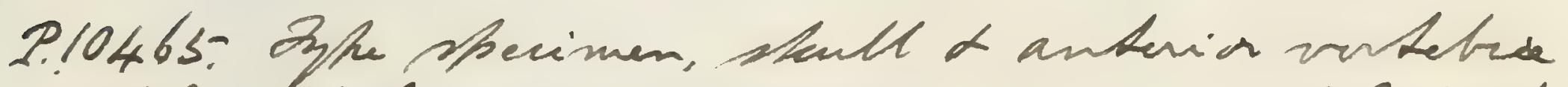

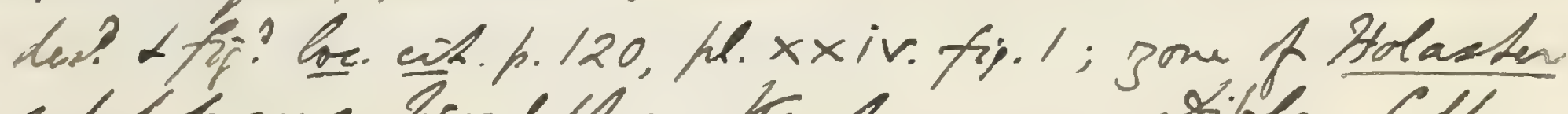
sutplotons, Louldham, Kent.

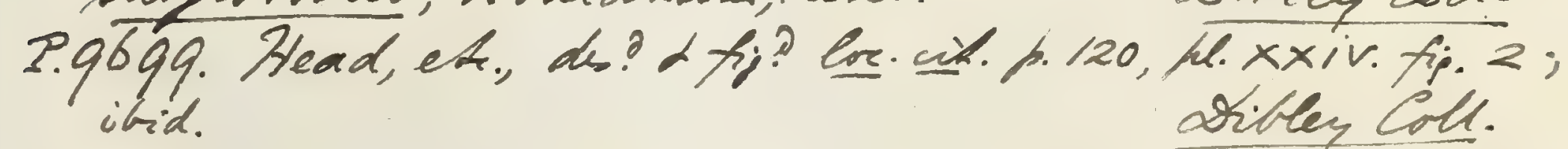

P.10466. Operenlar Gmes, te., des? a fis? Cor. cith h.120, hl. $\times$ xiv. fir. 3 ; ifid.

Sribler Coll.

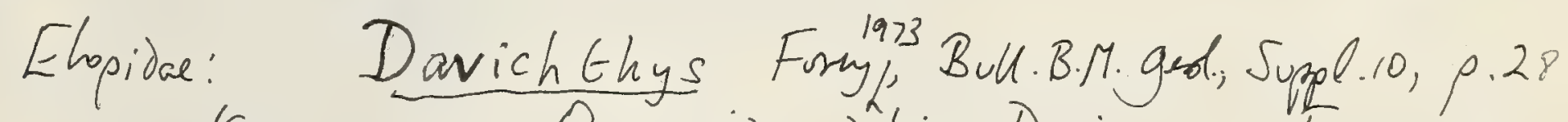
Kype-speries Osmervides dubios Davis., see Forey.ep.29-33.

Darichthys gardrai Forey 1973, BuK BM Gesk., Suppl.10,0.32 holoty pe BMNH P.49520, Hakel, Lebaron. also D. lacostei (Aromborry) - see p.20. 
1973 Lebonich(luys lessisi (Davis), P.L.Forey BuU.BM(Geol), Suppl. 10, p183, fig 92 
P. 4789, P. 4855 . Tro specimens about 0.22 in length, a little distorted, the second shown of the natural size in Pl. II. fig. 1, and displaying the nine broad upper branchiostegal rays $\left(b r_{\circ}\right)$, the subopereulum (s.op.), and operculum (op.).

Lewis Coll.

P. 4856. Trunk of similar specimen with disarranged and fractured squamation, also with ora.

Lewis Coll.

P. 9160,49548 . Two large distorted specimens, the first showing the smooth frontal bones, the second (Pl. II. fig. 2) displaying the mandible ( $m d$.) from beneath $\pi i t h$ the delicate gular plate $(g u$.$) and 13$ of the branchiostegal rass (br.) on the left side, besides sereral of the corresponding rays on the right. The foremost branchiostegal rays are rery slender.

Lewis Coll.

P. 9161, 49549. Nine large specimens fariously imperfect, crushed, and distorted.

Lewis Coll.

P. 4764. Distorted fish showing the gular plate and remains of the branchial arches from beneath.

Lewis Coll.

P. 9162, P. 4032. Two fine specimens about 0.16 in length.

Lewis Coll.

46545. Remains of head and abdominal region, with traces of minute tubercular teeth.

Purchased, 1875.

49550. Imperfect fish about $0 \cdot 16$ in length, displaying the dorsal fin and the depth of the anal fin.

Lewis Coll.

\section{Osmeroides lewisi (Daris).}

[Plate II. fig. 3.]

1887. Clupea learisii, J. W. Daris, Trans. Roy. Dublin Soc. [2] rol. iii. p. 571, pl. xxxiii. fig. I.

Type. Nearly complete fish; Edinburgh Museum and (counterpart) British ILuseum.

A species attaining a length of about 0.35 , with smooth external bones, but apparently stouter than 0 . gracitis, and the distance between the occiput and the origin of the dorsal fin exceeding that between the end of this fin and the base of the caudal.

Form.\& Loc. Cpper Cretaceous: Hakel, Mount Lebanon.

P. 4868. Counterpart of type specimen, unsatisfactorily described PART IV. 
and figured by Davis. Minute blunt teeth are observed in the mandible, and the foremost branchiostegal rays are very numerous and slender. The rertebræ cannot be counted in the abdominal region, but the caudals are about 20 in number in advance of the hypural. Small intermuscular bones are conspicuous in both regions. The dorsal fin is distinctly longer than deep, though imperfect; the anal fin exhibits 10 supports.

Lewis Coll.

P. 6024. A finer specimen of almost the same size, shown in Pl. II. fig. 3, from the left lateral aspect. Traces of the minute blunt teeth are seen in the jaws, and the upper branchiostegal rays are shown to be comparatively short and broad. The characteristic vertebral centra are displayed, nearly all slightly deeper than long, 20 or 21 belonging to the caudal region in adrance of the hypural, and 35 shown in the abdominal region behind the posterior margin of the operculum. The ribs and intermuscular bones are very slender; the expanded hæmal and neural spines at the base of the caudal fin resemble those in the trpical 0 . Tewesiensis. The dorsal fin is apparently nearly complete, exhibiting 17 or 18 supports and as many rays, the latter readily splitting into their two halves and very closely articulated distally; its extent equals the distance between it and the caudal fin. The small anal fin has at least 9 rays, which, like those of the dorsal, caudal, and pelrie fins, are very closely articulated distally. The exposed area of the scales is much deeper than bioad, and apparently smooth.

Presented by Prof. W. K. Parker, 1889.

The following specimen seems to represent another species of Osmeroides (named Osmeroides maximus by J. W. Daris, Trans. Roy. Dublin Soc. [2] vol. iii. 1887 , p. 566'), but is too imperfect to admit of formulating a specific diagnosis :--

P. 4765. Distorted and crushed remains of a fish measuring about 0.3 in length to the base of the caudal fin, described by Daris, loc. cit.; Upper Cretaceous, Sahel Alma, Mount Lebanon. The most conspicuous feature is the rugose ornamentation of the facial and opercular bones.

Lewis Coll. 
A inteterminatle Chpevid or Sefpine purte is nomed Ameroider maximus, thinw. by ? Gittich, Frotisble Vereins f. Erdte. Darmstredt, ser. iv. \$2.18 (1897), 6.43, hl. r. fin. 1-3. - In. Oliporeene; Eckelsheim, haing Busin. Clun. Den

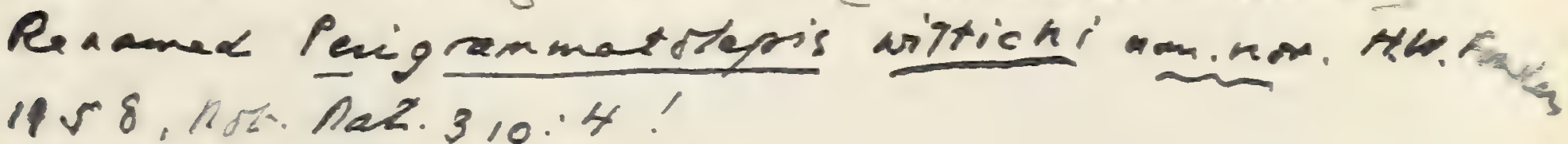


1903. Holcolefier attemuatur, O. P. Hay, Bull Smer. Nens. 1. H. vol. xix. p. 414 .

Clupeomopha, suborier inc. sedis.

Eype-species of Orhategulum, Forey, P.L., 1973, Can. Il Earth Sci. 10: 1304. 


\section{Osmeroides attenuatus (Daris).}

1887. Clupea attenuata, J. W. Davis, Trans. Roy. Dublin Soc. [2] vol. iii. p. 580, pl. xxxiii. fig. 4 .

1898. Osmeroides attemuatus, A. S. Wooc'ward, Ann. Mag. Nat. Hist. [7] vol. ii. p. 409.

Type. Imperfect fish; Edinburgh Museum.

An imperfectly known small species, attaining a length of about 0.12. Length of head with opercular apparatus considerably exceeding the maximum depth of the trunk and contained nearly three times in the length from the pectoral arch to the base of the caudal fin. Vertebræ at least 35 in the abdominal, 20 in the caudal region. Pelvic fins opposite anterior half of dorsal, midway between pectorals and anal; origin of dorsal fin nearly as far from occiput as its hinder end from base of caudal fin.

Form. \& Loc. Upper Cretaceous: Sahel Alma, Mount Lebanon.

Not represented in the Collection.

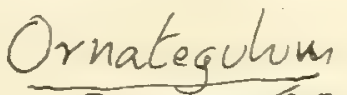

Osmeroides sardinioides (Pictet).

$$
\text { [Plate II. fig. 4.] }
$$

1850. Clupea sardinioides, F. J. Pictet, Poiss. Foss. Mt. Liban, p. 38, pl. vii. fig. 2.

1866. Chupea sardinioides, Pictet \& Humbert, Nour. Rech. Poiss. Foss. MIt. Liban, p. 66, pl. viii.

1866. Chupea lata, Pictet \& Humbert, ibid. p. 68, pl. vii. fig. 6 (errore), [Imperfect fish; Paris Luseum of Natural History.]

Type. Imperfect fish; Genera Museum.

A small species, attaining a length of about $0 \cdot 2$. Length of head with opercular apparatus about equal to the maximum depth of the trunk and contained nearly three times in the length from the pectoral arch to the base of the caudal fin. Bones of the hinder half of the cranial roof ornamented with coarse radiating rugæ, the opercular bones and upper branchiostegal rays more delicately rugose, Total number of vertebræ scarcely exceeding 50. Dorsal fin comprising about 15 rays, as long as deep, the distance between its origin and the occiput equal to that between its termination and the base of the caudal fin; pelric fins arising opposite the hinder end of the dorsal; anal fin small, with about 7 rays, arising much nearer to the caudal than to the pelvic pair. Exposed area of scales narrow and deep, ornamented with feeble, short radiating markings.

Form. \& Loc. Upper Cretaceous: Mount Lebanon, Syria. 
49498. Slab with two imperfect large specimens; Hakel. One fish exhibits the ornament of the cranial roof, the other that of the operculum and scales. The total number of vertebræ can scarcely have exceeded 50, though they are not readily counted.

Lewis Coll.

4956\%. Another large specimen, showing indications of the arched maxilla; Hakel.

Lewis Coll.

P. 103. Large specimen wanting the greater part of the cranium, but displaying ornament of opercular apparatus and seales; Hakel. The five broad upper branchiostegals are distinct; followed below by more delicate rays.

Lewis Coll.

47313. More imperfect large fish displaying the dorsal fin, but wanting the greater part of the caudal region; Hakel.

Presented by Sir Richard Owen, K.C.B., 1874.

49561. Fish about 0.14 in length; Hakel. The fins are shown, and there are indications of about 50 vertebræ.

Lewis Coll.

49500. Similar fish deepened by distortion; Hakel. Lewis Coll.

P. 104. Imperfect fish displaying the ornamented parietal, squamosal, and frontal bones in impression; Hakel. The complete specimen is shown of the natural size in Pl. II. fig. 4, while part of the impression of the cranial roof is represented three times enlarged in fig. $4 a$. Lewis Coll.

49568. Another imperfect fish deepened and shortened by distortion; Hakel. The scale-ornament is well displayed.

Lewis Coll.

Osmeroides cretaceus (W. von der Marck).

1863. Rhabdolepis cretaceus, W. von der Marck, Palæontogr. vol. xi. p. 26, pl. xii. fig. 1.

1868. Holcolepis cretaceus, W. von der Marck, ibid. vol. xv. p. 278.

1873. Holcolepis cretaceus, W. von der Marck, ibid. vol. xxii. p. 57, pl. i. fig. 1.

Type. Imperfect distorted fish; Academy of Münster.

The type species of the so-called genus Holcolepis, attaining a length of about $0 \cdot 4$. Length of head with opercular apparatus about equal to the maximum depth of the trunk, which is contained four times in the length from the pectoral arch to the base of the caudal fin. Vertebræ about 70 in number, 24 being caudal. 
Hoterleps lacostes s.n. Cenoman: Morvese, Carontoms 1958 nor. mem. Serv.girt. Marre 118 p.

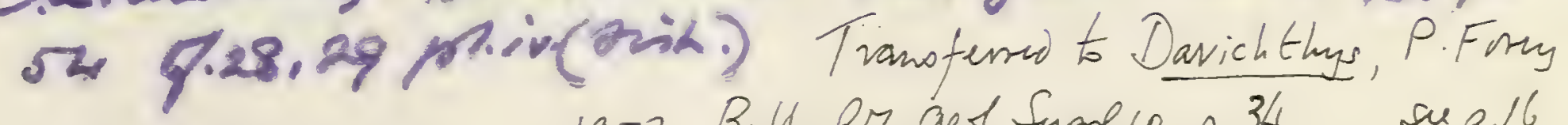
1973, Bu K. BM. Gest. Suppl. 10 , p.34. sue 16

1954. O.C. P. Sigg fuid, Palasmotor. 10E A p.9. Prit.s prii. $\%$. 
Amovides vinarencio, A. Fitzch d Z Bayer, Heve

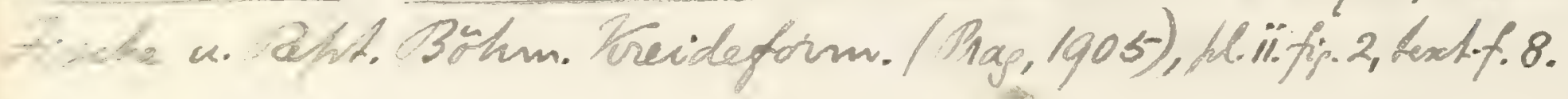


Dorsal fin comprising about 12 rays, of which the foremost four are undivided, arising at the middle point between the occiput and the caudal fin.

Form. \& Loc. Upper Cretaceous: Sendenhorst, Westphalia.

Not represented in the Collection.

The following specimens, apparently referable to the genus Osmeroides, are not specifically determined:-

P. 6850. Part of opereular and abdominal region of very large specimen, with remains of a pelvic fin unusually far forwards; Chalk, Willingdon, Eastbourne.

Presented by Miss Heinemann, 1893.

39433. Rernarkably elongated head and opercular apparatus, very imperfectly preserved, with some anterior vertebræ; English Chalk.

Bowerbank Coll.

P. 5679. Opercular, branchiostegal apparatus, \&c.; Lower Chalk, Kent. Harford Coll.

49752. Scattered remains of head showing gular plate; Chalk, Amberley, Sussex.

Capron Coll.

P. 8949. Portion of jaws and opercular apparatus, remarkably smooth, with large gular plate; Gault, Folkestone.

Purchased, 1898.

P. 9005. Imperfect head and trunk of the form bearing the MS. name Osmeroides vinarensis (A. Fritsch, Archiv naturw. Landesdurchf. Böhmen, vol. จ. no. 2, 1883, p. 88); Senonian (Iserschichten), Vinary, Bohemia.

Purchased, 1899.

P. 9188. Fish nearly 0.3 in length, in the counterpart halves of a nodule; Upper Cretaceous, Barra do Jardim, Serra de Araripe, Province of Ceara, Brazil. The head is too imperfect to determine the genus, and the squamation is more strongly ornamented by linear markings than usual in Osmeroides.

Purchased, 1900.

The following specimens seem to represent a genus related to Osmeroides, with wider gape and thinner and larger scales, but are too incomplete for precise determination :-

39432. Imperfect head and abdominal region, about 0.5 in length and 0.12 in depth, showing the long, straight maxilla, 
part of the mandible, and the pectoral, pelvic, and fragmentary dorsal fins; English Chalk. Bowerbank Coll.

P. 1812. Fragmentary head, probably of the same species; Lower Chalk, Dorking.

Egerton Coll.

The so-called Clupea curta (J. W. Daris, Trans. Roy. Dublin Soc. [2] vol. iii. 1887, p. 579, pl. xxxiii. fig. 5) is based on a fragment probably of Osmeroides from the Upper Cretaceous of Hakel, IIt. Lebanon. The type specimen is in the Edinburgh Museum of Science and Art (A. S. Woodward, Ann. Mag. Nat. Hist. [7] vol. ii. 1898, p. 409).

Generically and specifically indeterminable scales have also been described under the following names :-

Osmeroides belgicus, T. C. Winkler, Archiv Mus. Teyler, vol. iv. (1876), p. 3, pl. i. fig. 1.-Lower Eocene (Heersian); Limbourg, Belgium.

Osmeroides divaricatus, H. B. Geinitz, Denkschr. Ges. für Naturk. \&c. Dresden z. Feier 50 jähr. Bestehens, 1868, p. 42, pl. ii. figs. 18-22; A. Fritsch, Rept. u. Fische böhm. Kreideform. (1878), p. 34, fig. 58.-Turonian; Saxony and Bohemia. Osmeroides pectinotepis, G. D. Romanorsky, Material. Geol. Turkestansk. Kraya [in Russian], pt. iii. (1890), p. 122, pl. xvii. fig. 5.-Cretaceous; Turkestan.

Genus ELOPS, Linnæus.

[Syst. Nat. ed. 12, 1766, p. 518.]

Trunk somewhat laterally compressed, abdomen flattened. Parietal bones in contact in the median line; mandible a little prominent; two supramaxillary bones; margin of the jaws, the vomer, parasphenoid, palatine, and pterygoid bones, and the tongue, with clusters of minute pointed teeth. Gill-rakers long and slender; operculum simple; branchiostegal rays about 24 to 30 in number. Pectoral and pelvic fins each with an enlarged and elongated scale at the base; dorsal fin opposite or nearly opposite the pelvic pair; anal smaller than the dorsal fin; caudal fin deeply forked; no finrays excessively elongated. Exposed portions of canal of lateral line simple, never branching; scales usually ornamented with delicate radiating ridges.

A figure of the skeleton of Elops is given by Agassiz, Poiss. Foss. rol. v. pl. G. fig. 1.

Though now well represented in all tropical and subtropical seas, 


Dinelobs ornatus. A.S.W.

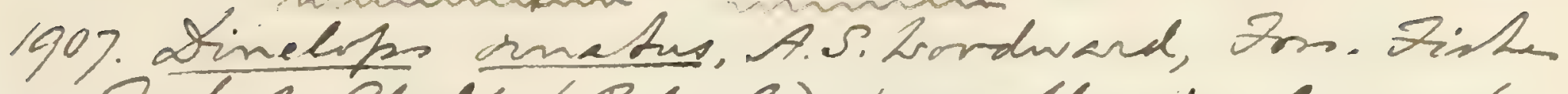
Enghit Chelte (O2l. Lf.), h. 121, hl. xxiv. fir. 4-6.

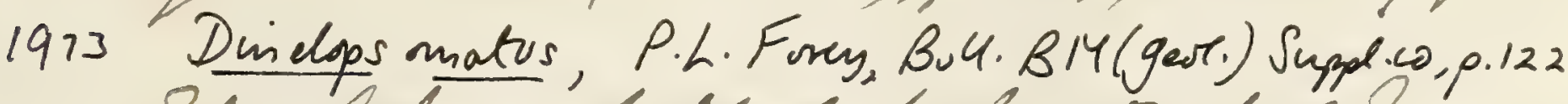

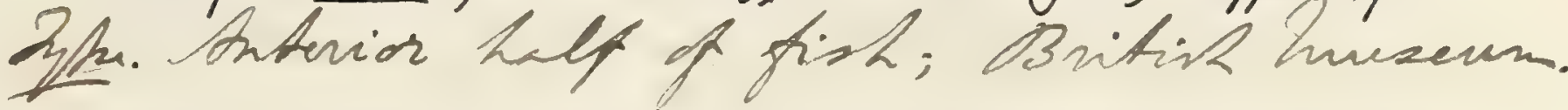
394.32. Onfere pheimen des? AfP? lore cith h. 122, fl. xxiv. fis. 4 .

1.1812. Dest d fip? loc wh. 12.122, hl. xxiv. fis s49091. Teft dentary des? $\alpha$ fig! lor. ith. h. 122 , hl. xxiv. fi. 6; Chalk, Rent.

Gu. Mmith'́ COLl

Btaldefir, Theinla.) in Geinols p.42.

Petaldepir divaricatur, 7. S. A. Cockerell, the Get. Finticales (1919), 1.173.

Petaldepio: filvillatur, 7.X. A. Cockerell, Ames. Cret. Find Peales (U. P. Geol. Surw. Rofess. Daper

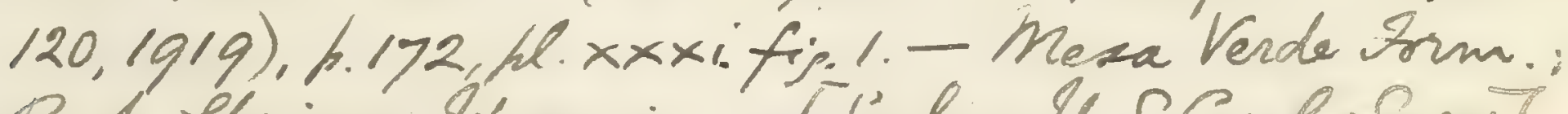
Rocte Ithimps, Wyoming. [Jicale; U. S. Geol. Surws]

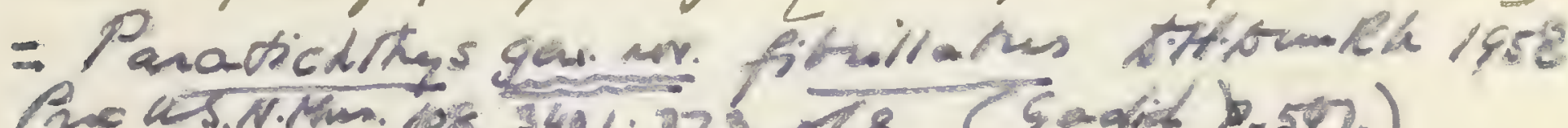

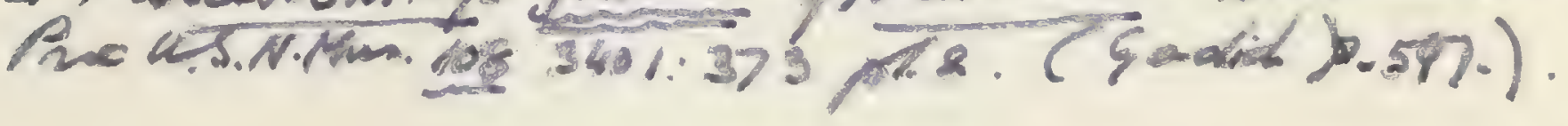

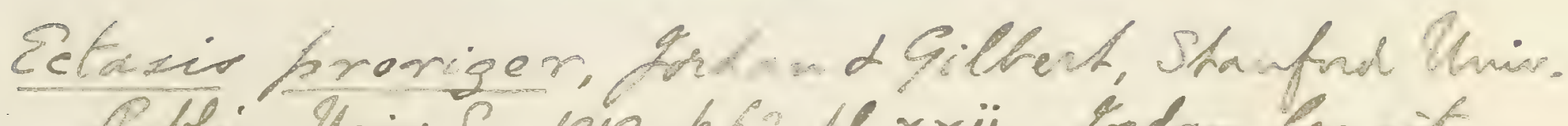

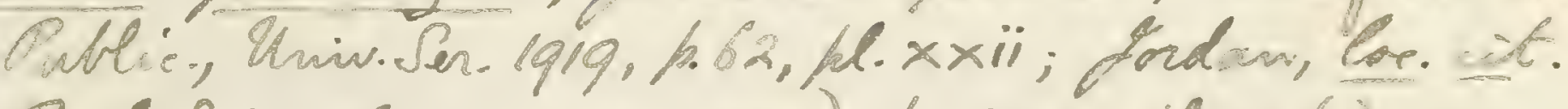
Bitl.Sei: val i. no. 4(1921), b. 242, pl.17(a). 


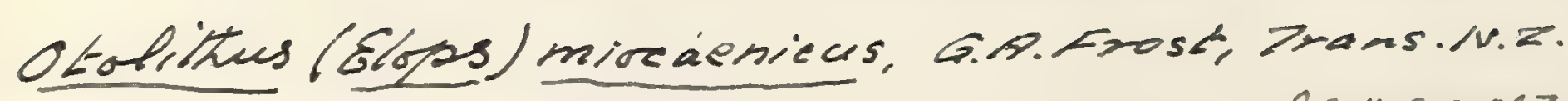

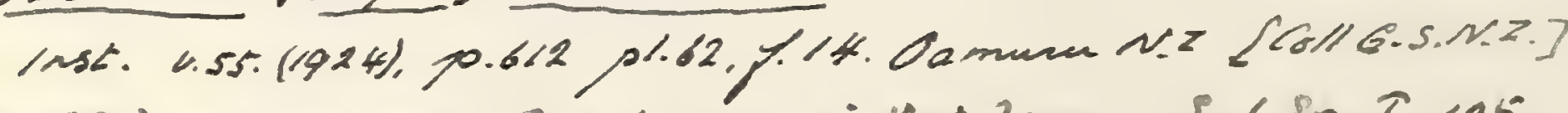

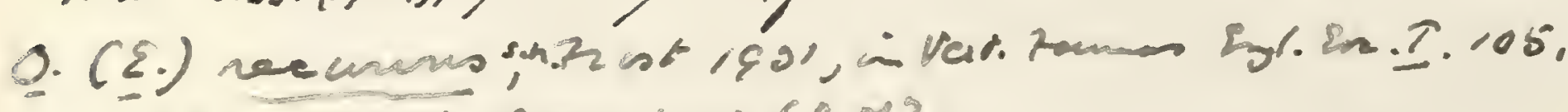
prof. 9. B.B. Qevey hoor P.M.? 
this genus has not hitherto been recognised among extinct fishes. To it, however, may probably be referred the following two specimens, which are too imperfect for precise determination :-

39443. Imperfect head and abdominal region of trunk, much crushed and obscured by decaying pyrites; London Clay, Sheppey. The length of the head with opercular apparatus is about $0 \cdot 14$, and the distance from the base of the pectoral to what seems to be the origin of the pelvic fins is not less than $0 \cdot 18$. The middle of the cranial roof exhibits a depression, gradually widening from the occiput to the hinder border of the orbits, then somewhat contracted again forwards. The large posterior suborbitals and ossified sclerotic are conspicuous; the very wide gape, prominent mandible, and gently arched maxilla are also shown, without any traces of teeth. The mandibular rami are crushed together and imperfect, thus destroying the branchiostegal apparatus between them. Part of the left pectoral fin is preserved, and at the hinder end of the fossil there is apparently the base of the right pelvic fin. A well-ossified vertebral centrum, not pitted but feebly striated on the side, also projects through the squamation at the hinder end of the abdominal region. The scales are beautifully ornamented in their exposed portion with fine radiating ridges.

Bowerbank Coll.

P. 1\%62. Portion of trunk of the same species, also much pyritised; London Clay, Sheppey. Robust vertebral centra are exhibited, each about as long as deep, not pitted at the sides but feebly striated; the neural arches are broken away, but seem to have been fused with the centra. Portions of the pelvic fins are preserved, and the scales are ornamented as in the last specimen.

Egerton Coll.

The following specimen was supposed by Agassiz to represent a genus allied to Elops :-

P. 3846. Imperfect impression of skeleton about 0.33 in length, too obscure for description and determination, labelled Elopides couloni by Agassiz; Upper Eocene (slates), Engi, Canton Glarus, Switzerland. The name is published without definition by Agassiz, Poiss. Foss. vol. v. pt. ii. (1844), p. 139 .

Erniskillen Coll. 


\section{Genus MEGALOPS, Lacépède.}

[Hist. Nat. Poiss. vol. จ. 1803, p. 289.]

Head and trunk laterally compressed, but abdomen flattened. Parietal bones in contact in the median line; mandible a little prominent; two supramaxillary bones; eye relatively very large; margin of the jaws, the vomer, parasphenoid, palatine, and pterygoid bones, and the tongue, with clnsters of minute pointed teeth. Gill-rakers long and slender; operculum subdivided by transverse suture; branchiostegal rays about 25 in number. Pectoral and pelvic fins each with an enlarged and elongated scale at the base; dorsal fin short-based and elevated, with much-produced hindermost ray, opposite or immediately behind pelvic pair; anal fin more extended than the dorsal, but also with produced hindermost ray; caudal fin deeply cleft. Scales not ornamented; sensory canal of lateral line radiating on the scales it traverses.

The skull of the existing Megalops is described and figured by R. W. Shufeldt, Ann. Rep. U.S. Commiss. Fisheries, 1883 (1885), p. 814 , pl. xiv. figs. 33,34 .

\section{Megalops priscus, sp. nov.}

[Plate III. figs. 3-6.]

1844-45. Megalops priscus, L. Agassiz, Poiss. Foss. vol. v. pt. ii. p. 114 (name only), and Rep. Brit. Assoc. 1844, p. 308 (name only).

1844. Hypsodon toliapicus, L. Agassiz, ibid. vol. v. pt. i. p. 101 (name only).

1854. Megalops priscus, R. Owen, Catal. Foss. Rept. \& Pisces, Mus. Roy. Coll. Surg. p. 172 (no description).

Type. Imperfect head; British Museum.

An imperfectly known large species, the head with opercular apparatus attaining a length of at least 0.3 . Length of head nearly equaiing its depth behind, and about twice as great as the maximum width of the operculum; length of cranial roof from occiput to postfrontal considerably less than its width at the position of the latter element. Maxilla extending backwards beyond the orbit; opercular borres and eneek-piates radiately sculptured.

Form. \& Loc. Lower Eocene (London Clay): Sheppey.

$360 \% 0$. Head with opercular apparatus, to be regarded as the type specimen, shown of one third the natural size from the left lateral and superior aspects in Pl. III. figs. $3,3 a$. The cranium is very imperfectly preserved, and the sutures between its elements are not distinct; but the contour of its roof is shown (fig. $3 a$ ), gradually widening 
Protaypon gen.usv. P. Forey 1973 Bume. BN. (exr.) Suppl. 10; 70

1966 M. prious, E. Casion. "London Clay"; 118

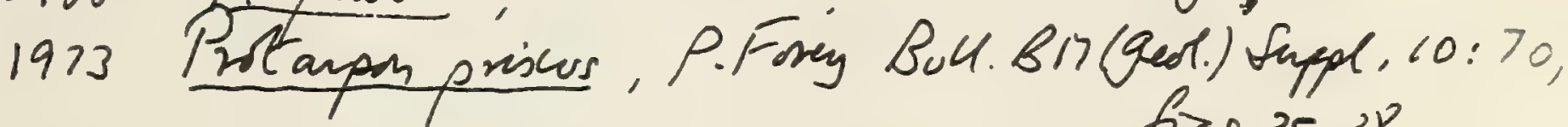
figs 35.38 
from the occiput to the prefrontal region immediately in advance of the eye. A certain amount of crushing and distortion is at the same time obvious. The sclerotic ( $\left.s c l_{\text {. }}\right)$ is ossified and, unless appearances are deceptive, the eye is smaller than in the recent $\lambda_{i}$. cyprinoides. Remains of the delicate cheek-plates, with radiating markings, are preserved both behind (s.o.) and in front (a.o.) of the eye. The relatively small premaxilla ( $p m x_{0}$.) underlaps the front extremity of the enormous maxilla $(m x$.), which exhibits a small knob $\left(x_{0}\right)$ for its anterior attachment to an inner element. The extent of the supramaxillaries is indicated only by the depression for their overlap of the maxilla. The whole length of the left mandibular ramus is displajed (d.), with its hollowed hinder articulation in contact with the condyle of the quadrate (qu.); and the latter element is directly apposed to the metapterygoid above, while apparently provided with a superiorly-pointed, slender, hinder process to grasp the small symplectic. The bases of clustered series of very minute teeth are shown on the margin of the jaws where preserved. The upper end of the hyomandibular ( $h \mathrm{~m}$.) is partly exposed, with its process for the support of the operculum (op.); and the latter element is well shown, with the preoperculum $(p . o p$.$) in front, and the suboperculum (s.op.)$ and interoperculum (i.op.) below. The spaced series of branchiostegal rays $(b i$ ) cannot have numbered less than 20 , although not so many are actually exhibited; and the gular plate $(g u$.$) is nearly half as long as the mandible.$

Purchased, 1861.

P. 63\%. Hinder half of skull, labelled Hypsodon totiapicus by Agassiz, and intended to be the type specimen of that species. The cranial roof is shown from above of two thirds the natural size in Pl. III. fig. 4, and the various elements can be readily distinguished as lettered. On the occipital face the exoccipital is shown to meet its fellow in the median line below the large, keeled supraoccipital; but the basioccipital is broken and crushed to the left, with one short and deep vertebral centrum adhering to it. There is clear evidence of a basicranial canal. The otic region exhibits its characteristic conformation, and an elongated facette for the hyomandibular is shown on the pterotic. 
P. 356. Imperfect hinder portion of skull, longitudinally bisected in the median line to exhibit the extent of the supraoccipital bone. As shown in the section (Pl. III. fig. 5), this element (s.occ.) is much thickened, and in its upper portion extends almost as far forwards as the investing parietals $(p a$.$) . The exoccipitals (ex.occ.), as in the pre-$ ceding specimen, clearly form the upper border of the foramen magnum; and there seems to be a persistent suture between the basioccipital (b.occ.) and basisphenoid $(b . s p$.$) . When viewed from behind (fig. 5 a$ ), the basioccipital exhibits the groove for the basicranial canal (b.c.).

Egerton Coll.

P. 4153. Imperfect hinder portion of skull, smaller than the preceding. The basicranial canal is indicated, and the remains of the otic region (Pl. III. fig. 6) are interesting. The pro-otic (pr.o.), pierced as usual by the oval foramen for the fifth nerve, is in contact above with the sphenotic or postfrontal ( $p t_{.}$. .) and the pterotic ( $\left.p t_{.0}.\right)$, these two latter bones meeting and forming the floor of a carity which exists between the outer part of the otic mass and the squamosal (sq.). The upper end of the hyomandibular must have articulated with two distinct facettes $\left(f_{0}\right)$, the largest and deepest on the pterotic, the smallest at the point of contact of the sphenotic with its adjacent elements already mentioned. There are indications of the great triangular hollow in the otic mass immediately behind the pro-otic, and of the similar hollow on the occipital face between the outer edges of the epiotic and pterotic.

Enniskillen Coll.

P. 1698. Crushed fragment of hinder part of large cranium, showing suture between basioccipital and basisphenoid, and the parasphenoid forming the floor of the basicranial canal.

Egerton Coll.

Megalops oblongus, sp. nov.

1844. Hypsodon oblongus, L. Agassiz, Poiss. Foss. vol. v. pt. i. p. 101 (name only).

Type. Imperfect cranium; British Museum.

A species somewhat larger than the preceding, known only by the imperfect cranium. Length of cranial roof from occiput to postfrontal equalling its width at the position of the latter element.

Form. \& Loc. Lower Eocene (London Clay): Sheppey. 


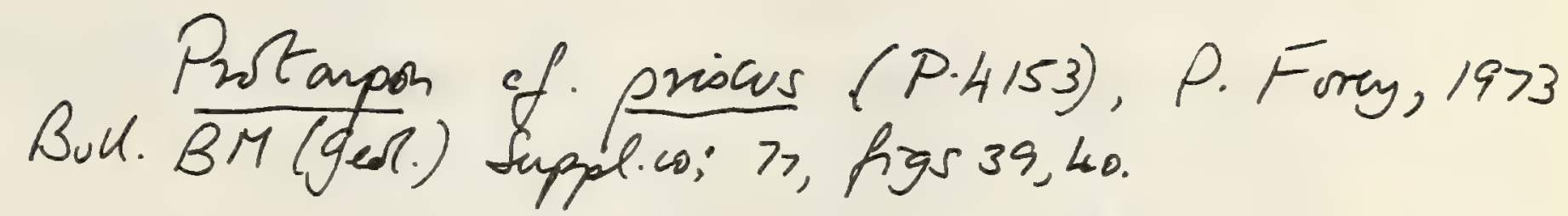

M. Sblongos, E. Casier, "Lowion Clay" "119, pli13, fig.,2 Protanpon Solongus, P. Fory, BuU. BM (geol) Suppel 10: 78 


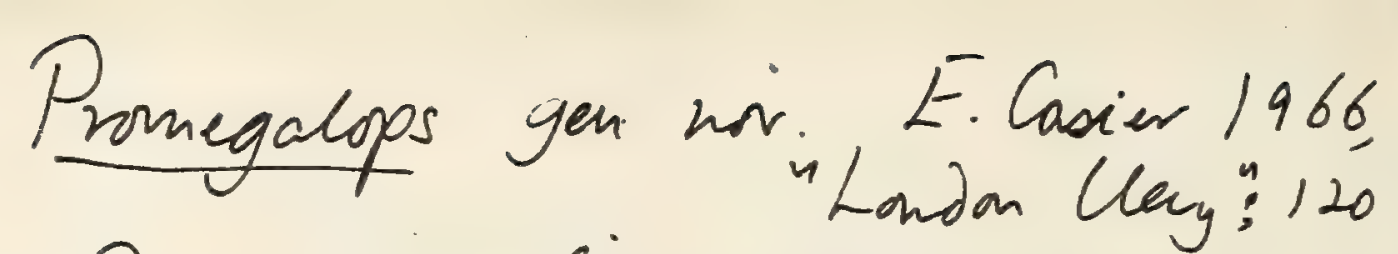

Eype-opecies P.signeutal Casier 1966.

Promegalops sigreuxae Casier, 1966, "Landon Clay :120 Lowim Clay, Slupgey, Holifype: Mus. Hist. Mat. Paris

Promegalops steppeyensis Casier 1966 "Lovim Clay: 14805pe: P.9192.

1973 Ponngalops steppeyensis, P. Forey, Bull. BM. Gerl) Suppl. 10: 80, figs $41-43$ 
P. 634. The type specimen labelled by Agassiz. It is the muchabraded cranium, wanting the region in advance of the postfrontals. The parietal bones are almost completely removed, thus exposing the supraoccipital which extends forwards beneath them. The characteristic otic region is well shown on the right side, and the basicranial canal is indicated beneath the axis of the cranium. Egerton Coll.

The following skull also appears to belong to a species of Megalops, characterised by a relatively short otic region, the length of the cranial roof from the occiput to the postfrontal not exceeding half its width at the position of the latter element:-

P. 9192. Cranium 0.125 in length; London Claj, Shepper. The roof exhibits the characteristic arrangement of the bones, and the basicranial axis is bent upwards as usual at the anterior end of the otic region. The presence of a basicranial canal is clearly indicated, but there does not appear to be a vertebral centrum fused with the basioccipital. The parasphenoid is abraded, but the spatulate romer is shown to have been corered with minute teeth. The long laminar entopterygoid is preserred on the left side, but its exposed oral face is abraded.

History unknown.

\section{Genus NOTELOPS, novum.}

Trunk somewhat laterally compressed. Parietal bones in contact in the median line; mandible a little prominent and gape extending to the hinder border of the orbit; margin of the jaws and some of the inner bones with small conical teeth. Operculum subdirided by a transverse suture. Vertebral centra slightly constricted, smooth or delicately striated, perforated for the passage of a remnant of the notochord. Pectoral fin with an enlarged and elongated scale at its base; dorsal fin opposite or nearly opposite the pelvic pair; anal smaller than the dorsal fin; caudal fin deeply forked; no fin-rays excessively elongated. Scales usually ornamented with delicate radiating ridges; a few very small thin scales extending over the caudal fin; lateral line inconspicuous.

\section{Notelops brama (Agassiz).}

1833. Amblypterus olfersi, L. Agassiz, Poiss. Foss. vol. ii. pt. i. p. 40.

1841. Phacolepis brama, L. Agassiz, Edinb. New Phil. Journ, vol. xxx. p. 83. 
1844. Rhacolepis olfersii, L. Agassiz, Comptes Rendus, vol, xviii. p. 1012, and Poiss. Foss. vol. iv. p. 293 (name only).

1887. Rhacolepis brama, A. S. Woodward, Proc. Zool. Soc. p. 539, pl. xlvi. fig. 1, pl. xlvii. fig, 4 .

Type. Head; British Museum.

The type species, attaining a length of about $0 \cdot 6$. Length of head with opercular apparatus exceeding the maximum depth of the trunk, and contained about four times in the total length of the fish. The two posterior suborbitals much broader than deep, but the lower less deep than the upper plate; postero-inferior suborbital of a deep triangular form; operculum almost as broad as deep. Pelvic fins arising slightly nearer to the anal than to the pectorals, opposite the hinder half of the dorsal fin, which has about 10 rays beyond anterior basal rays.

Form. \& Loc. Upper Cretaceous : Province of Ceara, N. Brazil.

All the following specimens were obtained from Barra do Jardim, Serra de Araripe:-

15490. Type specimen, the head, opercular apparatus, clavicle, and some anterior scales, figured in Proc. Zool. Soc. 1887, pl. xlvii. fig. 4. It is labelled by Agassiz.

Purchased from Mr. Gardner.

P. 195\%. More imperfect similar head, wanting the cheek-plates and displaying remains of internal bones, labelled "Rhacolepis Brama, Ag.," by Agassiz, and the parietals and teeth noticed Toc. cit. p. 536. Remains of the large gular plate are distinct.

Egerton Coll.

P. 1960, P. 3986. Small fish, in counterpart, figured loc.cit. pl. xlvi. fig. 1. The large gular plate is conspicuous between the mandibular rami.

Egerton \& Enniskillen Colls.

P. 1960 a, P. 3985 . More imperfect small fish, in counterpart, deepened and shortened by distortion, but showing the separate plate above the operculum, and displaying scaleornament.

Egerton \& Enniskillen Colls.

P. 1962 d, P. 3986 b. Still smaller fish, wanting caudal fin.

Egerton \& Enniskillen Colls.

P. 1962 b, P. 3986. Vertically crushed imperfect small fish.

Egerton \& Enniskillen Colis.

47886. Head and portion of abdominal region of large specimen, 
1907. Calamoplenur cylindricus, D. S. Godaw (errore), Bnll, ote ha. Ged Amin. Califi, we v, h. 139. hle.12.

1908. Calamofleurus cylindricus, D. S. Foddan \& J.C.

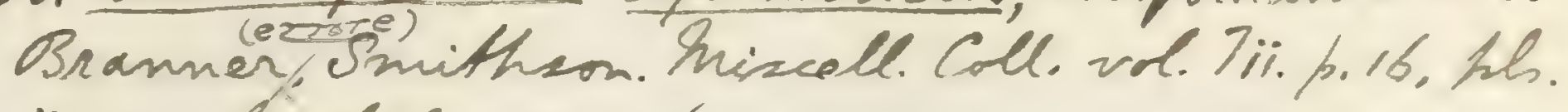
iii. iv. hesch-fige. 9, 11 . 5

1908. Notelope Grama, Endant Bramen, l-s.p.20, plvifol. 1920. Calamofleurue Urama, D. P. Lordan, Proc. Aread. hat. Sci. Philad. 1919. t5. 208.

1923. Calamopleurus brama, D.S.Tordan, 'Rixes crefaceos do Ceara e Pianky, Morn. Serv Geof e Min.

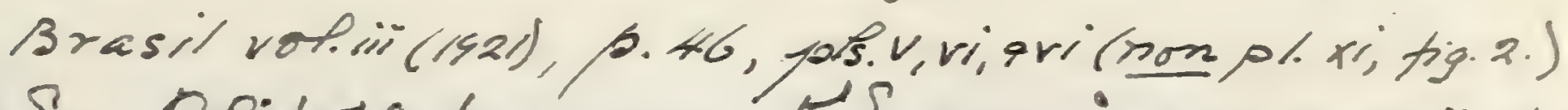

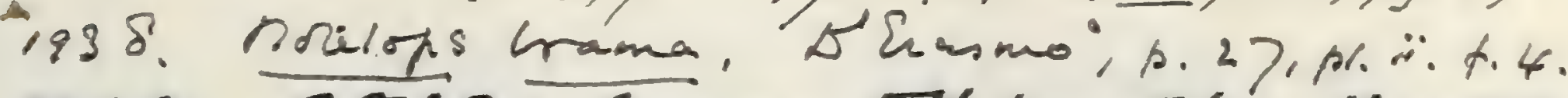
1940. Nowiogs ham- SH. tumRle, Lloydia 3

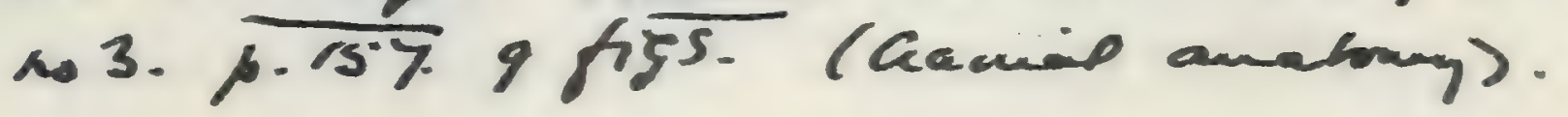



displaying suborbitals, the plate abore the opereulum, and part of the gular plate.

Presented by the Hon. Robert Marsham, 1877.

P. 9189. Smaller and more imperfect head with abdominal region, showing enlarged scale above pectoral fin.

History unknown.

15486. Still smaller head and remains of trunk.

Purchased from Mr. Gardner.

47900. Imperfect small trunk in counterpart, the axial skeleton noticed loc. cit. p. 537.

Presented by the Hon. Robert Marsham, 1877.

P. 1962 c, P. 3986 a. Small head and abdominal region in counterpart, doubtfully of this species.

Egerton \& Enniskillen Colls.

P. 2\%4. Portion of small trunk in counterpart, doubtfully of this species, showing scale-ornament.

Transferred from Museum of Practical Geology, 1880.

The following specimen seems to belong to Notelops, but its generic determination is uncertain :- Notelops mama E.th

47899. Fine large trunk, in counterpart, showing portions of all the fins. Presented by the Hon. Robert Marsham, 1877.

\section{Genus RHACOLEPIS, Agassiz.}

[Edinb. Now Phil. Journ. vol. xxx. 1841, p. 83 (Phacolepis).]

Trunk somewhat laterally compressed; abdomen flattened or rounded. Parietal bones small and sevarated by the supraoccipital; no deep depression in hinder part of frontal region; gape of mouth extending to the hinder border of the orbit; a single supramaxillary bone; margin of the jaws with a single series of small conical teeth. Operculum simple; branchiostegal rays about 20 in number. Vertebral centra slightly constricted, smooth or delicately striated, perforated for the passage of a remnant of the notochord. Pectoral fin with a large and elongated scale at its base; dorsal fin more or less directly opposed to the pelvic pair; anal smaller than the dorsal fin; caudal fin deeply forked. Scales usually ornamented with delicate radiating ridges; a few very small, thin scales extending over the caudal fin; lateral line inconspicuous.

The gular plate in this genus has not yet been clearly observed. 


\section{Rhacolepis buccalis, Agassiz.}

1831. Figure by Spix \& Martius, Reise in Brasilien, Atlas, pl. xxii. fig. 5.

1841. Phacolepis buccalis, L. Agassiz, Edinb. New Phil. Journ. vol. xxx. p. 83.

1844. Rhacolepis bucculis, L. Agassiz, Comptes Rendus, vol. xviii. p. 1011, and Poiss. Foss. vol. iv. p. 293.

1887. Rhacolepis buccalis, A. S. Woodward, Proc. Zool. Soc. p. 539, pl. xlvi. figs. 2-7, pl. xlvii. figs. 1-3.

Type. Imperfect anterior portion of fish; British Museum.

The type species, attaining a length of about $0 \cdot 3$. The length of the head with opercular apparatus considerably exceeds the maximum depth of the trunk, which is comprised about five and a half times in the total length of the fish. The two posterior suborbitals antero-posteriorly elongated and about equal in size, the postero-inferior plate also broader than deep; operculum much deeper than broad, its relative measurements being about $7: 4$. Pelvic fins arising much nearer to the anal than to the pectorals, immediately behind a point opposite the posterior end of the dorsal.

Form. \& Loc. Upper Cretaceous : Province of Ceara, N. Brazil.

All the following specimens were obtained from Barra do Jardim, Serra de Araripe :-

P. 4314a. Very imperfect head and abdominal region, showing fossilised gill-filaments and muscular fibres, marked by Agassiz as the type specimen and noticed by him, Poiss. Foss. vol. iv. p. 293, footnote.

Enniskillen Coll.

47890. Nearly complete fish about 0.27 in length, displaying the paired fins and the base of the anal and caudal fins. Twelve rays can te counted in one of the pelvic fins, which are remarkably close to the anal.

Presented by the Hon. Robert Marsham, 1877.

P. 4315. Almost similar specimen more imperfect, wanting the tail beyond the anal fin. There are doubtful indications of a relatively small gular plate. The right pectoral exhibits 15 or 16 rays.

Enniskitlen Coll.

47889. Fine small fish in counterpart, showing the paired, but wanting the median fins.

Presented by the Hon. Robert Marsham, 1877.

P. 1958 d. More imperfect small fish.

Egerton Coll. 
1908. Phacdepio buccalis, 2.S. Indan 2 9.C. Brannes,

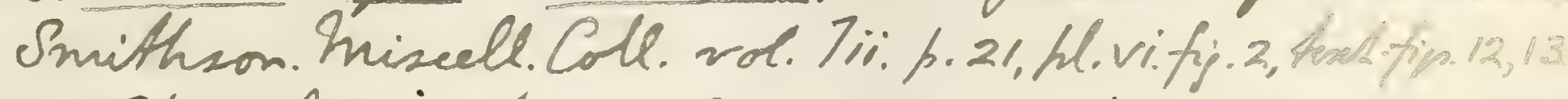
1923. Rhacolepes buccales, D. S. Jordan, Mongr. Sene Geob. Min. Brasil wot. iil, p.62, pt. viir. 6938. Rh. Zuccars, 5'Erasmo, p.29, pliv.f.2-4.

Rhacolefis de-firei s.u. Sthasmo1998.

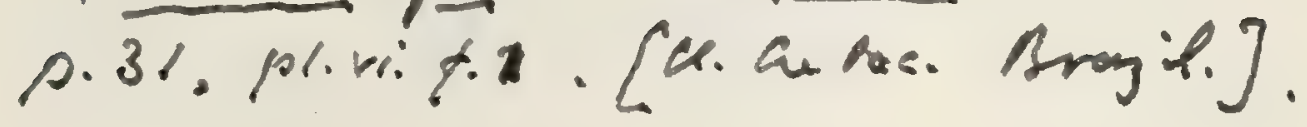



P. 1962, P. 4315 a. Very imperfect fish, in counterpart, showing part of paired fins and vertebræ.

Egerton \& Enniskillen Colls.

15485. Imperfect head and abdominal region, displaying some of the beautifully ornamented scales firured in Proc. Zool. Soc. 1887, pl. xlvi. fig. 6. Purchased from Mr. Gardner.

P. 1958. Another head and abdominal region partly exposed from above, the cranial roof figured loc. cit. pl. xlvi. fig. 3. The pelvic fins are shown to arise immediately behind a point opposite the end of the dorsal fin. Egerton Coll.

P. 3983 a. Head and abdominal region free from investing matrix, figured loc. cit. pl. xlvi. fig. 2.

Enniskillen Coll.

P. 3983 b, c, d. Three more imperfect specimens.

Enniskillen Coll.

28616 a, b. Two similar specimens in matrix. Purchased, 1853.

47890 a. Another similar specimen, in counterpart.

Presented by the Hon. Robert Marsham, 1877.

P. 1958 a. Imperfect large head and abdominal region, the suborbital plates figured loc. cit. pl. xlvi. fig. 5.

Egerton Coll.

28900 a. Head with branchiostegal rays, figured loc. cit. pl. xlvii. fig. 1.

Dixon Coll.

P. 1962. Remains of fish displaying vertebræ (one figured loc. cit. pl. xlvi. fig. 4 b) and pelric bones (one figured loc. cit. pl. xlvii. fig. 3).

Egerton Coll.

$28900 \mathrm{~b}$. Portion of abdomen with enlarged scale abore pectoral fin, figured loc. cit. pl. xlvi. fig. 7 .

Dixon Coll.

P. 1958 c. Portion of abdomen showing claricles, noticed loc. cit. p. 537.

Egerton Coll.

28616. Curiously distorted trunk, probably of this species, noticed loc. cit. p. 536.

Purchased, 1853.

P. 1958 e. Tail probably of this species, figured loc. cit. pl. xlrii. fig. 2.

Egerton Coll. 


\section{Rhacolepis latus, Agassiz.}

1841. Phacolepis latus, L. Agassiz, Edinb. New Phil. Journ. vol. xxx. p. 83.

1844. Rhacolepis latus, L. Agassiz, Comptes Rendus, vol. xviii. p. 1012, and Poiss. Foss. vol, iv. p. 293 (name only).

1887. Rhacolepis latus, A. S. Woodward, Proc. Zool. Soc. p. 539, pl. xlvii. fig. 5.

Type. Imperfect small fish; British Museum.

An imperfectly known small species with much-deepened trunk. The two posterior suborbitals a little broader than deep, and the postero-inferior suborbital of a deep triangular form; operculum about twice as deep as broad. Pelvic fins arising about midway between the pectorals and the anal, opposite the anterior half of the dorsal.

Form. \& Loc. Upper Cretaceous: Province of Ceara, N. Brazil.

P. 1959, P. 3984. Type specimen, in counterpart, described and figured loc. cit. 1887 ; Barra do Jardim, Serra de Araripe. Egerton \& Enniskillen Colls.

28616 c. Trunk doubtfully referred to this species, showing enlarged and elongated anterior dorsal fin-ray. Purchased, 1853.

15493. More imperfect similar trunk.

Purchased from $M r$. Gardner.

\section{Genus THRISSOPATER, Günther.}

[Figs. \& Descript. Brit. Organic Remains, dec. xiii.

(Mem. Geol. Surv. 1872) no. 1.]

Trunk somewhat laterally compressed; abdomen compressed to an edge. Parietal bones small and separated by the supraoccipital; a deep quadrangular median pit in the cranial roof in the hinder part of the frontal region; maxilla slender, with one supramaxillary bone; mandible a little prominent, and gape extending to the hinder border of the orbit; margin of the jaws with a single series of small conical teeth. Operculum simple; opercular bones and clavicular plates slightly dilated and smooth; branchiostegal rays about 30 in number. Vertebræ about 50 in number, the centra slightly constricted, smooth or delicately ridged. Pectoral fin with an enlarged and elongated scale at its base; pelvic fins opposed to the dorsal; anal fin relatively small; caudal fin deeply forked; no 
360

1908. Dhacelefir Latur, D.S. Fodan 2 2.C. Brammer, Snithson. Mizcell. Coll. vol. 7ii. p.22, pl. vi. fip. 3.

1923. Phacotepis latus, D.S. Tordan, Monogr. Serr. Geot.

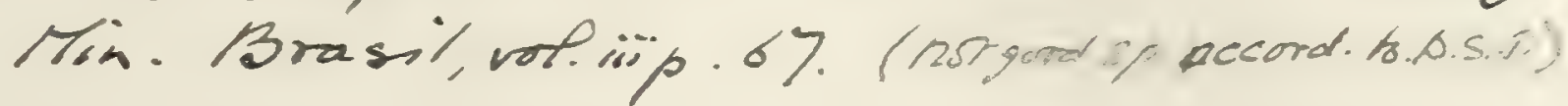

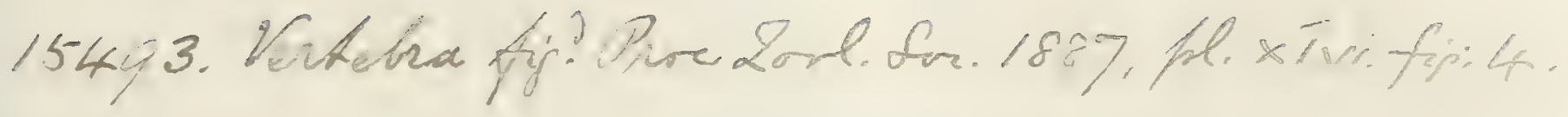


326

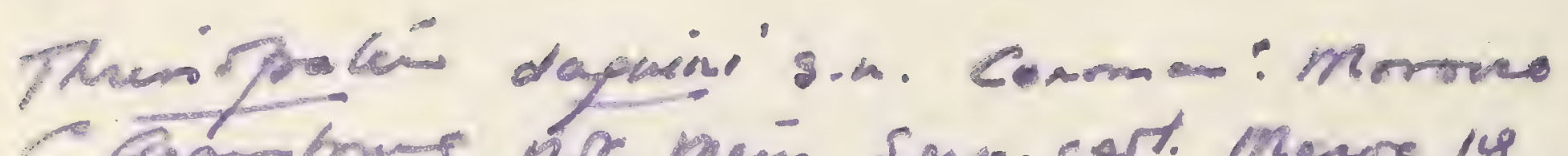

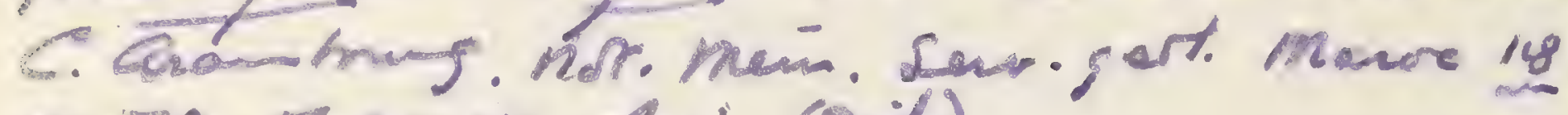

p. $70.7 \cdot 35-37 \mathrm{plvi}$ (Jith). 
Elopoides S. Weng 1965, Amls $38 \leq$. Pateont., $51: 4$.

type-species E. tmassoni Wienz

Elopsides Gomassoni Werz, 1965, Aunls Patéout, 51 :4,pl.1, taest-figs 1,2. U. Albian, Vallentigny, France Hollspe Mus. Mat.ltiol,

1973 E.tanassoni, P. Forey, Bull. BM (Gasl) Suppl co; 84. 
1908. Pachinghisodus/.) mapmus, A.S. Woodward,

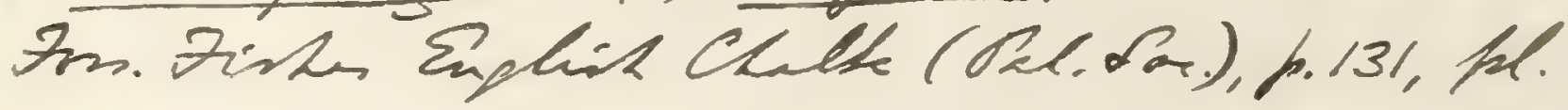
$x \times v$ iii. fig. 1. 
fin-rays excessirely elongated. Scales small or of moderate size, usually ormamented with delicate radiating ridges: no enlarged or thickened ridge-scales; lateral line inconspicuous.

Thrissopater salmoneus, Günther.

1872. Thrissopater salmoneus, A. Giinther, loc. cit. no. 1, pl. i.

Type. Imperfect fish; Woodwardian Museum, Cambridge.

The type species, attaining a length of about $0 \cdot \%$. Length of head with opercular apparatus contained three and a half times, maximum depth of trunk about four and a half times in the total length of the fish to the base of the caudal fin. Posterior suborbital plates radiately furrowed, and their extent exceeding one third the length of the skull; width of orbit less than this measure; width of operculum equalling at least half the length of the skull. About 5u scales in a transverse line on the trunk in front of the dorsal fin; the enlarged axillary scale longer than the rays of the pectoral fin; ornamental strix on scales often slightly wary.

Form. \& Loc. Albian: Kent.

P. 9052. Fine head, in crumbling condition, and probably incapable of permanent preservation; Gault, Folkestone. Between 25 and 30 branchiostegal rays and a small gular plate are shown.

Purchased, 1899.

47199. Crushed head showing form of cranial roof and maxilla;

- Gault, Folkestone.

Gardner Coll.

47194. Much fractured head and abdominal vertebræ of small fish; Gault, Folkestone.

Gardner Coll.

47202. Portion of abdominal region displaying the elongated scale (axillary appendage) at the base of the pectoral fin; Gault, Folkestone.

Gardner Coll.

4\%189. Imperfect large trunk displaying scales and caudal vertebræ; Gault, Folkestone.

Gardner Coll.

\section{Thrissopater magnus, sp. nor.}

[Plate V.]

1837-44. Hypsodon lewesiensis, L. Agassiz, Poiss. Foss. vol. v. pt. i.

p. 100, pl. xxva. fig. 1, pl. xxv b. figs. 4, 5 (errore).

Type. Imperfect head; British Museum.

A large species, known only by the head and other fragments. PART Tr. 
Posterior suborbital plates radiately furrowed and their extent exceeding one third the length of the skull; width of orbit much less than this measure; teeth of premaxilla not larger than those of the maxilla, those of the mandible somewhat the largest. Width of opercular apparatus apparently not exceeding one third the length of the skull.

Form. \& Loc. Turonian: S.E. England.

37981. Type specimen, a vertically crushed imperfect head, shown of two-thirds the natural size in Pl. V. fig. 1; Lower Chalk, Hollingbourn, Kent. The cranial roof is well exposed but damaged by an oblique fracture. Its most characteristic feature is the median depression in the hinder frontal region, where the bone becomes comparatively smooth. A trace of the small, finely-punctate supraoccipital (s.occ.) is obserred at the hinder border of the depression, while quite posteriorly on the left side an otic bone (apparently epiotic, ep.o.) is crushed outwards. The limits of the parietal ( $p a$.$) , squamosal (sq.), and$ frontal ( $f r$.) elements can also be distinguished; the lastnamed being relatively large bones, exhibiting a series of pits along either side of the depression where traversed by the slime-canal. The terminal ethmoid (eth.), finely punctate like the supraoccipital, is relatively small and pointed in front, without any expansion. The cheekplates are best shown on the left side, where the postêrior suborbitals (s.o.) with their slightly radiating furrows are conspicuous. The sutures between these are not distinct, and it is not quite clear whether there is a border of circumorbitals (c.o.) between them and the orbit. The anterior of the two circumorbitals above the orbit is relatively large and arched, curving downwards in front to meet the single long and narrow plate bordering the orbit beneath. There is also one small triangular antorbital plate (a.o.). The maxilla $(m x$.) is broken in front by a fracture and displacement which also crosses the mandible. It is overlapped for about half its length by the supramaxilla $(s \cdot m x$.$) , which is a little expanded behind. The teeth$ in its anterior half are only about half as large as those in its posterior half. The premaxilla ( $p m x$.) is a thin triangular bone, sharply notched in its hinder border, and bearing a close series of teeth as small as those of the front part of the maxilla. The mandible is also delicate 
37981. Des? a fip? A.S.W. 1908, h. 131, fh. xxviri. fi, . . 



$$
\text { - }
$$


and much tapering at the symphysis. The articulo-angular element is very short, with a large concave articular facette for the quadrate, best seen on the right side. The dentary (d.) bears a spaced series of teeth slightly larger eren than the largest on the maxilla. Of the opercular apparatus only fragments remain. The preoperculum seems to have been very narrow, and this is probably the displaced arched bone on the right side of the fossil, not shown in the figure.

Purchased, 1864.

4055. Slab of chalk exhibiting the imperfect hinder half of a larger skull associated with a quadrate, vertebræ, and other fragments, provisionally referred by Agassiz, loc. cit., to Hypsodon Tewesiensis; Chalk, Sussex. The skull and quadrate bone are figured by Agassiz, loc. cit. The cranial roof exhibits the characteristic median depression. The vertebræ are shorter than deep and strengthened by delicate longitudinal ridges. A fragment of jaw on the same slab bears traces of large hollow teeth like those of Portheus; but, if the determination here proposed be correct, this cannot have belonged to the same fish as the skull.

Lantell Coll.

490\%8. Hinder portion of small skull, with six anterior rertebral centra in position, partly invested with pyrites; probahly from the Lower Chalk of Kent. The portion of cranial roof is shown from above, of the natural size, in Pl. V. fig. 2 ; while two of the rertebral centra are represented in side-riew and from below in figs. $2 a, 2 b$. The sutures between the various elements of the cranial roof are distinct and arranged as already described in the type specimen. The constitution of the otic region is also well shown. The anterior vertebral centra do not exhibit lateral pits, except one facette near the ventral border for the articulation of the rib $\left(r_{0}\right)$. Their ventral face, however, is pitted and strengthened with longitudinal ribbings. Mrs. Smith's Coll.

Thrissopater (?) megalops, sp. nov.

[Plate VII. fig. 4.]

Type. Imperfect head; British Museum.

A species about as large as the type, known only by the head, opercular apparatus, and scales. Posterior suborbital plates D 2 
relatively narrow, their extent not exceeding one quarter the length of the skull; orbit very large, its width considerably greater than one third the length of the skull; teeth of premaxilla relatively long and slender, larger than those both of the maxilla and dentary. Opercular apparatus relatively narrow, its width not exceeding one third the length of the skull. Radiating lines on anterior scales few and indistinct.

Form. \& Loc. Turonian: Sussex.

49826. Type specimen, shown of the natural size from the left side in Pl. VII. fig. 4; Lower Chalk, Lewes. The head is imperfect and a fracture crosses the rostral region causing some displacement; but the general proportions seem to be determinable with sufficient accuracy. The posterior suborbital plates (s.o.) are exhibited only in an impression of their inner face, and it is uncertain how they were subdivided; the transverse fractures may or may not represent sutures. There is one long infraorbital (i.o.) beneath the eye, and in the orbit itself there is a trace of an ossitied sclerotic ( $s c l$.). The long, slender maxilla $(m x$.$) , imperfect at each end, has a very$ siightly sinuous oral border bearing small spaced teeth. The premaxilla $\left(p m x_{0}\right)$, with a regular series of larger and more slender teeth, is about one quarter as much extended as the maxilla. The mandible is imperfectly displayed, but the anterior end of the dentary $\left(d_{0}\right)$ bears slender teeth intermediate in size between those of the premaxilla and maxilla. The lower end of the preoperculum $(p . o p$.$) seems to be completely preserved,$ but is not much expanded and does not exhibit any radiating ridges. The operculum (op.) is very imperfectly shown, chiefly as an impression, but must have been nearly twice as deep as broad. The suboperculum (s.op.) is shown to have been smooth, with feeble traces of radiating lines, and its width is about, as great as its depth. The slender clavicle (cl.) is partially exposed, while the post-temporal (p.t.) and postclavicular plates (p.cl.) are conspicuous. A few of the anterior scales are also preserved, the relatively small exposed area marked with delicate radiating depressions.

Capron Coll. 


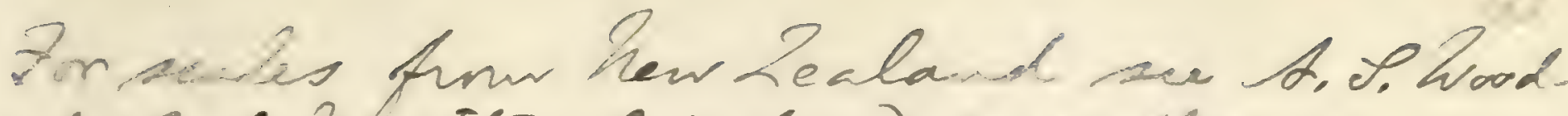
wand, Ged. Mag.[6] rol, iv. (1917), h. 341, hexxifip. 13; and 7. Chapman, hew Lealand Ged. Hw. Palosont. Bull, no. 7 (1918), h. 24, hl. vili. fip, s.

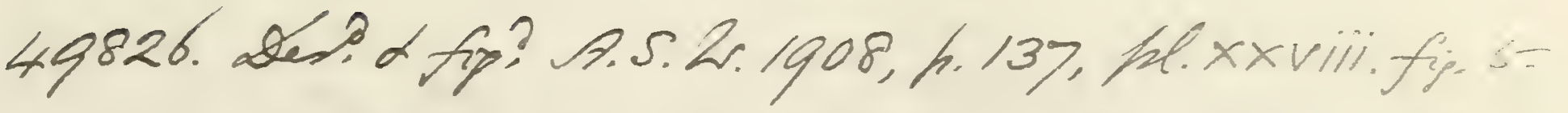

Pelycoragin's vasios p. 354

EThrissopater intestinalis, hoodie.

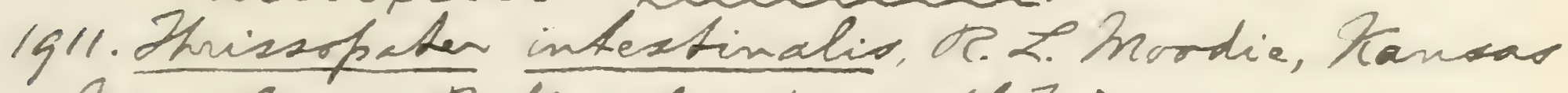
Iniv. Science Bule vol. v. h.281, hl. Txi.

Inpe. Imperfert firt; Kanses Aniv. Ged. husseun. Delvic fins mave remothe then in then terros epecies.

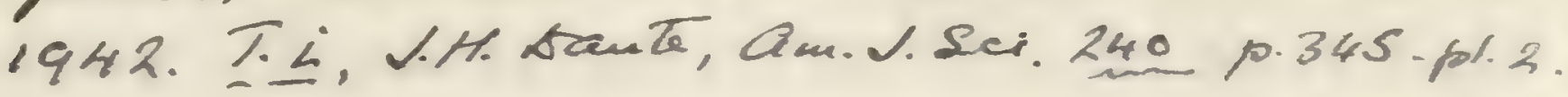

Frm.tor. Whur Getaceowo (Austin Shales):

Baylor, Jexar, U.S. A. 


Genus PACHYRHIZODUS, Dixon.

[Geol. Sussex, 1850, p. $37 \pm$ (ex Agassiz IIS.).]

Syn. Megaludon, L. Agassiz (non Sowerbs, 1829), Poiss. Fuss., Feuili. 1835, p. 55 (in part).

Hypsodon, L. Agassiz, ibid. 1837, p. 104 (in part).

Raphiosaurus, R. Owen, Trans. Geol. Soc. [2] rol. vi. 1812, p. 413.

Acrodontoscumen, J. W. Mason, Quart. Journ. Geol. Soc. vol. xxr. 1869, p. 44.

An imperfectly-known genus, hitherto represented merely by fragments. Parietal bones small and separated by the supraoccipital; no deep depression in hinder part of frontal region. Teeth robust and conical, fused at their expanded base with the supporting bone; mandible with a single close series nearly regular in size; premaxilla horizontally estended, with a single close series of small teeth round the antero-lateral border and two larger teeth within; maxilla robust, with a single series of teeth smaller than those of the mandible. Vertebral centra deeper than long, slightly constricted, not pitted at the sides.

\section{Pachyrhizodus basalis, Dixon.}

185̃0. Pachyrhizodus basalis, F. Dixon, Geol. Sussex, p. 374, pl, xxxiv. figs. 9, 10 .

Type. Premaxilla; British Museum.

The type species, known only by fragments of the upper jaw. Premaxilla narrow, its dentigerous portion about two thirds as broad as long; the small marginal teeth about 9 in number and inclined outwards, the large inner teeth with long and remarkably straight crown, which is not hooked.

Form. \& Loc. Turonian: S.E. England.

49014. Right premaxilla figured by Dixon, op. cit. pl. xxxir. fig. 9, to be regarded as the type specimen; probably from the Kentish Chalk. The outwardly-inclined bases of four marginal teeth are shown, there are three empty sockets, and a fragment of another tooth appears at each end of the series. The hinder inner tooth is represented only by its socket.

His. Smith's Coll.

P. 5655. Portion of premaxilla with similar large inner teeth and an abnormal tooth at the base, associated with four characteristic vertebral centra and other fragments; Kent. Harford Coll. 


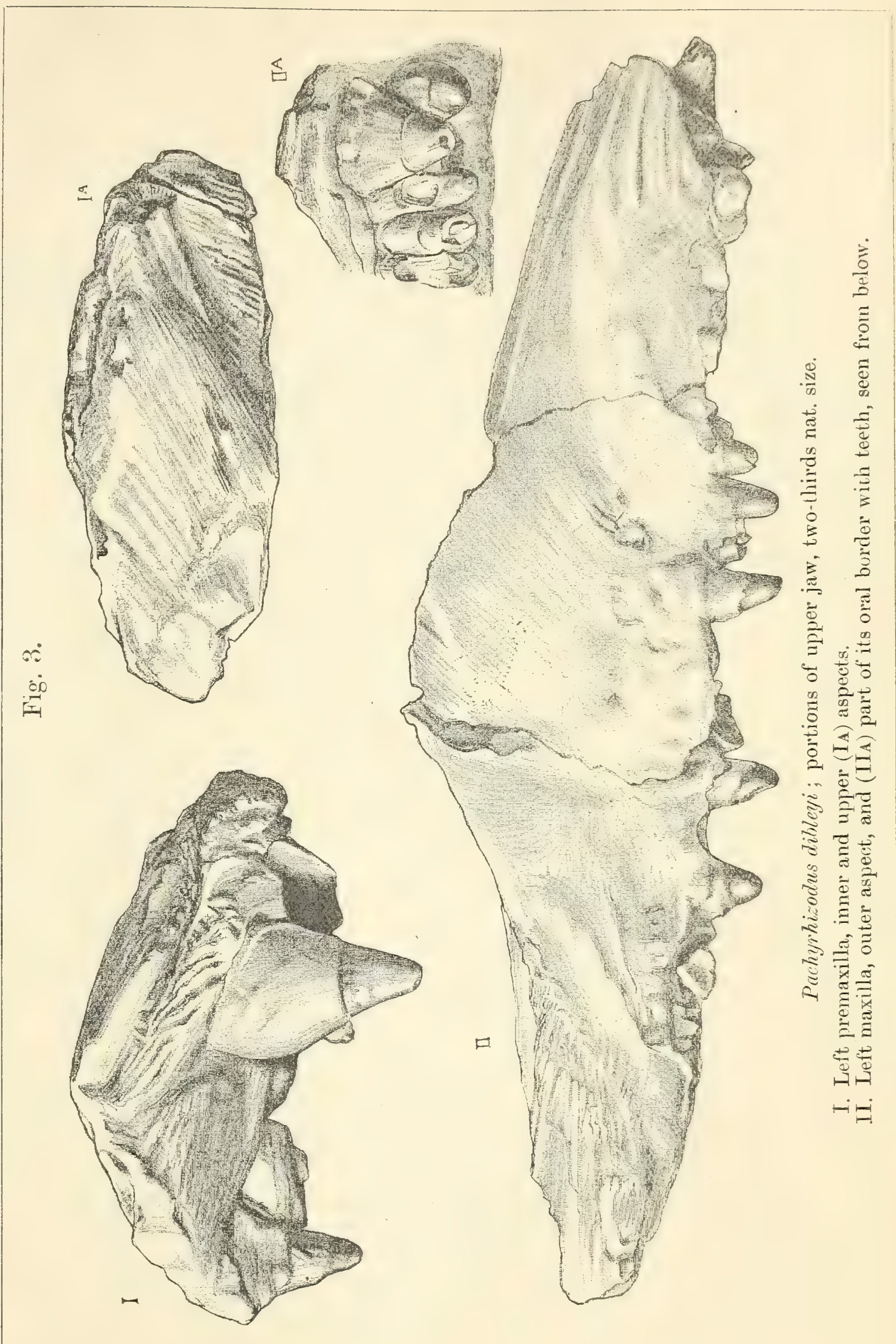




\section{Pachyrhizodus gardneri (Mason).}

1837-44. Hypsodon lewesiensis, L. Agassiz, Poiss. Foss., Feuill. p. 104 , vol. v. pt. i. p. 99, pl. xxv $a$. figs. 2, 4, pl. xxv b. figs. 6, 7 (in part). 1846. "Reptile or Fish," T. Smith, Lond. Geol. Journ. p. 21, \& woodc. 1869. Acrodontosaurus gardneri, J. W. Mason, Quart. Journ. Geol. Soc. vol. xxv. p. 444, pl. xix.

1877. Hypsodon lewesiensis, E. T. Newton, Quart. Journ. Geol. Soc. vol. xxxiii. p. 508 ,

1888. Pachyrhizodus gardneri, A. S. Woodward; Proc. Geol. Assoc. vol. x. p. 314.

Type. Portion of mandibular ramus; British Museum.

A large species, the mandible attaining a length of at least $0 \cdot 3$. Dentigerous portion of premaxilla nearly half as broad as long, its marginal teeth not inclined outwards, its inner teeth with muchexpanded base, very stout and curved inwards. Dentary bone rery deep, but rapidly contracting in front into a narrow thickened symphysis, and sharply bent inwards in the lower two-thirds throughout its length; its maximum depth equal to the base-line of 6 anterior teeth; a small groove on the outer face extending from the middle of the symphysial border in a longitudinal direction and slightly upwards until lost at the oral border; the stout incurved teeth somewhat over 20 in number if all were present.

Form. \& Loc. Turonian: Kent and Sussex.

4105. Fragmentary remains of jaws in a block of chalk, partly noticed and figured by Agassiz, tom. cit. p. 99, pl. xx figs. 2, 4, among the type specimens of Hypsodon lewesiensis; Chalk, Lewes. There are portions of the dentary of both sides, that of the left only shown in the figure. The characteristic premaxilla of the left side, much fractured, is exposed from the oral aspect and displays the two large inner teeth besides two of the marginal teeth. Remains of the left maxilla exhibit a series of smaller teeth. Mantell Coll.

41674. Slab of chalk with scattered remains of head, noticed by Toulmin Smith, loc. cit. 1846; Lower Chalk, Kent. Among the fragments of jaws the most conspicuous is the imperfect right dentary, exposed from within and partly shown in Smith's upper figure, loc. cit. The teeth on this bone are large and smooth, curved inwards, and arranged in very close series, the base of each much thicker measured from its outer to its inner face than from side to side; the alveolar border is greatly thickened to support 


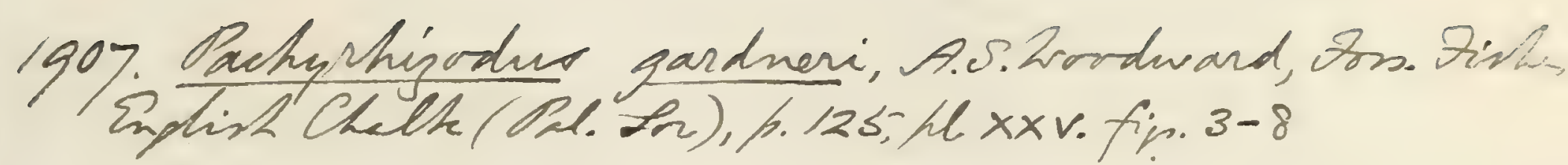

41674 . Ohemrsilla, mascilla, a dentary dest a fig? A.S.2. $1907,10.127$, hl. $\times \times$ v. fin. $4-6$. 
33257. Daydt hremaxilla des? affe? A.S.2.1907,

10.127. fl. $\times \times v$. fs. 3 .

Hlby ( Joulmin Auth Coll) dres und

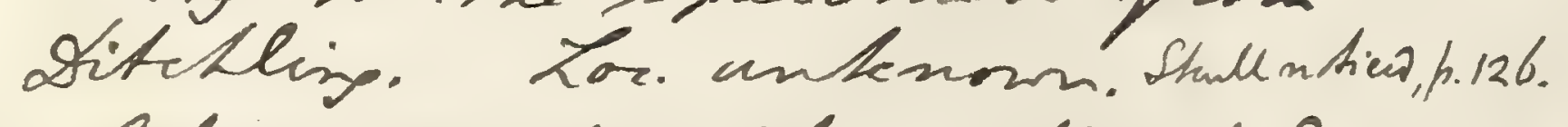

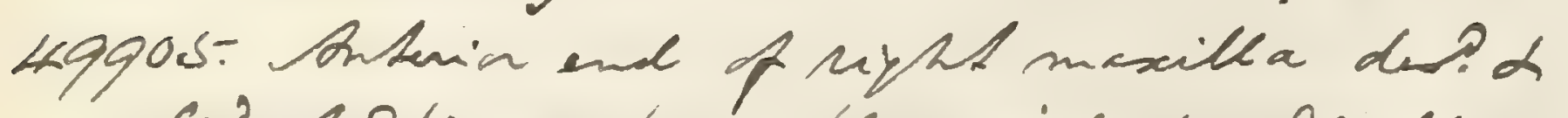
fip? A.S.W. 1907, 1. 12\%, hl. $\times$ xvi.fig.5. Stanle nthiend fo.126. 
this dentition. The left premaxilla, exposed from the oral aspect, is imperfectly shown in Smith's lorrer figure; all its teeth are imperfect, and the foremost of the trio large inner teeth is represented only by its hollow base; of the six outer teeth indicated, two exhibit the greater part of the crown and profs that they are implanted almost vertically. Another imperfect dentigerous bone shown from the outer aspect on the upper part of the slab seems to be the left maxilla. Its oral border, so far as preserred, is straight and bears teeth resembling those of the mandible, though much smaller; its outer face is flattened, but shorrs smooth and rounded irregularities; it is deepest in the anterior third but soon tapers to its anterior articulation. The latter is shomn to be much horizontally extended in a fragment of the right maxilla. Some bony laminæ corered with a cluster of minute pointed teeth, may represent the entopterygoid. Three of the large teeth have been sliced to display their pulpcarity. Among other fragments may be noticed one of the hyomandibulars, remarkably expanded and laminar in form, with the usual process for the support of the operculum.

Toutmin Smith Coll.

3325\%. Associated imperfect dentaries and right premaxilla; Lower Chalk, Burham, Kent. The narrow thickened mandibular symphysis is well shomn, and the premaxilla exhibits one of the large inner teeth besides some of the marginals.

Taylor Coll.

41671, 49905. Fragmentary remains of cranium, quadrate, maxillæ, other jaw-bones, and two rertebræ, found associated; Chalk, Ditchling, Sussex. Most of the outer face of the cranium is destroyed; but it is evident that the middle of the roof is only gently depressed, while the supraoccipital reaches the frontals and prerents the parietals from meeting in the middle line. Part of the ossified sclerotic is shown on the left side. The hinder end of the right maxilla is complete, and proves that, although the bone is much thickened in its front portion, it becomes com. pressed to a thin rertical lamina behind. Some fragments of inner bones of the mouth exhibit clustered minute teeth, as in the prerious specimen. Two anterior vertebræ are much deeper than long and not pitted at the sides. insling Hre Smith's Coll. and Capron Coll. 
P. 9016. Left ramus of mandible, showing articulo-angular bone: Lower Chalk (Schloenbachia Zone), Glynde, Sussex.

$$
\text { Purchased, } 1899 .
$$

P. 5656. A fine right dentary; Lower Chalk, Burham, Kent. Thirteen teeth are preserved, with spaces for about ten others. Harford Coll.

47236. Anterior end of similar right dentary, being the type specimen of the species, described as reptilian by Mason, loc. cit. 1869 ; Lower Chalk, Lyddon Spout, Folkestone. The oral margin of the bone is partly broken away from the bases of the teeth.

Gardner Coll.

33256. Imperfect dentaries associated with part of the left maxilla, and fragments of the inner tooth-bearing bones, doubtfully of this species; Burham.

Taylor Coll.

P. 5652. Imperfect oral border of the left dentary, probably of this species; Lower Chalk, Cuxton, Kent. Harford Coll.

4068. Vertebral centrum probably of this species, figured by Agassiz, 7oc. cit. pl. $\operatorname{xx}$ b. figs. 6, 7 ; Chalk, Lewes. Mantell Coll.

P. 1808 a. Two vertebral centra; Chalk, Sussex. Egerton Coll.

P. 4506. Group of imperfect vertebræ; English Chalk.

Enniskillen Coll.

P. 5658. Tertebral centra; Lower Chalk, Kent. Harford Coll.

\section{Pachyrhizodus latimentum, Cope.}

1872. Pachyrhizodus latimentum, E. D. Cope, Proc. Amer. Phil. Soc. vol. xii. p. 346.

1872. Pachyrhizodus kingii, E. D. Cope, ibid. p. 346. [Portion of maxilla.]

1875. Pachyrhizodus kingii, E. D. Cope, Vert. Cret. Form. West (Rep. U.S. Geol. Surv. Territ. vol. ii. 1875), p. 223, pl. xlvi. fig. 11.

1875. Pachyrhizodus latimentum, E. D. Cope, ibid. p. 223, pl. 1. fig. 5, pl. li. figs. 1-7.

1900. Pachyrhizodus latimentum, F. B. Loomis, Palæontogr. vol. xlvi. p. 263, pl. xxvi. figs. $7,8$.

Type. Mandible, \&c.; thon, hm. It it.

A species as large as P. gardneri, with nearly similar mandible but more numerous and relatively smaller teeth. Teeth not com- 
P.9016. De? affi? A.S.W. 1907, 10.127, hl. xxv. fis. 7.

P.5656. Des? dfip? A.S.W. 1907, h.127, hl. xxv.fup. 8.

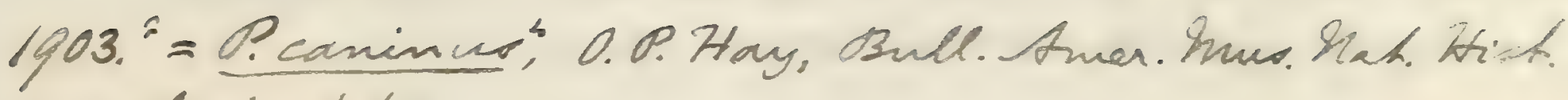
sol. xix h.60. 
1908. Dashynhijodur subulidens, A.S. Loodward,

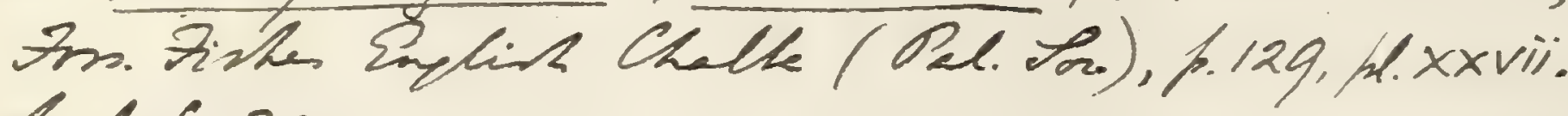
teath-fis. 39.

385-66. Hoticed A.S. L. 1908, f.129.

R.1808. Dipht maxilla \& sule des? \& fis? A.S.W. 1907. for. 130, 131, fal. xxvii. fin. 3, 4 . 
pressed or much expanded at the base, but smooth $\mathrm{O}_{2}$ with slight longitudinal ribbings, and the slender apex considerah 1 incurved. Premaxilla with 13 marginal alveoli ; maxilla with about 46 , dentary with about 39 alveoli.

Form. \& Loc. Cpper Cretaceous (Niobrara Group): Kansi s, U.S.A.

P. 9200. Imperfect crushed cranium, about as broad as lowg, with remains of maxill and two vertebral centra; Elkader, Logan Co., Kansas.

Purchased 1900.

\title{
Pachyrhizodus subulidens ( $O \pi e n)$.
}

\author{
[Plate VII. figs. 1, 2.]
}

1842. Raphiosaurus subulidens, R. Owen, Rep. Brit. Assoc. 1811, p. 190.

1850. Raphiosaurus lucius, R. Owen, in Dixon's Geol. Sussex, p. 385, pl. xxxix. figs. 1-3.

180̃1. Raphiosaurus subulidens, R. Owen, Rept. Cret. Form. (Mon. Palæont. Scc.), p. 19, pl. x. figs. 5, 6.

1889. Pachyrhizodus subulidens, A. S. Woodward, Ann. Mag. Nat. Hist. [6] rol. iv. p. 351.

Type. Anterior portion of left maxilla; Woodwardian Museum, Cambridge.

The type species of the so-called lacertilian genus Raphiosaurus, of comparatively small size, the maxilla attaining a length of about $0 \cdot 10$, and the mandible about $0 \cdot 15$. Teeth very smooth, intardly and backwardly curved. [Premaxilla unknown;] maxilla flattened externally, with a very large anterior process, and spaces for from 30 to 40 teeth. Dentary bone very deep, but rapidly contracting in front into a narrow thickened symphysis ; its outer face remarkably smooth, marked with two deep longitudinal depressions between which the middle part of the bone projects in a rounded longitudinal ridge ; its oral border with spaces for at least 30 teeth.

Form. \& Loc. Turonian: Cambridgeshire, Kent, and Sussex.

38566. Imperfect right maxilla and left dentary, associated with the metapterygoid and part of the hyomandibular; Lower Chalk, Hailing, Kent. Purchased, 1864.

P. 1808. Slab of chalk with right maxilla exposed from within (Pl. VII. fig. 1), associated with clavicle, other fragments, and scales; Sussex. The scales are ornamented in their exposed sector with a few discontinuous radiating grooves ; and one is figured by the present writer in Proc. Geol. Assoc. vol. x. pl.i. fig. 8.

Egerton Coll. 
36635. An imperfect mandible identical in character with that of no. 38536 ; Falling. The left dentary, so far as preserved, is shown of the natural size in Pl. VII. fig. 2, while the middle portion of the right dentary is shown in fig. 2a. The bone of each side is thus much distorted by crushing, while the lower border is complete only in part of the right ramus.

Purchased, 1862.

390\% . Enother imperfect right dentary, with incomplete lower border; Lower Chalk, Burham, Kent. Bowerbank Coll.

P. 652\% Portion of dentaries; Lower Chalk, Blue Bell Hill, Burham. Presented by S. J. Hawkins, Esq., 1891.

2. 4239. Tery small maxilla associated with hinder portion of cranium, doubtfully of this species; Lorer Chalk, Burham.

Enniskitlen Coll.

36138. Imperfect small maxilix and other associated fragments, also doubtfully of this species; Lower Chalk, Burham.

Purchased, 1861.

3908\%. Imperfect small right dentary, doubtfully of this species; Bromles, Kent.

Bowerbank Coll.

The following specimen probably belongs to a species of Pachyrhizodus :-

P. 5559. Imperfect caudal region corered with large and thin cycloid scales, which are either smooth or only feebly marked with radiating striæ; Lower Chalk, Cuxton, Kent. The vertebral ceutra are short and deep, without, lateral pits. The rays of the caudal fin exhibit very close transverse articulations.

Hurford Coll.

Species not represented in the Collection hare also been described on fragmentary eridence as follows:-

Pachyrhizodus caninus, E. D. Cope, Proc. Amer. Phil. Soc. vol. xii. (1872), p. 344, and Tert. Cret. Form. West (Rep. U.S. Geol. Surr. Territ. vol. ii. 1875), p. 221, pl. 1. figs. 1-4: F. B. Loomis, Palæontogr. vol. xlvi. (1900), p. 262, pl.xxrii.figs. 10-12 - Upper Cretaceous (Niobrara Group); Smoky Hill Rirer, Kansas. [Jaws.]- tmen. Mnus. 12. F.

Pachyrhizodus curvatus, F. B. Loomis, Palæontogr. vol. xlri. (1900), p. 265, pl. xxv. figs. 6-8.- Upper Cretaceous; 
36635. Dipht dentary des? Afi? A.S.2. 1907, h.130, he xxvii. fí. 3 a.

P.56.59. Dew? dfis? A.S.L. 1907, h. 124, hl. xxviffs

Pachyohizadus Sho, A.S. Lrodurard, Fons. Fisher inclint Chalte (Oal. On. 1912), h. 249, bl. Tiv. fip. 2

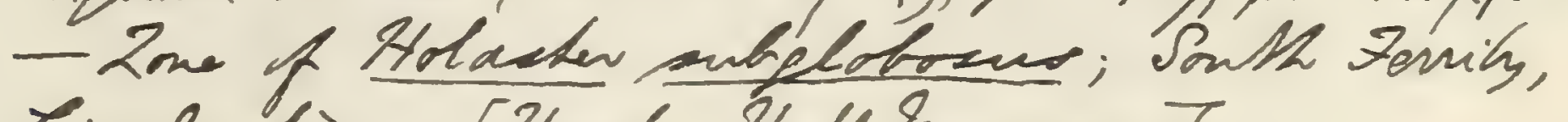
Limcolnstive. [Hiead; Hell husernn.T

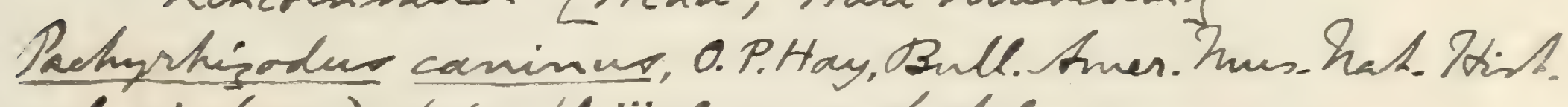

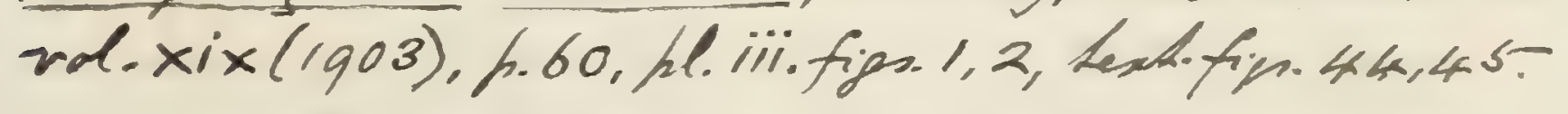


Duthrtisodur leptopiz, O.PHay, Brall. Amen. Mus. That. Hish. rol. xix (1903), h.64.

Cricardinus sheareri; O.P. Hay, Bull. Amen, Mnes. Nath bith. vol. xix (1903), h.64, hexh-fis. 46.

Pachyrhizodus marathonensis spsee p.107.

Behnhija antigua, 7. Priem, Priss. Ans. Bassin Parisien (Dute. Am. Paléont. .908), h.62, hexch.fis. 25.

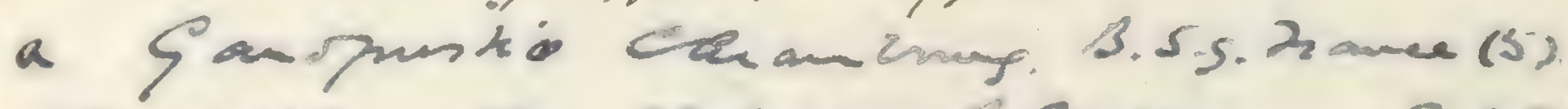

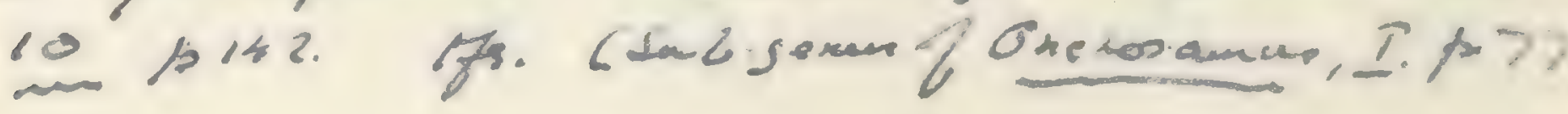


Kansas. [Maxilla and mandible; Palæontological Museum, Munich.]

Pachyrhizodus leptognalhus, A. Stewart, Kansas Univ. Quart. [A] vol. vii. (1898), p. 193, pl. xvii. fig. 1 ; F. B. Loomis, loc. cit. 1900, p. 264, pl. xxvi, figs. 10-16. -Upper Cretaceous (Niobrara Group); Kansas. [Nandible, \&c.; Kansas University M[useum.]

Pachyrhizodus Teptopsis, E. D. Cope, Bull. U.S. Geol. Surv. Territ. no. 2 (1874), p. 42 , and op. cit. 1875 , p. 225 , pl. li. fig. 8.-Ibid. [Fragments of mandible, \&c. . Am. Mus. 2. H. Pachyrhizodus minimus, A. Stewart, loc. cit. [A] vol. viii. (1899), p. 37, woodc.-Upper Cretaceous; Butte Creek, Logan Co., Kansas. [Mandible; Kansas University Museum.] Puchyrhizodus sheareri, E. D. Cope, loc. cit. 1872, p. 347, and op. cit. 1875, p. 225 : Oricardinus (?), E. D. Cope, Proc. Amer. Phil. Soc. vol. xvii. (1878), p. 177.-Upper Cretaceous (Niobrara Group); Kansas. [Jaw, wanting teeth.] Amer. Zmo. Kah. Htish

Pachyrhizodus velox, A. Stewart, loc. cit. [A] vol. vii. (1898), p. 193, pl. xvii. fig. 2.-Ibid. [Jaws; Kansas University Mruseum.]

An imperfect jaw of Pachyrhizodus from the Turonian (Plänerkalk) of Strehlen, Dresden, is described under the name of Hypsodon lewesiensis, Ag., by H. B. Geinitz, Palæontogr. vol. xx. pt. ii.(1875), p. 222, pl. xliii. fig. 1.

A renewed examination of the type specimen of Mosasaurus gracitis, Owen, from the Chalk of Sussex, in the Brighton Museum, has convinced the present writer that the fossil is truly part of the mandible of a Mosasaurian. It was therefore wrongly named Pachyrhizodus gracitis in A. S. Woodward, Proc. Geol. Assoc. vol. x. (1888), p. 314.

The genera and species described as follows are supposed to be related to Pachyrhizodus, but are too imperfectly known for precise determination. They are not represented in the Collection :-

Cyclotomodon vagrans, E. D. Cope. Proc. Acad. Nat. Sci. Philad. 1876, p. 113.-Phosphate Beds ; Charleston, South Carolina. [The type species. Fragment of jaw.]

Ischyrhiza antiqua, J. Leidy, Proc. Acad. Nat. Sci. Philad. vol. viii. (1856), p. 256 ; E. Emmons, Rep. N. Carolina Geol. Surv. (1858), p. 225, figs. 47, 48.-Tertiary ; Neuse River, North Carolina. [Tooth.] 
Ischyrhiza mira, J. Leidy, ibid. (1856), p. 221.-Cretaceous

Greensand; Burlington Co., New Jersey. [The type

species. Tooth.]; Amer. Hum, X, H.

Isihyrhiza (?) radiuta, W. B. Clark, Bull. U.S. Geol. Surv.

no. 141 (1896), p. 60, pl. vii. figs. 2 a-c.-Eocene; Clifton

Beach, Naryland. [Hypural and caudal vertebræ; Johns

Hopkins University.]

Oricardinus tortus, E. D. Cope, Proc. Amer. Phil. Soc. vol. xrii.

(1878), p. 177.- Upper Cretaceous; Kansas. [Haxilla and vertebræ; Cope Collection.]

\section{Genus BSOCELOPS, nov.}

Syn. Eurygnathus, L. Agassiz, Rep. Brit. Assoc. 1844 (1845), p. 307 (name only, non Furygnathus, Wollaston, 1853).

A genus known only by the head, which is both depressed and elongated. Frontal bones extending close to the occipital border, bent into a slight depression in their hinder portion; parietal bones very small. Mandible comparatively short, and gape of mouth not extending to the hinder border of the orbit; mandibular teeth stout and conical, laterally compressed, well spaced. Operculum simple; branchiostegal rays at least 15 in number; gular plate extending for not less than three-quarters the length of the mandible.

Esocelops cavifrons, sp. nor.

[Plate III. figs. 1, 2.]

1845. Eurygnathus cavifions, L. Agassiz, Rep. Brit. Assoc. 1844, p. 307 (name only).

Type. Imperfect head; British Museum.

The tspe species, with skull attaining a length of about $0 \cdot 1$. Maximum width of occiput exceeding the length of the postorbital region, and somewhat less than one half the length of the cranium. Length of mandible about equal to the distance from the end of the snout to the hinder border of the orbit. Bones of cranial roof slightly rugose or pitted; cheek-plates very delicate, ornamented with rounded radiating ridges. Operculum somewhat deeper than broad, and its width equalling about one third the length of the cranium; gular plate widest and spatulate behind, its maximum width slightly exceeding one third of its length.

Form. \& Loc. Lower Eocene (London Clay): Sheppey, Kent. 
Ischyriza ehiteesis, mos. Plesicsaurus chilensis Phillippi, zen

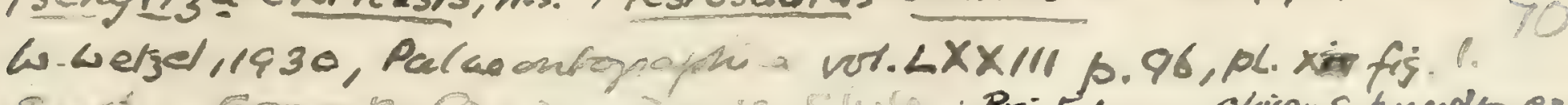

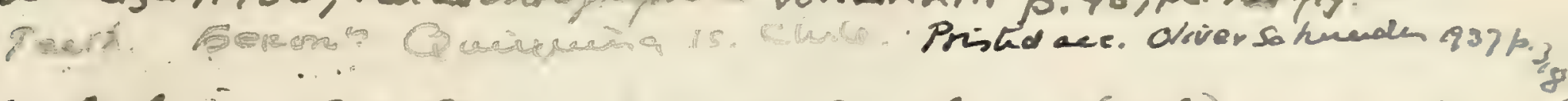

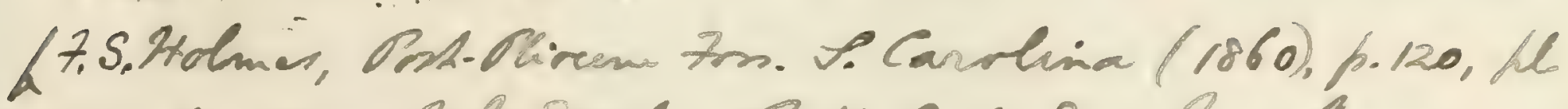

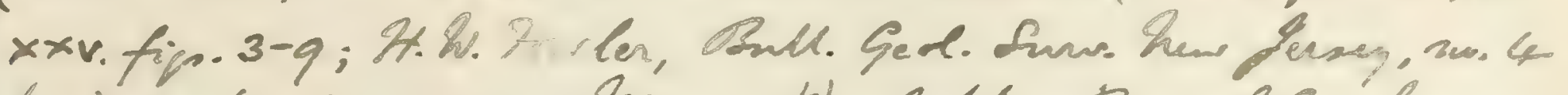

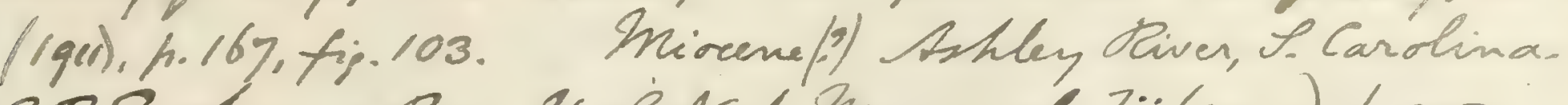
C.P.Sactman, Prov. H. .. Na L. Mus. vol. Tiil(1917). h. 298, H.xi.fip. 2 [Ripley Cretaceons. Dumar, Jiphath C., Wiss.]

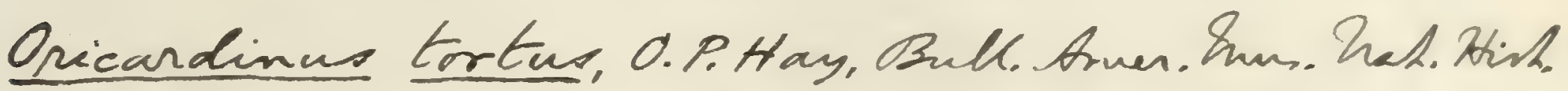
vol.xix (1903), h.65, Lexh.figes. 47-49. 

$$
\text { • }
$$ 
P. 1749. Type specimen, shown of two thirds the natural size from the left lateral and inferior aspects in Pl. III. figs. 1, $1 a$. The general proportions of the cranium are indicated, but the bones are much fractured and some may be distinguished more readily in the next specimen. The otic region is well ossified, and the sphenotic (or postfrontal, pt.f.) enters the anterior end of the facette for the h5omandibular. The latter element $(\mathrm{hm}$.) is much constricted and bent forwards mesially, while the slender process $(p$. for the support of the operculum (op.) arises from the lower end of its upper half. This bone seems to be a little displaced backwards by crushing, the remains of the quadrate (qu.) and probably of the symplectic (sy.) being well forwards. The fragments of the metapterygoid (mpt.) and ectopterygoid (ecpt.) do not suffice for description. The snout is incomplete, but the greater part of the mandible is shown on each side. The articulo-angular element $(\mathrm{ag}$.$) is relaticely large, with very low articular$ facette; the depth of the coronoid region seems to have equalled one quarter the total length of the ramus, and the dentary $(d$.$) gradually tapers forwards. The teeth in$ the anterior half of the mandible, so far as preserved, are much larger than those in its posterior half, which are best seen on the right side. All are smooth, acutely pointed, and inclined a little backwards. Part of a comparatively deep suboperculum (s.op.) is preserved; the uppermost branchiostegal ray $(b r$.$) is shown to be rather$ large, but the others, not less than 14 in number, are only imperfectly indicated; the gular plate (gu.) wants merely its anterior end.

Egerton Coll.

P. 640. Another imperfect head, displaying the hinder part of the cranial roof (Pl. III. fig. 2), remains of the characteristic cheek-plates, and part of the opercular apparatus. This specimen is labelled Eurygnathus cavifrons by Agassiz, and was intended by him to be the type of the species. The robust supraoccipital (s.occ.), with a posterior keel, is well shown at the back of the cranial roof, articulating with the large epiotic (epo.) on either side. The frontals $(f r$. are shown to extend close to this occipital border; they are bounded on either side in their hinder portion by membrane-bones which seem to be identifiable as squamosal (sq.), but the parietals cannot be recognised with 
certainty. The postfrontal or sphenotic ( $p t_{.} f$.) projects a little on each side and can be seen from abore. Remains of the cheek-plates (s.o.) on both sides are very delicate, and exhibit the characteristic radiating markings. The jaws are too imperfect for description, but one of the characteristic hinder mandibular teeth is seen. The operculum, though fragmentary, is shown to have been deeper than broad; while the preoperculum. must clearly have been very little expanded at its angle. Of the gular plate only the hinder end is preserved.

Eyerton Coll.

Genus SPAINIODOIN, Pictet.

[Poiss. Foss. Mt. Liban, 1850, p. 33.]

Syn. Lewisia, J. W. Davis, Trans. Roy. Dublin Soc. [2] vol. iii. 1887,

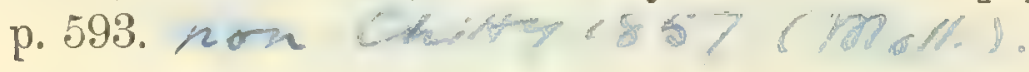

Trunk elongated and laterally compressed, abdomen trenchant. Cheek-plates robust, exhibiting radiating branches from the slimecanal; jaws toothless, except the anterior end of the mandible, which bears one or two pairs of large conical teeth. Branchiostegal rays at least 15 in number. Vertebral centra strengthened by a few longitudinal ridges; ribs rery delicate and nearly straight. Pectoral fins large and pelvic fins smaller, these opposed to the hinder end of the dorsal or slightly behind it; anal fin remote, small and not much extended; caudal fin deeply forked. No enlarged scale at the base of the paired fins; no enlarged ridgescales.

The skeleton of this fish is so delicate that it is usually distorted in the fossils. It is thus rery difficult to distinguish the species, which seem to differ from each other only in their general proportions and in the relative length of the vertebral centra.

\section{Spaniodon blondeli, Pictet.}

[Text-figure 4.]

1850. Spaniodon blondelii, F. J. Pictet, Poiss. Foss. MIt. Liban, p. 34, pl. v. figs. $2-4$.

1887. Spaniodon blondelii, J. W. Daris, Trans. Roy. Dublin Soc. [2] vol. iii. p. 587, pl. xxxiv. fig. 3.

(?) 1887. Spaniodon electus, J. W. Davis, ibid. p. 589, pl. xxxiv. fig. 2. [Nearly complete fish; Edinburgh Museum.]

Type. Imperfect fish; Geneva Museum.

The type species, attaining a length of about $0 \cdot 2$. The maximum depth of the trunk equals about two thirds of the length of the 

head with opercular apparatus, which is contained slightly more than twice in the length of the trunk from the pectoral arch to the base of the caudal fin. Vertebræ about 55 in number, somewhat more than half of them in the abdominal region; the centra as long as deep in the abdominal, relatitely longer in the caudal region. Pectoral fins with about 12 or 14 stout rays, all divided distally, and the foremost at least half as long as the head with opercular apparatus; pelvic fins not more than half as large as the pectorals, with 7 or 8 rays, arising opposite a point just behind the hinder extremity of the dorsal, not far from the remote anal fin; dorsal fin slightly deeper than long, with 15 or 16 rays, arising midway between the occiput and the caudal fin; anal fin much less elevated than the dorsal, with 15-16 rays, arising somewhat nearer to the pelvic pair than to the caudal fin, which comprises very stout rays. Scales smooth.

Form. \& Loc. Upper Cretaceous: Sahel Alma, Mount Lebanon.

49534. Fine specimen 0.19 in length, apparently not distorted but displaying the true proportions of the fish indicated in the specific diagnosis. One stout and slightly recurved tooth is preserved among the remains of the mandible.

Lewis Coll.

48069, P. 4749. Two equally large specimens somewhat distorted and with open mouth. In the second specimen there are parts of three enlarged teeth among the remains of the mandible; while some of the branchial arches are exposed, bearing very fine denticles on their anterior border. The squamation in both specimens is distinct. Lewis Coll.

P. 4788. Fine specimen about 0.17 in length.

Lewis Coll.

$46512-14,47355,48071,48075-76,48153$, P. 9163. Nine smaller and more imperfect specimens, variously distorted. No. 47355 might be interpreted as exhibiting two slender teeth in the premaxillæ smaller than those of the mandible, but the specimen is too much crushed and broken to be conclusive. In No. 48075 some of the hinder ribs seem to have been broken and repaired during the life of the animal.

Lewis Coll.

P. 9191. Fine specimen wanting the caudal fin. Immediately behind the head the triangular lower end of the preoperculum is shown, marked with radiating ridges; and the operculum is clearly narrow and deep. The neural spines are 


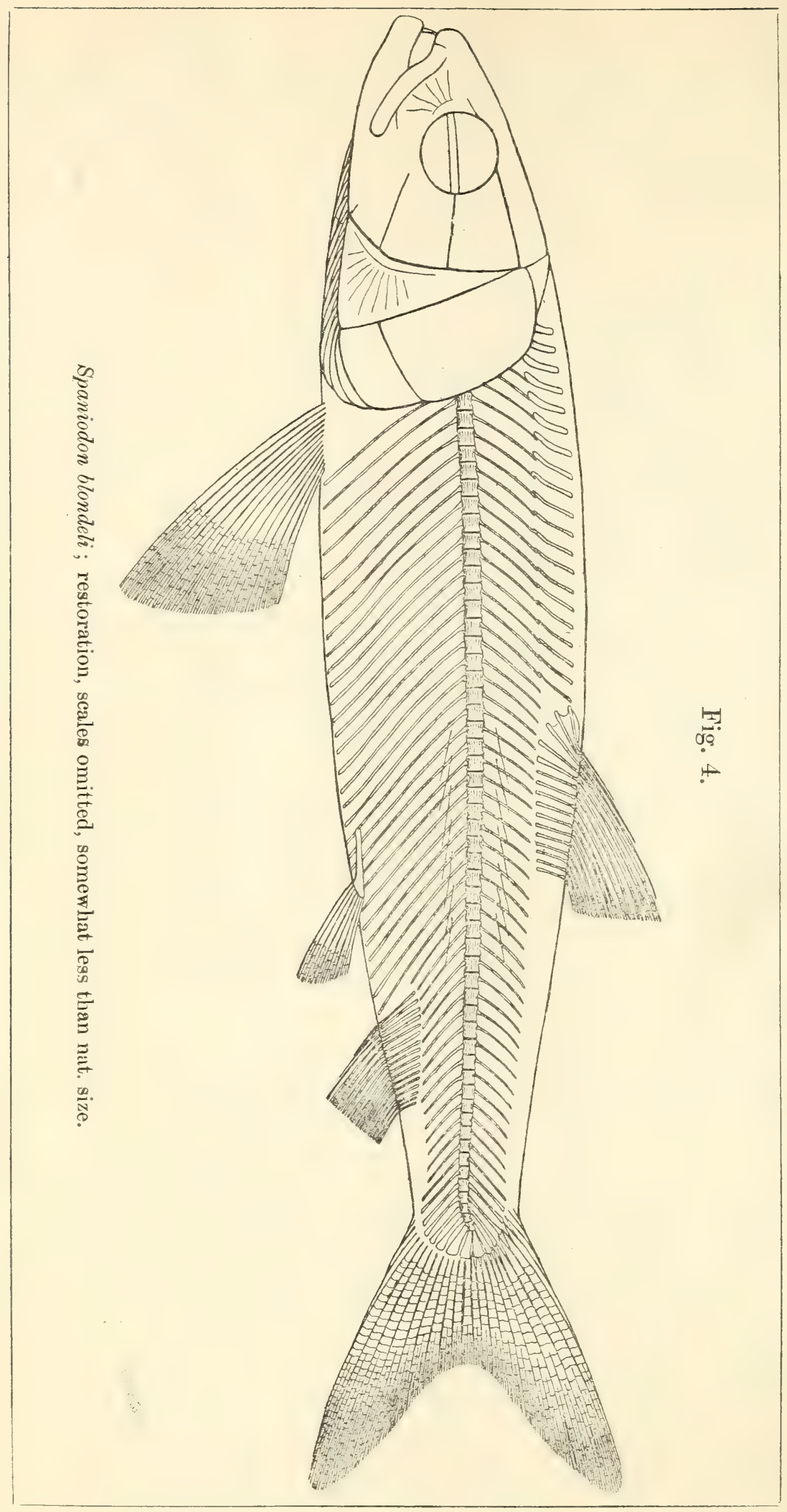




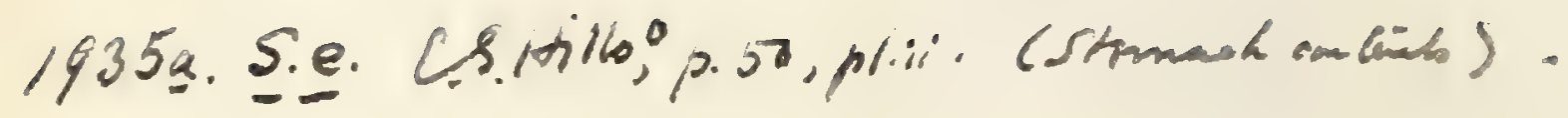


separable from the neural arches throughout the abdominal region, a few behind the head being excessively thickened, while those beyond are still comparatively stout and with a slight sigmoidal bend. There is an undigested fish between the ribs.

Lewis Coll.

47354, P. 4750, P. 4782 . Two slabs with various remains, and another slab with one small distorted fish associated with other genera and species.

Lewis Coll.

P. $915 \%$ Imperfect specimen.

Enniskillen Coll.

P. 187\%. Two imperfect small specimens.

Egerton Coll.

46509. Head with anterior abdominal region. A bone which seems to be the premaxilla is relatively small, and apparently extends slightly beneath the anterior end of the maxilla. The right ramus of the mandible is shown to bear one large slender conical tooth at the symphysial end, and a similar though smaller tooth further back. The anterior suborbital cheek-plate is relatively large and marked by radiating branches from the slime-eanal which traverses it.

Lewis Coll.

47350. Small trunk with fins.

Lewis Coll.

P. 9190. Mandible, hyoid arch, and branchiostegal apparatus of spaniodon, probably referable to S. blonrleti. The jaw is exposed from beneath and displays a relatively small gular plate.

Levis Coll.

Spaniodon elongatus, Pictet.

[Plate VII. fig. 3.]

1850. Spaniodon elongatus, F. J. Pietet, Poiss. Foss. MIt. Liban, p. 35, pl. vi. figs. 1,2 .

1866. Spaniodon elongatus, Pictet \& Humbert, Nouv. Rech. Poiss. Foss. Mt. Liban, p. 85, pl。 xii. figs. 1, 2.

1887. Spaniodon elongatus, J. W. Davis, Trans. Roy. Dublin Soc. [2] vol. iii. p. 588.

Type. Imperfect fish; Genera Museum.

A slender species, attaining a length of $0 \cdot 25$. Length of head with opercular apparatus twice as great as the maximum depth of the trunk, and equalling nearly half the length of the trunk from the pectoral arch to the base of the caudal fin. Vertebræabout 
55 in number, the centra more elongated than in the type species. Fins as in the type species:

Form. \& Loc. Upper Cretaceous: Sahel Alma, Mount Lebanon.

46521. Very large fish, partly shown only in impression, displaying the principal characters of the species. Lewis Coll.

P. 1878. Specimen about 0.2 in length.

Egerton Coll.

480\%. An equally large specimen displaying the head, which is shown of the natural size in PI. VII. fig. 3. The head is exposed from the left side, and is a little obliquely crushed so that the imperfect left mandibular ramus is displaced upwards. The cranium is shown to be elongated and depressed, with a straight basicranial axis. The pterygoquadrate arcade is shown to be delicate and apparently toothless; while the mandibular suspensorium is almost vertical, though arched, and the articular end of the mandible is beneath the back of the head. The front half of the left facial region is broken away, so that the characteristic maxilla of the right side is partly exposed from within, and there seem to be traces of a very short premaxilla at its anterior end. Above the maxilla ( $m x$.) the large antorbital cheek-plate is seen (a.o.), partly fractured and displaying the radiating branches from the slime-canal. Below the maxilla, adjoining the remains of the mandible $\left(d_{0}\right)$, there is an impression of the large conical tooth at its symphysis. Between the mandibular rami the left ceratohyal is partly exposed; and the series of branchiostegal rays is well displayed on this side, about 15 in number. Immediately behind the mandibular suspensorium, the preoperculum ( $p_{0.0 p}$ ) is well preserved, with a large triangular expansion at its lower end, marked with a few radiating branches of the slime-canal; but the operculum and subopereulum behind are too much crushed and fractured for recognition. Just behind the operculum there are traces of the thickened anterior neural spines.

Lewis Coll.

P. 595\%. Another large specimen apparently elongated by distortion.

Lewis Coll.

44831, 46516, 46519-20. Four nearly complete fishes. Lewis Coll. 
• 
Pramioden simus, 0.0. Hay, Bull. Ames. Hum. Hath. Fioh. rol. xix (1903), h.47, hliv.tige.1,2. 
48072. Head and part of abdominal region of a large specimen, displaying the very large tooth at the symphysis of the mandible and a smaller tooth further back. Lewis Coll.

\section{Spaniodon latus (Agassiz).}

1844. Clupea lata, L. Agassiz, Poiss. Foss. vol. v. pt. ii. p. 118, pl. 1xi. fig. 10.

1850. Clupea lata, F. J. Pictet, Poiss. Foss. Mt. Liban, p. 37, pl. vii. fig. 1.

1866. Spaniodon brevis, Pictet \& Humbert, Nouv. Rech. Poiss. Foss. Nit. Liban, p. 86, pl. xii. figs. 3, 4. [Imperfect distorted fish ; Geneva M[useum.]

1887. Spaniodon brevis, J. W. Davis, Trans. Roy. Dublin Soc. [2] vol. iii. p. 592, pl. xxxiv. fig. 1.

1887. Lewisia ovalis, J. W. Davis, ibid. p. 593, pl. xxxiii. fig. 6 . [Nearly complete fish; Edinburgh Iruseum.]

1899. Spaniodon brevis, A. S. Woodward, Ann. Mag. Nat. Hist. [7] vol. iv. p. 319.

Type. Imperfect distorted fish; olim Alex. Brongniart Collection.

A. somewhat smaller and stouter species than the type, with relatively shorter caudal vertebræ and deeper caudal pedicle. The total number of vertebræ seems to be about 50 , and the length of the head with opercular apparatus scarcely exceeds the maximum depth of the abdominal region.

Form. \& Loc. Upper Cretaceous: Sahel Alma, Mount Lebanon.

P. 7811. Distorted fish, described and figured by J. W. Davis, loc. cit.

Davis Coll.

48074. Fine specimen apparently not much distorted, but wanting the cranium. The supports of 16 rays are seen in the dorsal, 14 in the anal fin. V-shaped intermuscular bones occur in the anterior part of the abdominal region just below the vertebræ.

Lewis Coll.

$46398,46508,46515,47348-49$, P. 4787. Six imperfect and distorted specimens apparently of this species. Lewis Coll.

P. 1879. Three fragments.

Egerton Coll.

The following species has also been described but is not represented in the Collection:-

Spaniodon simus, E. D. Cope, Bull. U.S. Geol. Surv. Territ. vol. iv. (1878) p. 69.-Upper Cretaceous; Dakota. [Imperfect fish ; Cope Collection.] 
The so-called Spaniodon lepturus (W. ron der Marck, Palæontogr. vol. xli. 1894, p. 46, pl. v. fig. 5), from the Upper Cretaceous of the Baumberg, Westphalia, now in the Academy of Muinster, does not belong to this genus or even to the same family.

Genus THRISSOPTEROIDES, W. von der Marck.

[Palæontogr. vol. xxij. 1873, p. 61.]

Almost identical with Spaniodon, but the dorsal fin comparatively remote and opposed to the space between the pelvic and anal fins. The arched maxilla bearing a regular close series of minute teeth; a pair of enlarged teeth at the symphysial end of the mandible.

Thrissopteroides elongatus, W. von der Marek.

1873. Thrissopteroides elongatus, W. von der Marck, Palæontogr. vol. xxii. p. 61, pl, ii. fig. 3.

Type. Impression of nearly complete fish; Academy of Münster. The type species, attaining a length of about $0 \cdot 2$. I,ength of head with opercular apparatus twice as great as the maximum depth of the trunk, and contained about three times in the length of the trunk from the pectoral arch to the base of the caudal fin. Vertebræ approximately 70 in number, about 18 being caudal. Pectoral fins large, with at least 11 rays, the longest two thirds as long as the head with opercular apparatus; pelvic fins not more than half as large as the pectorals, arising considerably behind the middle point of the trunk; dorsal fin completely opposite the space between the pelvic and anal fins.

Form. \& Loc. Upper Cretaceous: Westphalia.

Not represented in the Collection.

Thrissopteroides latus, W. von der Marck.

1873. Thrissopteroides latus, W. von der Marck, Palæontogr. vol.xxii. p. 62, pl. ii. fig. 5 .

Type. Nearly complete fish; Academy of Münster.

A species about as large as the type, of comparatively stout proportions, the maximum depth of the trunk contained about four times in its length from the pectoral arch to the base of the caudal fin. Pectoral fins very large, with about 17 rays, the foremost undivided; pelvic fins about half as large as the pectorals, with 9 rays, the foremost undivided; dorsal fin comprising 3 undivided 
1954. I.E. P. Sugfied, Pataunhogr 106 A p. 10. plit \%. a

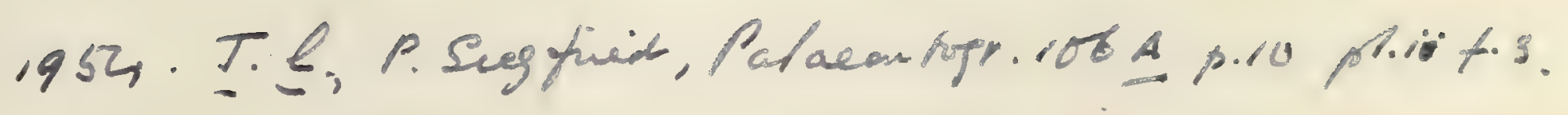




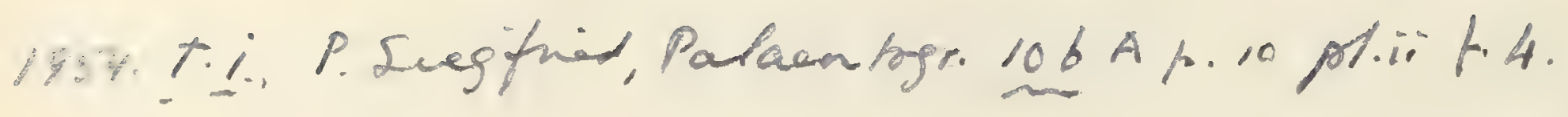


rays increasing in size and then 14 divided rays, the whole completely opposite the space between the pelvic and anal fins; anal fin with two small undivided rays, a larger undivided ray, and then 15 divided rays.

Form. \& Loc. Upper Cretaceous: Westphalia.

Not represented in the Collection.

Thrissopteroides intermedius, W. von der Marck.

1885. Thrissopteroides intermedius, W. von der Marck, Palæontogr. vol. xxxi. p. 258, pl. xxir. fig. 2.

Type. Nearly complete fish; Academy of Münster.

A comparatively robust species about as large as the type. Length of head with opercular apparatus less than twice as great as the maximum depth of the trunk and contained scarcely more than twice in the length from the pectoral arch to the base of the caudal fin. Vertebræ approximately 60 in number, 16 being caudal. Dorsal and anal fins apparently slightly less extended than in the last species.

Form.\& Loc. Upper Cretaceous: Westphalia.

Not represented in the Collection.

Thrissopteroides tenuiceps, A. S. Woodward.

1887. Chupea elongata, J. W. Davis, Trans. Roy. Dublin Soc. [2] vol. iii. p. 581, pl. xxxiii. fig. 2.

1898. Thrissopteroides tenuiceps, A. S. Woodward, Ann. Mag. Nat. Hist. [7] vol. ii. p. 408.

Type. Fish, distorted anteriorly; Edinburgh Museum.

A small species, attaining a length of about $0 \cdot 1$. Length of head with opercular apparatus twice as great as the maximum depth of the trunk, and contained about two and a half times in the length of the trunk from the pectoral arch to the base of the caudal fin. Vertebræ approximately 60 in number, about 18 being caudal. Pelvic fins arising considerably behind the middle point of the trunk; dorsal fin, with about 12 or 14 rays, directly opposed to the space between the pelric and anal fins; anal fin comparatively low and delicate, with about 15 rays.

Form. \& Loc. Upper Cretaceous: Mt. Lebanon.

49592. A larger example than the type specimen slightly elongated by distortion, noticed loc. cit. 1898, p. 408; Sahel Alma. Part of the displaced left maxilla is seen from within, 
exhibiting its regular series of minute teeth; and the right dentary is observed to bear its enlarged tooth at the symphysis. Cycloid scales are well preserved.

Lewis Coll.

P. 4736. Slightly smaller specimen than the type, elongated by distortion; Sahel Alma.

Lewis Coll.

\section{Thrissopteroides pulcher (Daris).}

1887. Clupea putchra, J. W. Davis, Trans. Roy. Dublin Soc. [2] vol. iii. p. 578, pl. xxxiii. fig. 3.

1898. Thrissopteroides pulcher, A. S. Woodward, Ann. Mag. Nat. Hist. [7] vol. ii. p. 408.

Type. Nearly complete fish; Edinburgh Museum.

A very small species, attaining a length of about 0.07 . Length of head with opercular apparatus not much exceeding the maximum depth of the trunk and contained nearly three times in the length from the pectoral arch to the base of the caudal fin. Vertebræ and fins as in the last species.

Form. \& Loc. Upper Cretaceous: Mt. Lebanon.

P. 9164. A typical specimen, showing the finely denticulated maxilla crushed upon the mandible; Sahel Alma. The characteristic antorbital cheek-plate can be imperfectly seen.

Lewis Coll.

The following specimens are not specifically determined:-

46522, 47809. Two imperfect fishes about $0 \cdot 17$ in length, with pelvic fins opposite origin of dorsal fin ; Upper Cretaceous, Sahel Alma, Mt. Lebanon.

Lewis Coll.

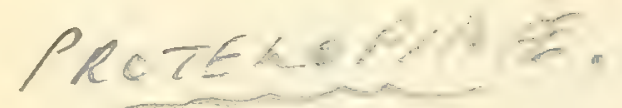

Genus PROTELOPS, Laube.

[Denkschr. k. Akad. Wiss., math.-naturw. Cl. vol. 1. 1885, p. 286.]

An imperfectly known genus. Cleft of mouth nearly horizontal and gape extending at least as far as the hinder border of the orbit. Teeth of moderate size, not in sockets but fused with the supporting bone, and each comprising a long, slender, hollow base tipped by a relatively small enamelled crown; these teeth more or less uniform in size on each bone, and arranged in two or more series on the border of the mouth and the pterygo-palatine arcade. 
47809 seem, to the a Thaniodon. Purkt? 876 .

Thissophervider? minutur. FPriem in F. de Morpan, Délépation en Buse. - Aum. d'thidh. rat. vol. ' (19,08), h. 6, pli. fir. 5, 6. - Ul. Cretaceons: Peraia. [omperfeit grish.]

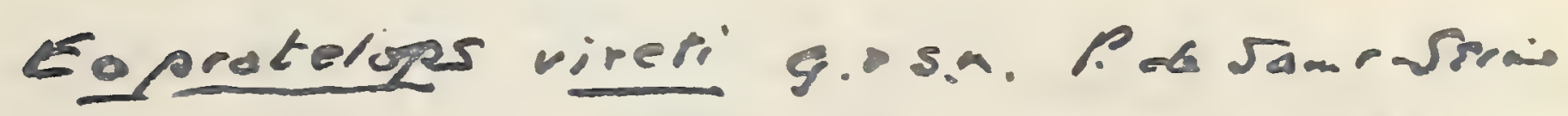

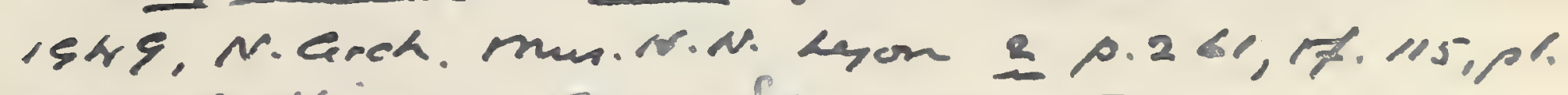

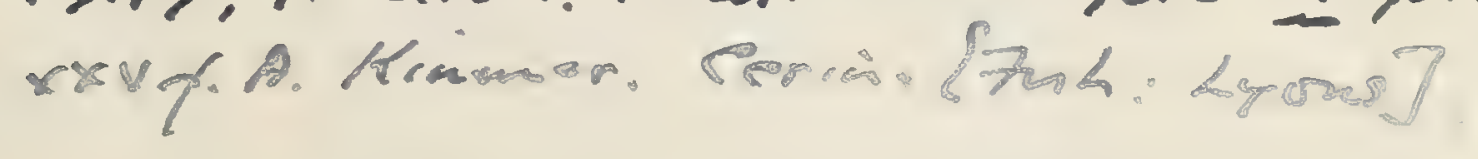


1908. Rostelops anglieus, A. T. Loordwand, Ans. Fisher Englits Chelte (S2l. Sh.), h.13), hl. xxix. fie.l, 2 .

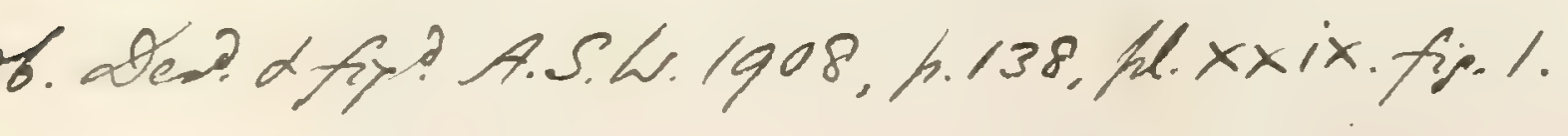

49780. Des? a fig? A.S.W. 1908, fr. 138, plexix.fis. 2.

Sea Chanos leopoldi, h.65. 


\section{Protelops geinitzi, Laube.}

1885. Protelops geinitzii, G. C. Laube, Denkschr. k. Akad. Wiss., math.natur'w. Cl. vol. l. p. 286, pl. i. fig. 1, and woode.

Type. Natural mould of fish, wanting tail; Geological Nuseum, German University, Prague.

The type species, known only by the type specimen. Length of head with opercular apparatus considerably exceeding maximum depth of trunk. Teeth on margin of jaws scarcely curved, those of dentary bone in four longitudinal series.

Form. \& Loc. Turonian: Bohemia.

P. 5734. Plaster cast of type specimen, described and figured by Laube, loc. cit.; Turonian, Weissen Berg, near Prague.

Purchased, 1888.

Protelops anglicus, A. S. Woodward.

1888. Stratodus anylicus, A. S. Woodward, Proc. Geol. Assoc. rol, x. p. 314, pl. i. figs. 3, 4 .

Type. Imperfect jaws; British Museum.

A species larger than the type, known only by fragments of jaws. Teeth of maxilla (? or palatine) slightly curred. Teeth of dentary in two longitudinal series.

Form. \& Loc. Turonian: Sussex.

49906. The type specimen, being imperfect remains probably of the maxilla, associated with other fragments; Lower Chalk, Glynde, Sussex. Part of the dentition is figured, loc. cit. pl. i. fig. 3.

Capron Coll.

49780. Imperfect left dentary showing bases of two series of teeth, figured loc. cit. pl. i. fig. 4, associated with part of the right dentary; Lower Chalk, Southeram, near Lewes.

Capron Coll.

The fishes described under the following names also probably belong to the family Elopidæ, but are not known by sufficiently perfect specimens for precise determination. They are not represented in the Collection.

1855 -0 0.G. Conca, 1/t. fors. 1tak. p.45, poiv.

Caeus leopoldi, O. G. Costa, Atti Accad. Pontan. vol. viii. (1864), p. 65, pl.x.; F. Bassani, Denkschr. k. Akad. Wiss., math.naturw. Cl. vol. xlv. (1882), p. 243.-Upper Cretaceous; Pietraroja, Province of Benevento, Italy. [Nearly complete fish; Geological Museum, Unicersity of Naples.]

Cucus, n.g. O.G. Costa 1857. Mem.r. Ace. Sci. Nap. II, p.235. 
Hemielopopsis gibbus, D. G. Kramberger, Soc. Hist. Nat. Croatica, vol. i. (1886), p. 128, and Rad Jugoslav. Akad. vol, eri. (1891), p. 67, pl. viii. fig. 3.-Cretaceous; Isle of Lesina, Dalmatia. [Imperfect fish; Museum of Imperial Geological Survey, Vienna.]

Hemielopopsis gracilis, F. Bassani, Verhandl. k.-k. geol. Reichsanst. 1879, p. 166, and Denkschr. k. Akad. Wiss., math.-naturw. Cl. vol. xlv. (1882), p. 216, pl. vi. fig. 3.-Ibid. [Imperfect fish; Geological Museum, University of Vienna. Probably generically identical with Histialosa.]

Hemielopopsis suessi, F. Bassani, loc. cit. 1879, p. 166, and loc.cit. 1882 , p. 215 , pl. v.; D. G. Kramberger, Rad Jugoslav. Akad. vol. lxxii. (1885), p. 29, and vol. cri. p. 66, pl. i. fig. 12. - Ibid. [The type species. Imperfect fish; Museum of Imperial Geological Survey, Vienna. Probably generically identical with Histiclosa.]

Histialosa thiollicri, P. Gervais, Ann. Sci. Nat. [4] Zool. vol. iii. (185̄5), p. 322, pl. iv. fig. 2.-Lower Cretaceous; Beaufort, Drôme. [Imperfect fish.]

Hypsospondylus bassanii, D. G. Kramberger, Rad Jugoslar. Akad. rol. Ixxii. (1885), p. 31, pl. v. fig. 1, and Soc. Hist. Nat. Croatica, rol. i. (1886), p. 130.-Cretaceous; Isle of Lesina, Dalmatia. [The type species. Imperfect fish; Geological M[useum, University of Agram.] D' Camo íqub p.6? Hyptius sebasticni, O. G. Costa, Atti Accad. Pontan. vol. vili. (1864), p. 80, pl. xi. figs. 6, 13, 14: Sauropsidium graciticauda, O. G. Costa, Toc. cit. vol. viii. (1864), p. 60, pl. ix. fig. 2. Prohably identical with Sauropsidium lcevissimum, as remarked by F. Bassani, 7oc. cit. 1882, p. 243.-Upper Cretaceous; Pietraroja. [Imperfect fish; Geological Museum, University of Naples.]

Sauropsidium leevissimum, O. G. Costa, loc. cit. vol. v. (1850), p. 322, pl. vi. fig. 1, and vol. viii. Append. (1864), pp. 96, 126, pl. vi. fig. 5; F. Bassani, Toc. cit. 1882, p. 241. Non O. G. Costa, loc. cit. vol. vii. (1853), p. 12, pl. i. fig. 1.Upper Cretaceous; Pietraroja. [The type species. Imperfect fish ; Geological Museum, University of Naples.]

Indeterminable detached scales from the Turonian of Saxony and Bohemia, perhaps mostly referable to fishes of the family Elopidx, have been described under the following names:-

Acrogrammatolepis steinlai, H. B. Geinitz, Denkschr. Ges. für Naturk. etc. Dresden z. Feier 50 jähr. Bestehens, 1868, p. 47 , pl. ii. fig. 23. 


It.pither, G. Y'Erasmo, Dalaent. Italiea, rdexxi(1915), th.

2q. pl.v. five 1-2.

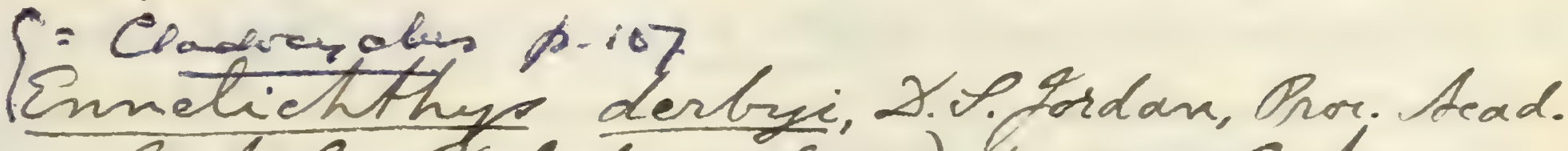
hat. Fai Shilad. 1919 (1920), \%.208. - Cretaceons; Barra do Lardimm ceará Bragil. Efterle. I.

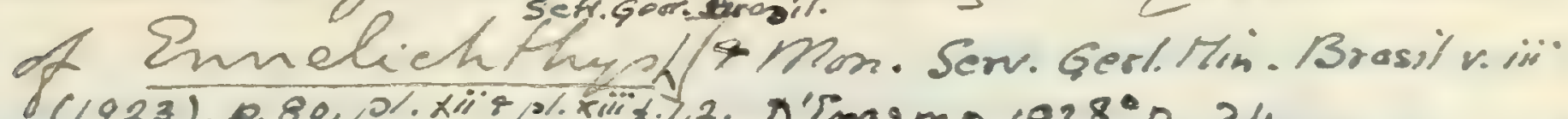

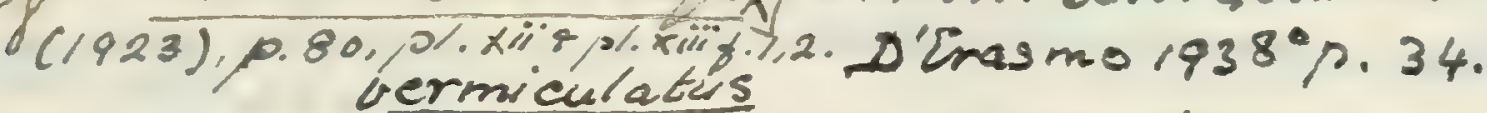

Helminitotepis, T.D.A.Cockerell, Brff. a,oers U.S. Geot

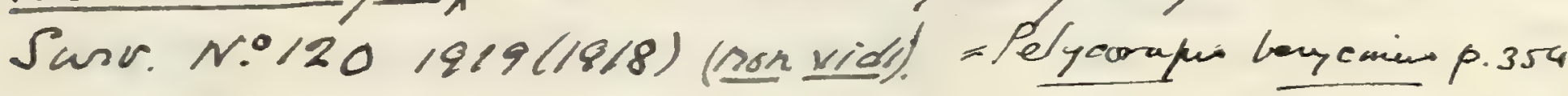

Enneles audax, D.J. Tordan, Smits. Misce Contri rol lï croog

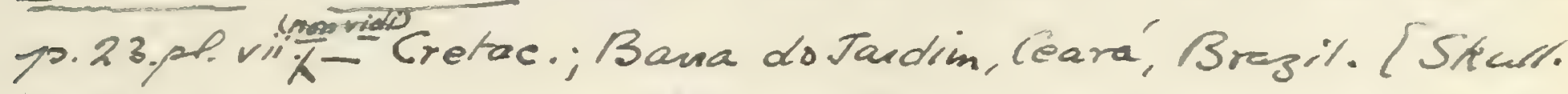

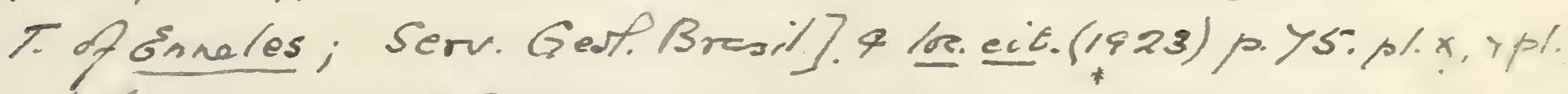

seep. 18

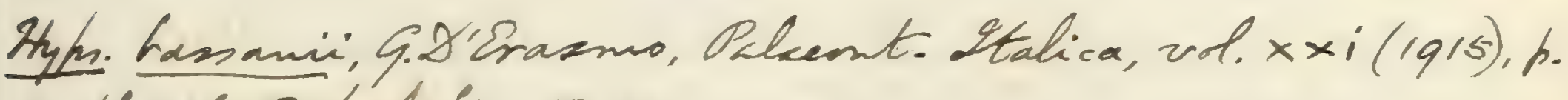
31, h. v. fij. 3 . Lest. fip. $28-31$.

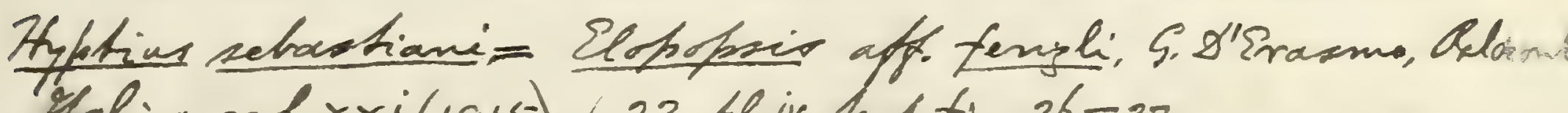

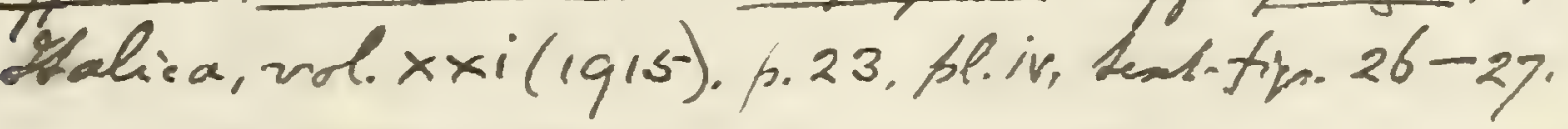

Browweria striata, B.robusta."

Suuropzidium lovissinum, G.D'Erasmo, Pakent. Italica, vd.xxi(1915), p.18, hl. iii. Lexh-fir. 23-2s-

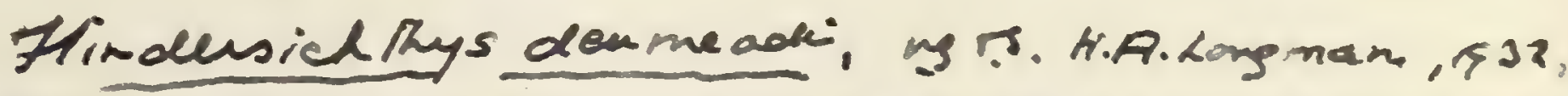

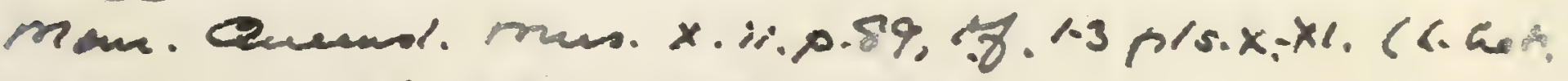

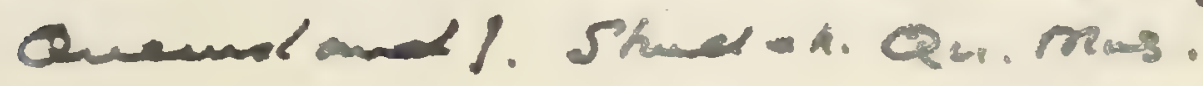

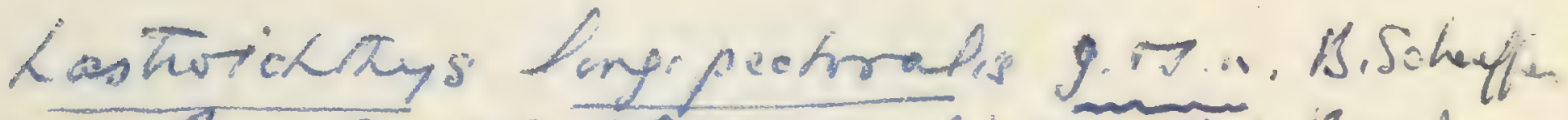

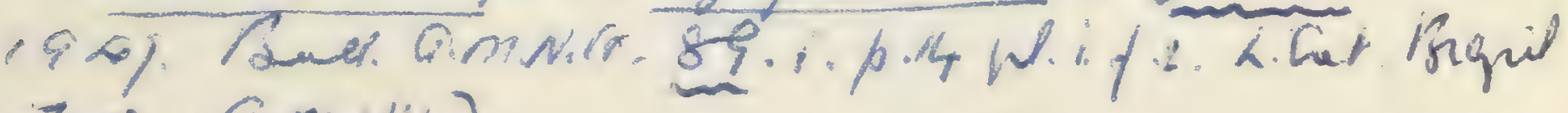
Ins. A.MN Nit.] 
Scaine $\rightarrow 10 \Rightarrow$

peconis' (

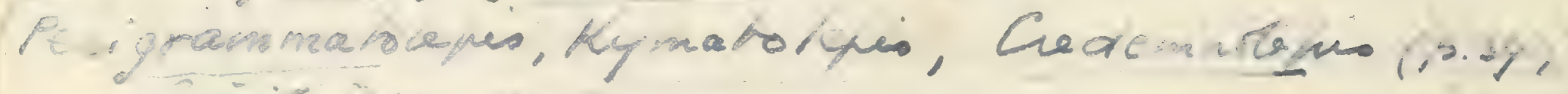
yeini's ind p. s9. ( A. a.)

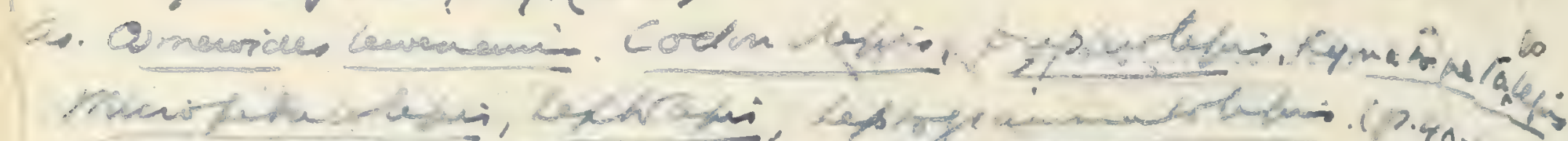

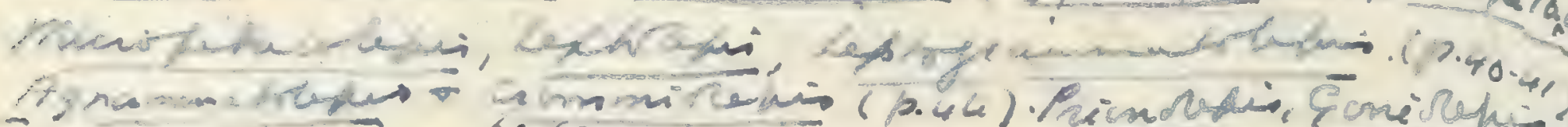

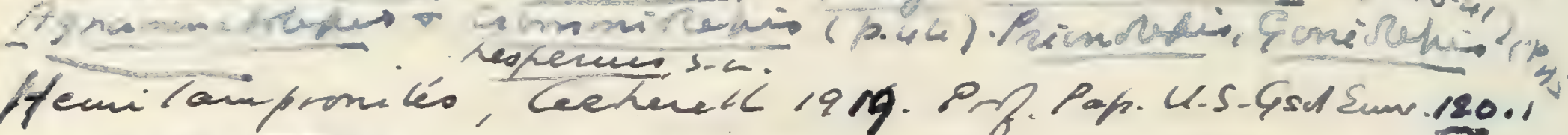

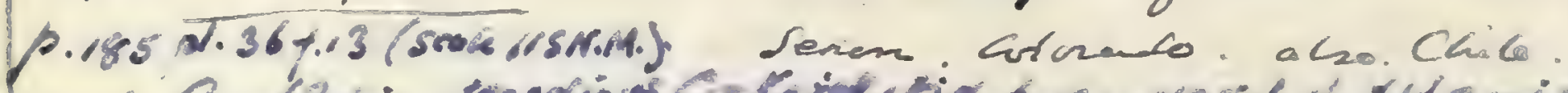

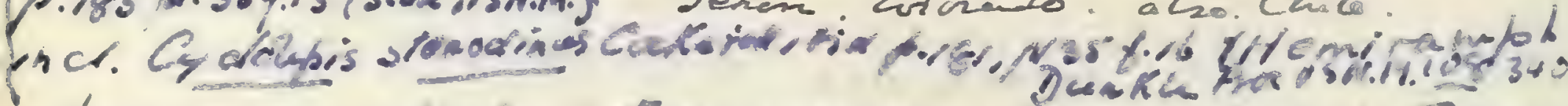

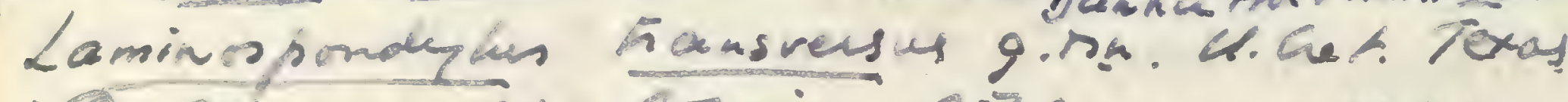

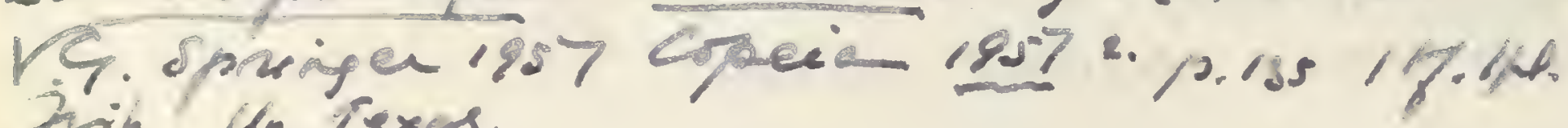
hin. Un. rexos.

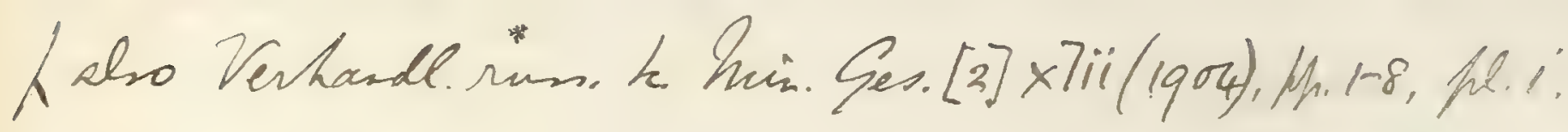

Geloider? incertur. J.D. A. Cockerell, Amer. Crat.

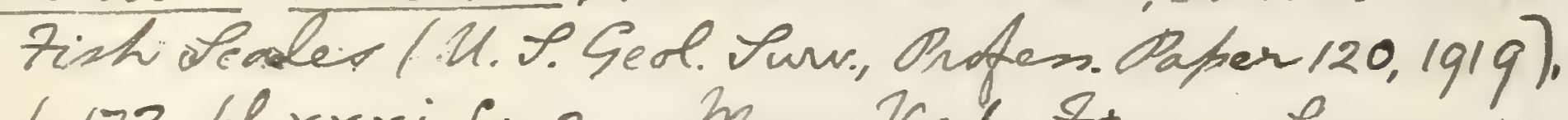
p.173, pl. xxxi.fis.2. - Mexa Verde Form.; Pyeamore. Wyoming. [Scale; U. S. Geol. Surv.]

Gumatopetalolepir geinit3i, 7.D. A. Corkerell

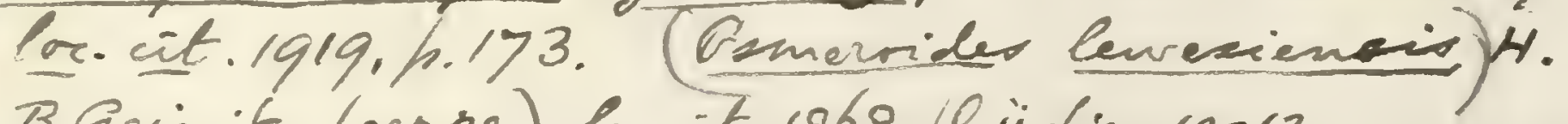
B. Geinit (errne), Po.cit.1868, hlii.fip.10-12. 




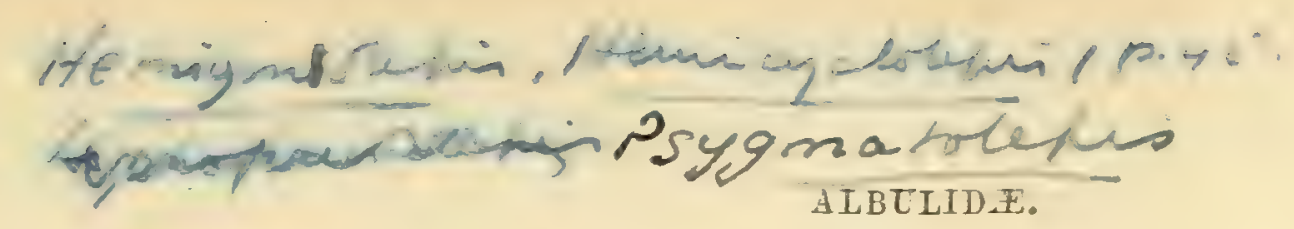

Aspidolepis steinlai, H. B. Geinitz, ibid. p. 40, pl. ii. figs. 3-6; A. Fritsch, Rept. u. Fische böhm. Kreideform. (1878), p. 35 , fig. 60 .

Cyclotepis agassizi, H. B. Geinitz, ibid. p. 39, pl. ii. figs. 1, 2 (=Autolepis reussi, H. B. Teinitz, Quadersandsteingeb. 1849, p. 86); A Fritsch, op.cit. (1878), p. 34, fig. 5\%. Hemicyclus strehtensis, H. B. Geinitz, ibid. p. 44, pl. ii. fig. 19. -p.274\%.3. Hemilampronites steinlai, H. B. Geinitz, ibid.p. 48, pl. iii. figs. 3, 4 . Osmerolepis reticulata, A. Fritsch, Archiv naturw. Landesdurchf. Böhmen, vol. ix., Geol. no. 1 (1893), p. 70, fig. 38.

Indeterminable cycloid scales have also been described thus:-

Cycloides incisus, T. C. Winkler, Archiv. Mus. Teyler, vol. iv. (1876), p. 3, pl. i. fig. 2.-Lower Eocene (Heersian); Limbourg, Belgium.

Lyiolepis caucusicus, G. Romanorsky, Verhandl. russ.-kais. Min. Ges. [2] rol. xxii. (1886), p. 305.-Lpper Cretaceous;

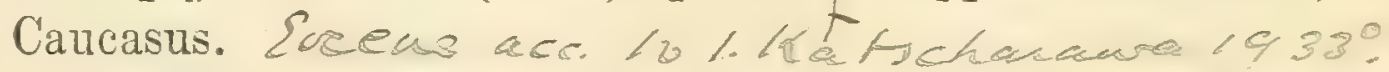

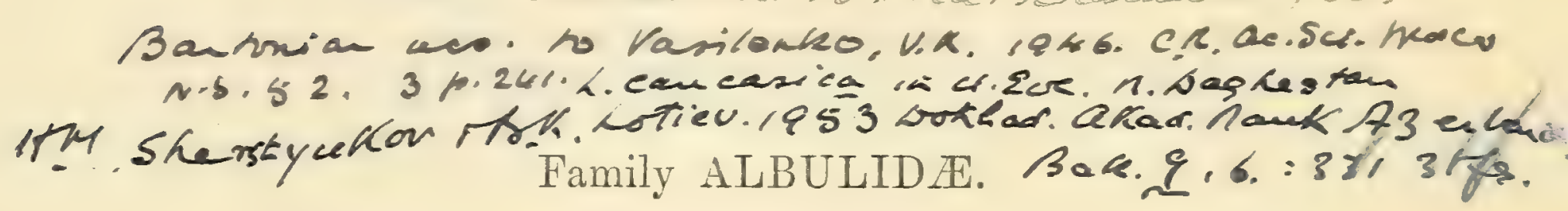

Supraoccipital bone not prominent, but sometimes separating parietals in the middle line; squamosals suturally united with parietals, and completely corering the otic region, except behind; snout not much produced; cheek-plates well dereloped. Nandibular suspensorium much inclined forwards and gape of mouth small; premaxilla small and maxilla relatirely large, both entering the upper border of the mouth; marginal dentition feeble or absent. Opercular apparatus complete, with tendency to reduction of branchiostegal rajs, and no gular plate. Vertebral centra well ossified, none with transrerse processes; ribs nearly encircling the abdominal cavity; hæmal arches more or less fused at the base of the tail. Fin-fulcra absent. Dorsal fin nearly median, sometimes much extended; no adipose dorsal. Scales thin, cycloidal and deeply imbricating, none extending orer the head; lateral line conspicuous.

$$
\text { Synopsis of Genera. }
$$

I. Dorsal fin short-based.

Parasphenoid, entopterygoid, and tongue with large crushing teeth; premaxilla, romer, and palatines with minute pointed teeth; parietal bones meeting in middle line.... Albula (p. 60). 
No inner crushing teeth: a fer stout conical

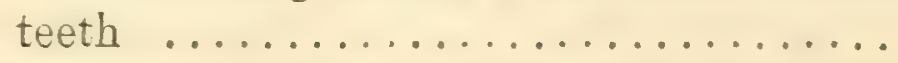

Teeth absent; parietal bones small and separated by supraoccipital; a scaly lamella at the base of each lobe of the tail .......

Teeth absent; no scaly lamella at the base of

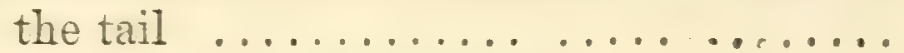

II. Dorsal fin more or less extended.

Chanoides (p. 68).

Chanos (p. 61).

Prochanos (p. 65).

Trunk deepened; jaws toothless; dorsal fin in hinder half of back ............. Ancylostylos (p.66).

Trunk elongated; minute teeth in single series on margin of jaws, stouter teeth within; dorsal tin occupring greater part of back. Istieus (p. 66).

As Istieus, but maroinal teeth apparently clustered...................... Anogmius (p. 71).

Genus ALBULA (Gronow), Bloch \& Schneider. [Sjst. Ichthyol. 1801, p. 432.]

Șn. Butyrinus, B. G. E. de Lacépède, Hist. Nat. Poiss. rol. r. 1s03, p. 45.

Glossodus, Curier, in Agassiz and Spix, Pisc. Brasil. 1829, p. 48.

Pisodus, R. Owen (ex Agrassiz, MS.), Odontogr. 1845, p. 138.

Trunk somewhat laterally compressed, and abdomen flattened. Snout pointed, and mouth not quite terminal ; dentary, premaxilla, romer, and palatines with clusters of minute pointed teeth; parasphenoid, entopterygoid, and tongue each with a patch of comparatirely large, closely-arranged tritoral teeth; maxilla toothless. Gill-rakers short and tubercular; branchiostegal rajs about $1 \pm$ in number. Tertebræ in the type species 43 in the abdominal, 25 in the caudal region. Pelric fins opposed to the dorsal, which is shortbased, but much larger than the anal; caudal fin deeply forked. Scales of moderate size, not pectinated.

One species of this genus survires in nearly all tropical and subtropical seas. The osteology of the head is $\pi$ ell described and figured by R. W. Shufeldt, Ann. Rep. U.S. Commiss. Fisheries, 1883 (1885), p. 808, pl. xii., pl. xiii. figs. $30,31$.

\section{Albula oweni (Owen).}

\section{[Plate IV.]}

1811. Pisodus ouvenii, L. Agrassiz, Poiss. Foss. rol. ii. pt. ii. p. 247 (name only).

o' 184. Pisodus owenii, R. Owen, Odontogr. p. 138, pl. xlvii. fig. 3.

185̃t. Pisodus ouenii, R. Oren, Cat. Foss. Rept. \& Pisces Mus. R. Coll. Surgeons, p. 167.

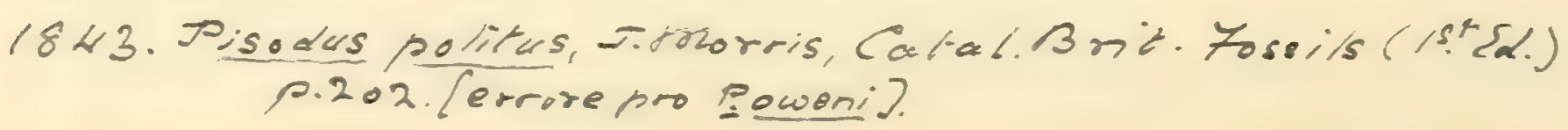


HAJULIA D.S.W 1842.

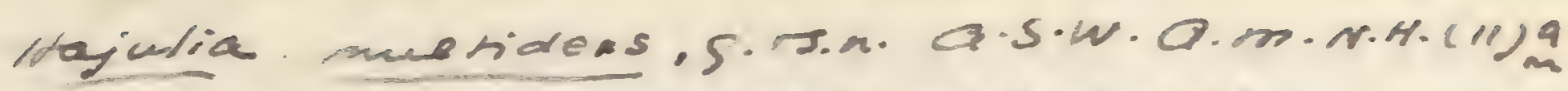

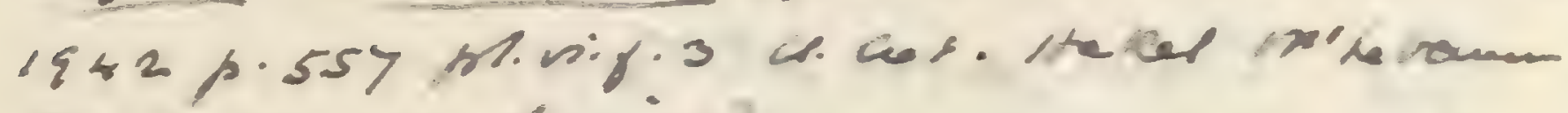
[orst. Am. san. Berrie?.

1973 H. multidens, P.L.Fores, BuU.BM(Gest) Sappl.co,p. 152

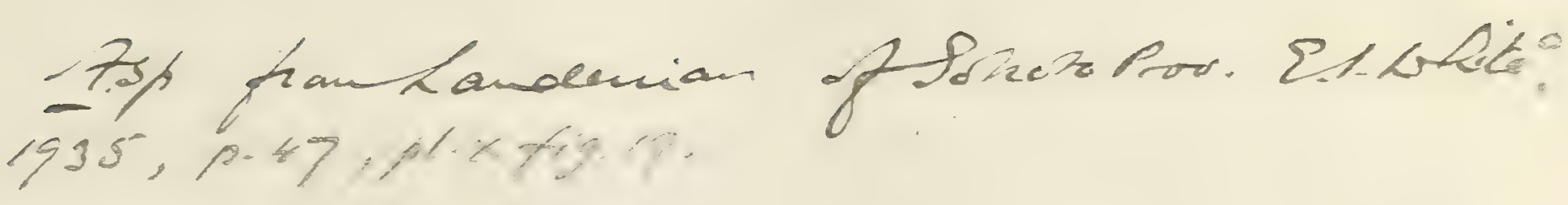


1908, Altula (Piscdur) oweni; 7. Priem, Poiss. Fors.

Bissin Parisien (Publ. Am. Palént.), 1.82, he.11-12, Lect-fip. 38. [Jeeth from Thane tian, Marme, Brame.] 1046. A. O. Casui p.122 M. ito N.12.

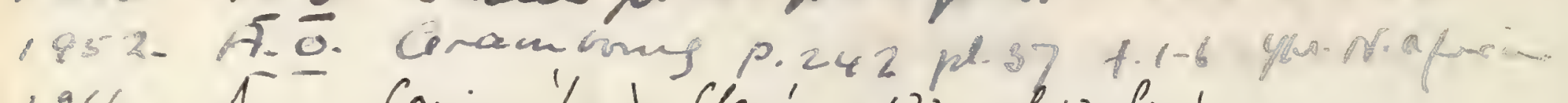

1966 A.0 Casier, London Clay', p.133, pl 13, fig.t

1973 A.0 , P.L. Forcy, BulbM(ger.) Suppl.co, figs 85.87 
1891-93. Pisodus oweni, A. S. Woodward, Geol. Mag. [3] vol, viii. p. 108, pl. iii. figs. 3-5, and Ann. Mrg. Nat. Hist. [6] rol. xi. p. 357, pl. xvii.

Type. Parasphenoid dentition; Royal College of Surgeons, London.

The type species of the so-called genus Pisodus, of large size, the head sometimes attaining a length of $0 \cdot 3$. Too imperfectly known to be precisely defined, but differing from the sole existing species in the proportions of the cranium; the distance from the end of the snout to the anterior notch of the frontals being about equal to that from this notch to the occiput, whereas the proportion of the same measurements in the recent $A$. vulpes ${ }^{1}$ is $2: 3$. Rostrum thus comparatively large.

Form. \& Loc. Lower Eocene (London Clay): Sheppey. Similar tritoral teeth in Middle Eocene (Bruxellian): Brussels.

P. 9158. Head with opercular apparatus, remains of the pectoral arch, and fragmentary scales; London Clay, Sheppey. The skull measures about 0.3 from the occiput to the end of the snout, and the cheek has a rery similar aspect to that of the recent species. The specimen is crushed obliquely, so that the roof of the cranium is shown entirely on the left side (PI. IV. fig. $1 a$ ), while the space below and behind the mandible, with some of the branchiostegal rays, appears on the right side (fig. 1). The whole of the fossil is permeated with pyrites, which may decay and eventually cause its destruction. (I) the cranium itself only the roof is exposed, but this is complete and merely a little fractured and in places obscured by pyrites. Behind the occiput the epiotic (ep.o.) is distinct on the leit side; the limits of the squamosals ( $s q$.$) , parietals ( p a$.$) ,$ and frontals $(f r$.$) are sufficiently clear. The postfrontal$ $(p t . f$.$) is also exposed a little, and the prefrontal ( p r . f$. still more on the cranial roof; and the form of the median depression in this roof is characteristically exhibited. The rostrum is comparatively long and slender, too imperfect for description; but the notch in the anterior border of the frontal is distinct on each side, this being situated about midway between the occiput and the end of the snout. Remains of the mandibular suspensorium and jaws are exposed on each side of the fossil; and the remarkably forward articulation of the mandible is well

1 See figure by Shufeldt, Rep. U. S. Fish Comm. 1883 (1885), pl. xiii. fig. 30. 
shown. The ossification of the hyomandibular is especially dense, as indicated by its upper end $(h \mathrm{~m}$.$) exposed on$ the right, and by its opercular process seen on the left side. The boundaries of the large, expanded metapterygoid (mpt.) are not completely shown; but its long anteroinferior border is exhibited in contact with the quadrate (qu.) on each side of the fossil. The latter element is very concave on its outer face immediately behind the articular condyle, and sends backwards a Jong process to clasp the symplectic, which is not clearly distinguishable, but seems to have been long and narrow. An excaration in the matrix on the left side has revealed a portion of bone bearing the characteristic Pisodus-teeth (x.), which may be entopterygoid. The maxilla $\left(m x_{0}\right)$ is fragmentary on both sides, and the premaxilla is destroyed; but the right mandibular ramus is well-displayed, showing the suture between the angular (ag.) and dentary (d.) bones. The articular facette for the quadrate condyle is remarkably concave; the bases of a cluster of minute teeth are vaguely indicated near the symphysis of the dentary. The sclerotic of the eye ( $\mathrm{scl}$. ) is ossified, and there are traces of cheekplates on the right side. The preoperculum (p.op.) is narrow and bent closely round the hinder border of the mandibular suspensorium. The operculum (op.) and suboperculum (s.op.) are much fractured on the right side, crushed inwards on the left; but it is evident that the former is not quite twice as deep as its maximum width, while the maximum depth of the latter equals somewhat more than half its width. The interoperculum is not, definitely identifiable; but the branchiostegal rays (br.) are well preserved on the right side to the number of nine or ten, though probably others are lost or obscured in front. Traces apparently of the basibranchial and robust hyoid bones project from the matrix below. The pectoral arch and large scales are too imperfect for description. Three short and deep rertebræ are indicated in section.

History unkinown.

39439. Imperfect cranium showing parasphenoid dentition, described and figured in Ann. Mag. Nat. Hist. [6] vol. xi. (1893), p. 357, pl. xvii.; Sheppey.

Bowerbank Coll.

30528. Fragmentary rostrum, shown of one half the natural size from the palatal aspect in Pl. IV. fig. 2; Sheppey. Abraded 
$502+8-2$ 
remains of the anterior end of the parasphenoid (pas.) exhibit the sockets for the characteristic tritoral teeth; the vomer $(v$. ) anteriorly bears a small transversely extended patch of comparatively minute teeth, of which only the bases for attachment are preserved. In front, the vomer joins the ethmoid (eth.) in a dentate suture.

Purchased, 18อ̃õ.

3882\%. Portion of parasphenoid dentition, partly figured in Geol. Mag. [3] vol. viii. (1891), pl. iii. fig. 5; Sheppey.

Bowerbank Coll.

3616\%. Another fragment showing parasphenoid teeth; Sheppey.

Cowderoy Bequest.

P. 5924. Eight detached teeth similar to those of the parasphenoid of this species, two figured in Geol. Mag. [3] vol. viii. pl. iii. figs. 3, 4; Bruxellian, Woluwe St. Lambert, Brussels. $\quad$ Presented by M. Houzeau de Lehaie, 1889.

\section{Genus CHANOIDES, novum. ${ }^{1}$}

Trunk laterally compressed. MIouth terminal, with a few stout conical teeth of uneertain position; no teeth on parasphenoid. Probably about 4 branchiostegal rays. Tertebræ about 45 in number, half being caudal; ribs stout. Pelvic tins opposed to the dorsal, which is short-based but much larger than the anal; caudal fin deeply forked. Scales cycloid, not pectinated.

\section{Chanoides macropoma (Agassiz).}

[Plate VI. fig. 3.]

1796. Clupea thrissa, G. S. Volta, Ittiolit. Veronese, p. cx, pl. xxr. fig. 1 (errore).

1796. Clupea cyprinoides, G. S. Volta, ibid. p. cxii, pl. xxv. fig. 2 (errore).

1796. Salmo marena, G. S. Volta, ibid. p. cxcri, pl. xlviii. fig. 2 (errore).

1796. Clupea sinensis, G. S. Volta, ibid. p. cclxxv, pl. lxv. fig. 4 (errore).

1818. Chupea murcenoides, H. D. de Blaincille, Nouv. Dict. d'Hist. Nat. vol. xxvii. p 343.

1818. C'lupen thrissoides, H. D. de Blainville, ibid. p. 343.

1834. Clupea macropoma, L. Agassiz, Verhandl. Ges. vaterländ. Mus. Böhmen, p. 66 (name only).

1835. Clupea macropoma, L. Agassiz, Neues Jahrb. p. 292.

${ }^{1}$ For the determination of the affinities of this genus the writer is indebted to Mr. G. A. Boulenger. 
1844. Clupea macropoma, L. Agassiz, Poiss. Foss. vol. v. pt. i. p. 14, pt. ii. p. 115, pl. xxxvii b. figs. 3,4 .

1876. Clupea macropona, F. Bassani, Atti Soc. Veneto-Trent. Sci. Nat. vol. iii. p. 187.

1897. Clupea macropoma, F. Bassani, Palæont. Italica, vol. iii. p. 86, pl. viii. fig. 3.

Type. Imperfect fish; Paris Museum of Natural History.

The type species, attaining a length of about $0 \cdot 16$. Length of head with opercular apparatus slightly exceeding the maximum depth of the trunk, and contained about three times in the total length to the base of the caudal fin. Dorsal fin with about 13 rays, almost entirely within the anterior half of the back; pelvic fins opposed to its hinder half, arising midway between the pectoral and anal fins; anal fin with about 11 relatively small rays.

Form. \& Loc. Upper Eocene: Monte Bolca, near Verona.

P. 186\%, P. 382\%. Two typical specimens somewhat fractured, the second in counterpart. Egerton \& Enniskillen Colls.

36201, 37226. Two imperfect larger specimens.

Purchased, 1861, 1863.

2839\%. Smaller distorted specimen.

Mantell Coll.

P. 1868 b, P. 3829 b. Immature fish, in counterpart, shown of the natural size in Pl. VI. fig. 3. The snout is imperfect, but there are traces of the large conical teeth. The squamation is scattered by crushing, thus distorting the true outline of the body. Egerton \& Enniskillen Colls.

Genus CHANOS, Lacépède.

[Hist. Nat. Poiss. vol. v. 1803, p. 395.]

Syn. Lutodeira, E. Rüppell, Neue Wirbelth. Abyssinien, 1835, p. 18.

Trunk somewhat laterally compressed, abdomen rounded or flattened. Snout obtuse and mouth terminal ; teeth absent. Branchiostegal rajs about 4 in number. Vertebræ in the type species 19 in the abdominal, 26 in the caudal region. Pelvic fins opposed to the dorsal, which is short-based but much larger than the anal; caudal fin deeply forked. An enlarged lateral scale or scaly lamella extending considerably over the base of each lobe of the tail. Scales not pectinated.

For notes on the skeleton see J. Hyrtl, Denkschr. k. Akad. Wiss., math.-naturw. Cl. vol. xxi. (1863), pp. 2-4. 
Chanoides Tebtostex (Itams).

Chanoides striata sin. W. Weiler. Jahra. Nassau. ver. Nacurte

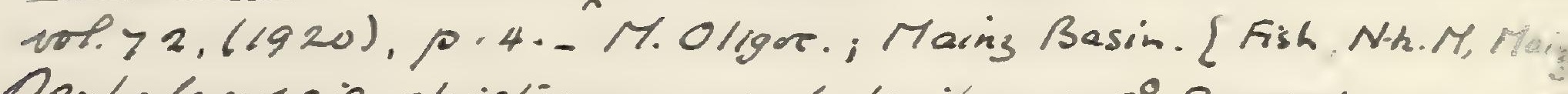

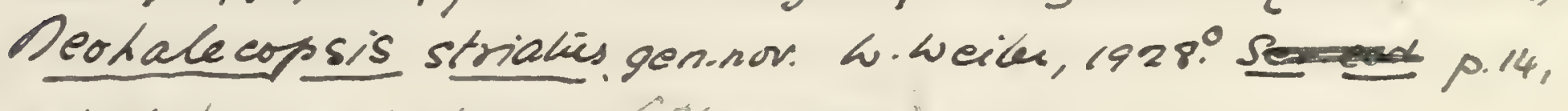
ph. vi.f.2iphir.f.3-5. (Clupeidae) 


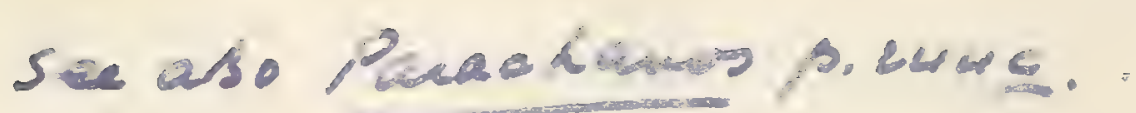

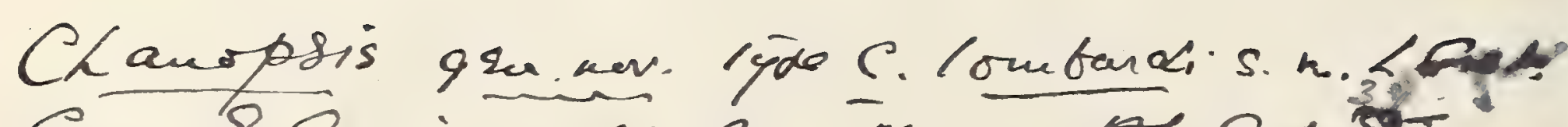

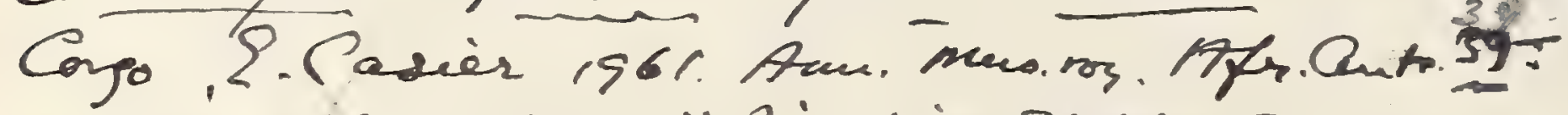

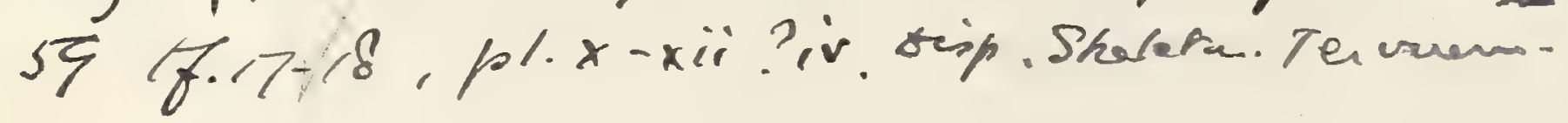

19:5: Chanos loopoldi (Costa), G.X'Erasme, Dalacont. Ytalica,

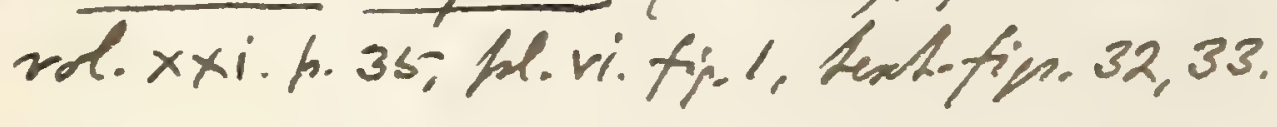


This genus is not represented in the Collection, but the following extinct species have been referred to it:-

Chanos brevis, R. Kner \& F. Steindachner, Denkschr. k. Akad. Wiss., math.-naturw. Cl. vol. xxi. (1863), p. 19, pl.i.; F. Bassani, Atti R. Accad. Sci. Napoli [2] rol. iii. (1889), no. 6, p. 45. Albula brevis, J. J. Heckel, Sitzungsb. k. Akad. Wiss., math.-naturw. Cl. vol. xi. (1854), p. 132.Lower Miocene; Chiaron, Vicentin. [Nearly complete fish; Court Museum, Vienna.]

Chanos forcipatus, Kner \& Steindachner, loc. cit. 1863, p. 21, pl. iii. Megalops forcipatus, J. J. Heckel, loc. cit. 1854, p. 132.-Upper Eocene; Nonte Postale, N. Italy. [Imperfect fish ; Court Museum, Vienna.]

Chanos zignii, Kner \& Steindachner, loc. cit. 1863, p. 20, pl. ii.; F. Bassani, loc. cit. 1889, p. 44. Albula de zignii, J. J. Heckel, loc. cit. 1854, p. 129. Albula lata, J. J. Heckel, ibid. p. 131.-Lower Miocene : Chiavon, Vicentin. [Tail; Court MIuseum, Vienna.]

\section{Genus PROCHANOS, Bassani.}

[Verhandl. k.-k. geol. Reichsanst. 1879, p. 165.]

A genus closely resembling Chanos and not yet precisely definable ; differing from Chanos in the absence of the enlarged lateral scale at the base of each lobe of the tail.

\section{Prochanos rectifrons, Bassani.}

1879. Prochanos rectifions, F. Bassani, Verhandl. k.-k, geol. Reichsanst. p. 165.

1882. Prochanos rectifrons, F. Bassani, Denkschr. k. Akad. Wiss., math.-naturw. Cl. vol. xlv. p. 218, pls. xiii.-xv.

Type. Head with abdominal region ; Imperial Geological Surrey, Vienna.

The type species, attaining a length of about 0.55. Length of head with opercular apparatus nearly equal to the maximum depth of the trunk, which is contained somewhat more than twice in the length from the pectoral arch to the base of the caudal fin. Vertebræ nearly 50 in number, of which 20 are caudal. Pelvic fins with about 6 , dorsal with about 14 , and anal with about 8 rays.

Form. \& Loc. Cretaceous: Island of Lesina, Dalmatia.

P. 7447. Imperfect specimen, crushed and distorted, the head being shown from above, the body chiefly from the side. The 
cranium is longer and narrower than in Chanos salmoneus, with the ethmoidal region attenuated and pointed. The quadrate bones are distinct behind the characteristic short, robust, and toothless jaws. The vertebral centra exhibit deep lateral pits. Fragmentary remains of all the fins occur, and the dorsal is shown to have been slightly deeper than long. 'The articulations of all the fin-rays are remarkably close. The remains of the squamation are obscure.

Purchased, 1895.

\section{Genus ANCYLOSTYLOS, Kramberger.}

[Djela Jugoslar. Akad. no. xvi. 1895, p. 42.]

Head and trunk much laterally compressed and deepened. Mouth terminal; jaws very stout but toothless. Branchiostegal rays probably about 6 in number. Vertebræ in the type species about 28 in the abdominal, 22 in the caudal region; ribs stout. Pelvic fins arising opposite the anterior part of the dorsal, which is somewhat extended but does not occupy more than the hinder half of the back; anal fin acuminate in front, opposed to the hinder portion of the dorsal; caudal fin deeply forked. Scales small, not pectinated.

\section{Ancylostylos gibbus, Kramberger.}

1895. Ancylostylos gibbus, D. G. Kramberger, loc. cit. p. 42, pl. ix.

Type. Nearly complete fish; Griock Museum.

The type species, attaining a length of about 0.3. Length of head with opercular apparatus somewhat exceeding half the maximum depth of the trunk, which is about equal to the length from the pectoral arch to the base of the caudal fin. External headbones and preoperculum finely granulated. Pectoral fins with 16 , pelvic fins with 12 stout rays, the latter not much shorter than the former; dorsal fin with about 33, anal with from 20 to 22 rays.

Form.\& Loc. Upper Cretaceous: Mrzlek, Croatia.

Not represented in the Collection.

\section{Genus ISTIEUS, Agassiz .}

[Poiss. Foss. vol. v. pt. ii. 1844, p. 91.]

Head and trunk much laterally compressed, but elongated.

3 This name is first mentioned, without definition, by Agassiz, Poiss. Foss., Feuill. 1835, p. 56. 



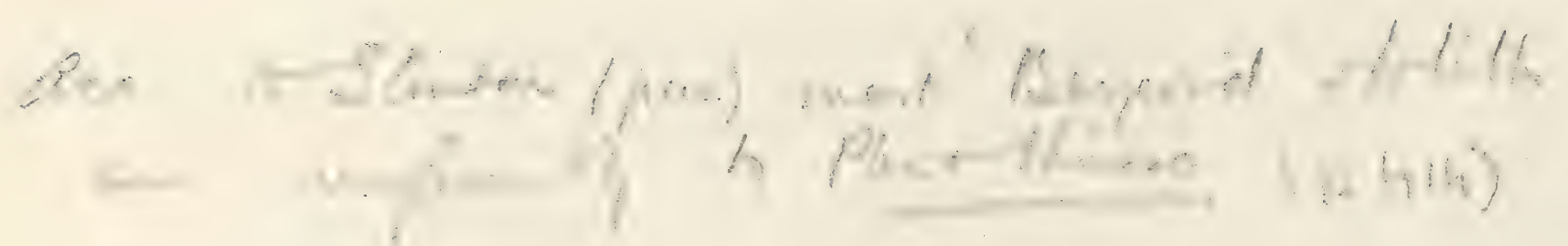

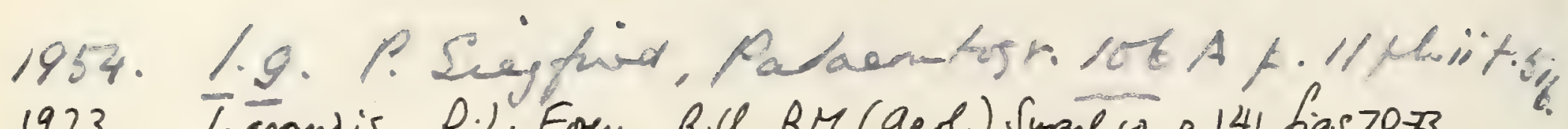

1973 T.grandis, P.L. Fory, Bull. BM (gerl) Suppl.w, p. 141 , figs 7073 
Mouth terminal, the mandible with truncated symphysis and high coronoid region; a single series of small, conical marginal teeth; stouter and blunter teeth within the mouth, but apparently not on the parasphenoid. About 10 branchiostegal rays. Vertebræ about 90 to 100 in total number, the centra short and deep, marked with delicate longitudinal ridges. Pelvic fins scarcely smaller than the pectorals, which are inserted high on the flank; dorsal fin extending for more than half of the back; anal fin short, opposed to or behind the posterior end of the dorsal; caudal fin deeply forked. Scales elliptical, not pectinated.

The existing deep-sea genus Bathythrissa (A. Günther, Ann. Mag. Nat. Hist. [4] vol. xx. 1877, p. 443) or Pterothrissus (F. Hilgendorf, Leopoldina, pt. xiii. 1877, p. 127), is not yet clearly distinguished from Istieus. For description and figure, see A. Günther, Rep. Deep-Sea Fishes, 'Challenger' Report, Zool. vol. xxii. (1887), p. 222, pl. lvi. fig. A.

\section{Istieus grandis, Agassiz.}

1842-44. Istieus grandis, L. Agassiz, Poiss. Foss. vol. v. pt. i. p. 13, pt. ii. p. 92, pl. xviii.

1842-44. Istieus microcephahus, L. Agassiz, ibid. pt. i. p. 13, pt. ii. p. 94, pl. xvii. [Imperfect fish; Palæontological Museum, Munich.]

1842 44. Istieus macrocephalus, L. Agassiz, ibid. pl. xvi. lower fig. (errore).

1858. Istieus grandis, W. von der Marck, Zeitschr. deutsch. geol. Ges. vol. x. p. 246.

18558. Istieus microcephahus, W. von der Marck, ibid. vol. x. p. 246.

1863. Istieus macrocoelius, W. von der Marck, Palæontogr. vol. xi. p. 37, pl. iv. figs. 1-5. [New name for I. grandis + I. microcephalus.]

1863. Istieus mesospondylus, W. von der Marck, ibid. vol. xi. p. 38, pl. v. fig. 1.

1863. Istieus macrocephalus, W. von der Marck, ibid. vol. xi.p. 39, pl. iv. fig. 6, pl. v. fig. 3 (errore).

1873. Istieus macrocoelius, W. ron der Marck, ibid. vol. xxii. p. 59, pl. ii. fig. 2.

1885. Istieus macrocoelius, W. von der Marck, ibid. vol. xxxi. p. $25 \tilde{3}$.

Type. Imperfect fish; Paris Museum of Natural History.

The type species, attaining a length of about $0 \cdot 6$. Length of head with opercular apparatus contained about two and a quarter times, maximum depth of trunk about three times in the length from the clavicle to the base of the caudal fin; width of caudal 
pedicle scarcely exceeding one third the maximum depth of the trunk. Pectoral fins comprising about 14 rays; pelvic fins with 7 or 8 rays, not shorter than the pectorals, arising midway between the latter and the anal; dorsal fin with about 55 rays, the two or three foremost being comparatively short and spinous, the first articulated ray the longest, and this not exceeding one half the depth of the trunk at its insertion; anal fin short and deep, extending backwards slightly beyond the dorsal, and comprising 15 rays, of which the two foremost are comparatively short and spinous.

The appearance of a barbel below the mandible, observed in one specimen by $\nabla$ on der Marek (loc. cit. 1863, p. 38, pl. iv. fig. 5), seems to be deceptive.

Form:\& Loc. Upper Cretaceous: Westphalia.

P. 3291. Fine specimen, chiefly in impression, nearly 0.5 in length, associated with remains of smaller individuals and of Sardinioides; Sendenhorst. The long and low cranium can be distinguished, and the mandibular suspensorium is clearly inclined forwards, the outline of the quadrate being traceable below the orbit. The small gape of the mouth is indicated, and there are remains of a series of small hollow conical teeth in the upper jaw. The operculum and preoperculum are shown in impression, and there is a series of 10 branchiostegal rays beneath. Towards the end of the tail the impressions of the short and deep vertebral centra exhibit their fine longitudinal ridges. About twelve rays of one of the pectoral fins are preserved not much below the vertebral column, and accidentally turned forwards. The pelric fins comprise comparatively few rays, but these must at least have equalled the pectoral fin-rays in length, and they are finely divided and articulated in their distal half. The dorsal fin consists of 54 rays, but those of its anterior portion are partly imperfect and displaced. The anal fin seems to comprise 14 or 15 rays, of which the first four gradually increase in length, while the fifth is the longest; the two foremost rays are spinous, the next two exhibit only close articulations towards the distal end, while all the others are both divided and articulated distally. There are numerous small fulcral rays at the base of the caudal fin both above and below. The characteristic scales are only partly shown in impression; but the 

large size of the canal of the lateral line is well indicated by a cast of it in the anterior abdominal region.

\section{Enniskillen Coll.}

P. 3885. An equally large fine specimen, with the parts of the abdominal region somewhat displaced; Sendenhorst. The mandible is shown to be truncated at its symphysis, much elevated in the coronoid region. The ribs are very slender. The fins, so far as preserved, are as in the last specimen. One of the scales in the dorsal region exhibits the extensive overlapped portion marked with a few grooves radiating from its centre. Enniskillen Coll.

35034. A slightly larger specimen wanting the greater part of the head; Sendenhorst. The uppermost comparatively broad branchiostegal rays are displayed, and there are remains of the pectoral fin on the flank not much below the vertebral column. The two articulated but undivided anterior rays are observed in the anal fin.

Purchased, 1860.

P. 2106. Another large specimen wanting the caudal fin ; Sendenhorst. A regular series of conical teeth is shown in impression on an undetermined portion of jaw; while remains of the epihyal and ceratohyal bear a series of 10 branchiostegal rays.

Egerton Coll.

P. 2106 a, P. 3886. Imperfect large fish in counterpart; Sendenhorst. Egerton \& Enniskillen Colls.

P. 3885 a. Large specimen with incomplete caudal region; Sendenhorst. The small gape of the mouth is complete, with traces of conical teeth; and there are remains of some of the stouter hollow teeth on part of an inner bone of the mouth. A few of the very slender ribs are shown.

\section{Enniskillen Coll.}

P. 210\%. Imperfect fish measuring about 0.19 from the pectoral arch to the base of the caudal fin; Sendenhorst.

Egerton Coll.

P. 2107 a, P. 3888 a. Similar specimen in counterpart; Sendenhorst.

Egerton \& Enniskillen Colls.

P. 3887. A comparatively small fish well preserved in impression; Sendenhorst. There are traces of conical teeth on the 
margin of the jaws, larger in the mandible than on the maxilla. The characteristic operenlum, preoperculum, and enlarged lower cheek-plates, with a few of the branchiostegal rays, are also distinct in impression.

Enniskillen Coll.

P. 3888. Small fish; Sendenhorst.

Enniskillen Coll.

P. 2108, P. 2108 a. Three more imperfect small specimens; Sendenhorst.

Egerton Coll.

P. 2105. Remains of small fish displaying some of the stout conical teeth clustered on one of the inner bones of the mouth; Sendenhorst. Some of the scales are also well preserved.

Egerton Coll.

35012. Scattered remains of head and abdominal region; Sendenhorst. Appearances are not quite conclusire, but suggest that the parasphenoid is a slender toothless bone, while the inner clustered dentition is borne by the long and laminar entopterygoid. The latter element, whatever its nature may be, is only imperfectly preserved, but the hollow bases of the teeth are shown in a patch extending along its middle region, not reaching the borders.

$$
\text { Purchased, } 1860 .
$$

20586. Imperfect trunk displaying parts of the fins and some of the vertebræ in section; Stromberg. Purchased, 1846.

The following specimens differ from $I$. grandis in the comparative slenderness of the trunk, and are thus of the form described under the name of Istieus gracitis (L. Agassiz, Poiss. Foss. vol. v. 1839-44, pt. i. p. 13, pt. ii. p. 94, pl. x deutsch. Kreidegeb. 1840, p. 111; W. von der Narck, Palæontogr. vol. xi. 1863, p. 40, pl. v. fig. 2). The type specimen, however, in the Palæontological Museum, Munich, and all others of the same form, seem to owe their slender proportions to distortion during fossilisation.

P. 3889. Two specimens about 0.3 in length associated on one slab; Sendenhorst.

Enniskillen Coll.

Istieus macrocephalus, Agassiz.

1842-44. Istieus macrocephalus, L. Agassiz, Poiss. Foss. vol, v. pt. i. p. 13, pt. ii. p. 93, pl. xvi. upper fig. (non lower fig.).

Type. Imperfect fish; British Museum. 


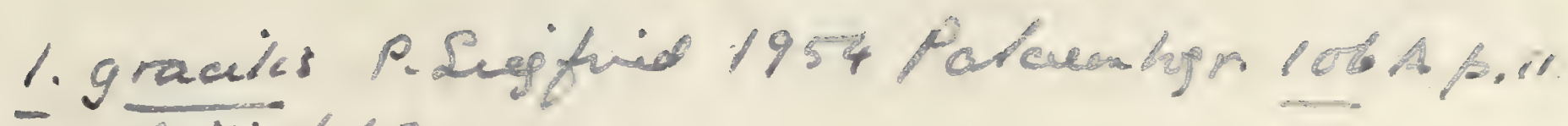
friir $f \cdot 1,2$.

1973 I. mansoupholus, P.L. Forey, BuU. BM (ger1) Suppl. wo, $\rho .14 \geqslant \$ 8.74$ 
A small slender species. Dorsal fin with about 45 rays; anal fin with 12 or 13 rays, almost completely behind the dorsal.

Form. \& Loc. Upper Cretaceous: Baumberg, Westphalia.

P. 3892. Type specimen, apparently elongated by distortion, described and figured by Agassiz, loc. cit. Enniskitlen Coll.

1275 (Sloane Catal. Fishes). Specimen about 0.16 in length, more. satisfactorily preserved. Recorded as "the skeleton of a small fish of a rusty colour lying in a fine-grained ashcoloured stone from Palestine"; but the matrix identical with that of specimens from the Baumberg, Westphalia.

Slocine Coll.

Istieus lebanonensis, Davis.

1887. Istieus lebanonensis, J. W. Davis, Trans. Roy. Dublin Soc. [2] vol. iii. p. 55̃3, pl. xxx. fig. 3 .

Type. Imperfect fish; Edinburgh Museum.

A small stout species, known only by the unique type specimen, which must have originally measured about 0.16 in length. Head relatively larger than in the type species; dorsal fin with about 40 rays; anal fin with about 10 rays, completely behind the dorsal.

Form. \& Loc. Upper Cretaceous: Sahel Alma, Mrt. Lebanon.

Not represented in the Collection.

The fragment from the Turonian of Bohemia named Isticus spottii by A. Fritsch (Sitzungsb. k. böhm. Ges. Wiss. 1879, p. 2) does not

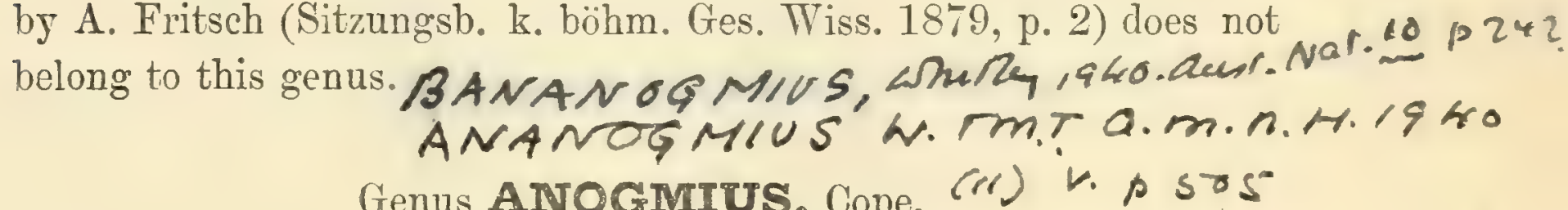

[Bull. U.S. Geol. Surv. Territ. vol. iii. 1877, p. 584 ․]

An imperfectly known genus, with an extended dorsal fin occupying the greater part of the back, and a small anal fin opposed to its hinder end. Teeth minute and clustered on the margiu of the jaws, also on the parasphenoid and other bones within the mouth. About 6 branchiostegal rays. Vertebræ about 80 in total number, the centra deeper than long and marked with fine longitudiual ridges or striæ. Scales elliptical, not serrated or pectinated. Not clearly distinguished from Istieus, but apparently differing in presence of teeth on parasphenoid and clustering of marginal teeth.

1 The generic name Anoginius was originally given by Cope in 1871 (Proc. Amer. Phil. Soc. vol. xii. pp. 170, 354) to some detached vertebræ, specifically termed $A$. contractus. In 1875 he concluded that these vertebræ belonged to Pachyrhizodus (Vert. Cret. Form. West, p. 220 A). In 1877 he used the same generic name again with a new definition as here giren. 


\section{Ananogmius polymicrodus, Stewart.}

1898. Beryx? polymicrodus, A. Stewart, Kansas Univ. Quart. [A] vol. vii. p. 195.

1899. Anogmius polymicrodus, A. Stewart, ibid. vol. viii. p. 117, pl. xxxi.

1900. Osmeroides polymicrodus, F. B. Loomis, Palæontogr. vol. xlvi. p. 256, pl. xxvi. figs. 1-4.

Type. Imperfect fish; Kansas University Museum.

A large species probably attaining a length of about 2.5. Length of head with opercular apparatus equalling about two thirds the maximum depth of the trunk. Cranial roof coarsely rugose, and snout tapering to an obtuse point; length of orbit contained three times in the length of the cranium and twice in its interorbital width.

This species seems to differ from $A$. aratus in its relaticely larger orbit; from $A$. evolutus in its less numerous longitudinal series of mandibular teeth; and from $A$. favirostris in the ornamentation of the cranium and its pointed snout.

Form.\& Loc. Upper Cretaceous (Niobrara Group): Kansas, U.S.A.

P. 9202. Head ànd abdominal region; near Elkader, Logan Co., Kansas. Length of head with opercular apparatus $0 \cdot 36$, that of trunk from pectoral arch to position of pelvic fins 0.65. The characteristic cranium is exposed from above, and the cheek-plates of the right side are well preserved. Nearly 40 vertebræ are shown in the length of trunk mentioned, and the ribs extend to the ventral border. Only a few of the supports of the dorsal fin remain; but the paired fins are preserved, one pectoral being especially well displayed on the flank. The scattered scales are moderately thick, showing only lines of growth; they appear to hare been deeply overlapping. Purchased, 1900 .

The following imperfectly known species are not represented in the Collection :-

An Anogmius aratus, E. D. Cope, Bull. U.S. Geol. Surr. Territ. vol. iii. (1877), p. 585.-Upper Cretaceous (Niobrara Group); Kansas. [The type species. Imperfect fish, showing part of dorsal and anal ins.]

an Anogmius evolutus, E. D. Cope, Proc. Amer. Phil. Soc. vol. xvii. (1878), p. 179. Osmeroides evolutus, F. B. Loomis, Palæ- 
1926. Anogmius polymecroves, D. S. Tordan, Bull. Umis Kansas $x \times v$, No.J, p220,pl. * xii.

P9202. Doticed A.S.h. Nuturabit 1923(5006.) p.298 fortarte,

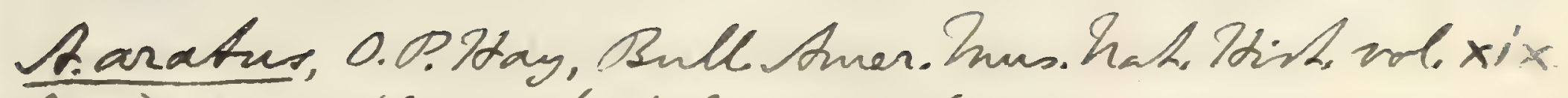
(1903), h.34, hl. ii. a Leath-fips. 23-26.

A.evolutur, 0.P.Hay, Lre. cit.1912, 1.46. Lexh-fis. 3y. 


ontogr. vol. xlvi. (1900), p. 257, pl. xxvi. figs. 5, 6.Upper Cretaceous; Kansas. [Mandible.]

Anogmius favirostris, E. D. Cope, loc. cit. 1878, p. 178.-Ibid. [Skull.]

The fragments of dentition catalociued below may perhaps belong to some unknown Cretaceous genus of Albulidæ, but their relationships are uncertain. Similar specimens have been described under, the names of Glossodus heckeli, O. G. Costa, Atti Accad. Pontan. vol. viii. (1864), p. 109, pl. ix. figs. 12, 13 (Upper Cretaceous: Pietraroja, Pror. Benevento, Italy); Egertonia gaultina, J. Cornuel, Bull. Soc. Géol. France [3] vol. v. (1877), p. 620, pl. xi. figs. 31, 32 (Gault; Moutier-en-Der, Haute Marne); and Pisodus foucardi, II. E. Sauvage, Bull. Soc. Sci. Nat. Yonne, vol. xxxiii.pt. ii. (1879), p. 50, pl. i. fig. 2 (Cenomanian; Bassou, Yonne).

4720\%. A convex, oval mass of well-worn teeth, without the supporting bone; Gault, Folkestone. Gardner Coll.

47286. Two more irregular fragments of similar dentition, one $50594-96$ convex, the other concave, both showing the small piles P.50594 of successional teeth; Gault, Folkestone. Gurdirer Coll.

37239. Convex group of well-worn smaller teeth; Chalk Marl, Dover.

Purchased, 1863.

P. 6107, P. 7498. Two groups of small teeth, less crowded and less worn; Gault, Folkestone. The unabraded dental crown exhibits a slight median apical pit, from which delicate striæ radiate outwards. No successional tecth are seen.

Purchased, 1889, 1895.

P. 9159. Similar group of small teeth; Gault, Folkestone.

Purchased.

\section{Family OSTEOGLOSSID丑。}

Trunk irregularly fusiform or elongated. External head-bones much thickened, and cheek covered by robust plates; supraoccipital bone not prominent, and parietals meeting in the middle line; no basicranial canal; snout not produced. Mandibular suspensorium nearly vertical or inclined forwards, and gape of mouth small or moderately wide; premaxilla much extended along the oral border, but maxilla also entering gape; marginal teeth with long base, in very shallow sockets and anchylosed with the jaw, usually in a 
single series; minute styliform or conical teeth on some of the inner bones and tongue. Suboperculum and interoperculum rudimentary or absent; branchiostegal rays slender, about 10 to 20 in number, and no gular plate. Vertebral centra well ossified, and those of the abdominal region with robust transverse processes for the support of the well-developed ribs; a compound hypural bone at the base of the tail. Intermuscular bones present. Fin-fulcra absent; fin-rays more or less divided and articulated distally; dorsal and anal fins remote and more or less extended. Scales thick and cycloidal, mosaic-like in structure, deeply imbricating.

'The surviving members of this family are confined to the freshwaters of the tropics. Osteoglossum occurs in Tropical America, Australia, and the East Indies ${ }^{1}$. Arapaima is characteristic of Brazil and the Guyanas; while Heterotis is a Tropical African genus.

The only extinct genus referable with certainty to the Osteoglossidæ is Dupedoglossus, from the freshwater Eocene of North America. Brychotus, from the marine London Clay of Sheppey, is also probably a member of the same family; but its scales, so far as known, do not exhibit the characteristic mosaic-like structure.

\section{Genus DAPEDOGLOSSUS, Cope.}

[Bull. U.S. Geol. Surv. Territ. vol. iii. 1877, p. 807.]

Syn. Phareodus, J. Leidy, Proc. Acad. Nat. Sci. Philad. 1873, p. 99 (undefined).

Trunk much laterally compressed, comparatively short and deep, and abdomen trenchant. Cleft of mouth extending to a point below the middle of the orbit, the mandible not prominent, the marginal teeth long and slender, the inner teeth smaller, stout, short and conical, apparently borne by the vomer, palatines, tongue, and basihyals. Branchiostegal rays in uncertain number, but more than 10 . Vertebræ about 45 in number, more caudal than abdominal. Pectoral fins with thickened and excessively elongated anterior ray; pelvic fins small; dorsal and anal fins directly opposed, the latter at least as much extended as the former, and well-separated from the caudal fin, which is very slightly excavated at its hinder margin. Scales large, displaying characteristic reticulate structure.

I Some points in the cranial osteology of Ostcoglossum are described by T. W. Bridge, Proc. Zool. Soc. 1895, p. 302, pl. xxii. 
Sclerpopes sp. Scales, M.Sanden, 1524; p.21, tho

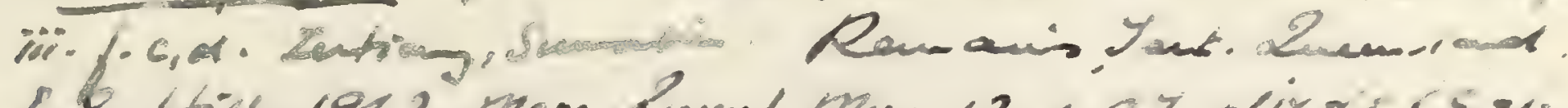

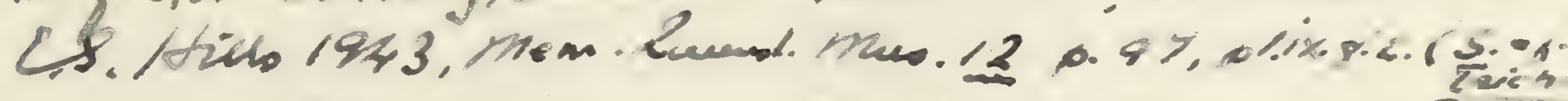
Muspecia, n.g. Sanoves isg $4^{\circ}$ serp. $\&^{\circ}$

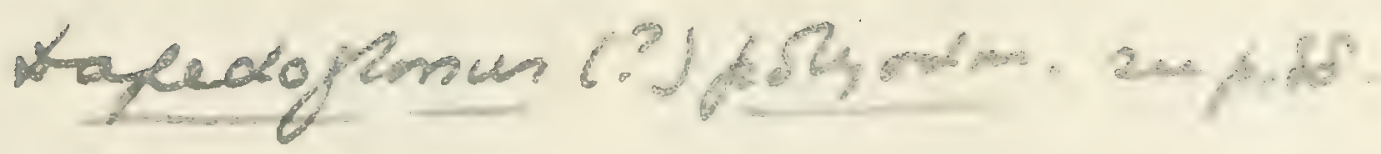




\section{Dapedoglossus testis, Cope.}

1877. Dapedoglossus testis, E. D. Cope, Bull. U.S. Geol. Surv. Territ. vol. iii. p. 807.

1884. Dapedoglossus testis, E. D. Cope, Vert. Tertiary Form. West, Book I. (Rep. U.S. Geol. Surv. Territ. vol. iii.), p. 71, pl. vii. fig. 1, pl. viii. figs. 1, 2.

Type. Nearly complete fish.

The type species, attaining a length of about $0 \cdot 25$. Length of head with opercular apparatus contained about four times, and maximum depth of trunk much less than three times in the total length of the fish. Anterior stout pectoral fin-ray closely articulated in its distal half, extending nearly as far backward as the rays of the pelvic fins, which are small and arise somewhat nearer to the anal than to the pectoral pair; dorsal fin with about 20 rays, arising behind the origin of the anal fin, which is more extended and comprises about 27 rays. Exposed aspect of scales rery finely granulated, not grooved.

Form. \& Loc. Eocene (Green River Shales): Wjoming, U.S.A.

P. 5824. Imperfect specimen about 0.19 in length, displaying the reticulate middle lajer of the scales. By exchange, 1888.

P. 7488. A much smaller specimen exhibiting the dentition, branchiostegal rays, and fins. Purchased, 1895.

\section{Dapedoglossus æquipinnis, Cope.}

1878. Dapedoglossus requipinnis, E. D. Cope, Bull. U.S. Geol. Surv. Territ. vol. iv. p. 77

1884. Dapedoglossus cequipinnis, E. D. Cope, Vert. Tertiary Form. West, Book 1. (Rep. U.S. Geol. Surv. Territ. vol. iii.), p. 73, pl. vii. fig. 2.

Type. Nearly complete fish.

A rery small species, differing from the type in the less elongation of the anterior pectoral fin-ray and in the almost equal size and extension of the dorsal and anal fins, each of which seems to comprise about 22 rays.

Form. \& Loc. Eocene (Green River Shales): Wyoming, U.S.A.

Not represented in the Collection.

The following species have also been founded on fragmentary specimens, of which there no examples in the Collection :-

Dapedaglossus acutus, E. D. Cope, Vert. Tertiary Form. West, Book I. (Rep. U.S. Geol. Surv. Territ. rol. iii. 1884), 
p. 72, pl. $\nabla$. figs. 18-20. Phareodus acutus, J. Leidy, Fhor's

Proc. Acad. Nat. Sci. Philad. 1873, p. 99, and Contrib. Extinct Vert. Fauna W. Territ. (Rep. U.S. Geol. Surv. Territ. vol. i. pt. i. 1873), p. 193, pl. xxxii. figs. 47-51; E. D. Cope, Ann. Rep. U.S. Geol. Surv. Territ. 1872 (1873), p. 637 (in part). Phareodon sericeus, E. D. Cope, ibid. (1873), p. 638 (palatine teeth).-Bridger Eocene; Wyoming, U.S.A. [Jaws. The type species of Phareodus.] Bapedoglossus encaustus, E. D. Cope, Bull. U.S. Geol. Surv. Territ. vol. iii. 1877, p. 808, and op. cit. 1884, p. 70, pl. vi. fig. 1. Osteoglossum encaustum, E. D. Cope, Ann. Rep. U.S. Geol. Surv. Territ. 1870 (1871), p. 430.--Eocene (Green River Shales); Wyoming, U.S.A. [Portion of squamation.]

\section{Genus BRYCHATUS, novum。}

[ex Agassiz, Rep. Brit. Assoc. 1844 (1845), p. 308 (name only).]

Syn. Pomaphractus, L. Agassiz, Rep. Brit. Assoc. 1844 (1845), p. 307 (name only).

Platops, R. Owen, Catal. Foss. Rept. \& Pisces Mus. Roy. Coll. Surgeons, 1854, p. 170 (undetined.)

A genus known only by the head and anterior abdominal region, which are much laterally compressed. Cleft of mouth extending to a point somewhat behind the orbit, and the mandible not prominent; marginal teeth large, in very close series, with somewhat tumid base and relatively short enamelled crown; inner teeth comparatively minute and clustered, but all stout and conical. Preoperculum much expanded; branchiostegal rays not less than 15 in number. Scales large and deeply imbricating, ornamented in their exposed portion with fine tubercles arranged more or less distinctly in radiating lines.

\section{Brychætus muelleri, sp. nov.}

[Plate I.]

1845. Brychetus muelleri, L. Agassiz, Rep. Brit. Assoc. 1844, p. 308 (name only).

(?) 1845. Pomaphractus egertoni, L. Agassiz, ibid. p. 307 (name only). [Portion of small skull; British Museum.]

(?) 1854. Platops subulitens, R. Owen, Catal. Foss. Rept. \& Pisces Mus. Roy. Coll. Surgeons, p. 170 (undefined). [Imperfect head; Royal College of Surgeons.]

Type. Imperfect head; British Museum.

The type and only known species, not yet precisely definable. 


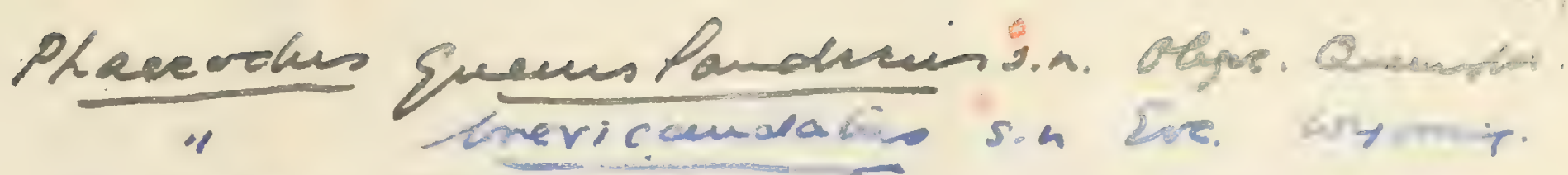
see aro Mufena p. $88^{\circ}$

Phoreodur encaustus, L. Huscate of. Bull. Amen- Mus. Nhat. Thish. vol. $\times \times v(1908), 1.8 \%$

Earychir Lindleyi, n.g. D. D.Jordan, Bell. Univ. Kamas

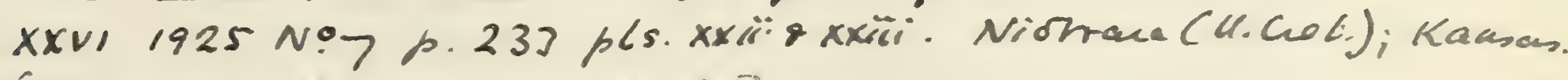
[aut. fort. firt, Kausas Unit?

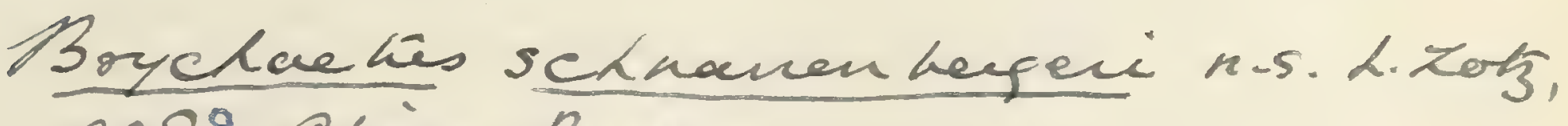
1928: Oligir: Baden.

1936. Brychatus muthi, Cosambongs; 431

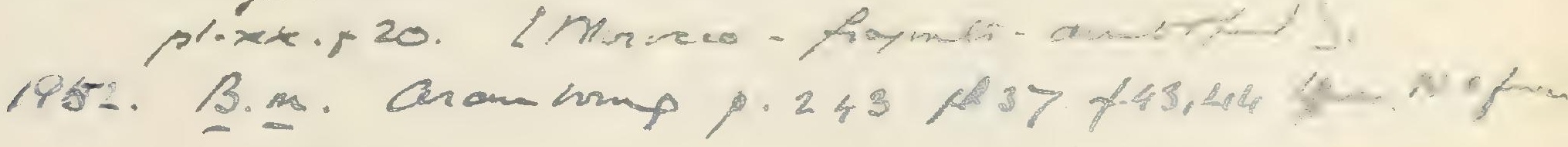



Head with opercular apparatus attaining a length of about 0.4 . Length of head to preopercular border scarcely exceeding its maximum depth at the occiput; width of frontal region between the orbits equalling about half the total length of the cranium. External bones of cranial roof marked with small pittings, the cheek-plates and opercular apparatus ornamented with radiating lines of very fine tubercles. Premaxilla extending to the anterior border of the orbit, at least two thirds as long as the more slender maxilla. Marginal teeth oroid in transverse section, their longer diameter at right angles to the length of the jaw, and all the enamelled crowns smooth; teeth of premaxilla largest, ten in number; those of maxilla considerably smaller, between 20 and 25 in number, decreasing in size backwards, where they become comparatively slender; mandibular teeth about 20 in number, nearly as large as those of the premaxilla and scarcely decreasing in size behind. Opereulum nearly twice as deep as broad. Anterior scales closely ornamented with very small tubercles often fused into short rugæ.

Form. \& Loc. Lower Eocene (London Clay): Sheppey, Kent.

P. 3893. Imperfect head with opercular apparatus, to be regarded as the type specimen, partly shown of one third the natural size from the left side and from above in Pl. I., figs. 1, 1 a. The cranium is much fractured, the outer surface of the ethmoidal region, the greater part of the right frontal and of the parieto-occipital region being broken away. The frontals $(f r$.$) are very wide between$ the orbits, narrowing behind, and they are much thickened, the outer surface preserved on the left side exhibiting numerous closely arranged pittings. The fossil has been broken across immediately behind the orbit, thus causing a gap in the left frontal; but its truncated posterior margin is conspicuous further back, well in advance of the occiput, and the corresponding suture on the right side is indicated by the direction of the growth-lines of the fractured bone. The anterior part of the left parietal ( $p a$. ) is shown to be superficially pitted in the same manner as the frontal; but the region beyond is obscure and more clearly observable in no. P. 157 (Pl. I. fig. 2). A very large and stout prefrontal is shown on the right side. The orbit (fig. 1, orb.) is indicated far forwards, and the great postorbital region is covered with two cheek-plates, which are very 
fragmentary on both sides of the fossil. The upper postorbital (s.o.1) is somewhat the smaller, and exhibits a series of clefts in its hinder border; both bear traces of the characteristic fine tubercular ornament. The ossified sclerotic is seen on the right side. The jaws and teeth are imperfect, but best preserved on the left (fig. 1). The premaxilla $(p m x$.$) is observed to extend to the front$ border of the orbit; while above the hinder half of the comparatively slender maxilla $(m x$.) there seems to be a small supramaxilla $\left(\operatorname{s.m} x_{0}\right)$. Most of the teeth are broken and display an internal cavity; but a few of those of the mandible and sereral of those of the maxilla are complete, with the smooth enamelled crown pointed and a little curved inwards at the apex. The wide expansion of the angle of the preoperculum is observable on the left behind the portion of the fossil figured, and the form of the large operculum can be dimly perceived on both sides. The large and deeply imbricating scales, of which one from the right side is shown of the natural size in fig. $1 \mathrm{~b}$, are externally ornamented with fine tubercles tending to arrangement in radiating lines; and there is no appearance either of a mosaic or reticulated structure even when this superficial lajer of ornament is removed.

Ennistiillen Coll.

32345. More imperfect head, the cranium a little crushed downwards on the right side. The frontals exhibit the same form, thickening, and superficially pitted character as before; their truncated hinder margin is also distinct in the same position immediately behind the orbit. The anterior thickened and pitted portion of each parietal is shown to be about as broad as long, and there are traces of the long, narrow squamosal on either side; but the occipital region is crushed and obscured. Some of the teeth are well shown on the left side. There are also characteristic remains of the squamation; and the right supraclavicle is shown to be very long and narrow.

Purchased, 1857.

P. 157. Imperfect head with cranial roof so fractured as to show its thickened character (P1. I. figs. 2, $2 a, 2 b$ ). The anterior thickened portion of each parietal $\left(p \alpha_{0}\right)$ is at least as long as broad, and its postero-lateral angles are a little produced backwards. The squamosal $(s q \cdot)$ is 
excessively long and narrow. There are remains of a short and broad ethmoid in front of the frontals $(f r$.$) not$ shown in the figure. The extent of the premaxilla $(p m x$.) is indicated on both sides, and it seems to have borne 10 teeth. The best preserved tooth, at the hinder end of the left premaxilla, is shown of the natural size in fig. $2 \mathrm{~b}$. The two postorbital cheek-plates are exhibited, the lower (s.o.2) much the largest as usual. The characteristic fine tubercular ornament is observed on the operculum (op.) and also slightly on the upper cheek-plate of the left side. Fourteen branchiostegal rays are preserved on the right. There are also some rays of the right pectoral fin $(p c t$.$) , the foremost being comparatively$ stout.

Purchased, 1880.

P. 638. A pyritised decaying specimen, labelled by Agassiz as intended to be the basis of his description of the species. It exhibits the large robust prefrontal bone on the right side. The maxilla is also well shown, with its characteristic dentition and a comparatively delicate small expansion behind. The preoperculum is evidently expanded at the angle, and there are remains of about 14 pairs of slender branchiostegal rays.

Egerton Coll.

39448. Another decaying specimen comprising the opereular and branchiostegal apparatus, with the postorbital plates. The well-ossified upper end of each hyomandibular projects from the indurated clay. The left operculum is shown to be somewhat more than half as broad as deep; while both this and the left lower postorbital plate exhibit remains of the superficial ornament of radiating tuberculated lines. The number of branchiostegal rays appears to be slightly greater than in the last specimen, but they are very imperfectly preserved. Bowesbank Coll.

43020. Block of indurated clay with scattered remains, comprising the right mandibular ramus ( $\mathrm{Pl}$. I. fig. 3), part of that of the left side, the right clavicle, scales, and other fragments. The dentary bone $\left(d_{0}\right)$ bears traces of about 21 teeth, and ascends behind into the front part of the coronoid elevation. The outer face of the clavicle is considerably expanded throughout its length, though widest in its lower portion.

Purchased, 1871. 
P. 1748. Fragment of right side of head showing parts of premaxilla, maxilla, and dentary, with teeth; also remains of a laminar inner bone of the mouth (probably entopterygoid) covered with a cluster of minute stout conical teeth. The premaxillary teeth are the largest.

Egerton Coll.

43021. Right premaxilla, with remains of a cheek-plate which is ornamented with radiating lines of fine tubercles. The premaxilla (Pl. I. figs. 4, 4a) is shown to have been attached to the ethmoidal region throughout its front half, which is not much deepened; and there is a deep longitudinal groove for the overlap of the maxilla on its hinder portion. The bone bears ten closely arranged, antero-posteriorly compressed teeth, two represented only by the base of attachment, and all the others except the foremost having lost the enamelled crown.

Purchased, 1871.

28424. Anterior end of small left dentary showing robust mandibular șmphysis. Mantell Coll.

P. 641. Hinder half of small skull with opercular apparatus, partly pyritised and imperfectly preserved, probably referable to a young individual of this species. The specimen is marked by Egerton as intended to be the type of the species Pomaphractus egertoni, Agassiz, loc. cit.

Egerton Coll.

39699. Remains of equally small head, showing jaws.

Purchased, 1866.

\section{INCERT $A$ SEDIS (? OSTEOGLOSSID $\mathrm{E}$ or ALBULID无).}

\section{Genus PLETHODUS, Dixon.}

[Geol. Sussex, 1850, p. 366.]

An imperfectly known genus, with deep laterally compressed skull and small mouth. External bones not ornamented. Premaxilla apparently fused with the short rostrum, this, the maxilla, and dentary bearing minute teeth; ectopterygoid very slender, also with minute teeth; a large smooth concave plate, consisting of rertical tubules of dentine fixed apparently to the parasphenoid; 
Osteutionid

It scale of fish rear to Scleropages onmosus reoreced on L.F de Bean fort. thas 3ry Sumaha, 1925, bert. Geot. mink. Gen. Ned. en Kol., Geob. Ser., viir, pp. $47-3 z$.

Pletriramaidas.

wiel - anozmins. pil.

Par apogmingloden Ceini, g. T.n. Lrailer 1986 p. 33, 17.4-6, p1.ir.t. S, 16, 26. Cenam an: Baharife: 7ugmenti. Stromen 1936; A 46, if. 3, 7 . 


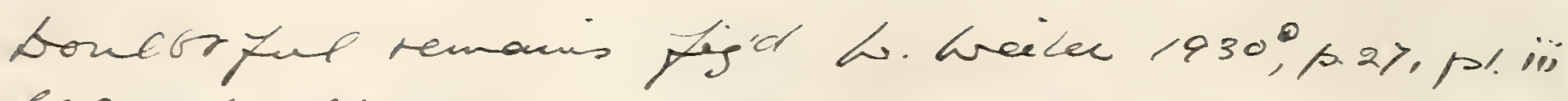
ff. 35-26; hi. ir. res.

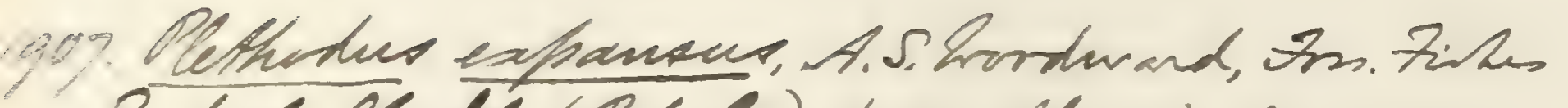

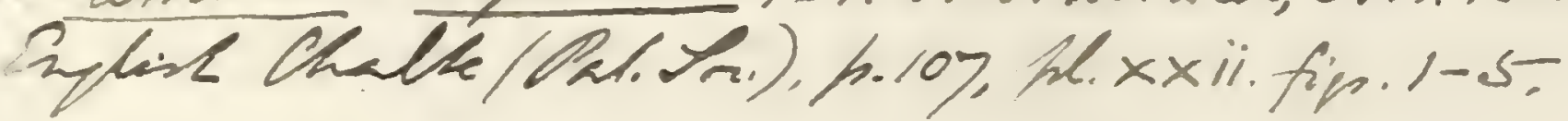

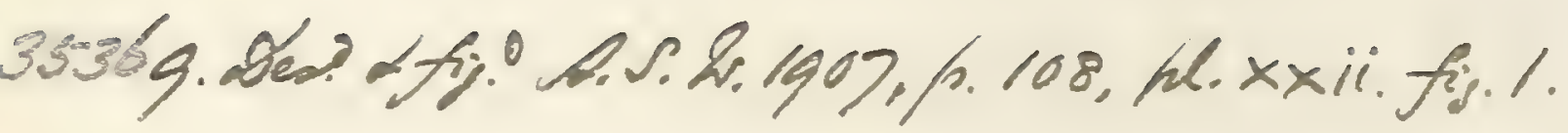


an opposing convex plate of similar structure supported probably by the basihyal bone.

The fragmentary remains of this genus hitherto discovered are discussed by the present writer in Ann. Mag. Nat. Hist. [7] vol. iii. (1899), pp. 353-361, pls. xiii., xiv.

\section{Plethodus expansus, Dixon.}

1850. Plethodus expansus, F. Dixon, Geol. Sussex, p. 366, pl. xxxiii. fig. 2.

1888. Plethodus expansus, A. S. Woodward, Proc. Geol. Assoc. vol. x. p. 331.

1899. Plethodus expansus, A. S. Woodward, Ann. Mag. Nat. Hist. [7] vol. iii. p. 354, pl. xiii. figs. 1-4.

Type. Portion of lower dental plate; Brighton Museum.

The type species, of large size, the lower dental plate sometimes measuring 0.1 in length by 0.075 in maximum breadth. Lower dental plate leaf-shaped, one end being comparatively broad and gently rounded, the other end nearly pointed; its grinding surface slightly convex except near the pointed end, where it becomes concave; its truncated border more or less tuberculated. Upper dental plate nearly as broad as long and regularly concave.

No bones of this species have hitherto been identified.

Form. \& Loc. Albian to Senonian : S.E. England.

\section{(i.) Lower dental plates.}

35369. Fine specimen, described and figured in Ann. Mag. Nat. Hist. [7] vol. iii. (1899), p. 354, pl. xiii. fig. 1 ; Cambridge Greensand. Purchased, 1859.

39103. Broad end of similar plate showing thick bony base, noticed ibid. p. 355 ; Cambridge Greensand. Bowerbank Coll.

35391-92, 35403, 35430. Two large and two small fragmentary specimens ; Cambridge Greensand. Purchased, 1859-60.

P. 1486. Fragment; Cambridge Greensand.

Egerton Coll.

P. 2691. Three fragments; Cambridge Greensand.

Enniskillen Coll.

P. 7274-76. Five imperfect specimens, one being very large and broad, another displaying the form of the broader end Cambridge Greensand.

Jesson Coll. 
28013. Fragment and vertical microscopical section of the same; Cambridge Greensand. Purchased.

0259. Another fragment and similar section; Cambridge Greensand.

Purchased, 1855.

P. \%. Imperfect specimen rather broad at the concave end, described and figured, loc. cit. p. 356, pl. xiii. fig. 4; Gault, Folkestone.

Gardner Coll.

P. 8. Fragment; Gault, Folkestone.

Gardner Coll.

46392. Fragment, with horizontal and rertical microscopical sections of the same; Chalk, S. Wiltshire. Cumington Coll.

25923 *. Fragment, probably from the Sussex Chalk. Dixon Coll.

39052. Fragment; Lower Chalk, Burham, Kent. Bowerbants Coll.

\section{(ii.) Upper dental plates.}

38585. Specimen showing bony attachments, described and figured loc. cit. p. 355, pl. xiii. fig. 2; Lower Chalk, probably Kent. Referred to Thryptodus sp., by F. B. Loomis, Palæontogr. vol. xlvi. (1900), p. 235. Purchased, 1864.

39091. More imperfect specimen, the aboral face described and figured loc. cit. p. 356 , pl. xiii. fig. 3 ; Lower Chalk, near Maidstone. Referred to Thryptodus sp. by F. B. Loomis, Palæontogr. vol. xlvi. (1900), p. 235. Bowerbante Coll.

P. 9014. Imperfect specimen displaying abraded aboral face; probably from Lower Chalk, Kent. $\quad$ Purchased, 1885.

43079. Fragment showing structure; Lower Chalk, Halling, Kent. Purchased, 1871.

39092. Fragment; Chalk, Gravesend. Bowerbank Coll.

P. 2692. Portion of large specimen; Lower Chalk, Lewes.

Enniskillen Coll.

527\%. Fragment; Lewes. Mantell Coll.

P. 7277. Two imperfect abraded specimens; Cambridge Greensand. Jesson Coll.

47188. Fragment in concretion; Gault, Folkestone. Gardner Coll. 
46392. Fes? a fi? A.S. 2. 1907. h. 108 , pl. xxil. fi. 5.

38585. Des? aff?? A.S. W. 1907. h. 108, fel. xxï. fip. 2.

390g!. Des! a fig? A.S. 2. 1907, p. 108, fl. xxï.fip. 3.

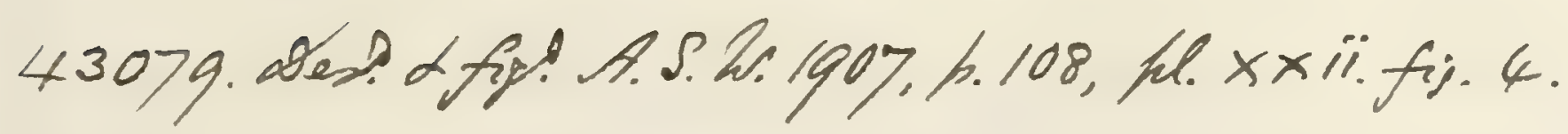


Plethodus pentagon, A. S. Woodward.

1899. Plethodus pentagon, A. S. Woodward, Ann. Mag. Nat. Hist. [7] vol:"iii. p. 356, pl. xiii. fig's. $\tilde{0}-\overline{7}$.

Type. Lower dental plate; British Museum.

A smaller species, the lower dental plate attaining a length of about 0.055 with a maximum breadth of 0.04 . Lower dental plate elongated, pentagonal in shape, widest near the pointed end, and the border of the truncated end slightly excarated; grinding surface slightly convex. Supposed upper dental plate quadrangular.

No bones of this species have hitherto been identified.

Form. \& Loc. Turonian: S.E. England.

41716 a. Lower dental plate, being the type specimen describe and figured loc. cit.p. 356, pl. xiii. fig. 5; Lower Chalk, Burham, Kent.

Toulmin Smith Coll.

47947. Pointed end of lower dental plate, figured loc. cit. pl. xiii. fig. 6 ; Burham. Presented by the Hon. Robert Marsham, 1877.

358\%4. Imperfect abraded lower dental plate, the truncated end exhibiting a deep accidental cleft; Lower Chalk, Dover.

Purchased, 1861.

P. 2693. Two fragments; Lower Chalk, Lewes. Enniskillen Coll.

P. 5626. Supposed upper dental plate, described and figured loc. cit. p. 357, pl. xiii. fig. 7; Lower Chalk, Kent. Referred to Thryptodus sp. by F. B. Loomis, Palæontogr. rol. xlri. (1900), p. 235.

Harford Coll.

49816. Portion of similar plate; Lower Chalk, Dorking, Surrey.

Capron Coll.

\section{Plethodus oblongus, Dixon.}

1850. Plethodus oblongus, F. Dixon, Geol. Sussex, p. 366, pl. xxxii.** fig. 4.

1899. Plethodus oblongus, A. S. Woodward, Ann. Mag. Nat. Hist. [7] vol. iii. p. 35̃, pl. xiv.

Type. Lower dental plate; Brighton Museum.

A very small species, the lower dental plate about 0.02 in length, elongated and irregularly oroid in shape, the broader end gently rounded, the narrower end truncated; grinding surface of this plate slightly convex.

A small skull in the Brighton Yuseum, described and figured by 
the present writer $70 c$. cit., exhibits the broader end of a dental plate much like that just defined, near the remains of the mandible. In the same specimen a concave dental plate of similar structure is clearly observed fixed to the base of the cranium. This imperfect fossil and another mentioned below have thus been provisionally ascribed to Plethodus oblongus, and exhibit the cranial characters. noted in the diagnosis of the genus given above.

Form. \& Loc. Cenomanian and Turonian: S.E. England.

49895. Imperfect head with opercular apparatus, described and figured loc. cit. p. 359, pl. xiv. fig. 2; Lower Chalk, Dorking.

Capron Coll.

The following dental plates, exhibiting the characteristic structure of Plethodus, are not specifically determined:-

P. 7279. Portion of very thick concave (upper) plate; Cambridge Greensand.

Jesson Coll.

P. 7280-81. Two portions of concave (upper) plates, the second remarkably thickened on the aboral face; Cambridge Greensand.

Jesson Coll.

35395. Another very concave specimen, almost longitudinally keeled; Cambridge Greensand. $\quad$ Purchased, 1859.

P. 6452. Small concave plate, with raised longitudinal ridge on aboral face; Grey Chalk, Dover. Beckles Coll.

The following species has also been named, but is not represented in the Collection :-

Plethodus furcatus, A. S. Woodward, Proc. Geol. Assoc. vol. x. (1888), p. 331. Chimara fureata, A. Fritsch, Rept. u. Fische böhm. Kreideform. (1878), p. 16, woode. fig. 40. -Turonian; Bohemia. [Imperfect dental plate; Royal Bohemian Museum, Prague.]

A cranium not yet clearly distinguished from that of Plethodus has also been described as follows:-

Syntegmodus altus, F. B. Loomis, Palæontogr. vol. xlvi. (1900), p. 253, pl. xxii. fig. 9.-Upper Cretaceous (Niobrara Group); Kansas, U.S.A. [Imperfect cranium; Palæontological Museum, Munich.] 


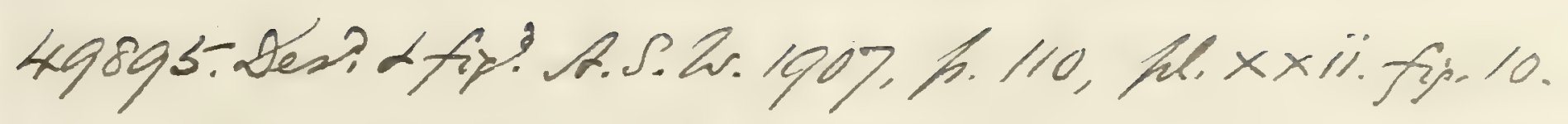

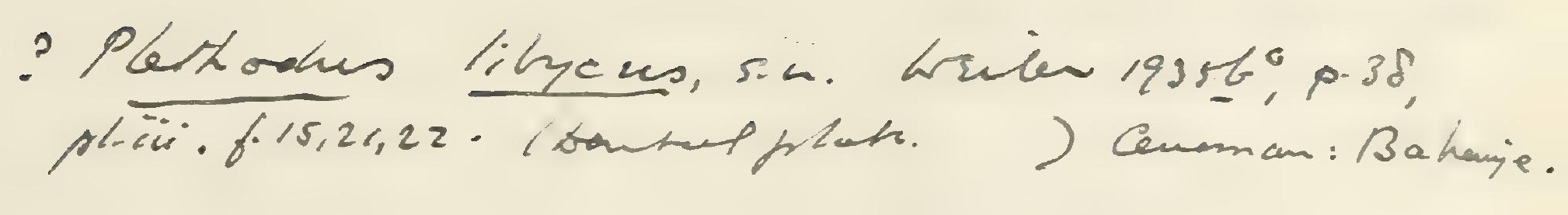

Anopming altur, O.P.Hay, Obull. Ames. hus. hath. Trist. vol.xix (1903), h.41, Lext-figs. 27,28.

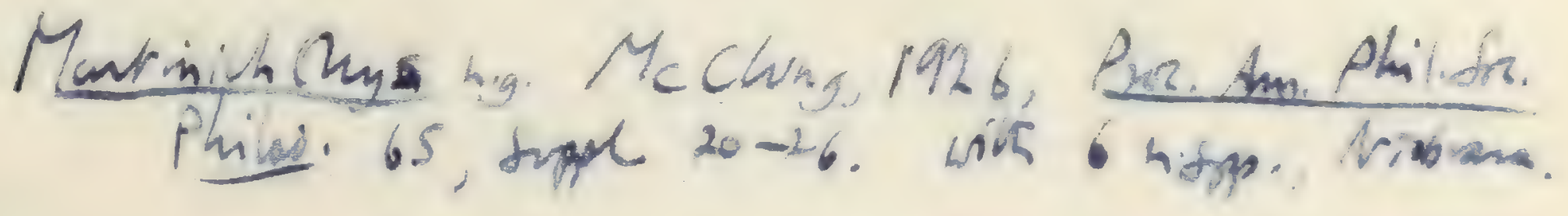


Dlethodont fragments frim Upper Retaceons of Lilyan abesent, A. Zuads. Palas on trper. nd. $x \times x(1902)$. p.31\%, fh. $\times \times$ viii. figa. $16.1 \%$

Pi29'2. Lover dental plate of Thryptodur rotundurs; Gove Co, Kansas. M.T. Martin Coll.

Ogheglossid pemanis from 3.Y Sumalia deseror L.7. de Beaufort, ver h. Geot. Mijnt. Gous hed a Koth Geoh Ser vir (1925) p2.49.

Cearana rocha, Z.S. Iordan a g.C. Bramer. Smithson. Miscell. Coll. wol. Tii, (1908), h. 27, hl. viii. fig. 2, hext-fin. 20,21. - Cretaceons; Cearó, Brayil. Comperfit firt, Inuseo Pocha, Ceará.' $T$ \& Cearand, $2 .+B$. Indeterminable. Ats. 13: Synmonows nit Jharrhia's - See vol. iii p. 5330 . 


\title{
Genus THRYPTODUS, Loomis.
}

\author{
[Palæontogr. vol. xlvi. 1900, p. 229.]
}

An imperfectly known genus with depressed skull and small mouth, apparently differing from Hlethodus in having two lower median dental plates opposed to the single upper plate.

Two species, not represented in the Collection, are recognised as follows:-

Thryptodus rotundus, F. B. Loomis, loc. cit. p. 235, pl. xxii. figs. 1, 2.-Upper Cretaceous (Niobrara Group); Kansas, U.S.A. [Upper and lower dental plates; Palæontological Museum, M[unich.]

Thryptodus zitteli, F. B. Loomis, loc. cit. p. 234, pl. xxi.-Ibid. [The type species. Skull; Palæontological Museum, Munich.]

- The rostrum of this fish closely resembles a fragment from the Chalk of Sussex, in the Brighton MLuseum, provisionally ascribed to an Acipenseroid by A. S. Woodward, Pros. Geol. Assoc. rol. xi. (1889), p. 31, pl..i. fig. 6 .

Imperfect remains of a nearly similar fish with free premaxillæ are described thus :-

Pseudothryptodus intermedius, F. B. Loomis, Loc. cit.p. 236, pl. xxii. figs. 3-8.-Ibid. [Remains of head; Palæontological Museum, Munich.]

\section{Family NOTOPTERID E.}

Supraoccipital bone prominent, but parietals partly meeting in the middle line; squamosal reduced and fused with pterotic; a basicranial canal; snout not produced; cheek-plates reduced. Mandibular suspensorium rertical or inclined forwarảs and gape moderately wide; premaxilla small and maxilla relatively large, both entering the upper border of the mouth. Opercular and branchiostegal apparatus much reduced, and no gular plate. Vertebral centra well ossified, those of the abdominal region with transrerse processes; ribs nearly encircling the abdominal carity. Finfulcra absent; caudal fin very small or absent. Scales thin and cycloid, extending over the head and opercular apparatus.

The surviving members of this family are confined to the freshwaters of the East Indies and West Africa. 
Genus NOTOPTrRUS, Lacépède.

[Hist. Nat. Poiss. vol. ii. 1800, p. 189.]

Trunk fusiform, with verJ short abdominal region and muck elongated and attenuated caudal region. Dorsal fin very small, in the caudal region; anal fin much extended and confluent with the rudimentary caudal fin. A double series of short ventral ridgescales in the abdominal region.

\section{Notopterus primævus, Günther.}

1876. Notopterus primcevus, A. Günther, Geol. Mag. [2] vol. iii. p. 439, pl. xix.

Type. Imperfect fish; British Museum.

An imperfectly known species, about 0.3 in length. Lower part of preoperculum and some ridges of mandible serrated. About 13 abdominal vertebræ. Dorsal fin above 14 th and 15th caudal vertebræ. Scales very small.

Form. \& Loc. Freshwater Tertiary Lignite: Padang, Sumatra.

47512. Type specimen described and figured by Günther, 7oc. cit.

Presented by Herr R. D. M. Verbeek, 1876.

\section{Family CHIROCENTRID无.}

Supraoccipital bone prominent, partly or completely separating the parietals in the median line; squamosals reduced, and otic region very prominent; parasphenoid enclosing a basicranial canal; snout not produced; cheek-plates well dereloped. Mandibular suspeysorium inclined forwards, but gape of mouth wide and more or less directed upwards ; premaxilla and maxilla robust and firmly fixed, both entering the upper border of the mouth; teeth acuminate, almost or exclusively confined to the premaxilla, maxilla, and dentary bones. Opercular apparatus complete, with branchiostegal rays, but no gular plate. Vertebral centra well ossified, none with transverse processes ; ribs nearly or completely encircling the abdominal cavity ; hæmal arches more or less fused at the base of the tail. Intermuscular bones present. Fin-fulcra absent; fin-rays divided and closely articulated distally; post-temporal bones in contact with postero-lateral angles of cranium; dorsal and anal fins remote. Scales thin and cycloid. In the recent genus :-No pseudobranchix; air-bladder incompletely divided into cells; no pyloric appendages; intestine short, with a rudimentary spiral valve. 


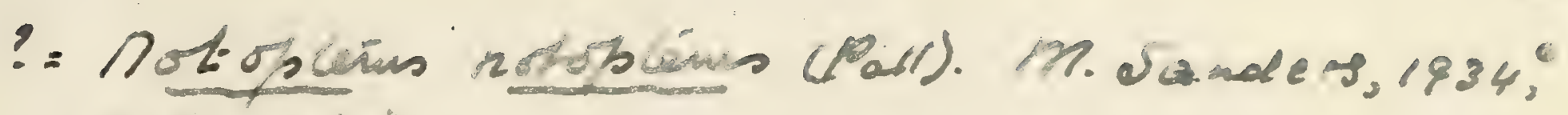
p. 8, phi.

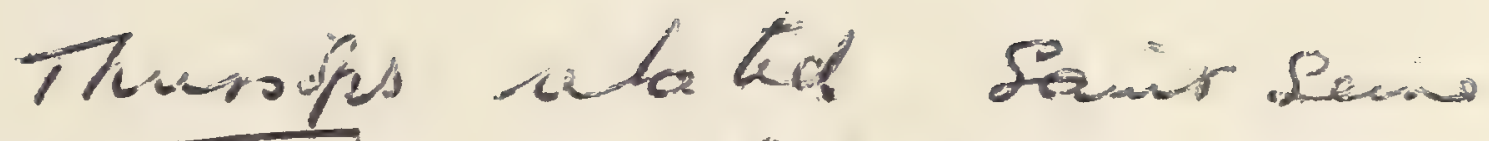

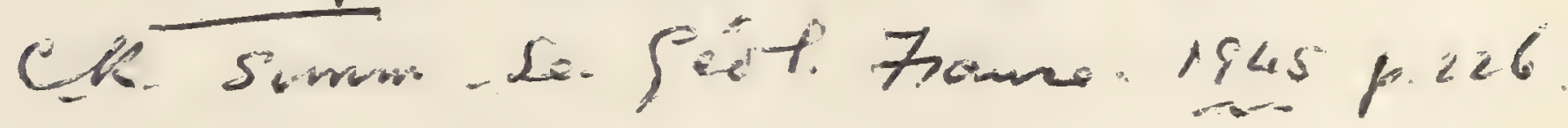

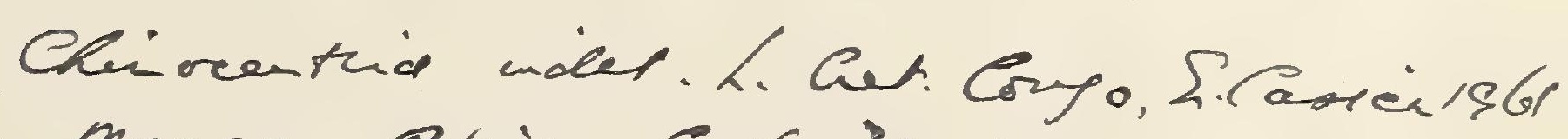

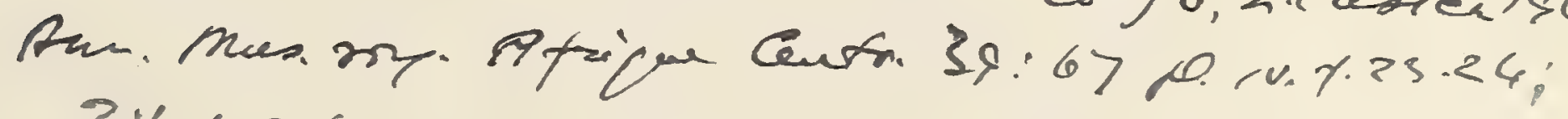
?V. $.5=6$ 



\section{Synopsis of Genera.}

I. Extended anal fin not elevated into an acuminate lobe anteriorly.

Teeth laterally compressed and firmly fixed in shallow sockets, much enlarged in premaxilla and dentary; pectoral fins normal......

Teeth small, nearly uniform in size, in close series; pectoral fins much

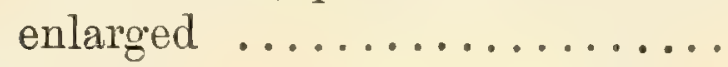

Teeth rounded in section, of moderate Chirocentrus (p. 88). size, in close uniform series, only one pair being enlarged at the mandibular symphysis; pectoral fins rather large ...........

II. Extended anal'fin [when known] elevated Chiromystus (p. 89). into an acuminate lobe anteriorly.

A. Teeth in sockets, irregular in size and much enlarged in premaxilla. About 20 branchiostegal rays; rays of paired fins much expanded; scales large and smooth ...... [Skull and jaws as in Chirocentrites, with deep supraoccipital crest; teeth with vertical successors, not compressed to a sharp edge, and no nutritive foramina or notches on the inner face of the jaw below the alveolar border. B. Teeth in sockets, nearly regular in Portheus (p. 92).]

Platinx (p. 89).

Chirocentrites (p. 90). size on each bone, not much enlarged in premaxilla.

(a) No presymphysial bone in mandible.

Teeth not compressed to a sharp edge; caudal vertebræ about 35 in number; rays of paired fins much expanded; dorsal fin short-based, opposed to anal; scales large and smooth ......

[Skull, jaws, and teeth as in SpathoSpathodactylus:(p. 98)。 dactylus, with small supraoccipital crest: teeth with rertical successors and no nutritive foramina or notcles on the inner face of the jaw below the alveolar border......... 
[As Spathodactylus, but dorsal fin longer than deep and opposed to pelvic fins ...........

(b) A presymphysial bone in mandible.

Similar skull and jaws, but the teeth compressed to a sharp edge, and a series of nutritive notches on the inner face of the jaw below the alveolar border.

Teeth compressed to a sharp edge, Cladocyclus (p. 107).] with germs of successors arising on the inner face, where there is a series of nutritive foramina below the alveolar border ....

Saurodon (p. 111).

Saurocephalus (p. 113).

\title{
Genus CHIROCENTRUS, Cuvier.
}

\author{
[Règne Animal, vol. ii. 1817, p. 178.]
}

Trunk elongated and laterally compressed; abdomen trenchant. Teeth laterally compressed, firmly fixed in shallow sockets; at least one pair of premaxillary teeth enlarged, the other premaxillary and maxillary teeth small and in single series; mandibular teeth very large, in a single series; minute villiform teeth on the palatines, pterygoids, and tongue. Eight branchiostegal rays. Ribs very deiicate. A long pointed osseous appendage at the base of each pectoral fin; pectoral fins of moderate size, the length of the rays much less than that of the head with opercular apparatus; pelvic fins very small; dorsal fin short, opposed to the anal, which is much extended but not elerated into a pointed lobe in front; caudal fin deeply forked.

This is the sole surviving genus of the family, and is represented only by one existing species in the Indian Ocean.

\section{Chirocentrus (?) polyodon, Günther.}

1876. Chirocentrus (?) polyodon, A. Günther, Geol. Mag. [2] vol. iii. p. 438, pl. xv. fig. 3 .

Type. Dentary bone; British Museum.

A species doubtfully of this genus, known only by fragmentary jaws. The teeth in the dentary are slender, numerous, mostly large but irregular in size, and very closely set; those of the maxilla are about as large as the hindermost teeth of the dentary.

Form. \& Loc. Freshwater Tertiary Lignite: Padang, Sumatra. 
Musfaia, n.g. Oskésinicab.

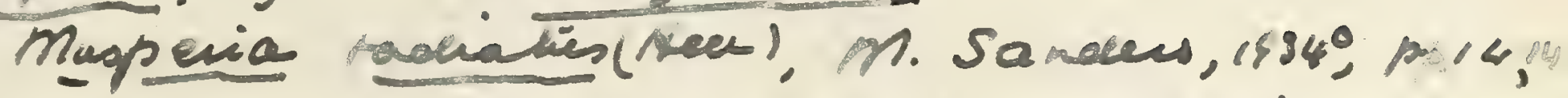

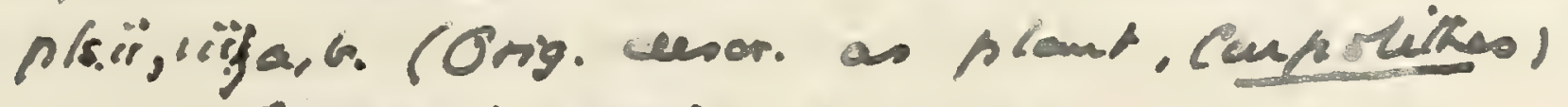

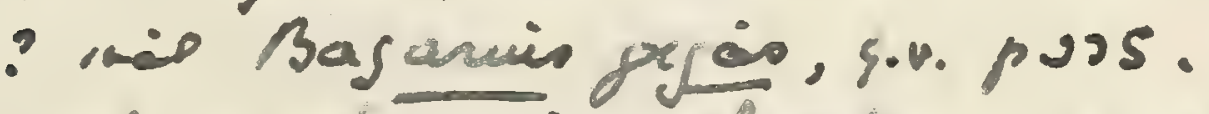

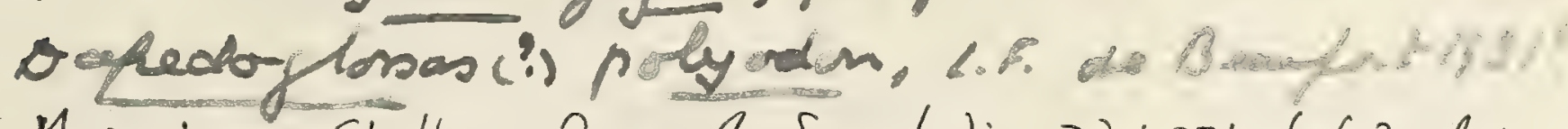

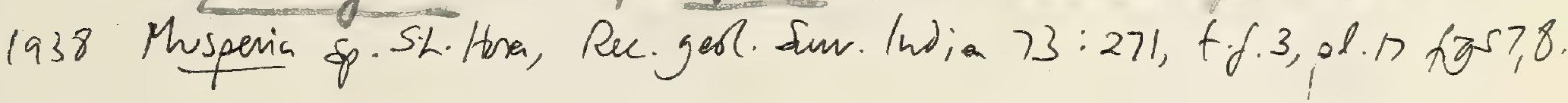




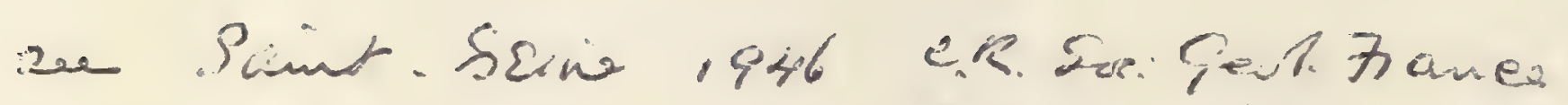

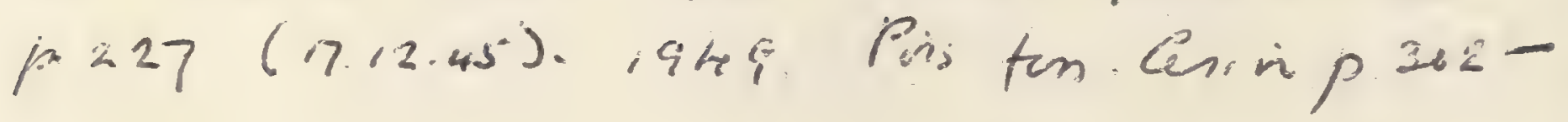

Latinx intermediue, code. Fastman, 1905, man. Sor.

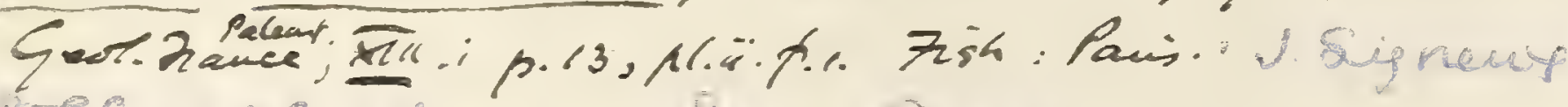

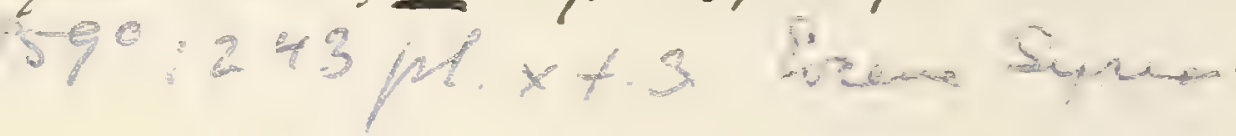

Monotherus pipar, C. Re. Sastman, Bull. Mur. Comp. Zool.

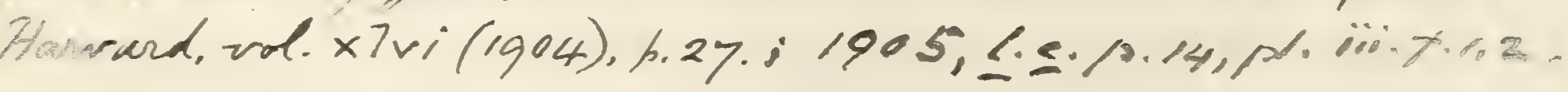


47514. Type specimen, comprising left dentary and impression of left maxilla. The extent of the mandibular dentition, which comprises 23 teeth, is 0.045 . Presented by Herr R. D. H. Verbeek, 1876.

\section{Genus PLATINX, Agassiz.}

[Neues Jahrb. 1835, p. 304.]

Syn. Thrissopterus, J. J. Heckel, Denkschr. k. Akad. Wiss., math.naturw. Cl. vol. xi. 1856 , p. 245.

Trunk elongated and laterally compressed; abdomen trenchant. Tecth small and in regular close series in both jaws, not enlarged in the premaxilla. About six or seven branchiostegal rays. Tertebræ approximately 70 in number, nearly half being caudal; ribs round in section. Pectoral fins considerably enlarged, the length of the rays exceeding that of the head with opercular apparatus; pelvic fins very small; dorsal fin low and much extencied, opposed to the anal, which is also much extended but not elerated into a pointed lobe in front; caudal fin deeply forked. Scales large and smooih.

The following species of this extinct genus are recognised, but are not represented in the Collection :-

Platinx catullii: Thrissopterus catullii, J. J. Heckel, Denkschr. k. Akad. Wiss., math.-naturw. Cl. vol. xi. (1856), p. 248, pl. xii. fig. 5.- - pper Eocene; Monte Bolca, near Terona. [The type species of Thirissopitius. Nearly complete fish; University Huseum, Padua.]

Platine elongatus, L. Agassiz, Teues Jahrb. 1835, p. 304, and Poiss. Foss. vol. v. pt. ii. (1835-44), p. 125, pl. xiv.; F. Bassani, Atti Soc. Teneto-Trent. Sci. Nat. rol. iii. (1876), p. 1-8. Esox macioptemus, H. D. de Blainrille, Nour. Dict. d'Hist. Yat. rol. xxrii. (1818), p. 342.-Ibid. [The type species. Nearly complete fish; Paris Iruseum

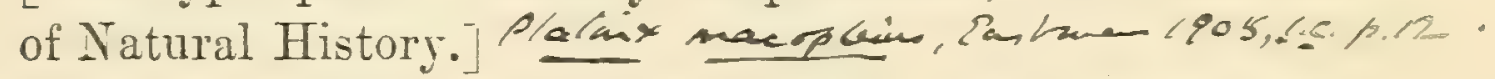

Platinx gigas, L. Agassiz, Teues Jahrb. 1835, p. 304 . Monopteros gigas, G. S. Tolta, Ittiolit. Teronese (1796), p. cxci, pl. xlrii.-Ibid. [Nearly complete fish; Paris Museum of Natural History.]

Genus CHIROMYSTUS, Cope.

[Proc. Amer. Phil. Soc. vol. xxiii. 1886, p. 4.]

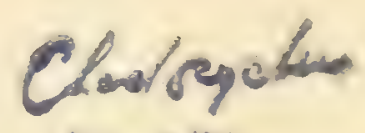
$p \cdot 1.87$

Trunk elongated and laterally compressed. Teeth rounded in section and hollow, not in deep sockets but firmly fixed to the jaws; 
upper teeth of moderate size, in a single uniform series; lower teeth in a similar single uniform series, but one pair at the symphysis much enlarged. Vertebræ about 50 in number, nearly half being caudal ; centra with iwo deep, longitudinally-extended pits on each side; ribs comparatively stout, flattened and impressed with a longitudinal groove. Pectoral fins rather large; pelvic fins very small; dorsal fin short, opposed to the anal, which is somewhat extended; caudal fin deeply forked. Scales large, smooth, and very thin.

The characters of the dentition are here given on the assumption that the skull recorded below is rightly referred to this genus.

\section{Chiromystus mawsoni, Cope.}

1886. Chivomystus mawsoni, E. D. Cope, loc. cit. p. 4.

1888. Chiromystus musosoni, A. S. Woodward, Ann. Mag. Nat. Hist. [6] vol. ii. p. 134.

Type. Imperfect trunk; Cope Collection.

The type species, attaining a length of about 0.4 . Depth of longest ribs with vertebral centra contained about four and a third times in the length from the pectoral arch to the base of the caudal fin. Origin of anal fin equidistant from the pelvic and caudal fins.

Form. \&. Loc. Upper Cretaceous: Bahia, Brazil.

P. 7345. Imperfect skull, of which the jaws are figured, upside down, by Allport, Quart. Journ. Geol. Soc. vol. xvi. (1860), pl. xiv. fig. 4. Presented by Samuel Allport, Esq., 1894.

P. 7110. Fragmentary remains of head and anterior part of $a b-$ dominal region with pectoral fin.

Presented by Joseph Mawson, Esq., 1893.

P. 5531. Portion of small caudal region, noticed by A. S. Woodward, loc.cit.; from Itacaranha.

Presented by Joseph Mawson, Esq., 1888.

Genus CHIROCENTRITES, Heckel.

[Sitzungsb. k. 'Akad. Wiss., math.-naturw. Cl. 1849, pt. i. p. 17.]

Trunk elongated and laterally compressed; abdomen trenchant. Teeth vot compressed to a sharp edge; very irregular in size, and at least one pair in the premaxillæ much enlarged. About 20 branchiostegal rays. Vertebræ approximately 60 in number, about 35 being abdominal; the centra exhibiting two deep, longitudinallyextended pits on each side; ribs comparatively stout, each flattened. 
$947 \mathrm{Cm}$ B. Sehueffe. BuVAmNH.SF ipos

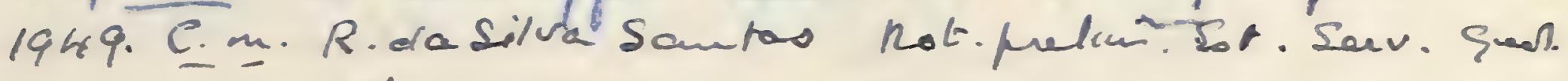

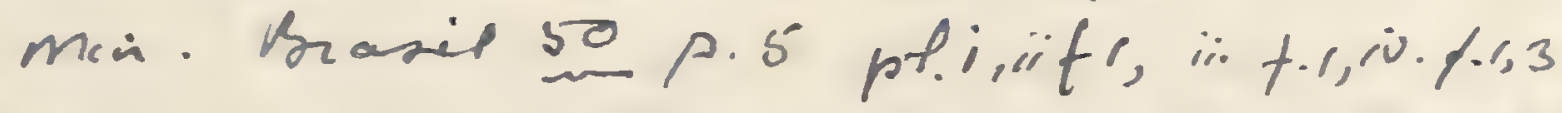

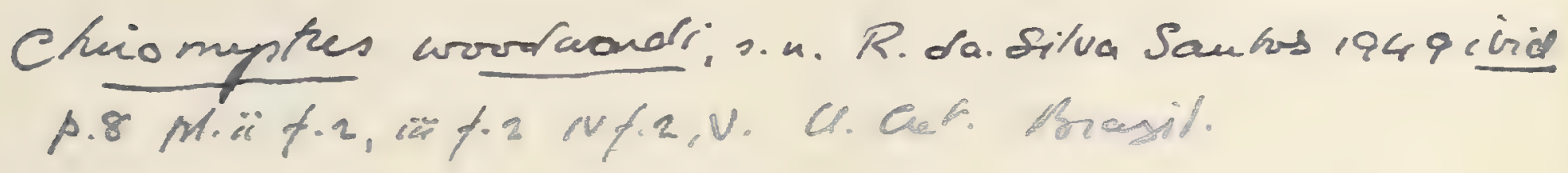

Chiromystur alagoensio, H. S. Gordan, Am. Carnepier Inur. vol. vii (1910), h.32, hl. ix.fip. 15, Sh. xii. xiii. - Blacte thale; Riacho Doce, slagios, Brazil. [Head d pectoral firr; Carmegie Luseum, Pittsburph.T B. Schoeplen. 1947 Lud a m.n.t. 89 i p.15 N.3. F.t. 
pis. Chirocentrites corominii, G.X'Erasmo, Paldeont. 9kalica, h. xxi, h.39, he, vi. fi. 2, terht-fir. 34-36.

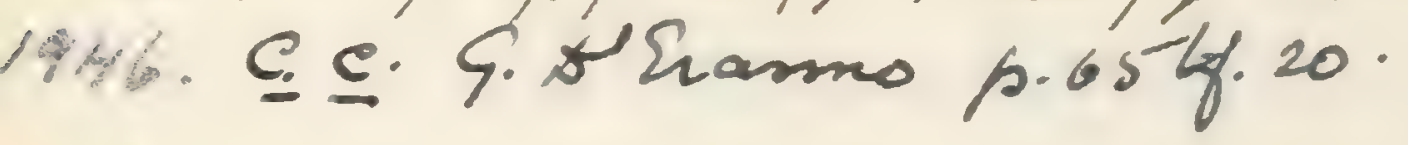


and impressed with a longitudinal groove. Paired fins with few much-expanded rays, the length of the pectoral rays not exceeding that of the head with opercular apparatus; dorsal fin short, opposed to the anal, which is much extended and is elevated into a pointed lobe in front; caudal fin deeply forked. Scales smooth.

\section{Chirocentrites coroninii, Heckel.}

1849-50. Chirocentrites coroninii, J. J. Heckel, loc. cit. p. 17, and Denkschr. k. Akad. Wiss., math.-naturw. Cl. vol. i. p. 203, pl. xiii., pl. xiv. figs. 1, 2.

1856. Chirocentrites coroninii, J. J. Heckel, Denkschr. k. Akad. Wiss., math.-naturw. Cl. vol. xi. p. 243.

1867. Chirocentrites coroninii, R. Kner, Sitzungsb. k. Akad. Wiss., math.-naturw. Cl. vol. lvi. pt. i. p. 189.

1885. Chirocentrites coroninii, D. G. Kramberger, Rad Jugoslav. Akad. vol. lxxii. p. 28.

Type. Nearly complete fish; Court Nuseum, Vienna.

The type species, attaining a length of about $0 \cdot 7$. Length of head with opercular apparatus slightiy exceeding its maximum depth, and contained about seren times in the total length of the fish; maximum depth of trunk equalling nearly one quarter of its length from the pectoral arch to the base of the caudal fin. Suborbitals and preoperculum serrated on lower margin. Dentigerous border of maxilla sinuous, the teeth smaller than those of the dentary and premaxilla, but stout and largest on the convex portion. Vertebræ about 35 in number in the abdominal, 28 in the caudal region. Pelvic fins arising twice as far from the pectorals as from the anal; dorsal fin with 15 rays, of which the foremost five are especially robust and adpressed, forming the anterior acumination; anal fin with about 34 rays, of which the foremost five resemble those of the dorsal.

Form. \& Loc. Neocomian: Goriansk, Görz, Istria.

Not represented in the Collection.

Like the so-called Chirocentrites microdon (Part III. p. 526), the following two species, which are not represented in the Collection, may belong either to Chirocentrites or to Thrissops:-

Chirocentrites gracilis, J. J. Heckel, Sitzungsb. k. Akad. Wiss., math.-naturw. Cl. 1849 , pt. i. p. 18, and Denkschr. k. Akad. Wiss., math.-naturw. Cl. vol. i. (1850), p. 208, pl. xv. Thrissops gracitis, F. Bassani, Denkschr. k. Akad. Wiss., math.-naturw. Cl. vol. xlv. (1882), p. 257.-Cretaceous; Comen, Istria. Thiss ofo graeifi Dthas no $1816 \cdot 16 \cdot 17$ 
Chirocentrites vexillifer, J. J. Heckel, loc. cit. vol. xi. (1856), p. 245, pl. ii. figs. 1, 2. Thrissops vexillifer, F. Bassani, Toc. cit. 1882, p. 257 ; D. G. Kramberger, Djela Jugoslav. Akad. vol, xvi. (1895), p. 36, pl, viii. fig. 6.-Ibid. TAun Tfs

Nothing is known of the so-called Chrocentrites? cavolini from the Cretaceous of Pietraroja (O. G. Costa, Atti R. Accad. Sci. Napoli, vol. ii. 1865 , no. 16 , p. 9, name only).

\section{Genus PORTHEUS, Cope.}

[Proc. Amer. Phil. Soc. vol. xii. 1872, p. 331.]

Syn. Megalodon, L. Agassiz (non Sowerby, 1829), Poiss. Foss., Feuill. 18355, p. 55 (in part).

Hypsodon, I. Agassiz, Poiss. Foss., Feuill. 1837, p. 104 (in part).

Xiphactinus, J. Leidy, Proc. Acad. Nat. Sci. Philad. 1870, p. 12.

A provisional name given to fragmentary remains of a genus of fishes, which has not yet been clearly distinguished from Chirocentirtes. Supraoccipital bone bearing a conspicuous median longitudinal crest; premaxillæ short and deep. Teeth confined exclusively to the premaxillary, maxillary, and dentary bones, all hollow, subcylindric or moderately compressed, but destitute of sharp or serrated edges, and lodged in deep sockets; very irregular in size, those of the premaxilla, middle of maxilla, and anterior end of dentary relatirely large. Successional teeth formed directly beneath the functional teeth, and no nutritive foramina on the inner face of the jaw below the alveolar border. All the vertebral centra, except a few immediately behind the head, exhibiting two deep, longitudinally-extended pits on each side. Both paired fins with few broad and stout rays, which are very finely articulated and divided quite at the distal end.

Notes on the osteology of this genus are published by 0. P. Hay, Zool. Bull. vol. ii. (1898), pp. 25-54, figs. 1-16.

\section{Portheus molossus, Cope.}

(?) 1870. Xiphactinus audax, J. Leidy, Proc. Acad. Nat. Sci. Philad. p. 12. [Fin-ray; National Museum, Washington.]

(?) 1871. Saurocephalus audax, E. D. Cope, Proc. Amer. Phil. Soc. rol. xi. p. 533.

1872. Portheus molossus, E. D. Cope, ibid. vol. xii. pp. 175, 333.

(?) 1873. Xiphactinus andar, J. Leidy, Contrib. Extinct Vert. Fauna

W. Territ. (Rep. U.S. Geol. Surv. Territ. vol. i. pt. i.), p. 290, pl. xvii. figs. 9, 10. 


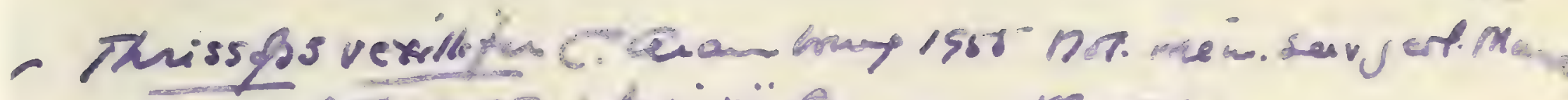
118 p.46.1.23.27 k4. vi.ni Cencman. Momes.

Chirocentrikes? guinensis Weiler.

1912. Enchoduslis sp. C.R. Eastman, Ann. Cannegie thes. vot viii p.3>> s. $x$. xir, f.l.

1922. Chioseninies? quinensis, W. Weicer, Pat. Zeitschr. Wd.v. p.149. F-f.1. (see sugpl. tothis poper in Separati.)

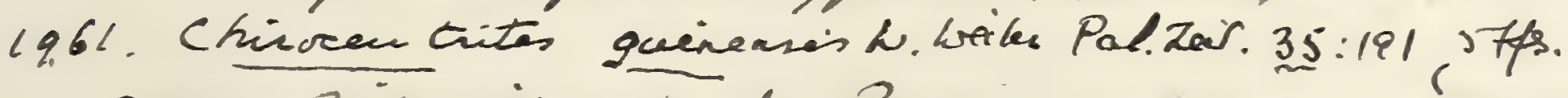

Type. Fish witent head; Preerss. Geot. Landesan.

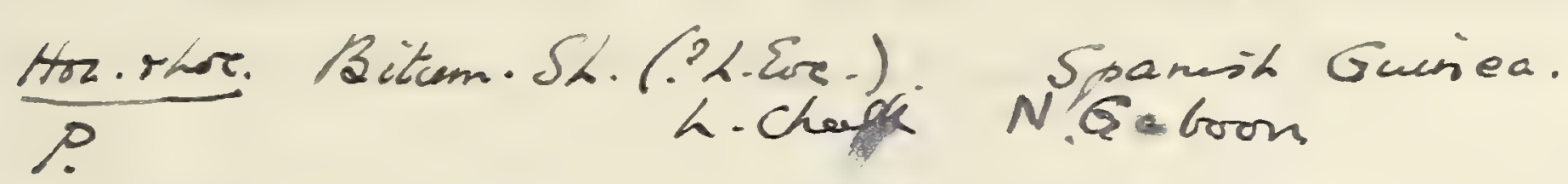


1875. Portheus molossus, E. D. Cope, Vert. Cret. Form. West (Rep. U.S. Geol. Surv. Territ. vol. ii.), pp. 184, 194, fig. 8 (woodc.), pls. xxxix.-xli.; pl. xliv. figs. 5, 10, 11; pl. xlF. figs. 9-11.

1892. Portheus molossus, A. R. Crook, Palæontogr. vol, xxxix. p. 11t, pl. xriii.

1898. Xiphactinus audax, A. Stewart, Kansas Unir. Quart. [A] vol. vii. p. 119 , pls. vii. $-\mathrm{x}$.

Type. Skull, with vertebræ and fin-rays;

The type species, of large size, the cranium attaining a length of 0.35. Premaxilla with two teeth, the foremost usually haring two thirds the diameter of the second. Maxilla three times as long as the premaxilla, much deepened at the anterior palatine articulation, and its oral border nearly straight; about five enlarged teeth in its anterior half. Depth of dentary at the symphysis nearly equalling one third the total length of the mandibular ramus, and its oral border very slightly undulating; about five enlarged teeth in front, the two foremost separated by a transverse groove from the three behind. Dental crowns smooth and not facetted, not curred at the apex. Cheek-plates marked with very feeble large tubereles and rugæ.

Form. \& Loc. Upper Cretaceous (Niobrara Group): Smoky Hill, Kansas, U.S.A.

P. 6326. Slab of friable chalk exhibiting a nearly complete head, right lateral aspect, associated with numerous vertebral centra, remains of the pectoral and pelvic arches, some of the pectoral fin-rays, and the greater part of the pelvic fins. The two halves of the pelvic arch are shown to be firmly united by suture, and one of the pelvic fins seems to be better preserved than any hitherto described. It exhibits five broad rays, all very finely subdivided and articulated in step-like sutures at their expanded distal end. The foremost ray is much the largest; the three diminishing hinder rays are crushed so as to exhibit their loosely apposed right and left halves. Purchased, 1891.

P. 632\%. Series of caudal vertebræ.

Purchased, 1891.

The following specimens from the English Chalk indicate a form of Portheus as large as $P$. molossus, probably distinct, but not specifically determinable :-

25923 x. Portion of cranium ; Chalk, Sussex.

Dixon Coll.

4057. Remains probably of maxilla and premaxilla; Chalk, Lewes. Mantell Coll. 
39063. Imperfect left maxilla, noticed by E. T. Nerton, Quart. Journ. Geol. Soc. rol. xxxiii. (1877), p. 510 ; Chalk, near Maidstone. Bowerbank Coll.

4102. Fragment probably of dentary showing two teeth, described and figured by Agassiz, Poiss. Foss. vol. v. pt. i. p. 100, pl. $\operatorname{xx\nabla a.fig.~3,~under~the~name~of~Hypsodon~lewesiensis,~}$ noticed by Newton, 2oc. cit.p. 510 ; Chalk, Lewes.

Mantell Coll.

P. 473. Remains of both dentary bones, described and figured by Agassiz, tom. cit. p. 100, pl. $\mathrm{x} \times \nabla$. fig. 3, under the name of Hypsodon Tewesiensis, subsequently further dirested of matrix; Lorrer Chalk, Burham, Kent. Egerton Coll.

P. 8252. Imperfect large left dentary; Lower Chalk, Burham.

$$
\text { Presented by G. E. Dibley, Esq., } 1895 .
$$

P. 5412. Two fragments of dentary; Lewes.

$$
\text { Presented by P. E. Coombe, Esq., } 1888 .
$$

46389. Fragment of jaw displaying large teeth, noticed by Newton, loc. cit. p. 510 ; Chalk, Warminster, Wiltshire.

Cunnington Coll.

P. 5720. Fragments of chain of rertebræ; Burham.

Harford Coll.

35\%01. Tertebral centrum and fragment; Lower Chalk, Dover.

Purchased, 1859.

39065. Large vertebral centrum; Chalk, Gravesend.

Bowerbank Coll.

41693. Imperfect scapular arch; Lower Chalk, Halling, Kent. Mrs. Smith's Coll.

P. 6531. Fin-ray wanting distal end; Lower Chalk, Blue Bell Hill, Burham, Kent. Presented by S. J. Hawkins, Esq., 1891.

P. $450 \%$. Base of similar fin-ray; Chalk, Maidstone.

Enniskitlen Coll.

39085, 39426. Portions of similar fin-rays; Burham.

Bowerbank Coll.

44625. Two portions of similar fin-rays; Upper Chalk, Bromley. Purchased, 1873.

43391. Associated bases of fin-rays; Lower Chalk, Burham. 


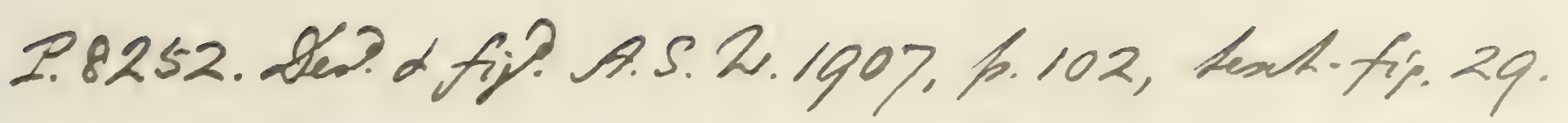

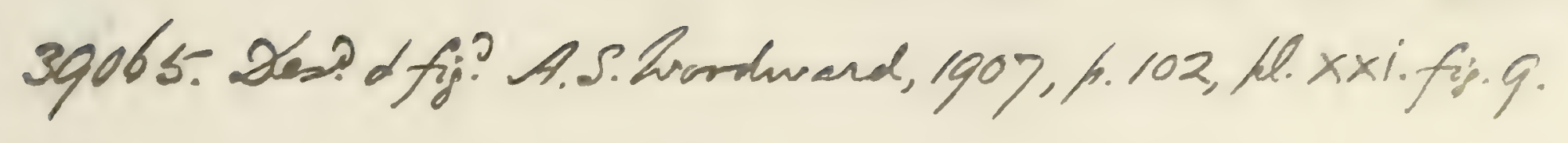


Potheus mantelli; A.S. frorcherd, son. Firhes

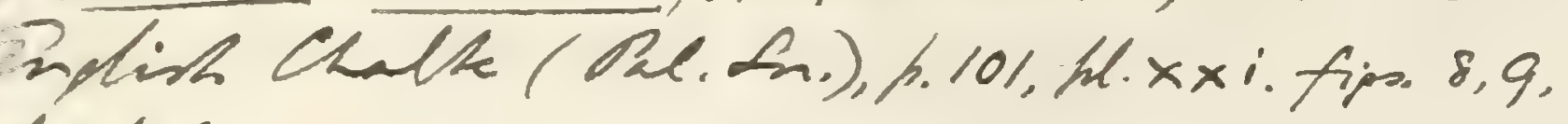
text fis

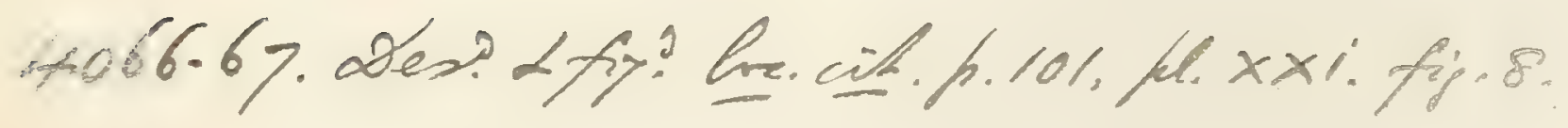

190\% Portheur daviesi, A.S. Wordevard, Fon. Firhes Entis chathe (Dal, Dh.), h. 102, hexh-fis. 30.

28388. Des? Lfig? A.S. W. 1907, h.103, texch-fis. 30. 


\section{Portheus mantelli, Newton.}

1822. "Unknown fish," G. A. Mantell, Foss. South Downs, p. 241, pl. xlii. figs. $1,3,4$.

1835. Megalodon sauroides, L. Agassiz, Poiss. Foss., Feuill. p. 5 j (name only).

1836. Megulodon? lexcesiensis, G. A. Mantell, Descript, Catal, Geol. \&c. Mus. Sussex Sci. Lit. Inst. ed. 5 , p. 30.

1837-44. Hypsodon lewesiensis, L. Agassiz, Poiss. Fuss. rol. v. pt. i. p. 100 (in part), pl. $x x \vee$ b. fiogs. ], 2.

1877. Portheus mantelli, E. T. Newton, Quart. Journ. Geol. Soc. vol. xxxiii. p. 510 .

Type. Imperfect left maxilla and premaxilla; British IIuseum.

A species of moderate size, the upper jaw attaining a length of about $0 \cdot 18$. Premaxilla with fire teeth of unequal size. Maxilla about four times as long as the premaxilla, and its oral border in the form of a slightly concave arch. Teeth smooth, not facetted.

Form.\& Loc. Turonian: Sussex.

4066-67. T'ype specimen, the premaxilla being in counterpart; Chalk, Lewes. Mantell Coll.

\section{Portheus daviesi, Newton.}

1877. Portheus daviesii, E. T. Newton, Quart. Journ. Geol. Soc. rol. xxxiii. p. 511, pl. xxii. fig. 13.

Type. Right maxilla; British Museum.

A species of moderate size, known only by the maxilla, which is unusually robust and exhibits a slightly convex oral border. The teeth are smooth and not facetted, largest in the middle of the bone at the summit of the convexity.

Form. \& Loc. Turonian: Kent.

28388. Type specimen, the right maxilla associated with a vertebral centrum and an imperfect undetermined bone; Lower Chalk, near Maidstone. Mantell Coll.

\section{Portheus gaultinus, Newton.}

[Text-figure 5.]

1877. Porthens gaultinus, E. T. Newton, Quart. Journ. Geol. Soc. vol. xxxiii. p. 512, pl. xxii. figs. 1-12, and woodeut.

Type. Imperfect head and associated vertebræ; IIuseum of Practical Geology, London.

A species of moderate size, the cranium attaining a length of about $0 \cdot 2$. Premaxilla with five teeth, the second and third much larger than the others. Maxilla four times as long as the pre- 
maxilla, deepened and very robust at the anterior palatine articulation, and its oral border very slightly sinuous, the feeble convexity in its middle third bearing the largest teeth. Depth of dentary at the symphysis equalling one third the total length of the mandibular ramus, and its oral border excavated in its middle

Fig. 5.

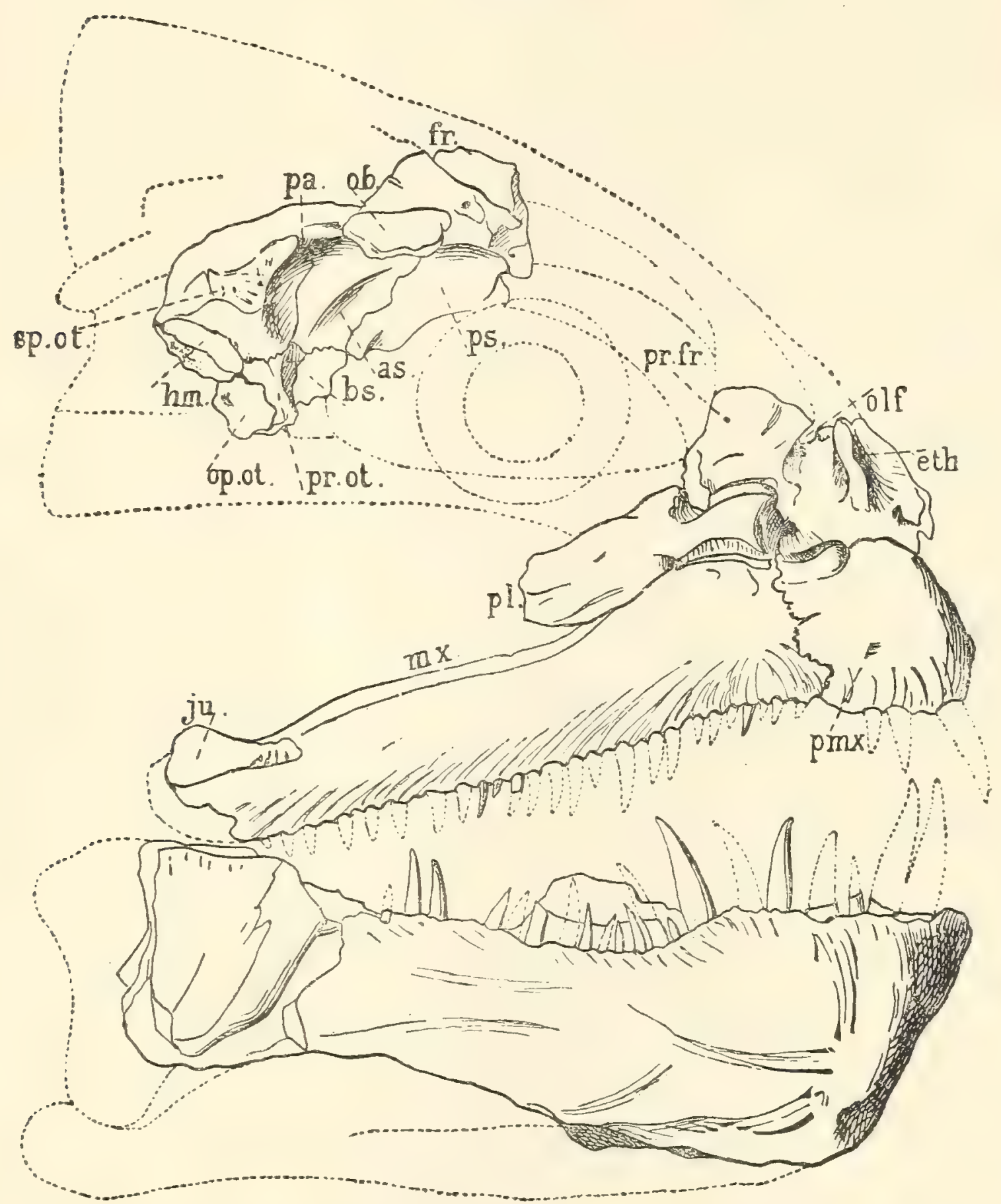

Portheus gaultinus; partial restoration of head by E. T. Newton, one half nat. size.

as., alisphenoid; bs., upper portion of basisphenoid ; eth., mesethmoid; fr., frontal; $h m$., facette for hyomandibular ; $j u$., supramaxilla ; $m x$., maxilla; $o b$. supraorbital; olf., foramen for olfactory nerve; op.ot., opisthotic; $p a$. , parietal region; $p l$. , palatine; $p m x$. , premaxilla; $p r . f r$. , prefrontal (ectethmoid) ; pr.ot., pro-otic; ps., orbitosphenoid (?); sp.ot., postfrontal (sphenotic). 



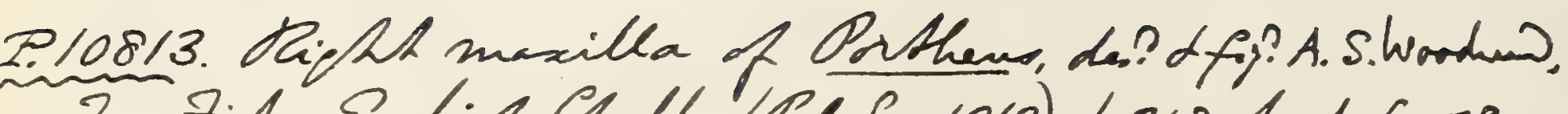

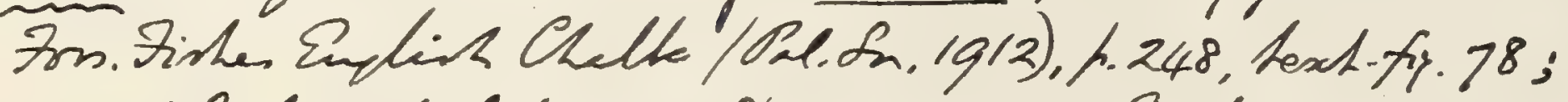

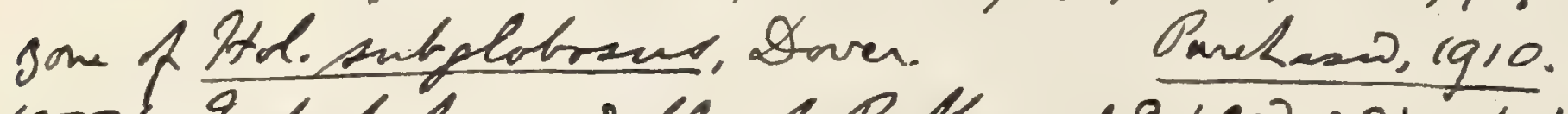

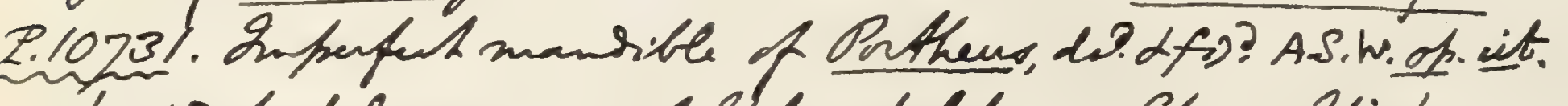

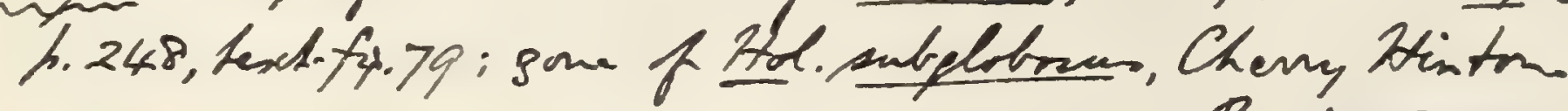
Parcheso, 1909.

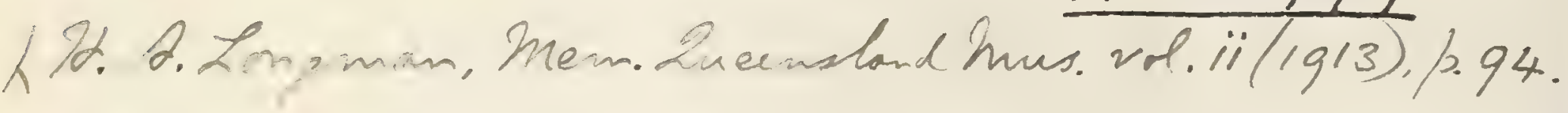

Pallews dumedineusis, s.n. 7. Camponan 19340 10.117,

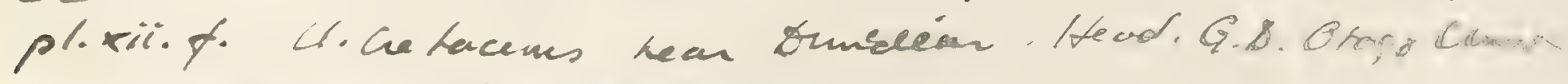
sermatroia ura Scomisines.

Puxcus, axarticus, sin. Riacosion 983 :

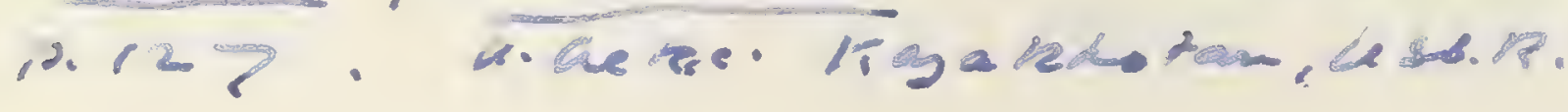


portion; about eight enlarged teeth of variable size in advance of the concavity. Dental crowns smooth, not facetted, the apex often a little curved inwards.

Form. \& Loc. Albian-Turonian: Kent.

4\%205. Imperfect right maxilla and associated vertebral centrum; Gault, Folkestone.

Gardner Coll.

40146. Imperfect mandible ascribed to this species by E. T. Newton, loc. cit. p. 520; Lower Chalk, Halling, Kent.

Purchased, 1866.

The following specimen is not specifically determined :-

32392. Fragmentary remains of large fish ; Upper Greensand, Isle of Wight.

Purchased, 1857.

The following species have also been based upon fragmentary remains of jaws with teeth, but are not represented in the Collection :-

Portheus australis, A. S. Woodward, Ann. Mag. Nat. Hist. [6] vol. xir. (189t), p. 444, pl. x. fig. 1.-Lower Cretaceous (Rolling Downs Formation); Clutha Station, near Hughenden, Gidgery Creek, Queensland. [Jaws; Geological Survey of Queensland, Brisbane.]

Portheus brachygnathus: Xiphactinus brachygnathus, A. Stewart, Kansas Cniv. Quart. [A] vol. viii. (1899), p. 107. Xiphactimus lestrio, A. Stewart, ibid. vol. vii. (1898), p. 118, pl. viii. (errore).- - Upper Cretaceous (Niobrara Group); near Gorham, Russell Co., Kansas. [Jaws; Kansas University Museum.]

Portheus lestrio, E. D. Cope, Proc. Acad. Nat. Sci. Philad. 1873, p. 337, and Vert. Cret. Form. West (Rep. U.S. Geol. Surv. Territ. vol. ii. 1875), p. 201, pl. xlii. figs. 1-3, pl. xlvii. fig. 1.-Upper Cretaceous (Niobrara Group); Kansas. [Imperfect skull; Cope Collection.]

Portheus lowi, A. Stewart, Kansas Cnir. Quart. [A] vol. vii. (1898), p. 24, pl. ii. fig. 2.- Tpper Cretaceous (Fort Benton Group); Fairbury, Nebraska. [Dentary bones; Kansas University M[useum.]

Portheus mudgei, E. D. Cope, Bull. U.S. Geol. Surv. Territ. no. 2 (1874), p. 40, and Vert. Cret. Form. West (1875), p. 203. - Upper Cretaceous (Niobrara Group); Kansas. [Imperfect upper jaw ; Cope Collection.]

Portheus thaumas, E. D. Cope, Vert. Cret. Form. West (1870), PART IV. 
p. 196, pl. xliii., pl. xlir. figs. 1-4, and Proc. Amer. Phil. Soc. vol. xii. (1872), p. 335. Saurocephalus thaumas, E. D. Cope, Proc. Amer. Phil. Soc. vol. xi. (1871), p. 533. "= Xiphactinus audax," A. Stewart, Kansas Univ. Quart. [A] vol. vii. (1898), p. 119.-Upper Cretaceous (Niobrara Group); Smoky Hill, Kansas. [Jaws, \&c.; Cope Collection.]

Fragments of jaws of large species of Portheus from the Turonian of Saxony and Bohemia are also described under the name of Hypsodon lewesiensis, Ag., by H. B. Geinitz, Palæontogr. vol. xx. pt. ii. (1875), p. 222, pl. xlii. (in part), and A. Fritsch, Rept. u. Fische böhm. Kreideform. (18:8), p. 40, pl. vi.

The names Portheus angulatus and Portheus gladius were originally given by Cope to fragments of Protosphyrcena (see Part III. pp. 413, 414).

\section{Genus SPATHODACTYLUS, Pictet.}

[Foss. Terrain Néocom. Voirons (Paléont. Suisse), 1858, pt. iii. p. 2.]

Trunk robust and moderately elongated, but laterally compressed. Teeth hollow, in deep sockets, not compressed to a sharp edge; those of the maxilla, as also those of the dentary, nearly uniform in size. Vertebræ approximately 60 in number, about 25 being abdominal ; the centra exhibiting two deep, longitudinally extended pits on each side; ribs comparatively stout, each flattened and impressed with a longitudinal groore. Paired fins with few muchexpanded rays, the length of the pectoral rays not exceeding that of the head with opercular apparatus; dorsal fin short, opposed to the anal, which is much extended and is elevated into a pointed lobe in front; caudal fin deeply forked. Scales smooth.

\section{Spathodactylus neocomiensis, Pictet.}

1858. Spathodactylus neocomiensis, F. J. Pictet, Foss. Terrain Néocom. Voirons (Palíont. Suisse), pt. iii. p. 2, pls. i., iii.

1882. Spathodactylus neocomiensis, F. Bassani, Denkschr. k. Akad.

Wiss., math.-naturw. Cl. vol. xlv. p. 247.

Type. Nearly complete fish; Geneva Museum.

The type species, attaining a length of about one metre. Maximum depth of trunk somewhat exceeding the length of the head with opercular apparatus, and contained rather more than three times in the length from the pectoral arch to the base of 
Proportheur Kamerumith. O. Zackel, Sth. Kr prews. ped. Zandesandh.n.s.pt.62 (1909), h.396, hl.iManfe Inmation; Cameroon, Africa. Imperfe L

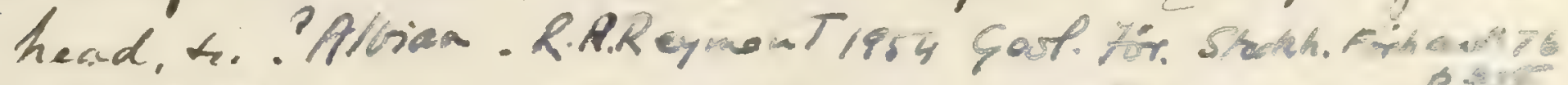

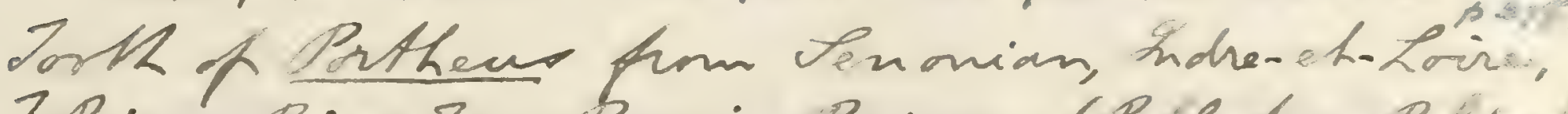

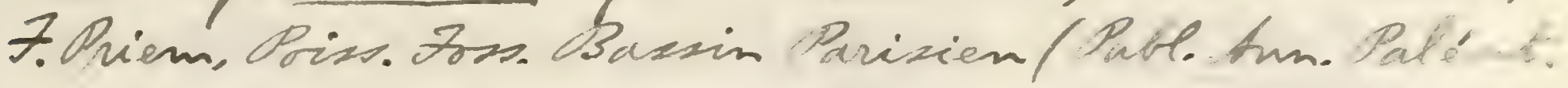
1908, h.61, texchsip. 23.

An indeterminable tellostean troth firm the Patagonian of Azpentina is named Porthens katagrnicur. 7. Amaghino, Anales Anur. Nac. Suenos

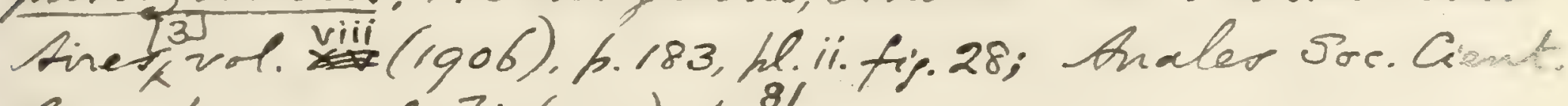
Azpentina, vol. 7i:(1901), hi. 
Notodectos argentimin 8.rs.4. Chere.

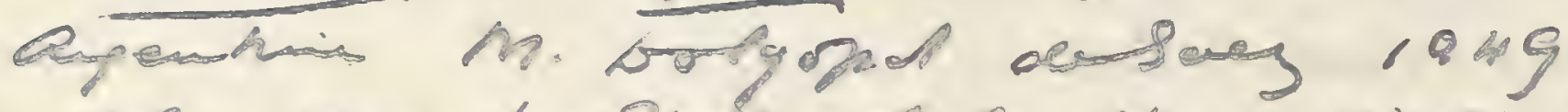

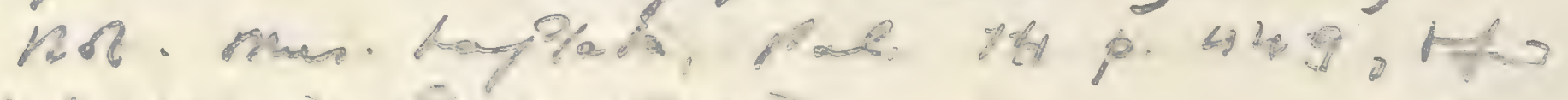

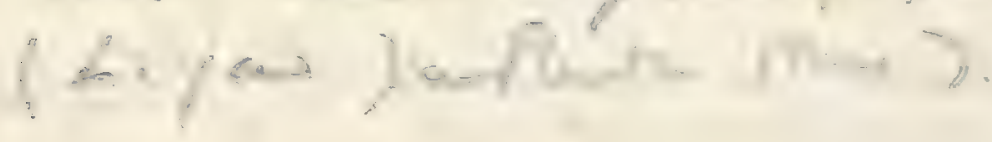


the caudal fin. Teeth smooth, stout, and nearly circular in transrerse section, those of the mandible slightly larger than those of the upper jaw; oral border of maxilla nearly straight, that of the dentary feebly sinuous. Vertebral centra as deep as long, about 25 in the abdominal, 35 in the caucial region. Dorsal fin opposite the middle of the anal fin, which comprises somewhat more than 30 rays, the foremost seven or eight closely adpressed and forming the lobe.

The unique original specimen of this species in the Genera Museum is preserved in counterpart; and although there is a fracture across the unusually short abdominal region, it does not appear to have lost any intervening portion. The skull is imperfect behind, but is shown to have been wide between the orbits, with a very robust prefrontal (ectethmoidal) ossification. The premaxilla is not preserved; and neither the fossil nor its counterpart now exhibits the anterior upper tooth-bearing fragment of bone represented in Pictet's figure. The characteristic maxilla is distinct, fractured across its anterior half and not intelligibly shown in the figure. The sinuous contour of the oral border of the mandible is also exaggerated in the latter; and the fossil is not sufficiently well preserved to determine whether or not the mandible really tapers to the symphysis so much as appearances suggest. There are remains of thin cheek-plates; and one preoperculum is displaced beneath the opercular region. A few traces of delicate branchiostegal rays occur below the mandible. The so-called anterior dorsal fin of Pictet is a false appearance due to the displacement of some neural spines, where the squamation has also been disturbed (as noted by Bassani, loc. cit.).

Form. \& Lor. Neocomian: Voirons, Geneva, Switzerland.

Tot represented in the Collection.

\section{Genus ICHTHYODECTES, Cope.}

[Proc. Amer. Phil. Soc. vol. xi. 1871, p. 536.]

Syn. Gillicus, O. P. Hay, Amer. Journ. Sci. [4] vol. vi. 1898, p. 230.

Teeth hollow, in deep sockets, not compressed to a sharp edge; those of the maxilla, as also those of the dentary, almost uniform in size, and those of the premaxilla not much enlarged. Successional teeth formed directly beneath the functional teeth, and no nutritive foramina on the inner face of the jaw below the alceolar border. No presymphysial bone. Tertebral axis, fins, and scales apparently as in Chirocentrites. 


\section{Ichthyodectes ctenodon, Cope.}

1871. Ichthyodectes ctenodon, E. D. Cope, Proc. Amer. Phil. Soc. vol. xi. p. 536.

1872. Ichthyodectes ctenodon, E. D. Cope, ibid, vol. xii. p. 340.

1875. Ichthyodectes ctenodon, E. D. Cope, Vert. Cret. Form. West (Rep. U.S. Geol. Surv. Territ. vol. ii.), p. 207, pl. xlvi. figs. 1-4.

1900. Ichthyodectes ctenodon, F. B. Loomis, Palæontogr. vol. xlvi. p. 244, pl. xxiii. figs. 7,8 .

Type. Associated maxillary and dentary bones, \&c.; Amer. Hus. 2. H.

The type species, with maxilla attaining a length of about $0 \cdot 16$. Oral border of maxilla straight, with about 40 alveoli; that of dentary slightly concave, with nearly 30 alveoli. Depth of dentary at symphysis about one third the total length of the mandibular ramus. Teeth small, slender and smooth, with the apex turned a little inwards.

Form. \& Loc. Upper Cretaceous (Niobrara Group): Smoky Hill, Kansas, U.S.A.

Not represented in the Collection.

\section{Ichthyodectes anaides, Cope.}

1872. Ichthyodectes anaides, E. D. Cope, Proc. Amer. Phil. Soc. vol. xii. p. 339.

1875. Ichthyodectes anaides, E. D. Cope, Vert. Cret. Form. West (Rep.

U.S. Geol. Surv. Territ. vol. ii.), p. 206, pl. xliv. figs. 14, 15, pl. xlv. figs. 1-8.

1892. Ichthyodectes anaides, A. R. Crook, Palæontogr. vol. xxxix. p. 111, pl. xv.

1900. Ichthyodectes anaides, F. B. Loomis, Palæontogr. vol. xlvi. p. 244.

Type. Remains of skeleton, including mandible and premaxilla; $\alpha$

The largest known species, the mandible attaining a length of about 0.18. Oral border of dentary slightly sinuous, with two convexities, and not prominent at the symphysis; its depth at the symphysis about equal to one third the total length of the mandibular ramus; its outer face gently sinuous, not sharply bent or ridged; teeth small and smooth but stout, with the apex curved inwards. Premaxilla a deep ovoid, very convex on the outer face, thinning laterally and above: teeth five in number, resembling those of the dentary. Maxilla a little deepened in front, and the oral border gently sinuous, with one median convexity; its teeth smaller than those of the premaxilla, and the dental sockets about 40 in number.

Form. \& Loc. Upper Cretaceous (Niobrara Group): Smoky Hill, Kansas. 
1. Clénodon (?), A.B.Reagan, 1927, Proc. Indiane Aead.

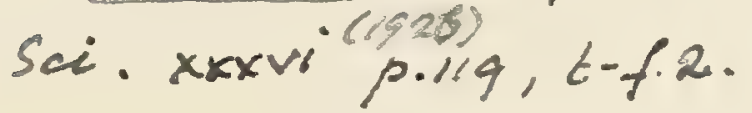

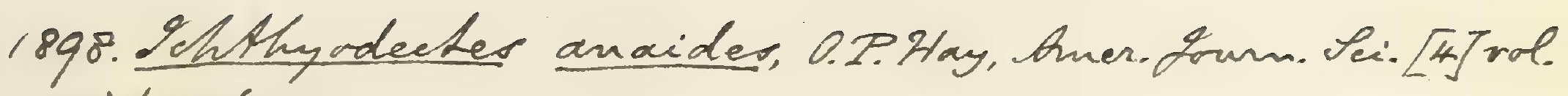
vi. p. 226, fis. 2 . 1903. Ychthyodecter anaides, 0.P. Hay, Bull. Amun. Anm. 


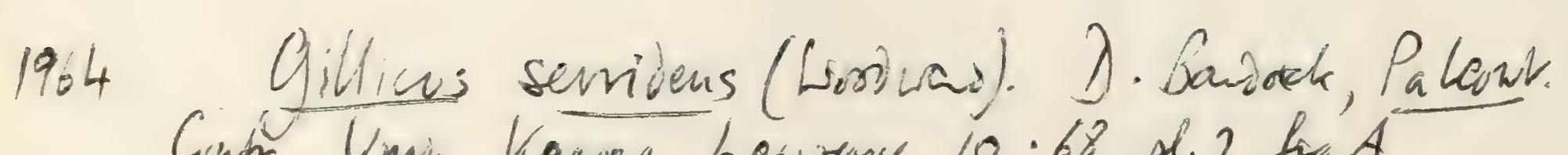
Cunir. Uni Kawses, haw rence, 10:68, pl. 2 fog. A. 
P. 6328. Imperfect jaws with remains of the anterior part of the cranium, displaying the palatine and prefrontal bones and the ossified sclerotic. The articular end of each mandibular ramus is also well shown. Purchased, 1891.

Ichthyodectes arcuatus, Cope.

1875. Portheus arcuatus, E. D. Cope, Vert. Cret. Form. West (Rep. U.S. Geol. Surv. Territ. vol. ii.), p. 204 (non pl. xlvii. figs. 7-9).

1878. Ichthyodectes arcuatus, E. D. Cope, Proc. Amer. Phil. Soc. vol. xvii. p. 177.

1892. Ichthyodectes polymicrodus, A. R. Crook, Palæontogr. vol. xxxix. p. 112, pl. xvi. [Imperfect skull with jaws; Palæontological Museum, Munich.]

1892. Ichthyodectes polymicrodus $=$ I. arcuatus, E. D. Cope, Amer. Nat. vol. xxvi. p. 942.

1898. Gillicus arcuatus, O. P. Hay, Amer. Journ. Sci. [4] vol. vi.p. 230. 1898. Gillicus polymicrodus, O. P. Hay, ibid. p. 230.

1900. Ichthyodectes occidentalis, F. B. Loomis, Palæontogr. vol. xlvi. p. 242, pl. xxiii. figs. 1-6 ${ }^{1}$.

Type. Maxilla; Cope Collection.

The type species of the so-called Gillicus, with maxilla attaining a length of about $0 \cdot 1$. All bones comparatively delicate. Oral border of maxilla strongly sinuous, sharply concave just below and behind the palatine articulation; dentary comparatively deep, and its oral border slightly concave; teeth very small, about 100 in the maxillary series.

Form. \& Loc. Upper Cretaceous (Niobrara Group): Kansas.

P. 9201. Vertically crushed cranium and imperfect jaws, associated with vertebral centra; Elkader, Logan Co., Kansas.

Purchased, 1900.

P. 8902. Fragments of cranium associated with vertebræ; Elkader. By exchange, 1898.

Ichthyodectes serridens, sp. nov. [Plate VIII.]

Type. Head, \&c.; British Museum.

Head and jaws closely resembling those of $I$. arcuatus, but anterior mandibular teeth relatively larger, and maxilla apparently more slender.

Form.\& Loc. Albian: Kent.

1 The extended median dorsal fin in the restoration of this species published by Loomis is entirely hypothetical and seems to be based on the erroneous assumption that such a in occurs in Spathodactylus. 
P. 8633. The type specimen, being the head and part of the abdominal region exposed from the right side, shown of the natural size in Pl. VIII.; Gault, Folkestone. The anterior ethmoidal end of the cranium is slender and pointed, while the supraoccipital (s.occ.) rises as usual into a rounded median crest. The ectethmoid or prefrontal ( $p r . f_{0}$ ) is relatively large and stout, with the usual flattened facette for the articulation of the anterior thickened end of the palatine $\left(p l_{0}\right)$. The premaxillæ (pmx.) are deeper than long, and meet in the middle line in front of the ethmoid. Their teeth are very small, but must have been slightly larger than those of the maxilla, which are quite minute. The maxilla $(m x$.) displays its articulation with the palatine in front, and is orerlapped behind by the cheek-plates : its oral margin is excavated just behind its anterior end, but is strongly convex further back. Its minute teeth are fixed just within the rugose border. The mandible is remarkably deep, and the symphysial end of the dentary $(d$.$) slopes slightly$ backwards and downwards. Its oral margin is only exposed in front, where the slender, styliform teeth are considerably larger than any shown in the upper jaw. There are remains of large, smooth, suborbital cheekplates (s.o.); and the sclerotic of the eye $\left(s c l_{0}\right)$ is well ossified. The preoperculum ( $p . o p$.) forms a great triangular expansion, rather thin and nearly smooth, with a slightly thickened anterior border. The operculum (op.) and other plates are fragmentary. Some of the anterior vertebral centra are slightly longer than deep, and display the characteristic pittings. The bases of some of the pectoral fin-rays ( $p c t$.) are very large and broad. There are also obscure remains of large, thin scales.

Purchased, 1897.

Ichthyodectes minor (Egerton).

1850. Hypsodon minor, Sir P. Egerton, in F. Dixon, Geol. Sussex, p. xir, pl, xxxii.* fig. 9.

1877. Ichthyodectes minor, E. T. Newton, Quart. Journ. Geol. Soc. vol. xxxiii. p. 520, pl. xxii. fig. 14.

Type. Imperfect mandible; British Museum.

A species known only by remains of the mandible, of moderate size. Oral border of dentary nearly straight, with a slight convexity towards its anterior end; its outer face not sharply bulging 


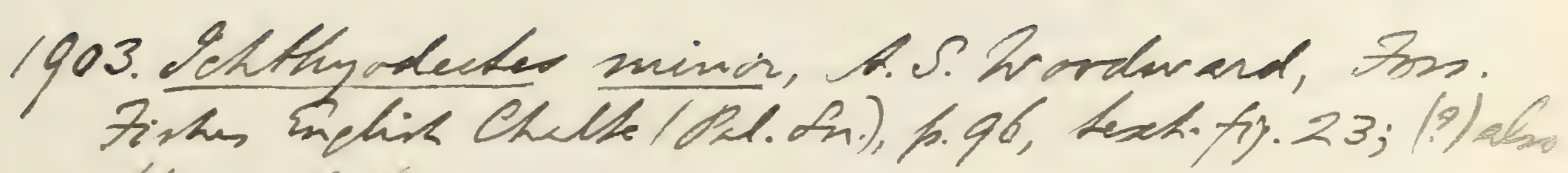
hexix.fir. 
outwards in a longitudinal ridge; its depth at the symphysis about equal to one quarter the total length of the mandibular ramus; teeth upright and straight, not curved at apex, and total number of sockets in dentary about 30 .

Form. \& Loc. Turonian: Sussex, Kent, and Surrey.

28894. Type specimen, figured by Egerton, described and figured by Newton, loc. cit.; Chalk, Sussex. The left mandibular ramus measures $0 \cdot 14$ in length. Dixon Coll.

39064. Portion of both dentaries; near Maidstone.

Bowerbank Coll.

49831. Fragment of dentary; Dorking, Surrey.

Capron Coll.

\section{Ichthyodectes elegans, Newton.}

[Plate IX. figs. 4, 5.]

1877. Ichtrinodectes elegans, E. T. Newton, Quart. Journ. Geol. Soc. vol. xxxiii. p. 521, pl. xxii. fig. 15.

Type. Imperfect dentary; British Museum.

A small species known only by the jaws. Oral border of dentary slightly concave, curved upwards to the beak-like symphysis; its outer face gently sinuous, not sharply bent or ridged; its teeth very small at the symphysis, but of moderate size and in regular series beyond, the crowns slender, all inciined a little forwards, with the apex slightly curved inwards; the dental sockets about 40 in number. Naxilla scareely deepened in front, and the oral border straight; teeth somewhat smaller, stouter, and less inclined than those of the dentary, minute at the hinder end of the bone.

Form. \& Loc. Turonian: Surrey and Kent.

4168\%. Type specimen; Lower Chalk, Dorking.

Toulmin Smith Coll.

P. 5644-45. Imperfect right and left dentaries and left maxilla, found associated; Lower Pit, Upper Halling, Kent. The left dentary is shown of the natural size, from the inner aspect, in Pl. LX. fig. 5, while the maxilla is similarly represented from the outer aspect in fig. 4 . Their specific characters are mentioned above in the diagnosis.

Harforle Coll.

47251. Fragment of right dentary; Lower Chalk, Dover.

Gardner Coll. 
Ichthyodectes tenuidens, sp. nov.

[Plate IX. fig. 6.]

Type. Imperfect skull; British Museum.

A small species known only by remains of the head. Oral border of maxilla and dentary nearly straight; depth of dentary at symphysis not exceeding one quarter the total length of the mandibular ramus. Teeth very slender and smooth, with apex slightly curved inwards.

Form. \& Loc. Turonian and (?) Albian: Kent.

49054. Type specimen, an imperfect head shown of the natural size in Pl. IX. fig. 6 ; Lower Chalk, Burham, Kent. The fossil exhibits the superior and right lateral aspects of the head, but is transversely fractured and partially displaced at the front border of the orbit. The cranial roof is narrow, exhibiting the usual median crest behind, and the frontal bone of the right side raised into a longitudinal ridge. The frontals seem to extend backwards as far as the hinder border of the orbit, and the very small median ethmoid is conspicuous at the end of the snout. None of the bones are externally ornamented. The very large size of the eye is indicated by fragments of the ossified sclerotic $\left(s c l_{0}\right)$; immediately behind this are the remains of the thin cheek-plates (s.o.), with traces of the slime-canal which seems to have had radiating branches; while in front may be observed the robust prefrontal $\left(p r: f_{\circ}\right)$, with its flattened inferior facette for the palatine. The maxilla $\left(m x_{0}\right)$ is long and slender, but much fractured, so that its anterior end is displaced and only three of the slender teeth remain; a facette postero-superiorly shows the extent of overlap of a supramaxillary bone. The general proportions of the mandible are indicated, but the anterior end of this is also fractured. At the symphrsis and behind the fracture a few of the characteristic teeth are preserved. The outer surface of the dentary $(d$. is smooth and only gently undulating, without any sharp longitudinal ridge. The preoperculum (p.op.) is shown to be much expanded, with thickened anterior margin, and the usual radiating branches of the sensory eanal.

Mrs. Smith's Coll.

41693. Fragment of jaw; Lower Chalk, Halling, Kent.

Toulmin Smith Coll.

4722\%. Imperfect right dentary; Gault, Folkestone. Gardner Coll. 


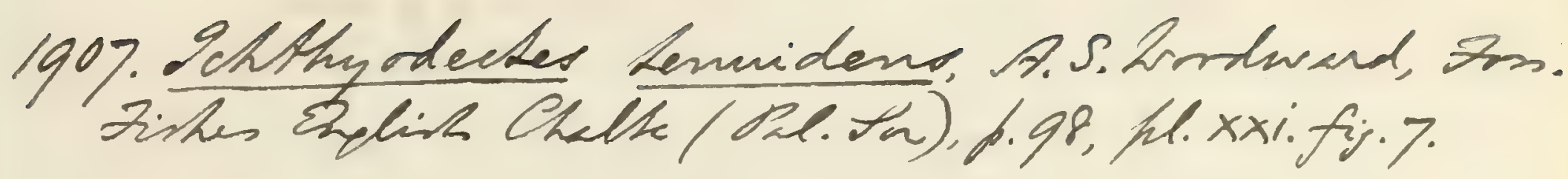

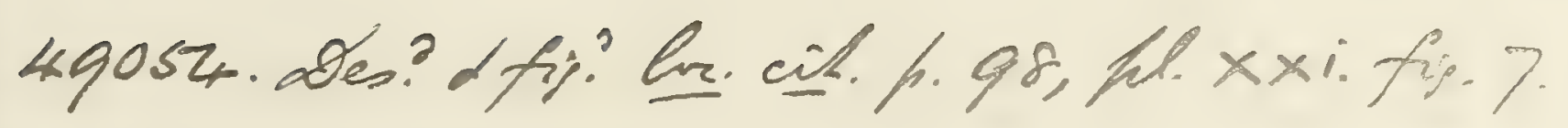


Senus Eubiodectes. Hay.

[Bull. Amen. Amon. H. H.wol. xix.1903, 6.415:]

1003. Eubiodectes litanicus, 0. P. Itay, Bull. Amen. Imm.

3). H. rd. xix. h. 4is. Hl. $x \times x$ fip.1. 
Ichthyodectes libanicus (Pictet \& Humbert).

(?) 1849. Clupea gigantea, J. J. Heckel, in Russegger's Reisen, vol. ii. pt. iii. p. 345. [Portion of abdominal region.]

1866. Chirocentrites libanicus, Pictet \& Humbert, Nouv. Reih. Poiss. Foss. MIt. Liban, p. 88, pl. xiii.

1887. Chirocentrites libanicus, J. W. Daris, Trans. Roy. Dublin Soc. [2] vol. iii. p. 585 .

Type. Anterior portion of fish; Geneva ILuseum.

A species attaining a length of about $0 \cdot 6$, known by the greater part of the fish, differing from Chirocentrites and resembling Ichthyodectes in the characters of the dentition. Maximum depth of trunk equalling somewhat more than one quarter of its length from the pectoral arch to the base of the caudal fin. Oral border of maxilla gently sinuous, concare in its anterior half; teeth of maxilla and dentary approximately equal in size, all very slender, straight, and closely arranged; premaxillary teeth somewhat stouter and more sharply pointed, the foremost larger than the others. Other characters as in Chirocentrites coroninii.

Form. \& Loc. Upper Cretaceous: Mount Lebanon, Syria.

39239. Imperfect large fish, in counterpart, wanting nearly the whole of the head and showing only fragments of the paired fins; Hakel. Part of the cranium is exposed from beneath. One side of this fossil seems to be described by Davis, loc. cit. p. 586; the other shows remains of about 60 vertebræ.

Tristram Coll.

39238. More imperfect remains of a smaller fish; Hakel. The anterior half of the maxilla is well shown, deepened at its robust palatine articulation. Beneath it is part of the mandible, half only in impression, with traces of teeth like those of the maxilla and possibly (though doubtfully) with a few slightly larger teeth. Very slender branchiostegal rays are also seen beneath the remains of the mandible, and the series is continued by larger rays beneath the opercular apparatus: these cannot have been less than 20 in number. The extremities of some stout pelvic and anal fin-rays are observed chiefly in impression. Tistram Coll.

P. 66. Remains of head and anterior portion of abdominal region of a large fish; Hakel. Parts of both maxillæ are identifiable, bearing the very slender teeth. The premaxillæ are also shown in impression; and that of one side bears 
an indication of a slightly enlarged auterior tooth followed by two smaller teeth. The broad, sharply-angulated preoperculum, with thickened auterior border and radiating markings, can be distinguished at the back of the head. The scattered pectoral fin-rays are remarkably robust; and the two examples apparently of the foremost ray exhibit much complexity at the dirided distal end. At this end the ray exhibits longitudinal clefts for the greater part of its width, büt numerous oblique sutures in its front portion.

Lewis Coll.

P. 6\%-70. Four portions of trunk, with remains of the pelvic, dorsal, and anal fins; Hakel. The stout foremost pelvic fin-ray exhibits oblique sutures; the dorsal fin has at least 12 supports. The scales are preserved, and the radiating groores in their covered portion are feebly indicated.

Lewis Coll.

The following specimens may also be referred to Ichthyodectes, but are too imperfect for specific determination :-

P. 9046. Hinder portion of cranium; Lower Chalk, Blue Bell Hill, Burham, Kent. Presented by S. J. Hawkins, Esq., 1891.

P. 1792. Anterior end of a pair of large dentaries, and a fragment, mith bases of teeth; Chalk, Lewes.

Egerton Coll.

P. 5646. Portion of jaw associated with other fragments; English Chalk. Harford Coll.

P. 179\%. Fragment of cery stout jaw, with tecth as slender as those of $I$. tenuidens: English Chalk.

Egerton Coll.

P. 4299. Portion of large dentary with undulating oral margin and similar teeth; Chalk, Sussex.

Enniskitlen Coll.

P. 6016. A much-elongated dentary with traces of similar teeth; Gault, Folkestone.

Purchased, 1889.

49113. Pair of elongated dentaries with sinuous oral border showing: bases of small teeth; Gault, Folkestone.

Mrs. Smith's Coll.

35160 a. Anterior half of right maxilla, showing palatine articulation and tooth-sockets; Cambridge Greensand, Cambridge.

Purchased, 1859.

P. 7268. Six fragments of jaws; Cambridge Greensand. 
Add Pizsqo, wrove hy cutalogned ar Thiseope fomosius in P1. III. 1. 522 .

2.9046. Desurted a fimmed, A.S. Zoodmend, Ans. Firhes En hirh Chalk (Pel. Son. 1903), h. 93, hl. xix. Fip.s.

49810. Oncomplete cranium;

hrsiced A.S.S. 1903, 10.93.

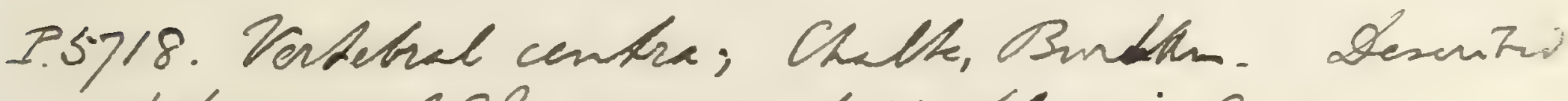
$\alpha$ tipune A.S.2. 1903-07. h.9.5. he. xxi.fip. 3.

Haifind Clll.

416 g'. Jerminal candal renhebos; Challe, Burtam.

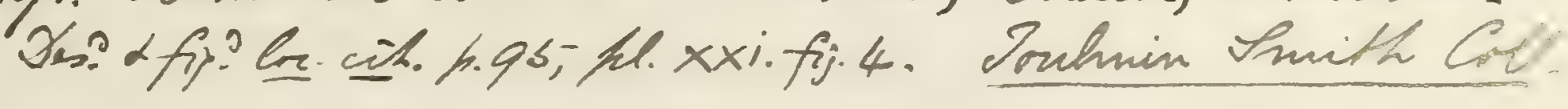




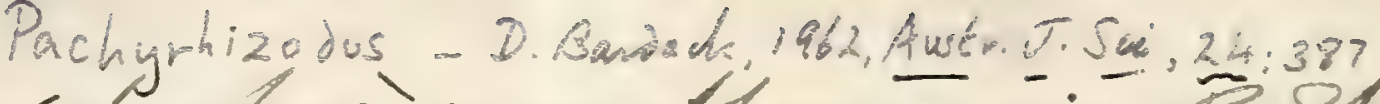

marathonenzit, "r. Stheridpe.

tree. Anstral. Mus. vol. vil(190s), hos, Me...ii.

Z. Cretaceons; Mrarathon, Hinders tiven, Lucenslan.

[Head, t.: B.9.Blwhe Gll.] R.

east of topke dho ine...

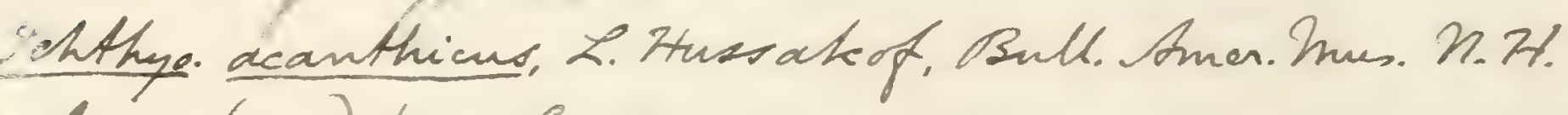

od. $x \times v(1908), h .75, f i s, 39$.

Sawroce thalue goodeanus, O.P. Hay, Bull. Amen. Inm.

hat. Fith, vol, xix (1903), h.52, Lext-fip. 41.

Whyodecter multidentatus, O.P. Hay, Bull. Amen.

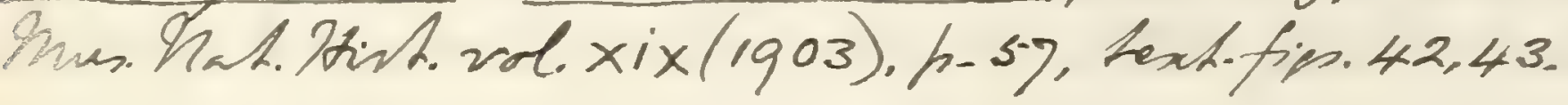

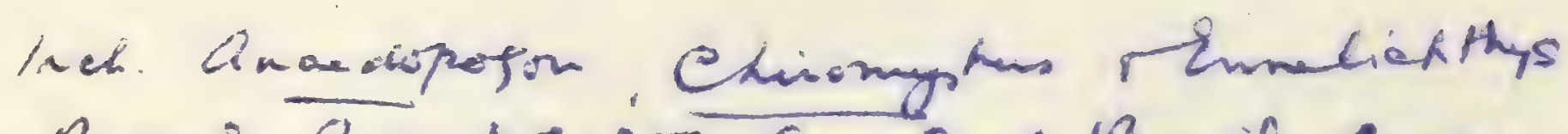

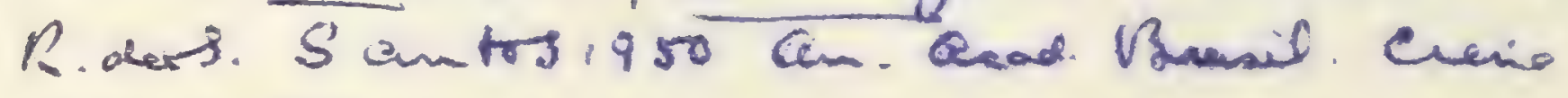
$22 p 123$ 
The following species have also been based upon fragmentary remains of jaws with teeth, but are not represented in the Collection :-

- Ichthyodectes acanthicus, E. D. Cope, Proc. Amer. Phil. Soc. vol. xvii. (1878), p. 177.-Upper Cretaceous; Kansas. [Dentary, \&c.; Cope Collection.]

Ichthyodectes cmuentus, O. P. Hay, Amer. Journ. Sci. [4] vol. vi. (1898), p. 225, woode. 1.-Upper Cretaceous; Butte Creek, W. Kansas. [Imperfect maxilla.]

Ichthyodectes goodeanus, E. D. Cope, Proc. Amer. Phil. Soc. vol. xvii. (1878), p. 176.-Cpper Cretaceous; Kansas. [Maxilla and premaxilla; Cope Collection.]

Ichthyodectes hamatus, E. D. Cope, Proc. Amer. Phil. Soc. vol. xii. (1872), p. 340, and Vert. Cret. Form. West (1875), p. 209, pl, xlvi. fig. 5; O. P. Hay, Amer. Journ. Sci. [4] vol. vi. (1898), p. 225 ; F. B. Loomis, Palæontogr. vol. xlvi. (1900), p. 243, pl. xxiií. fig. 9.-Upper Cretaceous (Niobrara Group); Kansas. [Imperfect jaws, \&c.; Cope Collection.]

Ichthyodectes multidentatus, E. D. Cope, Proc. Amer. Phil. Soc. vol. xii. (1872), p. 342, and Vert. Cret. Form. West (1875), p. 212, pl. 1. figs. 6, 7; F. B. Loomis, Palæontogr. vol. xlvi. (1900), p. 243.- - Upper Cretaceous (Niobrara Group); Kansas. [Premaxilla and imperfect maxilla; Cope Collection.]

Ichthyodectes prognathus, E. D. Cope, Proc. Amer. Phil. Soc. vol. xii. (1872), p. 341, and Vert. Cret. Form. West (1875), p. 210, pl. xlvi. figs. 6-10. Saurocephalus prognathus, E. D. Cope, Proc. Amer. Phil. Suc. vol. xi. (1871), p. 532.-Upper Cretaceous (Niobrara Group); Kansas.

[Premaxilla, maxilla, \&c.; Cope Collection.]

The name Ichthyodectes perniciosus was given by Cope to a portion of pectoral fin of Protosphyrcence (see Part III. p. 414).

\section{Genus CLADOCYCLUS, Agassi\%.}

[Edinb. New Phil. Journ. vol. xxx. 1841, p. 83.]

Syn. Anadopogon, E. D. Cope, Proc. Amer. Phil. Soc. vol. xii. 1871, p. 53.

Trunk laterally compressed and somewhat deeper than the head; ábdomen trenchant. CTeft of mouth directed sharply upwards, and not extending beyond the hinder border of the orbit; "Maxilla robust, with one supramaxillary bone; dentition feeble. Vertebral 
centra at least as long as deep, each impressed with two lateral pits; neural and hæmal spines of tail much depressed and imbricating. Paired fins small, with very stout rays; dorsal fin somewhat longer than deep, opposed to the pelvic pair; [anal fin unknown]; caudal fin deeply cleft. Scales very large, mostly deeper than broad; ornamented in their exposed portion with numerous small pittings, and marked in their covered portion by a few conspicuous radiating grooves.

This incomplete definition is based upon the type specimen of Ancedopogon tenuidens in the U.S. National Museum, several specimens of the same species in the Brazilian National Museum at Rio de Janeiro, and the small series of fragments from Brazil catalogued below. This fish would be referred to the genus Ichthyodectes if the dorsal fin were not so far forwards, as shown in a specimen in the Brazilian National Museum. The detached scales described from other localities under the name of Cladocyclus are doubtfully ascribed to the same genus. Most of them probably belong to species of Ichthyodectes and Portheus. Scales much resembling: those named $C$. occidentalis are shown on a specimen of Ichthyodectes in the Kansas University Museum.

\section{Cladocyclus gardneri, Agassiz.}

[Plate IX. fig. 1.]

1841. Cladocyclus gardneri, L. Agassiz, Edinb. New Phil. Journ. vol. xxx. p. 83.

1844. Cludocychus gardneri, L. Agassiz, Poiss. Foss. vol. v. pt. i. pp. 8, 103, and Comptes Rendus, vol. xviii. p. 1013.

1871. Ancedopogon tenuidens, E. D. Cope, Proc. Amer. Phil. Soc. vol. xii. p. 54. [Head and anterior portion of trunk; National Museum, Washington.]

1888. Cladocyclus gardneri, A. S. Woodward, Proc. Geol. Assoc. vol. x. p. 326.

1890. Anædopogon tenuidens=Cladocyclus gardneri, A. S. Woodward, Geol. Mag. [3] vol. vii. p. 394.

Type. Portions of fishes; British Museum.

The type species, with the head attaining a length of not less than $0 \cdot 15$. Dentary and premaxillary teeth small; maxillary teeth very small or absent. Orbit round, its diameter equalling about one fifth the length of the head. Most of the scales much deeper than broad, ornamented in their exposed portion with numerous small pittings, a few broad undulations concentric with the free hinder margin, and some lobed furrows diverging backwards. -

Form. \& Loc. Upper Cretaceous : Province of Ceara, N.- 
1908. Cladocycher gardneri: D. S. Fordan d \%. C. Brames,

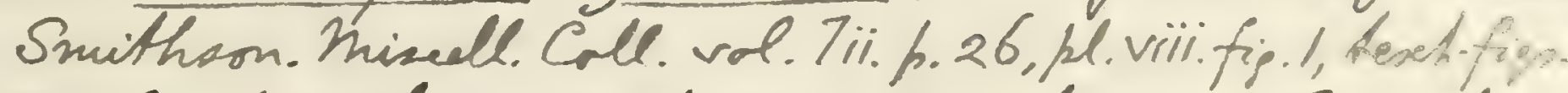

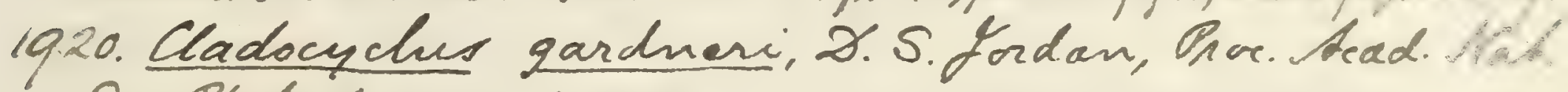
Sci. Philad.1919, p.208.

1923. Anóedopogon Kenuidens, D.S. Tordau, Mon. Serw Geof. Min. Brasit ot iiv. p.68, plix.

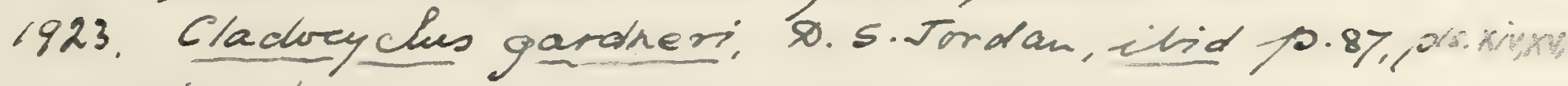
plixig.iz.

1938. Cl. gandmeri D'Wrasmo: 1036, pl. nit. 2-3.

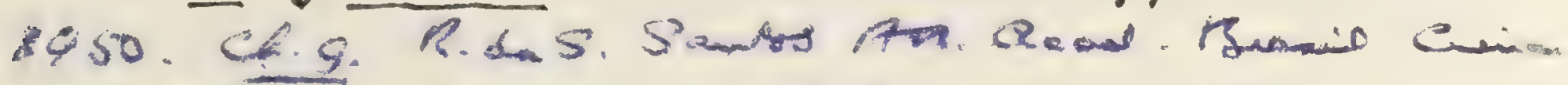

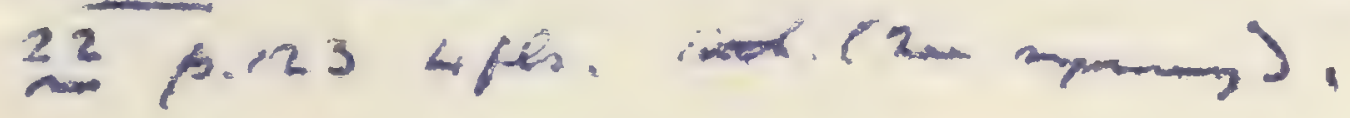




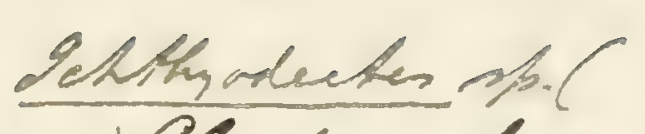

1903-07. Cladoundur lewesiensid A.S. Lordwend.

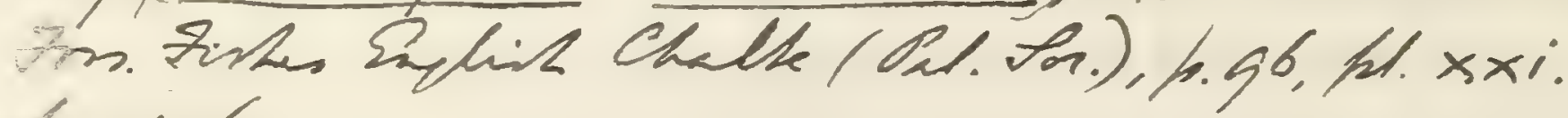
fin. 5,6 . 
All the following specimens were obtained from Barra do Jardim, Serra de Araripe :-

28901 a. Two fragments labelled by Agassiz and to be regarded as the type specimens. The first exhibits the much-fractured head, anterior abdominal scal ss, and remains of the pectoral fin; the second is a portion of the abdominal region, showing vertebræ with thick neural arches, delicate ribs, and scales.

Dixon Coll.

28901 b. Portion of very large abdominal region, displaying scales and vertebral centra. Some of the scales exhibit a little coarse crimping at the hinder border, and are shown of the natural size in Pl. IX. fig. 1.

Dixon Coll.

$28901 \mathrm{c}, \mathrm{d}$. Two more imperfect examples of squamation and vertebræ.

Dixon Coll.

P. 180\%. Two fragments, the first showing the operculum, the second only scales and vertebræ.

Egerton Coll.

47897. Imperfect caudal fin of large specimen, in counterpart.

Presented by the Hon. Robert Marsham, 187\%.

28901 e, P. $180 \%$ a. Portion of abdominal region of small fish, in counterpart.

Dixon and Egerton Colls.

P. 3872 a. Portion of small squamation.

Enniskillen Coll.

\section{Cladocyclus lewesiensis, Agassiz.}

[Plate IX. figs. 2, 3.]

1837. Hypsodon lewesiensis, L. Agassiz, Poiss, Foss. vol. v. pl. $\operatorname{xxv} a$ 。 figs. 5,6 (figures only).

1841. Cladocyclus, L. Agassiz, Edinb. New Phil. Journ. vol. xxx. p. 84.

1844. Cladocyclus lewesiensis, L. Agassiz, Poiss. Foss. vol, v. pt. i. pp. 8, 103.

1888. Cladocyclus levesiensis, A. S. Woodward, Proc. Geol. Assnc. vol. x. p. 326.

Type. Scales; British Museum.

A species as large as the type, known only by detached scales, which are mostly deeper than broad, ornamented in their exposed portion with very closely-arranged small pittings, each with a - raised border, marked in the covered portion by a few conspicuous radiating grooves which are often interrupted; hinder margin not crimped or ridged.

- Foxm. \& Loc. Cenomanian and Turonian: Sussex, Surrey, Kent, and Cambridgeshire. 
4066, 4462 . The two type scales described and figured by Agassiz, loc. cit.; Lewes.

Mantell Coll.

25861. Three fine scales, one shown of the natural size in Pl. IX. fig. 2 ; Sussex.

Dixon Coll.

49\%96. Fractured very deep and narrow scale; Glynde, near Lewes. Capron Coll.

4979\%. Imperfect abraded scale; Amberley, Arundel. Capron Coll. 49798. Group of imperfect scales; Dorking, Surrey. Capron Coll.

41712. Three small scales, one shown of the natural size in Pl. IX. fig. 3 ; Lower Chalk, Burham, Kent. Toutmin Smith Coll.

P. 1806. Three fragmentary scales, labelled by Agassiz; Burham. Egerton Coll.

P. 9045. Scale; Burham. Presented by S. J. Hawkins, Esq., 1891. P. 569\%. Three small scales; Kent. Harford Coll. P. 5843. Two small scales; Kent. Purchased, 1888. 49056. Four small scales; Kent. Mrs. Smith's Coll. P. 6052. Scale; Kent. Presented by F. Harford, Esq., 1889. 47938. Two comparatively broad small scales; Burham. Presented by the Hon. Robert Marsham, 1877. $3 \% 39 \%, 47260,49110$. Four small scales and imperfect group; Chalk Marl, Dorer.

Purchased 1863, Gardner Coll., \& Mlrs. Smith's Coll.

P. 7259. Three fragmentary small scales, doubtfully of this species; Cambridge Greensand, Cambridge.

Jesson Coll.

Some generically indeterminable scales, of which there are no examples in the Collection, are also described under the name of Claclocyclus as follows:-

Cladocyclus occidentalis, J. Leidy, Proc. Acad. Nat. Sci. Philad. 1856, p. 256, and Contrib. Ext. Vert. Fauna W. Territ. (Rep. U.S. Geol. Surv. Territ. vol. i. pt. i. 1873), p. 288, pl. xvii.figs. 21, 22, pl. xxx. fig.5. Referred to Ichthyodectes arcuatus by F. B. Loomis, Palæontogr. vol. xlvi. (1900), . $p_{:} 242$, but probably the scales of more than one species.-

Cretaceous; Sage Creek, Dakota. [Academy of Sciennces, Philadelphia, and National Museum, Washington.]

Cladocyclus strehlensis, H. B. Geinitz, Denkschr. Ges. für Naturk. 


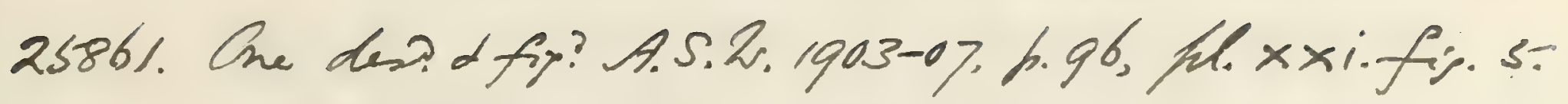

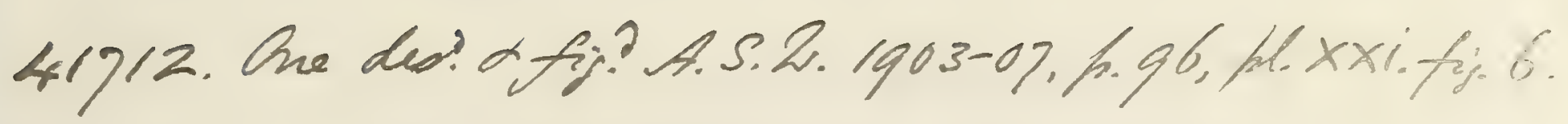

Clad. recidentalie, I. F. Whiteaver, Contrit.

Canadian Pelremh. vol, i (1889), h. 195, hl. xxvi fien 8, Q.

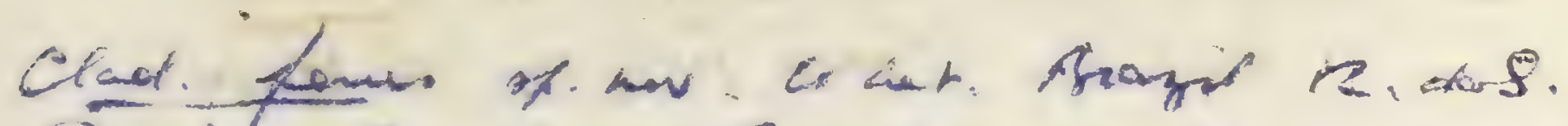

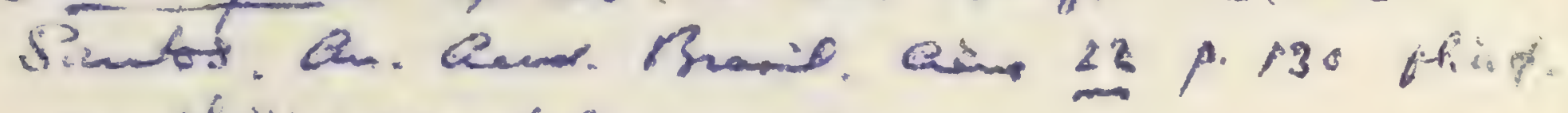

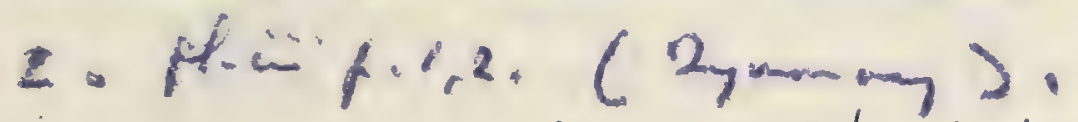

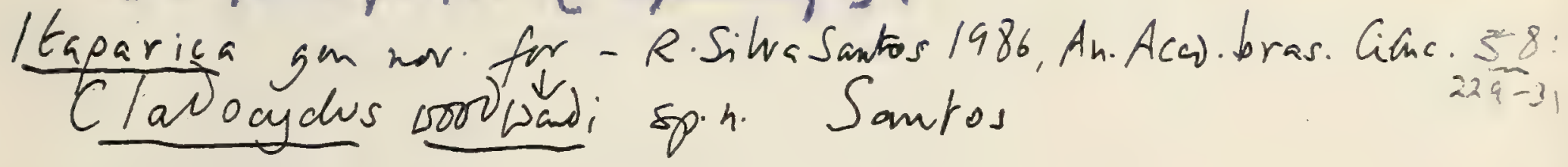


\&c., Dresden, 1868, p. 43, pl. ii. figs. 24, 25, pl. iii. figs. 5-18, 20-2:2, pl. ir. figs. 6,7 ; A. Fritsch, Rept. u. Fische böhm. Kreideform. (1878), p. 44, fig. 66; (?) G. D. Romanorsky, Material. Geol. Turkestansk. Kraya [in Russian], pt. iii. (1890), p. 121, pl. xvii. fig. 6.-Turonian : Saxony and Bohemia; (?) Turkestan. [Dresden Mruseum.] Cladocyclus sweeti, A. S. Woodward, Ann. Mag. Nat. Hist. [6] vol. xiv. (1894), p. 445, pl. x. figs. 2-6. - Cretaceous (Rolling Downs Formation); Queensland. [Collection of George Sreet, Esq., Melbourne.]

\section{Genus SAURODOI, Hays.}

[Trans. Amer. Phil. Soc. n. s. vol. iii. 1830, p. 475.]

Syn. Daptinus, E. D. Cope, Proc. Acad. Nat. Sci. Philad. 1873, p. 339.

Teeth hollow, in deep sockets, compressed to a sharp edge in front and behind; those of the maxilla, as also those of the dentary, almost uniform, only slightly increasing in size backwards, and those of the premaxilla not much enlarged; the inner margin of each dental alveolus deeply notched. A small toothless presymphysial bone in the mandible. Vertebræ as in Ichthyodectes and Chirocentrites.

The identity of the so-called Daptinus with this genus was determined by Cope after an examination of the type specimen of Saurodon leanus (Bull. U.S. Geol. Surv. Territ. vol. iii. 1877, p. 588).

\section{Saurodon leanus, Hays.}

1830. Saurodon leanus, I. Hays, Trans. Amer. Phil. Soc. n. s. vol, iii. p. 476 , pl. xri.

1857. Saurocephalus leanus, J. Leidy, Trans. Amer. Phil. Soc. n. s. vol. xi. p. 91, pl. vi. figs. 12-15.

1877. Saurodon leanus, E. D. Cope, Bull. U.S. Geol. Surv. Territ. vol. iii. p. 588.

Type. Imperfect jaws; National Museum, Washington.

The type species, with upper jaw about 0.07 or 0.08 in length. Dental crowns smooth, as deep as broad, with the sharp edges convex or slightly sinuous and the apex sometimes curved backwards; about 9 or 10 dental alveoli in the premaxilla, about 36 in the maxilla, and about 42 in the dentary. Length of oral border of premaxilla about three quarters its depth; length of oral border of maxilla about twice its maximum depth.

Form. \& Loc. Upper Cretaceous: Pensauken Creek, New Jersey.

Not represented in the Collection. 


\section{Saurodon phlebotomus, Cope.}

1871. Saurocephalus phlebotomus, E. D. Cope, Proc. Amer. Phil. Soc. vol. xi. p. 530 .

1873. Daptinus phlebotomus, E. D. Cope, Proc. Acad. Nat. Sci. Philad. p. 339.

1875. Daptinus phlebotomus, E. D. Cope, Vert. Cret. Form. West (Rep. U.S. Genl. Surv. Territ. vol. ii.), p. 213, pl. xlvii. figs. 3, 4, 6, pl. xlix. figs. 1-4.

1877. Saurodon phlebotomus, E. D. Cope, Bull. U.S. Geol. Surv. Territ. vol. iii. p. 588.

1898. Saurodon phlebotomus, A. Stewart, Kansas Univ. Quart. [A] vol. vii. pl. xvi. figs. 4, 5.

1900. Saurodon phlebotomus, F. B. Loomis, Palæontogr. vol. xlvi. p. 248, pl. xxiv. figs. 1-5.

Type. Jaws with teeth; Cope Collection.

The type species of the so-called Daptinus. Teeth slightly longer than in Soleanus, and those of dentary twice as large as those of maxilla. About 9 dental alveoli in premaxilla. Length of oral border of maxilla exceeding twice its maximum depth.

Form. \& Loc. Tpper Cretaceous (Niobrara Group): Kansas.

Not represented in the Collection.

\section{Saurodon intermedius (Newton).}

1878. Daptinus intermedius, E. T. Newton, Quart. Journ. Geol. Soc. vol. xxxiv. p. 440, pl. xix.

1890. Saurocephalus intermedius, Woodward \& Sherborn, Catal. Brit. Foss. Vertebrata, p. 181.

Type. Head, opercular apparatus, and vertebræ; British Museum.

A species with the upper jaw about 0.1 in length. Teeth much longer and less compressed than in the type species; only 5 dental alveoli in the premaxilla and about 32 in the maxilla. Maximum depth of maxilla contained about two and a half times in its length; maximum depth of mandible slightly less than one quarter of its length. Bones without external ornamentation.

Form. \& Loc. Turonian: Kent.

47250. Head with opercular apparatus and anterior vertebræ, being the type specimen described and figured by Newton, loc. cit.; Lower Chalk, Dover.

Gardner Coll.

The following specimen is not specifically determined :-

4201\%. Right maxilla, ornamented externally by fine granulations and pittings, described by E. T. Newton, loc. cit. (1878), p. 445 ; Lower Chalk, Dover.

Purchased. 


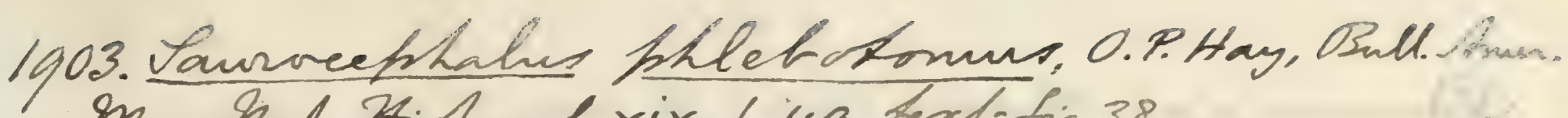
mue. hat. Brith. wol. xix. hik9. hexh fip. 38.

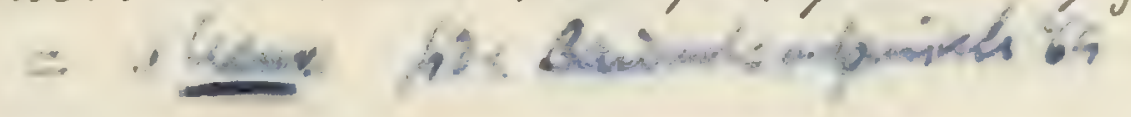

1907. Taurodon intermediur, A.S. Lordurard, Bos. Firhe. Esphit' Chalte (Dal. Dor.), h.104, texht-fis. 32.

47250. Des? Lfip? A.S. 2. 1907, h.104, texhefis 32. 


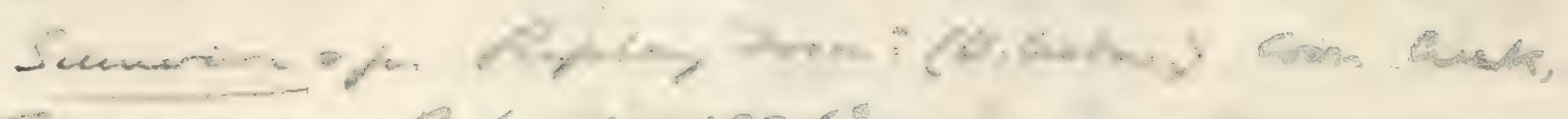

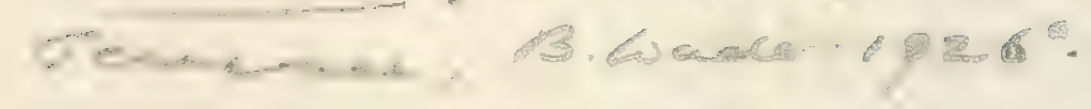

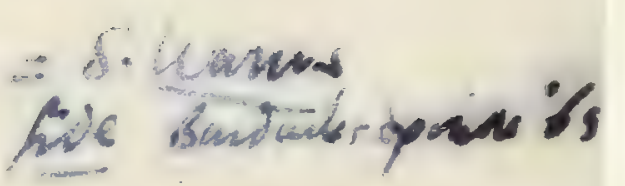

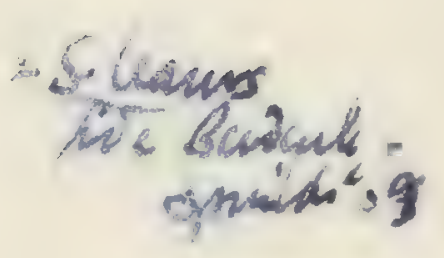

Sawrceftales xithirostrie, 0.P.Hay. Bull. Amen.

mus. Kat. Bist. vol.xix(1903), b.51, Lext-figs.39, k0

- Siluma har Raviander 
The following species, not represented in the Collection, are described on the evidence of fragments:-

Saurodon affinis, V. Kiprijanoff, Bull. Soc. Imp. Nat. Moscou, vol. xxxiii. (1860), pt. ii. p. 47, pl. i. fig. 1.-Neocomian; Kursk, Russia. [Teeth.]

Saurodon broadheadi, A. Stewart, Kansas Univ.'Quart. [A] vol. vii. (1898), p. 178. Daptinus broadheadi, A. Stewart, ibid. p. 24, pl. ii. fig. 1. Saurocephalus broadheadi, F. B. Loomis, Palæontogr. vol. xlvi. (1900), p. 252, pl. xxiv. fig. 6, pl. xxv. fig. 1.-Upper Cretaceous; Kansas. [Maxilla; Kansas Unirersity Mruseum.]

Saurodon ferox, A. Stewart, loc. cit. 1898, p. 183, pl. xv., pl. xvi. figs. 1-3.-Ibid. [Jaws, \&c.; Kansas University Museum.]

Saurodon pygmeus, F. B. Loomis, Palæontogr. vol. xlvi. (1900), p. 248, pl. xxiii. fig. 10.-Ibid. [Mandibular ramus; Palæontological M[useum, Munich.]

Saurodon xiphirostris, A. Stewart, loc. cit. 1898, p. 178, pl. xiv.Ibid. [Skull, \&c.; Kansas University Museum.]

A tooth, not of this genus, from the Eocene of Kressenberg, Bavaria, is named Saurodon conoideus by K. F. Schafhäutl, SüdBayerns Leth. Geogn. (1863), p. 247, pl. lxiv. fig. 10.

\section{Genus SAUROCEPHALUS, Harlan.}

[Journ. Acad. Nat. Sci. Philad. vol. iii. 1824, p. 337.]

Teeth hollow, in deep sockets, compressed to a sharp edge in front and behind; those of the maxilla, as also those of the dentary, almost uniform, only slightly increasing in size backwards, and those of the premaxilla not much enlarged. Successional teeth -formed on the inner side of functional teeth; and a series of nutritive foramina on the inner face of the jaw below the alveolar border. A small toothless presymphysial bone in the mandible. Vertebræ as in Ichthyodectes and Chirocentrites.

The presymphysial bone occurs in position in the type specimen of $S$. dentatus.

Saurocephalus lanciformis, Harlan.

1824. Scurocephalus lanniformis, R. Harlan, Journ. Acad. Nat. Sci. Philad. vol, iii. p. 337, pl. xii.

1830. Saurodon lanciformis, I. Hays, Trans. Amer. Phil. Soc. n. s. vol. iii.p. 476, pl. xvi. fig. 11 .

1841. Saurocephalus lanciformis, R. Owen, Odontogr. p. 130, pl. 1r. 



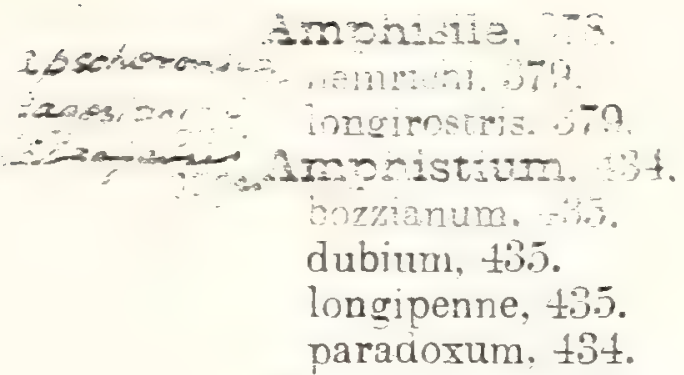

Amphodon, $47 t$. benedeni, 474 . curvidens, 47 .

Amyzon, 00 . brevipinne, :000. commune, 300 . fusirorme. 300 . mentale, 300 . pandatum, 300. A.ACANтнIт, 597

Anapterus, $25 \%$. albvi, 257 .

elongatus. $25 \%$ macrocephalus. 258 . mevistosoma. 257 . siculus, 257. sphekodes. 258 . tonia. 258.

Anarrhichas, 596. lupus. 596 .

Anchybopsis, :2:2. latus. 32.2.

Ancistrodon, 50. armatus. 570 . fissuratus, 570. ricentinus, 570

Ancylostylos, bir. gibbus. 65 .

Anareiooleura, 116. esimia. î̉. retustissima. $11 \%$.

Anædopogon, i0: tenuidens. 108.

Anenchelum, \pm 7 . brericauda. to9. brericens, 立政. dolsale. 178. glarisianum, t7. heteropleurum. 15. isonlenlum. tis. Jatum. $t 78$ longipenne, tre. marginatum, 2.2.

Anguilla. 44 . branchiostegaiis. 345. brevicuia, 42 . elegans, $8 \pm 5$. hakelensis, $310,0.88$. interspinalis, its. latisnina. 340 . leptontera. stt. muitimdiata. 345 nachruma, $: 31$.
Anzuilla conto.

sane-simie, 163 . rencializ. 11 .

Fidray, ati.

inograng, 31.

aratus, 72 .

contractus. 71 .

evolutus, $72,886$.

favirostris. 73 .

poirmicrodus, 72 .

Anormurus, 275 .

macrolevidotus, 27.

Anthias, 520. bassanii, 520 . stiriacus, 520.

Apateodus, 258 ionneti. glyphodus, 258. lanceolatus. $26 t$. striatus. 260 .

Apateopholis, 2.24, 293

laniatus. 232.

APHREDODFRID.E. 416 .

APODES. 3336.

Apogon, 521. krambergeri, 521 . macrolepis, 521 . spinosus, 021 . namizarien

Apostasis, 563. croatica, 563. experima i. sturi, 563.

inisprensicis

Apsopelix, $3 \%$. saulifornis. 3.5\%.

Aracaima, 74 .

Archæogadus, 21:. 200 guestphalicus, 200 .

Archroizes, 44. longicostatus, $44 \%$. longus, 44. macirus. $44 \%$.

Archæoteuthis, 524. glaronensis. 524.

Archæus. $4+2$. brevis, 443 . urlarisianus, 442

Argyreiosus, tin! minutus. 450 .

Arius. 330.

baroni. 334

bartonensis. $3 u 3$.

crassus, $30 \% 2$.

dutemplei, 616.

egertoni. 3.31. Germanicus. thrnnoides, 46.5

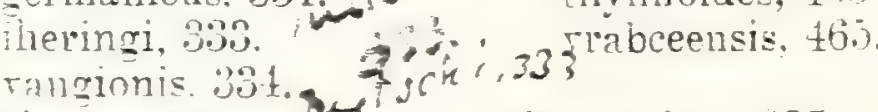

Asima, . isti. tur Bagarius. 395. urieri, 5in

ASTEOTID. Alti
Asineovs. 117

pacirndiarus, $4: 8$.

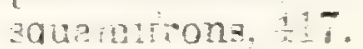

riricensis. $=17$

Aspicicopis, u.

steinlai, 59.

Aspidopleurus, 229, 280.

cataphractus, 230 .

Aspius. 318. brongniarti, 293. columnæ. 319. ecnomi, 319. elongatus. $160,614$. furcatus, 160 . gracilis, 318 . minutus, 318 . rexillifer, 319.

Astephus, 329 . macrocephala. 359

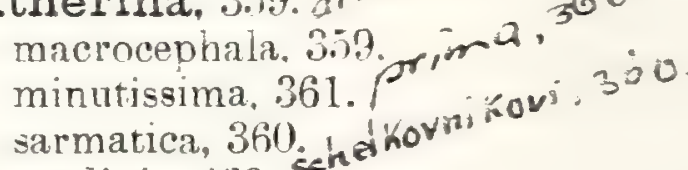
rardinis. 360 .

Atherinichthys, 361 .

Atrienivid. 358 .

Atherinoides, $: 361$.

Atherinops, $: 61$.

Atherinopsis, 361 .

Auchenaspis, Bleetier, 3.30.

Auchenilabrus, 552 . frontalis, 5.5:2.

Auchenoglanis, :30.

Auliscops, 372. sumatianus, $: 373$.

Aulolepis, 126. reussi, 59. trpus, $15,16,127$.

Aulorhamphus, 562 . bolcensis, 562 . canossæ, 563. capellinii, 563.

AULORHY.CHID E, 371.

Aulorhynchus, ü:sumatrensis. :37:?.

Aulostoma, 375. bolcense. 375. licatie, 376. nedian.576.

Auxis, $40 \%+63 \%$ croaticus, 465 . Came osen on is bis minor. 465 . propterggius, 46 t.

sirmaticus. 4.59

stiriacus. 165.

gigats. (j).

Furella oj! n. no 
ringorand pos

clomentian, 345

Pronanes: 239 .

Anocerisma bia.

Aoria 27.

Ancrodonten, 536.

Enanomicis, $\%$

- Zninacorecs 020.

- Aseruonue :

spivuroiden

Pstanx, -7

Th proosden

teteinsonelia 612

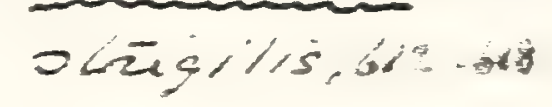

Th50 reix, jy of

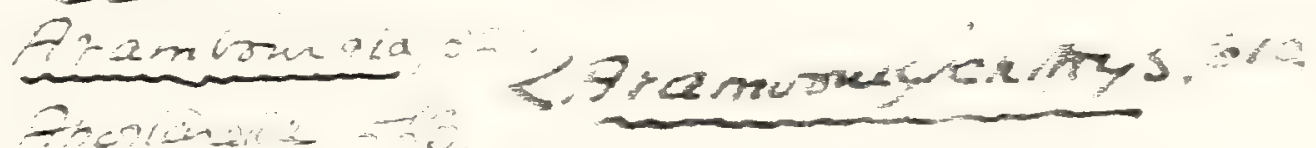

Aracana, 569.

Kershowi, $=\overrightarrow{0}$.

Aracostens, squ?

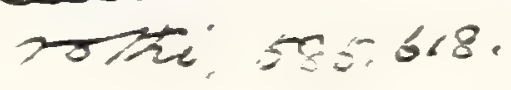

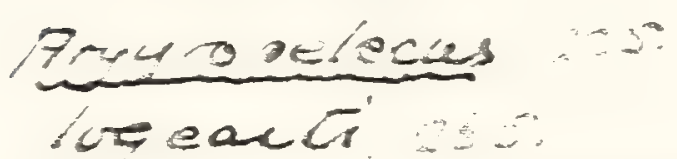

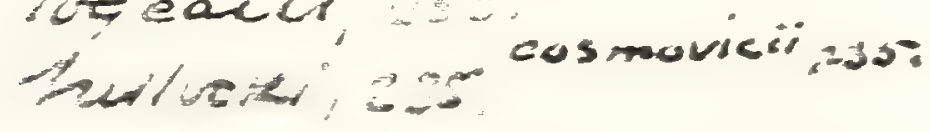

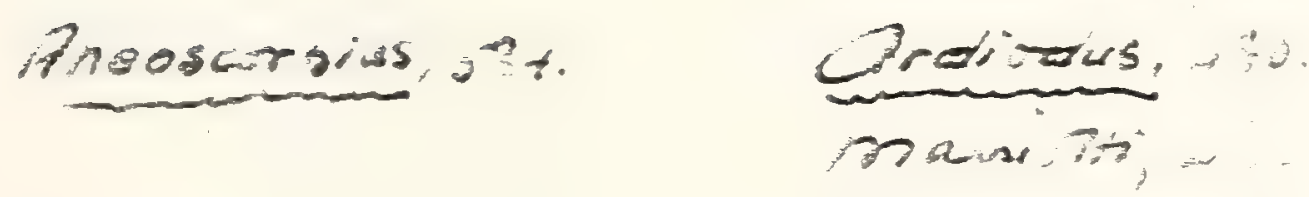

$=20 x-30$

Pristozion, wh s39. Avicolaciax,

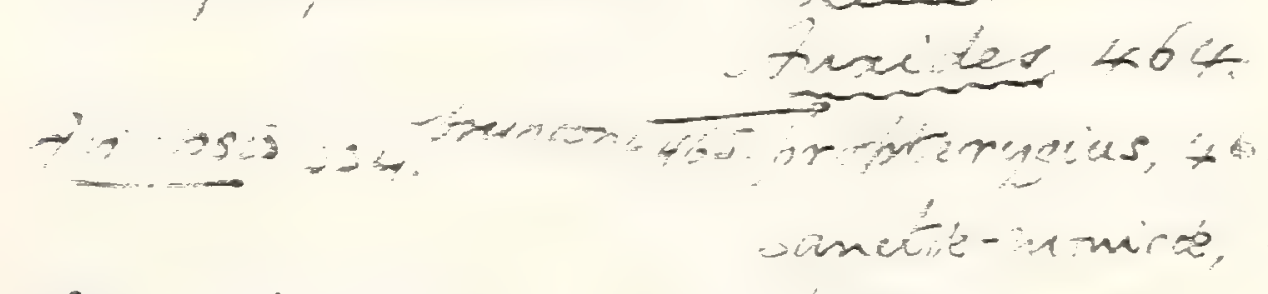

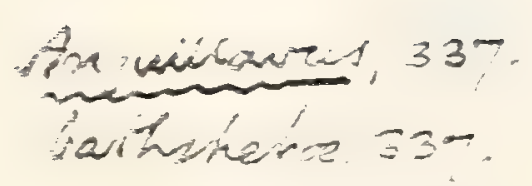

Aroderia, 603.

cios 5000 is

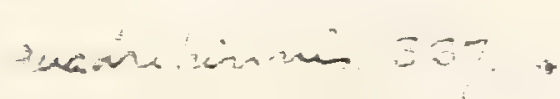

inisutas

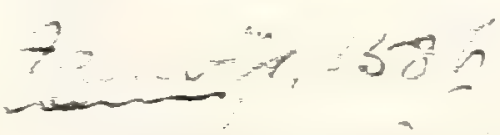

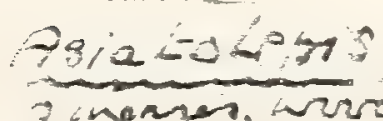





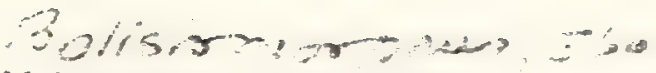

Bainanogmios, $7 \%$.

Bumachoides ofy

3.27\%

Conusaina, 14 .

Cessamera 244

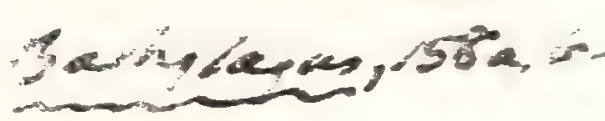

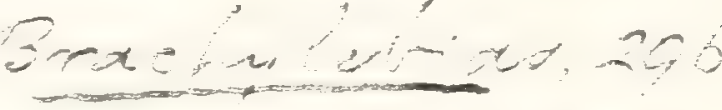

Baminax, 73

mpisinna, 73 .

Beríus 618

Betion, 358 .

peronides.35s.
Bachmanna, 324

, 324

Brannerion sen polll scirtac

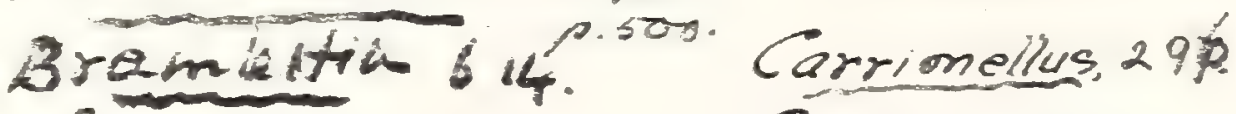

Bresnacew Cearana, 85.

rochat, 85.

resiomites 299.

Cepola 36 ?

Lanceulatin, 369 .

Centrareniter, 415.

coloradenar, 415.

CENTRARCMOAO 519.
$554.415,520^{\circ}$.

Cenpromis st

Callichthyidat 35 in

Cakibsicussen Go:

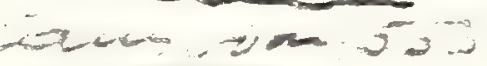

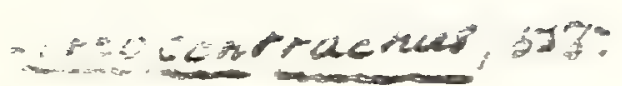

Sian

Canderent

ancici,

$V / c e a, 322$

yonemis,

20,20000000

Botus, 608

axesines, 608.

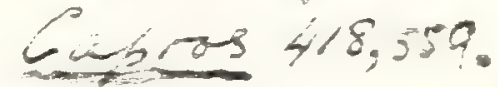

ingirsovis. 5 it

radeligiams

carthonvidus

$-\infty, 1.0 .0$.

Lrvisimanus 18

Cacrovesposus, 18 .
Craendinitey, 554.

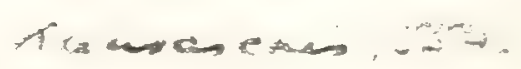

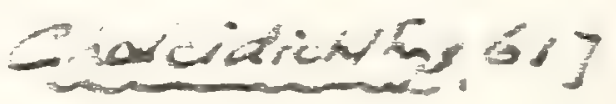

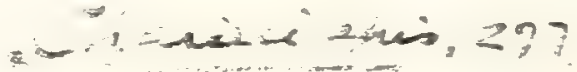




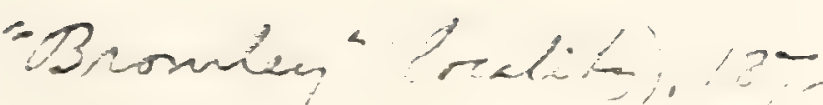

INDEX.

Bngrus aur :3:-

Balistes, jhis.

cairasii. 569

dubius. 589 cramises.

SBALIFTID.E. 565.

.

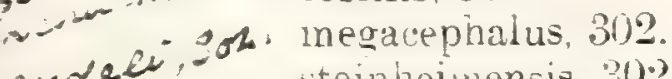

stemheimensis, 202 .

pulquris, 8 .

Basilichthys, 361 .

Bathysoma, \pm 49 . lutheni. 4ty.

Bathythrissa, 67.

Belone, úti.

nor $\$ 57$ acutirostris, $356,358$. - Hava. 357

havisers tenuis, $35 \%$

Belonostomus laniatus. 232.

Beryctide. 384.

Beryciforiles. 384.

Berycopsis, 428. plegans, to.

lindstromi, fㄴ.5.

Beryx, 255

ater, 80.2

dalmaticus, :86

dinolenidotus. 386.

germanus. \pm 21 .

insculptus, 886 .

lesinensis, 386.

microcephalus. 124.

muicidentatus.

niger, 80.2 .

ornatus. 397. 40 .

ovalis. 121.

polrmicrodus. i2.

-13.ratiacus - ladians. $1202134 .+13$

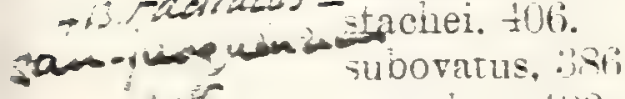

315 .

sudoratus, :siti.

superous, $\$ 11: 3$.

spriacus. 405 .

ralenciennesi, 386.

vexillifer. 120 .

zippei, 397.

BLETIIDE. ว95.

BlenNifuryes, 001.

Blennius, 506.

cuneiformis, jhi6.

fossilis. ig6,

oceilaris. $560^{\circ}$

Blocimdia. 501.

Blochius, 523.

longirostris. $59 \%$

macropterus. 593.

3 cops, $38 \%$

giuas. 5i:

Bothrosteus, $61:$

brepirons, il:

lutus. bil:?.
Bothrosteus (cont.)

millor. bill.

Brachygnathus, 519.

tenuicens. 51 .

Bracinyspondylus. 270

cretaceus. 270 .

inciicus, 326

saropterix. 823.

Brachyrhynchus,

497. -2uricus 479 soliclus, 497 .

tererirostria, 497 .

ranberieciensis, 497.: .

Brosmius, 602.00 mens elongatus, 60\%. こive fuch siunus, (3) strossmaveri. 602. susedanus, $60^{\circ}$.

Brctula. 605. longipinnata. $60 \%$.

Brychatus, 76. inveileri, 76.

Bucklandium, $3: 00$. dilurii. $390.5 \% 0$.

Butyrinus, 60.

Caeus, 57. leopoldi. 57.

Calamopleurus, 8.51

anglicus. 351.

Calamostoma tacrsiz, :383.

breviculum, 893

Calamostcma, Stein. ha.ruer. $353.5 t^{\circ} 2$

bolcensis. 562

cunossa. 569.

Callionymus, j8s.

macrocevhaius. 588.

restenx. 418 . srivus 58

Callipteryx, 589. recticaudus. 589. speciosus, 589.

Calopomus. 536. porosus. $580^{\circ}$

Cantharus, 537. ureianensis, 537.

Capito, :15.

Capitodus. 28. angustus. 5.56 . dubius. 537. incieus. 53:? interruptus, 537. subtruneatus. 29. truncatus, .806.

CARINGID.E. 205

Carangodes. 4.00 . cepualus, tin.

Carangopsis. $\frac{1}{2} 46$

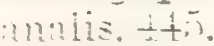

Carangopsis (int)

brevis. titi.

dorsalis, $\pm 4 \bar{i}$.

lanceolatus, $1 \pm 8$.

lation, 446 .

maximus, 148

Caranx, 441 .

carangopsis, 141 .

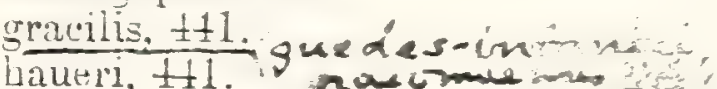

longipinnatus, $4+2 \ldots$

oralis, 44? - xpec row

rigiởicaudus, 442 . we the

Cariniceps, 458. compressus, 458 .

Catostomus, :99.

cristatus, :01).

shoshonensis. 200 .

Cexturscide. : :T.

Centriscus. 37.

nculeatus. 370.

longirostris, 37 \%

toni. 27.7 .

velitaris, 359 .

Chætodon, 5il)

areuatus, $\sin$.

argus, 561.

asper, 560 .

atreus, 449 .

cunescens, tox).

canus, 5.58.

chirurgus, 559 .

hoeteri, 560.

lineatus, $56 t$

mesoleucus, 5.59

nigricans, 565 .

papilio. $4: 33$.

pinnatiformis. $433 \%$

pinnatus, \pm 83.

nseudorhombus, $5 \not ็ 0$.

rhomboides, 45u,

559.

rhowbus. 559.560.

saxatiiis, +12 .

striatus. 415 .

subarcuatus, 561 .

subaurelts, $4+19$.

substriatus. 415.560 .

subrespertilio. 4.33.

triostesus, 56 f.

reiicans, töl.

relifer. 430 .

respertilio, 430.

Chemtodoxtin.e. 556 .

CHeTOdonthorues, J6.

Chanoides. 63. epruscec ...

malepola oncia, c-

brevis. 13.5 .

forcipatus. 6\%.

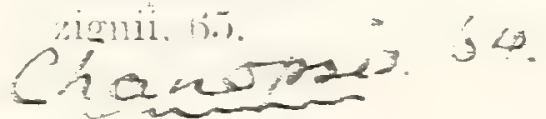




Charicixide, 297 .

Charitosomus, :71. formosus. 27:? hakelensis. 274 . lineolatus, 274 . major. 2:2.

Chatcessus, 158. breris, 158 . humiìis, $15 \tilde{\varepsilon}$. tenuis, 158.

Chelonia radiata, $\$ 91$.

Chimera furcata. 31.

Chirocentrites, 90. carolini, 92. coroninil, 91. gracilis, 91 . libanicus. 105. vexillifer. 92.

Chriocentrid.e. 86.

Chirocentrus, 83. polvodon. Es.

Chiromystus, 39.

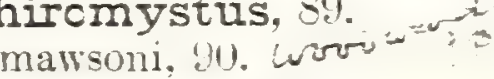

Chirostoma, 31 il.

Cimrothrilide. 279.

Chirothrix, 280 . guestialicus, $28 \%$. lewisi, 283.

libanicus, 290.

Chondrosteus. 11.5.

Chonarostoma, $311 \%$

bubalus, 310 .

elongata. 316.

laticauda, (ilo. minutum. 318. stephani, (i1\%.

Cinomid. 55 t.

Chrysichthys, 327. theobaldi. 327.

Chrysophrys, 501. agassizi, $33 \%$.

ino os v. v 534 arsenaritana. 386

brusinai. $534.7 N$.

- veincta, 535.

roce 250 hennii, 537. hertlei. $53 \pm$.

lawlevi, 534. miocenica, 537. seacchii. 53t. zignoi. 53 z.

Cimolichthys, 221 . $\therefore 2.7$.

anceps, 203 contractus. 2-2s.

- 228 .ghaiculus, 204.

lewesiensis. 221.

Tisbonensis. 2028.

merrili. 2:-3.

nenreolica.

semianceps.

sulcatus.
Cladocyclus, 107.

gardineri, 108.

lewesiensis, 109.

occidentalis, 110.

strehlensis. 110 . a i 110

Clarias, 324. sapentan is filconeri, 324. ' an w

Clinus, 597.

gracilis, 597.

Clupea, 146.

alta, Leidy, 145.

alta, Steindachner, 157.

antiqua, 138.

arcuata. 154.

attenuata, 19.

beurardi, 14 rassane

bosniaskii. $15 t$.

154.

bottæ, 2.50.

breviceps. 154 .

brevis, 270 .

brerissima, 1 to.

caudata. $15 t$

catopygoptera. 1tis.

cephuius, 158 .

chrysusoma. 158.

crenata. 15l.

aprinoides. 63.456.

rlentex, $15 t$.

denticiformis. $15 t$.

doljeana. 159.

dubia, 270

ecnorni, 155 .

elongata, Davis, 55.

elongata, steindachner.

$15 \%, 460$.

engrauliformis, 15\%.

evolans, 133.

fontannesi. $15 \%$.

gaudrri, 138.

gervaisi, 155.

Gigantea, 10.5 glyporoma

goidfussi, 158.

gracilis, 150.

gracillima, 155.

grandisquana, 155 .

grandonii. 155.

gregaria, 155.

guestphaiica, 297 .

baidingeri, 155.

heterocerca, 156.

humilis. Leidy, Itt.

humilis, Meyer. 1.50,

in ilata. 156 .

intermedia. 156 .

lanceolata. 150.

larteti, $1+1$.

ata. 19,53

aticauda. 158.

?atiscima, 106.
Clupea (cont.)

lawlevi, 158.

leptostea. $1.5 \%$

lesinensis, 138.

lewisii, 17 .

lorer. 156.

lundgreni, 1.56.

maceki, 156.

wacrocerca. 156.

macrophthaima. 13.5.

macropoma, 63.

megaptera, 147.

megapteryx, 1.ji.

melettaformis. I.j(i.

meneghinii, 158

wicroceptala, 158.

microsoma, 157.

minima, 240.

minuta. 149

minutissima, 158 .

mondainensis. 157.

mucronata. 157.

murenoides. 63.

numidica, 151.

ombonii, 157.

ophthalinica, 158.

opisthoptery, $15 \%$.

polyacianthina. $15 \%$.

presardinites. 1.7.

pulchra. 56.

pusilia. $14 \pm$.

sagorensis. 15t. 15

sardinites. $15: 2$

sardinoides, 19.

saulos. $15 \%$.

sauvagei. 158 .

scheuchzeri, 147.

sinensis 63 seviptars = 34

sphaerocephala, 154 .

sprattus. 153.

styriaca, $1.5 \%$.

tenuissima. 154.

thera. 140 .

thrissa, 63.

thrissoides, 63.

trinacridis. 157 .

rectensis, 146 .

rentricosa, 150 .

villosa. 161.

roirouensis, 138.

rukotinorici, $15 \%$.

zenoplanis. IJ?.

zanclea. 158. cuncyi,is

Cluperda, 129.

Clupeops, 159.

insignis. 159.

Cobitis, 320.

angustus. $: 21$.

bredai, 320.

centrochir, 320

ephitutes, ::21. 

$\operatorname{sochat}=-$

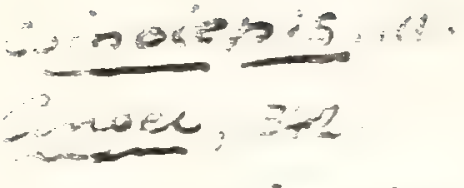 \\ inocinien \\ ,}

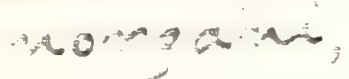

scances, , s.2.

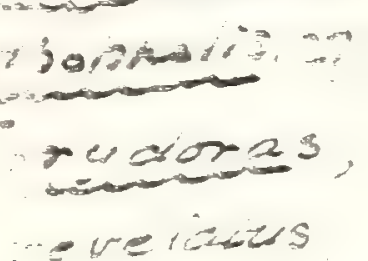

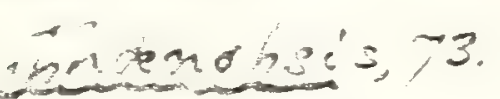

iक oris, -3

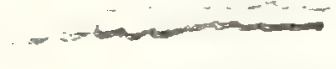

nicormis, 585.

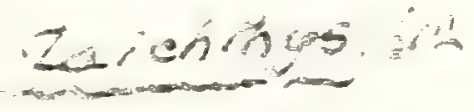

$$
\begin{aligned}
& \text { comsons :- }
\end{aligned}
$$

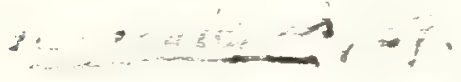

$$
\begin{aligned}
& \ldots-2=0
\end{aligned}
$$

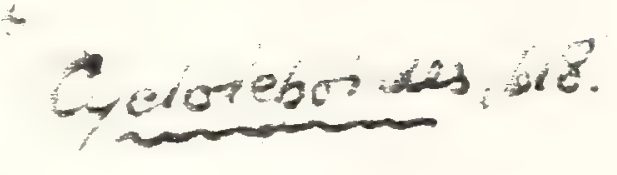

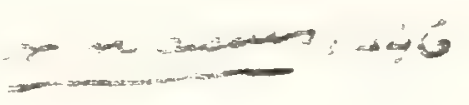

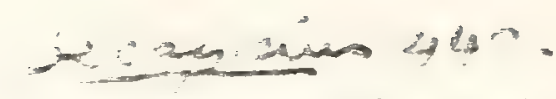

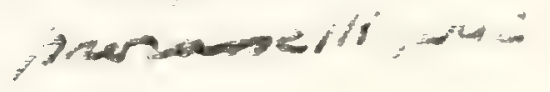

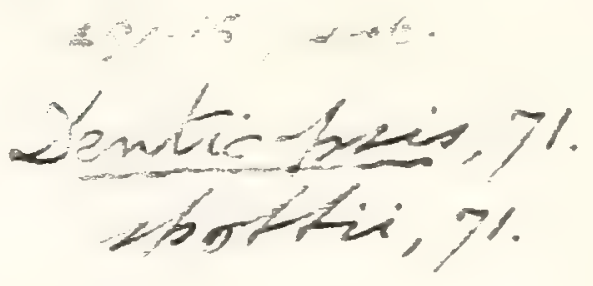

Desrandus, 340.

lestes, 34 .

Xernias, 336 .

enceninits, 236.

udidingeco, 500

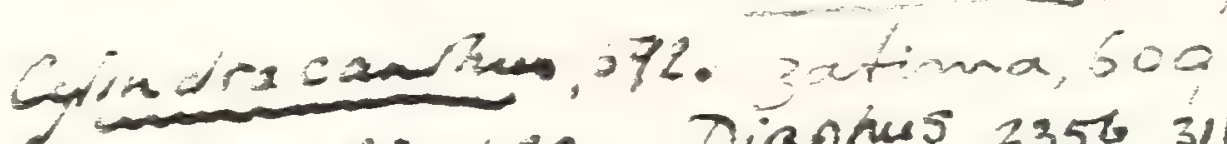

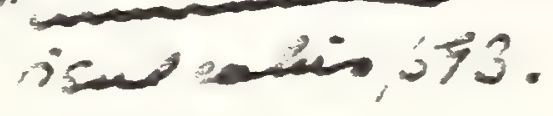

Diaprus 2356, औ. inc.

$=0,200$

$\overrightarrow{s i n}=\sin =\sin$

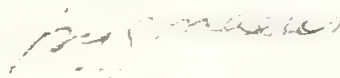

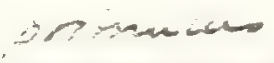

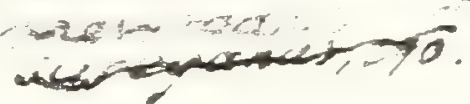

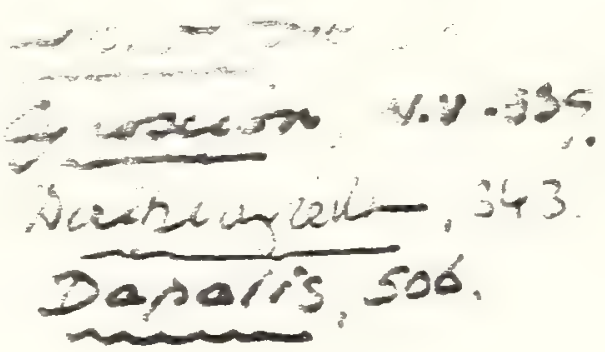

- isiderina $=19$

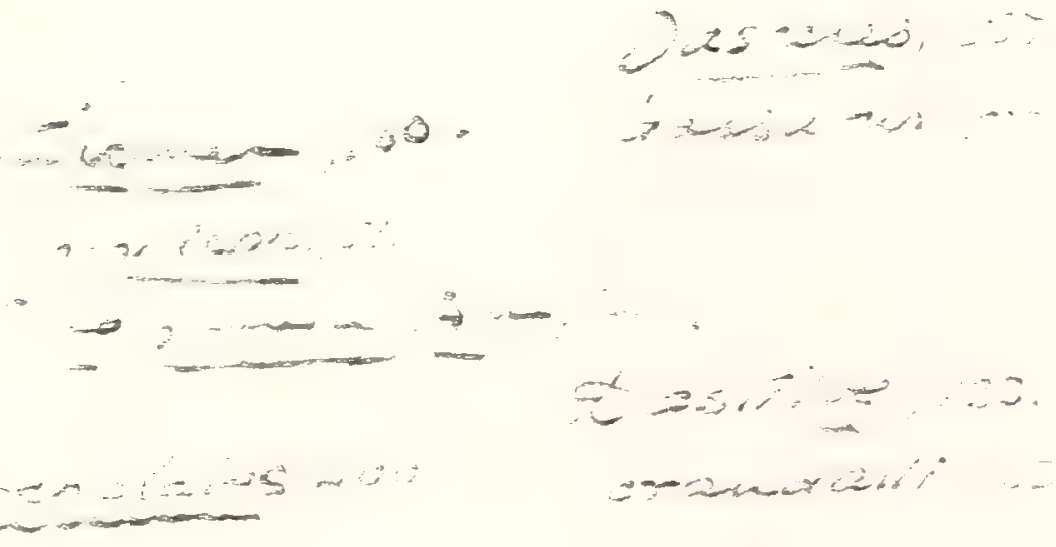


Jobitis min

longicens. - -

tricin.

Jobitorsis.

neurus. 35.5.

exilis. 45.5

Colocephailus, 1.7. samonels. tir.

Cologaster. H11; unilis. 113 .

caloperca. 31. iatipons. ji!?

Deioocma. T! rulei. †i).

curritum. \pm 0.2

lere. +iz.

Coloringnchus, $0 \%$

Comere hperior. :'t7.

Eonosauroos. kil:. bowmamil. il."

Gonozaurus, 112. Sormanni. 1it?

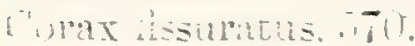

Coregonus, ill. iaraperus. 161.

Cortina gibberuius, side.

CUPTIDE. TAt).

Cottus. .5.

inies ino.

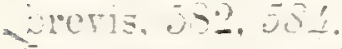

r.protremus.

diranicatus. 505.

Lurridus, is.j.

irpoceras. 55.

muitiminarus. st.

mornceus. 5.3.

jontitex.

guaciriconis.

inemaciss, ...

Grenilabrus. .it!

-zannociar. itl.

Truciwn rui. itt

Crommycdus, ...?. iprequiaris. 5.5\%.

Cristicees, -145

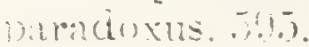

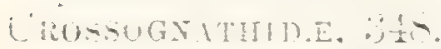

Grossognathus. ots. sivilucliantis.

Ciencdentex, . releniensis, 2.2.

Jtenoxoma, -7 omeifia j-!?

Ctencinrissa. 120. minpepinata.

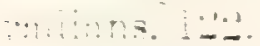

"exilitiel.

TESUTIIISTID.E, I]!

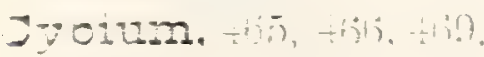

औronellse. $\rightarrow$ it

itus
Gvoium ant.

boctii. To, $3 n$

Tlunonti. $\div 0$.

wceisum, 197

linguatum. Hy?.

matropomm, to2.

maculatum, tis.

partacini. : 0

proosti, to unpetiensis. 4h

speciosum, $=36$.

cenue. \pm 70 .

Cycioides, 5 .

neisus, .il. Cyclolepis, 59.

Cyclopoma, Jut.

tis.s.

miceacanthenn. ittl.

spinosum. Silt

CYCLORERLE, JiT.

Cyclodterus. 5i.

lumbus, Jist.

Cyclotomodon.

pingrans. to.

Crelurus cousuns ona.

Crolinus minor, Jas.

Crolums nemopters. 563 .

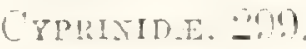

Cormonodon leratua, tlis.

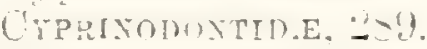

Dyprinus. :

bipunetatns, 315.

earnio, :ill.

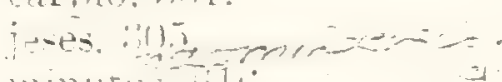

minutis. ili;.

vabyraeus.

miscus.

sulumosselis.

CYTTID.E. $11 \%$.

Cyttciaes. 117.

ghaponensis, 117 .

Dactylopogon.

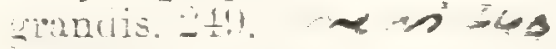
arrulis. -19 .

Dactylopterus, .in.

vilocenicus. int.

Tolitans. 506.

Dapedogicssus. 拄.

aeurus. 7.

requibinnis. .7.

encalletus. - Tis.

restis.

Daptinus. 111...?

vodiheadi. $11 \%$

inremetilus. I:

binlebotomus i12.

Dantex, -

mevicens. $\because$.

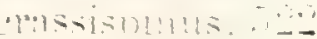

$\therefore \cdots$

Denter (dint. .

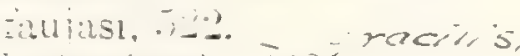

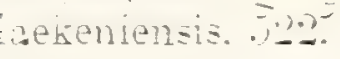

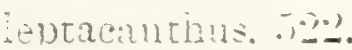

mierocion.

miensteri. .

nobilis, jo. - oficken

sariniensis. -20.

rentritis, iz

DERCETTDE. 1:1, wernnerme

Derceris. 17:?

elonequs. $13 t$

imuamnensis. 19 .

inguirer. 17 t.

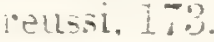

seututis. 17\%.

tenuia 1s.l.

matuerer. $7 \frac{1}{4}$

Darmatoptychus. i.)

merombthatum, $21 \%$

Desmichthys, tu

(aubrei, t.il).

Diaphyoutus, itl, - -

$$
\text { isi. }
$$

raiis. $5 \pm 0$.

- miqonella, itio.

Diastichus, $\because 2 \%$.

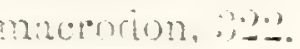

naloviens, ar.

rementiatus.

Dictyodus,

urilssiciens, $x-\cdots$

destuctor. $17 \pm$

misels. $47 \%$.

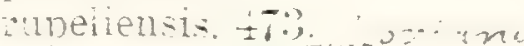

Dinoperys. 440

ininusus. 417.

Diocion, iil.

canchodes. $7 \div$.

intiquus. $57: \%$

orsicanus, 57 .

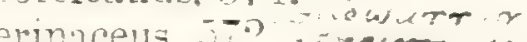

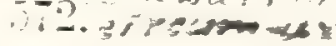

blevi. jit. grandu.

grgantorits. $37 \pm$

sentacionon.

seterorion.

siicendurn, his.

incertus. 5.5

: calicus, 5.5.

meristocius, J75.

nonsenulensis. .75.

Diatrodlis, .7.

orrsencie. $57 . y$

solilit, $\cdots$

-igmat. 79

senucius,

- mulsoinus. 97.5

rerus. in

Dixlomestus. Inn. 

Diplemystus (cont.). analis, 13:\% birci, 142 . brevissimus, 140 .

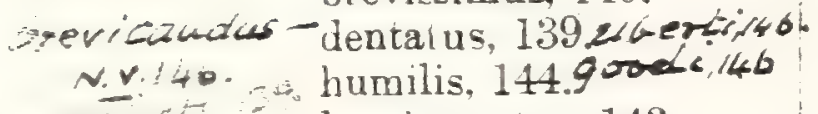
longicostatus, 143 .

pres sibepectorosus, 140. cirumingrs. theta, 140.

2. rectensis, 146.

Diplotomodon, 612. horrificus, 612.

Dipnolepis, 284. jahni, 234.

Ductor, 448 . leptosomus, 448.

Dules, 5:1. medius, 505. temnopterus, 521.

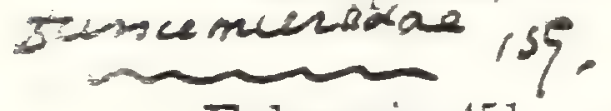

Echeneis, 451. gla ronensis, 451 .

Echenus, 613. politus, 613.

Echidnocephalus, 163 .

tenuicaudus. 163. troscheli. 163.

Egertonia, 550 . gaultina, $7: 3$ gosseleti, 551.7 N.r. isodonta. $551 .+N$

Electrolepis, $41 \%$. horrida, 415 .

ELOPIDE, 7.

Elopides, 23. couloni. 23.

Elopopsis. 8. crassus, 10. dontex. 205. fenzli, 9. haueri, 21 . beckeli. 10. inicrodon. 9. ziegleri. 10.

Elops, 22.

Embalorhynchus, 497.

kinnei, 497.

Empo, 221.

contracta. 228.

lisbonensis. …

merrilli. $2-9$.

nepaholica. 205.

semiancens, $2 \mathbf{2 0}$.

suicata.

Encheiziphins teretirostris. 4.7.

Enchelurus. 164. anglicus. 147.
Enchelurus (cont.). syriacus, 165. villosus, 164.

Enchelyopus, 343. tigrinus, 343.

Enchodontide. 189.

Enchodus, 190.9 92 amicrodus. '203. anceps, 203.

annectens, 195.

bleekeri, 466 . Lmencan

calliodon, 203.

carinatus, 204 .

corneti, 204. ensirus,

dolichus, 204 . 20 can?

faujasi, 196.

ferox, 204.

gladiolus. 204.

gracilis, 201 .

halocron, 191.

Aemonnieri, 198.

20\% lewesiensis, 191, 193.

IIy. itz Tongidens. 199.

lycodon, 204.

inacropterus, 202 .

major, 200 .

marcheset tii. 200 .

oxy tomus, 204 .

paryus, 204.

petrosus, 205 .

pressidens, 205.

pulchellus, 193.

recurvus, 201.

semistriatus, 205.

serratus, 203.

shumardi, 205 .

subæquilateralis, 205 .

tetracus, 205.

Engraulis, 183.

brevipinnis, 133.

evolans. $133,287$.

Iongipinnis. 133.

tenuis, $200,285$.

Enneodon, 571, 575. echinus. 574.

Enoplophthalmus, 323.

schlumbergeri, :323.

Enoplosus, 521.

pygopterus, 52].

Eocœlopoma, 470 . colei, 470 .

curratum. 472.

Eocottus, 080. veronensis, 581."

Eomyrus. : 40. dolloi. 340.

latispinus, 340.

rentruiis, 41 .
Eothynnus, 457. salmoueus. 457.

Ephippites, 617. peissen bergensis, 617 .

Ephippus, 5.7. longipennis, 559. nicolisi, 560 . oblongus, 560 . oweni, วัт0. rhombus, 559 .

Equula, 450 . scillæ, 450 .

Erismatopterus, 416. endlichi, 416 . levatus, 416 . rickseckeri, 416 .

Esocelops, 46 . cavifrons, 46.

Esocid.e, 287.

Esox, 287.

belone, 375 .

destructus, 615 .

falcatus, 48. .

lepidotus, 288.

lewesiensis, 191.

longirostris, 375 .

lucius, $288,289.366$.

macropterus, 89.

monasteriensis, 159.

otto, 289.

ottonis, 289.

papyraceus, 2289 .

robustus, 288.

saurus, 361 .

sphyræna, 361, 362.

366 .

spret. 362.866.

vulpes, 153 .

waltschanus. 289.

Eucynodus, tol.

hunteri, 481 .

Eurygnathus, Acassiz, 46 . cavifions. 46.

Eurygnathus, Daris, 190.

ferox, 200.

marchesettii. 200 .

Eurypholis, 207.

bcissieri, 207.

frejeri, 210.

longidens, 199.

major, 201.

sulcidens, 207.

Exocetus erolans, 1:3?.

Exocetus exiliens. 1330.

Exocœtoides. 286.

minor, 286 .

tenuis, 285 .

Fierasfer, 605. 

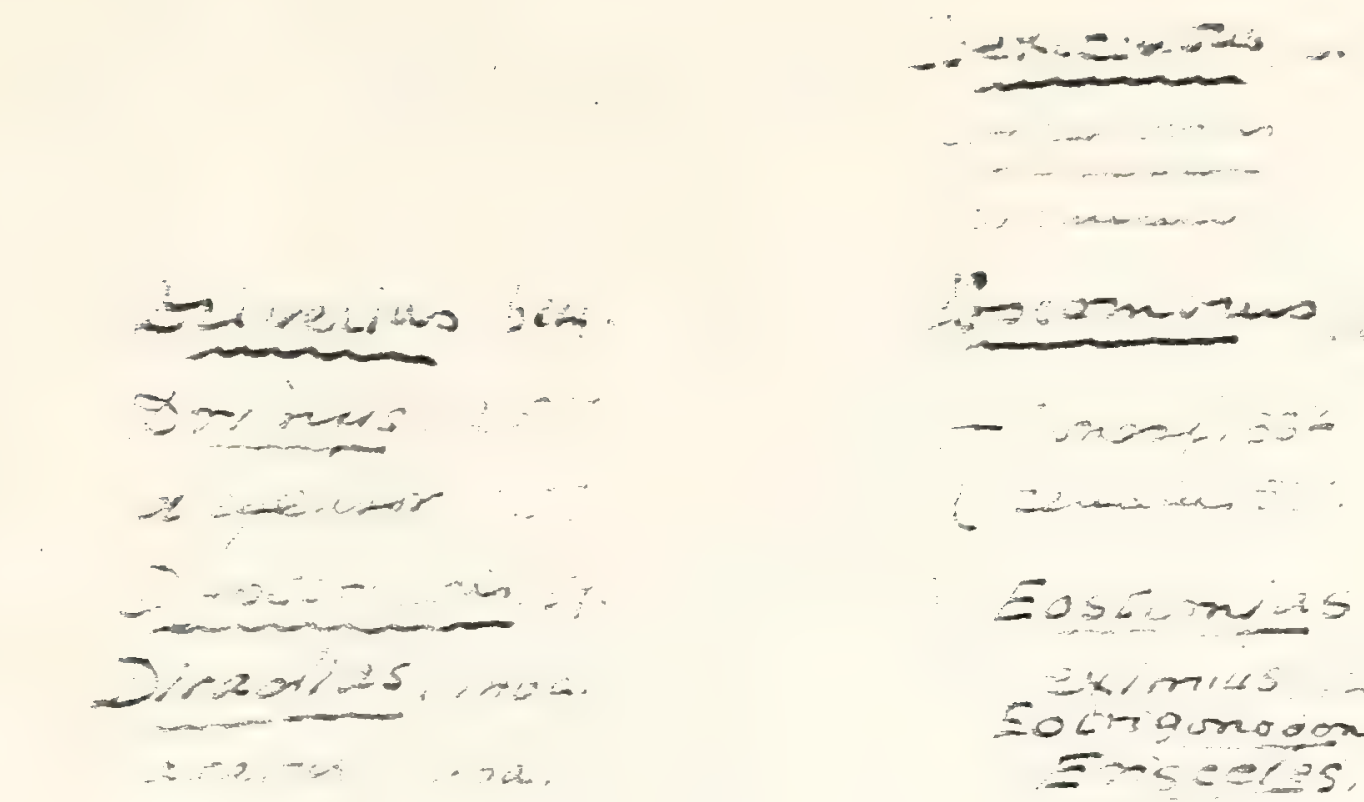

$x=6 x+40 s$

$\rightarrow-\infty$

$+\infty$

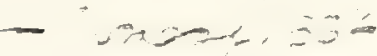

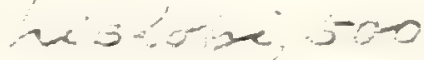

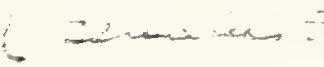

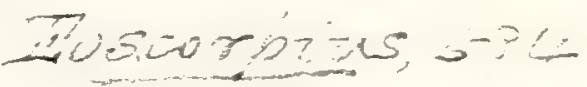

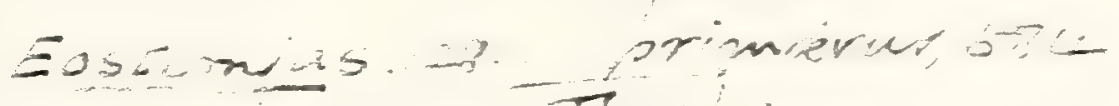
Eximiss tritima, this

Eocmanogor, sji. $=-5 e-135, \ldots$

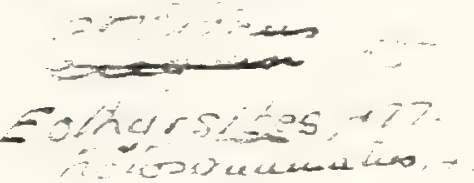

$$
\text { ances, } 1, \infty
$$

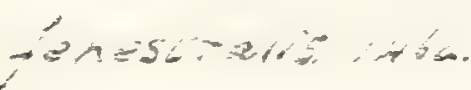

$\frac{-2-1=}{3-m-2-2 \pi}$

E017urszos $7 ?$

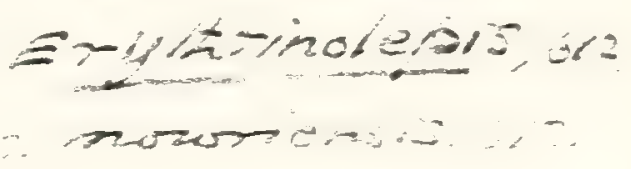

aenirui, 615.

$=2-1-3-1-2$ $=30,-6 x+3$ $=302+572$

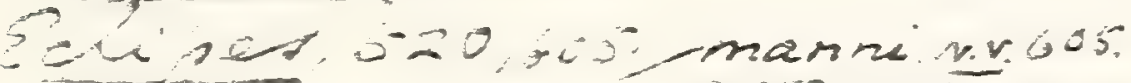

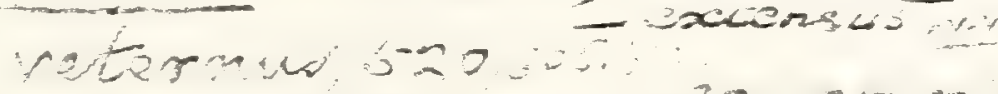

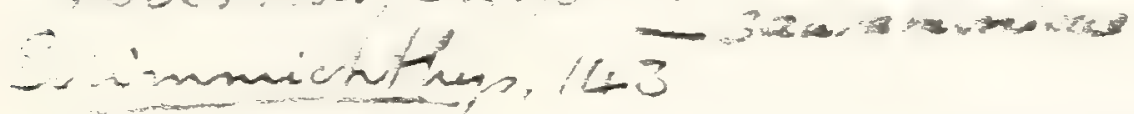

ompicsuram, 43

- blimmar iboc-

Granmeri, Lto

elenodenae, $146 \alpha$

-

rowneri, to

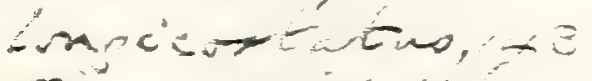

$T: 2<20-1000$

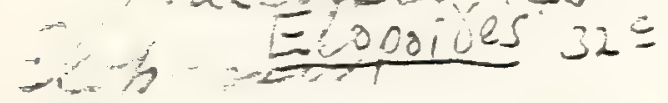

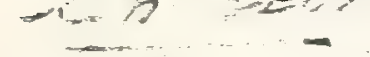

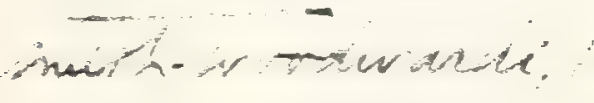

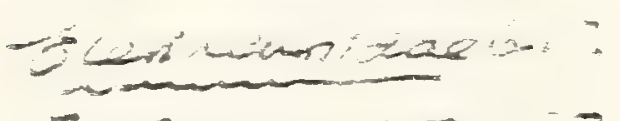

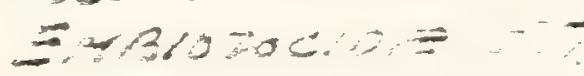

$\cdots$

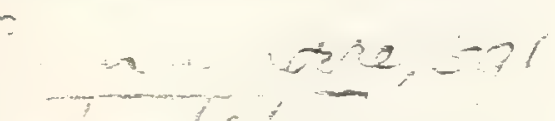

partates sol

$7+2=1$

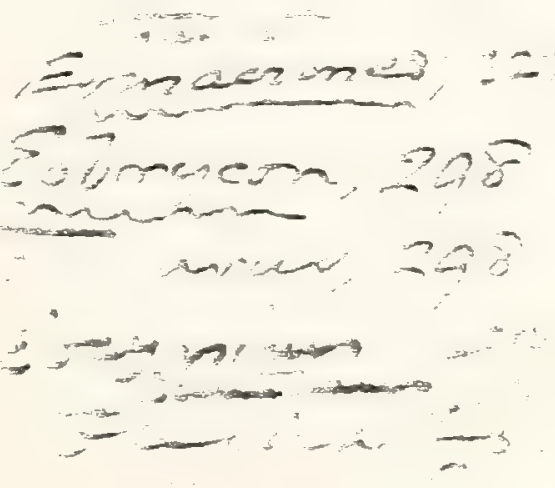

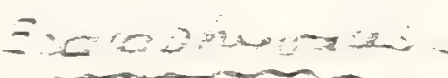

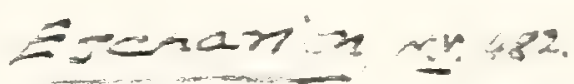

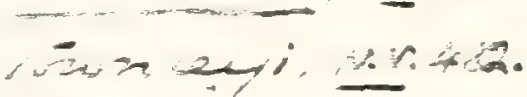

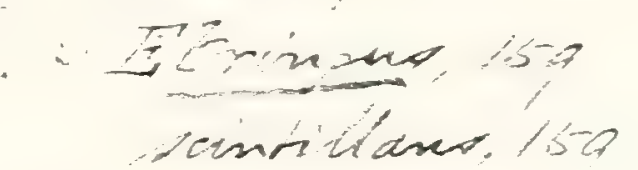

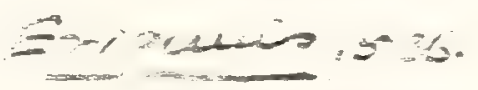

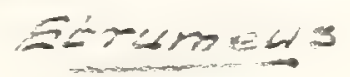

- arasect

$x+\because 4+0, \because 25=$

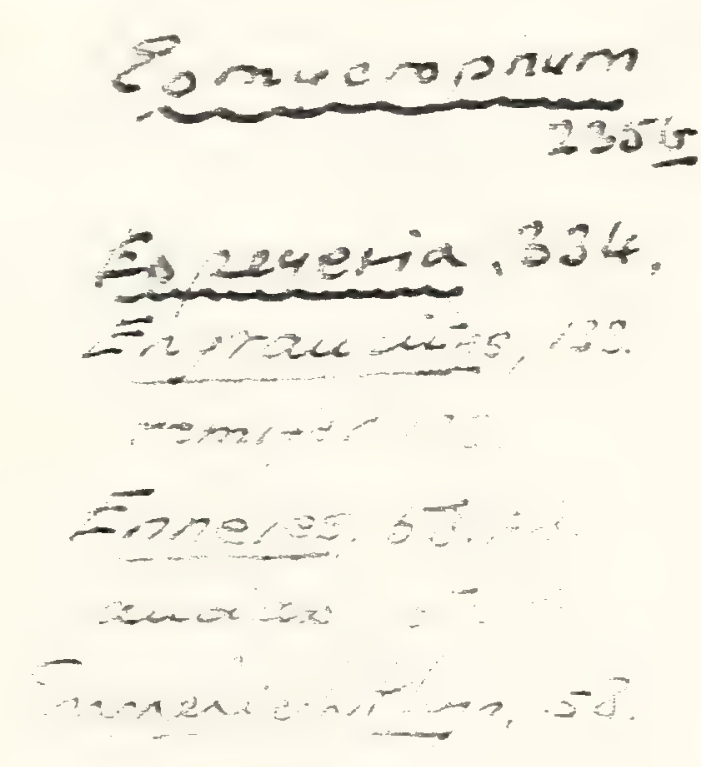

Facte-ing $=5-$

ararimen $\because=0$.

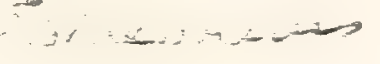

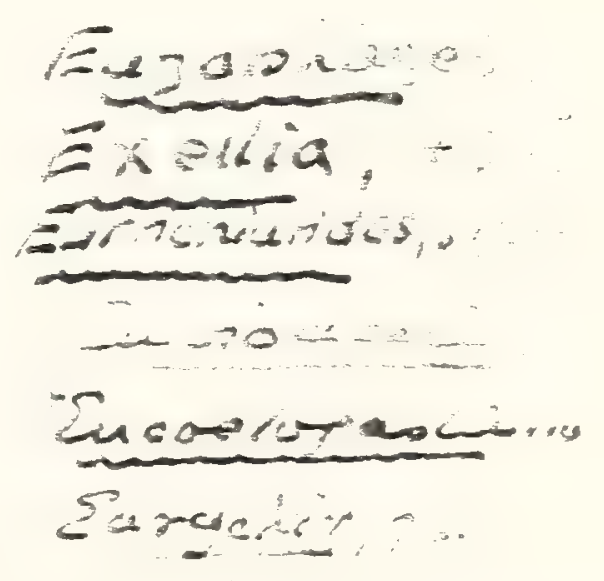

20.052 205

indent?

$+30=-1$

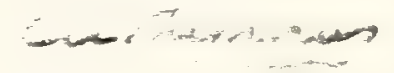

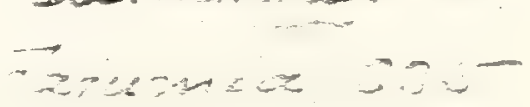



Finceniching, 58

cenmenti, 58.

Forfex, 358

nupuratio, 358,618.

Gomiditis, 07

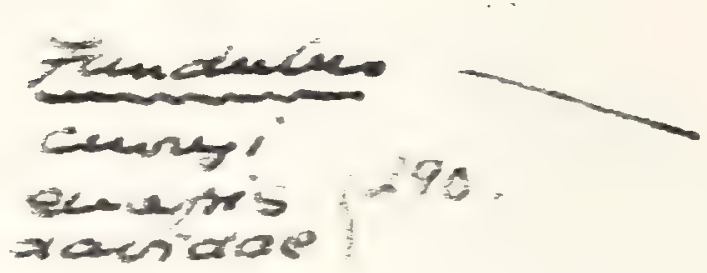

Hexaorammos, 580

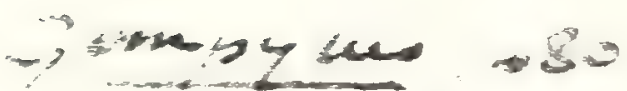
achrestus, 580

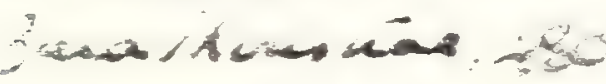

ipiexiow, 235 .

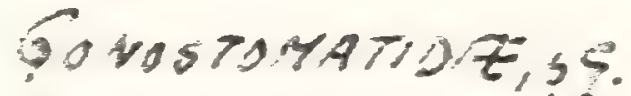

54

ciastroskeos, 340

hexecanohws 370

enty roving 503 .

Ginoessus 159 .

delepsyratra, 157. ois.

Gox Láraconitum.437

Anclyzer, 159 cameo, 150 56

- glepsarara, 15a

reter oszew, 370

vlimermi lehtromus, 370 dentieulatius, 234.

D. Plefor

Sivinañ

Genowien 171

Haplochine 290

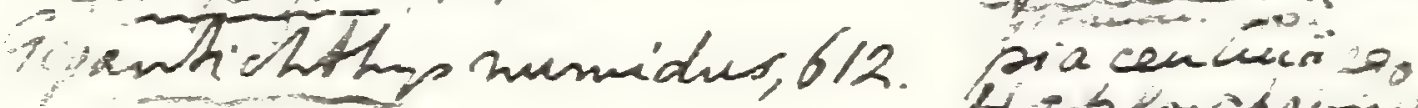

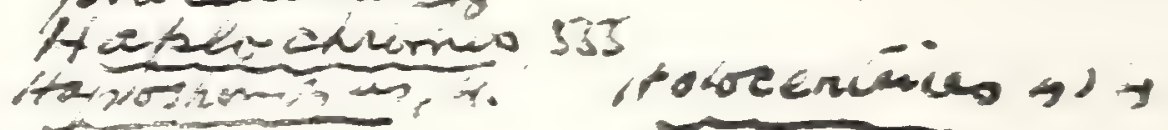

inen, Fania, 58 K

bhicoma, 559.

rossrides, s59.

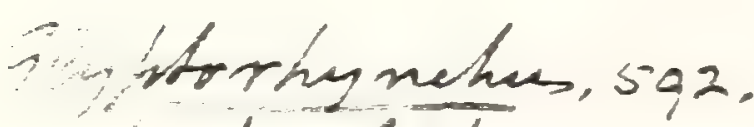
ientientatus, siga.

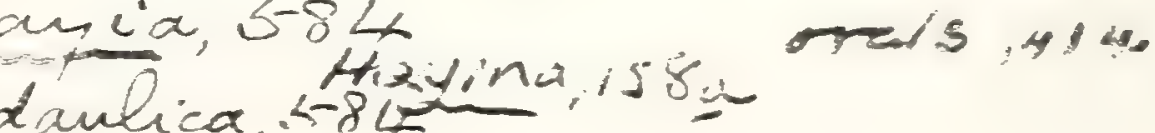

Holarentrsices 485.

notdaricus, als thippoglusoides, 60 s

Gymousana, 457. macespoia, 60\%, sivnyi, ast.

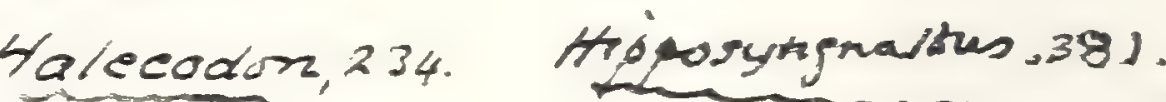

rentieulakis ast.

taksira

Heliojersis $11 !$

Helminitarepis, st?

vermiculestes s:

zier 00 .

to sisente

Hemaxolats

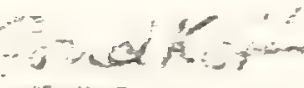

+1, 
Fierasier cunt

nuntius. $80 \%$. nusterns. 190.5.

Fiseniaria, 5 t.

boleensis, 87.

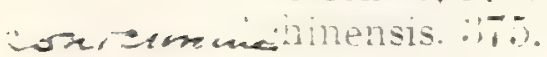

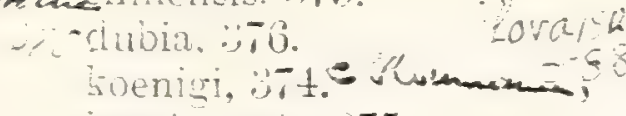
longirustris, tabitcaria. renuipostris, .7.5

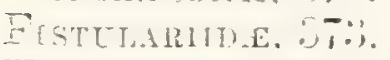

Fundulus, :-nll.

TaUdD. 597.

Gacoosis, 61:. brericens. $37 \%$.

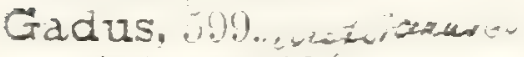
gieliaus jeasorks dol. elegans, bou).

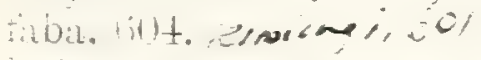

laticir, Sill wirieces or

inscus. 1000 .

meriancus, tiven.

sneriuctus. 59.

minutus, 101.

morrhua. dol.

pollachins. (t) 1 .

poignemus. hibl.

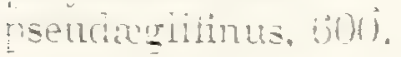

smmiex $(0) t$.

spectioilis. (1)!

stompanii. b01.

tenuis. ilj.

tubereniosus. 1004.

renuatus. biot.

rirens. 601.

Gasteronemus, \pm 37.

vijiongus. $t \pm 1$ ).

mombens. in?

تepinyrura, -16.

concentrica. -406.

Gerres, massaiongoi. ay.

Gigantichthys, il:. bialino. 61:.

Gilicus, 09 , 1.

apelarus. 101.

osirnicerocus. 201.

Giossodus, Grè, 190.

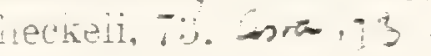

Ilyptocephalus. . .

acinens. nit).

Gusund . .

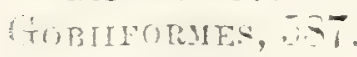

בcoio, :1\%?.

mais, 204.

major.

Fimus, itis.

Gobius. .A.

aptratia

YARE
Gobilis ront.

bassinit. iso.

brevis. 59\%.

sonicus. -85.

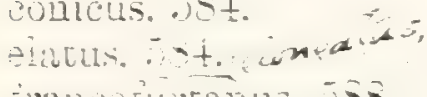

trancoruranus, sos.

.

Lobini, . 98.

macronctus. 588.

matrurus. 681.

: maximus.

microcepialus, 58 .

muitipinatus. jat.

oblongus. 5.t.ori"

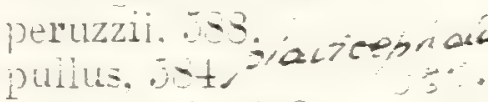

smyrnensis. 4 .

reronensis, .sl.

ricinalis jos.

riemensis. at.

Goniognathus, :-:

curputunoices. $37 \%$

maxiluris. 57.

Gonorimgento. 271.

Gonorhynchus, :-7l.

speri. - -1.

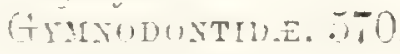

Gymnodus.

ciocion. 575.

heterucion. 3.5.

Lunsegurensis. 57.5.

Hacauetia. il:?

bolcensis. it:2.

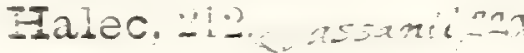

tunter rsme. $-1 \%$

grestipiaticus 20 .

inater. $21 \%$.

Lialuei.

microlepis. its.

=temberin. $21: 2$.

Jalecopsis,

metonir. $101 \frac{1}{x}$.

heris. 20.

Henosaldide. Ito.

Falosaurus, th.

H.promi. L.

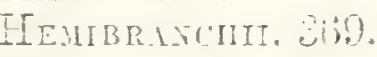

Femicyclus, 0 .

streulensis. $1 . \%$

Eemieioocosis, is.

gibbus.

racilis, 3.

uessi. ds.

Eemilampronites. 59.

teiniai. 59.

Femiramphus, $:-$.

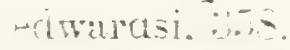

Pemirhoncisus. - iq. wipis. \pm 4 . zemirhonchus(cut.).

desintroi, tes.

zitteli, $\div$.

Femisauriaa,

neocomiensis. 200

Eemithyrsites, 481.

armacus. tob.

riactrs. tol.

lieni. maicontras

Fiemitrichas, :2:"

senisticulin, iz:?.

Feptadiocisn, ,11,

chinus, $.1 \pm$.

تieterobranchus.

:3.5.

naixindicus.

Eeteroleois. b12.

Eeterctis. $i$

Ferapsephus, "jo.

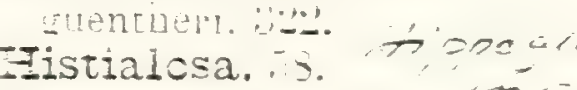

tiviliem - a

Eistuocepnaius. .7?

Eistiophorus. 415 .

antiguts. $+5 \%$

leshaves, toy an a am

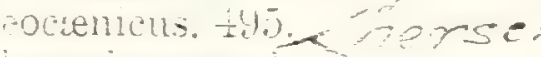

Eumaioneramohus, $\$ 7$.

purvulus, for.

prisetis, t!

pobustus. 497

motunius. 595.

Fistiothrissa. isl.

urassoninna, I:2.

adepochectia. $1: 1$.

Eistiurus. $1 \% \%$

eiatus. $1 \frac{1}{40}$.

seriuluicies, $1 \pm 6$.

rentricuslls. $1 \pm 6$.

Iclacanthus, Bit.

inicrocenbirius. wi.

Diopenorum, j1.

Folcodon. 111.

comuensis. 21?!.

ireodon. - - I $\frac{1}{2}$.

Eolcolepis, 11, \% " a

cretaceus. -1$) \quad \cdots+1$.

Folccentrum, 112, senew

cilculiter" st?.

inceriatum.

macroceninut +12

uncuirtuen, i)t.

neititense, +13 .

iscentiz. -13 .

rentem $+1 \pm$.

$=040 .+12$.

Eolosiens, - c 二

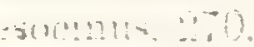

nations: $=5$ 


Homonotus, 407. dorsalis, 408.

rónunarus, 40a. pulcher, 392.

Homorhynchus, 488. bruxelliensis. 490.

Hoplopteryx, :96. revis 406 natiquus, 396.

yrevis, 406. Tewesiensis, 397. lewisi, 404.

3y men, minor, 406 . vblongus, 406.

Simucs, 409 spinosus, 407 . stachei, 406. superbus, 403. soriacus. 405. zippei, 397.

Hoplostethus, 41 . ingens, $t 14$. laciniatus, 411 . lawleri, +14 . nettelbladti. 414 . ostiolatus. $t 1 \pm$. pisanus. $41 \pm$.

Hyperlophus. 139.

Hypsodon, :T. 2. lewesiensis, $80.40,45$. $94,95,98,109$.

minor. 102. oblongus, 26. toliapicus, 24.

Hypsospondylus, 58. bassanii. 58.

Hyptius, 58. sebastiani. 58.

Ichthyodectes, 99. acanthicus. 107 . anaides. 100. arcuatus, 101. 110. cruentus. 107. ctenodon, 100. elegans. 103. goocieanus, 107. hamatus. 107.

Mibanicus. 105.

107 , minor, 102. multidentatus. 107.

- occidentalis. 101. perniciosus. $10 \%$. poiymicrodus, iol. prognathus, $10 \%$. serridens. 101. tenuidens. $10 t$.

Ichthyotringa, 265 , itiy.

tenuirnstris. 269.

Iguana (?) haueri. $5 i^{2} 4$.

Imogaster, $39 \mathrm{j}$ auratus. 894.413
Ischyrhiza, 46. antiqua 45 chisen 46 . mira. 46. radiata, 46.614 .

Ischyrocephalus, 190.

cataphractus, 202. gracilis, 201 .

intermedius, 202. macropterus, 202 .

Isodus, 190. sulcatus, 199.

Istieus, 66.

gracilis, 70 grandis, 67 .

lebanonensis. 71 . macrocephalus, 67,70 . macrocoelius, 67. meśospondrlus, 67 . microcephalus, 67 . spottii. 71.

Istiophorus, 495 .

Isurichthys, 453 .

- macrurus, $4.0 \%$ orientalis, 453 .

Isurus, Agassiz, 453. maerurus, 453.

Julis. $5+1$.

ayassizii, 540 . muensteri, 540. sigismundi, $5+1$.

Turtus relifer, 430,431 .

Labeo cuvieri, 616 .

Labidesthes, 361 .

Labrax, 509. bosniensis, 512 . delheidi, 512. elongatus, 512 . heckelii. 510 . intermeđius, 512. latus, 512 . lepidutus. 512. longiceps, 513. major, 513 mojsisoricsi, 513. multipinnatus, 513. neumasri, 513. oeningensis, 511. sagorensis, 513. schizurus, 510. steindacineri, 513. stiriacus, $\overline{1} 13$. ubinui, 510.

LABRID.E, 539.

Labrodon, $5 \pm 1$. atricanus, 5 t2. alsinensis. 545 . bizini, $54 \%$.
Labrodon (cont.). belgicus. 543 .

bourgeoisi. 543. britannus, $5+3$. canariensis. $5 \pm 2$. carolinensis, 543 . chantrei, $5+3$. cocchii, 543 . crassus, $54 t$. dilatatus, $5 \pm t$. edwardsi, $54 t$. gaudryi, 544 . haueri, $5 t t$. heterodon, $5+t$. multidens, $\check{\jmath} \pm$. parimentatum, $5 \pm t$. poijodoun 545. quenstedtr, 575 . rhedoum. 545. sacheri, $5+5$. rion sauvagei, 545 , sellæ, $\overline{5}+5$. soldanii, 545, superbus, $54 \%$, o ma trapezoidalis. 545 . trigonella, 546 .

Labrophagus, $b_{11 .}$ esocinus, 611 .

Labrus, 539.

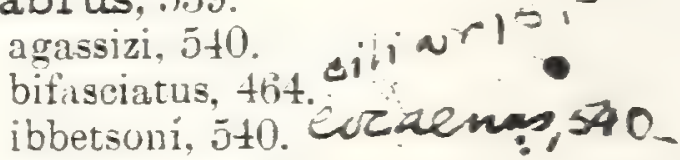

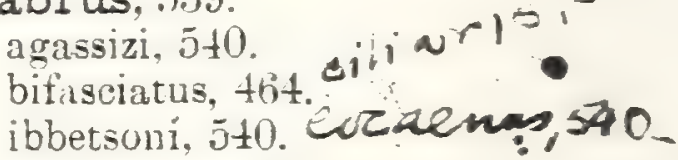
malapterus, 595 . merula, $5 \pm 0$. microdion, $5+0$. parrulus, $う+0$. priscus. 540 . punctatus, 55. rectifrons, 558. turdus, כ04. valenciennesi, 540 . woodwardi. 541 .

Laparus, 596. alticeps, 596.

Lates, 502

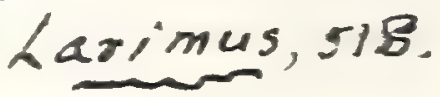

gibbus. 502. gracilis, 002 . heberti, 499 . macropterus, 503. maclurus, 503. notæus, 502 . partschi, 503. sagorensi-, 513 .

Lebias. 290 . - crispinasus, 503. aymardi, 292. cephalutes, 200 . rassicauclus, 205 . crassus, 296. eisgrabensis, 294. furcatus, 291 . raduri, 392. 


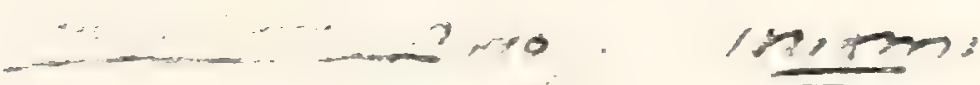

arrocion

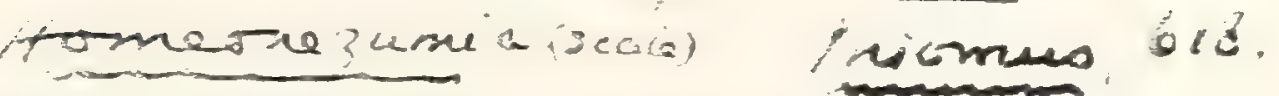

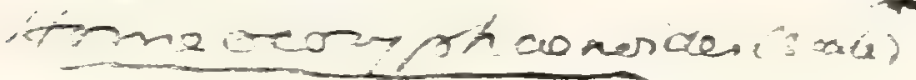

confertionen.

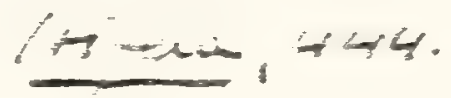

depressus, $-\cdots i c$

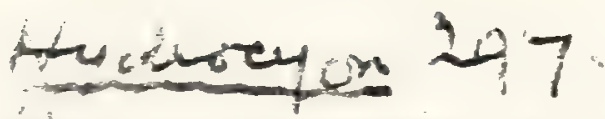

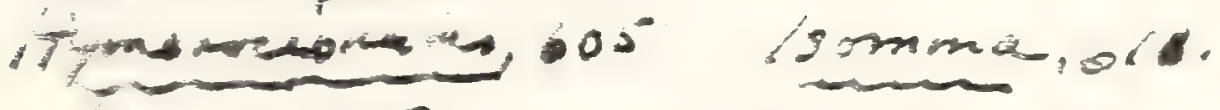

verus, 355 . ls nese.

Henammai, s5.

LEnavica, 110 .

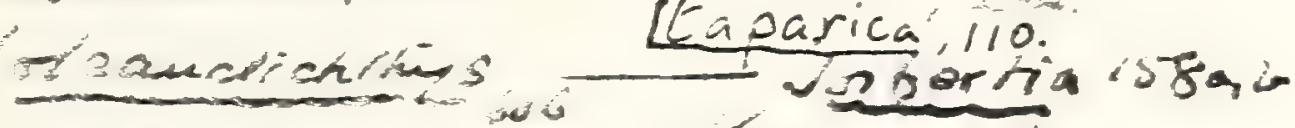

paucideres,

ondation log

APmichitury, 523.

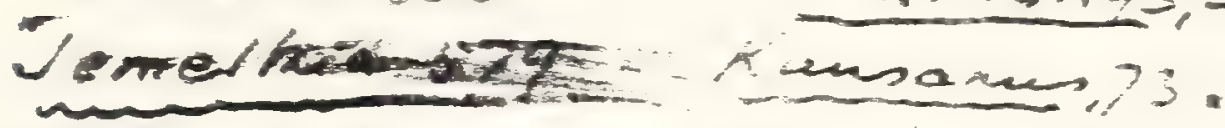

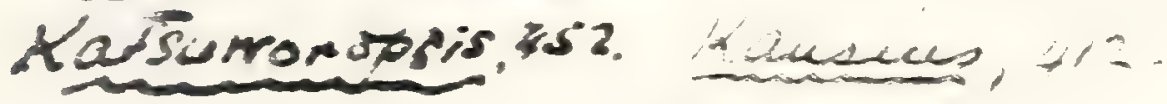

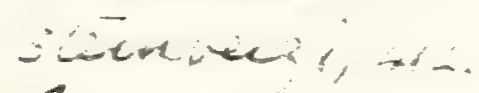

vaiklanti,

Rainderlin, bu Inishtia, 139ivist

Eocaena lite

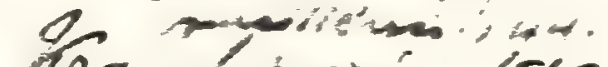

Trambereeria, sta.

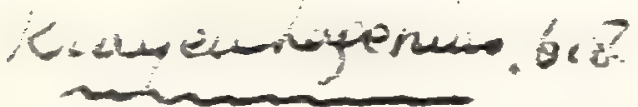

Laiminer sic

lancedeta, sig.

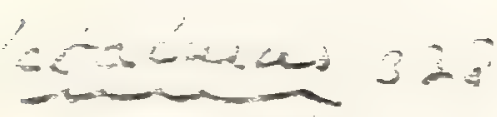

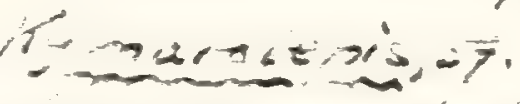
Eanubine, 60 .

verus $3 x-$

inssid. oy

and

Treion N. 53

monacising 50

$-$

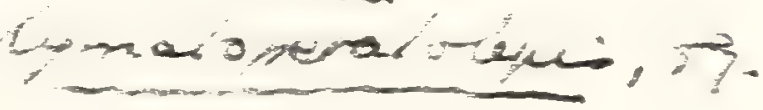

Pyrtogumareion, 571

satima,

Gongan Lomincosianos

penutive

Tix. 235

xis

entersich

raver zunearnu.

sacersu

Ficume ins:

wer nix

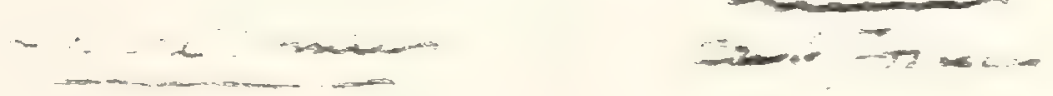

amonstis

$=$

canimitedta 


Lebrichthys 16

techeria, big.

Lemilens, 1sza.

meitlejonnil 153 a.

intia, $=100$

compeuciow, 4T7.

oswardi, 3".

moravicen, it.

orichei, \&79.

pachecoi, 306 .

zusatoi, 481 .

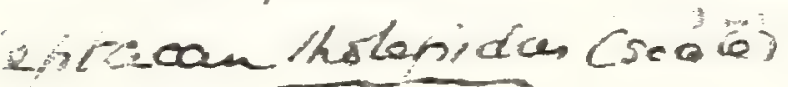

reddingi, 323.

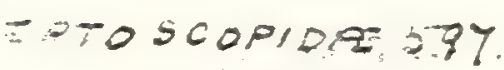

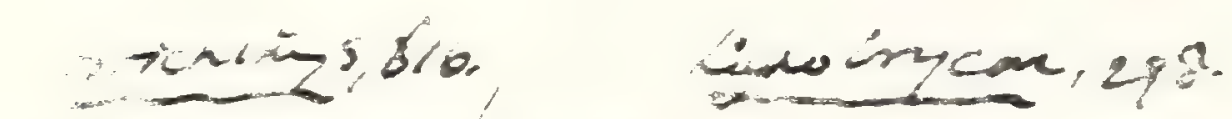

- orammantegen 5

Tiunis geiniés st.

mophaties, 3 . thation

Lotimmana =as.

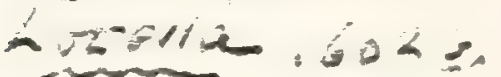

Lupleia, 521 .

carotti; 521 .

Lutianida, 524

Luriames 5.24 hagairi, 324

Luvares, №v48.

Iygisma, 158 E

tenaxe, 158 E, bis

-uxilicén.? 3

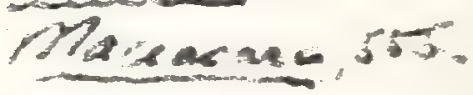

Macionorides:"

ansions,"

Maeropetailepis, 11.

Maerenied Thys.32?.

Maena 537

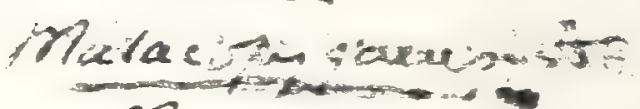

Mancrunichion.

unatorís, !

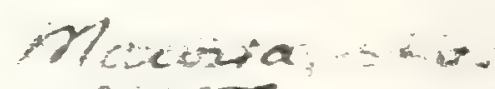

7 is

Maxcellieheira b2 is ?

Ya-arsina isz

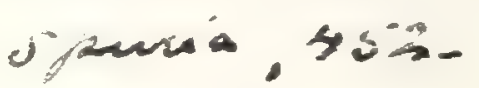

Lompochutes, nus sss.

bopkinsir wer 535.618

x esticnitrys, 200.

Fimhogwa, b39

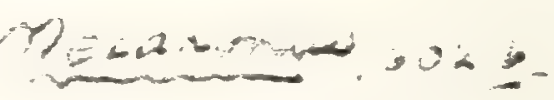

retsoses, 534.38

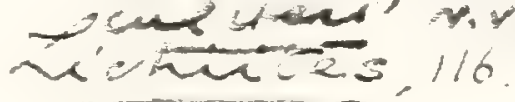

A utuchltyoss, 162 eretacens, 16.

Lithonerim

Thnar, - asto

mioestoms. 450 
Lebias mme:

zubio. -2t.

mereri, 2utt

minimus. ant.

perpusillus, 2.y1.

tenuls, oft.

lignoi. 2.)t.

Lepidenteron, 15.5.

lungissimum. 1:5.

Lepidoccttus, j31.

uries. 5:2.

brevis, jo.

dongatus. jot.

grachis, 617.

multiminnatus. j8t.

mapyracels. $58 \%$.

Lepicopides, tiT.

brevisnonditus, tol. ilubius. 481 .

lentosnoncivilus. \pm 81 .

Iepidopus, tri.

aibyi, tEl). PN

inguis, $t<0$.

brevicauda. ten.

"carparhicus. t\$0.

dubius. \pm 21 .

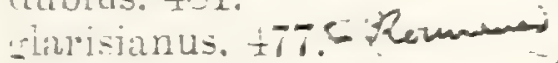
leptospondylus. tel. menegninii, tol.

Leptecodon, rectils. 238.

Lepticinthys, 616. ivilis. 1 ilt.

Leprccepnaius, üti.

racilis. itti.

medius.

renia, ith.

LePTOLEPIDE. 1.

Leptosomus, $-\frac{1}{2} 4$.

- thiopreers - ipassicostarns.

$\therefore \div 4$. eiongatus. 345.

guestninaicus. $2 \pm 5$

macrourus. 215 .

minimus. 는.

Leptotracinelus, $17 \%$

urmatus. $17 \frac{1}{2}$.

Hongatus, Ist.

sonir raciils. 150.

$z$ haketensis. ist.

Songipinnis. 1 -7.

sagttacus, 187.

minnerer, $1 \frac{1}{1}$.

Firenuitus. ¿sT.

Zeuciscus, 045.

acrovaster. 3iu.

unia. 311 .

osniaskii. :10.

Brevicuria. 810.

peris. 111.

mint14s, 311 .

Jotelinensis. 11 .
Leuciscus mut. .

secconii, 212.

cephalun. $517 \%$.

cephatus, $30 \%$.

colei, :

dorsalis. $811,312$.

dumerili, : $11,: 312$.

eibiswaiciensis, :jio.

elegans. 315.

erctiroputhaimus.

$$
: 0 \%
$$

eurrstomus. 311.

fritseni. bis.

ganbrensis. :11.

sibbus. :I1).

gracilis. :11. : osw

hartmanni. :1t.

beireticus. 615.

heterurus. 810.

krantzi, :311. sinas

larteti. $311 . \quad 3 \%$

latiuscuius, 805.

leptus. 309.

licatre. $: 11$.

macrurus, 2158.

meciius. :310. micermunum

jeningensis. 305.

papyraceus. 307.

piesionterus. :H1.

polysarcus.:11.

pneilaris, :il.

pusilins, our.

racaimuti.:311.

remotus ill.

rutilus, :0!)

sauragei. 12 .

sicanus, 311 . 12.

steninani, :311.615.

tarsiger, 315.

turneri. 811.

rexilitier. 311 .

Leucus, 22.

concionianus, 32:2.

hatus.

Leuresthes, :

Lewisia. 5 .

orails. 53.

Iichia, 4t.J.

dita. \pm 6 .

anais. $\frac{1}{1} 5$

lata, 4t.j.

prisca. $1+\frac{1}{4}$.

secunria.

stoplanii. $+4 b$.

Zoscaus.

peciemontanus. - .і35.

Locoterus. 115.

nectmatus +15

copurtote 1 .

Zopints.

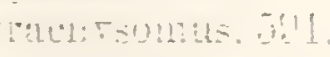

$x_{0}=00000$
Icpinius lonto. zuprel paragonicus.int.

piscutorius. 01.

Loricaria, syl. plecostomus. $\$ 1$.

Loxostomus. 011 . inancus, till.

Iucania, Lu.

Iucioperca. 21. stornili, 521.

Lucius anteciilusimus.

\begin{tabular}{c} 
20. \\
Lutianus epaippiurn, \\
\hline
\end{tabular} $00 \% .561$

Iutodeira, it.

Iycoptera, 1 .

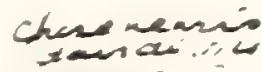
trisen.".

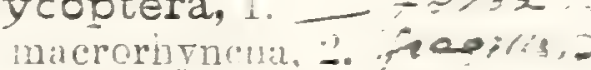

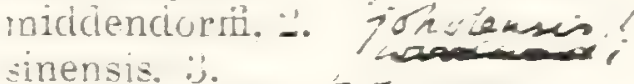

Iyriolepis. Themare

uducaloicus, 5it.

IAacrolepis, ploneatus. +15 .

Macrones,

Macrostcma. 61 .

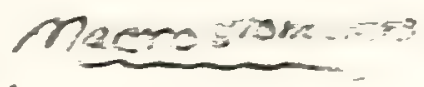

aitum. .ijl.

MACRERIDeE, lith.

Macrurus, $\%$. npercursur. its.

Mallotus, hit. rillosus. 1il.

Megaiodon, $\pi$. lewesiensis. 5. suroicies. 1.5.

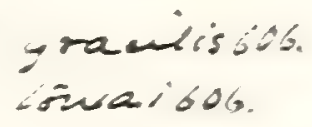

Megaiolepis. $15 \%, 593$

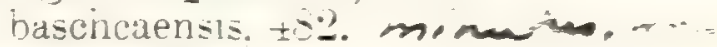

latus. \pm 8.2 .

Megalops, 21

forcinatus, ki.j.

oblongus. 215.

prische $2 !$

- Iegaiurites, $\pi 1$.

nitidum. ji:.

Ileganus, -1 . ruesttalicus. 2s:;

Megistorus, $211,234$.

questralicus, 20.

Meletta, $L \frac{1}{2} 5$.

crenuta. 151

doljeana. Lin.

raciliima. $25 \bar{j}$

rrancisauma, 1.j.

hecireli. I.j.

helerostoma. $15 \%$

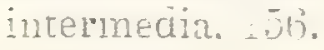

Gongimana 251.

misisoti. . . .

mpatirintes, $2 \pi$.

sinlevi 


Meletta (cont.). sardiuites, $15 \%$. scheuchzeri. 147. sturiaca, $15 \%$.

Melettina, 151.

Mene, 437 . oblongus, 440 . pusilla, 41 .

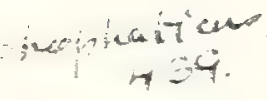
rhombeus, 439

Menidia, 361 .

Merlangus, 600. cognatus, $b 0 t$. spatulatus. 604. suffoltensis. 600 . rulgaris, 600 ).

Merlinus, 603. cristatus. 60)3.

Merluccius, 601. T303.

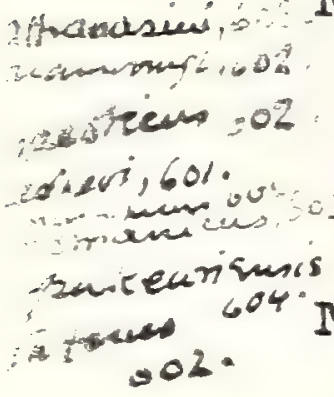
attenuatus. 604. balticus, 614 . mousogetam bosniaskii, 601 . emarginatus, $(, 0) t$ mineenicus. 104 . num? obtusus, 604.

Mesogaster, 61. cretaceus, : $66 \%$. gracilis. 254 . sphrimoides. $36 \%$.

Metoponichthys, $55 \%$.

longirostris, 5.50. actacunthus. 5\%).

Microccelia, 25:3. gramuiata, 202 . libanica. 250.

Mierocion nuchalis, toge.

Mírodon pulchellus. $t 21$.

Mioplcsus, 517. abbreviatus. 318. beani, 518. labracoiries. 517. longus, 51 . multidentatus. 518. saurageanus, 518.

Monocentris, 414 .

coxi, $4 / 3$. hospes 414 .

senm, 4r 3 . integer. 414. subrotundus, 115

Monopteros gigas, 89.

Morrhua, $y$. atgletinoides.601. extensa. bu1. tiaba. 604 .

lancecluta. 501. latid, ibi. macrontermia. 601. sminimit. bui. soellingensis. 610\%. bargatiatensis. (it)1.

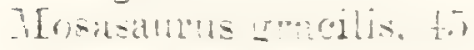

INDEX.

Yuilees, 5\%.

Mugil, 363. acer, 364 कs, Nummopalatus, j+1, brevis, 446 . frey $305^{\circ}$. 54 4.

cephalus, 364 . debilis, 36.5 cnoderinis $365^{\circ}$

abbas, 543.

africanus, 542.

bazini, 543.

belgicus, 543 .

bourgeoisi, 543 .

britannus, 543.

chantrei, $\check{5} 43$.

cocchii, $5+3$.

edwardsius, $\check{4} 4$.

gaudrri, 544 .

batieri. 544.

heterodon, $5+4$.

multidens, 544.

parimentatus, $\overline{0}+4$.

polrodon. $5+5$.

quenstedti, 54.5.

rhedonum, $5+5$.

sacheri, 545.

sauvagei, 545 .

trapezoidalis, 545.

Myripristis, 410 . homopterroius, 411 . leptacanthus. 410 . toliapicus. 410 meitensis, 413 .

Myrus, :30. rulgaris, öt1.

Odax carolinensis, 540.

Odonteus, 5.56 . depressus, 556 . prgmieus. 5.56.

Naseus, 564. brevirostris, 564 . nuclalis, 565 . rectifions, 564 .

Naupygus, 611. buckiandi. bill.

Nemachilus, bredai, :2:0. centrochir. 320 . cephalotes, 321. tener, 415 , mus tevieri, 321 Trmalis 320

Nematcnotus, $: 40$. botta. 250 .

Nemopteryx, i9s. messus. 508. fifonazu elongatus, 598. kuvacs trosebeli, 5!8. monstem

Nettastoma, : 41 . bolcense, 346 .

Noricartirde, lib.

Notacanthus, 169.

Notitus agassizii. Jtu.

Notelops, -2. brami.

Notogoneus,

curieri, 27.615. longiceps. 2-T.

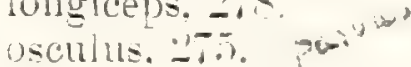
squamosetis, 20?

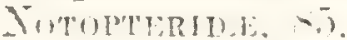

Notopterus, primilum. ali, sparoides, 506 .

Odontostomus, 189.

Oligobelus, : : 23 . arciferus, 308. laminatus, 323.

Oligoplarchus, .119. squamipinnis, $51 \%$.

Omiodon, 270 . cabassii, $2-10$.

Ommatolampes, $+90$. eichwildi. 491

Omosoma, 41 \% intermedium, $4: 0$. monasteri, $+\circ 201$. pulchellum, 421 . sahel-almix. 419.

Omosudis, 189.

Oncolepis, 595. isseli, 597 .

Opminidie, 6050

Ophidium, 605. 600

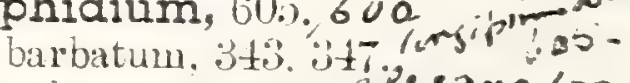
roltianum. 105. ezegams,600

OpHincepHILIDE. 360 .

Ophiocephalus, :369. striatus, $\pm 0^{\circ}+$

Ophisurus acuticaudus $\because 47$.

Opisthomyzon, til.

Opisthopteryx, zis.

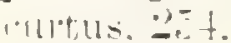

aracilis. 2it. 


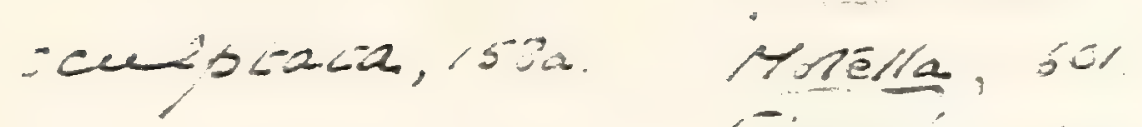

visimaria, for

Hrazesia

mointi

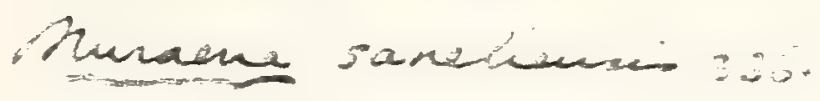

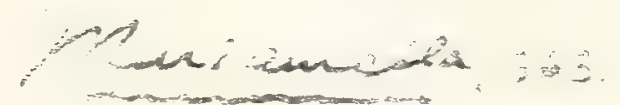

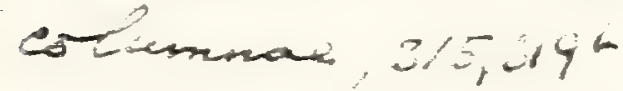
ectuandist ars:

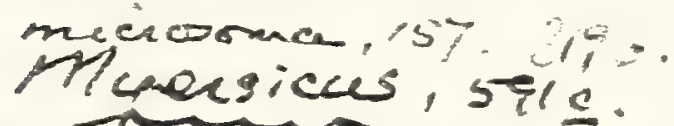

Merriamina, 605,500 Mutrompino, 343. ectaner, 605, 520 frangens, 343.

Inerziamella, $=63$ dorupsa, 363

Mesclupea, 129.

is

showchangersis, is.

raver a

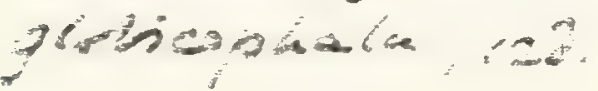

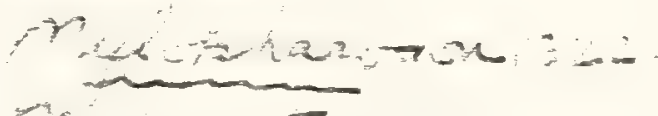

Nyctoonus

unes?

mierosoma

Geystias, is

sagivta, 482 . the

Otronerived

coposelisios.

Microedius nos Nartandir bit torene on

apropients sors

Neomaenis, szu

samaser, bi.

hagari

Oncinosauras

Onoinosmin

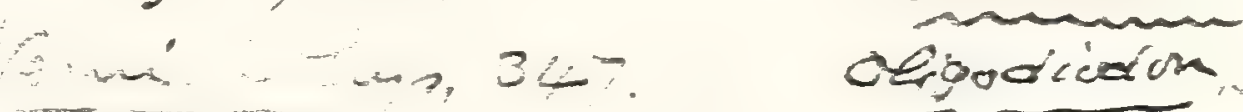

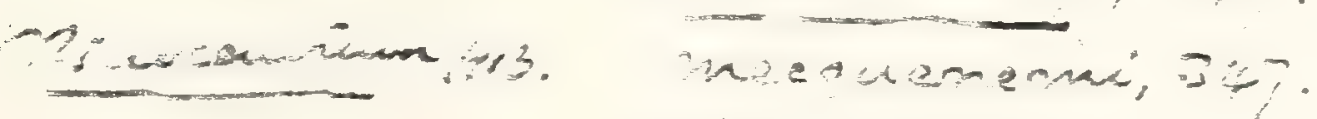

Ona oroum

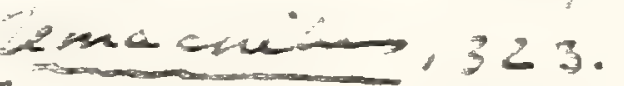

speciosus

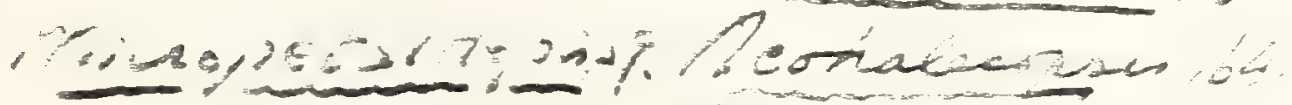

Ophisuses

Veocubium, 476

acmeicunow

Hostican rontrabum, 476 .

Cenicréon

Secisinen NIOBRARIDP

Oeliodomation Not-cen, is'

Santaction

Ditionus to Diphon, sob.

ogienis. Wl

sispinosus,

Pecenarand:

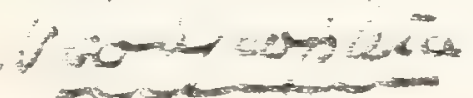

Giscomarion.

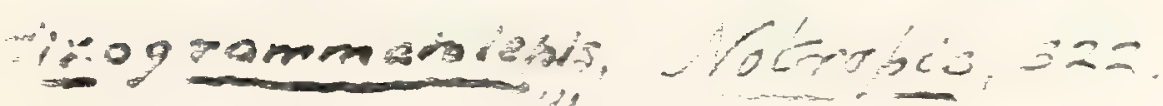

mane

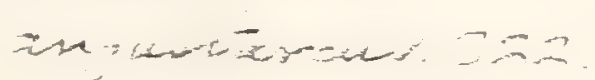

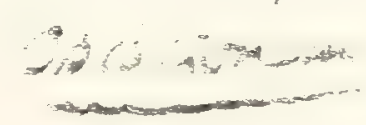



Irtsonimin, 523 .

bornholmiendit, 613.

$A+-\infty+2$

:remgus, 242

hamprotirensis, 617.

20nems. 263

Cscasiostoma, 129.

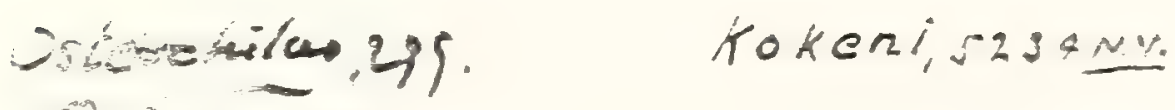

emaitio, $2 x$

Oxysonibpidus scole:

Osumandias, 4821m aiehent: 482rNo 
Orcynus, tit.

hounuschi, tori.

hanceviatus. tijo.

intior. t.j6.

medilis. toti. in en

saidisil, țó.

Oricardinus, $t h$.

tortus, \pm 10.

Orthagcriscus, .00. heiononsis. iti.

Osmeroides, 11.

uttenuatus. 1!.

belqicus, 202.

ureris. 16 .

rissils. 10.

cretaceus. 20.

diruricatus. …

lubius. 16.

EToilutus, "2.

ciarisianus. -

slurilis, Iij,

srunuiatus. 213.

insiunis. 101 .

Iatus. 16 .

leris. 15.

lemesiensis. 11 , $1 \%$

lemisi. 1.

manteilii, 1:2

maxinltis. 18.

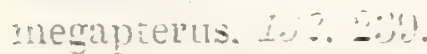

miurocentathe 2uT.

minur. L

munasterii, 2:5 20:

pectinoienis. …

mormicrodus. -2

surcinioides, 1 .

vinare:sis. "l.

Osm $\leq r c i e$ is, reticulata. in.

Osmerus, i:”.

klovi. 110 ?

cortieri. 207

d'achinedi. 160.

giarisianus, 25

lanteri. 160.

prouterogins, $\%$.

scarabellis. A

stimnos. 1!i2.

OstaizupHYSi, - -

USTEOGLOMIDA, T:

Osteogicssum. -

incalustum. "ii.

Ostracion. int.

inperiais. otiti. . . w

Inicrurus, . is:

ubluness. fing.

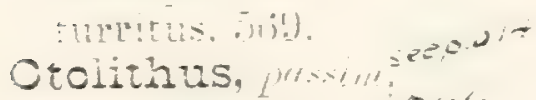

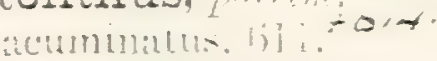

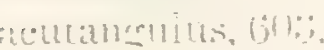

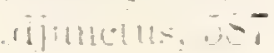

Otolithus wht.

iequals, iz: 298.

:Heldicants, til.

amoilts. 530.

apploximatus. 010 .

attenuatus. 1jot.

alticus bijt.

batrallous. but,

biscissus. ien.

boettgeri. alijo.

brerior. : $\div 7$.

clarbornensis. . A

cognatus. liot. scopeusent

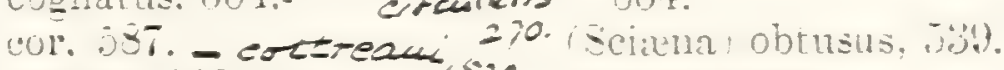

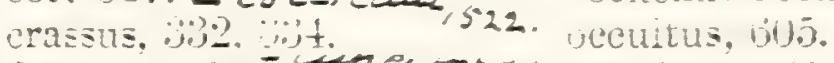

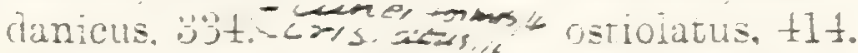

Berrciciarum: debilis, 115 .

(MIurididanun) debilis. :iij.

tiecipiens,

difiuruis. 105.

dismal. jus.

disinctus, jo. $q$ N.V.

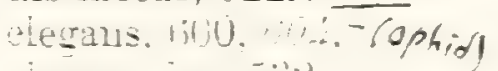

eleratus. (h)é.

elinticus, .97.

Berreiciulut

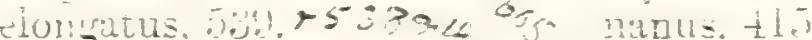

emaromatus, $1: 14$.

epolpectus, gis.

dibar. illt. Starianisfyl.

irancoruptinus. is.

frequens. or:-

sermmal, ojo.

gernianictis, yut.

grenon, $\frac{1}{2} 15$.

rioberulits, - $: 4 \%$.

giader. ill). (nacraresciós

gregninus, ins.

suestilizus ill.

Milgenciuri. Gij.

irolenticus. 5.

inusioes. $11 \pm$.

Itrbicius. 1,05\%,

ingens. $t 14$.

insiunis. eijo.

insuerus. . 3.

integer. $\neq 1 \pm$.

internedius, ins.

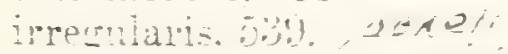

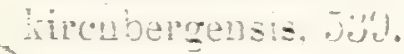

Paciuiartis. $+1 \pm$

avicutus. jug. anenck

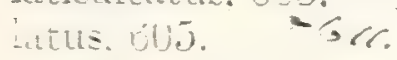

lawleri, $1 \div$.

-enticulintis. il1.

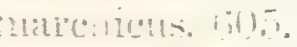

meririmalis at?

:10ita.
Delithus w...t - O.6lons: - onet..."

mentinus, 20 - 49

incuenatus, 1iljt.

inutavilis, silu

neviecrus. 415.

netteiblatiti. \pm 14.

nobilis. Je:"

nuntius, (39).

obotretus. 1305 .

MIelócecius) jbtusus.

oratus, jis.?

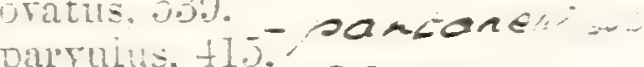

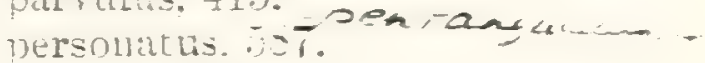

pisauns, 11 .

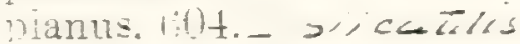

viebeins. 2. \& r.V.

iuncierosus, int.

pusterus, bus.

) Mecur:or,

) limas, ist.

aclians. or.

surewsi =nis

:Phomgus rienamu.

lilla

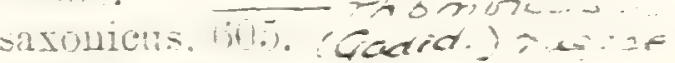

sector, ind

=epinndiciss, sel)

Murrilla; suelinrensis. 195.

(Spaldärannm) suentinzensis. . .

-imilis. jos.

simulex. (jot.

singular is bitio.

Enatulatts. 1004.

specioslis. rit!

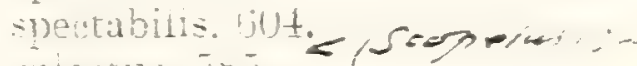

Hlicatlli. in. sabnoticis

surfolitensis, itil. Tarict...

sunnacrecicelis, ile

enuis. 1ilt.

-estis, 1,3.

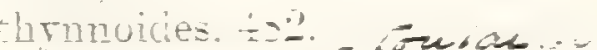

rnerculusis. Gly.

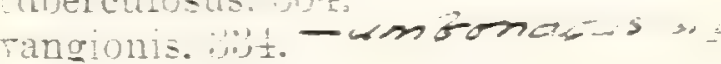

ravians.

renustus. 1i04.

rerus, bin?

- icinalis.

Hifaris. jlu!

Pachycephaids. : .

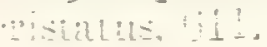




1530

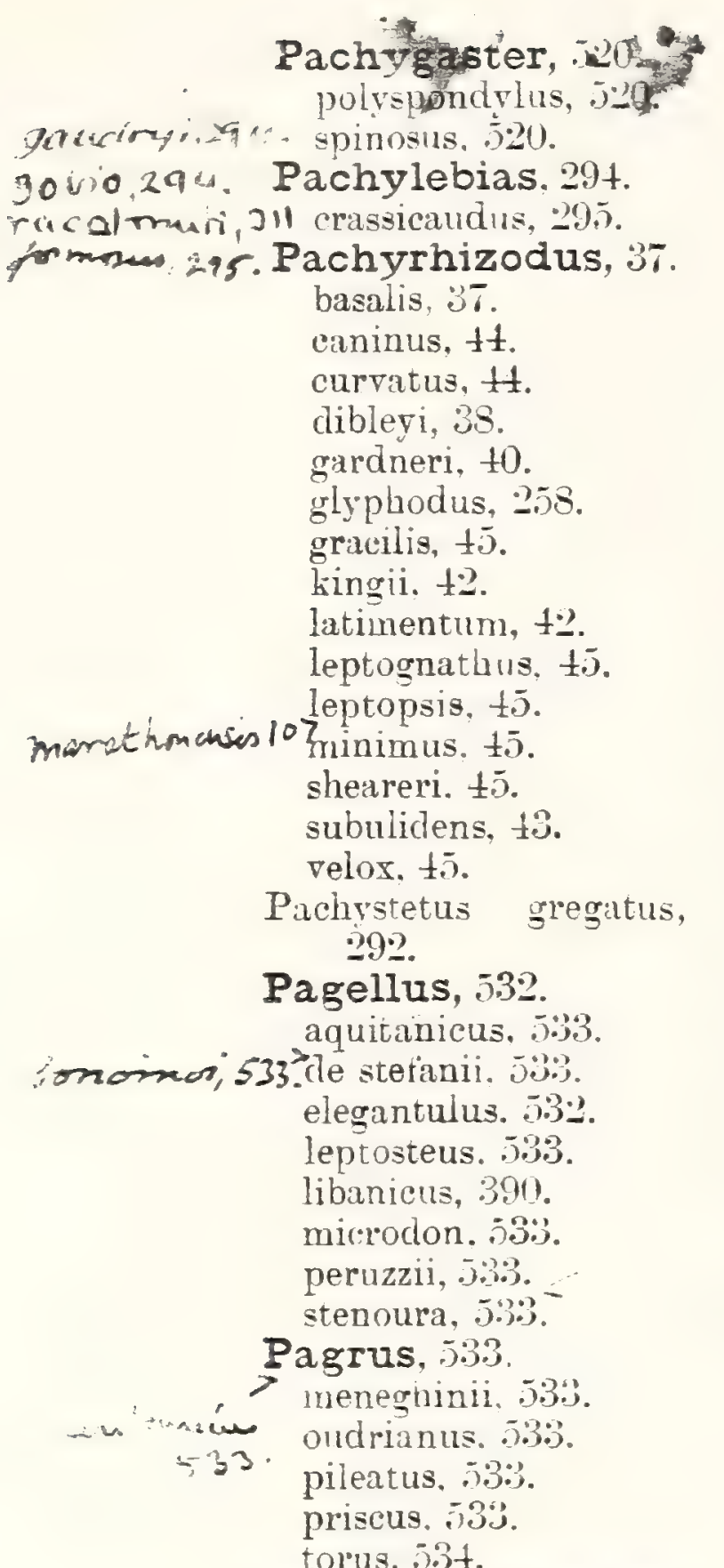

Palæobrosmius, 598. $2_{3} p=7 a$ elongatus, 368. inenirus troschelii, 598. - Palæolycus, 211 . dreginensis, 211 .

PALAORHY NCIID.E, 482.

Palæorhynchus, 483. bruxelliensis, 490 . colei, 488 .

descurnanni. 487. egertoni, $\pm=8$. giganteus. $\pm \$ 57$. Glarisianus. $\pm 83,48 \%$. gracilis. $480^{\circ}$.

latus. \pm 85.

longrostris, 186 .

medius, $45 \overline{5}$. microspondrlus, t89. riedli. 487 . zitteli. 487.

Palanarrhichas. j\%. crassus, 507 .
IFDEX.

Palimphemus, 270 . anceps. 270.

Palimphyes, 460 . brevis, tio. chasumicuer Percid E, 498. srassus, 460 . 461 . Perciforses, 497. elongatus, 460 . glaronensis, 460 . grarilis, 460 . latus, 460 . longus, 460 .

Pantopholis, 234 . clorsalis, $23 \pm$.

Paralates, 5:0. bleicheri, 520. A

Paralepis. 257 .

Paraleuciscus, 312 . ecnomı. 312.

Paranguilla, 343 . tigrina, 343.

Paraperca, 520. provincialis, 520.

Páraphyllodus, 546.

Parascopelus, 256. lacertosus, $\doteq 556$.

Parequula, 450 . albyi, 450 .

Pegasus lesiniformis, 269.

Pegasus natans, 383.

Pelamys, $48 \%$. adunca, 482. robusta, $48 \%$ sard $\alpha$,

Pelargorhynchus, $88^{2}$ 188.

blochiiformis, 188. dercetiformis, 188 .

Pelates, 523. quindecimalis, 523.

Pelycorapis, 354 . berycinus, 354. varius, 305.

Perca, 518.

alsheimensis, 513. beaumonti, 515 . cyprinodon. 5ogramen elongata, $51 \%$. fluviatilis, 518. forbesi, 510 . formosa, $410.1 g^{n}$ ot $a, s$ lepidota, $511.1 \mathrm{a}$ so lorenti, 518. lucioperca, 511 . macracantha, $51 \mathrm{~s}$. minuta, 506. moguntina. 512 . punctata. 366. radula, 5:6. lebonlii. $5: 0$. uraschista, 516. Percesoles it7.
Percichthys, 514. antiquus, 514. chiver, sth beaumonti, 515. Avowormin

Percostoma, 519. angustum, כ̄19.

Peristedion, $5 \% 6$. personatus, 587. urcianensis, 586.

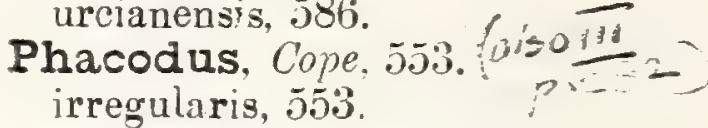

Phacolepis = Rhacolepis.

\section{priaghalacrus, 458 .}

Phareodus, 74, 泩, . acutus, 76. sericeus, 76......

Pharyngodopilus, $5 \pm 1,545$.

abbas, $5+3$.

africanus, $5+2$. alsinensis, $5+4$. bourgeoisi, 543. canariensis, carolinensis, 542. crassus, .544 . dilatatus, 544 . haueri, $5 \pm 5$. multidens, $5 \pm 4$. polyodon, 545 . quenstedti, $5 \pm 5$. sellæ, 545 . soldanii, 545. superbus, 54 ?

Phasganodus, 190. anceps, $20: 3$. australis, 615 . carinatus, 204. dirus, 204 . gentryi, 615 . gladiolus, 204 . semistriatus, 205.

Phasganus, 613. declivis, 613 .

Pholidophorus macrurhrnchus, 2.

Phycis, 602.

- suessi, 602.

Phylactocephalus, 21:. 218 . microlepis, 218 .

Phyllodus, 546. bowerbanki, 5te. culei. 549. corsicanus, $57 t$. cretaceus, 500 . curvidens, $5=0$. deborrei, $5 \overline{5} 0$. depressus, 500 . durali. 50. 


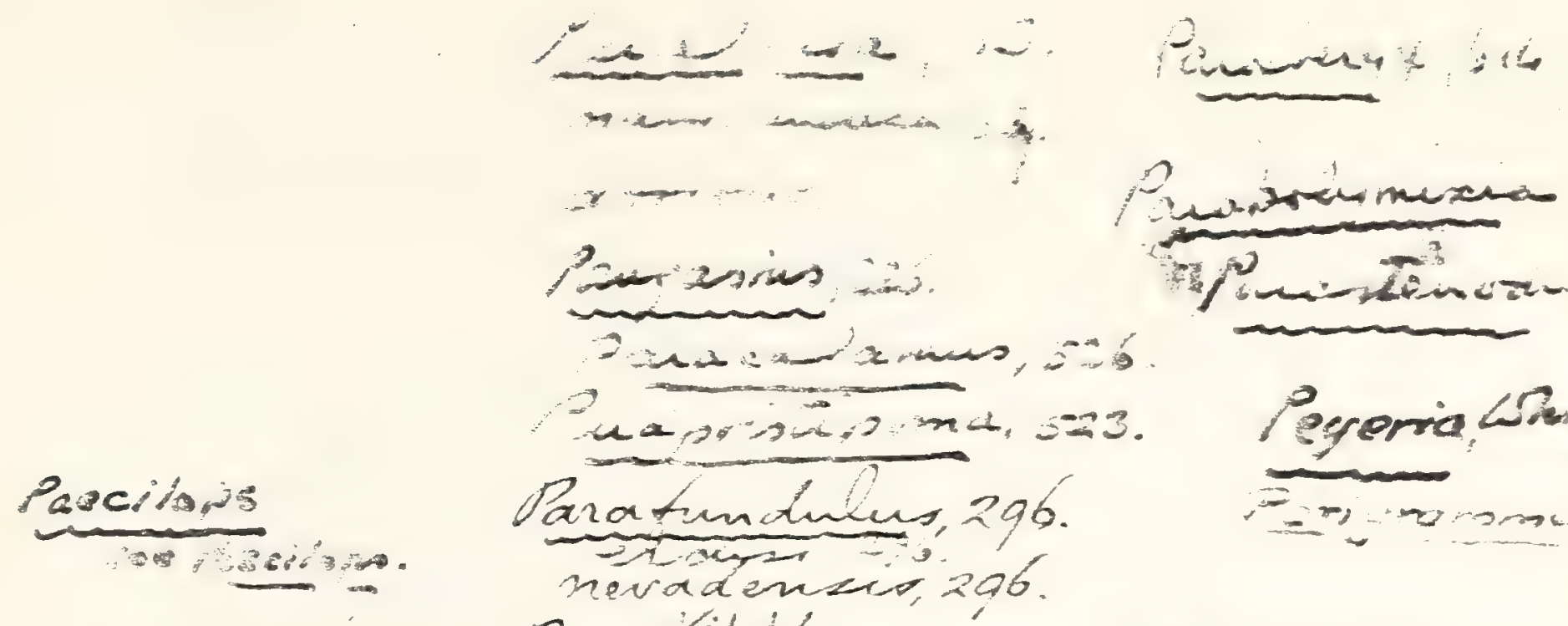

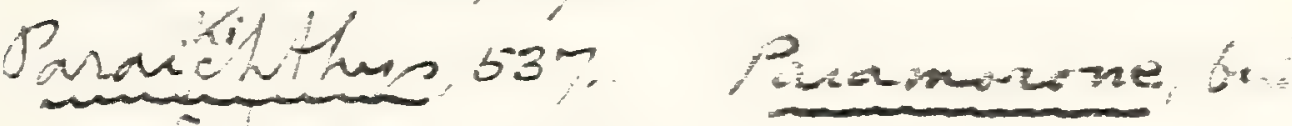
rinatinimes, 537.

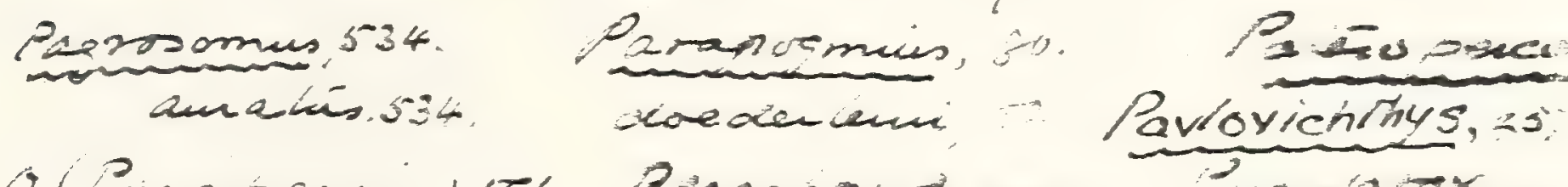

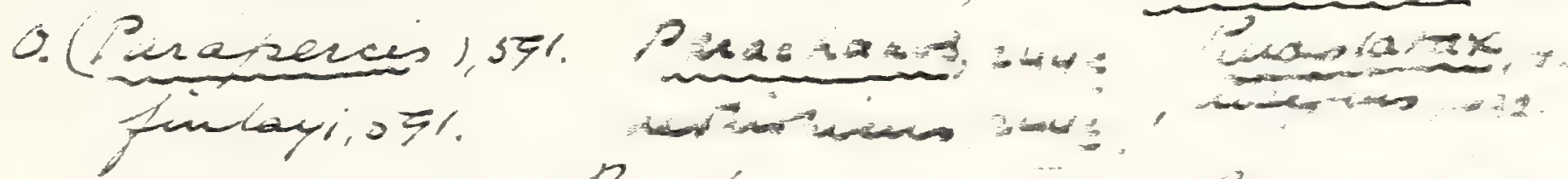

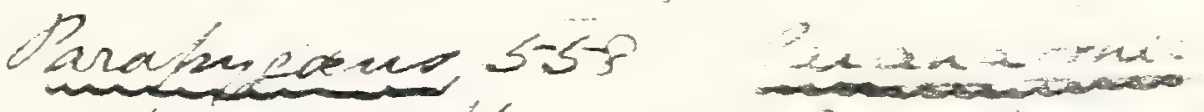

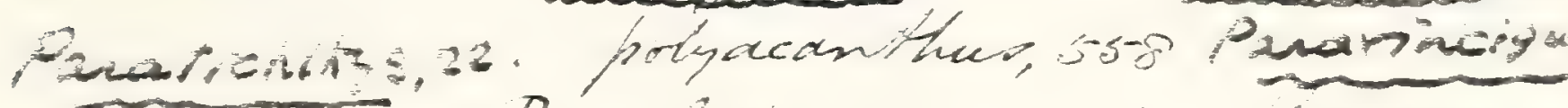
Parelober, $1 \%$

remensis, szo. oraratii, ll. Paicum uns 341

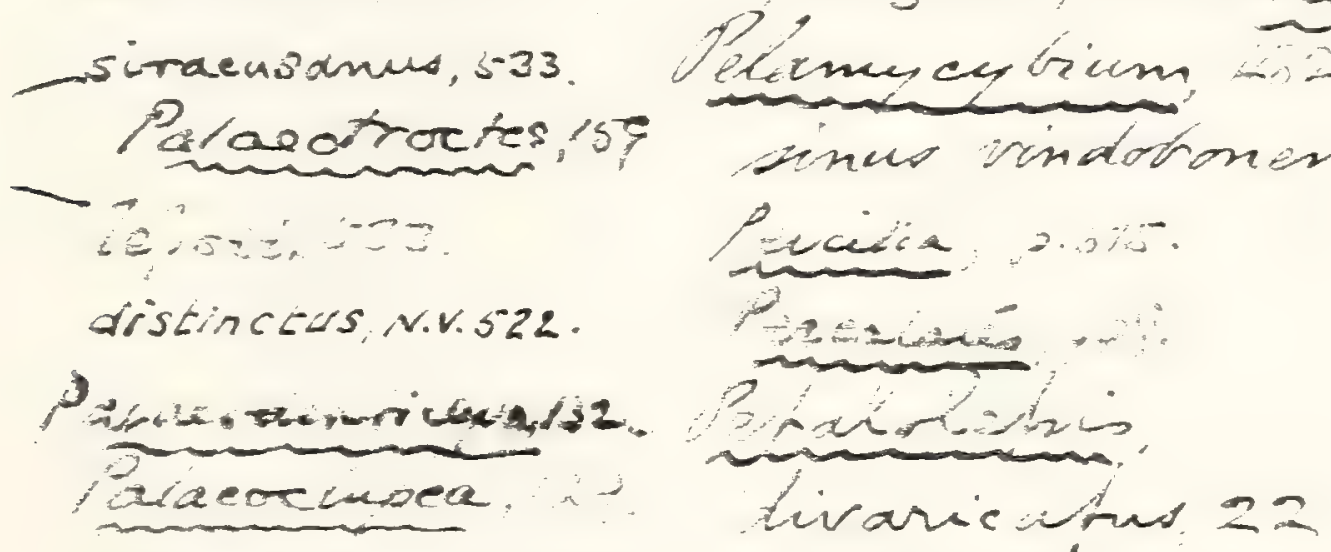

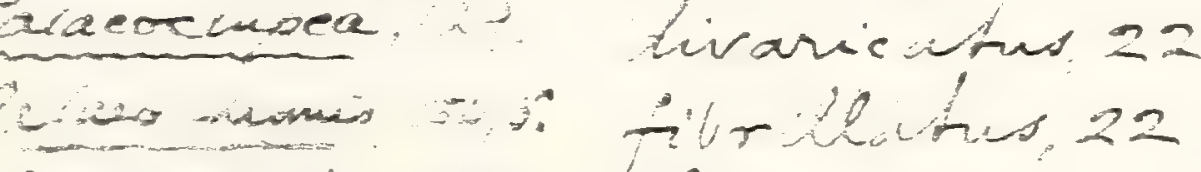

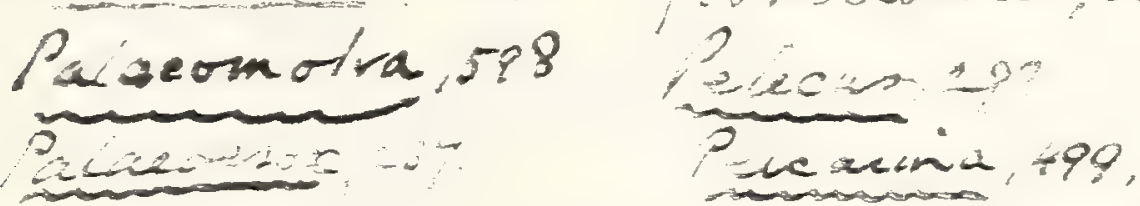

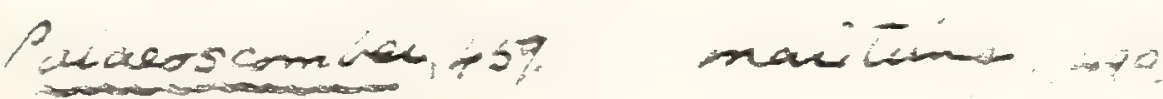
Apinoser, is?

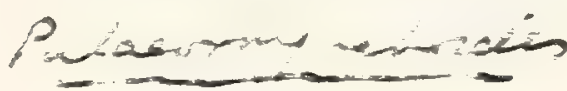

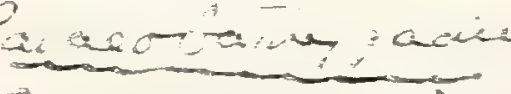




Proegrabersan, s,

Pinasicombrescx, blo

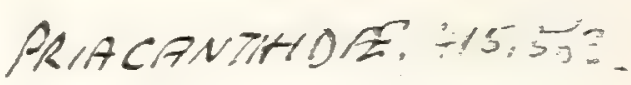

Priacentius, 563 .

Lohastas, ditz.

Plectrites 536. spinosus, 500.

Pisnsecthatus, 6r.

Q.

- sicurus, 606

As Scandatis 606 .

Pististana, 235.

minimus, 235.

insirenius, 594

dexion, 290
Pinithons. 541.

pisani: 642.

sismundianus,545. Problennius, b97.

Oliosileuress, 325.

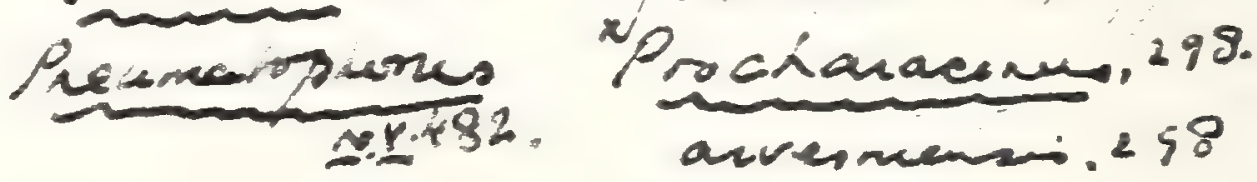

Phipmus, 235 b. Prysundin, :5

Polydactúlus,365. (Pisyumnetion, 5,15

Polypserolepis, III. Prothatrenco.278.

Pomadaridae.499. pellegnini.298.

Pomatomidas AD?

Pomplobes 1585.1644

Punoxis, 554
Promacumer (sak)

Promerlucsius 599. ondrusoris gad

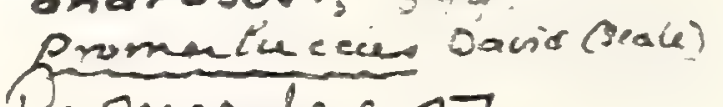
Promegaloas 27.

Proterconina, 499,

revili, 499 :

sesscimanm

P. hor hanz

2 
INTEX.

Phyllodus (mot.).

elegans, ju.

gerraisi. 5.50.

haneri. stt.

heragonalis, ite.

inparionrs. 1i.

incertus, $5-5$.

ineonstans, 5.00.

irreguiaris. 5 to.

latidens, 500.

Ceresquei, 550 .

mareinalis, jts.

medius, $5+8$.

muiticiens, itt.

petiolatus. $5 \pm 8$.

jlanus. 547 .

polrodus. 5t7.

sectundarius, jto.

speciosus, 54 .

subdemressus. jtt.

suomedius, $54 \%$.

toliapicus, Jthi.

umbunatus, 550 .

Pimelodus, :3.

antiauns. 320 .

2or. 27.

sadileri, 835.

Pisodus, $130,1$.

foumarii. Ti:

omeni. sit.

Plagycaus, 189.

Planesox, 519. 5oraz. 519.

Platacanthus, 509 .

ibinoi. 510 .

Platax. 432.

aitissimus. 133.

breris. $t 29$.

coicticus. tiet.

costatus. $4: 39$.

cuneus. 438 .

inacropterrgius, 408.

minor. $42,428$.

nuevalis. \pm 29 .

papilio. $\frac{1}{2} 33$.

pinseteroicie, \pm 30.

Dienm, 130.

pinnatiolmis. 193.

binianus, 40.30 .

sutrespertilio. 193.

rnouifardi. 40.2 .

Platessa. tus. sector. 609.

Platinz, 59.

caruilii, s9.

elongatus, 59.

gigis. 89.

Platcos. 73. =ubuidens, $-\therefore$.

Datycormus. 121 . gormanus. \pm 21 .
Platycormus wont i.

yibiousus. \pm in:

bolongus. tow.

Platygenys, 613.

pugosus, ili:.

Platylamus, 501.

colei. 0.11.

Platylates, 520. rupeliensis. 500.

Plectropomat urascuista, 516,616 .

Pleionemus, 442 . inacrosmonarius. 1 t.?

Plethodus (u). expansus. 81.

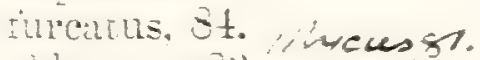

oblongus, 83. pentason, 53.

Pléuracantios serratus, $.67 \%$

Pleuronectes, 602.

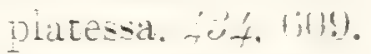
auaciratuis, $31 \%$.

Plecronectide. $150 \%$.

Plinthophorus, $2-1$. robustus, 2.2\%.

Plioplarchus, $5: 0$. sentemspinosus. 520 . serspinosus, 520 .

winitsi. 50.

Podocephalus, 519. nitidus, $51 \%$

Podocys, 502. minutus. 5.20.

Pccopteryx, 587. aibri, -107.

bosuiasti. 597.

Puecilia limetheri, 1515.

Precilia oeningensis. jo.2.

Pecilops, zit. breviceps, 296.

Pogonias multidentatus. sis.

Polynemus, 145 . quinquarius, $111, \pm 16$.

Pomacanthus, subarcuatus. 561.

Ponacextride. 55.5

Pcmaphractus, 76 . gertoni, $: 5,: 0$.

Pomognathus, 212, in

eumterrgius. 21:.

Portheus.

ungtuatus, os.

zecuatus. 101.

custralis, 7.

bracorguathus, 3.

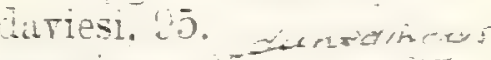

gautinus. 15.

ciadius. 0.
Portheus iont.

lestrio. 6.

lowi.

manteili, 95.

molussus, 2.

mucigei, $: \bar{T}$

thaumas,

Prionolepis, $29, \ldots$

angustus. 2.00 .

cataphractus, 280 .

laniacus. 23.2.

Priscacara. 5.5t. gmat,

(lifosa. 5.04 .

crpha. 555.

liups. 555.

oxtprion.

peaiei, 5.5.

serrata. 50 t.

testudinaria.

Pristigenys, $\$ 15$.

macropithaimus, 415.

Pristipoma. 23.

mpreacum, j2:3.

Prcantigonia. 5.5. evio tar 2. longirostra. $5 y$ icaprasso

octúcantha. $55 \%$.

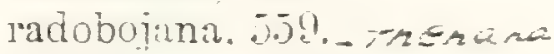

steindachneri. 559.

Proballostomus, Lefi.

Ionguius. "uth.

Prochanos.

rectifions. 1 .

Progymnodon, 572 , $5 \%$.

hilgenciorn, 575 .

Prolates, $4 ! 9$.

Leberti. $4 ! 9 \%$.

Prolebias, 200 .

brongniarti. 219.

cepinalotes, 200.

crussicaudus, 205.

davidi, $t$.

egeranus, 615.

furcatus, 291 .

gaudrri, 294.

gobio, 204.

goreti. 293.

gregatus, 292.

mereri, $20 t$.

minimus. 201 .

oustuleti. 290.

perpusilius. $-21 .-2-2=$

puichellus, 615.

stenoura, - 2u. $P$

Pronotacanthus, $16 \%$.

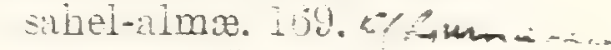

Properca, jit.

anglista. 515.

beammonti, 515.

lepidota, 511.

prisea, 5106.

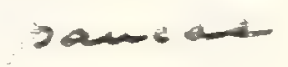






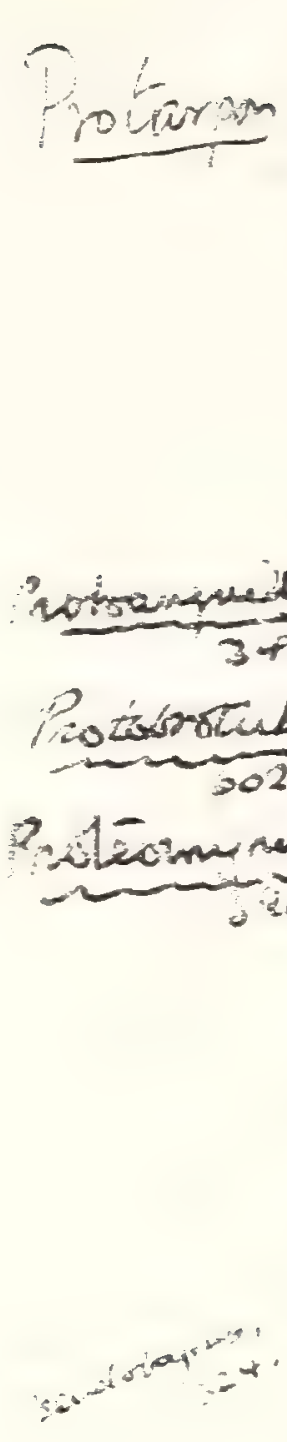

$8: 302$

$24,26$. bolcensis. 371.

Protautoga, 5.53. conidens. 5.53. longidens, 553.

Protelops, 56. anglicus, $5 \bar{t}$. geinitzi, 57.

Prothymalius, 611 . lusatus, bilt. princeps.tilt. rotobalistum, imperiale. 566. omboni, 267. 3025 Protocatostomus, 275.

- constablei. 275.

Protosphyrena albensis, 115.

Protosinyrana infleza. 115.

Protosyngnathus, 372.

sumatrensis. 373 .

Prymnetes, 116. longirenter. 116.

Pseudeutropius, 3\%. rerbeehi. $326 \overrightarrow{6}$.

Pseudoberyx, 129. bottix, 123.130. grandis, $1 u ̈$. longispina. 250 . svriacus, 120.

Pséudoeleginus, 501.

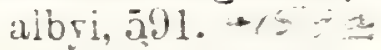
intermedius, 591 . jonas, 591 . majori, 591.

Pseudolates, 199. Sno heberti, 499.

Pseudospharcdon, $55 \%$.

hilgenduri. 552.

Pseudosyngnathus, is1.

opisthopterus, 381.

Pseudothryptodus, 35.

intermedius. 85.

Pseudovomer, 450 . minutus. 450 .

Ptericephalina, 146 , 153. eiongata. 158. macrograstrina, 158.

Pterothrissus, 67.

Pterygocephalus, 595. paradoxus, 595.

Ptychocepinalus, 487. raciatua, $=7$.

ITDEI.

auraíus, zqu.

Pycnosterinx, 391.

dariesi, 390 .

discoides. 393.

dorsalis, $392,393$.

dubius, 395.

elongatus, 395.

gracilis, 394 .

heckeli, 390.

latus, 395.

lewisi, $4(94$.

niger, 392.

russeggeri. 392.

Pygacanthus, 613. altus, 613.

Pygæus, 5.j.

coleanus, $55 \%$.

dorsalis, 5.7.

egertoni. $55 \%$.

gibbus. .iñ.

gigas, 5.58.

jemelka, 579 .

nobilis, 5.53 .

nuchalis, $5 \overline{3} 3$.

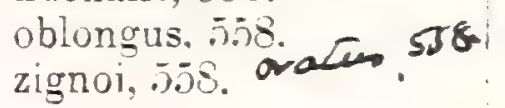

Rindamas. 536.

jugleri. j36.

Raniceps, 603.

latisulcatus, 603 . planus, 604 tuberculosus, 604 .

Raphiosaurus, $37,40$. lucius, 13.

subulidens, 43 .

Rhabdofario, 160. lacustris. 160 .

'Rhabdolepis. Marcl, 11.

cretaceus. 20 .

Rhacolepis, 29 .

brama, 23 .

buccalis, 30 gefines.

latus, 30.20

olfersii. 23.

Rhamphognathus, 361 .

paralepoides. $: 61$.

pompilius, $\ddot{6} 61$.

sphpranoides, 62.

verneuiii. 362.

Rhamphornimia, 269.

rhinelloides. 269.

Rhamphosus. 3ั\%. aculeatus. $37 \%$. biserratus. $3.8 .8 \%$

Rhineastes. $\because 29$.

arcuatus. 203.

calrus. 320\%. grayen.

pectinatus. 30.9 .

peltatus, ich.
Rhineastes (cont.).

ratdulus, 330.

rhieas, 329 .

smithi, 330.

Rhinellus, 265,269

curtirostris. 269.0 fucams.5.

damoni. 268.

ferox, $26 \%$.

furcatus, 236.

laniatus, 232.

longirostris, 282 .

nasalis, 269 .

robustus, 268.

schilli, 269.

tenuirostris, 269

Rhinocephalus, $60 ?$.

planiceps, (b) 3 .

Rhipidolepis, 613.

eleuans, 613.

Rhodeus, 316.

edwardsi, 317.

elongatus, 316.

exoptatus, 317.

latior, 317.

magnus, 317 .

oligactinius, 316 .

Rhombus, 606.

abropterrs. 100 .

bussanianus. 608.

caudiatus. 1308.

cutrensis, 608 .

fitzir geri, $60 \mathrm{~S}$.

gentiluomoi, 607.

heckeli, 608 .

hirchbelganus. 609.

ligusticus. $60 \mathrm{~s}$.

minimus. $60 \%$.

minutus fos.

nardii, $6 ! 8$.

parrulus, 608.

ruenan 15,608 .

richiardii, 608.

sauvagei, 608. . re

Rhonchus, 458 .

carangoides. 458.

Rhynchorhinus, 342 .

branchialis, :34?.

inajor, $\ddot{4}+3$.

Rita, 28.

granciscutata, 329 .

Salmo, 159.

crprinoides, $456^{\circ}$. derzhavin:

inmigratus. 150 .

lewesiensis, 11.

marena. $6 \%$.

tepiitiensis, 614 .

SALMOXID. 159.

Saudroserrus reboulii, 520 . 
prucougnis, Gan. in

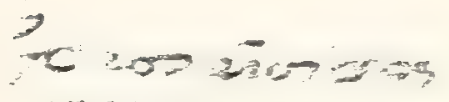

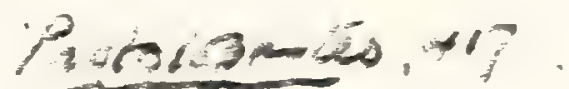

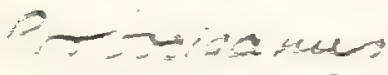

pacuara

ra $-y^{2}-2$
0 otopeita 603 .

23

$-9$

$$
603 \text {. }
$$

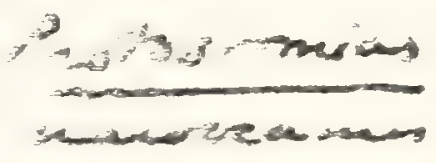

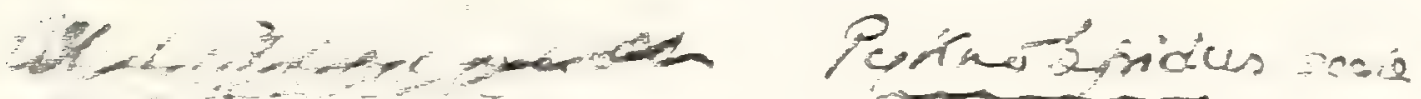

9.

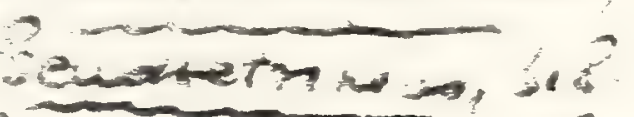

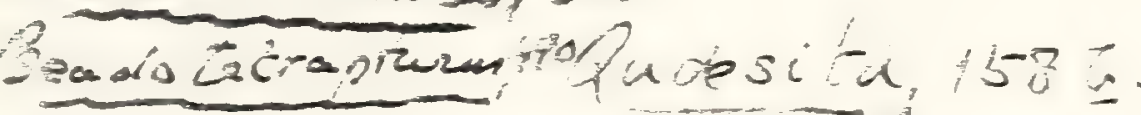
avissuinia, 1530.663.

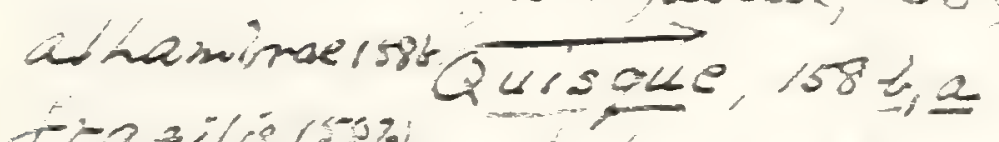

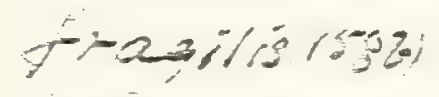

barkeri 15 al

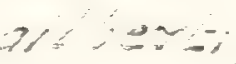

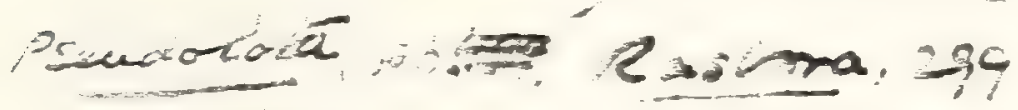

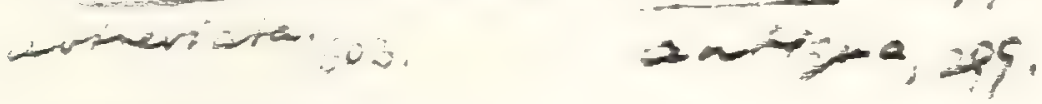

- nation 204

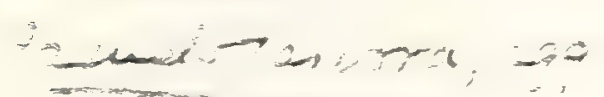

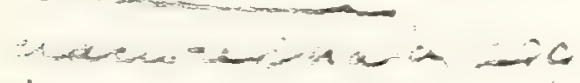

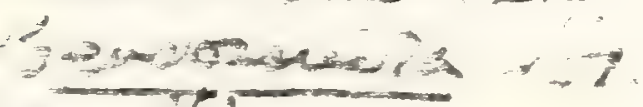

ofymosenis. $5 \%$

Ditions its

ascivition

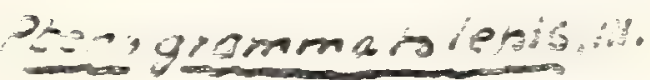

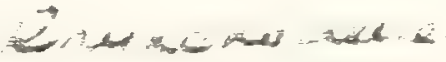

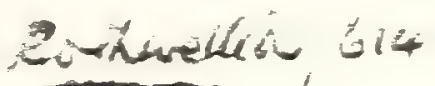

Phomuries

tuinacis.

Prutamias: 536 .

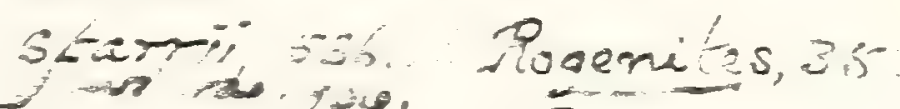

Rixasoristo: Rogenio, 35

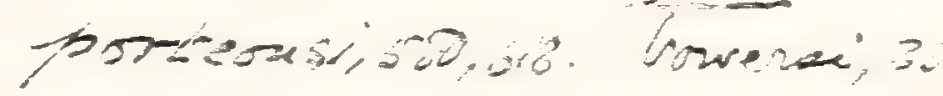
ir $0, j<$

retitusins, -

C... oramerei,

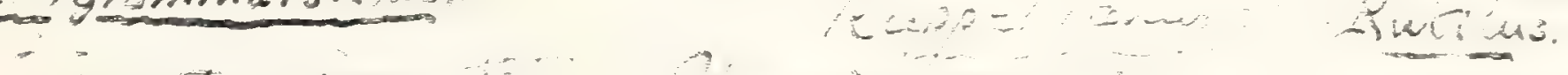

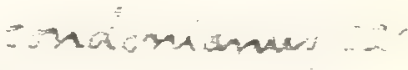

$\because \therefore$ moserimi

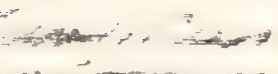

Pearios , zos

acting 




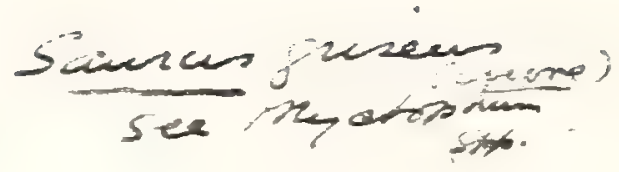

$\cos , 242$

Wis is vis, 243 .

$-x+0-10,150,0.155$.
Siomieressus, 358. acutilles, 358, 618. edwardsi, 358

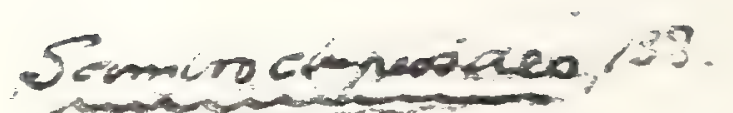

$\frac{\text { Serisosonondutus, } 188 .}{\text { huriens, } 188 .}$

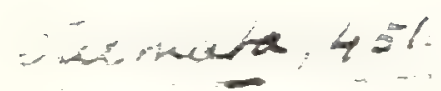

zisiéri,

Seivents 525 .

Titrastaves, 580.

varterialier, 500,618-

a.jons, 10 ?

Sezastinus, 580 .

Tarticu, 580.

inesiae, 680,618 .

Serastoèsus, 580 .

apoutates, 580 .

Sedentionsiza, 250 


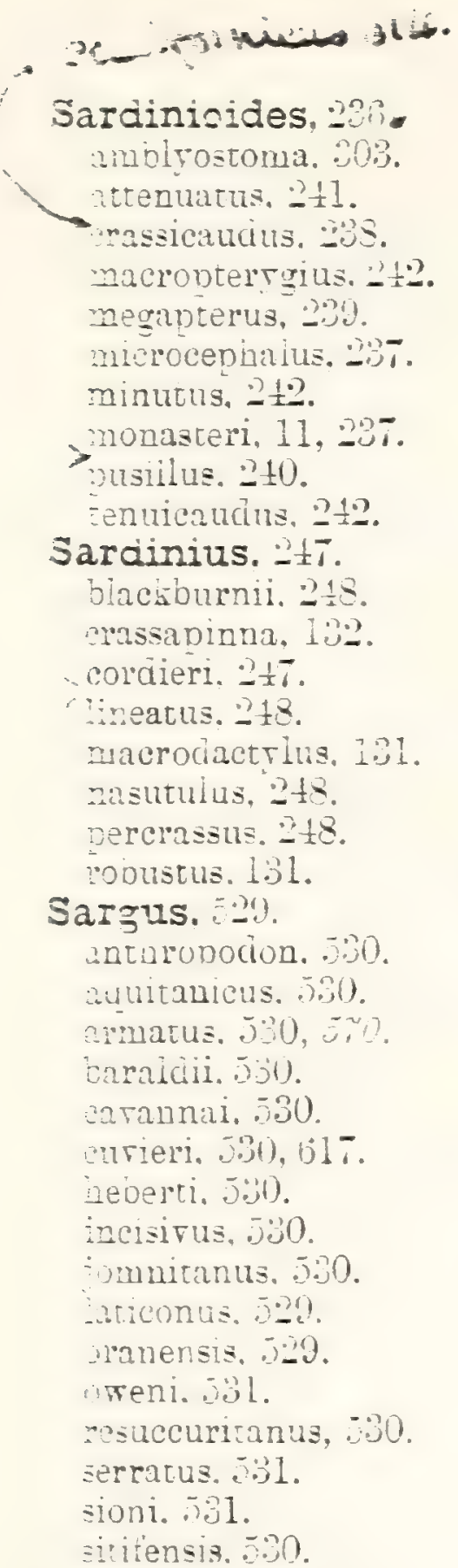

Saurocepnaius. i13.

abensis. 11 t. manahovius. $11 \frac{1}{2}$. ancias. 2. broaciheacii. 112 . Gentatus. $11 \pm$. dispar. 115. Gitumensis, 115. inceauais. 115. inexus. 115. incermedius. 112. anciformis. $11: 3$. Eanus. 111. ircodon. $20 \pm$. marginatus. 20 . monisterii. 115. niebocomus, 112 . vicreri. 115. mognathus. in. seriatus. - $-20.0 \pm$. suostriatus. 11\% -Haumas, ? Tookitarii. I. PARTI.
Saurodon. 111.

nIfinis. 123 .

broaciheacii. $11 \%$

conoideus. 113 .

eros. 113.

intermecius. 11:.

lanciturmis. 113.

leanus. 111, 231.

marginatus, 2029 .

phledocomus. 11: prgmieus. 119.

$\rightarrow$ sipnirostris, 113.

Saurorimampis, 207 319.

fieveri, 210

Sauropsidium. gracilicaucia, 53. lierissimum, jo.

Scarcinius cumeriii. 311.

Scarcinius sicanus. 311.

3̄carus. 5.53.

baitringensia. 530. 531.

miononicus. 553.

o weni. 391.

snericus, 5is.

cetrocion. 55.

Scatophagus, 501. atinnis. 501 .

cavelinii. 5131. frontais. joil.

Sciana, 30.

umuitus. 39.

holatticus, 589.

irresuiaris. 539.

jacularix. 261.

zirenoergensis, 539.

meridionais, 539.

ootusus, 539 . p/men $=4$

piumierii. 521 .

sneciosus. 539 .

unciecimais, $4 \pm$.

SCI.EYID.E. 538.

Sciænurus, $521,53 \%$

boweroanti. 527.

brerior, $5-7$.

erassior,

iongior. 519.

Sclerognathus, 800.

Scomber, 459

aracunga, 4.56

intiquus, \pm 59.00000 .9$

corciyla, 45.50

giaueus. \pm 18 .

znopiiis. 521

orcrnus. \pm íb.

peiagicus. \pm 14 .

celamis. $=04$.

Bianorarus.., \pm 9.

priseus. \pm 59 .

combeus. 439.

sib: aticus. $\div 5$ \%

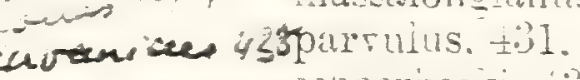

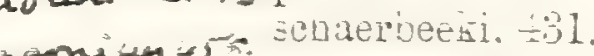

Semotilus.

Serucia, $\pm \frac{1}{1}$

sr? zivenhaves

$-02$

benedeni, 471 reirens. 41.

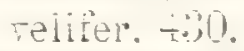

arircii. $: 20$

nosticus. $42 \%$

mails. \pm 4.5 .

Eerumontis. $\pm \pm t h$,

$\because 3 \%$

comoer (cont.)

steindacineri.

113. 159

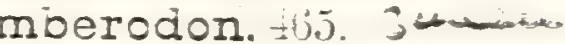

crassidens, 175 .

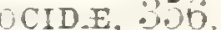
. 35 edwiout

obtusirostris. $35 \%$

7365

acrophthalma, 185.

pinuulata. 13.5.

COLID.E. $285 . \quad 340613$

meolisi, $2 \bar{z} b$.

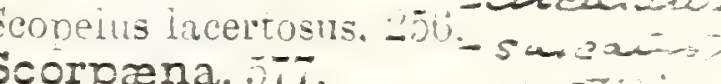

minima. 50., g-6um =

nrior, 570

serota. $50 \pm$.

SCORPEYTDE. 577

poporicii, Je0.

mopterus.

iluridens. j80.

STIOPIORI. 1.

Semiophorus, 100.

$$
\because \mathrm{I}
$$

$\rightarrow r a s i b s, \ldots=$ i 


Sericla (cont.).

lata. 445 .

prised. $4 \pm t$.

ua

acositus, 521.

retrex us, 521. distinctus. 522. 7 N.V.

smaneren, 521 dubius, 521 .

preacs,521 gracilispinis. 521.

microstomus. 5\%\%.

noetlingi, 5.2.

occipitalis. 527.

pentacantizus, 521 .

rucis, 521 .

- rugosus, 522 .

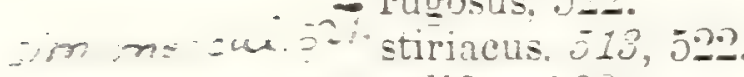

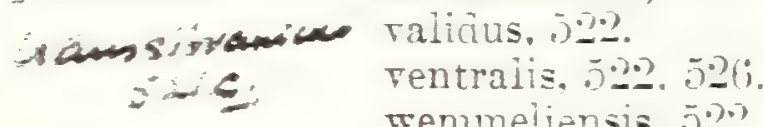
wenmeliensis, $52 \%$.

SILtRIDE, $20 \frac{1}{2}$.

Silurus, 325.

ascita, 359.

bagres. 362 .

carapinactus. 359.

catus. 13:3.

egertoni. 1.

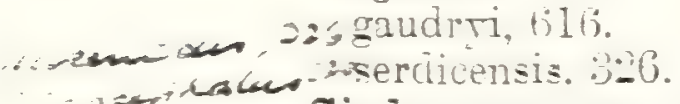

Siphonostoma, 35:.

albri. ¿3.?

castellii. 352.

Smerdis. $506^{\circ}$

aciuncus. jus.

anaiis, 50s.

buciensis, un.

elongatus. 508.

formosus. 517.

heersensis. j09.

isabelitix, 110 .

latior. jos

lorenit, $51=$

macrurus. $=07$.

micracanthus, 504.

minutus. joh.

pรيmæus.

rhoensis. 509.

sanabergeri. 509.

sauragei. jog.

siedosensis. 509.

iaramellii. 509.

asyos $=0$ ? rentralis. 509.616.

Solea. 609.

antiqua. 610

approximata, 610 .

riaber. 610.

_uestfaica. 011.

sircizbergana. 609.

lentichiaris ill.

plorinciais. oll.

rauragei. 511.

Soiencdon. 190.

esiniensis. "219.
Solenodon (cont.).

lobopterrgius, 219.

neocomiensis. 204 .

Solenognathus, Pictet of Humbert, 2-T1, 32 .

lineolatus, 274 .

Solenorhynchus, 380 .

elegans, 80 .

Solexostomatid.e. 379.

Scricidens, 320.

haueri. 3:3.

Spaniodon, 48.

blonrieli. 48.

brevis, 53 .

electus, 48 .

elongatus. 51 .

hakelensis, $2-7 t$

latus, 5.3.

lepturus. $5 t$.

sinu us, 53.

Sparide. 524.

Sparisoma, 5:\%.

Sparnodus. 5t.

altivelis. 525.

bowerbanki, 527 in nes

intlatus. a.

intermedius. 528.

lethriniformis. 225.

macrophthaim us. 525.

micracanthus, 525.

microstomus. 527.

moloni. 5.28. neise ys:o

oralis, $525 .<$

Sparoides, 587.

molassicus. $53 \%$.

robustus, 5.7.

sphiricus. 58.

tenuis. 536.

umbonatus. 537.

Sparcsoma. 528. oraiis. 523.

Snarus brama, 527.

Sparus buicanus. 5.5

Sparus chromis. 5e6.

Sparus dentex, 525.

Sparus errthrinus. 525.

Sparus macroplithalmus. 505.

sparus salpa, 526.

Sparus sarous, 505.

sparus ruigaris. 525. $5 \div 2$.

Spathodactylus, 08.

neoromiensis. 19.

Sphærodus.

annuiaris. 50.5.

araclasii.

cinctus sut 58.

pirculatus. 305
Sphærodus (cont.).

conicus, 537.

depressus. 536.

discus. 536.

insignis, 537 .

intermedius, 537 .

liergomardius, 53 J̄.

lejeanianus, 530 .

lens, 536.

oculus-serpentis, 537.

parrus. 588.

poityodon, 545

prgmæus, 533

subtruncatus, 5330.

truncatus, 538.

wiechmanni, 538.

Sphagebranchus. $3 \pm 7$.

formosissimus, :4t.

Sphenocephalus,

38.

cataphractus, 388.

fissicaudus. 36.

Sphenolepis, Agassiz, 27.5 .

cuvieri, 277.

squamosseus. 27\%

Sphyræna. 366.

amici $\quad 39$.

bolcensis, 366.

carinata, 204. raxeilifuss

croatica, 3 is.

gracilis, : 66 .

intermedia, 367.

major. $3 i 8$.

maxima. 360 . row - ind lampine

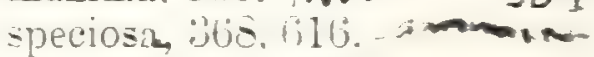

sternuergensis, $36 !$

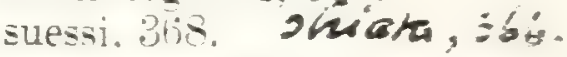

trrolensis, 616 .

viennensis, 368. fann:

winkleri. 369. we he is 36

SPHYRENIDE, 365.

Sphyrænodus, 1 \%。.

naeow botii, \pm 70 .

524 conoideus, 476

crassiciens. 475.

gracilis, \pm 69 .

lingulatus. 467 .

priscus, 473.

silorianus. 1 illi,

speciosus. (itb.

tenuis, \pm 69 .

Spinacanthus, $566^{\circ}$.

blenuioides, jbí.

Spinacites, 115 .

radiatus, 415 .

Soinax marginatis, 208

Squalius,

uncirerns. 20.0

barirdi. 203 . 


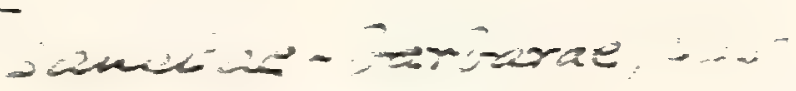
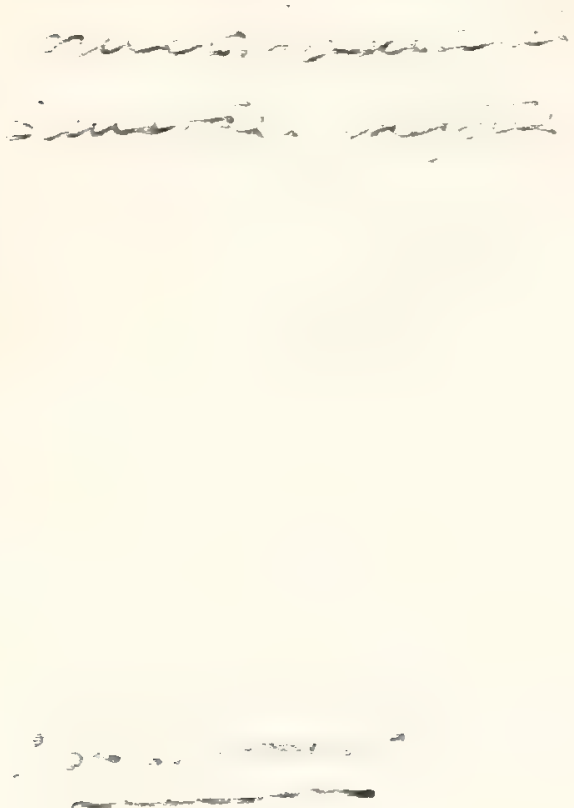

colecunewis:

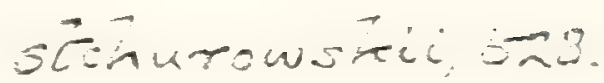

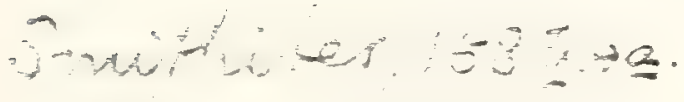

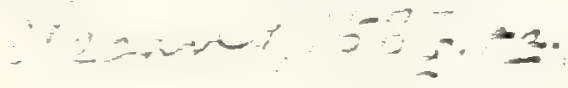

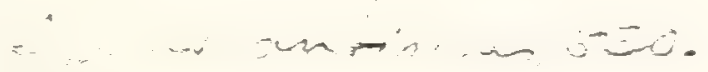

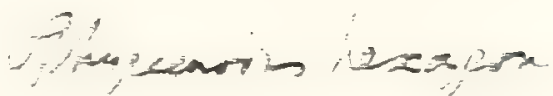

$$
\begin{aligned}
& \because \cdots
\end{aligned}
$$

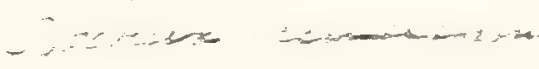

$$
\begin{aligned}
& -20,-2-\infty
\end{aligned}
$$

$$
\therefore
$$



Stickeren, $617,575$.

mativarai

Glichtoperes. =

hiortiuendi?

Stavias, ㄴ. 482 .

iserumes, 스. 482 .

Skrinsis, sozer.

Stesnberjia, $15 \%$.

waitei, 155 .

STERMAOTHCHEF

sternogin, $2=5$

Jrachichthyorides $40 y$

drisen, 225 .

TOM14-DAE

Sungarichthys, la.

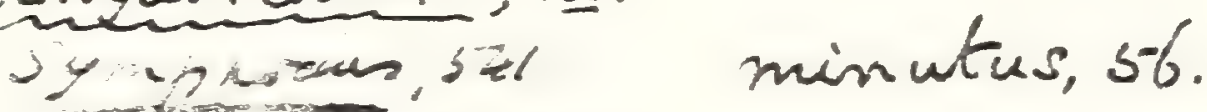

syangraxis 356

Sinowas A.9.

Indis, 209 ?

ineriocies.

"ueman, 25 s.

chmect:-

narensis, 270 .

Pactonsus. 9:0

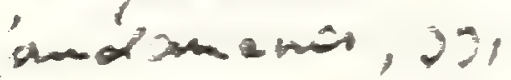

loostens.

cimalerves,

Temnodon, 449 .

isselitite. in.

albui, 456 .

huberif, 450

pliocenicus, tsó.

krambergeri.

Thyosoches. 481 envagz

(Jhyisites)

Kriegeri, 48:,018.

escharion, ㅅ. …482.

Jhyssodede. 247

anowion- 20

Thyrsion, 482 .

relox, w. 482 .

Tilanice, stz"

- fosmingsion

fospitis, $=-\infty$

nerompglourar ists. incompletier, 383

Irachumas 445

Jrichiouses,

leptumes, 482.

oshrummis,

lericiei, 480 . 
Squaitus :

maicurus. 928.

tieate.

pustiche. 283.

berainst.

Eterostema, 20

oucheila. $\div 05$

Stepnanccus.

EnLendiens. $0.3 \%$.

Sterecaus, 78

meitensis. $17 \%$

Strazcaus. 198

angicus. . .

atpicalis. 169

axtpogon. Is?

Stminsia, Uy.

nizta. vill.

FTROMITEID. 410

Stylocus, ....

Ebescontei. 50 :

Sucis. - - - -

Ey!lemus, :...

ingivers.

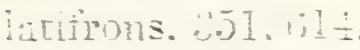

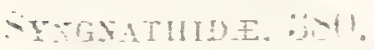

Jyngnathus, i:.

iinis,

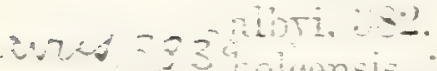

boltensis. $2 x$.

iretimatis

beereit. 3.

:timsi. 30.

mibontertas 61

Tpile $\mathrm{Bi}$.

Svredontis. 1.

synconrys. Ali.

monei, itis.

Simtegrncaus.

ㄴis: = 1 .

\section{Zachynsctes, :-}

mucurnterretus.

$-1$.

?ontpes - -

murotiartis -

Gursichents. a.

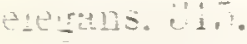

arsiger, $\% 15$

Faurinichtivs,

wrocentus. 50

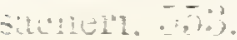

Thurag wnidens. …

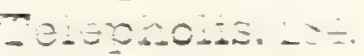

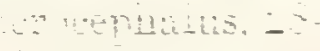

mitenthents.-

$>-2$ mats. - -5.

$>$ Zeraticntzrs.

munulutis. -

Denecias.

stredo.
Tetrasoncpterns. 茫:

?Tus. -

trmicus. 2ns.

Detraztruns. 400.

mine?.115.

misens. 1.

- Etroden 57 .

bismicils. jo

noilenenii. 50 .

hitieri, y.

netareus. 51.

suce Sil.

TELTIIDID. T2

Teuthis, 20.

Ghaumaturus. 130

reichumellerio ilt.

Hiopgatus. b1

Hertus. 160.0311.

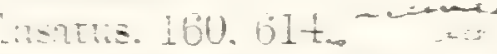

Thrssocoter

willente. $3 \%$.

nergions. 35.

silimoneus. 3 .

Thrisons aruchis, : ! .

Anhing

Thrisscptarcides. it.

iotsetis.

intermerilus. 55.

a...

micier. -19

arutcens.

Furisscoterus, s\}.

cotuliti. - 4 .

ThI yotedus. $3 \%, 3$,

ntundis. 05.

$\therefore=5$

Jhynnichthys, oin.

aibirosenta.

Thínnus. $=14$.

-ancustacus. $=57$.

Tolcensis. $=7$.

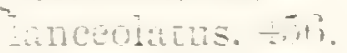

niwotacus. 4.)

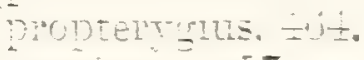

moxmlis.

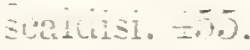

- Imnne. \pm 5.

tohianicns. $=5$.

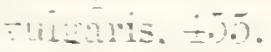

Thyrstes.

oriscitoi. - - 1 .

-hyritcoephaius. $=-10$

Minus

-

muncotritane :319.

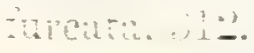

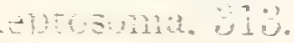

and $91 \%$
Fisca $\cdots n t$.

acuopterrgia, 315.

magna, ilz.

microprgontera, 314.

jotruncata. 816.

carsicer. 315.

Talünensis, 815.

Fuigaris. 31.

-tanichthys, Dames. iil.

pharko. 312.

Iomodon. 11?. currisens. 1:3.

Tomognathus, 116.

moriax, 117.

ielucius. 117.

Poropoma, 513.

volitum, 1918.

Zexotes. ili

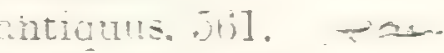

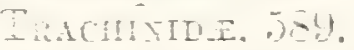

Fracninopsis, 01.

Eeriea. jul.

Tracinus, -in.

dracuncuitis. 500

meventiss. and.

intiadilis. ond

seetandicis. 500 .

rep!s. 50 .

Tracisnotus, 亡0u.

epureens. - 11.

Friacanthus. obs.

Triænaspis, 17.0.

Tiremintus. in.

Trichiurichthys. id?.

incereus. $4=:$.

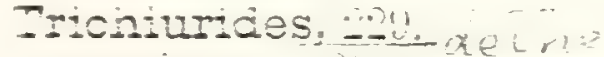

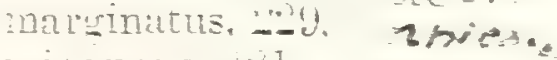

miverans. \pm 1 .

Trichophanes.

eonei. \pm 16 .

Euliarnom. $=16$.

tians, $+11 \%$.

Fragia, sto.

wdituneta. Est.

cor. $=-7$.

Hilintica. Dot.

incatisa.

Incurs. 50 .

Irra. -1.9

nurdii. sob. c rnomici. ...

simoneili, sot.

TRIGLIDE. 55.5

Trigiciaes, seb.

nutir. ...ti.

detuni stion.

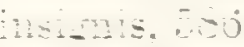

Tun renedinsis. boj.

Prigonocion. ji.

atin.....

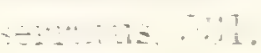

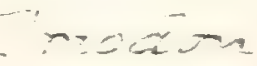

$\therefore-\therefore-10+\infty$ 


Tydeus, 257.

albvi, 207.

eiongatus, 257 .

megistosoma, 257 .

splekodes, 258.

Unater, ze?

Umbrina, 538.

pecchiolii. 588.

Uranoscspus, 590.

peruzzil, 590 . rastrum, 377.

Urencheiys, 337. anglicus. 339. avus, 337 .

imin menaid hakelensis, 338.

173. Uropterina, 146.

platyrachis, 158 .

Urosphen, 376 .

dubia, 376.

fistularis, 376 .

Vomer longispinus, 436.
Vomer parvulus, 451 .

Vomer priseus, 44.2 .

Vomeropsis, 435 .

elongatus, 437.

longispinus. \pm 36 .

valenciennesi, 437 .

Triens, 436.

Xiphactinus, 92. audax, 92, \%8.

brachygnathus, 97. lestrio, 97.

Xiphias, 490.

acutirostris. 357.

antiquus, 495 . wyoew 4

delfortriei, 497.

robustus, 497 . 9 iacliers in.

Xiphitde, 490.

Xiphopterus, 482.

falcatus. 482.

Xiphiorhynchus, 490.

elegans, 491.

ingavery, \& 84.
Xiphiorhyncinus

(cont.).

priseus, 491 .

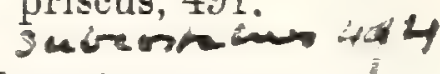

Zanclus, t.jo.

brevirostris, 450 . eoccenus, 450.

Zeus, 417 .

benoisti. 417.

gallus, 449 .

hoernesi, 417.

lewesiensis, 397.

licatæ, 418 .

platessa, 501 .

pliocenicus, 418 .

priscus, 516.

regleysianus, 501 .

rhombeus, 439 .

robustus, 418 .

spinosus, 500 .

triurus. 436.

vomer, 436 . 
Junitx, $x 81$

octaria, 481

Turio, rev.482.

willewn, wev, -82 .

wheri, No 618.

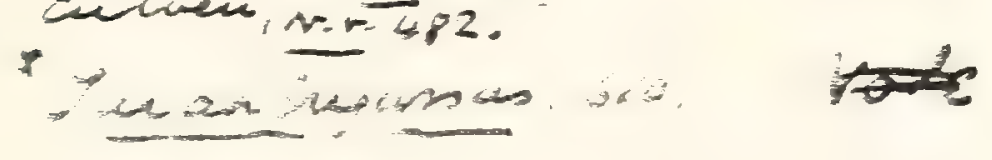

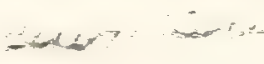

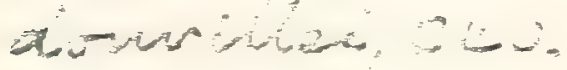

Venicer remens 322

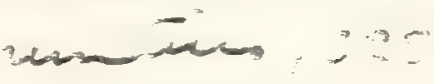

Przuor $\cdots$

indrecens

Uncicrims, 234

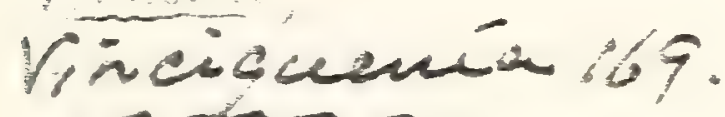

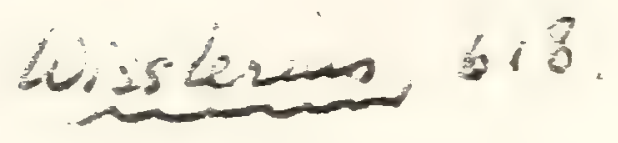

insore-arandiculius, 59
Teotias $46:$

iraris tiss. erifare, $<0$

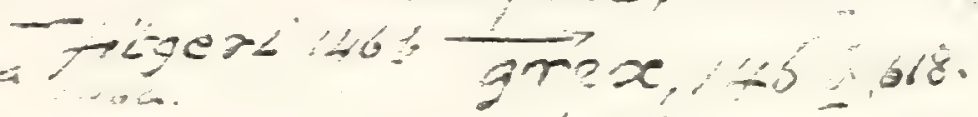

Zantechles. $36=$

runtrei, 3ón, ..."

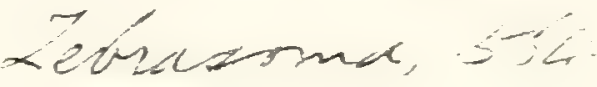

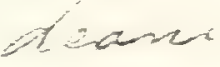

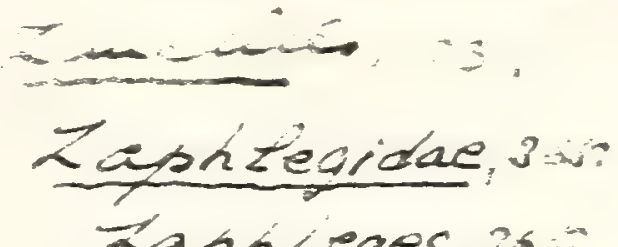

Xaphleges, 36:

longurio, 255.

Zasionidae. 6

Corrinius, 553,146a Zelosis, 15s

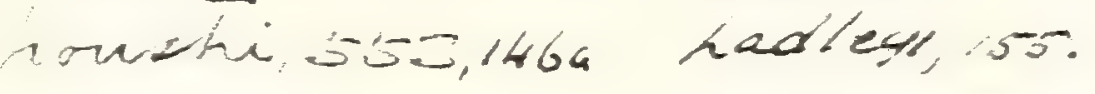

farberce, $146 \alpha$. Torortomin

elmoxiemae. $146 a$.

Zemiagrammix.

$$
\begin{aligned}
& \text { isiskivo, sol. } \\
& \vec{x} \text { ented } \\
& \text { xetorich } \\
& \text { chiden-in. }
\end{aligned}
$$

Zorobstra

sonames, 




\title{
SYSTEMATIC INDEX
}

\author{
$\mathrm{OF}$ \\ GENERA AND S P E C I E S \\ DESCRIBED IN PART IV.
}

Order ACTINOPTERYGII (continued) . . . . Page

Suborder IV. ISOSPONDYLI (continued) . . . • 1

Family LEPTOLEPID Æ (continued) . . . . . 1

Lycoptera . . . . . . . . . 1

— middendorffi . . . . . . . . 2

- sinensis . . . . . . 3

Family ELOPID $\mathrm{E}$ • • • • . . . . 7

Elopopsis . . . . . . . . 8

— fenzli . . . . . . . . . . 9

- microdon . . . . . . . . . 9

- heckeli . . . . . . . . . . 9

crassus . . . . . . . . . . 10

Osmeroides . . . . . . . . 11

— lewesiensis . . . . . . . 11

- levis . . . . . . . . 15

- gracilis . . . . . . . 16

— lewisi . . . . . . . . 17

— attenuatus. . . . . . . 19 
Family ELOPID无 (continued).

Osmeroides sardinioides ...... . 19

- cretaceus . . . . . . . 20

Elops . . . . . . . . . 22

Megalops . . . . . . . . . 24

— priscus . . . . . . . . . 24 oblongus . . . . . . . 26

Notelops . . . . . . . . . 27

brama . . . . . . . 27

Rhacolepis . . . . . . . . 29 buccalis . . . . . . . 30 latus . . . . . . . 32

Thrissopater . . . . . . . . . 32

salmoneus . . . . . . . . 33

magnus . . . . . . . . 33

(?) megalops . . . . . . . . 35

Pachyrhizodus . . . . . . . 37

basalis . : . . . . . . 37

dibleyi. . . . . . . . . 38

gardneri . . . . . . . . .. 40

latimentum . . . . . . . . 42

subulidens . . . . . . . 43

Esocelops . . . . . . . . . . . 46

carifrons . . . . . . . 46

Spaniodon . . . . . . . . . 48

blondeli . . . . . . . 48

elongatus . . . . . . . . 51

latus . . . . . . . . 53

Thrissopteroides . . . . . . . . 54

— elongatus . . . . . . . . 54 latus $\because .0 .0 .0 .054$ intermedius . . . . . . . . 55 tenuiceps . . . . . . . . 55 pulcher . . . . . . . 56

Protelops . . . . . . . . . . 56 geinitzi . . . . . . . . 57 anglicus : . . . . . . . 57 
Family ALBULID $\mathbb{E}^{.}$. . . . . . . 59

Albula . . . . . . . . . 60

—oweni........ . 60

Chanoides. . . . . . . . . 63

- macropoma . . . . . . . . 63

Chanos . . . . . . . . 64

Prochanos . . . . . . . 65

rectifrons . . . . . . . 65

Ancylostylos . . . . . . . . 66

gibbus . . . . . . . 66

Istieus . . . . . . . . . . 66

— grandis. . . . . . . . . 67

- macrocephalus . . . . . . 70

- lebanonensis . . . . . . . 71

Anogmius . . . . . . . . . 71

— polymicrodus . . . . . . . 72

Family OSTEOGLOSSID . . . . . . 73

Dapedoglossus . . . . . . . 74

— testis . . . . . . . 75

— æquipinnis . . . . . . . . 75

Brychætus . . . . . . . . 76

- muelleri . . . . . . . 76

Incertæ sedis . . . . . . . . 80

Plethodus . . . . . . 80

— expansus . . . . . . . . . 81

- pentagon . . . . . . . . 83

- oblongus . . . . . . 83

Thryptodus . . . . . . . . 85

Family NOTOPTERID $\mathrm{E}$. . . . . . . 85

Notopterus . . . . . . . . 86

primærus . . . . . . . 86 
Family CHIROCENTRID王

Chirocentrus. 88

(?) polyodon . . . . . . . . 88

Platinx

Chiromystus$$
\text { mawsoni }
$$

Chirocentrites coroninii

Portheus

molossus

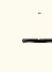

mantelli

daviesi .

gaultinus

Spathodactylus

neocomiensis

Ichthyodectes

- ctenodon

anaides.

100

$\div$

arcuatus

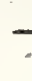
serridens

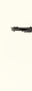
minor elegans tenuidens libanicus

Cladocyclus 107

— gardneri 108

—_lewesiensis

Saurodon . 111

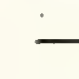
leanus phlebotomus intermedius

Saurocephalus 113

- lanciformis

- woodwardi 
Family CTEYOTHRTSSTD Page

Ctenothrissa . . . . . . . . 120

- vexillifer . . . . . . . 120

— radians . . . . . . . 122

- microcephala . . . . . . 124

Aulolepis . . . . . . . . . . 126

typus . . . . . . . . 127

Family CLUPEID王 . • . . . . . . . 128

Pseudoberyx . . . . . . . . . . 129

- syriacus : . . . . . . . . 129

- bottæ . . . . . . . . . . 130

- grandis . . . . . . . . 130

Histiothrissa . . . . . . . 131

- macrodactyla . . . . . . . 131

- crassapinna . . . . . . . 132

Engraulis . . . . . . . . . 133

Halecopsis . . . . . . . . . 133

- insignis . . . . . . . . 134

Scombroclupea . . . . . . . . : 135

— macrophthalma . . . . . . . 135

— gaudrji . • . . . • . . 138

Diplomystus . . . . . . . . . . 139

- dentatus . . . . . . . . 139

- brevissimus . . . . . . . 140

- birdi . . . . . . . . . 142

longicostatus . . . . . . . 143

- humilis . . . . . . . . 144

- altus . . . . . . . . 145

- vectensis . . . . . . . 146

Clupea . . . . . . . . . . 146

- scheuchzeri . . . . . . . 147

_ catopygoptera . . . . . . . 148

- humilis . . . . . . . . 150

- $\operatorname{crenata...~.~.~.~.~.~} 151$

- numidica . . . . . . . . . 151

- sardinites . . . . . . . . 152

- sprattus . . . . . . . . 153 
Family SALHONID无 . • . . . . . . 159

Salmo . . . . . . . . 159

Mallotus . . . . . . . . 160

villosus. . . . . . . . 161

Family HALOSAURID $\approx$. ・ . . . . 162

Echidnocephalus . . . . . . 163 troscheli . . . . . . . 163

Enchelurus . . . . . . . . 164

villosus. . . . . . . . 164

- syriacus . . . . . . . 165

— anglicus . . . . . . ' 167

Family NOTACANTHID无 . . . . . 168

Pronotacanthus . . . . . . . 169 sahel-almæ . . . . . . . 169

Family DERCETID $\mathbb{E}$. . . . . . . . 171

Dercetis . . . . . . . . 172

scutatus . . . . . . . 172

Leptotrachelus . . . . . . . . 173

— armatus . . . . . . . 174

— triqueter ... . . . . . . 174

— gracilis . . . . . . . . . . 180

— hakelensis . . . . . . . . . 184

— elongatus . . . . . . . . 184

Pelargorhynchus . . . . . . 188

— dercetiformis . . . . . . 188

Family ENCHODONTID $\Psi$. . . . . . 189

Enchodus . . . . . . . . 190

— lewesiensis . . . . . . 191

— pulchellus . . . . . . . . 193

- annectens . . . . . . . 195

— faujasi . . . . . . . 196

lemounieri . . . . . . . 198

— longidens . . . . . . . . 199 
Family ENCHODONTID王 (continued).

Enchodus major. gracilis . . . . . . . . 201

— macropterus . . . . . . . 202

Eurypholis . . . . . . . . 207

— boissieri . . . . . . . 207

freyeri . . . . . : . . . 210

Palæolycus . . . . . . . . 211

- dreginensis . . . . . . . 211

Halec . . . . . . . . . 212

sternbergi . . . . . . . 212

— eupterygius . . . . . . . . 213

microlepis . . . . . . . . 218

haueri . . . . . . . . 219

Cimolichthys. . . . . . . . . 221

lewesiensis . . . . . . . 221

- nepæolica . . . . . . . . 225

Prionolepis . . . . . . . . . . 229

— angustus . . . . . . . . 230

— cataphractus . . . . . . . 230

_ laniatus . . . . . . . . . 232

Leptecodon . . . . . . . . . 233

— rectus . . . . . . . . . 233

Pantopholis . . . . . . . . . 234

Family SCOPELID $\mathrm{E}$. . . . . . ... . . 235

Sardinioides . . . . . . . . 236

monasteri . . . . . . . 237

— crassicaudus . . . . . . . 238

— megapterus . . . . . . . . 239

— pusillus . . . . . . . 240

— attenuatus . . . . . . . . 241

Acrognathus . . . . . . . . 243

— boops .. . . . . . . 243

libanicus . . . . . . . . 244

Leptosomus . . . . . . . . . . 244

- guestphalicus. . . . . . . . 245 
Family SCOPELID帅 (continued).

Leptosomus elongatus.

macrourus. 245 minimus

Sardinius

cordieri

Dactylopogon

- grandis .

Nematonotus. bottæ

Microcoelia

granulata

libanica

252

Opisthopteryx

253

gracilis .

254

Scopeloides

$25+$

glarisianus

255

Parascopelus

256

lucertosus

256

Anapterus

megistosoma

257

Apateodus

258

glyphodus .

258

striatus .

260

lanceolatus . . . . . . : 264

Rhinellus.

265

furcatus

266

ferox

damoni .

268

Family GONORHYNCHID $\mathbb{E}$. . . . . 271

Charitosomus . . . . . . . . 271 formosus . . . . . . 272 major . . ...... . . 272 lineolatus . . ....... . 274 hakelensis . . : . . . . . 274 Notogoneus . . . . . . . 275 
Family GONORHYNCHID $\mathrm{E}$ (continued).

Notogoneus osculus

— squamosseus . . . . . . 276

— cuvieri '. . . . . . . . 277

— longiceps . . . . . . . . 278

Family CHIROTHRICID $Æ$. . . . . . . . 279

Chirothrix . . . . . . . . 280

Clibanicus . . . . . . . 280

— lewisi . . . . . . . . . . 283

_ guestfalicus . . . . . . . 283

Telepholis . . . . . . . . . 284

— acrocephalus . . . . . . . 284

— (?) tenuis . . . . . . . . . 285

Exocœtoides . . . . . . . 286

minor . . . . . . . . 286

Family ESOCID $\mathrm{E}$. . . . . . . . 287

Esox . . . . . . . . . 287

— lepidotus . . . . . . . . 288

Family CYPRINODONTIDE . . . . . 289

Prolebias . . . . . . . . . 290

— cephalotes. . . . . . . . 290

— furcatus . . . . . . . . 291

— gregatus . . . . . . . . 292

— stenoura . . . . . . . . 292

- goreti . . . . . . . . . 293

— brongniarti . . . . . . . 293

Pachylebias . . . . . . . . . 294

— crassicaudus . . . . . . . 295

Suborder V. OSTARIOPHYSI . . . . . . . 296

Family CHARACINID $巴$. . . . . . . 297

Tetragonopterus . . . . . . . . 298

— avus . . . . . . . . . 298

- ligniticus . . . . . . . . . 298 
Family CYPRINID E . . . . . . . . . 299

Catostomus . . . . . . . . 299

Amyzon . . . . . . . . 300

Cyprinus . . . . . . . . 300

- priscus . . . . . . . . 301

Barbus . . . . . . . . 301

megacephalus . . . . . . 302

Thynnichthys . . . . . . . 303

— amblyostoma . . . . . . 303

Gobio . . . . . . . . 303

analis . . . . . . . 304

Amblypharyngodon . . . . . 304

Leuciscus . . . . . . . . 305

— oeningensis . . . . . . 305

— papyraceus . . . . . . 307

— colei . . . . . . . . 308

- macrurus . . . . . . . 308

— leptus . . . . . . . . 309

Tinca . . . . . . . 312

furcata . . . . . . . . 312

leptosoma . . . . . . . 313

micropygoptera . . . . . . 314 tarsiger . . . . . . 315

Rhodeus . . . . . . . 316

— elongatus . . . . . . . 316

— latior . . . . . . . . 317

Aspius . . . . . . . . . 318

gracilis . . . . . . . 318

minutus . . . . . . . 318

Cobitis . . . . . . 320

centrochir . . . . . . . 320

angustus . . . . . . . 321

cephalotes . . . . . . . . 321

Hexapsephus . . . . . . . 322

guentheri . . . . . . . 322 
Family SILURID $\approx$

Page

Clarias .

324

. . 324

falconeri . . . . . . . . . 324
Heterobranchus . . . . . . 325

palæindicus . . . . . . . 325

Silurus . . . . . . . . 325

Pseudeutropius . . . . . . . . . 326 verbeeki . . . . . . . 326

Macrones . . . . . . . . 327

Rita . . . . . . . . . 328

Amiurus . . . . . . . . . 328

Rhineastes . . . . . . . 329

Bucklandium . . . . . . . . . 330

— diluvii . ........ . . 330

Arius . . . . . . . . . 330

— egertoni . . . . . . . 331

crassus. . . . . . . . 332

— (?) bartonensis . . . . . . . 333

— iheringi . . . . . . . . 333

Bagarius . . . . . . . . . 335

gigas

335

Suborder VI. APODES . . . . . . . . . 336

Family MUR ENID王 . . . . . . . . 336

Urenchelys . . . . . . . . . . 337

- arus . . . . . . . 337.

— hakelensis . . . . . . . 338

— anglicus • • • • • • . . . 339

Eomyrus . . . . . . . . 340

— dolloi . . . . . . . . 340

— latispinus . . . . . . . 340

- ventralis . . . . . . . . 341

Rhynchorhinus . . . . . . 342

— branchialis . . . . . . . 342

- major . . . . . . . . . 343 


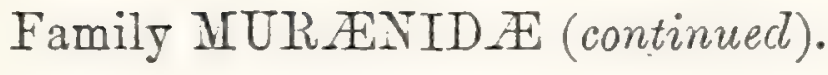

Paranguilla

tigrina . . . . . . . . 343

Anguilla

leptoptera .

elegans .

Nettastoma

Suborder VII. PERCESOCES.

Crossognathus . . . . . . . . 348

- sabaudianus . . . . . . . . 349

Syllæmus .

_latifrons

Family AMINODYTIDE .

Cobitopsis

354

- acutus' 354 .

Family SCOMBRESOCID $\mathrm{E}$. 356 Belone 356 tenuis 357 Scombresox 357 obtusirostris 357 Hemiramphus 358

Family ATHERINID王 358

Atherina . . . . . . . . 359 macrocephala . . . . . . 359 sarmatica . . . . . . . 360 vardinis 360

Rhamphognathus 361

— paralepoides 361 - sphyrænoides . 
Family MUGILID王 . . . . . . . . . 363

Mugil . . . . . . . . . . . 363

_

- radobojanus . . . . . . . 365

Family SPHYRANID王 . . . . . . . . 36 อ

Sphyræna . . . . . . . . . 366

bolcensis . . . . . . . 366

— intermedia . . . . . . . 367

— suessi . . . . . . . . 368

Suborder VIII. HEMIBRANCHII . . . • • . . 369

Family AULORHYNCHIDE . . . . . . 371

Protaulopsis . . . . . . . . 371

— bolcensis . . . . . . . 371

Aulorhynchus . . . . . . . . 372

- sumatrensis . . . . . . 373

Family FISTULARIID $Æ$. . . . • . . 373

Fistularia . . . . . . . 374

- koenigi . . . . . . . . 874

- longirostris . . . . . . 375

Aulostoma . . . . . . . . 375

- bolcense . . . . . . . . 375

Urosphen . . . . . . . . . . 376

- dubia . . . . . . . . 376

Family CENTRISCID $\mathrm{E}$. . . . . . . . 377

Rhamphosus . . . . . . . . 377

— aculeatus . . . . . . . 377

biserratus . . . . . . . . 378

Amphisile . . . . . . . . . 378

heinrichi . . . . . . . . 379

Family SOLENOSTOMATID无 . . . . . 379

Solenorhynchus . . . . . . . 380

elegans . . . . . . . 380 


$$
\begin{aligned}
& \text { Family SYNGNATHID } 巴 \text {. . . . . . . } 380 \\
& \text { Pseudosyngnathus . . . . . . } 381 \\
& \text { opisthopterus . . . . . . . } 381 \\
& \text { Siphonostoma . . . . . . . . } 382 \\
& \text { — albyi . . . . . . . . } 382 \\
& \text { Syngnathus . . . . . . . . . } 382 \\
& \text { Calamostoma . . . . . . . . } 383 \\
& \text { breviculum . . . . . . } 383
\end{aligned}
$$

Suborder IX. ACANTHOPTERYGII . . . . . . 384

$$
\text { Division A. Beryciformes . . . . . . . } 384
$$

Family BERYCID $巴$. . . . . . . . 384 Beryz . . . . . . . . . 385

Sphenocephalus . . . . . . . . 387

— fissicaudus .. . . . . . . 387

— cataphractus . . . . . . 388

Acrogaster . . . . . . . . . 388

— parrus . . . . . . . . . . . 389

— brevicostatus . . . . . . . 389

— beckeli . . . . . . . . . 290

— daviesi . . . . . . . . . 390

Pycnosterinx. . . . . . . . 391

russeggeri . . . . . . . . . 392

— discoides . . . . . . . 393

— gracilis . . . . . . . . . 394

Cubius . . . . . . . . 395

Hoplopteryx . . . . . . . . . 396

— antiquus . . . . . . 396

— zippei . . . . . . . . . . 397

— lewesiensis . . . . . . 397

— superbus . . . . . . . . 403

- lundensis . . . . . . . 404

— lewisi .. . . . . . . 404

— syriacus . . . . . . . . 405

— stachei . . . . . . . . 406 


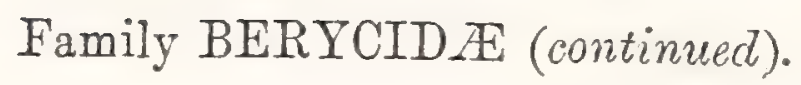

Dinopteryx

— spinosus . . . . . . 407

Homonotus . . . . . . . . 407

dorsalis. . . . . . . . 408

Myripristis . . . . . . . . . 410

- leptacanthus . . . . . . . . 410

- homopterygius . . . . . . 411

Holocentrum . . . . . . . . 412

— macrocephalum . . . . . 412

- melitense . . . . . . . . 413

Family APHREDODERID $巴$. . . . . . 416

Family CYTTID $Æ$. . . . . . . . . . . 417

Division B. Scombriformes . . . . . . . 418

Family STROMATEID E . . . . . . . . . 419

Omosoma . . . . . . . . 419

— sahel-almæ . . . . . . . 419

- intermedium . . . . . . . 420

— pulchellum ... . ... . 421

Platycormus .. . . . . . . . 421

— germanus . . . . . . . . 421

Berycopsis . . . . . . . . . 423

— elegans . . . . . . . . . 423

Family CARANGID $巴$. . . . . . . 425

Aipichthys . . . . . . . . . 42 ?

— pretiosus . . . . . . . . 427

— velifer . . . . . . . . 427

— minor . . . . . . . . . 428

- nuchalis . . . . . . . . 429

Semiophorus . . . . . . . . 430

— velifer .. . . . . . . 430

velicans . . . . . . . . 431

Platax . . . . . . . . 432 
Family CARANGID Æ (continued).

Platax woodwardi . . . . . . 432

Amphistium . . . . . . . . 434

— paradoxum . . . . . . 434

Vomeropsis . . . . . . . . . . 435

longispinus . . . . . . . . 436

elongatus . . . . . . . 437

valenciennesi . . . . . . . 437

Nene . . . . . . . . 437

— rhombeus . . . . . . . 439

oblongus . . . . . . . . 440

C'aranx. . . . . . . . . . . 441

Archæus . . . . . . . . . . 442

glarisianus. . . . . . . . . 442

Seriola . . . . . . . . . . 444

—_ prisca . . . . . . . . . . 444

lata. . . . . . . . 445

analis ... . . . . . . 445

Carangopsis . . . . . . . . 446

breris . . . . . . . 446

dorsalis . . . . . . . 447

Ductor . . . . . . . . . . 448

leptosomus : . . . . . . . . 448

Family SCOMBRID $\mathrm{E}$. . . . . . . . . . 451

Isurichthys . . . . . . . . . . 453

macrurus . . . . . . . 453

orientalis . . . . . . . . 453

Thynnus . . . . . . . . . 454

thynnus . . . . . . . . 455

scaldisi . . . . . . . . . 455

lanceolatus . . . . . . . 456

Eothynnus . . . . . . . . . . 457

salmoneus . . . . . . . . 457

Scomber . . . . . . . . 459

Palimphyes . . . . . . . . 460

elongatus . . . . . • . 460 
Family SCOMBRID无 (continued).

Scombrinus

Page

— nuchalis . . . . . . . . . 461

— macropomus . . . . . . . 462

Auxis . . . . . . . . . 463

(?) propterygius . . . . . . . 464

Cybium . . . . . . . . 465

speciosum . . . . . . . . 466

bleekeri . . . . . . . 466

excelsum . . . . . . . 467

- bartonense . . . . . . . $46 \pi$

_lingulatum . . . . . . . . 469

Eocœlopoma . . . . . . . 470

colei . . . . . . . 470

curvatum . . . . . . . . 472

Sphyrænodus . . . . . . . . 473

— priscus . . . . . . . . 473

Scombramphodon . . . . . . 474

__ benedeni . . . . . . . 474

— curvidens . . . . . . . . . 474

Crassidens . . . . . . . . . 475

Thyrsitocephalus . . . . . . . 476

alpinus . . . . . . . . . 477

Lepidopus. . . . . . . . . 477

__ glarisianus . . . . . . 477

brericauda . . . . . . . . 480

- albyi . . . . . . . . 480

Family PAL无ORHYNCHID仺 • . . . . 482

Palæorhynchus . . . . . . . 483

— glarisianus . . . . . . . 483

— longirostris . . . . . . . 486

— zitteli . . . . . . . . . 487

Hemirhynchus . . . . . . . 488

— deshayesi . . . . . . . 488

— colei. . . . . . . . . 488 


$$
\begin{aligned}
& \text { Family XIPHIID无 . . . . . . . . } 490 \\
& \text { Xiphiorhynchus. . . . . . . . . } 490 \\
& \text { — elegans . . . . . . . . } 491 \\
& \text { — priscus . . . . . . . . . . } 491 \\
& \text { Acestrus . . . . . . . . } 494 \\
& \text { ornatus . . . . . . . } 494 \\
& \text { Histiophorus . . . . . . . . } 495 \\
& \text { — eocæricus . . . . . . . } 495 \\
& \text { - rotundus . . . . . . . . } 495
\end{aligned}
$$

Division C. Perciformes . . . . . . . . . . 497

Family PERCIDÆ. . . . . . . . . . 498

Prolates . . . . . . . . . . . 499

— heberti . . . . . . . . . 499

Acanus . . . . . . . . 500

— spinosus . . . . . . . 500

— regleysianus . . . . . . . 501

Lates .. . . . . . . . . 502

gracilis . . . . . . . 502

Cycloporna . . . . . . . 504

— gigas . . . . . . . . 504

— (?) micracanthum .... . . . 504

Smerdis . . . . . . . . 06

— minutus . . . . . . . 506

formosus . . . . . . . 507

macrurus . . . . . . . 507

Labrax . . . . . . . . 509

ubinoi . . . . . . . . 510

schizurus . . . . . . . . 510

oeningensis . . . . . . . 511

Percichthys . . . . . . . . 514 antiquus . . . . . . . 514

Properca . . . . . . . . 514

- angusta . . . . . . . 515

— beaumonti. . . . . . . 515

— (?) prisea . . . . . . . 516 
Family PERCID E (continued). labracoides . . . . . . 517 Perca . . . . . . . . 518

Family TEUTHIDID $\approx$. . . . . . . . 523

Family SPARID王 . . . . . . . . . 524

Sparnodus . . . . . . . . 524

— macrophthalmus . . . . . 525

— elongatus . . . . . . . 526

— microstomus . . . . . . 527

bowerbanki . . . . . . 527

Sargus . . . . . . . . . . 529

- oranensis . . . . . . . 529

- laticonus . . . . . . . 529

Trigonodon . . . . . . . 531

- oweni . . . . . . . . 531

- serratus . . . . . . . 531

Pagellus .. . . . . . . . . . 532

Pagrus. . . . . . . . . . 533

Chrysophrys . . . . . . . . 534

Family SCI $e_{N I D}$. . . . . . . 538

Family LABRID $\mathrm{E}$. . . . . . . . . . . 539

Labrus . . . . . . . . . . 539

Julis . . . . . . . . . . . 541

Labrodon . . . . . . . . 541

— superbus. . . . . . . . 542

Canariensis . . . . . . 542

Phyllodus. . . . . . . . 546

— toliapicus ... . . . . . . . 546

Egertonia . . . . . . . . . 550

- isodonta . . . . . . . 551

Platylæmus . . . . . . . . . . 551

colei . . . . . . . . 551

Pseudosphærodon . . . . . . . . 552

hilgendorti . . . . . . . 552 
Family CHROMID $\mathbb{E}$

Priscacara

serrata. clivosa .

Dirision D. Chætodontiformes .

Family CHETODONTID 2

Pygæus

- coleanus

Proantigonia .

Ephippus. rhombus

Family ACRONURID无. . . . . . . 562

Aulorhamphus . . . . . . . 562

Apostasis . . . . . . . . . 563

Acanthurus . . . . . . 563

Naseus . . . . . . . . . 564

rectifrons

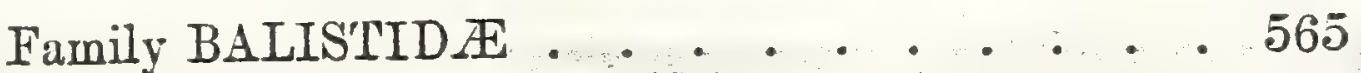

Spinacanthus . . . . . 566

Acanthopleurus . . . . . . . 566

—- serratus . . . . . . . . 567

Acanthoderma . . . . . . . 568

spinusum . . . . . . . . 568

Ostracion . . . . . . . . . . 569

Family GYMNODONTIDA . . . . . . 570

Tetrodon . . . . . . . . 571

Diodon. . . . . . . . . . . 571

erinaceus . . . . . . 572

scillæ . . . . . . . . 572

—

vetus . . . . . . 573

Orthagoriscus . . . . . . . 576 
Division E. Scorpæniformes

Family SCORP ENIDE . . . . . . • . 577

Ampheristus . . . . . . . . 577

- toliapicus . . . . . . 577

Family COTTID . . . . . . . . . 580

Eocottus . . . . . . . . 580

- veronensis. . . . . . . 581

Lepidocottus . . . . . . . . 581

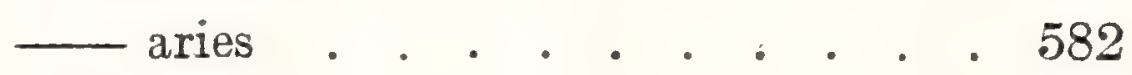

- brevis . . . . . . . . 582

— papyraceus . . . . . . 583

— multipinnatus . . . . . . 584

Cottus . . . . . . . . . 585

Eamily TRIGLID $\mathrm{E}$. . . . . . . . 585

Division. F. Gobiiformes . . . . . . • . 587

Family GOBIID无 . • • • • • • . • . . 587

Family TRACHINID王 . • • • • • • 589

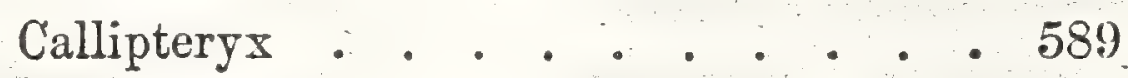

speciosus . . . . . . . . 589

- recticaudus . . . . . . 589

Division G. Blenniiformes . . . . . . . 591

Family BLOCHIID无 . . . . . . . . . 591

Blochius . . . . . . . . . 593

- longirostris . . . . . . . 593

Family BLENNIID $\mathrm{E} . . . . . \quad . \quad 595$

Pterygocephalus. . . . . . . 595

— paradoxus. . . . . . . . . 595 
1899. Saurocethalus lanciformio, 0. P.Hay, Amer.

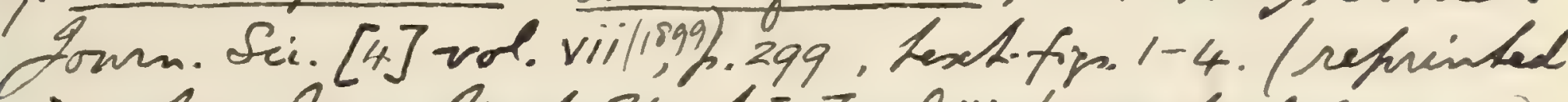
in Ann. Inag. hath. Thish. [7] vol. 1ii. p. 481, Lexth fin. 1-4). 1903. Saurocephalue lanciformis, 0.P.Hay, Bull. Amen. Inum Nat. Thist. vol. xix. h.50.

Ineluder Tarapachoving, cope, ace. To Z. Thussute of. Bull. Amer. Hus. Hath. Htint vol. xxv (1908), p.97.

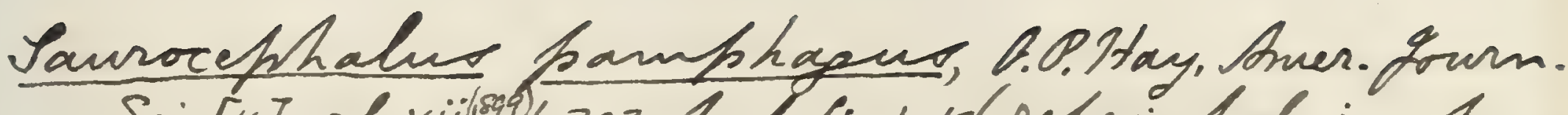

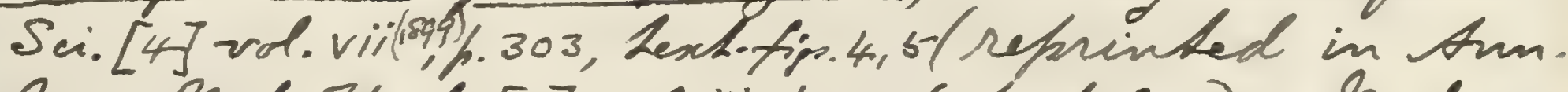

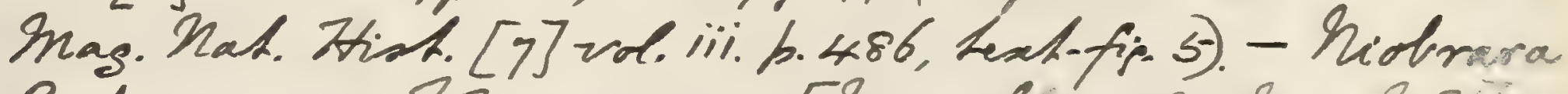
Cretaceno; Kancar. [Masill: Am. Mur. h. H] 
S.fajumensin = tortably Cytrium (7. Priem, Bull. Sor. Séd.

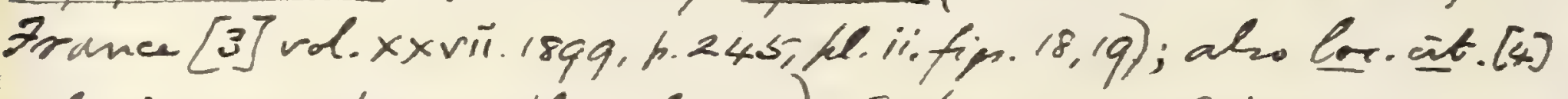
rol.xiv.1914, h.376, pl.x.fip. 27). Sphyzaence fajumensis,

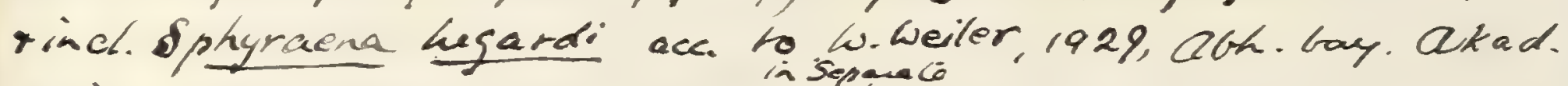
wiss. Mark. nakinw art. NF. T. P. Sol.vi f. 1-3, 38-40.

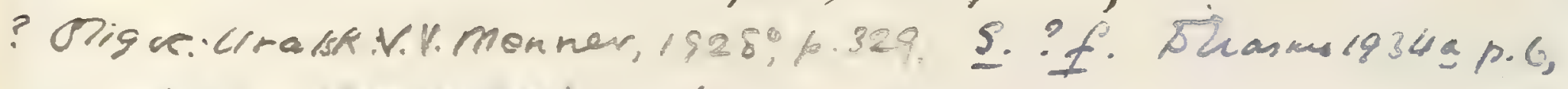

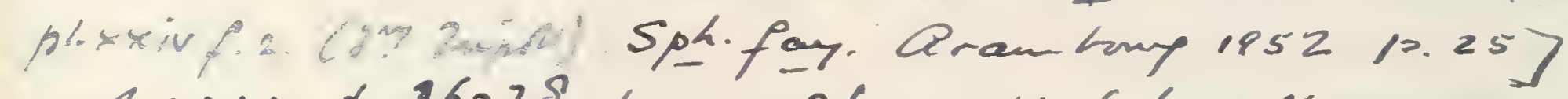

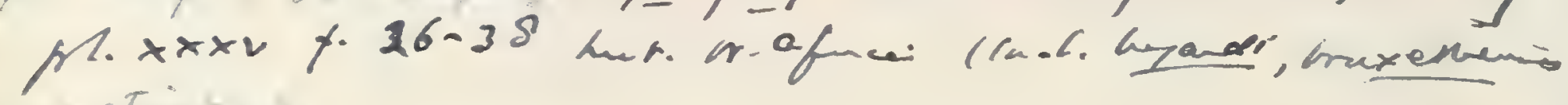


Env. Sainte-Croix (1858), p. 52, pl. vii. fig. 4. Protosphyrcence albensis, H. E. Sauvage, Bull. Soc. Sci. Nat. Yonne, vol. xxxiii.pt. ii. (1879), p. 51.-Aptian; Sainte Croix (Switzerland) and Yonne (France).

Saurocephalus? dispar, E. Hébert, Mém. Soc. Géol. France, [2] vol. v. (1855), p. 35̃2, pl. xxvii. fig. 5 ; H. B. Geinit\%, Palæontogr. vol. xx. pt. ii. (1875), p. 225, pl. xliii. fig. 11.-Senonian; Meudon, France. Turonian; Weinböhla, Saxony.

Saurocephalus fajumensis, W. Dames, Sitzungsb. k. preuss. Akad. Wiss., phys.-math. Cl. vol. ri. (1883), p. 147, pl. iii. fig. 12; F. Priem, Bull. Soc. Géol. France, [3] rol. xxvii. (1899), p. 245, pl. ii. figs. 18, 19.-Lower Tertiary; Birket-el-Qurun, Fajum, Egypt. [Probably teeth of

Cybium; Royal Natural History Museum, Berlin.]

Saurocephalus incqualis, G. von Münster, Beitr. Petrefakt. pt. rii. (1846), p. 26, pl. ii. fig. 21.-Lorer Tertiary; Grinzing, Vienna.

Saurocephalus inflexus, F. J. Pictet, op. cit. 1858, p. 51, pl. vii. fig. 3. Protusphyrcena inflexa, H. E. Sauvage, loc. cit. 1879, p. 51, pl. iii. figs. 13, 14.-Neocomian ; Sainte Croix and Yonne.

Saurocephalus monasterii, G. von Münster, op. cit. pt. rii. (1846), p. 48, pl. iii. fig. 15.-Upper Jurassic ; Linden, Hanover. [Probably Megalosaurian.]

Surrocephalus picteti, E. Arnaud, Ann. Soc. Lit. Sci. Apt (Tav. cluse), vol. i. (1865), p. 73, figs. 1-3.- - Tpper Cretaceons (Aptian); Apt, Vaucluse.

Saurocephalus substriatus, G. von Münster, op.cit. pt. vii. (1846), p. 26, pl. ii. fig. 0.-Wiocene; Neudörfl.

There are numerous fragmentary Cretaceous fossils in the Collection which seem to belong to undetermined Chirocentridæ. Among these the following may be enumerated:-

P. 4859. Imperfect caudal fin described and figured by J. W. Daris, Trans. Roy. Iublin Soc. [2] vol. iii. (1897), p. 501, pl. xxiv. fig. 1, as "Chondrosteus?"; Upper Cretaceons, Sahel Alma, Mt. Lebanon.

Lewis Coll.

47190. Hinder caudal vertebræ and base of caudal fin; Gault, Folkestone.

Gardner Coll.

P. 9019. Chain of small vertebræ and fragmentary pectoral firi, probably of two distinct fishes; Gault, Folkestone.

Piresented by F. G. Hitton Price, Esq., 1899. 
4078. Three caudal vertebræ erroneously referred to Tetrapterus minor by L. Agassiz, Poiss. Foss. vol. v. (1837-44), pt. i. p. 92, pl. Ix a. figs. 11-13; Chalk, Lewes. See Part III. p. 406.

Mantell Coll.

25838. Three associated caudal vertebræ named Tetrapterus minor, Ag., by F. Dixon, Geol. Sussex (1850), p. xiii, pl. xxxi. fig. 16 ; Chalk, Sussex.

Dixon Coll.

The following imperfectly known genera and species may also perhaps be referred to the Chirocentridæ, but there are no examples in the Collection :-

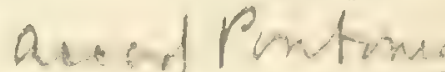

Andreiopteura vetustissima, O. G. Costa, Atti R. Accad. Scio

Napoli, vol. ii. (1865), no. 16, p. 27, pl. ii. (quoted as

A. esimia on p. 10).-Upper Cretaceous; Pietraroja,

Prov. Benevento, Italy. [Imperfect trunk; Geological

Nuseum, University of Naples.]

EuColpguster anatis, L. Agassiz, Neues Jahrb. 1835, p. 304 (name

only).--Upper Eocene; Monte Bolca, near Verona.

Prymnetes longiventer, E. D. Cope, Proc. Amer. Phil. Soc. vol. xii. (1871), p. 52.-Cretaceous or Tertiary; Tuxtla Chiapas, Mexico. [Nearly complete fish; National Museum, Washington.]

The caudal region of a fish from the Cretaceous of Lesina, Dalmatia, which also seems to belong to the Chirocentridx, is described by F. Bassani, Denkschr. k. Akad. Wiss., math.-naturw. Cl. vol. xlv. (1882), p. 212, pl. xvi.

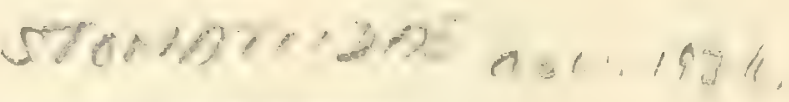

INCERT $\mathrm{E}$ SEDIS (? GHIROEMTPRDE).

Genus TOMOGNATHUS, Dixon.

[Geol. Sussex, 1850, p. 376.]

A genus known only by the head, which is short and deep and much laterally compressed, with excessively shortened rostral region. Skull with a delicate median occipital crest extending as far forwards as the back of the large orbit; cleft of the mouth horizontal, also terminating at a point opposite the hinder border of the orbit; dentigerous half of mandible slender, its hinder half deepened. Teeth hollow and conical, enamelled only in their distal half, and directly fused with the jaw, not implanted in sockets; those of the premaxilla and the symphysial end of the dentary much enlarged, while those of the maxilla are relatively small, decreasing in size 


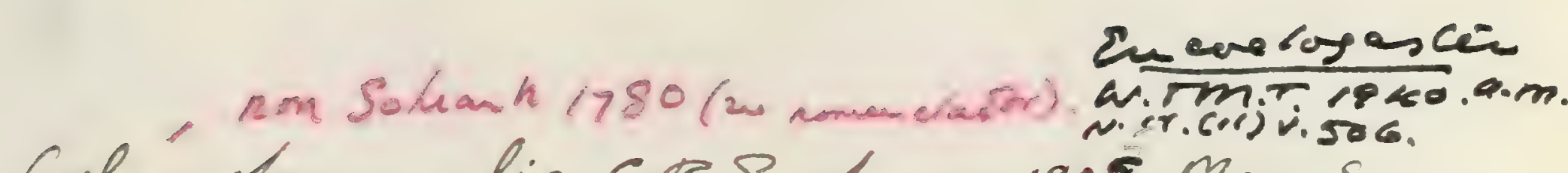
Cologaster analis, C. OC. Pactman, 1905, Mem. Sor.

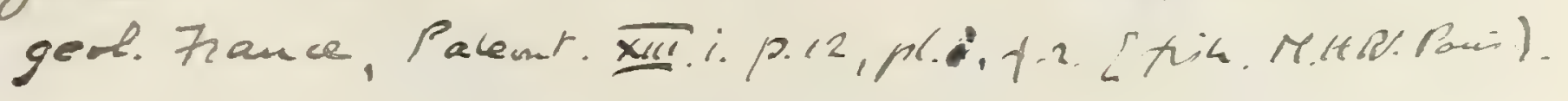

The following may be a tail of one of th. Chirrcentrida :-

Lichiches cretaceur. A. Fritsch $\alpha$ F. Bayer, Fene Fische u. Reth. Bithm. Treideform. (Thes, 1905), h. 9. hl. iii.fi. 4...Iurmian; Weissenberg, Bohemua. 


backwards; a series of small teeth on the ectopterygoid, and another very small series within the conspicuous row of mandibular teeth, this extending a little backwards upon the elevated coronoid region. Opercular apparatus complete, with some slender branchiostegal rays.

\section{Tomognathus mordax, Dixon.}

1850. Tomognathes mordax, F. Dixon, Geol. Sussex, p. 376, pl. xxxv. fig. 1.

1850. Tomognathus leiodus, F. Dixon, ibid. p. 377, pl. xxx. fig. 31. [Mandibular rami; British Museum.]

1888. Tomognathus mordax, A. S. Woodward, Proc. Geol. Assoc. vol. $\mathrm{x} . \mathrm{p} .313$.

Type. Imperfect skull, with jaws.

The type species, the head with opercular apparatus attaining a length of $0 \cdot 07$. Orbit occupying nearly half the total length of the head, the maxilla nearly three and a half times as long as its maximum depth, and the mandibular ramus a little more than three times as long as its maximum depth. The robust premaxillæ fused together, and each bearing four large teeth gradually decreasing in size from the middle line to the side; these teeth scarcely tumid at the base, nearly straight, enamelled and faintly fluted in their distal half. None of the maxillary teeth more than half as large as the latter, very slender, and rapidly becoming small in the very cluse series behind; about eight teeth in the ectopterygoid series as large as the anterior maxillary teeth. Outer mandibular teeth closely similar to those of the premaxilla, but those at the symphysis a little more tumid at the base and incurved at the apex; the foremost tooth relatively small, the next three the largest, then another small one as the first of a diminishing series of about six to eight teeth. Width of operculum nearly equalling one quarter the length of the skull; suboperculum wider than deep; both destitute of superficial ornament.

Form. \& Loc. Turonian: Kent, Sussex, and Surrey.

P. 923\%. Imperfect skull in counterpart halves of a block of chalk; unknown locality in S.E. England. The otic region of the skull, the pterygo-quadrate arcade (with teeth on the ectopterygoid), and the right mandibular ramus are displayed.

History unknown.

P. 4844. Imperfect skull exhibiting part of the median occipital crest, the right postfrontal, the hollowed frontal region, the premaxillæ, right maxilla, and the mandible; S.E. England.

Purctased, 1885. 
39051. Remains of mandible showing the bases of the two series of teeth on the ight side; S.E. England. Bowerbank Coll.

P. 4791. Jaws of small specimen showing the parasphenoid, possible palatines, and the extent of the angular bone of the 'mandible; S.E. England.

Presented by Sir Richard Owen, K.C.B., 1884.

P. 6460. Remains of head showing the right ectopterygoid dentition; S.E. England. The left hyomandibular is also well shown.

Beckles Coll.

P. 1701. Fragmentary remains of head, pectoral arch and pectoral fins: Kent. The inner mandibular teeth and the ectopterygoid teeth are displayed, also the much-expanded hyomandibular. The pectoral fin-rays seem to have been a little widened and articulated in the distal half. There are no traces of the vertebral column. Egerton Coll.

P. 3849. Jaws, displaying a coarse tubercular ornament on the maxilla; Kent. Traces of the inner mandibular and ectopterygoid teeth are distinct. Enniskillen Coll.

41684. Fragmentary remains showing toothed ectopterygoid; Lower Chalk, Burham, Kent. 49092

Toulmin Smith Coll.

49058, 49032. Parts of two small heads, the second displaying the premaxillix from the inner side; Burham.

Mrs. Smith's Coll.

P. 1702. Various fragmentary specimens, one showing the operculum, suboperculum, and preoperculum; Burham.

Egerton Coll.

P. 7646. A nother fragmentary large skull; Burham. Brodie Coll.

P. 56r5-76. One small imperfect skull, one upper jaw showing pterygoids, and two mandibular rami; Burham. The skull exhibits part of the occipital crest, the inner mandibular teeth, and the toothed ectopterygoid.

Harford Coll.

36172. Fragment; Lower Chalk, Rochester. Purchased, 1861.

39050. Head with opercular apparatus; Lower Chalk, Chatham.

Bowerbank Coll.

49761.62, -66. Three fine heads, the second showing part of the occipital crest; Lower Chalk, Southeram, near Lewes.

Capron Coll. 
39051. hrticed A.S.2. 1908, f., 141.

P.10632. Impufuth firt du? A fip? A.S.W. 1908, h.141, H1.xxix

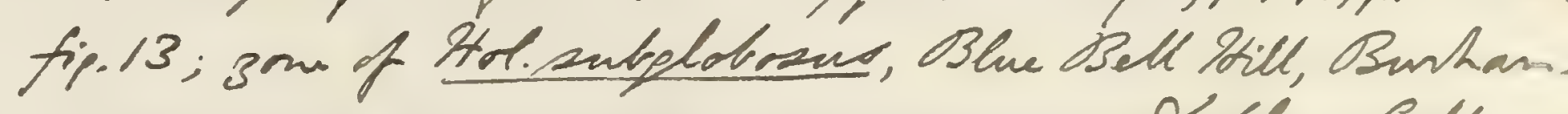
oribley Coll. PI701. Teft clavicle and base of pectoral fin des? $\alpha$ fip. A.S.W. 1908, h. 141 , hl $x$ xix. fip. 12.

P.7646. Des, a fy? A.S.W.1908, h. 140, he.xxix.f.j. 3.

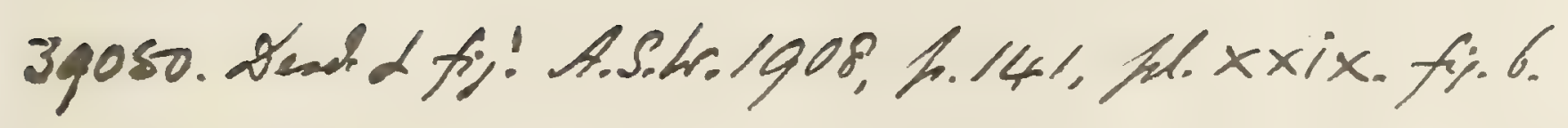

49762.2 en? a fig? A. S. W. 1908, h.140, hl xxix. fig. 4 . 49766 . Bre rays miticed ctill. 6.14t. 
49763. Tmperfect jaws: Southeram.

Capron Coll.

49764-65. Detached left dentary and a small skull, both fragmentary; Lower Chalk, Amberley Pit, Arundel.

Capron Coll.

P. 3849. Fragmentary jaws; Arundel.

Enniskillen Coll.

49767-68. Two small fragmentary heads; Lower Chalk, Dorking, Surrey.

Capron Coll.

25925. Imperfect left mandibular ramus and another fragmentary mandible, the first figured by Dixon, op. cit., as the type of a distinct species, Tomograthus Teiodus; Washington, Sussex.

Dixon Coll.

The following specimens are not specifically determined :-

P. 6460 a. Remains of small head and opercular apparatus, remarkable for the very large size of the anterior teeth, which are especially tumid at the base, incurred and not fluted even in the apical portion; Chalk, S.E. England. The nutritive foramina in the dentary are large, while the operculum and suboperculum are covered with small pits which have a raised border.

Beckles Coll.

47242. Fragmentary remains of a large head, exhibiting a nonfluted anterior mandibular tooth; Chalk Narl, Dover.

Gardner Coll.

37325. Fragment of small head; Chalk Marl, Dorer.

Purchased, 1863.

\section{Family CTENOTHRISSID ג.}

Supraoccipital bone prominent, but parietals partly meeting in the middle line; squamosal reduced and apparently fused with pterotic; snout not produced; cheek-plates reduced. Premaxilla small and maxilla relatively large and loose, both these bones entering the upper border of the mouth; two supramaxillaries; teeth acuminate, but feeble. Opercular apparatus complete, but few branchiostegal rays and no gular plate. Vertebral centra well ossified, none with transverse processes; ribs nearly encircling the abdominal cavity. Fin-fulcra absent, and simple rays in front of dorsal fin slightly spaced; post-temporal bones in contact with postero-lateral angles of cranium; post-clavicular plate overlapped by the clavicle; pelvic fins relatively large and advanced far forwards. Scales thin and deeply imbricating. 
P.3849. Dight maxilla dew LfY. A.S.L.1908, h.140, H.xxix.f. 12

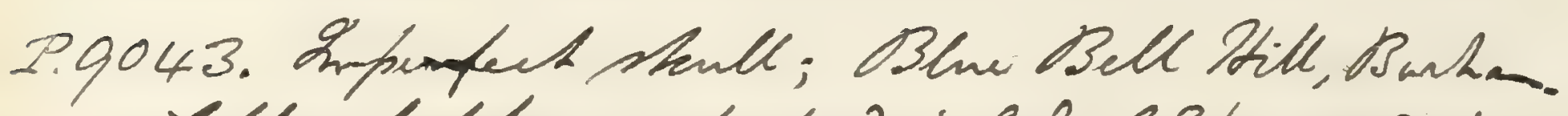
teft ectopterypoid den? \& fip? A.S.W. $1908, k$.

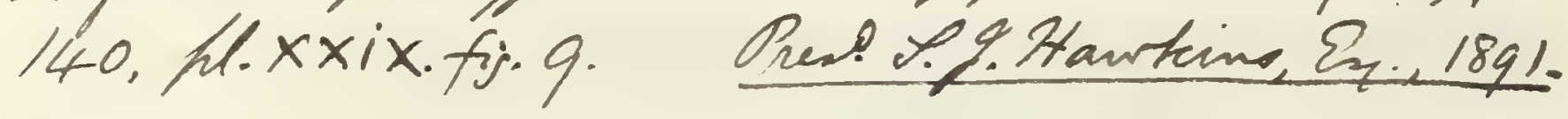


49763. Tmperfect jaws: Southeram.

Capron Coll.

49764-65. Detached left dentary and a small skull, both fragmentary; Lower Chalk, Amberley Pit, Arundel.

Capron Coll.

P. 3849. Fragmentary jaws; Arundel.

Enniskillen Coll.

49767-68. Two small fragmentary heads; Lower Chalk, Dorking, Surrey.

Capron Coll.

25925. Imperfect left mandibular ramus and another fragmentary mandible, the first figured by Dixon, op. cit., as the type of a distinct species, Tomognathus leiodus; Washington, Sussex.

Dixon Coll.

The following specimens are not specifically determined:-

P. 6460 a. Remains of small head and opercular apparatus, remarkable for the very large size of the anterior teeth, which are especially tumid at the base, incurred and not fluted even in the apical portion; Chalk, S.E. England. The nutritive foramina in the dentary are large, while the operculum and suboperculum are covered with small pits which have a raised border.

Beckles Coll.

47242. Fragmentary remains of a large head, exhibiting a nonfluted anterior mandibular tooth ; Chalk M[arl, Dover.

Gardner Coll.

37325. Fragment of small head; Chalk Marl, Dorer.

Purchased, 1863.

\section{Family CTENOTHRISSID \&.}

Supraoccipital bone prominent, but parietals partly meeting in the middle line; squamosal reduced and apparently fused with pterotic; snout not produced; cheek-plates reduced. Premaxilla small and maxilla relatively large and loose, both these bones entering the upper border of the mouth; two supramaxillaries; teeth acuminate, but feeble. Opercular apparatus complete, but few branchiostegal rays and no gular plate. Vertehral centra well ossified, none with transverse processes; ribs nearly encircling the abdominal carity. Fin-fulcra absent, and simple rays in front of dorsal fin slightly spaced; post-temporal bones in contact with postero-lateral angles of cranium; post-clavicular plate overlapped by the clavicle; pelvic fins relatively large and advanced far forwards. Scales thin and deeply imbricating. 
An extinct family, of the Cretaceous period, known only by two genera, one with ctenoid scales (Ctenothrissu), the other with cycloid scales (Aulolepis).

Genus CTENOTHRISSA, A. S. Woodward.

[Ann. Mag. Nat. Hist. (7) vol. iii. 1899, p. 490.]

Head large, trunk fusiform and laterally compressed. Maxilla robust and arched; mandible a little prominent, and gape not extending behiud the middle of the large orbit. Vertebræ 30 to 40 in number, half being caudal. Dorsal fin much deepened, occupying about half of the back; anal fin small; eaudal fin deeply forked. Seales pectinated, large and regularly arranged, none enlarged or thickened, and no rentral ridge-scales; lateral line conspicuous.

Fig. 6.

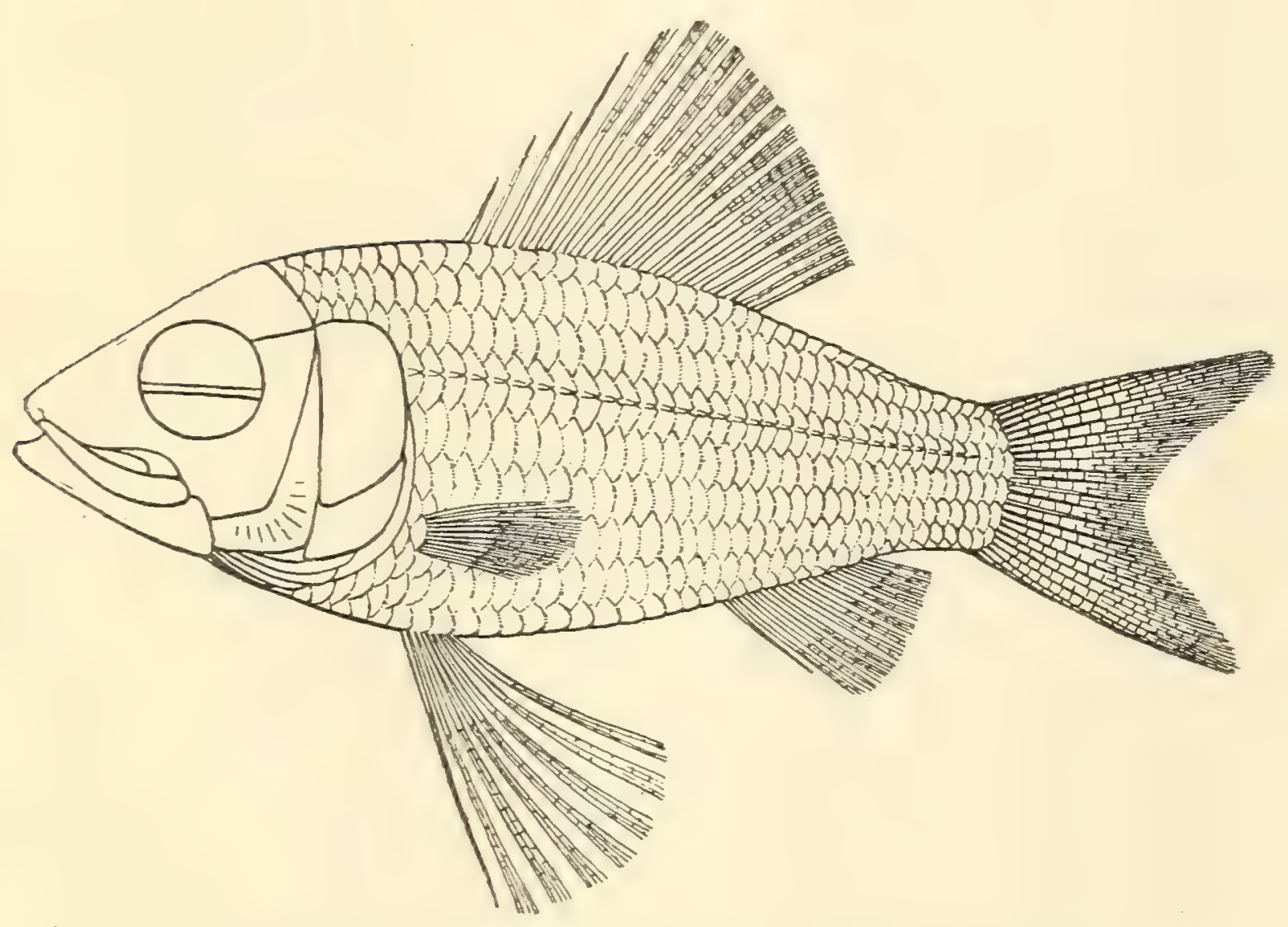

Ctenothrissa vexillifer; restoration, slightly enlarged.

\section{Ctenothrissa vexillifer (Pictet).}

[Text-figure 6.]

1850. Beryx vexilifer, F. J. Pictet, Poiss. Foss. Mt. Liban, p. 8, pl. i. fig. 1.

1866. Beryx vexillifer, Pictet \& Humbert, Nour. Rech. Poiss. Foss. Mt. Liban, p. 30, pl. ii. figs. 1-3. 

Fnothina. Mo Conmann, 1900, Rev. Git. Paleogort

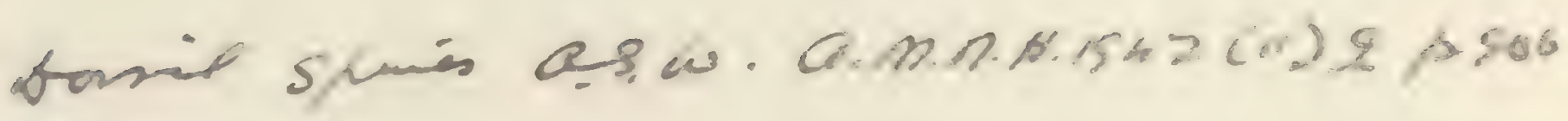
of. 5. 
1903. Ctenothiera vexillifer, A.S. Lordwand,

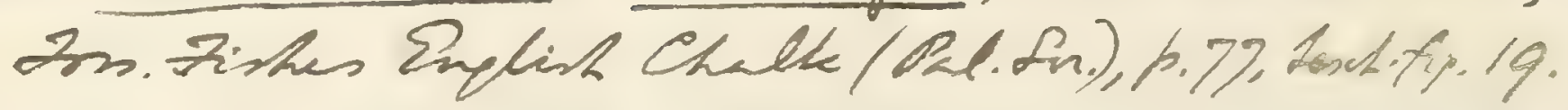


1887. Beryx vexillifur, J. W. Davis, Trans. Roy. Dublin Soc. [2] vol. iii. p. 508, pl. xix. fig. 2.

1899. C'tenoihrissa vexillifer, A. S. Woodward, Ann. Mag. Nat. Hist. [7] vol. iii. p. 490.

Type. Imperfect fish; Genera Museum.

The type species, attaining. a length of alyout 0.07 . Length of head with opercular apparatus approximately equal to the maximum depth of the trunk and contained about one and a half times in the length from the pectoral arch to the base of the caudal fin. Vertebræ 30 in number. Pectoral fins about half as long as the pelvic pair, which are inserted beneath the former and comprise 8 stout rays, the foremost only articulated distally, the others both dirided and articulated distally, the longest when adpressed to the trunk reaching the anal fin; dorsal fin comprising from 18 to 20 rays, none spinous, about the sixth being the longest, and its length equalling two thirds the depth of the trunk at its insertion; two thirds of the dorsal fin situated in the anterior half of the back, and the anal fin, with 13 or 14 rays, arising opposite its posterior third; the articulations of all the fin-rays rather distant. Scales rery finely pectinated.

Form. \& Loc. Upper Cretaceous : Hakel, Mrt. Lebanon.

P. 90. Large specimen, distorted by fracture across abdominal region.

Lewis Coll.

49493, P. 88, P. 5999. Three specimens, a little deepened by distortion, the second associated with a smaller fish on the same slab.

Lewis Coll.

P. 89, P. 91. Two specimens from 0.06 to 0.065 in length, scarcely distorted.

Lewis Coll.

49496, P. 107. Two well-preserved smaller specimens, the first displaying about 8 branchiostegal rays.

Lewis Coll.

P. 9238. Portion of small fish displaying dorsal fin, in counterpart. History unknown.

P. 93. Very small distorted specimen. Lewis Coll.

The following fish may possibly be a large individual of this species, deepened by distortion during fassilisation :-

P. 4759. Imperfect fish described as the type specimen of Beryx ovalis by J. W. Davis, Trans. Roy. Dublin Soc. [2] vol. iii. (1887), p. 508, pl. xxvii. fig. 4 ; Hakel. The cranium is so much broken and displaced that the frontal bones are 
exposed from abore. The narrowness of the opercular apparatus and the form of the preoperculum are well shown in impression. The rertebræ cannot be distinctly counted, but they do not appear to exceed 30 in number. Not more than 8 rays can be observed in either of the pelvic fins, which are crushed together. The dorsal fin shows at least $18 \mathrm{rays}$, and the foremost, though undivided, can scarcely be described as spines. The posterior rays of the anal fin do not extend any nearer to the caudal fin than in the typical C. vexillifer. Lewis Coll.

\title{
Ctenothrissa radians (Agassiz).
}

\author{
[Plate X. figs. 1-4.]
}

1835-38. Beryx radians, L. Agassiz, Poiss. Foss., Feuill. p. 55, and vol. ir. pp. 4, 118, pl. xiv b. fig. 7, pl. xiv c. figs. $7-9$.

1888. Beryx radians, A. S. Woodward, Proc. Geol. Assoc. vol. x. p. 326, pl. i. fig. 9.

1899. Ctenothrissa radiuns, A. S. Woodward, Ann. Mag. Nat. Hist. [7] vol. iii. p. 491.

Type. Imperfect fish; British Museum.

A robust species, attaining a length of about 0.25. Length of head with opercular apparatus somewhat less than the maximum depth of the trunk and contained about twice in the length from the pectoral arch to the base of the caudal fin. Head and opercular apparatus with a fine rugose ornament: the supramaxillaries remarkably short and deep; operculum about twice as deep as broad. Vertebræ approximately 40 in number. Pelvic fins with 7 or 8 stout rays which, when adpressed to the trunk, extend to the anal fin; dorsal fin arising opposite a point just behind the insertion of the pelvic fins; anal fin, with at least 12 rays, arising opposite the hinder end of the dorsal fin. Scales moderately large; lateral line extending along the ninth series above that which forms the ventral border of the flank; all the scales very finely serrated and deeply pectinated, those of the anterior portion of the fish also slightly rugose or tuberculated.

Form. \& Loc. Turonian: 'S.E. England.

4029. Type specimen, described and figured by Agassiz, loc. cit.; Lower Chalk, Lewes, Sussex. The appearance of a spine in front of the pelvic fins is proved by other specimens to be deceptive.

Mantell Coll.

P. 5418. Imperfect fish, displaying the characteristic mandible, 


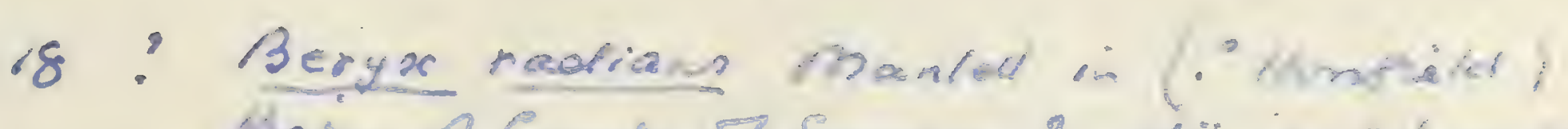

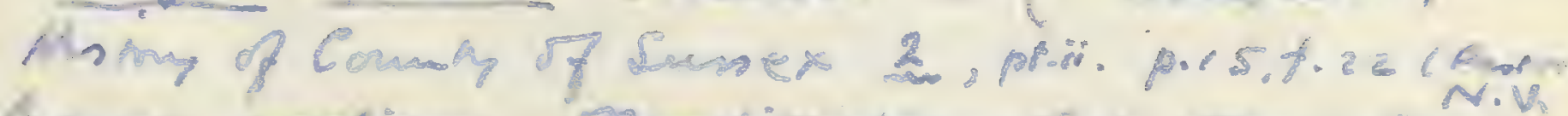

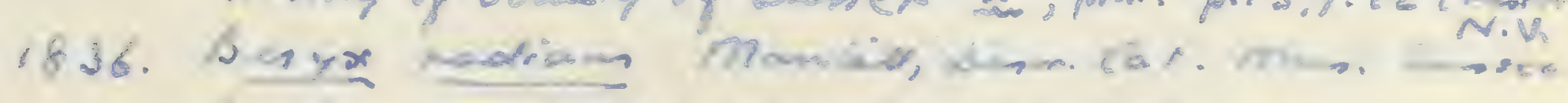

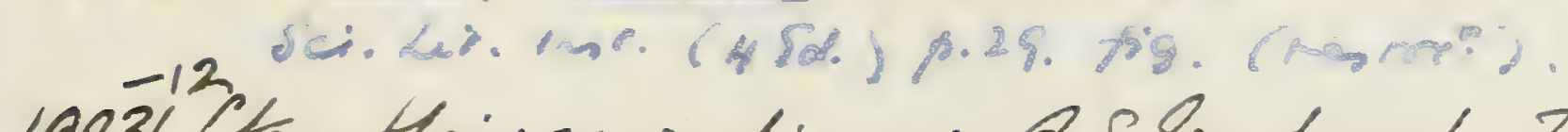

1903. Ctenothrisoa radiano, A.S. Lrodward, Fon. Dirhs

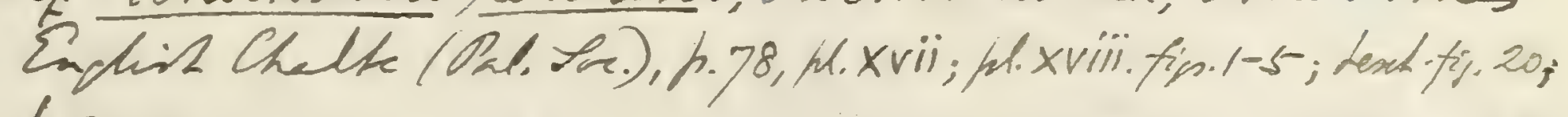
h.247.

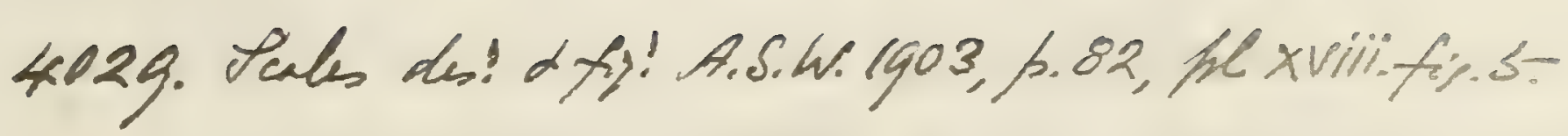

P.5418. Hyomandibulas uttived A.S.W. 1903, 6.79; huth h mandithe, b. So. 
41775. Imadrate noticed A.S.L. 1903, 6.79.

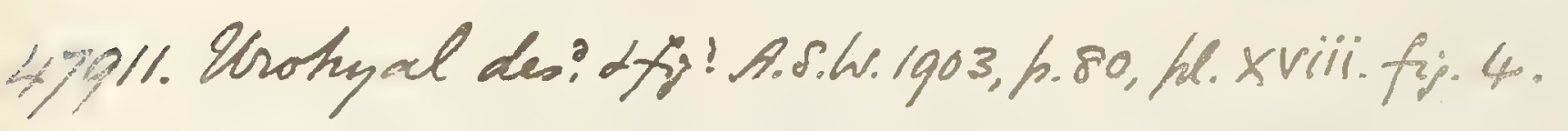

2.390. Desentw a figund A.S.L. 1903, f.81, he xviii. fig-1.

25936. Fhyrid aneh des? Lfip? A.S.W. 1903, h.80, hl.xviii.fis. 2; cramium naticent, pi.79.

w4.836. Ceratohyal a brovaps des? A fi?? A.S. W. 1903, h.80, he xviii. fip. 3.

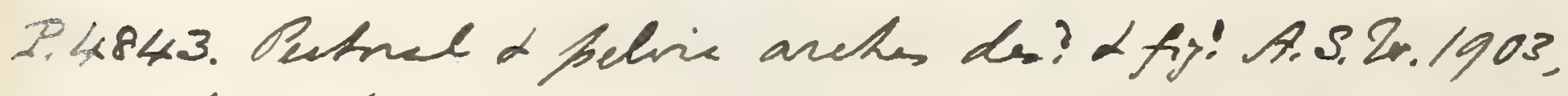

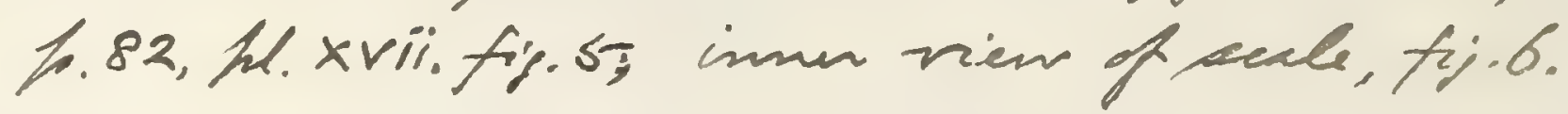


maxilla, and supramaxillaries, and the flattened ventral face of the abdominal region: Lewes.

Piesented by P. E. Coombe, Esq., 1888.

25840. Fractured specimen, with remains of the anal and caudal fins; Chalk, Sussex. Dixon Coll:

41775. Imperfect specimen, the parts somewhat scattered; Lower Chalk, Burham, Kent. There are remains of the large dorsal and pelric fins. Purchased, 1869.

47911. Smaller specimen, displaying postclaricular plates, wellpreserved scales, and remains of the dorsal. caudal, anf pelric ( $p l v$.$) fins, shown of the nat. size in \mathrm{Pl}$. X. fig. 1; Burham. Presented by the Hon. Robert Marsham, 1877.

P. 390-1. T\#o imperfect fishes, the second rather small, both displaying the vertebræ; probably from Lower Chalk, Burham. The vertebral centra are comparatively small, and the first specimen prores them to have been about 40 in number. Presented by the Earl of Ducie, 1881.

25936. Much-distorted specimen; Sussex. The imperfect cranium is shown in side riew, and the basicranial axis is obserred to be sharply bent upwards immediately in front of the otic region.

Dixon Coll.

4022-23. Fragmentary specimen in counterpart; Lewes. The cranial roof is imperfectly displayed. Mantell Coll.

49873. Feebly ornamented specimen, in counterpart; Lower Chalk, Dorking, Surrey.

Capron Coll.

498\%9. Remains of small head and trunk; Lower Chalk, Lewes. There are traces of an ossified sclerotic capsule.

Capron Coll.

44836 a. Fragmentary remains of head and trunk; Grey Chalk, Clayton Railway Tunnel, Sussex, 380 feet below the surface. The maxilla bears a series of rery small blunt teeth. Presented by Benjamin Bright, Esq., 1873.

P. 4843. Imperfect head and trunk, partly shown, nat. size, in Pl. X. fig. 2 ; Lower Chalk, Kent. The external ornament is well preserved. The complete right maxilla $(m x$.) and supramaxillaries $(s . m x$.$) are displaced forwards,$ exposing the remarkably deepened hinder half of the mandible, in which the suture between the angular $(a g$. 
and dentary (d.) is distinct. There is a narrow suborbital ring of cheek-plates, deeply channelled for the sensory canal; and below this the cheek is covered with scales like those of the trunk. Purchased, 1885.

47912-13. More fragmentary specimen displaying same features, also a smaller fragment; Burham.

Presented by the Hon. Robert Marsham, 187.

P. 5418 a. Remains of head and trunk with paired fins; Lewes.

Presented by P. E. Coombe, Esq., 1888.

49083. Remains of head and trunk with paired fins; probably from Burham.

Mis. Smith's Coll.

P. 7652. Fragment with part of dorsal fin; Kent.

Purchased, 1895.

P. 1946. Imperfect trunk; Burham.

Egerton Coll.

4907\%. Imperfect head, some scales, and part of dorsal fin ; probably from Burham. The relatively small premaxilla are apparently shown, one bearing minute teeth.

Mrs. Smith's Coll.

P. 5699. Better-preserved head, the right side shown of the natural size in Pl. X. fig. 3, and noticed in Ann. Mag. Nat. Hist. [7] vol. iii. (1899), p. 491 ; Kent. Both premaxilla $\left(p m x_{0}\right)$ and maxilla $\left(m_{*}\right)$ bear minute teeth : and the large supramaxillaries (s.mx.) are well preserved. All the bones of the opercular apparatus are displayed.

Harford Coll.

49052. Fragment displaying maxilla, inner aspect, with minute blunt teeth; probably from Burham. Mrs. Smith's Coll.

39429. Fragment showing length of pelvic fins, figured in Proc. Geol. Assoc. vol. x. pl. i. fig. 9 ; Kent. Bowerbank Coll.

25862. Fragment of squamation; Sussex.

Dixon Coll.

\section{Ctenothrissa microcephala (Agassiz).}

[Plate X. figs. 5, 6.]

1835-38. Beryx microcephalus, L. Agassiz, Poiss. Foss., Feuill. p. 55, and vol. iv. pp. 4, 119, pl. xiv b. figs. 3-6, pl. xiv c. fig. 10.

1850. Beryx microcephalus, F. Dixon, Geol. Sussex, p. 372, pl. xxxiv. fig. 3.

1850. Beryx radians, F. Dixon, ibid. p. 371, pl. xxxvi. fig. 4 (errore). 

P.5418 Q. Pectral fi' sutived A.S.L. 1903, h.82.

49083. Pectrul fin maticed A.S.W. 1903, t.8.8.

2.765-2. Tipramaxilla nsticed A.S.2. 1903, h.80.

P.1946. Excharged with Lund Lniv. Anus., Dee. 1903.

P.5699. Head des? dfy? A.S.2. 1903, 6.79, hl. xvii. fip. 2.

4905-2. Invailla des? afi! A.S.W. 1903, h. .99, hl. xvii. fip. 3.

P.5685. Prain of hranchial wet cith pill-retuer, des? afgl. A.S.h. 1903, h. 80, hl.xvii.fi.4; Chalte; CuxctonBasicramial concl sutire, hog9. Hayford Coll. Clavicle unticed, h.82. 

190 
1903. Ctenothrisea microcephald, A.S. Loodward, Bon.

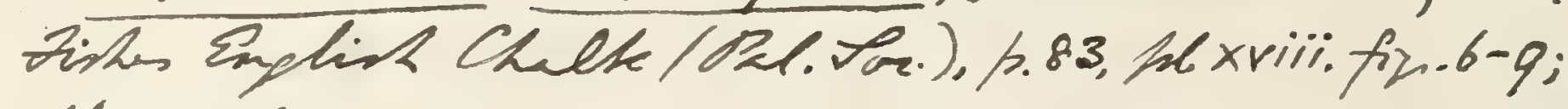
hl.xix.fin. 1,2 .

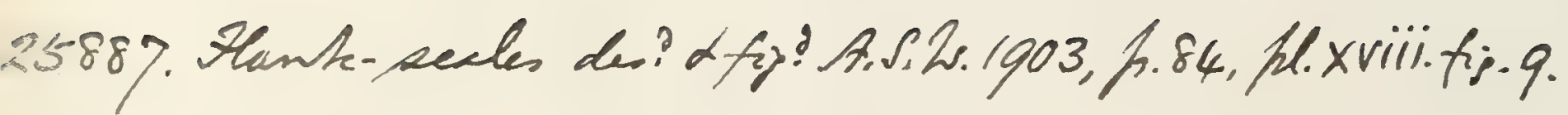

P.392. Desented a fipmul A.S. W. 1903, f.84, hl.xviii.fi, 6.

4.9881. Flanke-peale des? Lfi? A.S.W.1903, p.85, pl. Xviii. fij. B.

P.p656. Inpentult firh des? \& fir! A.S.2. 1903, 1.84,

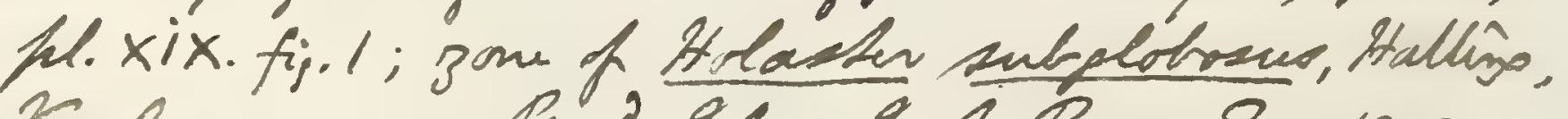
Rems. Pres? Ghu Z. 2. Dage, Br.1902. 


1883. Bery.x mirrocephalus, A. S. Woodward, Proc. Geol. Assoc. vol.x. p. 327.

1899. Ctenothrissa microcephala, A. S. Woodward, Ann. Mag. Nat. Hist. [7] vol. iii. p. 491.

Type. Imperfect fish; British Museum.

An elongated species, attaining a length of about 0.15 . Length of head with opercular apparatus equal to the maximum depth of the trunk, which is contained about twice in the length from the pectoral arch to the base of the caudal fin. Head and fins as in C. radians, except that the pelvic fins appear to be less elongated. Scales very large, the lateral line extending along the fourth series above that which forms the rentral border of the flank; serrations of scales coarser than in C. ractians.

Form. \& Loc. Turonian: S.E. England.

4034, 4036. The two trpe specimens described and figured hy Agassiz, Toc. cit.; Lower Chalk, Lewes, Sussex. In the first specimen, the short, toothed premaxillæ are distinct in front of the maxilix; in the second specimen, part of the maxilla bears similar blunt teeth. Mantell Coll.

2588\%. Small specimen erroneously referred to "Beryx" radians by Dixon, loc. cit.; Lower Chalk, Sussex. Dixon Coll.

P. 6466-68. Three large specimens, variously imperfect; Lower Chalk, S.E. England. Beckles Coll.

P. 392. Imperfect fish showing general proportions; Lower Chalk, S.E. England. Presented by the Earl of Ducie, 1881.

49881. Fine but imperfect specimen displaying the toothed maxilla, a supramaxilla, a preoperculum, parts of the fins, and the scales of the displaced squamation; Lower Chalk, Reigate, Surrey. There is an ovoid scale between the bases of the pelvic fins.

Capron Coll.

49874. More imperfect smaller fish, showing frontal region of cranial roof and maxillæ; Lewes. Capron Coll.

49875. Portion of small head and abdominal region; Clayton, Sussex.

Capron Coll.

P. 5419. Small trunk, showing pectoral and pelvic fins, associated with another fisb; Lewes.

Presented by P. E. Coombe, Esq., 1888.

49876. Imperfect small specimen, wanting tail; Lower Chalk, Glynde, near Lewes.

Capron Coll. 
49884. Another imperfect specimen, displaying premaxilla, maxilla, supramaxillaries, and small pectoral fin; Arundel, Sussex. Capron Coll.

41688-89. Partly displaced remains of typical specimen, and a fragment; Lower Chalk, Burham, Kent. The second specimen is shown from below, nat. size, in Pl. X. fig. 6, and displays the base of the pelvic fins ( $\left.p l_{\text {. }}\right)$.

Toulmin Smith Coll.

49914-15. Two small specimens, with incomplete head and tail; Burham. Presented by the Hon. Robert Marsham, 1877.

P. 1945, P. 1945,-a. Good specimen and two fragments; Burham. The third is shown, nat. size, in $\mathrm{Pl}$. X. fig. 5. Eyerton Coll.

49013. Remains of large fish, displaying eight rays in each pelvic fin, the foremost very stont but distinctly articulated distally ; probably from Burham. Mrs. Smith's Coll.

49014, 49049-51. Vertically-crushed small head and abdominal region, also three fragments; probably from Burham.

Mrs. Smithis Coll.

P. 5684. Two larger specimens; probably from Burham.

Hurford Coll.

P. 6534. Fragments; Blue Bell Hill, Burham.

Presented by S. J. Hawkins, Esq., 1891.

390\%5. Fragment; Kent.

Bowerbank Coll.

Genus AUI.OLEPIS, Agassiz.

[Poiss. Foss. vol. v. pt. ii. 1844, p. 109.]

Head and trunk not much laterally compressed, and abdomen flattened. Nandible a little prominent, and gape extending to hinder margin of orbit; maxilla much arched, with large supramaxillary bones; margin of the jaws with clusters of minute teeth. Vertebral centra not longer than deep, slightly constricted, and marked with small irregular longitudinal ridges; [probably between 40 and 50 in number]. No enlarged scale at the base of the paired fins; pectorals well on the side of the fish and the pelvic pair so far advanced that their basals almost reach the pectoral arch; anal fin small and remote; caudal fin forked, and its rays comparatively slender, with joints longer than broad, and subdivision only quite at the extremity. Scales large and stout, smooth 


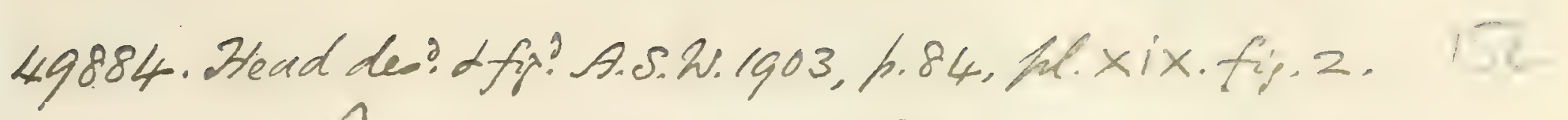

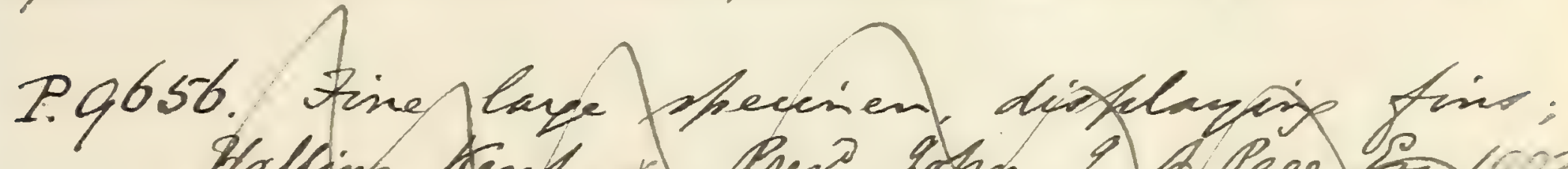

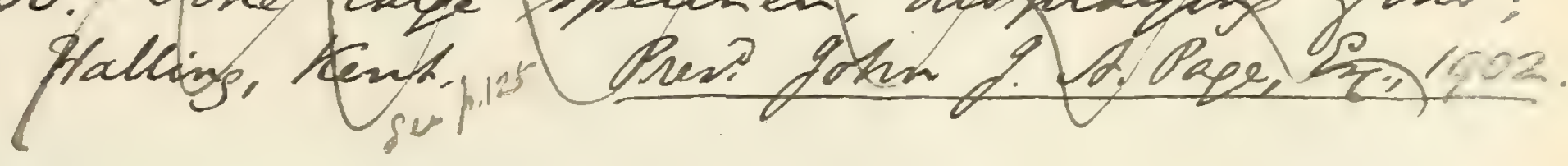
41689. Des? Lfig? A.S.W. 1903, h. 84, he. xvili.fig.7.

Ctenothrissa aignifer, O.P. Bay. Bull. Amen. Mus. M. H.

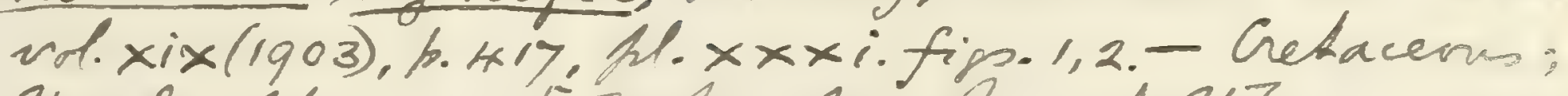
Hajula, Letranon. [Bish; Amer. Lus. N.th.] Pingza. Fist; Fajula.

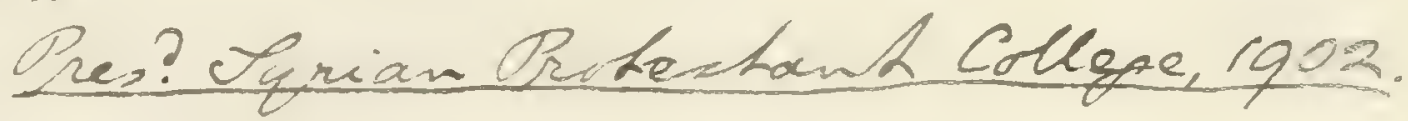




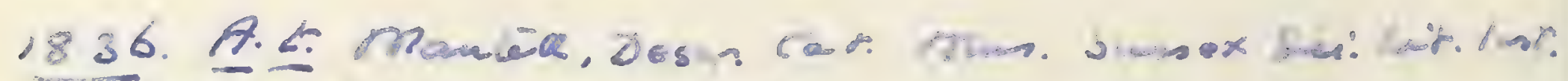

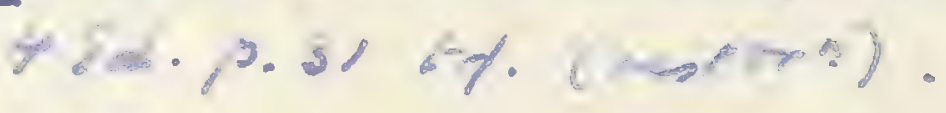

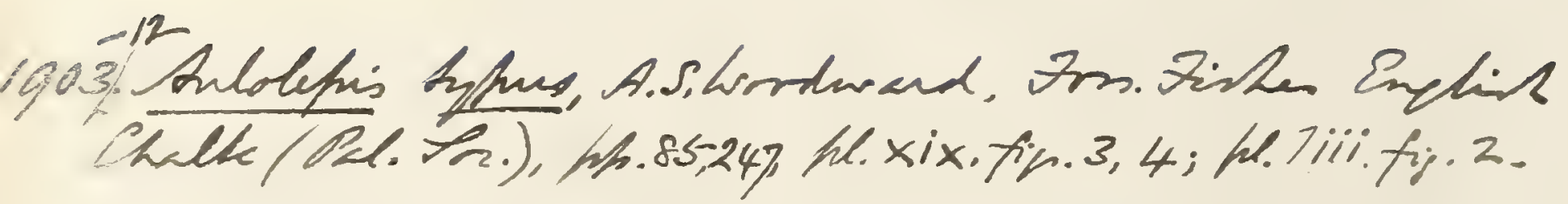

to33. Euthiced A.S.L.1903, 6.86.

49932. Ectoptemporid notiued A.S.W. 1903, 1.86. 


in their cxposed portion, marked with a few radiating grooves in their covered portion; hinder margin not pectinated; lateral line forming a conspicuous rounded ridge on the scales it traverses in the caudal region.

\section{Aulolepis typus, Agassiz. in Min. I}

1837-44. Aulolepis typus, L. Agassiz, Poiss. Foss. vol. v. pt. i. p. 14, pt. ii. p. 109, pl. lx $a$. figs. 5-8.

1888. Aulo'epis typus, A. S. Woodward, Proc. Geol. Assoc. rol. x. p. 324 .

1895. Aulolepis typus, A. S. Woodward, Proc. Zool. Soc. 1894, p. 660 (in part), pl. xliii. figs. 4, 6 (non figs. 2, 3, 5).

- 1900. Aulolepis typus, A. S. Woodward, Ann. Mag. Nat. Hist. [7] vol. v. p. 324, pl, ix. fig. 2.

Type. Imperfect fish; British Museum.

The type species, attaining a length of about 0.2. Length of head with opercular apparatus equalling about half that of the trunk from the pectoral arch to the base of the caudal fin. Length of the cranium somewhat less than the distance between the occiput and the origin of the dorsal fin; anal fin considerably nearer to the caudal than to the pelvic pair. Each ridge on the candal scales produced by the lateral line, smooth and widest in front.

Form. \& Loc. Turonian: Sussex, Kent, and Surrey.

4033. Type specimen; probably from Lower Chalk, Lewes. The right pelvic fin is shown and mistaken for the pectoral by Agassiz, whose figure is inaccurate in several respects. In this the mandibular ramus is restored, and the ridges of the lateral line are represented too far forwards; the indications of the pelvic and anal fins are hypothetically added; while the caudal vertebral centra are considerably too long as represented.

Mantell Coll.

P. 4247. Imperfect head and scattered remains of the trunk in sideview, with traces of the anal fin: probably the Earl of Enniskillen's fossil noticed by Agassiz and the basis for his statement that the pelvic fins "ont leur insertion à-peu-près à la moitié du corps"; (?) Burham. The head and preoperculum are figured loc. cit. 1894, pl. xliii. fig. 4 . Enniskillen Coll.

47932. Fine large fish in counterpart, much crushed and distorted, exhibiting nearly 30 of the vertebræ, the expanded hrmal spines at the base of the caudal fin, portions of this fin 
and the anal, also remains of the pectoral and pelvic arches as shown loc. cit. 1894, pl. xliii. fig. 6 ; Burham.

Presented by the Hon. Robert Marsham, 1877.

36097. Scattered remains of small specimen, including vertebræ and characteristic hinder scales of lateral line; Lower Chalk, Dorking, Surrey.

Purchased, 1861.

\section{Family CLUPEID Æ.}

Supraoccipital bone separating the small parietals in the median line: squamosal reduced, separated from parietals, and fused with pterotic; a basicranial canal; snout not produced; cheek-plates reduced. Premaxilla small and maxilla relatively large and loose, both these bones entering the upper border of the mouth; usually two supramaxillaries; teeth acuminate, but usually feeble, sometimes absent. Opercular apparatus complete, but few branchiostegal rays and no gular plate. Vertebral centra well ossified, some with very short transverse processes; ribs nearly or completely encircling the abdominal carity; hæmal arches not much fused at the base of the tail. Intermuscular bones numerous. Fin-fulcra absent. Post-temporal bones in contact with postero-lateral angles of cranium; post-claricular plate overlapping the clavicle. Dorsal fin small, nearly median, without adipose dorsal; anal fin variable in extent. Scales thin and deeply imbricating. In recent forms:pseudobranchiæ present; a large air-bladder; pyloric appendages numerous; oriducts complete.

Synopsis of Genera represented by Extinct Species.

I. Ventral ridge-scales absent.

A. Scales pectinated.

Paired fins small, the pelvic pair opposed to the dorsal .......... Pseudobery $x$ (p. 129).

B. Scales smooth and cycloid.

Naxilla rather short and arched, with small teeth; paired fins large ..

Maxilia very long and slender'; teeth rudimentary or absent; paired tins small ................... Engraulis (p. 133).

Mouth small; fins small............ Halec psis (p. 133).

II. Ventral ridge-scales present.

A few finlets behind the anal fin; no dorsal ridge-scales ...........

No firlets; dorsal ridge-scales between occiput and c.orsal fin ......... Diplomystus (p. 139):

No finlets; no dorsal ridge-scales.... Clupea (p. 146). 


36097. Teales of lateral livie dex? A fi? A.S.h. 1903, f.87, 21. xix. fip. 4.

49883. Clavicular a wh nthiced A.S.h. 1903, 1.8\%

Toales of Ctenothrissidde, to., in chalte flint

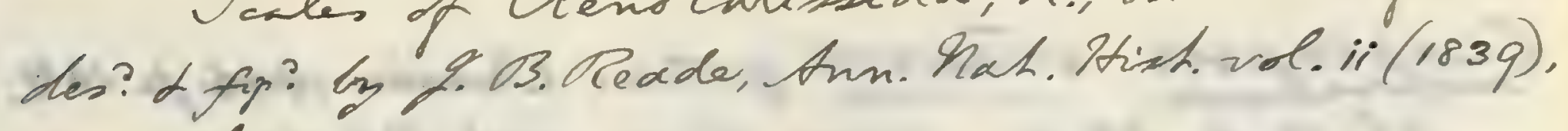
p.191, fll viii.

STOMATTIOE

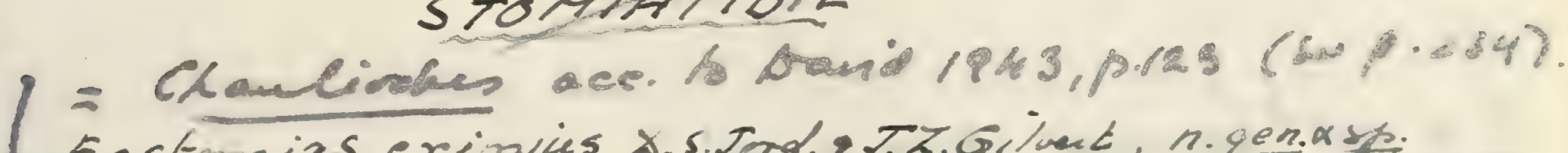

Eostomias eximius X.s. Jnd. TR.Giluet, n.genasp. stanf. Unir. Sool, Unir. Ser, Biok. Sci. vol. iv. (1925) 10. 13,

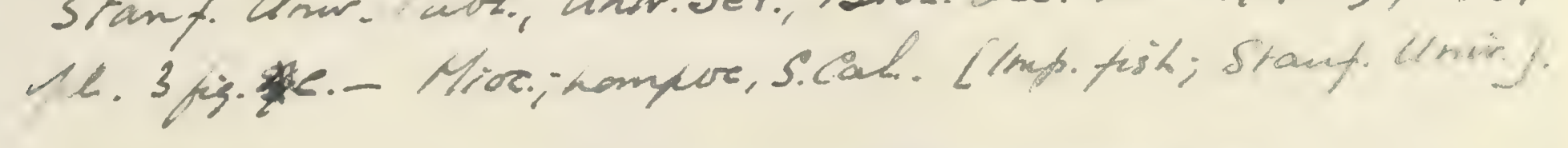

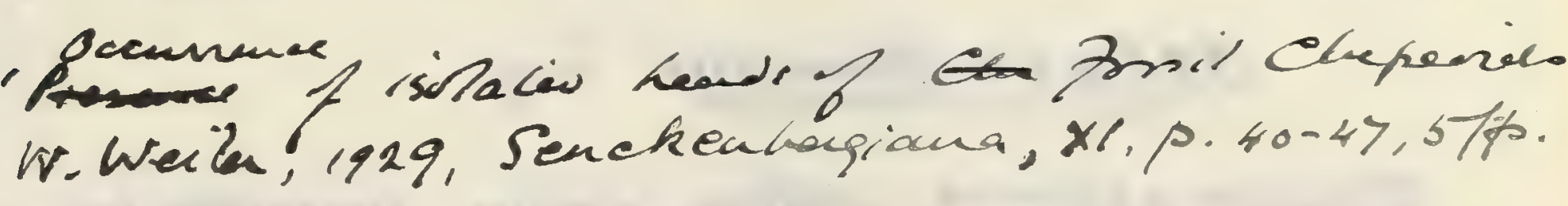

Eobution f Tlasseoides from Leptolepis

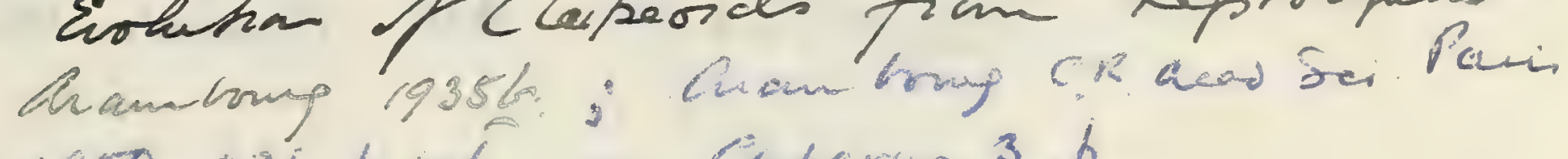
$195023 i$ p 4ib 2u Cimparms 3 f

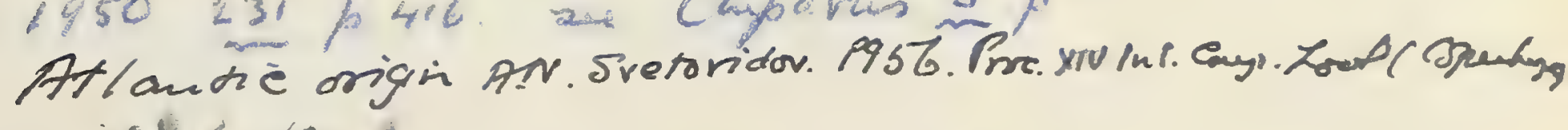
corityl $118-$

Messelpea, g.n. M. Sinmehongunonis.d. I

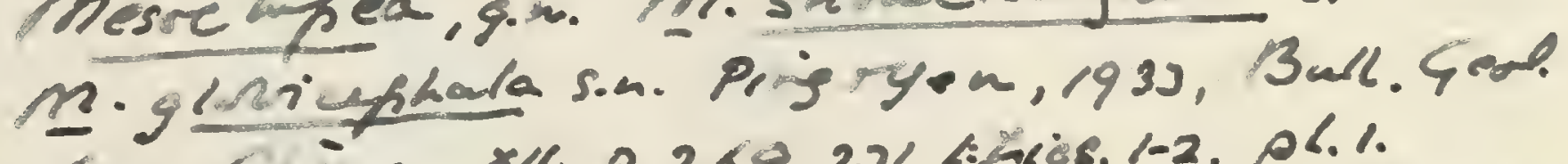
s.r. Clina X11. 0.269, 271, tifigs. 1-2, pl.1.

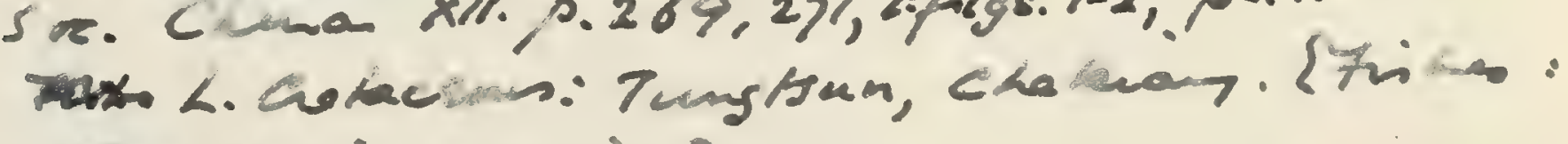

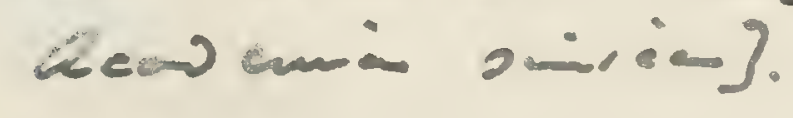


Palaevelupea dakotaensis g S.A. M. Hante,

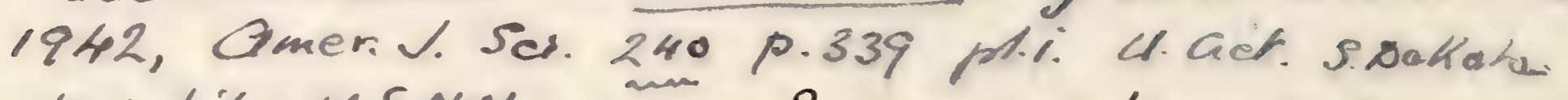
Imp.fín U.S.N.M.

= Palycorafir berycinis p.307

Clupeopsis sträleni G.JJn. Casein 1946.p.124, pe. ir. Y.16. Yhes. Bef. Zst.M.R.NAB.

P. F Rasmo isto6 p.74.

Ostariostomidae a.t.

ostariostoma wilseyi g.rs.n. Livingston form. (4. Get. on Palevene) montane. B.Scharffer, 19he, am. Mus.Nov. 1427 p.3,2 tfs. Fish: Prunceton uns 



\section{Genus PSEUDOBERYX, Pictet \& Humbert.}

[Nouv. Rech. Poiss. Foss. Mt. Liban, 1866, p. 32. ]

Head large, trunk deeply fusiform and laterally compressed. Maxilla robust and arched, with two large supramaxillary bones; mandible a little prominent, and gape not extending behind the middle of the large orbit; teeth minute. Preoperculum only slightly expanded; operculum and suboperculum deep and narrow. Vertebræ approximately 30 in number, half being caudal. Paired fins small, the pelvic pair inserted opposite the dorsal, which is short-based and nearly median; anal fin smaller than the dorsal; caudal fin deeply forked. Scales pectinated, large and regularly arranged, none enlarged or thickened, and no ventral ridge-scales; lateral line conspicuous.

Pseudoberyx syriacus, Pictet \& Humbert.

1866. Pseudoberyx syricacus, Pictet \& Humbert, Nouv. Rech. Poiss. Foss. Mt. Liban, p. 33, pl, ii. figs. 4-6.

1887. Pseudoberyx syriacus, J. W. Davis, Trans. Roy. Dublin Soc. [2] vol. iii. p. 509, pl. xix. fig. 3.

1887. Pseudobery. bottce, J. W. Davis, ibid. p. 633, pl. xix. fig. 4 (errore).

Type. Nearly complete fish; Geneva Museum.

The type species, attaining a length of about 0.08 . Length of head with opercular apparatus less than the maximum depth of the trunk, and contained twice in the length from the pectoral arch to the base of the caudal fin. Pelvic fins each comprising about 6 rays and inserted opposite the origin of the dorsal, which is about as long as deep, with 10 or 12 rays, occupying the middle third of the back; the small anal fin well behind the dorsal, with 6 or 8 comparatively short rays. Scales with deep posterior pectinations and arranged in about 30 transverse series; each principal transverse series of the flank comprising 8 or 9 scales.

No undoubted indications of spines have hitherto been observed in any of the fins of this species.

Form. \& Loc. Upper Cretaceous: Hakel, Mt. Lebanon.

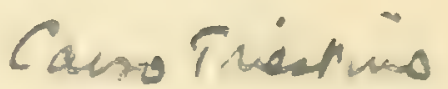

P. 8686. Fine large specimen, wanting the end of the snout.

Purchased, 1897.

P. 101. Smaller specimen figured by Daris, loc. cit. pl. xix. fig. 4, under the name of Pseudoberyx bottce.

Lewis Coll.

49569. Imperfect remains of large fish.

Lewis Coll.

PART IV. 
P. 868\%. Another imperfect large specimen. Purchased, 1897.

49495 P. 92. Two well-preserved fishes about 0.045 in length. Lewis Coll.

Pseudoberyx bottæ, Pictet \& Humbert.

1866. Pseudoberyx bottce, Pictet \& Humbert, Nouv. Rech. Poiss. Foss. Nt. Liban, p. 34, pl. ii. fig. 7 .

(?) 1887. Pseudoberyx bottce, J. W. Davis, Trans. Roy. Dublin Soc. [2] vol. iii. p. 510.

Type. Nearly complete fish; Geneva Museum.

A species about as large as the type, similarly ornamented and with similar scales and fins, but with less deepened trunk. Length of head with opercular apparatus exceeding the maximum depth of the trunk, and contained about twice in the length from the pectoral arch to the base of the caudal fin.

Form. \& Loc. Upper Cretaceous: Hakel, Mt. Lebanon. Carso Tweir.

P. 114. Imperfect specimen nearly 0.075 in length. Lewis Coll.

\section{Pseudoberyx grandis, Davis.}

1887. Pseudoberyx grandis, J. W. Davis, Trans. Roy. Dublin Soc. [2] vol. iii. p. 510, pl. xxviii. fig. 4.

Type. Nearly complete fish; British Museum.

A comparatively large species, known only by the unique type specimen. External ornamentation apparently feeble, and the pectination of the scales extremely delicate. Length of head with opercular apparatus about equal to the maximum depth of the trunk and contained one and a half times in the length from the pectoral arch to the base of the caudal fin. Fins as in the type species.

Form. \& Loc. Upper Cretaceous : Hakel, Mt. Lebanon.

P.4753. Type specimen $0 \cdot 17$ in length, described and figured by Davis, loc. cit. The frontal bones are finely sculptured behind. The pelvic fins are crushed together, thus giving a false impression of the number of rays ; and there is no evidence of an anterior spine. The scales seem to be somewhat abraded, and most of those preserved have a smooth posterior border; but a few behind the pelvic fins seem to exhibit traces of an original very fine pectination. 


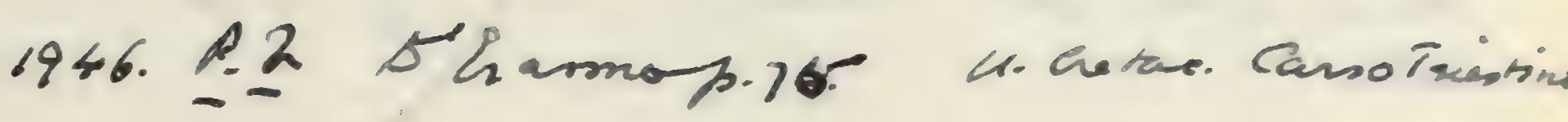

Peudrberyx? sp., F Priem, in I. de Inrean, Délégation en Perse. - Am. d'thish. Sat. rol. i (1908), p.7. hl.i.fies. 7,8.-U. Cretacerm; Persia. Comperfut firt. 


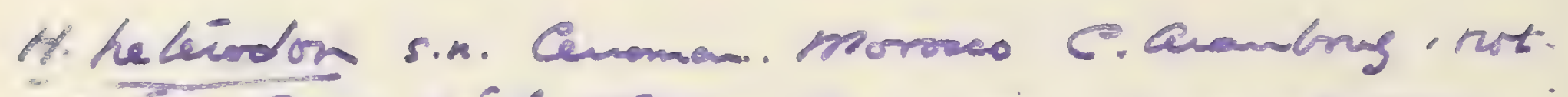

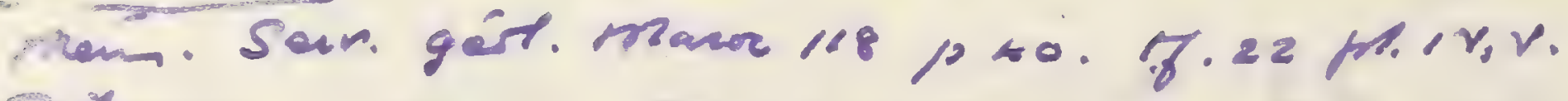
Bast.

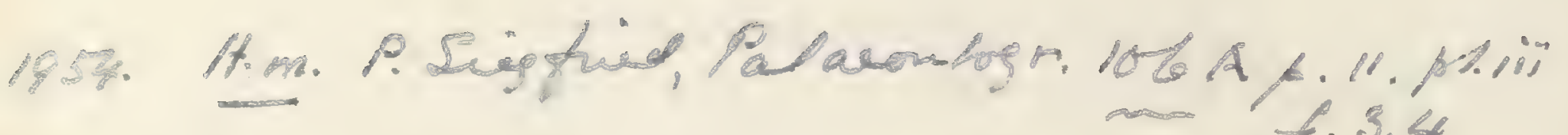




\section{Genus HISTIOTHRISSA, novum.}

Head and trunk laterally compressed. Cleft of mouth extending to the hinder border of the orbit; maxilla robust and arched, with two large supramaxillary bones; margin of jaws with regular series of very small pointed teeth. Branchiostegal rays about 12 in number. Gill-rakers very large. Vertebræ between 40 and 50 in number, about 20 being caudal; the centra about as long as deep, all constricted and marked with small longitudinal ridges. Fins relatively large, but no rays excessively elongated; postclavicular plates slightly dilated and smooth ; foremost ray of paired fins articulated, but not divided, and length of pectoral fin at least equal to the space between the origin of the pectoral and pelvic fins; dorsal fin deeper than long; anal fin longer than deep, and less elevated than the dorsal fin; caudal fin forked. Scales of moderate size, very deeply overlapping, none pectinated; no enlarged or thickened ridge-scales; lateral line inconspicuous.

Histiothrissa macrodactyla (W. von der Marck).

1858. Sardinues macrodactylus, W. von der Marck, Zeitschr. deutsch. geol. Ges. vol. x. p. 245.

1863. Sardinius macrodactylus, W. von der Marck, Palæontogr. vol. xi. p. 44, pl. vi. fig. 1.

Type. Nearly complete fish; Academy of Münster.

The type species, attaining a length of about 0.25. Length of head with opercular apparatus considerably exceeding the maximum depth of the trunk and contained twice in the length from the pectoral arch to the base of the caudal fin. Pectoral fins with 17 rays, the length of the foremost rery slightly exceeding the maximum depth of the trunk; pelric fins with 10 rays, two thirds as large as the pectorals, and opposed to the middle of the dorsal; dorsal fin with about 17 rays, the foremost two short and spinous, the next ray longest and articulated though not divided distally, arising about twice as far from the caudal fin as from the occiput; anal fin with 18 rays, the foremost three as in the dorsal, arising midway between the pelvic pair and the caudal.

The so-called Sardinius robustus (W. von der Marck, Palæontogr. vol. xv. 1868, p. 284, pl. xlii. fig. 2, and vol. xxxi. 1885, p. 254, pl. xxiii. fig. 1) is scarcely distinguishable from this species.

Form. \& Loc. Upper Cretaceous: Westphalia.

P. 2104. Finely preserved specimen about 0.23 in length; Sendenhorst. The mouth is opened by crushing, and there are 
traces of the characteristic teeth both on the maxilla and on the dentary. A patch of granulations is observed on the oral face of the entopterygoid. Several of the head and opercular bones are shown in impression: there is also an impression of the expanded postclavicular plate. All the fins are preserved, only the anal being damaged by a fracture across the fossil.

Egerton Coll.

P. 2104 a. Fine smaller specimen displaying the jaws and branchiostegal rays; Sendenhorst.

Egerton Coll.

P. 3819. More imperfect specimen, displaying the large gill-rakers in impression; Sendenhorst.

Enniskillen Coll.

43009. Fish wanting the greater part of the head and caudal fin; Sendenhorst.

Purchased, 1871.

P. 3819 a. Crushed remains of large fish ; Sendenhorst.

Enniskillen Coll.

Histiothrissa crassapinna (Davis).

1887. Osmeroides megapterus, J. W. Davis (errore), Trans. Roy. Dublin Soc. [2] vol. iii. p. 557 (in part), pl. xxxii, fig. 4 (non fig. 6).

1887. Osmeroides minor, J. W. Davis, ibid. p. 569, pl. xxxii. fig. 2. [Distorted fish; Edinburgh Museum.]

1887. Sardinius crassapinna, J. W. Davis, ibid. p. 567, pl. xxxii. fig. 5. [Distorted fish ; Edinburgh Museum].

1898. Sardinius crassapinna, A. S. Woodward, Ann. Mag. Nat. Hist. [7] rol. ii. p. 406.

Type. Imperfect distorted fish; Geneva Museum.

A smaller fish than the type species, attaining a length of about $0 \cdot 13$, resembling $H$. macrodactyla in general proportions and the fins, but not yet sufficiently well known to be precisely defined. All the known specimens are considerably distorted.

Form. \& Loc. Upper Cretaceous: Sahel Alma, Mt. Lebanon.

47368, P. 9165-6\%. Four specimens elongated by distortion, displaying the characteristic jaws and fins. No. P.9166 is noticed in Ann. Mag. Nat. Hist. [7] rol. ii. (1898), p. 407.

Lewis Coll.

47380. More imperfect distorted fish.

Lewis Coll.

P. 9175-\%8. Four distorted specimens.

Lervis Coll.

49598. Small specimen.

Lewis Coll.

48081. Slab with this and other fishes.

Lewis Coll. 
Donticiptia:

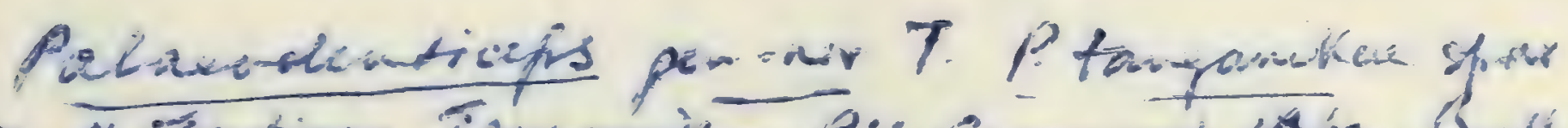

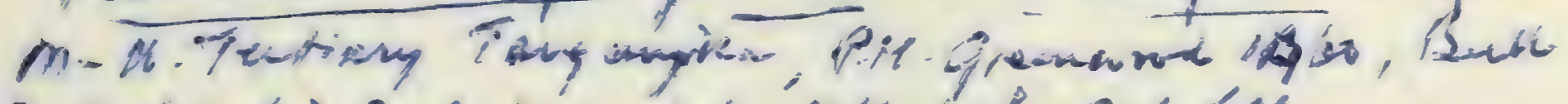

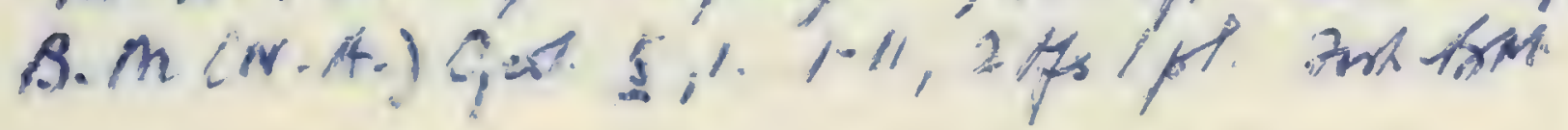




Genus EINGRAULIS, Curier.

[Règne Animal, vol. ii. 1817, p. 174.]

Head and trunk much laterally compressed, but ventral border not a sharp edge. Maxilla very long and slender, with two supramaxillary bones; suout prominent, and gape of mouth very wide; teeth rudimentary or absent. Branchiostegal rays 7 to 14 in number. Vertebræ from 40 to 50 in number. Dorsal and anal fins small, the former nearly median. Scales of moderate or large size, none pectinated; ventral ridge-scales small or absent; lateral line inconspicuous.

The following three extinct species of this genus are recognised on imperfect eridence, but none are represented in the Collection:-

Engraulis brevipinnis, J. J. Heckel, Sitzungsb.k. Akad. Wiss., math.-naturw. Cl. vol. xi. (1854), p. 129.-Lower Miocene; Chiavon, Vicentin. [Imperfect fish; Court Museum, Vienna.]

Engraulis evolans, L. Agassiz, Nenes Jahrb. 1835, p. 306, and Poiss. Foss. vol. จ. pt. ii. (1844), p. 121, pl. xxxrii. figs. 1, 2. Clupea evoluns, H. D. de Blainville, Nour. Dict. d'Hist. Nat. vol. xxvii. (1818), p. 344. Exocetus evolans, Siturus catus, and Exocetus exitiens, G. S. Tolta, Ittiolit. Veronese (1796), pp. cii, clxi, clxvi, pl. xxii. fig. 2, pl. xxxix. figs. 2, 5.-Upper Eocene; Ironte Bolca, near Terona. [Imperfect fish; Paris Museum of Natural History.]

Engraulis Tongipinnis, J. J. Heckel, loc. cit. 1854, p. 128.-Lower Miocene; Chiavon. [IImperfect fish; Court Museum, Vienna.]

\section{Genus HALECOPSIS, norum.}

[ex Agassiz, Poiss. Foss. vol. v. pt. ii. 1844, p. 139 (name only).]

An imperfectly known genus. Head and trunk laterally compressed, more so ventrally than dorsally, but the rentral border of the trunk not quite a sharp edge. Gape of mouth small: [teeth unknown]. Preperculum much expanded, with large lower limb. Paired fins small, the pelvic pair opposed to the median dorsal; anal fin relatively rery small. Scales of moderate or rather large size; none pectinated, but all marked with delicate radiating lines; no rentral ridge-scales; lateral line inconspicuous. 
Halecopsis insignis (Delvaux \& Ortlieb).

1844. Halecopsis lavis, L. Agassiz, Poiss. Foss. vol. v. pt. ii. p. 139 (name only).

1887. Osmeroides insignis, E. Delvaux \& J. Ortlieb, Ann. Soc. Géol. Belg. vol. xiv. Mém. p. 74, pl. iii. figs. 2-7, 10, 1 .

1888. Osmeroides insignis, E. Delvaux \& J. Ortlieb, Ann. Soc. Géol. Nord, vol. xv. p. 60, pls. i., ii.

Type. Imperfect fish; Delvaux Collection.

The type species, attaining a length of about $0 \cdot 3$. Lengtt of head with opercular apparatus contained about four and a half times, maximum depth of trunk five times in the total length of the fish to the base of the caudal fin. Extent of dorsal fin equalling about two thirds the depth of the trunk at its insertion; extent of anal fin only one third that of the dorsal.

Form. \& Loc. Lower Eocene: Chièvres, near Ath, Belgium (Ipresian Formation); London Basin (Loudon Clay).

43116, 43119. Two specimens displaying remains of the hinder portion of the head and part of the abdominal region, the second much the smaller; London Clay, Primrose Hill, London. The expanded preoperculum is shown in each, with traces of radiating branches from the slime-canal. In the large fossil the slime-canal is also shown with short branches on the postorbital cheek-plates. In the smaller fossil the upper aspect of the supraoccipital is exposed; and the frontal seems to extend downwards in a small plate on each side in front of the otic region.

Wetherell Coll.

41721. Imperfect head and auterior scales; London Clay, Sheppey. Toulmin Smith Coll.

28713 a. Branchial region with remains of vertebræ and scales; London Clay, Sheppey. Purchased, 18 53.

P. 174\%. Nine fragmentary specimens of head and scales; London Clay, Sheppey.

Egerton Coll.

P. 3845. Nine similar specimens; London Clay, Sheppey.

41409. Abraded specimen; Red Crag (derived from London Clay), Suffolk.

Purchased, 1869. 
1920. Halecopsir insignir, D. Bell, Am. Rep. Yorks. Bhil, Sor. 1919,h.7, fliii. fip. 1s:

160

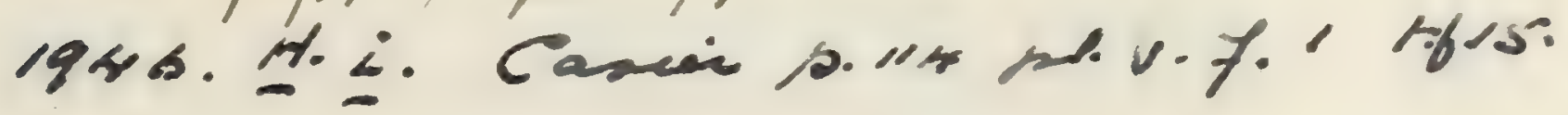




\section{Genus SCOMBROCLUPEA, Kner.}

[Sitzungsb. k. Akad. Wiss., math.-naturw. Cl. vol. xlviii. pt. 1863, p. 132.」

Head and trunk much laterally compressed, and abdomen compressed to an edge. Maxilla robust and arched, with two supramaxillary bones; mandible a little prominent, and gape not extending behind the anterior border of the orbit; teeth minute or absent. Preoperculum forming a great triangular expansion; operculum and suboperculum deep and narrow; branchiostegal rays about 10 in number. Vertebræ about 40 to 50 in number, the centra much constricted and strengthened with few longitudinal ridges. Clavicle bearing a large postclavicular plate above the pectoral fin. Paired fins small or of moderate size, the pectorals inserted above the rentral border, the pelvic pair opposite the dorsal; dorsal fin arising in front of the middle point of the back; anal fin not much extended, but followed behind by a few spaced fin-supports, each bearing one robust but closely articulated ray; caudal fin deeply forked; no fin-rays excessively elongated. Scales of moderate size, not pectinated, none thickened or enlarged on the ridge of the back, but a very stout series of ridge-scales, with lateral wings, extending along the ventral border between the pectoral arch and the origin of the anal fin; lateral line inconspicuous.

Scombroclupea macrophthalma (Heckel).

[Plate VI. fig. 1.]

1849. Clupea macrophthalma, J. J. Heckel, in Russegger's Reisen, vol. ii. pt. iii. p. 344 , pl. xxiii. fig. 2.

1863. Scombrochupea pinnulata, R. Kner, Sitzungsb. k. Akad. Wiss., math.-naturw. Cl. rol. xlviii. pt. i. p. 132, pl, ii., pl. iii. fig. 1. [Imperfect fishes; Unirersity of Vienna.]

1866. Scombrochepea macrophthalma, Pictet \& Humbert, Nouv. Rech. Poiss. Foss. NIt. Liban, p. 71, pl. ix.

1867. Scombrochupea pinnulata, R. Kner, loc. cit. vol. lvi. pt. i. p. 187, pl. i. fig. 2.

1882. Scombrochupea macrophthalma, F. Bassani, Denkschr. k. Akad. Wiss., math.-natur'w. Cl. vol. xlv. p. 225, pl. vii. figs. 7-13.

1886. Scombroclupea macrophthalma, D. G. Kramberger, Soc. Hist. Nat. Croatica, vol. i. p. 131.

1891. Scombrochupea macrophthalma, D. G. Kramberger, Rad Jugoslar. Akad. vol. cri. p. 65, pl. i. fig. 10 (preoperculum).

Type. Imperfect fish; olim Unger Collection, Gratz.

The type species, attaining a length of $0 \cdot 17$. Length of head 
with opercular apparatus contained somewhat more than three times, maximum depth of trunk about four times in the total length of the fish to the base of the caudal fin. Vertebræ about 40 in number, half being caudal. Pectoral fin with about 12 stout rays, articulated only quite at the extremity, and the length of the foremost equalling half the depth of the trunk at its insertion; pelvic fins about half as large as the pectorals, also with relatively stout rays, arising much nearer to the anal than to the pectorals and opposed to the anterior half of the dorsal; dorsal fin with 15 rass, slightly deeper than long, the distance between the occiput and its origin somewhat less than that between the caudal fin and its termination; anal fin arising a little in advance of the middle point between the pelvic and caudal fins, the total number of the rays being 13 , and the hinder 5 or 6 of these widely spaced along the ventral border almost to the base of the caudal. Ventral ridge-scales 25 in number, gradually diminishing in size behind the pelvic fins.

Form.\& Loc. Upper Cretaceous: MTt. Lebanon, Syria. Cretaceous: Istria; Isle of Lesina, Dalmatia.

P. $4 \% 4 \%$. Fine specimen displaying all the principal characters of the genus and species, shown of the natural size in Pl. VI. fig. 1 ; Hakel, Mt. Lebanon. The fish is exhibited in direct side-view, with the cheek and upper jaw crushed a little forwards. The form of the relatively small cranium is distinct, and the delicate parasphenoid is gently bent upwards at the anterior end of the otic region. Remains of the large pterygo-quadrate arcade occur beneath the cranium, the articular end of the quadrate $(q u$.$) for the support of the mandible being directly under$ the anterior margin of the orbit. The premaxillæ ( $p m x$. are shown, one being imperfect, the other only in impression; and these are proved to be longer than deep, though small compared with the maxillæ. One maxilla (apparently the left riewed from within) is especially well

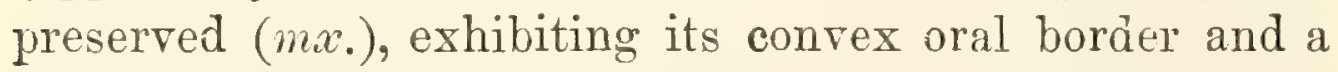
remarkably large anterior inwardly-directed process; but no teeth are distinctly seen, merely some fine transverse striations on the oral margin in its hinder half. Above the maxilla are remains of the two characteristic supramaxillary bones. The mandible $(d$.$) is remarkably short$ and deep, partly obscured by fragments of cheek-plates; searcely more than the anterior third of its upper margin can have entered the cleft of the mouth. Postero- 
A head with anterion vertetrae from the Boene of Wetea Pass, New Zealdnd, is very doubthlly referred to this species is F. Chapmar. New Zealand Ged. Sum., Daldent. Bull. no.7. 10.25. pl. viii.fig. 6.

Sron. Zeece, Itrely (D'Rasmo)- 

inferiorly the head is bordered by the great expanded preoperculum (p.op.), which has a thickened anterior margin and is nearly smooth, marked only very slightly by the delicate radiating branches of the slime-canal. The right ceratohyal (ch.) and hypohyal are crushed a little downwards, the former bearing nine branchiostegal rays $\left(b r_{.}\right)$, which are laminar in shape but contract to a point as they curve to their insertion. The operculum (op.) is imperfect, but clearly deep and narrow; the suboperculum is not recognizable. The vertebræ are all imperfect, but there are distinct indications of the slight longitudinal ridges by which the centra are strengthened. The ribs are as stout as in Clupea, and the neural spines in front of the dorsal fin are not fused with their respective arches. Intermuscular bones occur throughout the trunk both above and below the vertebral column. The clavicle and supraclaricle are shown to be slender; the postclavicle $($ s.op.) is relatively large. The rays of the paired fins are observed to be relatively as robust as those of the caudal; the rays of the dorsal fin are more slender. The detached anal fin-rays are distinct and shown to be very closely divided and articulated; their supports are connected with each other by a process extended along the ventral border of the tail. The squamation is well displayed in part, and the ventral ridge-scales appear to be destitute of serrations.

Lervis Coll.

49487, 4949\%. Two fine large specimens, slightly deepened by crushing; Hakel. The expanded postclavicular plate is distinct in both specimens. Many of the intermuscular bones in the caudal region are triradiate. Lewis Coll.

39240, -43. Two large distorted specimens; Hakel.

Purchased, 1865.

4815\%. Small slab with seattered remains of four indiriduals; Hakel. Lervis Coll.

P. 8678. Large slab exhibiting numerous distorted and fragmentary individuals associated with Diplomystus brevissimus; Hakel. Purchased, 1897.

49509. Another slab with distorted and fragmentary remains of this and other fishes; Hakel. Lewis Coll. 
Scombroclupea gaudryi (Pictet \& Humbert).

1866. Clupea gaudryi, Pictet \& Humbert, Nouv. Rech. Poiss. Foss. Mt. Liban, p. 60, pl. v. fig:s. 2-5.

(?) 1882. Clupea gaudryi, F. Bassani, Denkschr. k. Akad. Wiss., math.-naturw. Cl. vol. xlv. p. 223, pl. vii. figs. 1-4.

Type. Imperfect fish, with incomplete anal fin; Geneva Museum. A comparatively small and slender species. Length of head with opercular apparatus contained somewhat more than three times, maximum depth of trunk about five times in the total length of the fish to the base of the caudal fin. Vertebræ and fins apparently as in the type species.

Form. \& Loc. Upper Cretaceous: Hakel, Mt. Lebanon. (?) Cretaceous: Isle of Lesina, Dalmatia ${ }^{1}$.

49558-59. Two slabs, each with two specimens about 0.12 in length; Hakel. Lewis Coll.

39241. Similar fish wanting candal fin; Hakel. Lewis Coll.

47323. Distorted fish wanting caudal fin but displaying the characteristic anal fin with finlets.

Presented by Sir Richard Owen, K.C.B., 1874.

49503. Smaller, more imperfect distorted specimen, in counterpart, with incomplete and displaced anal fin. Lewis Coll.

The following imperfectly known species, not represented in the Collection, also probably belong to Scombrochupea:-

Clupea antiqua, F. J. Pictet, Foss. Terrain Néocom. Voirons (Paléont. Suisse, 1858), p. 31, pl. iv. figs. 7-13.Neocomian; Voirons, Switzerland. [Imperfect fish: ? Geneva Museum.]

Clupea lesinensis, D. G. Kramberger, Soc. Hist. Nat. Croatica, vol. i. (1886), p. 130, and Rad Jugoslav. Akad. vol. cri, (1891), p. 64, pl. i. fig. 9 (preoperculum).-Cretaceous ; Isle of Lesina, Dalmatia. [Imperfect fish; Geological Museum, University of Agram.]

Clupea voironensis, F. J. Pictet, op. cit. p. 37, pl. v. figs. 1-10.Neocomian; Voirons. [Imperfect fish; ? Geneva Museum.]

1 The specimens from Mrzlec and Comen referred to this species by Kramberger (Djela Jugoslav. Akad. vol. xvi. 1895, p. 37, pl. viii. figs. 3, 4) are too imperfect for certain determination. 


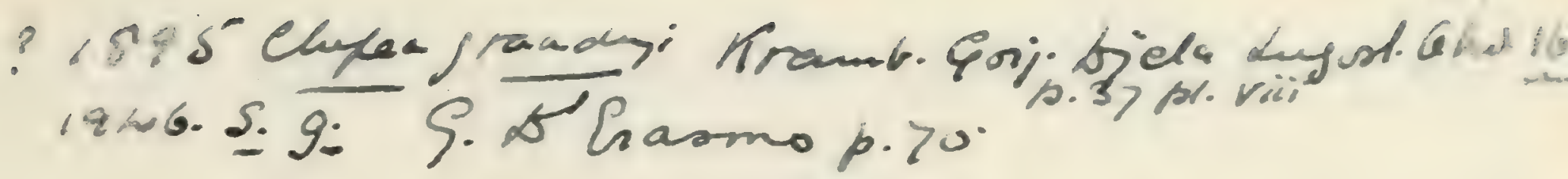

Scombrochpeides scutata, (A.S.Liordu.)

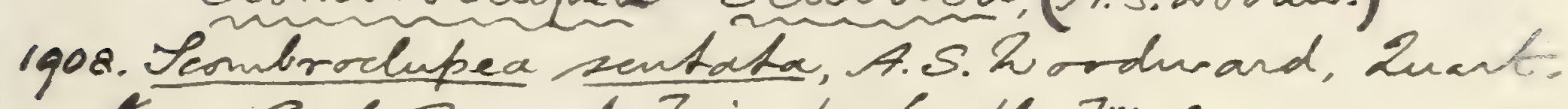
Lom. Ged.-Sor. vol. Txiv. h. 360, hl. xTiii. fiv. 3,4.

Tyke Inperfut firh: Britith Lusem.

In. \& Zor. Zower Getaceons: Slhéos, Bahid, Bnsigh.

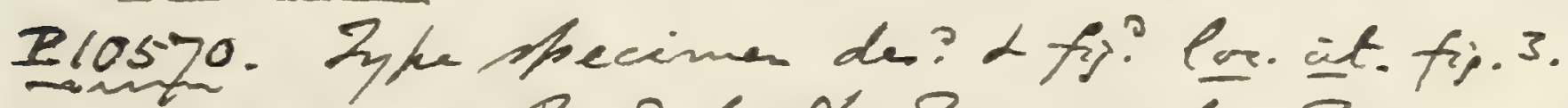

pres? ly Or. Enmee de Souza, 1907.

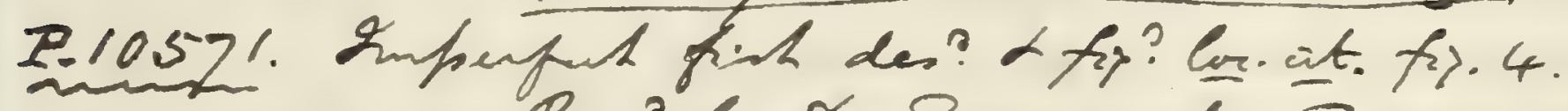

Pres? ly Ar. Enver de Soura, 1907.

1910. Scombradufiea sentata, 2. O. Fordaw, Am. Carnepie

inus. ade vii. p.32.

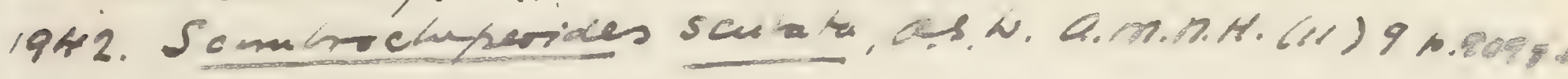




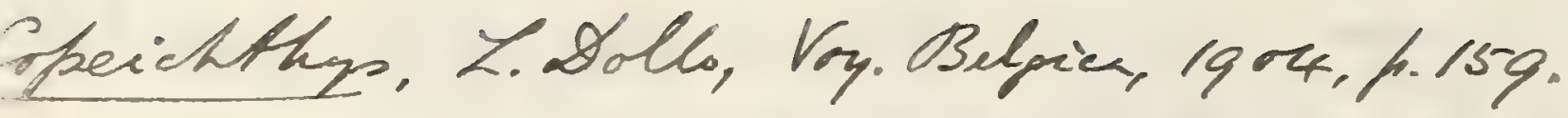

Imiphtia, D. S. Fidan, Bull. deht. Ged. Unir. Calif. wrl. $v, 1907,13.136$.

Ellimma, D. Lo Fordan, Dron. Buol. Sor Lachingto. rod. $\times \times v i(1913), B_{0}=$ Ellipes, Gordan(mon Senddin). An. Cannegie hur. vol. vii(1910), p.24.

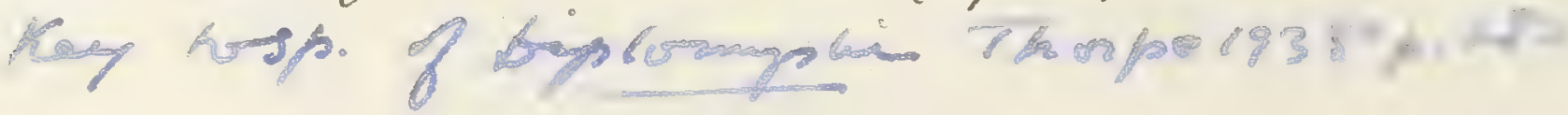

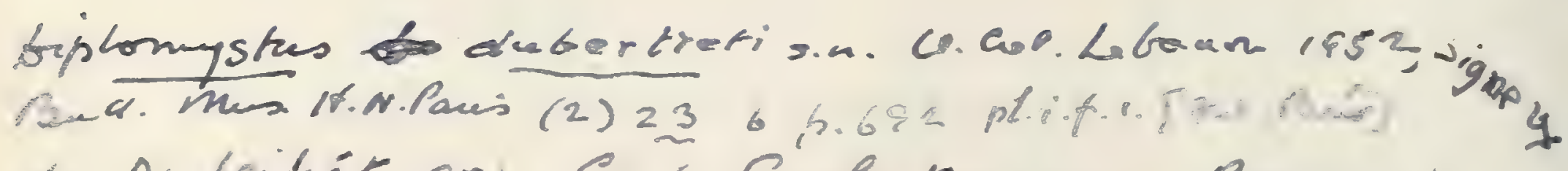

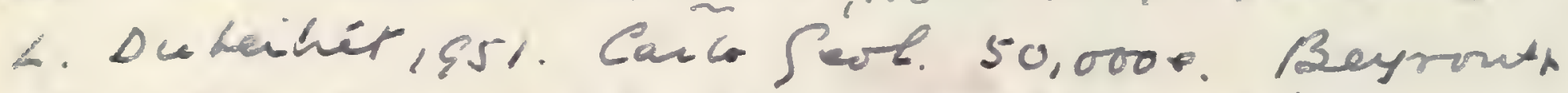
Dob. Hapt. Din. Tav. put. Reg. Lution. plix.

903. Siplonystur analior, L. Coulow, Bull. Sor. Śtude Su: - Nat. Elbenf, 2ht. year 1902, h. 154, tip.6.

gio. Siplomizhes dentahes, W. F. Holland, Am. cunegie mus. vol vii. p.24, ph. v, vi.

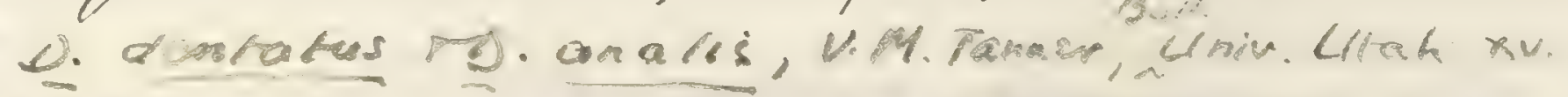

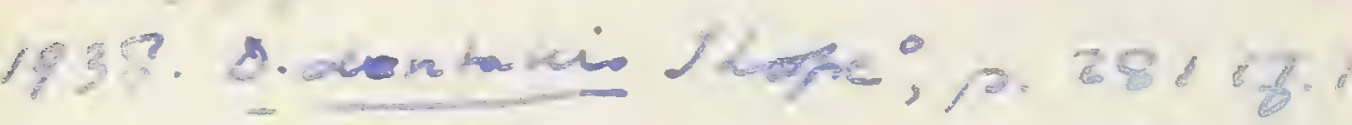

Q. anali $\quad 282.2$.

Didentatus - see gienus car.ol. 

. 


\section{Genus DIPLOIYSTUS, Cope.}

[Bull. U.S. Geol. Surv. Territ. rol. iii. 1877, p. 808.]

Syn. Histiurus, O. G. Costa, Atti Accad. Pontan. rol. v. 1850, p. 288.

Hyperlophus, J. D. Ogilby, Rec. Austral. Mus, vol. ii. 1892, p. 26.

Head and trunk much laterally compressed, and abdomen compressed to an edge. Maxilla robust and arched, with two supramaxillary bones; mandible a little prominent, and gape not extending behind the anterior border of the orbit; teeth minute or absent. Preoperculum only slightly expanded, operculum and suboperculum deep and narrow; branchiostegal rays about $10 \mathrm{in}$ number. Vertebræ from 34 to 46 in number, the centra much constricted and strengthened with few longitudinal ridges. Paired fins of moderate or small size, the pectorals inserted above the ventral border, the pelvic pair either in advance of the dorsal or opposite its most anterior rays; dorsal fin arising in front of the middle point of the back, nerer more but usually less extended than the anal, which is longer than deep; caudal fin deeply forked; no fin-rays excessively elongated. Scales small or of moderate size, not pectinated; a series of thickened ridge-scales, not produced into lateral wings, extending along the back between the occiput and the dorsal fin; a series of larger thickened ridge-scales, with lateral wings, similarly extending along the rentral border from the pectoral arch to the origin of the anal fin.

This genus is represented at the present day by species from the rivers of New South Wales and Chili.

\section{Diplomystus dentatus, Cope.}

1877. Diplomystus dentatus, E. D. Cope, Bull. U.S. Geol. Surr. Territ. rol. iii. p. 808.

1877. Diplomystus analis, E. D. Cope, ibid. p. 809. [Nearly complete fish.]

188t. Diplomystus dentatus, E. D. Cope, Vert. Tertiary Form. West, Book I. (Rep. U.S. Geol. Surv. Territ. vol. iii.), p. 74, pl. x. fig. 1. 1884. Diplomystus analis, E. D. Cope, ibid. p. 75, pl. vii. fig. 4, pl. viii. fig. 3, pl. x. fig. 2.

Type. Nearly complete fish; Amer. Kus hat. His.

The type species, attaining a length of about 0.5 , the caudal region comparatively slender but scarcely longer than the abdominal region. Length of head with opercular apparatus much less than the maximum depth of the abdominal region, which is contained about three times in the total length of the fish to the base of the caudal fin. Abdominal vertebræ about 18, caudals 23 in number. 
Each pectoral fin with about 12 rays, the longest not reaching the pelvic pair, which arises nearly midway between the pectorais and the anal, just in advance of the origin of the dorsal; dorsal fin deeper than long, with 11 or 12 rays, arising at the hinder end of the anterior third of the back; anal fin much extended, with 40 rays. Dorsal scutes about twice as broad as long, finely denticulated on the posterior border, and nearly 40 in number; ventral ridge-scales about 25 in number, not serrated, decreasing in size backwards.

The so-called Diplomystus theta (Cope, Toc. cit. 1877, p. 811, and 7oc. cit. 1884, p. 77 ; Clupea theta, Cope, Bull. U.S. Geol. Surv. Territ. no. 2, 1874, p. 51), founded on an imperfect specimen, may also belong to this species. Diplomystus pectorosus (Cope, loc. cit. $1877, \mathrm{p} .810$, and loc. cit. $1884, \mathrm{p} .76, \mathrm{pl}$. x. fig. 3) is also scarcely distinct.

Form. \& Loc. Eocene (Green River Shales): Wyoming.

P. 5230. Fine specimen 0.46 in length, displaying the median fins and remains of the paired fins; found 10 miles from Sillein, on the Oregon short line of railway, Wyoming. The jaws are crushed slightly forwards, the hroid arch a little downwards; the axial skeleton of the trunk is very well shown. Presented by Samuel Laing, Esq., 1887.

P. 7489-90. Two similar specimens, showing patches of minute stout conical teeth on some of the inuer bones of the mouth. Purchased, 1895.

P. 5218. Smaller fish 0.27 in length.

Presented by Lord Avehury, 1886.

P. 1860. Imperfect specimen $0 \cdot 18$ in length; labelled "Bear River, Idaho," but probably from the Green River Shales of Wyoming.

Egerton Coll.

P. 4928. Still smaller specimen displaying the ridge-scales.

Presented by R. Lydekker, Esq., 1885.

49166. Small fish about 0.105 in length.

Purchased, 1878

Diplomystus brevissimus (Blainville).

1818. Clupea brevissimus, H. D. de Blainville, Nouv. Dict. d'Hist. Nat. vol. xxvii. p. 364.

1859-44. Chupen brevissima, L. Agassiz, Poiss. Fuss. vol. v. pt.ii. p. 117, pl. lxi. figs. 6-9.

18.50. Chupea brerissima, F. J. Pictet, Poiss. Foss. Mit. Liban, p. 41, pl. viii. figs. 1,2 . 
Nk

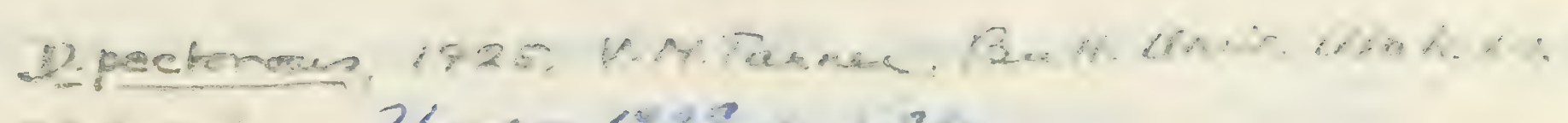

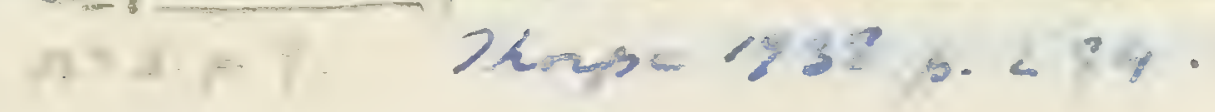


1915: Diplomystus Grevinimun, G.P'Snasmo, Paldeat. Ltalica, vol. $x \times$ i. to. 43 . pl. ir. fip. 3,4

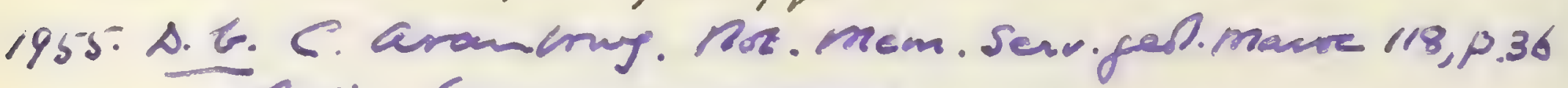
P. ii: Cenmen: menowe. 
1866. Clupea brevissima, Pictet \& Humbert, Nour. Rech. Poiss. Foss. Mt. Liban, p. 61, pl, vi.

(?) 1878. Chupea larteti, H. E. Sauvage, Bull. Soc. Géol. France, [3] vol. vi. p. 635, pl. xiii. fig. 3. [Distorted fish; Paris Museum of Natural History.]

1879. Clupea brevissima, F. Bassani, Verhandl, k.-k. geol. Reichsanst. p. 164.

1882. Chupea brerissima, F. Bassani, Denkschr. k. Akad. Wiss., math.naturw. Cl. rol, xlr. p. 219, pl. vii. figs. 5, 6, pl. viii. figs. 1-3.

1888. Diplomystus brevissimus, A. S. Woodward, Ann. Mag. Nat. Hist. [6] vol. ii. p. $13 \pm$.

Type. Nearly complete fish.

A small species, attaining a length of about 0.12 , the caudal region comparatively stout and slightly longer than the abdominal region. Dorsal region not much elerated. Length of head with opercular apparatus nearly equalling the maximum depth of the abdominal region, which is contained about two and a half times in the total length of the fish to the base of the caudal fin. Abdominal vertebræ 16, caudals 18 in number. Each pectoral fin with about 12 rays, the longest not reaching the pelvic pair, which arises nearly midway between the pectorals and the anal, opposite the origin of the dorsal; dorsal fin longer than deep, with 17 rays, occupying nearly the middle third of the back; anal fin much extended, with 29 rays, arising in advance of the hinder end of the dorsal. Dorsal scutes about twice as broad as long, with a longitudinal median keel; ventral ridge-scales about 25 in number, not serrated, decreasing in size backwards.

The fossilised examples of this fish are very variously distorted, and it is thus difficult to determine its precise form and proportions. The so-called Clupea larteti, Saurage, from Hakel, MLt. Lebanon, is probably a specimen elongated by distortion. It is stated by Saurage to have 38 vertebræ, but only 33 are shown in his figure of the type specimen.

Form. \& Loc. Upper Cretaceous: Hakel, MIt. Lebanon. Cretaceous : Comen, Istria; Isle of Lesina, Dalmatia.

49488-89, 49502. Three fine large specimens showing the dorsal scutes, the first noticed in Ann. Mag. Nat. Hist. [6] vol. ii. (1888), p. $134 . \quad$ Lewis Coll.

P. 9239. Mlore imperfect large specimen.

History unknown.

P. 402\%. Large specimen 0.12 in length, exhibiting small but stout conical teeth on an inner bone of the mouth. Lewis Coll.

P. 8683. Fish 0.11 in length, elongated by crushing. 
28398. Another imperfect fish 0.09 in length. Mantell Coll.

49490, 49499. Two smaller specimens deepened by distortion.

$$
\text { Lewis Coll. }
$$

P. 1861. Similar fish elongated by distortion, with 29 rays in the anal fin.

Egerton Coll.

47315-16. Tro specimens about 0.068 in length, the first in counterpart.

$$
\text { Presented by Sir Richard Owen, K.C.B., } 1874 .
$$

46397 , P. 103, P. 103. Three specimens about 0.058 in length.

Lewis Coll.

47316 d. Tery small fish 0.035 in length.

Piresented by Sir Richard Owen, K.C.B., 1874.

P. 121, P. 4784. Two large slabs exhibiting a shoal of these fishes. Lewis Coll.

47312. Smaller slab with a few fine specimens.

Piesented by Sir Richard Owen, K.C.B., 1874.

P. 9240. Slab with three specimens.

$$
\text { Presented by Lady Esther Stanhope. }
$$

25\%79. Another small slab with small specimens. Dixon Coll.

P. 9241. Slab with similar specimens. Enniskillen Coll.

P. 3825. Small slab with similar specimens, labelled by Beurard and Agassiz as being the type specimen of Clupea beurardi. H. D. de Blainrille, Nour. Dict. d'Hist. Nat, vol. xxrii. (1818), p. 365 ; noticed by Agassiz, Poiss. Foss. vol. จ. pt. ii. (18t4), p. 117. The fishes are typical D. brevissimus and do not agree either with Blainville's original description or with the specimen in the Régley Collection subsequently described by Agassiz (loc. cit. p. 117, pl. 1xi. fig. 2) as Clupea beurctrdi ${ }^{1}$.

Enniskillen Coll.

Diplomystus birdi, A. S. Woodward.

1895. Diplomystus biril, A. S. Woodward, Ann. Mag. Nat. Hist. [6] vol. xv. p. 3, pl. i. figs. $2-4$.

Type. Nearly complete fish; British Museum.

A small deep-bodied species attaining a length of about 0.06 , the

${ }^{1}$ Owing to the uncertain meaning of this specific name, it may best be suppressed. The present writer has never seen a specimen from Mit. Lebanon agreeing with the description given by Agassiz. 
. 
10. Slliper lonpicostatur, D. S. Gordan, Am. Camegie hnis. vol. vir p.29. pl. xi.

9. Slimmichthy longicostatur, D. P. Fordan, Zres. Fires T. Califormia (Shanford Umiv. Publi., Univ. Oer.). 1.27. [T. of Ellimmichthre.]

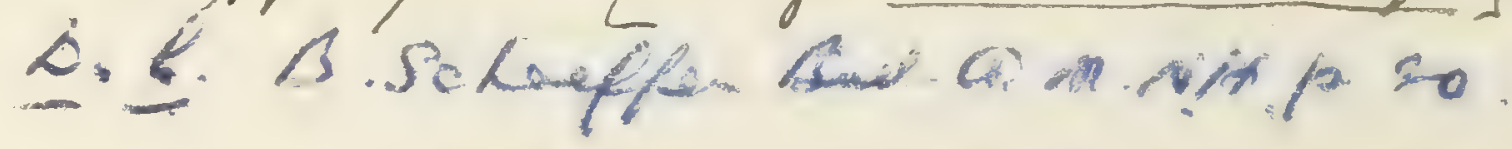


caudal region comparatively stout and slightly longer than the abdominal region. Dorsal region much elevated, the margin rising to the origin of the dorsal fin, where it is almost angularly bent. Length of head with opercular apparatus equalling about two thirds the maximum depth of the trunk, which is nearly or quite as great as its length from the pectoral arch to the base of the caudal fin. Abdominal vertebræ 14 to 16 , caudals 18 in number. Pectoral fins with rays sufficiently long to reach the pelvic pair, which arise opposite the origin of the dorsal; dorsal fin longer than deep, with about 17 rays, its extent equalling the distance from the occiput to its origin, but much exceeding that from the caudal fin to its hinder end; anal fin much extended, with 25 rass, arising in advance of the hinder end of the dorsal. Dorsal scutes about twice as broad as long, with a longitudinal median keel; ventral ridge-scales about 16 in number, not serrated, slightly increasing in size backwards.

Form. \& Loc. Upper Cretaceous : Hakel, Mt. Lebanon.

P. 96. Type specimen, figured loc. cit. pl. i. fig. 3. Lewis Coll.

P. 96 a. Smaller fish displaying the general form and proportions of the species, figured loc. cit. pl. i. fig. 4. Lewis Coll.

P. 83. Imperfect fish apparently shortened by crushing, figured loc. cit. pl. i. fig. 2.

Lewis Coll.

P. 84, P. 86, P. $8 \%$. Three more imperfect specimens shortened and deepened by crushing. The second displays the left pectoral fin, the third the broad dorsal scutes, which exhibit two or three posterior denticulations on each side in addition to the median point.

Lewis Coll.

\section{Diplomystus longicostatus, Cope.}

1886. Diplomystus longicostatus, E. D. Cope, Proc. Amer. Phil. Soc vol. xxiii. p. 3.

1895. Diplomystus longicostatus, A. S. Woodward, Ann. Mag. Nat. Hist. [6] vol. xv. p. 2, pl. i. fig. 1.

Type. Nearly complete fish; Cope Collection.

A deep-bodied species attaining a length of about $0 \cdot 13$, the caudal region comparatively small and slender, scarcely more than half as long as the abdominal region. Dorsal region much elevated, the margin rising to the origin of the dorsal fin. Length of head with opercular apparatus scarcely exceeding half the maximum depth of the trunk, which is nearly as great as its length from the pectoral arch to the base of the caudal fin. Abdominal vertebræ about 24 in number, caudal vertebræ not more than 12. Pectoral fins small; 
pelvic fins much smaller, these arising much nearer to the former than to the anal and opposed to the origin of the dorsal; dorsal fin with about 10 rays, occupying the middle fifth of the back; anal fin not much extended, with 8 rays, arising considerably behind the posterior end of the dorsal. Dorsal scutes broader than long, emarginate behind and thus heart-shaped; ventral ridge-scales comparatively small in adrance of the pelvic fins, but rapidly increasing in size backwards beyond it, the three hindermost scales relatively very large, but all smooth with only one sharp point and no serrations.

Form. \& Loc. Upper Cretaceous: Bahia, Brazil.

P. F109. Fine specimen described and figured by the present writer, 7oc. cit. p. 2, pl. i. fig. 1 ; from the beach between Itacaranha and Plataforma, near kilom. 7, Bahia and San Francisco Railway.

$$
\text { Presented by Joseph Mawson, Esq., } 1893 .
$$

P. 8256-58. Three specimens; near Itacaranha. Presented by Joseph Maruson, Esq., 1896.

P. 413. More fragmentary large specimen; near Itacaranha. Presented by Joseph Mawson, Esq., 1881.

P. 5530. Remains of small head and abdominal region, showing anterior ventral ridge-scales, noticed by the present writer in Ann. Мag. Nat. Hist. [6] vol. ii. (1888), p. 134; near Itacaranha. Presented by Joseph Mawson, Esq., 1881.

\section{KNIGHTIA Diplomystus humilis (-teidy).

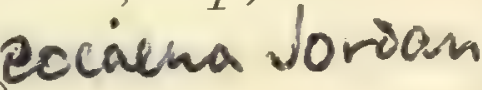

185̄6. Chupea humitis, J. Leidy, Proc. Acad. Nat. Sci. Philad. p. 256.

1870. Clupea pusilla, E. D. Cope, Proc. Amer. Phil. Soc. vol. xi.

p. 382 ; and Ann. Rep. U.S. Geol. Surv. Territ. p. 429.

-1873. Chrpea humitis, J. Leidy, Contrib. Ext. Vert. Fauna W. Territ. (Rep. U.S. Geol. Surv. Territ. vol. i. pt. i.), p. 195, pl. xvii. fig. 1.

1877. Diplomystus humilis, E. D. Cope, Bull. U.S. Geol. Surv. Territ. vol. iii. p. 811 .

1884. Diplomystus humilis, E. D. Cope, Vert. Tertiary Form. West, Book I. (Rep. U.S. Geol. Surv. Territ. vol. iii.), p. 77, pl. vi. fig. 3, pl. ix. fig. 8, pl. x. fig. 4 .

Type. Nearly complete fish; National Museum, Washington.

An elongated species attaining a length of about $0 \cdot 18$, the caudal region comparatively slender and much shorter than the abdominal region. Length of head with opercular apparatus slightly less than the maximum depth of the abdominal region, which equals nearly one third of the total length of the fish to the base of the caudal 

Huightia copei son. V.M. Tamner, 1925, Bullin.sx.

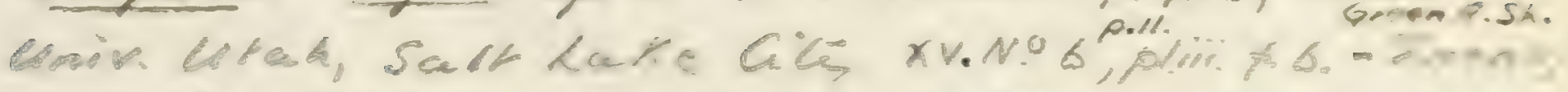

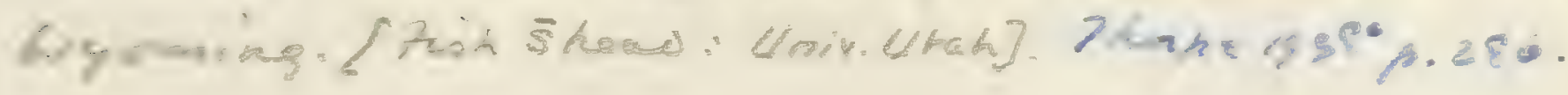

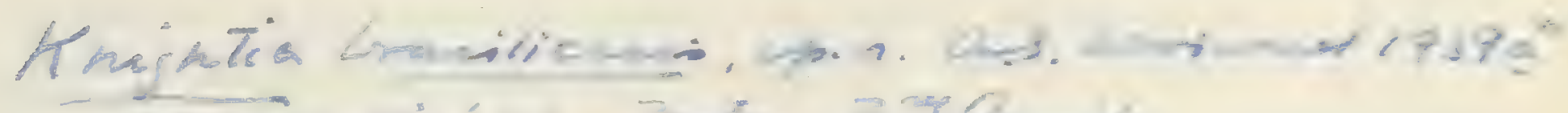

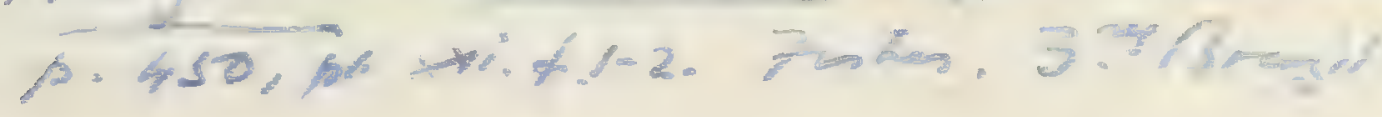

- (bsth humilis + posilla pre-ocupis inclupea $(p .150)$ ) 1997. Rmiphtia eraena, 2. S. Andan, Bull. OHWh. Geal

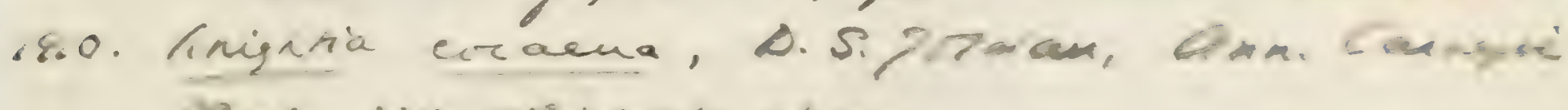

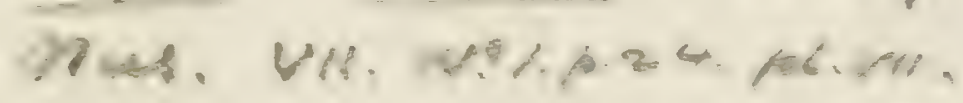

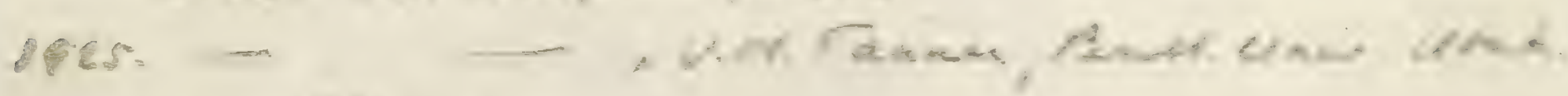

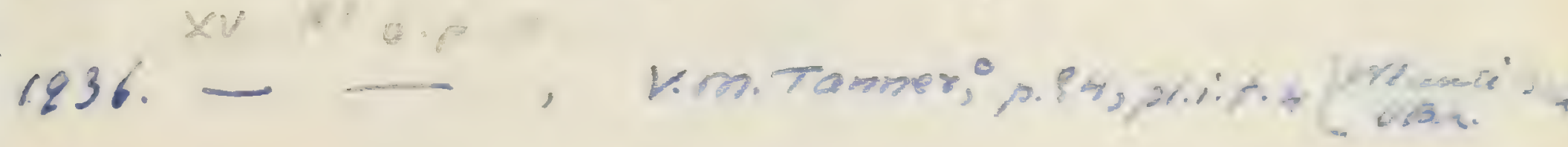


1907. Rniphtia alta, D.S. Gordan, lor.ash. 11.137.

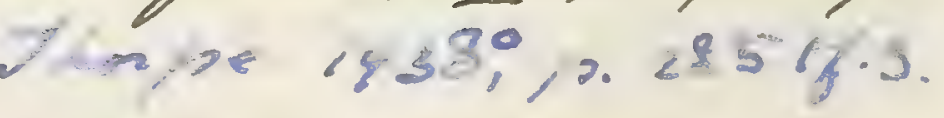


fin. Abdominal vertebræ about 23, caudals 13 to 15 in number. Paired fins small, the pelvic pair arising just behind the origin of the dorsal and midway between the pectorals and the anal; dorsal fin deeper than long, with about 12 rays, arising just before the hinder end of the anterior third of the back; anal fin not much extended, with 14 rays, arising far behind the dorsal, midway between the pelvic and caudal fins. Dorsal scutes narrow and longitudinally keeled, emarginate behind; ventral ridge-scales 20 to 25 in number, not increasing in size backwards, smooth and serrated, but each produced at its hinder inferior angle into a long spine.

Form. \& Loc. Eocene (Green River Shales): Wyoming.

P. 6185-86. Two large specimens $0 \cdot 18$ in length.

Purchased, 1890.

49168. Specimen $0 \cdot 13$ in length.

Purchased, 1878.

P. 1859. Fine specimen 0.105 in length, displaying some of the head-bones and the ventral ridge-scales. Egerton Coll.

P. 8693. Fractured specimen of the same size, with remains of the dorsal ridge-scales. Presented by Walter Crouch, Esq., 1894.

P. 4929. Well-preserved fish 0.09 in length.

Presented by R. Lydekker, Esq., 1885.

49167. Imperfect smaller fish, showing scales. Purchased, 1878.

P. 552\%. Small well-preserved fish 0.055 in length, showing both the dorsal and ventral ridge-scales. Purchased, 1888.

Diplomystus altus (Leidy).

1873. Clupea alta, J. Leidy, Contrib. Ext. Vert. Fauna W. Territ. (Rep. U.S. Geol. Surv. Territ. vol. i. pt. i.), p. 196, pl. xrii. fig. 2.

1877. Diplomystus altus, E. D. Cope, Bull. U.S. Geol. Surv. Territ. vol. iii. p. 811.

1884. Diplomystus altus, E. D. Cope, Vert. Tertiary Form. West, Book I. (Rep. U.S. Geol. Surv. Territ. vol. iii.), p. 79, pl. ix. figs. 9-11, pl. x. fig. 5.

Type. Nearly complete fish; National Museum, Washington.

A species almost identical with $D$. humilis, but exhibiting a deeper trunk, the maximum depth of the abdominal region slightly exceeding one third the total length of the fish to the base of the caudal fin.

Form. \& Loc. Eocene (Green River Shales): Wyoming.

P. 4846. Imperfect fish $0 \cdot 1$ in length.

Purchased, 1885. 


\section{Diplomystus vectensis (Newton).}

1889. Clupea vectensis, E. T. Newton, Quart. Journ. Geol. Soc. vol. xlv. p. 112, pl. iv.

1889. Diplomystus vectensis, A. S. Woodward, Geol. Mag. [3] vol. vi. p. 230 .

Type. Imperfect fish; G. W. Colenutt Collection, Ryde.

A small species, attaining a length of about 0.06 , the caudal region comparatively slender. Length of head with opercular apparatus slightly less than the maximum depth of the trunk and contained about four and a half times in the total length of the fish to the base of the caudal fin. Abdominal vertebræ about 25, caudals 15 in number. Dorsal fin deeper than long, with 14 or 15 rays; anal fin comparatively low and extended, with 16 or 17 rays. Dorsal scutes narrow; ventral ridge-scales 20 to 22 in number, not serrated, decreasing in size backwards.

Form. \& Loc. Lower Oligocene (Osborne Beds) : near Ryde, Isle of Wight.

P. 5930. Very small specimen; King's Quay, near Ryde. Presented by G. W. Colenutt, Esq., 1889.

P. 6853, -54. Small slab displaying small individuals, and several other specimens; King's Quay.

Presented by G. F. Harris, Esq-, 1893.

The imperfect specimens named as follows from the Upper Cretaceous of Pietraroja, Province of Benevento, Italy, also belong to Di.plomystus :-

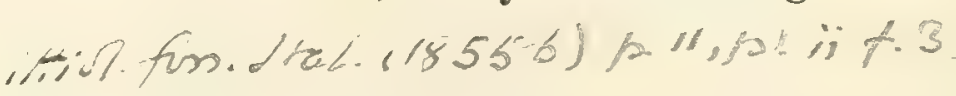

Histiurus elatus, O. G: Costa, Atti Accad. Pontan. vol. v. (1850), - p. 289, pl. vi. fig. 3, and ibid. vol. vii. (1853), p. 8, pl. i. fig. 2.

Histiurus serioloides, O. G. Costa, ibid. vol. viii. (1864), p. 60, pl. ix. fig. 3 .

Histiurus ventricosus, O. G. Costa, Atti R. Accad. Sci. Napoli, vol. ii. no. 21 (1865), p. 5, pl. ii. figs. 3-5.

The original specimens are in the Geological Museum, University of Naples.

Genus CLUPEA (Artedi), Linnæus.

[Syst. Nat. ed. 10, 1758, p. 317.]

Syn. Alosa, G. Cuvier, Règne Animal, ed. 2, vol. ii. 1829, p. 319.

Meletta, Cuvier \& Valenciennes, Hist. Nat. Poiss, vol. xx. 1847, p. 366.

Uropterina, P. Lioy, Atti Soc. Ital. Sci. Nat. vol. viii.1865, p. 413. Ptericephalina, P. Lioy, ibid. p. 414. 

Diblomysties marmarensis, A.S.W.

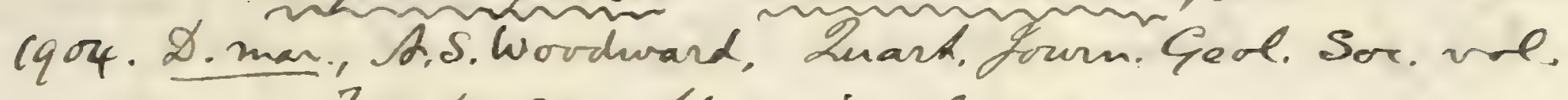
$7 x, h .284$, he. xxiv, fis, 28.

Iype. Imperfect fish; British Inuseum.

Irm. Ltor. Anircene (Tarmation): Gorpona Seré, near Tarkeni, tea of Inarmora. 1. Iope specin-

Puento in Col. Thomes Egehil, 1904.

Siplomystur 9oodi, C. Ne. Sastman, Arm. Carnepie grues. vol viii( (1912), h.375, hl.xxiii; xxiv.fig. 2. - Sarly Jestiary: Benito, shamish Guinea, Lr. Africa. Touperfert

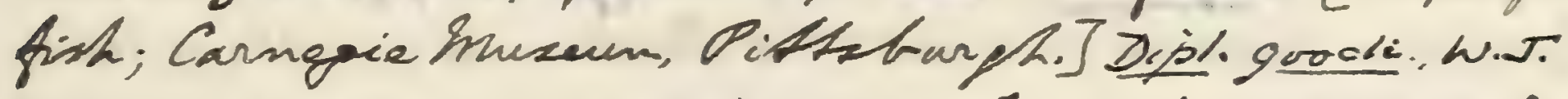

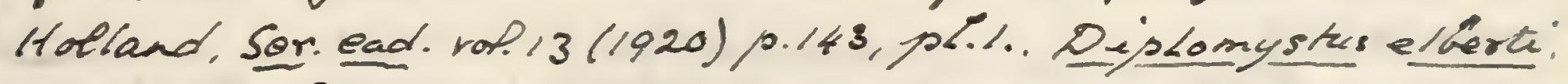

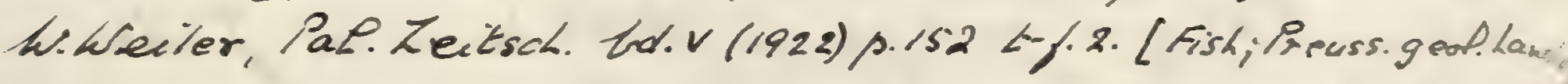

Pefurred to D. Grevinimus by G. X'Erasmo, Dalacont. Itadica, vol. $\times$ xi $(1915)$, b.4.3.

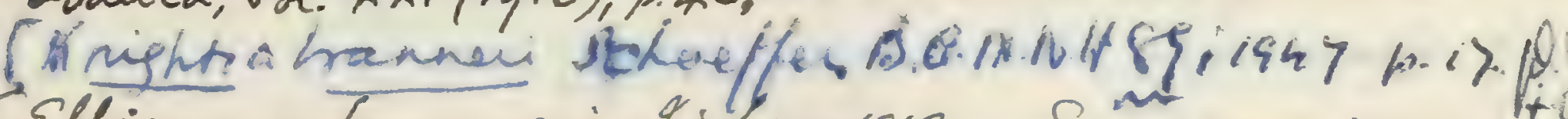
sllimma Grameni, Gordan, 19rq. Süner $\rightarrow$ Sllipe Gramneri. D. T. Fordan, Amm. Cannepie Muv. vol. viil(1910), b.25, hl, viii. fip. 3. - Blacte shale, Piacho Doce, Alagôar, Brazil. Comperfut fich: Carnegie hur., Riftslurght.] T. of Ellipes. slliper riacencir, D. T. Ford arv, Amm. Carnegie Mus. vol. viil(1910), p.28. pl.x. - Itid. [Ditt.]

See over $\rightarrow$

Liplompstur coverhamensir, F. Chatrman, hew Eealand Geol Surn, Paldeont. Bull. no. Y (1918), p.26, hl. vili.fis.4. - U. Cretaceons; Crver

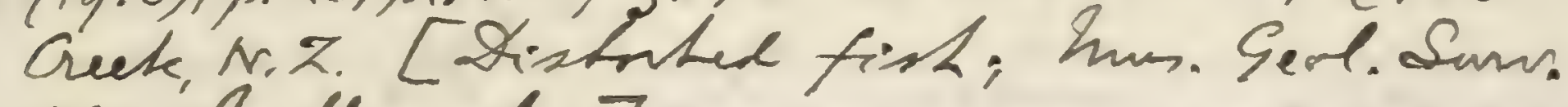
M.Z., Lietlingtm. I 
146 a ceneresp.

Ellikes, fordm, 1910 ( non Elliper, Seudder, 1902 ) Par, = Ellimma. Iodan, Prov. Birl. Sor. Wrast. $1913,6.79$.

'llimma elmodende, D.S. Gordan d F. Z. Gilkert. Frn. Firter M. California (Stangtod Univ.

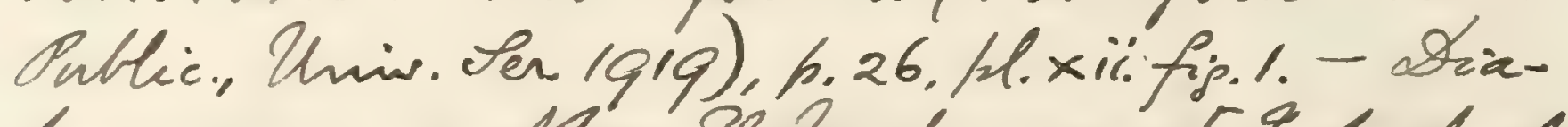
tomaceons eath; Se hurdena. [amperfork

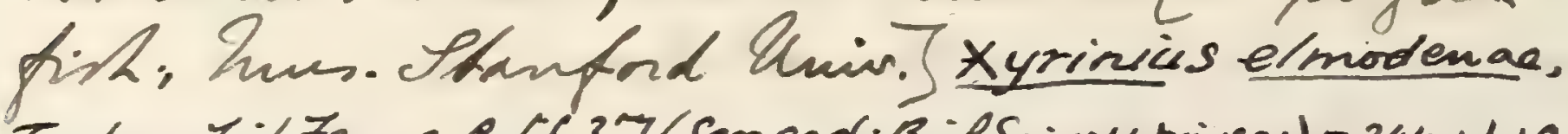

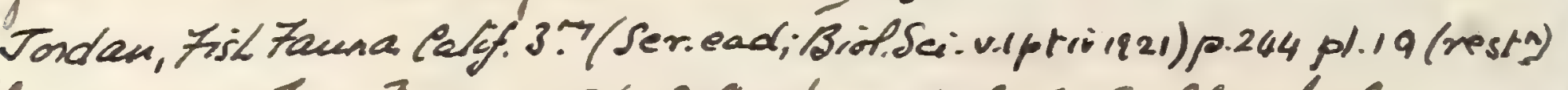
limma hartarde, 9. S. Gordaw a 2. Z. Gilherh, lo it. 1919. 6.2\%. Hl. ix. Fip. 3.- - hiocene; Carpinteria,

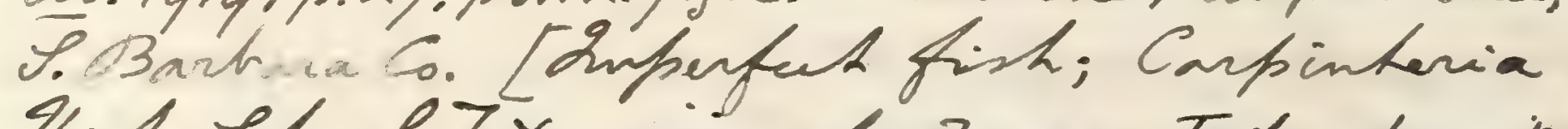

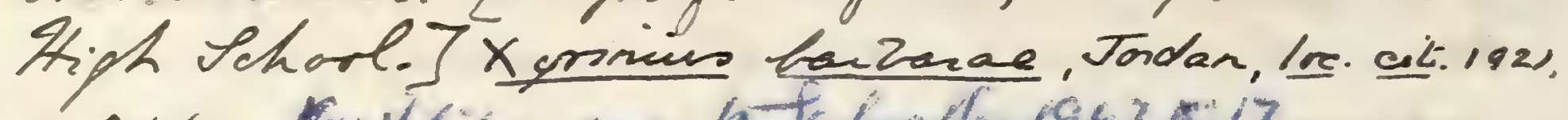

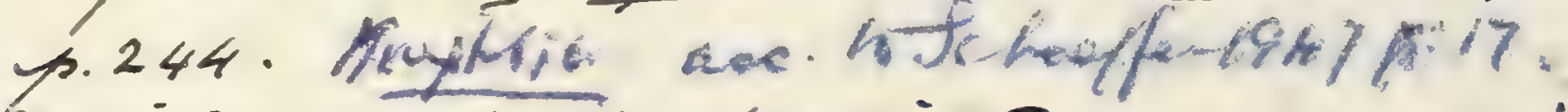
Yyosinim Loushi is a Lerrong Todan lor. at. $1921 . p .244$. see p.553.

perichthy morgani, F. Priem, in \%. de Moigan, gélégation en Perze, - Am.

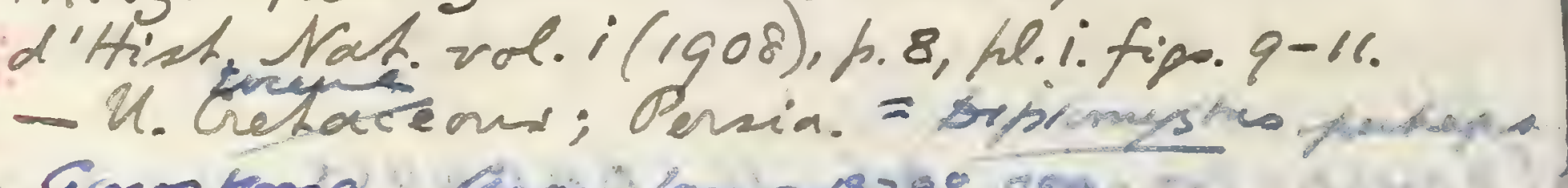
- Gorostomia, Acain laxige 1829;

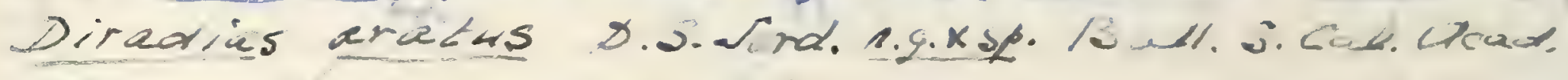

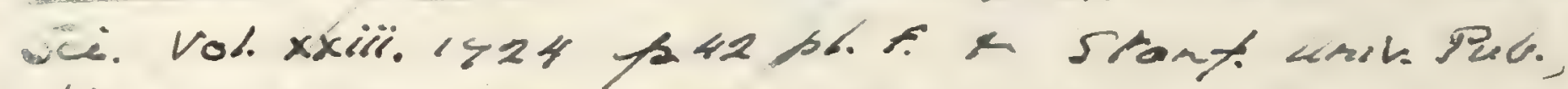

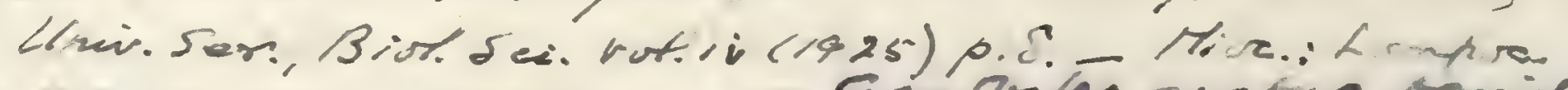

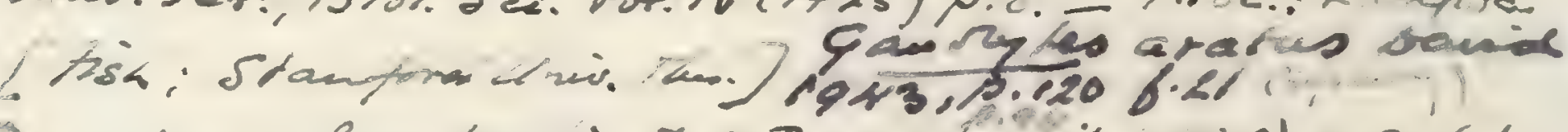

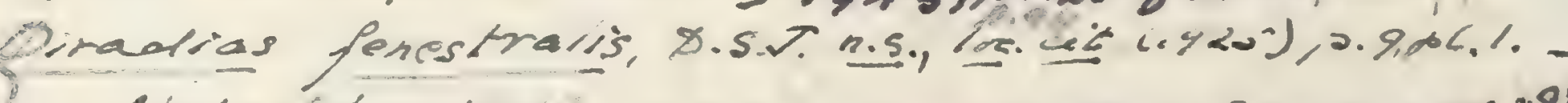

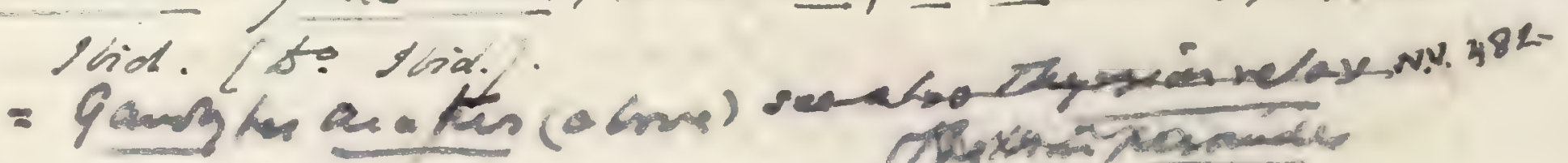

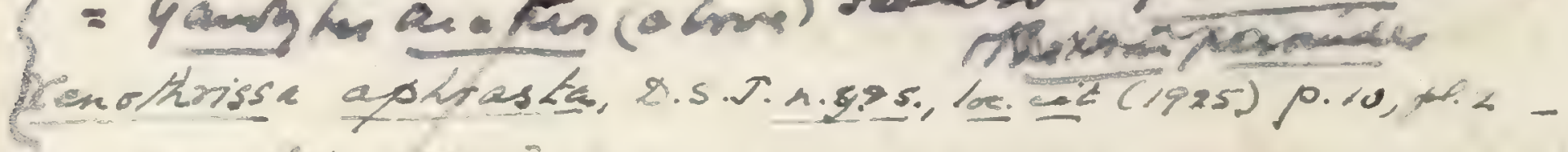
siat LFi onid?

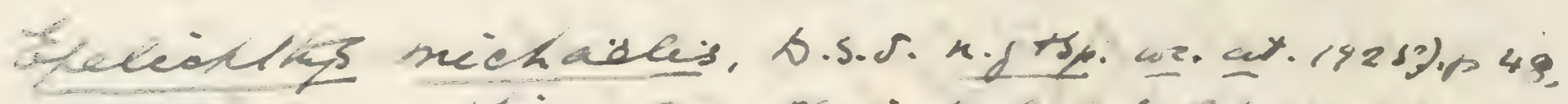

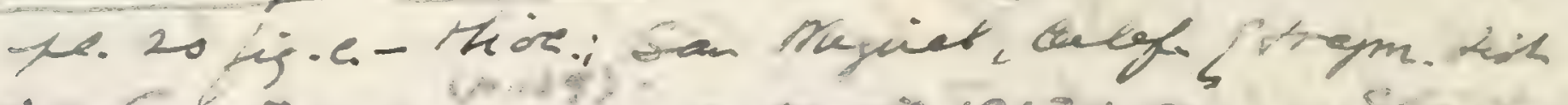
$x=$ Sainessu

$19436.82 \times$ 


Xyne, fordan d lillent. 1460

Hon. Fishes P.Califormia, 1919. h. 25.]

so clupea hat thicter enamelled scale, and stimger ventral scutes.

Xyne grex, Lous. ailh.

1919. Xine grex. D. F. Fordan d 2.2.Gilhert, Fon. Fi:he. S. Califormia (Stanfond Univ. Public., Univ. Ser.). h. 25. hl. ix. fip.l, hl, x. fip, 2, hl. xi. fien. 2, 3.

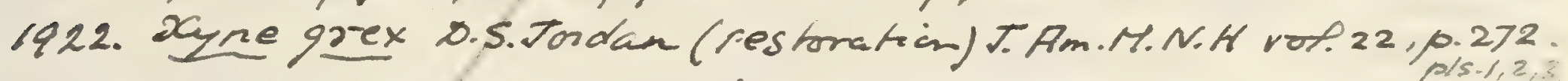

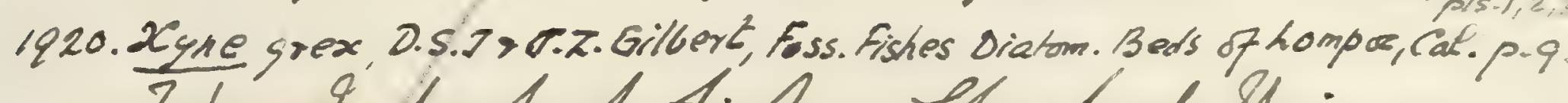
Jyke. Inperfut firts; Stanterd Univ.

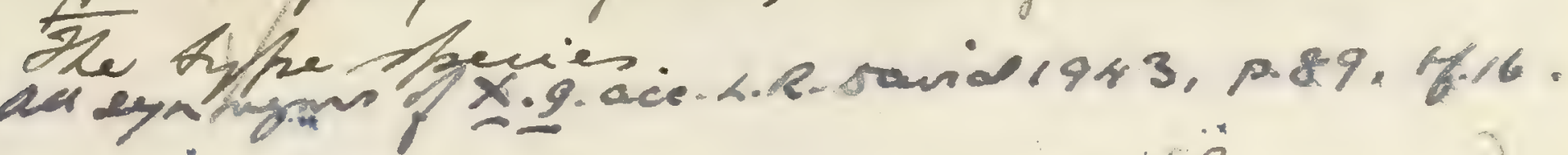

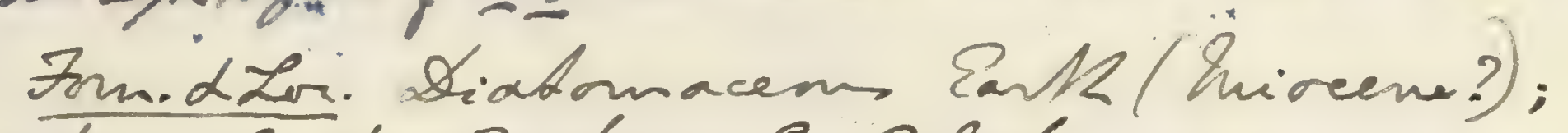
Lompoe, Tanta Bartara Ca, Califormia.

Pin2352. Ino slats ff firher in diatomaceour earth; Lompac. Pres: Ly 7. L. Borqui, Er.olgig.

(xyne fitgeri; Tordon a Gilkert, loc cow. 1920p.ll, pts. iv,v. [Fishes: Stanford Univ.] - Mioe. Califomia 


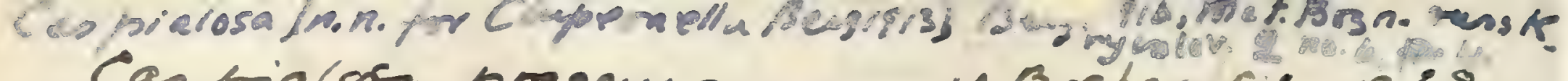

Caspialofa prascusorn.s. V. Bofha c. 1928 .

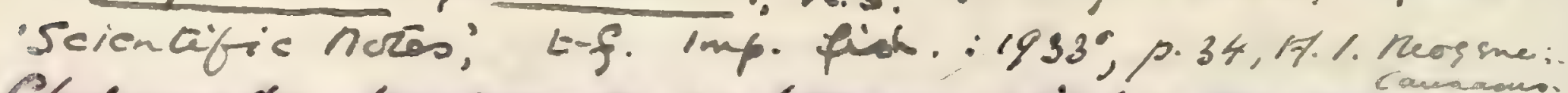

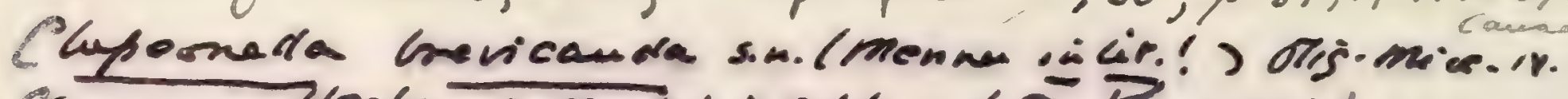

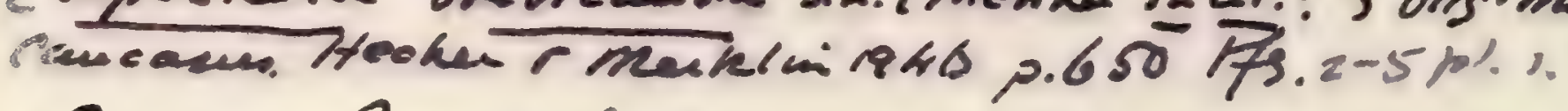

Seaces of Melelta, in sabalp. Molane. H.

Fröhlicher, 193s selot. Geol. Helvet, xxrv. $241-2$

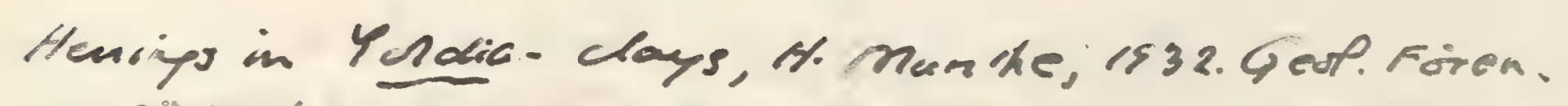

foik. hwo. po. 60 .

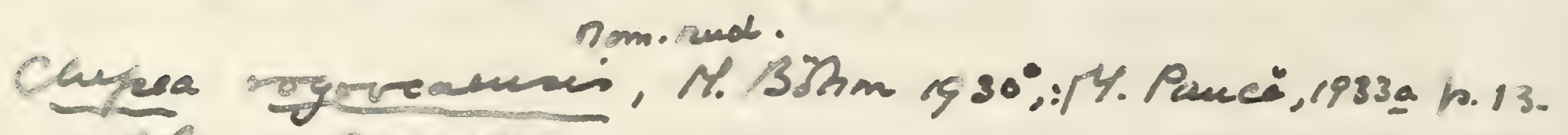

degre.

C. stamopobtimo s.n. V.r. Bughacherls $33^{\circ}$ p. 30, plovt 1-c. negre. Cancaums. Imp-funties.

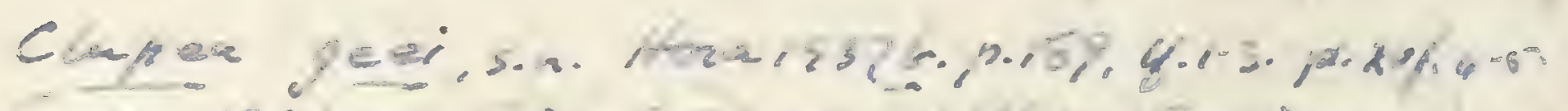

Cuppea tieje s.4. L.R. Gand 945 p.q2, p.12. mer. Calij. Fish: Univ.S.Cab.].

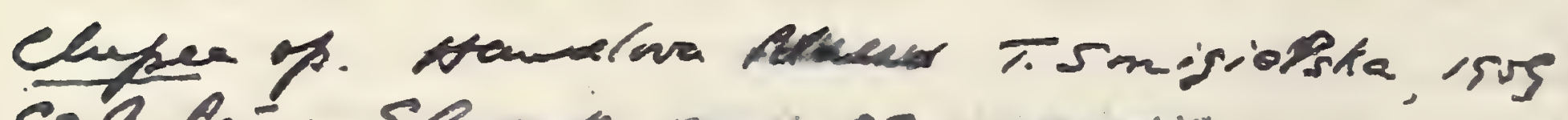

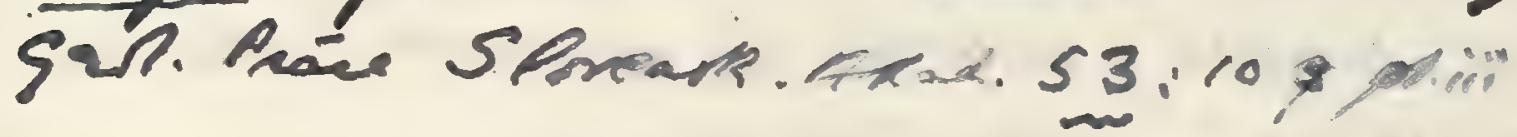






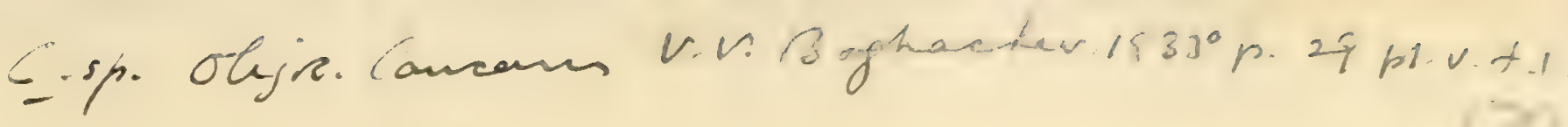

CLUPEID A.

Head and trunk much laterally compressed and abdomen compressed to an edge. Maxilla robust and arched, with two supramaxillary bones; mandible a little prominent, and gape not extending beyond the hinder border of the orbit; teeth rudimentary or absent. Preoperculum only slightly expanded; operculum and suboperculum deep and narrow; branchiostegal rays about 6 or 8 in number. Vertebræ from 45 to 60 in number, the centra much constricted and strengtheyed with few longitudinal ridges. Paired fins of moderate or small size; dorsal fin small and short-based, opposed to the pelvic pair; anal fin with less than 30 rays; candal fin deeply forked; no fin-rays excessively elongated. Scales of moderate or large size, not pectinated; a series of thickened ridge-scales, with ascending lateral wings, extending along the ventral border from the pectoral arch to the origin of the anal fin; no dorsal ridge-scales; lateral line inconspicuous.

\section{Clupea scheuchzeri, Blainville.}

1708. Figure by J. J. Scheuchzer, Querelæ Piscium, pl. ii.

1755. Figures by G. W. Knorr, Samml. Merkwürdigk. Natur, pl. xxi. figs. $2,3$.

1818. Clupea scheuchzeri, H. D. de Blainville, Nouv. Dict. d'Hist. Nat. vol. xxvii. p. 315.

1818. Chupea megaptera, H. D. de Blainville, ibid. p. 315.

1886. Meletta scheuchzeri, A. Wettstein, Fischfauna Tertiaer. Glarnerschief. (Denkschr. schweiz. Palaéont. Ges. vol. xiii.), p. 52, pl. i. fig. 4 , pl. iii. figs. $6,8,10$, (?) pl. viii. fig. 6 .

Type. Imperfect fish; Paris Museum of Natural History.

A species of slender proportions, attaining a length of about 0.25 , but not satisfactorily definable on account of imperfect preservation. Abdominal vertebræ about 22, caudals 24 in number. Length of head with opercular apparatus somewhat exceeding the maximum depth of the trunk and equalling one quarter of the total length to the base of the caudal fin. Dorsal fin with about 12 rays, not extending behind quite so far as the middle point between the occiput and the base of the caudal fin; pelvic fins arising opposite the middle of the dorsal, midway between the pectorals and the anal; the latter fin relatively small.

If the specimens labelled Clupea megaptera by Agassiz are correctly determined, the type specimen described by de Blainville under this name inust have been somewhat distorted and with incomplete dorsal fin.

Form. \& Loc: Oligocene : Canton Glarus, Switzerland.

P. 3832. Fine specimen about 0.13 in length, lahelled Clupea 
scheuchzeri by Agassiz, and employed as the basis for the specific description given above; Engi. Remains of the ventral ridge-scales are distinct both before and behind the pelvic fins.

Enniskillen Coll.

P. 1875, P. 3835, P. $425 \%$. Seven large specimens variously imperfect and distorted, labelled Clupea megapterce by Agassiz; Engi. The finest specimen is in counterpart and elongated by distortion. Egerton \& Enniskillen Colls.

4182\%. Slightly distorted fish about 0.13 in length; Engi.

Purchased, 1869.

P. 1875 a, P. 4257 a. Small imperfect fish, in counterpart, labelled. Clupea megaptera by Agassiz; Engi.

Egerton \& Enniskilien Colls.

Clupea catopygoptera, sp. nov.

[Plate VI. fig. 2.]

1844. Clupea catopygoptera, L. Agassiz, Poiss. Foss. vol. v. pt. ii. p. 120 (name only).

Type. Nearly complete fish; British Museum.

A species of slender proportions, attaining a length of about $0 \cdot 1$. Length of head with opercular apparatus somewhat exceeding the maximum depth of the trunk and nearly equalling one quarter of the total length of the fish. Vertebræ slightly over 40 in number, about half abdominal, half caudal. Dorsal fin as deep as long, with about 13 rays, and its origin twice as remote from the base of the caudal fin as from the occiput; pelvic fins arising opposite the anterior half of the dorsal, midway between the pectorals and the anal; the latter fin low and very remote, with about 15 rays.

Form. \& Loc. Upper Eocene: Monte Bolca, near Verona, Italy.

P. 3829 a. Specimen shown of the natural size in Pl. VI. fig. 2, labelled by Agassiz and to be regarded as the type of the species. The head and anterior abdominal region are slightly distorted, but the essential characters of the species. are displayed. Traces of the ventral ridge-scales are observable in front of, but not behind the pelvic fins.

Enniskillen Coll.

P. 285. Large distorted specimen, in counterpart.

Transferred from Museum of Practical Geologu, 1880. 
1922. S. catt. D. Fran ceschi, RaL. Ktal. vol xxviii.p.yplxiviti. 

21408 c. Another fine specimen deepened by the displacement of the squamation.

Purchased, 1847.

P. 9242. Large fish, slightly distorted.

History unknown.

13459. Fish wanting caudal extremity and showing traces of the ventral ridge-scales behind the pelvic fins. Purchased.

21408 a, 21529. Six specimens in various states of preservation.

Purchased, 1847.

23110 a. Imperfect fish, in counterpart.

Purchased, $18+8$.

28404. Distorted specimen.

Mantell Coll.

41385. Fish deepened by crushing, with traces of the ventral ridgescales behind the pelvic fins.

Purchased, 1869.

P. 9243. Two imperfect fishes.

History unknown.

42449. Small contorted specimen.

Purchased.

44874. Another contorted specimen, in counterpart.

Presented by Benjamin Bright, Esq., 1873.

P. 1868. Six specimens rariously preserved, some labelled by Agassiz.

Egerton Coll.

P. 4260. Distorted fish, labelled by Agassiz.

Enniskillen Coll.

P. 5132. Fine specimen, slightly deepened by distortion and showing the ventral ridge-scales.

Presented by Mrs. M. E. Tort, 1886.

P. 5279. Small well-preserved fish, showing the ventral ridgescales. $\quad$ Presented by Walter Myers, Esq., 1887.

P. 9244. Another small specimen showing ventral ridge-scales.

Purchased.

P. 1868 a. Distorted fish 0.035 in length, labelled by Agassiz as belonging to this species.

Egerton Coll.

13449-50. Equally small fish, in counterpart.

Purchased.

37228-29. Two small fishes.

Purchased, 1863.

P. 1866, P. 3830. Still smaller fishes evidently immature and probably belonging to this species, but labelled Clripec minuta ${ }^{1}$ by Agassiz. Egerton \& Enniskillen Colls.

I This name appears without description in Verhandl. Ges. vaterlärd. Mus. Böhmen, 1834, p. 66, and in Agassiz, Poiss. Foss. vol. v. pt. ii. p. 120. 


\section{Clupea humilis, H. von Meyer.}

1848. Clupea gracilis, H. von Meyer (non 'Temminck \& Schlegel), Neues Jahrb. p. 783 (name only).

1848. Clupea lanceolata, H. von Meyer, ibid. p. 783 (name only).

1851. Clupea humilis, H. von Meyer, Palæontogr. vol. ii. p. 92, pl. xiv. fig. 3, pl. xvi. fig. 12 (? pl. xiv. fig's. 5, 7-9).

1851. Chupea lanceolata, H. von Meyer, ibid. p. 93, pl. xiv. fig. 2, pl. xvi. fig. 11 (? pl. xiv. fig. 6). [Nearly complete fishes.]

1888. Clupea ventricosa, K. A. von Zittel, Handb. Palaeont. vol. iii. p. 276 , fig. 283.

Type. Nearly complete fishes.

A species attaining a length of about $0 \cdot 1$, perhaps sometimes larger. Length of head with opercular apparatus somewhat exceeding the maximum depth of the trunk and equalling one quarter of the total length of the fish. Vertebræ approximately 45 in number, about half abdominal, half caudal. Dorsal fin slightly deeper than long, with from 12 to 14 rays, and its origin less than twice as remote from the base of the caudal fin as from the occiput; pelvic fins arising opposite the anterior half of the dorsal, midway between the pectorals and the anal; the latter fin less elevated than the dorsal, with about 20 rays and extending close to the caudal. Ventral ridge-scales with very prominent backwardly-directed point, about 22 in number.

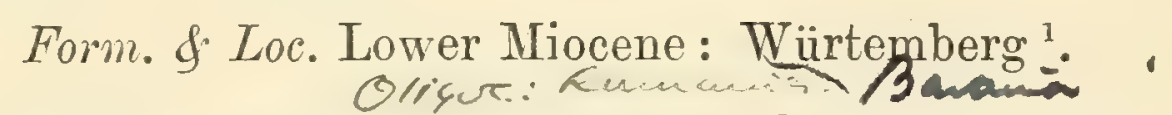

35500-07, 35521-23, 35\%50-51. One slab with many remains, another with four fishes, two others with two fishes, and ten detached specimens; Unterkirchberg, near Ulm.

$$
\text { Purchased, } 1860 .
$$

365\%9. Slab with one good, one imperfect specimen; Unterkirchberg. $\quad$ Purchused, 1862.

P. 1869-\%1, P. 3836-38. Four slabs with various remains, and six typical specimens; Unterkirchberg.

Egerton \& Ennisteillen Colls.

Specimens like the following are usually named Clupea ventricosa (after H. von Meyer, Palæontogr. vol. ii. 1851, p. 93, pl. xiv. fig. 1), but their comparatively deepened form seems to be due to distortion

I Also recorded from the Upper Miocene of Croatia by D. G. Kramberger, Beitr. Paläont. Oesterr.-Ungarns, vol. iii. (1883), p. 76 ; and doubtfully from the Lower Miocene of Chiaron, N. Italy, by F. Bassani, Atti R. Accad. Sci. Napoli, [2] vol. iii. no. 6 (1889), p. 38, pl. ii. fig. 5. 
1918. Oiflonyshur lancedatus, G. De Siefans, Mem D. Comit. Cieol. Ital. wel. vii. phi. p33,

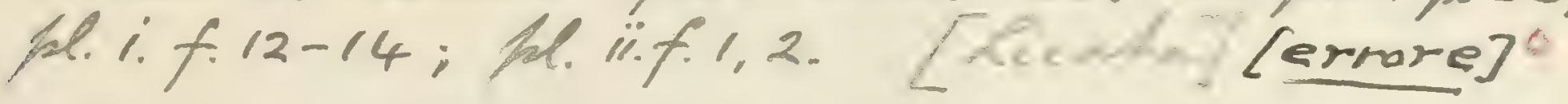

$192 \%$. Clupea humilis, M. Pauea $a^{\circ}, 0$, 2,

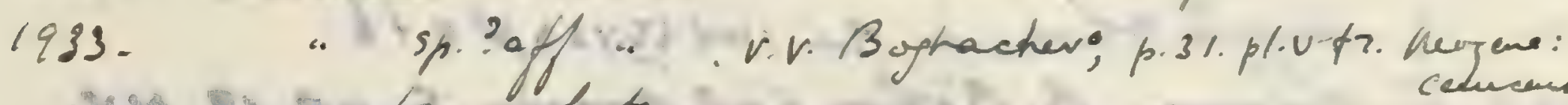

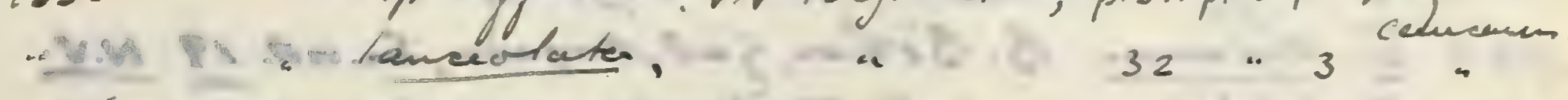

1936.

" ventiucosa

3) - 2 t. 1

1936.

31.

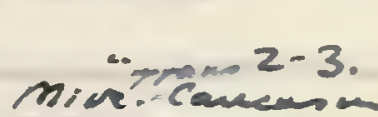

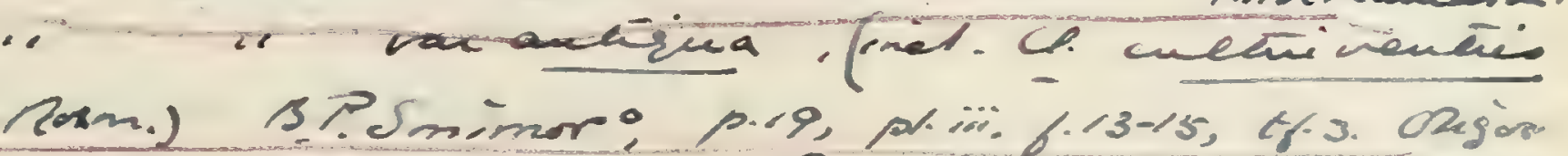

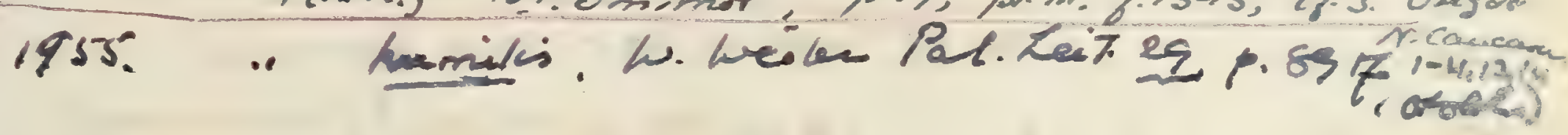

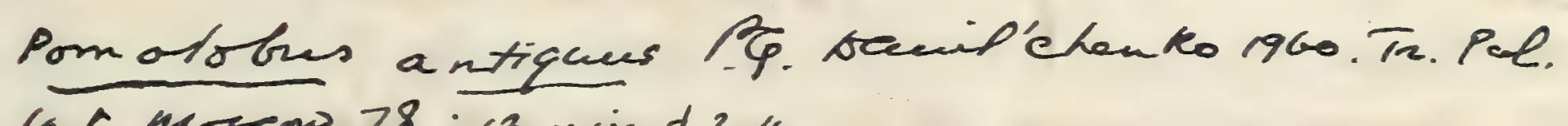

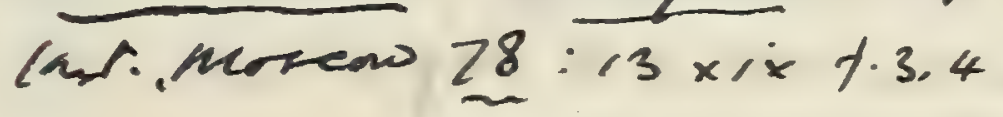

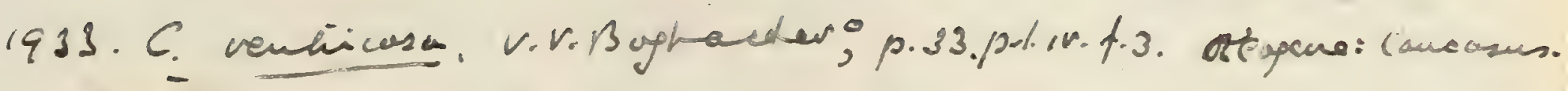




daring fossilisation, and they cannot be satisfactorily distinguished from Clupea humitis:-

36180. Specimen about 0.09 in length, much distorted anteriorly; Unterkirchberg. Purchased, 1861.

36580-81. Large and small specimen, still more distorted; Unterkirchberg.

Purchased, 1862.

P. 1872, P. 3839. Two typical examples eridently deepened by crushing; Unterkirchberg. Egerton \& Enniskillen Colls.

\section{Clupea crenata (Heckel). = C.Sandirités ace to}

1850. Meletta crenata, J.J. Heckel, Denkschr. k. Akad. Wiss., math.- Kw an Fal níh naturw. Cl. vol. i. p. 233, pl. xxvi.

1850. Metetta longimana, J. J. Heckel, ibid. p. 231, pl. xxv. [Imperfect 22:181 . fish; olim Heinrich Collection, Brünn.]

1870. Meletta sahleri, H. E. Saurage, Bull. Soc. Géol. France, [2] vol. xxrii. p. 407 , pl. ix. fig. 4.

1870. Meletta parisoti, H. E. Saurage, ibid. p. 403, pl. ix. fig. 6, pl. x. 1870. Meletta longimana, H. E. Saurage, ibid. p. 408, pl. ix. fig. 5 .

1880. Meletta crenata, D. G. Kramberger, Jahrb. k.-k. geol. Reichsanst. vol. xxx. p. 568, pl, viii. fig. 2.

1880. Meletta longimana $=$ Meletta crenata, F. Bassani, Atti Soc. Veneto-Trent. Sci. Nat. vol. vii. p. 81.

1881. Meletta heckeli, A. Ržehak, Abh. naturf. Verein. Brünn, vol. xix. pp. 70, 72, pl. i. figs. 1-3, 5. [Nearly complete fishes; Ržehak Collection, Brün].

1881. Meletta sahleri=? Melettina, A. Ržehak, ibid. p. 71. 4930 pt. viii: Can liaur Type. Scales, \&c.; otim Zeuschner Collection, Cracow.

An imperfectly known small species of slender proportions. Head with opercular apparatus occupying about one third the length of the fish to the base of the caudal fin. Vertebræ 40 to 42 in total number, the centra delicate. Pelric fins slightly behind origin of dorsal, which comprises 15 or 16 rays and arises in adrance of the middle of the back; anal fin low and extended.

Form. \& Loc. Lower Miocene (or Oligocene): Austria, Germany,

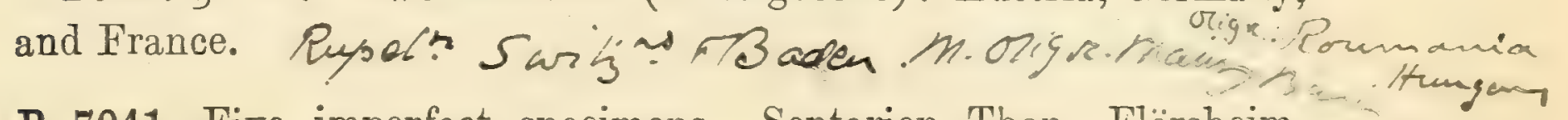
P. 7041. Five imperfect specimens; Septarien Thon, Flörsheim, Rhein Hessen. Purchased, 1893.

\section{Clupea numidica (Sauvage).}

1839-44. Alosa elongata, L. Agassiz (non Bennett, 1830), Poiss. Foss.

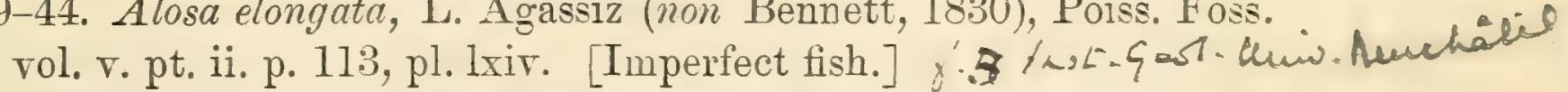
1873. Alosa crassa, H. E. Sauvage, Ann. Sci. Géol. vol. iv. art. no. 1, 
p. 243, fig. 67. [Imperfect fish ; Paris Museum of Natural History.]

1873. Alosa elongata, H. E. Sauvage, ibid, p. 245, figs. 52, 64. [Ditto.]

1873. Alosa numidica, H. E. Sauvage, ibid. p. 249, fig. 66.

1873. Alosa renoui, H. E. Sauvage, ibid. p. 253. [Ditto.].

Type. Imperfect fish; Paris Museum of Natural History.

A species attaining a length of about $0 \cdot 3$. Head with opercular apparatus large, its length exceeding the maximum depth of the trunk and contained about twice in the length from the pectoral arch to the base of the caudal fin. Vertebræ about 30 in the abdominal, 25 in the caudal region. Dorsal fin, with about 18 rays, almost completely in advance of the middle point between the occiput and the caudal fin; pelvic fins inserted opposite the middle of the dorsal; anal fin with 14 or 15 rays. Scales relatively large, sometimes pitted in their exposed portion.

All the known examples of this species are distorted and fragmentary; hence differences between various specimens which have been supposed to represent four distinct species. The name Clupea elongata cannot be used, having been employed by Lesueur in 1817 for an existing fish of another species.

Form. \& Loc. Upper Miocene: Oran, Algeria.

P. 9245. Three specimens.

History unknown.

P. 9246. Imperfect distorted fish, with some of the large scales showing pittings.

History unknown.

P. 1881. Three good specimens and various fragments.

Egerton Coll.

Clupea sardinites (Heckel). zícl. aenata etr. p.151

1850. Meletta sardinites, J. J. Heckel, Denkschr. k. Akad. Wiss., math-naturw. Cl. vol. i. p. 227, pls. xxiii., xxiv.

1870. Meletta sardinites, var. heterostoma, L. von Vukotinovic, Rad Jugoslar. Akad. vol. xiii. p. 208.

1883. Clupea (Meletta) sardinites, D. G. Kramberger, Beitr. Paläont. Oesterreich-Ungarns, vol. iii. pp. 76, 82.

Type. Nearly complete fish; Court Museum, Vienna.

A small slender species, attaining a length of about $0 \cdot 12$. Length of head with opercular apparatus contained four times, and the maximum depth of the trunk about six times in the total length of the tish. Vertebræ about 45 in number. Dorsal fin about as deep as long, with 13 rays, entirely in advance of the middle point between the occiput and caudal fin; pelvic fins arising opposite the 


1918. Chped finta (Cwien), G. De Atefano,

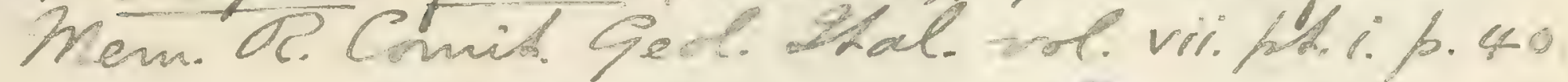
1927. Alesa elongala, C. Aramboung, p. 18, sh.ig, 1-3,

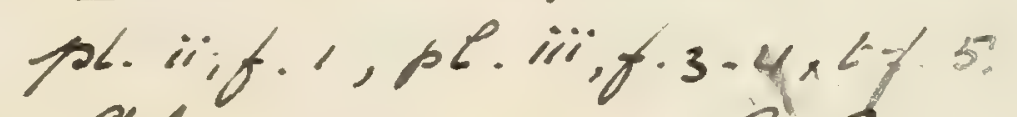

1922. Alosa chassa, C. drambong, ind p.21, phe if 4-s,

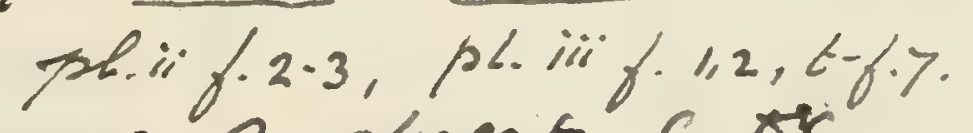

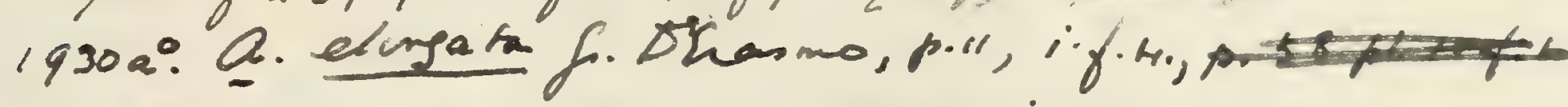
193060 a. crama $22, i, 1-2$.

- Q. elmgata - 25, i3. 3.

$19300^{\circ}$ a. chana 58 , is.

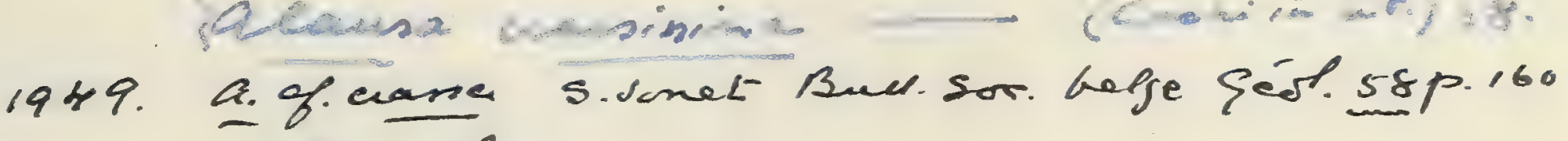

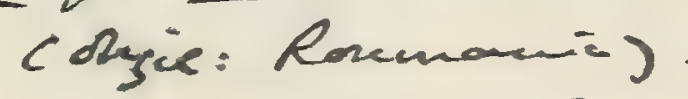

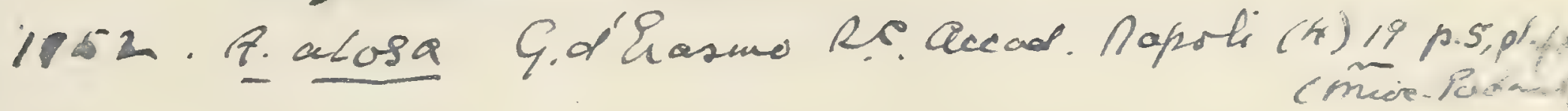

1928. Meletta sandinitio, h. 2orgi:

192ia. Compea sardinile, M. Pancá, P.27.

1933a. " aff." werler, p.29.4t19. I Ongor the ant?.

1933 -. "M. Panca; p. 35, plit.ti

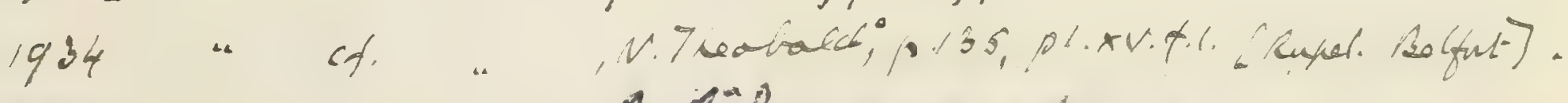

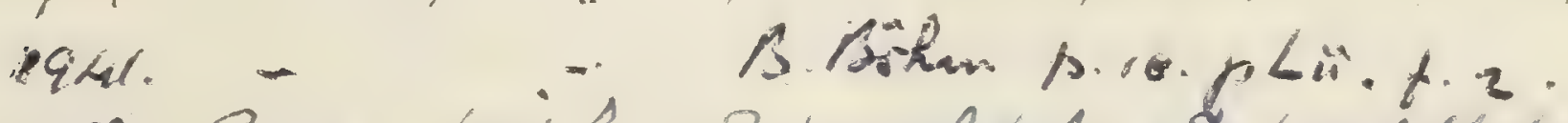

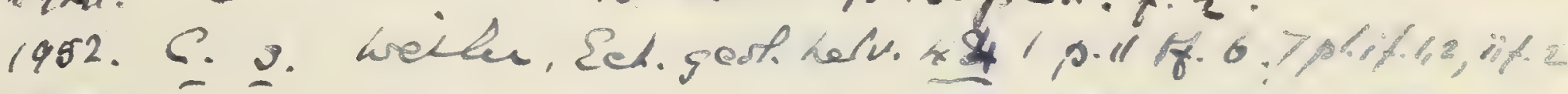

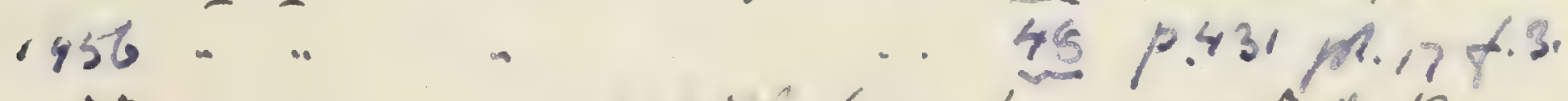

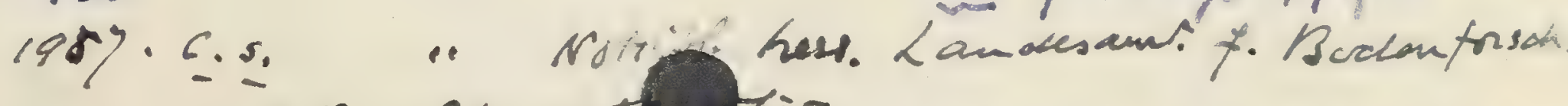
ssp. p.2x, 10 th tyos.

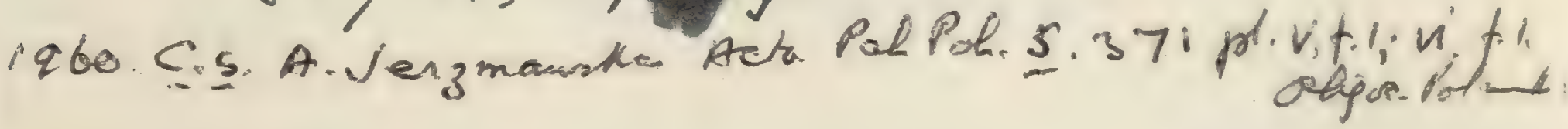




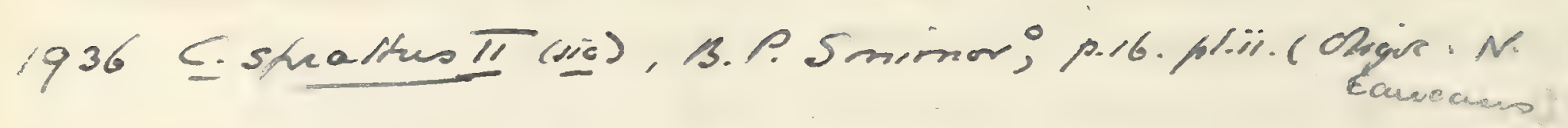

Chanoider leptostew, C.P. Sactmon, 
hinder part of the dorsal, nearer to the anal than to the pectorals; anal fin with 14 rays. M. Of

Form. \& Loc. Lower Oligocene: Radoboj, Croatia. Orama.

49161-64. Three fine specimens, and one immature individual probably of this species.

Purchased, 1878.

\section{Clupea sprattus, Linnæus.}

1758. Clupea sprattus, C. Linnæus, Syst. Nat. ed. 10, p. 318.

1868. Clupea sprattus, A. Günther, Catal. Fishes B. M. vol. vii. p. 419.

Type, Recent fish.

A small slender species, the length of the head with opercular apparatus about equal to the maximum depth of the trunk. Vertebræ 47 to 49 in total number. Pelvic fins directly opposed to the origin of the dorsal, which comprises 15 to 18 rays; anal fin with from 17 to 20 rays. About 12 ventral ridge-scales behind the pelvic fins.

Form. \& Loc. Pleistocene and Recent: Atlantic coasts of Europe.

P. 5265-67. Three specimens in nodules from Glacial Clay, Bindalen, Norway. Presented by Henry Tryon, Esq., 1887.

The following specimens are not specifically determined :-

P. 3831. Imperfect fish about 0.09 in length, labelled Clupea leptostea by Agassiz, apparently belonging to the species thus named without description in Nenes Jahrb. 1835, p. 306, and Poiss. Foss. vol. v. pt. ii. (1844), p. $120^{1}$; Upper Eocene, Monte Bolca, near Verona.

Enniskillen Coll.

21408 b. Another example of the same fish; Monte Bolca. Purchased, 1847.

3722\%. Imperfect smaller skeleton probably of the same species; Monte Bolca.

Purchased, 1863.

28437. Contorted fish about $0 \cdot 11$ in length, with relatively small head; Monte Bolca.

Purchased, 1853.

3633\%. Another specimen apparently of the same fish; Monte Bolca.

Bean Coll.

1 This undefined species is regarded as the type of a genus Ptericephatina by P. Lioy, Atti Soc. Ital. Sci. Nat. vol. viii. (1865), p. 414. One specimen is wrongly identified with Esox vulpes by Volta, Ittiolit. Veronese (1796), pl. lxiv. fig. 2. 
P. 1873. Fish wanting head, $0 \cdot 135$ in length from the pectoral arch to the base of the caudal fin; Tertiary, Crete.

Egerton Coll.

P. 1865, P. 3840. Imperfect specimens of the form provisionally named Clupea tenuissima by Agassiz (Verhandl. Ges. vaterländ. Mus. Böhmen, 1834, p. 66 [name only], and Poiss. Foss. vol. v. pt. ii, 1844, p. 120, pl. lxi. fig. $3^{1}$ ); Upper Miocene, Ragusa, Sicily. The type specimen is supposed to be contained in this collection, but is not recognisable.

Egerton \& Enniskillen Colls.

The following extinct species have also been distinguished, but are not represented in the Collection :-

Clupea arcuata, R. Kner, Sitzungsb. k. Akad. Wiss., math.-naturw. Cl. vol. xlviii. pt. i. (1863), p. 143, pl. iii. fig.2. Clupea $\frac{\text { Llosa arcosta }}{\text { Strasmo1930.0 }}$ sphaerocephala, L. von Vukotinovic, Rad Jugoslav. Akad. vol. xiii. (1870), p. 208. Clupea sagorensis, var. arcuaia, F. 30, i.7. lon $\propto$ Bassani, Atti Soc. Veneto-Trent. Sci. Nat. vol. vii. (1880), menghinir p. 88, and Atti R. Accad. Sci. Napoli, [2.] vol. iii. no. 6 ipn. (1889), p. 37, pl. ii. fig. 2; D. G. Kramberger, Beitr.

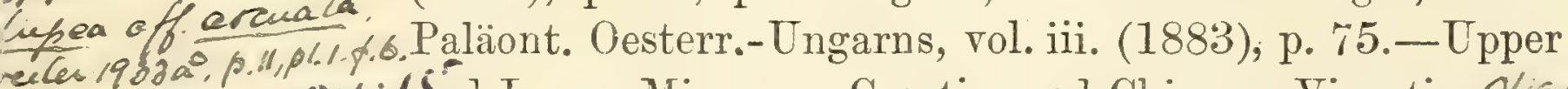

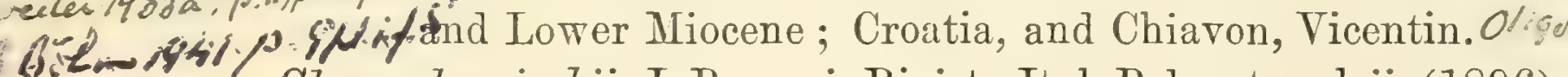
Clupea bosniciskii, I. Bonomi, Rivista Ital. Paleont. vol. ii. (1896), p. 215, pl. v. fig. 5.-Upper Miocene (Tripoli); Mondaino, Province of Forlì, Italy. [Distorted fish.]

Chupea breviceps, J. J. Heckel, Sitzungsb. k. Akad. Wiss., math.naturw. Cl. vol. xi. (1854), p. 333 ; F. Bassani, Atti R. Accad. Sci. Napoli, [2] vol. iii. no. 6 (1889), p. 34, pl. ii. fig. 1.-Lower Miocene; Chiavon, Vicentin. [Nearly complete fish; Court Museum, Vienna.]

Clupea caudata, H. E. Sauvage, Ann. Sci. Géol. vol. i. (1870), art. no. 7, p. 21, and ibid. vol. iv. (1873), art. no. 1, p. 238, pl. xiii. fig. 76 ; I. Bonomi, Rivista Ital. Paleont. vol. ii. (1896), p. 208.-Upper Miocene; Licata, Sicily, and Mondaino, Prov. Forlì, Italy. [Imperfect fish.]

Clupea dentex, H. D. de Blainville, Nouv. Dict. d'Hist. Nat. vol. xxvii. (1818), p. 362 ; L. Agassiz, Poiss. Foss. vol. v. pt. ii. (1844), p. 116, pl. lxi. figs. 4, 5.-Miocene; Murazzo Strutiano, Italy. [Imperfect fish.]

Clupea denticiformis, P. Lioy, Atti Soc. Ital. Sci. Nat. vol. viii.

1 Imperfect fishes from the Upper Miocene of Mondaino, Province of Forli, Italy, are also referred to this species by I. Bonomi, Rivista Ital. Paleont. จol. ii. (1896), p. 209, pl. v. fig. 2. 




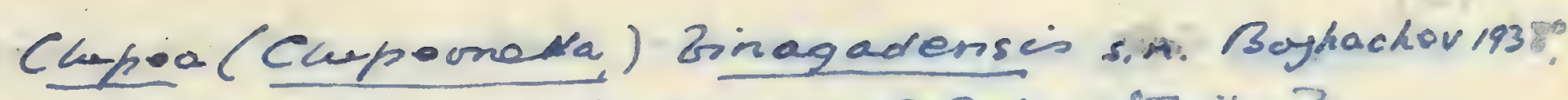

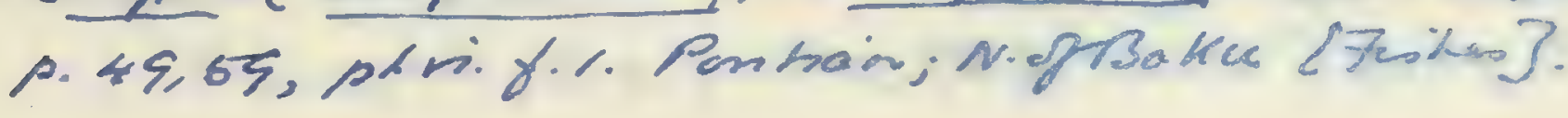

C.temissima $=$ C.megapteryze $=$ C. Gosmiastii - Drplomystur temuisaimun, Se thefano. mem. de. Comith. Geol. Ital. vol. vii. ph. il(1g18), f. 35, fl. ï. f. 3-q.

Cupea aloza, Cuvier: G. D' Rasmo, Bend. D. Acead. Sci. Napoli; 1922, no. ; h.12, hl.ii.-Lowen Pleistocene; Taranto. [Mmp. firh; Amir. haples]

Clupea aurita (Cur.dVal): S.2'Srasmo, lor.cit. 1922 , p.13, fl. iii.- Itid. [Sitto.]

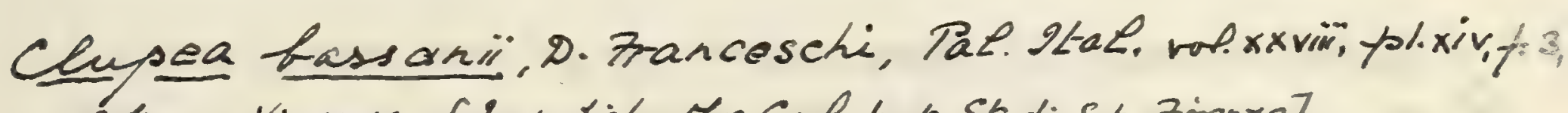
- Otigor.; Vicenza. [Imp. tish, Mus.Gedt Inst: Studi Sup, Trienze].

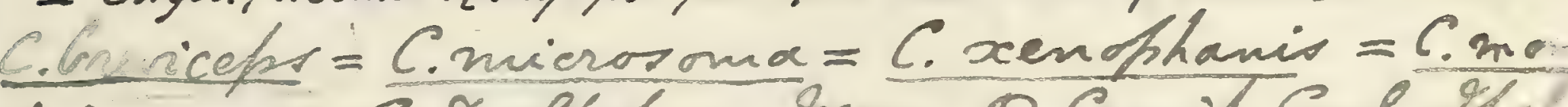
dainensis: 9. De Thefano, Mem. Or Comit. Ged. Otat.

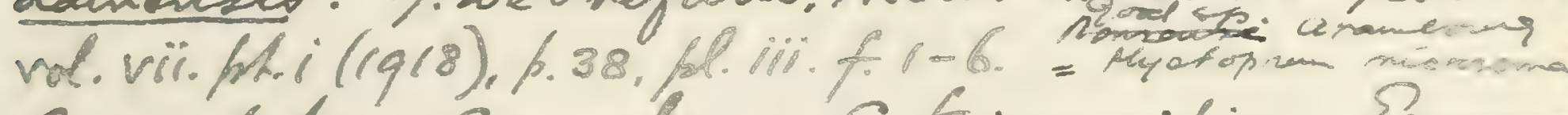
C. condata $=C$. sanlos $=C$. Frinacridis $=$ Ingranli enerasich hus (Linn), Gs De Dhefan, Inem R. Comill

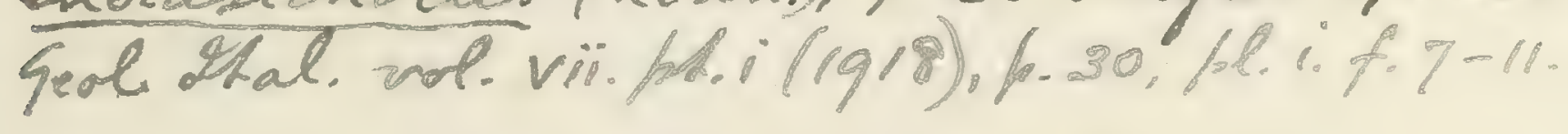

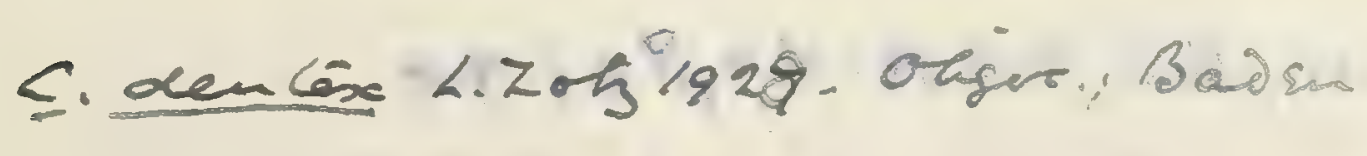

Clupea efr. delicetule nondmenn, Beregov 1938 ; 


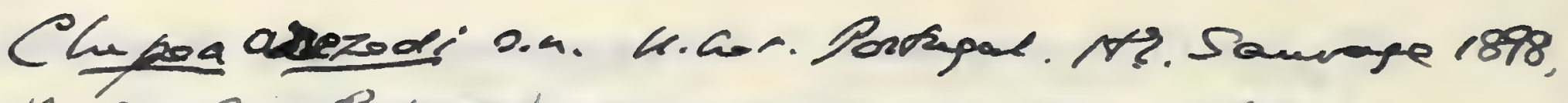

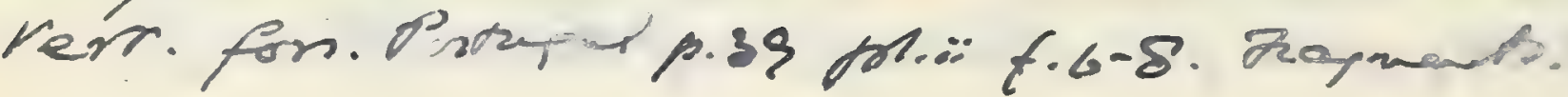

Chypea elugakes see Smikites elegan p.168 a cinol. Cosacrino-spnaltas pisti.

Curpea engranlifmmis Smimnor nec Loir $\rightarrow$. Sardinella engnaulin.

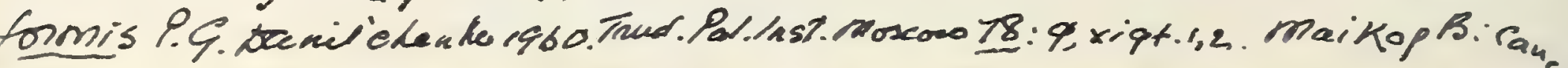

Goolyacanitina. D. Franceschi, Tafacont Halica

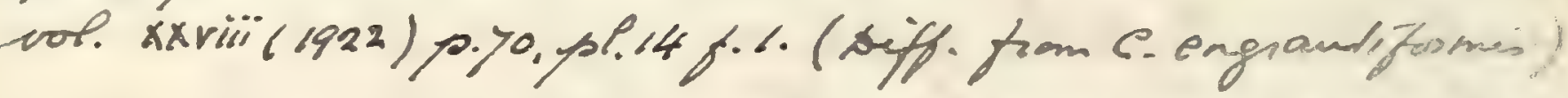

C. gluptopoma, D. Franceschi; 10r. cit. 1922, p.75, phxivy.4. oligor.; Vieenza. [mp. fist; Has. gert. Inst. Shiadi Sup. Firenze.]

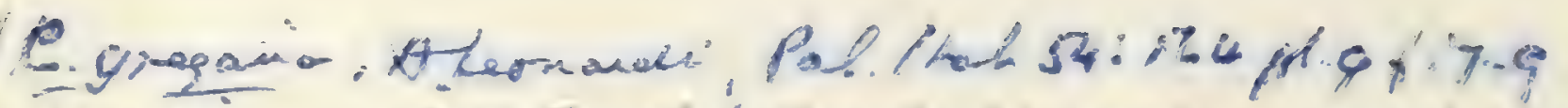

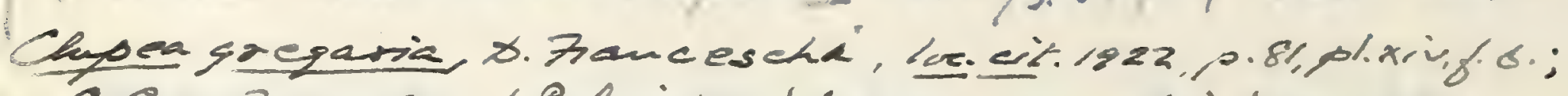

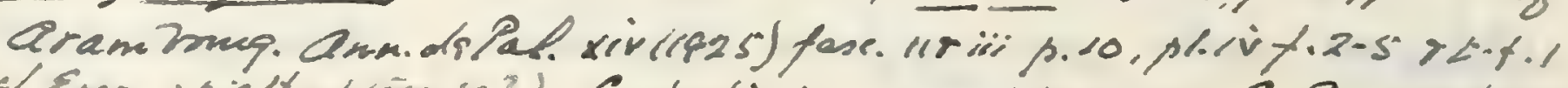

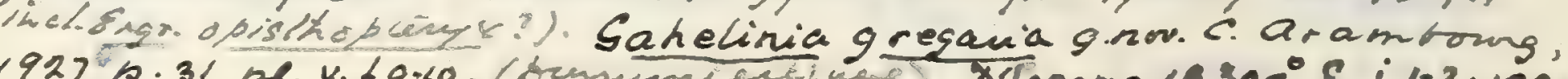

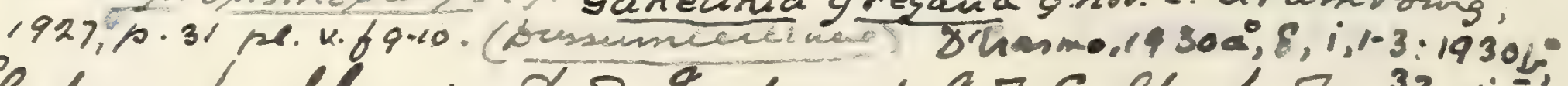

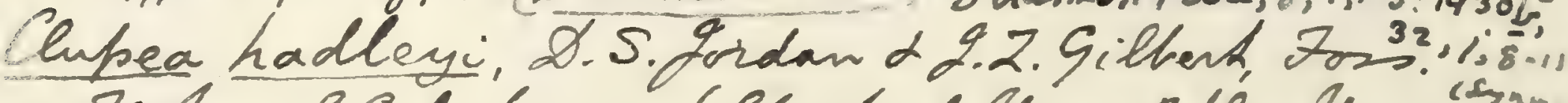

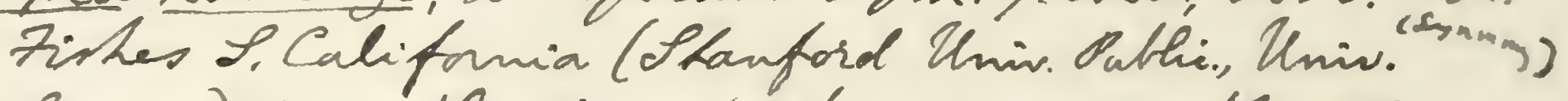

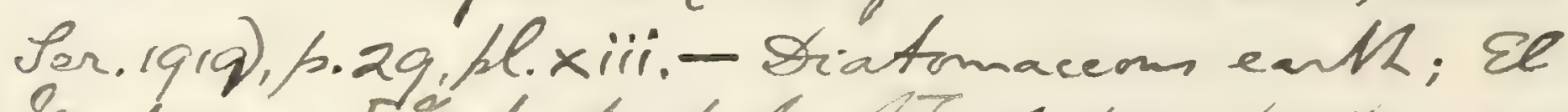

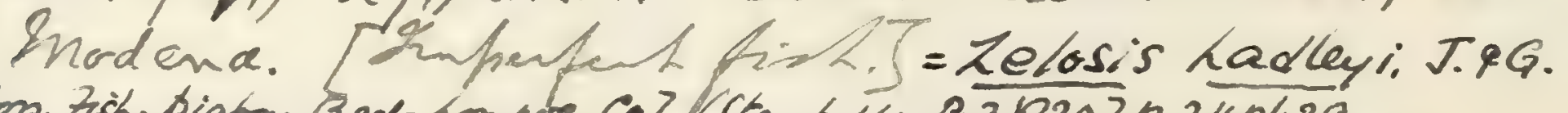

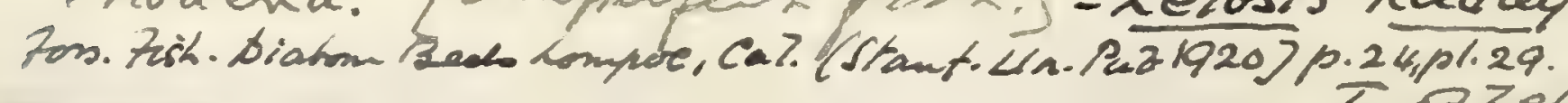




(1865), p. 413 ; F. Bassani, Palaeont. Italica, vol. iii. (1898), p. 86, pl. ix. fig. 10.-Upper Eocene; Monte Bolca. - [Imperfect fish.]

Clupea ecnomi, H. E. Sauvage, Ann. Sci. Géol. viol. iv. (1873), art. no. 1, p. 228, pl. vii. fig. 45, and ibid. vol. xi. (1880), art. no. 3, p. 45, pl. xxir. fig. 9.-Upper Miocene; Licata, Sicily. [Imperfect trunk.]

Clupea elongata, F. Steindachner, Sitzungsh. k. Akad. Wiss., Smernor math.-naturi. Cl. vol. xl. (1860), p. 556, pl. i. fig. 1 ; $1936 \%$ p.10

D. G. Kramberger, Beitr. Paläont. Oesterr. - Ungarns, sop speeth vol. iii. (1883), p. 74. -Upper Miocene; Hernals and Dolje, Croatia. [Imperfect fish; Court M[useum, Vienna.] Clupea engrauliformis, P. Lioy, Atti Soc. Ital. Sci. Nat. vol. viii (1865), p. 413; F. Bassani, Palaeont. Italica, vol. iii. (1898), p. 85, pl. ix. figs. 7-9. Clupea potyachanthina, P. Lioy, Toc. cit. p. 411.- - Upper Eocene; Monte Bolca. [Imperfect fish. 3; Mus. Geof. R. Inst. Stud. Super Firenze.]

Clupea fontannesi, H. E. Saurage, in F. Fontannes, Le Bassin de Crest (1880), p. 205, pl. vii. figs. 1-3. -Lower Miocene; Eurre, Drôme.

Clupea gervaisi, F. de Botella, Descrip. Geol. Murcia y Albacete (1868), pl. xi. figs. 8-11, and expl. (?) "Clupea elongata, Ag.," F. de Botella, ibid. pl. xi. figs. 1, 3, 4, 6, 12.-Lower Pliocene (?) ; Lorca, Murcia, Spain. [Imperfect fish.]

Clupea gracillima, F. Bassani, Atti R. Accad. Sci. Napoli, [2] vol. iii. no. 6 (1889), p. 36, pl. ii. fig. 3. Meletta gracillima, J. J. Heckel, Sitzungsb. k. Akad. Wiss., math.naturw. Cl. vol. xi. (1854), p. 129.-Iower Miocene; Chiaron, Ticentin. [Nearly complete fish; Court Iruseum Vienna.]

Clupea grandisquama: Meletta grandisquama, F. Steindachner, Jahrb. k.-k. geol. Reichsanst. vol. xir. (1864), p. 363.Miocene; Stampfen, Carpathians. [Scales.]

Clupea grandonii, F. Bassani, Atti R. Accad. Sci. Napoli, [2] vol. iii. no. 6 (1889), p. 41, pl. iii. fig. 4.-Lower Miocene ; Chiavon, Vicentin. [Nearly complete fish; Museum of Vicenza.]

Clupea gregaria, de Bosniaski, Atti Soc. Tosc.-Proc. Verb. vol. i. (1878), p. xix (name only); H. E. Sauvage, Ann. Sci. Géol. vol. xi. (1880), art. no. :3, p. 44.- Upper Niocene; Gabbro, Tuscany, and Licata, Sicily. Sa helian; oram.

Clupea haidingeri, J. J. Heckel, Denkschr. k. Akad. Wiss., math.naturw. Cl. vol. i. (1850), p. 235, pl. xxi.-Miocene; 
Margarethen, Vienna. [Imperfect fish; Imperial Geological Survey, Vienna.]

Clupea heterocerca, D. G. Kramberger, Beitr. Paläont. Oesterr.Ungarns, vol. iii. (1883), p. 80, pl. xiii. fig. 9.—Upper

Niocene: Podsused, Croatia. [Imperfect fish; Imperial Geological Survey, Vienna.]

Clupea inflata, L. von Vukotinovic, Rad Jugoslav. Akad. vol. xiii. (1870), p. 209 (as variety of C. ventricosa); D. G. Kramberger, Beitr. Paläont. Oesterr.-Ungarns, vol. iii. (1883), p. 75, pl. xiv. fig. 3 ; F. Bassani, Atti R. Accad. Sci. Napoli, [2] vol. iii. no. 6 (1889), p. 39.-Upper and Lower

Niocene; Podsused, Croatia, and Chiavon, Vicentin.

Clupea (Meletta) intermedia, D. G. Kramberger, Rad Jugoslav. Akad. vol. lxxii. (1885), p. 53, and Soc. Hist. Nat. Croatica, vol. i. (1886), p. 136.--Upper Miocene; Szakadát, Croatia. [Imperfect fish ; Museum of Imperial Geological Survey, Vienna.]

Clupea latissima, F. Bassani, Atti R. Accad. Sci. Napoli, [2] vol. iii. no. 6 (1889), p. 35, pl. ii. fig. 4. Alausa latissima, J. J. Heckel, Sitzungsb. k. Akad. Wiss., math.-naturw. Cl. vol. xi. (1854), p. 331.-Lower Miocene; Chiavon, Vicentin. [Nearly complete fish; Court Museum, Vienna.] Chupea Torcee, H. E. Sauvage, Bull. Soc. Géol. France [3] vol. vi. (1878), p. 635, pl. xi. fig. 5.-Lower Pliocene (?) ; Lorca, Murcia, Spain. [Fragmentary fish.]

Clupea lundgreni, J. W. Davis, Trans. Roy. Dublin Soc. [2] vol. iv. (1890), p. 427, pl. xlv. fig. 5.-Upper Cretaceous (Danian); Limhamn, Malmö, Sweden. [Indeterminable imperfect trunk; Geological Museum, University of Lund.]

Clupea maceki, D. G. Kramberger, Beitr. Paläont. Oesterr.Ungarns, vol. iii. (1883), p. 79, pl. xiii. figs. 10, 11.Upper Miocene; Vrabce, Croatia. [Imperfect fish; Geological Museum, University of Agram.]

Clupea macrocerca, I. Bonomi, loc. cit. (1896), p. 213, pl. จ. fig. 4.-Upper Miocene (Tripoli); Mondaino, Province of Forli, Italy. [Imperfect fish.]

Clupea megapteryx, H. E. Sauvage, Ann. Sci. Géol. vol. iv. (1873), art. no. 1, p. 231, pl. xiv. figs. 87, 88.-Upper Miocene ; Licata, Sicily. [Distorted fish.]

Clupea melettaformis, F. Steindachner, Sitzungsb. k. Akad. Wiss., math.-naturw. Cl. vol. xl. (1860), p. 558 ; D. G. Kramberger, Beitr. Paläont. Oesterr.-Ungarns, vol. iii. (1883), 


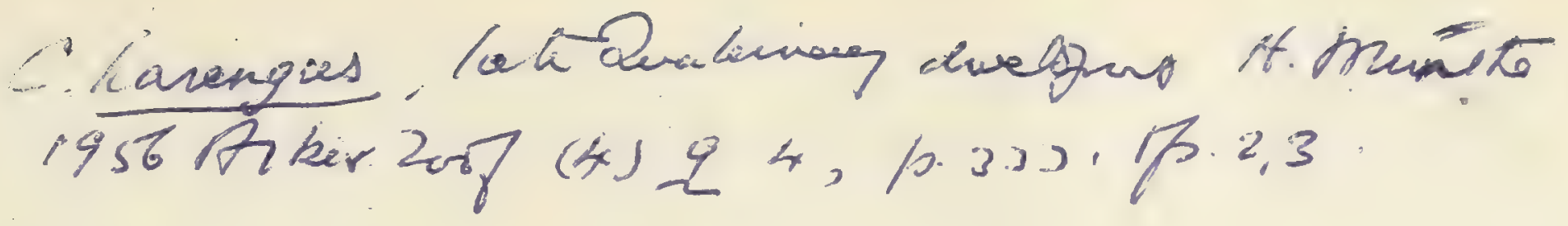

Chped linderi, F. Priem, Bull. Sor. Séol. France [4] rol. xii(1912), p.222, hl. vi.fip. 36.- Pliocene; to Fave (Gard), France. [Fish; Lichorl of Inines, Paris.] 


p. 74, pl. xiii. fig. 12.-Upper Miocene; Hernals and Dolje, Croatia. [Imperfect fish ; Court Museum, Vienna.] Clupea microsoma, H. E. Sauvage, Ann. Sci. Géol. vol. i. (1870), - Thetoptum art. no. 7, p. 20. Clupea sp., H. E. Sauvage, ibid. vol. iv. micres uma (1873), art. no. 1, p. 239, pl. xiii. fig. 75.-Upper Miocene; Licata, Sicily. [Imperfect fish.] : Fe ar mon Clupea mondainensis, I. Bonomi, loc. cit. (1896), p. 211, pl. $\nabla$. $=\quad$ fig. 3.- Upper Miocene (Tripoli); Mondaino, Province of Forli, Italy. [Distorted fish.]

Clupea mucronata, D. G. Kramberger, Djela Jugoslav. Akad. ff- L.Weien 19,32 vol. xvi. (1895), p. 58, pl. xi. fig. 3.-Middle Miocene; $0.315,6 \% 10$. Sagor, Croatia. [Nearly complete fish.]

Clupea ombonii, F. Bassani, Atti R. Accad. Sci. Napoli, [2] vol. iii. no. 6 (1889), p. 40, pl. iii. fig. 1.-Lower Miocene; Chiavon, Vicentin. [Nearly complete fish; Geological Museum, University of Padua.]

Olupea opisthopieryx, H. E. Sauvage, Ann. Sci. Géol, vol. iv. (1873), art. no. 1, p. 235, pl. xiv. fig. 84.-Upper Miocene ; Licata, Sicily. [Distorted fish.]

Clupea prosardinites: Meletta prosardinites, A. Ržehak, Abh. naturf. Verein. Brünn, vol. xix. (1881), p. 78, pl.i. figs. 8, 10.-Miocene; Gr. Seelowitz, Moravia. [Fragments; Ržehak Collection, Brünn.]

Clupea sagorensis, F. Steindachner, Sitzungsb. k. Akad. Wiss., math.-naturw. Cl. vol. xlvii. pt. i. (1863), p. 135, pl. ii. fig. 1 ; F. Bassani, Atti Soc. Veneto-Trent. Sci. Nat. vol. vii. (1880), p. 89, and Atti R. Accad. Sci. Napoli, [2] vol. iii. no. 6 (1889), p. 37, pl. iii. fig. 5. Clupea alta, F. Steindachner, Toc. cit. 1863, p. 137, pl. ii. fig. 2.-Middle and Lower Miocene; Croatia, and Chiavon, Vicentin.

Clupea saulos, H. E. Sauvage, Ann. Sci. Géol. vol. i. (1870), art. no. 7, p. 21, and ibid. vol. iv. (1873), art. no. 1, p. 232, pl. xiii. fig. 78.- Upper Miocene; Licata, Sicily. [Distorted fish.]

Clupea styriaca: Meletta styriaca, F. Steindachner, Verh. k.-k. geol. Reichsanst. 1863, p. 136.-Miocene; Leoben, Styria. [Imperfect fish; Imperial Geological Survey, Vienna.]

or Clupea trinacridis, H. E. Sauvage, Ann. Sci. Géol. vol. iv. (1873), art. no. 1, p. 234, pl. xiii. fig. 77 ; I. Bonomi, Rivista Ital. Paleont. vol. ii. (1896), p. 206.-- Upper Miocene; Licata, Sicily, and Moudaino, Prov. Forli, Italy. [Distorted fish.] Cluplea vukotinovici, D. G. Kramberger, Beitr. Paläont. Oesterr.Ungarns, vol. iii. (1883), p. 78, pl. xiii. figs. 7, 8.- 
Upper Niocene; Dolje and Vrabce, Croatia. [Imperfect fish; Geological Museum, University of Agram.]

Cluper xenophanis, H. E. Sauvage, Ann. Sci. Géol. vol. iv. (1873), art. no. 1, p. 237, pl. xiv. figs. 83,86 ; I. Bonomi, Rivista Ital. Paleont. vol. ii. (1896), p. 207.-Upper Miocene; Licata, Sicily, and Mondaino, Prov. Forli, Italy. [Distorted fish.]

Clupea zanclea, H. E. Sauvage, Ann. Sci. Géol. vol. iv. (1873), art. no. 1, p. 229, pl. vii. fig. 46, and ibid. vol. xi.(1880), art. no. 3, p. 42, pl. xxv. fig. 12.-Upper Miocene ; Licata, Sicily. [Imperfect trunk.]

Otolithus (Chipea) testis, E. Koken, Zeitschr. deutsch. geol. Ges. vol. xliii. (1891), p. 82, pl. i. figs. 1, 2.-Upper Oligocene; Germany. [Otolith.]

The following names are also ascribed to supposed Clupeoids from the Upper Eocene of Monte Bolca by P. Lioy, Atti Soc. Ital. Sci. Nat. vol. viii. (1865), pp. 411-414, but neither the genera nor species are scientifically defined or recognisable:-Clupea ophthalmica, C. chrysosoma, C. microcephala, C. minutissima, C. cephalus, Uropterina platyrachis, Ptericephatina macrograstrina, and $P$. elongata.

The so-called Clupea laticauda (F. J. Pictet, Poiss. Foss. Mt. Liban, 1850, p. 39, pl. vii. fig. 3) from the Upper Cretaceous of Hakel, Mt. Lebanon, does not belong to this genus. The type specimen in the Geneva Museum is too imperfect for precise determination, but seems to represent a member of the Enchodontidæ (A. S. Woodward, Aun. Mag. Nat. Hist. [7] vol. ii. 1898, p. 488).

The undefined name Clupea goldfussi is given by Agassiz (Poiss. Foss. vol.v. pt. ii. 184t, p. 120) to an unknown fish from the neighbourhood of Bingen. Clupea lawleyi, C. meneghinii, and C. sauvagei saese else are also merely names for undetermined fishes from the Upper Miocene of Gabbro, Tuscany (de Bosniaski, Atti Soc. Tosc.-Proc. Verb. vol. i. 1878, p. xix).

The existing genus Chatoessus (Cuvier, Règne Animal, ed. 2, vol. ii. 1829, p. 320) has been supposed to occur in the Upper Miocene of Podsused, Croatia (Chatoessus humitis, C. brevis, and C. tenuis, F. Steindachner, Sitzungsb. k. Akad. Wiss., math.naturw. Cl. vol. xxxriii. 1859, pp. 782-788, pl. iii.). The fishes thus named, however, are claimed by Kramberger to belong merely to a species of Clupea characterised by the elongation of the hinder- 
Clupeonella vexata s.n. Boghacher 1938; p. 45,58. p. vii.f. 2-4; vio. 1-3; Pontian Arstitek [Rthes

Qlosa novdmanni Outhpa (Ree-sp). Do. Pancá, 1931, Buk. Acad. nommaine Xrv. p.106 eplo. Pontica. Q. n. R. Beregov, $1938^{\circ}$ p.18, phiv. phof.s.

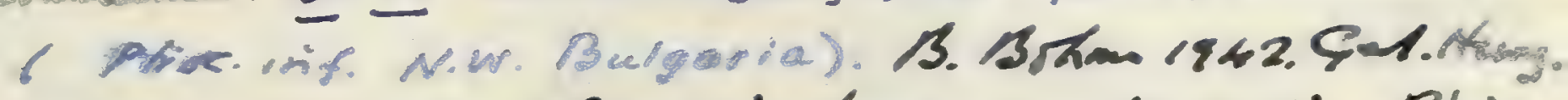
pot.ser 19 N.V. Cashialese nondmand. Phire

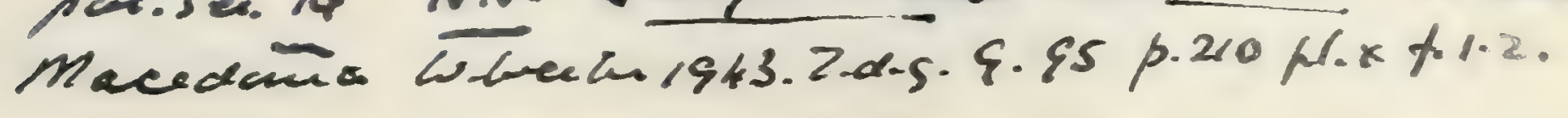

Hakelia gen-nev. C.S.W. 1842

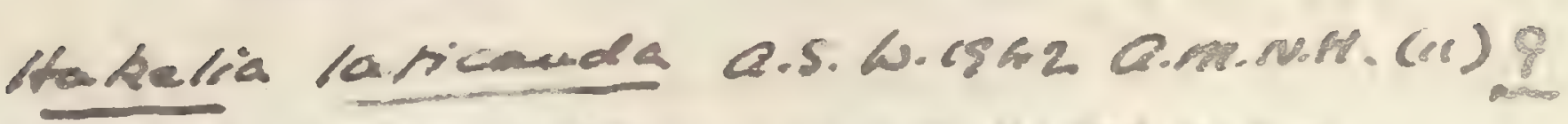

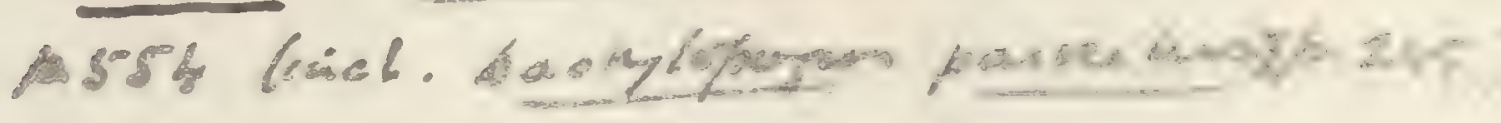


$13-8 a$.

CL.(Sardinella) Growwen

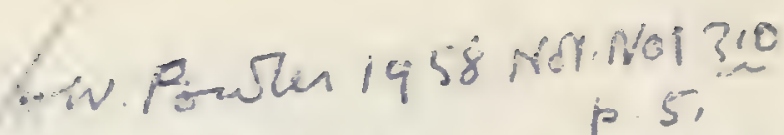

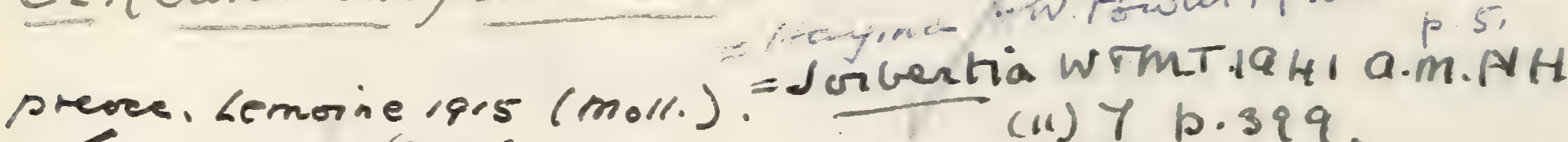
TSmitites elegans loper (II) Y 10.399.

telupea elongata, steindachner. G. Duncker. Loologiscter Anzeiger, rol. 56192319239.

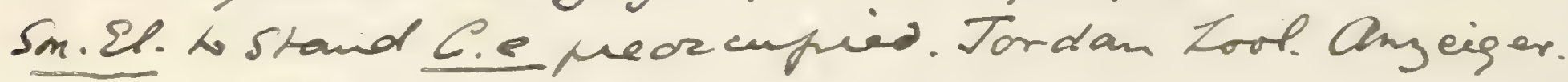

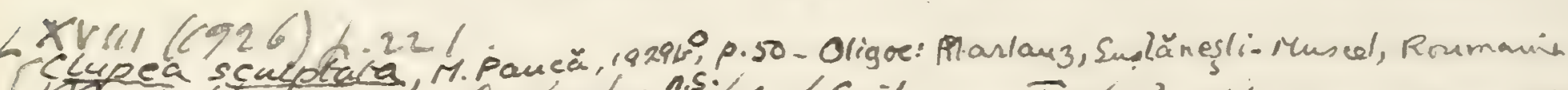

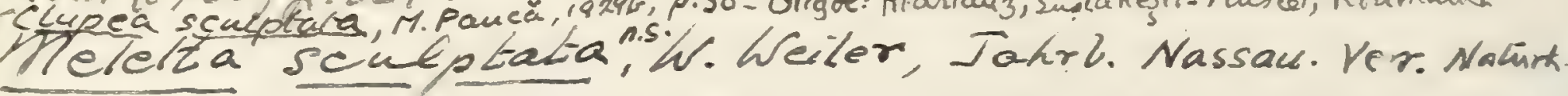
vol. Y2 (1920) p.2. - M.Oligar.; Mainz Bassin. (7ish.; N. H. M. Mainz)

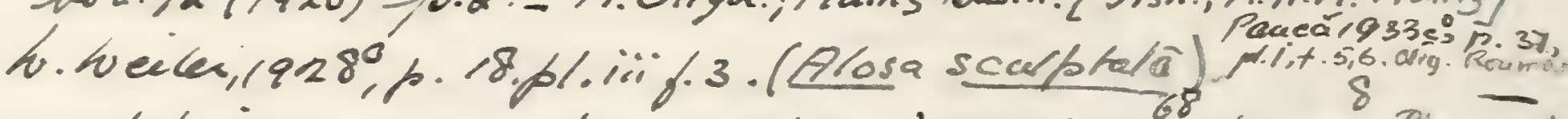

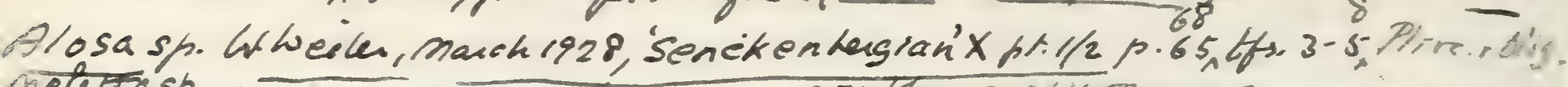

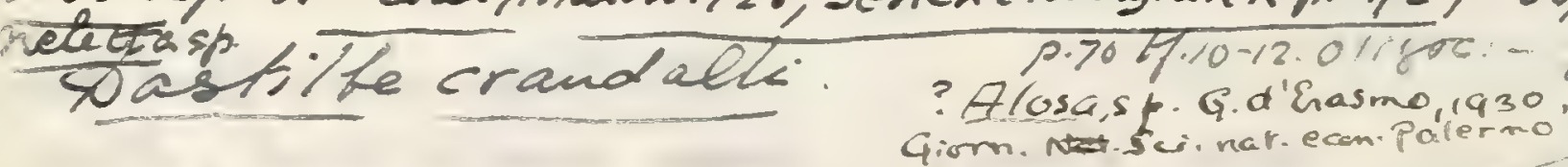
P. 94.

Stmatiadae (inel. TPhtichlyph 162) Gonostoma abbyi, C. Aramboug, Cam. de Pab. xir(1925)

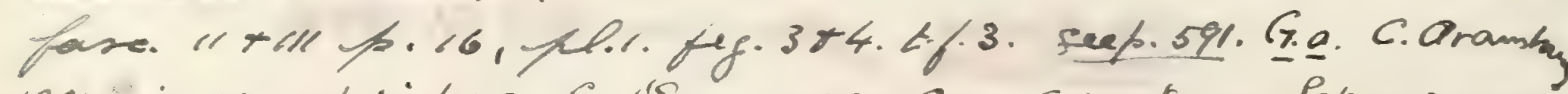
1927, p.32. pl.rif.1.2. G.d'hasmo, 1930, Grom. Sci.nat prom Palermo, xxxv. Brevontia sp. C. Aromboung, 1927, p. 24 pli iil fitt.

[Sahelian; Oran].

Quisque gicberti, D.S.Tozdam, Genera of Jishes

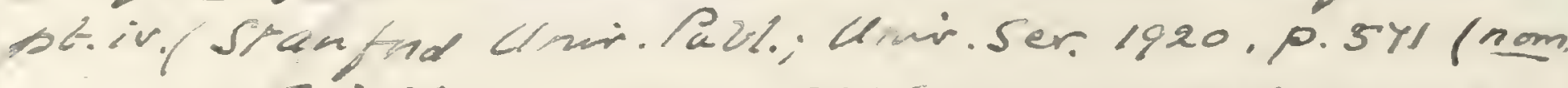

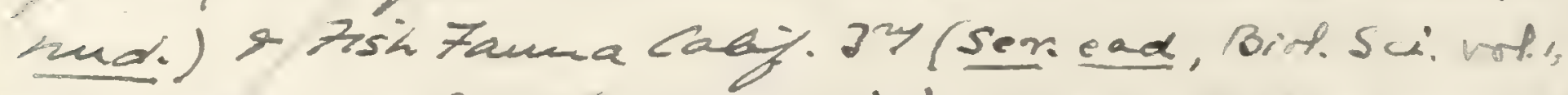

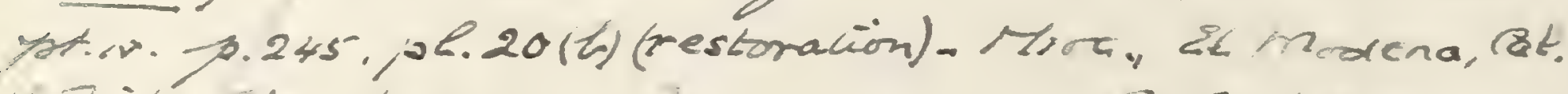

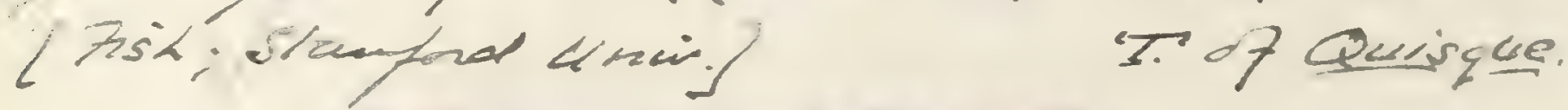

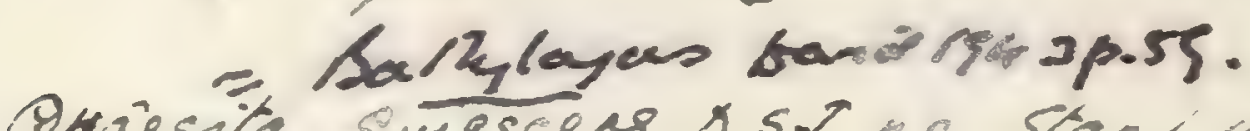

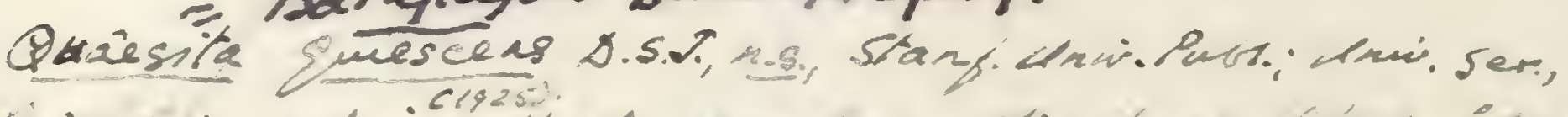

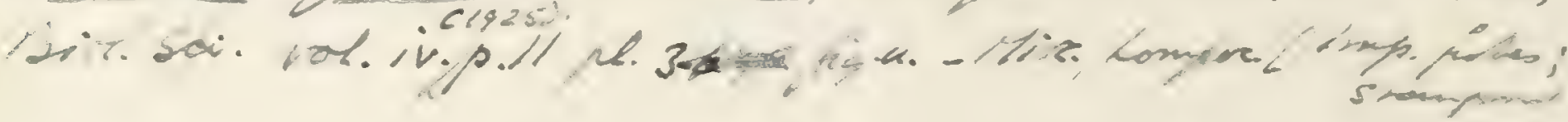

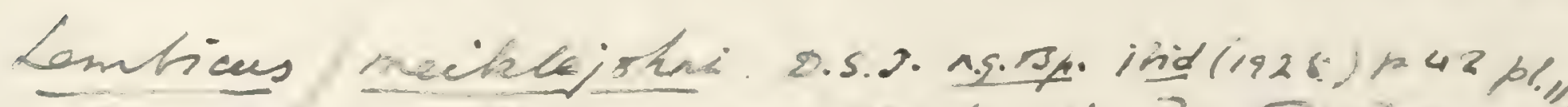

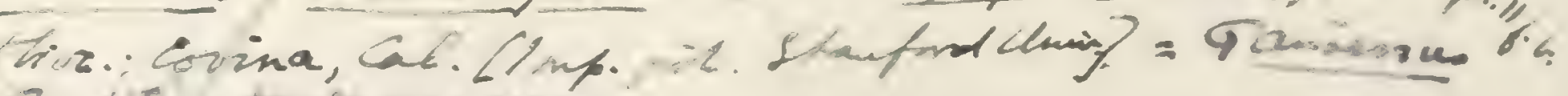

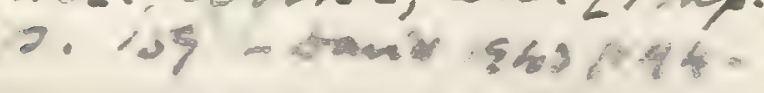






158.5

Pomolotus elicoensis 2.n.

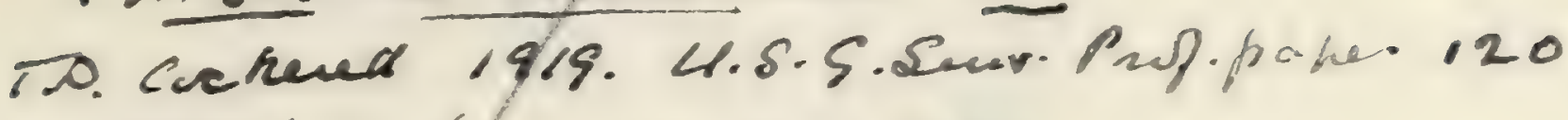

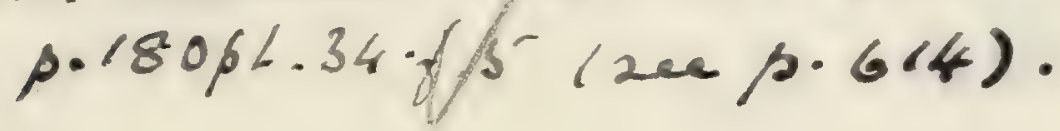

Saididerle ata suiknaiksprier, Runia, PG.

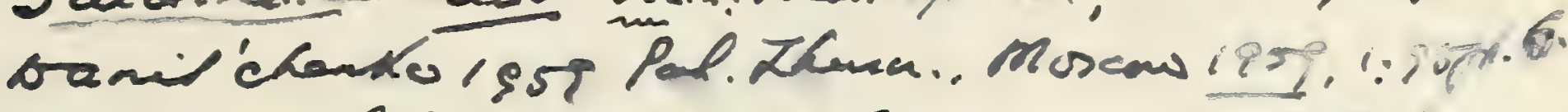

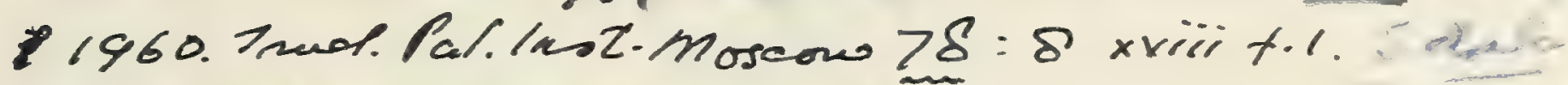

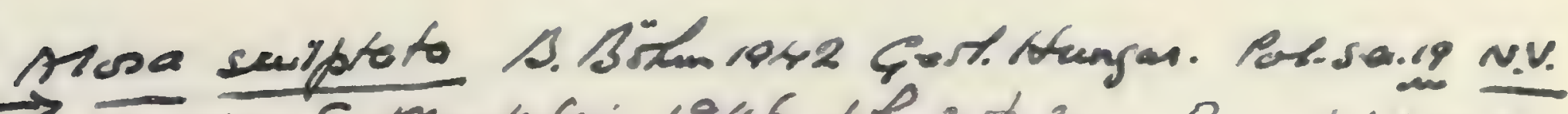

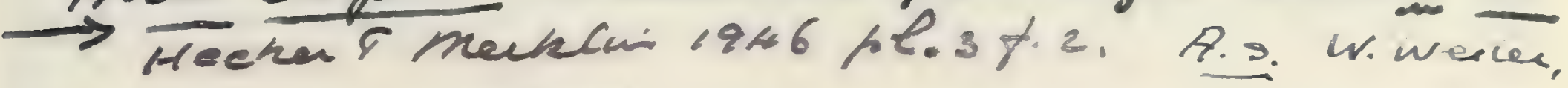

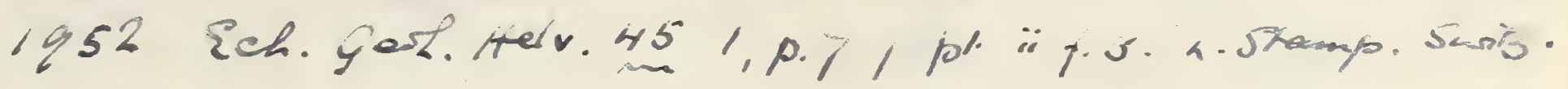

Pomolobres curtus sin. Maikoph. Cancosus P. S.

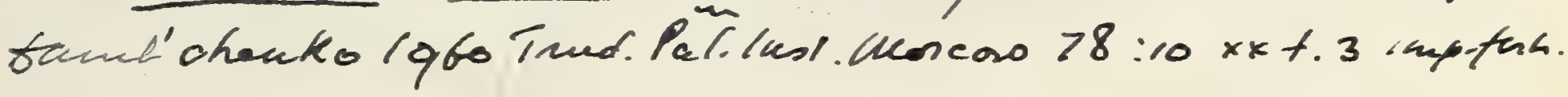

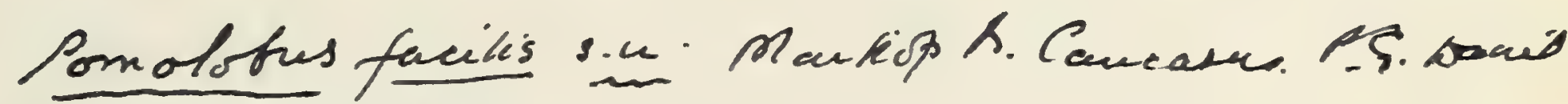

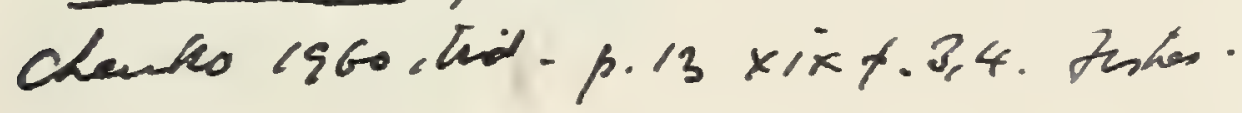

Plosa genvina s.h. Maikop S.Camecons P.g

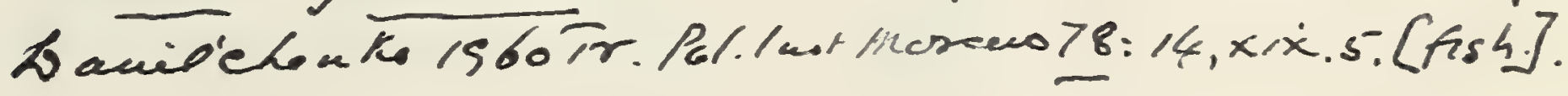





Alisea smandir.

Firhes T. California (Otanford Unir. Oublic, Univ. Ser. 1919), 1.28, pl. xvir.fis. 3. - Hiveene; San Pedro. [amperfert trunte; hus. Stanford Univ.]

T. If Alized.

Inithiter elepans, Iordan \& Gilkerh, lor.cit. 19r9, h.30, hl.xxix.fip.3. - Fiatomaceons enth:

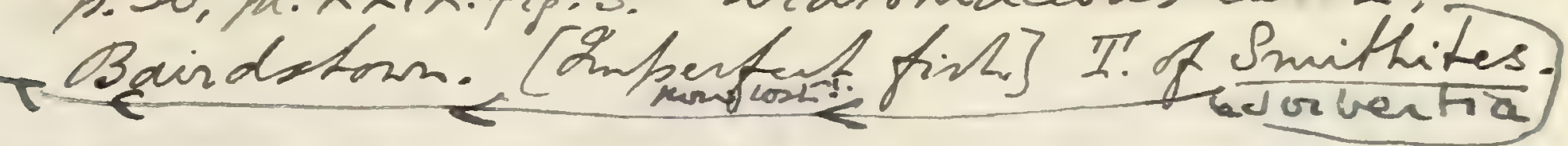

Ludesita quirquilia. Gordan \& Gilbert, lor. wh.1919, h. 31, hl. viii.fip. 3, fl. x. fip. 2, hl. xvii.fi, 1. - huiocene;

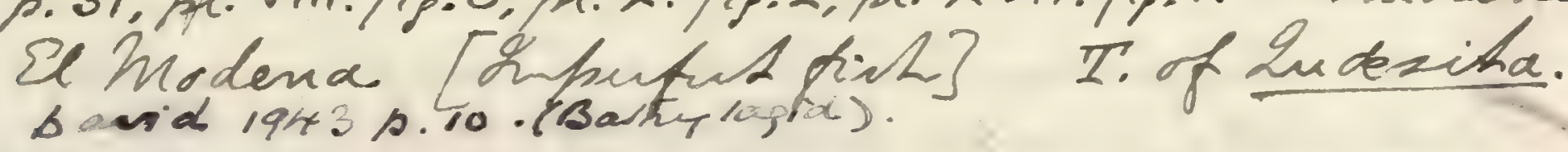

Azaloir angelensis, Iod an d Gillert, lor. eit 1919 h.32, hl. xv. Ap. 2. - Hiatom. eanM; Baindation. Balk logees augel tani I. of tisalois.

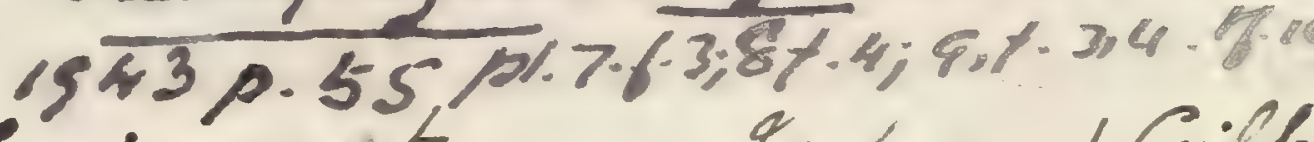

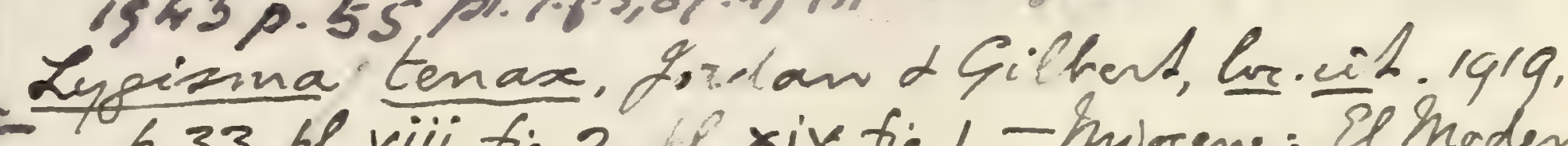

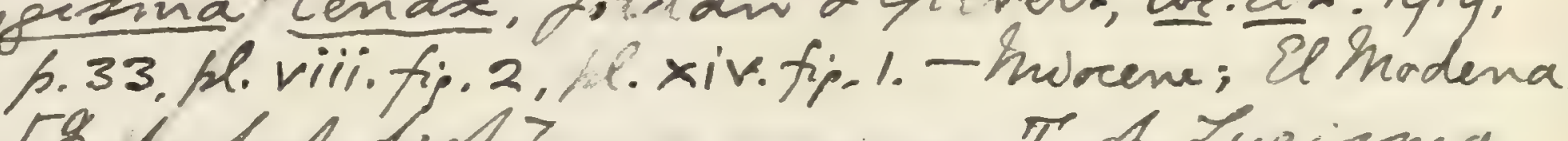
[Oupherfort fish]

T. of Zyoisma

Iquius mifpomiens 2. S. Gordan, Rroe. Calif. Sead. Si: 44$]$ rol. ix (1919), h. 27l, hl. 20, - Tertiary; istan of Iki, tapan. CFont half of firt; Mus. Cali:t. Sead. Sei.]

I. of Iquins.

Quisque bakere, 2.S. Fordan, Amer. Lown. Sci: [s-] vol. iii (1922). p.249, cith fip. - L. hircene; Jexces.

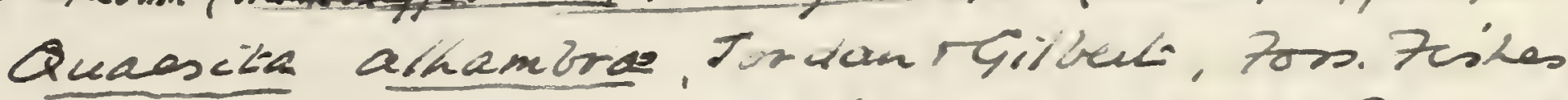
Diatom Bedes hompor, Cah. (Stauford Unir. Pubtio. 1920)

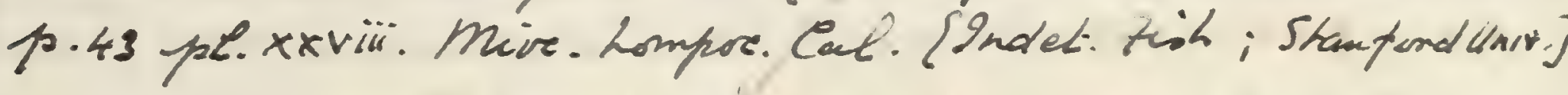

Quarsita fragills, Tordan FG elbet lor. cill 1920,p43

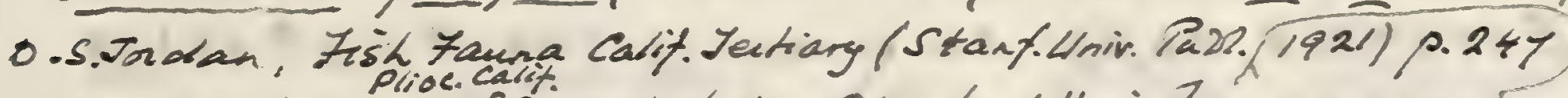

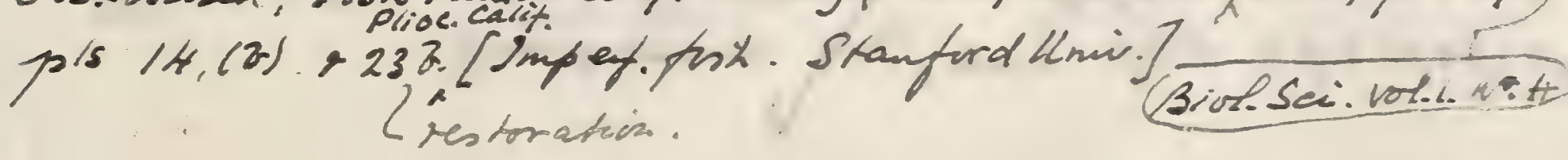




most dorsal fin-ray. They are grouped together by him under the name of Clupea (Meletta) doljecence (Kramberger, Beitr. Paläont. Oesterr.-Ungarns, vol. iii. 1883, p. 77, pl. xiv. fig. 4), and recorded from Dolje, Podsused, and Vrabce. There are no specimens in the

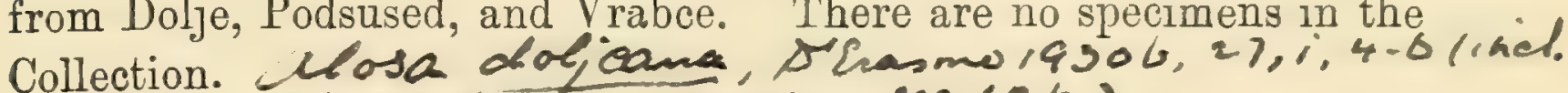
caycer méneghimin Fe. lavelan (p.p.)

The fishes described as follows are not represented in the Collec-

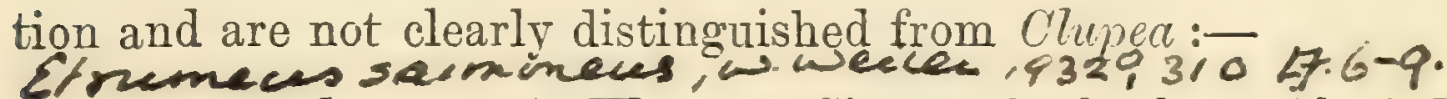

Alosina salmonea, A. Wagner, Sitzungsb. k. bay. Akad. Wiss., math.-phys. Cl. 1860, p. 54.-Upper Eocene: Wernleiten, near Traunstein, Bavaria. [Nearly complete fish; Palæontological Museum, M[unich.]

Clupeops insignis, H. E. Sauvage, in F. Fontannes, Le Bassin de Crest (1880), p. 209, pl. vii. figs. 4, 5.-Lower Miocene; Eurre, Drôme. [Type species of Clupeops. Imperfect fish.] Add Reohalecepis bus

To this or the closely-related family of Alepocephalide may probably be referred the portion of the trunk of a fish described as

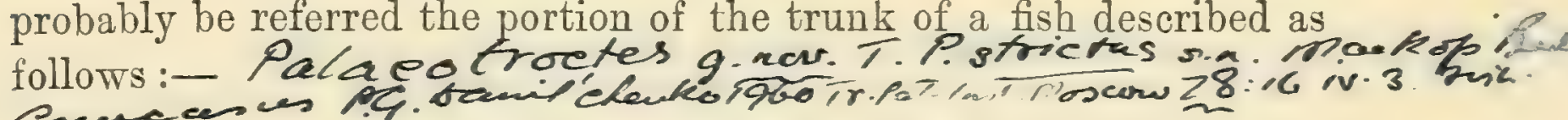
Cossox monasteriensis, W. von der Marck, Palæontogr. vol. xi. (1863), p. 32, pl. iii. fig. 3.-Upper Cretaceous : Sendenhorst, Westphalia. [Imperfect trunk: Academy of Münster.]

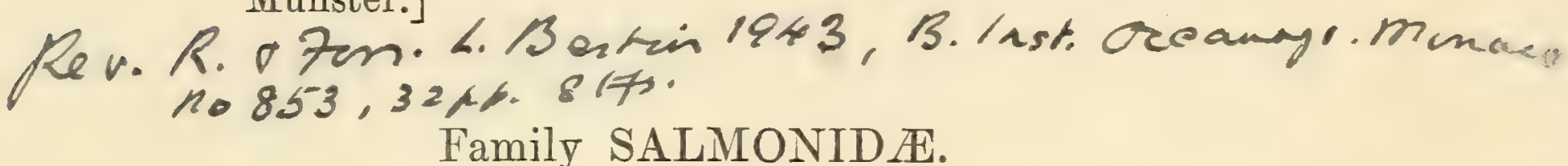

Recent fishes distinguished from the Clupeidx by the presence of an adipose dorsal fin and the incompleteness of the oriducts; also by the normal overlapping of the postclavicular plate by the clavicle. The extinct genera not being recognisable from their skeletons, the family was united by Agassiz with those of the Clupeoids under the comprehensive designation of Halecidæ.

Genus SAIMIO (Artedi), Linnæus.

[Syst. Nat. ed. 10, 1758, p. 308.]

Head large, and trunk elongate-fusiform with rounded abdomen. Mouth deeply cleft and dentition powerful; spaced conical teeth on the premaxilla, maxilla, dentary, vomer, and palatine, none on pterygoids. Paired fins of moderate size, the pelvic pair opposed to the median dorsal; anal fin short, with not more than 14 rays; caudal fin truncate. Scales small.

This genus ranges throughout the freshwaters of the arctic and 
temperate regions of the northern hemisphere. It is only definitely known among fossils by unimportant fragments of Pleistocene age, of which there are none in the Collection.

The following supposed extinct species is doubtfully determined :-

Salmo(?) immigratus, D. G. Kramberger, Rad Jugoslav. Akad. vol. cvi. (1891), p. 102, pl. vii. fig. 4.-Upper Miocene; near Podsused, Croatia. [Portion of trunk; University Geological Museum, Agram.]

The following supposed extinct genus and species is known only by the skull, which resembles that of Salmo but has the maxilla subcylindric or rod-shaped instead of flat or lamiuar :-

Rhabdofario lacustris, E. D. Cope, Proc. Amer. Phil. Soc. vol. xi. (1871), p. 546.-Pliocene; Idaho. [The type species, as large as Salmo salar.]

The fish-remains described as follows are supposed to represent another extinct genus, Thaumaturus, closely related to Salmo, but distinguished by the great obliquity of the cleft of the mouth and the crimping of the scales. There are no examples in the Collection.

Thaumaturus furcatus, A. E. Reuss, Geogn. Skizze aus Böhmen, vol. ii. (1844), p. 264; G. C. Laube, Sitzungsb. Ver. Lotos, 1900, p. 1, figs. 1-5. Aspius furcatus, H. von Meyer, Palæontogr. vol. ii. (1851), pp. 59, 64, pl. viii. figs. 1-4. Aspius elongatus, H. von Meyer, ibid. p. 61, pl. xii. figs. 5, 6.-Lower Miocene: Kutschlin, Bohemia. [The type species. Imperfect fish.]

Thaumaturus lusatus, G. C. Laube, Sitzungsb. Ver. Lotos, 1900, p. 6.-Lower Miocene: Warnsdorf, Bohemia. [Fish showing impression of adipose dorsal fin; Geological Museum, German University, Prague.]

\section{Genus MALLOTUS, Cuvier.}

[Règne Animal, ed. 2, 1829, p. 305.]

Head and trunk more or less laterally compressed, elongatefusiform. Mouth deeply cleft and dentition very feeble; mandible prominent. Paired fins relatively large, the pelvic pair opposed to the short median dorsal; anal fin not much extended; caudal fin forked. Scales minute, slightly enlarged along the lateral line.

Only one species is known. 




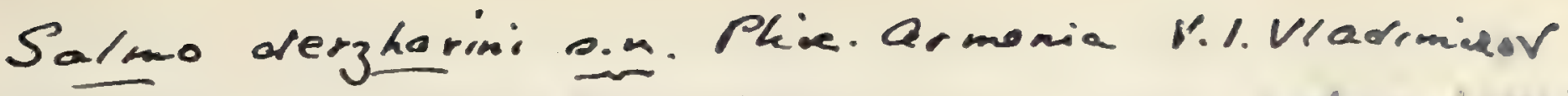

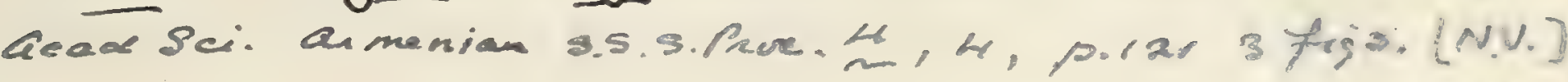

Cristivomer namaycush ( ), T. Hussatef, Loum. Geal. vol. $x \times$ iv (1916), h.685, with fip.Pleistreene; Menomonie, bumn Crunty, hiseonsin, U.S.S. CPortion of steull with jours; Ththe Ged. Sum. Riscensing

Solmonids in Slacial sopuits, R. Klecels bag, 1932, Z. f. Gletschentunde. Xx. G.r3y

Thamm a hinidas aff. PVozit. 19?"?

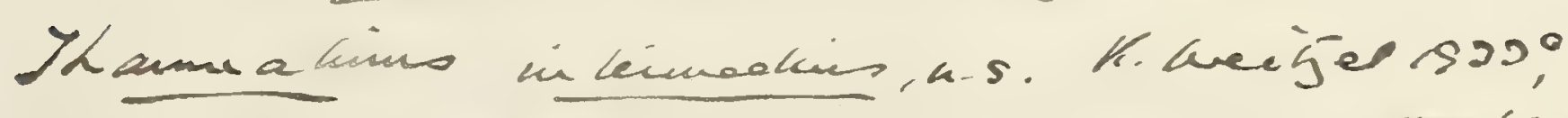

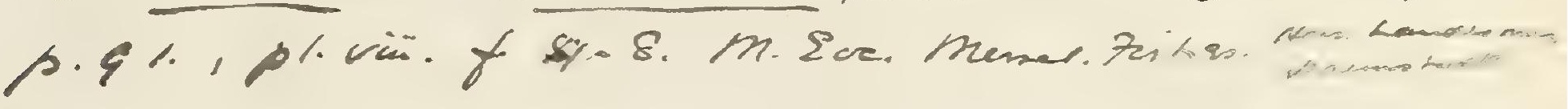

Thammakimes sparnmthi, u.s: EVoght, 1994; 0.43 ,

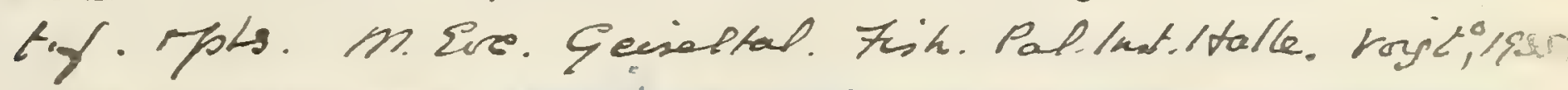

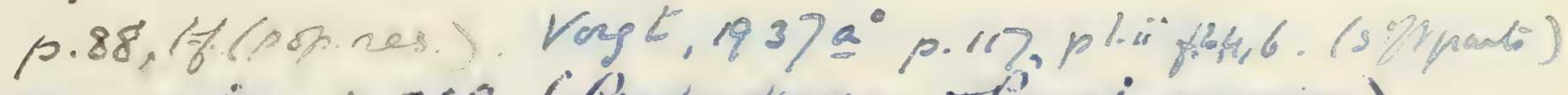

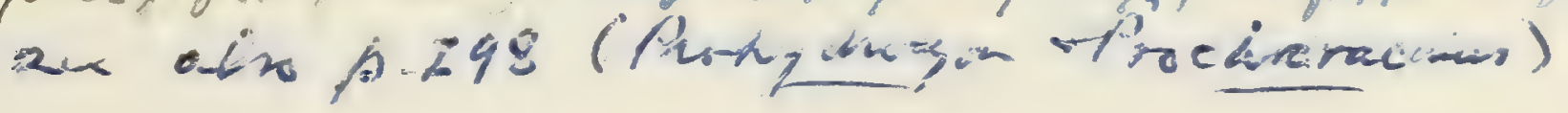




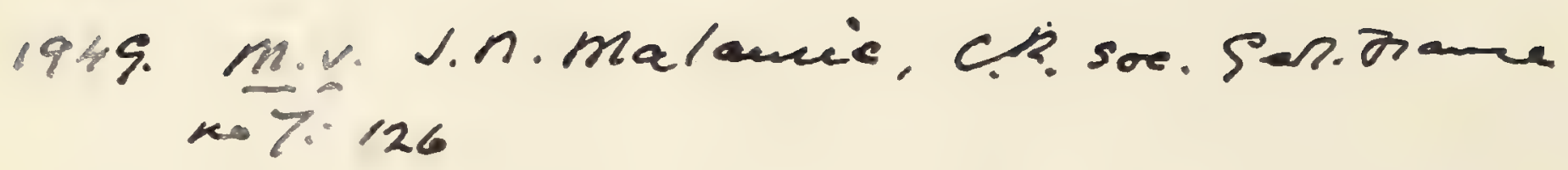

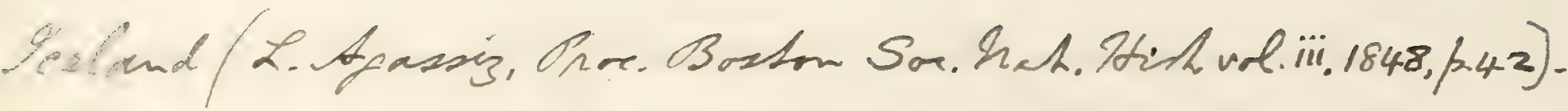

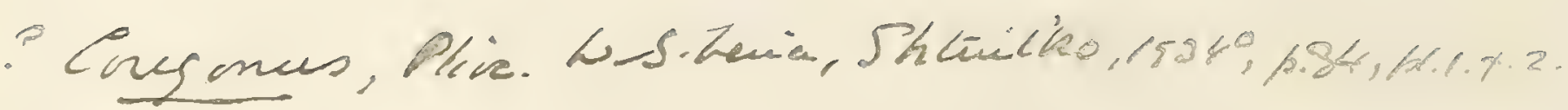




\section{Mallotus villosus (Müller).}

1776. Clupea villosa, O. F. Müller, Zool. Dan. Prodr. p. 50.

1838-44. Mallotus villosus, L. Agassiz, Poiss. Foss. rol. v. pt. ii. p. 98, pl. lx.

1848. Mallotus villosus, Cuviel \& Valenciennes, Hist. Nat. Poiss. vol. xxi. p. 392, pls. $622,623$.

1894. Mallotus villosus, J. W. Dawson, The Canadian Ice Age, p. 265, pl. viii. fig. 1.

Type. Recent fish.

The type species, attaining a length of about $0 \cdot 15$. Length of head with opercular apparatus considerably exceeding the maximum depth of the trunk, and nearly one quarter of the total length of the fish to the base of the caudal fin. Vertebræ about 68 in total number. Pelvic fins inserted opposite the origin of the dorsal fin, which arises at the middle of the back and comprises 13 or 1 t rays; anal fin with 21 to 23 rays, and its base-line forming a convex curve.

Form. \& Loc. Pleistocene and Recent: coasts of northern North

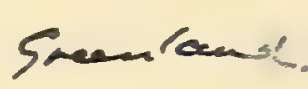
America and North-eastern Asia. S.E.Bosmia (see celter to ST.J.Bolkoy

The only known fossil examples of this species are contained in 27.8.25.5 concretionary nodules from Glacial Clay. In Greenland these nodules are split by the Eskimo along the plane of the contained fish and then used as scrapers.

P. 9247. Four specimens; coast of Greenland. History unknown.

P. 1851, P. 3813. Three specimens labelled by Agassiz; Greenland. Egerton \& Ennistillen Colls.

P. 119. Specimen in unusually thick nodule ; (?) Greenland.

Purchased, 1883.

P. 272. One specimen: Green's Creek, 10 miles below Bytown on the Ottawa River, Canada.

Transferred from Mus. Practical Geology, 1880.

44918. Similar specimen ; Green's Creek.

Purchased, 1873.

P. 1852, P. 3812. Six specimens; Green's Creek.

Egerton \& Enniskillen Colls.

P. 6931. Fish in remarkably thick nodule; Green's Creek.

Purchased, 1893.

Other fragmentary fossils have also been referred to existing genera of Salmonidæ, as follows:-

Coregonus lavaretus, Linn.: A. G. Nathorst, Geol. Fören. StockPART IV. 
holm, Förhandl. vol. xv. (1893), p. 574.-_Pleistocene ;

Skattmansö, Upland, Sweden.

* Osmerus albyi, H. E. Sauvage, Ann. Sci. Géol. vol. iv. (1873), art. no. 1, p. 215, fig. 53.-Upper Miocene; Licata, Sicily. [Imperfect fish.]

Osmerus d'achiardi, de Bosniaski, Atti Soc. Tosc.-Proc. Verb. vol. i. (1878), p. xix (name only).-Upper Miocene; Gabbro, Tuscany.

Osmerus larteti, H. E. Sauvage, Toc. cit. 1873, p. 213, fig. 41, and loc. cit. vol. xi. (1880), art. no. 3, p. 40, fro. 11.-Ibid. [Ditto.]

Osmerus propterygius, H. E. Sanvage, ibid. p. 216, figs. 54,62.Ibid. [Ditto.]

Osmerus scurabellii, I. Bonomi, Rivista Ital. Paleont. vol. ii. (1896), p. 218, pl. v. fig. 6.-Upper Nícene; Mondaino, Prov. Forli, Italy. [Ditto.]

Osmerus (?) stilpnos, H. E. Sauvage, Toc. cit. 1863 , p. 218, figs. 55, 63.-Ibid. [Ditto.]

The generie determination of these supposed species of Osmerus is very doubtful.

\section{Family HALOSAURID E.}

Trunk much elongated, the caudal region relatively large and tapering. Parietal bones in contact, excluding the supraoccipital from the cranial roof; squamosals suturally united with parietals and completely covering the otic region; snout a little produced; $a_{b}$ suborbital series of enlarged cheek-plates bearing the well-developed slime-canal. Mandibular suspensorium inclined forwards, and gape of mouth small; premaxilla chiefly forming the upper border of the mouth, but maxilla also entering it; teeth minute or rudimentary. Opereular apparatus incomplete, with numerous wellspaced slender branchiostegal rays, but no gular plate. Vertebral centra in the form of thin cylinders pierced by the notochord; ribs very short. Intermuscular bones present. Fin-fulcra absent; finrays bifurcated slightly and articulated at wide intervals in the distal half; pectoral fins placed well upon the flank, and pelvic fins well-developed, abdominal; a single dorsal fin about the middle of the back; anal fin much extended, sometimes confluent with the caudal. Scales thin and cycloid; lateral line conspicuous along the ventral portion of the flank.

This family survives only in the deep sea, where it is represented by Halosaurus and one or two other closely related genera. An 


Proaggentina gicon. T. Pindinatas.4. Mariop. Sos

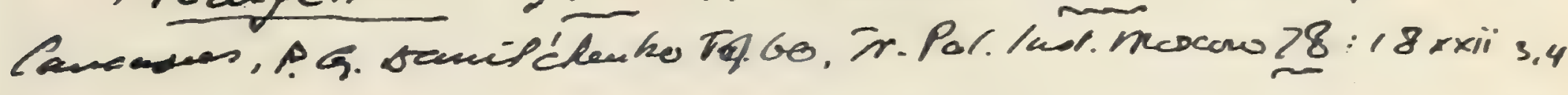

Q. Shy $=$ Mgctophus rafinespuer (Coceo). C. De Ptefano, Mem. Be. Comith. Gerl. Ital. vol. vii. ph.i $(19(8)$, h.so, pl.v.f. 4, s.

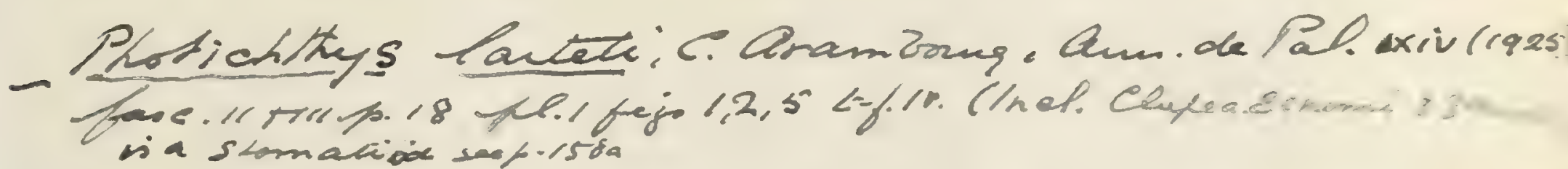

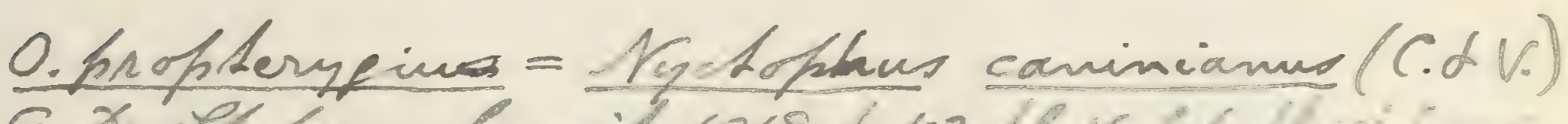

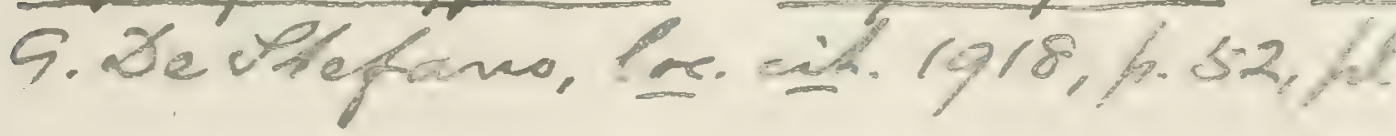

Lencichtypos vagans, T.t.p. Cockerell, Prof. Paperizo M.S. Swarey 1919l1918) (nom vidi:) Eretare Glnado. - also Chile?

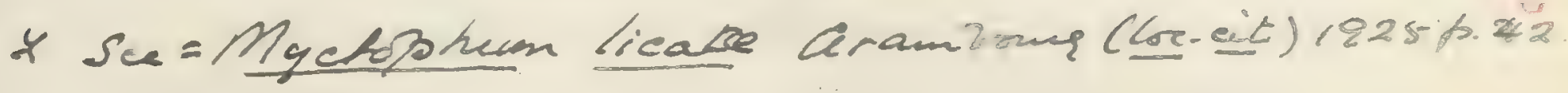

Laytonia calitomia Sirs.n. L.R. band

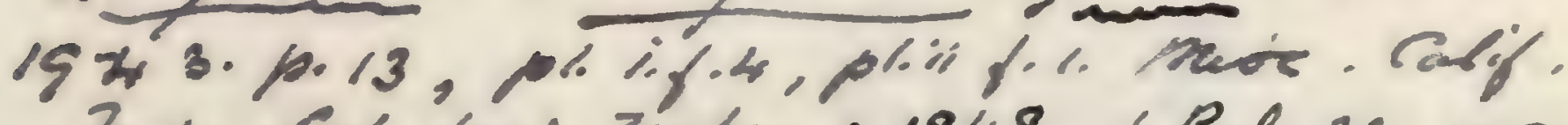

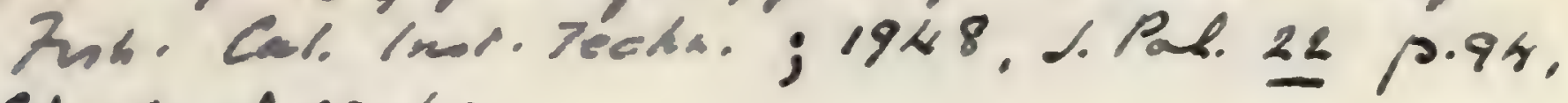
Qf. $2,2,423 \cdot f \cdot 3$.

Lay trixia? zemmani S.n. K.R.tand 1948.

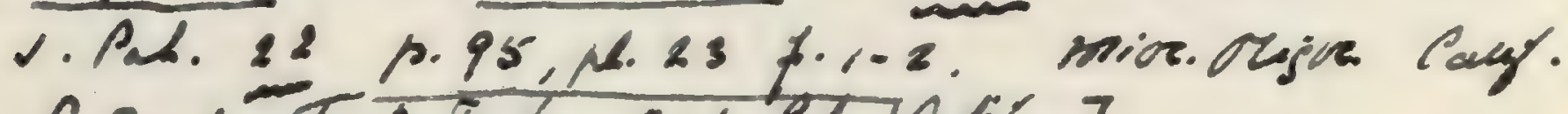

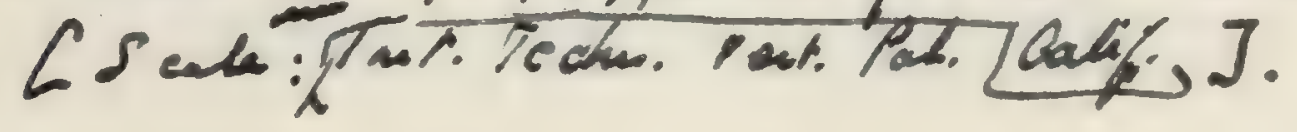




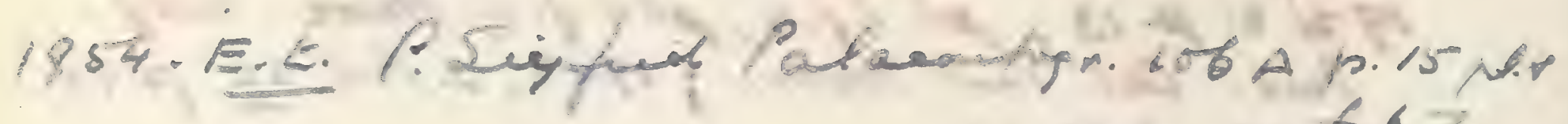
$\angle 6,3$. 
account of the osteology and the anatomy of some of the soft parts of the type genus is given by Günther ${ }^{1}$.

Genus ECHIDNOCEPHALUS, W. von der Marck.

[Zeitschr. deutsch. geol. Gesell. vol. x. 1858, p. 247..]

An imperfectly known fish from which the existing genus Haitosaurus is not yet clearly distinguished. The dentition, cheek-plates, and pectoral fin are unknown, while the number of rays in the dorsal and pelvic fins is slightly less than is usual in the recent genus. Branchiostegal rays about 12 in number. Vertebral centra very short and numerous as far as the middle of the caudal region, marked with delicate longitudinal striæ. Dorsal fin with two simple, and about six branched rays, arising behind the peivic pair and in advance of the anal, which is much extended and not differentiated from the caudal. Scales of lateral line thickened and apparently enlarged.

Echidnocephalus troscheli, W. ron der Marck.

1858. Echidnocephahus troschelii, W. von der Harck, Zeitschr. deutsch. geol. GeselI. vol. x. p. 247.

1858. Echidnocephalus tenuicaudus, W. von der Marck, ibid. p. 248. [Imperfect fish ; Academy of Münster.]

1863. Echidnocephalus troscheli, W. von der Marck, Palæontogr. vol, xi. p. 55 , pl. viii. fig. 1.

1863. Echidnocephalus tenuicaudus, W. von der Marck, ibid. p. 56, pl. viii. figs. 2, 3, pl. xiv. fig. 1.

1868. Eehidnocephalus troscheli, W. von der Marck, loc: cit. vol. xv. p. 288.

1873. Echidnocephalus troscheli, W. von der Marck, loc. cit. vol. xxii.p. 62.

1897. Echidnoceptcalus troscheli, A. S. Woodward, Proc. Znol. Soc. p. 268, pl. xviii.

Type. Imperfect distorted fish; Academy of Münster.

The type species, attaining a length of about 0.3 . Iength of head with opercular apparatus apparently twice as great as the maximum depth of the trunk, and equal to the distance between the clavicle and pelvic fins. Vertebral column as far as the middle of the caudal region comprising eighty short and deep centra; those beyond being relatively longer and less ossified. Pelvic fins, each with about 6 rays, arising midway between the pectoral arch and the anal fin; dorsal fin short and deep, arising nearly opposite the

${ }^{1}$ A. Günther, Deep Sea Fishes, 'Challenger' Rep.-Zool. vol, xxii. (1887), p. 232, pl. lx. figs. $1-8$. 
35 th rertebral centrum; anal fin less elevated and with more delicate rays than the dorsal, arising nearly opposite the 50th vertebral centrum.

The so-called E. tenuicaudus is still regarded as a distinct species by von der Marck in his latest list (Palæontogr. vol. xxxi. 1885, p. 240), but the only differences observed seem to be due to accidents in distortion and preservation.

Form. \& Loc. Upper Cretaceous: Westphalia.

P. 2111. Imperfect fish displaying some of the principal characters of the head and opercular apparatus, described and figured in Proc. Zool. Soc. 1897, p. 268, pl. xviii. fig. 1; Sendenhorst.

Egerton Coll.

P. 2114. Imperfect specimen on slab with other fishes, described ibid.p. 271; Sendenhorst.

Egerton Coll.

P. 4481. Impression of fish wanting the end of the snout, described and figured ibid. p. 269, pl. xviii. fig. 2 ; Sendenhorst.

Enniskillen Coll.

P. 5949. Head and greater portion of trunk in counterpart, described and figured ibid. p. 270, pl. xviii. fig. 3 ; Sendenhorst. The scales of the lateral line are especially conspicuous.

Purchased, 1889.

Another example of this species is preserved on a large slab numbered P. 9251.

Genus ENCHELURUS, W. von der Marck.

[Palæontogr. vol. xi. 1863, p. 58.]

An imperfectly known genus provisionally placed in this family on account of the general resemblance of its skeleton to that of Echidnocephatus. Vertebræ very short and numerous, marked with delicate longitudinal striæ; neural arches in the abdominal region expanded into narrow laminæ. Paired fins small, about equal in size; dorsal fin at least as deep as long, arising opposite to or behind the pelvic fins; anal fin much extended; a separate fringing caudal fin, pointed behind. Scales small, those of the lateral line apparently thickened but not enlarged.

Enchelurus villosus, W. von der Marck.

1863. Enchelurus villosus, W. von der Marck, Palæontogr, vol, xi. p. 58, pl. ix. fig. 5.

Type. Imperfect distorted trunk; Academy of Münster. 


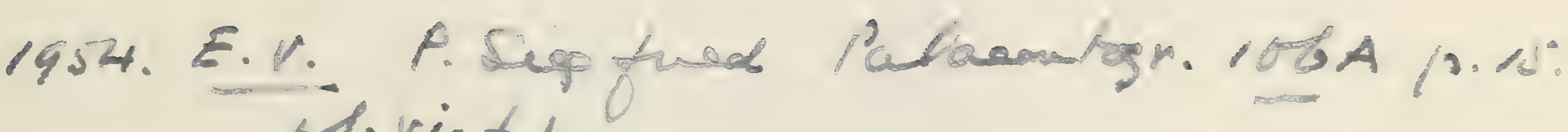
phi.t.l. 

The type species, known only by the unique type specimen, probably attaining a length of about $0 \cdot 2$. Anal fin with not less than 25 rays, and dorsal fin apparently completely opposed to it.

Form. \& Loc. Upper Cretaceous: Barmberg, Westphalia.

Not represented in the Collection. In the type specimen in the Academy of Münster some of the anterior vertebral centra seem to show that a large remnant of the notochord pierced thern. The hæmal spines are somewhat thickened but not fused together at the base of the caudal fin. Long and delicate intermuscular bones are conspicuous, extending nearly to the end of the tail. The extended anal fin ("dorsal" of von der Marck) is clearly separate from the caudal, and exhibits remarkably short supports. The dorsal fin is represented only by fire articulated and divided rays opposite the middle of the anal; but the specimen is so much distorted that the original relationships of these two fins are uncertain.

\section{Enchelurus syriacus, sp. nov.}

$$
\text { [Plate XII. figs. 1, 2.] }
$$

Type. Distorted fish; British Museum.

A species attaining a length of about $0 \cdot 12$. Iength of head with opercular apparatus equalling twice the maximum depth of the trunk, and probably contained about three times in the length from the pectoral arch to the base of the candal fin. Operculum nearly as deep as broad, its hinder border slightly produced into a broad crimped prominence. Vertebræ approximately 100 in number. Pelric fins, each with about 8 rays, inserted opposite the origin of the dorsal fin, which comprises from 16 to 18 rajs, and arises as far from the occiput as its termination from the base of the caudal fin ; anal fin with about 30 rays, arising opposite the hinder end of the dorsal fin.

Form. \& Loc. Upper Cretaceous: Sahel Alma, Mrt. Lebanon.

P. 5998. Type specimen, shown of the natural size in Pl. XII. fig. 1. The fish is accidentally bent upwards at the middle of the abdominal region, and the pectoral arch seems to be a little displaced backwards. The cranium is eridently low and elongated, but no other feature is recognisable in the head. There are remains of a tolerably robust opercular apparatus, with a few long and slender branchiostegal rays $(b r$.$) below. Part of$ the stout and broad claricle is seen, with remains of the scapular arch and pectoral fins behind. There is a large scapula abore a smaller coracoid, without any intervening 
vacuity; and four slender basals can be seen supporting the appended pectoral fin $\left(p_{c} t_{0}\right)$. The vertebral centra are obscure, but their arches are distinct; the characteristic expansions of the neural arches in the abdominal region are especially well shown. The pelvic fins $(p / v$.$) , with$ their closely apposed supporting bones, are preserved just in advance of the dorsal fin, which is opposed to the space between the pelvic pair and the anal. The rays of the dorsal fin, probably about 17 in number, are stouter than those of the anal, which seem to have been shorter and not less than 30 in number. Of the caudal fin, only a fragment remains.

Lewis Cull.

P. 9168. Larger and more imperfect specimen, shown of the natural size in Pl. XII. fig. 2. The head is vertically crushed and seen apparently from above. The postorbital portion of the cranium is longer than broad, while the interorbital and rostral portions are very slender. The left mandibular ramus is sufficiently complete to indicate that the quadrate articulation was beneath the hinder border of the orbit. The opereulum (op.) is trapezoidal in shape, and slightly crimped postero-superiorly; an impression on the right suggests that the preoperculum was much expanded: while there are remains of a suboperculum and very slender branchiostegal rays on the left. The vertebræ in the abdominal region bear the expanded neural arches, and also short, slender ribs. 'The column is distcrted just behind the dorsal fin. Imperfect remains of all the fins occur, including the large and fringing pointed caudal fin. The squamation is not well preserved; but one longitudinal series of scales near the ventral border is conspicuous, apparently by its being thickened, not enlarged. The latter series doubtless indicates the course of the lateral line.

Lewis Coll.

46529. Imperfect specimen, specially displaying the vertebræ and pelvie fins. The short and deep vertebral centra are marked with delicate longitudinal ridges. The ribs are short and slender, not supported by any transverse processes. The laminar neural arches in the hinder two thirds of the abdominal region are overlapped by extremely slender, separate neural spines.

Lewis Coll.

46560. Distorted fragment, showing robust clavicles, also remains of paired and dorsal fins.

Lewis Coll. 
$+$ - 
1903. Encholurew anglieus, A.S. Loodward, Bn. Bish

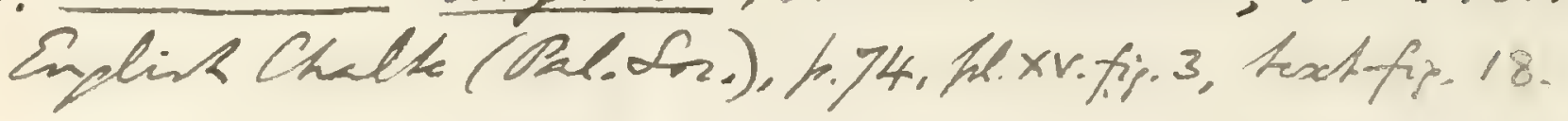


Enchelurus anglicus, sp. nor.

[Plate XII. fig. 3.]

Type. Imperfect anterior half of fish; British Museum.

A large species, probably attaining a length of about 0.25. Too imperfectly known for precise definition, but probably similar to E. sypiacus in general proportions. Operculum as deep as broad, gently rounded and not crimped at the hinder border.

Form. \& Loc. Turonian: S.E. England.

P. 4249. Type specimen, shown of the natural size in PI. XII. fig. 3; Lower Chalk, probably Kent. The cranium is exposed from abore, and its roof-bones are shown to be unornamented. The postorbital region is at least as broad as long, while the interorbital and rostral regions are much laterally compressed. The parietal bones $(p a$. are large, meeting in the middle line; while the squamosals ( $s q$.) cover the whole of the otic region, except perhaps behind. The frontals $(f r$. $)$ are extremely narrow in their anterior half; and the slender mesethmoid (eth.), which projects forwards beneath them, exhibits a slight expansion at its anterior end. Among the remains on the side of the cranium, there is a quadrate on the right, and an entopterygoid (enpt.) on the left. The quadrate bears a small postero-superior process, probably to clasp a symplectic. The entopterygoid is a large laminar bone, slightly more than twice as long as deep. Remains of the premaxillæ beneath the end of the mesethmoid indicate that they must have been relatively small, with a delicate rod-like extension behind. They distinctly bear very minute teeth. The maxilla ( $m x$.), shown on both sides, is relatively very large; its anterior portion being a stout narrow bar extending forwards above the premaxilla, while its larger hinder portion is a considerable laminar expansion, not externally ornamented. The evidence of teeth on this element is uncertain. The mandible (md.) seems to have been comparatively small, but its remains are imperfect and partly obscured. There is, howerer, reason to suspect that the gape was small, and that very little of the maxilla entered it. The left operculum (op.), though somewhat fractured, shows its characteristic smoothness and rounded posterior border. Fragmentary remains of the vertebral axis are preserved as far as the pelvic fins. The anterior vertebral centra 
are deeper than long, but those more posteriorly are about as deep as long; all are marked by very delieate longitudinal ridges. Traces of slender ribs occur, and all the neural arches bear curious laminar expansions. Portions of the pelvic fin-supports ( $p l v$.$) are distinguishable, and$ there are a few indications of very thin scales.

Enniskillen Coll.

The following specimen seems to belong to a species of Enchelurus, but is not satisfactorily determinable:-

$\mathbf{P}$, 9248. Imperfect distorted fish, nearly as large as the type specimen of $E$. anglicus, wanting caudal extremity; Upper Cretaceous, Hakel, Mt. Lebanon. The characteristic cranium is exposed from abore, and the left maxilla and mandibular ramus are well shown. There are also remains of a tubercular tritoral dentition on some of the inner bones of the mouth. The expansions of the neural arches cannot be seen. Remains of the pelvic, dorsal, and anal fins occur. The scales are marked by radiating grooves in their covered portion.

Lervis Coll.

\section{Family NOTACAN'THID无.}

Trunk much elongated, the caudal region slender and tapering, with or without a diminutive caudal fin. Parjetal bones partly in contact, but not completely excluding the supraoccipital from the cranial roof; squamosals suturally united with parietals and completely covering the otic region; snout a little produced; cheekpiates very delicate. Mandibular suspensorium inclined forwards, and gape of mouth small; premaxilla extended and excluding the maxilla from the upper border of the mouth; teeth slender, nerer much enlarged. Opercular apparatus complete, with a few branchiostegal rays, but no gular plate. Vertebral centra much constricted, those of the abdominal region with very short and broad transverse processes; ribs long and slender, inserted just below the neural arches. Intermuscular bones present, sometimes fused with the ribs. Pectoral arch connected with the skull by ligament. Finfulcra absent; paired fins well-developed, the pelvic pair being remote; dorsal fin rudimentary, its supports being widely spaced, and the rays, when present, being represented chiefly by small spines; anal fin low and much extended, its anterior portion at least spinous. Scales thin and cycloid; lateral line distinct along the upper part of the flank. 
49812. Ventebul columm and disael fin, desused If fipmed A.S.h. 1903, h. 76, hl. xv. fis. 3; zone of Holaster sulplobosus, Glynde. Capion Clel. 


1695

Gonofomatidae.

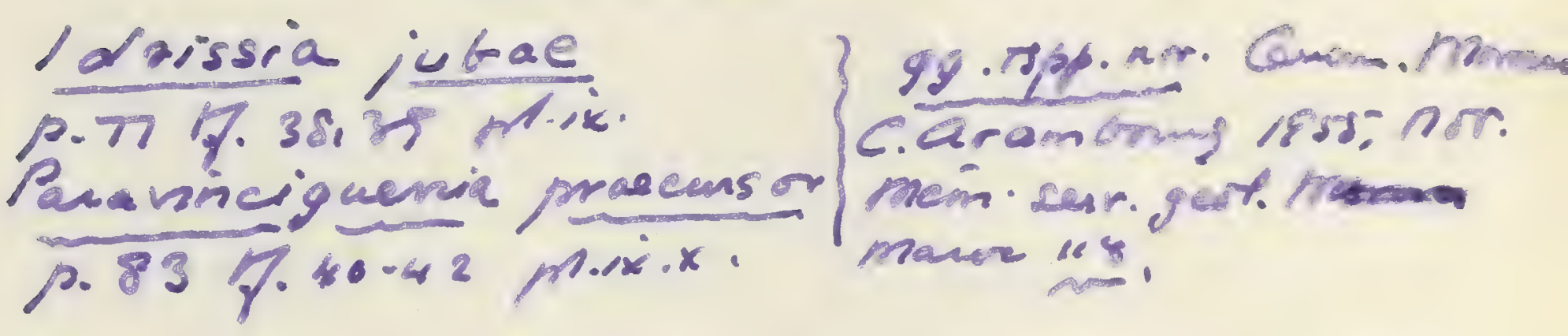

Idrission carpaltica sp.n. Olgoiens Cappatisin

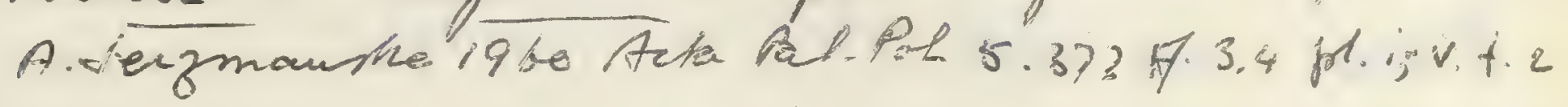


1695

P.5. 200 1690 
Noticanthus and two or three closely allied genera still exist in the deep sea. An account of the osteology and anatomy of some of the soft parts of the type genus is given by Günther ${ }^{1}$, and there is some reason to believe that the firh is truly physostomous ${ }^{2}$. Vaillant has observed bone-lacunæ in several parts of the skeleton ${ }^{3}$.

\section{Genus PRONOTACANTHUS, norum.}

An imperfectly known genus, with laterally-compressed trunk and an excessively elongated abdominal region which comprises at least 70 vertebræ. Teeth recurved, in single regular series in the mandible. A regular, spaced series of dorsal fin-supports extending along the whole length of the abdominal region, each support expanded distall $\bar{y}$, but not bearing either fin-ray or spine.

Pronotacanthus differs from all the existing genera in the absence of dorsal spines or fin-rays. It has already been mentioned in Ann. Mag. Nat. Hist. [7] rol. v. (1900), p. 322.

\section{Pronotacanthus sahel-almæ (Davis).}

[Plate XV. figs. 1, 2.]

1887. Anguilla sahel-almce, J. W. Davis, Trans. Roy. Dublin Soc. [2] vol, iii. p. 625, pl. xx. fig. 2.

Type. Imperfect fish; British Museum.

The type species, attaining a length of about $0 \cdot 25$. Length of head with opercular apparatus twice as great as the maximum depth of the trunk, which is contained about eight times in the distance between the paired fins. Number of dorsal fin-supports in the same space about 52 .

Form.\& Loc. Upper Cretaceous: Sahel Alma, Mrt. Lebanon.

46535, P. 4\%41. Type specimen in counterpart, unsatisfactorily described by Daris loc. cit., with figure restored from both sides of the fossil. The right side of the fossil is re-drawn in Pl. XV. fig. 1. The head is distorted and too imperfect for description, but the bones bordering the mouth are shown to be comparatirely stout, and there seems to be an antorbital cheek-plate traversed by a branching sensory canal. The much-constricted vertebral centra are mostly broken along the middle and partly obscured by the

${ }^{1}$ A. Günther, Deep Sea Fishes, 'Challenger' Rep.-Zool. vol. xxii. (1887), p. 245 , pl. lx. figs. 9-15.

${ }^{2}$ L. Vaillant, Expéd. Scient. Travailleur et Talisman.-Poissons (1888), p. 333.

${ }^{3}$ L. Vaillant, op. cit. p. 323. 
numerous delicate intermuscular bones, so that the nonappearance of the characteristic short transverse processes is perhaps to be explained by the imperfections in the mode of preservation. The neural arches and spines are very slender, and inclined sharply backwards throughout the length of trunk preserved; the delicate ribs seem to hare completely encircled the abdominal cavity. Traces of the contents of the intestine are observed throughout the greater part of the abdominal region, extending behind the pelvic fins nearly as far as the specimen is preserved. One pectoral fin is bent upwards and the other downwards, and they are sufficiently $\pi$ ell exhibited to indicate that they are comparatively large and robust, each with about 10 rays. The pelric fins ( $p l v$.) are very remote, and obserred to be supported by a pair of slender bones which are pointed in front. The pelvic fin-rays are much more slender than those of the pectoral fins, and perhaps about two thirds as long as the latter. The fish is broken away shortly behind the pelvic fins, and neither side of the fossil exhibits the additional fragment represented by Daris. Still further back on the left-hand slab, there occurs the terminal portion of a tail with a small differentiated caudal fin; but it is rery uncertain whether this belongs to the fish now deseribed. The dorsal fin-supports are well shown as indicated in the drawing, each with a small triangular expansion at its distal end; but there are no traces of fin-rays in connection with them. There are no undoubted remains of scales. Lewis Coll.

49542, P. 9169. Imperfect head and greater part of abdominal region, exhibiting a small fish swallowed tail foremost, in counterpart. The front half of the right side of the fossil is shown of the natural size in Pl. XV. fig. 2. The cranium in side-view appears less deepened than in the existing Notacanthus, but it has the same delicate parasphenoid bone. The maxilla, shown on the left side of the fossil, is gently curred and comparatively stout, but its hinder end is obscured. The mandible is still stouter, its articulation below the middle of the orbit, its hinder half very much deepened, its short oral margin still bearing three slender recurved teeth. The opercular apparatus is imperfect and distorted, but below it there are distinct remains of about ten delicate branchiostegal rays. The constricted vertebral centra are fractured, 
Ringn Chrodercuis Craminug 1948

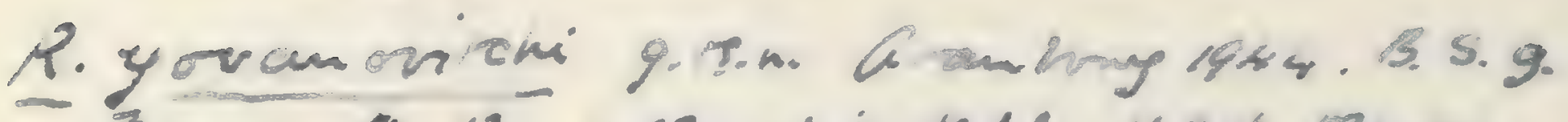

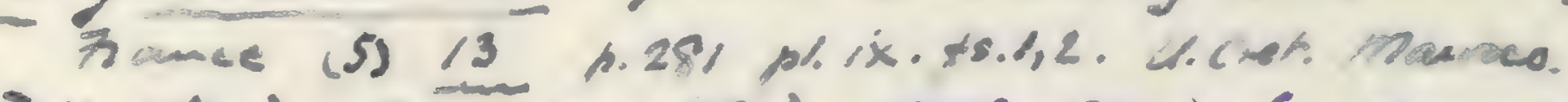

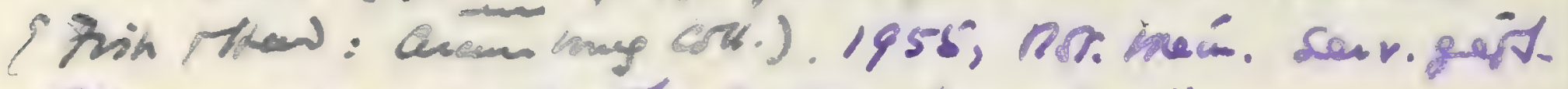

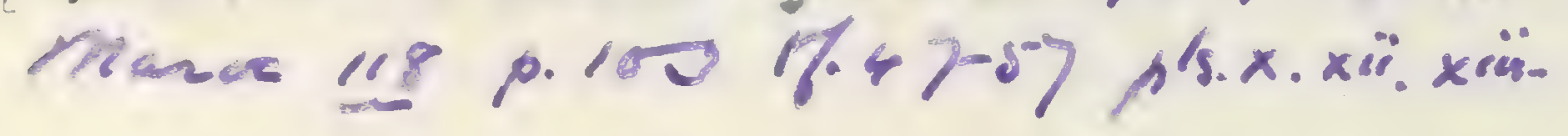

R. acutissimas 2.1. Cuer. Carso hieitur G. Sthasmo 1952, Getri. Mus. Gin. Stor. Nat. Tuesia 184, p.108,

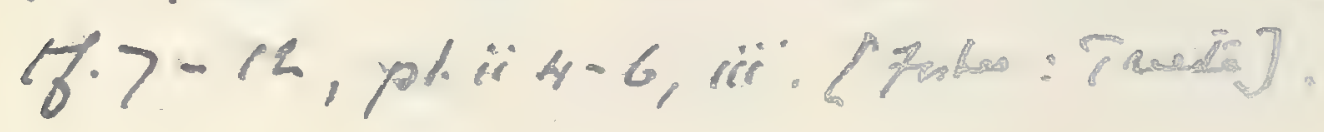


and there are no traces of transverse processes. The neural spines, ribs, and intermuscular bones are shown as in the previous specimen, and the characteristic dorsal fin-supports occur, without any traces of the fin itself. Remains of the clavicle and supraclavicle occur; and the longest rays of the pectoral fins are about half as long as the head with opercular apparatus. No scales can be distinguished.

Lewis Coll.

49522. See p. 182.

\section{Family DERCETID $\mathrm{E}_{\text {。 }}$}

Head and trunk much elongated. Parietal bones of moderate size and meeting in the middle line; squamosal suturally united with parietals and eompletely covering the otic region; snout considerably produced; cheek-plates delicate or wanting. Mandibular suspensorium vertical or inclined backwards, and gape of mouth very wide; premaxilla delicate, extending in front of the ethmoidal region, and apparently forming the greater part of the upper border of the month; teeth conical and slender, in a single series on the margin of the jaws, clustered on the pterygoid arcade and the inner side of the mandible. Opercular apparatus complete, with few slender branchiostegal rays, but no gular plate. Vertebral centra in the form of delicate constricted cylinders pierced by the notochord; ribs long and slender, borne by laminar transverse processes; neural and hæmal spines in the caudal region very short. Intermuscular bones present. Fin-fulcra absent; fin-rays bifurcated slightly and articulated at wide intervals in the distal half ; posttemporal bones in contact with the supraoccipital, and pectoral fins low down upon the flanks; pelvic fins well-developed, abdominal; a single dorsal fin, more or less extended; anal fin short; caudal fin separate. Ordinary scales small or wanting, but two or more continuous paired series of enlarged scutes along the flanks; no median dorsal or ventral scutes.

\section{Synopsis of Genera.}

I. No scales between scutes.

Dorsal fin occupying the greater part of the back, and anal fin opposed to its hinder portion; scutes much expanded .................

Dorsal fin not nccupying more than Dercetis (p. 172). one third of the back, and anal fin behind it; scutes not much expanded $\ldots \ldots \ldots \ldots \ldots$......... 
II. Small scales between scutes.

Trunk completely corered with scutes and small rhomboidal scales; dorsal fin occupring the greater part of the back, and anal fin opposed to its hinder portion .. Pelargorhynchus (p. 188).

\section{Genus DERCETIS, Agassiz.}

$$
\text { [Yenes Jahrb. 1834, p. 389.] }
$$

Esternal bones slightly ornamented with short ridges and rows of tubercles. Teeth in form of small, slender, hollow cones, more or less clustered. Tertebræ between 50 and 60 in number. Pelric fins arising nearer to the pectorals than to the anal; dorsal fin occupring the greater part of the back; anal fin opposed to the hinder part of the dorsal; caudal fin forked. Most of the dermal scutes considerably expanded, and the adjoining longitudinal series often in contact; a paired series along the dorsal and rentral borders, and another along the lateral line; no intermediate squamation.

\section{Dercetis scutatus, Agassiz.}

1834. Dercetis scutatus, L. Agassiz, Neues Jahrb. p. 390, and Poiss. Foss., Feuill. p. 20.

1811. Dercetis scututus, L. Agassiz, Poiss. Foss. rol. ii. pt. ii. p. 259.

Type. Nearly complete fish; Palæontological Museum, Munich.

The trpe species, attaining a length of about $0 \cdot 35$. Length of head with opercular apparatus equalling abont one tifth of the total length of the fish (including caudal fin). Pectoral fins much larger than the pelric fins, these tro pairs separated by a space about equal in length to the cranium; dorsal fin, $\pi i t h$ about 50 rays, arising $\pi$ ell in adrance of the pelric fins; anal fin, with not less than 16 rars, opposed to the hindermost part of the dorsal. Dermal scutes ornamented with fine tuberculations, and the three longitndinal series on each side almost or completely in contact.

Form. \& Loc. Tpper Cretaceous: Baumberg, Westphalia.

Tot represented in the Collection.

The following specimens from the English Chalk probably belong to Dercetis, but are not specifically determined:-

310 \%-82. Imperfect anterior portion of a large fish, comprising the head, claricle, abdominal rertebræ, many wellpreserred scutes, and one of the expanded pelric bones; Chalk, Grays, Essex. The cranium measures about 0.12 
Dercetis Tatiseutatus, A.s.W.

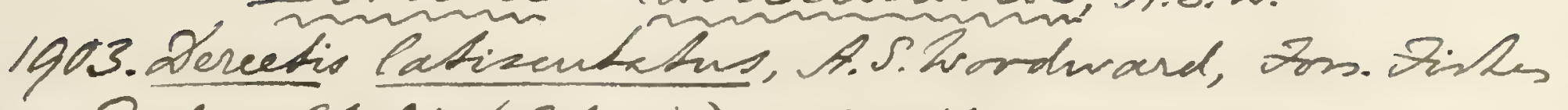

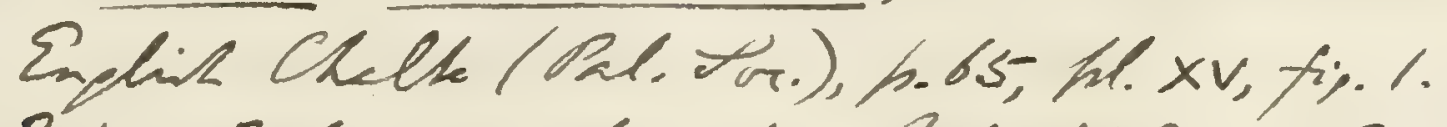

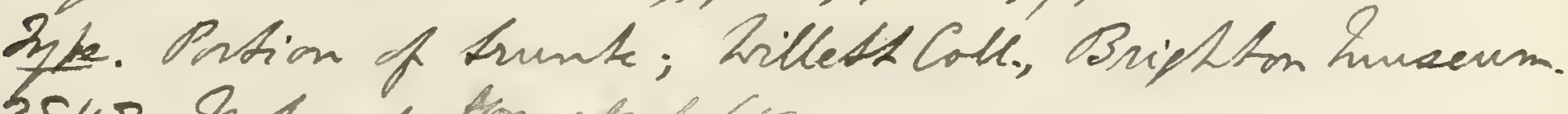
2.3847. hoticed terecto h.65.

Dercetis maximus, A.S.Z.

1903. Derretir maximus, A.S. Wordward, Bose. Filhes

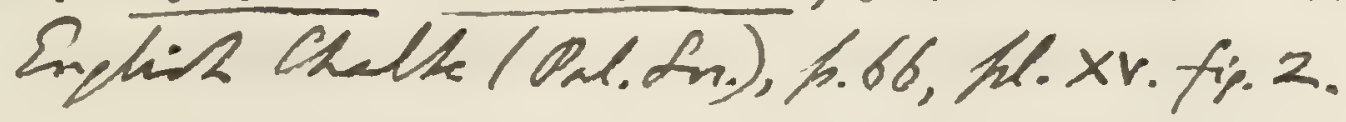

$31075=82$ di? \& fir! ln. wh. 
P.3847 = Dercetis latizentatus. Se h. 172 .

Urenchelys limhanmensio, A.S. Woodward, Amn. Mnoss-

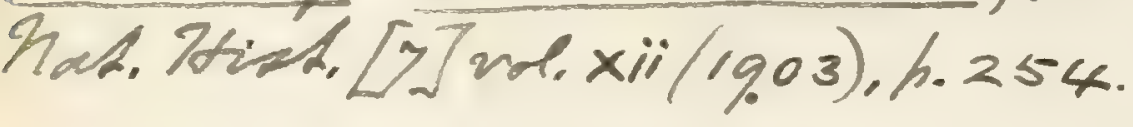


in length. The anterior vertebral centra are not more than twice as long as deep. The dermal scutes are large and very broad, with both the postero-lateral branches truncated and conspicuously ornamented with tubercles. The longitudinal series of scutes must have been in contact at least in the middle of the trunk; while those of the lateral line are scarcely more than half as large as those of the dorsal row.

Purchased, 1853.

P. 384\%. Remains of small head and trunk, with highly ornamented broad scutes; Chalk, Kent. Enniskillen Coll.

P. $384 \%$ a. Portion of series of similar scutes with an ornamentation more radiate than usual; Chalk, Sussex.

Enniskillen Coll.

The following species have been described on the evidence of unsatisfactory fragments, and are not represented in the Collection:-

Dercetis Timhamnensis, J. W. Davis, Trans. Roy. Dublin Soc. [2] vol. iv. (1890), p. 431, pl. xlv. figs. 1, 2.-Upper Cretaceous (Danian); Limhamn, near Nalmö, Sweden. [Imperfeet head and vertebræ; Geological Museum, University of Lund.]

Dercetis reussi, A. Fritsch, Rept. u. Fische böhm. Kreideform. (1878), p. 20, pl. ii. fig. 8, pl. iv. fig. 1, pl.x. figs. 1, 6, woodc. fig. 46.--Turonian; Bohemia. [Fragments; Royal Bohemian Museum, Prague.]

Genus LEPTOTRACHELUS, W. von der Marck. [Palæontogr. vol. xi. 1863, p. 59.]

Syn. Trianaspis, E. D. Cope, Bull. U.S. Geol. Surv. Territ. vol. iv. 1878, p. 67.

External bones slightly ornamented with short ridges and rows of tubercles; premaxilla longer than deep, produced to an acute point in front; all the teeth small, slender, hollow cones, only tipped with enamel, and more or less clustered. Vertebræ between 60 and 80 in number. Pelvic fins opposed to the dorsal, which does not occupy more than the middle third of the back; anal fin behind the dorsal; caudal fin forked. Most of the dermal scutes trirudiate, some narrow heart-shaped, and adjoining longitudinal series scarcely if at all in contact; a paired series along the dorsal and ventral borders, and another along the lateral line; no intermediate squamation. 
Leptotrachelus armatus, W. von der Marck.

1863. Leptotrachelus armatus, W. von der Marck, Palæontogr. vol, xi. p. 59, pl. x. fig. 3.

1885. Leptotrackelus armatus, W. von der Marck, ibid. vol. xxxi. p. 260.

Type. Imperfect fish; Academy of Münster, Westphalia.

The type species, attaining a length of about $0 \cdot \%$. Length of head with opercular apparatus contained about six times in the total length to the base of the caudal fin. Anterior abdominal region excessively slender, a series of about 10 anterior vertebræ equalling the length of the head. Pelvic fins much larger than the pectorals, arising at about the middle point of the trunk. Dermal scutes of abdominal region excessirely attenuated, those of the caudal region robust.

Form. \& Loc. Upper Cretaceous: Westphalia.

P. 2109. Imperfect head and abdominal region, with remains of the fins; Sendenhorst.

Egerton Coll.

\section{Leptotrachelus triqueter, Pictet.}

1850. Dercetis triqueter, F. J. Pictet, Poiss. Foss. Mont Liban, p. 47, pl. ix. figs. 5,6 .

1850. Dercetis linguifer, F. J. Pictet, ibid. p. 47, pl. ix. figs. 7, 8. [Fragment of abdominal region; Geneva Museum.]

1866. Leptotrachelus triqueter, Pictet \& Humbert, Nouv. Pech. Poiss. Foss. Mont Liban, p. 95, pl. xiv. fig's. 1, 2.

1887. Leptotrachelus triqueter, J. W. Davis, Trans. Roy. Dublin Soc. [2] vol. iii. p. 620, pl. xxxviii. fig. 1 .

Type. Fragment of abdominal region; Genera Museum.

A species attaining a length of about $0 \cdot 3$. Head with opercular apparatus occupying about one fifth of the total length of the fish to the base of the caudal fin. Anterior abdominal region not excessively elongated, its vertebral centra about twice as long as deep, and a series of 16 or 17 equalling the length of the head; the other vertebræ nearly similar in proportions. Pectoral fins each with about 11 rars, the length of the longest equalling one third that of the head with opercular apparatus; pelric fins slightly larger than the pectorals, arising just behind the anterior third of the trunk, each with not less than 7 or 8 rays; dorsal fin occupying the middle third of the trunk, with about 35 rays, the hindermost comparatively small and slender; anal fin with about 8 rays, twice as distant from the pelvic pair as from the caudal. Dermal scutes of moderate size and narrow, those on the dorsal and vuntral borders of the caudal region bearing a backwardly-directed smooth 


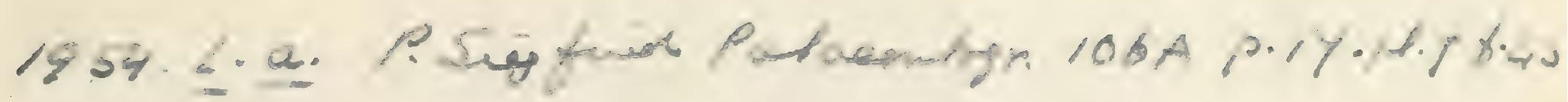

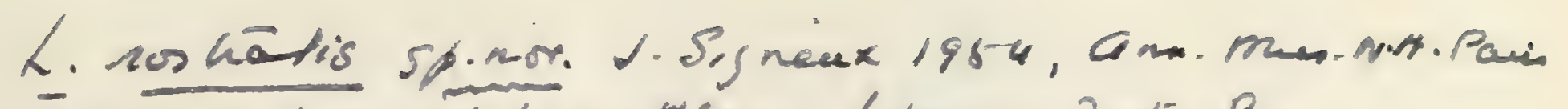

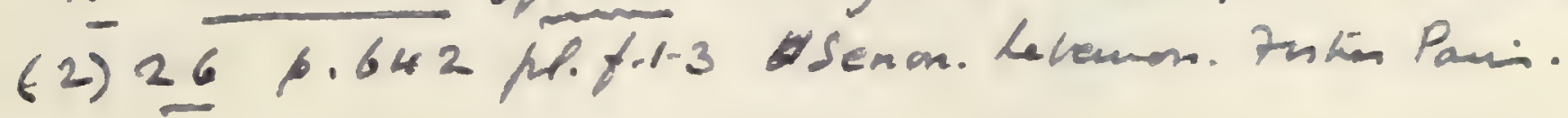

1903. Teptotrachelus Arigueter, A.S. Lovodward, Fon.

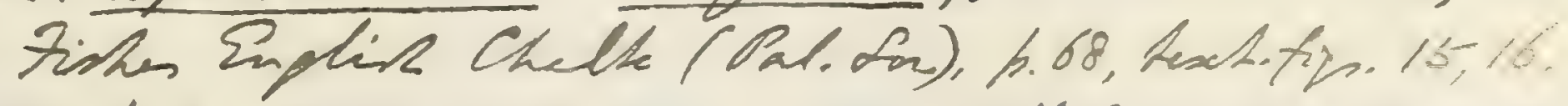
1954. 1.4. 1.5igneux. Amm. Mun. NHA Pais (2) 26, p.642 to 7 tis.4. 
uncinate spine, which is especially large in the region between the pelvic and anal fins, but becomes much reduced on the caudal pedicle; anterior abdominal flank-scutes narrow heart-shaped.

Form. \& Loc. Upper Cretaceous; Mt. Lebanon, Syria.

P. 400\%. Speeimen figured by Davis, loc. cit. pl. xxxriii. fig. 1 ; Sahel Alma. The head is much shortened by accident, the projecting premaxillaries being broken away in front, the cranium imperfeet behind; and the opercular region is also shortened by the distortion of the fish. The cranial roof appears to be exposed from within, and where the bone is flaked away a small impression of the right frontal shows the longitudinally-ridged ornament. The characteristie anterior termination of the mesethmoid is well-preserved. The extent of the very large orbit is shown in Davis' figure; in front there is the usual smooth, oroid eheek-plate. Some of the very slender, backwardly-curred teeth are exbibited in remains of the jaws. An impression of the left operculum is seen, but too imperfect for description. The vertebræe can be distinguished throughout the length of the fish and seem to have been slightly orer seventy in number; those towards the hinder edge of the abdominal region exhibiting the robust transverse processes, of which each bears a long and very slender rib. The anterior half of the abdominal region is much distorted, and the pectoral fin is preserved on either side, that of the left side being roost nearly complete. Ten rays can be counted in the latter, the three foremost being much the stoutest, with sparse artieulations in their distal half, the others comparatively delicate, both articulated and subdivided in their distal half. The pelric fins are also squeezed apart and exhibited one on either side of the fossil, arising about twice as far from the caudal as from the pectorals and comprising a few slender rays longer than those of the latter. The dorsal and anal fins are not preserved, but the caudal is nearly complete and shown to be slightly forked, with about six short fulcral rays at its base above and below. The scutes are largest and shown partly in double series on the margins of the fossil, and they distinctly form a continuous line along the regions which would be occupied by the dorsal and anal fins. They are all triradiate, with slender branches, and longitudinally 
ridged but apparently unornamented. On the ventral border of the caudal region each scute bears a welldeveloped, posteriorly-directed uncinate spine; and nearly the whole series here is exposed in side view. Scutes of this kind are similarly observed in the fragmentary type specimen described by Pictet. The scutes of the flanks are smaller and more delicate, but not clearly shown. Near the dorsal border of the anterior abdominal region some of these occur in a regular series, apparently pierced by the slime-canal of the lateral line, and having the anteriorly-directed pierced ray very large in comparison with the others. Somewhat larger scutes of the same form appear again in series below the vertebral column in the neighbourhood of the pelvic fins; and others seem to be crushed upon the transverse processes of the vertebræ in the same region. Remains of lath-shaped plates on the flank are also distinguishable on the anterior half of the caudal region.

Lewis Coll.

49536. A larger fish, wanting the greater part of the head but displaying the dorsal fin, noticed by Davis, loc. cit. p. 620 ; Sahel Alma. About 70 vertebræ can be distinguished, and those in the hinder part of the abdominal region exhibit the usual very large transverse processes, from the extremities of which very slender and nearly straight ribs are suspended. The remains of the paired fins are too fragmentary for description; but the pelvic pair seems to be in its natural position, arising just behind a point opposite the origin of the dorsal, and its rays are shown to be finely divided distally. The dorsal fin occupies nearly the middle third of the back, the distance between its origin and the occiput about equalling that between its termination and the caudal fin. All its rays are simple in the proximal half, but articulated at wide intervals and subdivided in the distal half. The foremost two or three rays are shown only in impression, but the others are well-preserved, and the total number seems to have been about thirty-five. About twelve of the hindermost rays are much more delicate and shorter than the others. The anal fin is wanting, but the caudal fin is preserved, showing the cluster of basal scales above and the distant articulations of its rays. The dorsal and ventral marginal scutes are preserved, but nearly all are 
displayed from the attached face, and only one specimen on the upper border of the caudal pedicle exhibits the uncinate spine. There are distinct traces of similar scutes along the base of the dorsal fin. Some of the obliquely-directed lath-shaped plates are observable on the caudal region.

Lewis Coll.

49540. Fish about 0.3 in length, vertically depressed anteriorly, shown in lateral aspect from the middle of the abdominal region backwards, noticed and figured in 'Natural Science,' vol. xii. (1898), p. 258, pl. x.; Sahel Alma. The specimen is interesting as enclosing an undigested fish 0.075 in length, which has been swallowed as usual head foremost, and distends the hinder abdominal region from a depth of less than 0.01 .5 to more than 0.02 . Among the fractured remains of the head the characteristic end of the rostral region is distinct, ornamented by a few smooth longitudinal ridges. Behind the head the pectoral fin is shown fragmentarily on each side. Nine rays seem to be indicated on the right side, those beyond the foremost four being comparatively delicate and short, but all with widely-spaced articulations at the distal end and the majority bifurcated. The foremost ray on the left side, also showing distal articulations, measures 0.02 in length. The number of rertebræ exhibited seems to be about 80 . The pelric fins, represented by that of the left side displaced downwards by the distended stomach, are as large as the pectorals, and nearly similar, but apparently with stouter rays which are only six in number. The pelvic fin-support is a delicate expanded lamina, not clearly seen. The anal fin is well-preserved, about twice as deep as long, comprising seven or eight stout, closely-arranged rays, each undivided in the proximal half, bifurcated and with distant articulations in the distal half. The distance between this fin and the pelvic pair (displaced) is somewhat less than that between the latter and the pectorals, and not quite twice as great as that between its origin and the caudal. The dorsal fin is wanting. The caudal is a little crushed, but exhibits the characteristic bifurcation. The triradiate dorsal and ventral scutes are shown along the entire length of the trunk as far forwards as the pectoral arch, except above the distended stomach and the base of the anal fin; all 
those in adrance of the pelvic fins being comparatirely slender. Most of those in the caudal region are exposed from the inner aspect, and the uncinate spine is thus only risible on a few dorsal scutes of the caudal pedicle. There are traces of scutes on the flanks, but they are not distinct.

Lewis Coll.

49541. Equally large fish, the head and anterior abdominal region exposed from helow, the remainder of the trunk from the side; Sahel Aima. The imperfect long and slender mandible is shown from below, the ramus of the right side with five large pits in sparse longitudinal series at its anterior end. A fracture seems to indicate the division between the dentary and articulo-angular elements; if so, the latter is almost as long as the former. Traces of very slender branchiostegal rays are obserred behind, sетеn bring indicated on the right, and possibly more on the left side. Slightly more than seventy vertebræ can be counted, and some of the characteristic centra in the anterior abdominal region exhibit the laminar transverse processes. The pectoral fins are imperfectly preserved on each side of the trunk, and that of the right distinctly indicates eleven rays, the hindermost excessively delicate. The pelvic fins are shown only in a fragment opposite the anterior end of the dorsal fin, of which the foremost nine or ten rays are preserved. The anal fin is almost destroyed, but the caudal fin is not much injured. The marginal scutes are of the usual form and proportions, distinctly in continuous series along the base of the dorsal and anal fins; some on the rentral border of the midcaudal region are exposed in side-riew and display the relatively large uncinate spine, which becomes greatly reduced on the corresponding scutes of the caudal pedicle. The appearances on the flank are difficult of interpretation; but below the vertebral column just behind the pectoral fins there is a series of narrow heart-shaped scutes shown from the inner face, which seem to have borne a median longitudinal keel; and below these again, especially a little further back, there are traces of the oblique lath-shaped plates, which are still better obserred on the caudal region. At the base of the anal fin, indeed, three of these lath-shaped plates seem to be directly continuous with the postero-superiorly inclined 
P.4863. hoticed A.S.hi, 1903, h.73. 
arm of three successive ventral scutes. Woreover, a few of the dorsal scutes here appear to have their posteroinferiorly inclined arm extended in like manner.

Lewis Coll.

P. 4018. Another fine specimen, showing the flank-scutes of the anterior abdominal region; Sahel Alma.

Lewis Coll.

49537. Imperfect contorted fish, with reflexed head; Sahel Alma. Immediately in front and behind the orbit there are remains of a delicate plate, which may belong to the cheek. Clustered slender conical teeth are observed in the jaws. Some of the anterior vertebræ exhibit the characteristic laminar transverse processes, while a few of the caudals still bear the short neural spine. The large pelvic. fins are crushed together in the usual situation. The dorsal fiu is evidently similar to that of no. 49536 , but the rays are depressed and cannot be counted; some of its supports are distinct in the hinder part, each much expanded at the articulation with the corresponding ray. Immediately before and behind the dorsal fin the double series of dorsal scutes is preserved, those of both sides being exposed from the inner aspect; it is also clear that this double series was continuous along the base of the fin. A few of the ventral scutes are shown from the external aspect, with spine broken away, in the hinder part of the caudal region; and those of the left side are exposed in continuous series above the base of the anal fin. The caudal fin is expanded by crushing. Lewis Colt.

P. 4863. Nearly complete fish bent in the middle and with imperfect fins; Sahel Alma. In the abdominal region the very slender ribs are shown suspended from the expanded transverse processes; and there are traces of the delicate laminar pelvic fin-supports. Here may also be distinguished some of the narrow heart-shaped flankscutes, becoming more markedly triradiate near the origin of the dorsal fin; while between this row and those on the ridge of the back there is a double series of relatively small and delicate triradiate scutes.

Lewis Coll.

49535. Imperfect head and abdominal region, lateral aspect; Sahel Alma. One small antorbital cheek-plate is observed on the inead, and there seems to be a more fragmentary postorbital; there is also a cluster of slender conical 
recurvel teeth in both jaws. The relatively great extent of the articulo-angular element of the mandible is distinct, while a few of the slender branchiostegal rays occur below. The clavicle is shown to be robust, and the pelvic fin-support expanded. Remains of an undigested individual, apparently of Leptotrachelus gracilis, extend along the whole length of the abdominal region; and there are some rounded bodies clustered in advance of the pelric fins, which may be ova.

Lewis Coll.

46524. Small imperfect fish, wanting the rostral end of the skull ; Sahel Alma.

Lewis Coll.

47361-62. Two imperfect examples of the trunk; Sahel Alma.

Lewis Coll.

The following specimen probably belongs to a large individual of Leptotrachelus triqueter, but its specific determination is uncertain :-

P. 1903, P. 4250. Vertically crushed skull and pectoral arch, in counterpart; Sahel Alma. The rostral region and an impression of the remainder of the cranial roof exhibit an ornamentation of delicate raised lines and rows of small tubercles; those on the mesethmoid in a longitudinal direction, those on the hinder part of the frontal more or less radiating and scarcely reaching its posterior border. The mandibular ramus of the left side is shown to be similarly ornamented with longitudinal series of fine tubercles. The slender teeth are clustered as usual. Remains of the slender spaced branchiostegal rays are seen, about 12 on the left side. The right pectoral fin exhibits 11 rays, all distantly articulated at the distal end, and all except the first two bifurcating twice distally. The anterior vertebral centra are not more than twice as long as deep.

Egerton \& Enniskillen Colls.

\section{Leptotrachelus gracilis, Davis.}

1887. Leptotrachelus gracilis, J. W. Davis, Trans. Roy. Dublin Sac. [2] vol, iii. p. 623, pl. xxxviii. fig. 3.

Type. Nearly complete fish; British Museum.

A very slender species attaining a length of about $0 \cdot 5$, but usually smaller. Length of head with opercular apparatus contained about inve and a half times in the total length to the base of the caudal 
1942. L.g. a S.d., a.m.M. (w) Q P.SDS 
fin. Anterior abdominal region excessively slender, and its vertebral centra about three times as long as deep, with much expanded transverse processes; a series of 13 or 14 anterior vertebræ equalling the length of the head; the other virtebral centra a little deeper in proportion to their length. Pelvic fins much larger than the pectorals, arising just in advance of the middle point of the trunk, the distance between the pectoral and pelvic pairs equalling twice the length of the head with opercular apparatus; dorsal fin occupying less than the middle third of the trunk; number of fin-rays probably as in L. triqueter. Dermal scutes narrow, those on the dorsal and ventral border of the elongated abdominal region excessively attenuated; anterior abdominal flank-scutes narrow heart-shaped.

It seems probable that the fragments named Dercetis tenuis by Pictet (Poiss. Foss. Mont Liban, 1850, p. 46, pl. ix. figs. 1-4) belong to this species; but they are too imperfect for certain determination.

Form. \& Loc. Tpper Cretaceous: Mr. Lebanon, Syria.

48086. Type specimen figured by Daris, loc. cit.; Sahel Alma. The end of the snout is broken away, and the flaking of the bone exposes some of the slender clustered teeth of the upper jaw. The delicate oroid plate at the anterior border of the orbit is distinct; and a curved plate much broader than deep, just in front of the clavicle, may be the suboperculum. The rery slender vertebræ of the somewhat distorted abdominal region exhibit the expanded transrerse processes; and the characteristic dermal scutes are distinct as far forwards as the pectoral fin. The total number of vertebræ seems to be between 70 and 80. The scutes on the rentral border become notably enlarged towards the base of the pelric fins, which seem to have been larger than the pectorals. The long transrerse processes of the vertebre are well shown in the region between the remains of the dorsal and pelric fins. Further back one of the ventral caudal scutes is exposed in side riew, displaying a small uncinate spine and one arm distinctly produced into one of the lath-shaped plates, which are very conspicuous. The anal fin is represented only by fire fragmentary rays. The caudal fin is similar to that of $L$. triqueter. Lewis Coll.

49538. More imperfect fish about 0.23 in length; Sahel Alma. One of the pectoral fins, imperfect distally, exhibits eight rays; the other fins are indicated merely by fragments. 
The very slender scutes are shown to extend forwards as far as the pectoral arch.

Lewis Coll.

P. 4738. Another fine but contorted specimen 0.31 in length; Sahel Alma. The slender pointed premaxillæ are shown extending forwards beyond the cranial rostrum. The long transverse processes of the vertebræ in the hinder abdominal region are shown in impression; the expanded pelvic fin-supports are also preserved. The very narrow ventral scutes of the anterior abdominal region are shown to pass rapidly into much larger scutes with widelyspreading lateral branches towards the base of the pelvic fins, and these continue for some distance beyond. Some of the marginal scutes of the hinder caudal region are very clearly produced into the lath-shaped plates of the flank.

Lewis Coll.

48085. A larger contorted specimen more imperfect, wanting the hinder half of the caudal region; Sahel Alma. The pelric fin-rays are shown to be remarkably long, closely articulated and subdivided at the distal end. The dorsal fin is evidently much extended, but its rays are depressed and cannot be counted.

Lewis Coll.

49522. Remains of two specimens on one slab, with Pronotacanthus sahel.almce; Sahel Alma. The more contorted specimen exhibits the double series of dorsal scutes on the anterior part of the caudal region, and there are remains of the dorsal fin extending between them. The characteristic transverse processes are also observed in the hinder half of the abdominal region.

Lewis Coll.

49539. Contorted small fish; Sahel Alma.

Lewis Coll.

4808\%. Another small specimen in counterpart; Sahel Alma. The double series of dorsal and ventral scutes are well shown on the caudal region. The anal fin arises somewhat nearer to the caudal than to the pelvic fins and comprises at least eight rays. The dorsal fin is shown, but its rays are depressed and cannot be counted. Lewis Coll.

47360. Anterior portion of two small fishes crossing cach other on one slab; Sahel Alma. The fragment without head is interesting as showing in the anterior abdominal region a series of narrow heart-shaped scutes of the flank, in addition to the dorsal and ventral series.

Lewis Coll. 
Letstrachehos serpentinus, Hay.

1903. Z. sent., O. P. Hay, Bull. Amer. hum. N. H. vol xix. p. 419. fl. $\times \times \times$ ii. fig 1.

Like. Fish; Amen. hus. M. H.

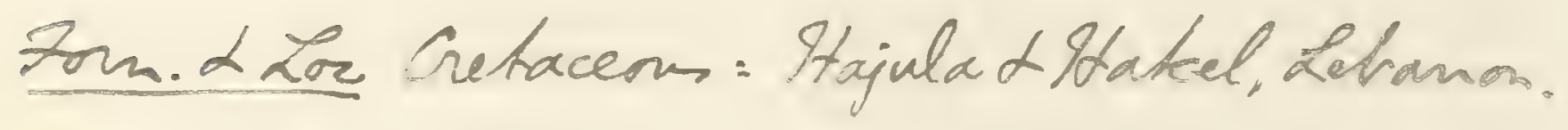


P. 9170. Remains of rery small contorted fish exhibiting eight rays in one of the pelvic fins; Sahel Alma. Lewis Coll.

47359. Imperfect trunk with anal fin; Sahel Alma. Lewis Coll.

48088. Imperfect trunk with dorsal fin, associated with Rhinellus furcatus; Sahel Alma.

Levis Coll.

$46533,-$ a. Two examples of caudal region, the second displaying more than 30 ruys in the dorsal fin; Sahel Alma.

Lewis Coll.

P. 1902. Hinder portion of fish, showing seren rays in the pelric, and eight or nine in the anal fin; Sahel Alma.

Egerton Coll.

The following specimens may represent unusually large individuals of Leptotrachelus grailis, but are too imperfect for satisfactory determination :-

P. 4852. Imperfect anterior portion of fish, noticed and the head figured by Daris (Trans. Roy. Dublin Soc. [2] rol. iii. 1887, p. 622, pl. xxxriii. fig. 2) under the name of Leptotrachelus triqueter, var. $a$; Sahel Alma. The head is shown in lateral aspect, much fractured, with some of the slender clustered teeth exposed; while fragments of the external bones in the hinder portion of the cranial roof and in the mandible are ornamented with very fine tubercles. These tubercles on the dentary and angular bones are arranged in obliquely-directed, nearly parallel lines. The opercular apparatus is evidently well-dereloped, though the separate elements cannot be distinguished. The rertebral centra are similar in proportions to those of $L$. gracilis, and show some of the expanded transverse processes supporting remarkably slender ribs. Above the vertebral column there are longitudinally extended rods stouter than the ribs, which seem to be intermuscular bones. Above the vertebræ at the hinder end of the fossil may also be observed the narrow heart-shaped scutes of the flank, which are ornamented with radiating lines of fine tubercles. The dorsal and ventral borders, with their scutes, are broken away.

Lewis Coll.

P. 4019. Hinder half of equally large fish; Sahel Alma. The characteristic vertebræ are imperfectly shown, and there are remains of the pelric, anal, and eaudal fins. The 
laminar expansion of one pelvic fin-support is distinct; and some of the bordering scutes on the eaudal region are observed to be prolonged into the lath-shaped plates.

Lewis Coll.

Leptotrachelus hakelensis, Pictet \& Humbert.

1866. Leptotrachelus hakelensis, Pictet \& Humbert, Nouv, Rech. Poiss. Foss. Mont Liban, p. 98, pl. xiv. fig. 3.

Type. Imperfect fish; Genera Museum.

An'imperfectly known small species about $0 \cdot 12$ in length, with much attenuated rostrum. Anterior abdominal region short, and vertebral centra not more than twice as long as deep; total number of vertebræ probably about 60 . Length of head with opercular apparatus about equalling the distance between the pectoral and pelvic fins; distance between the pelvic and anal fins considerably greater. Dorsal and ventral triradiate scutes much attenuated.

Form. \& Loc. Upper Cretaeeous: Mit. Lebanon, Syria.

P. 6001. Relatively large and well-preserved specimen, wanting the end of the tail; Hakel. The operculum seems to be nearly quadrangular in form, a little broader than deep; and it is bordered below by a suboperculum of about half its depth. The rertebræ are shown, with traces of the very delicate dermal scutes; and there are fragmentary remains of the pectoral, pelvic, and anal fins. Lewis Coll.

P. 4683. Smaller and more imperfect specimen, showing the form of the cranial roof; Hakel.

Presented by Sir J. William Dawson, K.C.M.G., 1884.

\section{Leptotrachelus elongatus (Ágassiz).}

[Plate XII. fig. 4.]

1835. Dercetis elongatus, L. Agassiz, Poiss. Foss, Feuill. p. 55 (name only).

1837-44. Dercetis elongatus, L. Agassiz, ibid. vol. ii. pt. ii. p. 258, pl. lxvi . figs. 1, 2, 5-8 (non figs. 3, 4).

1879. Dercetis elongatus, W. Davies, Geol. Mag. [2] vol. vi. p. 145.

1888. Dercetis elongatus, A. S. Woodward, Proc. Geol. Assoc. vol. x. p. 318.

Type. Imperfect fish; British Musenm.

A slender species, probably attaining a length of about $0 \cdot 6$, but usually sinaller. 'The postorbital region of the skull about as broad as long, this occupying the hinder quarter and the orbit the next 
2. afr L. Bakelewni Nharmo-1946 po2

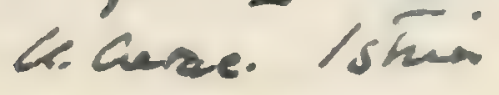

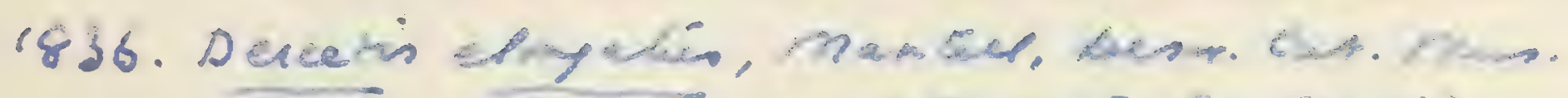

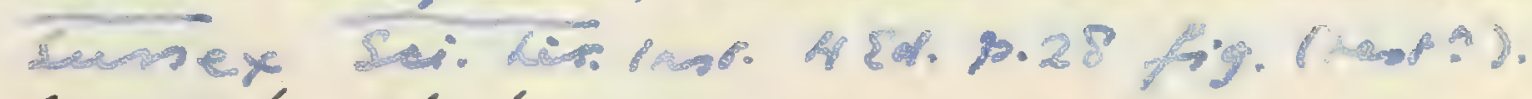

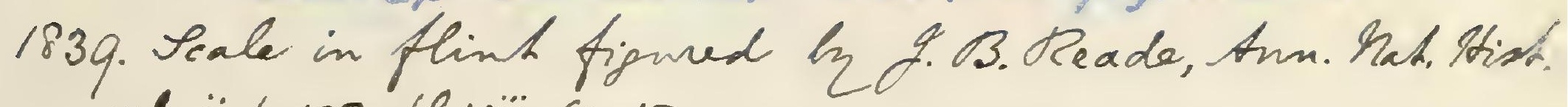
rd.ii.p. 198, pl. viii.fig. 13.

1903. Zeptotrachelus elomeatur, A.S. Arodwand, Doss. Dishes Ingtish Chalte ( Tal. For.), fi.68, hl. xvi. 
Imnaena! lewesiensi, C. Wiman, Ged. Fören. Stadth. Firhandll. vol. $39(1917), 10.237$.

4132.33. Desented a fijuned A.S.2.1903, h. 70, fl.xvi.fie, 1.

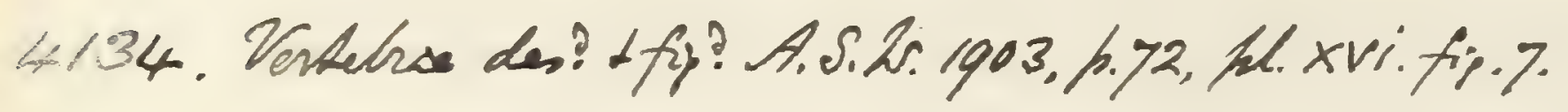

49793. Head ded? afi? A.S.W. 1903, h.70, He. xvi. fip., 2, suchtos he Xvi. fip, 8 . 
quarter of the cranial length; the length of the head with opercular apparatus contained between four and fire times in the total length of the fish to the base of the caudal fin. Anterior abdominal vertebral centra about three times as long as deep, those beyond less elongated, and those in the hinder half of the abdominal region with large transrerse processes. Pelvic fins in advance of the middle of the trunk; [other fins unknown]. Dermal scutes of moderate size and narrow, more or less ornamented with short ridges and spinous tubercles, those on the dorsal and rentral borders of the caudal region also bearing a slender backwardlydirected uncinate spine.

To this species Agassiz originally referred the specimens from the Chalk of Lewes described and figured as Murcena? lewesiensis by G. A. Mantell, Foss. South Downs (1822), p. 232, pl. xxxir. fig. 11, pl. xl. fig. 2. These fossils subsequently proved to be merely wormburrows lined with various scales of fishes (W. Daries, Geol. Mag. [2] vol. vi. 1879, p. 145); and similar specimens from the Turonian of Bohemia were described under the name of Lepidenteron longissimum (A. Fritsch, Rept. u. Fische böhm. Kreideform. 1878, p. 19, fig. 45).

Form. \& Loc. Senonian and Turonian: S.E. England.

4132-33. Type specimen, in counterpart, comprising the head and greater part of the trunk without fins, figured by Agassiz, tom. cit. pl. Ixri a. tigs. 1, 2, 6-8; Lewes, Sussex.

Mantell Coll.

4134. Fragment of caudal region of large fish, figured by Agassiz, ibid. fig. $\bar{~}$; Lerres.

Hantell Coll.

49793. Head and anterior part of trunk, in counterpart, the cranial roof shown of the natural size in Pl. XII. figs. 4, $4 a$; Lewes. This cranial roof is flaked in such a way that some pieces remain on one side of the fossil (fig. 4 ), and the rest on the counterpart (fig. $4 a$ ). The postorbital region of the skull occupies one quarter of its total length, and is about as long as broad, with parallel sides and the occipital border excavated by a sharp re-entering angle. The frontal region between the orbits is excessirely constricted in front. All the external bones are ornamented with a few delicate longitudinal ridges, occasionally subdivided into tubercles. When the roofing bones are removed, as in fig. 4 , the well-ossified though small supraoccipital can be observed beneatb, bearing a slight rertical median crest; but, as shown by the 
impression of the external aspect of the roof on the other side of the fossil, this bone is not exposed above. The parietals $(p a$.$) are an unsymmetrical pair of plates,$ broader than long, meeting throughout their length in a slightly sigmoidal suture, and marked by about two ridges which extend from border to border, while other short ridges and tubercles are observed behind. The squamosals $(s q$.$) seem to have been very narrow and$ insignificant plates at the postero-lateral angles of the skull, not extending further forwards than the parietals. The frontals ( $f r$.$) extend and expand backwards to form$ more than half the postorbital region of the cranial roof ; and these are not a symmetrical pair, that of the right side being wider and extending further backwards than that of the left side. The few ornamental ridges on these bones do not quite reach the hinder margin and are in no way connected or correlated with those on the parietals. The very narrow interorbital region is comparatively stout, and impressions suggest that a delicate crescentshaped wing extended upwards and outwards from the frontal on each side to protect the relatively large eyeball. The anterior end of the frontals seems to have expanded a little again on the rostral region, two wings of membrane-bone being crushed in the fossil on the sides of the ethmoid and these are apparently directly continuous with the frontals. The orbit (orb.) occupies one quarter of the length of the skull, and at its anterior border on each side there is a thin, ovoid, convex plate, which seems to be a dermal or membrane-bone. The well-ossified mesethmoid (eth.) is marked by numerous fine longitudinal ridges terminating a little behind the anterior end, which is scarcely expanded but is curiously truncated and hollowed in front in such a way as to give it the appearance of being a tube. The crushed jawbones lie on either side of the rostral region, and extend for a short distance in advance of it, tapering to an acute point. The bases of a single regular close series of minute teeth in the dentary are observable on the left side. Immediately behind the occiput, and pointing to its median re-entering angle, the pair of post-temporal plates (p.t.) is preserved; each being triangular in shape, longer than broad, and unornamented on its outer face. Just behind these again is one of the narrow heart-shaped scutes, 
216 



$$
\begin{aligned}
& \operatorname{lomentanes} \\
& \text { vige uno }
\end{aligned}
$$

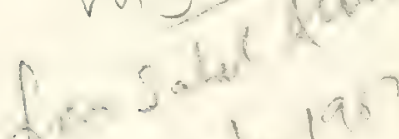

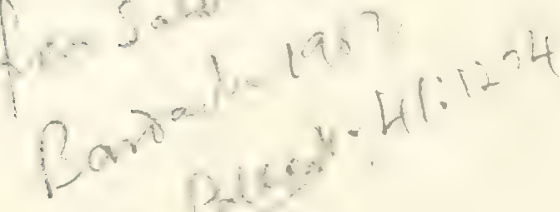

$$
\begin{aligned}
& \text { i. }
\end{aligned}
$$


exposed from its inner face, but distinctly shoming through its transparent bone an external ornament of tubercles. The triradiate scutes further back are also distinctly tuberculated and radiately striated, and in the region probably of the pelric fins three of these are sbown to be of relatively gigantic size, the hindermost and largest nearly as wide as the occiput.

Capron Coll.

41198. Imperfect coiled-up fish in counterpart, showing remains of the head and about 52 vertebræ; Upper Chalk, Charlton, Kent. Purchased, 1868.

43512. Another similar specimen in counterpart, displaying some, of the caudal scutes; Upper Chalk, Bromley, Kent.

Purchased, 1872.

43574. More imperfect specimen displaying the cranium and projecting premaxillæ; Bromler.

Purchased, 1872

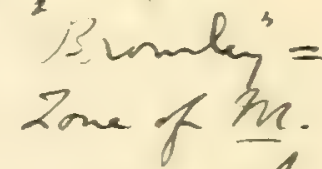

corany. Sh

\section{(1)}

44624. Fragment of caudal region; Bromley. Purchased, 1873.

P. 1905. Portion of anterior abdominal region; Kent.

Egerton Coll. Canden Park. Chizelhuars Egerton Coll.

P. 1905 a. Portion of trunk; Dorer. Beckles Coll.

P. 645\%. Fragmentary remains; English Chalk. teratey Gerling $1911,+.96)$.

43098. Remains of large skull, probably of this species, showing slender clustered teeth; English Chalk. Wetherell Coll.

P. 9100. Impression of part of trunk in flint, from beach at Hunstanton, Norfolk.

Presented by B. B. Woodward, Esq., 1899.

The following species have also been described but are not represented in the Collection:-

Leptotrachelus longipinnis, E. D. Cope, Bull. U.S. Geol. Surr. Territ.vol.ir. (1878), p. 68.-Upper Cretaceous (Niobrara Group); Dakota. [Imperfect fish.] Amen hm. X Id.) Leptotrachelus sagittatus, W. von der Marck, Palæontogr. rol. xxii. 6. s

(1873), p.63, pl.ii. fig. 1.-Upp Cretaceous; Sendenhorst,

Westphalia. [Imperfect fish; Academy of Münster.]

Leptotrachelus virgulatus: Tricenaspis virgulatus, E. D. Cope,

1oc. cit. 1878, p. 67.-Upper Cretaceous (Niobrara Group);

Dakota. [The type species of Tricenctspis. Imperfect fish.]
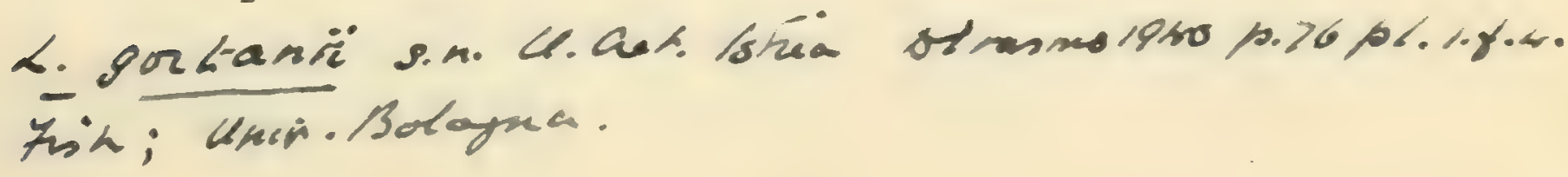
Genus PELARGORHYNCHUS, W. ron der Marck.

[Zeitschr. deutsch. geol. Ges. vol. x. 1858, p. 242.]

External bones slightly ornamented with short ridges and rows of tubercles. Teeth in form of small, slender, hollow cones, more or less clustered. Pelvic fins arising nearly midway between the pectorals and anal; dorsal fin occupying the greater part of the back; anal fin opposed to the hiuder part of the dorsal; caudal fin forked. Two paired series of scutes on the flank moderately enlarged, with a dense intermediate squamation of small rhomboidal scales.

Pelargorhynchus dercetiformis, W. von der Marck.

1858. Pelargorhynchus dercetiformis, W. ron der Marck, Zeitschr. deutsch. geol. Ges. vol. x. p. 243.

1858. Pelargorhynchus blochiformis, W. von der Marck, ibid. p. 244. [Imperfect trunk; Academy of Münster.]

1863. Pelargorhynchus dercetiformis, W. von der Marck, Palæontogr. vol. xi. p. 61, pl. xi., pl. xii. fig. 3.

1863. Pelargorhynchus blochiiformis, W. von der Marck, loc, cit. vol. xi. p. 64, pl. xii. figs. 4-6.

1885. Pelargorhynchus dercetiformis, W. ron der Marck, loc. cit. vol, xxxi.p. 261.

Type. Imperfect distorted trunk; Academy of Münster.

The type species, attaining a length of about 0.65 . Length of head with opercular apparatus contained about five times in the total length to the base of the caudal fin. Pelvic fins with one articulated, six articulated and divided rass, arising slightly nearer to the anal than to the pectorals, considerably behind the origin of the dorsal; dorsal fin with 64 rays, the foremost the longest and much deeper than the trunk, arising about twice as far from the occiput as is its termination from the caudal fin; anal fin with about 16 rays, its hinder end opposite that of the dorsal. Lateral scutes elongate-heart-shaped, marked with radiating lines or rows of minute tubercles, and the upper series larger than the lower series; intermediate squamation very finely granulated.

Form.\& Loc. Upper Cretaceous: Westphalia.

P. 2112. Imperfect trunk showing median fins and traces of the paired fins; Sendenhorst. Egerton Coll. P. 1906. Fragment of trunk; Sendenhorst. Egerton Coll.

As shown by a skull in the Kansas University Museum, Lawrence, the jaws described by Cope under the generic name of Stratodus 


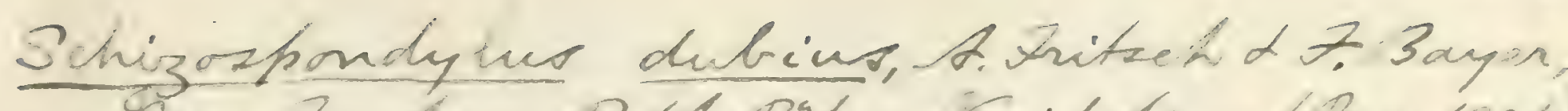

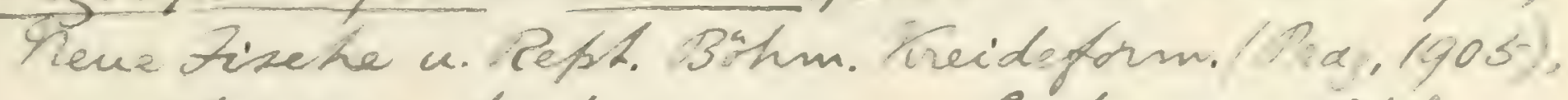
h.5. bliffip.6, Lexthfip. 4-7. - Cretacems; Vehlovic,

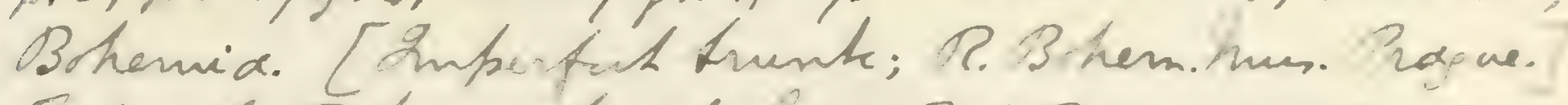
Type is Schizespondyluo, ta 3 .

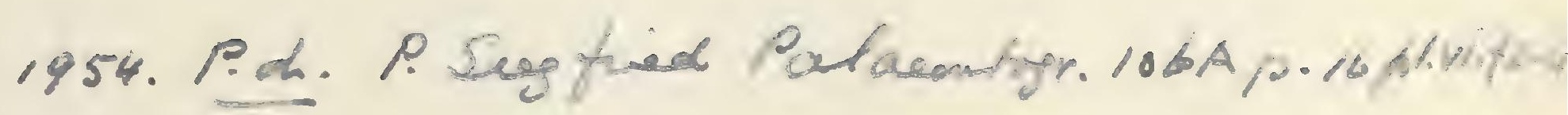




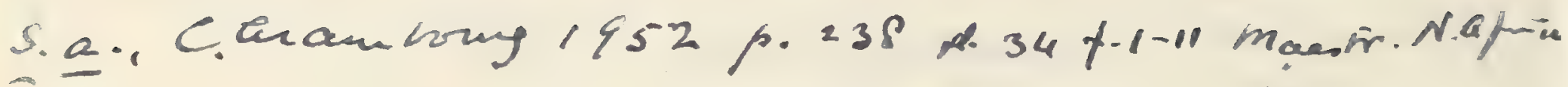

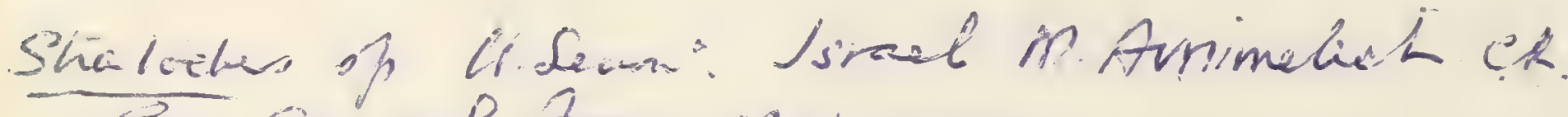

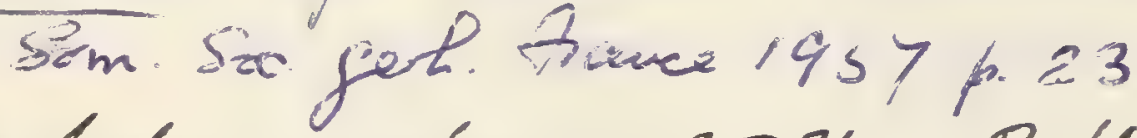

Tratodue oxykegen, O.P. Hay, Bull. Amen. Imus. N.H. vol. $x$ ix (1903), h. 80, fipo 66-68.

Enchodontidare deep sea (U. Cnot.) Tinor L.F.del3.1920.0

Alepisaurzs paronai G.J'Erasmo, Mem. Carta

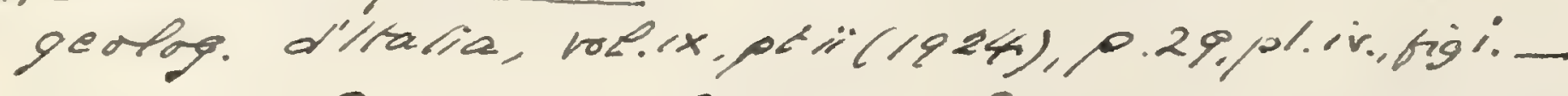
Miozene: Rosignano, Piedmont. GHead, Gedt. Mus. Turrint. 


(Proc. Amer. Phil. Soc. vol. xii. 1872, p. 349) belong to a member of the family Dercetidæ. The following species are distinguished, but are not represented in the Collection:-

Stratodus apicalis, E. D. Cope, Toc. cit, 1872, p. 349, and Vert. a decezeal Cret. Form. West (Rep. U.S. Geol. Surv. Territ. vol. ii. 1875), p. 227, pl. xlix. figs. 6_8.-Upper Cretaceous (Niobrara Group); Smoky Hill River, Kansas. [Jaw with teeth; Cope Collection.] A. Stement 60960 1. 1 P. 328,1

Strutodus oxypogon, E. D. Cope, Proc. Amer. Phil. Soc. vol. xiii. (1878), p. 180.-Upper Cretaceous; Kansas. [Remains of jaws; Cope Collection.]

\section{Family ENCHODONTID在.}

Supraoccipital bone not prominent, but extending forwards to the frontals and separating the small parietals in the median line; squamosal reduced, only partly covering the otic region, which projects laterally ; no basicranial canal; snout not produced; cheekplates well developed. Mandibular suspensorium vertical or inclined backwards, and gape of mouth wide; premaxilla delicate, considerably extended and excluding a great part of the slender maxilla from the upper border of the mouth; teeth fused with the supporting bone, not in complete sockets, those on the pterygopalatine areade and dentary the largest. Opercular apparatus complete, with few slender branchiostegal rays and no gular plate. Vertebral centra well ossified, none with transverse processes; ribs not completely encircling the abdominal cavity; a compound hypural bone at the base of the tail. Intermuscular bones present. Fin-fulcra absent; the rayed dorsal fin never much extended, usually near the middle of the back, and sometimes an adipose fin behind. Scales delicate or absent; but occasional longitudinal series of scutes, the dorsal series, when present, being unpaired.

The nearest living allies of this extinct family appear to be the Odontostomidæ and Alepisauridx, in both of which the margin of the upper jaw is formed exclusively by the premaxilla, while in the first the large teeth are depressible. Only three genera are known, Odontostomus, Omosudis, and Alepisaurus (Plagyodus), all from the deep sea.

\section{Synopsis of Genera.}

I. One large terminal palatine tooth.

Dorsal fin in front of anal; no postclavicular plate ...................... Enchodus (p. 190). 
Dorsal in in front of anal; a postclavicular

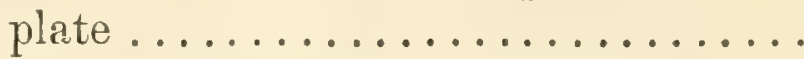

Dorsal fin opposed to part of much-extended anal; no postclavicular plate........

II. No enlarged palatine tooth.

Eurypholis (p. 207).

Palcolycus (p. 211).

Palatine teeth in one longitudinal series; no teeth barbed; no scutes, but minute

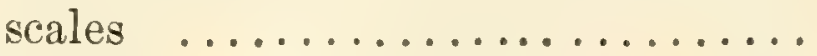

Palatine teeth in two longitudinal series; some ectopterygoid teeth semibarbed; dermal scutes present, but not deepened on flank .................

One much-deepened series of scutes on flank, supporting lateral line. . . . . . .

As Prionolepis, but with small upper and lower lateral scutes..............

Large teeth at mandibular symphysis; median dorsal scutes but apparently no others ................. Pantopholis (p. 234).

Halec (p. 212).

Cimolichthys (p. 221.)

Priono?epis (p. 229).

Leptecodon (p. 233).

Genus ENCHODUS, Agassiz.

[Poiss. Foss., Feuill. 1835, p. 55, and vol. v. pt. i. 1844, p. 64.]

Syn. Isodus, J. J. Heckel, in Russegrger's Reisen, vol. ii. pt. iii. 1849, p. 342 .

Phasganodus, J. Leidy, Proc. Acad. Nat. Sci. Philad. 1857, p. 167. Ischyrocephalus, W. von der Marck, Zeitschr. deutsch. geol. Ges. vol. x. 1858, p. 248.

(?) Tetheodus, E. D. Cope, Bull. U.S. Geol. Surv. Territ. no. 2, 1874 , p. 43.

Solenodon, D. G. Kramberger (non Brandt, 1833), Jahrb. k.-k. geol. Reichsanst. vol. xxxi. 1881, p. 373.

Holcodon, 1). G. Kramberger, Rad Jugoslar. Akad. vol. Ixxii. 1885, p. 18.

Eurygnathus, J. W. Davis, Trans, Roy. Dublin Soc. [2] vol. ii. 1887, p. 601.

Trunk elongate-fusiform, both this and the head laterally compressed. Cranial roof exhibiting a deep median longitudinal depression, its lateral and occipital margins ornamented, like the other external bones, with ridges and tubercles of ganoine. Iandible a little prominent, provided with an inner widely-spacerl series of large slender teeth, the largest in front, also a marginal series of minute teeth, all nearly or completely solid: premaxilla in the form of a vertical lamina, deepest in front, tapering behind, and with a single spaced series of small teeth; maxilla long and slender, either finely toothed or toothless at the oral border; palatine 


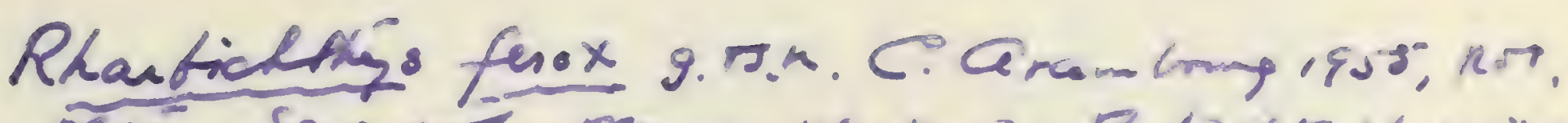

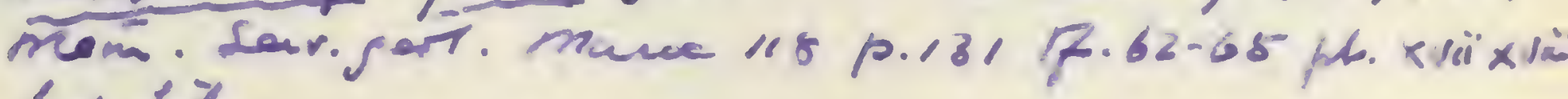
infifit.

Cumaman: Bahanje, berken 19356: p. 39, plisi. 19-20,24. Strmer 1906, ph.1.f.1-3.

Enot. renator s.a. Cenman: Moroses,

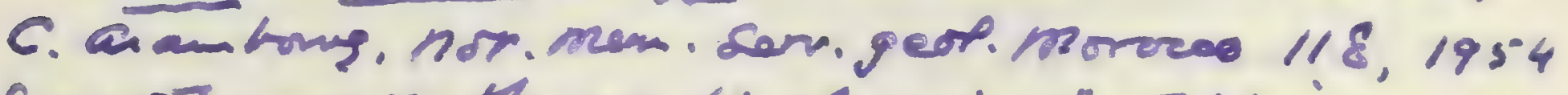

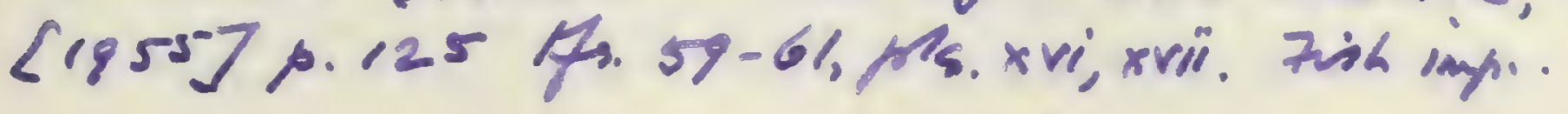




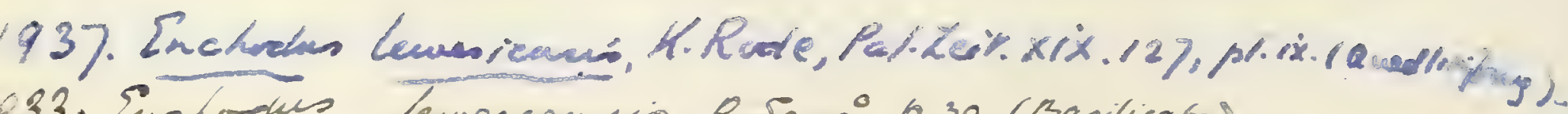

33. Suctodur Lewesemuis, R.Sanci, p.30 (Basilicara).

883. Enchodur halouion, G. Sosselet, Bprisze Gérl.

Nord France, hl. $\times \times$ ii. fij. I.

02. Inchadus levesiensio, Mr. Leriche, Am. Sor. Gérl. Nord, vol. xxxi.h.139, hliv. fip.'13.

3. Enchodus leveciencid, A. S. Woodward, Ino.

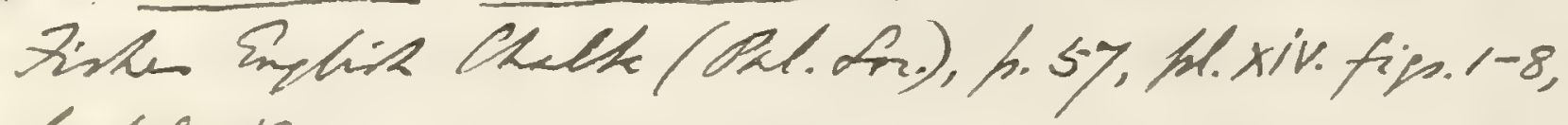
Lestefis. 13.

1906. Inchodur leweciencir, M. Leviche, hém. Sor. Géd. Nord, vol.v, f.gt, test.fig, s- [palatine].

8. Ench. lewesiencin, 7. Riem, Miss. Fus. Bassins

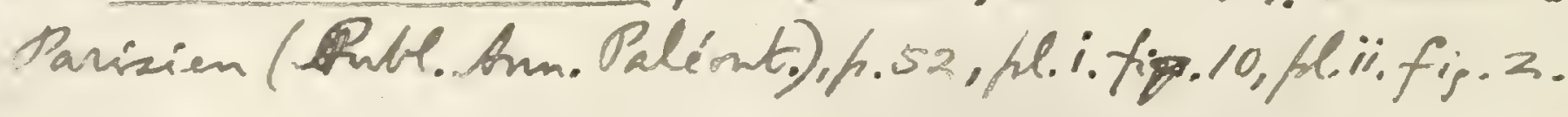


thickened and tumid, with only one large tooth fixed at its anterior end; ectopterygoid robust, with a single spaced series of large slender teeth, gradually diminishing in size backwards; no teeth barbed. Operculum strengthened on thə inner side by a ridge extending horizontally backwards from the point of suspension; branchiostegal rays about 12 to 16 in number. Vertebræ 40 to 50 in number, about half being caudal; the centra at least as long as deep, constricted mesially, and marked with small irregular longitudinal ridges. All except the foremost rays of each fin finely divided distally, but none excessively elongated. No postclavicular plate. Pectoral fins large, pelvic fins much smaller and arising far forwards; dorsal and anal fins large, neither much longer than deep, the former arising much in advance of the middle point of the trunk, the latter also far forwards ; [a posterior adipose dorsal fin observed in a few well-preserved specimens; ] caudal fin forked, with curved fulcral rays and stout, articulated, undivided rays at its base both above and below. Rudimentary dermal scutes, not overlapping, in a single median series between the occiput and the dorsal fin, and along the course of the lateral line; a pair of enlarged hook-shaped dermal scutes at the base of the tail, one on either side of the caudal pedicle.

The cranial osteology of Enchodus is best known from the specimens occurring in the English and Dutch Chalk; the trunk and fins are only satisfactorily shown in the nearly complete fishes obtained from the Upper Cretaceous of Westphalia and Mount Lebanon.

\section{Enchodus lewesiensis (Mantell).}

[Plate XI. fig. 1.]

1822. Esox lewesiensis, G. A. Mantell, Foss. South Downs, p. 237, pl. xxv. fig. 13, pl. xxxiii. figs. 2-4, pl. xli. figs. 1, 2.

1835-44. Enchodus halocyon, L. Agassiz, Poiss. Foss., Feuill. p. 55, and vol. v. pt. i. p. 64, pl. xxv c. figs. 1-16.

1850. Enchodus halocyon, F. Dixon, Geol. Sussex, p. 373, pl. xxx. figs. 20, 27, pl. xxxi. fig. 11.

(?) 1875. Enchodus halocyon, H. B. Geinitz, Palæontogr. vol. xx. pt. ii. p. 226, pl. xli. figs. 5-20 (in part).

1888. Enchodus levesiensis, A. S. Woodward, Proc. Geol. Assoc. vol.x. p. 315 (in part), pl. i. fig. 5 (non fig. 6).

Type. Fragments of jaws, \&c.; British Museum.

The type species, known only by fragmentary specimens, usually small, but the mandible sometimes attaining a length of $0 \cdot 1$. The sides of the cranial roof and the outer face of the mandible ornamented with numerous and closely-arranged sharp ridges, 
mostly radiating and each bearing a series of small tubercles; these ridges on the dentary bone radiating from the symphysis, on the articulo-angular bone radiating from the mandibular articulation. Palatine bone prodnced forwards as a short cylindrical extension in advance of the ethmoid articulation, and the long slender tooth, antero-posteriorly compressed, fixed at its extremity at right-angles to the long axis of the bone; the outer face of the premaxilla only sparsely ridged; dentary rapidly contracting almost to a point at the symphysis, where it exhibits about three large irregular processes; the mandibular ramus considerably deepened behind, its maximum depth nearly equalling one third of its total length; about six large mandibular teeth, all both slender and little curved. Teeth much compressed, and some delicately striated, none conspicuously serrated on the edges. Operculum nearly two thirds as broad as deep, marked by numerous sharp, radiating, tuberculated ridges.

The heads from the Turonian of Bohemia described under the name of Enchodus halocyon, Ag., by A. Fritsch (Rept. u. Fische böhm. Kreideform. 1878, p. 35, pl. vii. figs. 1-3) seem to differ from this species in the more slender proportions of the mandible.

Form. \& Loc. Senonian and Turonian: S.E. England. (?) Turonian: Saxony and Bohemia.

$4004,4049,4157,4160,4180-81,4183-84,4186,4198$. The series of type specimens figured by Mantell and Agassiz, except the detached teeth, which are also probably in the Mantell Collection but not identifiable; Chalk, Lewes. The original of Agassiz, loc. cit. fig. 1, shows the left premaxilla from the inner aspect, with remains of the pterygo-quadrate arcade and mandible; fig. 6 represents a portion of the ectopterygoid; figs. 9,10 represent the extremity of the palatine; and figs. 14, 15 two imperfect opercula.

Mantell Coll.

P. 5415. Small skull and mandible, displaying the cranial roof, premaxilla, maxilla, and dentary, described and figured in Proc. Geol. Assoc. vol. x. p. 315, pl. i. fig. 5; Lewes.

Presented by P. E. Coombe, Esq., 1888.

$25749,25755,25765$. Imperfect right dentary, with two detached large teeth doubtfully of this species, figured by Dixon, op. cit.; Chalk, Sussex.

Dixon Coll.

4001, 40\%1, 4182, 4201. Two very imperfect small skulls, and two fragmentary mandibles; Lewes.

Mantell Coll. 


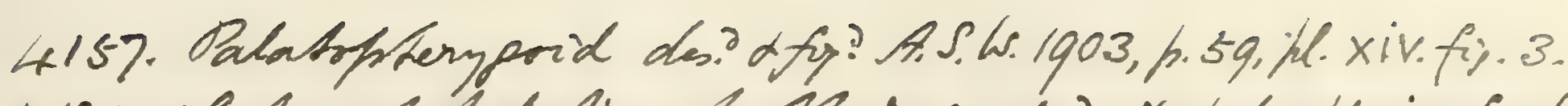

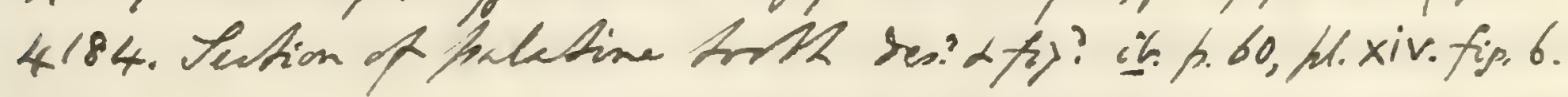

7.5415. hoticed A.S.2. 1903, h.58. 
25888. Ioll fip? ar Lamma acuminata by Lixon, Ged.ciuscex (1850), hl.xxx.fip.34.

sixon colle.

2.6461. hoticed A.S.2.1903.6.58.

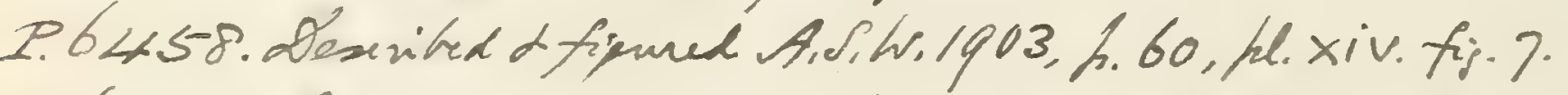

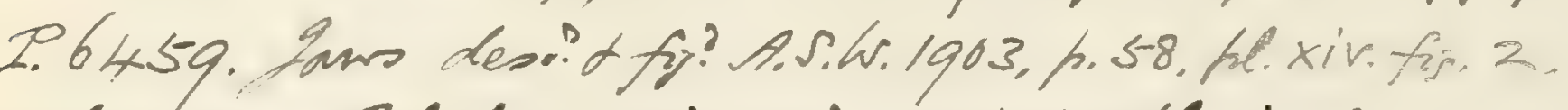

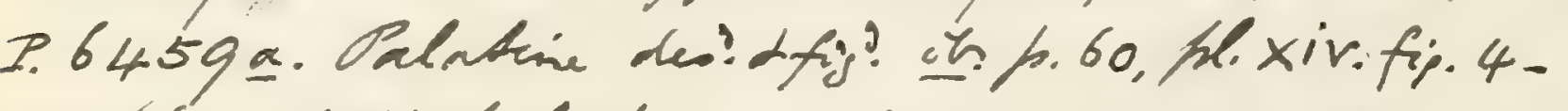

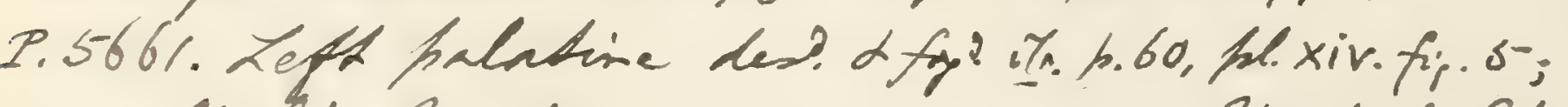
Chelte, kent.

Harford cle

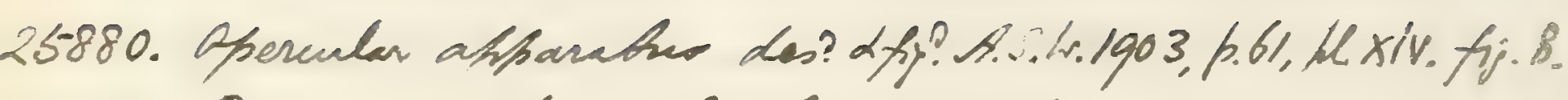
259921. Br. rays nuticed A.S.2. 1903, 1.61.

4y 926. Prvisionally refined to E. fulchellus, A.S. 2. 1903, h.63, he. xiv. fip. II.

1903. Inchodur bulchellew, A.S. Woodward, Brs. Firtes

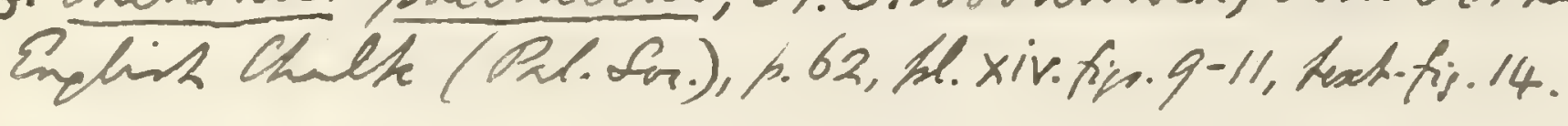




39080. Remains of small mandible and operculum; Brighton.

Bowerbank Coll.

P. 6461. Imperfect cranium; English Chalk. Beckles Coll.

P. 6459. Remains of small head, showing characteristic palatine bone; English Chalk. Bectiles Corl.

P. 6458. Imperfect large right dentary, abnormal in possessing tmo enlarged front teeth closely apposed; English Chalk.

Bectiles Coll.

49783. Portion of very small mandible; Upper Chalk, St. Catherine's Hill Pit, Guildford.

Capror Coll.

49744, 49782. Portions of two small mandibles; Cpper Chalk, Shalford, Guildford.

Capron Coll.

36332. Imperfect small right dentary; Chalk, Grays, Essex.

Daniels Coll.

44578. Imperfect large left deutary, its symphysial end shown of the naturaI size in PI. XI. fig. 1; Upper Chalk, Bromley, Kent.

Puichased, 1873.

25904. Imperfect mandible and opercular apparatus, with remains of vertebræ and pectoral arch, probably of this species; English Chalk.

Dixon Coll.

25921. Fragmentary mandible with branchiostegal rays, doubtfully of this species; Chalk, Sussex.

Dixon Coll.

47925. Very large left palatine, with imperfect tooth, of the form characteristic of this species; Chalk, Burham, Kent.

Presented by the Hon. Robert Harkham, 187.

\section{Enchodus pulchellus, sp. nov.}

[Plate XI. figs. 2, 3.]

1888. Enchodus levesiensis, A. S. Woodward (errore), Proc. Geol. Assoc. vol. x. p. 315 (in part), pl. i. fig. 6.

Type. Imperfect head; British Museum.

A species about as large as the type, known only from fragmentary specimens. Palatine bone produced forwards as a short cylindrical extension in advance of the ethmoid articulation, and the long: slender tooth, laterally compressed, fixed at its extremity at rightangles to the long axis of the bone; the outer face of the premaxilla ornamented with numerous sharp, tuberculated ridges radiating from the symphysis; mandibular ramus about four times 
as long as its maximum depth, ornamented with conspicuous tubercles, of which the large majority are not placed on ridges; more than six enlarged mandibular teeth. Teeth much compressed, sometimes with very delicate striations but not serrated.

Form. \& Loe. Turonian (?) : Kent and Sussex.

P. 1703. The type specimen, shown of the natural size in Pl. XI. fig. 2 ; Chalk, Kent. Only part of the left lateral border of the cranium is shown above the orbit and otic region, and exhibits the usual ornament of tubereles on ridges. A fragment of the parasphenoid, the left hyomandibular $(\mathrm{hm}$.$) , and left metapterygoid, are exposed, but too$ imperfect for description. The fractured remains of the left premaxilla $\left(p m x_{1}\right)$, with its characteristic ornament, obscure the palatine and part of the ectopterygoid (ecpt.), but most of the teeth of these inner elements are shown. The palatine tooth $(p a l$.$) is much the largest and exhibits$ very feeble traces of longitudinal striation. The left mandibular ramus is well-displayed, though imperfect anteriorly and a little fractured behind. The upper part of the dentary $\left(d_{0}\right)$ is flattened on the outer face and ornamented by tubercles with no definite arrangement, while in its lower portion a few tuberculated ridges radiate from the symphysis backwards and downwards; the precise boundary of the articulo-angular (ag.), which is similarly ornamented, is not clear. The mandibular teeth are straight and more slender than those of the palato-pterygoid arcade. The deep and narrow tuberculated preoperculum (p.op.) is partly shown, and there are traces of a small reflection at its lower end which may have been a short spine. The operculum (op.), exhibiting numerous radiating lines of small tubercles, is for the most part beautifully preserved; and the equally ornate suboperculum (s.op.), with rows of tubercles chiefly directed downwards, is also represented by a large fragment.

Egerton Coll.

P. 5416. Remains of another head in a small block of chalk, the left palato-ptersgoid arcade figured in Proc. Geol. Assoc. vol. x. pl. i. fig. 6 ; Chalk, Lewes. The imperfect right premaxilla exhibits the characteristic ornamentation much abraded, bears very slender well-spaced teeth, and is shown of the natural size in Pl. XI. fig. 3. The right palato-pterygoid arcade is exposed from the inner aspect, 
2.1703. Deanitio d figmed A. S.W. 1903, h.62, hl. xiv. fip. q.

P.5416. hoticed A.S.2. 1903, h.63. 
fractured right palatine ( $p a l$. ) is exposed from the inner aspect on the left side of the fossil; and there are obscured remains of the ectopterygoid (eept.) on both sides.

History unknown.

P. 5661. Imperfect right palatine with tooth exhibiting unusually conspicuous striations, shown of the natural size from the outer aspect in Pl. XI. fig. 5; probably from the Kentish Chalk. Harford Coll.

P. 398. More imperfect right palatine, with tooth less elongated; English Chalk. Presented by the Earl of Ducie, 1881.

25810. Remains of larger palatine, the tooth only in impression; English Chark.

Dixon Coll.

P. 6459. Smaller right palatine; English Chalk.

Beckles Corl.

Enchodus faujasi, Agassiz.

[Plate XI. fig. 6.]

1799. Figure by Faujas St. Fond, Hist, Nat, Morst. St. Pierre, Maestricht, pl. xix. fig. 10.

1843-44. Enchodus farjasii, L. Agassiz, Poiss. Foss. vol. v. pt. i. pp. 6, 65, pl. xxix. fig. 3.

1893. Enchodus faujasi, L. Dollo, Bull. Soc. Belge Géol. vol. vi., Proc.-Verb. p. 185, figs. 1, 3.

Type. Dentary bone; Paris Museum of Natural History.

A large species, known only by fragmentary speeimers, the manditle attaining a length of at least $0 \cdot 1$. The sides of the cranial roof marked with a few sharp ridges, not tuberculated; the outer face of the mandible remarkably smooth, not ornamented with tubercles, a few ridges and grooves radiating from the symphysis on the dentary, from the mandibular articulation on the articuloangular bone; premaxilla slightly and irregularly ridged; opercular apparatus ornamented with very fine tubercles in radiating lines. Palatine bone short and stout, the ethmoid articulation extending to its anterior end, where the long and slender tooth is directed downwards and a little forwards; dentary rapidly contracting almost to a point at the symphysis; the mandibular ramus considerably deepened behind, its maximum depth about equalling one third of its total length; about eight large mandibular teeth, all slender, some often irregularly curved, the foremost much the largest.

Form. \& Loc. Danian: Holland.

429\%6. Fine head associated with remains of the rertebral column; 
$27, b$

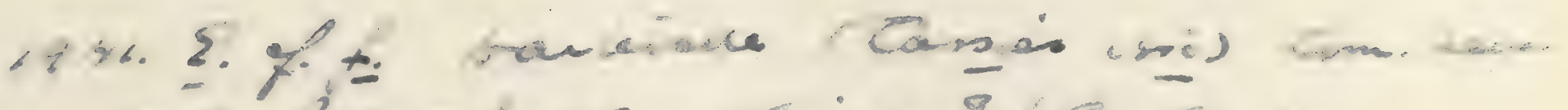

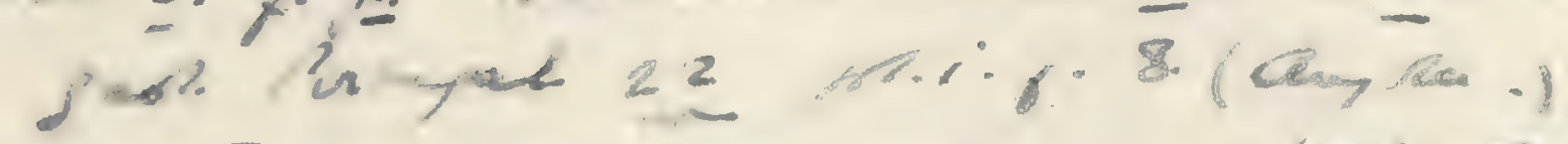

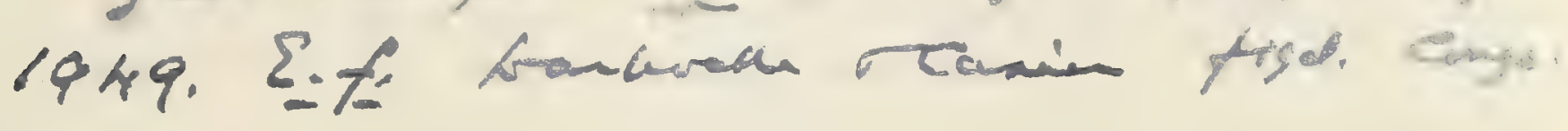



Maastricht. The cranium is somewhat obscured and fractured, but the general characters of the cranial roof (Pl. XI. fig. 6) can be obserred. The plane of the occiput is about at right-angles to that of the roof, and the occipital border exhibits the five prominences characteristic of the higher fishes. The small median eminence, partly broken away, is formed by the supraoccipital bone (s.oce.), which seems to enter the cranial roof as a short and broad plate. The inner pair of prominences are formed by the large and robust epiotics (ep.o.) ; the outer, or pterotic, prominences ( $\left.p t_{.0}.\right)$ are broken, but the right side of the fossil exhibits a delicate plate of bone extending forwards and inwards presumably upon the pterotic element to the ridge on the frontal at the level of the hinder border of the orbit. The outlines of the parietal bones are not shown, and the precise limits of the hinder end of the frontals are uncertain. The frontals $(f r)$, however, extend remarkably far backwards, and are evidently ridged in the manner characteristic of the genus, though the inwardly directed triangular ridged area spreading backwards along the postorbital region is broken away. The ridges are all sharp, but not tuberculated, and the smooth median area occupies nearly the inner half of the bone. The elements of the palato-pterygoid arcade are almost completely covered by matrix and the investing bones, though some of the teeth are partly seen. The delicate laminar premaxilla (fig. $6 a, p m x$.) is imperfectly shown on both sides, and that of the right is fractured by being crushed on one of the ectopterygoid teeth $\left(x_{0}\right)$; it is a deepened plate of bone in its anterior half, tapering to a very slender production behind, and must have formed the margin of at least half the gape. It bears a regular close series of very small teeth on its oral border, these being indicated by their bases on the left, by a few crowns on the right side. The very slender maxilla $\left(m x_{0}\right)$, best shown by a fragment on the right side, bears still smaller closely-set teeth. In its crushed state the region of the cheek on the left side is covered in front by two bones which cannot be satisfactorily determined. The foremost exhibits an external ornament of radiating lines of very fine tubercles, and may possibly belong to the opercular apparatus. The other is deep and narrow, with a triangular expansion below, exposed from the inner 
aspect, and perhaps representing the left clavicle. The mandible is fractured, and the articulo-angular element a little displaced with respect to the dentary. Both these bones are smooth, marked only by a few grooves and ridges. On the dentary ( $d$.) one groove extends directly backwards from the symphysis just below the oral border, widening on the upper hinder extension of the bone, which seems to reach the articular end of the mandible; while a band of about six similar groores extends backwards and a little downwards from a point near the symphysis to the short lower hinder extension of the bone. On the articulo-angular (ag.) the grooves radiate from the postero-inferior angle, one set continuing the lower band on the dentary already mentioned. Some of the characteristic large teeth are preserved, and the outer border of the dentary is shown to bear a clase regular series of small slender teeth. Behind the skull are remains of the right operculum bent inwards, this being ornamented with very delicate tubercles and radiating lines. Between the mandibular rami are observed traces of the hyoid apparatus and branchiostegal rays too imperfect for description. Numerous vertebral centra, in various states of preservation, are clustered round the head. They are longer than deep, much constricted, and strengthened with delicate longitudinal ridges at the side. A triangular hypural bone is also preserved.

Van Breda Coll.

4297\%. Right dentary exposed from the inner aspect, with eight teeth.

Van Breda Coll.

42978. Imperfect ectopterygoid.

Van Breda Coll.

42867, 42978 a. Two imperfect left palatines.

Tan Breda Coll.

42866,42978 b, c. Six detached teeth.

Van Brecia Coll.

\section{Enchodus lemonnieri, Dollo.}

1893. Enchodus lemonnieri, L. Dollo, Bull. Soe. Belge Géol. vol. vi., Proc.-Verb. p. 185, figs. 2, 4.

Type. Palatine and dentary; Royal Museum of Natural History, Brussels.

A large species, known only by jaws, in which the large teeth are comparatively short and broad and much laterally compressed. Palatine bone produced forwards in advance of its large tooth. 


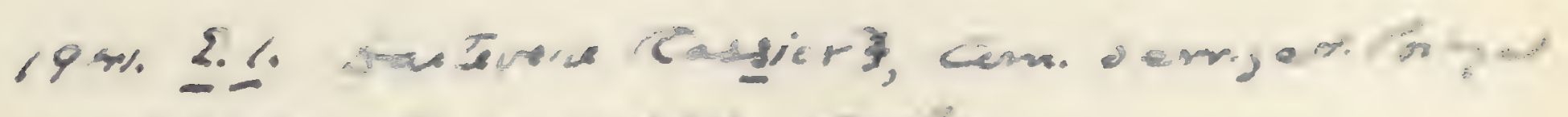

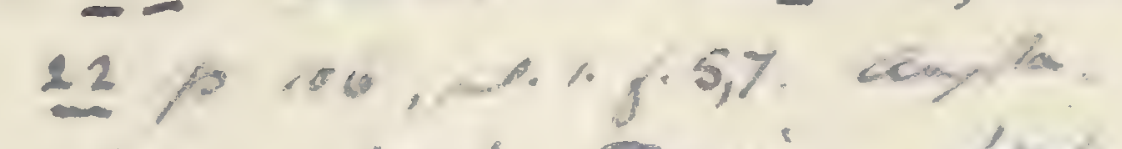

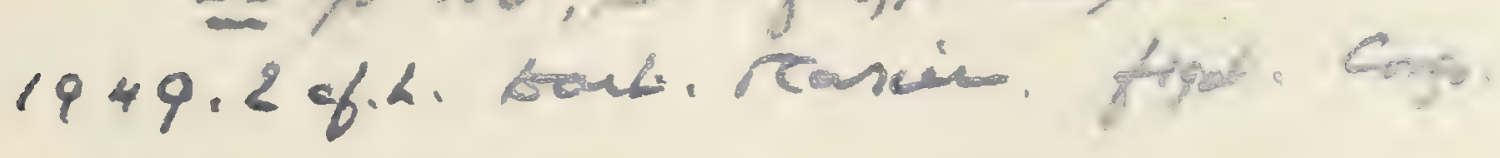


. 
Dentary bone with about eleven large teeth, of which the foremost does not much exceed the others in size.

Form. \& Loc. Upper Senonian: Belgium. Danian: Holland.

42978 d. Fragment of left dentary, w:th foremost large tooth; Danian, Maastricht.

Van Breda Coll.

30750. Detached tooth; Craie phosphatée, Ciply, near Mons.

Purchased.

\section{Enchodus longidens (Pictet).}

(?) 1849. Isodus sulcatus, J. J. Heckel, in Russegger's Reisen, vol. ii. pt. iii. p. 343, pl. xxiii. fig. 4. [Dentary bone.]

1850. Furypholis longidens, F. J. Pictet, Poiss. Foss. Mont Liban, p. 31, pl. v. fig. 1.

1866. Eurypholis longidens, Pictet \& Humbert, Nour. Rech. Poiss. Foss. Mont Liban, p. 105, pl. xvii.

1882. Eurypholis longidens, F. Bassani, Denkschr. k. Akad. Wiss., math.-naturw. Cl. vol. xlv. p. 274, pl. xii.

1887. Eurypholis longidens, J. W. Daris, Trans. Roy. Dublin Soc. [2] vol. iii. pp. 597, 602.

Type. Distorted smali fish; Genera Museum.

A small species known by nearly complete fishes attaining a length of about $0 \cdot 3$. Length of head with opercular apparatus much exceeding the maximum depth of the trunk and occupying one third of the total length to the base of the caudal fin. The mandible, operculum, and most of the other external bones ornamented with fine tuberculated ridges. Palatine bone produced forwards as a short cylindrical extension in advance of the ethmoid articulation, and the long slender tooth fixed at its extremity; outer face of premaxilla apparently smooth; dentary rapidly contracting almost to a point at the symphysis, and the maximum depth of the mandibular ramus contained about three and a half or four times in its total length. Teeth slender, much compressed, and often delicately striated. Vertebræ about 40 in number, 24 being caudal. Pelvie fins somewhat smaller than the pectorals, arising opposite the anterior half of the dorsal; dorsal fin with 16 rays, its depth about equalling that of the trunk at its insertion; anal fin much smaller, with 18 rays, arising nearer to the pelvic fins than to the caudal. Dorsal seutes three or four in number, broadly oval, and ornamented with delicate radiating lines.

Form. \& Loc. Upper Cretaceous: Sahel Alma, Mount Lebanon.

49505. Imperfect fish, a little elongated by distortion. The head is crushed forwards, exhibiting the proportions of the mandible and part of its ornamentation, besides remains 
of the premaxilla, palatine, and ectopterygoid. The pelvie, dorsal, caudal, and anal fins are preserved, though somewhat imperfect. Traces of the ornamented dorsal scutes, and the enlarged pair of spinous caudal scutes are shown. Remains of an undigested small fish are observable in the abdominal region.

Lewis Coll.

49508. Imperfect contorted fish, showing the mandible, palatines, and part of the premaxillæ and ectopterygoid.

Lewis Coll.

P. 4854. Another specimen shortened by distortion, with remains of the dorsal scutes, the very small scutes of the lateral line, and the enlarged pair of caudal spines. The latter are ornamented with delicate longitudinal striations, directed a little obliquely. Lewis Coll.

49506. Fish wanting hinder half of caudal region, displaying intermuscular bones, dorsal scutes, and both pectoral and pelvic fins.

Lewis Coll.

46534. Imperfect trunk, probably of this species, displaring median fins, the anal being crushed backwards by distortion.

Lervis Coll.

48149. Imperfect distorted trunk, with traces of the dorsal scutes and some of the small smooth scutes of the lateral line.

Lewis Coll.

The following specimens represent a form of Enchodus, named Eurygnathus marchesettii by D. G. Kramberger (I)jela Jugoslav. Akad. vol. xvi. 1895, p. 34, pl. vii. fig. 2), not yet clearly distinguished from $E$. longidens. The type specimen of the so-called E. marchesettii is in the Trieste Museum, and was obtained from Hakel, Mount Lebanon.

P. 4748. Well-preserved fish 0.17 in length, displaying the fins; Hakel.

Lewis Coll.

P. 9250. Smaller distorted specimen; Hakel. History unknown.

P. 95. Minute specimen with large head, probably young of this species; Hakel.

Lewis Coll.

\section{Enchodus major (Davis).}

1887. Eurygnathus ferox, J. W. Davis, Trans. Roy. Dublin Soc. [2] vol. iii. p. 602, pl. xxxvi. fig. 1. [Nearly complete fish; British. Museum.] 
1903. Enchodus marchesettiie, 0. P. Hay, Bull. Amer.

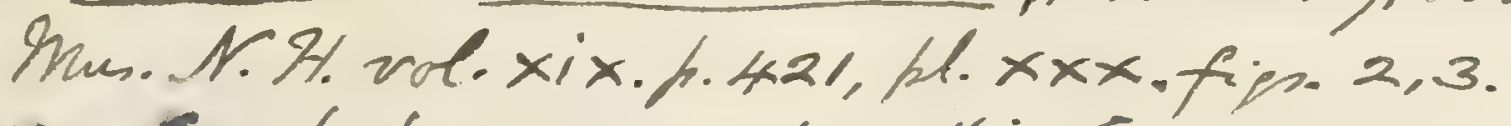
1\&52. Enchodes maceheselti C. Conancomp p. 232 ifso. 
$g$

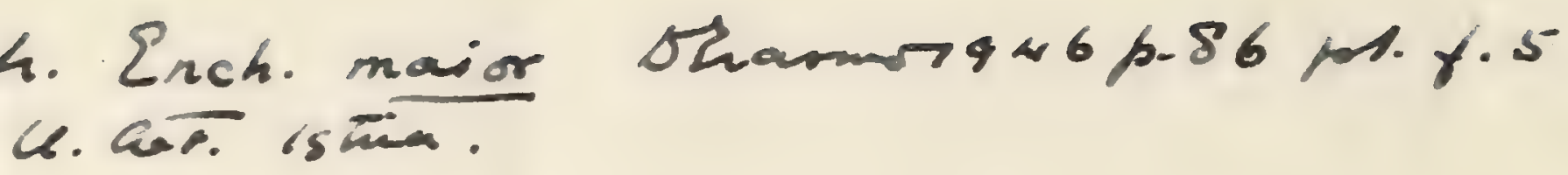


1887. Eurypholis majur, J. WT. Daris, ibid. p. 597, pl, xxx. fig. 2.

(?) 1887. Enchodus recurus, J. W. Daris, ibid. p. 522, pl. xxv. fig. 6.

[Imperfect mandibular ramus; Edinburgh .Iuseum.]

Type. Nearly complete fish; British Jiusenm.

The type species of the so-called Eurygnathus, attaining a length of about 0.4 . Closely resembling Enchodus longidens in form, proportions, and ornament, but differing in the slenderness of the mandible, of which the length is fire times as great as its maximum depth.

Form. \& Loc. Tpper Cretaceous: Sahel Alma, Mount Lebanon.

P. 4768. The type specimen deseribed and figured by Daris, Toc. cit. The end of the snout is broken awa.. Lewis Coll.

P. 4853. The type specimen of Eurygnathus ferox, described and figured by Daris, loc. cit. Traces of the characteristic external ornament are conspicuous, and the pointed anterior end of the dentary exhibits the usual irregular bony processes along the ssmphysis. Portions of the large teeth of the dentary and palato-pterrgoid arcade are exposed, and a fragment of the delieate premaxilla, with comparatively minute teeth, is seen in the midst of these remains. The head is a little lengthened by crushing and the operculum displaced backwards. The small smooth scutes piereed by the lateral line are well obserred on the caudal region, but the pair of enlarged spines on the caudal pedicle are fragmentary.

Lewis Coll.

P. 4763. Tery large head with greater portion of trunk, and the dorsal fin erushed somewhat formards.

Levis Coll.

49504. A contorted fish exposed chiefly from the rentral aspect, displaying the ornament of the mandible, some branchiostegal rars, the paired fins, caudal rertebræ, one of the caudal spines, and a few of the scutes of the lateral line. The lower end of the left claricle is also shown, not much expanded at the angle, but externally ornamented with radiating ridges.

Levis Coll.

48084. Imperfect abraded remains of head.

Lewis Coll.

Enchodus gracilis (W. ron der Marck).

1858. Ischyrocephalus gracilis, W. von der Marck, Zeitschr. deutsch. geol. Ges. vol. x. p. 248.

1863. Ischyrocephalus gracilis, W. ron der Marck, Palæontogr, vol, xi. p. 28 , pl. ii. fig. 2. 
1868. Ischyrocephalus cataphractus, W. von der Marck, loc. cit. vol. x́v. p. 281, pl. xlii. fig. 3, pl. xliii. fig. 8. [Imperfect fish; Academy of Münster.]

1873. Ischyrocephalus gracilis, W. von der Marck, loc. cit. vol. xxii. p. 58 , pl. i. fig. 2 .

1885. Ischyrocephalus cataphractus $=$ Ischyrocephalus gracilis, W. von der Marck, loc. cit. vol. xxxi. p. 249, pl. xxii. figs. 3, 4 .

Type. Imperfect fish; Academy of Münster.

The type species of the so-called genus Ischyrocephalus, attaining a length of about 0.35 . Length of head with opercular apparatus much exceeding the maximum depth of the trunk and occupying one third of the total length to the base of the candal fin. The mandible, operculum, and most of the other external bones ornamented with fine tuberculated ridges. Maximum depth of mandibular ramus contained about four times in its total length. Vertebræ about 50 in number. Pectoral fins with 14 or 15 rays; pelvic fins much smaller, with at least 6 rays, arising opposite the origin of the dorsal; dorsal fin with 18 rays, of which the three foremost are gradually lengthening spines; anal fin arising much nearer to the pelric fins than to the caudal and comprising 25 rays, of which the three foremost are gradually lengthening spines. Dorsal scutes four in number, elongate-rhomboidal in shape, and ornamented with delicate radiating lines.

An impression of the adipose dorsal fin has been observed in this species, opposite the hinder part of the anal fin.

Form. \& Loc. Upper Cretaceous: Westphalia.

P. 3848. Abdominal region of small fish, showing impression of operculum and remains of the pectoral, pelvic, and dorsal fins; Sendenhorst.

Enniskillen Coll.

Enchodus macropterus: (W. von der Marck).

1863. Ischyrocephalus macropterus, W. von der Marck, Palæontogr. vol. xi. p. 29, pl. iii. fig. 4.

1868. Ischyrocephalus intermedius, W. von der Marck, loc. cit. vol. xv. p. 282, pl. xliii. fig. ]. [Imperfect anterior portion of fish; Academy of Münster.]

1885. Ischyrocephalus intermedius = Ischyrocephalus macropterus, W. von der Marck, loc. cit. rol. xxxi. p. 249.

Type. Imperfect fish; Academy of Münster.

An imperfectly defined species much resembling $E$. gracilis, but attaining a somewhat larger size and apparently with a smaller head in proportion to the length of the trunk. The maudible seems 
232

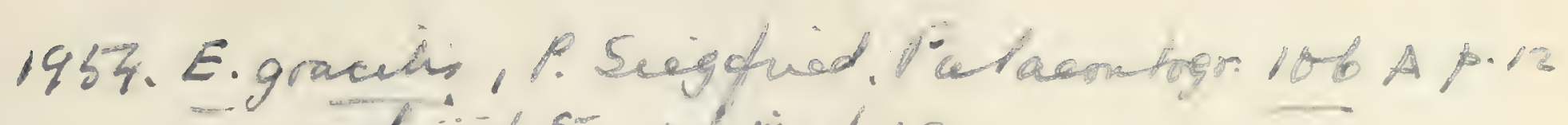

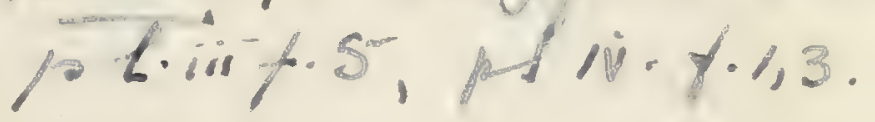

1954. E.m. P. Scegtind Paloomatify. 106A P. 15 M. iv. \%.2.4. 
Two other felth noticed as Enchodus

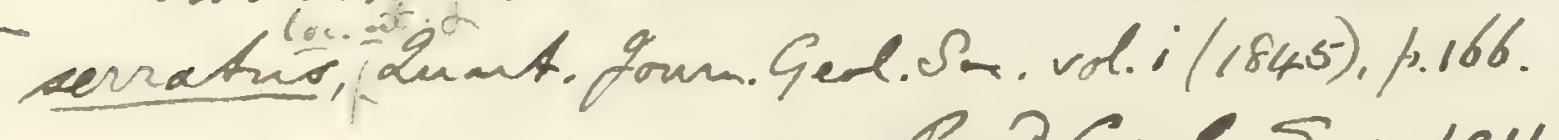
Re? Sed. Sn. 1911.

E. bussanxi's.n. Mantro xiapia arancoung resz

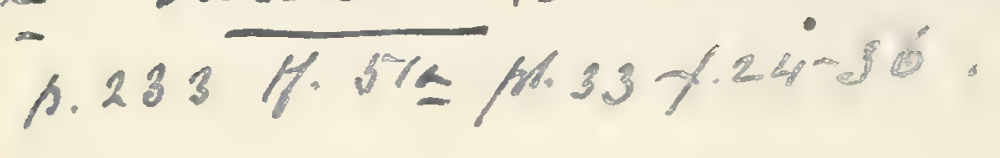


to be more slender than in the last-named species; while only 12 divided rays have hitherto been observed in the dorsal fin.

Form. \& Loc. Upper Cretaceous: Baumberg and Sendenhorst, Westphalia.

Not represented in the Collection.

The following specimens, mostly referable to the genus Enchodus, are not specifically determinable:-

49063. Remains of dentaries and palatine; Grey Chalk, Dover. Mrs. Smith's Coll.

P. 8945. Imperfect left dentary; Grey Chalk, Folkestone. Purchased, 1898.

P. 8754. Imperfect mandible; Grey Chalk, Folkestone.

Purchased, 1897.

35172. Palatine bone; Cambridge Greensand, Cambridge.

Purchased, 1859.

P. 7260-65. Various fragments of jaws; Cambridge Greensand, Cambridge. Jesson Coll.

P. 9181. Portions of palatine bones; Upper Cretaceous, Elkader, Logan Co., Kansas.

Presented by Handel T. Martin, Esq., 1899.

P. 9183. Portion of small right dentary; Elkader.

Purchased, 1900.

P. 598. Tooth described under the name of Enchodus serratus by Egerton, Proc. Geol. Soc. vol. iv. (1844), p. 383; Cretaceous, Pondicherry, Madras.

Egerton Coll.

Fragments of jaws and teeth, mostly referable to this genus, have also been described under the following names, but none of these forms seem to be represented in the Collection:-

Enchodus amicrodus, A. Stewart, Kansas Univ. Quart. [A] vol. vii. (1898), p. 193.-Upper Cretaceous; Kansas. [Dentary bone; Kansas University Museum.] = E. petrosus, goody Enchodus anceps, E. D. Cope, Vert. Cret. Form. West (Rep. U.S. Geol. Surv. Territ. vol. ii. 1.875), p. 301. Cimolichthys anceps, E. D. Cope, Proc. Amer. Phil. Soc. vol. xii. (1872), p. 352. Phasganodus anceps, E. D. Cope, op. cit. 1875, p. 236. - Upper Cretaceous (Niobrara Group); Kansas. [Right palatine ; Cope Collection.]

Enchodus calliodon, E. D. Cope, Proc. Amer. Phil. Soc. rol, xii. 
(1872), p. 394, and op.cit.1875, p. 240.-Ibid. [Tooth ; Cope Collection.]

Enchodus carinatus: Sphyrcena carinata, E. D. Cope, Proc. Acad.

Nat. Sci. Philad. 1868, p. 93, and Ann. Rep. U.S. Geol.

Surv. Territ. 1870 (1871), p. 424. Phasganodus carinatus, E. D. Cope, op. cit. 1875, p. 235.-Ibid. [Tooth ; Cope Collection.]

Enchodus corneti, H. Forir, Ann. Soc. Géol. Belg. vol. xiv. (1887), Mém. p. 37, pl. i. figs. 2, 3.-Upper Cretaceous (Danian);

Vieux-Fauquemont, Belgium. [Jaws; Forir Coll.]

Enchodus dirus: Phasganodus dirus, J. Leidy, Proc. Acad. Nat.

Sci. Philad. vol. ix. (1857), p. 167, and Contrib. Ext. Vert.

Fauna W. Territ. (Rep. U.S. Geol. Surv. Territ. vol. i. pt. i. 1873), p. 289, pl. xvii. figs. 23, 24.-Cretaceous; Cannon Ball River, Dakota. [Dentary bone; Academy of Sciences, Philadelphia.]

Enchodus dolichus, E. D. Cope, op. cit. 1875, pp. 239, 300, pl. liv. figs. 7, 8; F. B. Loomis, Palæontngr. vol. xlvi. (1900), p. 279, pl. xxvii. figs. 16, 17.- Upper Cretaceous (Niobrara Group); Kansas. [Palatine, \&c.; Cope Collection.] E glediohs, Enchodus fero.r, J. Leidy, Proc. Acad. Nat. Sci. Philad. 1855, Goody 1976 p. 397. Sphyrcena, S. G. Morton, Synops. Organ. Remains Cret. U. S. (1834), p. 32, pl. xii. tig. 1.Greensand; New Jersey. [Tooth.]

Enchoclus gladiolus, E. D. Cope, op. eit. 1875, p. 301. Phasganodus gladiolus, E. D. Cope, ibid. p. 235. Cimolichthys gladiolus, E. D. Cope, Proc. Amer. Phil. Soc. vol. xii. (1872), p. 353.-Upper Cretaceous (Xiobrara Group); Kansas. [Tooth; Cope Collection.]

Enehodus lycodon: Saurocephatus (?) lycodon, R. Kner, Sitzungsb.

k. Akad. Wiss., math.-naturw. Cl. vol. 1vi. pt. i. (1867), p. 174, pl. ii. (and ? pl. iii.). Solenodon neocomiensis, D. G. Kramberger, Jahrb. k.-k. geol. Reichsanst. vol. xxxi. (1881), p. 377. Holcodon lycodon, D. G. Kramberger, Rad Jugoslav. Akad. vol. lxxii. (1885), p. 19.-Cretaceous ; Comen, Istria, and (?) Isle of Lesina, Dalmatia. [Imperfect head; Imperial Geological Suræey Museum, Vienna. The type species of Solenodon, Kramberger, and Holcodon, Kramberger.] E.6. D'Liesme 19.46 p.85.

Enchodus oxytomus, E. D. Cope, op. cit. 187.5, p. 278.-Greensand; New Jersey. [Tooth; Cope Collection. $]=E$. petrosus Enchodus parvus, A. Stewart, Kansas Univ. Quart. [A] vol. vii. Goviy 1976 (1898), p. 192, woodc. Referred to E. shumardi by F. B. 



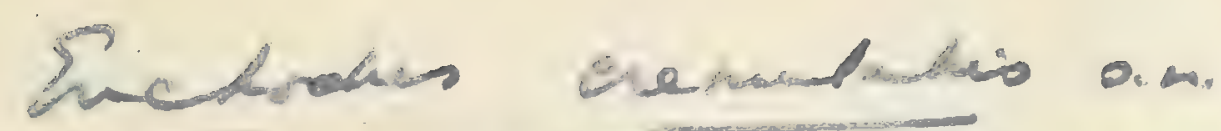

Cono

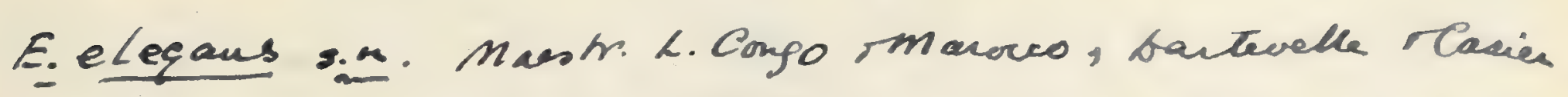

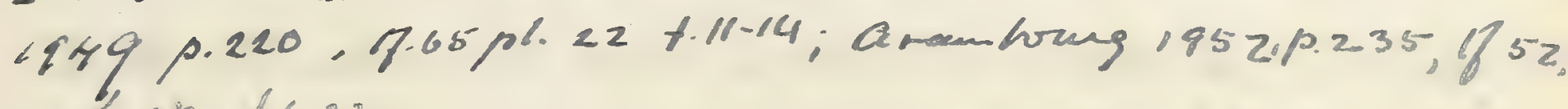
Nh.s., f.1025.

- Apateadus corneli: PKruizinga, Versl. gew verg. wis. nat. ofd. Kom. akad. bet. Cunstidam xxxir No10 (1924) p 977-978

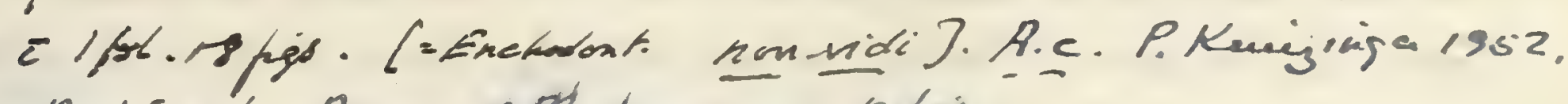

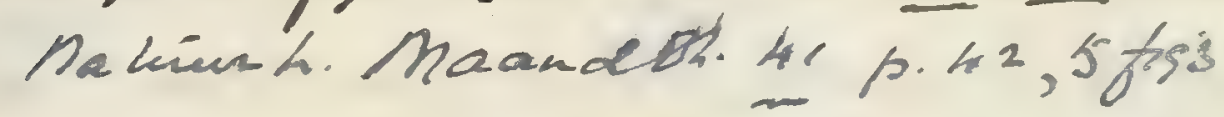

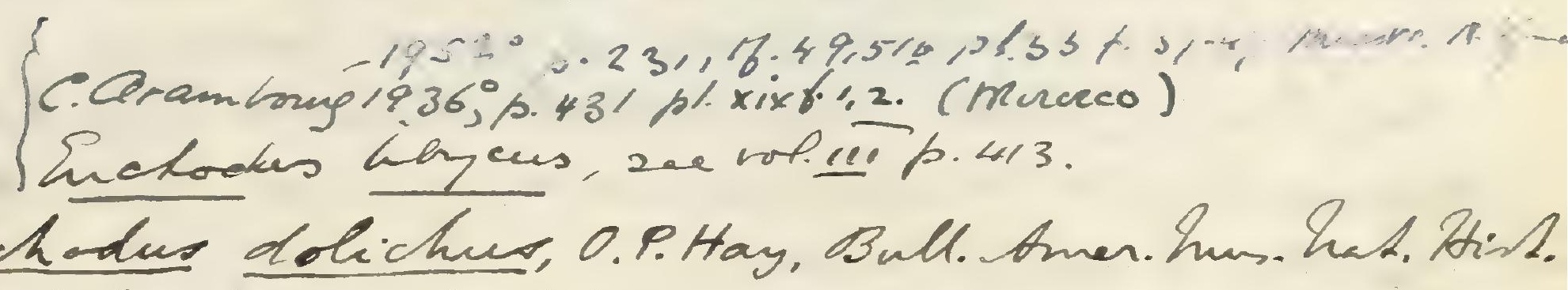
rol.xix $(1903), 5.72$, texthfige. 52, 53.

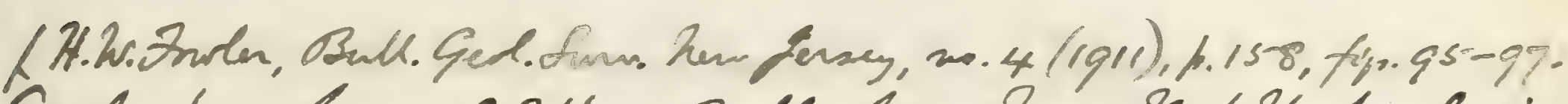
Enchodur ferox, O.P. Hay. Bull. Ames. Inus. Had Hist. vol. xix (1903), h.68, tent-fip. 50 .

Enchodur gladioluer, 0.PHay, Bull. Amer. Inur ha 212ish wol. xix $(1903), h .75$, texh-fipo $56.6 \%$

Enchodur gentryi. Lee fr.615.

Snehorho oliveinat, s.n. C.1. Many, 1930,

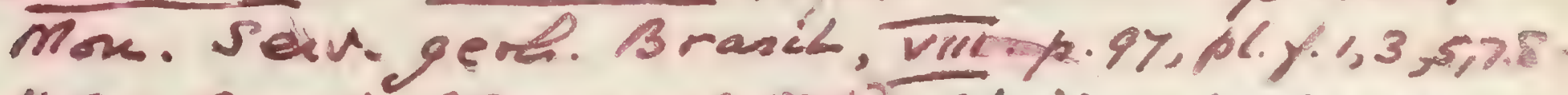

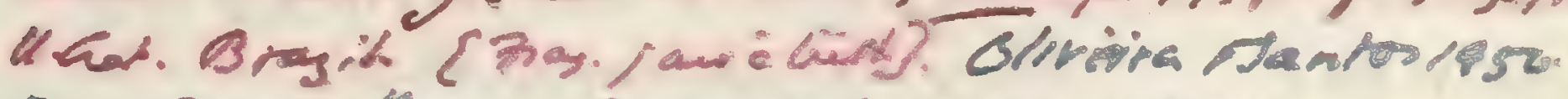
An. Q oud Browi Cunso 22

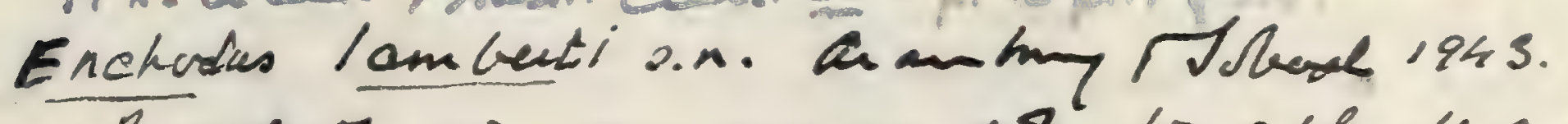

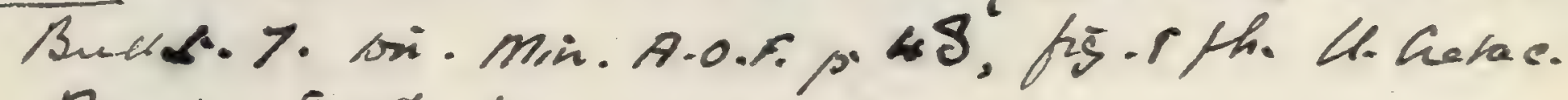
Migen. Teelx.ek. 

ENCHODORTIDE. ariby groig, $1976, p \cdot c 0205$

Loomis, Palæontogr. vol. xlvi. (1900), p. 280/- Cpper

Cretaceous (Niobrara Group); Gove Connty, Kansas.

[Dentary; Kansas University Museum.]

Enchodus petrosus, E. D. Cope, Bull. U.S. Geol. Surv. Territ. no. 2 (1874), p. 44, and op. cit. 1875, p. 239, pl. liv. figs. 4-6 ; F. B. Ioomis, Palæontogr. vol. xlvi. (1900), p. 278, pl. xxrii. figs. 13-15.- Tpper Cretaceous (Niobrara Group); Kansas. [Portions of skull, including palatine, and associated vertebra; Cope Collection.]

Enchodus pressidens, E. D. Cope, Proc. Amer. Phil. Soc. vol. xi. (1870), p.241.-Greensand; New Jerser. [Palatine bone.] Enchodus semistriatus, O. C. Marsh, Proc. Amer. Assoc. Adr.

Sci. 1869 (1870), p. 230. Phasganodus semistrictus,

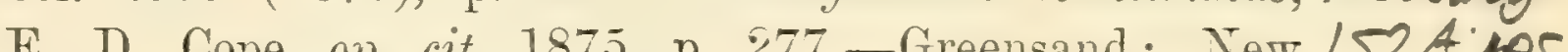
Jersey. [Teeth.]

Enchodus shumardi, J. Leidy, Proc. Acad. Nat. Sci. Philad. 18506, p. 257, and Contrib. Ext. Vert. Fauna W. Territ. (1873), p. 289 , pl. xvii. fig. 20 ; F. B. Loomis, Palæontogr. vol. xlvi. (1900), p. 280, pl. xxvii. figs. 18, 19.-Cretaceous; Sage Creek, Dakota. [Dentary bone; National Museum, Washington.]

Enchodus subcequilateralis, E. D. Cope, Proc. Amer. Phil. Soc. vol. xxiii. (1886), p. 3.—Cretaceous; Brazil. [Palatine.] Enchodus tetrcecus, E. D. Cope, op. cit. 1875, p. 278.-Cretaceous;

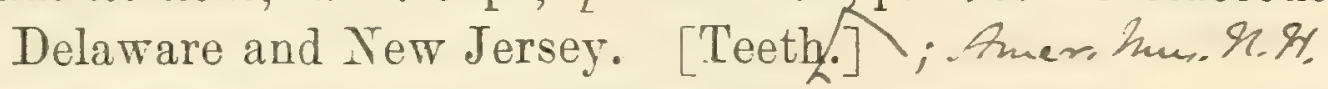
Enchodus valdensis, W. Dunker, Monogr. Norddeutsch. Wealdenbild. (1846), p. 62, pl. xv. fig. 24.-Wealden; N. Germany. [Indeterminable tooth, probably not of this genus.]

The jaws named as follows seem to differ from Enchodus only in the absence of the terminal tooth of the palatine, which may have been shed :-

Tetheodus pephredo, E. D. Cope, Bull. U.S. Geol. Surr. Territ. no. 2 (1874), p. 43, and Tert. Cret. Form. West (Rep. U.S. Geol. Surv. Territ. vol. ii. 1875), p. 23\%, pl. liv. figs. 1-3.-Upper Cretaceous (Niobrara Group); Kansas.

The imperfect fish described as follows also seems to belong to the genus Enchodus:-

Elopopsis dentex, J. J. Heckel, Denkschr. k. Akad. Wiss., math.naturw. Cl. vol. xi. (1856), p. 254, pl. xiii. fig. 2.Cretaceous; Comen, Istria. [Fish wanting end of tail; Rosthorn Collection.] Enckonen deufíx

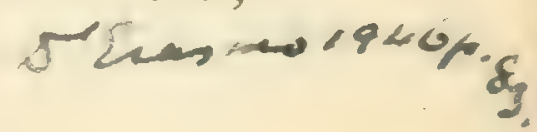




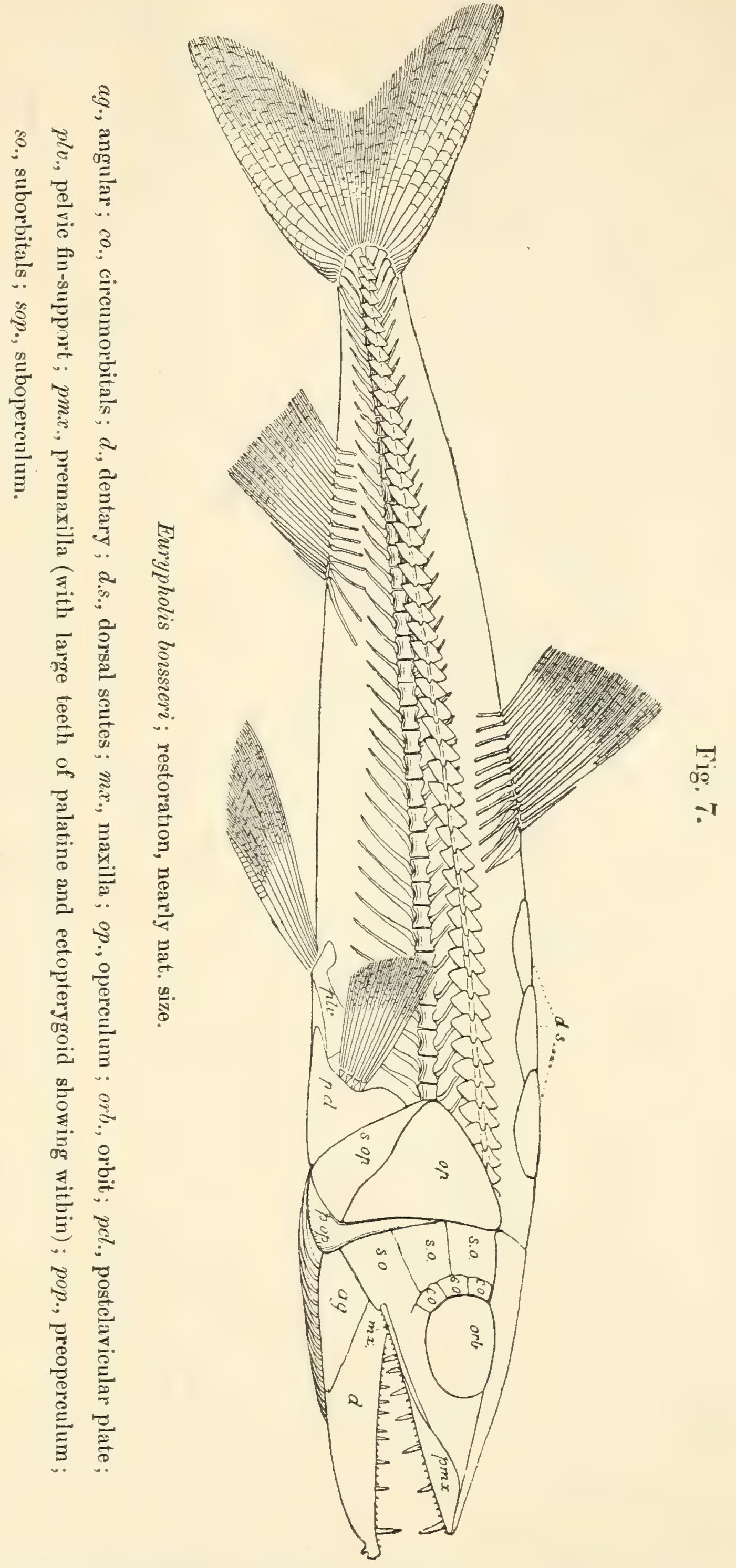




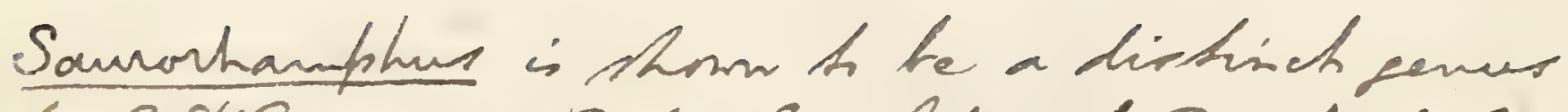

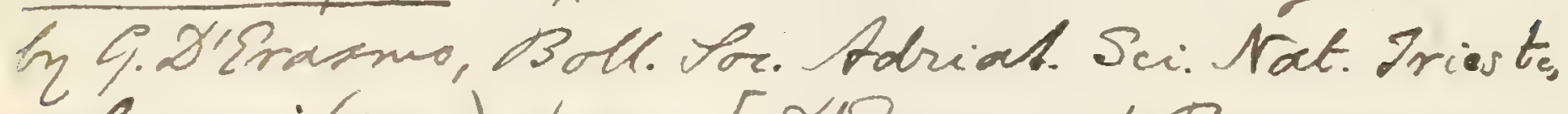

vol.xxvi(1912), p.87. [D'Prakmo d Basami showed me the dpecimens at Hapler in Apriel igll. Stist

Sumplolis as aucestory the Inioni, Sregong of comad. Eopeia, 1936 phl. p.26. 


\section{Genus EURYPHOLIS, Pictet.}

[Poiss. Foss. Mont Liban, 1850, p. 28.]

Syn. Saurorhamphus, J. J. Heckel, Denkschr. k. Akad. Wiss., math.naturw. Cl. vol. i. 1850, p. 217 (inaccurate definition).

Form and proportions, arrangement of jaws and dentition as in Enchodus. Cranial roof almost completely covered with tubercular ornament; cheek-plates comprising the hinder portion of a small circumorbital series, and large posterior suborbitals, also ornamented with tubercles. Preoperculum narrow and deep, its lower end expanded into a small, stout, posteriorly directed spine; operculum triangular in shape, its transverse inner ridge extending from the point of suspension to the hinder angle; branchiostegal rays about 15 in number. Vertebræ approximately 40 in number, the centra slender and much constricted. A large triangular ornamented dermal plate fixed to the lower half of the clavicle; the pectoral fin, of moderate size, arising above this upon the flank of the fish; pelvic fins very large and far forwards. Dermal scutes well-developed, some slightly overlapping, and all ornamented with tubercles; three or four large median scutes in series between the occiput and dorsal fin, and smaller scutes along the course of tho lateral line, but none enlarged on the caudal pedicle.

Many details in the osteology of this genus are illustrated by the specimens of the typical species described below.

\section{Eurypholis boissieri, Pictet.}

\section{[Plate XI. fig. 7.]}

1850. Eurypholis sulcidens, F. J. Pictet, Poiss. Foss. Mont Liban, p. 29, pl. iv. fig. 1. [Head and anterior abdominal region; Geneva Museum.]

1850. Eurypholis boissieri, F. J. Pictet, ibid. p. 30, pl. iv. figs. 2-4.

1866. Eurypholis boissieri, Pictet \& Humbert, Nouv. Rech. Poiss. Foss. Mont Liban, p. 102, pls. xv., xvi.

Type. Head with abdominal region; Genera Museum.

The type species, attaining a length of about 0.2. Head with opercular apparatus about twice as long as its maximum depth, occupying one third of the total length to the base of the caudal fin. Ornament consisting of closely-arranged rows of fine, wellseparated tubercles, covering all the external bones and scutes. The large palatine tooth smooth and inclined a little forwards; some of the other teeth slightly fluted at the base of the crown. Operculum an almost equilateral triangle; spine at the lower end 
of preoperculum short and stout; postclavicular plate triangular, somewhat longer than deep, and its postero-superior margin excavated. Pectoral fin arising just above the postclavicular plate, the large pelvic fin immediately behind this plate and in advance of the origin of the dorsal fin; dorsal fin somewhat deeper than long, comprising 12 rays, and the distance between its hinder end and the caudal fin slightly exceeding that between its origin and the occiput; anal fin smaller than the dorsal, at least as long as deep, comprising 13 rays, and arising much nearer to the caudal than to the pelvic fins. Three large dorsal plates behind the occiput, orate in form, very slightly overlapping, ornamented with closelyarranged concentric rows of tubercles, and not quite reaching the dorsal fin; lateral scutes much smaller, irregularly triangular and deeper than broad, perforated by the sensory canal.

Form. \& Loc. Upper Cretaceous: Hakel, Mount Lebanon, Syria.

49478. A vertically crushed specimen, displaying the head and opercular bones as shown in Pl. XI. fig. 7. The cranial roof is shown partly from within, partly in impression of the outer ornamented face; but it merely exhibits the large extent of the frontals ( $f r$.$) , not distinctly indicating$ the other elements. The extended premaxilla (pmo.), deepened in front and tapering, behind, is conspicuous on each side and exhibits the single series of small slender teeth, fixed on tumid bases. On the left side the slender maxilla $(m x$.), with small teeth in its hinder portion, also seems to be partly preserved. The orbit (o.) is bounded behind by a chain of small, tuberculated circumorbital plates (co.), of which four are preserved; while the whole of the cheek between these and the preoperculum is covered by posterior suborbitals (s.o.), of which the limits are not clear. Both mandibular rami are exposed from within and exhibit the characteristic teeth on tumid bases, while that of the right side shows two irregular prominences of bone at the tapering symphysis. Each ramus gradually deepens behind and seems to consist of two elements, dentary (d.) and articulo-angular ( $\left(g_{\circ}\right)$, of which the limits are indicated by the impression of the tuberculated outer face of the left side. The preoperculum ( $p . o p$. is a thickened vertical rod, almost reaching the cranial roof above, and terminated below by the short and stout posteriorly-directed spine; a narrow tuberculated lamina extends along its posterior margin. The triangular oper- 
culum (op.) exhibits its thickened inner rib, and is sufficiently transparent to admit of the radiating lines of fine tubercles on its outer face being seen. The suboperculum (s.op.) is imperfectly preserved only on the left side; its tubercular ornament is arranged in almost vertically directed lines. The dorsal scutes (d.s.) are exposed from within, and immediately behind the left operculum the inner face of the triangular post-clavicular plate $\left(p . c l_{0}\right)$ is also shown. One pelvic fin $(p l v$. ) is preserved behind. The other remains are too imperfect for description.

Lewis Coll.

P. 72. Another vertically crushed specimen, more imperfect. The dermal scutes of the lateral line are well shown.

Lewis Coll.

P. 1904. Smaller imperfect vertically crushed head and abdominal region.

Egerton Coll.

49479-82. Four specimens in side view, the second and third displaying the caudal fin, the fourth wanting it. All except the first exhibit the slender branchiostegal rays, while the third and fourth show the large anterior tooth on the thickened palatine bone.

Lewis Coll.

P. 74. Another fine specimen in side view, displaying one of the pelvic fins. The foremost ray of this fin is much the stoutest, closely articulated but not divided distally; it is also the shortest ray, and the others, to the number of about seven, gradually increase in length. Lewis Coll.

49555. Smaller fish in side view, displaying the dorsal and caudal fins. There are remains of a swallowed fish in the abdomen.

Lewis Coll.

P. 2\%6. Imperfect fish in side view, displaying the scutes and external ornamentation.

Transferred from Mus. Practical Geology, 1880.

P. 73. A rery fragmentary specimen, in counterpart. Remains of the branchial arches, hyoids, and branchiostegal rays are displaced below the pectoral region. Lewis Coll.

39235. Smaller imperfect specimen, with a fragment.

Tristram Coll.

PART IV. 
P. 71. Head and abdominal region of a similar specimen in side view, associated with small Urenchelys hakelensis.

Lervis Coll.

P. 75-77. Three small fishes in side view, showing the principal characters of the genus and species. In the second specimen the space originally occupied by the notochord is filled with calcite, which proves that a delicate thread persisted piercing each centrum. This and the third specimen also exhibit the peculiar form of the pelvic bones, one of which is restored in the diagram, textfig. 7. The main portion of this element gradually expands towards its anteriorly directed end; it is contracted presumably at the point of origin of the pelvic fin, and thence sends a small expanding process inwards to meet its fellow of the opposite side.

Lewis Coll.

49483. Fish only 0.095 in length, lateral aspect.

Lewis Coll.

P. 78. Trunk of another small fish.

Lewis Coll.

\section{Eurypholis freyeri (Heckel).}

1850. Saurorhamphus freyeri, J. J. Heckel, Denkschr. k. Akad. Wiss., math.-naturw. Cl. vol, i. p. 217, pls. xviii., xix.

1867. Saurorhamphus freyeri, R. Kner, Sitzungsb. k. Akad. Wiss., math.-naturw. Cl. vol. lvi. pt. i. p. 184.

Type. Imperfect fish; Museum of Laibach, Austria.

The trpe species of the so-called Saurorhamphus, attaining a length of about $0 \cdot 2$. Head with opercular apparatus occupying one third of the total length to the base of the caudal fin. Ornament apparently as in E. boissieri. Fins almost as in the latter, but abdominal region probably somewhat more elongated. Four large dorsal plates behind the occiput, ovate in form, very slightly overlapping, ornamented with fine tubercles, and not quite reaching the dorsal. fin; lateral scutes smaller, irregularly triangular, and notched (perhaps also perforated) by the sensory canal.

The erroneous restoration by Heckel gives a very false idea of this fish. Every feature in its osteology hitherto definitely discovered, suggests that its reference to the genus Eurypholis is correct.

Form. \& Loc. Cretaceous: Comen, Istria.

Not represented in the Collection. In addition to the type, the only known specimen is an imperfect fish in the Museum of the Imperial Geological Survey, Vienna, described by Kner, loc. cit. 
1912. Taurarhamphur freyerri G.D'Prasmo, Boll Soe. Adriat. Sci. Nat. Srieste, vol xxvi. h. 45, hh. i-ii, teath fier.1-15: 1946. Samorlanghes freycri, S. Stiasmos p.92

Fine collution in Inuses livico at Trieste Lear it at Sofeler in Afirl 1911 with Bassani ¿D'irasmo: 然了 


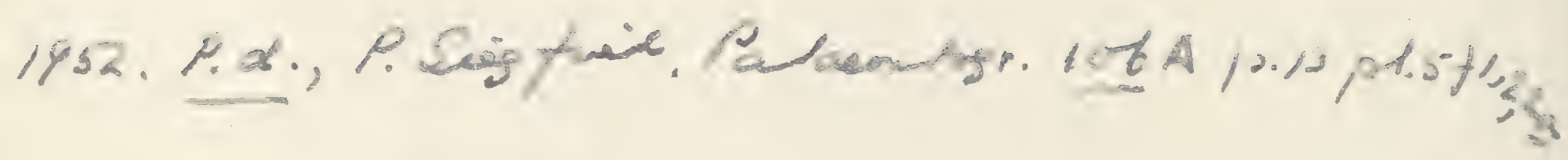


Genus PAL 25OLYCUS, W. von der Marck.

[Palæontogr. rol. xi. 1863, p. 31.]

Trunk much elongated, both this and the head laterally compressed. Jaws and dentition as in Enchodus and Eurypho'is. Vertebræ at least 70 in number, nearly half abdominal; the centra longer than deep, constricted mesially, and strengthened by at least one lateral longitudinal ridge. All except the foremost rays of each fin finely divided distaliy, but none excessively elongated. No postclavicular plate. Pectoral fins rather large; pelvic fins very small; dorsal fin also very small and remote, with one spine and about 8 divided rays, opposed to part of the much-extended anal fin, which has nearly 50 rays; caudal fin small and deeply cleft, with stout basal rays. A series of median dorsal scutes immediately behind the occiput, [but no other dermal covering hitherto observed].

Palaolycus dreginensis, W. von der Marck.

1863. Palcoolycus dieginensis, W. von der Marck, Palæontogr. vol. xi. p. 31, pl. iv. fig. 7 .

1885. Pulcenlycus dieginensis, W. von der Marck, loc. cit. vol, xxxi. p. 251.

Type. Nearly complete fish; Academy of Münster.

The type species, attaining a length of about 0.4 . Maximum depth of trunk contained about ten times, and length of head with opercular apparatus nearly eight times in the total length of the fish. Enlarged teeth longitudinally striated. Vertebræ 75 in number, about 32 referable to the abdominal region; the centra slightly pierced by persistent notochord. Pelvic fins arising slightly behind the middle point between the pectoral and anal fins; dorsal fin arising considerably behind the anal, but opposed to part of the anterior half of the latter, comprising one spine and 8 divided rays, the spine not much shorter than the first divided ray; anal fin extending along nearly the whole of the caudal region, with about 46 well-spaced divided rays, apparently no anterior spinous rays. Dorsal scutes perhaps about 6 in number, ornamented with fine radiating ridges.

Form. \& Loc. Upper Cretaceous: neighbourhood of Sendenhorst, Westphalia.

Not represented in the Collection. The above diagnoses are based especially upon the second specimen in the Academy of Münster described by W. von der Marck, loc. cit. 1885. 


\section{Genus HALEC, Agassiz.}

[Verhandi. Ges. vaterl. Mus. Böhmen, 1834, p. 67.]

Syn. Pomognathus, F. Dixon, Geol. Sussex, 1850, p. 367.

Archcoogadus, W. von der Marck, Palæontogr. vol. xv. 1868, p. 291.

Phylactocephalus, J. W. Davis, Trans. Roy. Dublin Soc. [2] vol. iii. 1887, p. 605 .

Trunk deeply fusiform, both this and the head laterally compressed. Cranial roof exhibiting a median longitudinal depression, its lateral and occipital margins ornamented, like the other external bones, with ridges and tubercles of ganoine. Mandible a little prominent, with several rows of recurved conical teeth, irregular in size and arrangement; premaxilla long and slender, with two or more rows of minute teeth; maxilla long and slender, underlapped by the premaxilla for the greater part of its length, but entering the gape behind, where it bears a spaced series of relatively large conical teeth pointing forwards; a conspicuous supramaxilla present; the comparatively stout palatine and ectopterygoid bones bearing a close series of acute, laterally-compressed teeth, which are largest in the middle and diminish towards each extremity; no teeth barbed. Preoperculum very narrow and deep, with a conspicuous posteriorly-directed spine at its lower end; operculum strengthened on the inner side by a ridge extending almost horizontally backwards to its postero-inferior angle; branchiostegal rays about 15 in number. Vertebræ from 35 to 45 in number, the centra at least as long as deep, much constricted mesially and somewhat strengthened with small longitudinal ridges. Fin-rays robust and all articulated, mostly also subdivided distally; no fin-rays excessively elongated. Paired fins large, the pelric pair not much smaller than the pectorals; the short dorsal fin within the anterior half of the trunk; anal fin relatively small and remote; caudal fin deeply forked. A regular squamation of very small scales, the exposed area of each quadrangular in shape; no enlarged scutes.

\section{Halec stembergi, Agassiz.}

1834. Halec sternbergii, L. Agassiz, Verhandl. Ges. vaterl. Mus. Böhmen, p. 67.

1814. Halec sternbergii, L. Agassiz, Poiss. Foss. vol. v. pt. ii. p. 12:3, pl. lxiii.

1845-46. Halec sternbergii, A. E. Reuss, Verstein. böhm. Kreideform. pt, i. p. 13, pt. ii. p. 118, pls. xxii., xxiii.

1878. Halec sternbergii, A. Fritsch, Rept. u. Fische böhm. Kreideform. p. 37 , pl. ix.

1883. Halec sternhergii, A. Fritsch, Archiv naturw. Landesdurchf. Böhmen, vol. v. no. 2, p. 89, fig. 47. 
1824

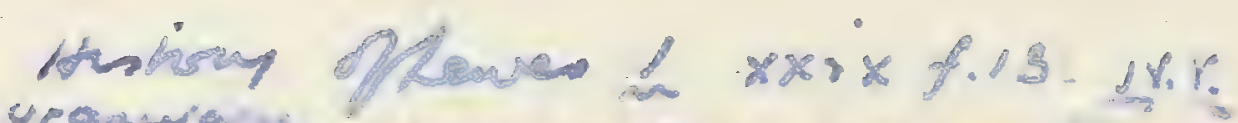

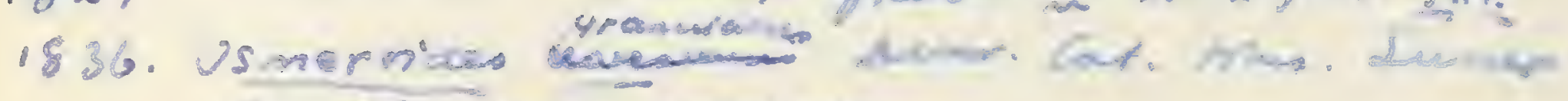

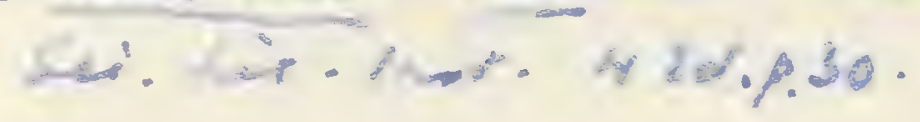

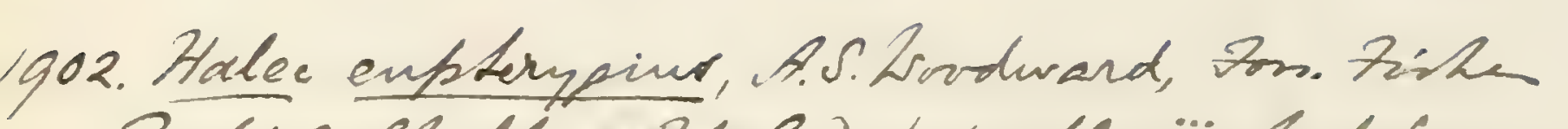

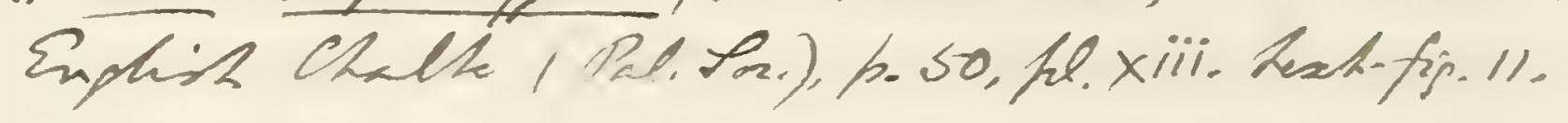

43388. hrtieed A.S.2. 1902, 5.51. 
Type. Imperfect fish, wanting tail; Royal Bohemian IIuseum, Prague.

The type species, attaining a length of about 1.0. Length of head with opercular apparatus contained approximately three times in the length from the pectoral arch to the base of the caudal fin. Opereulum comparatirely smooth, its breadth about two thirds as great as its maximum depth. Tertebræ about to in number.

Form. \& Loc. Turonian: Bohemia.

P. 5\%32. Plaster cast of type specimen; Jung Koldin, Bohemia. Piresented by Pirof. Anton Fritsch, 1888.

P. 9002-04. Three imperfect specimens in irregular fragments; Vinarj, Bohemia.

Purchased, 1899.

\section{Halec eupterygius (Dixon).}

1837. Osmeroides lewesiensis, L. Agassiz, Poiss. Foss. rol, r. pl, lx b. figs. 3,4 (errore).

(?) 184t. Osmeroides granulatus, L. Agassiz, ibid. rol. r. pt. i. p. 14 (name only).

1850. Pomognathus eupterygius, F. Dixon, Geol. Sussex, p. 367, pl. xxxv. figs. 6,7 .

1888. Pomognathus eupterygius, A. S. Woodward, Proc. Geol. Assoc. vol. x. p. 318.

Type. Imperfect fish; Brighton Iruseum.

The type species of the so-called Pomognathus, attaining a length of about 0.4 . Length of head with opercular apparatus much exceeding the maximum depth of the trunk, which is probably contained about four times in the length from the pectoral arch to the base of the cardal fin. Length of mandible somewhat exceeding the depth of the head at the occiput; operculum considerably deeper than broad; the infero-posterior spine of the preoperculum short, stout, and ornamented with tubercles. The external tubercular ornament very fine, arranged in more or less radiating lines on the sides of the cranial roof, the supramaxilla, mandible, opercular apparatus, claricle and supraclaticle. The stouter rajs of the paired and dorsal fins also omamented mith longitudinal series of very fine tubercles. Tertebræ about $4 \check{\partial}$ in number.

The squamation of this species is unknomn, probably on account of the soft nature of the chally matrix in mhich the specimens are preserved.

Form. \& Loc. Turonian and Senonian: Kent and Sussex.

43388. Remains of small fish, in counterpart; Lower Chalk, Burham, Kent. The general proportions are as stated in the 
diagnosis. The total number of vertebræ is shown to be about 45 , and of these the 21 caudals are well preserved. Fragments of all the fins exeept the anal are distinguishable.

Purchased, 1872.

32336. Imperfect head and abdominal region, with the greater part of the dorsal and paired fins; Lower Chalk, Maidstone. The fossil is broken across at the back of the head, and the opercular apparatus thas destroyed behind the preoperculum. The cranial roof is flattened, constricted behind, widest at the hinder border of the orbits, and marked by a sharp median depression between the orbits. The very large frontal bones extend almost to the occipital border, and are smooth in the middle portion which passes into the interorbital depression, but are marked with the characteristic ornament in the outer or lateral portion. Anteriorly they unite in a suture with the short and broad, smooth mesethmoid bone; anterolaterally they are overlapped by the nasal bones. The latter elements are well preserved, each being shown to be antero-posteriorly elongated, almost ovate though pointed behind, and very conspicuously ornamented with radiating series of tubercles. The otic region is too imperfect for description, and there are no traces of cheek-plates; but in side-view there are recognisable remains of the jaws. The triangular metapterygoid is completely displayed, but the remainder of the pterygopalatine arcade is obscured except at its upper border. The very long and slender premaxilla is imperfect in front, but exhibits the characteristic fine tubercular ornament in its hinder two thirds, while the oral margin still bears some of the minute teeth. The maxilla, though fractured, is preserved for the greater part of its length, underlapped more than halfway by the premaxilla; and its hinder third exhibits some of the large and characteristic spaced teeth, which are inclined with the point forwards. Above the hinder third of the maxilla is the highly ornamented supramaxilla, antero-posteriorly elongated, pointed in front and rounded behind. The mandible is crushed at the symphysis and otherwise fractured, but the suture between the dentary and angular is distinct, and the fine tubercular ornament is shown to cover the lower portion of both elements, being 


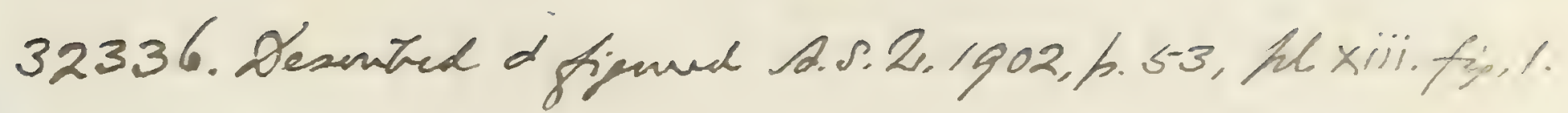




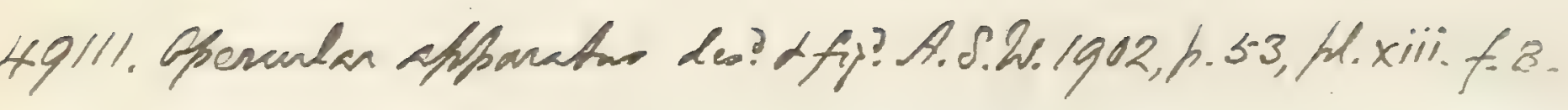

2.17032. Pierced vert. centra noticer A.S. W. 1902, h. 544.

D.365\%. Gono figmo d desentas A.S.W. 1902, h.53, he. xiii. fis.6; clavible nsticed, fi.s4. 
absent only in the area apparently overlapped by the upper jaw. The course of the sensory canal on the angular and dentary is marked by a deep open groove. The preoperculum is narrow and deep, with the long axis vertical; and its finely tuberculated lower end is scarcely bent forwards, being produced instead backwards into a short blunt spine, which is incomplete at the point in the fossil. Comparaticely slender and well-spaced branchiostegal rays are shomn beneath the hinder end of the mandible, perhaps eight or nine in number. The rertebral centra are much constricted, apparently strenothened only by one ridge on each side, with which the somewhat expanded head of the rib articulates. The neural arches are small and low laminar expansions, each extending along the anterior half of a centrum and bearing at its postero-superior angle the long and slender neural spine. The imperfect remains of the clavicle exbibit a large inner lamina nearly at right-angles to the more delicate lamina in the plane of the flank; and the pectoral fin is shown to be relatively large, with at least 12 stout rays, which are partly ornamented. The pelvic fins are also indicated as stout and far forwards, with antero-posteriorly elongated triangular supports. The anterior rays of the dorsal fin are shown to be very stout, ornamented with fine tuberculations and longitudinal rugæ; all are imperfect distally, but the foremost is shown to be articulated towards the end, while the second and doubtless the others are both articulated and divided distally. Purchased, 1857.

49111. Fragment of head and abdominal region, displaying the characteristic opercular apparatus; probably from the Lower Chalk, Burham. Mrs. Smith's Coll.

P. 1703 d. Fragment of head and abdominal region; Chalk, Kent. The ribs are shown to be compressed, not round in section; and the rertebral centra appear to have been pierced by the notochord.

Egerton Coll.

P. 3657. Head and fragment of abdominal region; English Chalk. The greater portion of the cranial roof is displayed, and the small posterior spine of the supraoccipital bore is conspicuous. In side view the maxilla is well exposed, being imperfect only at its hinder end. It is shown to be a slender bone, slightly deepened in front and curved 
inwards to the ethmoidal region, also slightly deepened again in its hinder third, where it bears the spaced series of comparatively large teeth. Its lower margin is ornamented with fine tubercles throughout its length. The supramaxilla, premaxilla, and dentary are also imperfectly preserved; and part of the thickened ectopterygoid is exposed within. The lower end of the preoperculum bears the usual posterior spine, and its fine tubercular ornament extends in a narrow band at least halfway up the ascending limb of the bone. The operculum is ornamented with close radiating lines of fine tubereles; and the more delicately marked suboperculum is shown to be relatively small. The clavicle is partly ornamented with elongated tabercles in radiating series; and the supraclavicle exhibits longitudinal rows of tubereles in its exposed hinder half. Enniskizlen Coll.

P. $453 \%$, -a. Fine small head with opercular apparatus, and a more imperfect specimen; Burham.

Enniskillen Colt.

$35104,-05$. Remains of a smaller head with vertebræ, also part of another small head in two pieces; Rochester, Kent. In the first specimen the great extent of the premaxilla is well shown.

Purchased, 1860.

47298. Remains of an equally small head and abdominal region, with traces of the dorsal and paired fins; Lower Chalk, Dorer. Judging from sections of the constrieted vertebral centra, a persistent thread of notochord seems to have pierced them.

Gardner Coll.

P. 9252. Remains of large head, the mandible 0.09 in length; English Chalk.

History unknown.

47916. More fragmentary remains of large head; Lower Chalk, Burham. Presented by the Hon. Rabert Marsham, 1877.

41106. Fragmentary remains of small head; Lower Chalk, Burham, Kent.

Puschased, 1868.

49082. Fragmentary head showing the ornamented anterior expansion of the premaxillæ; Burham. Mrs. Smith's Coll.

P. 9044. Remains of small head; Blue Bell Hill, Burham. Presented by S.J. Hawkins, Esq., 1891. 


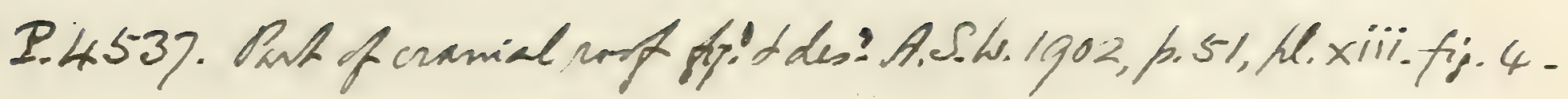

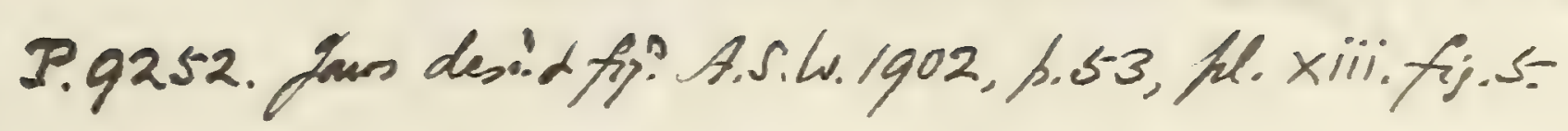

49082. Premaxilla suticed A.S.W. 1902, h. 53. 


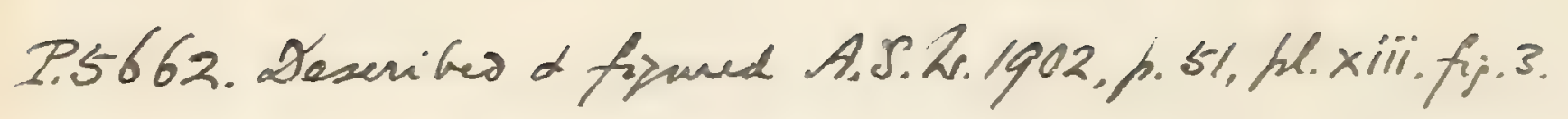

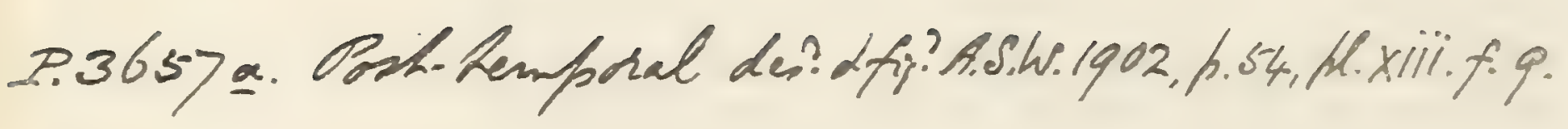

P.5414. Enesethmoid noticed A.S.W.1902, h.52.

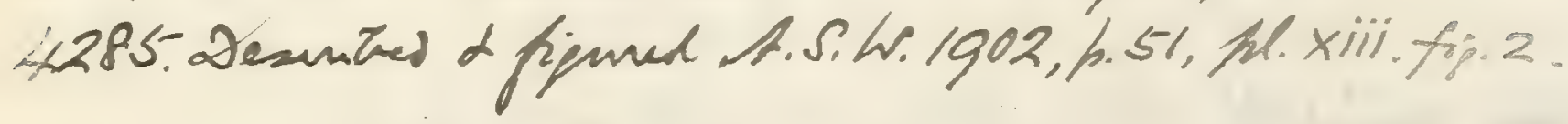


P. 5662, P. 5658. Small head and scattered remains of another; Chalk, Halling, Kent.

Harford Coll.

390\%2. Vertically crushed skull exposed from below; near Gravesend, Kent. The hyomandibular and pterygo-palatine arcade are imperfectly displayed from within, and the extent of the delicate premaxilla is well shown on the right side. A cluster of minute tubercular teeth seems to occur on the inner face of the hinder end of the ectopterygoid.

Bowerbank Coll.

P. 4289. Imperfect very small skull; Dover. Enniskillen Coll.

P. $365 \%$ a. Imperfect vertically crushed skull and other fragments; Lewes, Sussex. The two comparatively large posttemporal plates are shown to impinge on the middle of the occiput; and they seem to have been exposed only to a small extent postero-externally, where they are ornamented with radiating series of fine tubercles.

Enniskillen Coll.

39073. Remains of obliquely-crushed small skull and pectoral fins, exposed from below; Lewes. The horizontally-directed ridge of bone on the inner face of the operculum is indicated; and the lower end of the preoperculum displays its characteristic form. Twelve rays are shown in the left pectoral fin.

Bowerbante Coll.

P. 5413, -14. Two imperfect small skulls, the first with operculum; Lewes. Presented by P. E. Coombe, Esq., 1888.

4285. Imperfect skull erroneously referred to Osmeroides Tewesiensis by Agassiz, loc. cit., and noticed by A. S. Woodward in Proc. Geol. Assoc. vol. x. p. 318; Lewes. Also noticed and figured in Horsfield's 'History of Lewes,' vol. i. p. xi, pl. 29, fig. 13, as Amia lewesiensis, Mantell. On the right side the hyomandibular, quadrate, metapterygoid, entopterygoid, and ectopterygoid elements are exposed; and there seems to be a fragment of an ossified sclerotic. The large teeth on the ectopterygoid are proved to be hollow. On the left side the anterior ornamented end of the premaxilla is also preserved.

Mantell Coll.

49786. Imperfect skull; Glynde, near Lewes.

Capron Coll.

P. 1809. Imperfect small head; Sussex.

Egerton Coll. 
49750. Fragment displaying left premaxilla from the inner aspect; Brighton. This bone, which is imperfect behind, bears the characteristic minute teeth. Capron Coll.

49785. Fragment of small skull showing portion of ossified sclerotic; Brighton.

Capron Coll.

43392. Small cranium and part of jaws; English Chalk.

By exchange, 1872.

25804, 25813, 25896. Remains of jaws; Sussex.

Dixon Coll.

P. $365 \%$ b. Portion of dentary with teeth; Lewes.

Enniskillen Coll.

\section{Halec microlepis (Davis).}

1887. Phylactocephalus microlepis, J. W. Davis, Trans. Roy. Dublin Soc. [2] vol. iii. p. 605, pl. xxxv. fig. 2.

1888. Pomognathus, A. S. Woodward, Ann. Mag. Nat. Hist. [6] vol. ii. p. 355.

Type. Nearly complete fish; British Museum.

The type species of the so-called Phylactocephalus, attaining a length of about 0.2. Length of head with opercular apparatus scarcely exceeding the maximum depth of the trunk, which is contained somewhat more than twice in the length from the pectoral arch to the base of the caudal fin. Length of mandible about equalling the depth of the head at the occiput. Opercular apparatus and external ornament as in $H$.eupterygius. Vertebræ about 35 in number. Dorsal fin wirh about 17 rays, occupying the second quarter of the back, and pelvic fins opposed to its hinder half; anal fin very small, with 10 or 11 rays, arising twice as far from the pelvic fins as from the caudal. Scales smooth.

Form.\& Loc. Upper Cretaceous: Mrt. Lebanon, Syria.

P. 4757. Type specimen unsatisfactorily described and figured by Daris, loc. cit.; Hakel. The head and opercular bones preserved are chiefly those of the right side exposed from within. A fragment of the thickened ectopterygoid is seen bearing the characteristic teeth; immediately below it are remains of the slender maxilla, with spaced teeth at its hinder end. The right mandibular ramus is indicated chiefly as an impression of its tuberculated outer face; and fragments of the left ramus occur below this, with apparently an overlapping trace of the left premaxilla. The charaeteristic preopereulum, operculum 


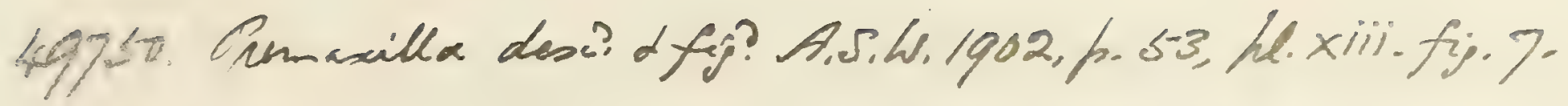

32335. Mresethmoid nrticed A.S.h.1902, h.522. 


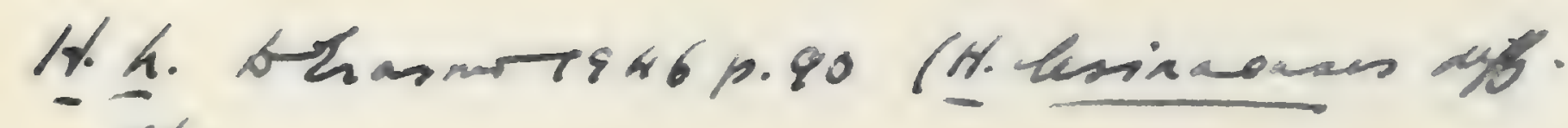


("preoperculum" of Davis), suboperculutn ("operculum" of Davis), and small interoperculum are shown, chiefly as impressions of the external ornamented face. There are also impressions of the broad ornamented external face of the claricle and supraclavicle. The number of vertebræ is approximately 35 , and about 17 may be reckoned as caudal. The dorsal fin is imperfect distally, and thus does not exhibit its true elevation; the caudal fin is distorted by erushing.

Lewis Coll.

P. 11\%. Head and abdominal region of a slightly larger fish, in counterpart; Hakel. Traces of the ornamented cranial roof and the charactaristic jars can be distinguished; and there are indications of at least 15 branchiostegul rays. The foremost pelvic fin-ray is shown to be comparatively stout and only articulated, not subdivided distally.

Lewis Coll.

P. 105. Small fish, somewhat distorted by crushing, apparently young of this species; Hakel. Each pelvie fin is shown to comprise about 10 rays; and the dorsal fin is nearly as deep as the trunk at its origin, the two foremost rays being only articulated, not subdivided distally. There are distinct remains of the muscle-plates of the trunk.

Lewis Coll.

P. 9151-52. Two imperfect impressions of the caudal region, much weathered; Hajoula.

Presented by A. S. Woodward, Esq., 1898.

\section{Halec haueri (Bassani).}

1879. Elopopsis haueri, F. Bassani, Verhandl. k.-k. geol, Reichsanst. p. i6ẽ.

1881. Solenodon lobopterygius, D. G. Kramberger, Jahrb. k.-k. geol. Reichsanst. vol. xxxi. p. 377. [Imperfect fish; University Museum, Agram.]

1881. Solenodon lesinaensis, D. G. Kramberger, ibid. p. 377. [Ditto.]

1882. Elopopsis haueri, F. Bassani, Denkschr. k. Akad. Wiss, math.naturw. Cl. vol. xlv. p. 214, pl, iv.

1885. Holcodon lesinaensis, D. G. Kramberger, Rad Jugoslav. Akad. vol. 1xxii. p. 20, pl. iv. fig. 2.

(?) 1895. Holcodon aff. lesinensis, D. G. Kramberger, Djela Jugoslav. Akad. vol. xvi. p. 35.

Type. Nearly complete fish; Imperial Geological Survey, Vienna. A small species attaining a length of about $0 \cdot 3$. Length of head 
with opercular apparatus much exceeding the maximum depth of the trunk, which is contained somewhat more than three times in the length from the pectoral arch to the base of the candal fin. Length of mandible somewhat exceeding the depth of the head at the occiput. Fxternal tubercular ornament very fine. Vertebræ about 35 in number. Fins and scales apparently as in the preceding species.

Form. \& Loc. Cretaceous: Island of Lesina, Dalmatia.

P. 7452. Imperfect fish wanting the caudal fin, slightly larger than the type specimen. Among the crushed remains of the head may be observed impressions of the characteristic teeth of the ectopterygoid; there are also traces of the fine tubercular ornament of the mandible. The rertebræ are rather large, and seem to have been about 35 in total number. The fins are very imperfect, and the number of their rays cannot be counted; but, so far as preserved, they seem to agree with those of $H$. microlepis. There are also obscure indications of the characteristic minute scales. Purchased, 1895.

P. 7453. IFore imperfect specimen, displaying the fine tubercular ornament of the external bones. The characteristic maxilla and supramaxilla are distinct. Purchased, 189 j.

The following specimen is not specifically determined:holotyas of Davichthys aaninen Forey. see 16 nolotype of 49520 . Fish with at least to vertebræ and dorsal fin more remote than usual; Cpper Cretaceous, Hakel, Mount Lebanon. There are traces of the small scales. Lervis Coll.

The following imperfectly defined species are known only by fragments, and are not represented in the Collection :-

Halec guestphalicus: Archcogadus guestphalicus, W. ron der Warck, Palæontogr. vol. xv. (1868) p. 291, pl. xlii. fig. 1, and ("= Halec stembergii") ibid. vol. xxxi. (1885), p. 241.- Upper Cretaceous (Pläner); near Dortmund, Westphalia. [Type species of Archceogadus. Imperfect head and anterior abdominal region; Academy of $M[$ iinster.]

IIalec laubei, A. Fritsch, Rept. u. Fische böhm. Kreideform. (1878), p. 38, pl.x. fig. 4.-Turonian (Pläner); Weissenberg, near Prague, Bohemia. [Imperfect head; German University, Prague.] 


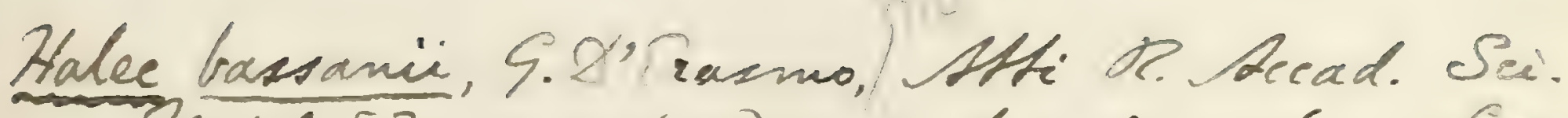
hiaprli; [2] vel Xv(1911), an. 5, h.3, fir. 1-6. - Cen Lacens: Acquarica del Cafo, Mron. Lecce, Ltaly. [Impenfert gith; Univ. Toples] 


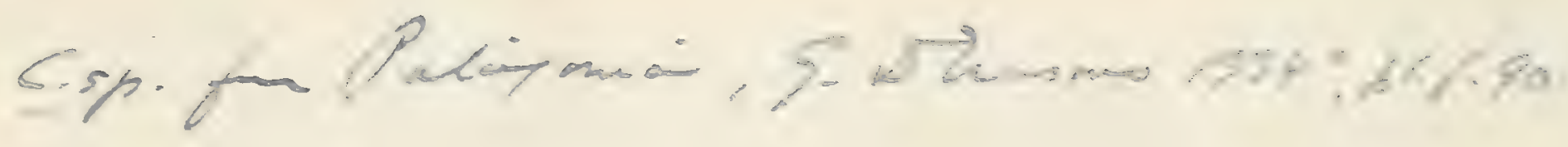

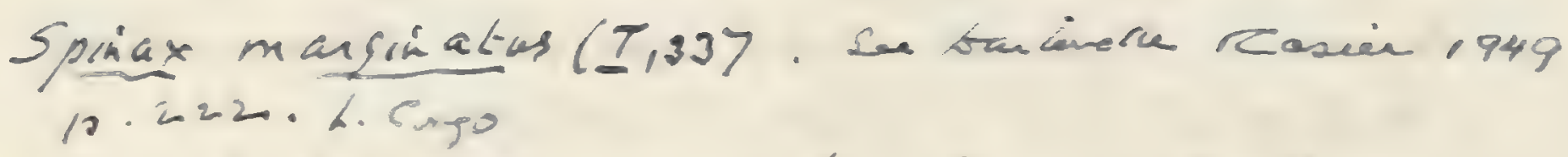

1902. Cimolichthye mazinatus, Mr. Ziriche, Am. Sn.

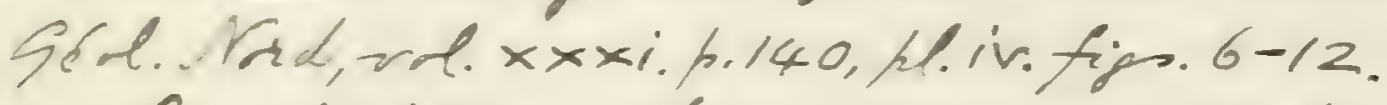

902. Cimolichthys Lewesiensid, A.S.Windwasd, Bn.

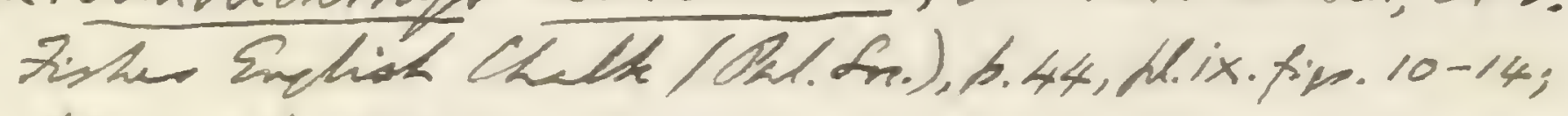
hlixi; texh-fip. 10. 


\section{Genus CIMOIICHTFYS, Leidy. \\ [Trans. Amer. Phil. Soc. vol. xi. 1857, p. 95.]}

Syn. (?) Plinthophorus, A. Günther, Geol. Mag. vol. i. 1864, p. 115.

Empo, E. D. Cope, Proc. Amer. Phil. Soc. vol. xii. 1872, p. 347.

Trunk elongate-fusiform. Cranium as in Enchodus. Premaxilla in the form of a vertical lamina, externally ornamented, and either toothless or with a series of minute teeth; maxilla long and styliform, similarly either toothless or with minute teeth where it enters the oral margin; ectopterygoid bearing a single spaced series of acute, laterally-compressed teeth, which are largest in front and sometimes exhibit a single posterior barb towards their apex; palatine with a double longitudinal series of teeth, none barbed, the largest behind; dentary thin, but so bent that it has a wide horizontal extent, with a close series of minute teeth on its extreme outer margin, another close series of larger teeth within this, and a third inner series of relatively large recurved teeth, well spaced, and not barbed at the apex. Operculum strengthened on the inner side by a ridge extending horizontally backwards from the point of suspension. Vertebræ from 50 to 60 in number, about half being caudal; the centra at least as long as deep, much constricted, and marked with fine irregular longitudinal ridges. A series of large dermal scutes along the dorsal ridge between the occiput and the dorsal fin; smaller scutes along the course of the lateral line.

One specimen of the trunk hypothetically ascribed to the soealled Empo exhibits three longitudinal series of rhombic scutes on the flank of the abdominal region. Their "apices are directed forwards, and the surface has a reticulate sculpture. In another species they appear to be smooth" (Cope). There is no certain eridence of intervening scales.

\section{Cimolichthys lewesiensis, Leidy.}

1835-44. Saurodon leanus, L. Agassiz, Poiss. Foss., Feuill. p. 55, and vol. v. pt. i. p. 102, pl. xxv c. figs. 30, 31 (errore).

1850. Saurodon leanus, F. Dixon, Geol. Sussex, p. 373, pl. xxx. figs. 28, 29, pl. xxxii *. fig. 10 (errore).

1857. Cimolichthys levesiensis, J. Leidy, Trans. Amer. Phil. Soc. vol. xi. p. 95 .

1878. Cimolichthys levesiensis, E. T. Newton, Quart. Journ. Geol. Soc. vol. xxxiv. p. 795.

1888. Cimolichthys leresiensis, A. S. Woodward, Proc. Geol. Assoc. vol. x. p. 316. 
Type. Imperfect ectopterygoid; British Museum.

The type species, not satisfactorily definable, with cranium attaining a length of about $0 \cdot 15$. Maximum width of cranium slightly exceeding one third its length, and premaxilla ornamented with radiating tuberculated ridges. All the teeth of the ectopterygoid, except the few small ones posteriorly, moderately slender and slightly barbed; the largest tooth of the inner mandibular series situated within the anterior half of the dentary.

Form. \& Loc. Senonian and Turonian: Sussex and Kent. Sen. Selgrear

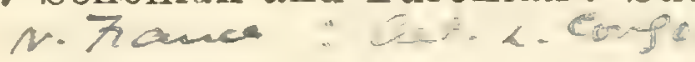

4039. Type specimen described and figured by Agassiz, loc. cit.; Chalk, Lewes. This is the hinder half of the left ectopterygoid exposed from within. Mantell Coll.

P. 5491. Imperfect skull and mandible, noticed by the present writer, loc. cit.p. 317; Chalk, Lewes. The specimen is damaged by an oblique fracture, and the rostral region of the cranium is obscure; but the frontal bones are well displayed and shown to extend close to the occipital border. Only a trace of the small supraoccipital, with its hinder keel, is preserved. There is a shallow, anteroposteriorly elongated fossa above the otic region on each side. Fragmentary remains of the premaxilla on each side prove it to have been an antero-posteriorly elongated laminar bone, bent inwards above on its long axis, and ornamented externally with tuberculated radiating ridges. The long and slender maxilla, which is almost smooth, is nearly complete on the left side, and extends forwards above the premaxilla to about the middle point of the latter. Neither the maxilla nor the premaxilla, as preserved, exhibits any indications of teeth. The imperfect mandible is seen from beneath, and two of its large recurred teeth are exposed. There are also remains of the pterggo-palatine arcade, with several of the characteristic barbed teeth, and with marks of the oval bases of attachment of similar teeth which have been broken away. The slender ceratohyal is preserved on the left side; while immediately above it is exposed part of a laminar bone, probably entopterygoid, bearing clustered minute teeth.

Enniskillen Coll.

P. 1810 a. More fragmentary skull and mandible, noticed by Loomis, Palæontogr. vol.xlvi.(1900), p. 267 ; Chalk, Kent. The maxilla does not exhibit any teeth; but a fragment, 


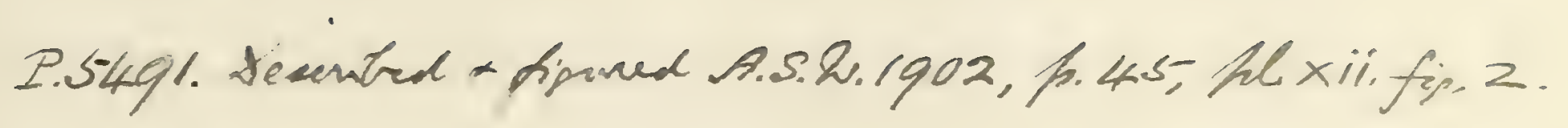

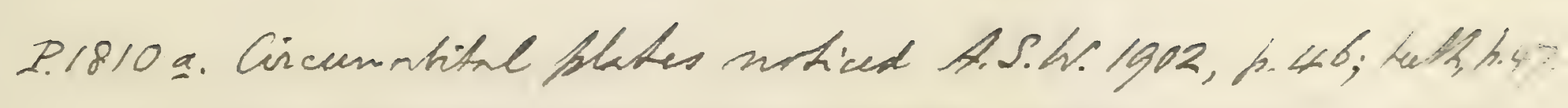



probably of the right premaxilla, bears part of a series of very small conical teeth. The large ectopterygoid teeth are shown to be hollow. The palatine seems to bear two longitudinal series of teeth. Part of the ossified sclerotic is preserved on the right side.

Egerton Coll.

P. $1810 \mathrm{~b}$. Very fragmentary remains of skull and mandible; Lower Chalk, Burham, Kent.

Egerton Coll.

P. 5663-4. Two specimens exhibiting remains of jaws, the first also displaying the characteristic preoperculum with the small spine at its postero-inferior angle; Chalk, Kent.

Harford Coll.

37752. Hinder half of left ectopterygoid associated with other fragments; Upper Chalk, near Brighton. Saull Coll.

P. 1810 c. Hinder half of large right ectopterygoid, associated with other fragments; Burham.

Egerton Coll.

P. 40\%. More imperfect fragment of ectopterygoid; English Chalk. Presented by the Earl of Ducie, 1881.

25756-5\%. Two large barbed teeth of the ectoptersgoid bone, figured by Dixon, op. cit. pl. xxx. figs. 28, 29; Chalk, Sussex.

Dixon Coll.

39122. Imperfect dentary bones with remains of the characteristic dentition; Chalk, Halling, Kent. Bowerbank Coll.

32343. Imperfect right dentary with teeth; Chalk, Maidstone.

Purchased, 1857.

49066. Imperfect left dentary with teeth; Lower Chalk, Kent.

IMrs. S'mith's Coll.

49064. Remains of associated dentaries ; Lower Chalk, Dover.

Mrs. Smith's Coll.

P. 7393. Associated remains of jaws either of this or an allied species; Lower Chalk, Dorer. The characteristic, ornamented premaxilla on each side bears traces of a single close series of minute conical teeth; but the fragments of maxilla are toothless. An unusually stout inner tooth is shown in the mandible.

Purchased, 1895. 


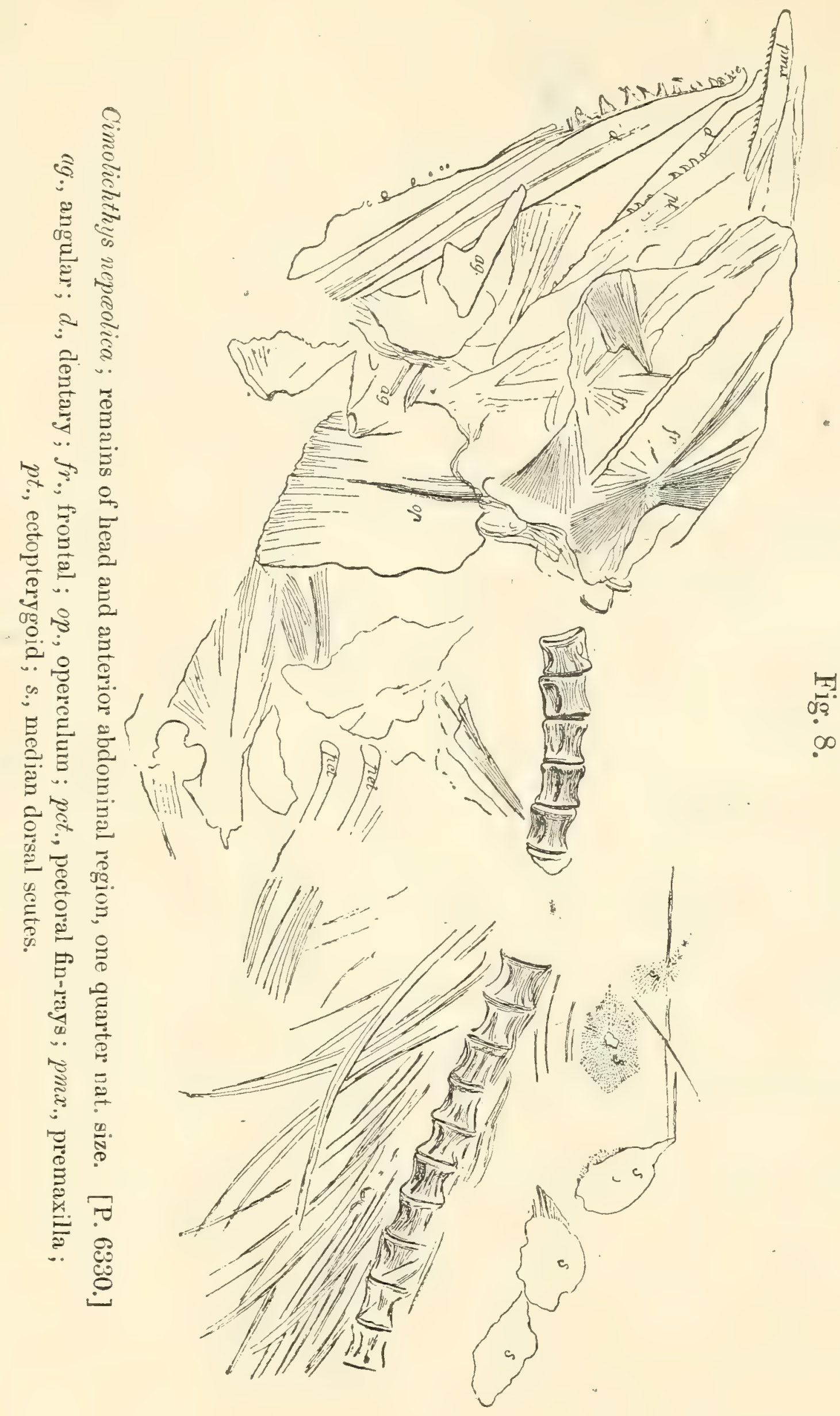




\section{Cimolichthys neprolica (Cope).}

[Text-figures 8,9.]

1872. Empo nepaholica, E. D. Cope, Pruc. Amer. Phil. Soc. rol. xii. p. 347 .

1872. Cimolichthys sulcatus, E. D. Cope, ibid. p. 351. [Dentary. A Am, hm, h. X.

1874. Empo sulcata, E. D. Cope, Bull. U.S. Geol. Surv. Territ. no. 2, p. 46.

1875. Empo nepreolica, E. D. Cope, Vert. Cret. Form. West (Rep. U.S. Geol. Surv. Territ. vol. ii.), p. 230, pl. xlix. fig. 9, pl. 1. fig. 8, pl. lii. fig. 1, pl. liii. figs. 3-5.

1900. Cimolichthys nepaeolica, F. B. Loomis, Palæontogr. vol. xlri. p. 271, pl. xxvii. figs. 1-3.

Type. Imperfect palatine bone; Cope Collection.

The type species of the so-called Empo, with skull from 0.3 to $0 . t$ in length. The sides of the cranial roof and the outer face of the mandible ornamented with numerous and closely-arranged sharp ridges, mostly radiating and bearing a series of minute tubercles; these ridges on the dentary bone radiating from the symphysis, on the articulo-angular bone radiating from the mandibular articulation. Maximum width of cranium across frontal region about half its length; maximum depth of mandibular ramus contained six or seven times in its length. Premaxilla a very thin lamina with a regular and uniform series of sharply recurved teeth, as small as the outermost teeth of the dentary; palatine inner teeth in close series, half as thick at the base as the large outer teeth, which are inclined somewhat outwards but strongly recurved towards the apex; ectopterggoid teeth few and large, the two foremost being the largest, compressed to a sharp edge in front; but not behind; mandibular teeth also compressed to a sharp edge only on their anterior aspect and strongly recurved. Operculum considerably broader than deep. Dorsal scutes in front of dorsal fin ovate and produced into a slender point in front, ornamented externally with radiating series of very fine tubercles.

Form. \& Loc. Upper Cretaceous (Niobrara Group): Kansas.

P. 6330. Imperfect head and abdominal region, sketched in outline in the accompanying fig. 8. The cranium is exposed from above, displaying the large frontals ( $f r$. ) but crushed at the occiput ard wanting the ethmoidal region. The remains of the jaws are displaced below and to the left of the cranium. The delicate laminar premaxilla ( $p m x_{0}$ ), with its small recurved teeth, is seen in front. The left palato-pterygoid arcade $(p t$.$) is imperfectly displayed, with$ 
some of its large teeth; and the two dentary bones $(d$.) of the mandible occur deeper in the matrix, that of the right side being partly obscured. The left articuloangular bone $\left(a g_{0}\right)$ is displaced, and also partly covered by other fragments. The imperfect left operculum (op.) is distinguishable from its inner face, but is turned so that its horizontal axis is directed downwards. Five of the anterior vertebral centra are exhibited, showing the deep infero-lateral pits for the ribs. Further back are other centra, beneath which the somewhat robust ribs are also preserved. There are obscure remains of the pectoral arch, with traces of very stout pectoral fin-rays (pct.); and there is only a fragment of one other fin, the dorsal, which has remarkably robust supports, but is not shown in the figure. Five of the characteristic scutes (s.), partly displaced, are observed on the ridge of the back in front of the dorsal fin, the two foremost being shown chiefly as an impression of the outer face.

Purchased, 1891.

P. 6329. Scattered remains of head and anterior abduminal region, sketched in outline in the accompanying fig. 9. The imperfect cranium, wanting the ethmoidal region, is exposed from beneath, and the well-preserved basioccipital (b.occ.) demonstrates the absence of a basicranial canal. The otic region is shown to be well ossified, and bounded in front by a prominent sphenotic or post-frontal $(s p .0$.$) . Further forwards there are remains of the large$ frontals $\left(f r_{0}\right)$. The displaced jaws are observed below the overturned cranium. The imperfect right palatine $(r . p l$.$) and anterior end of ectopterygoid (r.ecpt.) are$ partly obscured by the fragments of the frontal region. Next below is part of one of the thin laminar premaxillæe $(p m x$.$) , bearing the characteristic regular series of small$ recurved teeth. Then follow remains of the left palatine (l.pl.) and ectopterygoid (l.ecpt.), displaying the characteristic dentition. The hinder portion of the ectopterygoid is toothless, and curves downwards as it approaches the quadrate (qu.); while it seems to be bounded above by the entopterygoid (l.enpt.), which exhibits the bases of an antero-posteriorly elongated cluster of minute teeth. The fragmentary hinder portion of the right ectopterygoid (r.ecpt.) partly overlies the left 

dentary $(l . d$.$) , which is exposed from within and displays$ a few of the teeth of both series. The left articuloangular (l.ag.), with its terminal facette for the quadrate articulation, is slightly disp?aced. The imperfect right

Fig. 9.

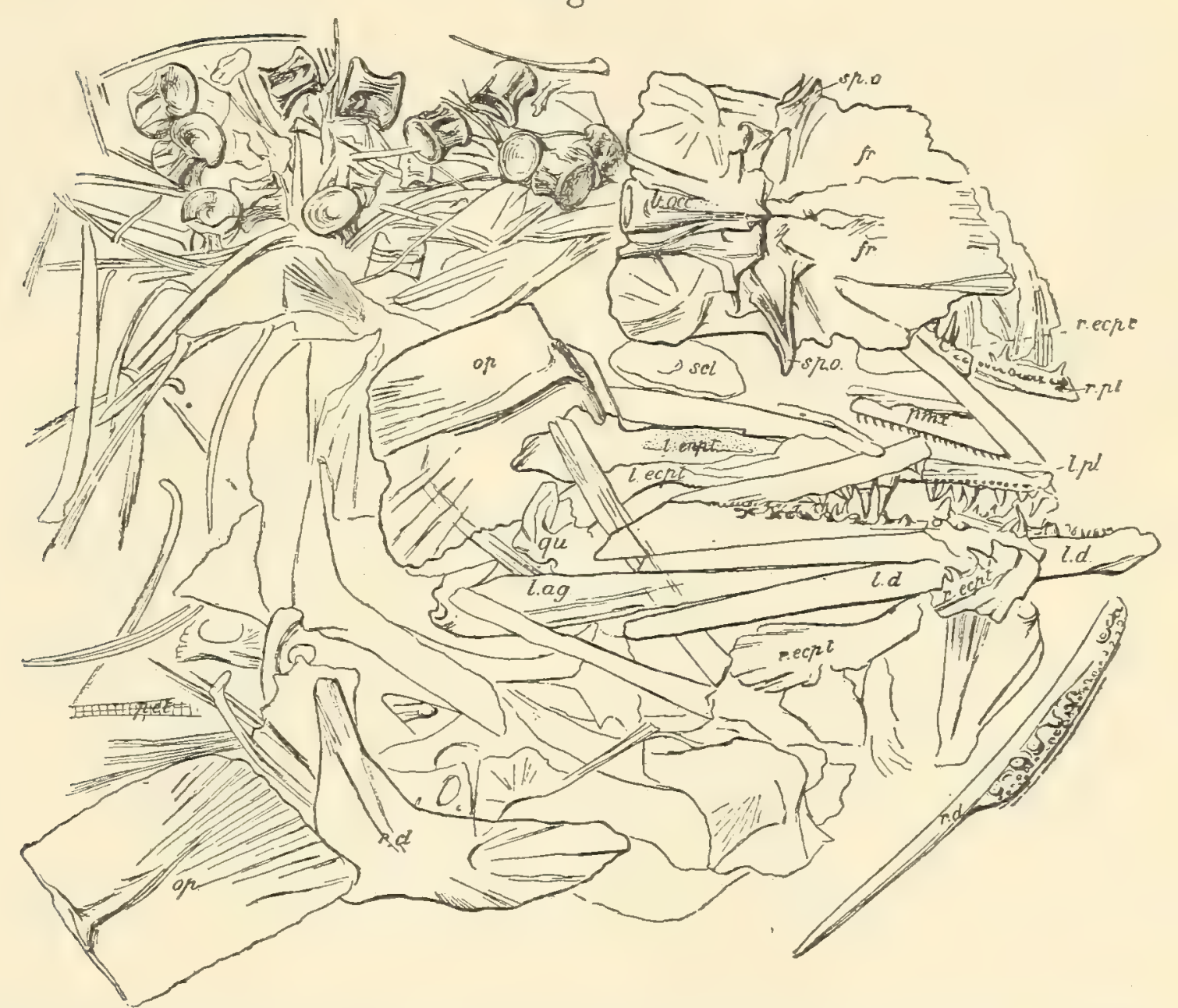

Cimolichthys nepceolica; head-bones, \&c., nearly one quarter nat. size. [P. 6329.]

b.occ., basioccipital; fr., frontal; l.ag., left angular; l.d., left dentary; l.ecpt., left ectopterygoid; l.enpt., left entopterygoid; l.pl., left palatine; op., operculum; pct., pectoral fin-rays; qu., quadrate ; r.cl., right clavicle; r.d., right dentary; r.ecpt., right ectopterygoid; r.pl., right palatine; scl., sclerotic plate; sp.o., sphenotic (post-frontal).

dentary $\left(r_{.} d_{0}\right)$ shows its oral border, with the bases both of small and large teeth. Among other remains behind the jaws, both opercula (op.) are seen from within: there is also the right clavicle $($ r.cl.), with a few scattered pectoral fin-rays ( $p c t$.$) . Vertebral centra, as in the$ previous specimen, are scattered behind the head.

Purchased, 1891.

The following specimens of Cimolichthys from the English Chalk are not sufficiently complete for specific determination:-

P. 4506. Imperfect cranium $0 \cdot 16$ in length, showing the frontal bones; locality unknown.

Enniskillen Coll.

Q 2 
49065. Imperfect mandible, equally large, with part of the palatopterygoid arcade; Kent. Mrs. Smith's Coll.

49824. Imperfect left palato-pterygoid arcade, showing three teeth and the bases of others; Lower Chalk, Southeram, Lewes.

Capron Coll.

36750. Imperfect palatine associated with anterior end of dentaries; Lower Chalk, Burham, Kent.

Purchased, 1862.

43101. Fragment of palatine; Kent.

Wetherell Colt.

The following species are unsatisfactorily defined, and are rrot represented in the Collection:-

Cimolichthys contractus, F. B. Loomis, Paixontogr. vol. xlvi. $(19110)$, p. 273, pl. xxvii. figs. 8, 9. Empo contracta, E. D. Cope, Bull. U.S. Geol. Sarv. Territ. no. 2 (1874), p. 46, and Vert. Cret. Form. West (Rep. U.S. Geol. Surv. Territ. vol. ii. 1875), p. 232, pl. liii. figs. 14-17.-Upper Cretaceous (Niobrara Group); Kansas. [Palato-pterygoid arcade.] Amen. hum he 2. 9to 2

Cimolichthys lisbonensis: Empo lisbonensis, A. Stewart, Kansas Univ. Quart.[A] vol.viii.(1899),p.111.-Upper Cretaceous (Lisbon Shales); Kansas. [Premaxilla; Kansas University Museum.]

Cimolichthys merrilli, F. B. Loomis, 7oc. cit. 1900, p. 272, pl. xxvii. fig. 7. Empo merrilli, E. D. Cope, loc. cit.1874, p. 46, and op. cit. 1875, p. 232, pl. liii. figs. 10-13.Upper Cretaceous (Niobrara Group); Kansas. [Palatine,

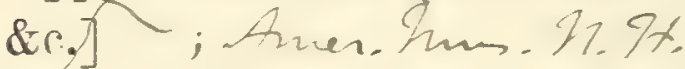

Cimolichthys semianceps, E. D. Cope, Proc. Amer. Phil. Soc. vol. xii. (1872), p. 351 ; F. B. Loomis, loc. cit. 1900, p. 273, pl. xxvii. figs. 4-6. Empo semianceps, E. D. Cope, op. cit. 18i5, p. 233, pl. liii. figs. 1, 2, 6-9.-Ibid. [Portions of jaws.] vime hm, n. Y.

Numerous detached barbed teeth of Cimolichthys have been described as follows:-

Spinax marginatus, A. E. Reuss, Verstein. böhm. Kreideform. pt. i. $(18+5)$, p. 8, pl. iv. figs. 10, 11. Acanthias marginatus, C. G. Giebel, Fauna d. Vorwelt, Fische (1848), p. 301. Anenchelum? marginatum, E. Hébert, Mém. Soc. Géol. France, [2] vol. v. (1855), p. 3500, pl. xxvii. fig. 4. Saurocephalus? marginatus, H. B. Geinitz, 




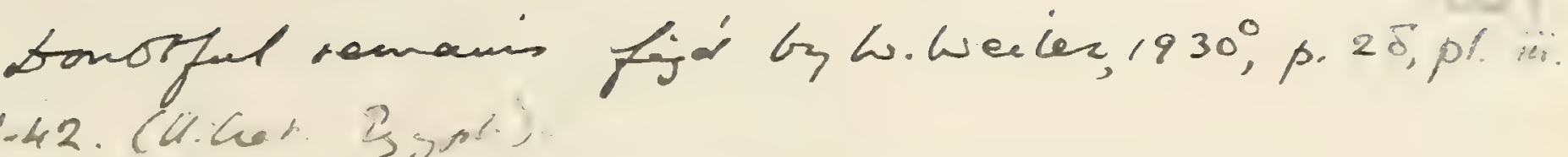

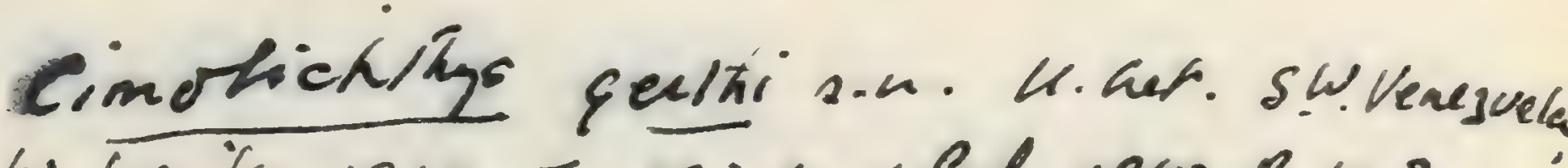
W. Wecter 1940 z. Min bed.Pal. 1940 B no.g. p. 240 if. 1,47ico. Feapmiti.

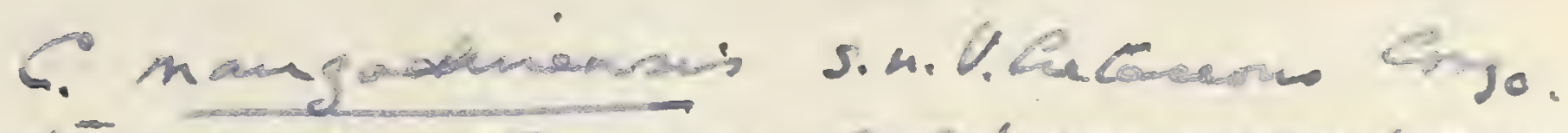

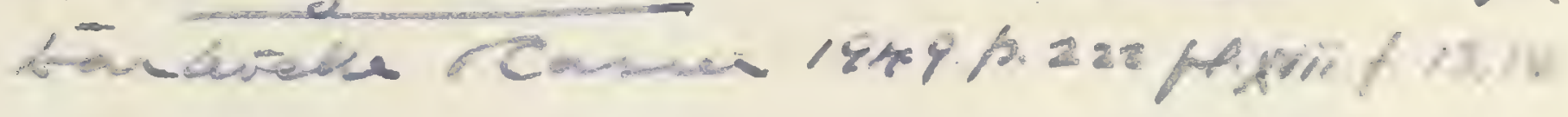

Sanocepheher marginatus, R. Zeonthard, Deloontrys.

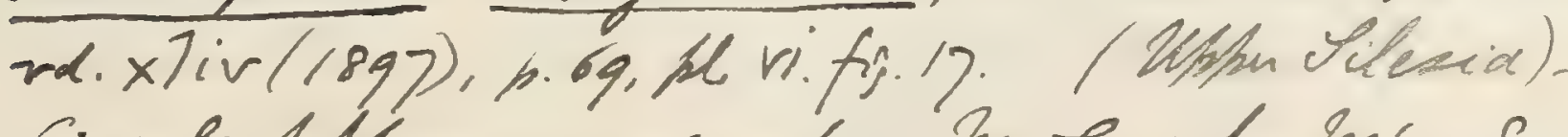
Cimolichthye marginatus, Mn. Zeriche, Mrém. Sar. Géol. Nad,

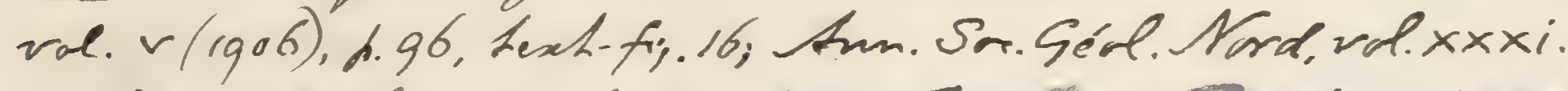

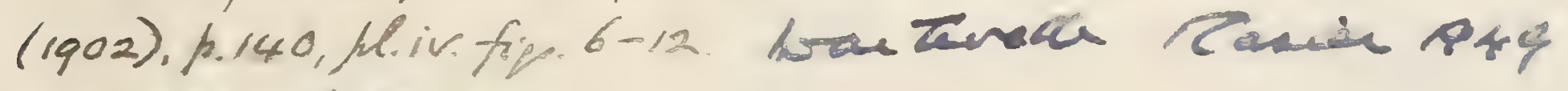
p.822 L cono. 


\section{Prionolepis angustus, Egerton.}

1850. Prionolepis angustus, Egerton, in Dixon, Geol. Sussex, p. 368, pl. xxxii.* fig. 3.

1888. Prionolepis angustus, A. S. Woodward, Proc. Geol. Assoc. vol. x. p. 306.

Type. Dermal scutes; British Museum.

The type species, known only by the scutes of the flank. The largest scutes about seven times as deep as broad, and the forwardly directed portion above the lateral line comparatively short; the hinder margin very regularly, closely, and deeply pectinated; the anterior portion either smooth or marked with very feeble vertical rugæ, except above the lateral line where these ruga are conspicuous.

Form. \& Loc. Turonian and Senonian: S.E. England.

P. 9253. Type specimen, an imperfect mass of scutes chiefly shown from the inner aspect, briefly described and figured by Egerton, loc.cit.; Lower Chalk, Burwell, neær Newmarket.

Dixon Coll.

29040. Three fragments of ehalk with remains of scutes; Upper Chalk, Swaffham, Norfolk.

$$
\text { Presented by C. B. Rose, Esq., } 1854 .
$$

46393. Group of scutes; Lower Chalk, Calne, Wiltshire.

Cunnington Coll.

35876. Imperfect scute; Grey Chalk, Dover. Purchased, 1861.

39058. Imperfect scute; Chalk, Kent.

Bowerbank Coll.

49776. Remains of scutes more ornamented than usual, but probably of this species; Lower Chalk, Dorking.

Capron Coll.

Prionolepis cataphractus (Pictet \& Humbert).

1866. Aspidopleurus cataphractus, Pictet \& Humbert, Nouv. Rech. Poiss. Foss. Mt. Liban, p. 109, pl. xviii. fig. 1.

1887. Aspidopleurus cataphractus, J. W. Davis, Trans, Roy. Dublin Soc. [2] vol. iii. p. 624, pl. xxxviii. fig. 4.

1887. Engraulis tenuis, J. W. Davis, ibid. p. 635, pl. xxx. fig. 5 (errore). 1898. Prionolepis cataphractus, A. S. Woodward, Ann. Mag. Nat. Hist. [7] vol. ii. p. 411.

Type. Imperfect fish; Geneva Museum.

The type species of the so-called Aspidopleurus, attaining a length of about 0.22 . Length of head with opercular apparatus 




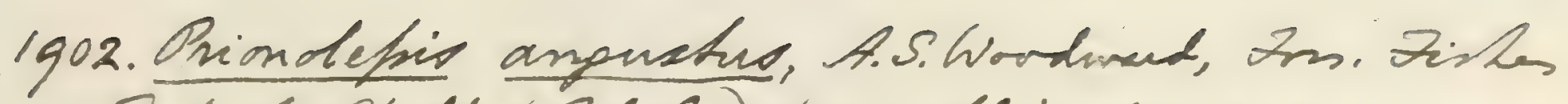
Englinh Chalte (Pal.obo), h. 42, hl. ix. fien. 4-9.

P.9253. Deantiol a firmed A.S.W. 1902, h.43, hl. ix. fip. 4 .

2q040. Fom seales desenitus d foumo A.S.W. 1902, f. 43, h. ix.f.5 =8.

46393. Feale desmbed a fis. und A.S.W.1902, f.43, hl. ix.fi). Q.

49776. Tah nhiead A.S.W. 1902, p.43.

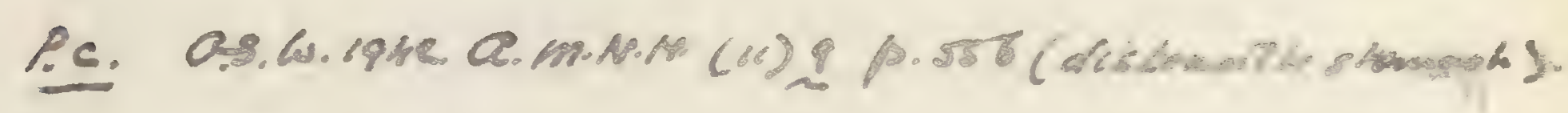



somewhat less than half the length of the trunk from the pectoral arch to the base of the caudal fin; maximum depth of trunk contained about seren times in the same measurement. Pelric fins arising somewhat in advance of the middle point of the trunk, opposite the hinder part of the dorsal fin, which comprises about 16 rays and is completely within the anterior half of the trunk; anal fin comparatively low and small, with about 14 rays, arising much nearer to the caudal fin than to the pelric pair. Lateral dermal scutes between 40 and 50 in number, and the largest about five times as deep as broad, with the forwardly directed portion above the lateral line two thirds as deep as the portion below it; the hinder margin deeply pectinated, though rather irregular, and the uppermost pectinations the iongest; the anterior portion marked with delicate and irregular vertical rugæ.

Form. \& Loc. Tpper Cretaceous: Mt. Lebanon.

P. 4864. Large fish in lateral aspect, wanting the dorsal and caudal fins; Hakel. The pelric fins are shown to be about as large as the pectorals, and the pelvis is very well displayed. The laminar pelvic bones taper forwards, and are firmly united at their distal end in an inter-digitating suture.

Lewis Coll.

P. 9149. Another large fish vertically crushed and partly in counterpart; Hajoula. An imperfect impression of the cranial roof seems to indicate a median hollowing and a lateral ornamentation of radiating lines and tubercles; while the ethmoidal region is clearly short and broad, though acutely pointed in front. The jaws are very imperfect, but they are proved to have been delicate; while the only remains of dentition are one slender lanceolate tooth in front and clustered minute blunt teeth behind. Posterior to the outwardly crushed cheek on either side there are remains of the narrow preoperculum and the rell-developed operculum; and the latter plate is shown to have been strengthened not only by the thickening of its anterior border, but also by a horizontally-directed ridge on its inner face, while the upper half of its outer face is marked with numerous delicate radiating lines which are partly tuberculated. The rertebral column is imperfectly preserved, comprising delicate constricted centra, longer than deep, each distinctly pierced for the persistence of the continuous notochord. The ribs seem to be short and comparatively 
stout, not supported by transverse processes. The upper and lower limbs of the bent claricle are equal in size; and one of the pectoral fins, which is displaced and apparently incomplete, shows remains of ten rays. The lateral scutes are very well exhibited, and each is pierced by a tubular perforation for the passage of the sensory canal of the lateral line. These scutes begin to appear immediately behind the pectoral arch and extend regularly to the base of the caudal fin; at least 45 are indicated on each side, and the series is probably not quite complete behind. Presented by A. S. Woodward, Esq., 1898.

P. 4004. Hinder abdominal and caudal regions of an equally large fish; Hakel. The scutes of the right side are displaced, exposing the vertebral column; and there are remains of the pelvic, dorsal, and caudal fins.

Lewis Coll.

P. 4006. Imperfect tail displaying scutes and vertebræ; Hakel.

Lewis Coll.

P. 4005. Imperfect smaller fish, about 0.16 in length; apparently somewhat elongated by distortion; Hakel. Lewis Coll.

P. 4754. Imperfect fish 0.115 in length, unsatisfactorily figured by Davis, loc. cit. pl. xxxviii. fig. 4; Hakel. A partial impression of the right operculum exhibits the characteristic ornament. There are traces of all the fins.

Lewis Coll.

P. 48\%1. A very small fish of which the counterpart (in the Edinburgh Museum) is figured by Davis, loc. cit., under the name of Engraulis tenuis; Hakel. The characteristic scutes and all the fins are displayed. There are about 14 rays in the pectoral fin, 8 rays in the pelvic, 14 or 15 rays in the dorsal, and about 14 rays in the anal fin.

Lewis Coll.

\section{Prionolepis laniatus (Davis).}

1887. Rhinellus laniatus, J. W. Davis, Trans. Roy. Dublin Soc. [2] vol. iij.p. 612, pl. xxxvii. tig. 1.

(?) 1887. Rhinellus longirostris, J. W. Davis, ibid. p. 611, pl. xxxvii. fig. 3. [Imperfect small fish shortened by distortion; Edinburgh Museum.]

1888. Belonostomus laniatus, A. S. Woodward, Rep. Brit. Assoc. p. 678.

1891. Apateopholis laniatus, A. S. Woodward, Proc. Zool. Soc. 1890, p. 634, pl. Iv. fig. 11.

Type. Nearly complete fish; British Museum. 

The type species of the so-called Apateopholis, attaining a length of about 0.35 . Length of head with opercular apparatus nearly equalling the length of the trunk from the pectoral arch to the base of the caudal fin; maximum depth of trunk contained four times in the same measurement. Pelvic fins arising just behind the middle point of the trunk, opposite the hinder part of the dorsal fin, which comprises about 20 rays and is almost completely within the hinder half of the trunk; anal fin comparatirely low and extended, with about 17 rays, arising nearer to the pelvic pair than to the caudal fin. Lateral dermal scutes very thin, between 40 and 50 in number, and the largest about four or fire times as deep as broad, ornamented with extremely delicate concentric ridges, sometimes subdirided into tubercles, following the lines of growth; the hinder margin not pectinated, but notched by the lateral line.

Form. \& Loc. Upper Cretaceous: IIt. Lebanon.

P. 4745. Type specimen described and figured by Daris, loc. cit. p. 612, pl. xxxrii. fig. 1, and further noticed in Proc. Zool. Soc. 1890, p. 634; Hakel. Some scutes are displaced dorsally in the abdominal region, and the ornament of one is well displayed.

Lewis Coll.

P. 4026. Fish about 0.18 in length; Hakel. Lewis Coll.

P. 48\%0. Still smaller specimen, wanting the extremity of the snout and tail; Hakel.

Lervis Coll.

P. 4869. Head of large specimen noticed by Davis, loc. cit. p. 614, described and figured in Proc. Zool. Soc. 1890, p. 635, pl. 1v. fig. 11; Hakel.

Lewis Coll.

39237. Imperfect caudal region of large specimen; probably from Hakel. There seem to be remains of a thickened scute of undetermined form on the caudal pedicle.

Tristram Coll.

Genus LEPTECODON, Williston.

[Kansas Univ. Quart. (A) vol. viii. 1899, p. 113.]

As Prionolepis, but with an additional series of scutes on the flank above and below those of the lateral line.

Leptecodon rectus, Williston.

1899. Leptecodon rectus, S. W. Williston, loc. cit. p. 113, pl. xxri.

Type. Imperfect fish; Kansas Unirersity Museum. 
The type species, attaining a length of about 0.25. Length of head with opercular apparatus contained about three times in the length of the trunk from the pectoral arch to the base of the caudal fin; maximum depth of trunk contained nearly seven times in the same measurement. Ornament of scutes reticulated, scarcely radiating.

Form. \& Loc. Upper Cretaceous (Niobrara Group): Smoky Hill River, Kansas.

Not represented in the Collection.

\section{Genus PAITOPHOLIS, Davis.}

[Trans. Roy. Dublin Soc. (2) vol. iii. 1887, p. 599.]

An imperfectly definable genus. Enlarged teeth near symphysis of mandible. Abdominal region much elongated, with a median dorsal series of orerlapping scutes extending from the occiput to the origin of the dorsal fin; apparently no other scutes.

The only known species of this genus is not represented in the Collection :-

Pantopholis dorsalis, J. W. Davis, loc. cit. p. 600, pl. xxxvi. fig. 2 ; A. S. Woodward, Ann. Mag. Nat. Hist. [7] vol. iv. (1899), p. 320.-Upper Cretaceous; Sahel Alma, Mt. Lebanon. [Distorted head with abdominal, region; Edinburgh Mruseum.]

The following specimen seems to belong to the Enchodontidx, but cannot be generically determined:-

P. 4008. Elongated fish with imperfect head, small median dorsal fin, much-extended anal fin, and forked caudal fin; Upper Cretaceous, Sahel Alma, Mt. Lebanon. There are doubtful traces of thin elongated scutes along the course of the lateral line.

Lewis Coll.

Indeterminable isolated tuberculated dermal scutes of Enchodontidæ have also been named as follows:-

Acipenser cretacens, A. Daimeries, Bull. Soc. Roy. Malacol. Belg. vol. xxvii. (1892), p. xvi.-Senonian; Folx-les-Caves, Belgium.

Dipnotepis jahni, A. Fritsch, Archiv, naturw. Landesdurchf. Böhmen, vol. ix. no. 1 (1893), p. 66, fig. 30.-Turonian (Priesener Schichten); Chotzen and Pardubic, Bohemia. [Royal Bohemian Museum, Prague.] 


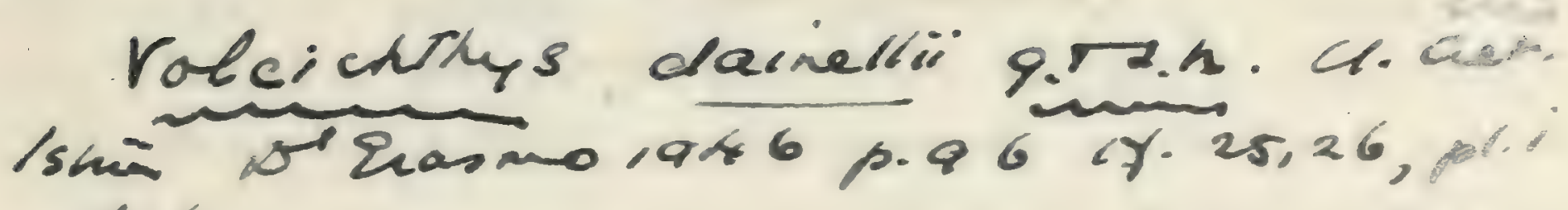
f. 6 .

Halecodon denticulatus, T.D.A. Cockerdl, Magh Bron

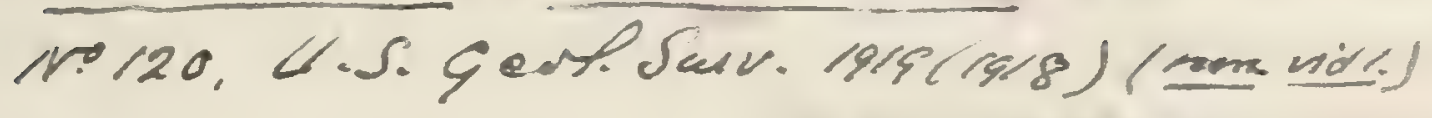






\section{ALPHABETICAL INDEX.}

[ Tote- The numbers of pages on which mere incicientai references occur are printed in italies.

Abramis. :16)

= orama. 313.

- iemthirs marginatrs. $\because 28$.

Acanthoderma, ibs. gruiculartum,

urale, its.

=pinosum. Fis.

Acanthomuilus. 1916.

isaijeilir. 110 .

Acanthonemopsis. $\frac{1}{ \pm}=4$.

camelinit. 50.

Acantinonemus, $14 \%$

ertiundia. $t+$ ?

Hiannentosus. 40 .

sibaurens. \pm \pm 9

Acanthonotcs. 101.

aratus, til.

atmatus, -1si.

Leatie. $4 \%$.

Acanthopnoria. $3=$ 341.

Ribanica, 80 .

Acanthopleurus.job. breris, in.

serracis, 7.

Acanthoosis, 0 .

nentus. $25 \%$

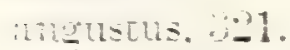

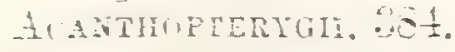

Acanthurus.

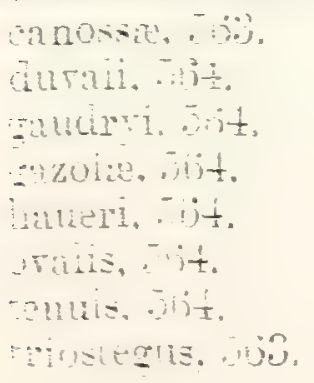

Acanus, 00.

ixquispina, 501.

aretlatus, $=01$.

croaticus, 563.

gracilis, 502.

Iongispina. 500.

minor. .00 .

wblongus. 501.

rais. 500.

periersianus. 渻1.

spinosus. 500 .

srumi. 50.0.

Acara, 505.

Acerina. . 2.?

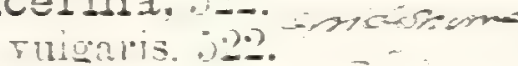

Acestrus. \pm 91 . oruatus. 194 .

Acinenser cretaceus. $-20 \pm$.

acrodontosaurus, i.

froneri, 40.

Acrogaster.

brevicostatus, 390 .

iariesi,

iecheli, sol.

minutus,

alltus. 05

Acrognathus. - 10 .

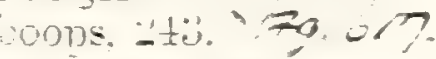

ibaniens. 214.

Acrogrammatolepis, $\therefore$.

stemlat. 5 .

AROXURIDE, BR.

Acroporna, 81

itia. $\pm=1$

Agonus.

mpimens.-.

sipichthys.

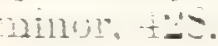

Aipichthys icunt. .

nuchalis \pm 2 ?

pretiosus. 407

reliter, 107

Alausa latissina. 100.

Albuia, 10 . andäna. 3

breris, 105.

de zignii. 15. = toosi.

Iata. 65

oweni. Bं).

Alzutidae. 59.

Alburnus.

miocienicus, $319,-s=0$ steindachneri. $31: ?$

Alepisaurus, 149 , parar.z

ALEPOCEPHALID. I. \%.

Alcsa. Ith.

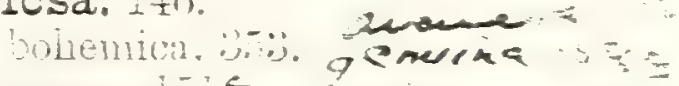

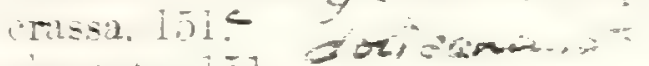

eiongatia. 151.

nuilicica. 1.2. now nami

renoui. Iis.

Alosina. 159

simonea. 15!

Amblypharyngo-

don. 04 .

imbirpterus olfersi. -7 .

Imia inciea, sitt.

Amia lewesiensis. ․1\%

Amiurus, 28. ancelietis. 828. maconveili, ys fribue

Ammodytes.

vobinus. Bil.

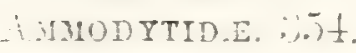

Amoneristus. 7.

colinulens.

Ampiniaga. 16.

bracirncera. $\$ 16$. 



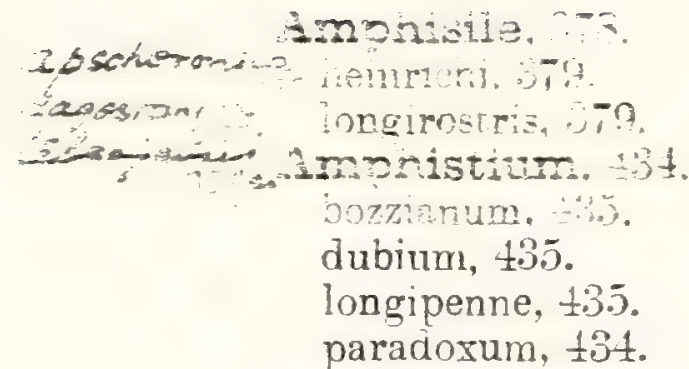

Amphodon, 77 . benedeni, 474 . curvidens, 47 t.

Amyzon, : 00 . brevipinne, 300 . commune, 300 . fusiforme. 300 . mentale, 300 . pandatum, 300 . Avacasthini, 597. Anapterus, $25 \%$. albri, 257 . elongatus, 257 . macrocephalus, 258 . mevistosoma. 257. siculus, $25 \%$. sphekodes. 258. tonia. 258.

Anarrhichas, $50 \%$. lupus. 596.

Anchyboosis, 2:2. latus. 322.

Ancistrodon, 570 . armatus. 570. fissuratus. 570. ricentinus. 50 .

Ancylostylos, thin. gibbus. $6 \%$

Andreiopleura, 116. esimia. 116. retustissima. 116.

Anædopogon, 10\%. tenuidens, 108.

Anenchelum. brericauda. 190 . breviceps, \pm 78 . dorsale. 478 . glarisianum. 17. heteronleurum, 175. isoplenum. 478 . latum, tis. longipenne, t78. margiratum.

Anguilia. $24 t$. branchiostegaiis. 340 . brevicula, $2 \pm 2$ elegans, its. hakelensis. 310 . n.8. intersninalis 545. latisnina. $3+n$. leptontera, 34. muitiradiata. 34 achrma, "3.
Anguilla cont. sanei-rimis. 160. rentialis. 41 . Filrajis 8th.

Arogmilis, 71. aratus, 72 . contractus, 71 . evolutus, 72,386 favirostris, 73 . polvmicrodus, 72 .

Anormurus, 275 . macrolepidotus, 27 .

Anthias, 520. bassanii, 520 . stiriacus, 520.

Apateodus, 258 glyphodus, 258 ion nat lanceolatus, $26 t$. striatus. 260 .

Apateopholis, 22!! 333

laniatus, 232 .

APHREDODERID.E, 416.

APODES, 336

Apogon, 521. hrambergeri, 5221 macrolepis, 521 . sninosus, 521 . mns 10 a

Apostasis, 563. croatica, 560. ceperiman, sturi, 56.5.

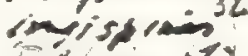

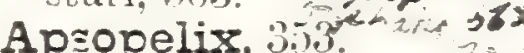
saurifornis, 3.3.3.

Arapaima, 74.

Archæogadus, 212, 320. guestphalicus, 220 .

Archæoijes, 4 ? longicostatus, $4+2$. longus, 449. macrurus. 4 4:.

Archæoteuthis, 524 . glaronensis. 524.

Archæus, 42. brevis, 443 . slarisianus, 422 .

Argyreiosus, 4.0 . minutus, 450 .

Arius, 330. baroni, 334. bartonensis. 303 . crassus, 3.92 . dutemplei, 616. egertoni. 331. germanicus. 3.3 iheringi, 383. rangionis $33 t .936^{4} ;, 33$

Asima. . i3t. ingleri, sini

A EINEOTID.E. 116 .
Asineops. 117. pauciratiatus. 41. saupinirons, it. riridersis, -17

Aspictopis, steinlai, 59 .

Aspidopleurus, 229, 230.

cataphractus, 230 .

Aspius. 318. brongniarti, 293. columnæ. 319. ecnomi, 319. elongatus, 160, 614. furcatus, 160 . gracilis, 318. minutus, 318 . vexillifer. $31 \%$.

Astephus, 829.
Atherina, $359 . \mathrm{ar}$ macrncephala. 359. minutissima. 361 .

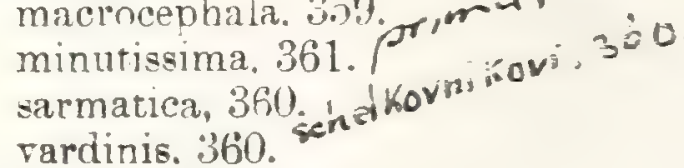

Atherinichthys, 361 .

Atirizinid. 358.

Atherinoides, 361 .

Atherinops, 361.

Atherinopsis, :361.

Auchenaspis, Bleeker, \$:30.

Auchenilabrus, 552.

frontalis. 50\%.

Auchenoglanis, :30.

Auliscops, :3:2. sumatranus.

Aulolepis, 126. reussi, 5.). trpus, $15.16,127$.

Atilorhamphus, 562 . bolcensis. $56^{\circ} 2$. canossæ. 563. capellinii. $56 \%$.

AULORHYACHIDE, 371.

Aulorhynchus, 3:2. sumatrensis. :7\%:

Aulostoma, 375. bolcense. 375. licatax, 376. media .076

Auxis, $40 \%$ t $60 \%$ croaticus, 465 , ave ase a , is b4 minor. 465 propterggius. thit. sarmaticus. 40 ? stiriacus. 165. thynnoides, this 33 abceusis, $\frac{1}{2} 6.0$

Bagarius. :je. gigas . on.

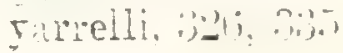




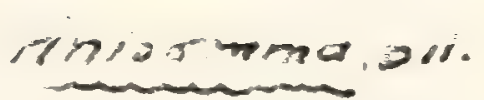

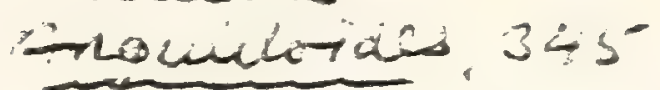

Pranim 289 .

Anokerisma, jio.

Aoria, 32y.

Pntrodontie, 536 .

Q2nanozmacis, 31

- Trinsacopera 520.

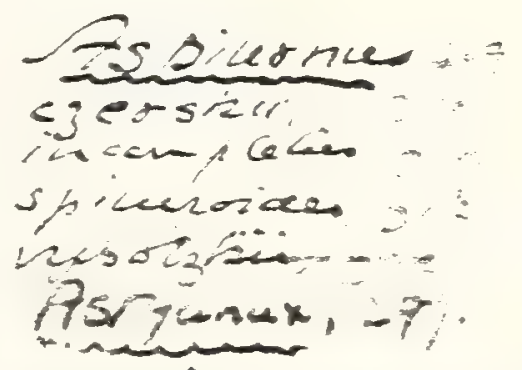

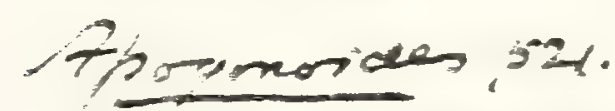

teterissonelis, 6/2

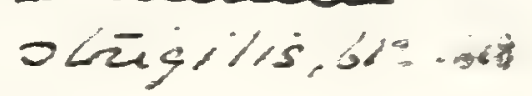

7h50 nelix, 307, or 6 .

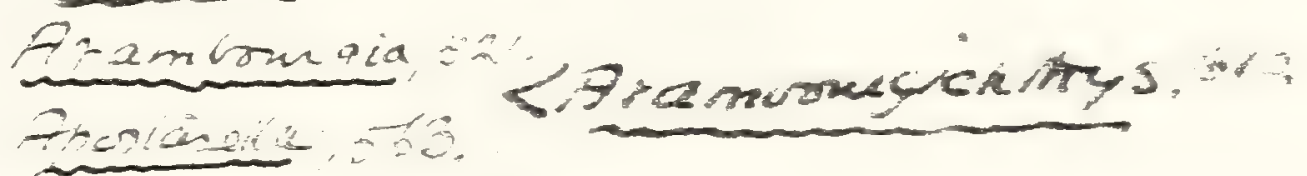

Aracana, 56 \%

Kershawi, 50\%

Aracostens, 083 :

rothi, 555.618.

Brentedeless,

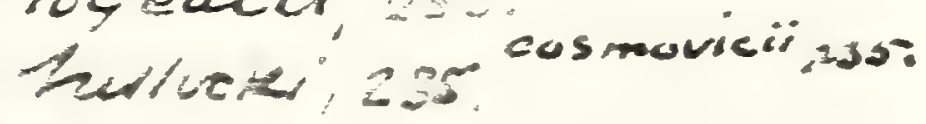

Aneoscurains, D.

Ardivars 40.

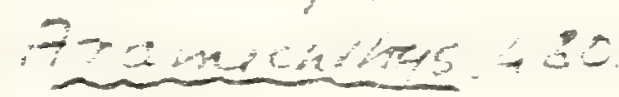

Anskozion, nus s39. Avitolakisax, emprepes, nus so. Aurata $=36$.

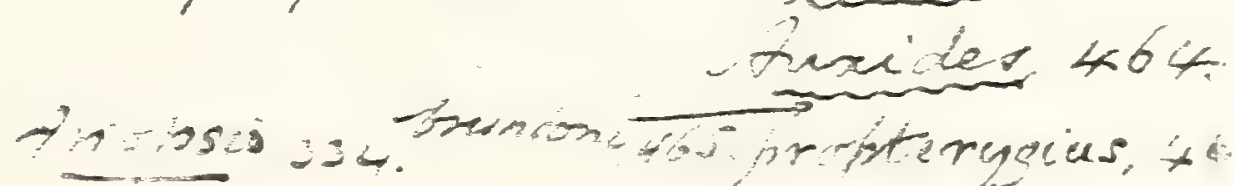

Answitarist, 337

Garthotherse 337 .

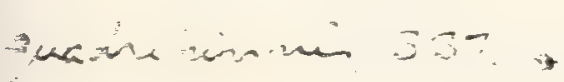

sinctite-inmiros.

Arroidina, 603 .

dasson. से की

in iv

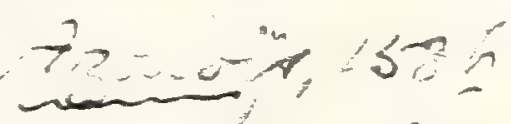

ancedentio.

Priatolons.

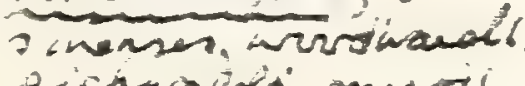




3anenogmios, 7r.

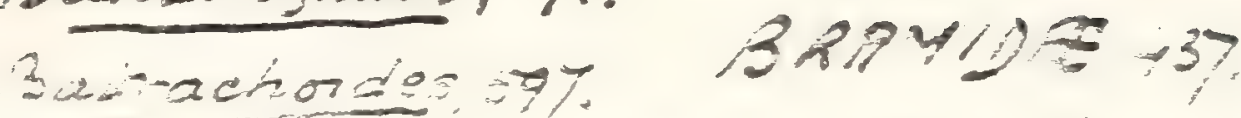

Bracum exa. 296.

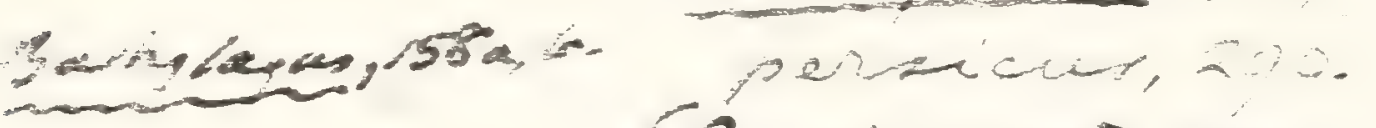

Bangia, 73

imsinna, 73.

Agerius bit

Beition, 358 .

peronides, 358 .

Bachmanna, 324

.324

Thenamus, 442

Cessonora 244.

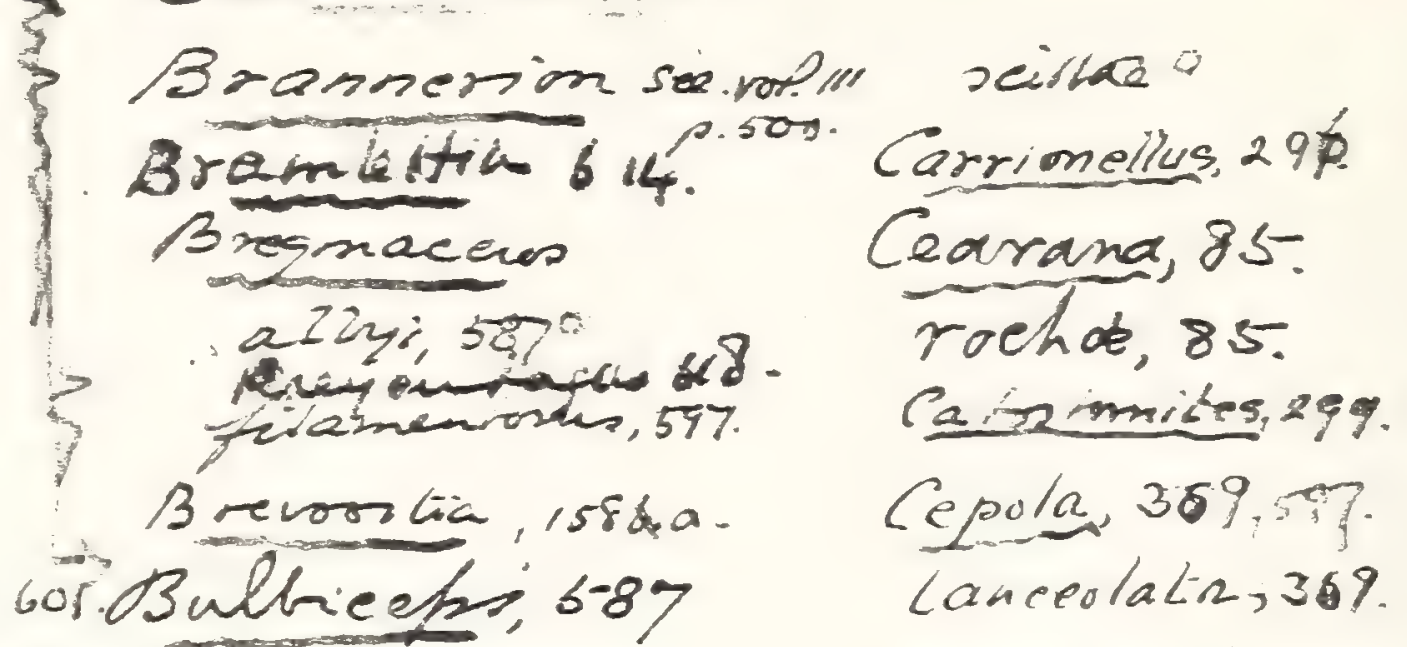

3 recmacersina, 607. Bulbiecte; 6-87

Bresnacenotidap 587,601 raninus, 587

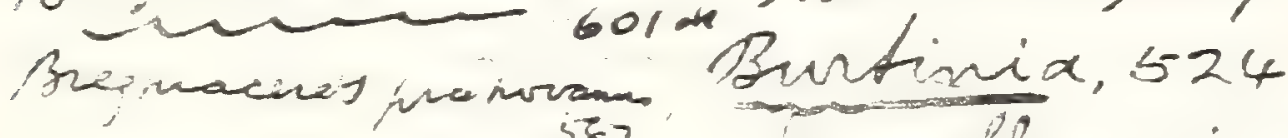

centrarehiles, 415.

537.

Uraselliensis, 524

3 zownin, 58.

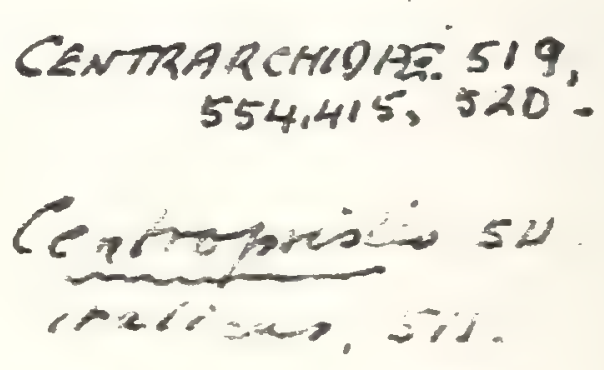

cytindricers 28 .

Callicithupidáe 33:

Carlibsidusiseob)

zancions:
CENTRARCHIOAS 519
$554.415,520$

coloradmai, 415.

$-x, 4 x-2, j 20$

opegentracines, s73:

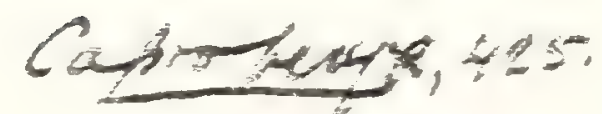

Cosos 418,559.

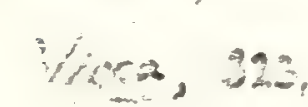

nonemis,

$0.2000=0$

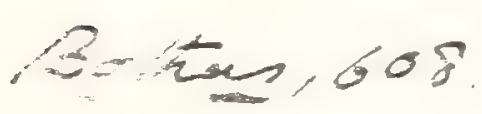

Longirasion. 559

raciobitioness so-

eaptorvidis :.."

Empitimianimals

Caprovespozus.418.
Chaenobroths, 554.

Hismosenis,

Leariaticherast

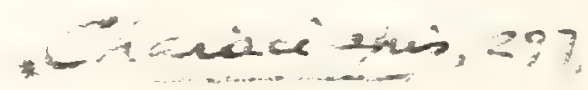


TPDET.

Bagrus nol. :"2\%.

Balistes, îto autusii, joly. dubius.

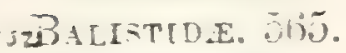

Barious, 301.

fossilis, 302 .

meqacephaius, 302.

steinheimensis. 30 ?

vulgaris.

Basilichthys, 61.

Bathysoma. \pm \pm \% lutieni. $44 y$.

Bathythrissa. 67.

Beione, "urt.

; 57 acutirustris, $357,358$. Hava. 057 . tenuis, $25 \%$

-Belonostomus laniatus. $23: 2$.

BERYCID.E. 3Tt.

Berycleror.ies, : 8 t.

Beryccpsis, fo?. elegans. 千并.

incistromi. 1.25.

Beryx, :०.

acer, in:?.

dalmaticus, 986 .

dinolenidotus, :86.

germauns, $\div 21$.

inscuiptus, ¿2t;.

lesinensis, ¿\&ł.

microcepialus. 124 .

muiridentatus. 880 .

viqer, i2?.

ornatus. $797.40 \%$.

ovuía, i:L1.

poirmicrodus. 72 .

racians. 20 $134 .-13$

Fariacs - achei. 106 .

-run sudoratus, :afi,

s.5. sumerous, $4(1)$.

striacus. 10.5 .

raienciennesi, 386.

теxillifar. 1:0).

ziopei, :40.

BLexiItide. 595.

BLExilforues. 591.

Blennius, 506.

cuneirormis. jib.

fossilis. so6.

oceilaris. 566

Blocitid x. 501.

3locinius. 503 Loneirostris. 599. wacrouterus. 593.

3cops, -igas. $.30 \%$

3othrosteus. 613. revirons, is]:

atus. 0l:
Bothrosteus (ront.)

"1inol: 511.

Bracinygnathus, $51 \%$.

$\rightarrow$ tenuicens.jl?

Brachyspondyius. 270

cretaceus.

incieus, 326 .

salopterix. 328.

Bracinthynchus,

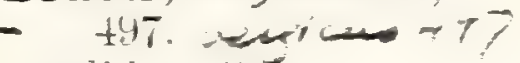
solidus, $\pm 9 \%$.

tererimostris. 497. ronbereciensis, 497.

Brosmius, 602. elonguttis, 602. trutues, fuch sianus, 602 . strossmaveri. 602. susecianus. no:?

Bretula. 605 .

lonuipinnata. 6(1)\%.

Brychatus, $76^{\circ}$.

mueileri. it;

Bucklandium, $3: 0$.

dilurii. $3: 30$. zin.

Butyrinus, 60 .

Caeus, leopoldi, .7.

Calamopleurus. .5.) 1. ingiicus. jol.

Calamostoma. 19cs:iz, :8:?. breviculim. 353.

Calamostcma. tein-

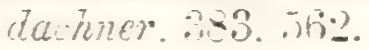

bolcensis, jti2. "isnossie. $56 \%$.

Callionymus, jR. macrocephaius. 588.

macrocephaius. 588 . pseucloriombus, 560 .

Callipteryz. jะ9. recticaudus. .09. speciosus, 589.

Calopornus. 5isti. porosus, 5060.

Cantharus, $.3 .3 \%$ upoimensis. $53 \%$.

Capito. 31.5.

Capitodus, $2: \%$ angustus. 50010. Mubius. 537. inciicus. 532 . intelruntus, $5.95 \%$.

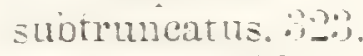
truncatus. 50 in.

C.IR.ATGID. 125

Carangodes. -ephails, \pm 0.

Carangopsis. $+110^{\circ}$ unilis. $\frac{1}{4} i$.

Caranx, $4 t$

pinnatiformis, $4: 39$.
Carangopsis iont.).

bievis. $t+4$.

dorsalis, $t 4 \pi$.

lanceolatus, $\frac{1}{2}+8$.

latior, 146 .

maximus, $\frac{1}{x} 8$

carangopsis. $\$ 11$.

gracilis. \pm 11 quedes-in- - su.

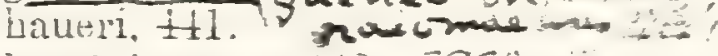
lungipinnatus, $4+2 \ldots-1$ oralis, 442. - poelrosis rigidicaudus, 412. we the

Cariniceps, 458 . compressis, 458 .

Catostomus. 299. cristatus. shoshonensis, :-30)

Cextriscinen, 行

Centriscus. $37 \%$

aculeatus. 370.

Longirostris, $37 !$ !

tom, 37.

Felitanis. 37\%?

Chretodon. itil).

areutus. jisl.

arous, jijl.

isper, 560 .

aureus, \pm+2 .

canescens, $\frac{1}{2}$ t).

canus, 5.53.

chirurgus, 559.

hoeteri. 560 .

lineatus, $56 t$.

mesoleucus. 5.59.

nigricans, .

papilio. tise.

binnarus, 483.

502.

rhombus, 559.560.

sasatilis, \pm 12 ?

striatus. 115.

subarcuatus, 51 .

subaureus, $4 \pm 9$.

substriatus. 415.560 .

subrespertilio, 130.

triostegus. $56 \mathrm{t}$.

relicans, 4.31 .

Teilier $4: 0$.

resnertilio, 4.3.

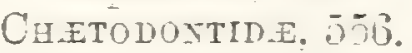

Chemodontiporues. 56.

Chanoides. 6\%. epcuster …

meropoina

chanos. ht. jüria,

brevis. 6.5.

torcipatus. ri.

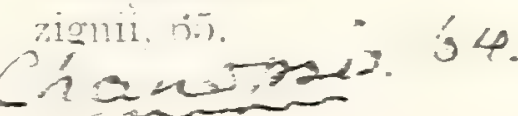




Characiside. 29\%.

Charitosomus, :27. formosus, 27:?

hakelensis, $27 t$.

lineolatus, 274 .

major, 272.

Chatoessus, 158.

breris, 158.

humilis, 158 .

tenuis, 158.

Chelonia radiata, 491.

Chimsera furcata. $8 t$.

Chirosentrites, 0

carolini, 9.2.

coroninii, 91.

gracilis, 91.

libanicus, 105.

Texillifer. 92.

Chrrocentrida, 86.

Chirocentrus, 83. polyodon, 88.

Chiromystus, 89.

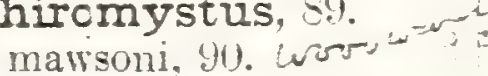

Chirostoma, $21 i l$.

ChIRothritide, 27\%.

Chirothrix, $8($ ).

guestialicus, 203.

lewisi, 283.

libanicus, 280.

Chondrosteus. 11.5.

Chondrostoma. 816

wheices, bubalus, 310

elongata, 316 .

laticauda, (ili).

miuutum. 318

stephani, (i1).

Chromide. 5.54.

Chrysichthys. 327 .

theobaldi.

Chrysophrys, jut.

agassizi, $0.3 \%$.

$r \rightarrow r=v .534$ arseniritana. 507.

$\Rightarrow$ brusinai, 531.+N

vincta, 535.

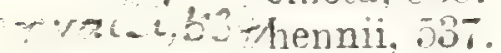

hertlei, $53 \pm$.

lawlovi, 534 .

miocenica, 537.

seacchii, 53t.

zignoi. 531.

Cimolichthys, $\because 21$. 2.27 .

anceps, 203 .

contracrus, 20).

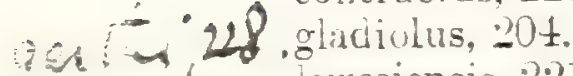

Jewesiensis, 201.

isbonensis. 208.

merriti. 2.23.

nepreolica, 20.5 .

semianceps. 20.

sulcatus. 2.2.)
Cladocyclus, 107.

gardneri, 108.

lewesieusis, 109.

occidertalis, 110 .

strehlensis. 110. sweeti, 111, or 0

Clarias, 324 . and :

filconeri. 324. s an

Clinus, 597.

gracilis, 597 .

Clupea, 146.

alta, Leidu, 1 to.

alta, Steindacñner, 137.

antiqua, $1: 35$.

arcuata. $1 j t$.

altenuata, 19.

beurardi. 14?-assane.

bosniaskii. $15 t$.

bottæ, 250 .

breviceps. 15 t.

brevis, 270

brevissima, 140

caudata. 151.

catoprgoptera. 148

cephidus, 158 .

chirrsosoma. 158.

crenata. $1 . \overline{1}$.

curta. 2.2. سis

coprinoicies. $6 \%$. 456.

dentex. $15 t$.

denticiformis, $15 t$.

doljeanu. 159.

Tubia, 270

ecroini, 15.5.

elongata, Davis. 5j.

elongata, steindachner. $155, \pm 60$.

engraulitormis, $15 \%$.

evolans, 133.

fontannesi. 155 .

gaudrix, $1: 8$.

gervaisi, 150.

gigantea. 10. glyporsama.

goidfussi, 1.5.

racilis, 150.

gracillima. $15 \overline{5}$.

grandisquama, $15 \%$.

grandonii. 155

gregaria. 15.

guestphailica. 207.

Laicingeri, 155.

heterocerca, 156.

humilis. Leiciy, $1 \pm t$.

bumilis. Hever. 1.00

in nata, $1 . \overline{6} 6$.

intermedia. $151 \mathrm{.}$

lanceolata. 150.

iarteti. $1+1$.

lata, $10,5: 3$.

aticauda. 158.

antisoma, 1. b.
Clupea (cont.)

lawleri, los.

leptostea, 1.39

lesinensis, 138.

lewisii, 17.

lorex. 156.

luncigreni, 156.

maceini. 156.

macrocerca. 1.76.

macrophtbaima. 135.

macropoma, 63.

megaptera, $1+\overline{7}$.

inegaptersx. 1.5t.

melettæiorais, $15 t i$.

meneghinii. 158

wicrocepbala, 1.58.

microsoma. 157.

minina, 245.246 .

minuta, $1 \pm 4$.

minutissima, 158.

mondainensis, 157

Z 2 mucronata. 157 .

murxenoides, $63 \%$

numidica, 151.

ombonii, 157 .

ophthaimica. 158 .

opisthoptervs, 15\%.

polrachanthina. 15\%.

præsardinites, $13 \%$.

pulchra. 5 ii.

pusilia. $14 t$.

sagorensis $15+$ pon

sagorensis. 10t. 1.7.

sardinites. 152 . Condino shar lín 157 .

sardinoides, 19 .

sauips. $15 \%$

sauvagei. 158.

scheuchzeri, $1 \pm 7$

sinensis, $63 \%$ scuiotat $=34$

sphaerocephala, 1.jt.

sprattus. 153.

strriaca, 15.

tenuissima. 154.

theta. 140.

thrissa. 6.8.

thrissoides, 63.

trinacridis. $15 \%$.

rectensis, $1 \pm 6$.

rentricosa, 150 .

villosa. 161.

roirouensis, 138.

rukotinorici, $1.5 \%$.

senophanis. 15R.

zanclea, 158 . icuncri, :5-

Clupeidin, 12S.

Clupeops, 159

insignis. 15.).

Cobitis. $: 20$.

ingustus. $\because 21$.

urertai. 20.

centrochin, 920 .

"ephitulutes, :3:1. 
-. Butanustod

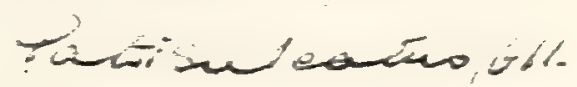

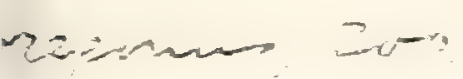

son- sus

Zinderi, ....

-

- an larias

dioctinicus, 224 -

C C

úcoreosi, 73.

$20 \leq a .322$.

sunelzuas, i? mpustarex; 322.

ASHCDONTS, :HA

$-x$

$a b-=.: 15$

unvitatase

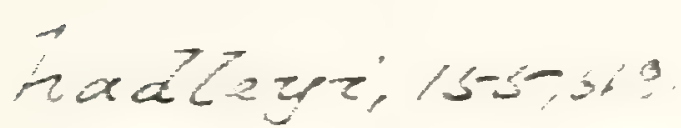

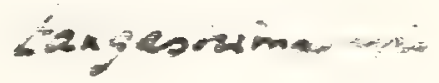

$c+5,=-3$

सexarens

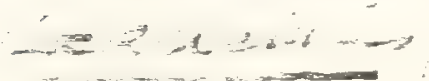



Sourdoti, $<>0$

Decostain 44?.

Coinolenis.ill.

Cinger, 342.

miciochines 342.

2abichlens,

norgani, los.

Encramus, 612. Cycloteboides.618.

Eutbondulis 3 ?

rydoras,

nevelauts, Gonasing: 446

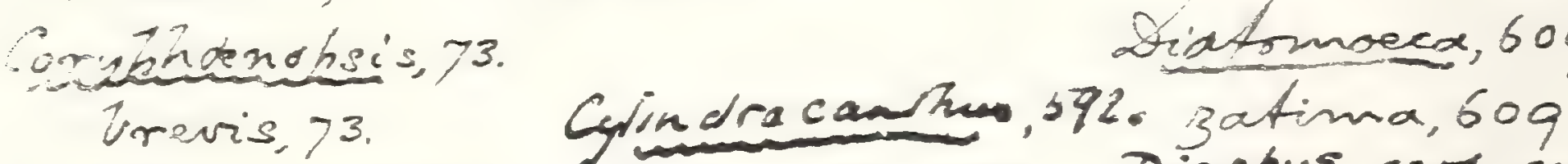

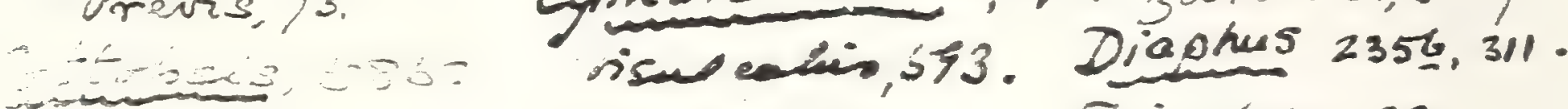

cerricomis, 585.

exichings bra

remsict 535

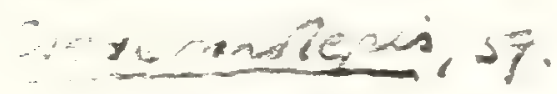

$\therefore \operatorname{sen}, 5=0$ presemelli, w42 agidis, L46.

Denticheis, 71

epothii, 7 .

Deprondus, 346 .

lestes, 34 b.

Derrhias, 336.

enantions, 336.

Diatomoecx, 609

Cuprinotion

primuin 290.

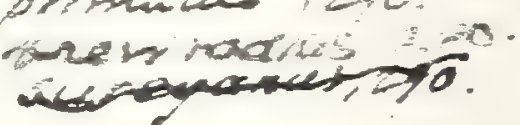

Oidel二3,22.

burmacess as.

Ged-tone a

Grascesix, v.y.539.

Datisiagreiler. 343

Daparis, 506 .

reistigerina, sia

Daseres, 537

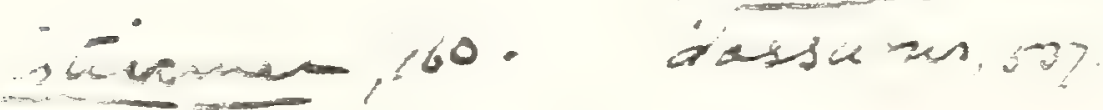

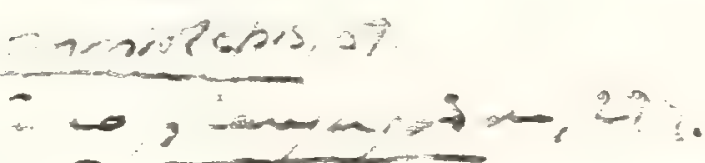

dastive, 133 .

- venclatos 400

cramerailitis.

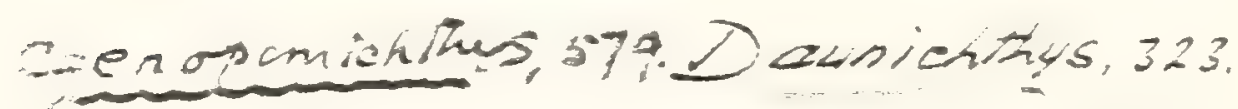

Bi give

groomionus 123 
Cobitis (cont.).

lonvicens, -T.

tevieri, : :-1.

Cobitopsis. :jt. acutus. Joj. exilis. :.j. 万.

Calocennaius, 457. saimoneus. $\frac{1}{2}$. $\%$.

Cologaster, 111 . analis. 116.

Coloperca, 519. latitrons. 5 [!!

Colopoma. 40 culei. \pm il

curratum. 垪? mere. :72.

Colorhynchus, i) $2 . \%$.

Cinser bierior. :j:

Conosaurors. (il.). bowmanni. il:.

Conozaurus. 1i12. bowmanni. ijiz. "urax tissuritus. j7).

Coregonus, hil.

lavaretus. 1 il.

Corrina gibberulus, 50?.

(i)TIDE. j)

Cottus. 59.5

aries. is?.

oreris. 592.584.

Pretotremus, 8.). diraricatus. j55. borridus. .5.).

Lypoceras. .7. rautipinnatus. .2. paprraceus, j=3. pontifex. .35\%. quaciricornis, 5.). uncinatus. .ja.j.

Crenilabrus, itil.

zainocu:e. $5+1$.

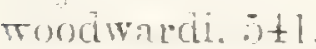

Crommycaus. .0.). irreculatris. 50:3.

Cristicens, $54 \%$.

paraciskis. $59 \%$.

Clussogrithuti.

Crossognathus. savanditunus. "jt't.

Crencalentex. .2.?.

itekeniensis. jo.

Ctenopoma, .7? jemeika. si!!.

cienothrissa. i:

minporeptralil. 10-1.

matians. I:-

verilliter. I-

CPFYotIMISTID.E. 11 ?

Cyoium. $\div 5 \%$ this th?

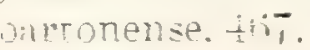

Apritio
Cybium tont.).

bottii. =71. a n.v

Ausnonci. \pm i?.

exceislum, 165.

linguiatum, +69 .

natropoinum. $\pm 6^{2} 2$.

maculatun. +16.

palrecini. $: 0$.

proosti. 170. mpetiensis.ti speciosum. $\frac{1}{2} 66^{\circ}$.

tenue. 170 .

Cycicides, $5 \%$

incisus. 5\%.

Cyclolepis. 5!)

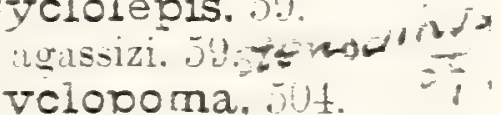

yciopoma.

micracuthum, 50)t.

spinosum. 5(1)t.

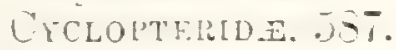

Cyclopterus. j37.

Lumbus. Ju\%. .j.

Cycioromodon. 15.

vagrans. 4.5.

Crclurus urassus. 509.

C"relinus inilar. 5.3.

Crelurus nemopterts.

5218.

Cyplumide. ZOU.?

Crnrinodion ieratus, +11 .

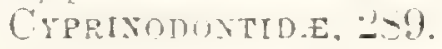

Cyprinus. : (1).

bipunctatus, 818.

arnio. 8111.

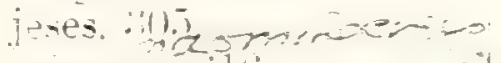

inimusus. 116 .

paptraceus. :07

pristus, :01.

sulumosents. $276^{\circ}$

CYTTIDE. $\frac{1}{1} \mathrm{I}$.

Cyttoijes. 117. glamonensis, \pm 17 .

Dactylopogon. 24 rrandis. $-\frac{1}{2} y$. barpuins. -219.

Dactyiopterus, Ji. piocenicus. As?. Tolitans.

Dapecogicssus. it. acutus.

aquinimnis, 3.

ancaustis. 70 .

restis. 7.5

Daprinus. 111. 12.

moriheacii, 113

mresmenius, 1 i.

shlebuinmus. 11?.

Dentax. .2.

brevicens,

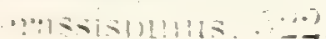

Dentex cont. - גuswor

fiulasi,$j-1.0$

iaeheniensis.

leptacantisus. jo.?.

racivis . . .

microcion.

muensteri. 5

nobilis. br. c sijosen

sarciniensis. 52 .

rentrais. 528.

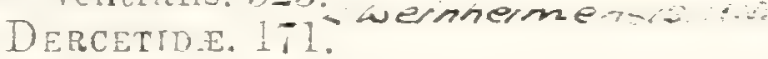

Dercetis. 17?.

elongarus. 1 t.

Limbaranensis. 17.

linguiper. 17 t.

pensisi, 170.

seutatis. 17.

telluis, 151

triaueter. $1 \% \frac{1}{1}$

Dermatoptychus.

$2310, \ldots 3$

meroninthaimus. ¿-t?.

Desmichthys, 们.

ianorei. 1.11.

Diaphyoaus, jt1, $=25$

orais. $5 \pm 0$.

trigoneila, itio.

Diastichus, :2\%.

inizerofon,

pal一itens.

stringuiatus. \%on

Dictycaus, $\frac{1}{2}$ i

urissicieus. tio.

destucror. $\pm 7 \pm$.

misclis. 47,3 .

"upeliensin, t7:?.

Dinopterys. $+1 k i$

sinusus. $-11 \%$.

Diodon. 71 .

rcantindes. $7 \frac{1}{4}$.

anciqums, $5 \%$ \%

coricanus, jit.

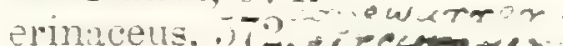

foleri. 57t. -otracius.

gigantodus, $5 \%$

ieniacionon. itt.

heterorton. 35.

bilgendomin. .7.

incertus. 575.

italicus, 57.5.

meristodus. j\%

monsegurensis, ,7.).

pirtrocilis, ji.

lurisendir. 57.y.

solilie. 57.

4 IInit. 50.

senocius. so.

entaspinus.

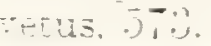

Dixiomystus. 130.

tUts. i - i
$-20 r$ rase

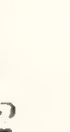



Diplcmystus (cont.).

analis, 139.

bircì, $1 \div 2$.

brevissimus, 140 .

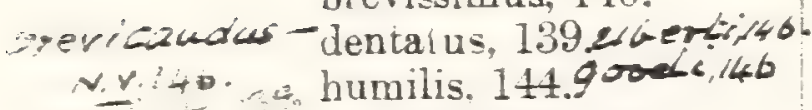

longicostatus, 143.

mapono Hbespectorosus, 140.

cincumsing theta, 140 .

29.

Diplotomodon, 612 . horrificus, 612.

Dipnolepis, 234 . jahni, 234.

Ductor, 448. leptosomus, 448.

Dules, 5:1. medius, 505. temnopterus, 521.

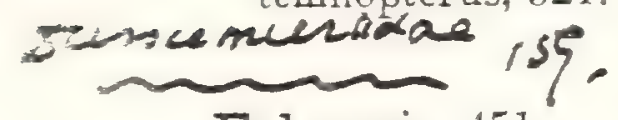

Echeneis, 151 . glaronensis, 451 .

Echenus, 613. politus, 613.

Echidnocephalus, 163.

tenuicaucius. 163.

troscheli, 163.

Egertonia, 550.

gauitina, 73 . gosseleti, 551.7 N.r. isodonta. $551 .+$ N. P.

Electrolepis, 415 . horrida, $\$ 15$.

ELOPIDE, 7.

Elopides, 23. couloni, 23.

Elopopsis, 8. crassus, 10. dontex. 205. fenzli, 9.

haueri, 219.

beckeli. 10.

inicrodon. 9.

ziegleri, 10.

Elocs, 22.

Embalorhynchus, 497.

kinnei. 497.

Empo, 221.

contracta. 208.

lisbonensis. 스.

merrilli. 2:-8.

nepaholica. 20\%.

semianceps, 228.

sulcata. 225 .

Encheiziphius teretirostris, 497

Enchelurus. 164. anglicus. 16it.
Enchelurus (cont.). syriacus, 165. villosus, 164 .

Enchelyopus, 343. tigrinus, 343.

Exchodontide. 189.

Enchodus, 190.4 92 amicrodus, 203. anceps, 203.

annectens, 195.

bleekeri, 466 . imences calliodon, 203.

carinatus, 204 .

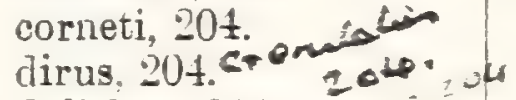

dolichus, 204. cen'?

faujasi, 196.

feros, 204 .

Yladiolus, 204. gracilis, :201.

haloeron, 191.

Memonnieri, 198

20 . lewesiensis, 191, 193.

Iily:-13 Tongidens. 199.

Ifcodon, 204.

macropterus, 202.

major, 200 .

marcheseltii. 200 .

oxytomus, 204 .

parfus, 204.

petrosus, 205.

pressidens, 205.

pulchellus, 193.

recurrus. 201.

semistriatus, 205.

serratus. 203.

shumardi. 205.

subæquilateralis, 205.

tetræcus, 205.

valdensis, 205 . y $\mathbb{C}^{\infty}$

Engraulis, 123. brevioinnis, 133 evolans. $133,287$.

Iongipinnis, 133

tenuis. $20,285$.

Enneodon, 571, 5\%5. echinus. 5it.

Enoplophthalmus, 323.

schlumbergeri. 323.

Enoplosus, 521.

pygopterus, 521.

Eocœlopoma, 470

colei. \pm 70.

curratum, 722.

Eocottus, 580. Ferchensis, 581.Eomyrus. 340.
dolloi. 340.

latispinus, 340 .

rentraiis, $3 \pm 1$.
Eothynnus, 45i. salmoueus, 457.

Ephippites, 617. peissen bergensis, 617 .

Ephippus, 55\%. lougipennis, 359. nicolisi, 560 .

oblongus, 560 . oweni, 570. rhombus, 559 .

Equula, 450. scilli, 450 .

Erismatopterus, 416 . endlichi, 416 . leviatus, 416 . rickseckeri, 416 .

Esocelops, 46 . carifrons, 46.

ESOCID.E, 297.

Esox, 287.

belone, 375 .

destructus, 615.

falcatus, 482.

lepidotus, 288 .

lewesiensis, 191.

longirostris, 375 .

lucius. $288,289,365$.

macropterus, 89.

monasteriensis, 159.

otto, 289.

ottonis, 289.

papyraceus, 289 .

robustus. 288

saurus, 361 .

sphyræua, 361, 36:2, 366 .

spret, 362. 366.

rulpes, 153.

waltschanus. 289.

Eucynodus, \pm 81 .

bunteri, 481.

Eurygnathus, Aaassiz. 46.

carifrons. 46.

Eurygnathus, Datis. 190.

feros. 200.

marchesettii. 200 .

Eurypholis. 207.

bcissieri, 207\%.

freveri. 210 .

longidens, 199.

major, 201 .

sulciciens, 207.

Erocetus evolans. 1:3.

Exocetus exiliens. $133^{\circ}$.

Exoccetoides, 286.

minor, 286 .

tenuis, 285 .

Fierasfer, 60\%. 




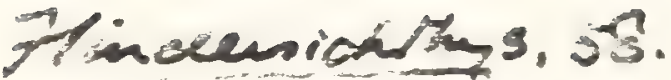

cencment, 58 .

Torfex 368

hupuratio, 358,6:3.

Gomitisis, 9

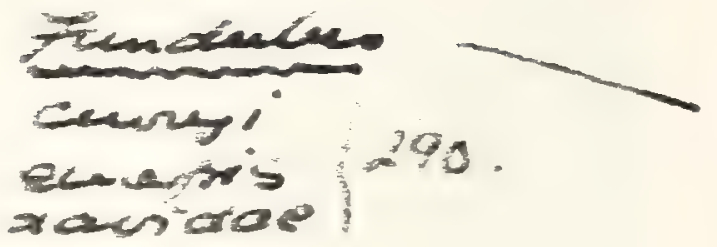

Hexaorammos, 580

$\Rightarrow$ and two

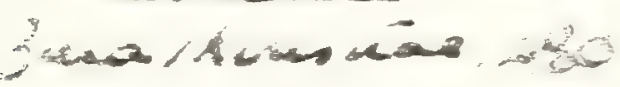

7ariexide 3555.

Castrosteops, 340

minexacanonus 370

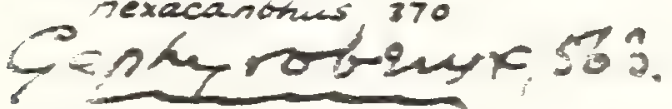

achrestus, 580

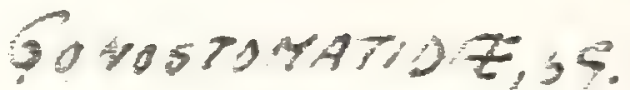

Suawencies's 169.

Sorortignchobs, 279.

Garoessus, 159.

depsyrota, 159. is.

Goxena canifum.437

conduses, 159 cannes, 159568

- cicinsgara, isa

zater ozizeuo, 370

woodwarak; 279.

Ponestoma, $150 a$ sद

acres;

morgani, 14sía

thippoglusoides, 608

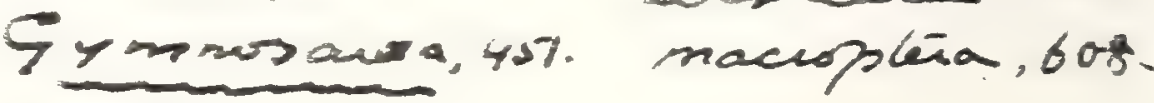

3aingyi, as 7 .

Halecodon,234. Hioforymgnaltus,381.

llimmoni lebtromus, 370 dentieulaties, 234.

sivatases 075

$\rightarrow$ phasen

visisint.

$\rightarrow$ mantion

anthidthes memidus, 612 .

Hakalik ist

Haplochives 280

Holarentrizes, 415. ia cen werios.

Hekurainmios 335

$-1, x+2$

thardoticensonsto

notolaricus, ins

$\therefore 20, \cdots$

Toura, $5-8 \not$

- thicina, sosa.

diculica, $4-84$ tina, is

areenisino 4 )

rossoides, 5.5y.

Heliojenis. II

Helmintaresis, st.

Horknutus, s92.

antioneatus, saa.

yermicuran-s

orear 3,49 is
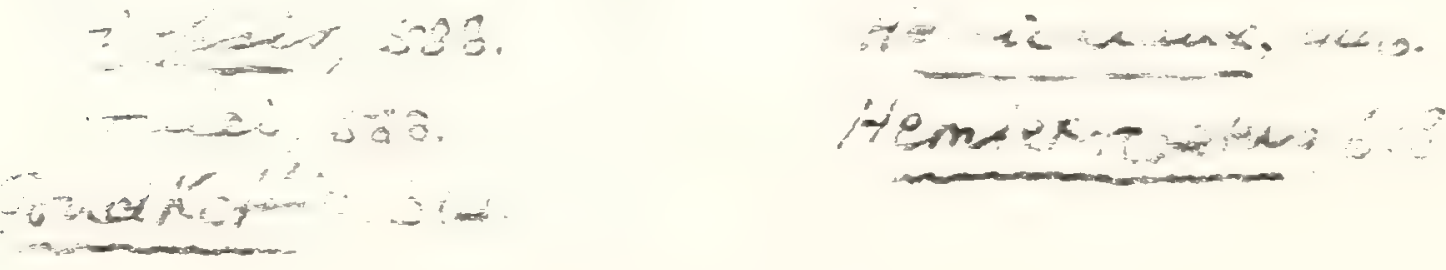
Fierasier (ont.).

imrius bos.

ousterus, (1).5.

Fistularia, $: 4$.

boleensis. $87 . \%$

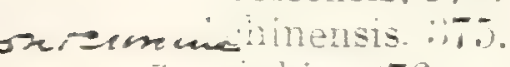

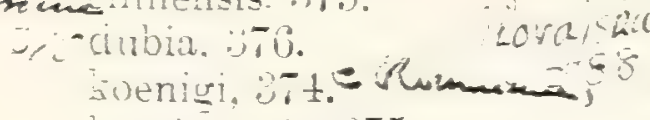

longirostris, :T.

cabaledria. 376.

renuirostris, 35.5.

EIstetatirna.e. $27 \%$

Euraulus, 2ul,

GAIDID. 597.

Gacopsis, $61 \%$. brericens. 67:?.

Gadus, 599 ruchimens wglelinus onsorks, col.

elegans. bo1).

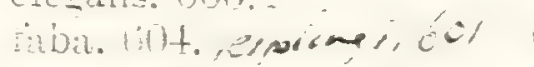

lariol. hill. wineces gor

insens. 600 .

saconiven

meriangus. 60011.

meriuceius. 589.

minutus, tol.

morrinua, 601.

poilacinus, 601 .

poirnemus. bl.

psethixuifinus, bou.

simplex. 004.

spectabilis. (1)4.

sompanii, 601.

tentus. 1504.

tuberculosis. 104 t.

renustus. 60t.

virens, col.

Gasteronemus, tis.

oolongus, \pm 41 \%.

wombeus. $\frac{1}{2}: 9$.

Gepnyrura, 26. mincentriea, -296.

Gerres,

Hassaiongoi, 528.

Gigantichthys, 112 . mixiro. $151 \%$.

Gilicus, 99, 17.

arcuatus. iol.

poirmicrocius. 101.

Glossodus, Guer, 130. lesckeli, 7.5. Enra its

Giptocephalus, .

maintus not)

Gusind . . . .

Gimiroturs, - ist.

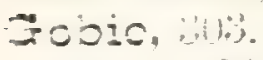

:malis. 04.

metion. 15.

Finins. 415.

Godius, sa.

mpretria. isl.

ZAS IF。
Gobius conte.

bascanil, jo.

breris 59.

cunicus. jot.

- pancorurtanus. 53.

tiptosomus, je8.

Lobini, 585.

macrotetus. 583.

muerurus, 581.

maximus, 5.98.

wicrocephalus, 588.

mutipinnatus. $5+\ldots, \ldots$

oblongus. 5st. ones.

peruzzii, 5s3. jiacicennaín

sincinensis, t4.

veronensis. 31.

ricinails 5 s.

rienuensiz. 53t.

Goniognathus, $5 \%$

corrplirnoirles, 57.

maxilaris. $57 \%$

GOForHYCHDE, 271.

Gonoriynchus, :-il.

ereyi. ‥

Grigodutru. . .70.

Gymnodus, $\%: 2$,

diocion. 57.5

heterucion. 375.

unonsegurensis. 575.

Fâcauetia, il:.

boicensis. $151 \%$.

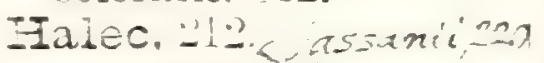

euntertotus, 21:3.

ruestphaticus, 20 .

Irateri. 219

Lubei. -2u.

microlepis. 15.

stemberit. 212.

Jalecopsis. $13 \%$.

msignis. lüt.

fervis. Uyt.

H.l.unatRD F. 16\%.

Faiosaurus, L $1 \%$.

H.MLOMI. L.

Fleitbrincint, 0190

Zemicyclus.

streulensis, 5.?.

Ifemieloocpsis. 58.

ginbus. $\mathrm{s}$.

sracilis, 28.

Eutessi, is.

Eemilampronites. 59

steiniai. 5.9.

Femirampinus. ritwarcision.

Iemirivvehus, ise

vite =
Eemirhynchus(cat.).

Resiliresi, 18 .

zitteil, $\div$ :

Hemisauriad, "I?

neocomiensis. 270.

Hemithyrsitas, $t 81$.

armatus, tôे.

clatus, til.

licatre. I:. maicoprees

Femitrichas, 32:.

senisticola, 323.

Feptajiodon, j.

echinus. 51.1.

Heterobrancinus,

:3.

palieindicus, 325.

IEeterclepis. $61 \%$.

Heterotis. 7 .

Hexapsephus, :0.2.

cuentrem.

IIistialosa. is. thioilieri. jo.

IIistiocephalus, 57 .

Histioniorus, tij. Tigrion the

antiquas, + 45 .

deshares. $\frac{1}{2}$ s.

rocenicus tis r berse.

Lomaionomptus, $+97$.

partuins. tor.

priscus, 191.

robuscus, 497.

menuilus. 195.

Eistiothrissa, 131.

unasaninna, $1: 2$.

macrociactria. 131.

IIistiurus. $1: 9 \%$

eiatus. 1 to.

serioluicies, $1 \pm 6^{3}$

rentricosus. $1+6$.

Hclacanthus,

microcepinalus. jis.

piopenorum, jil.

Folcodon, $140.2 \%$.

lesinaensis. 219.

lreodum. $-19 t$.

, $\cos$. nov

cretaceus, 20 .

Folccentrum. $11 \%$. evem

calcariter, 502

anceolatum, 51 .

macroceninaium, 412 .

ruacuintum. 4 .

meitense, $\div 13$.

progum, -10 .

prometura t1.

-60. $\div 12$.

Holosteus. - - 二

marioes $25 \%$ 


Homonotus, 407 .

dorsalis, 408.

roiundus, 409. pulcher, 392.

Homorhynchus, 488.

bruxelliensis. 490.

Hoplopteryx, :96.

3 antiquus, 396.

jrevis, 406. Tewesiensis, 397. lewisi, 404.

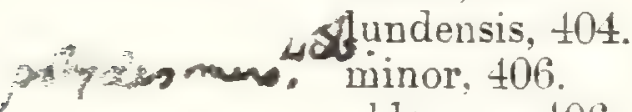
ublongus, 406.

Simus, 409 spinosus, 407 . stachei, 406 .

gith fos superbus, 403.

syriacus. 405.

zippei, 397.

Hopiostethus, 11 t.

ingens, 414 .

laciniatus, 414 .

lawlevi, 414 .

nettelbladti, 414 .

ostiolatus. 414 .

pisanus. 414 .

Hyperlophus, 139.

Hypsodon, 37.92. lewesiensis. $33, \pm 0,45$, $94,95.98,109$.

minor. 102 .

oblongus, 26 .

toliapicus, 24 .

Hypsospondylus, 58. bassanii. 58.

Hyptius, 58

sebastiani. 58.

Ichthyodectes, 99. acanthicus. 107. anaides. 100. arcuatus, 101, 110. cruentus, 107. ctenodon, 100. elegans. 103 goocieanus, 107 . hamatus, 107.

una tonensis Nibanicus, 105. 107, frinor, 102. multidentatus. 107. - occidentalis. 101. perniciosus. 107 . poiymicrodus, 101. prognathus, $10 \%$. serridens, 101. tenuidens, $10 t$.

Ichthyotring 2,265 , $26,9$.

tenuirnstris, 269.

Iguana (:) haueri. 564.

Imogaster, :91. auratus. 894.419.
Ischyrhiza, 46.0 antiqua 45 crien mira, 46 .

raciata, 46,614 .

Ischyrocephalus, 190.

cataphractus, 202. gracilis, 201 .

intermedius, 202. macropterus, 202.

Isodus, 190. sulcatus, 199.

Istieus, 66.

gracilis, 70 . grandis, 67.

lebanonensis. 71 . macrocephaius, $5 \%, 70$. macrocoelius, 67 . mesospondylus, 67. microcephalus, 67 . spottii, 71.

Istiophorus, 495.

Isurichthys, 453.

- macrurus, 450. orientalis, 453.

Isurus, Agassiz, 453. macrurus, 453.

Julis. $\check{0}+1$.

agassizii. $\check{4} \pm 0$.

muensteri, 540 .

sigismundi, $\check{t}+1$.

Kurtus relifer, 430,431 .

Labeo curieri, 616.

Labidesthes, : $: 61$.

Labrax, 509.

bosniensis. 51․․

delheidi, 512.

elongatus, 512 .

heckelii, . 10 .

intermedius, 512 .

littus, 512 .

lepidotus, 512.

longiceps, 513.

major, 513.

mojsisoricsi, 513 .

multipinnatus, 513.

neumatri, 513.

oeningensis, $ว 11$.

sagorensis, 513.

schizurus, j]0.

steindachneri, 513 .

stiriacus, 513 .

ubinoi, 510.

LABRID.E, 539.

Labrodon, $5 \pm 1$.

atricanus. $5+2$.

alsinensis. 545

bazini. 543
Labrodon (cont.). belgicus, $5 \pm 3$.

bourgeoisi. 548.

britannus, 543 .

canariensis, 542.

carolinensis, 543 .

chantrei, $5+3$.

cocchii, 543 .

crassus, $5+4$.

dilatatus, $\overline{5} t 4$.

edwardsi, 54 .

gaudryi, 544.

haueri, כ̇tt.

heterodon, $\overline{5}+4$.

multidens, $\bar{t} \pm 4$.

pavimentatum, $\check{5}+4$.

polyodọn 545.

quenstedtr, 54.5 .

rhedonum, 545 rimetion, 5 s

sauvagei, 5 ti).

sellæ, $5+5$.

soldanii, 54.,

superbus, 5t:o, ramon

trapezoidalis, 545 .

trigonella, 546 .

Labrophagus, 611 .

esocinus, bill.

Labrus, 539.

agassizi, $\overline{5} 40$.

bifisciatus, 464. ectaenas, 540 .

malapterus. 595.

merula, $5+0$.

microdon, 540.

parrulus, $\bar{\jmath}+0$.

priscus, $\overline{5}+0$.

punctatus, 558 .

rectifrons, $5 \overline{5} 8$.

turdus, 504 .

valenciennesi, 540 .

woodwardi, $5+1$.

Laparus, 596. alticens, 596.

Lates, $50 \%$

Larimus, s1B.

gibbus, 502.

gracilis, 502 .

heberti, 499.

macropterus, 503.

macrurus, 503.

notæus, 502.

partschi, 503.

zagorensir. 513

Lebias. 290. - Erispinasus, 503.

aymarài, 292.

cepinalotes, 200 .

crassicautus, 205.

crassus, 296 .

eisgrabensis, 294.

furcatus, 201 .

vaudryi, 294 . 


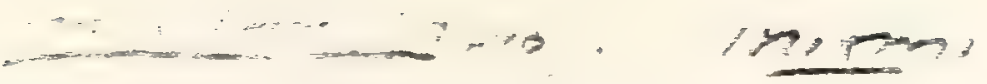

virracion

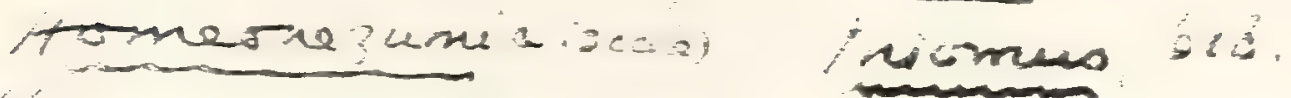

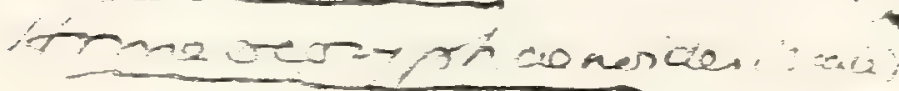

confertiden. on

Huserey 207

depressus, .........

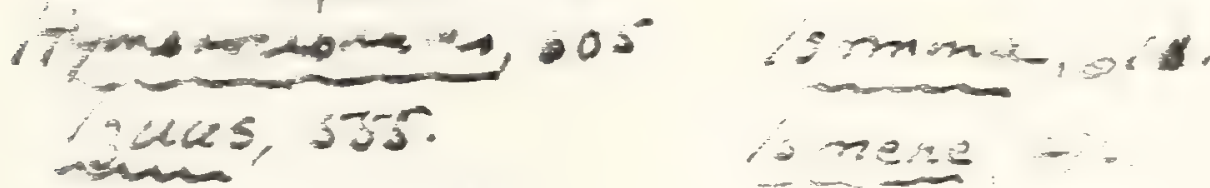

2 resen

hanimuacists

Lavarica, 110.

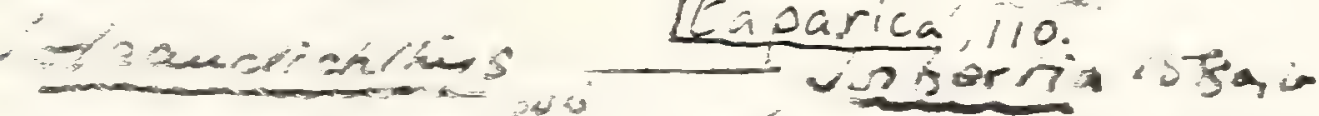

sanciténs.

Semer herbza.

tometounte, 5as.

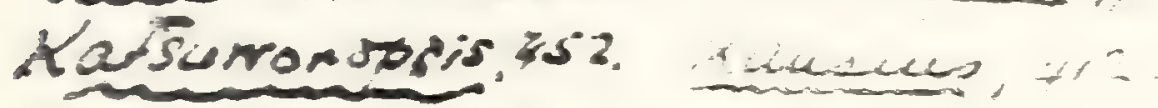

icien, ace

vactionti, :-

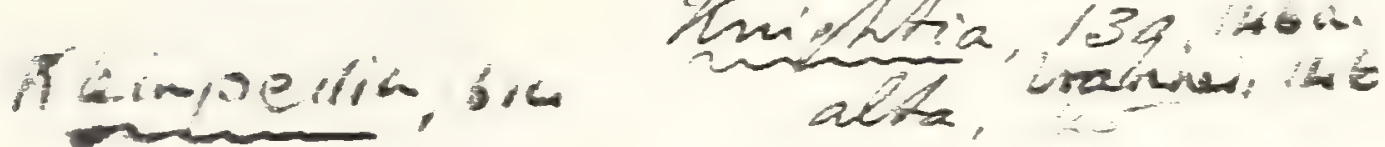

Braena, ice

Tramerizicía 519

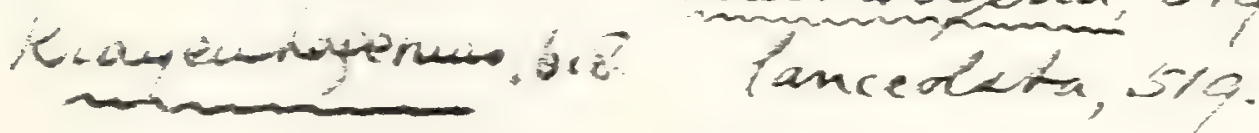

Leminer

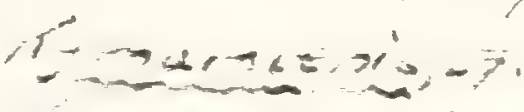

Xamionio, $b=$

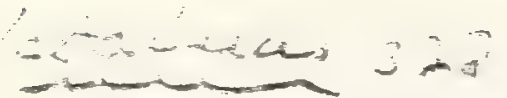
vecens saso

inssix, of

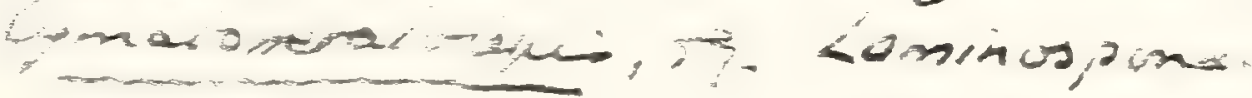

Batima.

Herseumnotion, 20

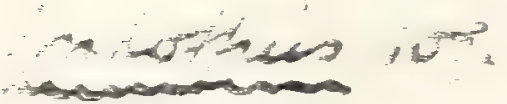

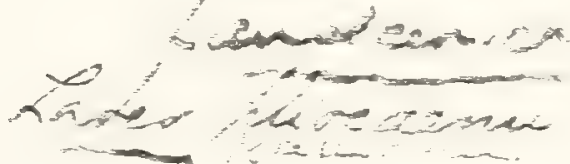

Trueion 스 so

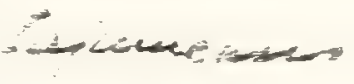

monparivis so

$x+2$

Tin. 205

ats

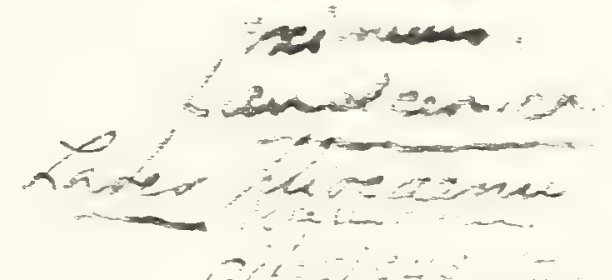

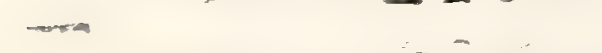

- 3 ind

$-2-3+2+c i n=1$ 


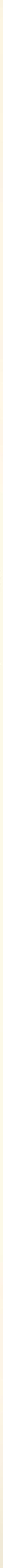



-ebrichthons 16

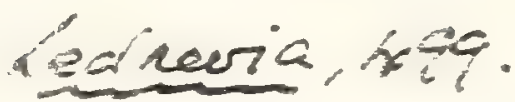

Lemicus, ista.

niklejerimi/sta.

$$
\begin{aligned}
& -2+i a=-0 \\
& \text { *inca, }
\end{aligned}
$$

timpousing, 477

arlatis 479 .

oswardi, 3ll.

moranicus, $3 i$.

pachecoi, 306 .

suabloi, $43 \%$

untrean holenida (sea

reddingi, 323.

$=0.050001092 .77$

2.046.

$=0$ pumanicens 5

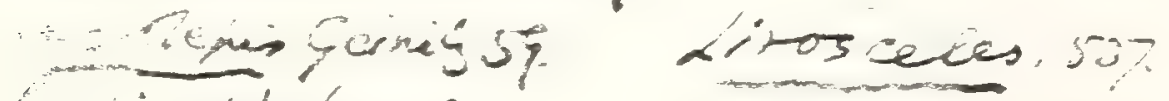

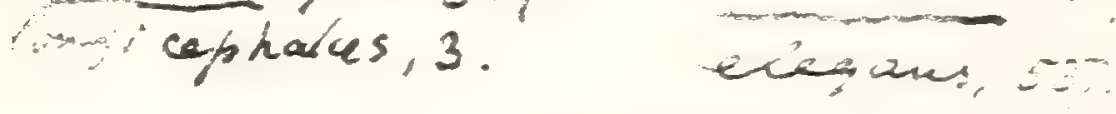

Lompochizes, n.r.s3s.

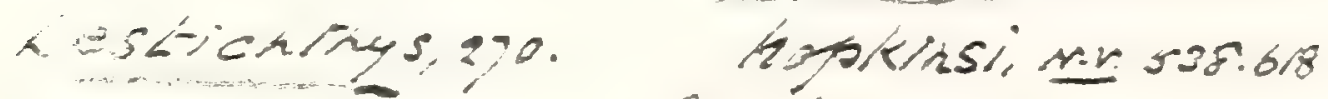

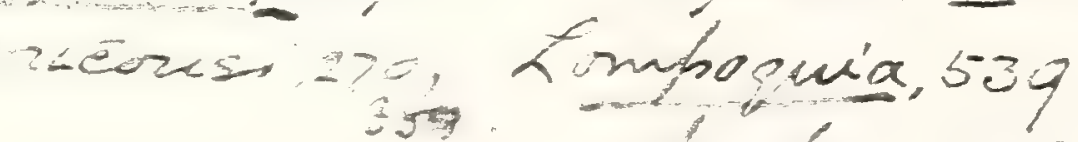

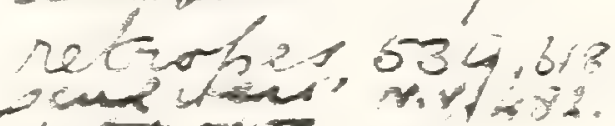

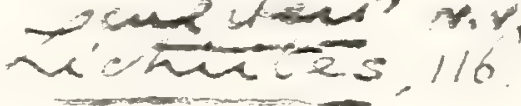

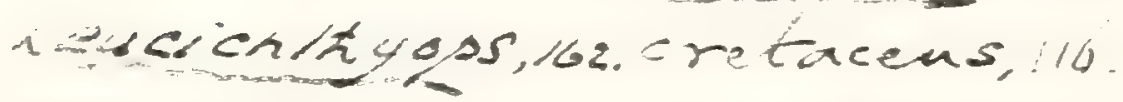

wand, 1 .

Likg $x=2, \cdots$

hulas bo

Lotimnona, 59o.

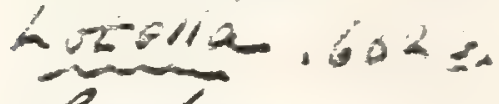

turkia, s21.

caroth: 521.

Lutianidat, 524

Lutiames 524 प्र०45, 3424 nagari, s2s

Luvarus, Nv 482 .

Iygisma, 158 E

tenaxe, 158 6,618

-uxilicen 73

Maceareno, 505.

Maconorides: ascsons,"

Maeropetalolepis, in. Macrensichoriyss. 32 ?

Maena 5.37

Mulacisingenonst.

Manchurichino,

unatokoi!

Mcicusia - sio.

Tis

Pustyctions

Marcullchella 52is:

Matarina, ys

opuna. 453-

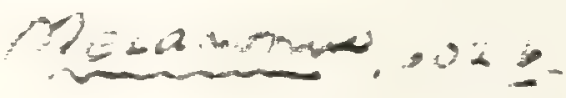

Topiar 4so

muiostemat tro 
Lebias (mont.

gobio. $\therefore \frac{1}{2}$.

meveri, :-9.

minimus. 204.

perpusililus. 291 .

tentus. $: 2 y$ t.

zignoi. $2 n t$.

Lepidenteron. 155.

longissimum. is.5.

Lepidocottus, jol.

iries. 50.

breris.

elongatus. ist.

tracilis, ili.

muitioinnatus. $5 t$

mpyracels, $38 \%$

Lepicopides, 77.

brevisponcirius, toi.

ilubilis. $\frac{1}{4} \mathrm{si}$.

lentosoncirlus. 481.

Lepicopus, $\pi$.

inori. \pm 01$) .2$.

anguis. \pm 0 .

brericaucia. \pm 80 .

"carpathicus tou.

dubius. $\frac{1}{1}=1$.

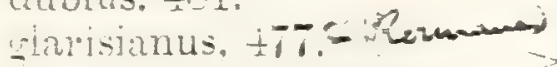

Leprosnondrins, tol.

menernini. $\pm>1$.

Leptecocion, rectus, 233.

Leptichthys, 1016. neitis. ilib.

Leptccephalus, ütt.

zprailis oti.

mecius sto.

lienia. üth.

LEPTOLEP1D.E. 1.

Leptosomus, 241.

oxiopices - crassicosiatus, $2 \frac{1}{2} 65$.

iste. elongatus : 45 .

vuestphailus. 215.

macrourtas $2 \frac{1}{2}$

ininimus. $-\frac{1}{2} t i$.

Leptotrachelus, 173.

urnatus, it.

elongatus, ist.

racilis. 1 io.

hakelensis. Iot.

loneipimnis. 1.7 .

sagitantus. ist.

manerer. 71.20.

riruintus. Ist.

Leuciscus, $: 15$.

acrogister. jlu.

ania.:311.

boniaskia. $: 10$.

revicimuin, :10.

peris :1!.

vinatis. in.

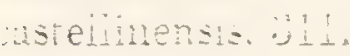

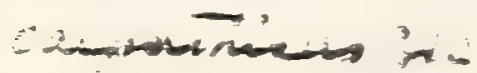

Eeuciscus (1:0nt.).

cecconii. :12.

cenhaion, :

cephalus.

colei. :U:.

dorsuits, :11, : 12 .

dumerili, 311.0312.

eibiswalcensis, 210 .

elegans. 815.

epriniopathalmus. $\because 0 \%$

eurrstomus. 311 .

fritseni. 015 .

gatobrensis. :311.

sibbus, :Il!.

gracilis. 11 . A cones

Gartmanni. 314.

belreticus. 805.

heterurus. 310 .

inantzi.:3il.

larteti. 311. So

latiuscuius. ê5.

leptus, :06?

licatie. 11 .

macrurus, .018.

medius, 310 . rascermun

veningensis 80.

papyraceus, $: 1 \%$.

plesiopterna 811.

polysareus 211.

pueilaris.:il1.

pusilus, ori.

pacrimuci. 11 .

remotus. Sil.

"utilus. 00

Eauragei. $31:$.

sicanus, :11. 312.

stepiani. 311. 013.

tarsiger. 315.

tumeri. 811.

- d.

Leucus,

enncioniruts. 320.

acus. 30.

Leuresthes. 301 .

Lewisia.. .

mais. 5.

Zicsia, 45.

aita, t+ti.

ianitis, to

Lativ. \pm+5 .

n) risen $\div 4$.

secumia, tri.

scompanti. +46.

Losccus.

reciemontantis, nio.

-obcpterus. t15.

nectintist = 15.

inptrin?

Jocinius.

mitrome.

$\therefore 0-\overrightarrow{0}=-3$
Icphius (ont... Juspel

patagonicus, -1)l.

biscatorius. 501.

Loricaria, 5.1.

bjecostonus, -.91.

Joxostomus, 11 .

vancus. 511.

Eucania, -200.

Eucioperca. 21.

storpiii. Jul.

Lucius antedihurianus. 288.

Lutianus epippiuta, $5=\infty$

Joz. 5101.

Iutocieira, it.

Iycoptera, 1.

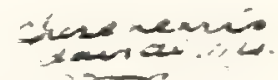

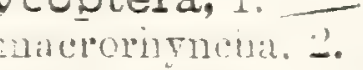

middenciorini. : 2.

sinensis. :i.

$-27 x$

icepirs.

yrioleois

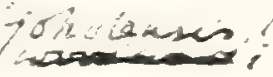

aucisicus, $5 \%$.

Macrolepis, 45.

pionurarus. $+1 \%$.

Macrones, :27.

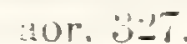

Macrostcma.....

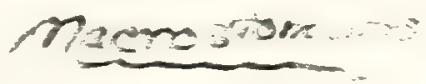

aitum, "il.

MLCRERIDE, iti.

Macrurus, 彷. vrecursur. (h).

Mallotus, 160 . Fiiiosus. lit.

Megalodor. it,

ewesiensis. 1:.

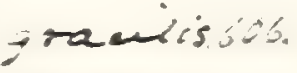

inuaíós.

surroicles. 4.5.

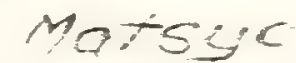

Megaiolepis, $\pm 5:, 5 \Rightarrow$

bascheaensis, to?.

iatus. ta:.

Al Iegalops, 2t.

forcipatus. 10.

oblongus. 26.

mpiscus. '-t.

- Iegaiurtes, ,il.

nicicium. ji:l.

IIegapus, :-1!. zuestalicus. - $8 ;$;

Megistopus, 2-11, 394.

ruestiainus. zsu.

Meletta. Itb.

urenata. 151.

Aolteana, 15o

zacilima. jo

mancisquama. jo.

cecieli. Li.

Leteroscoma. 150.

mermeciia. 1si.

ongimana i i

ausent, .

wamintintes 20

sinter? . . 


Meletta (cont.). surdinites, 152. scheuchzeri, 147. stvriaca, $15 \%$.

Melettina, 151 .

Mene, 437 . oblongus, $4 \pm 0$. pusilla, \pm 1 . rhombeus. $4: 39$.

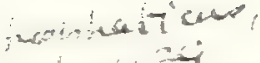

Menidia, 361

Merlangus, 600. cognatus, 604 . spatulatus. 604 . suffulkensis, 600 . rulgaris, $604 \%$

Merlinus, 603. cristatus. 60:3.

Merluccius, 601. To 03.

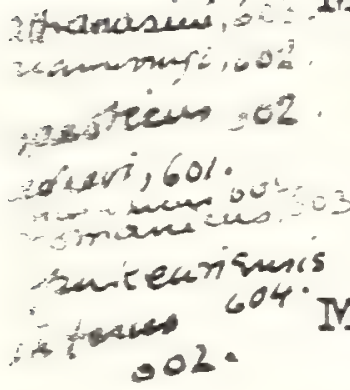
attenuatus, 604. =e9.

balticus, (ivt. manoactas bosniaskii. 601 . emarginatus, C04. miocenicus. $104.2 \mathrm{~m} 59$ obtusus, 604.

Mesogaster, 61. cretaceus, $\ddot{3}$ tiz. graciiis. 254 . sphrienoides. 362 .

Metoponichthys, 556.

longirostris, 5.59 . retacanthu. 5.59.

Microcoelia, $25 \%$ granulata, 2.2. libaniea. "250.

Microdion nuchalis, 4.29.

Microdon pulchellus. $4: 21$.

Mioplosus, 517 . abbreviatus. jl8. beani, 518.

labracoirles. 517. longus, 518. multidentatus. 518. sauvageanus. 518.

Monocentris, $41 \pm$. Coxisis. hospes, 414 . Senaris 43 . integer. 411 subrotundis. $\frac{1}{4} 5$.

Monopteros gigas, 89 .

Morrhua, 5yy atgletinoicies. 601. extensa. 601 . faba. 604 . lancecilata. latia. ist5. maclonterresia. (jo) Ininima. 6i! sellingensis. bili).

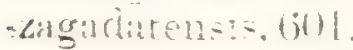

Irsilsullus molilis. A.
INDEX.

Mullus, 53 , 364 . 34 . Nummopalatus, jt1, brevis, 446 . frey 365 . 544 . cephalus, 364 chaderime $36 \mathrm{~s}$

Carres debilis, 365. miniax 305

abbas, 543.

a fricanus, 542. bazivi, 543.

belgicus, $\check{5} 43$.

bourgeoisi, 543 .

britannus, 543 .

chantrei, 543 . cocchii, $5+3$.

edwardsius, 544. gaudroi, $5 \pm 4$. halieri, 544 . heterudon, $54 t$. multidens, 544. pavimentatus, 044. poirodon. 54 a. quenstedti, 545. rhedonum, $5+5$. sacheri, 545 . sauvagei, it5. trapezordalis, jł5.

Myripristis, 410 homopterroius, $t 11$. leptacanthus. +10 . toliapicus, 412 meliten 515,413 .

Myrus, 3010. rulgaris, $: 311$.

Odax carolinensis, jtü.

Odonteus, 5.56. depressus, 556. prgmieus. 556.

Naseus, 564 . sparoides, 556. brevirostris, 564 . nuchalis, 565. lectifions, $56 t$.

Naupygus, 611 . buchlandi. bil.

Nemachilus, $: 20$. bredai, 320 . centrochir, 320 . cephalotes, 321. tener, 615 . inus tevieri, 321.0 primain 320

Nematcrotus, 249 . bottie. 250 .

Nemopteryx, 598.

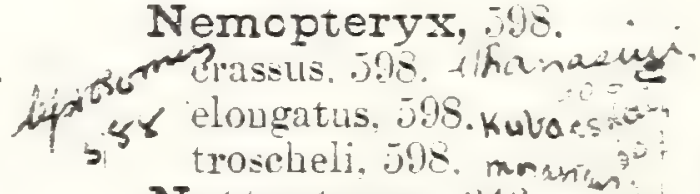

Nettastoma, ith. bolcense, $3+6$.

Notacasturis, 116.

Notacanthus, 1 hy.

Futirus agassizii. jto.

Notelops, -2 . brama.

Notogoneus, curieri, 27. 410. longicens, 278

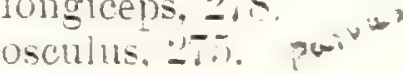
squamosells, $:-70$

Nomprerinte

Notopterus, -ii. plimituris. ati. equamipinnis. jlo.

OPIIOCEPIIILID.E. $360^{\circ}$
Odontost omus, 189.

Oligobelus, :3:? a reiferus, laminatus, 323.

Oligoplarchus, 519.

Omiodon, :70. cabassii, $2-0$.

Ommatolampes, 490. eichwildi. 491

Omosoma, +19. intermedium. $\pm: 20$ monasteri, +21 . pulchellum. 421 . sahel-almie, 419.

Omosudis, 189.

Oncolepis, 595. isseli, igt.

Opindinde. 605. Ophidium, 605. 600 a sim $35-$ poltianum. 505. ezeyano, 600

Ophiocephalus, :6\%. =triatus, tót.

Opinisurus acuticaudus. $\therefore+7$.

Opisthomyzon, fil.

Opisthopteryx, 2.3. urtus.

rateilis . - ot. 




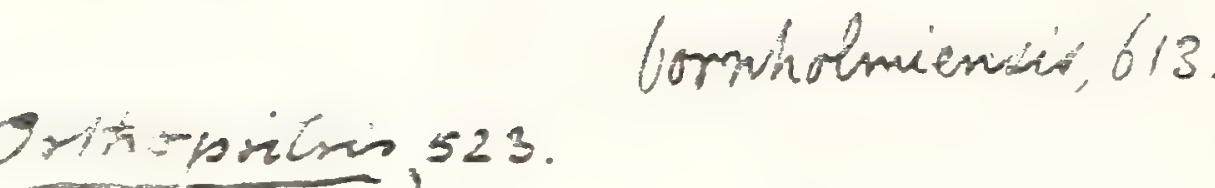

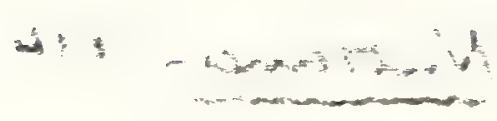

$\because$ iogens, 242

hamprotirensis, 617.

9 aram

Estaciostoma, 129 .

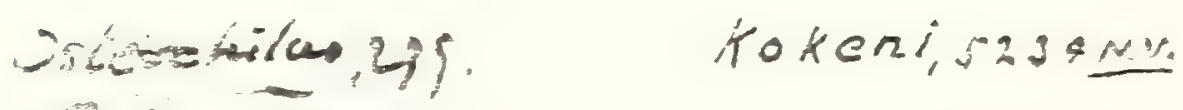

enision, is.

Oxysonibipidus iscale:

Osumandias, $4821 \mathrm{ma}$ gielent: 482rn.v 
Orcynus, tit

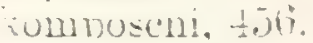
ancerolatus. $\pm j 6$.

intior. 1500

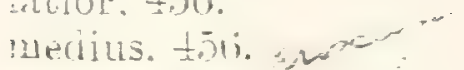

=caidisii, 450

Oricarainus, th.

tortus, \pm i.

Orthagoriscus, 10. (heiononsis. it)

Osmeroides, 11.

atennatus. 1y.

belgicus. 2.2.

uretis. 16.

(- ${ }^{2}: 15=i 1 \leq .10$

cretaceus. - U.

fivaricatas. ㅁ․

dubius. 16 .

eroiutus, i?.

Giarisiantas. - -

Iratis. 16 .

srantulitus. 213.

insignis, let.

litusis. 16 .

levis. 15.5

lewesiensis. $11, \ldots 2$.

lewi=i.1.

manteilii. 12.

maxintis. 18 .

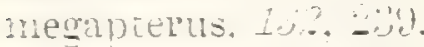

zuicrocentulus ․ำ.

minur. L:3:.

munasteril, 207. 20:0

nectinolepis. 20.

poirmicuodus, i:

sudinivides, 14 .

rindre:sis. "2h.

Osmerolepis, iy.

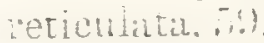

Osmerus, $1 \because$.

aibri. $11 \%$.

corrieri. $2 \pm 7$

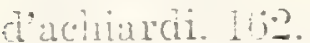

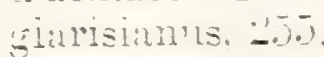

Laveti. L:"

promertegis, igi.

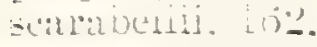

- tilpnus. Ltio.

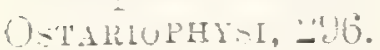

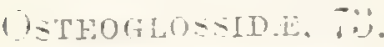

Osteogicssum. $7 \frac{1}{1}$. newustum. -;

Ostracicn. . ni!).

inuperiais. Aiti. ... -

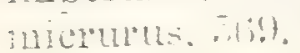

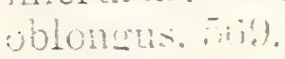

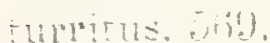

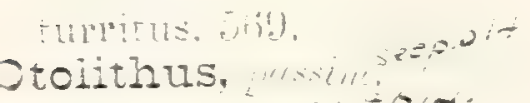
nemmlatlls ij for

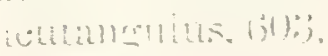

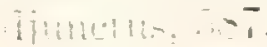

Otoithlis want.!

wquils, $12.2,98$.

atuericants. t.j.

ambius. os?

approximatus. 1510.

attenuatus. 604.

alticus, bot.

bavaricus. boti.

biseissus, 50. gnem,cu

boettgeri. 005.

breriur.

durbornensis.

Majems

circuiers

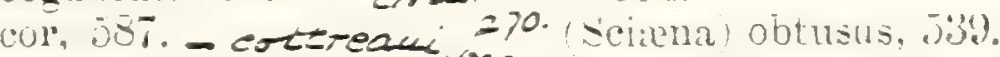

crassus, 3002 . 30 t.

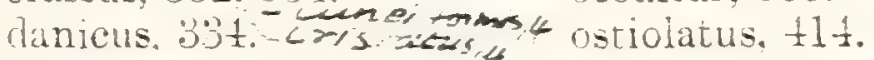

Berreidarun: lebilis, ovatus, 530 . $\pm 15$.

(Musilidarum) debilis. Bo.).

Clecipiens, .80.

cilfurmis, 105.

disbar, jos.

(iistinctus, $20.9 \mathrm{~N} . \mathrm{V}$.

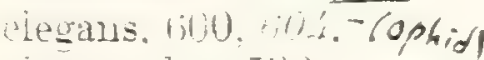

riegantulus. 9ü.

clevatus. $10: 3$.

plipticus, .

e/m joimas, ist.

Yindians.

- pancaneli w

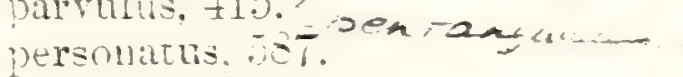

pisanus, $\frac{11}{ \pm}$.

jianus, $104 .-y, c \in \vec{a} i$ is

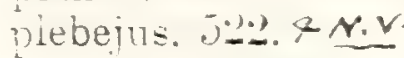

londerosus. Git.

inusterus, $61 \%$.

lrecursol., 1i0.

Berreidarum

surensiz-is

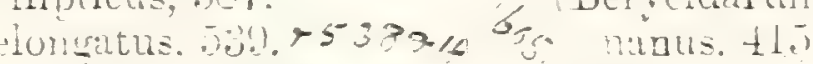

enullorinatus. biot.

epolrectus, eỉs.

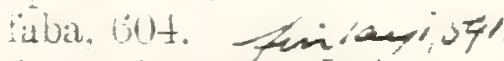

francorurtauns, sos.

frenvens. -2.2.

renima. .

sermanichs, züt.

relon, $\frac{1}{2} 15$.

zioberutus. - 94 .

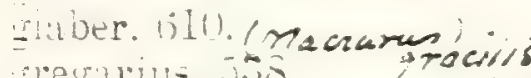

zlegullus.

ruestializus. ill.

inlrendoni. (jojo.

Bosaticus, - - 39)

iruspes. 114 .

is rbiutus. $10 \%$.

ingens. 11 t.

insignis.

insuetus. . on.

integer, 114

internecilus. jo.

iperularis $50 \%$, ackef

Sircubergensis, of o

Heciuatus. \pm 11 .

aviratus. otolo.

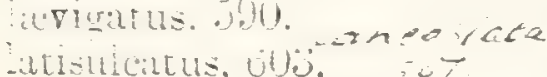

hilus. itis. - ore.

hwlet, 11 .

montularis. bill.

malenicus. 150.5

melidimmitis. ind?

11:101. $10 \%$
Phombus dienantis.

1ilis

saxouichs, $\overline{105}$ ). (Gadid.)

sector. bit!?

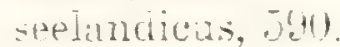

(Murrinal sueilinsensis. 605.

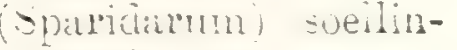
zensis. ory.

imilis. jos.

simbiex. $604 . \cdots$

singularis $6(16)$.

spatulatus. 0114

speciosus.

spectabilis. 604

sulcatus, -io.

Horotrincus. Il suinotizi

utrulkensis. biu. Cacici. -

mmoractaceus, 1ej.

enuis. lit).

restis. 1.s.

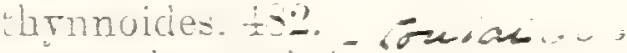

tubereulosus. bijt.

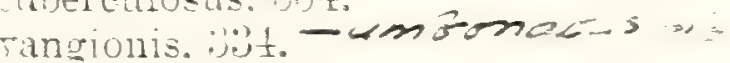

arians. 20.

enusets.

relus. Tis

Finalis. .

minaris. uld.

Pachrcephains. I!

?Hulutili. 

$6: 30$

\section{Pachygaster, 20} polvenondvlus, juge

genciryi, za spinosus. 520 .

3060.294 . Pachylebias, 294.

recaltrmari, 311 crassicaudus, 295.

formon, 215. Pachyrhizodus, 37.

basalis, 37 .

caninus, 44 .

curvatus, $t 4$.

diblevi, 38.

gardneri, to.

glyphodus, 258 .

gracilis, 45 .

kingii, +2.

latimentum, 4\%.

leptognathus, 45.

leptopsis, 45 .

marathmensis 10 minimus, 45 .

sheareri. 45 .

subulidens, 43.

velox. 45.

Pachrstetus gregatus, 29.2 .

Pagellus, 532.

aquitanicus, $0: 33$

Snoinori, $533^{2}$.de steranii. $53 \%$.

elegantulus. $53 \%$

leptosteus. 5.33 .

libanieus, $: 000$.

microdon, .53\%.

peruzzii, 503.

stenoura, 5.93.

Pagrus, 533.

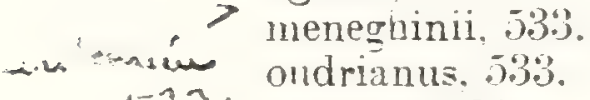

pileatus, $53 \%$

priscus. 533.

torus. 53 t.

Palæobrosmius, 598.

4.p = ráá elongatus, 598.

in jerimu troscheiii, 598 .

Palæolycus, 211.

dreginensis, 211 .

Patadorirychide, 482.

Palæorhynchus, 483. bruxeiliensis, 490 .

colei, 488 .

deschmanni, 487.

egertoni, 488 .

giganteus, 487 .

glarisianus, $483,48 \%$

graclis, 486 .

latus. \pm 85 .

longtrostris, 486 .

medius, 485.

mierospondiclus, 483 .

riedli. 487 .

zitteli. 487 .

Palanarrhichas. crassus. 597.
Palimphemus, 270 . anceps, 270.

Palimphyes, 460 .

brevis, 460 . crassus, \pm 60 . elongatus. tho. glaronensis, \pm 60 . grarilis, 460 . latus. 460 . longus, 460 .

Pantopholis, $2: t$ dorsalis, 2034 .

Paralates, 5:0. bleicheri, 520.

Paralepis, $25 \%$.

Paraleuciscus, :31:2. ecnom1, 312.

Paranguilla, : 13 . tigriuit. 343.

Paraperca, 520 . protincialis, 520.

Páraphyllodus, 546.

Parascopelus, 256.

lacertosus, 2056 .

Parequula, 450. albri, 450 .

Pegasus lesiniformis, 269.

Pegasus natans. 383.

Pelamys, 48\%. adunca, 482 . robusta, $48 \%$ sard $\alpha, 8^{2}$

Pelargorhynchus, 188.

blochiiformis, 188. dercetiformis, 188.

Pelates, 523. quinclecimaiis. 523.

Pelycorapis, berycinus, 354. varius, 354 .

Perca, 518.

alsheimensis. 513.

beaumonti. 515 .

cyprinodon. jog tounes?

elongata, $515 \%$

fluriatilis, 518.

forbesi, 510 .

formosa, t10. ignota,

lepidota, j11. a s

lorenti, 518.

lucioperca, 511 .

macracantha. 518.

minuta. 506.

moguntina. 512.

punctata. 866.

radula, 526.

rebonlii, 500.

urasehista, 516.

Percesules jat.
Percichthys, 511.

antiquus, 514 .

beaumonti, 515 .

Percide, 498.

4 GI. Perciforses, 497.

Percostoma, 519 .

angustum, 519.

Peristedion, 586.

personatus, 587.

urcianensis, 586.
Phacodus, Cope, 553. (aisu $\overline{i 11}$ irregularis, 553.

Phacolepis=Rhacolepis

Palacrus, 458 .

25 cybioides, 458

Phareodus, 74, 76 .

acutus, 76 .

sericeus, 76 .

Pharyngodopilus,

$5+1,540$.

abbas, $\overline{5}+3$.

africanus, $5+2$.

alsinensis, $5+4$.

bourgeoisi, 543.

canariensis, 542.

carolinensis, $54 \%$.

crassus, 544 .

dilatatus, $54 t$.

haueri, $5 \pm 5$.

multidens, $5+4$.

polyodon, 545 .

quenstedti, 545 .

sellæ, $\check{5} 5 \overline{\text {. }}$

soldanii, 545.

superbus, 542.

Phasganodus, 190.

anceps, 203 .

australis, 615 .

carinatus, 204 .

dirus, 204.

gentryi, 615.

gladiolus, 204 .

semistriatus, 20.5 .

Phasganus, 613. declivis, 613 .

Pholidophorus macrurhynchus, 2 .

Phycis, 602 .

. suessi, 602 .

Phylactocephalus, 212, 218 .

microlepis, 218 .

Phyllodus, 546.

bowerbanki, 54 .

culei, 549 .

corsicanus, $57 t$.

cretaceus, 5.50 .

curvidens, 550.

deborrei, 550

deplessus, 500 .

durali. jou.

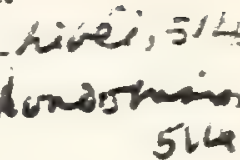

544

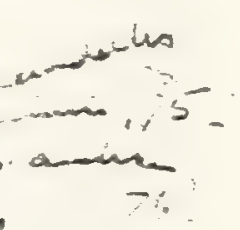

(n) 


Praegraberiza, of

Provicantrescx, sil

PRIACANTHADA HYS.

Fiacenturs, 563 .

Lolastas, 363 .

Plectrites 536 . spinosus, 500.

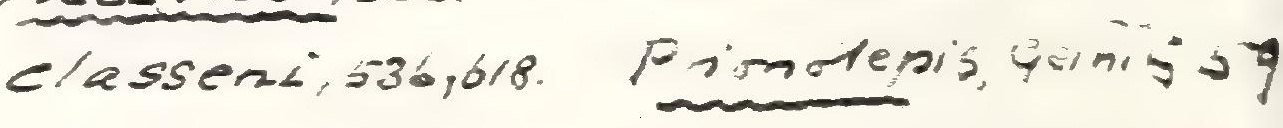

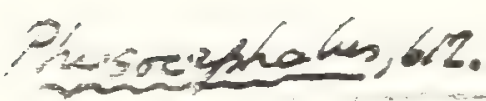

Psiculus, 606 .

A. Scandatín 606 .

P,tistana, 235

minimus, 235.

instienius 594

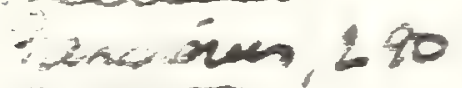

Poangentina, 162

Protaikigadus scale

irudiodon $5 \%$

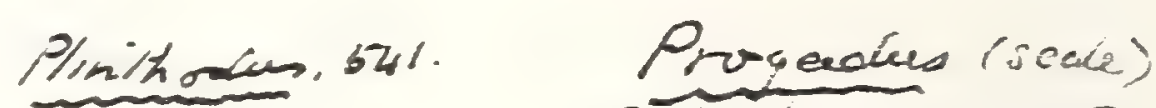
Procharax, 298.

pisani: 542

sismondianus, 545. Problennius, 5.?.

pliosieurus, 325. Fianeniosus, ston.

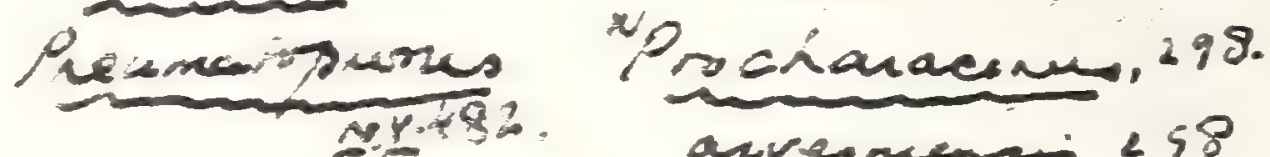
acrerncensi. 488

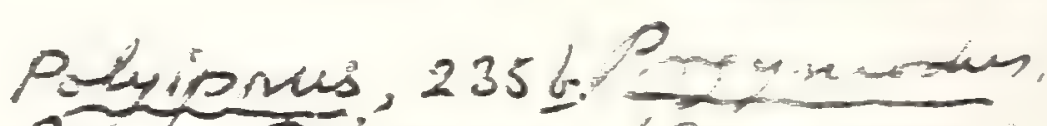

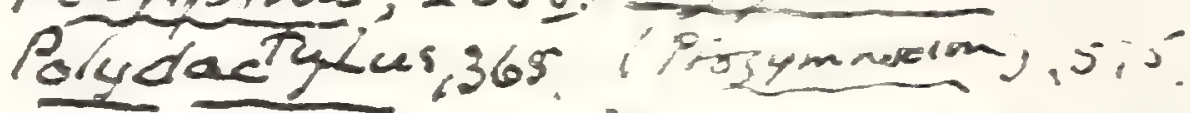

Polypterolepis, III. Prothdirencon,298.

Pomadasidae.499. pellegtini.258.

POMATOMIDAE TSY

Pomolober $156 \leq .16440$

Pmoxis, 554
Promacunes (sok)

Permerlusesius 599

ondirsoris gro

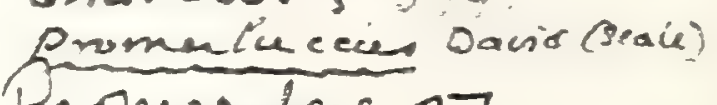

Promegalops 27.

Prostercenina, i99,

ereli, 499 .

Feeracimann

Probor then: 
Phyilcaus (mnt.).

elegans, j.o. servisi, jon. haneri. $54 t$. hexagonais, ity. hipparionsx, (il\%. incertus, 575 . inconstans, 5.) irregularis, j+o. latidens, 5.50 . levesumei, 5.50 . marumalis. jto. medius, $\bar{j} 48$. multiciens, itt. petinlatus, $5 \pm 8$. planus. $\overline{0} \pm \vec{\gamma}$. poirodus, $5 \pm 1$. secundarius. j $4 \%$. speciosus, 5 te. subdepressus. $5 \pm t$. subuecius. $54 \%$. toliapicus, jti. umbinatus. jon).

Pimelodus, "̈ll. antianus. 3209 nor $\because 27$. sacileri. 335.

Pisodus, 60.61. founardi, ï. otreni. (3).

Plagyodus, 189.

Planesox, j1\%. тolas. 519.

Platacanthus, 509. ubinoi. 510.

Pla aicissimus. 493. brevis. \pm 09 . colcuicus. $\frac{1}{2}$ t. costacus, \pm 0. cuneus. \pm 30 . macropterveius. 133. minor, $+3 \%, 28$. nucualis, \pm 209 papilio. 133 . bingseteroicle, to.;. pilenm, 㸺范. pinnatiolmis. $198 \%$. binianus. 430 . subresmertilio. 198. Tocrivali, të.

Platessa, 608. ser.tor, b09.

Dlatinz, sy. atuili. $=9$ zionutus, 89. zigas. so.

liatcps. 10. subuiliens, 70.

Platycormus. $\$ 21$. jermanus, 1.1.
Platycormus cont. gibbusus. $\pm 0 . \%$. ijolongus. t:-

Platygenys, $61 \%$ inusus. bi:

Platylamus, jul. colei, 5.51 .

Platylates, 20 . rupeliensis, 520 .

Plecropoma uraschista. $516,016$.

Pleionemus, $4+2$. microsnondirius. $t+2 \cdot$.

Plethodus $=0$.

expinsus. 81 . furcatus, 84. oblongus, $8 \%$. pentafon, 53.

Pleuracinthus serratus. 567.

Pleuronectes, 60. platessa. qút, 1ill!. guaciratulus, 194.

Plecronectid.e. Gili.

Plinthopinorus, :-1. robustus, $20 \%$.

Plioplarchus, $5: 0$. septemspinosus, j:0. sexspinosus, $5: 0$. whitioi. 500.

Podocephaius, 519.

nicicius. j1\%.

Podecys, -10 minutus, .jo0.

Pcaoperyx, 587. albyi, ist.

bosurasit. 537.

Pecilia hanetheri. (ilj.

Pecilia oeningensis. Joz.

- cacilops, 20. breviceps, zlo.

Pogonias muiticientatus. 5 .

Polynemus, 145 quinquarius, $\pm 11, \frac{1}{2} 46$.

Pomacanthus, jil. subareuatus, stil.

Pondcextride. Jej.

Pcmapinactus, 76. egertoni, 76.80 .

Pomognathus. 21:. 1 .

euvrelrgius, 21:0.

Portheus,

ingulatus. Is.

acuatus. 101.

a ustails. 97.

bmenronuchus, 7.

dariesi, 3.

ratints, 15.

- iacios, is.
Portheus ciunt.)

Iestrio.

lowi. 7.

manteili,

molussus. !o.

mudiei. $\%$.

thaumas. 17

Prionolapis,

angustus, 200

ataphractus, 200 .

liniatus. 23:2.

Priscacara, 5.5t.

ulicosa. int.

crpha, 55j.

liops, 5.55.

oxyprion. 555.

pealei, 55.5.

serrata. jest.

restudinaria.

Pristigenys, 415 .

macropinthalums, +15.

Pristipoma.

incatum, je:

Prcantigonia, jo, evio

longirostria. joty. apresso

octicantha. 59.

radobojina. 5.59. - -netaibus

steindiatneri. 50.

Proballostomus, $206 \%$ loneruius. 216.

Prochanos. rectifrons. 1.5.

Progymnocion, $5: 2$ jo.

hilgencior $\mathrm{n}, 575$.

Prolates. 199. Leberti. t:19.

Prolebias, - 400 . brongniarti, 218.

cephalutes, 200 .

crissicaucius, 205.

davicii. $t$.

egeranus. 615.

furcatus, 291.

gauciri, 294 .

robio, 294.

goreti. $-9: 3$.

gregatms. 202.

meyeri. ont.

minimus. 294 .

oustuleti. 293.

pernusiilus. 291

puicheilus, 615.

stenoura, 20. .

Pronotacantius, 169.

sidiei-aima, $16 y$.

Properca. jit.

angusta. j15.

beaumonti, 515.

Lepiciota, jil.

priscit, 516 . 



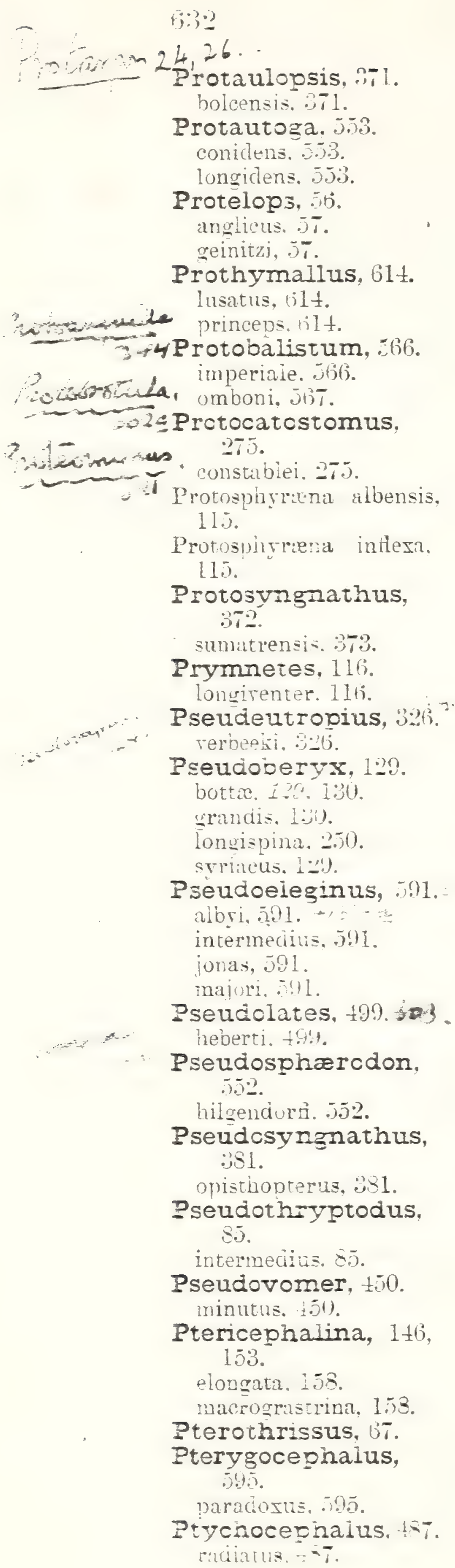

INDTE.

autalius, gáe.

Pycnosterinx, 391.

daviesi, $390 . \overline{5}$

discoides. 393.

dorsalis, :392, 393.

dubius. 395 .

elongatus, 395.

gracilis, 394.

heckeli, 390.

latus. 395.

lewisi, tot.

niger, 392.

russeggeri, 392.

Pygacanthus, 613. altus, 613.

Pygæus, 557.

coleanus, 557 .

dorsalis, 5.58.

egertoni, 5.57 .

gibbus. iñ.

gigas. 5.58.

jemelta, 579.

nobilis. 538 .

nuchalis, 058.

oblongus, jis.

Rndamas, 536.

jugleri. 536.

Raniceps, 603. latisuicatus, 603. tubercuiosus. 60 t?

Raphiosaurus, $37,40$. lucius. 43 .

subulidens, 43.

Rhabdofario, 160.

lacustris. 1601.

Rhabdolepis. March, 11.

cretaceus. 20

Rhacolepis, 29 . brama. "20.

buccalis, 30.

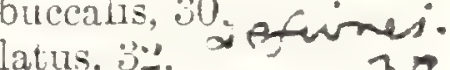

latus, 32.

30.

olfersii, 28

Rhamphognathus, 361 .

paralepoides. 361.

pontilius, étil.

sphrranoides, 662.

verneuili, 362

Rhamphornimia, $20 \%$

rhinelloides. 269

Rhamphosus, 37T.

aculeatus, $37 \%$.

biserratus, 878.

Rhineastes. 020 .

arcuatus. 823 . is tepitiensis, 61 t.

calrus. 320\% granch SALMONID.E, 159. pectinatus, ing peltatus, 20 ?
Rhineastes (cont.).

ritulus, 330 .

rhaas. 329.

smithi, 330.

Rhinellus, 265,269

curtirostris. 269.

damoni, 263 .

ferox, 267.

furcatus, 236 .

laniatus, 23:2.

longirostris, 282.

nasalis. 2699 .

robustus. 268 .

schilli, 2169

tenuirostris, 269

Rhinocephalus, 60\%.

planiceps. $60 \% 3$.

Rhipidolepis, 613. elegans, 613.

Rhodeus, 316. edwardsi, : 217. elongatus, 316. exoptatus, 317.

latior, 317.

magnus, 317 .

oligactinius, :316.

Rhombus, 1606.

abropterrs, $60 \mathrm{~s}$.

bassanianus. 603.

caudiatus. 608.

cutrensis, 608.

fitzir geri, 608.

gentiluomoi, 607 .

heckeli, 608.

kirchberganus. 609.

ligusticus. bos.

minimus. 607.

minutus $(608$.

nardii, 6 ! 5

parrulus, 608.

puenanis. (308.

richiardii, bus.

sauvagei, $608 .$. ro

Rhonchus, 453.

carangoicies. 453 .

Rhynchorhinus, if?.

branchialis, : "4:.

major. ¿'t?.

Rita, 23.

grandiscutata, 329 .

Salmo, 159.

crprinoides, 456.

immigratus, 160.

derzhavini

lewesiensis, 11.

marxua. 6.3.

Sandroserrus reboulii, - 19. 
ppuenolebis, Gan. ill

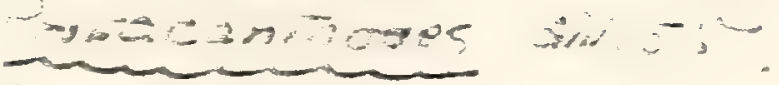

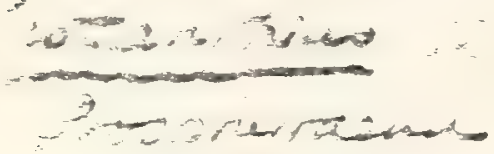

$$
\text { it }
$$

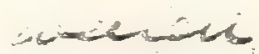

$2^{2} \cos 2 \cos 20$

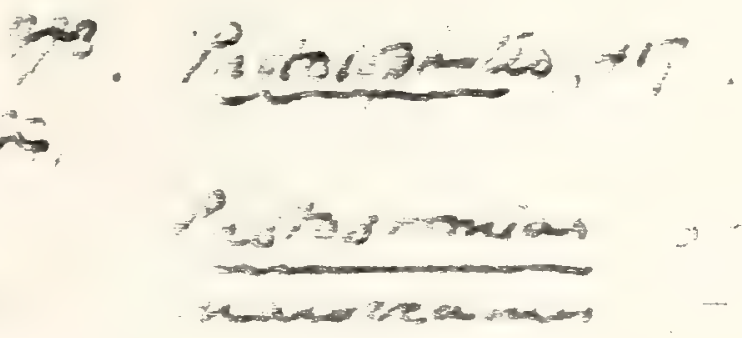

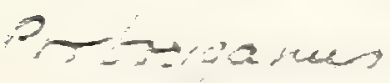

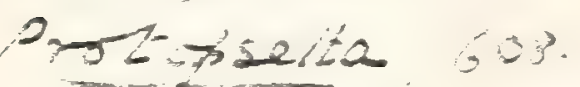

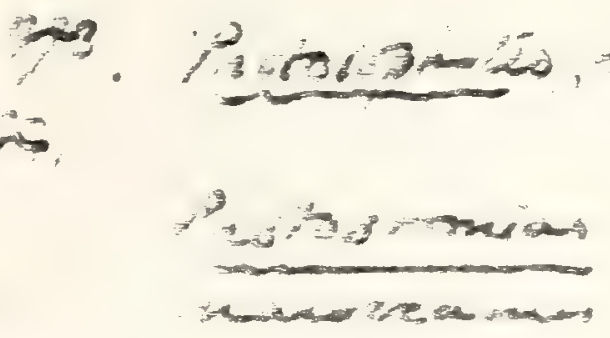

paculatio.

T-

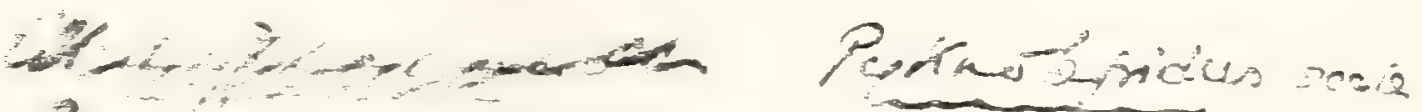

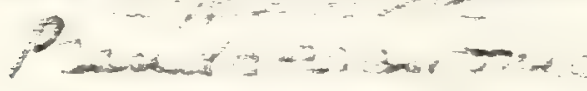

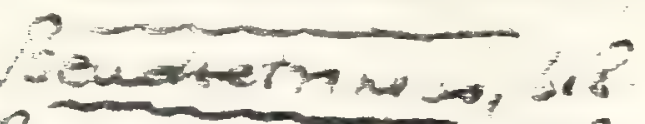

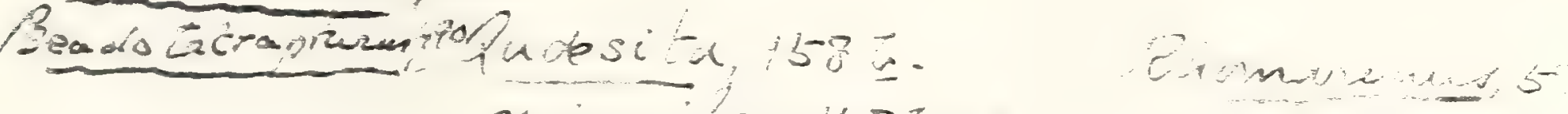

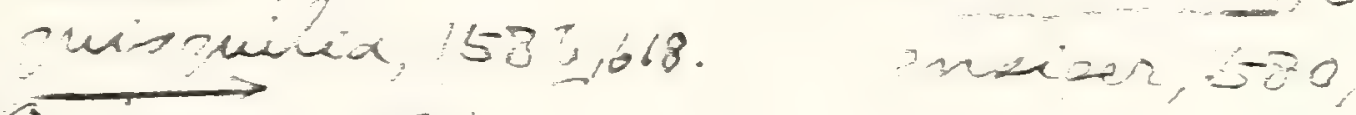

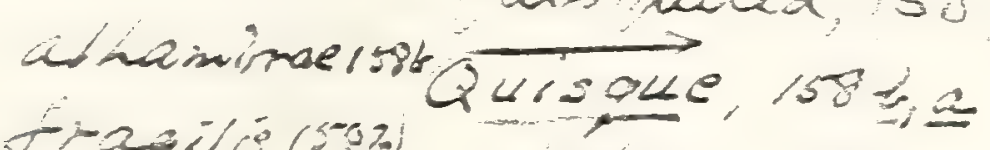

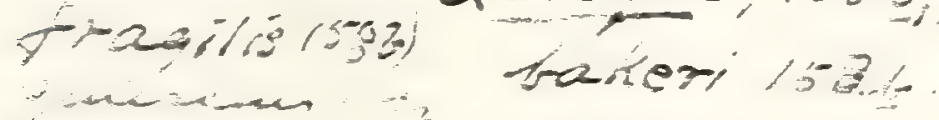

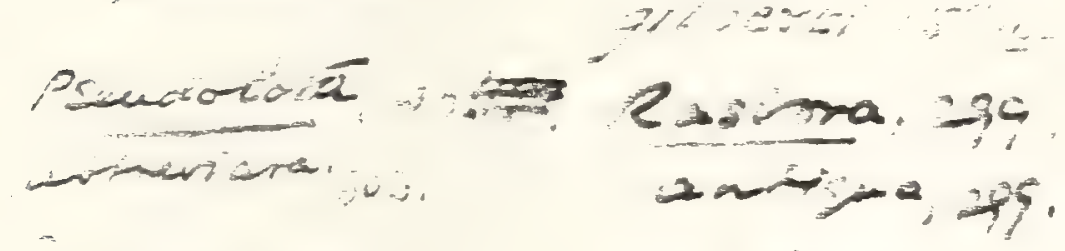

and

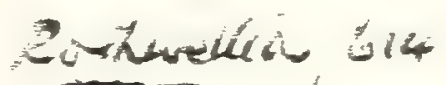

$\operatorname{man} 3$

Phomenrus :-

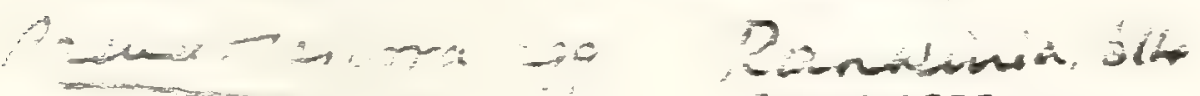

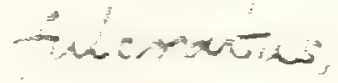

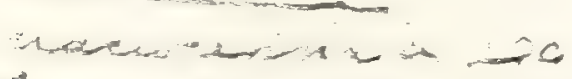

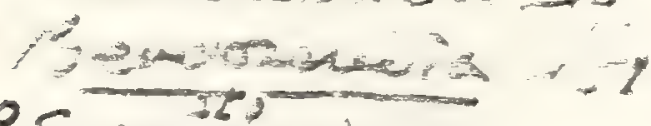

Sisgmiosis. 0

Pyizans

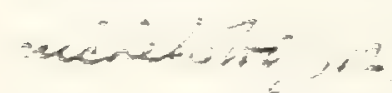

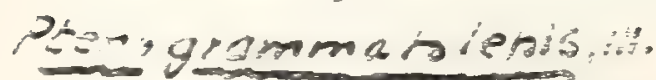

Priziniag, 235.

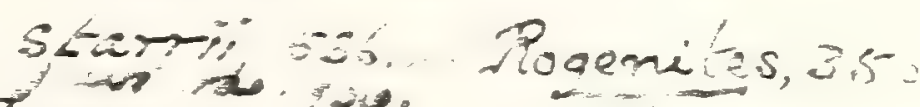

Pizc-orso: Popenio 35

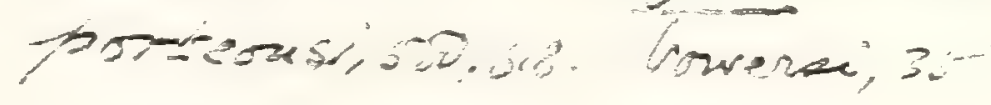
ireger

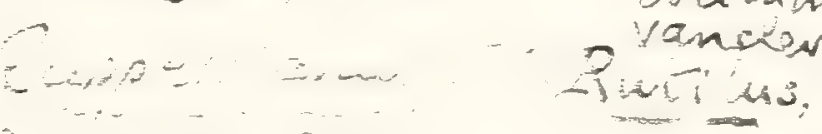

spituanis, ... vancessin,

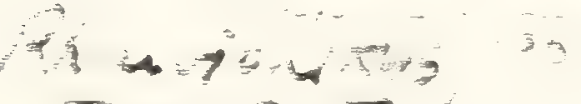

consionsemes an?

$\therefore$

$\therefore$ wionsines

Pundios =-

insurios. 


Sanar guseñus?

ematsis, 242.

Cin's ins, 248 .

Cuncein-11a, $1580,5.155$.
Seomieressus, 358. acutillus, 355, 618. edwardsi, 358

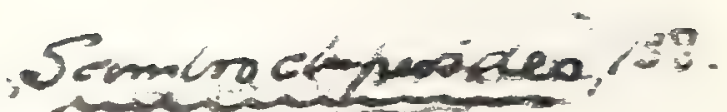

Sehisoshondulus, 188.

dubiess, 188.

-3iemara, 45\%

yzuéeri, ys?

Scianivis.538.

Tetastaves, 580.

vertabralio, 580,418

$\therefore$ axing, 107.

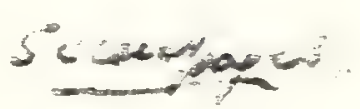

Selacotinus, 580 .

tampic, 580.

Serastoèsus, 480 .

apoutates, 580 -

iswitinapus, $1 / 4$.

Sedenkorslia, 252 
Sarainioides,

zMbirostona. $20 \%$.

rtenuatus. $-\frac{1}{2} 1$.

-rassicallais. 200

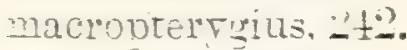

megroterus. - \%?.

microcedialus, 20\%

minucus, 2 12 .

monasteri. 11. 207.

pusilus, 2to.

cenuicaudns. 2:2.2.

Sardinius, -17 .

blaciburnil. $2 \frac{1}{2}$.

rassapinna, 182.

colcieri. 2ti.

lineactus. $2 \pm 8$.

uacrociactrius, 131.

nasutulus. 248 .

percrassus. 218 .

pobustus. 13L.

sargus.

untbronodion. 500

autranicus. 80.

armatus. $580,50$.

baraidii. jos).

zaramnai. 50

envieri. $330,61 \%$.

heverti. 5:00.

incisirus, 520.

imnitanus. 5.80.

ationus. 20 .

unensis, jo.

meni. 331.

sesuccuritanus,

serratus.

sioni. 531.

sicirensis. 50 .

Saurocephalus, 113.

libensis. IIt. smanahovius, 111. aucias. 2.

bronàneaui. 11 u.

dentatus. 11 t.

disnall. 115.

filjumensis, 115.

minauis, 115.

intexus, 115.

intermeains. 112.

ancirormis. 113.

eanus. 111.

Ircocion. 204.

corginatus. 202.

monusterii. ils.

niniebotomus. Il:

picteri, 115.

prognaturus, 107.

scriacus. $-150,010$

Enostriatus. 11.5.

- Hatumas. 8.

roociwarui. ilf.

Inims.
Saurodon. 111.

atfinis. 113.

broacibeaci. 11:

conoideus. ilu.

feror. 113.

intermeailus. 112.

lancifurmis, 113.

leanus. 111, 201.

marginatus, 2.29 .

piliebotomus, i12. prgmieus. 113.

$>$ xiphiroscris, 113.

Saurorhampins, 207 . 210.

freveri, 210

Sauropsidium. 58.

oraciicauda, $j 8$.

Levissimum, s.

Seariinius dumeriil. : 71.

Scarainius sicanus. 911.

Scarus, 5.53

baitringensia, 530. 5.31.

miocenteus. 550.

otreni. 31.

suericus. 553.

tetrodon. 558.

Scatophagus, 561.

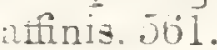

caveilinii. 501.

frontais. ótil.

Sciæna. 539.

ampius. $5 \%$ ?

hulsaticus, 539.

irreguiaris. $39 \%$.

jaculatrix. 561.

sirehbergensis, 539.

meridionais. 589.

votusus, 509 . gim $=\mathrm{crat}$

piumierii, 521.

speciosus. 520 .

uncieciraalis. \pm \pm .

SCI.EXID.E. 538.

Sciznurus. $524.50 \%$

botrerbanisi. 527.

bretior, 5-7.

crassior, $5-7$

longior. $51 \%$

Selerognathus, 000 .

Scomoer, 459 .

aiatunga, $156.90 \times-9$

corcitia, $4+5$.

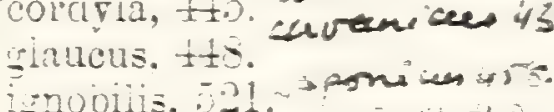

orctnus. $t$.

pelagicus, \pm 14 .

selamis. $40 \dot{t}$

Hianoratus. \pm 59

2.iscus, $\pm \overline{5} 9$.

Tomous. 439

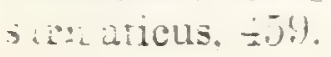

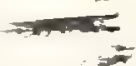

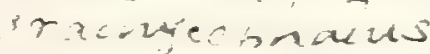

202
Scomier (cont.).

speciosus. $\div 6(6)$

steinciacuneri.

suiecianus. $\pm 5 \%$.

thrnnus $455 \%$

racinurus, töt is v oits

Scomiorodon. $=155$. उ山wis

dumonti, \pm 70 .

Scombramphodon. $\pm 7+$.

benedeni, $\pm 7 t$.

crassidens, 175 .

curridens, $17 \pm$.

$\therefore$ COMBRESOCIDE, Jü.

Scombresox, 357.

licatre, 858.

obtusirostris. 350

Scombrid.e, 451 . 7305

Scomibrtaroues, 418.

Scombrinus, 1 til.

macronomus, $46 \%$.

nuchalis. $+i j l$.

Scombrociupea. 195.

gaucirri. $1: 35$.

macrophthaima. 185.

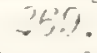

pinuulata. 135.

ECOPFLtD.e. 205.

Scopeicides, 2.5t.

sianisianus. 25.j.

nicolisi. 256 .

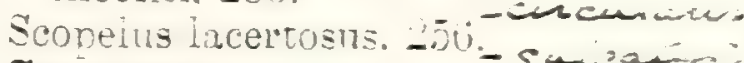

Scorpena. $5 \%$.

minima.

pilari. 579

prior, 570 .

serota. jot.

iessieri, 579

SCORP.ENIDE. $57 \%$

SCORREMIEORUES. $5 \% \%$

Scorprenoides, s.ju

poporicii. Sou.

Scoromopterus.

50.

silumiens, 580.

SCYPIIOpIIORI, 1.

Sebastodes, 570.

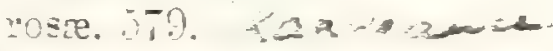

Semiopinorus, $\pm U$.

gass. \pm .30 .

massalongianus. $\angle 1$.

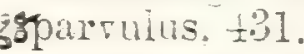

E0uaeroedi.

relizans,

Felifer.

Semotilus, 820.

barci, "2:.

yoscicus. $: 2 \%$.

Sericia. $\pm t$

mais, $\frac{1}{ \pm}$.

bealumonti, $\frac{ \pm}{A} t i$

$$
\because I
$$

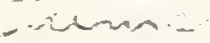

tracilis, - 



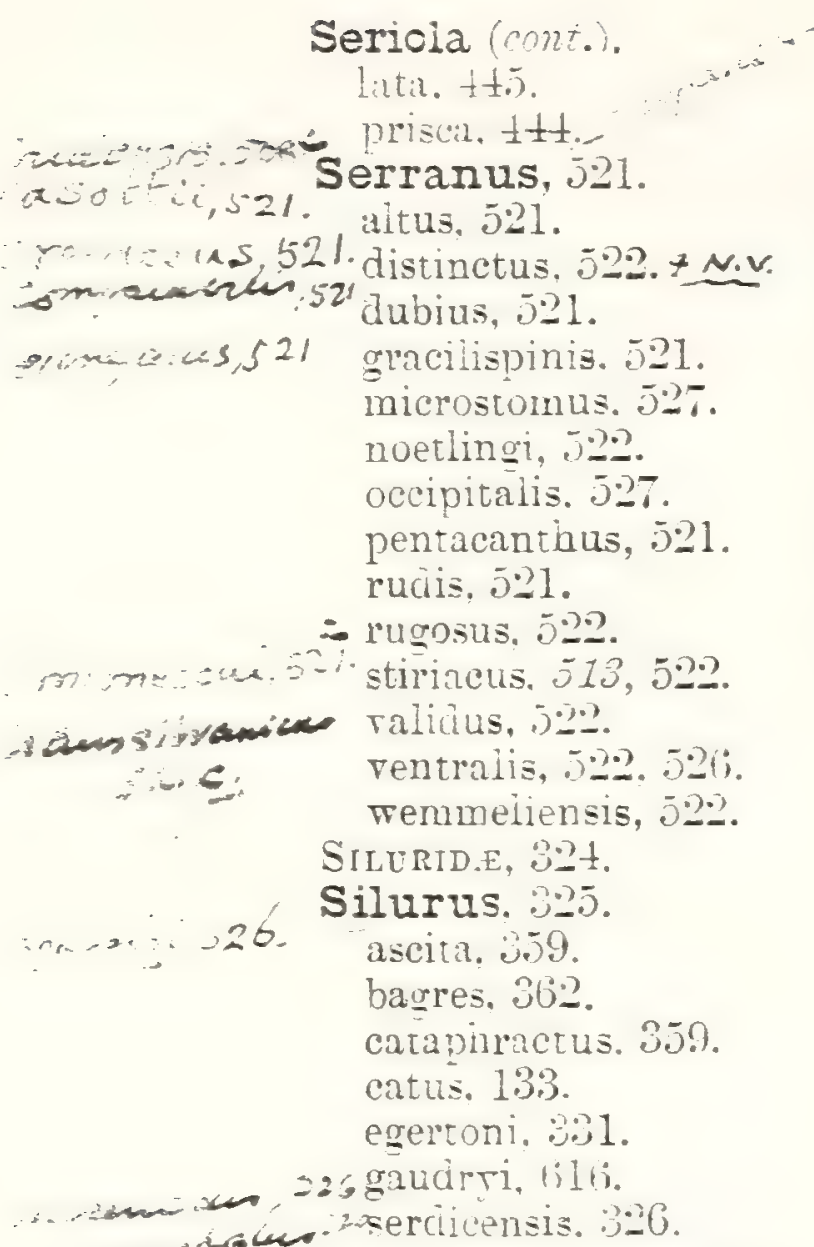

Siphonostoma, 25. albri, is?. casteilii. 98.2.

Smerdis. $511 \%$ aduneus. $50 \%$. anails. 00. buclensis, JuR. elongatus. 508 . formosus. 517. heersensis. $50 \%$ isabeiliz. $61 u$. latior. 508. lorenti, 515. macrurus. 507. micracanthus, 504 . minurus. 506 . premæus. 55. rioensis, 509. sancibergeri, 500 . sauragei, 509. sieblosensis, 509 . tarameilii. 509. Tentrais. 509. 616.

Solea. 509. antiqua. 610. anneximata. 610. 'oliver. b10. questialica, 611. Lircibererana. 600. lenticularis. ill. prorinciais. 611. sautraei. 311.

Solencdon. 100, lesimensis. :21!?.
Solenodon (cont.). lobopterroius, 219 . neocomiensis. 20t.

Solenognathus, Piciet if Humbert, 271 .

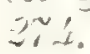

lineolatus. $27 \frac{1}{4}$

Solenorhynchus, 380 . elegan:, $: 00$.

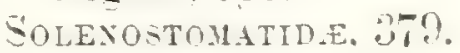

Scricidens. $32 \%$ Laueri. 3i:?.

Spanicdon. 40.

blonneli. \pm 2.

breris, 53.

electus, ts.

elongatus. $j 1$.

hakeiensis. 27.

latus, 5:3.

lepturus. it.

simus, 53.

SPARIDE. 521.

Sparisoma,

Sparnodus.

altivetis. . - is.

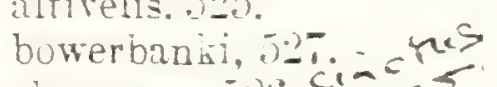

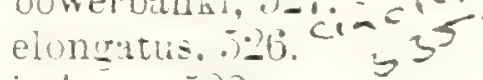

intiatus,

intermedius. 5.8.

lethriniformis. 525.

macrophtiaimus. 525.

micracantinus, 525.

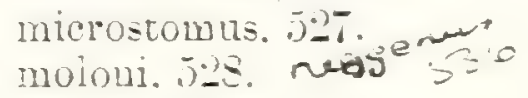

oralis, $52.5 .<$

Sparcides, 5.7.

molassleus. Jü

robustus. Ji,

splaricus. 5.87.

tenuis. 537.

umbonatus. 537.

sparcsoma, 320.

ovalis. 503.

Sparus brama, 527.

sparus buicants. Jesenancenottii, \pm 70 .

sparus chromis. 50.

Sparus dentex, 525.

Siparus ervtininus. 525.

sparus macropinthaimus. 525.

Sparus saina. 50.

sparus sargus, 505.

snarus Fugaris. 50. 5.7.

Spathodactyius, neoromiensis. !?.

Sphærodus, .i.

annularis. $50.5 \%$

andiasii, st.

cinetus cón.

cinguiatus. jo5.
Sphærodus (cont.:

conicus, 537.

depressus, 536.

discus, כ̄36.

insignis. 537.

intermedius, 537 .

liergomardius, 535.

lejemnianus, 50.

lens. 530.

ocuius-serpentis, 537.

parrus, 538.

poirodon, . 545.

prgmaus, $\overline{4} 35$

subtruncatus, 530.

truncatus. 588.

wiechmanni, $5: 8$.

Sphagebranchus. $34 \%$ pusillus, 347.

formosissimus, :

Sphenocephalus, $3.8 \%$.

cataphractus, 388.

fissicaudus. BSt.

Sphenolepis, Agassiz, $2-5$.

curieri. 27.

squamosseus. :-7?.

Sphyræna, 266.

amici 209.

bolcensis. 366 .

carinata, 20t. raxeditass

crontica, 3is.

racilis. :260\%.

intermedia, 867.

major.

maxima, :iti"

speciosian 368.6165.

sternbergensis, 20 ?

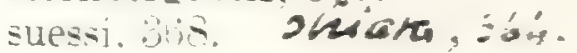

trrolensis, 616

viennensis. 206 pannar

winkieri. 369. veret.

SPHYRENTDE,

Sphyranodus, t7'.

524 conoidens, \pm 76

crassiclens, 475 .

gracilis, $\frac{1}{4} 69$.

Sinquhatus. 467 .

priscus, \pm 73.

silorianus. $41 \%$.

speciosus. 916 .

tenuis, $\neq 69$.

Soinacanthus, 566

biennioicies, jobf;

Spinacites, \pm 15 .

raciatus. $\$ 15$.

Spinax maprinatus, 20.2.

Squalius,

ircirems.

bairdi, :3:?. 

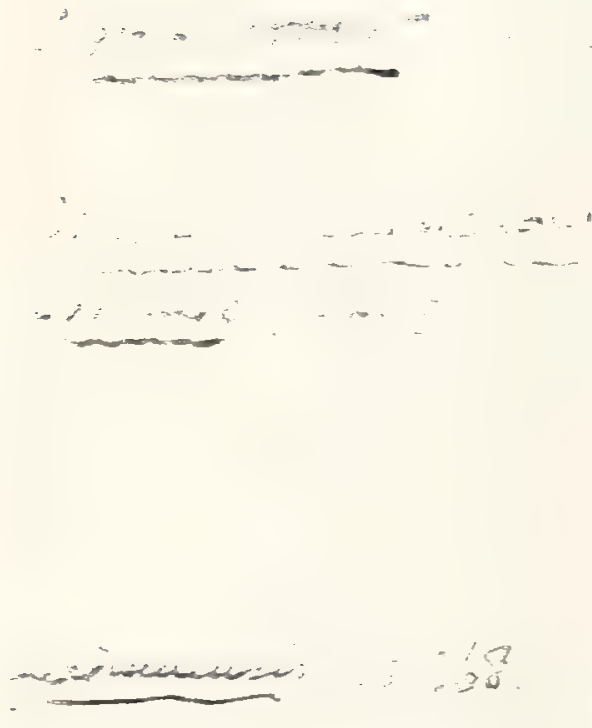

sểurowstici, san.

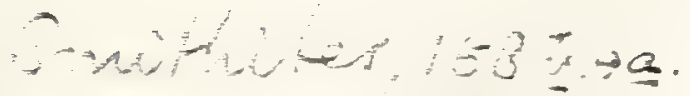

$\therefore=02,-2$

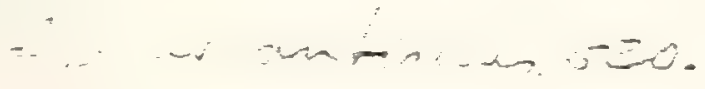

2000200002.00

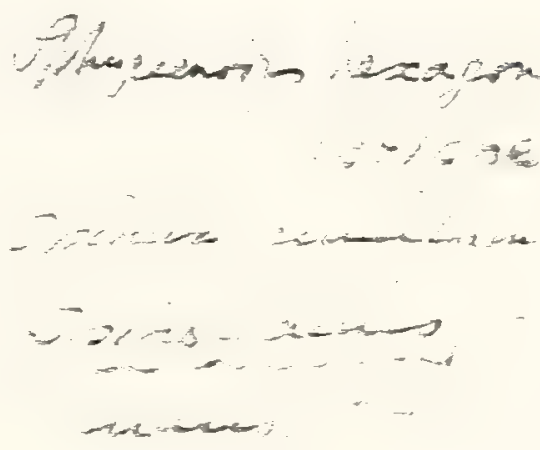

$+2$ 



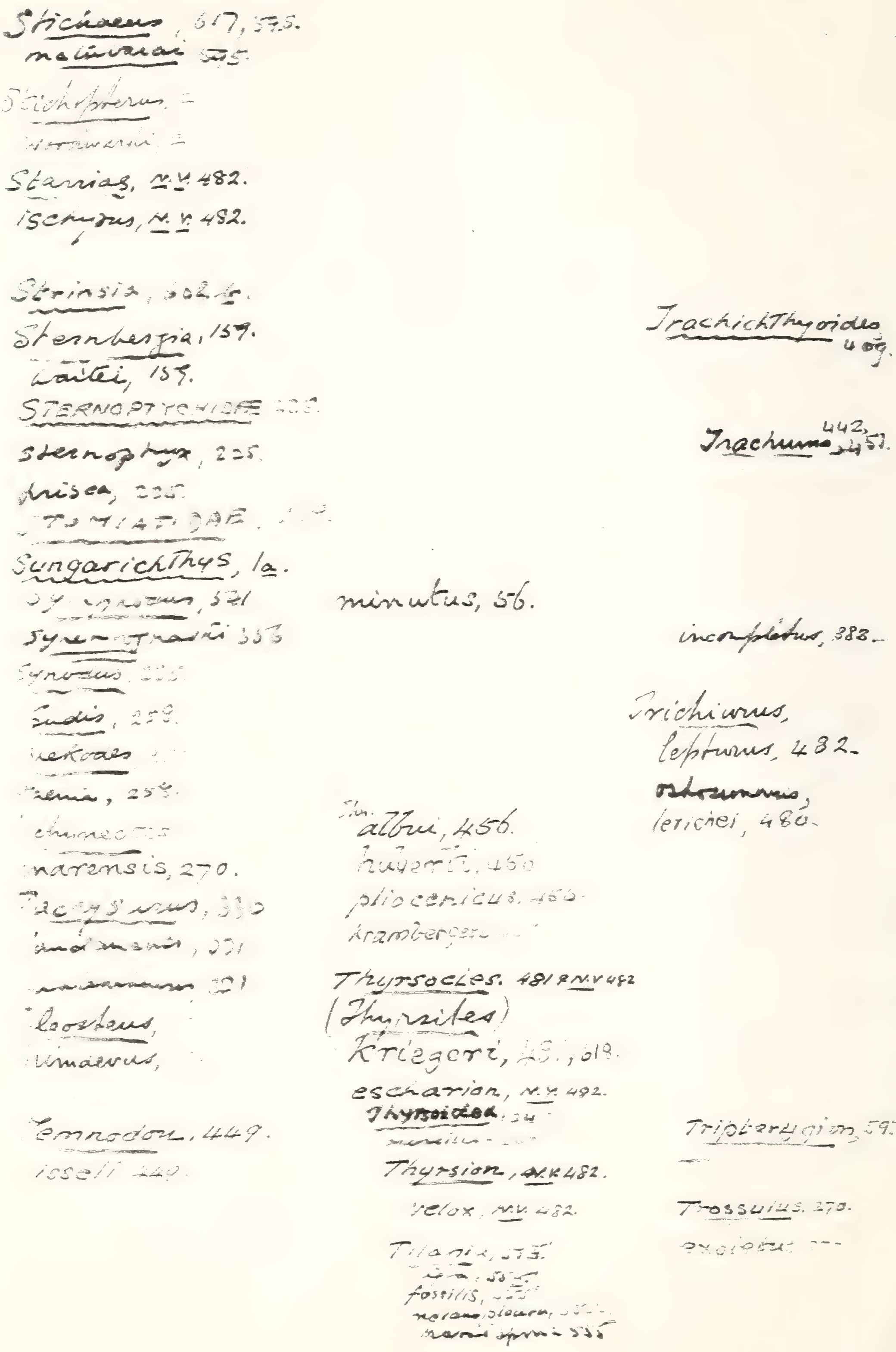


Squailus cont:

Iminatus, 980.

licatio, :̈ll.

uscions. 320

pacingi, 30.

Stenostcma,

puichella. +205 .

Stepnancdus, 5 entendens, $50 \%$.

Stereocus, $\$ 76$

meiitensis, $47 \%$.

Stratodus. 188

angiicus, 57 .

apicalis, 189. OXTpogon, 180.

Strinsia. $12 \%$ dara. 612.2.

STROYATEIDE, I1?

Stylocus. 51.5 . lebescontei .jo

sucis, $0 . \quad-3$

Syllæmus, $:$.

:ueicus, :Jis

latifons, $501,61 \pm$.

Svaratilde.

Syngnatisus, inisis. :28. ainri.:8:.

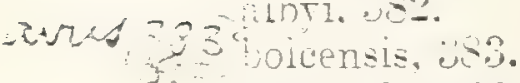
mericulus,

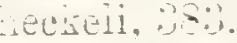

eimsi, 383.

misthonterts, 81.

Tphle $\mathrm{X}$.

Svncdentis, ,

Synopinty.

mone il:?.

Syntegmcaus.

itus. $: \frac{1}{t}$.

Pachynectes, :-

incurptertgins.

$$
\text { ... }
$$

Lonetpes $:-0$

malrociditrils. - - 0

Tarsicathys,

piequans. U1\%.

trsiger. 15.

Faurinichtays. 50.

wiocenicns.

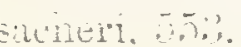

Tanogr contilens. . .

Delepsolis, -

crocephatus, -24

-inutembutus. 25

muis. $2-5$.

$>$ Eeratichtings,

nticuitucis, $+\frac{1}{4}$

Fernecaus, .to.

uninecio. 205
Tetragonoptervs, -ito.

2rus.

limpiticus, 201.

Tetracturus, 200.

minis, I1i.

)risens, $\left.\frac{1}{1}\right) 1$.

Tetrcacn, 571.

hispidus. Joth.

honchenii. 506.

lawiey, 371.

prgnaxus, 571.

scince. 051 .

TeUTHIDA. 523.

Teutnis, 228.

Thaumaturus, 180.

rieichuneileri. il $\frac{1}{2}$.

eiongatus. $01 t$.

uneatus, 160, 611.

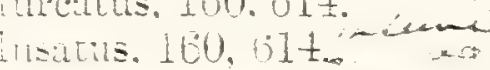

Tinrissopater,

miv?us,

megrotups.

sirmoneus.

[hrisouns aracilis, 6].

Thinsins rexilifer.

Thrisscpteroiaes, it.

jon urtus, it.

intermeritus, jo.

ittuls. it.

micher, oli

tenuicens.

Thrisscoterus, s. (artilii. - ?.

Thryptcaus, 33,83 ,

votincius. 85.

zitteili.

Thynnicithys, 819.

unbirostuma, 803.

Ththrisus. 54 .

angustacus. $45 \%$

boiceneis. \pm 57 .

Innceolitus, tho

1) inotatus. $\pm 5 \%$

propterryins. $=1 j \pm$.

posmus 45.

Ecculcisi, tis.

Exnnus \pm 5.5 .

tolianicus, tja.

rulunis. 40.5

Thyrsites, isl.

orisicui, $\div$ -

Thyrsitccephalus, $\pm T i$.

ininus.

Tisca, 812 .

francorirtana. 816.

furcura. U12.

lebrosmat. onterat
Finca (cont.).

macroptersgia, 315.

magna. 812.

micropscoptera, 214.

dotruncata,

tarsicer. 315 .

Taldanensis, 215.

priteris. 315.

Titanichtnys, Dames, bil:.

pharao. 612.

Tomodon, 112 .

horrificus. 61?.

Iomognathus, 116.

mortias, 117 .

leiodus. 117.

Toxopoma, 118.

politum, i13.

Tcrotes, 61.

antiqulis. jtil.

Trachixid .is.

Trachinopsis, 501.

iberica. il.

Tracininus, 00

irractineulus, 500.

hevienats. .019.

mutavilis. son.

seetancitens, 520.

7erus. 5in.

Trachynotus, enuretiss. - il.

Triacanthus,

Triænaspis, iz:. $00 \%$

vircularus. 1s 7 .

Trichiurichthys, $48 \%$.

incercus. te?.

Trichiurides, - - o nel

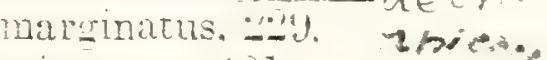

iniouenus. \pm 31.

-

Tricinophanes, 110 .

conei. 416 .

foliarum, 416 .

Lians, \pm 16 .

Trigla, 866.

adjuncta, 587.

cor a

nilipica. .887.

inrausta. jet.

licate. jet5.

Ivra. 589.

narciil. seb. e rnomitews.

simoneilii. 58 .

TrLGLIDE, 55.

Trigicides, 56.

viati. inti.

defurdini. sof woto.

molunis. joij

in senedensis iso.

Mrigonocion.

wrini. 1.

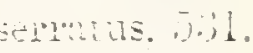

I'riocin

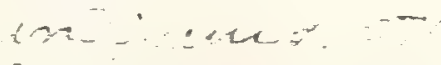




\section{.}


Tydeus, 257.

aibri, $25 \%$.

eiongatus, 257 .

megistosoma, 257 .

spinekodes, 258 .

Umbrina. 338.

pecchioiii. 538.

Uranoscspus, 590. peruzzii, 590. rastrum, 37.

Urencheiys, 337. angiicus. 39.

arus. $33 \%$

mo menaid habelensis. 338.

73. Uropterina, $1 \pm 6$. piatyracis. 158.

Urosphen, 376. dubia, 70 .

fistularis, 376 .

Vomer longispinus, 436.
Fomer partuius, 1501 .

Vomer priseus, \pm 42 .

Vomeropsis, 435 .

elongatus, 437.

longispinlis. tut?

raienciennesi, \pm 37 .

criens. 13 .

Xiphactinus, 92. audax, 92.93. brachrgnathus, 97. lestrio, 97.

Xiphias, 490 . acutirostris. 357. antiquus, 495 . delfortriei, 197 . robustus. 497 .

Xiphitde, 490.

Xiphopterus, 482. falcatus. 48.2.

Xiphiorhynchus, 490 .

elegans. 491.

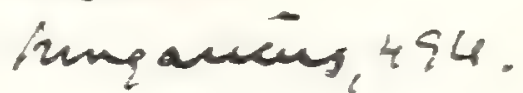

Xiphiorhyscinus

(cont.). priscus, 101.

3 ucsoriain 44

Zanclus, 4.00 .

brevirostris. 450 . eocœnus, 450.

Zeus, +17 .

benoisti. 417.

gailus, $4 \pm 9$.

hoernesi, 4].:-

lewesiensis, 397 .

licatæ, 418.

platessa, 501 .

pliocenicus. 41 . priscus, 516 . regievsianus, 501. rhowbeus, 439 . robustus, 418 . spinosus, 500 . triurus. 436. romer, 436 . 
Acurite, $x$ el

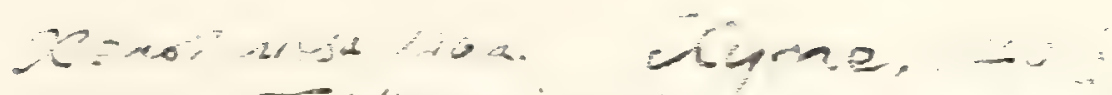

octaries, 481

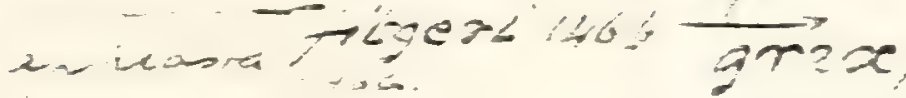

$45=$

zantechites, 36 a

TuYio, Ne.482.

Cestias 465

rumbia, 35 工

willun, wev, \&82.

iraius tisó.

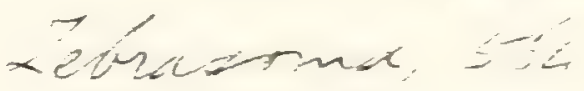

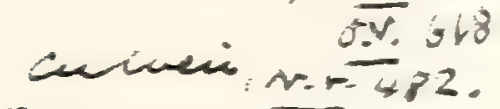

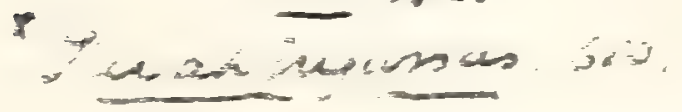

Zephzeardae, on

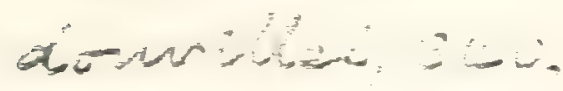

Xaphleges, o6.

Venicer reinus, i2:

longutio, 2át

un sim

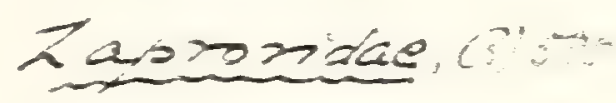

Pración

Cuminums, 553,46a Zelosis, 155

incriciens

nowaini, scislit64 hadley, 55.

Incichtims, 234.

barbarae, 146 a. Jorarnomin elmodiemae. $146 a$. pelicer. oc

Vinciscuenta 169.

Zemiagrammus

isisuies, gos.

zenerest.

totaricina

Livisuing sib.

ixicum

zorobseta

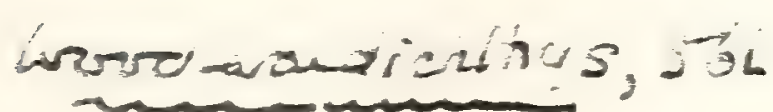

tonnem . . 



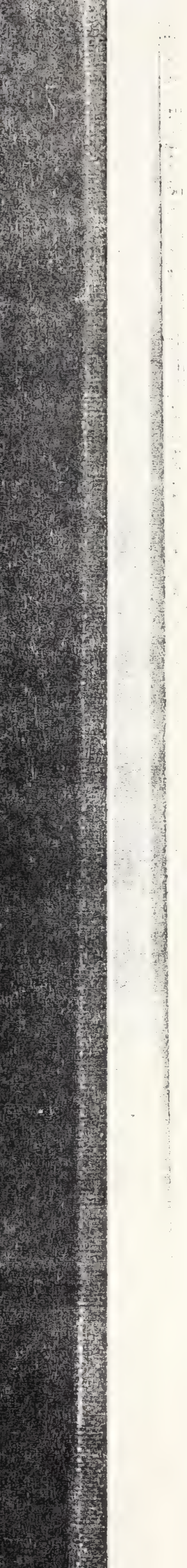




\section{SYSTEMATIC INDEX}

OF

\section{GENERA A N D S P E C I E}

DESCRIBED IN PART IV.

Order ACTINOPTERTGII (continued) . . . Page

Suborder IV. ISOSPONDYLI (continued) . . . . 1

Family LEPTOLEPID $\notin$ (continued) . . . . . 1

Lycoptera . . . . . . . . . 1

— middendorffi . . . . . . . . 2

— sinensis . . . . . . . . . 3

Family ELOPID $巴$. . . . . . . . . 7

Elopopsis . . . . . . . . . 8

— fenzli . . . . . . . . . . 9

— microdon . . . . . . . . . 9

— heckeli . . . . . . . . . . 9

Crassus . . . . . . . . . . 10

Osmeroides . . . . . . . . . 11

— lewesiensis . . . . . . . . 11

— levis . . . . . . . . 15

— gracilis . . . . . . . . . 16

- lewisi . . . . . . . . 17

PAPITIT.

attenuatus. . . . . . . 19 
Family ELOPID Æ (conínued).

Osmeroides sardinioides cretaceus

Elops

Megalops .

priscus oblongus

Notelops

Rhacolepis

- buccalis . . . . . . . 30

- latus . . . . . . . 32

Thrissopater . . . . . . . . 32

salmoneus. . . . . . . . 33 magnus . . . . . . . 33

(?) megalops . . . . . . . 35

Pachyrhizodus . . . . . . . 937 basalis . : . . . . . . 37 dibleyi . . . . . . . . 38 gardneri . . . . . . . . . 40 latimentum . . . . . . . . 42 subulidens ... . . . . . 43

Esocelops . . . . . . . . . . . 46 carifrons . . . . . . . 46

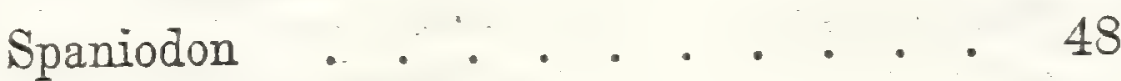
blondeli ........ . 48 elongatus . . . . . . . 51 latus . . . . . . 53

Thrissopteroides. . . . . . . . . 54

— elongatus . . . . . . . 54

— latus . . . . . . . . 54

— intermedius . . . . . . . . 55

— tenuiceps . . . . . . . . . 55

— pulcher . . . . . . . 56

Protelops . . . . . . . . . 56 geinitzi . . . . . . . . 57 anglicus : . . . . . . 57 
Family ALBULID $\mathbb{E}$

Albula

—oweni . . . . . . . . 60

Chanoides . . . . . . . . 63

— macropoma . . . . . . . 63

Chanos . . . . . . . . 64

Prochanos . . . . . . . . 65

rectifrons . . . . . . 65

Ancylostylos . . . . . . . 66

- gibbus . . . . . . . . . 66

Istieus . . . . . . . . . . . 66

— grandis . . . . . . . . . 67

— macrocephalus . . . . . . 70

— lebanonensis . . . . . . . . 71

Anogmius . . . . . . . . . 71

polymicrodus . . . . . . 72

Family OSTEOGLOSSID $\mathrm{E}$. . . . . . . 73

Dapedoglossus . . . . . . . 74

— testis .. . . . . . . 75

— æquipinnis . . . . . . . . 75

Brychætus . . . . . . . . . 76

muelleri . . . . . . 76

Incertæ sedis . . . . . . . . . 80

Plethodus . . . . . . . . 80

— expansus . . . . . . . . . 81

- pentagon . . . . . . . . . 83

- oblongus . . . . . . . . . 83

Thryptodus . . . . . . . 85

Family NOTOPTERID $巴$. . . . . . . . 85

Notopterus . . . . . . . 86

primævus : 


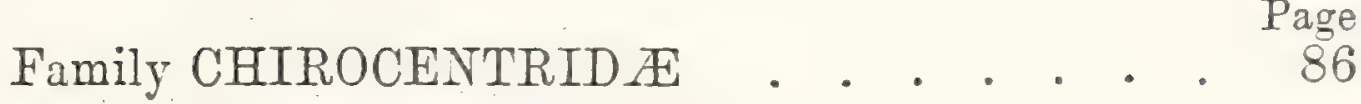

Chirocentrus. . . . . . . . 88

(?) polyodon . . . . . . . . 88

Platinx . . . . . . . . . 89

Chiromystus . . . . . . . . 89

— mavsoni . . . . . . . 90

Chirocentrites . . . . . . . 90

coroninii . . . . . . . . 91

Portheus . .. . . . . . . . 92

molossus . . . . . . . . . 92

mantelli . . . . . . . . 95

daviesi . . . . . . . . 95

gaultinus . . . . . . . 95

Spathodactylus . . . . . . . . . 98

neocomiensis . . . . . . . 98

Ichthyodectes . . . . . . . . . 99

- ctenodon . . . . . . . 100

- anaides. . . . . . . . 100

-

- serridens ........ . 101

- minor . . . . . . . . 102

— elegans ... . . . . . 103

— tenuidens.. . . . . . . . . 104

— libanicus . . . . . . . . . 105

Cladocyclus . . . . . . 107

— gardneri . . . . . . . 108

- lewesiensis . . . . . . . . 109

Saurodon . . . . . . . . . 111

- leanus . . . . . . . . . . 111

— phlebotomus . . . . . . . 112

- intermedius . . . . . . . . 112

Saurocephalus . . . . . . . 113

- lanciformis . . . . . . 113

—oodwardi . . . . . . 114

Incertæ sedis . . . . . . . . . 116

Tomognathus . . . . . . 116

$\operatorname{mordax}$. . . . . . . . 117 
Family CTRNOTHRISSTD Page

Ctenothrissa . . . . . . . . 120

vexillifer... . . . . . 120

radians . . . . . . . . . 122

microcephala . . . . . . . 124

Aulolepis . . . . . . . . . . 126

typus . . . . . . . . 127

Family CLUPEID王 . • . . . . • . 128

Pseudoberyx . . . . . . . . . 129

syriacus : . . . . . . 129

bottæ . . . . . . . 130

grandis. . . . . . . . . 130

Histiothrissa . . . . . . . 131

macrodactyla. . . . . . . 131

crassapinna . . . . . . . . 132

Engraulis . . . . . . . . . 133

Halecopsis . . . . . . . . 133

— insignis . . . . . . . . . . 134

Scombroclupea . . . . . . . . : 135

macrophthalma . . . . . . 135

— gaudrji •. • . • • • • . 138

Diplomystus . . . . . . . . . . 139

- dentatus . . . . . . . . . 139

- brevissimus . . . . . . . 140

— birdi . . . . . . . . . . 142

longicostatus . . . . . . . . 143

- humilis . . . . . . . . 144

- altus . . . . . . . . 145

— vectensis . . . . . . . 146

Clupea . . . . . . . . . . . 146 scheuchzeri . . . . . . 147

catopygoptera . . . . . . 148

humilis . . . . . . . 150

crenata. . . . . . . 151

numidica . . . . . . . . . 151

- sardinites . . . . . . . . 152

- sprattus . . . . . . . 153 
Family SALIIONID无 . . . . . . . . 159

Salmo . . . . . . . . 159

Mallotus . . . . . . . . 160

villosus.

Family HALOSAURID无 . . . . . . 162

Echidnocephalus . . . . . . 163

— troscheli . . . . . . . . . 163

Enchelurus . . . . . . . . 164 villosus. . . . . . . . . 164

- syriacus . . . . . . . 165

—anglicus . . . . . . . 167

Family NOTACANTHID $Æ$. . . . . 168

Pronotacanthus . . . . . . . . 169 sahel-almæ . . . . . . . 169

Family DERCETID $Æ$ ・ . . . . . . 171

Dercetis . . . . . . . . 172

— scutatus . . . . . . . . 172

Leptotrachelus . . . . . . . 173

- armatus . . . . . . . 174

_ triqueter ... . . . . . 174

— gracilis . . . . . . . 180

— hakelensis . . . . . . . . . 184

— elongatus . . . . . . . 184

Pelargorhynchus . . . . . . 188

dercetiformis . . . . . . 188

Family ENCHODONTID瓜 . . . . . . 189

Enchodus . . . . . . . . 190

lewesiensis . . . . . . . 191

— pulchellus . . . . . . . . . 193

annectens . . . . . . . . 195

faujasi . . . . . . . . 196

— lemonnieri . . . . . . . 198

_longidens . . . . . . . . . 199 
Family ENCHODONTID $巴$ (continued).

Enchodus major . . . . . . 200 gracilis . . . . . . . . 201

— macropterus . . . . . . . . 202

Eurypholis . . . . . . . . 207

— boissieri . . . . . . 207

— freyeri . . . . . . . 210

Palæolycus . . ' . . . . . 211

— dreginensis . . . . . . . . 211

Halec . . . . . . . . 212

sternbergi. . . . . . . . 212

eupterygius . . . . . . . 213

— microlepis . . . . . . . . 218

— haueri . . . . . . . . . 219

Cimolichthys. . . . . . . . . 221

— lerresiensis . . . . . . . 221

- nepæolica . . . . . . . 225

Prionolepis . . . . . . . . . . 229

angustus . . . . . . . . 230

— cataphractus . . . . . . . 230

— laniatus . . . . . . . . . 232

Leptecodon . . . . . . . . 233

— rectus . . . . . . . . 233

Pantopholis . . . . . . . 234

Family SCOPELID $\nexists$. . . . . . . . . . 235

Sardinioides . . . . . . . . 236

— monasteri . . . . . . . . 237

— crassicaudus . . . . . . . . 238

— megapterus . . . . . . . . 239

— pusillus . . . . . . . . 240

— attenuatus. . . . . . . . 241

Acrognathus . . . . . . . . . . 243

- boops . . . . . . . . . . 243

libanicus . . . . . . . . . 244

Leptosomus . . . . . . . . . . 244

— guestphalicus . . . . . . . 245 
Family SCOPELID $Æ$ (continued).

Leptosomus elongatus . . . . . . 245

- macrourus. . . . . . . . 215

minimus . . . . . . . 246

Sardinius . . . . . . . . . 247

cordieri . . . . . . . 247

Dactylopogon . . . . . . . 248

grandis . . . . . . . . 249

Nematonotus . . . . . . . . 249

bottæ . . . . . . . 250

Microcoelia . . . . . . . . 252

granulata . . . . . . . 252

libanica . . . . . . . 252

Opisthopteryx . . . . . . . . 253

gracilis . . . . . . . . 254

Scopeloides . . . . . . . . . $25 t$

glarisianus . . . . . . 255

Parascopelus . . . . . . . . . . 256

lacertosus . . . . . . 256

Anapterus . . . . . . . . 257

megistosoma . . . . . . . 257

Apateodus . . . . . . . . . . 258

- glyphodus . . . . . . 258

striatus. . . . . . . . 260

lanceolatus . . . . . . : 264

Rhinellus ......... . . 265

furcatus . . . . . . . 266

ferox . . . . . . . 267

damoni. . . . . . . . 268

Family GONORHYNCHID $巴$. . . . . . 271

Charitosomus . . . . . . . . 271

formosus . . . . . . . 272

major . . ...... . . 272

lineolatus . . ... . . . 274

hakelensis . . . . . . . . 274

Notogoneus . . . . . . . . 275 
Family GONORHYNCHID $\approx$ (continued).

Notogoneus osculus . . . . . . . 275

— squamosseus . . . . . . 276

— cuvieri . . . . . . . 277

— longiceps . . . . . . . . . 278

Family CHIROTHRICID $Æ$. . . . . . . 279

Chirothrix . . . . . . . . 280

— libanicus . . . . . . . . 280

— lewisi . . . . . . . . 283

— guestfalicus . . . . . . . . 283

Telepholis . . . . . . . . 284

— acrocephalus . . . . . . . 284

(?) tenuis . . . . . . . . . 285

Exocœtoides . . . . . . . . 286 minor . . . . . . . . 286

Family ESOCID无. . . . . . . . . . 287

Esox . . . . . . . . 287 lepidotus . . . . . . . 288

Family CYPRINODONTID $\mathrm{E}$. . • • . . . 289

Prolebias . . . . . . . . . 290

— cephalotes. . . . . . . . 290

- furcatus . . . . . . . . 291

— gregatus . . . . . . . . 292

- stenoura . . . . . . . . . 292

—oreti . . . . . . . . 293

— brongniarti . . . . . . . 293

Pachylebias . . . . . . . . 294

- crassicaudus . . . . . . 295

Suborder V. OSTARIOPHYSI . . . . . . . 296

Family CHARACINID $Æ$. . . . . . . . 297

Tetragonopterus . . . . . . . 298

— avus . . . . . . . . . 298

— ligniticus . . . . . . . . . 298 
Family CYPRINID $Æ$. . . . . . . . . . 299

Catostomus . . . . . . . . 299

Amyzon . . . . . . . . 300

Cyprinus . . . . . . . . 300

— priscus . . . . . . . . . 301

Barbus

301

megacephalus . . . . . 302

Thynnichthys . . . . . . 303

amblyostoma . . . . . . 303

Gobio . . . . . . . . 303

analis . . . . . . . 304

Amblypharyngodon . . . . . . . 304

Leuciscus . . . . . . . . 305

— oeningensis . . . . . . 305

— papyraceus . . . . . . 307

— colei . . . . . . . . 308

—-macrurus . . . . . . 308

— leptus . . . . . . . . 309

Tinca . . . . . . . . 312

furcata . . . . . . . . 312

leptosoma . . . . . . . 313

micropygoptera . . . . . . 314

tarsiger ... . . . 315

Rhodeus . . . . . . 316

elongatus . . . . . . 316

latior . . . . . . . 317

Aspius . . . . . . . . . . 318

gracilis . . . . . . . 318

minutus . . . . . . . 318

Cobitis . . . . . . . . . 320

centrochir . . . . . . . 320

angustus . . . . . . . . 321

cephalotes . . . . . . . . 321

Hexapsephus . . . . . . . . . 322

guentheri . . . . . . 322 
Family SILURID $\mathrm{E}$

Page

Clarias .

324

falconeri

324

Heterobranchus

325

palæindicus

325

Silurus

325

Pseudeutropius . . . . . . . . . 326

verbeeki

326

Macrones

327

aor

327

Rita

328

Amiurus . . . . . . . . . 328

Rhineastes . . . . . . . . . . 329

Bucklandium . . . . . . . . 330

— diluvii . . . . . . . . . . 330

Arius . . . . . . . . . . 330

— egertoni . . . . . . . . . 331

— crassus . . . . . . . . . 332

— (?) bartonensis . . . . . . . 333 iheringi . . . . . . 333 Bagarius . . . . . . . . 335 gigas

Suborder VI. $A P O D E S$. . . . . . . 336

Family MURANID瓜 • • • . . . . 336

Urenchelys . . . . . . . . 337

— avus . . . . . . . 337

— hakelensis . . . . . . . 338

— anglicus . . . . . . . . 339

Eomyrus . . . . . . . . . . 340

— dolloi . . . . . . . . . 340

Clatispinus . . . . . . . . 340

ventralis . . . . . . . . 341

Rhynchorhinus . . . . . . . 342

— branchialis . . . . . . . . 342 major . . . . . . . . . 343 
Family IIURENID无 (continued).

Paranguilla

Anguilla.

-

leptoptera

Nettastoma

Suborder VII. PERCESOCES . . . . . . . . 347

Family CROSSOGNATHID王 . . . . . . . 348

Crossognathus . . . . . . . 348

— sabaudianus . . . . . . . . 349

Syllæmus .

350

latifrons

351

anglicus

351

Family AIIIODYTID无 . . . . . . . 354

Cobitopsis . . . . . . . 354

- acutus' ........ . . 355

Family SCOJBRESOCID E . . . . . . 356

Belone . . . . . . . 356 tenuis . . . . . . 357

Scombresox . . . . . . . . 357

obtusirostris . . . . . . 357

Hemiramphus . . . . . . 358

Family ATHERINID $邓$. . . . . . . . 358

Atherina . . . . . . . 359

macrocephala . . . . . . 359

sarmatica . . . . . . 360

vardinis . . . . . . . 360

Rhamphognathus . . . . . . . 361

paralepoides . . . . . . . 361

sphyrænoides . . . . . . . 362 
Family MUGILID $\mathrm{E}$. . . . . . . . . . $366^{\circ}$

Mugil . . . . . . . . . . 363

-

- radobojanus . . . . . . . 365

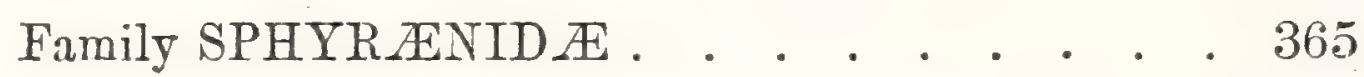

Sphyræna . • . . • • • . • • 366

- bolcensis . . . . . . . . 366

— intermedia . . . . . . . 367

—

Suborder VIII. HEMIBRANCHII . . . . . . . 369

Family AULORHYNCHID无 . . . . . . 371

Protaulopsis . . . . . . . . . 371

- bolcensis . . . . . . . . 371

Aulorhynchus . . . . . . . 372

— sumatrensis . . . . . . . 373

Family FISTULARIIDE

Fistularia . . . . . . . . 374

- koenigi . . . . . . . . . 374

longirostris . . . . . . . 375

Aulostoma . . . . . . . . 375

bolcense . . . . . . 375

Urosphen . . . . . . . . 376

dubia . . . . . . 376

Family CENTRISCID王 . . . . . . . . 377

Rhamphosus . . . . . . . 377

— aculeatus . . . . . . . 377

— biserratus . . . . . . . 378

Amphisile . . . . . . . . . . 378

¿ heinrichi . . . . . . . . 379

Family SOLENOSTOMATID王 . . . . . . 379

Solenorhynchus . . . . . . . . 380

elegans . . . . . . . . 380 


$$
\begin{aligned}
& \text { Page } \\
& \text { Pseudosyngnathus . . . . . . . } 381 \\
& \text { opisthopterus . . . . . . . } 381 \\
& \text { Siphonostoma . . . . . . } 382 \\
& \text { — albyi . . . . . . . . } 382 \\
& \text { Syngnathus . . . . . . . . . } 382 \\
& \text { Calamostoma . . . . . . . . } 383 \\
& \text { breviculum . . . . . . } 383
\end{aligned}
$$

Suborder IX. ACANTHOPTERYGII . . . . . . 384

$$
\text { Division A. Beryciformes . . . . . . . } 384
$$$$
\text { Family BERYCID无 • . . . . . . . } 384
$$

Beryx . . . . . . . . . 385

Sphenocephalus . . . . . . . . 387

$$
\begin{aligned}
& \text { — fissicaudus . . . . . . . . } 387 \\
& \text { cataphractus' . . . . . . } 388 \\
& \text { Acrogaster . . . . . . . . . } 388 \\
& \text { — parvus . . . . . . . . . . } 389 \\
& \text { —- brevicostatus . . . . . . . } 389 \\
& \text { — heckeli . . . . . . . . . . } 390 \\
& \text { daviesi . . . . . . . . } 390 \\
& \text { Pycnosterinx . . . . . . . . } 391 \\
& \text { — russeggeri . . . . . . . . } 392 \\
& \text { discoides . . . . . . . } 393 \\
& \text { — gracilis . . . . . . . . . . } 394 \\
& \text { dubius . . . . . . . . } 395 \\
& \text { Hoplopteryx . . . . . . . } 396 \\
& \text { — antiquus . . . . . . . } 396 \\
& \text { — zippei . . . . . . . . . . } 397 \\
& \text { — lewesiensis . . . . . . . } 397 \\
& \text { — superbus . . . . . . . . . } 403 \\
& \text { - lundensis . . . . . . . . } 404 \\
& \text { — lewisi . . . . . . . } 404 \\
& \text { — syriacus . . . . . . . . . } 405 \\
& \text { — stachei . . . . . . . } 406
\end{aligned}
$$


Family BERYCID $Æ$ (continued).

Dinopteryx . 406

— spinosus . . . . . . . 407

Homonotus . . . . . . . . 407

dorsalis. . . . . . . . 408

Myripristis . . . . . . . . 410

— leptacanthus . . . . . . . 410

- homopterygius . . . . . . . 411

Holocentrum . . . . . . . . 412

- macrocephalum . . . . . . 412

- melitense . . . . . . . . 413

Family APHREDODERID无 . . . . . . . 416

Family CYTTID 无 。 . . . . . . . 417

Division B. Scombriformes . . . . . . . 418

Family STROMATEID $Æ$ 。 。 . . . . 419

Omosoma . . . . . . . . . 419

— sahel-almæ . . . . . . . 419

— intermedium . . . . . . 420

— pulchellum ... . ... . . 421

Platycormus . . . . . . . . 421

- germanus . .. . . . . 421

Berycopsis . . . . . . . . 423

elegans. . . . . . . . 423

Family CARANGID $\mathbb{E}$. . . . . . . 425

Aipichthys .. . . . . . . 427

— pretiosus . . . . . . . . 427

— velifer . . . . . . . 427

— minor . . . . . . . 428

— nuchalis . . . . . . . . 429

Semiophorus . . . . . . . . . 430

— velifer . . . . . . . . . 430

— velicans . . . . . . . . 431

Platax . . . . . . . . . . 432 
Family CARANGID $\mathrm{E}$ (continued).

Platax woodwardi .

Amphistium

paradoxum

Vomeropsis

longispinus

elongatus .

valenciennesi .

Yene

rhombeus

oblongus

Caranx

Archæus

glarisianus .

Seriola.

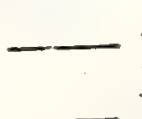
prisca

Carangopsis

Family SCOMBRID $\approx$

Isurichthys

macrurus

453 orientalis

Thynnus. thyonas

scaldisi.

lanceolatus

456

Eothynnus

salmoneus

Scomber

Palimphyes

elongatus 
Family SCOMBRID E (continued).

Scombring Page

Scombrinus . . . . . . . . 461

nuchalis . . . . . . . . 461

macropomus . . . . . . . 462

Auxis . . . . . . . . . . . 463

(?) propterygius . . . . . . . 464

Cybium . . . . . . . . 465

— speciosum . . . . . . . . 466

— bleekeri . . . . . . . 466

— excelsum . . . . . . . 467

- bartonense . . . . . . 467

— lingulatum . . . . . . . . 469

Eocolopoma . . . . . . . 470

— colei . . . . . . . . . . 470

— curvatum , . . . . . . . 472

Sphyrænodus . . . . . . . . 473

— priscus . . . . . . . . . . 473

Scombramphodon . . . . . . 474

— benedeni . . . . . . 474

— curvidens . . . . . . . . 474

— crassidens . . . . . . . 475

Thyrsitocephalus . . . . . . 476

alpinus . . . . . . . . 477

Lepidopus . . . . . . . . 477

— glarisianus . . . . . . 477

- brericauda . . . . . . . 480

- albyi . . . . . . . 480

Family PALEORHYNCHID $\mathrm{E}$. . . . . . 482

Palæorhynchus . . . . . . . 483

— glarisianus . . . . . . . 483

— longirostris . . . . . . 486

— ritteli . . . . . . . . . 487

Hemirhynchus . . . . . . 488

deshayesi . . . . . . 488

colei. . . . . . . . . . 488 


$$
\begin{aligned}
& \text { Family XIPHIID } \mathrm{E} \text {. . . . . . . } 490 \\
& \text { Xiphiorhynchus. . . . . . . } 490 \\
& \text { — elegans. . . . . . . . } 491 \\
& \text { — priscus . . . . . . . . . } 491 \\
& \text { Acestrus . . . . . . . } 494 \\
& \text { —ornatus . . . . . . } 494 \\
& \text { Histiophorus . . . . . . . } 495 \\
& \text { — eocænicus . . . . . . . } 495 \\
& \text { rotundus . ... . . . . . } 495
\end{aligned}
$$

Division C. Perciformes . . . . . . . . 497

Family PERCID $\mathrm{E}$. . . . . . . . . 498

Prolates .. . . . . . . . . . 499

heberti . . . . . . . . 499

Acanus . . . . . . . 500

- spinosus . . . . . . . 500

— regleysianus . . . . . . . 501

Lates .. . . . . . . . 502

gracilis . . . . . . . 502

Cyclopoma . . . . . . . 504

- -gigas . . . . . . . 504

- (?) micracanthum .... . . 504

Smerdis . . . . . $\quad 506$

- minutus . . . . . . 506

— formosus . . . . . . 507

— macrurus . . . . . . 507

Labrax . . . . . . . 509

ubinoi . . . . . . . 510

— schizurus . . . . . . . 510

— oeningensis . . . . . . 511

Percichthys . . . . . . . . . 514

— antiquus . . . . . . 514

Properca . . . . . . . . 514

—

beaumonti . . . . . . 515

(?) prisea . . . . . . 516 
Family PERCID $\mathrm{E}$ (continued).

Mioplosus. Page

_ labracoides . . . . . . 517

Perca . . . . . . . . . 518

Family TEUTHIDID $Æ$. . . . . . . . 523

Family SPARID $巴$. . . . . . . . . 524

Sparnodus . . . . . . . . 524

— macrophthalmus . . . . . . 525

— elongatus . . . . . . . 526

—- microstomus . . . . . . 527

bowerbanki . . . . . . 527

Sargus . . . . . . . . . . 529

- orauensis . . . . . . . . . 529

- laticonus . . . . . . . . 529

Trigonodon . . . . . . . . 531

oweni . . . . . . . 531

serratus . . . . . . . 531

Pagellus ... . . . . . . . . . 532

Pagrus . . . . . . . . . 533

Chrysophrys . . . . . . . . 534

Family SCI ENID 1 • . . . . • • . 538

Family LABRID $Æ$. . . . . . . . . . 539

Labrus . . . . . . . . . 539

Julis . . . . . . . . . . 541

Labrodon . . . . . . . . . 541

— superbus. . . . . . . . . 542

— canariensis . . . . . . 542

Phyllodus . . . . . . . . 546

— toliapicus ... . . . . . 546

Egertonia . . . . . . . . 550

— isodonta . . . . . . . 551

Platylæmus . . . . . . . . 551

— colei . . . . . . . . 551

Pseudosphærodon . . . . . . . 552

hilgendorfi . . . . . . 552 


$$
\begin{aligned}
& \text { Family CHROMID王 . . . . . . . . } 55 \\
& \text { Priscacara . . . . . . . . } 554 \\
& \text { serrata . . . . . . } 55 t \\
& \text { clivosa . . . . . . . . } 554
\end{aligned}
$$

Division D. Chætodontiformes . . . . . . . $556^{\circ}$

Family CHATODONTID王 . . . . . . . 556

Pygæus . . . . . . . . . . 557

— coleanus . . . . . . . . 557

Proantigonia . . . . . • . . . 558

Ephippus . . . . . . • . . 559

— rhombus . . . . . . . . . 559

Family ACRONURIDE • . . . • . . 562

Aulorhamphus . . . . . . . 562

Apostasis . . . . . . . . 563

Acanthurus . . . . . . . 563

Naseus . . . . . . . . 564 . .

rectifrons . . . . . . . 564

Family BALISTID $\mathrm{E} \ldots \ldots \ldots \ldots$

Spinacanthus • . • . . 566

Acanthopleurus .. . . . . . . 566

-

Acanthoderma . . . . . . . 568

— spinusum . . . . . . . . . 568

Ostracion . . . . . . . . . . 569

Family GYMNODONTID王 . . . . . . 570

Tetrodon . . . . . . . . 571

Diodon. . . . . . . . . . . 571

— erinaceus . . . . . . . . 572

— scillæ . • . . . . . . . . 572

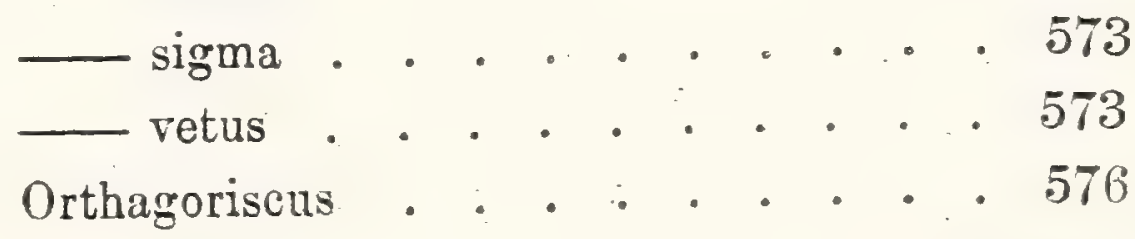


Division E. Scorpæniformes Family SCORP ENID $\mathrm{X}$. . . . . . . 577 Ampheristus . . . . . . . . 577 — toliapicus . . . . . . . 577

Family COTTID $\mathrm{E}$. . . . . . . . 580 . Eocottus . . . . . . . . . 580 — veronensis. . . . . . . . . 581 Lepidocottus . . . . . . . . . 581 — aries . . . . . . . . 582 - brevis . . . . . . . . 582 — papyraceus . . . . . . 583 — multipinnatus . . . . . . . 584 Cottus . . . . . . . . . . . 585

Family TRIGLID $\approx$. . . . . . . . 585

Division F. Gobiiformes . . . . . . . . 587

Family GOBIID $巴$. . . . . . . . . 587 Family TRACHINID $巴$. . . . . . . . . 589 Callipteryx . . . . . . . 589 — speciosus . . . . . . . . 589 — recticaudus . . . . . . 589

Division G. Blenniiformes . . . . . . . 591

Family BLOCHIID E . . . . . . . . 591 Blochius . . . . . . . . . 593 longirostris . . . . . . . 593

Family BLENNIIDÆ. . . . . . . . . 595

Pterygocephalus。 . . . . . . . . 595

— paradoxus . . . . . . . 595 




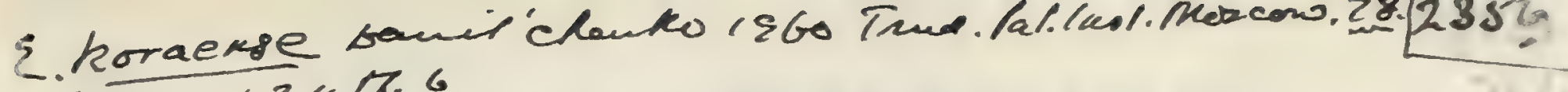

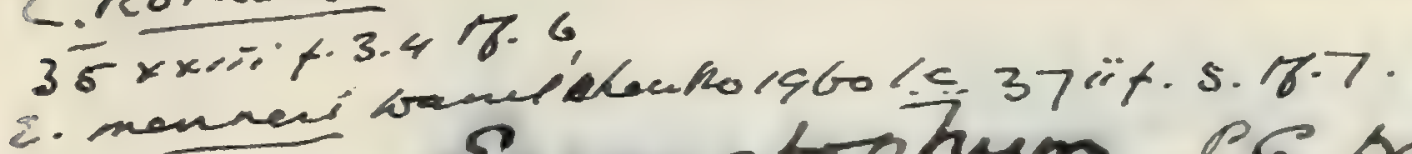

Sometophum PG. bawilchento 1947

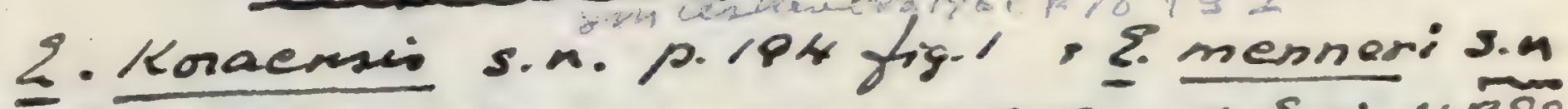

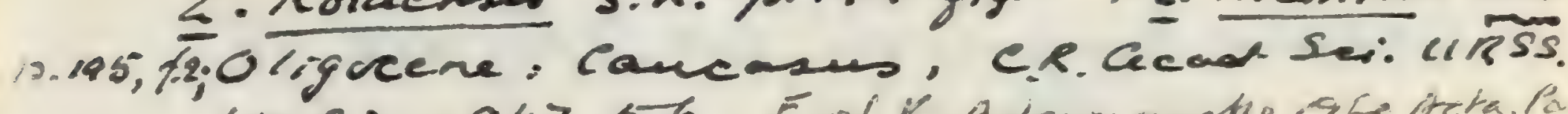

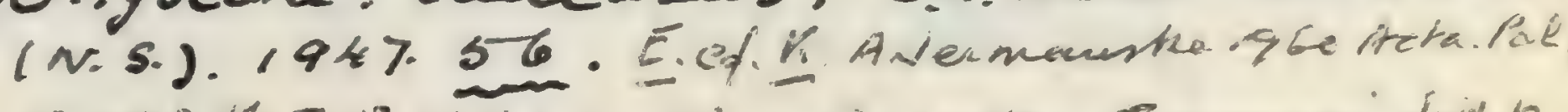

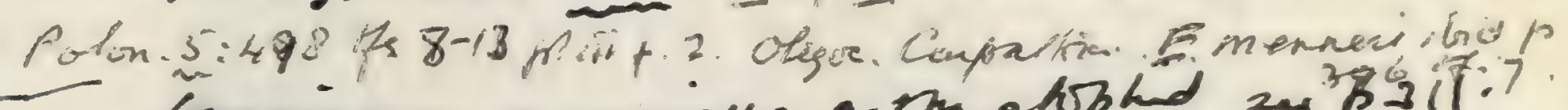

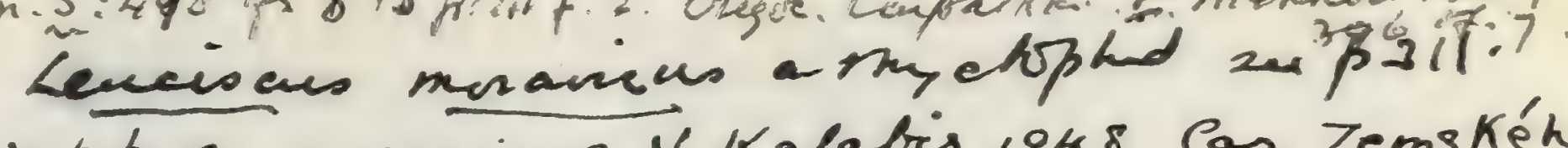
Diaphus moraricus V. Kalabis 1948 . Pas. Zenského mes. Brac $\frac{32}{32}-167$. 6.6. . .

siaphus menelitiens 2-n. Olysire Moravia, V. Kalabs

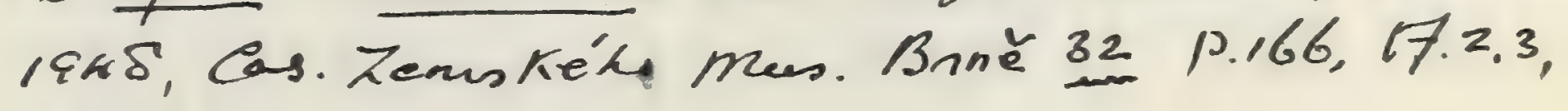
prit.z.

Diaphus? Pdysarcus p.z".

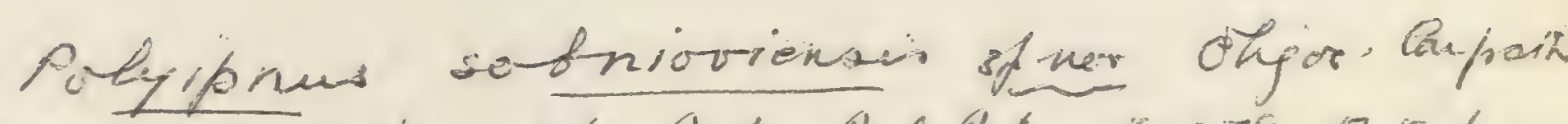

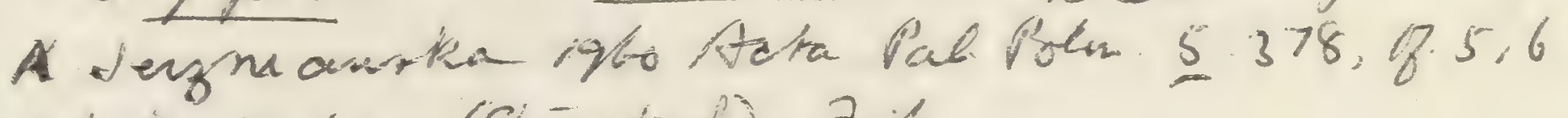

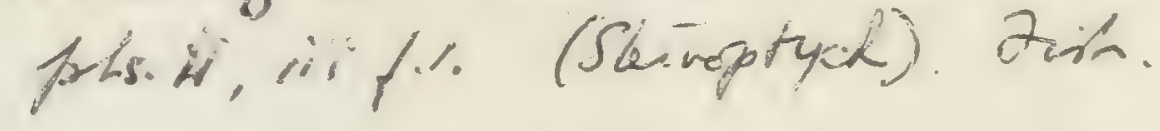

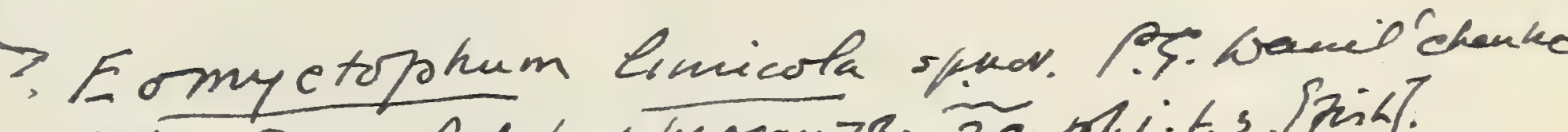

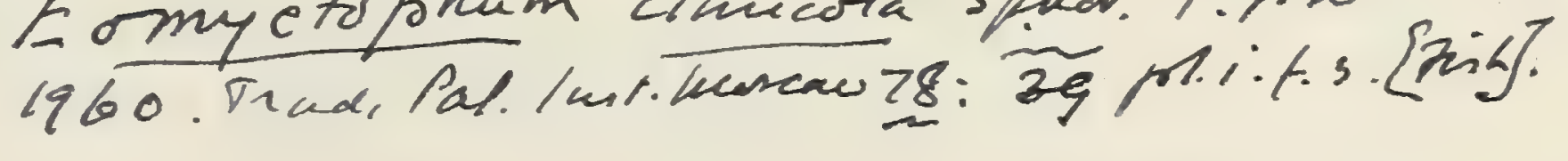

Polyipnus brevs spur menetiksh-Cappations

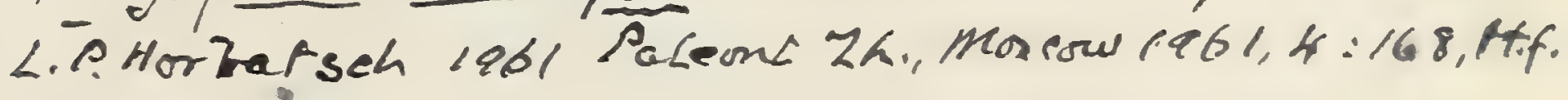
$V \cdot$ imp. fis. 
$235 \leq$

$$
\text { GALAX!DA }
$$

Galuias Raikorai s.a. Ge? Lhaly 1956 p.34 Plave NZ. 
Paired fins small; one dorsal fin-ray much elongated and closely articulated; anal fin very small; scales cycloid ..................

B. Normal forms with dorsal fin not

Nematonotus (p. 249). completely in advance of anal fin.

Teeth minute; pectoral fins small; dorsal and anal fins extended .... Microcoelia (p. 252).

Teeth minute; pectoral fins large; dorsal and anal fins short-based and acuminate; caudal fin with long slender lobes ..............

As Opisthopteryx, but teeth rather large and in spaced series .......

C. Much elongated forms with anal fin completely behind dorsal fin.

Pectoral fins large; pelvic fins small and far forwards; dorsal fin shortbased and median; anal fin somewhat extended...............

Paired fins small; dorsal fin shortbased and remote; anal fin much extended ................ Anapterus (p. 257).

II. Premaxilla very stout.

Premaxillæ and mandible scarcely extending further forwards than the

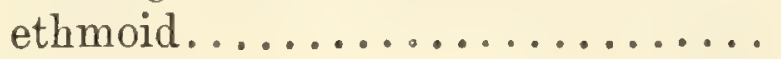

Premaxillæ and mandible produced into a long rostrum.............. Rhinellus (p. 265).

\section{Genus SARDINIOIDES, W. von der Marck.}

[Zeitschr. deutsch. geol. Gres. vol. x. 1858, p. 245.]

Syn. Dermatoptychus, W. von der Marck, Palæontogr. vol. xv. 1868, p. 287.

Head large, and the maximum depth of the trunk at the origin of the dorsal fin. Mandibular suspensorium nearly vertical; jaws moderately stout, and maxilla expanded behind; teeth very minute; cheek scaly. Branchiostegal rays about 9 in number. Vertebræ between 30 and 40 in number, about half being caudal; the centra longitudinaily striated and not longer than deep; ribs delicate. No fin-rays elongated, but two or three in front of the median fins undivided and spinous. Pectoral fins very delicate and small, well above the ventral border; pelvic fins well developed, with about 7 rays, opposed to the dorsal fin, which is nearly median and comprises from 10 to 18 rays; anal fin behind the dorsal, at least 
266

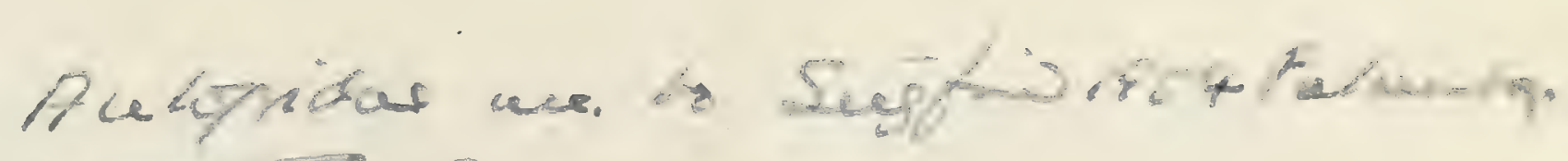
1004.18 . 
as deep as long, with about 10 rays; caudal fin slightly forked. Scales large and uniform, finely serrated on the hinder border, not deepened or thickened along the course of the lateral line.

So far as can be determined from the skeleton, this genus appears to differ from the surviving Scopelus only in the comparatively small size and remote situation of the anal fin, and in the serrated character of the scales.

\section{Sardinioides monasteri (Agassiz).}

18.39-44. Osmeroides monasterii, L. Agassiz, Poiss. Foss. vol. v. pt. ii. p. 103, pl. lx $d$. fig. 3 .

1839-44. Osmeroides microcephalus, L. Agassiz, ibid. p. 104, pl. lx d. fig. 4. [Distorted fish; Palæontological Museum, Munich.]

1858. Sardinioides monasterii, W. von der Marck, Zeitschr. deutsch. geol. Ges. vol. x. p. 245.

18.58. Sardinivides microcephalus, W. von der Marck, ibid. p. 245.

1858. Clupea guestphalica, W. von der Marck, ibid. p. 250. [Immature fish ; Academy of Münster.]

1863. Sardinioides monasterii, W. von der Marck, Palæontogr. vol. xi. p. 46 , pl. vi. fig. 2 , pl. vii. fig. 10 .

1863. Sardinivides microcephalus, W. von der Marck, loc. cit. vol. xi. pp. 47, 50, pl. vi. fig. 3, pl. vii. fig. 9.

1868. Sardinivides monasterii, W. von der Marck, loc. cit. vol. xv. p. 285.

1885. Sardinioides monasterii, W. von der Marck, loc. cit. vol. xxxi. p. 254.

1885. Sardinioides microcephalus, W. von der Marck, loc. cit. vol. xxxi. p. 255.

Type. Nearly complete fish; Palæontological Museum, Munich.

The type species, attaining a length of about $0 \cdot 2$, but usually smaller. Length of head with opercular apparatus considerably exceeding the maximum depth of the trunk, and equalling at least half the length of the trunk from the pectoral arch to the base of the caudal fin. Vertebræ about 32 in number. Pelvic fins arising opposite the origin of the dorsal, much nearer to the pectorals than to the anal; dorsal fin about as deep as the trunk at its origin, comprising 12 or 13 rays, of which the two foremost are short and spinous, the third the longest and articulated though not divided distally, and the others both articulated and divided distally; anal fin resembling the dorsal, but comparatively small and remote, with only 10 rays. Serrations of scales deep and conspicuous.

Form.\& Loc. Upper Cretaceous : Westphalia.

All the following specimens were obtained from Sendenhorst:35038. Fine large specimen, displaying the minute teeth in both jaws, and nine branchiostegal rays. Purchased, 1860. 
3505\%. More imperfect large specimen in impression.

Purchased, 1860.

35010. Another large specimen chiefly in impression, with traces of the minute teeth, the nine branchiostegal rays, and the base of the pectoral fin.

Purchased, 1860.

35040. Remains of another large fish, showing parts of jaws.

Purchased, 1860.

35011. Imperfect large trunk with median fins. Long intermuscular bones are seen in impression. Purchased, 1860.

P. 3822. Large fish, wanting the end of the tail. The mouth is widely open, displaying the maxilla and premaxilla. There are also some impressions of the finely serrated scales.

Enniskillen Coll.

P. 3820, a, b. Three smaller specimens, the third with an impression on the upper border of the tail perhaps to be interpreted as indicating a small adipose fin. Enniskillen Coll.

P. 4636. Small fish $0 \cdot 115$ in length, with open mouth and deepened by crushing.

Enniskillen Coll.

P. 2103. Three imperfect specimens, chiefly in impression.

Egerton Coll.

42006. Fish $0 \cdot 16$ in length, with traces of the clustered minute teeth in the mandible and a doubtful impression of the adipose dorsal fin.

Purchased, 1870.

43010. Two small fishes probably of this species, associated on one slab.

Purchased, 1871.

P. 1874. Impressions of two imperfect small fishes, about 0.09 in length, probably young of this species. Egerton Coll.

P. 3828. A still smaller fish deepened by crushing and with open mouth.

Enniskillen Coll.

Sardinioides crassicaudus, W. von der Marck.

1863. Sardinioides crassicaudus, W. von der Marck, Palæontogr. vol. xi. p. 45, pl. vi. fig. 4.

1888. Sardinioides monasteri, K. A. von Zittel, Handb. Palæont. vol. iii. p. 275, fig. 282 (errore).

Type. Nearly complete fish; Academy of Münster, Westphalia.

A larger and more robust species than the type, attaining a length of about 0.3. Fins as in the type species but relatively less 


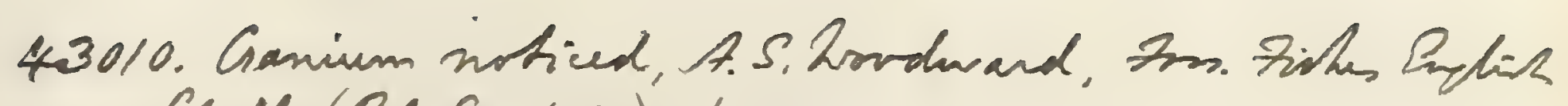
Chatk (Pal. An. 1902), h. 33.

1902. Sardinioides crassicanduo, A.S. Wordward, Mn. Fithes

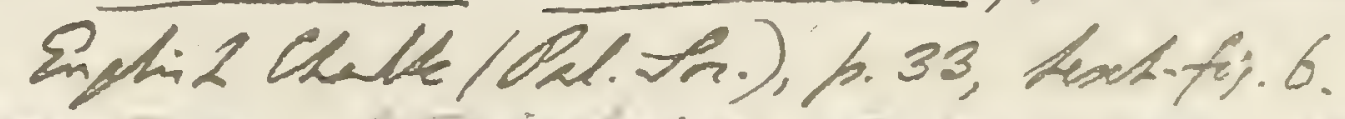

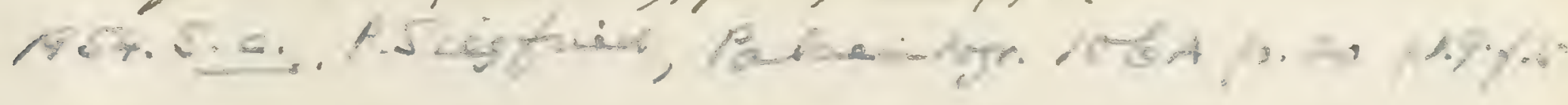



elevated; dorsal fin much less deep than the trunk at its origin, comprising 17 or 18 rays, of which the two or three foremost are short and spinous, the next the longest and articulated though not divided distally, and the others both articulated and divided distally. Serrations of scales deep and conspicuous.

Form. \& Loc. Upper Cretaceous: Westphalia.

P. 3821. Fine large specimen about 0.25 in length, with open mouth displaying the maxilla and premaxilla chiefly in impression. The greater part of the fish is shown only in impression, and there seems to be evidence of an adipose dorsal fin.

Enniskillen Coll.

P. 2101. Equally large fish, much broken and distorted before or during fossilisation, but displaying the characteristic Scopeloid mouth and most of the branchiostegal rays.

Egerton Coll.

P. 2102. Fragmentary specimen, displaying the greater part of the dorsal fin, and remains of the vertebræ and ribs in the abdominal region. The notochord seems to have passed through a small perforation in each vertebral centrum.

Egerton Coll.

P. 3823. Imperfect smaller fish on slab with remains of Sardinioides monasteri and Istieus grandis.

Enniskillen Coll.

P. 2101 a. Fish about 0.17 in length, wanting the greater part of the head.

Egerton Coll.

\section{Sardinioides megapterus (Pictet).}

1850. Osmeroides megapterus, F. J. Pictet, Poiss. Foss. Mt. Liban, p. 27 , pl. iii. fig. 3 .

1898. Osmeroides megapterus (=Sardinioides), A. S. Woodward, Ann. Mag. Nat. Hist. [7] vol. ii. p. 488.

Type. Imperfect distorted fish; Geneva Museum.

A species about 0.15 in length, known only by imperfect and distorted specimens insufficient for the basis of a precise diagnosis. General proportions apparently as in the type species, but the vertebræ 40 in number, the dorsal fin-rajs only 10 or 11 in number and the scales very feebly serrated.

Form. \& Loc. Upper Cretaceous: Sahel Alma, Mt. Lebanon.

49552. Imperfect fish shortened and deepened by distortion, exhibiting the characteristic mouth widely opened, seven 
branchiostegal rays, and parts of the pelvic, dorsal, anal, and caudal fins.

Lewis Coll.

P. 9171. Another specimen deepened anteriorly by distortion, showing the pectoral, dorsal, and caudal fins, and traces of the very fine serrations on some of the scales. The pectoral fin-rays are not less than 14 in number. Lewis Coll.

47356. Specimen elongated by distortion, with remains of about 40 vertebræ, and parts of the pelvic, dorsal, and caudal fins.

Lewis Coll.

Sardinioides pusillus, sp. nov.

[Plate XVI. figs. 2, 3.]

Type. Imperfect fish; British Museum.

A small robust species, attaining a length of about $0 \cdot 1$. Length of head with opercular apparatus not exceeding the maximum depth of the trunk, which is contained somewhat less than twice in the length from the pectoral arch to the base of the caudal fin. Vertebræ 30 in number. Fins as in the type species, except that the dorsal comprises only 10 or 11 rays. Serrations of scales deep and conspicuous.

Form.\& Loc. Upper Cretaceous: Sahel Alma, Mt. Lebanon.

48123. The type specimen, shown of the natural size in Pl. XVI. fig. 2. The open mouth displays very minute teeth, and its upper margin is clearly formed by the slender extended premaxilla. The maxilla, with its triangular distal expansion, is seen in imperfect impression above the premaxilla. The stout parasphenoid marks the base of the cranium. The vertebræ are clearly not more than 39 in number, and of these about 15 may be counted as caudal. The anterior abdominal region is much disturbed, and the paired fins are represented solely by an impression of the 6 rays of one of the pelvic pair. The dorsal fin comprises two comparatively short and slender spines, then the longest ray, articulated distally but not subdivided, and then 7 or 8 articulated and divided rays. The anal fin is relatively very small, apparently with 8 or 9 rays, but imperfectly preserved. The caudal fin is also imperfect, but distinctly forked. Where the scales are partially broken away, their posterior serrations are especially well seen upon the pale-coloured matrix. 

1903. umervider wordurardi [new name only]. O.P. Hids, Buk. Aner. Inur. N. H. vol. xix. p.424. 
P. 4482. Another imperfect specimen, represented of the natural size in Pl. XVI. fig. 3. The head is crushed backwards and the mouth widely opened, while the displaced hyoid apparatus bears the characteristic branchiostegal rays. 29 or 30 vertebræ can be distinctly counted, and the constricted centra seem to have been marked with fine longitudinal ridges. One of the small, delicate pectoral fins is partly seen; while the comparatively large and robust pelvic fins, each with 6 or 7 rays, are also preserved beneath the origin of the dorsal. The latter fin is well displayed; and the anal fin seems to exhibit 8 stout rays. The lobes of the caudal fin are imperfect distally. The serrations of the scales are very imperfectly shown, except as impressions on the matrix in front of the pelvic fins.

Enniskillen Coll.

47819, 49586. Two more imperfect specimens.

Lewis Coll.

P. 1950. Distorted fish.

Egerton Coll.

P. 4483. Imperfect fish.

Enniskillen Coll.

Sardinioides attenuatus, sp. nov.

[Plate XII. fig. 5.]

Type. Imperfect fish; British Museum.

A small elongated species, known only by the type specimen. Length of head with opercular apparatus considerably exceeding the maximum depth of the trunk, which is contained about three times in the length from the pectoral arch to the base of the caudal fin. Vertebræ 30 in number. Fins apparently as in the type species, except that the dorsal comprises only 10 or 11 rays. Serrations of scales deep and conspicuous.

Form. \& Loc. Upper Cretaceous: Hakel, Mt. Lebanon.

P. 8682. Type specimen, shown of the natural size in Pl. XII. fig. 5. The mouth is closed, but the form of the mandible is distinct, while the characteristic premaxilla and maxilla are well displayed above it. The vertebral column is displaced in a sigmoidal curve in the abdominal region: but there seem to be indications of 15 vertebræ here, and a similar number can be counted in the caudal region. One of the small, delicate pectoral fins is imperfectly shown; and there are obscure traces of the relatively large and stout pelvic fins. The dorsal tin is imperfect 
and partly depressed, but it seems to have comprised about 10 rays, the length of the longest approximately equal to the depth of the trunk at its insertion. The anal and caudal fins are also imperfect. The large, very finely serrated scales (fig. $5 a$ ) are especially well seen in the caudal region.

Purchased, 1897.

The following specimens seem to be referable to an undetermined species of Sardinioides, and are interesting as showing the small parietal bones meeting in the midale line of the skull :-

P. 3977. Vertically crushed imperfect fish, originally about 0.2 in length; English Chalk. The bones of the cranial roof exhibit a faint rugose ornament, and the short and broad median ethmoid projects forwards in front. The parietals are very small, but clearly overlie the supraoccipital and meet in the middle line. There is a large supraorbital bone on each side. The characteristic jaws and scaly cheeks are seen, while the opercular bones exhibit the same rugosity as the cranial roof. A few vertebral centra are exposed, and there are remains of the pectoral, pelvic, and dorsal fins. The large, feebly ctenoid scales are scattered.

Enniskillen Coll.

49057. Imperfect head; English Chalk. Mrs. Smith's Coll.

The following names have been given to fragments, which may be imperfect and distorted specimens of one or other of the Westphalian species described above :-

Sardinioides macropterygius, W. von der Marck, Palæontogr. vol. xxxi. (1885), p. 256, pl. xxiii. fig. 3.-Upper Cretaceous; Sendenhorst, Westphalia. [Distorted trunk; Academy of Münster.]

Sardinioides minutus, W. von der Marck, loc.cit. vol. xxxi. (1885), p. 255, pl. xxiii. fig. 2.-Ibid. [Ditto.]

Sardinioides tenuicaudus, W. von der Marck, loc. cit. vol. xi. (1863), p. 48, pl. vii. fig. 8.-Ibid. [Ditto.]

An examination of the undermentioned specimen has convinced the present writer that this must also be referred to the genus Sardinioides, the typical scales being clearly distinguishable, and the vertical banding of the fossil being due to the state of preservation of the muscle-plates:- 
n 
Sardinioides Mustrans, A.S.L.

1902. Fardinioided Illuetrane, A. S. Lrookward, Dos.

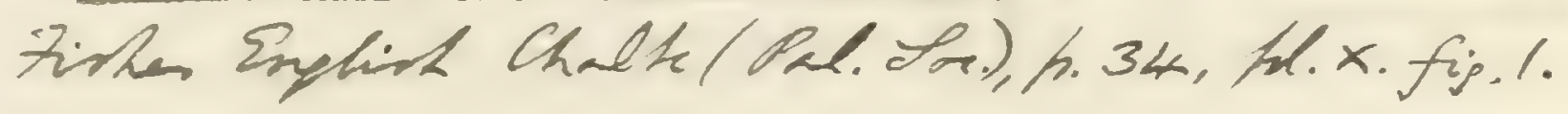

1.3977. Thre spevimen destafip lor wh

4905\%. Koticu A.S.W. 1902, h.34.

Sardinivides inatiest. Hanghef, Bull A.M. N. H. $x \times v(1908)$, f.96.

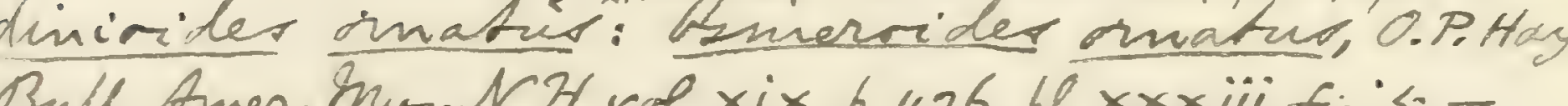

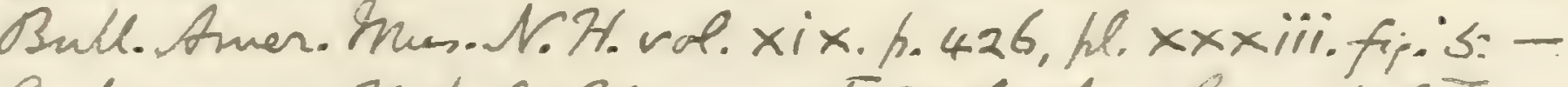

Gretaceons; Hakel, Retranon. [7ith; Amer mun. H. H.]

Jardinioides pontivagus: Omineroides pontivagus, O.P. Hay.

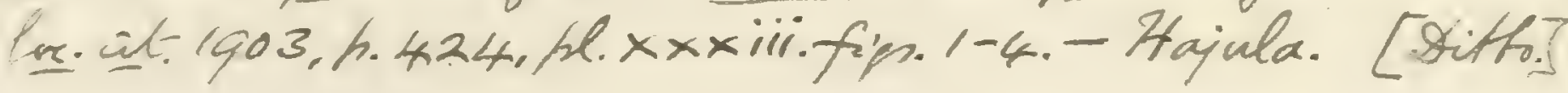




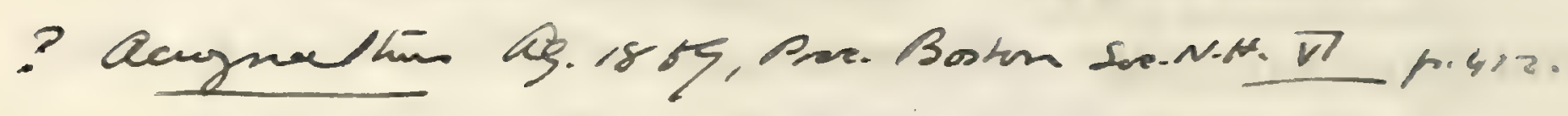

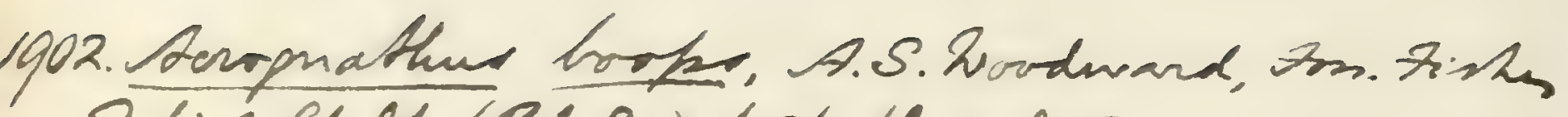

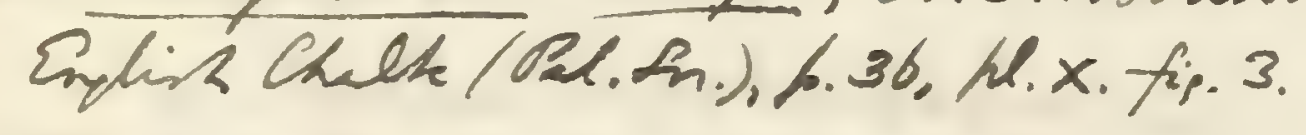

4304. Desn! afi? A. S.2. 1902, h. 36, hex. fis, 3. 

Dermatoptychus macrophthalmus, W. von der Marck, Palæontogr. vol. xv. (1868), p. 287, pl. xliii. fig. 4.-Upper Cretaceous; Sendenhorst, Westphalia. [Impression of fish, in counterpart; Academy of Münster. Type species of so-called Dermatoptychus.]

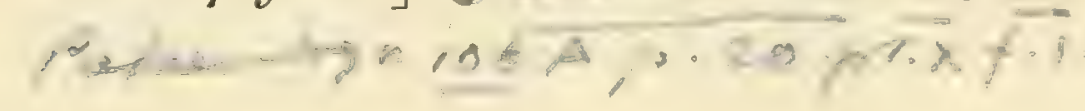

\section{Genus ACROGNATHUS, Agassiz.}

[Poiss. Foss. vol, v. pt. ii. 1844, p. 108.]

Head with remarkably large orbits and narrow interorbital region. Mandibular suspensorium nearly vertical; maxilla expanded behind; teeth very minute and clustered. Vertebræ between 30 and 40 in number. Pectoral fins delicate, inserted above the ventral border; pelvic fins comparatively large, with 7 or 8 very stout rays, inserted far forwards; dorsal fin short-based, in the anterior half of the back, without any excessively elongated ray; anal fin very small and remote; caudal fin forked. Scales large, thick, and uniform, not serrated on the hinder border; lateral line conspicuous.

\section{Acrognathus boops, Agassiz.}

1844. Acrognathus boops, L. Agassiz, Poiss. Foss. vol. v. pt. ii. p. 108, pl. lx $a$. figs. 1-4.

1888. Acrognathus boops, A. S. Woodward, Proc. Geol. Assoc. vol. x. p. 323.

Type. Imperfect distorted fish; British Museum.

The type species, imperfectly known, attaining a length of about $0 \cdot 12$. Length of head with opercular apparatus considerably exceeding the maximum depth, probably equalling about half the length of the trunk from the pectoral arch to the base of the caudal fin. Dentary and angular bones of mandible marked with sharp radiating grooves. Scales quite smooth.

Form. \& Loc. Senonian: Sussex and Surrey.

4304. Type specimen, which has lost the extremity of the tail since it was described and figured by Agassiz; Chalk, Lewes. The remarkable stoutness of the pelpic fins compared with the pectorals is well shown.

Mantell Coll.

49775. Portion of mandible and anterior vertebræ; Upper Chalk, Shalford, near Guildford. 


\section{Acrognathus libanicus, sp. nov.}

Type. Imperfect fish; British Museum.

An imperfectly known species about as large as the type, apparently of similar proportions, but with the mandible perfectly smooth and the scales marked with very delicate concentric lines following some of those of growth. Pelvic fins arising opposite the origin of the dorsal fin, which comprises 10 or 11 rays, the 2 or 3 foremost not divided distally; anal fin much smaller than the dorsal, with about 8 rays.

Form. \& Loc. Upper Cretaceous: Sahel Alma, Mt. Lebanon.

P. 9404. Type specimen, a small fish somewhat distorted at each extremity. The head is too imperfect for description. About 30 vertebræ are distinguishable. Remains of all the fins are preserved, but the dorsal is very imperfect. The characteristic squamation is partly removed, exposing an impression of the prominent ridge of the lateral line.

Lewis Coll.

P. 9405. Fragmentary large specimen displaying dorsal fin, characteristic upper jaw, and smooth mandible. Lewis Coll.

P. 9406. Another fragmentary specimen, showing the verticallycrushed head from above.

Lewis Coll.

49596-9\%, -99, 49601-02, P. 940\%. Ten imperfect specimens displaying the various characters of the genus and species.

\section{Lewis Coll.}

P. 9408. Small specimen displaying fins, associated with Acrogaster heckeli.

Egerton Coll.

The following specimens have a relatively deeper trunk and shorter head than those referred to A. libanicus, but it is uncertain whether the differences are due to accidental distortion :-

$47395,48110-11,48124,48145$. Five specimens showing the characteristic fins and scales: Sahel Alma. Lewis Coll.

Genus LEPTOSOIMUS, W. von der Marck.

[Palæontogr. vol. xi. 1863, p. 49.]

As Sardinioides, but paired fins apparently nearly equal in size, and scales not serrated.

All the known species are comparatively small, and the typical forms are slender. 
Acrosnathus dodper, Hay.

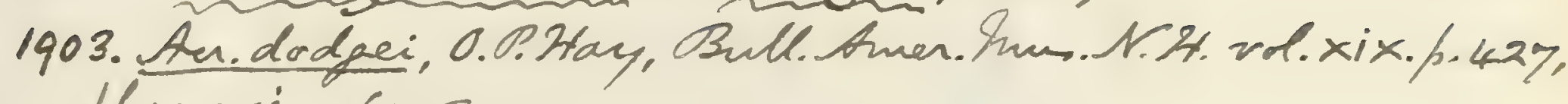
h. xxxiv.fis. 3.

Type. Firh; Amen. Hum. M. Ix.

Zrn. Ath. Cretaceons: Brajula \& Hakel, Letranon. I.9978. Fith; Hajula.

Pres? Iypian Protectant Collepe, lgor. 



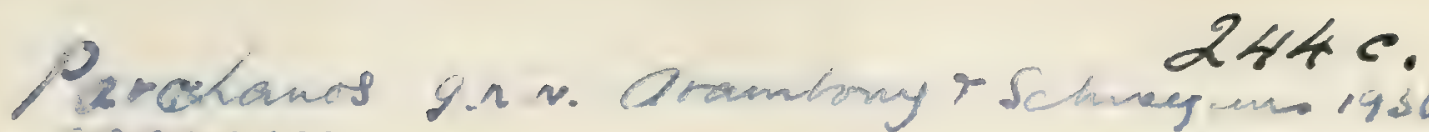

Leptosomus oltiopien heiles

19/2.(?) Diplomystiis sp. ind. C.R.Eastman, Onn.Carnggie last. rob viuipo. 376 .

1922. Leptosomus aettiopicus. W.Weiler, Pat. Zeikschr. Wr. p. 1sit Lefig. 3-5".

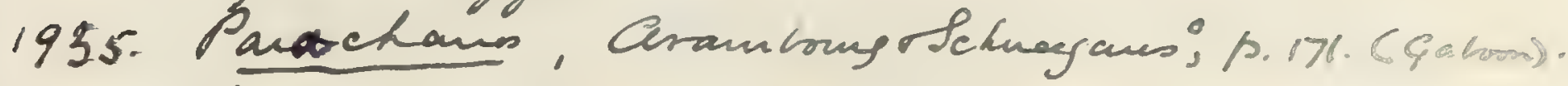

Type. Imp.ginh; Preuss - geol. Landesanstalt.

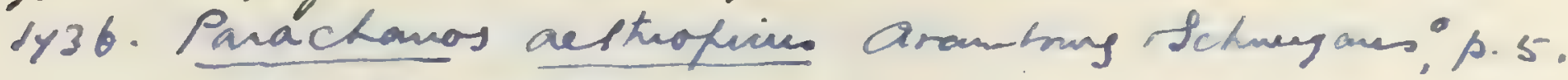
Nh. Fip (Galom) cret.

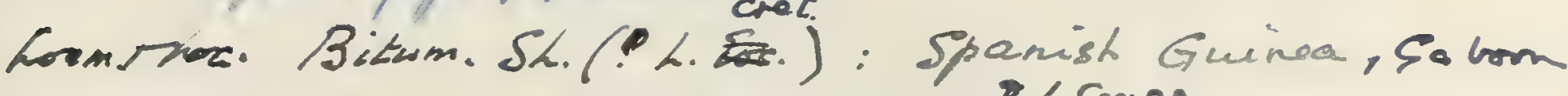

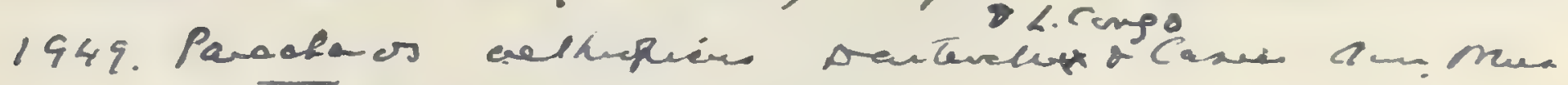

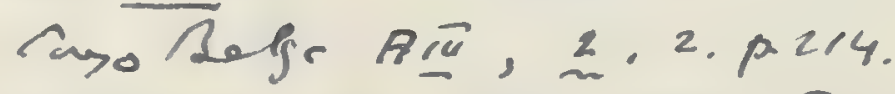

Panachanos op. Cor, cosso Tuestind G.S hasmo is $\sqrt{2}$

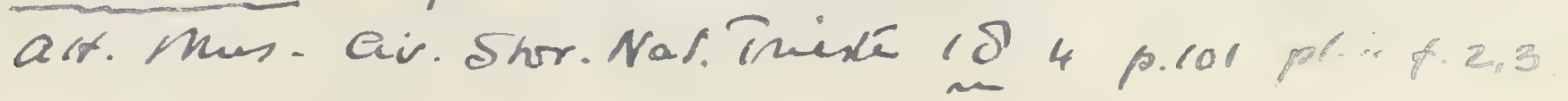




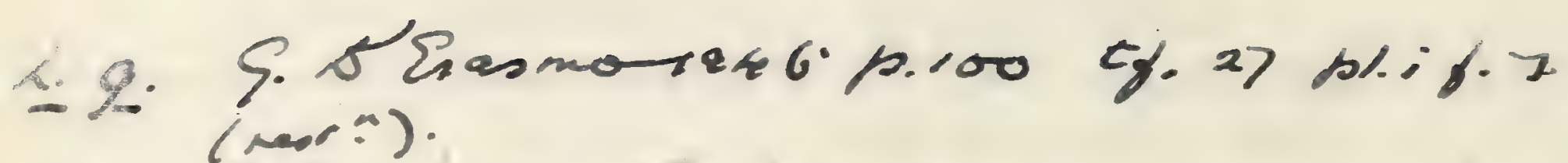

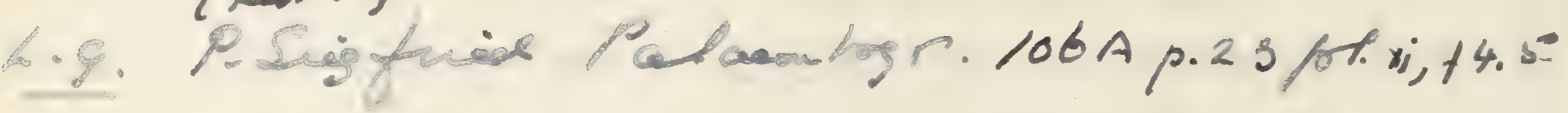

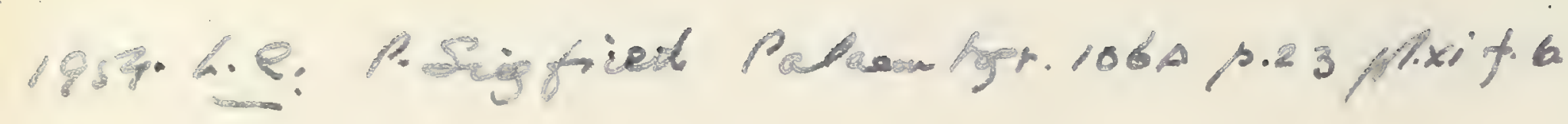


Leptosomus guestphalicus, W. von der Marck.

1863. Leptosomus guestphalicus, W. von del Marck, Palæontogr. vol. xi. p. 50, pl. viii. figs. 4,5 .

Type. Imperfect fish; Academy of Miuster, Westphalia.

The type species, attaining a length of about $0 \cdot 1$. Length of head with opercular apparatus contained twice, and maximum depth of truuk between three and four times in the length from the pectoral arch to the base of the caudal fin. Vertebræ approximately 33 in total number, the centra slightly longer than deep. Pelvic fins with 8 rays, arising opposite or immediately in front of the origin of the dorsal fin; dorsal fin with 2 undivided and 9 divided rays, nearly as deep as the trunk at its origin, arising at the middle point between the end of the snout and the base of the caudal fin: anal fin scarcely less elevated, with two undivided, and 9 or 10 divided rays, arising well behind the dorsal, but somewhat nearer to the pelvic pair than to the caudal fin.

Form. \& Loc. Upper Cretaceous: Westphalia.; CansoTresund.

P. 3828 a, P. 3841. Two typical specimens; Sendenhorst.

Enniskillen Coll.

35036. Imperfect distorted specimen; Sendenhorst.

Purchased, 1860.

P. 2110. Small distorted fish on slab with other remains; Senden. horst.

Egerton Coll.

Leptosomus elongatus, W. von der Marck.

1868. Leptosomus elongatus, W. von der Marck, Palæontogr. vol. xv. p. 286 , pl. xliii. fig. 3.

1885. Leptosomus elongatus, W. von der Marck, ibid. vol. xxxi. p. 256.

Type. Imperfect fish ; Academy of Münster.

A slender species, attaining a length of about $0 \cdot 1$. Length of head with opercular apparatus contained about three times, maximum depth of trunk about six times in the length from the pectoral arch to the base of the caudal fin. Fins almost as in the type species, but anal relatively larger and more remote.

Form. \& Loc. Upper Cretaceous: Sendenhorst, Westphalia.

Not represented in the Collection.

Leptosomus macrourus, Pictet \& Humbert.

1850. Clupe minima, F. J. Pictet, Poiss. Foss. Mt. Liban, p. 41, pl. vii. fig. 4 (errore). 
1866. Leptosomus macrourus, Pictet \& Humbert, Nouv, Rech. Poiss。 Foss. Mt. Liban, p. 75, pl. x. figs. 1-4.

1866. Leptosomus crassicostatus, Pictet \& Humbert, ibid. p. 76, pl. x. fig's. 5-7. [Distorted fish ; Geneva Museum.]

1887. Leptosomus macrourus, J. W. Davis, Trans. Roy. Dublin Soc. [2] vol. iii. p. 584, pl. xxxiv. fig. 5.

1887. Leptosomus crassicostatus, J. W. Davis, ibid. p. 584.

Type. Imperfect fish; Genera Museum.

A diminutive species, attaining a length of about $0 \cdot 06$. Length of head with opercular apparatus contained two and a half times, and maximum depth of trunk four times in the length from the pectoral arch to the base of the caudal fin. Vertebræ and fins as in the type species.

Form. \& Loc. Upper Cretaceous: Sahel Alma, Mt. Lebanon.

Among numerous specimens the following may be noted:-

P. 3842. Well preserved specimen figured by Davis, loc. cit. The skull is very imperfect, and the ceratohyal with its branchiostegal rays is crushed downwards beneath it.

Enniskillen Coll.

46454, 46546, 47388, 48141-43. Eight specimens, variously imperfect and more or less distorted, no. 48142 displaying the scales.

Lewis Coll.

P. 1884-5. Four similar specimens.

Egerton Coll.

46549, 47390, 48146-48, P. 9172. Eight specimens shortened and deepened by distortion, the first in counterpart.

Lewis Coll.

Leptosomus minimus (Agassiz).

1839 44. Clupea minima, L. Agassiz, Poiss. Foss. vol. v. pt. ii. p. 120, pl. Ixi. fig. 1 .

1866. Clupea minima, Pictet \& Humbert, Nouv. Rech. Poiss. Foss. Mt. Liban, p. 65.

Type. Imperfect fish; olim Amic Collection, Paris.

A diminutive species, attaining a length of about 0.04 . Length of head with opercular apparatus equalling nearly one half, maximum depth of trunk scarcely more than one third the length from the pectoral arch to the base of the caudal fin. Vertebræ about 30 in total number. Fins apparently as in the type species.

Form. \& Loc. Upper Cretaceous : Hakel, Mt. Lebanon.

4947\%, P. 80, P. 4783. Three slabs exhibiting a shoal of this species.

Lewis Coll. 


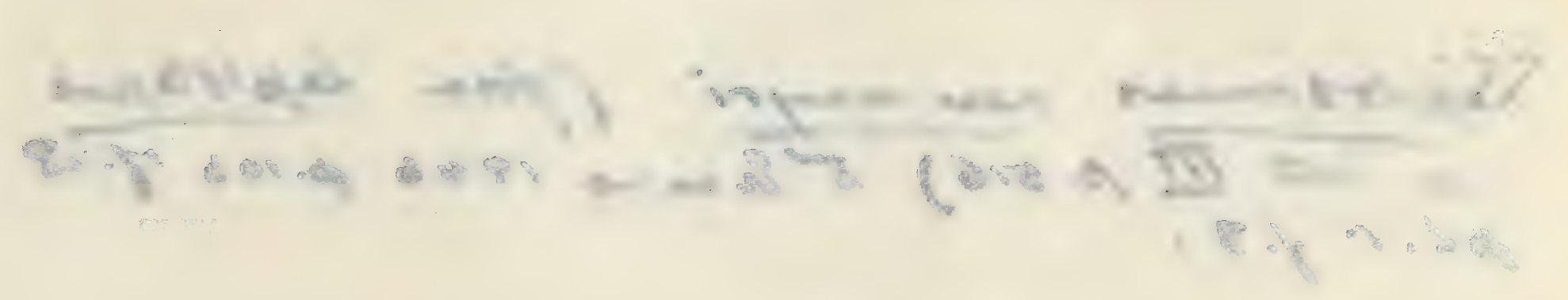


P. 4975. Similar small specimen.

Presented by J. E. Lee, Esq., 1885.

48161, 49492, 49608, P. 113. Four well-preserved fishes.

Lewis Coll.

P. 1863. Three small specimens.

Egerton Coll.

Genus SARDINIUS, W. von der Marck.

[Zeitschr. deutsch. geol. Ges. vol. x. 1858, p. 245.]

Head small and trunk moderately elongated, the maximum depth at the insertion of the dorsal fin. Mandibular suspensorium much inclined backwards, and cleft of mouth large; jaws slender, and maxilla not expanded behind; teeth minute, numerous and sharply pointed. Gill-rakers large and slender. Vertebræ about 45 in number, half caudal and half abdominal; the centra at least as long as deep, longitudinally striated; ribs delicate. No fin-rays elongated, but two or three in front of the median fins undivided and spinous. Pectoral fins with about 18 rays, relatively large and inserted just above the ventral border; pelvic fins smaller, with about 10 rays, opposed to the dorsal fin, which is nearly median and comprises about 18 rays ; anal fin behind the dorsal, longer than deep, with 20 rays; caudal fin slightly forked. Scales large and uniform, pectinated and serrated, not deepened or thickened along the course of the lateral line.

\section{Sardinius cordieri (Agassiz).}

1839-44. Osmerus cordieri, L. Agassiz, Poiss. Foss. vol.v. pt. ii. p. 101, pl. lx $d$. figs. 1,2 .

1858. Sardinius cordieri, W. von der Marck, Zeitschr. deutsch. gernl. Ges. vol. x. p. 245.

1863. Sardinius cordieri, W. von der Marck, Palæontogr. vol. xi. p. 43, pl. vii. figs. 6,7 .

Type. Nearly complete fish.

The type species, attaining a length of about $0 \cdot 13$. Length of head with opercular apparatus scarcely exceeding the maximum depth of the trunk, and a little more than one quarter the total length of the fish to the base of the caudal fin. Rays of pectoral fin, when adpressed, nearly reaching the base of the pelvic fins, which are opposed to the origin of the dorsal and slightly nearer to the anal than to the pectorals; dorsal fin deeper than long, the length of its longest ray equalling the depth of the trunk at its 
insertion. Scales marked with radiating grooves on the hinder part of their inner face.

Form. \& Loc. Upper Cretaceous: Westphalia.

P.1855. Fine specimen displaying all the fins; Baumberg.

Egerton Coll.

P. 1855 a. More imperfect specimen deepened by distortion; Baumberg.

Egerton Coll.

P. 381\%. Two distorted specimens; Baumberg. Enniskillen Coll.

P. 9058. Three specimens, two being small; Baumberg.

Purchased, 1899

P. 1856. Slightly distorted fish with dorsal fin displaced forwards, and a larger imperfect specimen; Sendenhorst.

Egerton Coll.

33058. Large trunk; Sendenhorst.

Purchased, 1858.

The following species in the Cope Collection, from the Upper Cretaceous (Niobrara Group) of Dakota, U.S.A., have also been described, but are not represented in the Collection :-

Sardinius lineatus, E. D. Cope, Bull. U.S. Geol. Surv. vol. iv. (1878), p. 71.

Sardinius nasutulus, E. D. Cope, ibid. p. 70.

Sardinius percrassus, E. D. Cope, ibid. p. 72.

The systematic position of the fish described as follows is quite uncertain :-

(?) Sardinius blackburnï, E. D. Cope, Amer. Nat. vol. xxv. (1891), p. 654.-Lower Tertiary (?); Ree Hills, South Dakota, U.S.A. [Imperfect trunk.]

$$
\text { Elopiform, P.C.goriy 1969, Am. Mus. Nov,t, } 2358
$$

Genus DACTYLOPOGON, W. von der Marck.

[Palæontogr. vol. xv. 1868, p. 278.]

Head small, trunk elongated and much laterally compressed. Cranial roof and posterior cheek-plates ornamented with radiating rugæ. Branchiostegal rays about 12 in number. Vertebræ approximately 70 in number, about half being caudal; the centra not longer than deep. Pectoral fins inserted close to the ventral border, the foremost ray much elongated and closely articulated but simple; pelvic fins smaller than the pectorals; dorsal and anal 
Sardinius? inbellir, O.P. Hay, Bull Amen. Mmen. Hal. Hist vol. xix (1903), h. 93, hl. iv. fig. Q. - hiobrara Cretacenus;

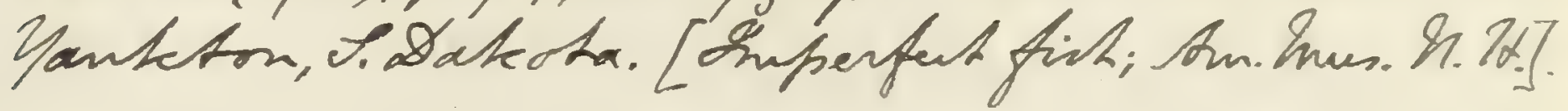

Leptozmus lineather, O. PHay. Bull. Anes. Kmas. Kat. Hist. vol. xix (1903), p. g2, hl.iv.fig.6. pl.v. fig. 2.

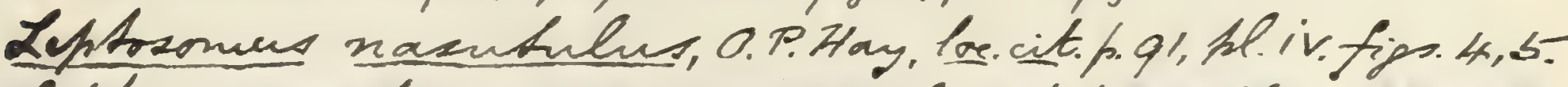
Leptozomus pererasaur, 0. P. Hay, lor.cit.p. 92, pl.v. fij. 3. 
fins about as deep as long, nearly equal in size, the former opposed to the space between the pelvic fins and the latter; caudal fin considerably forked. Scales delicate, longer than deep, none enlarged or thickened except a single ridge-scale at the base of the caudal fin above and below.

Dactylopogon grandis, W. von der Marck.

1868. Dactylopogon grandis, W. von der Marck, Palæontogr. rol. xr. p. 279, pl. xli. fig. 1.

Type. Nearly complete fish; Academy of Münster.

The type species, attaining a length of about 0.4 . Length of head with opercular apparatus about equal to the maximum depth of the trunk and contained nearly three and a half times in the length from the pectoral arch to the base of the caudal fin. Pectoral fin-rajs about 15 in number, the length of the foremost at least twice that of the cranium: pelvic fins with 1 undivided and 6 divided rays, inserted nearer to the anal than to the pectorals; dorsal with 6 gradually lengthening undivided rays followed by 18 divided rays, arising slightly in advance of the middle point between the occiput and the caudal fin; anal arising opposite the termination of the dorsal, with 5 gradually lengthening undivided rays followed by 19 divided rays. Some scales faintly crimped towards the hinder border.

Form.\& Loc. Upper Cretaceous: Sendenhorst, Westphalia.

Not represented in the Collection.

An indeterminable fragment, probably not of this genus, has been described as follows:-

Dactylopogon parvulus, D. G. Kramberger, Djela Jugoslar. Akad. rol. xri (1895), p. 41, pl. vii. fig. 3.-Upper Cretaceous; IIt. Lebanon. [Middle portion of small trunk; Trieste IItseum.] = Hakelia abicauses

Genus INEIMATONOTUS, A. S. Woodward. [Ann. Mag. Nat. Hist. (7) vol. iv. 1899, p. 318.]

Head large, trunk short and robust. Mandibular suspensorium nearly vertical; jaws delicate and maxilla apparently not expanded behind; teeth minute. Vertebræ about 30 in number, half being caudal; the centra at least as long as deep, with a few prominent longitudinal ridges; ribs moderately robust. Pectoral fins small, 
close to the ventral border; pelvic fins smaller, opposed to the dorsal fin, which is situated within the anterior half of the back and exhibits one anterior ray excessively elongated and closely articulated; anal fin very small and remote; caudal fin stout but deeply forked. Scales large, smooth, and uniform, moderately thick, not serrated at the hinder border; lateral line conspicuous.

\section{Nematonotus bottæ (Pictet \& Humbert).}

[Plate XVI. fig. 1.]

1866. Clupea botta, Pictet \& Humbert, Nouv. Rech. Poiss. Foss. Mt. Liban, p. 64, pl. vii. figs. 1-5.

1887. Chupea bottce, J. W. Davis, Trans. Roy. Dublin Soc. [2] vol, iii. p. 575 .

1887. Pseudoberyx longispina, J. W. Davis, ibid. p. 511, pl. xxv. fig. 2.

[Distorted fish; Edinburgh Museum.]

1899. Nematonotus botta, A. S. Woodward, Ann. Mag. Nat. Hist. [7] vol. iv. p. 317.

Type. Nearly complete fish; Geneva Museum.

The type species, attaining a length of about $0 \cdot 12$. Length of head with opercular apparatus apparently about equalling the maximum depth of the trunk, and half its length from the pectoral arch to the base of the caudal fin [but all known specimens considerably distorted]. Pectoral fins with about 10 rays, of which one or more of the foremost are very stout and closely articulated and not divided distally; pelvic fins with 7 or 8 stout divided rays, arising opposite the anterior half of the dorsal fin, much nearer to the pectoral pair than to the anal; dorsal fin comprising one short spinous ray in front, next a longer ray, closely articulated though not divided distally, next a simple, articulated ray excessively elongated to an extent equalling about two thirds the length of the back behind its insertion, finally 9 rays of moderate length, shortening backwards, all both articulated and divided distally; the space between the dorsal fin and the occiput slightly exceeding the length of its base-line, the space between the dorsal and caudal fins equalling from two to three times the same measurement; anal fin with about 8 rays, separated from the caudal by a space approximately equal to the length of its base-line.

Form. \& Loc. Upper Cretaceous: Hakel, Mt. Lebanon, Syria. A Hajula.

P. 9409. Large specimen considerably fractured. The anterior ends of the slender premaxilla and maxilla are seen, one behind the other; and the number of vertebræ is proved to be approximately 30. Remains of the stout pectoral 
GQ46. ?N. E. Thasmertiog.

1903. Nematonotus longishinus, O.P. Fray. Bull buver-

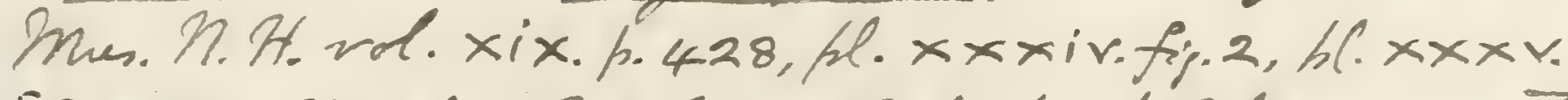
[P.9972. Htojula. Res? Squian Protestant College, 1902.] 

fin-rays exhibit excessively fine articulations in the distal portion; the numerous articulations of the elongated dorsal fin-ray are also partly shown.

Presented by the Earl of Aylesford, 1845.

49564. Another large specimen with imperfect head and fins.

Lewis Coll.

P. 8690. Large imperfect and distorted specimen, with characteristic toothed premaxilla displaced and well exhibited.

Purchased, 1897.

P."4028. Large, much distorted specimen, partly showing the upper border of the mouth and the characteristic dorsal fin.

Lewis Coll.

49565. Imperfect fish about 0.09 in length, deepened by distortion. The dorsal fin is very clearly shown, as described in the generic diagnosis; and in front of this fin there are evidently free neural spines, somewhat thickened, expanded and truncated distally. The course of the lateral line is marked upon the scales just above the vertebral column.

Lewis Coll.

49562. Equally small fish, somewhat imperfect and deepened by distortion, but displaying most of the generic and specific characters, shown of the natural size in Pl. XVI. fig. 1. The head is clearly short and deep, the opercular apparatus also short and deep, and the clavicle rather stout. Some of the ribs are seen beneath the scales; and there are similarly indications of three separated neural spines, thickened, expanded, and truncated distally, in front of the dorsal fin. The neural and hæmal spines of the caudal region are observed to be very stout. The characteristic dorsal fin, with its elongated ray, is almost completely shown; and there are fragmentary remains of all the other fins. The course of the lateral line is partly marked upon the scales immediately above the vertebræ.

Lervis Coll.

48159, 49491. Two small specimens, the first displaying the ribs and the elongated dorsal fin-ray.

Lewis Coll.

48160, P. 111 , P. 112. Three very small specimens, probably young of this species.

Lewis Coll. 


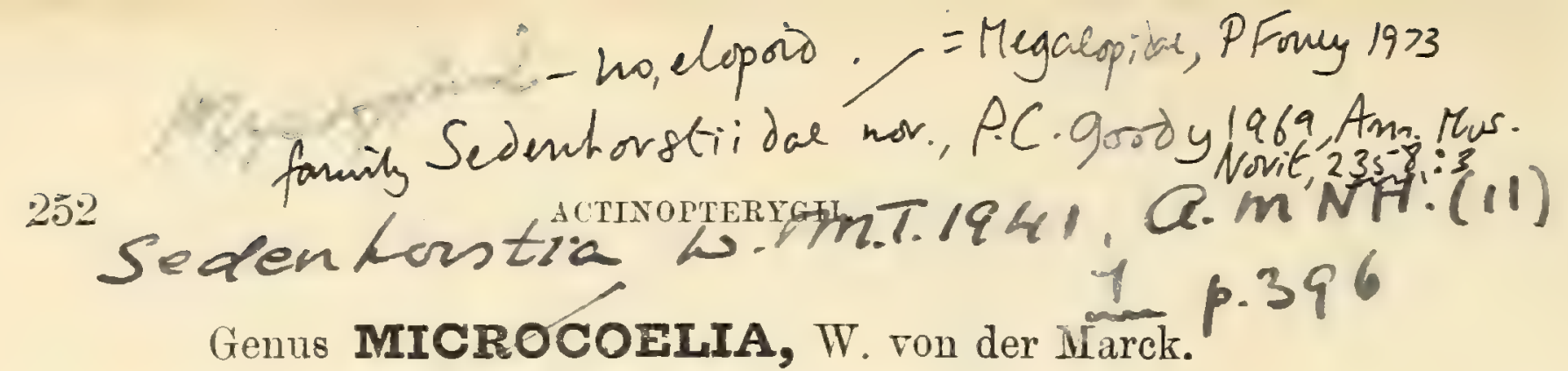

[Palæontogr. vol. xi. 1863, p. 48.]

Head large, trunk short and robust. Mandibular suspensorium nearly vertical; jaws delicate, and maxilla not expanded bebind; teeth rery minute. Vertebræ from 40 to 45 in number, about. half being caudal; the centra longitudinally striated and not longer than deep; ribs delicate. No fin-rays elongated, but from two to five in front of the median fins undivided and spinous. Paired fins delicate and small, the pectorals inserted close to the rentral border; dorsal and anal fins much extended, acuminate in front, low and fringe-like behind, partly or completely opposed; caudal fin forked. Scales large and uniform, smooth and not serrated.

Microcoelia granulata, W. von der Marck.

1863. Microcuelia granulata, W. ron der Narck, Palæontogr. vol. xi. p. 49, pl. r. fig. 4 .

1868. Microcoelia granulata, W. ron der Marck, loc.cit. vol. xv. p. 287, pl. sliii. fig. 9.

Type. Nearly complete fish; Academy of Münster.

The type species, attaining a length of about 0.08 . Length of head with opercular apparatus scarcely equalling the maximum dejth of the trunk, and contained two and a half times in the length from the pectoral arch to the base of the caudal fin. Paired fins nearly equal in size, the distance between them less than that between the pelvic pair and the anal; dorsal fin occupying about half the back, arising somewhat in front of its middle point, and comprising three short and two long undivided rays, followed by 24 divided rays; anal fin nearly similar to the dorsal, arising slightly behind the latter, and comprising two short and one long undivided rays, followed by about 24 divided rays; these median fins extending close to the caudal.

As already remarked by ron der Marck (loc. cit. 1868), the granulations on the scales mentioned in the original diagnosis are due to accident in fossilisation.

Form. \&. Loc. Upper Cretaceous : Sendenhorst, Westphalia.

Not represented in the Collection.

\section{Microcoelia libanica, sp. nov.}

Type. Imperfect fish; British Museum.

A species nearly twice as large as the type, but of similar pro- 
783

purse. by Gouncé 1852, that on the Stw gein Lep. 533 det

Genus reviensd lo P. Forey, 1973, Bull. BM(Gerr.) Supplico; $85-88$

1954. Ma.g. P. Sugfried Palaembfr. $106 \mathrm{~A}$ p.22 


Ticrocgelia Tazi, Hay.

0303. Ania. dayi; 0.P. Hoy, Sull. Amer Hun. N. H. Nh.xix.

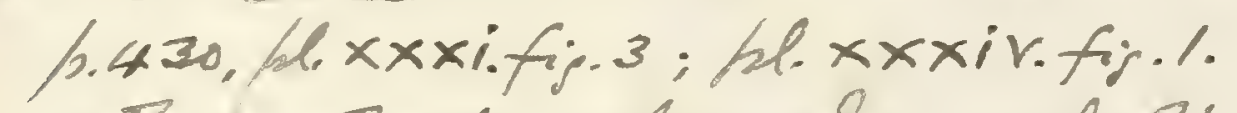

1969. Sedenhorstia day, P.gordy, Am. Mus. Novit 2358:4 figs. 1-3, 9.

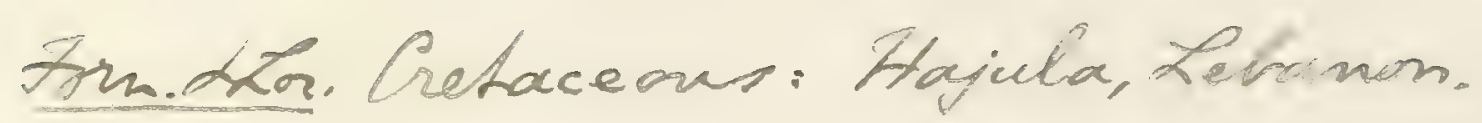

Sedenhorstia ovientalis, P. Gordy, 1969, Amn. Mus. Nnit $2358: 14, f i g .4$.

Cenanamion, Hajula, Lebanon. Holotype BM P.9983 


portions. Paired fins nearly equal in size, the pelric pair inserted midway between the pectorals and the anal; dorsal fin occupying about one third of the back, arising opposite the pelvic pair, and comprising 17 or 18 divided rays in addition to the anterior undivided rays; anal fin less extended than the dorsal, but with 17 divided rays, and arising opposite the hinder half of the dorsal; caudal fin apparently more deeply forked than in the type species.

Form.\& Loc. Upper Cretaceous: Hakel, MIt. Lebanon.

P. 4865. The type specimen, wanting the anterior half of the head, and measuring about 0.105 in length from the pectoral arch to the extremity of the caudal fin. The opercular apparatus is short and deep, and there are 7 or 8 branchiostegal rays in advance of the few stout rays noted by W. von der Marck in the Westphalian specimens. The axial skeleton and fins are well preserved, except the anterior rays of the dorsal and anal. The trunk is slightly deepened by crushing, and the dorsal margin in front of the fin is marked by curious crimpings, which are suggestive of hard, possibly serrated ridge-scales. The large smooth scales of the flank display a few radiating grooves on their covered portion. Lewvis Coll.

Genus OPISTHOPTERYX, Pictet \& Humbert.

[Nouv. Rech. Poiss. Foss. Mt. Liban, 1866, p. 78 (Opistopteryx).]

Head relatively large and trunk elongated, its maximum depth at the opercular apparatus. Mandibular suspensorium much inclined backwards, and cleft of mouth wide, extending below the orbit, which is very large and forwardly placed; teeth minute; gill-rakers large and robust. Vertebral centra not longer than deep, longitudinally striated, between 50 and 60 in total number, about half caudal and half abdominal; ribs very slender; separate and relatively stout sigmoidally bent neural spines in the abdominal region. Pectoral fins elongated, but not extending beyond the pelvic pair, inserted close to the rentral border; pelvic fins somewhat smaller; dorsal and anal fins short-based, very deep and acuminate, the former placed in the middle of the back, the latter arising opposite its hindermost rays; caudal fin large, deeply forked, with slender acuminate lobes. Scales thin, but apparently uniform and covering the whole trunk. 
Opisthopteryx gracilis, Pictet \& Humbert.

1850. Mesogaster gracilis, F. J. Pictet, Poiss. Foss. Mt. Liban, p. 24, pl. iii. fig. 2.

1866. Opistopteryx gracilis, Pictet \& Humbert, Nouv. Rech. Poiss. Foss. Mt. Liban, p. 80, pl. xi. figs. 1-4.

1887. Opistopteryx gracilis, J. W. Davis, Trans. Roy. Dublin Soc. [2] vol. iii. p. 569.

1887. Opistopteryx curtus, J. W. Davis, ibid. p. 569, pl. xxxii. fig. 3. [Fish distorted by crushing; Edinburgh Museum.]

Type. Distorted fish, wanting caudal fin; Geneva Museum.

The type species, attaining a length of about $0 \cdot 1$. Isength of head with opercular apparatus equalling about $t$ wice the maximum depth of the trunk and contained approximately four times in the total length of the fish. Longest ray of pectoral fins extending to the origin of the pelvic fins, which are about two thirds as large as the pectorals and arise midway between the latter and the anal; dorsal fin deeper than long, with about 11 rays, its origin as far from the occiput as is its termination from the base of the caudal fin; anal fin nearly as deep as the dorsal but less extended, with only about 8 rays, arising midway between the pectorals and the caudal.

The fossilised examples of this fish are usually much distorted, but its general characters and proportions seem to be correctly stated in the above diagnosis. One specimen, evidently shortened by crushing, is described by Davis under a distinct specific name, O. curtus.

Form. \& Loc. Upper Cretaceous: Mt. Lebanon, Syria.

P. 1886. Fine specimen slightly elongated by crushing, displaying the separate neural spines in the abdominal region; Sahel Alma.

Egerton Coll.

49604. Another fine specimen with head and anterior abdominal region distorted; Sahel Alma. Traces of the relatively large, pointed gill-rakers are seen. Lewis Coll.

47357-58, 47816, 49594. Four more imperfect distorted specimens, with traces of the minute teeth and well-developed gillrakers; Sahel Alma.

Lewis Coll.

Genus SCOPELOIDES, Wettstein.

[Fischfauna Tertiaer. Glarnerschief. 1886, p. 55.]

Head large and trunk elongate-fusiform. Mandibular suspensorium much inclined backwards; jaws slender; teeth moderately 
Inch. Mrazecia (q.r.p.235) r tol stomiatidae

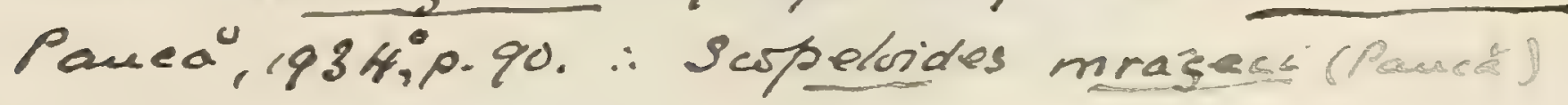


large, slender and pointed, widely spaced and irregular in size, Vertebræ about 40 in number, half being caudal; the ceutra rather longer than deep, and the arches in the caudal region comparatively short. No fin-rays excessively elongated, but the dorsal and anal fins much elevated in front and low behind. Pectoral fins comparatively large, close to the ventral border, the rays not quite reaching the pelvic fins, which are small; dorsal fin with about 10 rays, arising at or near the middle point between the occiput and the caudal fin; anal fin relatively large, arising opposite the hinder end of the dorsal and extending nearly to the caudal fin, with at least 20 rays; caudal tin considerably forked.

\section{Scopeloides glarisianus (Agassiz).}

18:39-44. Osmerus glarisianus, L. Agassiz, Poiss. Foss. vol. v. pt. ii. p. 102, pl. Ixii. figs. 3, 4 (Osmeroides glarisianus on plate).

1886. Scopeloides glaronensis, A. Wettstein, Fischfauna Tertiaer. Glarnerschief. (Denkschr. schweiz. Palaeont. Ges. vol. xiii.), p. 56, pl. ii. figs. 7-13.

Type. Nearly complete fish; British Museum.

The type species, attaining a length of about $0 \cdot 18$. Form and proportions uncertain owing to distortion of specimens, but the length of the head with opercular apparatus apparently nearly twice as great as the maximum depth of the trunk and about one third the length of the vertebral column. Teeth very slender, some recurved. Pelvic fins arising nearer to the anal than to the pectoral pair; dorsal fin arising at the middle point between the occiput and the caudal fin, the length of its base-line about half that of its longest ray which approximately equals the depth of the trunk at its insertion; anal fin arising nearly midway between the pectorals and the caudal, its front portion symmetrical with the dorsal, its hinder portion very low and fringe-like.

Form. \& Loc. Oligocene: Canton Glarus, Switzerland.

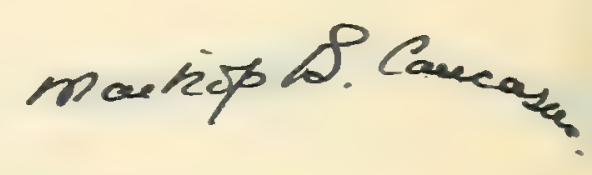

P. 3815-16. Type specimen and another described and figured by Agassiz, loc. cit. p. 102, pl. lxii. figs. 3, 4; Engi. Both are labelled "Osmeroides glarisianus, Ag." by Agassiz, but they also bear a second label in his handwriting, "Nov. gen. voisin des Scopelus." Enniskillen Coll.

P. $185 \%$ P. 3814. More imperfect specimen elongated by distortion, in counterpart, similarly labelled by Agassiz; Engi.

$$
\text { Egerton \&. Enniskillen Colls. }
$$


P. 5142. Fish shortened by distortion, in counterpart, and displaying the fins ; Engi. Labelled "1778. Ex Museo Gronoviano, No. 2494." Purchased, 1886.

P. 1857 a. Imperfect fish, elongated by distortion; Engi.

Egerton Coll.

The generic position of the imperfect fish described as follows, is not satisfactorily determined, and the species is not represented in the Collection :-

Scopetoides nicolisi, F. Bassani, Atti R. Accad. Sci. Napoli, [2] vol. iii. no. 6 (1889), p. 32, pl. i. fig. 5.-Lower Miocene; Chiavon, N. Italy. [Imperfect fish; Piovene Coll., Lonedo.]

Genus PARASCOPELUS, Sauvage.

[Ann. Sci. Géol. vol. iv. art. no. 1, 1873, p. 196.]

An imperfectly known genus, with much-elongated head and trunk. Cleft of mouth very large, with minute teeth. Pectoral fins very large; pelvic fins small and far forwards; dorsal fin short-based and median; anal fin remote, more extended than the dorsal; caudal fin forked. Scales large and uniform, not serrated at the hinder border.

\section{Parascopelus lacertosus, Sauvage.}

1870. Scopelus lacertosus, H. E. Sauvage, Ann. Sci. Nat. [5] vol. xiv. art. no. 7, p. 22.

1873. Parascopelus lacertosus, H. E. Saurage, Ann. Sci. Géol. vol. iv. art. no. 1, p. 196, figs. 50, 51.

Type. Imperfect fish.

The type species, attaining a length of about $0 \cdot 25$. Length of head with opercular apparatus contained about five times, maximum depth of trunk about seven times in the total length of the fish. Vertebræ about 54 in number, 30 being caudal. Pectoral fins as long as the head, with 14 rays; dorsal fin with more than 15 , anal with about 20 rays.

Form.\& Loc. Upper Miocene: Licata, Sicily.

P. 1161-62. Two imperfect specimens.

Egerton Coll. 


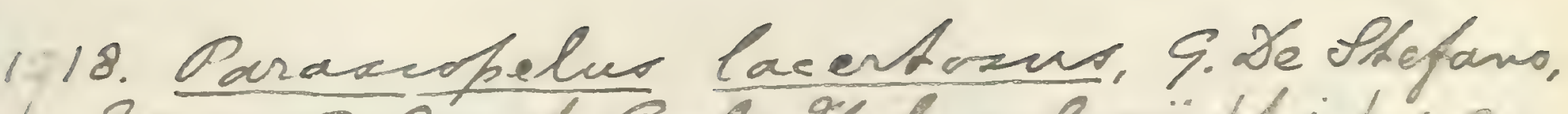

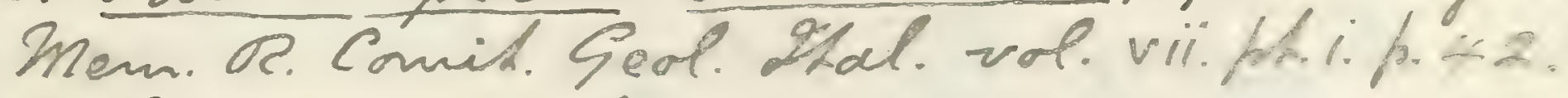
1925: Paraseopelus lacentoous, C. Aramiong, Amn.

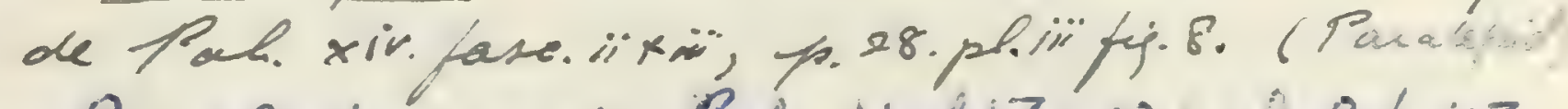

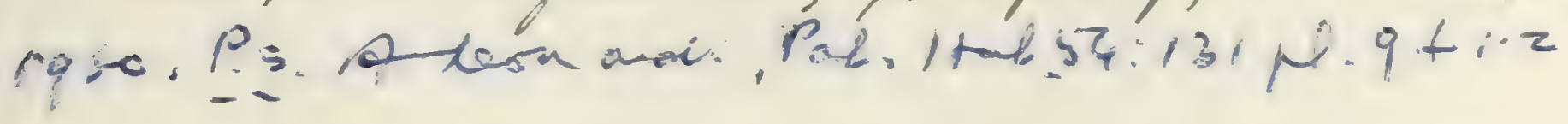





\section{Genus ANAPTERUS, Sauvage.}

[Ann. Sci. Géol. vol. iv. art. no. 1, 1873, p. 199.]

Syn. Tydeus, H. E. Sauvage (non Koch, 1842), Ann. Sci. Nat. [5] vol. xiv. art. no. 7, 1870, p. 23.

An imperfectly known genus, with much-elongated head and trunk. Cleft of mouth very large, with a few large spaced teeth and small unciform teeth between. Pectoral fins not much enlarged; pelvic fins small and remote; dorsal fin short-based, in hinder half of back but completely in advance of the extended anal fin; caudal fin forked. Scales of moderate size, uniform, and not serrated at the hinder border; lateral line conspicuous.

This genus is not yet clearly distinguished from the existing pelagic genera, Purctepis and Sudis. ...

\section{Anapterus megistosoma, Saurage.}

1870. Tydeus megistosoma, H. E. Sauvage, Ann. Sci. Nat. [5] vol. xiv art. no. 7, p. 25.

1873. Anapterus megistosoma, H. E. Sauvage, Ann. Sci. Géol. vol. ir. art. no. 1, p. 200, figs. 95, 96.

Type. Imperfect fish.

The type species, attaining a length of about 0.5 . Length of head with opercular apparatus contained about five times, maximum depth of trunk about ten times in the total length of the fish. Vertebræ nearly 100 in number. Pectoral fins with 20 rays; pelvic fins with 14 rays, opposite the origin of the dorsal, which comprises about 12 rays and is completely within the hinder third of the back; anal fin with at least 30 rays, extending close to the caudal. Scales of lateral line not enlarged.

Form. \& Loc. Upper Hiocene : Licata, Sicily. Sanelá, San.

P. 1163. Imperfect small distorted specimen labelled (apparently by Saurage) as young of this species. Egerton Coll.

The following species from the Tpper Miocene of Licata have also been recognised on the evidence of imperfect fishes, but are not represented in the Collection :-

Anapterus albyi, H. E. Sauvage, loc. cit. 1873, p. 203, figs. 93, 94.

Tydeus albyi, H. E. Sauvage, loc.cit. 1870, p. 24.

Anapterus elongatus, H. E. Sauvage, Toc. cit. 1873, p. 206, fig. 92.

Tydeus elongatus, H. E. Sauvage, Toc. cit. 1870, p. 25.

Anctpterus siculus, H. E. Sauvage, loc. cit. 1873, p. 205, fig. 4 , and ibid. vol. xi. art. no. 3 (1880), p. 39, fig. 4. 
Anapterus sphekocles, H. E. Sauvage, Toc. cit. 1873, p. 208, fig. 91. Tydeus sphekodes, H. E. Sauvage, Toc. cit. 1870, p. 23.

The last species is recorded from the Upper. Miocene of Mondaino, Province of Forli, Italy, by I. Bonomi (Rivista Ital. Paleont. vol. ii. 1896, p. 221), who has founded a new species Anapterus macrocephalus (loc. cit. p. 222, pl. $\nabla$. fig. 7) on another indeterminable fish. Anapterus toenia is an undefined name given by Bosniaski (Proc. Verb. Soc. Tosc. Sci. Nat. vol. i. 1878, p. xix) to a fish from the Upper Miocene of Gabbro, Tuscany.

The following remains of Scopelidæ with slender premaxilla are not generically or specifically determined:-

P. 4031, P. 4766. Small elongated fish, in counterpart; Upper Cretaceous, Sahel Alma, Mt. Lebanon. The jaws are slender and the mandible bears spaced conical teeth. The paired fins are rather large. The dorsal fin is median, deep, and short-based. Lewis Coll.

P. 3844. More slender and elongated fish associated with Spaniodon; Sahel Aima.

Lervis Coll.

P. 9410. Head 0.085 in length; London Clay, Sheppey. The cranium resembles that of Autopus, but the mandible bears large spaced conical teeth in addition to minute teeth.

History unknown.

$$
\text { Genus APATEODUS, norum. = Eneho dratacestr. }
$$

A genus known only by parts of the head, which is elongated and with pointed snout. Parietal bones separated by the supraoceipital, which appears in the middle of the cranial roof. Premaxillæ very stout, pointed in front but not produced forwards in advance of the ethmoidal region; teeth large in the middle of each jaw, laterally compressed, and fused with the supporting bone at their tumid base.

Apateodus glyphodus (C. C. Blake).

[Plate XIII. figs. 3-5.]

1863. Pachyrhizodus glyphodus, C. C. Blake, Geologist, vol. vi. p. 134, pl. xxi. figs. xii, xiii.

Type. Fragment of jaw ; British Museum.

The type species, known only by portions of jaws, the mandible probably attaining a length of about $0 \cdot 2$. Two teeth on the anterior half of the premaxilla much enlarged; the anterior about 
Paralefir spheteder. T.de thefano, Mem. As. Comit. Geol. Ptal. vol vir. ph. i (1918), p. 46, Al. iv. $f \cdot 1-4$

Sudis sptetiodes. C. Aromizomg Am de Pal.

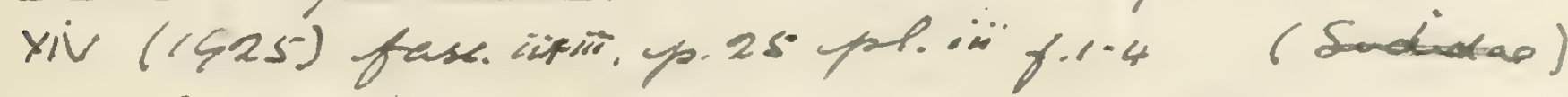
saveris ophekodes, S. Dhasmo, 1930an, 14, is 5-6. K.M. in

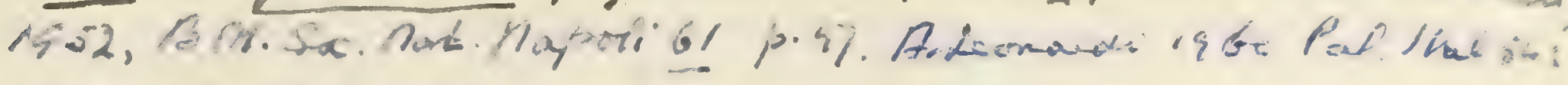
i2? He. 14 f. $1-5$.

Suaris Larnia fotharmo, 19306, 39, 11,577

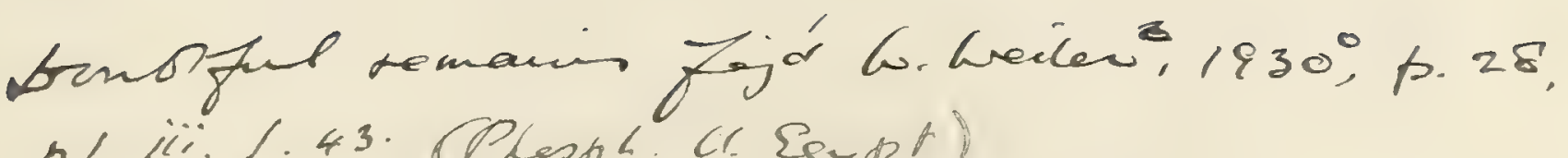

$$
\begin{aligned}
& \text { phii.f. 43. (Plespht. Cl Egyor). }
\end{aligned}
$$



two thirds as long as the posterior tooth, and the length of the latter less than the interspace between the two teeth, also less than half the length of the part of the premaxilla in front of its insertion. Mandible much attenuated in front, with two relatively large teeth in the middle of the dental series; the small recurved teeth in advance of these gradually increasing in size backwards.

Form. \& Loc. Albian (Gault): Folkestone, Kent.

37930. Type specimen, being a fragment apparently of the hinder part of the premaxilla.

Purchased, 1863.

47201. Imperfect left premaxilla associated with the greater part of the mandible and remains of three vertebræ, shown of the natural size in Pl. XIII. fig. 3. The premaxilla $(p m x$.$) is imperfect at each end, and fractured near its$ middle where it seems to be accidentally bent. Immediately in front of this fracture, the largest tooth is shown, with its distal portion obscured by the remains of the mandible. A slightly smaller tooth is imperfectly preserved a little further back; and then follow three or four still smaller spaced teeth, which are much laterally-compressed and vertically striated at the base. The dentary (d.) is considerably fractured and broken away behind, but its outer face is shown to have been smooth and rather tumid, impressed only by a deep longitudinal groove just below its upper border. Its anterior recurved teeth are preserved on both sides of the jaw, gradually increasing in size and becoming more widely spaced backwards; the very large middle teeth are wanting in the fossil; the hinder teeth are proved to have been very small.

Gardner Coll.

47204a. Right and left premaxillæ probably of one and the same individual, that of the right side shown of the natural size from the inner aspect in PI. XIII. fig. 4. Only the anterior half of the hone is preserved, and it seems to represent a larger fish than the last specimen. It tapers to a point in frout, while its inner face is smooth and flattened for articulation with the elongated ethmoidal region. Its oral face gradually widens backwards and forms a gently hollowed trough, which is filled at two points by the tumid bases of the large teeth. Both these teeth are well-preserved, exhibiting a laterally compressed, straight, lanceolate crown, finely striated at its base. The 
posterior is the larger tooth, inclined forwards, with a sharp edge in front and behind: while the anterior tooth is rounded behind, with a sharp edge only in front. Between the large teeth there are also traces of small ones of similar form, arranged in single series on the sharp outer margin of the bone. One of these small teeth, preserved on the left premaxilla, is slightly curved inwards in its apical portion. Remains apparently of the attenuated rostral region occur abore the right premaxilla.

Gardner Coll.

47204 b. Imperfect anterior half of a smaller left premaxilla, showing the base of the anterior enlarged tooth, and the whole of the posterior enlarged tooth, which is distinctly inclined forwards. Gardner Coll.

47204 c. The greater portion of the left dentary, much crushed, and imperfect both behind and below, shown from the outer aspect of the natural size in Pl. XIII. fig. 5. Five of the anterior recurved teeth are indicated, gradually increasing in size backwards. Then follow remains of two very large teeth with tumid, finely striated bases, the second much larger than the first. The outer face of the bone, so far as preserved, is smooth. G(crdnes Coll.

33311. Fragment of left premaxilla, with base of postorior enlarged tooth.

Purchased, 1858.

P. 9020. Anterior portion of small right premaxilla.

Presented by F. G. Hilton Price, Esq., 1899.

P. 5528. Remains of anterior half of mandible. Purchased, 1888.

$47204 \mathrm{e}-\mathrm{i}$. Small fragments of mandible.

Gardner Coll.

P. 35. Anterior end of small left dentary.

Gardner Coll.

Apateodus striatus, sp. nov.

[Plate XIII. fig.6, Plate XIV.]

(?) 1837-44. Saurocephalus striatus, L. Agassiz, Poiss. Foss. vol. v. pt. i. p. 102, pl. xxv c. figs. 17-20.

Type. Small head; British Museum.

An imperfectly known species, the mandible probably attaining a length of about 0.15. Two teeth on the anterior half of the premaxilla much enlarged; the anterior about two thirds as long as 


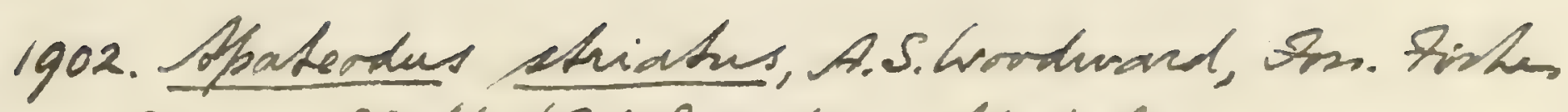

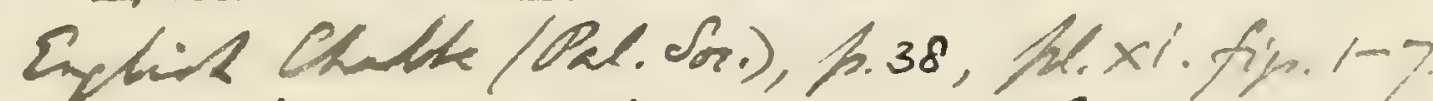
1912. Spaterdus stuicho, A.S. Wordward, Sit. h. 246. Hi. Tiv. fiy. 4 (sturle in hus. Drect. Geol). 
9821. Deseritid a fizmed A.S.W. 1902, h.39, pl.xi. fis. 1 
the posterior tooth, and the length of the latter equalling the interspace between the two teeth, also about half the length of the part of the premaxilla in front of its insertion. Naximum depth of mandible equalling about one fifth of its length; dentition occupying half its length, with two relatively large teeth of about equal size in the middle of the series, with small broad teeth behind, and still smaller recurved teeth in front. Large teeth much laterally compressed, and marked with very fine vertical striations in the basal portion.

The name striatus is given to this species, because it seems probable that the indeterminable fragment of jaw described by Agassiz as Saurocephalus striatus is the hinder part of a large premaxilla of the same form.

Form. \& Loc. Turonian: S.F. England.

49821. The type specimen, a small skull and mandible, partly broken and distorted, shown from both sides and from above in Pl. XIV. figs. $1,1 a, 1 b$; Lower Chalk, Southeram Pit, Lewes. The head is shown to have been long and laterally compressed, with a very acute snout; but the cranium is crushed downwards in the fossil and broken in a sharp transverse fracture at about its middle. The frontal bones $\left(f r_{0}\right)$ are very extensive, almost reaching the occipital border; and their inner half is remarkably smooth, marked only by radiating lines of growth. Immediately behind them the stout supraoccipital bone (s.occ.) is seen, distinctly separating the parietals, but not exhibiting any median crest or keel. The bones of the cheek are almost completely destroyed, but the characteristic anterior portion of the premaxilla $(p m x$.$) is$ indicated by fragments on both sides. On the right (fig. 1) the remains of this bone exhibit traces of the two enlarged teeth (I, II), and on both sides it is partly broken away to expose the middle enlarged teeth of the lower jaw. On the left (fig. $1 \alpha$ ) an undetermined fragment of bone $(x$.$) overlaps the anterior end of the$ premaxilla, but this probably has no connection with the jaws. The mandibular ramus is best displayed on the right, but its anterior pointed end is much broken here and the dentition is more completely displayed on the left. The ramus is deepest at the hinder end, where the dentary $\left(d_{0}\right)$ is seen to extend in a narrow band above the comparatively small articulo-angular bone $(a \%)$; it 
exhibits a characteristic gentle currature, with the concavity upwards; and its outer face is remarkably convex and smooth, with an incurved lower border. Of the two enlarged mandibular teeth, one occurs on the right, but both are preserved on the left; they are slightly recurved, apparently compressed to a sharper edge in front than behind, and the basal part of the outer face is marked by very delicate vertical striations. Six similar, but relatively small and short teeth, are preserved posteriorly on the right, while four remain on the left; of those on the right, the hindermost is the largest. Another similar though small tooth is seen just in front of the enlarged teeth on the left, and between this and the anterior end of the jaw there is a diminishing series of recurved denticles. At the hinder end of the right cheek part of the quadrate bone (qu.) is exposed; and immediately behind this there is the much-thickened anterior border of the preoperculum $(p . o p$. $)$.

Capron Coll.

P. 4512. A still smaller skull broken across the middle and in some respects more imperfect than the type specimen, shown of the natural size from both sides and above in Pl. XIV. figs. 2, $2 a, 2 b$; - English Chalk. The very narrow cranium, sharply compressed above the otic region, is indicated as before; and the remarkably acute snout is especially well shown. On both sides there are remains of extensive though delicate postorbital cheek-plates (s.o.); and the anterior attenuated ends of the characteristic premaxillx $(p m x$.$) are displayed apposed to the slender$ ethmoidal region (eth.), and apparently just meeting in front. The two enlarged premaxillary teeth are partly shown on both sides (I, II), but the second on the left seems to be a little displaced through fracture. The smooth, delicate mandible is much broken; but the extent of the small articulo-angular element ( $a g$.$) is seen especially on the$ right, and there are remains of the characteristic small teeth on both sides.

Enniskillen Coll.

4906\%. Group of remains of a small fish, comprising the anterior end of the right premaxilla, a quadrate, two vertebral centra, and other bones; Chalk, Kent. The anterior portion of the premaxilla is shown from the outer aspect (Pl. XIII. fig. 6) and bears the two enlarged teeth, which seem to display their normal proportions and mode of 
P.4612. Cheek-hleter noticed A.S.W. 1902, p.41.

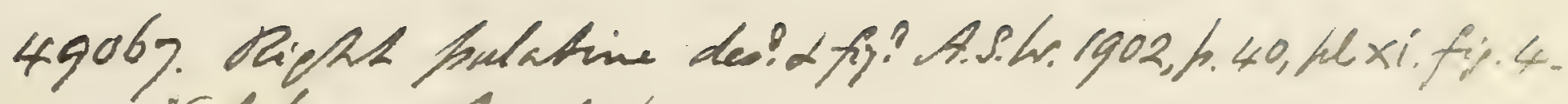
restetrue anticed, fo. 41. 
2.5666. Deserited d fimed A. S.4.1902, h.40, he.xififs.3.

2.56673. Desentred L fipund A.S.W. 1902, h.40, hl.xi. fip. .

2.9015:- Desenthd a fipured A.S.2. 1902, h. 39, hi.xi. fiv. 2. 
insertion. The vertebral centra are strengthened by a few longitudinal ridges.

Mrs. Smith's Coll.

P. 5666. Imperfect rostrum, split longitudinally, showing the anterior portions of the premaxillæ apposed to the slender ethmoidal region; probably from Lower Chalk, Cuxton, Kent. On the left side the anterior part of the premaxilla is proved to be solid, while its flattened oral border, to which the bases of the two enlarged teeth still remain fixed, is flanked by a slight rim or outer wall. The hinder part of the bone, which is somewhat bent downwards upon the anterior part immediately behind the second enlarged tooth, consists only of the thin, deepered outer wall with the tooth-bearing border fixed on its inner face like a shelf; the fragment preserved bears two teeth of considerable size. The two enlarged teeth of the right premaxilla are entirely broken away, but immediately in front of the attachment of the second there are remains of two very small teeth on the outer margin. There are also indications of the two posterior teeth already mentioned on the left.

Harford Coll.

P. 5673. Hinder end of jaws of left side; probably from Lower Chalk, Cuxton. The quadrate is shown, meeting the hyomandibular at its postero-superior angle but in contact with the almost reniform metapterygoid along its upper border. The hinder end of the premaxilla is imperfect, but still retains two typical teeth and the base of a third. The shape of the hinder end of the mandible resembles that on the right side of the type specimen; but the articulo-angular element is less exposed on the outer face than in the latter, where the dentary seems to have been partly flaked away.

Harford Coll.

P. 9015. Imperfect jaws and ossified sclerotic, rather large; Lower Chalk, Merstham, Surrey.

Purchased, 1899.

49070. Right dentary broken across the middle and imperfect behind; Chalk, Kent. One of the enlarged teeth is preserved, and there are remains of the small teeth both behind and in front. As on the right side of the type specimen, the hindermost tooth of the posterior series is slightly the largest.

Mrs. Smith's Coll.

P. 1804. Fragmentary mandible; Chalk, Kent.

Egerton Coll. 
P. 3953. Fragmentary mandible; Chalk, Sussex. Enniskillen Coll.

49799. Fragmentary mandible about 0.12 in length; Iower Chalk, Southeram, Sussex.

Capron Coll.

P. 9042. Fragment apparently of pterygoid arcade of this species; bearing characteristic teeth; Lower Chalk, Burham.

Presented by S. J. Hawkins, Esq., 1891.

The following specimens seem to be fragments of the hinder end of the premaxilla of large individuals of this species, but they can only be provisionally determined :-

4090. Five teeth and the base of a sixth fixed upon bone, described and figured by Agassiz loc. cit. as the type specimen of Saurocephalus striatus; Chalk, Lewes. Mantell Coll.

4091. Three more slender teeth in close series; Chalk, Lewes. Mantell Coll.

P. 564\%. Group of fragments including hinder end of very large premaxilla, with remains of characteristic teeth in slightly spaced series; probably from Lower Chalk, Cuxton.

Harford Coll.

33309. Smaller fragment with well-preserved teeth; Lower Chalk, Burham, Kent. Purchased, $18 \% 8$.

47924. Fragment with teeth of unequal size; Lower Chalk, near Maidstone. Presented by the Hon. Robert Marsham, 1877.

Apateodus lanceolatus, sp. nov.

[Plate XIII. fig. 7.]

Type. Anterior portion of premaxilla; British Museum.

A species smaller than the type form. Anterior part of premaxilla comparatively short, with two much enlarged, long and slender, lanceolate teeth, which are inclined slightly forwards; these teeth about equal in size, or the anterior slightly the larger, and the interspace between them much less than their height.

Form. \& Loc. Turonian: Kent.

39080. The type specimen, being the anterior portion of a right premaxilla, exposed from the outer aspect and shown of the natural size in Pl. XIII. fig. 7; Grey Chalk, Dover. The anterior extremity of the bone is broken away, but the two characteristic enlarged teeth are well preserved, 

P.go42. OAmpert des? Lfi? A.S.W. 1902, h. 40, hl. xi.fip, 6.

P.5647. Anturin verkebra noticed A.S.W. 1902, 10.41.

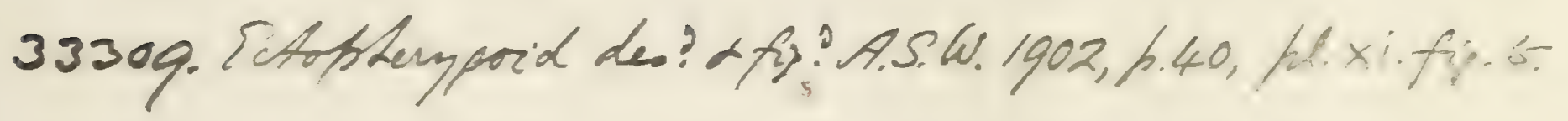

1902. Apateodus lancedatus, A. S. Lordurard, Fns Fishes Englide Chalk (Pal. Son.), h. Hl, ple xi. fis. 8.

39080. Hen: a fy: Ln. with.1902. 
Rh.? a ficams s.n. Cumom. Morved, 6.aram

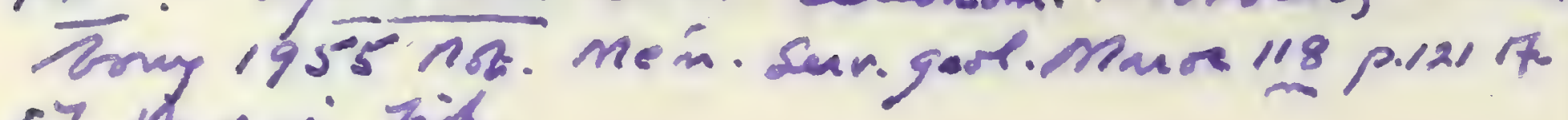
sy phaxi. ind. 
and a fragment of the more delicate posterior part of the element also remains. The latter bears another large tooth, which is comparatively short and broad, and this is immediately followed behind by a very small tooth of the same shape. The base of all the teeth is feebly marked with striations.

Bowerbante Coll.

P. 1798. Hinder extremity of left premaxilla, apparently of this species, with a well-spaced series of small teeth regularly diminishing in size backwards, and resembling in shape the hinder tooth of the last specimen; probably from Grey Chalk, Dover.

Egerton Coll.

49068. Hinder end of left dentary, apparently of this species; Grey Chalk, Dover. The hinder of the two enlarged teeth is preserved; behind this are three irregularly spaced teeth not quite half so much elevated; and after another short space there follows a gradually diminishing series of five teeth.

Mrs. Smith's Coll.

The following specimens and many other fragments seem to represent undetermined species of Apateodus:-

28390. Dentary bones of mandible, with widely-spaced, slender, lanceolate teeth; Chalk, Lewes.

Mantell Coll.

49823. The toothed border of a large dentary, with the two enlarged teeth and a diminishing series of nine broad teeth behind; Grey Chalk, Brighton.

Capron Coll.

\section{Genus RHINELLUS, Agassiz.}

[Poiss. Foss. vol. ii. pt. ii. 1844, p. 260.]

Srn. Ichthyotringa, E. D. Cope, Bull. U.S. Geol. Surv. Territ. rol. ir. 1878, p. 69.

Head excessively elongated by the production of the stout pre$\sec \geq j$ maxillæ and the mandible into a long, slender rostrum; teeth large in the middle of each jaw. Branchiostegal rays about 9 in number. Vertebræ about 45 in number, not less than 25 being abdominal; the centra slender, much constricted and strengthened by delicate longitudinal ridges of bone. Pelvic fins arising almost or exactly opposite the dorsal fin; dorsal fin with 12, and anal fin with about 14 rays. Trunk completely covered with a regular squamation, the scales not serrated at the hinder border, and only slightly thickened or enlarged in the course of the lateral line. 


\section{Rhinellus furcatus, Agassiz.}

[Plate XIII. figs. 1, 2.]

1844. Rhinellus furcatus, L. Agassiz, Poiss. Foss, vol. ii. pt. ii. p. 260, pl. lviii $b$. fig. 5 (non fig. 6).

1849. Rhinellus furcatus, J. J. Heckel, in Russegger's Reisen, vol. ii. pt. iii. p. 340 , pl. xxiii. fig. $1 b$.

1850. Rhinellus furcatus, F. J. Pictet, Poiss. Foss. Mt. Liban, p. 44, pl. viii. figs. $3-4$.

1866. Rhinellus furcatus, Pictet \& Humbert, Nouv. Rech. Poiss. Foss. Mt. Liban, p. 82, pl. xi. figs. 5-8.

1873. Rhinellus furcatus, W. von der Marck, Palæontogr. vol. xxii. p. 60, pl. ii. fig. 4 .

1887. Rhinellus furcatus, J. W. Davis, Trans. Roy. Dublin Soc. [2] vol. iii. p. 608.

Type. Head and abdominal region; olim Amic Collection, Paris.

The type species, attaining a length of about 0.2. Length of the head with opercular apparatus equalling or slightly exceeding the length of the trunk from the pectoral arch to the base of the caudal fin; maximum depth of trunk contained from four to five times in the same measurement. Dorsal fin arising at the middle point between the occiput and the base of the caudal fin ; pelvic fins about half as large as the pectorals and arising just in advance of the origin of the dorsal; anal fin completely behind the dorsal, arising behind the middle point between the pelvic pair and the caudal fin. Scales of the lateral line conspicuously thicker than the others.

Form. \& Loc. Upper Cretaceous: Sahel Alma, Mt. Lebanon : Sendenhorst, Westphalia.

48096-97. Two imperfect large specimens, with the trunk shortened by distortion. The second displays the small recurved teeth apparently in the mandible. Lewis Coll.

49525. A nearly complete fish slightly distorted, shown of the natural size in P1. XIII. fig. 2. The parts of the head and opercular apparatus are obscure; but there are traces of the close series of minute recurved teeth near the front of the jaws.

Lewis Coll.

P. 4762. Another nearly complete fish, with depressed fins, shown of the natural size in Pl. XIII. fig. 1. The thickened scales of the lateral line are displayed above the vertebral column in part of the abdominal region. Lewis Coll.

48090-91, 48092, 49544. Four imperfect specimens, the second and third displaying the thickened scales of the lateral line. 
1908. Dhinellur furcatus, Z. Priem, in G. de morgan, Délégátion en Perze, - Aum. d'Alr. rat. vol. i. h. 10, pl. i. fig. 13. [Pensia.]

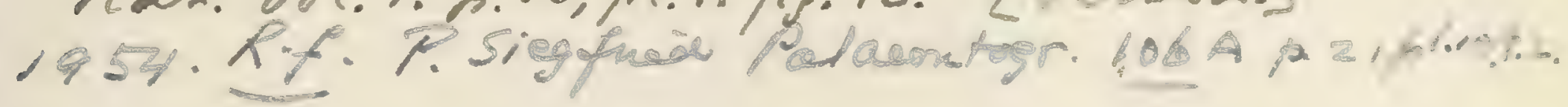



49523, 49591. Small slab with remains of three individuals, and another exhibiting one fish in association with an imperfect Thrissopteroides. In the first specimen may bo noted the expanded laminar form of the anterior neural spines, and the thickening of the scales of the lateral line.

Lewis Coll.

46527. Imperfect fish elongated by crushing.

Lewis Coll.

P. 1882 a. Imperfect distorted fish.

- Egerton Coll.

15600. Imperfect fish.

Purchased.

48089,48144 . Three very small imperfect specimens, two being distorted and deepened by crushing.

Lewis Coll.

P. 1882. Imperfect very small specimen, apparently an immature individual of this species with the rertebral centra in the form of hollow cylinders.

Egerton Coll.

Rhinellus ferox, Daris.

1887. Rhinellus ferox, J. W. Davis, Trans. Roy. Dublin Soc. [2] vol. iii. p. 614, pl. xxxvii. fig. 6.

Type. Imperfect fish; British Museum.

A large form apparently closely resembling the type species, but the trunk perhaps more slender and the hinder teeth of the premaxilla relatively larger.

Form. \& Loc. Upper Cretaceous: Sahel Alma, Mit. Lebanon.

P. 4851. The type specimen about 0.4 in length, described and figured loc. cit. The skull is crushed so that the right and left sides of the jaws are separated. The produced upper jaw is thus proved to consist only of the elongated premaxillæ, while the mandible is shown to be destitute of a presymphysial bone. The premaxilla bears a spaced series of large, slender, conical teeth, which are erect, gradually increase in size backwards, and are shown by fragments to have been very large on that part of the bone which is in contact with the cranial rostrum. Between the large teeth there are smaller denticles. The spaced teeth of the dentary are much smaller than those of the premaxilla, and seem to attain their greatest size in the middle of the bone, diminishing both backwards and forwards. The structure of the hinder part of the jaws is not clear, but the mandible does not seem to have been 
elevated in the coronoid region, and its articulation is almost as far back as the occiput. There seem to be remains of cheek-plates. The vertebral column of a swallowed fish can be distinguished in the abdominal region. The fins are too imperfect to admit of counting their rajs.

Lervis Coll.

P. 4737. Another fine specimen wanting end of snout, but displaying paired fins.

Lewis Coll.

49526. Imperfect specimen exhibiting the head and the greater part of the trunk, noticed by Davis, loc.cit. p. 615. Some of the anterior neural spines are laminar expansions, obliquely truncated above, tapering to a point below. The imperfect dorsal fin has 12 supports. The course of the lateral line is indicated by a thickening of the scales.

Lewis Coll.

49519. A much crushed and distorted imperfect specimen.

Lewis Coll.

48151. Imperfect head and distorted abdominal region, with remains of the rery large teeth at the base of the premaxilla.

Lewis Coll.

Rhinellus damoni, Davis.

1887. Rhinellus damoni, J. W. Davis, Trans. Roy. Dublin Soc. [2] rol. iii. p. 617 , pl. xxxvii. fig. 4.

1887. Rhinellus robustus, J. W. Davis, ibid. p. 608, pl. xxxvii. fig. 5. [Distorted fish ; Edinburgh Museum.]

Type. Nearly complete fish; British Museum.

A species as large as the type, but with shorter vertebræ and comparatirely stout trunk. Length of head with opercular apparatus considerably exceeding the length of the trunk from the pectoral arch to the base of the caudal fin; maximum depth of trunk contained about three times in the same measurement. Fins as in the type species; scales apparently thicker than in the latter, and those of the lateral line not conspicuous.

Form. \& Loc. Upper Cretaceous: Sahel Alma, Mt. Lebanon.

P. 4850. Type specimen described and figured loc. cit. Only 12 supports can be distinctly counted in the dorsal fin, 14 in the anal fin. The tail is deepened by crushing.

Lewis Coll.

49524. Slab exhibiting large specimen in association with an 

Phinellur Lemirostrio, O.P. Hay, Bull. Amen. Hus. In. H. vol. xix (1903), h. 94, fl.iv.fip. 7,8 .

pinellus delicatur, O.P.Hay, Bull. Amer. Hum. N.H. m.xix/(903), h.432. - Crehacems; Hajula, LChann.

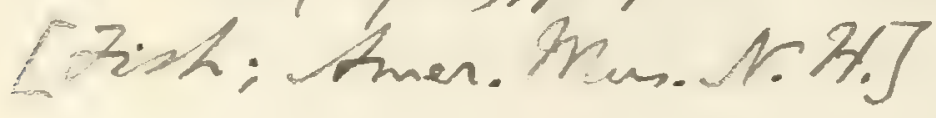

Th. shinelloider = indeterminable frougmes of Custacean (G.D.Prasmo, Rivista Stal. Palent. ol.xviii. (912, h. , hl.iii.fig.6). 
equally large but imperfect individual of $R$. furcatus. Five or six of the upper lath-shaped branchiostegal rays are showa.

Lewis Coll.

P. 4849. Slab exhibiting a much-distorted specimen in association with two small examples of $R$. furcatus. Levis Coll.

47367, 48093-95. Four imperfect smaller specimens. The first exhibits a series of at least nine branchiostegal rays, the upper four or five lath-shaped, the others more slender. The second specimen shows one of the large slender teeth towards the base of the premaxilla. The third specimen bears traces of the characteristically-expanded anterior neural spinés.

Lewis Coll.

47365-66, 47383, 47815, 49545. Fire still smaller specimens, variously imperfect.

Lerwis Coll.

The following species has also been described, but is not represented in the Collection :-

Rhinellus tenuirostris: Ichthyotringa tenuirostris, E. D. Cope, Bull. U.S. Geol. Surv. Territ. vol. iv. (1878), p. 69.-Upper Cretaceous; Dakota. [Type species of Ichthyotringa. Fragmentary fish ; Cope Collection.]

The so-called Rhinellus curtirostris (J. W. Daris, Trans. Ror. Dublin Soc. [2] vol. iii. 1887, p. 610, pl. xxxvii. fig. 2), from the Upper Cretaceous of Hakel, Mt. Lebanon, is founded on a fragmentary specimen of Scombroclupea macrophthalma, now in the Edinburgh Museum of Science and Art.

The name Rhinellus nasalis was given by Agassiz (Neues Jahrb. 1835, p. 291) to an indeterminable fish from the Upper Eocene of Nonte Bolca, described and figured as Pegasus lesiniformis by G. S. Volta, Ittiolit. Veronese (1796), p. clix, pl. sxxix. fig. 1.

The name Rhinellus schilli was given by H. von Meyer (Neues Jahrb. 1863, p. 4อ0) to some undetermined fragmerits, not of this genus, from the Lower Tertiary of Hammerstein, Baden.

Indeterminable fragments, of no scientific value, were described as follows and placed near Rhinellus:-

Rhamphornimia rhinelloides, O. G. Costa, Mem. R. Accad. Sci. Napoli, vol. ii. (1857), p. 108, pl. ii. fig. 2.-Upper Cretaceous; Mt. Lebanon. [Fragments, partly C'rustacean; Geological J[useum, University of Naples.] 
The following specimens seem to belong to a genus of Scopeloids, but are not, satisfactorily determinable:-

P. 447-8, P. 3833. The two type specimens (one in counterpart) of the so-called Clupea brevis, L. Agassiz, Poiss. Foss. vol. r. pt. ii. (1839-44), p. 119, pl. Ixii. figs. 1, 2; Oligocene, Engi, Canton Glarus, Switzerland, An apparently similar fish, elongated by distortion, is described under the name of Clupea dubia by A. Wettstein, Fischfauna Tertiaer. Glarnerschief. (Denkschr. schweiz. Palaeont. Ges, vol, xiii. 1886), p. 54, pl. iii. fig. 5. Egerton \& Enniskillen Colls.

P. 5148. Similar specimen; Engi.

Egerton Coll.

The following imperfectly defined genera and species, not represented in the Collection, may also perhaps belong to the Scopelidæ:-

Brachyspondylus cretaceus, W. von der Marck, Palæontogr. vol. xv. (1868), p. 283, pl. xliii. fig. 2.-Upper Cretaceous; Sendenhorst, Westphalia. [Imperfect trunk; Academy of Münster.]

Hemisaurida neocomiensis, R. Kner, Sitzungsb. k. Akad. Wiss., H. 5hasmolq46 math.-naturw. Cl. vol. Ivi. (1867), pt. i. p. 172, pl. i. p. 9 .

fig. 1.-Cretaceous; Comen, Istria. [Imperfect head.]

${ }^{x}$ Holosteus esocinus, L. Agassiz, Poiss. Foss. vol. v. pt. ii. (1839See p.25\%. 44), p. 85, pl. xliii. fig. 5.-Upper Eocene; Monte Bolca, near Verona. [Imperfectly restored fish.]

Omiodon cabassii, F. Bassani, Atti R. Accad. Sci. Napoli [2] rol. iii. no. 4 (1888), p. 2, pl. i.-Middle Eocene; Friuli, Province of Udine, Italy. [Imperfect fish; Cabassi Collection.]

Palimphemus anceps, R. Kner, Sitzungsb. k. Akad. Wiss,, math.naturw. Cl. vol. xl. (1862), pt. i. p. 490, pl. i. fig. 2, and ibid. vol. xlviii. (1863), pt. i. p. 148.—Middle Miocene (Leithaikalk); Margarethen, Vienna. [Imperfect fish.]

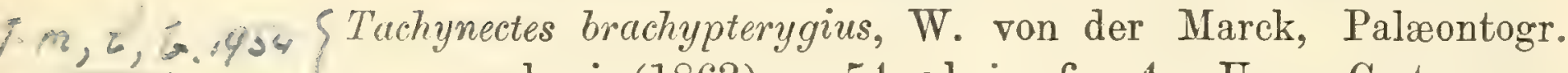
rol. xi. (1863), p. 54, pl. ix. fig. 4.-Upper Cretaceous ; Sendenhorst, Westphalia. [Imperfect fish; Academy of Mïnster.]

Tachynectes longipes, W. von der Marck, loc. cit. 1863, p. 52, pl. ix. fig. 3, pl. x. figs. 1, 2.-Ibid. [Ditto.]

Tachynectes macrodactylus, W. von der Marck, loc. cit. 1863, p. 51, pl. ix. figs. 1, 2. Tachynectes, W. von der Marck, Toc.cit. vol. sxxi.(1885), p. 260.-Ibid. [The trpe species. Ditto.] 

Otchithus (Scopelus) Eiarritzensir, Friem, Osull. So Géd. France [4] vod. $\times 1 i(1912)$, h.247, Lexh-fier. 5, 6. - UC Reme; Biarsity.

Otolithus (Scopehus) pulcher, 7. Priem, Bull. Sor. Sérl. Irance $[4]$ vol. xi (1911), h. 45, teat-fip.9. Q. (Berycidarum. pulcher, Prochazka

- Pircene; Heria

Corsica (Priem).

Trossulus exolebus, D.S. Fodan, 7ish Zaun a Calif. 3 n

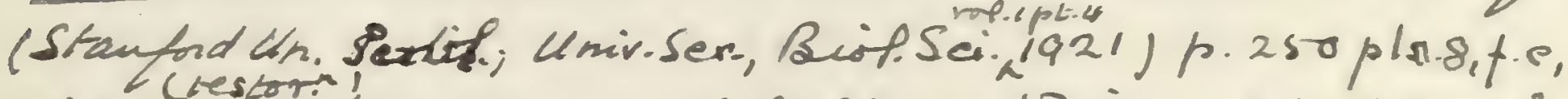

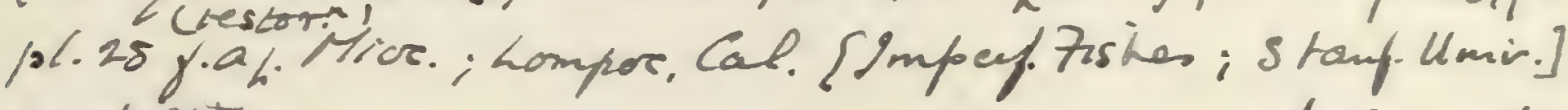
en phes T. of Trossulus. Lestichthys porteousi, D.S. Fond" Lor cic. 1921, p.250,pli, f.t.pl. 22 g.a (reshor.h) Hor. Lompore- [Impofish i itid]

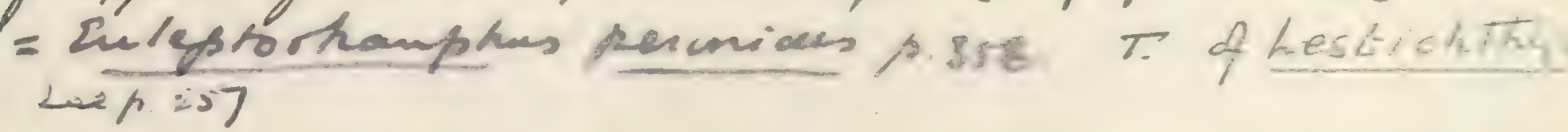
Xp 11172 . Fine specimen, in counterpart. Pund? 1913. Frolosteus escinus, C. R. Sastman, Bull. hues. Comp. Zool. Hawrard, vol. XTrillgo4). 1. 28. [Gagola Clel, Oaris huns.]

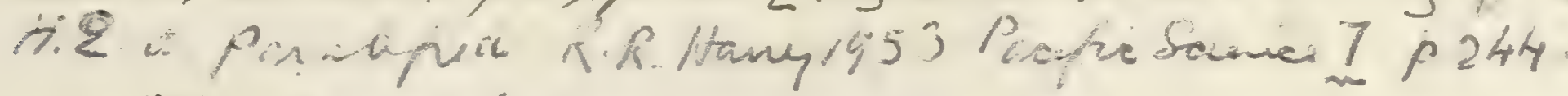
Of olitius (Scopelas) zulcakins, G.A. Frost, Trans.N.R. Inst. 1.55 $(1924)$ p.60) ploblif.. ( kegerencio)

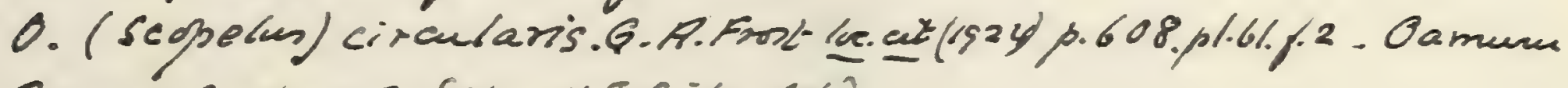

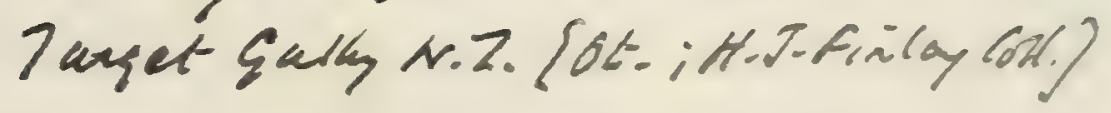

Jachynecher vinaremeid, A. Fitsh \& FBayer, Reu

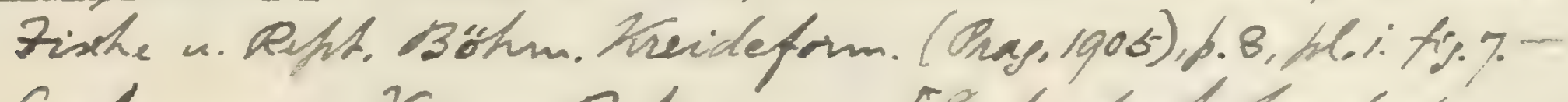
Cretaceons; Ninar, Bohemia. [ompirfu't head, tr.; Bary. Bohen. Murs, Pragure.] 


\section{Family GONORHYNCHID $\mathbb{E}$.}

Trunk fusiform or elongated, and caudal region relatively short. Supraoccipital bone not prominent, but extending forwards to the frontals and separating the parietals in the median line; squamosal suturally united with parietals and completely covering the otic bones except behind; snout not produced; cneek-plates rudimentary. Nandibular suspensorium much inclined forwards, and gape of mouth small; premaxilla smaller than maxilla, but excluding latter from the oral margin ; teeth, if present, chiefly or exclusirely on some inner bones of mouth. Opercular apparatus complete, with few branchiostegal rays and no gular plate. Vertebral centra well ossified, but usually pierced by notochord; abdominal vertebræ with robust transverse processes bearing delicate ribs, which do not completely encircle the abdominal eavity; a compound hypural bone at the base of the tail. Intermuscular bones present. Finfulcra absent; pectoral arch without precoracoid process; dorsal and anal fins small; no adipose dorsal fin. Scales narrow and elongated, very deeply imbrieated, and often extending over the cheeks and opercular apparatus.

The only known existing spesies of this family is Gonorhynchus greyi, which inhabits the seas off Japan, South Africa, Australia, and New Zealand. Its gill-cleft is narrow, and pseudobranchiæ are present; there is no air-bladder; the stomach is simple, without blind sac, while the pyloric appendages occur in small number.

Synopsis of Genera.

I. Teeth on pterrgoid and hyoid bones.

Dorsal fin scarcely if at all behind middle of back, and pelvic fins opposed to it; scales not covering head ...... Charitosomus (p. 2i1).

Dorsal fin far behind middle of back, and pelvic fins opposed to it; scales covering head .............. Gonorhynchus (Recent).

II. Teeth absent.

Dorsal fin nearly in middle of back, more or less directly opposite pelvic pair; scales corering head........

Notogoneus (p. 275).

Genus CHARITOSOMUS, W. von der Marck.

[Palæontogr. vol. xxxi. 1885, p. 257.]

Srn. Solenognathus, Pictet \& Humbert (non Swainson, 1839), Nour. Rech. Poiss. Foss. Mt. Liban, 1866, p. 54.

Head small and trunk much elongated, laterally compressed. 
Teeth apparently wanting on the margin of the jaws; but stout and blunt conical teeth present on some of the inner bones of the mouth, probably on the pterygoids and hyoid apparatus; upper branchiostegal rays comparatively broad. Vertebræ approximately 50 in number, 35 being abdominal and the remainder caudal; ribs short and delicate. Paired fins relatively large, the pectorals not much exceeding the pelvic pair in size, the latter remote and opposed to the origin or anterior part of the dorsal, which is scarcely if at all behind the middle of the back; dorsal and anal fins each with from 7 to 12 rays ; caudal fin slightly forked. Scales distinctly elongated [but their hinder margin not yet observed]; no scales extending over the head; strong fulcral scales on the borders of the caudal pedicle at the base of the caudal fin.

Charitosomus formosus, W. von der Marck.

1885. Charitosomus formosus, W. von der Marck, Palæontogr. vol. xxxi. p. 257 , pl. xxiv. fig. 1.

Type. Fish with imperfect head; Geological Museum, deademy of Münster.

The type species, known only by one imperfect specimen about 0.15 in length. Fins arranged as in the next species, and the trunk nearly similar in proportions to that of the latter, but the caudal pedicle apparently more robust.

Form. \& Loc. Upper Cretaceous : Baumberg, Westphalia.

Not represented in the Collection.

Charitosomus major, sp. nov.

[Plate XV. fig. 3.]

Type. Imperfect fish; British Museum.

A species attaining a length of about 0.2 . Length of head with opercular apparatus contained four and a half times, and maximum depth of trunk nearly nine times in the total length of the fish to the base of the caudal fin; depth of caudal pedicle about half that of the abdominal region. Dorsal fin almost median, arising justi in advance of the middle point between the occiput and the base of the caudal fin; pectoral fin-rays when adpressed extending nearly half way to the pelvic fins, which arise opposite the anterior half of the dorsal; distance between the pectoral and pelvic fins about one and a half times as great as the length of the head with opercular apparatus; anal fin arising slightly nearer to the caudal than to the pelvic fins.

Form. \& Loc. Upper Cretaceous: Sahel Alma, Mt. Lebanon. 
34

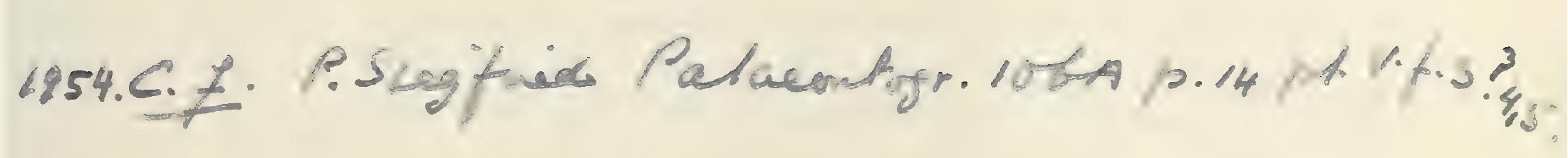



P. 9173. Type specimen, shown of the natural size in Pl. XV. fig. 3. The crushed remains of the head are exposed partly from the right side, partly from below. The cranium seems to be exposed from beneath, and displays the attenuated form of the elongated rostrum. Beneath its anterior extremity there lies a stout curved bone (mx.) shaped much like the maxilla of Gonorhynchus; while just behind this there appears to be the anterior pointed end of the toothless dentary (d.). Still further back there are remains of large bluntly-conical teeth, some apparently belonging to the upper jaw, but the largest $\left(t_{0}\right)$ occurring just above the ceratohyal as if they had been fixed upon the hyoid arch. All the vertebral centra are longer than deep and much constricted; while fractured examples, both in the abdominal and caudal regions, seem to indicate that a delicate strand of the notochord penetrated each of them. The ribs are shown to be short and slender, not reaching the ventral border of the fish; the neural and hæmal spines in the caudal region are straight, much inclined backwards, and comparatively stout, while there seems to have been scarcely any fusion or expansion of the hæmals supporting the caudal fin. The fins are closely adpressed to the trunk, so that at first sight they are not conspicuous. The remarkably elongated rays of the paired fins, however, are well preserved; and the arrangement of the fins is clearly as stated in the specific diagnosis. The caudal fin is shown to be cleft. The scales are antero-posteriorly elongated and striated, but their crushed remains are too much confused to permit the determination of their precise shape and characters. Stout styliform fulcral ridge-scales occur on each border of the caudal pedicle at the origin of the caudal fin.

Lewis Coll.

49543. More distorted specimen showing small mouth and characteristic dentition.

Lewis Coll.

4651\%. More imperfect specimen, wanting the anterior half of the head. Traces of the stout bluntly-conical teeth are preserved above and below. Some of the anterior neural spines of the abdominal region bear a laminar expansion. A few of the caudal vertebral centra are sufficiently well preserved to exhibit their lateral longitudinal ridge. The 
supports of the dorsal fin are dagger-shaped, having a aminar wing both in front and behind. Lewis Coll.

46518. Another more imperfect elongated specimen displaying part of the operculum of both sides, apparently with a small acumination on its hinder border.

Lewis Coll.

Charitosomus lineolatus (Pictet \& Humbert).

[Plate XV. fig. 4.]

1866. Solenognathus lineolatus, Pictet \& Humbert, Nouv. Rech. Poiss. Foss. Mt. Liban, p. 56, pl. iv. figs. $4-7$.

1887. Solenognathus lineolatus, J. W. Davis, Trans. Roy. Dublin Soc. [2] vol. iii. p. 531, pl. xxvi. fig. 6.

Type. Imperfect fishes; Geneva Museum.

The type species of the so-called Solenognathus (Pictet \& Humbert, non Swainson), attaining a length of about $0 \cdot 07$. Length of head with opercular apparatus contained five times, and maximum depth of trunk about thirteen times in the total length of the fish to the base of the caudal fin. Operculum bearing a small broad spine on its hinder border. Dorsal fin situated just within the hinder half of the trunk; pelvic fins arising opposite the origin of the dorsal, the distance between these and the pectorals equalling about twice the length of the head with opercular apparatus; anal fin arising just behind the middle point between the pelvic and vaudal fins.

Form.\& Loc. Upper Cretaceous: Sahel Alma, Mt. Lebanon.

P. 4752. Fine specimen 0.073 in length, displaying the form and proportions of the mandible and the greater part of the fins, imperfectly figured by Davis, loc. cit., re-figured in Pl. XV. fig. 4.

Lewis Coll.

46523, 48135-40, 47389. Eight specimens in various states of preservation. No. 48137 exhibits traces of the stout teeth at the back of the mouth. Lewis Coll.

P. 9174. Fire more fragmentary specimens, two showing the acumination on the hinder margin of the operculum.

Lewis Coll.

\section{Charitosomus hakelensis (Davis).}

1887. Spaniodon hakelensis, J. W. Davis, Trans. Roy. Dublin Soc. [2] vol. iii. p. 591, pl. xxxiv. fig. 4.

1898. Charitosomus hakelensis, A. S. Woodward, Ann. Mag. Nat. Hist. [7] vol. ii. p. 412. 
1903. Charitosomus hakelensis, 0.P. Hay, Sull. Amer. Inus. 1. $\%$. vol-xix. h.433. 
Type. Imperfect fish; Edinburgh Museum of Science and Art.

A species attaining a length of about $0 \cdot 15$. Length of head with opercular apparatus equalling about twice maximum depth of trunk, and contained four times in total length of fish to base of caudal fin. Pelvic fins arising behind origin of dorsal, which is in middle of back and comprises 12 rays; anal fin somparatively small, with 7 rays, slightly nearer to the caudal than to the pelvic fins.

Form. \& Loc. Upper Cretaceous: Hakel, Mt. Lebanon.

Not represented in the Collection.

\section{Genus NOTOGONEUS, Cope.}

[Amer. Naturalist, vol. xix. 1885, p. 1091.]

Syn. (?) Anormurus, H. D. de Blainville, Nouv. Dict. d'Hist. Nat. vol. xxvii. 1818, p. 374.

Sphenolepis, L. Agassiz (non Nees, 1834), Poiss. Foss. vol. v. pt. ii. 1844, p. 87.

Protocatostomus, R. P. Whitfield, Bull. Amer. Mus. Nat. Hist. vol. iii. 1890, p. 120.

Trunk fusiform and somewhat laterally compressed. Head pointed and mouth inferior; no teeth; suboperculum exhibiting a few deep clefts in its hinder border. Vertebræ approximately 50 in number, about 35 being abdominal and 15 caudal. Dorsal fin arising at about the middle point of the back, opposite or immediately behind the pelvic fins; caudal fin with slightly excavated posterior margin. The thickened hinder border of the scales fringed with slender denticles; small scales extending over the whole of the head and parts of the fins.

\section{Notogoneus osculus, Cope.}

1885-86. Notogoneus osculus, E. D. Cope, Amer. Naturalist, vol. xix. p. 1091, and Mem. Nat. Acad. Sci. rol. iii. p. 163, pl. with figs. 4,5 .

1890. Protocatostomus constablei $(?=$ Notogoneus osculus, Cope), R. P. Whitfield, Bull. Amer. Mus. Nat. Hist. vol. iii. p. 117, pl. iv. [Fish; American Museum of Natural History.]

1896. Notogoneus osculus, A. S. Woodward, Proc. Zool. Soc. p. 501, pl. xviii. figs. 1, 2.

Type. Nearly complete fish; Cope Collection.

The type species, attaining a length of about $0 \cdot 6$. Length of head with opercular apparatus about equal to the maximum depth of the trunk, and contained slightly more than five times in the 
total length of the fish. Four olefts in suboperculum, extending somewhat less than half its width. Dorsal fin slightly deeper than long, with twelve rays preceded by at least one short spine, arising. immediately in advance of the middle point between the occiput and the caudal fin; pelvic fins arising opposite the origin of the dorsal, each with about six rays; anal fin arising much nearer to the caudal than to the pelvic pair, short-based, with eight rays preceded by two small spines; caudal fin with nineteen rays and basal spines or fulcra. Denticles on hinder border of scales long and closely arranged.

Form. \& Loc. Eocene (Green River Shales): Wyoming, U.S.A

P. 7491. Fine specimen 0.54 in length, described (with figure of head and terminal vertebræ) by the present writer, loc.cit. Purchased, 1895.

\section{Notogoneus squamosseus (Blainville).}

i818. Cyprinus squamosseus, H. D. de Blainville, Nouv. Dict. d'Hist. Nat. vol. xxvii. p. 371.

1823. Esox sp., C. de Villeneuve, Statist. Dept. Bouches du Rhône, p. 8 , pl. iv. fig. 4.

1843-44. Sphenolepis squamosseus, L. Agassiz, Poiss. Foss. vol. v. pt. i. p. 13, pt. ii. p. 87, pl. xlv.

1896. Notogoneus squamosseus, A. S. Wondward, Proc. Zool. Soc. p. 502, pl. xviii. figs. 3,4 .

Type. Imperfect fish; olim Drée Collection.

The type species of Sphenolepis, Agassiz (non Nees, 1834), attaining a length of about $0 \cdot 6$. Length of head with opercular apparatus exceeding the maximum depth of the trunk, and contained about four times in the total length of the fish. Four clefts in suboperculum, extending less than half its width. Fins and scales. as in the type species of Notogoneus.

Form. \& Loc. Lower Oligocene: Aix-en-Provence.

8052. A fine large specimen wanting part of the abdominal region in front of the pelvic fins, also part of the dorsal, and the whole of the caudal fin. The characteristic suboperculum is displayed above the head, which is described and figured in Proc. Zool. Soc. 1896, p. 502, pl. xvili. fig. 3. The expanded neurals in the anterior abdominal region and the vertebral centra in the caudal region are also well shown. A well-preserved scale is figured toc.cit. pl. xriii. fig. 4 . 
Sepanele gernes.

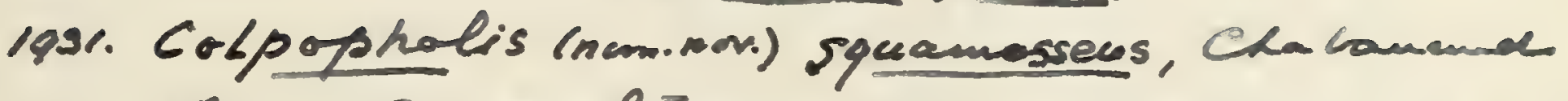
Bust. Sre. geot. trance [5] 1. p.508, (75.1,7,8.12, ph. $x \times x \cdot y \cdot 3$.

1934. Colpophols squamosus, chabananal, Onn. Mus. Nest. nat. Manseille xxyl. it 2phs. 
1908. Hotoponeus off. curien:, 7. Priem, Pins 7oss. Bassin Parisien (Publ. Amm. Paléont.), p.133, Hiir.f.4. [Olicrene; Bagnolet, Paine]

1911. Notogoneus aff. cuvieri, F.Priem, Am. Paléont: nl. vi. h. 33, hl. iv. fig. 2-4, pl.v. fir.l. 
32476. Imperfect remains of a much smaller fish, from which the proportions of the head and the situation of the dorsal fin may be estimated. Tesson Coll.

43436. Crushed remains of head and abdominal region of another large fish, partly in counterpart. Eleven supports are seen in the dorsal fin, the foremost expanded, as noted in Proc. Zool. Soc. 1896, p. 503.

Presented by Kenneth Murchison, Esq., 1872.

8053. Portion of contorted smaller specimen, chiefly tail.

Mantell Coll.

P. 1850. Similarly contorted small specimen, chiefly tail.

Egertois Coll.

P. 1850 a. Middle portion of trunk with remains of pelvic and dorsal fins.

Egerton Coll.

P. 3884. Two imperfect specimens of the hinder part of the trunk, one noticed in Proc. Zool. Soc. 1896, p. 503.

Enniskillen Coll.

P. 3884 a. Caudal region of large fish displaying the anal and caudal fins.

Eniriskillen Coll.

Notogoneus cuvieri (Agassiz).

(:) 1818. Anormurus macrolepidotus, H. D. de Blainville, Nouv. Dict. d'Hist. Nat. rol. xxvii. p. 374. [Fragmentary fish: olim Drée Collection.]

1822. "Cyprin," G. Curier, Oss. Foss. ed. 2, vol, iii. p. 346, pi. Ixxrii. fig. 15.

1843-44. Sphenolepis curieri, L. Agassiz, Poiss. Foss. vol. v. pt. i. p. 13, pt. ii. p. 89, pl, xliv. figs. 1, 2 (? figs. 4-12, non fig. 3).

1896. Notogoneus cuvieri, A. S. Woodward, Proc. Zool. Soc. p. 503.

Type. Imperfect fish; olim Drée Collection.

A small slender species, attaining a length of about $0 \cdot 3$. Length of head with opercular apparatus much exceeding the maximum depth of the trunk and contained about five times in the total length of the fish. Fins and scales as in the type species.

Form. \& Loc. Tpper Eocene (Gypsum of Montmartre): Paris.

P. 9154. Imperfect trunk displaying parts of the axial skeleton, the position of the dorsal and anal fins, and the base of the caudal fin. Eleven fin-supports are preserved at the base of the dorsal fin, and the characteristic fringe of 
denticles on the scales is seen immediately behind the anal fin. Noticed in Proc. Zool. Soc. 1896, p. 504.

History unknown.

Notogoneus longiceps (Meyer).

[Plate XV. fig. 5.]

1844. Cobitis longiceps, L. Agrassiz, Poiss. Foss. vol. v. pt. i. p. 10 (name only).

1848. Cobitis longiceps, H. von Meyer, Palæontógr. vol. i. p. 151, pl. xx. fig. 2.

Type. Imperfect fish.

A small slender species, attaining a length of about $0 \cdot 12$. Length of head with opercular apparatus about twice as great as the maximum depth of the trunk and occupying slightly less than one third of the total length to the base of the caudal fin. Five clefts in suboperculum. Dorsal fin arising immediately behind the pelvic pair; anal fin comparatively small, arising nearly midway between. the pelvic pair and the caudal fin.

Form.\& Loc. Upper Oligocene: Mayence Basin.

P. 766\%. Imperfect distorted large specimen; Mombach, near Mayence. There are indications of the scales extending over the cranium; and the characteristic clefts are observable in the hinder border of the suboperculum.

Purchased, 1895.

15674. Imperfect smaller specimen; Mombach. The vertebral centra are shown to be slender constricted cylinders, which must have been pierced by a rather stout remnant of the notochord. About 12 rays can be counted in the dorsal, 9 in the anal fin.

Purchased.

P. 1820. Partly distorted fish, shown of the natural size in Pl. XV. fig. 5; Mombach. The long and narrow cranium is exposed from above; while the smallness of the mouth is indicated by the position of the quadrate and articular end of the mandible preserved beneath. The greater part of the characteristic maxilla is shown in impression. The opercular apparatus is much crushed and displaced, but the fissures in the suboperculum are distinguishable. The delicate vertebral axis is well shown, though variously fractured; and the extent to which the notochord persisted is indicated by the calcareous matrix filling the constricted vertebral cylinders. The very delicate ribs 



are distinctly supported by broad transverse processes. Some of the characteristic long and slender intermuscular bones are seen beneath the dorsal fin. All the fins are imperfectly preserved. The squamation is shown to extend over the cranium.

Egerton Coll.

P. 4322. Imperfect vertically crushed fish, showing the ribs supported by transverse processes and the squamation extending over the head; Mombach. Einniskillen Coll.

48041 x. Fragmentary distorted specimen; Mombach.

\section{John Brou'n Coll. Presented by Sir Richard Owen, K.C.B., 1860.}

P. 1820 a. Crushed remains of head and anterior rertebræ, labelled Cobitis longiceps by Agassiz; Mombach. The comparatively short mandible is shown articulating with the quadrate, and the dentary displays the usual great ascending process. Some of the upper branchiostegal rays are preserved, and the suboperculum exhibits five clefts. The anterior vertebræ are provided with transterse processes.

Egerton Coll.

P. 1820 b. Another fragmentary specimen; Mombach.

Egerton Coll.

P. 3858, P. 3869. Four fragmentary specimens, displaying several characteristic features in the osteology of the fish; Nombach.

Enniskitlen Coll.

\section{Eamily CHIROTHRICID $\approx$.}

Trunk fusiform or elongated. Mandibular suspensorium inclined forwards, and gape of mouth small; premaxilla delicate and styliform, completely excluding the maxilla from the upper border of the mouth; jaws with feeble dentition or toothless. Opercular apparatus complete, with a few large branchiostegal rays. Vertebral centra with robust traneverse processes in the abdominal region; ribs short and slender; expanded hæmal arches scarcely fused at the base of the tail. Intermuscular bones present. Paired fins much enlarged, and the pelvic pair far forwards; a single large dorsal fin in the anterior half of the trunk, with stont triangular supports; anal fin small and remote; caudal fin separate.

An extinct family of pelagic fishes. 
Synopsis of Genera.

Pelvic fins excessively enlarged; caudal forked; no dermal scutes ..................

Iectoral fins larger than pelvic pair; caudal forked; dorsal dermal scutes ........... Chirothrix (p. 280).

Telepholis (p. 284).

Pectoral fins larger than pelvic pair; caudal rounded; ? no dermal scutes .......... Exocotoides (p. 286).

Genus CHIROTHRIX, Pictet \& Humbert. [Nouv. Rech. Poiss. Foss. Mt. Liban, 1866, p. 51.]

Syn. Megapus, C. Schlïter, Palæontogr. vol. xv. 1868, p. 276. Megistopus, H. Landois, Neues Jahrb. 1894, vol. ii. p. 234.

Head relatively large and jaws apparently toothless; the large branchiostegal rays 8 or 9 in number. Vertebræ between 50 and 60 in number, about 25 being caudal. Fin-rays mostly divided as well as articulated distally. Pectoral fins arising near the rentral border, delicate and much smaller than the pelvic pair, with only one ray considerably elongated; pelvic fins very large, with much expanded pelvic bones, close to the pectoral pair ; dorsal fin arising immediately behind the head, and occupying less than half of the back; caudal fin forked. No dermal scutes.

Chirothrix libanicus, Pictet \& Humbert.

[Text-figure 10.]

1866. Cheirothrix libanicus, Pictet \& Humbert, Nouv. Rech. Poiss. Foss. MIt. Liban, p. 52, pl. v. fig. 1.

1868. Megapus, C. Schlüter, Palæontogr. vol. xv. p. 275.

1882. Cheirothrix libanicus, F. Bassani, Denkschr. k. Akad.Wiss., math.naturw. Cl. vol, xlv. p. 273.

1887. Cheirothrix libanicus, J. W. Davis, Trans. Roy. Dublin Soc. [2] vol. iii. p. 527, pl. xxvi. figs. 3,4 .

1888. Cheirothrix libanicus, K. A. von Zittel, Handb. Palaeont. vol, iii. p. 311, fig. 319.

Type. Imperfect fish; Geneva Museum.

The type species, attaining a length of about $0 \cdot 11$. Length of head with opercular apparatus equalling twice the maximum depth of the trunk, and half its length from the pectoral arch to the base of the caudal fin. Pectoral fins with about 13 delicate bifurcating rays, decreasing in length both forwards and backwards, the fifth being excessively elongated; pelvic fins comprising about 17 rays, the longest reaching the caudal fin when adpressed to the trunk; dorsal fin, with 16 rays, much elevated, the length of the longest 


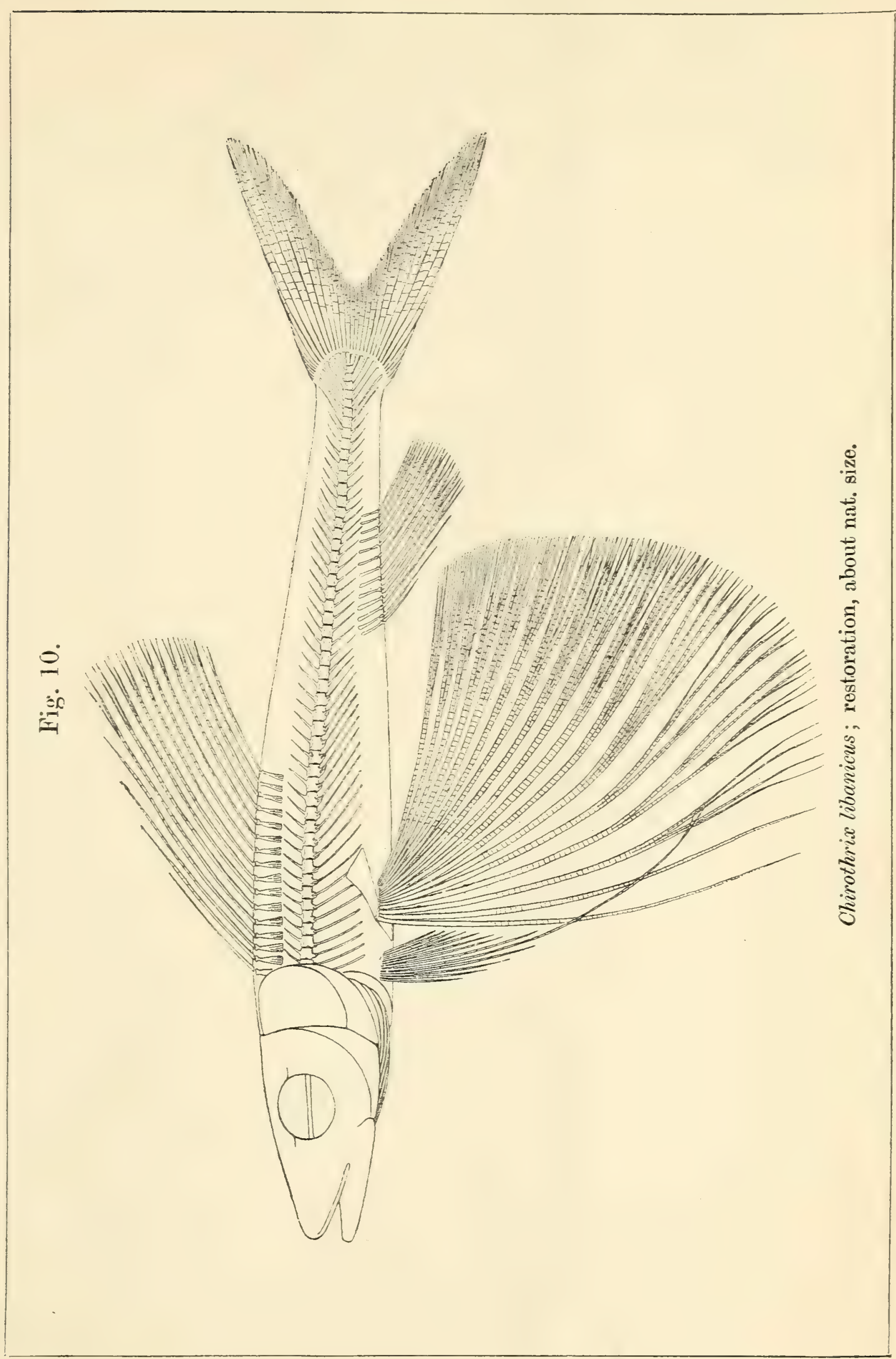


ray at least equalling half the length of the back trom the occiput to the base of the caudal fin; anal fin, with 13 rays, arising somewhat in advance of the middle point between the dorsal and the caudal, and distant from the latter a space equal in length to its own base-line; the maximum elevation of the anal half that of the dorsal fin.

Form. \& Loc. Upper Cretaceous: Sahel Alma, MIt. Lebanon.

49528. Specimen figured by Davis, loc. cit. pl. xxvi. fig. 3. The cranium is shown to be long and narrow, and the quadrate can be distinguished beneath it, the articulation for the mandible probably being below the anterior margin of the orbit. The mouth is opened, and a long and slender, gently arched bone in front may be the premaxilla. Both rami of the mandible are imperfectly preserved; but there are no traces of teeth. The branchiostegal rays are relatively large and scattered, but 12 can be counted, proving that there must have been at least 6 pairs. The clavicle is relatively small, though in the published figure detached bones below it are made to appear continuous with it. One of the pectoral fins is seen on the flank, and its single elongated ray is distinctly observable curving downwards, bifurcating at the distal end. Both pelvic fins are well preserved, but not spreading; and the characteristic dorsal and anal fins are depressed.

Lervis Coll.

49530. Specimen figured by Davis, loc. cit. pl. xxvi. fig. 4. The mandible is sufficiently well preserved to indicate the relatively small size of the terminal mouth: and below the head there are remains of the large branchiostegal rays. The number of vertebræ is shown to be about 50, and the short ribs are covered by one of the pelvic fins. One of the small pectoral fins is seen at the lower border of the trunk immediately behind the branchiostegal rays. It is imperfect distally, but clearly exhibits 12 delicate rays. The pelvic fins are crushed as usual, so that one is above the other, the lowermost spreading and displaying 17 rays, the uppermost closed. The dorsal fin seems to comprise about 16 rays, and some of its expanded triangular supports are well shown. It is difficult to determine whether or not delicate scales were present. Certain brownish markings, especially in the abdominal region, 


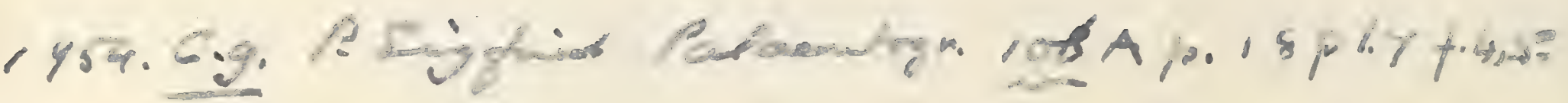


may be interpreted either as small, antero-posteriorly elongated scales, or merely as remains of the muscleplates.

Lewis Coll.

49529. Small trunk, displaying the fins. The relatively small pectoral exhibits its single, much elongated ray. The longest rays of the dorsal are considerably more than half as long as the trunk from the pectoral arch to the base of the caudal fin.

Lewis Coll.

4952\%. More imperfect distorted specimen, either of this or the next species.

Lewis Coll.

Chirothrix lewisi, Davis.

1887. Cheirothrix lewisii, J. W. Davis, Trans. Roy. Dublin Soc. [2] vol. iii. p. 528, pl. xxvi. fig. 2.

Type. Nearly complete fish; British Museum.

A robust species, attaining a length of about $0 \cdot 15$. Length of head with opercular apparatus equalling about twice the maximum depth of the trunk, and contained one and a half times in its length from the pectoral arch to the base of the caudal fin. Fins as in the type species.

Form. \& Loc. Upper Cretaceous: Sahel Alma, Mt. Lebanon.

48079, P. 4740. Type specimen, with incomplete counterpart, described and figured by Davis, loc. cit. One of the pectoral fins ("short subsidiary fins" of Davis) is imperfectly preserved, showing the elongation of one of its middle rays. The very stout pelvic arch ("pectoral arch" of Davis) is crushed upwards and exposed either from above or below, the pelric fin thus raised upon the flank ("pectoral fin" of Davis) being closed, while the other pelvic fin is widely expanded below. The two foremost rays of the pelvic fin are closely articulated but not divided distally, while all the others are finely divided. Most of the rays of the median fins are shown to be diridec distally.

Lewis roll.

48080. Fragmentary specimen.

Lewis Coll.

Chirothrix guestfalicus (Schliiter).

1868. Megapus guestfalicus, C. Schlïter, Palæontogr. rol. xv. p. 274, pl. xliii. fig. 5.

1894. Megistopus guestfalicus, H. Landois, Nenes Jahrb. vol. ii. p. 234, pl. v. 
Type. Imperfect fish; Academy of Münster.

The type species of Megistopus, attaining a length of about 0.12, and of slender proportions. Length of head with opercular apparatus equalling twice the maximum depth of the trunk, and slightly exceeding one third of its length from the pectoral arch to the base of the caudal fin. Pectoral fins apparently as in the trpe species; but the pelvic fins more remote, with about 13 rays, of which the longest scarcely reaches beyond the origin of the anal fin when adpressed to the trunk.

Form. \& Loc. Upper Cretaceous: Baumberg, Westphalia.

Not represented in the Collection.

\section{Genus TELEPHOLIS, W. von der Marck.}

[Palæontogr. vol. xv. 1868, p. 276.]

Head relatively large and jaws apparently toothless. Vertebræ between 40 and 50 in number, about half being caudal. Fin-rays mostly divided as well as articulated distally. Pectoral fins arising near the ventral border, delicate but larger than the pelvic pair, which comprise about 8 rays and are supported by much expanded pelric bones; dorsal fin arising opposite or somewhat in advance of the pelvic pair, and occupying less than half the back; caudal fin slightly forked. The dorsal region protected with a covering of small, thin, rounded or polygonal dermal scutes, each bearing a median tubercle.

One of the original specimens of the type species in the Academy of Münster (noticed by W. von der Marck, Palæontogr. vol. xxxi. p. 248) clearly exhibits the upper jaw. The slender toothless premaxilla is shown to form the upper border of the mouth, excluding the maxilla, which has a triangular expansion behind.

Telepholis acrocephalus, W. von der Marck.

1868. Telepholis acrocephalus, W. von der Marck, Palæontogr. vol. xv. p. 277 , pl. xliii. figs. 6,7 .

1873. Telepholis acrocephalus, W. von der Marck, ibid. vol. xxii. p. 57, pl. ii. fig. $2 a$.

1885̃. Telepholis acrocephalus, W. von der Marck, ibid. vol. xxxi. p. 248.

Type. Imperfect fish; Academy of Münster.

The type species, attaining a length of about $0 \cdot 18$. Length of head with opercular apparatus somewhat less than twice as great as the maximum depth of the trunk, which is contained between four and five times in its length from the pectoral arch to the base of 


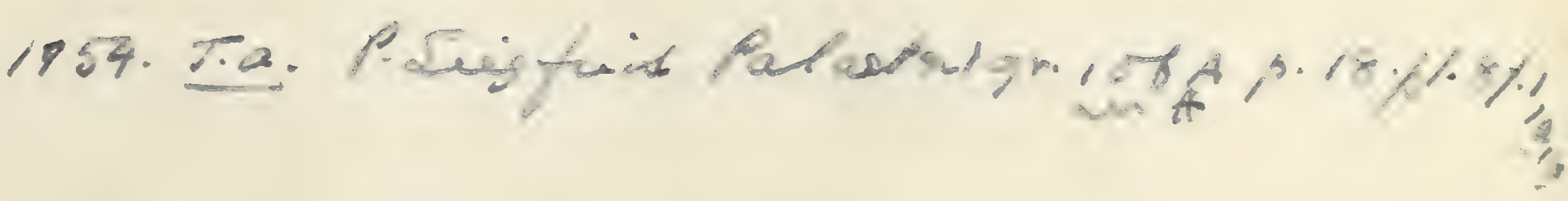



the caudal fin. Pelric fins arising within the anterior third of the space between the pectoral and anal fins, and when adpressed not reaching the latter; each pelvic fin comprising 8 rays of which all are divided and articulated except the anterior two, which are the longest and closely articulated without branching distally. Dorsal fin with 12 rays, the foremost shortest and apparently undivided, the others both divided and articulated distally. Anal fin with 2 comparatively short undivided rays in front, followed by 7 divided rays, separated from the caudal fin by a space equal in length to its own base-line. Tubercles on the scutes of the dorsal ridge between the fin and the occiput produced into small acute points.

Form. \& Loc. Upper Cretaceous : Sendenhorst, Westphalia.

Not represented in the Collection.

\section{Telepholis (?) tenuis (Davis).}

1887. Engraulis (?) tenuis, J. W. Davis, Trans. Roy. Dublin Soc. [2] vol. iii. p. 583, pl. xxx. fig. 4 (non fig. 5).

1895. Exoccetoides tenuis, D. G. Kramberger, Djela Jugoslav. Akad. vol. xvi. p. 39.

1898. Telepholis (?) tenuis, A. S. Woodward, Ann. Mag. Nat. Hist. [7] vol. ii. p. 410.

Type. Imperfect fish; Edinburgh Museum.

Somewhat smaller than the type species. Length of head with opercular apparatus contained about three and a half times in the length of the trunk from the pectoral arch to the base of the caudal fin Vertebræ about 26 in number in the abdominal, 21 in the caudal region. Pectoral fins when adpressed to the trunk extending beyond the insertion of the pelvic pair, and comprising about 16 delicate divided rays; pelvic fins situated probably as in the type species and resembling the latter except in haring only 7 rays; dorsal fin also apparently as in the type species.

Form. \& Loc. Upper Cretaceous: Hakel, MIt. Lebanon, Syria.

Not represented in the Collection.

An imperfect specimen has also been ascribed to this genus, as follows :-

Telepholis biantennatus, W. von der Marck, Palæontogr. vol. xxii. (1873), p. 56, pl. i. fig. 3.- Tpper Cretaceous; Sendenhorst, Westphalia. [Head with anterior abdominal region; Academy of Mïnster.]

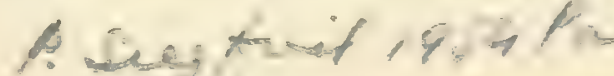


Genus EXOCOFOIDES, Davis.

[Trans. Roy. Dublin Soc. [2] vol. iii. 1887, p. 55̄0.]

Head relatively large and jaws apparently toothless. Vertebræ about 35 in number, 15 being caudal; the transverse processes in the abdominal region very stout. Rays of paired fins mostly both articulated and divided distally, those of median fins articulated but not divided. Pectoral fins delicate but very large; pelvic fins smaller, with about 7 stout rays, mostly divided distally; dorsal fin opposite or somewhat in advance of the pelvic pair, with only about 7 undivided rays; caudal fin rounded, not forked. [Squamation unknown.]

\section{Exocœtoides minor, Davis.}

1887. Exocotoides minor, J. W. Davis, loc. cit. p. 551, pl. xxvi. fig:s. 1, 5.

1895. Exocoetoides minor, D. G. Kramberger, Djela Jugoslav. Akad. vol. xvi. p. 39, pl. viii. fig. 2.

1899. Exocœtoides minor, A. S. Woodward, Ann. Mag. Nat. Hist. [7] vol. iv. p. 319.

Type. Imperfect fish; British Museum.

The type species, attaining a length of about $0 \cdot 06$. Length of head with opercular apparatus nearly half as great as the length from the pectoral arch to the base of the caudal fin. Pectoral fins with about 15 rays, the longest when adpressed to the trunk reaching the anal fin; pelvic fins inserted within the anterior quarter of the trunk and their longest rays less than half as long as the pectorals; dorsal fin entirely in advance of the pelvic pair and its longest rays much shorter than the pectorals; anal fin very small, with 7 rays, separated from the caudal fin by a space about equal to the length of its base-line.

Form.\& Loc. Upper Cretaceous : Hakel, Mt. Lebanon.

P. 4756. Type specimen figured by Davis, loc. cit. fig. 1, displaying all the characters mentioned in the generic and specific diagnoses. The anal fin is termed "dorsal" by Davis.

Lewis Coll.

P. 8685. Another fine specimen, dorsal aspect. Purchased, 1897.

P. 6003. Imperfect small specimen.

Lewis Coll.

The two following specimens may perhaps be immature examples of this species, but the length of the head with opercular apparatus is contained three times in the length from the pectoral arch to the 
318 


base of the caudal fin, while the characteristic great development of the pectoral fins is not shown:-

P. 6002. Fish 0.035 in length, showing dorsal aspect. Lewis Coll.

P. 9411. More imperfect specimen, dorsal aspect, of same size.

Egerton Coll.

The so-called Engraulis evolans, Ag. (suprà, p. 133), with a forked tail, is also referred to Exocoetoides by Kramberger, Djela Jugoslav. Akad. vol. xvi. (1895), p. 39.

\section{Family ESOCID $\approx$.}

Supraoccipital bone extending forwards to the frontals and separating the parietals in the median line; otic region prominent and squamosal reduced. Mandibular suspensorium inclined forwards, but gape large and dentition powerful; symplectic bone present; premaxillæ relatively small and separated by the ethmoidal rostrum; maxilla forming the greater part of the upper-border of the mouth. Opercular apparatus complete, with 12 to 20 branchiostegal rays and no gular plate; gill-opening very wide. Abdominal vertebræ without transverse processes ; ribs not completely encircling abdominal cavity. Intermuscular bones present. Pectoral arch without precoracoid process. A single dorsal fin, more or less remote, without adipose dorsal. Trunk covered with cycloid scales, which frequently extend over the opercular apparatus and cheeks.

Esox is the only known genus of this family, existing in the freshwaters of the northern temperate regions. The common pike (E. lucius, Linn.) occurs in Europe, Asia, and North America.

\section{Genus ESOX (Artedi), Cuvier.}

[Règne Animal, vol. ii. 1817, p. 183.]

Head depressed, but trunk elongate and more or less laterally compressed. Premaxilla with minute teeth; maxilla toothless, with one supramaxillary bone; the extended vomer and pterygopalatine arcade with clustered, recurved, pointed teeth; mandible with a single series of recurved, pointed teeth, small in front, very large in the middle of each side, large behind. Vertebræ approximately 60 in number, one third being caudal. Dorsal and anal fins about as deep as long, directly opposed; caudal fin forked. scales small or of moderate size; lateral line conspicuous. 
Esox lepidotus, Agassiz.

1708. Lucius antediluvianus, J. J. Scheuchzer, Piscium Querelæ et Tindiciæ, pl. i.

17อ๊อ. Figure br G. Wr. Knorr. Samml. Merkwïrdigk. Natur. pt. i. pl. xxri.

1818. Eso l' hucius, H. D. de Blainrille, Nour. Dict. d'Hist. Nat. Tol. xxrii. p. $37 \tau$ (errore).

1832. Esox lepidotus, L. Agassiz, Neues Jahrb. p. 136.

1839-13. Esox lepidotus, L. Agrassiz, Poiss. Foss. vol, v. pt. ii. p. 74 , pl. slii.

1861. Esor robustus, T. C. Minkler, Descript. Poiss. Foss. d'Oeningen (Natuuk. Verhandl. Holland. Maatsch. [2] rol, xir.), p. 53, pl. r. figs. 17, 18, pl. ri. figs. 19. 20. [Imperfect distorted fish; British Iusetm.

Type. Imperfect fish: Zürich Museum.

A species attaining a length of about 0.7 . Head with opercular apparatus occupying nearly one third of the total length to the base of the caudal fiu. Dorsal and anal fins each comprising about 15 dirided and articulated rass preceded by 3 or 4 short undirided rays. Pelric fins nearer to the anal than in E. lucius, and scales considerably larger than in the latter species.

It is difficult to count the fin-rays owing to imperfections and displacement of their right and left halres during fossilisation, but the formula giren for the dorsal and anal is approximately correct.

Form. \& Loc. Upper Yiocene: Oeningen, Baden.

42776. Large fish about 0.7 in length, in counterpart, the jats figured br Winkler, op. cit. pl. ri. fig. 19.

Tan Breda Colt.

P. 9412. Equally large specimen.

History untenown.

42775. Imperfect distorted fish with displaced skull, in counterpart. described and figured by Winkler op. cit. as the type specimen of Esou robustus.

Tun Breda Coll.

42771-74, 4277\%. Eight specimens.

Van Brecta Coll.

P. 2084. Imperfect fish about 0.46 in length, labelled by Agassiz.

Egerton Coll.

P. 9413. Fine specimen 0.42 in length, in counterpart.

Histomy unknoun.

28501. Fragmentary specimen labelled by Agassiz. Dixon Coll.

P. 9414. Two immature specimens.

History unknoum.

8044. Fragmentart remains of head.

Mantell Coll. 


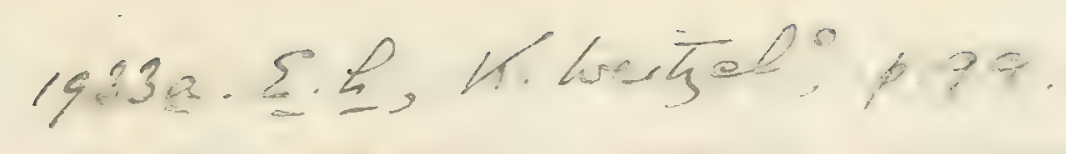




The following specimens seem to belong to the existing Esox Tucius, Linn. (Syst. Nat. ed. 12, vol. i. 1766, p. 516), which has already been recorded from the Norfolk Forest Bed Series (E. T. Newton, Vert. Forest Bed, 1882, p. 123, pl. xviii. figs. 11-14) :-

P. 4925. Portion of left dentary, teeth, and caudal vertebra; Forest Bed Series, West Runton, Cromer.

Presented by William Barker, Esq., 1885.

P. 8703, P. 8708-11. Various fragments; Forest Bed Series, near Cromer.

Savin Coll.

36858-60, P. 4848. Portions of dentaries, teeth, and rertebræ; Pleistocene, Copford, Essex. John Brown Coll. Presented by Sir Richard Owen, K.C.B., 1860.

45810. Teeth and fragments ; Pleistocene, Ilford, Essex.

Brady Coll.

36746. Numerous bones; Southerey Fen, Norfolk.

Presented by Prof. Alfied Newton, 1862.

The following extinct species have also been described, but are not represented in the Collection:-

Esox otto, L. Agassiz, Arbeiten schles. Ges. 1837 (1838), p. 87 (E. ottonis, name only), and Poiss. Foss. vol. v. pt. ii. (1843), p. 68, pl. xlvii._Pleistocene; near Breslau, Silesia. [Detached bones.]

Esox papyraceus, F. G. Troschel, Verhandl. naturw. Ver. preuss. Rheinl. vol. xi. (1854), p. 2, pl. i. fig. 1.-Upper Oligocene (Lignite); Rott, near Bonn. [Imperfect fish; Geological Museum, University of Bonn.]

Esox waltschanus, H. von Meyer, Neues Jahrb. 1848, p. 426, and Palæontogr. vol. ii. (1851), p. 49, pl. vi. figs. 1, 2, pl. vii. fig. 1.-Lower Miocene; Waltsch, Bohemia. [Imperfect fish.]

\section{Family CYPRINODONTID王.}

Supraoccipital bone extending forwards to the frontals and separating the parietals in the median line; otic region prominent and squamosal reduced. Mandibular suspensorium inclined forwards and gape small; symplectic bone present; premaxilla extended, excluding the maxilla from the upper border of the 
mouth; teeth on premaxilla and dentary, none on palate, except very rarely on vomer. Opercular apparatus complete, with few (4 to 6) branchiostegal rays and no gular plate. Abdominal vertebræ. with transverse processes; ribs stout and long. Pectoral arch without precoracoid process. A single dorsal fin, more or less remote, without adipose dorsal. Trunk covered with scales, which extend more or less over the head.

The existing Cyprinodonts are small fishes ranging throughout the temperate and tropical regions, except Australasia, the majority confined to freshwaters, but a few found in brackish water and on the sea-coast. ${ }^{1}$ Only one extinct genus is known with certainty, while a second is recognised provisionally.

\section{Genus PROLEBIAS, Sauvage.}

[Bull. Soc. Hist. Nat. Toulouse, vol. viii. 1874, p. 187.]

Trunk regularly fusiform, laterally compressed; caudal pedicle deep. Head very small, with obtuse snout; cleft of mouth relatively small; premaxillæ not produced forwards, and probably not protractile; teeth simply conical, apparently arranged in a single series. Transverse processes of abdominal vertebræ very short. Pelvic fins present but relatively small; dorsal and anal fins small, not much extended, directly opposed in the hinder half of the fish; anal fin never modified; caudal fin truncated or somewhat forked. Scales large, ornamented with fine parallel striations and pectinations. The two sexes apparently similar.

This genus seems to be most closely related to the existing Incania, Girard, of North America, and Fundulus, Lacépède, which has a still more extensive range in North America besides being abundant in tropical Africa and southern Europe.

\section{Prolebias cephalotes (Agassiz).}

1839. Lebias cephalotes, L. Agassiz, Poiss. Foss. vol. v. pt. ii. p. 48, pl. xli. figs. 1, 2, 9, 10.

1874. Prolebias cephalotes, H. E. Sauvage, Bull. Soc. Hist. Nat. Toulouse, rol. viii. p. 192.

1891. Lebias cephalotes, C. Pollini, Sciame Pesci foss. ricopr. Lastra Calc. marnoso, with photo.

Type. Slab with numerous fishes; otim Murchison Coll.

The type species, attaining a length of about 0.035. Length of head with opercular apparatus about equal to the maximum depth

1 S. Garman, "The Cyprinodonts," Mem. Mus. Comp. Zool. Harvard Coll. vol. xix. no. 1 (1895). 




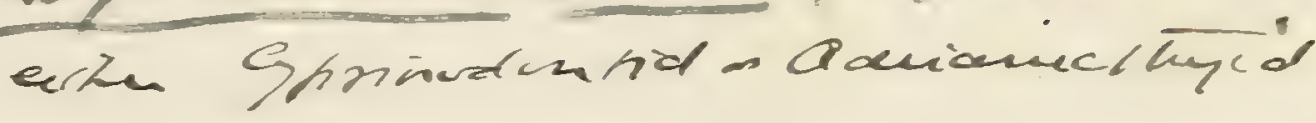

Cyprinodon pugmaeus, s.u. Piton, $1934^{\circ}$, p. 164, 185. 3,7.9.

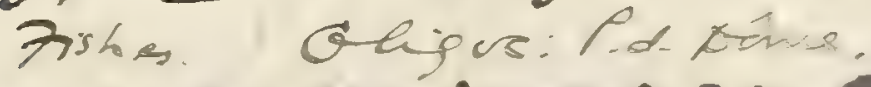

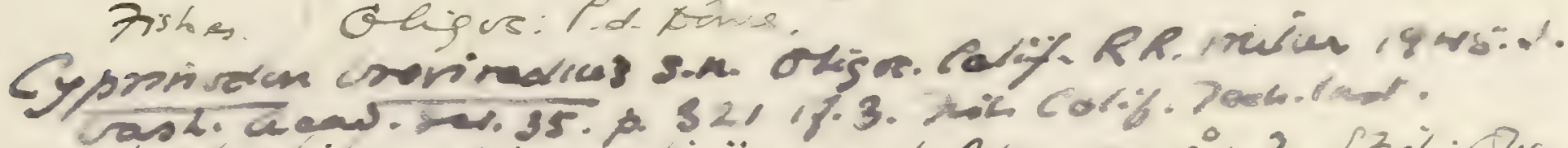

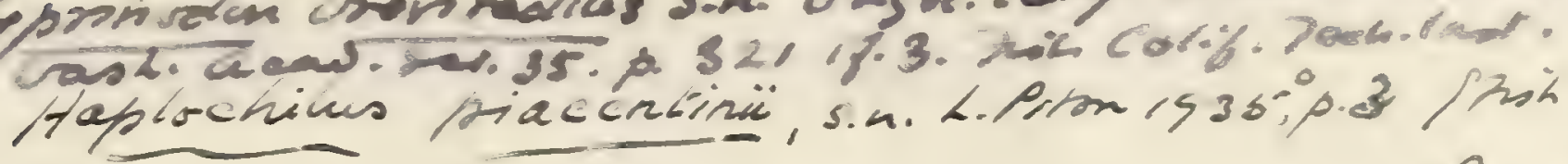

ish: Ougecino Fy-dedant?

Ghinoden (?) primukn, s.n. Cocherell $1936^{6}$, p. 3 f. I.

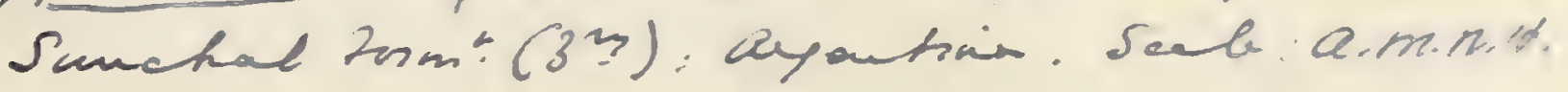

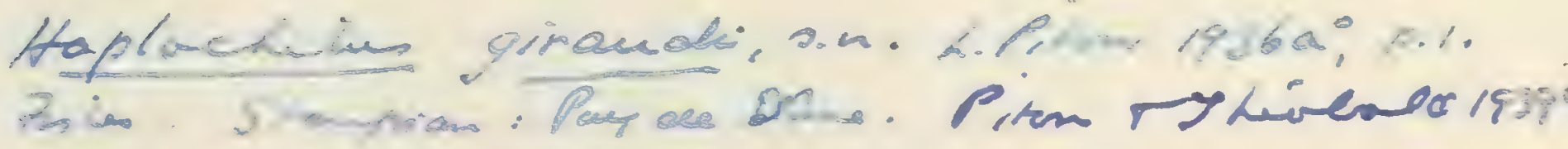
$p, 2,4, p$

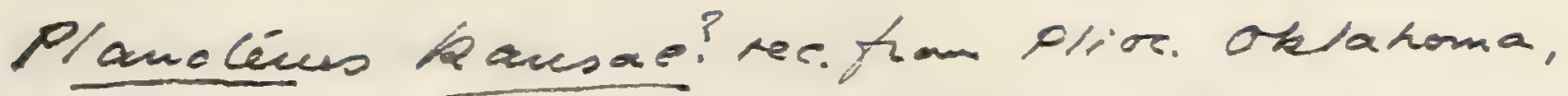
W. Shovake T W. M. Me Qnueby 1939, Omer. mid. Nat. 22

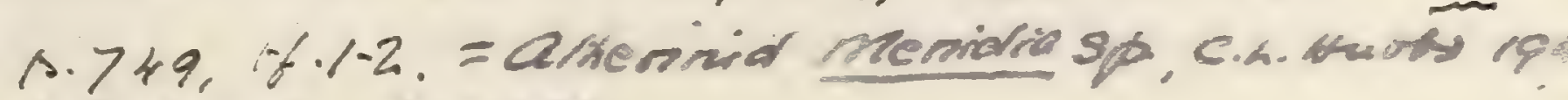
S.Paliont.

tundurkes detilac (AS) S.A. Hestand

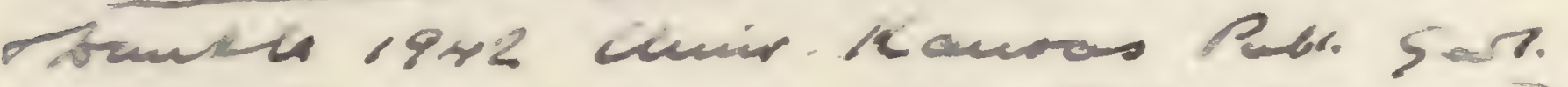

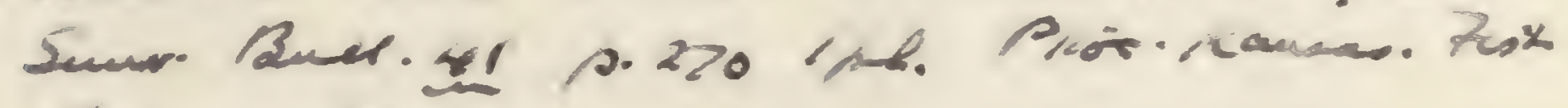
canon Minis.

Fundunes curryi, eurepis, decidap stiknn

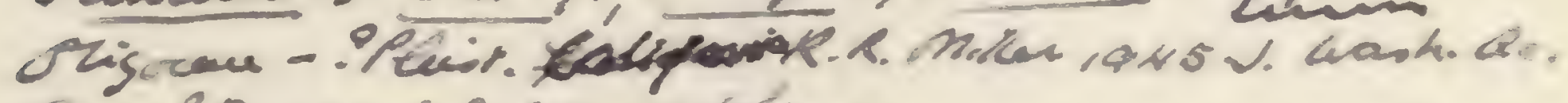
Ser. 35 ph. 3. 321 arto.

1903. Letrias cephalotes, L. Coulon, Bull.Sor. Stude Se: Nat. Slbenf, 2hl.year 1902, h. 1s?, fip. 4.

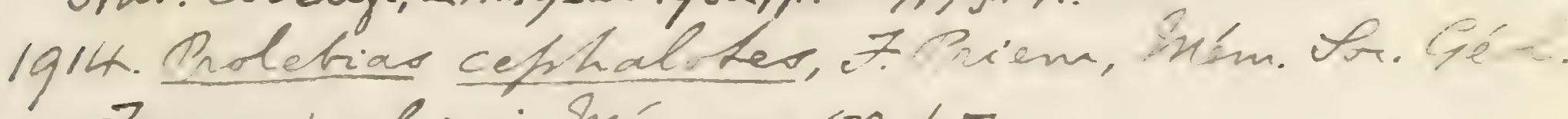

France, vol. xxi, Mném. no. s-0, h.7.

1934 . P.e. Pizono, p. Bu

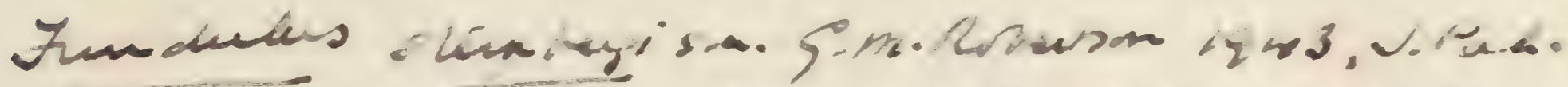

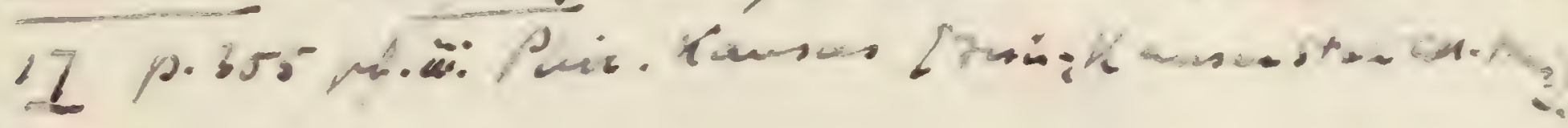


of the trunk, which is contained about three and a half times in the length to the base of the caudal fin. Vertebræ about 12 in the abdominal, 20 in the caudal region. Dorsal fin with or 10 rays, arising immediately behind the origin of the anal fin, which comprises from 12 to 14 rajs; caudal fin truncated or very slightly forked.

Form. \& Loc. Lower Oligocene: Ais-en-Provence.

P. 4266. Large slab of freshwater marl with shoal of fishes.

Enniskillen Coll.

200\%1. Small slab with similar shoal.

Presented by S. P. Pratt, Esq., $18+6$.

36131. Two similar small slabs.

Presented by Sir Roderick I. Iurchison, K.C.B., 1860.

P. 1831. Two smaller slabs and one detached specimen.

Egerton Coll.

21396. Two small slabs.

Purchased, 1847.

43438. Small distorted fish.

Presented by Kenneth Murchison, Esq., 1872.

21397. Two small distorted specimens.

Purchased, 1847 .

\section{Prolebias furcatus (Tinkler).}

(?) 1832. Lebias perpusillus, L. Agassiz, Neues Jahrb. p. 130 (name only).

(?) 1839. Lebias perpusillus, L. Agassiz, Poiss. Foss. vol. v. pt. ii. p. 49 , pl. xli."figs. 3-ō. [Imperfect distorted fish; olim Lavater Coll.]

1861. Lebias furcatus, T. C. Winkler, Descript. Poiss. Foss. d'Oeningen (Natuurk. Verhandl. Holland. Maatsch. [2] vol. xiv.), p. 44, pl. ir. fig. 15 .

(?) 1874. Prolebias perpusillus, H. E. Saurage, Bull. Soc. Hist. Nat. Toulouse, rol. riii. p. 194.

1874. Prolebias furcatus, H. E. Saurage, ibid. p. 190.

Type. Imperfect fish; British Museum.

A very small species with distinctly forked caudal fin. Slightly more slender than the type species, but rertebral column and all fins except the caudal similar.

Form. \& Los. Upper Miocene: Oeningen, Baden.

42784. Trpe specimen described and figured by Winkler, Toc. cit. The stain on the matrix causes the pedicle of the tail to appear more slender than in reality. Van Brecla Coll. 
42800. Two minute specimens on one slab. Van Breda Coll.

42801. Distorted fish, the anterior portion vertically crushed.

Van Breda Coll.

\section{Prolebias gregatus, Sauvage.}

1869. Lebias aymardi, H. E. Sauvage, Bull. Soc. Géol. France, [2] vol. xxvi. p. 1070, fig. no. 3.

1874. Prolebias gregatus, H. E. Sauvage, Bull. Soc. Hist. Nat. Toulouse, vol. viii. p. 190 (said to be Pachystetus gregatus, Aymard MS.).

Type. Imperfect fish.

A very small species. Length of head with opercular apparatus exceeding the maximum depth of the trunk and contained about three and a half times in the length to the base of the caudal fin. Vertebræ 14 in the abdominal, 20 in the caudal region. Dorsal fin with 10 rays, arising behind the origin of the anal, which comprises 12 rays; caudal fin truncated.

Form. \& Loc. Upper Oligocene: Puy-en-Velay, France.

P. 9218. Typical specimen 0.026 in length; Ronzon.

Presented by the Rev. F. St. John Thackeray, 1900.

P. 8c84. Smaller specimens, more imperfect, on similar slab of marl; Ronzon. Presented by Lady Prestwich, 1896.

\section{Prolebias stenoura, Sauvage.}

1874. Prolebias stenoura, H. E. Sauvage, Bull. Soc. Hist. Nat. Toulouse, vol. viii. p. 191, pl. i. figs. 4, 5.

Type. Imperfect fish.

A robust species attaining a length of about $0 \cdot 06$. Length of head with opercular apparatus slightly exceeding the maximum depth of the trunk and occupying about one third of the length to the base of the caudal fin. Vertebræ 12 to 14 in the abdominal, 20 in the caudal region. Dorsal and anal fins exactly opposed, each with 15 rays; caudal fin truncated.

Form. \& Loc. Upper Oligocene: Puy-de-Dôme, France.

28491. Sereral typical specimens; Le Puy-de-Corent. Croizet Coll.

P. 1832. Five similar specimens ; labelled "Clermont."

Egerton Coll.

284:6. Seren imperfect small specimens.

Bravard Coll. 
192\%" Proletios of. gregatus, M. heriche, p. 24 p pos iv.f.1-3. Rupel:" Baden.

1akg. P. of.g. 1. Bangá Rullan, BA. R. Sor. Eppari.MH. $47-2 . p .93$ f. 8 .

1914. Orolctiou stenoura, 7. Priem, Mém. Sor Géol. France, vol.xxi, Mém. no. 50, h.6. bli. fip. 6-9.

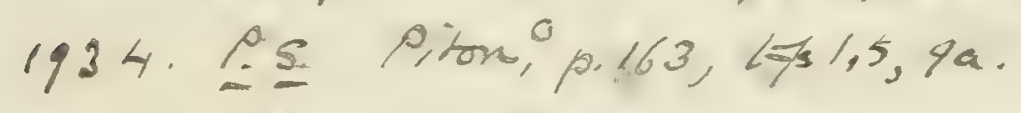

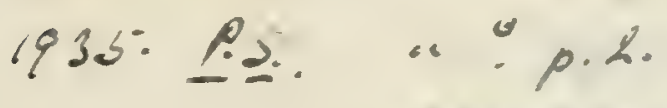




1908. Small distorted specimen, probably of this species.

Purchased.

\section{Prolebias goreti, Sauvage.}

1880. Prolebias goreti, H. E. Saurage, Bull. Soc. Géol. France, [3] rol. viii. p. 445 , pl. xii. figs. 1, 2.

Type. Imperfect fish.

A species with moderately robust skeleton about 0.045 in length. Length of head with opercular apparatus about equal to the maximum depth of the trunk, and contained nearly four times in the total length to the base of the caudal fin. Vertebræ 12 in the abdominal, 16 in the caudal region. Dorsal fin with 10 rays, arising immediately in front of the anal, which comprises 14 rays.

Form. \& Loc. Lower Miocene: Céreste, Basses Alpes.

P. 378. Imperfect fish, in counterpart; Céreste. Gardner Coll.

\section{Prolebias brongniarti (Agassiz).}

1834. Aspius brongniarti, I. Agassiz, Neues Jahrb. p. 383.

1835-39. Aspius brongniarti, L. Agassiz, Poiss. Foss. vol. v. pt. ii. p. 38, pl. 1 r. fig. 4 .

1874. Prolebias oustaleti, H. E. Saurage, Bull. Soc. Hist. Nat. Toulouse, rol. riii. p. 193, pl. i. figs. 6, 7. [Imperfect fish.]

1874. Aspius brongniarti, H. E. Saurage, ibid. p. $19 \check{\jmath}$.

Type. Imperfect fish; olim A. Brongniart Collection.

A large species, attaining a length of about $0 \cdot 13$. Length of head with opercular apparatus equal to the maximum depth of the trunk, which is contained four times in the length to the base of the caudal fin. Vertebræ about 20 in the abdominal, 20 in the caudal region; 17 pairs of ribs. Dorsal fin with about 12 rays, arising immediately in advance of the origin of the anal, which is more extended with 14 or 15 rays ; caudal fin slightly forked.

The synonymy here given assumes that the discrepancies between the two original definitions are due to imperfections in the specimens studied. The amended definition now proposed is based on the specimens enumerated below.

Form. \& Loc. Lower Miocene (Lignite): Puy-de-Dôme, France.

P. 3863. Impression of large fish about 0.13 in length, with traces of the dentition; Ménat. Enniskillen Coll. 
27736. Fine specimen about 0.095 in length, with imperfect caudal fin; Ménat. Indications of teeth in the premaxilla are distinct. Croizet Coll.

28492. Two fine small specimens showing the vertebral column; Ménat. Croizet Coll.

28492 a. Caudal fragment of large fish; Ménat. Croizet Coll.

The following species have also been referred to this genus, but are not represented in the Collection :-

Prolebias gaudryi, H. E. Sauvage, Bull. Soc. Hist. Nat. Toulouse, Pachylevion Samany; vol. viii. (1874), p. 190 (name only). Lebias gaudryi, G. d' hasmo, 930, p. H. E. Saurage, Ann. Sci. Géol. vol. iv. (1873), art. no. 1, co3.pl-f.8-9. p. 261.-Upper Miocene; Racalmuto, Sicily. [Imperfect fish ; Paris Museum of Natural History.]

Prolebias gobio, H. E. Sauvage, Bull. Soc. Hist. Nat. Toulouse, Pachylevies govio, vol. viii. (1974), p. 190. Lebias gobio, L. Agassiz (ex G.ä́rasmo, 1930, Griva.Münster MIS.), Poiss. Foss. vol. v. pt. ii. (1839), p. 49, Sci.nat. ecm. Rabumo pl.xli. fig. 6.-Lignite; Senssen, Fichtelgebirge. [Indexxxu. $0.98, p t+6 . \quad$ terminable distorted fish.

Prolebias meyeri, H. E. Saurage, Bull. Soc. Hist. Nat. Toulouse, G.5Easmo, 1930 @. vol. viii. (1874), p. 190. Lebias meyeri, L. Agassiz, tom. cit. (1839), p. 50, pl. xli. figs. 7, 8.-Upper Oligocene; Mayence Basin. [Imperfect fish.]

Protebias minimus, H. E. Saurage, Bull. Soc. Hist. Nat. Toulouse, vol. viii. (1874), p. 190. Lebias minimus, T. C. Winkler, Descript. Poiss. Foss. d'Oeningen (Natuurk. Verhandl. Holland. Maatsch. [2] vol. xiv. 1861), p. 42, pl. iv. fig. 14.-Upper Miocene; Oeningen, Baden. [Imperfect small fish ; Teyler Museum, Haarlem.]

A supposed Cyprinodont from the Middle Oligocene of Sieblos and Eisgraben, Bavaria, is also named Lebias eisgrabensis by T. C. Winkler, Archiv Mus. Teyler, vol. v. (1880), p. 98. [Imperfect fish; Geological M[useum, Univ. Würzburg.]

Nothing is known of the so-called Lebias tenuis and Lebias zignoi (Bosniaski, Atti Soc. Tosc. Sci. Nat.-Proc.-Verb. vol. i. 1878-79, pp. xix, lv), from the Upper Niocene of Gabbro, Tuscany.

\section{Genus PACHYLEBIAS, novum.}

A genus provisionally recognised on account of the remarkable hyperostosis of the vertebral axis. General proportions as in Prolebias; teeth apparently bifid or trifid; dorsal fin almost or 


270

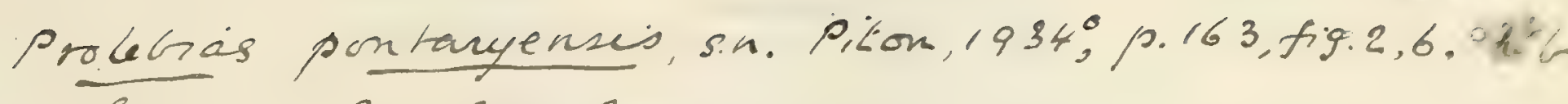
Oligucene: Por clome. Fhes.

Dias arvernenses, s.n. Pitom $1934^{\circ}$, p. 166, figs. 4

P asmeniacus s.a $(n \cdot n)$ an Tikhomito or izhtuge

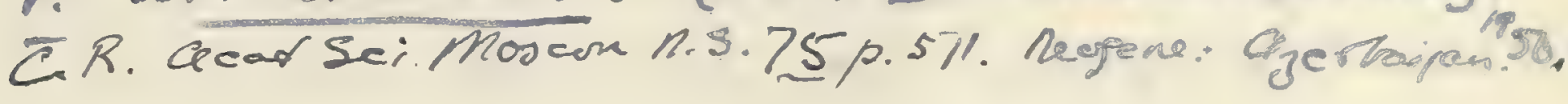

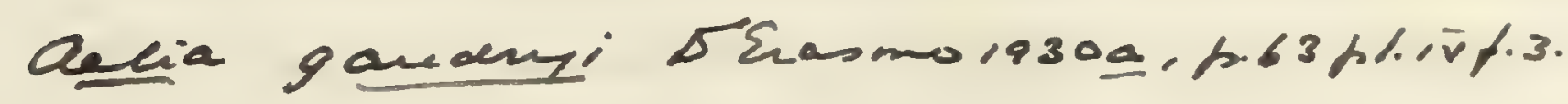

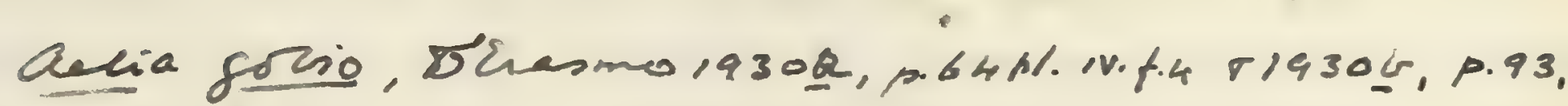
p.ovig.er.

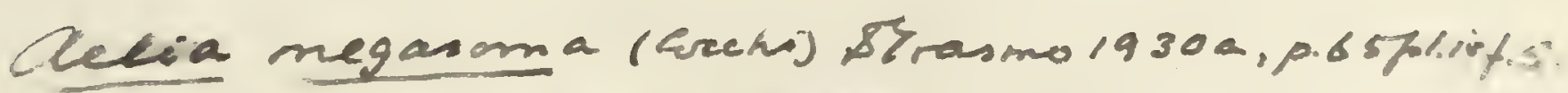

hevias neyeni, Lo. Zots, $1928^{\circ}$

Prolebias praecunsor, sn, Wheilen, 1929, Notizlt. Ver. Erdk. ek. (5) XI1. p.110, pl. vi.t. 14. M. Oligue. MairizB W.Thertald 19340 , p.122 (Beffor). V. Maiktorsty (7ish).

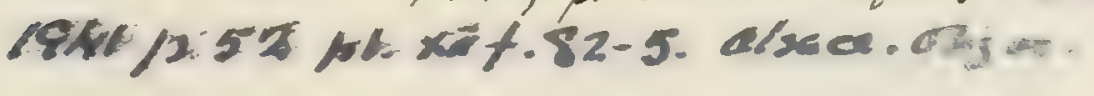

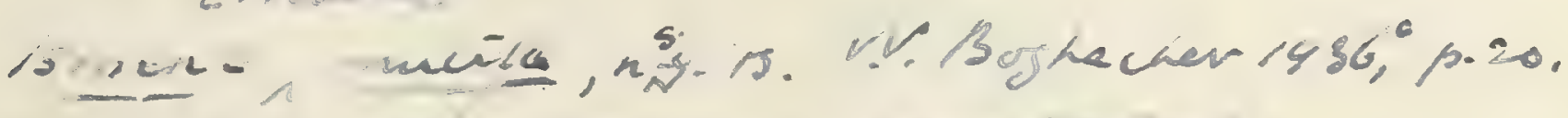

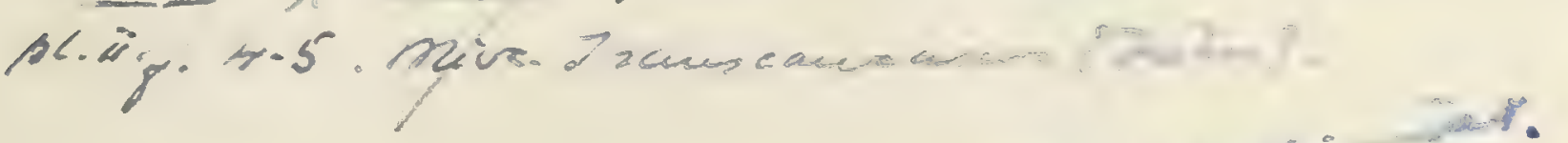

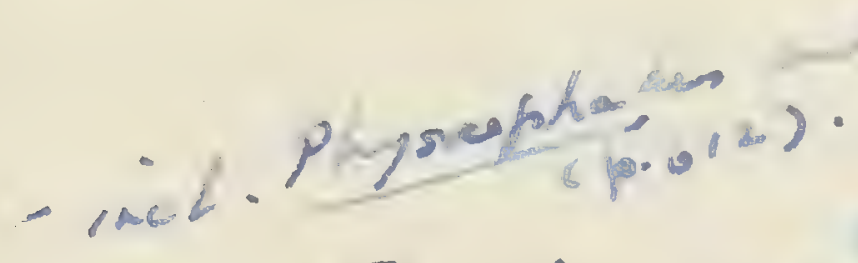

- Celai non talvicuis nee Ganj see Prolevios gancmi govisisume ak.

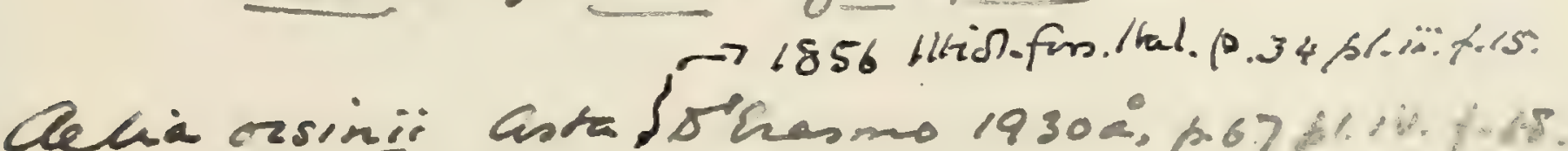

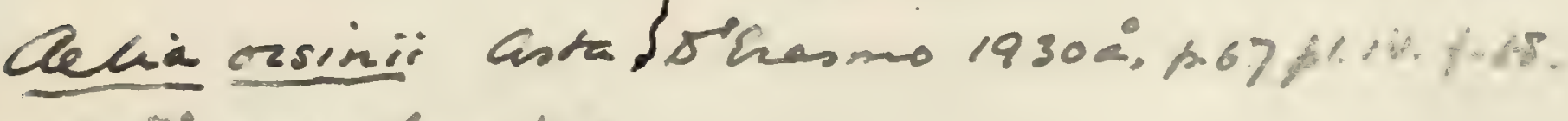
$18305004 f^{\circ}, 10$ of 170 


completely in advance of the anal fin, which is not modifed; caudal fir: truncated.

\section{Pachylebias crassicaudus ( 1 gassiz).}

1832. Lebias crassicaudus, L. Agrassiz, Neues Jahrb. p. 136 (name only).

1839. Lebias crassicaudus, L. Agassiz, Poiss. Foss. rol. ז. pt. ii. p. 56, pl. xli. figs. 11, 12 .

1849. Lebias crassicaudus, E. Sismonda, Mem. R. Accad. Sci, Torino, [2] vol. x. p. 13, pl, ii. fig. 59.

1874. Lebias crassiccuedus, G. Capellini, Mem. Accad. Sci. Istit. Bologna, [3] vol, iv. p. 556.

1874. Prolebias crassicaudus, H. E. Saurage, Bull. Soc. Hist. Nat. Toulouse, rol. viii. p. 190.

1891. Lebias crassicaudus, C. Pollini, Atti Soc. Ligust. Sci. Nat. rol. ii. p. 122.

Type. Imperfect fish.

The type species, attaining a length of about 0.08 , but usually smaller. Length of head with opercular apparatus slightly exceeding the maximum depth of the trunk and contained about three and a half times in the length to the base of the caudal fin. Vertebræ about 30 in number, half being caudal. Dorsal and anal fins with about 9 or 10 rays; the dorsal arising midway between the occiput and the caudal fin; the anal arising opposite the hinder end of the dorsal.

Form. \& Loc. Tpper Miocene: Italy, Sicily, and Crete.

32491-92, 38147. Three imperfect distorted specimens : Sinigaglia, Ancona, Italy.

Purchased, 1857, 186t.

P. 1833, P. 3850. Four similar specimens; Sinigaglia.

Egerton \& Enniskillen Colls.

P. 4. Seren specimens, one shoming some teeth; Racalmuto, Sicily. Purchased, 1879.

P. 1833 a. Slab with fragmentary remains; Racalmuto (?). Egerton Coll.

P. 1834. Fine specimen and three others; Crete. Egerton Coll.

P. 4505. Imperfect fish displaying caudal rertebræ; Crete. Ennistitlen Coll.

24555-56. Nine specimens, sereral exhibiting immature fishes with skeleton not jet much thickened; Crete. 
P. 28\%. Slab, with numerous specimens, mostly immature; Retimo, Crete. ' Transferred from Mus. Pract. Geology, 1880.

The following specimen may be a Cyprinodont, but is not generically determinable:-

42783. Type specimen of Lebias crassus, described and figured by T. C. Winkler, Descript. Poiss. Foss. d'Oeningen (Natuurk. Verhandl. Holland. Maatsch. [2] vol. xiv. 1861), p. 40, pl. iv. fig. 13; Upper Miocene, Oeningen, Baden. Referred to Prolebias by H. E. Sauvage, Bull. Soc. Hist. Nat. Toulouse, vol. viii. (1874), p. 190.

Van Breda Coll.

The following imperfectly defined genus and species, which is not represented in the Collection, is also referred to the Cyprinodontidx by Saurage:-

Pacilops breviceps, A. Pomel, Catal. Méthod. Vert. Foss. Loire (1853), p. 135 ; H. E. Sauvage, Bull. Soc. Hist. Nat. Toulouse, vol. viii. (1874), p. 195 (Pocilops).-Lower Miocene (Lignite); Ménat, Puy-de-Dôme.

A comparatively large skull from the Lower Pliocene, Siwalik Hills, India, now in the Dublin Museum, is provisionally referred to a Cyprinodont by R. Lydekker, Palæont. Indica, ser. x. vol. iii. (1886), p. 256, woode.

The following genera and species, regarded by Cope as possibly Cyprinodont, are too imperfectly known for systematic determination :-

Gephyvura concentrica, E. D. Cope, Amer. Nat. vol. xxr. (1891), p. 654.--Lower Tertiary (?) ; Ree Hills, South Dakota, U.S.A. [Imperfect fish.]

Proballostomus longulus, E. D. Cope, ibid.p. 655.-Ibid. [Ditto.]

\section{Suborder V. OSTARIOPHYSI.}

Vertebral centra always complete constricted cylinders; a few anterior vertebræ usually coalesced and fused with the occiput; a chain of small bones (weberian ossicles) connecting the air-bladder with the auditory organs. Mandible simple, each ramus consisting only of two elements (dentary and articulo-angular). Pectoral arch suspended from the cranium; precoracoid arch present; pectoral fin with not more than four or fire basals. Pelvie fins abdominal. In the living forms-air-bladder, if well developed, connected with 


328

Pardfundulus meradenzis, C.te. Sactman,

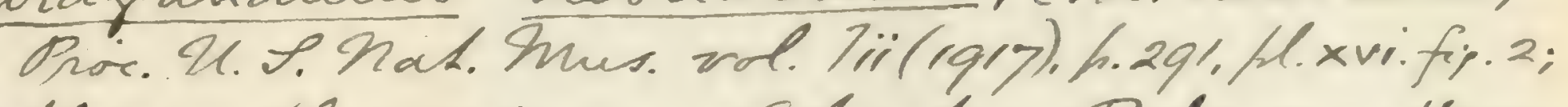
Ll.xvii ; Bl.xviri.fip.3. - Zah ontan Beds; nean Hazen, hevadd. [Bich: U.S. Nathurs] T t Parafundulus.

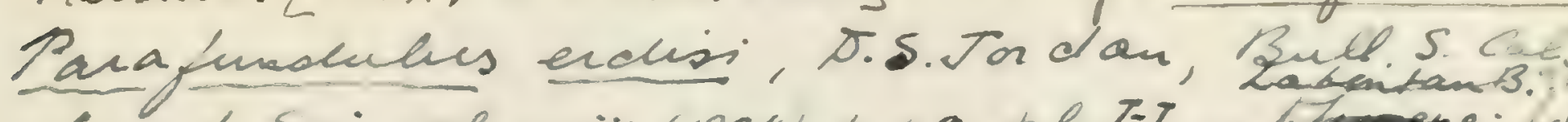

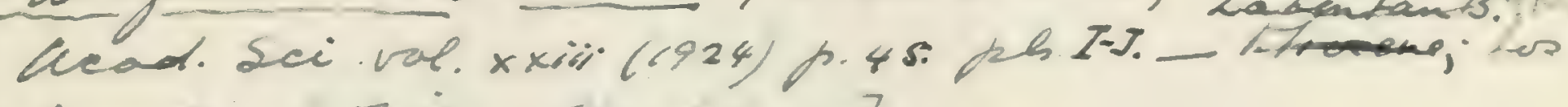
angetes. \& Fines; Stang. ilmir.].

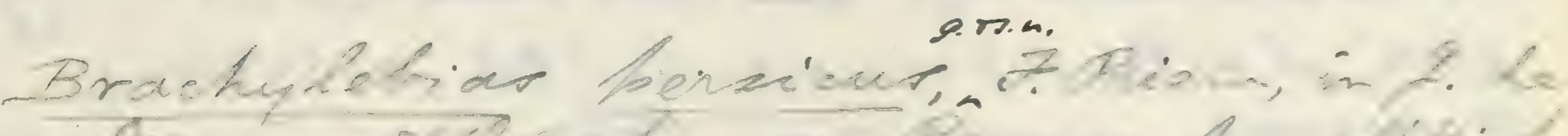

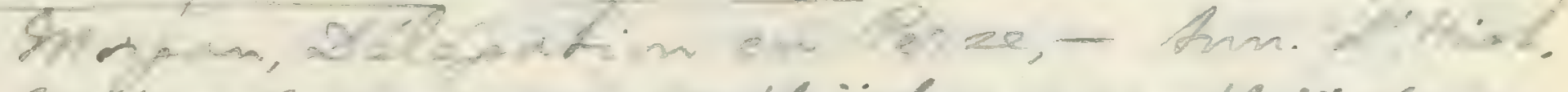

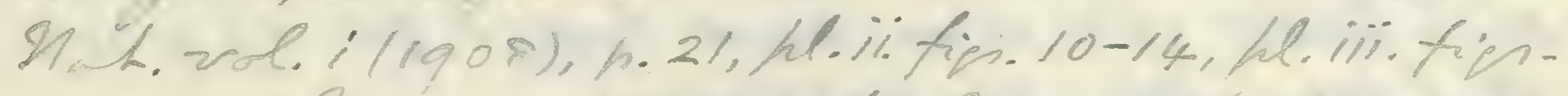
13,14. - Miocenel?); Tatee Purmidik.

Carrionellus diu-monkius 9.r.n. S.9. Whits, 192\%,

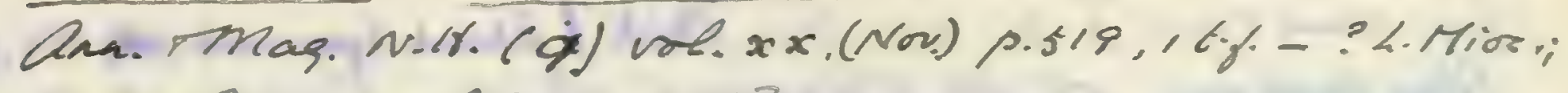
Loir. Sacadr. [7sik; B.M.).

Eephynura concentrica. C.R. Eastman, Drot. ES S. Tat, hus. vol. 7 ii (1917), p. 290 .

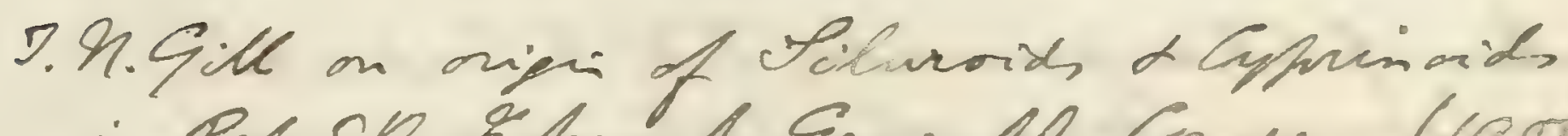

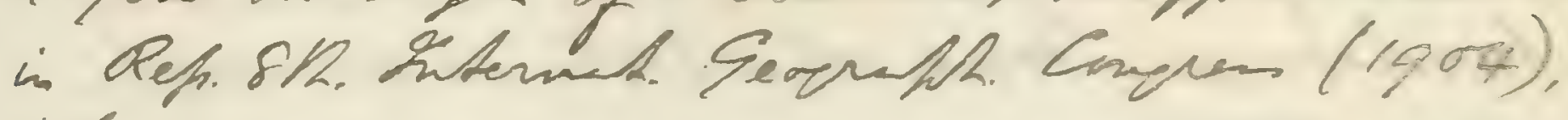
h. 617.

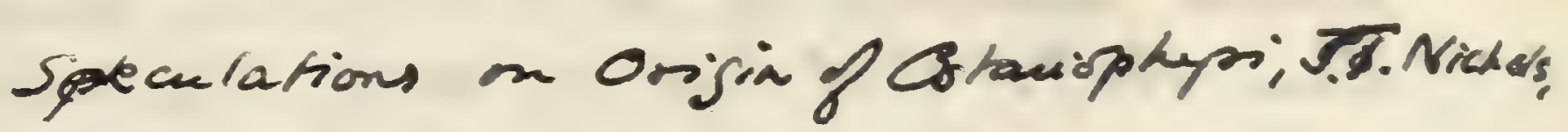
Copeia, $1930(4), p .148$. 


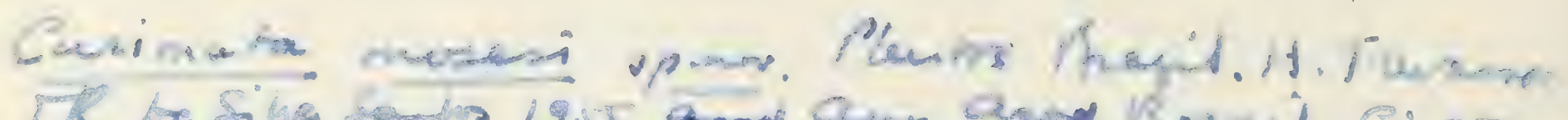

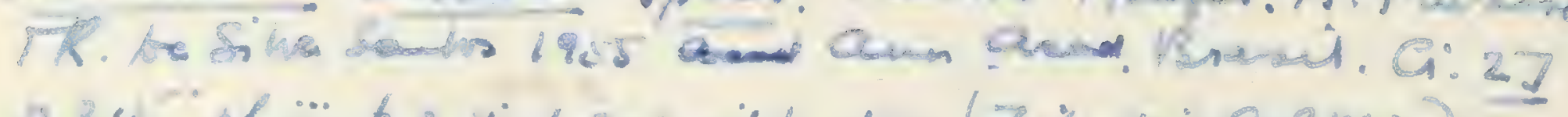

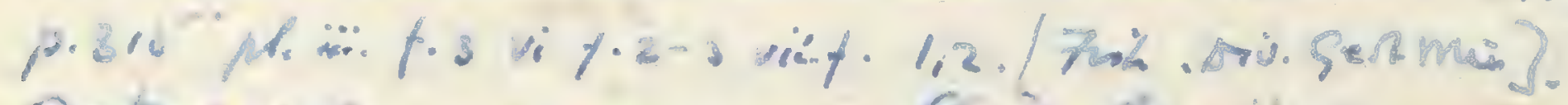

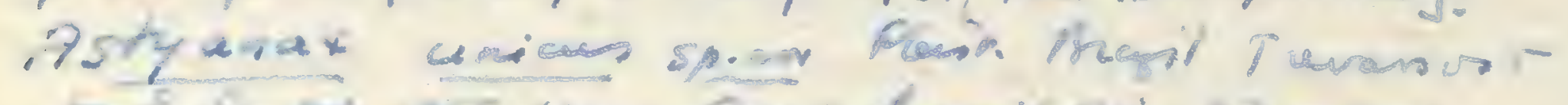

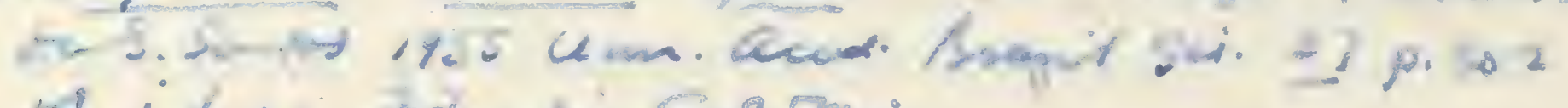

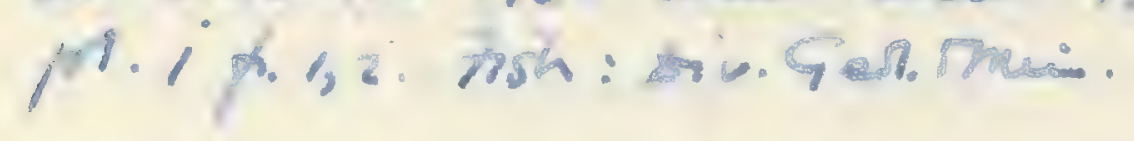

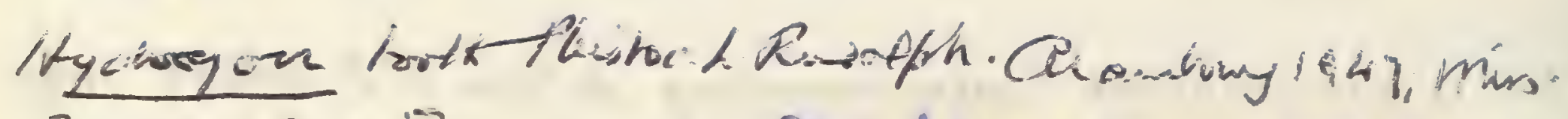

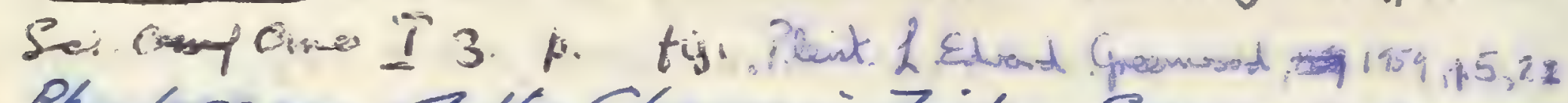

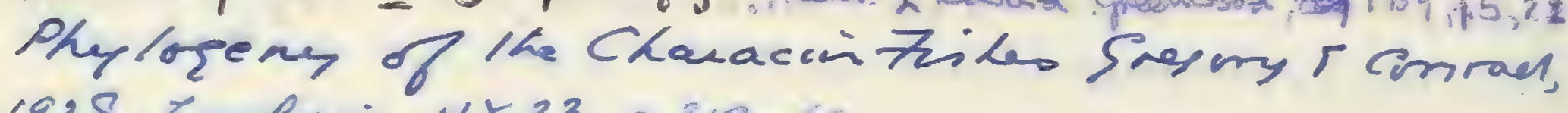

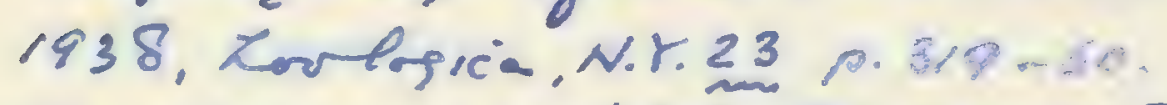

Onchosaurus bitt Characin? Sestman 1917, Buss. Cimer. Mus. N.H. 3y, art.25, 757.60 .

Characilepies Lipantitus, 7.2. A. Cockerell, por. A.S.hat. Mus. vol. $7 \mathrm{ix}(1921), h .19$, fip. $1-3$ - Bortiary; Huacho, Dene. LSeale; Ris. Hat. mus.]

Seales of Characinaid, P.D. A. Cockerbll, Ann. Camepie Anus, we ix (1914), the 92-113, hh. xxiii-xxvioi.

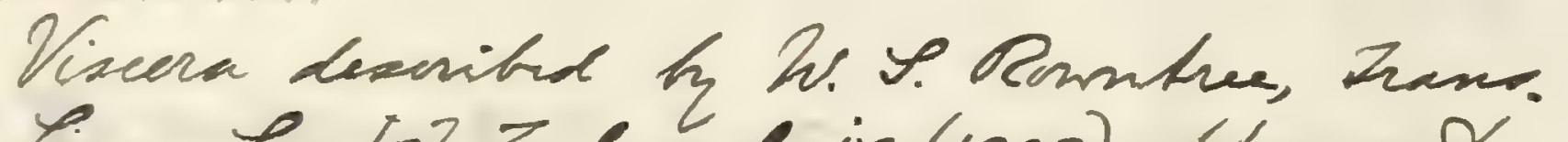
Limn. Dor. $[3]$ Zode. vol. ix $(1903)$, fh. 2. Do not saperet Amirid effinitien.

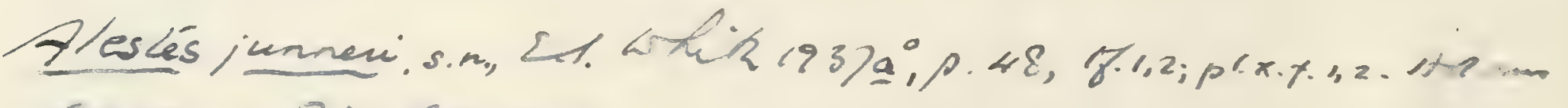

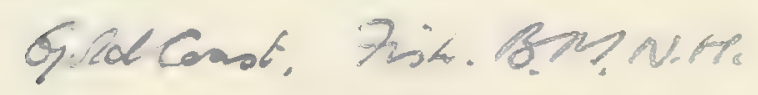




the œsophagus by a duct in the adult (physostomous); optic nerves decussating; intestine without spiral valve; reproductive organs with efferent ducts.

Synopsis of Families.

Premaxilla and maxilla usually entering the upper border of the mouth; teeth usually on margin of jaws, and lower pharyngeals not falciform; symplectic bone present; no barbels; adipose dorsal fin usually present; scales, but no bony scutes .............

Premaxilla excluding maxilla from upper border of mouth ; jaws toothless, but lower pharyngeals falciform and strongly toothed; symplectic bone present; barbels frequent; no adipose dorsal fin; scales, but no bony scutes ........................

Premaxilla almost always excluding maxilla from upper border of mouth; dentition very variable, but lower pharyngeals rarely falciform: no symplectic bone; barbels present; adipose dorsal fin usually present; no scales, but often bony scutes....
Characinide (p. 297).

Cyprinid

\section{Family CHARACINID $\approx$.}

Supraoccipital bone prominent, but not completely separating the well-developed parietals in the median line; squamosal suturally united with parietals and completely covering the otic bones except behind; cheek-plates usually well dereloped. Symplectic bone present; premaxilla small and maxilla relatively large, both entering the upper border of the mouth; teeth variable, more or less acuminate, chiefly on the premaxilla, maxilla, and dentary bones; lower pharyngeals not falciform. No barbels. Opercular apparatus complete, but few branchiostegal rays. Pectoral arch with separate supraclavicle; a single dorsal fin usually followed by a small adipose dorsal on the tail. Trunk corered with scales, but no bony scutes.

No extinct genera of this family are known with certainty. Th e - existing forms are distributed in the freshwaters of tropical America and Africa, attaining their maximum development in South America, where there are no Cyprinoids.

The structure of the Characinoid skull is described by M. Sagemehl, Morphol. Jahrb. vol. x. (1885), pp. 1-119, pls. i., ii. 


\section{Genus TETRAGONOPTERUS, Cuvier.}

[Règne Animal, vol. ii. 1817, p. 166.]

T'runk laterally compressed, but with rounded ventral border. Anterior teeth stout and incisor-like, lateral teeth smaller; those of dentary and premaxilla laterally compressed and notched, the former in single and the latter in double series. Dorsal fin median and short-based; anal fin more or less extended; caudal fin forked. Scales of moderate size, not serrated; lateral line conspicuous.

Existing species in the freshwaters of tropical America.

Tetragonopterus avus, A. S. Woodward.

$$
\text { [Plate XVII. fig. 1.] }
$$

1898. Tetragonopterus avus, A. S. Woodward, Rev. Mus. Paulista, vol. iii. p. 66, fig. 3.

Type. Imperfect fish; British Museum.

A species attaining a length of about $0 \cdot 2$. Length of head with. opercular apparatus about equal to maximum depth of trunk, which is contained slightly more than four times in the total length of the fish. Vertebræ about 20 in the abdominal, 22 in the caudal region. Dorsal fin with 9, anal fin with about 22 rays, the former completely in advance of the latter.

Form. \& Loc. Tertiary Lignite: Taubaté, Province of San Paulo, Brazil.

P. 9222. Type specimen, shown of nat. size in Pl. XVII. fig. 1. Presented by John Gordon, Esq., 1900.

P. 9223-25. Twenty-five imperfect specimens, mostly larger than the type. Presented by John Gordon, Esq., 1900.

P. 9013. Imperfect fish. By exchange, 1898.

Tetragonopterus ligniticus, A. S. Woodward.

[Plate XVII. figs. 2, 3.]

1898. Tetragonopterus ligniticus, A. S. Woodward, loc. cit. p. 67, fig's. 4, 5.

Type. Imperfect fish; British Museum.

A swaller fish than the preceding, of comparatively slender proportions. Vertebræ about 38 in total number, 20 being caudal. Pectoral fins relatively large, when adpressed reaching beyond the origin of the small pelvic fins. Dorsal fin with 8 or 9 rays, directly 


SPohyouvayon pellegrini, a.2.rs. 4.Pitow 19380

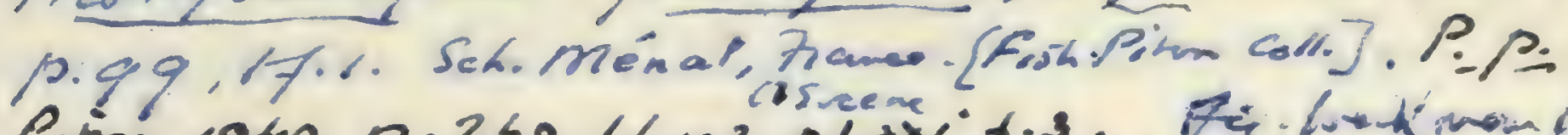

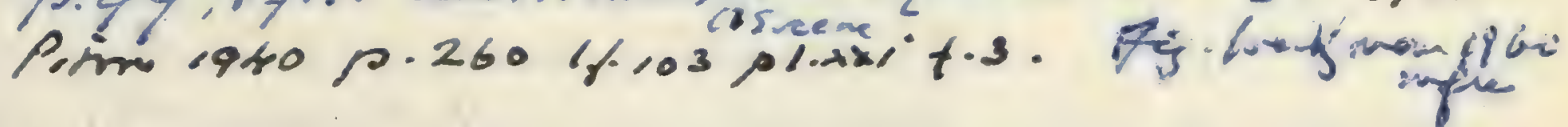

Procharacinus arverniensis, n.girs. L.Pition

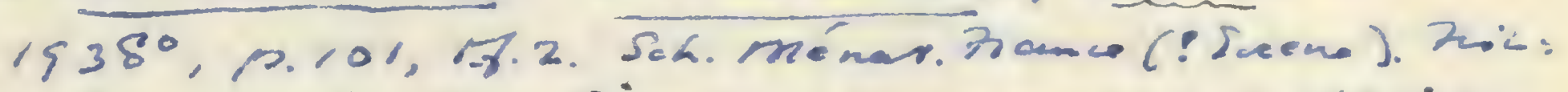

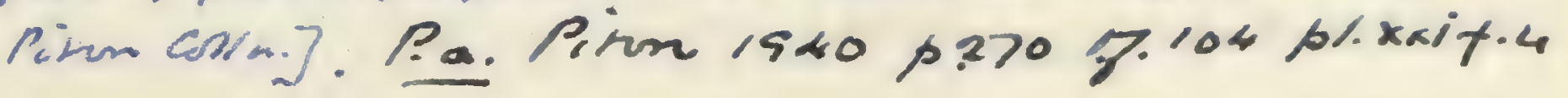
Procharax minor n.s is R.das. Sautos it Thavassos 1956 An acad fragit $C_{i}, 28$ p.190, 1 hl [lump. Jish].

1907. Sobryom avus, D.S. Gordan, Bull. atept. Gied. Anir. Calig- vol.v. h.140, fip. 31. ETyhe

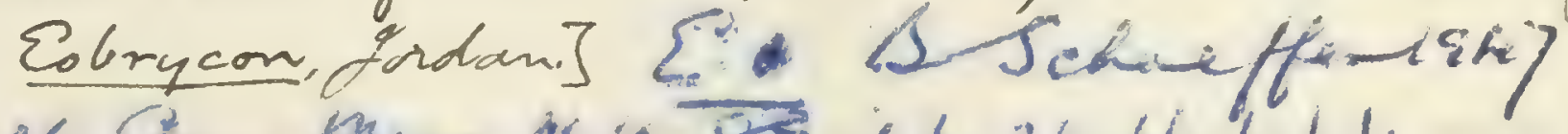

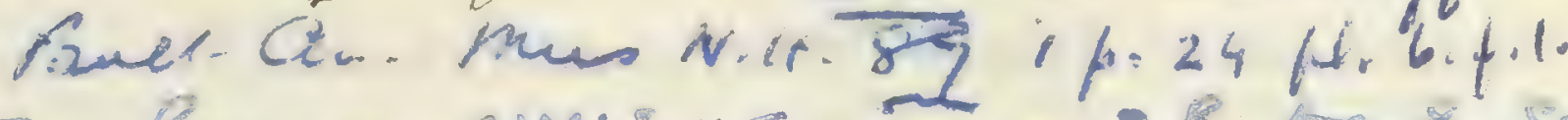

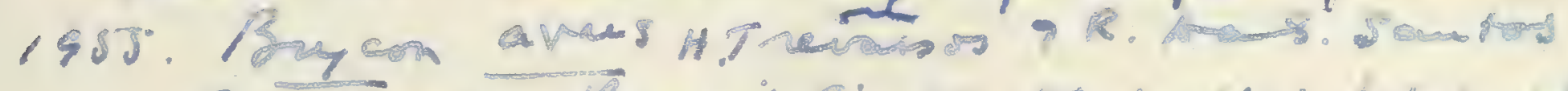

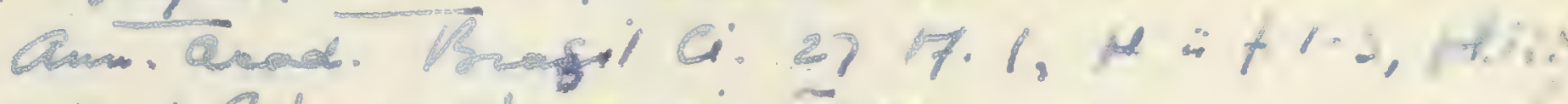
Inch. Entryan Gomusi. 299.

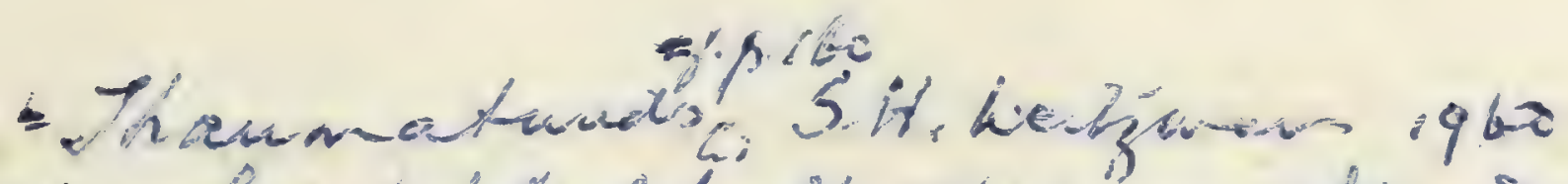

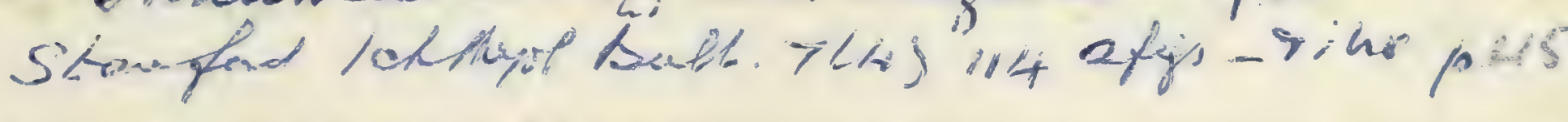

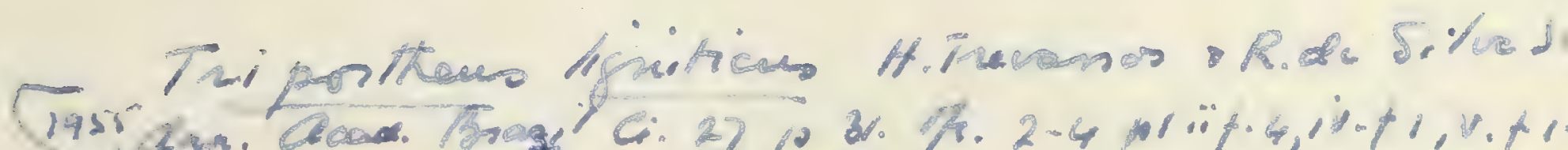
Lignourycon, nig.

1929fignodryem lignitiees, C.H. Eigenmann, ras. Myers, Men. Mus. Comp. Loot. Haward, $x<111, \bar{V}, p .5 \% 3$.

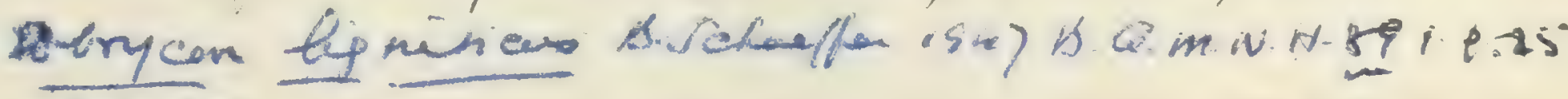
p.6.3.

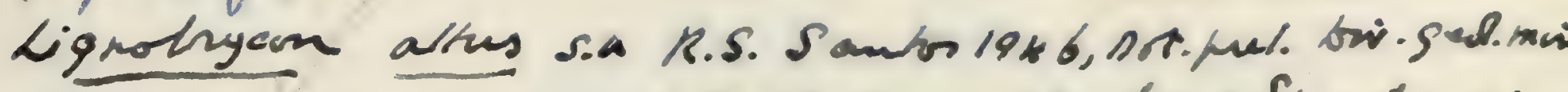

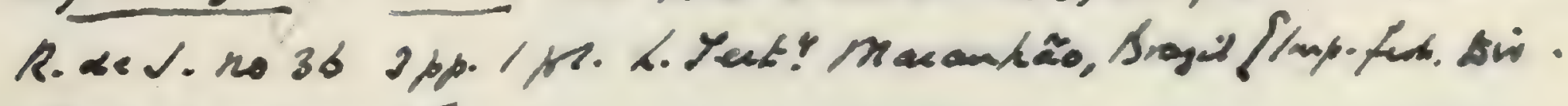
Ses.min, R.e. S.J. 

opposite the anterior part of the much-extended anal fin, which comprises 30 rays.

Form. \& Loc. Tertiary Lignite: Taubaté, Province of San Paulo, Brazil.

P. 9012. Type specimen, shown of nat. size in Pl. XVII. fig. 2.

By exchange, 1898.

F. 9226. Specimen figured in Pl. XVII. fig. 3.

Presented by John Gordon, Esq., 1900.

P. 922\%. Eleven specimens.

Presented by John Gordon, Esq., 1900.

\section{Family CYPRINID圧.}

Supraoccipital bone prominent, but not separating the welldeveloped parietals in the median line; squamosal suturally united with parietals and completely covering the otic bones except behind; cheek-plates much reduced. Mandibular suspensorium inclined forwards and gape small; symplectic bone present; premaxilla extended, excluding the maxilla from the upper border of the mouth, which is toothless; lower pharyngeals well dereloped, falciform, provided with teeth which are arranged in one, two, or three series. Barbels often present. Opercular apparatus complete, but not more than three branchiostegal rays. Abdominal vertebræ without transverse processes; ribs very stout and long, almost completely encircling the abdominal carity. Pectoral arch with supraclavicle; a single dorsal fin, without adipose dorsal. Trunk usually covered with scales, but no bony scutes.

The existing carps and their allies are abundant in the freshwaters of the Old World and North America. Their extinct representatives are known only from Tertiary freshwater formations in the same regions. There are no extinct genera of importance.

\section{Genus CATOSTOMUS, Lesueur.}

[Journ. Acad. Nat. Sci. Philad. vol. i. 1817, p. 89.]

Skeleton more or less imperfectly ossified, and cranium with a fronto-parietal fontanelle. Mouth small and inferior, with thickened lips; ventral border of abdomen not compressed to a sharp edge. Pharyngeal teeth very small and numerous, closely set in a single series. Dorsal fin in middle of back, more or less extended, with not more than about 17 rays and without anterior brony spine; anal fin short-based. Scales varying considerably in size in different species; lateral line distinct. 
Specially characteristic of the freshwaters of North America, but also living in Eastern Siberia.

The following extinct species have been described on imperfect evidence, but are not represented in the Collection :-

Catostomus cristatus, E. D. Cope, Proc. Acad. Nat. Sci. Philad. 1883, p. 160.-Lower Tertiary ; S.W. Idaho. [Hincer part of skull. 7 An. hm, $\Re$. $\%$

Catostomus shoshonensis, E. D. Cope, loc. cit. p. 159.-Ibid. [Skull.]

\section{Genus AMYZON, Cope.}

[Proc. Amer. Phil. Soc. vol. xii. 1872, p. 480.]

An extinct genus related to Catostomus, but with more extended dorsal fin. Scarcely distinguishable from Sclerognathus, but with pharyngeal bones expanded behind.

The following species are recognised, but are not represented in the Collection :-

Amyzon brevipinne, E. D. Cope, Proc. Acad. Nat. Sci. Philad. 1893, p. 402.-Lower Tertiary; Smilkameen River, British Columbia.

Amyzon commune, E. D. Cope, Bull. U.S. Geol. Surv. Territ. vol.i. no. 2 (1874), p. 50, and Vert. Tert. Form. West, Book I. (Rep. U.S. Geol. Surv. Territ. vol. iii. 1884), p. 749, pl. v. fig. 21.-Lower Tertiary; South Park, Colorado. [Nearly complete fish; National Museum, Washington.]

Amyzon fusiforme, E. D. Cope, Bull. U.S. Geol. Surv. Territ.

[2] no. 1 (1875), p. 5, and op. cit. 1884, p. 751.-Ibid. [Ditto.]

Amyzon mentale, E. D. Cope, Proc. Amer. Phil. Soc. vol. xii. (1872), p. 481, and op. cit. 1884, p. 749, pl. lix. fig. 2, pl. lx. fig. 2.-Lower Tertiary; Osino, Nevada. [Imperfect fish; National Museum, Washington.]

Amyzon pandatum, E. D. Cope, Bull. U.S. Geol. Surv. Territ. [2] no. 1(1875), p. 4, and op. cit. 1884, p. 750.-Lower Tertiary; South Park, Colorado. [Ditto.]

\section{Genus CYPRINUS (Artedi), Linnæus.}

[Syst. Nat. ed. 10, 1758, p. 320.]

Snout rounded and obtuse; ventral border of abdomen not compressed to a sharp edge. Pharyngeal teeth molariform, in three 

Catostomus batrach ks, R.P. Cope, Prou Sead. Kat. Sci. Philad. vol. $x \times x$ iv $(1883), h .151$; Z. Thussate of, Bull.

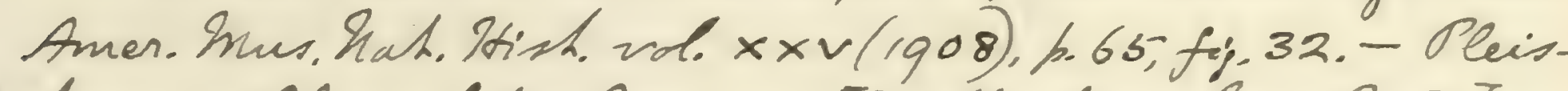
tocens; Silver Take, Oregon. [Steull, Smen. Mus. K. Zi.]

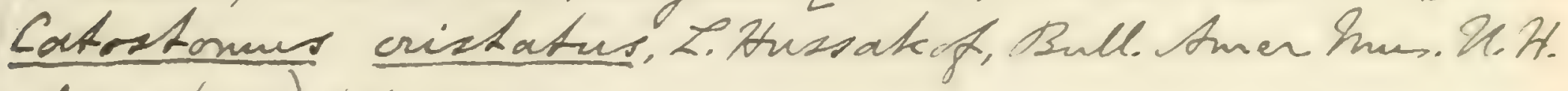
vol. $x \times v(1908), h, 65, f i j, 33$.

Chasmister reponur, E.C. Starter, Bnll. sum

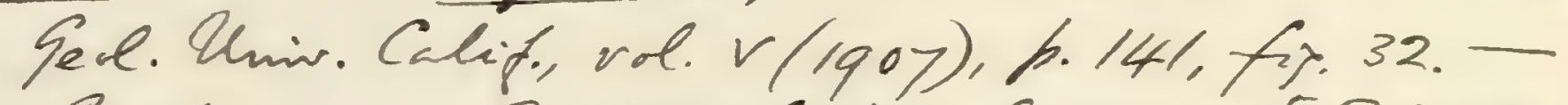
Luatermas; Arsil Latee, Brean. [Stanll; Uim. Calif?

Chamintes tratrachers (Coke), S.C. Starte, itide. 4.143, fr, 33 .

Stunture of sable A Anuson, 2.D. A. Cockerell, Zorl. Anzeigen, vol. xTV (1914), fr.190.

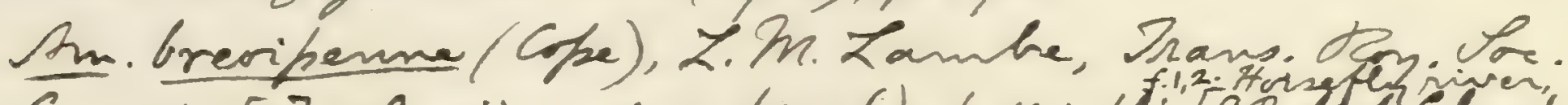

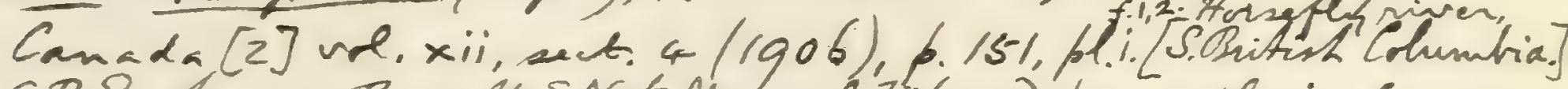

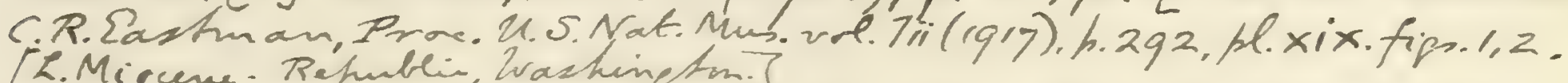

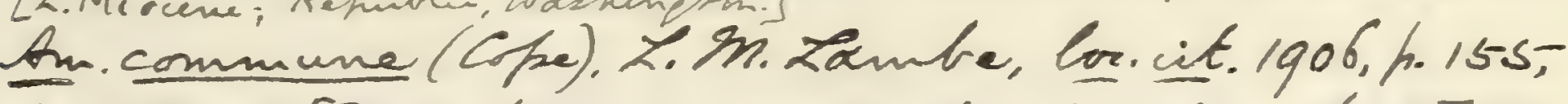
Heifip.3. [Htorsefles riven, S. Britioth Columbia.]

Catostomus reddingi, S. D. Cope, Prov. Acad. Kat. Sei: Ohilad. ad xxxiv(1883), 1.160 (nome onls); L. Thussateof. Bull. Ames. Huos. Y. H. vol. xxv (1908), 1.66, fis. 34.-

[Stuell; Amer. Knus. Kat. Btish.] 


series. Dorsal fin in middle of back, much extended, its foremost ray being a robust spine $\pi$ ith posterior serrations; anal fin rery short, with a similar spine and usually 5 or 6 dirided rays. Scales large; lateral line estending along the middle of the side of the tail. In the existing fauna indigenous in the temperate regions of Asia.

Figures of the skeleton of Cyprinus carpio are given by C. B. Brïhl, Zootomie aller Thierclassen (187i), pls. i.-iii., xix., xx.

\section{Cyprinus priscus, Мejer.}

1818. Cyprinus priscus, H. ton Meyer, Neues Jahrb. p. 782.

18.51. Cyprinus priscus, H. ron Meser, Palæontogr. rol. ii. p. 95, pl. xp. figs. 1-5.

1856. Cyprinus priscus, H. ton Meyer, ibid. vol. ri. p. 22, pl. i. fig. 1.

Type. Fragment of trunk.

A small species, attaining a length of about 0.2. Length of head with opercular apparatus much less than the maximum depth of trunk, which is contained about twice in the length from the pectoral arch to the base of the caudal fin. Dorsal fin supposed to be less extended than in the existing species; pelric fins inserted opposite its origin.

Form. \& Loc. Lower Niocene: Würtemberg.

35509,36902 . Imperfect fish, the middle portion being in counterpart; Cnterkirchberg, near Clm. Some of the rertebræ are displaced, and the fins are imperfect. The characteristic serrated spine of the dorsal fin is shomn.

Purchased, 1860-62.

P. 4980. Mrore imperfect specimen; Unterkirchberg.

Piesented by J. E. Lee, Esq., 1885.

Supposed fragments of the existing Cyprinus carpio from the Quaternary of Piànico, Lombardy (F. Bassani, Atti Soc. Ital. Sci. Tat. vol. xxix. 1886, p. 348, pl. ix. figs. 2-4), are not sufficiently complete for exact determination.

\section{Genus BARBUS, Curier.}

[Règne Animal, vol. ii. 181\%, p. 192.]

Pharyngeal teeth in three series. Barbels variable. Pseudobranchir present. Dorsal fin in middle of back, rarely with more than 9 rays, the third being longest, nsually ossified and frequently serrated; anal fin rery short and relatirely deep, without spine. 
Scales rariable in size; lateral line extending along the middle of the side of the tail.

Very numerous species existing in the freshwaters of the temperate and tropical regions of the Old World.

\section{Barbus megacephalus, Günther.}

1876. Barbus megacephalus, A. Günther, Geol. Mag. [2] vol. iii. p. 437, pl. xviii.

Type. Imperfect fish; British Museum.

An imperfectly definable species, referred to this genus chiefly on account of the aspect of the head and the general resemblance of the fish to living Sumatran species. Length of head with opercular apparatus about two thirds that of the vertebral column. Total number of vertebræ about 41, 18 being caudal. Dorsal fin comprising 3 simple and 9 divided rays, the third not thickened and not quite half as long as the head; anal fin with 3 simple and 5 divided rays, very short, abont two thirds as deep as the dorsal fin ; caudal fin deeply forked, its lower lobe about two thirds as long as the head.

Form. \& Loc. Freshwater Tertiary Formation: Padang, Sumatra.

P. 9431. Type specimen 0.6 in length, described and figured by Günther, loc. cit.

Presented by Herr R. D. M. Verbeek, 1876.

The following specimens are provisionally referred to the existing Barbus vulgaris (Fleming, Brit. Animals, 1828, p. 185) of Northern and Central Europe :-

P. 8740. Portions of two lower pharyngeal bones, described and figured as probably referable to Barbus vulgaris by E. T. Newton, Vert. Forest Bed (Mem. Geol. Surv. 1882), p. 124, pl. xviii. figs. 15, 16 ; Forest Bed Series (Upper Freshwater Bed), West Runton, Norfolk. Savin Coll.

P. 8719. Imperfect similar pharyngeal and six teeth; West Runton. Savin Coll.

The following supposed extinct species are not represented in the Collection :-

Barbus fossilis, K. Martin, Samml. Geol. Reichsmus. Leiden, [1] vol. iii. (1883), p. 20, pl. i. fig. 7.-Tertiary : Nauggung, Java. [Imperfect fish ; State Museum, Leyden.]

Barbus steinheimensis, F. A. Quenstedt, Handb. Petrefakt. (1852), 



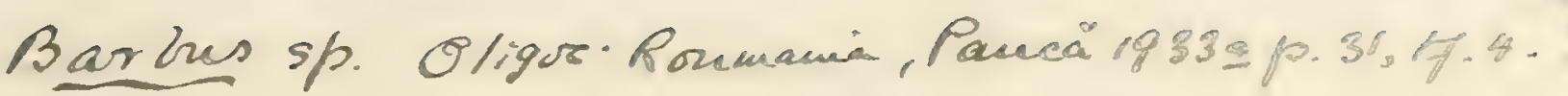

1934. B.m, M. Samders, p. 63 .

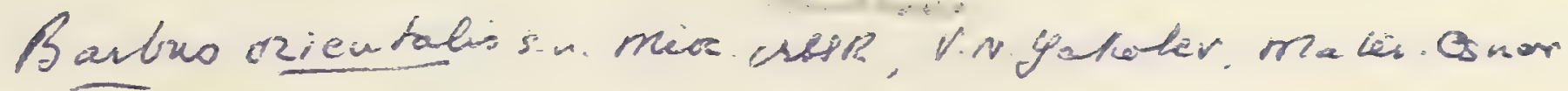
Poceons 3: 3121

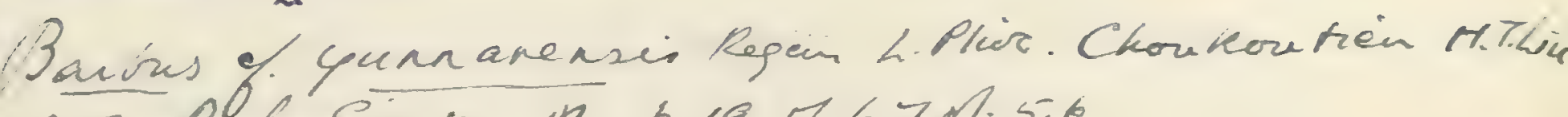
1954 Pal. Sinvia in p.19 P.6.7 M. sit.

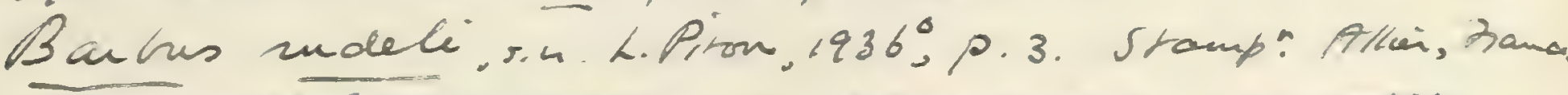

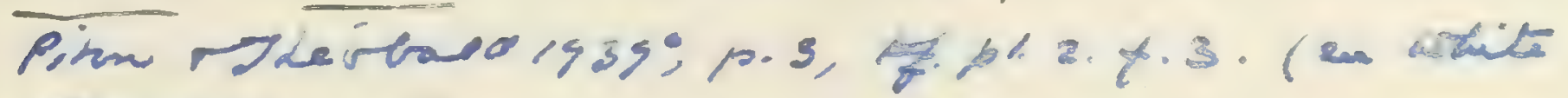
Pot zaum.

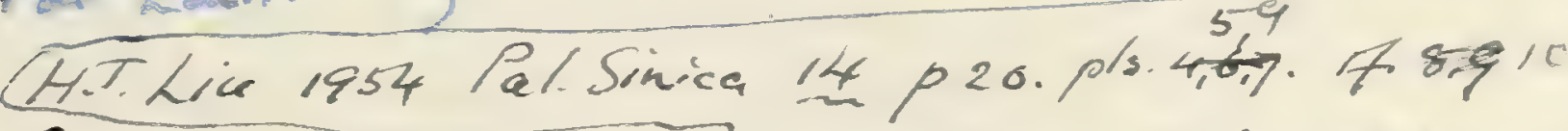

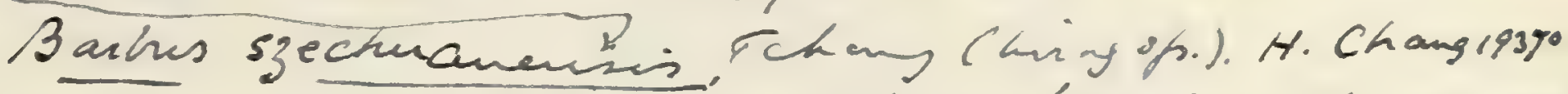

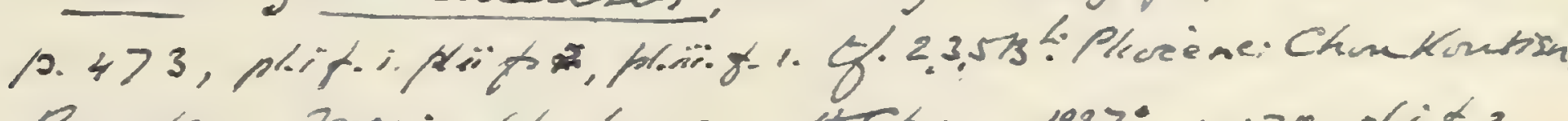

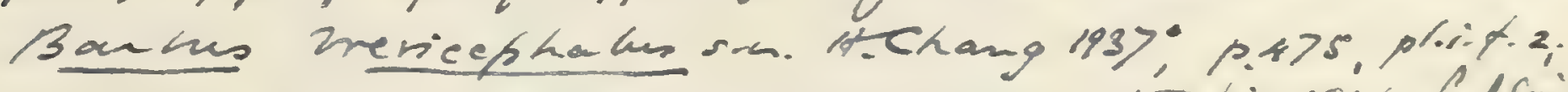

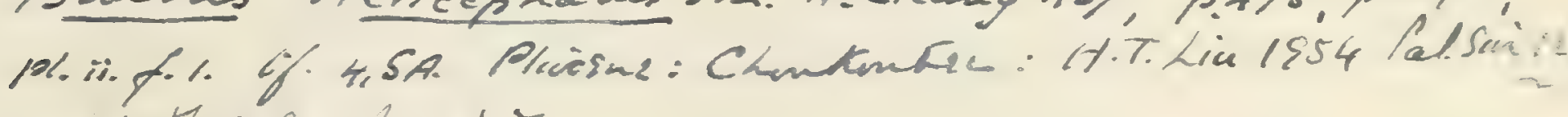

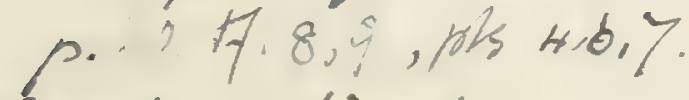

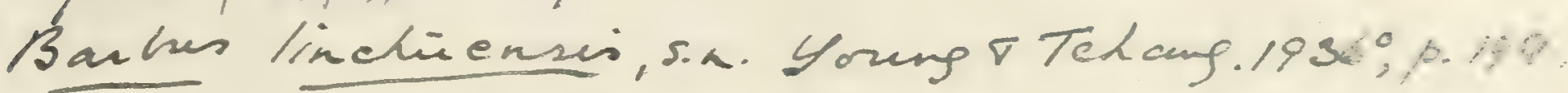

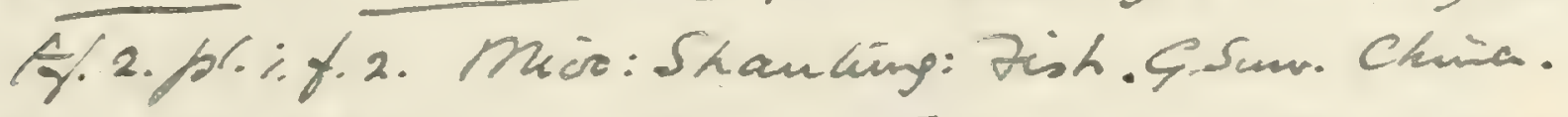

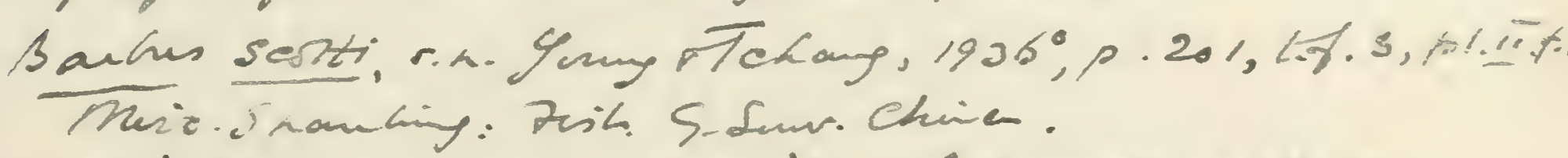

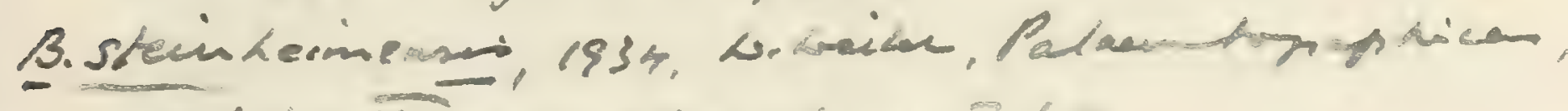

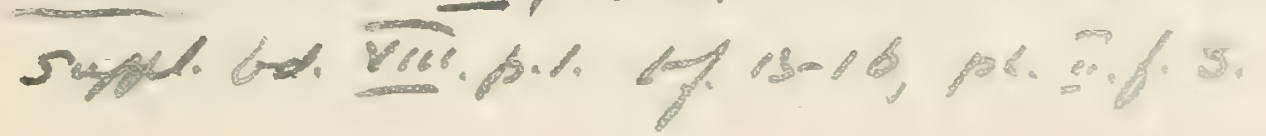


1934. T.Q." M-sandres, \%.36, pl.v.f.6. 
p. 236, pl. xix. figs. 1, 2.-Middle Miocene; Steinheim, Würtemberg. [Imperfect fish; Geological Huseum, University of Tübingen.]

\section{Genus THYNNICHTHYS, Bleeker.}

[Natuurk. Tijdschr. Nederl. Ind. vol. xx. 1860, p. 433.]

Head relatively large, and eye in the middle of the depth of the head; mouth anterior and lateral. Pharyngeal teeth lamelliform, with flat oblong crown, in three series which are wedged into each ather. Barbels and pseudobranchiæ absent. Dorsal fin in middle of back, with not more than 9 dirided rays and no bony spine; anal fin short. Scales small; lateral line extending along the middle of the side of the tail.

Existing in the freshwaters of the East Indian Archipelago and Pegu.

Thynnichthys amblyostoma (W. von der Marck).

1876. Sardinioides amblyostoma, W. von der Marck, Palæontogr. vol. xxii. p. 409, pl. xxiv. fig. 1.

1876. Thynnichthys amblyostoma, A. Günther, Geol. Mag. [2] vol. iii, p. 436, pl. xvii.

Type. Imperfect fish; Royal Geological Museum, Dresden.

A species attaining a length of about 0.3 . Length of head with opercular apparatus considerably exceeding half that of the vertebral column, which comprises about 36 vertebræ, 15 or 16 of these being caudal. Dorsal fin comprising 3 simple and 9 divided rays, the third and fourth being longest, about two thirds as long as the head; anal fin very short, with 3 simple and 5 divided rays, about two thirds as deep as the dorsal fin; caudal fin deeply forked, the length of the upper lobe not much less than that of the head.

Form. \& Loc. Freshwater Tertiary Formation: Padang, Sumatra. 47515-17. Three specimens described by Günther, loc. cit., and used in the composite figure, pl. xvii.

Presented by Herr R. D. M. Verbeek, 1876.

47518-25. Eight specimens, some rather small.

Presented by Herr R. D. M. Verbeek, 1876.

Genus GOBIO, Cuvier.

[Règne Animal, vol. ii. 1817, p. 193.]

Mouth inferior, with a pair of barbels at the angle. Pharyngeal teeth uncinate, in single or double series. Pseudobranchiæ present. 
Dorsal fin in middle of back, without spine, comprising not more than 9 divided rays; anal fin short. Scales of moderate size; lateral line extending along the middle of the side of the tail.

Existing in freshwaters of Europe.

Gobio analis, Agassiz.

1832. Gobio analis, L. Agassiz, Neues Jahrb. p. 134 (name only).

1835-39. Gobio analis, L. Agassiz, Poiss. Foss. vol. v. pt. ii. p. 15́, pl. liv. figs. 1-3.

Type. Imperfect fish; otim Lavater Coll., Zürich.

A species attaining a length of about $0 \cdot 1$, apparently less robust than the existing G. fluviatilis, with the pelvic fins closer to the anal than in the latter species, and the scales probably smaller. Vertebræ about 21 in number in the abdominal, 17 in the caudal region. Dorsal fin with 2 simple and 9 divided rays; anal fin with 1 simple and 8 divided rays. Each pelvic fin with 9 rays.

Form. \& Loc. Upper Miocene: Oeningen, Baden.

36123. Imperfect distorted specimen.

Purchased, 1859.

The following small specimens from Oeningen seem to represent a still more slender species:-

42790. Well preserved fish 0.067 in length. Van Breda Coll.

P. 1788, P. 3866. Two imperfect specimens of the same form.

Egerton \& Enniskillen Colls.

Genus AMBLYPFARYINGODON, Bleeker.

[Natuurk. Tijdschr. Nederl. Ind. vol. xx. 1860, p. 433.]

Lower jaw prominent and mouth very small. Pharyngeal teeth in three series, some being molariform. Barbels absent. Pseudobranchiæ present. Dorsal fin in middle of back, without bony spine, comprising not more than 9 divided rays; anal fin short. Scales small; lateral line incomplete.

This existing East Indian genus seems to be represented by the following specimen :-

47532. Pair of pharyngeal bones with dentition, referred to Amblypharyngodon sp. by Günther, Geol. Mag. [2] vol. iii. (1876), p.438,pl.xv. fig. 4; Freshwater Tertiary Lignite, Padang, Sumatra.

Presented by Herr R. D. M. Verbeek, 1876. 


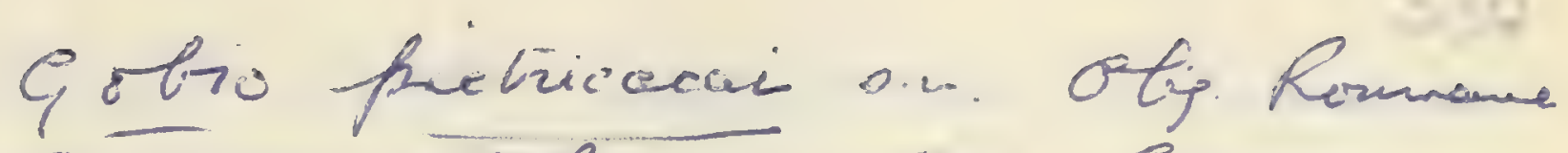
N. Eosmorici rimpaura, 195, Cormen.

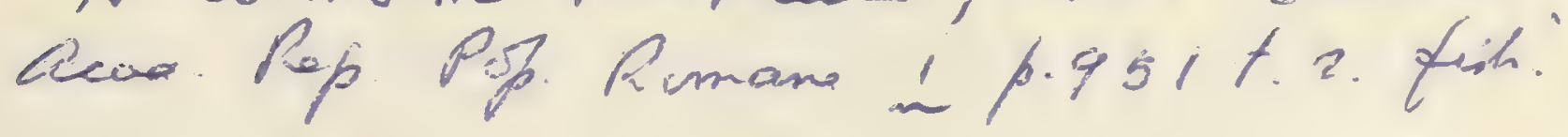

Alizadow minus, O.P.Hay, Proe. U.S. Nat. hues. vd.Triii (1920), f. 132, he. ix.fip. 8, 9. - Pleistorene; Bexear Co., Jexar. [Qharyngeal; U.S. Nat. This.] T. of Alizodon, Htay, 


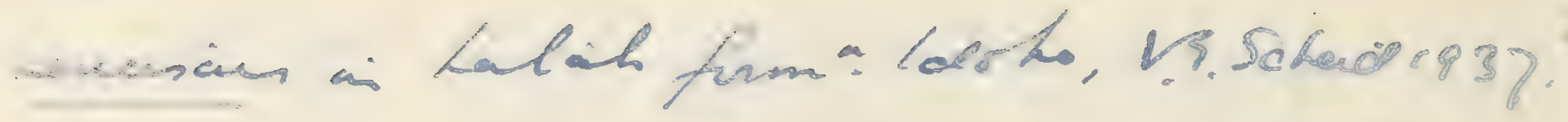

1930. Lenciscus of oeningensis, W. weiler, Senckents XII.

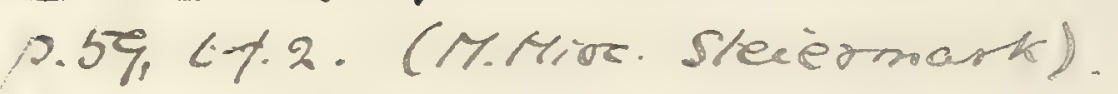

wholiums te, Aspós gianlis te.

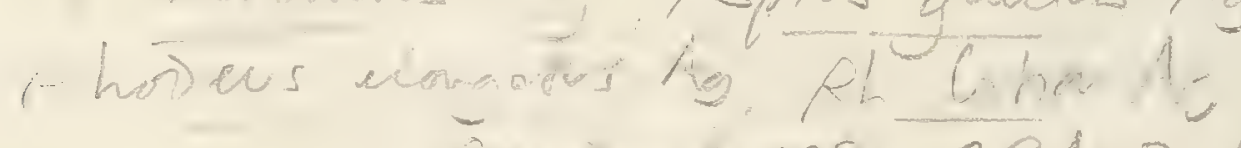
Somina 1980 CRACSaiPain 2940: 
Genus LEUCISCUS (Klein), Curier.

[Règne Animal, vol. ii. 1817, p. 194.]

Premaxillæ protractile. Pharyngeal teeth smooth, conical or compressed, in a single or double series. No barbels. Pseudobranchiæ present. Dorsal fin short, in middle of back, without bony spine; anal fin short, behind the dorsal; caudal fin forked. Scales large or of moderate size; lateral line low on the flank, extending along the middle of the side of the tail.

\section{Leuciscus oeningensis, Agassiz.}

1708. Capito, J. J. Scheuchzer, Piscium Querelæ et Vindiciæ, pl. iii.

175̃. Figure by d'Argenville, Hist. Nat. éclaircie ... Oryctologie, pl. $x$ riii. fig. 2.

1818. C'yprinus jeses, H. D. de Blainville, Nouv. Dict. d'Hist. Nat. vol. xxvii. p. 377 (errore).

1832. Leuciscus oeningensis, L. Agassiz, Neues Jahrb. p. 132.

1835-39. Leuciscus oeningensis, L. Agassiz, Poiss. Foss. vol. v. pt. ii. p. 24, pl. 1vii. figs. 4, 5, pl. 1viii.

1839-44. Lenciscus latinsculus, L. Agassiz, ibid. p. 26, pl. li a. figs. 4, 5. [Distorted fish; British Museum.]

1861. Lenciscus helveticus, T. C. Winkler, Descript. Poiss. Foss. d'Oeningen (Natuurk. Verhandl. Holland. Maatsch. [2] vol. xiv.), p. 19, pl. iii. figs. 7, 9 (? fig. 6). [Imperfect tish; Tesler Museum, Haarlem.]

1861. Leuciscus oeningensis, T. C. Winkler, ibid. p. 20, pl. iii. fg. 8.

Type. Imperfect fish; olim Lavater Coll., Zürich.

A species attaining a length of about $0 \cdot 18$. Length of head with opercular apparatus somewhat less than the maximum depth of the trunk, which is contained three times or slightly more in the total length to the base of the caudal fin. Vertebræ 18 or 19 in the abdominal, 16 in the caudal region; 13 pairs of ribs, the hindermost comparatively small. Pelvic fins, with about 9 rays, arising slightly in advance of the dorsal, which also comprises 9 rays, the foremost being a short spine, the second articulated, the others both articulated and divided distally; anal fin with 12 rays, like those of dorsal; caudal fin moderately forked.

The differences in proportions noted by Agassiz between $L$. oeningensis and the so-called L. latiusculus seem to be due to accidental distortion; while the absence of the small hindermost pair of ribs in the former probably results from defective preservation.

Form. \& Loc. Upper Niocene; Oeningen, Badeu.

P. 9115. Very large distorted specimen.

Purchased. PART IV. 
P. 9416. Fine specimen 0.15 in length, partly in counterpart.

P. 3855. Type specimen of so-called L. latiusculus, figured by Agassiz, tom. cit. pl. li a. fig. 4. Enniskillen Coll.

P. 445. More imperfect specimen, in counterpart, figured by Agassiz, tom. cit. pl. li a. fig. 5, as L. latiusculus.

Egerton Coll.

P. 941\%. Seven imperfect specimens, mostly smaller. Purchased.

42834-41. Seren good specimens of moderate size, three being in counterpart.

Van Breda Coll.

P. 9418. Imperfect specimen 0.115 in length. Purchised, 185 O.

P. 4318. Two imperfect specimens labelled $L$. oeningensis by Agassiz, but one clearly exhibiting 13 pairs of ribs.

Enniskillen Coll.

P. 4317. Imperfect trunk, labelled L. latiusculus by Agassiz.

Enniskillen Coll.

P. 1830. Distorted trunk, similarly labelled.

Egerton Coll.

P. 1828. Two specimens 0.09 in length, one being in counterpart.

Egerton Coll.

P. 9419. Equally small specimen, showing only 12 pairs of ribs.

Purchased, 1859.

43442. Small head and abdominal region.

Presented by Kenneth Murchison, Esq., 1872.

1046 (Sloane Cat.). Imperfect smaller specimen, wanting end of tail.

Sloane Coll.

P. 1828 a. Fragment of rery small fish, labelled L. oeningensis by Agassiz.

Egerton Coll.

The following specimens from Oeningen are also probably immature examples of this species, but bear the name of Leuciscus pusillus (Agassiz, Neues Jahrb. 1832, p. 132, and Poiss. Foss. vol. v. pt. ii. 1835-39, p. 27, pl. lvii. figs. 2, 3), the type being originally in the Lavater Collection, Zürich :-

P. 3857-58. Two fragments labelled L. pusillus by Agassiz, also a fine small fish in counterpart.

Enniskillen Coll.

P. 1829. Tw0 fragmentary specimens labelled L. pusillus by Agassiz. Egerton Coll. 
Zieucriscus Fachecori, R. Gomez.

38

1921. Lencizons pacheeri, Doyo Somes. OP. Sor. Espan.

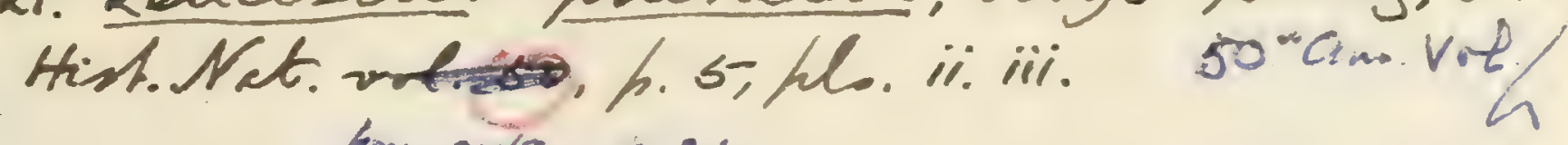
tom. extr. p.210

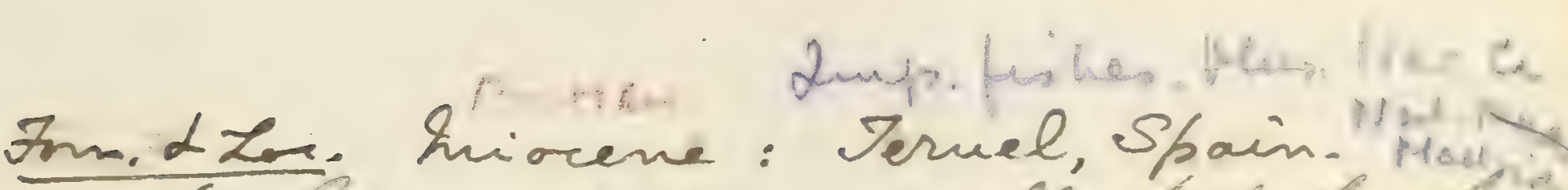

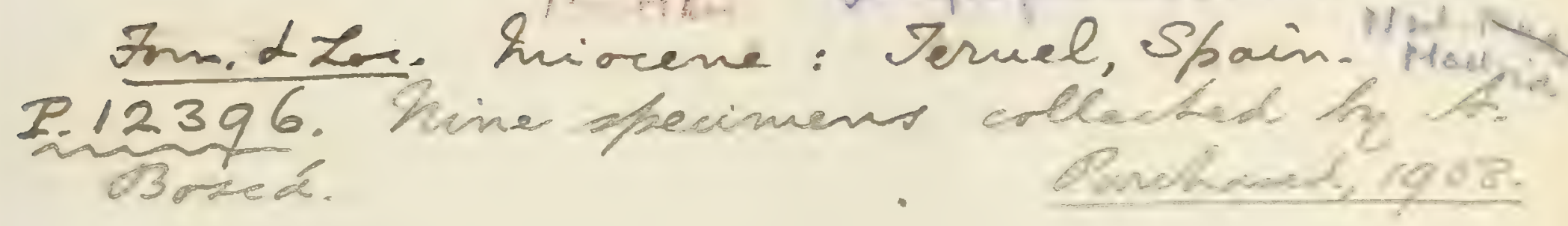

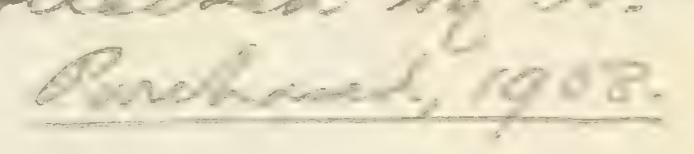


1930. Lenciscus papyracens, W. Weiler, Senekenb. xII. p.s k. k.f." (M. Mioc. Steiermark).

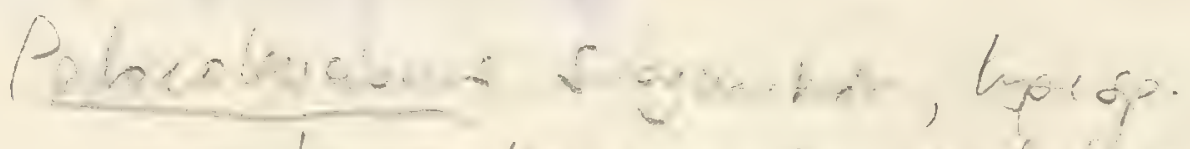

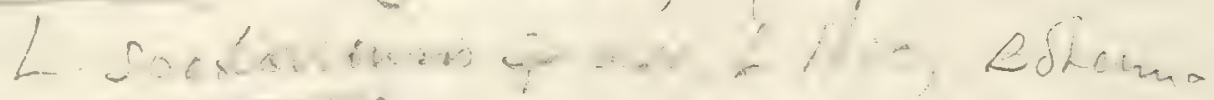

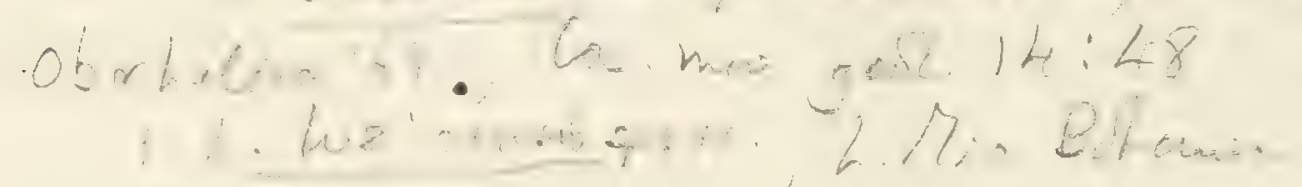




\section{Leuciscus papyraceus (Bronn).}

1828. Cyprinus papyraceus, H. G. Bronn, Zeitschr. f. Mineral. rol. i. p. 380 , pl. iii. fig. 9.

1832. Leuciscus papyraceus, L. Agassiz, Neues Jahrb. p. 132.

1833. Leuciscus cephalon, Zenker, Neues Jahrb. p. 395, pl. v. figs. З゙-5. 183อ̃-39. Leuciscus papyraceus, L. Agassiz, Poiss. Foss. vol. v. pt. ii. p. 31, pl. lvi. figs. 1-4 (?5).

1839. Leuciscus cephaton, L. Ayassiz, ibid. p. 32.

1848. Leuciscus papyraceus, C. G. Giebel, Fauna der Vorwelt, Fische, p. 110.

1854. Leuciscus papyraceus, F. G. Troschel, Verhandl. naturw. Ver. preuss. Rheinl. vol. xi. p. 19, pl. ii. fig. 2.

Type. Imperfect fish; olim Bronn Collection, Heidelberg.

A very small species with comparatively delicate skeleton. Length of head with opercular apparatus exceeding the maximum depth of the trunk, which is contained between four and five times in the total length of the fish to the base of the caudal fin. About 36 vertebræ, half being caudal; 14 pairs of ribs. Pelvic fins, with about 9 rays, arising opposite the origin of the dorsal, which also comprises 9 or occasionally 10 rays, the foremost being a short spine, the second articulated, the others both articulated and divided distally; anal fin similar to dorsal, arising much nearer to pelvic pair than to caudal fin.

Form. \& Loc. Upper Oligocene: Germany; (?) also Bilin, Bohemia.

P. 7666. Fine specimen $0 \cdot 1$ in length, associated with fragment; Lignite, Rott, near Bonn.

Purchased, 1895.

33297 a, 33499. Seven specimens; Rott. Purchased, 1858.

P. 1826. Three small specimens; Rott. Egerton Coll.

869. Imperfect small specimen; Rott. Purchased.

P. 1825. Three diminutive specimens, labelled "Leuciscus cephalon, Zenk." by Agassiz; Lignite, Linz on Rhine. 


\section{Leuciscus colei, Meyer.}

1848. Leuciscus colei, H. von Meyer, Neues Jahrb. pp. 425, 426.

1851. Lenciscus colei, H. von Meyer, Palæontogr. vol. ii. pp. 49, 53, pl. xii. figs. 2, 3.

Type. Imperfect small fish.

A very small species, essentially identical with $L$. papyraceus, but with slightly smaller head and more slender vertebral centra.

Form. \& Loc. Lower Miocene: Bohemia.

P. 9421. Two specimens, one being imperfect trunk; Semi-opal, Luschitz. Purchased.

37236-37. Two imperfect specimens, the first deepened by distortion; Semi-opal, Bilin.

Purchased, 1863.

P. 1827, P. 3860. Three fragments; Bilin.

Egerton \& Enniskillen Colls.

\section{Leuciscus macrurus, Agassiz.}

1839-44. Lenciscus macrurus, L. Agassiz, Poiss. Foss. vol. v. pt. ii. p. 30, pl. li $b$.

1854. Leuciscus macrurus, F. G. Troschel, Verhandl. naturw. Ver. preuss. Rheinl. vol. xi.p. 18.

Type. Imperfect fish: Rheinland Museum, Bonn.

A species attaining a length of about $0 \cdot 25$. Length of head with opercular apparatus scarcely exceeding the maximum depth of the trunk, which is contained between three and four times in the total length of the fish to the base of the caudal fin. About 36 rertebræ, half being caudal. Fins as in $L$ papyraceus, except that the dorsal is relatively large, being about as deep as the trunk at its insertion.

Form. \& Loc. Upper Oligocene: Germany.

P. 651, P. 3856. Inperfect large trunk, in counterpart, figured by Agassiz, loc. cit. pl. li b. fig. 3, considered by Troschel (loc. cit.) not to belong to this species; Lignite, Stösschen, near Bonn. The specimen is also mentioned by Horner, Trans. Geol. Soc. [2] rol. iv. p. 453, footnote.

Egerton \& Enniskillen Colls.

35545, P. 7665. Large fish with imperfect fins, in counterpart; Lignite, Rott, near Bonn. Presented by W.J. Neville, Esq., 1859, \& Purchased, 1895. 
300

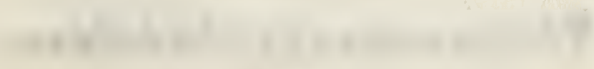

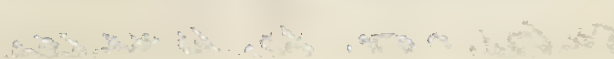

s. 


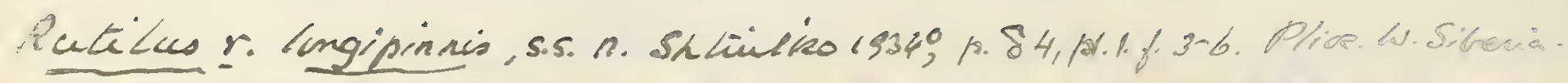

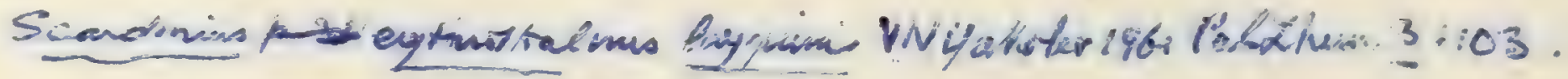
Lenciscus rulitis ho, ptiocenicus, subprnor. Wo. Weiler, 1928 mand

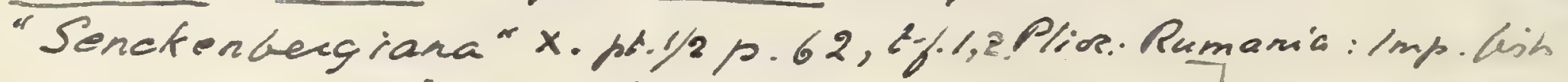

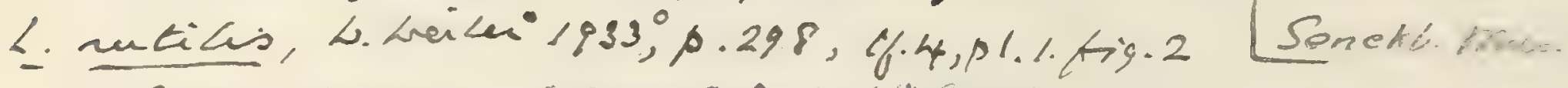

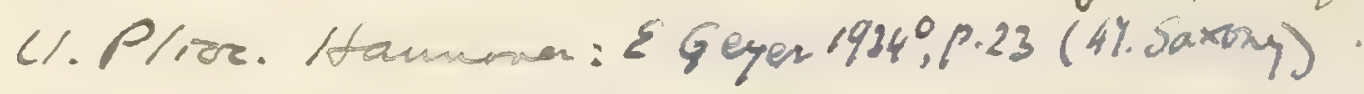

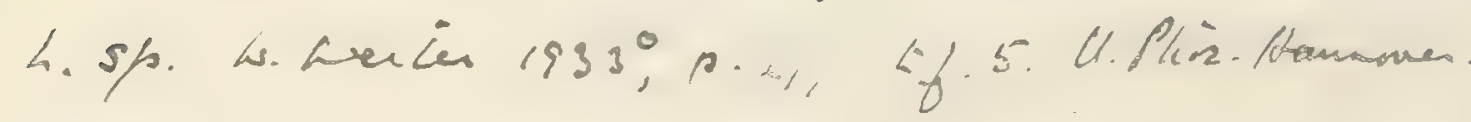


35709. Two large specimens, one wanting end of tail; Rott.

Purchased, 1860.

33491. Large tail ; Rott.

Purchas:d, 1858.

33297-98, 33488, 33495. Five small specimens; Rott.

Purchased, 1858.

35547. Small specimen, slightly elongated by distortion; Rott.

Presented by W.J. Neville, Esq., 1859.

42730 a. Imperfect small trunk; Rott.

Van Breda Coll.

P. 1824, P. 3861, P. 4319. Four small specimens; near Bonn.

Egerton \&. Enniskillen Colls.

28278. Portion of very large trunk, doubtfully of this species; Rott.

Purchased, 1853.

Leuciscus leptus, Agassiz.

1832. Leuciscus leptus, L. Agassiz, Neues Jahrb. p. 181 (name only).

1830̌-39. Leuciscus leptus, L. Agassiz, Poiss. Foss. vol. v. pt. ii. p. $2 \dot{8}$, pl. lix.

Type. Imperfect head and abdominal region.

A very small, imperfectly definable species, known only by fragments. Vertebræ 19 in abdominal, 17 in caudal region; 15 pairs of ribs. Fins and general proportions apparently as in

L. papyraceus.

Form. \& Lac. Lower Miocene: Germany.

28405-06. Two fragments; Polirschiefer, Habichtswald, near Cassel.

Mantell Coll.

43441. Two fragments; Habichtswald.

Presented by Kenneth Murchison, Esq., 1872.

P. 1823. Two fragments; Habichtswald.

Egerton Coll.

The three existing species Leuciscus rutilus (Linn.), L. erythrophthalmus (Linn.), and L. cephalus (Linn.), seem to be represented by pharyngeal teeth in the Forest Bed Series of Norfolk (E. T. Newton, Vert. Forest Bed [Mem. Geol. Surv. 1882], pp. 124-126, pl. xviii. figs. 17, 18). The first of these species is represented in the Collection by the following specimens :-

P. 8742. Right pharyngeal, figured by Newton, loc. cit. pl. xriii. fig. 17; Forest Bed Series, West Runton. Savin Coll. 
P. 8731-33. Detached pharyngeal teeth; Forest Bed Series, West and East Runton and Sidestrand.

Savin Coll.

280\%9. Detached pharyngeal teeth; Pleistocene, Grays, Essex.

John Brown Coll.

The following extinct species are either based on specimens too imperfect for recognition or are not represented in the Collection :-

Lenciscus acrogaster, A. E. Reuss, Geogn. Skizzen aus Böhmen, vol. ii. (1844), p. 263; H. von Meyer, Neues Jahrb. 1848, p. 427, and Palæontogr. vol. ii. (1851), p. 55, pl. xii. fig. 4.-Lower Miocene (Semi-opal); Luschitz, Bohemia. [Distorted fish.]

Lenciscus bosniaskii, F. Bassani, Atti Soc. Veneto-Trent. Sci.

Nat. vol. vii. (1880), p. 83, pl. viii.-Lower Miocene;

Eibiswald, Styria. [Imperfect fish; Imperial Geological Survey, Vienna.]

Leuciscus brevicauda, F. G. Troschel, Verhandl. naturw. Ver. preuss. Rheinl. vol. xi. (1854), p. 20, pl. ii. fig. 3-Upper Oligocene (Lignite); near Bonn. [Imperfect small fish ; Rheinland Museum, Bonn.]

Lenciscus brevis, L. Agassiz, Poiss. Foss. vol. v. pt. ii. (1839-44),

p. 35, pl. lic. fig. 4.-Loc.? [Imperfect fish; Royal

Bohemian Museum, Prague.]

Lenciscus (Chondrostoma?) bubalus, F. G. Troschel, loc. cit. (1854), p. 26, pl. ii. fig. 5. (?) Chondrostoma bubalus, D. G. Kramberger, Rad Jugoslav. Akad. vol. Ixxii. (1885), p. 38, and Soc. Hist. Nat. Croatica, vol. i. (1886),

p. 133.- Upper Oligocene; near Bonn (in lignite);

(?) Warnsdorf, Bohemia. [Distorted fish; Rheinland Museum, Bonn.]

Lenciscus eibiswaldensis, D. G. Kramberger, Rad Jugoslav. Akad. vol. cvi. (1891), p. 93, pl. vii. fig. 2.-Lower Miocene; Eibiswald, Styria. [Imperfect fish.]

Leuciscus gibbus, H. von Meyer, Palæontogr. vol. ii. (1851), p.98, pl. xv. fig. 6, and ibid. vol. vi. (1856), p. 24, pl. i. fig. 2.-

Lower Niocene; Unterkirchberg, near Ulm, Würtemberg. [Imperfect fish.]

Leuciscus heterurus, L. Agassiz, Neues Jahrb. 1832, p. 132, and Poiss. Foss. vol. v. pt. ii.(1835-39), p.27, pl. lvii. fig. 1.-

Upper Viocene; Oeningen, Baden. [Imperfect fish; olim Lavater Coll., Zürich.]

Leuciscus medius, A. E. Reuss, op. cit. rol. ii. (1844), p. 262 


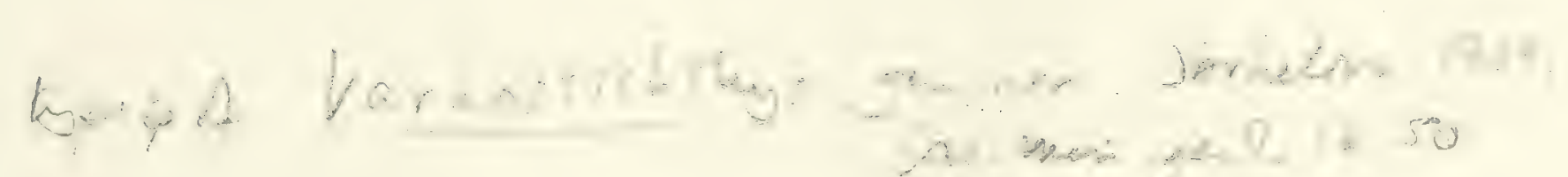

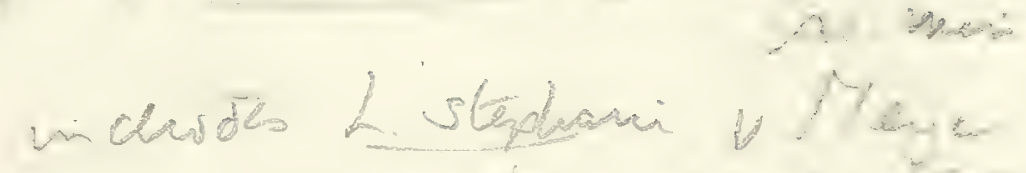

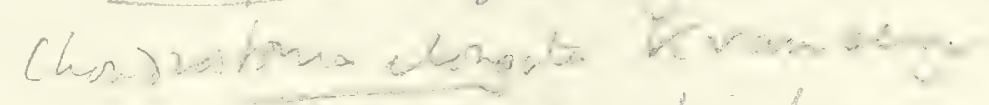

Laricantio Lawbe

towh o. Stets

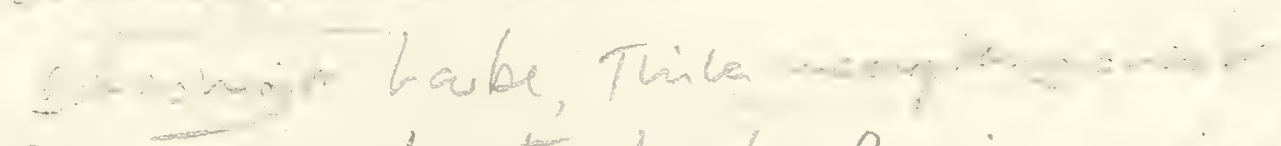

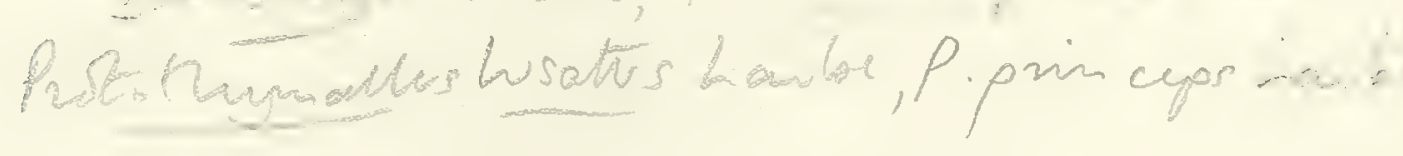





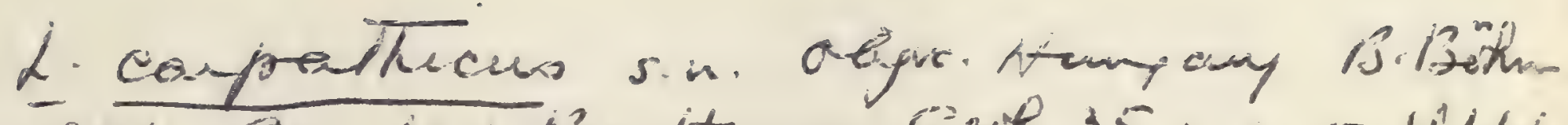

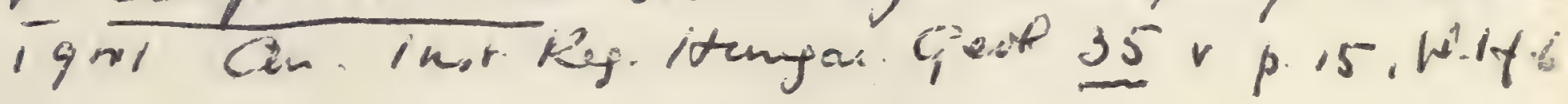

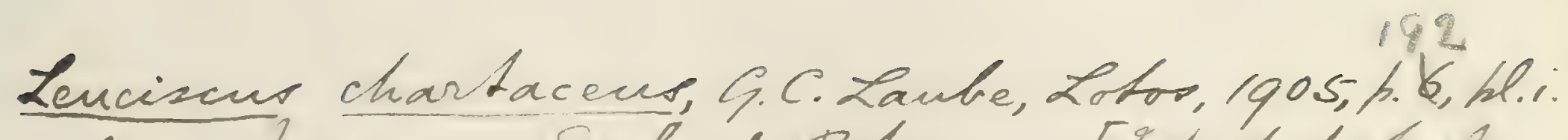

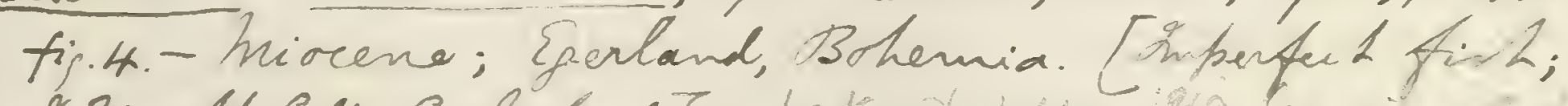

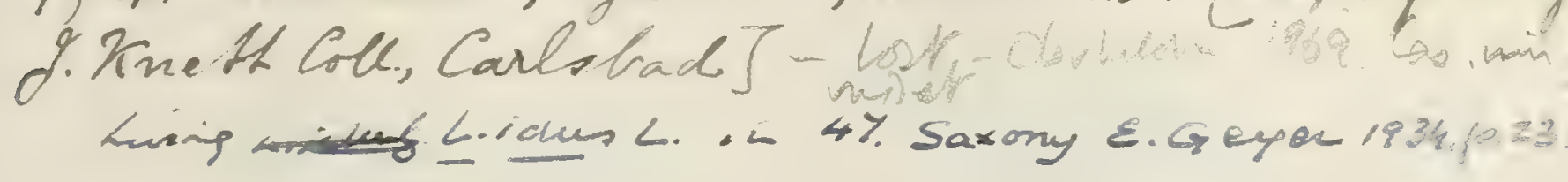

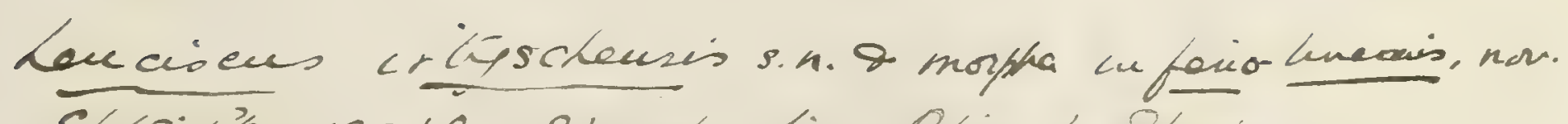

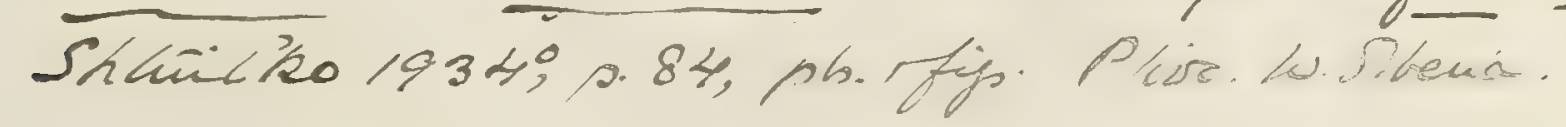

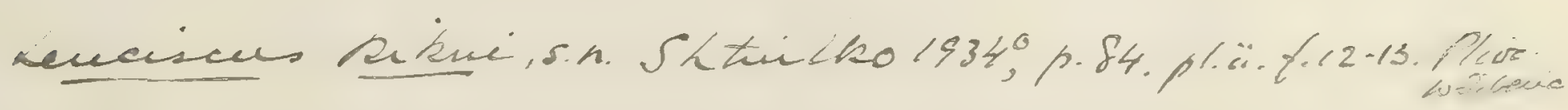



H. yon Meyer, Neues Jahrb. 1848, p. 427, and Palæontogr.

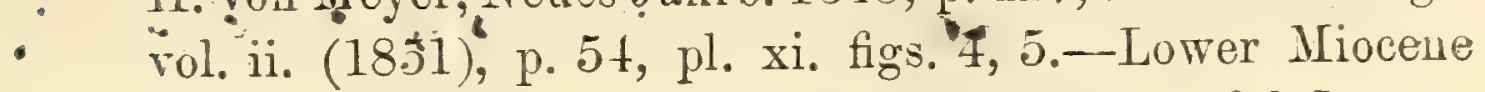
(Semi-opal); Luschitz, Bohemia. [Imperfect fish.]

Leuciscus polysarcus, D. G. Kramberger, Palæontogr. vol. xxvi. (1879), p. 66, pl. xvi. fig. 6.-Lower Oligocene; Baschka, Carpathians. [Imperfect fish; Palæontological I[useum,

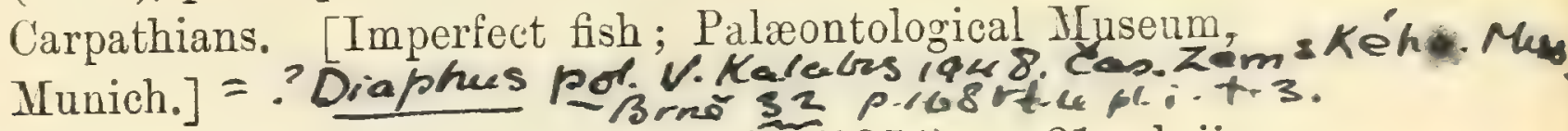
Lenciscus puellaris, F. G. Troschel, loc. cit. (1854), p. 21, pl. ii. fig. 4.-Upper Oligocene (Lignite); near Bonn. [Indeterminable fish; Rheinland Museum, Bonn.]

Leuciscus racalmuti, C. Pollini, Atti Soc. Ligust. Ssi. Nat. rol. ii.

(1891), p. 118. - Upper Miocene; Racalmuto, Sicily,

[Imperfect fish.] Pachylelias racalmut; G.d'Frasmo

Lenciscus stephani, H. von Meyer, Neues Jahrb. 18.48, p. 425, = W. and Palæontogr. rol. ii. (1851), p. 46, pl. v.-Lower Miocene; Waltsch, Bohemia. [Nearly complete fish.] Seep.615. Lenciscus turneri, F. A. Lucas, Proc. U.S. Nat. MLus. vol. xxiii. (1900), p. 333, pl. viii.-Tertiary ; Esmeralda Co., Nerada [Nearly complete fish; U.S. National Mruseum.]

Lenciscus vexillifer, G. C. Laube, Abhandl. Ver. Lotos, vol. ii. (1900), p. 54, pl. iv. fig. 3.-Miocene; Bohemia. [Imperfect fish; Menzel Collection.] p. if

The undefined names Leuciscus castellinensis and L. gabbrensis are given to fishes from the Upper Miocene of Gabbro, Tuscany, by Bosniaski, Atti Soc. Tosc. Sci. Nat.-Proc.-Verb. vol. i. 1879, p. Iv.

An imperfect fish from the Quaternary of Piànico, Lombardy, is referred to the existing Leuciscus aula by F. Bassani, Atti Soc. Ital. Sci. Nat. vol. xxix. (1886), p. 349, pl. ix. fig. 5.

Supposed species, not defined, from the Upper Oligocene Lignites near Bonn, have been named Leuciscus eurystomus, L. Krantzi, L. plesiopterus, and L. remotus (F. H. Troschel, Sitzungsb. niederrhein. Ges. Bonn, vol. xviii. 1861, p. 56).

Several imperfect fishes, apparently not Cyprinoids, from a marine Upper Miocene formation at Licata, Sicily, have been described under the names of Leuciscus dorsalis, L. (Scardinius) dumeriti, L. larteti, L. (Squalius) licatce, and L. (Scardinius) sicants by H. E. Saurage, Ann. Sui. Nat. [5] vol. xir. (1870), art. no. 7, pp. 12-14, and Ann. Sci. Géol. vol. iv. (1873), art. no. 1, pp. 175-187, figs. 82, 97-102, and ibid. vol. xi. (1880), art. no. 3, pp. 33-37, figs. 3, 10. Specimens in the Egerton Coll. (nos. P. 1844-18) are thus labelled, but do not exhibit characters sufficiently definite to admit of their determination. They are rather suggestive of Clupeoids. 
The so-called Leuciscus dorsalis, L. dumerili, and L. sicamus, with two supposed new species, $L$. cecconii and $L$. sauvagei, are also described from an Upper Miocene Tripoli at Mondaino, Province of Forli, Italy; but the original specimens appear to be as unsatisfactory as those from Licata (I. Bonomi, Rivista Ital. Paleont. rol. ii. 1896, pp. 227-232, pl, v. figs. 1, 8). Two specimens of this nature in the Collection are numbered P. 5548-49.

By exchange, 1888.

The fish described as follows is of equally doubtful affinities and is not represented in the Collection:-

Paraleuciscus ecnomi, H. E. Sauvage, Ann. Sci. Géol. vol. xi. (1880), art. no. 3, p. 38, fig. 2.-Upper Niocene; Licata.

\section{Genus TINCA, Cuvier.}

[Règne Animal, vol. ii. 1817, p. 193.]

Syn. Tarsichthys, F. G. Troschel, Verhandl. naturw. Ver. prenss. Rheinl, vol. xi. 1854, p. 11 (as sub-genus of Leuciscus).

Skeleton very robust and mouth anterior. Pharyngeal teeth cuneiform, slightly hooked at one end, in a single series. A pair of barbels at the angle of the mouth. Pseudobranchiæ rudimentars. Pelvic fins with foremost ray much thickened and expanded, closely articulated but not subdivided; dorsal fin short, in middle of back, without bony spice; anal fin short, behind the dorsal; caudal fin subtruncated or moderately forked; all fins enveloped in rather thick skin. Scales small, elongated and imbricating, imbedded in thick, mucus-secreting skin; lateral line complete, low on the flank, extending along the middle of the side of the tail.

An exclusively European genus, the existing species found principally among the weeds and mud of still freshwaters.

Tinca furcata, Agassiz.

1832. Tinca furcata, L. Agassiz, Neues Jahrb. p. 133 (name only, misprinted fuscata).

1835̃-39. Tinca furcata, L. Agassiz, Poiss. Foss. vol. v. pt. ii. p. 18, pl. lii.

1861. Tinca magna, T. C. Winkler, Descript. Poiss. Foss. d'Oeningen (Natuurk. Verhapdl. Holland. Maatsch. [2] vol. xiv.), p. 16, pl. ii. fig. 5. [Imperfect fish ; Teyler Museum, Haarlem.]

Type. Imperfect fish; olim Lavater Coll., Zürich.

A large species, attaining a length of about 0.35 . Length of head with opercular apparatus somewhat less than the maximum 
zee Myetof hewn W...entome

- Mngoppom

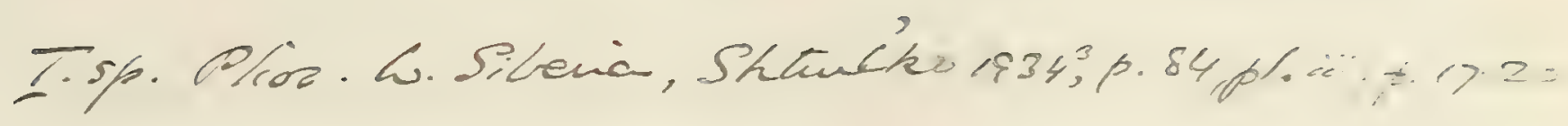

1934. Tinica fucabr, Paracontymphica, sepsh.Bd. DIII.

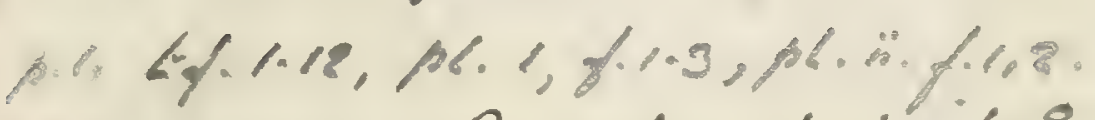

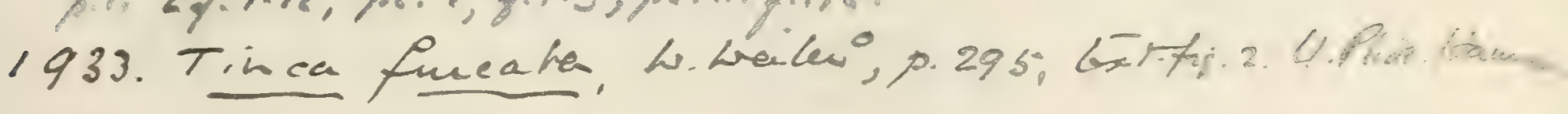




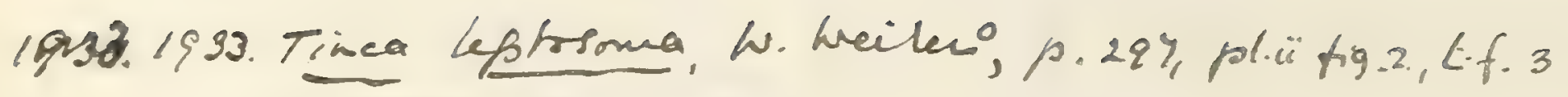
(U. Plioe Hammores? 
depth of the trunk, which is contained three times or slightly more in the total length to the base of the caudal fin. Vertebræ 18 in the abdominal, 16 in the caudal region. Pelvic fins, with at least 11 rays, arising opposite the origin of the dorsal, which comprises 10 rays, the foremost being a short spine, the second articulated, the others both articulated and dividel distally; anal fin with 9 rays, like the dorsal but much smaller; caudal fin distinctly forked. Exposed portion of scales marked with fine radiating lines.

Form. \& Loc. Upper Miocene: Oeningen, Baden.

P. 9422. Fine large specimen, in counterpart, distorted anteriorly, noticed by Agassiz, loc. cit. 1835, p. 19. The squamation is well preserved.

Old Collection.

P. 1815. Fragmentary large specimen.

Egerton Coll.

P. 4228, P. 4316. Two imperfect specimens about 0.25 in length, labelled by Agassiz.

Enniskillen Coll.

42762-66. Five imperfect small specimens, two being in counterpart.

Van Breda Coll.

36124-25. Two fragmentary small specimens, probably joung of this species, one showing pharyngeal teeth.

Purchased, 1859 .

P. 1815 a. Fragmentary specimen, probably young of this species.

Egerton Coll.

Tinca leptosoma, Agassiz.

1832. Tinca leptosomus, L. Agassiz, Neues Jahrb. p. 133 (name only). 1835-39. Tinca leptosoma, L. Agassiz, Poiss. Foss. vol. v. pt. ii. p. 19, pl. li.

Type. Imperfect fish; Carlsruhe Museum.

Closely resembling $T$. furcata, but smaller and more slender. Length of head with opercular anparatus slightly exceeding the maximum depth of the trunk, which is contained about four times in the total length to the base of the caudal fin.

Form. \& Loc. Upper Miocene: Oeningen, Baden.

42767-68. Two specimens, the second much distorted.

Van Breda Coll.

P. 1816. Very small fragmentary specimen, labelled by Egerton as belonging to this species.

Egerton Coll. 


\section{Tinca micropygoptera, Agassiz.}

1832. Tinca micropyyoptera, L. Agassiz, Neues Jahrb. p. 133 (name only).

1832. Leuciscus hartmanni, L. Agassiz, ibid. p. 132 (name only).

1832. Leuciscus gracilis, L. Agassiz, ibid. p. 132 (name only).

1839-44. Tinca micropygoptera, L. Agassiz, Poiss. Foss. vol. v. pt. ii. p. 20, pl. li $a$. figs. 1-3.

1839-44. Leuciscus hartmanni, L. Agassiz, ibid. p. 33, pl. li c. fig. 1. [Imperfect tail; olim Hartmann Coll.]

1839-44. Leuciscus gracilis, L. Agassiz, ibid. p. 34, pl. lic. figs. 2, 3. [Imperfect small fish; olim Hartmann Coll.]

1852. Tinca micropygoptera, F. A. Quenstedt, Handb. Petrefalit. p.237, pl. xix, fig. 6 .

1852. Leuciscus hartmanni, F. A. Quenstedt, ibid. p. 236.

1852. Leuciscus gracilis, F. A. Quenstedt, ibid. p. 236, pl. xix. fig. 3.

1880. Leuciscus gracilis, F. Bassani, Atti Soc. Veneto-Trent. Sci. Nat. vol. vii. p. 84.

1880. Tinca micropygoptera, F. Bassani, ibid. p. 86.

Type. Imperfect small fish; olim Hartmann Coll., Göppingen.

A large species, attaining a length of about $0 \cdot 45$. Length of head with opercular apparatus contained slightly more than three times, and maximum depth of trunk slightly more than four times in the total length to the base of the caudal fin. About 36 vertebræ, half being caudal. Pelvic fins arising opposite the origin of the dorsal, which is nearly as deep as the trunk at its insertion and comprises 10 rays, the foremost being a short spine, the second articulated, the others both articulated and divided distally; anal fin with 9 or 10 rays, like the dorsal but much smaller; caudal fin distinctly forked.

Form. \& Loc. Middle Miocene: Steinheim, Würtemberg.

36130. Tery large specimen with imperfect head, displaying right lower pharyngeal from outside. Purchased, 1860.

P. 3853. Fine specimen about 0.4 in length, showing two of the characteristic pharyngeal teeth.

Enniskillen Coll.

36443. Fine specimen 0.37 in length.

Purchased, 1862.

35754-59, 36181. Seren small specimens, the largest 0.2 in length. Some exhibit the much-expanded anterior ray of the pelvic fins.

Purchased, 1860-61.

P. 1821-22. Four very small imperfect specimens, two showing the thickened pelvic fin-ray.

Egerton Coll. 


P. 3854. Two rery small imperfect specimens. Enniskillen Coll.

20581. Two very small imperfect specimens. Purchased, 1846.

\section{Tinca tarsiger (Troschel).}

1854. Leuciscus (Tarsichthys) tarsiger, F. G. Troschel, Verhandl. naturw. Ver. preuss. Rheinl. vol. xi. p. 10, pl. i. figs. 2, 3 (wrongly named Leuciscus (Tarsichthys) elegans on p. 11).

Type. Imperfect fish; Geological Museum, University of Bonn.

A species known only by small specimens not more than 0.15 in length. Length of head with opercular apparatus contained three times, and maximum depth of trunk nearly four times in the total length to the base of the caudal fin. Pelvic fins unusually large aud stout, the expanded rays when adpressed reaching beyond the origin of the anal. Median fins as in preceding species.

Form. \& Loc. Upper Oligocene: Germany.

33496-98. Two imperfect small fishes, and portion of head and abdominal region of larger specimen; Lignite, Rott, near Bonn.

Purchased, 1858.

35547 a. Imperfect fish, partly distorted; Rott. Presented by W. J. Neville, Esq., 1859.

38146. Vertically crushed specimen; Rott. Purchased, 1864.

The following detached pharyngeal bones of Tinca are also comprised in the Collection :-

P. 8973-74. Three imperfect basioccipital processes and five imperfect pharyngeal bones, of the form provisionally named Tinca valdarnensis by R. Lawley, Nuori Studi sopra ai Pesci, etc., delle Colline Toscane (1876), p. 84; Lacustrine Pliocene, Monte Carlo, Upper Val d’Arno, Italy.

Castelli Coll.

P. 9229. Similar specimens; Monte Carlo.

$$
\text { Presented by Dr. C. I. Forsyth Major, } 1900 .
$$

P. 8741. Two portions of pharyngeals, referred to the existing Tinca vulgaris, Cuvier, by E. T. Newton, Vert. Forest Bed Series (Mem. Geol. Surv. 1882), p. 127, pl. xviii. figs. 21, 22 ; Forest Bed Series (Upper Freshwater Bed), West Runton, Norfolk.

Savin Coll.

P. 8727-28. Pharyngeal bone and pharyngeal teeth of Tinca vulgaris; Upper Freshwater Bed, West Runton. Savin Coll. 
The following extinct species, not represented in the Collection, have also been described:-

Tinca francofurtana, F. Kinkelin, Ber. Senckenb. naturf. Ges. [2] vol. xvi. (1884), p. 255, pl. iii. fig. 13.—Lower Niocene; Niederrad, near Frankfurt. [Pharyngeal teeth; Senckenberg M[useum.]

Tinca obtruncata, G. C. Laube, Abhandl. Ver. Lotos, rol. ii.(1900), p. 49, pl. iv. fig. 1.-Miocene; Bohemia. [Imperfect fish; Teplitz M[useum.].

The following extinct species, not represented in the Collection, is supposed to belong to the existing genus Chondrostoma:-

Chondrostoma elongata, D. G. Kramberger, Rad Jugoslav. Akad. vol. Ixxii. (1885), p. 39, pl. ii. figs. 2, 3, and Soc. Hist. Nat. Croatica, vol. i. (1886), p. 133.-Upper Oligocene; Warnsdorf, Bohemia. [Imperfect fish.]

\section{Genus RHODEUS, Agassiz.}

[Mém. Soc. Sci. Nat. Neuchâtel, vol. i. 1835, p. 37.]

Mouth subinferior. Pharyngeal teeth in single series, compressed, not denticulated, the berelled surface with a simple groove. No barbels. Pseudobranchiæ present. Dorsal fin short and deep, without bony spine, opposed to space between pelvic fins and anal fin, or partly opposite latter; anal fin longer than deep, with 12 or more rays; caudal fin forked. Scales large or of moderate size; lateral line incomplete, only on anterior part of trunk.

\section{Rhodeus elongatus, Agassiz.}

1832. Rhodeus elongatus, L. Agassiz, Neues Jahrb. p. 134 (name only). 1835-39. Rhodeus elongatus, L. Agassiz, Poiss. Foss. vol. v. pt. ii. p. 40, pl. liv. figs. 4-6.

1861. Rhodeus oligactinius, T. C. Winkler, Descript. Poiss. Foss. d'Oeningen (Natuurk. Verhandl. Holland. Maatsch. [2] vol. xi v.), p. 25, pl. iv. fig. 10. [Imperfect distorted fish; Teyler Museum, Haarlem.]

1861. Rhodeus elongatus, T. C. Winkler, ibid. p. 29.

Type. Imperfect fish; olim Lavater Coll., Zürich.

A very small species, attaining a length of about $0 \cdot 05$. Length of head with opercular apparatus about equal to the maximum depth of the trunk and slightly less than one third of the length to the base of the caudal fin. Vertebræ 18 in the abdominal, 17 in the caudal region; 13 pairs of ribs. Dorsal fin completely in adrance of anal, with 10 rays, of which the foremost is a short spine, 
35

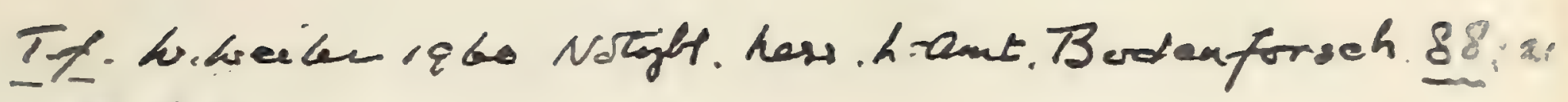
$7 \cdot 2-4$.

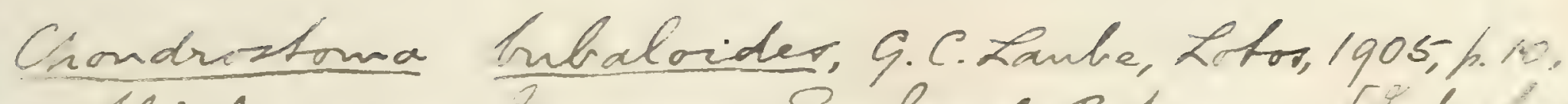

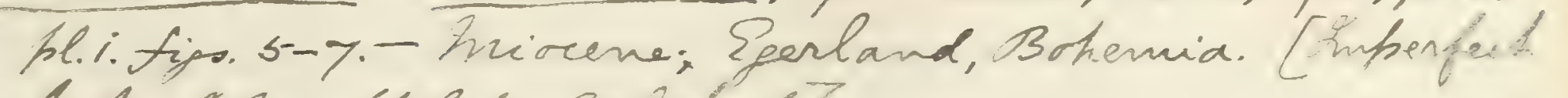
find; I. Kneth Coll, Carbatrad]

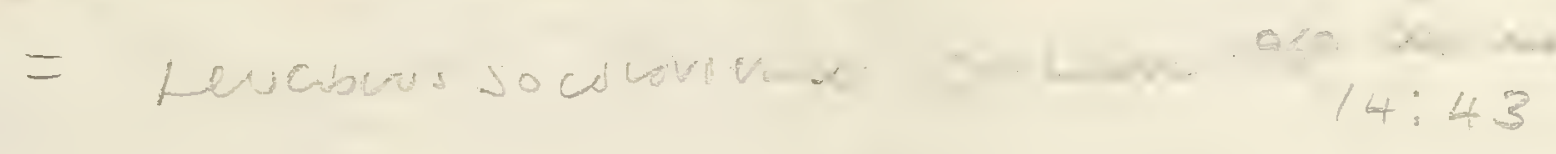

1930 L. R. E. G. acesmo; 97, iv.49. 
Pelwardai $=$ R.amanos (Bloch). Y. De Shefanio,

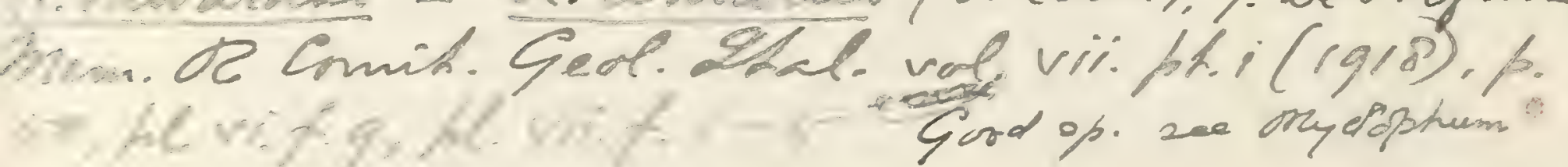


the second articulated, the others both articulated and divided distally; anal fin with about 14 rass.

Form. \& Loc. Upper Miocene: Oeningen, Baden, GaCers.

35524. Fine well-preserred specimen.

Purchased, 1859.

42786-87, 42796. Two good specimens, and one more distorted.

Van Breda Coll.

P. 9423. Imperfect fish.

History unknown.

P. 183\%. Two very small fishes and a tail, labelled by Agassiz.

Egerton Coll.

P. 3865. Another very small specimen.

Enniskillen Coll.

42788, 42793-94. Three very small imperfect specimens.

Van Breda Coll.

Rhodeus latior, Agassiz.

1832. Rhodeus latior, L. Agassiz, Neues Jahrb. p. 134 (name only).

1830̄-39. Rhodeus latior, L. Agassiz, Poiss. Foss. vol. v. pt. ii. p. 41, pl. lir. fig 7.

1861. Rhodeus magnus, T. C. Winkler, Descript. Poiss. Foss, d'Oeningen (Natuurk. Verhandl. Holland. Maatsch. [2] rol. xiv.), p. 28, pl. iv. fig. 11. [Imperfect fish; British Museum.]

Type. Imperfect fish ; olim Lavater Coll., Zürich.

Closely similar to preceding species but stouter and somewhat larger. Length of head with opercular apparatus slightly less than maximum depth of trunk.

Form. \& Loc. Upper Miocene; Oeningen, Baden.

42785. Type specimen of so-called $R$. magnus, described and figured by Winkler, loc. cit.

Lan Breda Coll.

P. 1838. Distorted specimen, labelled by Agassiz. Egerton Coll. 42797. Imperfect fish, probably of this species. Van Breda Coll.

A doubtfully-determined distorted fish from the Oligocene Lignite near Bonn is named Rhodleus exoptatus by F. G. Troschel, Verhandl. naturw. Ver. preuss. Rheinl. vol. xi. (1854), p. 22, pl. ii. fig. 1.

Another imperfect fish of quite uncertain affinities, from the Upper Miocene of Licata, Sicily, is named Rhodeus edwardsi by H. E. Sauvage, Ann. Sci. Nat. [5] vol. xiv. (1870), art. no. 7, p. 16, and Ann. Sci. Géol. vol. iv. (1873), art. no. 1, p. 192, figs. 73, 87. The same species is recorded from Mondaino, Province of Forli, Italy, by I. Bonomi, Rivista Ital. Paleont. vol. ii. (1896), p. 223. 


\section{Genus ASPIUS, Agassiz.}

[Mém. Soc. Sci. Nat. Neuchâtel, vol. i. 1835, p. 38.]

As Rhodeus, but pharyngeal teeth hooked and in two series; lateral line complete, extending along the middle of the side of the tail.

The extinct species mentioned below are merely referred to Aspius rather than to Rhodeus on account of their slender proportions.

\section{Aspius gracilis, Agassiz.}

1818. Cyprinus bipunctatus?, H. D. de Blainville, Nouv. Dict. d'Hist. Nat. vol. xxvii. p. 377.

1832. Aspius gracilis, L. Agassiz, Neues Jahrb. p. 134 (name only).

1835-39. Aspius gracilis, L. Agassiz, Poiss. Foss. vol, v. pt. ii. p. 37, pl. Iv. figs. 1-3.

Type. Nearly complete fish; olim Lavater Coll., Zürich.

A rery small species, attaining a length of about $0 \cdot 1$. Length of head with opercular apparatus about equal to the maximum depth of the trunk and contained four times in the length to the base of the caudal fin. Vertebræ 18 in the abdominal, 16 in the caudal region; 13 pairs of ribs. Pelvic fins with 9 rays; dorsal fin completely in advance of anal, with 10 rays, the foremost being a short spine, the second articulated, the others both articulated and divided distally; anal fin with 15 rays, the two foremost like those of the dorsal.

Form. \& Loc. Upper Miocene: Oeningen, Baden. Mir. Gallow. 36121-22. Fine specimen 0.1 in length, in counterpart. Purchased, 1859.

P. 3864. Smaller specimen, labelled by Agassiz. Enniskillen Coll.

\section{Aspius minutus (Winkler).}

1861. Chondrostoma minutum, T. C. Winkler, Descript. Poiss. Fuss. d'Oeningen (Natuurk. Verhandl. Holland. Maatsch. [2] vol. xiv.), p. 37, pl. iv. fig. 12.

Type. Nearly complete fish; British Museum.

A smaller and more slender species than $A$. gracilis, with larger head, only 9 rays in dorsal fin, and apparently 13 rays in anal fin; otherwise similar.

Form. \& Loc. Upper Miocene: Oeningen, Baden.

42789. Type specimen, in counterpart.

Vun Breda Coll. 
19306. A.9., 9.07rasmo, 99, iv.20.

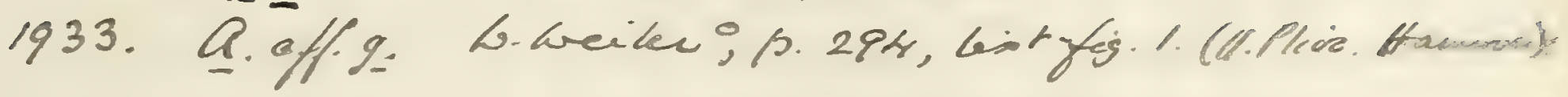


Blacea - p.323.

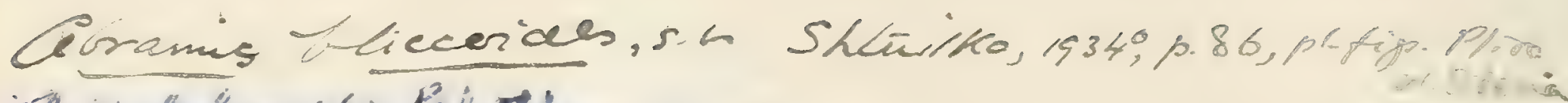

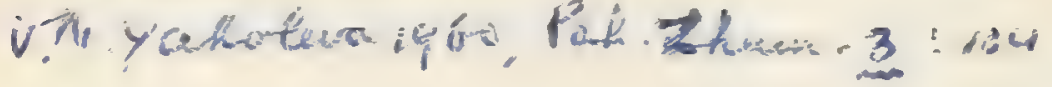

A. veaclifher = Tarner grizens (towe). G.De

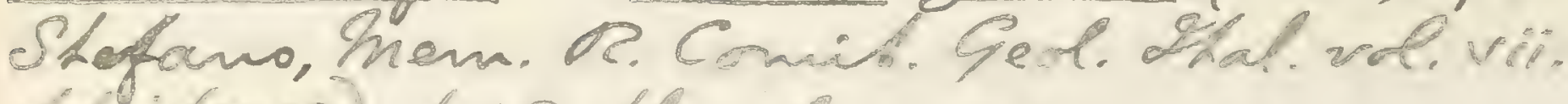

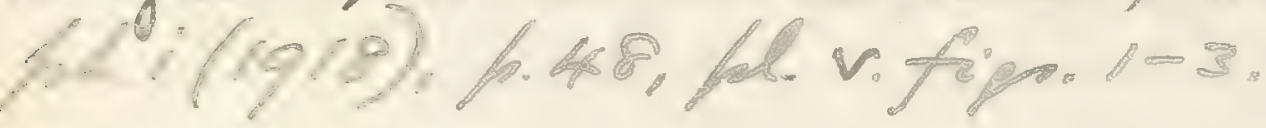

A.eenomi $=$ A columane $=$ Nyctophus reizer

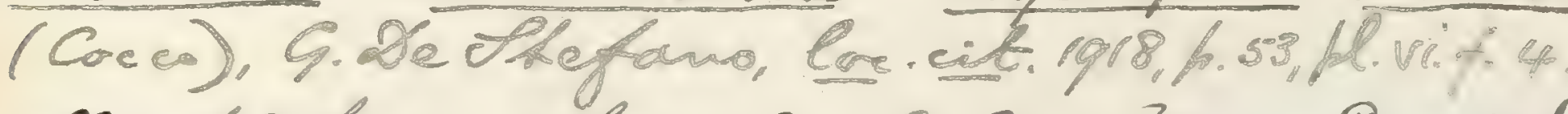
Myctopohern columnaie. C.Cramboung, Oum de Pal

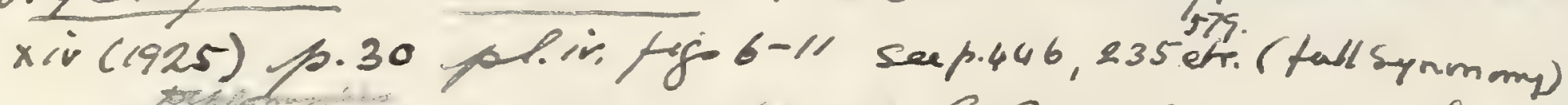

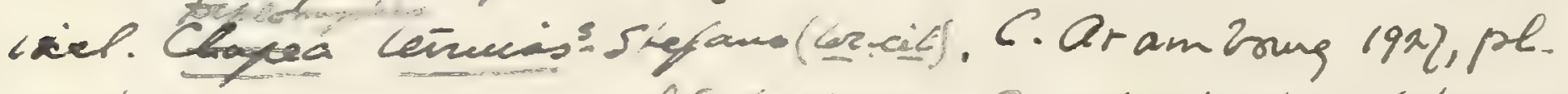

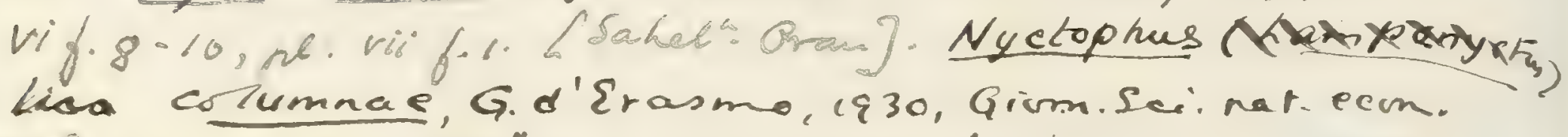

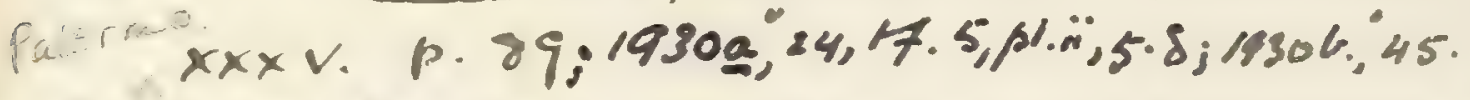

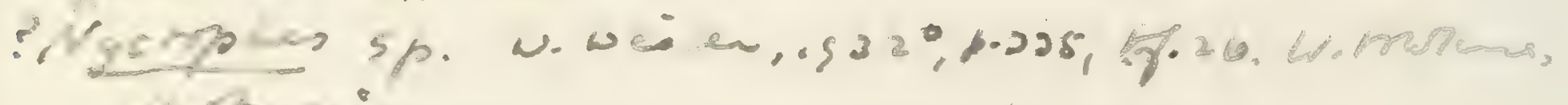
arkisin.

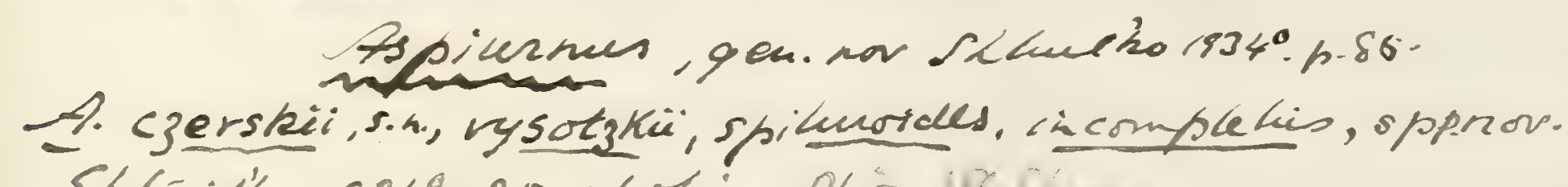

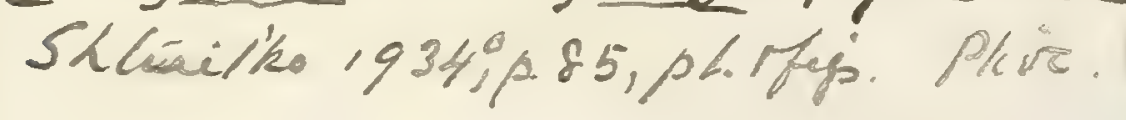

Alburmus eypridum, 9.C. Laube, Lotor, 1905, h.4. H. i. fips.1-3, texth-fige. 1, 2. - Mioreve; Egerland, Bohemic.

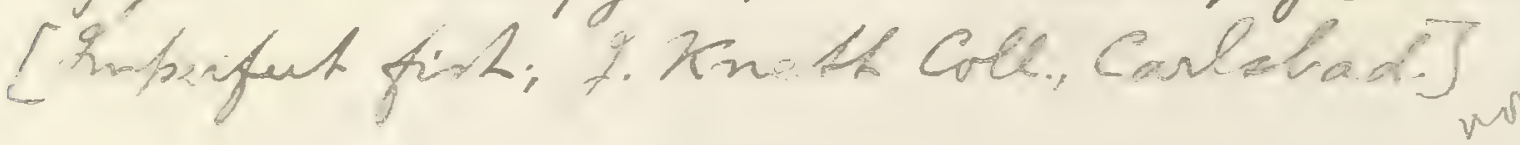

Albunus (?) psendorhodeus sa. Shlinicko 1934, p. 84,

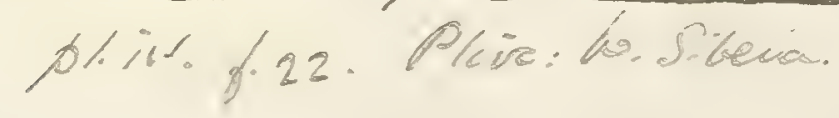

Albunnoides rhomboiclalis, gs.m. Shtivilko is36, p. 55,

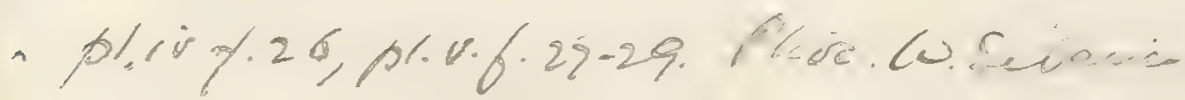






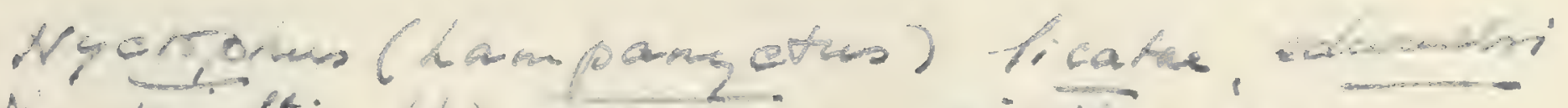
I. darnerti, h.j mucheroma, vexilifien, ecnomi

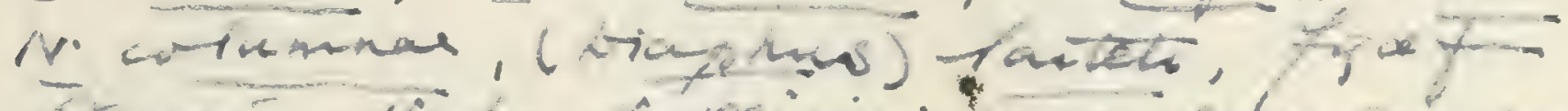

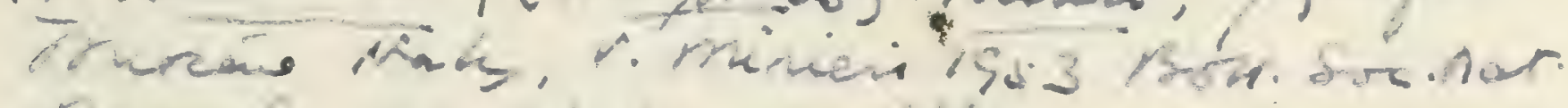
Pappla ol op is as llt.

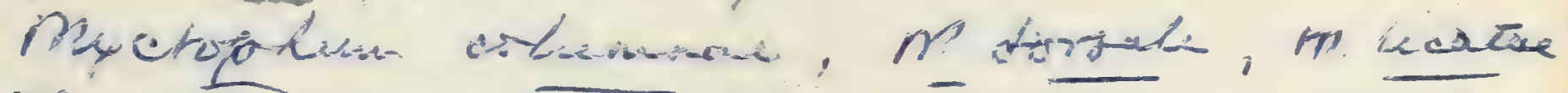

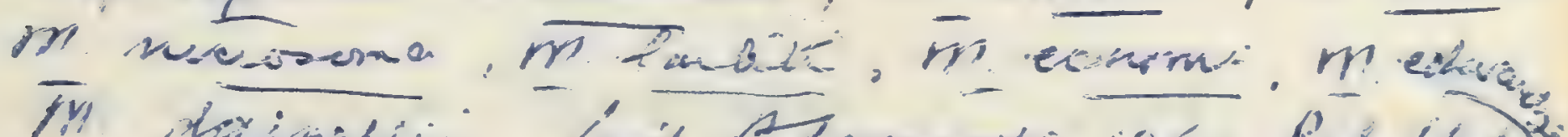

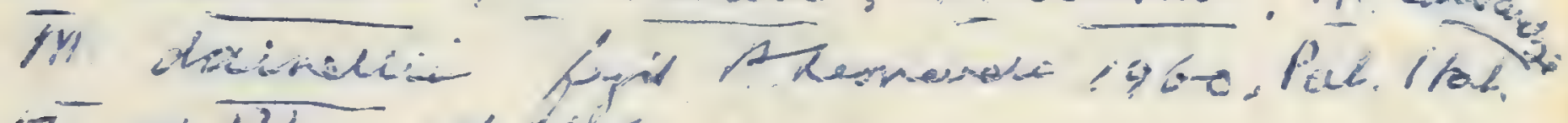

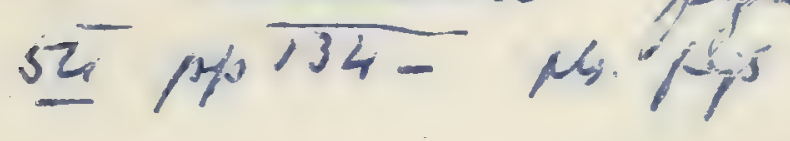


38.6

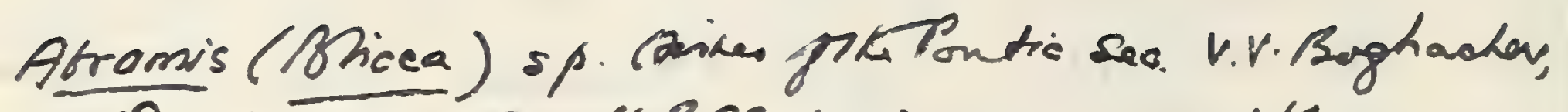
1958 CR. Acod. San: U.R.S.S. (n.S.) 122,4:727/f

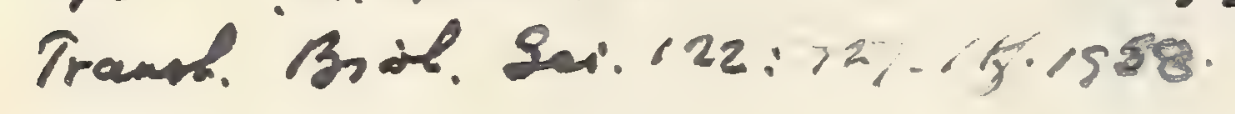

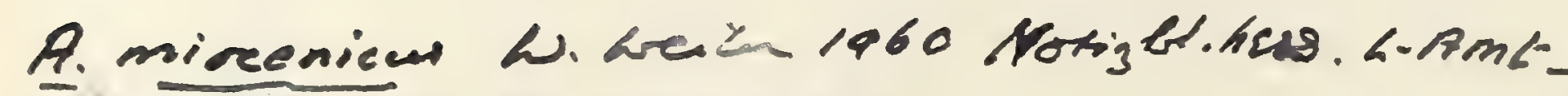
Boden forsech, $88: 218.5,6$. 
43443. Fragmentary larger specimen.

Presented by Kenneth Murchison, Esq., 1872.

Pharyngeal teeth of a species of Aspius are recorded from the Miocene of Bohemia by G. C. Laube, Abhandl. Ver. Lotos, vol. ii. (1900), p. 53, with fig.

The so-called Aspius vexillifer, Sauvage (Ann. Sci. Nat. [5] vol. xiv. 1870, art. no. 7, p. 15, and Ann. Sci. Géol. vol. iv. 1873, art. no. 1, p. 188, fig. 103), from a marine Upper Miocene formation at Licata, Sicily, does not appear to be a Cyprinoid. A specimen from Licata thus labelled in the Egerton Coll. (P. 1842), has the aspect of a Scopeloid but does not admit of precise determination.

The so-called Aspius ecnomi and A. columnoe (Saurage, Toc. cit. 1870 , p. 16, and loc. cit. 1873, p. 189, fig. 86), from Licata, are equally doubtful and not represented in the Collection. The latter is recorded from Racalmuto, Sicily, by C. Pollini, Atti Soc. Ligust, Sci. Nat. vol. ii. (1891), p. 121, and from Mrondaino, Province of Forli, Italy, by I. Bonomi, Rivista Ital. Paleont. vol, ii. (1896), p. 224.

The existing genus Abramis, Cuvier, seems to be represented by the following fossil :-

P. 8721. Pharyngeal tooth, similar to those in the Museum of Practical Geology referred to Abramis brama (Linn.) by E. T. Newton, Vert. Forest Bed (Mem. Geol. Surv. 1882), p. 126, pl. xriii. figs. 19, 20 ; Upper Freshwater Bed, West Runton, Norfolk.

Savin Coll.

The existing genus Alburnus, Heckel, is supposed to be represented by two extinct species, not in the Collection, described as follows :-

Alburnus miocaenicus, F. Kinkelin, Ber. Senckenberg. naturf. Ges. [2] vol. xvi. (1884), p. 252, pl. iii. figs. 3-12.-Lower Miocene; Niederrad, near Frankfurt. [Pharjngeal teeth; Senckenberg Museum.]

Alburnus steindachneri, G. C. Laube, Abhändl. Ver. Lotos, vol. ii. (1900),p.51, pl.iv.fig.2._Miocene; Bohemia. [Imperfect fish; Teplitz Museum.]

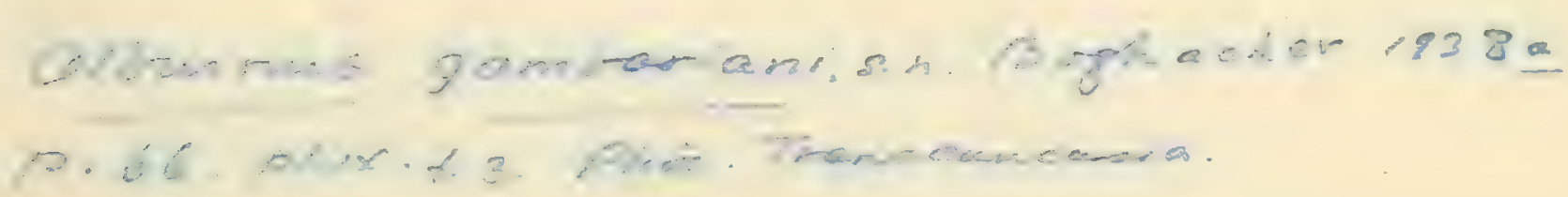




\section{Genus COBITIS (Artedi), Linnæus.}

[Syst. Nat. ed. 10, 1758, p. 303.]

Syn. Acanthopsis, L. Agassiz (non Van Hasselt, 1823), Neues Jahrb. 1832, p. 134.

Trunk elongate and laterally compressed. A small erectile suborbital spine on the cheek. Pharyngeal teeth in single series. Barbels on upper jaw. No pseudubranchiæ. Air-bladder enclosed in bony covering. Dorsal fin short, opposed to or immediately behind the pelvic pair; anal fin short; caudal fin rounded, truncate, or slightly forked. Scales minute.

Existing species occur only in the freshwaters of Europe and Asia. It is impossible with certainty to separate the extinct species here recorded from the genus Nemachilus, Cuvier (which has no erectile suborbital spine).

\section{Cobitis centrochir, Agassiz.}

1832. Cobitis centrochir, L. Agassiz, Neues Jahrb. p. 134 (name only). 1835-39. Cobitis centrochir, L. Agassiz, Poiss. Foss. vol. v. pt. ii. p. 11, pl. 1. figs. 1, 4 .

1861. Cobitis bredai, T. C. Winkler, Descript. Poiss. Foss. d'Oeningen (Natuurk. Verhandl. Holland. Maatsch. [2] vol. xiv.), p. 9, pl. i, tigs. 1-3. [Imperfect tish; Teyler Museum, Haarlem.]

1880. Nemachilus centrochir, H. E. Saurage, Bull. Soc. Géol. France, [3] vol. viii. p. 448.

1880. Nemachilus bredai, H. E. Sauvage, ibid. p. 449.

Tippe. Imperfect fish; olim Lavater Coll., Zürich.

A small species not exceeding 0.1 in length. Length of head with opercular apparatus slightly exceeding the maximum depth of the trunk and contained about five times in the length to the base of the caudal fin. Vertebræ 26 in the abdominal, 14 in the caudal region. Pelvic fins with 7 , dorsal and anal fins with 9 or 10 rays; dorsal fin arising midway between the extremity of the snout and the base of the caudal fin, directly opposed to the pelvic pair; anal fin arising midway between the pelvic pair and the caudal, which is rounded or truncated.

Form. \& Loc. Upper Miocene; Oeningen, Baden.

P. 1786, P. 386\%. Two rery small specimens, labelled by Agassiz. Egerton \& Enniskillen Colls.

42795. Similar specimen.

Van Breda Coll.

42:82. Imperfect large specimen, partly in counterpart. 
Cobitis C?) senogarlienssi bechi, örersmo, 19300,70,

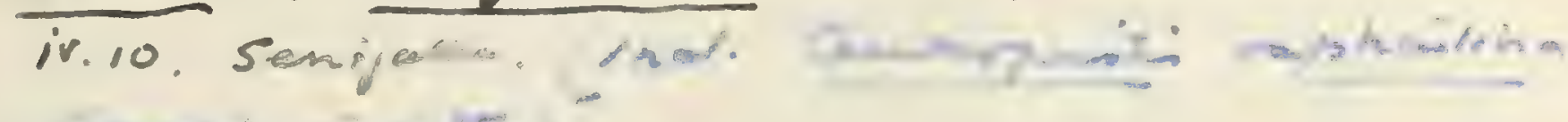

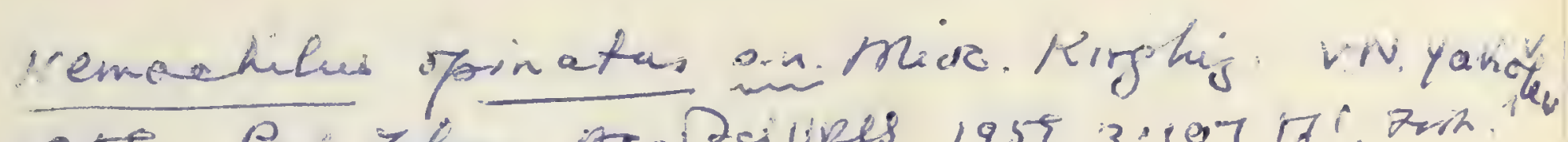

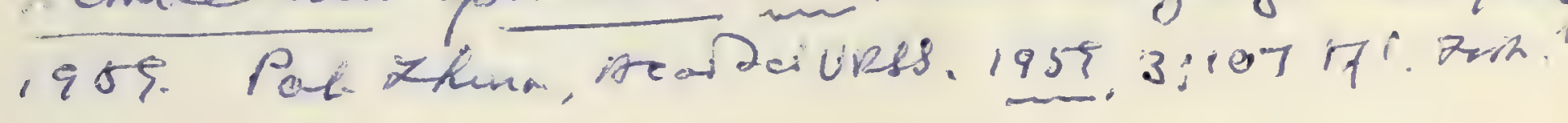


Cobitio Ap., F. Priem, Bull. Sor. Géd. France [4] vol.xii (1912), h.221, hl.vi.fi.35:-U.Mniorene; Andicthe. Eomperfect firt; 


\section{Cobitis angustus (Agassiz).}

1832. Acanthopsis angustus, L. Agassiz, Neues Jahrb. p. 134 (name only).

1830-39. Acanthopsis angustus, L. Agassiz, Poiss. Foss. vol. v. pt. ii. p. 8, pl. 1. figs. $2,3$.

1880. Cobitis angustus, H. E. Saurage, Bull. Soc. Géol. France, [3] vol. viii. p. 449.

Type. Imperfect fish.

A very small species, distinguished from the preceding by its more elongated form and slightly more remote position of the dorsal fin.

Form. \& Loc. Upper Hiocene: Oeningen, Baden.

36121 a. Fish 0.038 in length.

Purchased, 1859.

P. 1785. Smaller specimen, labelled by Agassiz.

Egerton Coll.

P. 9424. Two imperfect specimens.

Purchased.

\section{Cobitis cephalotes, Agassiz.}

1832. Cobitis cephalotes, L. Agrassiz, Neues Jahrb. p. 134 (name only). 1835-39. Cobitis cephalotes, L. Agassiz, Poiss. Foss. rol. v. pt. ii. p. 13, pl. l. figs. 5-7.

1861. Cobitis teyleri, T. C. Winkler, Descript. Poiss. Foss. d'Oeningen (Natuurk. Verhandl. Holland. Maatsch. [2] vol, xiv.), p. 13, pl. i. fig. 4. [Nearly complete fish; Teyler Museum, Haarlem.]

1880. Nemachilus cephalotes, H. E. Sauvage, Bull. Soc. Géol. France, [3] vol. viii. p. 449.

1880. Nemachilus teyleri, H. E. Sauvage, ibid. p. 449.

Type. Imperfect fish; Carlsruhe Museum.

A species attaining a length of about $0 \cdot 15$. Length of head with opercular apparatus much exceeding the maximum depth of the trunk and contained about three and a half times in the length to the base of the caudal fin. Vertebræ 24 in the abdominal, 15 in the caudal region. Fins as in $C$. centrochir, except that the caudal is forked.

Form. \& Loc. Upper Niocene: Oeningen, Baden.

P. 3868. Distorted hinder half of fish, labelled by Agassiz.

\section{Enniskillen Coll.}

43444. Distorted fragment, probably of this species, in counterpart. Presented by Kenneth IVurchison, Esq., 1872.

Fragmentary remains apparently of a species oî Cobitis are also recorded from a freshwater Upper Tertiary formation in Idaho, T.S.A. (E. D. Cope, Proc. Acad. Nat. Sci. Philad. 1883, p. 161). 


\section{Genus HEXAPSEPHUS, Günther.}

[Geol. Mag. (2) vol. iii. 1876, p. 439.]

An extinct genus known only by the pharyngeals and dentition. Pharyngeal bone falciform, bearing a single series of large, stout, conical or mammilliform teeth, few in number.

\section{Hexapsephus guentheri, sp. nov.}

1876. Hexapsephus sp., A. Günther, loc. cit. p. 439, pl. xvi. figs. 2, 3.

Type. Pharyngeal; British Museum.

The type species, with pharyngeal attaining a length of 0.026 . Only three large pharyngeal teeth in close series; foremost tooth smallest, much laterally compressed; middle tooth having crown surmounted with two small longitudinal ridges, of which the outer is divided by a notch into two tubercles; hindermost tooth conical, with apex excentric.

Form.\& Loc. Freshwater Tertiary Formation : Padang, Sumatra.

47534. Pharyngeal with dentition, the type specimen described and figured loc. cit. p. 439, pl. xvi. fig.(3); in carbonaceous shale. $\quad$ Presented by Herr R. D. M. Verbeek, 1876.

47533,-35. Two sets of pharyngeal teeth, one figured loc. cit. pl. xvi. fig. 2; also four detached pharyngeal teeth, and two small slabs of carbonaceous shale with other teeth.

Presented by Herr R. D. M. Verbeek, 1876.

Several detached pharyngeal bones and teeth of Cyprinidæ from a freshwater Upper Tertiary formation in Idaho have been described as follows:- ze nistpeye

Diastichus macrodon, E. D. Cope, Proc. Amer. Phil. Soc. vol. xi. (1870), p. 539, and Proc. Acad. Nat. Sci. Philad. 1883, p. 158. [Type species.]

Uy: ne Kekw Diastichus parvidens, E. D. Cope, Toc. cit. 1870, p. 540.

Diastichus strangulatus, E. D. Cope, loc. cit. 1883, p. 158.

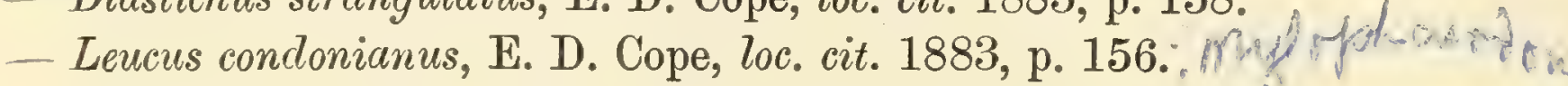

Leucus latus, E. D. Cope, loc. cit. 1883, p. 156. Anchybopsis

latus, E. D. Cope, loc. cit. 1870, p. 543. [Type species of so-called Anchybopsis.]

Mylocyprinus inflexus, E. D. Cope, loc. cit. 1883, p. 154.

Mylocyprinus robustus, J. Leidy, Proc. Acad. Nat. Sci. Philad. 1870, p. 70, and Contrib. Extinct Vert. Fauna W. Territ. (Rep. U.S. Geol. Surv. Territ. vol. i. 1873), p. 262, pl. xvii. figs. 11-17; E. D. Cope, loc. cit. 1883, p. 155. Includes $M$. Kingi and M. Tongidens, E. D. Cope, loc. cit.

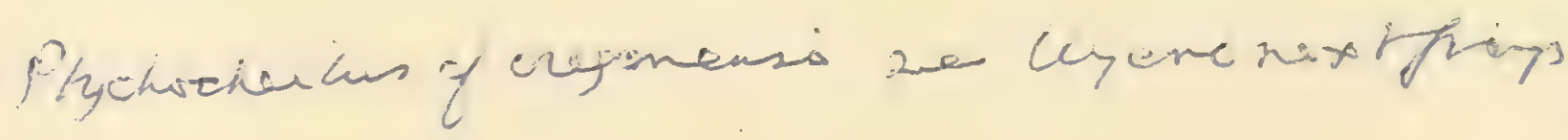



1934. H.9. M. Samoresi, po. B6.

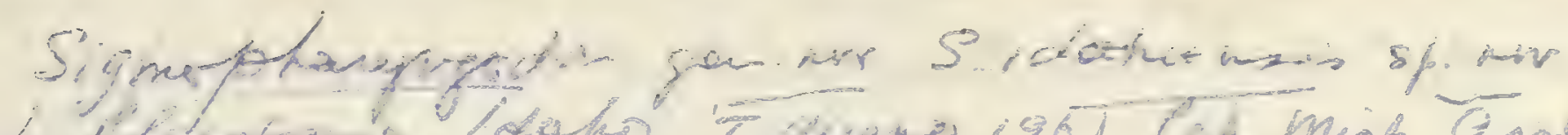

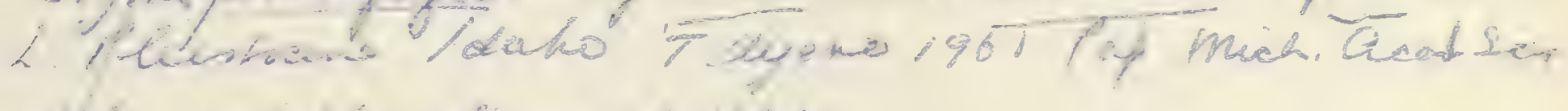

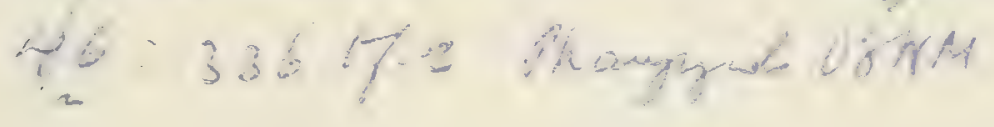

Notropir argencharcthus, 0.P. Hay, Bibl \& Catal. Fons. vert. (1902), h.396; Z. Arussate ff. Bull. Ames. Mnes. Math thish. vol. $x \times v(1908)$. p.84, pl. v. fige. 3, 4. . Alburn opes angustan-

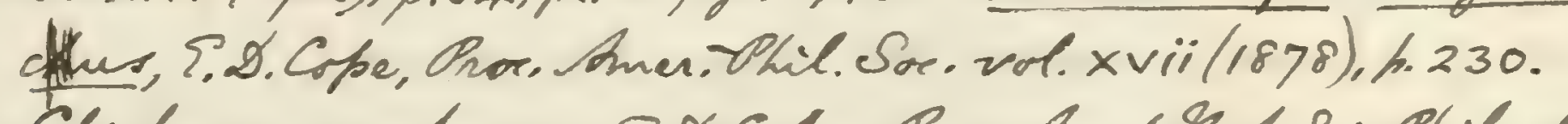

Cliola anguntarea, S. D. Cober Pror. Ated. Mat. Sci: Shilad. vol. xxxiv(1883),h.142. - Pleistreene; Pilver Zake, Orepon.

[Pharyngeals; An en. Mus. Mat. Thist.]

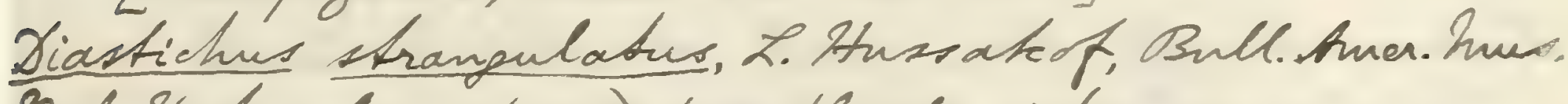

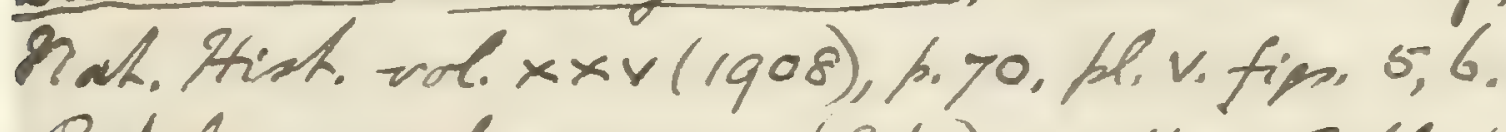

Rutilus condoniamus (Cope), O.P.Hay, Bibl. L Catal Aors. Vert. (1902), h.395; L. Ahussateof., Bull. Amer. Smus. Y. H1. vol. xxv (1908), 1.96, pl. v. fin. 7.8 .

Mnylocyprinus inflexurs, L. Stussate ff, Bulle. Amer. Mnes.

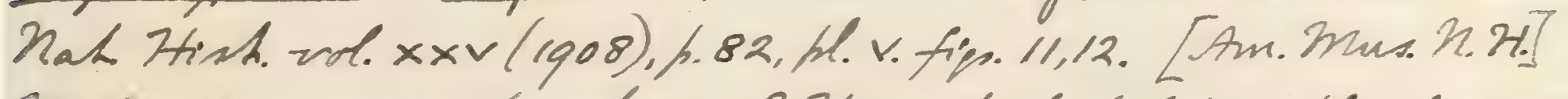

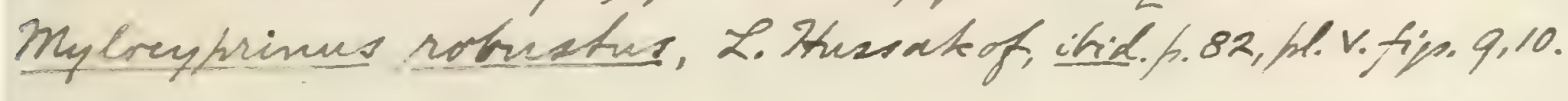

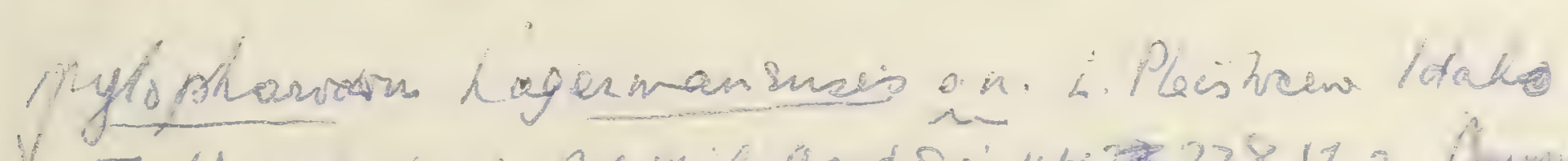

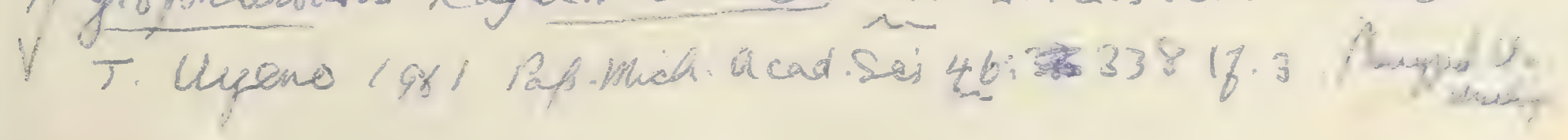


Remachilus musceli, s.n. M. Pancai,1929a, p.28.- Oligre.

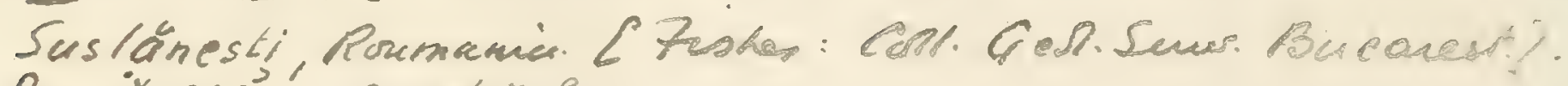

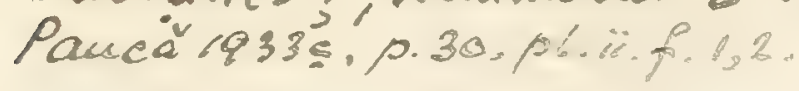

Varicortimus muntius, sin. Bgohacher, Am-herim state

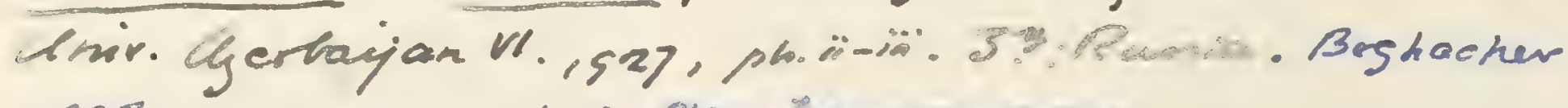

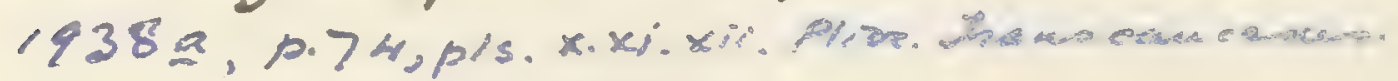

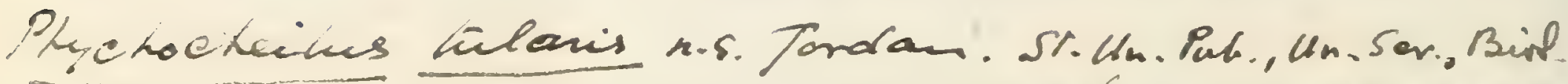

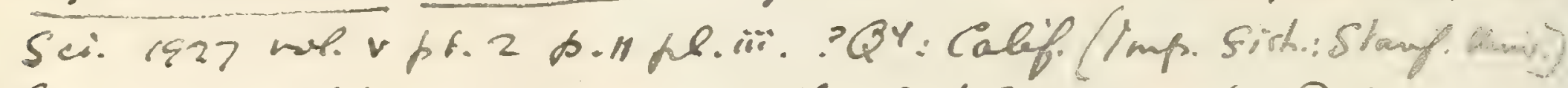

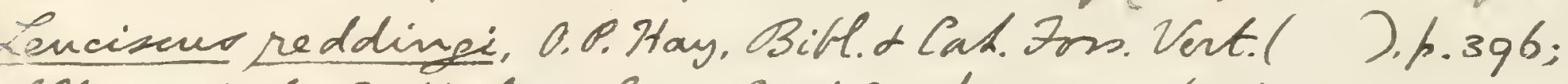

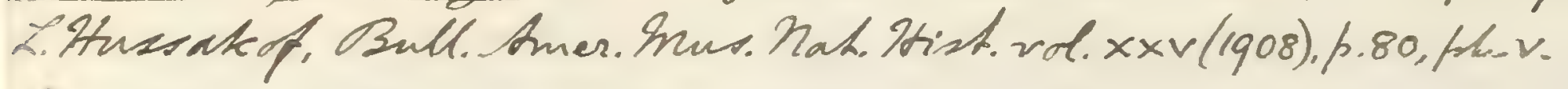
Fes. 1,2

Deunichthys gregorianus, g.ers.B. N. Amnandale \&SL. Hora,

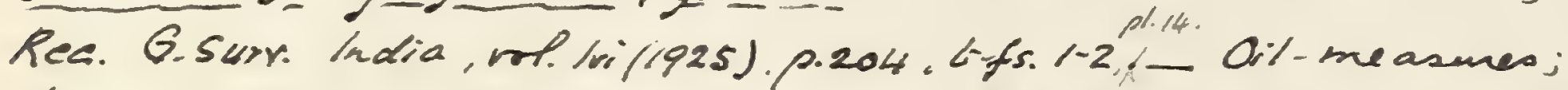

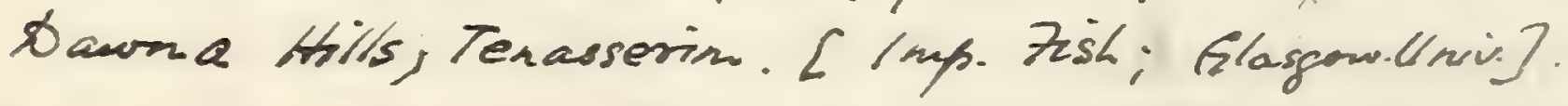

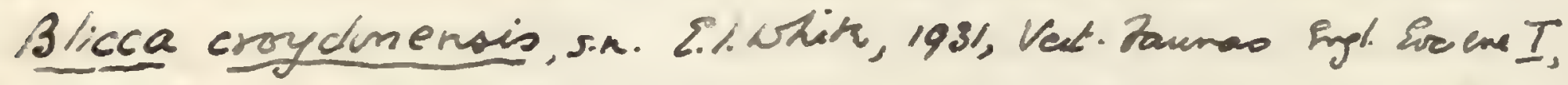

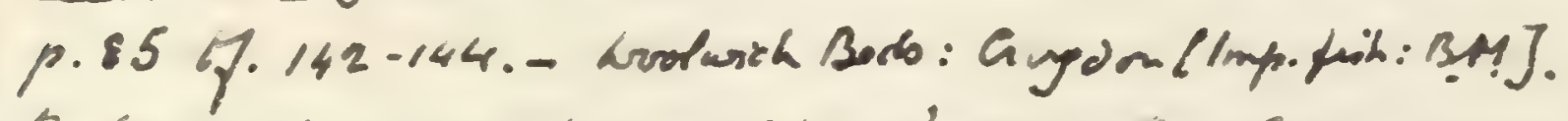

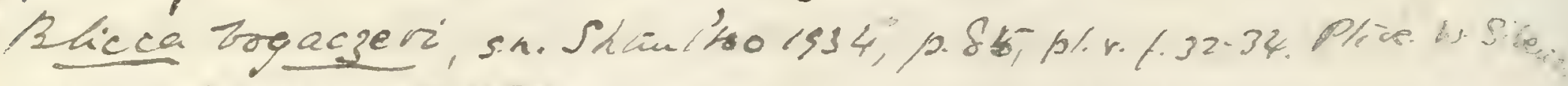

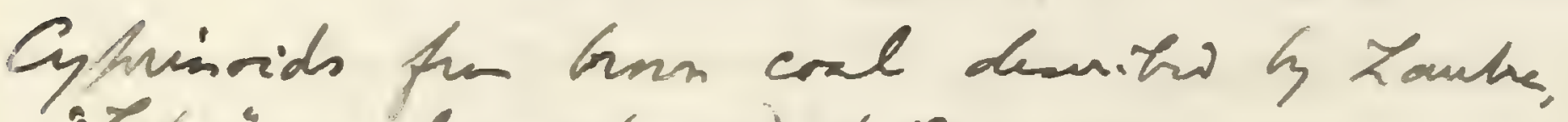
"Zoto, in.s. mel. $x \times v(1905)$ ), h. 187. 


1870, pp. 544, 545. [Type species. Genus apparently identical with existing Chinese Mylopharyngodon, Peters,

identical with existing Chinese Mylopharyngodon, Peters, we vew
Monatsb. k. preuss. Akad. Wiss. 1880, p. 925.] Wi culye

Squatius arcifernes, E. D. Cope, loc. cit. 1883, p. 158. Oligobelus arciferus, F. D. Cope, Toc. cit. 1870, p. 5 41 . [Type species of so-called Otigobelus.]

Squalius hairdi, E. D. Cope, loc. cit. 1883, p. 158. Semotilus bairdi, E. D. Cope, Toc. cit. 1870, p. 542.

Squalius laminatus, E. D. Cope, loc. cit. 1883, p. 157. Oligobelus Taminatus, E. D. Cope, loc. cit. 1870, p. 541.

Squalius posticus, E. D. Cope, loc. cit. 1883, p. 157. S'emotitus posticus, E. D. Cope, loc. cit. 1870, p. 541.

Squalius reddingi, E. D. Cope, Toc. cit. 1883, p. 157.

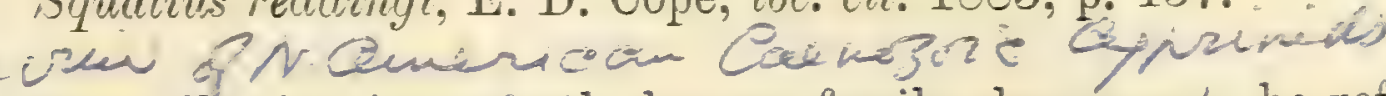

The following imperfectly known fossils also seem to be referable far cuctid to members of the family Cyprinidx:-

Brachyspondylus saropterix, W. von der Marck, Palæontogr. vol. xxii. (1876), p. 411, pl. xxiii. fig. 2-Freshmater Tertiars Formation; Padang, Sumatra. [Caudal region: Royal Geological Museum, Dresden.] Dovia sarbuzix, M. San

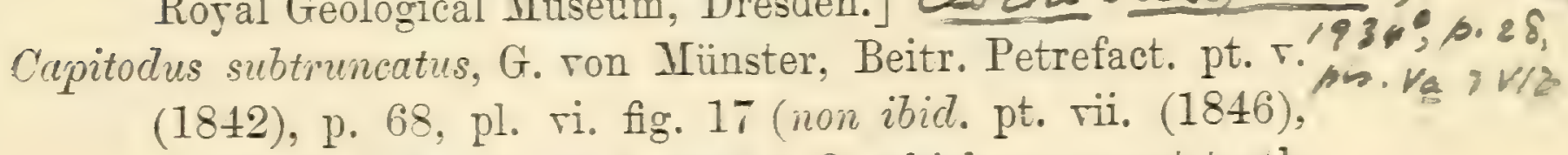
- 6339. p. 13 , pl. i. fig. 2 , pl. ii. figs. 1,8 , which represent teeth of Sparidæ); K. A. ron Zittel, Handb. Palæont. rol. iii. (1888), p. 282, fig. 292.-Wiocene; Neudörf-an-derIFarch, Tienna. [Pharyngeal teeth; Palæontological Museum, Munich. The type species of Capitodus.]

Hemitrichas schisticola, W. Peters, Monatsb. k. preuss. Akad. Wiss. 1877, p. 682, fig. 2.-Lower Oligocene (Lignite): Ponte, near Laverdà, Ticentin. [Imperfect fish.]

Soricidens haueri, G. ron Münster, op. cit.pt. . . p. 68, pl. ri. figs. 5-11.-Miocene: Neudörfl. [Pharyngeal teeth: Palæontological Museum, Munich. The type species of

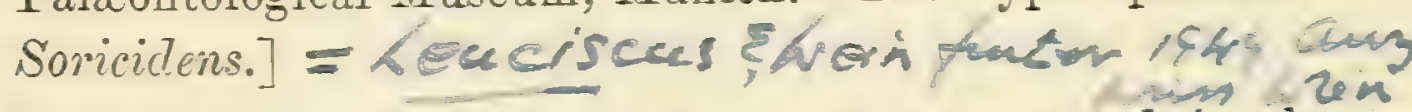

The following imperfectly known fish, not represented in the Collection, is commonly referred to the Crprinidæ but does not seem to belong to this family:-

Enoplophthatmus schlumbergeri, H. E. Saurage, Bull. Soc. Géol. France, [3] rol. riii. (1880), p. 449, pl. xii. fig. 3.-Lower Miocene; Céreste, Basses Alpes. [Type species of Enoplophthatmus. Imperfect fish.] 


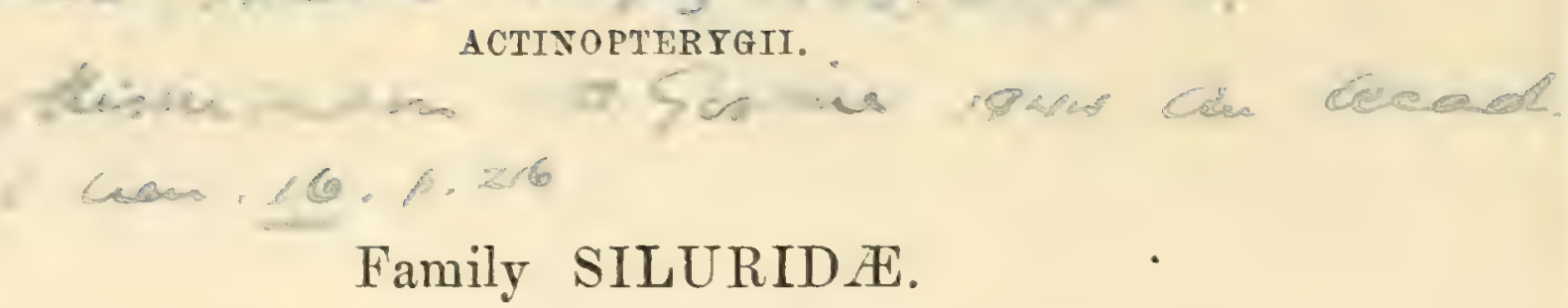

Supraoccipital bone prominent; otic region completely roofed by membrane-bones; brain-case produced forwards between the orbits: cheek-plates much reduced. Symplectic bone absent; premaxilla extended, almost always excluding the maxilla from the upper border of the mouth; teeth very rariable; lower pharyngeals rarely falciform and conspicuously toothed. Barbels present. Suboperculum usually absent, and branchiostegal rays few or wanting. Pectoral arch without distinct supraclaricle; a single dorsal fin often followed by an adipose dorsal on the tail. Trunk without scales, but often more or less armoured with bony scutes.

The existing members of this family are distributed in the freshwaters of all temperate and tropical regions, and a few are littoral marine species. To extinct genera of importance are known.

Figures of the skeleton of Symodontis are giren by C. B. Briibl, Zootomie aller Thierclassen (1884), pls. cxxxi., cxxxii. The weberian ossicles are described by Haddon and Bridge, Phil. Trans. 1893 B, pp. 65-333, pls. xi.-xis.

\section{Genus CLARIAs, Gronow.}

[Zoophyl. Gronor. 1781, p. 100.]

Head depressed and bones of cranial roof ornamented and exposed, or corered only with very thin skin; a small vacuity in the supraoccipital and frontal bones. Eyes small; cleft of mouth transverse, terminal, of moderate width; teeth on dentary, premaxilla, and romer. Pectoral fins with robust spine, often serrated on the anterior border; pelvie fins mith six rays; dorsal fin without spine, much extended and occupying nearly the whole of the back: no adipose dorsal; anal fin much extended; caudal fin rounded. Skin naked.

This genus survires in the freshwaters of Africa, the East Indies, and the intermediate portion of Asia.

\section{Clarias falconeri, Lydekler.}

18E6. Clarias falconeri, R. Lydekker, Pałæont. Indica, ser. x, vol. iii, p. 247. pl. xxxrii, fig. 1.

Type. Niddle portion of skull : British Museum.

A species probably about 0.45 in length, known only by the middle portion of the skull. Rugose ornament of cranial roof rather fine, 




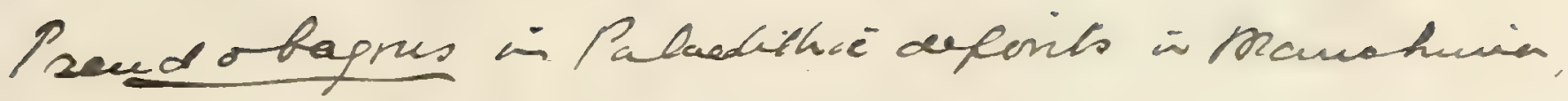
is Tohumapa TNaora, 1934, p.454.16.

Dethral phines

If Yiliñdee and

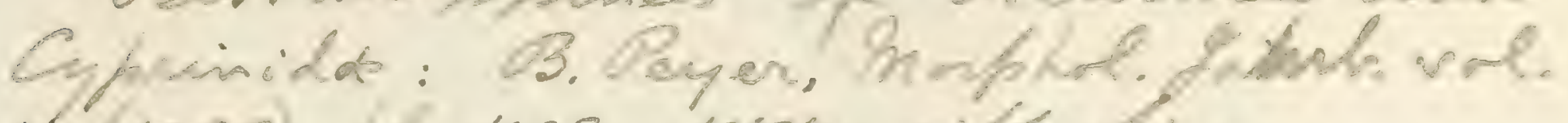
Sil1922), 4h93-5ist4, with fipes.

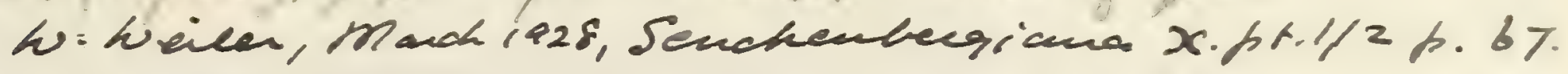

15.6. Plior.Rmmanin.

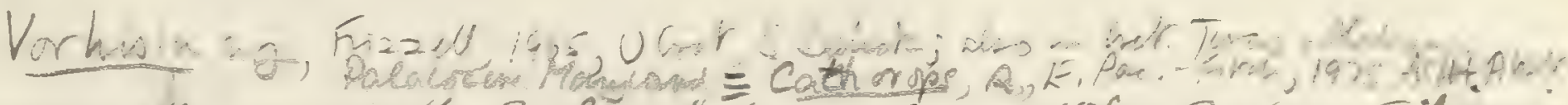

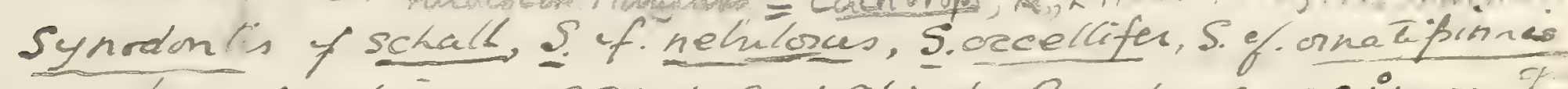

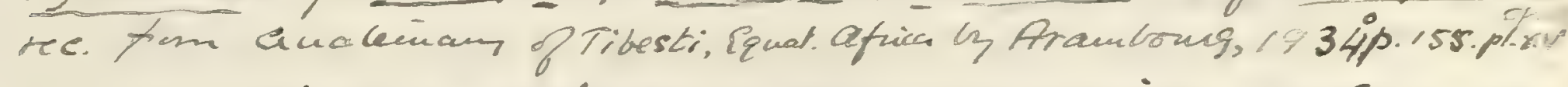

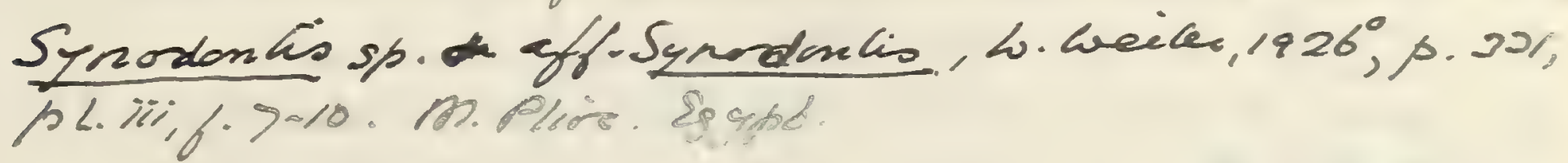

For stule of Gymotus, Dhamphichthes. aizenmannia, see M. In. Ellis, Mnem. Carnegie Snus. vol.vi(19/3), no. iii.

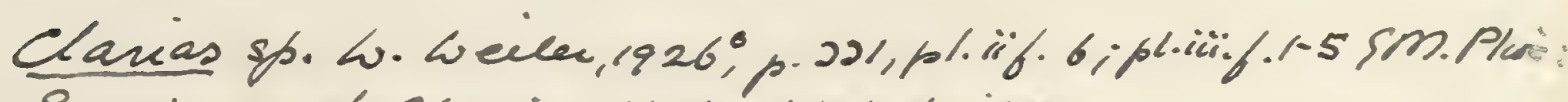
Esgpt. + of. Claneis ind pling. 6.

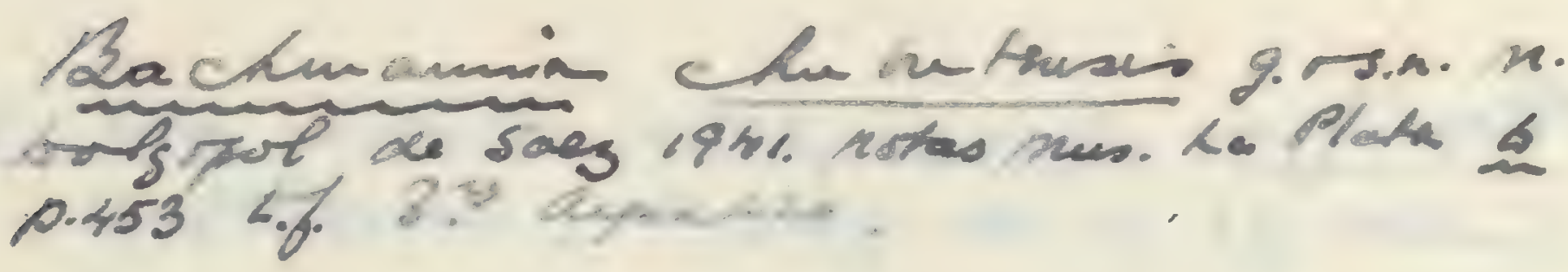

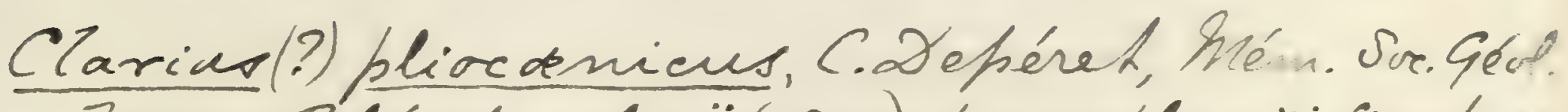
France, Paléont. vol. vii ( 1897$), 6.174$, pl. xviil.fig. 26-30. - Astian. Perpignan (Oyrénées-Orientales).

Clamais anguillais h.

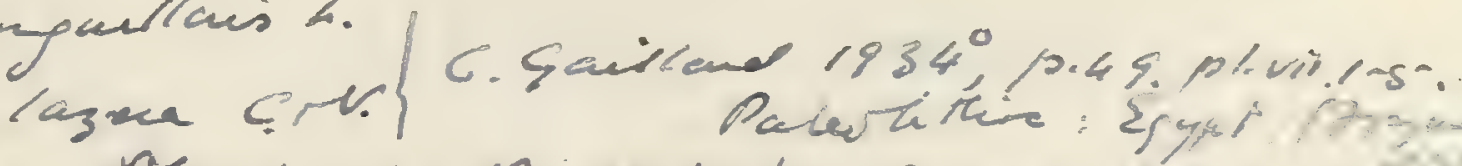

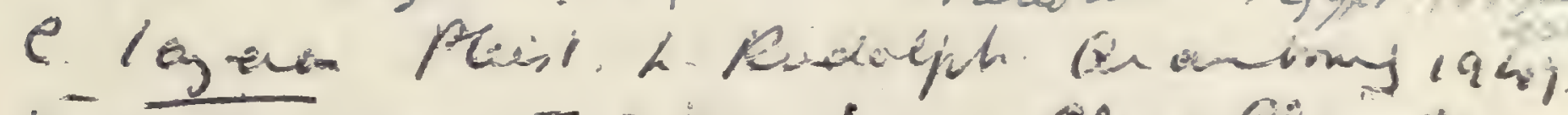

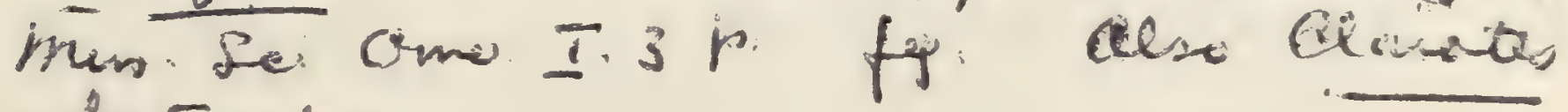
lanteys 
A. Gionsales

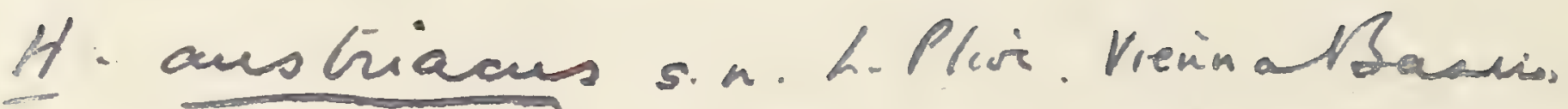
2. Themis 195 2. N.Salub. G. Pal. mimterah.

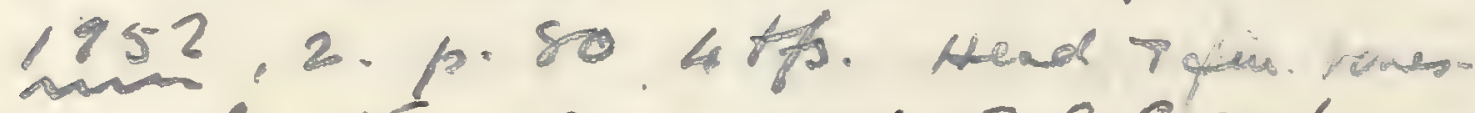

E. Weir funder 1954 . Mait. Qesl-Ges. Lrein 46 P. 33

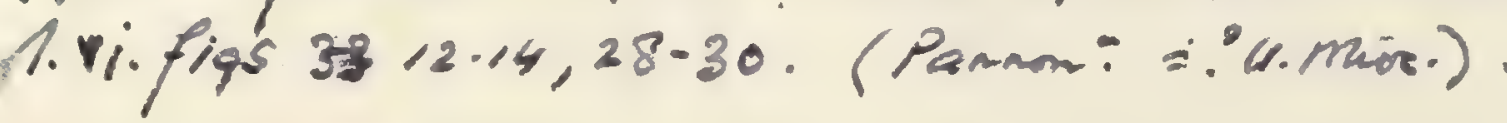

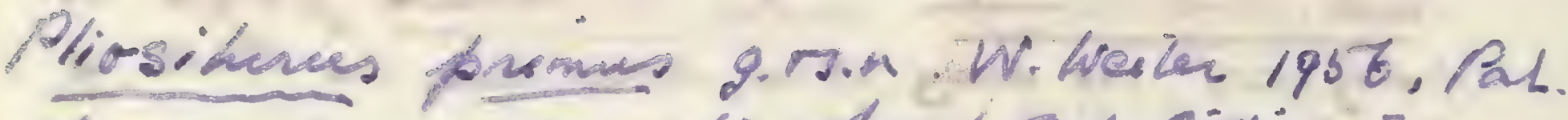

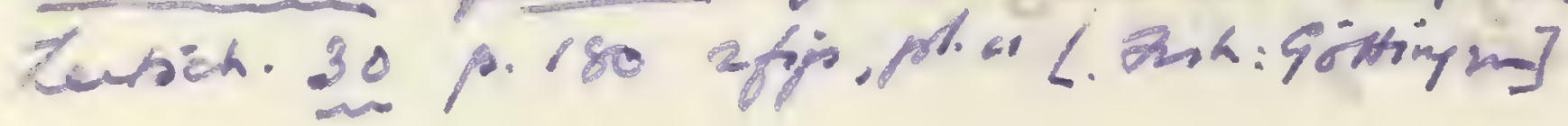


and the ridges rounded; supraoccipital slightly raised into a median prominence in its hinder half ; frontal vacuity not much elongated.

Form. \& Loc. Lower Pliocene: Siwalik Hills, Inảia.

16402 b. Type specimen.

Presented by Col. Sir Proby T. Cautley, K.C.B., 1842.

Genus HETEROBRANCHUS, Geoffroy St. Hilaire.

[Savigny, Descript. Egypte, vol. i. 1827, p. 305.]

As Clarias, but hinder portion of dorsal fin adipose.

Surviving in the freshwaters of Africa and the East Indian Archipelago.

Heterobranchus palæindicus, Lydekker.

1886. Heterobranchus palaindicus, R. Lydekker, Palæont. Indica, ser. x. vol. iii. p. 248, pl. xxxvi. fig. 4.

Type. Nearly complete skull; British Museum.

A species probably about 0.4 in length, known only by the skull, which is provisionally ascribed to Heterobranchus on account of its close resemblance to the skull of $H$. intermedius, and also on account of the long backward extension of its supraoccipital bone. Not yet precisely definable, but differing from $H$. intermedius in its relatively shorter and wider frontal vacuity and its ethmoid much narrowed in front.

Form. \& Loc. Lower Pliocene: Siwalik Hills, India.

16402 c. Type specimen.

Presented by Col. Sir Proby T. Cautley, K.C.B., 1842.

Genus SIIURUS, Linnæus.

[Syst. Nat. ed. 10, 1758, p. 304.]

Head not much depressed, the lateral muscles extending somewhat forwards over the cranial roof, and the whole covered with the soft skin. Gape of mouth extending to beneath the orbit; teeth very minute, villiform, present on the premaxillæ and dentaries, also on the vomer but not on the palatines. Pectoral fin with robust spine, serrated on the posterior or both borders; pelvic fins with more than eight rass, arising behind the dorsal fin, which is short-based and without anterior spine; no adipose dorsal; anal fin much extended, almost or completely united with the caudal, which is rounded. Skin naked.

The surviving species of this genus inhabit the freshwaters of the temperate parts of the Palæarctic Region, some extending even to the north of India. Fragmentary remains of a supposed extinct 
species from an Upper Tertiary deposit near Sofia, Bulgaria, are named Silupus serdicensis by F. Toula, Denkschr. k. Akad. Wiss., math.-naturw. Cl. vol. lv. (1889), pt. ii. p. 108, pl. ix.

The following specifically undetermined specimens probably belong to this genus:-

$16402 \mathrm{e}, 16403 \mathrm{a}$. Anterior end of snout and an abraded smaller skull, erroneously referred by Lydekker to young individuals of Bagarines yarrelli in Palæont. Indica, ser. $\mathbf{x}$. vol. iii. (1886), p. 255; Lower Pliocene, Siwalik Hills, India.

Presented by Col. Sir Proby T. Cautley, K.C.B., 1842.

\section{Genus PSEUDEUTROPIUS, Bleeker.}

[Nederl. Tijdschr. Dierk. vol. i. 1863, p. 106.]

Head almost or completely covered with soft skin; gape of mouth not extending backwards to the orbit, which is large; teeth minute and villiform, some on the vomer and palatines. Pectoral fin with robust spine, serrated on the posterior or both borders; pelvic fin with six rays; dorsal fin short-based, with a robust spine, more or less directly opposed to the pelvic pair; a very small adipose dorsal fin; anal fin much extended, terminating at some distance from the caudal, which is forked. Skin naked.

Surviving species in the East Indies.

Pseudeutropius verbeeki, Günther.

1876. Brachyspondylus indicus, W. von der Marck, Palæontogr. vol. xxiii. p. 412, pl. xxiv. fig. 2. [Imperfect fish ; Royal Greological Museum, Dresden.]

1876. Pseudentropius verbeekii, A. Günther, Geol. Mag. [2] vol. iii. p. $435, \mathrm{pl}$. xv. fig. 2.

Type. Imperfect fish; British Museum.

A species attaining a length of about $0 \cdot 6$. Length of head with opercular apparatus slightly less than half that of the trunk from the pectoral arch to the base of the caudal fin. Cranium rather elongate, and upper surface of snout granular. Pectoral fin-spines about as long and strong as the dorsal fin-spine, similarly marked with fine longitudinal striations and strongly serrated on the hinder border; pelvic fins with seven rays, inserted immediately behind the dorsal, which exhibits seven rays behind the spine; anal fin low, with twenty-eight rays; caudal fin very deeply forked, length of each lobe about equal to that of the terminal nineteen vertebræ.

Form \& Loc. Freshwater Tertiary Formation: Padang, Sumatra. 


Silurue apasszici. A. Bravard, Ansurps. Dess. Mas. Dere. Pasana (185-8), ho k9/ name onb). - Tertiony: Pasana. [Headbones.] Zis fortions of mandible in the Bavard Cole. (P.12635) are thes labelled in Beward himself.

Silurus of agassiss: Ti Hrenguelli, Bot Read Nas.

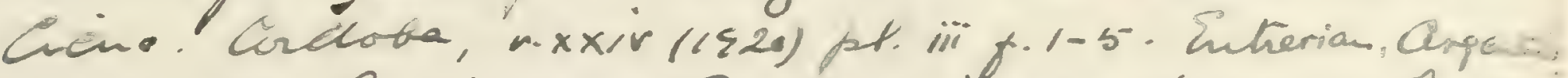

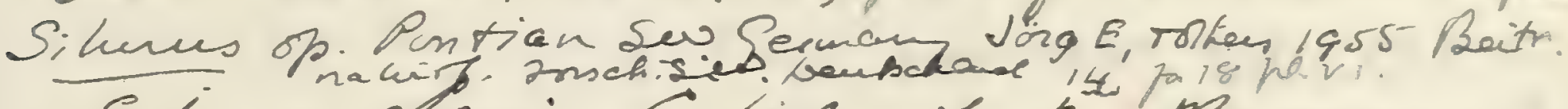
Selimen Stami, G. hiden trosk, Magyar Mir. Foldtani litegel Gukongye, 1916, xxiv pot th, p. 333 fll. vir, viri CPlior. Hengarys?

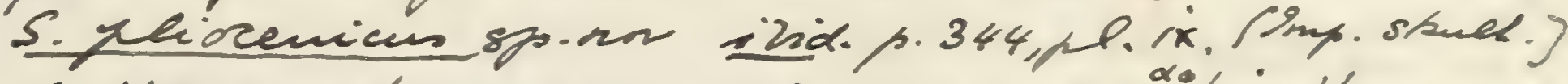

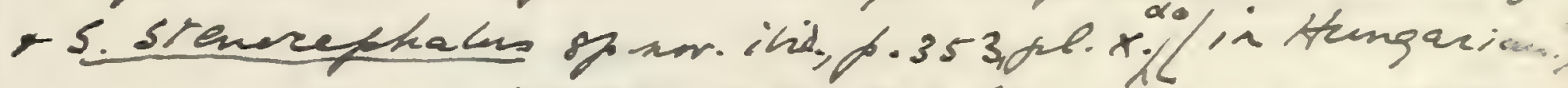

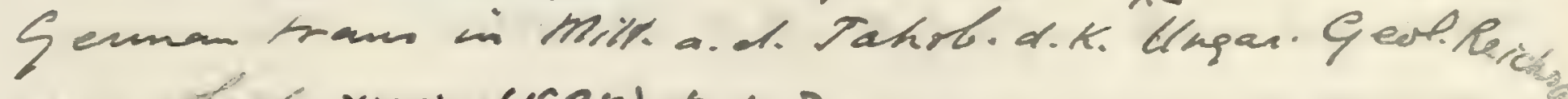
50 (1925) p.11).

Sandryi, heniche, 2eep.6/6.

L.glanis, L. Gietray. $93 \%$ Bull. Mus roz.H.n. Bey.

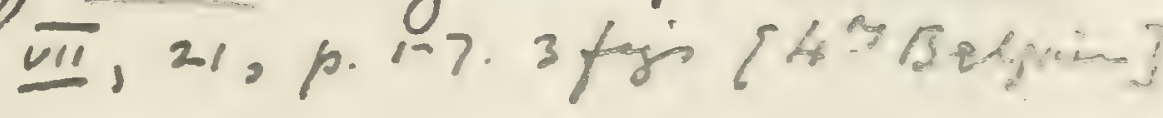

1934. Pangasius indicus, M. Janders, p. 22 phiv. 
Bagrus doomak.

Clarolés latiofes.

H

Nigeriam g.a.

1. usurecense,su.

N. gaokense, s.n.
Begruts sp. L.Weider, $1926 \% 332$ M. Plic. Egyfut.

Chrysichthys eaglesomei, s.m."

segescmia

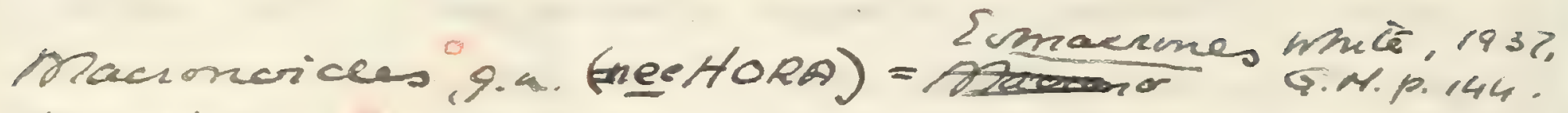

N. aritsons, s.4

num Baly $1863(\mathrm{COP})$

New hame BORIA D.S.Tordan - Macrones

preorcupied among heettes (Neamam 1841). Tive.

Acad. Nat. Sci. Plipad. 1949 pp. 341-4.

Su also Gavia sanoplinixp.32s.

Anacrones? sho, F Priem, Bull. Serr. Géal.

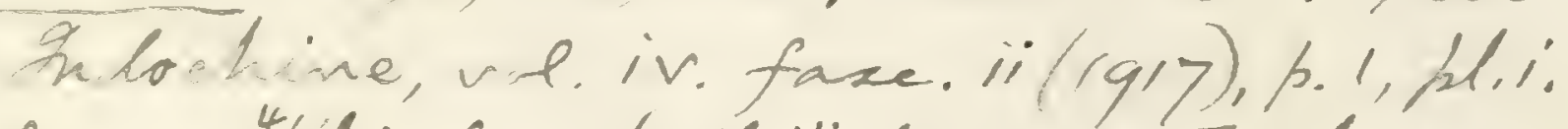

fig. 1, 2, thlii.fig. 3, 6, hl.il.fip.s. - Jertian:

Ban-han, Iran-minh, Zoos. Crish'

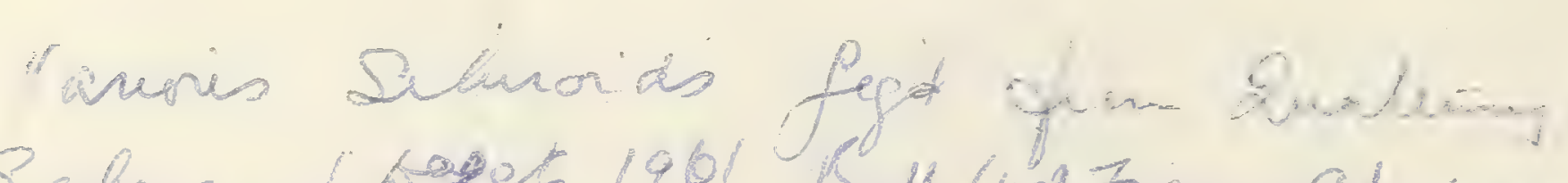
Sahene Sapet 1901 Bult. int Fone. Aprians

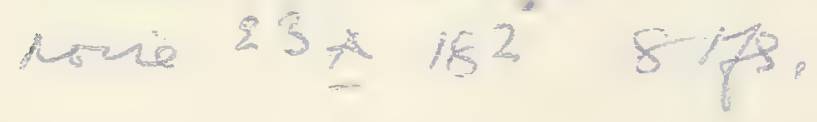




4752\%. Type specimen figured by Günther, loc. cit.

Presented by Herr R. D. M. Verbeek, 1876.

47531. Second specimen noticed by Günther, loc. cit. p. 435.

Presented by Herr R. D. M. Verbeek, 1876.

47528-30, 4753\%. Four specimens, the second being a very large tail. Presented by Herr R. D. M. Verbeek, 1876.

An indeterminable fragment has been referred to the existing African genus Chrysichthys, Bleeker, as follows:-

Chrysichthys (?) theobaldi, R. Lydekker, Palæont. Indica, ser. x. vol. iii. (1886), p. 249, pl. xxxvii. fig. 4.—Siwalik Formation; Punjab. [Hinder portion of cranium; Indian Museum, Calcutta.]

\title{
Macronichthys W. TM.T.1960 Genus MACRONES, Duméril. a.m.n.(r. ( ( ) .v.
}

\author{
[Ichthyol. Anal. 1856, p. 484.] SoS^.
}

Head depressed, the cranial bones solid, more or less ornamented and covered with thin skin; an antero-posteriorly elongated frontal vacuity. Gape of mouth moderately wide; teeth minute and villiform, some on the vomer and palatines. Pectoral fin with robust spine; pelvic fin with six rays; dorsal fin shortbased, with a robust spine and seven rays, in adrance of the pelric fins; an adipose dorsal fin of moderate length; anal fin short-based, with less than twenty rays; caudal fin forked. Skin naked.

An existing Asiatic genus.

\section{Macrones aor (Buchanan).}

1822. Pimelodus aor, F. H. Buchanan, Fishes found in River Ganges, pp. 205, 379, pl. xx. fig. 68.

1839. Bagrus aor, Cuvier \& Valenciennes, Hist. Nat. Poiss. vol. xiv. p. 405.

1864. Macrones aor, A. Günther, Catal. Fishes B. M. vol. v. p. 78.

1886. Macrones aor, R. Lydekker, Palæont. Indica, ser. x. vol. iii. p. 250, pl. xxxvi. fig. 5.

Type. Recent fish.

Defined by Günther, loc. cit.

Form. \& Loc. Lower Pliocene: Siwalik Hills, India. Recent in freshwaters of India.

40822. Imperfect skull and mandible, described and figured by Lydekker, loc. cit.

Presented by Charles Falconer, Esq., 1867. 


\section{Genus RITA, Bleeker.}

[Verhand. Natuurk. Ver. Nederl. Ind. vol. iv. 1858, p. 60.]

Closely resembling Chrysichthys and Macrones, but teeth on palate granular or molariform. Posterior border of supraoccipital plate notched to receive the basal bone of the dorsal spine.

Existing in the freshwaters of the East Indies, and probably represented in the Pliocene of India by the following species, of which there are no remains in the Collection:-

Rita grandiscutata, R. Lydekker, Palæont. Indica, ser. x. vol. iii. (1886), p. 251, pl. xxxvii. fig. 3.-Siwalik Formation; Punjab. [Very large basal bone of dorsal spine; Indian Museum, Calcutta.]

\section{Genus AMIURUS, Rafinesque.}

[Ichthyol. Ohioensis, 1820, p. 65 (Ameiurus).]

Head depressed and covered with soft skin; teeth minute, contined to the premaxilla and dentary. Pectoral fins with robust spine, serrated on the posterior border; pelvic fins with eight rays, behind the dorsal fin, which is far forwards and comprises one robust spine and six divided rays; adipose dorsal short or of moderate length; anal fin of variable extent; caudal fin forked or truncated. Skin naked.

A North-American and Chinese genus.

Detached vertebræ have been provisionally assigned to this genus under the following names:-

Amiurus cancellatus, E. D. Cope, Contrib. Canadian Palæont. (Geol. Surv. Canada), vol. iii. (1891), p. 3, pl. i. figs. 4, 5.Lower Miocene; Cypress Hills, N.W. Territory, Canada. [Canadian Geol. Surv. Museum, Ottawa.]

Amiurus maconnelli, E. D. Cope, ibid. p. 4, pl. i. figs. 6, 7.Ibid. [Ibid.]

A genus closely related to the existing Pimelodus is represented by the following specimen :-

P. 9010. Imperfect fish in Tertiary lignite; Taubaté, Province of San Paulo, Brazil. 


retalurus Sambea s.n Plirene Kansus,

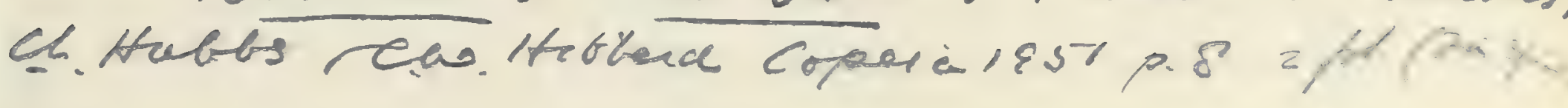

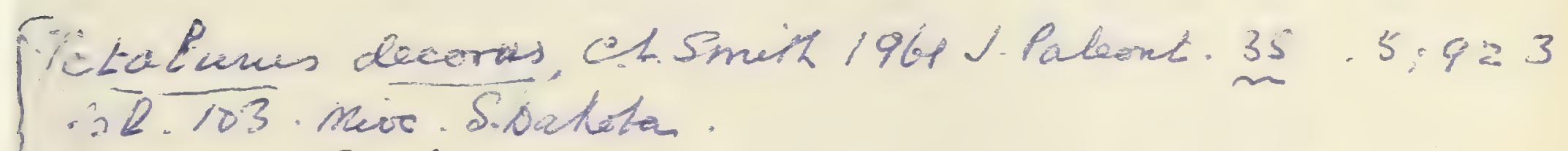

Ameirus? decorus, 0.P. Hay, Proe. Bial. So. hashingtom, vol. 37. 1.1, hl.i.f.r.1.- H. hiocene: Jexeas. [Pectoral eprine. T = letahimes

Ameiverus krimaevus, C.R. Sastman, Pror. U.S. Nat. Hus.

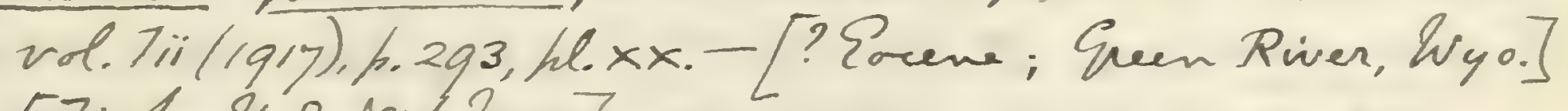
[Fish; U.S. Nat. hues]

cancelletn, Z.M. Tambe, Contrith. Canad. Paldeort. rd. iir. ph.iv (1908). p. 15.

macomelli, Z. Sn. Zambe, Ln. wit. (1908), h. 16.

A simitar specimen to PQ010 is fig't in the Guia de

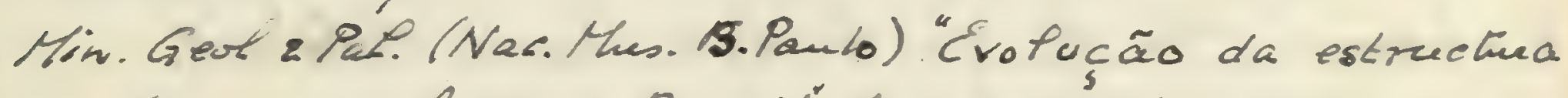
da Jena e gevbogia do Bragil",plp. 224 . (1924) 
Felichthess stauroforns sin. WG. Lynn TO.m. melland

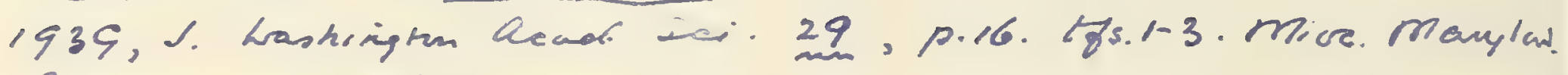
[skull: us n.m.

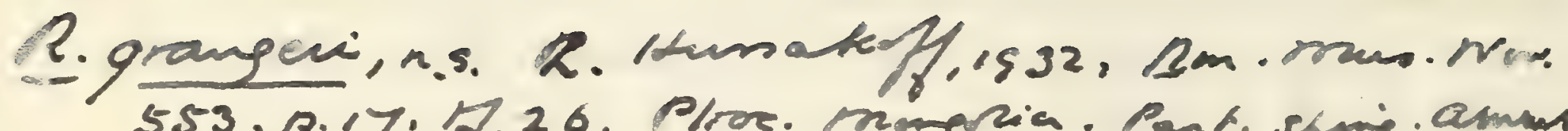

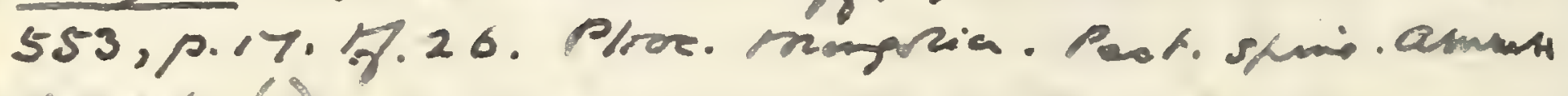
(ladet: ).

P. Nheas, L. Mr. Lambe, Contur Canad. Platent. and. iir. ph.iv (1908), hl. i, fin. 10-16, h.14. 



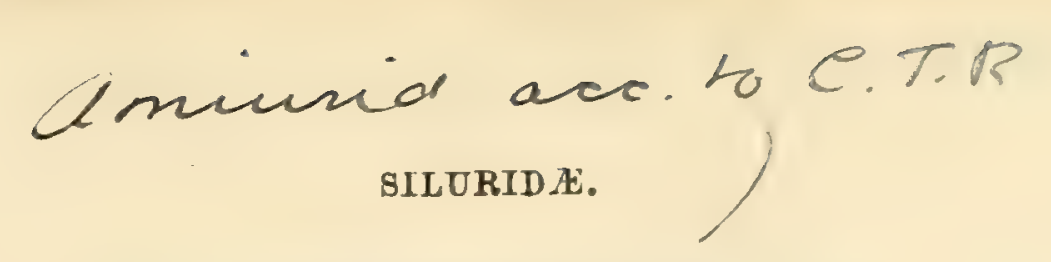

\section{Genus RHINEASTES, Cope.}

[Proc. Amer. Phil. Soc. vol. xii. 1872, p. 486.]

An imperfectly known genus related either to Pimelodus or to Arius. Head depressed and bones of cranial roof marked with conspicuous rugosity; frontal fontanelle closed, but marked by a smooth deep groove. Teeth minute and villiform, extending over vomer. Pectoral fin with robust spine, serrated on one or both borders; a nuchal shield between the supraoccipital and the spine of the dorsal fin.

In the typical species, $R$. peltatus, the nuchal shield is large and massive; in the other Eocene species (forming sub-genus Astephus, Cope) it is narrow and short.

The genus is known only by fragments from the Lower Tertiary of North America, and is not represented in the Collection. The following species have been named :-

Rhineastes arcuatus, E. D. Cope, Ann. Rep. U.S. Geol. Surv. Territ. 1872 (1873), p. 641, and Vert. Tert. Form. West, Book I. (Rep. U.S. Geol. Surv. Territ. vol. iii. 1884), p. 66, pl. v. fig. 12. Pimelodus antiquus, J. Leidy, Proc. Acad. Nat. Sci. Philad. 1873, p. 99 (name only), and Contrib. Extinct Vert. Fauna W. Territ. (Rep. U.S. Geol. Surv. Territ. vol. i. 1873), p. 193, pl. xxxii. figs. 44, 45.-Bridger Eocene; Upper Green River, Wyoming. [Pectoral finspine; National Museum, Washington.]

Rhineastes calvus, E. D. Cope, Toc. cit. 1872 (1873), p. 640, and op. cit. 1884, p. 65, pl. v. figs. 3-4.-Bridger Eocene; Upper Green Rirer. [Portion of cranium; National Museum, Washington.]

Rhineastes pectinatus, E. D. Cope, Bull. U.S. Geol. Surv. Territ. rol. i. no. 2 (1874), p. 49, and op. cit. 1884, p. 747, pl. v. fig. 13.-Lower Tertiary; South Park, Colorado. [Fragment of head and anterior abdominal region; National Museum, Washington.]

Rhineastes peltatus, E. D. Cope, Proc. Amer. Phil. Soc. vol. xii. (1872), p. 486, and op. cit. 1884, p. 63, pl. v. figs. 1, 2.Bridger Eocene; South Bitter Creek, Washakie Basin, Wyoming. [Associated head-bones, \&c.; National Museum, Washington. The type species.]

Rhineastes (?) rhceas, E. D. Cope, Contrib. Canadian Palæont. (Geol. Surv. Canada), vol. iii. (1891), p. 3, pl. i. fig. 3.Lower Miocene; Cypress Hills, N.W. Territory, Canada. [Vertebræ; Canadian Geol. Surv. Museum, Ottawa.] 
Rhineastes smithi, E. D. Cope, Proc. Amer. Phil. Soc. vol. xii. (1872), p. 486, and Ann. Rep. U.S. Geol. Surv. Territ. 1872 (1873), p. 639, and Vert. Tert. Form. West, Book I. (1884), p. 64, pl. v. figs. 5-11._Bridger Eocene; South Bitter Creek. [Associated head-bones, \&c.; National Museum, Washington.]

Some indeterminable fragments of ornamented bone, probably not of this genus, from the Bridger Eocene of Cottonwood Creek, Wyoming, are named Rhineastes radulus by E. D. Cope, Ann. Rep. U.S. Geol. Surv. Territ. 1872 (1873), p. 639, and Vert. Tert. Form. West, Book I. (1884), p. 67, pl. จ. figs. 14-17.

\section{Genus BUCKLANDIUM, König.}

[Icones Foss. Sect. 1825, p. 4.]

A genus known only by the imperfect skull and pectoral arch, which closely resemble the corresponding parts of the existing Auchenoglanis ${ }^{1}$ of the Nile and West African rivers. Distinguished from the latter by the complete fusion of the cranial roof-bones, the larger orbit and frontal fontanelle, and the relatively larger pectoral arch, which does not taper below. Head laterally compressed, with rounded tuberculated roof, evidently not covered with skin.

\section{Bucklandium diluvii, König.}

1825. Bucklandium diluvii, C. König, Icones Foss. Sect. p. 4, pl. viii. no. 91 .

1889. Bucklandium diluvii, A. S. Woodward, Rep. Brit. Assoc. 1888, p. 679 , and Proc. Zool. Soc. 1889, p. 208, pl. xxii.

Type. Cranium, \&c.; British Museum.

The type species, with cranium about 0.12 in length. Cranial roof strongly arched, ornamented with large, well-separated tuberculations, and the supraoccipital with a median longitudinal keel. Head probably about as deep as long.

Form. \& Loc. Lower Eocene (London Clay): Isle of Sheppey.

P. 9230. Imperfect type specimen, described and figured loc. cit. 1889.

History unknown.

Genus ARIUS, Cuvier \& Valenciennes.

[Hist. Nat. Poiss. vol. xv. 1840, p. 53.]

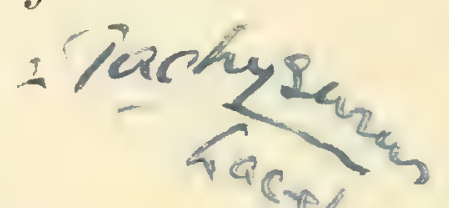

Head depressed and bones of cranial roof ornamented and exposed; an antero-posteriorly elongated frontal fontanelle; supra-

I Auchenaspis, Bleeker (non Egerton): Günther, Catal. Fishes Brit. Mus. vol. v. (1864), p. 137. 

7. Baymuia see Z. Reumayer, Paldentroraphica vol. $7 \mathrm{ix}(1913)$, h.25\%.

Phineaster errciferne (Cope) reended finm Belly Qiver Teries of Allenta b. Z. Mr. Zambe, Contut.

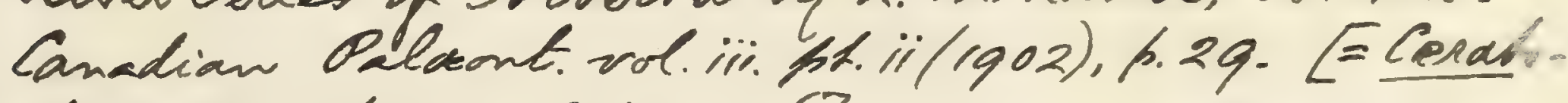
dus eruciferner. Cope. 1876.7

Peotral atives of a Mnodntid from Plivene fo Wadi Tatuen, Bupts: B. Oeye

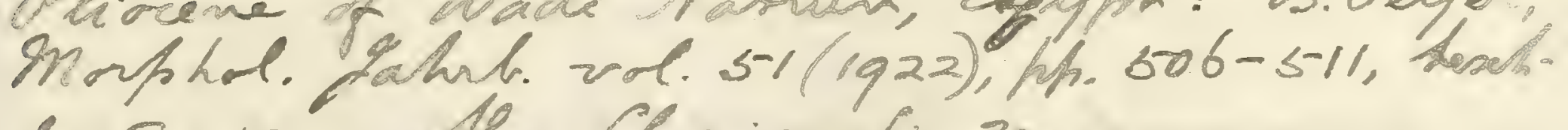
fip. 8-19. The Claviar, fis. 20.

Buctalandium said to be related to Ancharius of Inadagasear hy C. T. Repan. Bijdr. Sierteunde to. 3ool. Geno ottech. Aunsterdan. afle $\times$ xii (1922), p.20\%. Cin ariid are to err.

A. ayentinu spn. M. bols spot de Saez.

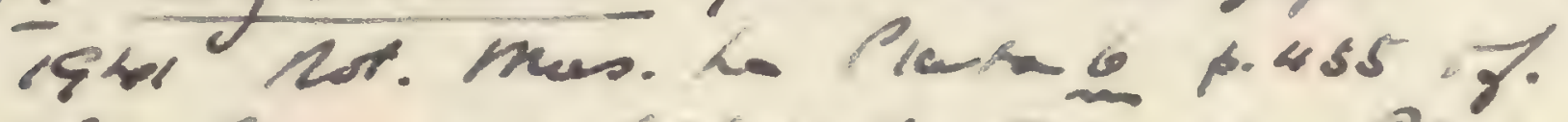

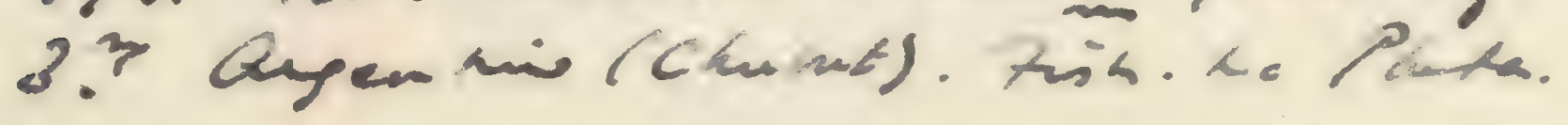




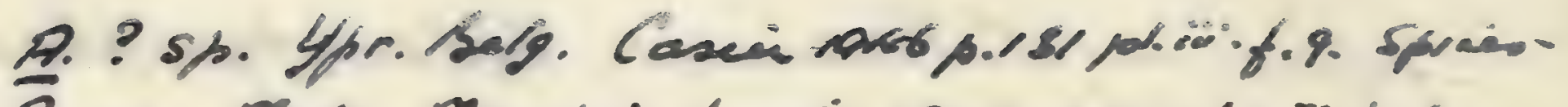

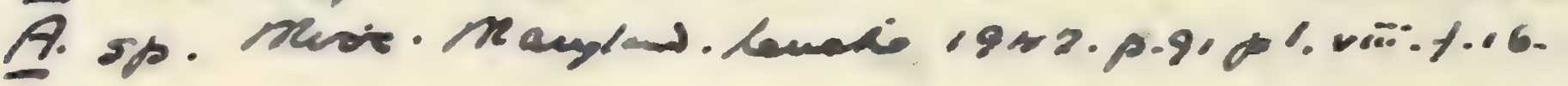

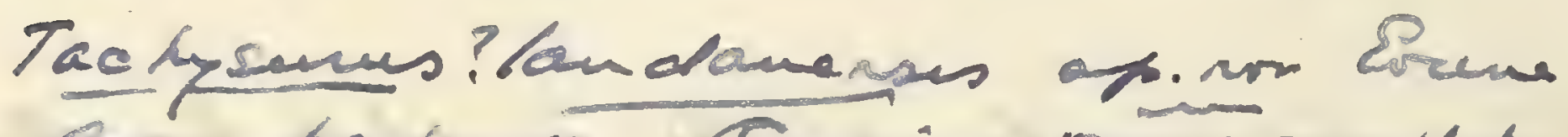
Enjo sandmen Casien 1949 p.214 M.t.

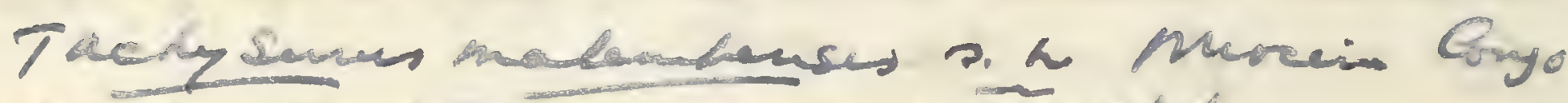

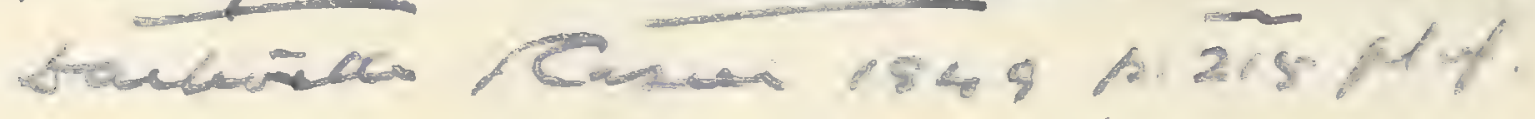

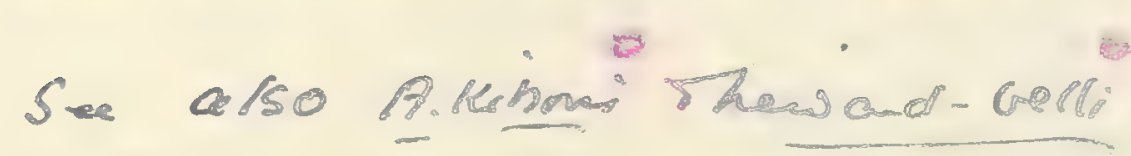

gab. Arius egertomi, In. Zeriche, Iném. Sor. Géal. Nord, vol.v.h.235, ph. xii. fip. 2-5, teat.fip. 54. 
occipital extending backwards to meet a nuchal plate. Cleft of mouth small, not extending beneath the orbit; teeth minute, villiform or granular, extending over the vomer and palatines. Pectoral fins with a robust spine, serrated on one or both borders; pelvic fins with six rays; dorsal fin far forwards, in advance of the pelvic pair, with one robust spine and six or seven divided rays; adipose fin short-based or of moderate extent; anal fin short-based; caudal fin forked. Skin naked.

The expisting species of this genus are both marine and freshwater, and range throughout the tropics of both hemispheres.

\section{Arius egertoni (Dixon).}

\section{[Text-figure 11.]}

1850. Silurus egertoni, F. Dixon, Geol. Sussex, pp. 112, 204, pl. xi. figs. 11-13.

1887. Arius egertoni, A. S. Woodward, Geol. Mag. [3] vol. iv. p. 304, figs. $1,2$.

1889. Arius egertoni, E. T. Newton, Proc. Zool. Soc. p. 206.

1889. Arius egertoni, L. Dollo, Bull. Suc. Belge Géol.vol, iii. Proc.Verb. p. 218.

Type. Pectoral arch and spine; British Museum.

A small species known only by fragments. External ornamentation of bony plates consisting of sharp conical tubercles, frequently united at the base by low and rounded reticulating ridges. Posterior extension of supraoccipital bone slightly broader than long, with nearly parallel sides, truncated hinder border, and a longitudinal keel; the anterior half of this bone marked with a pair of conspicuous grooves for the slime-canals diverging forwards from the median keel. Pectoral fin-spine compressed, with irregular longitudinal ridges, partly tuberculated, and with both borders serrated; post-clavicular plate triangular, as deep as long.

Form. \& Loc. Middle Eocene: Sussex; Belgium.

25612. Type specimen, the clavicle and pectoral spine, figured by Dixon and described by the present writer, loc. cit.; Bracklesham Beds, Bracklesham Bay. The spine measures about 0.09 in length.

Dixon Coll.

25735*,25736. Imperfect dorsal and pectoral spines, figured by Dixon, op. cit. pl. xi. figs. 12, 13; Bracklesham.

Dixon Coll.

25735, 2573\%, 25\%41. Portions of pectoral and dorsal fin-spines, and two ornamented head-bones; Bracklesham.

Lixon Coll. 
28086. Small pectoral spine; Bracklesham.

$$
\text { Presented by F. E. Edwards, Esq., } 1852 .
$$

38891-93, 39000. Head-bone, imperfect pectoral and dorsal spines, and fulcral spine of dorsal fin, the latter shown of the natural size in the accompanying fig. $11 \mathrm{~A}$; Bracklesham. Bowerbank Coll.

P. 4306. One imperfect dorsal, and two imperfect pectoral spines; Bracklesham.

Enniskillen Coll.

P. 1894-5. Two small pectoral spines, one being incomplete distally, a nearly complete supraoccipital and other head-plates; Bracklesham.

Egerton Coll.

P. 9425. Supraoccipital, shown of the natural size in the accompanying fig. $11 \mathrm{~B}$; Bracklesham.

Egerton Coll.

Fig. 11.

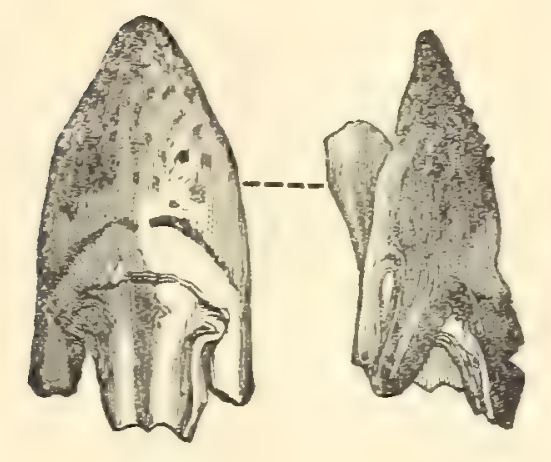

A

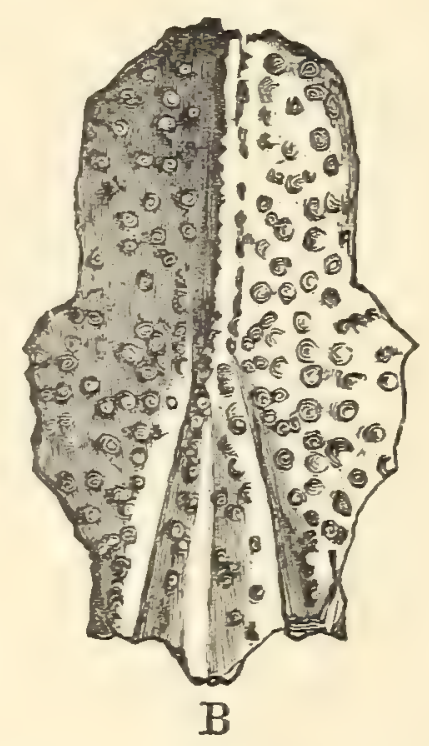

Arius egertoni; dorsal fulcral spine (A) and supraoccipital bone (B), nat. size.

38894-95. Two imperfect supraoccipitals, one being small; Bracklesham.

Bowerbank Coll.

P. 1894. One imperfect pectoral, and four imperfect dorsal spines, either of this or the next species, noticed by Woodward and Newton, loc. cit.; Barton Clas, Barton Cliff, Hampshire.

Egerton Coll.

\section{Arius crassus (Koken).}

1884. Otolithus (incertce sedis) crassus, E. Koken, Zeitschr. deutsch. geol. Ges. vol. xxxri. p. 559, pl. xii. fig. 13.

1889. Arius crassus, E. T. Nertton, Proc. Zool. Soc. p. 206, pl. xxi. figs. 1-3.

1891. Otolithus (Avius) crassus, E. Koken, loc. cit. rol. xliii. p. 80.

Type. Otolith; Royal Iuseum of Natural History, Berlin. 


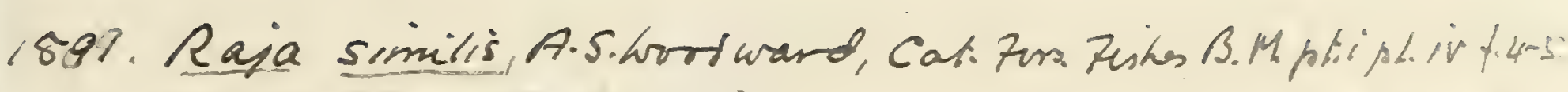
1915: Atolithur (Arius) cracens, R. Schubert,

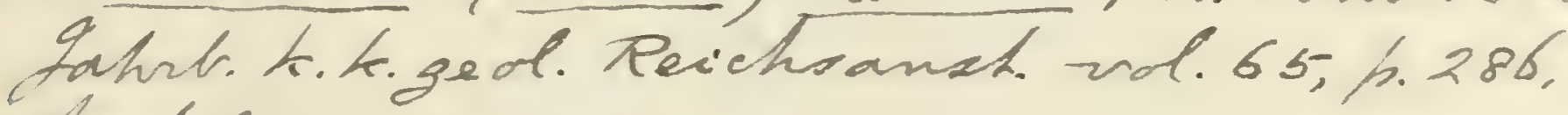
textifier. 1, 2. 


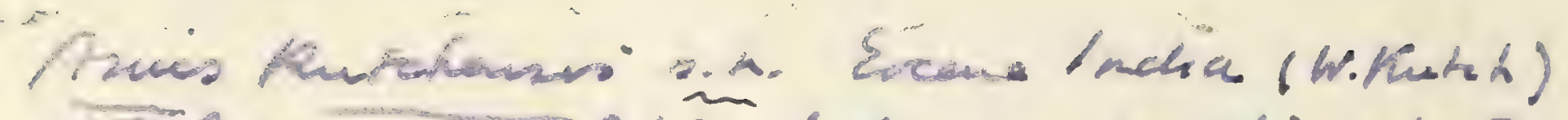
R.Rac 1956 J.Pel Sot. India 1 p.180 2fjo, Ml. 28 isturif.

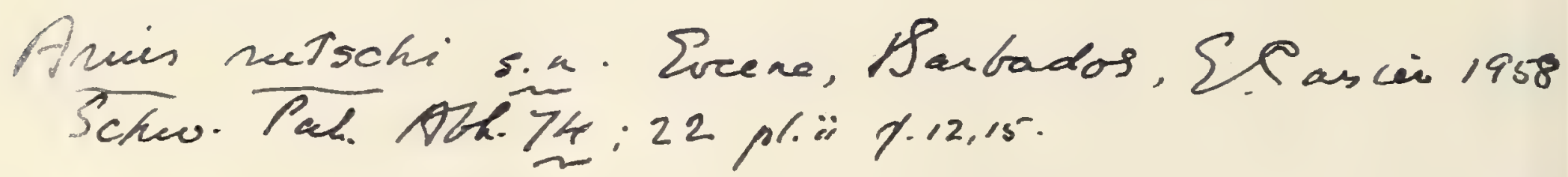


A small species, known only by the imperfect head. External ornamentation of bony plates much like that of $A$. egertoni, but the tubercles more numerous, more rounded, less united by reticular ridges, and more definitely arranged in radiating lines. Supraoccipital bone rather broad, not impressed by the slime-canals.

Form.\& Loc. Upper Eocene: Barton Cliff, Hampshire; Headon Hill, Isle of Wight. Oligocene: Germany.

A fine portion of cranium of this species, in the Museum of Practical Geology, is described by Newton, loc. cit.

28094. Eleven otoliths, including two figured in Part I. Pl. IV. figs. 4,5 , one of these and two others also figured by Newton, loc. cit. figs. 4-6, as of doubtful species; Barton Clay, High Cliff, Hampshire. Presented by F. E. Edwards, Esq., 1852.

29023. Four otoliths; Chutan, Hampshire.

Couderoy Bequest.

40283 , P. $3 \% 6$. Otoliths, probably either of this or the next species; High Cliff.

Edwards Coll.

Arius (?) bartonensis, A. S. Woodward.

1887. Arius (?) bartonensis, A. S. Woodward, Geol. Mag. [3] rol. ir. p. 306, fig. 3.

Type. Dorsal fin-spine; British Museum.

A very small species, of uncertain genus, known only by finspines. Dorsal fin-spine slender, much laterally compressed, finely striated on the sides, with recurved denticles on the anterior and posterior margins towards the apex, which curres a little forwards.

Form. \& Loc. Upper Eocene: Barton, Hampshire.

40280. Type specimen described and figured loc.cit, and five other imperfect fin-spines of which two are pectoral; High Cliff, Barton.

Edwards Coll.

P. 1894 a. Larger dorsal fin-spine, imperfect at the apex, noticed loc. cit.

Egerton Coll.

P. 6500. Dorsal fin-spine; Barton.

Purchased, 1891.

Arius iheringi, A. S. Woodward.

[Plate XVII. fig. 4.]

1898. Arius iheringi, A. S. Woodward, Rev. Mus. Paulista, vol, iii. p. 64 , figs. 1,2 .

Type. Impression of skull: British Museum. 


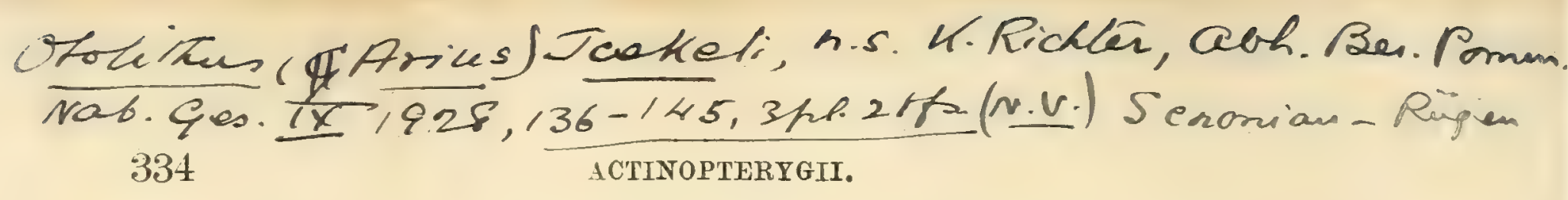

$A$ large species, the head measuring about 0.2 in length. External bones ornamented with a coarse rugosity, no distinct tubercles. Maximum width of cranium slightly exceeding half its length from the occipital border to the end of the snout; orbits situated exactly in the middle; posterior extension of supraoccipital bone narrow, not keeled, about twice as long as broad, with nearly parallel sides, and its hinder border slightly notched by an acute re-entering angle.

Form. \& Loc. Tertiary Lignite: Taubaté, Province of San Paulo, Brazil.

P. 9220. Type specimen, the skull chiefly in impression of dorsal aspect, shown of nat. size in Pl. XVII. fig. 4.

$$
\text { Presented by John Gordon, Esq., } 1900 .
$$

P. 9221. Larger, more imperfect specimen, very friable, noticed loc. cit. p. 64. Presented by John Gordon, Esq., 1900.

The following specimens also appear to be referable to Arius:-

P. 6331. Eight otoliths, described and one figured by E. T. Newton, Proc. Zool. Soc. 1889, p. 205, pl. xxi. fig. 7 (drawing not reversed), under the name of Arius baroni, sp. nov.; Recent (?), Ankoala, Madagascar.

Presented by Rev. R. Baron, 1889.

$16402 \mathrm{~d}$. Hinder part of large cranium, described and figured as Arius sp. $a$ by R. Lydekker, Palæont. Indica, ser. x. vol. iii. (1886), p. 252, pl. xxxvi. fig. 2; Pliocene, Siwalik Hills, India.

Presented by Col. Sir Proby T. Cautley, K.C.B., 1842.

P. 4923. Large, externally ornamented bone; Pliocene, Siwalik Hills. Transferred from India House Museum, 1880.

The following otoliths have also been ascribed to this genus :-

Otolithus (Arius) germanicus, E. Koken, Zeitschr. deutsch. geol. Ges. vol. xliii. (1891), p. 81, pl. i. fig. 3, pl. vi. fig. 8.Lower Oligocene; Lattorf, Westeregeln, and Osterweddingen. Niddle Oligocene; Söllingen, Weinheim, Waldböckelheim.

Otolithus (Arius) vangionis, E. Koken, loc. cit. 1891, p. 81, pl. vi. fig. 4.-Middle Oligocene; Waldböckelheim.

Otolithus danicus, E. Koken, loc. cit. 1891, p. 81. Otolithus cf. (incertce sedis) crassus, E. Koken, Abh. phys. Cl. k. Ges. Wiss. Göttingen, vol. xxxii. (1885), p. 116, pl. v. fig. 29.Lower Eocene; Copenhagen. 



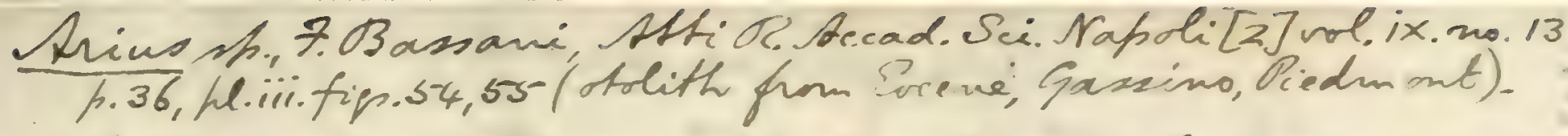

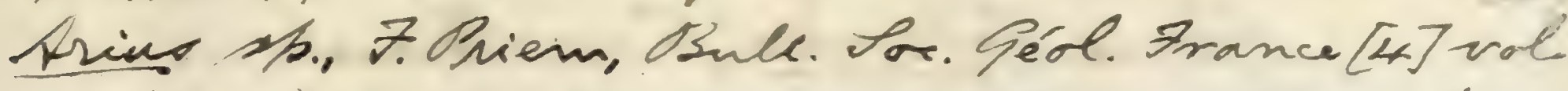

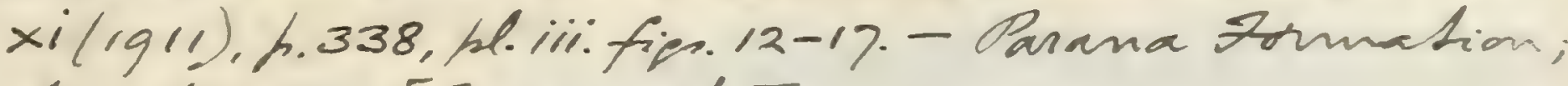
Aspentina. [Frapments.]

0.A?. Schafferi. n.s.

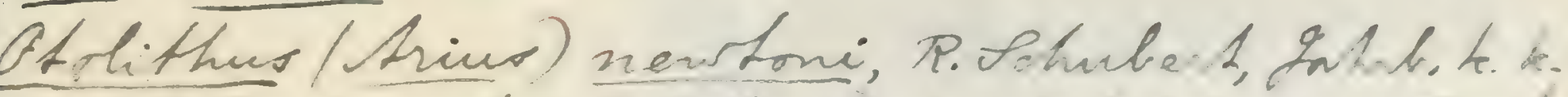
ged. Peichoanst. vel. 65(1915), B. 286, hexh-f:. 3.- Sactm

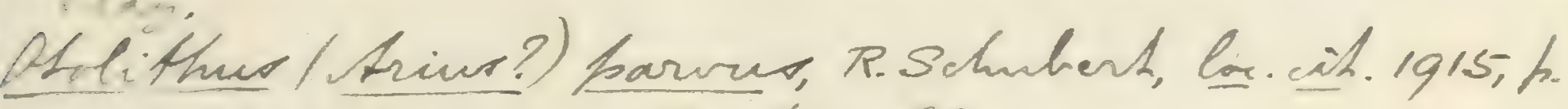
287. hl.vii. fije.24.- Barton Clay Q. (A). Africanus, anqulatios $*$ amekie nsis.

Boiss. Fons. Bussin Parizien (Pabl. Ann. Patén to.1908),

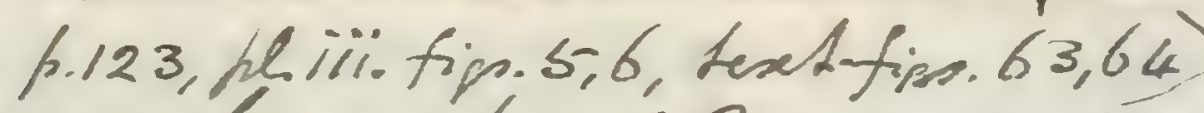

Ariur bommeti, 7. Priem, Bull. Sor- Géol. Arance [4] vol.iv(1904), f. 44, Lext figi.3-8, Bartomian: Mariner (Jeine-et-Dize), Franee.' (Fin-ahine;

Arivs? lemoinei, Priem = Acipenser (Pf.III, p.45).

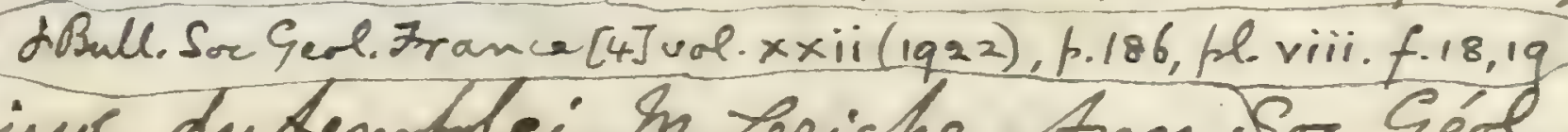
Ariur dutemplei, In Zeriche, Arn. So. Gérl. Now vol, xxix(1900), h.181, pli.i. fipa 13-1st; 7. Priem, Bull

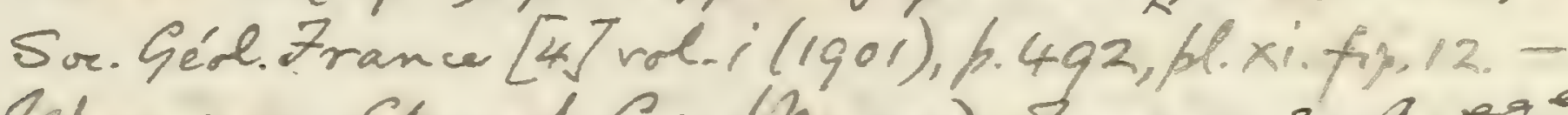

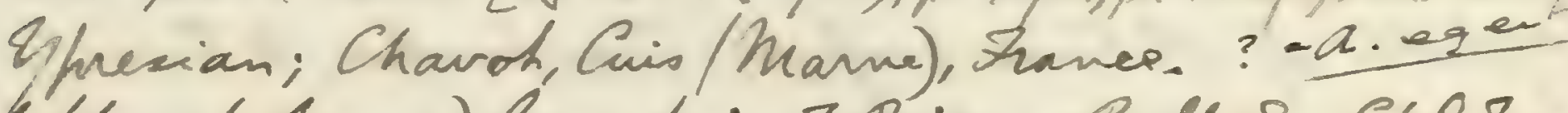
Atolithur (Ariur) lerichei, 7. Oriem, Bull. Sor. Geol. Im [4] rol.vi(1906), \%.277, Lext fir, 46, 47. Thanetian; Reims

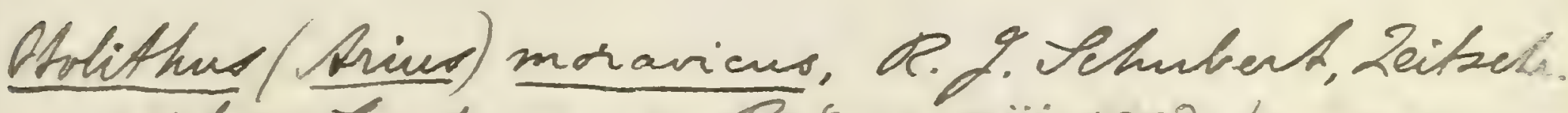
mähr, Zandesmus. Brimn, viii, 1908, p

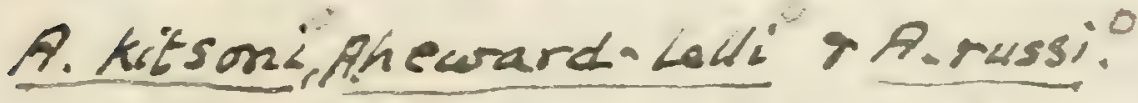

Arius damicur (kstem), M. Leriche, hén. Mus. Ron.

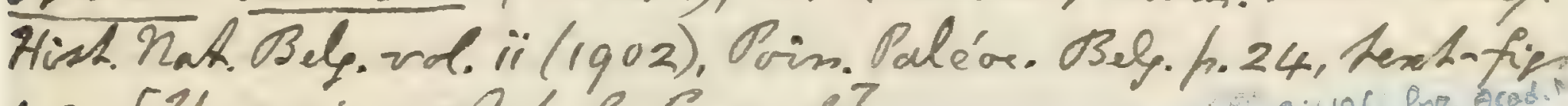
1.2. [Heersian; Onp-le-Grand.] Ariopers an Assial (eT.r) = Peyeria m.n Whinay $\uparrow$ Ariopsis gen. n., aegyptiacus sp. n. Eocene Egypt, PeYer Bayer. Akad.
Wiss. 32 p. 43 pl. v. 1atio (Non treila 1985) Puss.

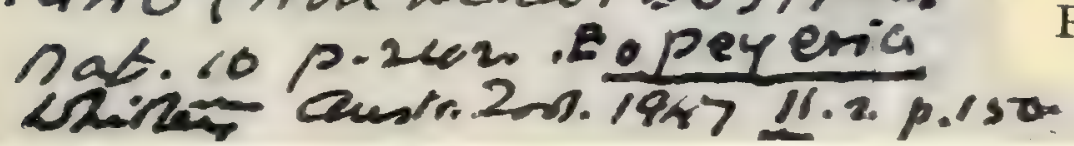
$\uparrow$ Arius fraasi sp. n. Eocene Egypt, 



\section{Genus BAGARIUS, Bleeker.}

[Nalez. Ichthyol. Faun. Bengal en Hindostan (Verhand. Batav. Genootsch. Wetensch. vol. xxv.), 1853, p. 121.]

Head depressed and bones of cranial roof exposed, those of the middle conspicuously ornamented; an antero-posteriorly elongated frontal fontanelle; cleft of mouth of moderate size; teeth clustered and unequal in size, some rather large, but none on the palate. Trunk and fins as in Arius.

\section{Bagarius gigas, Günther.}

1876. Bagarius gigas, A. Günther, Geol. Mag. [2] vol. iii. p. 436, pl. xvi. fig. 1.
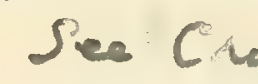

Type. Imperfect pectoral arch, \&c.; British Museum.

A provisional name for a fragment apparently of Bagarius.

Form. \& Loc. Freshwater Tertiary Formation: Padang, Sumatra.

47513. Type specimen described and figured by Günther, Toc. cit. Presented by Herr R. D. M. Verbeek, 1876.

The anterior portion of a large cranium from the Siwalik Formation of Náhan, India, now in the Indian Museum, Calcutta, seems to belong to Bagarius yarrelli, which still exists in the larger rivers of India and Java (R. Lydekker, Rec. Geol. Surv. Ind. vol. Xv. 1882, p. 105, and Palæont. Indica, ser. x. vol. iii. 1886, p. 254, pl, xxxvi.fig. 1). This specimen was originally assigned to a gigantic batrachian by T. Cantor, Journ. A siat. Soc. Bengal, vol. vi. (1837), p. 538, pl. xxxi., and first determined to belong to a Siluroid fish by J. M'Clelland, Calcutta Journ. Nat. Hist. vol. iv. (1844), p. 83, pl. ix.

An indeterminable pectoral fin-spine of a Siluroid from the Middle Pliocene of Perpignan, Rousillon, France, is described and figured by H. E. Sauvage, Ann. Sci. Géol. vol. xvii. (1885), p. 223, pl. iv. fig. 7 :

Two indeterminable fragments of fin-rays, doubtfully of this family, from a Tertiary sand (Miocene) in the Bihar Comitat, Hungary, are named Pimelodus sadleri, J. J. Heckel, Sitzungsb. k. Akad. Wiss. 1850, pt. i. p. 19, and Denkschr. k. Akad. Wiss., math.natur'w. Cl. vol. i. (1849), p. 213, pl. xiv. fig. 3.

An undetermined Siluroid from the Lower Miocene Brown-coal of Preschen, near Bilin, Bohemia, in the Geological Museum of the German University, Prague, is described by G. C. Laube, Verhandl. k.-k. geol. Reichsanst. 1897, p. 337. 


\section{Suborder VI. APODES.}

Notochord more or less persistent, but the rertebral centra always complete constricted cylinders, none coalesced; tail tapering, usually without expanded or fused neural or hæmal supports at the extremity. Symplectic bone absent; mandible simple, each ramus consisting only of two elements (dentary and articulo-angular). Pectoral arch not suspended from cranium; precoracoid arch absent; infraclavicular plates absent; pectoral fin with more than five basals. Pelvic fins absent. Scales rudimentary or absent. In the living forms-air-bladder, when present, connected with the œesophagus by a duct in the adult (physostomous), optic nerves decussating, intestine without spiral ralve, and reproductive organs without efferent ducts.

\section{Family MUR位NID.}

Trunk much elongated, the caudal region being relatively very long. Parietal bones large and meeting in a median suture; squamosal suturally united with parietals and covering the greater part of the otic region. Premaxillæ small and fused with the ethmoidal rostrum; maxilla well-developed, forming most of the upper border of the mouth; pterygo-palatine arcade much reduced or rudimentary. Branchial and opercular apparatus usually more or less reduced; generally a few delicate branchiostegal rays. Vertebræ very numerous, those of the abdominal region with short and broad transverse processes, small and delicate ribs, and very short neural spines. Intermuscular bones present. Fin-fulcra absent; fin-rays articulated and divided distally; dorsal and anal fins excessively extended, and a separate caudal fin almost always absent.

The extinct species of this family are too imperfectly known to be generically determined with certainty. It is evident, however, that they represent some of the more generalised types; and the Cretaceous genus mentioned below is unique in retaining a normal caudal fin.

A figure of the skeleton of Anguilla is published by Agassiz, Poiss. Foss. vol. v. pl. D. Some illustrations of cranial osteology are given by Storms, Bull. Soc. Belge Géol. rol. x. (1898), pl. vi. 


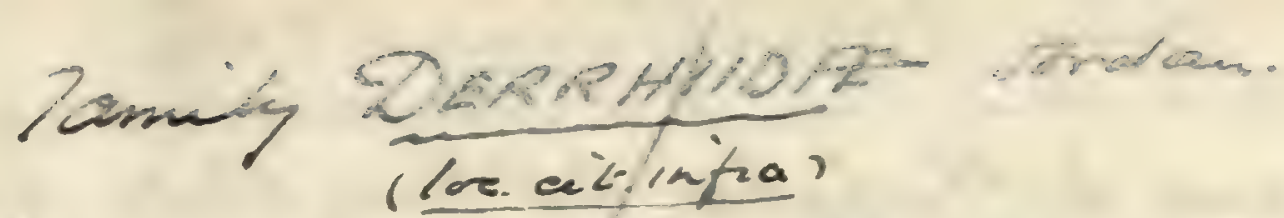

[ hile a moray fur wittpectorals.]

Derrhias enantius, D.5.5. n.genxsp. Stant. Univ. Pubto. unir. Ser, Biol. Sis. vot. in. (1925) p. 15 pt.5. fispa-z. ph. 6 .

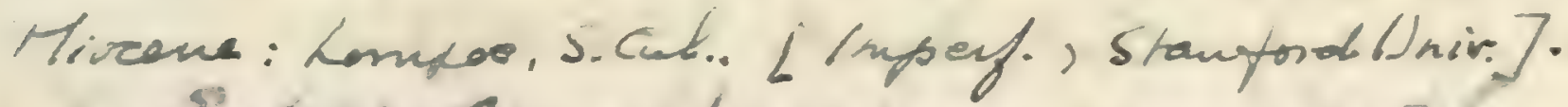

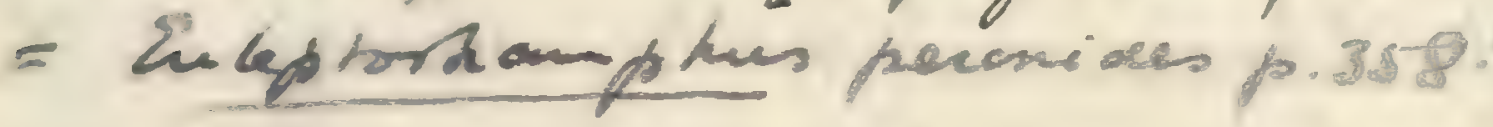

Muraena saheliensi's s.n. C. aramboung, 1927,

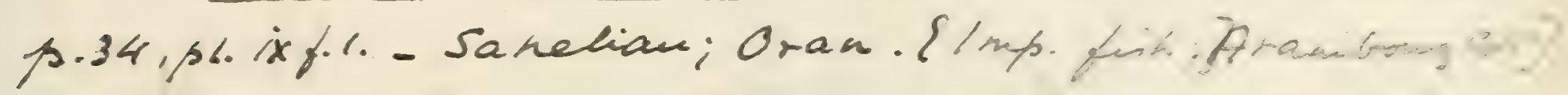



Genus URENCHELYS, A. S. Woodward.

[Ann. Mag. Nat. Hist. (7) rol. v. 1900, p. 322.]

Teeth small, bluntly conical, and arranged in numerous series. Slender branchiostegal rays not curving round the opercular apparatus. Vertebræ somewhat exceeding 100 in number, the hindermost bearing a pair of expanded hypural bones. Pectoral fins present; dorsal fin arising immediately behind the occiput and extending to the caudal fin, which has stouter rays and is very small but separate. Scales rudimentary.

\section{Urenchelys avus, sp. nov.}

[Plate XVIII. figs. 1, 2.]

Type. Imperfect fish; British Museum.

The type species, attaining a length of about $0 \cdot 3$. Length of head with opercular apparatus contained about six times in the total length to the base of the caudal fin; anal fin considerably more than twice as long as the portion of trunk in front of it. Anterior neural arches much expanded, their appended spines apparently small and low.

Form. \& Loc. Upper Cretaceous: Sahel Alma, Mount Lebanon.

P. 4860. Type specimen, shown of the natural size in PI. XVIII. fig. 1. A few of the blunt teeth are seen among the fractured remains of the cranium; while below it the extent of the mandible can be distinguished. The branchial region is probably shortened by crushing, and remains of the very slender branchiostegal rays lie across fragments of the branchial arches and the rather stout clavicle. The vertebræ cannot be readily counted, but there seem to be about 35 in front of the origin of the anal fin, and not less than 73 beyond. The neural arches in the abdominal region sre very stout laminæ, but their spines are not seen. The transverse processes and very short slender ribs are distinct. The long slender neural and hæmal spines in the caudal region are also conspicuous. The pectoral fins are not preserved. The dorsal fin clearly arises directly above the pectoral arch, extending continuously along the back to the caudal extremity, while the remarkably extended anal fin is continued equally far backwards. There are distinct indications of two expanded hypural bones at the tip of 
the tail, suggestive of a separate caudal fin, of which a few rays remain. The characteristic intermuscular bones are exhibited dorsally throughout the trunk, and below the vertebral axis in the caudal region. The limestone is stained by the fossil, but there are no traces of scales.

Lewis Coll.

P. 4751. Larger but more imperfect and distorted specimen, displaying parts of the head, pectoral arch, pectoral fin, and scales (Pl. XVIII. fig. 2). The stout supraoccipital bone of the skull (s.oce.) projects considerably backwards, and the rostrum is slender. The length of the cranium, indeed, appears to be more than three times as great as its width at the occiput. The right mandibular ramus is shown (md.), rising to a low coronoid process immediately behind its toothed portion. The clustered teeth are very stout and blunt. The vertebræ behind the head are exposed from above, but the neural spines are broken away from the much expanded arches. There are impressions of some of the short ribs; while a few of the pointed transrerse processes are preserved in the hinder part of the abdominal region. The tail is much distorted and too imperfect for description. The clavicles (cl.) are seen immediately behind the head, one of them displaying. its slender, arched form, with tapering upper end. One of the pectoral fins (pet.) is also preserved, though a little distorted and imperfect distally. Behind this, the brownish impression of the soft parts of the fish is curiously mottled, as if there were indications of small, rudimentary quadrangular scales. Further back, the course of part of the intestine is marked by its phosphatic contents.

Lewis Coll.

P. 4030. More imperfect small specimen, much distorted, showing the obtuse teeth.

Levis Coll.

48150. Portion of rery small eel, probably young of this species.

Lewis Coll.

\section{Urenchelys hakelensis (Daris).}

[Plate XVIII. fig. 3.]

1887. Anguilla hakelensis, J. W. Davis, Trans. Roy. Dublin Soc. [2] vol. iii. p. 626, pl. xx. fig. 3.

Type. Nearly complete fish; British Museum. 
373 
Vrenchelys sermanus, Hay.

1903. Ul.eerm., 0. D. Hay, Bull. Amer. Amm. N. H. vol xix.

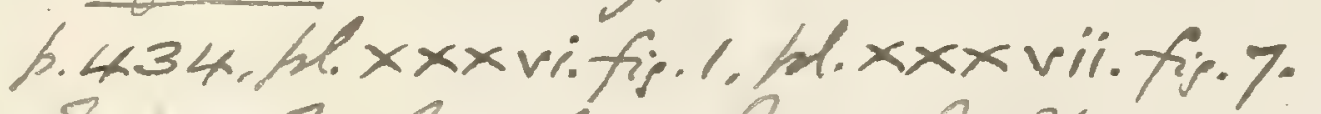

Fize. Finh; Amer hum. h. X.

Join. LZoz. Retaceous: Hajula, Zehanon. Pig963. One speciome.

Rer? Surian Protestant Collepsigoz.

1902. Urencholye anglieno, A. S. Wordward, Foss Gishes

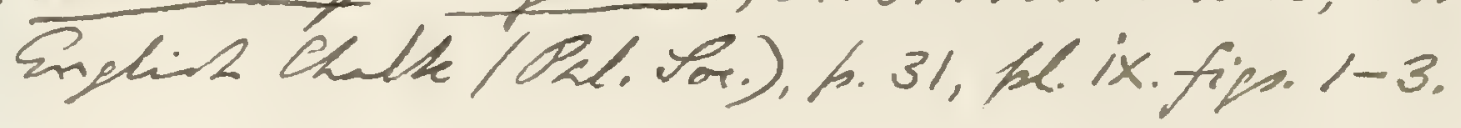




An imperfectly known species, represented only by small specimens not exceeding 0.1 in length. Length of head with opercular apparatus contained about seren times in the total length to the base of the caudal fin; anal fin less than twice as long as the portion of trunk in front of it.

A specimen of this fish in the Museum of the Syrian Protestant College, Beyrout, displays the caudal fin very clearly.

Form. \& Loc. Upper Cretaceous: Hakel, Nount Lebanon.

P. 4872. Type specimen, shown of the natural size in Pl. XVIII. fig. 3. The remains of the head are very imperfect, but present no features at variance with the interpretation of the affinities of the fish here suggested. The opercular apparatus is wide in proportion to its depth, and there seems to be a suboperculum between the operculum and the rery slender branchiostegal rays. The latter are long, but not curved upwards behind. The two sigmoidally bent claricles, with pointed ends, are partly shown; and there are traces of the scapular arch supporting a delicate pectoral fin. The vertebral column is imperfectly preserred, but throughout its length the expanded neural arches are shown to be relatively large. There are impressions of short, slenảer ribs in the abdominal region, while the neural and hæmal spines are stonter, though still slender in the caudal region. The rays of the dorsal and anal fins are very fine and difficult to observe. The former seems to extend along the whole length of the back, but in the abdominal region it is imperfectly preserved and crushed downwards upon the rertebral column. So far as preserved, the anal does not attain much more than half the extent of the dorsal fin. The imperfectly preserved caudal fin is clearly separate, and is formed of somewhat stouter rays supported by expanded hæmal spines.

Lewis Coll.

P. 4872 a. Fragment.

Lewis Coll.

P. 9423. Very small specimen, apparently showing caudal fin.

Egerton Coll.

Urenchelys anglicus, A. S. Woodward.

1900. Urenchelys anglicus, A. S. Woodward, Ann. Mag. Nat. Hist. [7] vol. v. p. 321, pl. ix. fig. 1.

Type. Imperfect head; Brighton Museum.

A comparatively large species, the skull attaining a length of 
about 0.07 . Head much deeper in proportion to its length than in the type species.

Form. \& Loc. Turonian: S.E. England.

38333. Fragmentary remains of small skull and mandible, showing delicate pterygoid arch and blunt mandibular teeth; Lower Chalk, Dover. Daniels Coll.

P. 4510 a. Fragment of somewhat larger skull and mandible; English Chalk.

Enniskitien Coll.

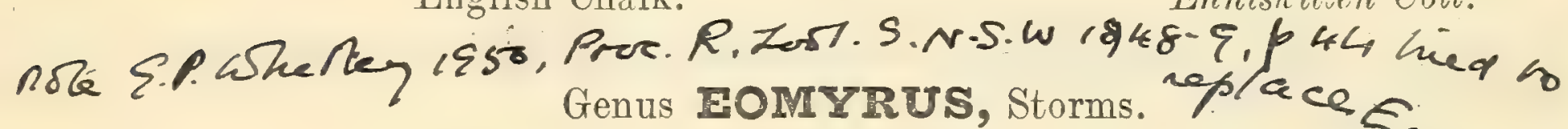

[Bull. Soc. Belge Géol. vol. x. 1898, Mém. p. 239.]

A genus founded on an imperfect cranium, which most closely resembles that of the existing Myrus, but differs from the latter in exhibiting a relatively larger basisphenoid and a larger anterior extension of the squamosal. Teeth on vomer and premaxillary region relatively large.

If the second and third extinct species mentioned below are correctly referred to this genus, its diagnosis may be extended thus:-Teeth bluntly conical. Vertebræ somewhat exceeding 100 in number. Pectoral fins small; dorsal fin arising above the pectoral arch and continuous with the anal round the pointed extremity of the tail. Scales absent.

\section{Eomyrus dolloi, Storms.}

1898. Eomyrus dolloi, R. Storms, Bull. Soc. Belge Géol. vol. x. Mém. p. 225, pl. v. figs. 8, 9, pl. ri. figs. 6-8.

Type. Imperfect cranium; Brussels Museum.

The type species, known only by the cranium and detached vertebræ. Length of cranium 0.03 , and maximum width at occiput $0.00 \%$.

Form. \& Loc. Upper Eocene (Wemmelian): Wemmel, Brussels.

Not represented in the Collection.

\section{Eomyrus latispinus (Agassiz).}

1835. Anguilla latispina, L. Agassiz, Neues Jahrb. p. 307 (name only).

1839-44. Anguilla latispina, L. Agassiz, Poiss. Foss. vol. v. pt. i. p. 15. pt. ii. p. 133, pl. xliii. fig. 4.

Type. Nearly complete fish; Paris Museum of Natural History. Length of head with opercular apparatus equalling about twice 


36133. Desunte afined A.S.W. 1902, p. 31, he. ix. fiy. 3.

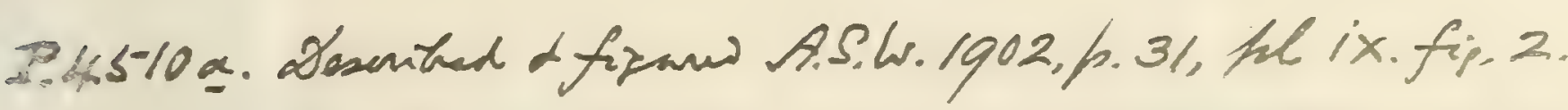

renchelys dowillei, F. Priem, in I.de Mnsan,

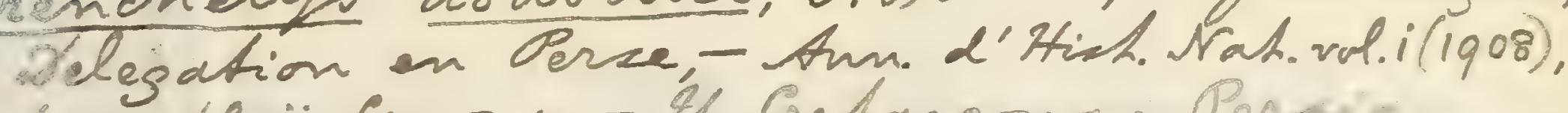

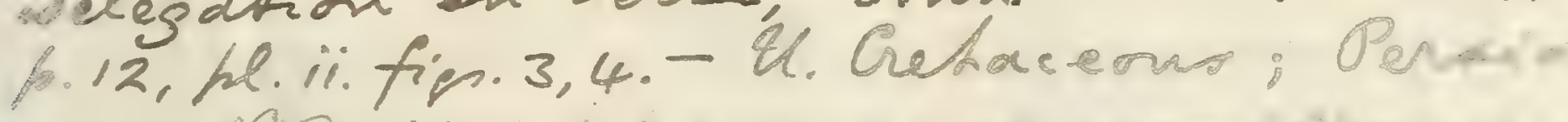

$\rightarrow$ of Eastin an (p.342), supparion the sp. now. ex.ty. ho refar wha genus! "y Eomurophis

10s: conym dollox, Mn. Teriche, Mém. Mme. Poy. Hish. Sat. Belg.vol.iii, Poirs. Eocines B.lg. p.210/reprinted in ném.e oc. Séol. Nond, vol. v. 1906, h. 288.

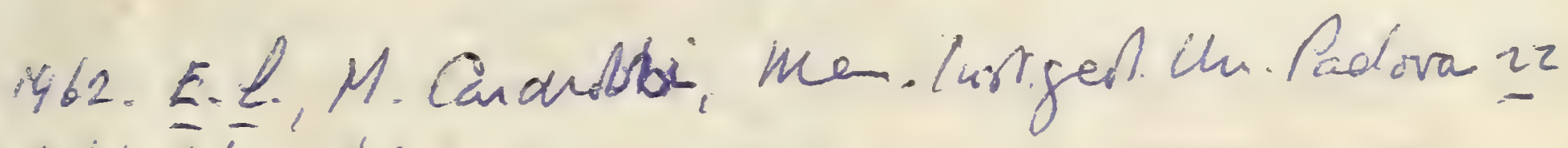
phel pher.y. 
R.10428. Fine specinen, in counterpart. Purcho"

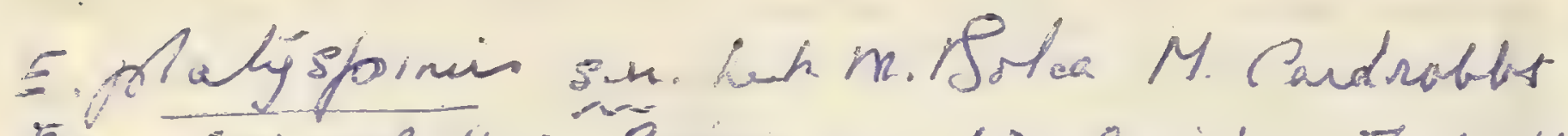

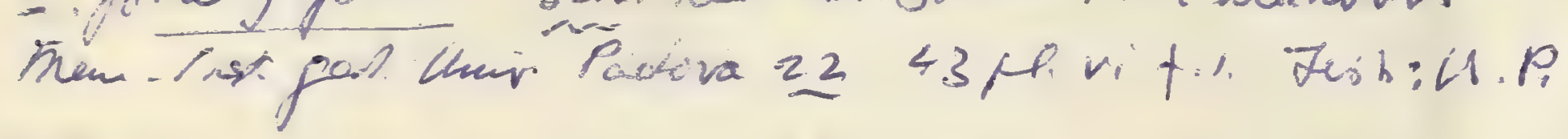

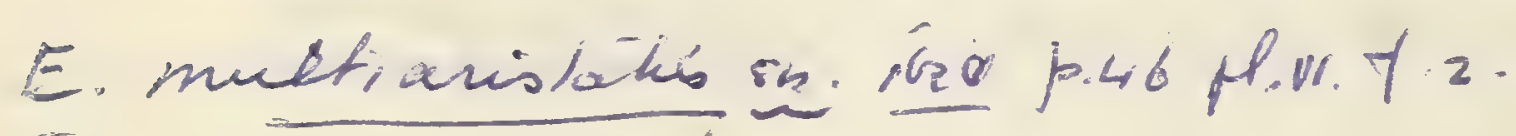

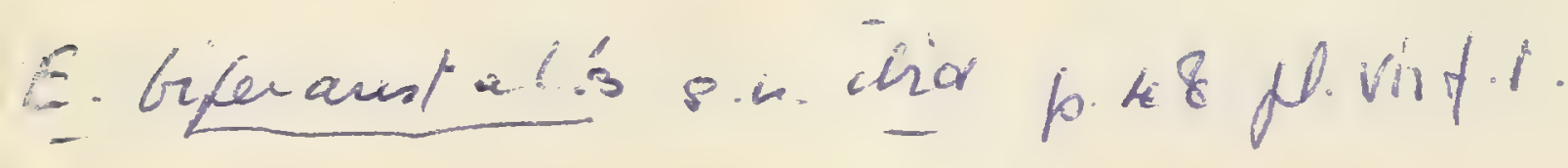

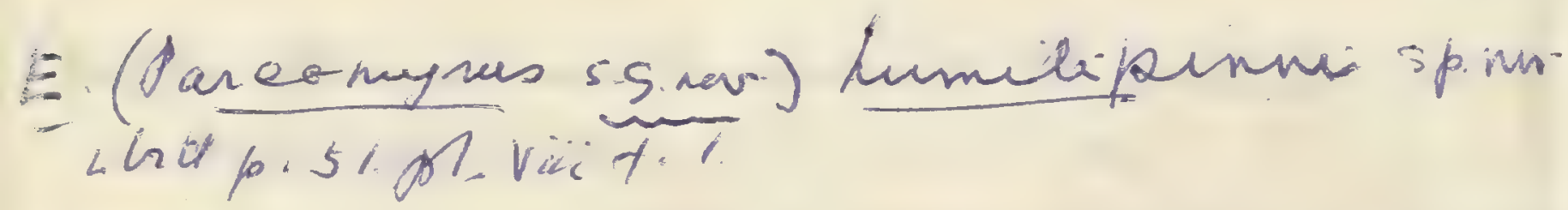

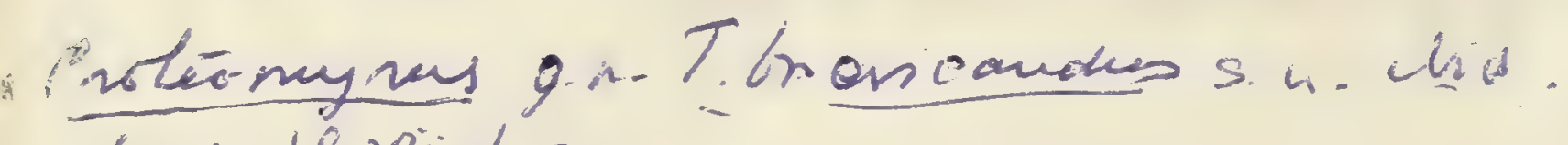

p.5 p p vi t. 2 .

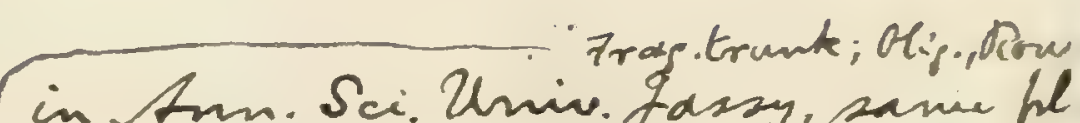
in Am. Sci. Univ. Yassy, samu $\mu$

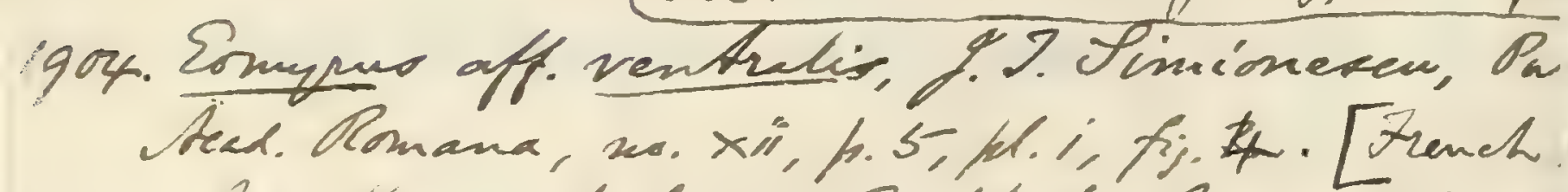

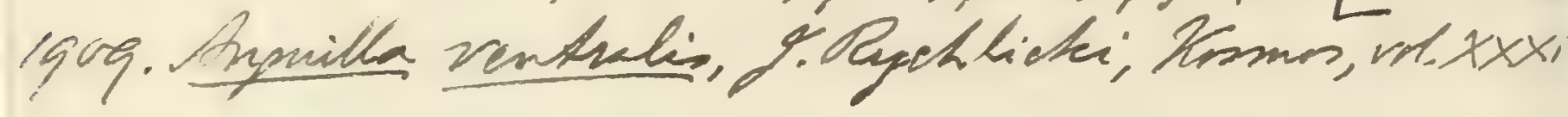




the maximum depth of the trunk and contained six times in the total length to the base of the caudal fin. Caudal region twice as long as the abdominal region. Anterior neural spines in form of rery broad laminæ.

This species is described by Agassiz as most closely related to the existing Myrus vulgaris, Kaup (Mircena myrus, Linn.), of the Mediterranean.

Form. \& Loc. Upper Eocene: N. Italy.

P. 942\%. Imperfect specimen wanting extremity of tail; Monte Bolca, near Verona. The maximum width of the cranium is shown to equal one third of its length, and the slightly expanded end of the slender rostrum is less elongated than in E. dolloi. The teeth, so far as preserved, are very stout and bluntly conical. The maxillæ are robust. The branchiostegal rays are not less than 15 in number, and do not curve upwards at their hinder end. The neural canal of the vertebral axis is seen to be rery large.

History unknown.

P. 8655. Fine specimen 0.3 in length; Monte Bolca. The head is more imperfect than in the prerious specimen, but similar branchiostegal rays are preserved. Remains of one of the small pectoral fins occur; and the dorsal fin is observed to arise directly above this fin. The hinder half of the caudal region is disturbed by an oblique fracture.

$$
\text { Purchased, } 1897 .
$$

P. 1889, P. 3875. Small specimen in counterpart, bent and broken at the hinder end of the abdominal region; Monte Bolca.

Egerton \& Enniskillen Colls.

Eomyrus ventralis (Agassiz).

1835. Anguill ventralis, L. Agassiz, Neues Jahrb. p. 307 (name only).

1839-44. Anguilla ventrcalis, L. Agassiz, Poiss. Foes. vol. v. pt. i. p. 15, pt. ii. p. 134, pl. xliii. figs. $2,3$.

1898. Anguilla ventralis (? = Eomyrus), R. Storms, Bull. Scc. Belge Géol. vol. x. Mém. p. 240.

Type. Nearly complete fish; olim Hartmann Collection.

A comparatively small and slender species, the length of the head with opercular apparatus contained eight times in the total length to the base of the caudal fin.

Form. \& Loc. Upper Eocene: Monte Bolca, N. Italऽ.

Not represented in the Collection. 
The small fish named Anguilla brevicula by Agassiz (Neues Jahrb. 1835, p. 307, and op. cit. vol. v. pt. i. p. 15, pt. ii. p. 134, pl. xliii. fig. 1), from Monte Bolca, may also belong to Eomigrus. It is not represented in the Collection.

Genus RHYNCHORHINUS, novum.

[ex. Agassiz, Poiss. Foss. vol. v.pt. ii. 1844, p. 139 (name only).]

An imperfectly definable genus, known only by the head, which closely resembles that of Eomyrus but appears to have a stouter rostrum.

\section{Rhynchorhinus branchialis, sp. nov.}

[Plate XVIII. fig. 4.]

1844-45. Rhynchorhinus branchialis, L. Agassiz, Poiss. Foss. rol. v. pt. ii. p. 139, and Rep. Brit. Assoc. 1844, p. 308 (name only).

Type. Abraded hinder portion of skull and mandible; British Museum.

The typo species, with skull about 0.05 in length. Width of occiput equalling about one third the total length of the cranium; length of coronoid region of mandible exceeding half that of the dentary border.

Form. \& Loc. Lower Eocene: London Basin.

P. 633. Type specimen, very imperfect and much abraded, comprising the hinder half of the cranium and mandible, both hyomandibulars, and part of the left preoperculum; London Clay, Sheppey. Egerton Coll.

P. 163. Slightly smaller abraded skull and mandible of the same type, shown in right side-view and from above of the natural size in Pl. XVIII. figs. 4, $4 a$; Sheppey. The occipital region is shortened by abrasion; but the limits of the parietals ( $p a$. ), extending as far forwards as the postorbital prominence, are shown. The squamosals (sq.) are extremely attenuated and produced in front. The anterior ends of the frontals $(f r$.$) are excavated in a$ sharp re-entering angle where they articulate with the relatively large mesethmoidal rostrum (eth.). The much expanded hjomandibular $\left(h \mathrm{~m}_{0}\right)$ is well preserved; and the mandibular articulation is directly beneath the postorbital prominence. The coronoid region of the mandible is relatively large; and the only well-preserved 
opp $\frac{\rho 42}{37}$

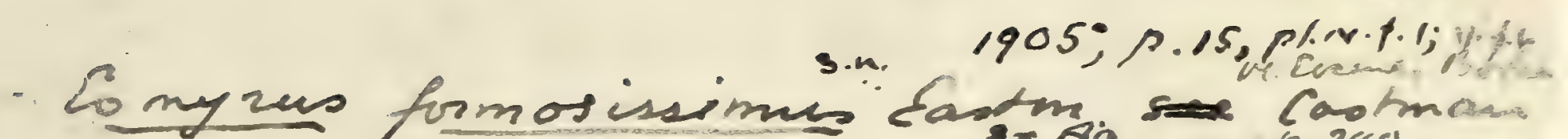

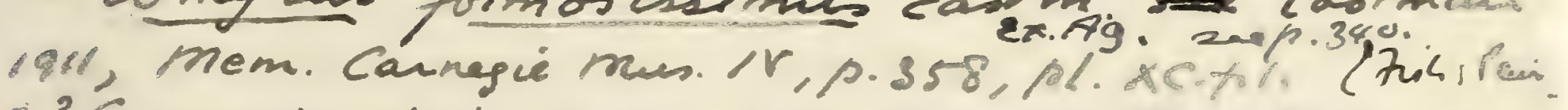

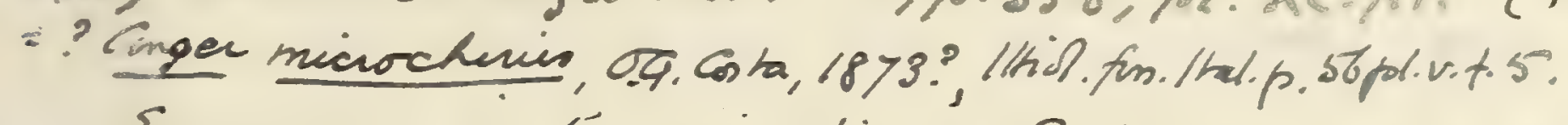

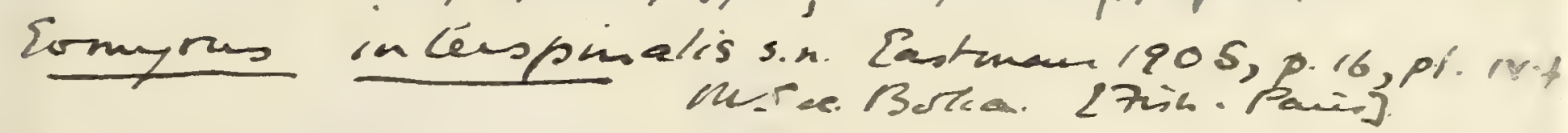

Ophisinus acuticandus, sere CP. Rashm

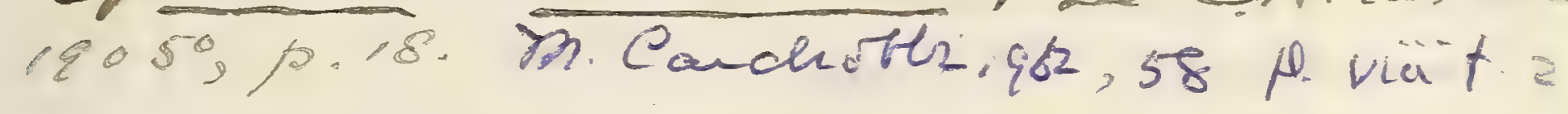

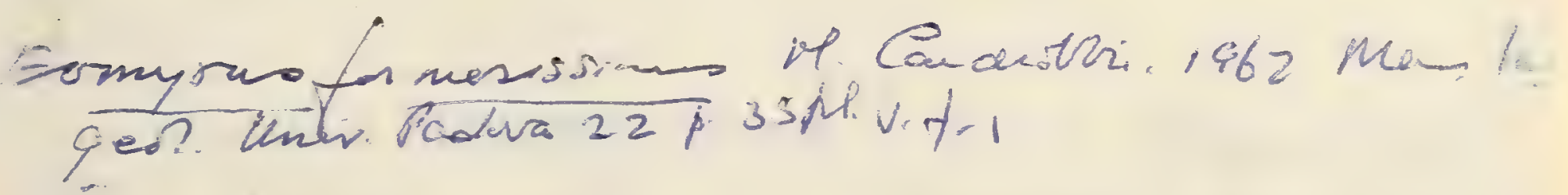


opp p. 343

R.m. Vogurd houd in Finier mus. Chusenge

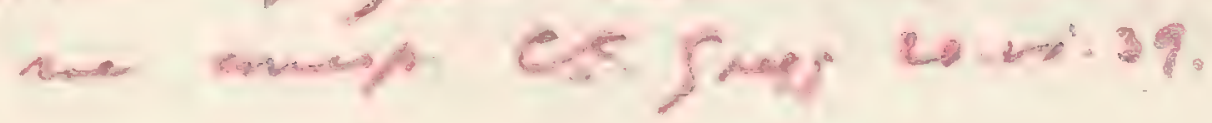

alpiozielli grar. Divericanda s.n Lut

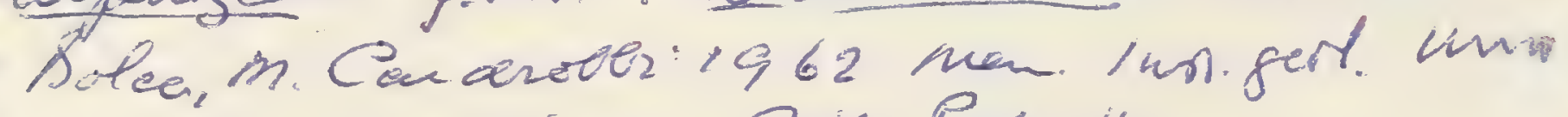

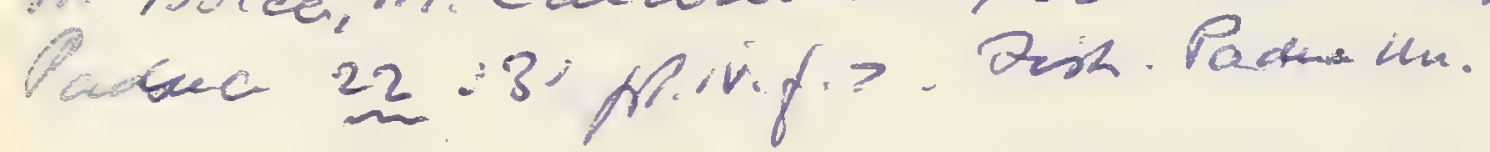

Mrylonurus franeens, 2.S. Lordur.

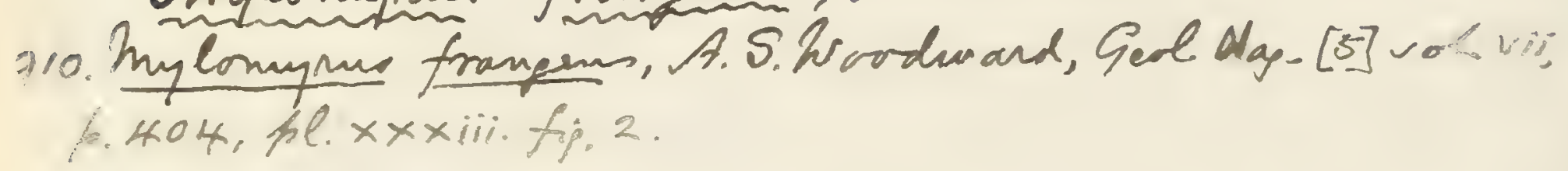

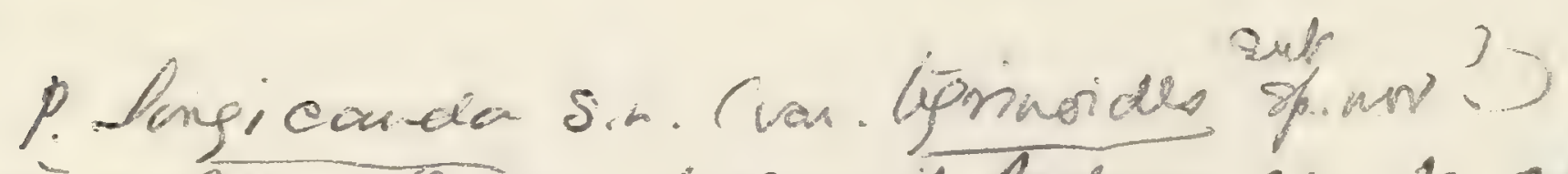

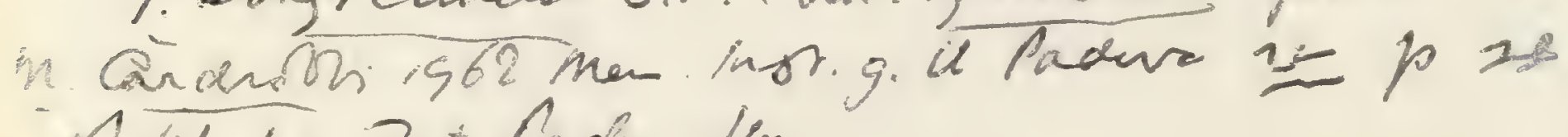
1. I.t.i. Dust Codure Un. 


tooth, near the symphysial end of the dentary, is rather large and sharply enical. An undetermined fragment of the upper jaw $\left(x_{0}\right)$ is preserved. Purchased, 1880. w.H.Shnutidle.

$28859,36118,36132,3889 \%-98,40521$. Imperfect pyritised skulls, partly of this, partly probably of the larger species; Sherpey.

Purchased, 1854-67.

Rojorom mojor.

Type. Imperfect head; British Museum.

About twice as large as the type species. Coronoid region of mandible about one third as long as the dentary border; tecth rery stout and bluntly conical.

Form. \& Loc. Lower Eocene: London Basin.

P. 1746 a. 'TJpe specimen, in nodule with pyrites; London Clar, Sheppey. The supraccipital forms a conspicuous crest. The squamosals are remarkably attenuated and produced forwards. The pterygoid arcade is shown to be moderately robust, with a cluster of bluntly conical teeth. Similar teeth are seen in the mandible, which, on the right side, exhibits the relatively short coronoid region noted in the specific diagnosis.

Egerton Cotl.

P. 1746 b. More imperfect larger head; Sheppey. The very small triangular operculum is shown, with remains of about 12 pairs of branchiostegal rays.

Egerton Coll.

P. 1745-46. More imperfect specimens, one exhibiting associated rertebræ; Sheppey.

Egerton Coll.

Genus PARANGUILLA, Bleeker.

[Atlas Ichthyol. vol. iv. 1864, pp. 5, 8.]

Syn. Enchelyopus, L. Agassiz (non Bloch \& Schneider, 1801), Poiss. Foss. vol. v. 1844, pt. i. p. 16, pt. ii. p. 137.

An eel generally resembling the species from Monte Bolca abore provisionally referred to Eomyrus, but distinguished by its more delicate skeleton and smaller head.

\section{Paranguilla tigrina (Agassiz).}

1796. Ophidium barbatum, G. S. Volta, Ittiolit. Veronese, p. clvii, pl. xxxviii. fig. (errore).

293

1835. Enchelyojus tigrinus, L. Agassiz, Neues Jahib. p. (nare

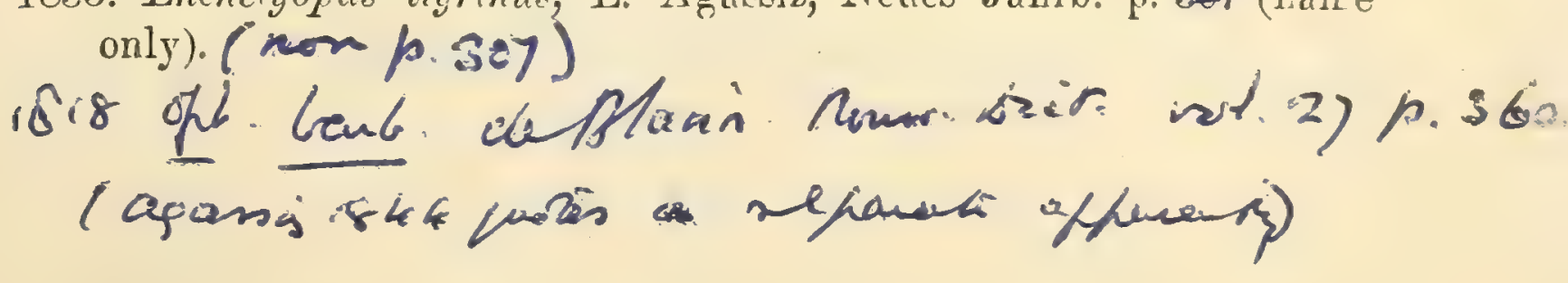


1839-44. Enchelyopus tigrinus, L. Agassiz, Poiss. Foss. vol. v. pt. i. p. 16, pt. ii. p. 137 , pl. xlix.

1864. Paranguilla, P. Bleeker, Atlas Ichthyol. vol. iv. p. 8.

1876. Enchelyopus tigrinus, F. Bassani, Atti Soc. Veneto-Trent. Sci.

Nat. vol. iii. p. 189.

Type. Nearly complete fish; Paris Museum of Natural History.

The type species, attaining a length of about 0.35. Length of head with opercular apparatus contained between nine and ten times in the total length to the base of the caudal fin; anal fin two thirds as long as the dorsal. Skin both of trunk and median fins mottled with large pigment spots.

Form. \& Loc. Upper Eocene: Monte Bolca, N. Italy.

Not represented in the Collection.

\section{Genus ANGUILLA, Shaw.}

[General Zoology, vol. iv. 1803, p. 15.]

Extremity of rostrum slightly expanded laterally for articulation with maxillæ; teeth small and arranged in longitudinal Tands or series. Operculàr apparatus well-developed, and the long, slender branchiostegal rays curving round it. Pectoral fins present; dorsal fin arising far behind the occiput, extending round the tail and continuous with the anal fin. Rudimentary scales embedded in skin.

Existing species both in the freshwaters and on the coasts of temperate and tropical regions.

\section{Anguilla leptoptera, Agassiz MS.}

1796. Murana conger, G. S. Volta, Ittiolit. Veronese, p. cvi. pl. xxiii. fig. 3 (errore) .

1835. Anguilla leptoptera, L. Agassiz, Neues Jahrb. p. 292 (name only).

Type. Nearly complete fish; Paris Museum of Natural History.

$A$ slender species attaining a length of about 0.3 . Length of head with opercular apparatus contained between nine and ten times in the total length to the base of the caudal fin; anal fin somewhat more than one and a half times as long as the portion of trunk in front of it; dorsal fin arising about midway between the pectorals and the anal fin. About 130 vertebræ.

Form.\& Loc. Upper Eocene: N. Italy.

P. 1890, P. 38\%6. Well-preserved specimen, in counterpart, bent and broken at the middle of the abdominal region; Monte 

Pa

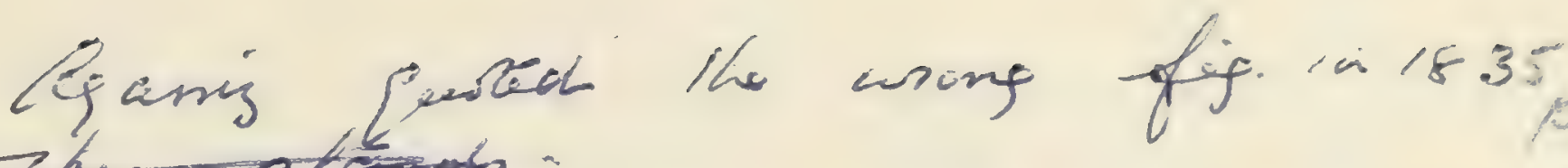

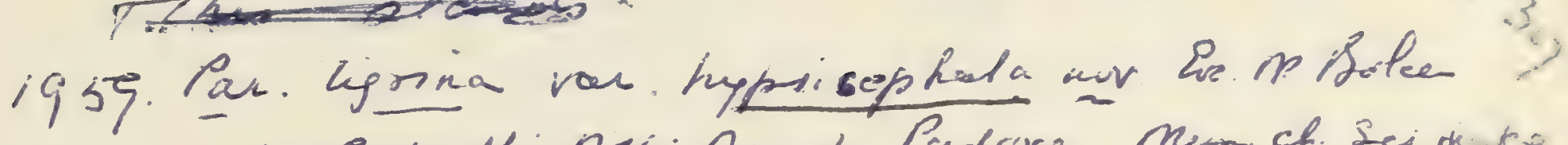

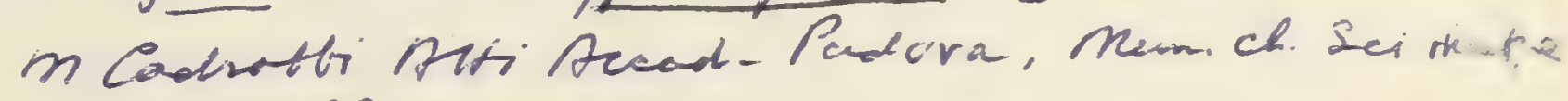
ner $Z^{\prime}, 2: 23 \cdot 7$, ith.

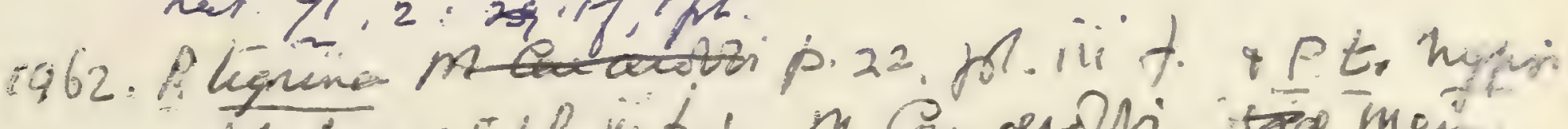

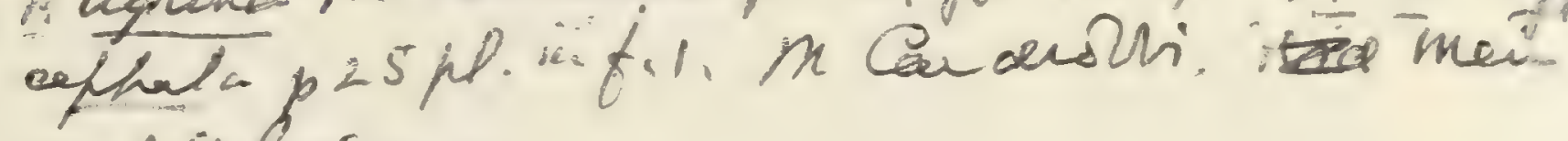
Instgen U. Gavera 22 .

Pisendoragcilla prinns

1962. P longipiunis sprist. In. Penartei

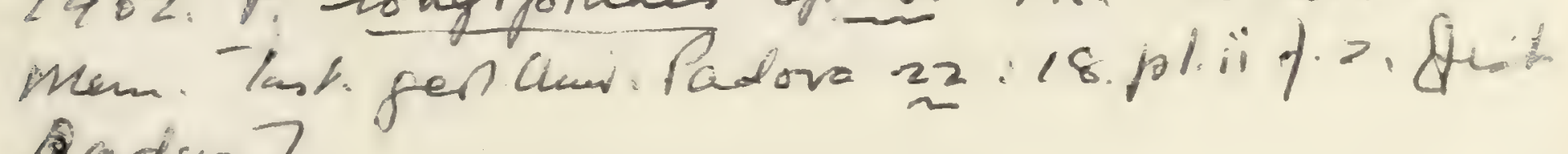
Padica 7

Poptonzuilla gre. hor.

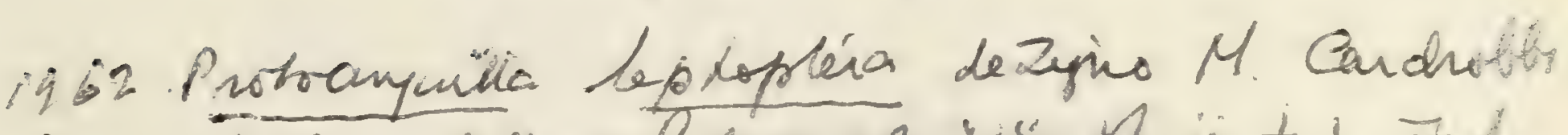

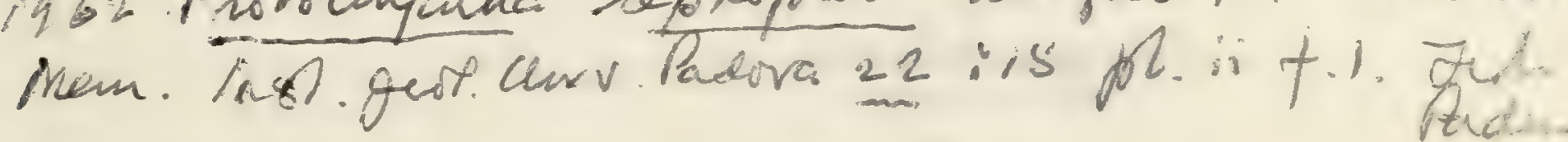
Ptidian. 
Anguilviales ghn nor.

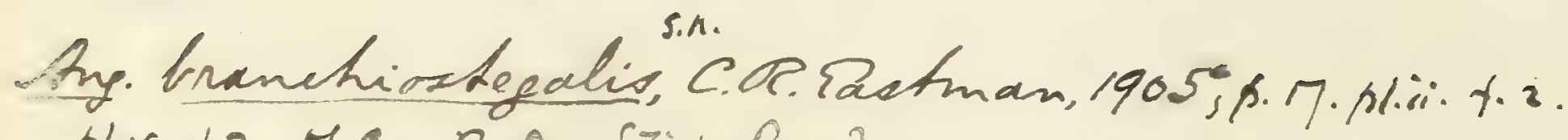
pl.v. r. 2. M. Era Bolea \{Fus: Paris\}.

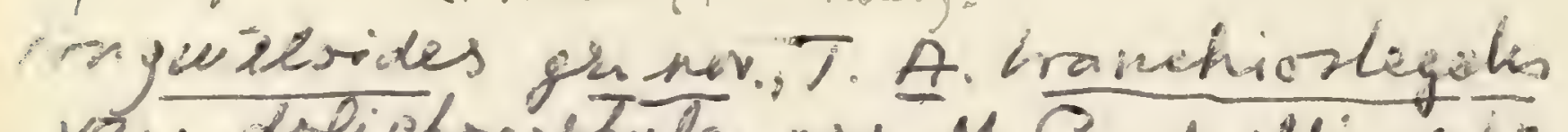

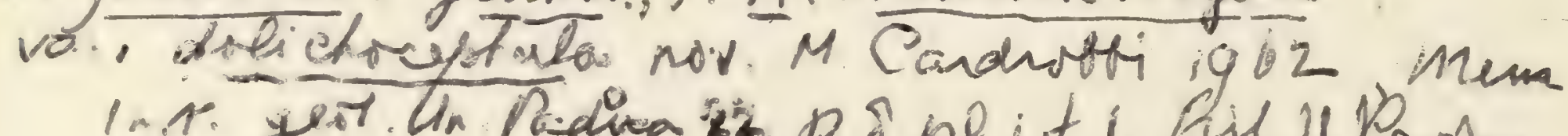

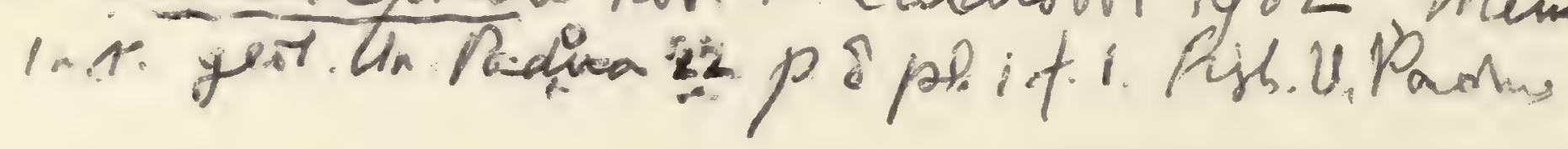

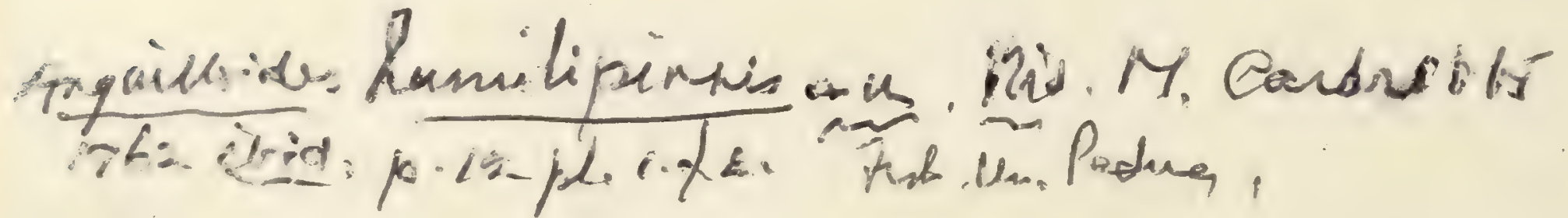


Bolca. The head is shown to be rather short, with stout jaws; and the rery slender branchiostegal rays curre round the remains of the opercular apparatus. The robust clavicles are exhibited, but the pectoral fins are destroyed. The median fins hare the extent noted in the specific diagnosis. No traces of scales can be distinguished.

Egerton \& Enniskillen Colls.

P. 1891 , P. $387 \%$. Imperfect small specimen, in counterpart, $0 \cdot 16$ in length, probably young of this species; Monte Bolca.

Egerton \&. Ennishillen Colls.

P. 3878. Fragmentary anterior half of fish labelled by Agassiz; Monte Bolca.

Enniskitlen Coll.

\section{Anguilla elegans, Winkler.}

1861. Anguilla elegans, T. C. Winkler, Descript. Poiss. Fuss. d'Oeningen (Natuurk. Verhandl. Holland. Maatsch. [2] vol. xiv.), p. 5i, pl. rii. fig. 21.

Type. Nearly complete fish; British Museum.

A robust species, attaining a length of about 0.5 . Length of head with opercular apparatus contained ninetimes in the total length to the base of the caudal fin; median fins as in A. leptoptera. About 100 vertebræ. Teeth slender, conical.

Form. \& Loc. Upper Miocene: Oeningen, Baden.

42769. Type specimen, in counterpart, described and figured by Winkler, loc. cit. Tan Breda Coll.

427\%0. Broken and imperfect specimen, in counterpart, noticed by Winkler, loc. cit. p. 57. Van Brecla Coll.

The following specific names have also been given to indeterminable specimens :-

Anguilla branchiostegalis, L. Agassiz, Neues Jahrb. 1835, p. 307 (name only).-Upper Eocene; Monte Bolca.

Anguilla interspinalis, L. Agassiz, ibid. p. 307 (name only).Upper Eocene; Monte Bolca. Se Conmyrus p.34z. Anguilla multiradiata, L. Agassiz, Poiss. Foss. vol. v. (1843-44), pt.i.p. 15, pt. ii. p. 135, pl. xxix. fig.1.-Lower Oligocene; Aix-en-Provence. [Portion of tail; olim John Murray Coll.]

Anguilla pachyura, I. Agassiz, ibid. (1843-44), pt. i. p. 15, pt. ii. p. 135, pl. xxix. fig. 2.-Upper Niocene; Oeningen, Baden. [Portion of tail : Geological Museum, Zürich. 
A portion of trunk, apparently of the existing Anguilla vulyaris, from the Quaternary of Piànico, Lombardy, is described by F. Bassani, Atti Soc. Ital. Sci. Nat. vol. xxix. (1886), p. 347, pl. ix. fig. 1.

\section{Genus IETTASTOMA, Rafinesque. \\ [Caratt. Alcuni Nuov. Gen., 1810, p. 66.]}

Snout much produced, slender and depressed; teeth small and conical but of unequal size, in clustered bands. Pectoral firs absent; median fins much extended, passing continuously round the tail. No scales.

Existing species in the deep sea off Japan and in the Mediterranean.

\section{Nettastoma bolcense, Bassani.}

1898. Nettastoma bolcense, F. Bassani, Palæontogr. Italica, rol. iii. p. 84 , pl. ix. fig. 6 .

Type. Tearly complete fish; Geological Museum, Unirersity of Padua.

A species attaining a length of about $0 \cdot 1$, with approximately 100 rertebræ. Head with opercular apparatus occupying about one fifth of the whole length of the fish.

Form. \& Loc. Upper Eocene: Monte Bolca, N. Italy.

Not represented in the Collection.

The following specimens are not generieally and specifically determinable:-

P. $188 \%$, P. $3880-81$. Three very slender imperfect fishes, tho longest 0.17 in length; Upper Eocene, Monte Bolca. The first two are lahelled Leptocephalus tonia by Egerton and Agassiz respectively, this name having been proposed, without definition, by Agassiz, Neues Jahrb. 1835, p. 307. Egerton \& Enniskillen Colls.

P. 1888 , P. 3879. Four very small, immature fishes, one being in counterpart and labelled Leptocephalus gracilis by Egerton and Agassiz; Nonte Bolca. The name mentioned was proposed, without defiuition, by Agassiz (Neues Jahrb. 1835, p. 307) for a specimen figured by G. S. Volta, Ittiolit. Veronese (1796), pl. xxiii. fig. 2. The species is also referred to by F. Bassani, Atti Soc. Veneto-Trent. Sci. Nat. rol. iii. (1876), p. 189.

Egerton \& Enniskillen Colls.

2340ミ. Similar specimen, in counterpart; Monte Bolea. 
DEPRANAIDAE! IONd.

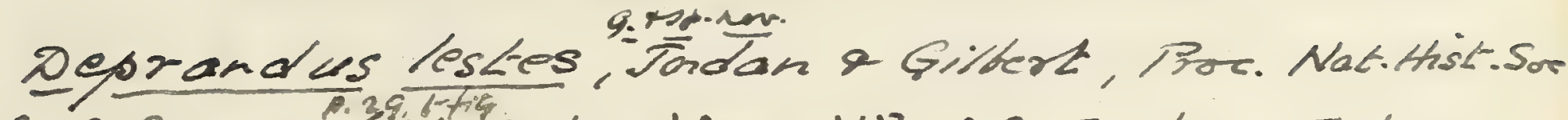

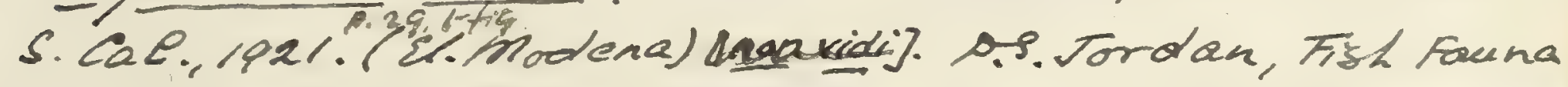

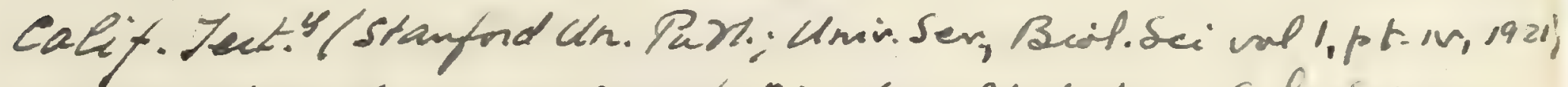

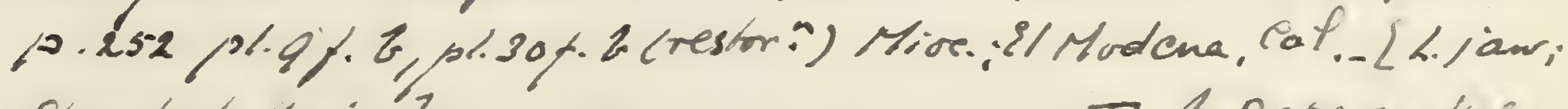
shanford duni.' I. of Deprandus. haull. S. Cah. Acad. Sci. xxiï $1924 p \cdot 49, p l s . \angle q L$.

$=$ 
Sphagebranchus (?) pusium

Mastygocercus rermiformis

Pphichthys acuticandus

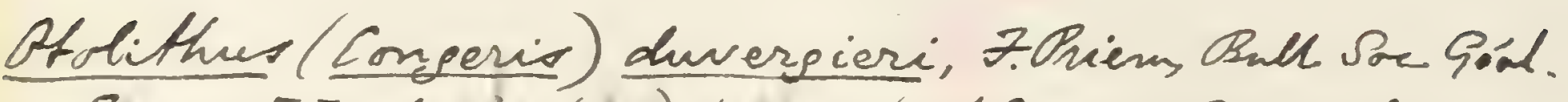
Drance [4] vd. xiv (1914), h.249, heat.fip.9.- Burdigalian; Léäenan, Gironde.

Ptolithus (Conperis) bapointi, 7. Priem, Bull. Sor. Sedl.

France [x] vol, vi $(1906), 6.275$, Lesch-fip. 40-43.Yhresian; Oize.

Remicththe mecenenemi, 7.0hiem, in F.de morgan, Dellépation en Verse, - Amn. d'thist.

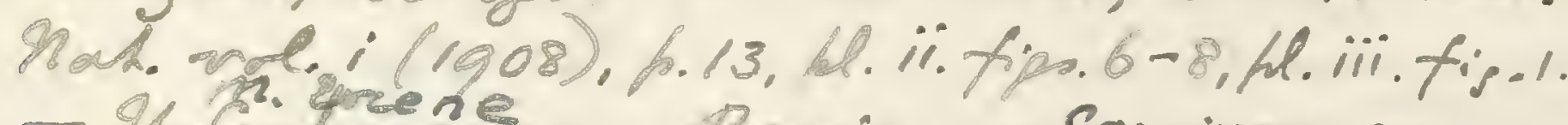

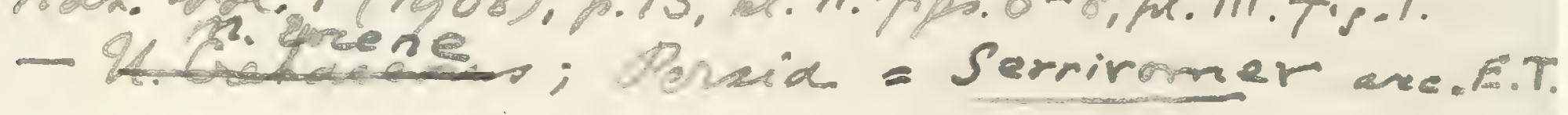



P. 8952-53. Two portions of similar immature fishes; Nonte Bolca.

Castelli Coll.

P. 8951. Immature fish with very small head, apparently of the form named Leptocephalus medius by Agassiz, without definition (Neues Jahrb. 1835, p. 307); Monte Bolca. A similar fish seems to be figured under the name of Murcena raca by Volta, op. cit. pl. liii. fig. 2.

Castelli C'oll.

The following species have not been defined and are not represented in the Collection:-

Ophisurus acuticaudus, L. Agassiz, Neues Jahrb. 1835, p. 307 (name only). Murcena ophis, G. S. Volta, Ittiolit. Veronese (1796), p. cliv. pl. xxiii. fig. 1 (errore).-Upper Eocene; Monte Bolca.

Sphagebranchus forrnosissimus, L. Agassiz, loc. cit. 1835, p. 307 (name only). Ophidium burbatum, G. S. Volta, op. cit. (1796), p. clvii. pl. xxxviii. fig. 1.- - Upper Eocene; Monte Bolca.

The otolith described as follows seems to belong to this family:-

Otolithus (Congeris) brevior, E. Koken, Zeitschr. deutsch. geol. Ges. vol. xl. (1888), p. 293, pl. xriii. fig. 7.-Lower Tertiary; Jackson River, Mississippi.

\section{Suborder VII. PERCESOCES.}

Vertebral centra always complete constricted cylinders, none coalesced. Supraoccipital extending forwards between the reduced parietals; squamosal rudimentary and fused with the large pterotic; mandible simple, each ramus consisting only of two elements (dentary and articulo-angular), rarely with a supplementary bone in the position of the coronoid. Pectoral arch suspended from the cranium; precoracoid arch absent; infraclavicular plates absent; pectoral fin with not more than four or five basals. Pelvic fins abdominal, their supports never in contact with the clavicle. Dorsal fin with or without an anterior spinous portion. In the living forms-air-bladder closed, without pneumatic duct, in the adult (physoclystous); optic nerves decussating; intestine without spiral valve.

For notes on the osteology of existing members of this suborder, sce E. C. Starks, Proc. U.S. Nat. Mus. rol. xxii. (1899), pp. 1-10, pls. i.--iii. 
Synopsis of Families.

I. Pelric fins without anterior spine.

Vertebræ numerous (above 40), none with transverse processes; spinous portion of dorsal fin imperfectly differentiated ...............

Vertebræ numerous (above 40), none with transrerse processes; dorsal fin extended, without spinous portion ..................

Vertebræ numerous (above 40), the abdominal centra with transverse processes; dorsal fin remote, without spinous portion .............

II. Pelvic fins with anterior spine.

Vertebræ numerous (above 30) ; dentition ustially feeble; pelvic fins far back .....................

Tertebræ few (about 24); dentition feeble or absent; pelvic fin-supports in contact with postclavicle ...... Tertebræ few (about 24); dentition powerful; pelvic fins far back ....

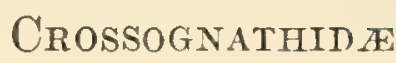

$[(p .348)$.

Amodytide (p. 354).

$[$ (p. 356).

Atherinide (p. 358).

Mugilide (p. 363).

Sphyranid (p. 365).

\section{Family CROSSOGNATHID E.}

Trunk more or less elongate and laterally compressed. Premaxilla excluding maxilla from border of upper jaw ; cleft of mouth small, with feeble dentition; opercular apparatus complete, with few branchiostegal rays. Vertebræ numerous, probably between 40 and 50 in total length. Pelvic fins more or less remote, without spine, but with only 6 to 8 divided rays; an extended dorsal fin, apparently with anterior spinous portion incompletely differentiated; anal fin small and remote or absent. Scales in regular series; lateral line distinct.

An imperfectly known extinct family represented only by Crossognathus, Syllamus, and probably allied genera of the Cretaceous period.

\section{Genus CROSSOGNATHUS, Pictet.}

[Foss. Terrain Néocom. Voirons (Paléont. Suisse), 1858, pt. iii. p. 27.]

Head and trunk laterally compressed, and snout acutely pointed though not produced. Orbit very large and sclerotic capsule 


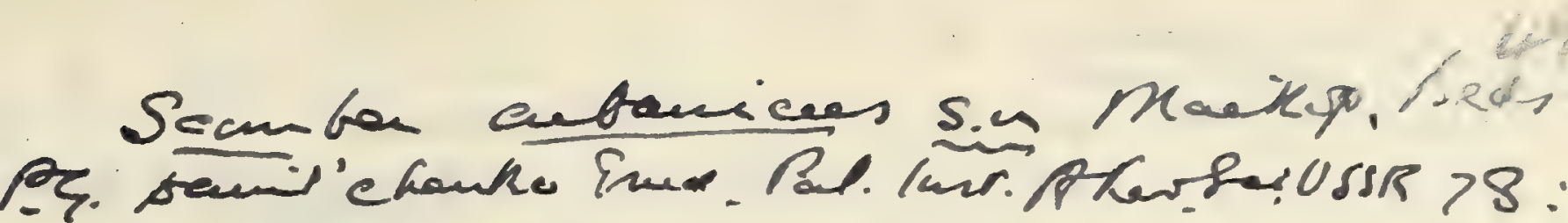
M. $16 \times 1,28.31$.

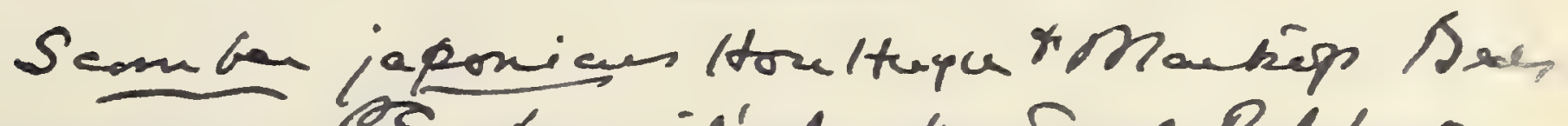

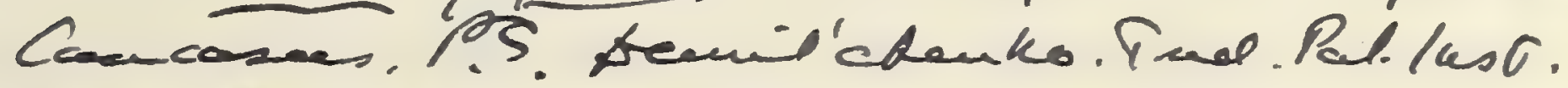
athow_su: wosh 1960 28 :157 M.22 f.2. 
Otisoplites Gill

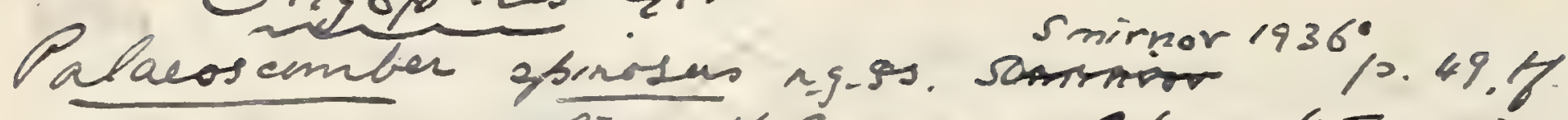
151679 , plin. Fejor. N. Cancasus. Olicopotiles spimosus

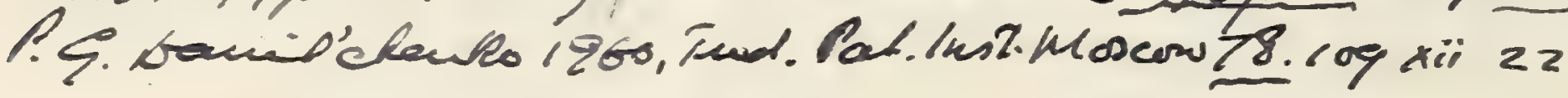

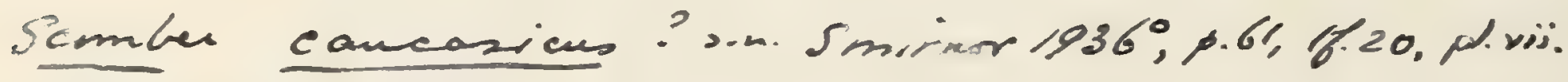

Fig.33. Oligir. N. Cancasms.

Scanken colvair Gmelni, Jorirnor 1936; p.64, plviil. 34 .

Olijue. N. Cancasus. (2uratsop-usp)

Secomber nomuerais.n 3.'S Sapan, H. NirNo 1952. Nokyo

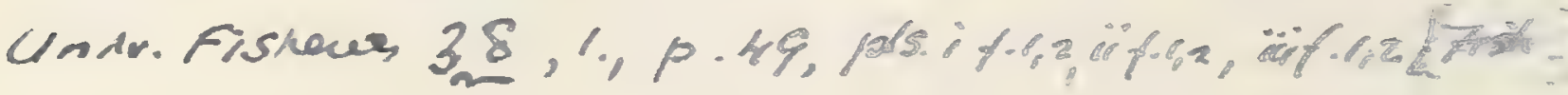

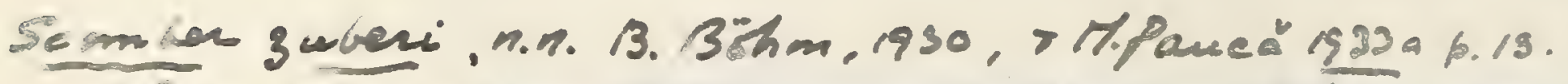

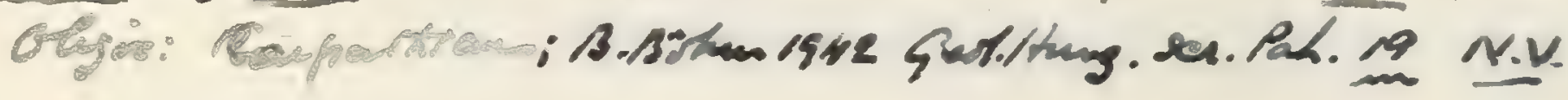

Scomber dolloi, Mr.Zeriche, Mém. Mmu. Mry. Hirt. Nato Belg.vd. (1905), h. ; Mém. Sor. Géd. Nord, vol.v(1906), p.239, pl.xiii.fig. - Bruxallian; Belgion. [Prtion f head; hus. Brussels.]

Fligurenicus

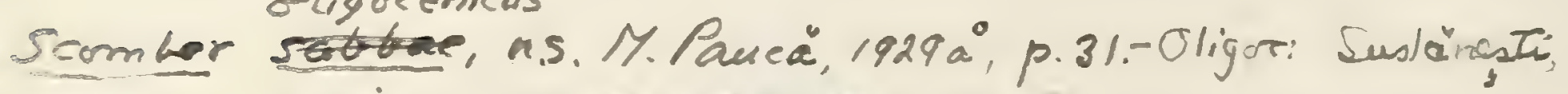
Roumenia. CFishes: Coll.

Scomber voitestii, a.j. M. Pauca", 1929, Bull. Sect. Seri. Cead. Roumaine,

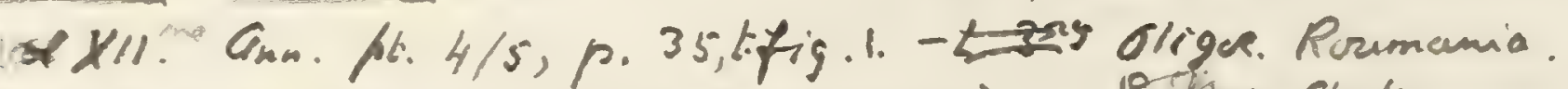

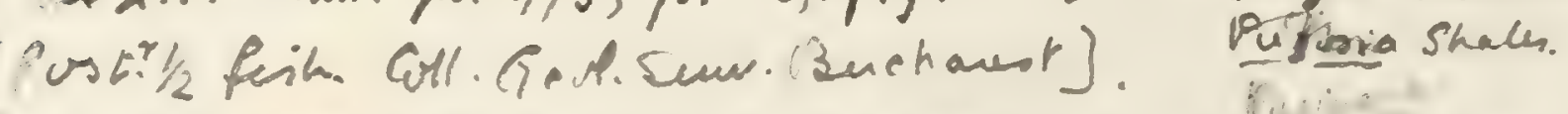

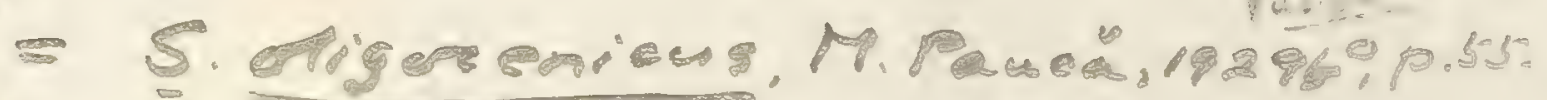

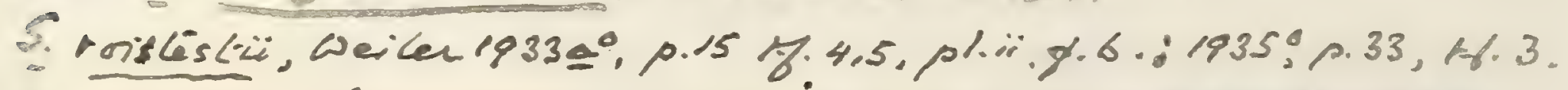

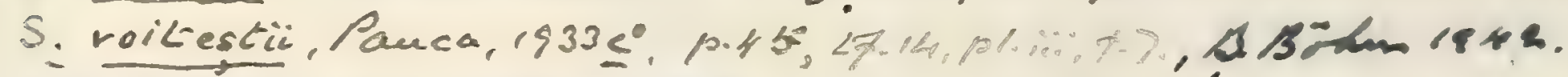

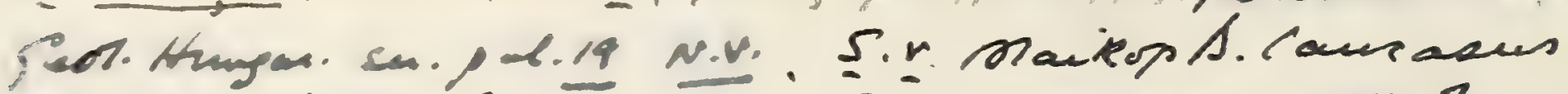

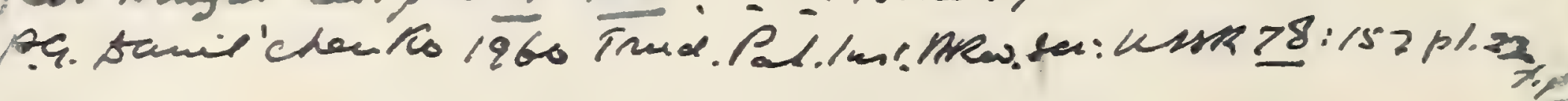






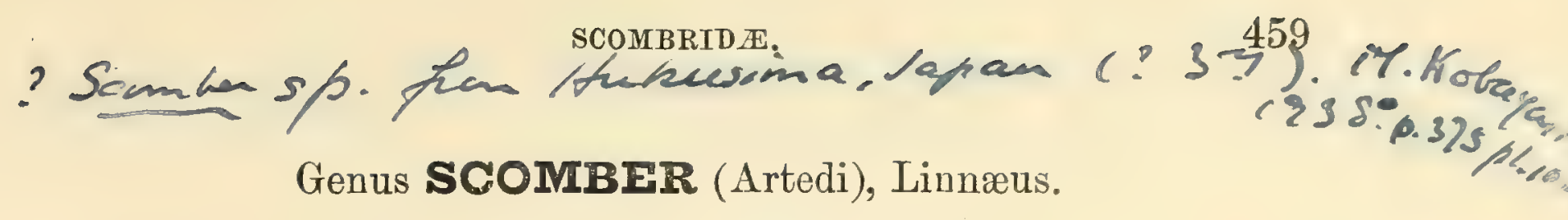

[Syst. Nat. ed. 10, 1758, p. 297.]

Trunk elongate-fusiform; the slender caudal pedicle without median lateral keel. Teeth small and cnnical, on margin of jaws, vomer, and palatines; gill-rakers long, slender, and numerous. Vertebræ about 14 in the abdominal, 16 or 17 in the caudal region; the centra much constricted, but without lateral pits ; all hæmal arches simple. Pectoral and pelvic fins small; dorsal fins widely separated, the anterior consisting of 9 to 12 spines simply articulated with their supports; posterior dorsal and anal fins small, similar, and opposite, followed by 5 to 9 detached finlets; caudal fin deeply forked. Scales very small, uniformly covering the trunk, scarcely if at all enlarged in the pectoral region.

Recent species are very widely distributed in temperate and tropical seas.

The following extinct species have also been referred to this genus, but there are no examples in the Collection :-

Scomber antiquus, J. J. Heckel, Denkschr. k. Akad. Wiss., math.naturw. Cl. vol. xix. pt. i. (1861), p. 74, pl. viii. fig. 11. (?) Scomber cfr. antiquus, F. Bassani, Atti R. Accad. Sci. Napoli [2] vol. iii. (1889), no. 6, p. 76, pl. xi. fig. 2, and Atti R. Istit. Veneto [7] vol. iii. (1892), pp. 1034, 1038.Middle Miocene; Margarethen, near Vienna. (?) Lower Miocene; Chiavon, Novale, \& Salcedo, Vicentin, N. Italy. [Imperfect fish ; Lyceum, Oedenburg.]

Scomber planovatus: Thynnus planovatus, D. G. Kramberger, Djela Jugoslav. Akad. vol. xvi. (1895), p. 63, pl. xi. fig. 2.-Upper Oligocene ; Trifail, Steiermark. [Imperfect fish ; Zilli Museum.]

Scomber priscus, D. G. Kramberger, Beitr. Paläont Oesterr.Ungarns, vol. ii. (1882), p. 119, pl. xxiv. fig. 3.-Upper Miocene ; Podsused, Croatia. [Imperfect fish ; University

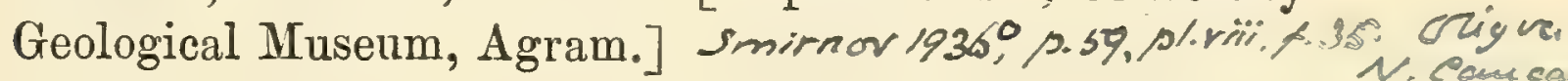

Scomber (Auxis) sarmaticus, D. G. Kramberger, Rad Jugoslav. Akad. vol. cri. (1891), p. 112, pl. viii. fig. 1.-Upper Miocene; Podsused and Dolje, Croatia. [Opercular bones, \&c.; University Geologieal Musenm, Agram..]

Scomber steindachneri, D. G. Kramberger, Beitr. Paläont. Oesterr.Ungarns, vol. ii. (1882), p. 119. Scomber sujedanus, F. Steindachner, Sitzungsb. k. Akad. Wiss., math.-naturw. 
Cl. vol. xxxviii. (1860), p. 776, pl. ii.-Upper Miocene; Radoboj, Croatia. [Imperfect fish; Court Museum, Vienna.]

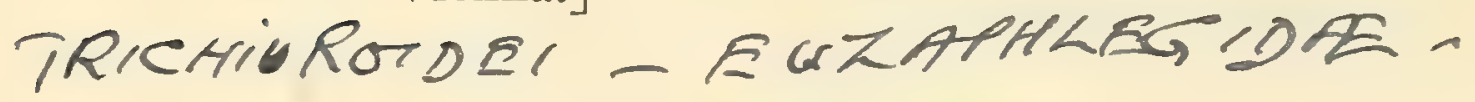

Genus PALIMPHYES, Agassiz.

[Poiss. Foss. vol. v. pt. i. 1844, p. 46.]

As Scomber, but caudal pedicle stouter, pectoral fins relatively large, and vertebræ slightly more numerous.

\section{Palimphyes elongatus (Blainville).}

1755. Figure by G. W. Knorr, Samml. Merckwürdigk. Natur, pt. 1. pl. xxi. fig. 1 .

1818. Clupea elongata, H. D. de Blainville, Nouv. Dict. d'Hist. Nat. vol. xxvii. p. 315.

1835-44. Palimphyes longus, L. Agassiz, Poiss. Foss. vol. v. pt. i. p. 46, pl. xix.

1835-44. Palimphyes brevis, L. Agassiz, ibid. p. 47, pl. xx., pl. xxi. figs. 1, 2. [Distorted fish; British Museum.]

1843-44. Palimplyyes latus, L. Agassiz, ibid. p. 48, pl. xxviii. fig. 1. [Distorted fish; Geological Museum, Zürich.]

1847-48. Palimphyes gracilis, C. G. Giebel, Neues Jahrb. 1847, p. 667, and Fauna d. Vorw., Fische, p. 70. [Distorted fish; Geological Museum, University of Halle.]

1847-48. Palimphyes crassus, C. G. Giebel, ibid. p. 666, and ibid. p. 71. [Ditto.]

1886. Palimphyes glaronensis, A. Wettstein, Fischfauna Tertiaer. Glarnerschief. (Denkschr. schweiz. Palaeont. Geș. vol. xiii.), p. 88, pl. ii. figss. 1-6. [Distorted fish; Geological Museum, Zürich.].

Type. Distorted fish; Geological Museum, Zürich.

The type species, attaining a length of about 0.4. Proportions uncertain, but length of head with opercular apparatus equalling about half that of the vertebral column. Vertebræ 16 in the abdominal, 22 in the caudal region. Pectoral fins, when adpressed, reaching the beginning of the caudal region; anterior dorsal fin consisting of 10 spines; posterior dorsal and anal fins with about 20 articulated rays, of which an uncertain number are detached finlets.

Nearly all the known specimens of this species are much distorted, and it seems probable that Wettstein is correct in proposing the synonymy given above.

Coupalations

Form. \& Loc. Oligocene: Canton Glarus, Switzerland.

P. 1994, P. 4128-29. Three imperfect specimens apparently elon- 


$$
\text { Sermier scomber Stefono } 1918=\frac{\text { Myctophumb }}{8 \cdot V \cdot 0}
$$

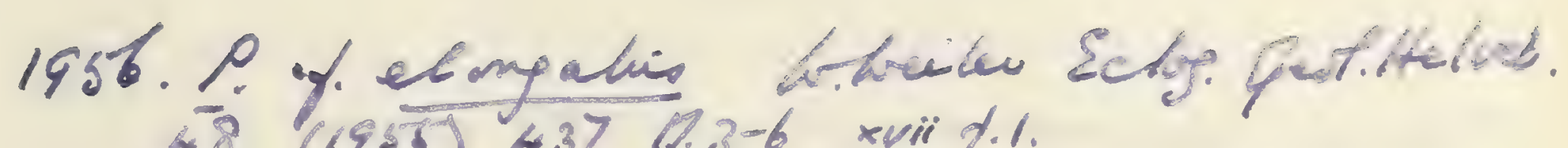
88 (1950) 437 f.3-6 xuii $\%$

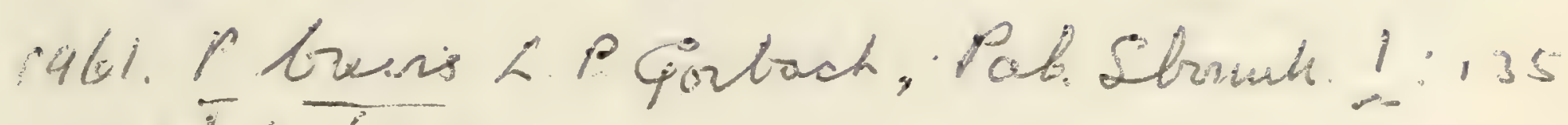
pit. $\bar{f} \cdot 2,3$. 
TRISMIUROID - EUZAPIKEGIDA

Palimphy2s chadumicuen s.4. Maiksp tPeds

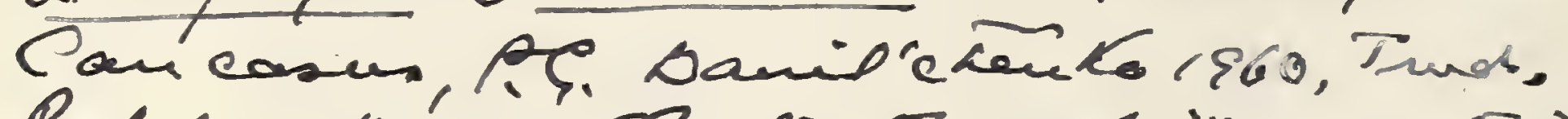

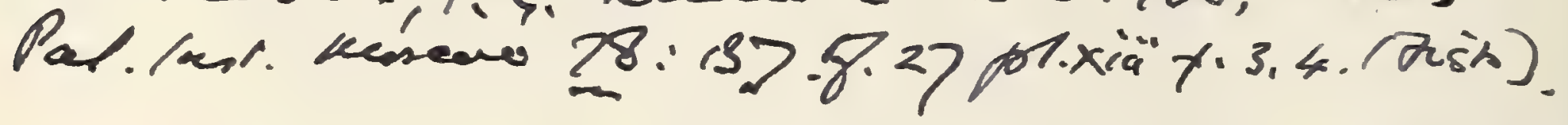

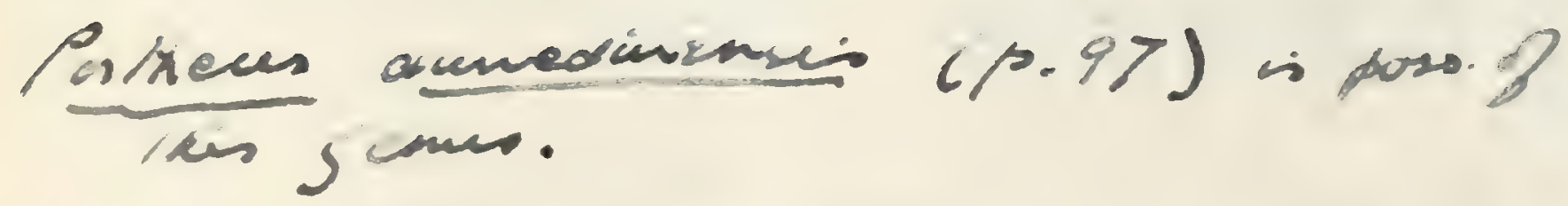


gated by distortion; Engi. Two are labelled "Palimphyes longus, Ag.," by Agassiz.

Egerton \& Enniskillen Colls.

P. 1993 a, P. 412\%. Type specimen of so-called Palimphyes brevis, in counterpart, figured by Agassiz, loc. cit. pl. xxi. figs. 1, 2; Engi. The fish is evidently shortened by crushing.

Egerton \& Enniskillen Colls.

36090. Specimen about 0.15 in length, apparently shortened and deepened by crushing; Plattenberg, near Matt.

Purchased, 1861.

33947. Imperfect specimen shortened by distortion.

Presented by Miss Elizabeth Warne, 1859.

P. 4952. Trunk of fish shortened by distortion; Plattenberg.

Presented by John Edward Lee, Esq., 1885.

P. 1993. Scattered remains; Engi.

Egerton Coll.

P. 5945. Scattered remains, labelled "Palimphyes glaronensis, Wettst." by Wettstein.

Purchased, 1889.

\section{Genus SCOMBRINUS, novum.}

[ex Agassiz MS., Rep. Brit. Assoc. 1844 (184a), p. 308.]

An imperfectly known genus founded on the skull, which is essentially identical with that of Scomber, but with larger teeth. Frontal bones flattened and rugose, the flattened area tapering backwards mesially to a point meeting the crest of the supraoccipital; fossæ for lateral muscles of trunk not extending forwards much beyond the hinder margin of the frontals. Teeth on margin of jaws rather large, stout, conical, and well-spaced, not much laterally compressed. Scales small and smooth, not much enlarged in the pectoral region.

\section{Scombrinus nuchalis, sp. nov.}

1845. Scombrinus nuchalis, L. Agassiz, Rep. Brit. Assoc. 1844, p. 308 (name only).

Type. Imperfect head; British Museum.

The type species, with head and opercular apparatus attaining a length of about $0 \cdot 12$, but usually smaller. Length of cranium equalling somewhat less than twice its maximum width; fossæ on cranial roof for lateral muscles extending forwards to the middle of the cranium above the middle of the orbit; maximum depth of 
mandible at least one third its length; superficial rugosity on cranial roof and dentary fine and delicate. Teeth moderately stout, quite smooth, with apices slightly incurved.

Form. \& Loc. Lower Eocene (London Clay): London Basin.

P. 4148. Very fragmentary small head with opercular apparatus, labelled as intended to be the type specimen; Sheppey. The jaws with teeth are not shown. Enniskillen Coll.

38919. Fragmentary head and abdominal region, showing scales with parts of the anterior dorsal and pelvic fins; Sheppey.

Bowerbank Coll.

P. 356 a. Two more imperfect specimens displaying anterior squamation, some of the scales extending over the operculum; Sheppey.

Purchased, 1881.

P. 9455. Fine comparatively large head with opercular apparatus, displaying teeth; Sheppey.

Purchased.

P. 9456. Two smaller imperfect heads, showing teeth; Sheppey.

Purchased.

P. 7524. Imperfect head with opercular apparatus; Sheppey.

Caleb Evans Coll.

40204. Fragmentary head; Sheppey.

Purchased, 1867.

P. $945 \%$. Smaller fragmentary head; Sheppey.

Purchased.

4311\%. Imperfect small head, displaying opercular bones; Primrose Hill, London.

Wetherell Coll.

P. 1742. Five fragmentary specimens; Sheppey. Egerton Coll.

P. 4147. Three fragmentary specimens; Sheppey.

Enniskillen Coll.

24614. Hinder half of cranium; Sheppey.

Purchased, 1850.

Scombrinus macropomus (Agassiz).

1835. Cybium macropomum, L. Agassiz, Poiss. Foss., Feuill. p. 42 (name only).

1839-44. Cybium macropomum, L. Agassiz, Poiss. Foss. vol. v. pt. i. p. 62, pl. xxvi. figs. 1-3.

1854. Cybium macropomum, R. Owen, Catal. Foss. Rept. \& Pisces Mus. Roy. Coll. Surg. p. 161.

Type. Imperfect head; Museum of Natural History, Paris.

A species known only by the head with opercular apparatus, 
which attains a length of about $0 \cdot 2$. Length of cranium equalling twice its maximum width; fossæ on cranial roof for lateral muscles not extending forwards beyond hinder border of orbit; maximum depth of mandible less than one third its length; superficial rugosity on cranial roof and dentary comparatively coarse. Teeth well spaced, not very variable in size.

Form. \& Loc. Lower Eocene (London Clay): London Basin.

P. 4145. Fine head, considerably larger than the type specimen; Sheppey.

Enniskillen Coll.

P. 4144. Abraded large head, labelled by Agassiz; Sheppey.

Enniskillen Coll.

28758. Head, wanting occipital region; Sheppey.

Purchased, 1853.

P. 1756. Imperfect rostrum of smaller skull; Sheppey.

37759. Cranium; Sheppey.

Egerton Coll. Saull Coll.

38920, 38943. Two imperfect crania; Sheppey. Bowerbank Coll.

P. 166. Cranium, broken across middle; Sheppey.

Purchased, 1880.

28713, 28759. Three imperfect occipital halves of cranium; Sheppey. Purchased, 1853.

4310\%. Similar specimen; Sheppey.

Wetherell Coll.

P. 9480. Similar specimen; Sheppey. Enniskillen Coll.

P. 175\%. Two more imperfect crania; Sheppey. Egerton Coll.

P. 7382. Fragmentary hinder portion of cranium, derived from London Clay ; Red Crag, Waldringfield, Suffolk.

Prestwich Coll.

P. 8985. Similar specimen; Coralline Crag, Sutton, Suffolk. Presented by Lady Prestwich, 1896.

\section{Genus AUXIS, Cuvier.}

[Règne Animal, ed. 2, vol. ii. 1829, p. 199.]

Trunk elongate-fusiform; the slender caudal pedicle with strong median lateral keel. Teeth minute and conical on margin of jaws, none on palatines, rare on vomer; gill-rakers long, slender, and numerous. Vertebræ 30 to 40 in total number; the centra much 
constricted, with one lateral pit; base of hæmal arches in hinder abdominal region a small trellis-work. Pectoral and pelvic fins small; dorsal fins widely separated, the anterior consisting of 10 to 16 spines, most of which are clasped by the enlarged $U$-shaped upper end of a shortened support ${ }^{1}$; posterior dorsal and anal fins small, similar, and opposite, followed by 5 to 8 detached finlets; caudal fin deeply forked. Small scales only on anterior part of trunk, those of pectoral region somewhat enlarged and compacted.

One existing species in Atlantic, Mediterranean, and Indian Oceans.

\section{Auxis (?) propterygius (Agassiz).}

1796. Scomber pelamis, G. S. Volta, Ittiolit. Veronese, p. lxvi. pl. xiv. fig. 2 (errore).

1796. Scomber trachurus, G. S. Volta, ibid. p. exxv. pl. xxix. fig. 2 (errore).

1796. Ophicephalus striatus, G. S. Volta, ibid. p. cxciii. pl. xlviii. fig. 1 (errore).

1796. Labrus bifasciatus, G. S. Volta, ibid. p. cciv. pl. 1. fig. 1 (errore).

1818. Scomber pelamis (?), H. D. de Blainville, Nouv. Dict. d'Hist. Nat. vol. xxvii. p. 345 .

1818. Scomber trachurus, H. D. de Blainville, ibid. p. 345.

1818. Labrus bifasciatus ("? une des espèces de scombres"), H. D. de Blainville, ibid. p. 351 .

1835. Thynnus propterygius, L. Agassiz, Neues Jahrb. p. 292 (name only).

1835-44. Thynnus propterygius, L. Agassiz, Poiss. Foss. vol. v. pt. i. p. 55, pl. xxvii.

1876. Thynnus propterygius, F. Bassani, Atti Soc. Veneto-Trent. Sci. Nat. vol. iii. p. 183.

1882. Thynnus propterygius (?=Auxis), D. G. Kramberger, Beitr. Paläont. Oesterr.-Ungarns, vol. ii. p. 118.

Type. Imperfect fish; Museum of Natural History, Paris.

An imperfectly known species attaining a length of about 0.25 . Length of head with opercular apparatus contained about three and a third times, maximum depth of trunk approximately five times in the total length of the fish to the base of the caudal fin. Vertebræ 30 in total number. Posterior dorsal and anal fins with about 12 articulated rays, followed by 7 finlets.

Form. \& Loc. Upper Eocene: Monte Bolca, near Verona.

P. 4137. Small specimen 0.1 in length, probably young of this species. The enlarged scales in the pectoral region are

${ }^{1}$ See Kramberger, Beitr. Paläont. Oesterr.-Ungarns, vol. ii. (1882), p. 117, fig. 1. 


\section{ALPHABETIOAL TNDEX.}

\section{Shrthe numbers wi pages on which mere incidentai reforences ocur are printeri in itailics.}

Abramis. $31 \%$

$=$ vrawa. 319

- zémtinias parginatis. ․․․․

Acanthederma. orbloulatum, os.

orate, is.

spinosum, his.

Acanthomuilus, 616 . saneliz. 1910 .

Acanthonemopsis. \pm (1).

aneinini. 450.

Acanthonemus, $24 \%$ bertiundi. \pm \pm ! hamencosus. $\frac{1}{4}+9$. subalurels. \pm 19 .

icanthonotos. IsI.

sialcus. $=1$.

armatus. yal.

licarix. $\pm 5 \%$

Acanthophoria, 5. 391.

1 bazica. 800.

Acanthopieurus

beris.

seratis. $=6 \%$

Acantisoosis, $\because 20$.

acutes, $05 \overline{5}$.

ungustus, 321 .

1. ANTH PTERTGIS. SEt.

icantisurus.

andisit, $00 \%$.

Aurain $-93 \frac{4}{2}$

sulurrit sit.

maine sit.

mueri. cit.

wais, it.

ments ontit.

moveres, â.
Acanus, evto.

:auispina. 01 .

äclartus, :01.

moaticus. $56 \%$

maeilis, 502.

Iongispina. S00.

minor. .iou.

golongus.

, Tails joul.

patersianus. 301.

sumusis. Ju!

smuri, ritis.

Acara. 55.

Acerina. vuluris. ido?

Acestrus, 41 uriacus. ti)t.

A cinenser metaceus. 201.

Acrociontosaurus, 3.

arcineri, +1$)$

Acrogaster.

brevicostatus, :09.

Riunesi, ol).

necreil, 80.

minutus. 00 .

mpt!s, $25 !$ ?

Acrognathus. $2 \frac{1}{2}$ coops. $2 \pm 0.09 .27$

Conicis. $-\frac{1}{2} \frac{1}{2}$

Acrogramratolepis. is.

Eremiuid.

AROTLRDE, Sh:

Acropoma, $=1$

iti. \pm 1 .

Agonus. í

ตาำ

- Bipichtints. -

minge 2 .
Aipichtings

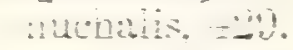
Dretiosia.

Teilier. $=-1$.

Alausa Latissima. Bbo.

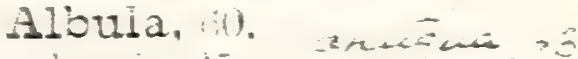

breris, 45.

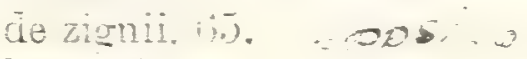

Zitia, 1is.

orfeni. 64

ALBUTIDE. T.

Alburnus. in

mioenenicus, 319.

steindachent 31.

Alepisaurus. i-2 ocis

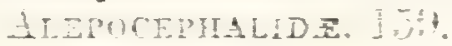

Alosa. $1+14$

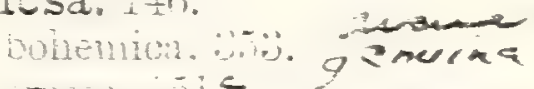

restabic gor:ar.

ciongata. 1,il.

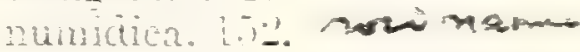

emoui :

Alosina.

samonead Lis:

Amolypharrngo-

$$
\text { son. } 544
$$

Amoroterns wifors:

$$
\because 7
$$

Amiar incier. it

Amir iarestensis. 2.?.

Amirus. 28

anceliatis 80.

maconnelli, the are : .

immodytes.

volunus 31 .

AMUnyma. 851 .

Amonemstus, …

unianums.

Ampiziaga.

bacisoterat. Ilds. 




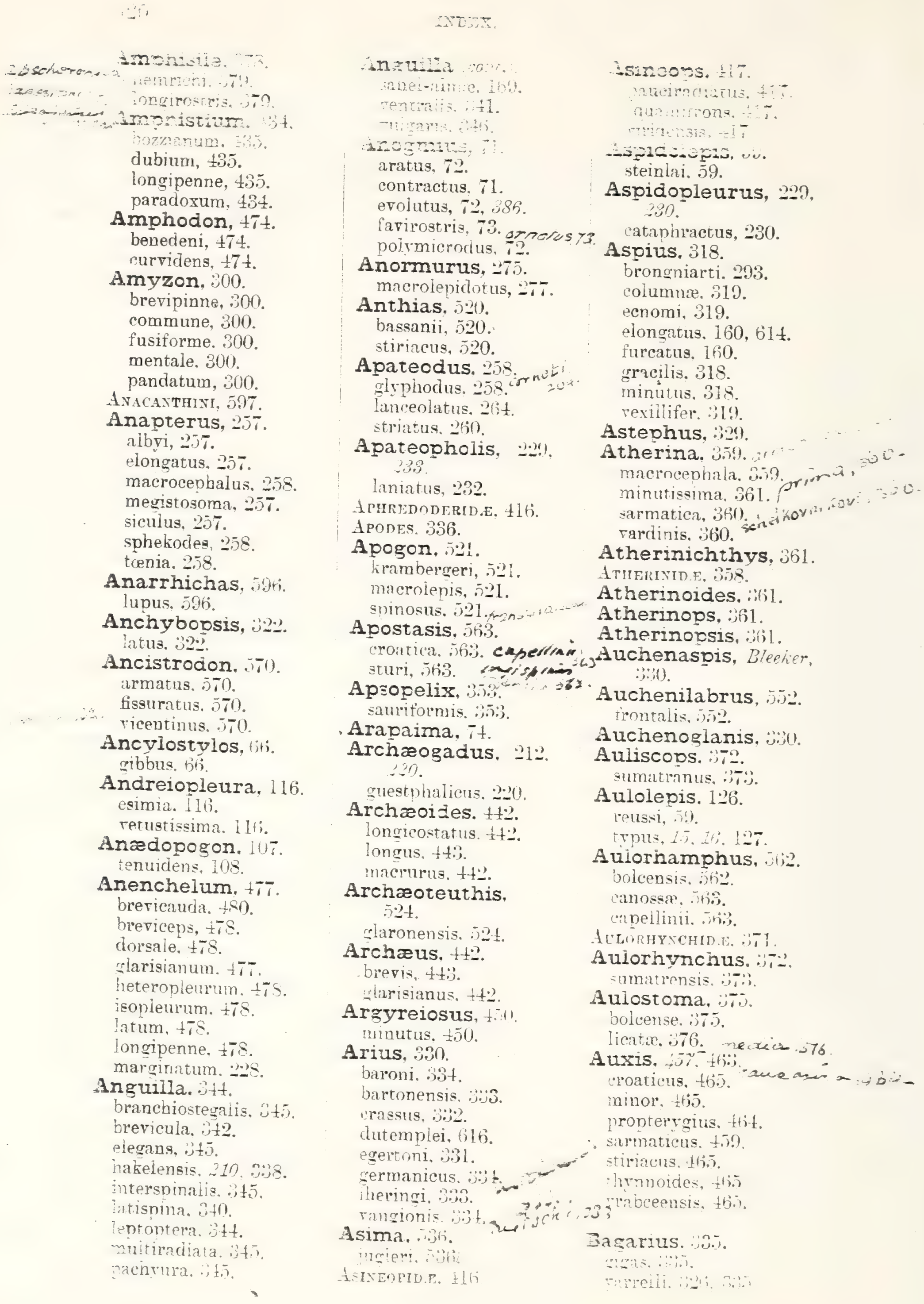


and

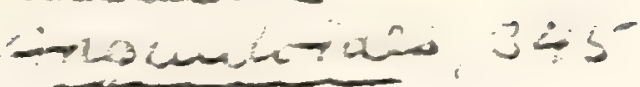

Pranum, 289 .

Anokerismu. ir.

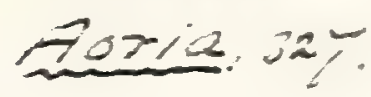

Antrodontan, 536 .

- Enciachenco. S20.

- Essietrum

spiverroider

तथल

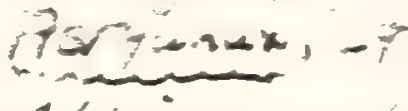

Ateringonella 612

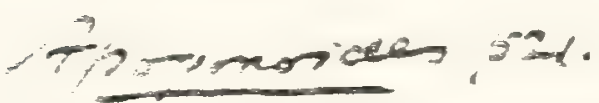

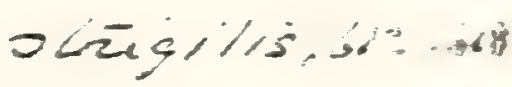

7450 2erix, 304,016 .

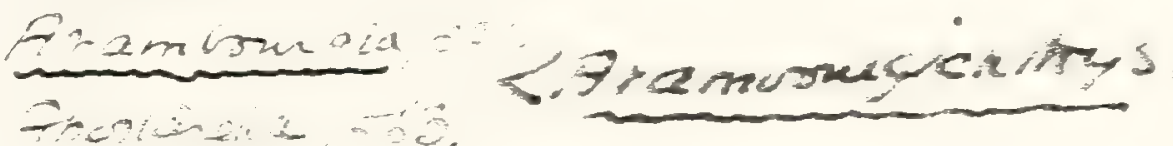

Aracena, sts

Kershawi, sô.

Aracostests, 08 :

701 550.618 .

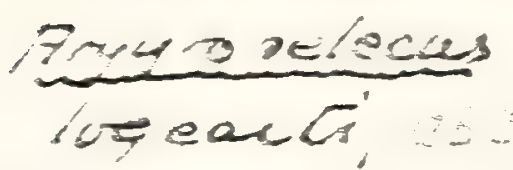

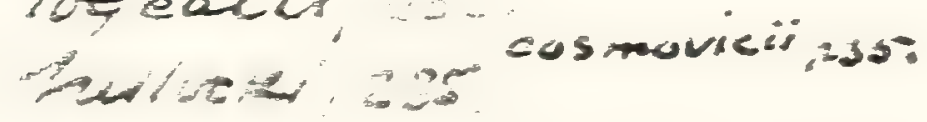

Pagosedis ont

Soresiviss

$-30$

Anstorion, nus s9. Avitolabiax,

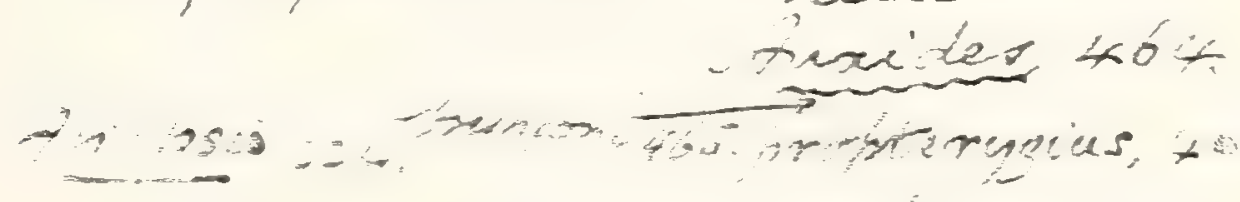

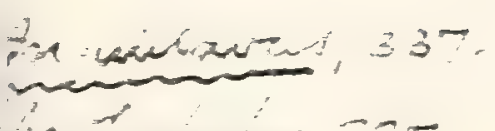

Arsolarias 603.

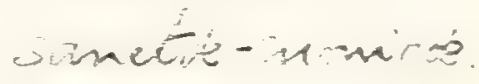

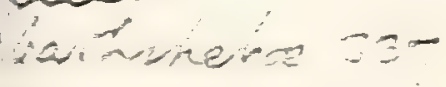

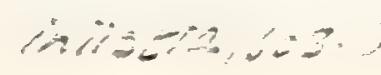

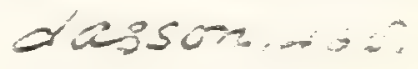

$78 \ldots-10,58$

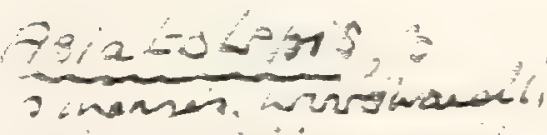




Baliswardant aso

Baizanopmios, 7\%

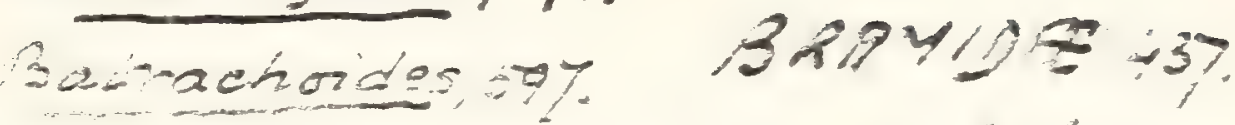

Cincuarna, 4 .

Cessanora $24 \mathrm{H}$.

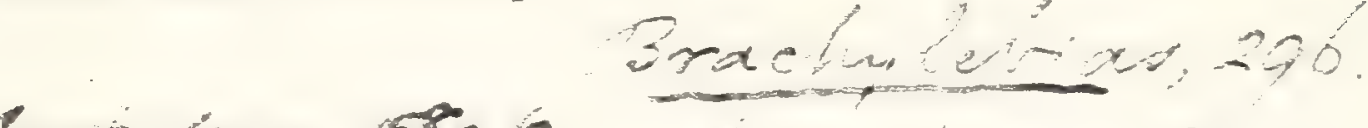

permecur, RQO

Sachmanna. 3z4 thenamus, 442.

Sansina, 73

moinima, 73.

Bering 68

Beition, 358 .

peronides.35s.

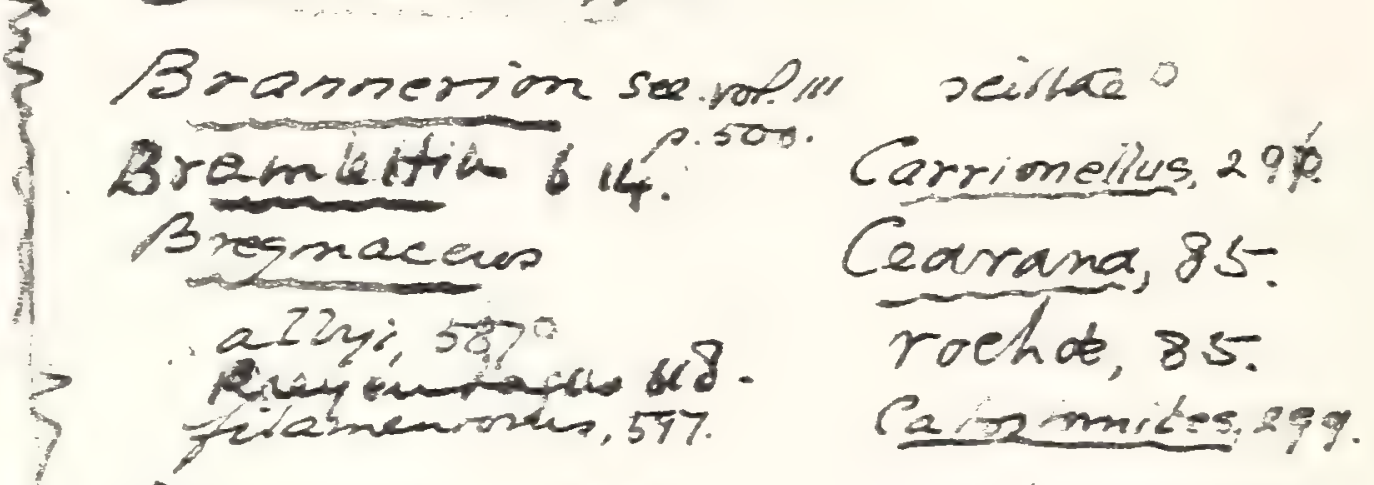

Brevostia, 1584a. Cepola, 369.7?

3 regmacensina, 60 Bulbiects, 587 Lanceolatin, 369.

Bregnacenotidap 587,601 raninus, 587 Centrarehile, 415.

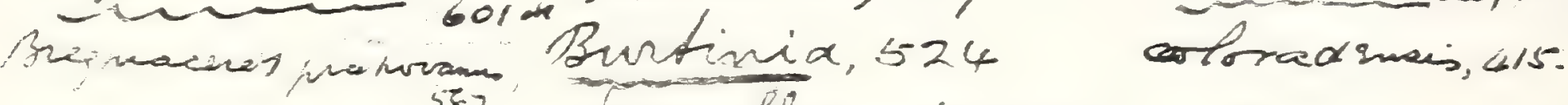

587 Vraxelliensis, 524

3 zownin, $5 s^{\circ}$

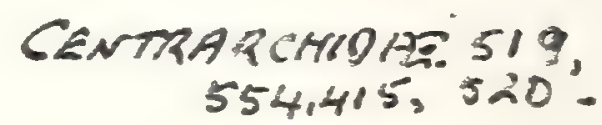

cylinanicus, 28 .

Cencorist so

Callicrithyidate 335

Carileniduspontes

vanciansis.

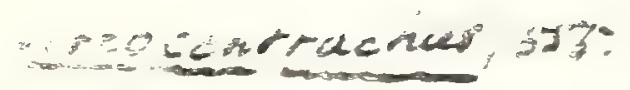

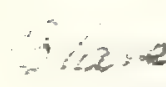

ancisic

Vices, 223

gyenemis,

$0=0,0=0$

Botes.608
Castroese, Ans

Cabos 418,559.

longirsinis, 550

raciobriones

saptorovion

- $x \sin x+\infty, \ldots$

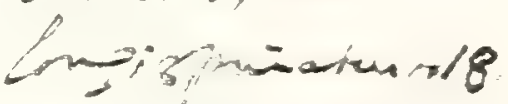

Camrovesaozus. 18 .
Chaenoinitus, 55\%

Trasumenesen

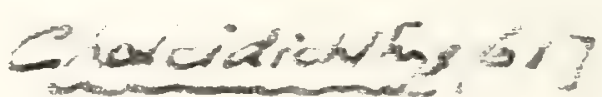

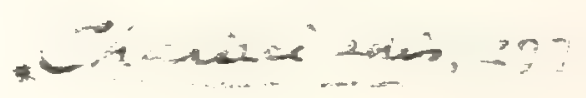


Bagrus :Lor. ":20.

Baistes.

2aitisii. $=60$ )

dubius.

32BatrTIU. 565

Barbus. :01.

fossilis. 202.

ineqacephaius, 31)2.

steinineiuensis. 02.

rulgaris.

Basilichthys, 861 .

Bathyscma, $1 \pm \%$. iutbeni. $4+4$.

Bathythrissa, 67 .

Belone, 35t.

357 acutiostris. $: 57,0.06$ Hava. 05

tenuis, : : 5

Belónostomus laniatus. $\therefore 3: 2$.

BERYCIIE. 巳̂t

BERYCIFORMES. DSt.

Berycopsis, ta?.

elerans. 10.

incistromi, $1: 50$

Beryx. 39.5.

wer, no. 2

duimaticus, $386^{\circ}$

dinolenidotus. :-26li rermauus, 21 .

inscuintus. Sti

iesinensis, 386\%.

microcenialus. 12t.

muiticientatus. esto.

niger, :32.

ornatus. $: 97$. 10?

otuiic. 121.

poirmicrocins. $:-$. radians, 120134. 13

reciozzis "adians. $12-$

suboratus, :36ti.

superous, $11 \%$.

spriacus. 40.5

ralenciennesi, sol.

vexillifer. 10 ?

zinpei, :

BLENTID E, O.5.

Buevrifongles. 91 .

Blennius. 06.

cuneitomis. itio.

fossibis. 56 .

ocellaris. 5yo

Blocimidia. ell.

Blochins. 503

longlustris. $31 \%$.

macronterus. . if?

3cons. Itons. 501.

3othrosteus, $11: 2$. oreritrons, til:?

atus. $01 \%$ 3othrosteus wont.

mincle. 611.

3rachygnathus, 518.

-enuicens. $51 !$

3 racinyspondylus. $\therefore 0$

cretaceus, 270 .

inciicus. 326 .

salopteris, iso.

Brachvrhynchus.

- 497. yesim-? suliclus. $19 \%$.

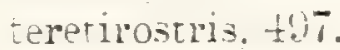

Trnbereciensis, 4.7.-

Brosmius, lio:. elongutus, 002. $\rightarrow$ tras

fuchsianus, biv. $\rightarrow 2$

strossmaveri. 602. susedianus, ro:.

Brctula, 105 . Inerininnata. bos.

Brycinatus, ii. nuelieri. $7 \%$.

Bucirlandium, ilurii. $200.5 \%$

Butyrinus, bi)

Caeus. ji Eopoidi. .r.

Calamopleurus... .1. maicus. 051.

Calamostcma. - 4 (y)

breviculum. 33.

Caiamostcma, itein.

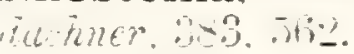

bolcensis. 5ti?.

cunosse. $56 \%$.

Callionymus, je?.

macrocephaius. 583.

restena. 4 te. a srivus 556

Callipteryx. 589

recticandus. joy.

sneciosus, .59.

Calopomus, 5eit. porosus. $500^{\circ}$

Cantharus. 537. ureiunensis. 395.

Capito. 35

Capitodus, 2 ?:?

ingustus. 536.

cirbius. 53.7.

incieus. 50.2

interpuptus. 585

strotrumeatus. $20 \%$

Enuncatus, 5.36 .

CARAKGDE. th.

Carangodes. 501 . enilatus, tinl.

Carangopsis. $\frac{1}{2} 46$. mulis. +i)
Carangoosis ...mt.).

olevis. tiri,

colvalis. $t 4 \bar{i}$.

lanceolitus, \pm 18 .

iarior, 446 .

maximus, 148 .

Carans. $\pm \pm 1 . \quad-=2=11$.

curaugopsis, \pm+1 .

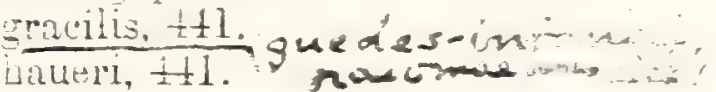

lungipinnatus, \pm+2 .

ᄀ delrow 's

rigidicaudus, +12. Wu the

Cariniceos, $4 \overline{3} 8$. complessirs, t58.

Catcstomus. :99.

cristatus. :1).

strosilonensis. .00).

Cextiaciden, :

Centriscus. :T.

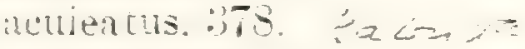

imgirostris, : $: \pi ! ?$

toni, 37.

relitalls. 3-1!).

Chrtodon. in

aleutatus. int

arsus, .j6il.

asper, jou.

auleus. $\frac{1}{2}+9$.

anescens, t5i).

anus. 5.58.

cinirulous. Jos.

hoeteri. 5130.

lineatus. 60 t.

mesoleucus, joit

niugricans. 565.

papilio. 438.

pinnatitormis, to3.

jinr!atus, \pm ỉ.

iseuciorthombus. 560

rhomboides, \pm 5()$,

.50 .

phombus. 559.570.

saxatilis, +12 .

striatus, 115 .

subalcuatus, fil.

subaureus, $\pm \frac{19}{4}$

substriatus. \pm 15.560 .

sunrespertilio. to.

triosteus, jht.

reicans, tist.

relifer, to

resnertilio. $4: 3 \%$

Ciempontin.e. .jo.

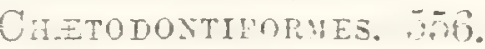

Chanoides. 00 . .eproster

meroboua byara, .

mevis. $6 . \overline{5}$.

nyerpacus tis.

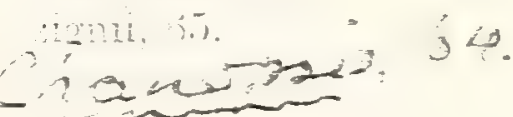




Charactyide. $2 y 7$.

Charitosomus, $: 71$. formosus. 272? bakelensis, $27 .-1$. lineolatus, 27. major, 272.

Chatcessus, 158. breris. 158 .

humilis, 158 . tenuis, 158.

Chelonia rudiata. 491 .

Chimæra furcata. $3 t$.

Chirosentrites, 00. carolini, 92. coroninii, 91. gracilis, 91. libanicus, 105. vexillifer. 92.

Chirocentride. 86.

Chirocentrus, 38. polvodon. 58.

Chircmystus, 59 .

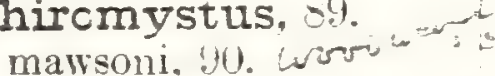

Chirostoma, Dil.

Chirothiritide, :-79.

Chirothrix, 281 ). guestialicus, 283. lewisi, 283.

libanicus, 280.

Chondrosteus. $11 \%$.

Chondrostoma. 316

bubalus, 310 .

elongata, 316 .

Laticauda, 615 .

minutum. 318 .

stephani, (ils.

Cirromide. 554.

Chrysichthys, $32 \%$

theobaidi.

Chrysophrys. 534 .

agassizi, 537.

oros. N.534:arsenaritana. 507

Drusinai, 5üt.7N.V

veineta, 035.

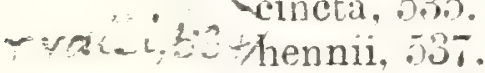

hertlei. 534 .

lawlevi, 534 .

miocenica, 230.

seacchii. 531.

zignoi. 53 .

Cimolichthys, 2.21. 227.

anceps, 203

contractus, 208

Ac 228 gladiolus. 204 .

lewesiensis, 221 .

lisbonensis, ‥23.

merrili. 2028

neproolica.

semianceps, :-2.

sulcatus. 20.5.
Cladocyclus, 107.

gardneri, 103.

lewesiensis, 109.

occidertalis. 110.

strehlensis, 110.

sweeti, 111 yorb

Clarias, 324 . srewowas is filconeri, 324.' an w ...

Clinus, 597.

gracilis, 597.

Clupea, $1 \pm 6$.

alta, Leidy, 145.

alta, Steindachner, $15 \%$.

antiqua. 138.

arcuata. 154.

attenuata. 19

beurardi. $1+2$ fassons

bosniaskii, 154.

bottx, 250 .

breviceps. 154 .

brevis, 270 .

brevissina. $1 \pm 0$

cauclata $15+$ inine is

catoprgoptera, 148.

cephalus, 158.

chrysosoma, 158.

crenata. 151 .

curta. 202.

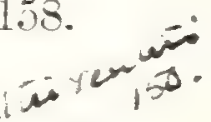

exprinoides. 19.456.

dentex. $15 t$.

denticiformis. $15 t$.

doljeann. 159.

dubia, 270

ecnorni, 15.5.

elongata, Davis, 55.

elongata, steindachner. $15 \%, 460$.

engrauliformis, $15 \pi$.

evolans, 133.

fontannesi. 15\%.

gaudrri, 138.

gervaisi, 155.

gigantea, 105 glypasema.

goidfussi, 1.58.

gracilis, 150 .

gracillima. 15.5.

grancisquama, 155.

grancionii. 155.

gregaria, 155.

guestpbaiica, 237.

Laidingeri, 155.

heterocerca. 156.

humilis. Leidin, $1+t$.

Lumilis. Heyer. 1.00 .

intiata, 1.66 .

intermedia. 156 .

lanceolata. 150.

larteti. $1+1$.

lata, 17, .53.

laticauda. 15s.

latis-ima, 156.
Clupea (cont.).

lawlevi, 158.

leptostea, $15 \%$.

lesinensis, 138.

lewisii, 17.

lorex, 156.

lundgreni, 156.

maceki, 156.

macrocerea. 156.

macrophthalma. 13.

macropoma, 63.

megaptera, 147 .

mexapteryx, $15 \%$.

melettæformis, 156.

meneghinii, 158.

microcephala, 158.

microsoma, $15 \%$.

minima, 245,246 .

minuta, 149 .

minutissima, 158.

mondainensis. 157.

mueronata. 157.

murienoides. $16 \%$.

numidica, 151.

ombonii, 157.

ophthaimica. 158.

opisthoptery $x, 15 \%$.

polyachanthina. 15\%.

præsardinites, $15 \%$.

pulchra, 56 .

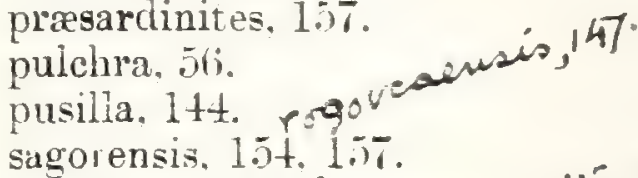

sardinites, 152 C

sarcinoides, 19

saulos. 157 .

sauvagei, 158.

scheuchzeri, $1+7$

sinensis, 63. Scuiplato $=32$

sphaerocephala, lijt.

sprattus, 153.

strriaca, 1.i- staurooresane, it?

tenuissima. 154

theta. 140 .

thrissa, 63.

thrissoides, 63.

trinacridis. 157

vectensis, 146 .

rentricosa, 150 .

villosa. 161.

roirouensis, 138.

rukotinovici, 157 .

zenophanis. 15s.

zinnclea. 158. puncri 5:

Culpeidin, 12:S.

Clupeops, 159.

insignis. 159.

Cobitis, 320 .

angustus. 321 .

bredai, 320 .

centrochir, 320

rephalotes, :2:1. 


sourdoil, $4>0-$

bectinen 44n.

Cuinolesis ill

cunser, 342

ricis crivan 242.

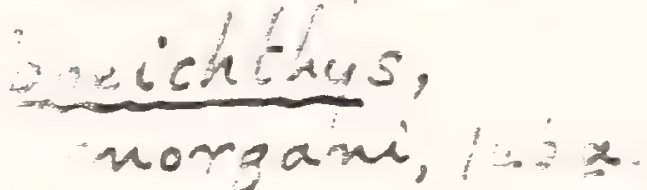

Encranus.62. Cyeloteboides.68.

chisonumis, 35

redores,

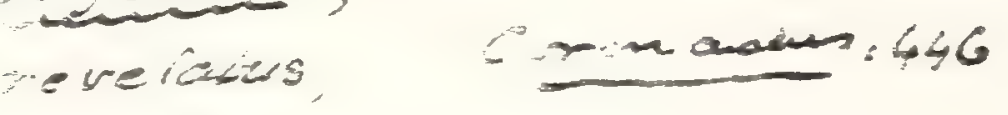

Orizuntenotsis, 73.

trovis, 73. Cylindracanke, b92. 3atima, 609 risurentio, 593 . Diaphus 2356.311.

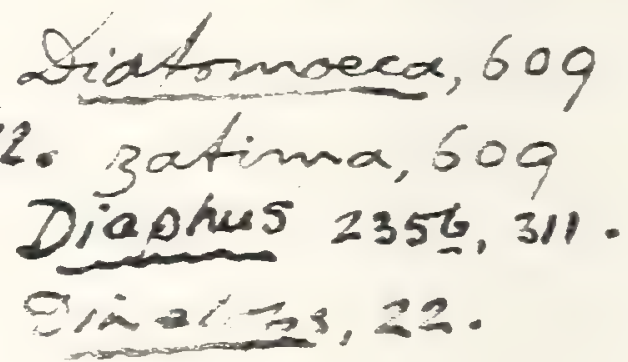

consricomis, 585.

$\therefore$ Zaichity ys ard.

uensis. 535.

$\therefore$ 4.

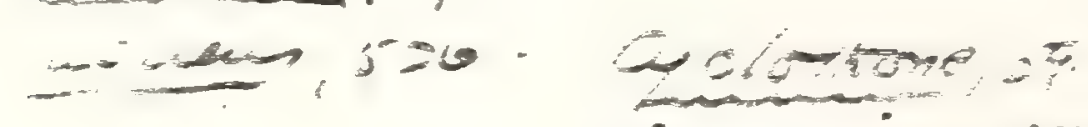

Enescein, v.v.53g.

Dakionzille. 343.

Dapalis, 506 .

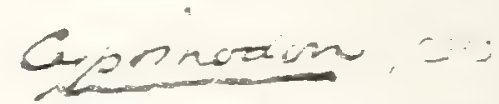

fupmases a

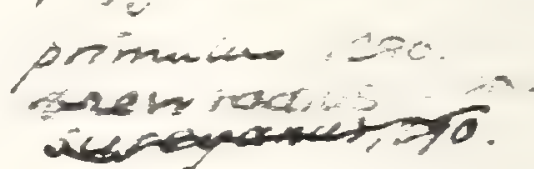

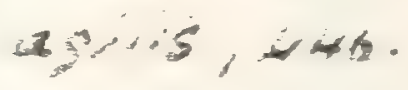

Dentic - 2 is, 71

whotitis, 71

Deprandus, 346.

lesies, 346 .

Derrhias, 336 .

enantions 336.

- cisigerina sia

Dasceles, 5?

iscivanen 160. diassu un so?

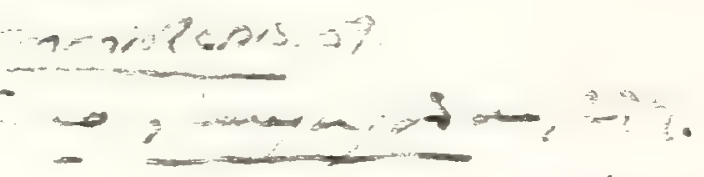

d astist, 133

wentas

eranoralli 35

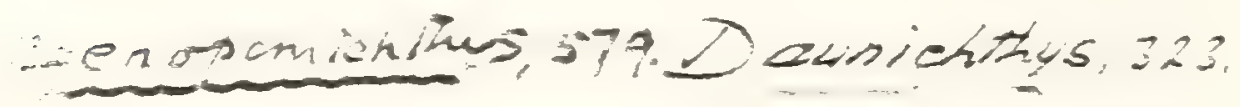

greortionus zzs. 
Sobitis ont. i. ionuicens. $2-3$ tevieri, 1 -

Cobitorsis. :J)t. acutus., $0_{0} .5$. exilis. :30.5.

Colocenhaius, 45. saimonells. $1.5 \vec{i}$.

Caiogaster, 111 . anails. 110 .

Coloperca, 519. ations. 51 ?

Colopcma, 70 culei. 17 . curpiltum. $17: 3$ laere. 12 .

Cceiorivnchus. $50 \%$. Conver bperior. : 47. Conosaurops. lil:. bowmami. il.'.

Csnosaurus, 112. bosminni, il: copar hisuritus, -700. Coregonus. Hil. laviperns. 10 l.

Corrins gibberulus, 5:3e.

Carterde.SO

Cottus. . .

aries. 52.

breris. 5-2. 034 .

errntotremus, -sis. difaricatus. 055. hupridus. .s.5. Lypocerns. .25. muttinnatus. $\mathrm{s}$. badracens, j=3. nontifer. . a. quaciriconnis. uncinatus, .5.5.

Crenilabrus. iti) stajnocus, $5+1$. Trondwnedi, it?

crommtodus. .5.3. irreguikits, joi:.

Cristicens. -11.5 Daradivins. .) "russogit ITHAD.E.

Crossognarbus. savauuianus. "f f!l

Ctenccentex. ...2. ineieniensis, i) 2.2.

duenopoma, .?.

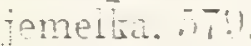

cenothrissa. 104. minoureviatil. $2 \frac{1}{2}$

merians. i:resillitel.

CTEYOTIPINID.R. II?

Syoium, tis. th, th? altonense. \pm 17

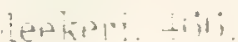

Cybium (ront.i.

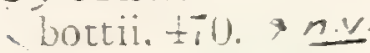

Aunonti, to. exceisum, $\frac{1}{4} 17$ lingulizeu:u. $419 !$ marropomum, -152 . macularum. 460 . partscini. 70 speciosum. $4 b^{2}$. tenue, \pm 70 .

Cycloides. 59. incisus. .)!! Cycloleois. 50.

Cyclopoma, 54.

uive:s, .04t

micracanthum, Stit. spinosum, Sity.

CYClumeride. JST.

Cycioprerus. $55 \%$ lumbus. 505. 507.

Cyclotomodon, 45 Figrans, 4.5.

Crchurus crassus, 509.

Crolrarus minor. 5.3.

Crelurus nemopterrs. 508.

Cyplimpe. zng.

Conrinudun ievatus, illi.

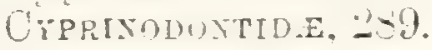

Cyprinus, :

bipunetatus, :18. carpio. Dll

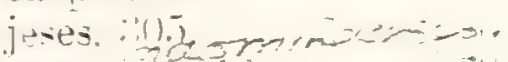
winutus. ilis. papsraceus. :07 pliserus. squannossens. 2-20.

CYTTIDE. 117

Cyttoijes. 417 . siarunensis, \pm 17 .

Dactylopogon. :-th. grancis $24 \%$ parruius. :45.

Dactyiopterus, 5s\%. pliocenicus, stit. Tolitans. 5=6.

Daxedogicssus. : acutis. 75 .

xquibinnis. 7\%

encrustus. 70 .

iestis. 7.)

Dactinus. 111, 㳕 bioacineacii. 11:3 internecilus, $1 \mathrm{~L}$. bilebotomus. 112.

Dentex. .2.

blericens. T.

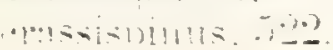

Dentex (cont.)

fautasi. .i-2.

laebeniensis, .2.2.

leptaciuthus.

microcion.

muensteri. .2.

nobilis, 5.3. - pirucen.

sardiniensis. 529

rentralis, 5?

Dercetidie. $17^{\top}$

Dercetis, 17 .

elongatus. $18 t$.

limbamnensis. 17 .

linguifer. 17 t.

rellsisi, 173.

seututis. 172.

tenuis. 181 .

trianerer. 174.

Dermatoptychus. -2:34,

meroninchaluus, $: \frac{1}{2} \%$.

Desmichtinys, 400 .

diubrei. t.il.

Diaphyodus, jt1,

$$
34 \%
$$

orails. $5 \pm 6$.

trigoneila, jth.

Diastichus, $\because 2$.$) .$

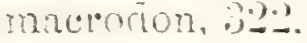
parriciens,

-trangulitus. ;20?

Dictyodus, $17:$.

erassidens, 17.5 destructor, $47 t$.

priseus, $\frac{1}{2} \because \because$.

pupeilensis. $\frac{1}{2} \div:$ ?

Dinopteryx. 410

suinosus, $\frac{1}{2} \mathrm{~T}$.

Dioan, $\% 1$.

acanthodes. 574.

antiquus. 570

colsicauns, jit.

cowntrar

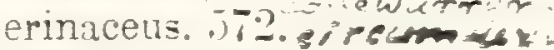

folevi. jit. -ormovin.

giganrodus. $57 \pm$

Lentadiorion. .7t.

beterorion.

bilgenciorti. 375

incertus. 57.5.

itaicus, 575

meristodus. 57.5 .

monsegurensis. .75 .5

platrodtis, Jis. achen

purrsendix. $57 \%$

scillie. ji:

sigmi. $=-7$

senocius. . - it.

tenuisninus. 57.

verus. ji:

Dixiomystus. 1., 


Diplcmystus (cont.).

analis. 139.

birdi, 142.

brevissimus, 140 .

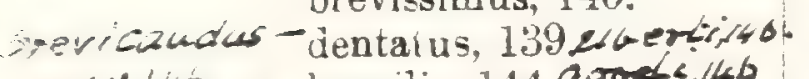

v. v.!46. ... humilis, $144.900=4,146$ longicostatus, 143.

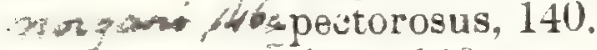

cinumsimpra theta, 140.

rectensis, 146.

Diplotomodon, 612. horrificus, 612.

Dipnolepis, 284. jahni, 234.

Ductor, 448. leptosomus, 448.

Duies, $5: 21$. medius, 505. temnopterus, 521 .

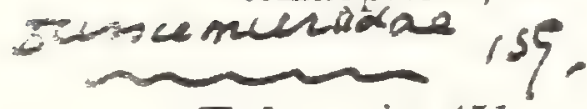

Echeneis, 451. glaronensis, 451.

Echenus, 613 politus, 613.

Echidnocephaius, 163.

tenuicaudus, 163. troseheli, 163.

Egertonia, 550 . gaultina, 73. gosseleti. $551 . ? \mathrm{~N}$ isodonta, 551.2 wr.

Electrolepis, 415 . horrida. 415 .

Elopide, 7.

Elopides, 23 . couloni. 23.

Elcpopsis. 8. crassus, 10. dontex. $2(1) 5$. fenzli, 9. haueri, 219 . beckeli. 10. inicrodon, 9. ziegleri, 10.

Elors, ㄴ?

Embalorhynchus, 497.

Linnei, 497.

Empo, 221.

contracta. 228 .

lisbonensis, 20 .

merrilli. 208.

nepaholica, 20:5.

sernianceps, 20.25.

suicata. 225.

Encheiziphius teretirostris. 197.

Enchelurus. 164. anglicus. $16 \%$.
Enchelurus (cont.). syriacus, 165 . villosus, 164 .

Enchelyopus, 343. tigrinus, 343.

EnCHODOnTIDe, 189.

Enchodus, 190.9 92 amicrodus, 203. anceps, 203.

annectens, 195.

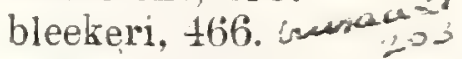

calliodon, 203.

carinatus, 204 .

corneti, 204.

dirus, $204.5+0$ som.

dolichus, 20t.

faujasi, 196.

ferox, 204 .

$>$ gladiolus. 204 . gracilis, 201 .

halocron, 191.

Memonnieri, 198.

204 lewesiensis, 191, 193

ryess Tongidens, 199.

lycodon, 204.

macropterus, 202.

major, 200.

marcheset tii, 200 .

oxytomus, 204.

paryus, 204.

petrosus, 205.

pressidens, 205.

pulchellus. 193.

recurrus. 201.

semistriatus. 205 .

serratus. 203.

shumardi. 205

subæquilateralis, 205 .

tetræcus. 205.

valdensis, 205 .

Engraulis, 133.

brevipinnis, 133 .

evolans. $133,287$.

Iongipinnis, 133.

tenuis, 280, 285.

Enneodon, 571, วั5. echinus. 574.

Enoplophthalmus, 323.

schlumbergeri, 323.

Enoplosus, 521. pygopterus, 52.1.

Eocœloporma, 470 . colei. 470.

curvatum, 172

Eocottus, 580.

veronensis, 581.-

Eomyrus, 340. dolloi. ¿210.

latispinus, 30

vent rails, 341.
Eothynnus, 45

silmoueus, 457.

Ephippites, 617.

peissenbergensis, 017

Ephippus, 559.
lougipennis, 559.

nicolisi, 560 .

oblongus, 560.

oweni, 570.

rhombus, 559

Equula, 450 . scillæ. 450 .

Erismatopterus, 416.

endichi, 416 .

levitus, \pm 16 .

ricksecheri, $\$ 16$.

Esocelops, 40 cavifrons, 46 .

Esocid.E. 297.

Esox, 287

belone. 375

destructus, 615 .

falcatus, 48.2 .

lepidotus, 288 .

lewesiensis, 191.

longirostris, 375 .

lucius. $288,289,2856$.

macropterus, 89.

monasteriensis, 159

otto, 239.

ottonis, 289.

papyraceus, 289 .

robustus, 288 .

saurus, 261 .

sphyrena, 361, 362. 366.

spret. 862.866.

vulpes, 153.

waltschanus, 289

Eucynodus, 481 .

bunteri, 481.

Eurygnathus, Alassiz. \pm 6 .

cavifrons, 46.

Eurygnathus, Davis, 190

feros, 200

marchesettii, 200.

Eurypholis. 20\%.

bcissieri, $20 \%$

freperi. 210 .

longidens, 199.

major, 201.

sulicidens, 207.

Esocetus evolans. I::

Exocetus exiliens, $13:{ }^{\circ}$

Exoccetoides. 236

minor. 286 .

tenuis. 285 .

Fierasfer, 005 


Findenicantsy. 3.05.

cenmencin, os.

70 fex, 358

hupuralio, 358,6is.

Gondidis 29

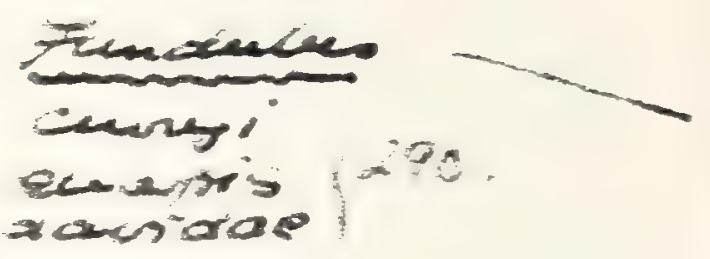

IExearammos, 580

$\because y+2 y=0$

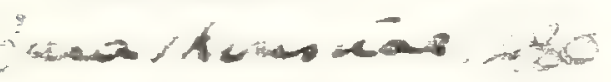

poiexion, 235 se.

cistrosteops, 340

7exacanonus, 370

Genkyobiny, s.83.

Ginossus, 159.

- lepsyratra, 1sa. sid.

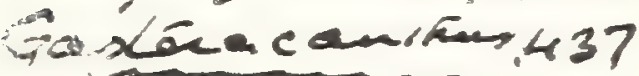

smotuzes, 159

cameo, 15054

- edebszaita, 150

reter opreu, 370

ll.

vilimenu lehtomens, 370 dentieuraties, 234.

paran

rivicint.

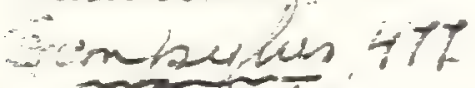

sinhicithes numidus, 612

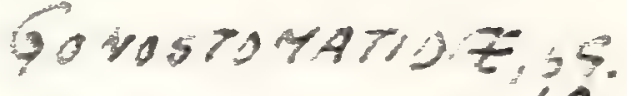

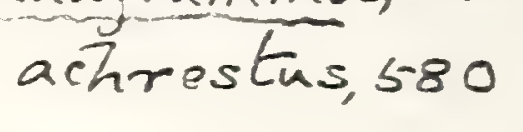

Suaventevis 169.

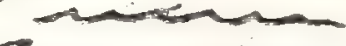

Gonorignchobs, 279.

worowarck; aY9.

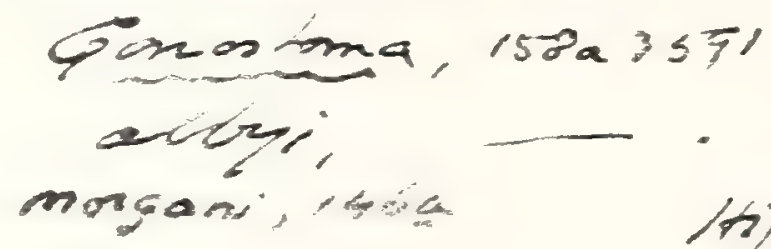

mogani, toga

trippoglusoides, 608

7 ymmos aus, 457 maceppleia, $60 \%$

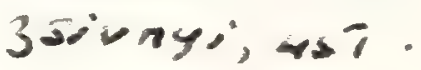

Halecodon, 234. Hipuryiggnaitus.381.

Haliadia

Haplochim 20

Hotarentrixes ys: motolaricus, $x$ :

Pia cencucs bo

teckecenkmio $\$ 35$

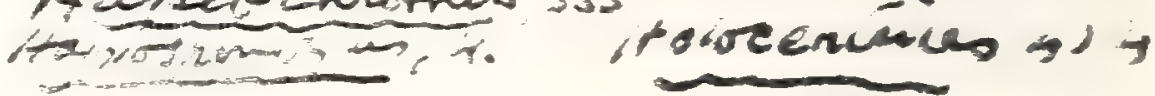

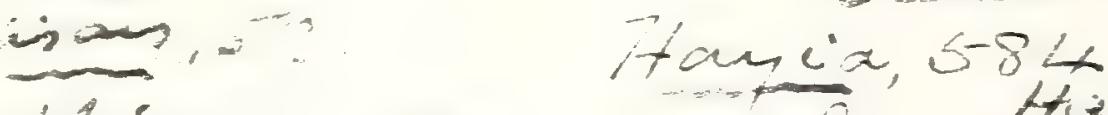

hinisina, sts

rossides, s50.

dimbica, <-8

rears; $1,1,1$

Heliofonis, $11 !$

tortymetes, s92.

Helminitaresis, of

entiendatus, siá.

permicusacis so.
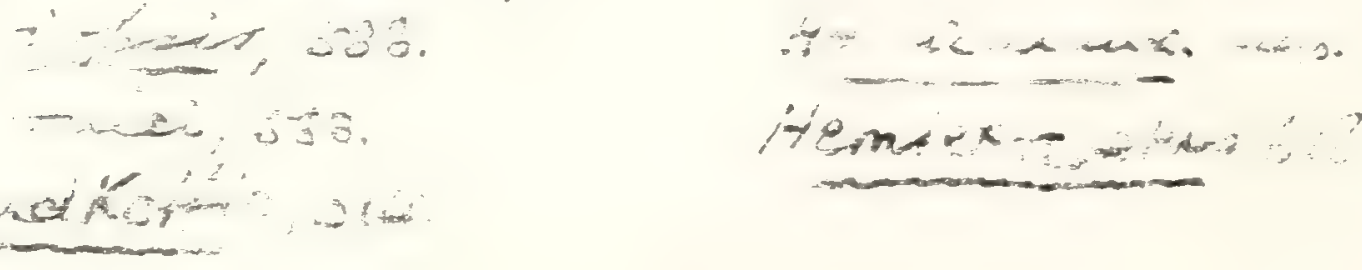
Fierasier

nuntius $60 \%$. nosterus, 16.5.

Fistuiaria, .7.

boleensis, $27 \%$

xaremondinensis.

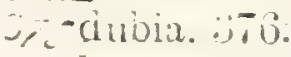

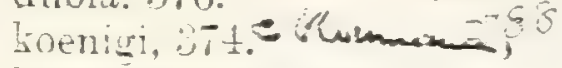
longirosiris, :5:5. tabataria. tenuipostis. $: 5.5$

Fistetarime.

Funauius, ㄴ.41).

Gidid. 50.7.

Gadopsis, $11:$. brericens. $13:$.

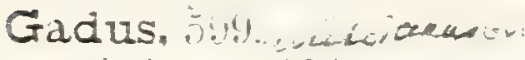

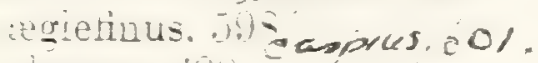
elegans. 150k.

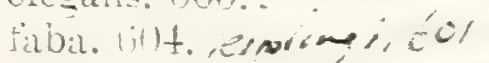

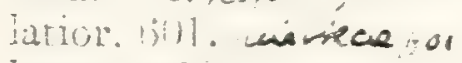
Inscus. (in) meriangus sol ineriuccius. $59 \%$ minutus. bot. morrina. s!l. polineinus. 601. polrnemus. bul.

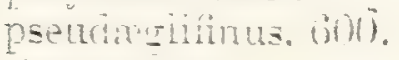

simulex. $(1)+\frac{1}{x}$. spectabilis. (4)4. sconpanii. 601. tenmis. ot. tubercuiosus. int. Tenuscus. Biot. Tirens, (i)1.

Gasteronemus, tis. oblongus. \pm 411 . mombeus. 4is?.

Gephyrura, 26. encentricn. 20.

Gerres, nassalongoi. 52:.

Giganticinthys, il. uha?'io, 51 .

Ciilicus, 19.21. arethatus, 101. poimicrodus. 101.

Glossodus, mer 60. heckeil. 7:3. isram 173

Giyprecephalus. . indiates. no

GовHD. Not. Tromiturues, -

Gobic, anatis. malor, i15. ricimzs. ils.

Gobius. ournatiz. ít. Din IT.
Gobius cont.

bassanii. 500.

brevis, 5.2.

conicus. $56 t$.

elacus. 5oterionums

trancorurtanus, corarain?

entosomus, jo8.

lobini, 583.

malacronetus. 588.

inacturus. 381.

maximus, j88.

mieroceplialus. 583.

muitipinarus. at

ublonisus. 58 t. 2re?

peruzzii. ise, jiacicengám.

smrpnensis, ty.

reronensis, jol.

ricinatis. 5as.

rienuensis. 3 t.

Goniognathus,

curpphenoicies. 57.

maxiliaris. $37 \%$.

Govormychion, 271

Genorinynchus, ㄹt. srevi.

Grisodusthe. 570 .

Gymnodus, 5.2.

cilodon. 575.

heterodion. 5.5

nonsegurensis. 56.5.

íacquetia, il:. bolcensis. 1512 .

Halec. 12 yesnid

eunterritus. $21: \%$

questphaticus. …?

haveri. 210.

Lububi.

microlepis, iss.

steminerici. 212.

Jalecopsis. $10 \%$

insignir. lüt.

laxtis. 10 土.

H.I.OSACRID.E, I6\%.

Halosaurus, $16 \%$.

H.remer. I.

Hentbrarenti, $819 \%$

Hemicyclus. $5 \%$

strenlensis. 5?.

Iemielopcpsis, 28.

siobus it.

gracilis. 0.

suesti, s.

Iemilampronites. 59.

sreiniai. 59.

Fiemiramphus, 8 .

edwardisi.jo

Oemirintuchus. :

vitiots.
Fiemirhoncisus cut.)

lieshutesi. ris.

zitteli. tor.

Hemisauriaa.

neocouiensis. 270.

Femithyrsites, \pm 81.

armatus. tol.

Hatus. 4.1 .

licatie, to. maicorpices

Hemitricinas,

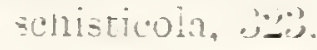

Feotaziodan, j, $5 \% 5$

echinus, eit.

ileterobrancinus.

$\therefore$.

maleindicus, 3\%5.

Tererclepis. 1:?.

Eeterctis. 7 .

Hexapsephus. :־:

suencheri.

Iistialosa. 5.

thinilieri. 2.

Zistiocepnaius. $5,7 \%$

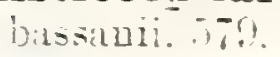

Fistiophorus. 4.15

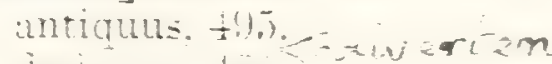

desuares, tos.

coctenicus, tys reore

Iomaiophamphos, $\pm \%$.

partuins. fis.

priscus. tell.

pobustus. 495 .

menundus. 45.

Iistiothrissa. $1: 31$.

upasaninna, Li:2.

macroritetria. 131.

Bistiurus. 18:0

atiatus. $1 \frac{1}{2}$.

serivivicies, $1 \pm 6$.

Fentricosis. itio.

İclacanthus. inl.

microcepiaius, sil.

piorenorum, jil.

Holcodon. 160.20\%.

lesinuensis. 219.

Holcolecis, 11,20 , inen

eretacelis. 2 ).

Folccentrum, $\div 1 \%$. waw of

calcarifer. son.

lancentatim. 2!

macrocepuatum, i2.

suachintum, int.

melitense, $41 \%$.

ersenin. 于10.

Degneum $11 \div$

(1) 12 . $\div$.

Folostens. - 0 二。

rumber.

marios: $=5$ 


Homonotus, 10 \% dorsalis, 408. ródincuns 40a) pulcher, 392.

Homorhynchus, 488. bruxelliensis. \pm 40 .

Hoplopteryx, $: 96$. : antiquus, 396. jrevis, 406. Tewesiensis, 307 lewisi, 404 . whensis, 104. Eimus, 409 vblongus, 406. stachei, 406. superbus, 403. spriacus. 405. zippei. 597.

Hopiostethus, 114 . ingens, 114 . laciniatus, 41 . lawieri, $+1 t$. nettelbladti. $\$ 14$. ostiolatus. $+1 t$. pisanus. 41 t.

Hyperlophus, 139.

Hypsodon, 3. lewesiensis. 33.40 .45$. $94,95.98,10 \%$ minor. 102. oblongus, $26 \%$. toliapieus, 24 .

Hypsospondylus, 58. ba:sanii. 58.

Hyptius, 58 . sebastiani. 58.

Ichthyodectes. 99. acanthicus. 10\%. anaices. 100. arcuatus, 101. 110. cruentus. 107. ctenodon, 100. elegans. 103. goocieanus. 107. hamatus, 107. aratonens Sibanicus. 105. 107 minor. 102. multicentatus. 107. - occidentalis. 101. perniciosus, $10 \%$. poirmicrodus. 101. prognathus, 107. serridens, 101. tenuiriens, 104.

Ichthyotringe, 265 , itiv. tenuirnstris. 299.

Iruana hauer?. 51 . Imogaster, :91. auratus. $204.2 \%$
Ischyrhiza, $t 6$. antiqua 450 chens? mira, 46. radiata, 46.614 .

Ischyrocephalus, 190.

cataphractus, 202. gracilis. :01. intermedius, 202. macropterus, $20 \%$.

Isodus, 190. suleatus, 199.

Istieus, 66.

- gracilis, 70 . grandis, 67 . lebanonensis, 71 . macrocephalus, $\%$, 70 . macrocoelius, 67 . mešospondrlus, 67 . microcephalus, 67. suottii. 71.

Istiophorus, 495.

Isurichthys, t.i3.

- macrurus, 4.0\%. orientalis, 4 อ3.

Isurus, Agassiz, 453. macrurus, tes.

Julis, $\check{\ddagger}+1$.

agassizi. $5 \pm 0$. muensteri, כૅto. sigismundi, $5+1$.

Furtus relifer, $430,131$.

Labeo curieri. 616.

Labidesthes, 201 .

Labrax. 509.

bosniensis, 512.

delheidi, 5l2.

elongatus, 512 .

beckelii. う10.

intermeđins, 512.

lictus, 512.

lepidstus, 51:2. lungiceps, 513. major, 5130.

mojsisoricsi, 513. multipinnatus, 513. neumarri. 513. oeningensis. 511. sagorensis, 513. schizurus, 510 . steiudacineri, 513. stiriacus, 513. 11 binoi, 510.

LABRID.E, 539.

Iabrodon, 541. atricanus, $5+2$. alsinensis, $5 \pm 5$. bazini, 43 .
Labrodon (cont.). belgicus, $5 \pm 3$. bourgeoisi. 543. britannus, $5+3$. canariensis, $5+2$. carolinensis, 543. chantrei, $5+3$. cocchii, 543. crassus, $5 \pm 4$. dilatatus, $54 t$. edwardsi, $54 t$. gaudryi, $54 t$. haveri, วtt. beterodon, $5 \pm t$. multidens, $5 \pm t$. pavimentatum, 54 . poljodoln 545. quenstedtri, 545 . rhedonum, 5.5. sacheri. $5 \pm 5$. riongetion, 5 as sauragei, 545. sellæ, $\overline{5}+5$.

soldanii, 54.5, superbus, $54^{\circ}$ : trapezoidalis, 545. trigonella. 5 th.

Labrophagus, 611. esocinus, till.

Labrus, 5.39. agassizi, 540 .

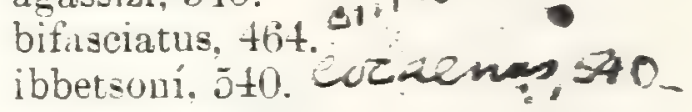
malapterus. 595.

meruia. $5 \pm 0$. microdon, $5+0$. parrulus. $\bar{y}+0$. priseus. j40. punctatus, $55 \%$. rectifrons, 558 . turdus, כut. valenciennesi, 540 . woodwardi. $5 \pm 1$.

I.aparus, 596.

alticeps, 596. Larimus, 578.
Lates, 502. gibbus. 502 . gracilis, 502 . heberti, 499. macropterus, 503. macrurus. 503. notrus, 502 . partsciai, 503. sagorensi- 513.

Lebias. 200. aymardi, 292. cephalutes, 2000. crassicauclus, 295 . crassus, 296 . eisorabensis, 294. furcarus, 291 . catudin. $29 t$. 


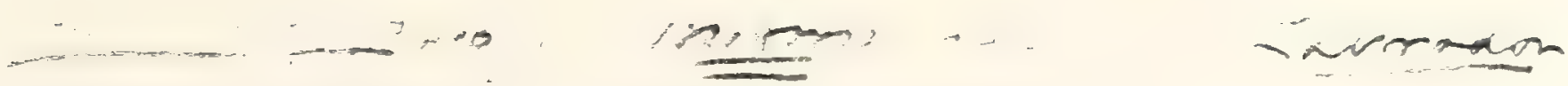

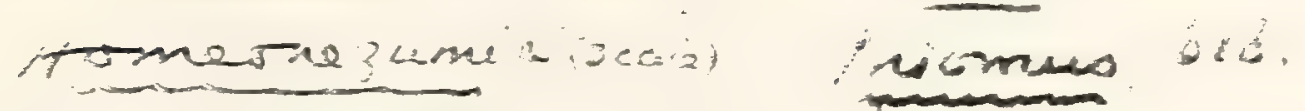

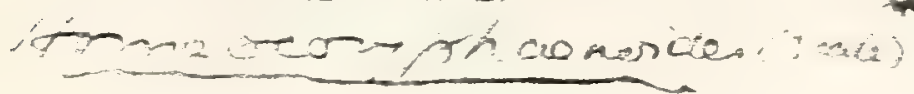

confertiden.

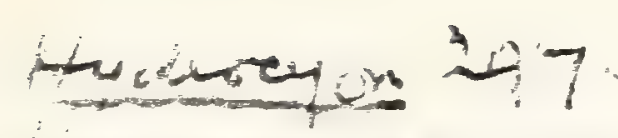

depressus, $\cdots \cdots i_{n}$

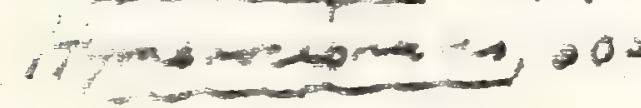

20us, $\$ 55$.

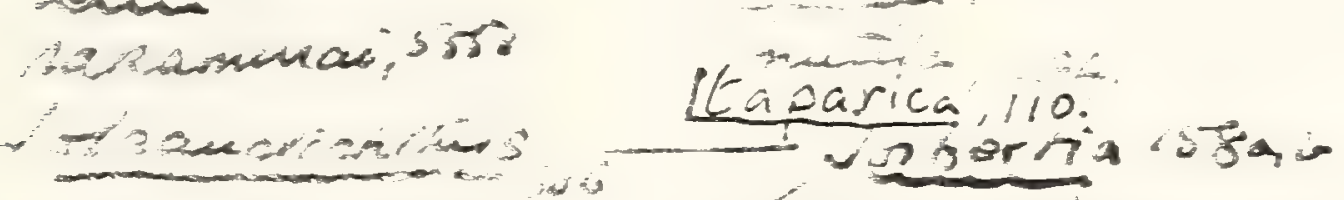

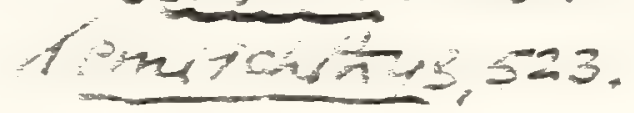

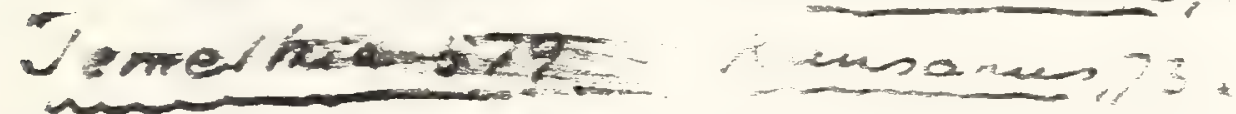

Xasurronsogis.

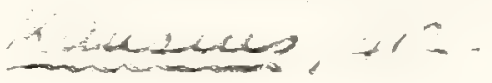

Thimperion, bic

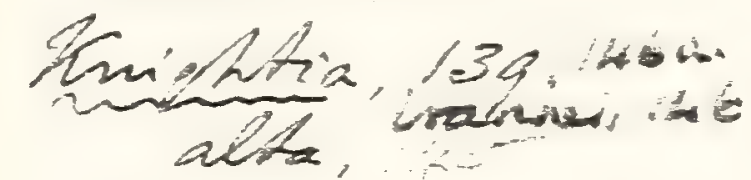

Pocaena ice

Iramoricería, st9.

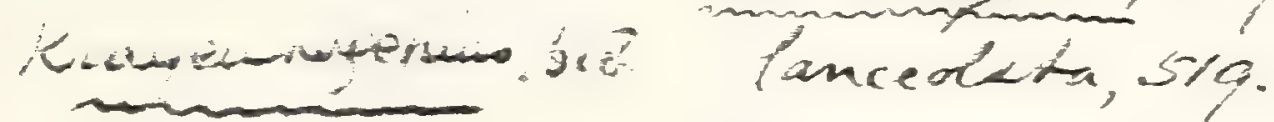

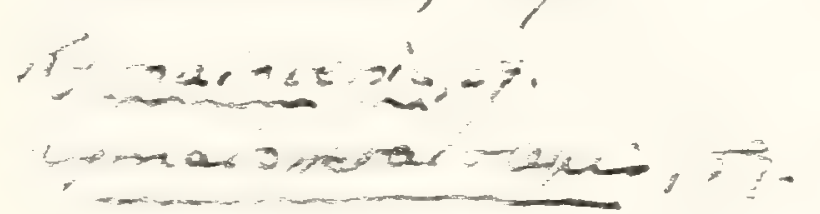

Veciuna as

issie, 0

Rurbaymartion paucideres,

ractiontio

Liminers ito

Eannisnio,

jatima.

raminospons

की

vencise

Tin. 235

sis

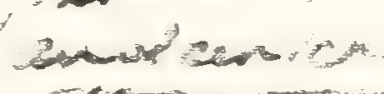

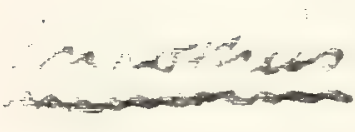

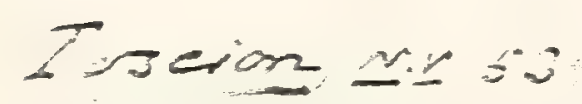

moreanising

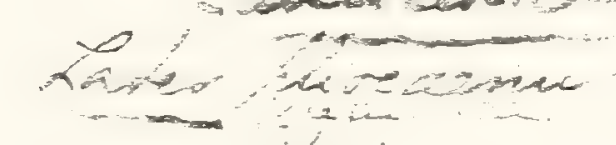

rivinats

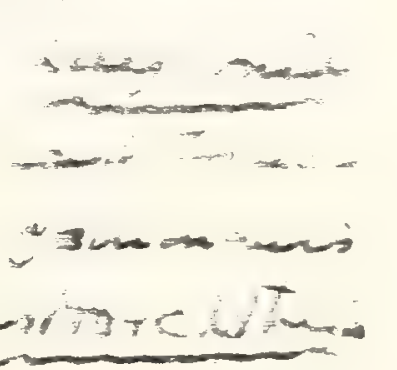




-2brichthons 16

eseria, bec.

Lemicus, Ista.

meitlejonni sola

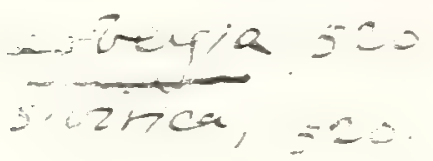

mycucrion, 477

oswardi, 3ll.

moravicus it:

pachecoi, 306 .

-isaloi, 481 .

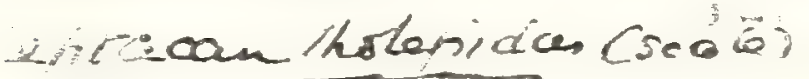

reddingi, 323.

$-010500810,257$.

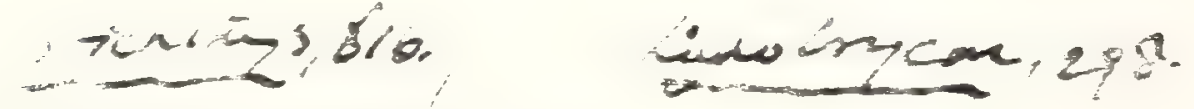

$$
\begin{aligned}
& x=2 \text { rummartiten } 50
\end{aligned}
$$

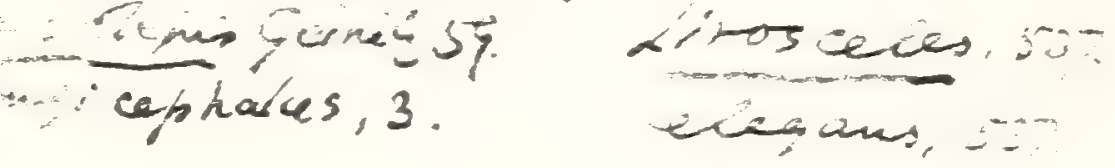

$$
\begin{aligned}
& \text { Lom pochizes, wev s3s. }
\end{aligned}
$$

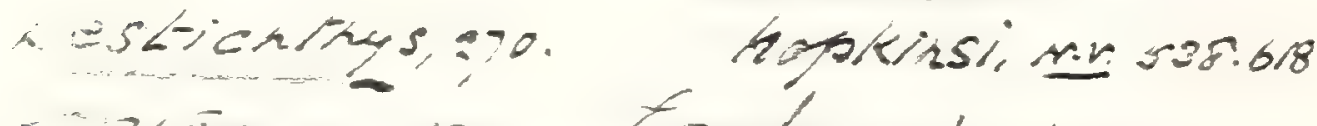

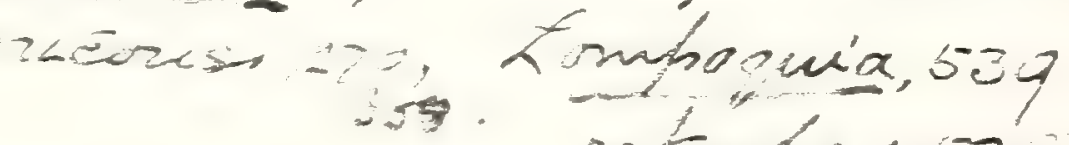

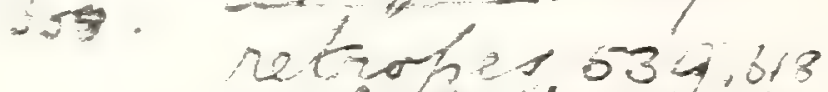

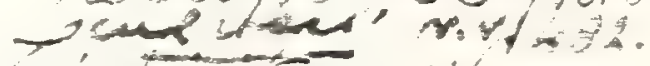

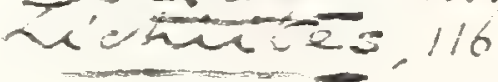

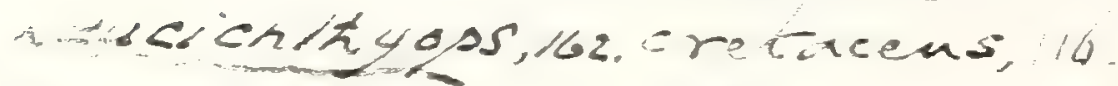$$
\rightarrow \rightarrow a n, 162 .
$$

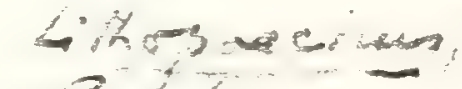

$$
\begin{aligned}
& \text { Tobax, 4so } \\
& \text { miacusmen, tso }
\end{aligned}
$$


Lebias mint.

zobio. -24 .

mereri, w.

minimus. 204.

perpusillus, :201.

tenuis. -2yt.

zignoi. -?t.

Lepiaenteron. is. longissimum. 15.5.

Iepidocottus, iol.

iries, 5.2.

breris, $0 \%$

elongatus. $38 t$.

reacilis, 117.

muitionnatus. mapyraceus.

Lepiaopides, $T$. previsnoncirius, $\pm \$ 1$. ilubius. $\div 1$.

lentosnoncirins. \pm SI.

Lepidopus, $\pi$. :Libil, \pm 01 . 2N :nguis, toc.

brericaucia. 40).

armpathicus tou.

dubius. \pm bl.

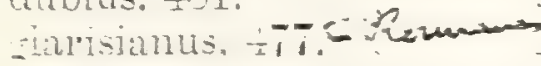

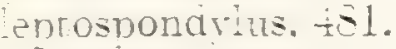
menegninii. tal.

Leptecccion, rectus. $23 \%$.

Leptichthys, 615 . nqiis. (illi.

Leptccepnaius, :Hti. spacilis. medius, 17 renia. ïth.

LEPTOLEPID.E. 1.

Letorosomus, -14.

nionocers - cpussicostatils. Ztb.

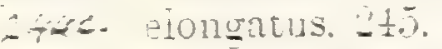

guesinimitus ,

macrourtis 2 t.

minimus. ㄴtiti

Leptotracheius, $17 \%$ rmatus, $17 \div$. eiongatus, $1= \pm$ rracilis. 180.

hatelensis. L St. Tuneininnis, -7 .

sagitatis.

moueter. - it.

Trinatus. 18T.

Eeuciscus

acrogaster. $\$ 10$.

ulia. ill

bosniasiti.

hericanchan. $31 !$

veris.

brinains, ,ill,

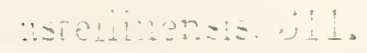

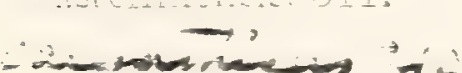

Zeuciscus (:ont.).

cecconii. $\because 12$.

cepiraton. 87.

cepinatus. :30\%.

colei. :

dorsilis $311,: 12$.

dumerili. $\ddot{11} 11.312$

eibiswaiciensis. :10.

elegans. :315.

errethophthaimus. $\because 09$.

emrromus. 311.

iritseni. 615.

gaobrensis. :̈11.

siobus. :10.

raciis. $31+$

bartmanni. $31 \frac{1}{1}$.

heireticus. 815.

heterurus. 310 .

amontzi. :ill.

larteti. 311.

latiuscuins, 8195.

leptus. $: 09$.

hicate. :311.

macrupus, :118.

mecilis, 310. resermun

veningensis. 05.

pastraceus. 070

plesionterus. 311 .

polysarens. 311.

nueliaris.:11.

pusilitus.

pacaimuci, :,11.

remotus. 311 .

rutilus, 009

saurigei, :12.

sieanus, 311.312.

stephani. 311. 615.

tarsiger, 315.

turneri. 811.

reriilite

Leucus, $2:$.

enncionianus, 32.2.

3ntus, 302.?.

Ieuresthes, ¿tol.

Jexrisia, .

opalis. 53.

Iicinia,. \pm \pm

aita. \pm 46 .

:mailis, \pm \pm 5

lata, $\pm \frac{1}{2} \overline{5}$.

prisen tit.

secumrtid. \pm 40 .

scompanti. +46 .

Lobcaus.

Deciemontanus. no.

Joocpterus. 15

nectmarth tis.

opperta

Joninius, 71 .

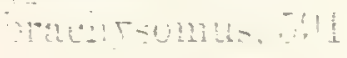

$\therefore$ क $502,-3$
Lcphius tomen

matagonicus. 591

viscitorius. jol.

Loricaria, 51.

plecostomus, 591.

Loxostomus. 611 .

:nanclis. $\{11$.

Iucania, :ulu.

Lucicperca. 521.

sicorpili. J21.

Iucius anteäilusianus,

258.

Iutianus epippium,

Lutodeira, it.

Iycoptera, 1.

\section{chensanis $-0>-x$}

macporinghia. "2. repils, =

micienciortin, :-2.

sinensis. 3.

Iyrzolepis.

ducisicus, 59.

Macrolepis, 45.

Honearus. $+1 \%$.

Macrones, 727 .

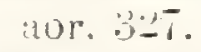

Iacrostcma, :

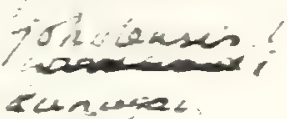

$3<0 n+\infty \sec$

aitum, : itl.

Micrerio.e. (it).

Macrurus, 60 . 7recursor. 605.

IIailotus, itit.

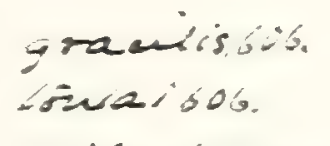
rilosus. lil.

Megalodon, i, 90.

सresiensis, 4.5.

sauroicies. in.

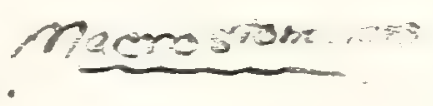

Iegaiolepis, 450,58

- oaschedensis, +28.

iatus. t2?.

Megaiops, 24.

toleinatus. 6.5.

ublongus. 25.

priscus. ㄴ.

- Iegalurites, .71.

niticium, jo:.2.

Iegapus, :20.

ruesttialieus. 2-:

Iegistopus, - (3). 34.

questiaitens, $28:$.

Melecta, $1 \pm 6$. menata. 151.

dolieana. 159.

Truilima. 55.

pancisquama, 155.

ieciseli. 1.51.

Leterostoma. 152.

intermedia. $15 \%$.

longimana 151.

mpisoti. . il.

apratroirites.

sdineri. 


Meletta (cont.). suritiutes, 152. scheuchzeri, 147. stvriaca, $15 \overline{7}$.

Melettina, 151.

Mene, t3í. oblongus, \pm \pm 0 . pusilla, 141 . rhombeus. 439 .

Menidia, 361 . Meriangus, 600 . cognatus, 604 . spatulatus. 604 . surfolkensis. 600. rulgaris, 600).

Merlinus, 603. eristatus. $60 \% 3$.

Meriuccius, $601.5+3$ attennatus, 60)t. baiticus. (i)t. manoefra bosniustii, 601. emarginatus, (j)t. mincenicus. b0t.
obtusus, 604.

Mesogaster, :61.

cretaceus, :hi:. gracilis. 254 . sphrranoides. 36:.

Metopcnichthys, $50 \%$

longirostris, 5.j9.

netacanthus, 5.).

Micrccelia, :-2.). gramuiata, 2002. Iibanica, :20-1

Microcton nuchalis, $4: 29$.

Mìrodon pulchellus. t21.

Mioplosus, 517 . abbreriatus, j]8. beani. 518 .

labrilcoiries. 517. longus. 518. muitidentatus. jls. saurageanus. 018.

Monccentris, $41 \pm$.

$\therefore x, 4 / 3$. hosies. 414.

enm:4 3 . integer. 411. subrotundus. t]5.

Iononteros gigas, 89.

Morrnua, 594 . zgietinoicies. 601. extensa. bitol. laba. 304. lanceclita. (i) 1. latiz. $31 \%$. matoromersia. 601 minamil. (i)! s(t) titingensis. $10 \%$.

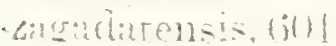

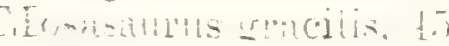

INDEX.

Mulleas. 37. Mugil, 36:3. acen, 364 . brevis, 446 . freys $362^{\circ}$ cepbalus, 364 .

lartes debilis, 365 . modiax 305

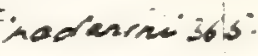

205 princeps, 36t.ornacum 365 radobojanus, 365 .

Megilide. 363.

Muræna cæeca, 847.

Muræna conger, $3+4$.

Mur:ena lèwesiensis. 185.

Muriena myrus, $3+1$.

Murana ophis, 347 .

MER.ENID.E. H36.

Mylccyprinus, 3̈2.). inflexus, 22:2. kingi, 323 . longidens, :3:3. robustus, :3:2?.

Mylcpharyngodon, 303.

Myripristis, 410 . homopteryoius, 411 . leptacanthus, 410 . toliapicus, 412) meliten sis, 413 .

Myrus, 340 ruigaris, $3 \pm 1$. crnueri,

Odas carolinensis, 543.

Odonteus, 5.56 . depressus, $5.50^{\circ}$ pygmaeus. 5.56 .

Naseus, 564. brevirostris, 561 . nuchadis, 565. rectitions, 564.

Naupygus, 611. bucklandi. 611 .

Nemachilus, $\because \because 0$. bredai, 300 . centrochir, 320 . cephalotes, 321 . tener, 1 is. mus tevleri, 321 . Tomalis 320

Nematcnotus, "2t?. bottae. 250 .

Nemcpteryx, -iss. sparoides, $\bar{j} 6$.

Odontostomus, 189.

Oligobelus, :":3.3. alcifterus, 303 laminatus. 3203.

Oligoplarchus, .ily. squamipinnis. $51 \%$.

Omiodon, 270. cabassii, 270 .

Ommatolampes, tel $)$ eichwaldi. 491

Omosoma, $41 \%$. intermediun. +20 . monasteri, f리. pulcisellum, $4: 21$.

elongatus, j98. Kuvacsa jabel-almit. 119

Nettastoma, $3+6$. bolcense, $\ddot{3}+6$.

Noticarirnde, lis.

Notacanthus, 169 .

Jutaus agassizil, jt).

Notelops, $2-$ braman. 2 .

Notogoneus, $\because 7$. जurieri, $27.61 \%$ longicens, 27s.

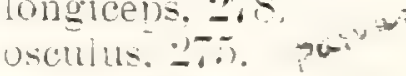
equamossells: :-7;

Oncolepis, 53. isseli, int.

OpHIDID.F. 605 .

Ophidium, 60\%. 600

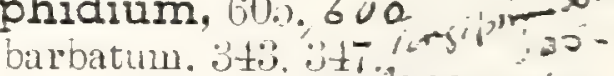
roltianum tioj ésomo, 600 PHUCEPIULID E, 36.9

Ophiocephalus, : 69 . striatus, $t 6+$ t.

Ophisurus acuticaudus. $\because 47$.

Opisthomyzon, til.

Tinoplymer.

Notopterus, iti. lumallis.
Opisthopterys,

-111 rus. -

suacilis ont 
curvocacis, $158 a$.

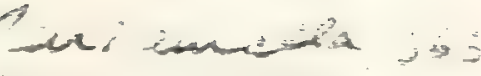

Rerriamina 605,500 ectenes, 605,520

perschipea, 129.

Anuchancesis, is

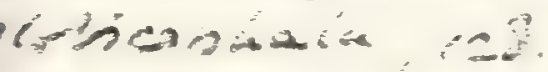

Mivoenuiv for

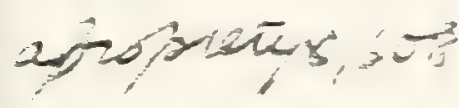

sompues, is:

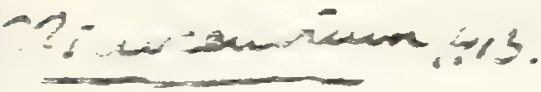

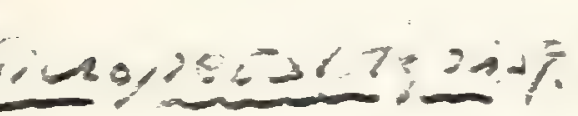

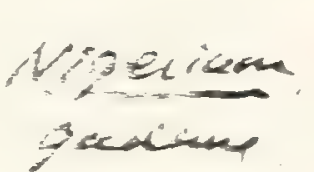

cususeress

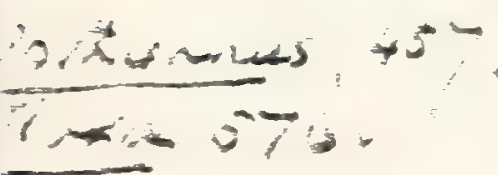

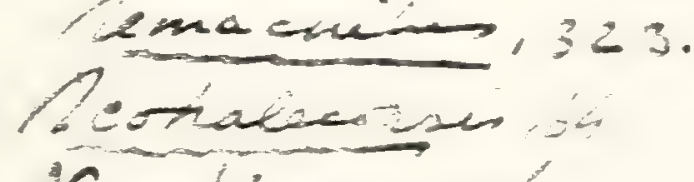

Vortancin oif

Neomaenis, s.

repari in

Emx.

Checsuemenn; I

Preocuing 475.

rescisation, 475.

NOBRPRIDE -

$\checkmark=-$ - ine, 73

Nepercis, =9?

nipion, sos

cisipinosus.

if

$-\infty$

- w

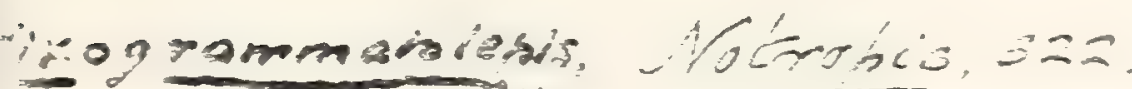

ismancicous.
Merziamedla, źs dorusse, Its?

Nuc-3on-4s

mierosoma is?

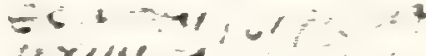

arin's

cus $2125,482,-1$

sagizta, - 82...10

Qtropentes t

Lugúlisios $=$

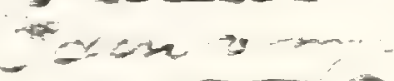

Cneresaness

Cnobosmin

nom

ceisodicerion.

Tra

Ona strum

Siscersus.

Oshisuses

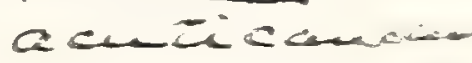

Convelon

Qohiodom atp.

than ractiom

osymand:

Carenesis:

Opleanarimiog

Coctimarion.

nener

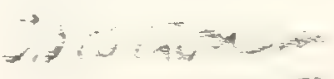




Oriteprivin, 523 .

bornhoumiensis, 613.

$\therefore$ ingugs, 242

hamprotivensio, 617.

Sisconemens 363

$90 \mathrm{x}$ my 3 ,

Cstariustoma,129.

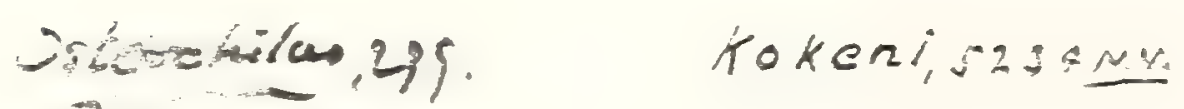

Enisis, 2 .

Oxysoniopitus iscole

Orymandias, 4821 giehent: 4820.N. 
Orconus, †it.

รับบน

sinceulatus. tjo.

Incior. tor.

meciins. Hivi.

suidisil. $\frac{1}{4}, 5$ :

Oricarainus, th.

ortus, $\frac{1}{*}$ it.

Orthagcriscus, .70. helononsis. int

Osmeroides, I1.

utremuatus. $1 \%$

beigicus. 20.

ureris. 16

imissis. 10.

cretaceus. 20.

(ivaricacus. …

dubins. 16.

eTrolitus. 7:2.

Gitriciandis.

Grome. 15

sranuinatus. $21 \%$

melunis. Ht.

intus. joi,

leris. 15.

lewesiensis. 11, ...

lewisi, :

minnelli, iz.

matrimlis. is.

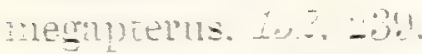

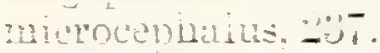

minur.

munasemi. 201. 20,

pectiolens. …

molmicrudis. -2.

sarcinidides, let.

inule sis, 21 .

Osmerciecis, 30.

"eticulital.

Osmerus, 므.

alibri. 192.

colnitel. $\because \frac{1}{5}$.

dachintio

girmianus, 25.5

iarieti. Li:

pronterrg?ts, ió.

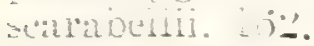

-iin)120s. 1:32.

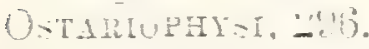

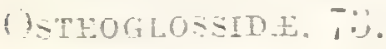

Dsteoglcssum, $; \frac{1}{2}$.

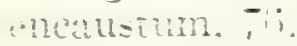

Ostracion. -1.1

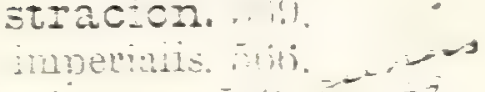

micipurts, -at?.

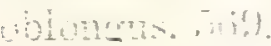

nulus.

otolithus. wat stedit

nembnatus if

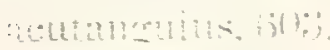

$-1$.
Otolithis wh:

wquits. $2,498$.

muericunus. tei.

amolis. ojos.

apploximatus. 10 .

intemuatus. (i)t.

halticus. 104.

bararicus. buti,

biscissule, . 130.

boerterer. 10.5.

- breriul.

Harbonensis jón

cognatis. (i) 4 .

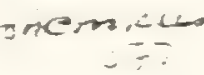

$-\div$

circuratos

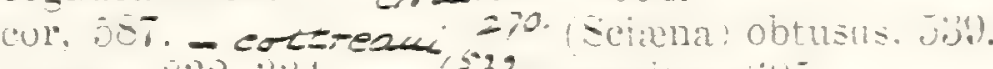

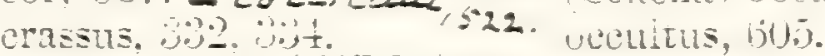

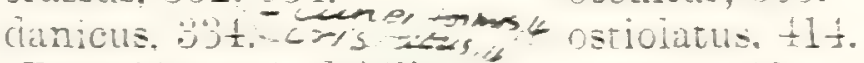

Belrciciarum clebiits. $\pm 15$.

OLusidiarun devilis, ijio.

decipiens.

ciliturmis. 105 .

dispal". is.

distinctus, 20.2 . $\mathrm{N}$. V

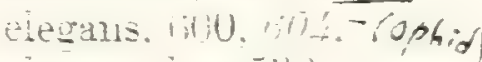

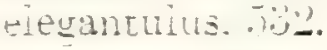

टletatus. ious.

ellibricus. $-\bar{T}$

e/simas, in.

oratus. $532 \%$

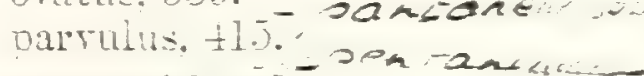

persouatus. on.

visanus. $\frac{1}{21}$

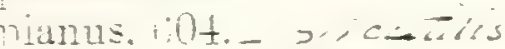

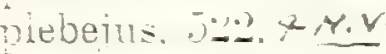

inncielosus. $611 \frac{1}{2}$

pusterus, 6il\%.

antrats at

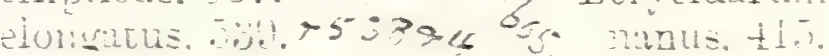

Emarinatus. (j) 4 .

epoprectus, jous.

taba. (1). Geniensijol

trancorutsums. ist

7requens. oz.

remmal, sot.

sermanions. jüt.

seron. \pm 15.

ziobernitus, net.

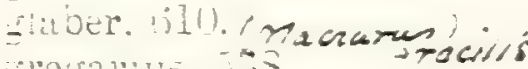

yernins, os.

- restriaizns.1011.

Inigenclum. G05.

holsuticus. - , jo.

huspes, $=1 t$

lisbilitis. it),

ingens. $41 \frac{1}{4}$

insignis, i.?

insuecus.

inceger. 14.

internedilus, -

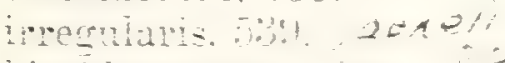

Hiponberrens!s, oun.

aciuiatis. $+1 \frac{1}{2}$

atrieatus. ent

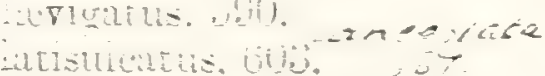

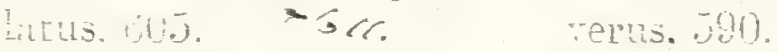

dalweri. $=11$.

onticulans: 511

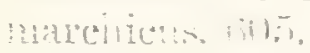

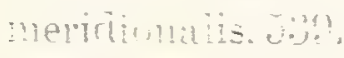

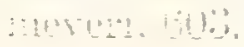

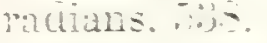

Berreidarum

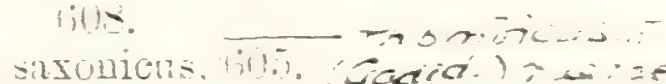

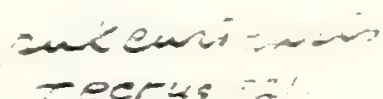

-ectis :-

IC.

sector. biit!

splitndicus, 9u!

Murritu, sutin-

- Sensis, 145

(s)allidintul svelingensis, os.

similis. jos.

singularis. viló.

Enatuiatus. Uilt

specroses . 20.6\%?

opectabilis. bilto seonerwi:-

Hidtll, - - -asnosicis.

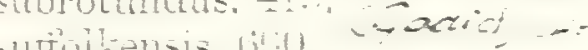

uIfulnellsis. U:th

envaracreracells, - í,

enuis. ! ity

cetis. 1.jo

hronnuides : : - - Furan...

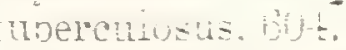

Tangionis. .jot. - wmonats $\Rightarrow$

ratiuns.

Tonalis. $-\infty$

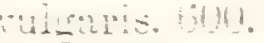

Pachroephains. :

vitilit.
:Rhombusmenamus.

simuier. viot. - 


\section{ר}





\section{Pachvgaster, -20 \\ polysugndrius, jogr}

Gerciry: za spinosus, 20.

jovio 294. Pachylebias, 29t.

ricalmuir, 211 crassicaudus, 295.

orman it5. Pachyrhizodus, 37.

basalis, $\because 7$.

eaninus, $4 t$.

curvatus, 4 .

diblevi, 38.

gardneri, \pm 0 .

glyphodus, 258.

gracilis, $4 \overline{5}$.

kingii, 42 .

latimentum, $4: 2$.

leptognathus, tj.

marcthmenses 107 minimus. $t \overline{\text { mopsis. }}$

sheareli. \pm 5 .

subuildens, 48 .

velor. $4 \pi$.

Pachrstetus gregatus, 292 .

Pagellus, 532. aquitanicus, 5033 .

33. Cle stetanii. $53: 3$ elegantulus. 5:3:. leptosteus. 5.33 . libanicus, 390 . mirorodon. $53 \% 3$. peruzzii, 5.3 .3$. stenoura, 5:30\%.

Pagrus, 033

menegninii. 5:3:3.

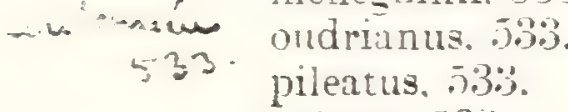

priscus. 533

torus. 534 .

Palæobrosmius, j乡8. elongatus, 598

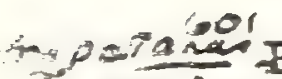

Palæogadus, 598.

in perimen troschelii, 598.

Palæolycus, 211 .

dreginensis, 211.

PAI EORIYYCIIID.E, 482.

Palæcrhynchus, \pm 83 .

bruxeiliensis, 490 .

colei. 188 .

deschmanni. 487.

egertoni, 458.

giganteus, 407.

glarisianus. $433,48 \%$.

gracilis. $186^{\circ}$.

latus. 185.

longrostris, $186^{\circ}$.

medius. 485 .

microsnonditus, 489.

riedli. \pm 87.

zitteir. 487.

Palanarrhichas, jo. crassus. 037
Palimphemus, 270 . anceps.

Palimphyes, $t 60$. brevis, \pm 60 . crassus, $t 50$. elongitus. $t 60$. glaronensis, $\frac{1}{4} 60$. grarilis, 460 .

latus, 460 . longus, 460 .

Pantopholis, 234 . dorsalis, -2ùt.

Paralates, 5:0. bleicheri. 520.

Paralepis. $25 \%$.

Paraleuciscus, $31 l^{\circ}$ ecnom?, :II.

Paranguilla, : 43 . tigriui. 343.

Paraperca, 520. provincialis, 520.

Páraphyllodus, $5+t i$.

Parascopelus, 256 . lacertosus, $250 \%$.

Parequula \pm 50 . albri, 4.50 .

Pegasus lesiniformis, 269.

Pegasus natans. 383.

Pelamys, 15:. adunca, $48 \%$. robusta, $18 \%$. $\operatorname{sar}^{2} \alpha, 8=$

Pelargorhynchus, 188.

blochiiformis. 188. dercetiformis. 188.

Pelates, 523. quindecimalis. 523.

Pelycorapis, $35 \mathrm{t}$. berycinus. 325. rarius, 354 .

Perca, 518. alsheimensis. 513. beaumonti. 515 . ceprinodion. jog touer: elongata, 515. fluviatil:s. 518 . forbesi, 510 . formosa, $410.19 \wedge 0 t a$. lepidota. 511.1 ses lorenti, 518. lucioperca, 511. macracantha. 51 . minuta. 506 . moguntina. 512. punctata. 666. radula, 526 . rebonisi. 520 . uraschista. 516.

Percesoles 47 .
Dercichthys, 511. antiquus. $51 t$. beaumonti. 515. Pelicid.e, 49 y.

4 Gi. Perciformes, 497.

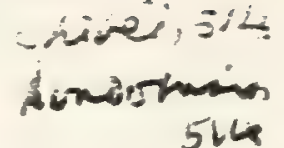

Percostoma. 519 . angustum, 510 .

Peristedion, 5₹6. personatus, 587.

Phacodus, Cope. 55:. irregularis, 503

Phacolepis $=$ Rhacolepis.

Phalacrus, t5s. crbioides. \pm 5.

Phareodus, it, 5 . acutus, 76 . sericeus, 76 .

Pharyngodopilus. $5+1, \bar{u} 45$.

abbas, $5+3$.

africanus, 54 .

alsinensis. $5+4$.

bourgeoisi, 543.

canariensis, $54^{\circ}$.

carolinensis, 5 te.

crassus, 544 .

dilatatus, $5 \pm 4$.

haueri, $5 \pm 5$.

multidens, $\bar{j} \pm t$.

polvodon, $\overline{4} \pm \overline{0}$.

quenstedti, $\check{2} \pm \bar{\partial}$.

sella, j+う.

soldanii. $\overline{ \pm} \pm \overline{.}$

superbus, 5t?.

Phasganodus, 100.

anceps, $20: 3$,

austrails, 615 .

carinatus. 204.

dirus, 204 .

gentryi, 615.

gladivlus, 204 .

semistriatus, $20 \%$.

Phasganus, 613. declivis. bi:?.

Pholidophorus macrorhynchus. 2

Phycis, (iv).

8 . suessi. 602.

Phylactocephalus, 21:? ?18.

microlepis. 218.

Phyllodus. j46.

borrerbanki, $5 \pm$.

colei. $5+9$.

corsicanus, $57 t$

cretaceus. 5.00 .

curviciens. 550.

deborrei, joll.

rieplessus, ..:0!.

turali. ejo. 


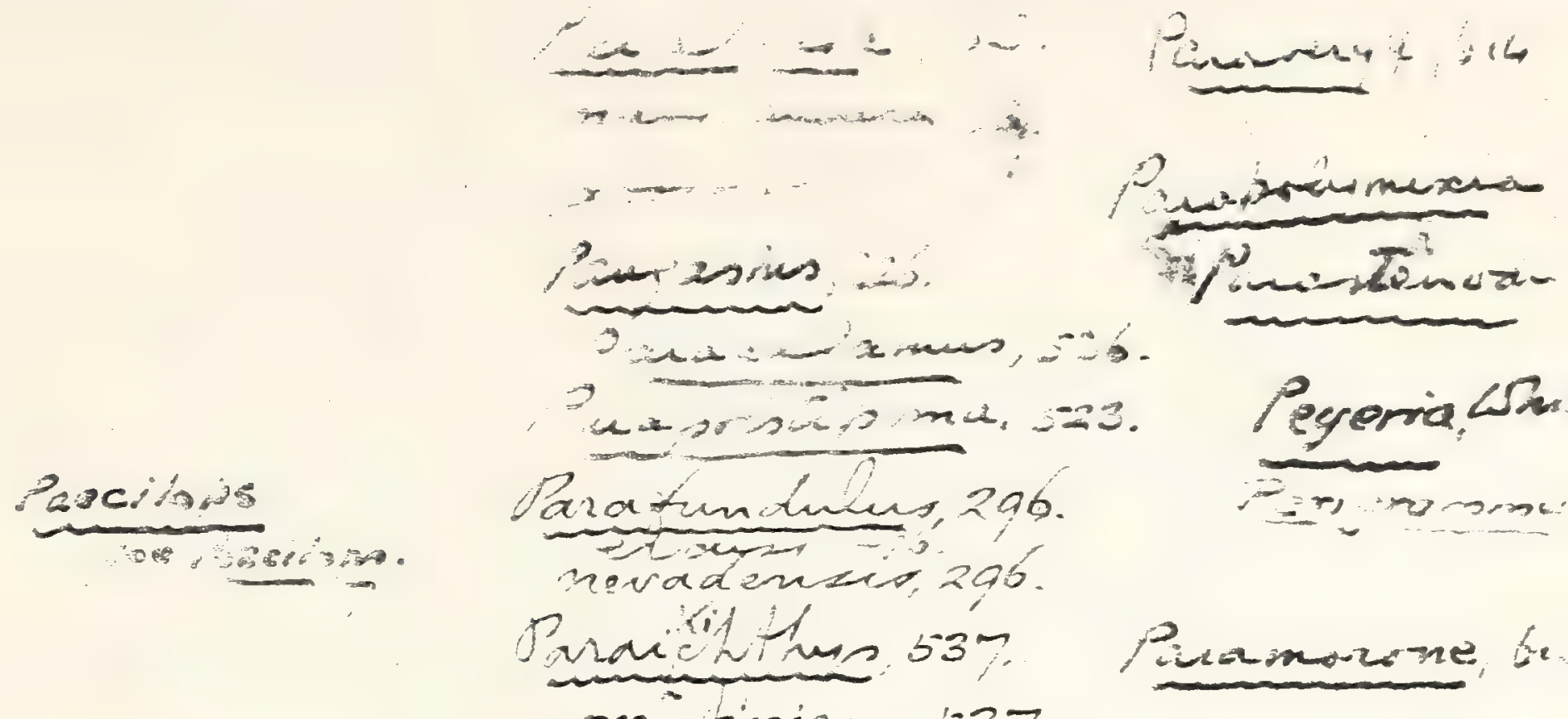

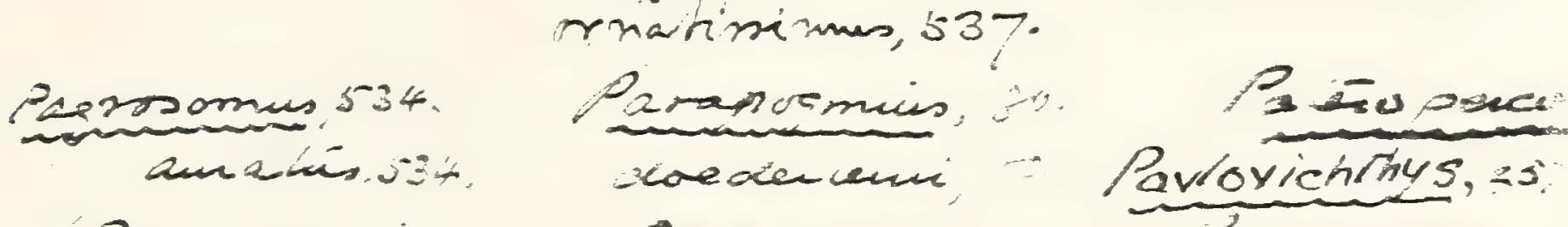

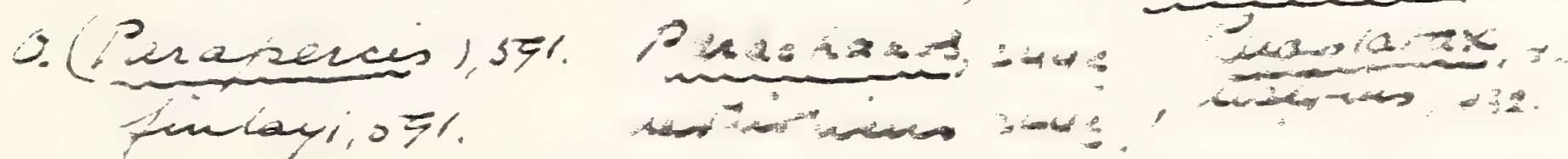

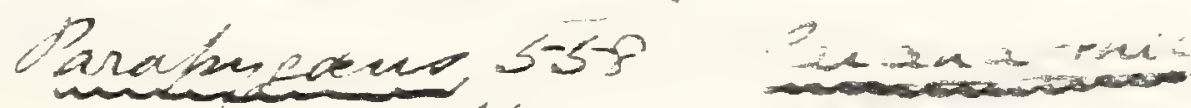

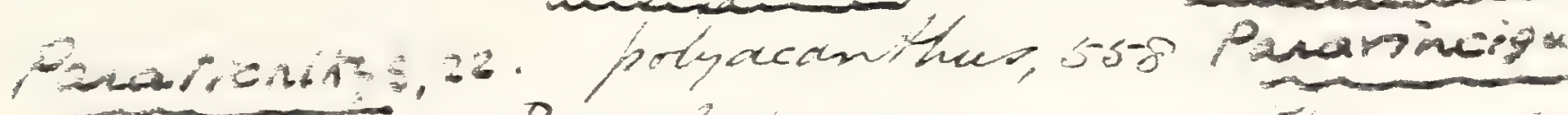

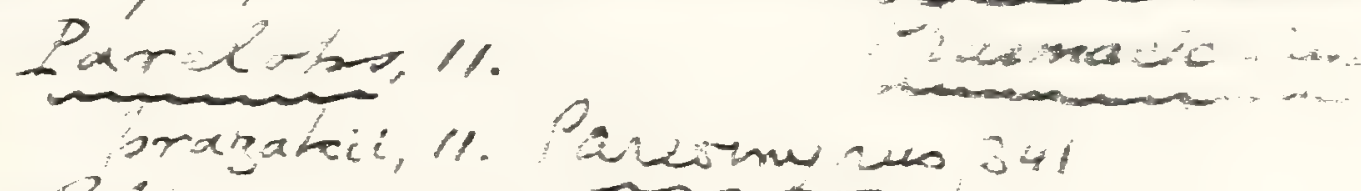

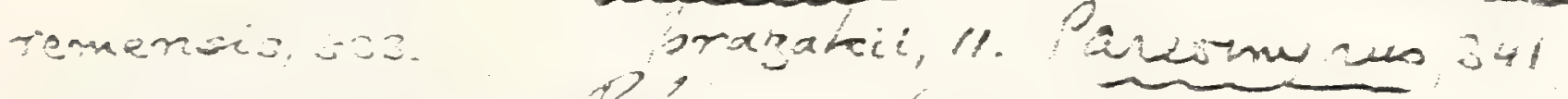

siracusanus, s-33. Petemuscybium,

distincess N.V.s22.

3

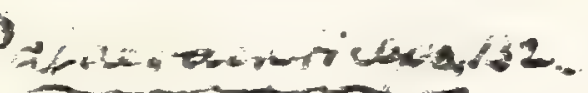

Pecien. 20,

ilaeorínsera

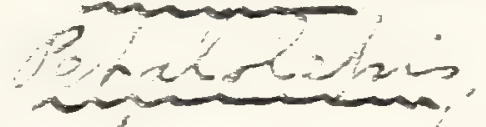

tiravicutas $2=$

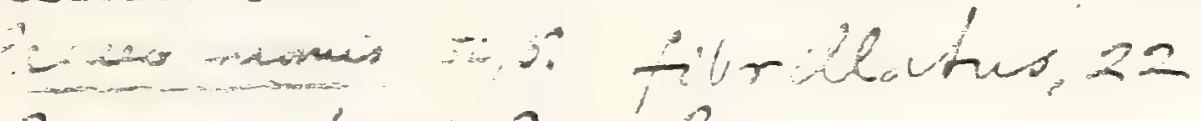

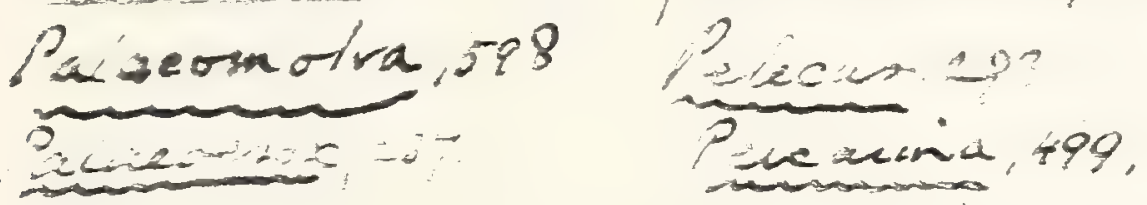

Putuerscominat t5

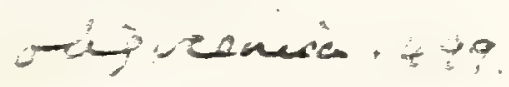

tosinen

spinosess

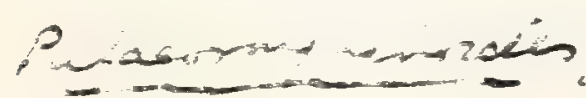

mavivinas

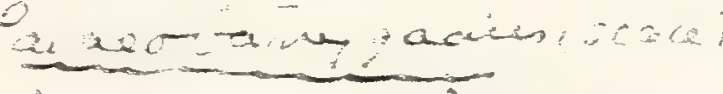






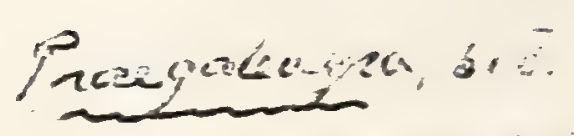

Prosicombresch, s?

PRIACANTHODE, Y5.5:

Fiacanthus, 563 .

lohasias, 33 .

Plectrites 536. spinosus, sod.

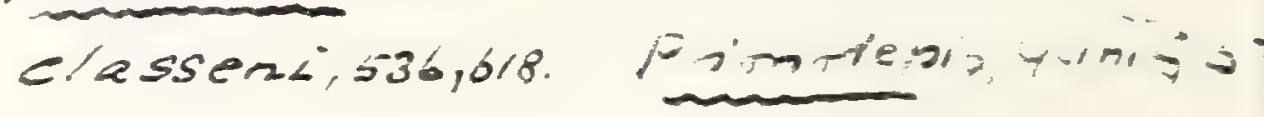

Piergezhation, 69.

2. sicuries, 606.

$\therefore-$ icandatis bolo.

Posisma, 235.

minimus, 235 .

intenias 5034

runcen, 20
Poangentina. 162.

Profarkig gadurs scun

rrodiodon $=-6$

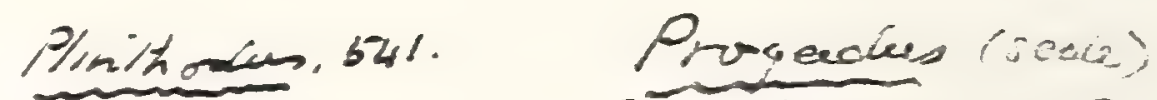
pisanitizz. Protehasax, 298.

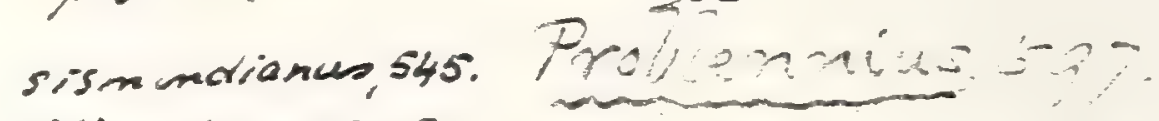

fliosituress, 325.

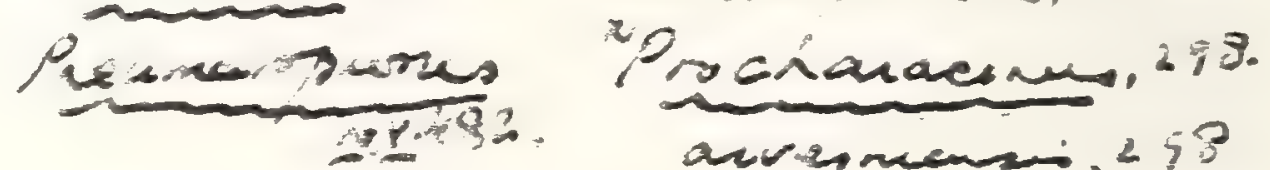

acrennemsin. 43

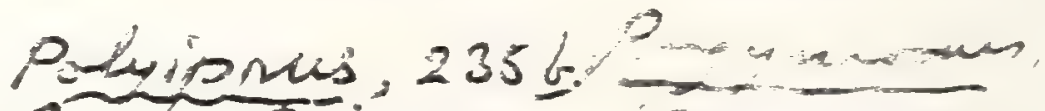

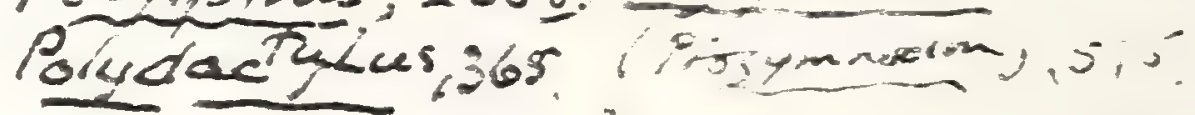

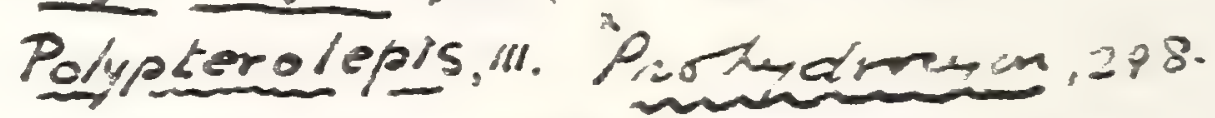

POMAdASIDAE 499 . pellegrion. 258.

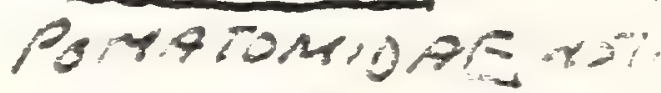

Pomolober 155 s. 64 ifo

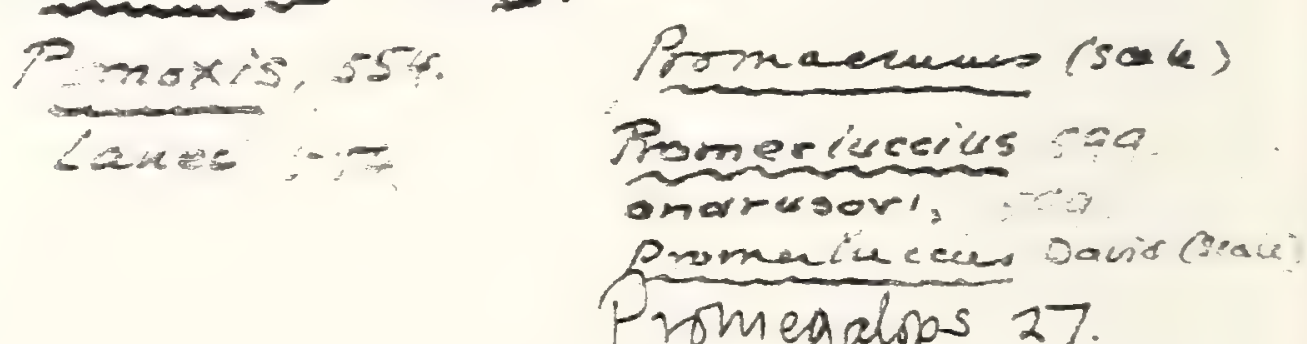

Promegaloss 27.

Prosereaninit, 91 .

ereili, 494.

ies 
Phyilccus (win.

elegans, jiu. gerriasi. 80

haneri. stt.

hexagonais. ite.

hipparionsx. (il.

incertus, 5.5.

inconstans. 500

irrequiaris. 5 ts.

latidens, 5.50 .

leresunei. 550.

mareinais, jts.

medius, $5 \pm 0$.

multiciens. $i t t$.

petiolatus. $5 \pm 8$.

planus. $\overline{5} \pm \bar{\pi}$.

poirodus. 5.t.

secundarius, j+9.

speciosus, 5t?.

sundebressus. $7 \pm t$.

suomedius, joty.

tolinpicus. Jti.

imbunatus. $5, j 0$.

Pimeiodus. 81 .

antiquus. 329.

aor.

sacileri. 385.

Pisodus, 60. 1. toueardi, $7:$.

omeni. (1).

Plagycaus. 189.

Planesox. Jiy. roras. 510.

Platacanthus, 509 .

ubinol. 510.

Platax, 32.

aitissimus. \pm 0.0.

Dreris, \pm 203 .

orehicus. \pm 1.

costatus.

cuneus. - $=0$

macronterrgius. $=83$.

minor. ....

nuciatis. $\div 29$

papilio.

pinrseteroicie, 40.

pileum,

binnatiformis, $4: 39$.

pinianus. 4030

suvrespertilio. 139.

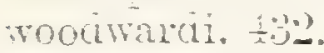

Platessa. :

servor. ut?

Placins. 9.

eatuitit. $=9$.

Blongarus. 89.

givis. =i.

3lace 0.9.

suoulidens, -3.

3latycormus. $=21$. jarmauns. fol.
Platycormus (10n\%.

giobuens.

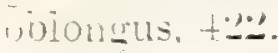

Platygenys. 113.

"ugusus. 130.

2latyiamus, 5i. colei, joit.

Platylates, 520 .

pupeliensis, 520.

Plectropoma upascisista. $516,016$.

Pleionemus, $1+2$. macrospuncirius t.2.

Plerhodus

ervansus. S1.

tupeurus. st.

oblongus. 8:3. ventasol1. 83.

Pleuracintisus serratus. $5+7$.

Pleuronectes, bols. piatessa. ón. (4). guadractulus, $017 \%$

Plecronectide. ith.

Plinthophorus, ․:-1. robustus. …?

Plioplarchus, 520. sentemsdinosus. 520. sesspinosus, 500 . whit?

Podccephalus, 310. nitidus. $51 \%$.

Podocys, 20. minutus, .00.

Podopteryx. ost. aibri, ist.

bosuinsit. ast.

Pecilia imetherit. 615.

Pachila oeningens1s, is.?.

Pecilops, tu. breviceds. $-216 \%$.

Pogonias muiticientatus, 5ip.

Poiynemus. 445 yinquarius. 111.116 .

Pomacanthus. il. subarcuatus. sti!

PonACENTRID. no.

Pcmaphractus, \%.

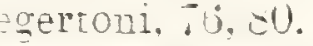

Pomognathus, 21:, in.

enptererins, 21:.

Portheus. ?.

inguiatus. 10.

meratus. 201.

ausurais.

srachtgathis. 07.

iariesi, 20

guitinus. 95 .

Giadius.

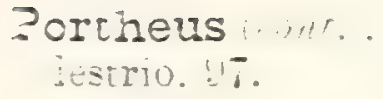

Towi. $\%$

mantelii, 45.

molussus. :1.2.

mucigei, $: 5$.

thanmas, 17.

Prionolepis. wh. H...m

angustus, 帚o.

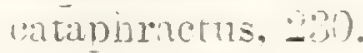

laniacus. 2:-

Priscacara. jot. $2 m i s, \ldots$

virosa. ist.

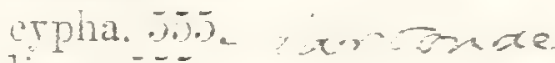

liups. 55.5.

uxyprion. 5.55.

pealei,

serrata. jut.

cestuiinaria. …i.

Pristigentrs. +15 .

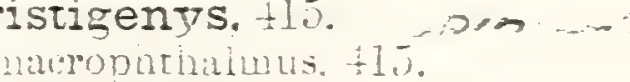

Pristipoma. 500.

inreatum, je:.

Prcantigonia. evia now . n

iungirostra. .jos avoresso

octieantha. 5.5.

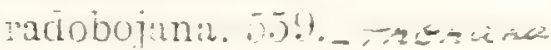

steindacuneri. 559

Probailostomus, :of.

lonquilus. . ¿t.

Prcchanos. (i).

rectitions. 1.5.

Progymnodon, $5:$,

$$
\text { ji. }
$$

hilgenciori. -7.5.

Prolates,

weberti. 1.19 .

Prciebias. - inl).

brongniarti, 218 .

cephialotes. 20.

crassicaucius, 245

ciaridi. t.

egeranus, 1315.

furcalus. -21.

gaudrei, 294.

gobio, -201.

soreti. $-20 \%$

greqatus. 202.

mereri. -14 t.

minimus. -24.

oustaleti. 290.

pernusiilus. -21

pulcheilus. 151.5.

stenoura. 200.

Pronotacantivus, 169.

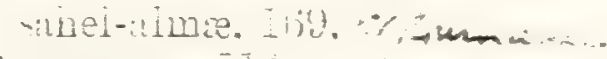

Procerca.

ngusta. 015.

Seatumonti.j15.

-epiciota. 11.

riser. 510 . 




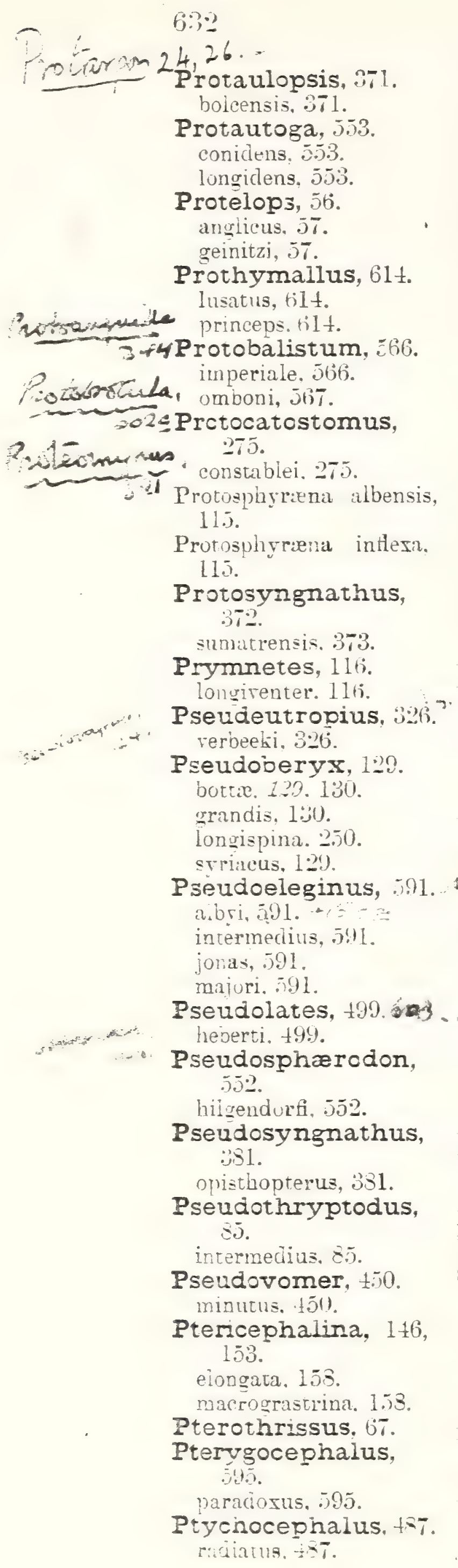

IYDES.

curalus, 394

Pycnosterinx, 391.

dariesi, $390 \overline{0}$.

discoides, 393.

dorsalis, $392,993$.

dubius, 395.

elongatus, 395 .

gracilis, 394.

heckeli, 390.

latus, 395.

lewisi, tot.

niger, 392.

russeggeri, 392.

Pygacanthus, 613.

altus. 613 .

Pygæus, 5ji.

coleanus, 5.57.

dorsalis. $5 \overline{5}$.

egertoni. 557 .

gibbus.

gigas, 558 .

jemelka. 579.

nobilis, 558 .

nuchalis, 558 .

oblongus. 558.

Radamas, 536.

jugleri, 536 .

Raniceps, 603.

latisuleatus, 603. tuberculosus, 604 ?

Raphiosaurus, $37,43$. lucius. 43 .

subulidens, 43 .

Rhabdofario, 160.

lacustria, 160 .

'Rhabdolepis, Harch, 11.

cretaceus, 20 .

Rhacolepis, 29 .

brama, 26.

buccalis, 30 .

latus, $3:$.

olfersii, 28 .

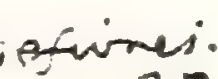

Rhamphognathus, 361 .

paralepoides. 361 .

pompilius, 361 .

sphyranoides, :62.

verneuili, 362.

Rhamphornimia, 269.

rhinelioides, 269

Rhamphosus. 377 .

aculeatus. 377.

biserratus, 378.

Rhineastes. 329 .

arcuatus. 323 .

calrus. $32 \%$ grmycu.

pectinatus, 20.9

peltatus,
Rhineastes (cont.).

ridulus, 330 .

rhæas, 329.

smithi, 330.

Rhinellus, 265, 269

curtirostris. 269.9 hicam

damoni, 268 .

ferox, 267 .

furcatus, 256 .

laniatus, 232 .

longirostris, 282.

nasilis, 269.

robustus, 268 .

schilli, 2179 .

tenuirostris, 269.

Rhinocephalus, $60 \%$. planiceps. 6013.

Rhipidolepis, 613. elegans, 613.

Rhodeus, 316 . edwardsi, 317. elongatus, 316. exoptatus, 317. latior, 317.

magnus. 317 . oligactinius. 316.

Rhombus, (306. abroptersy, 608 bassanianus. 608. caudatus. 608. cutrensis, 608. fitzir geri, 608 . gentiluomoi, 607 . heckeli, 608. kirchberganus. 609. ligusticus. 605 . minimus, 607. minutus 1308. nardii, 6.8. parrulus, 608. ruenan'xs. 608. richiardii, 608. sauvagei, 608.

Rhonchus, 458 . carangoides, 453.

Rhynchorhinus, 342 . branchialis, "'t?. inajor, :

Rita, 28. grandiscutata, 3229.

\section{Salmo, 159}

ceprinoides, 456 . cierzaravin: immigratus. 160. lewesiensis, 11. maræna, 63 . tepiitiensis, 614 . Salmoxide, 159. Sandroserrus reboulii, $\therefore 20$ 


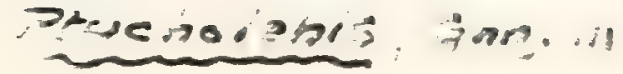

-

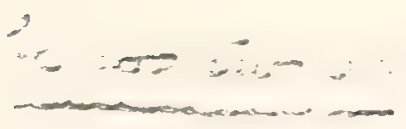

ancinasus

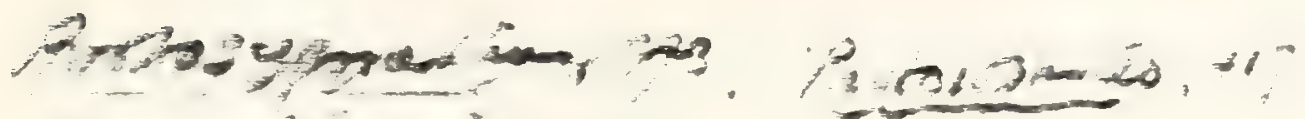

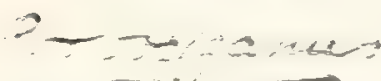

$2=-75214 a \quad 339$

gavaid

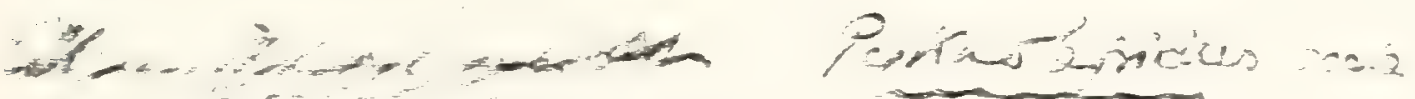

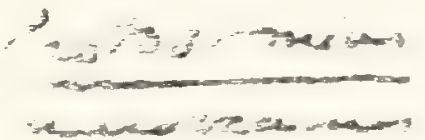

3

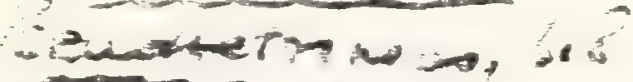

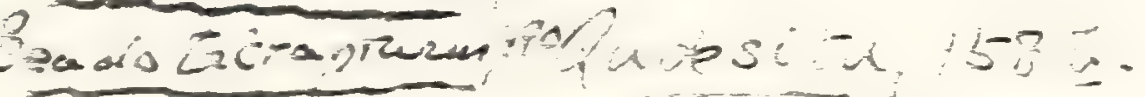

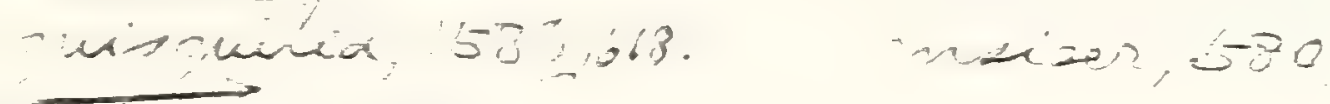

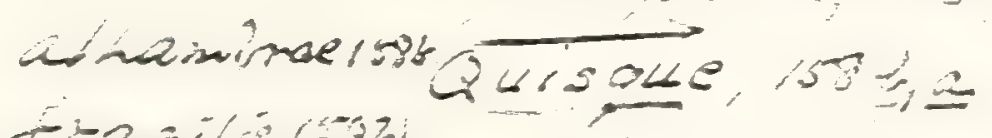

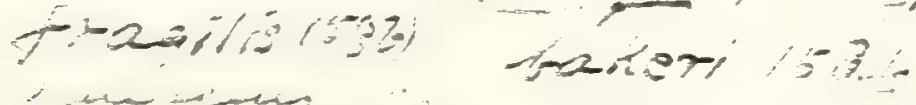

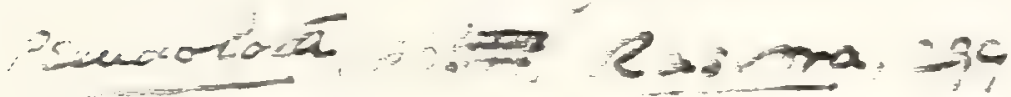

$\overrightarrow{x+\infty}+\infty-\infty-2$

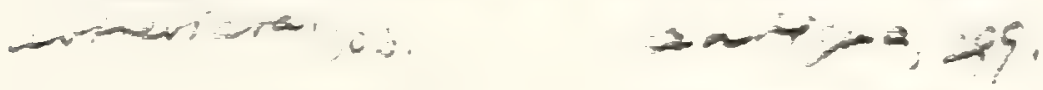

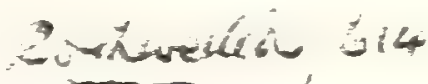

arisios, in

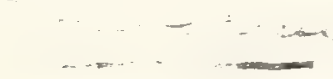

$-2 x-2, \cdots$

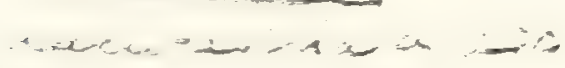

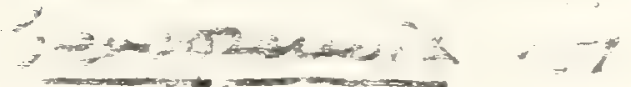

Sygmos =nis.

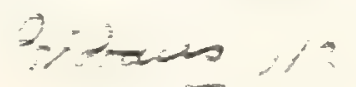

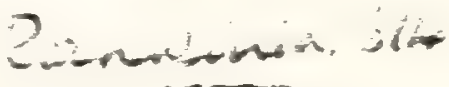

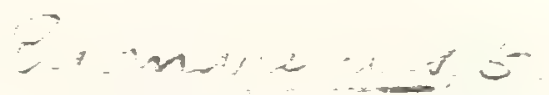






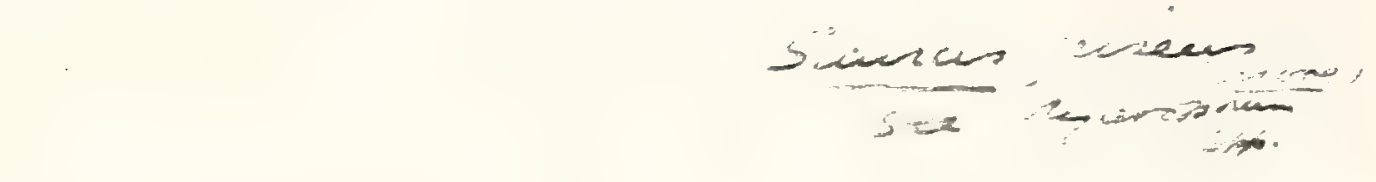

$m-20242$
$2,243$.
0.55
Siomaeresses, 358.

acuritus, 357, 018.

ed werdsi, 35 दे

$5=\sin r \cos 200+200$

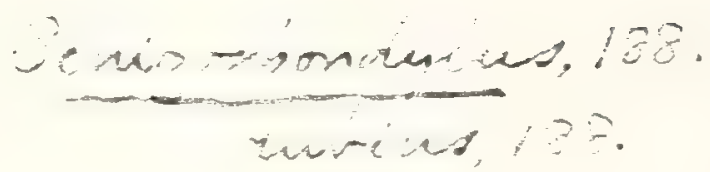

iraztarzes, $=80$.

revceupation 5e,ols

wes 107

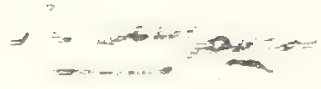

$S=2$ instinus, aso.

- vastiat, 580 .

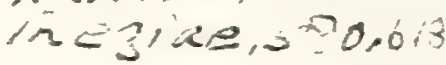

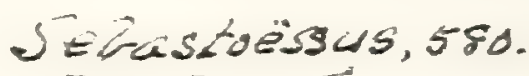

2, वes

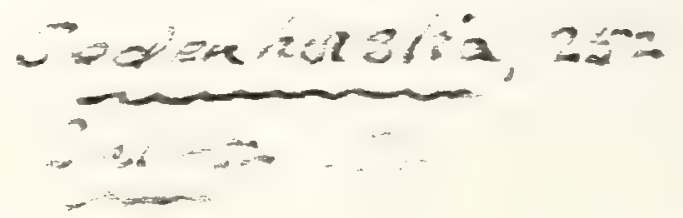




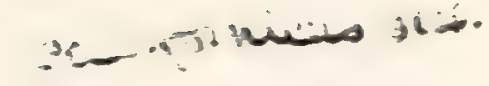

Sarcinisides.

undrostoma. $30 \%$.

xtenuatus, $2+11$.

- massicaudus. 20. macrovterroilus. 는. megancerus. - - . microcenhilus, 207. minucus, $2+2$. monasteri. 11. 207.

$>$ usilua. $2 \pm 19$. cenuicaucins. 2).?.

Sardinius. $-\frac{1}{4}$. blaciburnit. ㄴ. 15. massainna. - ¿2. cordieri. 2ti.

inacus. 2 $2 \frac{1}{4}$. wacrociactius. 101. nisutuius. $2 \frac{1}{2} 3$. percrassus. $2 \pm 8$. poustus. 1:31.

Sargus. =o!?

antulopocion. $5: 50$.

zunitauicus. -5.50 .

amatus. 530,020 .

caraidii. 50 .

carannai. $=00$.

arien. .80, 001\%.

zeverti. 5019 .

incisirus, 200.

jmnicanus. 50 .

Uitconus. - 20!

junensis.

steni. 531 .

-eslaccuritanus. $\because 30$.

Eerratus. 51.

sion1. 31 .

sivitensis, $-: 00$.

Saurcceonalus. 13 .

aivensis. : 1 . aravihovius. $11 \frac{1}{1}$ aucias. 2.

jroacheaci, 113.

dentatus. $11 \frac{1}{1}$

disnar. 115.

itjumensis, i15.

ingquais. 115.

intexus. 11:

inrelmedins. il2.

ancirormis. 113.

? 2anna. 111.

Trodion. - 1 t.

marginatus. 20.

monasterii. 115.

miebotomus, i iz.

jicceri. 115.

prognatuus. AT.

zriatus,

sucstriatus. 1.5.

thatumas, 8

Toodisarii. $-\frac{1}{2}$.

EARTIT.
Sauroaon. 111.

: inis. 113.

sroacileacil. 12:.

ronoidells. 213.

sror. 113.

inzermecilus. $12:$.

lancifumis. 11:

?eanus. 111.21.

murgnacus. 2arg.

pinieotomus. 112.

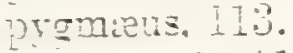

- Sipnipostris. 113.

Saurorhampinus. in.

inereri. 210.

Sauropsicium. 5 .

receilicaucia. is. Lerisimum.j5.

sarcinius dumeriil. :'Il.

Eerrinius sicanus. :31.

Scarus. -19

bairingensia, 500, 531.

miocentens.

oreni. 01.

=nericus 598.

terrodon. 53.

Scatophagus, jól.

atinis ól.

cuveiinit. 51.

contails.

Sciæna.

ampills.

Hesiticus. 509.

inreguiaris, 09

iculazix. $=01$.

zirucergensis, 539.

mencilunais. 00.

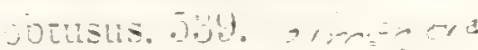

yumierii. 521.

इineciosus, 509 .

uncenalis. $=$.

SCIEYIDE. - SE.

Soimnurus.

botreponnisi.

bretiur, siz.

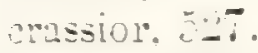

iongior. 510.

Scierognathus. 800

Scomoer. -5 ?

a.reunea, $\$ 50$.

contigutis. 59

comitia, $=5$.

smeus. $1 \pm$.

avoin, 21.

crernus. 土t.

ringiens. $= \pm 1$

cormis.

Thnoracus. 59

nos

- zomgent. - $=9$.

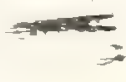

, a n a vus $=$

rrove m-4is

$-i_{2}$
J̈comcer,$n$ int.

sijecrosus. -136 .

steindacheri, $\div 5 !$

suecianus, \pm 59.

thannus $=5.5,=5$

trachurns. $\pm 01 . \cdots$ yo 15

Scomoerocion. =ij5. Jum

iumouti. -70

Scomorampiodon.

\pm t.

benecieni. $=71$

arasidens. $=0$.

curvilens.

SCOMBRESUCIDE. $\% 50$.

Scomoresor.

licatie, 4.8.

obtusirostris. 250

Scombrid 451 . $x=35$

Ścombrtrorses. +18.

Scomorinus.

macronomus, iti2.

nuchais. +151

Scomorociuxea, 1:j.

fuldirt. $1: 3$.

macruntianima. 595

Dinutiata, 255.

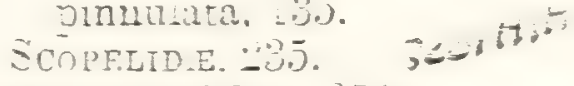

Scopeicicies, 2.t.

cicivinuns.

Bcoreins itceltosns.

Scorpæna. $7 \%$.

minuma 50

piaris 50

Drior, 570.

Enrota.

Eessierio

SCOR? EMIN工, .TT.

SCORREMTORuES DT:

Scorpanoices.

Donoricit. 31 .

Scorcenopterus.

(a)

siluriens, joo.

Sctpitopitorr. 1

Sebastocies.

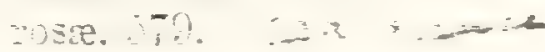

Semiopnorus.

- cos. - il).

mussiongitnns. :31

uvenizes ispellovilis. 1.

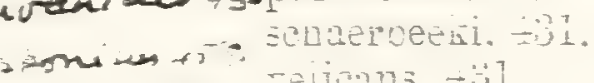

relionz. -1 .

- airer. - 0 l.

Semotius. Un

uircit. - -

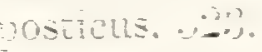

Sericia. $=$

andis. $=\$ 5 \%$

Palliulne: $=$;

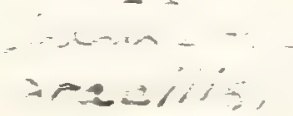




Seriola (cont. . lata, 145.

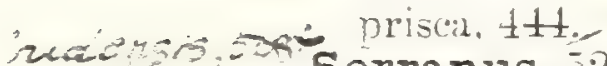
asotfic,s21 Serranus, j21. altus, 521 . roinze $11,5,521$ distinctus. 522.4 N.V. smaneri, 521 dubius. 521 . proceses,521 gracilispinis. 521. microstomus. 527. noetlingi, 520 . occipitalis. 527 . pentacanthus, 221. ruais, 521.

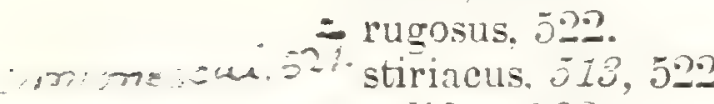

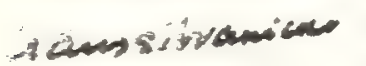

ralidus, 52.2 ventrais, 52.2. 526; wemmeliensis, $52 \%$.

SIIURID.E, 32t.

Silurus, $0: 5$. ascita, 359. bagres, 362 . cataphractus. 35.9 catus, 133. egertoni. 31 .

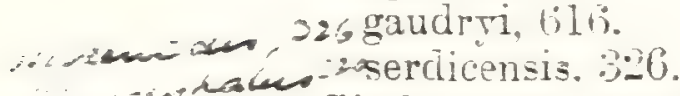

Siphonostoma, :82. albri, ¿20. casteilii, 352.

Smerdis, buth. aduneus, jos. analis, 508. buciensis, JUR. elongatus. 502. formosus. 50. heersensis, jog. isabeiliz, 110 . latior. 508. lorenti, 518. macrurus. $=07$. micracantiaus, 50 . ininutus, 50\%. pyomæus. .115 . lihoensis. 509. sandiberori. .j0\%. sauragei, jo9. sieblosensis. 509. taramellii. j09. A $20 \%$ Tentralis, $099,616$. Solea: 109 . antiqua. 610. approximata. 610. 'glaber. 610. guestfalica. 611. birchberona. 600. lenticularis. 611 . prorinciais. 611. sautagei. 611.

Solencadr. 100. 34. lesimansis. -19.
Solenodon (cont.). lobopterroius, 219. neocomiensis, 204 .

Solenognathus, Pic. tet of Humbert, 271 , $3 \pi 4$.

lineolatus, 274.

Solenorhynchus, 380 . elegans, :80.

SOLENOSTOMATID.E. $37 \%$

Scricidens, 303 . baneri, 3:2\%.

Spaniodon, 48.

blonrieli. $t 8$.

brevis, 23.

electus, 48

elongatus. 51 .

hakelensis, 274.

latus, 5.3.

lepturus, jt.

simus, 53.

SPARID.F, 50t.

Sparisoma, 52:.

Sparnodus. .5:4.

altivelis. 52j.

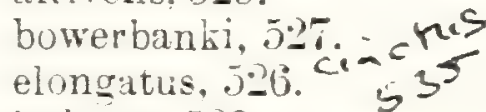
intiatus, $5: 3$.

intermedius. 528 .

lethriniformis, 525.

macrophtbalmus, 525.

micracanthus, 505.

microstomus, $52-6$

moloni. 528. nége s.o

oralis, 525.

Sparoides, 597.

mojassicus. 5336.

robustus, 507.

spharicus. 537.

tenuis, 537.

umbonatus, 537 .

Sparcsoma, 528. ovalis. 523

Sparus brama, 527.

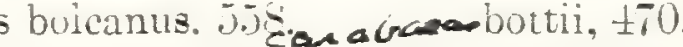

sparus chromis, 526

Sparus dentex, 525.

Sparus erythrinus. 525.

Sparus macrophthalmus. 505.

Sparus salpa, 526 .

Sparus saleus, 525.

sparus rulgaris, 525. $5: 27$.

Spathodactylus, 98. neoromiensis. 98.

Sphærodus, $53 \%$ annularis. $53 . \overline{5}$. araclasii, 545 .

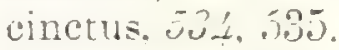
cinguiatus. 505.
Sphærodus (cont.)

conicus, 537.

depressus, 536.

discus, 536 .

insignis, 537 .

intermedius, 537 .

liergomardius, 535.

lejeanianus, $5: 30$.

lens, 536.

oculus-serpentis, 537.

parvus, อ̄ens

polyodon, 545 .

prgmæus, 235

subtruncatus, 536 .

truncatus, 538.

wiechmanni, 588.

Sphagebranchus. $34 \bar{i}$.

formosissimus, : $ّ 4$.

Sphenocephaius, $38 \%$.

cataphractus, 388 .

fissicaudus. 387.

Sphenolepis, Agassiz, 275.

cuvieri. 275.

squamosseus. 276.

Sphyræna, 66 .

amici $: 69$.

bolcensis, 366 . carinata, 204. uraxedifuss

croatica, 318 .

gracilis. $266 \%$

intermedia, 367

major, $3 i$.

maxima. $366^{\circ}$

sternbergensis, $36 \%$

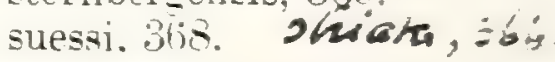

trrolensis. 616

viennensis, 368 . Pan ay

winkleri. 369. veteri.3 is

SPHYRENIDE, Utis.

Sphyranodus, $17 \%$.

524 crassiclens, +5 gracilis, 462 .

lingulatus. 467 . pliseus, 473 .

silorianus. 616 . speciosus. 616 . tenuis, 469 .

Spinacanthus, $566^{\circ}$ blennioides. j6ir;

Spinacites, 415 . radiatus, 415

Spinax maroinatus, 208

Squalius, ё̈े. alpeirerus. bairdi. 
$\ldots$

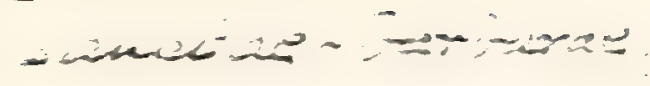

$\cdots+\ldots \ldots \ldots \ldots . . .+\ldots$

$-\cos x+\ldots$

$\therefore-\infty+\infty+\infty-\infty+\infty$

$+\ldots-\cdots$
$\therefore+\cdots-\cdots$

-

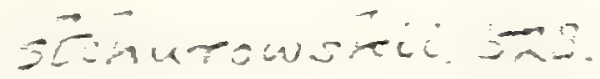

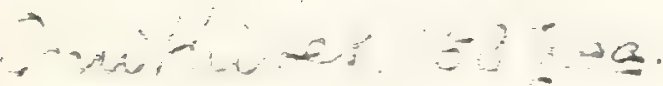

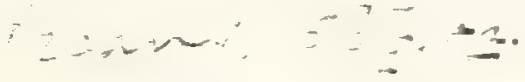

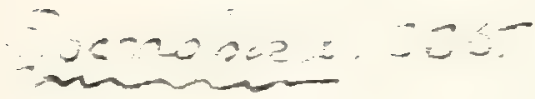

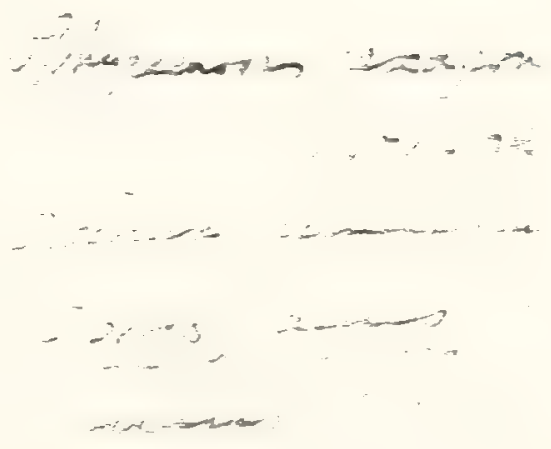






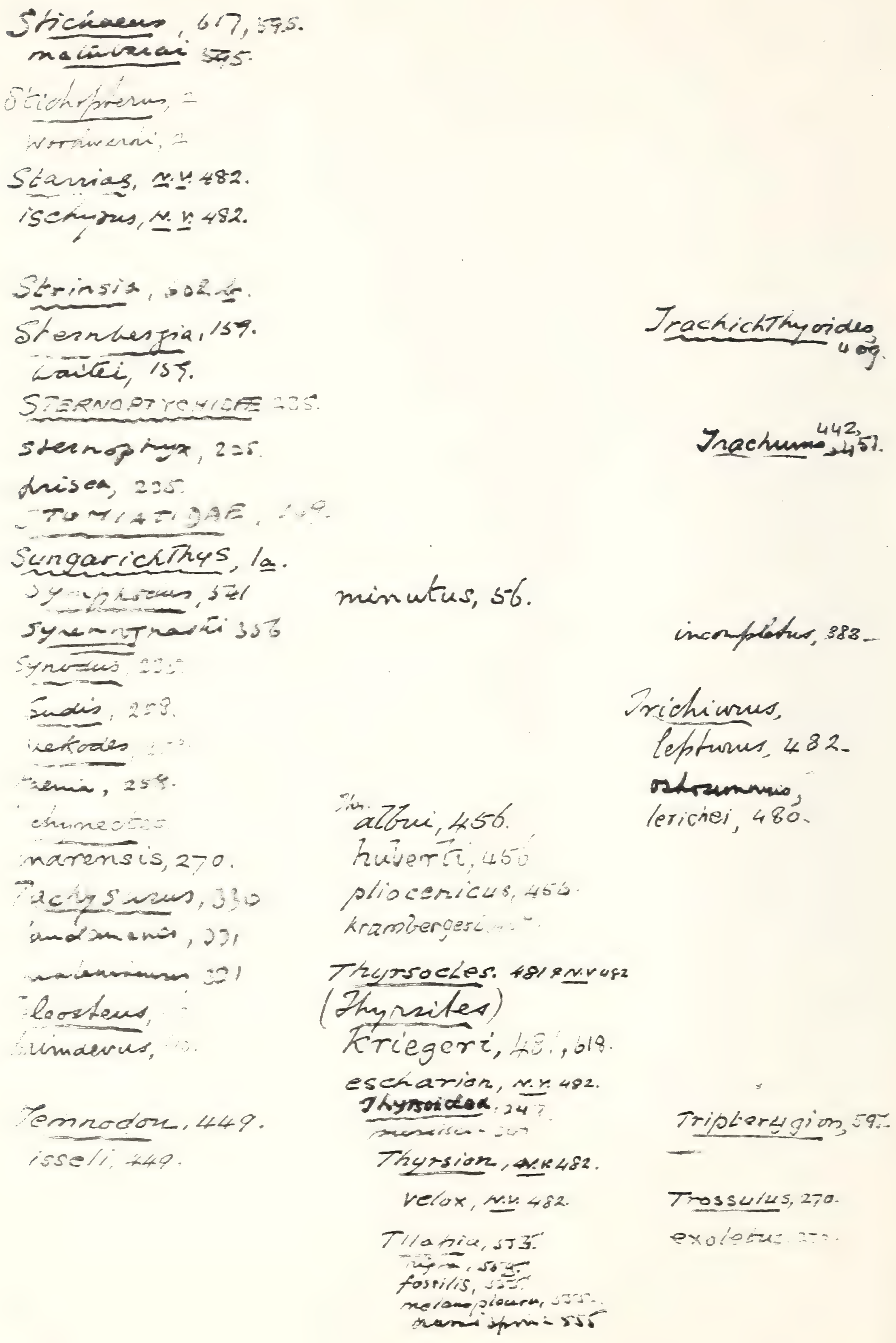


Baraitus $(00 \mathrm{n}$ minucus, ines.

ientoz. :11.

xisclells, $\because 293$.

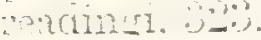

Stenostcma, -

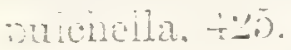

zteonancaus,

snencians. an?

Sterecaus, 176

aelicensis. $=16$

St-atodus. 1.t.

meiteus. it

anicalis. LSO.

सтр0u017. 1-9

Stmnsia,

ulita. is:

GTrOUATEL] E. - 12

StYiogis, ...\%?

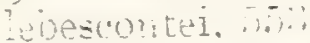

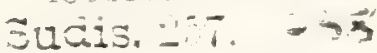

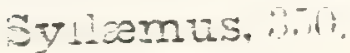

nuiluns, :oil. ititons. :31. bit.

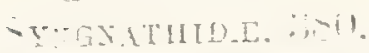

Eymonation, in Hin is . inri. ...2-

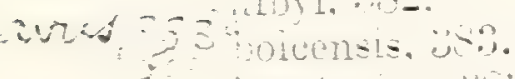

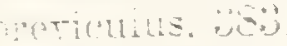
recieli, i,

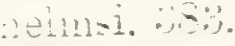
misthontertis, yel inile. :-it.

5Trcacnt:s,

3rmopirt: $11:$

- ind il:

Stmieorncaus. :!. ㅈis. = 1 .

Tacistrectes, -? incurnterregias. -1).

mipes - - 11

minomer tis. - -

I

dierans.

isiger, is

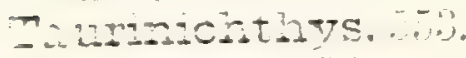
whenthichs. jü.

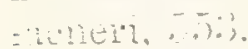

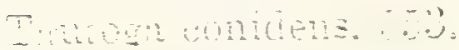

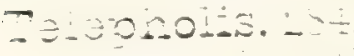

andendedts, - -2

Mromblate. $2=5$

- muls. $-5,5$

- -

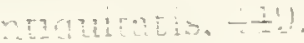

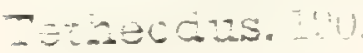

getraconop:eruñ, $\therefore=$

2T11. 295

limiticlis. ㄴ.t?

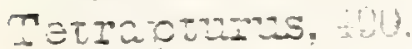

wiir) 1., Ii;.

1)riscus, 1.

Tetrocion. - 1

hismichus. Jil

moncisenit.

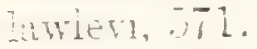

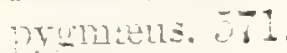

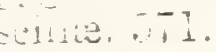

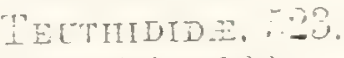

Deutois, au.

Gharmaturus.

delinumelleri. ilt.

ziongutas. il-

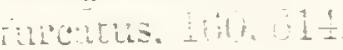

aritis. 1 tit

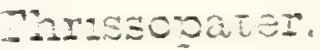

aidz?lic....

arteriuns.

sithonells, ar.

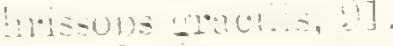

ओ?

for:sson-arciajes. it.

jui fitas, it

incennering, us.

ilizo i, t.

inciter.

mulems

T-2I:sscoterus. arillit - -!

orpotcaus.

$\because$ runctiss. 5.5 .

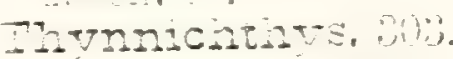

nTostonila w

Tatanus. it.

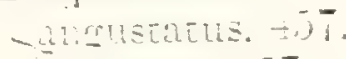

holcenss. - Th

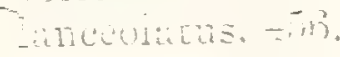

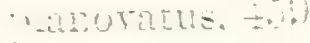

mortertand

moxnut

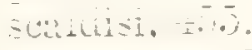

anmus. $=$

-olinniche =

-

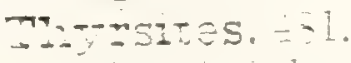

atroitul. $\rightarrow 1$.

- -yTSILocopnatus. $-3$

aninus :-7

anca.

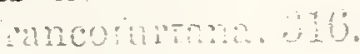

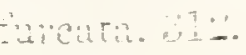

-

and
- $-\operatorname{ses}(\operatorname{cont})$

inacrontereria, 15

magua 212.

micronseropten, $21 \pm$.

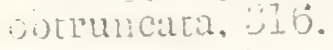

zicsirer, נ15.

raidinensis, 215 .

7าils?is. 15.

-itanicinthys. Dunué.

iil.

pinarao, ij:?

Fomodon, il:.

hurricus. HL.

Gomognatizus, 116.

inorutix. $11 \%$.

kionus, $11 \%$

Tozopoma, ile.

mitum, il:

Icrores, - inl.

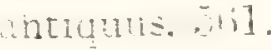

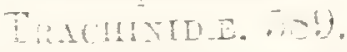

Trachinopsis, ol.

berien. . id 1 .

Trachinus, .

rimetuncults. - ond

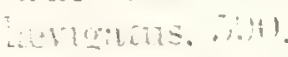

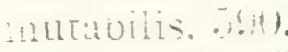

geelandicus. ont

zerus. -

Oracaretus. ijo

enuluens. ... il.

Twacanthus. Fiti

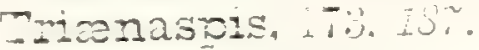

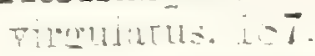

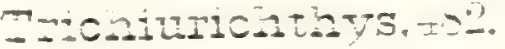

ncercus $+2=$

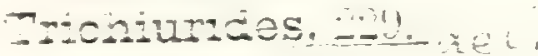

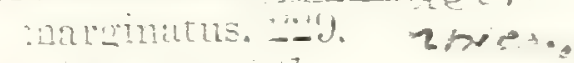

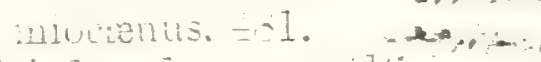

ㄱochonnanes. 16 .

urea 16

Siruntin, \pm 19 .

ins, -14 .

Znioba, rob.

siluneta. $-=\pi$

cor ${ }^{-}=-5$

-11butcis. - -

matista. $=$ ab.

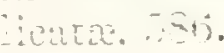

ivia.

marili orje conmici

sinonelii, sif

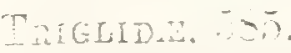

7maicases.

ditla. ...ii.

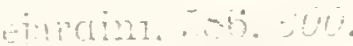

andis

-m enedensis. ou.

zmizonodon. ...il.

nस!I.

on:

$$
\because \text { nOand }
$$

in edere 

Tydeus, 257.

albvi, 257 .

elongatus, 257 .

megistosoma, 257 .

spickodes, 258.

Hetra $=8$

Umbrina, 538. pecchiolii. 538 .

Uranoscəpus, ว90. peruzzii, 590 . rastrum, 377.

Urenchelys, 337. anglicus, 239 avus, 337.

173. Uropterina, 146. platyrachis, 158.

Urosphen, 376.

dubia, 276 .

fistularis, 376 .

Vomer longispinus, 436.
Vomer parvuius, 451.

Vomer priscus, 4.2 .

Vomeropsis, 435 .

elongatus, 437.

longispinus, 436 .

valencienuesi, 437.

trunes: 436.

Xiphactinus, 92 . audax, 92, 98. brachygnathus, 97. lestrio, 97.

Xiphias, 490. acutirostris. 357. antiquus, 495 . of delfortriei, 197. robustus, $4970^{\circ}$

Xiphinde, 490.

Xiphopterus, 482. falcatus. 482.

Xiphiorhynchus, 490.

elegans, 491.

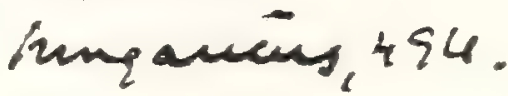

Xiphiorhyncinus

(cont.).

priseus, 491.

3ucontain 4 a 4

Zanclus, t.j0.

brevirostris, 450 . eocœnus, 450 .

Zeus, 417 .

benoisti. 417.

gallus, 449 .

hoernesi, $417^{\circ}$

lewesiensis, 397.

licatæ, 418.

platessa, 501 .

pliocenicus, 418 .

priscus, 516 .

reglevsianus, 501 .

rhombeus, 439 .

robustus, 418 .

spinosus, 500 .

triurus, 436 .

vomer, 436 . 
"Hunita, 481 setaria, 481

Turio, M.v.482.

witburi, w. 482 .

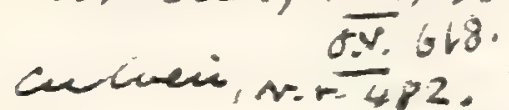

7 a.r. 482 .

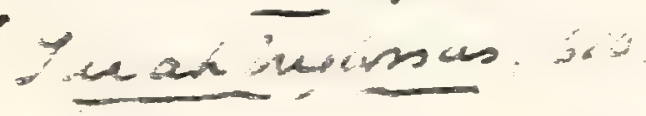

zun

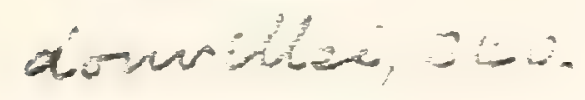

Venicerinims $2:$

suñin: $20=$

rzaciór

andicues?

Vencichims, 234.

Cyinime, 553,146a Zelosis, 155.

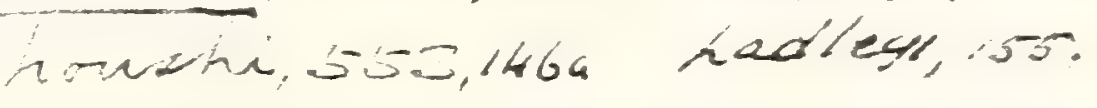

berberae, $146 a$. Jororhomin of elmodiemae. $146 a$. religer. 60.

rincicuencén 169.

Bisslesing Gis.

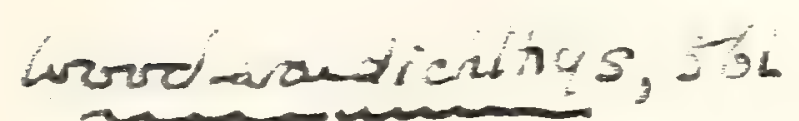

Temiagrammu

isistive, 500.

Zeures.

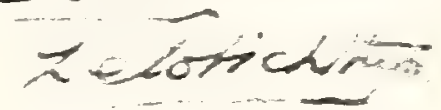

dicimuria

Zoronserga

Fenrexes, in 



\title{
SYSTEMATIC INDEX
}

\author{
$O F$ \\ GENERA AND S PECIES \\ DESCRIBED IN PART IV.
}

Order ACTINOPTERYGII (continued) ... Page

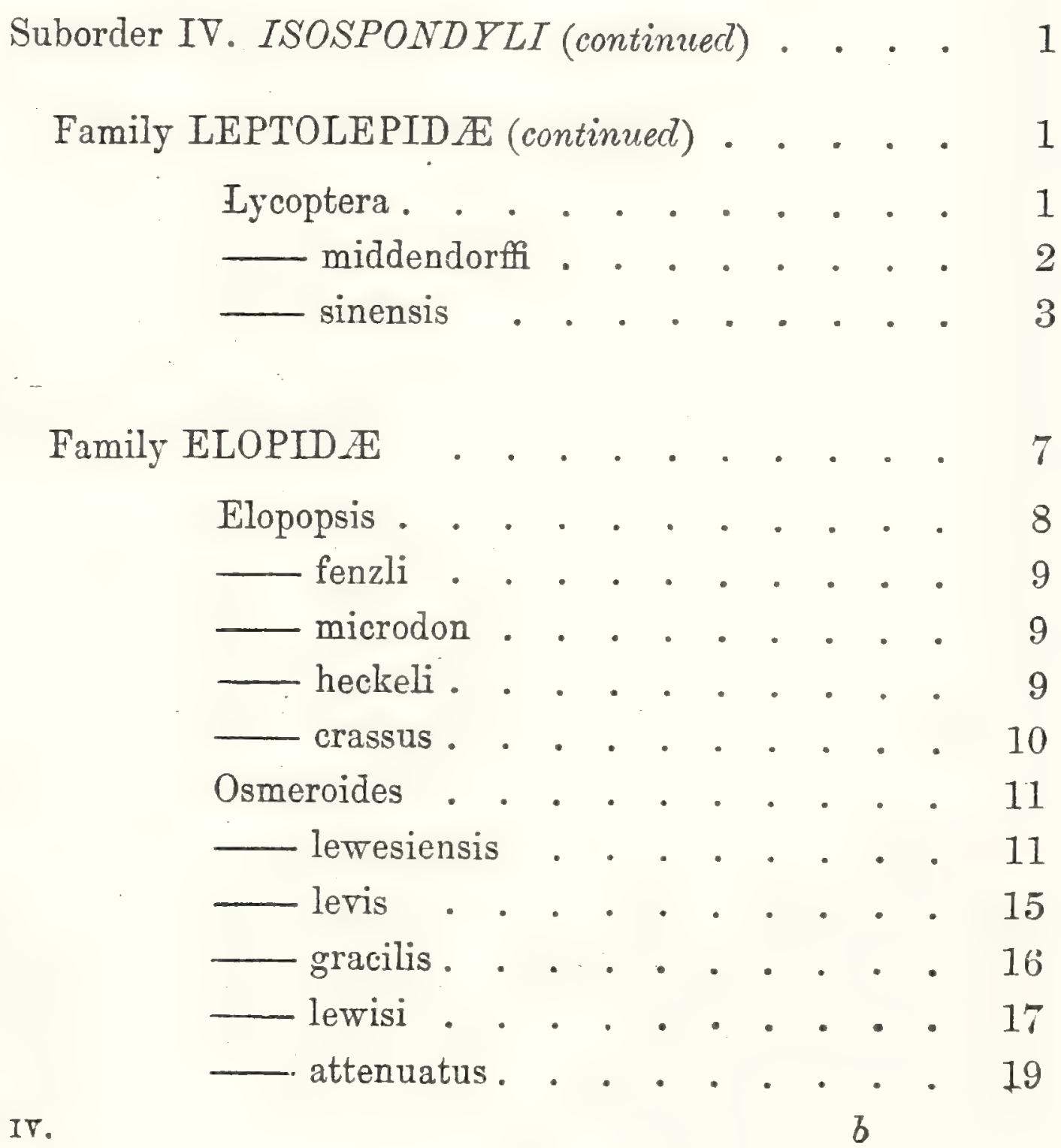


Family ELOPIDÆ (continued).

Osmeroides sardinioides

cretaceus.

Elops

Megalops

- priscus. oblongus

Notelops

brama

Rhacolepis buccalis latus

Thrissopater

salmoneus

Pachyrhizodus . . . . . . . 37 basalis

latimentum . . . . . . . . 42 subulidens . . . . . . . 43

Esocelops . . . . . . . . . . . 46 cavifrons . . . . . . . 46

Spaniodon blondeli . . . . . . . 48 elongatus . . . . . . . 51 latus . . . . . . . 53

Thrissopteroides . . . . . . . . . 54 — elongatus ... . . . . . 54 latus . . . . . . . 54 intermedius . . . . . . 55

— tenuiceps . . . . . . . . 55

- pulcher . . . . . . . . 56 Protelops . . . . . . . . . . 56 geinitzi . . . . . . . 57 anglicus : . . . . . . 57 
Family ALBULID 1 . . . . . . . . . Page 59

Albula . . . . . . . . . 60

—oweni....... . 60

Chanoides. . . . . . . . 63

- macropoma . . . . . . . 63

Chanos . . . . . . . . 64

Prochanos . . . . . . . 65

— rectifrons . . . . . . . 65

Ancylostylos . . . . . . . 66

- gibbus . . . . . . . . . 66

Istieus . . . . . . . . . . . 66

— grandis . . . . . . . . 67

— macrocephalus . . . . . . 70

— lebanonensis . . . . . . 71

Anogmius . . . . . . . 71

— polymicrodus....... . 72

Family OSTEOGLOSSID $\not$. . . . . . . 73

Dapedoglossus . . . . . . . 74

— testis . . . . . . . . 75

— æquipinnis . . . . . . . . 75

Brychætus . . . . . . . 76

- muelleri . . . . . . . 76

Incertæ sedis . . . . . . . . . 80

Plethodus . . . . . . . . 80

— expansus . . . . . . . . . 81

— pentagon . . . . . . . . . 83

— oblongus . . . . . . . 83

Thryptodus ........ . 85

Family NOTOPTERID $\mathrm{E}$. . . . . . . . 85

Notopterus . . . . . . . . 86

— primævus : . . . . . . . 86 
Family CHIROCENTRID $Æ$

Chirocentrus .

(?) polyodon

(?) polyodon . . . . . . . . 88

Platinx . . . . . . . . 89

Chiromystus . . . . . . . . 89

marsoni . . . . . . . . 90

Chirocentrites . . . . . . . . 90

coroninii . . . . . . . . 91

Portheus . . . . . . . . . 92

molossus . . . . . . . 92

mantelli . . . . . . . . 95

daviesi . . . . . . . . . 95

gaultinus . . . . . . . . 95

Spathodactylus . . . . . . . 98

neocomiensis . . . . . . . 98

Ichthyodectes . . . . . . . . . 99

— ctenodon . . . . . . . 100

— anaides. . . . . . . 100

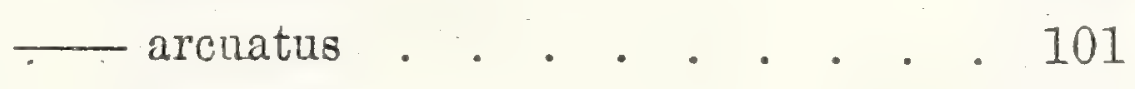

- serridens . . . . . . . 101

- minor . . . . . . . . 102

— elegans ... . . . . . . 103

- tenuidens.......... 104

libanicus . . . . . . . 105

Cladocyclus . . . . . . . 107

gardneri . . . . . . . 108

lewesiensis . . . . . . . 109

Saurodon........... . . 111

— leanus . . . . . . . . . . 111

— phlebotomus . . . . . . . 112

— intermedius . . . . . . . . 112

Saurocephalus . . . . . . . 113

- lanciformis . . . . . . . 113

woodwardi . . . . . . . . 114

Incertæ sedis . . . . . . . . . 116

Tomognathis . . . . . . 116 
Family CTHTOTHe

Ctenothrissa . . . . . . . 120

- vexillifer . . . . . . . 120

— radians . . . . . . . . 122

— microcephala. . . . . . . 124

Aulolepis . . . . . . . . . 126

typus . . . . . . . . 127

Famils CLUPEID王 . . . . . . . . . 128

Pseudoberyx . . . . . . . . 129

- syriacus : . . . . . . . 129

- bottæ . . . . . . . . 130

- grandis. . . . . . . . 130

Histiothrissa . . . . . . . 131

macrodactyla. . . . . . 131

crassapinia . . . . . . . 132

Engraulis . . . . . . . . . 133

Halecopsis . . . . . . . . . 133

insignis . . . . . . . . . . 134

Scombroclupea . . . . . . . : 135

— macrophthalma . . . . . . 135

— gaudryi •. • . . . . . . 138

Diplomystus . . . . . • . . . . . 139

- dentatus . . . . . . . 139

- brevissimus . . . . . . . 140

- birdi . . . . . . . . . . 142

- longicostatus . . . . . . . 143

- humilis . . . . . . . . 144

- altus . . . . . . . . . 145

- vectensis . . . . . . . . 146

Clupea . . . . . . . . . . . 146

- scheuchzeri . . . . . . 147

_ catopygoptera . . . . . . 148

- humilis . . . . . . . . 150

- crenata. . . . . . . . 151

— numidica . . . . . . . . . 151

sardinites . . . . . . . 152

sprattus . . . . . . . 153 


$$
\begin{aligned}
& \text { Family SALMIONIDE } \mathrm{E} \text {. . . . . . . . } 159 \\
& \text { Salmo . . . . . . . . } 159 \\
& \text { Mallotus . . . . . . . . } 160 \\
& \text { villosus. . . . . . . . . } 161
\end{aligned}
$$

Family NOTACANTHID $Æ$. . . . . . 168

Pronotacanthus . . . . . . . . 169

— sahel-almæ . . . . . . . . 169

Family DERCETID 1 E . . . . . . . 171

Dercetis . . . . . . . . 172

- scutatus . . . . . . . . 172

Leptotrachelus . . . . . . . . 173

armatus . . . . . . 174

— triqueter :.. . . . . . . 174 gracilis . . . . . . . . . 180

— hakelensis . . . . . . . . . 184

— elongatus . . . . . . . 184

Pelargorhynchus . . . . . . . 188 dercetiformis . . . . . . 188

Family ENCHODONTID $邓$. . . . . 189

Enchodus . . . . . . . . 190

— lewesiensis . . . . . . . . 191

— pulchellus . . . . . . . 193

— annectens . . . . . . . . 195

— faujasi . . . . . . . 196

- lemonnieri . . . . . . 198 longidens . . . . . . . 199 
Family ENCHODONTID $Æ$ (continued).

Enchodus major

— gracilis . . . . . . . . 201

— macropterus . . . . . . . 202

Eurypholis . . . . . . . 207

— boissieri . . . . . . . 207

— freyeri. . . . . . . . . 210

Palæolycus . . . . . . . . 211

— dreginensis . . . . . . . . 211

Halec . . . . . . . . 212

— sternbergi . . . . . . 212

— eupterygius . . . . . . . . 213

— microlepis . . . . . . . . . 218

haueri . . . . . . . . 219

Cimolichthys. . . . . . . . 221

lewesiensis . . . . . . 221

— nepæolica . . . . . . . . . 225

Prionolepis . . . . . . . . 229

— angustus . . . . . . . . 230

— cataphractus . . . . . . 230

— laniatus . . . . . . . . . 232

Leptecodon . . . . . . . . 233

rectus . . . . . . . . 233

Pantopholis . . . . . . . 234

Family SCOPELID $\approx$. . . . . . . . . . 235

Sardinioides . . . . . . . 236

monasteri . . . . . . . 237

crassicaudus . . . . . . . . 238

megapterus . . . . . . . . 239

pusillus . . . . . . . . . 240

attenuatus. . . . . . . . 241

Acrognathus . . . . . . . . . 243

- boops . . . . . . . . . . 243

libanicus . . . . . . . 244

Leptosomus . . . . . . . . . . 244

— guestphalicus . . . . . . . . 245 
Family SCOPELID $\mathbb{E}$ (continued).

Leptosomus elongatus. Page

macrourus .

minimus

Sardinius

cordieri

Dactylopogon grandis .

Nematonotus . bottæ

Nicrocoelia libanica

Opisthoptery $\mathrm{x}$ gracilis .

Scopeloides

lacertosus

_ striatus.

lanceolatus furcatus

Charitosomus formosus . . . . . . . 272 major . . .... . . . 272 lineolatus . . ..... . . . 274 hakelensis . . . . . . . . 274 
Family GONORHYNCHID Æ (continued).

Notogoneus osculus . . . . . . . 275

— squamosseus . . . . . . . 276

— cuvieri '. . . . . . . 277

- longiceps . . . . . . . . 278

Family CHIROTHRICID $\nexists$. . . . . . . . 279

Chirothrix . . . . . . . . 280

— libanicus . . . . . . . 280

— lewisi . . . . . . . . 283

- guestfalicus . . . . . . . . 283

Telepholis . . . . . . . . . 284

—_acrocephalus . . . . . . . 284

— (?) tenuis . . . . . . . . . 285

Exoccetoides . . . . . . . 286

- minor . . . . . . . . . 286

Family ESOCID无. . . . . . . . 287

Esox . . . . . . . . . 287

— lepidotus . . . . . . . 288

Family CYPRINODONTID王 . • • • . 289

Prolebias . . . . . . . . . 290

cephalotes. . . . . . . 290 furcatus : . . . . . . . 291

gregatus . . . . . . . 292

— stenuura . . . . . . . . 292

— goreti . . . . . . . . . 293

— brongniarti . . . . . . . 293

Pachylebias . . . . . . . . . . 294 crassicaudus . . . . . . 295

Suborder V. OSTARIOPHYSI . . . . . . . 296

Family CHARACINID $巴$. . . . . . . 297

Tetragonopterus . . . . . . . 298

- avus . . . . . . . . . 298

— ligniticus . . . . . . . . . 298 
Family CYPRINID无 . . . . . . . . 299

Catostomus . . . . . . . . 299

Amyzon . . . . . . . . 300

Cyprinus . . . . . . . . 300

- - priscus . . . . . . . . . 301

Barbus . . . . . . . . 301

megacephalus . . . . . . 302

Thynnichthys . . . . . . . 303

— amblyostoma . . . . . 303

Gobio . . . . . . . . 303

analis . . . . . . . 304

Amblypharyngodon . . . . . 304

Leuciscus . . . . . . . . . 305

— oeningensis . . . . . . 305

— papyraceus . . . . . . 307

— colei . . . . . . . 308

- macrurus . . . . . . 308 leptus . . . . . . : 309

Tinca . . . . . . . 312

furcata . . . . . . . . . 312

leptosoma . . . . . . . 313

micropygoptera . . . . . . 314

tarsiger ........... . . 315

Rhodeus . . . . . 316

- elongatus . . . . . . . 316

latior . . . . . . . 317

Aspius . . . . . . . . . 318

— gracilis . . . . . . . . 318

— minutus . . . . . . . 318

Cobitis . . . . . . . . . 320

— centrochir . . . . . . . 320

— angustus . . . . . . . . . 321

cephalotes . . . . . . . . . 321

Hexapsephus . . . . . . . 322

guentheri . . . . . . . 322 
Family SILURID A

Clarias .

-

falconeri

324

Heterobranchus

324

— palæindicus

Silurus

325

Pseudentropius

325

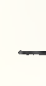
verbeeki

326

Macrones

326

Rita aor 327

Amiurus

Rhineastes

328

Bucklandium dilurii. 330 Arius 330

$\cdot \cdot \cdot \cdot \cdot \cdot \cdot \cdot 330$

— egertoni . . . . . . . . 331

— crassus . . . . . . . . . 332

— (?) bartonensis . . . . . . . 333

— iheringi . . . . . . . . . 333

Bagarius . . . . . . . . . 335

gigas 335

Suborder VI. APODES . . . . . . . . 336

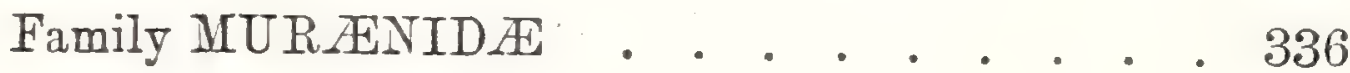

Urenchelys . . . . . . . . 337

—avus . . . . . . . . 337

— hakelensis . . . . . . . 338

— anglicus . . . . . . . 339

Eomyrus . . . . . . . . . 340

— dolloi . . . . . . . . . . 340

— latispinus . . . . . . . . 340

— ventralis . . . . . . . 341

Rhynchorhinus . . . . . . . 342

— branchialis . . . . . . 342

— major . . . . . . . . . 343 
Family MUR ENID无 (continued).

Paranguilla . . . . . . . 343

— tigrina . . . . . . . . 343

Anguilla . . . . . . . . 344

- leptoptera . . . . . . . . 344

elegans . . . . . . . . 345

Nettastoma . . . . . . . 346

bolcense . . . . . . . . 346

Suborder VII. PERCESOCES . . . . . . . . 347

Family CROSSOGNATHID $巴$. . . . : . . 348

Crossognathus . . . . . . . . 348

- sabaudianus . . . . . . . 349

Syllæmus . . . . . . . . 350

latifrons . . . . . . . 351

anglicus . . . . . . 351

Family AJIIODPTID $Æ$. . . . . . . 354 Cobitopsis . . . . . . . 354

- acutus'. . . . . . . . 355

Family SCOMBRESOCID

Belone . . . . . . . . 356 tenuis.............. 357

Scombresox . . . . . . . . 357 obtusirostris . . . . . . . 357

Hemiramphus . . . . . . 358

Family ATHERINID $\approx$. . . . . . . . 358

Atherina . . . . . . . . . 359

— macrocephala . . . . . . . 359

— sarmatica . . . . . . . 360

— vardinis . . . . . . . 360

Rhamphognathus . . . . . . 361

paralepoides . . . . . . 361

sphyrænoides . . . . . . . 362 
Family MUGILID $邓$

Mugil . . . . . . . . . 363

—- princeps . ... . . . . . 364

— radobojanus . . . . . . 365

Family SPHYRÆNID无 . . . . . . . 365

Sphyræna . . . . . . . . 366

— bolcensis . . . . . . . . 366

_ - intermedia . . . . . . . 367

—

Suborder VIII. HEMIBRANCHII . . . . . . . 369

Family AULORHYNCHIDE . . . . . 371

Protaulopsis . . . . . . . . 371

- bolcensis . . . . . . . . 371

Aulorhynchus . . . . . . . 372 sumatrensis . . . . . . . 373

Family FISTULARIID无 • . . . . . . . 373

Fistularia . . . . . . . . . 374

— koenigi. . . . . . . . 874

— longirostris . . . . . . 375

Aulostoma . . . . . . . 375

- bolcense . . . . . . . 375

Urosphen . . . . . . . . 376

—ubia . . . . . . . . 376

Family CENTRISCID $巴$. . . . . . . . 377

Rhamphosus . . . . . . . 377

— aculeatus . . . . . . . 377

— biserratus . . . . . . 378

Amphisile . . . . . . . . . 378

$\longleftarrow$ heinrichi . . . . . . . . 379

Family SOLENOSTOMATIDE. . . . . . . 379

Solenorhynchus . . . . . . . . . 380 elegans . . . . . . . 380 
Family SYNGNATHID $巴$

Pseudosyngnathus

- opisthopterus

Siphonostoma

- albyi

Syngnathus

Calamostoma .

Division A. Beryciformes . . . . . . . 384

Family BERYCID $巴$. . . . . . . . 384

Beryz . . . . . . . . . . 385

Sphenocephalus . . . . . . . . 387

— fissicaudus.. . . . . . . . 387

— cataphractus . . . . . . 388

Acrogaster . . . . . . . 388

— parrus . . . . . . . . . . 389

- - brevicostatus . . . . . . . 389

— beckeli . . . . . . . . . 390

daviesi . . . . . . . 390

Pycnosterinx. . . . . . . 391

russeggeri . . . . . . . . 392

discoides . . . . . . . 393

gracilis . . . . . . . . 394

dubius . . . . . . . . 395

Hoplopteryz . . . . . . 396

antiquus . . . . . . 396

zippei • . . . . . . • . 397

lewesiensis . . . . . . 397

superbus . . . . . . . . 403

Iundensis . . . . . . . . 404

lewisi . . . . . . . . . 404

syriacus . . . . . . . . 405

stachei . . . . 406 
Family BERYCID $\approx$ (continued).

Dinopteryx . Page

... . 406

- spinosus . . . . . . . 407

Homonotus . . . . . . . 407

dorsalis. . . . . . . 408

Myripristis . . . . . . . 410

- leptacanthus . . . . . . . 410

— homopterygius . . . . . . . 411

Holocentrum . . . . . . . 412

— macrocephalum . . . . . . . 412

melitense . . . . . . . 413

Family APHREDODERID无 . . . . . 416

Family CYTTID $Æ$. . . . . . . . . . 417

Division B. Scombriformes . . . . . . . . 418

Family STROMATEID $Æ$. . . . . . . 419

Omosoma........... . 419

— sabel-almæ . . . . . . . 419

— intermedium . . . . . . . 420

— pulchellum ... . .... . 421

Platycormus .. . . . . . . . 421

germanus . . . . . . 421

Berycopsis . . . . . . . 423

— elegans. . . . . . . . 423

Family CARANGID $巴$. . . . . . . 425

Aipichthys ... . . . . . . $42 \%$

— pretiosus . . . . . . . 427

— velifer . . . . . . . . 427

— minor . . . . . . . . . . 428

— nuchalis . . . . . . . . . 429

Semiophorus . . . . . . . 430

—

— velicans . . . . . . . 431

Platax . . . . . . . . 432 
Family CARANGID $A$ (continued).

Platax woodwardi . . . . . . 432

Amphistium . . . . . . . . 434

paradoxum . . . . . . . 434

Vomeropsis . . . . . . . . . 435

longispinus . . . . . . . . 436

elongatus . . . . . . . 437

valenciennesi . . . . . . . 437

Nene . . . . . . . . 437

rhombeus . . . . . . . . 439

oblongus . . . . . . . . 440

Caranx . . . . . . . . . 441

Archæus . . . . . . . . . . . 442

glarisianus. . . . . . . . 442

Seriola. . . . . . . . . . 444

—

— lata . . . . . . . . . . 445

analis . . . . . . . 445

Carangopsis . . . . . . . . . 446

- breris . . . . . . . . 446

dorsalis . . . . . . . 447

Ductor . . . . . . . . . . 448

leptosomus :. . . . . . . . 448

Family SCOMBRID $巴$. . . . . . . . 451

Isurichthys . . . . . . . . . . 453

macrurus . . . . . . . 453

orientalis . . . . . . . . 453

Thynnus . . . . . . . . 454

— thynnus . . . . . . . 455

- scaldisi. . . . . . . . 455

lanceolatus . . . . . . 456

Eothynnus . . . . . . . . . . 457

salmoneus. . . . . . 457

Scomber . . . . . . . . 459

Palimphyes . . . . . . . . . 460

elongatus . . . . . . • . 460 
Family SCOMBRID $\approx$ (continued).

Scombrinus

Page

$\cdot . \cdot .461$

- muchalis . . . . . . . . . 461

macropomus . . . . . . . 462

Ausis . . . . . . . . . . 463

(?) propterygius . . . . . . . . 464

Cybium . . . . . . . . . 465

— speciosum . . . . . . . . 466

— bleekeri . . . . . . . . . 466

— excelsum . . . . . . . . . 467

- bartonense . . . . . . . 46 ᄀ

- lingulatum . . . . . . . . 469

Eocœlopoma . . . . . . . . 470

- colei . . . . . . . . 470

- curvatum , . . . . . . 472

Sphyrænodus . . . . . . . . . 473

- priscus : . . . . . . . . . 473

Scombramphodon . . . . . . . 474

— benedeni . . . . . . . . . 474

— curvidens . . . . . . . . 474

- crassidens . . . . . . . . 475

Thyrsitocephalus . . . . . . . 476

alpinus . . . . . . . . 477

Lepidopus . . . . . . . . . 477 glarisianus . . . . . . . 477 brericauda . . . . . . . 480

- albji . . . . . . . . . 480

Family PALEORHYNCHIDE . • . . . . 482

Palæorhynchus . . . . . . . . 483

- glarisianus . . . . . . . . 483

- longirostris . . . . . . . . 486

- zitteli . . . . . . . . . . 487

Hemirhynchus . . . . . . . . 488

deshayesi . . . . . . . 488

colei. . . . . . . . . 488 
Family XIPHIID $\approx$

Xiphiorhynchus. (1) elegans . 491

— priscus

Acestrus ornatus

Histiophorus .

Division C. Perciformes . . . . . . . . . 497

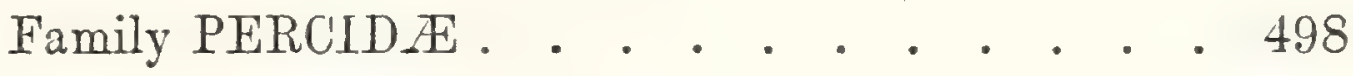

Prolates . . . . . . . . . . . 499

heberti. . . . . . . . 499

Acanus . . . . . . . 500

spinosus . . . . . . . . . 500

regleysianus . . . . . . 501

Lates

502

gracilis . . . . . . . 502

Cyclopoma . . . . . . . . 504

—- gigas . . . . . . . . 504

(?) micracanthum . . . . . 504

Smerdis . . . . . . 506

minutus . . . . . . 506

formosus . . . . . . : 507

macrurus . . . . . . 507

Labrax . . . . . . . . 509

ubinoi . . . . . . . . 510

schizurus . . . . . . . . 510

oeningensis . . . . . . . 511

Percichthys . . . . . . . . . . 514

— antiquus . . . . . . . . 514

Properca . . . . . . . . 514

—

— beaumonti. . . . . . . 515

(?) prisca . . . . . . . 516 
Family PERCID正 (continued).

Page

Mioplosus. . . . . . . . . 517

— labracoides . . . . . . 517

Perca . . . . . . . . . 518

Family TEUTHIDID $Æ$. . . . . . . . . 523

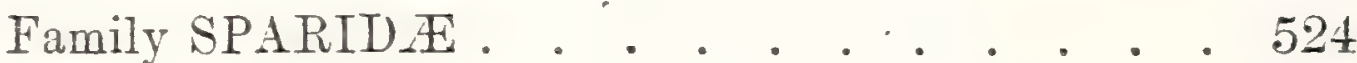

Sparnodus . . . . . . . . . 524

— macrophthalmus . . . . . . 525

— elongatus . . . . . . . 526

— microstomus . . . . . . 527

- howerbanki . . . . . . 527

Sargus . . . . . . . . . . 529

—

— laticonus . . . . . . . . 529

Trigonodon . . . . . . . . 531

oweni . . . . . . . 531

serratus . . . . . . . 531

Pagellus .. . . . . . . . . 532

Pagrus . . . . . . . . . . 533

Chrysophrys . . . . . . . . 534

Family SCIÆNID王 • . . . . . . 538

Family LABRID $Æ$ 。 . . . . . . . . . 539

Labrus . . . . . . . . . 539

Julis . . . . . . . . . . 541

Labrodon . . . . . . . . . 541

— superbus. . . . . . . . . . 542

canariensis . . . . . . 542

Phyllodus . . . . . . . . 546 toliapicus . . . . . . . . 546

Egertonia . . . . . . . . . 550

— isodonta . . . . . . 551

Platylæmus . . . . . . . . . 551

- colei . . . . . . . . . . 551

Pseudosphærodon . . . . . . . . 552 hilgendorfi . . . . . . . 552 

Family CHROMID王 . . . ‘ . . . . 554

Priscacara . . . . . . . . 554

- serrata. . . . . . . . . 554

— clivosa . . . . . . . . 554

Division D. Chætodontiformes . . . . . . . 556

Family CHETODONTIDÆ※ . . . . . . 556

Pygæus . . . . . . . . 557

coleanus . . . . . . . 557

Proantigonia . . . . . . . . 558

Ephippus . . . . . . . . . 559

— rhombus . . . . . . . 559

Family ACRONURIDE . . . . . . . 562

Aulorhamphus . . . . . . 562

Apostasis . . . . . . . . 563

Acanthurus . . ..... . . 563

Naseus. . . . . . . . . 564

rectifrons . . . . . . . 564

Family BALIS'TID $巴$. ... . . . . 565

Spinacanthus . . . . . 566

Acanthopleurus ... . . . . . 566

—- serratus . . . . . . . . 567

Acanthoderma . . . . . . . 568

— spinusum . . . . . . . . . 568

Ostracion . . . . . . . . . . 569

Family GYMNODONTID无 . . . . . . 570

Tetrodon . . . . . . . . 571

Diodon. . ... . . . . . . . 571

— erinaceus . . . . . . . . 572

— scillæ . . . . . . . 572

— $\operatorname{sigma} . . \quad . \quad . \quad . \quad . \quad . \quad .573$

vetus . . . . . . . 573

Orthagoriscus . . . . . . . . 576 

Family SCORP ENIDE . . . . . . . . 577 Ampheristus . . . . . . . . 577 — toliapicus . . . . . . . 577

Family COTTID王 . . . . . . . . . 580

Eocottus . . . . . . . . 580 veronensis. . . . . . . 581 Lepidocottus . . . . . . . . 581 $\longrightarrow$ aries . . . . . . . . 582

- brevis . . . . . . . . 582

— papyraceus . . . . . . 583 — multipinnatus . . . . . . 584 Cottus . . . . . . . . . 585

Famils TRIGLID王 . . . . . . . . 585

Division F. Gobiiformes . . . . . . . . . 587

Family GOBIID王 . . . . . . . . • . 587

Family TRACHINID王 • • • . • • • . 589

Callipteryx • . . . . . . . . 589

— speciosus . . . . . . . . . 589

— recticaudus . . . . . . 58 ?

Division G. Blenniiformes . . . . . . . . . 591

Family BLOCHIID王.. . . . . . . . . 591

Blochius . . . . . . . . . . 593 longirostris . . . . . . . 593

Family BLENNIID无. • . . . . . . . 595

Pterygocephalus. . . . . . . . 595

— paradoxus . . . . . . . 595 

ossified; cleft of mouth extending as far as or beneath the anterior half of the orbit; premaxilla very stout, deepest in front, and its slightly convex oral margin bearing a single close series of minute conical teeth; mandible short and deep, the backwardly ascending oral margin of the dentary with a similar regular series of slightly larger teeth; preoperculum forming a great triangular expansion, and suboperculum relatively deep. Vertebral centra much constricted and strengthened on the middle of each side by a sharp ridge. Pectoral fins arising near the rentral border; pelvic fins more remote than the anterior part of the dorsal, each comprising 7 or 8 rays; dorsal fin imperfectly known, but its anterior portion apparently consisting of about 8 spines in which the right and left halves are not fused together, its posterior portion of articulated and divided rays; anal fin comparatively small, partly or completely behind the dorsal ; caudal fin deeply forked, with slender lobes and their outermost rays exhibiting numerous closely arranged oblique articular lines, which are very finely jagged. Scales large, very deeply overlapping, smooth, and not serrated or crenulated on the posterior margin. Lateral line conspicuous, a simple tube piercing all the scales it traverses, arising low down on the flank not far above the pectoral fin.

This definition is based on the specimens enumerated below. An examination of the original specimen in the Genera Museum, on which the genus was founded, leaves many essential features in the structure of the fish doubtful. The large bone at the margin of the upper jaw appears, at first sight, to be a Clupeoid maxilla; but a consideration of the new specimens now described suggests that it is a premaxilla most closely resembling that of the Atherinidx. The dorsal fin in the type specimen is much more imperfect than is indicated in Pictet's rather diagrammatic figure, only a few fragments remaining. Two pelvic fin-rays in the same specimen seem to be displaced backwards; and the anal fin evidently comprises the series of comparatively small and delicate rays observed between these and the caudal fin.

\section{Crossognathus sabaudianus, Pictet.}

1858. Crossognathus sabaudianus, F. J. Pictet, Foss. Terrain Néocom, Voirons (Paléont. Suisse), pt. iii. p. 18, pl. ii., pl. iv. figs. 1-6.

Type. Imperfect fish; Museum of Natural History, Genera.

The type species, attaining a length of about 0.35 . Length of head with opercular apparatus considerably exceeding the maximum depth of the trunk, and contained about three and a half times in 
the total length to the base of the caudal fin. Pectoral fins long and narrow ; pelvic fins approximately midway between the pectoral and caudal fins; space between occiput and origin of dorsal fin about equal to length of craninm; anal fin probably with about 12 rays.

Form.\& Loc. Neocomian: Voirons, Switzerland; Hanover.

P. 8639. Imperfect fish, 0.21 in length, exhibiting general proportions and most of its essential characters ; "Hilsthon," Hildesheim, Hanorer. The mouth is shown, and the great extent of the dorsal fin is indicated by fragments. The course of the simple lateral line is traceable low on the flank of the anterior abdominal region.

Presented by Prof. A. von Koenen, 1897.

P. 7184a. Somewbat larger head and abdominal region; "Hilsthon," Hildesheim. The contours of the displaced premaxilla and mandible are distinct. The preoperculum is considerably expanded at the angle and is shown to hare been marked with delicate radiating grooves. The origin of the dorsal fin is indicated by remains of a few spinous rays. The course of the Iateral line, low on the flank and gradually rising behind, is conspicuous.

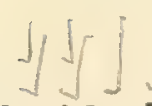

Purchased, 1894.

P. 8640-43. Three small imperfect specimens, of which two are in counterpart, also a detached tail as large as that of the type specimen; "HiIsthon," Hildesheim. No. P. 8642 shows the extent of the dorsal and anal fins, but both are too imperfect for precise description. The anal fin is in great part opposed to the hinder portion of the dorsal.

Presented by Prof. A. von Koenen, 1897.

P. 7184-85. Two small imperfect specimens, the first showing the small, slender, mandibular teeth, and also an impression of the characteristic, expanded preoperculum displaced above the head; "Hilsthon," Hildesheim.

Purchased, 1894.

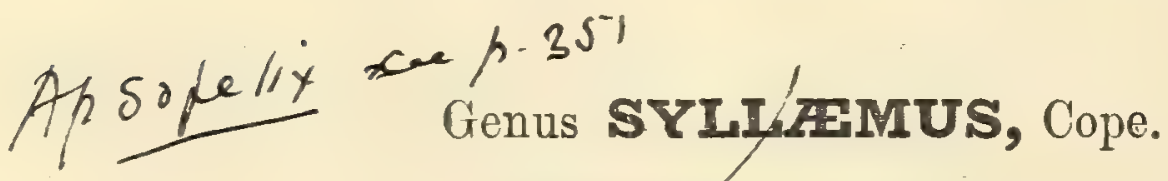

[Vert. Cret. Form. West (Kep. U.S. Geol. Surv. Territ. vol. ii. 1875), p. 180.]

Apparently differing from Crossognathus only in the still more remote position of the pelrie fins and the absence of an anal fin. 
Elopines

= Arsoperix p.353 sudeleptrantys p.6/6 
1914. Iyllemes latifiono, 2.2. A. Cockerell, Zool. suzeipen, vole $\times 7 v \cdot h \cdot 190$ (structure of sueles).

1903-07. Tylldmu andicus, A.S. Woodurard, 7n. Rishes Enchith Chelte (Oal. Oor.), h.89, hl.xx; bl. xxi. fig. 1, 2 .

1906. Sullomus arghieno, In. Zeriche, Mém. Sore SEd. Nozd, sol. v. h.64. [From Condé, Nord, in Univ. Lille.]

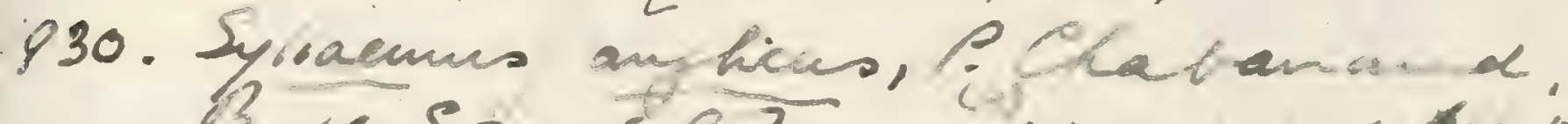

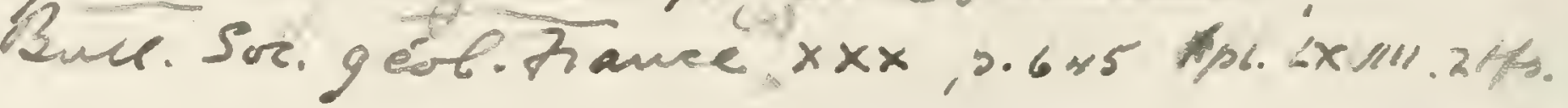




Truuk subcylindrical, not much laterally compressed; head and opercular region compressed to a sharp edge below. Cranial roof slightly arched from side to side, with a shallow rhombic median depression in the frontal region.

\section{Syllamus latifrons, Cope.}

1875. Syllemus latifrons, E. D. Cope, op.cit. p. 181.

Type. imperfect head and abdominal region.

The type species, probably attaining a length of about 0.3 . Length of head with opercular apparatus considerably exceeding. the maximum depth of the trunk, and probably contained about three and a half times in the total length to the base of the caudal fin. Nine transverse series of scales in advance of the dorsal fin; all scales quite smooth.

Form. \& Loc. Upper Cretaceous; Pike's Peak, Colorado.

Not represented in the Collection.

\section{Syllæmus anglicus (Dixon).}

1850. Calamopleurus anglicuz, F. Dixon, Geol. Sussex, p. 375, pl. xxxii. figss. 11, 12.

1888. Calamopleurus anglicus; A. S. Woodward, Proc. Geol. Assoc. vol. x. p. 324.

Type. Head and abdominal region; British Museum.

A large and robust species, attaining a length of about 0.45 . Length of head with opercular apparatus scarcely exceeding the maximum depth of the trunk and contained slightly more than four times in the total length to the base of the caudal fin. A narrow border of very fine granulations immediately above the teeth on the outer face of the premaxilla; anterior margin of preoperculum much thickened, especially at the angle, from which numerous undulations, almost ridges, radiate; operculum smooth. Pectoral fins long and narrow, with about 14 rays; pelvic fins with 8 rays, the foremost stoutest, arising much nearer to the caudal than to the pectoral fins; anterior dorsal, with not less than 8 rays, arising at a distance from the occiput equal to the total length of the skull. KAbout eight or ten transverse series of scales in advance of the anterior dorsal fin, each with approximately twelve scales on either side; the scales when abraded exhibiting traces of very fine parallel or slightly radiating lines directed antero-posteriorly in the exposed area.

This fish cannot belong to the genus Calamopleurus, which was founded on fragments from the Upper Cretaceous of Brazil, with 
vertebræ and caudal fin of a quite different type (see Part III. p. 499).

Form. \& Loc. Albian-Turonian: Kent and Surrey.

P. 611. The type specimen figured by Dixon, op. cit.; probably from the Lower Chalk, Burham, Kent. The premaxilla is broken at its anterior end, but displays the teeth and finely tuberculated border throughout the greater part of its length. The fragmentary scales exhibit the delicate striation.

Egerton Coll.

4973\%. Fragmentary remains of a small fish wanting the greater part of the head; Lower (?) Chalk, Shalford, near Guildford. The pectoral, pelvic, anterior dorsal, and caudal fins are shown, and some of the caudal vertebræ are exposed. One scale behind the upper end of the pectoral arch is strongly marked by radiating furrows, evidently in connection with a sensory canal.

Capron Coll.

P. 4246. Imperfect head exposed on the fractured left side: St. Catherine's, Guildford.

Enniskillen Coll.

47302. Imperfect head; Lower Chalk, Dover. Gardner Coll.

49055. Remains of head and abdominal region; probably from the Lower Chalk, Burham. The cranial roof exhibits the supraoccipital behind, the parietals, squamosals, and frontals, with the characteristic rhombic median depression. The scattered rays of the anterior dorsal fin occur in position, and there are traces of other fins, one probably the posterior dorsal. Mrs. Smith's Coll.

P. 6532. Imperfect abdominal region showing the bases of the paired fins; Lower Chalk, Blue Bell Hill, Burham. Traces of the characteristic vertebræ are seen, and the lateral line is conspicuous. There is an elongated postclavicular scale above the base of the left pectoral fin.

Presented by S. J. Hawkins, Esq., 1891.

47198. Imperfect head and much-fractured trunk; Gault, Folkestone.

Gardner Coll.

36170. Remains of head and anterior scales, exhibiting the dentition both of the premaxilla and dentary; Gault, Folkestone. 


P.611. Desunted finum A.S.2.1903, f.89, Hl xx, fip. I.

49737. Des.: d.fi? A.S.2.1903, h.89, hl. xx, fi. 2.

P.4246. Des: afy? A.S.2. (903-0), h.90, hl. xxi.fip, 1.

47302. In mailla notivew A.S.W. 1903, h.90.

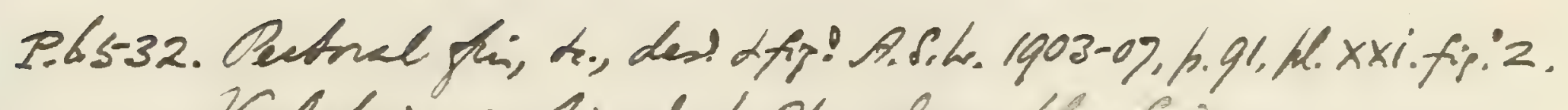
Vertebde ustived h. q1, also blu fins.

36190. Dentary noticed A.S. W. 1903, h. 90. 
Pig0s-3. Cincumatritalo noticed A.S. ho 1903, p.go.

R.85-3. Trtoperenlum noticed A.S.W. 1903, 6.91.

P.9698. Br nayp nuticed A.S.L. 1903, h.91; also dirsal fis. 
$47195,-96,-96$ a, 47201. Four fragmentary portions of hoad and trunk, rather friable; Gault, Folkestone. The occipital region of the skull is obscurely shown in the first specimen.

Gardner Coll.

36310. Portion of abdominal region; Gault, Folkestone.

$$
\text { Purchased, 1862. }
$$

P. 3\%. Another portion of trunk; Gault, Folkestone.

Gardner Coll.

P. 8753. Fragment of opercular apparatus and anterior squamation, showing the scale with radiating furrows behind the upper end of the pectoral arch; Gault, Folkestone.

Purchased, 1897.

P. 9053. Small hinder portion of head with opercular apparatus; Gault, Folkestone. Large posterior suborbitals are well shown.

Purchased, 1899.

The following specimens are apparently referable to undetermined species of Syllcemus with pelvic fins as remote as in S. anglicus:-

P. 7443. Imperfect remains of fish about 0.4 in length, somewhat scattered on slab; Cretaceous, Island of Lesin', Dalmatia. The rery remote pelric fins are well shown, apparently with 8 rays, of which the foremost is stoutest and appears to have been finely divided quite at the distal end.

Purchased, 1895.

P. 9184. Imperfect fish, with paired and caudal fins; Upner Cretaceous (Niobrara Group), Logan Co., Kansas, U.S.A.

Purchased, 1900.

To the same genus may probably be referred the fragment described as follows:-

Alosa bohemica, A. Fritsch, Rept. und Fische böhm. Kreideform. (1878), p. 39, pl. viii. fig. 2, pl. x. fig. 5.-Turonian (Malnitzer Schichten); Wchlowitz, near Prague. [Head and anterior abdominal region; Royal Bohemian Ifuseum, Prague.]

Remains of other Crossognathicæ are also known from the Cretaceous of North America, but there are no specimens in the Collection. The fragments described under the following names may probably be placed here :-

Apsopetix sauriformis, E. D. Cope, Ann. Rep. U.S. Geol. Surv. PART IV.

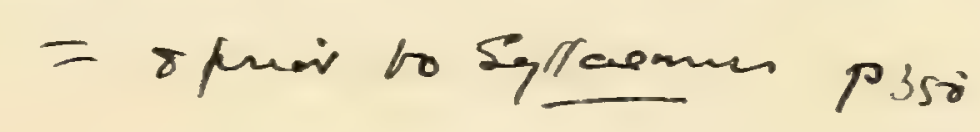




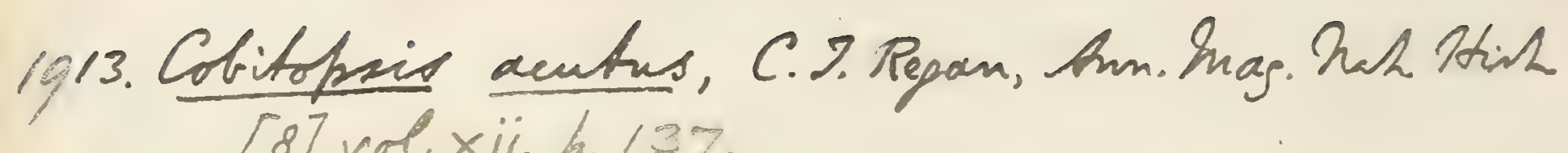
[8] vol. $x$ ii. th. 137 .

1914. Colitopsis (Acanthopaid) acutus, 7. Priem, Aném. Sor. Géd. Arance, vol. xxi, Mém, no. 50, p. II,

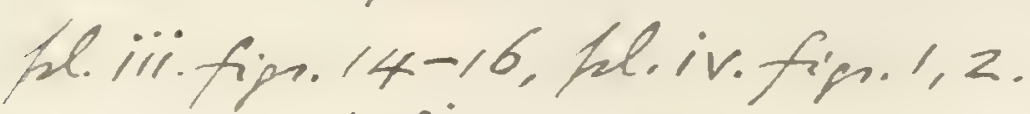

1935. S. a. L. Piton; p.4.

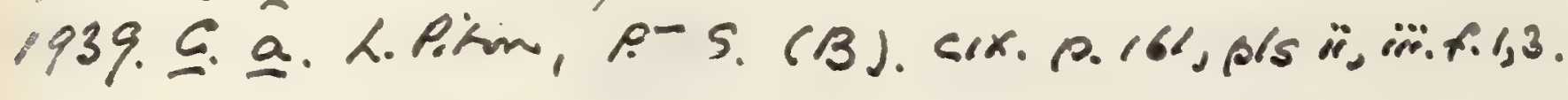


Cobitopsis acutus (Gervais).

[Text-figure 12.]

1852. Acanthopsis acutus, P. Gervais, Zool. et Pal. Franç., Poiss. p. 9, woodc.

1853. Cobitopsis exilis, A. Pomel, Catal. Méthod. Tert. Foss. Loire, p. 134.

1874. Cobitopsis acutus, H. E. Saurage, Bull. Soc. Hist. Nat. Toulouse, vol. viii. p. 196.

Type. Imperfect fish.

The type species, attaining a length of about $0 \cdot 1$. Length of head with opercular apparatus equalling a little more than twice the maximum depth of the trunk and slightly less than one third of the total length of the fish to the base of the candal fin.

Fig. 12.

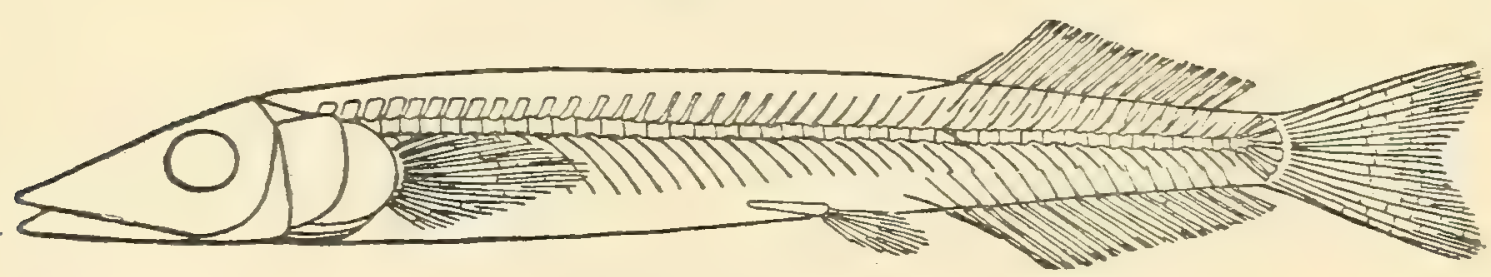

Cobitopsis acutus; restoration, about nat. size.

Pectoral fins with about 10 rays; pelvic fins inserted midway between the pectoral and caudal fins; dorsal and anal fins slightly elevated in front, each with 16 to 18 rays.

Form. \& Loc. Lower Oligocene: Puy-de-Dôme, France.

32485. Two fine specimens; St. Amand-Tallende, near Clermont Ferrand. The head and opercular bones are smooth, and the few branchiostegal rays are preserved. The articulation of the mandible is beneath the middle of the large orbit. The rertebral centra are shown to be delicate constricted cylinders, apparently pierced originally by the notochord: they are strengthened by slight longitudinal ridges only in the caudal region. The ribs are short, straight, and delicate. The short neural spines in the abdominal region are thickened, those near the occiput being small expanded laminæ. The pectoral fin has an extended base-line and is acuminate in shape; the pelric fin is not more than half as large as the pectoral. Although the specimens are so well preserved, there are no traces of scales.

Purchased. 
1814. Two more imperfect-specimens, displaving all the characters noted in the previous specimens; Puy-deDôme.

Egerton Coll.

P. 387 Two imperfect specimens; St. Saturnin, near St. AmandTallende. The cranium is partly exposed from above, showing the much-constricted interorbital region and the gently rounded roof of the brain-case. Enniskillen Coll.

P. 5946. Large imperfect specimen; St. Saturnin.

Purchased, 1889.

The following specimen may perhaps represent a member of the family Ammodytidæ, but it is too imperfect for satisfactory. determination:-

46540. Imperfect candal region 0.065 in length, associated with a specimen of Rhinellus; Upper Cretaceous, Sahel Alma, Mount Lebanon. The vertebral centra are too imperfect for recognition, but there are about 24 in the caudal region; the neural and hæmal arches are short. The dorsal fin is extended, probably with about 20 rays; the anal fin, with 14 rays, is opposed to the hinder half of the latter. The caudal fin is incomplete distally. The scales are indistinet.

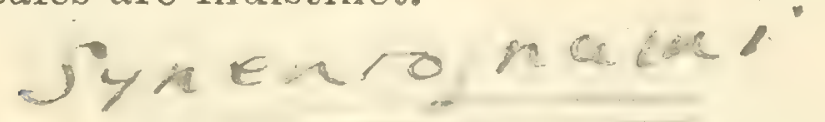

Lewis Coll.

\section{Family SCOMBRESOCID $\mathbb{E}$.}

Maxilla entering the border of the upper jaw; dentition feeble: opercular apparatus complete, with few branchiostegal rays, and the gill-opening wide. Lower pharyngeal bones united. Vertebræ numerous, from 45 to 85 in the total length; centra of abdominal vertebræ with transverse processes for the support of slender ribs. Pelvic fins without spine but with only about 6 divided rays; one remote dorsal fin, withont an anterior spinous portion; anal fin opposed to the posterior dorsal. Scales in regular series, but usually a keel along each side of the lower region of the body.

Nearly all the existing Scombresocidæ are marine, only a few small forms living in freshwater in the tropics. No extinct genus is known.

\section{Genus BELONE, Cuvier.}

[Règne Animal, vol. ii. 1817, p. 185.]

Head and trunk much elongated and slender. Jaws produced into an attenuated beak, the lower scarcely if at all exceeding the 


Peferred to "Cobitopside:-

Thomurus fuleratus, 2. O. Indan, Fors. Fishes S.

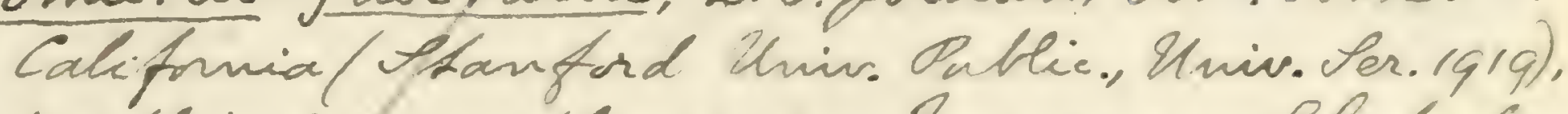

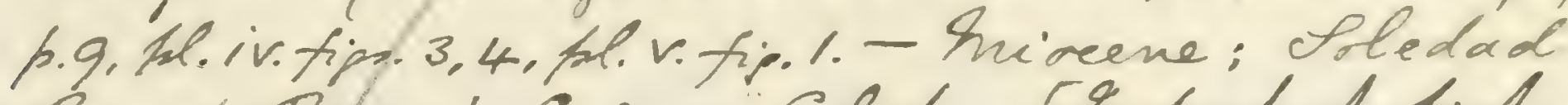
'an a Borms' Cañon, "alif. [2mperfuth firt: Shanfad Hiv.]

I. of Rhomurus.

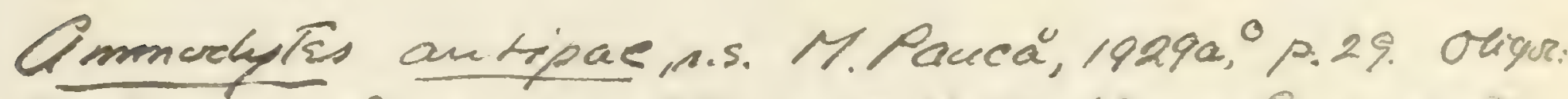

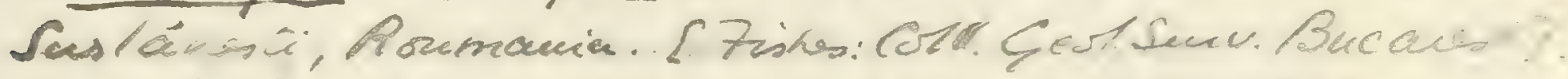

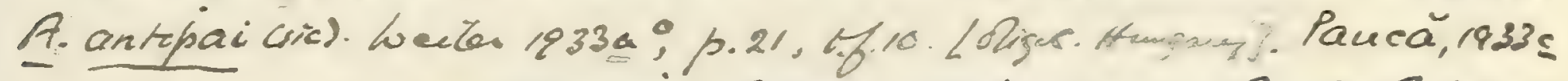

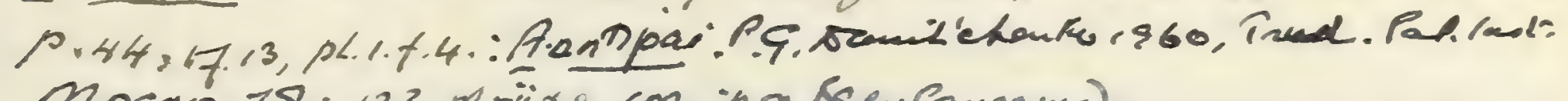

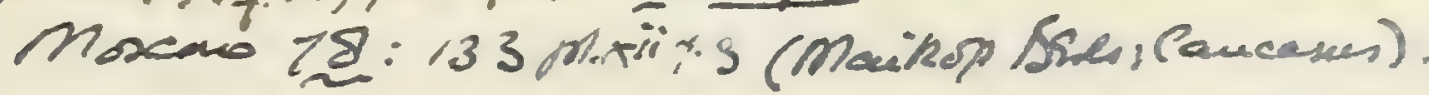

Ropenio Gowersi and D. colitudinis, D.S. Gordan, Bull. teph. Geal. Amiv. Califmia, vol. $r(1907)$, the 128, 130, furs. 23, 24.-hivene; Califinniz. Lamperfuth Unir.Calify

Rogenio Gowersi = Rogenites Gowerzi; D.S.

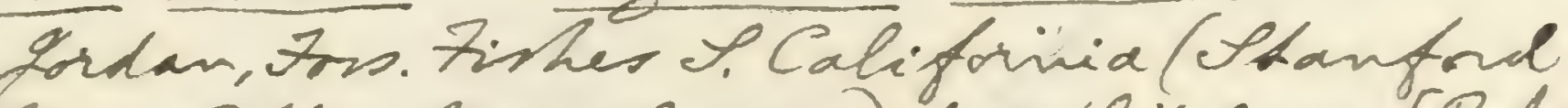
Univ. Public., Univ. Ler. 1919), p.8. pl ir.fip. 2. CPerkehs an ally 4 Hemiramphus.] T. of Pogenites.

Rogenis solitudinis said to represents setarshe family Rogeniedde, 2. P. Yordan, loc cit.1919, h. 8. pl.ii.fip.l.

T: of Rogenio.

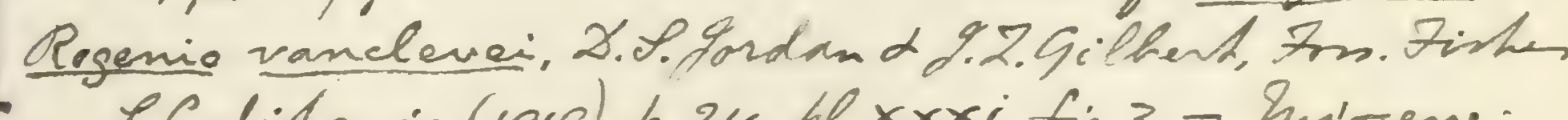
P.Califormia (1919),h.24, hl.xxxi. fip.3. - hivene:

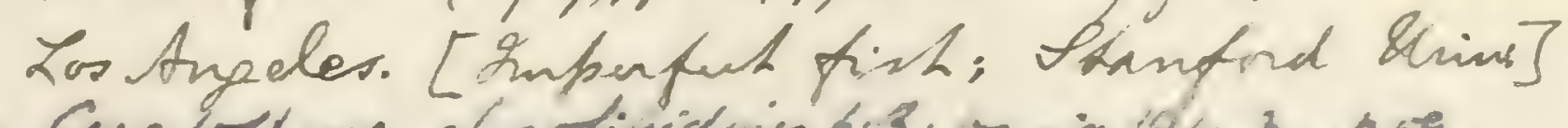

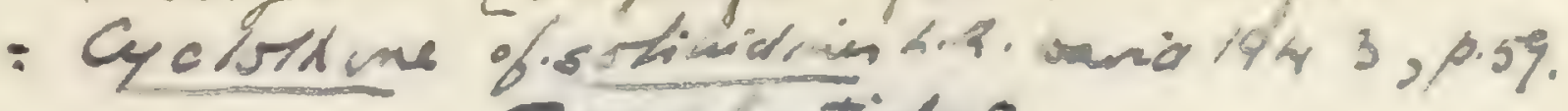
Tseifatidap

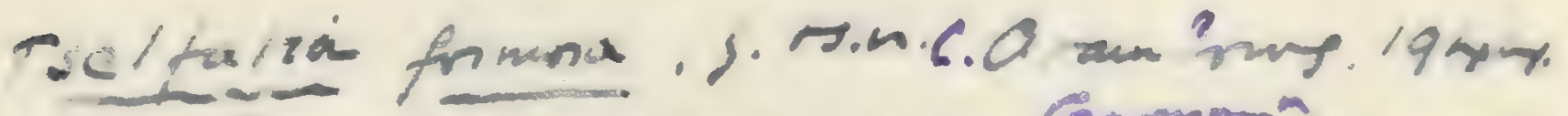

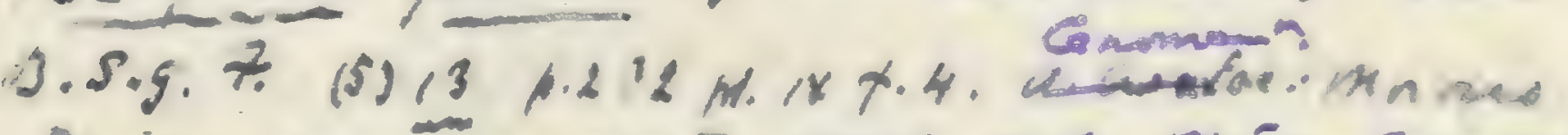

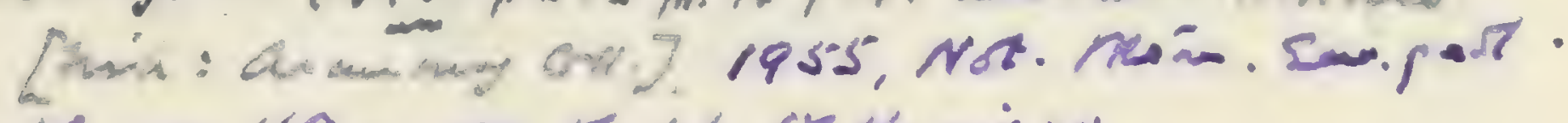

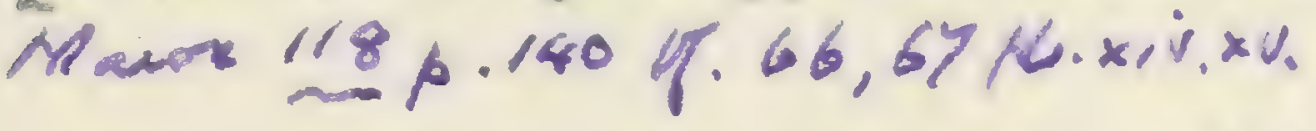

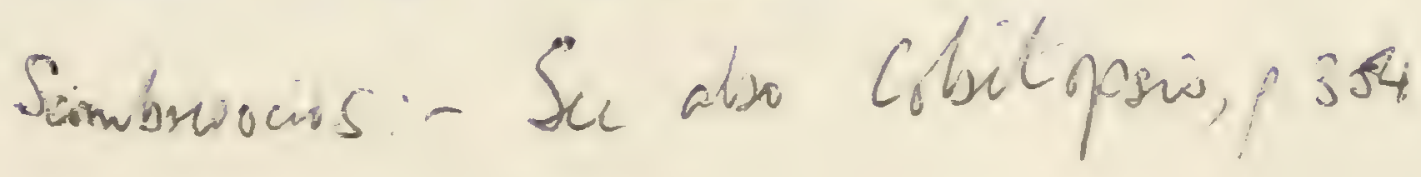




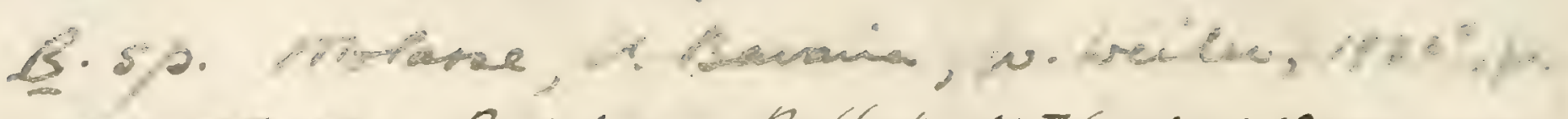

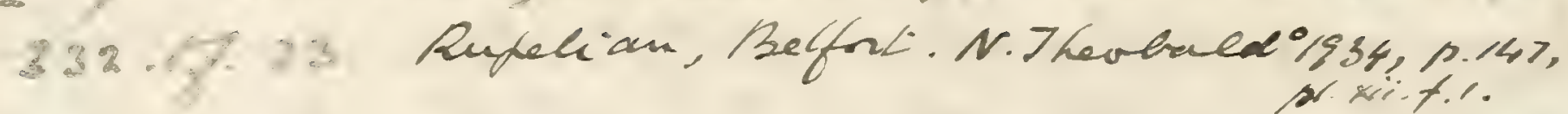

Betme palaeortynchoides crin 1.4. B.P. Smuinar 1936;

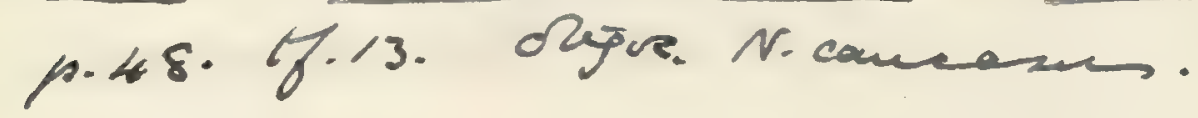

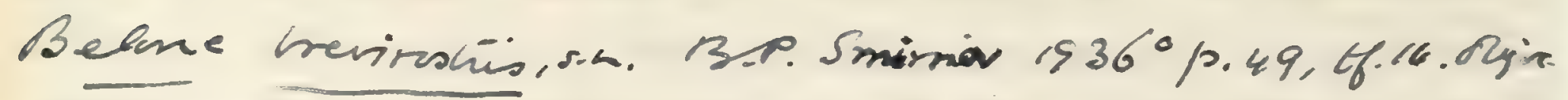
r. Cancons.

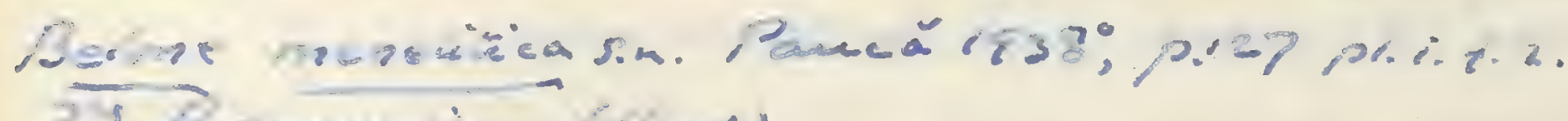

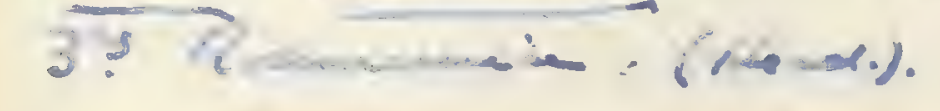

B. of. acutirostrio, G.De Stefano, Memi. D. Conit. Geol. Esal. vol. vii. ph.i (1918), p.60.

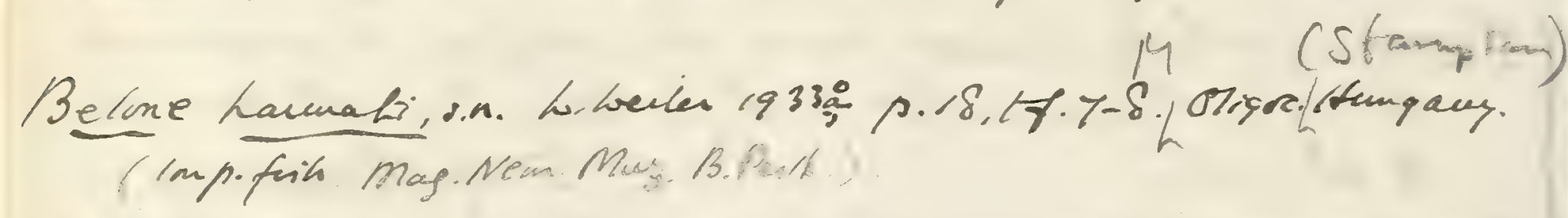

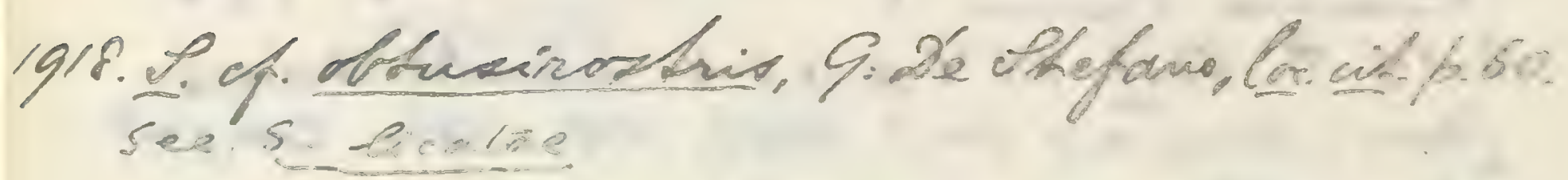




upper jaw in length; teeth minute and. clustered, with larger elender conical teeth at intervals. Tertebræ from 55 to 85 in number. Paired fins small; dorsal ard anal fins similar, without posterior finlets; caudal fin forked or nearly truncate. Scales small and cycloid.

Belone tenuis, Kramberger. $=H$

1894. Belone tenuis, D. G. Kramberger, Rad Jugoslar. Akad. vol. cxx. p. 73.

1898. Belone tenuis, D. G. Kramberger, Glasnik Soc. Hist. Nat. Croatica, rol. x. p. 26, pl. ii. fig. 1.

Type. Tearly complete fish; Tational Museum, Agram.

A small species, about 0.25 in length. Head with opercular upparatus occupying nearly one third of the total length to the base of the caudil fin; jaws apparently equal in length. Approximately 57 rertebræ. Pelric fins about midray between pectoral and caudal fins; anal fin with from 16 to 18 rars.

Foim. \& Loc. Tpper Miocene: Jurjerčani, near Plesirica, Croatia.

Not represented in the Collection.

Fragments of imperfectly defined species not represented in the Collection are also described thus:-

Belone acutirostris, H. E. Saurage, Ann. Sci. Géol. rol. ir. (1873), art. no. 1, p. 25 (in part), fig. 2 (non figs. 3, 68), and ibid. rol. xi. (1880), art. no. 3, p. 46. Xiphias acutirostiris, H. E. Saurage, Ann. Sci. Nat. [j] rol. xir. (1870), art.no. 7. p. 11.- Tpper Miocene; Licata, Sicily. [Head.] Belone flava, E. Delraux, Ann. Soc. Géol. Belg. rol. xir. (1887), Iŕm. p. 71, pl. iii. figs. 1, 8, 9.-Lower Eocene (Loțer Ipresian); Belgium. [Scales, \&c.]

Genus SCOMBRESOX, Lacépède.

[Hist. Nat. Poiss. rol. F. 1803, p. 3tt.]

As Belone, but all teeth minute, and a few finlets behind dorsal and anal fins.

Scombresox obtusirostris, Saurage.

1873. Belone acutivostris, H. E. Saurage, Ann. Sci. Géol. rol. ir. art. no. 1, p. $25 \%$ (in part), fig. 68 (errore).

1880. Scombresox obtusirostris, H. E. Saurage, ibid. rol. xi. art. no. 3, p. 48.

Type. Fearly complete fish.

An imperfectly known species, attaining a length of about 0.35 . 
Maximum depth contained somewhat more than eight times in total length (excepting rostrum). Vertebræ 32 in abdominal, 38 in caudal region. Dorsal and anal fins directly opposed, former with at least 9, latter with 10 rays. (Sauvage.)

Form. \& Loc. Upper Miocene: Oran, Algeria.

Not represented in the Collection.

The following fragment of a form not represented in the Collection has also been ascribed to this genus :-

Scombresox licatce, H. E. Sauvage, Toe. cit. 1880, p. 48. Belone Sc. Licatae, C. s. 52, he. $x_{i} f \cdot 1$ to. 19.6 Full. symon? acutirostris, H. E. Sauvage, Toc. cit. 1873, p. 257 (in part), fig. 3 (errore).-Upper Miocene; Licata, Sicily. [Imperfect head.] =ahe?

\section{Genus HEMIRAMPHUS, Cuvier.}

[Règne Animal, vol. ii. 1817, p. 186.]

As Belone, but only the mandible produced into an attenuated beak.

Common on the coasts of tropical seas, and some species existing in freshwaters. Only one extinct species known, and this not represented in the Collection:-

Hemiramphus edwardsi, F. Bassani, Atti Soc. Veneto-Trent. Sci. Nat. vol. v. (1876), p. 146, pl. ̈i. fig. 1.-Upper Eocene; Moute Bolca, near Terona.

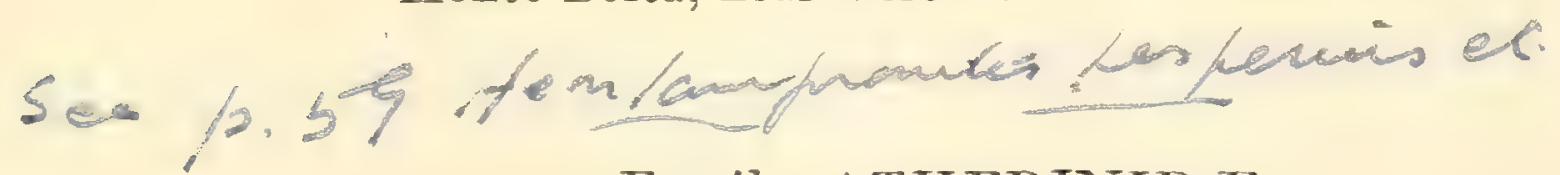

\section{Family ATHERINID王.}

Trunk more or less elongate and subcylindrical. Premaxilla excluding maxilla from border of upper jaw ; mandible not prominent, and cleft of mouth small, with dentition usually feeble; opercular apparatus complete, with about five branchiostegal rays, and the gill-opening wide. Lower pharyngeal bones separate. Vertebræ numerous, varying from about 30 to 60 in total number; centra of abdominal vertebræ with transverse processes for support of slender ribs. Pelvic fins with one spine and five divided rays; two dorsal fins, the anterior being spinous; anal fin opposed to the posterior dorsal. Scales in regular series, large or of moderate size.

In the existing fauna, these are carnivorous fishes inbabiting the seas of temperate and tropical regions, while several species enter or live entirely in freshwater. No extinct genera are satisfactorily determined. 



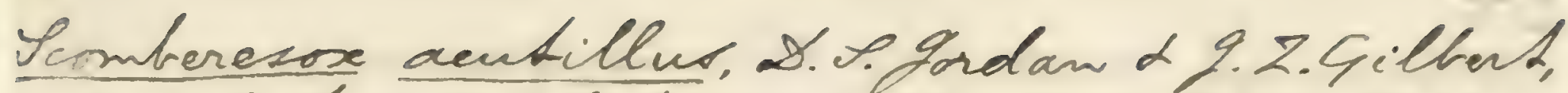
Foss. Firhes T. California (Atanford Univ. Oublic., Uliv. Ler. 1919), f. 3\%, pl. xiv. fi. 2. - Miocene; Sl hodena.

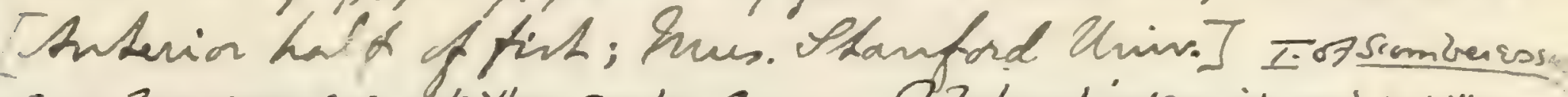

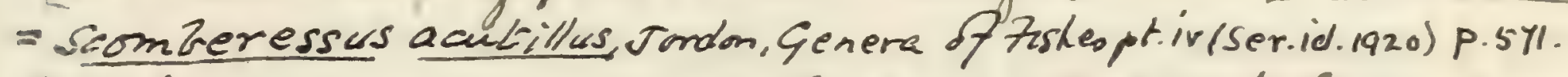
comberezoxe edwardaci. Indow d Gilbert, lor. cit. 1919, 15.37. Hexviii.- Mnicene; Los Angeles. [Head Labdis. inu. Stanford Unir.] Sembereasus edwardsi, Fodan, 1921 loc. cit sifra, p. $25 \%$

Beltion peranides, D.S. Tordan, Geneca of Tishesphir, (Stauford Unir

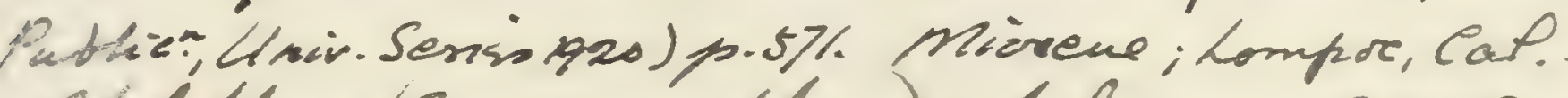
Ordithus (Hemiramphus) italicus, S. G. Bassoli, Riv. Ihal. Pale gut. vol. xii(1906), h.37, hl.i.fij.8. - y

Family Forficidde, Iordan[d Gillent].

Forfex hypuralis, D. F. Fordan, Fon. Firhes S. Caligt. Ftanford Amiv. Oublic., Univ. Aer. (g19), f. 36, hl xiv. fig. 3. - Mircene; Pine Cañon, S. Barlarde C. Campenfest firs, Mus. Stanford Shim] I! of Forfex.

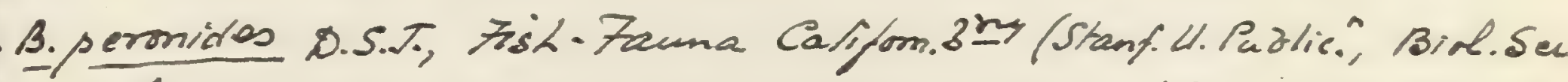

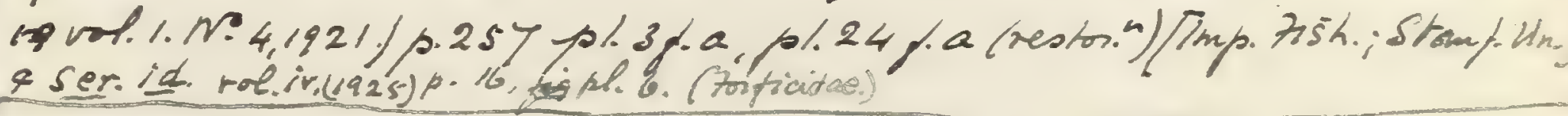

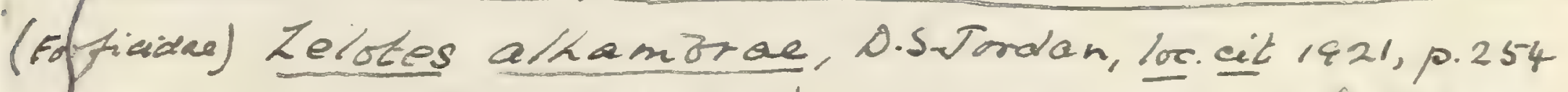
pliret.a, pl.26, f.a (restoration). Mior.; S1 Modena Cat. I Candal region: Stanford Univ. I

I. of zelotes

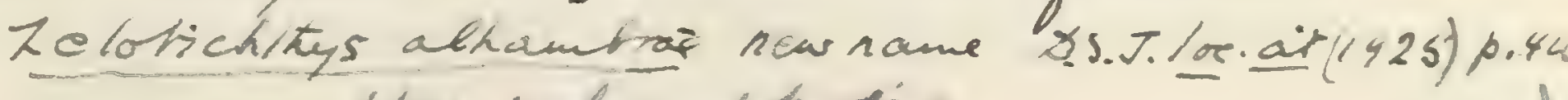
lde mighom hadie

Culephost am pous

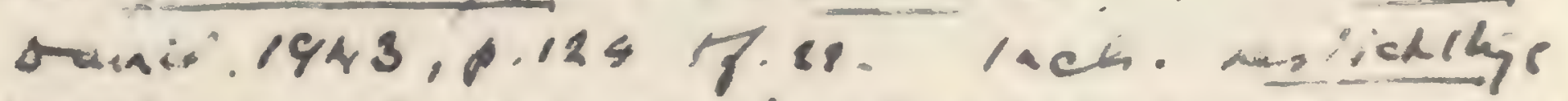
ponlinar: $(p .270)$ o bentrias in andion $(p .336)$ Serota E.Stand $194270 \%$. 3001. 


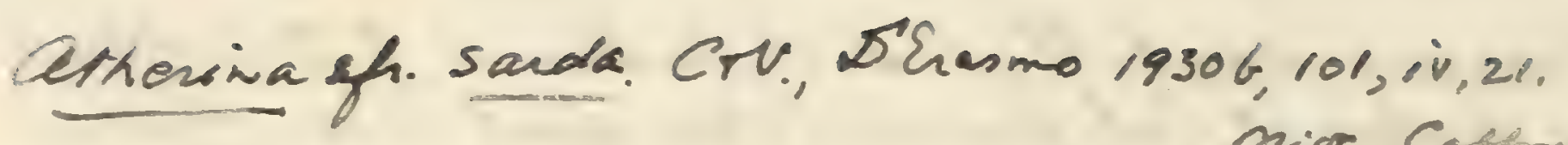
nior. Easirs.

Prospluyraena weileri, n.g.rs. M. Panca" 1935 Z,

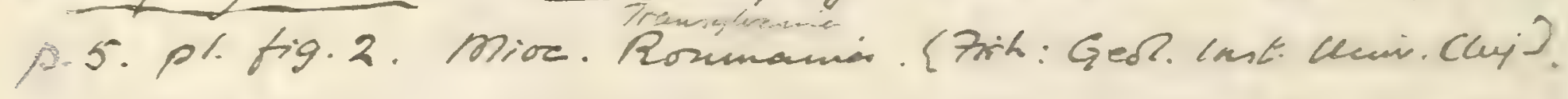




\section{Genus ATHERINA, Linnæus.}

[Syst. Nat. ed. 10, 1758, p. 315.]

Trunk not keeled either above or below; head laterally compressed, especially below, and snout obtusely pointed, not produced. Cranial roof flattened and partly depressed mesially, the small supraoccipital not raised into a crest; orbit enormous; cleft of mouth straight, oblique, extending to or beyond the anterior margin of the eye. Pectoral fins on the flank and the pelvic pair not more remote than the anterior dorsal fin; posterior dorsal and anal fins nearly similar and opposed; a series of free fin-supports between the two dorsal fins; caudal fin deeply forked. Scales large, very deeply overlapping, smooth, and not serrated, rarely crenulated on the posterior margin; some extending over the opercular apparatus and cheeks. Lateral line indistinct. Airbladder present. Pyloric appendages none.

\section{Atherina macrocephala, sp. nov.}

1796. Silurus cataphractus, G. S. Volta, Ittiolit. Veronese, p. cli. pl. xxxv. fig. 5 (errore).

1796. Silurus ascita, G. S. Volta, ibid. p. cxeviii. pl. xlviii. fig. 3 (errore).

1818. "Silurus cataphractus," H. D. de Blainville, Nouv. Dict. d'Hist. Nat. vol. xxvii. p. 343.

1835. Atherina macrocephala, L. Agassiz, Neues Jahrb. 1835, p. 305, and Poiss. Foss. vol. iv, p. 43 (name only).

Type. Imperfect fish; Paris Museum of Natural History.

A very small species, scarcely attaining a length of 0.04 . Length of head with opercular apparatus contained about four times, and maximum depth of trunk between five and six times in the total length of the fish. Width of orbit about equalling length of snout and one thira the total length of the head with opercular apparatus. Vertebræ about 40 in number. Pelvic fins arising much nearer to the pectorals than to the anal, and directly opposed to the dorsal, which cımprises six or seven spinous rays and arises nearer to the occiput than to the second dorsal. The distance between the origin of the two dorsal fins about equal to that between the origin of the posterior dorsal and the caudal fin; anal and posterior dorsal fins exactly opposite.

Form. \& Loc. Upper Eocene: Monte Bolca, near Verona.

P. 1970,-a. Two small slabs labelled by Agassiz. Egerton Coll.

P. 1970 b, c. Two similar specimens, one being about 0.037 in length, showing a long blackened patch in the abdominal 
region, and with traces of furrows or ridges on the scales (? orerlapped portion).

Egerton Coll.

P. 4530. Two good specimens.

Enniskillen Coll.

P. 5280. Good specimen. Presented by Walter Myers, Esq., 1887.

21529. Three specimens.

Purchased, 1847.

Atherina sarmatica, Kramberger.

1891. Atherina sarmatica, D. G. Kramberger, Rad Jugoslav. Akad. vol. cvi. p. 116, pl. iii. fig. 2.

Type. Imperfect fish; Geological Museum, University of Agram.

A rery small species much resembling $A$. macrocephala, but vertebræ about 45 in number and maximum depth of trunk contained between seven and eight times in the total length of the fish.

Form. \& Loc. Upper Miocene (Sarmatian): Dolje, Croatia.

Not represented in the Collection.

\section{Atherina vardinis, Sauvage.}

1883. Atherina vardinis, H. E. Saurage, Bull. Soc. Géol. France, [3] vol. xi. p. 491, pl. xi. fig. 4.

Type. Imperfect fish.

A small species, attaining a length of about $0 \cdot 1$. Length of head with opercular apparatus contained about four and a half times, and maximum depth of trunk between six and seven times in the total length of the fish. Width of orbit about equalling length of snout, and one third the total length of the bead with opercular apparatus. Vertebræ from 45 to 50 in number. Pelvic fins arising much nearer to the pectorals than to the anal and far in advance of the anterior dorsal, which seems to comprise only four or fire spinous rays and is almost as far from the occiput as from the tail. The distance between the origin of the two dorsal fins somewhat less than that between the origin of the posterior dorsal and the caudal fin; anal fin arising somewhat in advance of the posterior dorsal. Scales not crenulated, probably about 45 in a longitudinal, 10 in a transverse series.

Form.\& Loc. Upper Eocene: Gard, France.

P. 6007-9. One slab with five specimens, and two detached examples, showing the principal characters of the species; St. Hypolite de Caton. Purchased, 1889. 
Pi2518. inperfent fick with needies of Pimus; IRTadotori] Croatia.

Punchased.

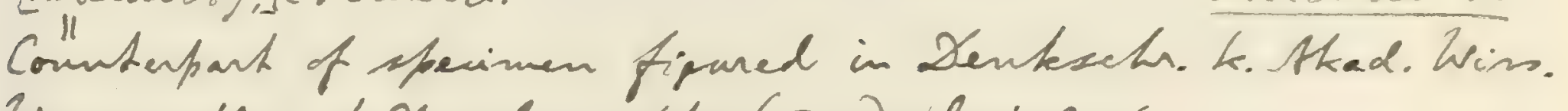
Wien, math. net. A. vol. 38, 121.1 (1877), pl. vi.fis. 6.

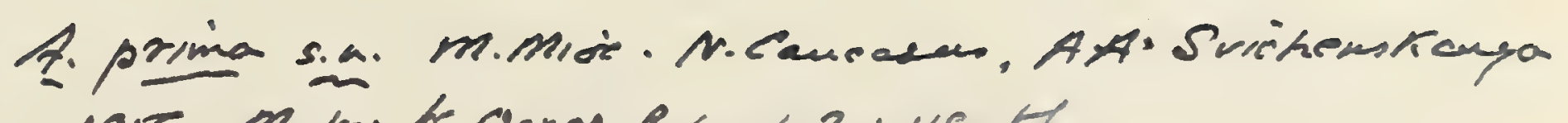

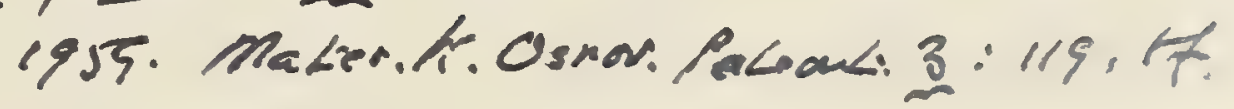

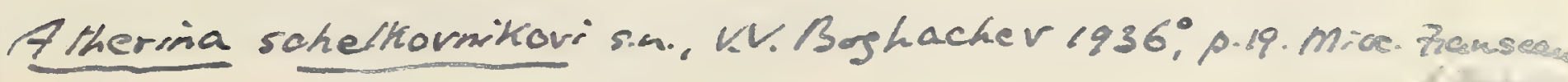

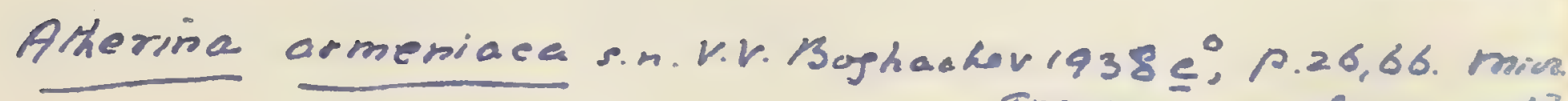

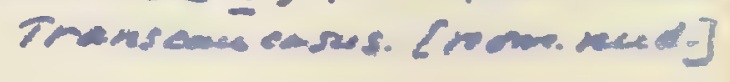


Menidia see Planoternes fi.kpo. 
The undefined name Atherina minutissima was also giren by Agassiz (Poiss. Foss. vol. iv. 1835, p. 43) to a fish from Monte Bolea.

\section{Genus RHAIMPHOGNATHUS, Agassiz.}

[Poiss. Foss. vol. v. pt. i. 1844, pp. 9, 104.]

Syn. Mesogaster, L. Agassiz, ibid. pp. 9, 105.

As Atherina, but snout elongated to an acute point and scales relatively smaller.

In the present state of knowledge it is impossible to distinguish this fish satisfactorily from the existing Atherine genera named Chirostoma (Swainson, 1839), Menidia (Bonaparte, 1840), Atherinoides (Bleeker, 1853), Atherinichthys (Bleeker, 1853), Basilichthys (Girard, 1854), Atherinopsis (Girard, 1854), Labidesthes (Cope, 1870), Atherinops (Steindachner, 1875), and Leuresthes (Jordan \& Gilbert, 1880). Opinions vary as to how many of these are s!nonymous.

Rhamphognathus paralepoides, Agassiz.

1796. Esox sphyrana, G. S. Volta, Ittiolit. Veronese, p. crii. pl. xxir. fig. 2 (errore).

1796. Esox saurus, G. S. Volta, ibid.p. ccri. pl. 1. fig. 2 (errore).

1796. Ammadytes tobianus, G. S. Volta, ibid. p. cexx. pl. liii. fig. 3 (errore).

1818. "Ammodytes tobianus," H. D. de Blainville, Nouv. Dict. d'Hist. Nat. vol. xxvii. p. 360.

1835. Rhamphognathus paralepoides, L. Agassiz, Neues Jahrb. p. 292 (name only).

1839-44. Rhamphognathus paralepoides, L. Agassiz, Poiss. Foss. vol. v. pt. i. p. 104, pl. xxxviii. fig. 1 ( $R$. pompilius on plate).

1876. Rhamphognathus paralepoides, F. Bassani, Atti Soc. VenetoTrent. Sci. Nat. vol, iii. p. 186.

1898. Rhamphognathus paralepoides, F. Bassani, Palæont. Italica, vol. iii. p. 81, pl. ix. fig. 3.

Type. Imperfect fish; Paris Museum of Natural History.

The type species, attaining a length of about $0 \cdot 2$. Length of head with opercular apparatus contained nearly four times in the total length of the fish. Teeth very minute and pointed. Vertebræ 24 in the abdominal, 22 in the caudal region. Pelvic fins arising somewhat nearer to the pectorals than to the anal. Anterior dorsal fin with at least 8 spines, situated opposite the middle of the space between the pelvic and anal fins; posterior dorsal and anal fins directly opposed, with from 7 to 9 rays.

Form. \& Loc. Upper Eocene: Monte Bolea, near Verona.

Not represented in the Collection. 
Rhamphognathus sphyrænoides (Agassiz).

1796. Silurus bagres, G. S. Volta, Ittiolit. Veronese, p. lxx. pl. xiv. fig. 3 (evrore).

1796. Esox sphyrana, G. S. Volta, ibid. p. cvii. pl. xxiv. fig. 3 (errore). 1818. Esor spret, H. D. de Blainville, Nouv. Dict. d'Hist. Nat. vol. xxvii. p. 341 (errore).

1818. "Silurus bugre," H. D. de Blainville, ibid. p. 343.

1835-44. Mesogaster sphyranoides, L. Agassiz, Neues Jahrb. 1835, p. 292 (name only), and Poiss. Foss. vol. v. pt. i. p. 105, pl. xxxriii. figs. $2,3$.

1876. Mesngaster sphyranoides, F. Bassani, Atti Soc. Veneto-Trent. 19 sci, Nat. vol. iii. p. 187.

Type. Imperfect fish; Paris Museum of Natural History.

The type species of the so-called genus Mesogaster, attaining a length of about 0.2. Length of head with opercular apparatus contained about three and a half times, and maximum depth of trunk about seren times in the total length of the fish. Premaxillary border apparently straight and teeth very minute. Vertebræ about 18 in the abdominal, 22 in the caudal region. Pelvic fins arising somewhat nearer to the pectorals than to the anal. Anterior dorsal fin, with six slender spinous rays and the third the longest, arising opposite a point just behind the pelvic pair; space between the two dorsal fins about equal to that between the origin of the posterior dorsal and the caudal, and this space exhibiting a series of ten free fin-supports; posterior dorsal and anal fins equal and directly opposed, each with nine or ten rays, the foremost being a short spine.

Form. \&. Loc. Upper Eocene: Monte Bolca, near Verona.

P. 5128. Fine specimen about 0.2 in length, showing all the generic and specific characters mentioned above except the minute teeth. The straight cleft of the mouth clearly extends as far as the orbit. Remains of a small undigested fish are observed in the abdomen.

Purchased, 1886.

28437. Somewhat smaller distorted specimen with rery imperfect head.

Purchased, 1853.

The so-called Rhamphognathus verneuili (F. de Botella, Descrip. Geol. Murcia y Albacete, 1868, pl. xi. fig. 5), from Lorca, Spain, is an indeterminable fragment.

Mesogaster cretaceus (W. von der Marck, Palæontogr. vol. xxxi. 


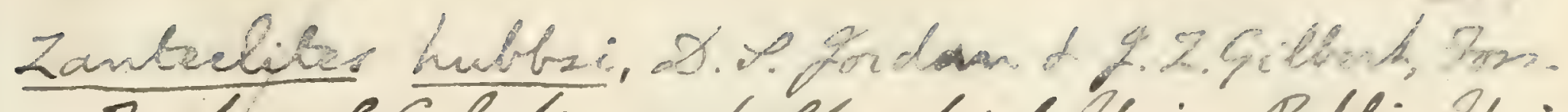
Fisher T.California / Stanford Univ. Oublie., Mniv. Sen. (919), f. 39, hl. xv. fig. 3, hl xvi.- hivene="

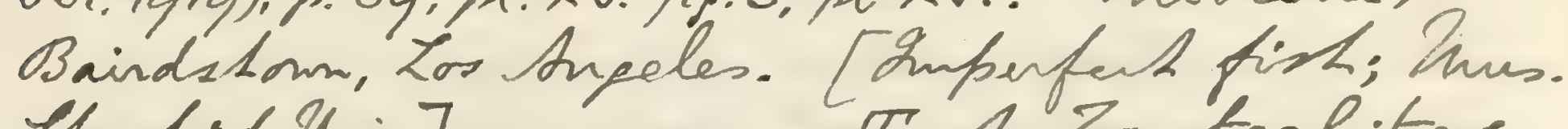
thanford. Univ.]

T. of Zanteelites-

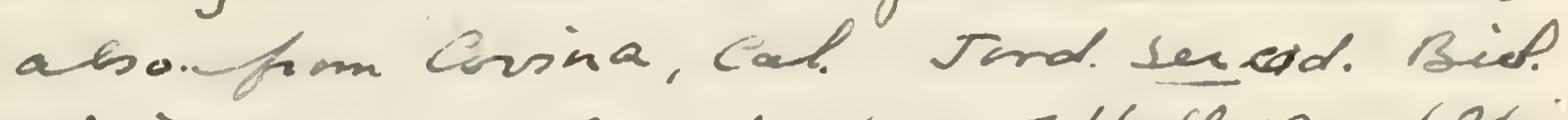

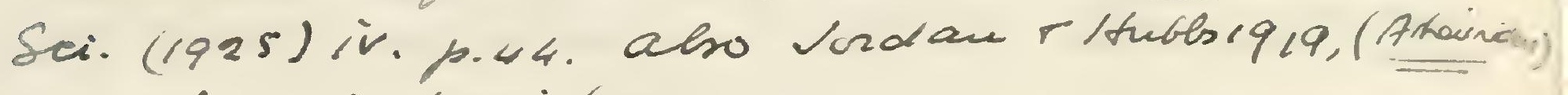
en-oad. p.10, plin xitipo. 
Merridmella doinzen, A.S. Goidan, Bulle. Deth.

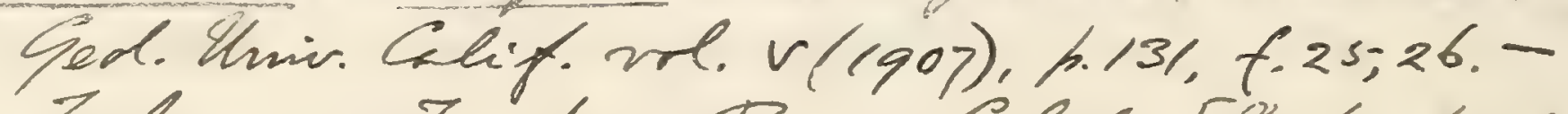

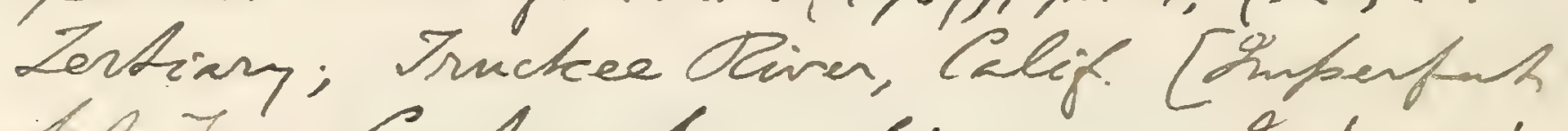

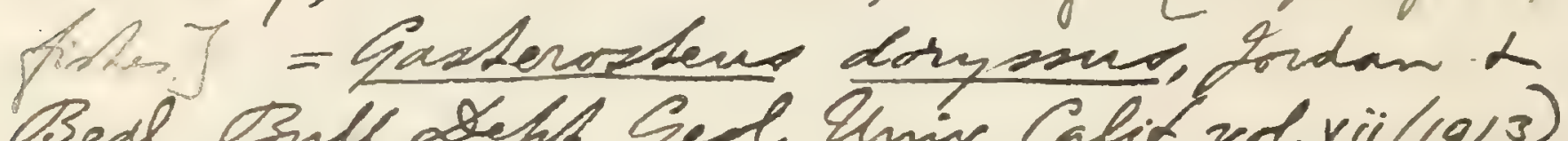
Bede, Bull. otefth. Ged. Amiv. Calif. vde viil(19/3). 1.256. = Gaskesrsteur williamsoni Leptosomis,

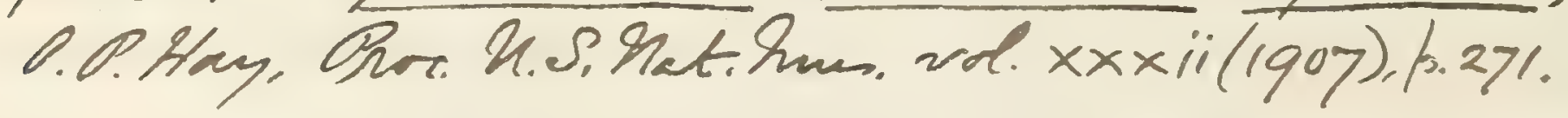

ANABANTOUDEA.

Isphronemus gromy Lac. Mn. Sauders M34: p.75. plix. ('Tre Pumahios)? 
1885, p. 247, pl. xxii. fig. 2), from the Upper Cretaceous of Westphalia, does not belong to this genus or even to the Atherinidxe. The type specimen, in the Academy of Münster, is too imperfect for exact determination but seems to be a Scopeloid fish.

\section{Family MUGILID $Æ$.}

Trunk more or less elongate and laterally compressed. Premaxilla excluding maxilla from border of upper jaw ; mandible not prominent and cleft of mouth small, with dentition feeble or absent; opercular apparatus complete, with about fire branchiostegal rays, and the gill-opening wide. Lower pharyngeal bones separate. Vertebræ fer, not more than 24 to 26 in number; centra of abdominal vertebræ with transverse processes for support of ribs. Pelvic fins with one spine and five divided rays, abdominal, but the pelvic bones in contact with the postclavicle; two dorsal fins, the anterior spinous and with very few rays; anal fin opposed to the posterior dorsal. Scales in regular series, large or of moderate size.

In the existing fauna, these are fishes with a protractile mouth feeding chiefly on organic substances or small animals mixed with mud or sand. The organs of the pharynx are accordingly modified into a filtering apparatus. The various genera, with numerous species, now inhabit the coasts and freshwaters of all the temperate and tropical regions. The only known extinct species seem to belong to the surviring genus Mugit.

Genus MUGIL, Linnæus.

[S5st. Nat. ed. 10, 1758, p. 316.]

Snout short and obtuse, and the cleft of the mouth not reaching the orbit; no true teeth in the mouth, but a calcified setiform fringe on the border of both jaws; anterior extremity of mandible acute; antorbital cheek-plate serrated; eleren or twelre abdominal and thirteen or twelve caudal vertebræ; the abdominal vertebræ with strong, broad transverse processes, while several of the anterior neural spines are expanded into short and broad laminæ, sometimes partly confluent. Pelvic fins inserted in advance of anterior dorsal fin; anterior dorsal comprising four spines; posterior dorsal and anal nearly similar and opposed; caudal fin forked. Scales of moderate size, smooth and very rarely crenulated or serrated; some 
extending over the head. No differentiated lateral line, but the slime-canal-system piercing scales all over the Alank. A division of the stomach extremely muscular.

A figure of the skeleton of the existing Mugil is published by Agassiz, Poiss. Foss, vol, v. pl. F.

\section{Mugil princeps, Agassiz.}

1818. Mugil cephalus, H. D. de Blainville, Nouv. Dict. d'Hist. Nat. vol. xxvii. p. 370 (errore).

1843-44. Mugil princeps, L. Agassiz, Poiss. Foss. vol. v. pt. i. p. 121, pl. xlviii. figs. 1, 2.

Type. Imperfect fish; School of Mines, Paris.

A small species, attaining a length of about $0 \cdot 25$. Length of head with opercular apparatus slightly exceeding maximum depth of trunk and occupying nearly one quarter of the total length of the fish. Foremost spine of anterior dorsal fin much stouter and larger than the others; distance between the origin of this and the posterior dorsal fin greater than that between it and the occiput, about equal to the distance between the origin of the posterior dorsal and the caudal; posterior dorsal relatirely small, with one spine and seven articulated rays; anal much larger than the posterior dorsal, about half in advance of the latter, exhibiting apparently three spines and eight or nine articulated rays.

Form. \& Loc. Lower Oligocene: Aix-en-Provence, Frunce.

8065. Remains of large specimen in friable marl, wanting caudal fin.

Mantell Coll.

8056. Head and abdominal region of still larger specimen, better preserved. The operculum is shown to be about as broad as deep. The pelric fins exhibit indications of five articulated rays and an anterior spine. The scales are especially well-preserved, displaying the square form and radiating grooves of their overlapped portion, and often the round median perforation for the slime-canal.

Mantell Coll.

8067. Small fish, resembling the two smaller specimens figured by Agassiz.

Mantell Coll.

40520, 43440. Two similar specimens. Purchased, 1867, and Presented by Kenneth Murchison, Esq., 1872. 


1918. Mupil of. Frincepo. 9. De Atefano, Mem. of

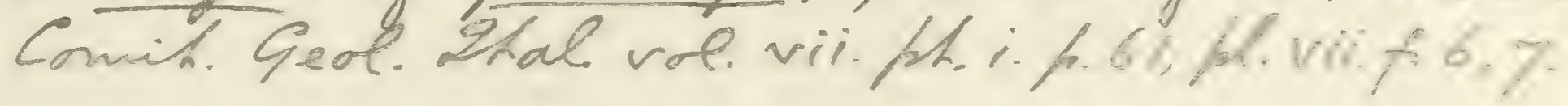

M. Acet ap.nar. Sarmation mobsevia A-A. Surchenstian Tr. Pabent. Zhura. 1955, 1:8817.

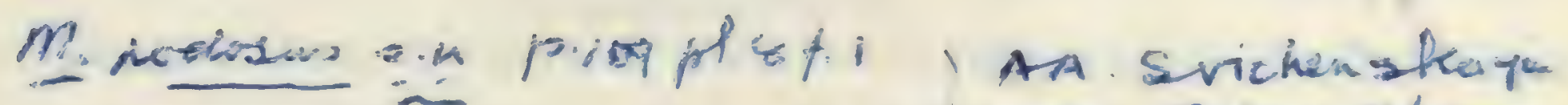

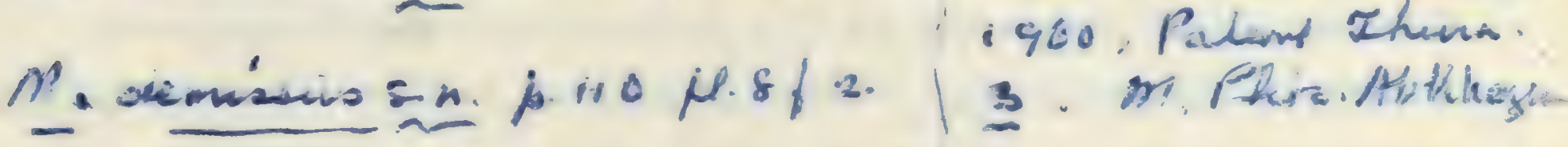

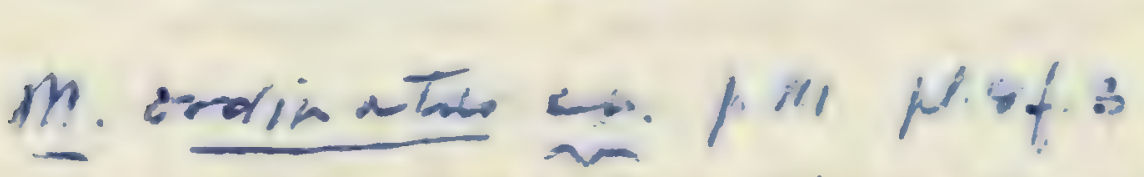

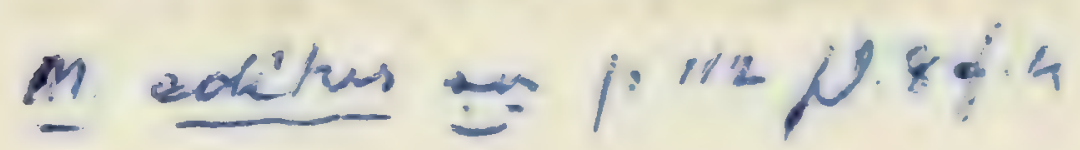



P. 1974,-a. Two similar specimens displaying the pores in the scales for the slime-canal-system, and the second also showing the serrated antorbital cheek-plate. Egerton Coll.

P. 4531. More imperfect specimen, slightly larger.

Enniskillen Coll.

Mugil radobojanus, Kramberger.

1882. Mugil radobcjanus, D. G. Kramberger, Beitr. Paläont. Oesterr.Ungarns, vol. ii. p. 114, pl, xxviii. tigs. 2-4.

Type. Imperfect fish; Imperial Geological Surrey, Vienna.

A species attaining a length of about 0.25. Length of head with opercular apparatus contained about four times, and the maximum depth of the trunk about six times in the total length of the fish. Fins as in $M I$. princeps [but relative proportions of foremost dorsal fin-spine uncertain].

Form. \& Loc. Upper Miocene (Sarmatian): Radoboj and Vrabce, Croatia.

Not represented in the Collection.

The following otolith is also supposed to be referable to a member of this family :-

Otolithus (Iurgilidarum) debilis, E. Koken, Zeitschr. deutsch. geol. Ges.vol.xl.(1888), p.288, pl. xvii. fig. 8.-Lower Tertiary; Jackson River, Mississippi.

\section{Family SPHYR ANID无.}

Trunk more or less elongate and subcjlindrical. Premaxilla excluding maxilla from border of upper jaw; mandible prominent, cleft of mouth wide, and dentition prowerful, the larger teeth fixed in sockets; opercular apparatus complete, with few branchiostegal rays, and the gill-opening wide. Lower pharyngeal bones separate. Vertebræ few, about 24 in number; centra of the 5 anterior abdominal vertebræ without transverse processes. Pelvic fins with one spine and five divided rays; two dorsal fins, remote from each other, the anterior being spinous; anal fin opposed to the posterior dorsal. Scales in regular series, small or of moderate size.

These are carnivorous fishes, of which one genus (Sphyroma) now survives in nearly all the seas of the temperate and tropical regions. 
Genus SPHYRAENA (Artedi), Bloch \& Schneider.

[Syst. Ichthyol. 1801, p. 109.]

A widely-spaced series of large conical teeth, more or less laterally compressed, on part at least of the dentary and premaxilla, with an outer regular close series of comparatively minute teeth; large teeth also on the palatines, but no teeth on the vomer. Cranial roof flattened, the small occipital crest not rising above the level of the frontal plane, and the anterior end of the ethmoidal region contracting to a point. Seven branchiostegal rays. Pelvic fins more or less directly opposed to the anterior dorsal, which consists of five spines; caudal fin forked. Scales small and smooth, not crenulated or serrated, continued to a varying degree over the head and opercular apparatus. Lateral line distinct.

A figure of the skeleton is published by Agassiz, Poiss. Foss. vol. v. pl. F.

\section{Sphyræna bolcensis, Agassiz.}

1796. Esox sphyrana, G. S. Volta, Ittiolit. Veronese, p. cvii. pl. xxiv. fig. 1 (errore),

1796. Perca punctata, G. S. Volta, ibid.p. ccviii. pl. li. fig. 1 (errore).

1796. Esox lucius, G. S. Volta, ibid. p. ccliii. pl. Ixii (errore).

1818. Esox spret, H. D. de Blainville, Nouv. Dict d'Hist. Nat. vol. xxvii. p. 341 (errore).

1835. Sphyrana bolcensis, L. Agassiz, Neues Jahrb. pp. 292, 294, 305.

1835. Sphyvæena gracilis, L. Agassiz, ibid. p. 305.

1835. Sphyræena maxima, L. Agassiz, ibid. p. 305.

1843-44. Sphyrena bolcensis, I. Agassiz, Poiss. Foss. vol. v. pt. i. p. 95, pl. x. fig. 2.

1843-44. Sphyrana gracilis, L. Agassiz, ibid. p. 96, pl. x. fig. 1. [Imperfect distorted fish; Palæontological Museum, Munich.]

1844. Sphyrena maxima, L. Agrassiz, ibid. p. 97. [Name only, proposed for fish named Esox lucius by Volta.]

1876. Sphyrcena bolcensis, F. Bassani, Atti Soc. Veneto-Trent. Sci. Nat. vol. iii. p. 185.

Type. Imperfect fish; Palæontological Museum, Munich.

A species attaining a length of nearly one metre, but usually smaller. Length of head with opercular apparatus equalling about half that of the trunk from the pectoral arch to the base of the caudal fin; maximum depth of trunk contained nine or ten times in the total length of the fish. Space between the pectoral and pelvic fins about one fourth of that between the latter and the anal; anterior dorsal fin with five nearly equal slender spinous rays, arising immediately behind a point opposite the pelvic pair, and the space 
Sphyrama op. Otigrane, Elungay, D.W eiber1933a:;

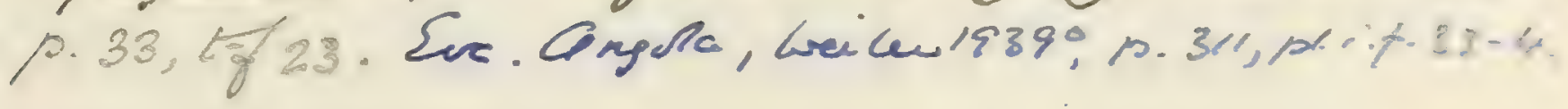

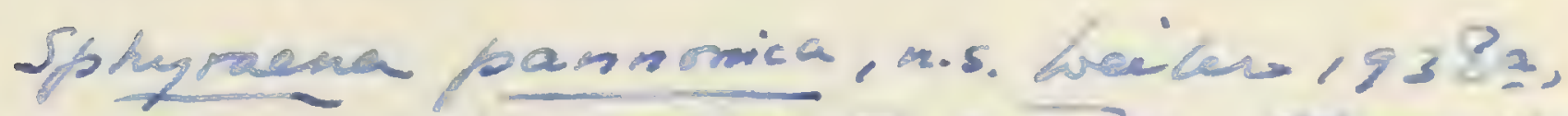

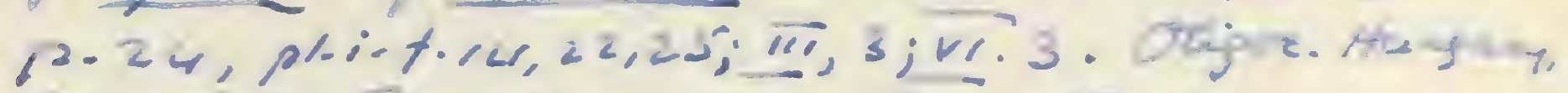

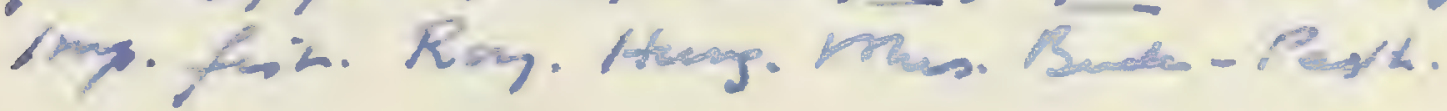

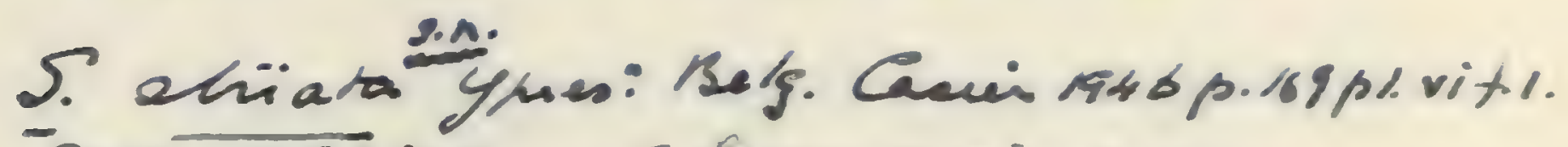
Tont M.R.H.T.B. = S. faycumensin pols.

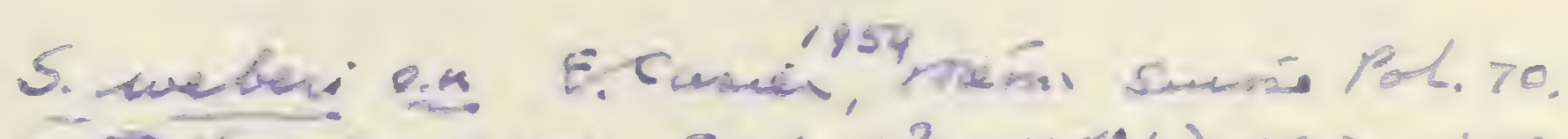

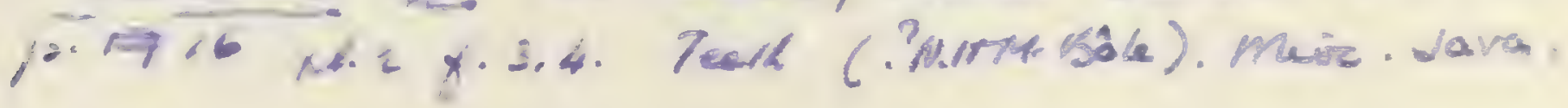




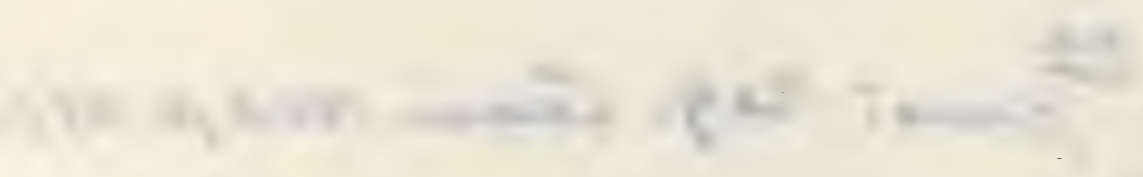


between the origin of the two dorsals about equal to that between the posterior dorsal and the caudal, and scarcely one quarter of the total length of the fish; posterior dorsal fin deeper than long, with ten rays, the foremost a slender spine half as long as the first articulated ray; anal fin directly opposed to the posterior dorsal, apparently similar but perhaps with only nine rays, the two foremost short and spinous.

From. \& Loc. Upper Eocene: Monte Bolca, near Verona. ${ }^{1}$

P. 1781, P. 3950. Slightly distorted specimen 0.36 in length, in counterpart, labelled by Agassi\%. There are traces of the large mandibular teeth, and an undigested fish occupies the abdomen. Egerton \& Enniskillen Colls.

21398-99. Two more fine specimens, nearly as large as the abore, the second in counterpart.

Purchased, 1847.

P. 3950 a. Fish about 0.27 in length, labelled by Agassiz, and displaying nearly all the principal characters of the species.

Enniskillen Coll.

P. 3949. Fish about 0.28 in length, labelled "Sphyrcence gracilis, Agass." by Agassiz, but with endoskeleton as robust as in any of the preceding specimens and differing from no. P. $3950 a$ in the mode of crushing and preservation. One large anterior premaxillary tooth is shown with striated base.

Enniskillen Coll.

P. 1782. Imperfect distorted specimen, somewhat smaller.

Egerton Coll.

Sphyræna intermedia, Bassani.

1889. Sphyrena interniedia, F. Bassani, Atti R. Accad. Sci. Napoli, [2] vol. iii. no. 6, p. 97 , pl. xiv. tig. 4 .

Type. Imperfect fish; Piovene Collection, Lonedo.

A smaller and stouter species than S. bolcensis, the maximum depth of the trunk contained about six times in the total length of the fish. Fins apparently as in the last species.

Form. \& Loc. Lower Miocene: Chiavon, Vicentin, N. Italj.

Not represented in the Collection.

I A nearly similar fish from the Lower Miocene of Chiavon, is described by F. Bassani, Atti R. Accad. Sci. Napoli, [2] vol. iii. no. 6 (1889), p. 96, pl. xviii. fig. 1 . 


\section{Sphyræna suessi, Kramberger.}

1882. Sphyrcena suessi, D. G. Kramberger, Verh. k.-k. geol. Reichsanst. p. 29.

1891. Sphyrana suessi, D. G. Kramberger, Rad Jugoslav. Akad. vol. cri. p. 88.

Type. Imperfect fish; Geological Museum, University of Vienna.

A species about 0.35 in length, similar in general proportions to S. intermediu, but having pelvic fins opposed to anteriur dorsal, and anal fin completely behind the posterior dorsal.

Form. \& Loc. Upper Oligocene: Sagor, Krain, Austria.

Not represented in the Collection.

The following teeth also seem to be referable to Sphyrona, but are not specifically determinable:-

P. 1770-71. About twenty-five teeth, much laterally compressed, some resembling the smaller teeth named Sphyrcena major by Leidy (see below); Upper Eocens, Clarke County, Alabama, U.S.A.

Egerton Coll.

P. 9235. About twenty similar teeth, from the same formation and locality.

Eirniskillen Coll.

P. 1392. More slender tooth; Middle Tertiary, Bissex Hill, Barbados.

Presented by Col. H. W. Filden, 1892.

The following species have also been named, but on the evidence of specimens too imperfect for precise specific determination :-

Sphyrana croatica, D. G. Kramberger, Beitr. Paläont. Oesterr.Ungarns, vol. ii.(1882), p. 112, pl. xxviii. fig. 1.-Upper Miocene(Sarmatian); Podsused, Croatia. [Imperfect trunk of fish: Geolngical Museum, University of Agram.]

Sphyrona major, J. Leidy, Proc. Acad. Nat. Sci. Philad. 1855, p. 397, and Journ. Acad. Nat. Sci. Philad. [2] vol. viii. (1877), p. 254, pl. xxxiv. figs. 37-41.-Phosphate Beds ; Ashley Rirer, South Carolina, U.S.A. [Teeth; Academy of Sciences, Philadelphia.]

Sphyrona speciosa, J. Leidy, Proc. Acad. Nat. Sci. Philad. rol. viii. (1856), p. 221.-Miocene; Cumberland Co., New Jersey. [Tooth.]

Sphyrona viennensis, F. Steindachner, Sitzungsb. k. Akad. Wiss., math.-naturw. Cl. rol. xxxvii. (1859), p. 681, pl.i. fig. 4.-Upper Miocene; Hernals, near Vienna. [Imperfect small fish; Court Museum, Vienna.] 


S. malembeanser 3.n. Mivis. Cirpo

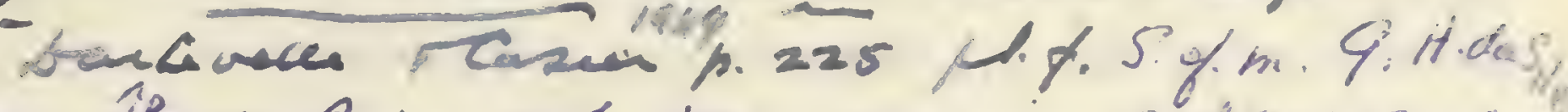

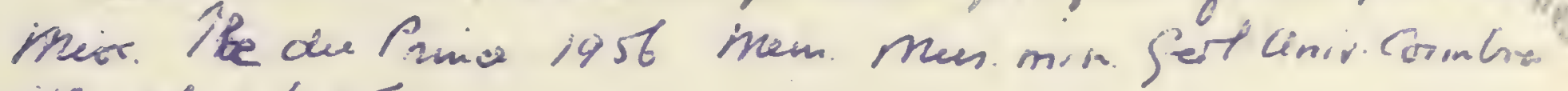
$43 \mu .7 .5 . \overline{6}$

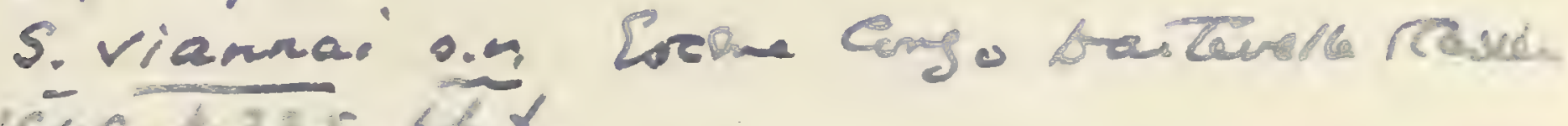

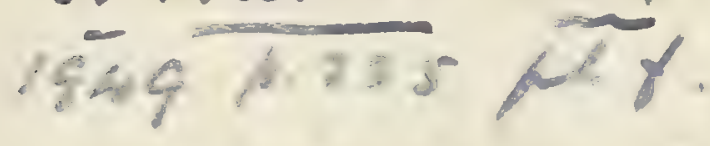

S. Erassidens?

S. Uugardi: $=5$. fajumensis? $p .1 / 5$.

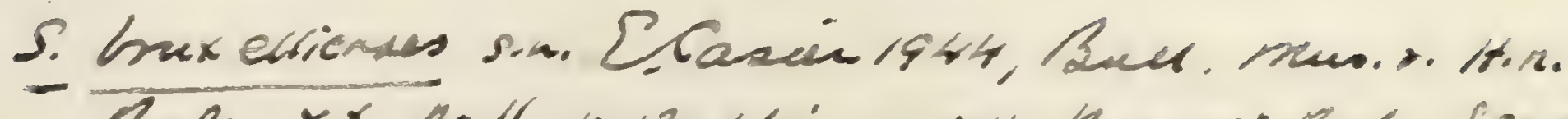

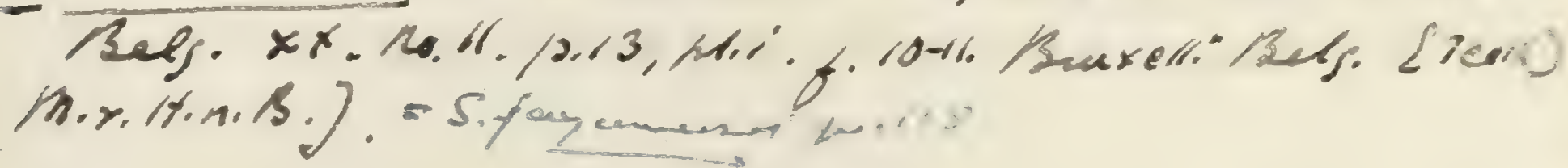

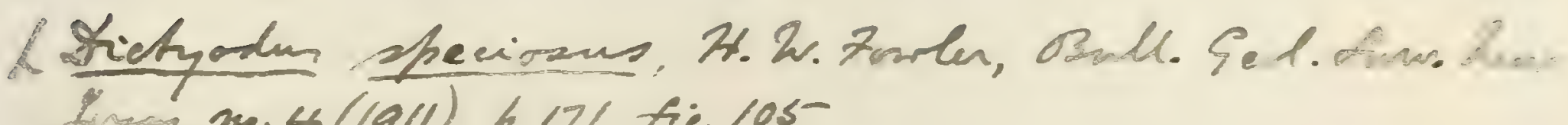

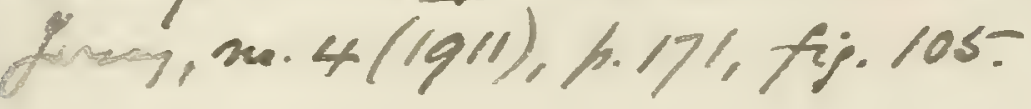


Remanis of the 'Snook' (S. nover.Rollandiae, Ginmt) are

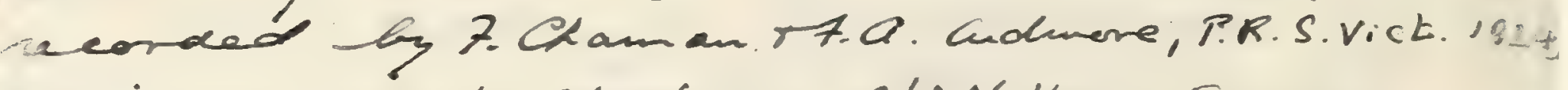
sxavi ns. p. 146 fr. Pleistocen of W. Mellomme Sivanp.

Llithur (Shyyrena) hanofuchei, B.f.Schubest, - Miocene; Vöslau.

Q.(S.) aff. havofuchei, 7. Priem, Sullofo. Géol. France tr.7vol. xiv(1914), f.25-5, f.22.- Helvetian; Gironde.

Ophiocephakes palaeostriakis 2in. Meist Java. M. Boeseman 1949, Znol. Mededel. 30 , p-83.phs. iis. iv.

Fontal and pereulum from Irinil, Lava, Neferred to Qhiocefthalus by E. Hennig. in Selentea d Blanchenhom, hecentherpus-Schichten (1911), f. 59. pl. xi.fip. 13,14.

FOMily CEPOLIDAE.

Sepsla Lanceolata, w.heiter, ard. hess. ged. Landesanst.

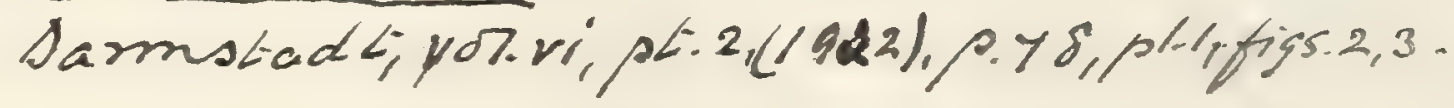


Sphyscena sternbergensis, T. C. Winkler, Archiv Tereins Fr. Naturg. Mecklenburg, vol. xxix. (18i5), p. 123, pl. iii. figs. 17, 18.- - Tpper Oligocene; Sternberg. [Jaw and scale.]

Sphyrena winkleri, R. Lawley, Nuori Studi Pesci, etc. Colline Toscane (1876), p. 77.-Lower Pliocene; Orciano, Tuscanj. [Teeth.]

The so-called Sphyrcina amici (L. Agassiz, Poiss. Foss. rol. r. pt. i. 18t3-4t, p.97, pl. x. fig. 3) is founded on remains of a skull, not of this genus, from the Upper Cretaceous of Mount Lebanon.

With the Percesoces are sometimes placed the OpHocephalid.玉, a family of freshwater fishes common in the Indian region, rarer in Africa. To extinct representatices are definitely known, but the following fossils have been referred to the existing genus Ophiocephatus:-

15374-75, 15402,-a. Four fragmentary heads; Siwalik Formation (Pliocene), Siwalik Hills, India. Noticed by R.Iydekker, Palæont. Indica, ser. x. vol. iii. (1886), p. 246 , the third specimen being figured, loc. cit. pl. xxxrii. fig. 2, also noticed by J. IrClelland, Calcutta Journ. Nat. Hist. rol. iv. (184t), p. 83.

Presented by Col. Sir Proby T. Cauttey, K.C.B., 1842.

\section{Suborder VIII. HEMIBRANCHII.}

Tertebral centra always complete constricted cylinders, those immediately behind the occiput more or less modified or coalesced. Supraoccipital extending forwards between the reduced parietals; squamosal rudimentary and fused with the large pterotic; mandible simple, each ramus consisting only of two elements (dentary and articulo-angular). Branchial arches always more or less reduced. Pectoral arch suspended from cranium; large infraclaricular plates present; pectoral fin with not more than four or fire basals. Pelvic fins usually abdominal, but sometimes advanced so that their supports are in contact with the pectoral arch. Dorsal fin with or without an anterior spinous portion. In the living forms:air-bladder closed, without pneumatic duct, in the adult (physoclistous); optic nerves decussating; intestine without spiral ralve.

Following the suggestions of Kner and Steindachner ${ }^{1}$ and Cope ${ }^{2}$

1 Denksehr. k. Akad. Wiss., math.-naturw. Cl. vol. xxi. (1863), p. 28, footnote.

2 E. D. Cope, Origin of the Fittest (1887), p. 323. 
to their logical conclusion, the so-called Lophobranchii may be regarded as extremely specialised members of this suborder.

\section{Synopsis of Families.}

I. Gills normal, pectinated; opercular apparatus complete.

Trunk fusiform, and snout not much produced; anterior vertebræ slightly elongated; pelvic fins far forwards, each with one spine and one or two divided rays; a few free spines in front of dorsal fin; anal with one anterior spine; no scales, but frequently bony scutes ....................

Trunk elongated and snout much produced into a tube; anterior vertebræ slightly elongated; pelvic fins each with one spine and few divided rays; free spines in front of dorsal fin; anal with one anterior spine; skin with degenerate squamation or small, partly concealed bony plates ...........

Trunk elongated, and snout much produced into a tube; four anterior vertebræ much elongated and fused together; pelvic fins without spine but with five or six divided rays; free spines in front of dorsal fin rudimentary or absent; anal fin without spine; skin naked, or with small scales ..

Trunk laterally compressed, irregularly oblong or deepened, and snout much produced into a tube; some anterior vertebre usually elongated;; pelvic fins without spine but with about five divided rays; anterior part of dorsal fin with few spines, one being excessively enlarged; anal fin without spine; scales present, with bony scutes dorsally and ventrally $\ldots . . . . .$.

II. Gills tufted, in form of rounded lobes; oper-
cular apparatus much reduced. (Lophobranchii.)

Gill-opening wide; all fins present, including an anterior spinous dorsal ...........

Gill-opening very small; pelvic and anterior dorsal fins always wanting, others variable.
Gasterosteide

(Recent).

\section{AשLORHYNCHID}

(p.371).

\section{Fistularinde}

(p. 373).

\section{Centriscidet}

(p. 377).
Solenostomatid ex

Syngnathid 2

(p. 380). 




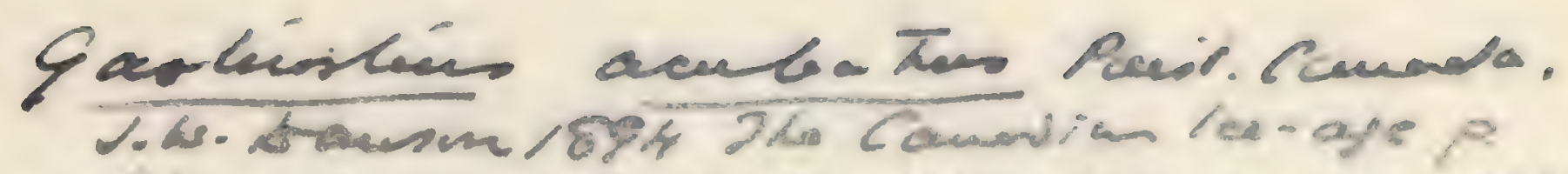
Gasterosten williamsoni leptosomur, O.P.Hay,

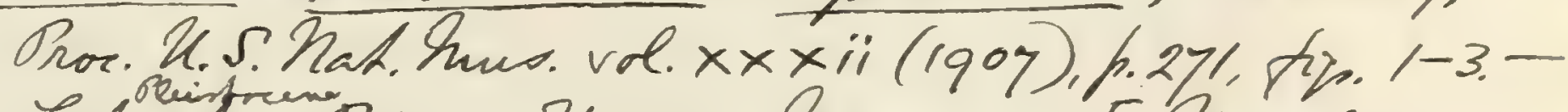
Lahoutan Bes: Hajen, hevadd. Lhesily camplete fint; H.S. Kat. Kuns.]

G G. doryssus p.s.gordan, Publ. Univ. Cal., vol. 5, 1907. No5 5.13 / fegs, 25,26; ' Smitson. Mise. Coll. val.52, 1910, p.11\%. (doryssus hasprienilis nersidi).

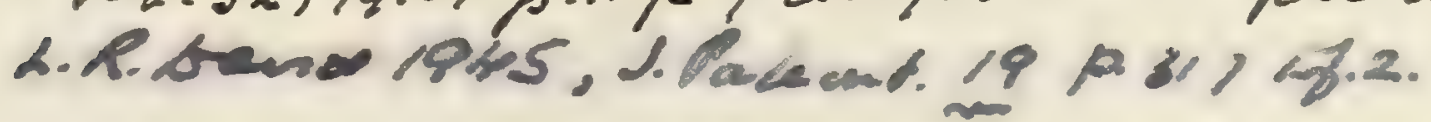

Gastrastieops hexacanthus Shtuil'ko, 1934. Trans. Uniti Geol.

Prosp. Seru. U.S.S.R., Fasc. 359, p.59; plix, f.58-62. elpper? Pliocene; River Irtysh, $55 \mathrm{~km}$ N. J J Omsk, Siberia.

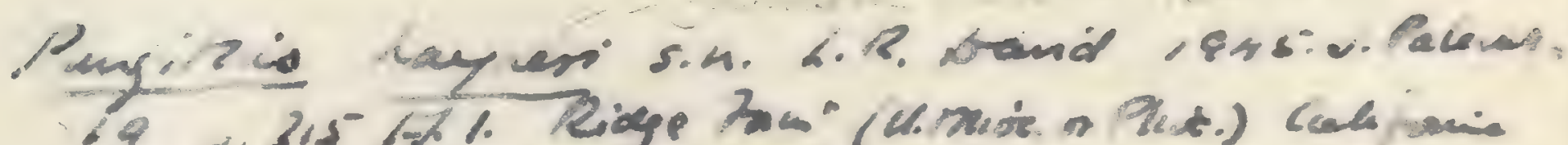

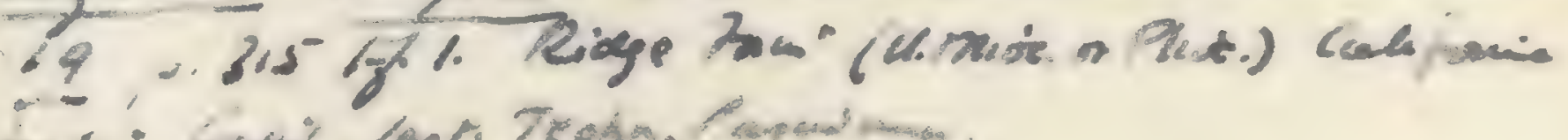

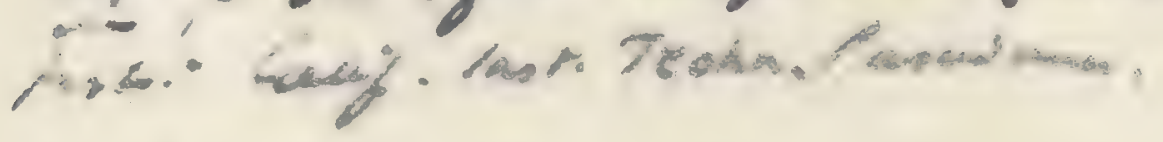




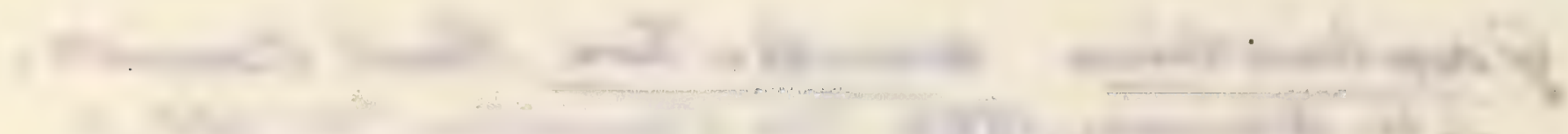

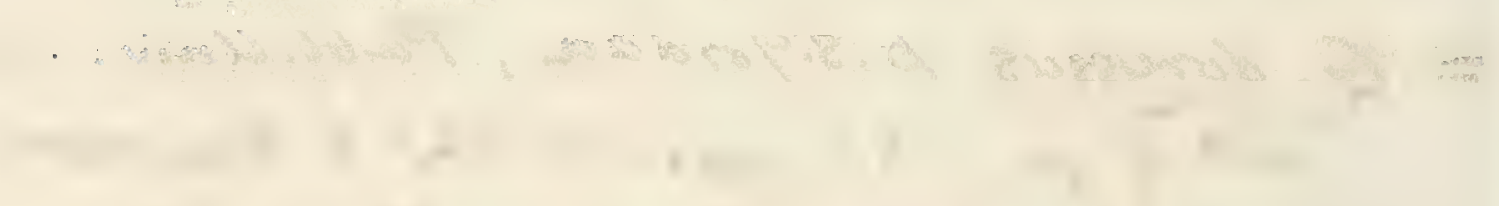

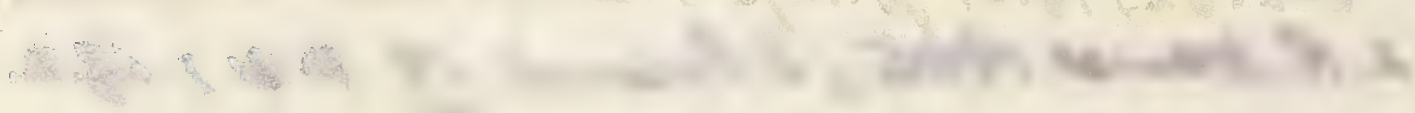

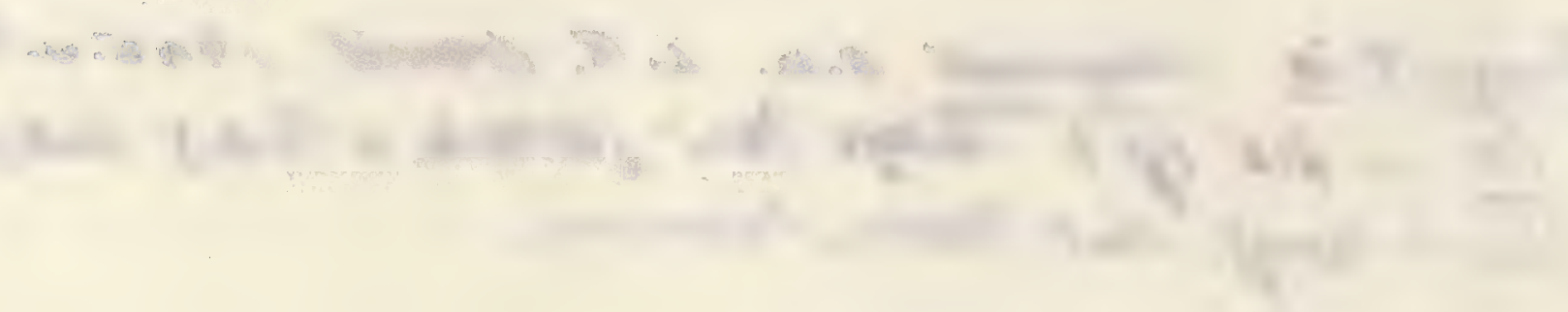




\section{Family AULORHYNCHID E.}

Trunk elongated, and snout much produced into a tube. Premaxilla excluding maxilla from upper margin of mouth, which is small and terminal; teeth minute or absent. Gills pectinated; opercular apparatus complete. Anterior vertebræ somewhat elongated, and all those of the abdominal region with large transverse processes. Pelric fins with anterior spine and 4 to 6 divided rays; free spines in front of the dorsal fin, of which the soft portion is directly opposed to the anal; anal fin with one anterior spine; caudal fin distinct. Skin with degenerate squamation or rows of small bony plates.

\section{Synopsis of Genera.}

Pelvic fins about midway between pectorals and anal; regularly arranged small plates in skin ......................... Protaulopsis (p. 371).

Pelvic fins far forwards; few longitudinal series of bony plates ................... Aulorkynchus (p. 372).

\section{fenus PROTAULOPSIS, norum.}

Vertebræ between 50 and 60 in total number, about half being in the caudal region. Pelvic fins not far forwards, with one spine and about 6 divided rays; anal fin-spine relatively small; caudal fin of moderate size, forked. At least one longitudinal series of enlarged bony scales, probably on the dorsal margin, and the skin completely covered with very small, regularly arranged plates.

\section{Protaulopsis bolcensis, sp. nor.}

Type. Imperfect ish; British Museum.

The type species, attaining a length of about 0.25 . Length of head with opercular apparatus equalling that of trunk from pectoral arch to base of caudal fin. Pelvic fins nearly as large as the pectorals, and arising slightly nearer to the latter than to the anal; anal fin with very small spine and 10 stout divided rays, arising midway between the pelvic pair and the caudal fin. Enlarged lateral dermal scutes apparently smooth and about as long as a vertebral centrum.

Form. \& Loc. Upper Eocene: Monte Bolca, near Verona.

3387\%. Type specimen, in counterpart, abont 0.25 in length. The head and abdominal region are exposed from below, the caudal region in side-riew; anâ the specimen is damaged 
in parts by transverse fractures. An impression of part of the frontal region bears traces of minute tubercles arranged along the radiating lines of growth. The operculum is quite smooth. The vertebral centra are delicate much-constricted cylinders, apparently pierced by a persistent thread of notochord; and large transverse processes bearing the ribs are conspictious in the anterior portion of the abdominal region. Long, very slender intermuscular bones are also seen. The neural and hæmal spines in the caudal region are rery short, broad, and recumbent. The pelvic fin-supports are expanded laminx, and the anterior pelvic fin-spine is nearly as long and stout as the foremost divided ray, which seems to be followed by five others. Of the dorsai fin, only a fragment is distinguishable opposite to the anal. The diminutive anal fin-spine is borne by a considerably expanded support; while the length of the foremost divided anal ray probably exceeds the depth of the trunk at its insertion. The imperfect caudal fin, consisting of very broad rays, seems to have been forked. A series of enlarged dermal scutes is only preserved between the pelvic and dorsal fins on one side; but the whole of the trunk is covered by very small, rounded or rhomboidal scutes of uniform size, which do not appear to have been in contact.

Purehased, 1862.

\section{Genus AULORHYNCHUS, Gill.}

[Proc. Acad. Nat. Sci. Philad. 1861, p. 169.]

Syn. Auliscops, W. Peters, Monatsb. k. preuss. Akad. 1866, p. 510.

Protosyngnathus, W. von der Marck, Palæontogr. vol. xxii. 1876, p. 406.

Premaxillie much expanded, and mandible prominent; marginal teeth acute, almost in one series; palate toothless. Vertebræ about 50 or 60 in total number, rather more than half being in the caudal region. Pelvic fins far forwards, with one spine and four divided rays, their supports in contact with the pectoral arch. About 25 separate spines, diminutive and equal in size, in front of dorsal fin ; soft dorsal and anal nearly equal and opposite, acuminate in front; saudal fin small, slightly forked. No scales, but small bony scrutes buried in skin in few longitudinal series.

Only one existing species of this genus is known from the North Pacific Ocean. 


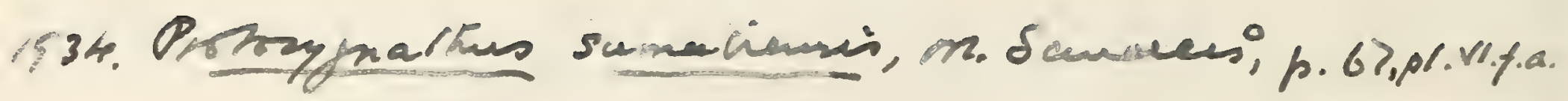


A.ulorhynchus sumatrensis (W. v. d. Marck).

1876. Protosynynathus sumatrensis, W. von der Marck, Palæontogr. vol. xxii. p. 407, pl. xxiii. fig. 1.

1876. Auliscops sumatrasus, A. Günther, Geol. Mag. [2] vul. iji p. 434, pl. xv. fig. 1 .

Tzpe. Imperfect fish; Royal Geological Museum, Dresden.

The type species of the so-called Protosyngnathus, attaining a length of about 0.35 . Length of head with opercular apparatus occupying about one quarter of the total length of the fish; caudal peuicle shorter than the head. All external bones finely tuberculated. Vertebræ apparently 27 in the abdominal, 31 in the caudal region. Dorsal and anal fins arising at the 12th caudal vertebra, each comprising about 12 rays.

Form. \& Loc. Freshwater Tertiary Formation: Padang, Sumatra. 4\%50\%. Specimen described and figured by Günther, loc. cit. The caudal fin-rays are imperfect distally, so do not exhibit the precise shape of the fin.

Presented by Herr R. D. M. Verbeek, 1876.

47508-11. Four imperfect specimens noticed by Günther, loc. cit.

Presented by Herr R. D. M. I'erbeeti, 1876.

\section{Family FISTULARIID 2 .}

Trunk elongated, and snout much produced into a tube. Premaxilla excluding maxilla from upper margin of mouth, which is small and terminal; teeth minute or absent. Gills pectinated; opercular apparatus complete. Four anterior vertebræ much elongated and fused together, all those of the abdominal region and some anterior caudals with large transverse processes; ribs rudimentary or absent. Pelvic fins without spine, but with 5 or 6 divided rays; free spines in front of dorsal fin rudimentary or absent; anal fin without anterior spine, opposed to the soft dorsal; caudal fin distinct. Skin naked or with small scales.

Only three genera of this family are known, two being still widely distributed in tropical seas.

\section{Symopsis of Genera.}

No free dorsal spines; caudal fin forked, with elongrated median rays; no scales .........

A series of free dorsal spines; caudal tin rhombic, without elongated ray; small ctenoid scales present ....................... Imperfectly known, but all caudal fin-rays much elongated; no scales

Fistularia (p. 871$)$.

Aulostoma (p. 375).

Urosphen (p. 376). 


\section{Genus FISTULARIA, Linnæus}

[Syst. Nat. ed. 10, 1758, p. 312.]

Teeth minute. Vertebræ very numerous, between 70 and 90 in total number, less than half being caudal. Pectoral fins on flank; infraclavicles much extended, and small pelvic fins inserted not far behind them; no free spines in front of dorsal fin, which is remote; anal fin similar to dorsal; candal fin forked, with few much elongated median rays. Scales absent, but a series of rudimentary bony scutes along the lateral line and the median dorsal line.

Existing species occur on the shores of the Indian Ocean and of the tropical region of the Atlantic Ocean.

A figure of the skeleton of the existing $F$. tabaccaria is given by Agassiz, Poiss. Foss. vol. jv. pl. xxxv. fig. 1 (wrongly labelled Aulostoma chinense).

\section{Fistularia koenigi, Agassiz.}

1839-42. Fistularia koenigii, L. Agassiz, Poiss. Foss. vol. iv. p. 279, pl. $x \times x v$. fig. 5 .

1859. Fistularia koenigii, G. vom Rath, Zeitschr. deutsch. geol. Ges. vol. xi. p. 124, pl. v. fig. 2.

1886. Fistularia koenigi, A. Wettstein, Fischfauna Tertiaer. Glarnerschief. (Denkschr. schweiz. Pal. Ges. vol. xiii.), p. 92.

Type. Imperfect head and abdominal region; British Museum.

An imperfectly known species, attaining a length of about $0 \cdot 6$. Cranial roof with three finely denticulated longitudinal ridges, the median the largest; opercular apparatus ornamented with radiating series of minute tubercles, and ridge of preoperculum with a series of conspicuous denticles. Vertebræ about 74 in total number, of which 30 are caudal ; length of fused anterior vertebræ approximately one fifth of the column. Dorsal and anal fins with 11 or 12 rays; two elongated median caudal rays.

Form. \& Loc. Oligocene: Glarus, Switzerland.

P. 9236. Type specimen, in counterpart, described and figured by Agassiz, loe. cit.; Engi.

Old Collection.

P. 1975 a. Obscure remains of head and anterior vertebræ, labelled by Agassiz and mentioned loc. cit.; Engi. Egerton Coll.

P. 1975 , P. 4000. Scattered remains of small specimen, in counterpart; Engi. The cranial roof is shown.

Egerton \& Enniskillen Colls. 


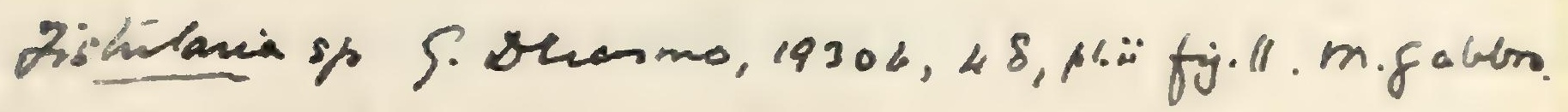

7. Op. OZj̄or. Roumania S. Nonot 4949 p.168. 
Fistularia contermina sin. Maitop Beas. Camransus,

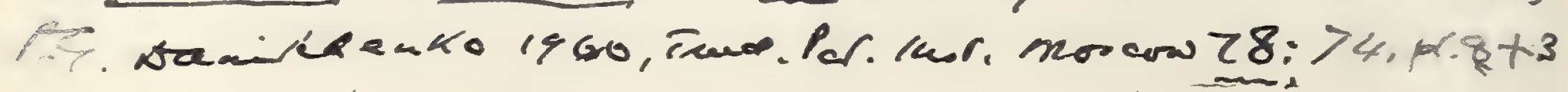




\section{Fistularia longirostris (Blainville).}

1796. Esox belone, G. S. Volta, Ittiolit. Veronese, p. xviii. pl. v. fig. 2 (errore).

1818. Esox longirostris, H. D. de Blainville, Nouv. Dict. d'Hist. Nat. vol. xxvii. p. 341 .

1835. Fistularia tenuirostris, L. Agassiz, Neues Jahrb. p. 291 (name only).

1839-42. Fistularia tenuirostris, L. Agassiz, Poiss. Foss. vol.iv. p. 280, pI. xxxv. fig. 4.

1876. Fistularia tenuirostris, F. Bassani, Atti Soc. Veneto-Trent. Sci. Nat. vol. iii. p. 181.

Type. Imperfect fish; Museum of Natural History, Paris.

A very small species, attaining a length of about 0.2 . Imperfectly known, but anterior fused vertebræ considered by Agassiz to be relatively shorter than in the other known species. Dorsal fin with 12 or 13 rays, anal fin with at least 9 or 10 (according to Bassani).

Form. \& Loe. Upper Eocene: Monte Bolca, near Verana.

Not represented in the Collection.

\section{Genus AULOSTOMA, Lacépède.}

[Hist. Nat. Poiss. vol. v. 1803, p. 357.]

Teeth very minute, only on mandible and vomer. Vertebræ about 50 to 65 in total number, at least half being caudal. Intermuscular bones very numerous and long. Pectoral fins on flank; infraclavicles not much extended; small pelvic fins remote; a series of very slender, small free spines in front of dorsal fin, which is remote; anal fin similar to soft dorsal; caudal fin rhombic, without elongated ray. Scales small and ctenoid.

Existing species distributed like those of Fistularic.

\section{Aulostoma bolcense (Blainville).}

1796. Fistularia chinensis, G. S. Volta, Ittiolit. Veronese, p. xvi. pl. v. fig. 1 (errore).

1818. Fistularia bolcensis, H. D. de Blainville, Nouv. Dict. d'Hist. Nat. vol. xxrii. p. 340.

1835. Aulostoma bolcense, L. Agassiz, Neues Jahrb. p. 291 (name only).

1839-42. Aulostoma bolcense, L. Agassiz, Poiss. Foss, vol. iv. p. 282, pl. $\mathrm{xxxv}$. figs. $2,3$.

1876. Aulostoma bolcense, F. Bassani, Atti Soc. Veneto-Trent. Sci. Nat. vol. iii. p. 181.

Type. Imperfect fish; Museum of Natural History, Paris. 
A small species, attaining a length of about $0 \cdot 18$. Length of head with opercular apparatus somewhat less than half that of the trunk from the pectoral arch to the base of the caudal fin. Vertebræ about 50 in number. Pelvic fins inserted nearer to the anal than to the pectorals; dorsal and anal fins comparatively shortbased, apparently with not more than 17 and 15 rays respectively; anal arising nearer to the caudal than to the pelvic fins.

Form. \& Loc. Upper Eocene: Monte Bolca, near Verona.

P. $19 \% 6$, P. 4119. Imperfect small specimen, in counterpart, showing most of the principal characters of the genus and species; wrongly labelled Fistularia tenuirostris by Agassiz. Egerton \& Enniskillen Colls.

The following species, known only by a fragment, has also been ascribed to this genus, but is not represented in the Collection :-

Aulostoma licatce, H. E. Sauvage, Ann. Sci. Géol. vol. xi. art. no. 3 (1880), p. 33.-Upper Miocene; Licata, Sicily. [Head, \&c.]

\section{Genus UROSPHEN, Agassiz.}

[Poiss. Foss. vol. iv. 1844, p. 284.]

Teeth minute. Vertebræ between 50 and 60 in number. Anal fin similar and opposed to remote soft dorsal; caudal fin relatively very large. Scales absent.

\section{Urosphen dubia (Blainville).}

1796. Fistularia tabacaria, G. S. Volta, Ittiolit. Veronese, p. cxxx. pl. xxix. fig. 4 (errore).

1818. Fistularia dubia, H. D. de Blainville, Nouv. Dict. d'Hist. Nat. vol. xxvii. p. 341.

1835. Urosphen fistularis, L. Agassiz, Neues Jahrb. p. 293 (name only).

1839-42. Urosphen fistularis, L. Agassiz, Poiss. Foss. vol. iv. p. 284, pl. $x \times \times 7$, fig. 6.

1876. Urosphen fistularis, F. Bassani, Atti Soc. Veneto-Trent. Sci. Nat. rol. iii. p. 182.

Type. Imperfect fish; Museum of Natural Histors, Paris.

The type species, attaining a length of about 0.45 , the head in such a specimen measuring $0 \cdot 135$, the vertebral column $0 \cdot 199$, and the caudal fin 0.118 in length. Dorsal and anal fins probably with about 20 rays.

Form. \& Lov. Upper Eocene: Monte Bolca, near Ferona.

Not represented in the Collection. 


Aulostonnes fraetus s-u-Mauksp Peds: Cauragus,

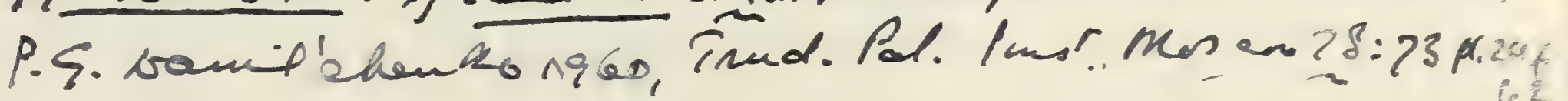

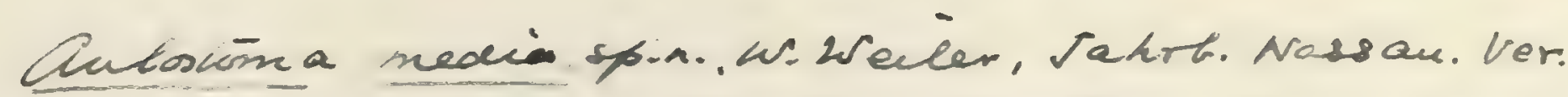

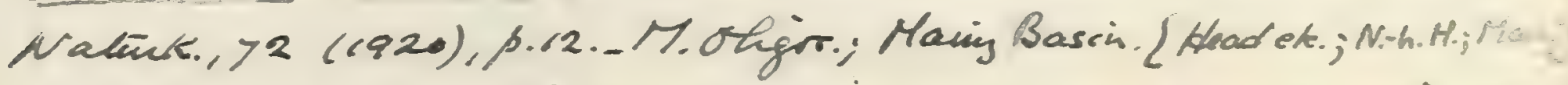

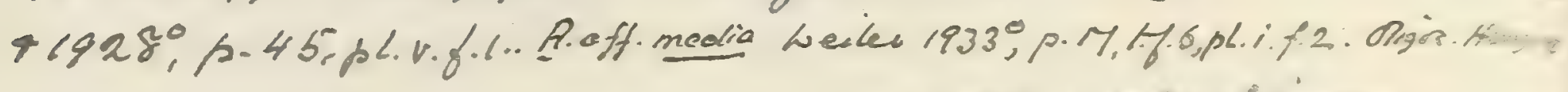
= yory dutire Troshien aEtenuata, Pastman. 191". Urostihen dubia, C.OC. Oastman (errore), Mem. Carnegie Enus. vol. iv. h. 361, hl, xevi. for. 2 . 1914. Unosphen attemuata, C.P. Soctman, Inem. Carnegie hus. vol. vi. -h, 326, Lext.fip. 2 . 
$\therefore$ hewrehi $p .379$.

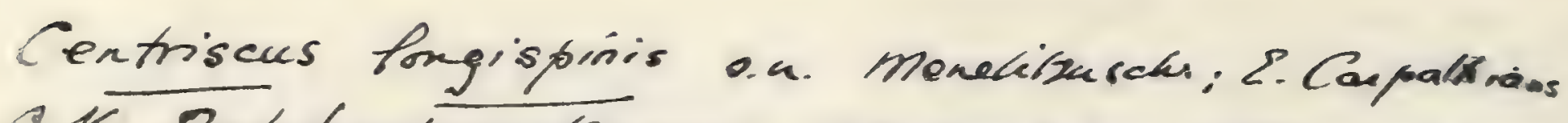

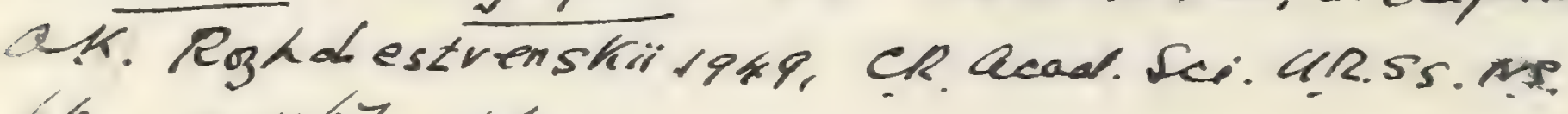
6 p. p.lly if.

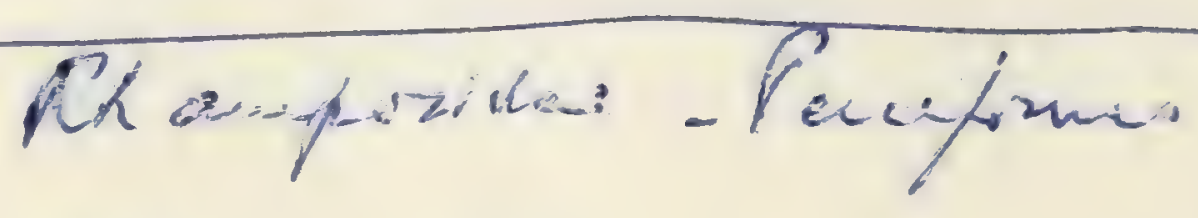

CHe g, 1940, p wel 


\section{Family CENTRISCID E.}

Trunk laterally compressed, and irregularly oblong or deepened; snout much produced into a tube, and small toothless mouth terminal. Gills pectinated; opercular apparatus complete. Some anterior vertebræ usually elongated, those of the abdominal region and some anterior caudals with large transverse processes. Pelric fins without spine but with 5 or 6 dirided rays; an enlarged spine and usually other small spines in front of the dorsal fin; anal fin mithout anterior spine, opposed to the soft dorsal; caudal fin distinct. Skin with a partial bony armour and also with small scales.

These are small marine fishes, very midely distributed.

$$
\text { Synopsis of Genera. }
$$

Caudal region relatively large; few dorsal spines, the second excessively enlarged; pelric fins considerably behind pectorals; bony plates dorsally and rentrally and flanks covered with small scales....................

Caudal region relatively large; pelric fins partly Centriscus (Recent). beneath pectcrals; bony plates dorsally, not rentrally, but flanks corered with small scales..........................

Caudal region relatively rery small; pelric fins Rhamphosus (p.37\%). reduced, considerably behind pectorals; dorsal and ventral bony dermal armour extensire, but no scales .................... Amprisile (p. 878).

Isolated spines from the Lower Pliocene of Orciano, Tuscany, are ascribed to Centriscus under the name of $C$. toni by I. Lawlej, Tuori Studi Pesci, etc., Colline Toscane (1876), p. 79.

\section{Genus RHAMPHOSUS, Agassiz.}

[Poiss. Foss. vol. iv. 1844, p. 270.]

Trunk only moderately deepened; caudal region relatively large, with about 14 rertebræ. Pelric fins mell-dereloped and far forwards, partly beneath the pectorals ; caudal fin rounded. Bony plates dorsally in abdominal region to support the large spine, but no rentral armour; small rough scales covering flanks.

\section{Rhamphosus acteatu (Blinille). rastrum ( Vola).}

1796. Uranoscopus rastrum, G. S. Volta, Ittiolit. Veronese, p. xxii. pl. v. fig. 4.

1796. Centriscus, G. S. Volta, ibid. pl. lxxr. fig. 1 (errore). 
1818. Centriscus aculeatus, H. D. de Blainville, Nouv. Dict. d'Hist. Nat. vol. xxvii. p. 339.

1835. Rhamphosus aculeatus, L. Agassiz, Neues Jahrb, p. 291 (name only).

1839-42. Rhamphosus aculeatus, L. Agassiz, Poiss. Foss. vol. iv. p. 270 , p1. xxxii. fig. 7 .

1888. Rhamphosus aculeatus, L. Vaillant, Expéd. Scient. Travailleur et Talisman-Poissons, p. 339.

1898. Rhamphosus aculeatus, F. Bassani, Palæontogr. Italica, vol. iii. p. 82, pl. ix. fig. 4.

Type. Imperfect fish ; Museum of Natural History, Paris.

The type species, attaining a length of about 0.12. Proportions somewhat uncertain owing to imperfection of few known specimens; but snout extremely attenuated, the length of the head with opercular apparatus probably equalling that of the trunk from the pectoral arch to the base of the caudal fin, also about equalling the length of the dorsal fin-spine, which bears posterior denticulations. Probably 8 abdominal vertebræ, and 14 caudals. Dorsal and anal fins equal and directly opposed, each with 9 rays. Scales very minute.

Form. \& Loc. Upper Eocene: Monte Bolca, near Verona.

P. 5125. Small specimen wanting caudal fin and with dorsal spine imperfect.

Purchased, 1886.

Rhamphosus biserratus, Bassani.

1876. Rhamphosus biserratus, F. Bassani, Atti Soc. Veneto-Trent. Sci. Nat. vol. v. p. 151, pl. ii. fig. 3.

Type. Imperfect fish; Geological Museum, University of Padua.

Rather larger than the type species, with comparatively short and stout spine, the length of this apparently not greater than the depth of the trunk at its insertion.

Form. \& Loc. Upper Eocene: Monte Bolca.

Not represented in the Collection.

Genus AMPHISILE (Klein), Cuvier.

[Règne Animal, vol. ii. 1817, p. 350.]

Trunk oblong and much laterally compressed, with very small caudal region curved downwards. About 6 large and elongated abdominal vertebræ, 14 very small caudals. Pelvic fins rudimentary, well behind the pectorals; caudal fin rounded. Bony plates dorsally and rentrally in abdominal region, the dorsal armour intimately connected with the endoskeleton; no scales.

Existing species of this genus occur in the shallow seas of the tropics from the eastern coast of Africa to China. 




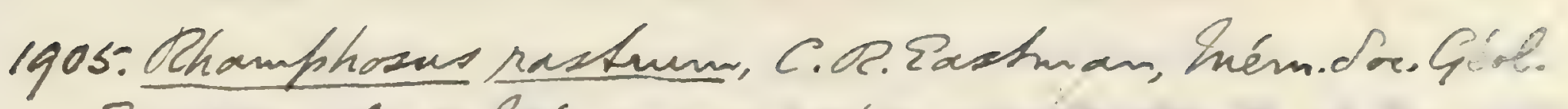
Fronea, vol., Iném. no.34, f.20.

1911. Thamphosus aculeatus, C.C. Cashuan, hrem. Carngpie mus. vol. iv. h. 362.

1914. Champhosue rastum, C.R. Sactman, Inem. Carnogio. hue volv vi. p. 324, hl. xTiv. fip. 1-3.

P9834, P14400. Tine specimen in Cintpit.

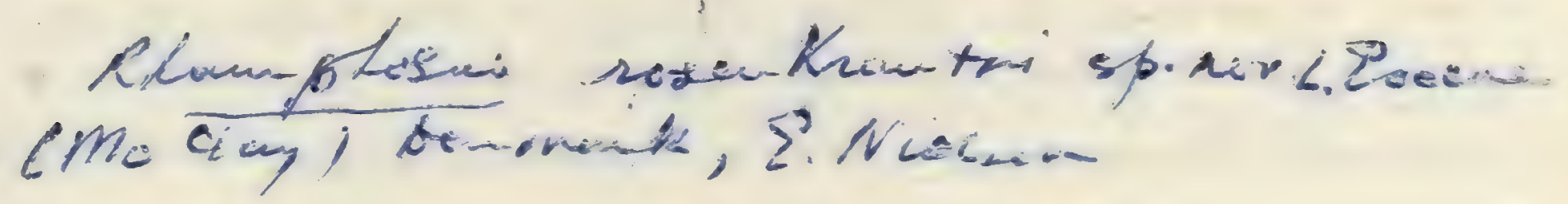


$195 \%$ S. h

1950. Centriscus herintichi, AK. Rogh destvenski;, Tr. Pollat Acad

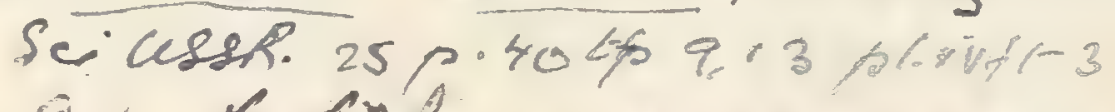

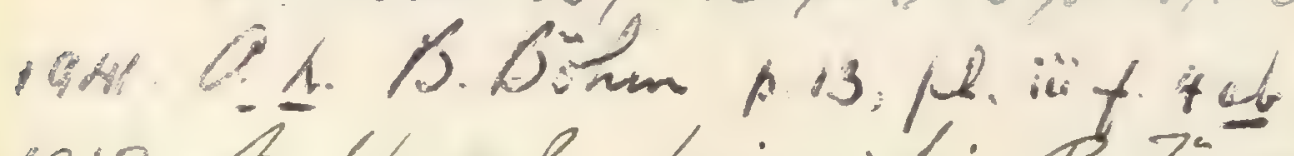

1913. Amphisyle heinvichi, S. Finster, Mitth. Geol.

Xonderanst. Elsaso-Zothr. vol. viii.p.8, hl.i. fij.q.

1928. A.h., b.weiken, p.42,ph.ik. f.2.

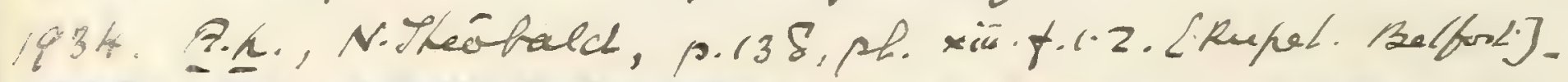

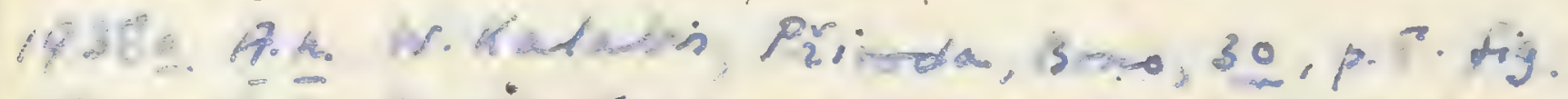

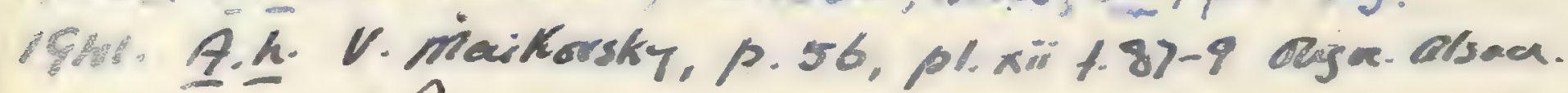

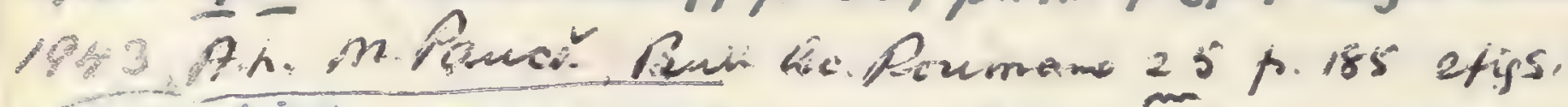

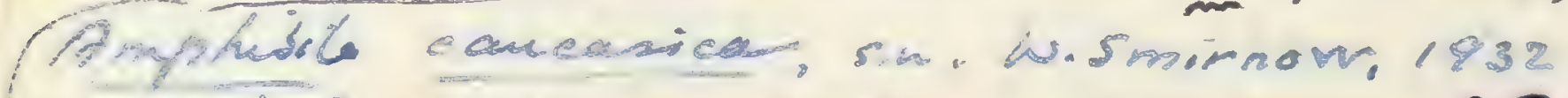

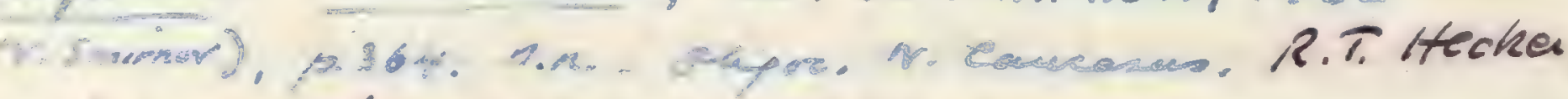

12. Makhi 1946 p. 646 ts.

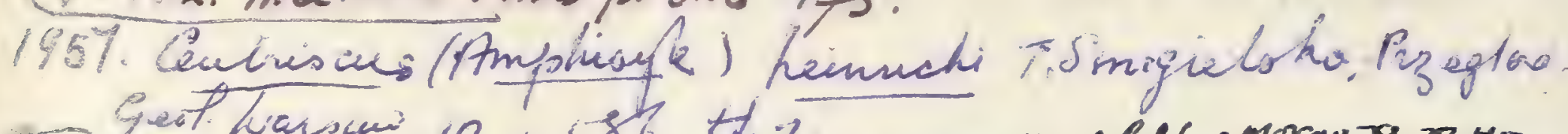

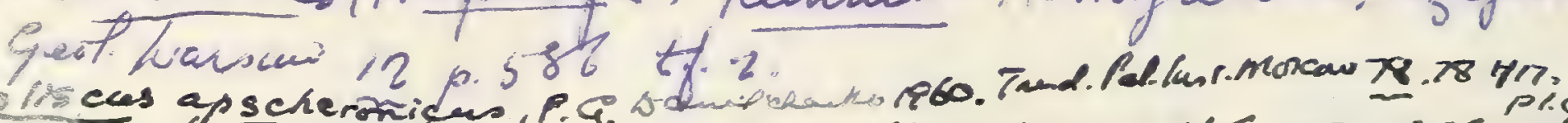

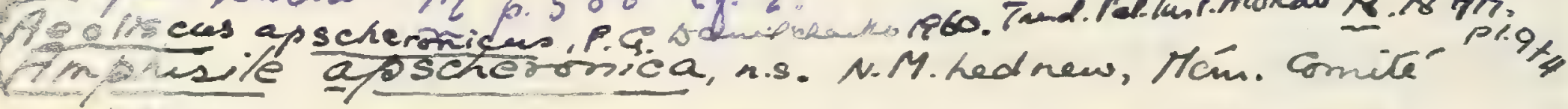

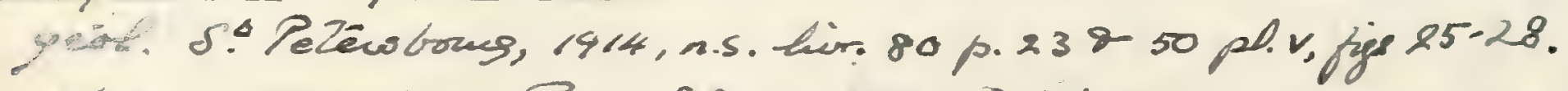

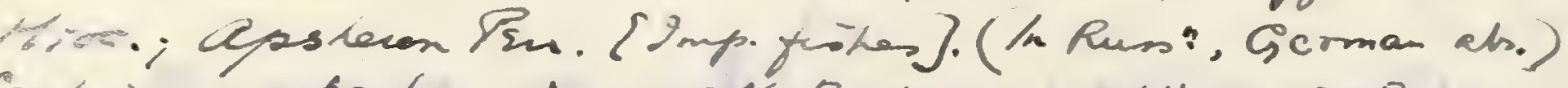

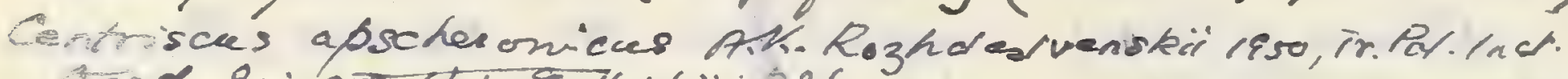

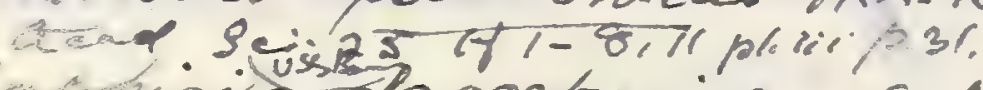

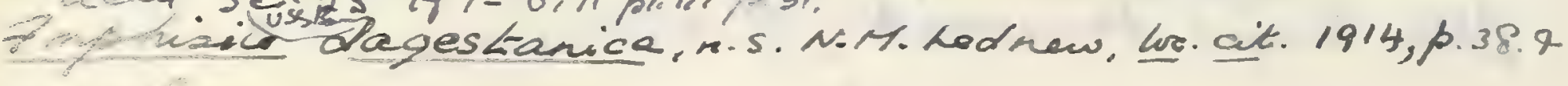

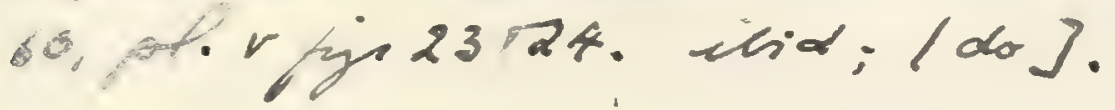

Pmphisile Leloajensis s.n. Oljor Rumanis, s. Jonet 1949, uch. Sor. belge gósh. 5 \& p.161, 36l,

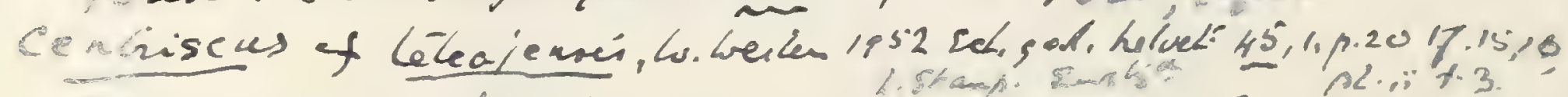
"entriscas Ka bistanicus 9.4. Ak. Rozhdestuenstis

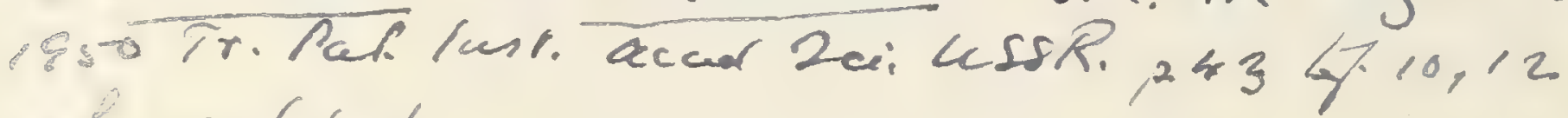
$10.6 \cdot 4-6$ 



\section{Amphisile heinrichi, Heckel.}

1850. Amphisyle heinrichi, J. J. Heckel, Denkschr. k. Akad. Wiss., math.-naturw. Cl. vol. i. p. 224, pl. xxii.

1870. Amphysile heinrichii, H. E. Sauvage, Bull. Soc. Géol. France, [2]

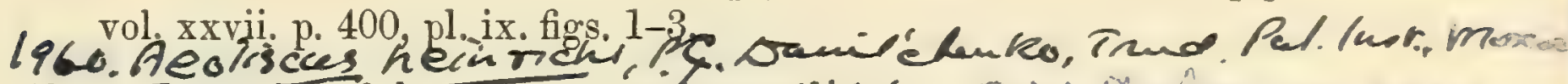

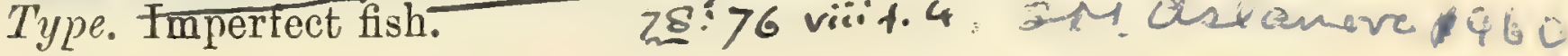

A species attaining a length of about 0.05 . Length of head with opercular apparatus nearly equalling the length of the dorsal shield behind the operculum; maximum depth of trunk slightly exceeding one quarter of the same measure. Operculum and suboperculum nearly equal in size, the former ornamented with radiating striæ. Anal fin with 13 or 14 rays. Dermal armour finely tuberculated; the posterior terminal spine longitudinally ribbed and slightly shorter than its pediele.

Form. \& Loc. Oligocene: Krakowiza, near Imwald, Galicia ; Vienna ${ }^{1}$; Hammerstein, Baden ${ }^{2}$; Flörsheim, Rhein-Hessen ; Mülhausen, Alsace ${ }^{3}$; Froidefontaine.

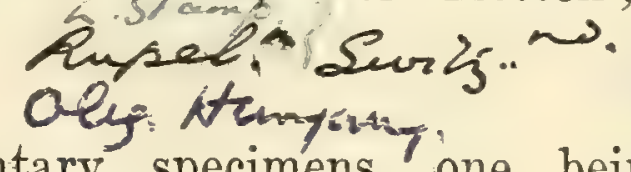

P. 7042, P. 8788. Four fragmentary specimens, one being in counterpart; Flörsheim, Rhein-Hessen.

Purchased, 1893, 1898.

An imperfectly known species, not represented in the Collection, has also been described as follows:-

Amphisile longirostris, L. Agassiz; Neues Jahrb. 1835, p. 295 (name only), and Poiss. Foss. vol. iv. (1844), p. 275. Centriscus velitaris, G. S. Volta, Ittiolit. Veronese (1796), pl. Ixiii. fig. 2 (errore). Centriscus longirostris, H. D. de Blainville, Nouv. Dict. d'Hist. Nat. vol. xxvii. (1818), p. 339.-Upper Eocene: Monte Bolca, near Terona. [Imperfect fish ; unknown.]

\section{Family SOLENOSTOMATID E.}

Trunk more or less elongated; snout much produced into a tube, and small toothless month terminal. Gills tufted, in form of rounded lobes; opercular apparatus reduced to operculum and very few branchiostegal rays; gill-opening wide. Two dorsal fins, the

1 E. Suess, Sitzungsb. k. Akad. Wiss., math.-naturw. Cl. rol.liv.pt. i. (1866) p. 115.

${ }_{2}$ H. von Meyer, Neues Jahrb. 1863, p. 449.

${ }^{3}$ Schimper, L'Institut, vol, xxvii. (1859), p. 193. 
anterior spinous; paired fins, anal and caudal fins always present. Trunk encased in rings of bony plates; no scales.

The existing Solenostoma inhabits the Indian Ocean.

Synopsis of Genera.

Trunk much compressed, somewhat dilated; pelvic fins opposite anterior dorsal .... Solenostoma (Recent). Trunk more elongated, not dilated; pelvic fins in advance of anterior dorsal ...... Solenorhynchus (p. 380).

\section{Genus SOLENORHYNCHUS, Heckel.}

[Sitzungsb.k.Akad. Wiss., math.-naturw. Cl. vol. xi. 1854, p. 126.]

Trunk extremely elongated and slender ; caudal region relatively short. Pelvic fins in advance of anterior dorsal; posterior dorsal and anal fins similar and directly opposed; caudal fin very large, not forked. Trunk encircled completely in the bony dermal rings.

\section{Solenorhynchus elegans, Heckel.}

1854. Solenorhynchus elegans, J. J. Heckel, loc. cit. p. 125.

1868. Solenorhynchus elegans, Kner \& Steindachner, Denkschr. k. Akad. Wiss., math.-naturw. Cl. vol, xxi. p. 31, pl. v. fig. 1.

1874. Solenorhynchus elegans, A. de Zigno, Mem. R. Istit. Veneto, vol. xviii. p. 297, pl. x. fig. 5.

Type. Imperfect fish; Royal Court Museum, Vienna.

The type species, attaining a length of about $0 \cdot 1$. Head with opercular apparatus occupying about one quarter of the total length of the fish to the base of the caudal fin. Pelvic fins beneath the 16th body-ring; anterior dorsal fin with 5 spines, arising behind 21st ring; posterior dorsal and anal larger, with 17 rays, separated from anterior dorsal by 12 rings; caudal fin with 12 rays. About 36 body-rings in the abdominal, 9 in the caudal region, provided with few small and delicate spines.

Form. \& Loc. Upper Eocene: Monte Postale, N. Italy.

Not represented in the Collection.

\section{Family SYNGNATHID $Æ$.}

Trunk more or less elongated; snout much produced into a tube, and small toothless mouth terminal. Gills tufted, in form of rounded lobes; opercular apparatus reduced to operculum; gillopening very small. Pelvic fins absent; one soft dorsal fin; 
45

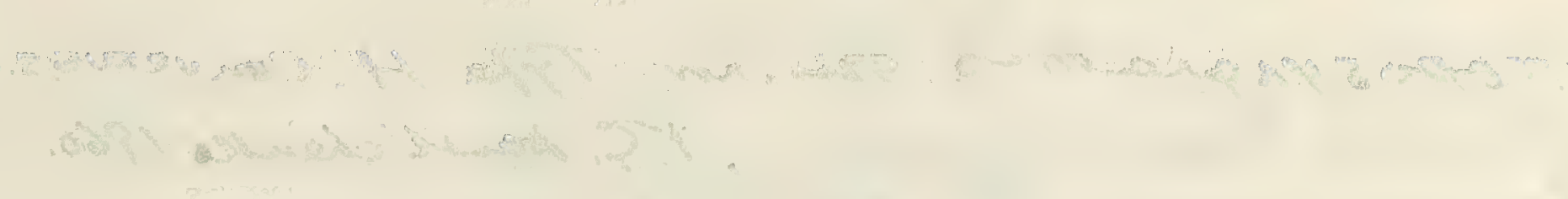

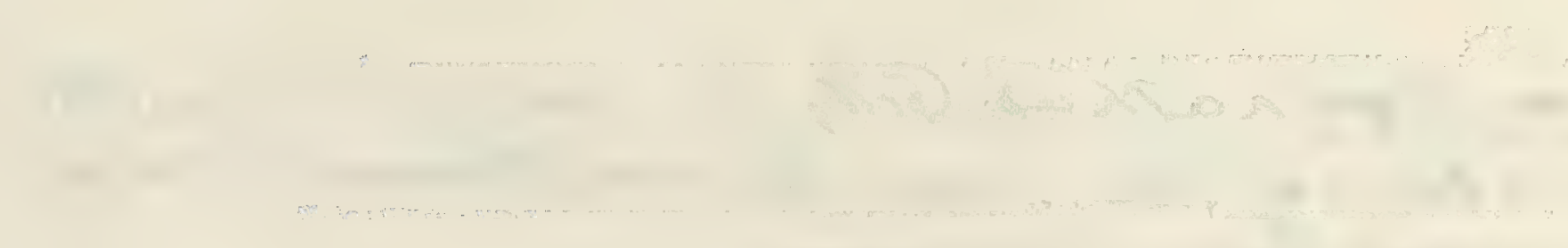


Itipkosyngraothes gen.nor. Tyle H. Convexus,s.n. thaikep Peds: Canceser, Pf tamit'chenke 1960. Trud! Pab.lurt, keoneno 78 : 85 ps.28 6.3 .4 .

Feantóswarkas Giri, P. spaalidus su.PG.

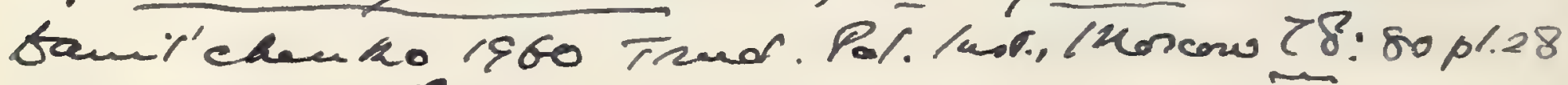
f.r, 2 Maik of Lede, Couceosu.

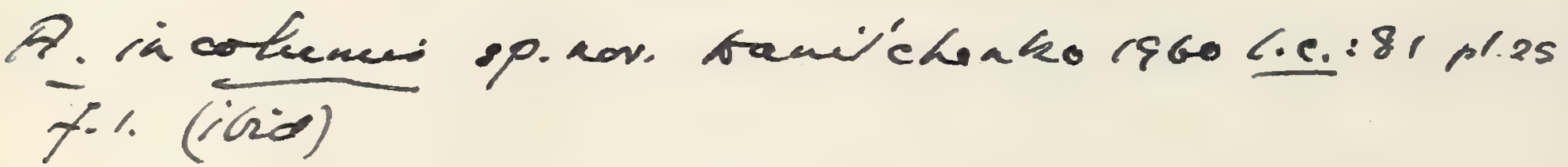


pectoral, anal, and caudal fins variable. Trunk more or less encased in rings of bony plates; no scales.

Small coast fishes living among seaweeds in temperate and tropical regions, swimming chiefly by peculiar motion of dorsal fin.

\section{Synopsis of Genera with Extinct Representatives.}

All with axis of head in continuation of that of trunk; with caudal fin and non-prehensile tail.

Trunk much elongated; dermal armour incomplete, probably absent on caudal region .... Trunk much elongated; dermal armour complete; clavicular arch not rigid at lower end; anal fin minute......................

As Siphonostoma, but clavicular arch rigid at lower end....................... Trunk only moderately elongated; dermal armour complete; all median tins well developed .. Pseudosyngnathus $[($ p. 381).

Siphonostoma

$[(\mathrm{p} .382)$. Syngnathus (p. 382).

Calamostoma

$[($ p. 38: $)$

Genus PSEUDOSYNGINATHUS, Kner \& Steindachner.

[Denkschr. k. Akad. Wiss., math.-naturw. Cl. vol.xxi. 1863, p. 28.]

Trunk much elongated, not dilated. Pectoral fins present; dorsal fin small and very remote; caudal fin small, truncated behind. Dermal armour apparently incomplete, perhaps wanting on the caudal region.

According to Kner and Steindachner, the form and disposition of the supports of the dorsal fin suggest that its rays had not the peculiar power of motion obserred among existing Syngnathidx.

\section{Pseudosyngnathus opisthopterus (Agassiz).}

1796. Syngnathus typhle, G. S. Volta, Ittiolit. Veronese, p. ccxxxix. pl. 1viii. fig. 1 (errore).

1818. Syngnathus typhle, H. D. de Blainville, Nouv. Dict. d'Hist. Nat. vol. xxvii. p. 339 (errore).

1833-44. Syngnathus opisthopterus, L. Agassiz, Poiss. Foss. vol. ii. pt. i. p. 18 , pt. ii. p. 276.

1863. Pseudosyngnathus opisthopterus, Kner \& Steindachner, Denkschr. k. Akad. Wiss/, math.-naturw. Cl. vol. xxi. p. 29, pl. vi. fig. 1.

Type. Imperfect fish; Museum of Natural History, Paris.

The type species, attaining a length of about $0 \cdot 35$. Vertebræ apparently between 55 and 60 in number. Dorsal fin just within hinder quarter of back, with 8 or 9 rass; caudal fin with 13 or 
14 rays. Lateral scutes in abdominal region marked with fine longitudinal striæ.

Form. \& Loc. Upper Eocene: Monte Bolca, near Verona.

Not represented in the Collection.

\section{Genus SIPHONOSTOMA, Kaup.}

[Catal. Lophobr. Fish. Brit. Mus. 1856, p. 48.]

Trunk much elongated, not dilated. Clavicular arch not rigidly fixed at lower end. Pectoral and caudal fins well-developed; dorsal fin not much extended; anal fin minute. Dermal armour complete; dorsal edges of tail not continuous with dorsal edges of trunk, but passing on each side into ridge of lateral line.

Existing species occur on the European coasts.

\section{Siphonostoma albyi, Sauvage.}

1870. Syngnathus albyi, H. E. Sauvage, Ann. Sci. Nat. [5] vol, xiv. art. no. 7. p. 3.

1873. Siphonostoma albyi, H. E. Sauvage, Ann. Sci. Géol. vol. iv, art. no. 1. p. 81, fig. 42 .

1896. Siphonostoma albyi, I. Bonomi, Rivista Ital, Paleont. vol. ii. p. 204.

Type. Imperfect fish.

A species attaining a length of about $0 \cdot 25$. Length of head with opereular apparatus about one fifth of the total length of the fish. Dorsal fin with about 38 rays; caudal fin with 12 rays. Dermal rings apparently 18 or 19 in the abdominal, 34 in the caudal region; the scutes with a smooth longitudinal ridge and marked with regular vertical lines of large tubercles. (Sauvage.)

The generic determination of this fish is uncertain. $V_{\text {sympultus }}$.

Form. \& Loc. Upper Miocene: Licata, Sicily; Mondaino, Prorince of Forli, Italy. Sahelian; Oran.

P. 197\%. Very imperfect specimen; Licata. Egerton Coll.

Siphonostoma castellii is an undefined name given to a fish from the Upper Miocene of Gabbro, Tuscany, by G. Capellini, Mem. R. Accad. Lincei [3] vol. ii. disp. i. (1878), p. 285. Sec Caramzoung

Genus SYNGINATHUS (Artedi), Linnæus.

[Syst. Nat. ed. 10, 1758, p. 336.]

Essentially similar to Siphonostoma, but clavicular arch rigidly fixed at lower end. 
19.8. Gygnathus aur (Limn.), C. De Shefano. Inem. O? Comith Ged. Ital nol vii. pho i. p. 6?, ph. vii. to \&. (errore ace 10.C.A.csas)

1925. Nyngnattus albyi C. Arambourg, Am.de Pal.

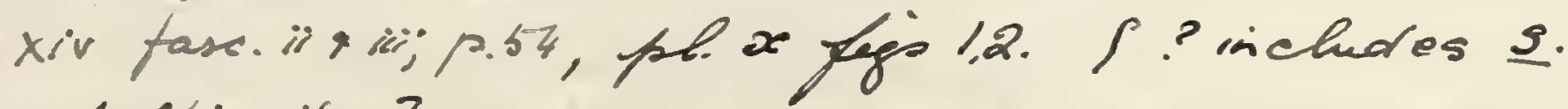
caspelli; inifre]

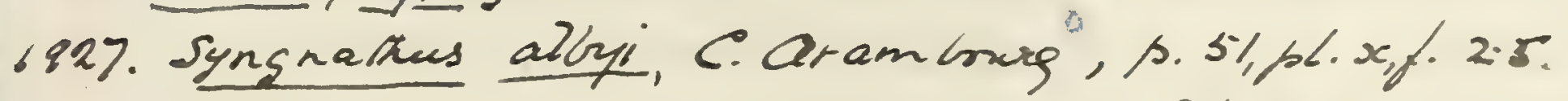

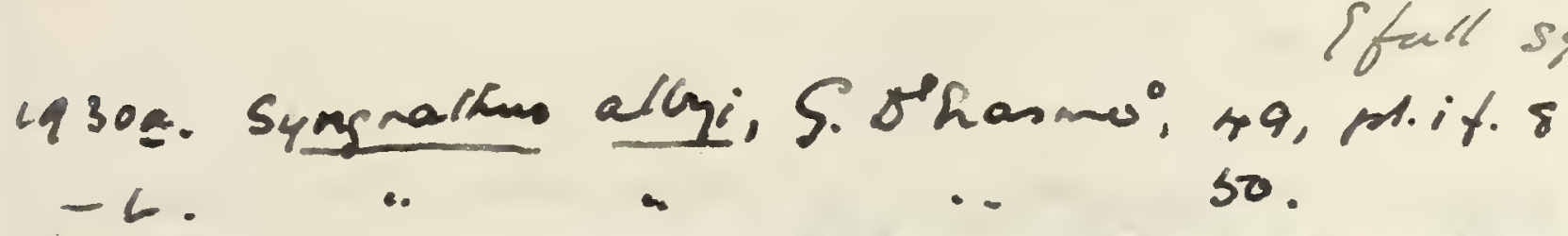

1853

1964

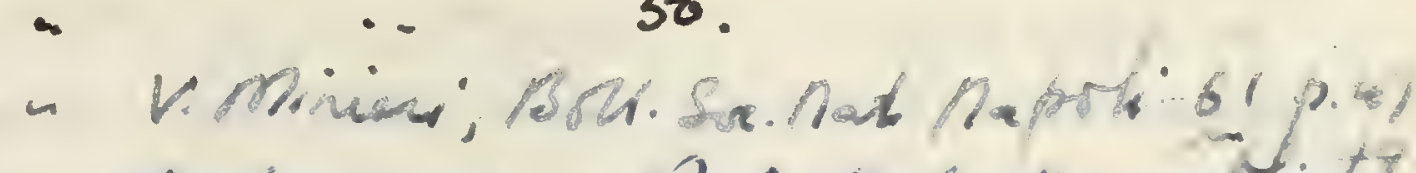

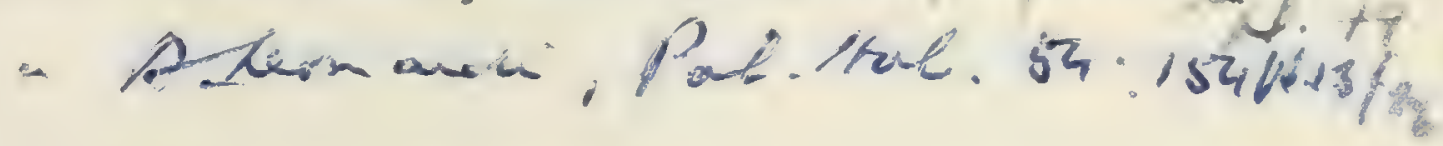


$\tan 21843, p .7001 .9 \cdot 8 \cdot 6.4 .10 f \cdot 1.2$

iyngnather aves, D. S. Fordan d 2. 2. Gillert,

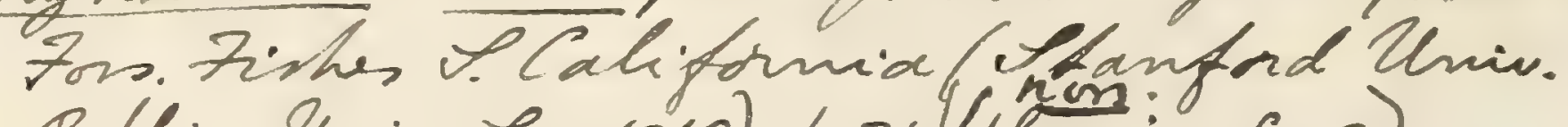

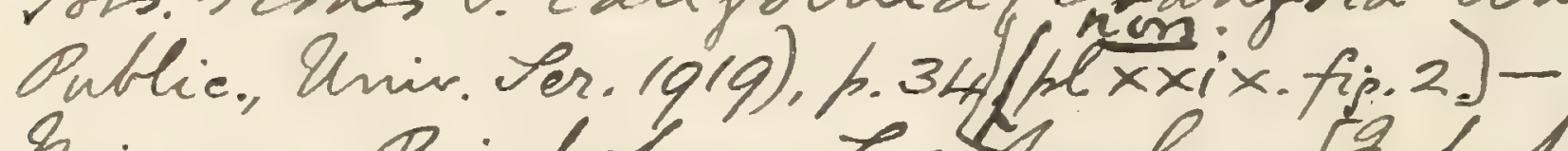

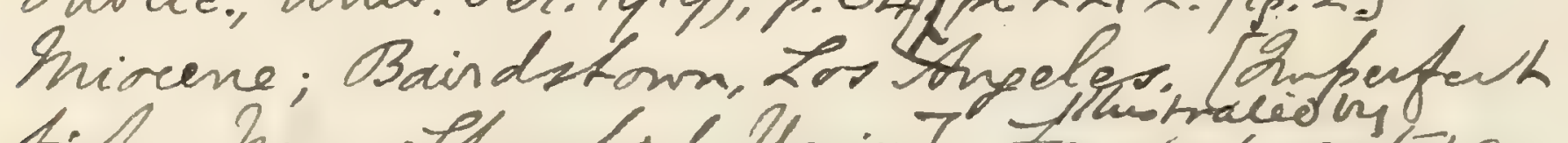

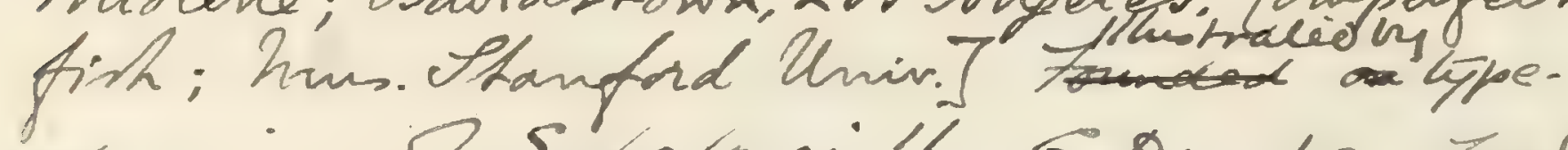

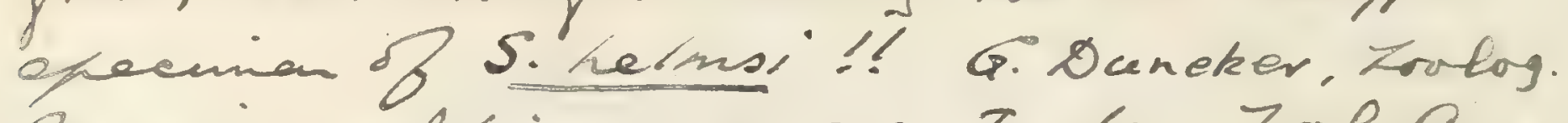
Anzegier, wolvi, 1923 p.239. Tordan, Zovt. Anzeys

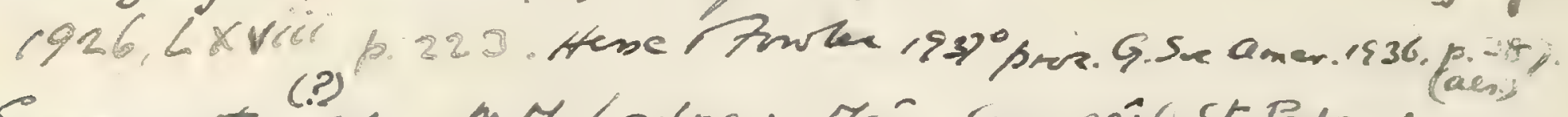

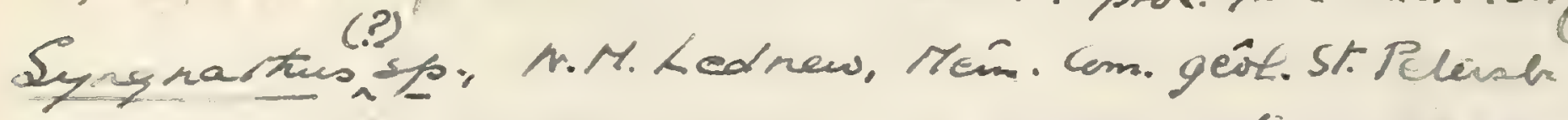

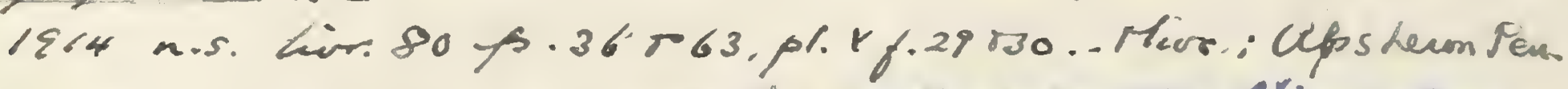

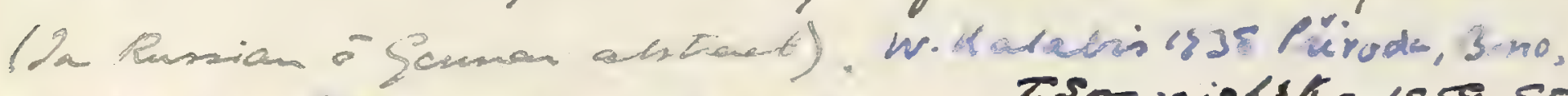

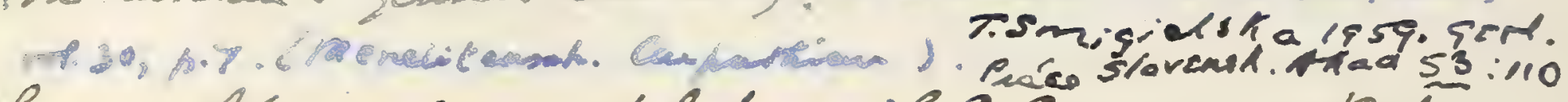

Iympnathers incompletur. L. C.Cosmovici, Bull. Fo. Hed Tei: Kat. Gasey, vol.i, no. 3/1889). p.g6, for. I I. D. Simionecu, Publicat. Atad.

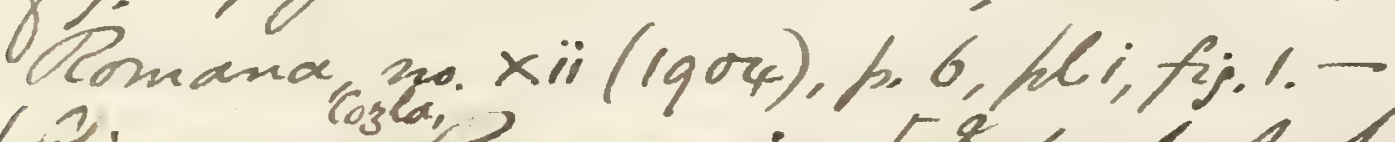

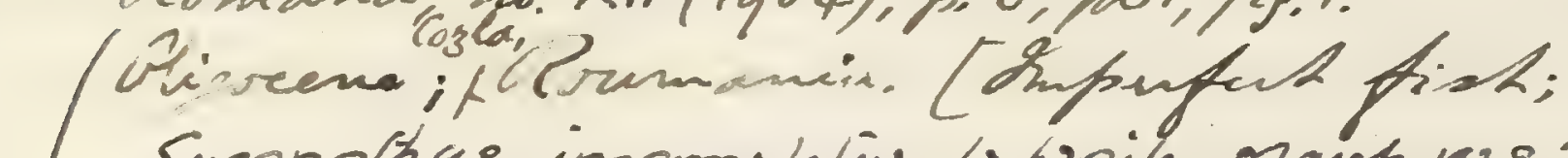

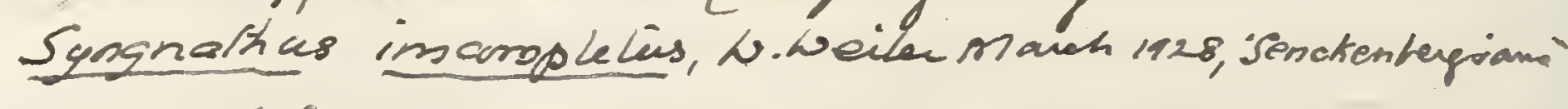
$x \cdot p \cdot 7^{4}, y .15$.

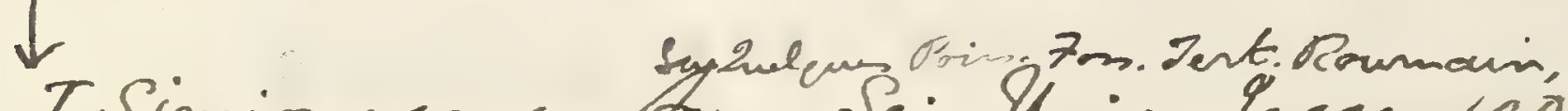

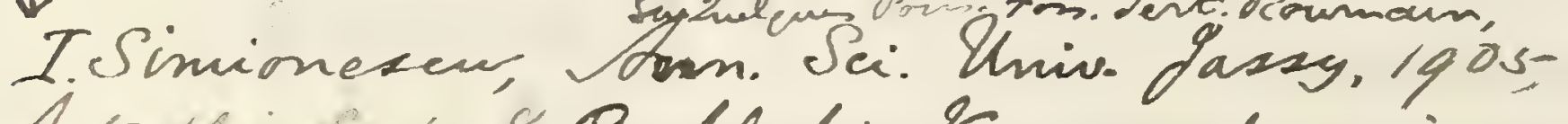

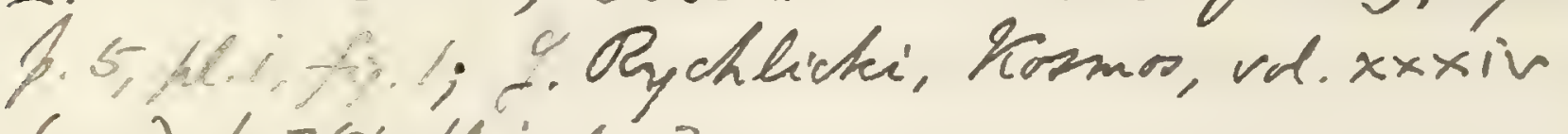

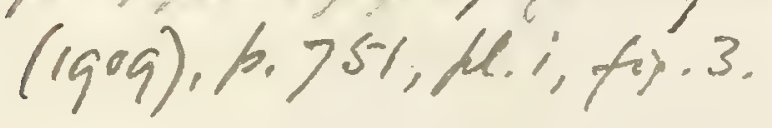

Syrgratkes nicertus sia. Dego-mio. Tamrano

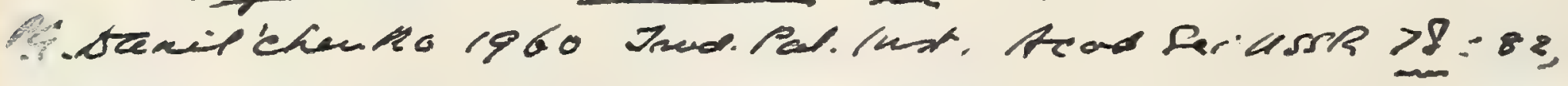
ple erist 3 .

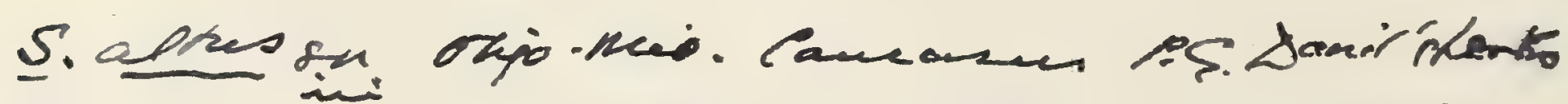

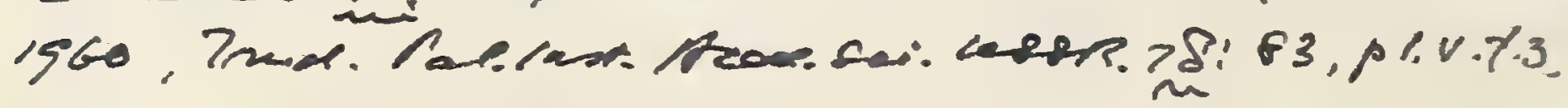



Imperfectly known extinct species are referred to this genus under the following names, but are not represented in the Collection :-

Syngnathus affinis, D. G. Kramberger, Rad Jugoslav. Akad. vol. cri. (1891), p. 99, pl. 1ii. fig. 4.--Upper Miocene (Sarmatian); Dolje, Croatia. [Imperfect fish; Geological Museum, University of Agram.]

Syngnathus bolcensis, A. de Zigno, Mem. R. Istit. Teneto, rol. xxiii. (1887), p. 24, fig. 6.-Upper Eocene; Monte Bolca, near Verona. [Imperfect fish; Zigno Collection, University of Padua.]

Syngnathus heckeli, A. de Zigno, Toc. cit. rol. xviii. (1874), p. 295, pl. x. fig. 4.-Upper Eocene; Monte Bolca, near Verona. [Imperfect fish ; Zigno Collection, University of Padua.]

Syngnathus helmsi, F. Steindachner, Sitzungsb. k. Akad. Wiss., math.-naturw. Cl. vol. xl. (1860), p.571, pl. iii.-Upper Niocene (Sarmatian); Radoboj, Croatia. [Imperfect fishes; Court Museum, Vienna.] See S. aves.

\section{Genus CALAmostomA, Agassiz.}

[Poiss. Foss. vol. ii. pt. i. 1833, p. 18.]

Trunk moderately elongated, not dilated. Pectoral fins feeble; dorsal, anal, and caudal fins well-developed; caudal fin rounded, with few rays. Dermal armour complete.

\section{Calamostoma breviculum (Blainville).}

1796. Pegasus natans, G. S. Volta, Ittiolit. Veronese, p. xxi. pl. v. fig. 3 (errore).

1818. Syngnathus breviculus, H. D. de Blainville, Nouv. Dict. d'Hist. Nat. vol. xxvii. p. 339.

1833-44. Calamostoma breviculum, L. Agassiz, Poiss. Foss. Tol. ii. pt. i. p. 18, pt. ii. p. 276, pl. lxxiv. fig. 1.

Type. Imperfect fish; Museum of Natural History, Paris. ( K wht on

The type species, attaining a length of about 0.7 . Length of Fasman 1905 head with opercular apparatus slightly exceeding two thirds of length from pectoral arch to base of caudal fin. Fire longitudinal series of scutes on flank; no external ornament.

Form. \& Loc. Upper Eocene: Monte Bolca, near Terona.

P.9430. Well-preserved specimen, wanting dorsal fin; Monte Bolca. A few long rays at middle of ventral border represent either a pelvic or an anal fin, probably the latter.

History unknown. 


\section{Suborder IX. ACANTHOPTERYGII.}

Vertebral centra always complete constricted cylinders, none modified or coalesced. Supraoccipital extending forwards between the reduced parietals; squamosal rudimentary and fused with the large pterotic; premaxilla always excluding maxilla from upper border of mouth; mandible simple, each ramus consisting of not more than two elements (dentary and articulo-angular). Pectoral arch suspended from cranium; precoracoid arch absent; no infraclavicular plates; pectoral fin with not more than four or five basals. Pelvic fin-supports in contact with clavicle, and fins thus thoracic or jugular; each pelvic fin usually with an anterior spine and five (rarely six to eight) articulated and divided rays. Dorsal and anal fins usually more or less spinous anteriorly. In the living forms:-air-bladder closed, without pneumatic duct, in the adult (physoclistous); optic nerves decussating; intestine without spiral valve.

\section{Dirision A. BERYCIFORMES.}

Pelric fins thoracic, usually with more than five articulated rays in addition to the spine. No bony stay between circumorbital ring and preoperculum.

$$
\text { Synopsis of Families. }
$$

Head with extensive superficial cavities for mucus; premaxillæ protractile; lateral line conspicuous ................. BERYCID五 (p. 381). Head with superficial cavities for mucus; premaxillæ not protractile; lateral line inconspicuous................... APHREDOderid (p. 416). Head without superficial cavities for mucus; premaxillæ protractile; lateral line inconspicuous................... Суtтid

\section{Family BERYCID $\nexists$ E.}

Head-bones more or less ridged, thus forming extensive carities which are filled with mucus in the living fish; premaxillæ protractile, and dentition usually feeble. Branchiostegal rays 7 or 8 in number. Vertebræ from 24 to 30 in number; the posterior abdominal centra with downwardly bent transverse processes. Pelric fins (unless rudimentary) with one spine and more than five 
CPre 15 mone p. 617 
erticulated rays; dorsal and anal fins with anterior spines, which are usually not so numerous as the articulated rays. Squamation more or less regular and continuous, sometimes with a few enlarged seutes; lateral line conspicuous.

All the known Berycidx are marine, and most of the existing genera live at considerable depths, while many are tjpical members of the deep-sea fauna.

\section{Synopsis of Extinct Genera and Genera represented by Extinst Species.}

I. Dorsal fin undivided.

A. With few crowded spines in front.

Vertebræ $10+14$; anal fin much extended; scales ctenoid, none enlarged. Beryx (p. 38.5).

Vertebræ $12+16$ or 18 ; anal fin shortbased; scales ctenoid, enlarged along lateral line ................

Vertebræ 12+14; anal fin moderately extended; scales thin and cycloid, none enlarged ...................

Vertebræ $12+16$ or 18 ; anal fin extended; scales small, thick, and ctenoid, none enlarged............

B. With anterior spines more or less spaced.

Dorsal fin-spines 5 to 9 , anal 3 to 5 ; scales large and ctenoid ...........

Dorsal fin-spines 14 , anal 7 ; scales small and cycloid ...................

Dorsal fin-spines about 12, anal 4; scales thin and ctenoid ..............

II. Spinous portion of dorsal fin separated from articulated portion.

Preoperculum merely serrated, without spine ...................... Mypipristis (p. 410).

Preoperculum with large spine at angle. Holocentrum (p. 412).

Genus BERYX (Artedi), Curier.

[Règne Animal, ed. 2, rol. ii. 1829, p. 151.]

Trunk laterally compressed, but not much deepened; abdomen fiattened, not carinated. Frontal region of skull deeply ridged for mucus-cavities; cleft of mouth oblique, and jaws with very minute. teeth; orbit much enlarged; preoperculum without spine, only finely serrated. Vertebræ about 10 in the abdominal, 14 in the caudal region. Pelric fins with one spine and 7 or more articulated 
rays, inserted more or less directly beneath the origin of the pectorals. Dorsal fin almost or completely in adrance of the anal, rery few of its anterior rays in form of slender spines which are crowded; anal fin considerably extended, with four spines; caudal fin deeply cleft. Scales ctenoid, of moderate size, none enlarged or thickened; small scales extending orer the opercular apparatus, head, and base of the median fins.

A figure of the skeleton of the existing Beryx decadactylus is given by A. Günther, Rep. Deep-Sea Fishes, 'Challenger' Reports, Zool. vol. xxii. pl. vi.

No extinct species of this genus are known with certainty, although numerous fragmentary fossils have been ascribed to it. The supposed species recorded in the following list are not generically determinable and are not represented in the Collection:-

Beryx dalmaticus, F. Bassani, Denkschr. k. Akad. Wiss., math.naturw. Cl. vol. xlv. (1882), p. 262, pl. x. fig. 1. Beryx lesinensis, F. Steindachner, Sitzungsb. k. Akad. Wiss., math.-naturw. Cl. vol. xlvii. pt. i. (1863), p. 128, pl. i. fig. 1; F. Bassani, Atti Soc. Veneto-Trent. Sci. Nat. vol. vii. (1880), p. 12, pl. B. fig. 2.-Cretaceous; Cape Sesto, near Sebenico, Dalmatia. [Imperfect fish; Imperial Geological Survey, Vienna.] frenmo196'6 pirz.

Beryyx dinotepidotus, G. Fiseher de Waldheim, Bull. Soc. Imp. Nat. Moscou, 1841, p. 465, pl. viii.-Upper Cretaceous; Gort. Voronej, Russia. [Portion of trunk.]

Beryx insculptus, E. D. Cope, Proc. Amer. Phil. Soc. vol. xi. (1869), p. 240, and Vert. Cret. Form. West (Rep. C.S. Geol. Surr. Territ. vol. ii. 1875), pl. lii. fig. 4.-Greensand no. 5; New Jersey. [Portion of trunk. ] Am.Mm.n.H.

Beryx multidentatus, A. Stewart, Kansas Univ. Quart. [A] vol. vii. (1898), p. 196.-Upper Cretaceous; Kansas. [Indeterminable mandible and maxilla, referred to Anogmius evolutus by F. B. Loomis, Palæontogr. vol. xlvi. (1900), p. 257 ; University of Kansas.]

Beiny subovatus, F. Bassani, loc.cit. (1882), p. 226, pl. viii. fig. 4. -Cretaceous ; Isle of Lesina, Dalmatia. [Imperfect fish ; Imperial Geological Survey, Vienna.]

Beryx valenciennesi, E. Hébert, Mém. Soc. Géol. France, [2] vol. v. (1855), p. 349, pl. xxvii. fig. 2.-Upper Senonian; Meudon, France. [Imperfect fish, wanting greater part of fins.] 


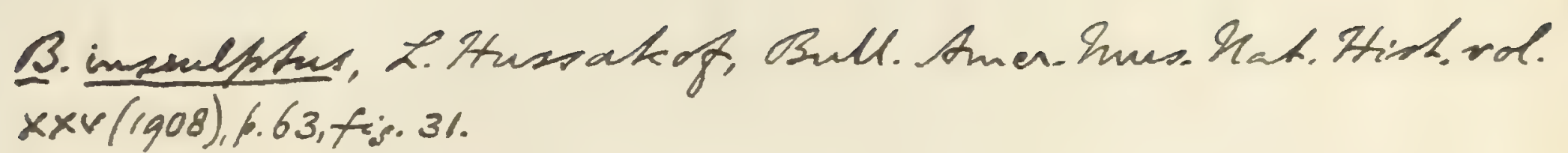




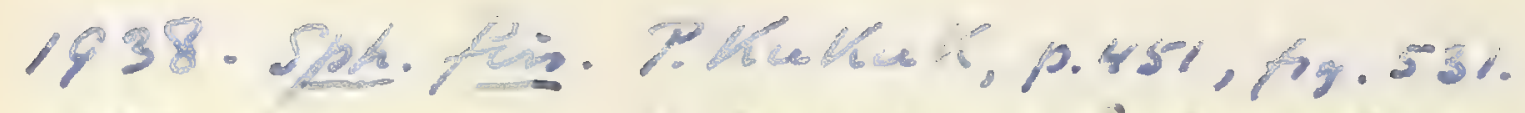

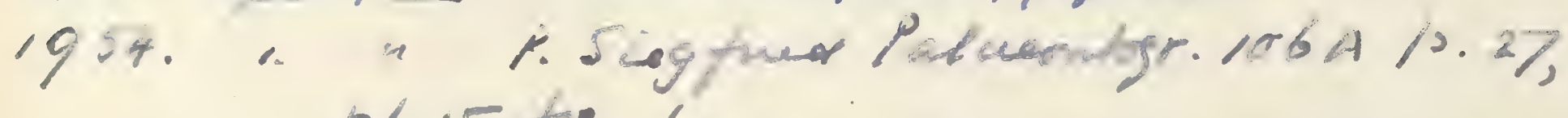
pl. 15 ts . . 


\section{Genus SPIENOCEPHALUS, Agassiz.}

[Poiss. Foss. vol. iv. 1838, p. 4.]

Trunk elongated and laterally compressed. Cleft of mouth little oblique, and jaws with very minute teeth. External bones more or less ornamented with rows of tubercles. Vertebræ about 12 in the abdominal, 16 to 18 in the caudal region. Pelvic fins with one large, longitudinally ridged spine and 7 soft rays, which are both articulated and divided; these fins inserted slightly behind the origin of the pectoral pair. Dorsal and anal fins about as long as deep, each with 4 stout, Iongitudinally ridged spines gradually increasing in length, and closely pressed together; caudal fin moderately cleft. Scales ctenoid, of moderate size, more or less ornamented with granulations; one series enlarged along the course of the lateral line.

\section{Sphenocephalus fissicaudas, Agassiz.}

1838-39. Sphenocephalus fissicaudus, L. Agassiz, Poiss. Foss. vol. ir. pp. 4, 129, pl. xvii. figs. 3-5.

1858. Sphenocephalus fissicandus, W. von der Marck, Zeitschr. deutsch. geol. Ges. vol. x. p. 253.

1863. Sphenocephalus fissicaudus, W. von der Marck, Palæontogr. vol. xi. p. 17, pl. iii. fig. 2.

Type. Nearly complete fish; Palæontological Museum, Munich.

The type species, attaining a length of about $0 \cdot 25$. Length of head with opercular apparatus about equal to the maximum depth of the trunk and contained somewhat less than twice in the length from the pectoral arch to the base of the caudal fin. Dorsal fin with 10 or 11 divided rays, completely in advance of the anal, which comprises 9 similar rays.

The squamation noted in the generic diagnosis has not been clearly observed in this species.

Form. \& Loc. Upper Cretaceous: Westphalia.

P. 9059. Imperfect large fish originally about 0.23 in length; Baumberg.

Purchased, 1899.

P. 8772-74. Three imperfect specimens, the first unusually large and much distorted by crushing; Baumberg.

Purchased, 1897.

P. 3932. Imperfect fish about 0.12 in length, also distorted; Baumberg.

Enniskillen Coll. 
P. 2100. Fish of nearly similar size and proportions apparently of this species, but, if so, with dorsal and anal fins incomplete behind; Sendenhorst.

Egerton Coll.

Sphenocephalus cataphractus, W. von der Marck.

1863. Sphenocephahus cataphractus, W. von der Marck, Palæontogr. vol. xi. p. 18, pl. iii. fig. 1, pl. vii. figs. 3-5.

Type. Nearly complete fish; Academy of Münster.

A slightly smaller species than the type, with relatively larger head. Length of head with opercular apparatus considerably exceeding the maximum depth of the trunk, and contained one and a half times in the length from the pectoral arch to the base of the caudal fin. Dorsal fin with 9 divided rays; anal fin arising opposite the fifth or sixth of these rays, also eomprising 9 divided rays. Scales of lateral line about twice as deep as broad, two or three times as deep as those immediately below them.

Form. \& Loc. Upper Cretaceous: Westphalia.

35039, P. 3824. Characteristic specimen, in counterpart; Sendenhorst. Purchased, 1860, \& Enniskillen Coll.

P. 2100 a. Fine specimen, displaying ornamented head and scales in impression; Sendenhorst.

Egerton Coll.

P. 3824 a. Imperfect fish, deepened by distortion; Sendenhorst. Enniskillen Coll.

\section{Genus ACROGASTER, Agassiz.}

[Poiss. Foss. vol. iv. 1838, p. 5.]

Syn. Acanthophoria, D. G. Kramberger, Djela Jugoslav. Akad, vol. xvi. 1895, p. 45.

Trunk much deepened and laterally compressed. Cleft of mouth large and oblique, and jaws with very minute teeth; preoperculum with a few stout spines round the posterior border of its lower portion. Vertebræ about 12 in the abdominal, 14 in the caudal region. Pelvic fins arising below the origin of the pectorals, with one stout spine and 6 or 7 divided rays. Dorsal fin occupying from a third to half of the vack, with from 3 to 5 small slender spines and 10 to 14 stout divided rass; anal fin only slightly less extended, with 3 or 4 small stout spines and 9 to 11 well-spaced, stout, divided rays; caudal fin deeply cleft. Scales thin, apparently cycloid, none thickened or enlarged along the dorsal or ventral borders. 


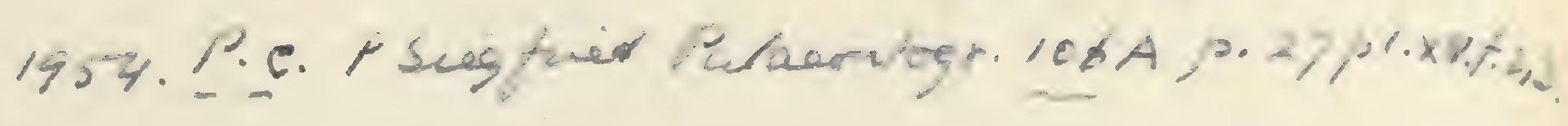

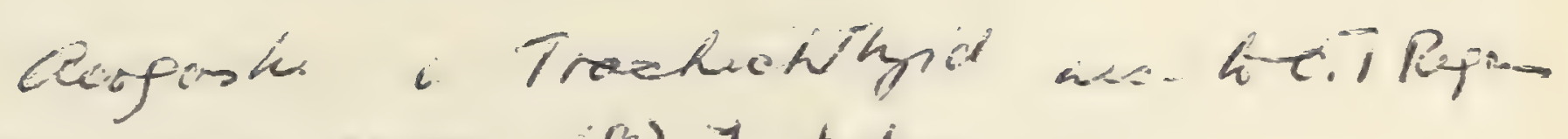
rau a.ran, is) 1 p 6 . 


\section{Acrogaster parvus, Agassiz.}

1838-39. Acrogaster parvus, L. Agassiz, Poiss. Foss. vol. iv. pp. 5, 134, pl. xvii. fig. 1 (? fig. 2).

1858. Acrogaster parvus, W. von der Marck, Zeitschr. deutsch. geol. Ges. vol. x. p. 25:2.

1863. Acrogaster minutus, W. ron der Marck, Palæontogr. vol. xi. p. 23, pl. rii. fig. 1. [Imperfect fish; Academy of IIünster.]

1863. Acrogaster parvus, W. von der Marck, ibid. p. 23.

Type. Imperfect distorted fish; Palæontological Museum, Munich.

The type species, imperfectly known by two distorted specimens about 0.06 in length. Maximum depth of trunk less than its length from the pectoral arch to the base of the caudal fin, and about three times as great as the width of the caudal pedicle. Dorsal fin with $\bar{\jmath}$ spines and 10 divided rays, the distance between its hinder end and the caudal fin equal to the length of its own base-line; anal fin with 3 or 4 spines and 10 divided rays, arising opposite the middle of the dorsal fin, and the length of its base-line nearly equal to that of the latter fin.

W. von der Marck considers that the scales are enlarged along the course of the lateral line. $\mathrm{He}$ also regards the second and larger specimen, provisionally ascribed by Agassiz to this species, as truly representing a distinct form. He erroneously applies the name $A$. parvus to the latter.

Form. \& Loc. Upper Cretaceous: Baumberg, Westphalia.

Not represented in the Collection.

Acrogaster brevicostatus, W. von der Marck.

1863. Acrogaster brevicostatus, W. von der Marck, Palæontogr. vol, xi, p. 24, pl, vii. fig. 2.

Type. Nearly complete fish; Academy of Mrünster.

A species attaining a length of about $0 \cdot 1$. Maximum depth of trunk slightly less than its length, and about four times as great as the width of the caudal pedicle. Dorsal fin with 3 spines and 11 divided rays, the distance between its hinder end and the caudal fin equalling about half the length of its own base-line; anal fin probably with 3 spines and 11 dirided rays, arising opposite the middle of the dorsal fin, and the length of its base-line approximately equal to that of the latter fin.

Form. \& Loc. Upper Cretaceous: Sendenhorst, Westphalia.

Not represented in the Collection. 


\section{Acrogaster heckeli (Pictet).}

1850. Pycnosterinx hectielii, F. J. Pictet, Poiss. Foss. Mt. Liban, p. 15, pl. ii. figs. 1, 2.

1866. Pycnosterinx heckelii, Pictet \& Humbert, Nouv. Rech. Poiss. Foss. Mt. Liban, p. 40, pl. iii. figs. 3, 4 .

1887. Pycnosterinx heckelii, J. W. Davis, Trans. Roy. Dublin Soc. [2] vol. iii. p. 532 (? pl. xxvii. fig. 1).

Type. Imperfect fish ; Geneva Museum.

A species attaining a length of about $0 \cdot 08$. Length of head with opercular apparatus not exceeding the depth of the abdominal region below the vertebral column. Maximum depth of trunk about equal to its length, and about four times as great as the width of the caudal pedicle. Dorsal fin with 3 spines and 14 divided rays, the distance between its hinder end and the caudal fin equalling about half the length of its own base-line; anal fin with 3 spines and 9 or 10 divided rays, less extended than the dorsal and arising opposite the middle of the latter.

Form. \& Loc. Upper Cretaceous: Sahel Alma, Mt. Lebanon.

47373, 49570-72, P. 6181. Five typical specimens displaying all the characters of the genus and species. Lewis Coll.

$46531,47378,47813,4811 \%$. Four small specimens, the fourth showing traces of the lateral line without thickened or enlarged scales.

Lewis Coll.

P. 1955 Fish about 0.07 in length, with displaced upper jaw.

Egerton Coll.

P. 1954. Very small specimen.

Egerton Coll.

P. 4154-55. Two imperfect specimens, the first displaying a pelvic fin.

Enniskillen Coll.

\section{Acrogaster daviesi (Daris).}

(?) 1850. Pagellus libanicus, F. J. Pictet, Poiss. Foss. Mt. Liban, p. 11, pl. i. figs. 2, 3 (named $P$. ovalis on plate). [Imperfect fish; Geneva Museum.]

1887. Pycnosterinx daviesii, J. W. Davis, Trans. Roy. Dublin Soc. [2] vol. iii. p. 537, pl. xxix. fig. 2.

(?) 1887. Pagellus libanicus, J. W. Davis, ibid. p. 507.

1895. Acanthophoria libanica, D. G. Kramberger, Djela Jugoslav. Akad. vol. xvi. p. 46 , pl. viii. fig. 1 .

1898. "Pagellus libanicus," A. S. Woodward, Ann. Mag. Nat. Hist. [7] vol, ii. p. 488. 


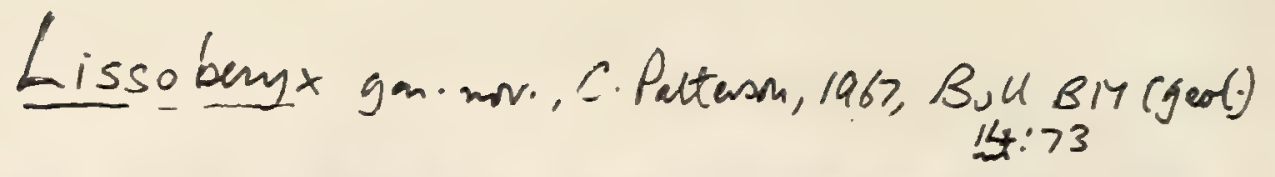

derogader dayi sin. O.SW.

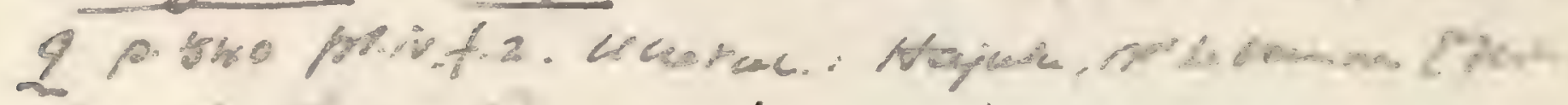
type-sp of Lissobugx, Pattuan 1967, figs/-3

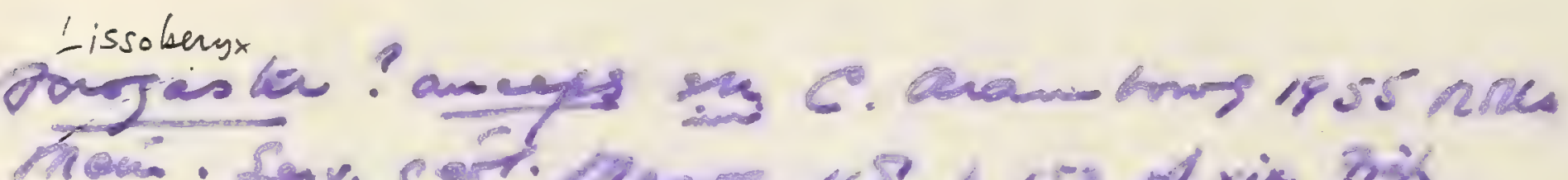

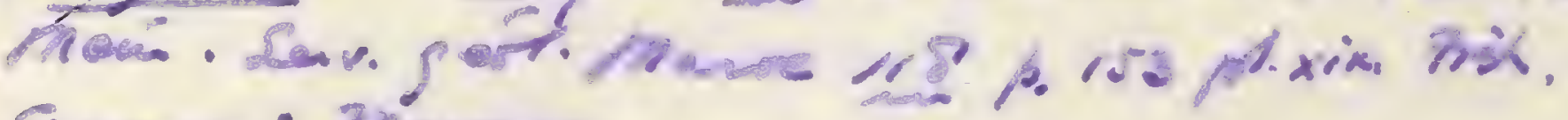

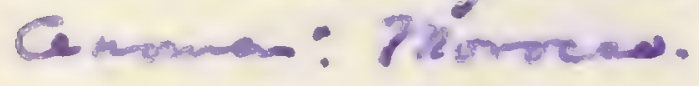

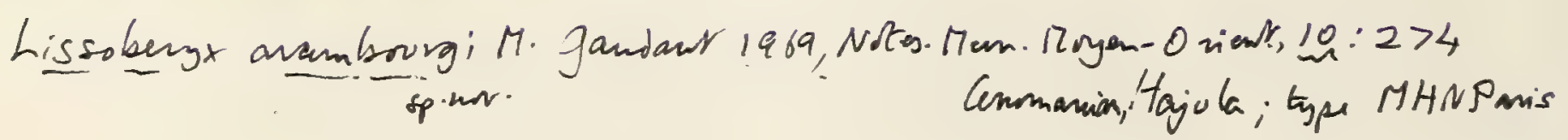

Pycnosferisides asw rater. 


Type. Nearly complete fish; British Museum.

A species attaining a length of about $0 \cdot 12$. Length of head with opereular apparatus somewhat exceeding the depth of the abdominal region below the rertebral column. Maximum depth of trunk considerably less than its length, but four times as great as the width uf the caudal pedicle. Fins as in A. heckeli.

The so-called genus Acanthophoria is based on a specimen supposed by Kramberger to be specifically identical with the imperfect tishes originally named Pagellus libanicus by Pictet.

Eorm. \& Loc. Upper Cretaceous: Sahel Alma, Mt. Lebanon.

49582. Type specimen described and figured by Davis, loc. cit. There can scarcely have been more than 26 rertebræ, and of these only 14 are to be reckoned as caudal. Three slender spines and 14 divided rays are clearly indicated in the dorsal fin; the spine in front of the pelvic fin is shown to be shorter than the divided rays which follow. Very large gill-rakers are displayed on one of the branchial arches.

Lewis Coll.

$48130,49581,49585$. Three good specimens, the first showing a rudimentary fourth spine at the origin of the anal fin, and apparently 6 divided rays in one of the pelvic fins.

Lewis Coll.

$46530,47370-72,47379,48121,48132$. Seven more imperfect, distorted specimens; the third showing the impression of a rudimentary fourth spine at the origin of the dorsal fin.

Lewis Coll.

P. 1953 a. P. 4155 a. Imperfect small specimen, in counterpart. Egerton \& Enniskillen Colls.

48120. Still smaller distorted specimen, probably of this species.

Lewis Coll.

Genus PYCNOSTERINX, Heckel.

[In Russegger's Reisen, vol. ii. pt. iii. 1849, p. 337.]

Syn. Imogaster, O. G. Costa, Mem. R. Accad. Sci. Napoli, vol. ii. IEs7, p. 102.

Trunk more or less deepened and laterally compressed. Cleft of mouth large and little oblique, and jaws with very minute teeth; preeperculum without spines. Vertebræ about 12 in the abdominal, 16 to 18 in the caudal region. Pelric fins arising below the origin 
of the pectorals. Dorsal fin considerably extended, occupying nearly half the length of the back, with from 5 to 8 stout spines, gradually increasing in length, and closely pressed together; anal fin also much extended and more or less completely opposed to the dorsal, with 3 or 4 stout spines, gradually increasing in length, and closely pressed together; caudal fin deeply cleft. Scales small and thick, feebly ctenoid, extending orer the cheek and the bases of the dorsal and anal fins; no ridge-scales, and none modified along the course of the lateral line.

This genus is provisionally placed in the Berycidæ, the number of the pelvic fin-rays not yet having been exactly ascertained.

\section{Pycnosterinx russeggeri, Heckel.}

1849. Pycnosterinx russeggeri, J. J. HeckeI, in Russegger's Reisern, vol. ii. pt. iii. p. 338, pl. xxiii. fig. 1.

1850. Pycnosterinx dorsalis, F. J. Pietet, Poiss. Foss. Mt. Liban, p. 17, pl. ii. fig. 3. [Imperfect fish ; Geneva Museum.]

1857. Beryx niger, O. G. Costa, Mem. R. Accad. Sci. Napoli, vol. ii. p. 100, pl. ii. fig. 1 (named Beryx ater in expl. of plate, p. 112). [Imperfect fish ; Geological Museum, University of Naples.]

1866. Pycnosterinx dorsalis, Pictet \& Humbert, Nouv. Rech. Poiss. Foss. Mt. Liban, p. 41.

1866. Pycnosterinx russeggerii, Pictet \& Humbert, ibid. p. 41.

1866. Pycnosterinx niger, Pictet \& Humbert, ibid. p. 43.

1887. Pycnosterinx russeggerii, J. W. Davis, Trans. Roy. Dublin Soc. [2] vol. iii. p. 533.

1887. Pycnosterinx dorsalis, J. W. Davis, ibid. p. 533, pl. xxviii. fig. 2 a (non fig. 2).

1887. Pyenosterinx niger, J. W. Daris, ibid. p. 534.

1887. Homonotus pulcher, J. W. Davis, ibid. p. 5]9, pl. xxv. fig. 3. [Distorted fish; Edinburgh Museum.]

1898. Pycrosterinx dorsalis, A. S. Woodward, Ann. Mag. Nat. Hist.

[7] vol. ii. p. 489.

1899. Pycnosterinx russeggeri, A. S. Woodward, loc. cit. vol. iv. p. 319.

Type. Imperfect fish.

The type species, attaining a length of about $0 \cdot 1$. Length of head with opercular apparatus somewhat exceeding the maximum depth of the trunk, which is contained two and a half times in the total length of the fish to the base of the caudal fin; caudal pedicle very slender, its width scarcely exceeding one quarter of the maximum depth. Dorsal fin with 5 longitudinally ribbed spines and about 18 divided rays, arising approximately at the middle point between the end of the snout and the base of the caudal fin; anal fin much less extended, with a rudimentary spine at the 
1912. Beryx niger = Pyenosherinxe sussegseri, 9

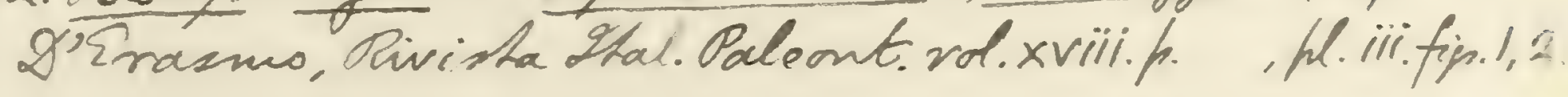



origir, 3 longitudinally ribbed spines and 14 dirided rays, arising opposite the middle of the dorsal fin.

A careful study of the specimens enumerated below suggests that the supposed differences between the various named forms here included in $P$. russeggeri are due to imperfections in the preservation of the specimens. The shape of the fish and the arrangement of its dorsal and anal fins conduce to very variable distortion; while the longitudinal ribbing of the fin-spines frequently affords a false impression of their number.

Form. \& Loc. Upper Cretaceous: Sahel Alma, Mt. Lebanon.

47820, 49579. Two fine large specimens exhibiting the principal characters of the genus and species. Lewis Coll.

P. 9143. Large specimen.

Piresented by A. S. Woodward, Esq., 1900.

49577. Imperfect specimen figured by Davis, loc. cit. pl. xxviii. fig. $2 a$.

Lewis Col!.

46399, 46541, 47375, 47818, 49576. Five imperfect and distorted small specimens, the second in counterpart. Lewis Coll.

P. 1953 b. Small well-preserved fish, partly in impression.

Egerton Coll.

Pycnosterinx discoides, Heckel.

1819. Pycnosterinx discoides, J. J. Heckel, in Russegger's Reisen, vol. ii. pt. iii. p. 340, pl. xxiii. fig. 3.

1850. Pycnosterinx discoides, F. J. Pictet, Poiss. Foss. Mt. Liban, p. 14.

1866. Pycnosterinx discoides, Pictet \& Humbert, Nour. Rech. Poiss. Foss. Mt. Liban, p. 38, pl. iii. figs. 1, 2.

1887. Pycnosterinx discoides, J. W. Daris, Trans. Roy. Dublin Soc. [2] vol. iii. p. 532, pl. xxvii. fig. 3.

1887. Pycnosterinx dorsalis, J. W. Davis, ibid. ph xxriii. fig. 2 (errore).

Type. Imperfect fish.

A deep-bodied species, about as large as the type. Length of head with opercular apparatus considerably less than the maximum depth of the trunk, which much exceeds one half the total length of the fish to the base of the caudal fin; width of caudal pedicle equalling one quarter of the maximum depth. Fins as in the type species, except that the dorsal and anal each comprise one or two additional dirided rays, while the anal may arise slightly further forwards.

It seems probable that the imperfect fish from Sahel Alma in the 
Naples Cniversity Museum, described as the type specimen of Imogaster auratus by O. G. Costa (Mem. R. Accad. Sci. Napoli, rol. ii. 1857, p. 103 , pl. i. fig. 2), is referable to Pycnosterinx discoides. According to F. Bassani (communicated MS.), the specimen exhibits about 26 vertebræ, of which 16 are caudal. The dorsal fin comprises 5 spines and about 23 divided rays, the anal fin 2 or 3 spines and about 18 rays. The scales are too imperfectly preserved to decide whecher or not they are ctenoid.

Form. \& Loc. Upper Cretaceous : Sahel Alma, Mt. Lebaun.

P. 4760. Fine specimen about 0.095 in length, apparently very little distorted, and exhibiting the true proportions of this species.

Lewis Coll.

49578. Another fine specimen, slightly distorted, so that the mouth is opened and the pelvic and anal fins are displaced backwards ; figured by Davis, 7oc. cit. pl. xxviii. fig. 2, as P. dorsalis.

Lewis Coll.

47811-12, 48114, 48118, 49573, P. 4861. Six specimens, more or less imperfect, shortened and deepened by distortion.

Lewis Coll.

P. 1955 a, P. 4156. Two small specimens shortened and deepened by distortion.

Egerton \& Enniskillen Colls.

\section{Pycnosterinx gracilis, Davis.}

1887. Pycnosterinx gracilis, J. W. Davis, Trans. Roy. Dublin Soc. [2] vol, iii. p. 539, pl. sxix. fig. 1.

Type. Imperfect fish; British Museum.

A rather elongated species, attaining a length of about $0 \cdot 15$. Length of head with opercular apparatus about equal to the maximum depth of the trunk, which is contained two and a half times in the total length of the fish to the base of the caudal fin; caudal pedicle as in the type species. Dorsal fin with 5 slightly ribbed spines and about 24 divided rays; anal fin not much less extended, with 4 slightly ribbed spines and 18 or 19 divided rays, arising opposite the foremost divided rays of the dorsal fin.

Form. \& Loc. Upper Cretaceous : Sahel Alma, Mt. Lebanon.

48131. Type specimen described and figured by Daris, loc. cit. Ninute teeth are observable on the extended premaxilla and on the dentary. The preoperculum is very narrow, as usual, and not larger than the operculum. The trunk is obliquely distorted, so that the dorsal fin is crushed 
Inopapter airatus $=$ Penozherinse auratus, 9. Z. Erasmo, Rivista Ital. Paleont. vol. xviii(1912), p. , hliiifip. 3, 4 . 
Pycnosteroides assuram.

Monosterinde levizhinozus, O. P. Hay, Bull. Amen.

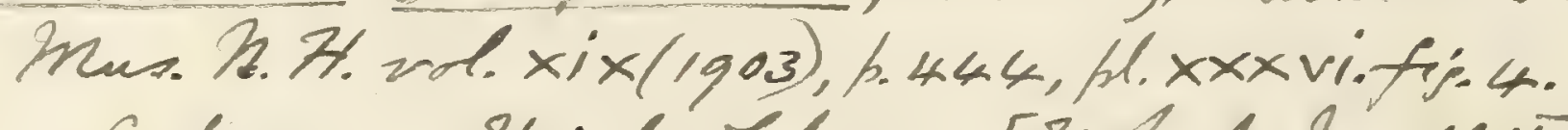

- Getacems; Hajula, Zehouon. [Firh; Am. hmo. N.H.]

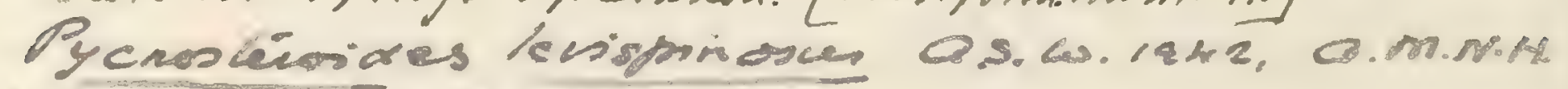

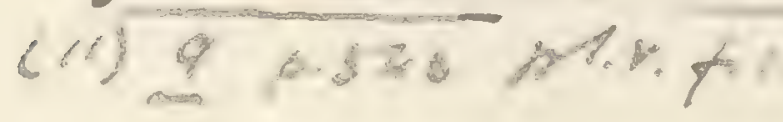


backwards. Though the vertebral column is imperfectly shown, it is evident that there cannot have been less than 12 vertebræ in the abdominal, and 17 or 18 vertebræ in the caudal region. The dorsal fin clearly exhibits 5 spines and 24 divided rays; while the anal has 4 imperfectly preserved spines and 18 divided rays. Levvis Coll.

P. 9440. More imperfect specimen displaying the dorsal and anal fins, with scales extending over their basal portion.

Lewis Coll.

48133. Another more imperfect specimen.

Lewis Coll.

Pycnosterinx dubius, Davis.

1887. Pycnosterinx dubius, J. W. Davis, 'Trans. Roy. Dublin Soc. [2] vol. iii. p. 540, pl. xxix. fig. 3.

Type. Imperfect fish; British Mruseum.

A deep-bodied species about as large as the type. Length of head with opercular apparatus about equal to the maximum depth of the trunk, which is contained rather more than twice in the total length of the fish to the base of the caudal fin. Dorsal fin occupying nearly half the length of the back, with 7 or 8 longitudinally ribbed spines and about 21 divided rays; anal fin somewhat less extended, with 4 longitudinally ribbed spines and 16 divided rays, arising opposite the foremost divided ray of the dorsal fin.

Form. \& Loc. Upper Cretaceous : Sahel Alma, MIt. Lebanon.

48129. Type specimen described and figured by Daris, loc. cit. There are only 7 spines in the dorsal fin.

Lewis Coll.

46543. Obliquely distorted specimen displaying the median fins, the dorsal with 8 spines.

Lewis Coll.

The following species, which are not represented in the Collection, are not satisfactorily known:-

Pycnosterinx elongatus, Pietet \& Humbert, Nouv, Rech. Poiss. Foss. Mr. Liban (1866), p. 42, pl. iii. figs. 5, 6; J. W. Daris, Trans. Roy. Dublin Soc. [2] vol. iii. (1887), p. 537, pl. xxvii. fig. 6.-Upper Cretaceous; Sahel Alma. [Imperfect fish ; Geneva Museum.]

Pycnosterine latus, J. W. Davis, loc. cit. 1887, p. 534, pl. xxvii. fig. 2.-Ibid. [Fragmentary fish of indeterminable genus; Edinbürgh Museum of Science \& Art.] 


\section{Genus HOPLOPTERYX, Agassiz.}

[Poiss. Foss. vol. iv. 1838, p. 4.]

Trunk much deepened and laterally compressed. Frontal region of skull deeply ridged for mucus-cavities; cleft of mouth little oblique, and jaws with very minute teeth; orbit small or of moderate size; preoperculum without spine, only serrated. Vertebræ about 10 in the abdominal, 14 in the caudal region. Pelvic fins arising below or somewhat behind the origin of the pectorals, with one stout spine and 7 or 8 divided rays. Dorsal fin much extended, its anterior half consisting of 5 to 9 stout spines, not closely pressed together; anal fin comparatively short, with 3 to 5 stout spines, not closely pressed together; caudal fin more or less deeply cleft. Scales ctenoid, rather large, rarely ornamented with granulations, and none much enlarged or thickened; lateral line forming a conspicuous discontinuous ridge.

\section{Hoplopteryx antiquus, Agassiz.}

1838-39. Hoplopteryx antiquus, L. Agassiz, Poiss. Foss. vol. iv. pp. 4, 131, pl. xvii. figs. 6-8.

185̃. Hoplopteryx antiquus, W. von der Marck, Zeitschr. deutsch. geol. Ges. vol, x. p. 252.

1863. Hoplopteryx antiquus, var. minor, W. von der Marck, Palæontogr. vol. xi. p. 13, pl. i. fig. 4.

1863. Hoplopteryx antiquus, var. major, W. von der Marck, loc cit. vol. xi. p. 14, pl, ii. fig. 1.

1885. Hoplopteryx antiquus, W. von der Marck, loc. cit. vol. xxxi. p. 243.

Type. Nearly complete fish; Palæontological Museum, Munich.

The type species, attaining a length of about $0 \cdot 3$, but usually smaller. Length of head with opercular apparatus nearly equal to the maximum depth of the trunk, and contained about one and a half times in the length from the pectoral arch to the base of the caudal fin. Origin of pelvic fins opposite to that of the dorsal, which occupies one half the length of the back (measured from occiput to caudal fin), comprising 6 ribbed spines and 11 divided rays; anal fin with 4 similar spines, gradually increasing in length, and 9 or 10 divided rass, terminating behind slightly beyond the dorsal.

Form. \& Loc. Upper Cretaceous: Westphalia.

There is no typical example of this species in the Collection, but, as observed by W. von der Marck (loc. cit. 1885), the small form 




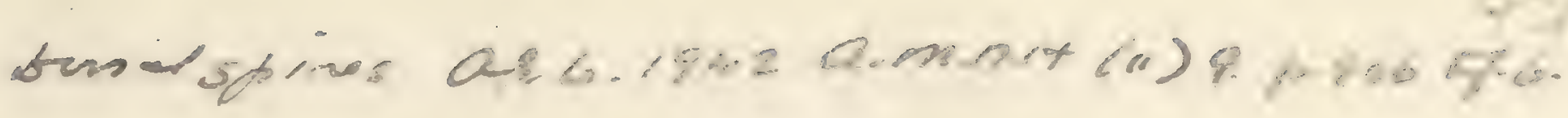

For existiy precien of Hoplopterve ser C.D.

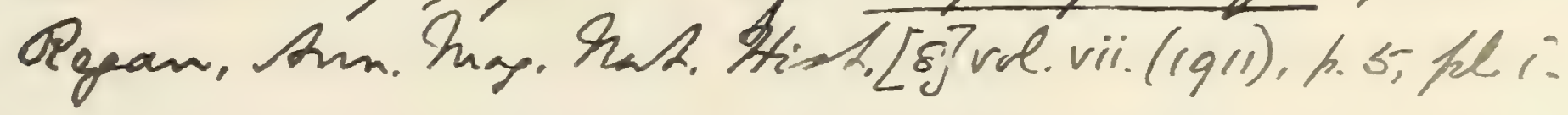

lfoploptingr sprimlosus s.4. As w. 1942

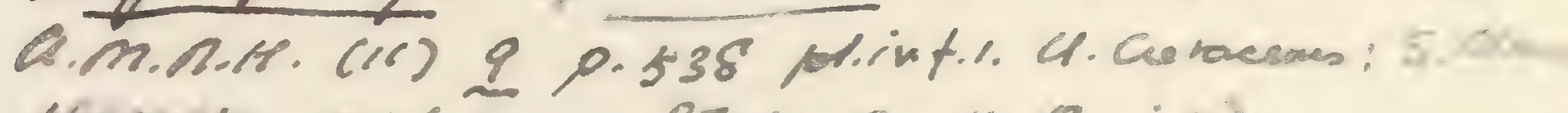

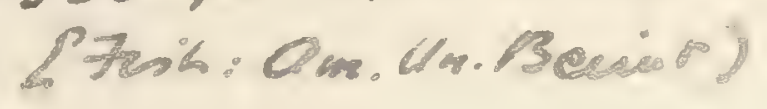

1957. It. A., Piesfied Pabrentogr. 10t A p.25 ph. xiiif. 3.4, × ì f.1,2. 


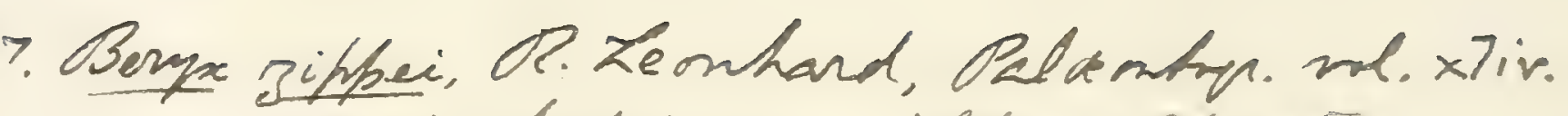
fo.68, teatifi, 12. [Wipher Tilesia]

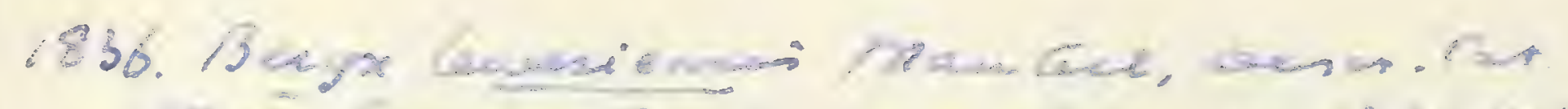

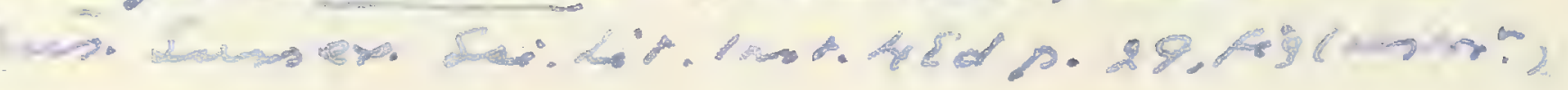

19.2. Hoplopherye leweciensio, A.S. Woodward.

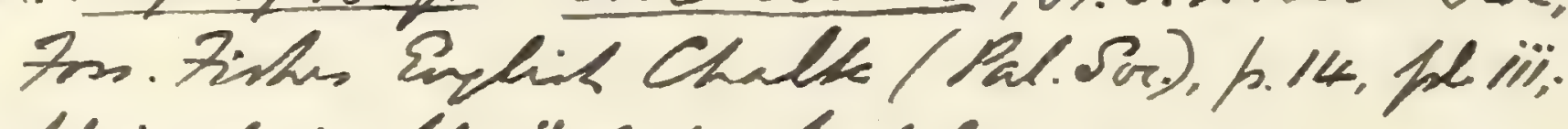

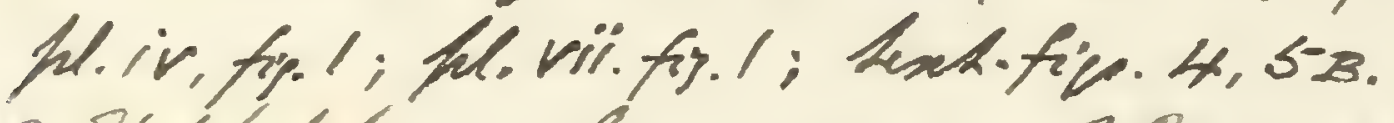

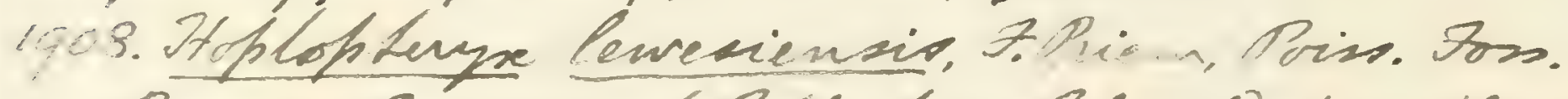

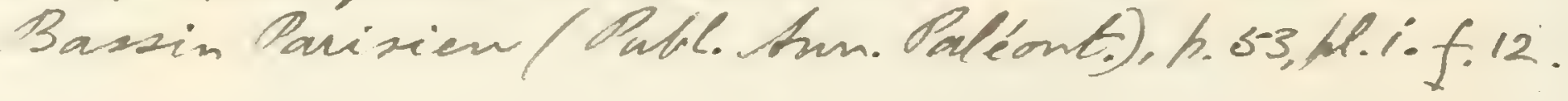


represented by the following specimen may be only an immature stage of the same:-

P. 8771. Fragmentary remains of head and abdominal region of a small fish, resembling the form described by W. von der Marck, Palæontogr. vol. xi. (1863), p. 15, pl. i. figs. 5, 6, under the name of Hoplopteryx gibbus; Baumberg.

Purchased, 1897.

\section{Hoplopteryx zippei (Agassiz).}

1834. Beryx zippei, L. Agassiz, Verhandl. Ges. vaterländ. Mus. Böhmen, p. 68.

1838-39. Beryx zippei, L. Agassiz, Poiss. Foss. vol. iv. pp. 4, 120, pl. xv. fig. 2.

1845. Beryx zippei, A. E. Reuss, Verstein. böhm. Kreideform. pt. i. p. 11, pl. i., pl. ii. fig. 1 .

1878. Beryx zippei, A. Fritsch, Rept. u. Fische böhm. Kreideform. p. 41 , woodc. fig. 62 , pl. v. fig. 1 .

1887. Hoplopteryx zippei, J. W. Davis, Trans, Roy. Dublin Soc. [2] vol. iii. p. 514.

Type. Imperfect fish; Royal Bohemian Museum, Prague.

An incompletely known species, closely resembling the preceding in form and proportions, but supposed to comprise only 5 spines in the dorsal fin, which terminates opposite the posterior end of the anal.

Form. \& Loc. Upper Cretaceous (Turonian): Bohemia.

P. 9006. Imperfect specimen; Plänerkalk, Weissenberg, near Prague. Purchased, 1899.

47497. Plaster cast of well-preserved specimen; Plänerkalk, Bohemia. Presented by Prof. Anton Fritsch, 1876.

Hoplopteryx lewesiensis (Mantell).

[Plate XVI. fig. 4. Text-figure 13.]

1822. Zeus lewesiensis, G. A. Mantell, Foss. S. Downs, p. 234, pls, xxxv., xxxvi.

1835-39. Bery.x ornatus, L. Agassiz, Poiss. Foss., Feuill. p. 55, and vol. iv. p. 115, pl. xiv $a$. pl. xiv b. figs. 1, 2, pl. xiv $c$. figs. 1, 3-6 (non fig. 2), pl. xiv $d$ (exc. fig. 2).

1850. Beryx ornatus, F. Dixon, Geol. Sussex, p. 371, pl. xxxvi. figs. 1, 3, pl. xxxiv. figs. $4 a, 4 c$.

1888. Hoplopteryx lewesiensis, A. S. Woodward, Proc. Geol. Assoc. vol. x. p. 327.

Type. Imperfect fish; British Museum. 


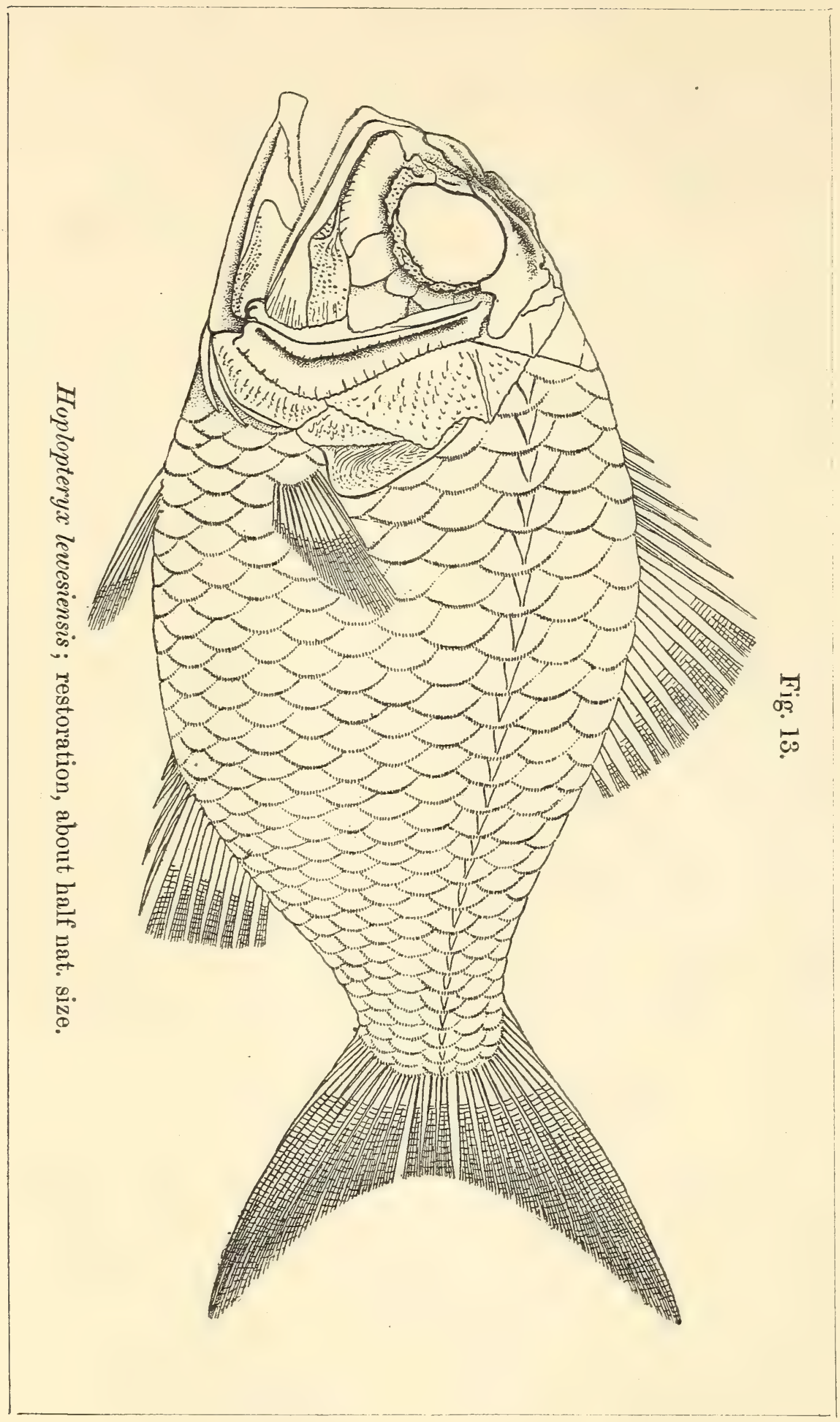


4014-15.- Hoticed A.S.2. 1902, fo.15: 
A species attaining a length of about $0 \cdot 3$. Length of head with opercular apparatus considerably less than the maximum depth of the trunk, which nearly equals the length from the hinder margin of the clavicle to the base of the caudal fin. Dorsal fin occupying nearly one half of the back, comprising 6 very stout, longitudinally ribbed spines and 8 to 10 divided rays, the length of the longest spine almost equalling one third the depth of the trunk at its insertion; anal fin with 7 or 8 divided rays preceded by 3 or 4 very stout spines, which gradually increase to a length about equalling that of the longest dorsal. Scales very finely and delicately pectinated; the lateral line traversing about the ninth longitudinal series from the ventral border.

In the fossils from the English Chalk recorded below, the superficial layer of the external bones and scales is frequently destroyed, at least in part, producing an accidental smoothness.

Form. \& Loc. Turonian and Senonian: Sussex, Surrey, and Kent ${ }^{2}$.

4014-15. Type specimen in counterpart, described and figured by Mantell, op. cit. p. 234, pl. xxxv. fig. 2, pl. xxxvi., and by Agassiz, tom. cit. p. 116, pl. xivd. fig. 1; Upper Chalk, Lewes. There are clearly four anal fin-spines, of which the two foremost are very small and short. Mantell Coll.

4030-31. Fine specimen in counterpart, figured by Agassiz, tom. cit. pl. xiv $a$; Lewes.

Mantell Coll.

4016. More imperfect fish, figured by Agassiz, tom. cit. pl. xiv b. figs. 1,2 ; Lewes.

Mantell Coll.

4008. Small specimen, figured by $\Delta$ gassiz, tom. cit. pl. xiv $c$. fig. 1 ; Lewes.

Mantell Coll.

4027. Imperfect small caudal region, figured by Agassiz, tom. cit. pl. xiv d. fig. 3 ; Lewes.

Mantell Coll.

$4011,-12,-19,-21,-26,-46,-48,4103,-09,4242$. Thirteen more or less fragmentary specimens; Lewes. No. 4019 shows 8 branchiostegal rays.

Mantell Coll.

25781. Head and imperfect trunk, the head figured by Dixon, op. cit. pl. xxxir. fig. 1; Sussex. Tubercles are shown

1 Fragments from the Turonian of Bohemia and Saxony, too imperfect for specific determination, are also ascribed to this species by A. E. Reuss, Verstein. böhm. Kreideform. pt. i. (1845), p. 12, pl. ii. fig. 2, pl. xii. figs. 1, 2; A. Fritsch, Rept. u. Fische böhm. Kreideform. (18j8), p. 43, pl. จ. figs. 2, 3. 
on the ridges of the cranial roof; and the hinder border of the post-temporal is pectinated. Dixon Coll.

2582\%. Imperfect small fish, figured by Dixon, op. cit. pl. xxxvi. fig. 1 ; Sussex.

Dixon Coll.

25839. Imperfect trunk, figured by Dixon, op. cit. pl. xxxri. fig. 3 ; Sussex.

Dixon Coll.

$25841,25863,25869,25905,2590 \%, 25912-13,25915-16$, 25918-19. Nine fragmentary specimens, two being in counterpart; Sussex.

Dixon Coll.

49862-63, 49870-71. Four imperfect specimens, the first displaying the greater part of the vertebral column and part of a pectoral fin; Upper Chalk, Lewes.

Capron Coll.

P. 1948,-a,-b. One fragmentary small fish, a block containing two imperfect small fishes, and a large head; Sussex.

Egerton Coll.

P. 397\%. Small head and fragment of abdominal region; Sussex. Enniskillen Coll.

P. 5420. Fine head, with some anterior scales, shown of the natural size in Pl. XVI. fig. 4; Lewes. The cranium exhibits some of the deep cavities between the tuberculated or pectinated ridges on its roof. The proportions of the orbit are clear, the greater part of the cheek being covered by a chain of suborbital plates (s.o.). The orbital margin (c.o.) of each of these plates is everted and tuberculated, while the lower margin, immediately above the maxilla, is distinctly serrated; the middle part of the plates is quite smooth, and forms a deep channel for the reception of the slime-apparatus. The mandibular suspensorium is nearly vertical, the gape of the mouth extending just behind the eye. The long, slender premaxilla $\left(p m x_{0}\right)$ bears traces of clustered minute teeth throughout its length; and the maxilla $\left(m x_{0}\right)$ immediately abore it is quite smooth, with a triangular expansion behind. A large supramaxilla $\left(s . m x_{0}\right)$ is ornamented with tuberculated ridges on its outer face, and is excavated in front as if for the reception of a smaller anterior supramaxilla. The dentary $(d$. $)$ bears numerous, clustered, minute blunt teeth, like those of the premaxilla; its outer face is deeply channelled below for the slime-canal, and the longitudinal ridge above the 
25863. Check-scales misiced A.S. W. 1902, P. 18.

49862. Natkehal colums deserited fiuned A.S.L 1902, h.19, Ml.ir. fig. I. 
2.6463. Bxcharged with Lund Univ. Inus, 1903.

41104 = H. supenhes. Desd? LFig. A.S.W. 1902 . p. 21, heviis fip. 2 .

35712. Desurithd a fiymed A.S.W. 1902, h. 16, he. iii. fip. 
channel is tuberculated. The angular ( $a g$.) has a similar conformation, but its tuberculated ridge is widened into an extensive radiately-ornamented area. The preoperculum (p.op.) also exhibits a deep groove for the slime-canal, and is not much expanded at the angle. The other opercular bones display their characteristic rugose ornament. The deep and narrow operculum (op.) is produced into two short and broad spines at its hinder margin, the upper being connected by a strong ridge with the point of suspension. The suboperculum (s.op.) is relatively small, with a large anterior ascending process. The interoperculum (i.op.) is of remarkable extent. The upper expanded portion of the clavicle is more finely and closely ornamented than the opercular apparatus. The large and deep anterior scales are broken and displaced.

Presented by P. E. Coombe, Esq., 1888.

P. 5421-23. Four fragments; Lewes.

Presented by P. E. Coombe, Esq., 1888.

P. 7189. Head and anterior scales; Southover, Lewes.

Presented by J. S. Valentine, Esq., 1894.

P. 6462-64. Four fragmentary small specimens, two displaying a small and delicate supraoccipital crest; probably from Sussex. Beckles Coll.

49868. Portion of large trunk; Lewes.

Capron Coll.

49865-67, 49872, 49888. Five fragmentary small specimens; Upper Chalk, near Guildford.

Capron Coll.

P. 388-9. Three imperfect fishes, two displaying a considerable part of the dorsal fin; probably from Kent.

Presented by the Earl of Ducie, 1881.

P. 9441. Fine distorted specimen; Rochester.

Purchased.

2301\%. Remains of small head and trunk; Dover.

Purchased, 1848.

41104-05. Two imperfect heads, the first associated with some flank-scales; Lower Chalk, Halling, Kent.

Purchased, 1868.

35712. Fine specimen, displaying the greater part of the paired and dorsal fins; Rochester. The pectoral fin consists PART IV. 
of 10 or 11 very delicate rays. The dorsal exhibits the remarkably stout supports for the six anterior spines.

Purchased, 1860.

42063. Large head; Warne's Place, Rochester. Purchased, 1870.

41692. Scattered remains of head, including premaxillæ; Lower Chalk, Burham, Kent.

Toulmin Smith Coll.

49036, 49043. Imperfect small fish and distorted large fish; probably from Burham. The first specimen exhibits $;$ articulated rays in the anal fin; the second has 9 branchiostegal rays.

Mrs. Smith's Coll.

44836. Imperfect fish with parts of paired fins and anal fin-spines; English Chalk. Presented by Benjamin Bright, Esq., 1873.

49037. Head; probably from Burham. The cranium is well shown, and seems to differ from that of Beryx decadactylus in its relatively larger ethmoidal region. The division of the suborbitals into three plates is exhibited on the right; and there is a small distinct anterior supramaxilla.

Mrs. Smith's Coll.

49042. Imperfect dentary bones, apparently the specimen figured by Dixon, op. cit. pl. xxxir. figs. $4 a, 4 c$; probably from Burham.

Mrs. Smith's Coll:

49033-35, 49038-41, 49059, 49110. Nine fragmentary specimens; probably from Burham.

Mrs. Smith's Coll.

P. 1948. Two imperfect specimens; Kent.

Egerton Coll.

P. 3978. Imperfect fish; Kent. Enniskillen Coll.

P. 4842. Imperfect small fish, somewhat distorted; Lower Chalk, Kent.

Purchased, 1885.

P. 5687-94, P. 5697-98. Ten specimens, more or less fragmentary ; Lower Chalk, Cuxton, Kent.

Harford Coll.

P. 6047. Imperfect fish; Cuxton.

Presented by F. Harford, Esq., 1889.

P. 6533. Three fragmentary specimens; Lower Chalk, Blue Bell Hill, Burham. Presented by S. J. Hawkins, Esq., 1891.

34062. Imperfect small fish in flint; English Chalk. Purchased. 


41692. Right fremaxillere dese? A fir? A.S. W. 1902, hols. deliii.fi, 3 .

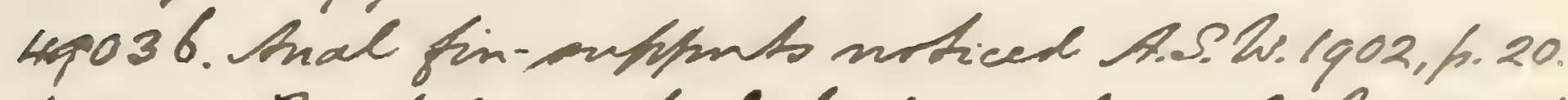
49043. Rrunded ventral brder nuticed A.S.2. 1902, h.16; scales over cramial inf. f.17; nine branchiostegat rays. fr. 19.

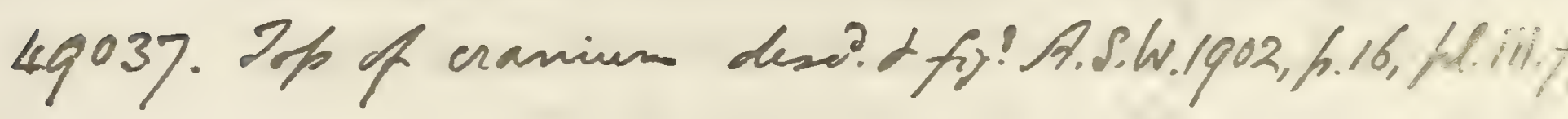

49038. Granial inf noticed A.S.W. 1902, 1.1\%.

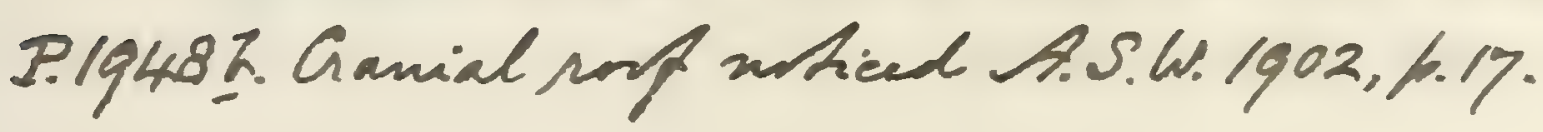

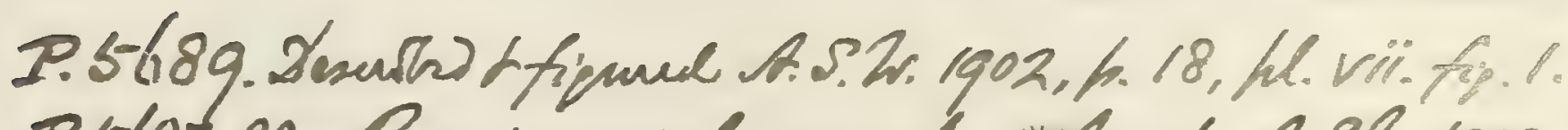
P.5687-88. Basieranial canal suticed A.S.2. 1902, f.16;

post.tenfoul of P.5-688, h.19.

2.5694. Moth-hemponal maticed A.S.S. 1902, h.19. P. 5692. Prot. davide noticed A.S. Le 1902, h.19. 


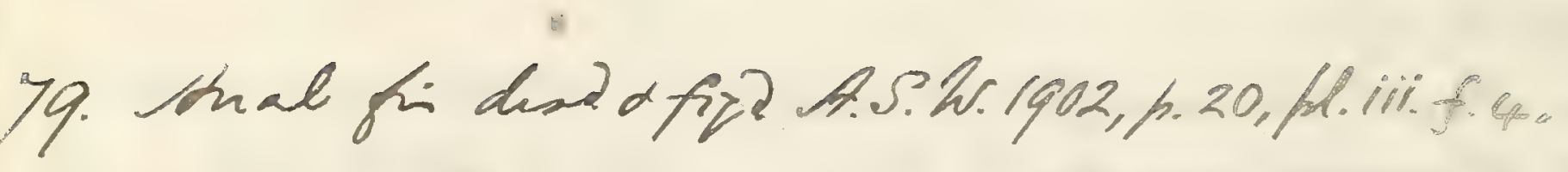

1902. Hoplopterye unperbur, A.S. Wooderend.

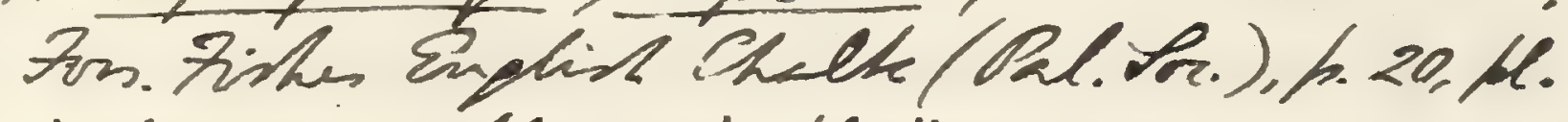
iv. fiv. 2, 3; hes. v, vi; heviiffor.2-5-

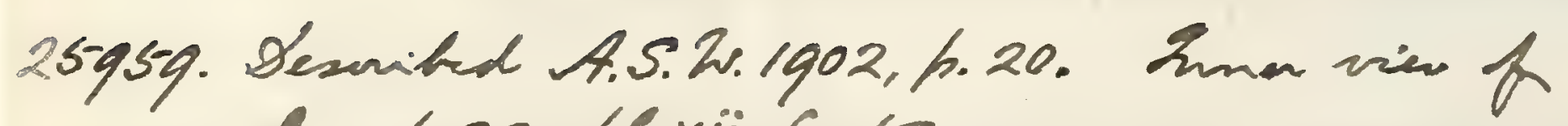
acals, h. 22, hl. vii. fip. S.

R.3982. Opereadum maticed A.S.W. 1902, h.21.

P.g153. Fij? in "Ylluchated Times," 24th. hor. 1855, h.405, $\alpha$ said to have been fround near Rochecter, Kent. Dead Afi! A.S.2. 1902, kp. 21,22, fh. iv. fes.2; Hev. 


47249, 47300. Three fragmentary remains of a small fish, perhaps of this species; Lower Chalk, Dorer. Gardner Coll.

P. 7394. Similar small head; Lower Chalk, Folkestone. Purchased, 1895.

P. 9442. Imperfect head, \&c.; English Chalk. History unknown. 36917. Remains of fish 0.08 in length, doubtfully young of this species; Rochester. Purchased, 186

\section{Hoplopteryx superbus (Dixon).}

1850. Beryx superbus, F. Dixon, Geol. Sussex, p. 372, pi. xxxri. fig. 5.

1887. Hoplopteryx superbus, J. W. Davis, Trans. Roy, Dublin Soc. [2] vol. iii. p. 514.

1888. Hoplopteryx superbus, A. S. Woodward, Proc. Geol. Assoc: vol. x. p. 328.

Type. Imperfect trunk; British Museum.

A species attaining a length of about 0.45 , with fins apparently similar to those of $H$. lewesiensis but the trunk slightly more elongated and the scales relatively larger than in the latter species. Scales very thick and completely ornamented in their exposed portion with rugæ and pectinations which radiate to the hinder pectinated border; lateral line traversing about the sixth longitudinal series from the ventral border.

Form. \& Loc. Turonian and Senonian: Sussex and Kent.

25959. Type specimen figured one half natural size by Dixon, op. cit., in counterpart; Lower Chalk, Southeram, near Lewes.

Dixon Coll.

4005, 4007. Two fragments; Lewes.

Mantell Coll.

P. 3979-80. Large trunk with well-preserred squamation, and a fragmentary specimen; Sussex. _. Enniskillen Coll.

P. 9153. Slab of chalk with remains of sereral small specimens; Sussex. One specimen exhibits traces of clustered minute teeth on the vomer and palatines, as in Beryx. The pelvic fins are shown to consist of one spine and seren articulated rays. The ventral aspect of the body is flattened as far back as these fins, and is then compressed to an acute edge.

Beckles Coll.

49869. Fragment of squamation; Brighton.

Capron Coll. 
32340-41. Imperfect fish about 0.3 in length showing proportions of trunk, also two fragments; near Maidstone.

Purchased, 1857.

33486, 39431. Two large imperfect specimens in association, and a detached trunk; Kent. One of the two specimens displays the head, which seems to have been identical with that of $H$. lewesiensis.

Purchased, 1858, and Bowerbank Coll.

33129. Imperfect small head and anterior part of trunk; Kent.

Purchased, $185 \%$.

Hoplopteryx lundensis, Davis.

1890. Hoplopteryx lundensis, J. W. Davis, Trans. Roy. Dublin Soc. [2] vol. iv. p. 417, pl. xliii. figs. 1-3.

Type. Imperfect fish; University Geological Museum, Lund.

An elongated species, attaining a length of about 0.25. Length of head with opercular apparatus exceeding the maximum depth of trunk, which is contained twice in the length from the clavicle to the base of the caudal fin. Dorsal fin occupying more than. half the length of the back, with about 9 stout spines and 8 to 10 divided rays; anal fin with 3 stout spines.

Form. \& Loc. Upper Cretaceous (Danian): Limhamn, Scania. Not represented in the Collection.

\section{Hoplopteryx lewisi (Davis).}

1887. Pycnosterinx lewisii, J. W. Davis, Trans. Roy. Dublin Soc. [2] vol. iii. p. 535, pl. xxvii. fig. 5.

Type. Imperfect fish; British Museum.

A small, deep-bodied species about 0.1 in length, the maximum depth of the trunk approximately equalling its length from the pectoral arch to the base of the caudal fin. Dorsal fin apparently occupying slightly more than half the length of the back, with 8 nearly smooth spines and 8 very stout divided rays, the length of the longest spine less than half the depth of the trunk at its insertion; anal fin with 4 nearly smooth spines, gradually increasing in length backwards, followed by 8 very stout divided rays, this fin arising opposite the foremost divided ray of the dorsal. Scales feebly serrated. 
P.763-3. Dibs moticed A.S.W. 1902, k22, seale over hercurher, h. 22.

32340. Desentsi \& fieund A.S.W. 1902, h.21, Ml.iv.fis.3.

2 seab, he.vilifion. 3.

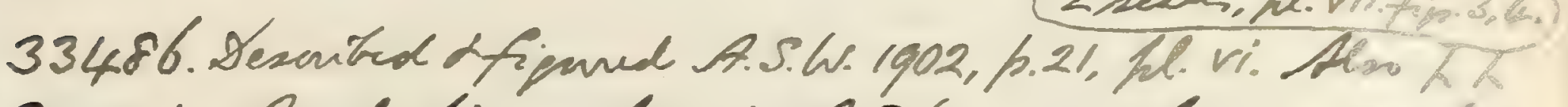

39431. Anal fin noticed A.S.W. 1902, F22, pocles ner fresenluen, p. 22.

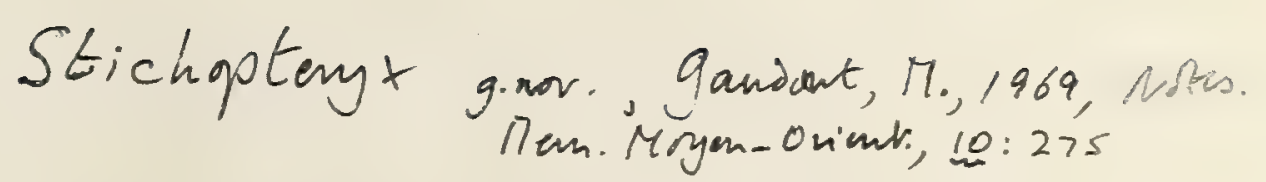
bype-spenies, H. Uesisi (Davis) - ganjout hig.3 
Alloberyx gan. nor. M. Gaudont 1969, Notes Men. Mogar. Urient. 10: 278 .

type speries Buyx syriacus P.H. - Ganobnt fig.5 
Form. \& Loc. Upper Cretaceous: Hakel, Mrt. Lebanon.

P. 4758. Type specimen described and figured by Daris, Toc. cit. Impressions of the maxilla and the lower end of the preoperculum exhibit a radiating ormamentation. The vertebræ are stout, and 13 or 14 may be reckoned as caudal. A pelvic fin exhibits one long spine and the bases of six divided rays. The characters of the dorsal and anal fins are mentioned in the above diagnosis. The caudal fin, with very stout rays, is clearly forked. The feeble serrations of the scales are especially distinct in the abdominal region.

Lervis Coll.

P. 94. Fragmentary distorted specimen.

Lewis Coll.

P. 8689. Imperfect fish. Purchased, 1897.

Hoplopteryx syriacus (Pictet \& Humbert).

1866. Beryx syriacus, Pictet \& Humbert, Nouv, Rech. Poiss. Foss. Mt. Liban, p. 28, pl. i.

1887. Hoplopteryx syriacus, J. W. Davis, Trans. Ros. Dublin Soc. [2] vol. iii. p. 514.

Type. Imperfect distorted fish; Geneva Musenm.

A species attaining a length of about $0 \cdot 15$. Length of head with opercular apparatus considerably less than the maximum depth of the trunk, and contained about one and a half times in the length from the pectoral arch to the base of the caudal fin. Dorsal fin occupying one half of the back, comprising $S$ very stout, longitudinally-ribbed spines and about 12 divided rays, the length of the longest spine equalling half the depth of the trunk at its insertion; anal fin with 5 very stout spines, which gradually increase to a length equalling that of the longest dorsal, arising opposite the foremost divided ray of the dorsal. Serrations of scales very deep and fine.

Form. \& Loc. Tpper Cretaceous: Mount Lebanon, Syria.

49553. Imperfect fish, apparently not distorted, displaying the 8 dorsal spines and good impressions of the 5 anal spines; Sahel Alma.

Lewis Coll.

$46507,48108,48109$. Three fragments of trunk, the last two displajing remains of the 5 anal spines; Sahel Alma.

Lewis Coll. 
Hoplopteryx stachei (Kramberger).

1895. Beryx stachei, D. G. Kramberger, Djela Jugoslar. Akad. vol. xvi. p. 43, pl. i. figs. $3,4$.

Type. Imperfect fish; Trieste Museum.

A small species attaining a length of about $0 \cdot 1$, much resembling $H$. syriacus but with more extended dorsal fin, which comprises 9 large spines and about 12 divided rays. Number of vertebræ stated to be 24 , but more indicated in the figure of the type specimen.

Form. \& Loc. Cretaceous: Comen, Istria.

Not represented in the Collection.

The following specimen may perhaps represent an undetermined species of Hoplopteryx:-

48122. Fragmentary fish with tuberculated large scales; Upper Cretaceous, Sahel Alma, Mt. Lebanon. Lewis Coll.

The following species are not represented in the Collection and are very doubtfully determined:-

Hoplopteryx minor, J. W. Davis, Trans. Roy. Dublin Soc. [2] vol.iv. (1890), p. 421, pl.xlv. figs. 3, 4.-Upper Cretaceous (Danian); Limhamn, Scania. [Fragmentary fish; Royal State Museum, Stockholm.]

Hoplopteryx oblongus, J. W. Davis, loc. cit. [2] vol. iii. (1887), p. 515, pl. xx . fig. 1.-Upper Cretaceous; Sahel Alma, Mt. Lebanon. [Imperfect fish; Edinburgh Museum of Science \& Art.]

Remains aprarently of Hoplopteryx occur also in the Chalk of the Dept. Somme, France (Beryx, P. Gervais, Zool. et Pal. Franc. 1852, Poiss. Foss. p. 6, pl. lxx. figs. 1, 2).

\section{Genus DINOPTERYX, novum.}

Trunk elongate-ovoid and laterally compressed. Cleft of mouth little oblique, and teeth minute; preoperculum without spine. Vertebræ about 15 in the abdcminal, 15 in the caudal region. Pelvic fin-spine very stout and large. Dorsal fin much extended, occupying the greater portion of the back, with about 14 stout spines, nearly similar in length, not closely pressed together; anal fin comparatively short, with about 7 stout spines not closely pressed together; caudal fin deeply cleft. Scales cycloid and smooth, rather small, none much enlarged or thickened. 


1946. H.s. p.141 .8.29. Frlsasmo.

H. pry dermie s.a. Qumman: Morreces, S.OAn

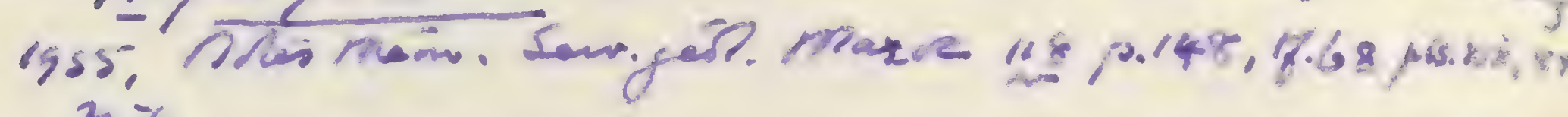
zing.

Hophopheryx Erevis, Arituh \& Bayer, hene tise he u. Rept. Bshm. Freideform. (Rag, 1905), 1.8, Hliii.fi. 3. - Inronian; Weissenberg, Bhemia. C'mperfuth firs; Doy. Brhem. Mus, Prapue. I 

The pelvic fins being incompletely known, the systematic position of this fish is somewhat uncertain. The arrangement of the median fins exhibits considerable resemblance to that observed in the existing Teuthis.

\section{Dinopteryx spinosus (Davis).}

1887. Hoplopteryx spinosus, J. W. Davis, Trans. Roy. Dublin Soc. [2] vol. iii. p. 516, pl. xxviii. fig. 1.

Type. Imperfect fish; British Museum.

The type species, attaining a length of about $0 \cdot 15$. Length of head with opercular apparatus exceeding the maximum depth of the trunk and contained about one and a quarter times in the length from the pectoral arch to the base of the caudal fin. The stout finspines ornamented with conspicuous longitudinal ridges. Dorsal fin arising over the hinder border of the operculum, its anterior portion of 14 spines three times as much extended as its hinder portion of about 9 articulated and divided rays; the foremost five or six spines slightly bent, the others quite straight. Anal fin arising opposite the last dorsal spine, its anterior portion of 7 spines as much extended as its hinder portion of about 9 articulated and divided rays; the foremost anal spines rather shorter and more curved than the following spines. Caudal pedicle very short and slender.

Form. \& Loc. Upper Cretaceous: Sahel Alma, Mt. Lebanon.

P. 4761. Type specimen described and figured by Davis, loc. cit. p. 516, pl. xxviii. fig. 1.

Lewis Coll.

48128. Second specimen noticed by Davis, loc. cit. p. 518. The characteristic toothless maxilla is conspicuous, and there are traces of minute teeth in the mandible. The large pelvic fin-spine is shown in impression; and some of the scales are weil preserved.

Lewis Coll.

46536. Another characteristic specimen, showing impression of ridged pelvic fin-spine and traces of the succeeding articulated rays.

Lewis Coll.

\section{Genus HOMONOTUS, Dixon.}

[Geol. Sussex, 1850, p. 372.]

An imperfectly known genus, with the trunk much deepened and laterally compressed. Dorsal fin much extended, its anterior portion comprising at least 12 long and slender spines, which are 
not pressed closely together; anal fin with four large spines gradually increasing in length backwards. Scales ctenoid, remarkably delicate, none enlarged or thickened.

\section{Homonotus dorsalis, Dixon.}

1850. Homonotus dorsalis, F. Dixon, Geol. Sussex, p. 372, pl. xxxv. fig. 2.

1888. Homonotus dorsalis, A. S. Woodward, Proc. Geol. Assoc. vol. x. p. 329.

Type. Imperfect fish; Brighton Museum.

The type species, probably attaining a length of about $0 \cdot 15$. Length of head with opercular apparatus less than the maximum depth of the trunk and exceeding half its length from the pectoral arch to the base of the caudal fin. Dorsal margin much arched, the dorsal fin arising at the highest point, nearly midway between the tip of the snout and the base of the caudal fin. The 12 dorsal fin-spines feebly furrowed, and the length of some at least equalling half the depth of the trunk at their insertion; the hinder part of the dorsal fin comprising probably 10 articulated and divided rays. Anal fin with smaller and stouter smooth spines than the dorsal, arising opposite the hinder end of the spinous portion of the latter. Serrations of scales small and inconspicuous.

Form. \& Loc. Senonian: S.E. England.

43264. Imperfect fish, in counterpart, with the head-bones and squamation much fractured; Upper Chalk, Bromley, Kent.

Purchased, 1871

33230. Remains of fish about 0.14 in length; Upper Chalk, Northfleet, Kent. Purchased, 1854.

P. 1952 a. Remains of head and trunk about 0.11 in length; Kent. Egerton Coll.

P. 7651. Fragmentary trunk, with pelvic fin showing 6 or 7 rays in addition to the spine; English Chalk.

Purchased, 1895.

P. 9443. Remains of small trunk, with spines of the dorsal and anal fins; English Chalk.

History uniknown.

39074. Fragmentary remains, showing some caudal vertebræ and portions of the pelvic, dorsal, and anal fins; Upper Chalk, Gravesend.

Bowerbank Coll.

P. 5682. Imperfect small trunk, in counterpart; (?) Grays, Essex. Harford Coll. 


1902. Homonotus dosalie, A.S. Loodurard, Fon. Fishe,

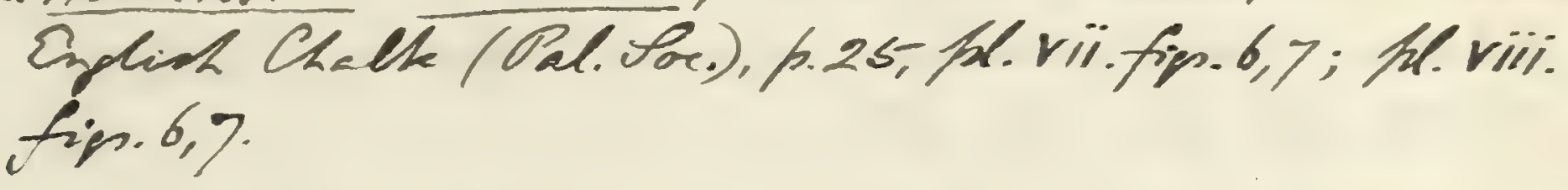

43264. Ocsunited a fipuned A.S. W. 1902, h.25, he. viil fis.7. 33230. Deserithd a fipured 2.S.2. 1902, 5.2\%, hl. vii. fis.7. Rigsza. Rsticed A.S.W. 1902, 5.25,26.

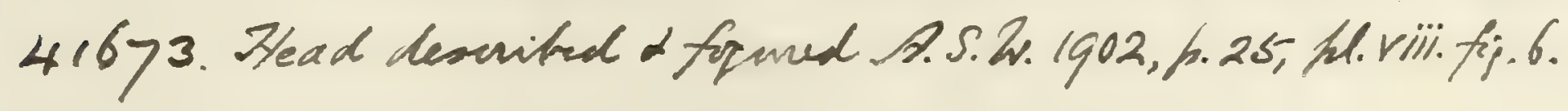

39074. Deseribed a figned A.S.2. 1902, h. 27. AL, vil.fi, 6.

$$
\text { P.5682 = H. rotindus. }
$$




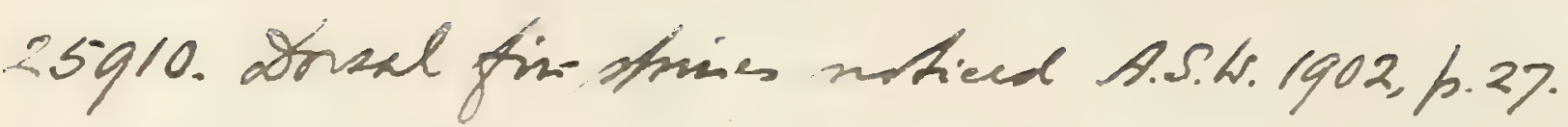

Homonotur rotundus, A.S.W. 190.2. Homonthe rotundur, A.S.Wordward, Fon.

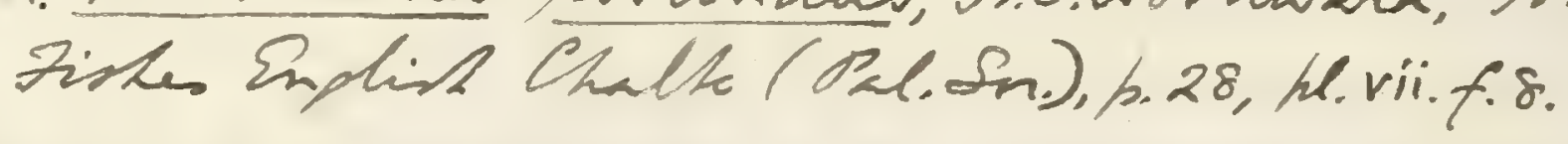

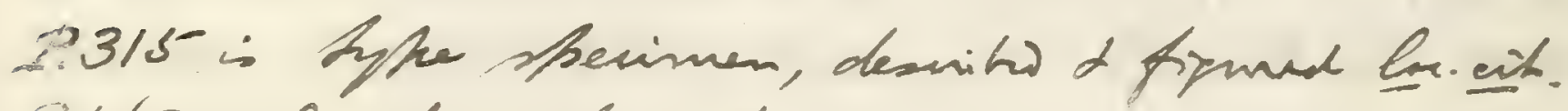
2.5682 also here, low. it.

Foplobteryx simus, A.S.W.

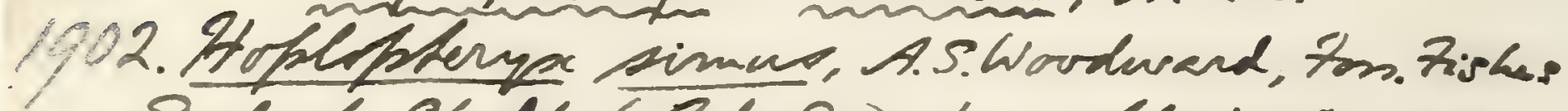

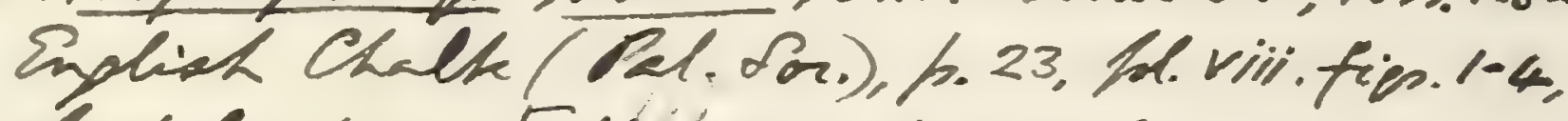
trat-fip. Se. [Sew 1912, f.246.]

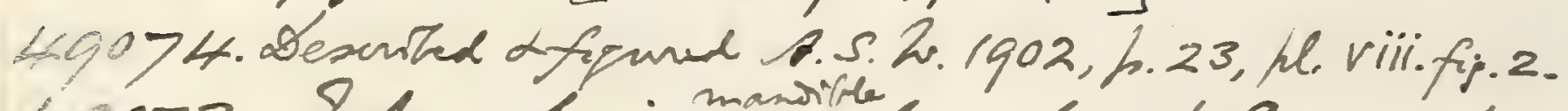

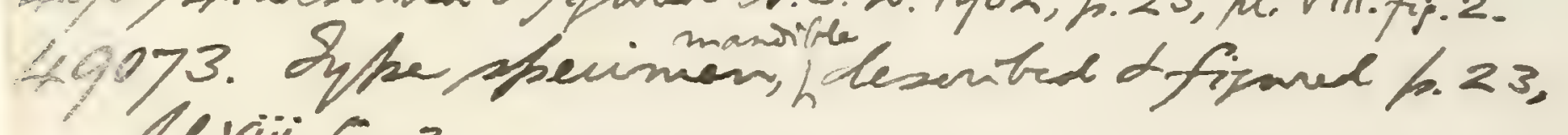
he. viii. fir. 3.

RY) 700. Basicranial canal usticed A.S.W. 1902, 6.23, head descit fir? fi. 23, hl.viii.fis. 1.

F387. Articed A.S.W. 1902, h. 23; fim, h.24; seabs dessibos a firmed, p. 24, hl. viil. fis. 4 . sook. Dertebure miticed A.S.W. 1902, 1,24.

Frackichnyodies - ps.563.

Genus TrachichEhyoides, A.S.W.

Trachichingoides omna Eus, A.S.2.

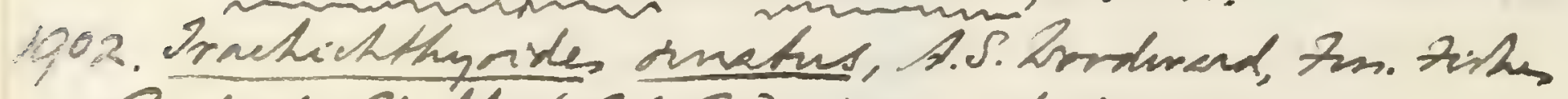

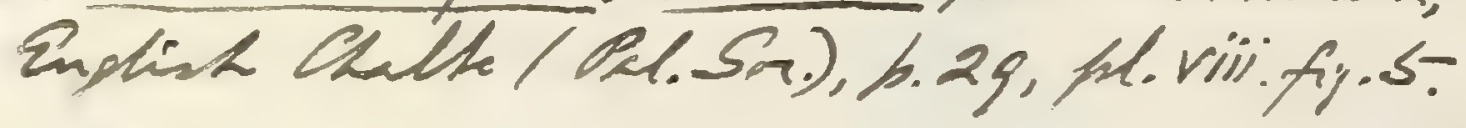

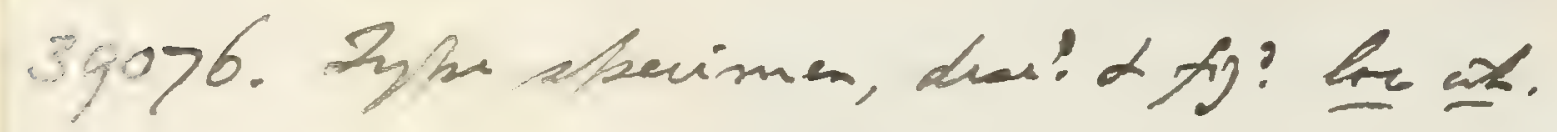




43575. Imperfect caudal region; Upper Chalk, Bromley.

$$
\text { Purchased, } 1872 .
$$

P. 1952. Imperfect caudal region, displaying part of dorsal and anal fins; Malling, Kent.

Egerton Coll.

P. 315. Very small distorted specimen, showing imperfect median fins and ctenoid scales; Westwell, Charing, Kent.

Harris Coll.

25910. Remains of small fish, with dorsal fin-spines; Sussex.

Dixon Coll.

28393. Imperfect distorted small fish, apparently of this species, figured as Beryx ornatus by Agassiz, Poiss. Foss. vol. v. pl. xiv c. fig. 2 ; Lewes.

Mantell Coll.

The following specimens from the English Chalk are not determined, but seem to belong to fishes related to some of the preceding genera:-

49073-75. Fine head and two fragmentary specimens, much resembling the head of Hoplopteryx but more coarsely ornamented; Kent.

Mrs. Smith's Coll.

39071. Similar smaller head; Lower Chalk, near Maidstone.

Bowerbank Coll.

P. 5700. More fragmentary similar head, displaying rostrum, upper jaw, and cheek-plates; Kent. Harford Coll.

49886. Fragmentary similar head and anterior scales; Lower Chalk, Dorking. Capron Coll.

P. 38\%. Fragmentary similar head with portion of trunk; English Chalk.

Presented by the Earl of Ducie, 1881.

4004. Fragments of similar head with anterior vertebræ, figured by Agassiz, Poiss. Foss. vol. iv. pl. xiv d. fig. 2, under the name of Beryx ornatus; Lewes.

Mantell Coll.

P. 5701. Small head; Kent.

Harford Coll.

P. 3982. Large distorted fish, with unusually broad tuberculated rim of circumorbital plates; Kent.

Enniskillen Coll.

390\%6. Ornamented head of unusual form, with operculum produced into one large broad spine; Bromley, Kent.

Bowerbank Coll.

Numerous otoliths from the Gault of Folkestone also seem to belong to the Cretaceous Berycoids. Most of these specimens are numbered 47213 and contained in the Gardner Coll. 


\section{Genus MYRIPRISTIS, Cuvier.}

[Règne Animal, ed. 2, vol. ii. 1829, p. 150.]

Trunk more or less elongated and laterally compressed. Frontal region of skull gently rounded, not ridged; cleft of mouth small, mandible prominent, and teeth minute. Opercular bones serrated; operculum pointed or produced into a spine behind; preoperculum without spine. Vertebræ 10-12 in the abdominal, about 15 in the caudal region. Pelvic fins with one spine and 7 divided rays, arising somewhat behind the origin of the pectorals. Dorsal fin much extended, almost or completely dirided into two halves, the foremost spinous; anal fin not much extended, with 4 spines; caudal fin deeply cleft. Scales large and ctenoid, more or less uniform, extending over the cheeks and opercular apparatus.

A figure of the skull of this genus is given by Agassiz, Poiss. Foss. vol, iv. pl. B. fig. 2. The existing species live at the surface of tropical seas.

Myripristis leptacanthus, Agassiz.

1796. Perca formosa, G. S. Volta, Ittiolit. Veron. p. Ixxx. pl. xvii. fig. 2 (errore).

1818. "Perca formosa," H. D. de Blainville, Nouv. Dict. d'Hist. Nat. vol. xxvii. p. 347.

1838-39. Myripristis leptacanthus, L. Agassiz, Poiss. Foss. vol. iv. pp. 5, 111, pl. xv. fig. 4 .

1876. Myripristis leptacanthus, F. Bassani, Atti Soc. Veneto-Trent. Sci. Nat. vol. iii. p. 176.

Iype. Imperfect fish ; Palæontological Museum, Munich.

A species attaining a length of about $0 \cdot 15$. Length of head with opercular apparatus very slightly exceeding the maximum depth of the trunk, which is contained three times in the total length to the base of the caudal fin. Operculum not produced behind into a spine. Spinous portion of dorsal fin, with 15 or 16 remarkably slender spines, more than twice as much extended as the soft portion, which comprises about 15 divided rays; anal fin more extended than the soft dorsal, the 4 spines gradually increasing in size, and followed by about 18 divided rays. Serrations of scales uniform.

Form. \& Loc. Upper Eocene: Monte Bolca, near Verona.

P. 1940, P. 393\%. Fine specimen, in counterpart, displaying all the fins.

Egerton \& Enniskillen Colls.

P. 1940 a, P. 3937 a. Good smaller specimen, in counterpart.

Egerton \& Enniskillen Colls. 


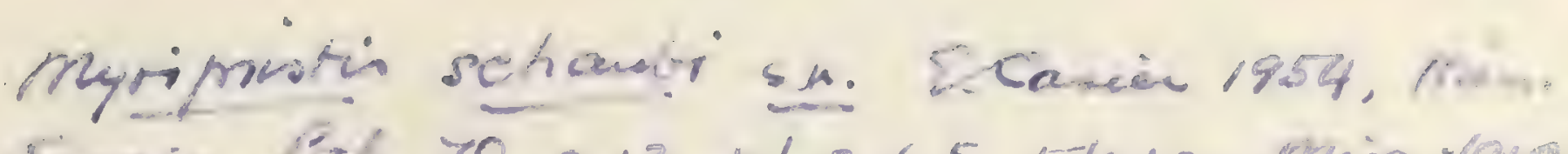

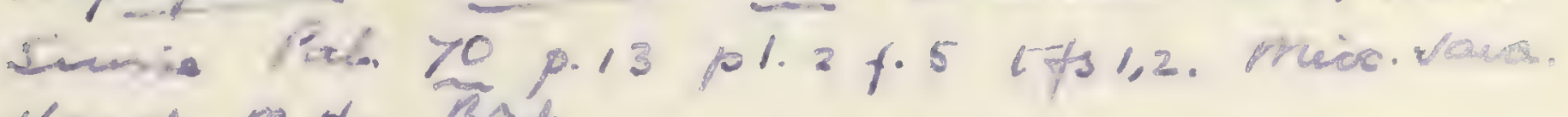
Head m.dn. Batle. 

P. 1940 b, P. 393 b. Slab with two imperfect fractured specimens, in counterpart, one displaying operculum.

Egerton \& Enniskillen Colls.

P. $1940 \mathrm{c}, \mathrm{d}$. Two good specimens, the second labelled by Agassiz.

Egerton Coll.

P. 4284. Fish $0 \cdot 15$ in length.

Enniskillen Coll.

P. 5134. More imperfect larger specimen, with scales and fin-rays partially scattered. Presented by Mrs. M. E. Fort, 1886.

13454, 21404-05. Three specimens, the third being counterpart slabs showing two small fishes.

Purchased, 1847.

ZZ, 1 (Cracherode Catal.). Imperfect small fish, in counterpart.

Cracherode Bequest.

P. 9444. Two small fishes on slab.

Purchased.

P. 1940 e, P. 3937 c, d. Three very small specimens, labelled by Agassiz.

Egerton \& Enniskillen Colls.

P. 1941. Very small specimen.

Egerton Coll.

P. 1943. Fish 0.038 in length, probably of this species.

Egerton Coll.

\section{Myripristis homopterygius, Agassiz.}

1796. Polynemus quinquarius, G. S. Volta, Ittiolit. Veron. p. cliii. pl. xxxvi. small figs. (errore).

1796. Perca, G. S. Volta, ibid. pl. lxxii. fig. 4 (errore).

1834. Myripristis homopterygius, L. Agassiz, Verhandl. Ges. vaterländ. Mus. Böhmen, p. 66 (name only).

1838-39. Myripristis homopterygius, L. Agassiz, Poiss. Foss. vol. iv. pp. 5, 112, pl. xv. fig. 3.

Type. Imperfect fish; Palæontological Museum, Munich.

Essentially identical with $M$. leptacanthus, but described as exhibiting stouter dorsal fin-spines, the head relatively longer, and the scales shorter in proportion to their depth.

Form. \& Loc. Upper Eocene: Monte Bolca, near Verona.

44866. Fine specimen 0.125 in length, in counterpart.

Presented by Benjamin Bright, Esq., 1873.

25952. Smaller, more imperfect specimen, labelled by Agassiz. 
P. 1939 , P. 1942 , P. 3936 b, P. 3938 . Two fine specimens in counterpart, and a more imperfect fish, all labelled by Agassiz. Egerton \& Enniskillen Colls.

P. 9445. Fish 0.09 in length, in counterpart. Purchased.

P. 1939 a, P. 3936 a. Two small specimens from the Gazola Collection. Egerton \& Enniskillen Colls.

P. 5135. 'Two imperfect small specimens.

Presented by Mrs. M. E. Fort, 1886.

The following specimens are too imperfect for determination, but the first was referred to Myripristis by Agassiz:-

P. 644-a. Two imperfect heads with opercular apparatus, the first intended to be the type specimen of Myripristis toliapicus, Agassiz, recorded by name only in Rep. Brit. Assoc. 1844 (1845), p. 307 ; London Clay, Sheppey. The incomplete cranium in the second specimen seems to be quite different from that of Myripristis.

Egerton Coll.

\section{Genus HOLOCENTRUM (Artedi), Curier.}

[Règne Animal, ed. 2, vol. ii. 1829, p. 150.]

Trunk more or less elongated and laterally compressed. Frontal region of skull gently rounded, not ridged; cleft of mouth small, mandible not prominent, and teeth minute. Opercular bones and suborbitals serrated; operculum with two spines; angle of preoperculum produced into spine. Vertebræ 10 or 11 in the abdominal, 15 or 16 in the caudal region. Pelvic fins with one spine and 7 divided rays, arising behind the origin of the pectorals. Dorsal fin much extended, divided into two portions, the foremost spinous; anal fin not much extended, with 4 spines, of which the third is relatively stout and long; caudal fin deeply cleft. Scales large and ctenoid, more or less uniform.

A figure of the skeleton of an existing species of this genus is given by Agassiz, Poiss. Foss. vol. iv. pl. B. fig. 1. The existing species live at the surface of tropical seas.

Holocentrum macrocephalum, Blainville.

1796. Holocentrus sogo, G. S. Volta, Ittiolit. Veron. p. ccx. pl. li. fig. 2 (errore).

1796. Chretodon saxatilis, G. S. Volta, ibid. p. cclxv. pl, lxiv. fig. 1 (errore). 


HOLOCENTRIDR.

Kansius sternberg; n.9.n.s, L. Hussakott, 1929, Cimer.

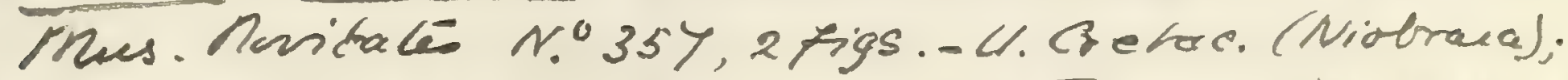

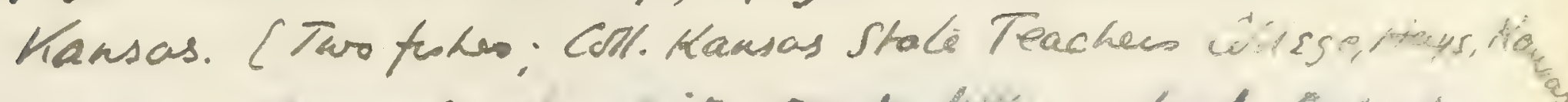

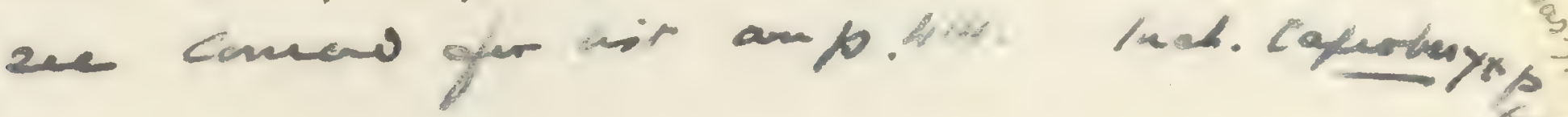

Tenvicentrum pattersoni gen +sp.nor., L. Sorbini 1975, Mem. Mus. Verma, furi serie, p.456. L. Eocerre, Moute BAca, anplate fish, gest. Inst, Ninir Padua.

Eoholocutrum gen wor. L. Sorbinit R. Tirapelle, 1974 , Mem. Tho . Verma, fuci serie, E.manouphalum, typersp. Sorbenite Tivagelle '74, pls + figs 
19il, CR. Eastmon, Mem. Camegie Muss. Iv, pl.xeis. loos. 10.21.

Monocentris coxi sin Soe. Maubadot, Plasien 1958, Sches. Pah. Hbh. Zik: 23 pliit.13

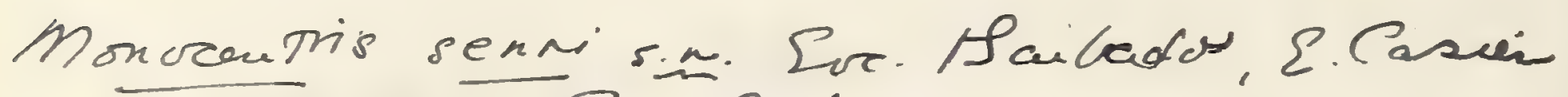
1958, Sckev. Pah. Abh. Zle: 24, Hiil tik.

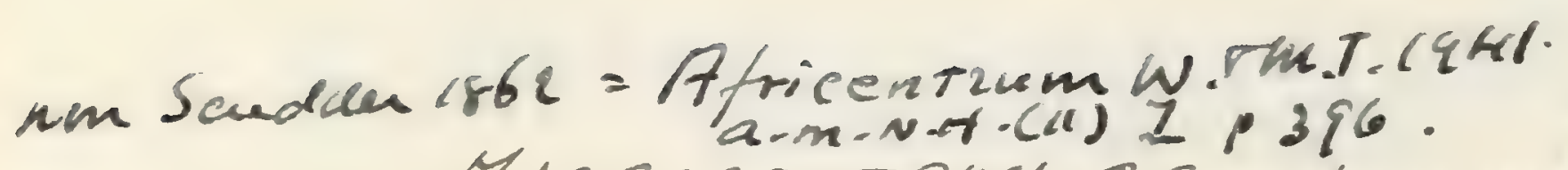
M/CRocem-ver.al) I 1396 .

MICROCENTRUM, C. Arambous 1927.

1927. Microcentiun mekitonse, C. Aramboung, p.76, pl.xit/s: sh. xiff.1.2. Sanelian; Oran.

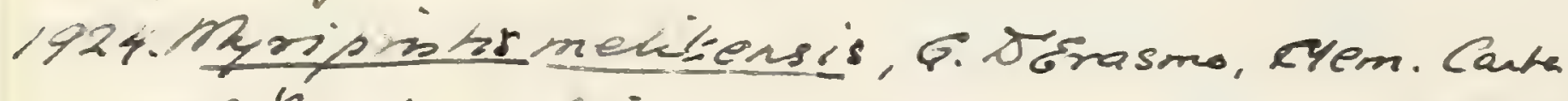

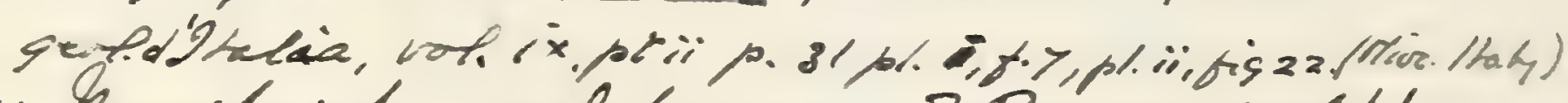

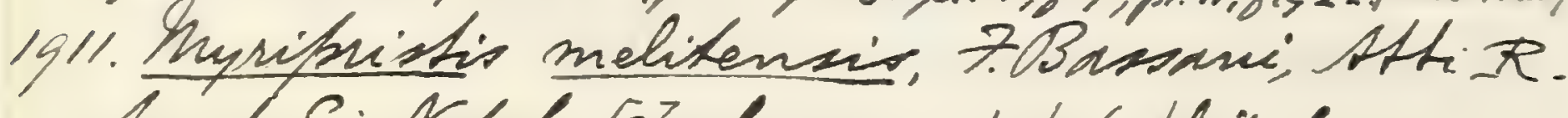
Acead. Sai Stapdi [z] rd. xv. no. 1, h. 6, hl. ii. fip. 2.

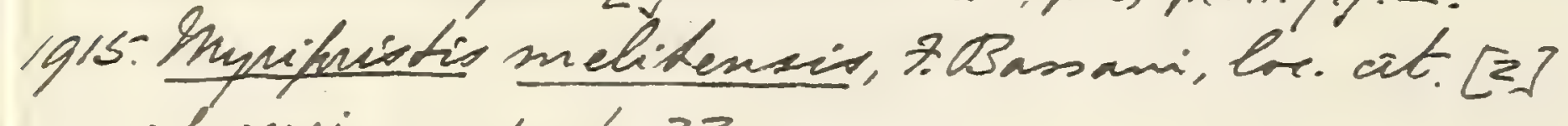
vol Xvi. no. 4, p. 33 .

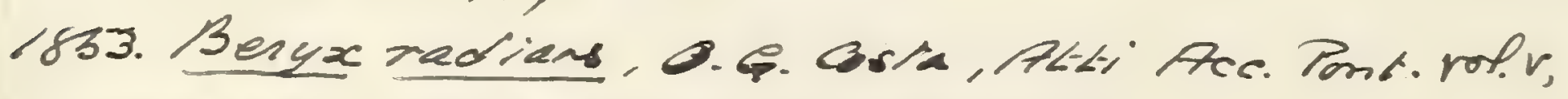

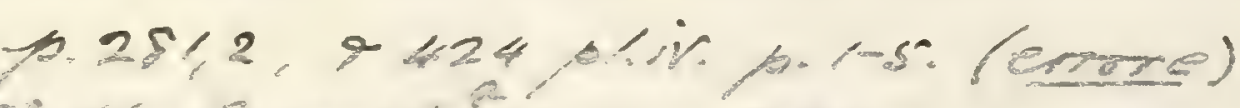

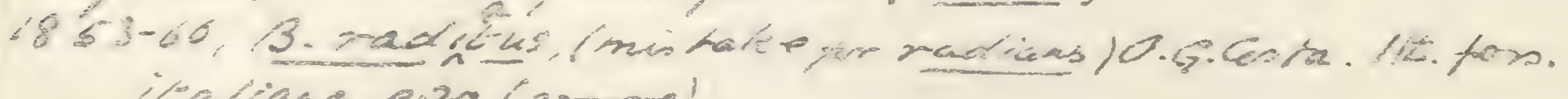




1796. Chatodon, G. S. Volta, ibid. pl, lxxii. fig. 1 (errore).

1818. Holocentrus macrocephahus, H. D. de Blainville, Nour. Dict. d'Hist. Nat. vol. xxvii. p. 349.

1818. Chatodon saxatilis, H. D. de Blainville, ibid. p. 3533 (errore).

18.,44-36. Holocentrum pygcum, L. Agassiz, Poiss. Foss. vol. iv: pp. 6, 107, pl. xiv. [Imperfect fish ; Carlsruhe Museum.]

Type. Imperfect fish; Paris Museum of Natural History.

A species attaining a length of about $0 \cdot 15$. Length of head with opercular apparatus about equal to the maximun depth of the trunk and contained one and a half times in the length from the pectoral arch to the base of the caudal fin. Opercular apparatus conspicuously ornamented with irregular ridges and tubercles; preopercular spine very short; upper opercular spine large and broad, lower spine comparatively insignificant. Dorsal fin with 11 ribbed spines and 11 or 12 divided rays, the latter portion comparatively deep but less than half as much extended as the former portion; anal fin with 4 ribbed spines and 8 or 9 divided rays, the fourth spine very slender, the stout third spine only feebly ribbed and as long as the longest dorsal spines, of which the length scarcely equals half the depth of the trunk at their insertion. Scales very delicately serrated.

Form. \& Loc. Upper Eocene: Monte Bolca, near Verona.

P. 1925, P. 3981. Fine large specimen, in counterpart, labelled Holocentrum pygceum by Agassiz, displaying the fins and the large opercular spine. Egerton \& Enniskillen Colls.

P. 1925 a, P. 3981 a. Smaller, more imperfect specimen, in counterpart. Egerton \& Enniskillen Colls.

P. $1925 \mathrm{~b}-\mathrm{d}$. Three small specimens. Egerton Coll.

P. 3981 b. Imperfect small specimen. Ennistitlen Coll.

3,p203-04. Two more fragmentary small specimens, the second displaying the operculum chiefly in impression and a detached preoperculum.

Purchased, 1861.

Holocentrum melitense, A. S. Woodward.

1887. Holocentrum melitense, A. S. Woodward, Geol. Mag. [3] rol, it. p. $35 \tilde{r}$.

Type. Imperfect fish, wanting head; British Museum.

An imperfectly known species, attaining a length of about 0.35 . Maximum depth of trunk contained somewhat less than one and a 
half times in the length from the pectoral arch to the base of the caudal fin. Dorsal fin-spines apparently shorter and scales relatively larger than in the preceding species. Serrations of scales very fine.

Form. \& Loc. Miocene: Malta.

P. 5310. Type specimen, described loc. cit. Purchased, 1887.

The following extinct species is not represented in the Collection :-

Holocentrum pygmceum, L. Agassiz, Poiss. Foss. vol. iv. (1835-39), pp. 6, 47, 109, 1l. xv. fig. 1.-Upper Eocene; Monte Bolca. [Imperfect fish; Paris Museum of Natural History.]

Otoliths apparently of this family, not represented in the Collection, have been described as follows :-

Otolithus (Hoplostethus) ingens, E. Koken, Zeitschr. deutsch. geol. H.i mut. granat, Ges. vol. xliii. (1891), p. 117. O. (Apogonidarum) éris nov. B. Meléndez ingens, E. Koken, loc. cit. vol. xxxvi. (1884), p. 550,

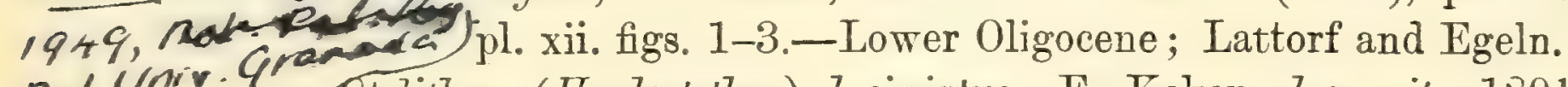
Bot Univ.Gratolithus (Hoplostethus) laciniatus, E. Koken, loc. cit. 1891, 2t p.132 blivis p. 117, fig. 10. O. (Apogonidarum) laciniatus, E. Koken, plivi.2 Gravad Abh. phys. Cl. k. Ges. Wiss. Göttingen, vol. xxxii. (1885), p. 115, pl. v. fig. 26.-Lower Eocene; Copenhagen.

tolithus (Hoplostethus) lawleyi, E. Koken, loc. cit. 1891, p. 115, pl. ix. fig. 2.-Pliocene; Orciano, Tuscany.

Otolithus (Hoplostethus) nettelbladti, E. Koken, loc. cit. 1891, p. 116, pl. ix. fig. 6.- Upper Oligoceno; Sternberg.

Otolithus (Hoplostethus) ostiolatus, E. Koken, Toc. cit. 1891, p. 116, pl. ix. figs. 4, 5.-Middle Oligocene; Waldböckelheim.

Otolithus (Hoplostethus) pisanus, E. Koken, loc. cit. 1891, p. 115, pl. ix. fig. 1.-Pliocene; Orciano.

Ototithus (Monocentris) hospes, E. Koken, Toc. cit. 1891, p. 119. O. (Apogonidarum) hospes, E. Koken, loc.cit. vol. xl. (1888), p. 278, pl. xviii. fig. 15.-Lower Tertiary; Jackson River, Mississippi.

Otolithus (Morocentris) integer, E. Koken, loc. cit. 1891, p. 119, fig. 13. O. (Apogoridarum) integer, E. Koken, loc. cit. 1885 , p. 114, pl. . fig. 27.-Lower Eocene; Copenhagen. 



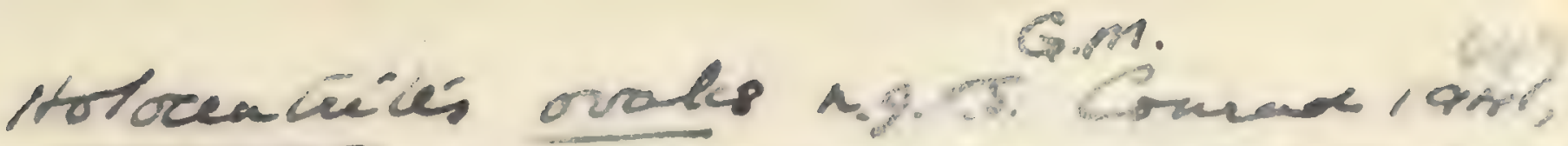

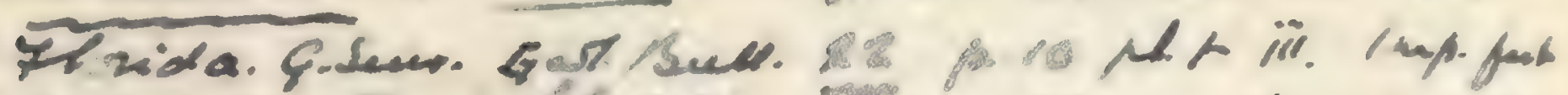

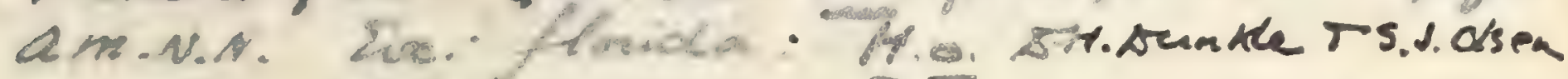

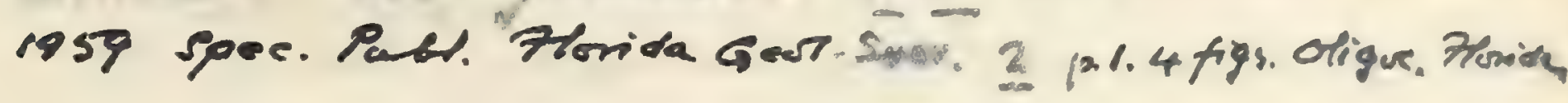

P. 6310 fj: Ls Banami, 1911 .

O. (Hoflostethers) magnuo, K. Pieragnoli, Div. 2tal. Dalents.

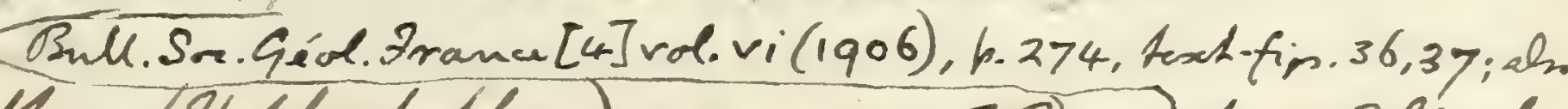
Otrlithus (Asplostethus) sauvapei, Friem, trun-Paléont. rd.viliqull, h.2\%, Lexh-fir. 19, 20. - Luthation; Grignon, Pormes. [Mm. 1. H. Paria]

Molithur (Hoplostether) Gambergex, FRiem, Bull. Sor. Géd. France $[4]$ rol. xiii. $(1913), 1$. 153,fij.5.- Erene (Zutetion); Le Boir Gouet, Toire Inférieure, France.

Hoplostethur hexaponalio, Mn. Seriche, Mém. Soe. Géol. Nod, vol. v (1906), h.238, texthfi.s.5:-

Otolithus (Mnoreentris) Gellovacinuo, FPriem, then

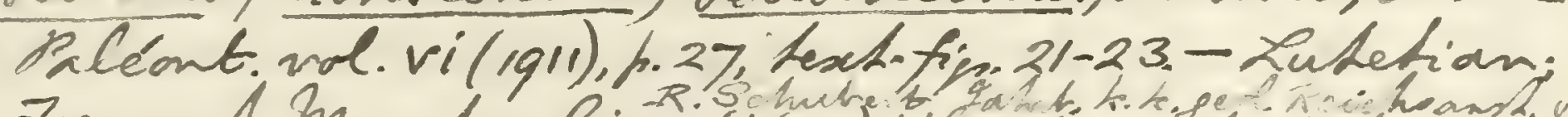

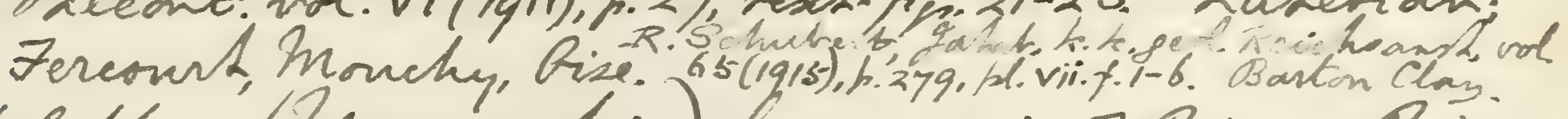
Strlithus (Mvocentris) lemoinei, 7. Piem, Diss. Frs. Bassin Parisien (Publ. Arm. Paléont. 1908), 1.83, testofip. 39-42. O. (Sparidarum) lemrinei I. Priem, Bull. Sor. Ge'vl. Irance [4] vol, villgob), h.273, Haxl:34,35:- Thanetian; Marme, Mance. How centrir Lemoinei, Sn. Leriche, Am. Sor. Géol. Nad, vol. xxxvii/(1908), r.246, hl, vi.fin 7,8 .

Otolithers (Mionocentir.) Cerichei, R. Schubert, gahb.

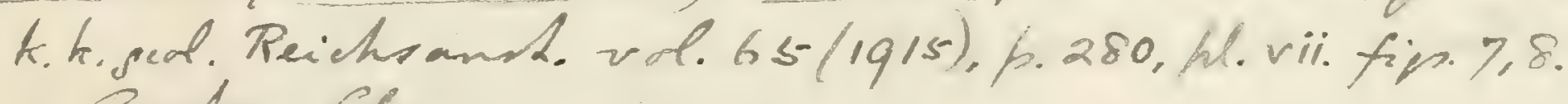
- Bartorn Clay. 
Aflithur (Beryadarrum?) Gorryi, 7. Biem, Bull.

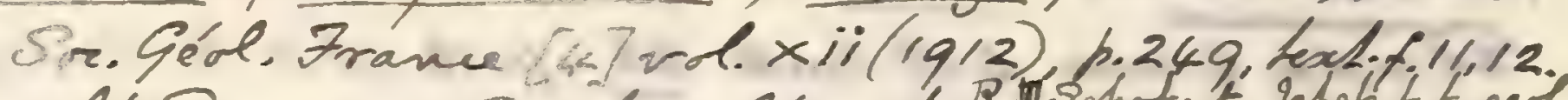

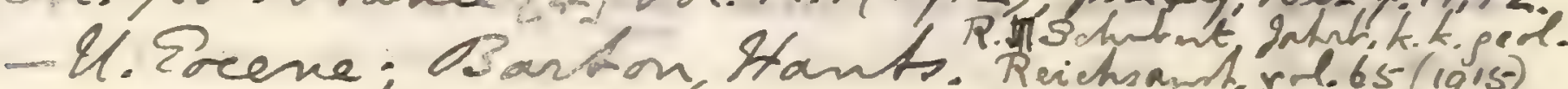

Reichnant rlel.65 (1915),

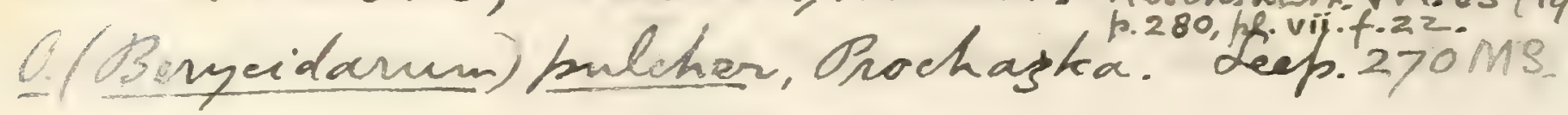

Hothus (Beryx?) Garkmensis, R. Schubert. whr. K. te.ged. Peichsanst. vol. 65-(1915), p.279.

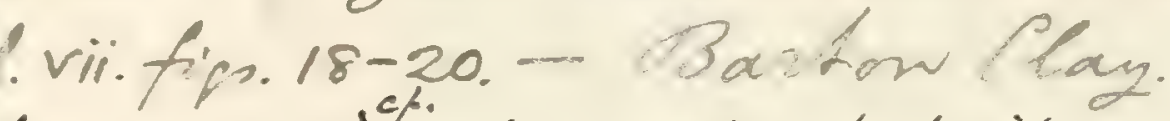

0. (Monocentris) subrotundus, W. Weilkr, abh. hess gerthandesanst.

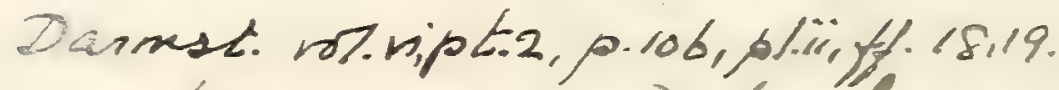

(Beycidanun) Fonlei d oubicularis, sup.323.

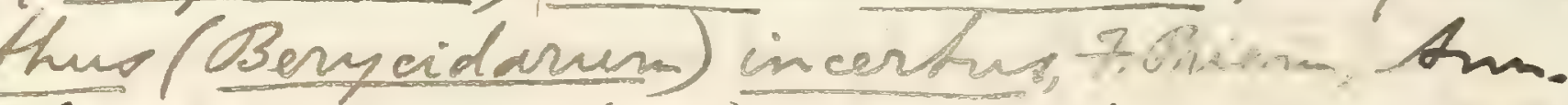
aléant. vol. vi(1911), h.28, test.tip. 24,25: Lutetion; Bercourt, near Mouchy, Rise.

Eitima evider. D. T. Findan d 4. Z. Gilbert, Fon. The P.California / Ptanford Unir. Public., mir. Ter. (919), p. 40, pl. xxiii.tip, 1. - L. Plicene;

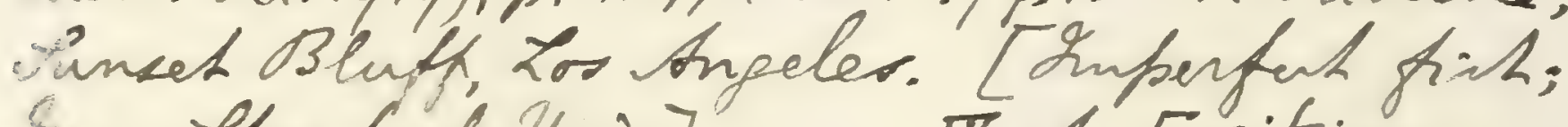
Sus. Thanford Univ.? T. of Eritima. Belugs io Apogenida Tondan, Fish tauna Calif.

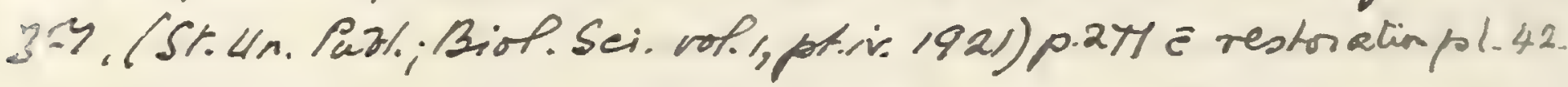

Cenciarchies edonadenser, 7. O.O. Cekenell

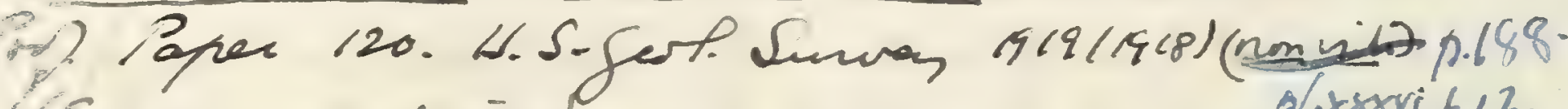
sucentianchioicf ploxexvit.12. Hreacentrotices mupcovicus, n.g.rs. M. Paural, 1931, Buer. Acad. Loumacin, xir. p.33 kf.

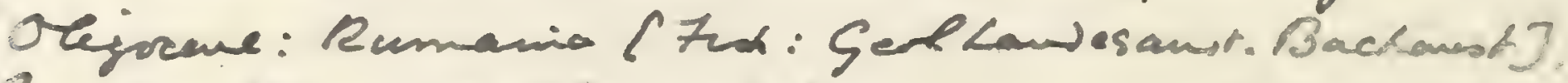
Pruca, 1933, h. $20,1 \% \cdot 2$, 

Otolithus (Monocentris) subrotundus, E. Koken, 7oc. cit. 1891, p. 118, fig. 12. O. (Apogonidarum) subrotundus, E. Koken, loc. cit. 1884, p. 552, pl. xii. figs. 4, 5.-Lower Oligocene;

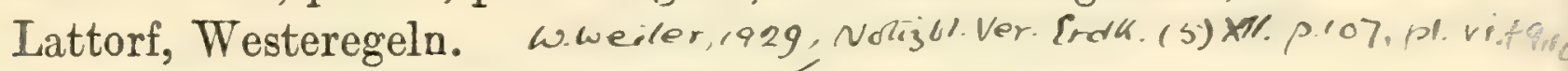

Otolithus (Berycidarum) debilis, geron, parvulus, neglectus, and rhenanus, E. Koken, loc. cit. 1891, pp. 120-123, pl. v. figs. 3, 10, pl. viii. fig. 5, pl. ix. figs. 7, 8, pl. x. figs. 4, 5, 16.-Oligocene and Lower Miocene; Germany.

Otolithus (Berycidarum) supracretaceus, E. Koken, Palæontogr. vol. xxxviii. (1891), p. 39, fig. 3.-Upper Cretaceous; Siegsdorf, Bavaria.

Indeterminable fragments possibly of Berycoids, from the Turonian of Bohemia, now in the Royal Bohemian Museum, Prague, are described as follows:-

Electrolepis horrida, A. Fritsch, Archiv naturw. Landesdurchf. Böhmen, vol. ix. no. 1 (1893), p. 72, fig. 45. [TJpe species. Scales.]

Spinacites radiatus, A. Fritsch, ibid. p. 72, fig. 46. [Type species. Fin-spine.]

The specimens described as follows have also been referred to the Berycidæ, but they are too imperfect for precise systematic determination :-

Lobopterus pectinatus, D. G. Kramberger, Djela Jugoslav. Akad. vol. xvi. (1895), p. 45, pl. viii. fig. 5.-Cretaceous; Comen, Istria. [Type species. Imperfect small abdominai region; Trieste Museum.]

Macrolepis elongatus, W. von der Marck, Palæontogr. vol. xi. (1863), p. 16, pl. xii. fig. 2.-Upper Cretaceous; Sendenhorst, Westphalia. [Type species. Imperfect fish; Academy of Münster.]

Pristigenys macrophthalmus, L. Agassiz, Neues Jahrb. 1835, p. 299 (name only), and Poiss. Foss. vol. iv. (1839), p. 136 (no figure published). Choetodon striatus, G. S. Volta, Ittiolit. Veronese (1796), p. xcii. pl. xx. fig. 2 (errore), Chcetodon substriatus, H. D. de Blainville, Nouv. Dict. d'Hist. Nat. vol. xxvii. (1818), p. 352.-Upper Eocene; Monte Bolca. [Type species. Imperfect fish; Paris Mustum of Natural History.] Pristrgenys subsiriates

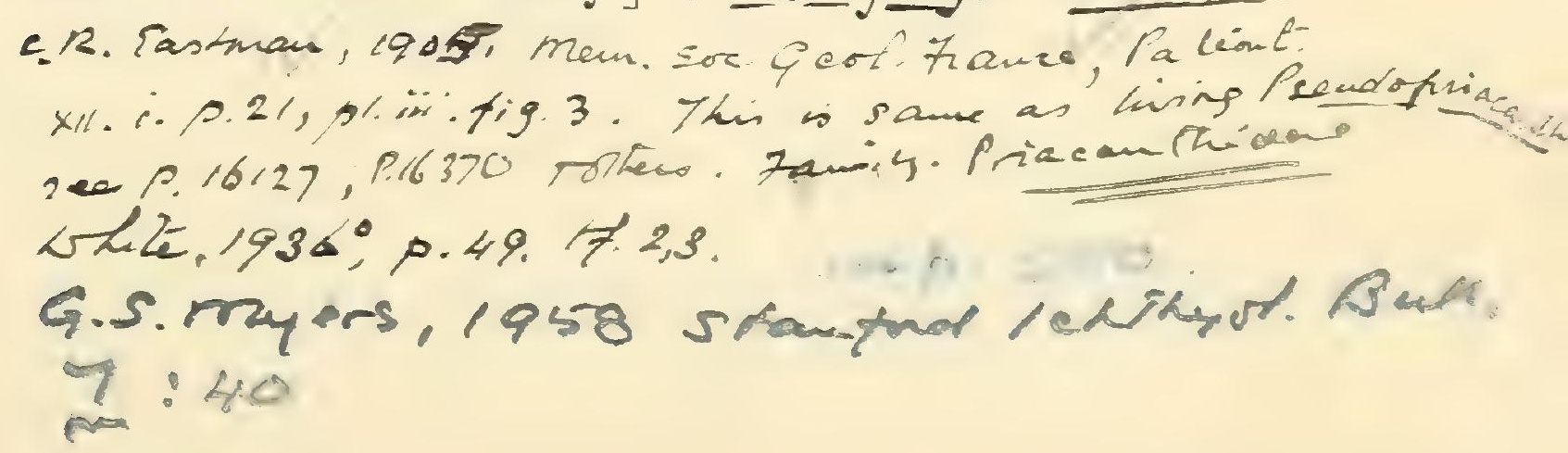




\section{Family APHREDODERID压.}

American freshwater fishes, essentially similar to the Berycidæ, but with premaxillæ not protractile, no distinct lateral line, and the vent very far forward. Each pelvic bone forked.

No extinct members of this family are represented in the Collection, but the following genera and species have been described from American freshwater formations :-

Amphiplaga brachyptera, E. D. Cope, Bull. U.S. Geol. Surr. Territ. vol. iii. (1877), p. 812, and Vert. Tert. Form. West, Book I. (Rep. U.S. Geol. Surv. Territ. vol. iii. 1884), p. 84, pl. xii. fig. 4.-Eocene (Green River Shales); Twin Creek, Wyoming. [The tspe species. Imperfect trunk; National Museum, Washington.]

Erismatopterus endlichi, E. D. Cope, Toc. cit. 1877, p. 811, and op. cit. 1884, p. 82, pl. xii. fig. 5.-Eocene (Green River Shales); Wyoming. [Imperfect fish; National Museum, Washington.]

Erismatnpterus levatus, E. D. Cope, Ann. Rep. U.S. Geol. Surv. Territ. 1870 (1871), p. 428, and op. cit. 1884, p. 80, pl. ix. figs. 6, 7. Cyprinodon levatus, E. D. Cope, Proc. Amer. Phil. Soc. vol. xi. (1870), p. 382.-Ibid. [Ditto.] Erismatopterus rickseckeri, E. D. Cope, loc. cit. 1870, p. 427, and op. cit. 1884, p. 81, pl. vi. fig. 2.-Ibid. [The type species. Ditto.J ? Amen. Mmen. $27 \%$

Trichophanes copei, Osborn, Scott, \& Speir, Palæont. Rep. Princeton Sci. Exped. 1877 (1878), p. 98.-Lower Tertiary; Florissant, South Park, Colorado.

Trichophanes foliarum, E. D. Cope, Bull. U.S. Geol. Surv. Territ. vol. iv. (1878), p. 73, and op. cit. 1884, p. 753, pl. lix. fig. 4.-Lower Tertiary; Florissant, Colorado. [Imperfect fish ; National Museum, Washington.]

Trichophanes hians, E. D. Cope, Proc. Amer. Phil. Soc. vol. xii. (1872), p. 480, and Ann. Rep. U.S. Geol. Surv. Territ. 1872 (1873), p. 642, and op. cit. 1884, p. 753, pl. lix. fig. 3.-Lower Tertiary; Osino, Nevada. [The type species. Ditto.]

The following genus, with two species, is supposed to represent an extinct family AsINEOPID $\mathbb{x}$, closely related to the Aphredoderidx but having the pelvic bones not forked:- 
451 
Arinesps aguamifroms, 7.D. A. Cockerell, Zod. Angeigen, od. xTr (1914), h.19i (stmeture of sealer.

Lojustatao

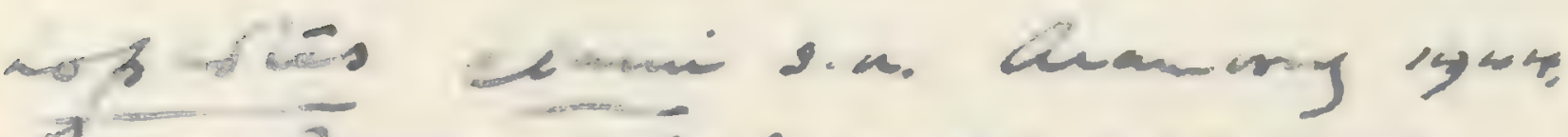

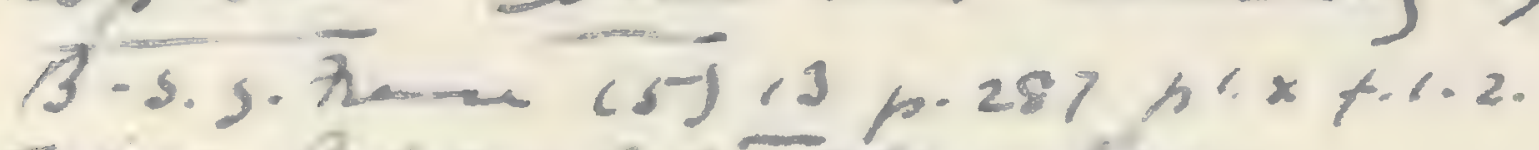

poto bolotes gen. av. elami, V. watters, 1957, Copreia $1957,1,0.60$.

Zeiformen.

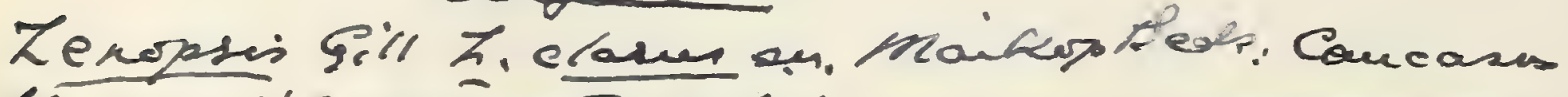

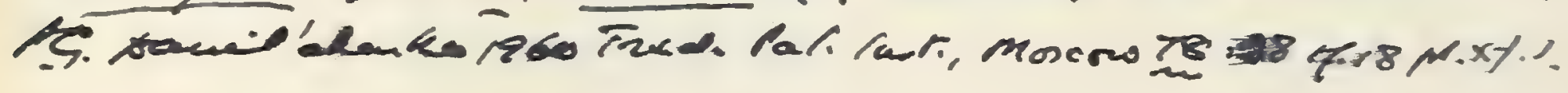

Theocth:

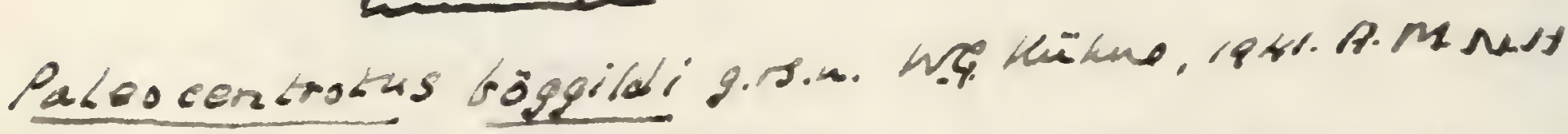

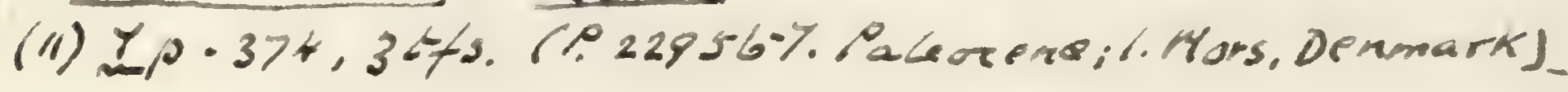

Heus primaeves Cooki, G. Frrarmo, 1930\% p.s3, phi.g.g. Senisaccicos.

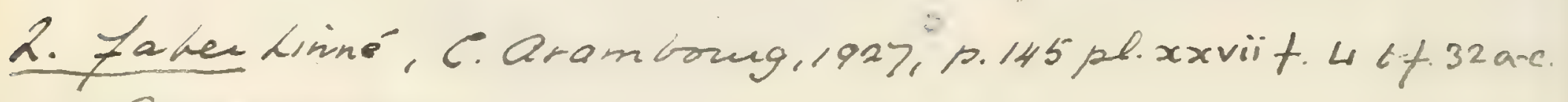
Saheliams oran. 


Asineops panciradiatus, E. D. Cope, Bull. U.S. Geol. Surv. Territ. vol. iii. (1877), p. 813, and op. cit. 1884, p. 87, pl. xiv. fig. 1.-Eocene (Green River Shales); Twin Creek, Wyoming. [Imperfect fish; National Museum, Washington.]

Asineops squamifrons, E. D. Cope, Proc. Amer. Phil. Soc. vol. xi. (1870), p. 381, and Ann. Rep. U.S. Geol. Surv. Territ. 1870 (1871), p. 426, and op. cit. 1884, p. 85, pl. ix. fig. 5, pl. xi. Asineops viridensis, E. D. Cope, Ann. Rep. 1870 (1871), p. 426.-Eocene (Green River Shales); Green River, Wyoming. [The type species. Ditto.]

\section{Family CYTTID $\mathbb{E}$.}

Head without superficial carities for mucus; premaxillæ protractile, and dentition feeble. Branchiostegal rays 7 or 8 in number. Vertebræ about 30 in number; the posterior abdominal centra with downwardly bent transverse processes. Pelvic fins with one spine and more than five articulated rays; dorsal and anal fins extended, the former at least with anterior spines, which are not so numerous as the articulated rays. Squamation either irregular, very fine, or absent, often comprising only a few scutes ; lateral line inconspicuous.

There do not appear to be any fossils in the Collection referable to this family.

A distorted fish, with incomplete pelvic fins, too imperfect for precise determination, has been compared with the existing genus Cyttus and described as follows:-

Cyttoides glaronensis, A. Wettstein, Fischfauna Tertiaer. Glarnerschief. (Denkschr. schweiz. Palæont. Ges. vol. xiii. 1886), p. 91, pl. viii. fig. 5.-Oligocene; Glarus. [Imperfect distorted fish; Glarus Museum.]

Extinct species of the existing genus Zeus are also imperfectly known as follows:-

Zeus benoisti, R. Lawley, Nuovi Studi Pesci, \&c., Colline Toscane (1876), p. 65, pl. iv. fig. 5.-Lower Pliocene; Orciano, Tuscany. [Dermal plate.]

Zeus hoernesi, D. G. Kramberger, Rad Jugoslav. Akad. vol. cri. (1891), p. 86, pl. i. figs. 2, 4-7, pl. vi. figs. 1, 2.-Upper Oligocene; Tüffer, Steiermark. [Fragmentary fish.] 
Zeus pliocenious, R. Lawley, op. cit. p. 65, pl. ir. figs. 4, 6.Lower Pliocene; Orciano. [Dermal plate.]

Zeus robustus, D. G. Kramberger, 7oc. cit. 1. 88, pl. i. figs. 1, 3, 8, pl. ri. fig. 3, and Djela Jugoslar. Akad. rol. xri. (1895), p. 62, pl. xii. fig. 1.- Tpper Oligocene: Tüffer. [Fragmentary tish.]

Indeterminable fragments of fishes from the Upper Miocene of Licata, Sicily, are named Zeus Ticatce by H. E. Saurage, Ann. Sci. Nat. [5] rol. sir. (1870), art. no. 7. p. 7, and Ann. Sci. Géol. rol. ir. (1873), art. no. 1, p. 147, figs. 43,4 .

\section{Dirision B. SCOMBRIFORMES.}

Pelric fins thoracic, nerer with more than fice articulated rass in addition to the spine, rarely without spine but more than five articulated rays. Dorsal and anal fin-spines either rery few or comparatirely feeble. Caudal pedicle much contracted. No bony staj betrreen circumorbital ring and preoperculum.

Synopsis of Famities represented by Extinet Genera or Species.

I. Snout not produced.

Ferr crowded spines in front of much-extended dorsal fin; rertebræ 28 to 40 in total number. Spinous portion of dorsal fin much less extended than articulated portion; Fertebre $2 \pm(10+14)$ in total number, rarely one more or less ...............

Spinous portion of dorsal fin more extended than articulated portion; vertebre 30 to 160 in total number .............

II. Snout produced into elongated rosStromateide (p. 419)

Caraxgide (p. 425). trum.

Skeleton rery delicate; rertebræ 50 to 60 in total number; pelric fins complete ............. Sheleton rery robust; rostrum formed by premaxilli; vertebræ 24 to 26 in total number; pelric fins reduced or wanting...... PALAORHYNCHIDAe (p. 482). SCOMBRIDE $(p, 451)$. Xiphime (p. 490). 

CAPROIDE.

Capros aper Lac., C. Aramboug, $1927, p .148, p l \cdot x x+$ i f.2-4, ph.xxviïf.1, 6.6.33, 34A.B. Sahelian; Oran. G. Siranono

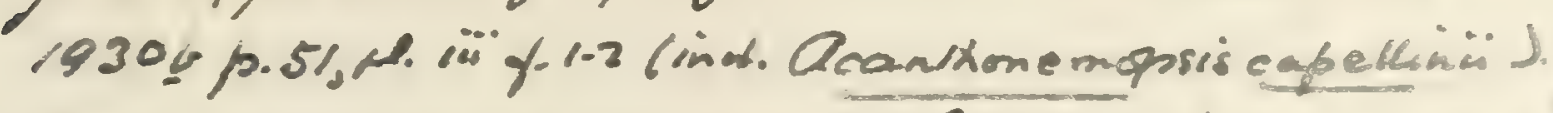

Copros steindachneri, n.s., C. Aramboung, $1927, p .152, p 1$.

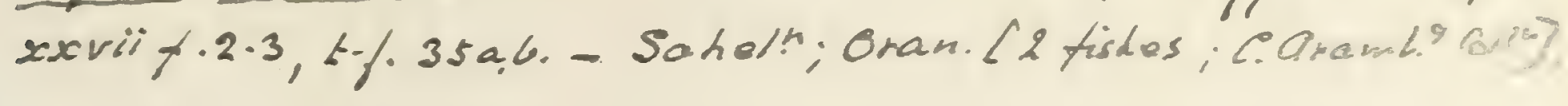

Revision of tornil spp. M. Paucai, 1930, Bull Acal.

Roumanis, x III " p. I

See also pp. soo (Acames) ' 363 (Okestaneí) b. $4 \sin 1932^{\circ}, 192-4$, tProantigmia) $55 y$

Caprovesposas gen nor. T. S. parms en.

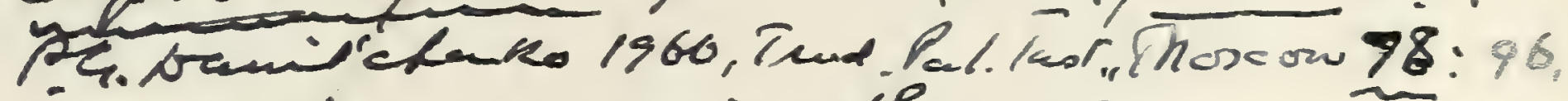
F. 20 pli ix f. 2.3. Naikup Heds, Camagen.

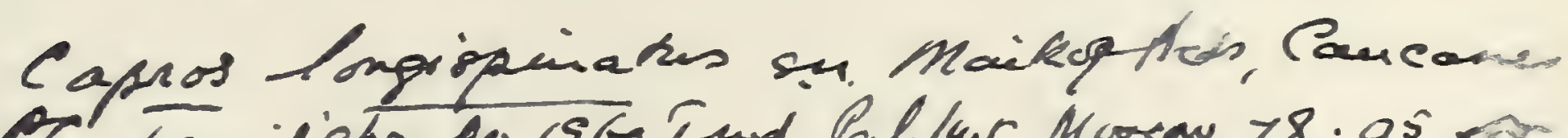

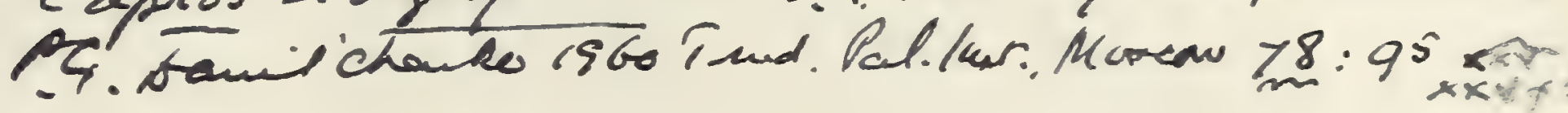




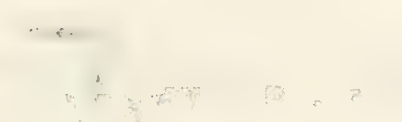



1912. Omosoma pathel almot, 9.2'Erasmo, Rivirta Ital. Daleont. wsl. xviii.t., pl.iii.ti.s- 


\section{Family STROMATEID A.}

Snout not produced into an elongated rostrum; premaxillæ sometimes protractile; dentition feeble. Vertebræ between 28 and 40 in number; the posterior abdominal centra with downwardlybent transverse processes. Pelvic fins, when present, thoracie, with one spine and five articulated rays; corsal and anal fins much extended, each with few crowded anterior spines gradually increasing in length to foremost articulated ray, which is longest. Scales very small and regular, usually extending over the cheek and bases of the median fins; lateral line conspicuous. In the existing forms :air-bladder usually absent; œesophagus pierced and armed with numerous horny, barbed gill-rakers.

Pelagic and littoral fishes very widely distributed in tropical and temperate regions.

The three extinct genera recorded below are only provisionally placed in this family.

\section{Genus OMOSOIMA, Costa.}

[Mem. R. Accad. Sci. Napoli, vol. ii. 1857, p. 106.]

Cleft of mouth small, only slightly oblique, and jaws with very minute teeth. Vertebræ about 12 in the abdominal, 16 to 18 in the caudal region. Postclavicle much elongated and slender, reaching ventral border; pelvic fins slightly behind the pectorals; dorsal and anal fins acuminate in front, with very few, moderately stout, anterior spines, gradually lengthening and closely pressed together; caudal fin deeply forked. Scales small, smooth, and cycloid, apparently longer than deep, extending over the opercular apparatus, head, and base of dorsal and anal fins.

\section{Omosoma sahel-almæ, Costa.}

1857. Omosoma sach-el almee, O. G. Costa, Mem. R. Accad. Sci. Napoli, vol. ii. p. 106, pl. i. fig. 1.

1887. Omosoma sah-el-alma, J. W. Davis, Trans. Rog. Dublin Soc. [2] vol. iii. p. 543, pl. xxv. fig. 5.

1887. Imogaster auratus, J. W. Davis, ibid. p. 541, pl. xxviii. fig. 3 (errore).

Type. Imperfect fish; Geological Museum, University of Naples.

The type species, attaining a length of about $0 \cdot 1$. Length of head with opercular apparatus equal to maximum depth of trunk and one third total length of fish to fork of tail. Dorsal fin with about 
35 , anal with not more than 30 articulated rays ; each probably with four anterior spines.

According to Bassani (communicated MS.), the type specimen exhibits about 36 articulated rays in the dorsal fin and not less than 27 in the anal fin. The number of spines is uncertain.

Form. \& Loc. Upper Cretaceous: Sahel Alma, Mt. Lebanon.

49583, P. 4862. Two distorted large specimens, the first with traces of ova, the second erroneously referred by Davis 7oc. cit. to Imogaster auratus. In the second, there seem to be four anterior spines distinguishable both in the dorsal and anal fin.

Lewis Coll.

49580. Fine specimen, apparently showing natural proportions of fish. Minute teeth are seen on the premaxilla.

Lewis Coll.

48082. Imperfect specimen on slab with other fish-remains.

Lewis Coll.

47392, 4781\%, 48126, 49584. Four imperfect specimens, the fourth largest and displaying the jaws with minute teeth.

Lewis Coll.

Omosoma intermedium, sp. nov.

Type. Nearly complete fish; British MIuseum.

A small species, attaining a length of about 0.07. Length of head with opercular apparatus considerably less than maximum depth of trunk, and contained twice in length from pectoral arch to base of caudal fin; maximum depth of trunk less than its length. Fins as in the type species.

Form. \& Loc. Upper Cretaceous: Sahel Alma, Mt. Lebanon.

48112. Type specimen about 0.07 in length. The cleft of the mouth is indicated below and in front of the very large orbit, and the head is clearly covered with scales. The vertebræ are distinctly 12 in the abdominal, 18 in the caudal region; the ribs are stout, not reaching the ventral border. There are fragments of the paired fins, and the characteristic median fins are well preserved. Traces of stout free finsupports are seen, as usual, in adrance of the dorsal fin. The lateral line is arched like the back. The scales are quite smooth.

Lewis Colt.

48113, 4958\%. Two distorted small specimens.

Lewis Coll.

47374. Imperfect trunk, comparatively large.

Lewis Coll. 



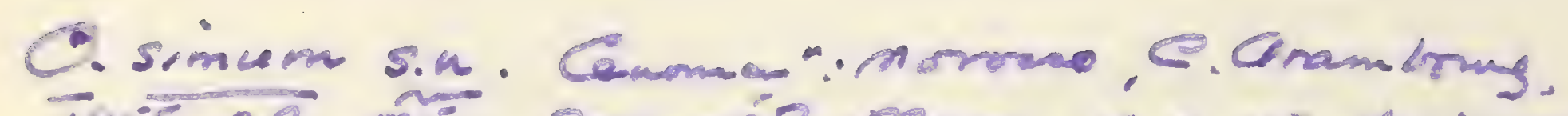

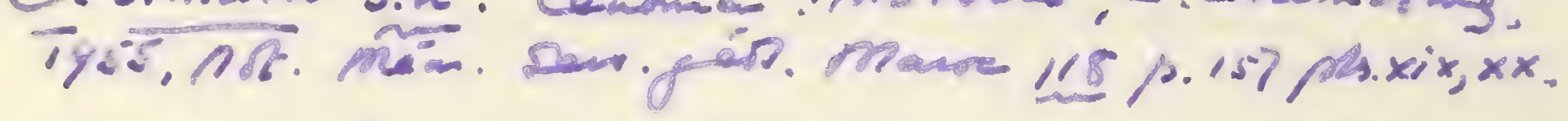

$\operatorname{san} \log R$. 


\section{Omosoma pulchellum (Davis).}

1887. Microdon (?) pulchellus, J. W. Daris, Trans. 'Roy. Dublin Soc. [2] vol. iii. p. 501, pl. xxiv. fig. 3.

Type. Small distorted fish; Edinburgh Mruseum of Science and Art.

A deep-bodied species, attaining a length of about 0.07. Maximum depth of trunk equal to its length from pectoral areh to base of caudal fin. Fins as in the type species.

Form. \& Loc. Upper Cretaceous: Sahel Alma, MIt. Lebanon.

48115. Fine specimen, originally about 0.065 in length.

Lewis Coll.

48119-a, 49575. Three imperfect and distorted specimens.

Lewis Coll.

The generic determination of the following species is uncertain:Omosoma moncesteri, W. von der Marck, Palæontogr. vol. xxxi. (1885), p. 245, pl. xxii. fig. 1.-Upper Cretaceous; Baumberg, Westphalia. [Imperfectfish ; Academy of Münster.]

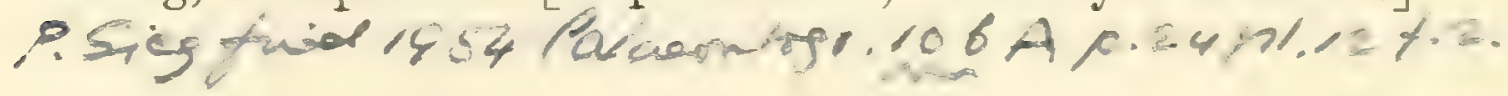

Genus PLATYCORMUS, W. von der Marck.

[Zeitschr. deutsch. geol. Ges. vol. x. 1858, p. 251.]

Cleft of mouth oblique, and jaws with very minute teeth. Vertebræ about 14 in the abdominal, 20 in the caudal region. Postclaricle much elongated and slender, reaching ventral border; pelvic fins with small spine, not directly below but somewhat behind the pectoral pair; dorsal and anal fins acuminate in front, each with a few very stout anterior spines, gradually lengthening and closely pressed together; caudal fin deeply forked. Scales ctenoid, of moderate size, more or less ornamented with granulations, and extending over the opercular apparatus, head, and base of the median fins; no enlarged or thickened scales even on the zentral border of the trunk.

\section{Platycormus germanus (Agassiz).}

1837-39. Beryx germamu, L. Aggassiz, Poiss. Foss. vol. iv. p. 121, pl. xiv $e$.

1858. Platycormus germanus, W. von der Marck, Zeitschr. deutsch. geol. Ges. vol. x. p. 251.

1863. Platycormus germanus, W. von der Marck, Palæontogr. vol. xi. p. 20, pl. i. figs. 1-3. 
1863. Platycormus oblongus, W. von der Marck, loc. cit. vol. xi. p. 21, pl. i. fig. 7. [Nearly complete fish ; Academy of Münster.]

1868. Platycormus oblongus, W. von der Marck, loc. cit. vol. xr. p. 273. 1885. Platycormus germanus, W. von der Marck, loc. cit. vol. xxxi. p. 244.

Type. Nearly complete fish; Bonn University Museum and British Museum.

The type species, attaining a length of about $0 \cdot 25$. Length of head with opercular apparatus considerably exceeding half the maximum depth of the trunk, and the latter measure nearly equalling the length from the pectoral arch to the base of the caudal fin. Pelvic fins comprising a relatively short spine, one simple ray closely articulated distally, and four rays both articulated and divided distally; dorsal fin arising in advance of the anal but extending as far backwards as the latter to the base of the short caudal pedicle; dorsal fin with seven stout, sharply-ridged spines, the seventh about two thirds as long as the next ray, which is the longest, simple but closely articulated distally, and followed by from 22 to 26 gradually shortening rays, both divided and articulated distally; anal fin much less elevated than the dorsal, with four similar spines, one simple articulated ray, and from 18 to 22 divided rays. Scales very fincly and uniformly granulated and serrated.

The differences between the two forms distinguished by W. von der Marck seem to be due entirely to accidents in preservation.

Form. \& Loc. Upper Cretaceous: Westphalia.

P. 506. Counterpart of type specimen in the Museum of the University of Bonn, described and figured by Agassiz, loc. cit.; labelled "gewonnen auf'm Baumberg, 1819."

Egerton Coll.

P. 3976. Fine fish, chiefly in impression, apparently counterpart of the specimen figured by W. von der Marck, loc. cit. 1863, pl. i. fig. 1 ; Sendenhorst. The finely-ribbed spines in advance of the dorsal fin are especially well displayed; and there seems to be an impression of a short, delicate spine at the base of the foremost articulated but undivided ray of the pelvic fin. The fine granulations and serrations of the scales are distinctly shown in impression.

Enniskillen Coll.

P. 3976 a. Smaller impression, equally fine; Sendenhorst. The five soft rays of the pelvic fin are distinct, the foremost being only articulated distally, not divided. The squamation is also well shown.

Enniskillen Coll. 


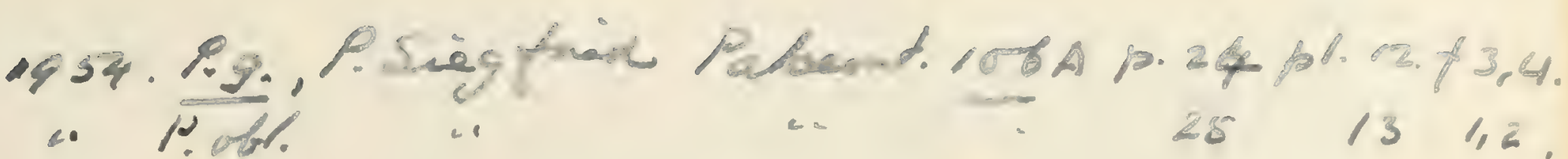
a. P.ofl. 
1902. Beryecpeid elepan, A.S. Lordwerd, Frn.

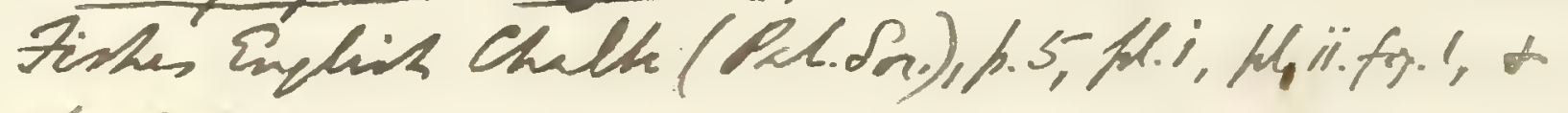
Sodofy 2

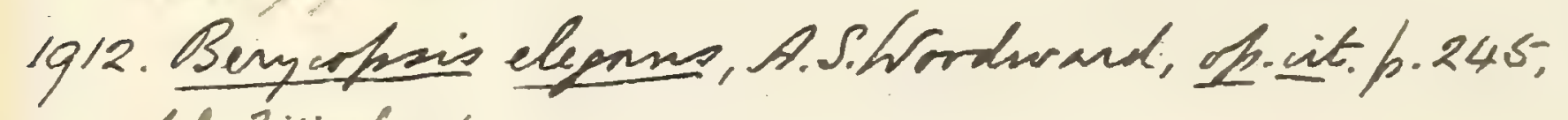
bl Piiififo. 
35033. Another fine fish about 0.18 in length, displaying all the fins except the pectorals, but the anterior dorsal spines apparently abraded; Sendenhorst. The dorsal and anal fins exhibit the unusual number of 26 and 23 divided rays respectively. The caudal pedicle is apparently shortened by crushing. Purchased, 1860.

35032. More imperfect specimen; Sendenhorst. Purchased, 1860.

P. 1944. Imperfect trunk, with remains of branchial arehes bearing: large gill-rakers; Sendenhorst.

Egerton Coll.

P. 2113. Imperfect and partially scattered remains of a large fish; Sendenhorst. Egerton Coll.

35009. Equally imperfect large specimen; Sendenhorst. Purchased, 1860.

The following species is not yet precisely definable, and is not represented in the Collection :-

Platycormus gibbosus, W. von der Marck, Verhandl. naturh. Vereins preuss. Rheinlande u. Westfalens, 1873, Corresp. p. 62, and Palæontogr. vol. xxxi. (1885), p. 244, pl. xxi. fig. 1.-Upper Cretaceous; Baumberg, Westphalia. [Imperfect fish, wanting caudal fin; Schliuter Collection, Bonn.]

\section{Genus BERYCOPSIS, Dixon.}

[Geol. Sussex, 1850, p. 372.]

Syn. (?) Stenostoma, F. Dixon, ibid. 1850, p. 373.

An imperfectly known genus, not yet satisfactorily distinguished from Platycormus. Pelvic fin-spine comparatively larger than in the latter genus. Circumorbital plates small, except the foremost (antorbital), which is much expanded. Scales more or less feebly rugose and crenulated, scarcely ctenoid.

\section{Berycopsis elegans, Dixon.}

1850. Berycopsis elegans, F. Dixon, Geol. Sussex, p. 372, pl. xxxv. fig. 8.

1888. Berycopsis elegans, A. S. Woodward, Proc. Geol. Assoc. vol. x. p. 328.

Type. Imperfect fish; Brighton Iluseum. 
The type species, probably attaining a length of about $0 \cdot 3$. Length of head with opercular apparatus somewhat exceeding two thirds the maximum depth of the trunk, which nearly equals the length from the pectoral arch to the base of the caudal fin. Dorsal fin with 6 short and stout spines, which are nearly smooth; anal fin arising much nearer to the pectorals than to the caudal. External head-bones and scales very feebly rugose, the latter sometimes quite smooth; nearly 30 scales in each transverse series in the abdominal region.

Form. \& Loc. Senonian and Turonian: Sussex and Kent.

25881. Fine small specimen, about $0 \cdot 15$ in length, showing the head, the origin of the dorsal and anal fins, traces of the pectoral and caudal fins, some caudal vertebræ and scales; Chalk, Sussex.

Dixon Coll.

P. 6465. Larger imperfect fish; probably from Sussex. The characteristic head is shown, and there are indications of 30 vertebræ, of which at least 12 are abdominal. The pectoral fin is proved to have been very small, with from 10 to 12 rays; and there are three delicate anal finsupports as far back as the 7 th and 8 th vertebræ from the end of the tail.

Beckles Coll.

403\%, 4305. Fragmentary head and trunk, and a small piece of squamation; Chalk, Lewes. An ossified sclerotic and some rays of the dorsal fin are exhibited. Mantell Coll.

P. 3931, P. 4294. Fragment of small, and fragment of large head and trunk; Chalk, Sussex.

Enniskillen Coll.

37751. Large head with abdominal region much fractured, but displaying some of the flank-scales; Chalk, near Maidstone.

Purchased, 1863

49053. Remains of opercular apparatus and trunk, showing vertebræ, clavicle, anterior part of dorsal fin, and smooth squamation; Chalk, Kent.

Mrs. Smith's Coll.

P. 1951. Two fragmentary specimens, one showing the top of the cranium; Chalk, Kent.

Egerion Coll.

P. 5683. Remains of head and abdominal region, displaying scapular arch and part of squamation; Lower Chalk, Burham, Kent. 




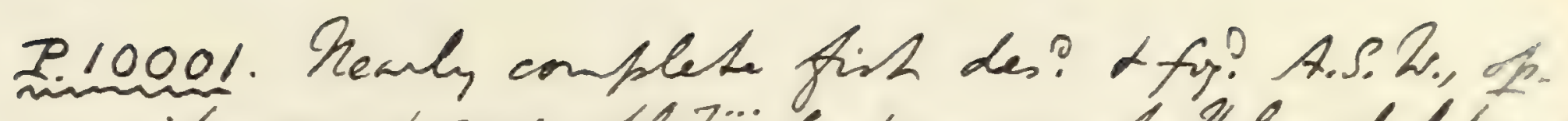

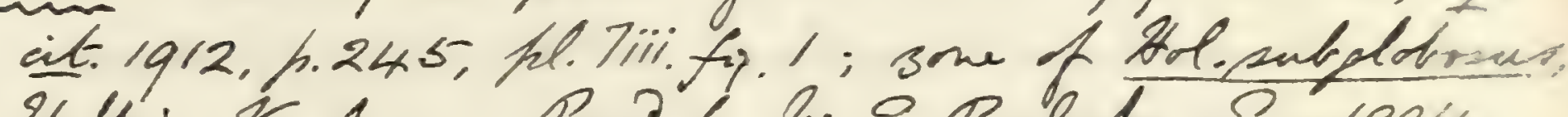

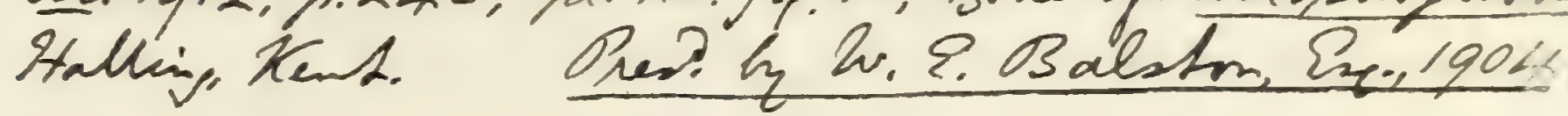

25-881. Besunted a fipund A.S.2. 1902, h.6, h.i. fip.l.

P.646.5: Branehiostepal pay nhired A.S.W. 1902, k. 9;

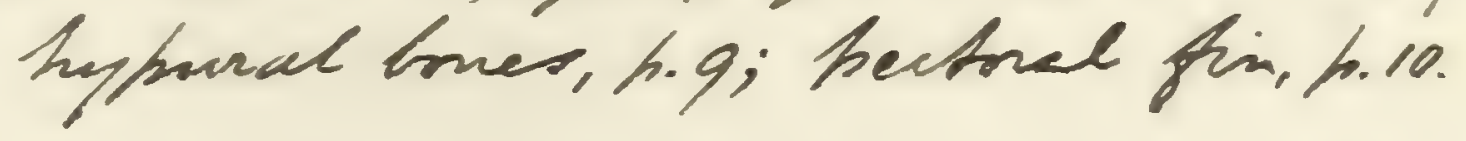

37751. Dabie fin-sulfment noticed A.S.W. 1902, h.10.

49053. Seales and coval fin Finner A.S.2.1902, h... hl.i. fip. 4 .

P.1951. Ane exchamed with Land Umir. Imes, Dee. Othen desc.' fig! A.S.S. 1902, h.6, he i.fy.?.

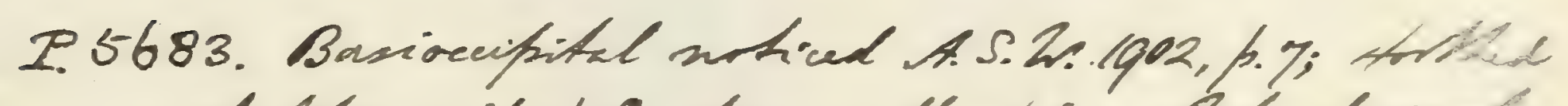
ectopteryprid, h.8; fremasilla, h.8. Dectreat avel. dest thy? h.9. H. il. fi 
2.5696. Deseribed and Fipured A.S. 2. 1902, f.y. pl. i. fip. 2.

9.6049. Inesathmoid noticed A.S.W. 1902, 1.7; chack. seales, hig.

P.5tg5. Gill-nakens moticed A.S. W. 1902, p.9.

2.6535: Doveal fin moticed A.S.2.115.10,11.

25866. Deseribed as Beryorpio kulchella. A.s.2.1902, h. 13.

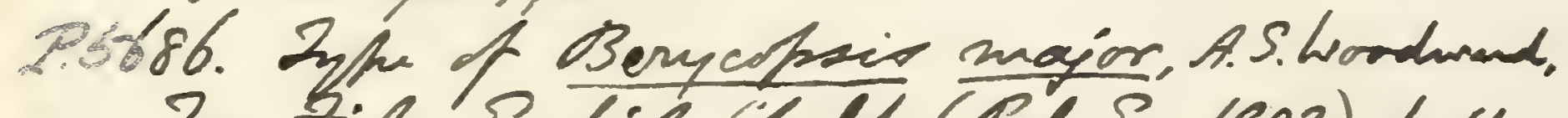

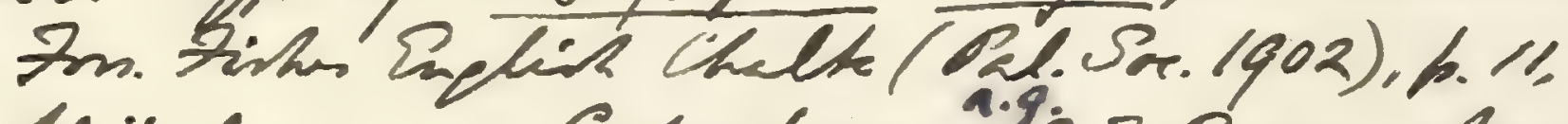

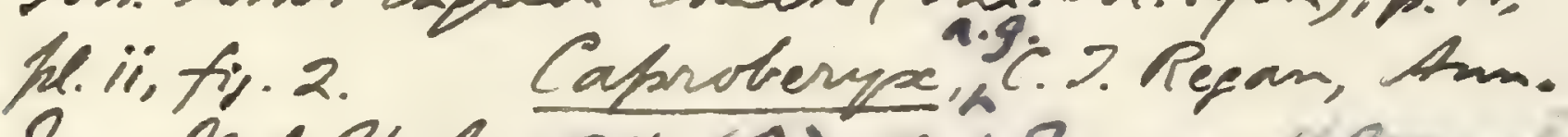

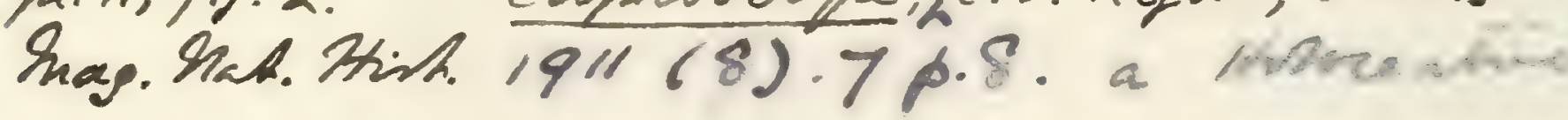

49062. Prtion $f$ mall thunte noticed as Berzespsio ste. A.S.W.1902, p.13;

Erey Challe, Strver. 


P. 5696. Fine large head; Cuxton, Kent. The occipital portion of the cranium is lost, but the characteristic cheek-plates and jaws are well preserred, with the opercular apparatus, pectoral arch, and remains of five anterior vertebræ. The external bones are very finely rugose, and the operculum is almost completely covered with scales. Harford Coll.

P. 6049. Smaller head, pectoral arch, and scales; Chalk, Kent. Rugose scales are shown to cover the cheek.

Presented by F. Harford, Esq., 1889.

The following specimens seem to represent undetermined species of Berycopsis:-

25886. Imperfect small fish described and figured as the type specimen of Stenostoma pulchella by F. Dixon, Geol. Sussex (1850), p. 373, pl. xxxvi. fig. 2; Chalk, Steyning, Sussex. The cheek-plates, maxilla, and supramaxilla seem to be those of Berycopsis, and the scales extend over the operculum. The dorsal fin-supports prove that the fin arose far forwards. The scales are small, rather thick and finely pectinated, not clearly serrated. Divon Coll.

P. 5686. Large head and trunk with finely pectinated scales; Chalk, Cuxton, Kent. Harford Coll.

The so-called Berycopsis lindstromi (J. W. Davis, Trans. Roy. Dublin Soc. [2] vol. iv. 1890, p. 422, pl. xliv.), from the Upper Cretaceous of Limhamn, Scania, is based on a generically indeterminable portion of trunk in the Royal State Ifusem, Stockholm.

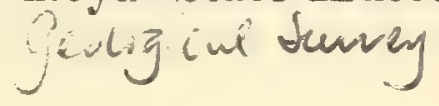

\section{Family CARANGID王.}

Snout not produced into an elongated rostrum; dentition feeble or absent. Vertebræ 10 in the abdominal, 14 (very rarely 13 or 15 ) in the caudal region; the posterior abdominal centra usually with downwardly bent transverse processes. Pelvic fins, when present, thoracic, with one spine and not more than five articulated rays; spinous portion of dorsal and anal fins much less extended than articulated portion. Scales small or absent; lateral line conspicuous, sometimes armoured with enlarged scales or bony scutes. 
Synopsis of Extinct Genera and Genera represented by Extinct Species.

I. Trunk deepened, and extended dorsal fin continuous.

Paired fins small; dorsal fin deep in front; anal fin about half as much extended as dorsal; caudal fin forked; thickened ventral ridge-scales. .............

Pelvic fins very large; dorsal fin excessively deepened in front; anal tin much extended, low and fringe-like; caudal fin slightly forked; no enlarged scales ....

Paired fins moderate; dorsal and anal fins much deepened in front; caudal fin rounded or truncate; no enlarged scales......................

Paired fins small; dorsal and anal fins not much elevated, about equally extended; caudal fin rounded; no enlarged scales. .

Pelvic fins with 2 or 3 much-elongated rays; few anterior dorsal fin-rays much elongated; anal fin low and fringe-like; caudal fin rounded or truncated; no enlarged scales ................

One pelvic fin-ray excessively elongated; dorsal and anal fins low and about equally extended; caudal fin truncated or slightly forked; no scales ..............

II. Trunk elongate-fusiform, and spinous portion of dorsal fin separate.

Teeth minute; preoperculum not serrated; posterior dorsal and anal fins of equal extent, latter with 2 free spines; caudal fin forked; scales enlarged along lateral line ......................

Apparently as Caranic, but no scales ......

As Caranx, but anal fin shorter than posterior dorsal, and no enlarged scales....

Teeth larger; anal tin less extended than posterior dorsal and its anterior spines not free; no enlarged scales .........

Preoperculum serrated; anal fin less extended than posterior dorsal; no enlarged scales $\ldots \ldots \ldots \ldots \ldots \ldots \ldots \ldots$

Aipichthys (p. 427).

Semiophorus (p.430).

Platax (p. 432).

Amphistium (p. 434).

Vomeropsis (p. 435).

Mene (p. 437).

Caranx (p. 441).

Archaus (p. 442).

Seriola (p. 444).

Carangopsis (p. 446).

Ductor (p. 448). 
For stenle $\alpha$ vertibue Carampidde see R. I. Thufeldt, Gomm. Iurephol. vol. "i (1888), th. 271 296, with tentifiv. ( Grammicolepis and (aranx).

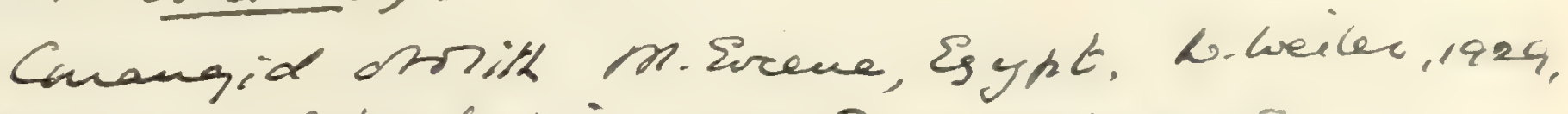
abh. bay. Akad. wirs. N.F. . p.34.ph.rf.Y.8. 
1946 A.p. Fliasmo p.103 -7.30.

Aipichthys formosus, Hay.

1903. Sig. fors. O.P.Hay, Bull. Amen. Mue. H. H. vd. xix. \%. 445, kh, xaxii fir 2, 3.

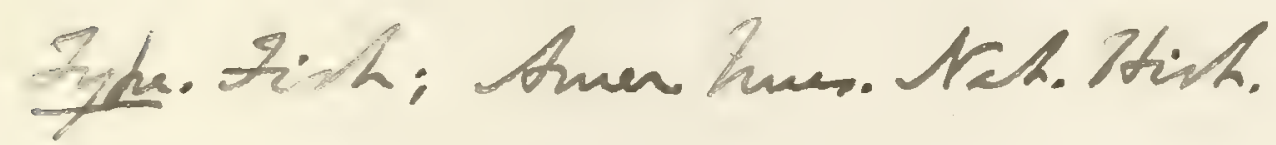

trm.Lto. Cretaceons: Hojula, Lebanon.

1902. Aipichthe velifer, A.S. Wordurand, Am. Fish

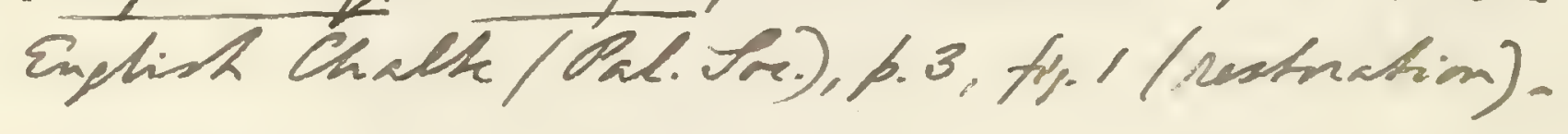


. 



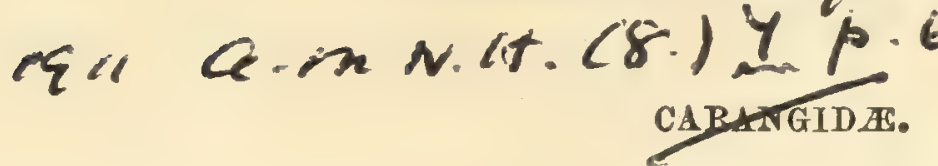

Genus AIPICHTHYS, Steindachner.

[Sitzungsb. k. Akad. Wiss., math.-naturw. Cl. vol, xxxviii. 1860, p. 763.]

Trunk much deepened, and head short and deep, with a large supraoccipital crest. Eye rather small; cleft of mouth oblique and wide, the gape extending to the hinder border of the orbit; maxilla expanded behind; teeth minute but numerous. Pelvic fins inserted directly below the pectorals, somewhat larger than the latter; dorsal fin much elevated and extending along nearly the whole of the back, with 2 to 4 very short and rather stout anterior spines; anal fin comparatively low, opposed to the hinder half of the dorsal, with 3 or 4 short and stout anterior spines; caudal fin deeply forked. Scales thin and small, except a series of ventral ridge-scales on the short abdominal region.

\section{Aipichthys pretiosus, Steindachner.}

1860. Aipichtys pretiosus, F. Steindachner, loc. cit. p. 763, pl. i. fig. 1.

1882. Aipichthys pretiosus, F. Bassani, Denkschr. k. Akad. Wiss., math.-naturw. Cl. vol, xlv. p. 262.

1895. Aipichthys pretiosus, D. G. Kramberger, Djela Jugoslar. Akad. vol. xvi. p. 46, pl. ii. fig. 3.

Type. Nearly complete fish; Court Museum, Vienna.

The type species, attaining a length of about 0.09. Maximum depth of trunk equalling four fifths of total length of fish to base of caudal fin; length of head with opercular apparatus about half that of vertebral column. Dorsal fin with 3 spines and about 30 articulated rays, of which the fourth is excessively elongated, its length at leust equalling the depth of the trunk at its insertion; anal fin with 3 spines and about 19 articulated rays.

The type specimen does not exhibit any distinct evidence of more than 10 vertebræ in the abdominal region.

Form. \& Loc. Cretaceous: Comen, Istria; Isle of Lesina, Dalmatia.

Not represented in the Collection.

Aipichthys velifer, sp. nov.

1887. Platax minor, J. W. Davis, Trans. Roy. Dublin Soc. [2] vol. iii. pl. xxv. fig. 7 (errore).

Type. Nearly complete fish; British Museum.

A species about as large as the type, of similar proportions. 
Rays of pelvic fins, when adpressed, extending beyond the anal spines; dorsal fin with 3 or 4 spines and 22 or 23 articulated rays, of which a few are excessively elongated anteriorly, the length of the longest at least equalling the depth of the trunk at its insertion; anal fin with 4 spines and about 18 articulated rays, extending backwards for the length of two vertebræ behind the dorsal fin.

Form. \& Loc. Upper Cretaceous: Hakel, Mt. Lebanon.

P. 4743. Type specimen, very imperfectly figured by Davis toc. cit. and erroneously ascribed by him to the so-called Platax minor. The sharply-pointed supraoccipital crest is conspicuous, and the comparatively small eye is indicated by a black stain. The cleft of the mouth is shown to be very oblique, and the maxilla is clearly expanded behind. Ten branchiostegal rays are preserved in position below the smooth opercular apparatus. 10 abdominal and 14 caudal vertebræ can be counted. The pectoral fin is small, composed of very delicate rays; a long, slender postclavicle extends backwards and downwards beneath it to the ventral border. The comparatively stout rays of the pelvic fins are adpressed to the ventral border and overlap the anal spines. Four or five anterior articulated rays of the dorsal fin are excessively elongated, forming a peak in the front part of the fin, which rapidly becomes quite low in its hinder half. The low anal fin, with at least 3 gradually lengthening stout spines and 18 articulated rays, extends backwards for the length of two vertebræ behind the dorsal fin. The middle rays of the caudal fin are very short and rather sparse; this fin being deeply forked and with sharply-pointed lobes. The scales are not distinct.

Lewis Coll.

P. 4744. Fine large specimen, displaying most of the principal characters of the genus and species, but with elevated portion of the dorsal fin destroyed.

49486, P. 85. Two small distorted specimens.

Lewis Coll.

Lewis Coll.

\section{Aipichthys minor (Pictet).}

1850. Platax minor, F. J. Pictet, Poiss. Foss. Mt. Liban, p. 19, pl. ii. fig. 4.

1866. Platax minor, Pictet \& Humbert, Nouv. Rech. Poiss. Foss. Mt. Liban, p. 48, pl. ir. figs. 1-3. 
1902. Aipichthys muchalix, A.S.Woodwoud, Ama Fishen Enclish Chalte (Pal. Jor.), p.4. 
1887. Platax brevis, J. W. Davis, Trans. Roy. Dublin Soc. [2] vol. iii. p. 524, pl. xxv. fig. 4. [Distorted fish; Edinburgh Museum of Science and Art.]

Type. Imperfect fish; Geneva Museum.

A species nearly as large as the type, with the trunk slightly deeper in proportion to its length. Pelvic fins when adpressed just reaching the anal spines; dorsal fin with 2 or 3 spines and 29 or 30 articulated rays, the length of the longest anterior rays not exceeding half the depth of the trunk at their insertion; anal fin with 3 spines and 19 articulated rays, not extending backwards beyond the dorsal fin.

The type specimen of the so-called Platax brevis is evidently somewhat shortened and deepened by distortion.

Form.\& Loc. Upper Cretaceous: Hakel, Mt. Lebanon.

P. 81. Fine specimen showing most of the principal characters of the genus and species.

Lewis Coll.

P. 6000. Distorted specimen showing displaced ventral ridge-scales.

Lewis Coll.

P. 6183. Small fish displaying all the fins and teeth in the premaxilla.

Lewis Coll.

49484-85, P. 82. Three imperfect distorted specimens.

Lewis Coll.

P. 8691. Small distorted fish. Purchased, 1897.

\section{Aipichthys nuchalis (Dixon).}

1850. Microdon nuchalis, F. Dixon, Geol. Sussex, p. 369, pl. xxxii. fig. 7 .

1887. Platax (?) nuchalis, A. S. Woodward, Ann. Mag. Nat. Hist. [5] vol. $\mathrm{xx} \cdot$ p. 342 .

Type. Portion of head and trunk; British Museum.

A species known only by the unique type specimen, smaller than A. pretiosus and apparently with more delicate vertebral column, but not yet definable.

Form. \& Loc. Senonian: Sussex.

257\%0. Type specimen, described and figured 7oc. cit.; Chalk, Washington, Sussex.

Diron Coll. 
[Poiss. E.oss. vol. iv. 1838, p. 14.]

Trunk oblong, somewhat deepened, and head relatively large, without prominent supraoccipital crest. Eye large; cleft of mouth small, the gape not extending behind the anterior border of the orbit; maxilla expanded behind; teeth minute or absent. Pectoral fins small; pelvic fins very large and inserted in advance of the latter; dorsal fin extending along the whole of the back, pressed forwards over the head, with a few short anterior spines, its anterior portion excessively elevated, its hinder portion low and fringe-like; anal fin much extended, low and fringe-like; caudal fin widely expanded but only slightly forked. Scales thin and small, none enlarged, some extending over the bases of the median fins.

\section{Exelia}

\section{Semioptrorus velifer (Volta).}

1796. Kurtus velifer, G. S. Volta, Ittiolit. Veronese, p. xxvii. pl. vii. figs. 1, 2 (non fig. 3).

1818. Chetodon velifer, H. D. de Blainville, Nouv. Dict. d'Hist. Nat. vol. xxrii. p. 3อ̃์.

1835. Semiophorus velifer, L. Agassiz, Nenes Jahrb. p. 301 (name only).

1838-42. Semiophorus velifer, L. Agassiz, Poiss. Foss. vol. iv. pp. 14, 219, pl. xxxvii $a$.

1859. Semiophorus velifer, A. B. Massalongo, Specimen Photogr. Anim. Foss. Agr. Veron. p. 27, pl, vi.

1876. Semiophorus velifer, F. Bassani, Atti Soc. Veneto-Trent. Sci. Nat. rol. iii.p. 179.

(?) 1878. Semiophorus gigas, A. de Zigno, Mem. R. Istit. Veneto, vol. xx. p. 448, pl. xv. [Imperfect fish; Zigno Collection, University of Padua.]

Type. Nearly complete fish; Museum of Natural History, Paris.

The type species, attaining a length of about $0 \cdot 18$. Length of head with opercular apparatus considerably less than the maximum depth, and contained three times in the total length of the fish (including caudal fin). Pelvic fins when adpressed not reaching the caudal fin; dorsal fin with about 5 small anterior spines and from 50 to 55 articulated rass, the elevation of the anterior half of the fin somewhat less than twice the depth of the trunk at its insertion; anal fin with one or two small anterior spines and from 25 to 30 articulated rajs, its extent slightly more than half that of the dorsal.

The proportions of the dorsal and pelric fins vary in different specimens according to the state of preservation, though perhaps 


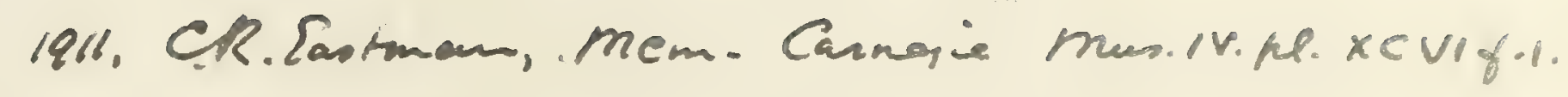



also due in part to original individual variations. The type specimen of the so-called Semiophorus gigas is probably imperfect at the extremities of the dorsal and pelvic fins.

Form. \& Loc. Upper Eocene: Monte Bolca, near Verona.

P. 2088, P. 3945. Two large imperfect specimens, partially restored, labelled by Agassiz, and the second in counterpart.

Egerton \& Enniskillen Colls.

21373. Fine specimen 0.095 in length, in counterpart. One pelvic fin is folded, the other expanded, the former thus appearing pointed distally, while the latter has a comparatively broad and rounded end.

\section{Presented by Chambers Hall, Ëq., 1847.

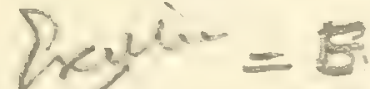 \\ Semiophorus velicans (Blainville).}

1796. Kurtus velifer, G. S. Volta, Ittiolit. Veronese, pl. vii. fig. 3.

1818. Chretodon velicans, H. D. de Blainville, Nouv. Diet. d'Hist. Nat. vol. xxvii. p. 355.

1835. Semiophorus velicans, L. Agassiz, Neues Jahrb. p. 301 (name only).

1837-42. Semiophorus velicans, L. Agassiz, Poiss. Foss. vol. iv. pp. 14, 222, pl. xxxvii.

1874. Semiophorus massalongianus, A. de Zigno, Mem. R. Istit. Veneto, vol. xviii. p. 292, pl. x. fig. 2. [Imperfect fish; Zigno Collection, University of Padua.]

Type. Nearly complete fish; Museum of Natural History, Paris.

A smaller species than the type, with slightly more elevated dorsal fin, and the pelvic fins when adpressed reaching beyond the base of the caudal fin.

Form. \& Loc. Upper Focene: Mronte Bolca, near Verona.

P. 196\%. Imperfect partially restored specimen.

Egerton Coll.

The following species has also been distinguished, but is not represented in the Collection :-

Semiophorus parvulus, W. Szajnocha, Pamiet. Wydz. matem.przyr. Akad. Umiejet. Krakow. vol. xii. (1886), p. 109, pl. iv. fig. 1.-Upper Eocene: Monte Bolca, near Verona. [Nearly complete fish; Geological Museum, University of Cracow.]

A generically indeterminable fragment has also been described as follows:-

Semiophorus schaerbeeki, P. J. Van Beneden, Bull. Acad. Roy. 
Belg. [3] vol. i. (1881), p. 119, with plate._Middle Eocene (Bruxellian); Schaerbeek, near Brussels. [Fragments of trunk with median fins; Royal Museum of Natural History, Brussels.

\section{Genus PLATAX, Cuvier.}

[Règne Animal, vol. ii. 1817, p. 334.]

Trunk much deepened, and head short and deep, with a large supraoccipital crest. Eye very large; cleft of mouth small, the gape not extending behind the anterior border of the orbit; relatively small maxilla expanded behind; teeth in premaxilla and dentary setiform and clustered, those of the outer series largest and notched at the apex. Pelvic fins inserted directly below the pectorals, somewhat larger than the latter; dorsal fin much elerated and extending along nearly the whole of the back, with 3 to 7 short anterior spines; anal fin also considerably elevated, with 3 short anterior spines; caudal fin rounded or only slightly forked. Scales thin and small, none enlarged, some extending over the bases of the median fins.

Existing species occur in the Indian Ocean and the western part of the Pacific Ocean.

\section{Platax woodwardi, Agassiz.}

1833. Figures by S. Woodward, Geol. Norfolk, pl. iii. figs. 31-33.

1842-44. Platax woodwardii, L. Agassiz, Poiss. Foss. vol. iv. p. 250, pl. xix. fig. 3.

1882. Platax woodwardii, E. T. Newton, Vert. Forest Bed (Mem. Geol. Surv.), p. 122, pl, xix. figs. 1-3.

1891. Platax woodwardi, E. T. Newton, Vert. Pliocene Deposits, Britain (Mem. Geol. Surv.), p. 89.

Type. Detached bones, thickened by hyperostosis.

An indeterminable large species known only by detached bones, most of which are thickened by hyperostosis.

Form.\& Loc. Lower Pliocene (Red and Coralline Crags): Suffolk. Upper Pliocene (Norwich Crag, Weybourn Crag, and Forest Bed): Norfolk and Suffolk.

$301-3,305-6,308,312,31 \%-8,321,323,32 \%$. Numerous thickened bones of different forms, some polished to show structure; Crag, Norfolk and Suffolk.

Purchased, 1837.

23200. Four vertebral centra; Crag, Norfolk.

Presented by S. P. Woodward, Esq. 


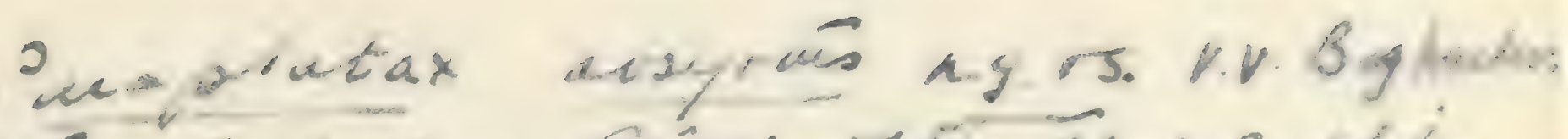

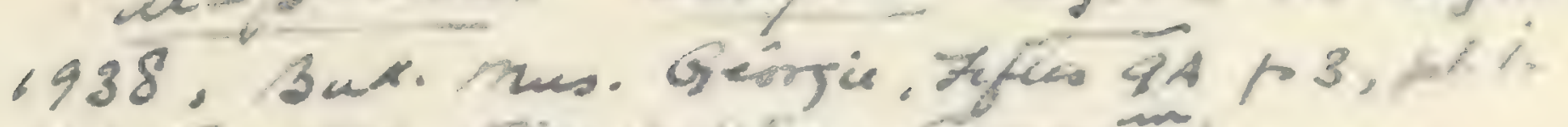

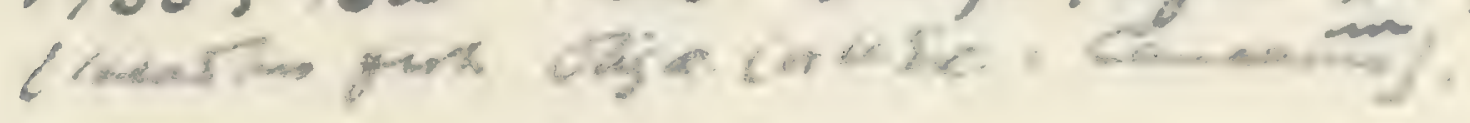


Bones homit hyperostrie from Parana

Brmation, Anpentina, des? Lfi? Iy F. Priem,

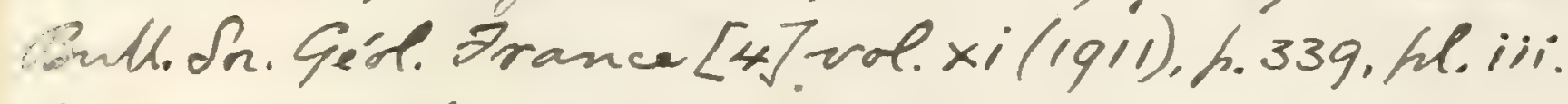
fig. 25=27. hl. iv. fip. 1-19.

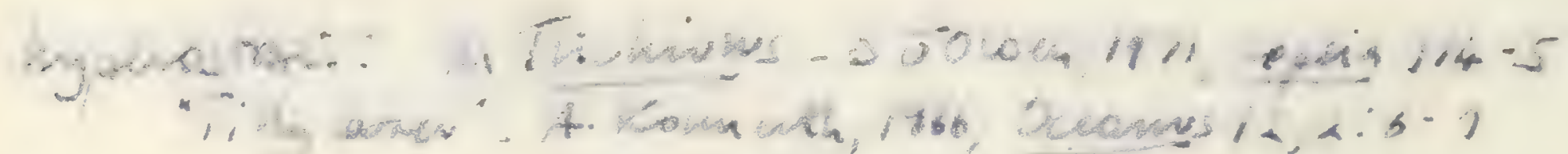

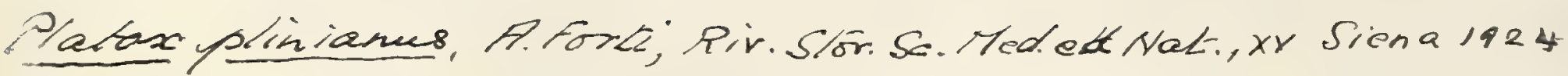

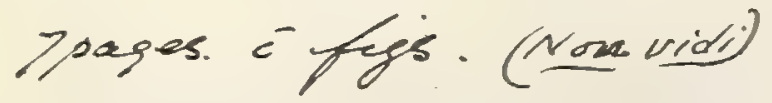




$$
\text { . }
$$



40525-26. Vertebral centra and thickened clavicles and other bones; Crag, Norfolk.

Purchased, 1867.

P. 1981. Similar remains, including so-called "butterfly bone"; Crag, Norfolk.

Egerton Coll.

P. 8992, P. 8995-95, P. 8998. Similar remains; Norwich Crag, Southwold, Suffolk. Presented, by Lady Prestwich, 1896.

P. 9024. Two thickened clavicles; Norwich Crag, Easton Bavent, Suffolk.

Purchased, 1897.

P. 7381. Thickened bone.

Prestwich Coll.

P. 8704-07, P. 8736. Numerous similar thickened bones, including. so-called "butterAy bone" figured by Newton, op. cit. 1882, pl. xix. fig. 2 ; Forest Bed Series, near Cromer, Norfolk.

Savin Coll.

Detached bones from the Lower Pliocene (Crag) of Antwerp, similarly thickened by hyperostosis, have been named Platax costatus, P. cuneus, P. pileum, and P. physeteroide, by P.J. Van Beneden, Bull. Acad. Koy. Belg. [3] vol. i. (1881), pp. 119-125, figs. 1-5.

Extinct species of this genus have also beon described as follows, but are not represented in the Collection :-

Platax papilio, L. Agassiz, Neues Jahrb. 1835, p. 292, and Poiss. Foss. vol.iv.(1835-42), p. 245, pl.xlii. Chatodon papilio, G. S. Volta, Ittiolit. Veronese (1796), p. exiv. pl. xxvi. fig. 1, and H. D. de Blainville, Nouv. Dict. d'Hist. Nat. vol. xxvii. (1818), p. 355.-Upper Eocene; Monte Bolca, near Verona. [Imperfect fish ; Paris Museum of Natural History.]

Platax pinnatiformis: Chatodon? pinnatiformis, H.D. de Blainville, loc. cit.1818, p. 35̃1. Platax, Cuvier \& Valenciennes, Hist. Nat. Poiss. vol. vii. (1831), p. 239. Chcetodon pinnatus, G. S. Volta, op. cit. 1796, p. xiii. pl. iv. (errore). Platax altissimus, L. Agassiz, loc.cit. 1835, p. 291, and op. cit. vol. iv. (1839-42), p. 249, pl. xli.-Ibid. [Ditto.]

Platax plinianus, A. B. Massalongo, Specimen Photogr. Anim. Foss. Agr. Veron. (1859), p. 29, pl. v.-Ibid.

Platax subvespertilio: Choetodon subvespertilio, H. D. de Blainville, loc. cit. 1818, p. 352. Chatodon vespertitio, G. S. Volta, op. cit. 1796, p. xx又. pl. vi. (errore). Plataw maciopterygius, L. Agassiz, loc. cit. 1835, p. 291, and op.cit. vol. iv. (1839-42), p. 247, pl. xli a.-Ibid. [Ditto.]

PART IV.

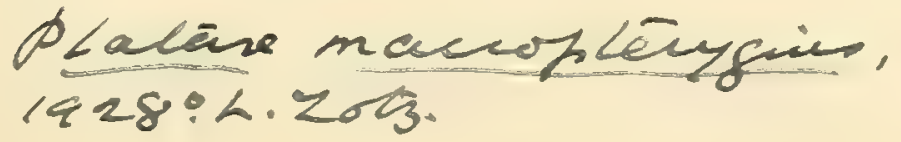


The so-called Platax (?) colchicus from the Lower Tertiary of the Caucasus (Simonovich, Batzerich, and Sorokin, Material. Geol. Kavkaza, 1875, p. 162, pls. i.-iii.) does not belong to this genus, and cannot be satisfactorily determined from the published description and figure.

\section{Genus AMPHISTIUM, Agassiz.}

[Poiss. Foss. vol. v. pt. i. 1844, p. 44.]

Trunk much deepened, and head short and deep, with rather large supraoccipital crest. Eye large; cleft of mouth of moderate size and directed upwards; teeth minute or absent. Paired fins small, the pelvic pair inserted in adrance of the pectorals; dorsal fin not much elevated, extending along the greater part of the back, with 3 or 4 feeble anterior spines; anal fin almost or quite as much extended as the dorsal, with 3 or 4 feeble anterior spines; caudal fin rounded. Scales very small, none enlarged or thickened.

\section{Amphistium paradoxum, Agassiz.}

1796. Pleuronectes platessn, G. S. Volta, Ittiolit. Veronese, p. clxxix. pl. xliv. fig. 1 (errore).

1818. Pleuronectes platessa, H. D. de Blainville, Nouv. Dict. d'Hist. Nat. vol. xxvii. p. 357 (errore).

1835. Amphistium paradoxum, L. Agassiz, Neues Jahrb. p. 294 (name only).

1834-44. Amphistium paradoxum, L. Agassiz, Poiss. Foss. vol. v. pt. i. p. 44 , pl. xiii.

Type. Nearly complete fish; Museum of Natural History, Paris.

The type species, attaining a length of about $0 \cdot 2$. Length of head with opercular apparatus somewhat exceeding half the maximum depth of the trunk, which is contained twice or slightly less in the total length to the base of the caudal fin. Dorsal and anal fins gently rounded and equally elevated, each with from 21 to 23 stout, articulated and divided rays.

Form. \& Loc. Upper Eocene: Monte Bolca, near Verona; Montmartre, near Paris.

P. 1982. Fine large specimen, wanting extremity of caudal fin; Monte Bolca. The articulation of the mandible is beneath the orbit, and the upturned mouth bears traces of minute teeth. The operculum is quite smooth. The caudal portion of the vertebral column is nearly straight, but the very short abdominal portion curves sharply upwards. 


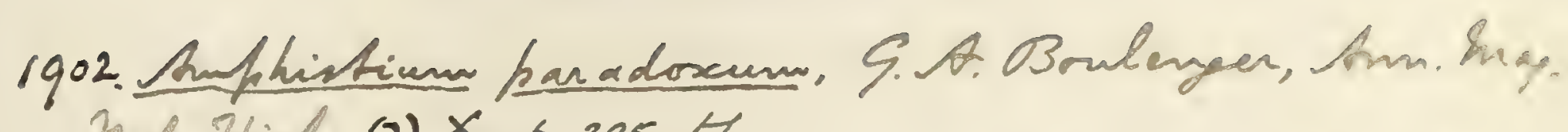
Nat. Fiath. 0).X. p.295. t.

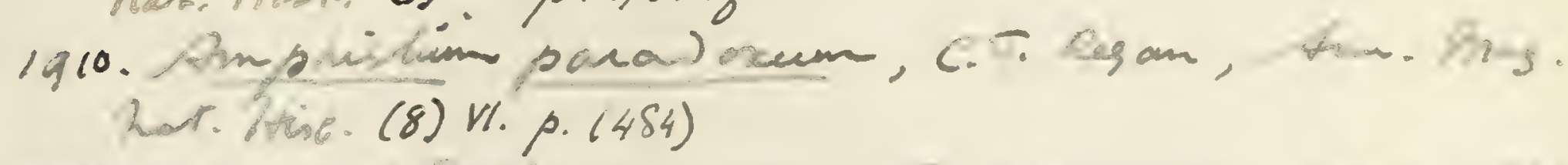

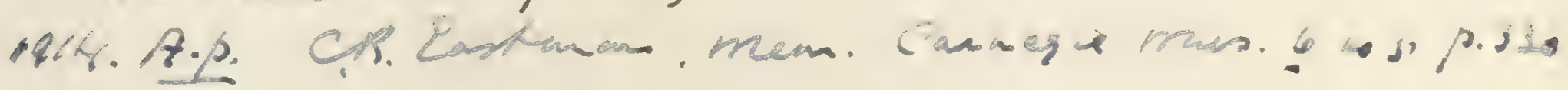


1914. Anphistion bozzianum, C. R. Sastman, Inen. Carnegie huw, vol, vi. f. 332 , pl. xTv. fip. 4. 
The hinder neural spines in the abdominal region curve forwards in their upper portion. The slender postclavicle does not reach the ventral border. The very small scales are well shown.

Egerton Coll.

P. 3940. Impression of slightly more elongated fish, 0.175 in length; Montmartre. Enniskillen Coll.

The so-called Amphistium bozzianum (Massalongo, MIS.) from Monte Bolca, is considered to be identical with $A$. paradoxum by Bellotti (see Massalongo, Spec. Photogr. Anim. Foss. Agr. Veron. 1859, p. 37, pl. xiii. fig. 2), but regarded as a distinct species by A. de Zigno (Mem. R. Istit. Veneto, vol. xxiii. 1887, p. 14).

The following species are not represented in the Collection, and do not belong to this genus, the first probably not to the family Carangidæ:-

Amphistium dubium, F. Bassani, Atti R. Accad. Sci. Napoli [2] vol. iii. (1889), no. 6, p. 85, pl. xiii. fig. 1.-Lower Miocene; Chiavon, Vicentin, N. Italy. [Imperfect small fish ; Town M[useum, Verona.]

Amphistium longipenne, A. de Zigno, Mem. R. Istit. Veneto, vol. xxiii. (1887), p. 12, fig. 1.-Upper Eocene; Monte Bolca, near Verona. [Immature fish, probably Platax; Gazula Collection, Verona.]

\section{Genus VOMEROPSIS, Heckel.}

[Sitzungsb. k. Akad. Wiss., math.-naturw. Cl. vol. xi. 1854, p. 135.]

Trunk irregularly fusiform, somewhat deepened; head relatively large and distorted, the small mouth being directed upwards; a very large supraoccipital crest, continued forwards beyond the orbit. Teeth minute. Pectoral fins well developed; pelvic fins with two or three rays much elongated, inserted in advance of the pectorals; dorsal fin extending along the greater part of the back, with very feeble anterior spines, the foremost few articulated rays much elongated, the others low and fringe-like; anal fin about as much extended as the dorsal, with very feeble anterior spines, low and fringe-like; caudal fin slightly rounded or truncated. Foremost anal fin-support much expanded at its lower end. Scales cycloid, of moderate size, none enlarged or thickened.

The pelvic fin-rays in this genus are very finely divided, as shown by a specimen described below (no. P. 1990). Kner and Steindachner were thus probably misled in their determination of 8 or 9 rays in the pelvic fins of $V$. tlon, atus. 


\section{Vomeropsis longispinus (Agassiz).}

1796. Zeus vomer, G. S. Volta, Ittiolit. Veronese, pl. xxxv. fig. 3 (errore).

1796. Zeus triurus, G. S. Volta, ibid. p. clxxxi. pl. xliv. fig. 2 pre):

1836-44. Vomer longispinus, L. Aggassiz, Poiss. Foss. vol.v. pt. i. pp. 4, 28, pls. v., vi.

1854. Vomeropsis longispinus, J. J. Heckel, Sitzungsb. k. Akad. Wiss., math.-naturw. Cl. vol. xi. p. 135.

Type. Imperfect, partly distorted fish; Museum of Natural History, Paris.

The type species, attaining a length of about $0 \cdot 2$. Length of head with opercular apparatus slightly less than maximum depth of trunk, which is contained twice in the total length to the base of the caudal fin. Pectoral fin with about 13 rays; dorsal fin with nearly 40 rays, of which the foremost 2 or 3 are rudimentary spines; anal fin slightly more extended than the dorsal, arising just in advance of the latter, with about 30 rays, of which the foremost 1 or 2 are rudimentary spines; caudal fin slightly rounded.

Form. \& Loc. Upper Eocene: Monte Bolea, near Verona.

36200. Imperfect large specimen with traces of scales.

$$
\text { Purchased, } 1861 .
$$

P. 1990. Fine small specimen, in counterpart, labelled by Agassiz. The head is well shown, with its great supraoccipital crest, small upturned mouth, and traces of minute teeth. There are about 8 branchiostegal rays. The vertebræ are evidently $10+14$ in number; the centra are much constricted, and some show a single sharp lateral keel; the hinder four or five neural spines in the abdominal region curve forwards at their upper end. The clavicle is slender and sigmoidally bent, with a long rod-like postclavicle extending to the ventral border of the fish. The coracoid extends downwards to the clavicular symphysis by a falciform process from its postero-inferior angle. The pelvic fin-support is somewhat expanded, forked anteriorly, and is in contact with the clavicle at the two extremities of this bifurcation. The anterior spine of the pelvic fin is very small; the length of the two (or possibly three) next rays equals at least half the depth of the trunk at their insertion; while both these and the succeeding diminutive rays are finely divided distally. The rays of the dorsal and anal fins are not very satisfactorily displayed, but all except two or three anterior rudimentary 


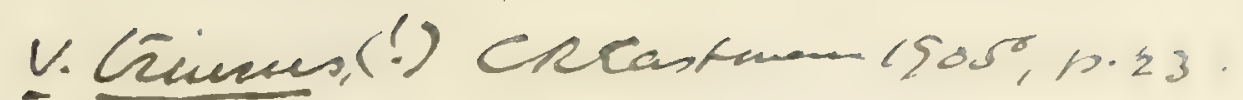

1911. Clerastmas. Man. Cannegie mus. IV. pl.xelï Su. Iongiopines C!SS 
BPATIIDE

Protompang aswist?

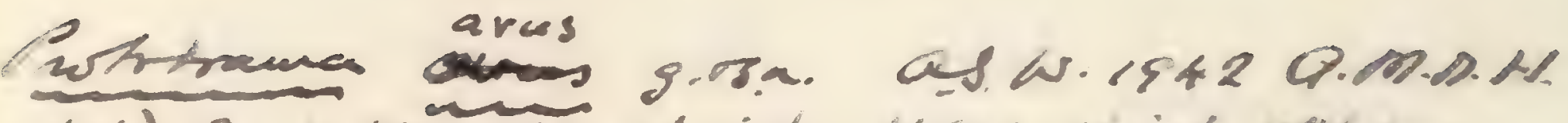

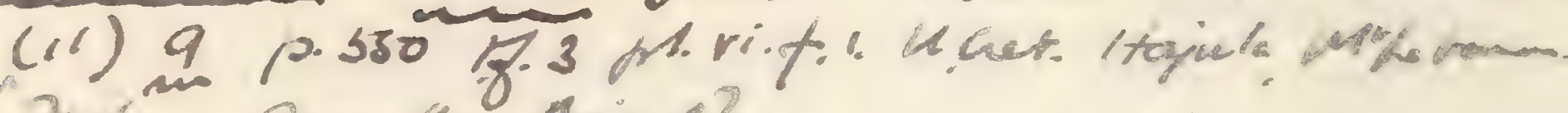

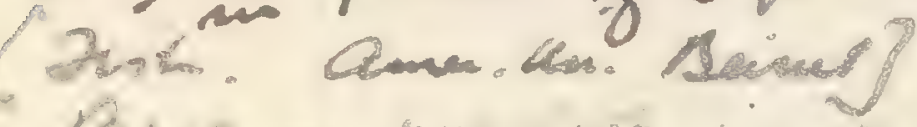

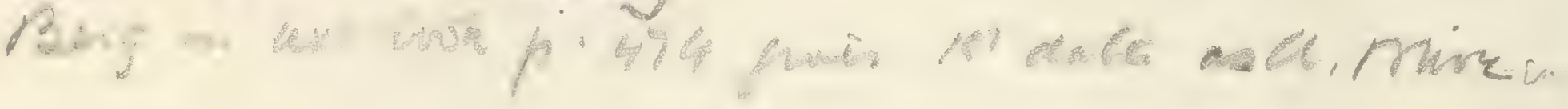


spines must have been at least articulated, if not also divided distally. The length of the foremost articulated dorsal fin-rays, as preserved, equals the depth of the trunk at their insertion; but the fin rapidly diminishes to a low fringe behind. The foremost dorsal fin-support has an anterior expansion, and there are two free fin-supports between this and the occipital crest. None of the anal fin-rays are elongated. The caudal fin is slightly rounded behind.

Egerton Coll.

\section{Vomeropsis elongatus, Heckel.}

1854. Vomeropsis elongatus, J. J. Heckel, Sitzungsb. k. Akad. Wiss., math.-naturw. Cl. vol. xi. p. 134.

1862. Vomeropsis elongatus, Kner \& Steindachner, Denkschr. k. Akad. Wiss., math.-naturw. Cl. vol. xxi. p. 24, pl. iv.

Type. Imperfect fish; Zigno Collection, University of Padua.

Closely resembling the type species, but more elongated. Length of head with opercular apparatus about equalling maximum depth of trunk, which is less than half total length of fish to base of caudal fin.

Form. \& Loc. Upper Eocene; Monte Bolca.

Not represented in the Collection.

\section{Vomeropsis valenciennesi, Bassani.}

1876. Vomeropsis valenciennii, F. Bassani, Atti Soc. Veneto-Trent. Sci. Nat. vol. v. p. 148, pl. ii. fig. 2.

Type. Nearly complete fish; Geological Museum, University of Padua.

A comparatively small, deep-bodied species. Maximum depth of trunk at least equalling two thirds the total length of the fish to the base of the caudal fin.

Form. \& Loc. Upper Eocene: Monte Bolca.

Not represented in the Collection.

\section{Genus MENE, Lacépède.}

[Hist. Nat. Poiss. vol. v. 1803, p. 479.]

Syn. Gasteronemus, L. Agassiz, Poiss. Foss. vol, v. pt. i. 1833, p. 17.

Trunk much deepened and laterally compressed, with prominent abdomen; head relatively large and distorted, the small mouth being directed upwards; maxilla with a large rounded expansion behind; a very large supraoccipital crest. Teeth minute, only on 


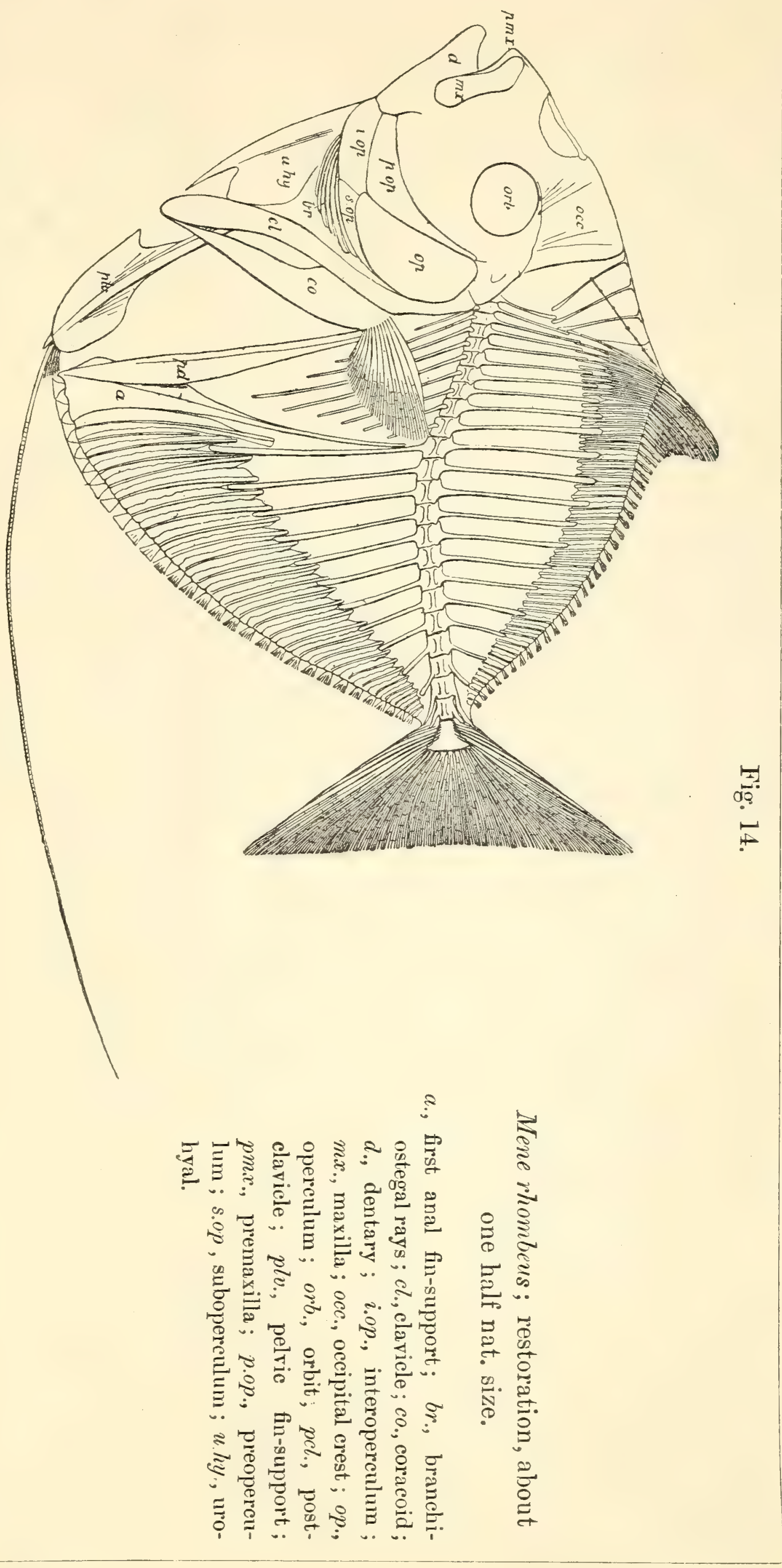




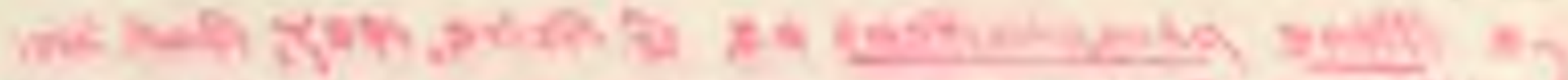

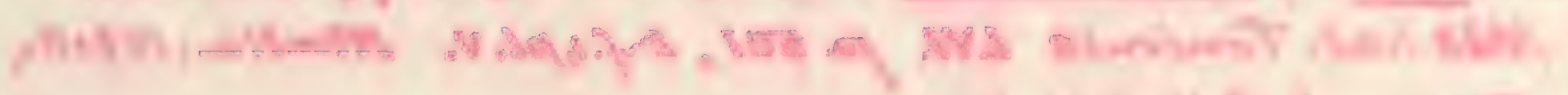

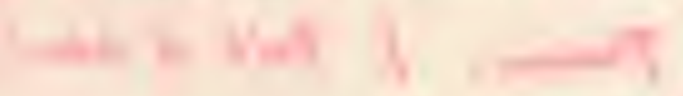




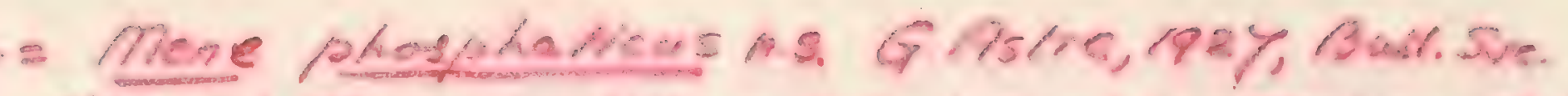
thist nat. Tombrase LW. pa sol, Lf.4ph.v. Mmtian; Mibella

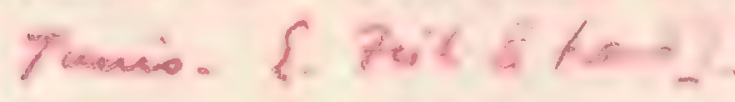

1906. Inene rhombens, R.Cramer, Zeitsch. dentsch ged.

Gea. rod. Tviii. p. 181, pl.x.

908. Mene aff-rhoutreus, F Prem, Bull. Sragér.

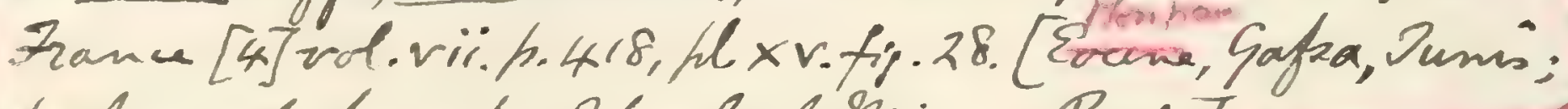

portion of tumbe, Pchool of Mines, Paris.] 


\section{.}



margin of jaws. Pectoral fins well dereloped; pelvic fins minute, except foremost articulated ray, which is thickened and greatly elongated; dorsal fin extending along the greater part of the back, with few feeble anterior spines, acuminate in front but otherwise low and fringe-like; anal fin at least as much extended as the dorsal, without spines, but the rays very short and expanded; caudal fin widely expanded, truncated or slightly excarated behind. Scales absent.

The only known existing species occurs in the seas of the East Indies. The generic identity of the so-called G'asteronemus with Mene was pointed out by J. Müller, Zeitschr. deutsch. geol. Ges. vol. ii. (1850), p. 66. The relationship of the type species was also observed by de Blainrille, Nouv. Dict. d'Hist. Nat. vol. xxrii. (1818), p. 356.

Mene rhombeus (Volta).

[Text-figure 14.]

1796. Scomber rhombeus, G. S. Volta, Ittiolit. Veronese, p. Ixxxir. pl. xviii.

1818. Zeus rhombeus, II. D. de Blainville, Nouv. Dict. d'Hist. Nat. vol. xxvii. p. 356.

1833. Gasteronemus rhombeus, L. Agassiz, Poiss. Foss. vol. v. pt. i. p. 20, pl. ii.

Type. Nearly complete fish; Palæontological Museum, MLunich.

The type species of the so-called genus Gasteronemus, attaining a length of about 0.25 . Head with opercular apparatus occupying slightly more than one third of the total length to the base of the eaudal fin; dorsal border of trunk gently arched, rentral border sharply bent at the insertion of the pelvic fins; maximum depth of trunk exceeding its length from the pectoral arch to the base of the caudal fin. Length of enlarged pelric fin-ray at least equalling the total length of the fish; dorsal fin with about 3 feeble anterior spines and 40 articulated rays; anal fin with 30 articulated, expanded rays ; caudal fin scarcely forked.

Form. \& Loc. Upper Eocene: Monte Bolca, near Verona.

44868. Large specimen, in counterpart, displajing the maxilla and / premaxilla. Presented by Benjamin Bright, Esq., 1873.

P. 2086, P. 4479. Fine specimen 0.2 in length, in counterpart.

Egerton \& Enniskillen Colls.

19944 a. Well-preserred specimen $0 \cdot 18$ in length, with enlarged pelvic fin-rays also 0.18 in length. The rudimentary pelvic fin-rays and spine are distinguishable. Purchased, 1846. 
P. $\$ 446$. More imperfect specimen 0.185 in length, showing anterior spine and rudimentary articulated rays of pelvic fin. As in the previous specimens, the slender, rod-like postclavicle, extending downwards to the ventral border of the fish, bears a narrow wing along its hinder margin. Purchased.

P. 5130. Two good specimens. Presented by Mrs. M.E. Fort, $1886^{\circ}$.

P. 2085. Another specimen 0.185 in length, in counterpart. Some calcifications evidently belong to the slime-canal extending from the occiput to the origin of the dorsal fin.

Egerton Coll.

P. 4135. Smaller specimen, also showing the calcifications for the slime-canal estending from the occiput to the origin of the dorsal fin.

Enniskillen Coll.

P. 944\%. Much-fractured specimen about 0.105 in length.

Purchased.

ZZ. 3 (Cracherode Catal.). Smaller specimen, imperfect dorsally. Cracherode Bequest.

23110 a. Imperfect and distorted immature specimen, in counterpart.

Purchased, 1848.

\section{Mene oblongus (Agassiz).}

1833. Gasteronemus oblongus, L. Agassiz, Poiss. Foss. vol. v. pt. i. p. 22 , pl. i.

Type. Nearly complete fish; Museum of Natural History, Paris.

Closely resembling $M$. rhombeus, but more elongated, and ventral border more gently curved, not bent at the insertion of the pelvic fins. Maximum depth of trunk not exceeding its length from the pectoral arch to the base of the candal fin.

Form. \& Loc. Upper Eocene: Monte Bolca, near Verona.

P. 4134. Imperfect fish 0.21 in length. The calcifications along the slime-canal between the occiput and the origin of the dorsal fin are distinct.

Enniskillen Coll.

P. 208\%. Smaller specimen. The dentated sutures between the plates at the lower end of the anal fin-supports are shown in impression.

Egerton Coll.

A very small immature fish has also been described under the following name:- 


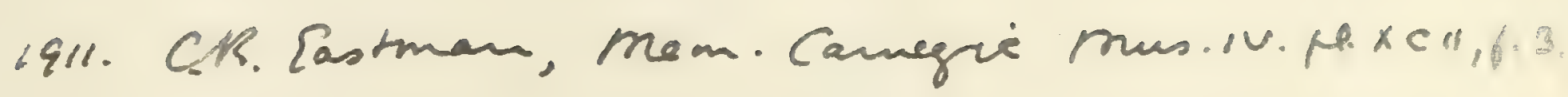


Mene novde-hispanide, C. D. Sastman, Mem. Camapia Mnus, vol. vi(1914), h. 346, tersh-fip. 4 . "Bld-wife," I. Byam; Ohil. Trans. vol, ix (175-5), h.295, plix. - Jertiary; Intigua. [7ish]

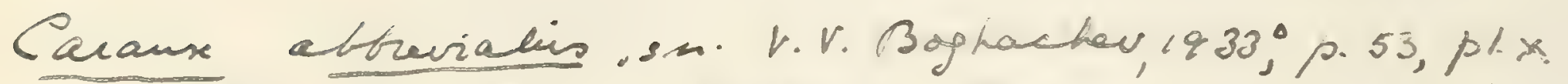
Figs. 3,4. Frin. Regene, Cancasas.

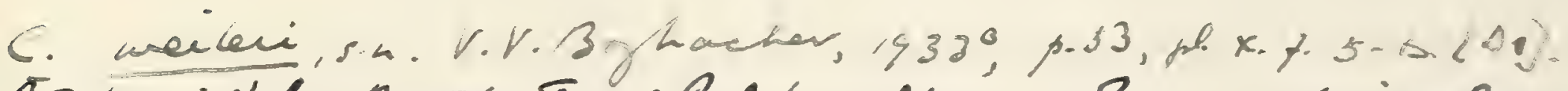

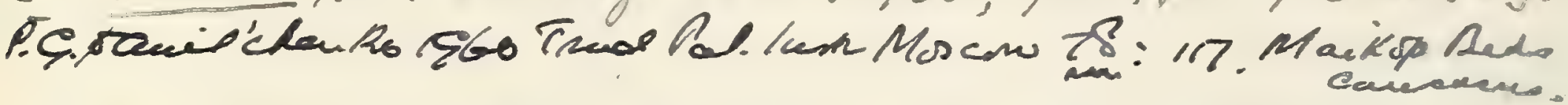

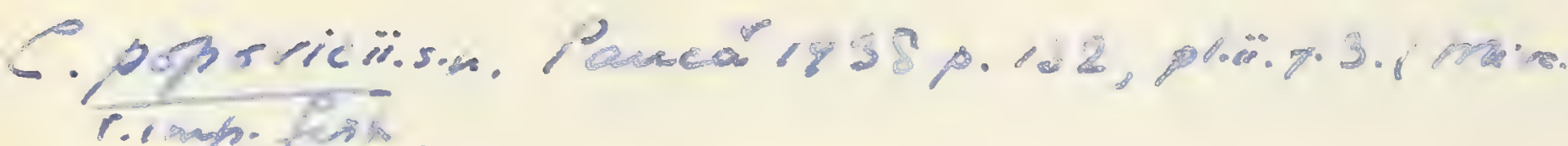

Caranxe guedex-infar hei, 7. Priem, Comm. Serw. Se'ol.

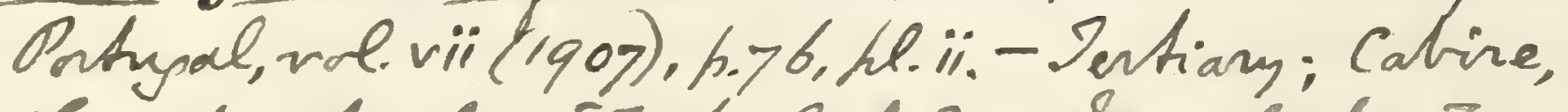
Zoanda, Angola. [Fith: Ged. Surv. Imus. Listom.] 
. 

Mene oblonga, var. pusilla, F. Bassani, Atti R. Accad. Sci. Napoli [2] vol. iii. (1889), no. 6, p. 78, pl. xiv. fig. 5.-Lower Miocene; Chiavon, Vicentin. [Imperfect small fish; Geological Museum, University of Padua.]

Genus CARANX, Cuvier.

[Règne Animal, vol. ii. 1817, p. 314.]

Trunk laterally compressed, more or less elongated, regularly fusiform, with much constricted caudal pedicle. Head large, with low supraoccipital crest, extending forwards between the orbits; eye rery large; mouth small or of moderate size, with very minute teeth; maxilla expanded behind, with a supramaxilla; preoperculum not serrated; about 7 branchiostegal rays. Paired fins small, the pectorals falciform; an anterior dorsal fin of about 8 feeble spines, closely followed by a more extended dorsal of articulated rays; anal fin opposed to the posterior dorsal and of equal extent, preceded by two short and separate anal spines; caudal fin forked. Scales thin and small, thickened or enlarged at least along the caudal portion of the lateral line; lateral line arched in front, straight behind.

Numerous species of Caranx are common in tropical and temperate seas. No extinct species are represented in the Collection, but the following have been described on the evidence of imperfect specimens :-

Caranx carangopsis, J. J. Heckel, Jahrb. k. k. geol. Reichsanst. vol. iii. pt. ii. (1852), p. 161; F. Steindachner, Sitzungsb. k. Akad. Wiss., math.-naturw. Cl. vol. xxxrii. (1859), p. 685, pl. จ. figs. 2-12, pls. vi., vii.Upper Miocene ; Hernals, near Vienna. [Detached bones, several thickened by hyperostosis; Court Museum, Vienna.]

Cararix gracilis, D. G. Kramberger, Beitr. Paläont. Oesterr.P. G.Dam<'cheakdungarns, vol. ii. (1882), p. 128, pl. xxvii. figs. 2-4, and 1460, Teud. Rh./as Rad Jugoslav. Akad. vol. cri. (1891), p. 82.-Upper Uencen 78: IIS xi. 2 Miocene; Radoboj, Podsused, Vrabce, \& Dolje, Croatia. Markeftea: Upper Oligocene; Sagor and Trifail, Croatia. [Nearly complete fish; University Geological Museum, Agram.]

Caranx haneri, D. G. Kramberger, loc. cit. 1882, p. 126, pl. xxvi. figs. 3, 4, pl. xxvii. fig. 1.-Upper Miocene; Podsused, Croatia. [Imperfect fish; University Geological Museum, Agram.] 


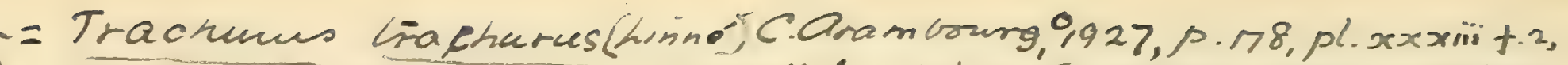

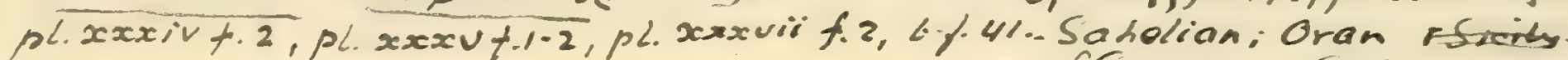

_Caranix longipinnatus, D. G. Kramberger, loc. cit. 1882, p. 128, pl. xxiv. figs. 7, 8.-Ibid. [Nearly complete fish; University Geological Museum, Agram.]

Caranx ovalis, J. J. Heckel, Sitzungsb. k. Akad. Wiss., math.naturw. Cl. vol. xi. (1854), p. 329, and Denkschr.k. Akad. Wiss., math.-naturw. Cl. vol. xix. pt. i. (1861), p. 63 ; Kner \& Steindachner, ibid. vol. xxi. (1863), p. 32, pl. vii. fig. 1; F. Bassani, Atti R. Accad. Sci. Napoli [2] vol. iii. (1889), no. 6, p. 80.--Lower Miocene ; Chiavon, Vicentin, N. Italy. [Imperfect fish; Court Museum, Vienna.]

Caranx rigidicaudus, J.J. Heckel, loc. cit. 1854, p. 330, and loc. cit. 1861, p. 66 ; Kner \& Steindachner, loc. cit. 1863, p. 32, pl. vii. fig. 2 ; F. Bassani, loc. cit. 1889, p. 80.Ibid. [Imperfect fish; Court Museum, Vienna.]

Genus ARCHAUS, Agassiz.

[Poiss. Foss. vol. v. pt. i. 18t4, p. 49.]

Syn. Pleionemus, L. Ayassiz, ibid. 1844, p. 52 (name only).

Archaoides, G. vom Rath, Zeitschr. deutsch. geol, Ges. vol. xi. 1859, p. 112.

A genus not yet clearly distinguished from Caranx, but no squamation observable in known specimens.

\section{Archæus glarisianus, Agassiz.}

1843-44. Archaeus glarisianus, L. Agassiz, Poiss. Foss. vol. v. pt. i. p. 49 , pl. xxviii. fig. 3.

(?) 1844. Vomer priscus, L. Agassiz, ibid. p. 31 (name only).

1844. Pleionemus macrospondylus, L. Agassiz, ibid. p. 52 (name only). [Fragment; British Museum.]

1859. Archaoides longicostatus, G. vom Rath, Zeitschr. deutsch. geol. Ges. vol. xi. p. 113, pl. iii. fig. 3. [Imperfect fish; Geological Museum, University of Bonn.]

1886. Archaus glaronensis, A. Wettstein, Fischfauna Tertiaer. Glarnerschief. (Denkschr, schweiz. Palæont. Ges. vol. xiii.), p. 84.

1886. Archæooides macrurus, A. Wettstein, ibid. p. 86, pl. vii. figs. 7-9, 11. [Nearly complete fish; Museum of Winterthur.]

1886. Archceoides longicostatus, A. Wettstein, ibid. p. 86.

Type. Fragmentary distorted fish; Geological Museum, Polytechnicum, Zürich.

The type species, attaining a length of abont $0 \cdot 15$. Length of head with opercular apparatus equalling maximum depth of trunk, 


$$
\text { . }
$$



Caranx Macovaii, n.s. M.Paucü, $1929^{\circ}$, p. 30. Oligor: Suslänesti;

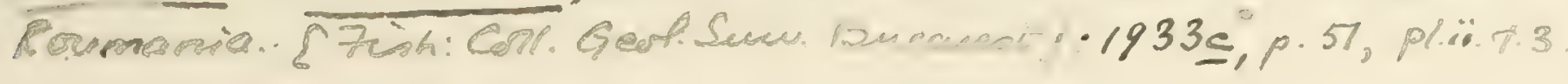

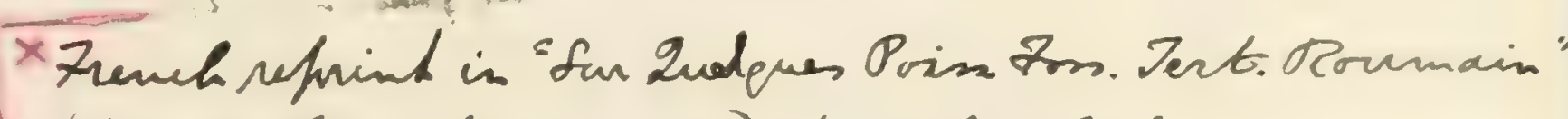
(Amm. Sci. Aniv. Lassy, 1905), h.7. hl. il. fip.6.

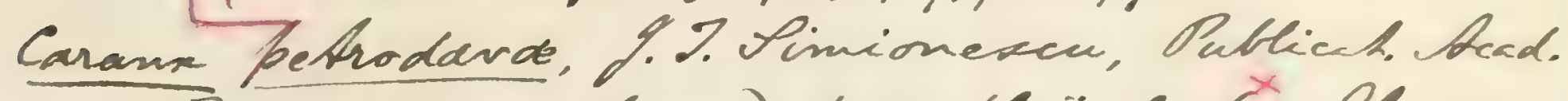
Domana, no.xii (1904), p. 8, hl. Ii, fiy. 6. - Dliporene; Roumania. (Amperfert fich:

Caranx primatrus. C. De Ractman, Bull. Anus. Comph. Zool. Harwand, vol. $\times 7 v i(1904), 1.28$, pl. i. fij. 4. Leath. fig_B. - U. Soeene; Monte Boled LFish; Mus. Comp. Zose. Harwand Kniv.J

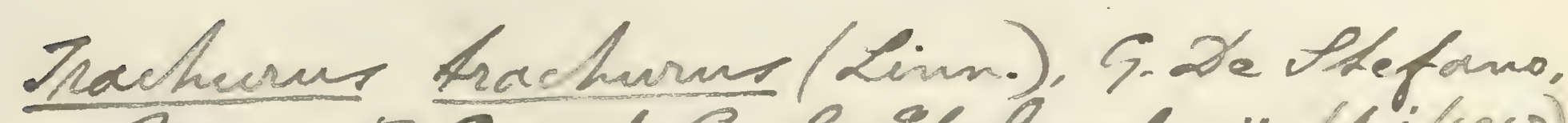

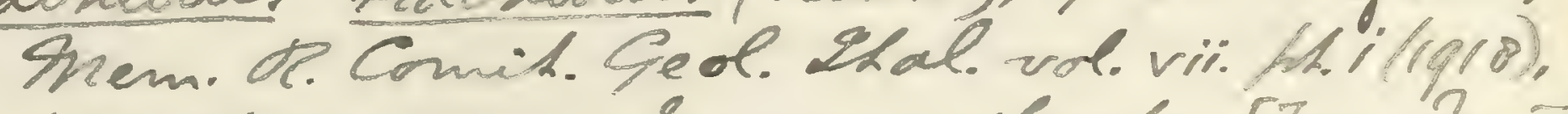
p.6\%. pl. viii.f.1.2. - mioreene; Licata. [Jurinhmi]

Caranx rhenanus n.sp., w. Weiler, Tahrt. Nassau. Ver. Naviuk. Y2 (1920)p.7.- M.Okjors; Mainz Basin. LHeadless Fish; N. h. M, Mainz J.?

E. bablruschi" comerio

G. (Decaptêns] pronurelli s.n, C. Arübourg, 1927\%p.

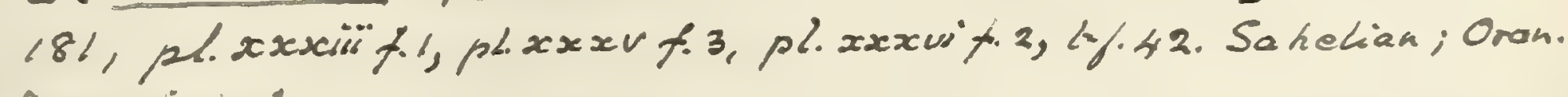
[Ompifislos].

$L=$ Caranx cfr. Archaeus ('Caranx) glarisianus, w. weiler,

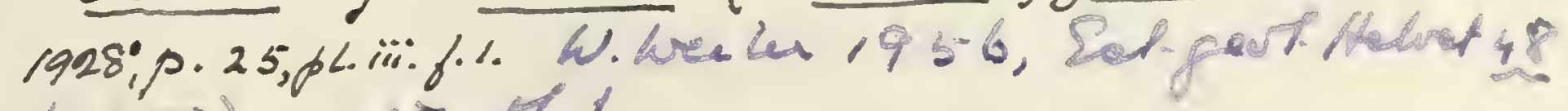

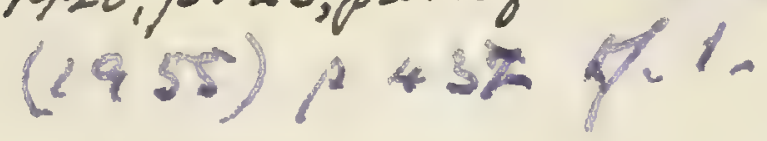

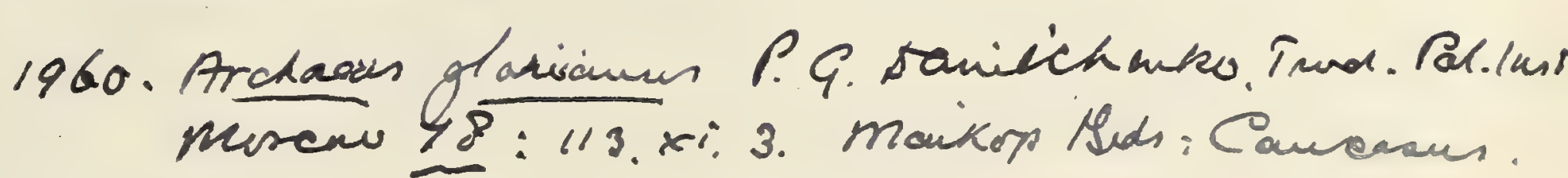



which is contained three times in the total length of the fish to the base of the caudal fin. Anterior dorsal fin with 8 spines, the longest apparently exceeding in length any of the articulated dorsal rays; posterior dorsal with 23 to 25 articulated rass; anal fin with 21 to 23 articulated rays.

Most of the known specimens of this species are much distorted in various directions.

Form. \& Loc. Oligocene: Canton Glarus, Switzerland.

P. 5944. Two imperfect specimens not much distorted, labelled Archcooides glaronensis by Wettstein. One distinctly exhibits 14 caudal vertebræ, and in the same specimen the two separate anal spines are conspicuous.

Purchased, 1889.

P. 1998 , P. 3944 , P. 4519 . Two imperfect specimens, obliquely distorted, in counterpart; Engi, Glarus.

$$
\text { Egerton \& Enniskillen Colls. }
$$

33960. Imperfect specimen showing vertebral column and dorsal and anal fins. Presented by Miss Elizabeth Warne, 1859.

33976-77. Fractured and distorted small specimen, in counterpart. Presented by Miss Elizabeth Warne, 1859.

P. 449. Imperfect trunk probably of this species, labelled as intended to be the type specimen of Pleionemus macrospondylus, Agassiz; Engi.

Egerton Coll.

P. 1991, P. 4521. Much-deepened trunk with median fins, in counterpart, resembling the deepened specimens ascribed to Archoooides macrurus by Wettstein, loc. cit. pl. vii. figs. 9, 11, and labelled "Vomer priscus, Ag." by Egerton; Engi.

Egerton \& Enniskillen Colls.

P. 1991 a, P. 1992, P. 4521 a. Two more imperfect similarly deepened specimens, one being in counterpart; Engi.

Egerton \& Enniskillen Colls.

36089. More imperfect deepened specimen, in counterpart; Plattenberg, Glarus.

Purchased, 1861.

The imperfect and distorted specimen described as follows, is not determinable :-

Archoeus brevis, L. Agassiz, Poiss. Foss. vol. v. pt. i. (1843-44), p. 50, pl. xxviii. fig. 2. Archceoides longus, A. Wettstein, Fischfauna Tertiaer. Glarnerschief. (1886), p. 86.Oligocene; Glarus. 
Genus SERIOLA, Curier.

[Règne Animal, vol. ii. 1817, p. 315.]

As Caranx, but pectoral fins relatively small, anal shorter than posterior dorsal, and no enlarged or thickened scales along lateral line.

Existing species in nearly all temperate and tropical seas.

Seriola prisca (Agassiz).

1796. Scomber pelagicus, G. S. Volta, Ittiolit. Veronese, p. Ixxiv. pl. xvi. (errore).

1796. Coryphana, G. S. Volta, ibid. pl. 1xviii. (errore).

1818. Scomber pelagicus?, H. D. de Blainville, Nour. Dict. d'Hist. Nat. vol. xxvii. p. 346.

1835. Lichia prisca, L. Agassiz, Neues Jahrb. p. $2: 2$ (name only).

1834-44. Lichia prisca, L. Agassiz, Poiss. Foss. vol. v. pt. i. p. 34, pls. xi., xi $a$.

1854. Seriola prisca, J. J. Heckel, Sitzungsb. k. Akad. Wiss., math.naturw. Cl. vol. xi. p. 136.

1876. Lichia prisca, F. Bassani, Atti Soc. Veneto-Trent. Sri. Nat. vol. iii. p. 184.

Type. Nearly complete fish; Palæontological Museum, Munich.

A species attaining a length of about 0.4 . Length of head with opercular apparatus equalling maximum depth of trunk and somewhat less than one third the total length of the fish to the base of the caudal fin. Anterior dorsal fin with 8 spines, the second to fourth about as long as the longest articulated dorsal rays; posterior dorsal with one short spine and about 30 articulated rays; anal fin with about 20 articulated rays, directly opposed to the hinder two thirds of the posterior dorsal. Scales very small.

Form. \& Loc. Upper Eocene: Monte Bolca, near Verona.

P. 1983, P. 4140. Fine large specimen, in counterpart. Egerton \& Enniskillen Colls.

P. 9448. More imperfect smaller specimen.

Purchased.

21409. Fine specimen 0.28 in length, the head a little elongated by crushing.

Purchased, 1847.

P. 1983a. Fish about 0.25 in length, slightly deepened by crushing. Egerton Coll.

21428. Fragmentary large specimen, in counterpart.

Purchased, 1847.

P. 9449-50. Two small specimens, in counterpart. Purchased. 
SERIOLIDR.

Irifera ringens n.g.et.s. Terdan, S6. Un. Pab. Wn. Ser.,

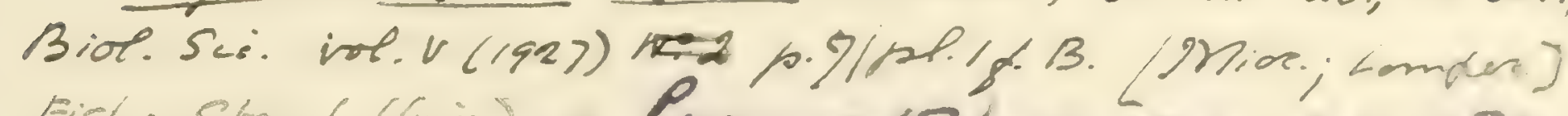

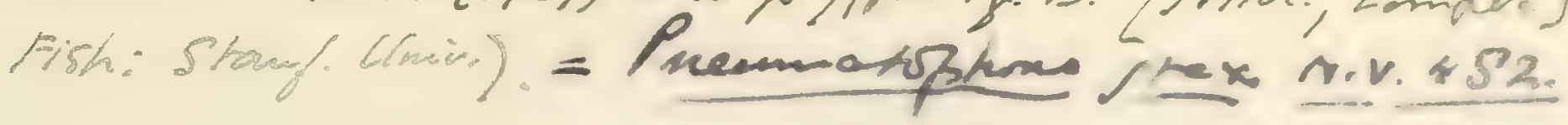

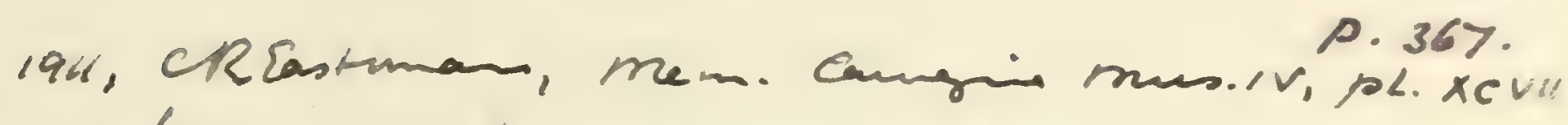
$6.6 ; x$ cres $y \cdot 1 ; x<1 x, 6 \cdot 3,61.6 .2$. 


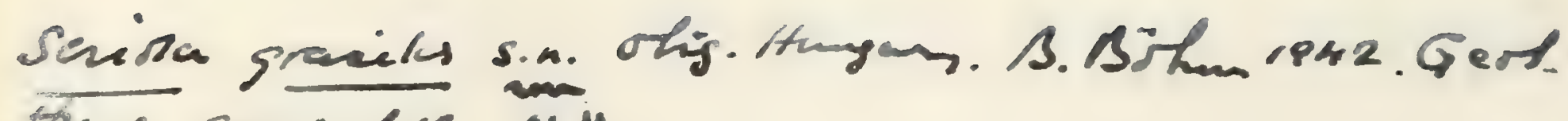
Aturg. Sen paticg N. N.

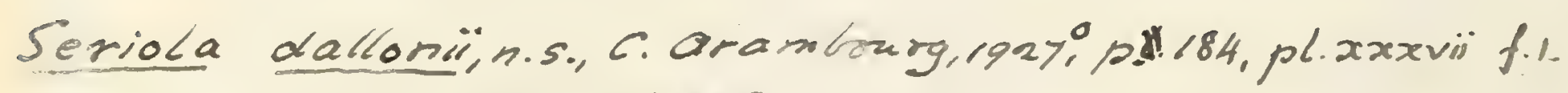
Sahelian; Oran. - Ilmp. fisheg?

Seriota sanctae-1nexide. Tondan 1.spo. Stanf. Univ. Putle,

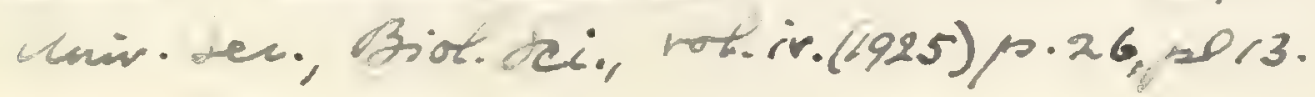

Seriofe sancto-tantarae, D.S. Tordan, Fish-Fauna Calit,

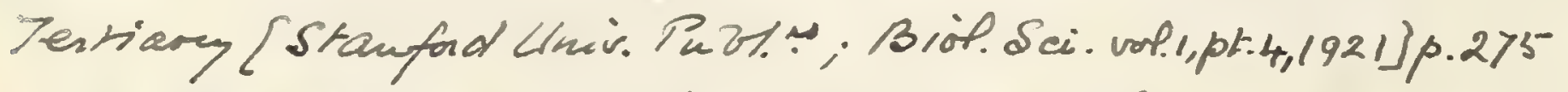

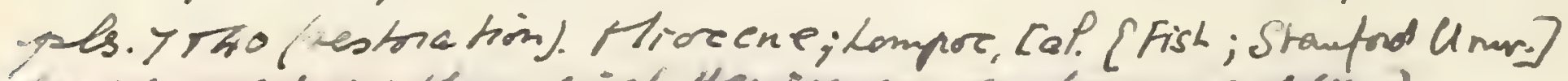

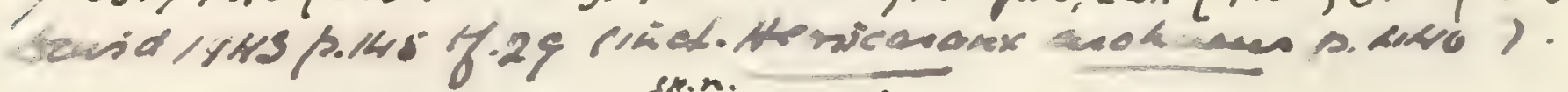

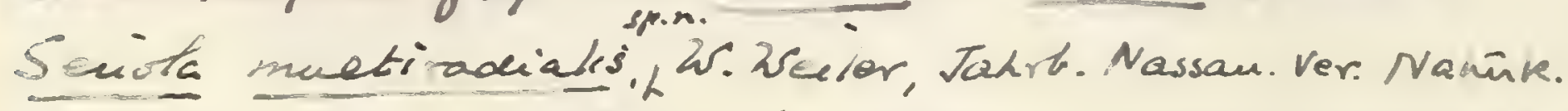

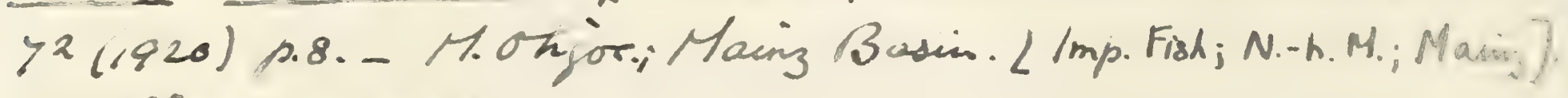
T1928, p. 28 , phing. 




\section{Seriola lata, Heckel.}

1796. Scomber cordyla, G. S. Volta, Ittiolit. Veron, p. cxxi. pl. xxriii. (errore).

1854. Seriola lata, J. J. Heckel, Sitzungsb. k. Akad. Wiss., math.naturw. Cl. vol, xi. p. 136.

T'ype. Nearly complete fish; Zigno Collection, University of Padua.

A comparatively robust species. Length of head with opercular apparatus considerably less than maximum depth of trunk, which is contained about two and a half times in the total length of the fish to the base of the caudal fin.

Form. \& Loc. Upper Eocene: Monte Bolca, near Verona.

P. 1983 b, P. 4139 . Imperfect fish in counterpart, labelled Lichia prisca by Agassiz.

Egerton \& Enniskillen Colls.

Seriola analis (Agassiz).

1796. Scomber, G. S. Volta, Ittiolit. Veronese, pl. lxix. fig. 1 (errore). 1796. Polynemus, G. S. Volta, ibid. pl. lxxv. fig. 3 (errore).

1835. Carangopsis analis, L. Agassiz, Neues Jahrb. p. 304 (name only). 1843-44. Curangopsis analis, L. Agassiz, Poiss. Foss. vol, v. pt. i. p. 42, pl. ix. fig. 1 .

1848. Lichia analis, C. G. Giebel, Fauna d. Vorwelt, Fische, p. 76.

Type. Imperfect fish: Palæontological Museum, Munich.

A comparatively small and slender species. Length of head with opercular apparatus exceeding maximum depth of trunk, which is contained about three and a half to four times in the total length of the fish to the base of the caudal fin. Fins as in type species, except anal slightly longer, apparently with 22 articulated rays.

Form. \& Loc. Upper Eocene: Monte Bolca, near Verona.

P. 1983 c. Fragmentary specimen 0.175 in length, showing minute teeth in premaxilla and dentary. Egerton Coll.

P. 9451. Similar specimen, somewhat distorted. Purchased.

P. 1983 d. Fish $0 \cdot 115$ in length, labelled "Lichia prisca-jeune,Ag." by Agassiz.

Egerton Coll.

The following species may also perhaps belong to this genus, but are insufficiently known and are not represented in the Collection:-

Lichia lata, F. Bassani, Atti R. Accad. Sci. Napoli [2] vol. iii. (1889), no. 6, p. 84, pl. x.-Lower Miocene; Chiaron, Vicentin. [Imperfect fish; Piovene Collection, Lonedo.] 
Lichia stoppanii, F. Bassani, ibid. p. 82, pl. ix. fig. 2.-Ibid.

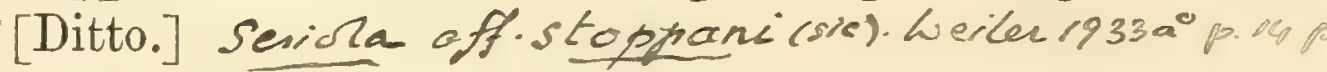

The following names relate to generically indeterminable fragments:-

Lichia alta, D. G. Kramberger, Rad Jugoslav. Akad. vol. cri. (1891), p. 82, pl. v. fig. 3.-Upper Oligocene; Trifail, Croatia. [Caudal portion of fish; Imperial Geological Survey, Vienna.]

Lichica secunda, T. C. Winkler, Archiv. Mus. Teyler, vol. v. (1880), p. 96, pl. iii. figs. 9, 10.-Middle Oligocene (Lignite); Sieb]os, Bavaria. [Imperfect fish; Geological Museum, Univ. Würzburg.]

The so-called Seriola beaumonti (F. de Botella, Descrip. Geol. Murcia y Albacete, 1868, pl. xi. fig. 2), from Lorea, Spain, is not recognisably described or figured.

\section{Genus CARANGOPSIS, Agassiz.}

[Poiss. Foss. vol. v. pt. i. 1344, p. 39.]

As Caranx, but with larger teeth, no enlarged or thickened scales along lateral line, anal fin shorter than posterior dorsal, and anal fin-spines insignificant, not separate from the fin.

\section{Carangopsis brevis (Blainville).}

1796. Pulynemus quinquarius, G. S. iVolta, Ittiolit. Veronese, p. cliii pl. xxxii. (errore).

1818. Mugil brevis, H. D. de Blainville, Nouv. Dict. d'Hist. Nat. vol. xxvii. p. 344.

1835. Carangopsis latior, L. Agassiz, Neues Jahrb. p. 293 (name only). 1843-44. Carangopsis latior, L. Agassiz, Poiss. Foss. vol. v. pt. i. p. 40, pl. ix. fig. 2.

1876. Carangopsis latior, F. Bassani, Atti Snc. Veneto-Trent. Sci. Nat. vol. iii. p. 18 .

Type. Imperfect distorted fish; Museum of Natural History, Paris.

The type species, attaining a length of about $0 \cdot 25$. Length of head with opercular apparatus about equal to maximum depth of trunk, and contained three times in total length to base of caudal fin. Anterior dorsal fin with 8 spines, the second to fifth somewhat longer than any articulated dorsal rays; posterior dorsal with one short spine and 20 or 21 articulated and dirided rass; anal fin with 
Seriola dumerili, Nisso: G.D'Rrasmo, Rend. D. Acead. Sci. Kapoli, 1922, no., hi. 1), hl. i. fij.3.- -

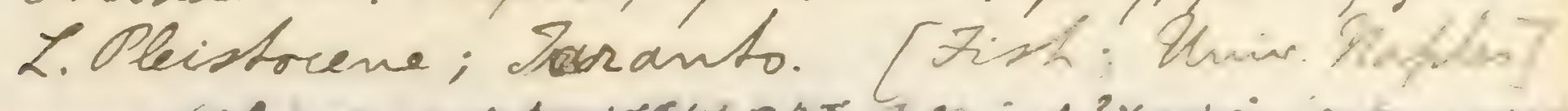

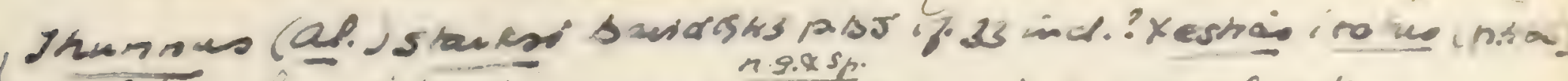

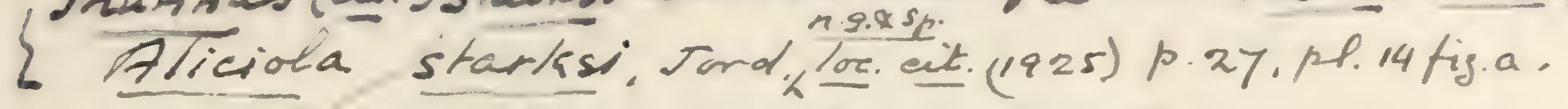

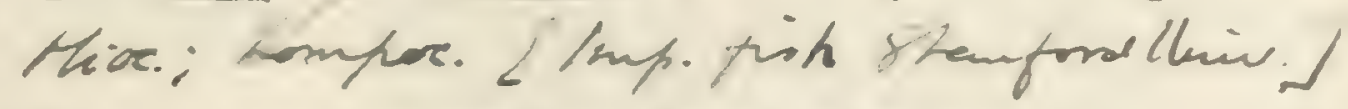

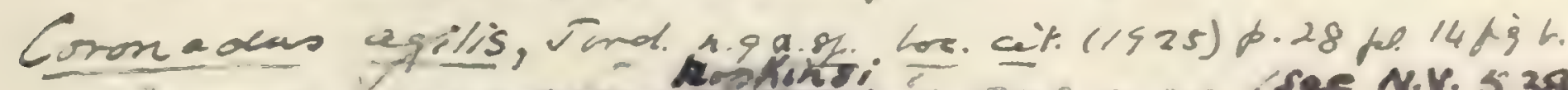

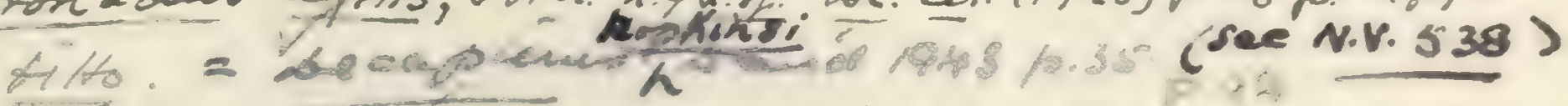

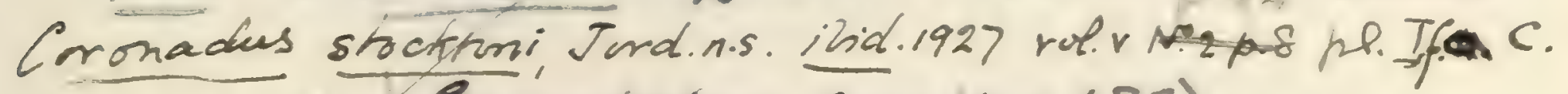

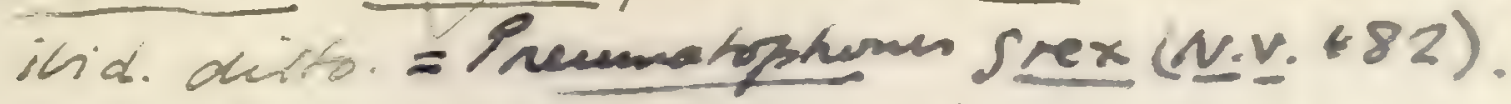

Lichia of. planea (Limn.) \& I. chamia/Lim.), G. De Theyano, Inem. OC. Comith. Geol. Ital vol vii: hh.i (1918), th. 69, 70, hl, viriff 3, 40 - Licada $?=$ H. columiras Aramiorugh p.319.

Hemicananx archacus n. S. Jordan 1827

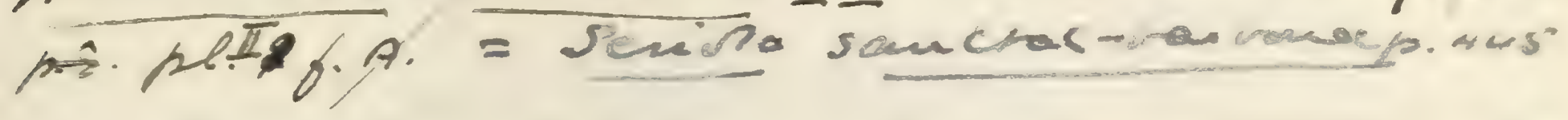


CP. Eastanon, 1961, Men. Caragrio Mus. Iv, p. phe xef.fo. 
2 short spines and 16 to 18 articulated and dirided rays, directly opposed to the hinder two thirds of the posterior dorsal.

Form. \& Loc. Upper Eocene: Monte Bolca, near Terona.

25955*. Large specimen, displaying closely arranged conical teeth. The hinder end of the anal fin seems to hare lost two or three rays.

Dixon Coll.

P. 9452. More imperfect large specimen. The dentary and premaxilla, bearing conical teeth, are remarkably stout.

Purchased.

35676. Smaller fish, displaring the dorsal and anal fins. Ten rertebræ are clearly shown in the abdominal, apparently only 13 in the caudal region.

Bean Coll.

P. 1984, P. 4130 a. Fine small specimen, in counterpart. Egerton \& Enniskillen Colls.

P. 1986. Imperfect trunk, labelled Carangopsis latior by Agassiz.

Egerton Coll.

\section{Carangopsis dorsalis, Agassiz.}

1796. Sciena undecimalis, G. S. Volta, Ittiolit. Veronese, p. ccxrii. pl. liii. fig. 1 (errore).

1818. Scicena undecimalis ?, H. D. de Blainville, Nouv. Dict. d'Hist. Nat. rol. xxrii. p. 348 .

1835. Carangopsis dorsalis, L. Agassiz, Neues Jahrb. p. 301 (name only).

1831-41. Carangopsis dorsalis, L. Agassiz, Poiss. Foss. rol. t. pt. i, p. 41, pl. riii.

Type. Imperfect fish; Museum of Natural History, Paris.

Length of head with opereular apparatus somewhat exceeding maximum depth of trunk, which is contained four times in the total length to the base of the caudal fin ; anal fin with 14 or 15 articu. lated rays. Otherwise resembling the type species.

Form. \& Loc. Upper Eocene: Monte Bolca, near Verona.

P. 1985, P. 4130, P. 4132. Three good specimens, from 0.15 to 0.19 in length, in counterpart. No. P. 4130 is labelled by Agassiz.

Egerton \& Enniskillen Colls.

890-91. Well-preserved specimen, in counterpart, elongated by distortion. The preoperculum seems to exhibit a few serrations on its lower limb.

Purchased.

36031. Imperfect specimen deepened by distortion.

Purchased, $1 \S 61$. 
43448. Head and trunk, wanting end of tail.

Presenterl by Kenneth Murchison, Esq., 1872.

The undefined name Carangopsis maximus was given by Agassiz (Nenes Jahrb. 1835, p. 292) to a fish from Monte Bolca in the Paris Museum, originally referred to Scomber glaucus by G. S. Volta, Ittiolit. Veronese (1796), p. xxxvii. pl. xxi.

The so-called Carangopsis lanceolatus (F. Bassani, Atti Soc. Veneto-Trent. Sci. Nat. vol. v. 1876, p. 153, and Palæont. Italica, vol. iii. 1898, p. 77, pl. viii. fig. 1), founded on a fish from Monte Bolca in the Geological Museum, University of Padua, does not belong to the family Carangidæ. It may represent a species of Myripristis.

\section{Genus DUCTOR, Agassiz.}

[Poiss. Foss. vol. v. pt. i. 1844, p. 53.]

Trunk much elongated but fusiform. Head much elongated, and supraoccipital crest insignificant; eye large; mouth small and teeth minute; preoperculum with fine radiating markings and apparently serrated; branchiostegal rays 7 or 8 , relatively large. Paired fins small; an anterior dorsal fin of 6 or 7 feeble spines, closely followed by a more extended dorsal of articulated rays; anal fin less extended than posterior dorsal, probably with two small feeble spines in front; caudal fin small. Scales very small and uniform, all antero-posteriorly elongated; lateral line not observable.

\section{Ductor leptosomús, Agassiz.}

1796. Callionymus restence, G. S. Volta, Ittiolit. Veronese, p. cxl. pl. xxxii. tig. 2 (errore).

1796. Gobius smyrnensis, G. S. Volta, ibid. p. ccxli. pl. lviii. fig. 2 (errore).

1818. "Callionymus vestena," H. D. de Blainville, Nouv. Dict. d'Hist. Nat, vol, xxvii. p. 359.

1818. "Gobius smyrnensis," H. D. de Blainville, ibid. p. 358.

1834. Ductor leptosomus, L. Agassiz, Verhandl. Ges. vaterländ. Mus. Böhmen, p. 66 (name only).

1835. Ductor leptosomus, L. Agassiz, Neues Jahrb. p. 293 (name only). 1834-44. Ductor leptosomus, L. Agassiz, Poiss. Foss. vol. v. pt. i. p. 53, pl. xii.

1876. Ductor leptosomus, F. Bassani, Atti Soc. Veneto-Trent. Sci, Nat. vol. iii. p. 184.

Type. Imperfect fish; Museum of Natural History, Paris.

The type species attaining a length of about $0 \cdot 2$. Length of head with opercular apparatus about twice as great as maximum depth 
455

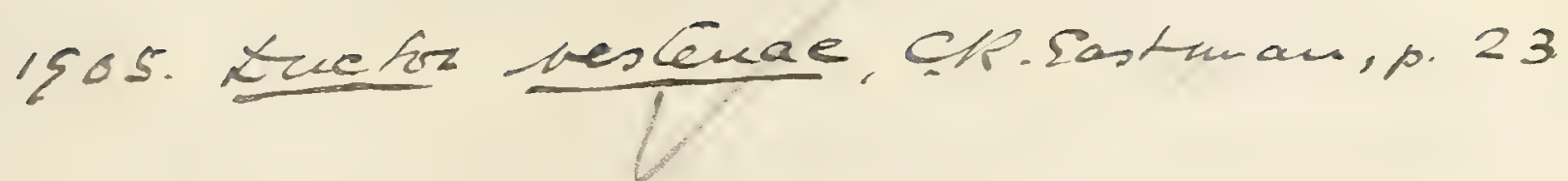


Yeunodou isseli, R. Santucci 130ll. Soe. geol. Ital. 1923 (1922) rolxli, p.204, plolli, fogs 2.2a.

P.9940. Deanthonemes; Munte Boles. Putand, 1903. 
of trunk, and contained slightly more than three times in the total length to the base of the caudal fin. Anterior dorsal fin with 6 spines, the length of the longest about equal. to that of the longest articulated dorsal ray; posterior dorsal with 16 articulated rays; anal fin probably with 2 small spines and 14 articulated rays.

Form. \& Loc. Upper Eocene: Monte Bolca, near Verona.

P. $198 \%$, P. 4133 . Large specimen, in counterpart.

Egerton \& Enniskillen Colls.

P. 4133 a. Smaller specimen.

Enniskillen Coll.

21410. Similar but distorted specimen, in counterpart.

Purchased, 1847.

P. 1987 a, b, P. 4503. Two small distorted specimens, one being in counterpart and labelled by Agassiz.

Egerton \& Enniskillen Colls.

13448, 19011, 28436. Three small imperfect specimens.

Purchased, 1836, 1844, 1853.

The following specimen may possibly represent an unknown member of the Carangidæ, but it is too incomplete for determination :

28\%60. Imperfect head, noticed and figured under the name of Teratichthys antiquitatis by C. Koenig, Icon. Foss. Sect. (1825), p. 4, figs. 79, 79*; London Clay, Sheppey. From collection of Archibald Robertson, Sheerness.

Purchased, 1853.

The following extinct genera and species have also been referred to the Carangidæ, but are not represented in the Collection:-

Acanthonemus bertrandi, L. Agassiz, Poiss. Foss. vol. v. pt. i. (1834), p. 27.-Upper Oligocene; Schio, Vicentin. [Imperfect fish.]

Acanthonemus subaureus: Chatodon subaureus, H. D. de Blainville, c. R. Sasman, Nouv. Dict. d'Hist. Nat. vol. xxvii. (1818), p. 354. Zeus $191 \%$, men. Con gallus and Chotodon aureus, G. S. Volta, Ittiolit. Veronese mus.rv,h.370 M. (1796), pp. lxxxvii., cexii., pl. xix., pl. li. fig. 3 (errore). Acanthonemus filamentosus, L. Agassiz, Poiss. Foss. vol. v. pt. i. (1834), p. 25, pls. iii., iv.-Upper Eocene; Monte Bolca. [The type species. Imperfect fish; Paris Museum of Natural History.]

Bathysoma lutkeni, J. W. Davis, Trans. Roy. Dublin Soc. [2] vol. iv. (1890), p. 424, pl.xlvi.-Upper Cretaceous ; Lim- 
hamn, Scania. [Fragmentary fish; Royal Zoological Museum, Copenhagen. Very imperfectly known, and number of vertebræ not exactly ascertained.]

Carangodes cephalus, J. J. Heckel, Denkschr. k. Akad. Wiss., math.-naturw. Cl. vol. xi. pt. i. (1856), p. 262, pl. xii. figs. 1-4.-Upper Eocene; Monte Bolca. [Imperfect fish ; Geological Museum, University of Padua. Excluded from Carangidæ, as defined, by more numerous vertebræ $(15+17)$.]

Desmichthys daubrei, H. E. Sauvage, Bull. Soc. Géol. France [3] vol. vi. (1878), p. 634, pl. xiii. fig. 1.-Tertiary; Bouchesdu-Rhône. [Imperfect fish; Paris Museum of Natural History.]

Parequula albyi, H. E. Sauvage, Ann. Sci. Géol. vol. xi. (1880), Steindeckien art. no. 3, p. 25, fig. 1.-Upper Miocene; Licata, Sicily. [Indeterminable imperfect fish; Paris Museum of Natural Caranxe allyi, cearamtourg, ann.dePal.xiv (1925)

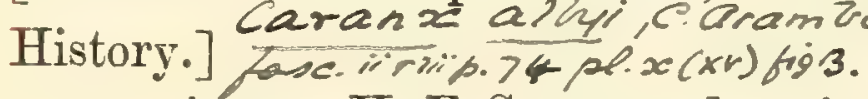

Pseudovomer minutus, H. E. Sauvage, loc. cit. vol. iv. (1873), art. no. 1, p. 153, fig. 14. Argyreiosus minutus, H. E. Sauvage, Ann. Sci. Nat. [5] vol. xiv. (1870), art. no. 7, p. 10.-Ibid. [Ditto. If 16 caudal vertebræ are present, as described, this fish is excluded from the Carangidæ. $]=P$ mincalis,

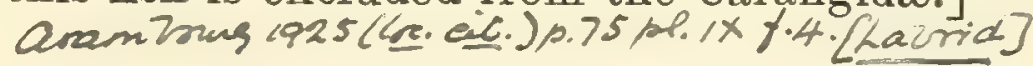

The following extinct genus and species is undefined :-

Acanthonemopsis capellinii, Bosniaski, Atti Soc. Tose. Sci. Nat.Proc.-Verb. vol. i. (1878), p. xix.-Upper Miocene; Gabbro, Tuscany. see Capros apar.

Unsatisfactorily determined extinct species of existing genera have also been described as follows:-

L. "Sp Bgeor Equula scillae, H. E. Sauvage, Ann. Sci. Géol. vol. iv. (1873), art. no. 1, p. 156, fig. 90.- Upper Miocene; Licata, Sicily. [Imperfect distorted fish.] Laranx.

Poiss. Foss. vol. v. pt. i. (1834-44), p. 36, pl. vii. Chatodon rhomboides, G. S. Volta, Ittiolit. Veronese (1i96), p. clxii. pl. xxxix. fig. 3 (errore).-Upper Eocene; \begin{tabular}{ll} 
Eozandus gan.nov., & $(1796)$, p. clxii. pl. xxxix. fig. 3 \\
\hline
\end{tabular}

type $\cdot$ sp. $=$ Zanclus brevirostris, L. Agassiz, Toc. cit. 1835, p. 292, and op. cit. J Blset + C.V V w2, 1974, vol.iv. (1835-42), p. 236, pl. xxxviii. Chatodon canMem. Mus. Vercha, furi escens, G. S. Volta, op. cit. 1796, pl. xxvi. fig. 2 (errore).

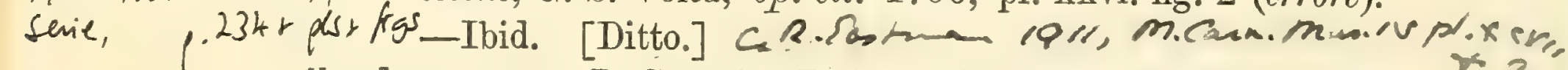
Zanclus eocoenus, P. Gervais, Zool. et Pal. Franç. (1852), Poiss. 
P.9946-48. Three speimen of Bathyeome títheni. Byexhare, Smir. Zund, 1903.

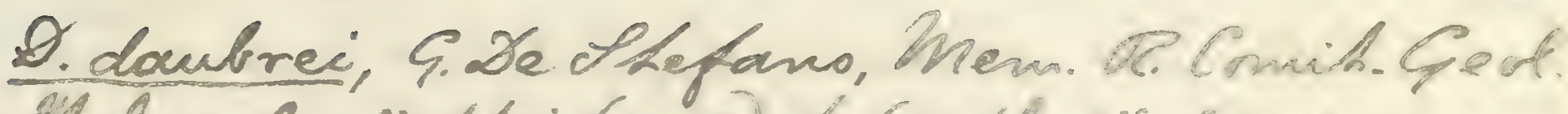

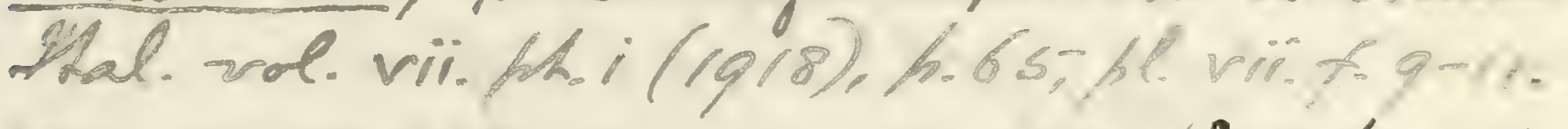

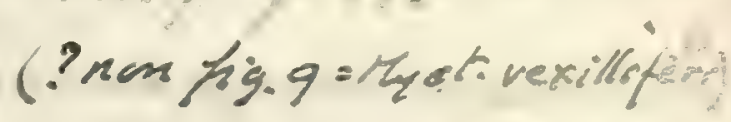

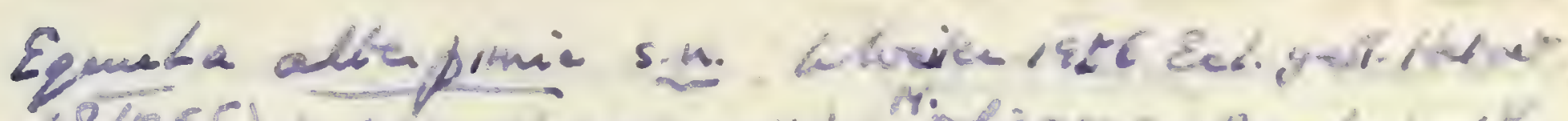

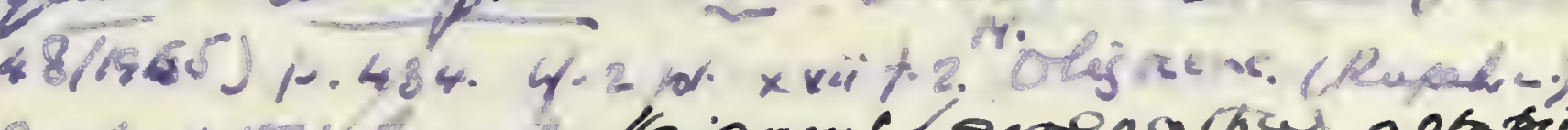

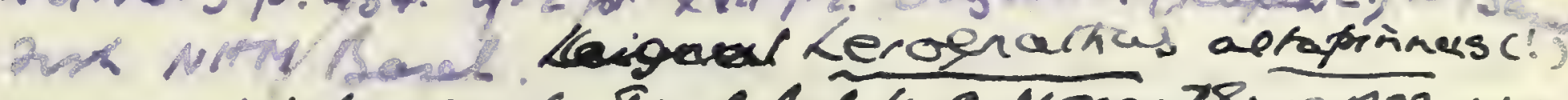

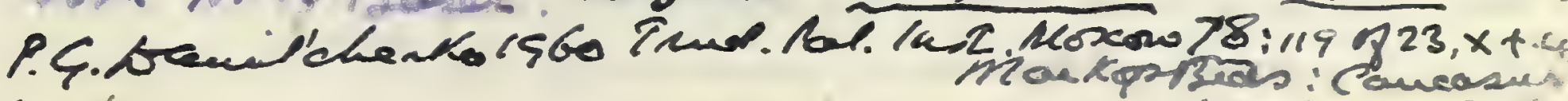
Lophar miocdenus, D. P. Fordan d 9. 2. Gillert, Fon hithe P. California (Ptanford Anive. Publie., Univ. Ses. 1919), p.44 pliii.fi. 2, hls. xix, xx. - Mircene; Zos Angele. Lmpmpwit firk, S. Calif. Lead, Zos Anglle.]

T. of Zophar.

Enula ff. E.farciata, Zacép; : G. De Lte fano, Boll. Lor.

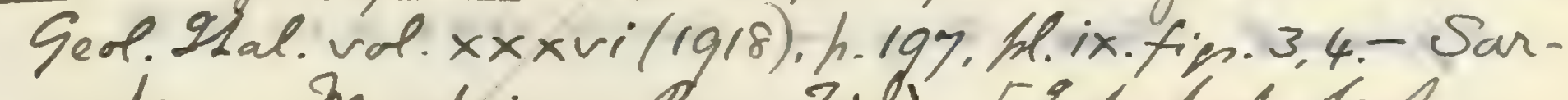
mation: Mnodaino, Phn, Forli. [Ampinfut firt: R. Ziceo R. Q. Visconti, Rome.]

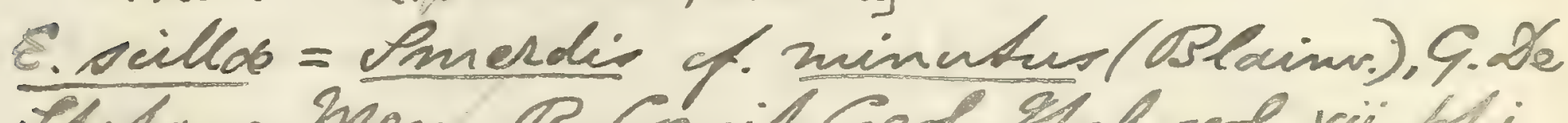
Thefano, Mem. O. Comith Ged. Ital wol vir. bhi

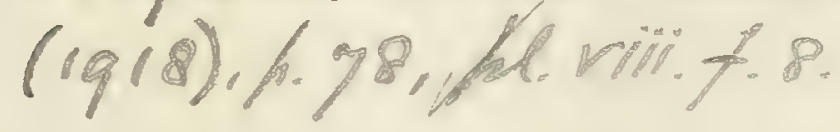

- Trachartís Lenuicefes C.R. Rastman, 1911, Mem.

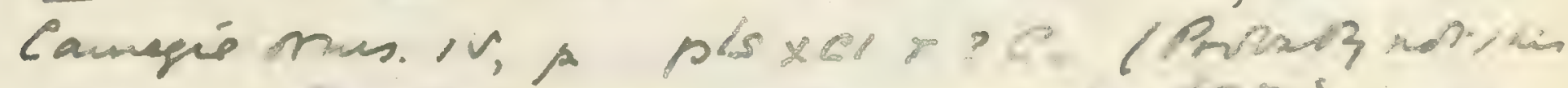
stumed the Tractingats. 


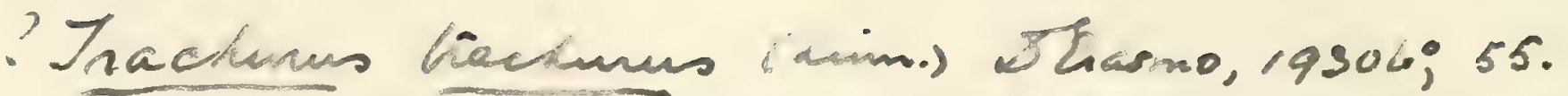
Scminar hächumen. Prot. Smirnor 1936;0.66.80 21-23, phvirit.36. Jigure N. Cancasus. Seep. 442.

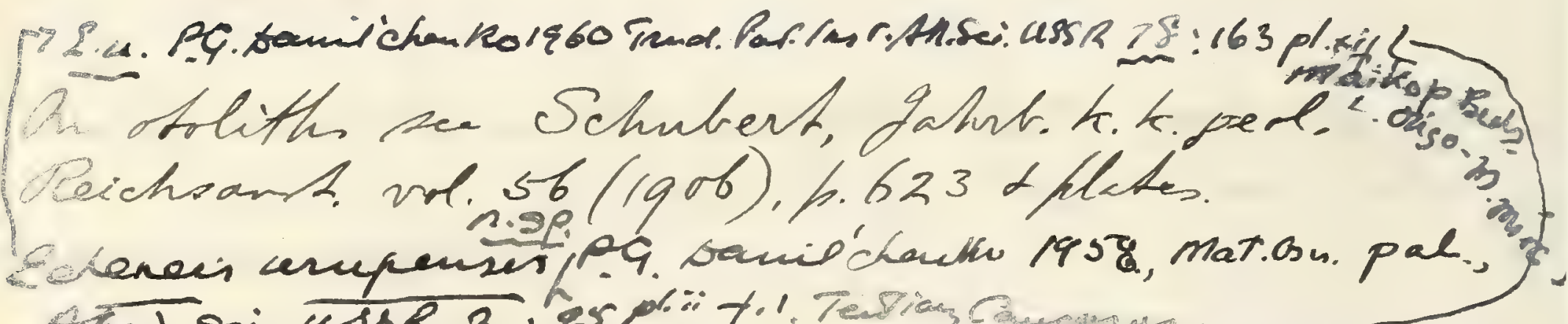

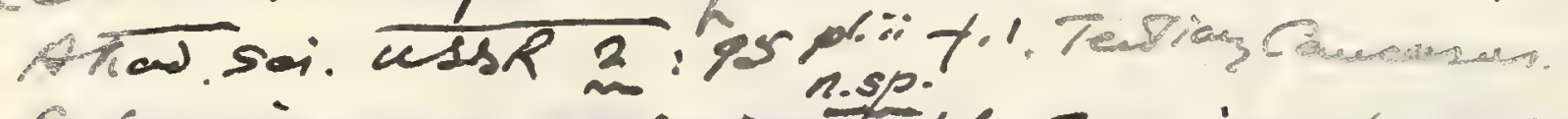

Echereis cappatmica., W. $S_{3}$ ajrucha, xeniis

Gorjanovic-Kramberg. Separation imprens um 6 Sre.

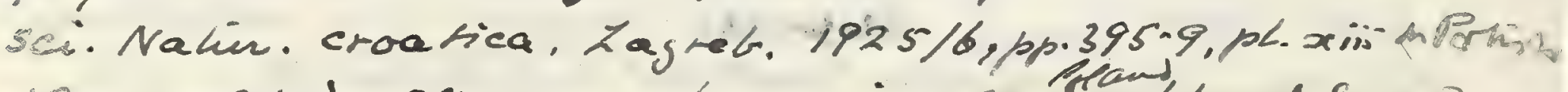

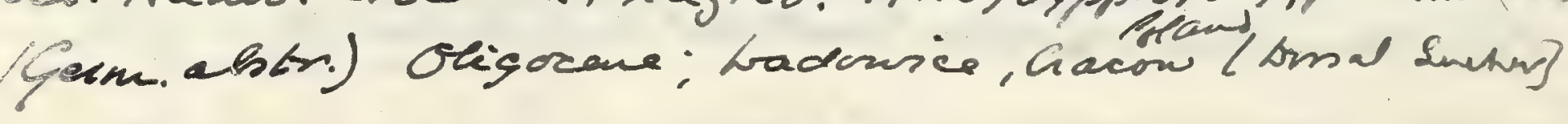

PMMOTOMIDAE

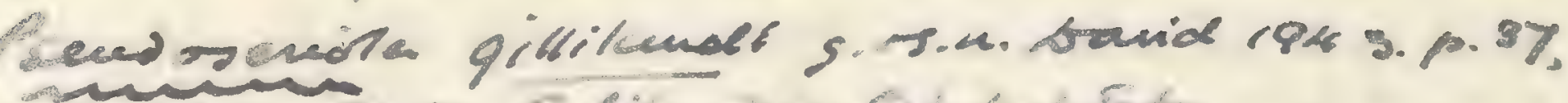

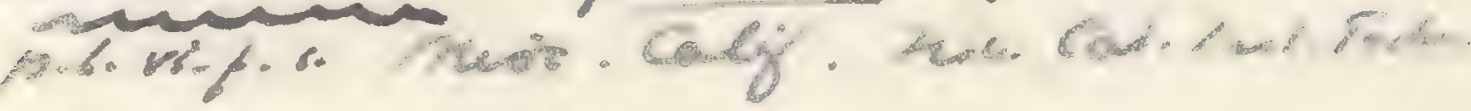

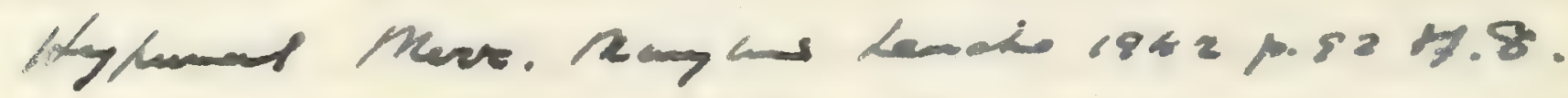

Saimata prazriteleri, g.s.n. V.r. Bgoharher, 19930

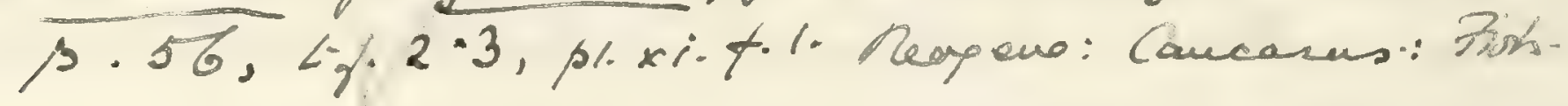

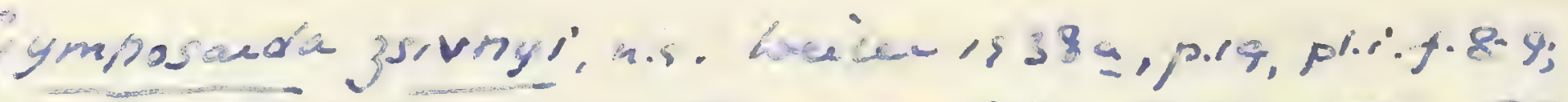

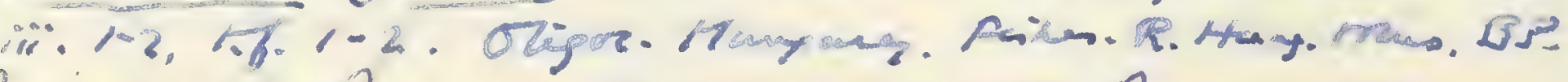

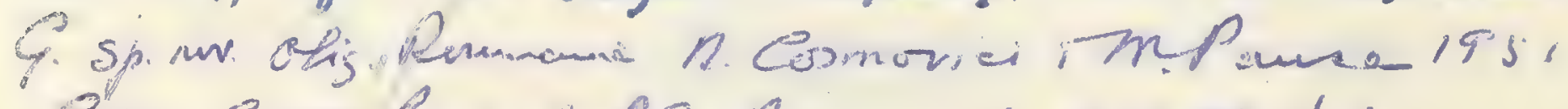
eam. Acoos Repuld. Pof Rumane 1 \% $949 \% 1$. 


Foss. p. 8, pl. lxxii. figs. 3-5, and woodc.-Middle Eocene (Calcaire Grossier); Paris. [Generically indeterminable imperfect fish; Paris Museum of Natural History.]

Nothing is known of the so-called Vomer parvulus (L. Agassiz, Poiss. Foss. vol. v. pt. i. 1844, p. 31) from the Upper Cretaceous of Mt. Lebanon.

The following otolith is supposed to belong to a member of this family :-

Otolithus (Carangidarum) americanus, E. Koken, Zeitschr. deutsch. geol. Ges. vol. xl. (1888), p. 277, pl. xvii. figs. 1-3.-Lower Tertiary; Vicksburg \& Jackson River, Mississippi.

The existing genus Echeneis, with the anterior dorsal fin modified into an adhesive disk, is usually placed with the Scombridæ; but it is represented by an extinct species in the Oligocene slates of Canton Glarus, Switzerland, which is remarkable as exhibiting only 10 abdominal and 13 caudal vertebræ. This fish is known only by one specimen in the Berne Museum, which has the disk narrower and a little further back than in the typical Echeneis. It is described as Echeneis glaronensis by A. Wettstein, Fischfauna Tertiaer. Glarnerschief. (Denkschr. schweiz. Palaeont. Ges. vol. xiii. 1886), p. 82, pl. vii. fig. 10, and is discussed by R. Storms, Ann. Mag. Nat. Hist. [6] vol. ii. (1888), p. 73. The new generic name Opisthomyzon is proposed for it by E. D. Cope, Amer. Nat. vol. xxiii (1889), p. 355.

\section{Family SCOMBRID王.}

Snout not produced into an elongated rostrum; no supramaxillæ gape wide, and teeth conical, forming a more or less powerful dentition. Vertebræ from 28 to 160 in total number; centra of abdominal region with transverse processes in fusiform types, but without these processes in the more elongate types. Pelvic fins, when present, thoracic, with one spine and not more than five articulated rays; spinous portion of dorsal fin more extended than articulated portion; usually finlets behind dorsal and anal fins. Scales small or absent, and no bony scutes; lateral line distinct.

All the existing members of this family are marine, most of them being pelagic, some characteristic of the deep sea. In outward shape and the derelopment of the median fins, the genera are as 
varied as those of the existing Isospondylous family Mormyridx. ${ }^{\text {I }}$ The more elongated and degenerate types are those inhabiting great depths.

All the known fossil Scombridæ occur in marine deposits.

\section{Synopsis of Extinct Genera and Genera represented by}

I. Trunk fusiform. Extinct Species.

A. Two dorsal fins close together.

Posterior dorsal and anal fins much extended, perhaps without finlets ..

Posterior dorsal and anal fins short and deep, with 8 to 12 finlets........

[Skull resembling that of Thynnus, but deeper in proportion to its width ...................

B. Two dorsal fins well separated.

Teeth very small and conical; about 30 vertebræ; caudal pedicle without lateral keel; paired fins small; no enlarged pectoral scales .......

As Scomber, but with nearly 40 vertebræ and larger pectoral fins ....

[Skull resembling that of Scomber, but with larger teeth ............

As Scomber, but caudal pedicle with lateral keel and pectoral scales enlarged .................

Marginal teeth large and laterally compressed, in single series; caudal pedicle with cartilaginous lateral keel ...................

[Skull resembling that of Cybium, but shorter and without median frontal crest ..................

[Jaws as in Cybium, but teeth round or ovoid in section $\ldots . . . \ldots .$.

[Jaws as in Sphyrcenodus, but small teeth on dentary outside series of large teeth ..........................

II. Trunk much elongated.

Paired fins small ; finlets behind dorsal and anal fins ...............

Pelvic fins rudimentary; dorsal fins continuous; no dorsal or anal finlets ................... Lepidopus (p. 477).

1 G. A. Boulenger, Proc. Zool. Soc. 1898 (1899), p. 780. 


In osterlorge of Teombroido see S.C. Ptanter, Iomm. Inophhl. vol. xxi(19), h.77, and Stantod Aniv. Oublice. no. s-("gil).

Jable of charecters of several servere, in.

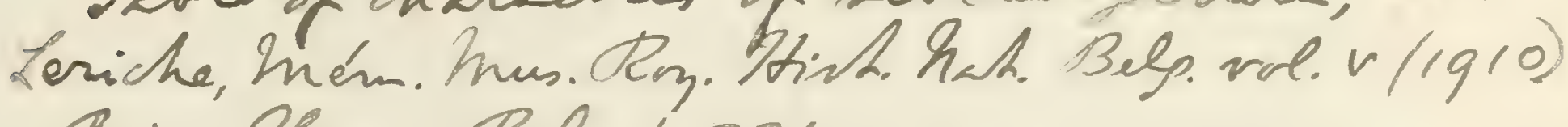
- Poins. Dligre. Belp. tr. 321.

Mabucria spuria G. S.4. W. Sogracer.

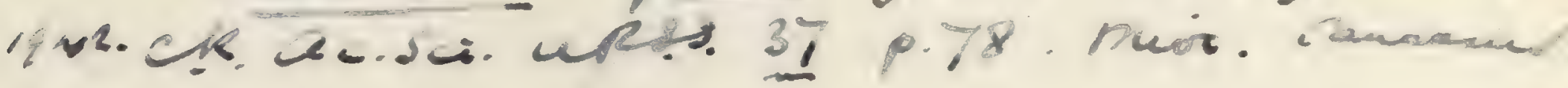

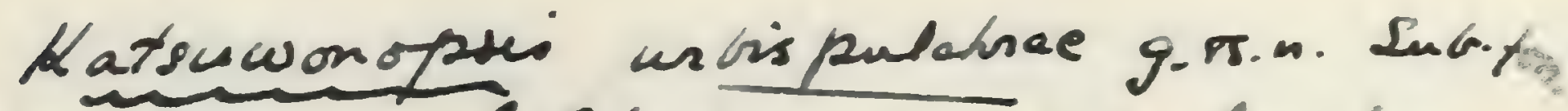

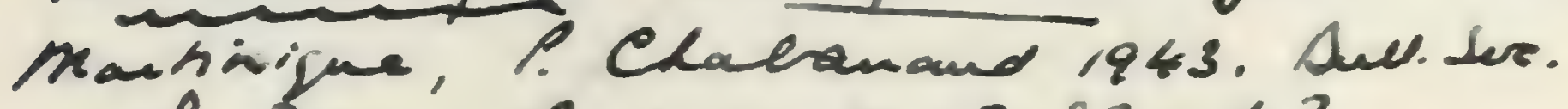
sort. Hance is p.140. 17.1-8. [tagents].

Loudamichlects gin.am

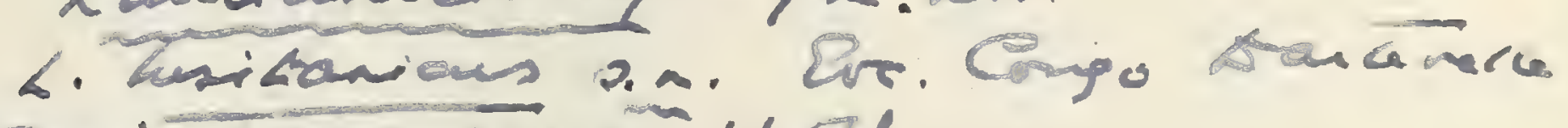
Tasin 1849 p.232 भ.

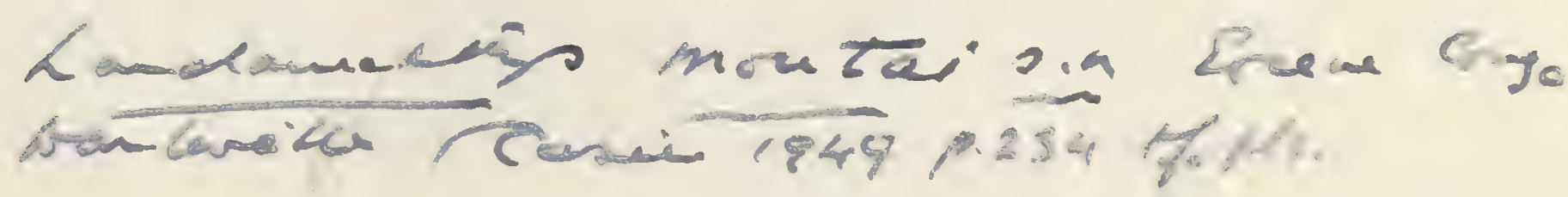




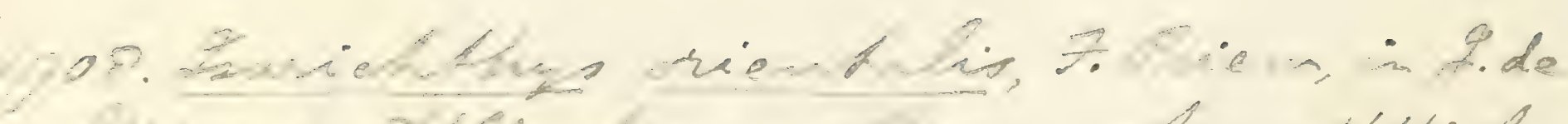

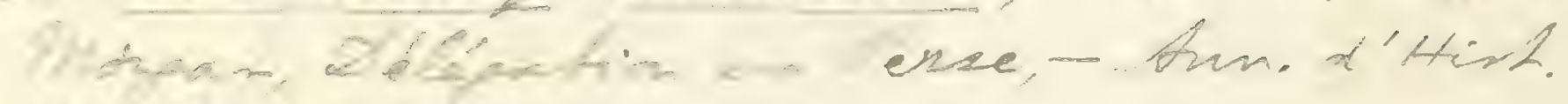
net. Hei, 22 
Genus ISURICHTHYS, nom. nov.

Syn. Isurus, L. Agassiz (non Rafinesque, 1810), Poiss. Foss. vol. v. pt. i. 1844, p. 51.

Trunk deeply fusiform, the much-contracted caudal pedicle apparently without bony keel. Teeth probably minute. Vertebræe about 30 in number, the centra much constricted, apparently with two lateral pits separated by a longitudinal ridge; all hæmal arches simple. Paired fins apparently small; dorsal fins scarcely separated, the anterior consisting of about 8 to 10 spines; posterior dorsal and anal fins considerably extended, perhaps without finlets; caudal fin deeply forked. [Scales unknown.]

\section{Isurichthys macrurus (Agassiz).}

1837. Isurus macrurus, Sir P. Egerton, Catal. Foss. Fish (name only).

1842-44. Isurus macrurus, L. Agassiz, Poiss. Foss. vol. v. pt. i. p. 51, pl. xxi. figs. 3,4 .

1886. Isurus macrurus, A. Wettstein, Fischfauna Tertiaer. Glarnerschief. (Denkschr. schweiz. Palaeont. Ges. vol, xiii.), p. 90, pl. vii. figs. 1-6.

Type. Imperfect fish; British Museum.

The type species, attaining a length of about $0 \cdot 15$. Proportions uncertain, but length of head with opercular apparatus probably about equalling maximum depth of trunk and one third total length of fish to base of caudal fin. Vertebræ 12 in the abdominal, 16 in the caudal region. Anterior dorsal fin consisting of 8 spines, posterior dorsal of 16 to 18 well-spaced articulated rays; anal fin with 15 or 16 articulated rays.

All known specimens are imperfect and considerably distorted.

Form. \& Loc. Oligocene: Canton Glarus, Switzerland.

P. 453, P. 3999. Type specimen, in counterpart, described and figured by Agassiz, loc. cit.; Engi.

Egerton \& Enniskillen Colls.

36088. Larger, obliquely-distorted specimen, in counterpart; Plattenberg. $\quad$ Purchased, 1861.

41820. Well-preserved caudal region; Engi. Purchased, 1869.

Isurichthys orientalis, $\mathrm{sp}$. nov.

Type. Nearly complete fish; British Museum.

Apparently a smaller and more slender species than the type. 
Length of head with opercular apparatus considerably exceeding maximum depth of trunk, but equalling one third total length of fish to base of caudal fin. Vertebræ 14 in the abdominal, 16 in the caudal region. Anterior dorsal fin consisting of 10 slender spines, the posterior fin of about 20 rays, the first perhaps a spine; anal fin with 2 or 3 feeble spines and about 20 articulated rays.

Form. \& Loc. Tertiary : Persia.

P. 7130. Type specimen in compact, limestone, partly obscured by oxide of manganese; Shushter, Persia. The orbit is shown to be very large, and the mouth rather small, with minute, closely-set teeth. The operculum is rounded, and there are 7 branchiostegal rays. The pectoral fins are small and low on the flank; the pelvic fins, with one slender spine and 5 articulated rays, are inserted slightly further back. The forked tail is well shown. There are no indications of scales.

Presented by Alfred Holland, Esq., 1894.

\section{4 souit}

Genus THYNNUS, Cuvier.

[Règne Animal, vol. ii. 1817, p. 313.]

Syn. Orcynus, G. Cuvier, ibid. 1817, p. 314.

Trunk very robust and elongate-fusiform ; slender caudal pedicle, with strong median lateral keel formed by bony ridge on vertebral centra. Median pair of fossæ for anterior extension of lateral muscles of trunk produced forwards over frontal bones and separated by median frontal ridge continuing the large supraoccipital crest; lateral pair of fossæ also produced half-way over frontals. Teeth small and conical, and in single series on margin of jaws, minute and clustered on vomer and palatines. Vertebræ about 40 in number, the centra constricted, with two lateral pits separated by a longitudinal ridge; all hæmal arches simple. Pectoral fins elongate, but not extending beyond origin of anal; pelvic fins small; dorsal fins scarcely separated, the anterior consisting of 12 to 15 spines; posterior dorsal and anal fins srnall but elevated, similar and opposite, followed by 8 to 12 detached finlets; caudal fin deeply forked, with slender lobes. Scales very small, uniformly covering the trunk, except in the pectoral region, where they are somewhat enlarged and compacted.

The typical existing species is pelagic and attains gigantic proportions. 
1922. Thymur off. pealdici, G.X'irasmo, Pend. P. Hecad. Sci. hap di, no., h. 22, pl. ifij.4. [2. Pleirh.; Faranto. Fish: Amiv. Naples.J 1926. Th. Scaldienses, M.lerido, p. $442^{\circ}$ 


\section{Thynnus thynnus (Linnæus).}

1758. Scomber thynnus, Linnæus, Syst. Nat. ed. 10, p. 297.

1831. Thynnus vulgaris, Cuvier \& Valenciennes, Hist. Nat. Poiss. vol. viii. p. 58, pl. cex.

1860. Thynnus thynnus, A. Günther, Catal. Fishes B. M. vol. ii. p. 362.

1890-91. Thynnus thynnus, E. T. Newton, Geol. Mag. [3] vol. vii. p. 264, \& Vert. Pliocene Depositsj Britain (Mem. Geol. Surv.), p. 91, pl. ix. fig. 8 .

Type. Recent fish.

The type species, attaining a length of 3 to 4 metres. Length of head with opercular apparatus slightly exceeding maximum depth of trunk, which is contained about four times in total length of fish. Vertebræ 16 in abdominal, 23 in caudal region. Pectoral fins, when adpressed, nearly reaching end of anterior dorsal, which comprises 14 spines; posterior dorsal with 1 spine, 13 articulated rays, and 9 finlets; anal fin with 2 spines, 12 articulated rays, and 8 finlets.

Form.\& Loc. Pleistocene (Forest Bed Series): Norfolk.

P. $873 \%$. Abdominal vertebra described and figured by E.T. Newton, loc. cit.; Forest Bed, East Runton. Savin Coll.

36168-69. T'wo larger vertebral centra; Hasbro'. Layton Coll.

\section{Thynnus scaldisi, Storms.}

1890. Thynnus (Orcynus) scaldisii, R. Storms, Bull. Soc. Belge Géol. vol. iii. Mém. p. 175, pl. vii. figs. 17-23.

1890. Thynnus scaldisiensis, A. S. Woodward, Ann. Mag. Nat. Hist. [6] vol. v. p. 294.

1891. Thynnus scaldiensis, E. T. Newton, Vert. Pliocene Deposits Britain (Mem. Geol. Surv.), p. 90.

Type. Vertebræ; Brussels Museum.

Somewhat smaller than the type species, known only by vertebræ. The centra behind the 30th are longer in proportion to their width than in the latter species.

Form. \& Loc. Lower Pliocene: Antwerp; Suffolk.

P. 9453. Caudal vertebra, described by A. S. Woodward, loc. cit.; Coralline Crag, Aldborough, Suffolk.

Presented by Searles V. Wood, Esq.

P. 5583. Smaller caudal vertebra, described ibid.; Coralline Crag, Suffolk. Harford Coll. 


\section{Thynnus lanceolatus (Agassiz).}

1796. Scomber alatunga, G. S. Volta, Ittiolit. Veronese, p. cxxiii. pl. xxix. fig. 1 (errore).

1796. Salmo cyprinoides, G. S. Volta, ibid. p. ccxiv. pl. lii.

1818. Clupea cyprinoides, H. D. de Blainville, Nouv. Dict. d'Hist. Nat. vol. xxvii. p. 343.

1818. Scomber altalunga, H. D. de Blainville, ibid. p. 345 (errore).

1835. Orcynus lanceolatus, L. Agassiz, Neues Jahrb. p. 293.

1835-44. Orcynus lanceolatus, L. Agassiz, Poiss. Foss. vol. v. pt. i. p. 59, pl. xxiii.

1876. Orcynus lanceolatus, F. Bassani, Atti Soc. Veneto-Trent. Sci. Nat. vol. iii. p. 183.

1889. Thynnus lanceolatus, R. Storms, Bull. Soc. Belge Géol. vol. iii. Mém. p. 178.

Type. Imperfect fish; Paris Museum of Natural History.

A comparatively small species, with the caudal region more elongated and slender than in T. thynnus. Vertebræ 14 in the abdominal, 22 in the caudal region. Pectoral fins relatively large, when adpressed reaching beyond end of anterior dorsal; posterior dorsal with 12 or 13 rays, arising at middle point between end of snout and base of caudal fin; anal fin with 2 spines and 6 articulated rays, slightly behind the origin of the posterior dorsal; 12 dorsal and anal finlets.

Form. \& Loc. Upper Eocene: Monte Bolca, near Verona.

P. 3946. Imperfect fish 0.22 in length, partly distorted.

Egerton Coll.

The extinct species described under the following names also seem to belong to this genus, but are not represented in the Collection :-

Orcynus komposchi, D. G. Kramberger, Verhandl. k. k. geol. Reichsanst. 1882, p. 29 (name only), and Rad Jugoslav. Akad. vol. Ixxii. (1885), p. 48, pl. iii. fig. 1, and Soc. Hist. Nat. Croatica, vol. i. (1886), p. 135.-Upper Oligocene; Trifail, Steiermark. [Imperfect trunk; University Geological Museum, Agram.]

Orcynus latior, L. Agassiz, Neues Jahrb. 1835, p. 294, and Poiss.

Foss. vol. v. pt. i. (1835-44), p.60, pl. xxiv. Scomber orcynus, G. S. Volta, Ittiolit. Veronese (1796), p. ccxxvi. pl. Iv. fig. 2.-Upper Eocene; Monte Bolca. [Imperfect fish ; Paris Museum of Natural History.]

Orcynus medius, F. Bassani, Atti R. Accad. Sci. Napoli [2] vol. iii. (1889), no. 6, p. 74, pl. ix. fig. 1.-Lower Miocene: 




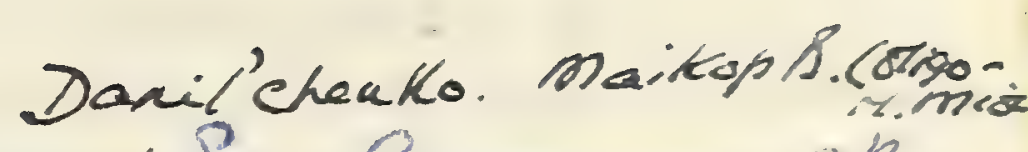

Thunnus abchazicos 2 in Live. Pewasm, ek.

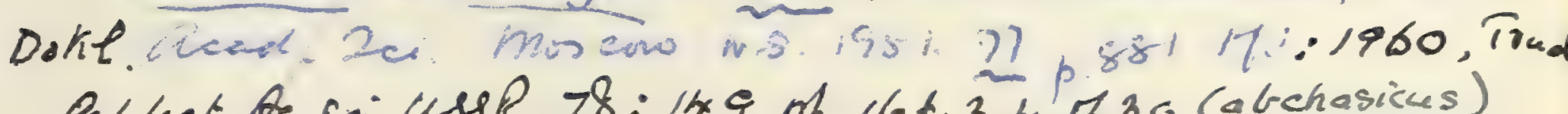

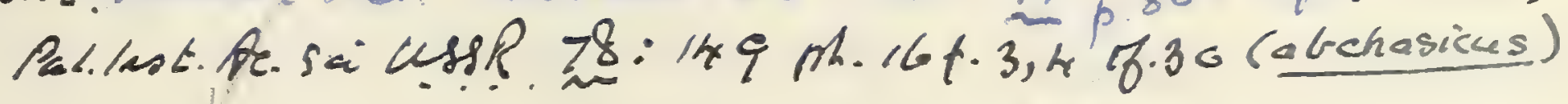

Thynnus plidernicus, P.Sanluecei, Boll. Sor ged. Ihal.

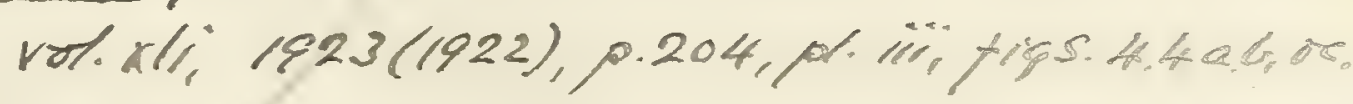

Euthynnus sp. C. Aramboung, 1927, p. 168, ty 39,pl. xaxixti

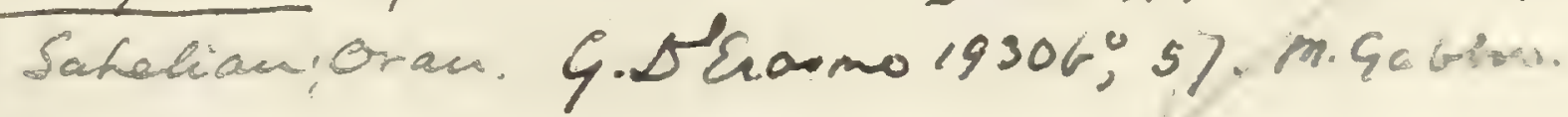

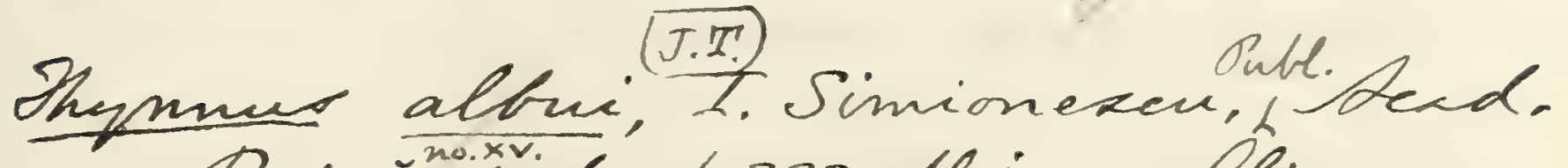
Comána,klgob, 1. 322, hlii. - Plipocene: Cosla, nem Diatra- Reambs, Doumania-

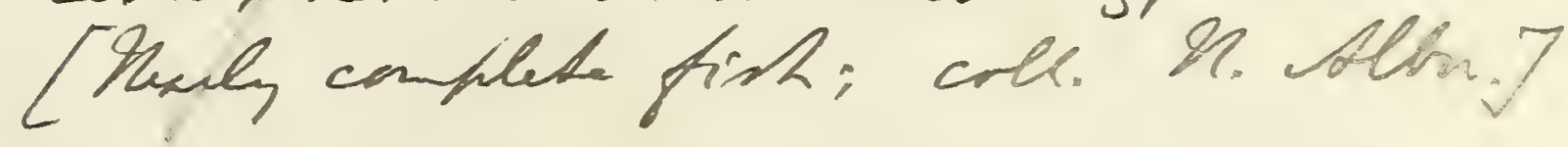

Thynnus huberti, P.H. Fritel, Bull. Com. Tud. Hist. Pei. Afrique Decid. Frane. no. $3(1920)$.

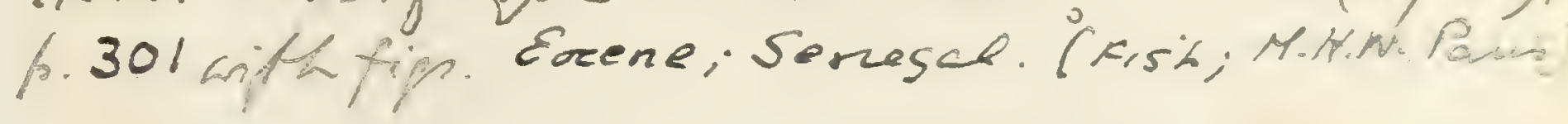




\section{"}



Chiavon, Vicentin. [Imperfect fish; Piovene Coll., Lonedo.]

The fragmentary fossils described under the following names do not appear to belong to this genus:-

Thynnus angustus, H. E. Sauvage, Ann. Sci. Nat. [5] vol. xiv. (1870), art. no. 7, p. 6, and Ann. Sci. Géol. vol.iv. (1873), art. no. 1, p. 144, fig. 21. Aiuxis (?), D. G. Kramberger, Beitr. Paläont. Oesterr.-Ungarns, vol, ii. (1882), p. 118. -Upper Miocene; Licata, Sicily.

Thynnus bolcensis, L. Agassiz, Neues Jahrb. 1835, p. 305, and Poiss. Foss. vol. v. pt. i. (1844), p. 57 (undescribed). Scomber thynnus, G. S. Volta, Ittiolit. Veronese (1796), p. cxix. pl. xxvii. (errore).-Upper Eocene; Monte Bolca. [Imperfect fish ; Paris Museum of Natural History.]

Thynnus (?) proximus, H. E. Sauvage, loc. cit. 1870, p. 7 , and 1873, p. 146, fig. 24.-Upper Miocene; Licata. [Portion of trunk.]

\section{Genus EOTHYNNUS, novum.}

Syn. Coelocephalus, L. Agassiz, Poiss. Foss. vol. v. pt. ii. 1844, p. 139 (name only) ${ }^{1}$.

A genus known only by the head, which is essentially identical with that of Thynnus, but seems to be deeper in proportion to its width. Teeth on margin of jaws very small and clustered in more than one series.

Eothynnus salmoneus, sp. nov.

1844-45. Coelocephalus salmoneus, L. Agassiz, Poiss. Foss. vol. v. pt. ii. p. 139, and Rep. Brit. Assoc. 1844, p. 308 (name only).

Type. Imperfect cranium; British Museum.

The type species, with head and opercular apparatus sometimes nearly 0.25 in length. Width of cranium at occiput about two thirds maximum depth of head. Maximum depth of operulum about twice its greatest width.

Form. \& Loc. Lower Eocene (London Clay): London Basin.

P. 623. Very imperfect cranium, labelled by Egerton as intended to be the type specimen of this species; Sheppey. Egerton Coll.

28757. Large head, with some anterior vertebræ much like those of Thynnus ; Sheppey.

Purchased, 1853.

1 This generic name has been employed for an existing Macrurid by Gilbert \& Cramer, Proc. U.S. Nat. Mus. vol. xix. (1897), p. 422. 
19114. Smaller bead, less distorted, showing most of the principal characters; Sheppey. The three anterior vertebral centra are shown in position.

$$
\text { Presented by Rev. F. W. Hope, } 1845 .
$$

P. 1750. Imperfect head, partly decaying, showing the jaws and the bases of the clustered minute teeth on the premaxillæ; Sheppey. Egerton Coll.

There seem to be no satisfactory characters by which the following specimens, from the London Clay of Sheppey, can be generically separated from Eothynnus:-

38900. Imperfect head with opercular apparatus, deeper than in E. salmoneus.

Bowerbank Coll.

P. 629. Small imperfect head, similarly deepened, marked by Egerton as intended to be the type specimen of Rhonchus carangoides, Agassiz (named in list in Rep. Brit. Assoc. 1844 [1845], p. 308) ${ }^{1}$.

Egerton Coll.

P. 9454. Hinder part of similar small head.

Egerton Coll.

P. 1744. Hinder portion of larger head with remains of opercular apparatus, marked "Rhonchus n.s." by Egerton.

Egerton Coll.

3505\%. Hinder portion of similar head with opercular apparatus. Purchased, 1861.

P. 628. Hinder portion of cranium, apparently with crests worn away, marked by Egerton as intended to be the type specimen of Phalacrus cybioides, Agassiz (named in list in Rep. Brit. Assoc. 1844 [1845], p. 308). Egerton Coll.

To Eothynnus may also probably be referred the vertebræ from the London Clay of Sheppey in the Royal College of Surgeons, named Thynnus toliapicus, R. Owen, Catal. Foss. Rept. \& Pisces (1854), p. 174, no. 697. The following are similar specimens :-

3611\%. Three terminal caudal vertebræ; London Clay, Sheppey. Purchased, 1861.

38885. Three caudal vertebræ; Sheppey. Bowerbank Coll.

P. 4300 a, P. 4301 . Three caudal vertebræ; Sheppey.

Enniskillen Coll.

${ }^{1}$ Apparently the same as a specimen in the Royal College of Surgeons, named Cariniceps compressus, R. Owen, Catal. Foss. Rept. \& Pisces (1854), p. 165 , no. 663 . 


\section{ALPHABETICAL INDEX.}

[Tute-The numbers of pages on which mere incidental reforences ocenr are printed in italies.

Abramis, :D19.

= corama. $\$ 10$.

Leantinits marginatus.

$$
\because 28 .
$$

Acanthoderma. $\overline{6} 68$.

oroculatum,

oriale. ins.

- pinosum. 5 ris.

Acanthomuilus, 116. Seabelie, 416 .

scanthonemopsis. ¿il)

aneilinit. 450.

Acanthonemus, $\$ 10$.

berrinuci. 14 .

ilimentosus. 49 .

suoamens. \pm \pm 9 .

- icanthonotes. 151.

ilatus, \pm l.

anmatus. 451 .

Hicatie, 45\%.

Acanthophoria, 38. $3: 1$.

Siburica. 300.

Acanthopieurus,

breris, Jit.

sermatis. $=67$.

Acanthopsis, 20 .

neutus. 55.5 .

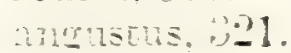

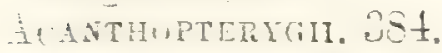

Acantalums,

anosic, $10 \%$.

ancrii. ist.

zaucres sit.

szoine it.

marterio rit.

urins, rit.

randis, it.

minstt qus. jư.
Acanus, 500.

¿quispina. vol.

arenatus, $\overline{0} 01$.

croaticus, 563 .

racilis, 502.

iongispina. 500 .

minor. 500 .

oblongus. jol.

arilis. 500.

reglersianus, 501.

apinosus. 500 .

sturi, $56 \%$.

Acara, 55.5.

Acerina, 520. ruigaris, oz:?

Acestrus. 191 .

ornatus. titt.

Avinenser cretaceus. zut.

Acrodontosaurus. $3 \%$.

urcineri, 40 .

Acrogaster,

brevicostatus. 89 .

lariesi, :00.

heeneii. :99).

minutus. $29 \%$

arrus. $63 !$

Acrognathlis. $-\frac{1}{2} \ddot{0}$ boons. $-40^{\circ}=0.0 \%$ libaniens, $-1+14$

Acrogrammatolepis.

$$
\text { is. }
$$

steinkil. is.

LROTLRDE, Jti?.

Acropoma, 1

iita. $=1$

Agonus.

pimils. $-1, j$.

Apichthys. -

minur,
Aicichthys tount.

isuchilis. \pm 02 . preciosizs. $\frac{1}{2}=-4$.

velitel, $=-7$

Hlausa latissina. 10yj.

Albuia, 0. smisua = brevis, 05.

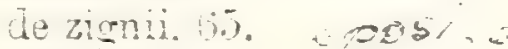

ลata. 8.5.

oweni.

ALELTIDE. J)

Alburaus. :ig

miocienicus.:31?.

sieindichneri, $31 !$ ?

Alecisaurus. ing pato

ILIPOCERHALDE, I.J.

Alosa. iti

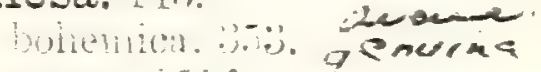

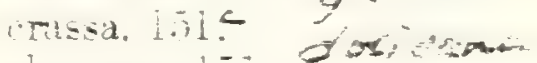

alongat? 1.71 .

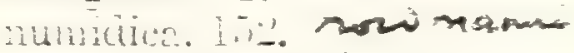

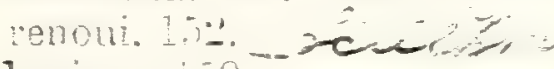

Alosina,

saluoneit. 10:!

Amblypharyngo don. 114

Amoiroterus iforst $\because-7$

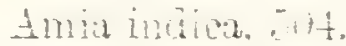

Amin lesvesiensis. 21.

Amiurus, :

anceliatus. 20?

maconnelli, 7 are nat

Ammodytes.

tucianus. unl.

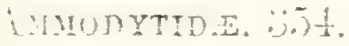

Amxher:stus. $.7 \%$

ofinulurs.

Amphiplaca. +11;.

oncispcera. 16. 



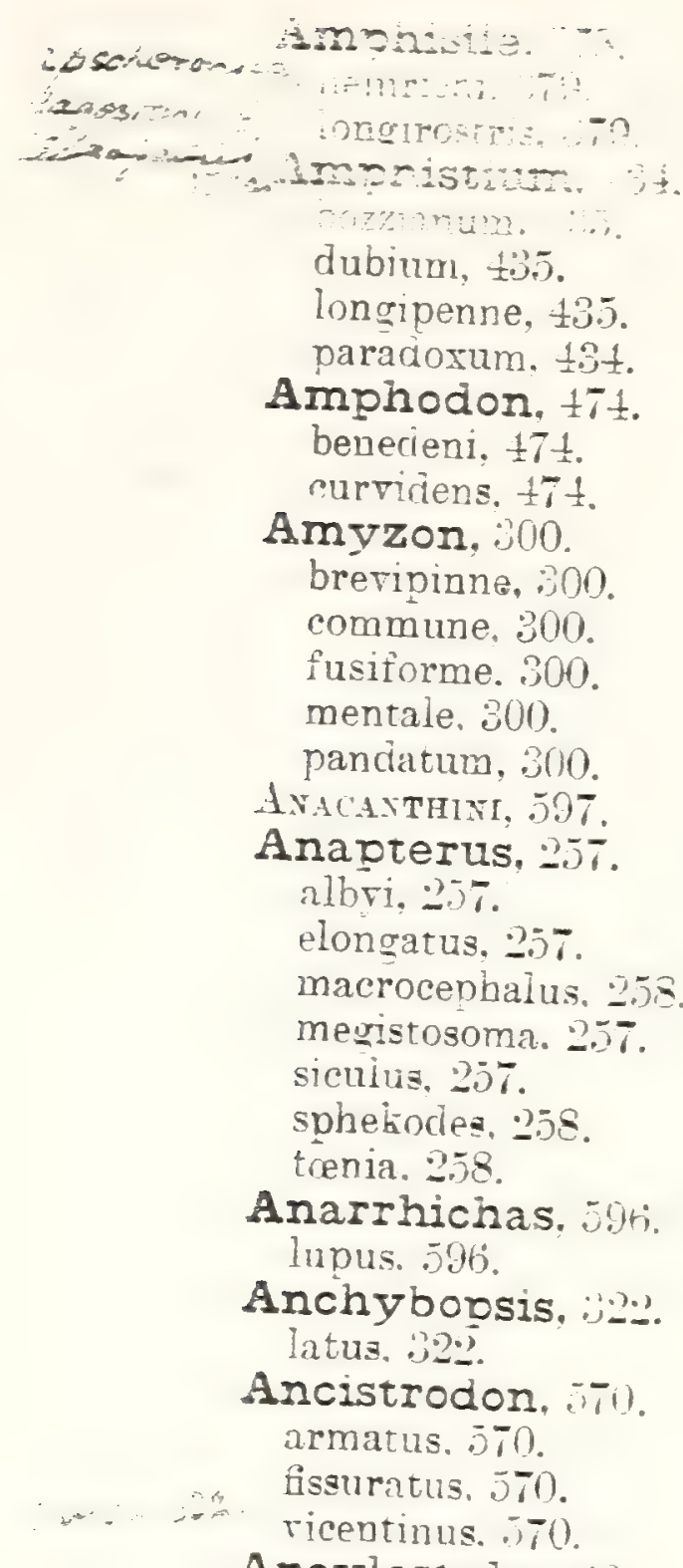

Ancylostulos, titi. gibbus.

Anareiopleura. 116. esimia. 116. retustissima. HIi.

Anædopogon. 10-. tenuidens. 108.

Anenchelum. $+\pi$ brericauda. tial. brevicens, \pm is. dopsale. 78. glarisianum, $\frac{1}{2} 7$ heteronlenrum, $\frac{1}{ \pm}$ s isoplenpum. tos. latum. $+\pi \varepsilon$. longipenne. $\pm \pi$. margiratum, is.

Anguilla. $1 t$ branchiostegais. ütu. brevicula, \pm 2 . elegana. hakelensis. 310 . n.s. intersninailas $: 45$.

latisnina. $3+1$.

lentontera, ilt. muitradiata. rachmon,, 5.

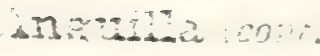

zane-4hr.e. Ish!

renta

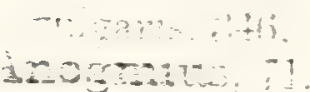

aratus, 72 .

contractus. 71 .

erolutus, 72. $385^{\circ}$.

favirostris, 73

polimicrocius. ??

Anormurus, 275.

macrolepidotus, 27.

Anthias, 5 ?).

bassanii. 520 .

stiriacus, 520.

Apateodus, 258

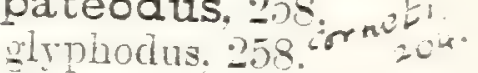

lanceolatus. $2($ tit.

striatus. 2(60).

Apateophois, 2.2!t, 393

laniatus, 232.

IPHREDNDERID.E. $416 \%$

APODES. 336 .

Apogon, 5:1.

krambergeri, 5 in.

mernienis, 521.

sninosus. 521 .

Apostasis, 56.3 .

croitica, 569. ceperian sturi. shis?

Apsopelix, 3.3

sauritolnis, $3.5 \%$.

Arabaima, $7 t$.

Archæogadus, 21:. in.

Éuestnhalicus, 2:-0.

Archæoides. 412

longicostatus, $4+2$.

iongus. $44 \%$

macruris. $4+2$.

Arcinaoteuthis. $52 \frac{1}{1}$.

firronensis. int.

Archaus. 44.

brevis, $14:$.

Starisianus. $t^{2} 2$

Argyreiosus,

minutus, \pm 50

Arius.

baroni. sit.

bartonensis. $3: 0$.

trilssus, $\because \cdots: ?$

dutemniei. 616 .

pgertoni. 2.31 .

rermanicus.

rermanicus öj t.

Asima, int

1meri and

ANIEOPIDT.

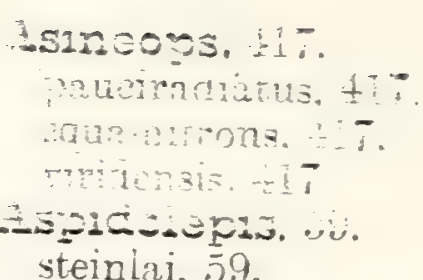

Aspidopleurus, 229, ?马O

cataninactus, 230 .

Aspius, 318.

brongniarti. 293.

columnæ. 319.

ecnomi. 319.

elongatus, $160,614$.

furcatus, 160.

gracilis. 318.

minutus. 318

rexillifer. 319

Astephus, 329

Atherina. $3.6 \%$

macrncephala. 359

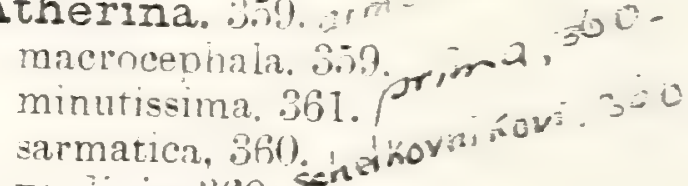

rardinis, 360 .

Atherinichthys, 361 .

Atrifiridd

Atherinoides, 361.

Atherinops, 361.

Atherinocsis. 661 .

Auchenaspis, Blecker. :30.00.

Auchenilabrus, 5.52

trontalis, 5id.

Auchenoglanis, :30.

Auliscoos. :3:?

sumatianus. :37:

Aulolepis. 126.

reussi, 50

trpus, 15. 16, 127.

Aulornamphus, 182.

bolcensis. Jri:?

canossa. $57 \%$.

capellinii. .j6\%.

ALLORHYACHIDE, TI

Aulorhynchus, $\%$ sumatrensis. :3: :

Aulostoma.

bolcense. :36.5.

licatic, 276.

Auxis, $16 \%$ ckich 576

roaticus, $\frac{1}{4} b^{\circ}$. ave asen a is binimor, $\frac{1}{2} 65$.

propterrgins. thit.

sarmaticus. 150

stiriacus. $16 \%$.

hrnuoices. Ith

33 mbceensis, 160.

Bagarius.

ginas, pio.

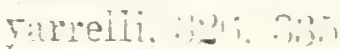





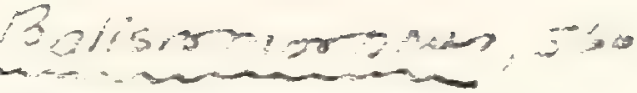

3ainarogmios, 7 .

3y-ackordes, s7\%

$3+29-1=-37$.

cisinarsa, 4 is.

Ciszanorar 244.

Heringheres, 534,10 Fracine

Thenamus, 442 .

ackmanua, 324

controctumi, 324

Bayerid, 73

moinima, 73.

13 acícs bis

Seition, 358 .

pesonides, 358 .

Brannersion seanolll scilla

Bramiatia 6 if.

3 mesmacens

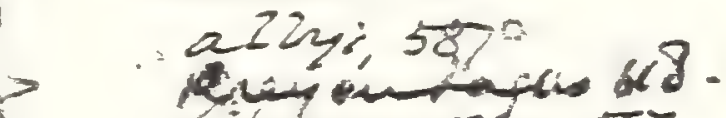

Teiasnemoshe, 577.

3 revortia, $1586 a$.

13 regmacerma, 60 . 3 whicess; b-g7

Bresnacenotickap 587,501 naminus, 587

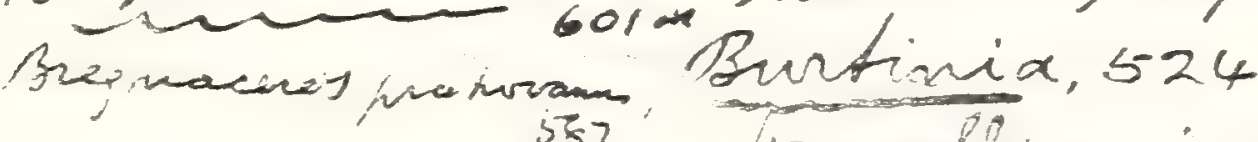

357. Uraxeduenais, 524

Cearana, 85 .

Ca.p2imiks. 297.

Cepola, 369.

Lasecolatis, 369

Centraredile 415

extoradines: 415 .

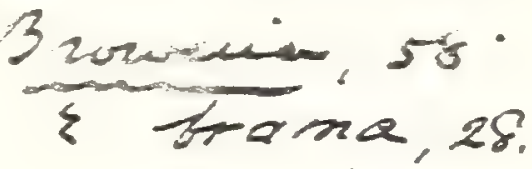

$$
\begin{aligned}
& \text { ertitaricersig. }
\end{aligned}
$$

CENTRARCHIOE: 519, $554.415,520$.

Callichitruidáe 33:-

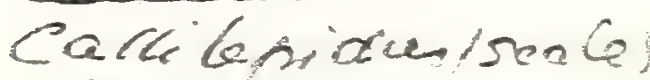

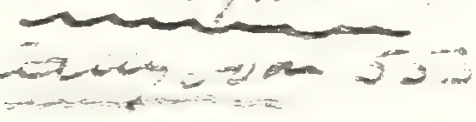

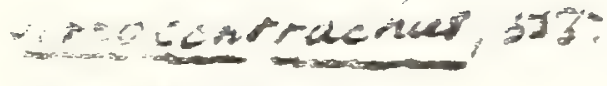

$4,5 \rightarrow \infty$

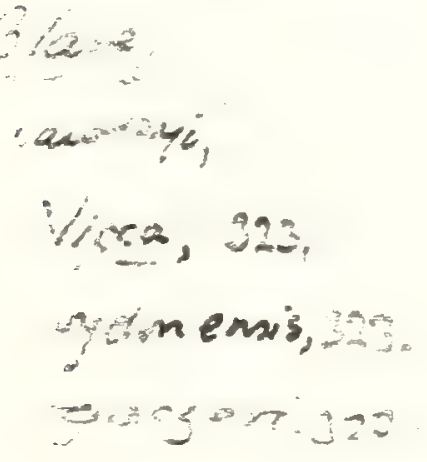

$30.2 x, 60 \%$

nasumen, boy.

$=0,52,2:-$

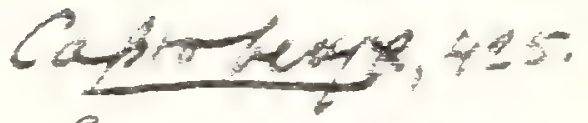

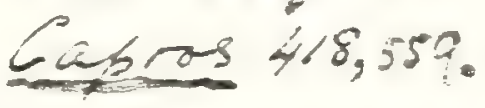

lengiroxisis. $559^{\circ}$

raciobrianus. Est-

reflondin :-

$-2+\cdots,-0$.

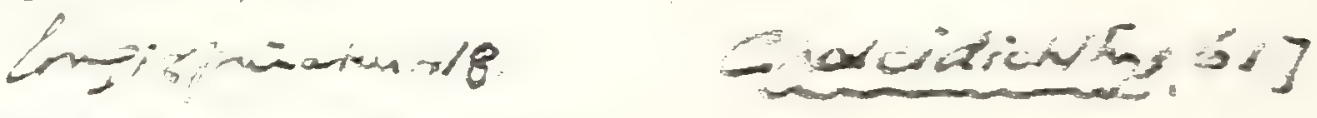

Caprorespoens.tis
Craconomintes, 554

or mo, enm, w

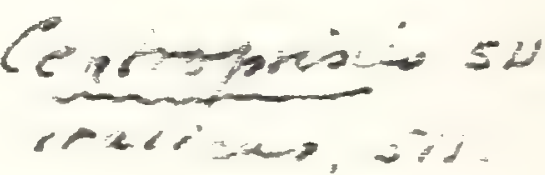

$2,40,520$. 
Bagurs : 201, :32-

Balistes. $5+18$ caifusii, snto. dubius. 569.

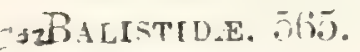

Barbus, 301

fossilis, 302.

megacephalus, 302. steinheimensis. vulgaris, 30 .

Basilichthys, $36 \mathrm{~L}$.

Bathysoma. $14 \%$. lutheni. 449 .

Bathythrissa, 67.

Belone, 3506.

57 acutirnstris, $357,358$. Hava. $: 5.5$. tenuis, $35 \%$

Belónostomus laniatus. 232.

Berycin e. 384.

Berycifories. 384.

Berycopsis, 423.

elevans, t2u.

lincistromi, 425.

Beryx, 385.

ater, 302 .

dalmaticus, :386

dinolepidotus. B:6. germanus, $\frac{12}{2} 1$.

inscuiptus. 366

lesinensis, 38ti.

microcephalus, 124.

muitidentatus, 886 .

niger, 392.

ornatus, 307. 409.

ovaiis. 121.

poirmicrodus, : 2

raciaus. 120.134. 13

raviazs - stachei. t106.

suboratus, :3isi,

superbus, 403 .

syriacus. 405.

ralenciennesi, 386.

vexillifer. 120.

zippei, 397.

BLeñinde. 595.

Blenriforaes. 591.

Blennius, 596.

cuneiformis, 566.

fossilis. 596 .

oceilaris. 566

Brocinid at, 591 .

Blocinius. 593.

longirostris. $59 \%$.

macronterus. 593.

3cops, $35 \%$.

Iigas. 537.

Bothrosteus, 618. arevifrons, til:

atus. 618.
Bothrosteus (ront.). minor, ill.

Brachygnathus, 519. tenuiceps. jl!?

Brachyspondyius, 270

cretaceus, 270 .

inciicus, 326.

saropterix. 828.

Brachyrhynchus,

\section{- 497. -2uricus $-7 \%$} solillus, $\pm 9 \%$.

teretirostris, 497 .

Fanberedensis, 497.

Brosmius, 602.0 menas elongatus, 602. ־نr fuch sianus, 60?. strossmaveri. 60?. susedanus. 60\%.

Brctula. 105. lonoipinnata. 6 in.)

Brychætus. 76.

mueileri. 76.

Bucklandium, $3: 0$.

diluvii.

Butyrinus, 60 .

Caeus, 57. leopoldi. $\pi 7$.

Calamopleurus, 3.51 . avgicus, 351.

Calamostoma, Locrsiz: :383.

breviculum. ¿33.

Calamostcma. Stein. ather. 383. jtio.

bolcensis. 562 .

cunossie. 563.

Callionymus, 588.

macroceplatus. 588.

Festena. 148 . x stivus 256

Callipteryx. 589. recticaudus. 5.59. speciosus, 589.

Calopornus. 536. porosus. 536.

Cantharus, .337.

ureiunensis. 537.

Capito. 3115.

Capitodus, $92 \%$.

angustus. 596 .

dubius. 5.37 .

inciicus. 502.

interruptus. .737.

subtruncarus. 900.9 .

truncatus, 530.

CARANGID.E. 12.5.

Carangocies, 150 .

cephails, 1.50

Carangopsis. $4+10^{\circ}$

unilis. +4 .
Carangoosis ("un:.).

brevis. ttitj.

dorsalis, $47 \overrightarrow{6}$.

lanceolatus, $\$ 48$.

latior, $4 \pm 6$.

maximus, 148 .

Caranx, $\$ 1$.

calangopsis. +41

Gracilis, $t+1$ quedes-inmin

longipinnatus, 442 ....

oralis, 442. - vpecroas

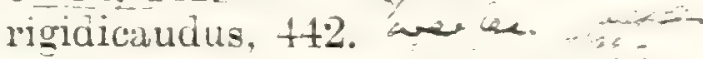

Cariniceps, 4.58

compressus. 458 .

Catostomus, :-99.

cristatus. 300 .

shoshonensis, :300.

Cestrisciden.

Centriscus, $37 \%$.

aculeatus. :78.

hongirostris. 37 ?

tonl, 37.

relitaris. $35 \%$

Chætodon, 56).

areuatus,

argus, 561.

asper, 560 .

aureus. \pm 49 .

canescens. +50 .

canus, 358.

chirurgus, 559.

hoeteri, 560 .

lineatus, 564 .

mesoleucus, 559

nigricans. $56 \%$

papilio. $4: 33$.

pinnatiformis, teis.

pinnacus, 433 .

pseudorhombus, 560.

. rhomboides, tão,

559.

rhombus, 559, 560 .

saxatilis, 412 .

striatus, 415 .

subarcuatus, 561 .

subauretu, 449 .

substriatus. 415.560 .

subrespertilio, $+: 93$.

triostesus. 564.

reilcans, 431 .

relifer. 430 .

respertilio, 4.898.

Ch.étodostin E, 550 .

Chemodonthorues, Job.

Chanoides, 63. . eplosker

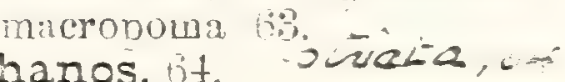

Chanos. 14 .

toreipatus, 6.\%.

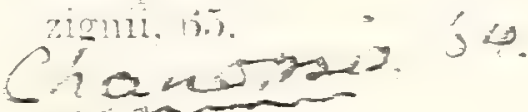




Charactinde. 247.

Charitosomus, 271 . formosus. ㄱ:?

hakelensis, 274 .

lineolatus, 274 .

major, 272 .

Chatoessus, 128. brevis, 158.

humilis, 158 .

tenuis, 158.

Chelonia radiata. \pm 91 .

Chimera furcata, $3 t$.

Chirosentrites, 90.

carolini, 92.

coroninii, 91.

gracilis, 91.

libanicus, 105.

vexillifer. 92.

Chirocentride, 86.

Chirocentrus, 88. polyodon. 38.

Chiromystus, 89. mawsoni, 90. wavis:

Chirostoma. 36 il.

Chimotirutide. 279.

Chirothrix, 280.

guestialicus, -

lewisi, 28:3.

libanicus. 280.

Chondrosteus. 11.5.

Chondrostoma, "ilti.

- a. - 25 , bubalus, 310.

elongata, :316.

laticauda, tils.

minutum, 318

stephani, (ilit.

Cinromen. 551

Chrysichthys, 327.

theobaldi. 3:-

Chrysophrys, jut.

agassizi, 337 .

$p$ rs v.534. arsenaritana. 5.3.

- - brusinai, 531.7N.

vincta, 53.5

hennii. 53\%

hertlei. $5.3 \pm$.

lawlevi, 534 .

miocenica, 507.

seacchii, $53 t$.

zignoi. 534.

Cimolichthys, 2.21. 207.

anceps, 203 .

contractus, 20.

701208 glaciulus, 204 .

jewesiensis, 2:1.

lisbonensis, 203 .

merrilii. 2:28.

nepieolica. 205.

semianceps, 20.

sulcatus. 20.7.
Cladocyclus, 107.

gardneri, 108.

lewesiensis, 109.

occidentalis. 110 .

streblensis, 110.

sweeti, 111. ord juati

Clarias, 32 t.

fialconeri. 324.

Clinus, 597.

gracilis. 597.

Clupea, $1+6$.

alta, Leidu, $1 \pm 5$.

aita, Steindachner, 157.

antiqua. 138 .

arcuata. 154.

attenuata, 19.

beurardi, $1+2$ - assona

bosniaskii. $15 t$.

bottæ, 250 .

breviceps. $15 t$.

brevis, 2.70.

brevissima. 140

cauclata. 154.

catopygoptera. 148.

cephaius, 158.

chirssosoma, 158.

crenata. 1.31 .

curta. 20. 20 is

rprinoicies. 63.456.

clentex, $15 t$.

denticiormis. 1jt.

doljeana, 159.

lubia. 270

ecnomi, 15.5.

tlongata, Davis, 55.

elongata, steindachner. 155,460 .

engraulitormis, $15 \%$.

evolans, 133.

fontannesi. 15.5 .

gaudrri, 1838 .

gervaisi, 155.

gigantea. 10.9lyompoma,

coldifussi, 158.

gracilis, 150.

gracillima. 155.

grancisquama, 155.

grandonii. 155.

gregaria. 155.

guestpbaica. 257.

baidingeri, 155.

heterocerca. 156.

humilis, Leidy, $14 t$.

humilis. Mever. 1,0).

in rlata, 156 .

intermedia. $15 \%$.

lanceolata. 150.

larteti, $1+1$.

lata. 19, 53 .

aticauda. 158.

atiscima, lato.
Clupea (cont.).

lawlepi, 158.

leptostea, 1.3.

lesinensis, 138.

lewisii, 17.

lorce. 156.

lundgreni, 1.56.

maceki. 156.

macrocerca. 156.

macrophthaima. 135.

macropoma, 63.

megaptera, 147.

megapterrs. 1.xti.

melettæformis. 1.56.

meneghinii. 158 .

microcephala, 158 .

microsoma, 157.

winima, 25,246 .

minuta, 149 .

minutissima, 158 .

mondainensis, 157 .

¿2 mucronata. $15 \%$.

mursenoides. 63.

numidica, 151.

ombonii, 157.

ophthainica. 158.

opisthopteryz, 157.

polsachanthina. 15.

presardinites, 1.7 .

pulchra, sti.

pusilia. 144 .

sagorensis. 15 t. 157.

sardinites, 152.6 andino-spallim 157 .

sardinoides, 19.

saulos. 157.

sauvagei. 158.

scheuchzeri. $1 \pm 7$

63 seviptors: = 3 c

sphaerocephala, 15t.

sprattus, 153.

styriaca, $15 \%$.

tenuissina, 15 t.

theta. 140.

thrissa, 63.

thrissoides, 63.

trinacridis. $15 \%$.

rectensis, 146 .

rentricosa, 150 .

villosa. 161.

roironensis, 138.

rukotinovici, $15 \%$.

xenophanis. 15R.

zanciea, 158. fonckl, 5?

Cllupeida, 10s.

Clupeops, 159.

insignis. 159.

Cobitis, 320 .

angustus. 321 .

bredai, :200.

centrochir, 320.

rephatores, :01.

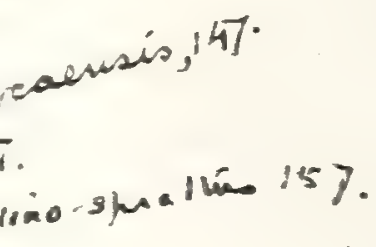

staurobritiana, i4 
O. Binasusport

atision's ar

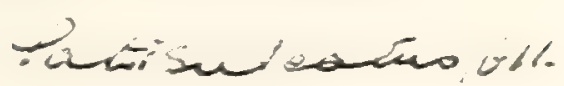

nzisman. Dis

coscoss

Iinderi, sis

-

$-1-2 . \quad$ Carias

pliocepnicus, $324-$

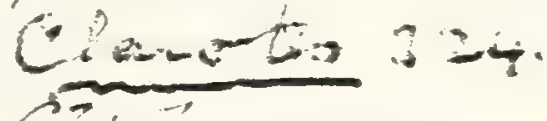

ícosepis, 79

toba $32=$

zurelatiós. 23 mpuctarex, 322.

ASHODONT, SPI:

$a b-=, \therefore-$

unvitar $15 \%$

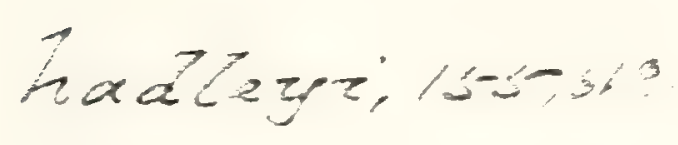

$2.5-1 \%=0.5$

Livayesosuma ....

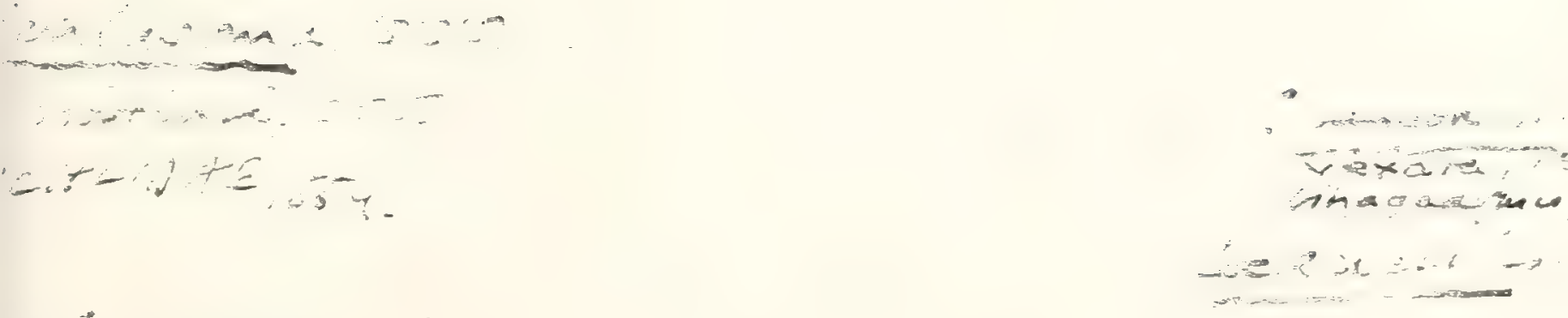




jourdoti, $4>0$

Cainoden:s. H.

Cinger, 342.

niciochines, 342.

2osichthes,

norgani, fox

Encsannes.612. Cyclotepoides.618.

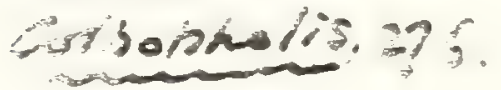

$\infty$

rydoras,

pevelauts.

Cxm ands, 446

Orizhdenohsis, 73.

Urevis, 73

-

actoge

cenaricomis, 585.

- Zarchithys. 62 .

$$
\begin{aligned}
& \text { - semsias } 585
\end{aligned}
$$

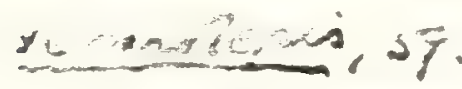

$$
\begin{aligned}
& \text { coscen, } 3=0
\end{aligned}
$$

coskigerina, sla

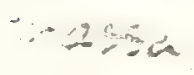

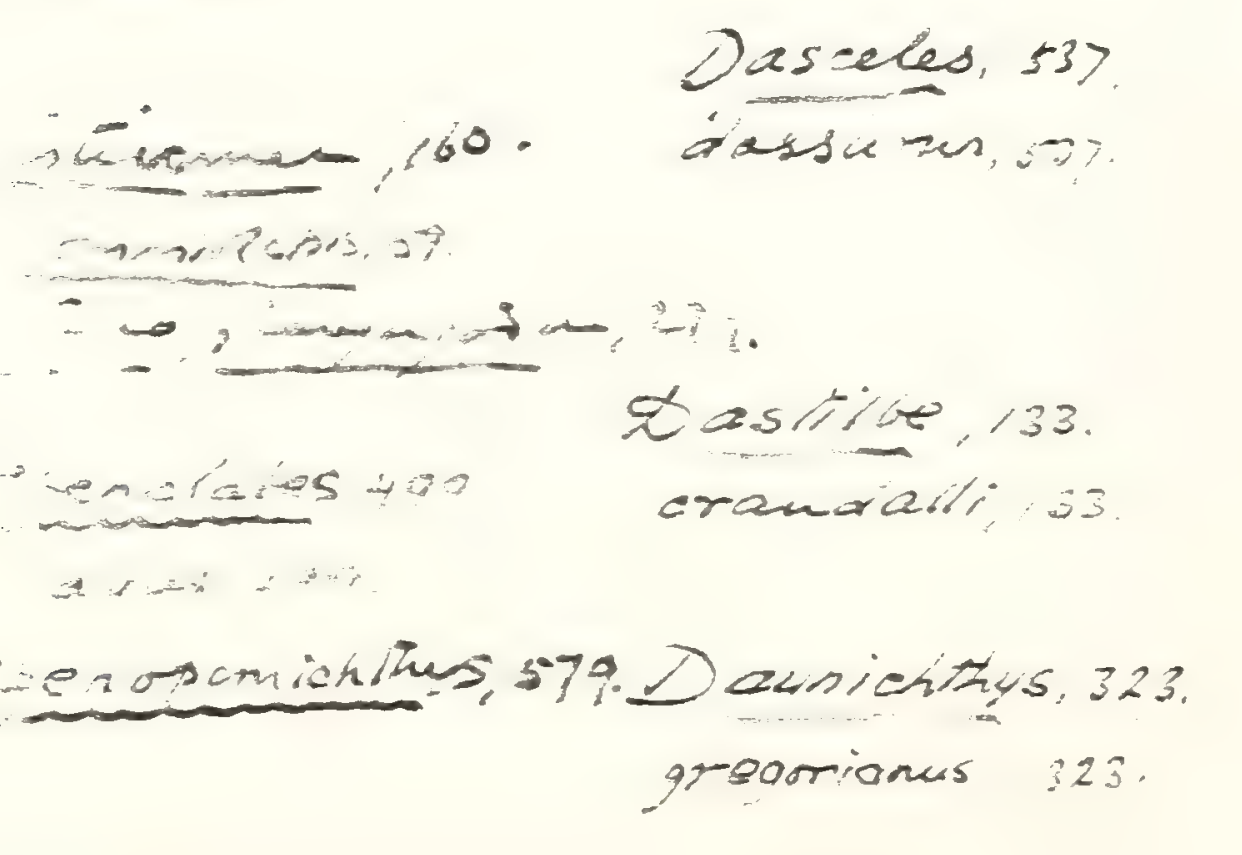$$
\text { ecterone }
$$$$
\text { Eurseson, v.v.539. }
$$$$
\text { Datsiagielle } .343 .
$$$$
\text { Deparis, } 506 .
$$

Cylindra can hum, b7

Cylindra cantan, s92

Diatomoece, 609

Deprandus, 346.

lestes, 346 .

Derorhias, 336.

enantins, 336 .

- 3atima, 609

Diaphus 2356.311.

Dis ariss, 22.

Cuprivoion

purmaews dis.

porimules , 200.

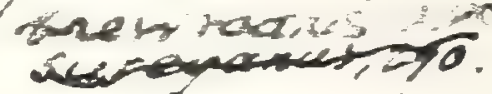


Cobitis

ongicens. -2 .

terieri.

Cobitorsis.

ucutus, $: 3,55$.

silis.

Cœlocephaius, 45.

saimoneus tis.

Cologaster, 111i. inalis. 116.

Coloperca, 519. latifions. .) l!!

Colopcma. 40 colei. tio. curpitum $47: 2$ lare, +72.

Colorinynchus, 59:).

Cincer biprior, :iti.

Conosaurops. lil:. bowmanil. iji.

Conosaurus. 112. bowminui. fi:.

Cigrax fissuratus, iro.

Coregonus, hil. Lavarerns. 161.

Corrina gioberuis, $5: 39$.

Cittid.e. 590.

Cottus. 58.5.

inries. 82.

vreris. 582. 534

Treptotremus. 53.\%. diraricatus. 585. ¿ulriaus, 585. Lispocerns, 585. rauitipinnatu: Sat. mantraeus. $5=3$. pontifex. isis. quauricornis. 58.5. incinatus. 50.5.

Crenilabrus, ito. zajnocite, $5+1$. Tondwardi. bt

Crommyocus. .j.j. lreguluris, 5.\%.

Cristiceps. 0.54. arndo $(13,5.5 \%$

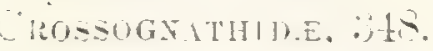

Crossognathus, savaucitimus, :4t?

Ciencientex. 52. uekeniensis, ,iz?.

ctenoroma.

meitia. $.7 ! !$

Cienothrissa, i:0.

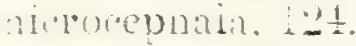

"ritans. 120

exiliter. I.

Texothrissid.e. 11 \%

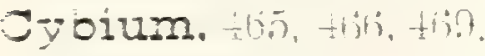
uronesse. $+6 \%$

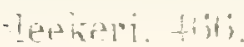

Cybium

bottii. +70. anv

Aumonti. 100 . excelsitm. tir.

lingulitum. $+15 ?$ maropomแn, +62. macuiatum, $\frac{1}{ \pm}(6)$. partseni. 100

proosti, 170. mpefiensis.t speciosum. 166 . tenue, $+i 0$.

Cycloides, incisus. 5!.

Cyclolepis. 5 ?

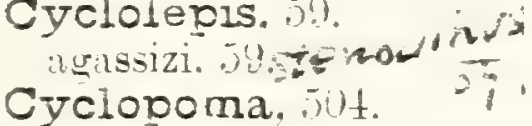

yig?s.04t

micracantium. 504. spinosum. 514 .

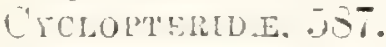

Cyclopterus, 5\% Iumpus, jof. 396.

Cyclotomodon, 45 . Fagrans. 4.5.

Crciurus crassun, 598.

Crehirus minor, 53.3.

Crelurus nemopters. .598.

Crprisine. 2099.

Crprinodion levatus. +16 .

Ciprinomertide, 209.

Cyprinus.

bipunetatus, 318.

carpin. 8101

jeses,

uminuts.

papsraceus.

pliseus. 801.

squanosseus. $2-16$.

CrtTide. 117 .

Cyttoides, 417 . giaronensis, \pm 17 .

Dactyiopogon. : 45

srandis. $-2+9$

parruius. :-19).

Dactyiopterus. 5ot.

phiocenicus, istj. rolitans. 586.

Dapedogicssus. it. acutus. 7.7

aduinnts. 75 .

encallsus. 70.

tescis. 7.0.

Daptinus. 111. 112

broadineadi. 113

internedius, $11 \%$.

phlebotomus. 112.

Dentex.

herevicens. it.

Prasitimblas
Dentex

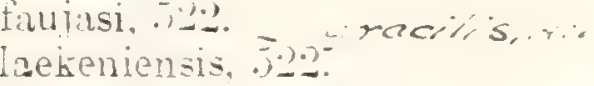

leptacanthus.

mierocion.

muensteri.

nobilis, oly. a plocen...

sardiniensis. 529.

Dentrulis. 523

Dercetis, 17:

elongatus, $15 t$.

limbamnensis. $17 \%$

linguifer, $17 t$.

reussi, 173.

scutatis. 172.

tenuia. 18.

triqueter. 17t.

Dermatoptychus. $235 . \cdots$.

macrontheimus, $24 \%$.

Desmichthys, tiu.

dizuorei. t.î).

Diaphyodus, j+1, $2-2$

$$
54 \%
$$

oralis. $5+6$.

trigoneila, ith

Diastichus, $: 2.2$.

macerion, 2.2.

parviciens

tranguiatus.

Dictyodus,

(rassicieus. ti.).

destructor. 17 t.

priseus. 478.

rupeliensis, $47: 3$.

Dinopteryx. +115

sininosus, \pm 10 .

Diodon. .71 .

acanthodies. 574.

antiquus. $57 \%$.

corsicauns, jit.

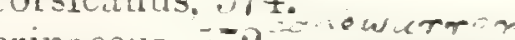

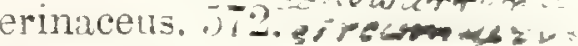

folevi. irt. rormanin.

gigantodus. 57.

ineplaciorion. 5it.

Leterorion. $5 \%$

Lilgendorti, 175.

incertus. 575.

italicus, 57.5 .

meristocius. 575 .

monsegurensis. iti.

platrodis, 57.5

rupisenác. jor

seilie. or:?

sigma. 573

senotils. 5T.

enuispmus. 57.

vecus. .7.:.

Diplomystus. 1.90.

ittus. 15

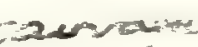






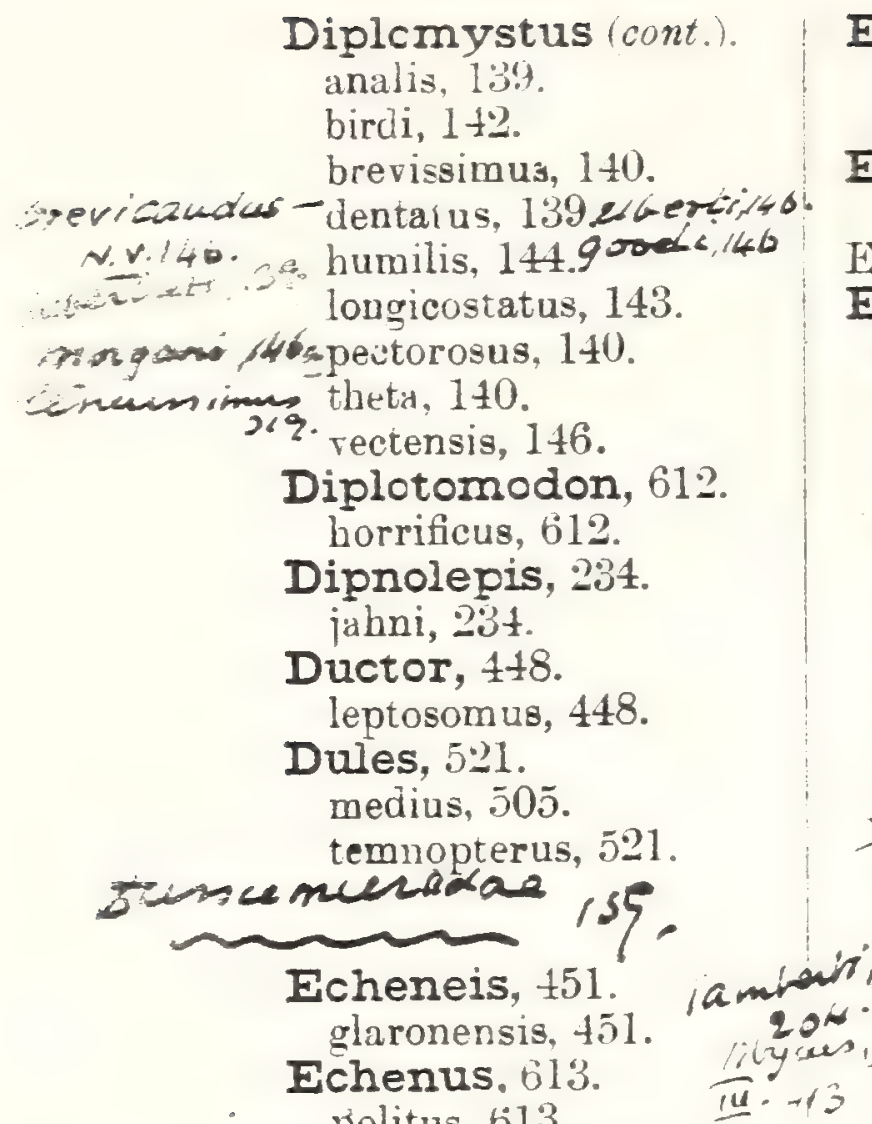

politus, 613.

Echidnccephalus, 163.

tenuicaudus. 163.

troscheli. 163.

Egertonia, 550 .

gaultina. 73.

gosseleti, $551.7 \mathrm{Nar}$

isodonta. $551.9 . \mathrm{N}$

Electrolepis, $4 \overline{15}$. horrida, \pm 15 .

Elopide. 7.

Elopides, 23. couloni. 23.

Elopopsis. 8. crassus, 10. dantex. 205 . fenzii, 9.

haueri, 219.

beckeli. 10.

microdon, 9 .

ziegleri, 10.

Elops, 22.

Embalorhynchus, 497.

kinnei, 497.

Empo, 221.

contracta. 228.

lisbonensis. .1.?

merrilli. 208

nepaholica. 20:5.

sernianceps, 225 .

sulcata.

Encheiziphius teretirostris, 497.

Enchelurus. 16 it. anglicus. 1 tif.
Enchelurus (cont.). sy riacus, $16 \overline{5}$. villosus, 164.

Enchelyopus, 343. tigrinus, 343.

Encilodontide, 189.

Enchodus, 190.4 92 amicrodus, 203 . anceps, 203. annectens, 195. bleekeri, 466 . imsanzo calliodon, 203. carinatus, 204 . corneti, 204. 204 ons dolichus, 204. is rans: foujasi, 196. ferox, 204.

gladiolus, 204. gracilis, 201 . halocron, 191. Memonnieri, 198. 2on lewesiensis, 191, 193. 14: Tongidens. 199 lycodon, 204. macropterus, 202. major, 200 . marchesel tii, 200. oxytomus, 204. partus, 204. petrosus, 205. pressidens, 205. pulcheilus. 193. recurvus. 201. semistriatus, 205 . serratus. 20\%. shumardi, 205. subæquilateralis, 205. tetræcus. 205 valdensis, 205 . uer $\mathrm{d}^{\circ}$

Engraulis, 183. brevipinnis. 133. evolans. 133, 287. longipinnis. 133. tenuis. $230,285$.

Enneodon, 571, 5ั5. echinus. 574

Enoplophthalmus. 323.

schlumbergeri, 220.

Enoplosus, 521. pygopterus, 521.

Eocœlopoma, 170 . colei, 470 . curvatum, 172.

Eocottus, 530. Teronensis, 581."

Eomyrus. 310. dolloi. :40.

latisninus. 340 . ventrails, : 11 .
Eothynnus, 457. salmoueus. 457.

Ephippites, 617. peissenbergensis, 617

Ephippus, 55\%.

longipennis, 569 . nicolisi. 560 ). oblongus, 560 . oweni, 570. rhombus, 559 .

Equula, 4.50. scillæ. 450 .

Erismatopterus, 416 . endlichi, 416 . levatus, 416 . rickseckeri, 416 .

Esocelops, 16 . cavifrons, 46.

EsOCIDE, 257 .

Esox, 287. belone. 375 . destructus, 615 . falcatus, 48.2 . lepidotus, 288. lewesiensis, 191. longirostris. 375. lucius, $288,289.356$. macropterus, 89. monasteriensis, 159 . otto, 289.

ottonis, 289. papyraceus, 289 . robustus, 288 . saurus, 361 . sphtræna, $361,362$. 360. spret. 362.366. vulpes, 153 . waltschanus. 289.

Eucynodus, \pm 81 . hunteri, 481.

Eurygnathus, Aqassiz. 46 . cavifrons, 46.

Eurygnathus, Davis, 190.

ferox. 200. marchesettii, 200.

Eurypholis. 207. boissieri, 201\%. freyeri, 210. longidens, 199.

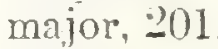
sulcidens, 207 .

Erocetus evolans. 1:3?.

Exocetus exiliens. 133

Exocœtoides. 286 . minor, 2866 . tenuis. 285.

Fierasfer, 0.05 . 

Mincenich/ng.58.

cenmensi, os.

Torfex, 358

hupwatis; $35-8,6$.

Gomidiesis, 7

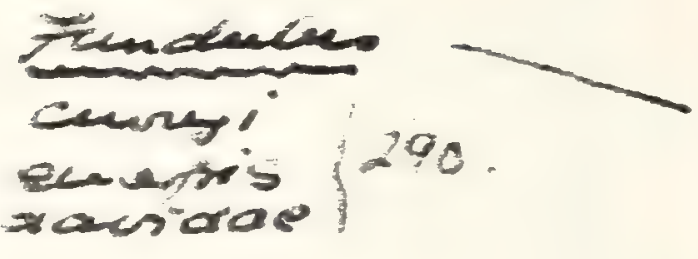

$\frac{\text { Hexagrammos, } 580}{\text { achrestus, } 580}$

$\rightarrow+x y-30$

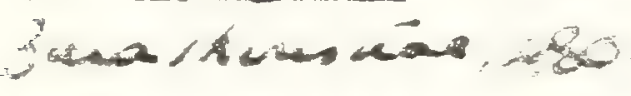

fiariaxias, 2355.

ciastrosteops 3 Y0

mexacanonus 370

Conky rob-2ux, so3.

GOUSTMYATIZ, S5.

Suavenichis 169.

neman

Gonorkgnchops, 279.

wordwardi; 279.

Girnessus, 159.

Pencosiona, $150 a 3571$.

clepsyratra, is o. 18.

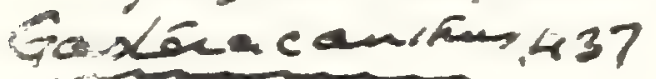

Dindycter, 159

ancus $r=$

cames. 150518

- Clepsigara, 159

veter opzew, 370

actersi,

mogan, ,yóa

thippoglusoides. 608

Yymorsouxa, 457 . macupleira, 60 t.

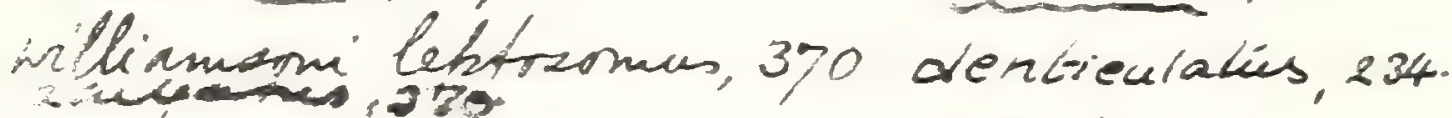

$\rightarrow \rightarrow$ habur so

$\rightarrow p$ paran

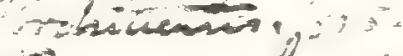

Gempelies itt

sentidith numidus, 612.

3ivingi, ist.

Halecodon, 234. Hipurymparthes.381.

Hariosia is?

Haplochim 280

Hotarentrices, 4/5. bia cen uncsiso.

Heble divinios 533

incia

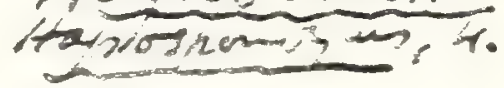

notolavicus, $\rightarrow$ :

ines,

irosecenimies 4 )

$\therefore$ phisine, 550 .

avidostides, sisg.

$17 a y c i a, 58$ W

dambica, $4-84$ tina, is

Heliolenis. 111.

ofroynches, s92.

Helmintalepis, ar.

entientates, sig2.

vermiculatus, 506 .

$=-1=i, 538$.

-vis अ3.

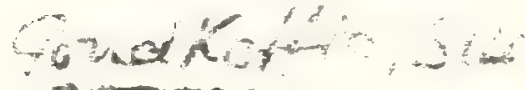

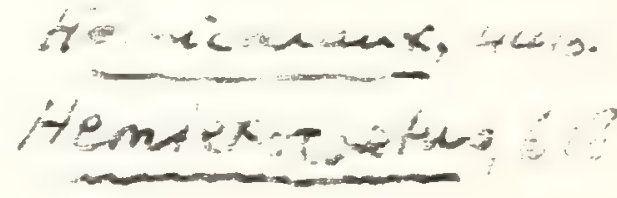


Fierasfer int. .

nuntius. 605. iosterus. (i).

Fistularia, $: 74$. bolcensis, $0 \%$.

aremandinensis. $: 5.5$.

-

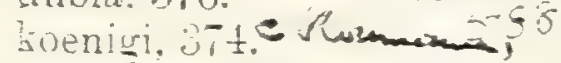
longirosiris, $7 \%$. tabalaria. 30. cenuirostris. 37.5.

Fistelatumen. 87:

Fundulus, 네)

GADIDE. 507.

Gacopsis, bi:. brericens. 1973.

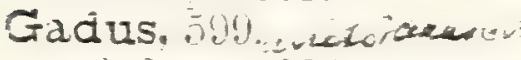
ugletinus. Jasorus col. elecans. 6000.

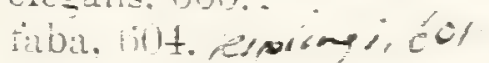
latior. bitl. un vieces sol Inseus. 600. merianetis. ou meriuceits. 599. minutus. bit. morrina. 601 . poilicinus. 01. polrnemus, biol.

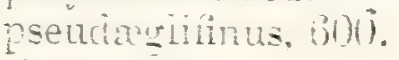
simplex. vut. spectabilis. illt. stoppanii. tenitis. 104. tubercuiosus, itit. renustus. 60t. Tirens. 01.

Gasteronemus, tis. oblongus, tit. mombeus. 439 .

Gepiyrura, 20.6. encentrica. -26.

Gerres, 328. massatongoi, 520.

Gigantichthys, 32 minario. vil.

Gillicus, 99. 1. arenatus, It)I. vioirmicrodus. 101.

Glossodus, leier, 150. heckeii, - sona :'s

Glyprocephalus, 5.0 mailacus.

GOBLDE. ST.

GoBIFORMES,

Fobic, thais. 04 mator, tis. ricinus. tis.

Gobius, in.

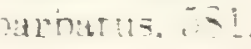
TIEIT.
Gobius ant.)

bassanii. 58.

breris. 5\%?.

conicus. jst.

trancolurtanus, 2.5. Covariat? toutosomus, jes.

!ubini, 5so.

iatcroactus. 588. macrurus. 51. masimus. j88. microcepialus, 588.

muitipinatus. 58. volongus. 58 t. $2 \mathrm{r}^{3}$ peruzzil se8.

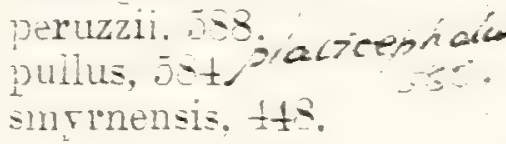
reronensis, ist.

ricinalis. sas.

riemuensis. jat.

Goniognathus, iT cursphanoicies. $5 \%$. maxiliaris. 07.

Goronimucind E, 2:1. Gonornynchus, :-il. Ereri. 21.

GMYODOXTHE. 50.

Gymnodus, $7: 2, \cdots$ diocion. 575.

heterucion. 575. wonsegurensis. 375.

Fäcauetia. 1i2. bolcensis. 1512.

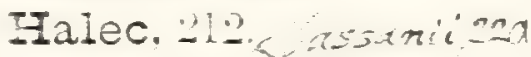
eunterrens, $21 \%$. guestpuaticus, 20 . Eaver. -10. aubei. ㄱo? microlenis. 218. sternberg?. 21:.

Ialecopsis. 130. msigni- ü1. irTis. $13 t$

Hilosatride. I6?. Halosaurus, $16 \%$.

H.iplome L

Hentbrifenti, 360.

Eemicycius. 00 screinlessis, 59.

Hemieiopcosis, is. sibbus. gracilis. 5. Eliessi, s.

Iemilampronites. 59. sieiniai, -9.

Eemirampinus, ciwurcisi. jos.

Femiringohus, olei,
Alempranchus cont.

desiaresi, tos.

zitteli. 5.

Femisauriaa.

neocomiensis. 270.

Hemithyrsitas, -31. mpartus. tol.

alatns. tis.

licula, ts. maicryorces

Hemitrichas, :2?.

senisticola, 32.

Heptajioden, :il. jij.

echinus. St.

Feterobranchus.

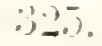

maixinaicus. 325.

Heteroleois. 612 .

Feterctis. it.

Hexapsephus, :2:2:

untencuert.

Iistialosa, t, t, ono al

thiolieri. jo.

Eistiocephaius. 5.9

bissinii .ro.

Fistionnorus, thj.

antiquus. this andian

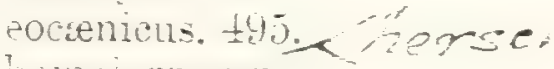

Lom:Lionamphus. 497.

parvuitus, 497.

priscus. 491

inobustlis. $\frac{1}{4} 9 \%$

rotundus. 105

Yistiothrissa. 131.

crassanima, i⿱日2).

macrodactria. 1.31.

Fistiurus, $[: 19$

ehatus, $1+0$.

Eerioluicies, $1 \pm 6$.

rentricosus. $1+6$.

Fclacanthus. 31. microceniailus. in1. piorenorum, jol.

Eolcodon, 190,206 esinuensis. 219.

Heodion. - vt.

Iolcolepis, 11 . 20. aw eretaceus. :-4).

Folccentrum. 110 . wew

anicarifer. 50?.

lanceolatum. 1.

macrocevinim, 12 .

inacuintum: oft.

melitense, $\div 1 \%$.

promum, -19.

pyginiatim $=14$

sogo. +12 .

Holosteus. $=0$

soonus ito.

marions: $=5$ 


Homonotus, 407. dorsalis, 408. rcóundus, 409. pulcher, 392.

Homorhynchus, 488. bruxelliensis, 490 .

Hoplopteryx, 396 . I. nintiquas, 396.

irevis, 406. Tewesiensis, 397. lewisi, 404.

W Tdundensis, 404.

Simus, 409 vblongus, 406. spinosus, 407 stachei, 406 . superbus, 403 . svriacus. 405. zippei, 397.

Hoplostethus, $41 t$. ingens, 414 . laciniatus, 414 . lawleri, 414 . nettelbladti. $\$ 14$. ostiolatus. $t 14$. pisanus, $41 t$.

Hyperlophus. 139.

Hypsodon, 37. 2. lewesiensis, $3.3 .40,45$ $94,95,98,109$. minor. 102. oblongus, $2 t$. toliapicus, 24 .

Hypsospondylus, 58. bassanii, 58.

Hyptius, 58. sebastiani. j.8.

Ichthyodectes, 99. acanthicus. 107. anaides. 100. arcuatus, 101. 110. cruentus, 107. ctenodon, 100. elegans. 103. goodeanus. 107. hamatus, 107. andenensésibanicus, 105. 107. minor, 102. multidentatus. 107. occidentalis. 101. perniciosus. $10 \%$. polymicrodus. 101. prognathus, 10\%. serridens, 101. tenuiriens, 104.

Ichthyotringz, 265 , itii. tenuirostris, 259

Iguana (?) haueri. $56 t$.

Imogaster, 391. auratus. 024 . $2 ?$
Ischyrhiza, 46 . antiqua. $45 . \mathrm{Cwinen}_{4} 6$. mira, 46 . radiata, 46. 614 .

Ischyrocephalus, 190.

cataphractus, 202. gracilis, 201.

intermedius, 202.

macropterus, 202.

Isodus, 190. suleatus. 199.

Istieus, 66 .

* gracilis, 70 . grandis. 67. lebanonensis. 71 . macrocephalus, $5 \%, 70$. macrocoelius, 67 . mesospondrlus. 67. microcephalus, 67. spottii. 71.

Istiophorus, 495.

Isurichthys, 453 . macrurus, 45.3. orientalis, 453 .

Isurus, Agassiz, 453 . macrurus, 453.

Julis, $\bar{t}+1$.

aqassizii, $5 \pm 0$. muensteri, 540 . sigismundi, $\bar{j}+1$.

Kurtus relifer, $430,431$.

Labeo curieri, 616.

Labidesthes, $: 361$.

Labrax. 509.

bosniensis, 512.

delheidi, 512.

elongatus, 512 .

heckelii, 510 .

intermedius, 512.

litus, 512.

lepidotus, 512.

longiceps, 513 .

major, 513.

mojsisovicsi, 513.

multipinnatus 513.

neumarri. 513.

oeningensis, ว11.

sagorensis, 513.

sehizurus, 510.

steiudachneri, 513.

stiriacus, 513.

ubinoi, 510 .

LABRID.E, 5:39.

Labrodon, $2 \neq 1$. atricanus, $5 \pm 2$. alsinensis, 545. bizini. 543.
Labrodon (cont.). beigicus, 543. bourgeoisi, 543. britannus, 543. canariensis, $5+2$. carolinensis, 543 . chantrei, $5 \pm 3$. cocehii, 543. crassus, 544 . dilatatus, $54 t$. edwardsi, 544. gaudryi, 5t4. baueri, 514. heterodon, 544 . multidens, 544 . pavimentatum, $5+4$. polyodoln 545. quenstedti, 5 \%5. rhedonum, 545 sacheri, $5+5$. ringretos, 5 s sauvagei, 545 ). sellæ, วิt5. _ _ _ soldanii, 545 superbus, $54 \%:$ or oru trapezoidalis, $5 \pm 5$. trigonella, $5+6 \%$.

Labrophagus, 611. esocinus, bill.

Labrus, 539. agassizi, 540 .

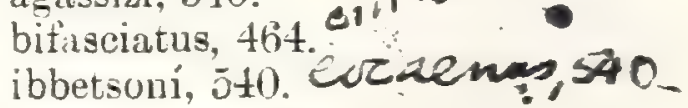
malapterus, 595 . merula, $\bar{t}+0$. microdon, $\bar{\jmath} 40$. parvulus. $5+0$. priscus. $5+0$. punctatus, 558 . rectifrons, 558 . turdus, 504 . valenciennesi, 540 . woodwardi, $5 \pm 1$.

I a parus, 596. alticeps, 596 . Larimus, 518.

Lates, 502 gibbus. 502. gracilis, 502 . heberti, 499. macropterus, 503. macrurus, 503. notæus, 502. partschi, 503. sagorensi-, 513.

Lebias, $2900^{-}$trispinasus, 503 aymardi, 292 . cephalutes, 2900 . crassicaucis, 295 . crassus, 2906 . eisgrabensis. 204. furcatus, 291. gatudrvi, 294 . 


\section{$\ldots$}

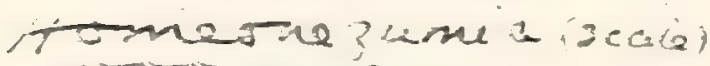

rame wrom somende.

\section{$3,+3$}

nichnus ol of.

8

depressus, itic

Hesonew 20:7

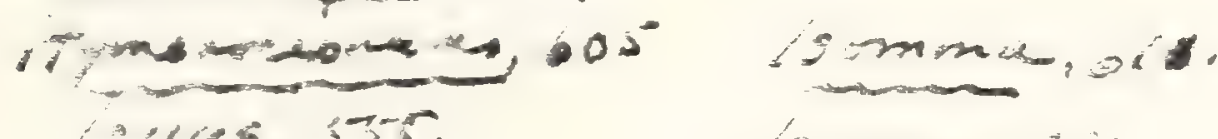

inces, 355

arinumais, 35

- 3 surapentions.

sones.

$\therefore \cos ,+44$

$-\quad-1000$

Yomed hatarat?

Havuron sopis ist.

LEaparica, 110.

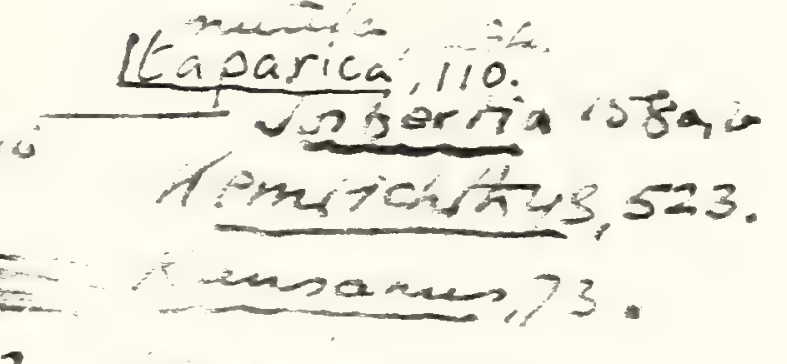

naucideres,

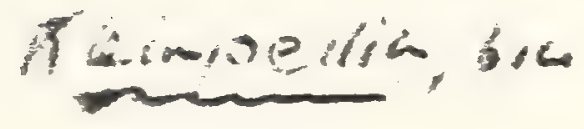

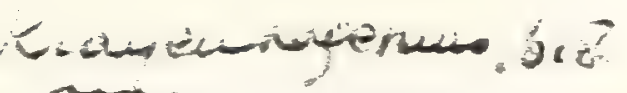

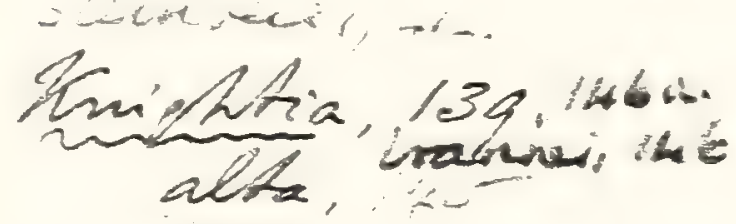

vacikanti, -...;

Acinzaces, $4=$

Pocaina ilice

Iramorienia 579

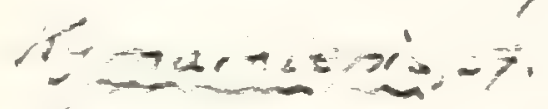

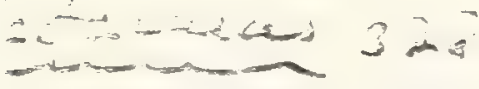

werkes, $3 x^{2}$.

ingsid. of

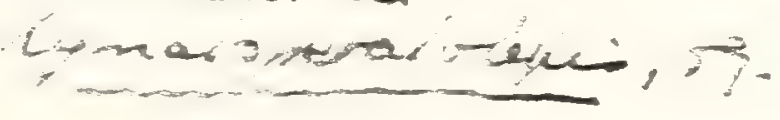

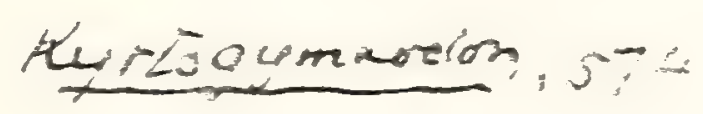

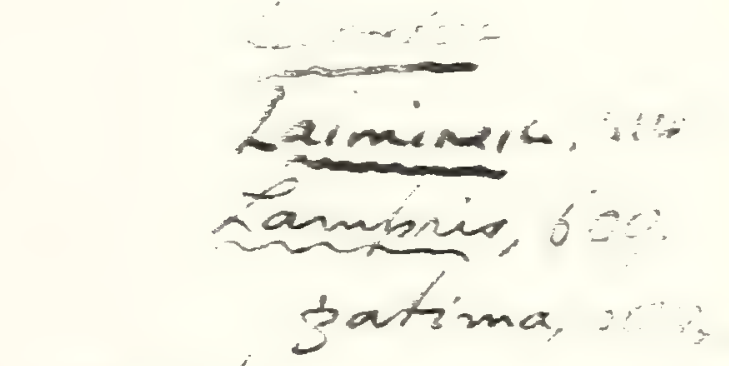

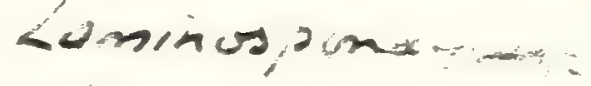

tein

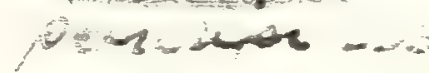

T:D, 23

I"

4

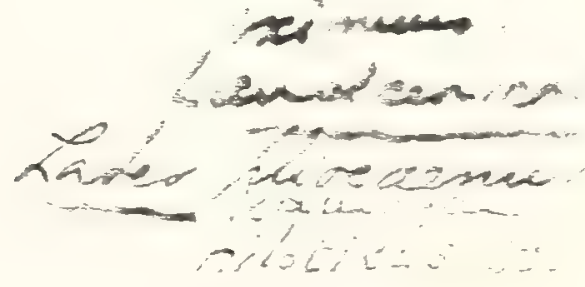

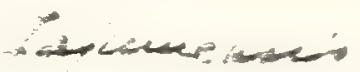

Torion Nis 50

manasin.

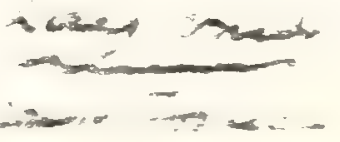

ans-mis

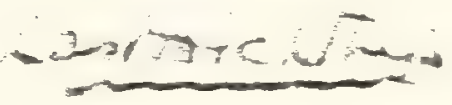




Lebonichthys 16

écheria, hica.

Lemivicus, ista.

meitlejotini 158a.

zinuria 520

sirinca, $5=0$

tonyeucius, 4T7

oswardi, 3/l.

moravices, औi:

'prichei, 479 .

visatoi, 481 .

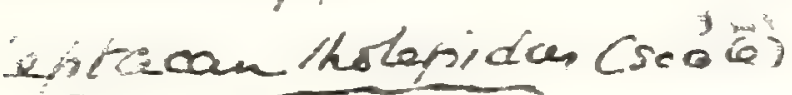

reddingi, 323.

PHTOSCOPIDES STY.

27006 z 5860

- orammariezen se

$\therefore=0$ Remingering 57

tomit cephalus, 3.

K. $=5 \angle$ Stichithys, 290.

acencsi 970

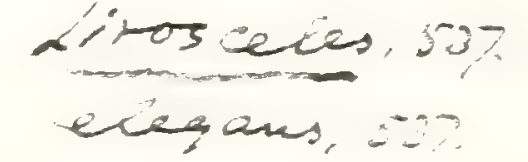

ixwirzen, 298.

Lompochizes, ㅆ.⿲丿丨 535 .

ropkinsi, 从1. 538.618

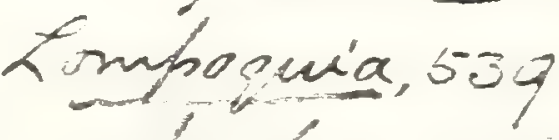

22 topes.534.613

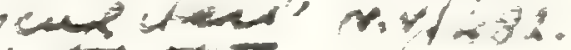

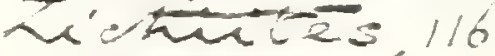

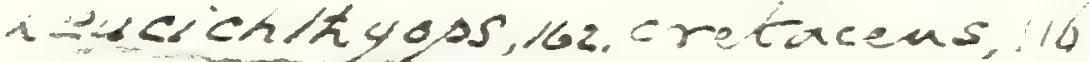

ingans, 162.

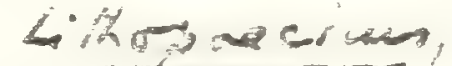

$40,2=0$

Tobuar, 4ho

miocuenus, 4so $\cos 200$

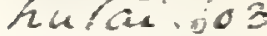

Lotimmona $=98$.

Locolla ibos.

Lusped, 521

carotti: 521.

Lutianida, 524 Lutiames, 524

tris, 34 hagari, s24

Luvarus, №v 482 .

Iygisma, 158 E

tenaxe, 158 L, 618

Luxilicín.73

Macermo.505.

Meaonorides"

astoni,

Macropelalolepis, II.

Maerenieb Thyi.3z?.

Maena 5.37

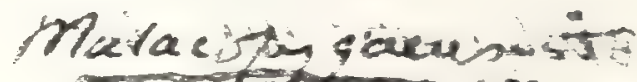

Manchuriching,

uwatrkor, !.

Mcresia =.

$m-5$

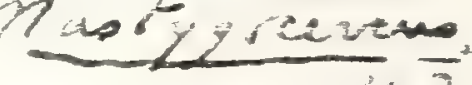

Marculleheila 525.

Mabarena rta

opuria, 4siz-

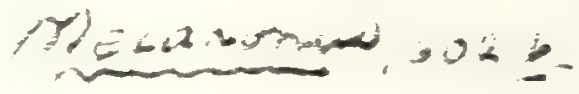


Lebias (r) nlt. gobio. $29 t$. mereri, $20 t$ minimus, 294. perpusiilus, al. tenus. 2yt. zionoi. -nt.

Lepidenteron, isj. longlssimum. (s).

Iepidocottus, j31. iries. 52 ?

bretis, 55:. elongatus. $3 \pm$. gracilis, 117 . muitipinnatus. 584. mapyraceus, jo:

Lepidopides, t7 blerisponcirius, $=81$. tubius, to1. entosonncivins. $\$ 81$.

Iepicopus, ti. niovi, 181). N. :anguis, t>0. brevicauda. $\$ 80$. carpaticus. \pm 80. dioius. $1 \leq 1$.

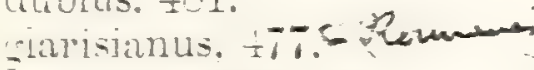
Leprosponarius. 451. meneghinii. tol.

Leptecodon, -ü. recris, - 23.

Lepticintiss, 616. oilis. ill.

Leptccephaius, ن̈t6. rracilis. ëtr. nedius, tenia. "jti.

LEPTOLEPID.E. 1.

Leprosomus, - $-\frac{11}{2}$.

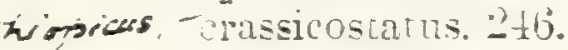

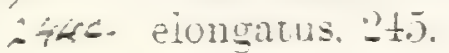
Illestphailus. 215 . matcroupus. 245. minimus. $-2+1$.

Leptotrachelus, $17: 3$. armatus. 1.t. iongatus. 1st. gracilis. 1 (s). narejensis. It. longipinnis. 19-. sagitiatus, ist. l'icherer, 71 . 33. Firiliatus, ET.

Leuciscus, zerogister. 310. uluial. Oili. os=niashii. :14! rericancia. 14 ! peris, eill. uninis, :311. "stellimensis. "ult.

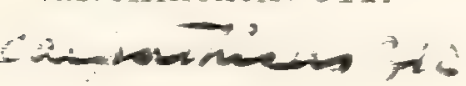

Leuciscus cont.). cecconii, il:. cephaton, eepinatus, :09. colei, :U2. dorsulis. 811.912

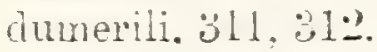
eibismaiciensis, :310. elegans. 315. errtiropathaimus. 00 .

eurgstomus, 311 . fritseni, 615. gavbrensis. ill. gibbus. 311. gracilis. ilt. An hartmanni. ilt. helreticus. $0.5 \%$ heterurus. 10 . Kirantzi, :311. larteti. 311 . latiuscuins. 05. leptus, :U9. licatie, macrurus, meciius, 110 . msterman veningensis. 305. papyraceus.: :07. piesiopterns. polrsareus. $: 311$. pueliaris, :ill. pusillus. racaimuti. 11 . remotus. 311 . mutilus. 09 squragei. 12. sicanus, 311 . 312 . stepiani. :311. 0315. tarsiger. 315. turneri. 311 . resillier. 11 . yrao.

Leucus, :20?. condonizuus. 32.2. Tatids. Hzon.

Leuresthes, :̈bl.

Lewisia, 5 . oralis. 5.

Iichia, $4 \pm j$. aita. $\pm+b$. andilis. \pm \pm 5 .

lita, \pm \pm 5 . prisea. $\frac{1}{2}+\frac{1}{4}$. secuncia. \pm+6 . stopranti. -+16 .

Lobcaus. nedemontanus. הT Eobcoterus. 15 necrinatus th Eoprarnd: I.

Eocinins, 11

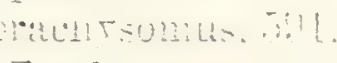

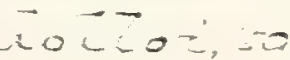

Iephius ("ont.: upel matagonicus. otgl. jiscatolius, 591.

Loricaria, 5.)1. plecostomus, j91.

Loxostomus, $0 \mathrm{ll}$. :nanens, bl1.

Iucania, -

Lucioperca, j:I. skorpili, 521 .

Lucius antedilurianus. 208.

Lutianus ephipniuz, $;=-$

Lutodeira, 6 it.

Lycoptera, 1.

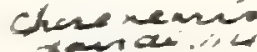

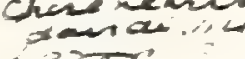

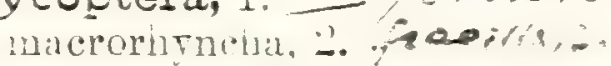

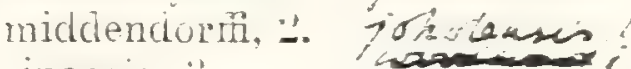
sinensis. is

Lyriolepis. cducasicus, $5 \%$.

Macrolepis, 4.5. ilongirtus, $\frac{1}{2} 1 \bar{r}$.

Macrones, $\%$ 10\%.

Macrostcma, 1 . aitum. : 61 .

MEACRERID.E. (U).

Macrurus, npieculsur. 6its.

Mallotus, I (i)

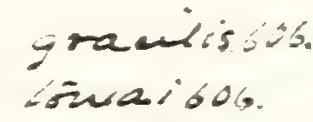
viliosus. Lil. MOTSEC

Megalodon, : $7.0 \%$ 他wesiensis. 45. sinuroicies. $! 5$.

Megalolepis, $450,5 \vec{y}$

- bascheaensis, to.. litus. 1E.

Megalops, $2 \frac{1}{2}$. folcipatus. 1\%. oblongus, $20^{\circ}$. priscus. "2t.

Megalurites, .7. nitidum, 57:?

Megapus, 280. questialicus. :-8:?

Megistopus, 286. $23:$ questiaicus. 283.

Meletta, $1 \pm 6$. crenata. 151 . dolieana, 150. sucilima. Lé. grandisquama, 1.5.5. becheii. 1.j.

helerostoma. 152. intermedia. Lngimana. 151. mprisoti, il. pracenclinites. ㄱ. adieri. - s. 


Meletta (cont.). suriliuites, $15 \%$. scheucuzeri. $1 \pm 7$. stvriaca, $15 \%$.

Melettina, 151.

Mene, 437. oblongus, 440 . pusilla, $\$ 1$. rhombeus. 439.

Menidia, 361 .

Merlangus, 600. cognatus, 604. spatulatus. 604. suifolkensis. 600. ruigaris, 600 \%.

Merinus, 603. cristatus. 603.

Merluccius, 601, Tb : 3.

Thandesent so

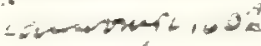
sien 02 giesti, 601. 10. encearisurs , 02 . ittenuatus. 0104 baiticus, 6104 . mansoactar bosniaskii, 601 . emarginatus, 604 , in bhtusus, 604.

Mesogaster, 61. cretaceus, :36\%. gracilis, 254 . sphrrienoides. $31 \%$.

Metopcnichthys, $53 \%$.

longirustris, 5is?. nctacanthus. 5.5\%.

Microccelia, 25.2. granuiata, 2.2. Jibanicar, 20.

Microcion nuchalis. foge

Mirrodon pulchellus. 4.1.

Mioplosus, 517. abbleviatus. j18. beani, 518. labratoiries. 517. longus, 510. multidentatus. 518. saurageanus, 518 .

Monocentris, 414 .

- $3 x$. 3 . inteses. 414 subiotundirs, t]j.

Mononteros gigas, 89.

Morrhua, 59 . itgierinoicies. b01. extensa. bil. liaba. 604.

laneectivta. (s)1. latia. 515 . miteronterrit. 601 . Linimit. U191. suelingensis 140. watgatitens?s tint

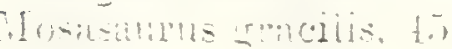

LSDEX.

Yulleas: sor.

Mugil, 363 . aces. 364 . incyans" Nummopalatus, $j+1$

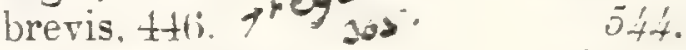

cephalus. $36 t$. debilis, 365-nadenrinis $36 s^{\circ}$

lares - debilis, onceps, minax -os: radobojanus. 365

Megilid a. 363.

Muræna cæca, 347.

Muræna conger, $34+4$

Mur:ena lewesiensis. 185

MIuriena mylus, $3+1$.

Murana ophis. 347 .

IIUREAID.E. 3930.

Mylccyprinus, 3:2. intlexus, :20.2. kingi, : longidens. :i:? robustus. 32.20.

Mylcpharyngedon, $3: 23$.

Myripristis, 410 .

homoptervoius, +11 .

leptaceanthus. 410. toliapicus. t] 2 melitens 5 , 413 .

Myrus, : fo. : cnumi, Odax carolinensis. itu. rulgaris, $3 \pm 1$.

Odonteus, 5.56 . depressus, 5060. prgmieus, 5ist.

Naseus, 564. brevirostris, 564. nuchalis, 505. rectifions, 50 t. sparoides, iób.

Naupygus, i11. buchiandi. ill.

Nemachilus, bredai, eّ-0. centruchir. $: 30$. cerhalotes, 321 .

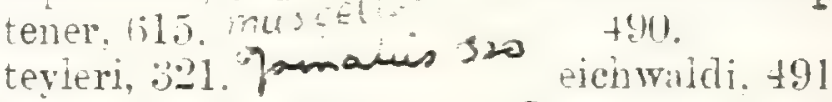

Nematcrotus, 249. bottie. 250 .

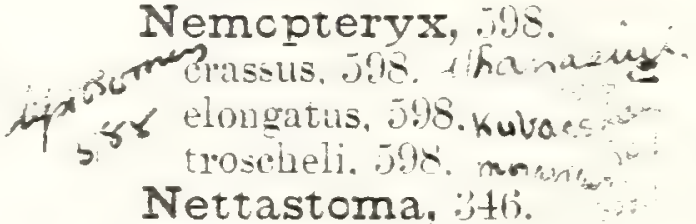

Nettastoma, 46 . bolcense. 346 .

Nophatrime. llit.

Notacanthus, 169.

Vutieus agatesizil. jty).

Notelops. -7. brama. $\because$.

Notogoneus,

untiepi. $27.51 \%$.

longicens. Equamuseths.

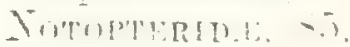

Notopterus, -i; mplntilus. ati. abbas, 543.

africanus, 342 .

bazini, $54 \%$.

bourgeoisi, 543.

britannus, 543 .

chantrei, $5+3$.

cocchii, $5+3$.

edwardsius. $54 t$.

gaudroi. 544.

hatieri. $54 t$.

heterodon, itt.

multidens, 544 .

parimentatus. $54 t$. polrodion. 545 .

quenstedti, 54.5.

rhedonum. $5+5$.

sacberi. j45.

sauragei, its.

trapezordalis, 545 . belgicus, 543 . monasteri, tol.
$1310+13=$
Odontostomus, Is?

Oligobelus, : $: 3$.

ureiferus,

laminatus, 32:3.

Oligopjarchus, 519. equamipinnis. jl!

Omiodon, ㄱo. cabassii, $2-0$.

Ommatolampes, eichwaldi. 491.

Omosoma, +19 intermedium. \pm 20 . pulciellum. 421 sahel-almie, 419).

Omosudis, $18 !$.

Oncolepis, 595. isseli, int.

Opindida.e. (i05).

Ophidium, 60\%. 600

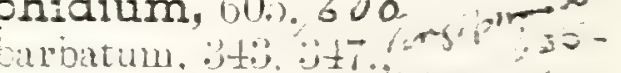

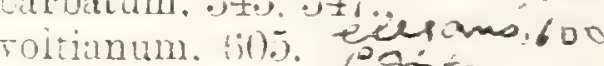

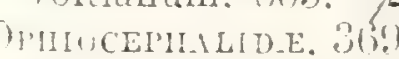

Ophiocephalus, -triatus, tot.

Orisisurus aenicuntu " +7 .

Opisthcmyzon. til

Opisthopteryx. 


Oritopien, 523 .

bormatniensis, 613.

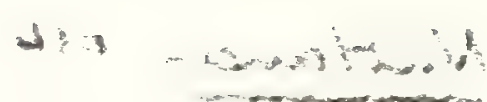

tingens, 242

hamportirensis, 617.

Siponderems 263

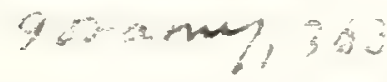

Cstasiostoma, 129.

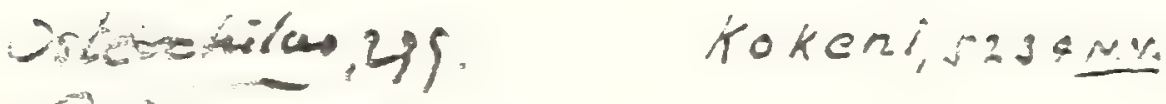

Existis. $2 \pi$.

Oxysonibjitus scal:

Orumandias, 4821ra giehent: 482r.N. 
Orcynus. tit.

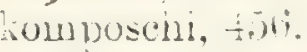

hanceviatus, tov.

latior. +56 .

medius, Inti. von

sculuisii, tos).

Oricardinus, $t h$.

tortus. $t(i$.

Orthagoriscus, 70 . "helonopsis. Jili.

Osmeroides, 11.

ittenuatus. 1\%.

beleicus. 22.2.

brevis, 16.

('ri)ssils, 10 .

cretacens. 2U.

fivaricatus, ․․․

dubius, 16.

evolutus. $7: 2$.

siarisianus, 25.5.

sparilis. 16\%

grumulatus. - 19.

insignis. $13 \mathrm{t}$.

latus. $\mathrm{i} 6 \mathrm{j}$.

Levis. 15.

lewesiensis, $11, \ldots \%$

lewisi. 17.

maneilii, 12.

maximlis, 18.

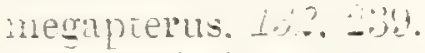

microcenhatus, …7.

minor. Lï2.

nunateri1, 207. 2008.

pectinoiepis. ㄹ.

moimicrodus. 7.2.

surimiojcles, 1\%.

vinare sis. -1 .

Osmeroleois, $5 \%$.

peticulatir. -..?.

Osmerus, iliz.

aibri. $16 \%$.

corcileri. $2 \frac{1}{2}$

d'achitroi. 16\%.

giarisianus,

lianeti. Iliz.

propterrgius, 190.

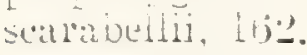

-tilpnos. Lliz.

O-TARUPHY,

(1) STEOCLOSIDE, i:;.

Osteoglossum. $\overrightarrow{7}$

precilletum. 7i.

Ostracion. .ili!,

inueriails, sitif. . . . s

micrumus, fis!

obiongus. ais.

uritus, ji!l.

Otolithus.

iccumblillas, lif:- or

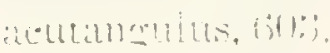

alimulio.
Otolithlis $m$.

wquilis. iz, 193.

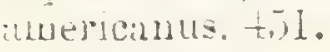

ambits. roy.

apploximatus. (j1).

attenuatus. tiot.

caitious, hot.

batrilleus. Goti.

biscissus, . ily).

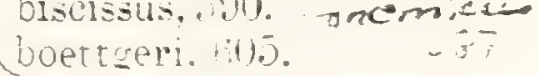

breviue. $y+7$.

darbornensis.

cognatus, (ii) icopecus

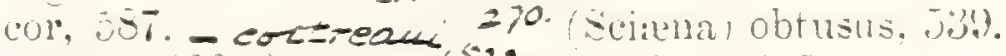

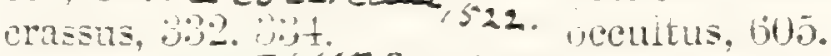

danicus. $03 \frac{1}{2}$.

Berrciclarum) clebilis, 11.5.

(Iusiciclarum) debilis, ijo.).

deciniens, - ,

ciiturus. 6105.

tispar, jo.

distinetus, 0.2 .9 N.V.

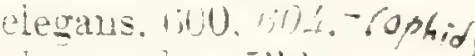

tegantuius. ö̈.

eleracus. hus.

ellinticus, -57 .

ephod primas. ist.

(Berreiciurum

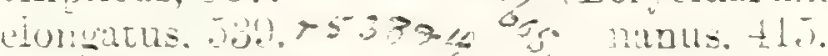

etrilininatus, (i)t.

epolrectus, jejs.

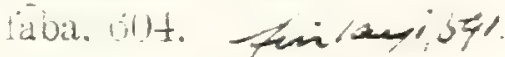

irancorurtauts, ises.

fientiens, .

selmmit.

semmanicts. Jüt.

rejon. $\$ 15$.

zoberuino, ...?

-aber. ill). (macumusacis

grempris.

vuestalizus, 1911.

Elidrendorti. vils.

inolsittius. - .

liusbes. $\$ 14$.

hrbinicus, ii)\%.

invens. +14 .

insignis.

insuetus, $\because$.

interer. $\div 14$.

interntilus. is.

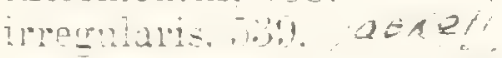

lincuperoensis. eü.

Pucinidus. $+1 \frac{1}{1}$.

noitatus. -ito.

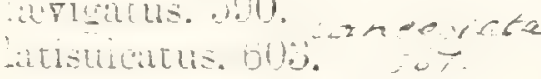

hitus nis. $=3 \mathrm{cr}$

bilwer- $-1 \pm$.

ienticularis. il il.

metrentems, ists.

merichlon is an.

: $\cdots+\cdots,+(1):$,
(? Rhondion mienanus, bis.

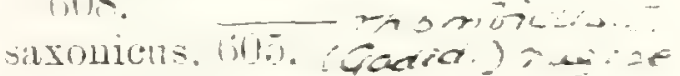

sector, 6019)

sepinncilicis, rol

(Mvorinas) sueblizrensis, 605.

(spallidimnt) sueilin-

gensis. ois.

similis, jos.

simpiex. (1)4. -

singulatis, filli.

spatuiatus. (6)4

speciostis. - . in:t.

spertabilis. Gitt

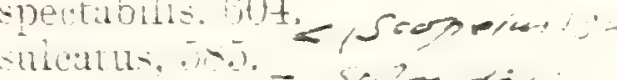

subrotandus. Tl, -ainoticis

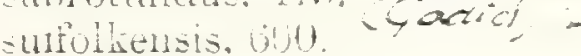

supracreracens, ilis.

tenuis, tillt.

iestis. 1.5.9.

thrnnuides. 150. - Feran...

varians, 502.

renustus. (i)t.

relus. ogo.

ricinalis. on

Tulsuris.

Dachyceninails. i.

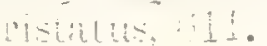



$13: 30$

\section{Pachygaster,}

polvepondylus. Jofr.

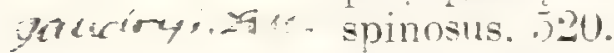

Zovo.29. Pachylebias. 294.

recalmusi, 211 crassicaudis, 295 .

grmas 95 . Pachyrhizodus, 37.

basalis, :í.

caninus, $t t$.

curratus, 4 .

diblevi, 38.

garcineri. to.

glyphodus. 258.

gracilis, t.j.

kingii, 42 .

latimentum, 42.

leptognatbus, \pm 5 .

leptopsis. 15.

maratiminsis 10 hrinimus. 4.5 .

sheareri, 15.

subuiidens, 43 .

velox. 45.

Pachrstetus gregatus, 292.

Pagellus, 532.

aquicanicus. $.5: 33$.

onomeci, 533 tle steranii. $530 \%$

elegantulus. 5 r. $^{2}$.

leptosteus.

libaniens, :on!

mircrodion. $=3 . ;$.

peruzzil, $3.6 \%$.

stenoura. 5:30.

Pagrus, 5:\%

meneghinii. .3:3.

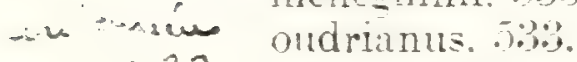

ร3. pileatus, $53: \%$

priscus. 533.

torus. 534 .

Palæobrosmius, $5 \%$.

- pezaner elongatus, 598.

in perimen troscheiri, 508.

5 Palæolycus, 211 .

dreginensis, :211.

PATERIYYCIIDE, t52.

Palæcrhynchus, t83.

bruxeiliensis, \pm 90 .

colei, tos.

deschinanni. 487 .

egertoni, $\frac{1}{2}=8$.

giganteus. \pm 57 .

glarisianus. 150 , for.

gracris. tisn.

latus. 185 .

longrosuris. 486.

medius. 4.5 .5 .

microsnoncicius, to?

liedli. 187.

zitteli. 45.

Palanarrhichas. 30 crassue Th.
Palimphemus, 270.

anceps. 270.

Palimphyes, 460 .

brevis, $4(60)$. rerassus, 460 .

elongatus, $t 60$.

glaronensis, $\frac{1}{ \pm} 60$.

grarilis, 460 .

latus, 460 .

longus, 460 .

Pantopholis, 2:34.

dorsalis, $23 t$.

Paralates, $5 \div 0$.

bleicheri. 520 .

Paralepis, $25 \%$.

Paraleuciscus, 312. ecnom1. $31 \%$.

Paranguilla, : 43 . tigriuit. 343.

Paraperca, 520. protincialis, 520 .

Paraphyllodus, $5+6$.

Parascopelus, 256 .

lacertosus, 2056 .

Parequula, 450. albyi, 4.50 .

Pegasus lesiniformis, -269.

Pegasus natans, 383.

Pelamys, 48:. adunca, 482 .

robusta, $48 \%$. sard $\alpha$,

Pelargorhynchus, 188.

blochifformis, 188.

dercetitormis, 188.

Pelates, 523.

quinciecimails, 723.

Pelycorapis, :jet.

berveinus.

varius, 354.

Perca, 518.

alsheimensis. 513.

beaumonti, 515 .

cyprinodon. 50grouer's

elongata, 515 .

fluviatilis, 518 .

forbesi, 510 .

formosa, +10 . ignota,

lepidota. 511 .

lorenti, 518.

lucioperca, 511.

macracantha. 518.

minuta. 506 .

moguntina. 512 .

punctata. 366.

radula, 526 .

reboniii, 50.

uraschista. 516.

PERTESOLE Jis.
Sercichthys, 514 . antiquus, 514. Liver, 514 beaumonti, 515 . Percide, 498.

\# 61 . Perciformes, 497.

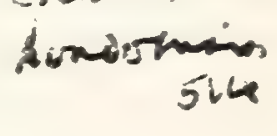

Percostoma, 519.

angustum, 510 .

Peristedion, 586.

personatus, 587 .

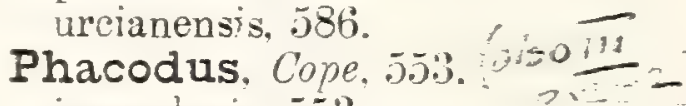
irregularis, 553 .

Phacolepis=Rhacolepis.

Phalacrus, 458 .

257 crbioides. 458.

Phareodus, $74,75 . \ldots$ acutus, 76 . sericeus, 76 .

Pharyngodopilus, $5+1,5+5$.

abbas, $\breve{5}+3$.

africanus, $5+2$.

alsinensis. $5+4$.

bourgeoisi, 543.

canariensis, $54 \%$.

carolinensis, 543 .

crassus, 544 .

dilatatus, 54 .

haueri, $5+5$.

multidens, $5+4$.

polyodon, 545.

quenstedti, $5 \pm 5$.

sella, $\check{5} 45$.

soldanii. 545.

superbus. $5+2$.

Phasganodus, 190.

anceps, :20:3.

australis, 615.

carinatus, 204 .

dirus, 204 .

gentryi, 615.

gladiolus, 204 .

semistriatus, 20.5 .

Phasganus, 613.

declivis, $61 \ddot{\text { ë. }}$

Pholidophorus macrurhrnchus, 2.

Phycis, 602 .

78 . suessi, 602.

Phylactocephalus, 212. 218.

microlepis, 218 .

Phyllodus, 546.

bowerbanki, 54 ?.

culei. $5+9$.

corsicanus, $57 t$.

cretaceus, 5.50 .

curvidens, 50.

deborrei, 5.n.

depressus, 5.0.

turali. jou. 


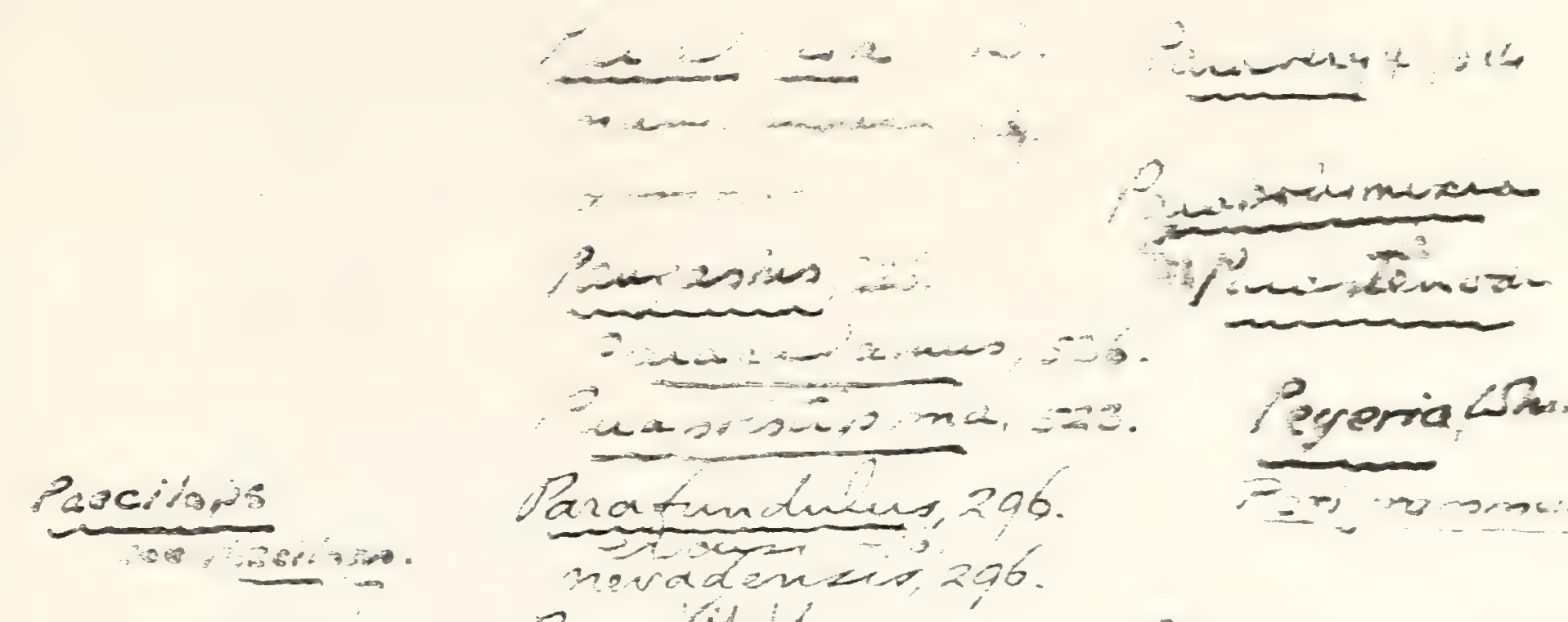

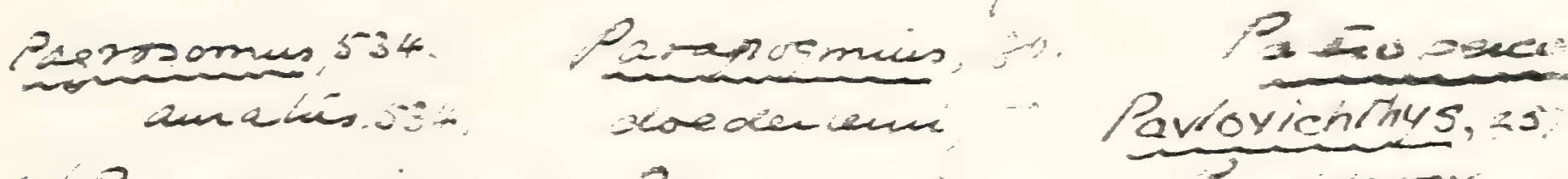

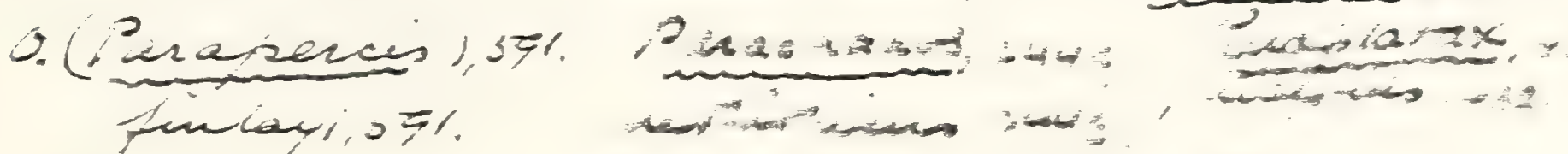

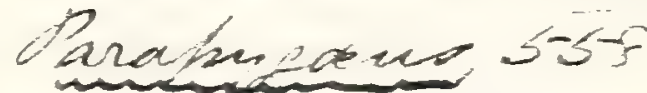

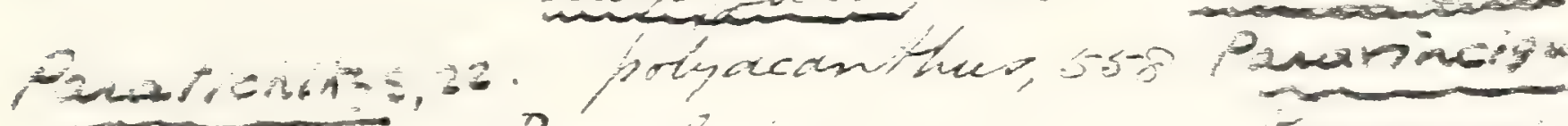
Paricis: 11.

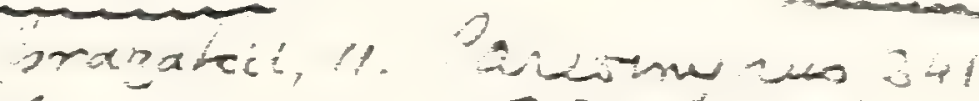

remenzis, sc2.

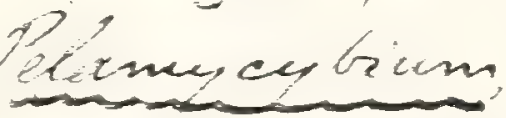

Palaootorits, is

zinus cindofonemeir,

distincless N.V.522.

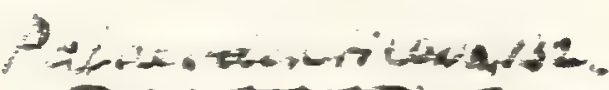

Peviria

Praercinver

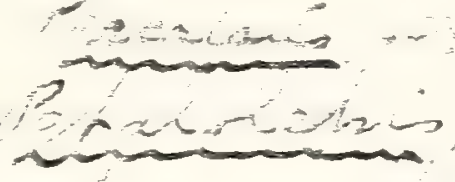

- tivancetios $=2$

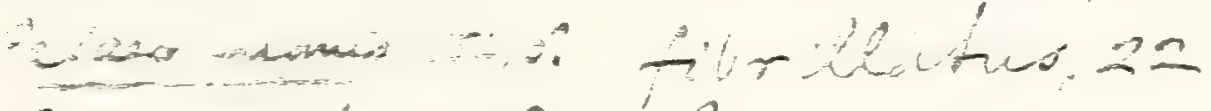

Paceoseriva se8

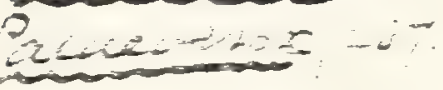

Pencencin, 199 ,

$\tan 20$

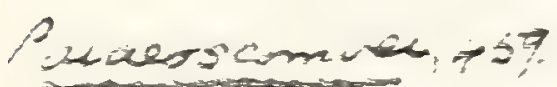

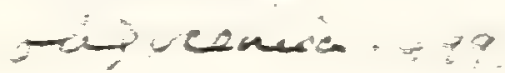

o.

spinotios, is?

Pulavorms anciesin.

atasery parken 



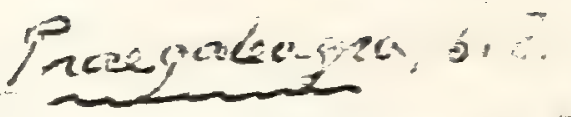

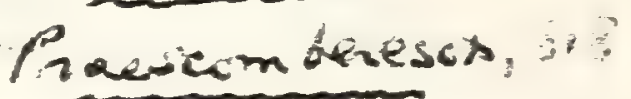

PRACANTHOAST H5:

Fiacenthus, 563 .

zolastas, 30 .

Plectrities 536 . spiñosus, 500.

$$
\text { classeni, s36,618. Fimdeniz, yinis ofy }
$$

Pescezhation, 622

9,

siciculus, 606 .

20. Sicandaties 606.

Pittisina, 235.

minimens, 235.

zsitenias 594

zarsien, 190
Poansedina. 162.

Profarkiggadurs scais

rrediodor $=-6$
Plinitionem. but. Progeadus (soele) pisanitsiz. Procharax, 298.

sismmdianus, 545. Problennius :-9.

Pliosicuress, w25.

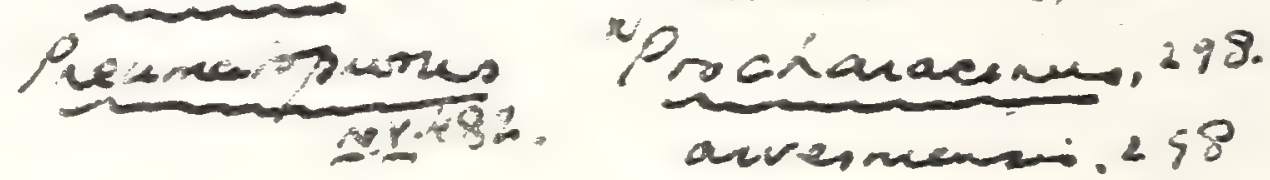

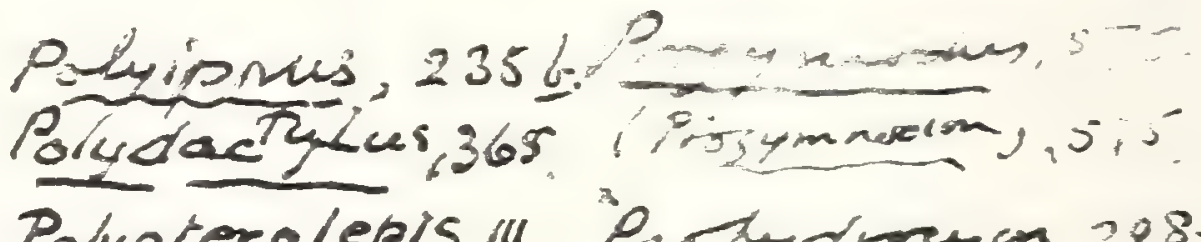

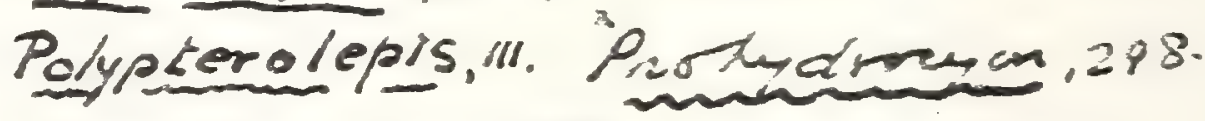

Pomadasidae.499. peilesion. 258 .

POMATOMIOAERT:

Pomolobes 1565.16440

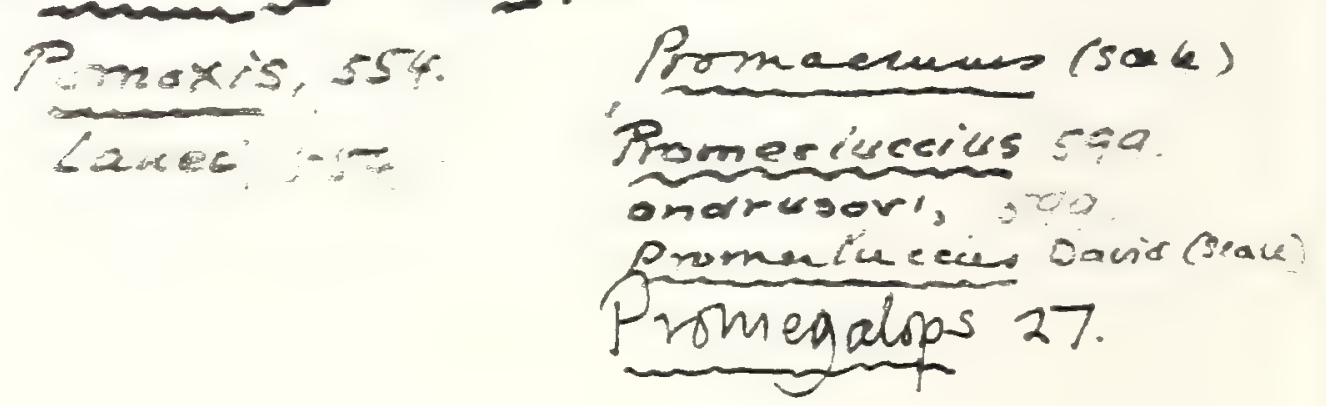

Protencenina: -79 ,

epii, 499.

serpa imanm

o 
Phyilodus (innt.).

rlegans. jo.

serraisi. 300 .

haneri, stt.

hexagonais, ity.

hippariony. i17.

incertus, 575.

inconstans. 5.51 .

irregularis. jts.

latidens, 5.50 .

leresquei, 550.

marenalis, jts.

medius. $5+8$.

muiticlens, itt.

petiolatus. 548.

planus. 547 .

polrodus, $5+7$.

secundarius. jto.

sneciosus, jt9.

sundenressus. $54 t$.

submedius, jto.

toliapicus, $5+6$.

imbinatus. 5.50 .

Pimelodus.

antianus. 29.

aor.

sacileri. ê3.

Pisodus, b0. 61.

touenrai, 7:.

areni. 100 .

Plagycaus, 189.

Planesox, 519. rorax. 519.

Platacanthus, 509 . cioinoi. 510.

Platax, 432.

aitissimus. 439.

breris. \pm 29.

coleticus. tot.

costatus, fie.

cuneus, $\pm 3 \ddot{0}$.

macropterrgius. te๊

ininor.

nucians. \pm 29 ,

papilio, tois.

pircseteroicle, $\pm 30 \%$

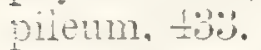

pinnaltiformis. 189.

pinianus. $=33$

subrespertilio. 493.

moociwari, for.

Platessa, bus.

setror, 60\%.

Platinx, 59.

cacuilii. $=9$.

elongarus. 39.

qigns. $\mathrm{s}$.

Placeos. 10.

subuidiens, $7 i$

Platycormus. 21 . jarmauns, ㄴ.1.
Platycormus (cont).

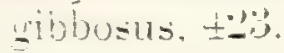

i) olonetls, t\%2.

Platygenys, 113.

mugusus. i1:3.

Plaiylamus, jjI. colei, 5.1 .

Platylates, 500. mpeliensis, 5?0.

Plectropoma uraschista, $511 ;, b 16$.

Pleionemus, $4+$ ? macrospondrius. ty.?.

Plethodus ().

expinsus. 81.

fureutus. 81.

oblongus. 83.

pentayon, 53.

Pleuratintisus serratus. วิธ土丷.

Pleuronectes, 608.

platessa. qúf, 1919\%. quadritulus, t5ir.

Pretronectidi.e. ijus.

Plinthophorus, :-21. robustus. 2.29.

Plioplarchus, $5: 0$.

sentemspinosus. 50 . serspinosus, 5:0.

whitei, 50 .

Podocephaius, 319.

niticus. 519.

Podocys, 520 .

minutus, 520 .

Pcdopteryx, 58.

aibri, nis.

bosuiasti. 587.

Pectilia lametherii, 1515.

Pcecilia oeningensis. je:.

Pœcilops, *ul

breviceps, 296.

Pogonias muitidentatus, $5: 3$.

Polynemus, 445 . quinquarius. $\pm 11, \frac{1}{2} 16$.

Pomacanthus, 61 . subareuatus. jhi.

Pomacertriden, joje.

Bcmaphractus, -6. egertoni. 76,50 .

Pomognathus. 212, ï̌.

eupterscius, $21:$.

Portheus.

unculatus. Us.

areuatus. 101.

australis, 7.

braentgnarthus, 07.

laviesi. 25.

qauitinus. 5.

riadius. :
Portheus ant.).

iestrio. 27.

luwi. $\%$

manteili, 5.

molussus. !!

mucigei,

thaumas. $\%$

Prionolepis, …?

angustus, 200.

watahractus, $2: 00$.

Imintus. 28:2.

Priscacara. 5.54.

clirosa. .67 .

crpha. 505.

liups. 5.55.

oxyprion. 55.

pealei. 55.5.

serrata. 554.

tescudinaria. 50.5.

Pristigenys. \pm 15 .

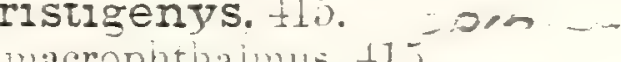

(5. +15

Pristipoma.

fureatum, i:?

Prcantigonia. jevio an

longirosti.u. $.5 \%$ in arresso

octueantha. $5.5 \%$.

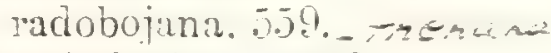

steindachneri, 552

Proballostomus, -294\%.

longuius, wh.

Procinanos.

rectifions. 15.5.

Progymnodon. . .1.2,

0.5.

hilgendor 0.56.

Prolates, 499.

beberti. 409.

Prolebias. 200 .

bronemiarti. 2.19.

ceninalutes, 2040.

crassicaucius, 20.5

davidi, t.

egeranus, 015.

furcatus, 291 .

gaudrsi, 204.

gobio, 2 . 4 .

goreti. $29: 3$.

gregatus, 202.

meveri. nut.

minimus. 294.

oustaleti. 293.

pernusillus. 291 .

puicheilus. 1315.

stenoura, $-10 \%$.

Pronotacantivus, 16 .

sibei-nimæ. $15 y$.

Properca. it.

sunusta. 515.

beamonti. 315.

lepiciota. 311.

niser. 310 . 




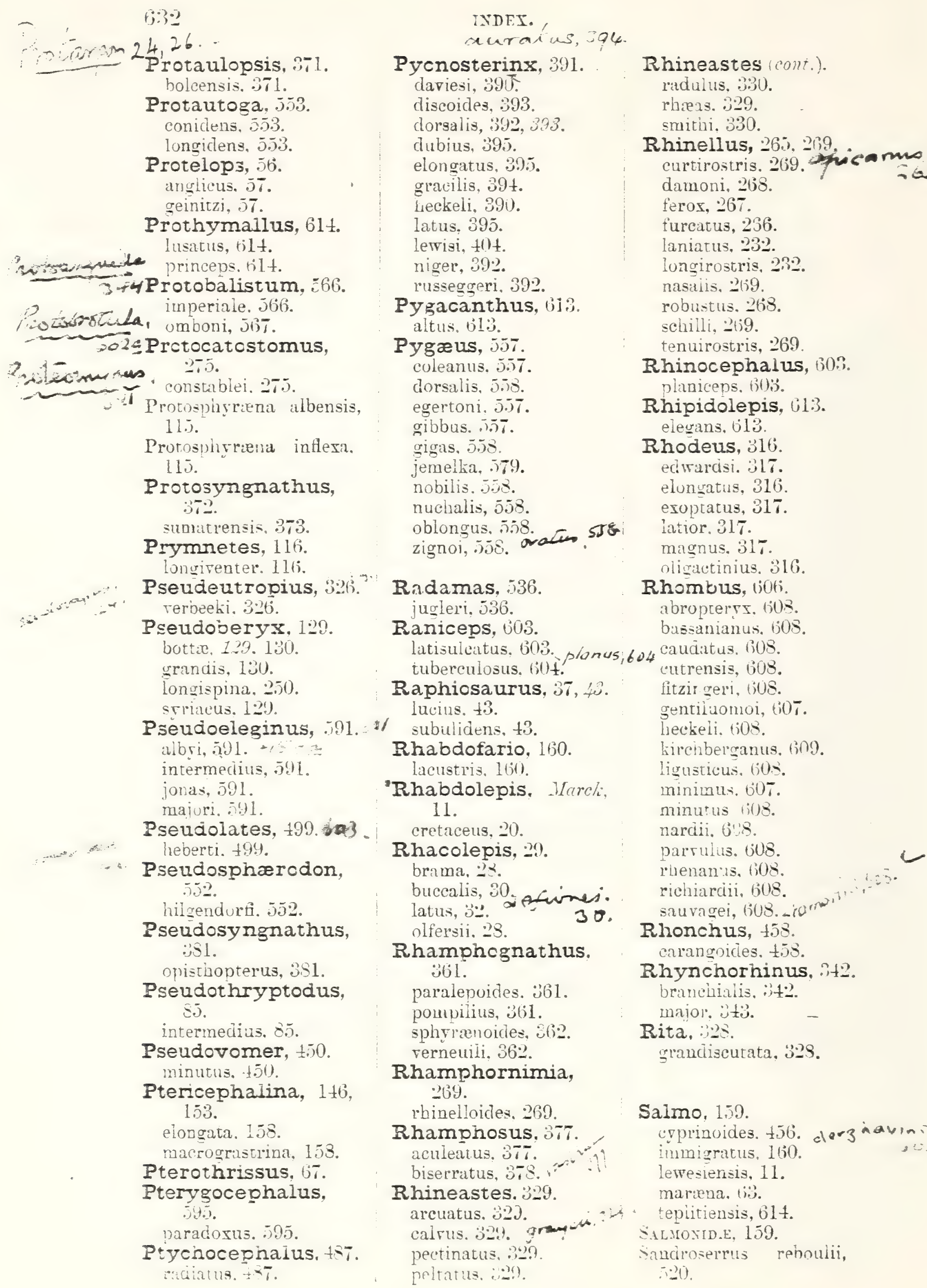

- 193301

$2 \frac{4,26}{\text { Protaulopsis, } 971 .}$

bolcensis. 371.

Protautoga. 5.53.

conidens, 5.53.

longidens, 5.53.

Protelops, $56^{\circ}$.

anglicus. 57. geinitzi, 57.

Prothymailus, 614. lusatus, bilt.

noside princeps.tilt. rotobalistum,

$\rightarrow$ inperiale. 566 .

Coziortula, umboni, 5137.

202 Prctocatostomus,

2.150 . 25.5

Protosphyrena albensis, 11.j.

Protosuhrrena inflera. 115.

Protosyngnathus, $37 \%$.

sumutrensis, 973.

Prymnetes, 116.

longiventer. 116.

Pseudeutropius, 326. rerbeeki. 326.

Pseudoberyx, 120. bottic, 1.29. 130. urandis, 130 longispina, 250 . srivacus. 12y.

Pséudoeleginus, .91. albri, intermedius, 501. jonas, 591 . majuri. -141.

Pseudolates, 199.ta3 heberti. 494.

Pseudospinarodon, $5 . \%$.

hilgendurfi. 552 .

Pseudosyngnathus, ¿S1.

opistiopterus, 391.

Pseudothryptodus, 85.

intermedius. 85.

Pseudovomer, 150 . minutus, \pm 50 .

Ptericephalina, $1 \pm 6$, 153. elongata. 158. macrogrustrina, 153.

Pterothrissus, 67.

Pterygocephalus, .59 .3$.

varadoxus. 505.

Ptychocepnaius, 487.

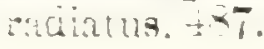

IXDEX.

auraius, ja4.

Pycnosterinx, 391.

dariesi, 390.

discoides, 393.

dorsalis, $392,393$.

dubius, $395 \overline{.}$

elongatus, 395.

gracilis, $39 t$.

Leckeli, 390 .

latus, 395.

lewisi, 404.

niger, 392 .

russeggeri, 392.

Pygacanthus, 6i:. altus. 613.

Pygæus, 557.

coleanus, 5.57 .

dorsalis, 5.5.

egertoni. 5.57 .

gibbus..$\overline{7} \pi$.

gigas, 505 .

jemelka, .779.

nobilis. 553 .

nuchalis, 558 .

oblongus, 5.58.
zignoi, 508 . 558

Rndamas, 536 . jugleri, 536.

Raniceps, 603. latisulcatus, 603 . plonus 604 tuberculosus. $60 t$.

Raphiosaurus, 37,40 . lucius. 43.

subulidens, 43.

Rhabdofario, 160 .

lacustis. 160.

"Rhabdolepis, Harcl, 11.

cretaceus, 20 .

Rhacolepis, 29.

brama, 22 .

buccalis, 30 efirmei.

latus, 32.

olfersii. 23.

Rhamphognathus. :361.

paralepoides. $₫ 61$.

pompitius, 361 .

sphyranoides, 66?.

verneuili, 36\%.

Rhamphornimia, 269.

rbinelloides. 269 .

Rhamphosus, $37 \%$ aculeatus. 37 biserratus, 27, \% :

Rhineastes, 829. arcuatus, 32 . calrus. 320. gramis. pectinatus, $90 \%$ peltatis. :on?

Rhineastes (cont.).

ritululus. 330 .

rhæגs. 829.

smitini, 330.

Rhinellus, $26 \%, 289$.

curtirostris. 269 .

damoni, 268.

ferox, 267 .

furcatus, 236 .

laniatus, 23\%.

longirostris, 232.

nasails, 269

robustus. 268 .

schilli, 269 .

tenuirostris, 269 .

Rhinocephalus, $60 \%$. planiceps. $60 \%$.

Rhipidolepis, 61:3. eleuans. 013.

Rhodeus, 316 .

ecirardsi. 317.

elonvatus, 316.

esoptatus, 317.

latior. 317.

magnus. $31 \%$.

olioactinius. 316.

Rhombus, loti.

abropcerss. 608.

bussanianus. 603.

caudistus. 608.

cutrensis, 608.

fitzir geri, bus.

gentiluomoi, 6i07.

heckeli. 608 .

kirchberanus, 6 ing.

livusticus. 60s.

minimus. 607.

minutus li()8.

nardii. 6!:8.

parrulus. 608.

rienan'us, 608.

richiardii, 608.

sauvagei, 6U8. - rom

Rhonchus, 458.

carangoicles. $t 5 s$.

Rhynchorhinus, . 42 .

branchialis, : 4.2 . major, itu.

Rita, :2s.

grandiscutata, 323.

Salmo, 159

coprinoides. 456 . derzhavin. immigratus, 160.

lewesiersis, 11.

mariena. 193.

tepiitiensis, 614.

Stmorate, 159.

Siandroserrus rehoulii, $\therefore 0$. 


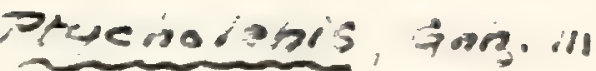

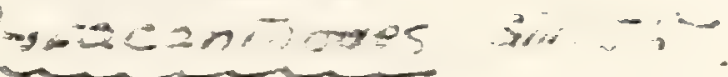

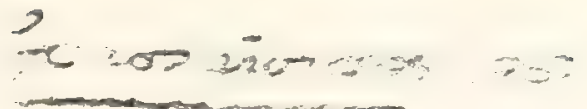

is

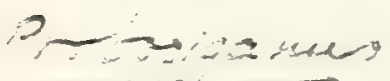

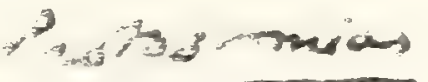

$0 x-2$ oseita 603 .

wenesesens

acasia.

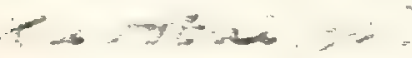

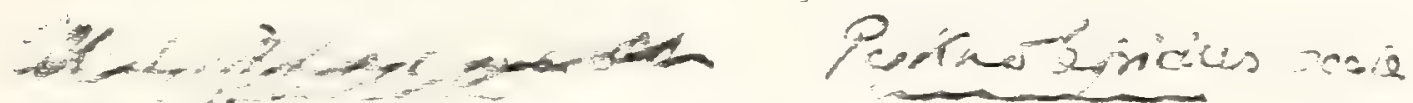

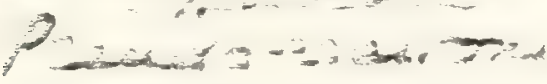

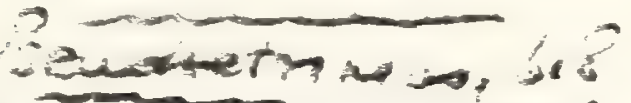

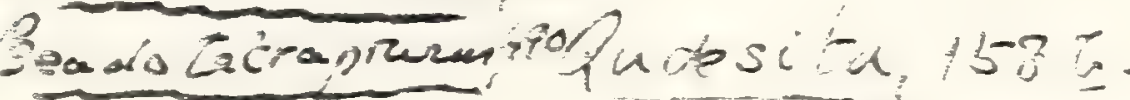
owisuíia, $1533,668$.

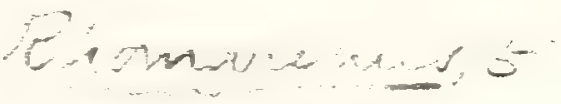

meipes, 100

chaminder 586 Q

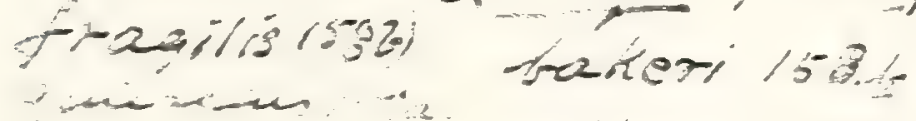

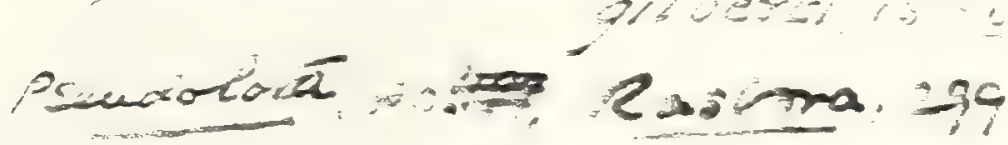

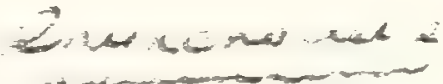

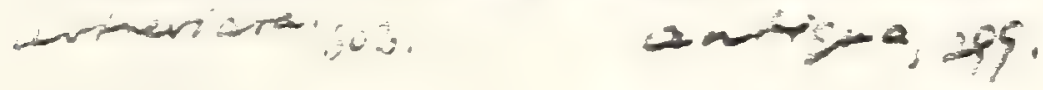

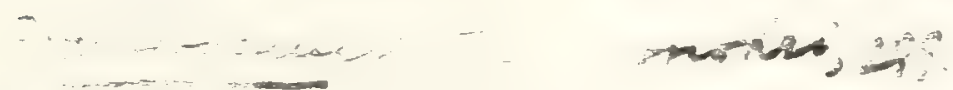

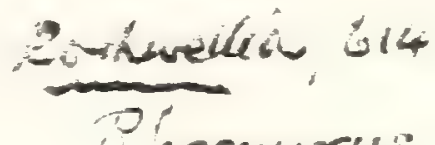

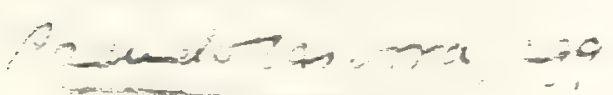

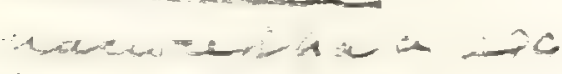

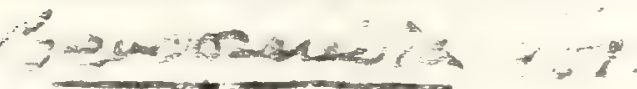

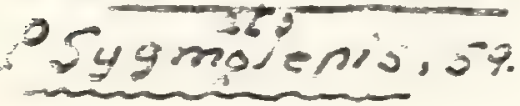

Oidion

ariciertion

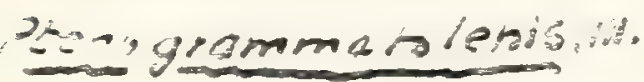

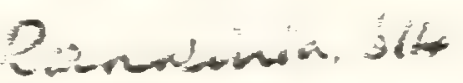

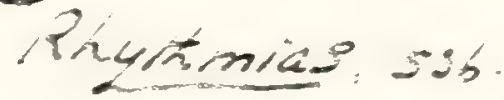

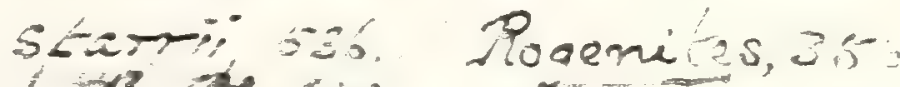

Pizalog són. Pogenio, 35

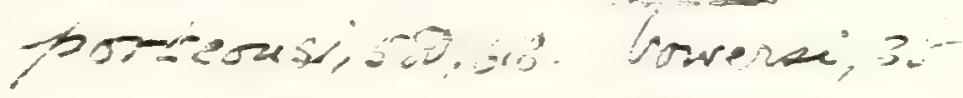

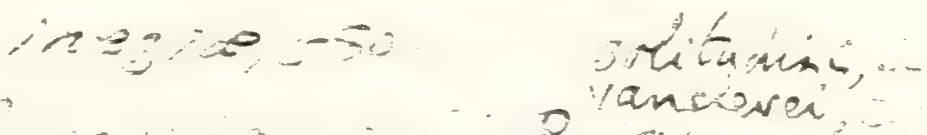

tuerati.

otancesos

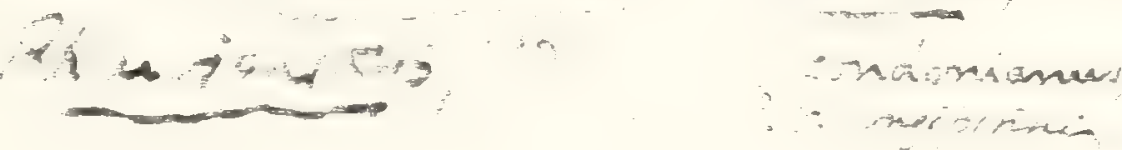

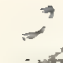

-

Pourtios ins

prisp. 

Sanar pusen

gmansis, 242.
Siemieressus, 358. acurives, 358, 618. ed wardsi, 358

ins is, 248.

$\therefore \ldots+14 a, 1580,5.155$.

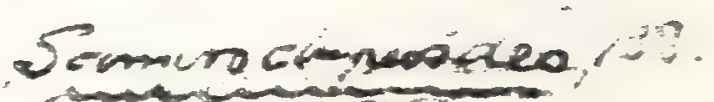

$\frac{\text { Sehisenondentus, } 188 .}{\text { Antins, } 188 .}$

vingare, 451.

- gzizíeri, y'?

Sciventio. 582 .

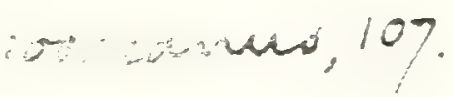

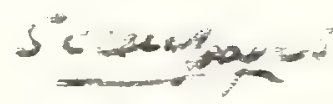

Fleastaves, 580.

r.vtabaliv, 580,018

$S$ teastinus, spo.

rarrits, 580.

inezike, 580.613

Serastoessus, 580 .

apeotates, siso.

cepens, /14.

Dodenisersita. 200 


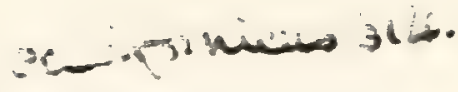

Sardinioides,

zinblrostoma, $80 \%$.

ittenuatus, $2 \pm 1$.

rassicaucus.

macroptervoius. 2t?. meganterus,

microcephatus. 237.

minutus, 212.

monasteri, 11, 297.

pusillus. 240 . Enuicaudus, 2.20.

Sarcinius. $-\frac{1}{2} 7$. biaciburnii, 2018. crassapinna, 132. cordieri. 247

lineatus. 248 . :uacrociactrins. 131. nasutulus, $2 \pm 8$. percrassus. 노․ ropustus. 131 .

Sargus, 29. antiropocion. 530. aquitauicus, 530 . armatus. $530,5 \% 0$. baraicii. 530. carannai, 530. curieri, $530,617$. Leverti, $3: 30$. incisirus, 530 . Somnitanus. 500 . ariconus. 529. ornensis. jog. 1) weni. $53 \mathrm{~L}$. resuccuritanus, 300. serratus. 51. sioni. 531. sitifensis. 580 .

Saurocepnaius. 113.

albensis, ilt. uranairovitu, 11 t. auciax. ye. bronaheadi. 113. cientatus. $11 \pm$. dispar. 115. fijumensis, 115 . incequais. 115. indexus, 115 . intermecins. 112. ancirormis. IIs. eanus. 111. 1 rcodon. 204. marginatus. monisterii. 115.

hiebotomus. I1:. picteti. 115. prognatins. 107. striatlus. 20.01. sabstriatus. $11 \%$. - hatumas. 18. moocisardi. PARTIT.
Saurodon. 111.

affinis, 113.

broaciheacii, 113.

conoideus. 113.

ferox. 113.

incermeciius. 112.

lanciformis, 113.

leanus. $111,201$.

marcinarus, 220 .

phlebotomus. 112.

pygmeus. 113.

-xipuirostris, 113.

Saurorinampius, $\simeq 07$, 310.

freveri. 210.

Sauropsiaium. 58. gracilicauda, 58. Imvissimum, 58.

Senriinius dumeriil. : 31 . Searcinius sicanus. 311.

Scarus, 5.53.

baitringensis, 530, 591.

miorenteus, 533.

oweni. .

suericus. 559.

tetrocion. 553.

Scatophagus, 561.

uInnis. 061 .

alveilinii. 581.

frontalis. onl.

Sciæna, .39.

umpius.

holsaticus. 539.

irresuiaris. 539.

juculatrix, 561.

zireubergensis, 5.39 .

meridionaiis, 539.

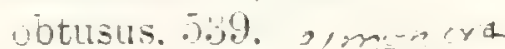

piumierii. 521.

sneciosus. 539.

unciecinais, \pm 77 .

Scr.exid e. Jies.

Scimnurus, $524.52 \%$

bomeroanzi. 527.

breviur, 527.

crassior, $52-\bar{\sigma}$

iongior. 519.

Sclerognathus, 800

Scomber. +.59 .

diarunua, \pm 56 . antiquts. 459 .

Corcigia, $\frac{1}{4} 5$. ghateus. $\frac{1}{2} 8$. snudiis, 521 .

orcynus.

neirgieus. $1 \pm \pm$

velamis. 501 .

Dianorarus. 454

priseus. 450.

Hombeus. 499.

intriticus, $15 ! ?$

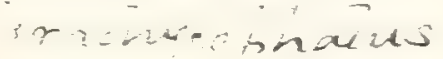

Li2
Scomoer (nnt.).

speciosus. -titi.

reinciacuneri. $\frac{1}{1} 59$ ).

stretianus. 459 .

:hennus. $45.5,45$.

rachurus, t6t.

Scomberodon, 4150 . Hendmos.

Uumonti, \pm 70 .

Scombramphodon. $\pm 7 \div$.

benecieni, $\pm 7 \pm$.

arasiciens. 475 .

curpiriens. tit.

COMBRESTCIDE, 350 .

Scombresox, 857.

licatre, 85.

obtusirostris. 357 .

Scoubride, t51. \% 325

SCombrtForues. 418.

Scomorinus, \pm 161 .

macronomus, 460 .

suctalis. 461 .

Scombroclupea, 135.

raucipri. 1:5.

macrophthalma, 155.

$$
350
$$

pinuulata. 185.

SCopflid.e. 205.

Scopeloides. $25 t$

slarisianus -4.5.

Sconelus iacertosns. 250 - Sumcunim.

Scorpena.

reinima. 59.

pilari. 50

prior, 579.

serota, 5it.

zessieri, 579.

SCORPEYTDE, $5 \%$.

SCORP.ENTFORMES. $56 \%$

Scorpanoides,

ponorieii. 580.

Scorpanopterus, 50 .

siluriciens, j50.

Scypiropirori. 1.

Sebastodes, 579.

rose. $07 \%$. $\quad-x=300=2$

Semiopinorus, :uU.

cigess, tolu.

massalongianus. 4, 1 .

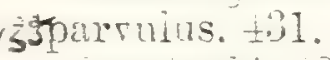

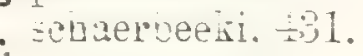
reicans, sil.

-aifer. $=0$.

Semotilus.

arcii, 30 ?

osticus.

Serricia. $\pm \frac{1}{2}$

inatis. $\frac{1}{2} j$.

ealunonti. $\div \frac{1}{4}$ ii,

$\because \mathrm{T}$

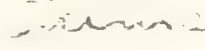

oraziigi, - 



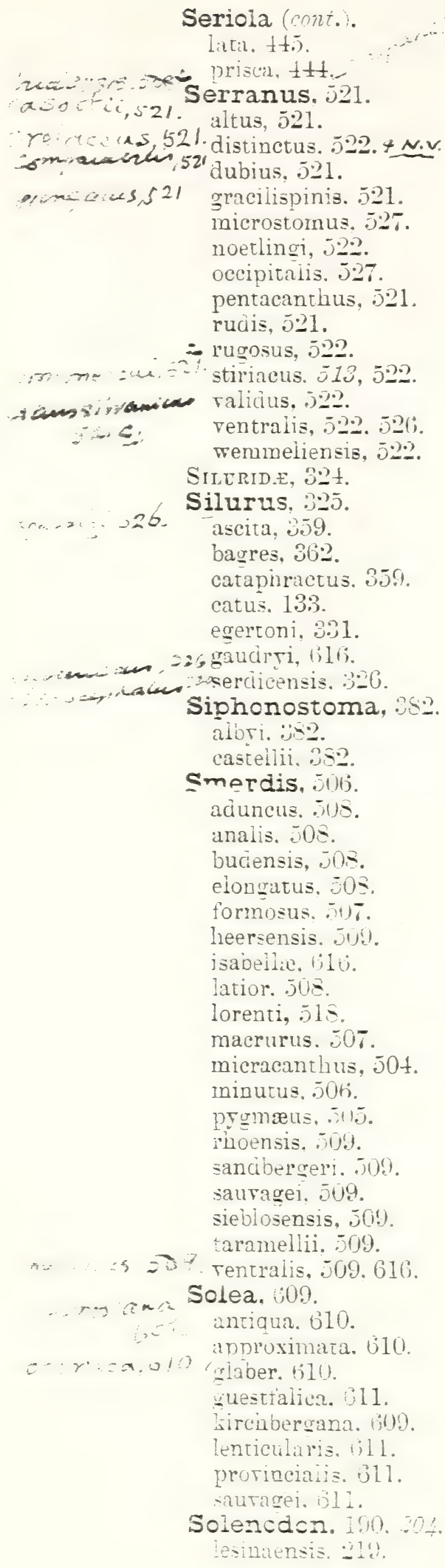

Seriola (cont.). litir. 44.5 .

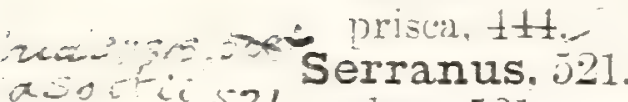

aco i ci, s21. altus, 521.

Yo: re: 15,521 distinctus. $522 .+$ N.v

ormianencir 521 dubius, 521 .

oricaces, 521 gracilispinis. 521 . microstornus. $5 \%$. noetlingi, 520.

occipitalis. 527 .

pentacanthus, 521 .

ruais, 501 .

- rugosus, 522.

stiriacus. 513,522

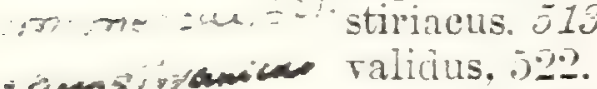

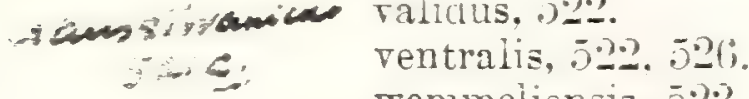
wemmeliensis, 520.

SILTRID.E, 324 .

Silurus, 820.

ascita, 859

bagres, 362 .

catapinractus. $35 \%$

catus. 13.3.

egertoni, $3: 31$.

s26 gaudrri, 616.

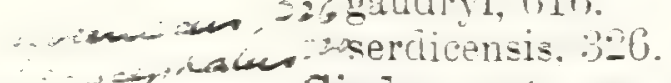

Siphonostoma, $5: 2$.

alori. :us?

castellii. 052

Smerdis, 506.

aduncus. jus.

analis. 508.

buciensis, jos.

elongatus, 508

formosus. 547.

heersensis. jug.

isabeilia, 1910

latior. 508

lorenti, 518.

macrurus. 507

micracanthus, 504 .

ininutus, 50 h.

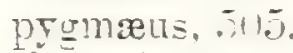

phoensis, jog.

sanciberceri. .00?.

sauragei, 509.

sieblosensis, 500.

taramellii. 509.

Tentralis, j09.616.

Solea, :09.

antiqua. 0210.

approximaza. 010 .

glaber. 610.

guesttalica. 011

Eircinbercana. 609

lenticularis. ill.

protinciais. 011 .

sautagei, j11.

Solencdon. 100.004.

tesimaensis. 21!!

Solenodon (cont.).

lobopterrgius. 219.

neocomiencis. 20t.

Solenognathus, Pictet of Humbert, 271 . 204.

lineolatus. 27t.

Solenorhynchus, 280 elegans. 80 .

SOLEXOETOMATID.E. 37?.

Scricidens, 30.

baueri. :3:3.

Spaniodon. 48.

blonrieii. 13.

bretis. 53 .

elecrus. 18.

elongatus. jl.

hakeiensis. it.

latus. $0 \%$

lepturus. 5 t.

simus, 03.

SPARID.玉.j.

Sparisoma,

Sparnodus. .it.

altivelis. 525

bowerbanki, 5\% a ches

elongutlis. job. $\operatorname{cis}_{5} 3$

intatus, os.

intermedius. 525 .

lethriniformis. 525.

macrophthaimus. 525.

wicracanthus. 505.

microstowus, 5:-

moloni. 5.2s neagen:

oralis, 525.

Sparoides, 5.37

molassicus. 5üli.

robustus, $5.5 \%$

spbaricus. 587.

tenuis. 536.

umbonatus, 5.37.

Sparcsorna, jo?.

ovaiis. 3 -3.

Sparus brana. .727.

sparus buicanus. 5.je

spalus chlomis.

Sparus cientex, 525.

Sparus errthinus. 5:5.

Sparus macrophthalmus. .05

Snarus scilpa, 526 .

Sparus sargus, 525.

sparus tulgaris. 525, 5.

Spathodactyius, is. neoromiensis. 15.

Spharodus. .j.

annularis. $50 \%$.

araciasii, jó.

cinctus üú...j.

cingutus. jion.
Sphærodus (cont.:

conicus, 537.

depressus, 536.

diseus. 586.

insignis, 537.

intermedius, 537

liergomardius, 535.

lejeanianus, 230 .

lens. $5: 36$.

ocuius-serpentis, 537

parrus. 338.

polyodon, $54 \bar{t}$.

pygmaeus, $5: 35$

subtruncatus, 530 .

truncatus, 5.8.

wiechmanni. 5:3.

Sphagebranchus. :3ti. pusillus, 347.

formosissimus. "jti.

Sphenocephailus, 3is.

cataphractus. 288 .

fissicaudus, 357.

Sphenolepis, Agassir, 275

cuvieri. 27.

squamosseus. 2-7

Sphyræna, 366.

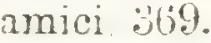

bolcensis, 366.

carinata, 20t. raxeslifoss

croatica. 318.

gracilis. $: 66$.

internerita, 267

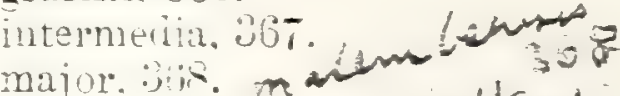

maxima.

rova

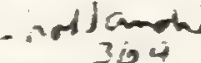

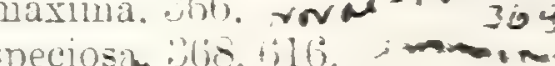

=ternberaensis. $20 !$.

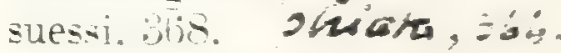

trrolensis. 616 .

viennensis. 360 : 2 n

winileri 89

SPHYRENIDE, Uli.j.

Sphyrænodus, 17:

ar anceo botti, $\frac{1}{=}$.

524 conoideus, \pm 76

crassidens. 475

gracilis, 469.

lingulatus. \pm 67 . priscus, $\frac{1}{17} 3$.

silorianus. illo.

speciosus. 616.

tenus. $\left.46^{\circ}\right)$

Spinacanthus. 166.

blennioicies. itif\%.

Spinacites, 115.

mairatus. \pm 15 .

Spinax maroinatus, 205.

Squailus, ï:?.

arcirepus. ",:

bairdi. :30 
- - : - - -

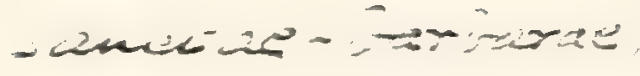

$=-1-\ldots+\ldots$

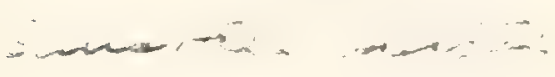

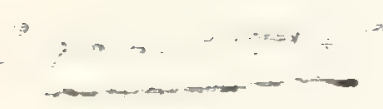

$\because+\ldots+\cdots+\cdots$

- $\quad-30$

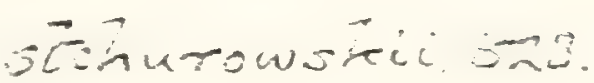

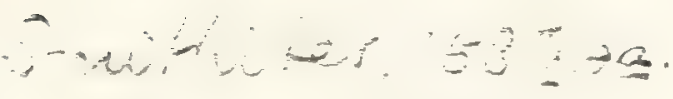

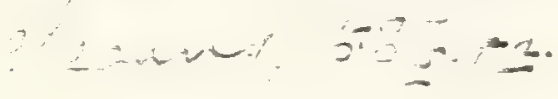

$\therefore=200=202,400$

is

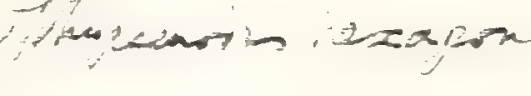

$\because y,=$

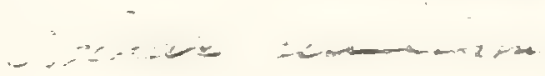

$\because-3+2-2-2$

$-x-x+2$

$\because \therefore+\cdots$ 



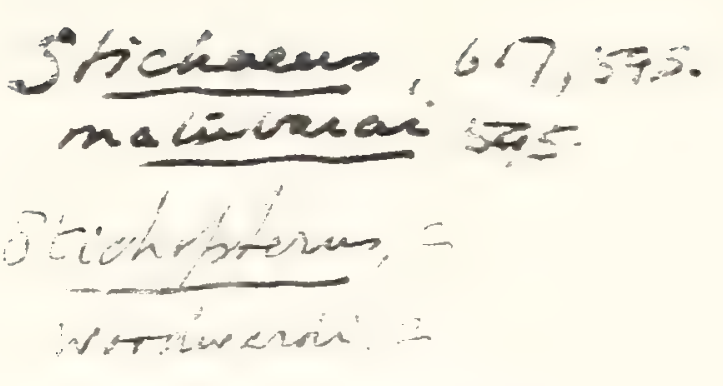

Stanias, ㄴ. 482 . 482

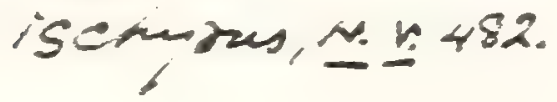

$3 \cos ^{2} \sin , 02 \mathrm{ar}$

oreanbestia, 1s7.

bavai, 1s5.

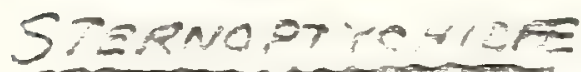

sternog tex, $2=3$

Anisea, $=25$

$-1,4+1,1)$

sungarichthys, la.

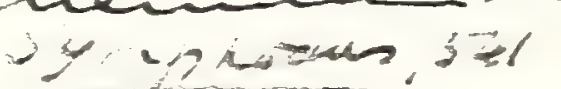

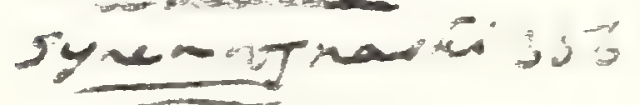

Truaces a.

r

indis, is:

ientodes.

isma, 25 sts.

enamects=

narensis, 270 .

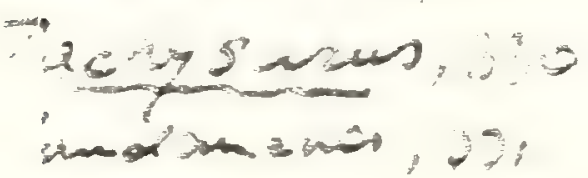

andanamen tol

Loortens.

imaerces.

Tomnodou, 447 .

isselitity. minutus, sto.

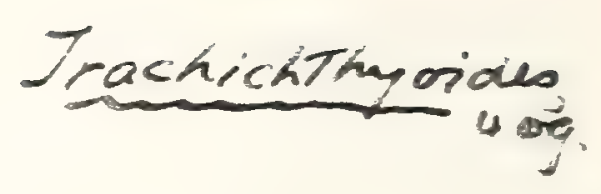

\section{Trachum 442,51}

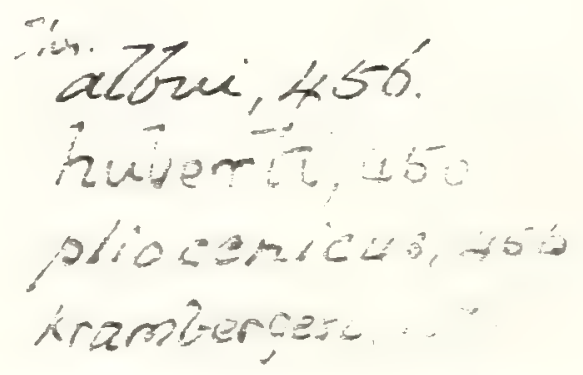

ThuTSOCLES. 481 RNV (Ohn vites)

Xriegeri, , ol

escharion, v. 482.

JAysotadex. 24

-eanesis -

Trursion, N. 482 .

$$
\text { selox, wh } 452 .
$$

THADiz, UJ"

in

fospilis,

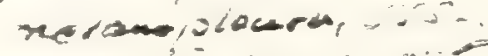

Tripkerugion, iq.

Trichiurus,

leptunus, 482.

ochamming

lericnes, 480.
Trossulus, 270.

oxuloses? 
Sarains ront

numutus, . .

Acarco ill.

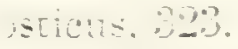

and

Eterostcma.

vuicheila. $+20-5$

Stephancdus.....

sulenciens. 530.

Sterecaus.

melitensis.

stratocus. 1ss

nericus.

unicails. 189.

oxtnoyon. 1 .

Strinsia,

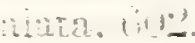

STROYITEIDE。 11 .

Stycatis . is.

Eescontei. 55.

Suais. 27.

$-7.5$

Eytemus,

inuiturts. 3.51 .

Latipons. $051,01 \pm$.

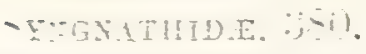

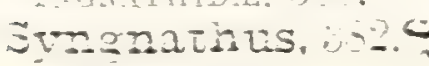
isinis, on.

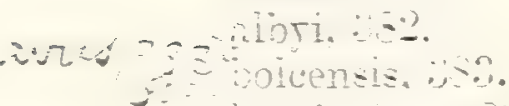

metirturs, 83

- ectil. 93.

ent.

misthonterts. 81.

trinle, $;-1$.

Soncantis.

staconrys, ilis.

3ymeg 10

Syntegmodus. =t cains. $=1$.

Tachyncoras, ‥ mutntertsin.

$-7 !$

mipes $\therefore$

waromotris, -

Garsaconges.

terens. $11 \%$

ariger, 1 .

Gaurnichthys, ....

wioceniens.

aneri.

Intivg onidens...

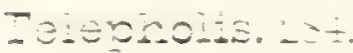

wenditis. - -

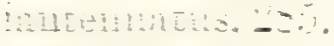

$\therefore-2$.

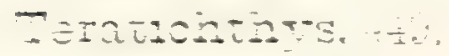

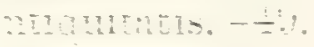

DEshecans. -

miledio. -

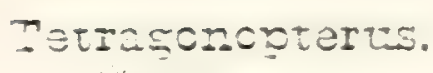

ㄴ.:

2 .718. 258.

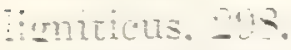

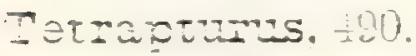

minup. I Ii.

miscus. I. 1 .

Fetrocis. 11.

nisnidus. Jis.

noncisenii. 5.6.

Lutier, si

rematus. 31 .

vitie

TECTIIDID E.

Beuthis.

-haumaturus. 180.

deicinuelleri, 14 .

- Hurgetus, olt.

Sirentus. 190.611.

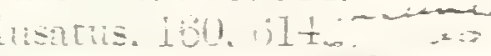

Thrissopater.

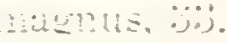

netroluns.

s:1 nonens.

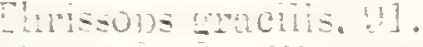

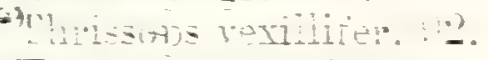

-hrisscetercios. ut.

-ioncutus.

surepmering, jo.

artic. $-\frac{1}{2}$.

Hicter, 5 ,

ienuicens. $-\pi$,

- Dr:sscoterus, -nt?ulis - - !

-7IYotecus. 3. je.

utinctis. s.j.

Atos,

- - YRIDCAthys. OH.

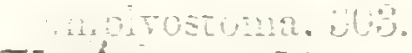

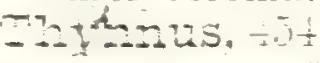

- cimergtatrs. 45.

Tolcensis. =5

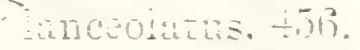

mantatus. tol?

moncerrenis. $=$ -

moxmus $=5$.

junilisis

itronis. $=-5.5$

onimicus. $=0$

Migis. 15.5.

7ay-sites. \pm 1 .

Hisutul. - 1

Bhy sitocepiaics, $-i ;$

inints. $=7$

Zi-cos. 210

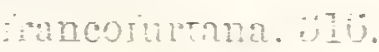

ducara.

Evosmin.

w15ind 015
Iinca int.).

: macrontertgia. 15.

mavar, 312.

micropreoptera, 214.

(a)truncuta. :16.

zarsiger. 315.

Taldarnensis, 15 .

mileris. :15.

Gitanichthys, Domes.

612

vizario. 012.

Tomocion. 1:.

homiens. 112.

Gomognathus, 116.

morcils, 117 .

leiocius. 117.

Toxopoma, ils.

puitum, tils.

Texotes. 151.

intianis. ju1. -o

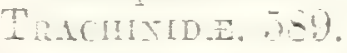

Grachinon:is, 91.

berica.

Tracininus, $0(9)$

exneuncuins. 50

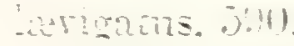

murabilis. 500.

seelandicus. solo.

repus.

Trachynotus. 150.

enuicens. I.il).

Triacanthus, 5no

Erimnaspis. i7.j. Firecuintus. is

Trioniurichthys. $\$ 9$.

incertus. it:?.

Fachiurides, ㄴon, $\pi \in e_{y}$

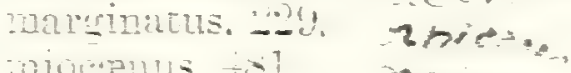

michoonanes. 160.0

cope1. $=16$.

- viarum. 116 .

Kians, $\pm 11 \%$

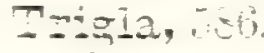

adiuncta. อこT.

cor $=5$.

-iliptica, $-\leq-\leq \pi$.

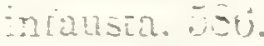

Iicatie. - sij.

iTra. j-9

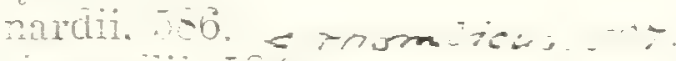

simoneili, - 86.

TngLIn. 5.5.

Drizio:zes. iab.

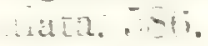

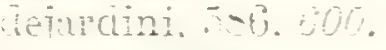

melsis, sión

-in benedunis. juj.

angorodon.

itrill

vilutis.

Tiodar

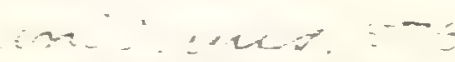


, 
Tydeus, 257 .

aibri, 2057 .

eiongatus, 257 .

megistosoma, 257 .

ina $2=$

splekodes, 258 .

Umbrina, 538.

pecchiolii. 538.

Uranosc эpus, 590 .

peruzzij, 590 . rastrum. 877.

Urencheiys, 387. angiicus, 339. arus. 337 .

m.: menoia halelensis, 338.

73. Uropterina, 146.

platyracisis, 158.

Urosphen, 376.

dubia, 376.

fistularis, 376 .

Fomer longispinus, 436.
Vomer parvulus, 451.

Vomer priscus, 442.

Vomeropsis, 135.

elongatus, 437.

longispinus, 436 .

ralenciennesi, \pm 37 .

ciunas, 436.

Xiphactinus, 92 .

audas, $92,98$.

brachrgnathus, 97.

lestrio, 97.

Xiphias, 490. acutirostris, 357. antiquus, 495 delfortriei, 197 . robustus, 497 .

Xiphinde, 490.

Xiphopter'us, 482. talcatus. 482.

Xiphiorhynchus, 490.

elegans, 491. imparaces, 454.
Xiphiorhyncinus

(cont.)

priseus, 491 .

Puirentioun

Zanclus, t.50.

brevirostris, 150 . eoccenus, 450.

Zeus, $\$ 17$.

benoisti. 417.

gallus, 449 .

hoernesi, 417.

lewesiensis. 397.

licatre, 418 .

platessa, 501 .

pliocenicus. 118. priscus, 510 .

reglevsianus, 501 .

rhow beus, 439 .

robustus, 418 .

spinosus, 500 .

triurus. +36 .

pomer, 436 . 


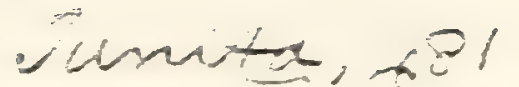

retaria, 481

Turio, Neisz.

wilturi, rev 482 .

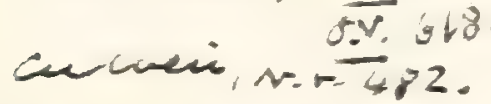

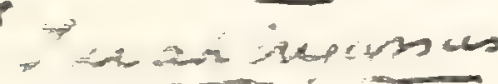

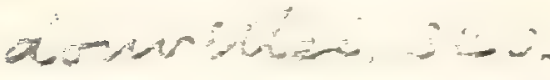

Vanicer reminas, 3220.

sum in : ?

previón

intresens

toucicatims, 234.

rivicueñ́a 899.

bivilexies

खियक-

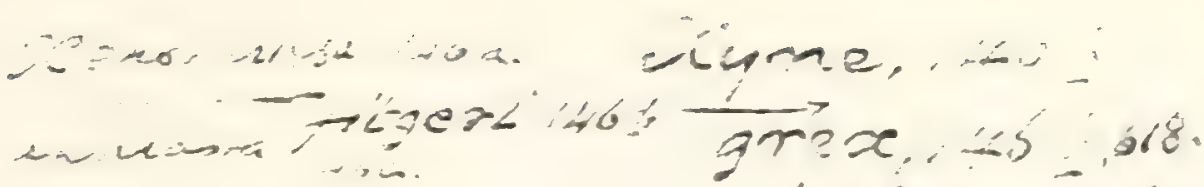

Zantechites, 06=

cestias 465

huvifui, $56=$

rarien 405 .

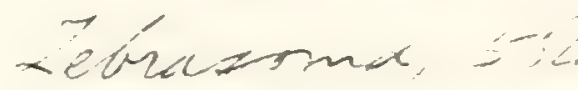

Zephzeirdae, 3a:

Taphleoes, 360

Conqutio. 365?

Zanderdae. (l)

Curionius, 553,1469 Zelosis, 150.

rowahi, sis.1464 hadley, 15.

berberce, $146 a$. Tororhomin wi elmodemae. 1460 .

velicers o

Zemiagrammes isistives, sol

zeknest

TEATicano

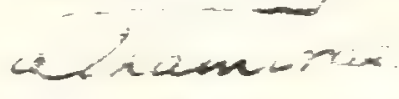

Zoroossiga

Tentaici. 


\title{
SYSTEHATIC INDEX
}

\author{
$O F$ \\ GENERA AND S PECIES \\ DESCRIBED IN PART IV.
}

Order ACTINOPTERTGII (continued) .. . . $\quad 1$

Suborder IT. ISOSPONDYLI (continued) . . . . 1

Family LEPTOLEPID E (continued) . . . . . 1

Lycoptera . . . . . . . . . 1

— middendorff . . . . . . . . 2

—

Family ELOPIDÆ. . . . . . . . . . 7

Elopopsis . . . . . . . . . 8

— fenzli . . . . . . . . . . 9

- microdon . . . . . . . . . 9

— heckeli. . . . . . . . . . 9

C crassus. . . . . . . . . . 10

Osmeroides . . . . . . . . . 11

- lewesiensis . . . . . . . . 11

— levis . . . . . . . . 15

— gracilis. . . . . . . . . . 16

- lewisi . . . . . . . . 17

PAPT IV. 
xviii

SYSTEMATIC INDEX.

Family ELOPID $Æ$ (coninued).

Osmeroides sardinioides ...... 19

— cretaceus . . . . . . 20

Elops . . . . . . . . . 22

Ylegalops . . . . . . . . 24

priscus . . . . . . 24

oblongus . . . . . . 26

Notelops . . . . . . . . 27

brama. . . . . . . 27

Rhacolepis . . . . . . 29

buccalis . . . . . . 30

latus . . . . . . . 32

Thrissopater . . . . . . . . 32

salmoneus . . . . . . . 33

magnus . . . . . . 33

(?) megalops . . . . . . . 30

Pachyrbizodus . . . . . . . . 37

basalis . . . . . . . 37

dibleyi. . . . . . . 38

gardneri . . . . . . . . 40

latimentum . . . . . . . . 42

subulidens ... . . . . . 43

Esocelops . . . . . . . . . . . 46

carifrons . . . . . . . . 46

Spaniodon .. . . . . . . . 48

— blondeli . . . . . . . . . 48

— elongatus . . . . . . . . 51

- latus . . . . . . . . 53

Thrissopteroides. . . . . . . . 54

elongatus . . . . . . . . . 54

latus . . . . . . . . 54

intermedius . . . . . . . 55

tenuiceps . . . . . . . . 55

pulcher . . . . . . . . 56

Protelops . . . . . . . . . 56

geinitzi. . . . . . . . 57

anglicus . . . . . . . 57 
Family ALBULID $\mathrm{E} . . . \quad . \quad . \quad . \quad \begin{array}{r}\text { Page } \\ 59\end{array}$

Albula . . . . . . . . 60

— oweni... . . . . . 60

Chanoides. . . . . . . . . 63

- macropoma . . . . . . . . 63

Chanos . . . . . . . . . 64

Prochanos . . . . . . . 65

- rectifrons . . . . . . . 65

Ancylostylos . . . . . . . . 66

- - gibbus . . . . . . . . 66

Istieus . . . . . . . . . 66

- grandis. . . . . . . . 67

- macrocephalus . . . . . . . 70

— lebanonensis . . . . . . . 71

Anogmius . . . . . . . . 71

polymicrodus . . . . . . 72

Family OSTEOGLOSSID $Æ$. . . . . . 73

Dapedoglossus . . . . . . . . 74

— testis . . . . . . . . 75

— æquipinnis . . . . . . . 75

Brychætus . . . . . . . . 76

— muelleri . . . . . . . . 76

Incertæ sedis . . . . . . . . . 80

Plethodus . . . . . . . . 80

— expansus . . . . . . . . . 81

— pentagon . . . . . . . . . 83

— oblongus . . . . . . . . 83

Thryptodus . . . . . . . 85

Family NOTOPTERID $\mathrm{E}$. . . . . . 85

Notopterus . . . . . . . . . 86

primærus . . . . . . . 86 
Family CHIROCENTRID王

Chirocentrus .

-

(?) polyodon

Chiromystus

\section{.} mawsoni

Chirocentrites

coroninii

Portheus

molossus

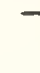
mantelli daviesi gaultinus

S

Spathodactylus

Ichthyodectes

ctenodon

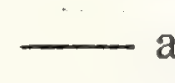

anaides .

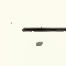

arcuatus

. serridens

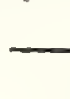
mino

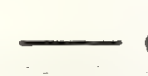
elegans

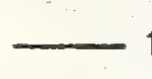
tenuidens. libanicus

Cladocyclus 105

- gardneri

- lewesiensis . . . . . . . . 109

Saurodon. . . . . . . . . 111 leanus . . . . . . . 111 phlebotomus . . . . . . 112

— intermedius . . . . . . . . 112

Saurocephalus . . . . . . . . 113

— lanciformis . . . . . . 113 woodwardi

Incertæ sedis . . . . . . . . . . 116

Tomognathus . . . . . . 116

- mordax. . . . . . . . 117 
Familo CrTEYTHe Family CTENOTHRISSIDA . . . . . . . 119

Ctenothrissa . . . . . . . 120

— vexillifer... . . . . . 120

radians . . . . . . . 122

- microcephala . . . . . . 124

Aulolepis . . . . . . . . . 126

$\longrightarrow$ typus . . . . . . . . . 127

Family CLUPEIDA . . . . . . . . . 128

Pseudoberyx . . . . . . . . 129

— syriacus . . . . . . . . . 129

- bottæ . . . . . . . . . 130

- grandis . . . . . . . . 130

Histiothrissa . . . . . . . 131

macrodactyla . . . . . . . 131

- erassapinna . . . . . . . 132

Engraulis . . . . . . . . . 133

Halecopsis . . . . . . . . . 133

— insignis . . . . . . . . . . 134

Scombroclupea . . . . . . . . : 135

macrophthalma . . . . . . . 135

- gaudryi •. • . • • . . . 138

Diplomystus . . . . . . . . . 139

- dentatus . . . . . . . . 139

- brevissimus . . . . . . . 140

- birdi . . . . . . . . . . 142

longicostatus . . . . . . . 143

— humilis . . . . . . . . . 144

- altus . . . . . . . . . 145

- vectensis . . . . . . . 146

Clupea . . . . . . . . . . . 146

- scheuchzeri . . . . . . . 147

— catopygoptera . . . . . . . 148

- humilis . . . . . . . . 150

- crenata. . . . . . . . 151

- numidica . . . . . . . . 151

- sardinites . . . . . . . 152

- sprattus . . . . . . . 153 


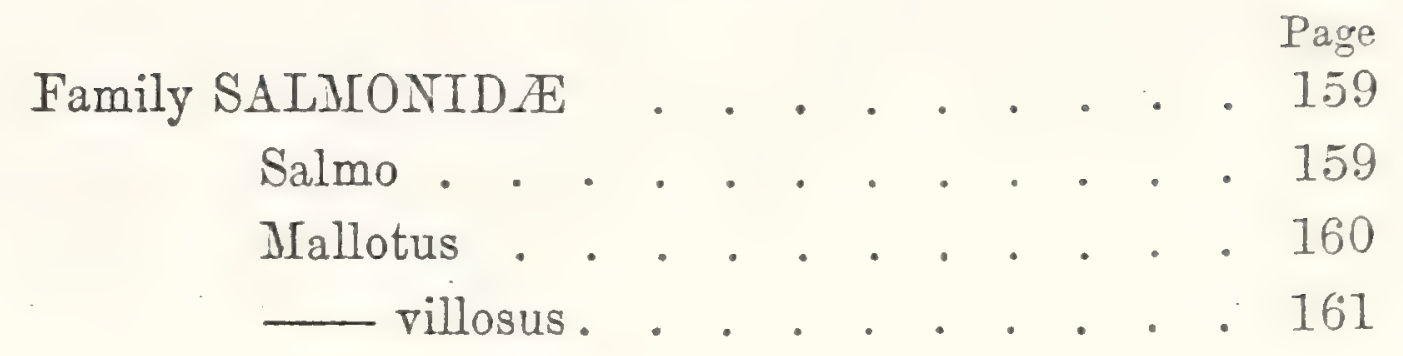

Family HALOSAURIDA . . . . . . . 162

Echidnocephalus . . . ... . 163

— troscheli . . . . . . . 163

Enchelurus . . . . . . . . 164

- villosus . . . . . . . . 164

- syriacus . . . . . . . . 165

- anglicus . . . . . . . 167

Family NOTACANTHIDA . . . . . . . . 168

Pronotacanthus . . . . . . . . 169

sahel-almæ . . . . . . 169

Family DERCETID王 . . . . . • . . . 171

Dercetis . . . . . . . . 172

scutatus . . . . . . . 172

Leptotrachelus . . . . . . . . 173

- armatus . . . . . . . . 174

triqueter :......... . 174

— gracilis . . . . . . . 180

- hakelensis . . . . . . . 184

— eloñgatus . . . . . . . . 184

Pelargorhynchus . . . . . . . 188

— dercetiformis . . . . . . 188

Family ENCHODONTID王 . . • . . . . 189

Enchodus . . . . . . . . . 190

- lewesiensis . . . . . . . . 191

— pulchellus . . . . . . . . 193

— annectens . . . . . . . 195

- faujasi . . . . . . . . . . 196

— lemonnieri . . . . . . . . 198

— longidens . . . . . . . . . 199 
Family ENCHODONTID㤅 (continued).

Enchodus major . gracilis . . . . . . . 201

macropterus . . . . . . . 202

Eurypholis . . . . . . . . 207

— boissieri . . . . . . . . . 207

freyeri . . . . . . . . . 210

Palæolycus . . . . . . . . 211

dreginensis . . . . . . . 211

Halec . . . . . . . . . 212

— sternbergi . . . . . . . 212

— eupterygius . . . . . . . 213

— microlepis . . . . . . . . 218

haveri . . . . . . . . 219

Cimolichthys. . . . . . . . . 221

— lewesiensis . . . . . . 221

— nepæolica . . . . . . . . 225

Prionolepis . . . . . . . . . . 229

angustus . . . . . . . 230

— cataphractus . . . . . . . . 230

- laniatus . . . . . . . . 232

Leptecodon . . . . . . . . . . 233

—. rectus . . . . . . . . 233

Pantopholis . . . . . . . . 234

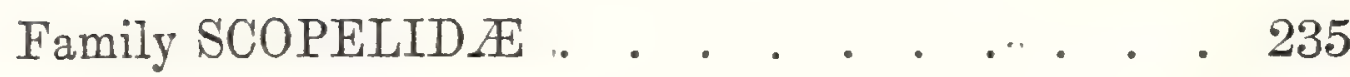

Sardinioides . . . . . . . . . 236

— monasteri . . . . . . . 237

— crassicaudus . . . . . . . 238

— megapterus . . . . . . . . 239

- pusillus . . . . . . . . 240

- attenuatus . . . . . . . . 241

Acrognathus . . . . . . . . . . 243

- boops . . . . . . . . . 243

— libanicus . . . . . . . . 244

Leptosomus . . . . . . . . . . 244

— guestphalicus . . . . . . . . 245 
Family SCOPELID $\approx$ (continued).

Leptosomus elongatus . . . . . . . 245

- macrourus. . . . . . . . 245

— minimus . . . . . . . . . 246

Sardinius . . . . . . . . . 247

cordieri . . . . . . . 247

Dactylopogon . . . . . . . 248

grandis. . . . . . . . 249

Nematonotus. . . . . . . . 249

bottæ . . . . . . . . 250

Nicrocoelia . . . . . . . 252

- granulata . . . . . . . . 252

libanica . . . . . . 252

Opisthopteryx . . . . . . . 253

gracilis . . . . . . . $25 t$

Scopeloides . . . . . . . . 254

— glarisianus . . . . . . . . 255

Parascopelus . . . . . . . . . . 256

— lacertosus . ........ . 256

Anapterus . . . . . . . . 257

— megistosoma . . . . . . 257

Apateodus . . . . . . . . . 258

- glyphodus . . . . . . . 258

— striatus . . . . . . ... . 260

_lanceolatus . . . . . . . : 264

Rhinellus . . . . . . . . 265

— furcatus . . . . . . . 266

$\longrightarrow$ ferox . . . . . . . 267

damoni. . . . . . . 268

Family GONORHYNCHID $\approx$. . . . . . 271

Charitosomus . . . . . . 271

formosus . . . . . . 272

major . . ..... . . . 272

lineolatus . . ..... . . 274

hakelensis . .. : . . . . . 274

Notogoneus . . . . . . . . . 275 
Family GONORHYNCHID $Æ$ (continued).

Notogoneus osculus . . . . . . $27 \%$

— squamosseus . . . . . . 276

— cuvieri . . . . . . . . 277

- longiceps . . . . . . . . . 278

Family CHIROTHRICID $Æ$. . . . . . . 279

Chirothrix . . . . . . . . 280

libanicus . . . . . . . . 280

- lewisi . . . . . . . . 283

— guestfalicus . . . . . . . . 283

Telepholis . . . . . . . . . 284

— acrocephalus . . . . . . . 284

- (?) tenuis . . . . . . . . . 285

Exocœtoides . . . . . . . . 286

minor . . . . . . . 286

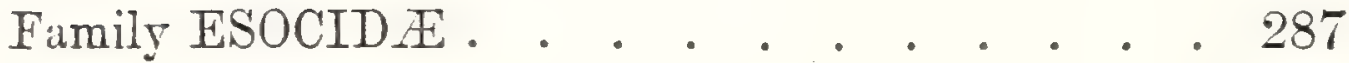

Esox . . . . . . . . 287

lepidotus . . . . . . . 288

Family CYPRINODONTID $\mathrm{E}$. . . . . . 289

Prolebias . . . . . . . . . 290

— cephalotes . . . . . . . 290

- furcatus : . . . . . . . 291

— gregatus . . . . . . . . 292

- sienoura . . . . . . . . . 292

—

— brongniarti . . . . . . . 293

Pachylebias . . . . . . . . . . 294

crassicaudus . . . . . . . 295

Suborder V. OSTARIOPHYSI . . . . . . . 296

Family CHARACINID $\mathrm{E}$. . . . . . . 297

Tetragonopterus . . . . . . . 298

— avus . . . . . . . . . 298

— ligniticus . . . . . . . . . 298 
Family CYPRINID瓜

Catostomus

Amyzon

Cyprinus

priscus

Barbus

— megacephalus

Thynnichthys

— amblyostoma. 303 Gobio

analis 303

Amblypharyngodon

Leuciscus.

oeningensis 305 papyraceus colei 307

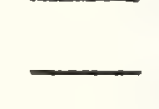

marurus 308

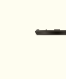
lept

\section{Tinca} leptus 308

furcata. 309

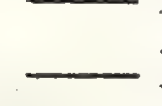
furcata 312 leptosoma 312 micropygoptera 313

tarsiger 314

Rhodeus 315

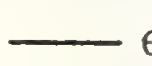
elongatus 316 - 1 latior 316 Aspius .

gracilis 318

Cobitis minutus 318

Cobitis centrochir

angustus cephalotes 318

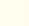

apsephus . guentheri 
Family SILURID 1

Clarias .

Heterobranchus . . . . . . . 325

— palæindicus . . . . . . . 325

Silurus . . . . . . . . 325

Pseudeutropius . . . . . . . 326

—

Macrones . . . . . . . . 327

Rita $0 . \cdot 327$

Rita . . . . . . . . . . 328

Amiurus . . . . . . . . 328

Rhineastes . . . . . . . . . 329

Bucklandium . . . . . . . 330

— diluvii . . . . . . . . 330

Arius . . . . . . . . . 330

egertoni . . . . . . . 331

crassus . . . . . . . . . . 332

(?) bartonensis . . . . . . . 333

iheringi . . . . . . . 333

Bagarius . . . . . . . . 335

gigas . . . . . . . 335

Suborder VI. APODES . . . . . . . . . 336

Family MURENID无 . . . . . . . . . 336

Urenchelys . . . . . . . 337

\begin{tabular}{|c|c|c|c|c|c|c|c|}
\hline _ hakelensis & $\cdot$ & . & $\cdot$ & . & & & \\
\hline - anglicus & & . & - & 。 & & & \\
\hline Domyrus . & . & . & . & . & . & & \\
\hline - dolloi & & & . & . & . & & \\
\hline - latispinus & - & & . & - & . & & \\
\hline - ventralis & & & . & & . & & \\
\hline hynchorhinus & & & . & & • & & \\
\hline - branchia & & & - & & & & \\
\hline major & & & & & & & \\
\hline
\end{tabular}


Family MUR ENID无 (continued).

Paranguilla . . . . . . . 343

— tigrina . . . . . . . . 343

Anguilla . . . . . . . 344

- leptoptera . . . . . . . 344

— elegans. . . . . . . . 340

Nettastoma . . . . . . . 346

bolcense . . . . . . 346

Suborder VII. PERCESOCES . . . . . . . 347

Family CROSSOGNATHID $巴$. . . . . 348

Crossognathus . . . . . . 348

sabaudianus . . . . . . 349

Syllæmus . . . . . . . . . 350

— latifrons . . . . . . . . 351

— anglicus . . . . . . . 351

Family AMMODYTID $\approx$. . . . . . . . 354

Cobitopsis . . . . . . . . 354

- acutus' . . . . . . . . . 355

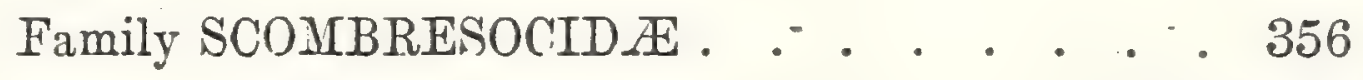

Belone . . . . . . . . 356

tenuis . . . . . . 357

Scombresox . . . . . . . 357

obtusirostris . . . . . . 357

Hemiramphus . . . . . . 358

Family ATHERINID $\mathbb{E}$. . . . . . . . 358

Atherina . . . . . . . . 359

macrocephala . . . . . . 359

sarmatica . . . . . . . 360

—

Rhamphognathus . . . . . . 361

paralepoides . . . . . . 361

sphyrænoides . . . . . . . 362 
Family MUGILID $巴$

Page Mugil . . . . . . . . 363

—

— radobojanus . . . . . . . 365

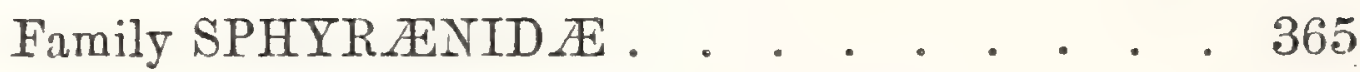
Sphyræna . . . . . . . . 366

- bolcensis . . . . . . . . . 366

- - intermedia . . . . . . . 367

— - suessi . . . . . . . 368

Suborder VIII. HEMIBRANCHII . . . . . . . 369

Family AULORHYNCHID

Protaulopsis . . . . . . . . 371 bolcensis . . . . . . 371

Aulorhynchus . . . . . . . 372

— sumatrensis . . . . . . 373

Family FISTULARIID $巴$. . . ' . . 373

Fistularia . . . . . , . 374 koenigi . . . . . . . 374 longirostris . . . . . . . 375 Aulostoma . . . . . . 375

- bolcense . . . . . 375

Urosphen . . . . . . . . 376 dubia . . . . . . . 376

Family CENTRISCID $\mathrm{E}$. . . . . . . 377

Rhamphosus . . . . . . . 377

— aculeatus . . . . . . . 377

— biserratus . . . . . . . 378

Amphisile . . . . . . . . . 378

heinrichi . . . . . . . 379

Family SOLENOSTOMATID仺。 • . . . . 379

Solenorhynchus . . . . . . . 380 elegans. . . . . . . . . 380 


$$
\begin{aligned}
& \text { Family SYNGNATHID } \quad \text { Page } \\
& \text { Pseudosyngnathus . . . . . . } \\
& \text { —opisthopterus . . . . . . . } 381 \\
& \text { Siphonostoma . . . . . . . } 382 \\
& \text { albyi . . . . . . . } 382 \\
& \text { Syngnathus . . . . . . . . } 382 \\
& \text { Calamostoma. . . . . . . . } 383 \\
& \text { breviculum . . . . . . } 383
\end{aligned}
$$

Suborder IX. ACANTHOPTERYGII . . . . . 384 Division A. Beryciformes . . . . . . . 384

Family BERYCID $\mathrm{E}$. . . . . . . . . 384 Beryx . . . . . . . . . 385

Sphenocephalus . . . . . . 387

$$
\begin{aligned}
& \text { — fissicaudus .. . . . . . . . . } 387 \\
& \text { cataphractus . . . . . . . } 388 \\
& \text { Acrogaster . . . . . . . . . } 388 \\
& \text { parvus . . . . . . . . . . } 389 \\
& \text { —- brevicostatus . . . . . . . . } 389 \\
& \text { heckeli . . . . . . . . . . } 290 \\
& \text { daviesi . . . . . . . } 390 \\
& \text { Pycnosterinx . . . . . . . . . } 391 \\
& \text { russeggeri . . . . . . . . } 392 \\
& \text { discoides . . . . . . . } 393 \\
& \text { gracilis . . . . . . . } 394 \\
& \text { dubius . . . . . . . . } 395 \\
& \text { Hoplopteryx . . . . . . } 396 \\
& \text { — antiques . . . . . . . } 396 \\
& \text { — zippei . . . . . . . . . } 397 \\
& \text { — lewesiensis . . . . . . } 397 \\
& \text { - superbus ... . . . . . . } 403 \\
& \text { lundensis . . . . . . . } 404 \\
& \text { lewisi .. . . . . . . . } 404 \\
& \text { syriacus . . . . . . . } 405 \\
& \text { stachei . . . . . . } 406
\end{aligned}
$$


Family BERYCID $Æ$ (continued).

Dinopteryx Page

spinosus . . . . . . . . 407

Homonotus . . . . . . 407

dorsalis. . . . . . . 408

Myripristis . . . . . . . 410

— leptacanthus . . . . . . . 410

- homopterygius . . . . . . . 411

Holocentrum . . . . . . . 412

— macrocephalum . . . . . 412

— melitense . . . . . . . 413

Family APHREDODERID $\AA$. . . . . . 416

Family CYTTID $\mathrm{E}$. . . . . . . . . 417

Division B. Scombriformes . . . . . . . . 418

Family STROMATEID $Æ$... . . . . . . 419

Omosoma.......... . . 419

— sahel-almæ . . . . . . . 419

— intermedium . . . . . . . 420

— pulchellum ... . .... . 421

Platycormus .. . . . . . 421

— germanus . . . . . . . 421

Berycopsis . . . . . . . 423

— elegans . . . . . . . . 423

Family CARANGID $巴$. . . . . . . 425

Aipichthys ... . . . . . 427

— pretiosus . . . . . . . . . 427

— velifer . . . . . . . . 427

— minor . . . . . . . 428

— nuchalis . . . . . . . 429

Semiophorus . . . . . . . 430

— velifer . . . . . . . 430

velicans . . . . . . 431

Platax . . . . . . . . 432 
Family CARANGID $Æ$ (continued).

Platax woodwardi .

Amphistium

paradoxum

Vomeropsis

longispinus elongatus

valencienn si

Mene

rhombeus

oblongus

Caranx .

Archæus

glarisianus.

Seriola

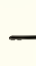
prisca lata. analis

Carangopsis 446 breris 446 dorsalis

Ductor . leptosomus 448

Family SCOMBRID $巴$.

Isurichthys 453 macrurus 453 orientalis 453

Thynnus 454 thynnus 455 scaldisi. 455 lanceolatus 456

Eothynnus 457 salmoneus.

Scomber 459

Palimphyes 460 elongatus 460 
Family SCOMBRID压 (continued).

Scombrinus

nuchalis

macropomus . . . . 462

Auxis . . . . . . . . . . . 463

(?) propterygius . . . . . . . . 464

Cybium . . . . . . . . . 465

— speciosum . . . . . . . 466

- bleekeri . . . . . . . 466

- excelsum . . . . . . . . 467

- bartonense . . . . . . . 467

— lingulatum . . . . . . . . 469

Eoculopoma . . . . . . . . . 470

— colei . . . . . . . . 470

— curvatum , . . . . . . 472

Sphyrænodus . . . . . . . . . 473

— priscus . . . . . . . . 473

Scombramphodon . . . . . . . 474

—_ benedeni . . . . . . 474

— curvidens . . . . . . . 474

— crassidens . . . . . . . . 475

Thyrsitocephalus . . . . . . 476

alpinus . . . . . . . . 477

Lepidopus . . . . . . . . . 477

- glarisianus . . . . . . 477

- brericauda . . . . . . . 480

- albyi . . . . . . . . 480

Family PAL EORHYNCHID王 . . . . . . 482

Palæorhynchus . . . . . . . . 483

glarisianus . . . . . . . . 483

- longirostris . . . . . . . 486 zitteli . . . . . . . . . . 487

Hemirhynchus . . . . . . . 488

deshayesi . . . . . . . 488

colei . . . . . . . . . 488 
Family XIPHIID $\mathbb{E}$

Xiphiorhynchus.

- elegans .

priscus .

Acestrus .

ornatus

494

Histiophorus

494

eocæricus rotundus

Division C. Perciformes

Family PERCIDÆ. . . . . . . . . 498

Prolates . . . . . . . . . . . 499

heberti. . . . . . . . 499

Acanus . . . . . . . . 500

spinosus . . . . . . . 500

regleysianus . . . . . . . 501

Lates

502

gracilis .

502

Cyclopoma

504

- gigas

(?) micracanthum

504

Smerdis

minutus

504

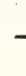

formosus

macrurus

- 506

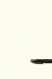

Labrax ubinoi . schizurus oeningensis

506 - 507 507

\section{P} P chthys antiquus Properca angusta beaumonti . (?) prisca 
Family PERCID $\approx$ (continued).

Mioplosus $\quad$ Page

— labracoides . . . . . . 517

Perca . . . . . . . . . 518

Family TEUTHIDID $\mathrm{E} . . \quad . \quad . \quad . \quad . \quad 523$

Family SPARII $\mathrm{E}$. . . . . . . . . 524

Sparnodus . . . . . . . . 524

— macrophthalmus . . . . . 525

— elongatus . . . . . . 526

- microstomus . . . . . . 527

— bowerbanki . . . . . . 527

Sargus. . . . . . . . . . 529

—

— laticonus . . . . . . . . . 529

Trigonodon . . . . . . . . 531

—oweni......... . 531

— serratus . . . . . . . 531

Pagellus ............. . . 532

Pagrus . . . . . . . . . . 533

Chrysophrys . . . . . . . . 534

Family SCI ENID $\approx$. . . . . . . . 538

Family LABRID $Æ$ 。 . . . . . . . . . . 539

Labrus . . . . . . . . . . 539

Julis . . . . . . . . . 541

Labrodon . . . . . . . . . . 541

— superbus. . . . . . . . . 542

— canariensis . . . . . . . 542

Phyllodus. . . . . . . . . 546

toliapicus ... . . . . . . . 546

Egertonia . . . . . . . . . 550

— isodonta . . . . . . . 551

Platylæmus .. . . . . . . . 551

— colei ... . . . . . . . . 551

Pseudosphærodon . . . . . . . 552

hilgendorfi . . . . . . . 552 
Fumily CHROMID $\mathrm{E}$

Division D. Chætodontiformes .

Family CH ETODONTID E . . . . . . 556

Pygæus . . . . . . . . 557

coleanus . . . . . . . . 557

Proantigonia . . . . . . . . 558

Ephippus . . . . . . . . . . 559

— rhombus . . . . . . . . 559

Family ACRONURIDE . . . . . . . 562

Aulorhamphus . . . . . . 562

Apostasis . . . . . . . . . 563

dcanthurus . . . . . . . 563

Naseus. . . . . . . . . 564

rectifrons . . . . . . . 564

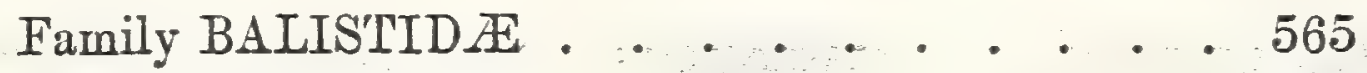

Spinacanthus . . . . . . 566

Acanthopleurus . . . . . . . 566

—- serratus . . . . . . . . 567

Acanthoderma . . . . . . 568

— spinusum . . . . . . . 568

Ostracion . . . . . . . . . 569

Family GYMNODONTID

Tetrodon . . . . . . . . 571

Diodon. . ... . . . . . . 571

— erinaceus . . . . . . . 572

— scillæ . . . . . . . . . . 572

—

— vetus . . . . . . . 573

Orthagoriscus . . . . . . . 576 
Dirision E. Scorpaniformes Family SCORP无NIDE . . . . . . . . . 577 Ampheristus . . . . . . . . 577 - toliapicus . . . . . . . 577

Family COTTID王. . . . . . . . . 580

Eocottus . . . . . . . . 580

- veronensis. . . . . . . . 581

Lepidocottus . . . . . . . . 581

- aries . . . . . . . . . 582

- brevis . . . . . . . . . 582

— papyraceus . . . . . . . 583

- multipinnatus . . . . . . 584

Cottus . . . . . . . . . . . . 585

Family TRIGLID王 . . . . . ! . . 585

Division F. Gobiiformes . . . . . . . . . 587

Family GOBIID王 . . . 。 . . . . . . 587

Family TRACHINID王 • . . . . • . . 589

Callipteryx - . . . . . . . . 589

— speciosus . • • • . . . . . 589

— recticaudus . . . . . . . 589

Division G. Blenniiformes . . . . . . . . 591

Family BLOCHIID王 . . . . . . . . . 591

Blochius . . . . . . . . . . 593

longirostris . . . . . . . 593

Family BLENNIID王. • . • • • • • • 595

Pterygocephalus. . . . . . . . . 595

paradoxus . . . . . . . 595 
see nite as flyllol ixpp $459 \cdots$

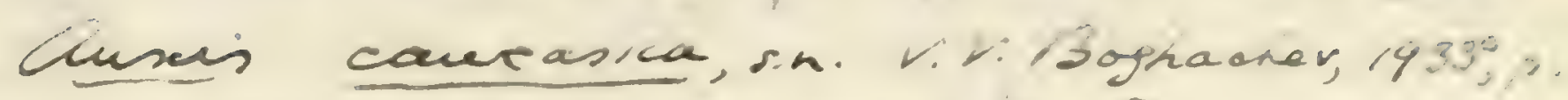
55, plitigl. Reyene (ancasus. (7ist).

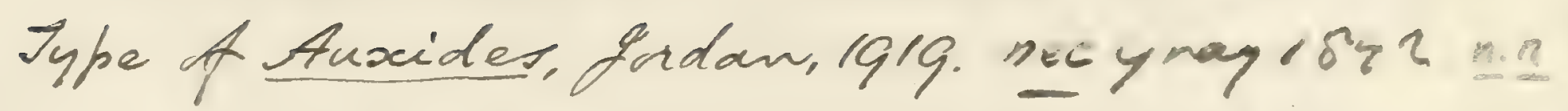
1919. Anxides kropterypius, D. O. Gordan, Jors. Finhes S.Califarnia (Stanford Univ. Oublic, Mmir. Ser.1919), b. II.

Rlobos. Wed-preserved wanting Lail.

Witched Gilk Jand?os: 


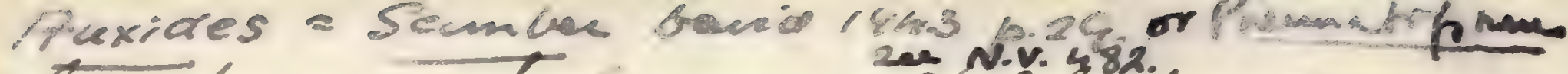
threider saneta-monico, D. N. Iordan, Fon.

Fishes T. Califormid/Ptant ord Univ. Public., Hniv. Ter. (q 19), \%.10, pl.v. fis. 2. - Mircene; Bronss Cañon, Calin. [Portion of firt; Stanghol Univ.] (Stanf. Univ. Punt; Biol. Sei. vol.1.pt.iv. 1921)p. 269 , pl. 3 fis. b, pl.36 f.a (restoration) Nioc.; El Modena, Palif.

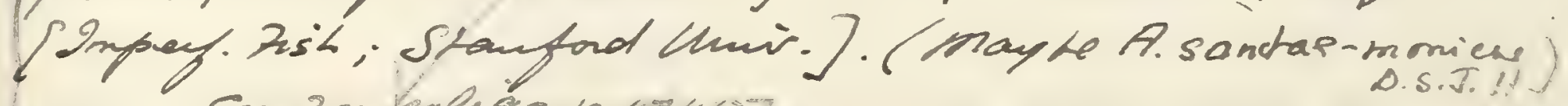
see Scomiar everos p.49457.

Auxcoies bruntoni, J.S. Tondan wo ait. 1921 p. 270

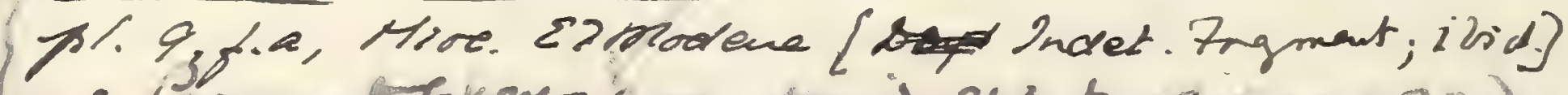

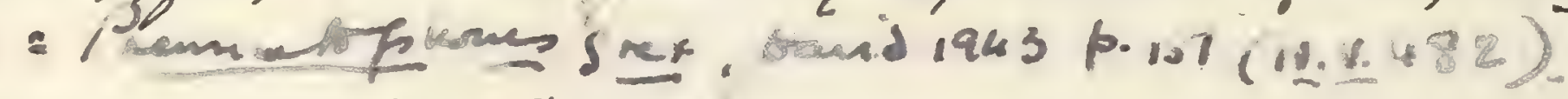
restias iratus. D.S.Tnd. 1or.at. $1921, p .270$ pl.4f.a,

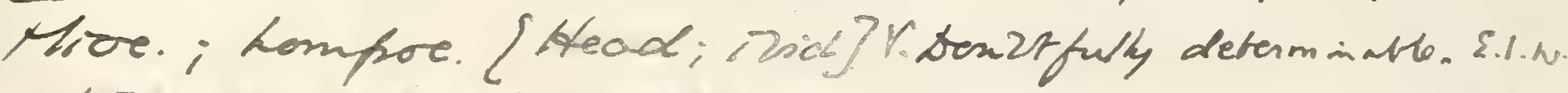
$=$ ! Junkes stauts p.tak.

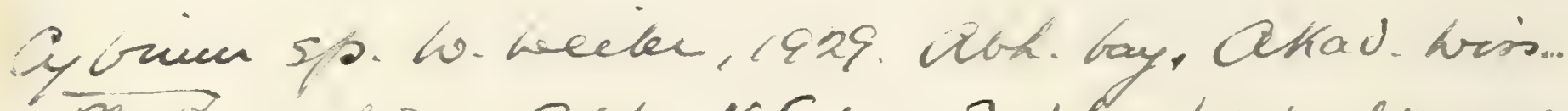

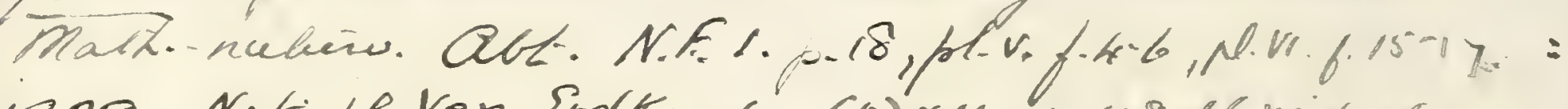
1929, Nolizbl. Ver. Endkunde, (s) $x 11$, p. 108 plitit. 16.

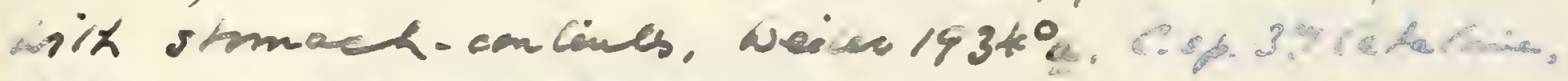

Sancle wa Alatile

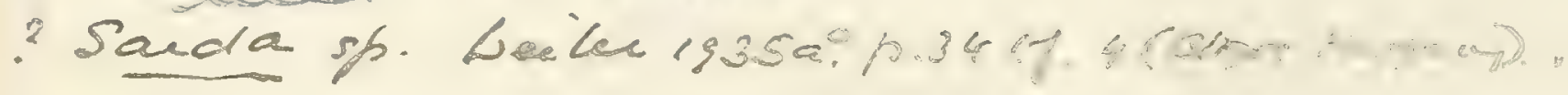

“" $1933 a^{0}$, p.32, pliiri th

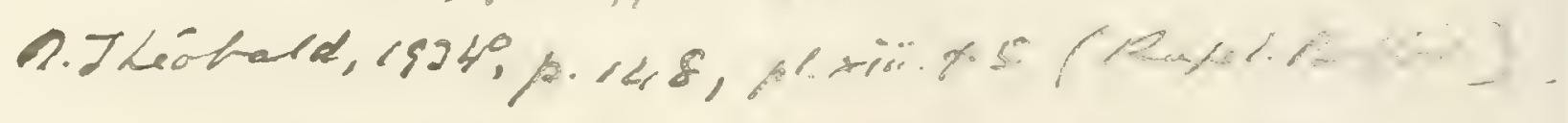

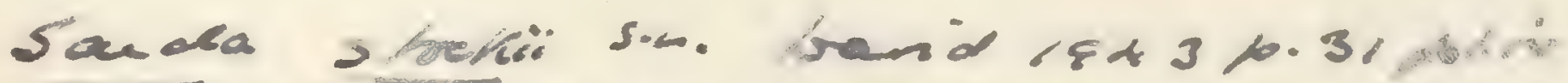

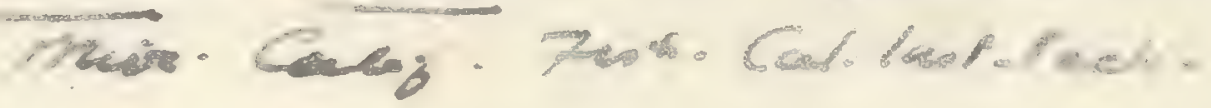


. 
distinct. Immaturity is indicated by the radiating ridges and serrations on the preoperculum. Enniskillen Coll.

The following species have also been founded on imperfect fossils, but are not represented in the Collection:-

Auxis croaticus, D. G. Kramberger, Beitr. Paläont. Oesterr.Ungarns, vol. ii. (1882), p. 121, pl. xxr. fig. 1.-Upper Niocene; Radoboj, Croatia. [Imperfect fish; University Geological Museum, Agram.]

Auxis minor, J. G. Kramberger, loc. cit. 1882, p. 123, pl. xxiv. figs. 5, 6.-Ibid. [Imperfect trunk; Imperial Geological Survey, Vienna.]

Auxis stiriacus, D. G. Kramberger, Djela Jugoslar. Akad. vol. xri. (1895), p. 64, pl. xi. fig. 4, pl. xii. fig. 2.-Oligocene; St. Georgen, near Zilli, Croatia. [Imperfect fish; Zilli Museum.]

Auxis thynnoides, D. G. Kramberger, Toc. cit. 1882, p. 125, pl. xxvi. figs. 1, 2.--Upper Miocene; Podsused, Croatia. [Imperfect trunk, in counterpart; Imperial Geological Survey, Vienna, and Unirersity Geological Museum, Agram.]

Auxis vrabceensis, D. G. Kramberger, loc.cit. 1882, p. 122, pl. xxiv. fig. 4.--Upper Miocene; Vrabce, Croatia. [Imperfect trunk; University Geological Museum, Agram.]

\section{Genus CYBIUM, Cuvier.}

[Règne Animal, ed. 2, vol. ii. 1829, p. 199.]

Syn. Scomberodon, P. J. Van Beneden, Bull. Acad. Roy. Belg. [2] vol. xxxi. 1871, p. 504.

Trunk elongate-fusiform; the slender caudal pedicle with strong median lateral keel formed by cartilaginous ridge on vertebral centra. Median pair of fossæ for anterior extension of lateral muscles of trunk produced forwards over frontal bones and separated by median frontal ridge continuing the supraoccipital ridge. Teeth on margin of jaws large, conical, and laterally compressed, with opposite sharp edges; minute teeth on vomer and palatines; gillrakers few. Vertebral centra constricted, with two lateral pits separated by a longitudinal ridge; all hæmal arches simple. Paired fins small; dorsal fins well separated, the anterior consisting of 14 to 18 feeble spines; posterior dorsal and anal fins small but elevated, similar and opposite, followed by 7 to 10 detached finlets; caudal fin deeply forked, with slender lobes. Scales very small 
and uniform or rudimentary, scarcely enlarged or compacted in the pectoral region.

The existing species are large fishes of the tropical Atlantic and Indian Oceans.

\section{Cybium speciosum, Agassiz.}

1796. Scomber speciosus, G. S. Volta, Ittiolit. Veronese, p. clxix. pl. xli. (errore).

1818. Scomber speciosus (?), II. D. de Blainville, Nouv. Dict. d'Hist. Nat. vol. xxvii.p. 346.

1835. Cybium speciosum, L. Agassiz, Neues Jahrb. p. 293.

1835-44. Cybium speciosum, L. Agassiz, Poiss. Foss. vol. v. pt.i. p. 61, pl. $x \times v$.

Type. Imperfect fish: Museum of Natural History, Paris.

A small species, attaining a length of about $0 \cdot 35$. Length of head with opercular apparatus somewhat exceeding maximum depth of trunk, and slightly less than one third the total length of the fish to the base of the caudal fin. Teeth slender. Vertebra 15 in the abdominal, 15 in the caudal region. Posterior dorsal and anal fins apparently with 10 articulated rays followed by 8 finlets.

This imperfectly known species differs remarkably from the existing $C$. muculatum in the number of vertebræ, the latter having 45. The number of vertebræ is not recorded in other species.

Form. \& Loc. Upper Eocene: Monte Bolea, near Verona.

P. 1389, P. 4136. Small specimen, in counterpart. Egerton \& Enniskillen Colls.

\section{Cybium bleekeri (Winkler).}

1876. Enchodus bieekeri, T. C. Winkler, Archiv. Mus. Teyler, vol. iv. p. 43, pl. ii. figs. $24,25$.

1891. Cybium (?) sp., A. S. Woodward, Geol. Mag. [3] vol, viii. p. 109.

1892. Cybium bleekeri, R. Storms, Bull. Soc. Belge Géol. vol. vi. Mém. p. 3, pl. i.

Type. Teeth.

A large imperfectly known species, with skull about $0 \cdot 16 \mathrm{in}$ length. Teeth broad and much laterally compressed, nearly uniform in size in premaxilla. Anterior end of premaxilla shaped as in C. excelsum (fig. $15 \mathrm{~A}$ ); dentary more contracted at symphysis.

Form. \& Loc. Middle Eocene: Belgium.

P. 5923. Six teeth; Bruxellian, Woluwe St. Lambert, Brussels. Presented by Monsieur A. Houzeau de Lehaie, 1889. 
P.g9k2. Infrical firth. Bunkend, 1903.

1906. Cy Gimm bleckeri, M. Leriche, Mém. Sor. Géol. Nord, vol.v. F. 241 .

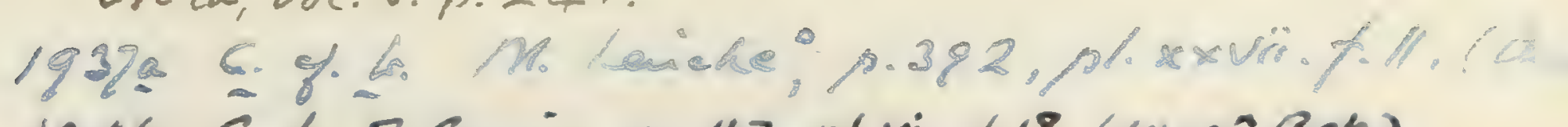

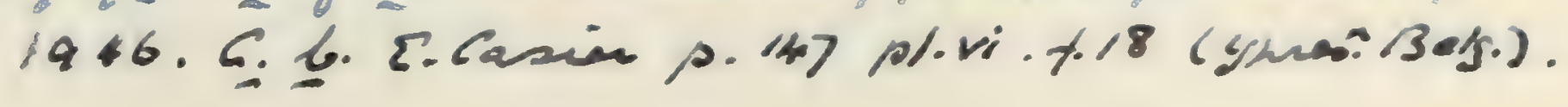




\section{Cybium excelsum, sp. nov.}

[Text-figure 15.]

Type. Remains of head; British Museum.

A very large, imperfectly known species, with skull nearly 0.4 in length. Teeth broad and much laterally compressed, not very variable in size, those of front portion of premaxilla scarcely smaller than the anterior mandibular teeth. Anterior end of premaxilla more deepened and less attenuated than in the next species; the whole premaxilla probably longer in proportion to its depth than in the Eocene Cybium bleekeri.

Form. \& Loc. Upper Eocene (Barton Clay): Barton Cliff, Hampshire.

P. 1528. Associated remains of head and vertebral column in very friable condition. This is the type specimen, and was discovered by Barbara, Marchioness of Hastings, in Barton Cliff. So far as it can be compared, the skull resembles that of Cybium. Both premaxillæ are imperfectly preserved, and that of the right side is shown from the outer aspect, of two thirds the natural size, in fig. $15 \mathrm{~A}$. The left dentary bone is more fragmentary, but its symphysial end, shown in fig. 15 в, bears two teeth. The centrum of the first vertebra is distinguishable, and portions of other typical centra occur among the remains. Egerton Coll.

\section{Cybium bartonense, sp. nor.}

[Text-figure 16.]

Type. Portions of jaws; British Museum.

A very large species known only by the jaws, with mandible about 0.45 in length. 'Teeth broad and much laterally compressed, those of front portion of premaxilla considerably smaller than the anterior mandibular teeth. Anterior end of premaxilla less deepened and more attenuated than in $C$. excelsum and C. bleekeri. Symphysial end of mandible relatively deeper than in $C$. bleekeri and C. lingulatum.

Form. \& Luc. Upper Eocene (Barton Clay): Barton Cliff and High Cliff, Hampshire.

P. 53. Associated remains of jaws and two anterior vertehræ, the type specimen near Christchurch, Hampshire. The anterior end of the right premaxilla is shown of two thirds the natural size, from the outer aspect, in fig. $16 \mathrm{~A}$, 


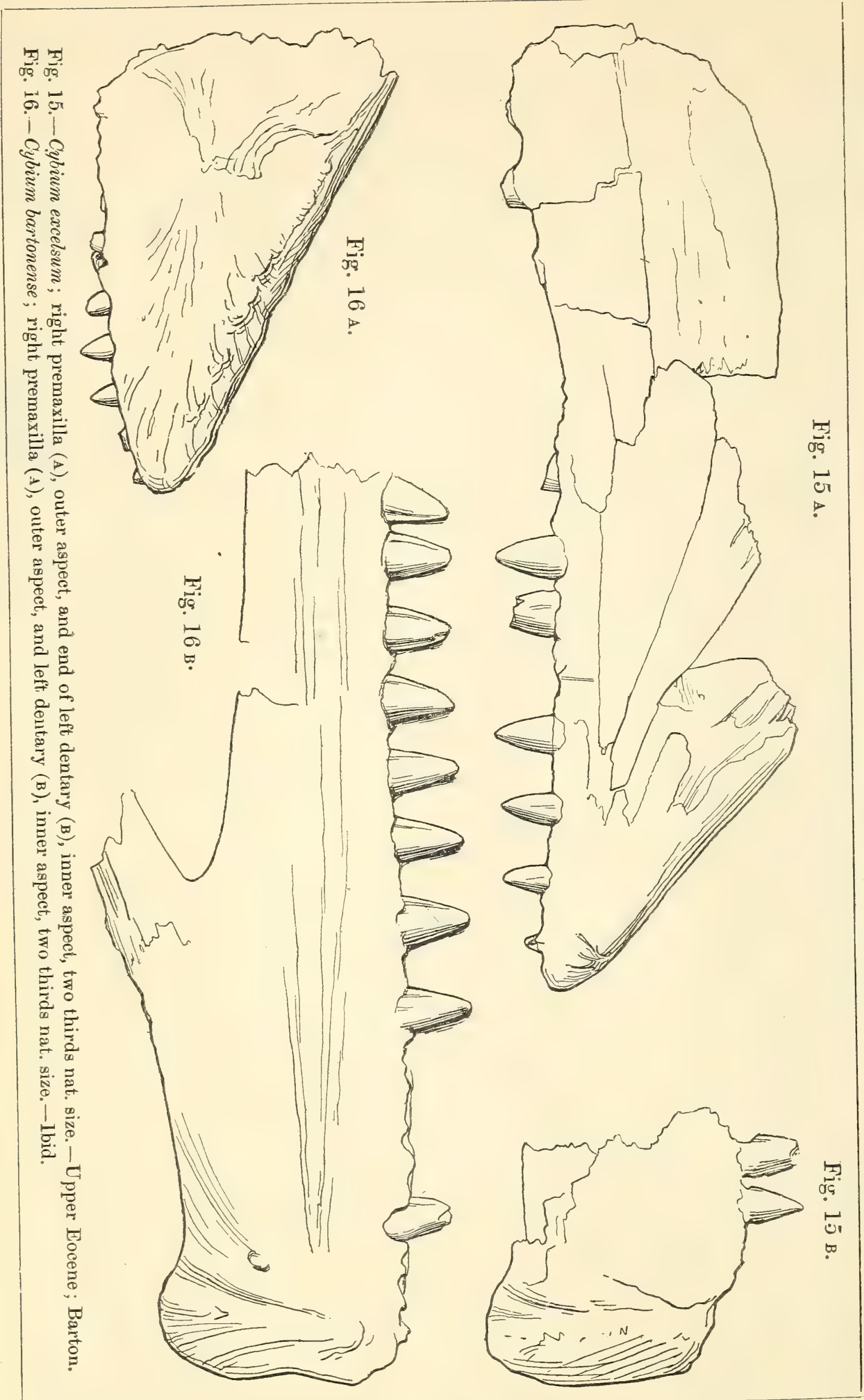


1898. Lictyodus Aingulatur, E. Wittich, Notizhl. Vereins f. Rrobte. Dammstadt, ser.iv, fh. 19, f.40, blifis. 9 .

1922. Gybium Lingulatum, w. weiler, ath. hess. geol. Landesanst. Darmst. rot.vi, phe.2, (1922), p.114, pl.2, fig. 21.

1928:. Gybium Lingulation, W. Weilor, p.24, ph.sif. th.

1931.

$19333^{\circ}$

rescioi, ..

Qhet -

P48. $\therefore \quad, 7,7.40,14$.

- p.el, fl.20,al, oldy is i.

- post.

wh.t. $3-s$.

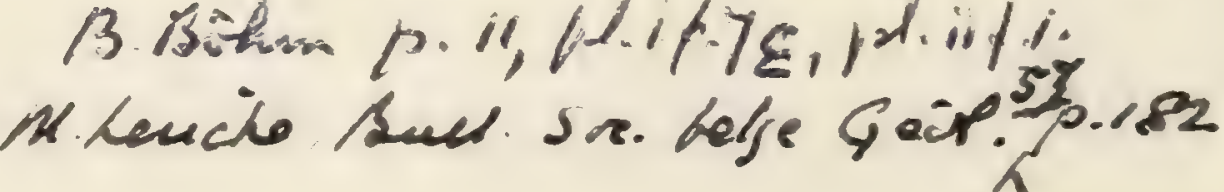


This is associated with a hinder portion of premaxilla and parts of the two dentaries, that of the left side nearly complete but with teeth broken away.

Presented by Sir Richard Owen, K.C.B., 1880.

P. 3958. Imperfect right mandibular ramus, showing many of the teeth ; Barton Cliff. Enniskillen Coll.

37315. Anterior portion of left dentary, with teeth, shown of two thirds the natural size, from the inner aspect, in fig. $16 \mathrm{~B}$; High Cliff. This is probably the specimen noticed by Dollo \& Storms, Zool. Anzeig. 1888, p. 266.

Purchased, 1863.

P. 4545. Imperfect small left premaxilla; Barton Cliff.

Enniskillen Coll.

P. 1531. Anterior half of smail left dentary; Barton Cliff.

Egerton Cour.

28882. Anterior end of small left dentary; Barton Cliff.

Daniels Coll.

\section{Cybium lingulatum (Meyer).}

1846. Sphyranodus lingulatus, H. von Meyer, Neues Jahrb. p. 597 (name only).

1851. Sphyrcenodus lingulatus, H. von Meyer, Palæontogr. vol. i. p. 280, pl. xxxiii. fig. 14.

1892. Cybium, R. Storms, Bull. Soc. Belge Géol. vol. vi. Mém. p. 13.

Type. Imperfect dentary.

A large species with broad, much-compressed teeth; known only by the dentary bone, which is more contracted at the symphysis than that of the two preeeding species.

Form. \& Loc. Middle Oligocene: Hesse Darmstadt.

P. 3959. Much-abraded anterior half of dentary, with bases of teeth; marked "Dr. Kaup," but locality not recorded.

Enniskillen Coll.

The following specimen may also be a fragment of a premaxilla of Cybium, but is too imperfect for determination:-

25819. Type specimen of Sphyronodus tenuis, F. Dixon, Geol. Sussex (1850), p.112, pl. xi. fig. 24 (misprinted S. gracilis, p. 205); Middle Eocene, Bracklesham, Sussex. 
Fragments probably of this genus have also been described under the following names:-

Cybium bottii : Sphyrownodus bottii, G. Capellini, Mem. Accad. Sci. Istit. Bologna, [3] vol. ix. (1878), p. 250, pl. iii. figs. 18.-Middle Miocene : Lecce. [Premaxilla and dentary ; Provincial Museum, Lecce.]

Cybium dumonti, Dollo \& Storms, Zool. Anzeig. 1888, p. 267\% G.aff. A. Cinan ton Scomberodon dumonti, P. J. Van Beneden, Bull. Acad. . Roy. Belg. [2] vol. xxxi. (1871), p. 504, pl. iii.-Middle

Oligocene (Rupelian); Boom, Antwerp.

Cybium partschi, G. von Münster, Beitr. Petrefact. pt. vii. (1846), p. 25, pl. iii. fig. 1.-Middle Miocene; Inzersdorf,

Vienna. [Jaws; Palæontological Museum, Munich.]

Cybium proosti, R. Storms, Revue Quest. Sci. [2] vol. xii.(1897), p. 244, figs. 1-3/-Middle Eocene (Bruxellian); Maransart, Waterloo. [Jaws and vertebræ; Royal Museum of Natural History, Brussels.]

The name Cybium tenue was proposed by Agassiz (Neues Jahrb. 1835, p. 305) for an undescribed fish from the Upper Eocene of Monte Bolca. An undetermined species has also been recorded from corresponding strata at Monte Postale (F. Bassani, Atti R. Accad. Sci. Napoli, ser. 2, vol. iii. 1889, no. 6, p. 77).

\section{Genus EOCELOPOMA, novum.}

Syn. Coelopoma, L. Agassiz (non Adams, 1867), Rep. Brit. Assoc. 1844 (1845), p. 307 (name only).

A genus known only by the head. Cranium rather short and broad; fossæ for lateral muscles of trunk extending forwards much beyond the hinder margin of the frontals to a point above the middle of the orbit; frontals nearly as broad as long, marked with rugosity laterally, sharply depressed mesially just in front of the posterior fossæ, and the hinder part of their median suture at the anterior end of the low supraoccipital ridge gaping to form a small vacuity. Teeth on margin of jaws rather large, stout, conical, and well-spaced, not much laterally compressed; minute teeth on vomer.

\section{Eocœlopoma colei, sp. nor.}

1845. Coelopoma colei, L. Agassiz, Rep. Brit. Assoc. 1844, p. 307 (nume only).

Type. Imperfect head; British Museum.

The type species, with head and opercular apparatus probably 

Cyorim 1uczyis.n.:

Eghoum intermedtum "

Sci. Nat. e Reon. Palermos, vol xii

Gybium Gottii, 7. Bassani, Atti D. Recad. Sei.

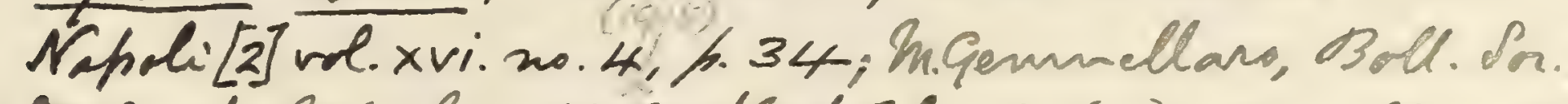

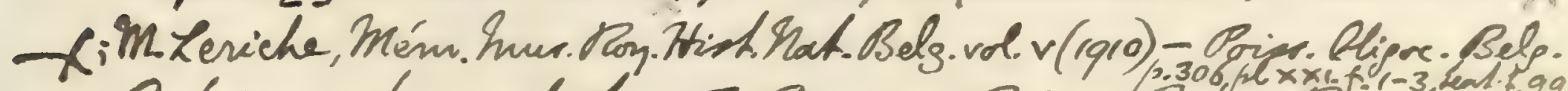

Cybium Lourdoti, 7. Priem, Prins. Jon. Baisin

Parisien (Publ. Amm. Paléont. 1908), 12.123, Leshlys, 65:Bartorian; Foyel, Gize. [Prtion of deritazy.] In.

Leriche, Bull. Sor. Géol. France [4] vol, xxii (1922), p.190.

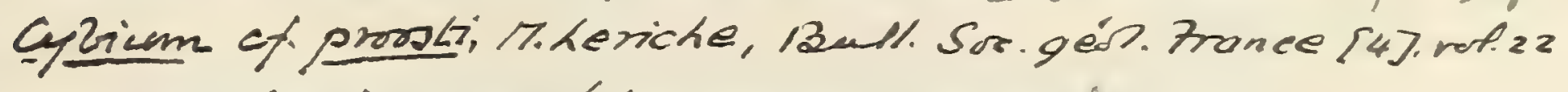
1922 (1923), p184. (Landenian- Asisne.)

LM. Zeriche, Mém. Soe. Géal. Nord, vol. v (1906), h. 242 ,

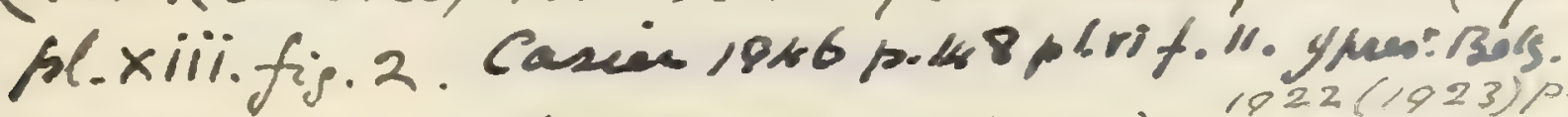

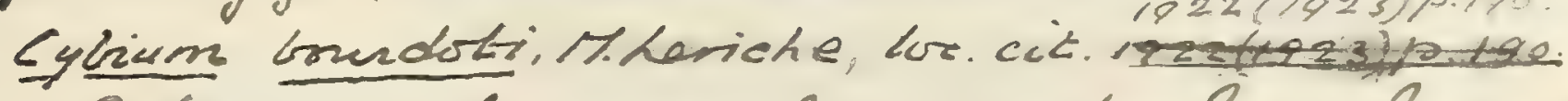

Gybium stormzi, M. Feriche, hém. Inuo. Poy. Thith.

Nat. Belp, vol. (1905), h.

; Mném. Sor.

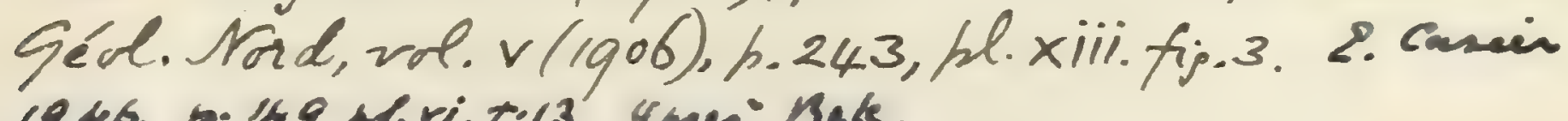
1946. 10. 199 Mrvi.tol3 ymes: Bels.

Ghium Sh., Priem, Pin. For. Bassin Parizien

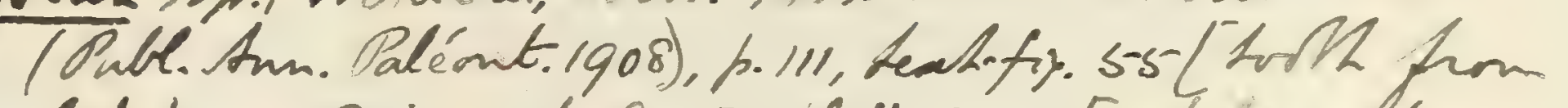
Zutetion, Seime-et-Gize], bl. ii.tip.7 [restet a from Calcaire Grossier, Pario]. Leviche, 19aY, p. 20, ph. it.4.

Cybrim upelienses spon, w. Weiler, vanth hassm. ren.

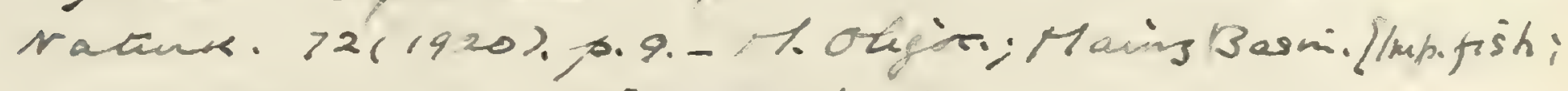
N.-h. M., Mainz]. T $1928^{\circ}$ p.22.pl.vf.z.

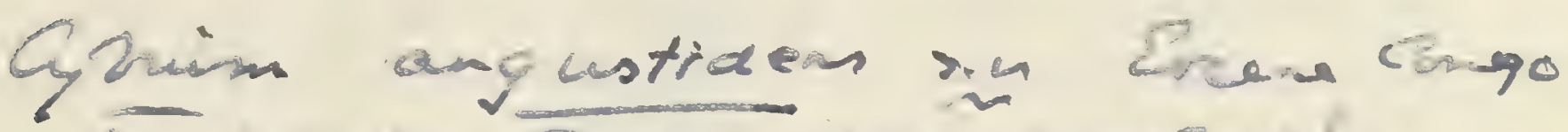

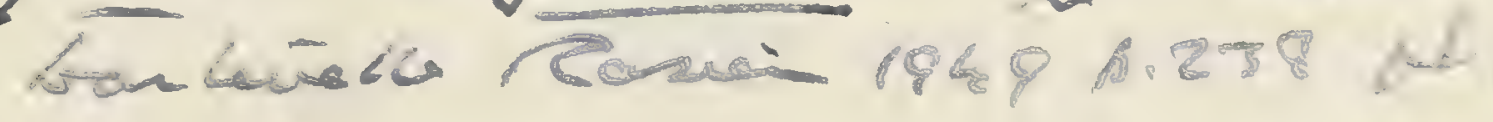


attaining a length of about $0 \cdot 3$, but usually smaller. Head slightly longer than deep; inner pair of postero-superior fossæ on cranium somewhat expanded in front, extending half the length of the cranium. Bones of opercular apparatus marked with irregular, radiating, rounded wrinkles or ridges.

Form. \& Loc. Lower Eocene (London Clay): London Basin.

P. 623 a. Imperfect head with opercular apparatus, about 0.16 in length, marked by Egerton as intended to be the type specimen of this species; Sheppey. The irregular wrinkling on all the opercular bones is well shown.

Egerton Coll.

P. 1753. More imperfect similar head, partly decaying, labelled by Egerton; Sheppey.

Egerton Coll.

35687. Equally small imperfect head, showing jaws ; Sheppey.

Purchased, 1859.

28856. Large head, showing jaws; Sheppey. Purchased, 1854.

38916. Cranium 0.095 in length, with foremost vertebral centrum fused with basioccipital; Sheppey. The parasphenoid is partly broken away, exposing a large basicranial canal. 'The vomer bears minute teeth arranged in a small, median, longitudinally-extended patch. Bowerbank Coll.

P. 1755. More imperfect larger cranium; Sheppey. Egerton Coll.

P. 1698 a. Smaller cranium, showing minute teeth on edge of palatine bone; Sheppey.

Egerton Coll.

P. 1698 b. Imperfect head, partly decaying, displaying mandible ; Sheppey.

Egerton Coll.

39445. More imperfect decaying head; Sheppey. Bowarbank Coll.

P. 9481. Pyritised and partly decaying larger specimen; Sheppey. Ennistillen Coll.

392.1. Fine head $0 \cdot 17$ in length from hinder border of quadrate to tip of premaxilla; Sheppey. The premaxillæ are less produced in front of the cranium than in Cybium and Aeanthocybium.

Bowerbank Coll.

P. 159. Imperfect large cranium; Sheppey.

Purchased, 1880.

28624. Imperfect larger cranium; Sheppey. Purchased, 1853.

33305. More imperfect large cranium; Sheppey. Purchased, 1858. 
28855. Imperfect large head, with some anterior vertebræ, probably of this species; Sheppey. The anterior vertebral centra are not longer than deep, not much constricted, and scarcely marked by lateral pits. Purchased, 1854.

P. 9458. Imperfect cranium 0.23 in length, probably of this species; Sheppey. The basioccipital region is comparatively short and broad.

Egerton Coll.

P. 8459. Slightly smaller imperfect cranium, probably of this species; Sheppey.

Purchased.

\section{Eocœlopoma curvatum, Owen.}

1815. Coelopoma leve, L. Agassiz, Rep. Brit. Assoc. 1844, p. 307 (name only).

1854. Colopoma curvatum, R. Owen, Catal. Foss. Rept. \& Pisces Mus. Roy. Coll. Surg. p. 162.

Type. Imperfect head; Royal College of Surgeons, London.

A much smaller species than the type, with opercular bones quite smooth.

Form. \& Loc. Lower Eocene (London Clay): London Basin.

P. 1751. Imperfect pyritised head, partly decaying, labelled by Agassiz and marked by Egerton as intended to be the type specimen of $C$. loeve; Sheppez.

Egerton Coll.

P. 1752. More fragmentary specimen, labelled by Agassiz; Sheppey. Egerton Coll.

P. 1698 c. Fragmentary head; Sheppey.

Egerton Coll.

P. 1698 d. Imperfect head, showing parts of jaws and smooth opercular apparatus; Sheppey.

Egerton Coll.

P. 1698 e-h. Imperfect cranium, small head, and two fragments of occiput; Sheppey.

Egerton Coll.

P. 4151-52, P. 9482. Four imperfect heads; Sheppey.

Enniskillen Coll.

28499. Imperfect pyritised head; Sheppey.

Purchased, 1853.

43126. Large fragmentary head; Hampstead Tunnel.

Wetherell Coll.

44877. Small specimen showing jaws; Sheppey.

Presented by Benjamin Bright, Esq., 18:3.

P. 9460. Imperfect smail head; Sheppey.

Purchased. 

24613. Cranium probably of this species, with large patch of vomerine teeth transversely expanded; Sheppey.

Purchased, 1850.

38922-23. Two other crania, the first showing normal vomerine teeth, the second very imperfect; Sheppey.

Bowerbank Coll.

Genus SPHYRFNODUS, Agassiz.

[Poiss. Foss. vol.v. pt. i. 1844, p. 98.]

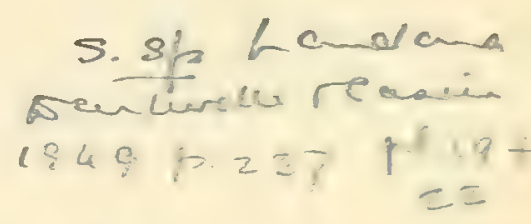

An extinct genus comprising large species known only by portions of skull and dentition. Teeth large and conical, not laterally compressed, in single series on margin of jaws [and on palatine bone, according to Dollo and Storms].

The dentition is more powerful and the premaxillæ are relatively larger than in the existing genus Pelamys.

\section{Sphyrænodus priscus, Agassiz.}

1841. Sphyranodus priscus (Dictyodus), R. Owen, Odontogr.'p. 129, pl. liv.

1839-44. Sphyræenodus priscus, L. Agassiz, Poiss. Foss. vol. v. pt. i. p. 98, pl. xxvi. figs. $4-6$.

1890. Dictyodus priscus, Woodward \& Sherborn, Catal. Brit. Foss. Vert. p. 64.

Type. Jaws and associated remains; British Museum.

The type species, with mandible attaining a length of $0 \cdot 16$. Jaws much elongated, the maximum depth of the mandibular ramus contained about four times in its length. Teeth plicated at the base, slightly incurved at the apex, remarkably uniform in size.

Form. \& Loc. Lower Eocene (London Clay): London Basin.

P. 395\%. Type specimen, described and figured by Agassiz, Toc.cit.; Sheppey. Only obscure fragments of the cranium are shown.

Enniskillen Coll.

An undescribed species of Sphyrcenodus also occurs in the Middle Oligocene of Boom, near Antwerp (Dictyodus rupeliensis, Dollo \& Storms, Zool. Anzeig. 1888, p. 266).

The generic name Dictyodus, Owen (Rep. Brit. Assoc. 1838 [1839], Trans. Sect. p. 142), was considered as a synonym of Sphyroenodus by Owen, Odontogr. (1841), expl. pl. liv.; but it seems to have been based on some fragmentary jaws in the Royal 
College of Surgeons, which were subsequently named Dictyoclus destructor, Owen (Catal. Foss. Rept. \& Pisces Mus. Roy. Coll. Surg. 1854, p. 161). These specimens exhibit large, low and broad teeth, much laterally compressed, and vertically striated at the base, and are too imperfect for satisfactory determination. The following specimen may perhaps belong to this genus and species:-

36166. Imperfect jaws, each exhibiting a single series of the characteristic large teeth flanked externally with a row of very small but similar teeth; London Clay, Sheppey.

Purchased, 1860.

Genus SCOMBRAMPHODON, novum.

Syn. Amphodon, R. Storms (non Amphodus, Peters, 1872), Ann. Soc. Géol. Belg. vol. xiî. 1887, Mém. p. 265.

An extinct genus known only by portions of skull, dentition, and vertebræ. Marginal teeth large and conical, not laterally compressed, in single series on premaxilla, in less regular series on dentary, which bears a supplementary external row of comparatively small teeth; minute clustered teeth on palatine. Dentary bone rapidly deepening behind the contracted but thickened symphysis. Vertebral centra not longer than deep, with two lateral pits.

\section{Scombramphodon benedeni, Storms.}

1887. Amphodon benedeni, R. Storms, Ann. Soc. Géol. Belg. vol. xiii., Mém. p. 2035, pl. iv.

Type. Associated portions of skull and vertebræ.

The type species, with mandible probably about 0.15 in length. Large teeth strongly plicated at base, not much incurved at apex; those of dentary in a regular series, firmly fixed in rather deep sockets.

Form. \& Loc. Middle Oligocene (Rupelian): Rupelmonde, Belgium. Maniz Basin.

Not represented in the Collection.

Scombramphodon curvidens, Storms.

1887. Amphodon curvidens, R. Storms, Ann. Soc. Géol. Belgr. vol. xiii., Mém. p. 266, pl. v.

Type. Associated portions of dentary and premaxilla.

Large teeth of dentary more incurved than in the type species 

Sphyraenodus sp. Lo. weiler, 1928; p.25, dlip. 8. M.okijo. Maing Basin.

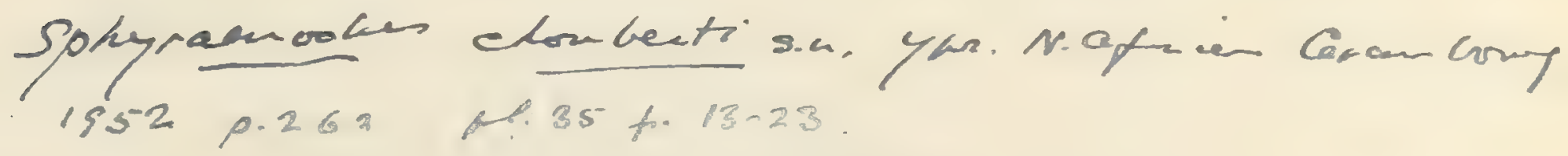

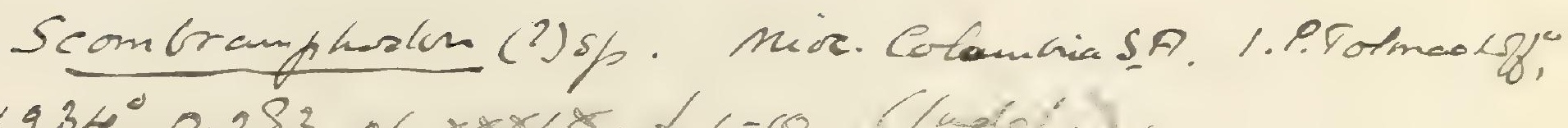

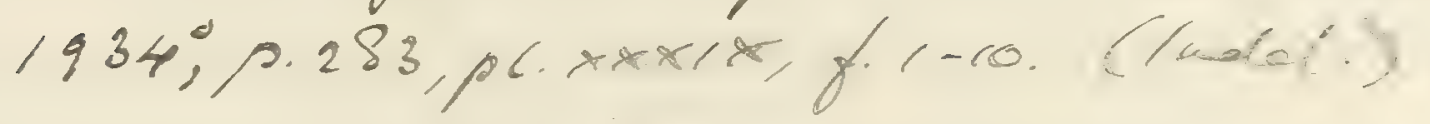
? S. wordarandi:

1910. Ceombramphodon Genedeni, Mr Lericha, Mém. Mur.

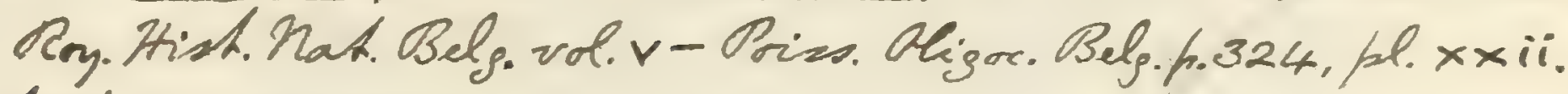
fenth-fip. $122-129$.

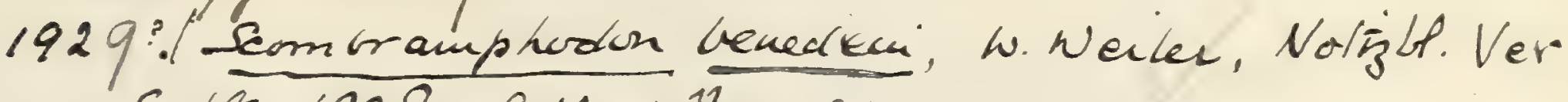
fidk, 1928, ule V. pli. 11, p. 123 . 

and less deeply inplanted at the base; small outer teeth forming a cluster at the mandibular symphysis.

Form. \& Loc. Middle Oligocene (Rupelian): Rupelmonde, Belgium.

Not represented in the Collection.

\section{Scombramphodon crassidens, sp. nov.}

1844. Sphyranodus crassidens, L. Agassiz, Poiss. Foss, vol. v. pt. i. p. 99 (name only).

1890. Dictyodus (?) crassidens, Woodward \& Sherborn, Catal. Brit. Foss. Vert. p. 64 (name only).

Type. Fragments of jaws: British Museum.

Apparently closely similar to $S$. curvidens, but the apices of the teeth less incurved, and the teeth on the anterior half of the dentary less regularly arranged.

Form. \& Loc. Lower Eocene (London Clay): London Basin.

P. 1779. Abraded fragments of jaws in matrix showing the large teeth with plicated bases, labelled by Agassiz and intended to be the type specimen of this species; Sheppey.

Egerton Coll.

P. 158. Fragmentary head; Sheppey. The cranium seems to have considerably resembled that of Scomber and Scombrinus, but is deeper and more laterally compressed. The premaxilla is long and slender, not much expanded in front. It bears a single series of large teetb, which are deeply plicated in their basal half and not incurved at the apex. The hinder portion of the right dentary exhibits traces of the outer series of small teeth. Purchased, 1880.

38945. Anterior half of left dentary, showing bases of teeth, rather irregular in arrangement, elustered on the symphysis; Sheppey. Each tooth has a very small pulp-cavity.

Bowerbank Coll.

P. 1780. Hinder portion of small left dentary and premaxilla; Sheppey. The bases of the two series of mandibular teeth are shown.

Egerton Coll.

28755. Imperfect small head, doubtfully of this species; Sheppey. Purchased, 1853.

38907. Smaller imperfect head, doubtfully of this species. 
The following specimens are not specifically determined :-

P. 5205. Fragment of left dentary, rather stout and large, showing bases of teeth; London Clay, Sheppey. Gardner Coll.

25740. Anterior end of small right dentary; Middle Eocene, Bracklesham Bay. Dixon Coll.

The indefinable Scombroid genus Stereodus (R. Owen, Geol. Mag. vol. ii. 1865, p. 147), from the Miocene of Malta, has smooth, round teeth much like those of Scombramphodon. The large type species, Stereodus melitensis (R. Owen, loc. cit., and J. H. Cooke, Geol. Mag. [3] vol. viii. 1891, p. 546), is represented in the Collection by the following specimens, all from the yellow limestone of Malta and Gozo:-

P. 3903. Imperfect base of caudal fin.

Enniskillen Coll.

P. 620\%. Terminal caudal vertebræ and remains of caudal fin-rays. Each vertebra in advance of the hypural exhibits two lateral pits separated by a rounded median longitudinal ridge. Presented by Sir John Murray, K.C.B., 1890.

P. 6207 a. Nearly similar specimen, but having two very short and deep vertebral centra, without median lateral ridge, immediately in front of hypural.

Presented by Sir John Murray, K.C.B., 1890.

P. 343. Nearly similar specimen, but three last ridged caudal vertebral centra relatively shorter and deeper.

Purchased, 1881.

P. 7537. Various remains of end of tail and caudal fin-rays.

Presented by P. T. Godsal, Esq., 1895.

The fragment of jaw from the Middle Oligocene of Flonheim, in the Mayence Basin, named Sphyroenodus conoideus by H. von Meyer (Neues Jahrb. 1846, p. 597, and Palæontogr. vol. i. 1851, p. 281, pl. xxxiii. fig. 13), closely resembles the so-called Stereodus.

\section{Genus THYRSITOCEPHALUS, G. vom Rath.}

[Zeitschr. deutsch. geol. Ges. vol. xi. 1859, p. 114.]

Trunk elongated and laterally compressed. Orbit relatively small ; mandible prominent; teeth few and large, smallest in front of the jaws. Vertebræ about 54 in number, nearly half being abdominal; ribs small. Paired fins small; dorsal fins scarcely 
Senur Neocytium, Leriche.

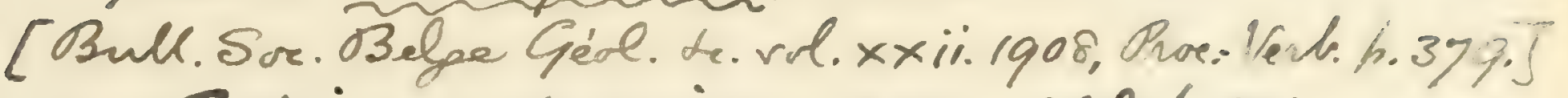

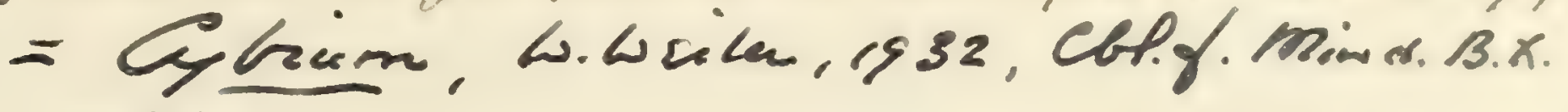
100542.

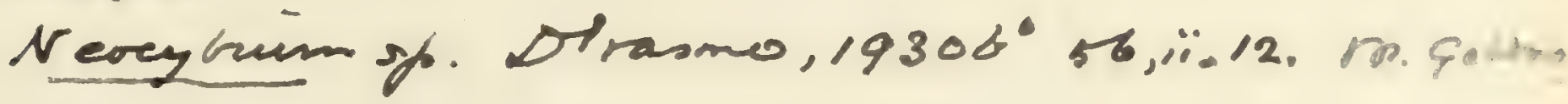

éocytiun rostratum, teriche.

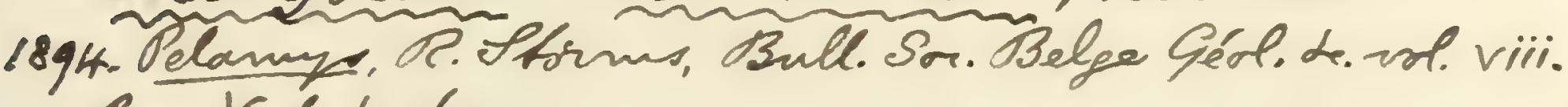
Sise. Verh. h.262.

1908. Keocybium roshatum, In. Leriche, lac. it. h. 379 . 1910.

M. Leviche, Mém. Hus. Dory.

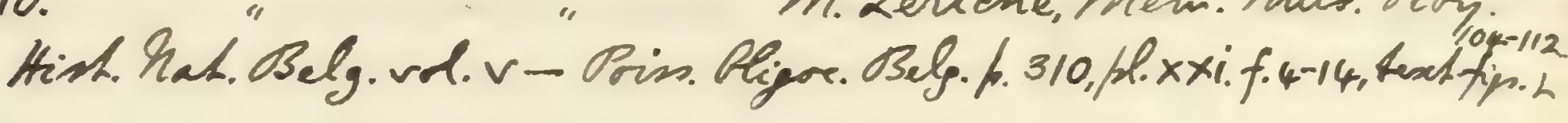


Eolhyrsitas hollosquanoties, g.rin. . . Chapmen, $1934^{\circ}$, p.119,

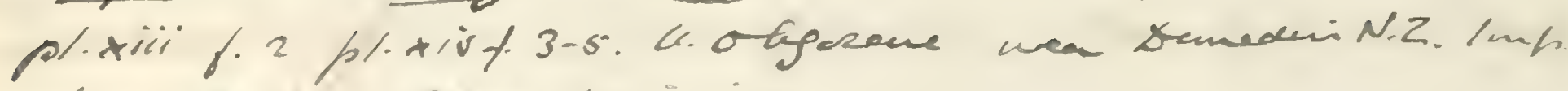

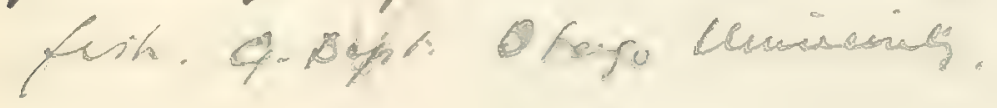

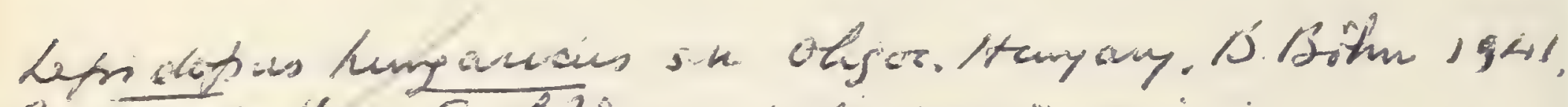

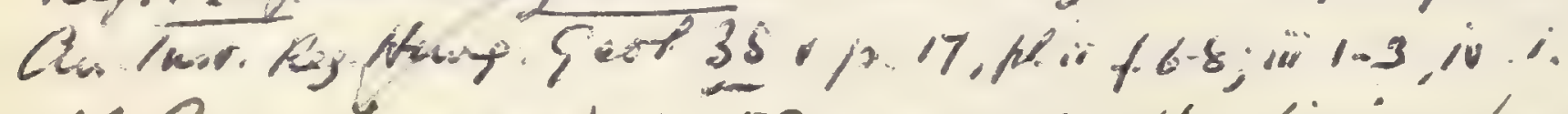

M. Paucä, 19 b p.53, reands th living Lepidopus canesa kin (Euptras) from the Tigorene of Valear

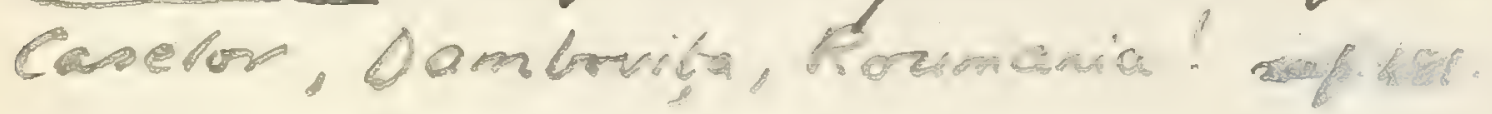

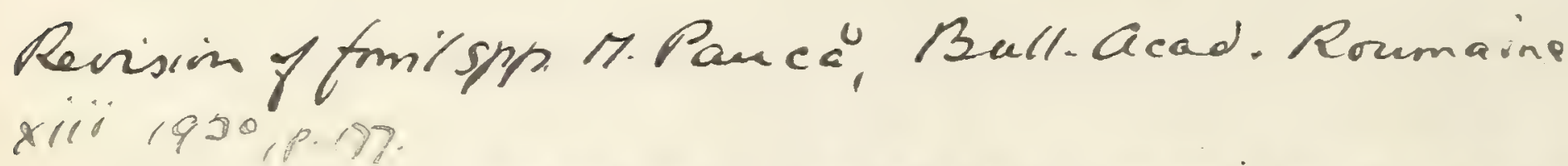

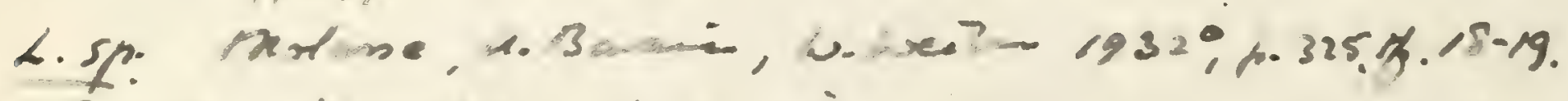

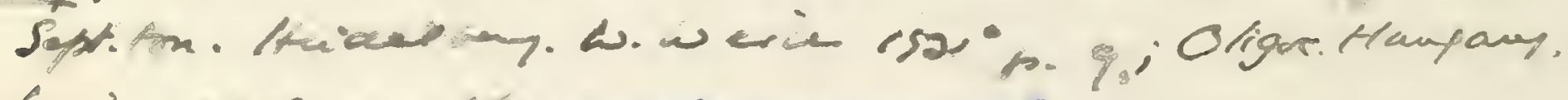

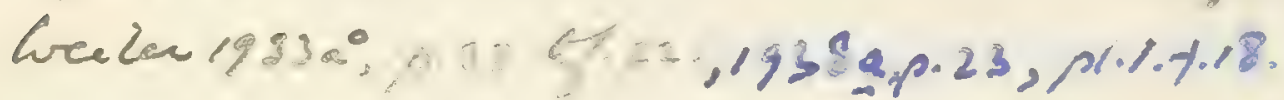

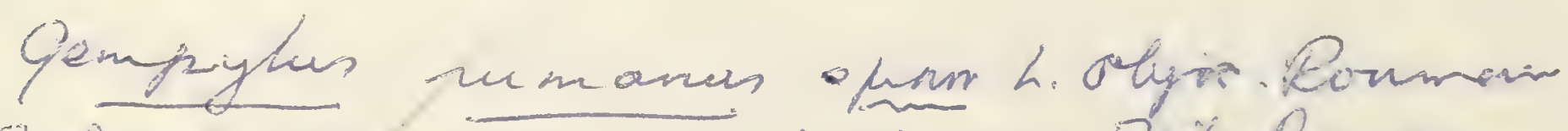

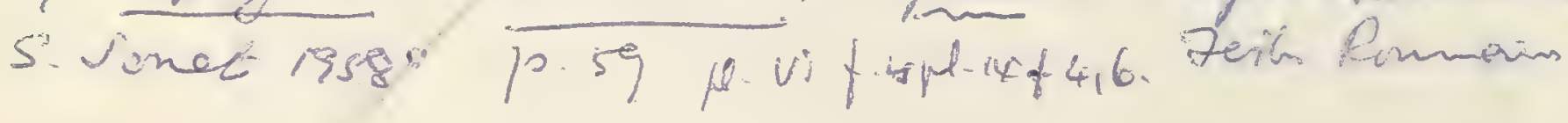



separated, the anterior with more than 20 spines, arising above the paired fins; posterior dorsal and anal fins of equal extent, and followed by about 20 finlets; caudal fin deeply forked. [Scales unknown.]

An extinct Oligocene genus.

Thyrsitocephalus alpinus, (x. vom Rath.

1859. Thyrsitocephalus alpinus, G. rom Rath, loc. cit. p. 114, pl. iii. fig. 4 .

1886. Thyrsitocephalus alpinus, A. Wettstein, Fischfauna Tertiaer. Glarnerschief. (Denkschr. schweiz. Palaeont. Ges. vol. xiii.), p. 70.

Type. Nearly complete fish; Geological Mnseum, University of Bonn.

The type species, attaining a length of about $0 \cdot 16$. Length of head with opercular apparatus somewhat exceeding maximum depth of trunk, and contained five times in total length of fish. Teeth recurved, about 12 in each jaw. Anterior dorsal fin with 22 or 23 spines, posterior dorsal with 10 articulated rays, anal fin with 10 or 12 articulated rays.

Form. \& Loc. Oligocene: Canton Glarus, Switzerland.

Not represented in the Collection.

\section{Genus LEPIDOPUS, Gouan.}

[Hist. Nat. Poiss. 1770, p. 185.]

Syn. Anenchelum, H. D. de Blainville, Nouv. Dict. d'Hist. Nat. vol. xxvii. 1818, p. 314.

Lepidopides, J. J. Heckel, Denkschr. k. Akad. Wiss, math.naturw. Cl. vol. i. pt. i. 1850, p. 239.

Trunk laterally compressed and excessively elongated. Orbit large; mouth large and mandible prominent; marginal dentition powerful, a few teeth much enlarged, recurved, and barbed. From 90 to 110 vertebræ, none with transverse processes. Pectoral fins well developed, but pelvic fins rudimentary; dorsal fin continuous and nearly uniform in eleration along the whole length of the back; numerous rudimentary anal fin-spines; no finlets; caudal fin deeply forked. Scales absent.

Pelagic and deep-sea fishes of wide range.

\section{Lepidopus glarisianus (Blainville).}

1708. Figure by J. J. Scheuchzer, Pisc. Querelæ et Vindiciæ, pl. ii.

1818. Anenchelum glarisianum, H. D. de Blainville, Nouv. Dict. d'Hist. Nat. vol. xxvii. p. 314.

1834. Anenchelum glarisianum, L. Agassiz, Neues Jahrb. p. 302. 
1834. Anenchelum latum, L. Agassiz, ibid. p. 302 (name only).

1834. Anenchelum isspleurum, L. Agassiz, ibid. p. 302 (name only).

1834. Anenchelum heteropleurum, L. Agassiz, ibid. p. 302 (name only).

1842-44. Anenchelun glarisianum, L. Agassiz, Poiss. Foss. vol. v. pt. i. p. 70, pl. xxxvii. figs. $1,2$.

1842-44. Anenchelum isopleurum, L. Agassiz, ibid. p. 71, pl. xxxvii. fig. 3. [Immature distorted fish; British Mliseum.]

1842-44. Anenchelum dorsale, L. Agassiz, ibid. p. 72, pl. xxxvii. fig. 4, pl. xxxvii $a$. figs. 1, 2. [Fragmentary distorted specimen; British Museum.]

1842-44. Anenchelum heteropleurum, L. Agassiz, ibid. p. 73, pl. xxxvii $a$. fig. 3. [Distorted large fish; British Museum.]

1842-44. Anenchelum latum, L. Agassiz, ibid. p. 74, pl. xxxvi. [Imperfect anterior half of fish ; Zürich Museum.]

(9) 1844. Anenchelum longipenne, L. Agassiz, ibid.p. 74 (name only).

(?) 1847-48. Anenchelum breviceps, C. G. Giebel, Neues Jahrb. 1847, p. 665, and Fauna d. Vorw., Fische, p. 80. [Imperfect distorted fish ; University Geoloyical Museum, Halle.]

18乞̃. Anenchelum latum, G. vom Rath, Zeitschr. deutsch. geol. Ges. vol, xi. p. 122, pl. iii. fig. 6, pl. iv.

185.9. Anenchelum dorsale, G. vom Rath, ibid. p. 122, pl. iii. fig. 8.

1859. Anenchelum glarisianum, G. vom Rath, itid. p. 122, pl. iii. fig. 5. 1859. Anenchelum heteropleurum, G. vom Rath, ibid. p. 123.

(?) 1859. Anenchelum breviceps, G. vom Rath, ibid. p. 123. 1859. Anenchelum isoxleurum, G. vom Rath, ibid. p. 123.

1886. Lepidopus glaronensis, A. Wettstein, Fischfauna Tertiaer. Glarnerschief. (Denkschr. schweiz. Palaeont. Ges. vol. xiii.), p. 42 , pl. v. figs. 1, 3, 5, 9, 10, pl. vi. figs. 1, 3, 5-8.

Type. Imperfect fish.

A slender species attaining a length of over one metre. Length of head with opercular apparatus contained eight times, maximum depth of trunk about nineteen times in the total length of the fish to the base of the caudal fin. About 12 teeth on the margin of each jaw above and below; one enlarged at anterior end of premaxilla; those of middle of dentary twice as high as those in front and behind; the largest more or less recurved. Vertebræ 32 to 35 in the abdominal, 72 to 75 in the caudal region. Pectoral fins unusually large, the length of the two lowest rays equalling twice the depth of the trunk; dorsal fin arising above first vertebra, terminating over sixth from caudal fin, and its anterior 10 or 12 rays the lungest; anal fin terminating opposite end of dorsal; caudal fin larger than in the existing species.

This is the type species of Anerchelum. The known examples are very variously distorted, and it is difficult to determine its exact proportions.

Iorm. \& Loc. Oligocene: Canton Glarus, Switzerland.

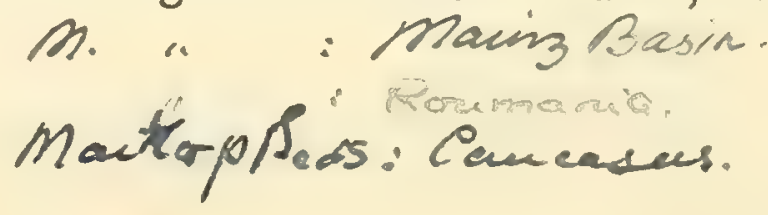


1928: Lepidopus glarisianus, b. weiler, p.32 pliff. 1929a: Lepidupus glarissianus, (sic) M. Pauca", p. 30 . (olog. Roumania).

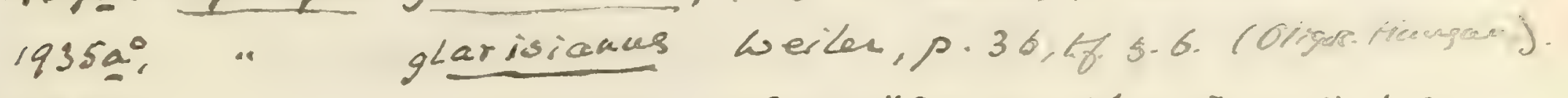

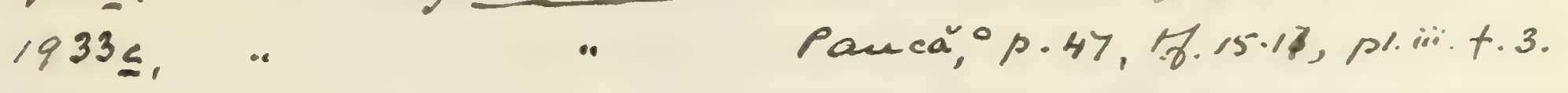

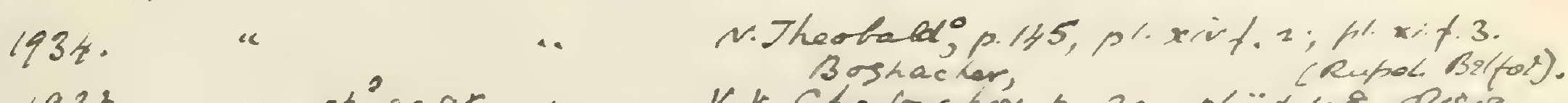

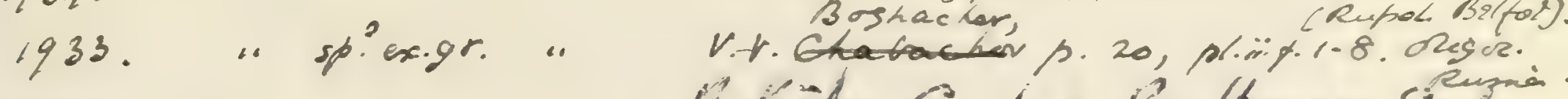

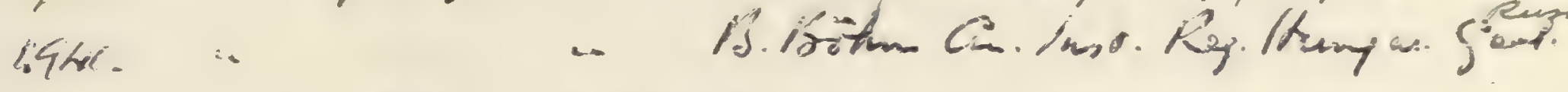

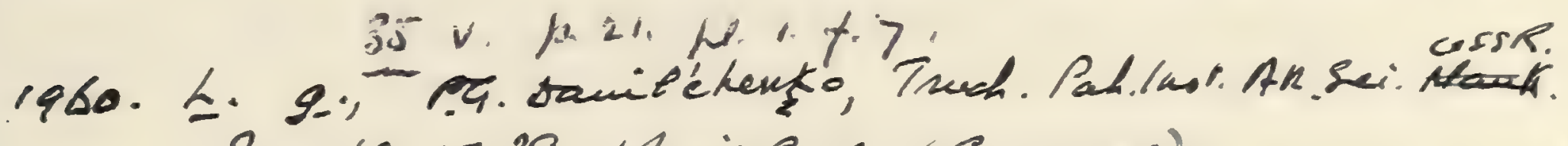

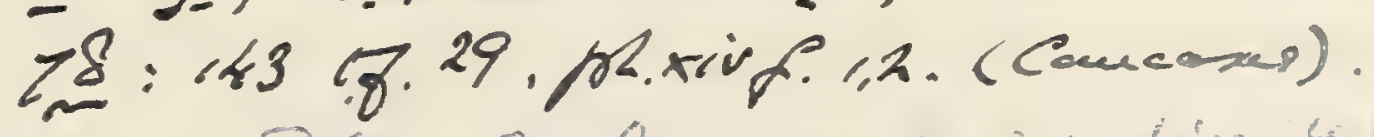


Lepidsaus levichei sin. 2. Casevi 1950 schw.

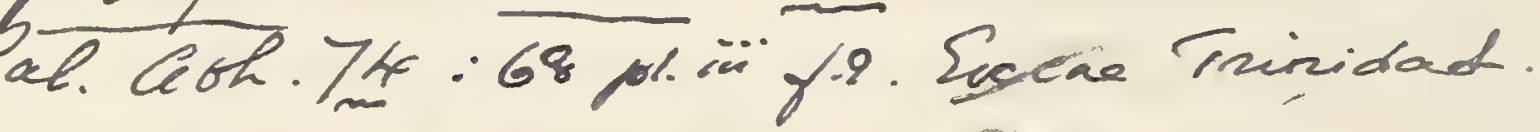


P. 451, P. 3996, P. 501, P. 3995. Small fish and large caudal region, in counterpart, much elongated by distortion, described and figured by Agassiz, loc. cit. 1842-4t, as belonging to this species; Engi.

Egerton \& Enniskillen Colls.

P. 442. Bent and distorted small specimen, described and figured by Agassiz, ibid., as the type of Anenchelum isopleurum; Engi.

Egerton Coll.

P. 3993. Larger specimen noticed by Agassiz, ibid. p. 72, as Anenchelum isopleurum; Engi.

Enniskillen Coll.

P. 3998. Type specimen of Anenchelum dorsale, figured by Agassiz, ibid. pl. xxxvii $a$. fig. 2 ; Engi. The teeth are obscured by matrix and inaccurately drawn in the figure.

Enniskillen Coll.

P. 502, P. 3990. Type specimen of Anenchelum heteropleurum, in counterpart, described and figured by Agassiz, ibid.; Engi. The teeth are inaccurately shown, being obscured by matrix.

Egerton \& Enniskillen Colls.

41803, 41805-06, 41809-11, 41813. Remains of seven large fishes, well divested of matrix; Engi.

Purchased, 1869.

41804, 41808, 41812. Similar remains of three smaller fishes; Engi.

Purchased, 1869.

7848. Caudal region; Engi.

Mantell Coll.

33936, 33942, 33945-46, 33950-51, 33954, 33963-71, 33982, 33985. Fight imperfect specimens, six being in counterpart ; Engi. Presented by Miss Elizabeth Warne, 1859.

36086-87. Small specimen and portion of another fish bent behind the head, both in counterpart; Plattenberg.

Purchased, 1861.

P. 5214. Caudal region; Plattenberg.

Presented by J. E. Lee, Esq., 188 o.

P. 1706, P. 1708-09, P. 2067-68, P. 3991-92, P. 3997. Various distorted portions of large specimens; Eugi.

Egerton \& Enniskillen Colls.

41807. Immature fish ; Engi.

Purchased, 1869.

P. 1711-12. Three immature fishes, the third about 0.1 in length; Engi.

Egerton Coll.

P. 3991. Another immature fish; Engi.

Enniskillen Coll. 


\section{Lepidopus brevicauda (rom Rath).}

1859. Anenchelum brevicauda, G. vom Rath, Zeitschr. deutsch. geol. Ges. vol. xi. p. 124, pl. v. fig. 1.

1886. Lepidopus brevicauda, A. Wettstein, Fischfauná Tertiaer. Glarnerschief. (Denkschr. schweiz. Palaeont. Ges. vol. xiii.), p. 43, pl. v. figs. $2,7,8$, pl. vi. fig. 4 .

Type. Imperfect fish ; Unirersity Geological Museum, Bonn.

A small species attaining a length of about 0.5 . Maximum depth of trunk contained about fifteen times in length of vertebral column. Teeth apparently more numerous than in L. glarisianus. Vertebræ about 36 in the abdominal, 53 in the caudal region. Length of longest pectoral fin-rays not exceeding depth of trunk; dorsal and anal fins low.

Form. \& Loc. Oligocene: Canton Glarus, Switzerland.

Not represented in the Collection.

\section{Lepidopus albyi, Saurage.}

1870. Lepidopus albyi, H. E. Saurage, Ann. Sci. Nat. [5] vol. xir. art. no. 7, p. 5.

1873. Lepidopus albyi, H. E. Saurage, Ann. Sci. Géol. vol. iv. art. no. 1, p. 123, fig. 25.

Type. Imperfect fish.

A small species, apparently not more than 0.3 in length. Length of head with opercular apparatus contained about seven times, maximum depth of trunk about sixteen times in total length of fish. Vertebræ 35 in the abdominal, 58 in the caudal region. Pectoral fins small.

Form. \& Loc. Upper Miocene : Licata, Sicily.

P. 1705. Fragmentary remains of head and abdominal region.

Egerton Coll.

The following extinct species have also been described, but there are no examples in the Collection :-

Jepidopus anguis, H. E. Sauvage, Ann. Sci. Nat. [5] vol. xiv. (1870), art. no. 7, p. 6, and Ann. Sci. Géol. vol. it. (1873), p. 128, fig. 27 ; I. Bonomi, Rirista Ital. Palecnt. จol. ii. (1896), p. 232.-Upper Miccene; Licata, Sicily, and Nondaino, Prov. Forli, Italy. [Small fish.]

Lepidopus carpathicus, D. G. Kramberger, Palæontogr. vol. xxvi. (1879), p. 57, pl. xvi. fig. 1.-Lower Oligocene ; Baschka, Galicia. Fragment of caudal region; Palæontological Museum, Munich.] 



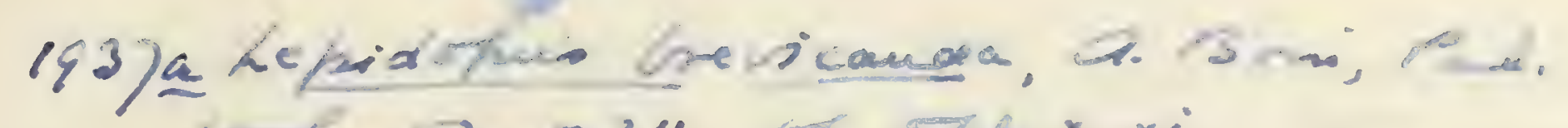
s2, ip.2". if. Thes $x-x i$.

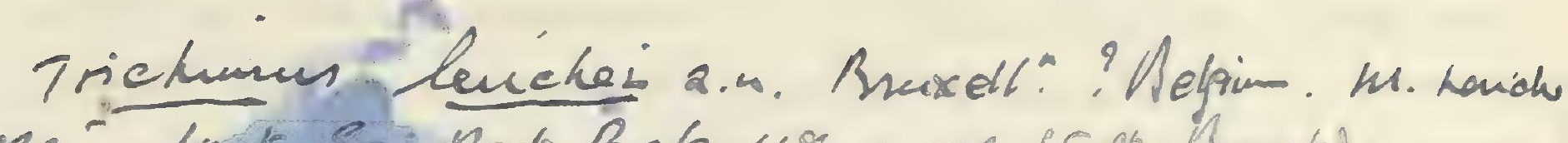

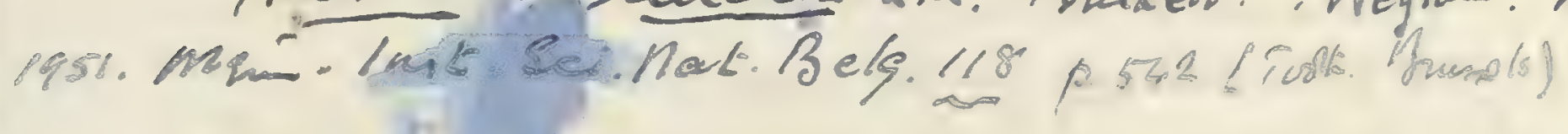

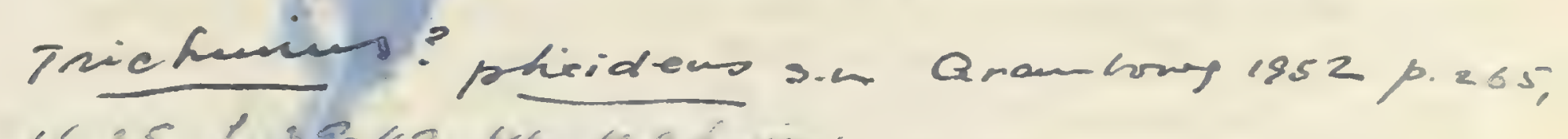

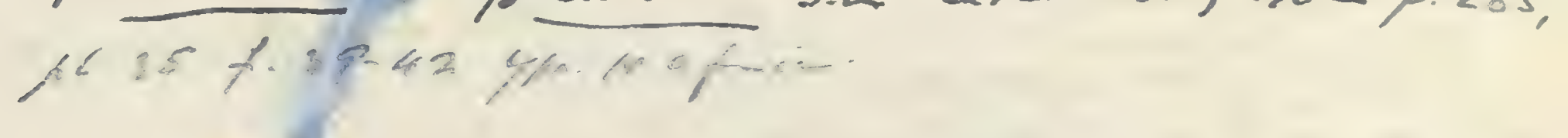

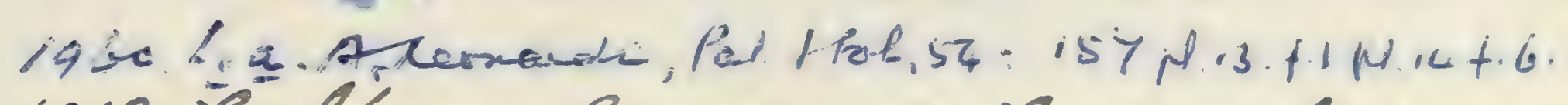
1918. Z. altyc $=$ L. aneni $=\not$. menephinii $=$ L.candatur (Euphraren), C.De Stefans,

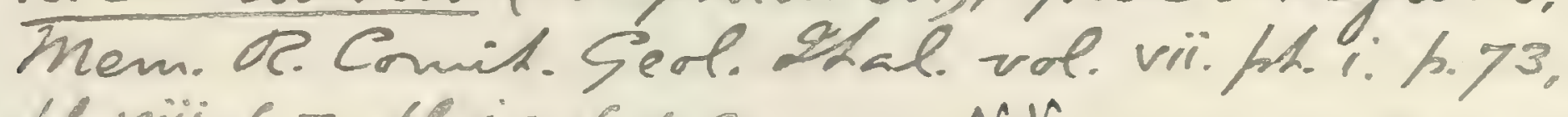

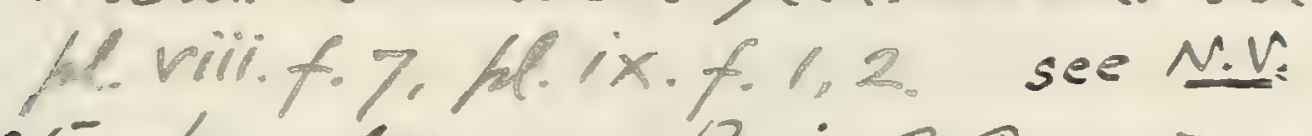

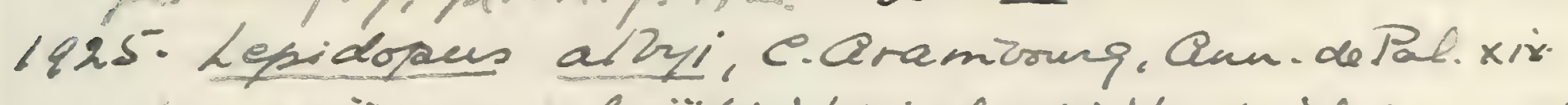

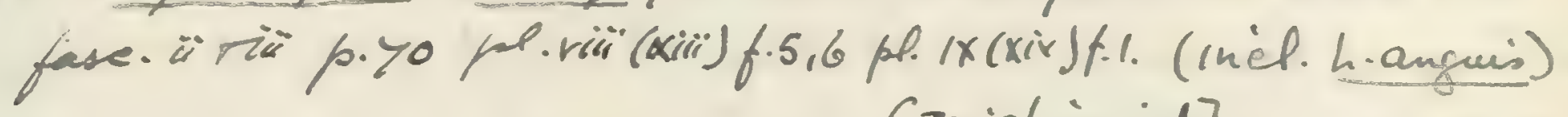
[Trichinrid].

19305. L. a. S. Shasmo, 59,

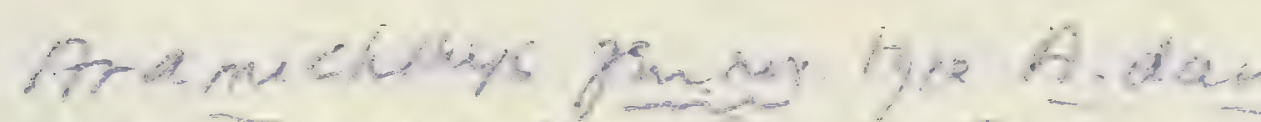

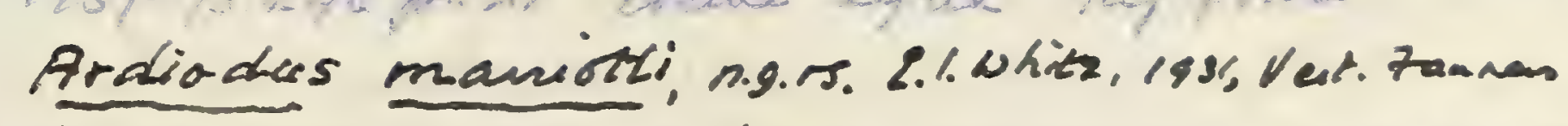

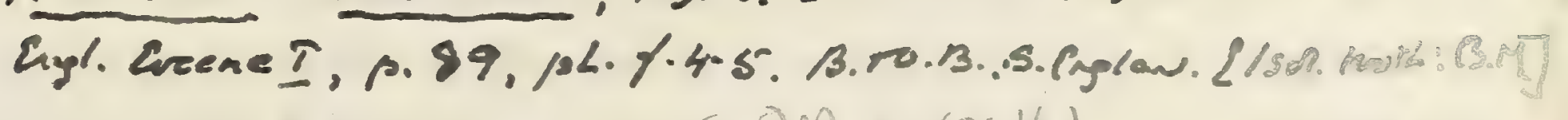

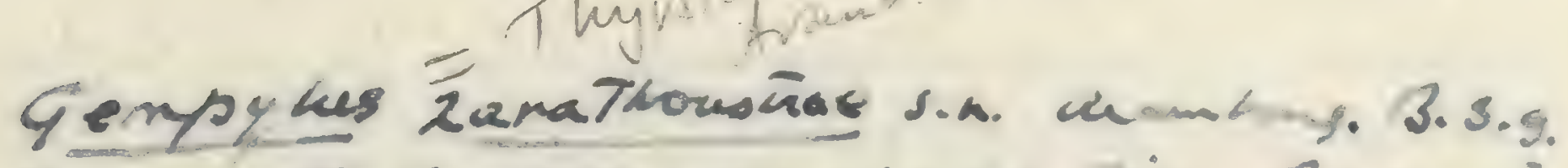

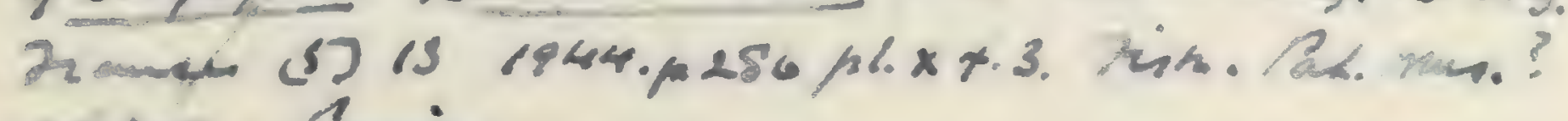
vijun. Sunsio.

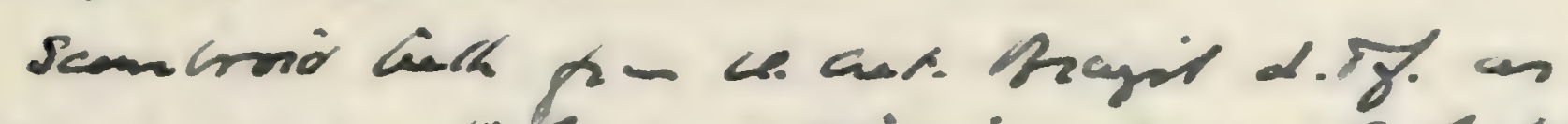

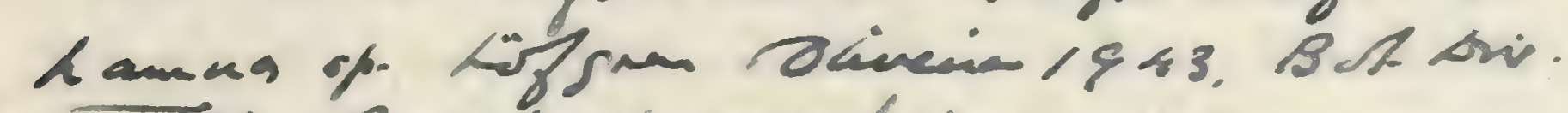

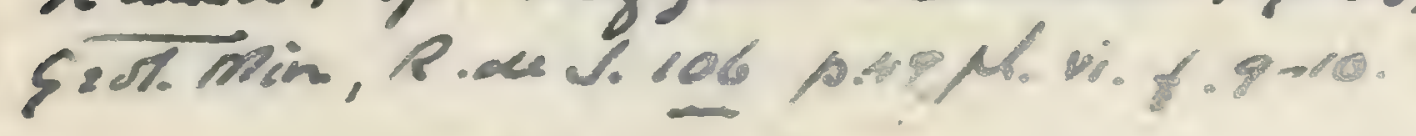


. 
Lepidopus dubius, D. G. Kramberger, loc. cit. 1879, p. 55, pl. xiv. fig. 1. Lepidopides dubius, J. J. Heckel, Denkschr. k. Akad. Wisș., math.-naturw. Cl. vol. i. (1850), pt. i. p. 241; F. Bassani, Atti Soc. Veneto-Trent. Sci. Nat. vol. vii. (1880), p. 76 . Lepidopides brevispondylus, J. J. Heckel, loc. cit. 1850, p. 241, pl. xxvii.-Lower Oligocene: Baschka, Galicia; Maunitz, Moravia; and Ofen, Hungary. [Portion of trunk; Court Museum, Vienna.]

Lepidopus leptospondylus, D. G. Kramberger, loc. cit. 1879, p. 57. $?=$ L.eandorm. Lepidopides leptospondylus, J. J. Heckel, loc. cit. 1850,

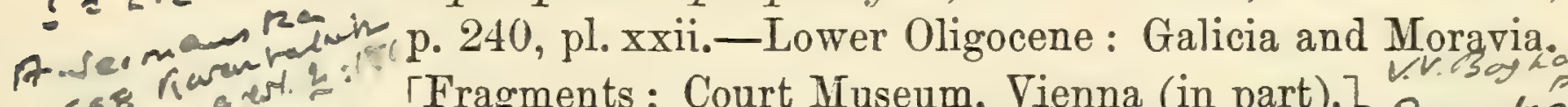

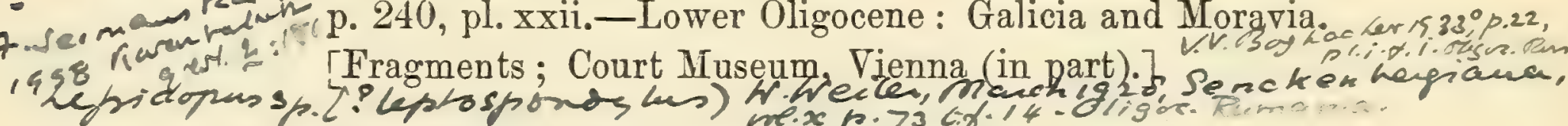

Lepidopus meneghinii is an undefined name for a fossil fish from the Upper Miocene of Gabbro, Tuscany (de Bosniaski, Atti Soe. Tosc.-Proc.-Verb. rol. i. 1878, p. xix.).

Barbed teeth like those of Lepidopus have also been described from the Oligocene of Alsace (A. Andreae, Mitth. geol. Landesanst. Elsass-Lothr. vol. iii. 1890, p. 108, figs. 3, 4); from the Niocene of Saucats, Gironde (Trichiurides mioccenus, E. Delfortrie, Actes Sce. Linn. Bordeaux, vol. xxxi. 1876, p. 32, figs. 1-5); and from the Miocene of Sardinia (Thyrsites lovisatoi, F. Bassani, Atti R. Accad. Sci. Napoli, [2] vol. iv. 1891, no. 3, p. 54, pl. i. fig. 5, pl. ii. Atti P. Accad fig. 23).

The following extinct genera and species also appear to belong to this family, but are not satisfactorily definable. Except perhaps the two first-mentioned species, which are unrecognisable, none are represented in the Collection:-

-Acropoma alta, R. Owen, Catal. Foss. Rept. \& Pisces, Mus. Roy. Altipoma Coll. Surg. 1854, p. 164, no. 661.-London Clay; Sheppey.

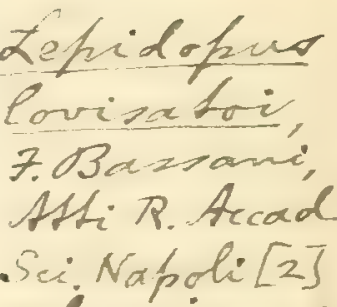
vol. $x$ vi 200.4 $(1915), p .36, p l$ i. fip $=22-24$ Psivelan michelliz: $2 \cdot 4 \cdot 26 / 2$.

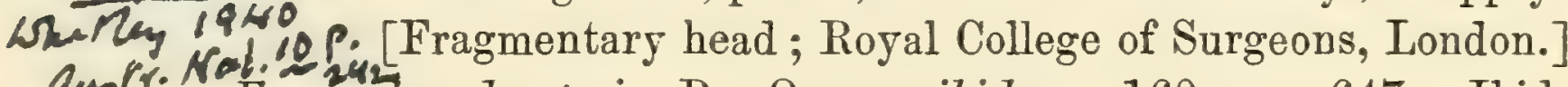
Eucynodus hunteri, R. Owen, ibid. p. 160, no. 647.-Ibid. [Ditto.]

Hemithyrsites alatus, H. E. Sauvage, Ann. Sci. Géol. vol. iv. (1873), art. no. 1, p. 136, figs. 37, 40. Acanthonotos alatus, H. E. Sauvage, Ann. Sci. Nat. [5] vol. xiv. (1870), art. no. 7, p. 10.-Upper Miocene; Licata, Sicily. [Imperfect fish.] Dea H.armalios.

Hemithyrsites armatus, H. E. Sauvage, loc. cit. 1873, p. 133, fig. 36. Acanthonotos armatus, H. E. Sauvage, loc. cit. 1870, p. 9.-Ibid. [Type species, also of Acanthonotos, Sauvage 1870, non Accnthonotus, Bloch-Schneid. 1801.

Imperfect fish.] 


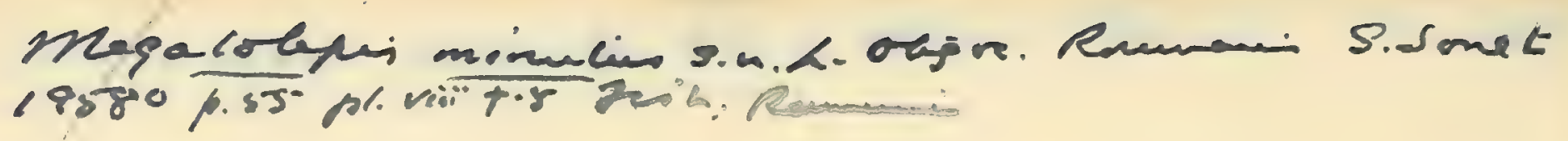

482

H. Maicopices SCTINOPTERYGII.

Hemithyrsites licatce, H. E. Saurage, loc. cit. 1873, p. 139. Acanthonotos licatoe, H. E. Sauvage, loc. cit. 1870, p. 10. -Ibid. [Fragments.] see \%anmakes.

Megalotepis baschcaensis, D. G. Kramberger, Palæontogr.vol. xxvi. (1879), p. 61, pl. xvi. frg. 3-Lower Oligocene ; Baschka, Galicia. [Type species. Imperfect fish; Palæontological Museum, Munich.] = Palaeopadus p.578

Megalolepis latus, D. G. Kramberger, ibid. p. 62, pl. xvi. fig. 2. -Ibid. [Imperfect fish; Palæontological Museum, Munich.]

× Trichiurichthys incertus, H. E. Sauvage, Ann. Sei. Géol. vol. iv. (1873), art. no. 1, p. 130, fig. 28.-Upper Miocene; Licata, Sicily. [Imperfect caudal region.] 0

haver Xiphopterus falcatus, L. Agassiz, Neues, Jahrb. 1835, p. 295, and N. am. Sei. rat. ${ }^{2}$ Poiss. Foss. vol. v. pt.i. (1844), p. 77. Esox falcatus, Bolopa 4.329 G.S. Volta, Ittiolit. Veronese (1796), p. ccxxzvii. pl. Ivii. -Upper Eocene; Monte Bolca. [Fragmentary fish; Paris Museum of Natural History.]

Unsatisfactory fragments of jaws and other bones have also been referred to supposed extinct species of the existing genus Pelamys as follows :-

Pelamys adunca, R. Lawley, Nuovi Studi Pesci, \&c., Colline Toscane (1876), p. 64, pl. จ. fig. 6.-Lower Pliocene; Orciano, Tuscany.

Pelamys robusta, P. J. Van Beneden, Bull. Acad. Roy. Belg. [2] vol. xxxi. (1871), p. 512.-Middle Oligocene (Rupelian); Basele, Belgium.

An otolith, fot represented in the Collection, has been described as follows :-

Otolithus (Scombridarum) thynnoides, E. Koken, Zeitschr. deutsch. geol. Ges. vol. xliii. (1891), p. 130, pl. x. fig. 10.-Middle Oligocene; Waldböckelheim.

\section{Family PALAORHYNCHID压。}

Trunk much elongated and laterally compressed. Snout much produced; mandibular suspensorium inclined sharply forwards, but gape of mouth wide; teeth minute or absent. Vertebræ 50 to 60 in number; ribs completely encircling the abdominal cavity; 

Holmer, Psth-Pleive. Fors. T. Cardind (1860). h. 121. plexxv.fig.2. - Post. Diocene; Rimmonis Bluff

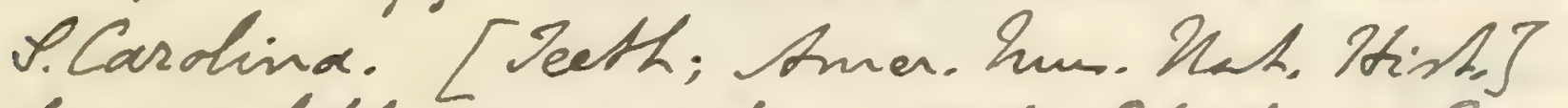

* Trichiurichthe ineertwr, G. De Shefano, Bnem. P.

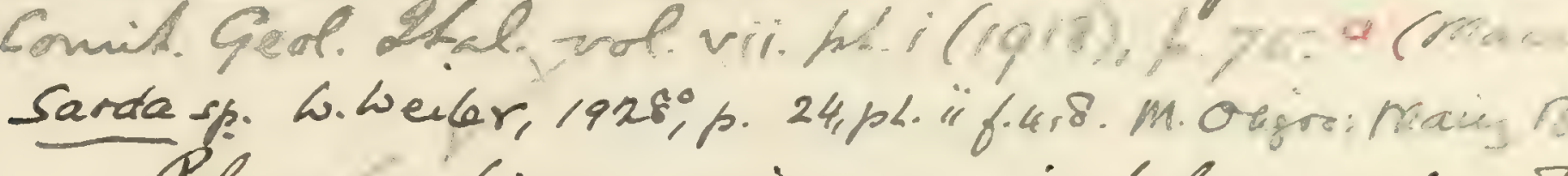
Pelany cybium sinus vindobonensir, F Toula,

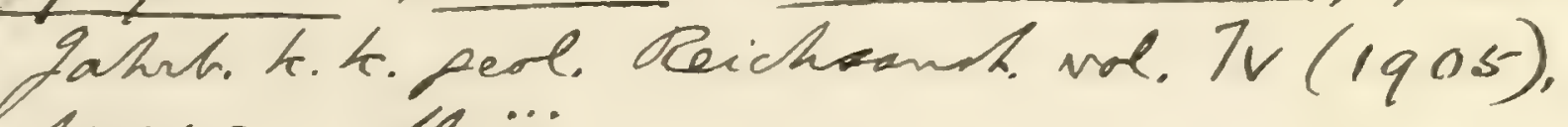

plang. 51-84, Ke. iii.

Pelamye sarda (Timn): G.2hasmo, Bend. D. Stecad. Sci. Topoli, 1922, no. , h. 20, hl. iv. - L. Pleistrcene; Jaranto Crish

Oulamys Grachycefthala. Mr Leriche, Sull. Sor. Belge Gede. to

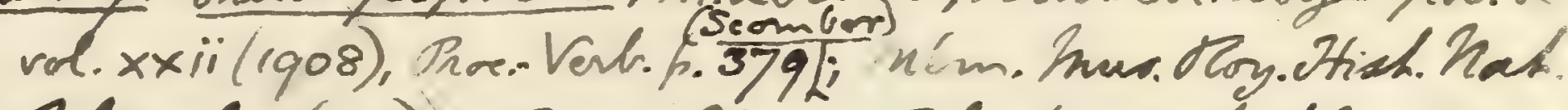
Belp.rol. r(1910)-Doires. Oligov. Belp. h. 314, Leachfip.113-120. - Rupelian; Belgium. [Fead, dr.; Cll Delheidt Hasse

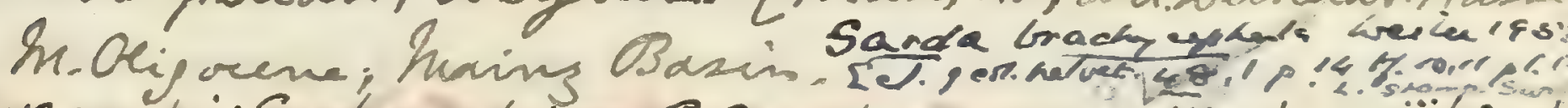

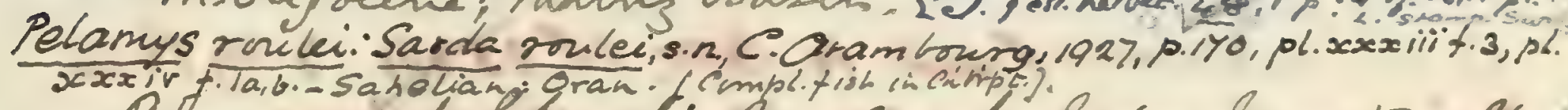

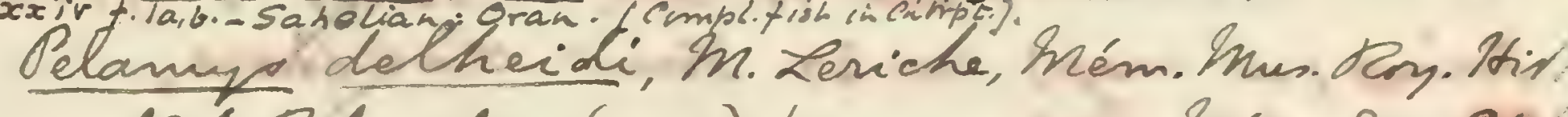
rat. Belp. vole (1906), h. ; Iném. Soc. Géd

- Nord,vol, v(1906), h.240, pl.xiii. fip.4.- Bruxcelian; Ixelles. [Dentary; Delheid Coll.]

Pelamp? halcereina. M. Leriche, Aum dor. Géal. Norl, vol, xxxvi

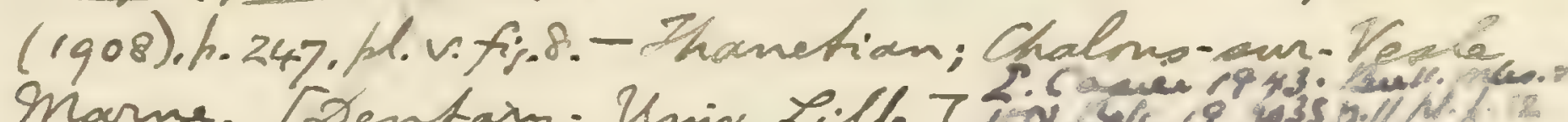

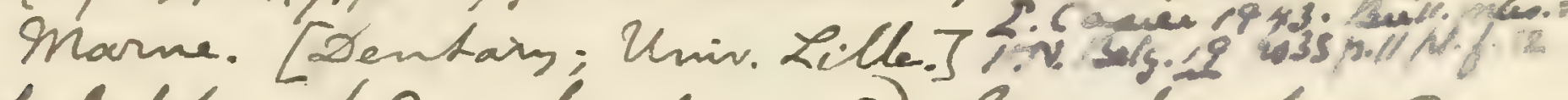
Adolithus (Scantridarun?) lamberti; Friem,

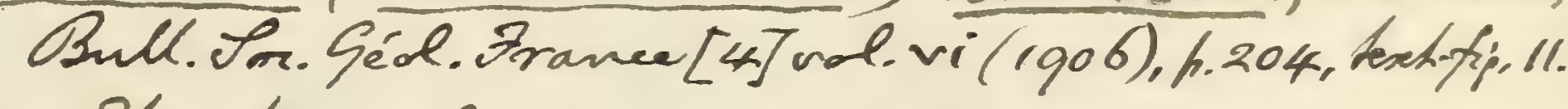
- Stampian; Ormoy

Ozymandias gillerti, F. F. Fordan, Fons. Firher

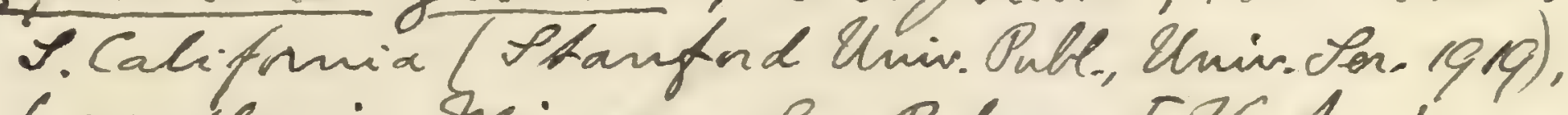
F.43, fl. xxi- Mvivene; Lan Pedro. CVerh., L.." Unir. Calif.] grov I. of Bzymandias.

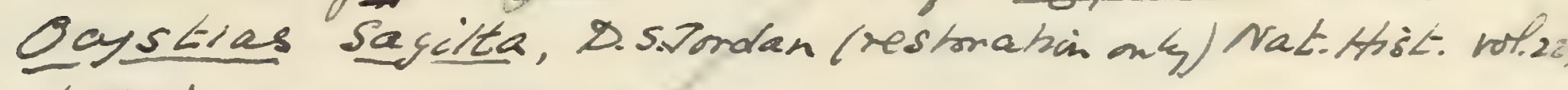
(1922) p.272. Dee 1.K. 
See Grogon Tourad 1837. Am. num

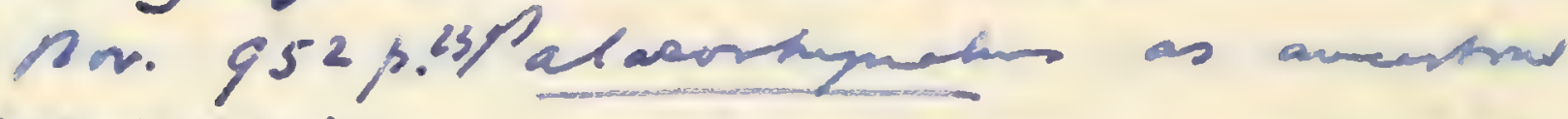
istionsurio

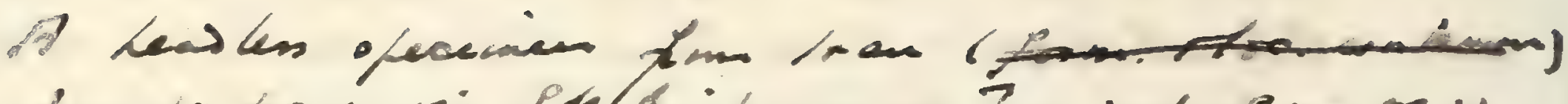

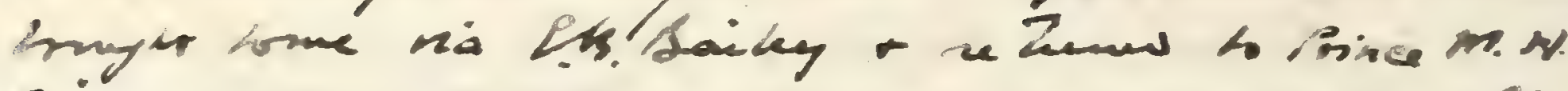

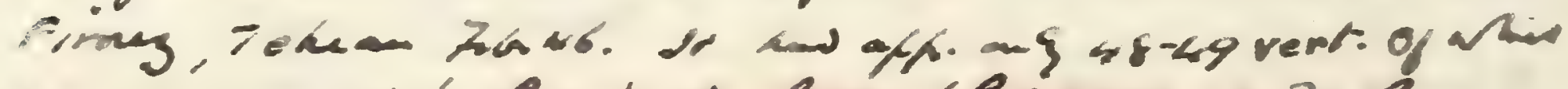

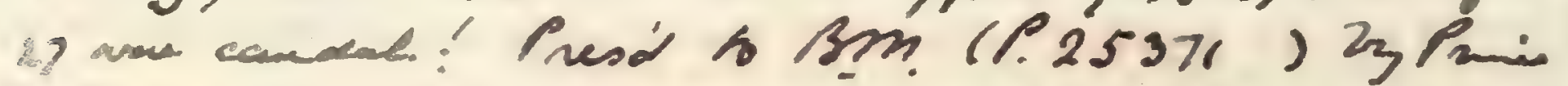

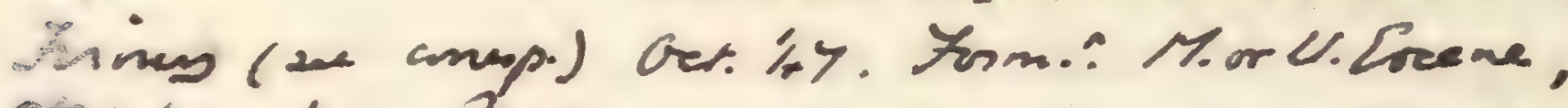

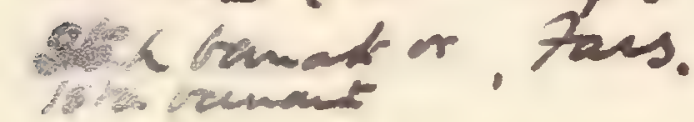

Esp. h. Stamf. Suig' W. Weilon 1952 Ed ged. helwot us 1, p. 18 \&.12,13 pe. 

neural and hæmal spines with a thin laminar expansion on the hinder border. Pectoral fins small; pelvic fins large; dorsal and anal fins much extended, the greater part consisting of feeble spines; caudal fin distinct and well developed. Scales thin and cycloid, or absent.

An imperfectly known extinct family, inhabiting the seas of the Eocene, Oligocene, and Miocene periods. The precise constitution of the cranial rostrum is undetermined.

\section{Synopsis of Genera.}

Jaws of equal length; dorsal fin-spines as numerous as vertebræ below them ...... Palceorhyrchus (p. 483).

Mandible about half as long as rostrum; dorsal fin-spines much more numerous than vertebræ below them................ Hemirhynchus (p. 48.).

\section{Genus PALFORHYNCHUS, H. D. de Blainville.}

[Nouv. Dict. d"Hist. Nat. vol. xxvii. 1818, p. 3il4.]

Articulation of mandible beneath anterior border of orbit, and slender jaws nearly of equal length; teeth apparently absent; preoperculum large and triangular, ornamented with numerous radiating grooves; operculum quadrangular. Vertebræ about 25 in the atdominal, 35 in the caudal region. Pectoral fins small and delicate; pelvic fins large, directly beneath the peotorals, each with 6 rays; dorsal fin extending almost the whole length of the back, its spines consisting of imperfectly-fused right and left halves, and as numerous as the vertebræ below them; anal fin also very extensive, the greater part consisting of spines resembling those of the dorsal; caudal fin forked. Dorsal and anal fin-spines supported by small fan-shaped bones, which are strengthened by three radiating ribs, the shortest extending along the margin of the trunk, the others diverging towards the vertebral axis. Scales small and ovoid.

Palæorhynchus glarisianus, Blainville.

[Text-figure 17.]

1716. Figure by J. J. Scheuchzer, Mus. dilurianum, pl. ix. fig. 6 .

1818. Palcoorhynchum glarisianum, H, D. de Blainville, Nouv. Dict. d'Hist. Nat. vol. xxvii. p. 314.

1834. Palceorhynchum glarisianum, L. Agassiz, Neues Jahrb. p. 303. 1842-44. Palcorhynchum glarisianum, L. Agassiz, Poiss. Foss. vol. v. pt. i. p. 81, pl. xxxiv. 


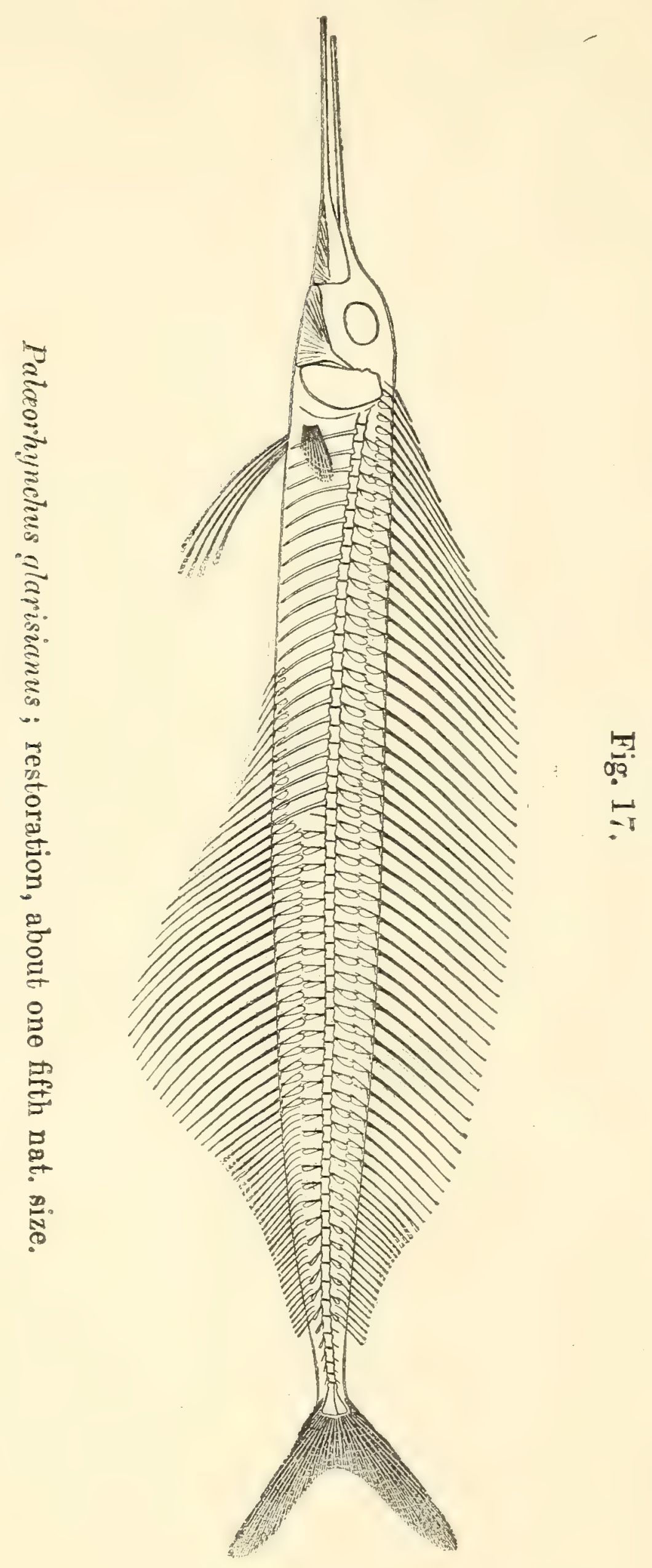


$-5+4 x^{2}$.

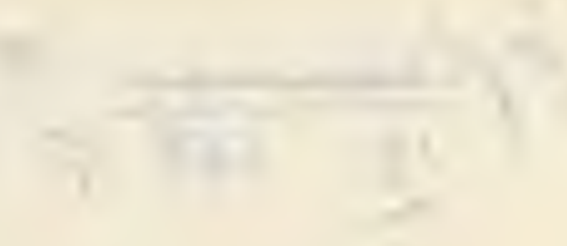


1928. Palaeorhynehus glarisianus, W. beiter, p. 30, pliit fis. pl. iii.t.

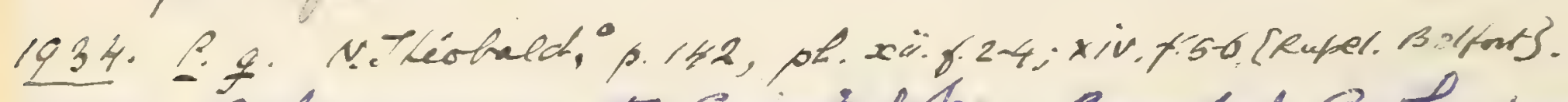

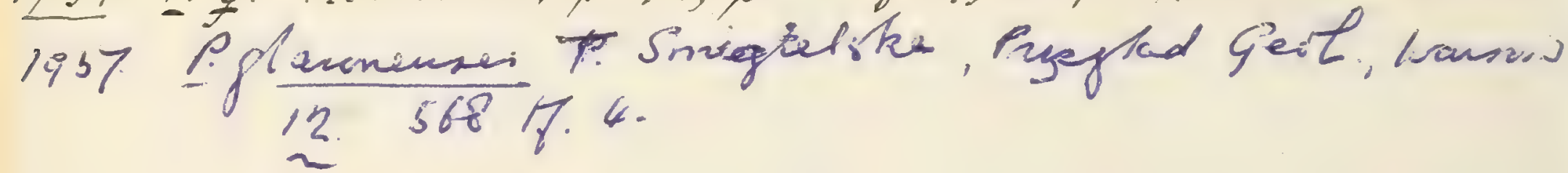


1842-44. Palcorkynchun latum ', L. Agassiz, ibid. p. 82, pl. xxxii. fig. 2, pls. xxxv., xxxvi. [Distorted fish; British Museum.]

1842-44. Paleorkynchum medium ${ }^{1}$, L. Agassiz, ibid. p. 84, pl.xxxiii.

[Fragmentary fish; Zürich Museum.]

1886. Paleorhyrechus glaronensis, A. Wettstein, Fischfauna Tertiaer.

Glarnerschief. (Denkschr. schweiz. Palaeont. Ges. vol.xiii.), p. 73, pl. ii. figs. 14-16.

Type. Imperfect fish.

The type species, attaining a length of about 0.8. Complete length of head with opercular apparatus little less than one half that of the vertebral column; maximum depth of trunk contained about 14 times in total length of fish. Neural and hæmal spines of vertebræ straight and vertical in anterior part of caudal region. Nearly 50 dorsal fin-spines, the length of the longest about equalling that of 10 rertebræ; 15 to 18 short divided rays in the hinder part of the dorsal fin; anal fin with about 35 spines and 32 divided rays, the spines gradually increasing in length to the middle of the fin where they are longer than the dorsal spines.

Almost all the known fossilised examples of this species are considerably distorted, and it is difficult to determine the exact proportions of the fish. The accompanying restoration (fig. 17) seems to be approximately correct.

Form. \& Loc. Oligocene: Canton Glarus, Switzerland.

P. 1713. Head with abdominal region, described and figured as belonging to this species by Agassiz, tom. cit. p. 81, pl. xxxir. fig. 1; Engi. Some of the elongated rays of both pelvic fins are shown.

Egerton Coll.

P. 503, P. 4123. Type specimen of the so-called Palcorhynchum latum, in counterpart, figured by Agassiz, tom. cit. pl. xxxii. fig. 2 ; Engi. The skeleton, which is deepened by distortion, is much obscured by matrix, the false appearance of a large crest on the head in the figure being due to this circumstance. A lithographed plate of this specimen was published by the Earl of Enniskillen (when Lord Cole) in 1820.

Egerton \& Enniskillen Colls.

41814. Fine specimen 0.8 in length, but a little elongated by crushing; Engi. There are remains both of pectoral and pelvic fins; and three of the pelvic fin-rays preserved seem to bifurcate distally. The separation of the two halves of the dorsal fin-spines is distinct.

Purchased, 1869.

1 These specific names were first published without definition in Egerton's Catal. Foss. Fish, 1837. 
P. 2070. Imperfect fish shortened and deepened by distortion, also showing the separation of the two halves of the dorsal and anal fin-spines; Engi.

- Egerton Corl?

P. 4125. Another large distorted specimen, labelled P. glasisianum by Agassiz; Engi.

Enniskillen Coll.

P. 1715. Small fish labelled $P$. medium by Agassiz, apparently noticed, tom. eit. p. 84 ; Engi.

Egerton Coll.

36085. Remains of another small fish, in counterpart; Plattenberg. Purchased, 1861

41815-16, -18. Imperfect small fish and two fragments, well disengaged from matrix, displaying parts of head, preopercula, and median fins; Engi.

Purchased, 1869.

P. 4523. Imperfect small slender specimen, labelled Palcoshynchum gracite, Egerton; Engi.

Enniskillen Coll.

42812. Another small imperfect specimen.

Van Breda Coll.

P. 1714, P. 1716-17, P. 4126, P. 430\%. Various fragments, some labelled by Agassiz; Engi. Egerton \& Enniskillen Colls.

\section{Palæorhynchus longirostris, Agassiz.}

1842-44. Palceorhynchum longirostre, L. Agassiz, Poiss. Foss. vol. v. pt. i. p. 79, pl. $x x x i v a$. fig. 3.

1886. Palcorhynchus longirostris, A. Wettstein, Fischfauna Tertiaer. Glarnerschief. (Denkschr. schweiz. Palaeont. Ges. vol. xuii.), p. 75.

Type. Imperfect fish; British Museum.

The largest known species, attaining a length of about $1 \cdot 5$. Skeleton stouter than in the type species; neural and hæmal spines of vertebræ gently arched backwards in anterior part of caudal region; total number of vertebræ about 55.

Form. \& Loc. Oligocene: Canton Glarus, Switzerland.

P. 456, P. 4124. Type specimen, in counterpart, described and figured by Agassiz, loc. cit.; Engi.

$$
\text { Egerton \&. Enniskillen Colls. }
$$

41817. Remains of head and abdominal region of larger fish; Engi. Purchased, 1869. 
1932: W. Weiler, $10.326,6.8 .21$. 
$1976^{\circ}$

Palacerhynchus efr. 3rikeli, M. Pauca", p.53. Oligre.

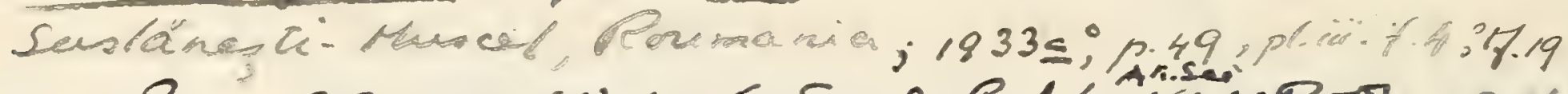

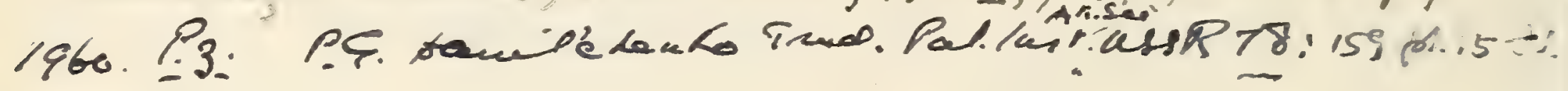




\section{Palæorhynchus zitteli (Kramberger).}

1879. Hemirhynchus zitteli, D. G. Kramberger, Palæontogr. vol. xxvi. p. 59, pl. xv. fig. 1 .

1886. Palcorhynchus zitteli, A. Wettstein, Fischfauna Tertiaer. Glarnerschief. p. 72.

1888. Palaorhynchus zitteli, K. A. von Zittel, Handb. Palæont. vol. iii. p. 301, fig. 312 .

Type. Imperfect fish ; Palæontological Museum, Munich.

An imperfectly known species closely resembling the type, but apparently a little deeper in proportion to its length.

The type specimen is important as showing the laminar expansions of the vertebral arches and fin-supports.

Form. \& Loc. Lower Oligocene: Rajcza, Galicia.

Not represented in the Collection.

Fragmentary specimens of species not represented in the Collection have also been deseribed as follows:--

Palcorhynchus deschmanni, D. G. Kramberger, Rad Jugoslav. Akad. vol. lxxii. (1885), p. 41, pl. i., pl. iii. fig. 3, and Soc. Hist. Nat. Croatica, vol. i. (1886), p. 134.-Upper Oligocene ; Sagor, Croatia. [Portion of trunk.]

Paloorhynchus giganteus, A. Wagner, Sitzungsb. k. bay. Akad. Wiss. 1860, p. 52.-Upper Oligocene; Siegsdorf, near Traunstein, Bavaria. [Imperfect fish; Palæontological Museum, Munich.]

Pulcorhynchus cfr. glaronensis, F. Bassani, Atti R. Accad. Sci. Napoli [2] vol. iii. no. 6 (1889), p. 98, pl. xv. fig. 2.Lower Miocene; Chiavon, Vicentin. [Imperfect fish ; Piovene Collection, Lonedo.]

Paloeorhynchus riedli, D. G. Kramberger, Djela Jugoslav. Akad. vol. xvi. (1895), p. 61, pl. xi. fig. 1.-Upper Oligocene; Trifail, Croatia. [Imperfect fish; Zilli Museum.]

Paloorhynchus is also known from the Oligocene of Buchsweiler and Froidefontaine in Alsace (F. Steindachner, Sitzungsb. k. Akad. Wiss., math.-naturw. Cl. vol. liv. pt. i. 1866, p. 150).

The following fragmentary specimens from the London Clay of Sheppey closely resemble the corresponding parts of Palocorhynchus and cannot jet be generically distinguished:-

P. 646-7. Two imperfect crania, one being 0.085 in length, labelled by Egerton as intended to be the type specimens of Ptychocephalus radiatus, Agassiz, recorded by name only in 
Poiss. Foss. vol. v. pt. ii. (1844), p. 139, and Rep. Brit. Assoc. 1844 (1845), p. $307 . \quad$ Egerton Coll.

P. 1741. Similar cranium with mandibular suspenśrium, and fragments of mandible and opercular apparatus. Egerton Coll.

33136, 35692. Two imperfect crania. Purchased, 1858-59.

Genus HEMIRHYNCHUS, Agassiz.

[Poiss. Foss. vol. . . pt. i. 1844, p. 87.]

Syn. Homorhynchus, P. J. Van Beneden, Bull. Acad. Roy. Belg. [2] vol. $x \times x v .1873$, p. 210.

Head as in Palocorhynchus, but slender rostrum about twice as long as mandible. Vertebræ about 25 in the abdominal, 28 in the caudal region. Pectoral fins small and delicate; pelvic fins larger; dorsal fin extending almost the whole length of the back, its rays about twice as numerous as the vertebræ; anal fin also very extensive, with rays much more numerous than the vertebræ; caudal fin forked. Dorsal and anal fin-supports as in Palcoorhynchus.

Hemirhynchus deshayesi, Agassiz.

1839. Histiophorus deshayes, L. Agassiz, Poiss. Foss. vol, v. pl. xxx.

1844. Hemirhynchus deshayes, L. Agassiz, Poiss. Foss. vol. v. pt. i. p. 88.

1852. Hemirhynchus deshayes, P. Gervais, Zool. \& Pal, Franç., Poiss. Foss. p. 7, pl. lxxi. figs. 2, 3.

Type. Imperfect distorted fish; Paris Museum of Natural History.

The type species, attaining a length of about $0 \cdot 45$. Maximum depth of trunk contained about eight times in length from pectoral arch to base of caudal fin.

Snout incomplete in known specimens.

Form. \& Loc. Niddle Eocene (Calcaire Grossier): Paris.

Not represented in the Collection.

\section{Hemirhynchus colei (Agassiz).}

1842-44. Palcorhynchum egertoni ${ }^{1}$, L. Agassiz, Poiss. Foss. vol. v. pt. i. p. 80, pl. xxxiv a. fig. 1. [Imperfect fish; British Museum.]

1842-44. Palcorhynchum colei ${ }^{1}$, L. Agassiz, ibid. p. 85, pl. xxxii. fig. 1.

1 These specific names were first published without definition in Egerton's Catal. Foss. Fish, 1837. 
1906. Palleontynthus deshayesi; An. Leriche, Iném Sor. Gér. vord vol. v. h. 364 .

1908. Paldeorhynchus deshayeai; FPriem, Poins Aors Bassin Parisien (Oubl. Amn. Paléont.). p. 112, plev.

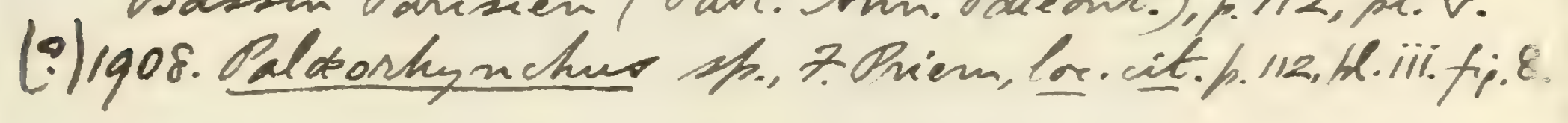




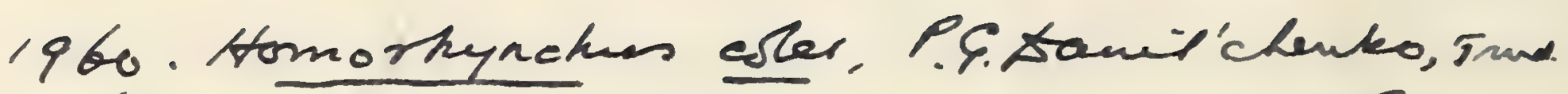

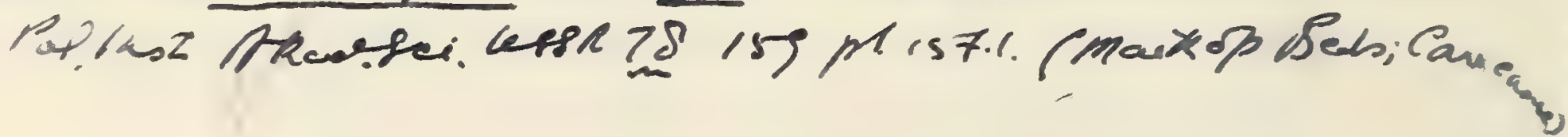


1842 44. Palcoorhynchum microspondylum ${ }^{1}$, L. Agassiz, ibid. p. 85, pl. xxxiv $a$. fig. 2. [Distorted trunk; British Museum.]

1886. Hemirhynchus colei, A. Wettstein, Fischfauna Tertiaer. Glarnerschief. (Denkschr, schweiz. Palaeont. Ges. vol. xiii.), p. 78.

Type. Imperfect fish; British Museum.

A species attaining a length of about $0 \cdot 6$. Head depressed, its maximum depth about two thirds that of the trunk; length from end of snout to anterior border of orbit equalling nearly one quarter of total length of fish to base of caudal fin; mandible not quite half as long as rostrum. Length of longest dorsal fin-spines less than half as great as depth of trunk at their insertion; soft dorsal fin beginning at eleventh vertebra, soft anal at fourteenth vertebra from caudal fin.
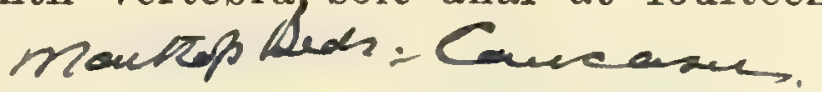

Form. \& Loc. Oligocene: Canton Glarus, Switzerland.

P. 4122. Type specimen described and figured by Agassiz, Toc. cit.; Engi. The skeleton is much obscured by matrix, and the remains in the abdominal region cannot be satisfactorily interpreted. The rays apparently of the pelvic fins are inaccurately multiplied and extended in the drawing.

Enniskillen Coll.

P. 455, P. 4120. Type specimen of the so-called Palcoorhynchum egertoni, in counterpart, described and figured by Agassiz, loc. cit.; Engi. The skeleton is much obscured by matrix, and the so-called "two singular plates of oval form" supporting the caudal fin, are merely the artist's interpretation of a film of slate. So far as the obscurity of the specimen permits judgment, it seems that the soft dorsal and anal fins had the same extent as in H. colei; and there is no evidence that the supports of the dorsal finspines differed from those in this species.

Egerton \& Enniskillen Colls.

P. 504, P. 4121. Type specimen of the so-called Palcoorhynchum microspondylum, in counterpart, described and figured by Agassiz, loc. cit.; Engi. It is an imperfect trunk shortened and deepened by distortion.

Eyerton \& Enniskillen Colls.

33943-44. Imperfect trunk in counterpart; Engi.

Presented by Miss Elizabeth Warne, 1859.

40178. Imperfect hinder portion of small trunk; Engi. 
The end of the tail of an undetermined species of Hemirhynchus has also been described as follows:-

Homorhynchus bruxelliensis, P. J. Van Beneden, Bull. Acad. Roy. Belg. [2] vol. xxxv. (1873), p. 210, with plate. Paloeorhynchum bruxelliense, H. Le Hon, Prélim. Mém. Poiss. Tert. Belg. (1871), p. 14 (name only)-Middle Eocene (Bruxellian); Brussels.

\section{Family XIPHIID疋.}

Trunk fusiform, with much-contracted caudal pedicle and large, forked caudal fin; skeleton very robust. Premaxillæ produced into an elongated rostrum and fused together towards their anterior extremity; dentition feeble or absent. Vertebræ 24 to 26 in number, about half being caudal; the centra firmly united, and the neural and hæmal spines expanded into laminæ. Pectoral fins of moderate size; pelvic fins with less than 5 articulated rays, or entirely absent; dorsal fin much extended, with few anterior spines, a small posterior portion sometimes separated; anal fin also extended, sometimes with small separate posterior portion. Squamation more or less discontinuous or absent. Air-bladder large.

"Sword-fishes" are common in all tropical and subtropical seas, and three genera are distinguished as follows :-

Rostrum rounded in section; teeth minute, persistent; pelvic fins with 2 or 3 rays; dorsal fin much elevated, undivided; scales present ................ Histiophorus.

Rostrum rounded in section; teeth minute, persistent; pelvic fins a single spine; dorsal fin not deeper than trunk, divided in adult; scales present ..........

Rostrum much depressed, a flattened blade; teeth absent in adult; pelvic fins absent; dorsal fin much elevated, usually divided in adult; scales absent in adult....

\section{Tetrapturus.}

Xiphias.

The known fossils are too imperfect to be referred with certainty to their respective genera. Most of them probably belong to Histiophorus or Tetrcpturus; but at least one genus from the Eocene is distinguished from the existing members of the family by the form of the cranial roof and the duplication of each nutritive canal in the premaxillæ (Xiphiorhynchus).

Genus XIPHIORHYNCHUS, Van Beneden.

[Bull. Acad. Roy. Belg. (2) vol. xxxi. 1871, p. 499.]

Syn. (?) Ommatolampes, G. Fischer de Waldheim, Ommatolampes et Trachelacanthus, 1851, p. 4. 


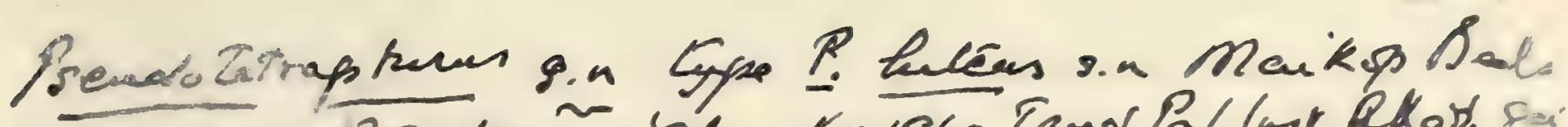

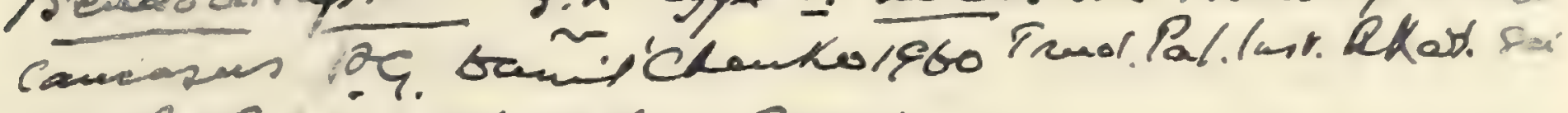

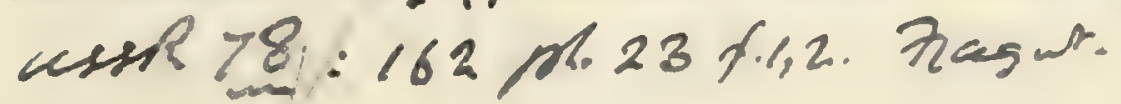

Paldortupucturs sto, Mr. Zeriche, Inén. Sou. Géd. Nord, rol.v (1906), h.250; Hném. hum. Dem. Thist. Nat. Bele, vol. iii (1905), Drin. Sócènes Belpo.th.15\%.

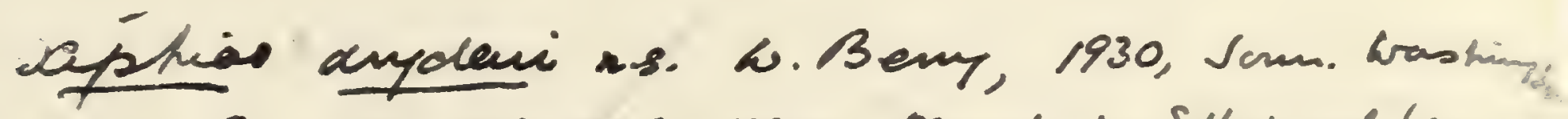

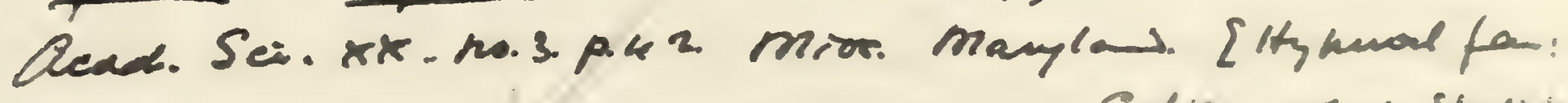
ferimu, omis sblicund

For stmeture of roztrum see C. 2. tagan, Am. Indg. hath. Thish. [8] rol. iii (1909), h.73.

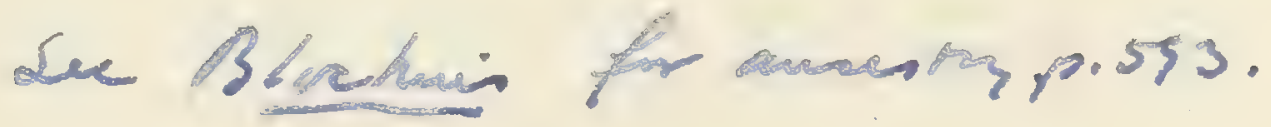




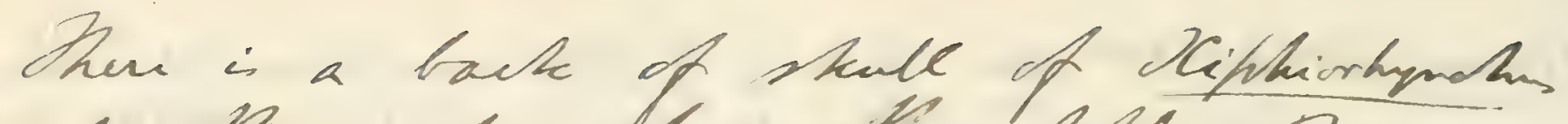
coth the rostra from the Ashler Riven Phosphates in the Amun. Hum. hat. Thish, suen by SADOS Deph 1904 .

1906. Xiphiorhymehur elepans, In. Leviche, Aném. Sor. Séd. sord, wol.v. h.2s-2, hl. xiv. fis. $z$.

190s: Xiphiorhynchur prisens, In. Leriche, Mnem. Anus. Roy.

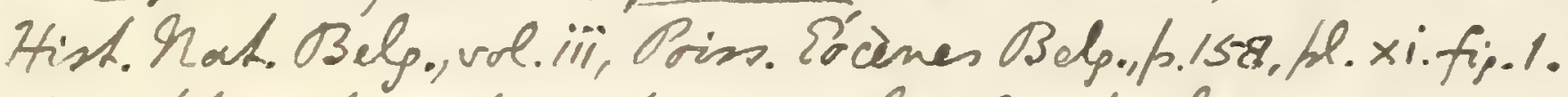
1906. Xiphiorhynehus prizuns, Mr.Zeriche, hém. Sor. Se'd. Nord, vol. v. f. 251, hl. xiv. fip. I.

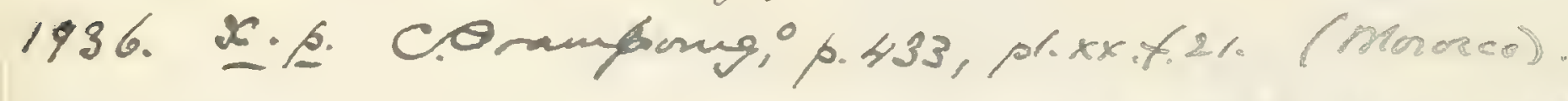

1952. X.P.

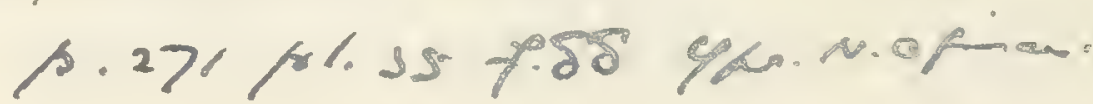





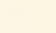


Roof of cranium gently and regularly convex, the fossæ for the forward production of the lateral muscles of the trunk very slightly extended over the occipital border; rostrum rounded in section, and each premaxilla traversed by two principal longitudinal nutritice canals, one above the other. Teeth minute and clustered.

This genus is only definitely known by the skull, but typical Xiphioid vertebræ occur in the same formations as the fossils referred to it.

\section{Xiphiorhynchus elegans, Van Beneden.}

1871. Xiphiorhynchus elegans, P. J. V'an Beneden, Bull. Acad. Roy. Belg. [2] vol. xxxi. p. 499, pl. ii. figs. $3,4$.

Type. Rostrum; Abbey of Affligem, Melle, near Ghent.

The type species, known only by the rostrum, about 0.2 in length by 0.03 in width at the base. Rostrum rather depressed, twice as broad as deep near the base.

Form. \& Loc. Hidlle Eoeene (Brux ellien): Belgium.

Not represented in the Collection.

\section{Xiphiorhynchus priscus (Agassiz).}

[Plate XIX. figs. 1, 2. Text-figure 18, no. 1.]

(?) 1829. Chelonia radiata, G. Fischer, Nouv. Mém. Soc. Imp. Nat. Moscou, vol. i. p. 297, pl. xx. fig. 2. [Portion of skull; Geological Nuseum, University of Mescow.]

1834. Tetrapturus, L. Agassiz, Nenes Jahrb. p. 303.

1839-4t. Tetrapterus priscus, L. Agassiz, Poiss. Foss. vol. v. pt. i. p. 91, pl. xxxi.

(?) 1851. Ommatolampes eichwaldi, G. Fischer de Waldheim, Ommatolampes et Trachelacanthus, p. 3, pl. i. [=Chelonia radiata, 1829].

1869. Histiophorus priscus, E. D. Cope, Proc. Boston Soc. Nat. Hist. vol. xii. p. 310.

Type. Imperfect skull ; Museum of Natural History, Paris.

Rather larger than the type species, with a less depressed rostrum, which is always more than half as deep as broad.

In physical characters the type specimen of the so-called Ommatolampes is identical with the fossils from the London Clay of Sheppey. It is said to have been obtained from Siberia, but in the original description (1829) the exact losality and circumstances of its discovery are stated to be unknown.

Form. \& Loc. Lower Eocene (London Clay): London Basin.

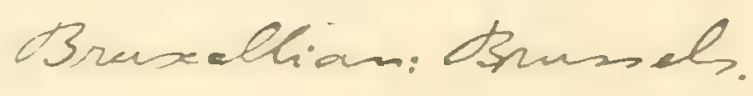


28711. Imperfect anterior portion of cranium, wanting rostrum, shown of the natural size from the upper and left lateral aspects in Pl. XIX. figs. 1, $1 a$; Sheppey. The bones exhibit a coarsely fibrous texture. The greater portion of the left frontal $(f r$.$) is seen, with a fragment of that of$ the right side. In front of these there occurs a median element (eth.), which seems to be a membrane-bone on the ethmoidal region rather than the mesethmoid itself. Another median pair of bones, evidently long and narrow, quite at the base of the rostrum, are doubtless to be interpreted as nasals (na.). The position of the orbit is marked by remains of the ossified sclerotic (scl.). Shortly in advance of this a trace of the prefrontal (ectethmoid) projects through the matrix on the left side ( $p r . f$.$) , while$ its fellow is still better exposed on the right. The maxilla $\left(m x_{0}\right)$ is preserved on both sides, and its upper expansion is articulated with the antero-external border of the frontal, besides being almost or quite in contact with the ethmoidal plate, and distinctly in contact with the hinder part of the outer border of the nasal. The rod-like backward extension of the maxilla beneath the orbit is shown on the right side, though it is broken away from the main part of the bone. Remains of the premaxilla, which is much smoother than the other bones, are seen on both sides. Part of this element occurs in its natural position on the left ( $p m x$.$) ; while the fragments$ on the right show that it bore clustered minute teeth (fig. $1 b$ ) and completely excluded the maxilla from the gape.

Purchased, 1853.

32387. Hinder half of cranium in hard nodule, exposing the cranial roof, which is shown of the natural size in Pl. XIX. fig. 2 ; Sheppey. The two pairs of fossæ for the forward extension of the lateral muscles of the trunk are very small and restricted to the occipital border. The roof is gently and regularly convex. The supraoccipital (s.occ.) is large and extends forwards to the frontals; it is a little expanded in front, and bears a small median vertical crest behind. Its postero-external angle is in contact with the epiotic (ep.o.), which is large and prominent but only preserved on the right side. The parietals ( $p a_{.}$) are long and narrow bones extending nearly as far forwards as the supraoccipital; they are flanked by an equally long and narrow pair of squamosals $(s q$.$) . The otic region beneath$ 
the latter is evidently well ossified, and the postfrontal or sphenotic (pt.f.) is seen on both sides. The frontal bones $(f r$.$) are incomplete anteriorly. All the bones have the$ peculiar squamous and radiating texture, well represented in the figure. Purchased, 1857.

36133. Two imperfect rostra, one shown in outline in fig. 18, no. 1 (p. 496), the other in three transverse sections, fig. 18, nos. $1 a, b, c$; Sheppey. The proximal transverse section of the second specimen (no. 1 a) exhibits incomplete fusion of the premaxillæ, and a large median cavity with which the upper pair of premaxillary canals are confluent. The next transverse section (no.1b), which corresponds approximately with the line marked $b$ in no. 1 , shows the premaxillæ fused and the central cavity small, with two pairs of nutritive premaxillary canals. The third transverse section (no. 1c) has the canals, but not the central cavity.

Purchased, 1861.

38921. Small hinder portion of cranium, doubtfully referred to young of this species; Sheppey.

Bowerbank Coll.

The following Xiphioid vertebral centra probably belong to this genus, some perhaps to this species:-

38887-88. Four specimens; London Clay, Sheppey.

Bowerbank Coll.

P. 4301. Two large abdominal vertebral centra associated in matrix; Sheppey.

Enniskillen Coll.

39444. Three imperfect large caudals, associated in matrix; Sheppey. Bowerbank Coll.

P. 165. Small abdominal vertebral centrum; Sheppey.

Purchased, 1880

30530. Small caudal; Sheppey.

Purchased, 1855.

32389. Two very small centra; Sheppey.

Purchased, 1857.

P. 5441 a. Imperfect caudal centrum; Bracklesham Reds, Bracklesham, Sussex. Presented by P. E. Coombe, Esq., 1888.

The following imperfect Xiphioid rostra are not generically determined :-

P. 1765. Portion of depressed and much-elongated rostrum, showing one central canal; London Clay, Sheppey. Egerton Coll. 
P. 4300. Another slender flattened rostrum, smaller and showing two longitudinal canals; London Clay, Sheppey.

Enniskillen Coll.

P. 9483. Acuminate end of flattened rostrum; London Clay, Sheppey.

History unknown.

\section{Genus ACESTRUS, novum.}

[ex Agassiz MS., Rep. Brit. Assoc. 1844 (1845), p. 308.]

A genus known only by the hinder portion of the cranium, considered by Agassiz to belong to a fish of the family Xiphiidx. Cranium flattened and depressed, the sides of the roof slightly sloping downwards and outwards; the three pairs of fossæ for the forward production of the lateral muscles of the trunk extending to the frontals, which are large and ornamented with conspicuous radiating smooth ridges.

\section{Acestrus ornatus, sp. nov.}

[Plate XIX. fig. 3.]

1845. Acestrus ornatus, L. Agassiz, loc. cit. p. 308 (name only).

Type. Hinder fragment of cranium; British Museum.

The type species, with cranium as much as 0.075 in diameter at occiput. Special characters of roof shown in the figure.

Form. \& Loc. Lower Eocene (London Clay): London Basin.

P. 62\%. Abraded fragment of hinder part of cranium, labelled by Agassiz and marked by Egerton as interded to be the type specimen; Sheppey.

Egerton Coll.

P. 1739. Larger specimen, weli preserved but partly pyritised, shown from above of the natural size in Pl. XIX. fig. 3 ; Sheppey. The epiotics (e.p.o.) are relatively large and prominent; the exposed ornamented portions of the supraoccipital $(s . o c c$.$) , parietals (p a$.$) , and squamosals$ $(s q$.$) are comparatively small. The ornamentation of the$ large frontals $\left(f r_{c}\right)$ is well shown. The postfrontal or sphenotic projects outwards a little on each side.

Egerton Coll.

P. 1739 a. Imperfect hinder half of very small skull; Sheppey.

Egerton Coll. 
Xyphiorhynchus courcellis.n. C. Aramboury, 1927, p. 173, ph. 2xxvit3, L-Fig.40. - Sahelian: Oran. [A ostrum].

Xiphionhynehus sho, M. Zeriche, Mném. Soe Géol. Nod, rol V (1906), f. 322.- Ledian; Cassel (Nod), Inance

Xiphiorthynches aegyptiacus us. W. Weich, Is

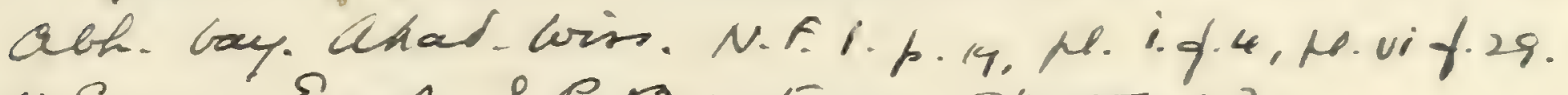

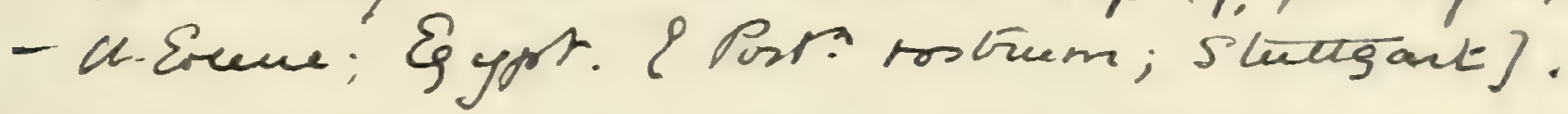

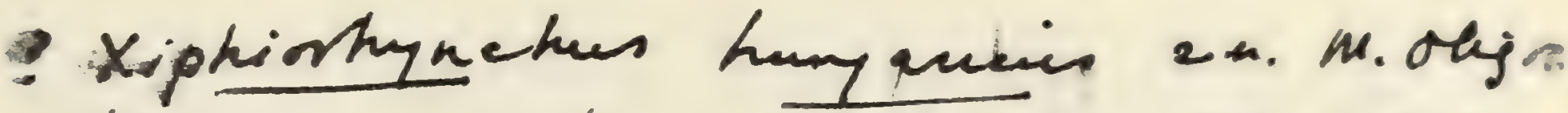
thangary, W. Weake F.d.g.Ser.95 p.214 p.ex f.3-9 (Rustium).

aptiofhyratur sabcostakis s.4. Poenn

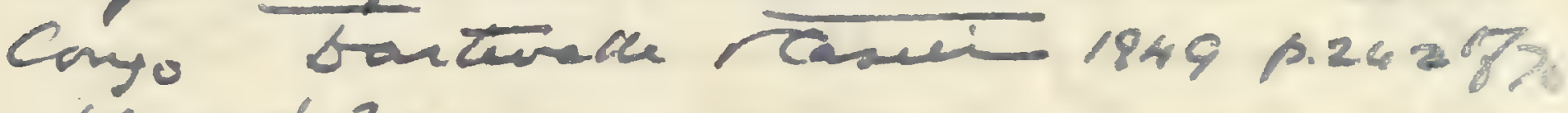
Ne. $x$ \&. 2 . 
1220ks. Ind $f$ mall rostum fortably of his spacier f from the each shore of tolsen Bill where the Bretclestham Beds hases into the Znudow Clay.

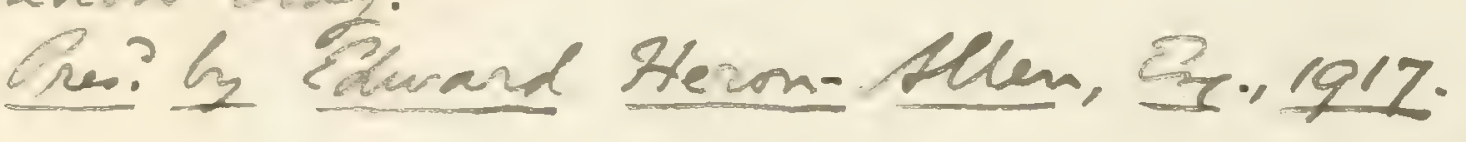

S. Barbolanidimontruts,

Bistighorus hersehelis (Gray), (Palaeont. stalica, vol, xvil (1910), b. ", th. i, iiPhireene; Tuscam. 
. 
Genus HISTIOPHORUS, Lacépède.

[Hist. Nat. Poiss. vol. iii. 1802, p. 374 (Istiophorus).]

The fossils provisionally ascribed to this genus are fragments of rostrum, named only for convenience of reference. Each premaxilla is traversed by one principal longitudinal nutritive canal, which disappears towards the extremity of the bone.

\section{Histiophorus eocænicus, sp. nor.}

[Text-figure 18, no. 2.]

Type. Rostrum; British Museum.

Rostrum rather short and stout, depressed oval in transverse section, its outlines shown in fig. 18, no. 2. Premaxillæ firmly fused distally and nutritive canals soon obliterated.

Form. \& Loc. Niddle Eocene: Bracklesham Bay.

25744. Type specimen, vertically erushed in its anterior half; its outline shown from above and in transverse section of one third nat. size in fig. 18, nos. 2, 2a. The nasal bones are large, and the rostrum is already quite solid at the point marked $a$, where the transverse section $2 a$ has been cut. The surface of the bone seems to have been quite smooth.

Dixon Coll.

Histiophorus rotundus, sp. nov.

[Text-figure 18, no. 3.]

Type. Rostrum; British Museum.

Rostrum very short and stout, not much depressed, its outlines shown in fig. 18, no. 3.

Form. \& Loc. Tertiary Phosphate Beds: South Carolina, U.S.A.

P. 8799. Type specimen, shrown in outline from above and in transverse section, of one third nat. size, in fig. 18, nos. 3, $3 a$; Cooper River, Charleston. The premaxillæ are completely fused together, and the outer face, as preserved, is rugose.

Presented by Thomas Royle, Esq., 1898.

Fossil rostra have also been ascribed to this genus under the following names:-

Histiophorus antiquus, E. D. Cope, Proc. Boston Soc. Nat. Hist. vol. xii. (1869), p. 310. Xiphics antiquus, J. Leidy, Proc. Acad. Nat. Sci. Philad. vol. vii. (1856), p. 397.Eocene Greensand; Burlington Co., New Jersey.

Histiophorus parvulus, O. C. Marsh, Proc. Amer. Assoc. Adv. Sci. 1869 (1870), p. 227.-Eocene; New Jersey. 
ACTINOPTERYGII.

Fig. 18.

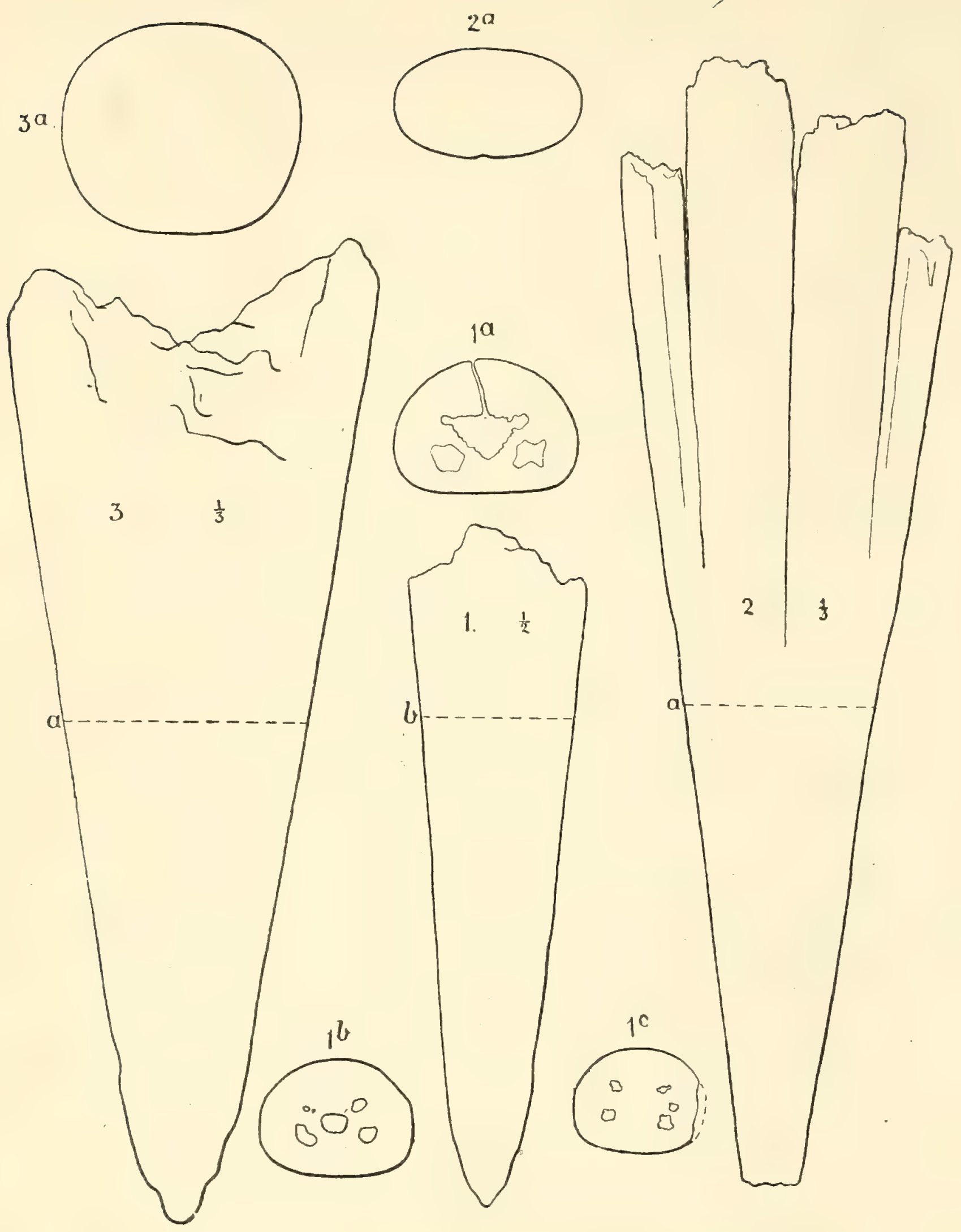

Outlines of Rostra of Extinct Xiphiidæ.

1. Xiphiorhynchus priscus; upper aspect and transverse sections ( $1 a-c)$, one half nat. size.-London Clay; Sheppey.

2. Histiophorus eocenicus; upper aspect and transverse section ( $2 a)$, one third nat. size.-Middle Eocene; Bracklesham.

3. Histiophorus rotundus; upper aspect and transverse section, one third nat. size.-Tertiary Phosphates; South Carolina. 
Istiophorus calvertensis, 2? W. Berry, Amer goum. Sci. [4] rol. x 7iii (19'7), h. 461, texhtofip. 1, 2. - Miocene (Caloert Fomation); Jar Bay. ropinix. LPRostum 

$\leftarrow$ Histiophorus robustus, E. D. Cope, Toc. cit. 1869, p. 310. Xiphias robustus, J. Leidy, in F. S. Holmes, Post-Plioc. Foss. S. Carolina (1860), p. 119, pl. xxvii. figs. 3-5.-Tertiary

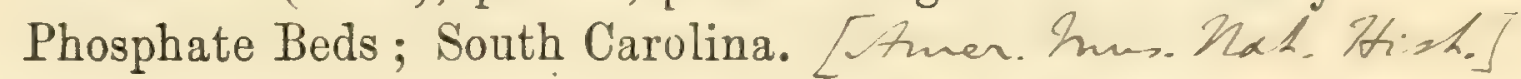
Histiophorus homalorhamphus, E. D. Cope, Proc. Boston Soc. Nat. Hist. vol. xii. (1869), p. 310.-Eocene; Squankum, N.J.

The fossil rostra described as follows are not clearly distinguishable from those of Histiopleorus:-

Brachyrhynchus solidus, P. J. Van Beneden, Bull. Acad. Roy. Belg. [2] vol. xxxi. (1871), p. 498, pl. ii. figs. כ- - Middle Eocene (Brtuxellian); Ghent, Belgium. [Abbey of Affligem, M[elle, near Ghent.]

Brachyrhynchus teretirostris, P. J. Van Beneden, ibid. p. 495, pl. i., pl. ii. figs. 1, 2 ; (?) G. Capellini, Mem. Accad. Sci. Istit. Bologna [3] vol. ix. (1878), p. 255, pl. iii. figs. 9, 10. Encheiziphius teretirostris, L. Rütimeyer, Verhandl. naturf. Ges. Basel, pt. 1 (1857), p. 561.-Pliocene; Montpellier, Southern France, and Antwerp, Belgium. (?) Miocene; Lecce, Italy. [Type species. Natural History Museum, Soleure.]

Brachyrhynchus van-benedensis, R. Lawley, Nuovi Studi Pesci, etc., Colline Toscane (1876), p. 70.-Lower Pliocene; Orciano, Tuscany.

Embalorhynchus kinnei, O. C. Marsh, Proc. Amer. Assoc. Adr. Sci. 1869 (1870), p. 228.--Eocene; Squankum, N.J.

The base of a rostrum, not yet described, from the Lower Pliocene of Orciano, Tuscany, is named Xiphias delfortriei by R. Lawley, op. cit. 1876, p. 67. Deferred to X-gladius, Limn, by

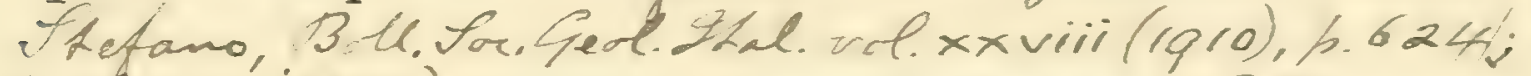
aum $x \times x i\left(9^{/ 2}\right)$, Division C. PERCIFORMES. p.o.

Pectoral fins with hourglass-shaped basals, which are longer than broad; pelvic fins thoracic, with one spine and four or five articulated rays. Dorsal fin-rays well-developed, and anal usually with two or more powerful spines. No bony stay between circumorbital ring and preoperculum.

Synopsis of Families represented by Extinct Genera or Species.

I. Lower pharyngeal bones very rarely fused together.

Teeth small and conical, some on inner bones; spinous dorsal usually as much PART IV. 
extended as articulated dorsal; anal usually with 1 to 3 , rarely with 5 to 7

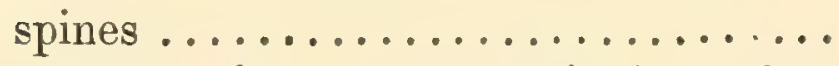

As Percidæ, but only marginal cuttingteeth, and anal with 6 or 7 spines ....

As Percidæ, but marginal teeth prehensile or cutting and molariform ..........

Teeth conical and only marginal; spinous dorsal much less extended than articulated dorsal, which is longer than anal; anal with 1 or 2 spines ........... ScLenrd

II. Lower pharyngeal bones fused together (Pharyngognathi).

Nostril double on each side; vertebræ without transverse processes .......... LABRID 2 (p. 539).

Nostril single on each side; most abdominal vertebræ with transverse processes.... Chromid (p. 554).

\section{Family PERCID $\approx$.}

Teeth small and conical, usually extending over inner bones of mouth; preoperculum serrated. Lower pharyngeal bones nearly always separate. Spinous portion of dorsal fin usually at least as much extended as articulated portion; anal fin usually with 1 to 3 , rarely 5 to 7 spines, nearly equal and opposite to the hinder dorsal fin.

Marine and freshwater fishes universally distributed in temperate and tropical regions.

For figures of skulls and notes on the osteology of the Percidæ, see G. A. Boulenger, Catalogue of the Perciform Fishes in the British Museum, ed. 2, vol. i. (1895).

\section{Synopsis of Extinct Genera and Genera represented by Extinct Species in the Collection.}

I. Three anal fin-spines.

Vertebræ $10+14$; dorsal fin continuous, the two parts nearly equal; caudal rounded ................... Prolates (p. 499).

Vertebræ $10+13$; dorsal fin continuous, hinder part comparatively small; caudal slightly forked ............ Acanus (p. 500).

Vertebræ $12+13$; spine at angle of preoperculum; one spine at hinder edge of operculum; two dorsal fins; caudal rounded or slightly forked ......... Lates (p. 502). 



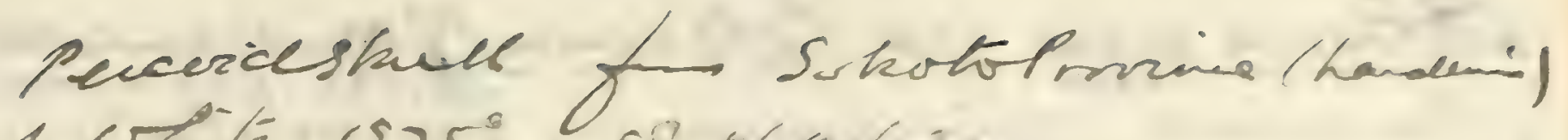

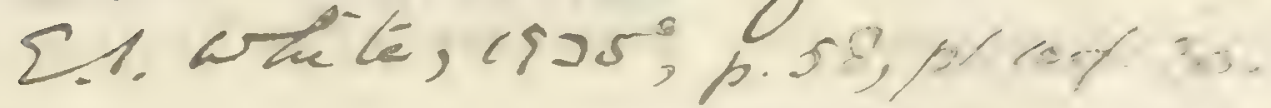

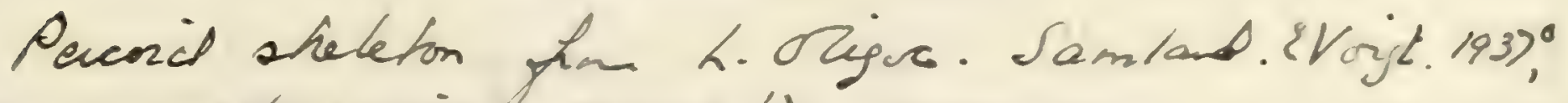

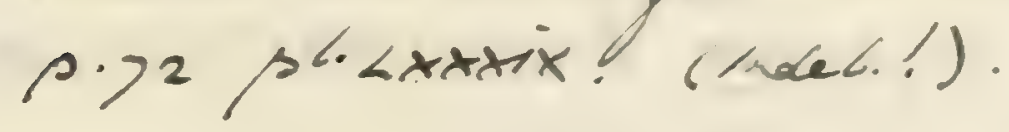

Parérpercen as.w.1842.

Paisioperca libanica 0.85.4. G.54. 1942. A.m?!

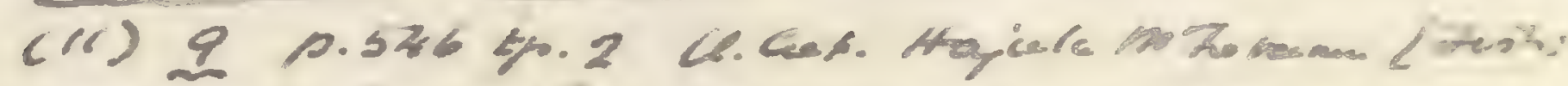

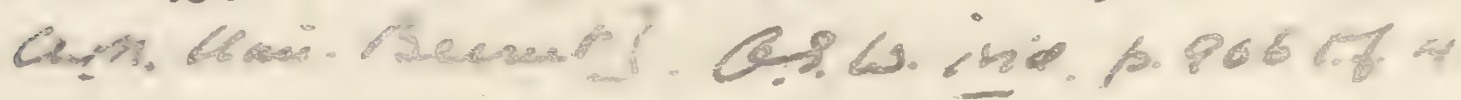

Famu in poponion.

Goman Revand Rams Oysicy

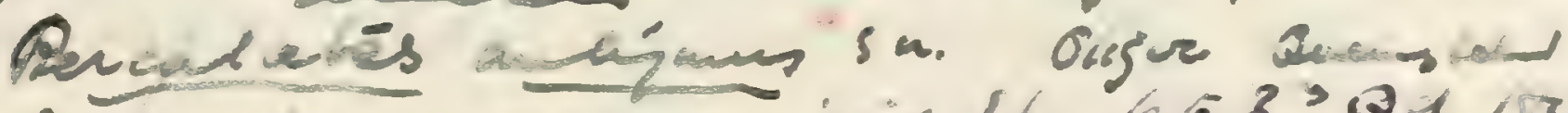

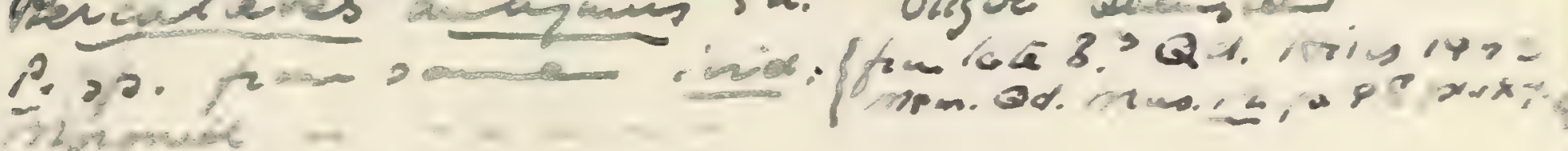

Also Percilia aryusta p.515.

Monone sp. Ma aequalis (wo.sin) M.mozush

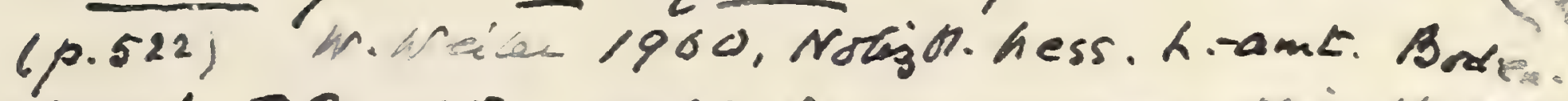
foseh.88:25- fo $2013-20 ; 23 ; 24$ resp. Mir. Itzfie. 


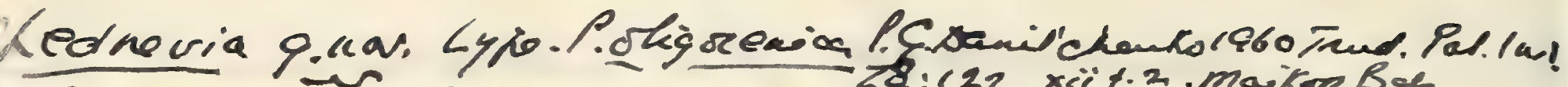

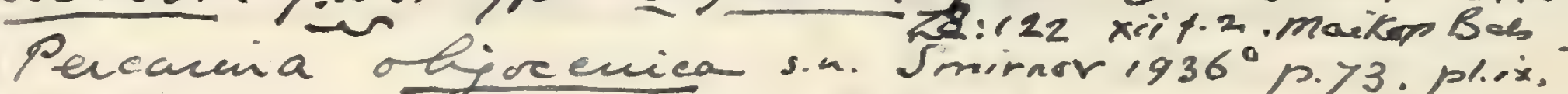

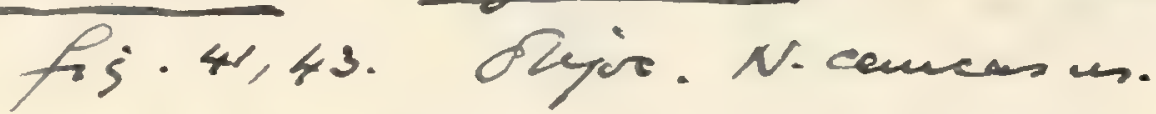

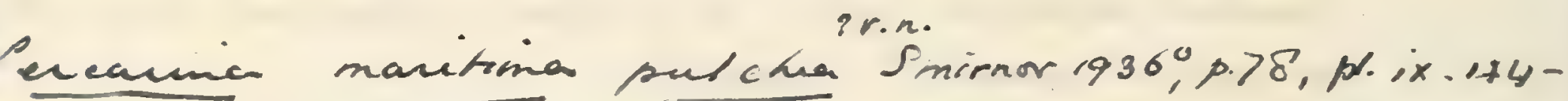

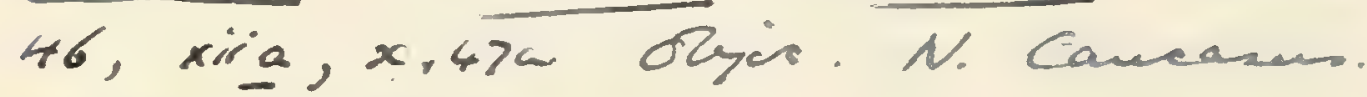

see Boghachev 19385 p. 44 .

Popercasina n.g. M. Pancä, $19296^{\circ} \% .51$.

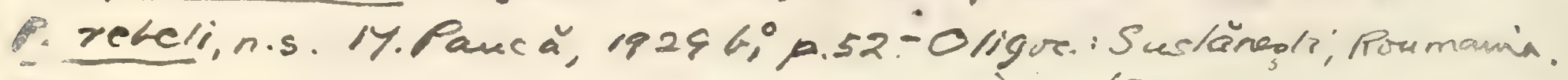

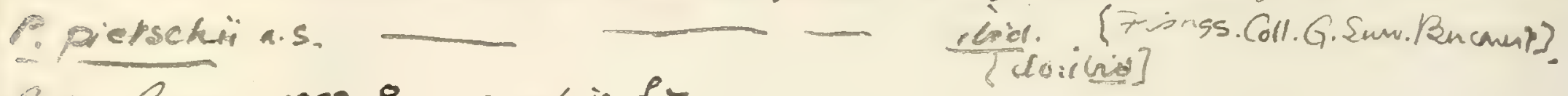

P. Pauca $1930 \varrho^{\circ} p .54$, pliv-f. 7 .

P.p. a $\quad$ a 55 , pliv.f. 6.4.19.

Clémerlales avers s.n. O.S. boudwand 1902, RC.

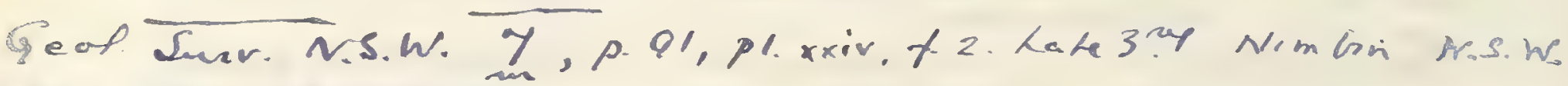
imp. fir G.S. Ir.S. W. Th 

As Lates, but no preopercular spine ......

Vertebræ $10+14$; no preopercular spine;

two dorsal fins; caudal forked ...... Smerdis (p. 506).

Vertebræ $12+13$; no preopercular spine; two feeble spines at hinder edge of operculum; two dorsal fins; caudal truncated or slightly forked .......

Vertebræ 14 or $15+18$ to 20 : no preopercular spine; one opercular spine; two dorsal fins; caudal truncated or slightly forked .................

Vertebræ 10 to $12+16$ to 18 ; no preopercular spine; two dorsal fins;

caudal forked ............... Properca (p. 514).

II. Two anal fin-spines; two dorsal fins.

Vertebræ 10 or $11+14$ or 15 ; opercuIum

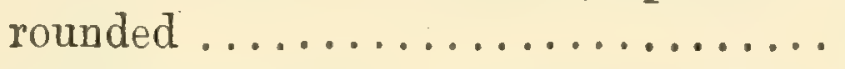

Vertebræ $21+20$ or 21 ; one spine at hinder edge of operculum

Cyclopoma (p. 504).

$\operatorname{Labrax~(p.~509).~}$

Percichthys (p. 514).

Mioplosus (p. 517).

Perca (p. 518).

\section{Genus PROLATES, Priem.}

[Bull. Soc. Géol. France, (3) vol. xxvii. 1899, p. 252.]

Syn. Pseudolates, F. Priem (non Macleay, 1877), loc. cit. vol. xxvi. 1898, p. 408.

Trunk laterally compressed and deeply fusiform. Articulation of mandible not behind middle of orbit; anterior suborbital with deep pectinations; ascending limb of preoperculum with fine pectinations, lower limb with larger, spaced, slender spines, all retrorse; operculum with one spine. Vertebræ 10 or 11 in abdominal, 14 in caudal region. Dorsal fin apparently continuous, with 8 or 9 smooth spines and about 10 articulated rays; anal fin with 3 stout spines and about 7 articulated rays; caudal fin rounded. Scales small and very finely serrated; lateral line conspicuous and arched like the back.

An extinct Cretaceous genus.

\section{Prolates heberti (Gerrais).}

1852. Lates heberti, P. Gervais, Zool. et Pal. Franç., Poiss. Foss. p. 3. 1883. Lates heberti, H. E. Sauvage, Bull. Soc. Géol. France [3] vol. xi. p. 481, pl. xiii. fig. 2 .

1890. Lates heberti, A. Gaudry, Enchaînem. Nonde Animal, Foss. Second. p. 162, fig. 260.

1898. Pseudolates heberti, F. Priem, Bull. Soc. Géol. France [3] vol. xxvi. p. 405, pl. x. figs. $7,8, \mathrm{pl}$. xi. fig. 1.

1899. Prolates heberti, F. Priem, loc. cit. vol, xxvii. p. 252. 
Type. Imperfect fish.

The type species, attaining a length of about $0 \cdot 15$. Length of head with opercular apparatus equalling about three quarters of the maximum depth of the trunk and one third of the total length of the fish to the base of the caudal fin. Fourth to sixth dorsal spines longest; second anal spine largest and stoutest, equalling the third dorsal spine.

Form. \& Loc. Upper Cretaceous (Montian): Mont Aimé, Marne.

28291. About 15 specimens, large and small, showing all the principal characters of the genus and species.

Purchased, 1851.

P. 1914. Fine small specimen, displaying the serration of the anterior suborbital and preoperculum, also the delicate pectoral fin.

Egerton Coll.

Genus ACANUS, Agassiz.

[Poiss. Foss. rol. iv. 1838, p. $4^{1}$.]

Trunk laterally compressed and deeply fusiform. Articulation of mandible not behind middle of orbit; preoperculum finely pectinated. Vertebræ 10 in the abdominal, 13 in the caudal region. Dorsal fin continuous, with 10 very large ribbed spines and about 12 comparatively small articulated rays; anal fin with 3 large ribbed spines and about 13 articulated rays; caudal fin truncated or slightly forked. [Seales unknown.]

An extinct Oligocene genus.

\section{Acanus spinosus (Blainville).}

1818. Zeus spinosus, H. D. de Blainville, Nouv. Dict. d'Hist. N'at. vol. xxvii. p. 317.

1838-39. Acanus ovalis, L. Agassiz, Poiss. Foss. vol. iv. pp. 5, 124, pl. xvi. fig. ]. [Imperfect distorted fish; Carlsruhe Museum.]

(?) 1838-39. Acanus minor, L. Agassiz, ibid. pp. 5, 127, pl. xvi. fig. 4. [Fragmentary fish; Berne Museum.]

1886. Acanus longispina, A. Wettstein, Fischfauna Tertiaer. Glarnerschief. (Denkschr. schweiz. Palaeont. Ges. vol. xiii.), p. 65, pl. iii. figs. 1, 2, 3, 9 .

Type. Imperfect distorted fish.

The type species, attaining a length of about $0 \cdot 5$. Depth of trunk at end of abdominal region about equal to length of caudal vertebræ. Of the dorsal fin-spines only the two foremost smaller

1 This name first appeared without definition in Neues Jahrb. 1834, p. 305. 
. 

Foserramis, A.S.Zoodurad.

[Saldent. Indica, n.s. vol iii. no. 3, 1908, h.3.]

Maxilla muct expanded behind, with one velatively lagee supramaxilla; teeth minnte and clustered, withont caniner; preobereulem gently rounded and sencted, the perritions somewhat enlayed ( hith not phaced) on the rounded angle and slieftly inclined frrwars where the diminist on the lnver limb; operculum smorth, bat ove ridge on its insur faer endiy in a hos. Aerior shine; seabs mall and cycloid, exteno ver at least part of the sperculum.

Eoserramus Zistoki, A.S.Zordw,

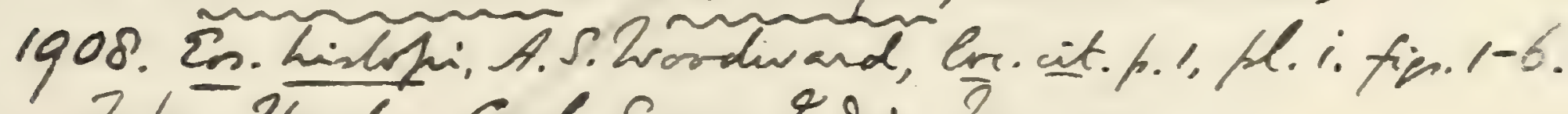
Jyke. Hiead; Ged. Dum. Inbra Znusem.

Foundter. Zameta Bess: India

Pint26-27. Fur fragments from Dongargaon. pres? Diventr, Ged. Sum. In dia, 1909.

1938 F.hislopi ASW, S.L. Hona, Ree gerl. Sum. India, 73:275, 6-6.6.

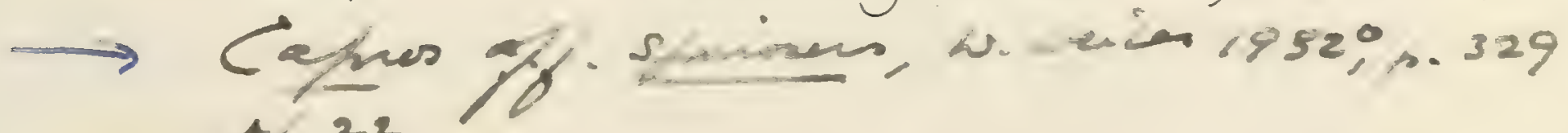

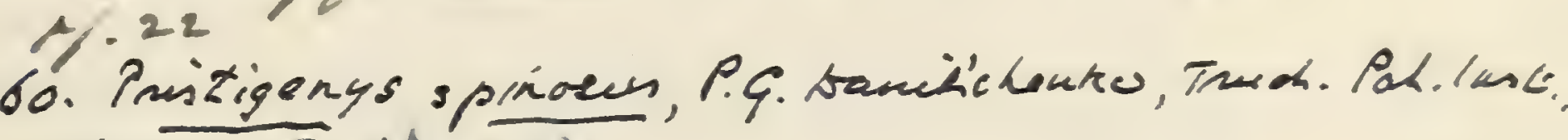
moscow 15 : 45. 

than the others, which are nearly equal in size; pelvic and third anal fin-spines as long as the hindermost dorsal spine.

Form. \& Loc. Oligocene; Canton Glarus, Switzerland. Manoph. Cancerus.

P. 1956, P. 3934. Fragmentary fish in counterpart, displaying the characteristic anal fin-spines, erroneously labelled Acanus oblongus by Agassiz and apparently noticed tom. cit. p. 126 ; Engi. Egerton \&. Enniskillen Colls.

Acanus regleysianus (Blainville).

1818. Zeus regleysianus, H. D. de Blainville, Nouv, Dict. d'Hist. Nat. vol. xxvii. p. 316.

1818. Zeus platessa, H. D. de Blainville, ibid. p. 317. [Imperfect fish; olim Brongniart Collection. J

1838-39. Acanus regley, L. Agassiz, Poiss. Foss. vol. iv. pp. 5, 125, pl. xvi. fig. 2.

1838-39. Acanus oblongus, L. Agassiz, ibid.pp. 5, 126, pl. xvi. fig. 3. [Imperfect fish ; Neuchâtel Museum.]

1838-39. Acanus arcuatus, L. Agassiz, ibid. pp. 5, 127. [Imperfect fish; British Museum.]

1886. Acanus regley, A. Wettstein, Fischfauna Tertiaer. Glarnerschief. p. 65 , pl. iii. figs. 4,7 .

Type. Imperfect distorted fish; olim Regley Collection.

Usually smaller than the type species, with relaticely deeper trunk and smaller spines. The three foremost dorsal fin-spines shorter than those following; pelvic and anal spines shorter than those of the dorsal fin.

Form. \& Loc. Oligocene: Canton Glarus, Switzerland.

P. 3933. Type specimen of so-called Acanus arcuatus, briefly described by Agassiz, tom. cit. p. 127 ; Engi.

Enniskillen Coll.

33966. Imperfect deepened trunk, displaying large pelvic fin-spine; Engi. $\quad$ Presented by Miss Elizabeth Warne, 1859.

P. 3935. Imperfect deepened specimen; Engi. Enniskillen Coll.

P. 4950. Another deepened specimen; Plattenberg.

Presented by John Edward Lee, Esq., 1885.

The following species have also been recognised, but are not represented in the Collection :-

(?) Acanus aequispina, A. Wettstein, Fischfauna Tertiaer. Glarnerschief. (1886), p.67. Acanus oblongus, G. vom Rath, Zeitschr. deutsch. geol. Ges. vol. xi. (1859), 
p. 111, pl. iii. fig. 1 (? errore).- Oligocene ; Canton Glarus, Switzerland. [Imperfect fish; Geological Museum, University of Bonn.]

Acanus gracilis, G. vom Rath, Toc. cit.1859, p.112, pl. iii. fig. 2; A. Wettstein, Toc. cit. 1886, p. 66, pl. viii. fig. 9.-Ibid. [Ditto.]

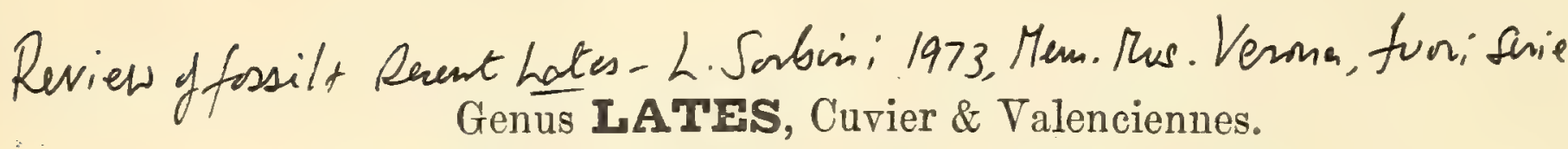

[Hist. Nat. Poissons, vol. ii. 1828, p. 88.]

Head and trunk laterally compressed. Mouth large and protractile, with bands of villiform teeth on the premaxilla, dentary, vomer, palatine, and ectopterygoid; supramaxilla present; suborbitals reduced and serrated. Upper limb of preoperculum serrated, lower limb with few large spines (some antrorse), and angle with a strong spine; operculum with one spine behind; seven branchiostegal rays. Vertebræ 12 in the abdominal, 13 in the caudal region; some hinder ribs borne by transverse processes. Two dorsal fins subequal in extent and connected at the base, the anterior with 7 or 8 spines, the posterior with one spine and 10 to 12 articulated rays; anal fin small, with 3 spines and 8 or 9 articulated rays; caudal fin rounded or slightly forked. Scales large or of moderate size, finely denticulated, extending partly over the head, also partly ensheathing the dorsal and anal fins. Lateral line complete, extending over the candal fin.

The existing species of Lates inhabit the freshwaters of tropical Africa, and the mouths of rivers and coasts of south-eastern Asia and northern Australia.

\section{Lates gracilis, Agassiz.}

1796. Holocentrus calcarifer, G. S. Volta, Ittiolit. Veronese, p. Ixxxii. pl. xrii. fig. 3 (errore).

1796. Lutianus ephippium, G. S. Volta, ibid.p. cexxxv. pl. lvi. fig. 4 (errore).

1833-34. Lates gracilis, L. Agassiz, Poiss. Foss. vol. iv. p. 25, pl. iii.

1833-34. Lates gibbus, L. Agassiz, ibid. p. 27, pl. iv. [Distorted fish.]

1833-34. Lates notreus, L. Agassiz, ibid. p. 29, pl. v. [Imperfect distorted fish; Palæontological Museum, Munich.]

1876. Lates gracilis, F. Bassani, Atti Soc. Veneto-Trent. Sci. Nat. vol. iii. p. 174.

1876. Lates gibbus, F. Bassani, ibid. p. 174.

Type. Well-preserved fish; Paris Museum of Natural History.

A species attaining a length of about $0 \cdot 25$. Length of head 


Lates Karangae sp.uov. P.H. Greenuord IS51. A.MA.Mt?

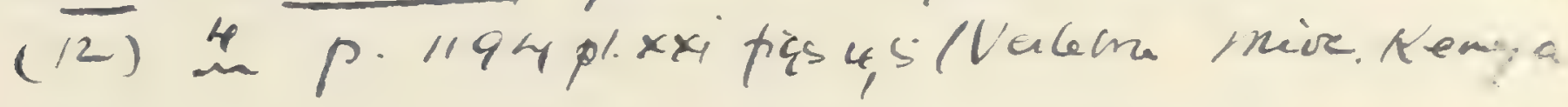

Eolates gen wor. L. Sorbini, Mém Mus Civ. SC Nat.

Plivise Lype-sp. Lates grailis Ag. Verma, is.p." $13 \mathrm{~s}$. 3 .

Zates nilitions furm Pleistocene of Fayum. Eyph / Friem, Iném. Sor. Géal. France, rol. xxi, prt.

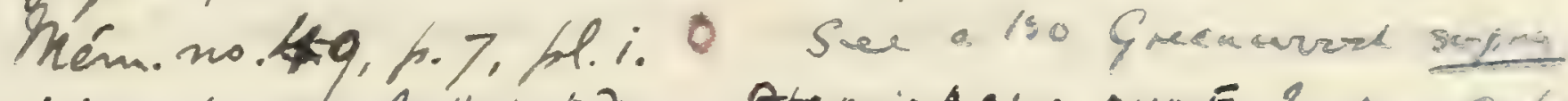

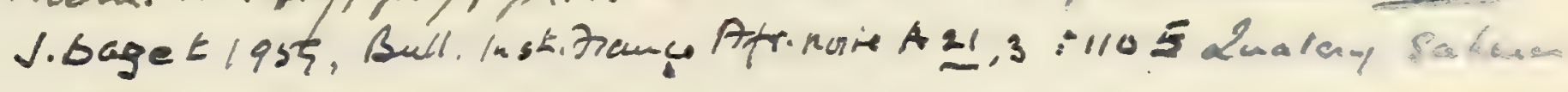

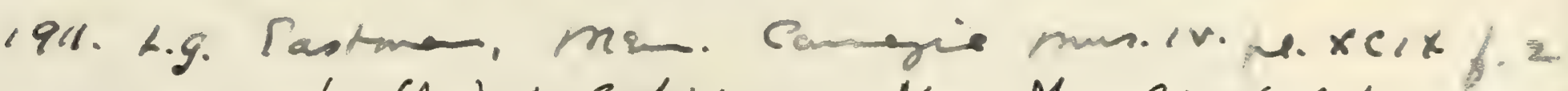

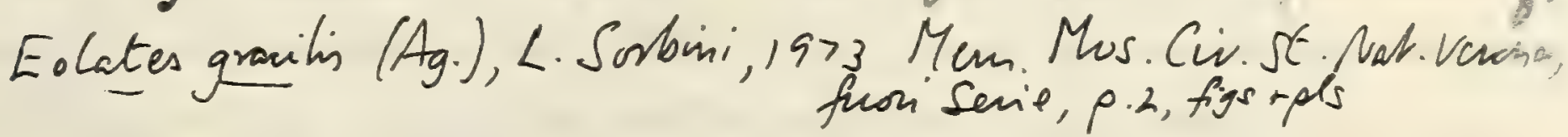


Lates miloticus C+V., L. Sabini 1973, Mem Mus Verona, furiserie, p. 34 Pliocene, Wadi Natrum, Egypt.

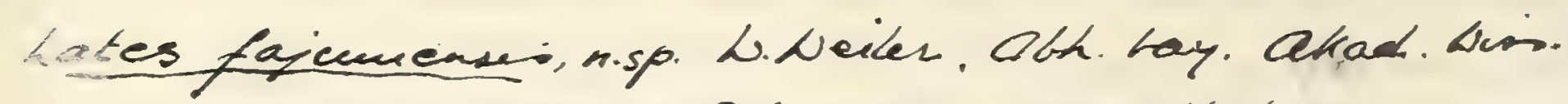

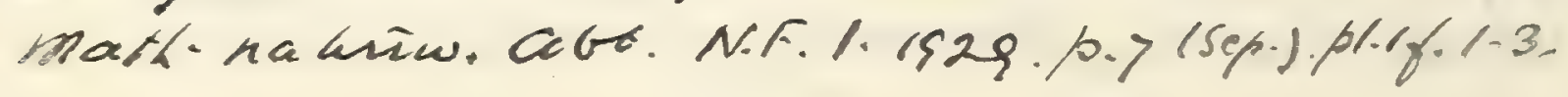

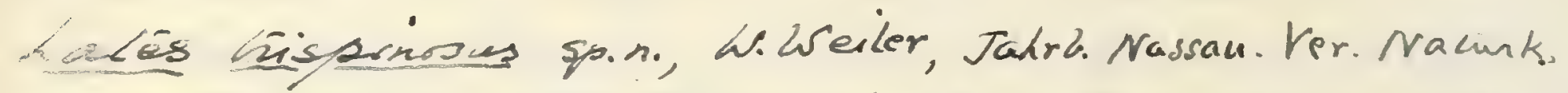

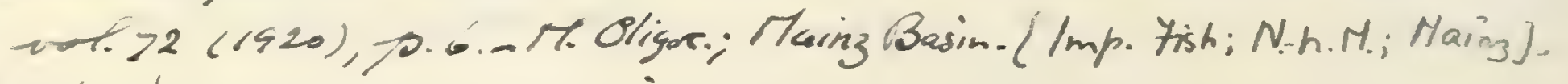

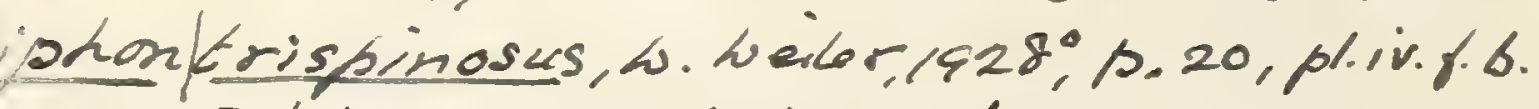

Eolates macwrus ( Ag), L. Solboini 1973 , Mem Mus cí. St. nat. Verona, fuon serie, $\quad$.26

pliordenes, A. Toch, Ins. Anes. hat. Huagen. ns. ii (1904), fr.52, fll. vi. f. 14. -

Beocsin. 
with opercular apparatus about equal to the maximum depth of the trunk, which slightly exceeds one third the total length to the base of the caudal fin. Anterior dorsal fin with 7 spines, posterior dorsal with 1 spine and 12 articulated rays, the third spine being stoutest and longest, its length somewhat exceeding half the depth of the trunk at its insertion; anal fin with 3 spines and 8 articulated rays, the spines being relatively short, the second stouter than the third but of equal length.

Form. \& Loc. Upper Eocene: Monte Bolca, N. Italy.

P. 3918. Well-preserved fish labelled by Agassiz, displaying all the fins except the pectorals.

Enniskillen Coll.

P. 2095, P. 3918 a. More imperfect larger specimen, in counterpart, showing serrated suborbital plate.

Egerton \& Enniskillen Colls.

1900\%. Imperfect distorted large specimen,

Purchased, 1845.

P. 1913. Imperfect fish displaying fins, preopercular spines, and seven branchiostegal rays.

Egerton Coll.

P. 9461. Smaller specimen, in counterpart.

Presented by the Earl of Aylesford, 1847.

P. 1913 a, P. 3918 b. Imperfect fish deepened by distortion, labelled "Lates gracilis, Ag." by Agassiz.

Egerton \& Enniskillen Colls.

37225. More imperfect small specimen, similarly distorted.

Purchased, 1863.

P. 1913 b, P. 3918 c. Fragmentary remains of fish about 0.12 in length, in counterpart.

Egerton \& Enniskillen Colls.

The following extinct species, not represented in the Collection, have also been referred to this genus :-

Lates macropterus, F. Bassani, Atti R. Accad. Sci. Napoli [2] vol. L.Sabimi,1973 iii. (1889), no. 6, p. 51, pl. iv. fig. 5.-Lower Miocene; Menn Muskersio, fuoisenie, p.31 University Geological Museum, Padua.]

Lates macrurus, L. Agassiz, Poiss. Foss. vol. iv. (1833-34), p. 29, Chiavon, Vicentin. [Imperfect trunk; Zigno Collection,

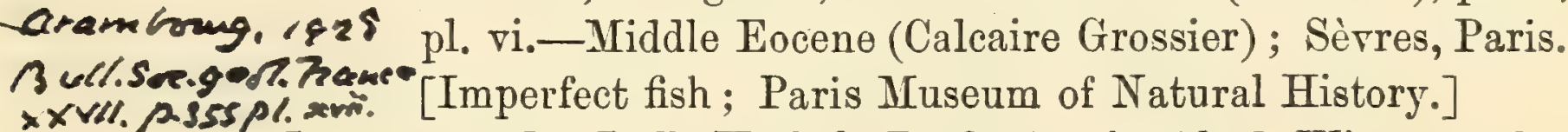

Lates partschi, J. J. Heckel, Denkschr. k. Akad. Wiss., math.L.Smbini, 1973 naturw. Cl. vol. xi. (1856), pt. i.p. 265, pl.xv. fig. 1.1 $\mathrm{mm}$. Thus. Verma, Middle Miocene; Breitenbrunn, Vienna. [Fragmentary funi seric, p.32 fish; Court Museum, Vienna.] 


\section{Genus CYCLOPOMA, Agassiz.}

[Poiss. Foss. vol. iv. 1833, p. 17.]

Scarcely distinguishable from Lates, but preoperculum withont spine at angle, its serrations gradually increasing in size downwards and the lowest and largest directed forwards.

The species of this supposed extinct genus are referred to Lates by P. Bleeker, Archiv. Néerland. vol. xi. (1876), p. 263.

\section{Cyclopoma gigas, Agassiz.}

1796. Labrus turdus, G. S. Volta, Ittiolit. Veronese, p. ccii. pl. xlix. (errore).

1796. Scorprena, G. S. Volta, ibid. pl. lxxiv.

1833. Cyclopoma gigas, L. Agassiz, Poiss. Foss. vol. iv. p. 18, pl. ii.

Type. Imperfect fish; Paris Museum of Natural History.

The type species, attaining a length of about 0.5 . Length of head with opercular apparatus about equal to maximum depth of trunk and contained four times in total length of fish. Posterior dorsaI fin with 1 spine and 10 articulated rays, anal fin with 3 spines and 8 articulated rays.

Furm. \& Loc. Upper Eocene: Monte Bolca, N. Italy.

P. 9462. Very large specimen, in fragments, in counterpart.

History unknown.

P. 2093, P. 4278. More fragmentary specimen, 0.40 in length, in counterpart. Egerton \& Enniskillen Colls.

A stouter fish, with larger head, not represented in the Collection, has also been described as follows:-

Cyclopoma spinosum, L. Agassiz, Poiss. Foss. vol. iv. (1833), p. 20, pl. i. Scorpana scrofa, G. S. Volta, Ittiolit. Veronese (1796), p. cxlv. pl. xxxiv. (errore).-Upper Eocene; Monte Bolca. [Imperfect fish; Paris Museum of Natural History.]

Cyclopoma (?) micracanthum (Agassiz).

1796. Holocentrus maculatus, G. S. Volta, Ittiolit. Veronese, p. ccxxxiv. pl. lvi. fig. 3 (errore).

1796. Amia indica. G. S. Volta, ibid. p. cxlix. pl. xxxv. fig. 4 (errore). 1818. Amia indica, H. D. de Blainville, Nouv. Dict. d'Hist. Nat. vol. xxvii. p. 347.

1835. Smerdis micracanthus, L. Agassiz, Poiss. Foss. rol. iv. p. 33, pl. viii. figs. 1, 2 . 


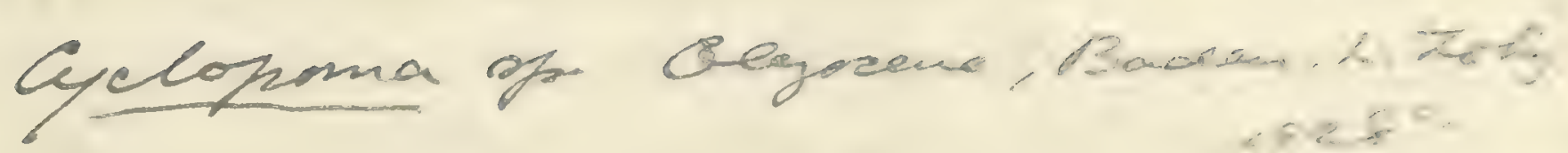
Revision of Gyclopona , related to Percolates; L. Sortionit 17.S. Figo, 1973, Mem. Mus. Versona, fuori serie, $\rho .57$

C.gigasts, frigo + Sorbini 1973. includes Simendio minoranthus Ag.

synongm of Cigigas Ag., Frigo + Saboini 1973 


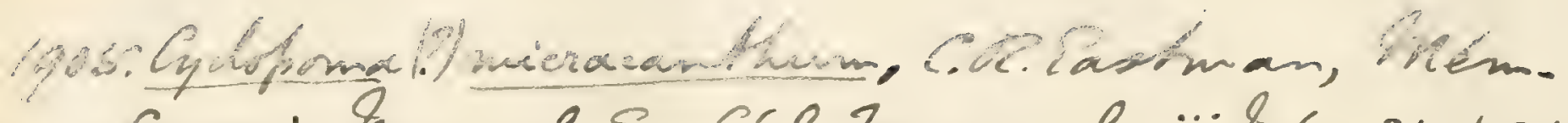
1909. Sor. Géd. Irance, vol. xiii. Mén. 34, p.25-

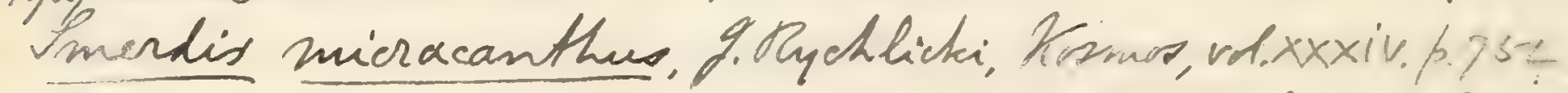

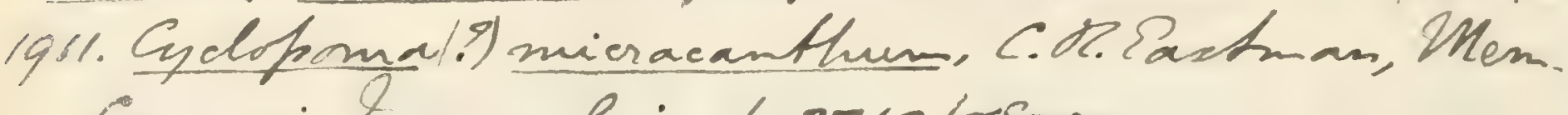
innegic mus ard iv. h. 375?

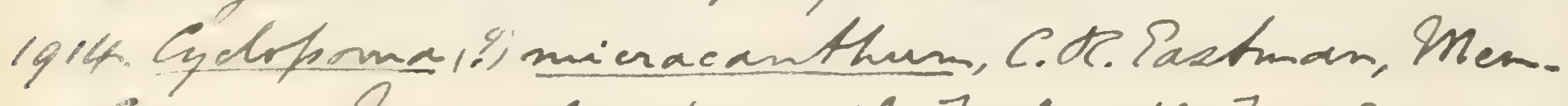

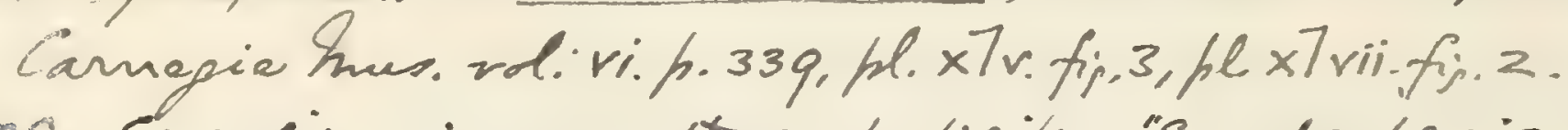
1928. Smendis micracanttas, L. Neiles, "Sencken beyiana"x. p.s. $1 / 2, p .>1.6 f \cdot 7 l$.

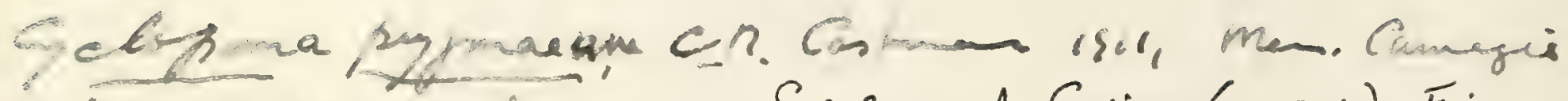
nus."v.p.xevas of.5. - Synomyn of Cgigas (p.504), Frigo + Sorbini 1973, Mem. Mus. Versona, furisiserie, p.55 


1836. Dules nedius, L. Agassiz, ibid. p. 93, pl. xiii. fg. 4. [Imperfect fish; Palæontological Museum, Munich.]

Type. Imperfect fish; otim Hartmann Coll., Göppingen.

A very small species, attaining a length of about $0 \cdot 1$. Length of head with opercular apparatus about equal to the maximum depth of the trunk and slightly exceeding one third of the total length to the base of the caudal fin. Anterior dorsal fin with 7 or 8 spines, posterior dorsal with 1 spine and 8 or 9 articulated rays, the anterior origin as far from the occiput as the termination from the caudal fin; the second to fourth dorsal spines about equal in size, their length not exceeding one half the depth of the trunk at their insertion, and scarcely exceeding that of some of the divided rays. Anal fin with 3 spines and 6 articulated rays, less than the posterior dorsal in extent; the second anal spine stoutest, but not longer than the third.

Several examples of this species show the preoperculum characteristic of Cyclopoma, quite different from that of Smerdis.

Form. \& Loc. Upper Eocene: Monte Bolca, near Verona.

P. 1924, P. 391\%. Imperfect large fish, in counterpart, labelled Dules medius by Egerton. Egerton \& Enniskillen Colls.

36202. Slightly smaller imperfect specimen, deepened by distortion. Purchased, 1861.

P. 1926, P. 3903-04. Five good specimens, most of them labelled by Agassiz, two in counterpart.

Egerton \& Enniskillen Colls.

P. 8955. Fine specimen 0.063 in length, in counterpart.

Castelli Coll.

13466. Two similar specimens, in counterpart

Purchased.

The following specimens from Monte Bolca seem to be immature individuals of this species, but are regarded as a distinct form, Smerdis pygmaus, by Agassiz, tom. cit. 1836, p. 53, pl. viii. figs. 3, 4 :--

P. 1927 a, b. The two type specimens of S. pygmaeus, described and figured by Agassiz, loc. cit.

Egerton Coll.

P. 1927, P. 3905. Five specimens, two heing labelled by Agassiz.

Egerton \& Enniskillen Colls.

37222-24. Three specimens.

Purchased, 1863.

P. 290. Specimen in counterpart.

Transferred from Mus. Practical Geology, 1880. 


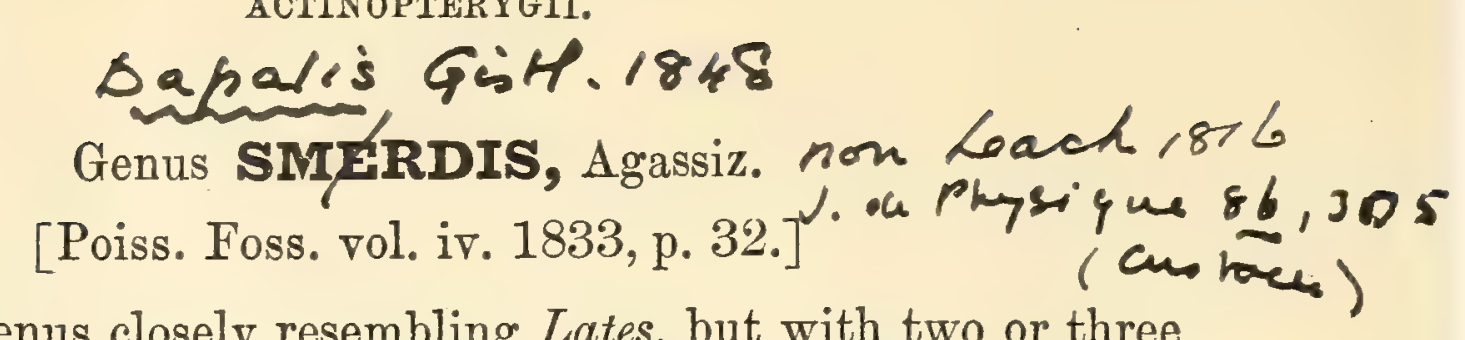

An extinct genus closely resembling Lates, but with two or three fewer divided rays in the dorsal and anal fins, and the caudal fin forked. Preoperculum with gently rounded angle; its serrations largest at the angle, rapidly decreasing both upwards and forwards, and all retrorse on the lower limb. Vertebræ 10 in the abdominal, 14 in the caudal region.

\section{Smerdis minutus (Blainville).}

1818. Perca minuta, H. D. de Blainville, Nouv. Dict. d'Hist. Nat. vol. xxvii. p. 370.

1836. Smerdis minutus, L. Agassiz, Poiss. Foss. vol. iv. pp. 39, 54, pl. viii. figs. 5,6 .

Type. Imperfect fish; Paris Museum of Natural History.

The type species, attaining a length of about 0.07 . Length of head with opercular apparatus somewhat less than the maximum depth of the trunk, which equals about one third of the total length to the base of the caudal fin. Anterior dorsal fin with 7 spines, posterior dorsal with 1 spine and 9 articulated rays, its termination further from the caudal fin than its origin from the occiput; the second dorsal spine much the largest, its length nearly equalling the depth of the trunk at its insertion, the following five spines gradually decreasing in length. Anal fin with 3 spines and 7 articulated rays, about equal to the posterior dorsal in extent; the second anal spine much stouter and slightly longer than the third. Caudal fin considerably forked.

Form. \& Loc. Lower Oligocene: Aix-en-Provence. ${ }^{1}$ Senegatha

21529. Three specimens, one distorted.

28101-03. Three fine specimens.
Purchased, 1847. Mantell Coll.

P. 1929-30. Three distorted typical specimens, and three immature fishes. One shows the small retrorse serrations on the lower limb of the preoperculum.

Egerton Coll.

1 Distorted fragmentary specimens from the Lower Miocene of Unterkirchberg near Ulm, Würtemberg, are referred to this species by $H$. von Meyer, Palæontogr. vol. ii. (1851), p. 109, pl. xvi. figs. 1-4. It is also recorded from the Lower Miocene of Chiavon, N. Italy, by J. J. Heckel (Sitzungsb. k. Akad. Wiss., math.-naturw. Cl. vol. xi. 1854, p. 327), and F. Bassani (Atti R. Accad. Sci. Napoli [2] vol. iil. 1889, no. 6, p. 55). 


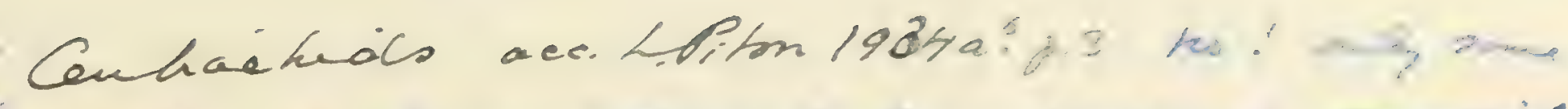

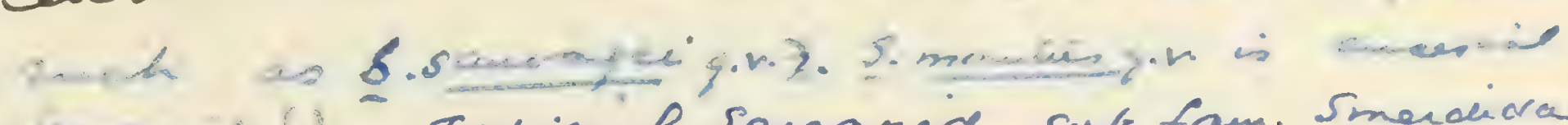
berler 1939 .

1903. Smerdis minutus, R. Coulon, Bull. Sor. Śtude Sci. Nat. Elbenf! 2 bt. year 1902, h.156. fis. 2. 1930a. Smerds minulies. G. DGasmo: 74, iv.12. 493). 
1955. Smerdis formosen Whailer Paltiteit. Og $0.95 \% .7 .8$.

1:04. Amerdir of. macrumus, A. Koch, Foldtani Kösling. vd. xxxiv. p. 366. [M. Mredituranean; Hungary] 1914. Smerdie macrume, F. Priem, Mém. Sor. Géol.

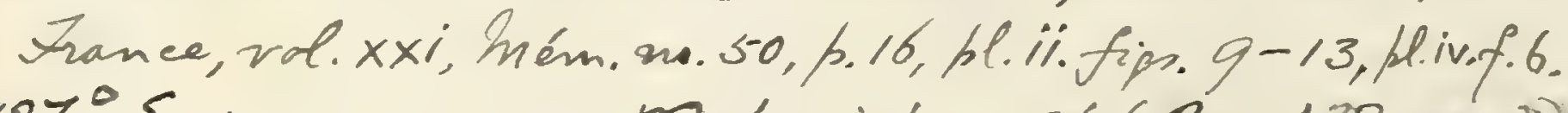

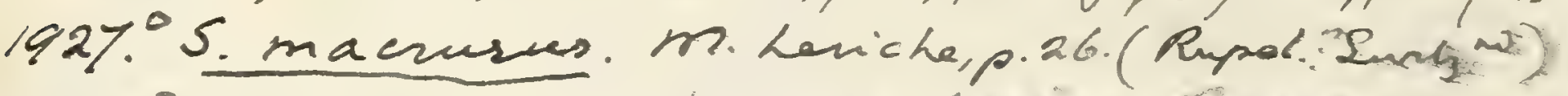

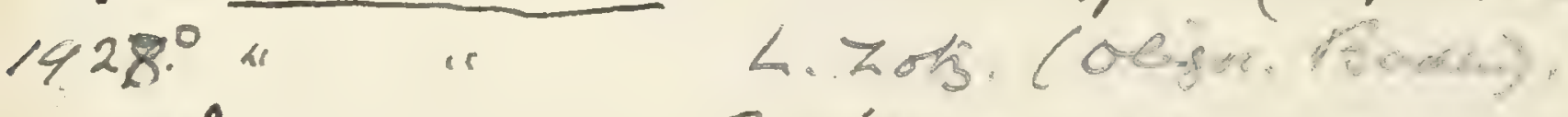

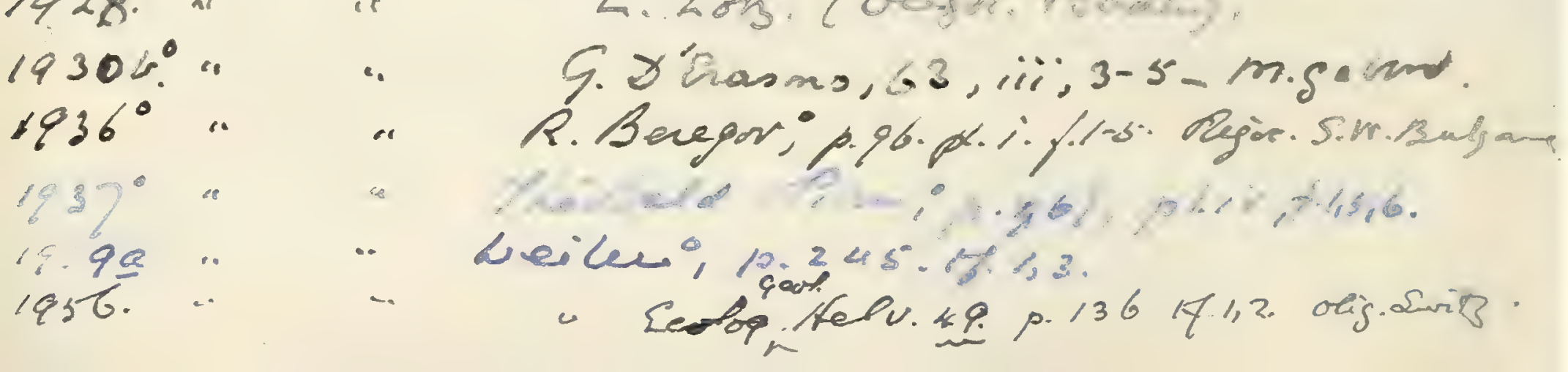


P. 390\%. Five specimens, four being labelled by Agassiz. Enniskillen Coll.

P. 9463. Fine specimen 0.045 in length.

Purchased.

8064. Fish deepened by distortion.

History unknown.

43437 , -a. Five specimens, the largest especially well preserved. No. 43437 a exhibits the characteristic preoperculum.

Presented by Kenneth Murchison, Esq., 1872.

21419 a-c. Three small specimens.

Purchased, 1847.

32486-88. Three small specimens.

Tesson Coll.

\section{Smerdis formosus, Meyer.}

1848. Smerdis formosus, H. von Meyer, Neues Jahrb. p. 78.3.

1851. Smerdis formosus, H. von Meyer, Palæontogr. vol. ii. p. 110, pl. xvi. fig. 5 .

Type. Imperfect fishes.

An imperfectly known small species, about 0.05 in length. Closely resembling $S$. minutus, but with length of head and opercular apparatus slightly exceeding maximum depth of trunk, which is comparatively slender; second anal spine not much larger than the third.

Form. \& Loc. Lower Miocene: Würtemberg.

35510-11. Two fine specimens; Unterkirchberg, near Ulm. The second shows small retrorse serrations on the lower limb of the preoperculum.

Purchased, 1860.

P. 3908-09. Four specimens; Unterkirchberg. Enniskillen Coll.

35512, 35519. Two imperfect immature specimens; Unterkirchberg. Purchased, 1860.

Smerdis macrurus, Agassiz.

1835. Smerdis macrurus, L. Agassiz, Poiss. Foss. vol. iv. p. 57, pl. vii.

1880. Smerdis macrurus, H. E. Sauvage, Bull. Soc. Géol. France [3] vol. viii. p. 441, pl. xii. figs. 4, 5 .

Type. Imperfect fish.

The largest known species, comparatively slender, attaining a length of about $0 \cdot 2$. Length of head with opercular apparatus slightly exceeding the maximum depth of the trunk, which is contained between three and four times in the total length to the base of the caudal fin. Anterior dorsal fin with 7 spines, posterior 
dorsal with 1 spine and 9 articulated rays, its anterior origin about as far from the occiput as its termination from the caudal fin; the second to seventh dorsal spines gradually diminishing in size backwards and the length of the second considerably less than the depth of the trunk at its insertion. Anal fin with 3 spines and 7 articulated rays, its extent slightly less than that of the posterior dorsal; second anal spine very little exceeding the third in size. Caudal fin considerably forked. Switgerland Form. \& Loc. Lower Miocene and Upper Oligocene: France; \&

P. 6005-06. Two large specimens, 0.175 and 0.13 in length respectively; Les Vachères, Basses Alpes. Purchased, 1889.

P. 313-14. Numerous specimens, variously imperfect and distorted, the largest about 0.2 in length; Céreste, Basses Alpes.

Purchased, 1881.

28496. Seven imperfect specimens; Apt, Vaucluse. Bravard Coll.

21529 a. Imperfect small fish ; Apt.

Purchased, 1847.

P. 294. Small specimen; St. Saturnin, Apt. Transferred from Mus. Practical Geology, 1880.

The following species have also been referred to this genus, but are not represented in the Collection:-

Smerdis aduncus, J. J. Heckel, Sitzungsb. k. Akad. Wiss., math.naturw. Cl. vol. xi. (1854), p. 326 ; F. Bassani, Atti R. Accad. Sci. Napoli [2] vol. iii. (1889), no. 6, p. 54, pl. v. fig. 1.-Lower Miocene; Chiavon, N. Italy. [Imperfect fish ; Court Museum, Vienna.]

Sinerdis analis, J. J. Heckel, loc. cit. (1854), p. 325; F. Bassani, loc. cit.(1889), p. 54.-Lower Miocene; Chiavon. [Imperfect fish ; Court Museum, Vienna.]

Smerdis budensis, J. J. Heckel, Denkschr. k. Akad. Wiss., math.Macikos Lens naturw. Cl. vol. xi. pt. i. (1856), p. 264, pl. xi. figs. 16, Cameasen 7.-Miocene; Blocksberg, Buda-Pesth. ${ }^{1}$ [Ditto.]

Smerdis elongatus, H. von Meyer, Palæontogr. vol. ii. (1851), p. 110, pl. xvi. fig. 6.-Lower Miocene; Unterkirchberg, near Ulm, Würtemberg. [Imperfect small fish.]

Smerdis latior, L. Agassiz, Poiss. Foss. vol. iv. (1836), p. 59,

The fish from the Cretaceous of Sahel Alma, Mt. Lebanon, now in the Tübingen Museum, referred to this species by Quenstedt (Handb. Petrefakt. ed. 3,1883, p. 378, pl.xxx. fig. 1), seems to the present writer to be a Pycnosterinx. 


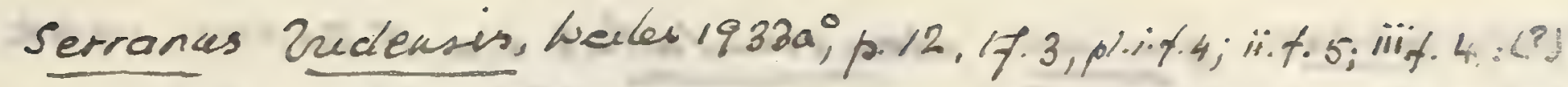

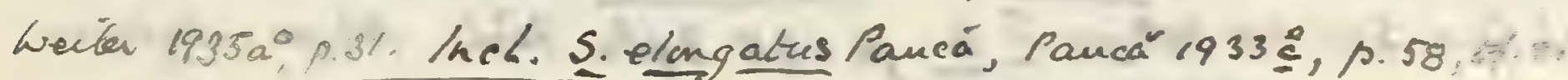

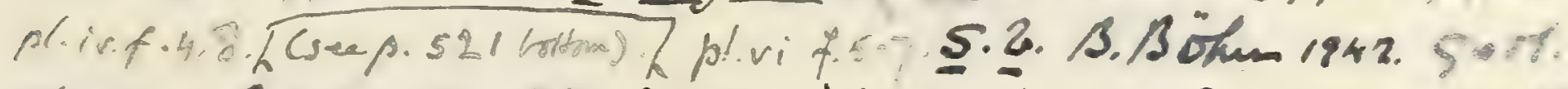

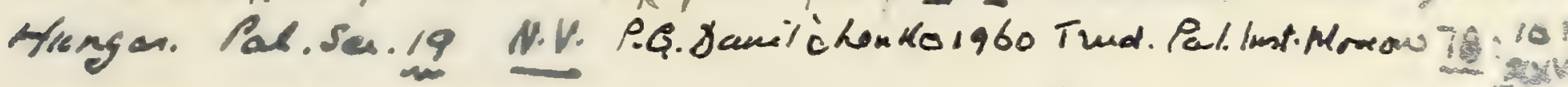

Smerdis Stangeaudi; Z Priem, Aném. So. Géal France,

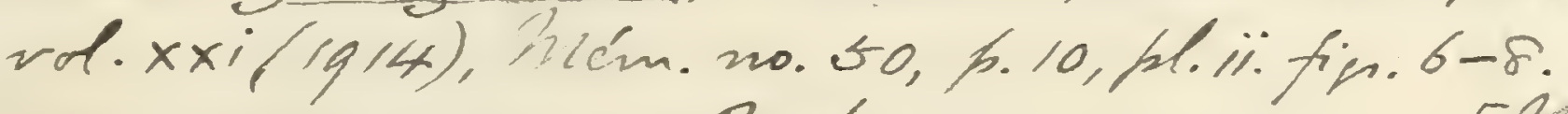
complete fint; Unis. Clermont. Zenand. I 
Smerdir saurapei, FPrem, Mém. Sr. Géol. Irance, vol.xxi(1914). Mém. no. 50, h.9, pl.i. fij.12, plii.fin.1-s=

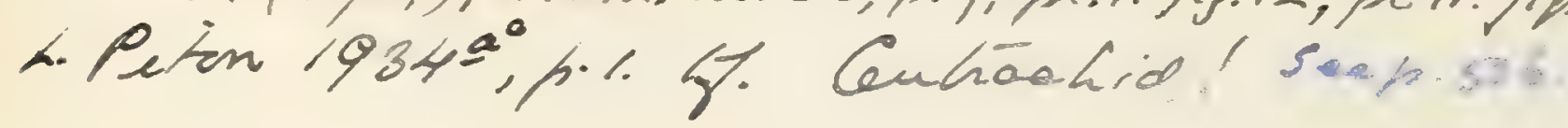

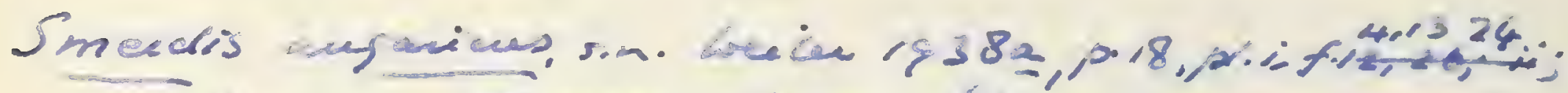

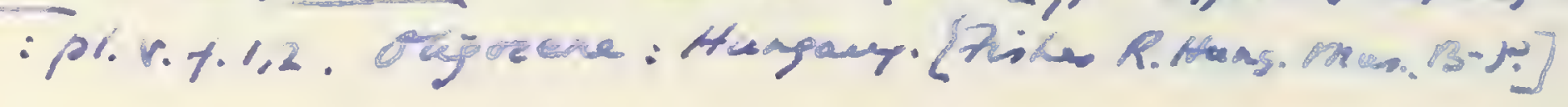

Snerdis (?) sp. M. H. Led new, Meim. Comité' geät. 1914, M.5.,

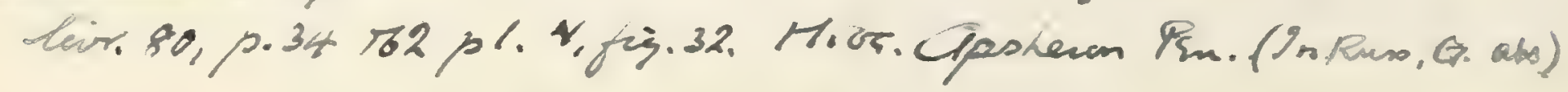

Buitolablax geninor. clenticulatus o.m. Frakoi, 1942, I. Fac. Sci. 1.4.10kyo II b p.135 3fts. Fih. Mici. Japan.

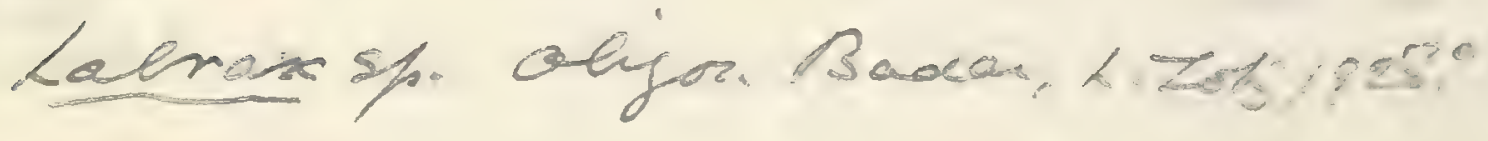



pl. viii. fig. 8.-Form. \& loc. unknown. [Indeterminable distorted specimen.]

Smerdis rhoensis, T. C. Winkler, Archiv. Mus. Teyler, vol. v. (1880), p. 92, pl. iii. figs. 5, 6.-Lower Miocene (Lignite); Rhoen. [Imperfect fish; Geological Museum, Univ. Würzburg.]

Smerdis sandbergeri, T. C. Winkler, loc. cit. (1880), p. 89, pl, iii. figs. 1, 2.- Middle Oligocene (Lignite); Sieblos and Eisgraben, Bavaria. [Imperfect fish; Geological Museum, Univ. Würzburg.]

Smerdis sauvagei, C. Brongniart, Bull. Soc. Linn. Normandie [3] vol. iv. (1880), p. 356, pl. iii. Smerdis sp., H. E. Sauvage, Bull. Soc. Hist. Nat. Toulouse, vol. viii. (1874), p. 186, pl. i. figs. 2, 3.-Lower Miocene (Lignite); Ménat, Puy-deDôme. [Imperfect fish, referred to S'. aduncus by F. Bassani, Atti R. Accad. Sci. Napoli (2) vol. iii. 1889, no. 6, p. 54.]

Smerdis sieblosensis, T. C. Winkler, loc. cit. (1880), p. 91, pl. iii. figs. 3, 4.-Middle Oligocene (Lignite); Sieblos, Bararia. [Imperfect fish; Geological Museum, Univ. Würzburg.]

Smerclis taramellii, F. Bassani, Atti R. Accad. Sci. Napoli [2] vol. iii. (1889), no. 6, p. 56, pl. v. figs. 2, 3.-Lower Miocene; Chiavon. [Imperfect fish; Zigno Collection, Univ. Padua.]

Smerdis ventralis, L. Agassiz, Poiss. Foss. vol. iv. (1836), p. 58, pl. viii. fig. 7. Cyprinodon?, G. Cuvier, Oss. Foss. ed. 2, vol. iii. (1822), p. 346, pl. Ixxvi. fig. 14. Perca cyprinodon ?, H. D.de Blainville, Nouv. Dict. d'Hist. Nat. vol. xxvii. (1818), p. 375.-Upper Eocene (Gypsum); Montmartre, Paris.

Indeterminable fragments of a sinall fish from the Lower Eocene of Belgium are also named Smerdis heersensis by T. C. Winkler, Archiv. Mus. Teyler, vol. ii. (1869), p. 301, pl. xxxriii. figs. 3-7.

Genus LABRAX, Cuvier \& Valenciennes.

[Hist. Nat. Poissons, vol. ii. 1828, p. 55.]

Syn. Platacanthus, G. Fischer de Waldheim, Bull. Soc. Imp. Nat. Moscou, vol. xxiii. 1850, pt. i. p. 286.

Supramaxilla absent; suborbitals not serrated; preoperculum merely sorrated without spine at angle, and operculım with two feeble spines behind. Vertebræ 12 in abdominal, 13 in caudal 
region. Anterior dorsal fin with 8 to 10 spines, posterior dorsal with 1 spine and 11 to 14 articulated rays; anal fin with 3 spines and 8 to 12 articulated rays; caudal fin more or less forked.

The existing species of Labrax occur on the coasts of the North Atlantic and Mediterranean, and in the freshwaters of North America.

Labrax ubinoi (Fischer de Waldheim).

1850. Platacanthus ubinoi, G. Fischer de Waldheim, Bull. Soe. Imp. Nat. Moscou, vol. xxiii. pt. i. p. 286, pl. vi.

1863. Labrax heckelii, F. Steindachner, Sitzungsb. k. Akad. Wiss., math.-naturw. Cl. vol. xlvii. pt. i. p. 140, pl. iii. [Imperfect fish; Court Museum, Vienna.]

Type. Fragmentary head, \&c.

The type species of the so-called Platacanthus, attaining a length of about $0 \cdot 45$. Length of head with opercular apparatus equalling maximum depth of trunk and contained about three and a half times in the total length to the base of the caudal fin. Anterior dorsal fin with 9 spines, posterior dorsal with 1 spine and 13 articulated rays, the fifth dorsal spine being the longest; anal fin probably with 3 spines and 12 articulated rays, the second anal spine being shorter but stouter than the third.

Form.\& Loc. Tertiary: Eubœa, Greece.

P. 8948. Fine specimen about 0.42 in length, fractured across the anterior abdominal region. Purchased, 1898.

P. 3911. Another fine large specimen, wanting the caudal fin, bearing the MS. name "Perca Forbesi, Ag."

Enniskillen Coll.

P. 1921-22. Two more imperfect specimens, the second showing the hinder part of the cranial roof. Egerton Coit.

P. 2018. Impression of skeleton probably of this species, obtained by Rear-Admiral T. Spratt "from a freshwater deposit" at Koumi, Eubœa. Apparently the specimen referred to by Spratt, Quart. Journ. Geol. Soc. vol. iii. (1847), p. 69.

Egerton Coll.

\section{Labrax schizurus, Agassiz.}

1836. Labrax schizurus, L. Agassiz, Poiss. Foss. vol. iv. p. 89, pl. xiii. figs. $2,3$.

Type. Imperfect fish; Paris Museum of Natural History. 
A slender species, attaining a length of about $0 \cdot 15$. Length of head with opercular apparatus about equal to the maximum depth of the trunk, which is contained four times in the total length to the base of the caudal fin. Anterior dorsal fin with 9 spines, posterior dorsal with 1 spine and 11 articulated rays, its anterior origin slightly nearer to the occiput than its termination to the base of the caudal fin; dorsal spines slender, the fourth the longest. Anal fin with 3 spines and 12 articulated rays opposed to the posterior dorsal, and its spines very slender. Caudal fin considerably forked.

Form.\& Loc. Upper Eocene: Monte Bolca, N. Italy.

P. 3895. Imperfect large specimen, labelled by Agassiz.

Enniskillen Coll.

2140\%. Slab with four specimens about 0.09 in length.

Purchased, 1847.

P. 9479. Fish 0.08 in length, in counterpart.

Dixon Coll.

44875. Fine specimen 0.095 in length, in counterpart.

Presented by Benjamin Bright, Esq., 1873.

P. 1912. Two small specimens labelled by Agassiz. Egerton Coll.

Labrax oeningensis, nom. nov.

1823. Perca lucioperca, J. F. Krüger, Gesch. d. Urwelt, vol. ii. p. 648 (errore).

1832. Perca lepidota, L. Agassiz, Neues Jahrb. p. 136.

1836. Perca lepidota, L. Agassiz, Poiss. Foss. vol. iv. p. 75, pl. x.

1880. Properca lepidota, H. E. Sauvage, Bull. Soc. Géol. France [3] vol. viii. p. 452.

1895. Properca lepidota, F. Bassani, Atti R. Accad. Sci. Napoli [2] vol. vii. no. 7 , p. 2 , tig. 1.

Type. Imperfect fish; Carlsruhe and British Museums.

A robust species, attaining a length of about $0 \cdot 5$. Length of head with opercular apparatus about equal to the maximum depth of the trunk, which is contained a little more than three times in the length to the base of the caudal fin. Anterior dorsal fin with 9 spines, posterior dorsal with 1 spine and 14 articulated rays, the third to fifth spines being longest and thickest; anal fin with 3 spines and 9 articulated rays, the second spine as stout as the third but slightly shorter.

Form. \& Loc. Upper Miocene: Oeningen, Baden; Murlo, Prov. Siena, Italy. 
P. 2005. Counterpart of type specimen, described by Agassiz, loc. cit. There is no clear evidence of more than 3 anal spines.

Egerton Coll.

P. 9464. Imperfect larger fish in counterpart, deepened by distortion in the abdominal region. The vertebral column is shown to have comprised not more than 25 vertebræ, of which 13 or 14 are caudal.

Purchased.

The so-called Perca moguntina (H. von Meyer, Neues Jahrb. 1846, p. 476, and Palæontogr. vol. vii. 1859, p. 22, pl. iii. figs. 2-13), known only by detached bones from the freshwater Upper Oligocene of the Mayence Basin, is probably also referable to Labrax, and is represented in the Collection by the following fragments :-

P. 1919, P. 3914. Two small slabs with detached bones, including the operculum; Mayence. Egerton \& Enniskillen Colls.

The following extinct species have also been referred to Labrax, but are not represented in the Collection :-

Labrax bosniensis, F. Siebenrock, Wissensch. Mitth. Bosn. u. Hercegov. vol. vii. (1900), p. 687, pl. xii. fig. 2.-Upper Tertiary; near Sarajevo, Bosnia. [Imperfect fish; Sarajevo Museum.]

Labrax delheidi, R. Storms, Bull. Soc. Belge Géol. vol. vii. (1893), Mém. p. 170, pl. vii._Middle Oligocene; Steendorp, near Ruppelmonde, Belgium. [Portion of trunk; Delheid Collection.]

Labrax elongatus, D. G. Kramberger, Verhandl. k. k. geol. Reichsanst. 1882, p. 28 (name only), and Rad Jugoslıv. Akad. vol. cri. (1891), p. 74, pl. v. figs. 1, 2.-Upper Oligocene; Trifail, Styria. [Imperfect fish; Imperial Geological Survey, Vienna.]

Labrax intermedius, D. G. Kramberger, Beitr. Paläont. Oesterr.Ungarns, rol. ii. (1882), p. 100, pl. xxii. fig. 6. Perca (cf. angusta, Ag.), F. Bassani, Atti Soc. Veneto-Trent. Sci. Nat. vol. vii. (1880), p. 88.-Upper Miocene; Radoboj, Croatia. [Imperfect fish ; Court Museum, Vienna.]

Labraw latus, D. G. Kramberger, Rad Jugoslav. Akad. vol. cvi. (1891), p. 71, pl.iv. fig. 1.-Upper Oligocene; Fohnsdorf, Styria. [Imperfect fish.]

Labrax (?) lepidotus, L. Agassiz, Poiss. Foss. vol. iv. (1836), p. 85, pl. xiii. fig. 1.-Upper Eocene; Monte Bolca. [Fragmentary fish; Palæontological Museum, Munich.] 


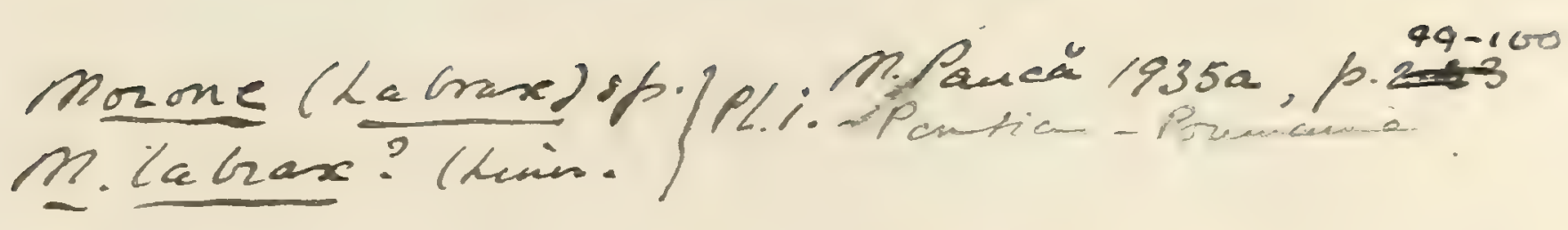
$=$ Acropoma Lepidoters (Mg), L. Sorbuii, 1974, Mem Mes Verona furi 
La Irax rogdiii s.n. V.P. Soghaclev 1942, ER. Acad. Sci.

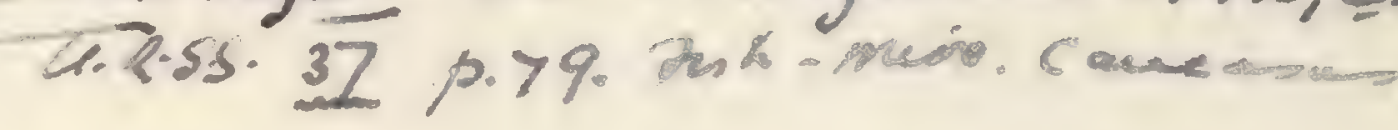

Atrithus (Labrax) lucidus, 9.5. Basodi, Divishe Ithal

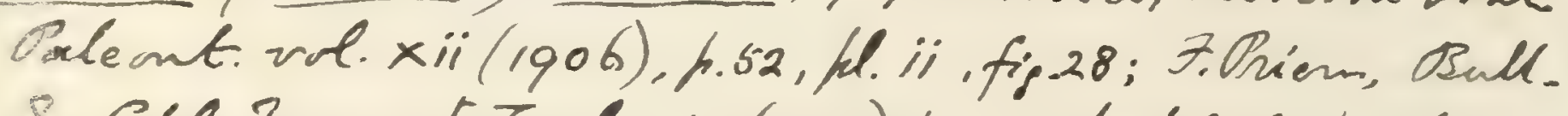
So. Ge'sl. Arance [4J vol. xiv (1914), h. 247, teal-ff; 6; h.262,

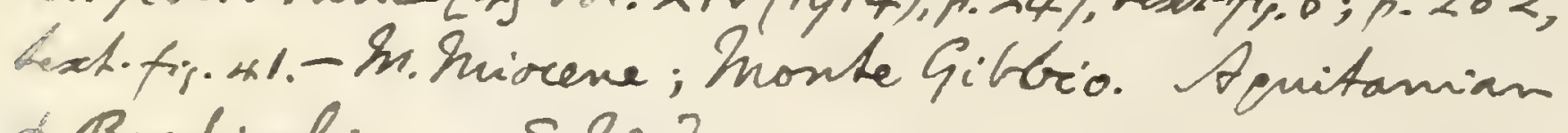
Bundigalian; S. W. Arance. 
Labrax longiceps, F. Siebenrock, loc. cit. 1900, p. 685, pl. xii. fig. 1.-Upper Tertiary; near Sarajevo. [Imperfect fish ; Sarajero Museum.]

Labrax major, L. Agassiz, op. cit. vol. iv. p. 87, pl. xii.; P. Gervais, Zool. et Pal. Franç. (1852), Poiss. Foss. p. 7, pl. lxxi. fig. 1. - Middle Eocene (Calcaire Grossier); Passy, Paris. [Imperfect fish ; Paris Museum of Natural History.]

Labrax mojsisovicsi, D. G. Kramberger, Rad Jugoslav. Akad. vol. cri. (1891), p. 73, pl. iv. fig. 2.-Upper Oligocene; 'Trifail, Styria. [Fragmentary fish; Imperial Geological Survey, Vienna.]

Labrax multipinnatus, D. G. Kramberger, Beitr. Paläont. Oesterr.Ungarns, vol. ii. (1882), p. 99, pl. xxiii. fig. 2.-Upper Miocene; Nedelja, Croatia. [Imperfect fish; Geological Múseum, Agram.]

Labrax neumayri, D. G. Kramberger, ibid. (1882), p. 97, pl. xxii. fig. 5.-Upper Miocene; Dolje, Croatia. ${ }^{1}$ [Imperfect fish ; Geological M[useum, Agram.]

Labrax sagorensis, D. G. Kramberger, Rad Jugoslav. Akad. vol. cvi. (1891), p. 77, pl. iv. figs. 3, 4. Lates sagorensis, F. Siebenrock, loc. cit. 1900 , p. 685.-Upper Oligocene; Sagor, Croatia. [Imperfect fish; Geological Museum, University of Vienna.]

Labrax steindachneri, F. Siebenrock, loc. cit. 1900, p. 689, pl. xiii. fig. 3.--Upper Tertiary ; near Sarajevo. [Imperfect fish ; Court Museum, Vienna.]

Labrax stiriacus, D. G. Kramberger, Verhandl. k. k. geol. Reichsanst. 1882, p. 28, and Rad Jugoslar. Akad. vol. cri. (1891), p. 77. Serranus (?) stiriacus, F. Rolle, Sitzungsb. k. Akad. Wiss., math.-naturw. Cl. vol. xxx. (1858), p. 21, pl. i. fig. 1.-Upper Oligocene; Sagor, Croatia. [Imperfect fish ; Geological M[useum, University of Vienna.]

The imperfect trunk described as follows, also probably belongs to a species of Labrax:-

Perca alsheimensis, H. von Meyer, Palæontogr. vol. vii. (1859), p. 19, pl. iii. fig. 1.-Upper Oligocene; Alsheim, near Mayence.

1 Somewhat similar fish from Lower Miocene of Chiavon, Vicentin, also described by F. Bassani, Atti R. Accad. Sei. Napoli [2] vol. iii. (1889), no. 6, p. 52 , pl. v. fig. 6 . 


\section{Genus PERCICHTHYs, Girard.}

[Proc. Acad. Nat. Sci. Philad. 1854, p. 197.]

Head and trunk laterally compressed. Mouth protractile, with minute teeth on premaxilla, dentary, vomer, and palatine; supramaxilla present. Preopereulum with serrations, those on lower limb antrorse; operculum with one spine behind; six or seren branchiostegal rays. Vertebræ 14 or 15 in the abdominal, 18 to:20 in the caudal region. Two dorsal fins, the anterior with 8 to 11 spines, the posterior with 1 or 2 spines and 10 to 13 articulated rays; anal fin with 3 spines and 8 to 10 articulated rays; caudal fin truncate or slightly forked. Lateral line complete.

A South-American freshwater genus found in Chili and Argentina.

\section{Percichthys antiquus, A. S. Woodward:.}

1898. Percichthys antiquus, A. S. Woodward, Rev. Mus. Paulista, nol. iii. p. 68, figs. 6,7 .

Type. Imperfect fish; Senckenberg Museum, Frankfurt.

A species attaining a length of about $0 \cdot 12$. Maximum depth of trunk about equalling length of head with opercular apparatus, which is contained three and a half times in total length of fish. Dorsal fins with 11 spines and 9 or 10 articulated rays; anal fin with 3 spines and 8 or 9 articulated rays.

Form. \& Loc. Tertiary Lignite: Taubaté, Province of San Paulo, Brazil.

P. 9011. Dorsal portion of trunk, described and figured, loc. cit. P. 68 , fig. 7 .

By exckiange, 1898.

Genus PROPERCA, Sauvage. Percilia Girand [Bull. Soc. Géol. France (3) vol. viii. (1880), p. 452.] is is L.P.ton,

Head and trunk laterally compressed. Mouth large, and all teeth minute. Preoperculum gently rounded and serrated, without spine at angle. Vertebræ 10 to 12 in the abdominal, 16 to 18 in the caudal region. Anterior dorsal fin more extended than the posterior dorsal, the two probably connected at the base; anterior dorsal with 9 spines, posterior dorsal with 1 spine and 9 to 12 articulated rays; anal fin small, with 3 spines and 8 to 10 articulated rays; caudal fin forked. Scales large or of moderate size, finely denticulated. 

Pevcichthys chibëi,s.n. S. Sahaki, 1929, 1.Gw.

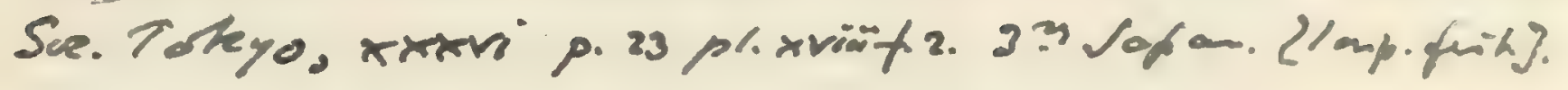

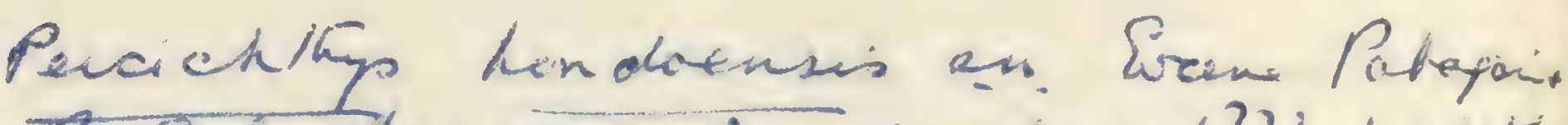

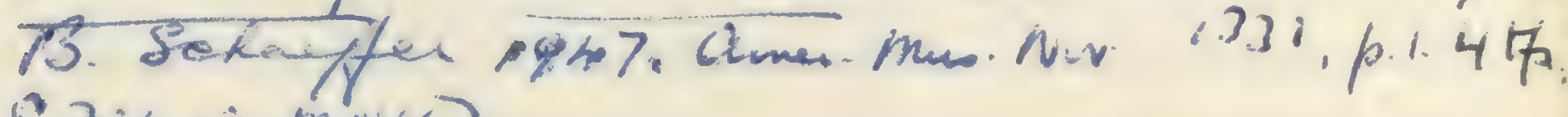
[Dis (x.motit).

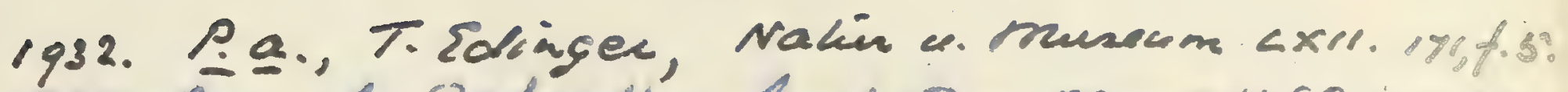

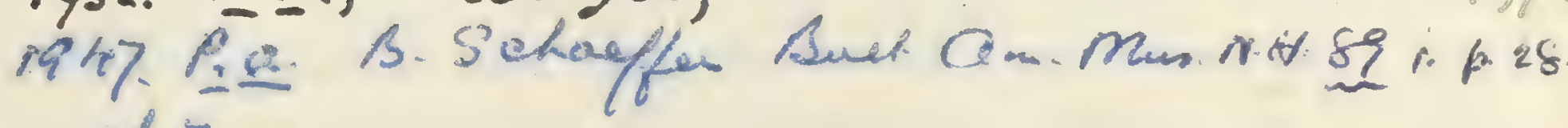
pl.y.

P.11203. Inperfut firt

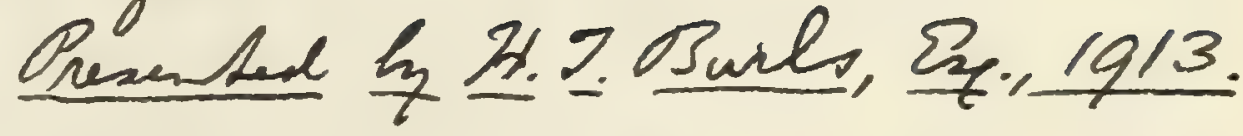

Percichthye Mh, G. De Thefars, Mem. Pe Comith

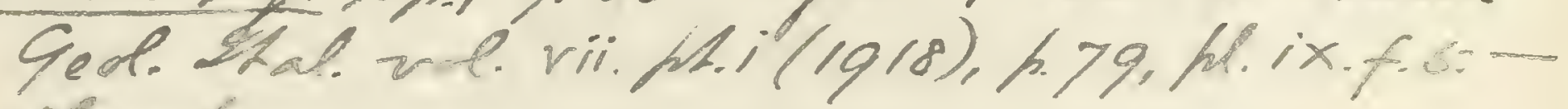
Zicals.

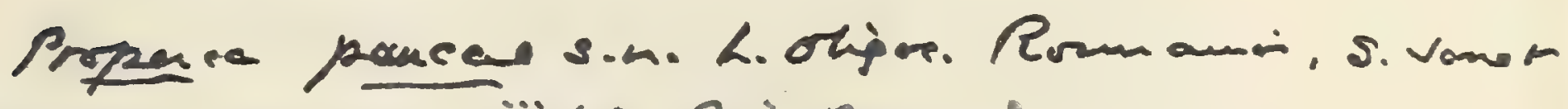
$18588^{\circ} 0.62$ pr. vilits. Bosh Rormente 


\section{Properca angusta (Agassiz).}

1834. Perca elongata, L. Agassiz, Neues Jahrb. p. 383.

1836. Perca angusta, L. Agassiz, Poiss. Foss. rol. iv. p. 79, pl. xi.

1874. Perca angusta, H. E. Saurage, Bull. Soc. Hist. Nat. Toulouse, vol. viii. p. 183.

1880. Properca anyusta, H. E. Saurage, Bull. Soc. Géol. France $[3]$ rol. viii. p. 452.

Type. Imperfect fish; otim Brongniart Collection.

The trpe species, attaining a length of about 0.2 . Length of head with opercular apparatus much exceeding the maximum depth of the trunk, which is contained nearly four times in the total length to the base of the caudal fin. Dorsal spines gradually increasing in length to the fourth, thence diminishing; but the length of the longest spine considerably less than the depth of the trunk at its insertion and less than the length of the longest dirided ray of the posterior dorsal fin. Anal spines very stout; the second not much larger than the third, but all considerably shorter than the succeeding divided rays.

Form. \& Loc. Lower Miocene (Lignite): Pus-de-Dôme, France ${ }^{1}$. 27736. Fine specimen 0.175 in length, and fire fragments; Ménat. Croizet Coll.

P. 1920, P. 3913. Portions of two larger specimens; Ménat. Egerton \& Eimistillen Colls

27\%36 a. Six immature specimens; Ménat. Croizet Coll.

P. 1918. Immature specimen; Mrénat. Egerton Coll.

\section{Properca beaumonti (Agassiz).}

1834. Perca beaumonti, L. Agassiz, Neues Jahrb. p. 383.

1836. Perca beaumontii, L. Agnasiz, Poiss. Foss. vol. iv. p. 81, pl. xi a. 1873. Perca (Percichthys) beaumonti, H. E. Saurage, Bull. Soc. Géol. France [3] vol. i. p. 388.

1880. Properca beaumontii, H. E. Sauvage, Bull. Soc. Géol. France [3] rol. viii. p. 452.

Type. Imperfect fish; School of Mines, Paris.

A comparatively robust species, attaining a length of about 0.2 . Length of head with opercular apparatus not exceeding the maximum depth of the trunk, which is contained about three times in the total length to the base of the caudal fin.

1 This species is also recorded from the Upper Miocene of Radoboj, Croatia, by F. Bassani, Atti Soc. Veneto-Trent. Sci. Nat. vol. vii. (1880), p. 88. 
Form. \& Loc. Lower Oligocene: Aix-en-Provence.

P. 1916. Small imperfect fish, labelled by Agassiz as belonging to this species.

Egerton Coll.

\section{Properca (?) prisca (Agassiz).}

1844. Zeus priscus, L. Agassiz, Poiss. Foss. vol. v. pt. i. p. 32, pl. xlriii. fig. 4. [Imperfect trunk; Breslau Museum.]

1844. Perca uraschista, A. E. Reuss, Geogn. Skizzen aus Böhmen, vol. ii. p. 259.

1851. Perca uraschista, H. von Meyer, Palæontogr. vol. ii. p. 57, pl. xi. figs. 1-3.

1885. Plectropomx uraschista, D. G. Kramberger, Rad Jugoslav. Akad. vol. lxxii. p. 36, pl. ii. fig. 1, pl. v. fig. 2.

Type. Imperfect fish; Royal Bohemian Muserm, Prague.

A comparatively robust small species, attaining a length of about 0.15. Length of head with opercular apparatus slightly less than maximum depth of trunk, which considerably exceeds one third the length of fish to base of caudal fin. Fourth dorsal fin-spine longest, the third twice as long as the first.

The two dorsal fins are not so clearly separated in this species as in the typical $P$. angusta, and the tenth or hindermost spine has not been observed.

Form. \& Loc. Lower Miocene (Semi-opal): Bohemia.

21412 b. Distorted head and trunk, wanting end of caudal region, in counterpart; Kutschlin.

Purchased, 1847.

P. 1917. Imperfect trunk; labelled as from Luschitz.

Egerton Coll.

The following specimen probably represents an undetermined species of Properca:-

P. 3910. Robust fish about 0.05 in length, somewhat distorted; Middle Oligocene (Lignite), Sieblos, Bavaria.

Enniskillen Coll.

The following are undetermined Percoids with three anal spines :-

P. 1928, P. 3906. Slender fish 0.07 in length, in counterpart; Upper Eocene, Monte Bolca. The preoperculum has antrorse serrations on the lower limb. Vertebræ apparently $10+14$. Anterior dorsal fin with 9 spines, the third especially elerated and those behind rapidly 
decreasing in length; posterior dorsal relatively low, with short spine and 8 articulated rays; anal with 3 short spines and 7 articulated rays; caudal fin forked. Scales very small.

Egerton \& Enniskillen Colls.

P. 3912. Nearly similar Percoid $0 \cdot 105$ in length, with 11 articulated rays in posterior dorsal and 8 articulated rays in anal fin, and caudal fin rounded; Lower Oligocene, Aix-enProvence.

Enniskitlen Coll.

\section{Genus MIOPLOSUS, Cope.}

[Bull. U.S. Geol. Surv. Territ. vol. iii. 1877, p. 813.]

Trunk laterally compressed and elongate-fusiform. Articulation of mandible beneath hinder border of orbit, and all teeth very small; ascending limb of preoperculum smooth, lower limb coarsely serrated; operculum rounded, without spines. Vertebræ 10 or 11 in abdominal, 14 or 15 in caudal region. Two dorsal fins, the anterior with 9 spines, the posterior with 1 spine and 12 to 14 articulated rays; anal fin with 2 spines and 10 to 14 articulated rays; caudal fin slightly forked. Scales finely serrated.

An extinct North-American freshwater Eocene genus.

\section{Mioplosus labracoides, Cope.}

1877. Mioplosus labracoides, E. D. Cope, Bull. U.S. Geol. Surv. Territ. vol. iii. p. 814.

1884. Mioplosus Labracoides, E. D. Cope, Vert. Tert. Form. West, Book I. (Rep. U.S. Geol. Surv. Territ. rol. iii.), p. 89, pl, xii. fig. 1.

Type. Nearly complete fish; National Museum, Washington.

The type species, attaining a length of about 0.35 . Maximum depth of trunk about equalling length of head with opercular apparatus, and contained four times in total length of fish. Third dorsal finspine longest ; 12 articulated rays in dorsal, 14 in anal fin.

Form. \& Loc. Eocene (Green River Shales): Wyoming, U.S.A.

P. 5217. Slightly distorted specimen 0.25 in length.

Piesented by Lord Avebury, 1886.

P. 7492. Larger, more distorted specimen.

Purchased, 1895.

The following species, all except the fourth from the Green River Shales of Wyoming, have also been distinguished, but only differ very slightly from the type species:- 
Mioplosus abbreviatus, E. D. Cope, loc. cit. 187\%, p. 814, and op. cit. 1884, p. 88.

Mioplosus beani, E. D. Cope, loc. cit. 1877, p. 816, and op. cit. 1884, p. 91, pl. xii. fig. 2.

Mioplosus longus, E. D. Cope, loc. cit. 1877, p. 815, and op. cit. 1884, p. 90 , pl. xii, fig. 3.

Mioplosus multidentatus, E. D Cope, Amer. Nat. vol. xxv. (1891), p. 657.-Lower Tertiary (?); Ree Hills, South Dakota.

Mioplosus sunvageanus, E. D. Cope, op. cit. 1884, p. 92.

Genus PER CA (Artedi), Linnæus.

[Syst. Nat. ed. 10, 1758, p. 289.]

Trunk laterally compressed and elongate-fusiform. Mouth large and protractile, and all teeth rery small; preoperculum with serrations, those of lower limb antrorse; operculum with one spine; seven branchiostegal rays. Vertebræ 21 in the abdominal, 20 or 21 in the caudal region. Two dorsal fins, the anterior with 12 to 16 spines, the posterior with 2 or 3 spines and 12 to 15 articulated rays; anal fin with 2 spines and 8 to 10 articulated rays; caudal fin slightly forked. Scales small and lateral line complete.

Existing in the freshwaters of the Northern hemisphere, and not known to be represented by any extinct species.

The following specimens are referable to the typical Perca

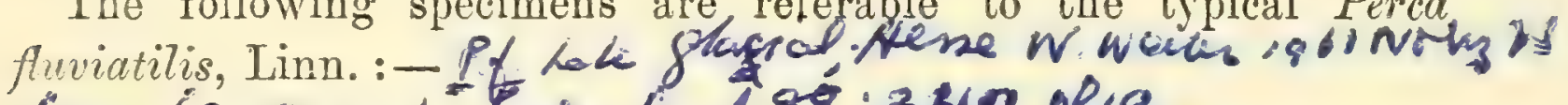

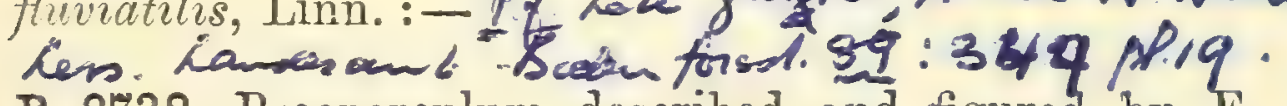

P. 8738. Preoperculum described and figured by E. T. Newton, Vert. Forest Bed (Mem. Geol. Surv. 1882), p. 120, pl. xviii. fig. 1; Forest Bed Series (Upper Freshwater Bed), West Runton, Norfolk.

Savin Coll.

P. 8734-35. Maxillæ and scales; West Runton.

Savin Coll.

The fishes described as follows are not represented in the Collection, and their systematic position is uncertain:-

Perca (Smerdis?) Torenti, H. von Meyer, Neues Jahrb. 1845, p. 456, and Palæontogr. vol. i. (1847), p. 105, pl. xii. fig. 3. (?) Ichthyolites, Sir P. Egerton, Quart. Journ. Geol. Soc. vol. x. (1854), p. 374, pl. xiii.-Lower Tertiary ; Mokattam Hills, Cairo, Egypt. [Imperfect fish; Mannheim M[useum.]

Perca macracantha, T. C. Winkler, Archiv. Mrus. Teyler, vol. v. (1880), p. 94, pl. iii. figs. 7,8 - Middle Oligocene; 


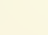



Miopionen abbreviatus, L. Hussate of, Bull. Smen. Mnes.

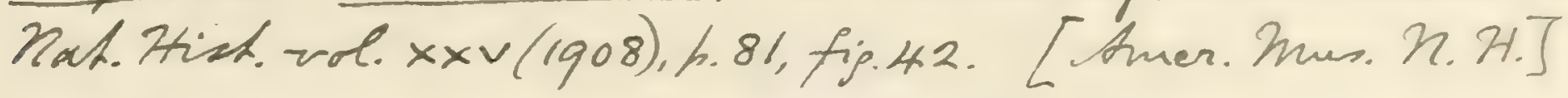

Mn.metidentatus repanded as type of Eoperea,

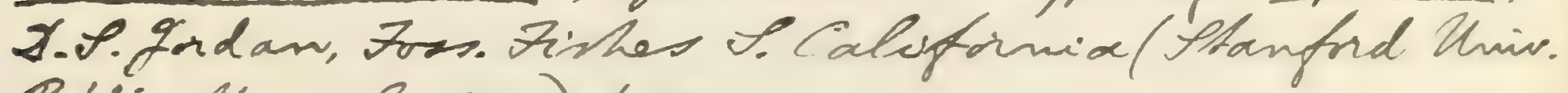
Oublic., Unin. Aer. (919), h.12.

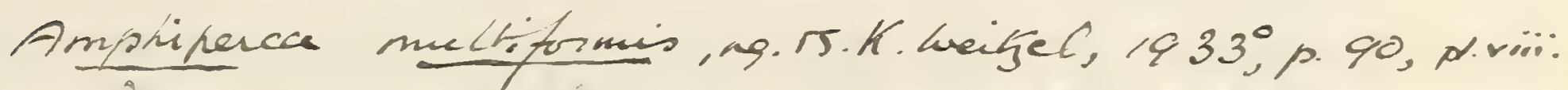

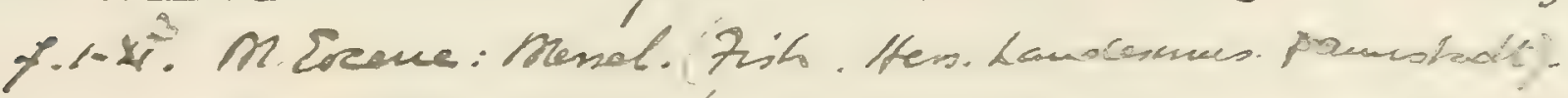
Perca elmota berler - see p.575.

Perea edlaveri s.u.UPannon (Plov.) Auntria.

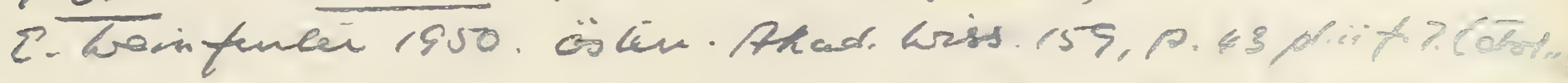

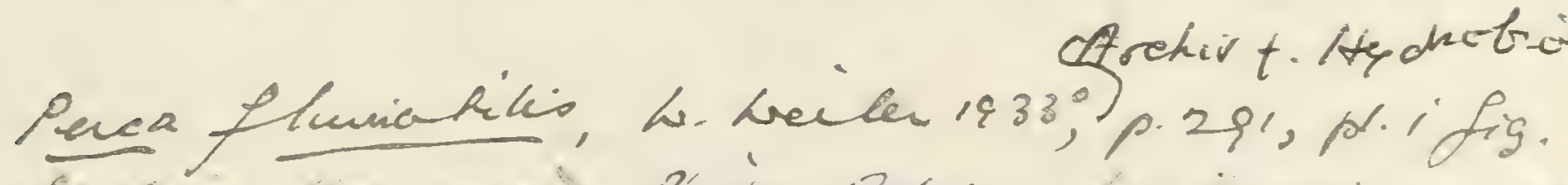

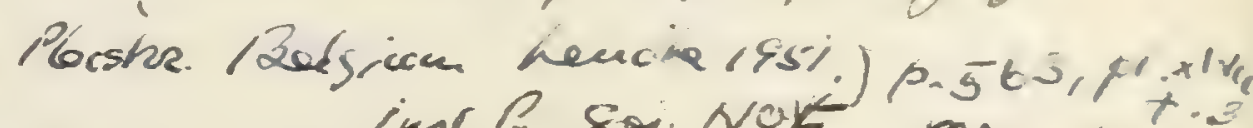

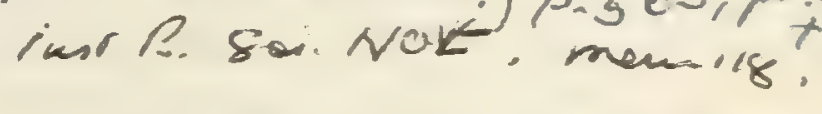

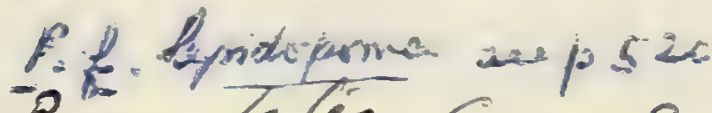

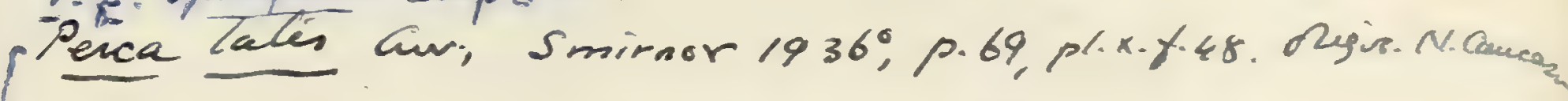

Penca igrota s.u. Sminnor 1936, p-70, slix t.40,42; xixia

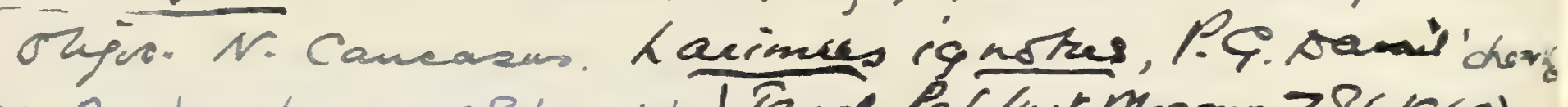

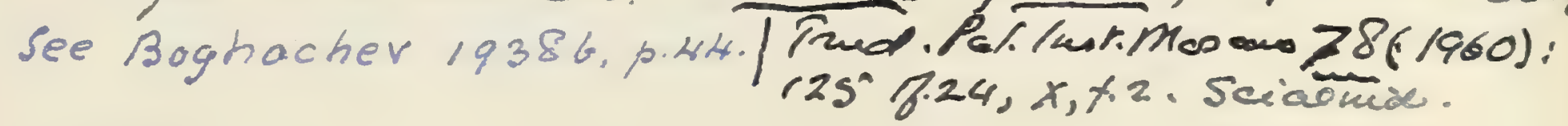

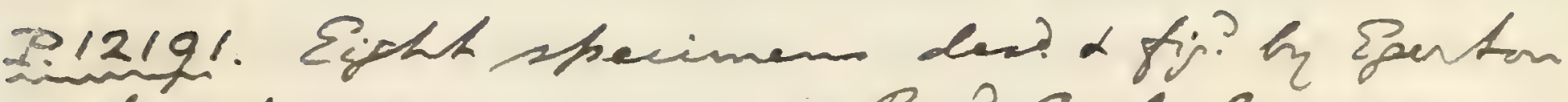
La. i.t. 1854 .

Res? Ged. Doe. 19 "1. 
Sieblos, Bavaria. [Imperfect fish; Geological Museum, University of Würzburg.]

The following indeterminable fragmentary remains from the Lower Eocene (London Clay) of Sheppey, Kent, also seem to belong to genera of the family Percidce:-

P. 642. Hinder half of cranium labelled by Agassiz as intended to be the type specimen of Coeloperca latifrons, recorded by name only in Rep. Brit. Assoc. 1844 (1845), p. 307.

Egerton Coull.

P. 648. Three fragmentary small heads labelled by Agassiz as intended to be the type specimens of Podocephalus nitidus, recorded by name only, loc. cit.p.307. Egerton Coll.

P. 1743, P. 3920. Four fragmentary specimens ascribed to Podocephalus by Egerton. Egerton \& Enniskillen Colls.

P. 643. Imperfect head labelled by Agassiz as intended to be the type specimen of Brachygnathus tenuiceps, recorded by name only, loc. cit. p. 307.

Egerton Coll.

36135. Similar head, better preserved. This fossil appears to be generically and specifically identical with that in the Royal College of Surgeons named Scicenurus longior by R. Owen, Catal. Foss. Rept. \& Pisces, Mus. Roy. Coll. Surg. (1854), p. 171, no. 683.

Purchased, 1861.

P. 1698 b. Fragmentary smaller head, \&c.

Egerton Coll.

P. 639. Fragmentary remains of head labelled by Agassiz as intended to be the type specimen of Percostoma angusta, recorded by name only, loc. cit. p. 307. Egerton Coll.

32388. Head of the same form as that in the Royal College of Surgeons named Planesox vorax by Owen, Catal. Foss. Rept. \& Yisces, Mus. Roy. Coll. Surg. (1854), p. 169, no. 678 .

Purchased, 1857.

41319. Imperfect smaller nearly similar head. Purchased, 1869.

P. 1698 x. Hinder portion of nearly similar head. Egerton Coll.

The following genera and species, not represented in the Collection, are too imperfectly known for discussion, but most of them seem to represent extinct Percoids :-

Oligoplarchus squamipinnis, E. D. Cope, Amer. Nat. vol. xxr. 
(1891), p. 656.-Lower Tertiary (?); Ree Hills, South Dakota, U.S.A. [Imperfect fish.]

Pachygaster polyspondylus, C. G. Giebel, Fauna der Vorw., Fische (1848), p. 22.-Oligocene; Canton Glarus, Switzerland.

[Distorted fish.]

Pachygaster spinosus, C. G. Giebel, Neues Jahrb. 1847, p. 667, and op. cit. p. 22.-Ibid. [Type species. Ditto.]

Paralates bleicheri, H. E. Sauvage, Bull. Soc. Géol. France [3] maik owsky 19 yl vol. xi. (1883), p. 485, pl. xi. figs. 1, 2.-Oligocene;

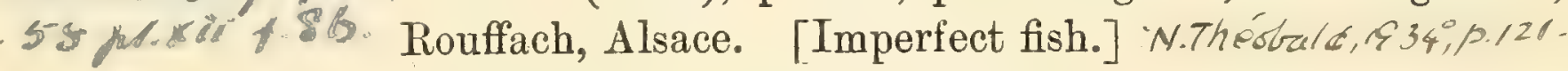
Paraperca provincialis, H. E. Sauvage, loc. cit. [3] vol. iii. (1875), p. 639, pl. xxiii. fig. 2.-Lower Oligocene; Aix-enProvence. [Imperfect fish, perhaps Cottoid; Paris Museum of Natural History.]

Perca (Sandroserrus) reboulii, P. Gervais, Zool. et Pal. Franȩ. (1852), Poiss. Foss. p. 8, pl. Ixxiii. fig. 1.-Pliocene; Pézenas, Hérault. [Imperfect fish; University of Montpellier.]

Platylates rupeliensis, R. Storms, Bull. Soc. Belge Géol. vol. i. (1887), Mém. p. 111, pl. vi._Middle Oligocene (Rupelian); Rumpst, near Boom, Antwerp. [Imperfect trunk ;

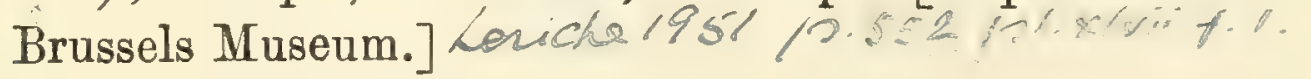

Plioplarchus septemspinosus, E. D. Cope, Amer. Nat. vol. xxiii. (1889), p. 626.-Tertiary; John Day River, Oregon. [Imperfect fish.]

Plioplarchus sexspinosus, E. D. Cope, Amer. Journ. Sci. [3] vol. xxv. (1883), p. 416, and Vert. Tert. Form. West, Book I. (Rep. U.S. Geol. Surv. Territ. vol. iii. 1884), p. 729.-Tertiary; W. Dakota. [Imperfect trunk.]

Plioplarchus whitei, E. D. Cope, loc. cit. 1883, p. 414, and op. cit. 1884, p. 728, pl. xxiv G. fig. 1.-Ibid. [The type species. Imperfect fish.]

Podocys minutus, L. Agassiz, Poiss. Foss. vol. iv. (1838-39), pp. 5, 135, pl. xvi. fig. 5; A. Wettstein, Fischfauna Tertiaer. Glarnerschief. (Denkschr. schweiz. Palaeont. Ges. vol. xiii. 1886), p. 69, pl. viii. fig. 8.-Oligocene; Canton Glarus, Switzerland. [Imperfect fish; Zürich Museum.]

The following extinct species have also been referred to existing genera of Percidæ, but are not represented in the Collection:-

Anthias bassanii, D. G. Kramberger, Rad Jugoslar. Akad. vol. cri. (1891), p. 77. Anthias cfr. stiriacus, F. Bassani, Atti 



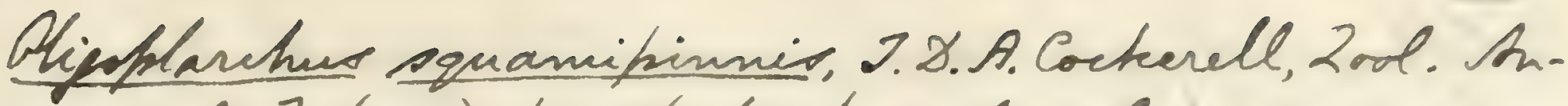
Beigu, orl X7v/1914), p.191 (cturcture of secales).

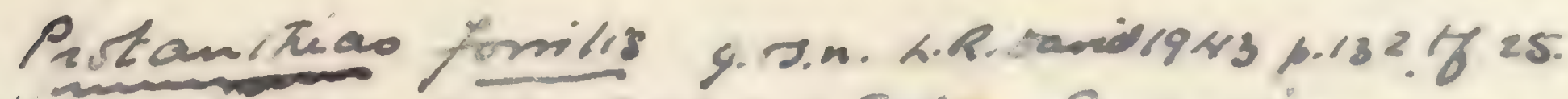

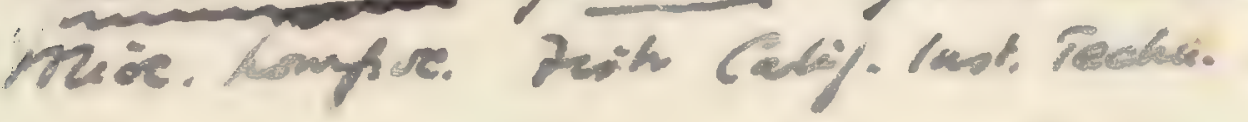

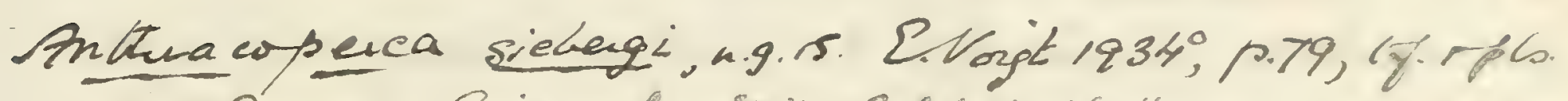

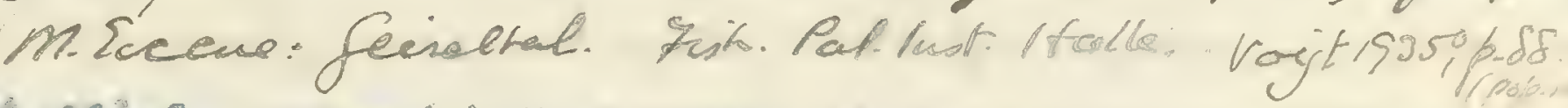

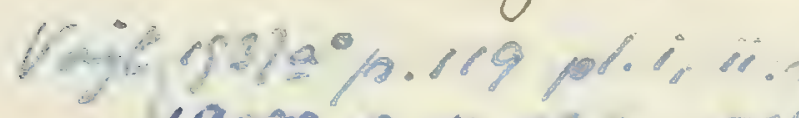

$1935^{\circ}, 0.144 .8 .8,1835=p .2 .8 \cdot 4$.

Olatylates rupeliensir, Mn. Leriche, Mém. Mus. Dong. Hsist. Nat. Belg.

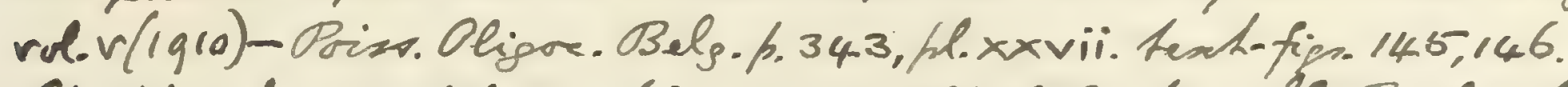
Olioplarehur epkemspinozur, 2. 2. A. Cockerell, 2od. An. Beiger, vd. $\times 7 v(1914)$, h.191 (Aturture of cacles); C.P. Sastmon,

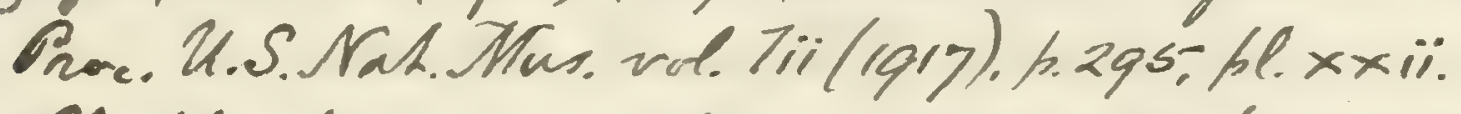

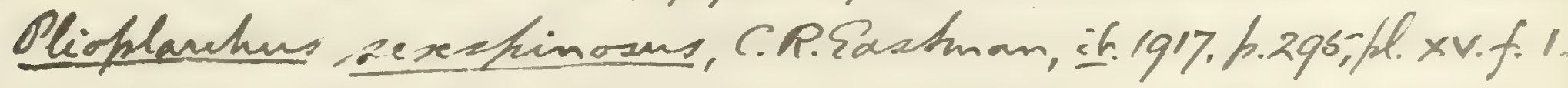

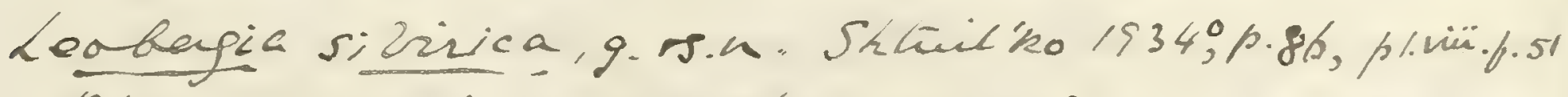
plizr. W. silverico. (hear herictencon).

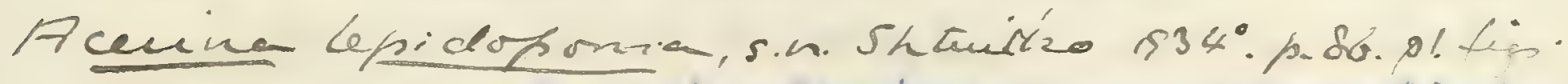

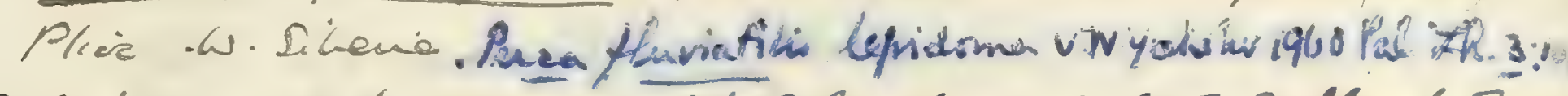
Eclipes vetermus, D. Po Gordand 9.2. Gillert, For. rishes P. Califormia (Thanford Unir. Public, Univ. Sen. 1919), fo.4\%, pl. viir.fip. 4. - Miacene; Pl hodend. Lumperfuth fidh:T I. of Eicle bes. Merrianina ectches is a syionym of celpes veliernus, Fondan FGilbut, tossil Fishes Diatom

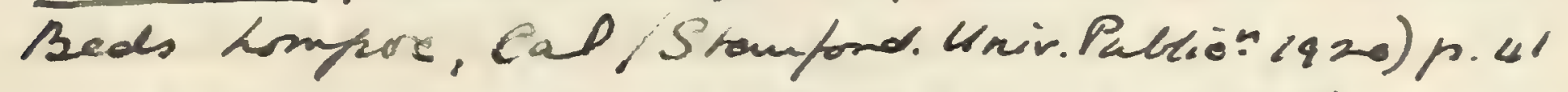

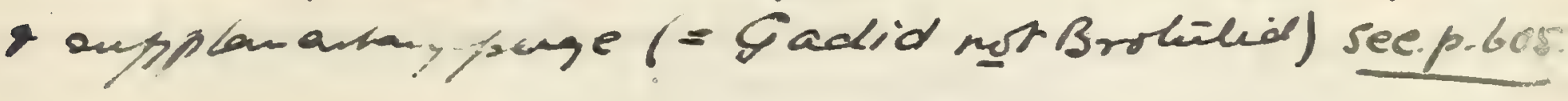



5216

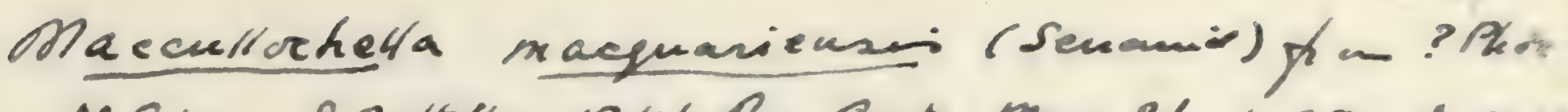

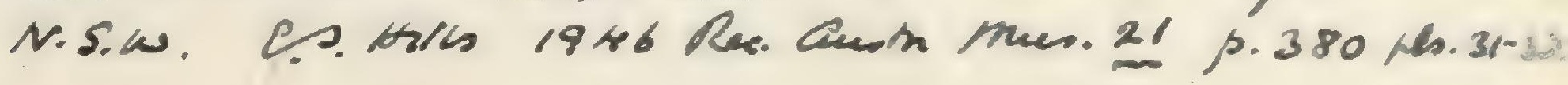

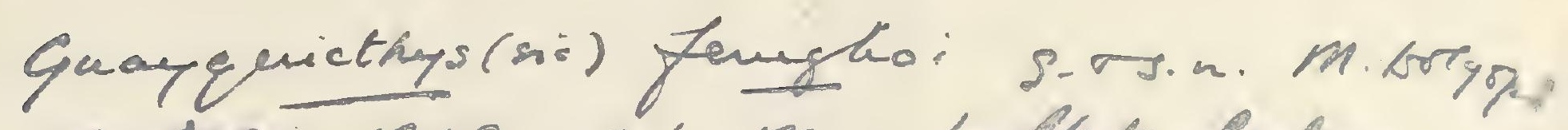

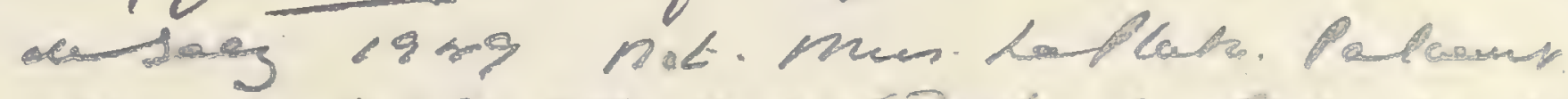

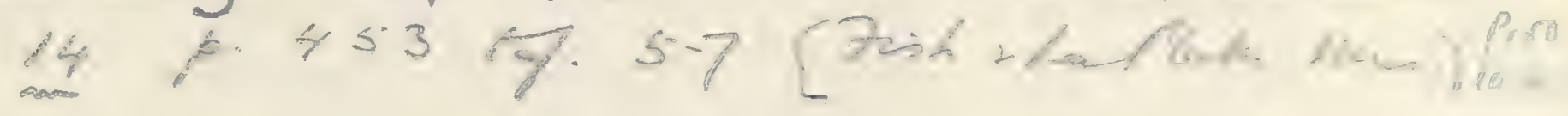

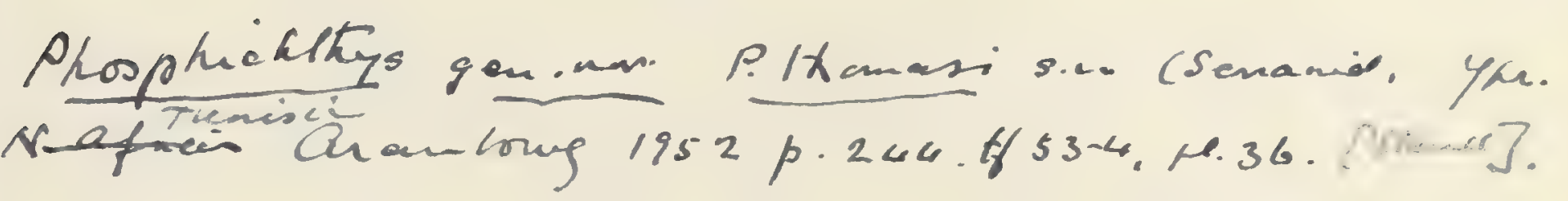

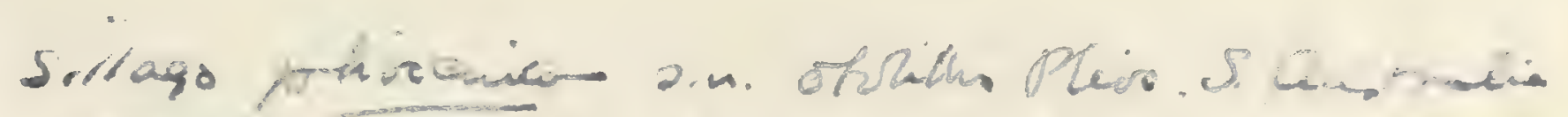

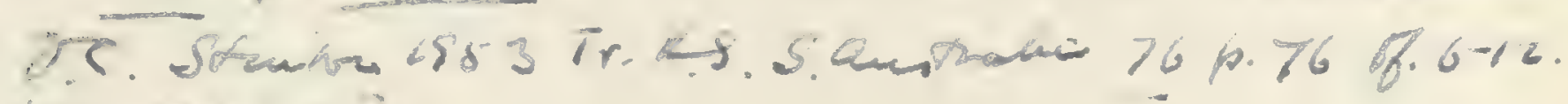
[An. Auenarion]. 
Serranus comparabiti s.a. Maiksp beds, Canoasu

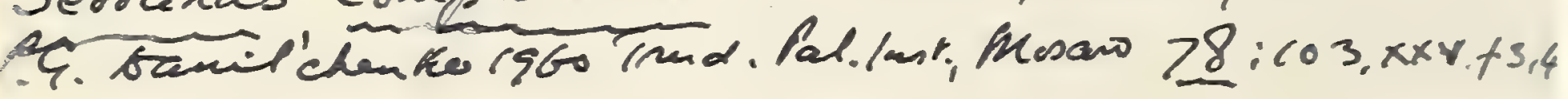

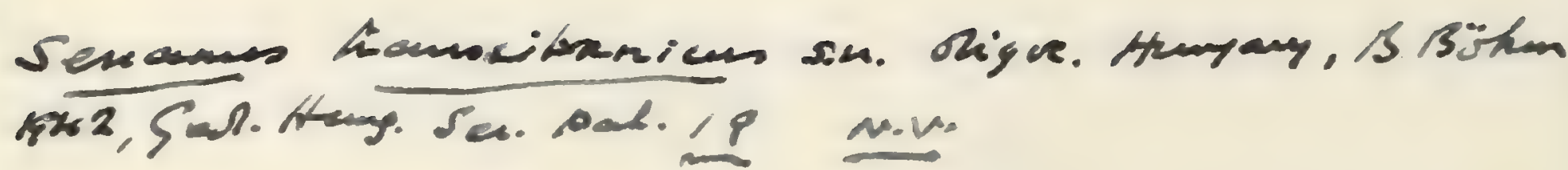




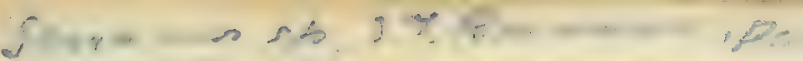

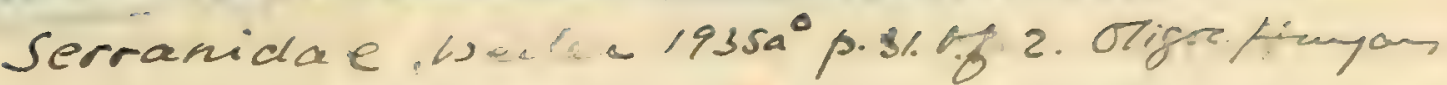

Apogon lánylyanicas 8.4.

\section{PERCID王.}

R. Accad. Sci. Napoli [2] rol. iii. (1889), no. 6, p. 61, pl. vi. fig. 1.-Lower Miocene; Chiavon, Vicentin. [Imperfect fish ; Piovene Coll., Lonedo.]

Apogon krambergeri, F. Bassani, loc. cit. 1889, p.59, pl. v. fig. 4.

-Ibid. [Ditto.]

Apogon macrolepis, R. Storms, Bull. Soc. Belge Géol. vol. $x$. (1897), Ném. p. 220, pl. จ. figs. 3-7.-Upper Eocene;

Wemmel and Neder-over-Heembeek, Brussels. [Imperfect head and remains of trunk.]

Apogon spinosus, L. Agassiz, Poiss. Foss. vol. iv. (1836-37), p. 65, pl. ix. figs. 2-4. Holocentrus lanceolatus, G. S. Volta, Ittiolit. Veronese (1796), p. cexxxii. pl. lri. fig. 2

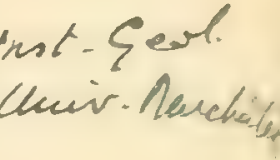
(errore).--Upper Eocene; Monte Bolca. [Imperfect fish; Paris MIuseum of Natural History.]

Dules temnopterus, L. Agassiz, tom. cit. 1834-36, p. 91, pl. xxi.;

F. Bassani, Atti Soc. Veneto-Trent. Sci. Nat. vol. iii. (1876), p. 175. Sciena plumierii, G. S. Volta, op. cit. 1796, p. clхxxт. pl. xlr. fig. 2 (errore).-Ibid. [Ditto.]

Enoplosus pygopterus, L. Agassiz, tom. cit. 1836-37, p. 62, pl. ix. fig. 1; F. Bassani, loc. cit. 1876, p. 175. Scomber ignobilis, G. S. Volta, op. cit. 1796, pl. xir. fig. 1 (errore). - Ibid. [Ditto.]

Incioperca skorpili, D. G. Kramberger, Rad Jugoslav. Akad. vol. cri. (1891), p. 125, pl. viii. figs. 4-8.-Pleistocene(?); Sofia, Bulgaria. [Detached bones.]

Serranus altus, D. G. Kramberger, Beitr. Paläont. Oesterr.Ungarns, vol. ii. (1882), p. 101, pl. xxiii. fig. 1.-Upper Miocene; Agram, Croatia. [Imperfect fish; Geological Nuseum, Univ. Agram.]

Serranus dubius, D. G. Kramberger, Toc. cit. 1882, p. 103, pl. xxriii. fig. 5.-Upper Niocene; Podsused, Croatia. [Fragment; Geological Museum, Univ. Agram.]

Serranus gracilispinis, F. Siebenrock, Wissensch. Mitth. Bosn. u. Hercegov. vol. vii. (1900), p. 691, pl. xiii. fig. 4.-Upper Tertiary; near Sarajevo, Bosnia. [Imperfect fish; Sarajevo MLuseum.]

Serranus pentacanthus, J. J. Heckel, Denkschr. k. Akad. Wiss., math.-naturw. Cl. rol. xix. pt. i. (1861), p. 68, pl. viii. fig. 8.-Middle Miocene; Margarethen, Vienna. [Fragment of head, \&c.]

Serranus rudis, F. Bassani, 7oc. cit. 1889, p. 63, pl. vi. fig. 2.Lower Miocene; Chiaron. [Imperfect fish; Piorene Coll.]

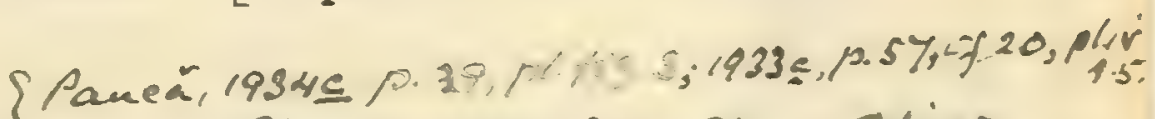
Serranus simimescui. n.s. M. Paunci, $1929 a^{\circ}$, p.31. - Oligr:

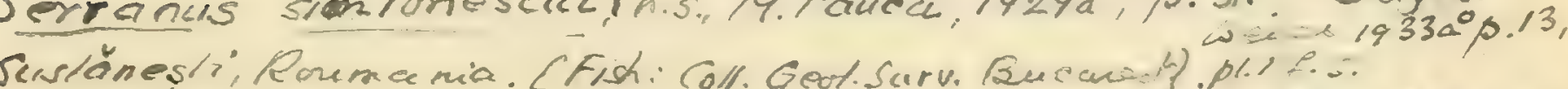


Serranus rugosus, J. J. Heckel, Sitzungsb. k. Akad. Wiss., math.naturw. Cl. vol. xi. (1854), p. 137. Founded on Serranus ventralis, Agassiz (in part), Poiss. Foss. vol. iv. pl. xxiii $b$. (upper fig.).-Upper Eocene; Monte Bolca. [Imperfect fish.]

Serranus stiriacus, D. G. Kramberger, Djela Jugoslav. Akad. vol. xri. (1895), p. 60, pl.x. fig. 3.-Upper Oligocene; Tüffer, Steiermark. [Imperfect trunk.]

Serranus validus, D. G. Kramberger, loc. cit. 1895, p. 59, pl. x. fig. 2.-Ibid. [Ditto.]

Serranus wemmetiensis, R. Storms, Bull. Soc. Belge Géol. vol. x. (1897), Мém. p. 210, pl. v. figs. 1, 2.-Upper Eocene; Neder-over-Heembeek, Brussels. [Head, \&c.]

Otoliths from the Oligocene and Miocene of Germany have also been referred to Percoid fishes under the names of Otolithus (Serranus) noetlingi, O. (Serranus) distinctus, O. (Percidarum) varians, O. (P.) plebejus, O. (P.) frequens, O. (P.)- Cequalis, and p4990. (P.) moguntinus (E. Koken, Zeitschr. deutsch. geol. Ges. $\zeta$ vol. xliii. 1891, pp. 124-128, pl. viii. figs. 1, 4, pl. x. figs. 1, 2). An otolith from the Forest Bed, West Runton, Norfolk, now in the Museum of Practical Geology, is supposed to belong to the existing Acerina vulgaris (E. T. Newton, Vert. Forest Bed-Mem. Geol. Surv. 1882-p. 121, pl. xviii. fig. 9).

The following extinct species, imperfectly defined and not represented in the Collection, are referred chiefly to existing genera intermediate between the Percidæ and Sparidæ :-

$\cong$ Ctenodentex laekeniensis, R. Storms, Bull. Soc. Belge Géol. vol. x. (1896), Mém. p. 199, pl. iii., pl. iv. figs. 3-6.-Dentex laekeniensis, P.J. Van Beneden, Bull. Acad. Roy. Belg. [2] vol. xxxiv. (1872), p. 423, with plate.-Upper Eocene (Wemmelian); Belgium. [Type species of Ctenodentex. Imperfect fish; Brussels Museum.]

Dentex crassispinus, L. Agassiz, Poiss. Foss. vol. iv. (1839), p. 147.-Upper Eocene; Monte Bolca, near Verona. [Imperfect fish; Paris Museum of Natural History.] Dentex faujasi, L. Agassiz, tom. cit. 1839, p. 150. Coryphona, Faujas St. Fond, Ann. Muséum, vol. i. (1802), p. 355. - Middle Eocene (Calcaire Grossier); Nanterre, Paris. [Fragmentary fish.]

Dentex leptacanthus, L. Agassiz, tom. cit. 1839, p. 144, pl. xxvi. -Upper Eocene; Monte Bolca. [Imperfect fish; Paris Museum of Natural History.] 

Otolithus (Percidarum) cotheaui, 7. Priem, Buticior. Gérl. France $[4]$ vol, xii (1912), h. 246, hext-fig. 1-4.- In. Eoeene;

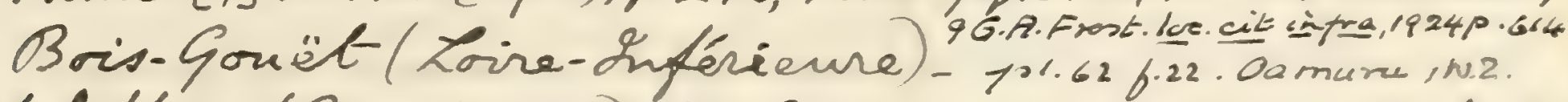
Otolithus (Pervidarum) Eartonensis, F Priem, Bull. Sor Géd. France [4] vol. xil (1912), h.248, texh-figs. 7, 8.1-U1. Eveene; Banton, Hants. T. Pchubert, Lahtsk.k.geol.

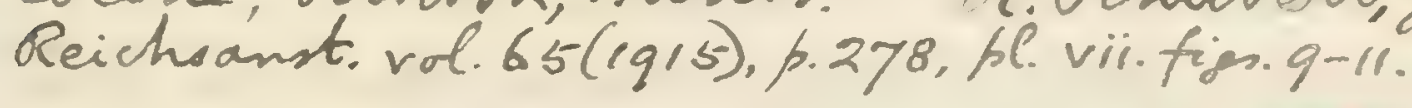

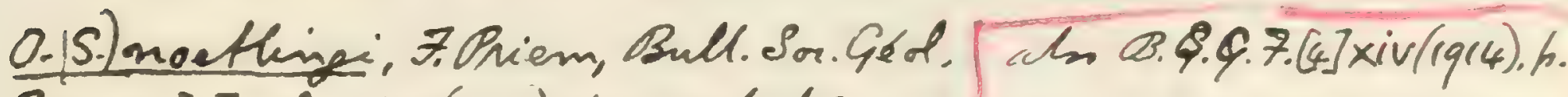
France [u]vol. xiv (1914), h.248, texh.fi. $]$; $247, f .4 ; h .258, f .28-31 .-$

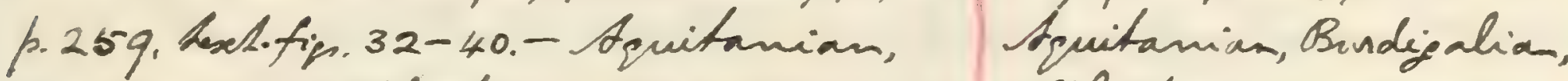
Bundigalian, LBelvetion; S.W. Irance. DFelvetion; S.W. France.

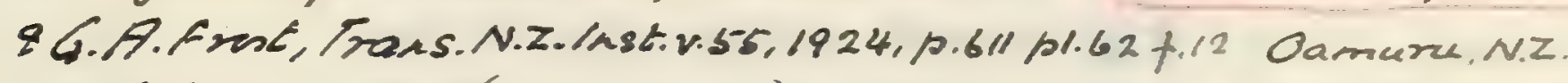
Otolithus (Terranur) eLeinabunnensir, T. T. (19ob), p. he. tis.

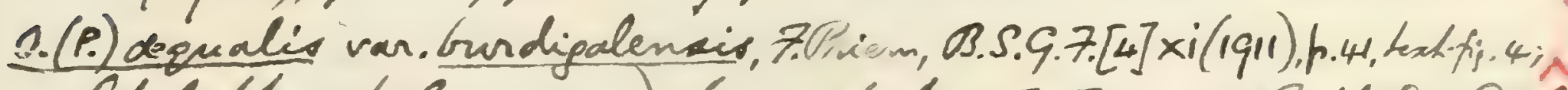
Otolithue (Denamer) bourdsti, F. Priem, Bull. So. Géd. France $[4]$ vd. vi $(1906), 6.26 \%$ fir. 3-6; Aun. Paléont. rol vi (1911), h. 28, texat-fies-26, 27. - Luthetian; Paris Basion.

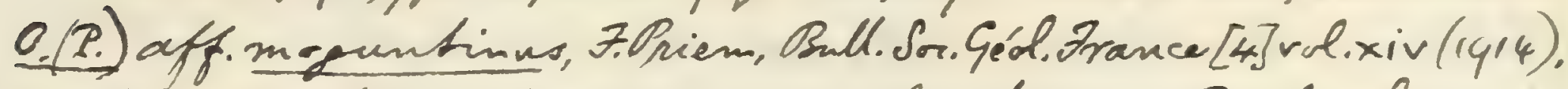

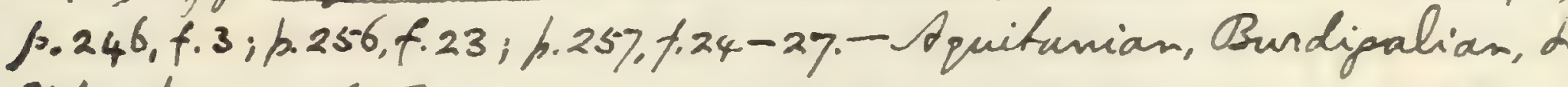
Helvetion; S. Wr France.

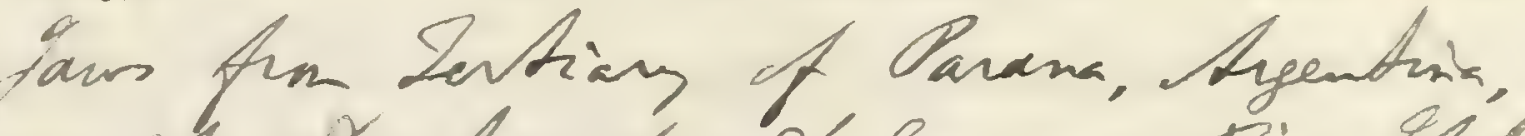
compared wth bentex hy D. Sanginge, Dirs Odal.

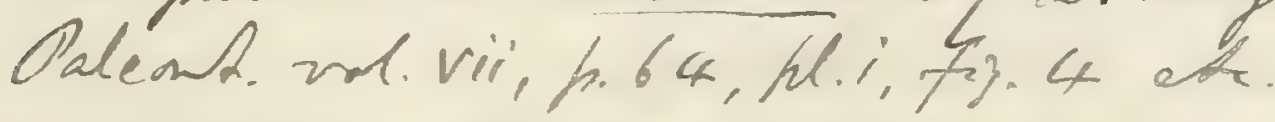

Yentex chateleti, Loglexud, Sném. Srad. Vaucluae, [2] vol vi(19 06) h.353. - Helvetian; Bompar. [Joolh] Dentex of. venteanio, C.dK: In. Gemmellars, Giom. Sci. Nat. Com. Palermo, vol $x \times x(1914)$, p. 105, fhe. it. fir. $25-30$.

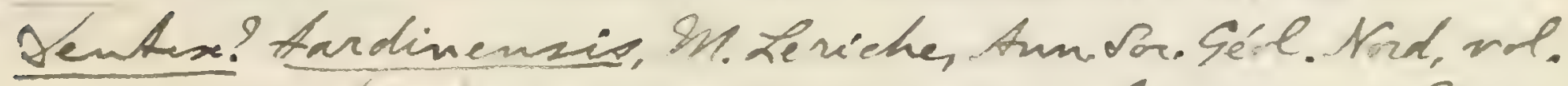
xxxvii (1908), h. 254, hl. vi.fin, 12,13.- Yhrescian; Bonrey, Iname. [Otdith, Molot Coll, Reims.]

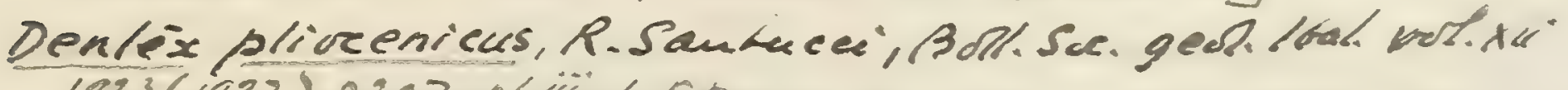
$1823(1922), 0.20 \geqslant$, pliil, f. 5,5a. 
Atrlithus (Pridarum) acutus, 7.Priem, Am. Paléat. rol. vil(1911), fo.29, teath-fin. 31,32.- Lutetian; Fercount,

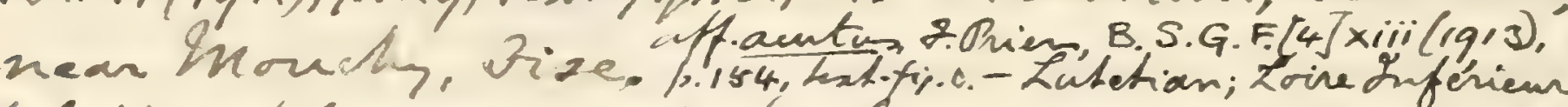

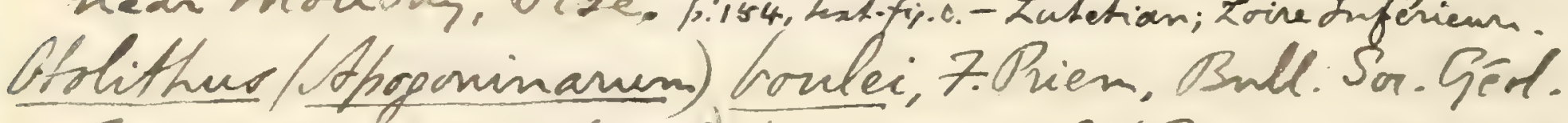
France [u] vol vil(190b), ha.272,t-f.28,29. Q. (Berycidarma) Goulei, Y.Priem, Amn.Paléont.vol. vil(1911), h.26.

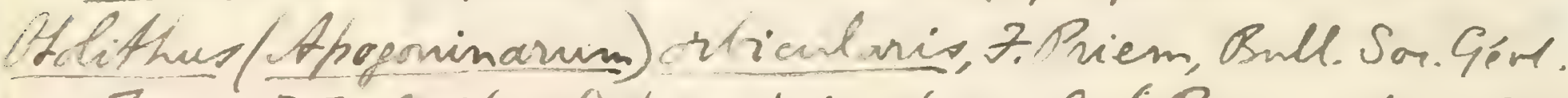

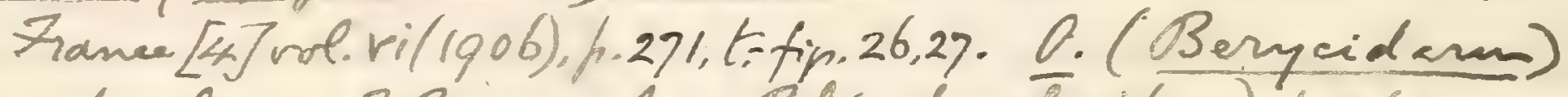
crubieularis, 7. Priem, Amm, Paléant. vol, vi (19i1), p. 26. (tollithur (Dentex) dubius, 7. Piem, Bull. Sor. Géd. France [4] rol, vil(1906), h.268, Lest-fin. 9, 10-U. Ypeesian;

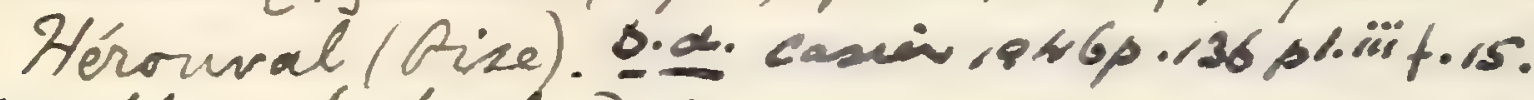

Atlithm (Dentex) pausramencis, R. 2.

Schubert, Zeitseth. mähn. Zandermus.

Brimn, viii, 1908, p.

Otrlithero (Percidarum) concavers, 7. Priem, Bull. Sac.

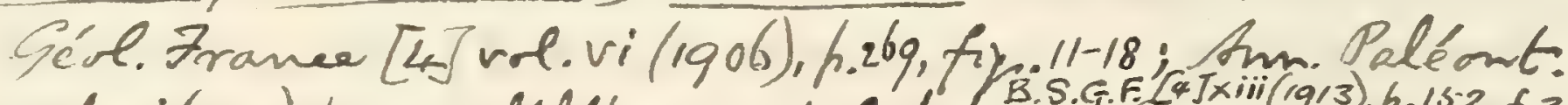

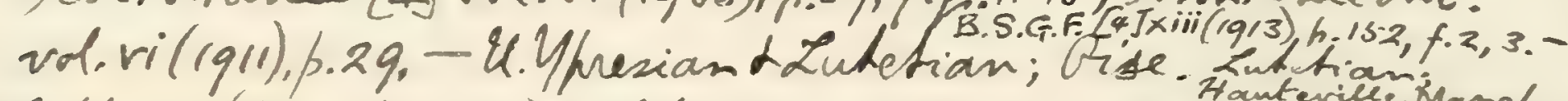

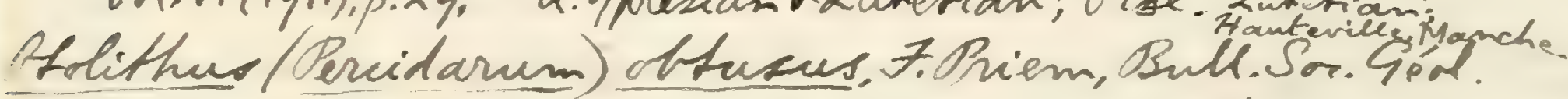

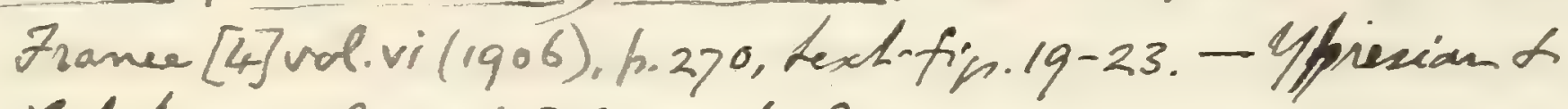
Lutation; Oise $\alpha$ Seine-et. Dize.

Atilithus (Peridarum) humgaricus, R. Schubest,

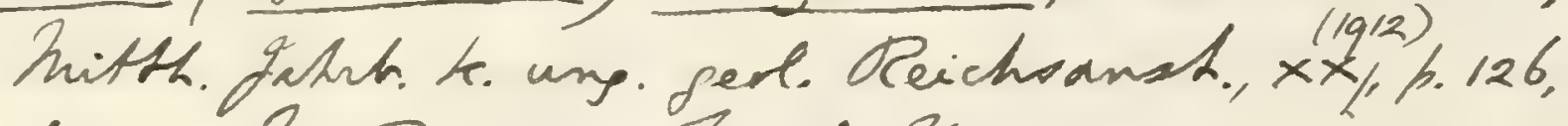
fip..- In. Borene; Kósd, Aturgary. Otolithus (Pereidarum) sp., G. Stefanini, Mrem. Latit. Gere. Univ. Padrva, vol iv (1917), h. 15, pl.i.fir.11. rnivene (Jottonian): Veneto, Itely.

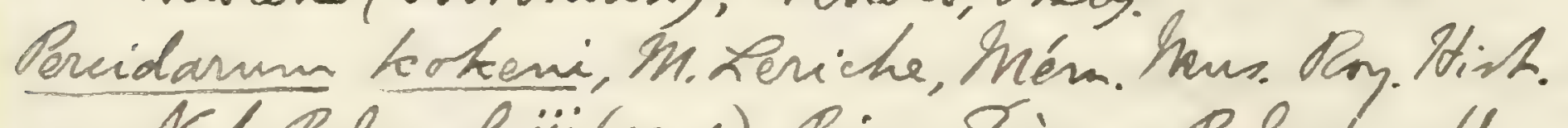

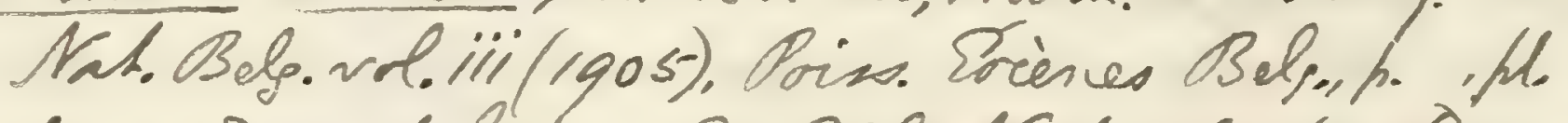

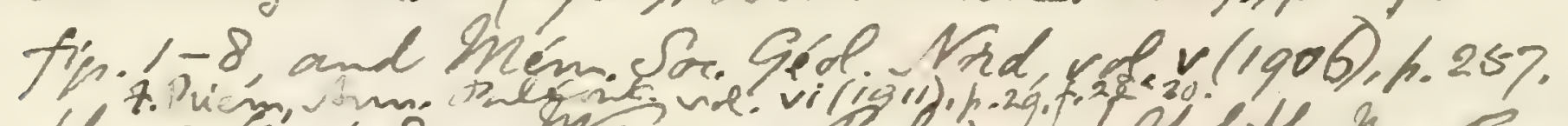

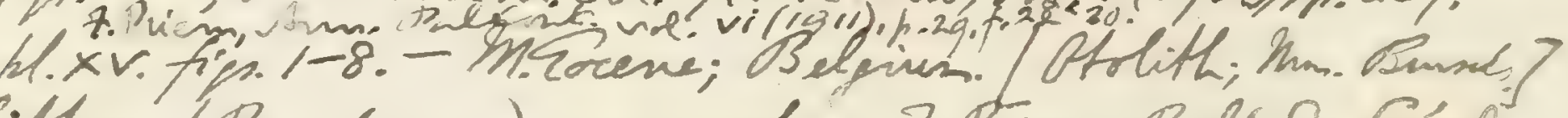

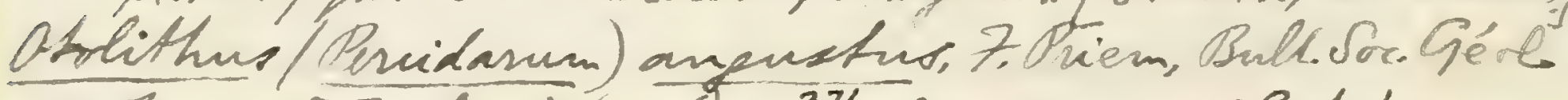

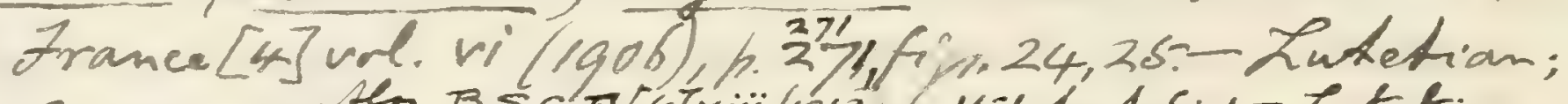

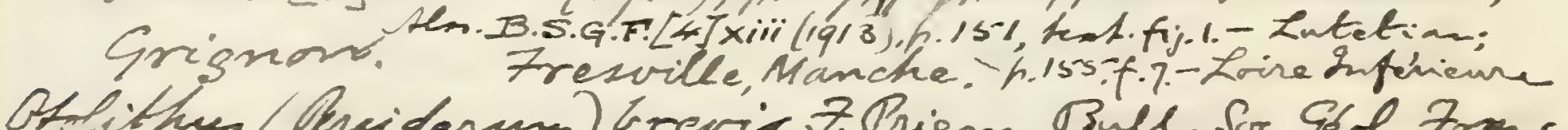

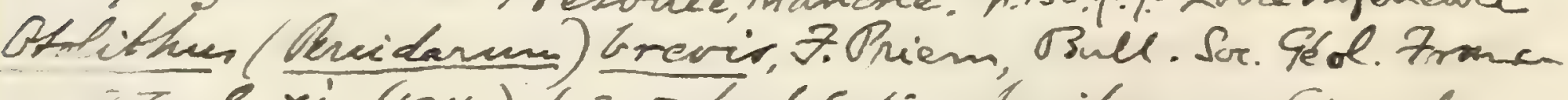

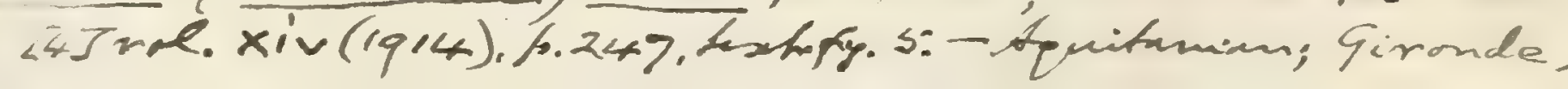




Dentex microdon, L. Agassiz, tom. cit. 1839, p. 146, pl. xxvii.

fig. 2.-Upper Eocene; Monte Bolca. [Imperfect fish; Palæontological Museum, Munich.]

Dentex muensteri, G. Meneghini, Ann. Univ. Tosc. vol. viii. pt. ii. م- (1866), p. 19, with plate.-Lower Pliocene; Volterrano, Tuscany. [Jaws, \&c.; University of Pisa. ${ }^{1}$

Dentex sardiniensis, D. Lovisato, Pendic. R. Accad. Lincei [5] vol. v. pt. ii. (1896), p. 78 (name only).-Miocene; Sardinia. [Teeth; University of Cagliari.]

Dentex ventralis, L. Agassiz, tom. cit. 1839, p. 150.--Upper Eocene; Monte Bolca. [Imperfect fish; olim Hibbert Collection.]

Otolithus (Dentex) nobilis, E. Koken, Zeitschr. deutsch. geol. Ges. vol. xliii. (1891), p. 124, pl. viii. fig. 8.--Upper Oligocene; Germany. [Otolith.] 0.(D) uff. mokilis?, 7. Oriem, 03.S.9.7. [4] xiv Gerres massatongoi, J. J. Heckel, Sitzungsb.k. Akad. Wiss., math. $(19 / 4) .6 .262, f$ naturw. Cl. vol. xi. (1854), p. 327; F. Bassani, Attigalian; Girmole R. Accad. Sci. Napoli [2] vol. iii. (1889), no. 6, p. 58, pl. xiii. fig. 2.-Lower Miocene; Chiavon, Vicentin. [Imperfect fish; Court Museum, Vienna.]

Pelates quindecimalis, L. Agassiz, tom. cit. 1834-36, p. 95, pl. xxii.; F. Bassani, Atti Soc. Veneto-Trent. Sci. Nat. vol. iii. (1876), p. 175.- Upper Eocene; Monte Bolca. [Imperfect fish ; Paris Museum of Natural History.]

Pristipoma furcatum, L. Agassiz, tom. cit. 1839, p. 177, pl. xxxix. fig. 1.--Ibid. [Ditto.]

Sparosuina ovalis, H. E. Saurage, Bull. Soc. Géol. France [3] rol. xi. (1883), p. 487, pl. xiii. fig. 3.--Lower Oligocene ; Aix-en-Provence. [Type species of Sparosoma, Sauvage, 1883, non Sparisoma, Swainson, 1839. Imperfect fish ; School of Mines, Paris.]

Q6. (Dentex) aff. subnowis. Schubert. for ref. see G.A.frost, Trous.

N.Z. Inst: v. 55. (1924) p.613p1.62.8.18 ( Toammu.N.z.)

Family TEUTHIDID

As Percidæ, but only cutting teeth on margin of jaw; each pelvic fin with an outer and inner spine; anal fin with 6 or 7 spines.

One genus (Teuthis, Linn.) with numerous species in the IndoPacific Ocean, and an allied extinct genus with one species which is not represented in the Collection:-

1 Two fragments of mandible and two vertebræ from the Lower Pliocene of Orciano, may perhaps represent this species (47031. Purchased, 1875). $\mathscr{J}$.

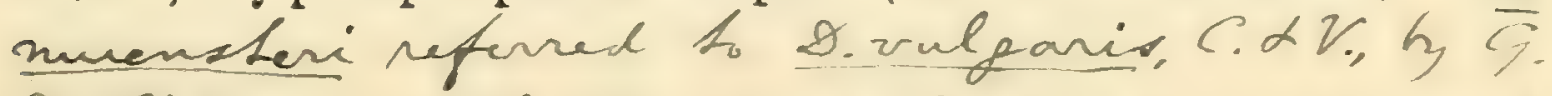
We Steftano, Boll. Lou. Geol. Ital. vol.xwiii (1910), h.611, hl. xix. fige. 19, 21, 24-26, bl. xx. fips.17-2: 
Archceoteuthis glaronensis, A. Wettstein, Fischfama Tertiaer. Glarnerschief. (Denkschr. schweiz. Pal. Ges. vol, xiii. 1886), p. 67, pl. viii. fig. 11.-O Oligocene ; Canton Glarus, Switzerland. [Imperfect fish with 12 dorsal and 6 anal fin-spines; Basle Museum.] Procosigences, nom.now.

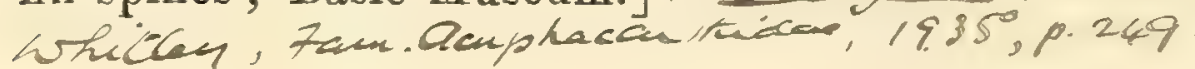

\section{Family SPARIDÆ.}

As Percidæ, but dentition of premaxilla and dentary specialised, so that there is either a sharply cutting margin or a prehensile or cutting margin with inner molariform teeth; palate toothless or with rudimentary dentition.

In the existing fauna, these are marine fishes found on all temperate and tropical coasts.

\section{Synopsis of Extinct Genera and Genera represented by Extinct Species.}

Single series of stout, obtusely-conical teeth, with minute similar teeth within ........ Incisiform front teeth, and two or more series of molariform hinder teeth........... sargus (p. 529).

Very broad incisiform teeth in front......... Trigonodon (p. 531).

Minute clustered front teeth, with few enlarged canines, and two or more series of molariform hinder teeth................. Conical prehensile front teeth, and two series of molariform hinder teeth............. Pagrus (p. 533).

As Pagrus, but three or more series of molariform hinder teeth, usually irregular..... Chrysophrys (p. 534).

\section{Genus SPARIVODUS, Agassiz.}

[Poiss. Foss. vol. iv. 1838, p. 10.]

Syn. Scianurus, L. Agassiz, Rep. Brit. Assoc. 1844 (1845), p. 295.

A single series of stout obtusely-conical teeth on the margin of the jaws, longest at the symphysis, gradually becoming very short behind; a few irregular, minute, obtusely-conical teeth within. Preoperculum pectinated and very finely serrated. Dorsal fin with 10 spines, anal fin with 3 spines. Scales large or of moderate size, not serrated but very finely rugose in their exposed portion, extending over the operculum and cheek, and forming a sheath at the base of the dorsal and anal fins.

An Upper Eocene and Lower Miocene genus. 

Family LUTIANIDEE.

Gemes Burtinia, P. Van Beneden.

[Paléont. des Vertéteés in Patria Belgica, thi, $1873,4.381$.

Burtinia bruxelliensis, P. Tan Beneden, loe.

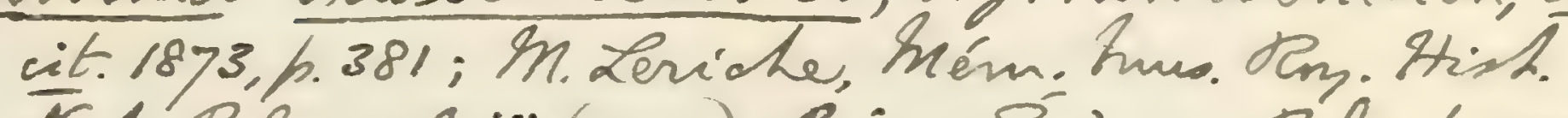
Tat. Bels. vol. iil (1905), Brins. Eocènes Belp. h.20\%, teat.fij. 61, and Iném. Sre. Géol. Nord, vol. v (1906). k.280, Lexh.tip. 70. - E. Eocene (Zedian); Hetelperm, Belgiurs. [Steull; hum. Osmusseh.]

Lutianus hagari, O. P. Fordaw 2 9. 2. Gilbert, Fons. Firhes P. Californial Stanford Univ. Public, Univ. Ser. 1919), p.48, hl. xiv. fip. 1, 4.- - Inicuene; SlModena. [Ouprerfut firh.] veomaeme hagari, Trdan,

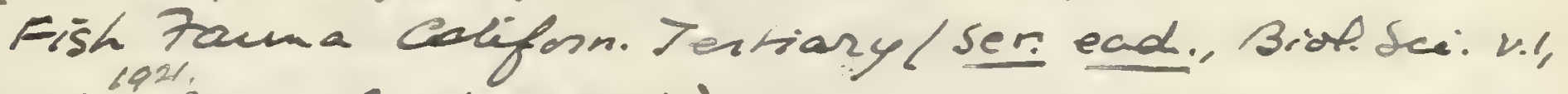
ptirip.278 ple.46(restor.")

Luticans is o

Shachine of teeth of Sargodon, T.T.Thamasset, C.-R. Soe. geist. France M. 0,1924 f.27.

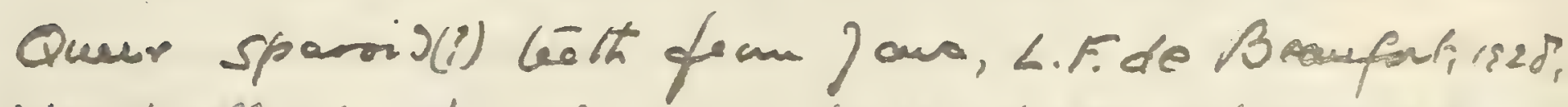

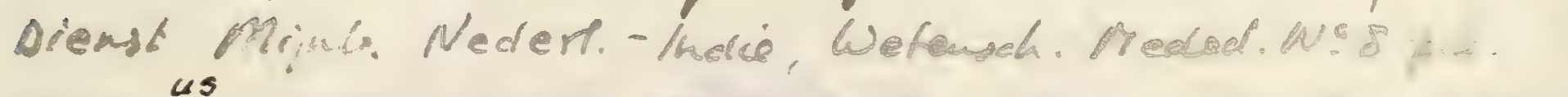
Lutian uvus, n.s, W.K.Gregory, 1930, Florida State Ged. Surv. Bull. 5, p.7, 2 4s, pls 1-4. L. Oligor. Florida U.S.A. (Imp. remaing, A.S. G.S.)

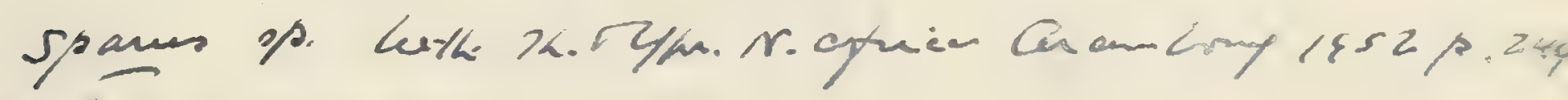
he. 3 ? $+2 \sim 19$.

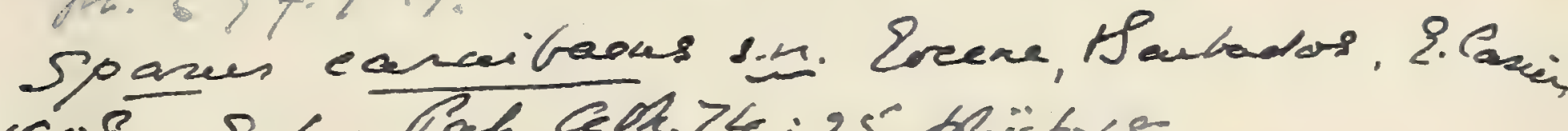

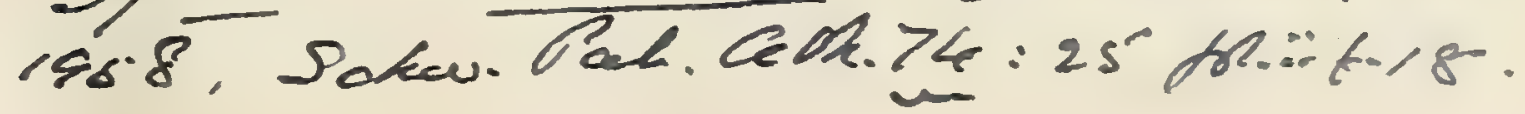


Sparnodus macrophthalmus, Agassiz.

1796. Sparus macrophthalmus, G. S. Volta, Ittiolit. Veronese, p. ccxlvii. pl. lx. fig. 2 (errore).

1796. Cyprinus, G. S. Volta, ibid. pl. 1xxiii.

1796. Sparus dentex, G. S. Volta, ibid. p. Ixii. pl. xiii. fig. 1 (errme).

1796. Sparus sargus, G. S. Volta, ibid. p. Ixxvi. pl. xvii. fig. I (errore).

1796. Sparus erythrinus, G. S. Volta, ibid. p. cexlix. pl. lx. fig. 3 (errore).

1818. Sparus vulgaris, H. D. de Blainville, Nour. Dict. d'Hist. Nat. vol. xxvii. p. 349.

1835. Sparnodus macrophthalmus, L. Agassiz, Neues Jahrb. p. 300 (name only).

1835. Sparnodus ovalis, L. Agassiz, ibid. p. 300 (name only).

1835. Sparnodus altivelis, L. Agassiz, ibid. p. 300 (name only).

1835. Sparnodus micracanthus, L. Agassiz, ibid. p. 300 (name only).

1839. Sparnodus macrophthalmus, L. Agassiz, Poiss. Foss. vol. ir. p. 158, pl. xxviii. fig. 3.

1839. Sparnodus ovalis, L. Agassiz, ibid. p. 161, pl. xxix. fig. 2. [Imperfect fish ; Paris Museum of Natural History.]

1839. Sparnodus altivelis, L. Agassiz, ibid. p. 162, pl. xxix. fig. 3. [Ditto.]

1839. Sparnodus micracanthus, L. Agassiz, ibid.p. 164, pl. xxriii. fig. 2, pl. xxix. fig. 1. [Ditto.]

1886. Sparnodus lethriniformis, W. Szajnocha, Pamiet. Wydz. matem.przyr. Akad. Umiejet. Krakow, vol. xii. p. 106, p]. i. fig. 1. [Imperfect fish; University Geological Museum, Cracow.]

1876. Sparnodus ovalis, F. Bassani, Atti Soc. Veneto-Trent. Sci. Tat. vol. iii. p. 177.

1876. Sparnodus micracanthus, F. Bassani, ibid. p. 177.

Type. Imperfect fish; Paris Museum of Natural History.

The type species, attaining a length of about 0.3 . Trunk very stout, its maximum depth equalling three times that of the caudal pedicle and exceeding the length of the head with opercular apparatus, which occupies slightly more than one third of the total length to the base of the caudal fin. Dorsal fin with 10, anal fin with 8 or 9 articulated rays.

Form. \& Loc. Upper Eocene : Monte Bolca, near Verona.

44867, 44870-72. Three specimens in counterpart, the second measuring 0.27 in length, and the third shortened and deepened by distortion. No. 44867 displays the fine serrations of the preoperculum, and shows the scales extending over the cheek. 
P. 1963. Fine specimen 0.24 in length, labelled by Agassiz and apparently referred to in Poiss. Foss. vol. iv. p. 160.

Egerton Coll.

21394. Fine specimen 0.22 in length, in counterpart.

Purchased, 1847.

$13448,-50,19944,21426,21529$ a. Four smaller specimens, three being in counterpart.

Purchased.

P. 1936 , P. 1965 , P. 2090, P. 3898-99, P. 3928-29, P. 4235.

Eight small specimens, three being in counterpart.

Egerton \& Enniskillen Colls.

\section{Sparnodus elongatus, Agassiz.}

1796. Percr vadula?, G. S. Volta, Ittiolit. Veronese, p. cxxxiv. pl. xxxi. fig. 1 (errore).

1796. Sparus chromis, G. S. Volta, ibid. p. cxxxviii. pl. xxxii. fig. 1 (errore).

1796. Sparus salpa, G. S. Volta, ibid. p. ccxxx. pl. Ivi. fig. 1 (errore).

1835. Sparnodus elongatus, L. Agassiz, Neues Jahrb. p. 300 (name only).

1835. Serranus ventralis, L. Agassiz, ibid. p. 293 (name only).

1839. Serranus ventralis, L. Agassiz, Poiss. Foss. vol. iv. p. 104, pl. xxiii b. (lower figure). [Imperfect fish; Paris Museum of Natural History.]

1839. Sparnodus elongatus, I. Agassiz, ibid. p. 165, pl. xxviii. fig. 1.

Type. Imperfect fish; Paris Museum of Natural History.

Trunk somewhat less deepened and head relatively smaller than in the type species, otherwise similar.

Form. \& Loc. Upper Eocene: Monte Bolca.

P. 1900, P. 3901. Fine specimen about 0.2 in length, in counterpart. Egerton \& Enniskillen Colls.

P. $1937-38$, P. 2091, P. 3897, P. 3900, P. 3926. Four specimens in counterpart, the largest 0.22 in length and labelled by Agassiz.

Egerton \& Enniskillen Colls.

37220. Imperfect fish in counterpart, about 0.21 in length.

Purchased, 1863.

P. 6855. Imperfect smaller fish, in counterpert. Purchased, 1893. 


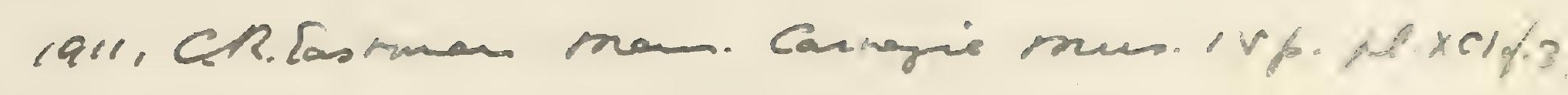




\section{Sparnodus microstomus (Agassiz).}

1796. Sparus brama, G. S. Volta, Ittiolit. Veronese, p. clxxxvii. pl. xlv. fig. 3 (errore).

1818. Sparus brama = Sparus vulgaris, H. D. de Blainville, Nouv. Dict. d'Hist. Nat. vol. xxvii. p. 350.

1835. Serranus microstomus, L. Agassiz, Neues Jahrb. p. 299 (name only).

1835. Servanus occipitalis, L. Agassiz, izid. p. 300 (name only).

1835. Dentex breviceps, L. Agussiz, ibid. p. 300 (name only).

1839. Serranus microstomus, L. Agassiz, Poiss. Foss. vol. iv. p. 100, pl. xxiii $a$.

1839. Serranus occipitalis, L. Agassiz, ibid. p. 102, pl. xxiii. [Imperfect fish ; Paris Museum of Natural History.]

1839. Dentex breviceps, L. Agassiz, ibid. p. 149, pl. xxvii. figs. 3, 4. [Imperfect fish ; Palæontological Museum, Munich.]

Type. Imperfect fish; Paris Museum of Natural History.

A smaller species than the type, of similar general proportions, hut frontal profile apparently steeper, scales smaller, articulated dorsal fin-rays 12, articulated anal fin-rays 10 in number.

Form. \& Loc. Upper Eocene: Monte Bolca.

13452-53, 21425, 21529. Three specimens in counterpart, the first very imperfect.

Purchased.

P. 1935. Two small specimens.

Egerton Coll.

P. 3896, P. 3902. Two small specimens, the first labelled Serranus microstomus, the second Dentex breviceps by Agassiz.

Enniskillen Coll.

P. 1966. Imperfect fish 0.175 in length, doubtfully of this species.

Egerton Coll.

\section{Sparnodus bowerbanki (Agassiz).}

1845. Scianurus bowerbanki, L. Agassiz, Rep. Brit. Assoc. 1844, p. $295, \mathrm{pl} . \mathrm{xl}$.

1845. Scianurus crassior, L. Agassiz, ibid. p. 307 (name only).

(?) 1854. Scianurus brevior, R. Owen, Catal. Foss. Rept. \& Pisces, Mus. Roy. Coll. Surg. p. 171, no. 681. [Fragmentany head.]

Type. Fragment of head and trunk; British Museum.

The type species of the so-called Sciconurus, known only by fragments. Larger than the preceding species, with the anterior suborbital and preoperculum more coarsely and prominently crimped. 
In the restoration published by Agassiz, the pelvic and anal fins are too far forwards.

Form. \& Loc. Lower Eocene (London Clay): London Basin.

P. 650. Four fragmentary examples of head and trunk, labelled by Agassiz and Egerton as intended to be the type specimens; Sheppey.

Egerton Coll.

23404. Large portion of head and trunk, much pyritised; Sheppey.

Purchased, 1849.

39442, 39342, 39441, 39768. Three imperfert heads with anterior squamation; Sheppey. In the first specimen the oral face of the premaxilla displays the bases of attachment for one row of large marginal teeth and two or three irregular rows of minute inner teeth.

Bowerbank Coll.

P. 9465. Similar specimen, displaying the preoperculum with its characteristic plication and very fine serration; Sheppey. The base of the right pectoral fin is preserved.

5073 c. Remains of head; Sheppey.

Purchased.

25\%0\%. Another head; Sheppey.

Diron Coll.

28\%13. Another head; Sheppey.

Purchased, 18 อ̃3.

P. 649. Imperfect head labelled as intended to be the type specimen of Scicenurus crassior, Agassiz; Sheppey. Egerton Coll.

P. 4515. Heads and other fragments, one labelled Scioenurus crassior by Agassiz.

Enniskillen Coll.

P. 9466. Fragment showing some anterior vertebral centra; Sheppey.

Purchased.

The following species have also been ascribed to this genus, but are not represented in the Collection :-

Sparnodus inflatus, D. G. Kramberger, Rad Jugoslav. Akad. vol. cri. (1891), p. 80, pl. v. fig. 4.-Upper Oligocene; Trifail, Styria. [Imperfect trunk; Imperial Geological Survey, Vienna.]

Sparnodus intermedius, F. Bassani, Atti R. Accad. Sci. Napoli [2] vol. iii. (1889), no. 6, p. 67, pl. vii. fig. 2.-Lower Miocene; Chiavon, Vicentin. [Imperfect fish; Piovene Collection, Lonedo.]

Sparnodus moloni, F. Bassani, ibid. p. 66, pl. vii. fig. 1.-Ibid. [Ditto.] 
Sparmodur stchurowskii, Bogowiteh,

2.Lahusen, Paleontologie, 1895 [in Dussian].

fip. $1076.1 .540 .-$

Fier, Oursia.

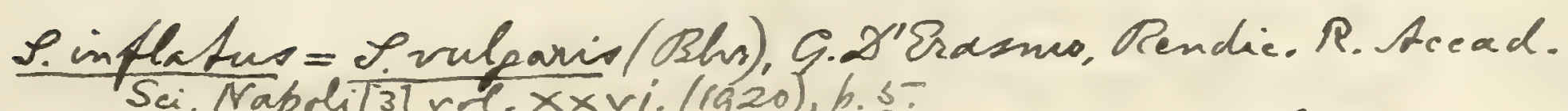

Otolithus (Sparidarum?) cofled, A. Wollemann,

gahil. He. hrewas. Landesant. 20l. xxir (1903)

h.42, hl.v. fis. 12. - Gaulh; Slgenmiszem, Hanorer. 
= Diplodus Raf. Indice d'thiot. Siritiana, 1810, p. 54 (D. anmenlaris?

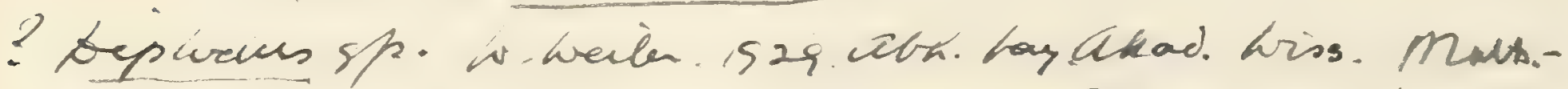
nakino, abt. N.F.1. p. 14. K. Paskactan, Eypt.

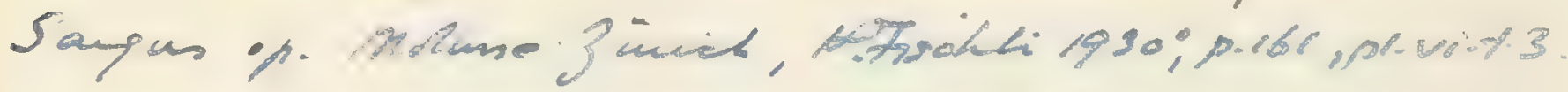

192\%. Diplodus oranensis, CAramboung, p. 126, ph. $x x_{1}$ t. 1,2 .

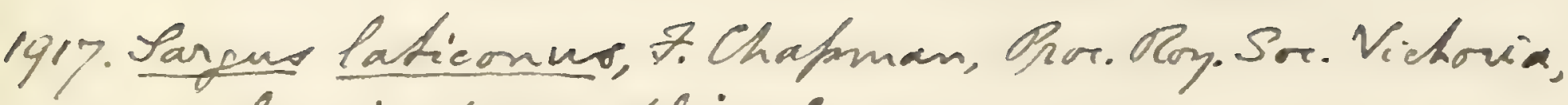
n.s. vol. $x$ xix.p.140, fl.ix.fig. 9 .

1918. Lazpur laticomu, 7. Chafrman, hew Zealand Gerl-Sur. Palde onh. Bull no. Z1 h. 28, pl. vii. fies. 3-7. 
$$
\text { . }
$$ 
Sargus aquitanicus, E. Delfortrie, Actes Soc. Linn. Bordeaux, vol. xxix. (1873), p. 85, pl. i. fig. 8.-Miocene; Dept. Gironde.

Sargus armatus, P. Gervais, Zool. et Pal. Franç. (1852), Poiss. Foss. p. 5, pl. lxix. figs. 1-8, 11-13.-Eocene; Dept. Aude. Lenide 1951 P. 542 .

Sargus heberti, F. Bassani, Atti Soc. Veneto-Trent. Sci. Nat. vol. vi. (1879), p. 50, pl. จ. fig. 15._Middle Miocene; Gahard, Ille-et-Vilaine.

?Rullar" Sargus incisivus, P. Gervais, op. cit. p. 5, pl. 1xix. figs. 14, 16 ; Ba ' Bassani, Atti Soc. Veneto-Trent. Sci. Nat. vol. vi. (1879), p. 48, pl. r. figs. 9-12 ; H. E. Saurage, Mém. Soc. Th. 18. .7 ( miv . Sci. Nat. Saône-et-Loire, vol. iv. (1882), p. 64, pl. i. Majorea). figs. 7-9; G. de Alessandri, Mem. R. Accad. Sci. Torino J. Barzó Rullan, 1949.2] vol. xlv. (1896), p. 289, pl. i. fig. 28 ; L. Seguenza, $R$ sor.esp HN. tom.ernkBoll. Soc. Geol. Ital. vol. xix. (1900), p. 515, pl. vi. $1946 p 496, \mu .30 t \cdot 16$ figs. 38, 39. Scarus battringensis, J. Probst, Württ.

Jahresh. vol. xxx. (1874), p. 282 (in part), pl. iii. figs. 8, 9 (non figs. 7, 10, 11). (?) Sphcerodus lejeanianus, M. Rouault, Comptes Rendus, vol. xlvii. (1858), p. 100.Niocene; France, Würtemberg, Italy, and Sicily.

Sargus jomnitanus, A. Valenciennes, Ann. Sci. Nat. [3] vol. i. (1844), p. 103, pl. i. fig. 1.-Upper Niocene; Algeria.

Sargus rusuccuritanus, A. Valenciennes, ibid. p. 103, pl. i. figs. 2, 3.-Ibid.

Sargus sitifensis, A. Valenciennes, ibid. p. 103, pl. i. fig. 4,Ibid.

The fossils named as follows are not generically determinable :Sargus anthropodon, H. Le Hon, Prélim. Mém. Poiss. Tert. Belg. (1871), p. 14 (name only).-Eocene; Belgium.

Sargus baraldii, R. Lawley, Nuovi Studi Pesci etc. Colline Toscane (1876), p. 57.-Pliocene ; Tuscany. [Imperfect jaw.]

Sargus cavannai, R. Lawley, ibid. p. 57, pl. . fig. 1.--Ibid. [Ditto.]

Sargus cuvieri, L. Agassiz, Poiss. Foss. vol. iv. (1839), p. 168 [no fig. published]. Sparus, G. Curier, Ossem. Foss. ed. 2 (1822), vol. iii. p. 338, pl. Ixxvi. figs. 16, 17.Upper Eocene (Gypsum); Montmartre, Paris. [Fragment of trunk.] 
, 

heberti $=$ incizirus, Mr. Leriehe, Am.S. Géd. Mord, rol. $x \times x v(1906), h .310$.

Sarpan incisirm, S. De Ltefano, Boll. An. Ged.

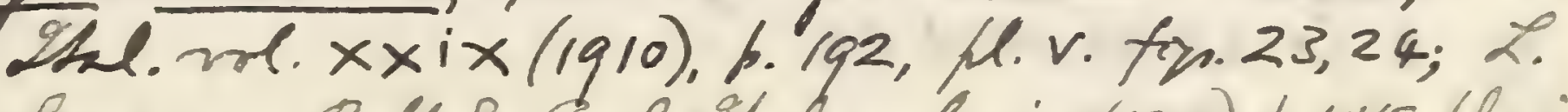
Saguenza, Boll. Sor. Geol, Edal. vol xix (1900), h. 515, hl vi:

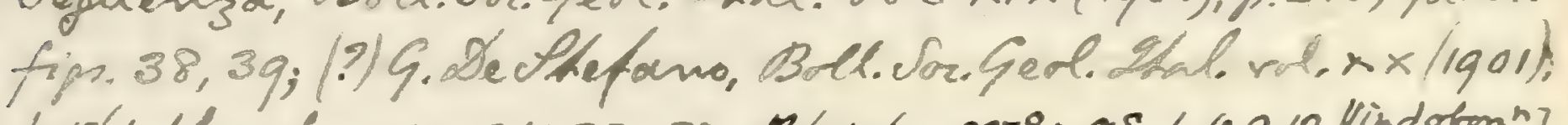

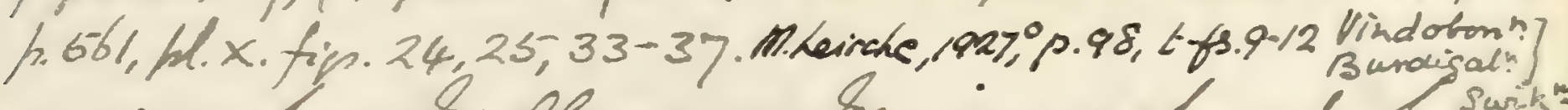
Lourer jour from hr. Olipocene, Inains, referred Lo swils"s

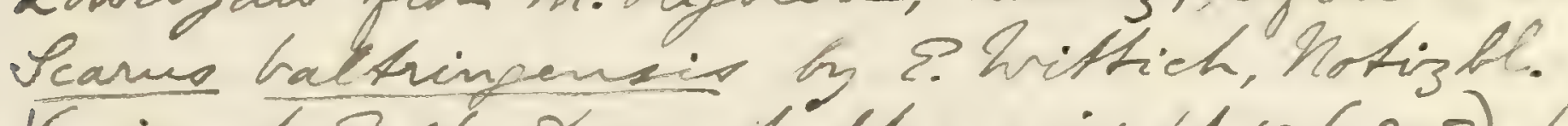
Veneins f. Endk. Darmstadt, ser. iv phe 19 (1898),

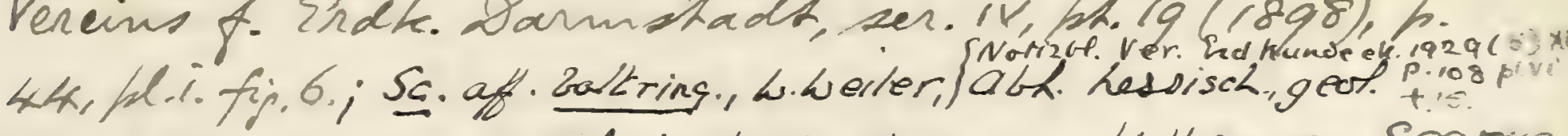
Landesanst. Desmst. pol. vi, pLt2, (1922), p.10y, pl.1, ff. 30-32. Scaras

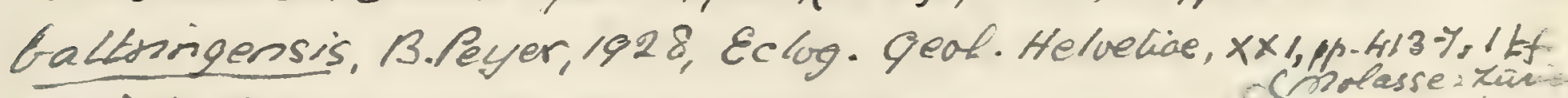
oxplodus jomnitanus, C. Ar amboung 19R7, p. 129,pl. $x+x i$

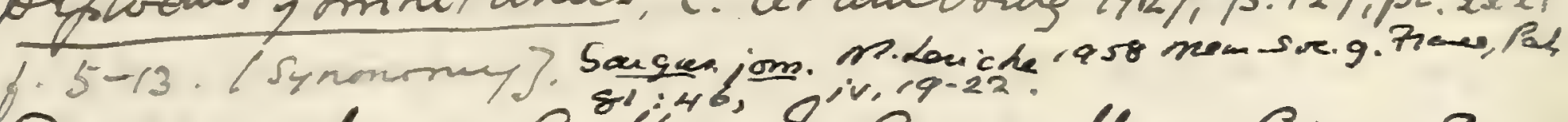

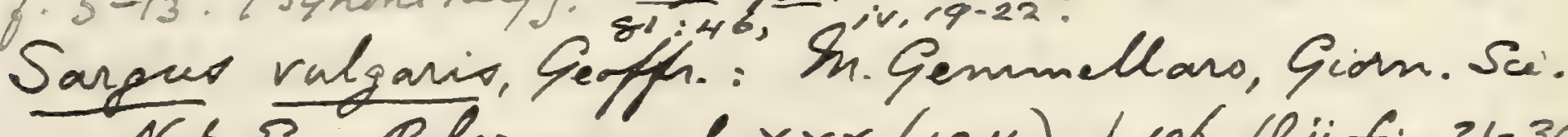
Nat. Econ. Dalermo, vol. $\times \times \times(1914)$, p.106, hliit fir. 31-39.

Tireus incentur, A. Bravard, Mronops. En. Mas. Jere. Darma $(185-8)$, h. 49 (name mly). - Testiary: Parana. [Dorth.]

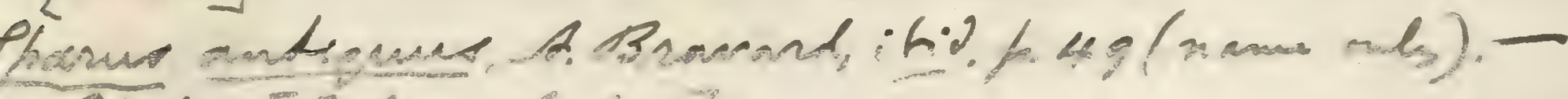
Ifid. [Ontion of pune.] 


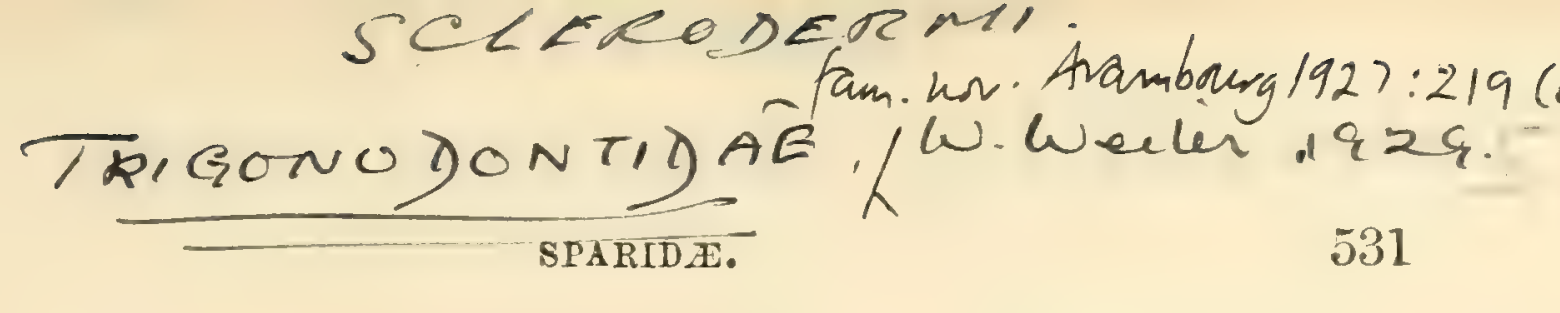

Genus TRIGONODON, Sismonda.

[Mem. R. Accad. Sci. Torino (2) rol. x. 1849, p. 25.]

A genus known only by the front teeth, which are trenchant like those of Sargus but much broader and perhaps only in one pair.

\section{Trigonodon oweni, Sismonda.}

1849. Trigonodon oveni, E. Sismonda, loc. cit. p. 25, pl. i. figs. 14-16.

1858. Sargus sioni, M. Rouault, Comptes Rendus, vol. xlvii. p. 100.

1874. Scarus baltringensis, J. Probst, Württ. Jahresh. vol, xxx. p. 282 (in part), pl. iii. figs. 10, 11 (non figs. 7-9).

1875. Sargus sioni, H. E. Sauvage, Bull. Soc. Géol. France [3] vol. iii. p. 632, pl. xxii. figs. 3,4 .

1879. Sargus sioni, F. Bassani, Atti Soc. Veneto-Trent. Sci. Nat. vol. vi. p. 49, pl. v. figs. 13,14 .

1882. Sargus sioni, H. E. Sauvage, Mém. Soc. Sci. Nat. Saône-et-Loire, vol. iv. p. 63.

1890. Scarus oweni, F. Sacco, Bcll. Soc. Geol, Ital. vol. ix. p. 296.

1895. Sargus (Trigonodon) oweni, F. Bassani, Atti R. Accad. Sci. Napoli [2] vol. vii. no. 7 , p. 6 , fig. 3.

1896. Sargus oweni, G. de Alessandri, Mem. R. Accad. Sci. Torino [2] vol. xlv. p. 289 , pl. i. fig. 27.

1897. Trigonodon oweni, G. de Alessandri, Mem. Soc. Ital. Sci. Nat. n. s. vol. vi. no. 1, p. 25.

Type. Worn tooth.

The type species, with a rather stout cutting-tooth, which is high in front, becoming rapidly low behind, and not serrated or crimped on the trenchant border, but sometimes with slight vertical folds at the base of its inner face.

Form. \& Loc. Miocene: Italy, Würtemberg, and Brittany. Pliocene: Tuscany.

$$
\text { Neyan. Wiranes. }
$$

P. 9467. Tooth 0.017 in length, not much worn; locality unkuown. History untenown.

P. 5525. Plaster casts of two teeth; Pliocene, Tuscany. Presenterl by Prof. G. Capellini, 1888. Eotrigoundontidar - White 1935: 5? (sokoto)"replacumat Eo-Trigonodon serratus (Gervais). name [Trigonnionkidal Arambongy

1852. Sargus? serratus, P. Gervais, Zool. et Pal. Franç., Poiss. Foss. p. 2, pl. lxvii. fig. 7 (non fig. 8).

1891. Trigonodon serratus, A. S. Wnodward, Geol, Mag. [3] rol. riii. p. 109, pl. iii. fig. 6.

Type. Anterior tooth.

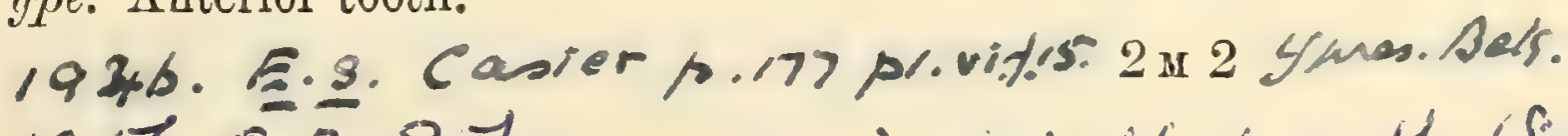

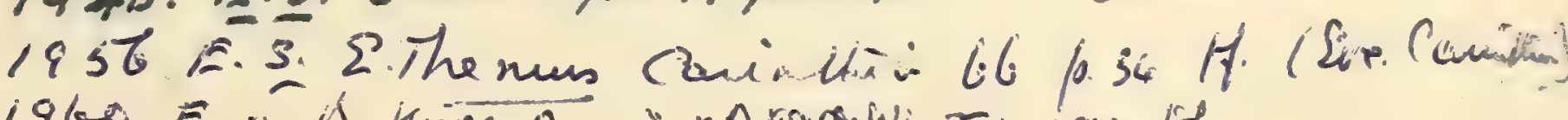

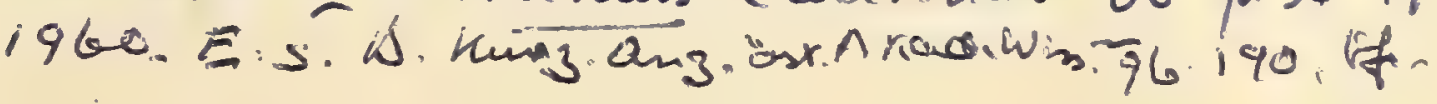


Trenchant border of crown nearly parallel to basal margin, prominently and delicately crimped when unworn. A smaller and much thinner tooth than that of the type species.

Form. \& Loc. Lower Eocene: France. Middle Eocene: Belgium. Jise, France.

P. 5926 a. Partially abraded tooth, figured by A. S. Woodward, loc. cit.; Bruxellian, Woluwe St. Lambert, Brussels.

Presented by Monsieur A. Houzeau de Lehaie, 1889.

P. 5926. Larger, more worn specimen; Woluwe St. Lambert.

Presented by Monsieur A. Houzeau de Lehaie, 1889.

Another form of tooth, apparently of this genus, from the Eocene of the Punjab, has been named Capitodus indicus by R. Lydekker, Rec. Geol. Surv. India, vol.xiii. (1880), p.61, and Palæont. Indica, ser. x. vol. iii. (1886), p. 245, pl. xxxr. fig. 11.

Stouter teeth, more deeply crimped but otherwise much resembling those named Trigonodon, have also been described as follows:-

Stephanodus splendens, K. A. von Zittel, Handb. Palæont. vol. iii. (1888), p. 298, fig. 310\% - Upper Cretaceous; Dachel Oasis, Sahara. [Type species of Stephanodus, Zitte], non Stephanodon, Meyer, 1847. Tooth; Palæontological Museum, Munich.] = Aneistrodon libycus, 21.6mié,1935

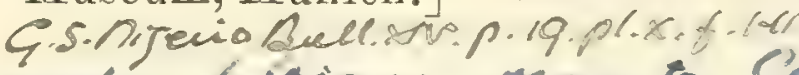

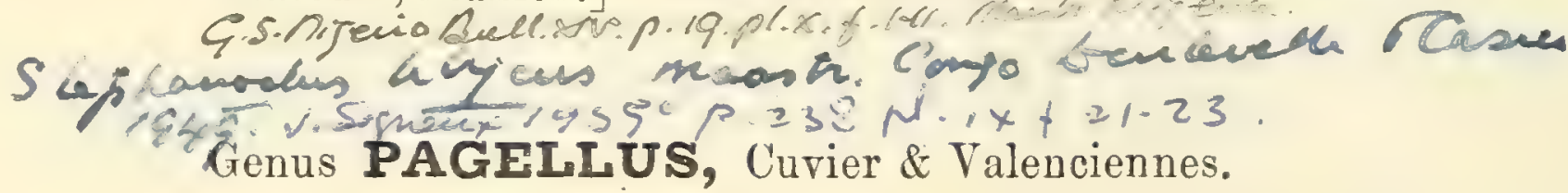

[Hist. Nat. Poiss. vol. vi. 1830, p. 169.]

Anterior teeth acutely conical, minute and clustered, with few large canines; hinder teeth rounded and molariform, in two or more series. Preoperculum fimbriated, not serrated. Dorsal fin with 11 to 13 spines. Scales of moderate size, fincly serrated, extending over the operculum and cheek, and forming a sheath at the base of the dorsal fin.

Existing in the Mediterranean and on the eastern shores of the Atlantic.

There are no fossils in the Collection certainly referable to this genus, and those described as follows are not generically doterminable:-

Otolithus (Pagelli) elegantulus, E. Koken, Zeitschr. deutsch. geol. Ges. vol.xl. (1888), p. 279, pl. xvii. figs. 5, 6.-Lower Tertiary; Jackson River, Mississippi. [Otolith.] 
. 

See ales Finglymostma delffortiei: I.p.348,

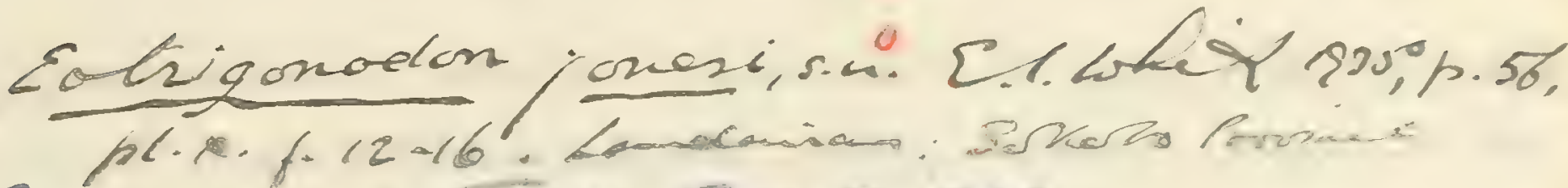

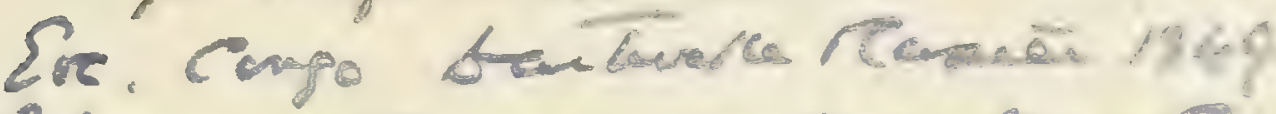

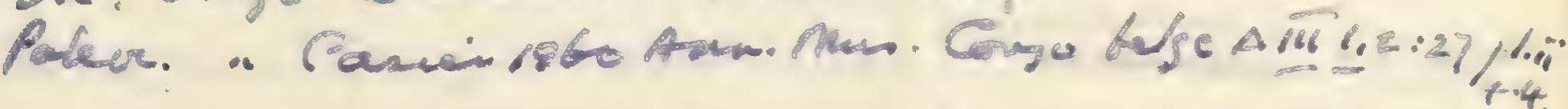

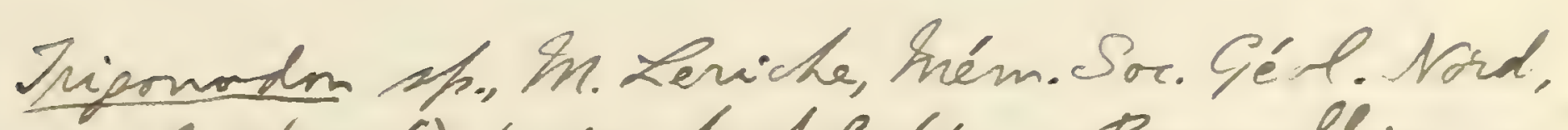
vol.v(1906). p.259, Lext.fy.65:- Bruxcellian; Belpium.

Irieonodon latevis, F Priem, Bull. Lor. Ge'd, Arance L4Jvol, vii.

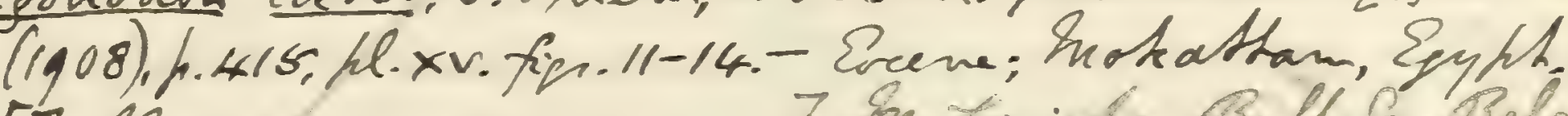
Hork:

7 In. Zeriche, Bull.'Bo. Belear

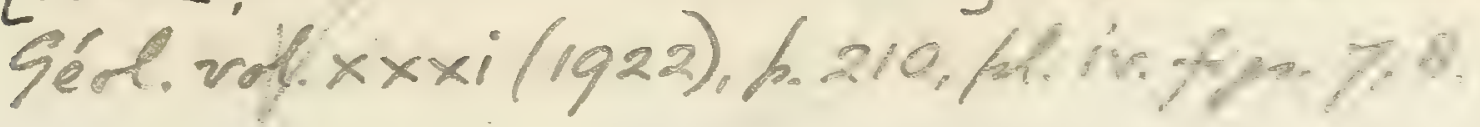

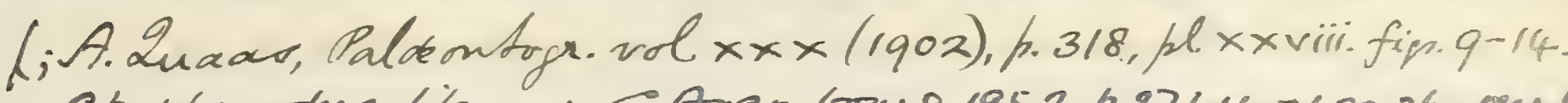

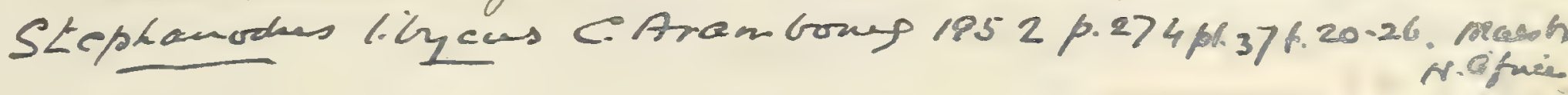

Box, Diplodus I Pagellus kix fun L. Pleverio majorea 13 anzá Rullán 18so Bot. Sor.exp. N. A. 47 p.653 phos

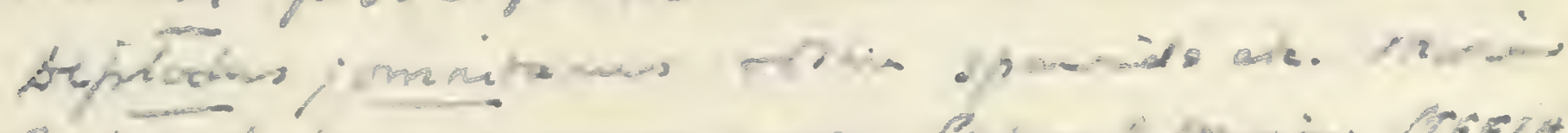

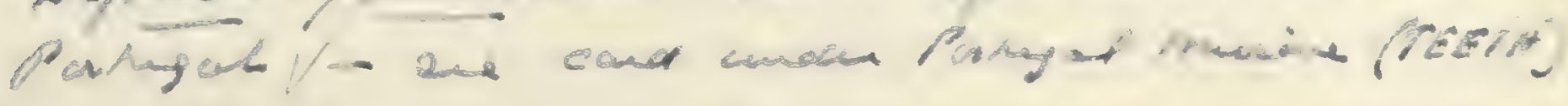




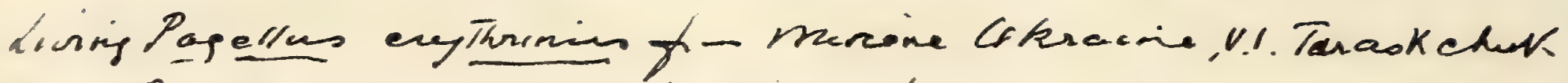
1957 Rop.tear Sci. Whracke 66 i2 1 tis.

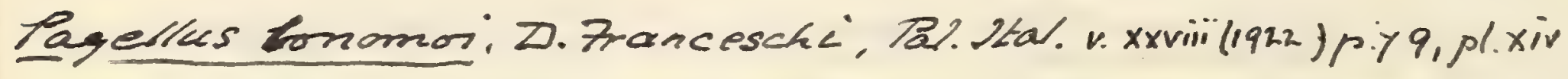

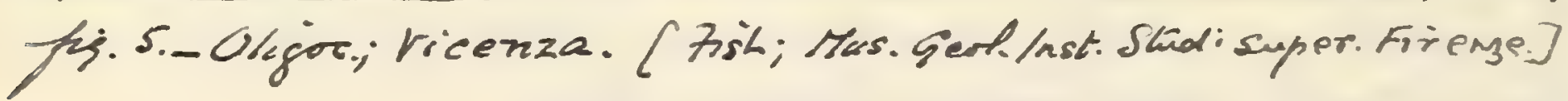

Pagellus leptosomus

S.n., C. Aramboung 1927, p.123, pl. $x x+19$,

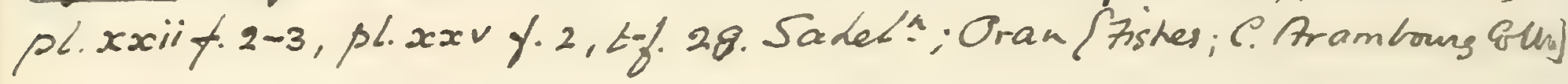

Papellur remenzio, In. Leviche, Am. Sor. Géal. Nord, vd. xxxvii(1908). h. 249. Ll.vifien.9-11. - Thanction; Châlous-aur-Vesle, Manne. [Btolith; thiv. Lille] Pagellus siracusamus, G. J'Rramo, Mendic. R. Acead. Sci. Napoli [3] vol. xxvi (1920), p. 7. fi. 2.- Miocene; Syracuse. [Omperfut fist: Geol. Mus. Univ. Balermo.] Othithur (Dapellur?) greparive, K. Schubent, gahsh. k. k. ged Peichsanst. vol. 65-(1915), p. 278, hl. vir.fip. 12, $13(? 14,21)$. Barton Clay.

O. (P) concaves.

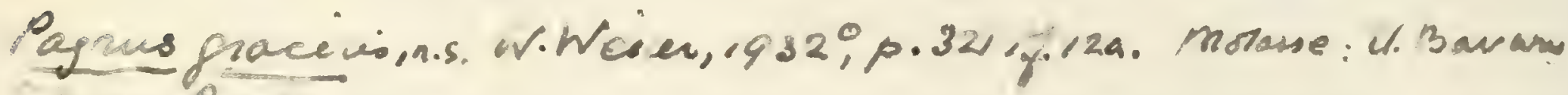
nogm. Proxi.

Pagrus mauritaniaus s.h. C. Arambruns, 1927, p. 119, pl.xix.t.";

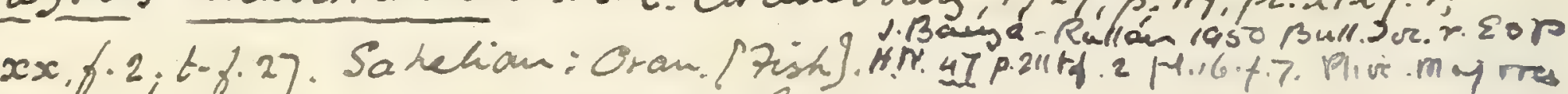

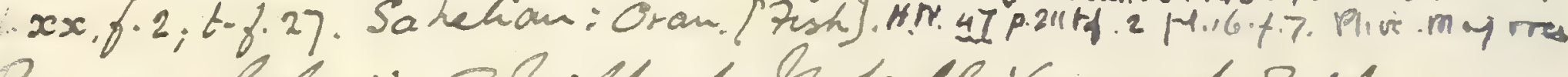

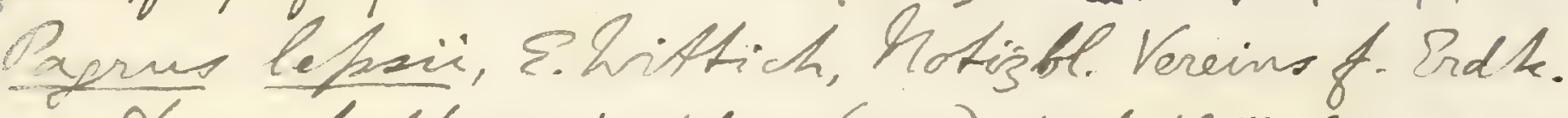
Darmstadt, sen. iv. ph. 21 (1900), k.26, ph. iii.fig. $5=8$,

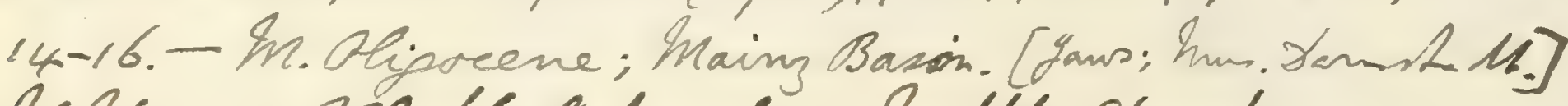
h. Wagner- Klett. Gahrest. u. hitth. Olerrhein. geal. Verein. n. s. val. viiiligig). h. 110 . [Jeath; Baden] Pagrus lepsii. W.Weiler, abh. hessisch. geol Landesanst. (1922), vol. ri, pt.2,p. la, plü, fig. 3 .

Pagrus sp.(ordim). W.Weiler, 1929, wotight. Ver. Gdk. eh. (5) X11. p.loy, ph.vi. Y.12. M. Oligir. Mering B.

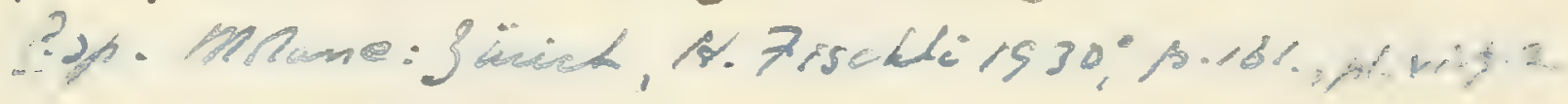




Pagallus aquitanicus, E. Delfortrie, Actes Soc. Linn. Bordeaux, vol. xxix. (1873), p. 84, pl. i. fig. T.-Miocene; Dept. Gironde. [Teeth.]

Pagellus leptosteus, L. Agassiz, Poiss. Foss. vol, ir. (1839), p. 154 (no fig.); Pictet \& Humbert, Your. Rech. Poiss. Foss. Mt. Liban (1866), p. 50.-Form. \& loc. unknown. [Imperfect fish; olim Zürich Museum.]

Pagellus microdon, L. Agassiz, Neues Jahrb. 1835, p. 300 (name only), and Poiss. Foss. vol. iv. (1839), p. 152, pl. xxrii. fig. 1.-Upper Eocene; Monte Bolca, near Verona. [Imperfect fish ; Paris Museum of Natural History.]

Pagellus stenoura, H. E. Saurage, Ann. Sci Géol, vol. iv. (1873), art. no. 1, p. 118, figs. 15, 15 a.-Upper Niocene; Licata, Sicily. [Imperfect trunk; Paris Museum of Natural History.]

Pagellus de stefanii and Pagellus peruzzii are undefined names given to fishes from the Upper Niocene of Gabbro, Tuscany (de Bosniaski, Atti Soc. Tosc. Sci. Nat.-Pros.-Verb. vol. i. 1878, p. xix).

\section{Genus PAGRUS, Cuvier.}

[Règne Animal, vol. ii. 1817, p. 272.]

Stout conical prehensile teeth at the symphysis of the jaws, and two series of large rounded molariform teeth behind. Preoperculum not serrated. Dorsal fin with 12 (rarely 11) spines. Scales of moderate size, very finely serrated, estending over the operculum and cheek, and forming a sheath at the base of the dorsal fin.

Almost cosmopolitan on existing coasts.

There do not appear to be any recognisable remains of extinct forms of this genus in the Collection, but various fossils have been described as follows:-

Pagrus meneghinii, F. Rassani, Atti R. Accad, Sci. Tapoli [2] vol. iii. (1889), no. 6, p. 69, pl. xv. fig. 1.-Lower Miocene; Chiavon, Vicentin. [Imperfect fish; Piorene Collection, Lonedo.]

Pagrus oudrianus, E. Delfortrie, Actes Soc. Linn. Bordeaux, vol. xxix. (1873), p. 83, 1l. i. fig. 5.-Pliocene; Dept. Gironde. [Portion of jaw.]

Pagrus pileatus, P. J. Van Beneden, Bull. Acad. Roy. Belg. [3] rol. i. (1881), p. 125.-Pliocene Crag; Antwerp. [Hyperostoses.] we Or Kgoriscas put.p.

Pagrus priscus, R. Kner, Sitzungsb. k. Akad. Wiss., math.-naturw. 
Cl. vol. xlv. pt. i. (1862), p. 495, pl. ii. fig. 3.-Middle Miocene; Margarethen, Vienna. [Dorsal half of trunk; Court Museum, Vienna.]

Pagrus torus, P. J. Van Beneden, Toc. cit. 1881, p. 125._Pliocene

Crag ; Antwerp. [Hyperostoses.]

Pagrus sp., W. Dames, Sitzungsb. Ges. Naturf. Freunde, Berlin, 1890, p. 162, woodc.-Recent Deposit: Melbourne, Australia. [Skull; Geological Mnseum, Univ. Breslau.]

\section{Genus CHRYSOPHRYS, C'uvier.}

[Règne Animal, ed. 2, vol. ii. 1829, p. 181.]

As Pagrus, but molariform teeth in three or more series, usually irregular.

Almost cosmopolitan on existing coasts.

This genus is not represented in the Collection by any specifically determinable fossil remains, and the extinct forms described as follows are not very satisfactorily determined :-

Chrysophrys brusinai, D. G. Kramberger, Beitr. Paläont. Oesterr.Ungarns, vol. ii. (1882), p. 107, pl. xxii fig. 7.-Upper

Miocene; Podsused, Croatia. [Imperfect fish; Geological Museum, Unirersity of Agram.]

Chrysophrys hertlei, D. G. Kramberger, Verhandl. k. k. geol. Reichsanst. 1882, p. 29 (name only), and Rad Jugoslav. Akad. vol. cri. (1891), p. 81, pl. vii. fig. 1.-Upper Oligocene ; Trifail, Styria. [Fragment of head and trunk; Imperial Geological Survey, Vienna.

Chrysophrys lawleyi, P, Gervais, Journ. de Zool. vol. iv. (1875), 1.G.Xe Statano, Boll. Soritieol Ital vol $\times \times$ viii $(1910), p, 617$, bl. xvii.fip, 31 , hl, xix.fip.

p. 517, p]. xvii. Sphorodus cinctus, R. Lawley (errore), Atti Soc. Tose. Sci. Nat. vol. ii. (1876), p. 61, pl. ii. (reprinter by Gervais, loc. cit.).-Pliocene; Volterrano, Tuscany. [Associated upper and lower jaws.]

Chrysophrys scacchii, F. Bassani, Atti R. Accad. Sci. Napoli [2] vol. iii. (1889), no. 6, p. 72, pl. xii.-Lower Miocene; Chiavon, Vicentin. [Nearly complete fish; Piovene Collection, Lonedo.]

Chrysophrys zignoi, F. Bassani, ibid. p. 71, pl. viii. figs. 1, 2, and Atti R. Istit. Veneto [7] vol. iii. (1392), p. 1032.-Ibid. [Imperfect small fish; Zigno Collection, Univ. Padua.]

Most of the following detached teeth probably belong to Chrysophrys, but some may be referable to other genera of the family :- 



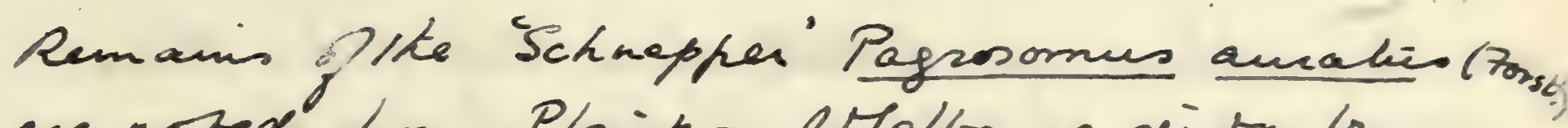
are noted fim Pleistor. of Hellonine distr. Is

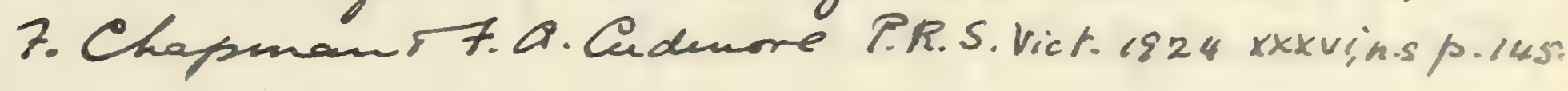

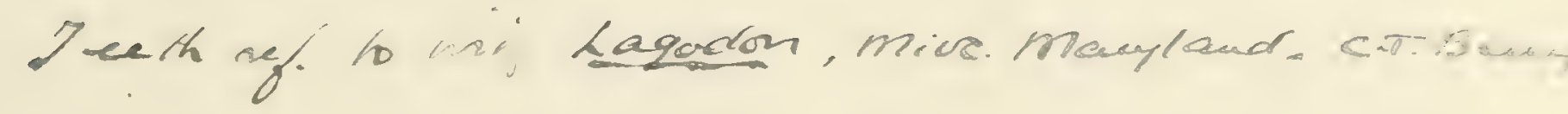

Chrysophny deydieri, Z. Goleaud, Mém. Acad. Vauchuse [2] volvi(1906), p.350.- Helvetion; Bonpas, th. [Jeeth.]

Chussophrys gervaisi, Mr. Leriche, Compter Tendus Ars. Frunc. Av. Sci. 1906 (1907), h. 347, text-fis. 2. Plicene (Atitian); Montpellier (Hérault). [Gouvs.]

Chuperfhrpe aurata (Zim.): In. Gemmellaro. Giom. Sci. Nat. Econ. Palermo, vol. $x \times x(19 / 4)$, h. 107. fl. ii. fir. 40-44-

Chryoflary coeruleosticta, CotV. In. Gemmellaro, En. int. h. 108, h. ii. figs. $455-48$.

Chuysphens cincta, var. astensis, 7 Saces,

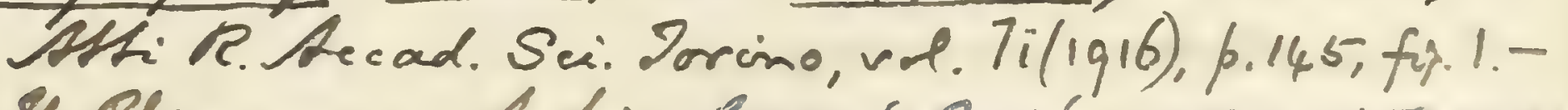

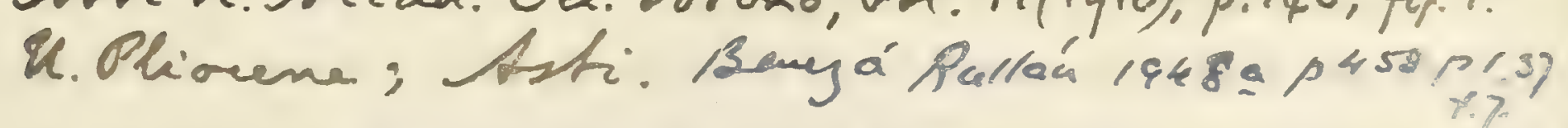

Chyorphrye schoffiei, E. Littich, Notigbl Verim

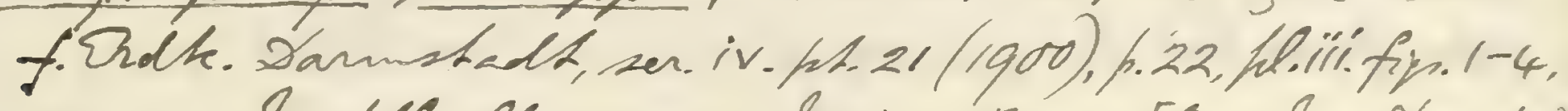

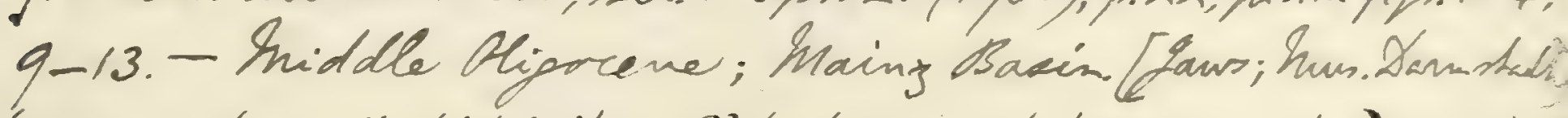
Chrys. schoppir, W. Weiler, Alh hess geol Landesanst. Dormstodt,

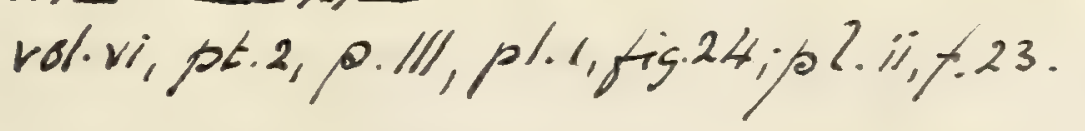

Charax hangi, L. Goleaud, Mném. Brad. Vauchundivd.vif(1906) B.35.2. - Helvetian; Bonpar. [Incisor Lorth.' 
1920. Chrysufhurye she. A. Bell. Anm. Tep. Yortes. Dhil, Sou. 1919.h. , hlili.fip. 12. CPotion of jour from Red Gag, Suffolk; York Mus.]

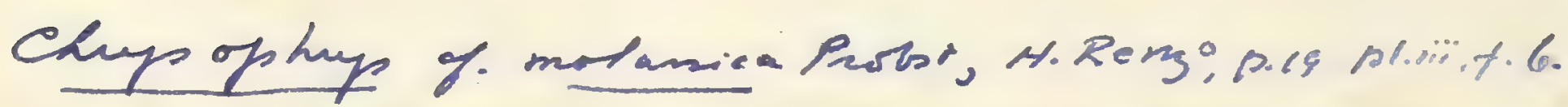

Themannel $1930^{\circ}, 18.55$

Chrysophng cincta, G. Stefanimi, Mnem. 2stik. Geil. Univ. Padora, vol.iv (1917), i. 16, pl.i.fip. 9, 10; G. de Alessandri,

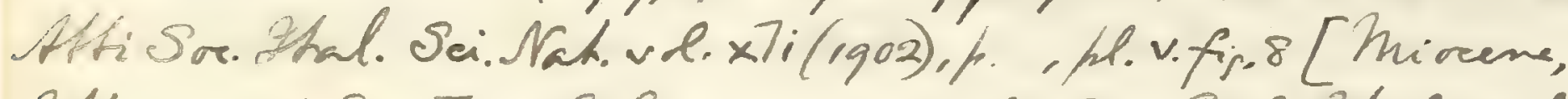
Itthmus of Sues?; L. Seguenza, Boll. Sor. Yeol. athal. vol.

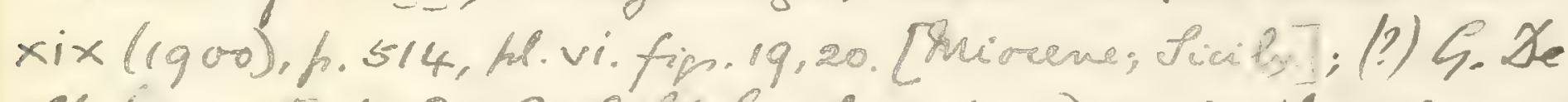
Shefano, sole. Sor. Gesl. Bhat. vel. xx(1901), h. 560, hl.x. fips. 25-29, 31,32. [Oliveene; Callahia]

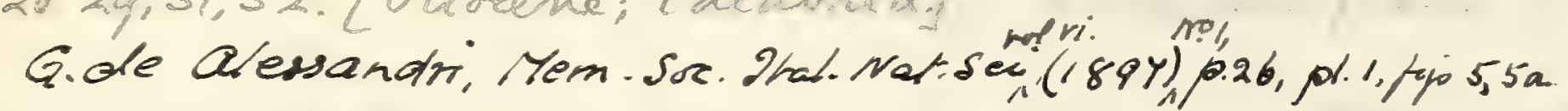
[Miou, Predmont]. C. of. crincta, S. Vardatasso, Mom. Mats gerl. R. Cmiv. Paderva volvi (1922) p.17.

Sparus cinchin, C-aramlourg, 1927, p.116, Salelh, Orem

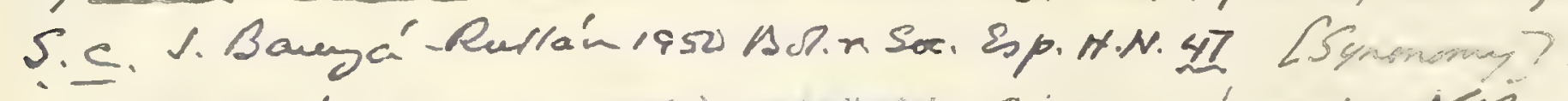

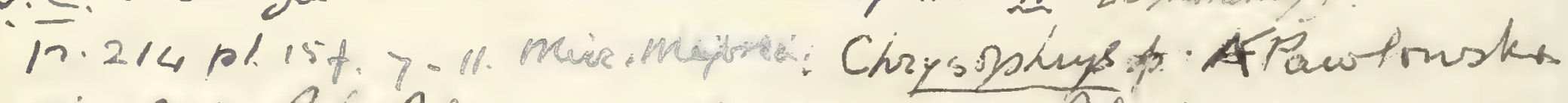

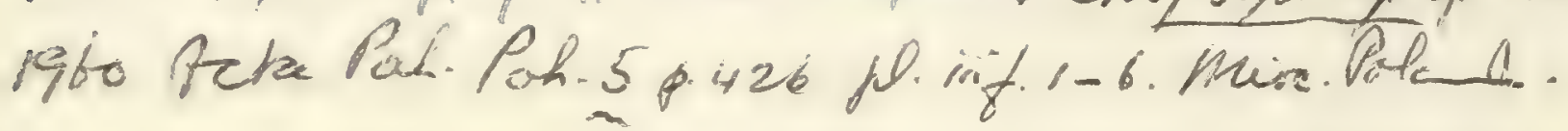

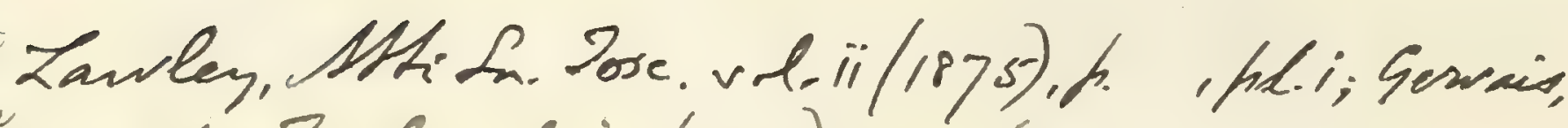

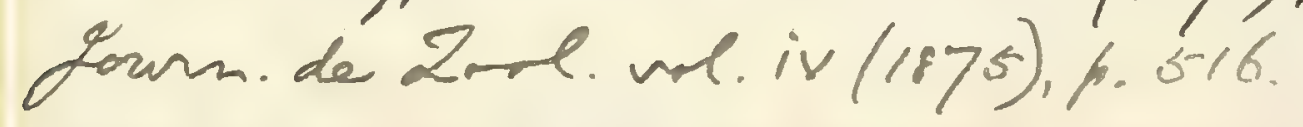



P. 8720. Three molariform teeth; Weybourn Crag, East Runton. Savin Coll.

46968. Prehensile tooth; Red Crag, Woodbridge, Suffolk. Purchased, 1876.

P. 7098. Two prehensile teeth and fragment of jaw; Red Crag, Boyton, Suffolk. Purchased, 1894.

P. 8988. Four prehensile teeth; Red Crag, Waldringfield, Suffolk. These and the preceding specimens resemble teeth from the Crag referred to an undetermined species of Chrysophrys by E. T. Newton, Vert. Pliocene Dep. Britain (Mem. Geol. Surr. 1891), p. 88, pl. x. figs. 1-3.

Presented by Lady Prestwich, 1896.

34194. Numerous teeth of the form named Sphorodus cinctus by Agassiz, Poiss. Foss. vol. ii. pt. ii. (1839-44), p. 214, inst. Geal. tiacapl. lxxiii. figs. $\underbrace{68-70}{ }^{1}$; Miocene, Las Palmas, Grand Canary. Presented by Sir Charles Lyell, Bart.

36816. Similar molariform teeth; Miocene, Isle of Gozo.

Presented by Prof. A. Leith Adams, 1862.

P. 1693. Similar teeth; Miocene, Malta.

Egerton Coll.

28385. Similar teeth, like those ascribed to Chrysophrys cincta by Sauvage, loc. cit., and apparently of the form named Sphcerodus kergomardius by M. Rouault, Comptes Rendus, vol. xlvii. (1858), p. 100 ; Middle Miocene, St. Jurat, near Dinan. Purchased, 1853.

P. 9468. Similar but larger molariform tooth, labelled by Münster as being Sphoeroctus annularis, Ag., from Ceylon.

Ennistillen Coll.

P. 9469. Numerous teeth of the form named Sphoerodus cingulatus by Münster, Beitr. Petrefact. pt. vii. (1846), p. 3 ; Middle Miocene, Neudörfl-a.-d.-March, Vienna.

Purchased.

P. 1681-82, P. 4663. Similar teeth; Neudörfl.

Egerton \& Enniskillen Colls.

P. 1690. Two minute molariform teeth, of the form named Sphcerodus pygmceus by Münster, op. cit. pt. v. (1842), p. 65, pl. vi. fig. 4 ; Tertiary, Vienna.

Egerton Coll.

1 Chrysophrys cincta, H. E. Saurage, Mém. Soc. Sci. Nat. Saône-et-Loire, vol. iv. (1882), p. 61, pl. i. figs. 1-6. See especially F. Bassani, Atti R. Accad. Sci. Napoli [2] vol. iv. (1891), no. 3, p. 49, pl. ii. figs. $2-9$. 
P. 1695. Two minute prehensile teeth of the form named Capitodus angustus by Münster, op. cit.pt. v. (1842), p. 68, pl. xv. fig. 8 ; Tertiary, Vienna.

Egerton Coll.

P. 1684, P. 1694. Prehensile teeth of the form named Capitodus truncatus by Münster, op. cit.pt. จ. (1842), p. 67, pl. ri. figs. 13, 14; Middle Miocene, Neudörf. Egerton Coll.

P. 1683. Prehensile tooth of the form named Sphorodus subtruncatus by Münster, op. cit.pt. vii. (1846), p. 4, pl. ii. fig. 0 ; Tertiary, Vienna.

Egerton Coll.

P. 1685. Two molariform teeth of the form named Sphorodus depressus by Agassiz, op. cit. vol. ii. pt. ii. (1839-44), p. 213, pl. lxxiii. figs. 3-10 ; Miocene, Salzburg, Austria.

Egerton Coll.

P. 9470. Molariform teeth of the form named Sparoides molassicus by F. A. Quenstedt, Handb. Petrefact. (1852), p. 248, pl. xix. figs. 7-14, and J. Probst, Württ. Jahresh. rol. xxx. (1874), p. 289, pl. iii. figs. 12-15; Middle Miocene (Molasse), Baltringen, Würtemberg.

Purchased.

35828. Similar teeth and prehensile teeth.

Purchased, 1860.

P. 1689. Small teeth of the form named Sphcerodus lens by Agassiz, op. cit. vol. ii. pt. ii. (1839-44), p. 212, pl. lxxiii. figs. 2261 ; Oligocene, Osnabrück.

Egerton Coll.

P. 1686, P. 4664. Four imperfect molariform teeth of the form named Sphrerodus discus by Agassiz, op. cit. vol. ii. pt. ii. (1839-44), p. 214, pl. lxxiii. figs. 62-67; Tertiary, Algarves, Portugal.

Egerton \& Enniskillen Colls.

The following indeterminable specimen is supposed to represent a Sparoid fish :-

P. 645. Fragmentary and partly pyritised head with abdominal region, labelled by Agassiz as intended to be the type specimen of Calopomus porosus, recorded by name only in Rep. Brit. Assoc. 1844 (1845), p. 307 ; London Clay, Sheppey.

Egerton Coll.

Tarious indeterminable fossil teeth have also been referred to Sparidæ under the following names:-

Asima jugleri, C. G. Giebel, Fauna d. Vorw., Fische (1848), p. 184. Radamas jugleri, G. von Münster, Beitr. Petrefact.

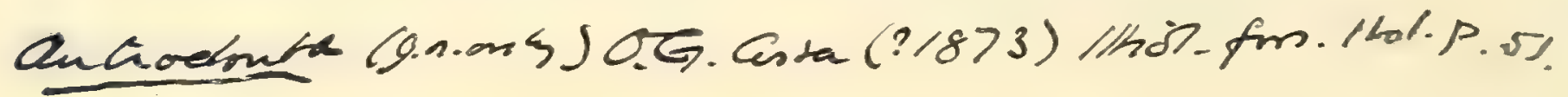



$n$

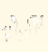

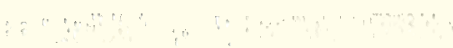

$+3$

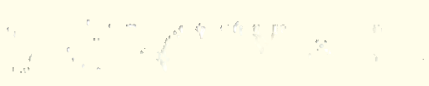

i

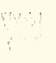

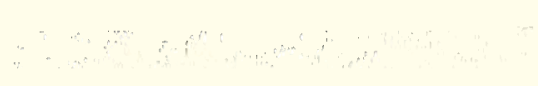


Rhyltmies starrii, D.S. Todan T.R. Gilvent, Foss. Fishes Diatom Beds oflompore, Cak. (Stan ford Univ. Public." 1920) p.28. pl.xvion.-Xvii Miocene; CaL. L Impenf. Fish; Stanford Univ. Type of Phythmias. Pestoration, DS. Tordan. Nat. History vol. 22 , pt.3 May.June 1922, p.273. tamd. 1943 p.139.15. \&1

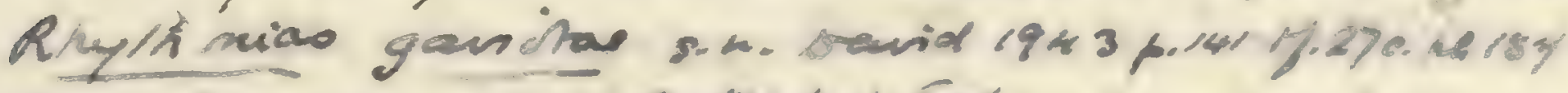

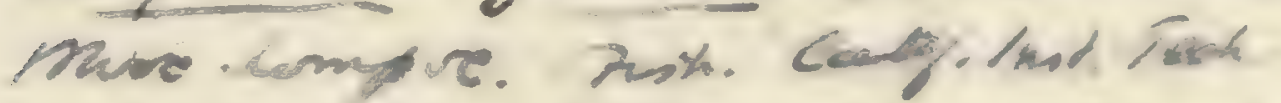

Pectrites classeni, D.S. Tondan in Tordan Titbent, luc. cet $1920,0.29, j \%$ xviö. - ihid. L tritt; ifidfle = Phythmias

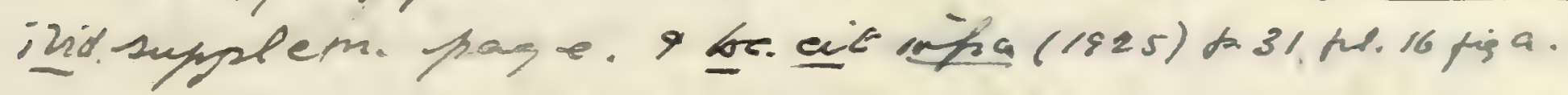

Aurata georgesii sin. Crobjor. ww. German, W. Werten 1943 Ber. Reidisams Bodcutorsh. p.82 17.27 .

Eriquius plectrodesny.ty. Tord. Bued. S. Cary. Ecad. Sci, rot. xxiii (1924) to.44 pr. H. \& Sang. Umir. Pubt, Unir ser, 3ot. fai, rotiv(1425) p.30ph.1s? -

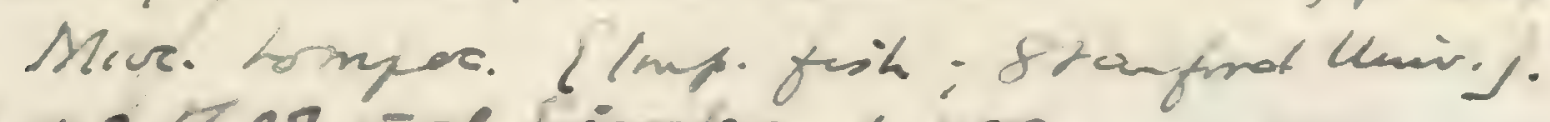

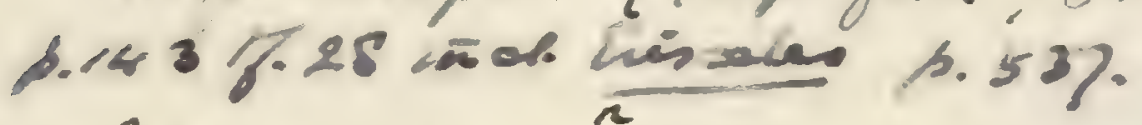

Spans neogeñs s.n." C. aramboug $|q m\rangle, p . " 17, p l-x x$

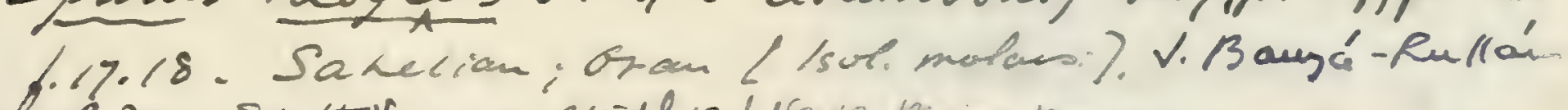

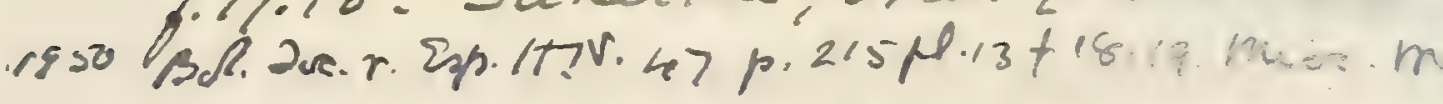

Spans? compactus s.n., C. Aramboung. 1927 , p. 122 , pl. xxy. Salelian, Oran. (Fisi wanting head).

Paracalamus doumerqui g.rs.m, C. Aramboug, $1927, p .130, p h . x x i v g .1,6 \% .29$ (1mp.fish. Sahelian i oran.

Box roulei n.s. C. Aramtoung, $1927, \mathrm{p} / 3 \mathrm{H}, \mathrm{pl}$. $x$ ixt.3,

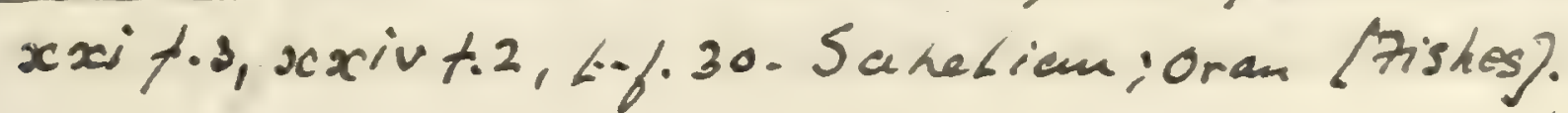

Crosidens in kermeduis n.5. C. Aramisung, 1927, p.136, ph. xx: t.la.s. - Sahelian; Oran. (Complebefish in Cutpli.).

Box gortanii, G. Yhasmo, 1930 0 , 64, ploiii, 6-1. Nive. Souno. (zivial. 


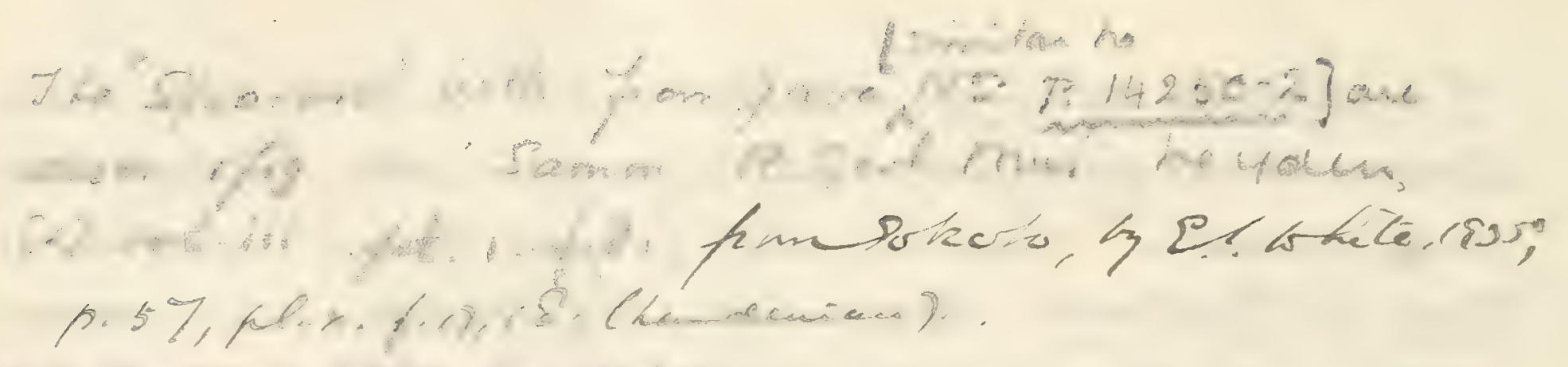

Cantharner? Ahex., O. Sangiozgi, Riv. Ital. Pale ont. vd. vii (1901), p.64, pl.i. fip.4-9. Tertiary; Paranix, Anpentina. [Boves: Geol. Mus. Unir. Parma.]

Chrys.agassizi, 7.9. Rheeca, Mioceno Mar. Muro (Jral. Mus. Nas.

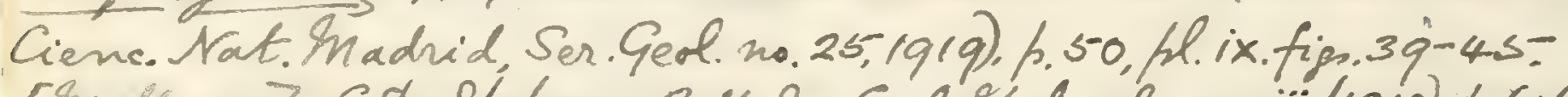

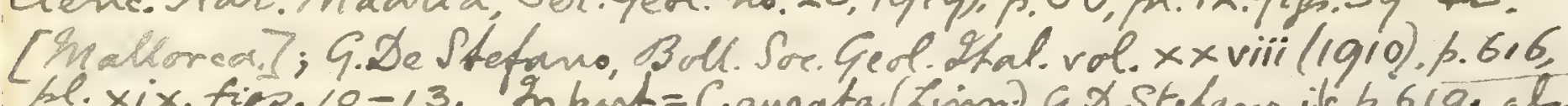

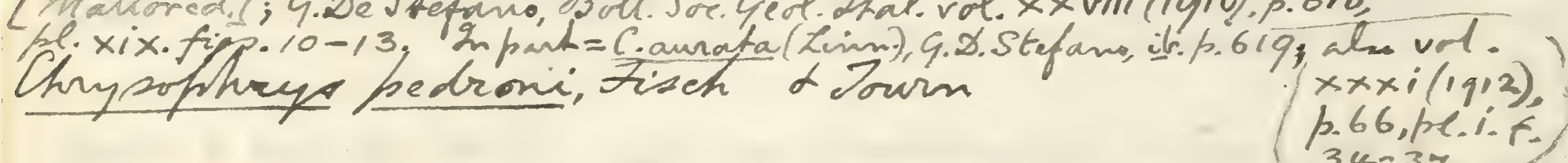
$34-3 z$

C.honi.

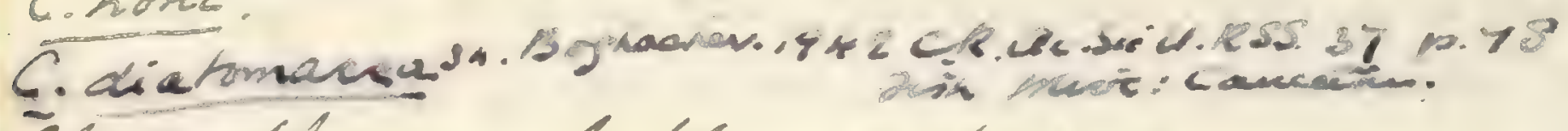

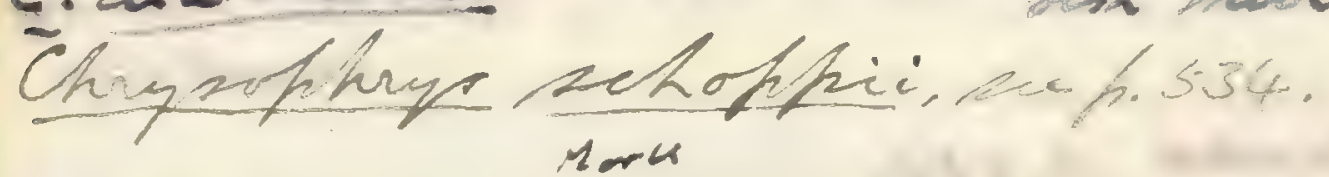

C. b̆lanckenthorni sp. $\mathrm{n}$...Eocene S.T.W.

Africa,J. Вінм Die Diamantenwüs'e

Südwest-Afrikas 2 p. 83 pl. xxxiii figs. 17-30. In aut. tsok. aects.

Daracecthye sinatissimus, F. Ameghino, Sinotra Geob-Paleont. Angentina - Supplen.(1899). h.10.Supprsed Cretacems; Datagonia. (Prunded thecth on bone-] Paraikichthye ornatiminum, 7. Anaghimo, Andes Soc. Cient. Azgentina, vol. 7.(1900), 1.217 (nameromb).

EMß10тос102

Lirosceles elegans, M.g.tp. Tord. Stant unir Pudt, Unir. Ser

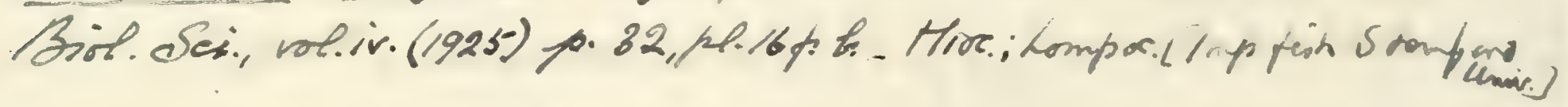

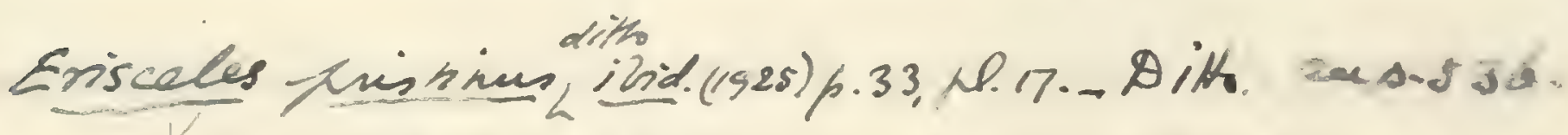

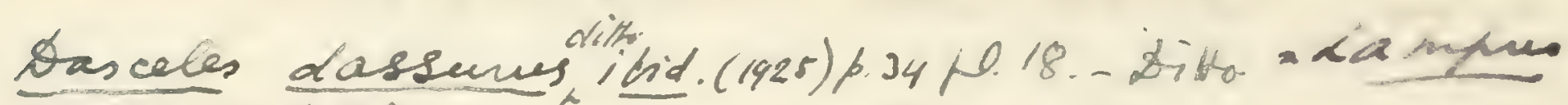

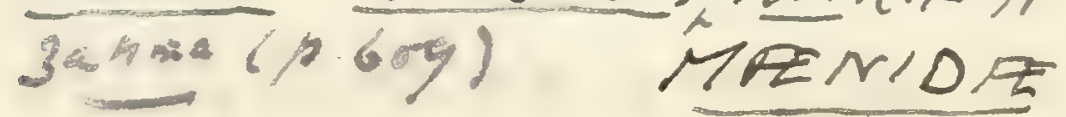

Mâena clivingsii 1.s. C.Aramboung, $1927, p .143, p l . x \times r t .3$

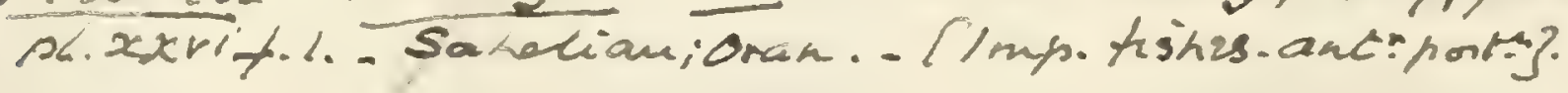


, 

pt. vii. (1846), pp. 11, 28, pl. i. fig. 6.-Middle Miocene ;

Neudörfl-a.-d.-Narch, Vienna. [The type species of Asima.]

Boops gigas, R. Lawley, Nuovi Studi Pesci, etc. Colline Toscane (1876), p. 54.-Pliocene; Tuscany.

Cantharus urcianensis, R. Lawley, ibid. p. 54, pl. i. fig. 6.Pliocene ; Orciano, Tuscany.

Capitodus dubius, G. von Münster, Beitr. Petrefact. pt. vii. (1846),

p. 17, pl. ii. figs. 10-16.-Tertiary; Viemna Basin.

Capitodus (?) interruptus, G. von Mïnster, ibid. p. 15, pl. i. fig. 3. -Ibid.

Chrysophrys agassizi, E. Sismonda, Mem. R. Accad. Sci. Torino,, P.Xe Alemanori

[2] vol. x. (1849), p. 15, pl. ii. figs. 44-49-_Pliocene; Sci. Jorinio [2]

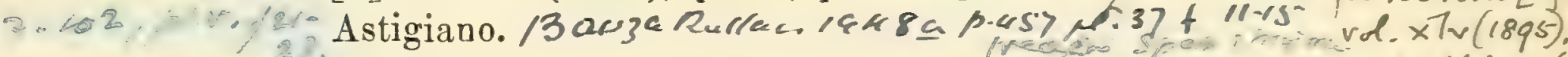

Chrysophrys arsenaritana, A. Valenciennes, Ann. Sci. Nat. [3]p.288, hliff.26.

rol. i. (1844), p. 103, pl. i. fig. 6.-Upper Miocene;

Algeria.

Chrysophrys hennii, P. J. Van Beneden, Bull. Acad. Roy. Belg.

[2] vol. xxxi. (1871), p. 503.-Pliocene; Antwerp.

Chrysophrys miocenica, F. Bassani, Atti Soc. Veneto-Trent. Sei.

Nat. vol. vi. (1879), p. 47, pl. v. figs. 1-8.— Middle

Miocene ; Gahard, Ille-et-Vilaine.

Lobodus pedemontanus, O. G. Costa, Ann. Accad. Aspir. Nat. [3]

vol. จ. (1866), p. 81, pl: i. figs. 1-5; F. Bassani, Atti

R. Accad. Sci. Napoli [2] vol. ix. (1899), no. 13, p. 41,

pl. iii. figs. 42-53.--Upper Focene; Gassino, Piedmont.

Sparoides robustus, J. Probst, Württ. Jahresh. vol. xxx.(1874),

p. 294, pl. iii. figs. 22-25.-Middle Miocene; Baltringen,

Würtemberg.

Sparoides spharicus, J. Probst, ibid. p. 295, pl. iii. figs. 26-31.Ibid.

Sparoides tenuis, J. Probst, ibid. p. 292, pl. iii. figs. 20, 21.Ibid.

Sparoides umbonatus, J. Probst, ibid. p. 291, pl. iii. figs. 16-19. -Ibid.

Sphcerodus conicus, L. Agassiz, Poiss. Foss. vol. ii. pt. ii. (1839-

44), p. 215, pl. lxiii. fig. 82.-Tertiary; Ceylon.

Sphcerodus insignis, P. J. Van Beneden, Bull. Acad. Roy. Belg.

[2] vol. xxxi. (1871), p. 503.-Pliocene; Antwerp.

Sphcerodus intermedius, G. G. Gemmellaro, Atti Accad. Gioenia

Sci. Nat. [2] vol. xiii. (1857), p. 291, pl. i. fig. 2.-

Pliocene; Prov. Caltanisetta, Sicily.

Sphcerodus osulus-serpentis, L. Agassiz, op. cit. vol. ii. pt. ii. 
(1839-4), p. 215, pl. 1xxiii. figs. 20, 21.-Form. and loc. unknown.

Sphcerodus parvus, L. Agassiz, op. cit. rol. ii. pt. ii. (1839-44), p. 213, pl. Ixxiii. figs. 11-18.-Oligocene; Cassel and Weinheim.

Sphoerodus truncatus, L. Agassiz, op. cit. vol. ii. pt. ii. (1839-44), p. 215, pl. lxxiii. fig. 19.-Oligocene; Osnabrück.

Spharodus wiechmanni, T. C. Winkler, Archiv Vereins Fr. Naturgesch. Mecklenburg, vol. xxix. (1875), p. 121, pl. iii. figs. 13-16. -Upper Oligocene; Sternberg, Mecklenburg.

Otoliths from the Oligocene of Germany have been referred to undetermined genera of this family under the names of Otolithus (Sparidarum) gregarius and O. (S.) soellingensis (E. Koken, Zeitschr. deutsch. geol. Ges. vol. xxxvi. 1884, p. 556, pl. xii. fig. 11, and 2oc. cit. vol. xliii. 1891, pp. 128, 144, pl. vii. figs. 7, 8). Another form from the Lower Tertiary of the Jackson River, Mississippi, is named O. (S.) insuetus (E. Koken, Toc. cit. vol. xl. 1888, p. 280, pl. xrii. fig. 9).

\section{incl. Diaphyetion qu Family SCIENIDE.}

Head-bones more or less hollowed for well-dereloped slime-canal system; teeth conical and only on margin of jaws; lower pharyngeal bones usually separate. Spinous portion of dorsal fin much less extended than articulated portion; anal fin short-based, with 1 or 2 spines.

Littoral fishes of tropical and sub-tropical regions, sometimes entering freshwaters. Not satisfactorily known among fossils, but supposed to be represented by the following extinct species, of which there are no remains in the Collection:-

Pogonias multidentatus, E. D. Cope, Proc. Boston Soc. Nat. Hist. vol. xii. (1869), p. 310.-Miocene; Westmoreland Co., Virginia. [Upper pharyngeal.]

Henandri, Umbrinc pecchiolii, R. Lawley, Nuovi Studi Pesci, ete. Colline I. R. Acead. Sci. Jorino[zjuol)

T'oscane (1976), p. 78, pl. v. fig. 5.-Lower Pliocene; Tuscany. [Otoliths and teeth.]

he.ifis.z. Ce. Otolithus (Scicnidarum) claybornensis, decipiens, eporrectus, fund to Scidena. sp. Go G. Le Thetano, 3-1.Sor. Geol. Ital. vol.xxviii(1910), h. 621, fl, xviii.fig. 33 , gemma, intermedius, radians, and similis, E. Koken, Zeitschr. deutsch. geol. Ges. vol. xl. (1888), pp. 280-286, pl. xriii. figs. 16, 17, pl. xix. figs. 1-11, 13, 14.--Lower Tertiary; Alabama and Mississippi. [Otoliths.] 


Otdither (Sparidarum?) coffea, A.Wollemann. Jahrhe.

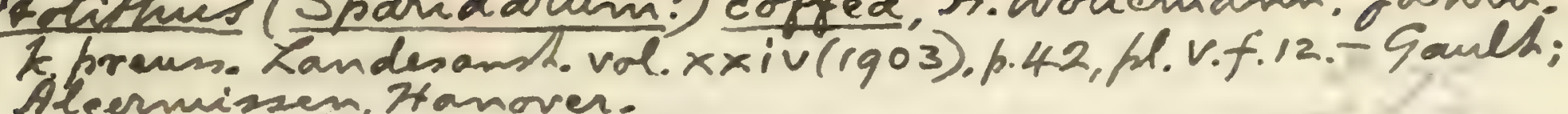
Aksermizsen, Hanover.

Holither (Sparidarum) elongatus, Friem, Bull. Sor. Géd. France [4] rol. xiii (1913), h.15-6, Lext.fip. 10-12. Lutetian; Loire Inférieure. Q. A. Foost. Trans. N.z.Inst. v.55(1924) p.612 p1. 62.\%.16 Oamum N.Z.

Q. (s.) Sregarius, 7. Priem, Bull Sor. Géol. Arance [4] vol. xiv/1914), h.264,

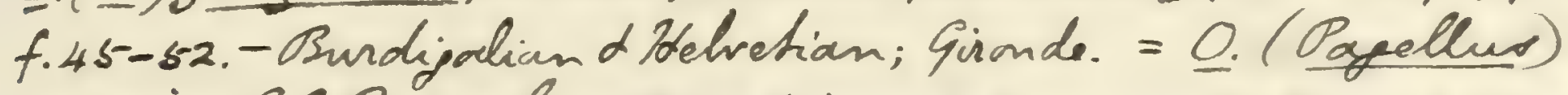

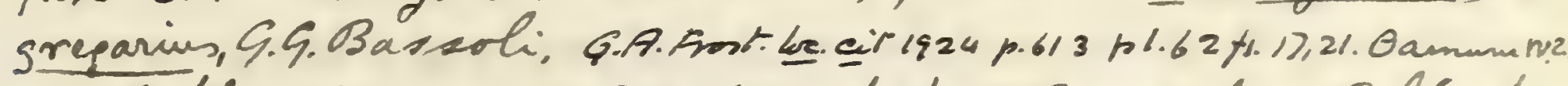

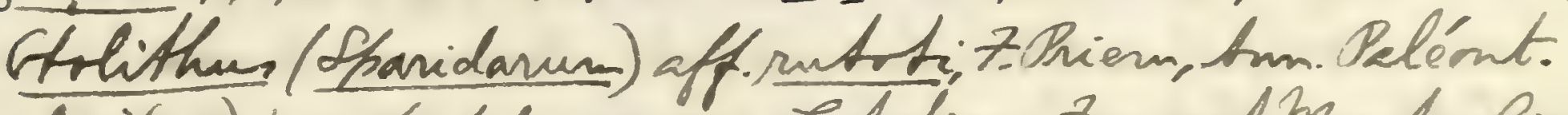

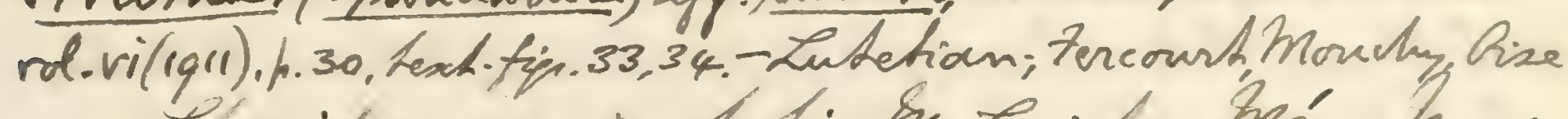

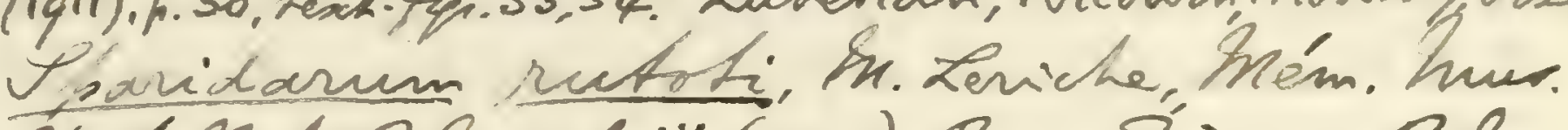

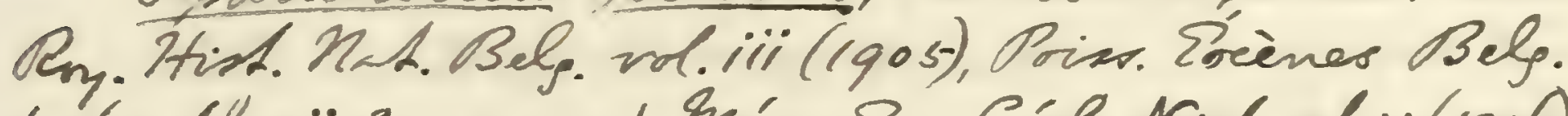
j.165; fl. xii.fig. q, 10; a Mém. Soc. Céd. Nord, vol. v (1906), p.260, hl. Xv. fie. q,10:- Bruxellian: Belgium. Otolithur (Sparidarm) saurapei, 7. Prien, Inll. Son. Géd. Irance [4] vol vi (1906), 10.274, hexh-tip. 36, 37.- Lutatian; Grignon.

Holithur (Shavidarum) simplexe. F. Priem, Bull. Sor. Gérl. Zrancu [4Jvol. xiii (1913), h.152, Lach.f2\}. 4.- Lutetian; Hauteville, Manche. Remains of hicropogeon furnieri, Derm., from Thiddle Pampeon of Za Dlata are recnded hi to Ameghino, Segundo Censso de la Bepútlica Argentina, vol i (1898), p. 242 .

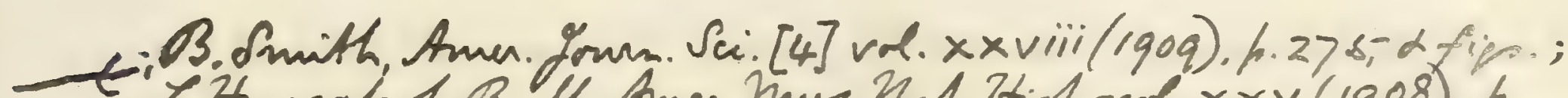

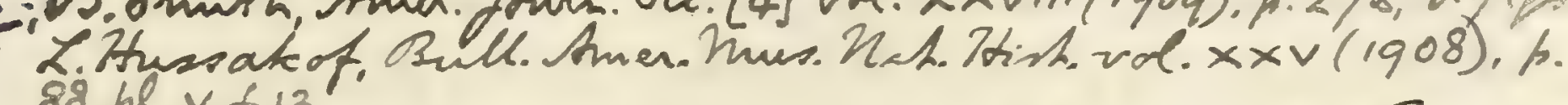
P.9997. Pharmperel and rutchade of Poponido Pasciatur from Pampean Armation at Orew. Walt F Reid, Be., lgot.

Otilithus (Untorina) subcinhosus, D. F. Thubert,

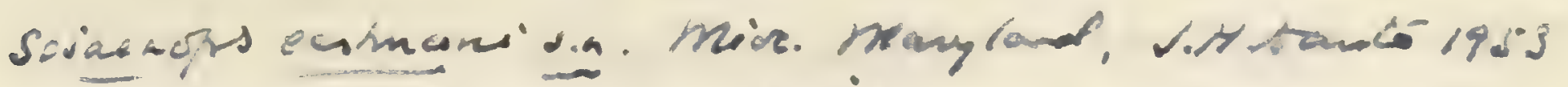
S.Pah. 27 P.878 F.t.s. Orosids.

Karimen see p.518. 


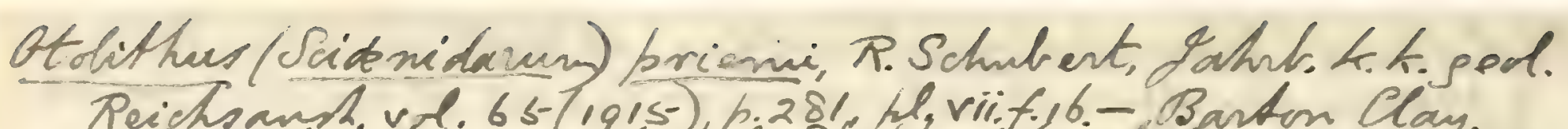

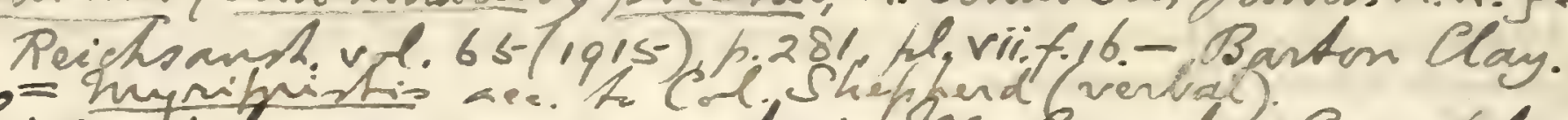
Ciobnidarum manchei. M. Zeriche, Com Stes Rendus trsor. Franç. Av. Sci. 1906 (1907). h. 354, bliiifir.5-8. - Asuitamian Montellier [Otolitt] Otolithus (Jcianidarum) coric: R.J.Schnbent,

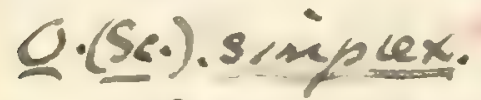

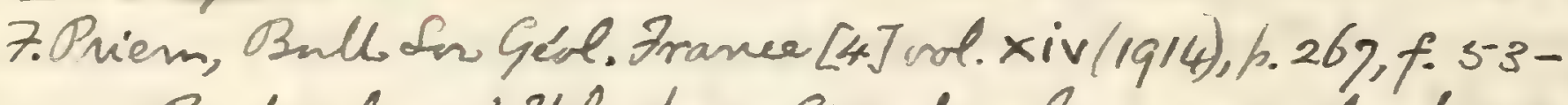
5s:- Burdigalian d trelvetian; Gironde. Iniocene; Aushria. Otolithus (Sidenidarum) pyrenaicus, 7. Priem, B.ll. Sor. Géd. France [4] vol. xi (1gi1). p. 43, f.7; aho love att. vol. xiv (1914), h.269, f. 5-6-59. - Bndipalian a HelveIian: S.W. Arance.

Helithus (Peidenidarum) gemmoides, R.T.Schmbert,

0.(5.) off-gemmoides, 7. Priem, B.S.9.7. [4] od. xiv (1914), b.270, f. 60-62. - Mircene; Austria. Oundigalian and Helveti.n; S.W. France.

Holithus (Pcionidarum) subpermma, R.T. Schubut,

Q.(5.) aff. subpenma, 7.Oriem, 0.5.9.7. [4] Xiv (1914), 6.271.f.63. - $96 . d$.

Tholithus (Jeidnidarum) gracilis, R. J. Schubert.

0.(5.) subgenma, var, sallensis, 7. Priem, B.S.9.7. [4] xiv (1914), h.272, f-64.- Helvetion; Salles, Yironde.

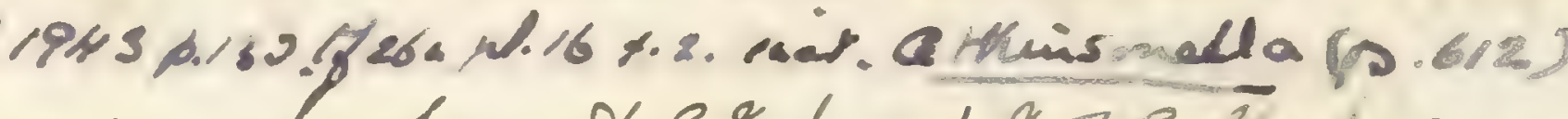

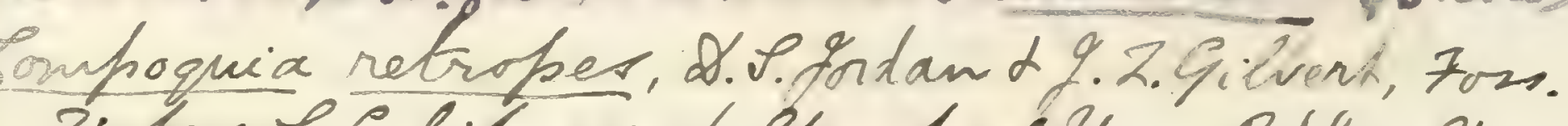
Fisher T. California / Stanford Unir. Oublic. Univ. Per.1919), p.4q, pl.xxiv. fip.1. - Diatomaceons Carth; Lompoe, S. Bartara Co. [imperfuth firh; Stonfine Univ. 7

T. of Eompoquia.

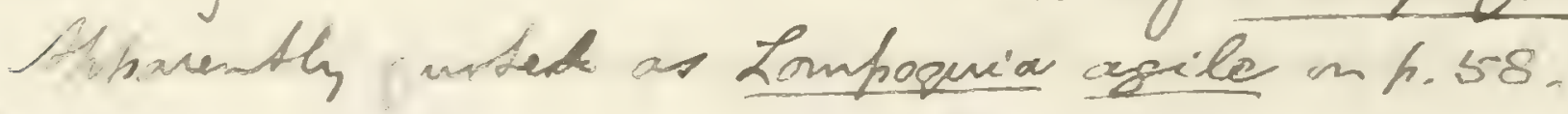

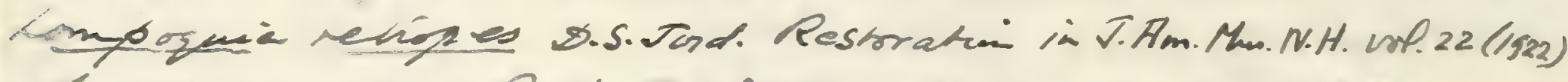

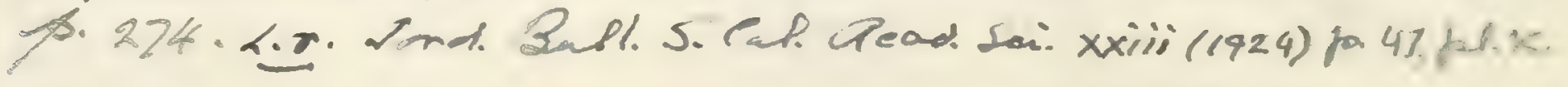


. 



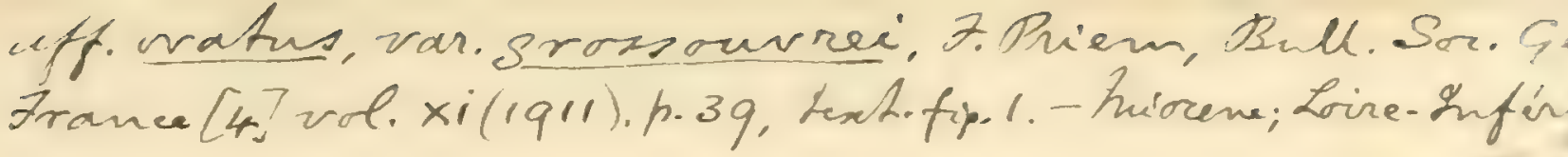

SCIENID F.-LABRID王。

Otolithus (Corvina) gibberulus; Otolithus (S'cicence) amplus, holsaticus, irregularis, kirchbergensis, merictionalis, obtusus, and speciosus; Otolithus (Sciceniclarum) elongatus, insignis, and ovatus, E. Koken, loc. cit. vol. xxxri. (188t), pp.55t, rotsome. 555, pl. xi. fig. 7, pl. xii. figs. 6-8, and vol. xliii.(1891), pp.107-112, with figs._-Oligocene and Miocene; Germany.

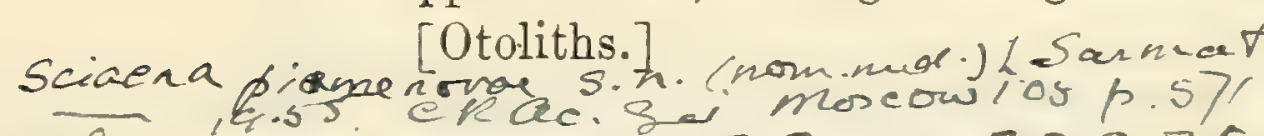

\section{$\rightarrow$ aln i. Trien, S. S. C.7. [4] uol. xil(1911). h. 42, f. s. 6.}

\section{Family LABRID王。}

Narial opening double on each side. Margiual teeth prehensile; vomer and palatines toothless; lower pharyngeal bones (rarely also upper pharyngeals) fused together. Spinous portion of dorsal fin at least as much extended as articulated portion; anal fin with 2 to $\dot{s}$ spines, nearly equal to and opposite to the hinder dorsal fin. Scales usually cycloid, rarely feebly ctenoid.

Littoral marine fishes with thick lips, almost universally distributed.

\section{Synopsis of Extinct Genera \&. Genera repiesented by Extinct Species.}

Lower pharyngeal triangular, with tritoral teeth having only one successor at a

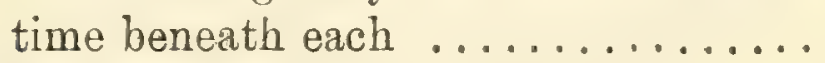

Pharyngeal teeth small, not tritoral..... Lower pharyngeal as in Labrus, but pile of successional teeth beneath each

functional tooth .............. Labrodon (p. 541).

Lowel pharyngeal leaf-shaped, with large tritoral teeth, middle the largest, each with pile of successional teeth ......

As Phyllodus, but pharyngeal teeth nearly

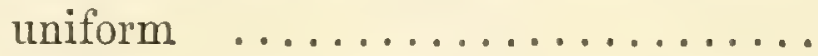

Pharyngeals with layer of ganodentine,

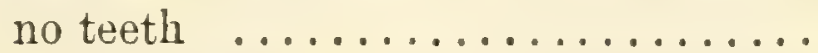

Pharyngeals with large ovoid teeth of

coarse vasodentine ............ Pseudospharodon (p. 552).

Labrus (p. 539).

Julis (p. 511).

Phyllodus (p. 546).

Egertonia (p. 5:0)

Platylamus (p. 551).

Genus LABRUS (Artedi), Linnæus.

[Syst. Nat. ed. 10, 1758, p. 282.]

Snout pointed; trunk oblong and laterally comprossed. Marginal teeth conical and in single series; pharyngeal teeth tritoral and closely arranged, each with one successor at a time beneath it; lower 
pharyngeal bone triangular, and upper pharyngeals not fused together. Preoperculum serrated in young, smooth in adult. Vertebræ about 35 to 40 in number, nearly half being abdominal. Dorsal fin much extended, with more than 20 rays, of which at least 13 are spinous; anal fin with 3 spines; caudal fin rounded. Scales of moderate size, not serrated, extending orer the opercular apparatus and cheek.

Existing species range along the coasts of the temperate regions of Europe and Africa. The only fossil in the Collection referable to this genus is the following:-

P. 5526. Imperfect lower pharyngeal bone, rather large and massive, recorded by Woodward \& Sherborn, Catal. Brit. Foss. Vert. (1890), p. 108 ; Red Crag, Suffolk.

Purchased, 1888.

The following imperfectly known extinct species have been referred to this genus and to Crenilabrus, but the systematic position of all except the first is very doubtful :-

Labrus agassizi, J. J. Heckel, Denkschr. k. Akad. Wiss., math.naturw. Cl. vol. xi.pt. i. (1856), p 268, pl.xv. figs. 2-4; F. Bassani, Atti R. Accad. Sci. Napoli [2] vol. iii. (188?), no. 6, p. 47, pl. iv. fig. 2 . Notceus agassizii, G. von Münster, Beitr. Petrefact. pt. rii. (1846), p. 27, pl. iii. fig. 2. Julis ayassizii or Julis muensteri, R. Kner, Sitzungsb. k. Akad. Wiss., math.-naturw. Cl. vol. xlv. pt. i. (1862), p. 487.-Middle Miocene; Margarethen, Vienna. Lower Miocene; Chiavon, Vicentin, N. Italy. [Imperfect fish; Palæontological Museum, Munich.]

Labrus ibbetsoni, L. Agassiz, Poiss. Foss. rol. v. pt. i. (1844), p. 116 (undescribed).-Miocene (Molasse); Switzerland. [Lower pharyngeal.]

Labrus parvulus, J. J. Heckel, Toc. cit. 1856, p. 271 , pl. xv. fig. 5.Middle Miocene; Margarethen, Vienna. [Imperfect small fish, probably not Labroid (R. Kner, Sitzungsb. k. Akad. Wiss., math.-naturw. Cl. vol. xlv. pt. i. 1862, p. 487).]

Labrus priscus, R. Lawley, Nuori Studi Pesci, etc. Colline Toscane (1876), p. 71.-Lower Pliocene; Spedaletto, Tuscany. [Upper pharyngeal.]

Labius valenciennesi, L. Agassiz, Neues Jahrb. 1835, p. 293, and Poiss. Foss. vol. v. pt. i. (1839-44), p. 116, pl. xxxix. fig. 2 (lettered Labrus microdon). Labrus merula, G. S. 
D. Binnati; stti tor. Ital. Tei hat. wol. xTriii (1909), f.103, hl. iv.

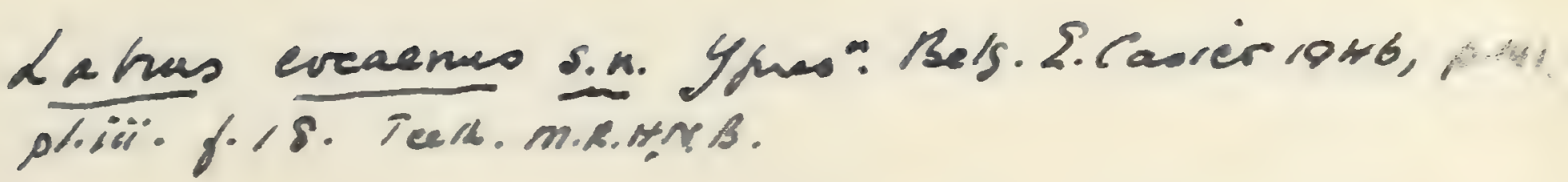

Labus merula, Zim.: Bunati; Lr. with 
Volta, Ittiolit. Veronese (1796), p. clv. pl. xxxvii. (errore).-Upper Eocene; Monte Bolca, near Verona. [Imperfect fish, not Labrus according to Heckel, loc. cit. p. 269 ; Paris M[useum of Natural History.]

Labrus (Crenilabrus) woodwardi, D. G. Kramberger, Rad Jugoslav. Akad. vol. cri. (1891), p. 119, pl. ii. fig. 4.Upper Miocene; Dolje, Croatia. [Imperfect fish; Geological Museum, University of Agram.] See p-opp.

${ }^{\times}$Crenilabrus szajnochce, A. de Zigno, Мem. R. Istit. Veneto, vol. xxiii. (1887), p. 17, fig. 3.-Upper Eocene; Monte Bolca. [Imperfect fish; Zigno Coll., University of Padua.]

\section{Genus JULIS, Curier.}

[Règne Animal, vol. ii. 1817, p. 261.]

Much resembling Labrus, but fewer vertebræ, only eight dorsal fin-spines, and scales scarcely if at all extending over opercular apparatus and cheek. Pharyngeal teeth not tritoral.

Existing in Mediterranean and warmer seas. Supposed to be represented by the following extinct species, of which there are no specimens in the Collection:-

Julis sigismundi, R. Kner, Sitzungsb. k. Akad. Wiss., math.naturw. Cl. vol. xlv. pt. i. (1862), p. 488, pl. i. fig. 1.Middle Miocene (Leithakalk); Margarethen, Vienna. [Imperfect fish ; Cniversity Geological Mruseum, Vienna.]

Genus LABRODON, Gervais.

[Mém. Acad. Montpellier, Sect. Sci. rol. iii. 1857, p. 515.]

Syn. Nummopalatus, M. Rouault, Comptes Rendus, vol. xlvii. 1858,

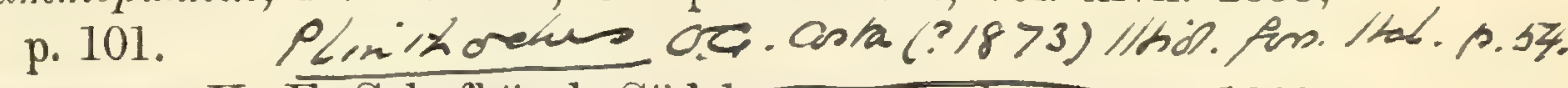

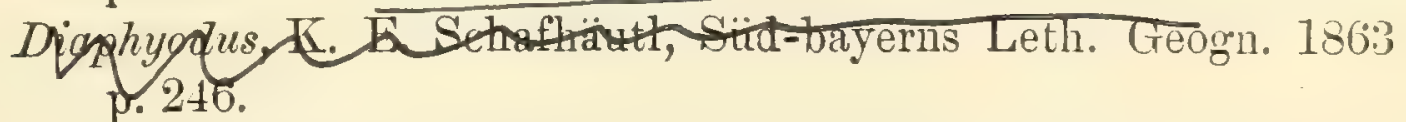

Pharyngodopilus, I. Cocchi, Ann. R. Mus. Fis. Firenze [2] vo?. i. 1866, p. $123^{1}$.

An extinct genus, known only by the pharyngeals, which resemble those of Labrus, but exhibit a pile of successional teeth beneath each functional tooth.

${ }^{1}$ Separate copies of the memoir by Cocchi, entitled "Monografia dei Pharyngodopilidie," were distributed by the author in 186 . 


\section{Labrodon superbus (Cocchi).}

1866. Pharyngodopilus superbus, I. Cocchi, Ann. R. Mus. Fis. Firenze [2] vol. i. p. 136, pl. iv. fig. 16.

Type. Lower pharyngeal dentition.

Lower pharyngeal dentition nearly twice as broad as Jong, produced to a sharp median point in front; teeth rounded, none elongated. Width of lower pharyngeal dentition about 0:06.

Form. \& Loc. Lower Pliocene: Tuscanj.

P. 8968. Upper pharyngeal dentition, probably of this species; Orciano.

Castelli Coll.

\section{Labrodon canariensis (Cocchi).}

1866. Pharyngodopilus canariensis, I. Cocchi, loc. cit. p. 134, pl. iv. fig. 6.

1866. Pharyngodopilus aficanus, I. Cocchi, loc. cit. p. 132, pl. iv. figs. 7, 8. [Pharyngeal dentition; British Museum.]

1882. Labrodon africanus, H. E. Sauvage, Mém. Soc. Sci. Nat. Saôneet-Loire, vol. iv. p. 74.

1891. Nummopalatus africanus, Rothpletz \& Simonelli, Zeitschr. deutsch. geol. Ges. vol. xlii. p. 726.

Type. Upper pharyngeal dentition; British Museum.

Very small; upper pharyngeal dentition with only one relatirely large inner tooth, bounded by small teeth; lower pharyngeal dentition about 0.015 to 0.02 in width, with posterior row of teeth relatively largest and antero-posteriorly elongated.

Form. \& Lo:. Miocene: Grand Canary.

F. 9471. Type specimen; probably from Las Palmas.

History unknown.

P. 9172. Type specimens of so-called $P$. africanus, being upper and lower pharyngeal dentition, described and figured loc. cit.; said to be from West coast of Africa, but probably from Las Palmas.

History unknown.

P. 9473. Slightly larger lower pharyngeal dentition, probably from Las Palmas, noticed by Cocchi, loc. cit. p. 134.

History unknown.

The following specimens are not specifically determined :-

40339. Fragment of small dentition; Lower Eocene, Dulwich, London. Purchased, 1867. 


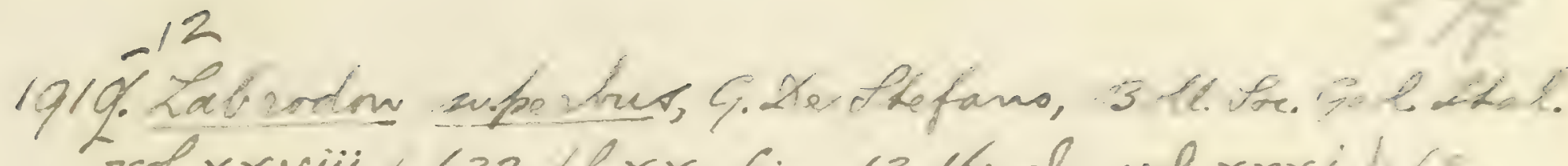

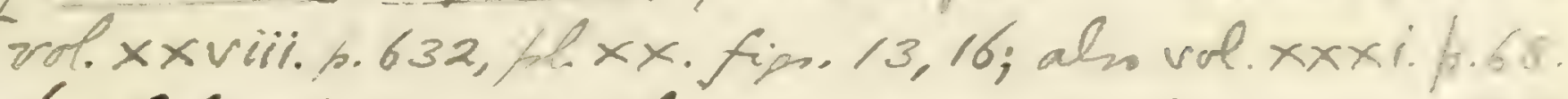
1916. Labrodon superbum var. exe Bisanii, F. Sueco, R. Acead. Sci. Jorino, vol. Ti, h.149. fip. 4. 1923. Labrodon supentum, P. Santucei. BNi. Sore.ged. thal. p. 210, pliil fige. 9.9a.

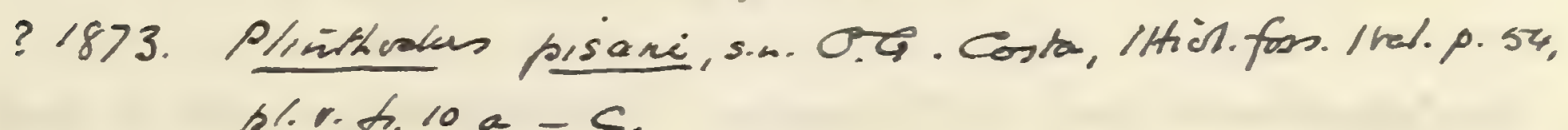
pl.r.t. $10 a-s$. 
P2313 = Labrodon enfertidens Chapm. qPitch.

Labrodn Pf., Friem, Bull. Sor. Géol. France [4] vol. xiv (1914). h.125- pliii.f. 14. [H. Shanymeed, Burdipalian, Gironde]

L. batesfordiensis FChapman MFA. Cadmorz, PR. S. Vict.

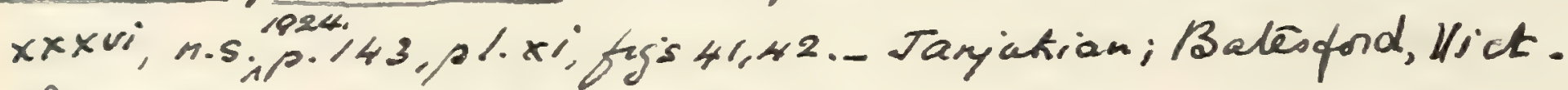
[h. pharyngeal; Nat. Mus. Heblowne].

Larizeas Preuderomen p.4so.

Laburdon confertideno, T. Chapaman LiBitchud, Pur. Try. Sor. Vich. n. s. vol. $\times \times(1907)$, 6.6. pl.v. fis. \% - Base of Rulimman Beds; Crmpe Burm, mum Hamilton, W. Nictria. [L.pharyngeal;

nak. Mus. Methrume.] 7. Chaproan, Norealand

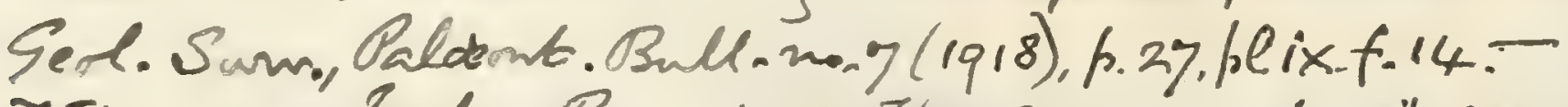

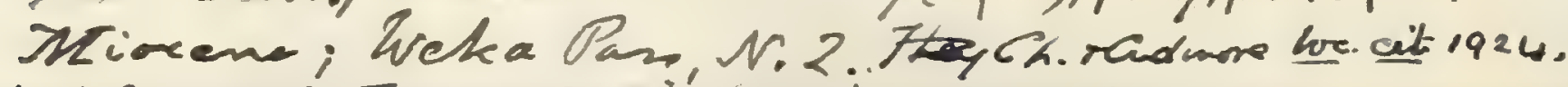

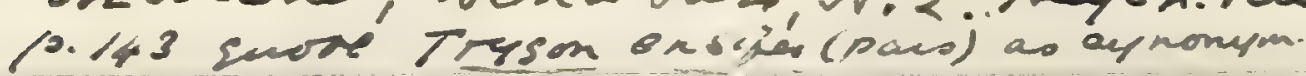




P. 2312. Fragment of larger dentition; Otatara Formation, New
By exchange, 1876.

48995. Lower pharyngeal dentition; Tertiary, Coquimbo, Chili. Presented by C. J. Lambert, Esq., 1878.

The following species, not represented in the Collection, have also been recognised:-

Labrodon bazini, H. E. Sauvage, Mrém. Soc. Sci. Nat. Saône-etLoire, vol. ir. (1882), p. 75. Nummopalatus bazini, H. E. Saurage, Bull. Soc. Géol. France [3] rol. iii. (1875), p. 625, pl. xxii. fig. 16.-Miocene; Quiou, near Rennes. [Upper pharyngeal.]

Labrodon belgicus: Nummopalatus belgicus, A. Daimeries, Ann.

Soc. Roy. Mralacol. Belg. [4] rol. vii. (1892), Bull. p. xr.-

Upper Eocene (Laekenian); St. Gilles, Brussels.

Labrodon bourgeoisi, H. E. Saurage, loc. cit. 1882, p. 76. Pharyngodopilus bourgeoisi, I. Cocchi, Ann. R. Mus. Fis. Firenze [2] vol. i. (1866), p. 135, pl. ir. fig. 5. Nummopalatus bourgeoisi, H. E. Saurage, loc. cit. 1875, p. 626, pl. xxii. fig. 18, pl. xxiii. fig. 6. Pharyngodopitus abbas, I. Cocchi, loc. cit. 1866, p. 136, pl. ir. fig. 4. Nummopalatus abbas, H. E. Saurage, loc. cit. 1875, p. 627. -Miocene; Touraine and Maine-et-Loire. [Upper pharyngeal.]

Labroclon britannus, H. E. Saurage, Toc. cit. 1882, p. 72. Nummopalatus britannus, H. E. Sauvage, loc. cit. 1875, p. 627, pl. xxiii. fig. 11.-Miocene; Brittany. [Lower pharyngeal.]

Labrodon, carolinensis: Odax carolinensis, J. Leidy, Proc. Acad. Tat. Sci. Philad. vol. rii. 1856, p. 396. Pharyngodopilus carolinensis, J. Leidy, Journ. Acad. Nat. Sci. Philad. [2] rol. viii. (1877), ,. 256, pl. xxxiv, figs. 19-24.-Tertiary Phosphate Beds; Ashley Rirer, South Carolina. [Lower pharyngeal.]

Labrodon chantrei, H. E. Sauvage, loc. cit. 1882, p. 68, pl. ii. fig. 6 . Nummopalatus chantrei, H. E. Saurage, Toc. cit. 1875, p. 618, pl. xxiii. fig. 10.-Miocene; Bordeaux and Rennes. [Lower pharyngeal; Lyons M[useum.]

Labrodon cocchii, H. E. Saurage, Toc. cit. 1882, p. 75. Nummopalatus cocchii, H. E. Saurage, loc. cit. 1875, p. 623, pl. xxii. fig. 10.-Miocene; La Chausserie, near Rennes. [Cpper pharyngeal.] 
Labrodon crassus: Pharyngodopilus crassus, I. Cocchi, loc. cit . 1866, p. 143, pl. iv. fig. 14, pl. v. fig. 5, pl. vi. fig. 5.-

Pliocene; Tuscany. [Lower phargngeal ; Pisa Museum.]

Labrodon dilatatus: Pharyngodopilus dilatatus, I. Cocchi, Toc. cit. 1866, p. 141, pl. $\nabla$. figs. 1, 2, 8, pl. vi. fig. 4.Ibid. [Ditto.]

Labrodon edwardsi: Nummopalatus edwardsius, M. Rouault, Comptes Rendus, vol. xlvii. (1858), p. 101.-Miocene; Brittany. [Type species of Nummopalatus.]

Labrodon gaudryi: Nummopalatus gaudryi, H. E. Sauvage, loc. cit. 1875, p. 619, pl. xxii. figs. 5, 6.-Miocene; Dax, Gironde. [Lower pharyngeal; Paris Museum of Natural History.]

Labrodon haueri, H. E. Saurage, loc. cit. 1882 , p. 66, pl. ii. figs. 7, 8; L. Seguenza, Boll. Soc. Geol. Ital. vol. xix. (1900), p. 512, pl. vi. fig. 9. Phyllodus haueri, G. von Münster, Beitr. Petrefact. pt. vii. (1846), p. 6, pl. i. fig. 1. Nummopalatus haueri, H. E. Sauvage, Toc. cit. 1875, p.621, pl. xxii. fig. 19, pl. xxiii. figs. 4, 5.-Miocene; Vienna Basin, Italy, Sicily, and Brittany. [Upper pharyngeal; Palæontological Museum, Munich.]

Labrodon heterodon, H. E. Sauvage, loc. cit. 1882, p. 73. Nummopalatus heterodon, H. E. Sauvage, Toc. cit. 1875, p. 629, pl. xxii. figs. 11-13, pl. xxiii. figs. 7, 8.-Wiocene ; near Rennes, and Dax, Gironde. [Upper pharyngeal.]

Labrodon multidens, H. E. Sauvage, loc. cit. 1882, p. 74 ; L. Seguerza, Boll. Soc. Geol. Ital. vol. xix. (1900), p. 513, pl. vi. fig. 8. Phyllodus multidens, G. von Münster, Beitr. Petrefact. pt. vii. (1846), p. 7, pl. i. fig. 5. Phyllodus subdepressus, G. von Münster, ibid. p. 9, pl.i. fig. 7. Pharyngodopilus multidens, I. Cocchi, loc. cit. 1866, p. 127, pl. iv. figs. 9-12. Nummopalatus multidens, $\mathrm{H}$. E. Sauvage, loc. cit. 1875 , p. 629 , pl. xxiii. fig. 9 ; K. A. von Zittel, Handb. Palæont. vol. iii. (1888), p. 289, fig. 299.-Niocene; Vienna Basin, Brittany, Turin and

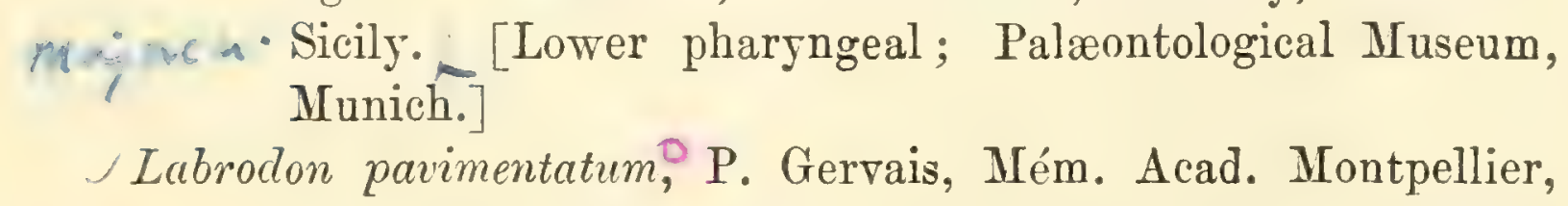
Sect. Sci.vol. iii. (1857), p. 515, pl. v. fig. 6, and Zool. et Pal. Franç. ed. 2 (1859), p. 512, with woode.; H. E. Sauvage, loc. cit. 1882 , p. 69 , pl. ii. fig. 5. Nummopalatus pavimentatus, H. E. Saurage, loc.cit. 1875 , p. 617 , pl. xxiii. fig. 3. Pharyngodopilus alsinensis, I. Cocchi, 



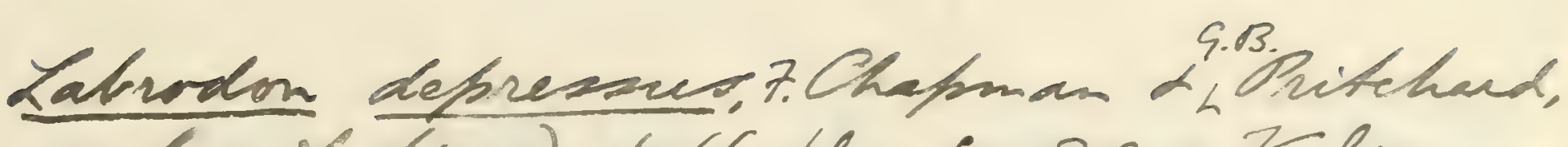

Co.cilh. (1907), h.66, hl.v. fir. 8,9. - Kalimman Beds; Beaumario, Prt Bhillip, Nictoria. [R.pharympeal; Pritchand Coll.] F.Chapmon, Hew Zealand Ged. Sun., Paldeont-Bull. no.y (1918), 6.27, pl. vi.fis, 13, - Mirene; Coleridge Gully. Nummopalales depressus Chapm an Tandmore, wer eitt.1924 p.143, pl.xif.43.

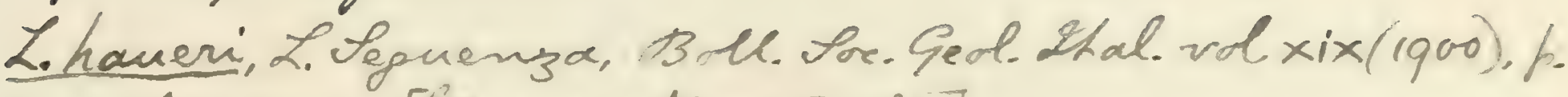

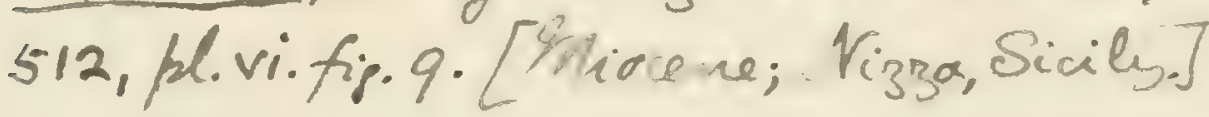

Zabroden multidens, G. de Alessandri, Atti Soe. Shali Sei. Nat.

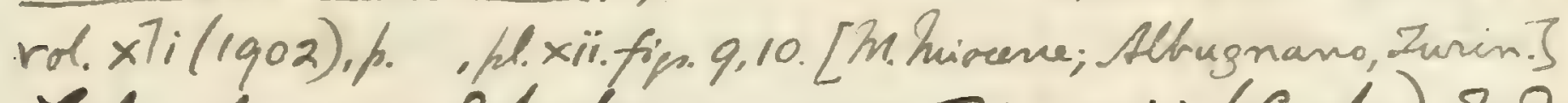
Labrodow multidens, var. Pisanii (Costa), F. Sacco, Atti R. Secad. Sei. Jorins, vol. $7 i(1916), p .148$, fij. 3-Plocene; Stold di Pianosa. (= Plinthodur Pisanii, 0.9. Costa,

Z-multidens, Z. Oegurenza, Boll. Lor. Ged. Ital. vol xix (1900),

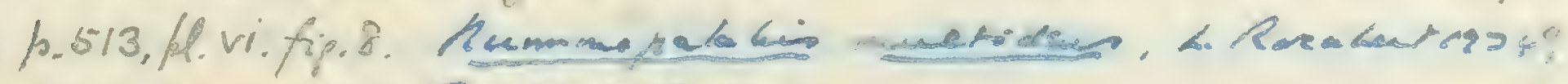

Labudon havimentatum, var. lipustica, F Sacw,

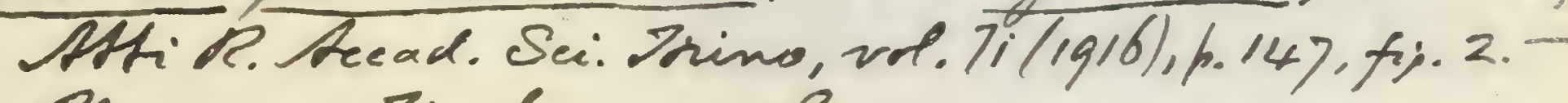
Pliceene; Zinola, near Sarona.

Zatrodm hourimentatum, M. Leviche, Ann. Sor. Séd. vord, vol. $\times \times \times v(1906)$, o. 314 [long synoriymej]; G. De

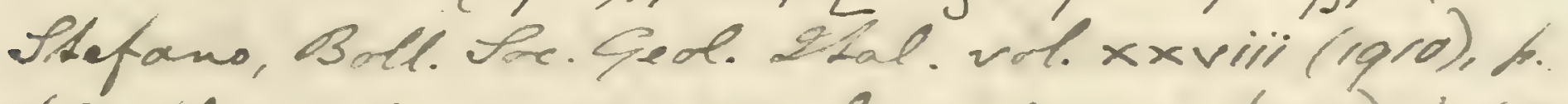
630, hl. $x \times$. figs. 3, 14, 15; also wh. $\times x \times 1(1912), k, 68$

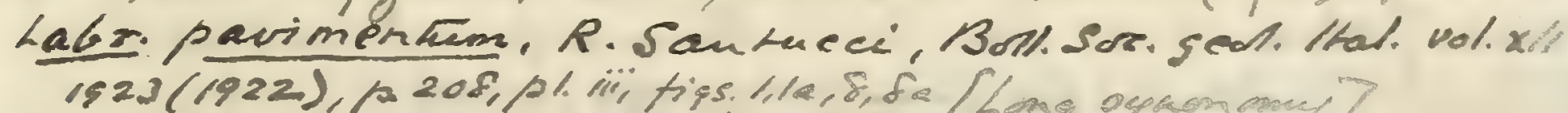


Labrodon paucidens, F. Riem, Bull. Sor. Gëol. Frana

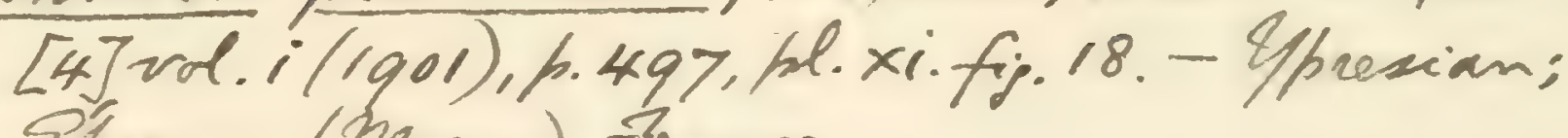
20.may (Marne), Dranee.

Eodiaphyoum Lrichei g.Jun. Ceracems engo sencevedu cosin 1949 p.226 y. .

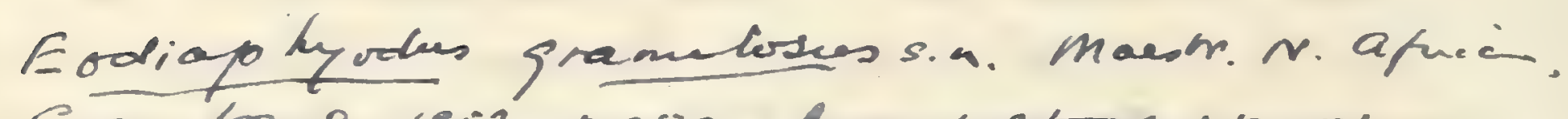

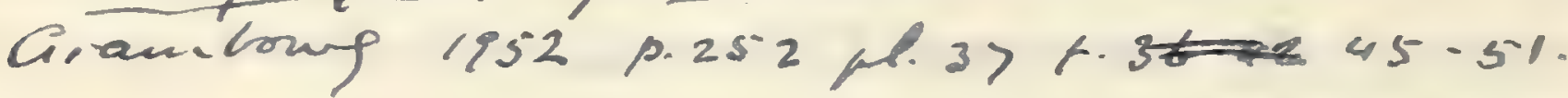

habrodon voveretoi, R. Sanhieci, Boll. Soe ged. Itall

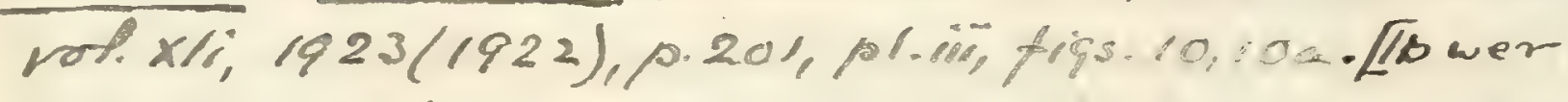
pharyngeal tooth]-pliac. Ligursia. [Genoa univis]

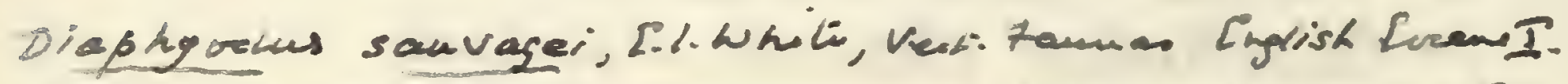

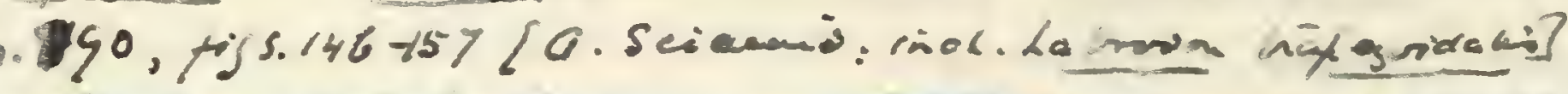
Mork.

$\nmid$ Labrodon stromeri sp. n. Eocene S.W. Africa, BöHM Die Diamantenwüste Südwest.Afrikas 2 p. 82 pl. xxxii fig. 6 text-îg. B. 19.

Labuden Arapezoidahi, Mr. Leriche, Am. Sor. Geol. Nord,

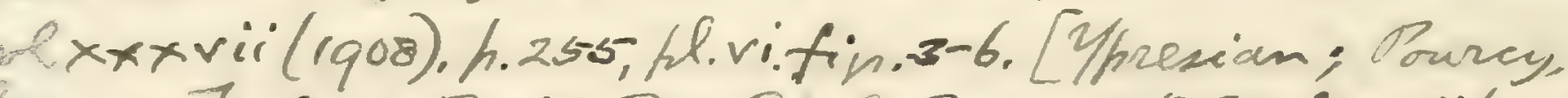

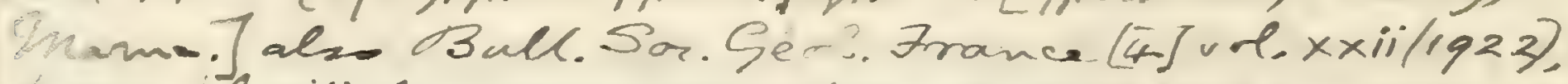

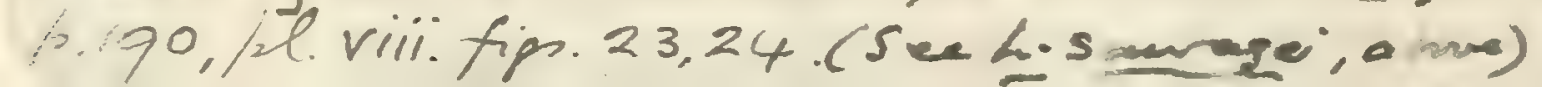




Toc. cit. 1866, p. 138, pl. iг. fig. 15, pl. r. figs. 3, 4, 9, 10 ; P. Vinassa de Regny, Rivista Ital. Paleont. vol. v. (1899), p. 84, pl. ii. fig. 19. Labrodon alsinensis, H. E. Sauvage, 7oc. cit. 1882, p. 70, pl. ii. figs. 2-4.-Pliocene; Hérault and Tuseany. Miocene; La Chausserie, near Rennes.

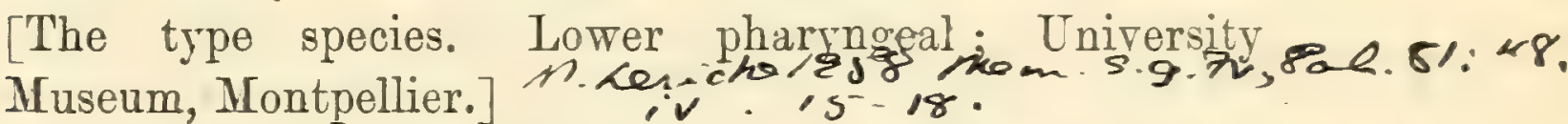

Labrodon polyodon, H. E. Sauvage, loc. cit. 1882, p. Tt. Nummopalatus polyodon, H. E. Saurage, loc. cit. 1875, p. 629. Sphcerodus polyodon, E. Sismonda, Mera. R. Accad. Sci. Torino [2] vol. x. (1846), p. 19, pl. i. figs. 5-7. Pharyngodopitus polyodon, I. Cocchi, Zoc. cit. 1866, p. 125, pl. iv. fig. 3.-Miocene; Turin and Brittany. [Type species of Pharyngodopitus. Lower pharyngeal; Turin Museum.] Plinithodus sismondiames O.G-Corta (1873?) Iftiol. Fin. Ital

Labrodon quenistedti: Nummopalatus quenstedti, H. E. Saurage, loc. cit. 1875, p. 623. Pharyngodopilus quenstedti, J. Probst, Württ. Jahresh. vol. xxx. (1874), p. 278, pl. iii. figs. 1, 2. Pharyngodopilus haveri, I. Cocchi, loc. cit. 1866, p. 131, pl. iv. fig. 13 (errore).-Wiocene; Vienna Basin, Würtemberg, and Brittany. [Lower pharyngeal.]

Labrodon rhedonum, H. E. Sauvage, Toc. cit. 1882, p. 75. Nummopalatus shedonum, H. E. Saurage, Toc. cit. 1875, p. 624, pl. xxii. fig. 17.-Miocene; Brittany. [Upper pharyngeal.]

Labrodon sacheri, H. E. Sauvage, loc. cit. 1882, p. 72. Nummopalatus sacheri, H. E. Sauvage, loc. cit. 1875, p. 624, pl. xxii. figs. 7-9.-Miocene; near Remnes. [Upper pharyngeal.]

Labrodon sauvagei: Nummopalatus sauvagei, C. H. Leriche, Ann. Soc. Géol. Nord, rol. xxix. (1901), p. 177, pl. i. fig. 2.Lower Eocene; Cuis, Epernay, Marne. [Upper pharyngeal ; University of Lille.]

Labrodon sellce: Pharyngodopilus sellce, I. Cocchi, loc. cit. 1866, p. 145, pl. v. fig. 11.-Miocene; Pianosa. [Lower pharyngeal; Florence Nuseum.]

Labrodon soldanii: Pharyngodopilus soldanii, I. Cocchi, loc. cit. 1866, p. 146, pl. v. fig. 6, pl. vi. fig. 6. Sphcerodus arcadasii, G. G. Gemmellaro, Atti Accad. Gioenia Sci. Nat. [2] rol. xiii. (1857), p. 289, pl. i. fig. 1, pl. vi. fig. 1.

Pliocene; 'Tuscany and Sicily. [Upper pharyngeal.] $M$.

Labrodon trapezoidalis: Nummopalatus trapezoidalis, C. $\mathrm{I}$. Leriche, loc. cit. 1901, p. 178, pl. j. figs. 3-5.-Lower PART IV. $2 \mathrm{~N}$ 
Eocene; Cuis. [Upper pharyngeal; University of Lille.]

Labrodon trigonella: Diaphyodus trigonella, K. E. Schafhäutl, Sean Süd-bayerns Leth, Geogn. (1863), p. 246, pl. $\operatorname{lx} c$. fig. 15.- Unper Eracene; Bavaria. [The type species of Diaphyodus. Upper pharyngeal dentition.]

The tooth from the Upper Eocene of Bavaria named Diaphyodus ovatis by Schafhäutl (op. cit. p. 247, pl. lxiv. fig. 3), seems to belong to Phyllodus.

\section{Genus PHYLIODUS, Agassiz ${ }^{1}$}

[Poiss. Foss. vol. ii.pt. ii. 1844, p. 238.]

An extinct genus, known only by the pharyngeal dentition, which is compact, tritoral, and leaf-shaped, and exhibits a pile of successional teeth beneath each functional tooth; middle teeth much larger than marginal teeth. Upper pharyngeal bones apparently fused together like the lower pharyngeals.

\section{Phyllodus toliapicus, Agassiz.}

1839-44. Phyllodus toliapicus, L. Agassiz, Poiss. Foss. vol. ii. pt. ii. p. 239, pl. lxix a. figs. 1-3.

1841. Phyllodus toliapicus, R. Owen, Odontogr. p. 138, pl, xliv. fig. 2.

1866. Phyllodus toliapicus, I. Cocchi, Ann. R. Mus. Fis. Firenze [2] vol. i. p. 104, pl. ii. figs. 8, 9, 15.

Type. Convex (upper) pharyngeal plate; Oxford IIuseum.

The type species, with pharyngeal dental plate attaining an antero-posterior length of about $0 \cdot 045$. Four principal median teeth not much broader than long; surrounding teeth small and numerous.

Form. \& Loc. Lower Eocene (London Clay): London Basin.

21618. Fine convex (upper) plate; Sheppey. Purchased, 1850.

38815. More imperfect specimen, noticed by Cocchi, Toc. cit.p. 105 ; Sheppey. Bowerbank Coll.

P. 3961-62. Four imperfect specimens, one (of concave or lower plate) described and figured by Cocchi, loc. cit. p. 106, pl. ii. fig. 9 ; Sheppey.

Enniskillen Coll.

1 The subgeneric name Paraphyllodus has been proposed for those pharyngeal plates of this genus in which the rather small median teeth are surrounded by numerous rows of lateral teeth (H. E. Sauvage, Bull. Soc. Géol. France [3]

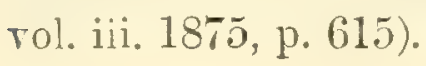



Zabrodor vaillanti, FRiem, Bull don: Géoh Brance [4] voli (1901). 1.497, hl xi.fip. 16,17. - 1/presian; Épernay (Marne), France.

Charympodopilur lepsii, o. Wittich, hotigll. Vereine ff Sidte. Damstadk, ser. iv, fhe 19 (1898), p.42, hli.ifi, S.- Mr. Rligocene; haing. ELomen $\alpha$ wher fharymgeals; Hur. Darmstadh. S

1905=06. Phyllodur toliapicus, Mr. Zeriche, Mém. Kuns.

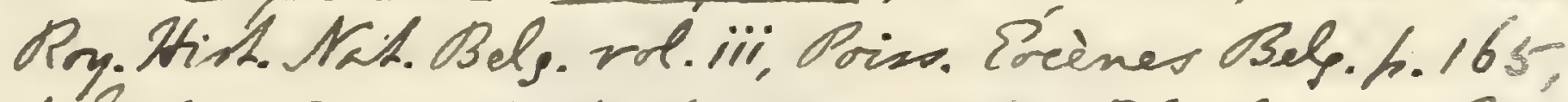

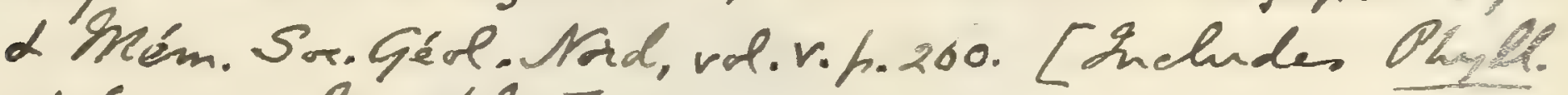
deforrai, hintlen.J

1908. OMyllodur toliapien, M. Zeriche, Arm. Sor Géd. Nond, vol. xxxvii.h. 255, hl.vi.fi. 2. CYhresian; Pourcy, havinen

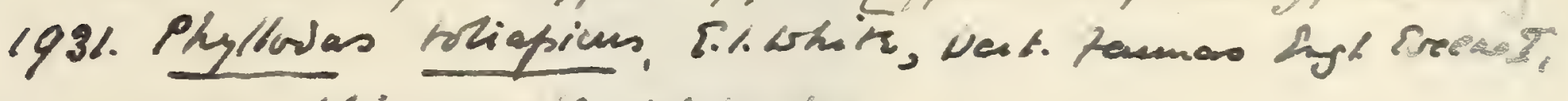

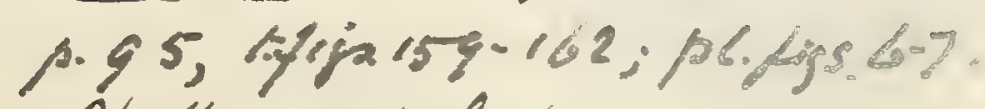

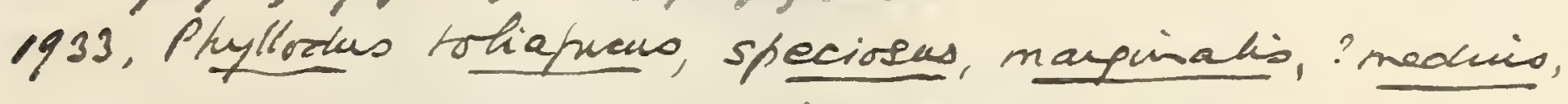
Gilders leve; p.380 L. L. Eocene, virpinial.

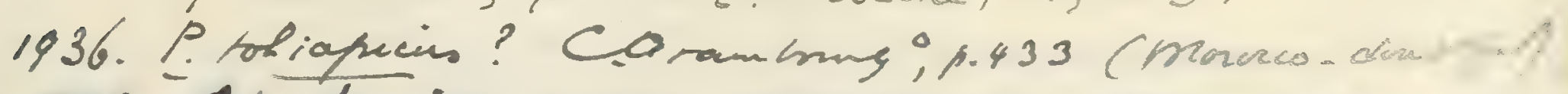

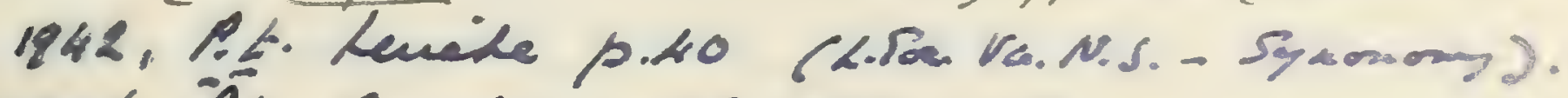

1946. P. Cosin p.138 phis. 9.8

1950. PA "D A 25

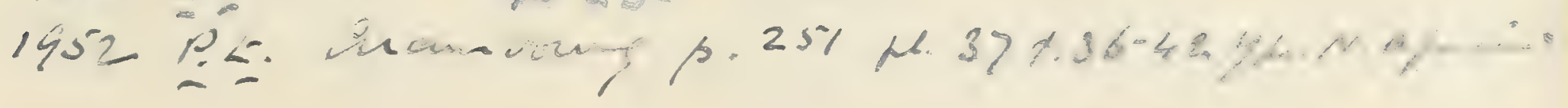


H, llodur of. Flanum, M. Leriche, Ann. Sor. Géd. Nord, val $x \times x$ vii (1908), h.25\%, hl, vi.fi.1. [Bowilly, havme]

1920. Phyllodus holyodus, A. Bell, Am. Deth. Yorks. Ohil. Sor.1919.h. , hl. ii. fip.17. 
P. 190\%. Portion of concave (lower) plate; Sheppey.

Egerton Coll.

P. 169. Fragment; Sheppey.

Purchased, 1880.

27614. Fragment provisionally referred to this species by Cocchi, 7oc. cit. pl. ii. fig. 15 ; led Crag, Suffolk (derived from London Claj).

Purchased, 1852.

The pharyngeal dental plates of Phylloctus occurring in the London Clay are very rariable in the relative proportions of the teeth, and hare receired many specific names. The following is an illustratice series :-

P. 590. Imperfect convex (upper) pharyngeal plate, resembling the specimen in the Oxford Museum which is described and figured as Phyllodus planus by Agassiz, Poiss. Foss. rol. ii. pt. ii. (1839-44), p. 239, pl. lxix a. figs. 4, 5; Shepper. This specimen is described and figured by Cocchi, Ann. R. Mus. Fis. Firenze [2] vol. i. (1866), p. 95, pl. i. fig. 4.

Egerton Coll.

41720. Nearly similar specimen; Sheppey. Toulmin Smith Coll.

38816. Fine convex (upper) plate, noticed by Agassiz, tom. cit. p. 240 , as belonging to the same species as a specimen in

Fig. 19.

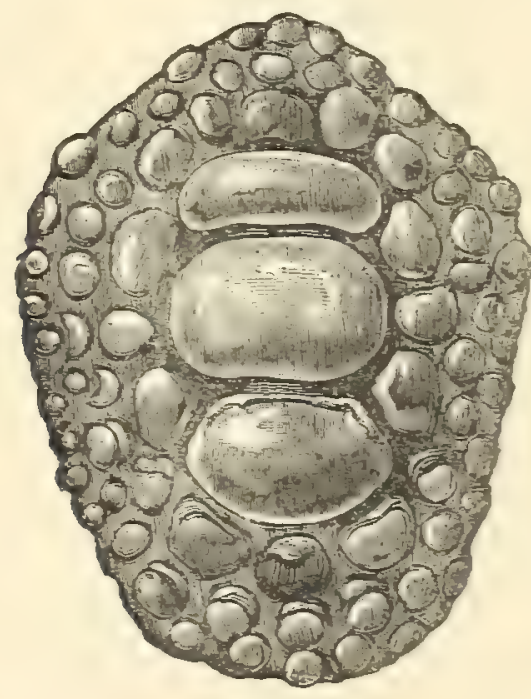

Phyllodus polyodus; upper pharyngeal dentition, nat. size. int. Eest. Clmiv. Reuchâcel.

the Ortuseum described and figured as Phy?lodus polyodus, Agassiz, tom. cit. p. 240, pl. lxix a. figs. 6, 7; Sheppey.

Bowerbank Coll.

P. 591. Larger, narrower specimen referred to P. polyodus by Cocchi, loc cit.p. 107, pl. iii. fig. 8; Sheppey. Egerton Coll. 
$35 \% 70,-a$. Two similar specimens, the first shown of nat. size in accompanying fig. 19; Sheppey. $\quad$ Purchased, 1860.

P. 1909. Half of nearly similar plate; Sheppey. Egerton Colt.

43104. Small but nearly similar plate; Sheppey. Wetherell Coll.

P. 3164. Imperfect concave (lower) plate described and figured by Cocchi, loc. cit. p. 99, pl. ii. fig. 1, and referred to Phyllotus marginalis, Agassiz (tom. cit. p. 240, pl. lxix a. figs. 8,9), which is founded on a specimen in the Oxford Mrseum; Sheppey.

Enniskillen Coll.

P. 589. Imperfect convex (upper) plate described and figured by Cocchi, loc. cit. p. 112, pl. iir. fig. 7, as the type specimen of Phyllodus irregularis, which is mentioned by Agassiz, tom. cit. p. 241 (name only); Sheppey. E'gerton Coll.

38820. Fragment referred to the same species by Cocchi, Toc. cit. p. 112 : Sheppey. Bawerbank Coll.

P. 3968. Imperfect concave (lower) plate, the type specimen named Phyllodus medius by Agassiz, tom. cit. p. 241, described. and figured by Cocchi, loc. cit. p. 114, pl. ii. fig. 10 ; Sheppey.

Enniskillen Coll.

38810. Imperfect upper (convex) plate referred to $P$. medius by Cocchi, loc. cit. pl. ii. fig. 14 ; Sheppey. Bowerbank Coll.

P. 3969. Another specimen referred to P. medius by Cocchi, 7oc. cit. p. 115, pl. ii. fig. 11; Sheppey. Enniskillen Coll.

P. 1908. Portion of upper (convex) plate described and figured as P. medius by Cocchi, loc. cit. p. 115, pl. ii. fig. 12 ; Sheppey. Egerton Coll.

41\%19. More nearly complete similar plate; Sheppey.

Toulmin Smith Coll.

3880\%. Fine convex (upper) plate described and figured by Cocchi, loc. cit. p. 109, pl. iii. fig. 2, and referred to Phyllodus petiolatus, Oren (Catal. Foss. Rept. \& Pisces, Mius. Roy. Coll. Surg. 1854, no. 675), which is founded on a specimen in the Royal College of Surgeons (also figured in Owen's Odontogr. 1841, pl. xlvii. figs. 1, 2); Sheppey.

Bowerbank Coll.

38813. Smaller specimen of same form described and figured by Cocchi, 2oc. cit. p. 109, pl. iii. fig. 5 ; Sheppey. 
P. 3960. Another specimen described and figured as belonging to the same species by Cocchi, loc. cit. p. 109, pl. iii. fig. 6; Sheppey.

Enniskillen Coll.

P. 3963. Imperfect convex (upper) plate, the type specimen of Phyllodus colei, Cocchi, loc. cit.p. 91, pl.i. fig. 1 ; Sheppey. Enniskillen Coll.

24618 a. Middle of plate, the type specimen of Phyllodus hexagonalis, Cocchi, loc. cit. p. 92 , pl. i. fig. 3 ; Sheppey.

Purchased, 1850.

P. 588. Fragment referred to same species by Cocchi, 7oc. cit. p. 92, pl. i. fg. 2 ; Red Crag, Suffolk (derived from London Clay).

Egerton Coll.

P. 9474. Convex (upper) plate, the type specimen of Phyllodus speciosus, Cocchi, 7oc. cit. p. 96, pl. i. fig. 6 ; Sheppey.

History unknown.

P. 3965. Concare (lower) plate referred to the same species by Cocchi, loc. cit. p. 97, pl. i. fig. 7 ; Red Crag, Suffolk (derived from London Clay).

Enniskillen Coll

27614 a, 30538. Two imperfect specimens referred to the same species by Cocchi, loc. cit. p. 97, pl. i. fig. 8 , pl. ii. fig. 6 ; Red Crag, Sutton, Suffolk (derived from London Clay).

Purchased, 1852.

38818-19. Two imperfect large specimens, nearly similar to $P$. speciosus; Sheppey.

Bowerbank Coll.

36565. Half another nearly similar plate; Red Crag, Sutton, Suffolk (derived from London Clay). Purchased, 1853.

38808-09. Imperfect conrex (upper) and concave (lower) plates, the type specimens of Phyllodus bowerbanki, Cocchi, loc. cit. p. 100, pl. ii. figs. 2, 3 ; Sheppey. Bowerbank Coll.

38812. Imperfect plate, the type specimen of Phyllodus secundarius, Cocchi, loc. cit. p. 102, pl. ii. fig. 7 ; Sheppey.

Bowerbank Coll.

41903. Another specimen referred to the same species by Cocchi, loc. cit.p. 103, pl. vi. fig. 3 ; Sheppey. Purchased, 1870.

38811. Imperfect concave (lower) plate, the type specimen of Phyllodus submedius, Caechi, loc. cit.p.118, pl. ii. fig. 13 ; Sheppey.

Bowerbank Coll. 
P. 3966. Two fragments of the same form, one noticed by Cocchi loc. cit. p. 119 ; Sheppey.

Enniskillen Coll.

P. 396\%. Fine concave (lower) dental plate of the same form; Sheppey.

Enniskillen Coll.

33304. Imperfect convex (upper) plate; Sheppey.

Purchased, 1858.

The following species have also been named, but are not represented in the Collection :-

Phyllodus curvidens, O. C. Marsh, Proc. Amer. Assoc. Adv. Sci. 1869 (1870), p. 229.-Miocene; Shiloh, Cumberland Co., N.J. [Portion of pharyngeal dentition.]

Phyllodus deborrei, T. C. Winkler, Archiv. Mus. Teyler, vol. iv. (1876), p. 28, pl. ii. figs. 14-18._Niddle Eocene; Brussels. [Frayments; Teyler Museum, Haarlem.]

Phyllodus elegans, O. C. Marsh, loc. cit. 1870, p. 228.-Eocene Greensand; Farmingdale, N.J., [Pharyngeal dentition; Yale University Museum.]

Phyllodus gervaisi, I. Cocchi, loc. cit. 1866, p. 121. Phyllodus, P. Gervais, Zool. et. Pal. Franç. (1852), Poiss. Foss. p. 5, pl. Ixviii. figs. 30, 31.-Lower Eocene; Paris Basin. [Imperfect pharyngeal dentition.]

The so-called Phyllodus cretaceus (A. E. Reuss, Geogn. Skizze aus Böhmen, vol. ii. 1844, p. 222, and Verstein. böhm. Kreideform. 1846 , p. 11, pl. iv. figs. 62,63 , pl. xii. fig. 16), from the Upper Cretaceous of Bohemia, Phyllodus umbonatus (Münster, Beitr. Petrefact. pt. vii. 1846, p. 10, pl. i. fig. 8), and Phyllodus depressus (Münster, ibid.p. 10), from the Miocene of Vienna, are founded on generically indeterminable teeth, probably not referable to Labridæ.

The following are merely names for fossils from the Lower Eocene of Cuise-Lamotte, Oise:-Phyllodus duvali, P. inconstans, $P$. latidens, and P. levesquei (Pomel, in L. Graves, Essai Topogr. géognost. Oise, 1847, p. 588).

\section{Genus EGERTONIA, Cocchi.}

[Ann. R. Mus. Fis. Firenze (2) vol. i. 1866, p. 121.]

A genus known only by the pharyngeal dentition, which resembles that of Phyllodus but has the middle teeth scarcely if at all larger than the marginal teeth. 



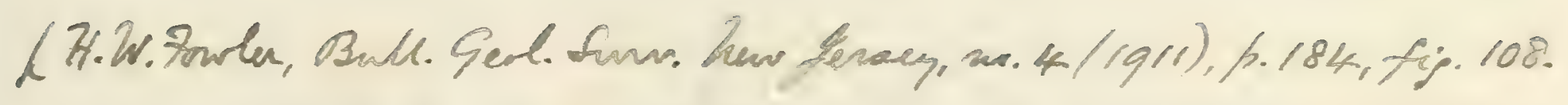

Pinllodus gaudryi, Foriem, Bull. Soe. Géd- Arane Fforl. i (1901), h. 4q4. fl. xi.fig.14, hexh-fip. 4. Ypresian: Spernay (Maine), Brance.

Pseudregatonià skäeleni g. T.a. Er.

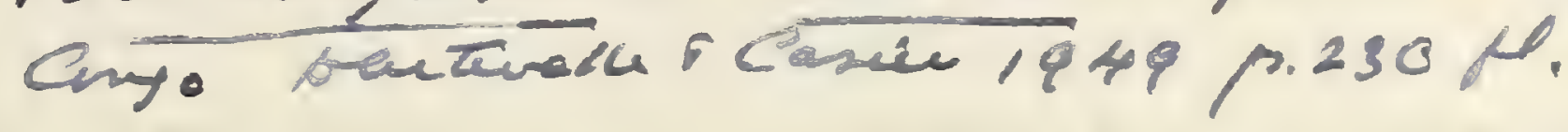

P. Levianoi 7.n. Eor. Congo p.290 pl. tonarice

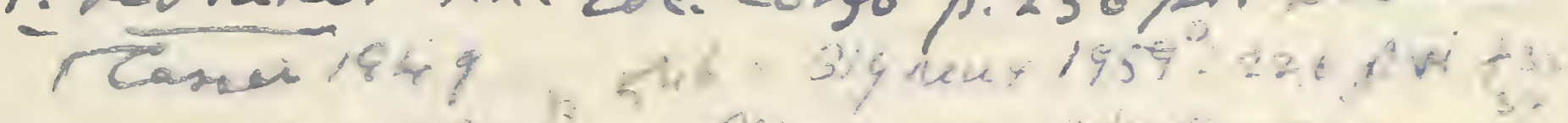

$-b_{0} \log \operatorname{Res}$

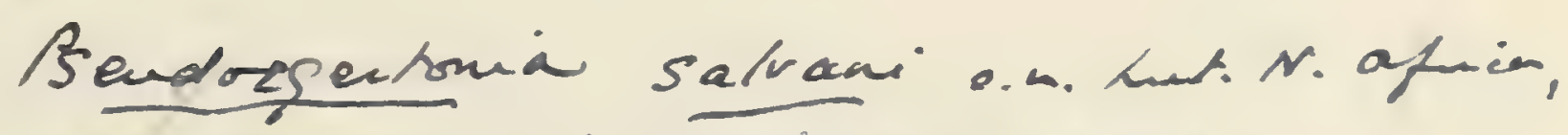
aramboungrosip. 254 of.s5 pl. $353726-38$ 
See nsw 10.

Sectonia stromeni, n.5. W. Weiler, Cbth bay Qkad-Wirs.

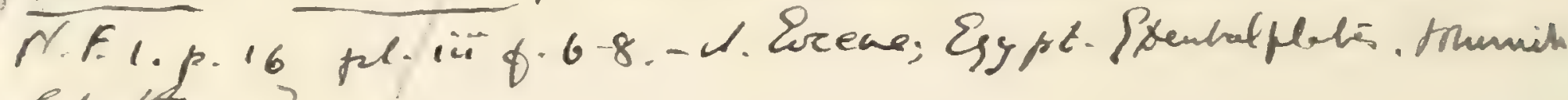
Shutsur?.

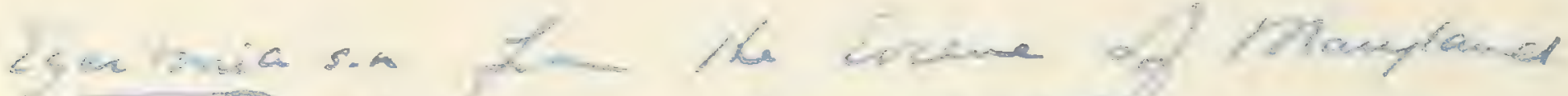

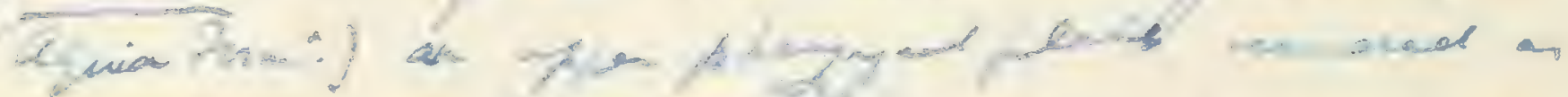

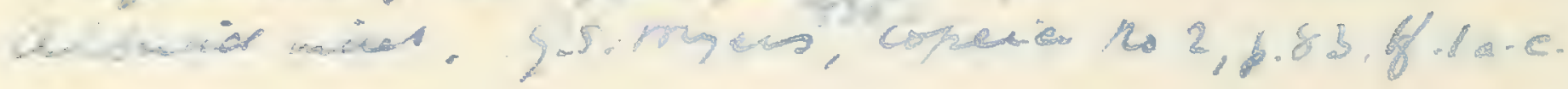

Escoseletivefured to ?: isodouta by Priem, ull. Soe. Géol. France [4] vol.i (1901), p.496, ph.xi.f.1s: Sibaration maintained \&y Irr. Teriche, Mém. So Géol. Nord, und.v(1906), p. 347; aho Bull. Sor.Geot. France $[4] \mathrm{vol} \times \times \times 1 i(1922)$, p. 18\%, Ill vill.fij.22.

see new urt.

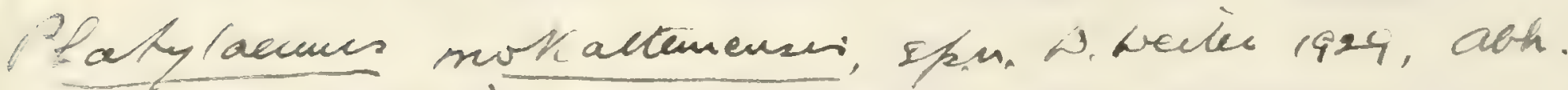

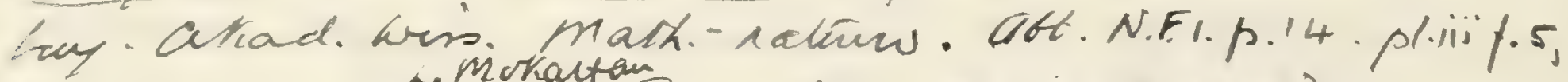

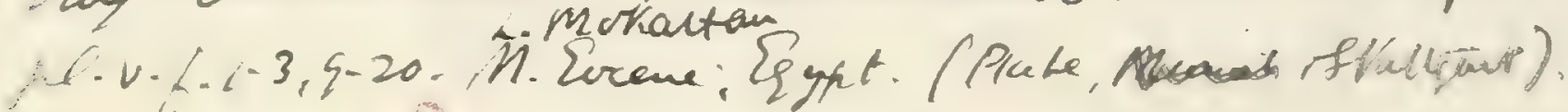
Pangeriensis. 


Egertonia isodonta, Cocchi.

1866. Egertonia isodonta, I. Cocchi, loc. cit. p. 122, pl. iv. figs. 1, 2.

Type. Convex (upper) pharyngeal dentition; British Museum.

The type species, with all pharyngeal teeth hemispherical, and the dental plate measuring as much as 0.025 antero-posteriorly.

Form. \& Loc. Lower Eocene (London Clay) : London Basin.

38814. Type specimen, figured loc. cit. pl. iv. fig. 2 ; Sheppey.

Bowerbant Coll.

P. 58\%. Concave (lower) pharyngeal dental plate, described and figured loc. cit. p. 123, pl. iv. fig. 1 ; Sheppey.

Egerton Coll.

28713 a. More imperfect specimen; Sheppey. Purchased, 1853.

The following species has also been described, but is not represented in the Collection:-

Egertonia gosseleti, Leriche, Ann. Soc. Géol. Nord, vol. xxix. (1901), p. 175, pl.i. fig. 1.-Lower Eocene ; Cuis, Epernay, Marne. [Upper pharyngeal dentition; University of Lille.]

\section{Genus PLATYLFMUS, Dixon.}

[Geol. Sussex, 1850, p. 205.]

An extinct genus, known only by the pharyngeals, each nearly or completely covered by a crushing plate, which consists of coarse vascular dentine invested with a very thin layer of ganodentine. Upper pharyngeal bones separate.

\section{Platylæmus colei, Dixon.}

1850. Platylamus colei, F. Dixon, Geol. Sussex, p. 205, pl. xii. figs. 11-13, pl. x. fig. 23.

Type. Lower pharyngeal; British Museum.

The type species, with triangular lower pharyngeal somewhat more than two thirds as long as broad. Upper pharyngeal dental plate slightly concave.

Form. \& Loc. Middle Eocene: Sussex.

25692. Lower pharyngeal dental plate, figured by Dixou, op. cit. pl. xii. fig. 12, to be regarded as the type specimen; Bracklesham Beds, Bracklesham, Sussex. Dixon Coll. 
25693, 25\%18. Lower pharyngeal and left upper pharyngeal, figured ibid. figs. 13, 11; Bracklesham.

Dixon Coll.

38821-23. Three abraded upper pharyngeal teeth, the first figured ibid. pl. x. fig. 23 ; Bracklesham. Bowerbank Coll.

25694. Fragments; Bracklesham. Dixon Coll.

P. 17\%2, P. 3970. Fragments; Bracklesham.

Egerton \& Enniskillen Colls.

\section{Genus PSEUDOSPIFRODON, Noetling。}

[Abh. geol. Specialk. Preussen u. Thïring. Staaten, vol, vi. pt. iii. 1885, p. 102.]

An extinct genus, possibly Labroid, known only by remains of the pharyngeal dentition. Pharyngeals bearing one or few large, rounded or irregularly ovoid, crushing teeth, which consist of coarse vasodentine invested with a thin layer of ganodentine. Upper pharyngeal bones separate.

\section{Pseudosphærodon hilgendorfi, Noetling.}

1885. Pseudosphcerodon hilgendorfi, F. Noetling, loc. cit. p. 104, pl. xi. figs. 1-8.

Type. Pharyngeal teeth; Prussian Geological Survey, Berlin.

The type species, known only by irregularly ovoid, sometimes nearly triangular teeth, which are smooth and tumid, often slightly plicated at the sides.

Form.\& Loc. Middle Eocene: Samland, Prussia; Hampshire Basin.

P. 3752. Right upper pharyngeal, bearing one tooth; Bracklesham Beds, Bracklesham, Sussex.

Enniskillen Coll.

30888. Large worn tooth, measuring 0.038 in longest diameter, and showing successional tooth directly beneath it; Bramshaw, Wiltshire. Purchased, 1856.

The following indeterminable specimen is supposed to represent an extinct genus and species of this family :-

P. 626. Fragment of hinder portion of cranium labelled by Agassiz as intended to be the type specimen of Auchenilabrus frontalis, recorded hy name only in Rep. Brit. Assoc. 1844 (1845), p. 308 ; London Clay, Sheppey. 
P.tychadrides,

Beudosfhordow novienlavis, M. Leriche,

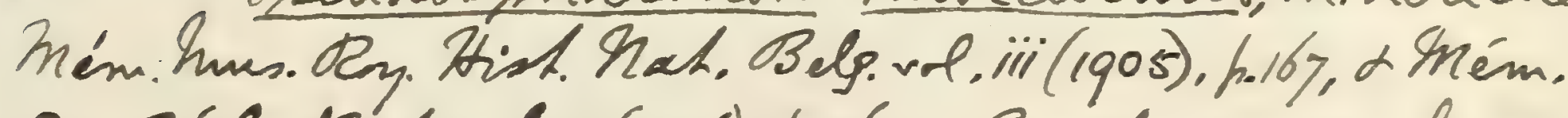
Soc. Sérl. Nord, vol. v(1906), 6.262: Gyrodus navicularis, J.C.Winkler, Ar hiv. Inus. Deyler, we.iv (1876), h. 30, bl. iifigr-19-21. - Bruxdlian: Belgium. CYolsted

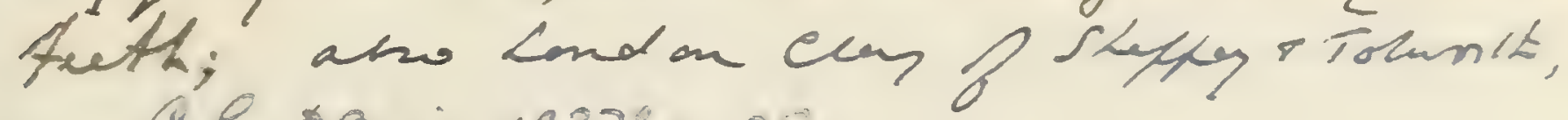
ac bavis $1239^{\circ} \% .28$. 


Portions of dentition, apparently Labroid but not represented in the Collection, have also been described as follows:-

Crommyodus irregularis, E. D. Cope, Proc. Amer. Phil. Soc. vol. xi. (1870), p. 243. Phacodus irregularis, E. D. Cope, Proc. Boston Soc. Nat. Hist. vol. xii. (1869), p. 311.Miocene; Shiloh, Cumberland Co., New Jersey, U.S.A. [Type species; also of Phacodus, Cope non Dixon.]

Protautoga conidens, J. Leidy, Contrib. Extinct Vert. Fauna W. Territ. (Rep. U.S. Geol. Surv. Territ. vol. i. 1873), p. 346, pl. xxxii. figs. 56, 57. Tautoga (Protautoga) conidens, J. Leidy, Proc. Acad. Nat. Sci. Philad. 1873, p. 15.Miocene; Richmond, Virginia. [The type species. Premaxilla.]

Protautoga Tongidens, G. de Alessandri, Atti R. Accad. Sci. Torino, vol. xxxi. (1896), p. 729, pl. i. fig. 11.-Upper Tertiary; Paraná, Argentine Republic. [Tooth; Geological Museum, Turin.]

Styloctus lebescontei, H. E. Sauvage, Mém. Soc. Sci. Nat. Saône-etLoire, vol. iv. (1882), p. 77, pl. ii. fig. 12.-Miocene; Brittany. [The type species, founded on upper pharyngeal.] Taurinichthys miocenicus, I. Cocchi, Ann. R. Mus. Fis. Firenze [2] vol.i. (1866), p. 152, pl. vi. fig. 10. Scamesmiocenicus, G. Michelotti, Rer. et MLag. Zool. vol. xiii. (1861), p. 355, pl. x. fig. 3.-Miocene; Turin. [The type species, founded

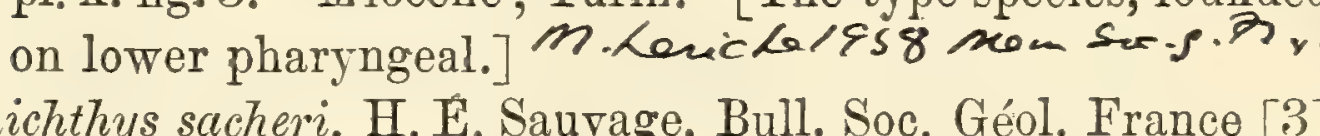
vol. iii. (1875), p. 631, pl. xxii. fig. 20, and loc. cit. 1882, p. 79, pl. ii. figs. 10, 11.--Miocene ; Brittany. [Portion of upper pharyngeal.]

Also an unnamed pharyngeal from the Miocene of Brittany $(H$. E. Saurage, Bull. Soc. Géol. France [3] vol. xi. 1883, p. 490, pl. xii. fig. 15).

The fragment of jaw described as follows may perhaps represent the existing genus Scarus:-

Scarrus suevicus, J. Probst, Württ. Jahresh. vol. xxx. (1874), p. 281, pl. iii. fig. 6.-Miocene ; Baltringen, Würtemberg '

Nothing is known of the so-called Scarus tetrodon, Pomel (I Graves, Essai Topogr. géognost. Oise, 1847, p. 586), from Lower Eocene, Cuise-Lamotte, Oise.

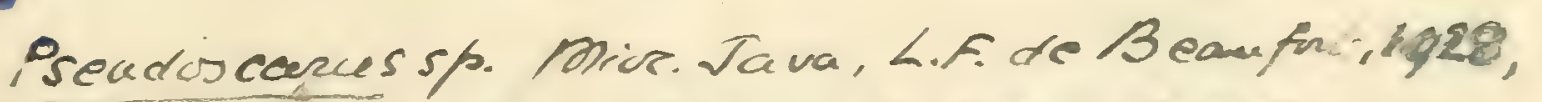
Dient. 

Chomis sarornini n.s. C. Aramboung, $1927,0.162$,

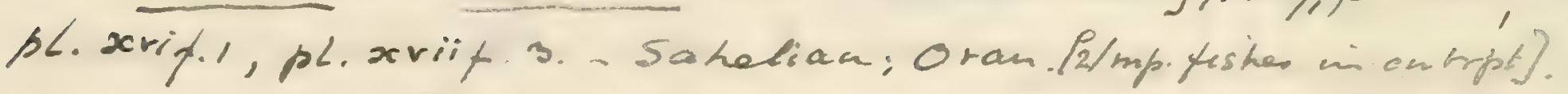

Palaieochromis dacestei, g. Jph. H.S.Sanage, 1910, Mateir. cauce geát. Algeicir (I). Pabent. Ni 4. p.s.2, ph. viï. f. la,b, p., x. f., Mave. Sahelian) quelma, Aegeria. I Imp. fuires?.

Powseleti, sp.nor. Samage ivid.p. 53, he viir. f. 2 a.e. cuith ifid.

Tee a thesis:- T. Pellepin, "Ontuiktim à létude matomigue, Giologie $\alpha$ haxinomique des Prisom de la Fanille des Cichlidés," Zille 1904.

Heso G. D. Haveman, Bull. Amer. Kuns. hat. tish. vol. $\times x \times i(1912)$, lp. $97-101$.

Riscacara cmiderel th the Berenid (Centrarchido) hy C. T. Depar, Biolorgix Centruli- Amerieana, Intion. Vol. (1915), t. 106. Relater to Eupomotio, als cith cralesced lower fharyzeel.

= Mylophtes sematur, Che his. (Z.Lussaterf. Bull. Amen. mun. Hat. Fist. wol $\times$ xv. 1908, h. q2).

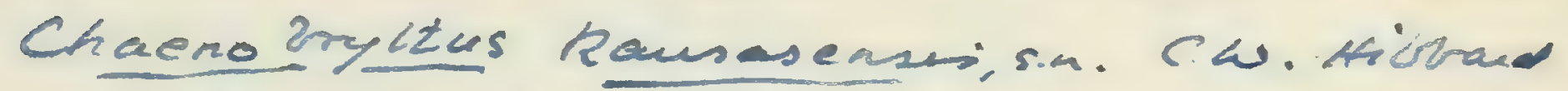

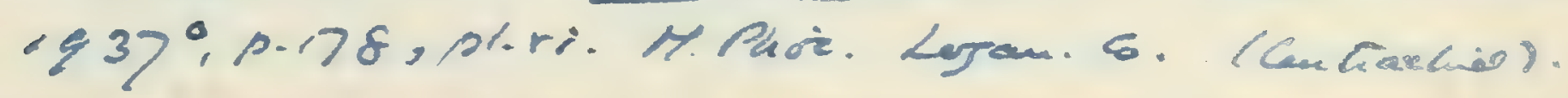

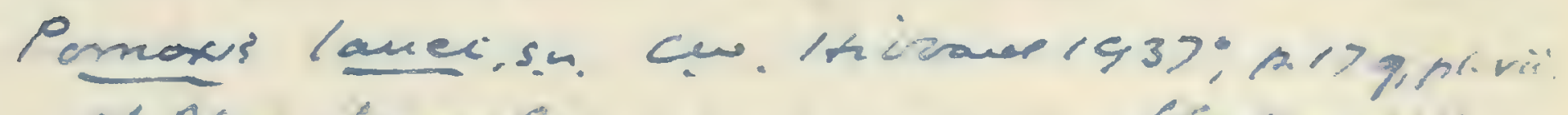
MPlive $x \operatorname{arn} 6$ (ciantiarebol)?

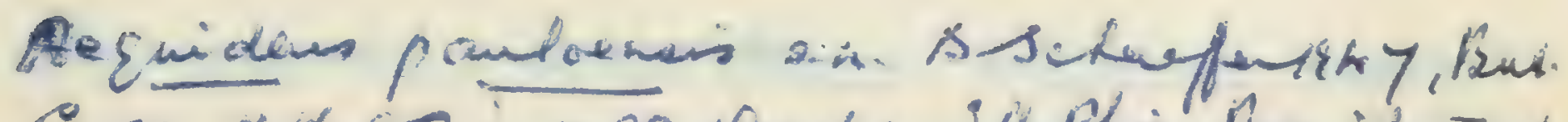

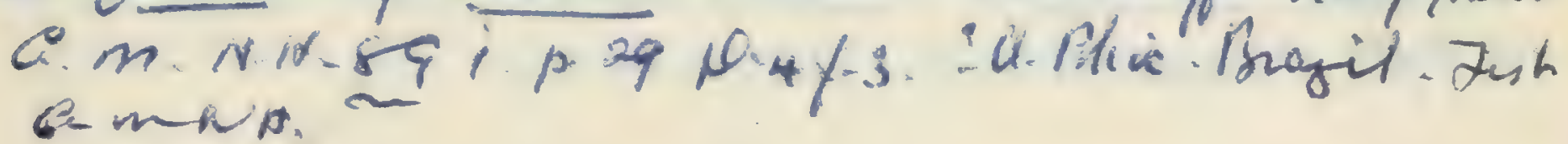




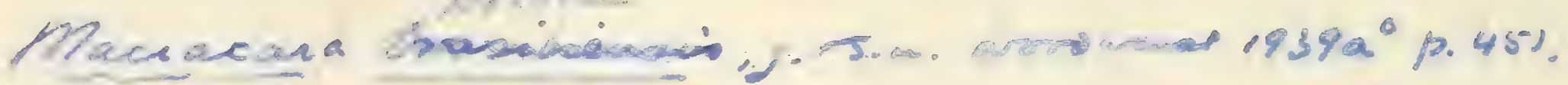
plotvi.t. Fuino. 3.t Brog.\%.

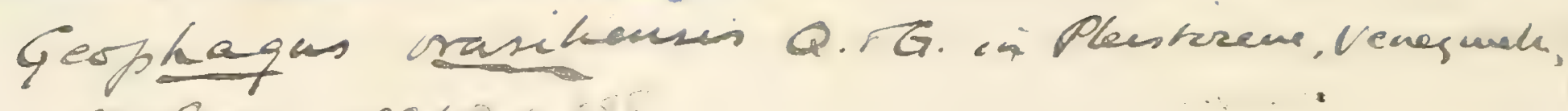
c. B Bency 1934

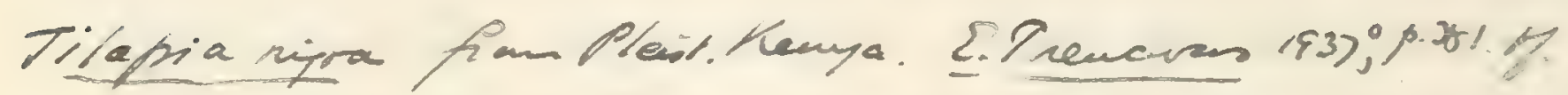

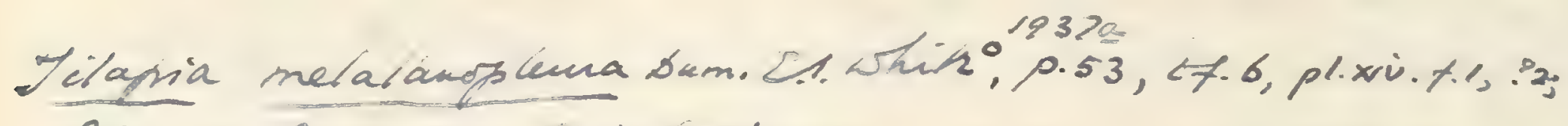
Polocene, Bosuntīi, Gold Lust.

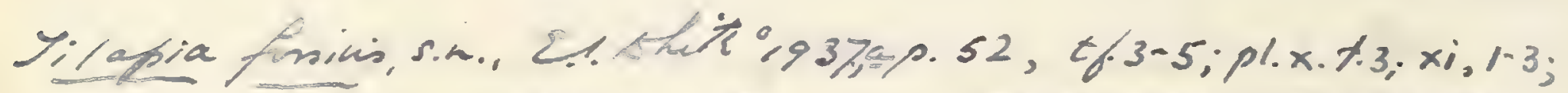

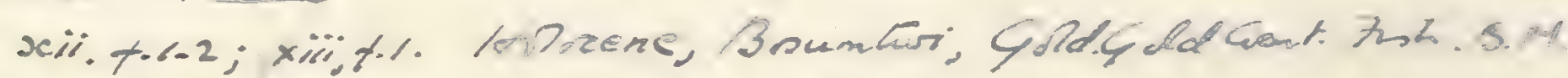

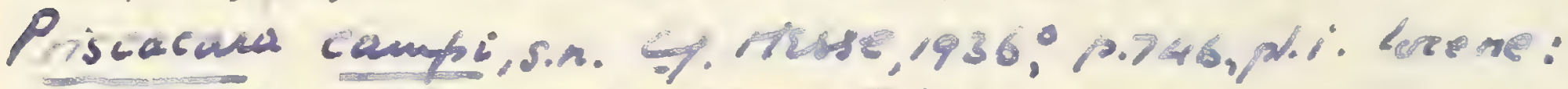

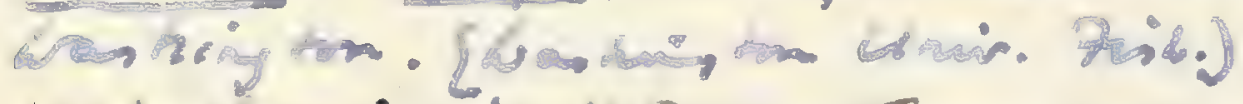

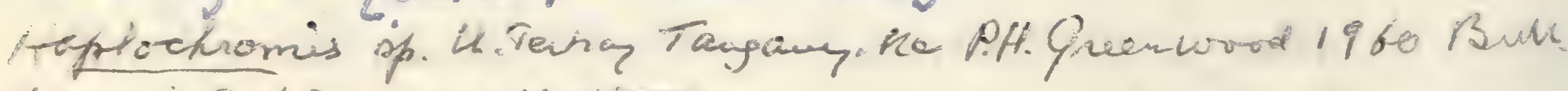

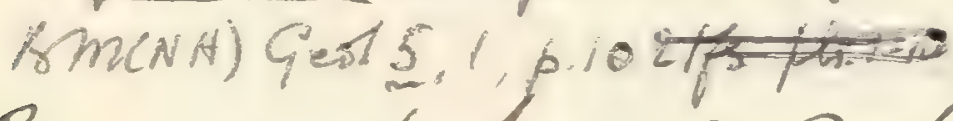

Priscacara dartonde, C.R.Sactman. Prov. U.S. Tak. Mus vol. Tii (1917), h.296, pl. xxiri. - Given thiven Shales; Wyomizy. (77idh; U.S.Mat. Mus.]

Palcochromis daresti and Prowseleti fren Fiddle Zention, Guelma, Teybruse, 2. S. Semurer, Omphtes Pendus, CxTV(1907), hp. 360-361.

Piseacara hypsacantha, S.D. Cope, Mem. Nath. Acad. Sei. rol. iii (1886),p.164, pl.i.fig.6. - Eocene. [Small fist: Amen. Hus. H. 21.]

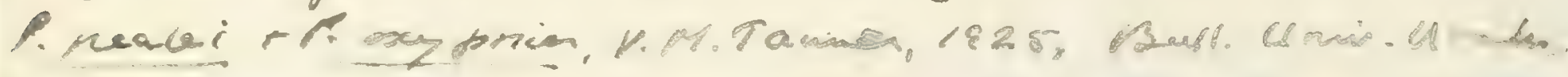

Cichlasoma woodringi, J.2. A. Cockenall, Proc. U.S. Nat. Inus. vol.63 (1923), ant.7. p.2, pl.i- hiocene; Las Caholow, Haiti: [mpf. hish: US.Nat. Mur.]

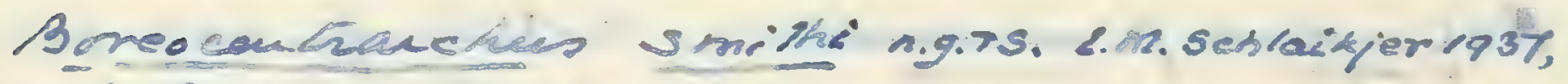

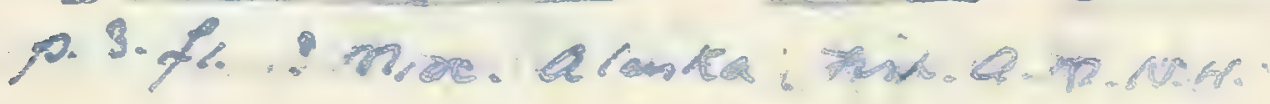




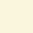





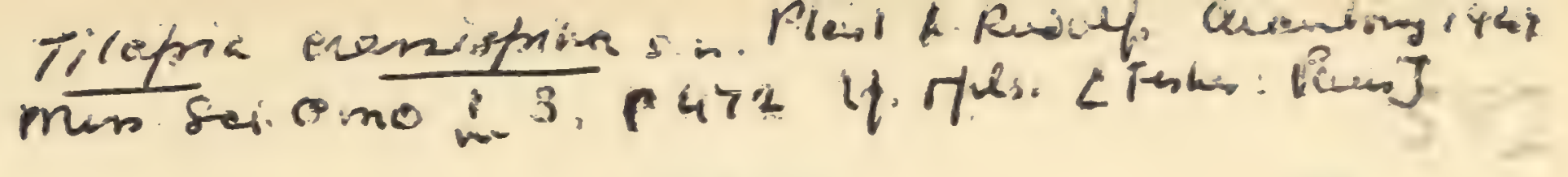

CHROMID王.

1884. Priscucara clivosa, E. D. Cope, Vert. Tert. Form. West, Book I. p. 96, pl. xiii. fig. 3.

Type. Imperfect fish; National IIuseum, Washington.

Yore elongated than the type species, maximum depth of trunk contained somewhat more than twice in total length to base of caudal fin. Profile very steep in front of origin of dorsal fin.

The specimens enumerated below as probably referable to this species, seem to exhibit 9 vertebræ in the abdominal, 15 in the caudal region.

Form. \&. Loc. Eocene (Green River Shales): Twin Creek, Iroming, U.S.A.

P. 5928. Imperfect specimen apparently of this species, with incomplete soft dorsal and anal fins.

Presented by T. A. Rickard, Esq., 1889.

P. 6187, P. 7494. Two fine specimens. Purchased, 1890, 1895.

P. 7493. Two small specimens on one slab. Purchased, 1895.

The following species hare also been distinguished, but are not represented in the Collection :-

Pirscacara cypha, E. D. Cope, Bull. U.S. Geol. Surv. Territ. rol.iii. (1877), p. 817, and Vert. Tert. Form. West, Book I. (188t), p. 94, pl. xiii. fig. 2.-Eocene (Green River Shales); Wyoming, U.S.A. [Imperfect fish; National Museum,

Washington.]

Cokerellices Pisiscacara liops, E. D. Cope, Toc. cit. 1877, p. 818, and op. cit.

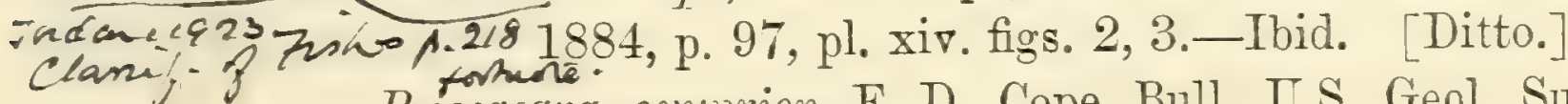

Priscacara oxyprion, E. D. Cope, Bull. U.S. Geol. Surv. Territ. vol. iv. (1878), p. 74, and op. cit. 1884, p. 94, pl. xir. fig. 5.-Ibid. [Ditto.]

Priscacara peatei, E. D. Cope, loc. cit. 1878, p. 75 , and op. cit. 1884, p. 96, pl. viii. fig. 4, pl. xiг. fig. 4._Ibid. [Ditto.] Priscacara testudinaria, E. D. Cope, op. cit. 1884, p. 98, pl. i. fig. 7.--Lower Eocene; Manti, Utah. [Portion of trunk.]

Remains apparently of the existing tropical American genus Acara have been recorded from a freshwater Tertiary Lignite at Taubaté, in the Province of San Paulo, Brazil, by A. S. Woodward, Rev. Mus. Paulista, vol. iii. (1898), p. 69.

The marine family of Powacentrid guishable from that of the Chromidæ, is supposed to be represented 
by the extinct genus Odonteus with the following species, of which there are no remains in the Collection :-

Odonteus pygmaeus, A. de Zigno, Mem. R. Istit. Veneto, vol. xviii. (1874), p. 291, pl. x. fig. 1; F. Bassani, Palæont. Italica, vol. iii. (1898), p. 83, pl. ix. fig. 5.-Upper Eocene; Monte Bolca, near Verona. [Imperfect fish ; Zigno Coll., University of Padua.]

Odonteus sparoides, L. Agassiz, Poiss. Foss. vol. iv. (1839), p.178, pl. xxxix. fig. 2; F. Bassani, Atti Soc. Veneto-Trent. Sci. Nat. vol. iii. (1876), p. 176. Odonteus sparoides, var. depressus, F. Bassani, Palæont. Italica, vol. iii. (1898), p. 83, pl. viii. fig. 2.-Ibid. [The type species. Imperfect fish; Paris Nuseum of Natural History.]

Odonteus aff. sparoides, F. Bassani, Atti R. Accad. Sci. Napoli [2] vol. iii. (1889), no. 6, p. 94, pl. xiii. fig. 3.-Lower Miocene; Chiaron, Vicentin. [Imperfect fish; Piovene Coll., Lonedo.]

\section{Division D. CHETODONTIFORMES.}

As Perciformes, but brain-case very short, and facial region of skull much produced, with terminal small mouth. Specialisation resulting in degeneration of fins and shortening of vertebral axis.

Synopsis of Families represented by Extinct Genera or Species.

I. Fins normal, the dorsal spines well-developed.

Maxilla separate from premaxilla.... Chetodontide (p. 556).

Maxilla fused with premaxilla ...... ACRONURID

II. Fins reduced, the dorsal spines rarely more than 3 , usually absent (Plectognathi).

Maxilla fused with premaxilla, but marginal teeth distinct ......... BaLISTID e (p. 565).

Maxilla fused with premaxilla, and no distinct marginal teeth .......... Grunodontid 2 (p. 570).

\section{Family CH五TODONTID王.}

Trunk deepened, with scales more or less densely covering articulated portions of median fins. Maxilla separate from premaxilla; teeth minute and clustered. Vertebræ 9 or 10 in abdominal, 13 or 14 in caudal region. Anal fin with 3 or 4 spines. Scales small or minute, more or less ctenoid.

Carnivorous fishes chiefly occurring in tropical seas in the neigh- 

? Prmasentivel

Luus nathamurai g.rs.n. Yokuna I Saito,

1938, Sap. Jomn. Geot. Gegr. [ro2] p.83, 1.7.

L. Miocue : Izu, Japon [lmp. fish].

Odonteus sparoides, C. D. Eastman, Mem. Carnepie thus. vol. iv (1911), h. 379, hl. xcvii. fis. 1, and lor. cit. vol.vi (1914), h. 338, pl. x7vii.fi, 1.

Phasmacichtiss colper.

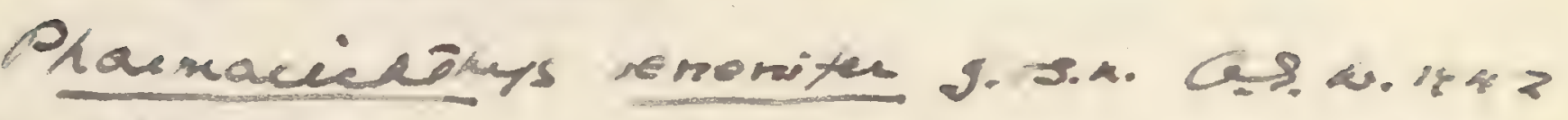

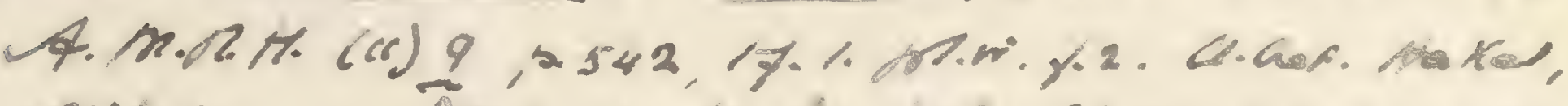

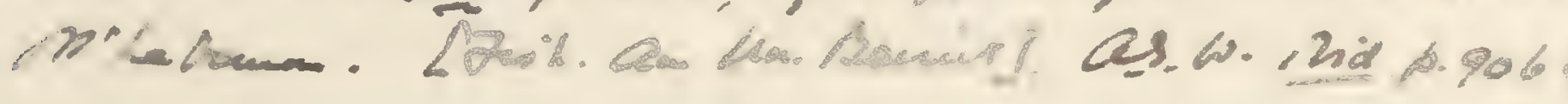


Fgecidde, D. S. Fordan, feience, n.s. vol. $x \times(1904)$, p.246.

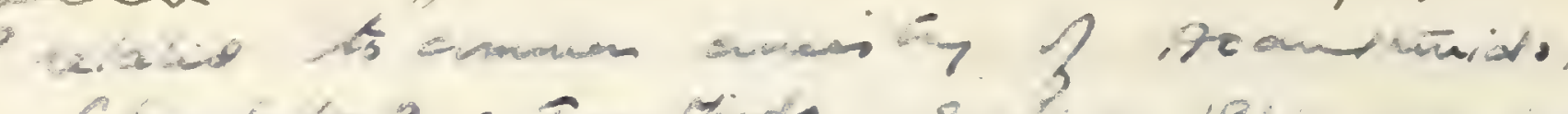

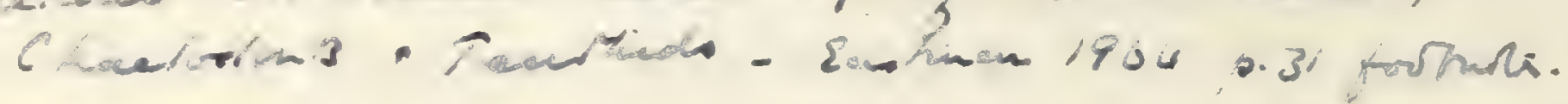

creceind 
bourhood of coral reefs. A few genera seem to date back to the early part of the Tertiary period, when they ranged further north than at the present day. Only two extinct genera, Pygceus and Proantigonic, are profisionally placed here.

\section{Genus PYGFUS, Agassiz.}

[Poiss. Foss. vol. iv. 1838, p. 16.]

An imperfectly known extinct genus, with spinous portion both of dorsal and anal fin as much extended as articulated portion. Dorsal fin continuous and occupring nearly the whole of the back, gently rising in front, as gently falling behind; anal fin with 8 or 9 spines, similar to dorsal but less extended.

The genus is supposed to be related to the Aphredoderidæ by Cope (Vert. Tert. Form. West, 1884, p. 85), but no known specimen clearly exhibits more than 5 articulated rays in the pelvic fins.

\section{Pygæus coleanus, Agassiz.}

1838-42. Piggaus coleanus, L. Agassiz, Poiss. Foss. vol. iv. pp. 16 *, 256 , pl. xliv. fig. 5.

- 1838-42. Pygarus eyertoni, L. Agassiz, ibid. p. 257. [Imperfect fish; British Museum.]

1838-42. Pygaus gibbus, L. Agassiz, ibid. p. 257. [Distorted fish; British Museum.]

Type. Imperfect fish; British Museum.

A small species about 0.04 in length. Naximum depth of trunk somewhat less than its length from pectoral arch to base of eaudal fin; length of head with opercular apparatus contained twice in same length of trunk. Dorsal fin with 14 spines and 15 articulated rays, the latter not longer than the former; anal fin with 9 spines and 11 articulated rays.

Form. \& Loc. Upper Eocene: Monte Bolca, near Verona. ${ }^{2}$

P. 551 x, P. 3921. Type specimen in counterpart, exhibiting all the characters mentioned in the specific diagnosis.

Egerton \& Enniskillen Colls.

P. 3923. Smaller well-preserved fish.

Enniskillen Coll.

P. 1978. Type specimen of so-called Pygcus egertoni, apparently differing from the preceding specimens only in its state of preservation.

Egerton Coll.

1 An allied species from the Lower Miosene of Chiavon, Vicentin, is described by F. Bassani, Atti R. Accad. Sci. Napoli [2] vol. iii. (1889), no.6, p. 90, pl. xiv. figs. $1,2$. 
41994. Imperfect small fish. Purchased, 1870.

P. 498, P. 3922. Imperfect fish in counterpart, shortened by distortion, described by Agassiz as the type specimen of the so-called Pygceus gibbus. Egerton \& Enniskillen Colls.

The following species, which are not represented in the Collection, have also been ascribed to this genus, but they are very imperfectly known :-

Pygceus dorsalis, L. Agassiz, Nenes Jahrb. 1835, p. 302, and Poiss. Foss. vol. iv. (1838-42), pp. 16*, 255, pl. xliv. fig. 1.-Upper Eocene; Monte Bolca. [Imperfect fish ; Palæontological Museum, Munich.]

Pygceus gigas, L. Agassiz, 7oc. cit. 1835, p. 302, and tom. cit. 5. 24 1838-44, pp. 16, 252, pl. xx. Sparus bolcanus, G. S. Volta, Ittiolit. Veronese (1796), p. cexliii. pl.lix. Labrus ciliaris punctatus, G. S. Volta, ibid. p. clxxxix. pl. xlvi. (errore). Labrus rectifrons and L. punctatus, H. D. de Blainville, Nouv. Dict. d'Hist. Nat. vol. xxvii. (1818), p. 351.—Ibid. [Imperfect fish ; Paris Museum of Natural History.]

Pygceus nobilis, L. Agassiz, 7oc. cit. 1835, p. 302, and tom. cit. 1833-42, pp. 17, 253, pl. xliv. figs. 6, 7. Chotodon canus, G. S. Volta, op. cit. 1796, p. cclxx. pl. lxv. fig. 1 (errore).-Ibid. [Imperfect fish; Palæontological Museum, Munich.]

Pygoeus nuchalis, L. Agassiz, loc. cit. 1835, p. 302, and tom. cit. 1838-44, pp. 16*, 255, pl. xliv. fig. 2.-Ibid. [Ditto.]

Pygceus oblongus, L. Agassiz, tom. cit. 1838-44, pp. 16*, 254, pl. xliv. figs. 3, 4.-Ibid. [Imperfect fish.]

Pygceus zignoi, F. Bassani, Atti R. Accad. Sci. Napoli [2] vol. iii. (1889), no. 6, p. 93, pl. xvii.-Lower Miocene; Chiavon, Vicentin. [Imperfect fish ; Zigno Coll., University of Padua.]

\section{Genus PROANTIGOINIA, Kramberger.}

[Beitr. Paläont. Oesterr.-Ungarns, vol. ii. 1882, p. 130.]

Syn. Metoponichthys, D. G. Kramberger, loc. cit. 1882, p. 104.

An imperfectly known extinct genus comprising small species with large head and snout not much produced. Preoperculum with small spines at angle, and supraclavicle serrated. Spinous portion of dorsal fin much more elevated and extended than articulated portion; pelvic fin-spine very large, accompanied by 5 articulated rays. Scales thin, bearing few spinous tubercles. 




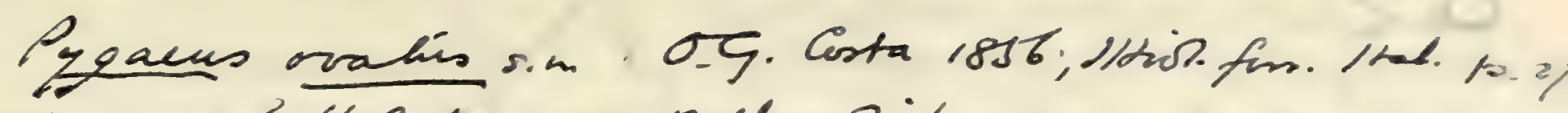

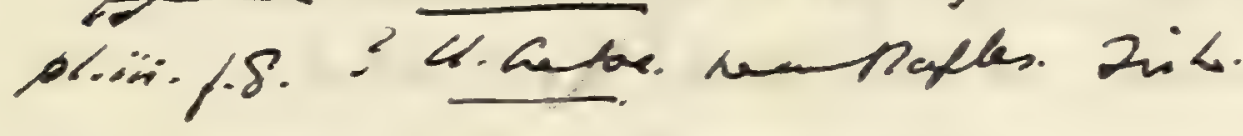

Parapypour, F. Pelleprin, Bull. Lor. Philom. Pario, 1907, N.votix, p.171.

P. polyoeanthur. G. Oellepin, chid!' inth 2 text-gtips - Al. Porene; Sunte Bolca. Fitel coll.

Pygeus concinmus, Mr. Leriche, Mém. Sor. Géd. Nod, vol. r(1906), h.387. hl. xvii. - H. Ercene; howhe Bolca. [Firh: Univ. Zille]

M. Zeriche, Mém. Sor. Géol. Nad, vol. v(1906), 6.387, divides species thes :-

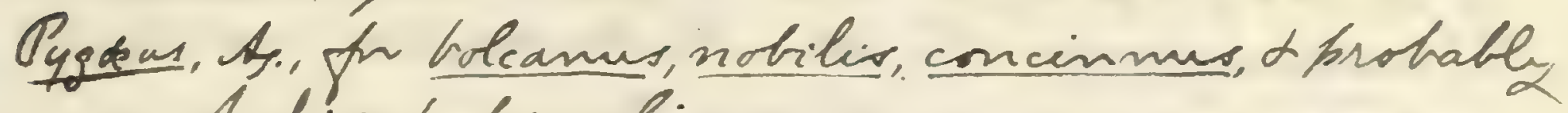
muchalis a dorsalir.

Malacepyeckus, pen.nor. An Hongens.

Acanthopizgotentigen.nor. for coleamer a opassizi.

Oypan apassize: C. Or. Sactman, Bull. hum. Comp. Zol. Iraward, rd. $\times 7$ vi (1904), f.31, kl. ii. - \&. Erene;

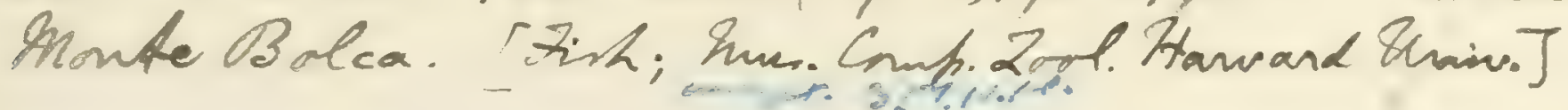




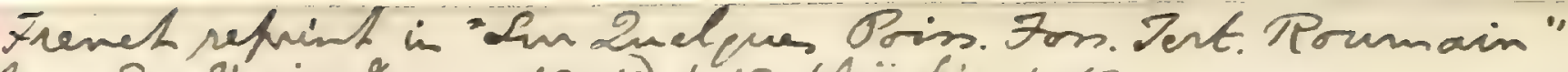

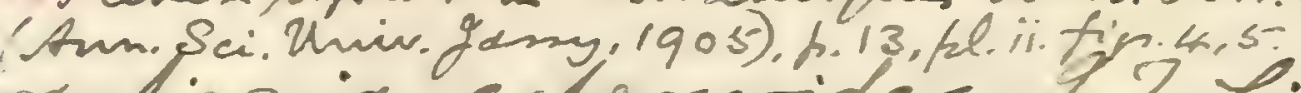
dunjionia caprossoider, f. T. Timionescu, Publicat. Acad. Romana, no. xii (190k), h. 13, hl. ii, Ar.4,5:- Glyphizma caproserider, L.C.Como-

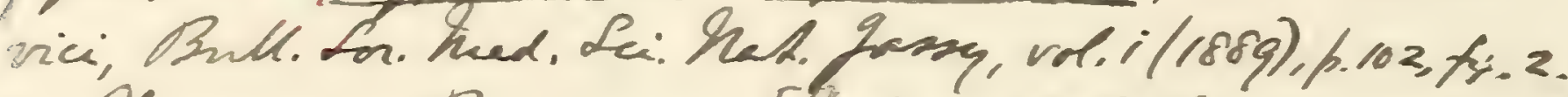

- Mierceme: Doumania. Compufent firh; Simionescen, Publicet. Scad. Domana, no. Xii (1904). 12, fl. Ii, fis. 3. - Oliporenel?); Roumania. mench reprint in "Lur Zueleper Poist. Fons. Test. Poumain"

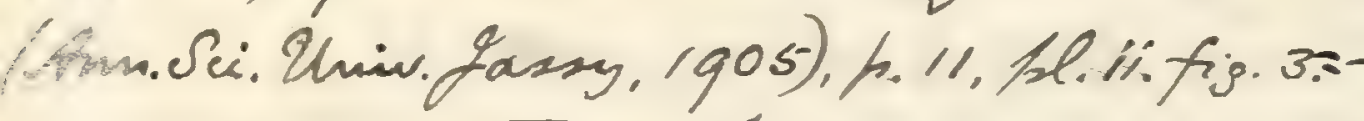

antigoria thenana s\%.n. W. Werler, Jahnt. Nossou. Vor.

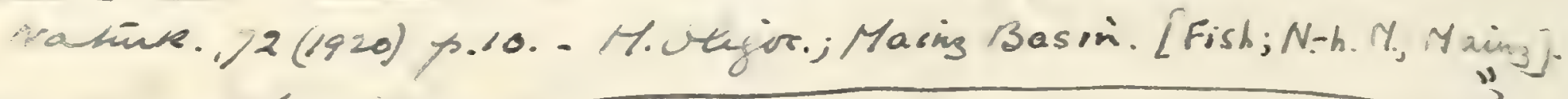

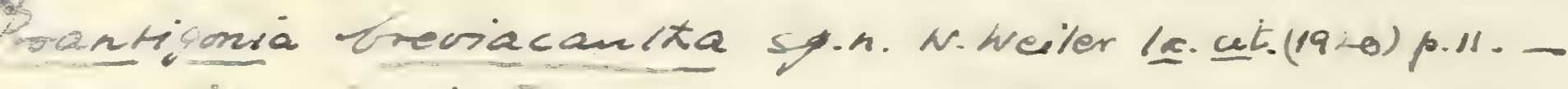
Ivid. [ toito J.)

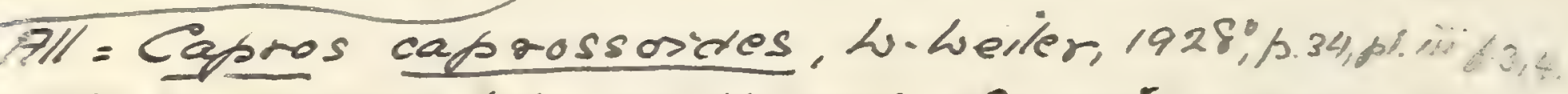
- Capros raclobianes (Aramb). Pan cá 1933 sip po.

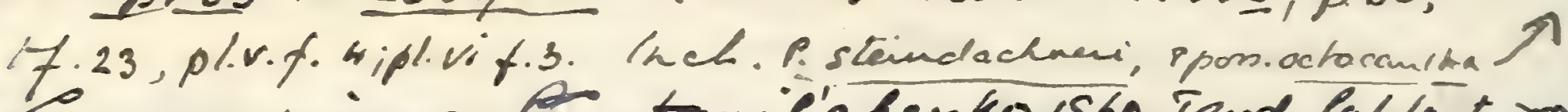

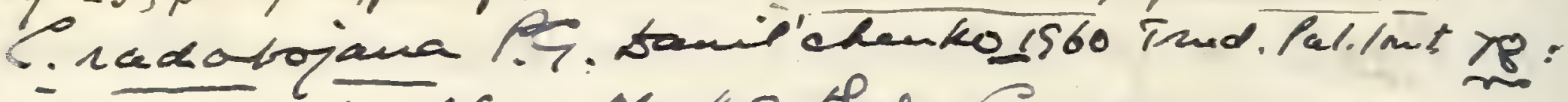

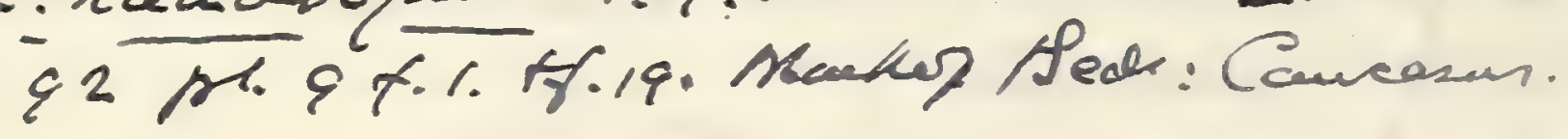




The following species have been described but are not represented in the Collection :-

Proantigonia longirostra, D. G. Kramberger, Rad Jugoslav. Akad. rol. cri. (1891), p. 110. Metoponichthys longirostris, D. G. Kramberger, Beitr. Paläont. Oesterr.-Ungarns, 33 . Oligere. vol. ii. (1882), p. 104, pl, xxir. fig. 1.-Upper Miocene; Suslänesci, Rour Dolje, Croatia. [Type species of Metoponichthys. Im-1933 5 ; p.b3,

perfect fish ; Geological Museum, University of Agram.] (7.24, p.p', v.t,
Proantigonia octacantha, D. G. Kramberger, loc. cit. 1891, p.111, Capros longirostris 4. Pancán 1924 ? pl. ii. fig. 1. Metoponichthys octacanthus, D. G. Kramberger, Toc.cit.1882, p. 106, pl. xxiv. fig. 2.-Ihid. [Ditto.] Proantigonia radobojana, D. G. Kramberger, loc. cit. 1882, p. 131, pl. xxvii. figs. 5, 6.-Upper Miocene; Radoboj, Croatia.

[Type species. Ditto.] = Capros r. Cace. t/shor Proantigonia steindachneri, D. G. Kramberger, loc. cit. 1882, p. 132, pl. xxvii. fig. 7, and loc. cit. 1891, p. 111, pl. ii. fig. 2 (scale only).-Ibid. [Ditto.] = Capros 2.

\section{Genus EPHIPPUS, Cuvier.}

[Règne Animal, vol. ii. 1817, p. 335.]

Snout short, with upper profile parabolic owing to hyperostosis of cranial roof; no palatine or vomerine teeth; preoperculum finely serrated but without spine. Pectoral tins small, not falciform; dorsal fin deeply notched between spinous and articulated portions, the former not scaly but comprising 8 or 9 spines, of which the middle are the longest; 3 anal fin-spines; caudal fin truncate or slightly emarginate. Scales small and regularly arranged.

Existing in the tropical Atlantic and Indian Oceans.

\section{Ephippus rhombus (Blainville).}

1796. Chætodon mesoleucus, G. S. Volta, Ittiolit. Veronese, p. xli. pl. x. fig. 1 (errore).

1796. Chatodon chirurgus, G. S. Volta, ibid. p. clxxvii. pl. xliii. (errore).

1818. Chatodon chirurgus, H. D. de Blainville, Nouv. Dict. d'Hist. Nat. vol. xxvii. p. 35.3.

1818. Chatodon rhombus, H. D. de Blainville, ibid. p. 353.

1823. Chatodon rhomboides, J. F. Krüger, Gesch. Urwelt, pt. ii. p. 671 .

1842-44. Ephiprus longipennis, L. Agrassiz, Poiss. Foss. vol. iv. pp. 15, 22., pl. xl. [Imperfect fish; Paris Nuseum of Natural History.]

1859. Ephippus longipennis, A. B. Massalongo, Specimen Photogr. Anim. Foss. Agr. Veron. p. 34, pl. ix. 
1876. Ephippus longipennis, F. Bassani, Atti Soc. Veneto-Trent. Sci, Nat. vol. iii. p. 179.

1886. Ephippus longipennis, W. Szajnocha, Pamiet. Wydz. matem.przyr. Akad. Umiejet. Krakow, rol. xii. p. 108, pls. ii., iii.

Type. Imperfect fish; Paris Museum of Natural History.

A species attaining a length of about 0.25. Maximum depth of trunk about equal to length from pectoral arch to base of caudal fin. Anterior dorsal fin with 8 spines, the fifth to seventh longest, all more slender at apex than in recent species; posterior dorsal with 1 spine and 18 to 20 articulated rays; anal fin with 16 articulated rays in addition to the 3 spines.

Form. \& Loc. Upper Eocene: Monte Bolca, near Verona.

P. 2092, P. 3925. Fine specimen, in counterpart, showing ova in abdominal carity as noticed by Agassiz, Poiss. Foss. vol.v. pt. ii. p. $76 . \quad$ Egerton \& Enniskillen Colls.

P. 9475. Smaller, more imperfect specimen, in counterpart.

History unknown.

The following extinct species hare also been described but are not represented in the Collection :-

Ephippus nicolisi, F. Bassani, Boll. Soc. Geol. Ital. vol. vii. (1888), p. 279, with plate-Widdle Eocene; Val Sordina, near Lonigo, Verona. [Imperfect fish; Nicolis Coll., Verona.]

Ephippus oblongus, L. Agassiz, Neues Jahrb. 1835, p. 292, and Poiss. Foss. vol. iv. (1839-44), pp. 15, 228, pl. xxxix. fig. 3. Chatudon asper, G. S. Volta, Ittiolit. Veronese (1796), p. xc. pl. xx. fig. 1. Chotodon substriatus, H. D. de Blainville, Nouv. Dict. d’Hist. Nat. vol. xxvii. (1818), p. 352.-Upper Eocene; Monte Bolca. [Imperfect fish; Paris Museum of Natural Histors.]

Extinct species, not represented in the Collection, have also been referred to existing genera of Chætodontidæ as follows:-

Chcetodon hoeferi, D. G. Kramberger, Djela Jugoslav. Akad. vol. xvi. (1895), p. 60, and Soc. Hist. Nat. Croatica, vol. x. (1898), p. 30, pl. ii. fig. 2, pl. iii.-Upper Oligoeene; Tüffer, Steiermark. [lmperfect fish; Academy of Mines, Leoben.]

Chcetodon pseudorhombus, P. Gervais, Zool. et Pal. Franȩ. (1852), Poiss. Foss. p. 9, pl. Ixxiii. fig. 2 (Chotodon rhombus on plate).-Pliocene; Montpellier. [Generically indeterminable imperfect trunk.] 
$$
\text { . }
$$ 



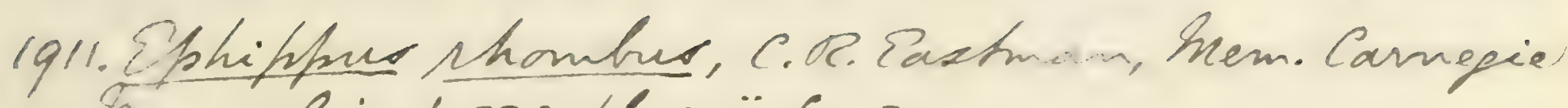
sum vol.iv. h.380, pl. xcii. fij. 2.

1914. Ophitfrus rhombus, C.D. Sashman, Mem. Carnepie sues. vol. vi. f. 334, hl. xTvi. fip. 1.

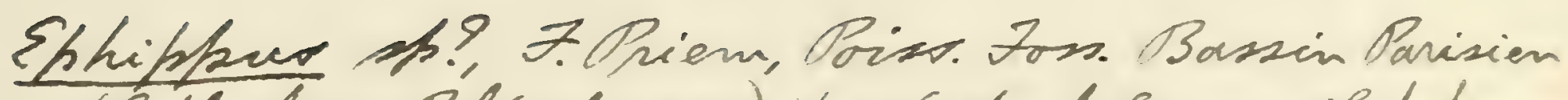
(Dubl. Inm. Paléont. 1908), h.116, texh-fip;59.-Intchion; Nanterre, Seine. [mperfut fird; Serle Nom Paris.]

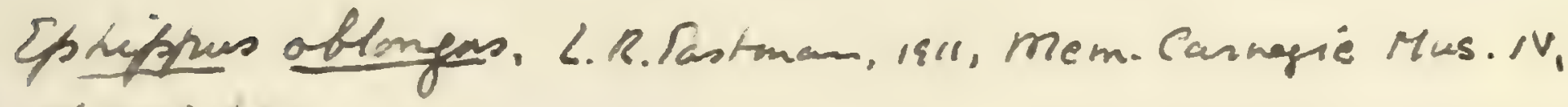

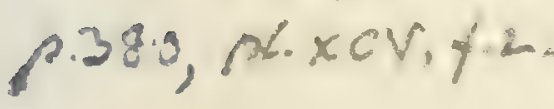

Chelmo fossin:

Chactodon ficheari, n.s., C. Arambourg, 1927, 10. 154.4\%36.

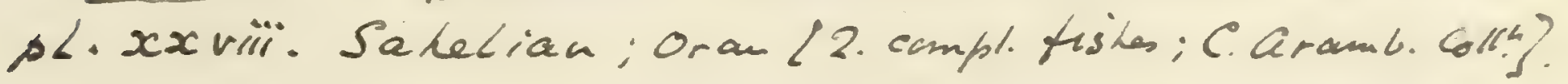


MULLCDAE

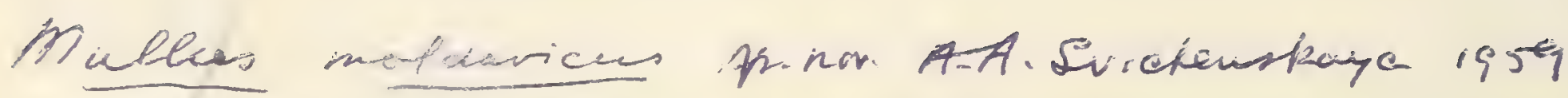

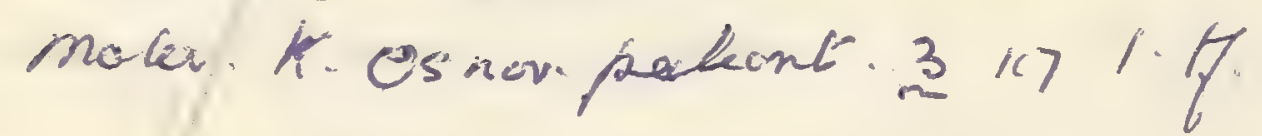

Guldia [nor.gent] mur. vol vi (1914), B⿸丆. 337,345

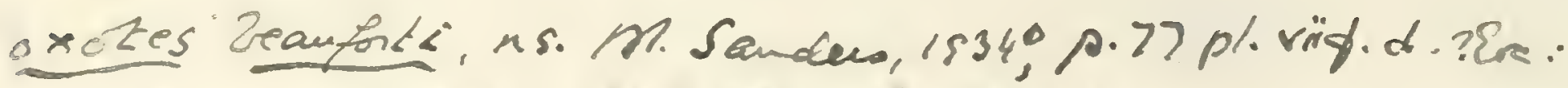

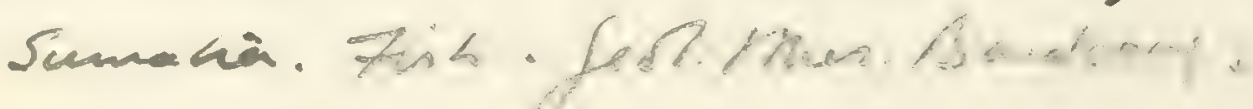

Mecrontima Ag. ron Rusio $4826=$ boodwondechtigs nme.nov. W. TMT. a.m. M.1r. (11) Y lakr 10.396 . Macios tomerides ith. Fowler 1960, Not. NaT.310:15.11] 


Holacanthus microcephalus, L. Agassiz, Poiss. Foss. vol. iv. (183942), p. 243, pl. xxxi. figs. 1, 2.†-Middle Eocene; Châtillon, near Bagneux. [Generically indeterminable imperfect fish; School of Mines, Paris.]

Holacanthus piovenorum, F. Bassani, Atti R. Accad. Sci. Napoli [2] vol. iii. (1889), no. 6, p. 89, pl. xviii. fig. 2.-Lower Miocene; Chiavon, Vicentin. [Imperfect fish; Piovene Coll., Lonedo.]

Pomacanthus subarcuatus, L. Agassiz, Neues Jahrb. 1835, p. 291 , and Poiss. Foss. vol. iv. (1842-44), p. 241, pl. xix. fig. 2. Chcetodon arcuatus, G. S. Volta, Ittiolit. Veronese (1796), p. xxxi. pl. viii. fig. 1 (errore). Choetodon subarcuatus, H. D. de Blainville, Nouv. Dict. d'Hist. Nat. vol. xxvii. (1818), p. 352.-Upper Eocene; Monte Bolca. [Imperfect fish ; Paris Museum of Natural History.]

Scatophagus affinis, F. Bassani, loc. cit. 1889, p. 88, pl. xvi. fig. 3, and Atti R. Istit. Veneto [7] vol. iii. (1892), p. 1035.-Lower Miocene; Chiavon. [Imperfect fish; Piovene Coll., Lonedo.]

Scatophagus capellinii, F. Bassani, loc. cit. 1889, p. 86, pl. xvi. figs. 1, 2.-Ibid. [Ditto.]

Scatophagus frontalis, L. Agassiz, Neues Jahrb. 1835, p. 291, and Poiss. Foss. vol. iv. (1839-42), p. 231, pl. xxxix. fig. 4; A. B. Massalongo, Specimen Photogr. Anim. Foss. Agr. Veron. (1859), p. 32, pl. viii. Chcetodon argus, G. S. Volta, Ittiolit. Veronese (1796), p. xliv. pl. x. fig. 2 (errore); Cuvier \& Valenciennes, Hist. Nat. Poiss. vol. vii. (1831), p. 14 5 (errore).-Upper Eocene; Monte Bolca. [Imperfect fish ; Paris Museum of Natural History.]

Toxotes antiquus, L. Agassiz, Neues Jahrb. 1835, p. 302, and Poiss. Foss. vol. iv. (1835-42), pp. 16*, 264, pl. xliii. Scicena jaculatrix, G. S. Volta, Ittiolit. Veronese (1796), p. clxxxiii. pl. xlv. fig. 1 (errore). Lutjanus ephippium, H. D. de Blainville, Nouv. Dict. d'Hist. Nat. vol. xxvii. (1818), p. 347 (errore).-Upper Eocene; Monte Bolca. [Imperfect fish; Paris Museum of Natural History.]

The following imperfectly known extinct genus and species is also sometimes placed here, but its systematic position is quite uncertain :-

Macrostoma altum, I. Agassiz, Poiss. Foss. vol. iv. (1839-44), pp. 15, 260, pl. xxx.-Middle Eocene; Hauterive, Paris. [Imperfect fish; olim Regley Collection.] 


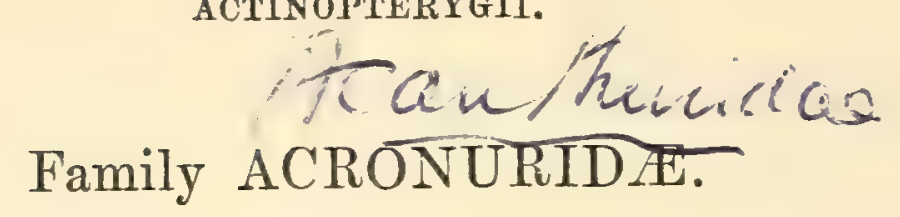

Trunk deepened. Maxilla fused with premaxilla; incisiform teeth in single series. Vertebræ 9 or 10 in abdominal, 13 or 14 in caudal region. Pelvic bones firmly united; anal fin with 2 or 3 spines. Scales minute, more or less ctenoid or spinous.

Herbivorous, perhaps partly carnivorous, fishes common in tropical seas in the neighbourhood of coral reefs. Three extinct genera probably belong to this family, while the existing Acanthurus and Naseus seem to date back to the Eocene period, when they ranged far north into the present temperate zone.

\section{Synopsis of Extinct Genera and Genera represented by Extinct Species.}

I. No lateral caudal spines; spinous portion of dorsal fin more developed than articulated portion.

Scales stellate

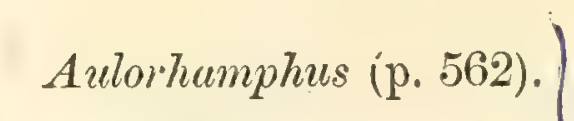

II. Lateral caudal spines; spinous portion of dorsal fin less developed than articulated portion.

One erectile caudal spine ............ Acanthurus (p. 563).

One to three (usually two) non-erectile caudal spines................ Naseus (p. 564).

\section{Genus AULORHAMPHUS, A. de Zigno.}

[Mem. R. Istit. Veneto, vol. xxiii. 1887, p. 19.]

Syn. Calamostoma, F. Steindachner (non Agassiz, 1833), Sitzungsb. k. Akad. Wiss., math.-naturw. Cl. vol. xlvii. 1863, pt. i. p. 133.

An extinct genus comprising small species with much-produced snout. Spinous portion of dorsal fin much more developed than articulated portion. Scales stellate; no caudal spines.

The following species have been described but are not represented in the Collection :-

Autorhamphus botcensis, A. de Zigno, Mem. R. Istit. Veneto, vol. xxiii. (1887), p. 20, fig。 4. Calamostoma bolcensis, F. Steindachner, Sitzungsb. k. Akad. Wiss., math.-naturw. Cl. vol. xlvii. (1863), pt. i. p. 133, pl. i. figs. 2, 3.-Upper Eocene; Monte Bolca, near Verona. [The type species. Imperfect fish ; Court Museum, Vienna.] 


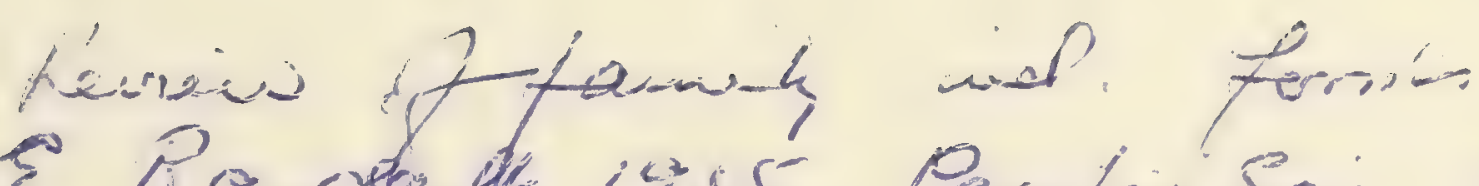

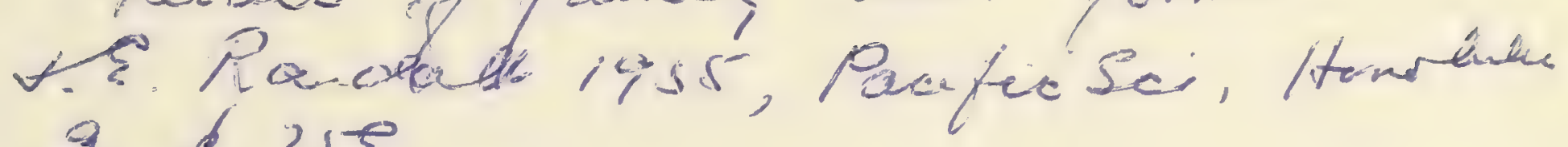
21.355 
Trackinkingaios p.45G.

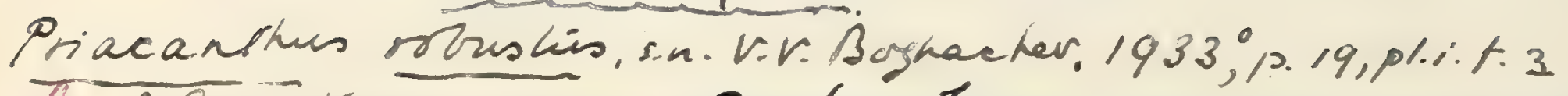

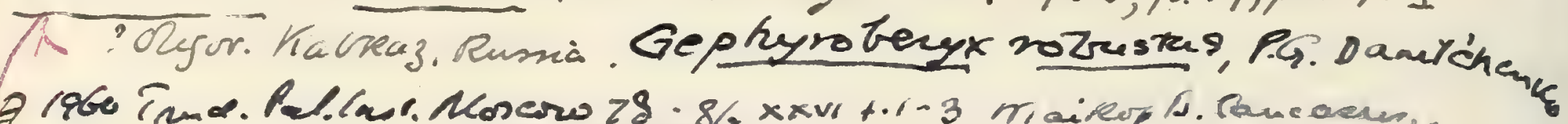

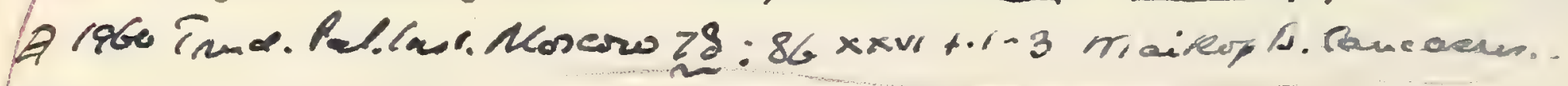

Priacarthus (Moostasis) Ongrispiries, ns. M.M. Lednew, Mcm.

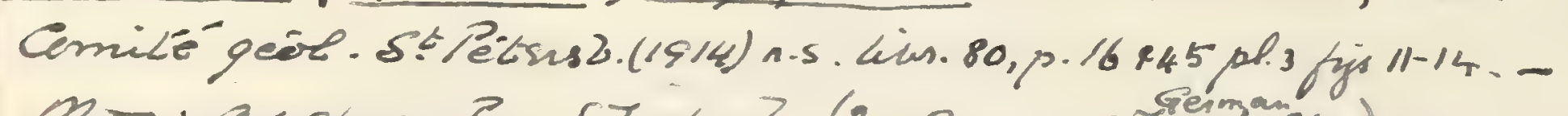

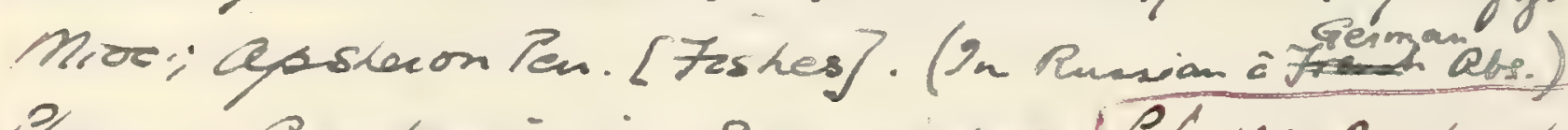

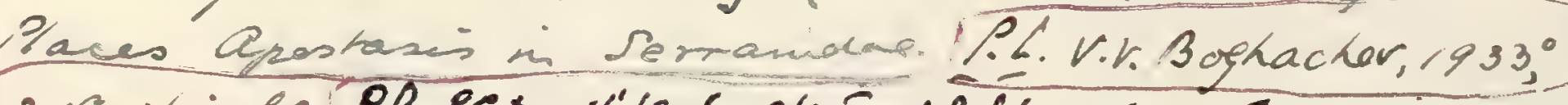

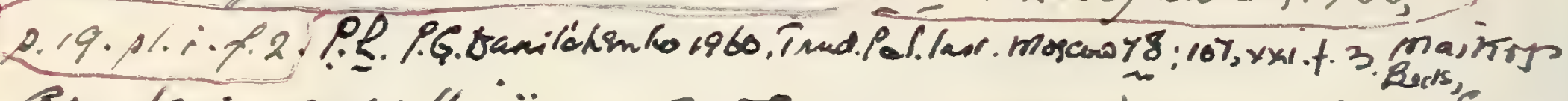
epostaxis capellinii, a.s. F. Dtrasmo, 1930 ․, 68, iii. 8-9. mici:Gavero. Buin?

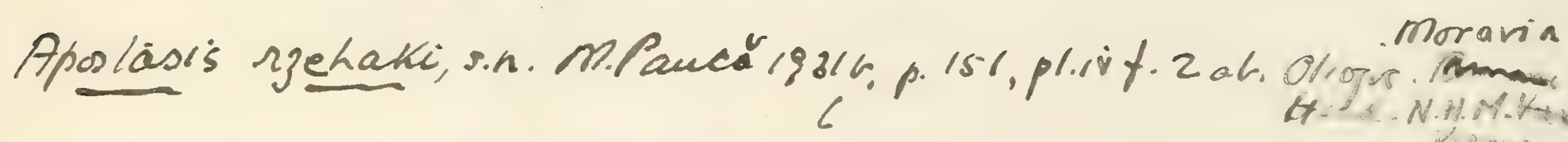

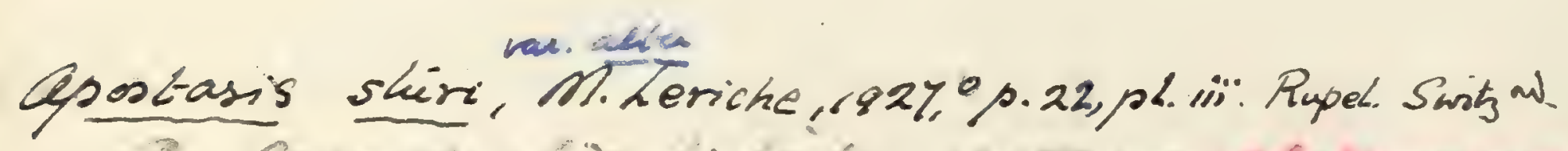

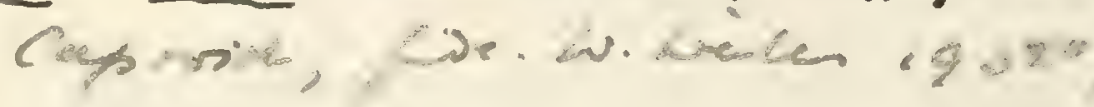




Autorhamphus canossa: Acanthurus canossce, J. J. Heckel, Denkschr. k. Akad. Wiss., math.-naturw. Cl. vol. xi.pt. i. (1856), p. 258, pl. xii. figs. 6, 7 ; A. B. Massalongo, Specimen Photogr. Anim. Foss. Agr. Veron. (1859), p. 25, pl. vii. fig. 2. Calamostoma canossce, F. Steindachner, loc. cit. 1863, p. 133.-Ibid. [Imperfect fish; Court Museum, Vienna.]

Autorhamphus capellinii, A. de Zigno, loc. cit. 1887, p. 23, fig. 5. -Ibid. [Imperfect fish; Zigno Coll., University of Padua.]

Aponlasella winow Whitcer, 1935, p. 249

- Genus APOSTASIS, Kramberger.
[Rad Jugoslav. Akad. vol. cri. 1891, p. 104.]

An imperfectly known extinct genus, comprising small species with snout not much produced and teeth simply conical. Preoperculum serrated. Spinous portion of dorsal fin more developed than articulated portion. Scales with thickened hinder border bearing few stout spines; no caudal spines.

The following species have been described but are not represented in the Collection :-

Apostasis croatica, D. G. Kramberger, Rad Jugoslav. Akad. vol. cri. (1891), p. 106, pl. iii. fig. 1. Acanus croaticus, D. G. Kramberger, loc. cit. vol. lxxii. (1885), p. 60.Upper Miocene; Podsused, Croatia. [The type species, supposed to have 6 or 7 articulated rays in pelvic fins but uncertain. Imperfect fish; Geological Museum, University of Agram.]

Apostasis sturi, D. G. Kramberger, Toc. cit. vol. cvi. (1891), p. 106. Acanus sturi, D. G. Kramberger, Jahrb. k. k. geol. Reichsanst. vol. xxx. (1880), p. 566, pl. viii. fig. 1.-Niddle Oligocene; Wurzenegg, near Prassberg, Steiermark.

- Priescan Thur (Agosians )sline.

Genus ACANTHURUS, Forskål.

[Descr. Anim. 1775, p. 59.]

Teeth lobate and denticulated. Spinous portion of dorsal fin less extended than articulated portion; anal fin with 3 spines. All scales minute and ctenoid, sometimes spiny; one erectile spine on each side of the caudal pedicle.

The skeleton of Acanthurus triostegus is described by A. Günther, Catal. Fishes B. I. vol. iii. (1861), p. 327. 
There do not appear to be any fossil remains of species referable to this existing genus in the Collection, but the following have been described:-

Acanthurus duvali, P. Gervais, Zool. et Pal. Franç. (1852), Poiss. Foss. p. 8, pl. lxxii. figs. 1, 2.-Middle Eocene (Calcaire Grossier): Paris. [Generically indeterminable imperfect fish.]

Acanthurus haueri, L. Agassiz, Neues Jahrb. 1846, p. 471. Iguana (?) haueri, H. von Meyer, in Münster, Beitr. Petrefact. pt. v. (1842), p. 33, pl. vi. fig. 12.-Tertiary; Vienna. [Teeth.]

Acanthurus ovalis, L. Agassiz, Poiss. Foss. vol. iv. (1838-44), pp. 13, 210, pl. xix. fig. 1.-Upper Eocene; Monte Bolca. [Imperfect fish; Bristol Museum.]

Acanthurus tenuis, L. Agassiz, Neues Jahrb. 1835, p. 293, and Poiss. Foss. vol. iv. (1838-42), pp. 13, 208, pl. xxxvi.

fig. 1. Chotodon lineatus, G. S. Volta, Ittiolit. Veronese (1796), p. cxxxvi. pl. xxxi. fig. 2 (errore); H. D. de Blainville, Nouv. Dict. d'Hist. Nat. vol. xxvii. (1818), p. 354.-Ibid. [Imperfect fish; Paris Museum of Natural History.]

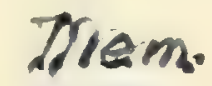

The so-called Acanthurus gaudryi (A. de Zigno, Veneto, vol. xxiii. 1887, p. 14, fig. 2), and Acanthurus gazolce (A. B. Massalongo, Specimen Photogr. Anim. Foss. Agr. Veron. 1859, p. 26, pl. rii. fig. 1) from Monte Bolca, do not belong to this genus and are probably Chætodontidæ.

Genus NASEUS (Commerson), Cuvier.

[Règne Animal, ed. 2, vol. ii. 1829, p. 224.]

Teeth denticulated. Spinous portion of dorsal fin less extended than articulated portion; anal fin with 2 spines. Scales shagreenlike; one to three (usually two) non-erectile spines on each side of the caudal pedicle.

The skeleton of the existing Nasens brevirostris is described by A. Günther, Catal. Fishes B. M. vol. iii. (1861), p. 349.

Naseus rectifrons, Agassiz.

1796. Chretodon triostegus, G. S. Volta, Ittiolit. Veronese, p. cxliii. pl. xxxiii. (errore).

1818. Chatodon triostegus, H. D. de Blainville, Nouv. Dict. d'Hist. Nat. vol. xxrii. p. 354. 
Tebracoma deani, 2. Hussakt, Bull. Amen.

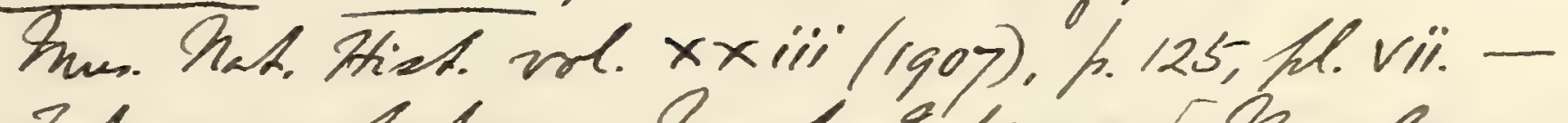
Tertiary; Antipua, hect midier. Meanly complete fish: Amen. Sims: h. H, hem Yorte.

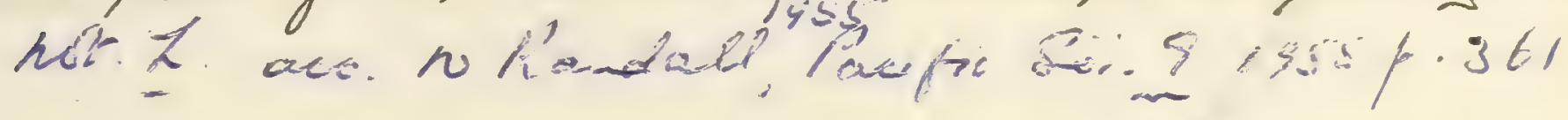

Acanthures sandryi wrtably of new semen near Jenthis and Letrazoma: W.S. Iordan, Science, n. S. [Acanthumes rol. $\times \times(1904), p .246$. 


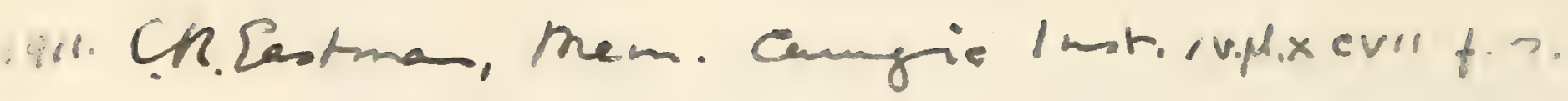

2.10k2\%. Tine upecimen.

Punchers, 1907.

21173. Snother ppecimen, in counterpont. Onuti! 1913.

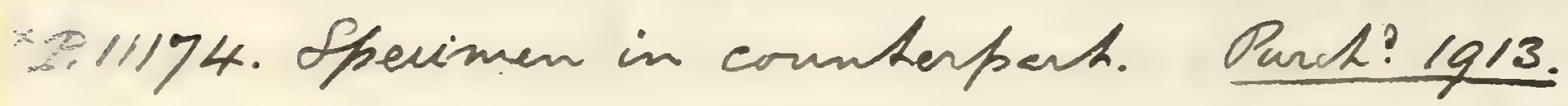

Oplegnathida

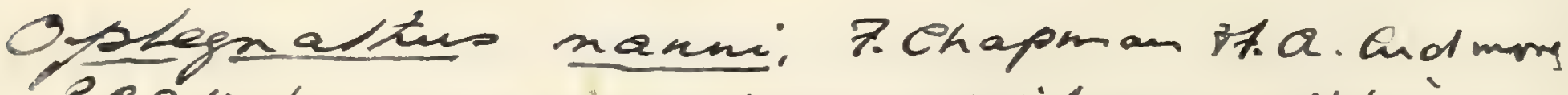

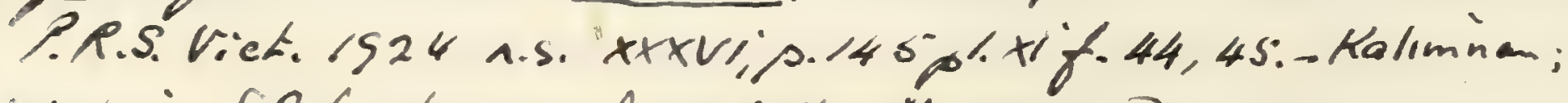
victoria. [R.h. pharygeat; Nat. Man. Heblorume?] 
. 

1838-42. Naseus rectifrons, L. Agassiz, Poiss. Foss. vol. iv. pp 13, 213, pl. xxxvi. fig. 3.

1859. Naseus rectifrons, A. B. Massalongo, Specimen Photogr. Anim. Foss. Agr. Veron. p. 22, pl. xii. fig. 1.

1876. Naseus rectifrons, F. Bassani, Atti Soc. Veneto-Trent. Sci. Nat. vol. iii. p. 178.

Type. Imperfect fish; Paris Museum of Natural History.

A species attaining a length of about $0 \cdot 25$. Maximum depth of trunk not much less than length from pectoral arch to base of caudal fin. Dorsal fin with 6 spines and 30 to 35 articulated rays; anal fin with about 24 articulated rays besides the two spines.

Form. \& Loc. Upper Eocene: Monte Bolca, near Verona.

41890. Imperfect fish, $0 \cdot 2$ in length.

Purchased, 1870.

21393. Fragments of larger specimen.

Purchased, 1847.

43490. Small specimen 0.05 in length, in counterpart, probably young of this species.

Presented by F. G. Beckford, Esq., 1872.

The following extinct species has also been described but is not represented in the Collection:-

${ }^{\times}$Nasens nuchalis, L. Agassiz, Nenes Jahrb. 1835, p. 292, and Poiss. Foss. vol. iv. (1838-42), pp. 13, 212, pl. xxxvi. fig. 2. Chcetodon nigricans, G. S. Volta, Ittiolit. Veronese (1796), p. c. pl. xxii. fig. 1.-Upper Eocene; Monte Bolca. [Imperfect fish; Paris Museum of Natural History.] C.R.Castanan iq 16 , mem. Canngie mus. iv pl.xcv+l.

\section{Family BALISTID无.}

Trunk deepened. Maxilla fused with premaxilla; few large incisiform teeth in single or double series. Vertebræ 7 to 9 in abdominal, 10 to 14 in caudal region. Fins more or less reduced, spines being always absent in the anal fin; pelvic bones firmly united. Skin with minute tubercles or bony plates.

Small littoral fishes, chiefly of tropical regions.

\section{Synopsis of Extinct Generce and Genera represented by Extinct Species.}

I. With minute dermal tubercles.

Six or seven large dorsal spines; posterior dorsal and anal small .... Spinacanthus (p. 566). 
About four dorsal spines, the foremost only large; posterior dorsal and anal fins low but extended; pair of pelvic fin-spines ...........

About three dorsal spines, the foremost Acanthopleurus (p. 566)。 only large; posterior dorsal and anal fins low but extended; no pelvic fins............... Acanthoderma (p. 568).

II. With polygonal dermal plates.

No spinous dorsal or pelvic fins; dermal plates forming rigid armour .

Ostracion (p. 569).

\section{Genus SPINACANTHUS, Agassiz.}

[Poiss. Foss. vol. v. pt. i. 1844, p. 107.]

Syn. Protobalistum, A. de Zigno (ex Massalongo, MS.), Mem. Soc. Ital. Sci. [3] vol. vi. no. 4, 1885, p. 3.

Teeth very stout, apparently in single series. Pectoral fins delicate; [pelvic fins unknown;] six or seven very large dorsal spines in spaced series extending from above the eje along more than half of the dorsal border, gradually decreasing in size backwards; posterior dorsal and anal fins relatively small and short-based; caudal fin rounded. Dermal tubercles minute.

This extinct genus is known only by two imperfect specimens from the Upper Eocene of Monte Bolca, near Verona; the first being in the Paris Museum of Natural History, described and figured by Agassiz (Poiss. Foss. vol. v. pt. i. 1839-44, p. 107, pl. xxxix. fig. 1) under the name of Spinacanthus blennioides; the second in the Verona MLuseum, described and figured by A. de Zigno (Mem. Soc. Ital. Sci. [3] vol. vi. no. 4, 1885, p. 4, figs. 1, 2) under the name of Protobalistum imperiale. The first specimen differs from the second in exhibiting serrations on the anterior dorsal spine. It was originally ascribed in error to Blennius ocellaris by G. S. Volta (Ittiolit. Veronese, 1796, p. lxiv. pl. xiii. fig. 2), and subsequently named Blennius cuneiformis by H. D. de Blainville (Nouv. Dict. d'Hist. Nat. vol. xxvii. 1818, p. 359). The second specimen was originally recorded under the name of Ostracion imperialis by A. B. Massalongo (Neues Jahrb. 1857, p. 775$)$.

Genus ACANTHOPLEURUS, Agassiz.

[Poiss. Foss. vol. ii. pt. ii. 1844, p. 253.]

A supposed extinct genus, not yet clearly distinguished from the existing Triacanthus. [Teeth unknown.] [Pectoral fins unknown;] 

Oligobalistes ginn. Sype Q.robustas s.a. Maikop veves, Cancasus. PG. Facirichanto Imde Pah. lask, Phenesci. Usik. 78 1960: 16548.32 pl.ntt zih.

Marosia huismani.

Bakistonosphus I. G.ll 1888, Amer. Malinakivo 22. 4 k8 (name quored-dourr know reof).

Eoplectus bloti, grop.h, J.C.Tyler 1973 , Mem. Mus. verma, forniserie,

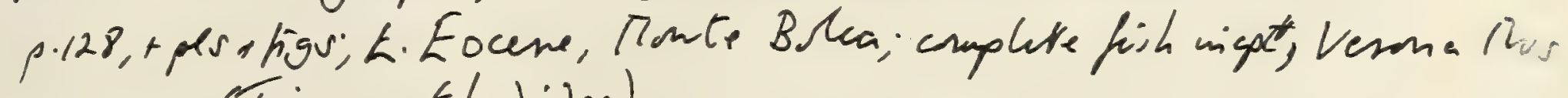
(Thiacanthodidae).

Spinax cumei formin, CR Eastman 1905\% s.31.

Protiacanitur gortanio g.r.n U-arer. Istice

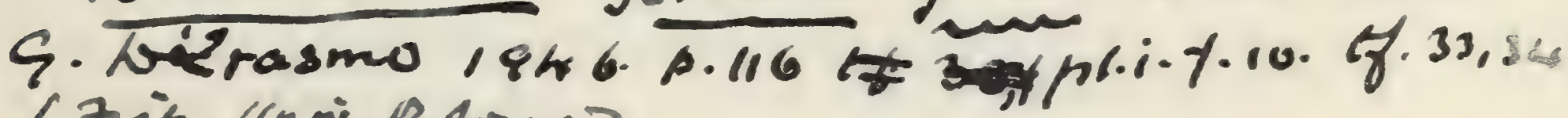

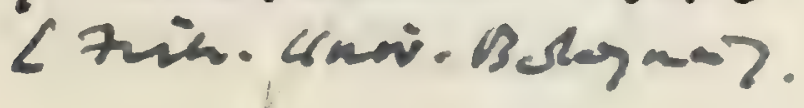

Triacouthus? sp. W.Weiler, 1929, abh. bay.

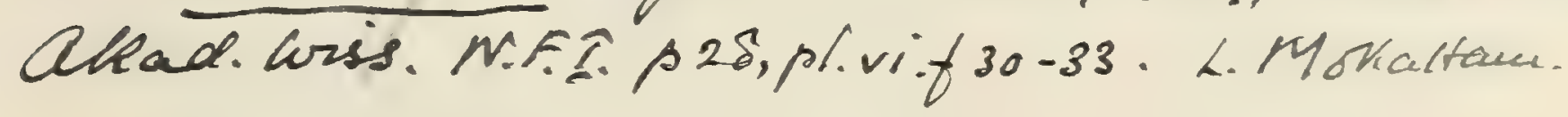


Cryptobalistes gennir. J.C. Tylur, 1968, Mangr. Awar Nat. Sei. Philad, 16:243

- Gyar-specios Atanthopleuns brevis vom Ras

Protacanthodes (n-g) mboni; T. Gill! 888 , Omer. Naluin. 
pelvic fins represented by a pair of stout, moveable spines; one large dorsal spine, followed by about three very small and comparatively slender spines; posterior dorsal and anal fins low but considerably extended; caudal fin rounded. Dermal tubercles small and shagreen-like.

The name Acanthopleurus was preoccupied by Acanthopleura, Guilding, in 1829, but may be retained until the extinct species placed here are satisfactorily known.

\section{Acanthopleurus serratus, Agassiz.}

1842. Pleuracanthus serratus, L. Agassiz, Poiss. Foss. vol. ii. pl. lxxv. figs. 1, 2.

1844. Acanthopleurus serratus, L. Agassiz, tom. cit. pt. ii. p. 253.

1814. Accuthopleurus brevis, L. Agassiz (ex Egerton, MS.), tom. cit. pt. ii. p. 253 (name only).

1859. Acanthopleurus brevis, G. vom Rath, Zeitschr. deutsch. geol. Ges. vol. xi. p. 131, pl. v. fig. 4.

1859. Acanthopleurus serratus, G. vom Rath, ibid. p. 132, pl. v. fig. 5.

1886. Acanthopleurus serratus, A. Wettstein, Fischfauna Tertiaer. Glarnerschief. (Denkschr. schweiz. Palaeont. Ges. vol, xiii.), p. 47, pl. viii. figs. 1-4.

Type. Imperfect fish; British Iruseum.

The type species, attaining a length of about 0.12. Maximum depth of trunk contained about three times in length of vertebral column, which comprises 19 vertebræ. Anterior dorsal spine nearly straight, tuberculated, its length about equal to maximum depth of trunk; posterior dorsal fin arising at middle point of back; pelvic spines tuberculated, as long as anterior dorsal spine.

Form.\& Loc. Oligocene: Canton Glarus, Switzerland.

P. 454, P. 3974 . Type specimen in counterpart, described and figured by Agassiz, loc. cit.; Engi. The fossil is much elongated by distortion. Egerton \& Enniskillen Colls.

P. 1893, P. 4522. Three imperfect specimens, one being in counterpart; Engi. Eyerton \& Enniskillen Colls.

P. 1892. Imperfect impression of small fish, intended to be the type specimen of $A$. brevis ; Engi.

Egerton Coll.

P. 524. Another imperfect impression. Purchased, 1837.

The following extinct species, which is not represented in the Collection, also appears to belong to Acanthopleurus:- 
vi. no. 4 (1885), p. 5, figs. 3-5.-Upper Eocene; Monte Bolca. [Imperfect fish; Geological Museum, University of Padua.]

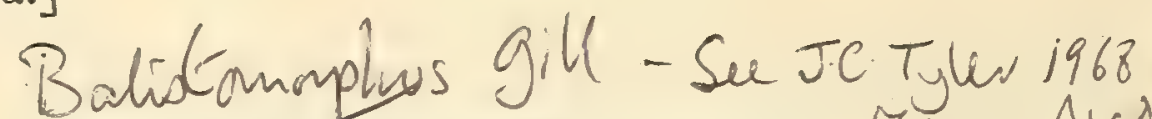
Genus ACANTHODERMA, Agassiz. Mohugro A a d hal [Poiss. Foss. vol. ii. pt. ii. 1844, p. 251.]

A supposed extinct genus, not yet clearly distinguished from the existing Balistes. [Teeth unknown.] Pectoral fins very small; large pelvic bone without fins or spine; one large dorsal spine, followed by about two very small and comparatively slender spines; posterior dorsal and anal fins low and much extended; caudal fin rounded. Dorsal tubercles small and shagreen-like, apparently none enlarged.

The name Acanthoderma was preoccupied by Cantraine in 1835, but may be retained until the extinct species placed here is satisfactorily known.

\section{Acanthoderma spinosum, Agassiz.}

1842-44. Acanthoderma spinosum, L. Agassiz, Poiss. Foss. vol. ii. pt. ii. p. 252, pl. lxxv. fig. 4.

1842-44. Acanthoderma ovale, L. Agassiz, tom. cit. pt. ii. p. 251, pl. lxxv. tig. 3. [Distorted fish; Neuchâtel Museum.]

1879. Acanthoderma orbiculatum, O. Heer, Urwelt d. Schweiz, ed. 2, p. 257, with fig. [Distorted fish; Glarus Museum.]

1886. Acanthoderma spinosum, A. Wettstein, Fischfauna Tertiaer.

Glarnerschief. (Denkschr. schweiz. Palaeont. Ges. vol. xiii.), p. 49.

Type. Imperfect fish; British Museum.

The type species, attaining a length of about $0 \cdot 12$. Maximum depth of trunk equalling length of vertebral column, which seems to comprise 17 vertebræ. Large dorsal spine with a row of large tubercles along its anterior border, partly ribbed, partly tuberculated on its sides. Posterior dorsal fin occupying half of back, with 20 to 25 rays ; anal fin shorter and apparently with fewer rays.

Form. \& Loc. Oligocene : Canton Glarus, Switzerland.

P. 500, P. 3973. Imperfect type specimen, in counterpart, described and figured by Agassiz, loc. cit.; Engi. There are indications of one or perhaps two very small spines behind the large dorsal spine.

Egerton \& Enniskillen Colls.

41819. Scattered but well-preserved remains of fish; Engi. A 
1835. A. S. Cig. Pins. for tamilekn p.27. 
If alliglés crassiders Sin. C. Caoven 1958, Schw.

Pal. avh. Th: 14tos.\%. Mioc. Trinidad.

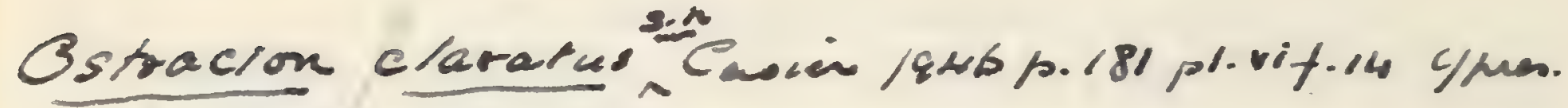
Bals. Sendes. MPR.H.N.B.

Ostracion sp. W. heiler, 1928 " "senekentergiane," $x$. $1.754 .161 \%$ oligrems, Rumania?

Eolactania sorbinii g+sp. nos. T.Tyler 1973, Mem. Mus. Verone, foni sevie, p.106+ph.

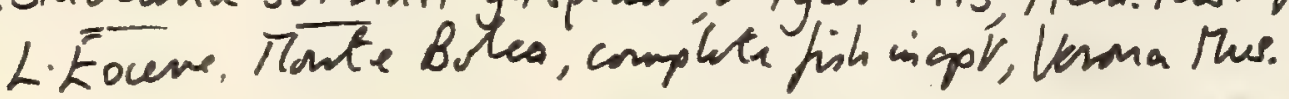

Btracion meretrix, A. Daimeries, Amm. Sor. Rry. Malar. Bels.vol. xxvi(/8q1), Bull Seánces,

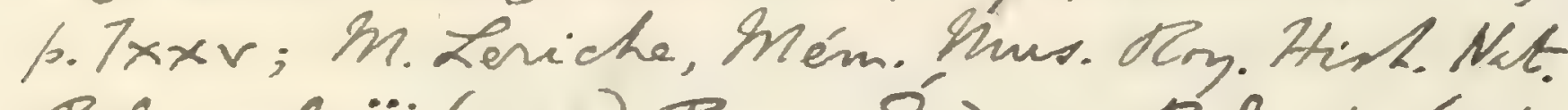

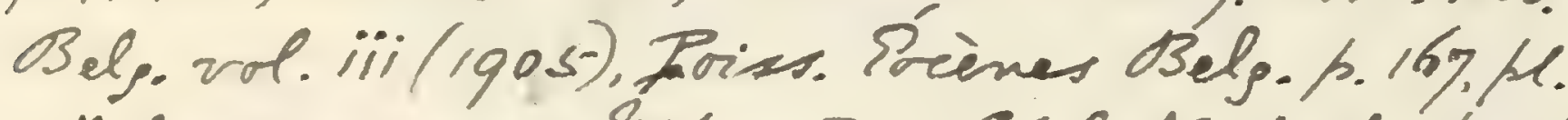
xii. fir. 11-15, and Mném. Sor. Géd. Nord, vd. v(ligob). 1.263, 12l. Xv. figs. 11-15:- Bruxellian d Lackemin: Brnasel s. FDermal plates; Mur. N.H. Brusads.]

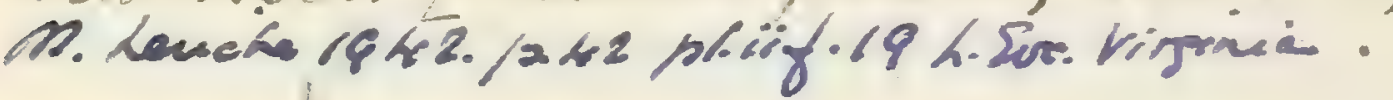

Aracana Kershawi, Fchapman Tf A. Godmorr, PR. S.

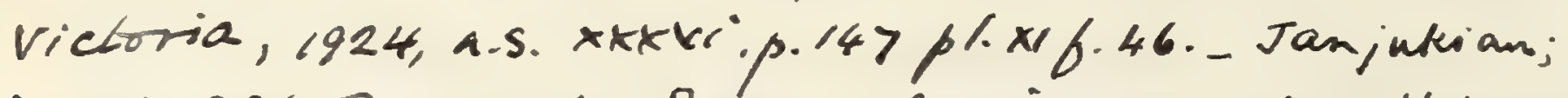
Yable Capse, Tasmania - [ Sermal spins; Nat. Mus., Meltrome]

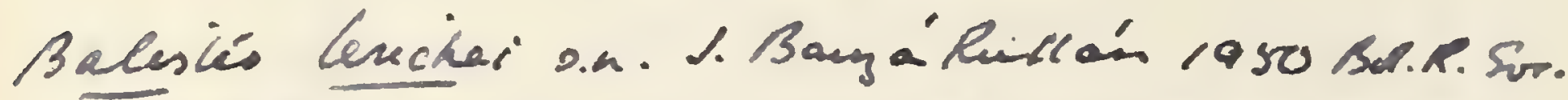

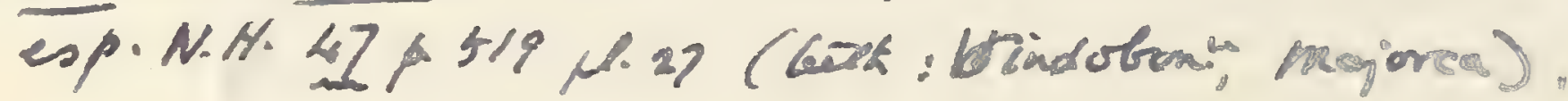

= Babister caprizcur, Gmel, G. De Stefano, Boll Ior. Gerl. Z2al. ush xxviii(1910), h.639.

batister sol.

Balistes procapriscus, s.n., C. Aramtourg, 1927, p.21y, pl. xlirt.1. Sahelian; Oram. L Jish']. 

few short, delicate rays may perhaps represent the pectoral fin; while appearances suggest that there are two short spines immediately behind the large dorsal spine.

Purchased, 1869.

\section{Genus OSTRACION, Linnæus.}

[Syst. Nat. ed. 10, 1758, p. 330.]

Teeth much elongated, in single series. Vertebræ reduced to 14. Pectoral fins small, and pelvic pair absent; no dorsal spines, the posterior dorsal and anal fins small and opposed; caudal fin rounded. Greater portion of trunk encased in firmly-united polygonal bony plates.

The following small extinct species, not represented in the Collection, seems to belong to this genus :-

Ostracion micrurus, L. Agassiz, Poiss. Foss. vol. ii. (1833-44), Proaracana ganm,pt. i. p. 17, pt. ii. p. 263, pl. Ixxiv. figs. 4, 5. Ostracion ( 1., Y. Le Danois 1961, pl. xlii. fig. 1 (errore). Cyclopterus lumpus, G. S. Volta, Mem. Tus.nat. H,r t. plqp. cit. p. cclxxii. pl. lxv. fig. 2 (errore). Balistes dubius, Proarceana dubia (Bl.), H. D. de Blainville, Nouv. Dict. d'Hist. Nat. vol. xxvii. J.Tyler, 1973, Mem.Rus. (1818), p. 337.-Upper Eocene; Monte Bolca. [Im-

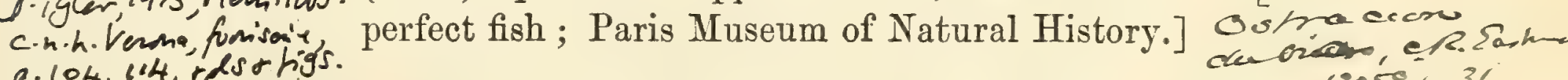
p.104, 14 , ros The so-called Ostracion oblongus from Monte Bolca (A. de Zigno," $105^{\circ} \% .3 \%$ Mem. R. Istit. Veneto, vol. xviii. 1874, p. 294, pl. x. fig. 3) does not appear to belong to this genus. - See J.T.Tyler 1973 Mem. Mus. Vorma,

The following teeth seem to belong to a member of the Balistidæ :-

P. 6316. Three stout incisiform teeth, bluntly pointed; Tertiary,

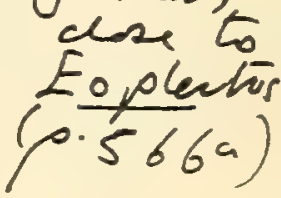
St. Croix, Trinidad.

Presented by R. J. Lechmere Guppy, Esq., 1891.

A more slender form of tooth, not represented in the Collection, has been named thus :-

Balistes caifassii, R. Lawley, Nuori Studi Pesci, etc. Colline Toscane (1876), p. 76, pl. i. fig. 7.-Lower Pliocene; Orciano, Tuscany. $=$

The following undetermined teeth have been compared with the pharyngeal teeth of Balistes by W. Dames (Zeitschr. deutsch. geol. Ges. vol. xxxv. 1883, p. 660), who has also described nearly similar teeth from the Oligocene of the Vicentin, Italy, under the 
name of Ancistrodon vicentinus (loc. cit. 1883, p. 667, pl. xix. fig. 10$)^{1}:-$

P. 5925. Five teeth of the form named Corax fissuratus by $T$. C. Winkler, Archiv. Mus. Teyler, vol. iii. (1874), p. 300, pl. vii. fig. 4, and ibid.vol.iv. (1876), p. 27, pl. ii. figs. 11, 12; Middle Eocene, Woluwe St. Lambert, Brussels. Noticed as Ancistrodon fissuratus by $\mathbf{A}$. S. Woodward, Geol. Mag. [3] vol. viii. (1891), p. 108, and identified by Dames with Sargus? armatus (P. Gervais, Zool. et Pal. Frane. 1852, Poiss. Foss. p. 5, pl. Ixix. figs. 9, 10) from the French Eocene; recorded by Dames (loc. cit. 1883, p. 664, pl. xix. fig. 2) as Ancistrodon armatus.

Presented by Monsieur A. Houzeau de Lehaie, 1889.

The name Glyptocephalus radiatus is proposed by Agassiz (Poiss. Foss. vol. ii. pt. ii. 1844, p. 264) for the tuberculated skull of a supposed member of the Balistidæ from the London Clay of Sheppey, said to have been placed in the British Museum by König and labelled by him Ephippus owenii. This is the head of a Siluroid fish already described above (p. 330) as Bucklandium diluvii.

\section{Family GYMNODONTIDÆ.}

Trunk deepened. Maxilla fused with premaxilla; no separate teeth, but often dental plates imbedded in the bone of the jaw, these continually replaced by vertical successors. Vertebræ usually much reduced. No spines in dorsal or anal fins. Skin usually with small spines or spinous bony plates, sometimes naked.

Chiefly tropical and sub-tropical marine fishes, most of them surface-dwellers and capable of inflating their body by filling the distensible œesophagus with air. A few Tetrodonts live in large rivers. No clearly recognisable extinct genera are known.

\section{Synopsis of Genera represented by Extinct Species.}

I. Caudal region normal.

Each jaw with median suture at symphysis, and only marginal dental plates; small dermal spines without expanded root ...............

Each jaw fused at symphysis ; marginal Tetrodon (p. 571). and inner dental plates; dermal 
Peetognati". Torigmodentidae.

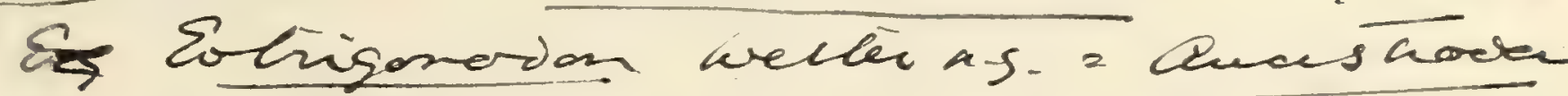

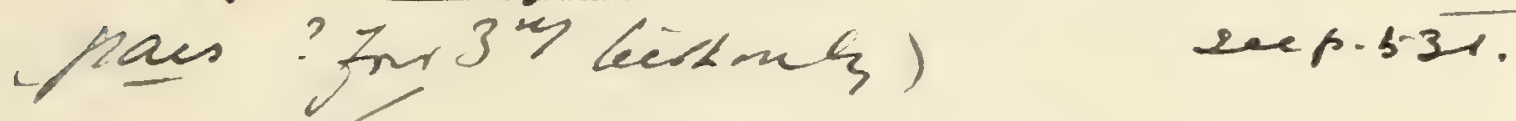

cristrolow Lamexi, A. Ddimeries, Am. Soe. Dry. Malac. Belp. vol. xxiv (188q), Bull. Séances, p. rii. Aneistrolon armatus, Priem, Bull Sor. Géol. France [3] vol. Xxv (1897), p. 220, pl. vii.fip. 15;

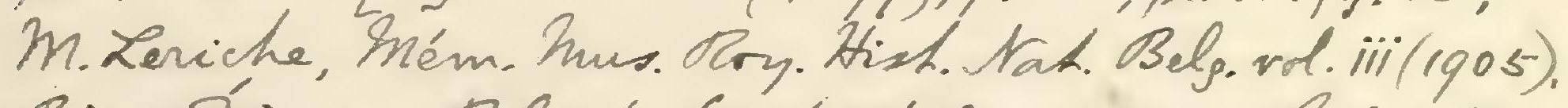

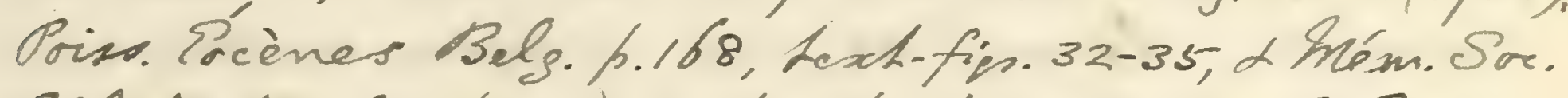
Géal. Mrad, rol. v(1906), h.264, texh-fin-66-69; 7. Priem, Bull. Sor. Géd. Arance $[4]$ vol. vii (1908), p. 4is, hl.xv. f. is=22 [Erem, hotedtham]-also wan. teilhandi, h.416, hl.xv. f.23-2s.

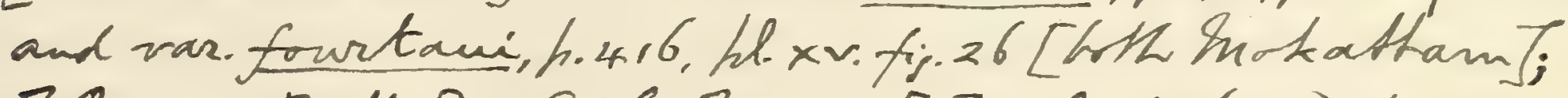
7. Priem, Bull. Sor. Séd. Arance [4] rol. xiv (1914), h. 3y,-

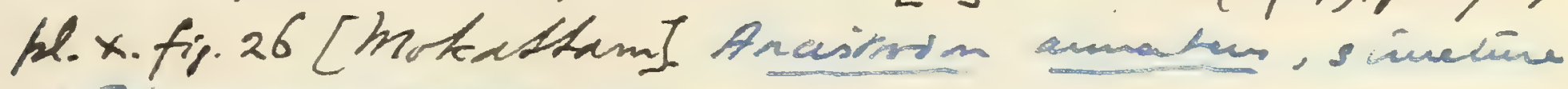

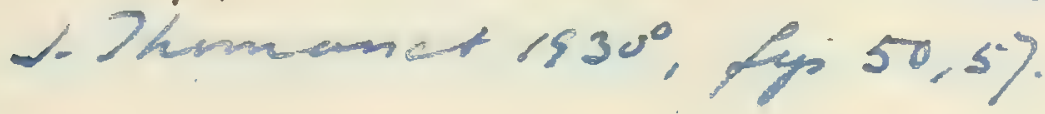



spines with two horizontally-ex-

tended roots ................ Diodon (p. 571).

II. Caudal region aborted.

Both jaws fused at symphysis, and no dental plates................. Orthagoriscus (p. 576).

\section{Genus TETRODON, Linnæus.}

[Syst. Nat. ed. 10, 1758, p. 332 (Tetraodon).]

Each jaw with median suture at symphysis, the sharp edge strengthened with dental plates. Separate caudal fin. Dermal spines small or absent, always without expanded root.

The following specimens seem to be jaws of undetermined species of this genus :-

P. 6130. Imperfect ramus of jaw; Miocene, Mt. San Giuseppe, Cagliari, Sardinia.

Presented by Prof. D. Lovisato, 1889.

47033. Two rami; Lower Pliocene, Orciano, Tuscany.

Purchased, 1875.

P. 5524. Plaster casts of two rami; Pliocene, N. Italy.

Presented by Prof. G. Capellini, 1888.

Extinct species, not represented in the Collection, hare also been described as follows :-

Tetrodon lawleyi, A. Carraroli, Rivista Ital. Paleont. vol. iii. (1897), fasc. 3, p. 26, pl. i. figs. 6, 7.-Pliocene; Piacentin. [Jaws.]

Tetrodon pygmcers, A. de Zigno, Mem. R. Istit. Veneto, vol. xxiii. (1887), p. 27, fig. 8.-Upper Eocene; Monte Bolca. [Very small fish; Zigno Coll., University of Padua.]

Tetrodon scillex, R. Lawley, Nuovi Studi Pesci, etc. Colline Toscane (1876), p. 80, pl. iii. fig. 3 (wrongly identified with Diodon scillce, Ag.).-Pliocene; Tuscany. [Jaws.]

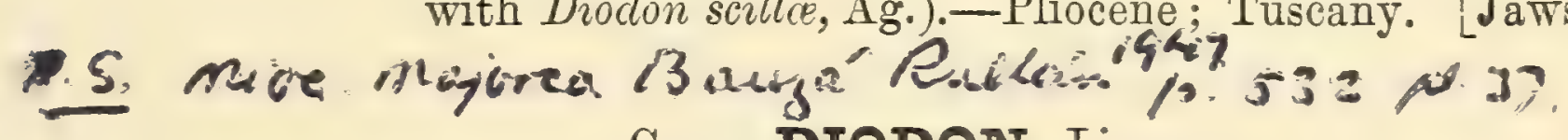
Genus DIODON, Linnæus.

[Syst. Nat. ed. 10, 1758, p. 334.]

Syn. Megahurites, O. G. Costa, Atti Accad. Pontan. vol. v. 1850, p. 370. Enneodon, J. J. Heckel (non Prangner, 1845), Sitzungsb. k. Akad. Wiss., math.-naturw. Cl. vol. xi. 1854, p. 127.

Heptadiodon, H. G. Bronn, Leth. Geogn. ed. 3, vol. iii. 18555, p. 677 . 
Gymnodus, E. Delfortrie, Actes Soc. Linn. Bordeaux, vol. xxviii. 1871, p. 232.

Progymnodon, W. Dames, Sitzungsb. k. preuss. Akad. Wiss., phys.-math. Cl. pt. i. 1883, p. 148.

Each jaw fused at symphysis; each with small dental plates round the margin and a symmetrical pair of more or less oblique piles of plates closely pressed together within. Separate caudal fin. Dermal spines erectile, each with two horizontally-extended roots.

\section{Diodon erinaceus, Agassiz.}

1844. Diodon erinaceus, L. Agassiz, Poiss. Foss. vol. ii. pt. ii. p. 274.

1859. Diodon erinaceus, A. B. Massalongo, Specimen Photogr. Anim. Foss. Agr. Veron. p. 21, pl. xii. fig. 2.

1876. Diodon erinaceus, F. Bassani, Atti Soc. Veneto-Trent. Sci. Nat. vol. iii. p. 189.

Type. Imperfect fish; British Museum.

A small species, attaining a length of about $0 \cdot 1$. Not precisely definable, but dermal spines small and rather sparse, most comparatively short and stout.

Form. \& Loc. Upper Eocene: Monte Bolca, near Verona.

P. 3873. Type specimen, exposed from ventral aspect. The dentition is much obscured, and no fins are seen except part of the caudal. The largest and most slender spines are at the sides of the middle of the trunk.

Enniskillen Coll.

\section{Diodon scillæ, Agassiz.}

[Text-figure 20.]

1844. Diodon scille, I. Agassiz, Poiss. Foss. vol. ii. pt. ii. p. 274.

1850. Megalurites nitidum, O. G. Costa, Atti Accad. Pontan. vol.v. p. 370, pl. x. figs. 1-4.

1873. Diodon scille, G. Guiscardi, Atti R. Accad. Sci. Napoli, vol. v. no. 16 , with plate.

1879. Diodon, A. L. Adams, Quart. Journ. Geol. Soc. vol. xxxv. p. 529.

1889. Diodon scilla, A. Portis, Boll. R. Comit. Geol. Ital. vol. xx. p. $356^{\circ}$

Type. Inner dental plates; British Museum.

A large species known only by the inner dental plates, which are

- of the form represented in the accompanying fig. 20. At least 20 plates in complete pile. Typo species of so-called Megcurites, 
, 

D.sp. po. " mevien p picobarls. K.K. nawi Pros. nol. Ind. Scir Invese II ho z. p.lst s.er.t. 6-?.

1904. Liodon erinaceus, C. R. Sustman, Bull. Irus. Comp.

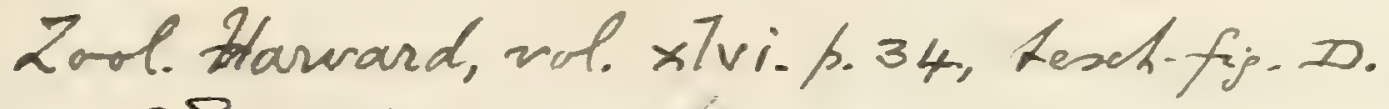
1952. Poodiodor enjecen E. Casian P.10.

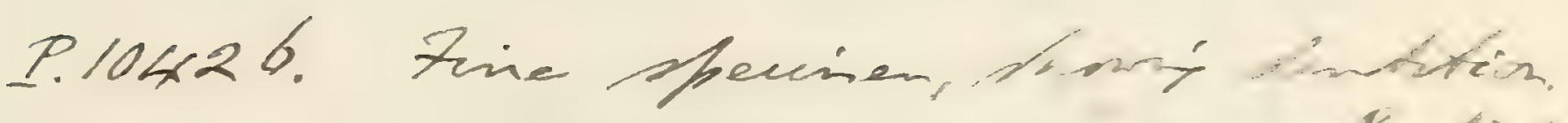
cunctigoz

1915. Diodon seillai, 7. Bassani, Atti A. Acead. Sei Napoli[2] vol. xvi. no. 4, h. 46 .

189\%. Drodon Scivae, D. Pantanelli; Mem. Ace. (Wontrim zof)

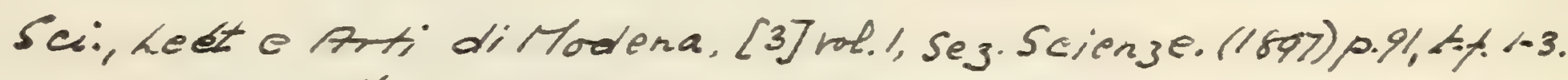
1905. Oriadon scillae, M. Pasquale, Rend. R. Aec Se fis.e muz: Napolip. Y8. (Complete ofnonomy)

Q44)

19dr- D. skillae: R. Tarani a los. Son. Tose. saina! $62 \mathrm{~A}$

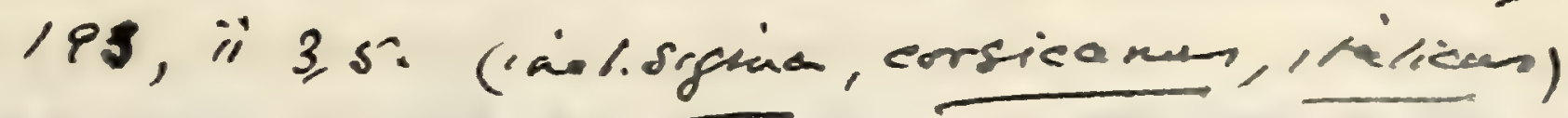


diodon sigma " oniscillae, 10a seit. 1905.7.78.

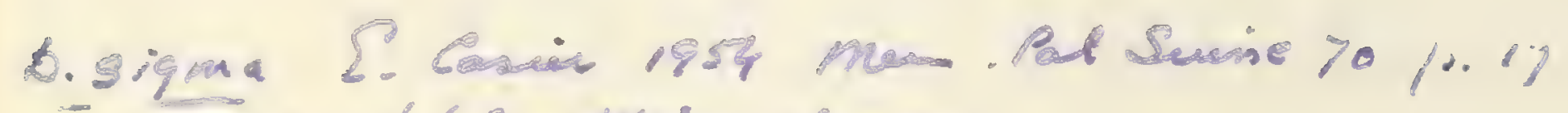

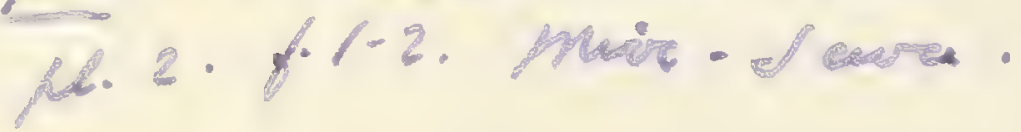

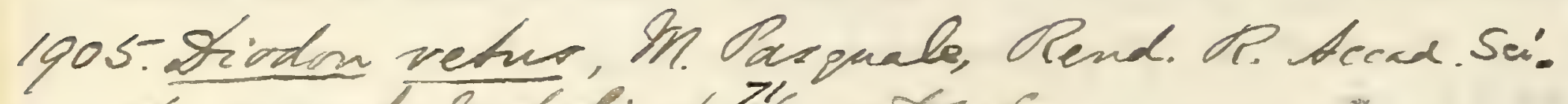
fis. a mat. hafoli, hy, with firs.

1915. Dicdon vetus, Fo Basani, Mtti. P. Arcad. Sci: Nape. [2] rol, xvi.no.4, p. 47, pliv.fip. 8, 9. [Miocene; Lecce, Otrant.]

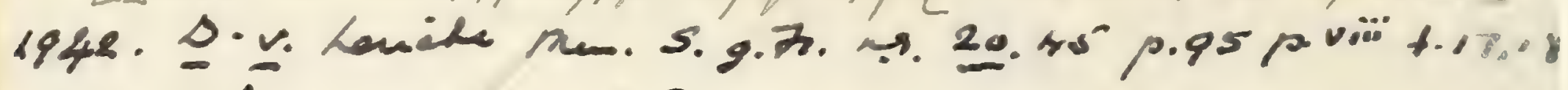
1952. Olejodiodon v. A.Tanani: 191 
based on inner dental plates in Geological Museum, University of Naples.

Form.\& Loc. Miocene: Italy, Sicily, and Malta.

Fig. 20.

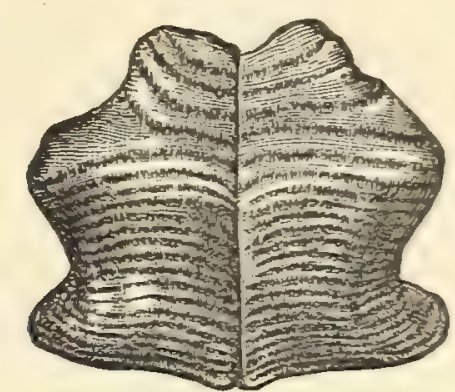

Diodon scille; inner dental plates, inner aspect, nat. size.

P. 3874. The type specimen labelled by Agassiz, being the inner dental plates, shown of the natural size, from the inner aspect, in fig. 20 ; Malta.

Enniskillen Coll.

P. 3874 a. Two more imperfect specimens, one being only half the pile of plates; Malta.

Enniskillen Coll.

36815. Fragments of larger dental plates, doubtfully of this species; Isle of Gozo. Presented by Dr. A. Leith Adcams, 1862.

\section{Diodon sigma, Martin. 2aep. 572}

1883. Diodon sigma, K. Martin, Samml. Geol. Reichsmus. Leiden [1] vol. iii. p. 16, pl. i. fig. 5.

1891. Diodon sigma, Rothpletz \& Simonelli, Zeitschr. deutsch. geol. Ges. vol. xlii. p. 726, pl. xxxri. fig. 1.

Type. Inner dental plates; Leyden Museum.

Inner dental plates much like those of $D$. scillox, but inner face of pile apparently less flattened, more rounded from side to side.

Form. \& Loc. Miocene: Java; Canary Islands.

P. 9476. Well-preserved dental pile and a fragment; Las Palmas, Grand Canary. Presented by Sir Charles Lyell, Bart.

\section{Diodon vetus, Leidy.}

1855. Diodon vetus, J. Leidy, Proc. Acad. Nat. Sci. Philad, rol, vii. p. 397.

1875. Diodon antiquus, E. D. Cope, in W. C. Kerr, Rep. Geol. Surv. N. Carolina, vol. i. Append. p. 31.

1877. Diodon vetus, J. Leidy, Journ. Acad. Nat. Sci. Philad. [2] vol. viii.

p. 255 , pl. xxxiv. fig's. $15-18$.

Type. Imperfect jaw ; National Museum, Washington. 
A small species known only by the jaw. Marginal dental plates in contact, forming continuous series. About 10 superposed plates in complete inner pile.

Form. \& Loc. Tertiary Phosphate Beds: South Carolina. Miocene: North Carolina.

P. 860\%. Portion of inner dental plates; Phosphate Beds, South Carolina.

Slatter Coll.

The following specimens referable to Diodon are not specifically determined :-

36819. Imperfect fish about 0.12 in length, with spines fewer and larger than in $D$. evinaceus; Upper Niocene, Oran, Algeria.

Purchased, 1853.

P. 1910-11. Imperfect inner dental plates; Eocene, Clark Co., Alabama, U.S.A. Egerton Coll.

P. 4792. Base of very large inner pile of dental plates, which are less broad in proportion to length than those of $D$. scillax; Miocene, Malta.

Presented by Sir Richard Owen, K.C.B., 1884.

The following extinct species have also been described on imperfect evidence, but are not represented in the Collection :-

Điodon accunthodes, H. E. Sauvage, Ann. Sci. Nat. [5] vol. xiv. ligoelioelon gounor (1870), art. no. 7, p. 4, and Ann. Sci. Géol. vol.iv. (1873), Art. no. 1, p. 91, figs. 70-72.-Upper Miocene; Licata, sce. Tose. Sus.nos. "Sicily. [Imperfect fish, including jaws.] : 181.190 , 0.a. ${ }^{\circ}$ (1889), p. 379. Phyllodus corsicanus, A. Locard, Faune 190, ii. 70 and Terr. Tert. Мoy. Corse (1877), p. 11, pl. i. figs. 1, 2.$57^{2}$ Miocene; Corsica. [Dental plates.] D. Scillar, R. Pas cuele Diodon foteyi, R. Lydekker, Rec. Geol. Surv. India, vol. xiii. (1880), p. 60, and Palæont. Ind. ser. x. vol. iii. (1886), p. 257, pl. xxxv. fig. 10.-Eocene; Isle of Ramri, Arakan, India. [Dental plates].

Diodon gigantodus, A. Portis, loc. cit. 1889, p. 358, pl. x. figs. 1, 2. - Upper Eocene; Castel Madama, near Tivoli. [Dental plates: University of Rome. Progymmorom 9:, G.ramani 1955 Diodon heptadiodon, A. Portis, loc. cit. 1889, p. 364. Enneodon echinus, J. J. Heckel, Sitzungsb. k. Akad. Wiss., math.naturw. Cl. vol. xi. (1854), p. 127, and Denkschr. k. Akad. Wiss., math.-naturm. Cl. rol. xix. (1861), p. 76, 




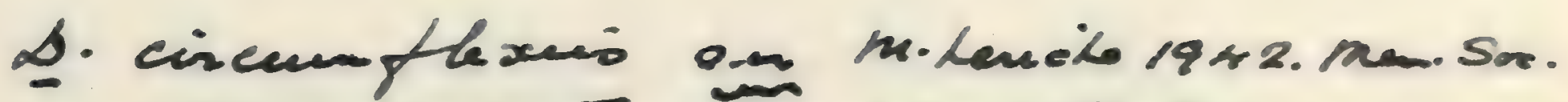

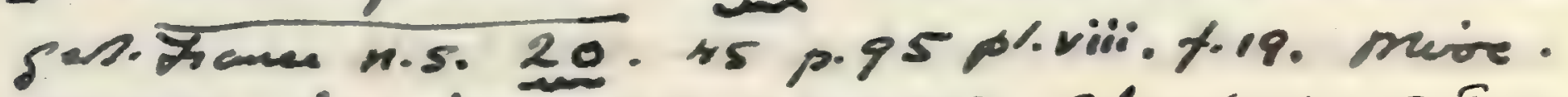

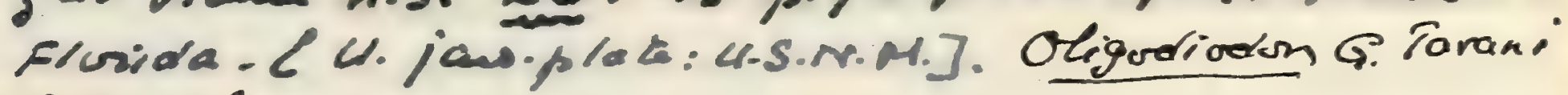
$1955: 183$

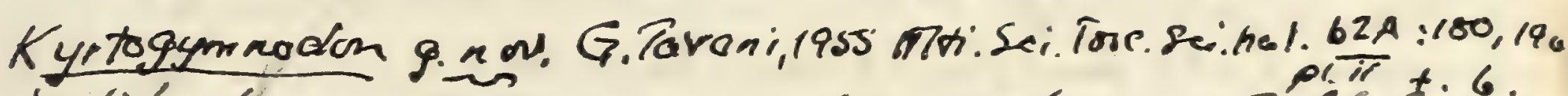

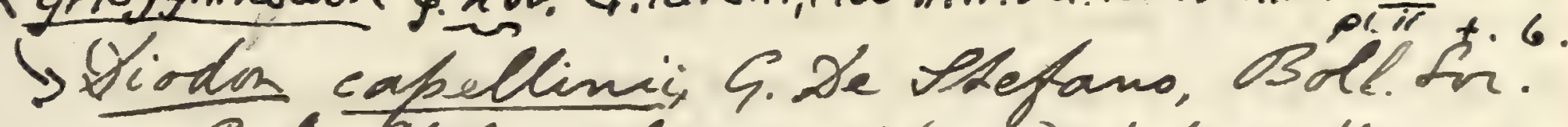
Ged. Ital. vol. $x \times$ viii (1910), p.642, hl. $x \times$. fip. 2, 11.- Plivene; Tirice, Zuscany. [Ged. Inus. Univ. Bolerpra]

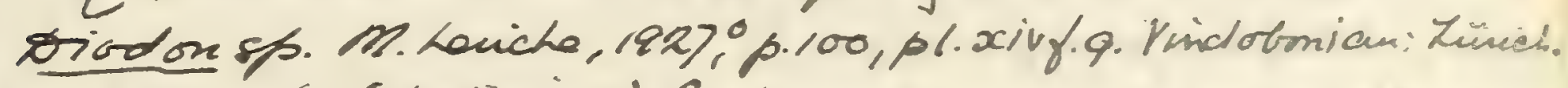

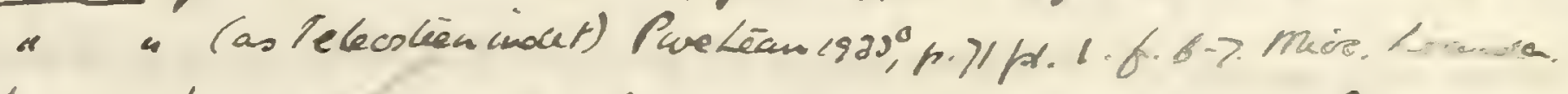
Chilomycterus acantaboles, c. Aramburg, 192yi p. 221, sl. xilf. 3. Sohecien; Oran.

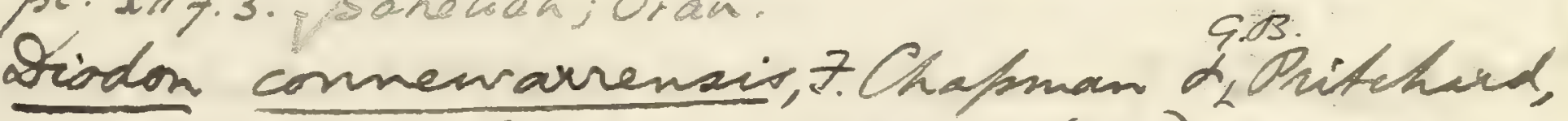

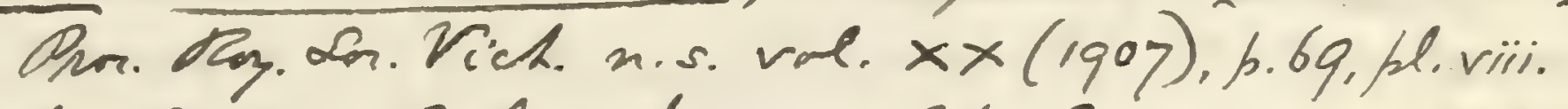
fips-8-10. - Balcombian; Late Connewarre, near Geelong, Vistria. [Demual shimes; Mriter Coll]

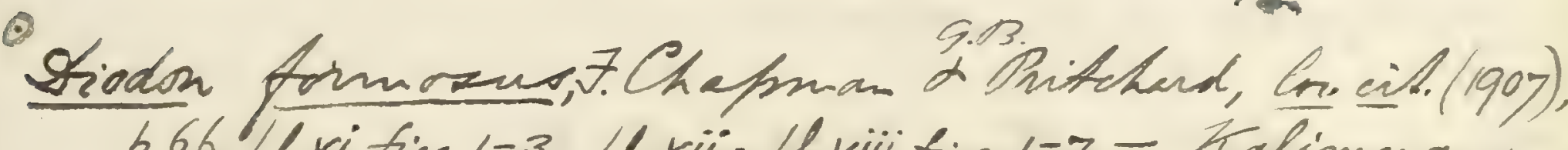

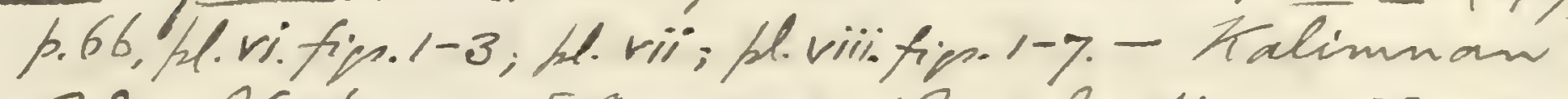
Bes; Victoria. [Gaws; Natshus. Mnellowrne.]

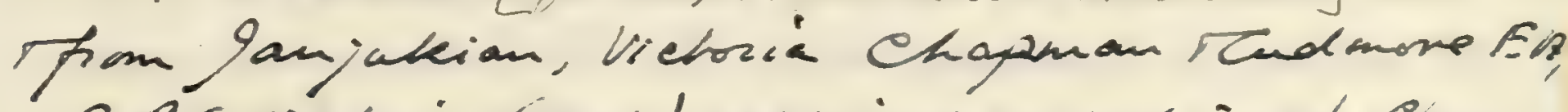
P.R.S. Victerion (1924) $\times x \times$ Vin.S. p. $146 . i \mathrm{rg}$. Chapmy "Austivlasion Torsils, p.220. pls. 13/f.

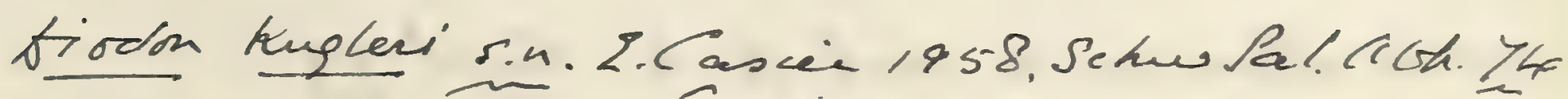

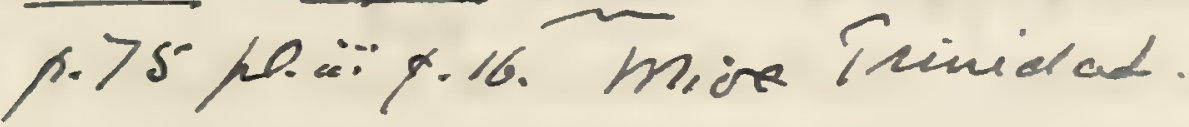





$$
-5=x
$$


pl. viii. fig. 13. Heptadiodon echinus, H. G. Bronn, Leth. Geogn. ed. 3, vol. iii. (1855), p. 677.--Upper Eocene; Monte Postale, N. Italy. ['Type species of so-called Enneodon or Heptadiodon, showing no clear differences from Diodon. Imperfect fish; Zigno Coll., Cniversity of Padua.]

Diodon heterodon, A. Portis, loc. cit. 1889, p. 363. Gymnodus x diodon, E. Delfortrie, Actes Soc. Linn. Bordeaux, vol. xxviii. (1871), p. 233, pl. xii. fig. 54. Gymnodus heterodon, E. Delfortrie, ibid. p. 234, pl. xii. fig. 57.Upper Miocene; Gironde, France. [Type species of socalled Gymnodus. Jaw.]

Diodon hilgendorfi, A. Portis, Toc. cit. 1889, p. 364. Progymnodon hilgendorfi, W. Dames, Sitzungsb. k. preuss. Akad. Wiss., phys.-math. Cl. pt. i. 1883, p. 148, pl. iii. fig. 13.Lower Tertiary; Birket-el-Qurūn, Egypt. [Type species of so-called Progymnodon, with anterior dental plates in close contact with inner plates. Dental plates; Royal Museum of Natural History, Berlin.]

Diodon incertus, F. Bassani, Atti R. Accad. Sci. Napoli [2] vol. ix. (1899), no. 13, p. 34, pl. iii. figs. 66-68. Phyllodus incertus, G. Michelotti, Rev. et Mag. Zool. vol, xiii. (1861), p. 355. Diodon rovasendce, A. Portis, loc. cit. 1889, p. 371, pl. x. figs, 9-13.-Upper Eocene; Piedmont. [Dental plates.]

Diodon italicus, G. de Alessandri, Mem. R. Accad. Sci. Torino [2] 2er p.4-72 .vol. xlv. (1896), p. 286, pl. i. fig. 23, and Mem. Soc. Ital. Sci. Nat. n. s. vol. vi. (1897), no. 1, p. 27, pl. i. fig. 5.-

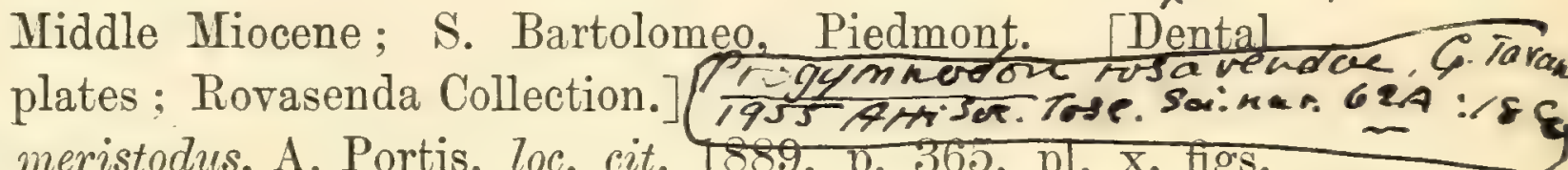

Diodon meristodus, A. Portis, loc. cit. 1889 , p. 365, p1. Х. tigs. 3, 4.--Lpper Eocene ; Gassino, Piedmont. [Dental plates.] Olesio Diodon monsegurensis, A. Portis, loc. cit. 1889, p. 363. GymnoG-Torani TST $^{2}$ dus monsegurensis, E. Delfortrie, Actes Soc. Linn. Bordeaux, vol. xxviii. (1871), p. 236, pl. xii. fig. 64.Lower Miocene; Gironde, France. [Imperfect jaw.] olgjoDiodon platyodus, A. Portis, loc. cit. 1889, p.367, pl. x. figs. 5-8,

Q. Tavans - Middle Oligocene; North Italy. [Dental plates; Cour Aiti Joe $\dot{0}$ University of Rome.] $192^{07}$ :it 4. Diodon stenodus, A. Portis, loc. cit. 1889, p. 376, pl. x. figs. 14, 15.

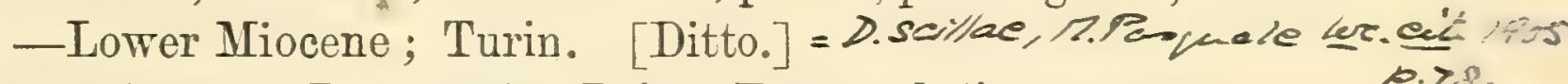
- Diodon tenuispinus, I. Agassiz, Poiss. Foss. vol. ii. (1833-44), pt. i. p. 17, pt. ii. p. 273, pl. Ixxiv. figs. 2, 3. Tetrodon 
hispidus, G. S. Volta, Ittiolit. Veronese, 1796, p. xxxv. pl. viii. fig. 3 (errore). Tetrodon honckenii, G. S. Volta, ibid. p. xxxiii. pl. viii. fig. 2 (errore).-Upper Eocene; Monte Bolca. [Imperfect small fish, probably not showing pelvic fins; Paris Museum of Natural History.]

\section{Genus ORTHAGORISCUS, Bloch \& Schneider.}

[Syst. Ichthyol. 1801, p. 510 (Orthragoriscus).]

Trunk much laterally compressed, truncate behind. Each jaw fused at symphysis, without dental plates. Dorsal and anal fins acuminate in front, meeting round the atrophied tail. No dermal armour.

The species of this genus attain a very large size, and are almost unknown among fossils.

The undescribed Orthagoriscus chelonopsis (P. J.Van Beneden, Bull. Acad. Roy. Belg. [3] vol. vi. 1883, p. 133), from the Pliocene Crag of Antwerp, is represented by large typical jaws in the Brussels Museum. The so-called jaw of Orthagoriscus recorded from the Sussex Chalk by F. Dixon (Geol. Sussex, 1850, p. xiii. pl. xxxii. figs. 3, 4) seems to be a Chelonian dentary bone (A. S. Woodward, Proc. Geol. Assoc. vol. x. 1888, p. 276).

The following specimen probably belongs to this genus:-

P. 9088. Portion of typical jaw; Patagonian Formation, Chubut, Argentine Republic.

Purchased, 1899.

\section{Division E. SCORP EINIFORMES.}

Pectoral fins with much extended base on flank; pelvic fins thoracic, never with more than five articulated rays in addition to the spine. One bone of the circumorbital ring modified into a bony stay between it and the armoured preoperculum.

Synopsis of Families represented by Eutinct Genera or Species.

I. Post-temporal bone free, and supraclavicle normal.

Abdominal vertebræ with transverse processes bearing ribs ; 3 anal fin-spines; scaly or

naked $\ldots \ldots \ldots \ldots \ldots \ldots \ldots \ldots \ldots \ldots$
Vertebral transverse processes not bearing the

ribs; no anal fin-spines; scaly or naked. СоттіD жz (p. 580).

SCORPANIDA (p. 577)。 

Diodon Mf., Gi de Alessandri, Atti Soe Ital. Sci. Nat.vol.x.

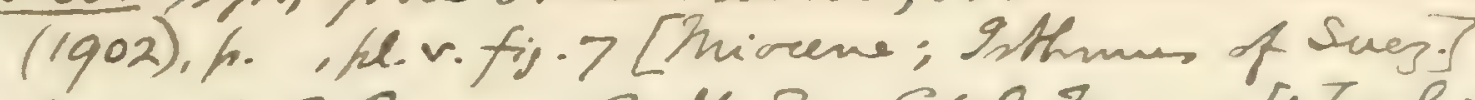

Diodon sh. 7. Priem, Bull. Soz. Geol. Irance [4u] vol. xiv (1914), h.125: hliii.fij.17.- L. Surdigalian; Gironde.

Iriodow antiguns, In. Leriche, Mém. Mur. Znz.

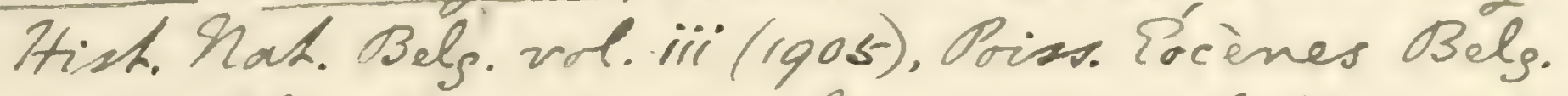
10.170, pl xii.figr.16-31, \& Iném. Sor. Géd. Nord, vol.v (1906), to.266, pl.xv. fin. 16-31. - Bruxallian L Zae-

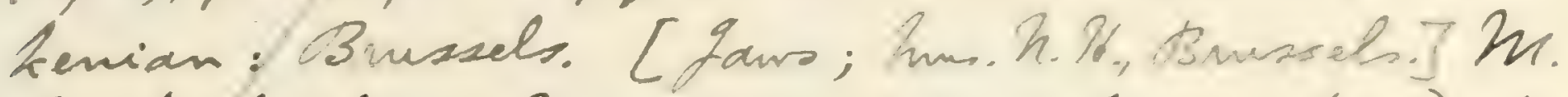
Lericha, Anm. Mniv. Lyon, n.s. I. Sciences, tase, 22 (1908), fo 3, pl-ilfig. 2. [Z.Lutetian; Ande.] Casier 1946 p.175 p.vi\%?]

Orthaporisen st., Mn. Leriche, Comptes Dendur Asso. Franc. Aw. Sie. 1906 (1907), p.351. Dortions

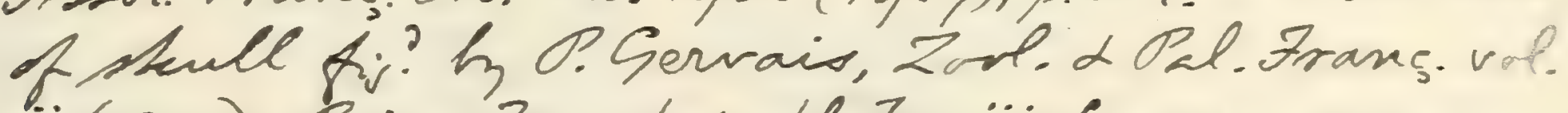

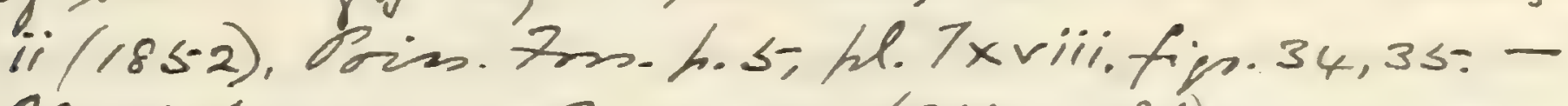
Vindotonian; Pruszar ( Hérault).

O. hileakis (Benedr) M.Lencho 1926, p.453.tforty

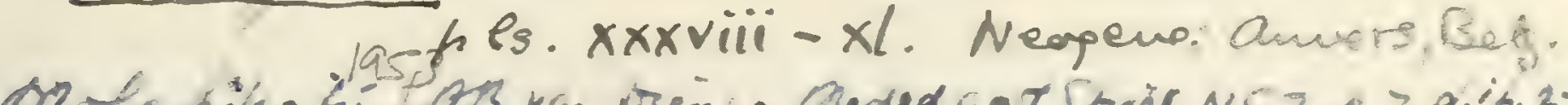

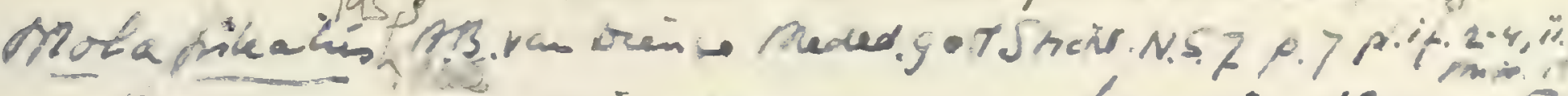
7 rioefor cabindensis s.4 hamak 1920 ilew.

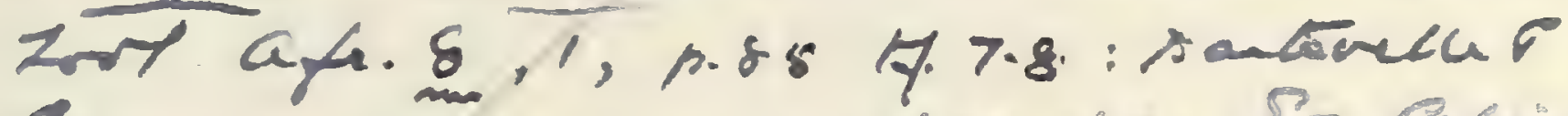

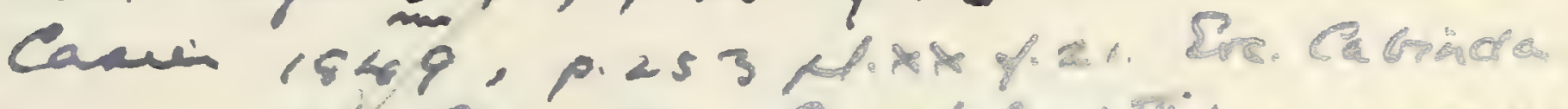

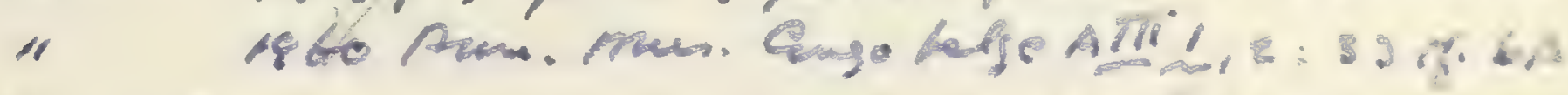
? . OC.

E. Gutberlet, Gstedogy of the Ronicati, Illinois Bidopical humgrafho, rol. ii, no. 2 (Whana, 1915). 


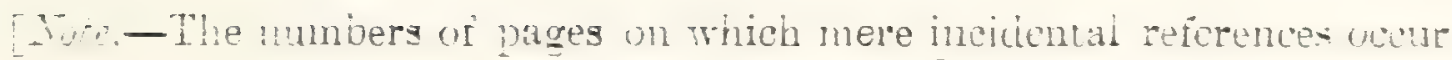
are printed in icalies.

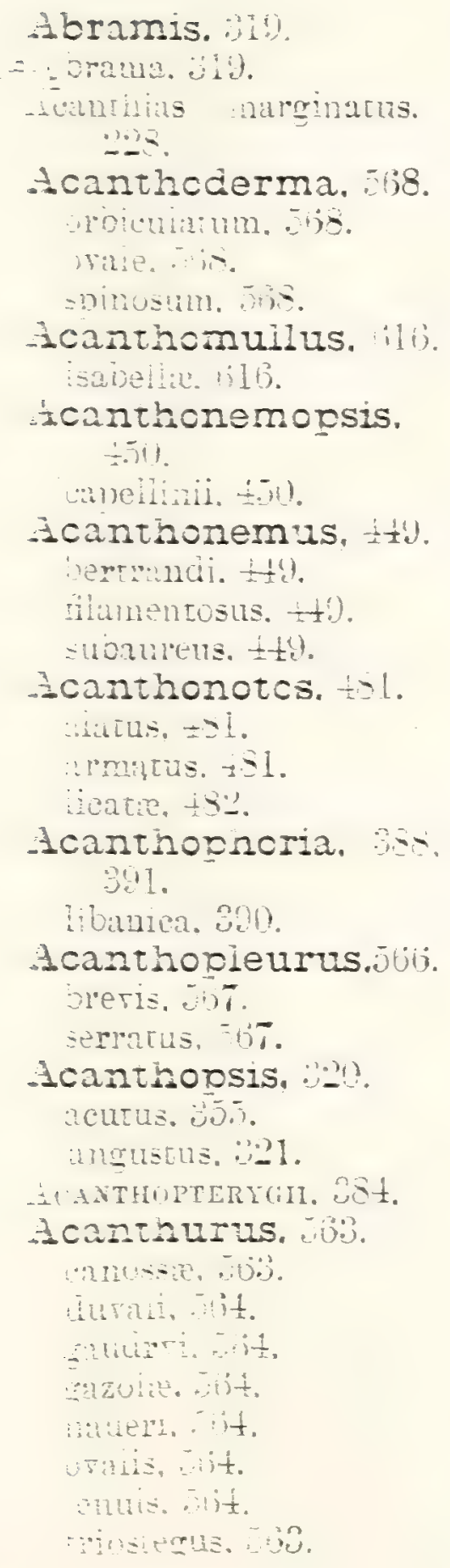

Acanus, i(4).

requispina, 501 . arenatus. 01. moaticus. 563. remelis, 502 . ingispina $\overline{000}$ minor. 500. wiongus. jul. ovalis. 500. neriersianus. .iill. - villosis, j001. sturi. -160.

Acara, $5 \overline{5}$

Acerina, i. . . vulunis. 20 . Acestrus, $\left.\frac{1}{1}\right) 1$. (1)"matus, t!)t.

Alinenser retalcus. 201. Acrodontosaurus. :i. Struneri. +0 . Acrogaster, :se. orevicosiatus, : 59. (iaviesi, .) iecheii. 200 . minutus. $3-3 !$ Ditrus. $0=$ ?

Acrognathus, $-1 \%$. Doops. $24 \%$. $\%$ : banicus. 214.

Acrogrammatolepis. is. semiai, 59.

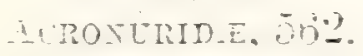
Acropoma, $\$ 1$. ilia. $=1$. +gonus. $5 \leqslant 5$ mimils. Ts. Aipichthys. minur, 2.
Aipichthys icunt.

nucinalis. pretiosus. 揭 velitel, $=07$

Alausa latissina. 100.

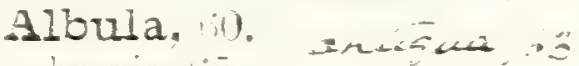
bremis, (6i). de rignil, ies. oposing ata. 13.5 . oweni. bi?

AIBEIIİE. - 0.

Albirnus. :i?. miocienicus. :j19. $\quad 00=0$ steindacimeni. $31 ! !$

Alepisaurus, 189, , o $>$ ALEROEDHAIDE. L.J. Alcsa. $\frac{1}{2}$ \%

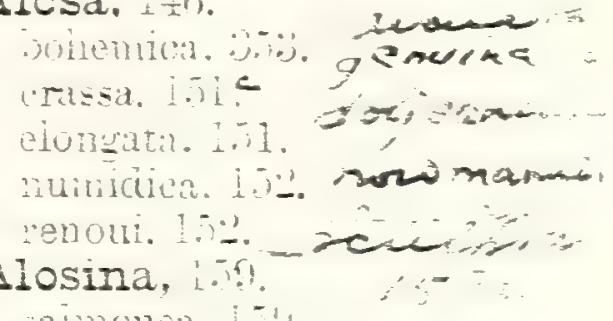
saimonea. He!

Ambivpnaryngodon. ilt.

imbirnterus ifersi. $2 \%$

Amia indiua, - 14.

Amir lemesiensis. 21 .

Amiurus,

ancellatus,

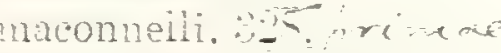
Ammoaytes. it. tudianus oil. IHONYTID. B广t. Amoberistus. . . olinulens,

Amphiplaga. 16. bracurpten. $\$ 16$. 




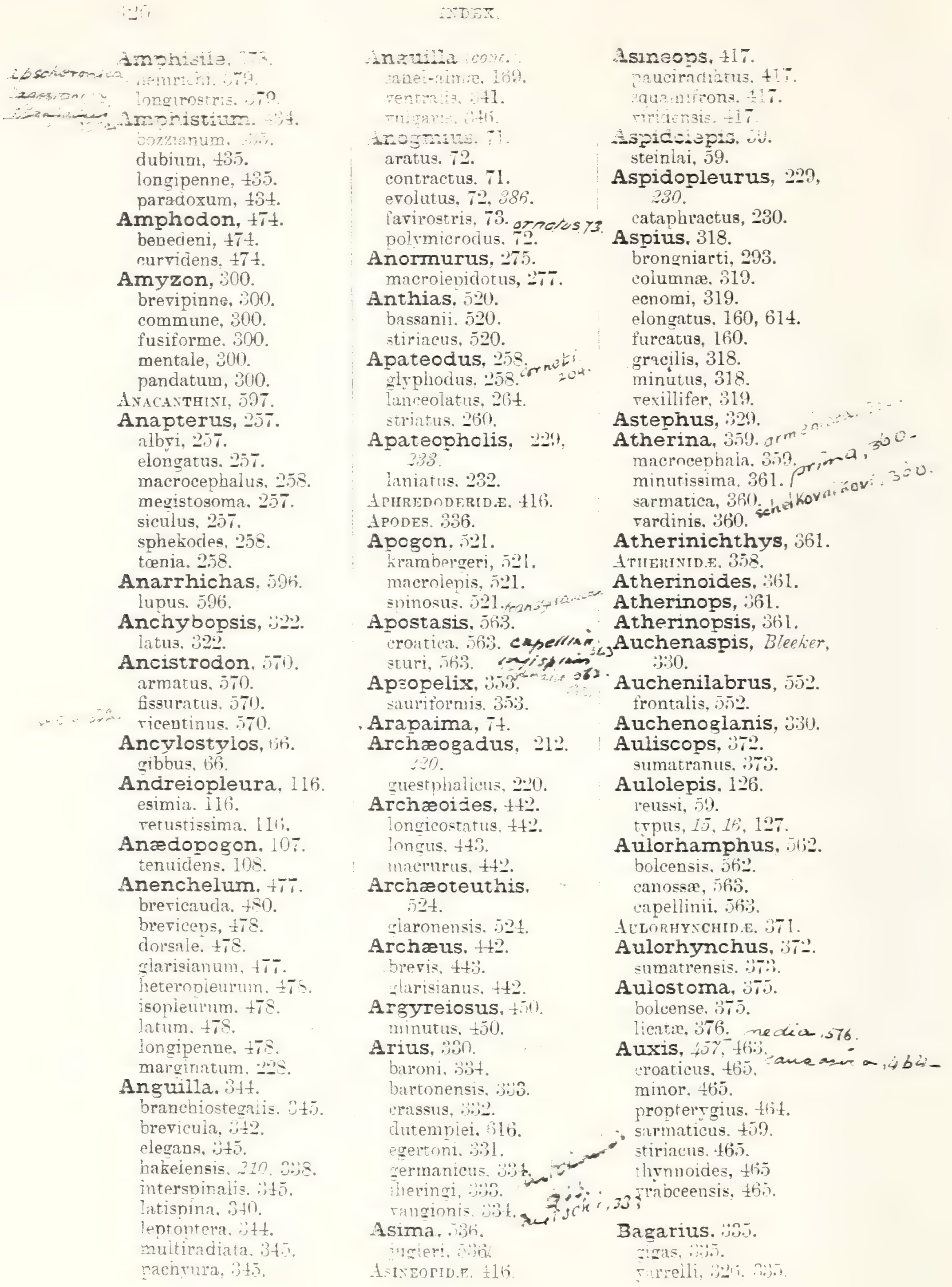






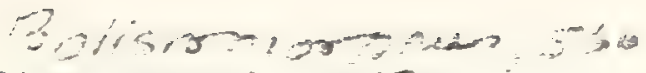

Sairanopios, 71.

$2 \pi--2 \cos d e s, 57$

$29,412 \div 37$

sex

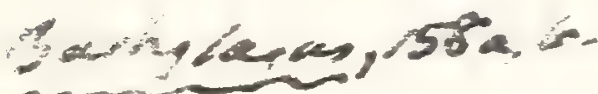

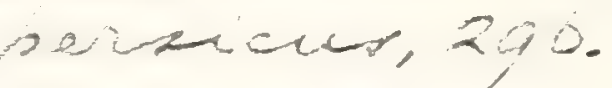

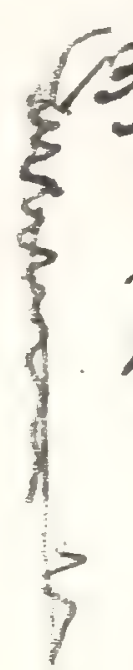

ecchmanat 324 Bresnacens a $72 y ; 57^{\circ}$

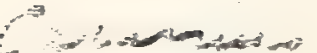

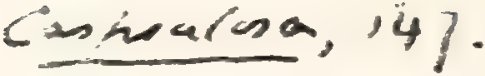

Cassanora 244.
Sawidid, 73

mecima, 73.

19 ocitius, 6id

Soltion, 358 .

peponides, 358 .

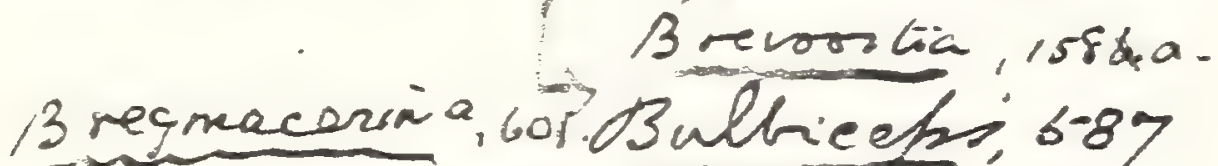
is res macenotickap 587 , 1 bor ate

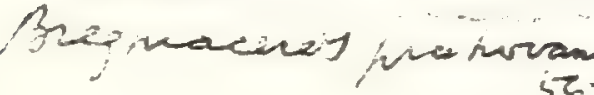

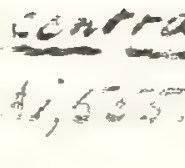

$$
\begin{aligned}
& 432=2
\end{aligned}
$$

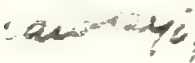

$$
\begin{aligned}
& \text { Yoro, 233. } \\
& \text { yon ensis, .... } \\
& 5-30-3=5
\end{aligned}
$$

S. $2 x, 608$

rinasim, 608. s37.

raminus, 587 Burtinia, 524 Graxelliensis, 524 3 zonwenis, $58^{\circ}$ \& trama, 28.

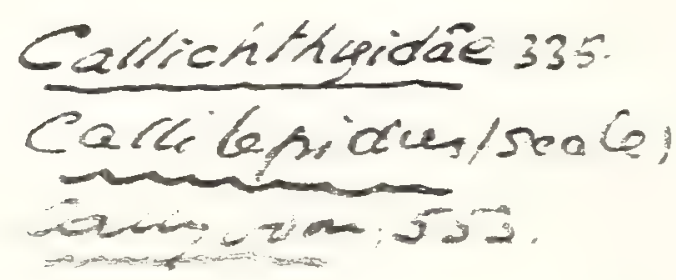

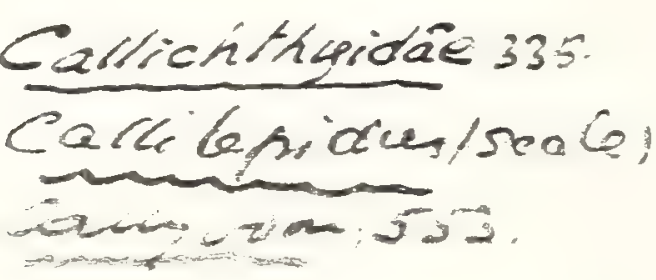

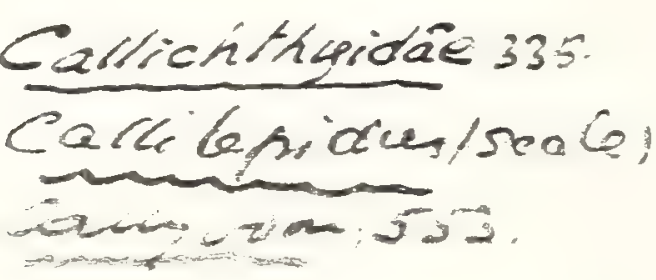
敉等:
Brannerion ser.rolil scilla. Brembitin 614 .

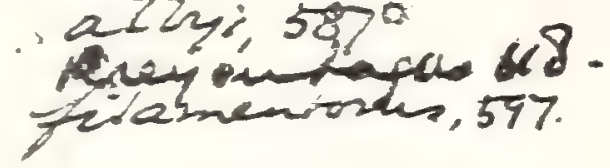

$$
\begin{aligned}
& \text { Castrowe, tas. } \\
& \text { Cusos 418,559. } \\
& \text { Ingirnizis. } 559^{\circ} \\
& \text { raclobianus, Est } \\
& \text { cantanesid, sin } \\
& -3+-3,-0 .
\end{aligned}
$$

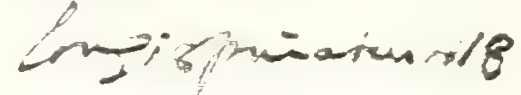$$
\text { Caprorespozus. } 18 \text {. }
$$

Craenolnentes: 554 Tranosenis,

\section{Qiarciatrints bos?}


Dagrus ivul. :30.

3alistes, jos.

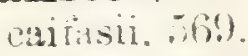
dubius. $56 ! 9$.

BALISTIDE. 510.

Barbus, 301.

fossilis, $30^{\circ} 2$.

- inegacephalus. 302.

steinheinensis, 02 .

pulgaris.

Basilichthys, 361 .

Bathysoma, $\pm \pm \%$.

lutbeni. 14 t.

Bathythrissa, 67 .

Belone, "jit.

.57 acutirostris. 357,350 thara, Des.

tenuis, $: 35 \%$

- Belonostomus laniatus. 232.

Berycu1).e.39t.

BeryciFor.IES. 354.

Berycopsis, to?.

regans, t2i.

lindstromi, 125.

Beryx. 35.5.

ater, :30.

dilimaticus, 886

dicoienidotus, :-sio.

germanus, \pm 21 .

insculptus. $386 \%$

lesinensis, 286.

microcepialus. 124 .

muiticientatus, $\Xi 86$.

Diger, 392.

ornatus. 397.400.

ovulis, 121 .

poitmicrodus, :-2.

padians. 120 1.24. - 3

3. Javizess - sachei. A101.

- ind subovatus, :Bati.

3.5. superbus. 4113.

striacus. \pm 05 .

raienciennesi, 386.

vexillifer. 120.

zinpei, 397.

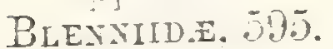

Pleyilforines. 591.

Blennius, 596.

cuneitormis. job.

fossilis. 596 ,

oceilaris $566^{\circ}$

Buocimida. 501 .

Blochius. 598.

iongirosiris. 59 .

macronterus, jog.

3cons, 50.

riyns. 5076

30tarosteus, ill?.

revirons. hil:

atus. bile:
Bothrosteus (ront.).

minol, bll.

Bracinygnathus, ji?. renuicens. 51 ?

Brachyspondylus. 270

cretaceus, 270

indicus, 326 .

salopterix. $: 2.3$.

Brachyrhynchus,

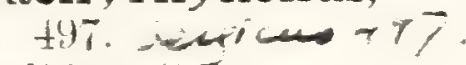
soliclus, \pm 97 .

teretirostris, 197.

ranberieriensis. $497 .=$

Brosmius, b02. elongatus, 602. Truets fuebsianus, $60 \%$. strossmaveri. 602. susedinus. ho?.

Brctula. $1 i 0 ;$

lunuipinnata. 60).

Brychatus, 60. nuelleri. 76.

Bucklandium, 3:10. diluvii. $3: 30.5 \%$

Butyrinus, 60

Caeus, leopoldi. .7.

Calamopleurus. 31. : nqiicus, 51 .

Calamostoma Aqussiz. 383.

brevicuitum. 293.

Calamostcma, stein. da funer, .83. 5ti2.

bolcensis, $56 \mathrm{~g}$.

cinossz. $567 \%$.

Callionymus, jes.

macrocephalus. 588.

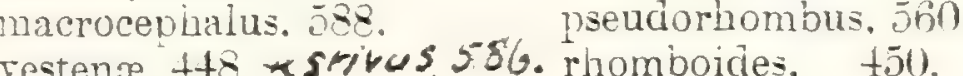

Callipteryx. 589. recticaudus. 589. speciosus, 589 .

Calopornus, 536 . porosus. 536 .

Cantharus, .37. uroianensis. $53 \%$.

Capito. 015

Capitodus, $92:$ ? angustus. 506. Tubius. 537.

indicus, $50 \%$. interruptus. .397. subtruncatus, "3:3. truncatus. 5isi.

CARAXIDE, I25.

Carangodes. 1.01 . ephaius, \pm 011.

Carangopsis. 116 . knails.tis.
Carangopsis ("int.).

brevis. $t+t i j$.

dulsalis, \pm+7 .

lanceolatus, $\frac{1}{2} \pm 8$.

latior, 146.

maximus, 48 .

Caranx. $1+1$. ir

carangopsis, +11 .

gracilis, +11 suedes-intons

longipinnatus, $4+2$..

oraîis. 142. - péproas

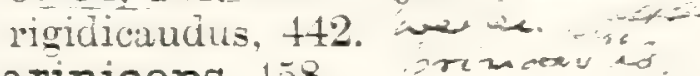

Cariniceps, 458 . complessis, 458 .

Catostomus, 299. Caspritat

cristatus, :00.

shoshonensis,, 00 .

Cestrisciden, :\%

Centriscus. $37 \%$

aculeatus, $: 378$.

Longirostris, 37!?

toni, e.T.

velitalis, $37 \%$.

Chatodon, ibl

arcuatus.

areus, jol.

asper, 560 .

aureus. \pm \pm 9

canescens, 1 j).

canus, $5 \overline{5} 8$.

chirurgus. 509.

hoeferi. 560 .

lineacus. $56 t$.

mesoleucus. 5.59 .

nigricans. $56 \%$

papilio. $4: 38$.

pinnatiformis, $4: 3$.

pinratus, 433.

pseudiorhombus. 5nก

559.

rhombus, 559.560.

saxatilis, 112 .

striatus, 410 .

subarcuatus, 561 .

subaureus, \pm 49 .

substriatus. \pm 15.560

subrespertilio. t3:3.

triosteous. 564.

velicans, 431 .

relirer, $\$ 30$.

respertilio. 438.

Ch.etopontine, 356.

Ch.etodontiformes. 556 .

Chanoides. 63. eprister.

macropolna Oñata, w

brevis. 15.5.

torcipatus. 6.5.

Cioni. 


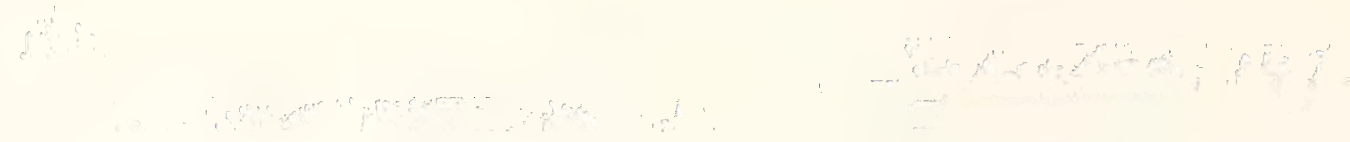

$$
\begin{aligned}
& \text {... }
\end{aligned}
$$

$(10-2+2=$ 
, 
Characiside. oyt.

Charitosomus, :-71. formosus. 27:?. Lakelensis, 274 . lineolatus, $27 t$ major, 272.

Chatcessus, 1.18. breris. 158. humilis, 158. tenuis, 158.

Chelonia radiata. $\$ 91$.

Chimsera furcata, $\$ t$.

Chirocentrites, 00.

carolini, 92. coroninii, 91. gracilis, 91. libanicus, 105. vexillifer. 92.

Chrrocentrid.e. 86 .

Chirocentrus, 33. polyodon, s8.

Chiremystus, 8\%. mawsoni, 90. wors wh

Chirostoma. 3 lil.

Chirothritide. 279.

Chirothrix, 281). guestialicus, 280. lewisi, 283.

libanicus. 200.

Chondrosteus. 11.;.

Chondrostoma. 316.

bubalus, 310 .

plongata, :316.

laticauda, (ils. minutum. :312. stephani, (ili).

Chromida. 5.54.

Chrysichthys. 327

theobaldi. 307.

Chrysophrys, jut.

agassizi, $53 \%$

-ress v. v34arsenaritana. $0 \%$

- Drusinai. $531.7 N . V$

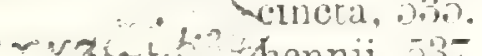

hertlei. 534

lawleri, 534 .

miocenica, 5035 .

seacchii. 53t.

zignoi. 53 t.

Cimolichthys, 201 . 20.7.

anceps, 203

contractus, 2028 .

$\Rightarrow 28$ glaciulus, 204.

lewesiensis, 201 .

isbonensis. 23 .

mervili. 20s

neproolica. 25 .

semiancens, …

sulcitus.
Cladocycius, 107.

gardueri. 103.

lewesiensis, 109.

occidentalis, 110.

streblensis. 110.

sweeti, 111 y or ba

Clarias. 324. filconeri, $32 t$.' 20

Clinus. 597.

gracilis. 597

Clupea, $1 \pm 6$.

aita, Leidu, $1 \pm 5$.

alta, Steindachner, 157.

antiqua. 1:38.

arcuata, $1 \bar{y}$.

aitenuata. 19

beura ii 1 toassane

bosniaskii. $15 t$.

154.

bottæ, 2.00 .

brericeps. $15 t$.

breris. 270

brevissina. 140.

cauciata. 1.54 .

catoprgoptera. 148

cephaius. 158.

chresosoma. 153. crenata, $15 \mathrm{~L}$. curta. 20. wing. -r prinoides, 63.456. dentex. $15 t$

denticitormis. $1 \mathrm{jt}$.

doljeana. 159

dubia. 270

ecuomi. 15.5

elongata, Davis, 5j.

elongata. steinciachner.

$15.5, \pm 60$.

engraulitormis, $15 \%$.

evolins, 133.

fontannesi. 15\%.

gaudrei, $1: 0$.

gervaisi, 150.

gigantea. 10.7 Glyporama

enidussi, 108.

gracilis, 100 .

uracillima. 15.5.

grancisquana, 155.

yrancioni. 15.5.

gregaria. 155

questriaica, 237 .

Laidingeri, 15.5.

heterocerca, 156.

humilis, Leidy, $1+4$.

humiis. Hever. 1, (1)

innata. 15i6.

intermedia. 156.

lanceolata. 150.

arteri, $1+1$.

ata. 1, .73

aticanda. 1es.

at issinna, 1.5\%.
Clupea (cont.)

lawlevi, 1.58 .

leptostea, $1.5 \%$

lesinensis, 138.

lewisii, 17 .

lorce, 156

lundgreni, 156.

maceki, 156 .

macrocerca. 1.56.

macrophthaima, 135.

macropoina, 63.

megaptera. $1 \pm 7$.

megapteryx. 1.56.

melettæformis. 1.56.

meneghinii. 158.

microcepLala, 158.

microsoma. 157.

minina, 345,246 .

minuta, 149.

minutissima, 158.

mondainensis, 157.

mucronata. 157.

muræenoides. 63.

numidica, 151.

ombonii, 157.

ophthaimica. 158.

opisthopteryx, $15 \bar{T}$

polyachanthina. 15\%.

præsardinites, $15 \%$.

pulchra. 54 .

pusilia. 144.

sagorensis. 15 t. $15 \pi$

sardinites, $15 \%$

sardinoides, 19.

saulos. 157 .

sauvagei, 158 .

seheuchzeri. 1 t7

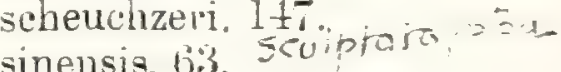

sphaerocenhala, lit.

sprattus, 153.

strriacu. 15i stawrobistans, 14 ?

tenuissima. 151

theta. 140 .

thrissa, 6.3.

thrissoides, 63.

trinacridis. $15 \%$

rectensis, $1 \pm 6$.

rentricosa, 150 .

villosa. 161.

roiromensis. 138.

rukotinorici, 157

senophanis. 15s.

zanclea, 158. ioncri, s?

Cluperdi., 128

Clupeops, 159

insignis, 159.

Cobitis, 220 .

angustus. 21 .

uredai, :20

centrochir. 300

.enhalotes, :2:1. 
9. Bincusuoglodl.

Tasisuleatio wh 

. 
bourdoti: 470 .

Cainodenis. 111.

Cinger, 342.

sucischives, 342 .

- 2 enchleces,

norgani, ito $x$

Encsanne, 612. Cycloteboides, 618.

corborindis 37 ?

-rydoras,

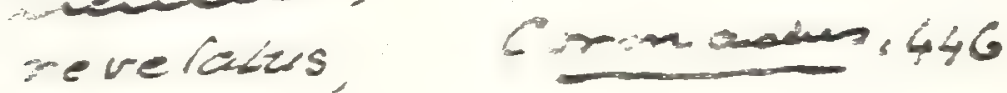

becaplaim 447. proseneselli, wh 2 acios, 446. Denticheis, 71. epothii, 7 .

Deprondus, 346. lestes. 346 .

Derrhias, 336 . enantirs, 336.

orvehtenohsis, 73.

Urevis, 73.

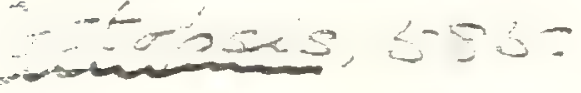

-n. $x$

sernicomis, 585.

a Zaichings. 6r.

anemsis, 585

yinesens, sT.

$$
\text { 돈, } 5=0
$$

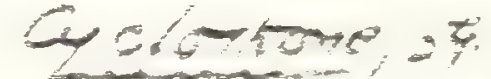

Cunsecox, v.v.535.

Dalsiarzille. 343.

Deparis, 506 .

Criskigerina, sia

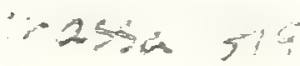

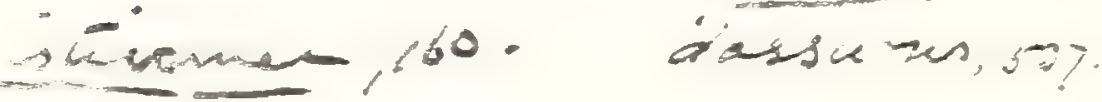

narostenis 29

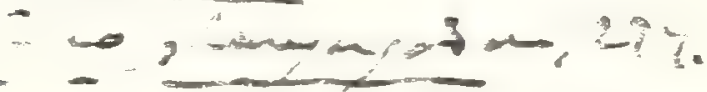

$$
\text { destive, } 133 \text {. }
$$

venclatis 400

erandaiti, 33

a cots 20.5

Genoscmiaklins, 579.Dewnichtys, 323.
Diatomoeca, 609 692. zatima, 609 Diaphus 2356.311. ginetsi, 22 .

Cesprovion bufmaeus, =9: primuln 280. rention. 
Cobitis ani.)

longicens, 27.

ievieri. $\because 1$.

Cobitonsis, :.jt.

acutus., 30.5.

exilis, us,.

Colocerhaius,

saimoneus. $\frac{1}{2} .7$.

Cologaster, 11 it. anails. 110 .

Coloperca. 510

litifions. 51?.

Colopcma, 70 .

culei. tio.

curritlin. 470

laere. +72.

Ccelorhynchus. .59:?.

Unger biprior. :jti.

Conosaurops. lil:.

bowmanni. til..

Conosaurus. i12. bowmanni, 11:

lonx hissuritus. .7).

Coregonus. libl. lataretrs. 161.

Corrins gioberuius, =

Cortidz。 iso.

Cottus.

aries.

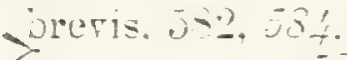

Creptotremus. .5\%.

difaricatus. 555.

burricus, is.5.

hypocerns. $>25$.

muitipinnatus. .84

papyraceus .593.

pontifex. . isi.

quaciricomis. 5.5.7.

uncinat:s. .5.5.

Crenilabrus:" it

szajnocuie. $5 \pm 1$.

wonciwari. $5 \pm 1$

Crominyodus. 5.53

irpeoulatis. jor:

Cristicens.

bitracu(sess. $5.1 \%$.

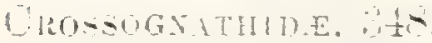

Crosscznathus, savinucianus, :jt:

Çencdentex. .?.

latemiensis, i.t.

Ctenoocma, . :?

jameita. .7!?

Cunothrissa. it.

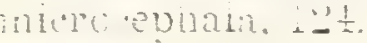

moinns for.

veriblet. int

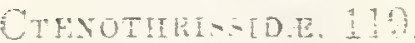

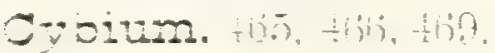
maronense thit.

olpetirlom tili
Cybium (:ont.

bottii. 150. 3 n?

Clumonti. +71$)$

exceisum. 197

linguizcum. +15i?.

inaropoinum, ti2.

maculatum, $\frac{1}{2}$ iti.

pal'seni. 19 .

proosti. \pm 0 . empetiensis. 4 speciosum. $16 \%$.

renue, $\pm \vec{i}$ ).

Cycloiajes, $5 \%$

incisus. $51 !$

Cycloiepis, 5!.

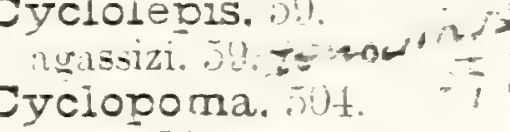

vis:s. . il)t

micracantlum. 501 $\frac{1}{2}$

spinosum. illt.

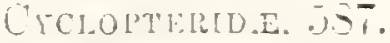

Cycioprerus. joi.

lumpus. $59 \%$. $5 \%$.

Cycloronodon.

Faurins. t.j.

Creiurus crussus. 509

Crobirus minor, jo

Crcilurus netuopterrs, 518.

Cypriside. 2006?

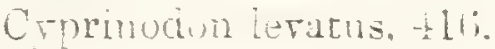

CYPrrmontro.e. 20?.

Cyprinus. : (1).

bipunctatis, o1s.

carpio. inl.

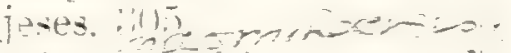

แinutus. 11\%.

papraceus. :

priscus. 01.

syuanosens. 200.

CYTTIDE, $17 \%$

Cyttcijes. $11 \%$ glaronensis, \pm 17 .

Dactylopogon, -th

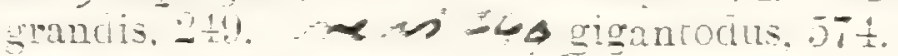

narruins.

Dactyionterus. Asi.

bhocenieus, joti.

Tulitans. $300^{\circ}$

Daredogicssus. 7 .

acutus. $j$.

requibinnis.

pncallstis. Ji.

testis. $7 . \overline{3}$

Daptinus. 111. 21?

broarieacii. $11: 3$

intermentus. 112 .

mhlebommus. $11 \%$.

Denter.

heticens, -2.

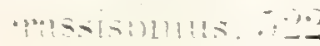

Dentex cont.: Dindons

Ẽujasi, . .

Lekeniensis, 502

levtacinthus.

microcion. 50.

muensterion.

nobilis, jiv. L pivesen

sarciniensis. 520.

rentralis. jo?.

Dercetide. 171.

Dercetis, it?

elongarus, $15 \frac{1}{2}$

imuamnensis. 17:.

inguiter, 17 t.

pellsi. 173.

selutatis, $17 \%$

tenuia, 1Si.

triqueter. $17 \div$.

Derinatoptychus. $2: 1 \%$. : ? nacronintialuus. 2) $\frac{1}{2}$ \%

Desmichthys, tou.

tiubrei. 10.

Diapinyodus. $\quad j+1,5^{-}=-$<smiles>C1[C@H]2C[C@H]12</smiles>

таї. $5+6$.

mivonella, jth. -20,

Diastichus, $\because 2$. .

merorion, :2:-3.

arpinens,

stringuiltus, 20.0

Dictycaus.

rrassidens, tio.

destrueror. $17 t$.

priscus. $47 \%$.

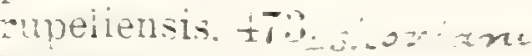

Dinopteryx, 4

sulinosus. 415.

Diodon. 31

reanthodes. 57 t.

antiquus. $510 \%$.

corsicantus, 57 .

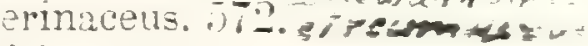

tolevi. jit. ormasus.

ieplaciorion. itt

zeterorion. $7 \%$.

Lilgendiorn. 575.

incertus. 57.5

italicus, 075 .

meristodus. $3 \bar{i}$.

monsegurensis. .75.

platrodus. 37.7 .3 zichellu

iurasenaia. $57, y$

scilice, . $7: 3$.

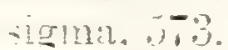

senurius, $3 \%$

enuispinus. jo.

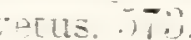

Dipiomvstus. [., 

Diplomystus (cont.).

analis, $1: 34$.

bircii, 142 .

brevissimus, $1 \div 0$.

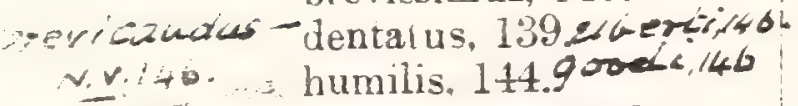

longicostatus, 143

to pectorosus, 140.

cincumiongra thetid, 110 .

\%. rectensis, 146 .

Diplotomodon, 612.

horrificus, 612.

Dipnolepis, 284.

juhni, 284.

Ductor, $4+8$.

leptosomus, 448.

Duies, 5:1.

medius, 505 .

temnopterus, 521.

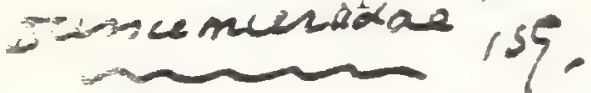

Echeneis, 451 . glaronensis, 451 .

Echenus. 613. politus, 513 .

Echidnocephalus, 163.

tenuicaudus. 163.

troacheli, 163

Egertcnia, 50 .

gaultina. 3.

gosseleti, $551 . ? \mathrm{Nur}$

isodonta. $551.2 \mathrm{NP}$

Electrolepis, 415. horrida, \pm 15 .

ELOPIDE. 7 .

Elopides, 23. couloni. 23.

Elopcpsis, 3. crassus, 10. dontex. 205 fenzli, 9 .

haueri, 219. beckeli. 10. microdon. 9 ziegleri, 10.

Eloos, 22.

Embalorhynchus, 497.

kinnei, 497.

Empo. 221.

contracta. 228.

lisbonensis.

merrilli. 20.8.

nepaholica, 20.7.

sernianceps, ‥2s.

sulcata, 205.

Encheiziphius teretirostris. 497.

Enchelurus. 164. angilicus. itif.
Enchelurus (cont.). sy riacus, 165 .

villosus, 164.

Enchelyopus, 343. tigrinus, $34 \%$.

Exciodontide, 189.

Enchodus, 190.9 92. amicrodus, 203 . anceps, 203.

annectens, 195 .

bleekeri, 466 . inesans

calliodon, 203.

carinatus, 204 .

corneti, 204.

dirus, $204.0+e n 20$ ses.

dolichus, 20t.

faujasi, 196.

ferox, 204 .

gladiolis, 204.

gracilis, 201 .

haloevon, 191.

lamber clemonnieri, 198.

cyy'ses Tongidens, 199.

lycodon, 204.

macropterus, 202.

major, 200.

marcheset tii, 200 .

oxytomus, 204.

parvus, 204.

petrosus, 205.

pressidens, 205.

pulcheilus, 193.

recurrus. 201.

semistriatus. 205.

serratus, 203.

shumardi, 205 .

subæquilateralis, 205 .

tetræcus, 205

valdensis, 205. y e $\mathrm{m}^{30}$

Engraulis, 133. brevipinnis, 133.

evolans, 133, 287.

longipinnis. 133.

tenuis. 230,285 .

Enneodon, 571, 5\%5. echinus. 574.

Enoplophthalmus, 323.

schlumbergeri, 323.

Enoplosus, 521.

pygopterus, 521.

Eocœlopoma, 470 . colei, 470 .

curvatum, 472.

Eocottus, 550. Fircinensis, 581 .

Eomyrus, 340.

dolloi. $\$ 10$.

latispinus, 340 .

ventritis,
Eothynnus, 45̃.

salmoueus. 457.

Ephippites, 617.

peissenbergensis, 617 .

Ephippus, 55\%.

longipennis, 559.

nicolisi, 560 .

oblongus, 560.

oweni, 570.

rhombus, 559 .

Equula, 450 .

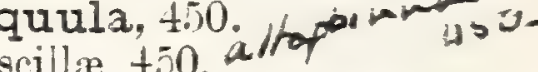

Erismatopterus, 416 . endlichi, $\$ 16$.

levatus, 416.

rickseckeri, 416 .

Esocelops, 46. cavifrons, 46.

ESOCID.E, 287.

Esox, 287

belone, 375 .

destructus, 615 .

falcatus, 482 .

lepidotus, 288 .

lewesiensis, 191.

longirostris, 375 .

lucius, 288,289 , 385 .

macropterus, 89 .

monasteriensis, 159.

otto, 289 .

ottonis, 289.

papyraceus, 289

robustus, 288.

saurus, 361 .

sphyriena, 361, 362. 366.

spret, 862.366.

vulpes, 153.

waltschanus. 289

Eucynodus, 481 .

bunteri, 481.

Eurygnathus, Aqassiz, 46.

cavifirons. 46.

Eurygnathus, Daits, 190.

ferox, 200.

marchesettii. 200.

Eurypholis, 207.

bcissieri, 2Ui\%.

freseri, 210.

longidens, 199.

major, 201.

sulcidens. 207.

Exocetus evolans, 1:3:?.

Erocetus exiliens, 133

Exocœtoides. 236.

minor, 286.

tenuis, 285.

Fierasfer, $60 \%$. 


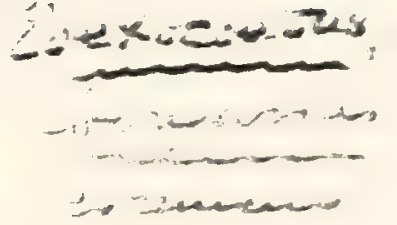

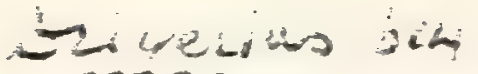

ing coming is

$-3+2 y$.

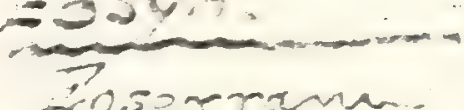

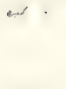

wiskofisciso

$x$ xines

- inosis.52

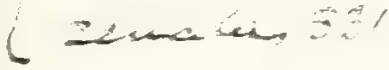

Bus.corbizas, $\rightarrow$ -

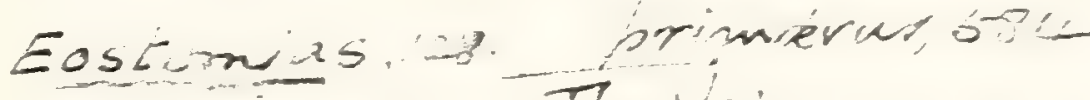

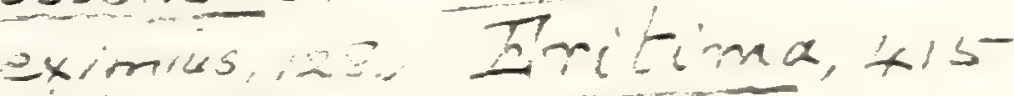
Socramodon, ss? Exse- $25, \quad=$ onstinem

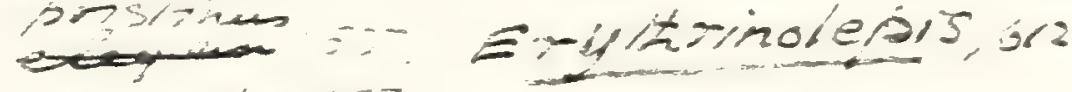

Eoldersibes, 47 .

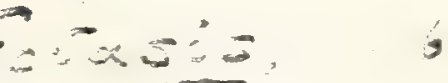

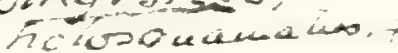

sines is is gentryi, b15.

Eoxisan $5 ?, 5$

$-2-3=3$

572

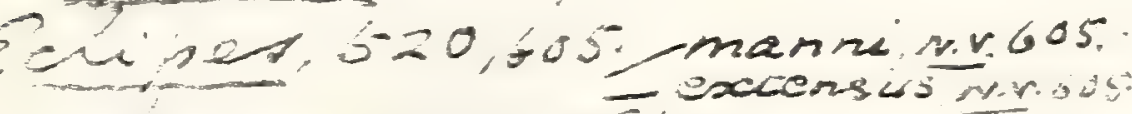

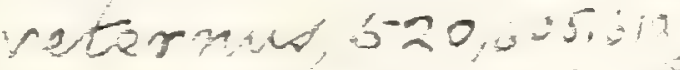

5 immaichther, 143

inpicoptatus, 143

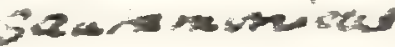

Ex-rasin w 42.

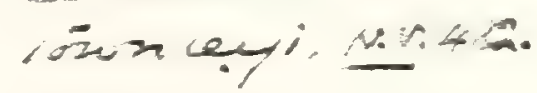

$\therefore$ EDirineno, 159 is tembitidxe, 150

E- - isceris s s -36 .

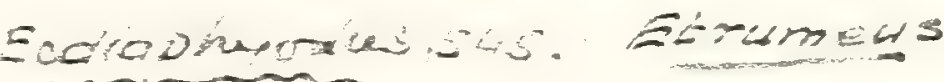

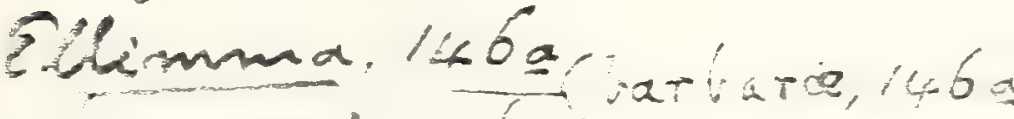

jouneri, 646

equnodente, $146 \alpha$

320.300

rimane, 146

bxpcentétem, $<3$

-iacention $=00010 \mathrm{es} 325$

$-1-7-2=$

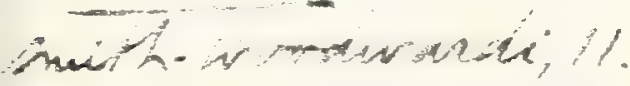

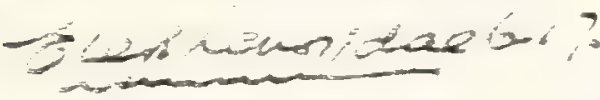

$-0-360=00000-7$

$$
\text { ase, spl }
$$

rickethiter, sol

Thomatis. $\quad \Rightarrow$

$$
\begin{aligned}
& -122^{2} \\
& \text { remileryos. } \\
& \text { Liperes. } 5 \overrightarrow{0} \cdot z \\
& \text { wax } x=x, \quad 5
\end{aligned}
$$

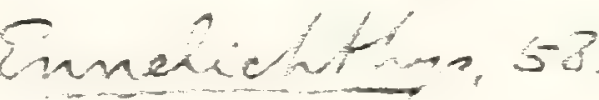

$$
\begin{aligned}
& x=20-i \\
& \text { Ermanane8, 327. } \\
& \text { Solmegan, 208 } \\
& \text { anises 298 }
\end{aligned}
$$

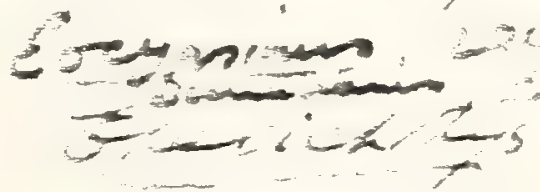

Eolzereria. 334. In praw ines, i3.

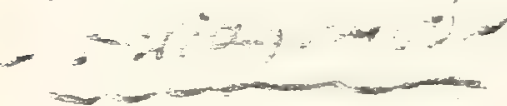$$
\text { pranec }
$$ 


Findenionthy. 58.

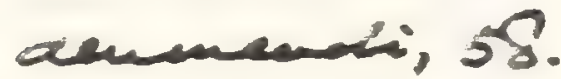

Jorfex $35-8$

hupuratis, 358,6:

Gomidityis, 5

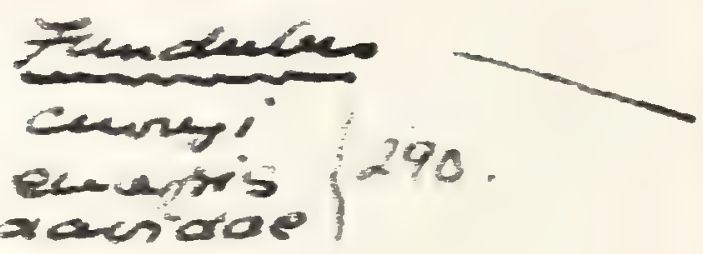

$\Rightarrow$ thy

Hexagrammos, 580

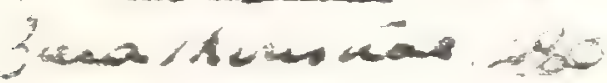

Tianian, 255.

ciestrosteops, 340

minexacanonus 370

Centeroting 503.

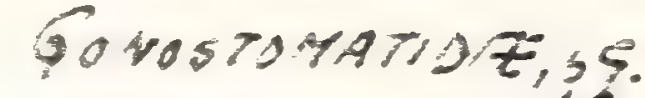

achrestus, 580

Cuackiveris 169.

Gonortignchobs, 279.

Ginoessus, 159.

elepsyrata, ssy. ofy.

Gaxena caniker.437

Armogles, 159

acieras. o.

cameo, is $50 \$ 13$

$\rightarrow$ clepsigara, is

rster opzew, 370

ilicmen. peht

lehot

- phequs

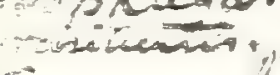

3rimpulus itt

antidthes numidus, 612.

wood wandic; 279.

Gonesíma, 158a 357l.

ecter;

magam, <4a

thippoglusoides, 608

Fymnos and is7. macupstia, 6ot.

3ivnyi; irst.

Halecodon,234. Hifporymgmaltus,381. dentieulakis, 234.

Hakalia is? Hopíchive 290

Hotarentrices, 415 not daricus, in 3-

bic encurint?

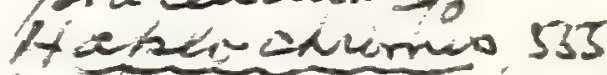

iscion

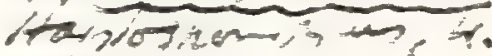

itotoceniences of

$i m, \infty$

$\rightarrow$ phicoma, 559.

- inssides, 559.

Fouria, 58 L

diulica, $4-84$ tina, $158=$

mads, 4, se

\section{Heliolosis. 11 .}

Helmintroretos, st.

fortunnelus, s02.

yermiculatus sob.

zenticulatus, sqa.
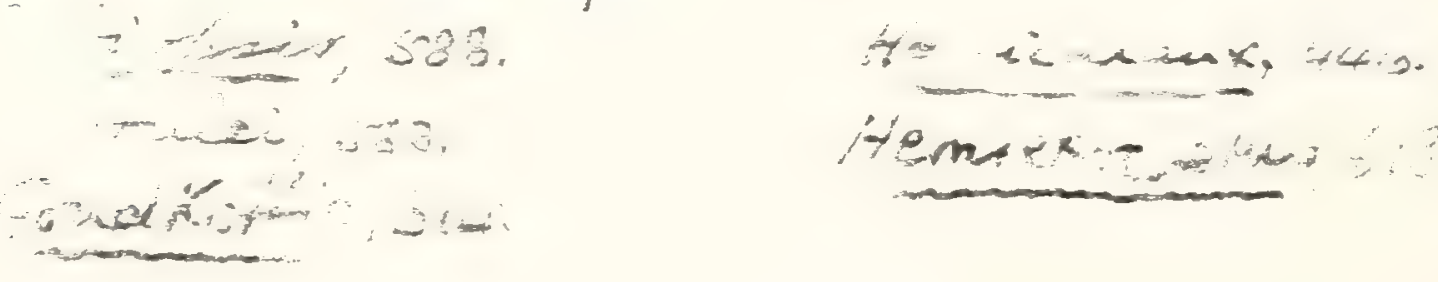
Fierasier (unt i.

inutius. 1305. osterus. 160.

Fistularia, 任.

bolcensis, 95.

oneramendinensis. $: 75$.

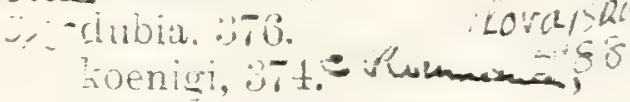

longirostris, : :T.

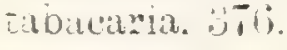

renuirostris. $.7 \%$

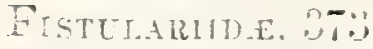

Funcuius, zul

GADID. 597 .

Gacopsis, $131 \%$. brericens, $197 \%$.

Gadus, 599.,vidzienmon

pulelizus gasorus él.

elemans. b00\%.

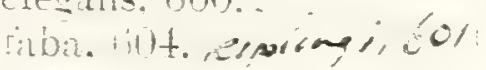

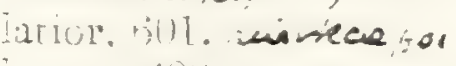

Insens, tion).

meriangus, bil).

meriuccius. 799.

minutus, 1301.

morrhua, tol.

poikreinius. 601.

poirnemus. bul.

nsencixglinus, boi.

simpiex. 604 .

$\therefore$ nectabilis. 164.

stoppanii. 601.

tenins. 150t.

tubercuiosus. 104 .

renustus. 60 t.

virens, i, ()l.

Gasteronemus,

oblongus. \pm 11 .

wombeus. 40.9

Gepisyrura, 26. roncentrica, 296.

Gerres, 20. ilassaiongoi. 528.

Gigantichthys, juarro. $61 \%$.

Gillicus, 99, 11 . arenarus. 111.

yoirmurecius. 101.

Glossodus, mier. heckeli. 7:. Sura 1?

Glyptocephalus, 70

mailatus.

GuBMD.F.

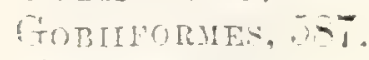

Gobic,

mails. 04.

mator. Bto.

Fininus. $11 \%$.

Gobius. ist.

arnitus. jal.

OHET TY.
Gobius iconto:

bassulni. jos.

brevis, 592.

conicus. jot.

elatur, 5togiconatios.

trancofurcanus. 589.

oralymentosumus, 283.

5 lobini, 583.

macroactus. 538.

mucrupus, 581.

maximus, .588,

wicrocephalus, 588.

muitipinnatus. 54

wblongus. $534.2 \pi^{3}$

peruzzil. 588 diacicentán.

smprnensis, 4 s.

Teronensis, 531.

ricinalis, 588.

riemensis, 584.

Goniognathus,

curephenoides, $5 \%$.

maxilaris. 577.

Goxonhromide, 271.

Gonornynchus, :-71. rrevi. 2.71.

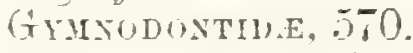

Gymnodus, $5 \%$,

diodon. 575.

heterudou. 575.

inonseyurensis, 575.

Facquetia. ill.

bolcensis. bl:2.

Falec, 2l: a nsamicina

eupterrgins. $21 \%$.

questminaticus, $\therefore 20$.

haveri, 219.

laubei, 2-20.

microlepis. 215.

sternbergi. 212.

Ialecopsis. $13:$

insignir. ligt.

heris. 131.

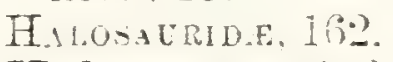

Ealosaurus, li:.

H.MLOM. 1

Hembratimi, 36.

Eemicyclus. 5.

strehlénsis, .9.

Iemieiopcpsis, 58.

gibbus. is.

aracilis. 5.

suessi, 5.

Iemilampronites. 59.

steiniai. 59.

Femiramonus. citwardsi. 50.8.

Femiringahus. fis.

colit. $y$.
Iemiraynchus cut.).

lestritresi, Ise.

zitteii. \pm 07 .

Iemisauriada.

neocouiensis. 270.

Femithyrsites, 131.

ilmatus. tot.

elatus, tol.

licutie, tro. maicoppoes

Hemitzichas, :2:?.

sehisticolin, sur.

Heptajioden, .71. 汾.

echinus, sit.

Ieterobrancinus, 32.5.

naleindicus. 3.2.5.

Eeterolepis. bi:.

Ieterctis, it.

Ilexapsephus. :0:2.?

zuentien.

IIistialosa. is.

biollieri, 29.

Eistiocephalus, $5 \%$ ?

bassimii.

Fistiophorus, 495.

antiquils. $f$ !n.

deshintes, tos.

eactenieus. 495 .

Lumaionamphus, 497.

pirpulus. $19 \pi$.

priseus, \pm 91 .

robustus. 497 .

"ntundus. 195.

IIistiothrissa. 131.

crassapinna, 132 .

macrociactia. 131.

Iistiurus, $1: 39$

elarus, 110.

serivivides, $1 \pm 6$.

rentricostis, $1 \pm 6 \%$

Zclacanthus,

microcenhaius.

piofenorum, 501.

filolcodon, 130, $20 \%$

iesinaensis. 21\%.

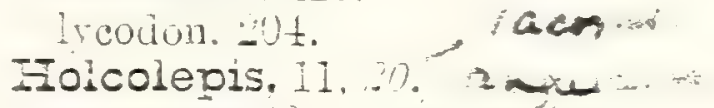

cretaceus. :-9.

Folccentrum, $11 \%$. Men a

calcarifer. Din.

lanceriatum, 1 .

macrocepiainu, 112.

macuiatur ot.

inelitense, $\div 13$.

preteus, $\div 13$.

proman 11 .

Soyo, 112.

Folosteus, :0, 二心

pucinus ato

marios $25 \%$ 


Homonotus, 407. dorsalis, 408.

counaus, 409. pulcher, 392.

Homorhynchus, 488. bruxelliensis, tey.

Hoplopteryx, :96. - antiquus, 396. revis, 406. Tewesiensis. 397. lewisi, 404. witundensis, 404. vblongus, 406 . Eimes, 4 . 9 spinosus, \pm 07 . stachei. 406 . superbus, 403. siriacus. 405. zippei. 397.

Hopiostethus, 414 . ingens. +14 . laciniatus, 414 . lawleri, 41 . nettelbladti. 414 . ostiolatus. 414 . pisanus. 414 .

Hyperlophus, 139

Hypsodon, 37.2. lewesiensis. $3: 40,45$. $9+25.98,109$. minor, 102 . oblongus, 26 . toliapicus, 24.

Hypsospondylus, 58. bassanii. 28.

Hyptius, 08 . sebastiani. 58.

Ichthyodectes, 99. acanthicus. 107. anaides. 100. arcuatus. 101. 110. cruentus. 107 . ctenodon. 100 elegans. 10:3. goocieanus, 107 . hamatus. 107.

Slibanicus. 105

107 minor, 102. multicientatus. 107.

. occidentalis. 101. perniciosus. $10 \%$. poitmicrodus, 101. prognathus. 107. serridens. 101. tenuiriens. 104.

Ichthyotring 2,265 Ifiy.

tenuirnstris. $26 \%$

Iquana(:) Laueri. jht.

Imogaster. 391. auratus. 394.73 .
Ischyrhiza, 46 .

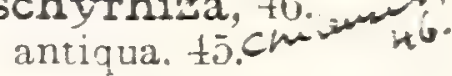
mira. 46. racliata. 46.614 .

Ischyrocephalus, 190.

cataphractus, 202 . gracilis, 201 .

intermedius, 202 .

macropterus, 20.2 .

Isodus, 190. sulcatus. 199.

Istieus, 66.

gracilis, 70 . grandis, 67. lebanonensis. 71 . macrocephalus, $5 \%, 70$. macrocoelius, 67 . mešospondylus. 67. microcephalus, 67. spottii, 71.

Istiophorus, 495 .

Isurichthys, 453 .

- macrurus $\pm 5 \%$ orientalis, 453.

Isurus, Agassiz, 453. macrurus, tj3.

Julis, $5+1$.

ayassizii. 540 . muensteri, $\overline{5} 40$. sigismundi, $\bar{b} t$.

Turtus relifer, $4: 30.431$.

Labeo cuvieri, 616.

Labidesthes, 261 .

Labrax. 509.

bosniensis. อ̄l2. delheidi, 512. elongatus, 512. heckelii. 510 . intermedius, 512. littus, 512 . lepidutus, .512. lungiceps, 513 . major, 510. moisisoricsi, 513. multipinnatus 513. neumarri. 513.

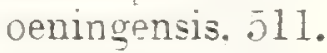
sagorensis, 513. sehizurus. jlo. steindacineri, 513. stiriacus, 513. ubinoi. 510.

LABRID.E, $5: 39$.

Iabrodon, $\mathrm{j} t 1$. africanus. $5 \pm 2$. alsinensis. 515. bazini. 5t:
Labrodon (cont.). belgicus, 543. bourgeoisi, 543. britannus, 543 . canariensis, $5 \pm 2$. carolinensis, 543. chantrei, 543. cocchii, 543. crassus, 544 . dilatatus, $5+4$. edwardsi, $54 t$. gaudroi, 5tt. Laueri. $54 t$. heterodon, $5+4$. multidens, $5 \pm t$. parimentatum, $54 t$. pajyodow 545. quêristedtri, 545 . rhedonum, 545. sacheri, $5+5$. ringretos, 520 sauragei, 5 t5. sellæ, $5+5$. soldanii, 545, superbus. 5f: trapezoidalis. 545. trigonella. 5 ti.

Labrophagus, lill. esocinus, till.

Labrus, .399. a gassizi, $5+0$.

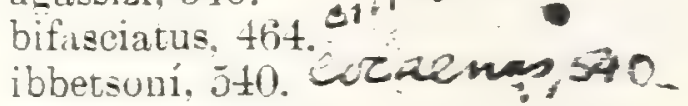
malapterus, 595. merua. $5+0$. microdon. $5+0$. parruius. 540. priscus. $5 \pm 0$. punctatus, 5.58 . rectifrons, 558. turdus. jut. ralenciennesi, $5 \pm 0$. woodwardi, $5+1$.

I.aparus, 596. aiticens. 596. Larimus, 518.

Lates, 30.2

gibbus. 50 ?. gracilis. 502. heberti. 499. macronterus, 503. macrurus. 503. notxus. 502. partscbi, 503. sagorensis, 513 .

Lebias. 200. Erispinasus, 503. aymarai. 292. cephilites, 200 . rassicauciss, 295 . crassus, 206 . eisorabensis, 294. fureatus, 201 . citudivi, 294. 


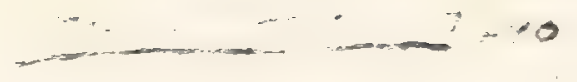

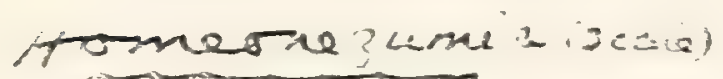

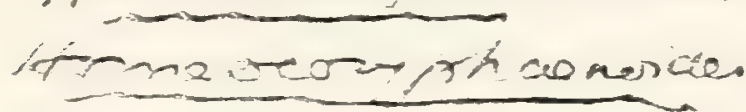

\section{ras?}

i2:

\section{ticmus its.}

\section{ivraxan}

confentiden

depressus, ……

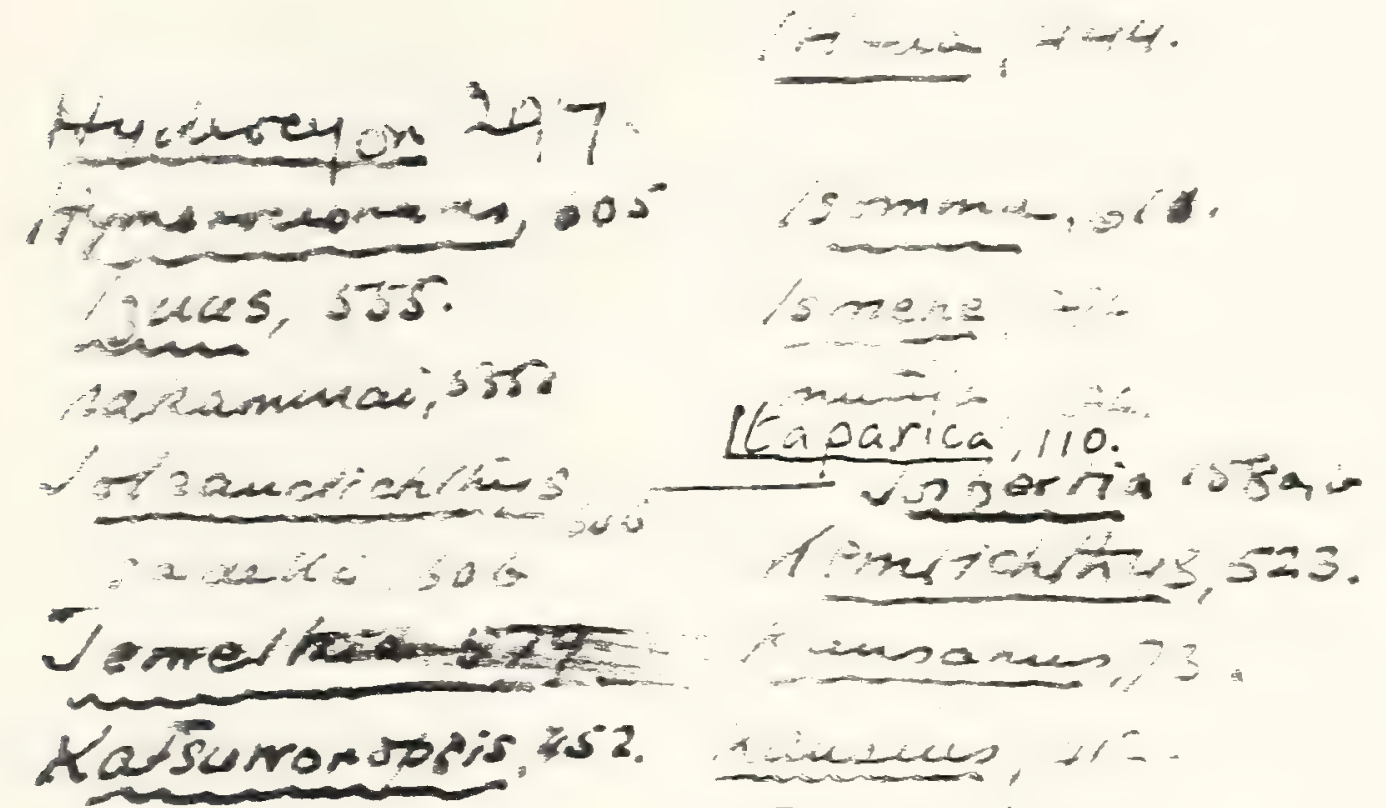

. -

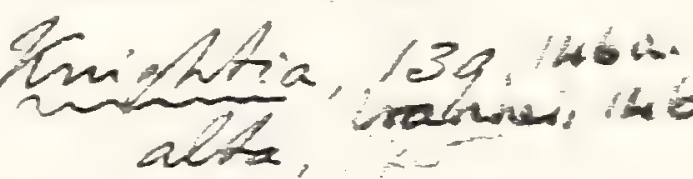

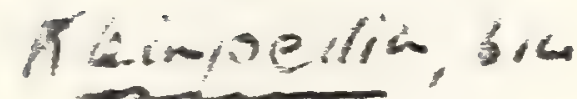

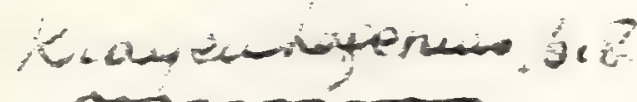

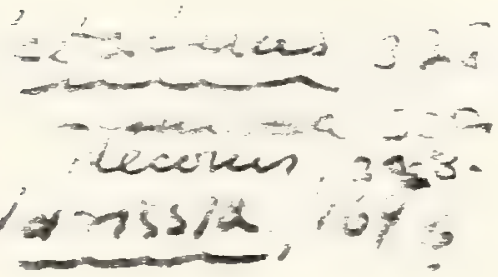

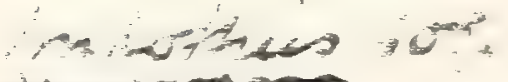

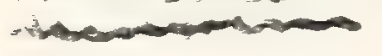

Touron vis 53

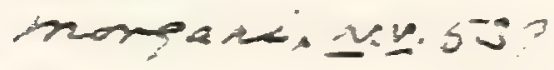

goraens,

Viambiercia, 579.

tancedets, 5y?

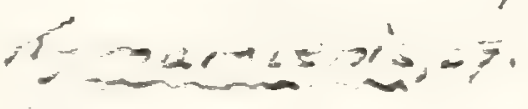

ixmas,

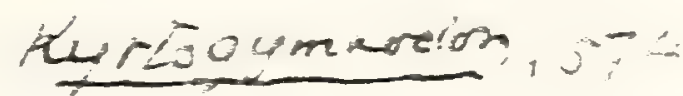

racitanti, :

souceiteres, - :- 


-itorichting 16

serkeria, roc

Lemicus, $15 \mathrm{ba}$.

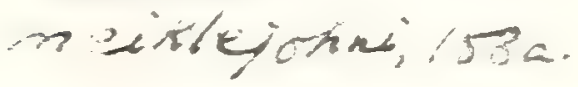

$\therefore \frac{\text { I-4ia }}{2+C a,}=0$

sumpousion, 477

schei, \&79.

oswardi, 3/l.

moravicus,

visaloi, 481 .

pachecoi, 306 .

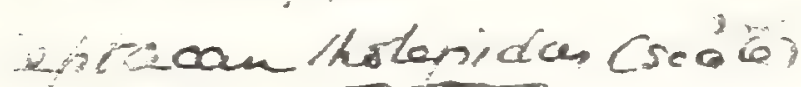

reddingi, 323.

$-0,0500010,2=2.79$

7isazisio,

Sew incer, 29.

orummatien on

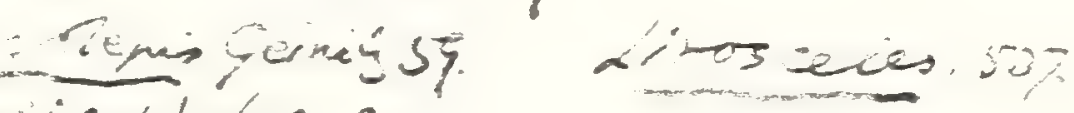

cephares, 3.

viegins, ....

Lompocrizes, 쓰. 538 .

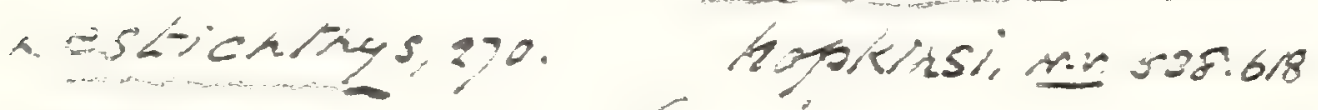

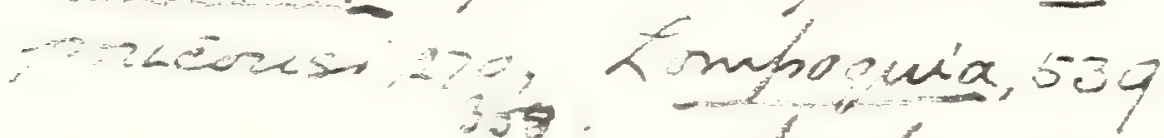

$$
\begin{aligned}
& \text { retorbes, o3 - 613 }
\end{aligned}
$$

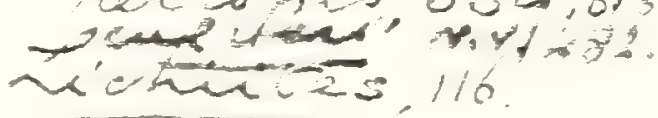

A.tusichlt yoss, 162 . cretacens, 16.

mans. 10 ?

whe werians
$40=2,0$

Lotimoneía, 278 .

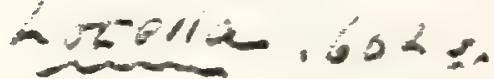

Lusteia, 521 . carothi; 521 .

Lutianidae, 524

Lutiamus 524 hagani, s24

Luvares, №v4 12 .

Tygisma, 158 ?

tenaxe, 1582 , b18

-uxilicie.73

Mosecues.555.

Macionorides"

wasonis,"

Maeropetalolepis, 11. MacreniebJhys.32\}.

Maena 5.3 T

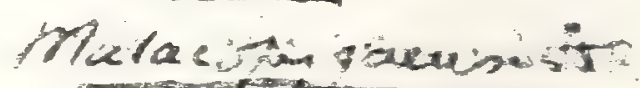

Manchurichion.

nuartion, i.

Mcousia, $=40$

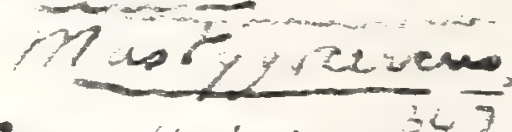

Marallekella sisis?

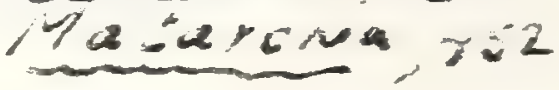

jounia, 4sis

$00+20000000$

Tobrar, asto

miacesmen, 450 
Lejias (fout.?

zobio, 294 .

mereri, $2 ! \frac{1}{2}$

minituus. 294.

perpusious, 201.

ipnuls. 20 t.

ionoi. - z)t.

Eepidenteron, 1.5.

longissimum, (25).

Jepiciocottus, isl.

aries. 520

hretis.

clongatus. 5st.

inacilis. 177.

muitipinnatus, set.

napyracens. 33

Iepidopides. 17

berismonarius, $\pm \$ 1$.

Rubius. \pm 1 .

intosponritins, 151 .

Iepicopus, ti.

nioyi. IS11. N. W.

inguis. 180 .

brericaucia. 180 .

$\therefore$ camathiens, 400.

Lubius. :s.

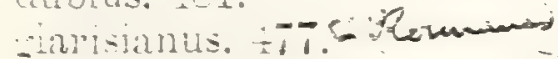

ieprospondrius, $t 31$.

menequinil, $t: 1$.

Leptecosion, $2 \% \%$. rectis. 23:?.

Jeptichthys, 616.

aris. 416.

Leṕrcephalus, utl.

pracilis utr.

mecilus.

ania utr.

LEPTOLEPIDE. 1.

Jeotosomus, : - t.

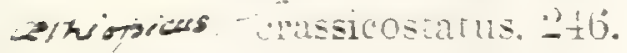

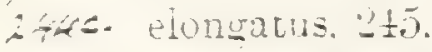

questnimalius. 2:15.

macrourlis. $-\frac{1}{2} 5$.

minimus. -

Leptotracinelus, $17: ;$

armirlis, 14

riongatus, ist.

rraciils. 1 E0.

hateiensis. it.

longipiunis. $1=-$.

sirottallis. ist.

maneter.

Pinulirtis, 57.

- Jelcascus

werouster. Jlu.

uiri. Ul.

onnias : : :10.

hericundin, ind!

peria, :3!!

'unatils..11!

vien

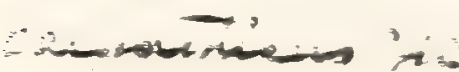

Leuciscus mt.

vecconit. "̈l̈.

cephatum.

cephatus. voy.

coler. uive.

dorsulis. $: 11$. 12 .

Aumerili. :11, 51:2

eibiswalcensis. :ju.

eleoans. 315.

elrothopuciaimus. $\because 04$.

PurptomLs. 811.

titsent. 615.

gaobrensis. : 11 .

ribbus, ¿̈i?

yacils.

Lartmuni. 31 t.

neireticts. .15.

heteruns. :10.

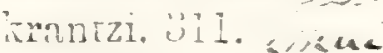

larteti. 11. is

hatuscuins. 95.

intus. 009 .

licatie, 311.

macruins. ¿1).

medius. 311\% reverman

geningensis. 305 .

papylaceus. :17.

piesioncer?a. 311 .

polysalens : 11.

puellaris.: :11.

pusilils.

racainuti, 11 .

getmotus. 31 .

mutilus.

saurigei, :12.

sicanus. jil, ull.

stepinani. 11. j10.

tarsiger. 15.

tumeri. 11.

rexillier. 11 . yra.

Leucus, 2.2 .

conciontix uns. 30$)$.

?atus. 00.2 .

Leuresthes,

Lewisia, :-:

opais. 53.

Iichia, t5.

aita. $\pm \frac{1}{2} 6$.

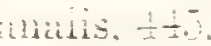

Latia. $\frac{1}{ \pm} 5$.

vised t-1!

secumbit. =tio.

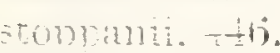

Lobcans. . T.

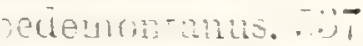

-oocotartis. $=1$.

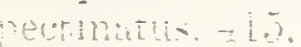

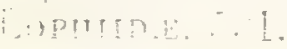

- 0 anivs. 11

$\therefore=-10=\cdots$
Icpnius l... Zorel

piltugunicus. . 11.

pisculturius, 201.

Loricaria,

piecustomus., 181.

Zusostomus, 011.

nancus, : 11.

¿ucania, : -

Iucionerca.

sompiii. .21.

Iucius antecilurimus. $\therefore 8$.

Litianus epuipnilim.

-iil. jil.

Iutoceira, it.

Jycontera, 1 .

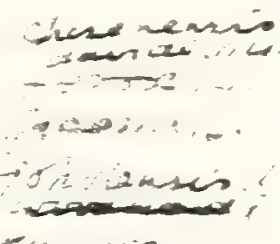

sulurorhpncial. -

micienchom. 2.

zinensis.

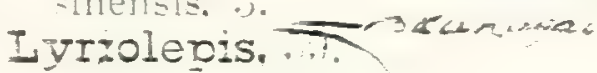

uducaislcus, $5 \%$

Iacroiepis, 4 .

iomentus. $\frac{1}{2} 1.5$

Macrones,

:10r,

Hacrostcma, Bi.

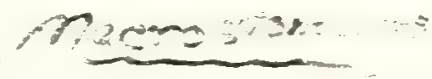

attum. -il.

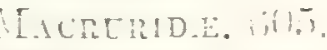

Macrurus, ㅅ․

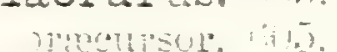

Iallocus,

Megaicaon....

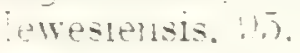

impoicies. $: .5$

Megaioleois, 12.5

baschutenss. Is:?

atus. - +2.

Tegalors, 2t.

jopcmatus. í.

ubluneus, -5 .

prisule. - $\frac{1}{\div}$

- Megaiurizes. .1.

niticium. ST:

Iegapus. :-11.

vuestinitus. :-2:?

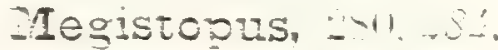

ruestialiuts. …

- Teletta, $1+1 b$.

cremila. joj.

dobana. is

gncinima. is.

rancisquama, jij.

recteli, sil.

Zaierostoma, -

mermedin.

- momana s.

ansoti. . 


Meletta (cont.). surdiutes, 152. scheucbzeri. 147. styriaca, 157.

Melettina, 151 .

Mene, 437 .

oblongus, $4 \pm 0$. pusilla, 41 . rhombeus. 439.

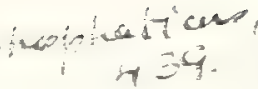

Menidia,-361.

Merlangus, 600 .

cognatus, 604 . spatulatus, 604 . suffulkensis, 600 . rulgaris, 600).

Merlinus, 603. cristatus. 603.

Merluccius, 601. To 03 .

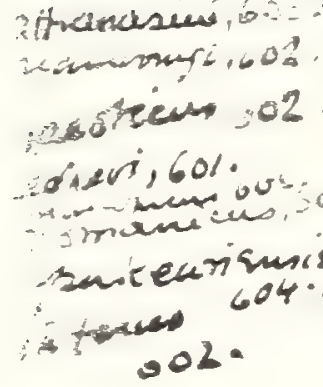

attenuatus, 604 . balticus, $6(1)$. macsuactar bosniaskii, b01. emarginatus, 604

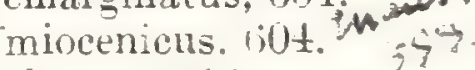
obtusus, 604.

Mesogaster, :61. cretaceus, $: 26 \%$ gracilis, 205 sphyrienoides. $360^{\circ}$.

Metoponichthys, 5อ๊.

longirostris, 5.50. octacanthus. 5.59.

Microcoelia, 25. grauulata, $2,2.2$. libanica. 250

Mierodon nuchalis, foug.

Miscrodon pulchellus. $4 \% 1$.

Mioplosus, 517. abbreviatus. 518. beani, 518.

labracoirles. 517. longus, jo. multidentatus. 518 . saurageanus, j18.

$6 x i 4 / 3$.

Monccentris, 414 .

cox 3 . hospes, 414 .

integer. 411 subrotundua, 415.

Monopteros gigas, 89.

Morrhua, $y 9$.

axglefinoicies. 601.

extensa. b01.

liaba. 604.

lancecliata.

latid, bis.

matoptersia. 601.

minima. bul.

soellingensis. $10 \%$.

zargariatensis. $(401$.

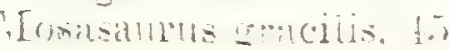

IY DEX.

Yulles, $53 \%$

Mugil, 263. brevis, 446 . freysins. cephalus, 364

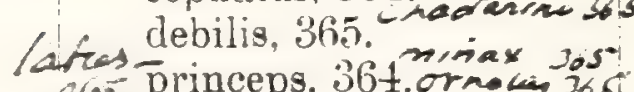

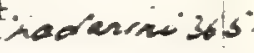

36) princeps, 364 .or

MUGILIDE. 363.

Muræna cæca, 347.

Muræna conger, 3t+千.

Muriena lewesiensis. 185.

Muriena myrus, $3+1$.

Muræna ophis. 347.

Her.ENID.E. :336.

Mylocyprinus, 320. inflexus. 82:.

kingi, 323 .

longidens, $: 323$.

robustus, $32 \%$.

Mylcpharyngodon, 323.

Myripristis, 410 . homopterygius, 411 . leptacanthus, 410 toliapicus, 410 . meitens $15,413$.

Myrus, 340. vulgaris, $3 \not 1$. cnumvi itit

Odax carolinensis, jłü.

Odonteus, 5.56. depressus, 5.56 prgmieus, 5.56.

Naseus, 564. brevirostris, 564 . nuchalis, 565 . reetitions, $56 t$.

Naupygus, $b 11$. bucklandi. bill.

Nemachilus, $3: 0$. bredai, :3:0. centrochir, 320 . cephalotes, 321. tener, 6is. risuselle $320 \quad+90$. teyleri, 321. Tpmah 320 eichwaldi, 491

Nematcnotus, $2+29$. bottie. '200.

Nemopteryx, 598 Af to elougatus, 598. Kubaes as

Nettastoma, ; 46 . bolcense. $3+6$.

Noracartiride. 1 is.

Notacanthus, 169

Nutitus agassizii. otu.

Notelops, $:-7$ brama, 2 ?

Notogoneus, 27. curieri, 27.1515. longiceps, 278 usculus. $20 \%$ pwits squanuselus.

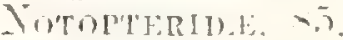

Notopterus, - ti ylimilull..
Nummopalatus, $\overline{1} 1$, 544 .

abbas, 543.

africanus, 542 .

bazini, 543.

belgicus, 543 .

bourgeoisi, $5+3$.

britannus. 543 .

chantrei, $5+3$

cocchii, $5+3$.

edwardsius, $54 t$.

gaudryi, 544 .

hatieri. 544.

heterodon, 544 .

multiciens, $5+4$.

pavimentatus, 544 .

polrodon. 545.

quenstedti, 545 .

rhedonum, 545 .

sacheri, 545 .

sauvagei, 545 .

trapezordalis, $\overline{3} 45$.
Odontostomus, 189.

Oligobelus, :3:23.

areiferus, 328.

laminatus, 323.

Oligopłarchus, 519. squamipinnis, jl\%.

Omiodon, 270 . cabassii, 270 .

Ommatolampes,

Omosoma, 419 . intermedium. $t: 20$. monasteri, 421 . pulchellum, 1.21 . sahel-almax, 419 .

Omosudis, 189.

Oncolepis, 595. isseli, 597 .

OpHIDIID.F. 605

Ophidium, 605. 600

OPIIOCEPIALIDE. 36 ,

Ophiocephalus, $: 60$ striatus, 464 .

Ophisurus acuticaudus, $: 47$.

Opisthomyzon, fil.

Opisthopteryx, 2:20. intus.

aracilis : 2ist.

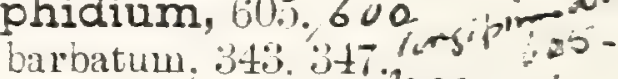
roltianum. 605. ejesans, 600 


$$
\text { coupocicia, iso. }
$$

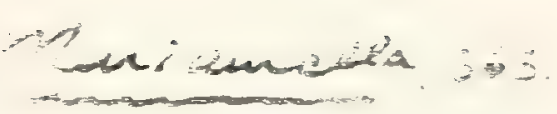

Mresla, sor

mivenain, Sor.

yonesia a $=3$ ?

mriz-ci

Amaen santimens 336

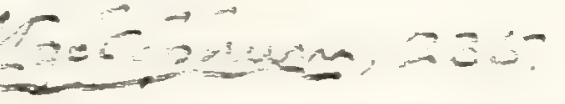

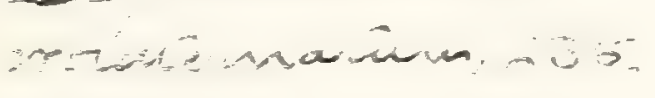

coliemonar, 015194 ectwandist is a

mireorma, ist. 14 .

Mersiamella, 3bs dorussa, 360 nerriamina, 605,520 Muptoraypus,343. ectener, 605,520 frangens, 343.

merchinea, 129.

Showchangersis, =8.

ptricopuatue in

Nicroekinis, sos

apropients, son

sanopei, 6.1.

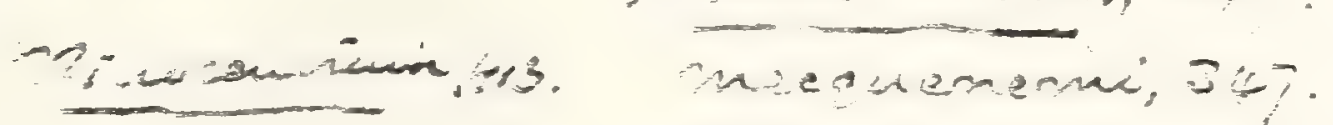

emacsice, 323.

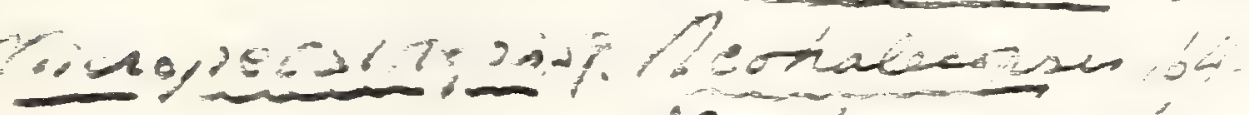

reocuine, 476.

Hiseriem roltratum, 476 .

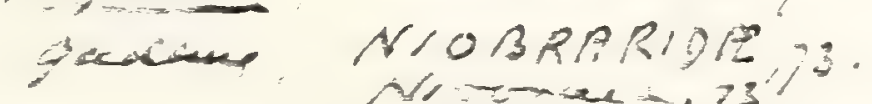

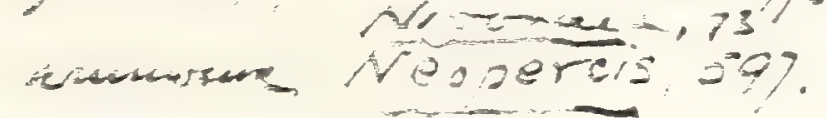

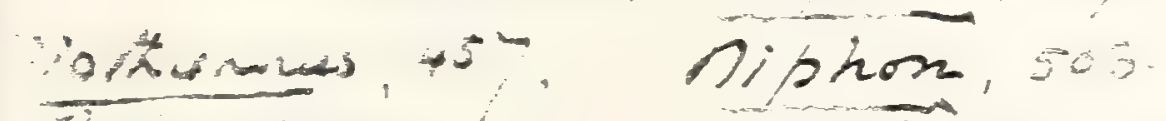

rispin osus,

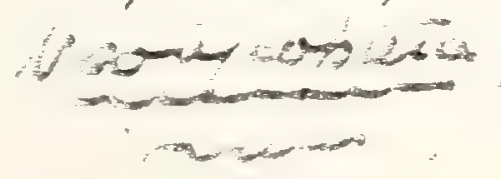

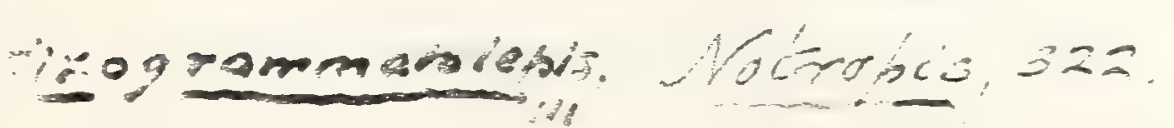

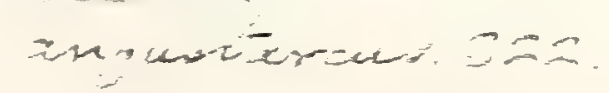

Nyctoones

microsoma

Geustias, $482, \ldots$

Sagizta, 482 . Her

Otigonentey

ongavelistes

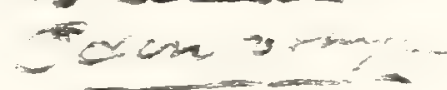

Oncinosceurces

Onoinosmic

ofigodición.

Orna fotienum

susciosus

Ophosures

acumicanar

Cenivelon

Qeliodon

by radiand

Oolesis.4.

Opiegnara-ón

Oplemariz.

manom;

abs 




\section{9ritorien, 523}

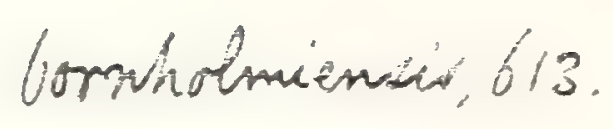

$4: 3$

$\therefore \operatorname{rag} u s, 242$

hampstivensis, 617.

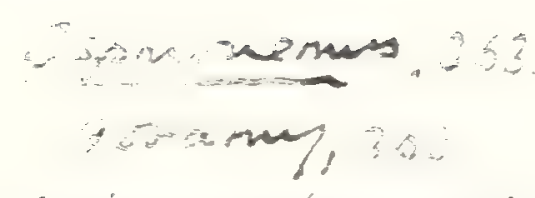

stasiustoma, 129 .

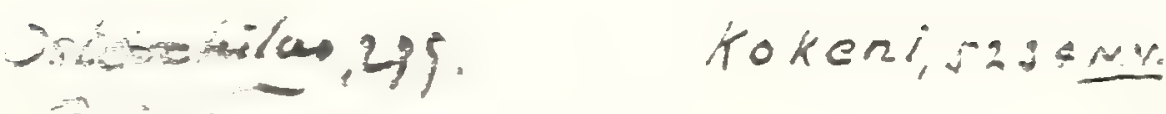

Emas $-2 x$.

Oxysonirapitus scolo

Osumandiad, 4821m gielect: 482ruv. 
Orcyntus, fit

humbuscni. 1 .

Enceolarus, $\frac{1}{2} 56$.

lation. 4.)i.

mrcilus.

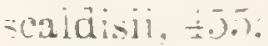

Oricarainus, $\div$.

tortus. ti.

Orthagcriscus. vineiononsis. ori,

Osmeroices, 11.

uttenuarus. 1\%.

belqieus. ㅡ.

brevis. 16.

14issis. 10.

cretacens. -

(iifalicatus, …

4ubius. 16 .

ETOL Litus. ?:).

cimisiancus.

-1monis. 16j.

smumutis. 21?.

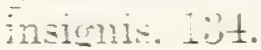

antus. $11 \%$

Lefis a

lewesiensis. $11, \ldots$. .

? misi. - .

mintellii, 12.

marsinulis, :

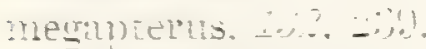

mivrocenduils.

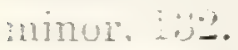

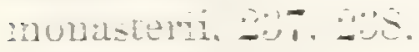

pectinofepis. -..

voimmicrocits. -3

sarcinioicles, I\%

vinale sis. $\because 1$.

Osmerciepis, -1. vericuiaru. in?

องก.

cibri.

(104iel. $2 \frac{1}{4}$

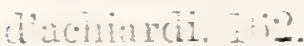

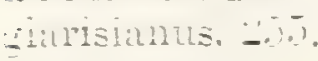

hateti. $\because 2$.

montergas.

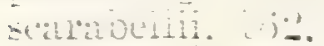

Gimmos. Iliz.

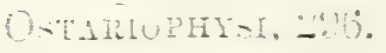

(1)TEORLU:SIDE, - $\because$.

Osteogicssum.

oncerlustum. " "

Ostraczen, , i!.

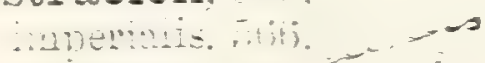

aterartas - is?

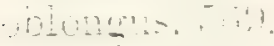

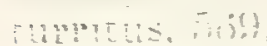

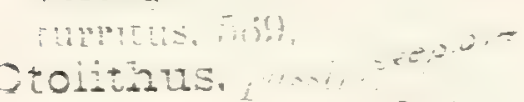

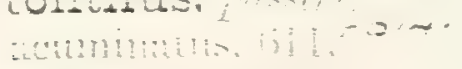

geoithus whe

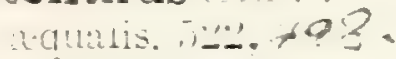

atueriounus tril.

ambilis. ofid.

a)olosimatus. 1:13.

attenuatus. ilyt.

aliveus. illt.

butaricus. Umi,

biscissus. all1. areman

boetseri. (inj.

brevior.; $; 5$

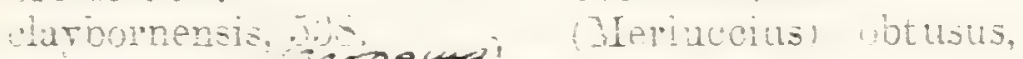

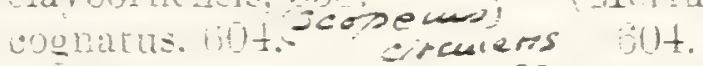

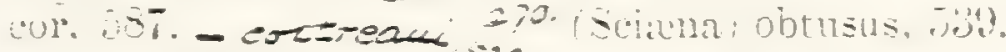

crassils, 30.2 .

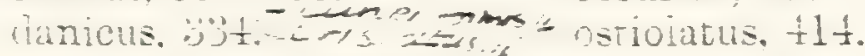

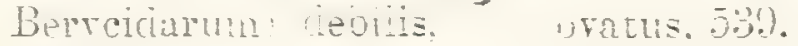

$\div 1.5$.

Mincielarum debilis.

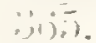

teuipiens.

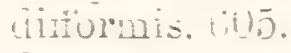

Uispal", on.

Cisinctus. . - . \& N.V

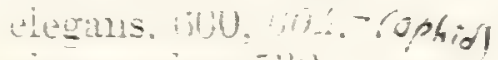

Fegmtuius. .ju.

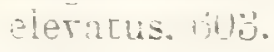

eilinticus. -2.

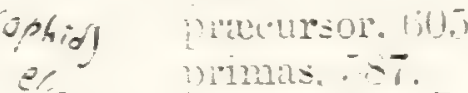

Himas. -7. - sukewin,,$\ldots$

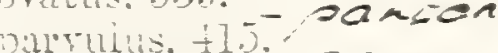

verernatis. $=7$

visanus, $+1+$.

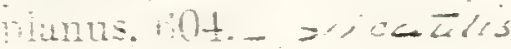

nebeius. - a N N.V.

vonuerosus.

i) useluls, (i)

matiuns. Ons.,

Berreiclurum

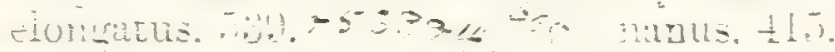

-Haiphutus, inta.

morrectus.

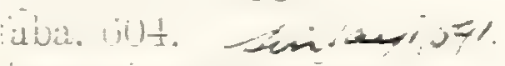

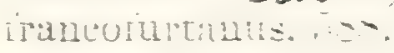

treruens.

remmat. . .

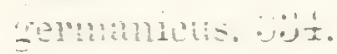

-

-ioberuins. - o.t.

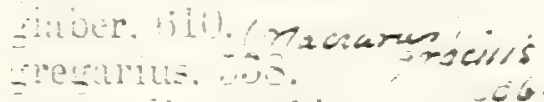

-nestahous. 141 .

-

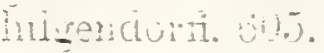

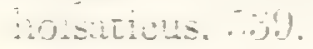

!nsoles. $\pm 1 \pm$.

ironicus. is.

incens. $1 \frac{1}{4}$.

insityls.

insuctis. $\cdots$.

inceger. 14 .

internecilus. :-

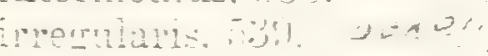

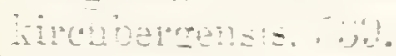

Nunitate $1 \frac{1}{2}$.

arviritus,

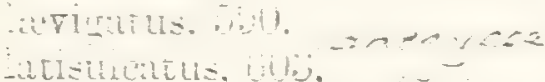

and $20 \%$

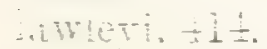

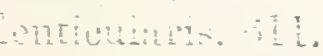

merencuso 115

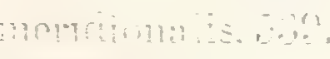

Rhumbust henmun.

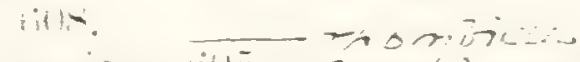

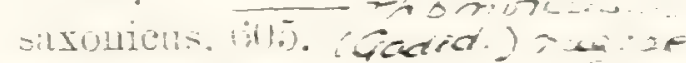

sector. ! itis!

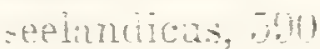

MLlpinal suetion-

zensis. inte.

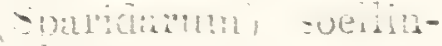

-2nsin a - is

simile. vas.

=imniex. 004 .

singular is

sourulatus. ilit

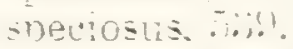

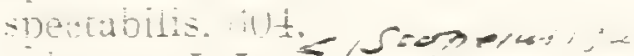

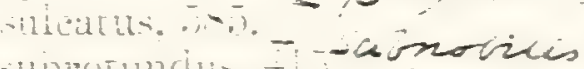

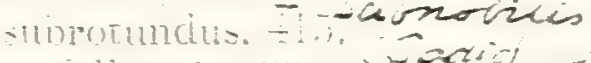

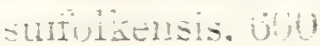

-anracreticens: th.

renuis. litit.

zestis, is.

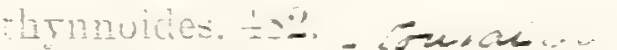

uberelilusus, bijts

rangionis. jut.

miuns. - -

renusis. MH.

revis. exid).

remulis.

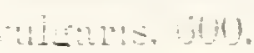

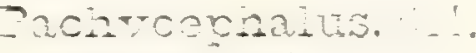




(i:3)

\section{Pachygester, ion polvsuondylus, 520} gaciryiz" spinosus. 520. 3060.294. Pachylebias, 294 ricalmuri, 311 crassicaudus, 295. pormen, 215. Pachyrhizodus, 37.

basalis, 37 . caninus, $4 \pm$. curratus, 44. dibleri, 38. gardneri, to. glyphodus, 258. gracilis, $4 \overline{5}$. kingii, 42 . latimentum, 42 leptognatuus, 45 . leptopsis. $\pm \overline{5}$. marsthmenses 10 hinimus. $t 5$. sheareri, $\pm \bar{j}$. subulidens, 43 . velox. tio.

Pachrstetus gregatus, 20?.

Pagellus, 532. aquitanicus, .0.33. moinco, 533. de stetanii. 53:elegantulus. 5\%:3. leptosteus. .333 . libanicus, 390 ). microdon, 533 . peruzzii, $.3 \% 3$. stenoura, 5.30\%.

Pagrus, 5:3.

menegninii, 53:3. - u. onem ondrianus. 533. pileatus, $53: 3$. priscus. 533 torus. 534.

Palæobrosmius, 598. 4, parain palaogadus. j98. in enimu. troschelii, 598. Palæolycus, 211 . dreginensis, 211 .

PALAORUYYCIID.e, 482.

Palæorhynchus, $\$ 83$. bruxelliensis, 490 . colei, 488 .

descimanni. 487. egertoni, $4=8$. givanteus, 187 . glarisianus, $\pm 83,49 \%$. gracilis, $486^{\circ}$. latus. 185. longrostris, 186 medius. 485 . microsnondrlus, $48 \%$. riedli. $\frac{1}{2} 87$. zitteii. 48T.

Palanarrhichas, 5\%. crassus. .37 .
Palimphemus, 270 anceps. 270 .

Palimpinyes, 460 . brevis, 460 . crassus, 460 . elongatus, 460 . glaronensis, $\frac{1}{2} 6 \mathrm{U}$. grarilis, 460 . latus, 160 . longus, 460 .

Pantopholis, -ut. dorsalis, ’’’t.

Paralates, 00 . bleicheri, 50.

Paralepis. $25 \%$.

Paraleuciscus, 312 . ecnomi, 312.

Paranguilla, it3. tigriui, 343.

Paraperca, 520 . provincialis, 520 .

Paraphyllodus, $5 \pm 6$.

Parascopelus, 256. lacertosus, 256.

Parequula, 450 . aibri, 4.50 .

Pegasus lesiniformis, 269 .

Pegasus natans. 383.

Pelamys, $19 \%$. adunca, 482 . robusta, 18\%. sard $\alpha$,

Pelargorhynchus, 188.

blochiiformis, 188. dercetiformis, 188.

Pelates, 523. quinderimais, 523.

Pelycorapis, 35 berycinus. $325 t$. varius. 354 .

Perca, 518.

alsheimensis, 513 .

beaumonti, 515 .

cyprinodon. jofrower" elongata, 510 . Huviatilis, 518. forbesi, 510. . ${ }^{n}$ to $a$, lepidota. 511 lorenti, 518. lucioperca, 511 . macracantha, 518. minuta, .506. moguntina. 512 . punctata. $366^{\circ}$ radula, $5: 6$. reboulii. 50 . uraschista, 516 .

Percesoces. 궁.

Bercichthys, 51 . antiquus, 514 . beaumonti, 515 . Percida, 498.

4 G. Perciforjes, 497.

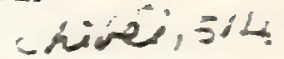

Acresturin 514

Percostoma, j19. angustum, 519.

Peristedion, 5₹6. personatus, 587 .

urcianensis, 586.
Phacodus. Cope, 553. $0150, \widehat{131}=$ irregularis, 5503

Phacolepis $=$ Rhacolepis

Phalacrus, \pm 58 . 257 cybioides, 458 .

Phareodus, it, \%5. acutus, 76. sericeus, 76 .

Pharyngodopilus, $5+1,545$. abbas, $\overline{5} \pm 3$. africanus, $5+2$. alsinensis. $5+4$. bourgeoisi, 543. canariensis, 54.2. carolinensis, $5+3$. crassus, $5 \pm 4$. dilatatus, 5.t. haueri, 545. muitidens, $\overline{5} \pm$. polyodon, 545 . quenstedti, 545 . sella, 545.

soldanii, $\overline{5} \pm \bar{\jmath}$. superbus, $5+2$.

Phasganodus, 190. anceps, 203 . australis, 615. carinatus. 204. dirus, 204. gentryi, 615. gladiolus, 204 . semistriatus, 205.

Phasganus, 613. declivis, $61 \ddot{\text {. }}$

Pholidophorus macrorhychus, 2.

Phycis, $60^{\circ}$. - suessi, 602 .

Phylactocephalus, $21: 218$.

microlepis, 218 .

Phyllodus, 546. bowerbanki, $5 \pm 9$. culei. 549. corsicanus, 57 . cretaceus, 500. curvidens, 5.50 . deborrei. jö!. depressus, jo. durali. 50 . 


Proegrabagra, o.

Practicombrescts, bis

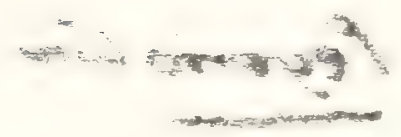

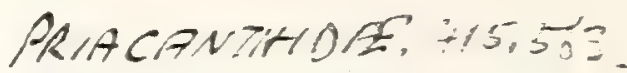

Fiacenthus, 563 .

Lohastus, 563 .

Plectrites,536. Spinosus, 500.

Pistoretholus, 6R.

Prossentina. 162

Protakiggadurs scale

15icubus. 606.

Trediodon 50

3. ticandotien 606.

Distisma, 235

Pinitholen. bul.

Progadus (scale) pisani: 642.

minimus, 235.

- surenias, 587 sismudianus, 545.

Pliosiluress, 325.

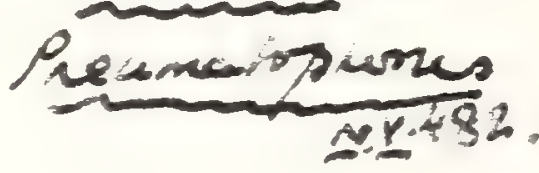
Procharax, 298. Problenniks, 597

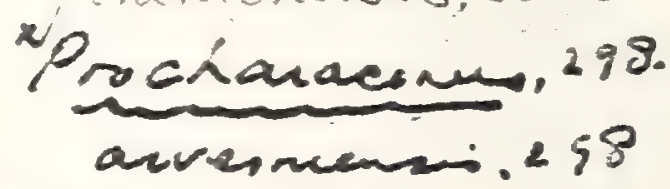

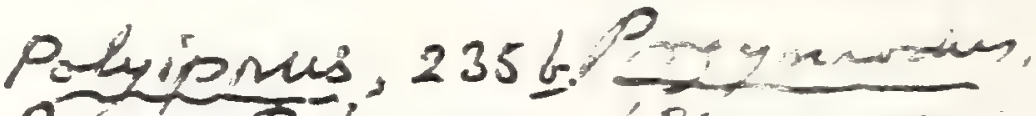
Polydactulus,365. Prozymnetern, 15,5 Polypterolepls, III. Protzadreyen.298.

Pomadatsidae.499. pellegmins.248.

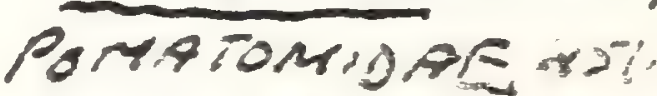

Pomolobus 158s., 64t.

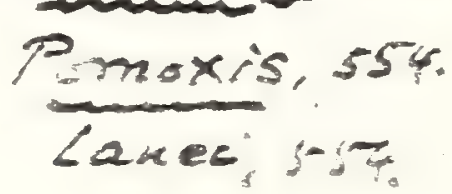

Promacuens (sak)

Promerlucsius 599

ondrosori, sao

Promentusecier Davis (Peaie)

Promegaloss 27.

Protencanina, 499,

reli, 499

zeeres imann

$P$ 
Phyllodus (nnt.).

elegans. 5.0. servaisi. 5.50 . haneri. $54 t$. hesagonalis. 549. hipparionrs. $61 \%$. incertus, 5.5. inconstans, 5.00 . irregularis. 5 ts. latidens, 5.50 . leresunei, 550 . mareinalis. Jt8. medius, $5 \pm 8$. muitidens, $i t t$. petinlatus. 5ts. planus, $\overline{0} \pm \overline{7}$. polrodus. 5 ti. secundarius. 5+9. speciosus, 549. sundepressus. jtt. submedius, $5+9$. tolinnicus. jti. umbunatus. 500 .

Pimelodus, 3:?. antiquus. 329 . aor. $32 \%$ sacileri, 385.

Piscaus, 60.61. toueraid. 73. omeni. 60.

Plagyodus, 189.

Planesox, 519. тorax, 519.

Platacanthus, 509. ubinoi. 510.

Platax, 432.

altissimus. 439. brevis, $\pm \div 29$. colchicus. $\pm 3 \pm$. costatus. +93. cuneus, 438. macropterrgius, ton. minor, 420. nuebalis. 129. papilio, \pm 33 . pirseteroide. 453. pienm, \pm 33 . pinnatiformis. $4: 3$. pinianus. $430 \%$ subrespertilio. \pm 38 . Troociwardi, 19:2.

Platessa, ills. sector, 109.

Platinz, 59. gacuilii. 89. 2iongatus, 89. rigas. 59.

2latcos, 76. subuidens, is.

Plarycormus. 21 . permizus, 41.
Platycormus (10nto) 3 bus bloneus. +200.

Platygenys, 618. arosus, 610.

Platylamus, jol. olei. 5.11.

Platylates, 520 . mupeliensis, jou.

Plestronoma urasenista. 516,1515 .

Pleionemus, 4 ?. macrospundius, $1 \frac{1}{2}$.2.

Plethodus 0. expansus. B1. zucartus, 34. oblongus. B.;. ventagon. 53.

Pleuracintins serratus. 5 tio.

Pleuronectes, bols. viatessat. út. inis. guaciratulus. 607.

Plecroxectid.e. cuti.

Plinthoohorus, ․ㅡ. robustus.

Pliopiarcinus, 520 . sертещspinosus. jo. sesspinosus, $5 \div 0$. rinit?i. 520 .

Podccephalus, 510. mitidus. $31 \%$

Podocys, 20. ninutus. 50

Padopteryx, ssi. abiol, -si. josniasti. 537.

Pecilia lanetherii. 615.

Perilia oeningensis. jez.

Pecilops, . breviceds.

Pogonias multidentatus, 5i:.

Polynemus, 4.5. guinquarius, $111,+16$.

Pomacanthus. jol. subarcuatus, 5 til.

Pomacextride. 5jo,

Pemaphractus. 60. gertoni. $76,80$.

Pomognathus, 212, 230.

euntergrius, 21:.

Portheus.

ngulatus, $1 \mathrm{~s}$.

menatus. 101.

antrails. $\%$

maciegcarhus, U.

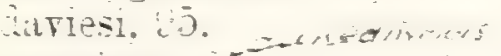

gautinus. 5.

Tacius. $\because 9$.
Portheus (ant.)

lestrio. \%.

lowi. 7 .

manteili, \%.

moks mos. (1)?2.

mucigei. :T. jacroonuch.

thaumas. y.

Prionolepis,

ingustus, 20.0.

catapnractis, 200.

Imiacus. 20:.

Priscacara. 554 .

clirosk, jist.

crpia. 555e zerotonae

liups. 555.

oxtprion. 55.5

pealei, 555.

serrata. jut.

testucinaria.

Pristigenys, 415 . macropithamus, 415.

Pristipoma. 53 .

turcacum, jz:s.

Prcantigonia, 5.85-vevion an a longirostra. 5.5\%" apreseso

octicantha. $5.5 \%$ radoboiuna. 5.59. therana. steincicienneri. 5.50.

Probailostomus, 206 . Zonutulus. 206\%.

Prochanos. (i. rectifions. (is).

Progymnodon, 572 , hilgenciorfi, 575.

Proiates, 1.9. beberti. 199.

Prolebias, $20 \%$

brongniarti.

cephalutes. -

criassicaucius, 205.

davidi, $t$.

egeranus. 615.

fureatus. 291.

gaucirsi. 204.

goolo, -21.1

goreti. $29 \%$.

gregatus, 2y2.

mever. $-2 t$.

minimus. 294 .

oustaieti. 293.

pernusilus. 291 .

puicheilus, 615.

stenoum, 20.2.

Pronotacantisus, $16 \%$.

sibei-rima. $16 \%$.

Properca. it.

uneusta. 315.

bealimonti, sis.

ieniciota. 311.

pisca. 310.

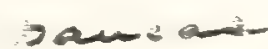






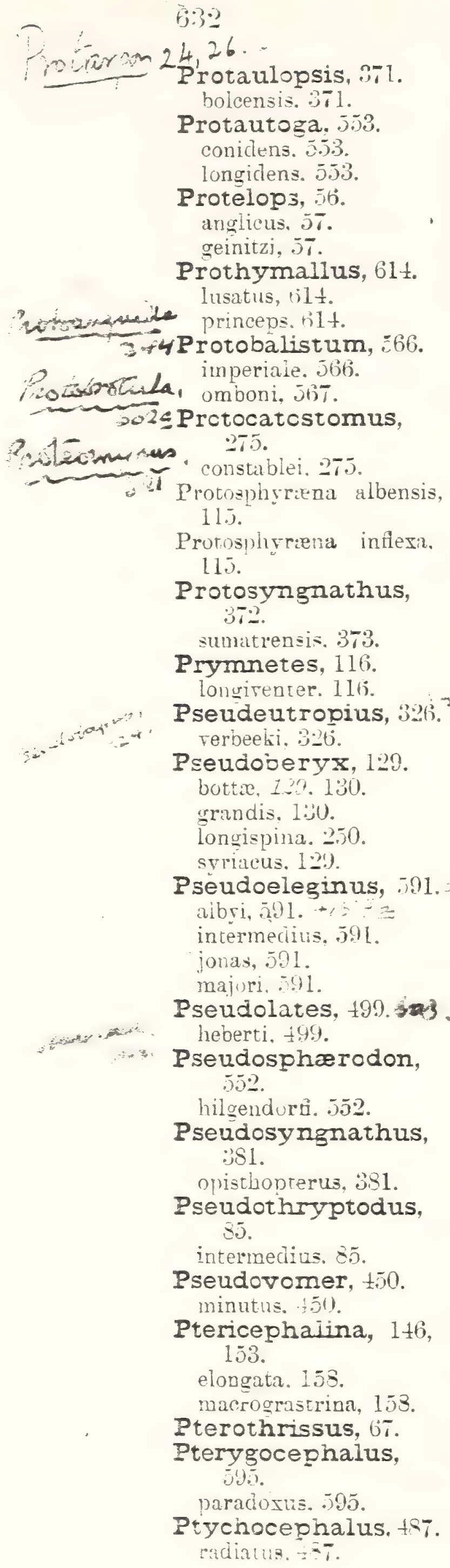
is1. sphyrixnoides, 362.
INDEI.

auratus, 396

Pycnosterinx, 391.

daviesi, 890 ?

discoides, 393.

dorsalis, $392,893$.

dubius, 395.

elongatus, 395.

gracilis, 394.

heckeli, 890.

latus, 395 .

lewisi, 404 .

niger, 392 .

russeggeri. 392.

Pygacanthus, 613.

altus, 613.

Pygæus, 557.

coleanus, 557 .

dorsalis. 550.

egertoni, 557 .

gibbus. 757 .

gigas, 558.

jemelka, 579.

nobilis. 558 .

nuchalis, 558.

oblongus, 5.58 .

zignoi, 558 .

Rndamas, 536 .

jugleri, 536.

Raniceps, 603. latisuleatus, 603. tuberculosus. 60 t.

Raphiosaurus, 37, 49. lucius. 43 .

Rhabdofario,
lacustris, 160 .

"Rhabdolepis, Harck, 11.

cretaceus, 20 .

Rhacolepis, 29 .

brama, 25 .

buccalis, 30 .

latus, $3:$ olfersii. 28.

Rhamphognathus. 361 .

paralepoides. ¿361. pompilius, :̈bil. verneuili. 36?.

Rhamphornimia, 269.

rhinelloides, 269.

Rhamphosus, 37. aculeatus, $37 \%$. biserratus, 378.

Rhineastes. 329 . arcuatus. 323 . calrus, 329. pectinatus, $: 320$ peltatus, $20 \%$.
Rhineastes (cont.).

radulus, 330 .

rhæas, 329.

smithi, 330 .

Rhinellus, 265, 209

curtirostris. 269.

damoni, 268.

ferox, $26 \pi$.

furcatus, 236

laniatus, 232 .

longirostris, 232 .

nasalis, 269 .

robustus, 268 .

schilli, 269 .

tenuirostris, 269.

Rhinocephalus, 608. planiceps, 60:3.

Rhipidolepis, 613. elegans, 613 .

Rhodeus, 316. edwardsi, 817 . elongatus, 316. exoptatus, 317 . latior, 317. magnus, 317 . oligactinius, 316 .

Rhombus, 606. abropteryx. 608. bassanianus. 608 . caudatus. 608. cutrensis, 608. fitzir geri, 608 . gentiluomoi, 607 . heckeli, 608 .

hirchberganus. (309). ligusticus, 608 . minimus, 607 . minutus 608 . nardii, 6 . pal'rulus, 608. rhenan us, 608 . richiardii, 608 . sauvagei, 608. . fom

Rhonchus, 458. criangoides, 4.58.

Rhynchorhinus, $:+2$. branchialis, : $4: 2$. major, :343.

Rita, :328. grandiscutata, 328 .

Salino, 159.

eyprinoides. 456 . derzhavini immigratus, 160 . lewesiensis. 11. maræna. $(i 3$. tepiitiensis, 614 .

Salmoxide, 159.

Sandroserrus reboulii, 520 . 
presnaienis, Fan. il

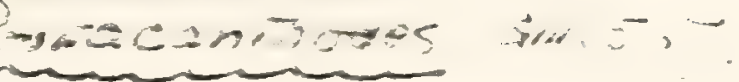

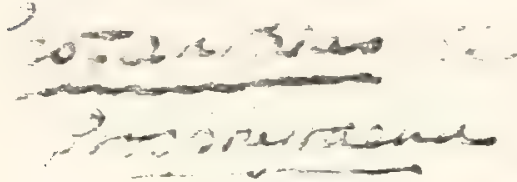

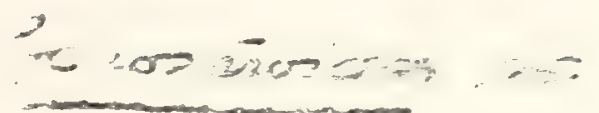

dosiclions

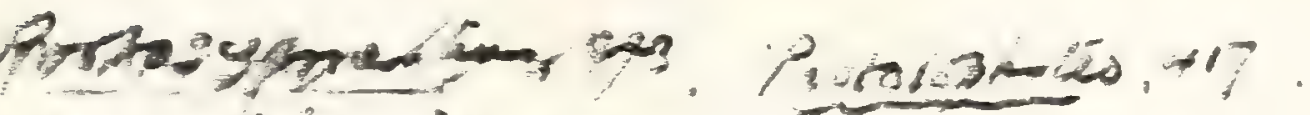

P. jus nes.

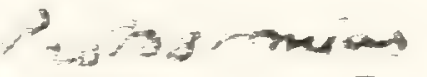

Proterselta 603 .

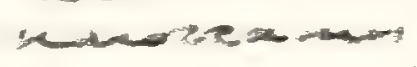

parvía. jo:

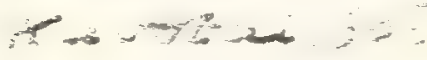

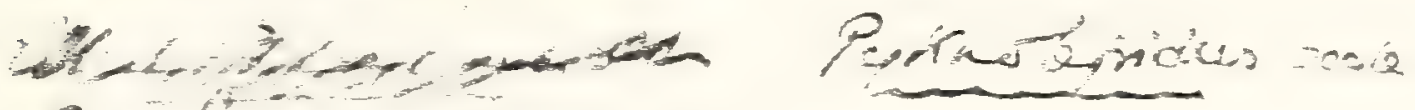

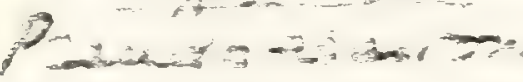

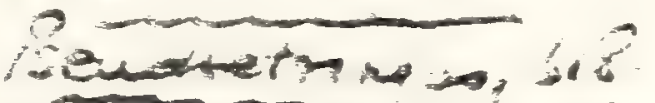

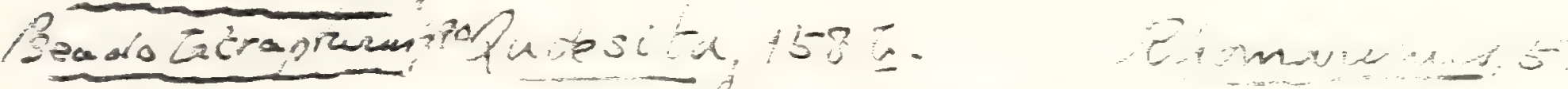

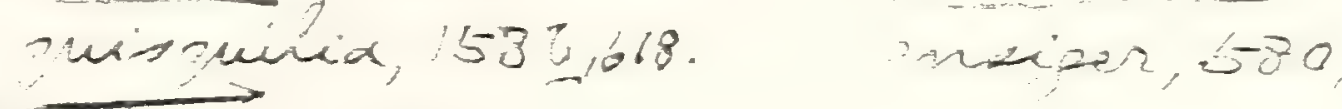

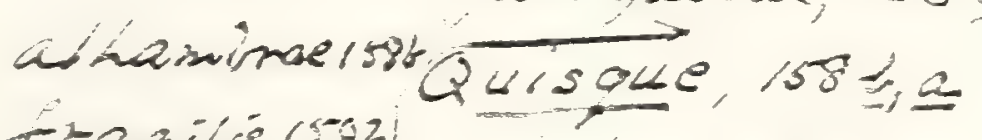

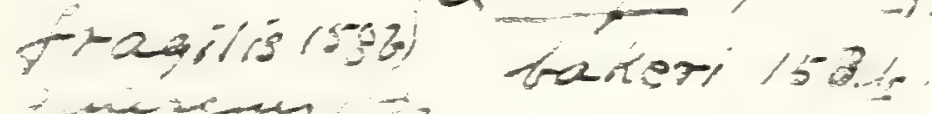

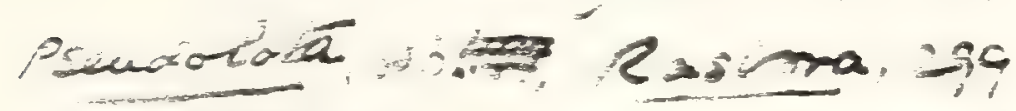

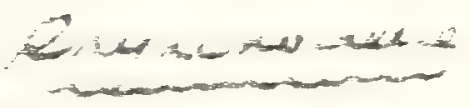

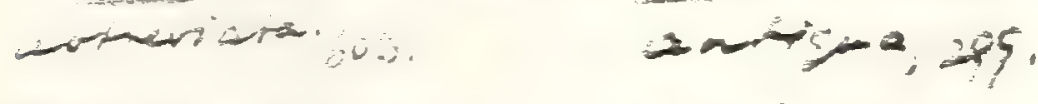

$\because=0-10$ manj,
Avarited bit Phomures.

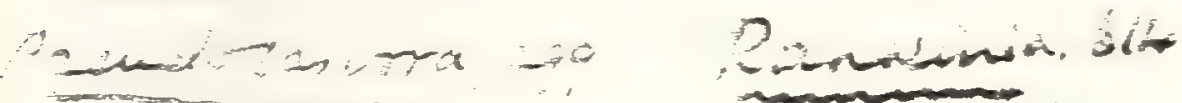
turation.

vaew instic an tic

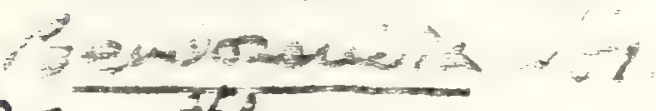

Sygmoseris. 5\%

Pitum is

ucinitific is

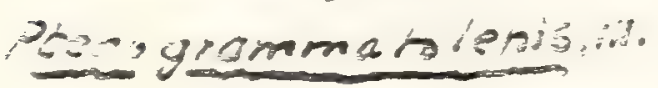

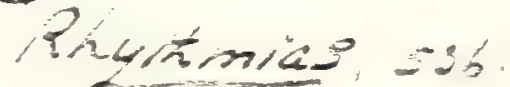

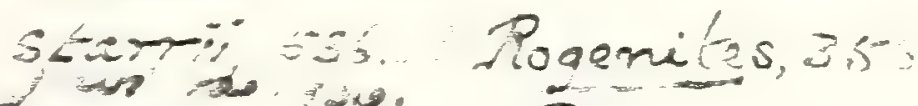

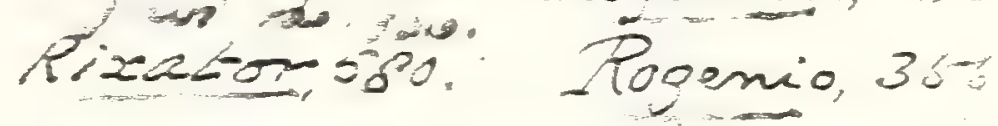

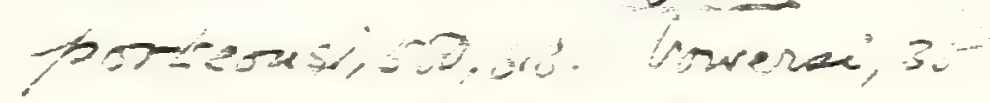

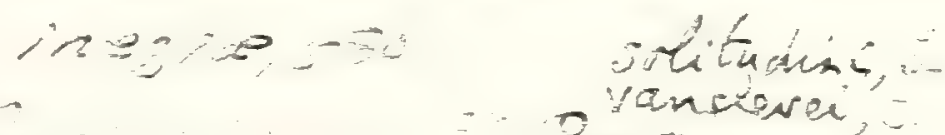

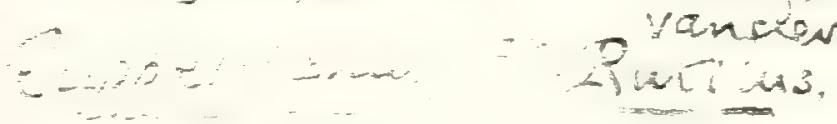

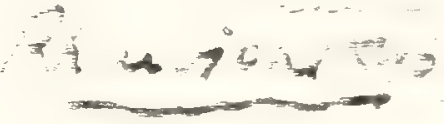

strasmasmes

somina

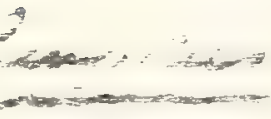

Psoontios 205

$-\ldots$ 




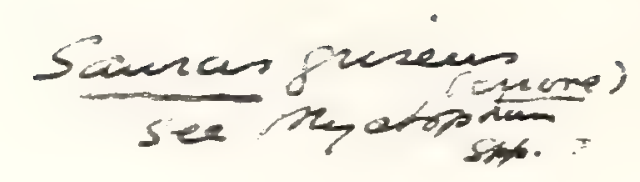

arections, 242 .

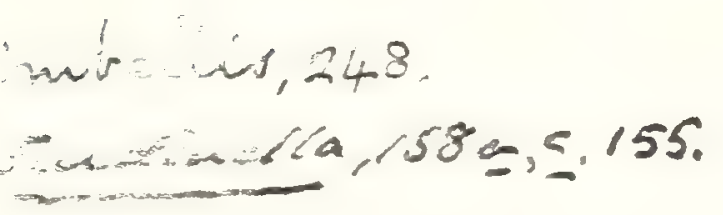

Siomberesses, 358. acutilles, $358,618$. edurerdsi, 358

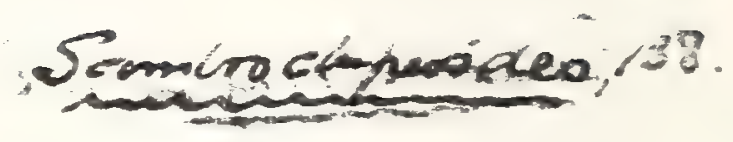

$\frac{\text { Sehissthondutus, } 188 .}{\text { dubius, } 188 .}$

Eernata, $45 \%$

zuéeri, y's

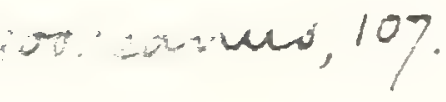

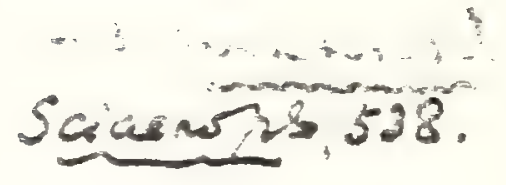

5 ciencis, 538 .

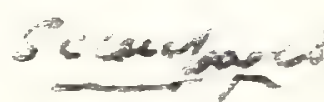

Telastavis, 580 . ventelralis, 580,418

Sezastinus, 580.

- tarnitui, 580 . inejike, 580,618

Selastoësus, 580 .

apostatios, 580 -

Sedentionslia, 25:

wabiapens, //4.

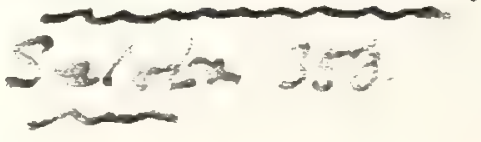




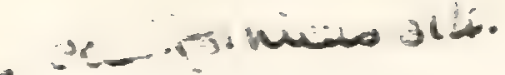

Sardinisides, 23 .

zmolrostoma. 803 .

attenuatus, -11 .

zrassicaudus.

macrovterrgius. ㄴ․ megapterus, 299.

micrucephalus. 203 .

minutus, 2.2.

monasteri. 11, 237.

7 pusilue. $2 \pm 10$.

Eenuicaudus. 24:2.

Sardinius, - \pm .

blacésurnii. 218 .

arassapinna. 1:20.

coldieri. $2 \pm 7$.

ineactus. $2 \frac{1}{2} 8$.

zacrociactrítis. 131.

masutulus. 248 .

pererassus. ㄴ․ 18 . robustus, 131.

Sargus.

anchronocion. 500. aunitauicus. 530. nimatus. 530 , 50. Daraiciii. 50 . carannai, 580. curier. $500,017$. heberti. 500 .

incisirus. 50

jmnitanus, $3: 0$.

arriconus, 20 .

Manensis. 50 .

sreni. $33 \mathrm{l}$.

resuceuritanus, 830.

serratus. 531.

sioni. 531.

siricensis, 50.00.

Saurocephaius. 113.

aibensis. I1t. manahơvitus. $11 \frac{1}{1}$ andiax. 92

broacheacii. 113.

Tentatus. 111

dispar. 115.

fujumensis. 115.

inequalis, 115.

nuexus. 115.

intermedius. 112.

uncitormis. 113.

¿anuз. 111

iscodion. -

marginatus. 2028.

monasterii. 115.

ohlebotomus. 11:.

ictet. 115.

nrognatius. 107 .

striatus. 200.201.

suostriatus. 11j.

thaumas, 8

roocisarci. 114.

PARTT.

MOEI.

Saurocion. 111.

athinis. 113 .

brozciheacii. 11?.

conoicieus. 11:.

Perox. 113

incermeciius, 112.

lanciturmis. 113.

leanus. 11, :31.

marcinatus, 2.29 .

phleboromus. 112.

promieus. 11:.

$\rightarrow$ Iipulirostris, 113 .

Saurorhampinus, 207 , $\therefore 11$.

freveri. 210

Sauropsidium, 58. aracilicauda. j3.

levissimum, 58.

Senrimins dumerili. : 11 .

Seardinius sicanus. $: 11$.

Scarus. 553.

baitringensis. 530, 531.

: aiosenicus. $55 \%$

ureni. .31.

snericus. 553.

tetrocion, 553.

Scatophagus. 561.

atinis 501 .

cuveilinit. jol.

frontails, 561 .

Sciæna. 539.

umpius. 59.

Holsuticus. 539.

irreguiaris. 539

jeculatrix. 201.

sirenbergensis, 539.

melidionais, 589.

votusus. 509 9. girnsonera

viumierii, 521 .

sneciosus, 539?

uniecinalis, 447 .

SCIEYIDE. 503.

Sciænurus, $524.52 \%$

botrerbanit. 527.

brevior, $5-7$.

crussior, 5-6.

longior. 519.

Scierognathus, 000.

Scomoer. 159

aiacunga, 456.

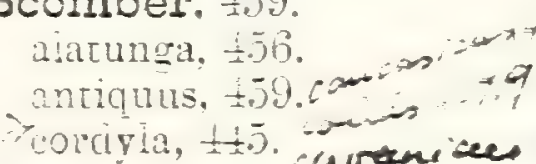

stitueus. \pm 40.

anovilis, 21

uresnus. \pm so.

pelagicus. 14 .

pelamis tot.

iknoratus. \pm 59 .

priseus. $=59$.

rombeus. 439 . nat

-.w. aticus, 5

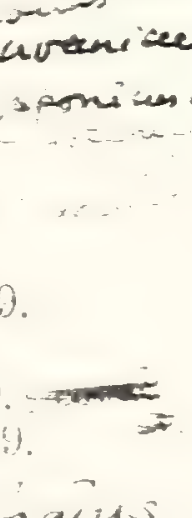

irac-ute- ondus

132
Scomber (nt.).

sneciosus, tib.

steinciacineri. 159 .

sulecianus. 459.

ihrnnus. $45 \overline{5}, \pm 5$.

rracinurus. $\frac{1}{1} 6 \pm .457$ y oit

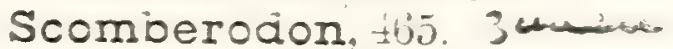

dumonti. $\pm \pi 0$.

Scombramphodon. $\pm 7 t$.

benedieni, \pm 74 .

crassidens. 175 .

curririens. $\pm i t$.

SCONBRESOCIDE. $350^{\circ}$.

Scombresox, 357.

licatie, 258 .

obtusirostris. 357

SCOUBRID.e, \pm 51 . \& 365

SCOMBriforJes. 418.

Scombrinus, $t$ til.

macronomus, $46 \%$.

!nchais. $\div 61$.

Scombroclupea. 195.

gaudrri. 1 :

macrophtialma, 185 5E.

pinuulata. 135.

Scopflid 235.

Scopeloides, 25.

giarisianus. 255

nicolisi. 250.

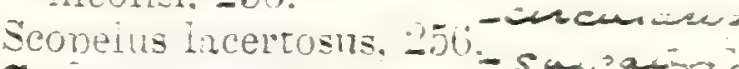

Scorpæna.

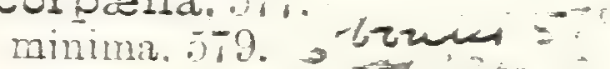

pilari, 579.

prior, 579.

serota, jut.

tessieri. 570.

SCORPEYIDE. 57.

SCORrEMIForMEs. $57 \%$

Scorpanoides, 50.

poporicii, 580.

Scorpanopterus.

50.

silurictens, j50.

SCrpilopirori. 1.

Sebastodes, 5.0.

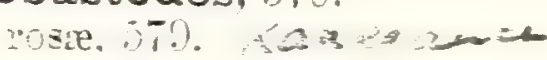

Semiophorus, 100.

gigas, tibl.

mussalongranus. 4, 1

y35arruius.

sovaerbeesi, 10.

reilcans, \pm 1.

reifier. $: 30$.

Semotilus, 320

barcii. :2u?.

poscicts, 30.

Sericla. $\pm \frac{1}{2}$.

mais, $\frac{1}{2}+5$.

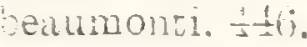

$$
\therefore \text { I }
$$

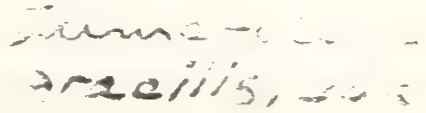






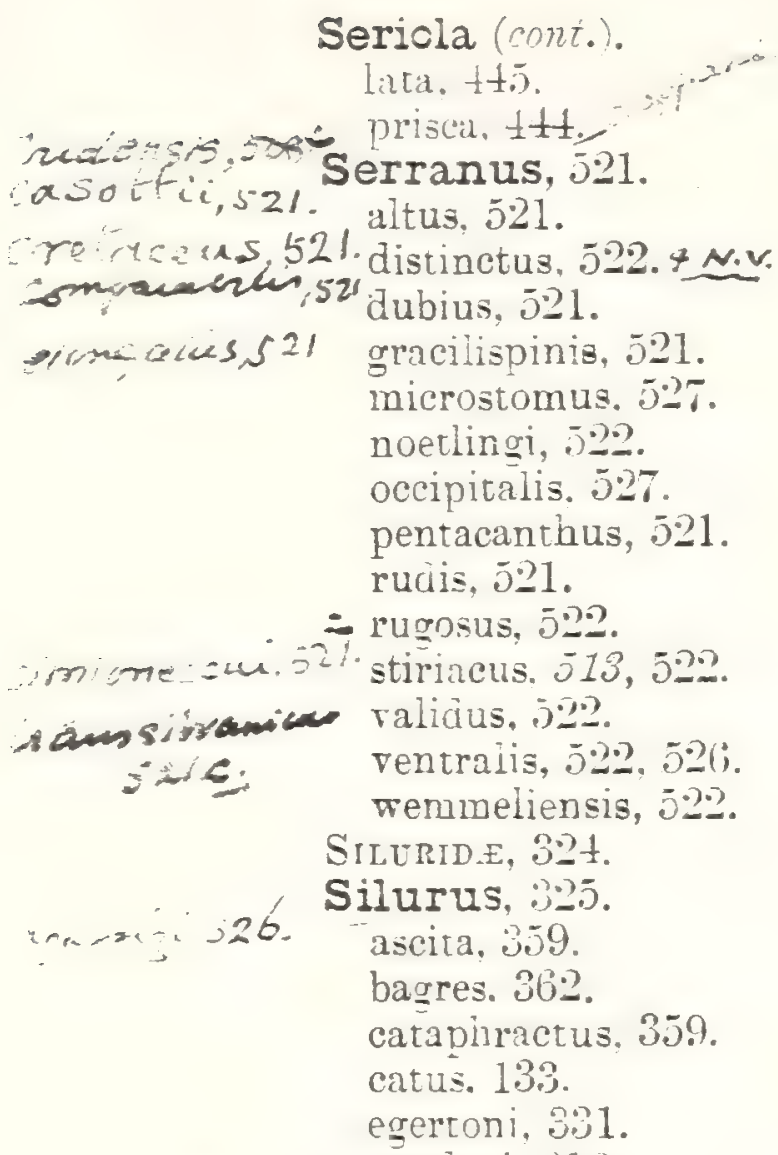

Solenodon (cont.). loboptel'rgius, 219. neocomiensis, 204 .

Solenognathus, Pic-

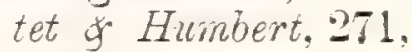
324 .

lineolatus, 27.

Solenorhynchus, 380. elegans, :\$0.

Solexostonatid.e. 379.

Scricidens,

baueri. 3023.

Spariodon, 48.

blonrieli. $t 8$.

brevis, 53 .

electus, 18 .

elongatus. 51.

hakeiensis: 27 .

latus, 53.

lepturus. $j \mathrm{t}$.

simus, 53.

SPARID... 524.

Sparisoma, 52\%.

Sparnodus. 54

altivelis. 525. bowerbanki, 527 and intlatus, 528

intermedius. 528.

lethriniformis. 525.

macrophthalmus, 525 .

micracanthus, 525.

microstonus, j27. nem

oralis. 525.

Sparoides, 537.

molassicus. jüt\%.

robustus, 557.

spharicus. 537.

tenuis, 537.

umbonatus, 537.

Sparosoma, 520 ovaiis. $5 \% 3$.

Sparus brama, 527.

Sparus bulcanus. 35

Sparus chromis, job.

Sparus dentex, 525.

Sparus erythrinus. 525.

Sparus macrophthalmus. 505.

Sparus salpa, 526.

Sparus sarous. 525.

sparus ruigaris. 525, 527.

Spathodactylus, 28. neoromiensis. 19.

Sphærodus,

annularis. 505.

araciasio, of.

cinctus.

cinguilatus. $5 \% 5$.
Sphærodus (cont.)

conicus, 537.

depressus, 536.

discus, 536.

insignis, 537.

intermedius, 537 .

kergomardius, 535.

lejeanianus, 530 .

lens. 536.

oculus-serpentis, 537.

parvus, હ̄3ิ8.

polyodon, 545 .

prgmæus, 535.

subtruncatus, 5300.

truncatus, 538.

wiechmanni, 538.

\section{Sphagebranchus.} 347 formosissimus, 34 .

\section{Sphenocephaius,}

337.

cataphractus, 883 .

fissicaudus. 387.

Sphenolepis, Agassiz, 265 .

curieri, 277.

squamosseus. 276 .

Sphyræna, 366 .

amici 209.

bolcensis, 366 .

carinata, 204. Coxedifuses croatica, 318.

gracilis. : 660 .

intermedia, 367 .

maior. zis.

maxima. :360. \%

speciosa :368, til6.

sternbergensis, 36 ?

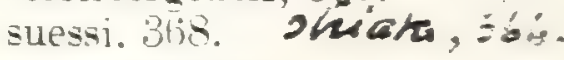

trrolensis, 616 .

viennensis, 368. Pen a

winkleri. 369 vete 3

SPHYRENDE,

Sphyrænodus, 473.

arauceanbottii, \pm 70 .

54 conoideus, 476
crassidens, 475

gracilis, 469.

lingulatus. \pm 67 . priscus. 473.

silorianus. 416 .

speciosus. 616.

tenuis, 469 .

Spinacanthus, 566

blenuioicies, $566 \%$

Spinacites, 415 .

radiatus, $\$ 15$.

Spinax marginatus, 2.28

Squalius, 223. ircirepus, 200.

bairdi. 8.3. 


Stickeren, 617,5750

malienciai sis.

Gichofitern.

is ordiwerdi, ב

Stavias, ㄸ. 482 .

isemones, 스느482.

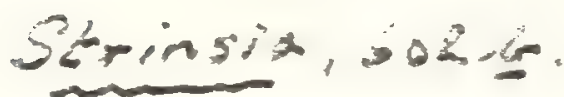

Shernbesjia, 189.

ivitei, 155.

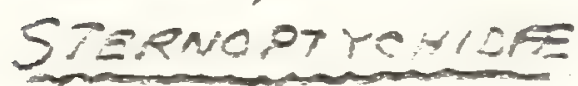

steenoptax, $2=5$.

Jrachichtingoides

40

pirisen, 205 ?

Irechume 442,51

To 1640.96

Sungarichthys, la.

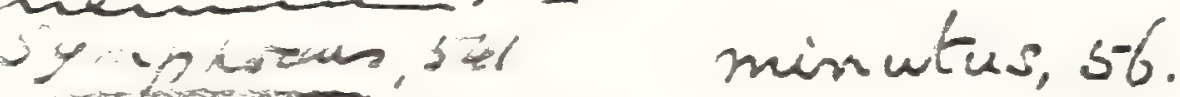

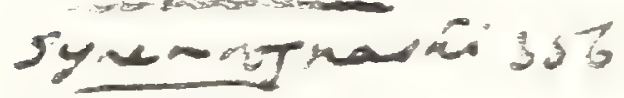

incomplitur, 383.

Gynawas $28: 0$

indis, 259

Irichiouses,

inerodes

Semia, $25 \%$

ehmectis.

albui, 456 .

lepturus, 482.

narensis, 270 .

huverti, 450

lericiei, 480 .

Pecysucus, is:

pliocenicus, tós.

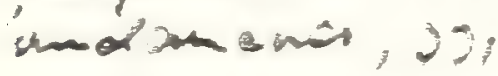

krambercesi

Thyosocles. 481 gnvagz

Coostens,

(Thyrites)

cimaerus.

Kriegeri, $19 ., 618$.

emnodon, 449 .

escharion, ris.482.

JAysodidex: 24 ?

Triplaregion, ig

isseli $x 40$.

Thyrsion, 482 .

velox, whe 482 .

Trossulus, 270 .

Tlanie, stz:"

exoblen: =.

fossilis, w:-

nerang placurm is 
Eataalius (mont)

Imminatus. 20.

licatio, ill.

nosciclls. 923.

reacinusi.

Stenostcma, pulcheila, +20.

steprancous, $\%$ sulenciens. $50 \%$.

Sterecaus, $\$ 76$. melitensis. $=76$.

jิtratcaus. iss andicus. it. ipicais. 159. oxppogon. $15 \%$.

Strinsia, vil. nicuta, ini"s.

STROM LTEIDE. 112.

Stviocius. in:? Eebescontei, 5j).

Sucis, $25 .-5.5$

Sy:-3emus, i.il.

angicus. :3i.

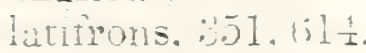

Srrgatitide. :19.

Syngnathus. inc

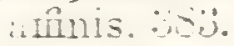

aliori. :-2.

bolcensis, $: 8$.

bericuins.

hecteil. 3.

oninsi. as.

mistiontertis. :-LL.

rpinte. Bi.

Jvncdentis, $: \frac{1}{4}$

Svnopirts, il:

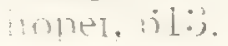

Symegomcaius, st. andis. $=i$

Tacingrectes, . pricutoterrgins. -0 .

Ionuipes - - 10

maciolitertins. - -

Zarsichthys. I.

piegens. ent.

tasiger. "is.

Taumisicintzos. 50.

wiocenicus. .ju.

sunent, ......

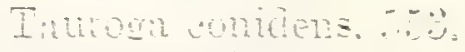

Telepnosia. - ㄴ.

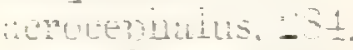

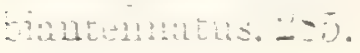
कulis. -

$>$ Teratichtars. .

natiouratis. +14 .

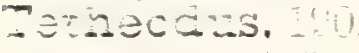

numpeo. .
Tetragonopterus. Zis.

nTus. 203.

limiticus. 248.

Tetraxturus, 90

uinor, 116 .

miseus, t!: 1.

Tetrodon. 51.

hispicius. 50 is.

honciseni. 50.

zwieri. 57.

Hemats.

:1. 5 . 51 .

TECTHDID. 528.

Teuthis, 20

Thaumaturus, 100 .

cielchmueileri. sit.

elungacus. 61 t.

vireitus. 150.011.

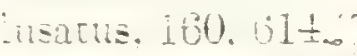

Thrissopater, ,

Libinus

ategriups. $3 \%$

- iinoneus. $3 \%$.

[hrisoons uracilis, $\left.{ }^{\prime}\right]$.

Art..issins rexillitel.

Thrisscpteroides, it.

jongutus. $\frac{1}{5}$

intermeritus.

$\therefore$ u․

aricher, sio

enuicens. \%.

Thrisscioterus,

aruilit. 4.

Thryptcaus, a, s, 27

utuncins. E.j.

zicieli.

Thynnicinths, oil?

anjostonna. 403

mythaus, 101.

- gustatis. 5.5

Uuicensis. \pm 57 .

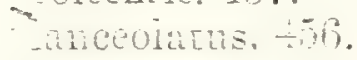

panuratus. ton.

poterogins. $40 \pm$.

motimus, 4.50

Ecricisi, t5.j.

¿Tnnus. $\pm \overline{5}$.

rolianicus. \pm s.

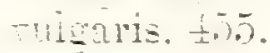

myrsites. \pm 1 .

risitol. A-1.

Thyrsitccephaius, 垙.

ininus. 17 .

Iinca, siz.

zuncoitutana. is 6.

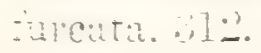

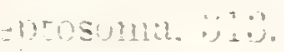

anilua
Iinca (cont.).

uncropterrgia, j15.

magna, 312.

micropsgoptera, ilt.

otruncata, 316 .

tarsiger, :15.

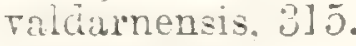

7uigaris. 315.

Titanichthys. Dumes. 1i12.

pharao. 612.

Tomodon, il:.

hurifcus. 310.

Tomognathus, 116.

morcils, $11 \%$.

teivius, 117.

Toropoma, b1:.

pulitum, iil:.

Icrotes, .101

antiques. joil.

THACHIXIDE, Dis!

Tracninoosis, .01.

cericir. Jl.

Tracninus, -ti).

diracuncuins, jou.

Surigatus. 5ol.

inutadilis. 5.t).

seetancicus, 500 .

remus, 54 .

Trachynotus, i5u. enuicens. t.ju.

Triacanthus. Fi.

Trianaspis, $17 \%$. $3 \%$.

Firoututus. IST.

Frichiuricisthys, 18?.

incertus. $4: 0$.

Tricniurias, - -10

niocienus. -1 -

Trichoohanes. 116

ronei. 1160 .

Evilapun. $\$ 10$.

ilians, $+10 ;.$

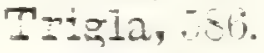

aciuncta. 55.

(0) 1.5

Hiprica. 59.

iniausca. jư.

Ticatm, 580.

Irra, joy.

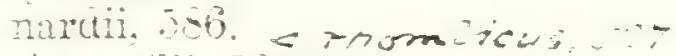

simonejii. Sofi.

TIIGLID_E. $\overline{0}$

Trigloides, j86.

diutir. - oti.

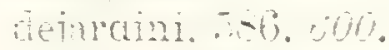

meiriss. osi

ran oenerienis joo.

Trigonodon. Jil.

weril. deil.

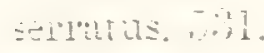

riniocin

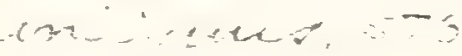

$=3-\infty,+\infty+\infty$ 


Tydeus, 257 .

albyi, $25 \%$.

eiongatus, 257 .

megistosoma, $25 \%$.

splekodes, 258.

Umara, Umbrina. 538.

pecchiolii. 538.

Uranosc $=$ pus, 590 . peruzzii, 590 . rastrum, 377.

Urenchelys, 333. anglicus. 339. avus, 33. .

hakelensis. 338.

73. Uropterina, 146.

platyrachis, 158.

Urosphen, 376 .

dubia, 376.

fistularis, 376.

Vomer longispinus, 436.
Vomer parvulus, 451.

Vomer priscus, 44.2.

Vomeropsis, 435 .

elongatus, 437.

longispinus, 436 .

raienciennesi, 437 .

cinuss.436.

Xiphactinus, 92.

audax, 92, 98.

brachygnathus, 97.

lestrio, 97.

Xiphias, 490. acutirostris, 357.

antiquus, $49 \overline{5}$.

delfortriei, 497 .

robustus, 497 .

XIPHIIDE, 490.

Xiphopter'us, 482. falcatus, 482.

Xiphiorhynchus, 490 .

elegans. 491 .

rengaveng, is4.
Xiphiorhyncinus

(cont.).

priscus, 191.

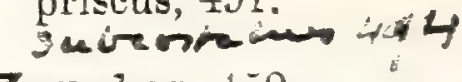

Zanclus, tŏ0.

brevirostris, 450 . eoconus, 450.

Zeus, 117 .

benoisti. 417.

gallus, 449 .

hoernesi, $417 .^{\circ}$

lewesiensis, 397.

licatæ, 418.

platessa, 501 .

pliocenicus, 418 .

priscus, 516 .

regleysianus, 501.

rhombeus, 439 .

robustus, 418 .

spinosus, 500.

triurus, 436 .

vomer, 436.

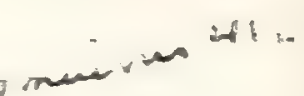


vinita, 281 octaria, 481,3

Turio, rev.482. wilturi, wev 482

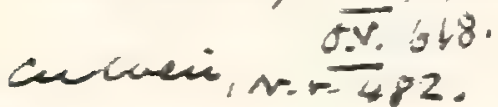

7 ar. 482 .

Yuarimanas iso.

downthas, 340

Venieer rinus, 200. suminin :2?

reviór

incresens

Incichims: 234.

vinciáceunía $\$ 69$.

bigskenes sis.

Laverarowdichitis, sol

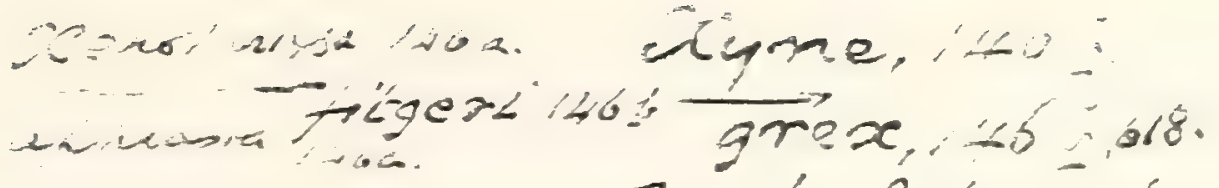

Zantechites, 36 a

Cestias 465

huvbri, sia iratus 465 .

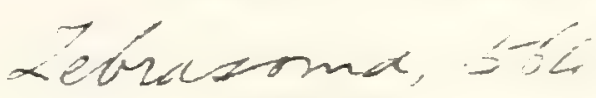
deane.

Zucuiv,, 3.

Zaphtegidae, 3iv Xaphleges, os:

longutio, 365 ?

Zasporidae, $17.7 \%$

Curinius, 553,1464 Zelosis, 155.

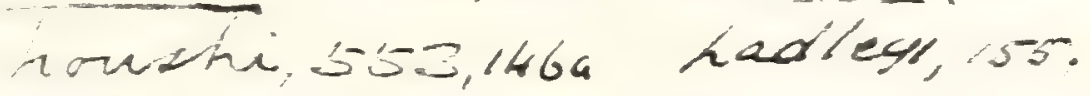

berbence, $146 a$. Jororhomin. if elmadiemae. $146 a$. veliger.

Zemiagramma isistivo, 500 - 0 zeures.

Teforich

aliam-ina

Zarobseta

Tentates. 






\title{
SYSTEUATIC INDEX
}

\author{
OF \\ GENERA A N D S PECIES \\ DESCRIBED IN PART IV.
}

Order ACTINOPTERYGII (continued) Page Suborder IV. ISOSPONDYLI (continued) . . . . 1 Family LEPTOLEPID $Æ$ (continued) • . . . . 1 Lycoptera . . . . . . . . . . 1

— middendorffi . . . . . . . 2

— sinensis . . . . . . . . . 3

Family ELOPID\& . • . . . . . . . 7

Elopopsis . . . . . . . . 8

— fenzli . . . . . . . . . . 9

— microdon . . . . . . . . . 9

— heckeli . . . . . . . . . . 9

Crassus . . . . . . . . 10

Osmeroides . . . . . . . . 11

— lewesiensis . . . . . . . . 11

— levis . . . . . . . . 15

— gracilis . . . . . . . . 16

- lewisi . . . . . . . . 17

—attenuatus. . . . . . 19 
Family ELOPID $刃$ (continued).

Osmeroides sardinioides .. . . . . 19 cretaceus . . . . . . . 20

Elops . . . . . . . . . 22

\legalops . . . . . . . . . . 24

priscus . . . . . . . . . 24

oblongus . . . . . . . 26

Notelops . . . . . . . . 27

brama . . . . . . . . 27

Rhacolepis . . . . . . . . 29

buccalis . . . . . . . 30

latus . . . . . . . . 32

Thrissopater . . . . . . . . 32

salmoneus. . . . . . . . . 33

magnus . . . . . . . . 33

(?) megalops . . . . . . . . 35

Pachyrhizodus . . . . . . . . . 37

basalis . . . . . . . . 37

dibleyi. . . . . . . . . 38

gardneri . : . . . . . . 40

latimentum . . . . . . . . 42

subulidens ... . . . . . 43

Esocelops . . . . . . . . . . . 46

carifrons . . . . . . . 46

Spaniodon . . . . . . . . . . 48

blondeli . . . . . . 48

elongatus . . . . . . . . 51

latus . . . . . . . 53

Thrissopteroides . . . . . . . . 54

elongatus . . . . . . . 54

latus $. . .9 . . .54$

intermedius . . . . . . . 55

tenuiceps . . . . . . . . 55

pulcher . . . . . . . 56

Protelops . . . . . . . . . . 56

geinitzi . . . . . . . . 57

anglicus : . . . . . . 57 
Family ALBCLID $巴$. . . . . . . . . . 59

Albula . . . . . . . . . 60

—oweni . . . . . . . 60

Chanoides . . . . . . . . 63

macropoma . . . . . . 63

Chanos . . . . . . . . 64

Prochanos . . . . . . . . . 65

rectifrons. . . . . . . . 65

Ancylostylos . . . . . . . . . 66

- gibbus . . . . . . . . . 66

Istieus . . . . . . . . . . 66

grandis . . . . . . . . 67

macrocephalus . . . . . . 70

lebanonensis . . . . . . . 71

Anogmius . . . . . . . . . 71

polymicrodus. . . . . . . 72

Family OSTEOGLOSSID $巴$. . . . . . . 73

Dapedoglossus . . . . . . . . 74

— testis . . . . . . . . . 75

— æquipinnis . . . . . . . 75

Brychætus . . . . . . . . . 76

— muelleri . . . . . . . 76

Incertæ sedis . . . . . . . . . 80

Plethodus . . . . . . . . 80

— expansus . . . . . . . . . 81

— pentagon . . . . . . . . . 83

—oblongus ... . . . . . . 83

Thryptodus . . . . . . . . . 85

Family NOTOPTERID无 . . . . . . . 85

Notopterus . . . . . . . . 86

primævus . . . . . . . 86 
Family, CHIROCENTRID $\mathbb{E}$

Chirocentrus . . . . . . . . 88

(?) polyodon . . . . . . . . 88

Platinx . . . . . . . . 89

Chiromystus . . . . . . . 89

mawsoni . . . . . . . 90

Chirocentrites . . . . . . . 90

coroninii . . . . . . . . 91

Portheus . . . . . . . . 92

molossus. . . . . . . . 92

mantelli . . . . . . 95

daviesi . . . . . . . . 95

gaultinus . . . . . . . . 95

Spathodactylus . . . . . . . . . 98

neocomiensis . . . . . . . 98

Ichthyodectes . . . . . . . . 99

ctenodon . . . . . . 100

anaides. . . . . . . 100

arcuatus . . . . . . . 101

serridens ......... 101

minor . . . . . . . 102

elegans ... . . . . . . 103

tenuidens... . . . . . . 104

libanicus . . . . . . . 105

Cladocyclus . . . . . . . . 107

— gardneri . . . . . . . 108

lewesiensis . . . . . . . 109

Saurodon . . . . . . . . 111

_ leanus . . . . . . . . . 111

— phlebotomus . . . . . . . 112

intermedius . . . . . . . . 112

Saurocephalus . . . • . . . . 113

— lanciformis . . . . . . . 113

— woodwardi . . . . . . . 114

Incertæ sedis . . . . . . . . 116

Tomognathus . . . . . . . 116

$\operatorname{mordax} . . .9 . . .9117$ 
Page Family CTENOTHRISSID五 . . . . . . . 119

Ctenothrissa . . . . . . . . 120

— vexillifer. . . . . . . . 120

- radians . . . . . . . 122

— microcephala . . . . . . . 124

Aulolepis . . . . . . . 126

typus . . . . . . . . . 127

Family CLUPEID $\approx$. . . . . . . . . . 128

Pseudoberyx. . . . . . . . . . 129

syriacus : . . . . . . . 129

bottæ . . . . . . . . . 130

grandis . . . . . . . . 130

Histiothrissa . . . . . . . 131

macrodactyla . . . . . . . 131

crassapinna . . . . . . . 132

Engraulis . . . . . . . . . 133

Halecopsis . . . . . . . . 133

— insignis . . . . . . . . . . 134

Scombroclupea . . . . . . . . : 135 macrophthalma . . . . . . 135 gaudryi . . . . . . . . 138

Diplomystus . . . . . . . . 139

— dentatus . . . . . . . . . 139

— brevissimus . . . . . . . 140

- birdi . . . . . . . . . . 142

— longicostatus . . . . . . . . 143

- humilis . . . . . . . . 144

— altus . . . . . . . . . . 145

— vectensis . . . . . . . . 146

Clupea . . . . . . . . . . 146

- scheuchzeri . . . . . . . 147

catopygoptera . . . . . . . 148

- humilis : . . . . . . . 150

— crenata. . . . . . . . 151

- numidica . . . . . . . . . 151

— sardinites . . . . . . . . 152

— sprattus . . . . . . . . . 153 


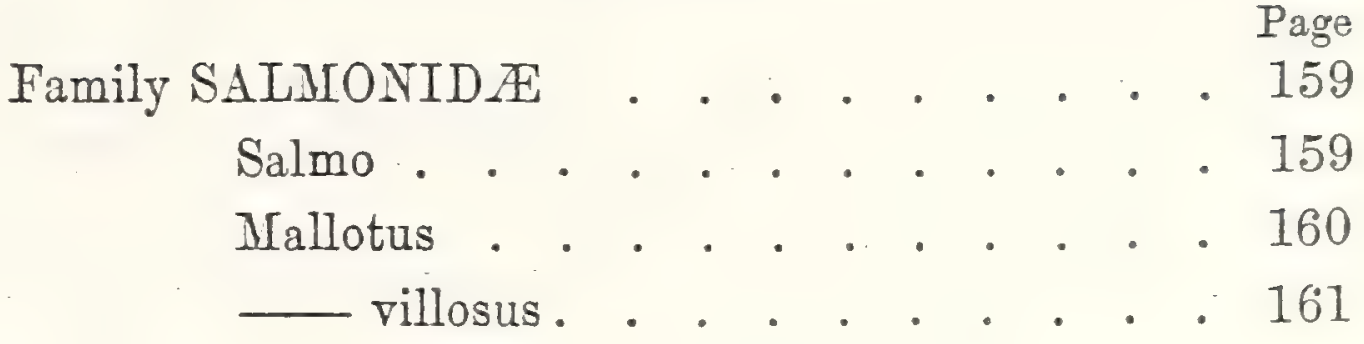

Family HALOSAURID无 . . . . . 162

Echidnocephalus . . . . . . 163 troscheli . . . . . . . 163

Enchelurus . . . . . . . . 164

- villosus. . . . . . . . . . 164

— syriacus . . . . . . . 165

— anglicus . . . . . . . . 167

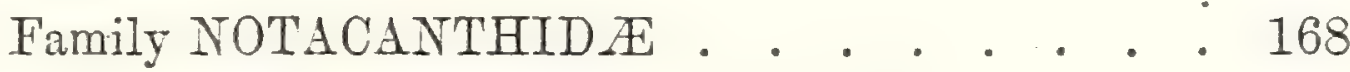

Pronotacanthus . . . . . . . . 169 sahel-almæ . . . . . . 169

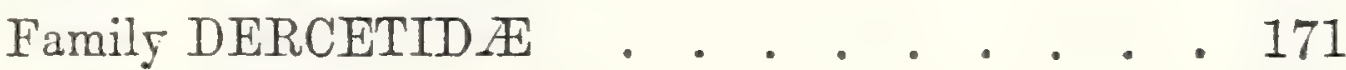

Dercetis ........ . . 172

— scutatus . . . . . . . 172

Leptotrachelus . . . . . . . . 173

— armatus . . . . . . . 174 triqueter ... . . . . . . 174 gracilis . . . . . . . 180

— hakelensis . . . . . . . . . 184

— elongatus . . . . . . . . 184

Pelargorhynchus . . . . . . 188

— dercetiformis . . . . . . . 188

Family ENCHODONTID $巴$. . . . . . 189

Enchodus . . . . . . . . . 190

— lewesiensis . . . . . . . . 191

— pulchellus . . . . . . . . . 193

annectens . . . . . . . 195

faujasi . . . . . . . . 196

lemonnieri . . . . . . . 198

longidens . . . . . . . . 199 
Family ENCHODONTIDE (continued).

Enchodus major . . . . . 200

— gracilis . . . . . . . . . 201

— macropterus . . . . . . . . 202

Eurypholis . . . . . . . . 207

- boissieri . . . . . . . 207

— freyeri . . . . . . . . . 210

Palæolycus . . . . . . . . . . 211

— dreginensis . . . . . . . . 211

Halec . . . . . . . 212

— sternbergi . . . . . . . 212

— eupterygius . . . . . . . . 213

- microlepis . . . . . . . . 218

- haueri . . . . . . . . . 219

Cimolichth5s. . . . . . . . 221

- lewesiensis . . . . . . 221

— nepæolica . . . . . . . . . 225

Prionolepis . . . . . . . . . . 229

— angustus . . . . . . . . . 230

— cataphractus . . . . . . . 230

Claniatus . . . . . . . . 232

Leptecodon . . . . . . . . . 233

rectus . . . . . . . 233

Pantopholis . . . . . . . . 234

Family SCOPELID $\mathbb{E}$.. . . . . . ... . . 235

Sardinioides . . . . . . . . 236

— monasteri . . . . . . . . 237

— crassicaudus . . . . . . . 238

— megapterus . . . . . . . . 239

— pusillus . . . . . . . . . 240

—attenuatus. . . . . . . . . 241

Acrognathus . . . . . . . . . . 243

- boops . . . . . . . . . . 243

libanicus . . . . . . . . 244

Leptosomus . . . . . . . . . . 244

— guestphalicus . . . . . . . . 245 
Family SCOPELID王 (continued).

Leptosomus elongatus

- macrourus .

245

minimus

Sardinius

Dactylopogon

grandis

248

Nematonotus . bottx

Nicrocoelia

- granulat

Opisthopteryx gracilis .

Scopeloides

lacertosus 256

Anapterus 257 megistosoma 257 Apateodus 258

— glyphodus . . . . . . . . 258

- striatus . lanceolatus

264 Rhinellus 265 — furcatus . . . . . . . . 266

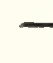
ferox damoni. 268

Family, GONORHYNCHID $\mathbb{E}$ 271 Charitosomus 271 formosus 272 major 272 lineolatus . . . . . . . 274 hakelensis . . . . . . . . 274 Notogoneus 
Family GONORHYNCHID $巴$ (continued).

Notogoneus osculus . . . . . . 275

— squamosseus . . . . . . . 276

- curieri '. . . . . . . 277 longiceps . . . . . . . . . 278

Family CHIROTHRICID $Æ$. . . . . . . . 279

Chirothrix . . . . . . . . 280

_libanicus . . . . . . . 280

- lewisi . . . . . . . . 283

- guestfalicus . . . . . . . . 283

Telepholis . . . . . . . . . 284

— acrocephalus . . . . . . 284

— (?) tenuis . . . . . . . . . 285

Exocœtoides . . . . . . . 286

minor . . . . . 286

Family ESOCID $e^{2}$. . . . . . . . 287

Esox . . . . . . . . . 287

lepidotus . . . . . . 288

Family CYPRINODONTID $巴$. . . . . . 289

Prolebias . . . . . . . . . . 290

— cephalotes. . . . . . . 290

- furcatus : . . . . . . . 291

— gregatus . . . . . . . . 292

—- stenıura . . . . . . . . . 292

- goreti . . . . . . . . 293

— brongniarti . . . . . . . 293

Pachylebias . . . . . . . . . 294

— crassicaudus . . . . . . 295

Suborder V. OSTARIOPHYSI • • . . . . . 296

Family CHARACINID $巴$. . . . . . . 297

Tetragonopterus . . . . . . . 298

avus . . . . . . . . 298

ligniticus . . . . . . . . 298 
Family CYPRINID正

Catostomus

Amyzon

Cyprinus

- priscus

Barbus

megacephalus

Thynnichthys

amblyostoma

Gobio

analis

Amblypharyngodon

Leuciscus

oeningensis

papyraceus

colei

macrurus

leptus

Tinca

furcata.

leptosoma .

micropygoptera tarsiger

Rhodeus

elongatus

latior

Aspius .

gracilis .

minutus

Cobitis

centrochir

angustus

cephalotes .

Hexapsephus .

guentheri 
Clarias .

. . 324 falconeri . . . . . . . . 324

Heterobranchus . . . . . . . 325

— palæindicus . . . . . . . 325

Silurus

Pseudeutropius

326 verbeeki

Macrones

Rita aor

Amiurus 328

Rhineastes

328

Bucklandium

329 diluvii 330 Arius

330

•. • • • • • . . 330

egertoni

331 crassus.

332 (?) bartonensis . . . . . . . 333 iheringi Bagarius 333 gigas 335 335

Suborder VI. APODES 336 Family MUR ENID无 336

Urenchelys . 337

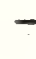
avus 337

- hakelensis 338

Eomyrus 339 - dollo 340

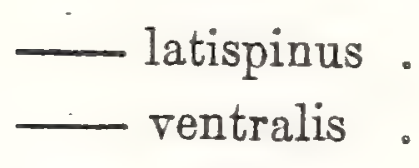


Family MURENIDE (continued).

Paranguilla . . . . . . . 343

— tigrina . . . . . . . . 343

Anguilla . . . . . . . . . 344

— leptoptera . . . . . . . . 344

— elegans . . . . . . . . 345

Nettastoma . . . . . . . . 346

bolcense . . . . . . . 346

Suborder VII. PERCESOCES . . . . . . . 347

Family CROSSOGNATHID $\mathrm{E}$. . . . . . 348

Crossognathus . . . . . . . 348

sabaudianus . . . . . . 349

Syllæmus . . . . . . . . . 350

— latifrons . . . . . . . . 351

— anglicus . . . . . . . 351

Family AMMODYTID无 . . . . . . . 354

Cobitopsis . . . . . . . 354

acutus' . . . . . . 355

Family SCOMBRESOCID无 . . . . . . 356

Belone . . . . . . . 356

tenuis. . . . . . . 357

Scombresox . . . . . . . . 357

obtusirostris . . . . . . 357

Hemiramphus . . . . . . 358

Family ATHERINID $₫$. . . 。 . . . 358

Atherina . . . . . . . 359

macrocephala . . . . . . . 359

sarmatica . . . . . . . 360

vardinis . . . . . . . 360

Rhamphognathus . . . . . . . 361

— paralepoides . . . . . . 361

— sphyrænoides . . . . . . . 362 
Page Family MUGILID王 . . . . . . . . . 363 Mugil . . . . . • . . . . . . 363 —— princeps . . . . . . . . 364 — radobojanus . . . . . . . 365

Family SPHYR ENID王 . . . . . . . . . 365

Sphyræna . . . . . . . . . 366

- bolcensis . . . . . . . . 366

— intermedia . . . . . . . 367

— suessi . . . . . . . 368

Suborder VIII. HEMIBRANCHII . . . . . . . 369

Family AULORHYNCHIDE . . . . . . 371

Protaulopsis . . . . . . . . 371

— bolcensis . . . . . . . 371

Aulorhynchus . . . . . . . . 372

- sumatrensis . . . . . . . 373

Family FISTULARIID王 . . . . . . . 373

Fistularia . . . . . . , . . 374

— koenigi . . . . . . . . 874

— longirostris . . . . . . . 375

Aulostoma . . . . . . . . . . 375

bolcense . . . . . . . . 375

Urosphen . . . . . . . . . . 376

Jubia . . . . . . . . 376

Family CENTRISCID王 • • • . • • • • 377

Rhamphosus . . . . . . . . 377

— aculeatus . . . . . . . 377

— biserratus . . . . . . . . 378

Amphisile . . . . . . . . . . 378

- heinrichi . . . . . . . . 379

Family SOLENOSTOMATIDA . • • • • . 379

Solenorhynchus . . . . . . . 380 elegans . . . . . . . 380 
Family SYNGNATHID 死 Page

Pseudosyngnathus . . . . . . . 381

— opisthopterus . . . . . . . 381

Siphonostoma . . . . . . . . 382 albyi . . . . . . . . 382

Syngnathus . . . . . . . . 382

Calamostoma . . . . . . . . . 383

breviculum . . . . . . 383

Suborder IX. ACANTHOPTERYGII . . . . . . 384

Division A. Beryciformes . . . . . . . 384

Family BERYCID $巴$ • . . . . . . . . 384

Beryx . . . . . . . . . 385

Sphenocephalus . . . . . . . 387

— fissicaudus .. . . . . . . . . 387

— cataphractus . . . . . . . 388

Acrogaster . . . . . . . . 388

— parvus . . . . . . . • . . 389

—- brevicostatus . . . . . . . . 389

- beckeli . . . . . . . . . 290

daviesi . . . . . . . . 390

Pycnosterinx . . . . . . . . 391

russeggeri . . . . . . . . . 392

discoides . . . . . . . . 393

gracilis . . . . . . . . . 394

dubius . . . . . . . . 395

Hoplopteryx . . . . . . . . 396

— antiquus . . . . . . . . 396

— zippei . . . . . . . . . 397

— lewesiensis . . . . . . . 397

— superbus . . . . . . . . 403

— lundensis . . . . . . . . 404

—ewisi . . . . . . . . . . 404

syriacus . . . . . . . 405

stachei . . . . . . . 406 
Family BERYCID $Æ$ (continued).

Page

Dinopteryx . . . . . . . . . 406

— spinosus . . . . . . . . 407

Homonotus . . . . . . . . 407 dorsalis. . . . . . . 408

Myripristis . . . . . . . 410

- leptacanthus . . . . . . . 410

— homopterygius . . . . . . 411

Holocentrum . . . . . . . . 412

— macrocephalum . . . . . . . 412

melitense . . . . . . . . 413

Family APHREDODERID $巴$. . . . . . 416

Family CYTTID 1 . . . . . . . . . . 417

Division B. Scombriformes . . . . . . . 418

Family STROMATEID $Æ$. . . . . . . 419

Omosoma.......... . . 419

— sahel-almæ . . . . . . . 419

—intermedium . . . . . . . 420

— pulchellum .... . ... . . 421

Platycormus .......... . . 421

— germanus . . . . . . . . 421

Berycopsis . . . . . . . . 423

elegans . . . . . . . . 423

Family CARANGID $巴$. . . . . . . 425

Aipichthys .. . . . . . . 427

— pretiosus . . . . . . . . 427

— velifer . . . . . . . . . 427

- minor . . . . . . . . 428

- nuchalis . . . . . . . . 429

Semiophorus . . . . . . . . 430

— velifer . . . . . . . . 430

— velicans . . . . . . . . 431

Platax . . . . . . . . 432 
Family CARANGID E (continued).

Platax woodwardi .

rhombeus

Caranx .

glarisianus .

Seriola. prisca

breris dorsalis

Ductor. leptosomus

Family SCOMBRID压.

Isurichthys

macrurus

orientalis

Thynnus

Eothynnus

salmoneus 
Family SCOMBRID $Æ$ (continued).

Scombrinus

$\cdot 461$

- nuchalis . . . . . . . . 461

- macropomus . . . . . . . 462

duxis . . . . . . . . . . 463

(?) propterygius . . . . . . . 464

Cybium . . . . . . . . . 465

— speciosum . . . . . . . . 466

— bleekeri . . . . . . . 466

- excelsum . . . . . . . . . 467

— bartonense . . . . . . . 46

— lingulatum . . . . . . . . 469

Eocœlopoma. . . . . . . . 470

— colei . . . . . . . . 470

- curvatum , . . . . . . . 472

Sphyrænodus . . . . . . . . . 473

priscus . . . . . . . . 473

Scombramphodon . . . . . . . 474

- benedeni . . . . . . . 474

— curvidens . . . . . . . . . 474

C crassidens . . . . . . . . 475

Thyrsitocephalus . . . . . . . 476

alpinus . . . . . . . . 477

Lepidopus . . . . . . . . . . 477

glarisianus . . . . . . 477

brericauda . . . . . . 480

albji . . . . . . . 480

Family PALAORHYNCHID E . . . . . 482

Palæorhynchus . . . . . . . . 483

glarisianus . . . . . . . 483

— longirostris . . . . . . . 486

— ritteli . . . . . . . . 487

Hemirhynchus . . . . . . . 488

deshayesi . . . . . . . 488

colei. . . . . . . . 488 


$$
\begin{aligned}
& \text { Family XIPHIID王 . . . . . . . . . . } 490 \\
& \text { Xiphiorhynchus . . . . . . . } 490 \\
& \text { __ elegans . . . . . . . . } 491 \\
& \text { — priscus . . . . . . . . . . } 491 \\
& \text { Acestrus . . . . . . . . . . } 494 \\
& \text { - ornatus . . . . . . . . } 494 \\
& \text { Histiophorus . . . . . . . . } 495 \\
& \text { — eocænicus. . . . . . . } 495 \\
& \text { - rotundus . . . . . . . } 495
\end{aligned}
$$

Division C. Perciformes . . . . . . . . 497

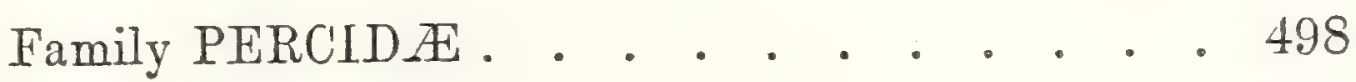

Prolates .. . . . . . . . 499 heberti. . . . . . . . 499 Acanus . . . . . . . . 500 — — regleysianus . . . . . . . 501 Lates .. . . . . . . . . . 502 gracilis . . . . . . . 502 Cyclopoma . . . . . . . . 504 — - gigas . . . . . . . 504 (?) micracanthum ... . . . 504 Smerdis . . . . . . 506 - minutus . . . . . . 506 — formosus . . . . . . 507 macrurus . . . . . . 507 Labrax . . . . . . . . . 509 ubinoi . . . . . . . . 510 schizurus . . . . . . . . 510

— oeningensis . . . . . . 511 Percichthys . . . . . . . . . 514 — antiquus . . . . . . . . . 514 Properca . . . . . . . . . 514 — angusta . . . . . . 515 beaumonti . . . . . . 515 — (?) prisca . . . . . . . 516 
Family PERCID $\mathrm{E}$ (continued).

Mioplosus .

Fumily TEUTHIDID A 523

Family SPARID王 . 524

Sparnodus 524 inacrophthalmus. 525 elongatus 526 microstomus . . . . . . 527 bowerbanki . . . . . . 527 Sargus . 529

— oranensis . . . . . . . . 529

— laticonus . . . . . . . . 529

Trigonodon . . . . . . . . 531

— oweni . . . . . . . 531

— serratus . . . . . . . 531

Pagellus ... . . . . . . . 532

Pagrus . . . . . . . . . 533

Chrysophrys . . . . . . . . 534

Family SCI ENID $Æ$. . . . . . . 538

Family LABRID $\mathrm{E}$. . . . . . . . . . . 539

Labrus . . . . . . . . . 539

Julis . . . . . . . . . 541

Labrodon . . . . . . . . 541

— superbus. . . . . . . . . 542

Canariensis . . . . . . . 542

Phyllodus. . . . . . . . 546

— toliapicus .. . . . . . . . 546

Egertonia . . . . . . . . . 550

— isodonta . . . . . . 551

Platylæmus . . . . . . . 551

colei . . . . . . . 551

Pseudosphærodon . . . . . . . 552 hilgendorfi . . . . . . . 552 
F.mily CHED Page Priscacara . . . . . . . 554

-

— clirosa . . . . . . . . 554

Dirision D. Chætodontiformes . . . . . . 556

Family CHETODONTID $\mathrm{E}$. . . . . . 556

Pygæus . . . . . . . . 557

— coleanus . . . . . . . 557

Proantigonia . . . . . . . 558

Ephippus . . . . . . . . . 559

— rhombus . . . . . . . 559

Family ACRONURIDE . . . . . . 562

Aulorhamphus . . . . . . . 562

Apostasis . . . . . . . . . 563

Acanthurus . . . . . . . 563

Naseus. . . . . . . . 564

rectifrons . . . . . . . 564

Family BALISTID $\nsubseteq$ • . . . . . . 565

Spinacanthus . . . . . 566

Acanthopleurus ... . . . . . 566

- - serratus . . . . . . . 567

Acanthoderma . . . . . . . 568

spinusum . . . . . • • . 568

Ostracion . . . . . . . . . 569

Family GYMNODONTID

Tetrodon . . . . . . . . . 571

Diodon. . . . . . . . . . 571

erinaceus . . . . . . . 572

scillæ . . . . . . . 572

sigma . . . . . . . . 573

vetus . . . . . . . 573

Orthagoriscus . : . . . . . . 576 
Dirision E. Scorpæniformes $\quad \begin{array}{r}\text { Page } \\ 576\end{array}$

Family SCORPÆNID $巴$. . . . . . . 577

Ampheristus . . . . . . . . 577

toliapicus . . . . . . . 577

Family COTTID无 . . . . . . . . . 580

Eocottus . . . . . . . . . 580

veronensis. . . . . . . 581

Lepidocottus . . . . . . . . . 581

—

— brevis . . . . . . . . . . 582

— papyraceus . . . . . . . 583

— multipinnatus . . . . . . 584

Cottus . . . . . . . . . . 585

Family TRIGLID $巴$. . . . . . . . . 585

Ditision. F. Gobiiformes . . . . . . . 587

Family GOBIID $巴$. . . . . . . . 587

Family TRACHINID $\mathrm{E}^{\circ}$. . . . . . . . 589

Callipteryz . . . . . . . 589

— speciosus . . . . . . . . . 589

- recticaudus . . . . . . 58?

Division G. Blenniiformes . . . . . . . . 591

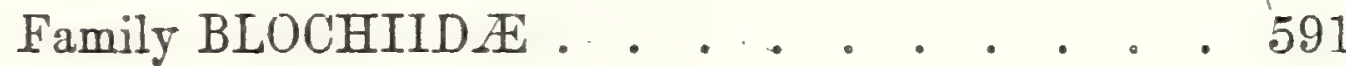

Blochius . . . . . . . . . 593

longirostris . . . . . . . 593

Family BLENNIID $\mathrm{E} . . \cdot . . .595$

Pterggocephalus. . . . . . . . . 595

— paradoxus . . . . . . . . 595 

II. Post-temporal almost or completely fused with cranial roof, and supraclavicle displaced backwards so that post-temporal and clavicle are in contact.

Vertebral transverse processes short or absent; no anal fin-spines; scaly or only with bony plates along lateral line......... TRIGLID 2 (p. 585).

\section{Family SCORP ANID $\mathbb{E}$.}

Head more or less armed with spines; mouth large and terminal, with minute teeth. Vertebræ 24 to 31 in total number, those of abdominal region with transverse processes supporting ribs. Posttemporal bone free from cranium, and supraclavicle normal. Large pectoral fins with pelvic fins directly beneath; dorsal fin much extended, with 8 to 16 strong spines; anal fin with 3 spines. Trunk covered with a regular squamation or naked.

These are marine fishes of wide distribution and varied habit. Five supposed extinct genera are known by unsatisfactory fragments, but only one of them is represented in the Collection.

A figure of the skeleton of the existing Scorpona is given by Agassiz, Poiss. Foss. vol. iv. pl. L, fig. 2.

\section{Genus AIPHERISTUS, König.}

[Icones Foss. Sect. 1825, pl. xv. fig. 190 (undefined).]

Syn. Goniognathus, L. Agassiz, Poiss. Foss. vol. v. pt. i. 1844, p. 63 (name only).

An apparently extinct genus, known only by remains of the head, vertebral column, and scales. Orbit very large; interorbital portion of cranial roof concave, with a pair of small prominences above the hinder part of the orbital rim; only two pairs of short longitudinal ridges on the postorbital portion of the frontal region, forming an incomplete $\mathrm{W}$; lower border of mandible sharply bent inwards. Preoperculum with 5 broad spines; suborbital stay probably very stout. Vertebræ probably about 24 in total number.

\section{Ampheristus toliapicus, König.}

\section{[Text-figure 21.]}

1825. Ampheristus toliapicus, C. König, op. cit. pl. xv. fig. 190.

1844. Goniognathus maxillaris, L. Agassiz, Poiss. Foss. vol. v. pt. i. p. 63 (name only).

1844. Goniognathus coryphrenoides, L. Agassiz, tom. cit. p. 63 (name only). 
Type. Hinder half of cranium; British Museum.

The type species, with skull about 0.1 in length and 0.05 in maximum width. Two upper preopercular spines inconspicuous.

Form. \& Loc. Lower Eocene (London Clay): Sheppey, Kent.

P. 9432. Well-preserved postorbital portion of cranium, the type specimen figured by König. The two median frontal ridges are shown.

Old Collection.

3571yे. Remains of head displaying the right preopercnlum, which is shown, nat. size, in the accompanying fig. $21 \mathrm{~A}$. The

Fig. 21.

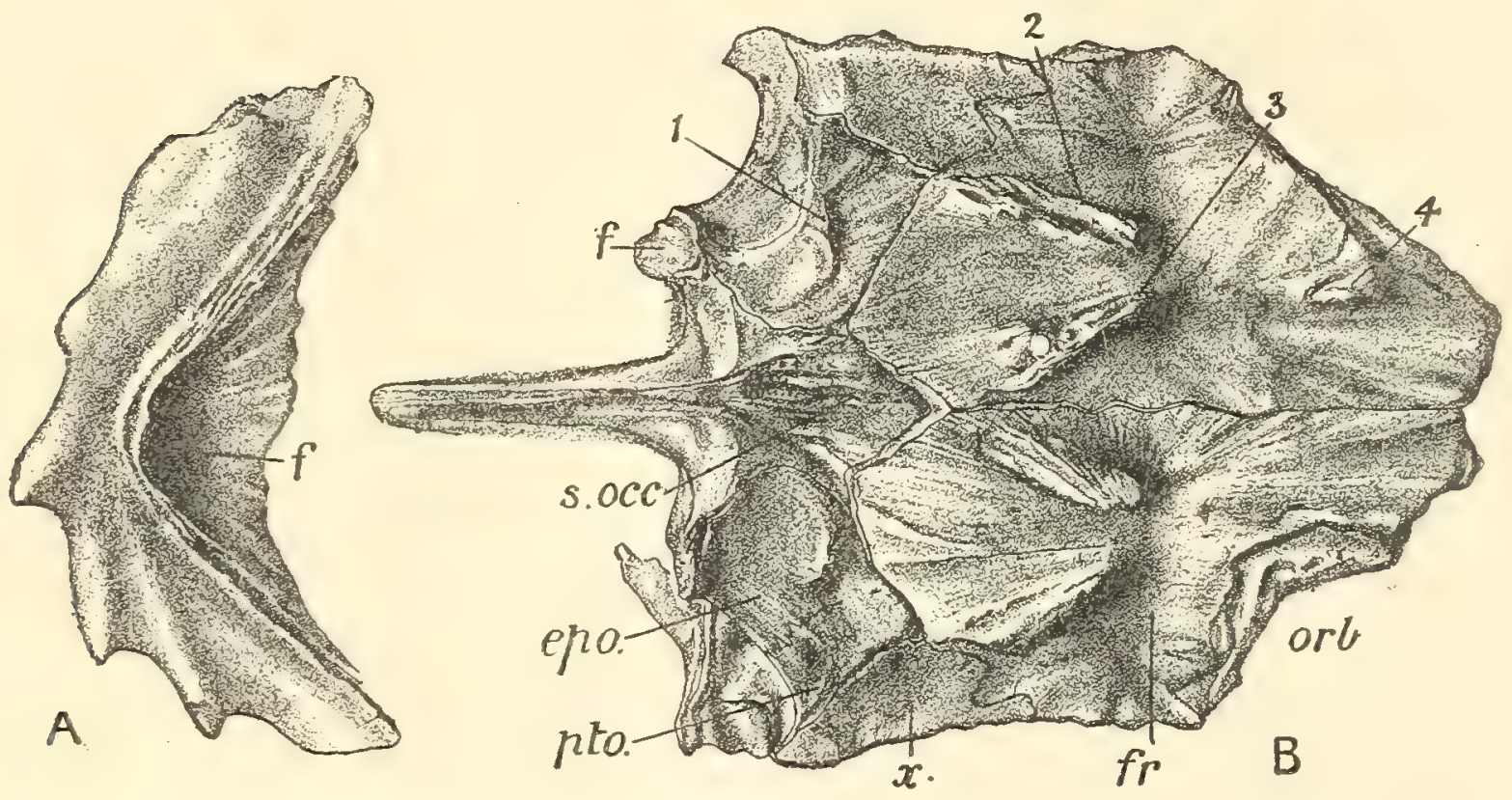

Ampheristus toliapicus; right preoperculum, outer aspect (A), and hinder portion of cranium, upper aspect (B). nat. size. epo., epiotic ; $f$., facettes ; fr., frontal ; orb., orbit ; pto., pterotic; s.occ., supraoccipital ; $x$., squamosal (?); 1-4, ridges.

lowermost spine is broken, and the upper end of the bone is incomplete. A ridge and facette $(f)$ indicate the attachment of the bony suborbital stay. Purchased, 1860.

P. 630. Fragmentary head and three anterior vertebræ, labelled by Agassiz and Egerton as intended to be the type specimen of Goniognathus coryphonoides.

35718. Imperfect head.

Egerton Coil.

P. 9433-35. Three imperfect heads, one showing 8 pairs of branchiostegal rays.

History unknown.

38899. Remains of head.

Bowerbank Coll.

P. 4143, P. 4540. Five imperfect specimens, the first showing the frontal ridges, as represented in the accompanying 

fig. 21 B. The extended low supraoccipital spine is seen behind, and the supraoccipital (s.oce.) is observed to extend forwards between the hinder ends of the frontals ( $f r$.$) .$ The incomplete $\mathbf{W}$ formed by the postorbital frontal ridges $(2,3)$ is distinet; and the small supraorbital prominence (4) is seen on the left side. Enniskillen Coll.

P. 1698, P. 1759. Three imperfect specimens.

Egerton Coll.

38912. Portion of skull and greater part of vertebral column. The hinder abdominal vertebræ bear large, laminar, downwardly-directed transverse processes. Bowerbank Coll.

The following supposed extinct species of this family, not represented in the Collection, have been referred to existing genera:-

Scorpcena minima, D. G. Kramberger, Beitr. Paläont. Oesterr.Ungarns, vol, ii. (1882), p. 110, pl. xxii. fig. 2.-Upper

Miocene; Dolje, Croatia. [Imperfect fish; Geological

Museum, University of Agram.]

Scorpoena pilari, D. G. Kramberger, loc. cit. 1882, p. 109, pl. xxii. Panca", 1933s, fig. 1.-Upper Miocene; Radoboj, Croatia. [Imperfect

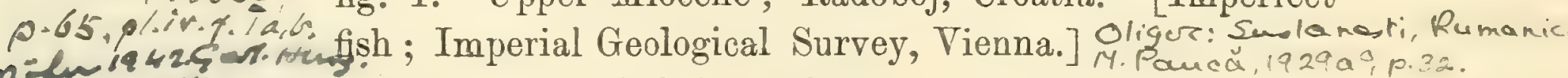
B. Br. Pet 19. M.Scorpcena prior, J. J. Heckel, Denkschr. k. Akad. Wiss., math.naturw. Cl. vol. xix. (1861), pt. i. p. 72, pl. x. fig. 10.Middle Miocene (Leithakalk); Vienna. [Imperfect fish ; Court Museum, Vienna.]

Scorpcena tessieri, H. E. Sauvage, Ann. Sci. Géol. vol. iv. (1873), art. no. 1, p. 114, fig. 69.-Upper Miocene; Oran, Algeria. [Imperfect fish; Paris Musenm of Natural History.]

Sebastodes (?) rosa, C. H. Eigenmann, Zoe, vol. i. (1890), p. 16, with fig.-Tertiary; Port Harford, California. [Preoperculum.]

The following extinct genera and species, which are not represented in the Collection, are supposed to be related to Scorpana :-

Ctenopoma jemelka, J. J. Heckel, Denkschr. k. Akad. Wiss., math.naturw. Cl. vol. xi. (1856), pt. i. p. 272, pl. xv. figs. 6-9. Pygous jemelka, J. J. Heckel, Neues Jahrb. 1849, p. 500 (name only).-Middle Miocene; near Dedenburg, Vienna. [The type species. Imperfect fish; olim Jemelka Coll.,

a.M.N. It. ${ }_{\text {Histrocephalus bassanii, A. de Zigno, Mem. R. Istit. Venetn, }}$ vol. xxiii. (1887), p. 31, fig. 9.-Upper Eocene; Monte $2 \times 2$

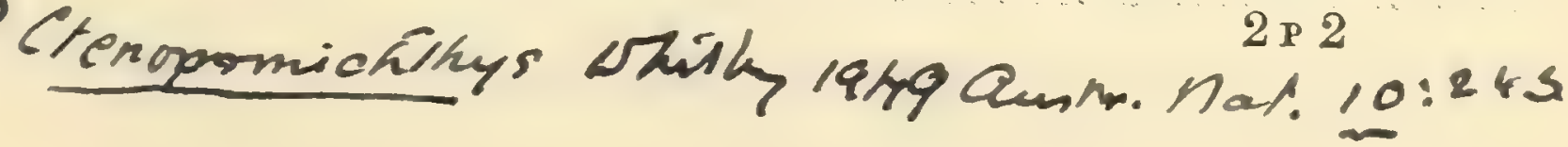




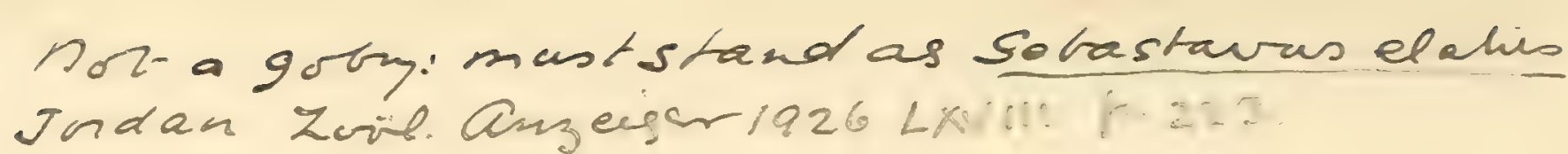

Bolca, near Verona. [Imperfect fish; Zigno Coll., University of Padua.]

Scorpcenoides popovicii, F. Priem, Bull. Soc. Géol. France [3] vol. xxтii. (1899), p. 248, pl. ii. figs. 27-30.-Eocene; Valea Caselor, Jalomitza, Roumania. [Imperfect fish.] Scorponopterus situridens, F. Steindachner, Sitzungsb. k. Akad. Wiss., math.-naturw. Cl. vol. xxxvii. (1859), p. 694, pls. ii.-iv., pl. $\nabla$. fig. 1.- Upper Miocene; Hernals, Vienna. [The type species. Detached bones; Court Museum, Vienna.]
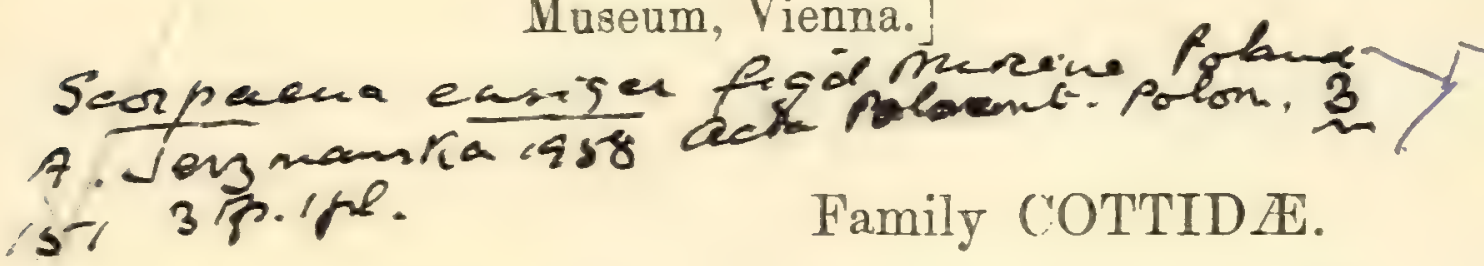

Head usually broad and depressed, with narrow interorbital region; mouth terminal, with minute teetít. Vertebræ 24 to 50 in total number, most of those of abdominal region with small transverse processes, but ribs attached to centra behind these. Post-temporal bone free from cranium, and supraclavicle normal. Large pectoral fins, with pelvic fins directly beneath; extended dorsal fin usually subdivided into two parts, the anterior consisting of 6 to 18 slender spines; anal fin without spines. Trunk covered with a regular squamation or small prickles or naked.

Small littoral fishes, almost universally distributed, sometimes occurring in freshwater. The only two known extinct genera have a regular squamation.

Descriptions and figures of the skeleton of existing Cottidæ are given by C. Girard, 'A Monograph of the Cottoids,' Smithson. Contrib. vol. iii. art. no. 3 (1850).

\section{Genus EOCOTTUS, novum.}

Preoperculum with large antrorse spines on lower limb. Vertebræ about 10 in the abdominal, 14 in the caudal region. Pectoral fins very delicate; pelric fins relatively large, with one slender spine and 5 articulated rays; dorsal fins continuous, the anterior portion comprising about 8 relatively short spines; anal fin with 8 to 10 rays; caudal fin rounded. Small scales completely covering trunk.

An extinct genus known only by one species from the marine Tpper Eocene of Italy. According to Heckel (Sitzungsb. $\mathbf{k}$. Akad. Wiss., math.-naturw. Cl. vol. ii. 1850, p. 148), this species is closely related to Callipteryx; but it is distinguished from that genus by the presence of 'scales and the short and stout form of the neural arches in the abdominal region. 


Founded an Gype (any) of gobius elales, Sein dachuer. 5. Ouncker, Zoofogischer Bnzegjer raplvi 1923 p.239. elastaver vertelralis, D. F. Fordan $\alpha$ 2. 2. Gilbert, Foss. Fivher P. Caligfonia (Manform Umiv. Public., Univ. Ser. (q19), p.50, pl. xxxi.fig, miocene; El Modena. Comperfert turnte; Inus. Thang 2 Unirs] see alove,

I. of Sebactavis. Thomarchus enciger, D. F. Fordan t \%.Z. Gillent, lor. cit. h. 51 , fl. $\times \times \times$ i. fis.s. - Itid.

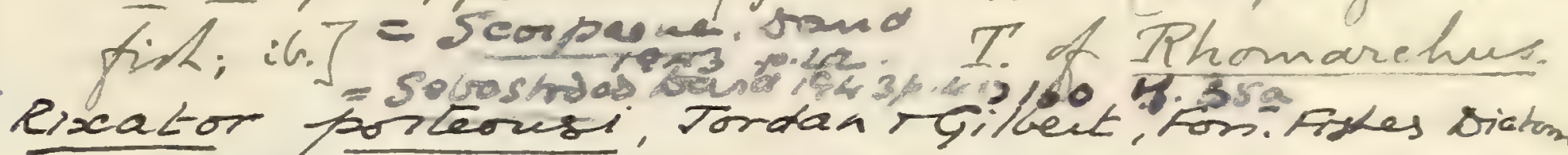

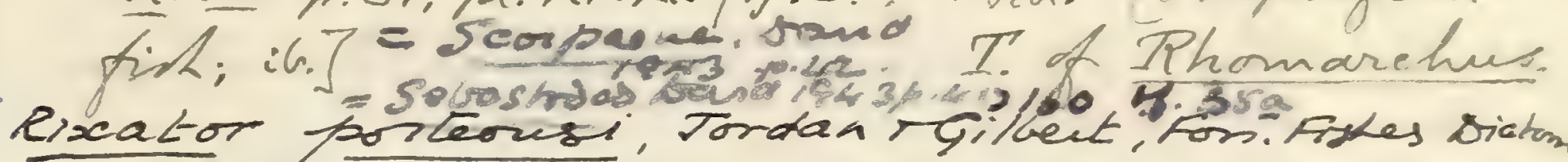
heds ffhompre, Cat. (Stant. Univ. Peedt. 1920) p. 33, pts xxi"

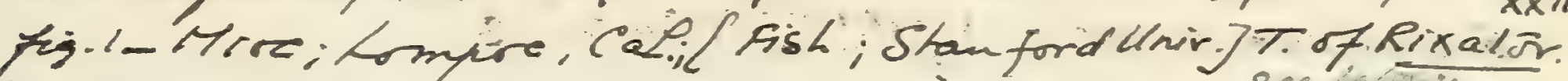

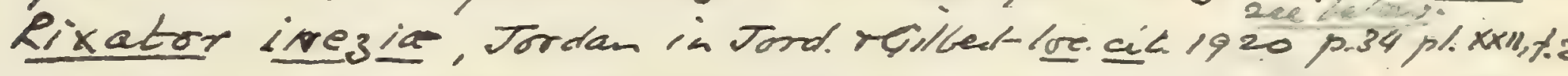
- ilid - [Fish wilionthead; itid].7

Hexagrammos achrectus, 2. To godan 2.2. Gillerd, loc.cit. 1919, f. 52, pl. xxiv. fip. 2. - Siatomac. Ean 12 ;

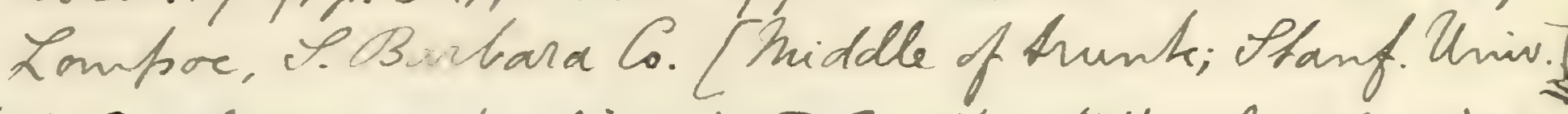

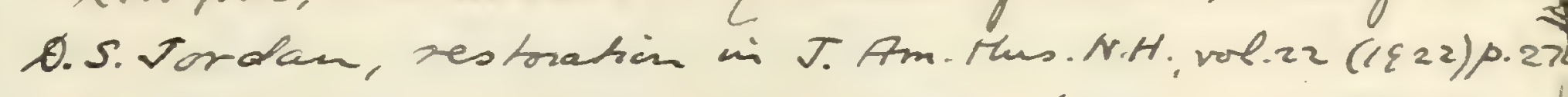
$\rightarrow$ Sebastinus inezia, D.S Jordan, 'Genere of Fisha.,

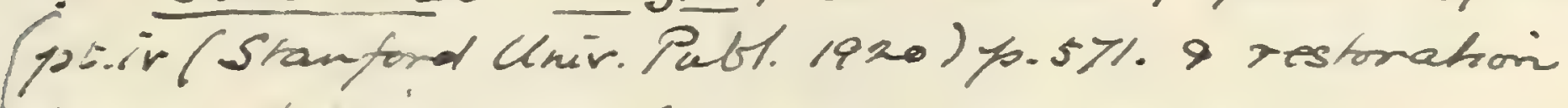
Natura trstry 001.22 Ma, Kune,1922 p. 274.

Hexagrammos actrestus. Tondan rgillert, we ait. 1920, p.36 g6.xix.

Selastồssus apostates, D.S. Jordan, Genera of fishes ptiv.

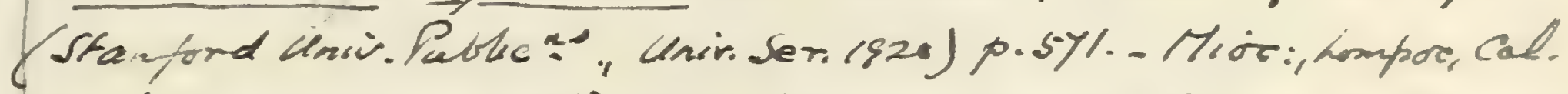

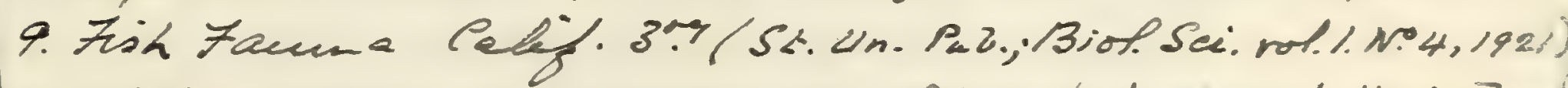
p. 285 pl. $14, \%$ a, pol. 53 lrestorationl [ Imp. fish; Stant. Umiv.] Achrestogrammur acheshis Tordan 6.5. Lit. 1921. 0.289 .

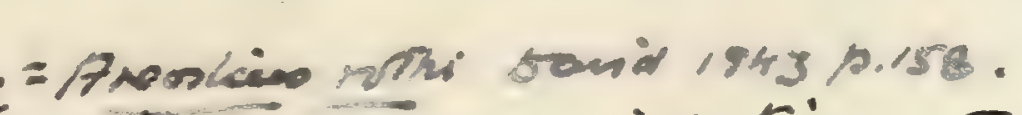

T. of Pchrestigranmus.

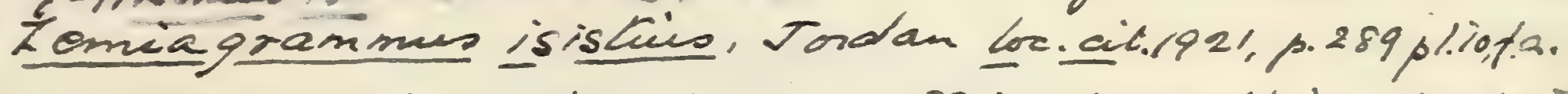

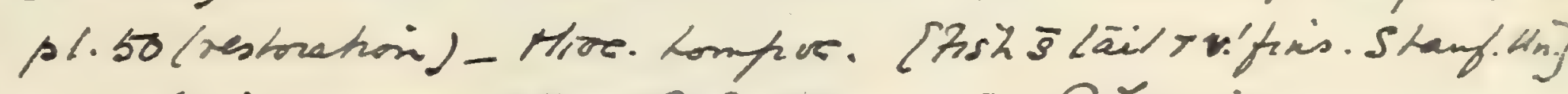

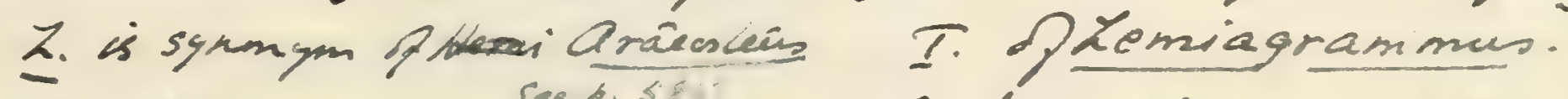

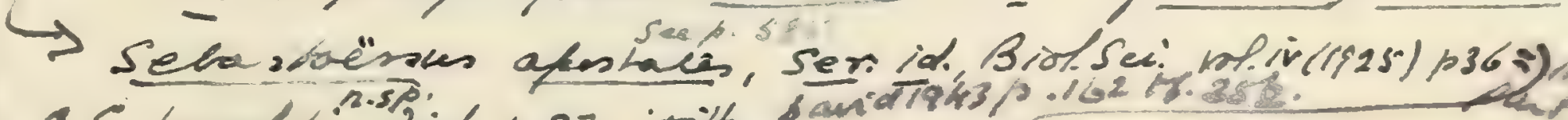

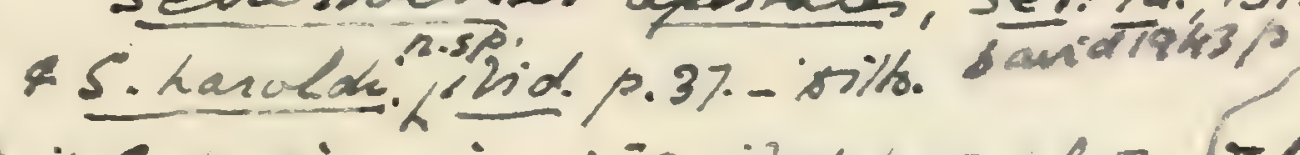

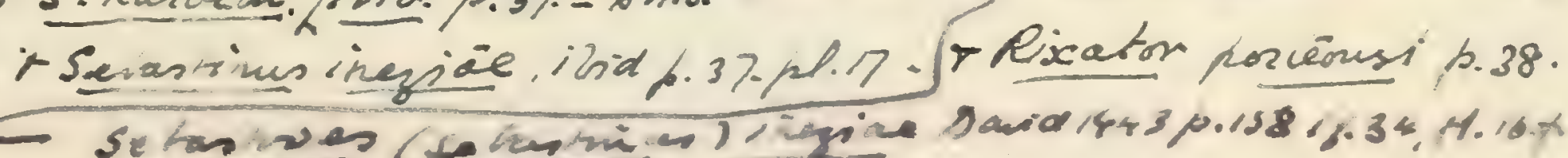


1911. Socothe veronencio, C.R. Eustman, Mem Carngie inus.vol. iv. h. 385, hl.xcix.fig. 1.

1913. Everthe [8]rol. xi. f. 181 .

, C.P.Dapan, Anm. huy, Nat. Hidh.

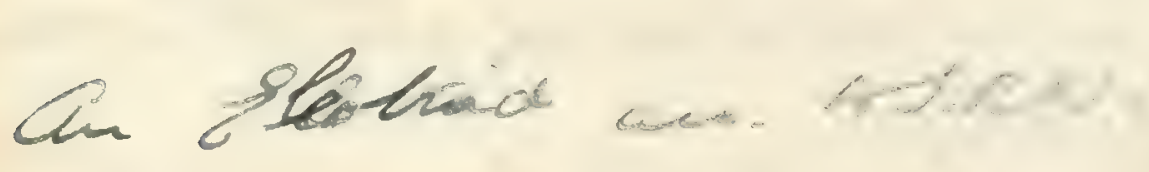




\section{Eocottus veronensis (Volta).}

1796. Gobius barbatus, G. S. Volta, Ittiolit. Veronese, p. xlviii. pl. zi. fig. 1.

1796. Gobius veronensis, G. S. Volta, ibid. p. li, pl. xi. fig. 2.

1818. Gobius veronensis, H. D. de Blainville, Nouv. Dict. d'Hist. Nat. vol. xxvii. p. 358.

1835. Gobius macrourus, L. Agassiz, Ne zes Jahrb. p. 291 (name only). 1838-39. Gobius macrurus, L. Agassiz, Poiss. Foss. vol. ir.pp. 12, 203, pl. xxxiv. figs. 3,4 .

1876. Gobius macrurus, F. Bassani, Atti Soc. Veneto-Trent. Sci. Nat. vol. iii. p. 180.

Type. Imperfect fish; Paris Museum of Natural History.

The type species, attaining a length of about $0 \cdot 2$. Length of head with opercular apparatus contained slightly more than three times, maximum depth of trunk about five times in total length to base of caudal fin. Posterior portion of dorsal fin with about 10 articulated rays; anal fin directly opposed to latter, with 8 or 9 articulated rajs; caudal fin sharply rounded, about $i$ wice as long as deep.

Form.\& Loc. Upper Eocene: Monte Bolca, near Verona.

P. 1968, P. 3947. Fine specimen, in counterpart. The head is much crushed, but the inferior spines of the preoperculum are well shown. There are clearly only 10 abdominal and 14 caudal vertebræ; the former with very short and stout neural arches and with robust transverse processes overlapped by short and stout ribs. There are traces of the delicate pectorals, and all the other fins are well preserved. The caudal fin is supported by five expanded hæmal arches, the uppermost the largest. The scales are seen and exhibit fine radiating markings in their covered portion, but their hinder margin is not clearly observable. The lateral line is conspicuous.

Egerton $₫$ Enniskillen Colls.

Genus LEPIDOCOTTUS, Sauvage.

[Bull. Soc. Géol. France (3) vol. iii. 1875, p. 637.]

As Cottus, but with fewer vertebræ, and trunk regularly covered with ctenoid scales.

An Oligocene and Miocene European genus, probably freshwater. 


\section{Lepidocottus aries (Agassiz).}

1839. Cottus aries, L. Agrssiz, Poiss. Foss. vol. iv. p. 186.

1875. Lepidocottus aries, H. E. Sauvage, loc. cit. p. 637, pl. xxiin. fig. 1.

Type. Imperfect fish.

The type species, attaining a length of about 0.12. Length of head with opercular apparatus equalling half that of the trunk from the pectoral arch to the base of the caudal fin. Preoperculum with 4 subequal spines; 5 branchiostegal rays. Vertebræ 10 in the abdominal, 16 in the caudal region. Dorsal spines 6 , articulated rays 9 in number; anal fin with 11 rays, arising slightly in advance of the posterior dorsal.

Form. \& Loc. Lower Oligocene: Aix-en-Provence, France ${ }^{2}$.

P. 1971. Fino specimen $0 \cdot 11$ in length, depressed in front half, side view in caudal region. The two foremost rays of the anal fin are obscured or wanting. The ctenoid scales, with radiating markings on their covered portion, are well shown.

Egerton Coll.

43439. Four small specimens.

Presented by Kenneth Murchison, Esq., 1872.

\section{Lepidocottus brevis (Agassiz).}

1832. Cottus örevis, L. Agassiz, Neues Jahrb. p. 137.

1839. Cottus brevis, L. Agassiz, Poiss. Foss.vol. iv.p. 185, pl. xxxii。 figs. $2-4$.

1861. Poecilia oeningensis, T. C. Winkler, Descript. Poiss. Foss. d'Oeningen (Natuurk. Verhandl. Holland. Maatsch. [2] vol. xiv. no. 2), p. 51, pl. iv. fig. 16. [Imperfect fish ; British Museum.]

(?) 1891. Gobius brevis, D. G. Kramberger, Rad Jugoslav. Akad. vol. cvi. p. 95, pl. vii. fig. 3 .

1898. Poecilia oeningensis $=$ Cottus brevis, A. S. Woodward, Geol. Mag. [4] vol. v. p. 392.

Type. Imperfect fish : olim Lavater Coll., Zürich.

A slender species attaining a length of about 0.06 , possibly sometimes much larger. Length of head with opercular apparatus equalling nearly twice maximum depth of trunk and half its length from pectoral arch to base of caudal fin. Vertebræ 12 in the abdominal, 16 in the caudal region. Dorsal spines 6, articulated

1 Imperfect fishes from the Lower Miocene of Chiavon, Vicentin, have also been referred to this species by F. Bassani, Atti R. Accad. Sci. Napoli [2] vol. iii. (1889), no. 6 , p. 49, pl. iv. figs. 3,4 . 
1919. Emidorottus Grevis, D. L. Girdan d 9.2. Gillest, Foss. Firher S.Californid (Stanford Univ. Oublic., Univ. Yer.), h. 5s, kl. $\times \times \times$. fip.4. 


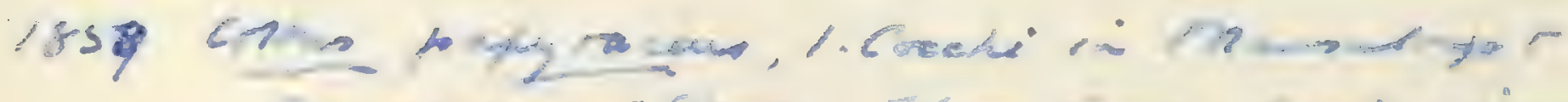

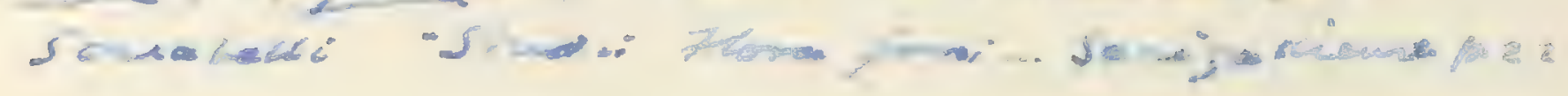


rays 12 in number; anal fin with 9 rays, arising slightly behind origin of posterior dorsal.

Form. \& Loc. Upper Miocene: Oeningen, Baden. (?) Lower Miocene : Eibiswald, Styria.

42779. Type specimen of so-called Poecitia oeningensis in counterpart, described by A. S. Woodward, loc. cit.

Van Breda Coll.

42778, 42780-81. Three good specimens, the first being in counterpart, noticed by A. S. Woodward, loc. cit.

Van Breda Coll.

P. 1972, P. 4533. Imperfect small specimens labelled by Agassiz, and described by him, tom. cit. p. 186.

Egerton \& Enniskillen Colls.

35529, 36119. Three imperfect small specimens. Purchased, 1859.

42802. Imperfect small specimen, in counterpart. Van Breda Coll.

The following specimen seems to be the caudal region of a large scaly Cottoid, and it may possibly represent a gigantic individual of Lepidocottus brevis :-

P. 3871. Type specimen of Cyclurus minor, Agassiz, described and figured in Poiss. Foss. vol, v. pt. ii. (1839), p. 45, pl. liii. fig. 1; Upper Miocene, Ueningen. The median fins are distorted by crushing, and the articulations of the rays seem to ve closer together than in the normal small specimens of L.brevis.

Enniskillen Coll.

\section{Lepidocottus papyraceus (Agassiz).}

1832. Cottus papyraceus, L. Agassiz, Neues Jahrb. p. 137.

1839. Cottus papyraceus, L. Agassiz, Poiss. Foss. vol. iv. p. 187, pl. xxxii. fig. 1.

1875. Lepidocottus papyraceus, H. E. Sauvage, Bull. Soc. Géol. France, [3] vol. iii. p. 637.

Type. Imperfect fish; olim Bronn Coll., Heidelberg.

A stouter species than the preceding, attaining a length of about 0.07. Vertebræ 8 in the abdominal, 18 in the caudal region. Dorsal spines 6 , articulated rays 10 in number; anal fin with 9 rays.

Form. \& Loc. Upper Oligocene: Monte Viale, near Vicenza. Also recorded by Agassiz from Upper Miocene of Sinigaglia and Melilli. 
38148-49. Two distorted specimens, the first showing vertebræ and median fins, the second scales: Lignite, Monte Viale.

Purchased, 1864.

49336. Impression of skeleton; Lignite, Monte Viale. Presented by A. W. Water's, Esq., 1878.

P. 1973, P. 4534. Two imperfect distorted specimens; Lignite, Monte Viale. Egerton \& Enniskillen Colls.

\section{Lepidocottus multipinnatus (Meyer).}

1848. Gobius multipinnatus, H. von Meyer, Neues Jahrb. p. 783.

(?) 1851. Gobius (?) conicus, H. von Meyer, Neues Jahrb. p. 80.

1851. Cottus (P) multipinnatus, $H_{\text {. }}$ von Meyer, Palæontogr. vol. ii. p. 106, pl. xvii. fig. 1.

1851. Cottus brevis (?), H. von Meyer, loc. cit. rol. ii. p. 107, pl. xvi. figs. 7-10.

1856. Gotius (?), H. von Meyer, Inc. cit. vol. vi. p. 27 , pl. i. fig. 6.

Type. Imperfect fish.

Much resembling $L$. brevis, but dorsal fin with 13 or 14 articulated rays and anal fin with 12 rays.

Form. \& Loc. Lower Miocene: Würtemberg. Gattmo.

35513-14, 35518. Three specimens, one being depressed and distorted; Unterkirchberg, near Ulm. Purchased, 1860.

35752-53. Two fragmentary specimens; Unterkirchberg.

\section{Purchased, 1860.}

The following species has also been described, but is not represented in the Collection:-

Lepidocottus elongatus, F. Bassani, Atti R. Accad. Sci. Napoli, [2] vol. iii. (1889), no. 6, p. 50, pl. จ. fig. 5.-Lower Miocene; Chiavon, Vicentin. [Imperfect fish; Piovene Coll., Lonedo.]

Some other small Tertiary fishes referred to Gobius probably belong to Lepidocottus. Among these may be mentioned the socalled Gobius elatus, oblongus, and viennensis from the Upper Miocene of Hernals, Vienna (F. Steindachner, Sitzungsb. k. Akad. Wiss., math.-naturw. Cl. vol. xl. 1860, pp. 561-565, pl. i. figs. 2-4, pl. ii. fig. 1); also Gobius pullus from the Upper Miocene of Dolje and Podsused, Croatia (D. G. Kramberger, Beitr. Paläont. Oesterr.Ungarns, vol. ii. 1882, p. 133, pl. xxv. figs. 2, 2a). 




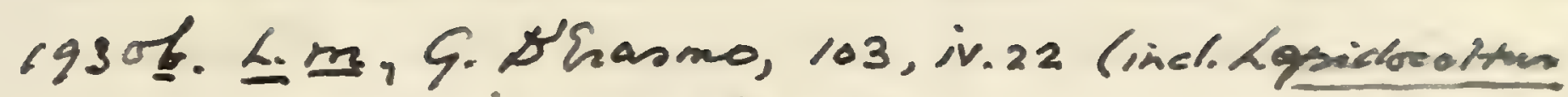
metripinathe, (Bosno).

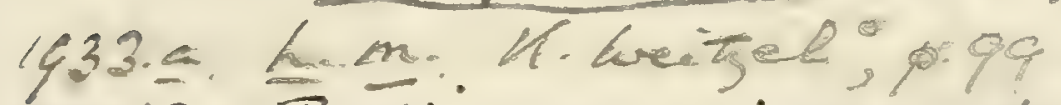

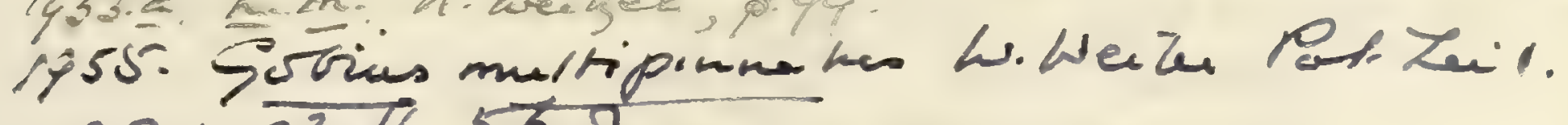
$29 p 93.5,6,8$

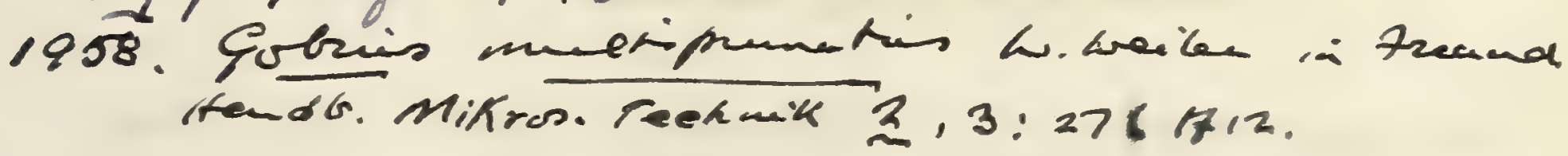

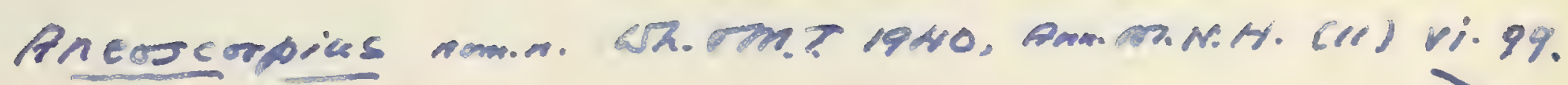

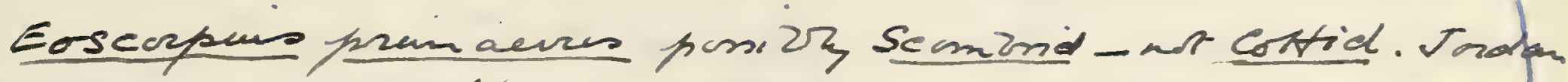
Fish Fauma Caly. 300/(5.4.P; Bid. Sair.1p1.41921) p. 284.

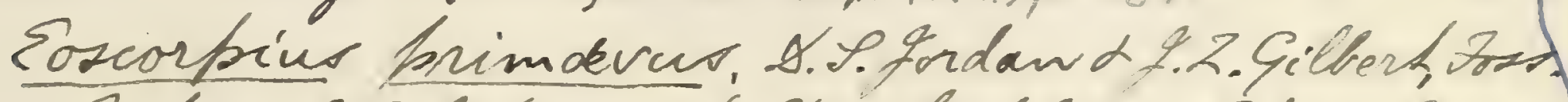
Fishes I. California (Mtanford Emive Public., Eniv. Der.1919), 1.53, hl. xxx. - Hiceene; Bairdatown.

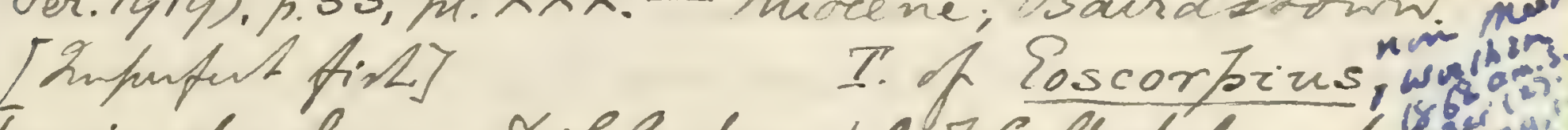

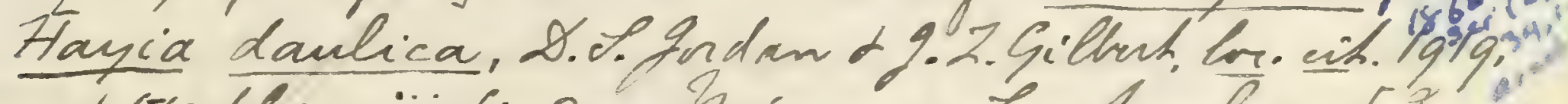
1.55. pl. xxiii.fip. 2. - Mnoune; Zos Anpeles. Comherfuth firlt? I. of Hayia.

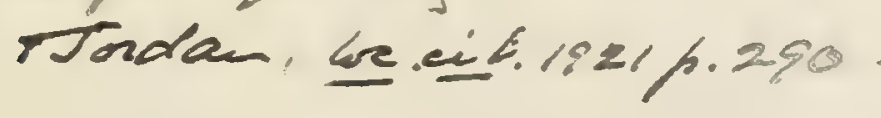






\section{Genus COTTUS (Artedi), Linnæus.}

[Syst. Nat. ed. 10, 1758, p. 264.]

Head feebly armed; preoperculum more or less spiny; 6 branchiostegal rays. Vertebræ about 30 to 35 in number, more than half being caudal. Pelvic fins with one small spine and four articulated rays; dorsal fins separate, the first with 6 to 10 slender spines; anal fin with 9 to 20 rays; caudal fin rounded. Scales absent, but minute prickles sometimes present.

Characteristic of the freshwaters and shores of northern temperate regions.

There do not appear to be any fossils in the Collection referable to this genus. Remains of the existing Aretic species, Cottus uncinatus, Reinhardt, bave been recorded from nodules in Pleistocene Clay, Green's Creek, Ottawa, Canada (J. W. Dawson, Canad. Record Sci. vol. iv. 1890, p. 86). Detached bones of the existing Cottus quadricormis, Linn., var. relicta, Lilljeborg, have also been identified from the Pleistocene of Skattmansö, Upland, Sweden (A. G. Nathorst, Geol. Fören. Stockholm Förhandl. vol. xv. 1893, p. 569, figs. $8,9,12,13$ ).

The names Cottus cryptotremus, divaricatus, hypoceras, and pontifex are given to preopercula supposed to represent four extinct species from Freshwater Tertiary deposits in Idaho and Oregon, thish. U.S.A. (E. D. Cope, Proc. Acad. Nat. Sci. Philad. 1883, pp. 162-164). Nothing is known of the undescribed Cottus horridus (J. J. Heckel, Neues Jahrb. 1849, p. 499) from Wieliczka, Galicia.

An otolith from the Lower Tertiary of the Jackson River, Mississippi, has been referred to a member of this family under the name of Otolithus (Cottidarum) sulcatus (E. Koken, Zeitschr. deutsch. geol. Ges. vol. xl. 1888, p. 287, pl. xriii. fig. 12).

\section{Family TRIGLID $\approx$.}

Suborbitals enlarged and covering cheek; mouth terminal, with minute teeth. Abdominal vertebræ with transverse processes very short or absent. Post-temporal bone fused with cranium, and supraclavicle displaced backwards so that the post-temporal and clavicle are in contact. Pectoral fins laterally placed and expanded, with pelvic fins directly beneath; spinous dorsal less extended than soft dorsal, which is similar to the spineless anal. Squamation regular, and no bony scutes except along lateral line. 
Widely distributed marine fishes, almost unknown among fossils. A figure of the skeleton of the existing Trigla is given by Agassiz, Poiss. Foss. vol. iv. pl. F.

There appear to be no remains of members of this family among the fossils in the Collection, but various fragments of supposed extinct species of Trigla have been named as follows:-

Trigla infausta, J. J. Heckel, Denkschr. k. Akad. Wiss., math.naturw. Cl. vol. xix. (1861), pt. i. p. 70, pl. ix. fig. 9.Middle Miocene (Leithakalk); Vienna. [Imperfect head and abdominal region.]

Trigla licatee, H. E. Saurage, Ann. Sci. Nat. [5] vol. xiv. (1870), art. no. 7, p. 12, and Ann. Sci. Géol. vol. iv. (1873), art. no. 1, p. 111, fig. 1, and ibid. vol. xi. (1880), art. no. 3, p. 21, fig. 8.-Upper Miocene; Licata. [Imperfect fish.]

Trigla nardii, de Bosniaski, Atti Soc. Tosc. Sci. Nat.-Proc.-Verb. "Carionymus teatirs vol. i. (1878), p. xix (name only). - Upper Miocene; Gabbro, Tuscany.

Trigla simonellii, I. Bonomi, Rivista Ital. Paleont. vol. ii. (1896), p. 234, pl. . fig. 10.-Upper Miocene; Mondaino, Prov. Forli, Italy. [Fragmentary small fish, indeterminable.]

Fragments of ornamented bones more or less resembling those of Triglidæ have also received the following names :-

Dactylopterus pliocenicus, R. Lawley, Nuovi Studi Pesci, etc., Colline Toscane (1876), p. 61.-Lower Pliocene ; Orciano, Tuscany. [Undescribed, but bones said to be perfectly identical with those of existing $D$. volitans.]

Peristedion urcianensis, R. Lawley, ibid. p. 63.-Ibid.

Trigloides alata, R. Lawley, ibid. p. 63.- Upper Miocene ; Gabbro, Tuscany.

Trigloides dejardini, P. J. Van Beneden, Bull. Acad. Roy. Belg. [2] vol. xxxi. (1871), p. 501, pl. ii. figs. 9, 11 (non fig. 13) ; R. Lawley, op. cit. 1876, p. 62,-Lower Pliocene; Belgium and Tuscany. [Type species of so-called Trigloides.]

Trigloides insignis, R. Lawley, op. cit. 1876, p. 62. - Lower Pliocene; Volterrano, Tuscany.

Trigloides van benedensis, R. Lawley, ibid. p. 62. - Lower Pliocene; S. Luce, near Orciano.

Otoliths from the Lower Tertiary of the Jackson River, Missis- 

Trigla aramboungi, s.n., W.Weilor, $1928 \% \cdot 38,61 . v i f .1 .00$. Origurene;

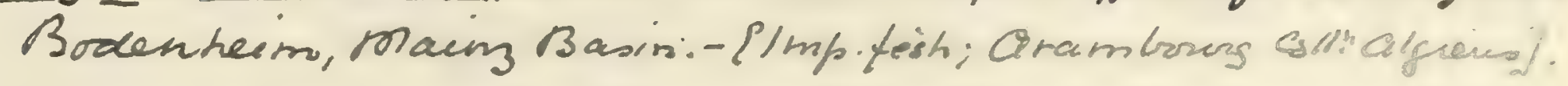

Trigla (Chelidonichitys) macroptera, s.n, C. Orambourg, 1927"

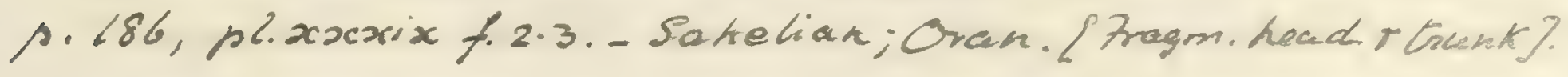

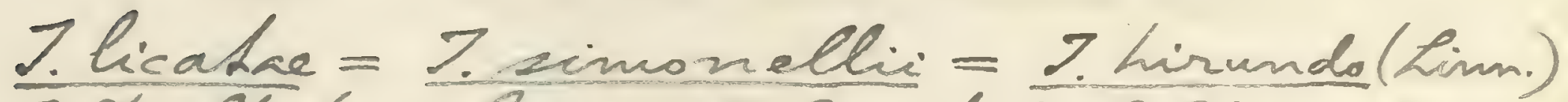
G.We Thefans, Mem. R. Comih. Geol. Fhal. vol vii. ph.i (1918), h.83, hl. X.f. 3, 4. Cneither simonalli nor himendo

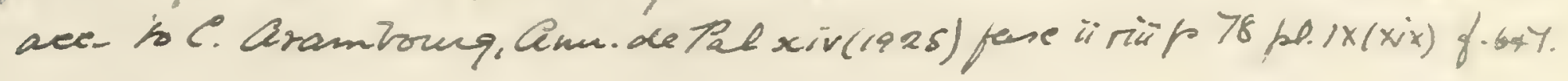

Operculum of Dripla. R. Stoms, Bull. Sor. Bels.

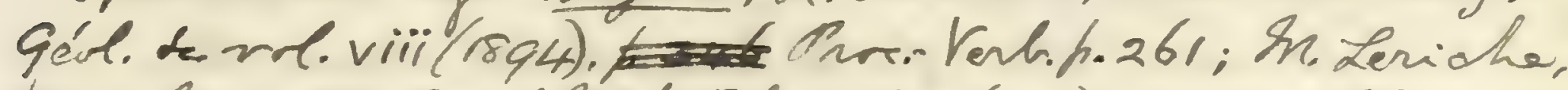

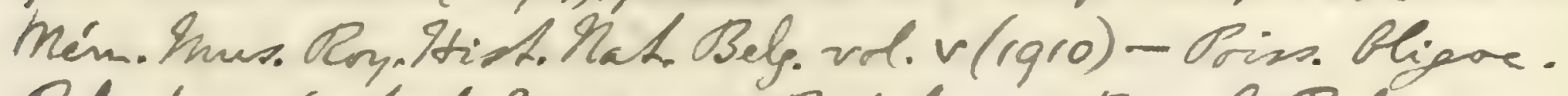
Belp.p.346, Leah-fij, 147. - Rupeline; Bazel, Beleium.

Ki ..Bazsani, Afti R. Accad. Sei. Napoli [z] vol-xvi. no. 4 (1915), h. 47 , pl. iv. fige. 10,11. 
Otolithuo (Jrigla) Rhombicus, D. G.Schubert, Takrbuch

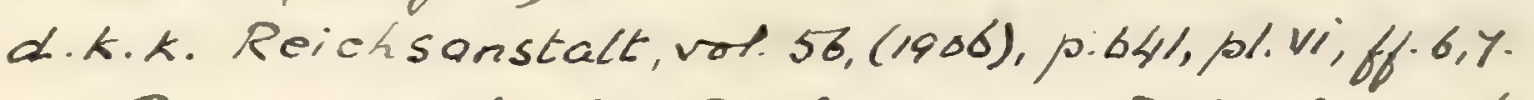
7. Priem, Bull. Sor. Géol. Irance [4] vol. xiv(1914), h. 272, f.65:- Mnircene; Anstria. Sundigalian; Gironde.

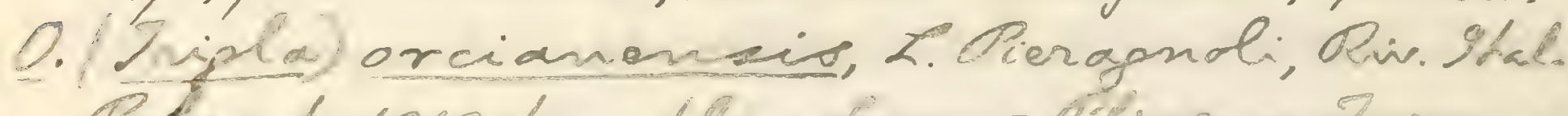
Bateont. 1919.t. - Oriacens.

righle rhomisica, wheiler, abh. hess geot. Landesanst. Danmst: vol. ri. pt.2, p. Ty, pli,f.4. (1922).

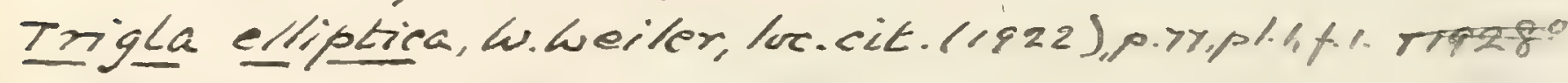

Bulbicefor raninus, 2. P. Iodan, Foss. Firhes P. Califomia (Mtanford Unirs Publie., Univ. Ser. 1919), p.12, hl.vi. - hivene; Soledad. Cimperfos fist; Stantand Wims.] T. of Bullicefes, said to be related to Liparis. May be Gobiesocid

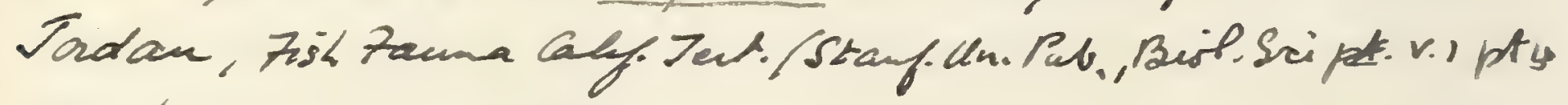
$1921 /$ p. 291.

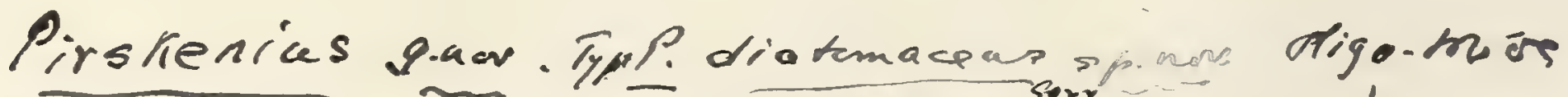

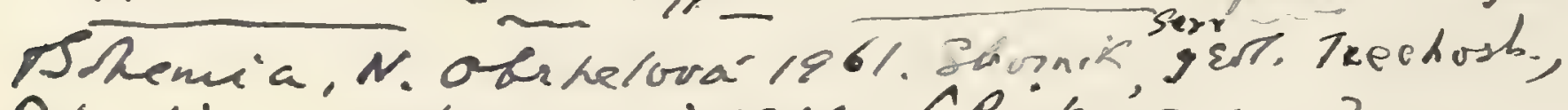

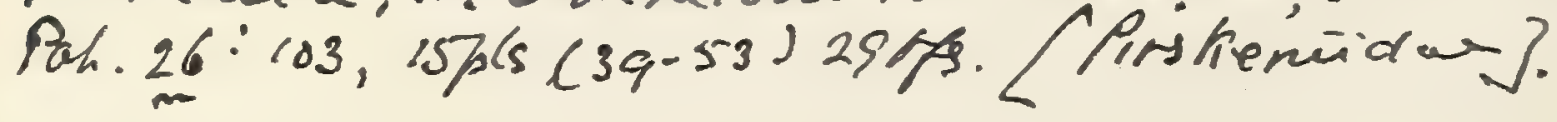

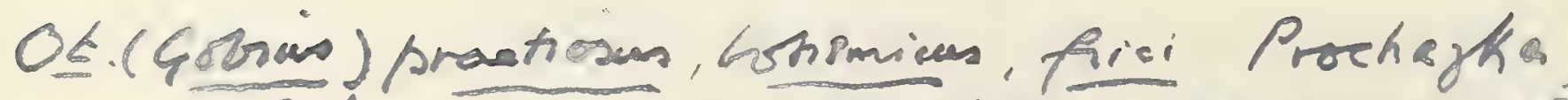

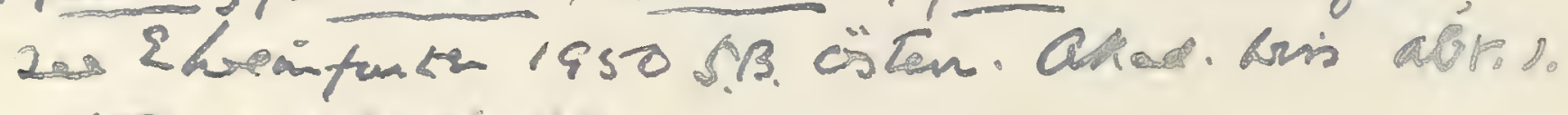

159 


sippi, hare been named Otolithus (Triyloe) cor (E. Koken, Zeitschr. deutsch. geol. Ges. vol. xl. 1888, p. 287, pl. xviii. fig. 10). Others from the Oligacene of Germany hare been named Ototithus (Trigla) ellipticus, O. (Trigla) adjunctus, O. (Peristedion) personatus, and O. (? Agonus) primas (E. Koken, loc. cit. vol. xliii. 1891, pp. 130 132 , pl. x. figs. 6,9 ; also loc. cit. vol. xxxvi. 1884, p. 555, pl. xii. figs. 9, 10).

The following extinct genera and species, not represented in the Collection, have been compared with 'l'riglidæ, but are too imperfectly known for systematic determination:-

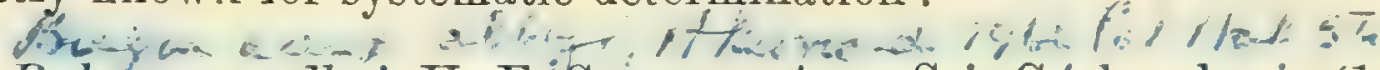
Podopteryx albyi, H. E. Sauvage, Ann. Sci. Géol. vol. xi. (1880), art. no. 3, p. 17, figs. 5, 6.-Upper Miocene; Licata, Sicily. [The type species. Imperfect fish.]

Podopteryx bosniaski, H. E. Sauvage, ibid. p. 19, fig. 7.--Ibid.

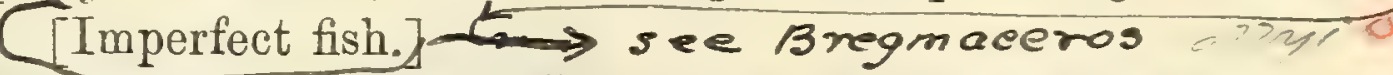

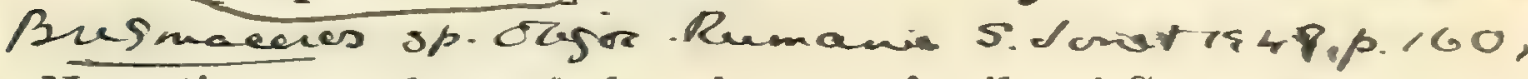

No extinct members of the aberrant family of CycLopteRID $z$ are known, but remains of the existing Cyclopterus lumpus, Linn., have been found in nodules in Glacial Clay in Green's Creek, Ottawa, Canada (J. W. Dawson, Canad. Nat. n. s. vol. vi. 1872, p. 403).

\section{Division F. GOBIIFORMES.}

Pectoral fins with much extended base on flank; pelric fins thoracic or jugular, never with more than five articulated rays in addition to the spine, often modified. Dorsal fin-spines few, usually flexible, sometimes absent: anal fin with one or two feeble spines or none. No bony stay between circumorbital ring and preoperculum.

Synopsis of Famities represented by Extinct Genera or Species. " All abdominal vertebræ with large transverse processes supporting ribs ........... GoBIID (p. 587).

Abdominal vertebræ without transverse processes........................ Trachinid es (p. 589).

\section{Family GOBIID $\mathbb{E}$.}

Elongated fishes with stout caudal pedicle. Gill-opening reduced. All abdominal vertebræ with large transverse processes supporting ribs. Pelric fins variously modified, often united into a 
disk; posterior dorsal and anal fins equal and opposite, more extended than the anterior spinous dorsal.

Small fishes almost universally distributed on the coasts of temperate and tropical seas, sometimes occurring also in freshwater.

There appear to be no fossil remains in the Collection referable to this family, and very little evidence of extinct species has been discovered. Imperfect fossils have been described as follows :-

Callionymus macrócephalus, D. G. Kramberger, Beitr. Paläont. Oesterr.-Ungarns, vol. ii. (1882), p. 134, pl. xxv. fig.3.Upper Miocene; Radoboj, Croatia. [Imperfect fish exhibiting the characteristic branched preopercular spine of the existing Callionymus; University Geological Museum, Agram.]

Otolithus (Gobiidarum) dispar, E. Koken, Zeitschr. deutsch. geol. Ges. vol. xliii. (1891), p. 133, pl. x. fig. 12.-Miocene; Frankfurt. [Otolith.]

Otolithus (Gobius) francofurtunus, E. Koken, ibid. p. 132, pl. vi. Racion. W. Leeiew fig. 7.-Lower Miocene; Frankfurt, Eckenheim, Ginheim, 3ir : 85 if5. and Bornheim. Middle Miocene; Portsteich. [Otolith.]

Otolithus (Gobius) vivinalis, E. Koken, ibid.p. 133, fig. 21.Miocene; Unterfeld and Oberfeld. [Otolith.] priverne

= Gobius bassanii, G. lobini, G. maximus, and G. peruzzii are merely names for undetermined fishes from the Upper Miocene of Gabbro, Tuscany (de Bosniaski, Atti Soc. Tosc. Sci. Nat.-Proc.Verb. vol. i. 1878-79, pp. xix, lv). Smenkackis m. A. Jermansta

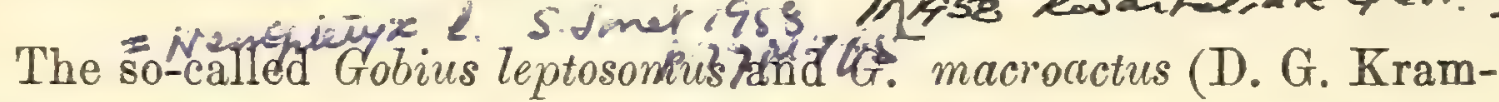
berger, Palæontogr. vol. xxvi. 1879, pp. 63-65, pl. xvi. figs. 4, 5), from the Lower Oligocene of Galicia, are too imperfectly known for certain reference to this systematic position. The same remark applies to Gobius microcephalus, which was only doubtfully placed here by Agassiz (Poiss. Foss. vol. iv. 1839, p. 204, pl. xxxiv. fig. 2), and is probably a Blennioid though not satisfactorily determinable. The last species is represented in the Collection by the following specimen :-

44873. Typical specimen of the so-called Gobius microcephatus, Agassiz, in counterpart; Upper Eocene, Monte Bolca, near Verona. The dorsal fin is continuous, with about 18 rays. The pelvic fins are rather large.

Presented by Benjamin Bright, Esq., 1873.

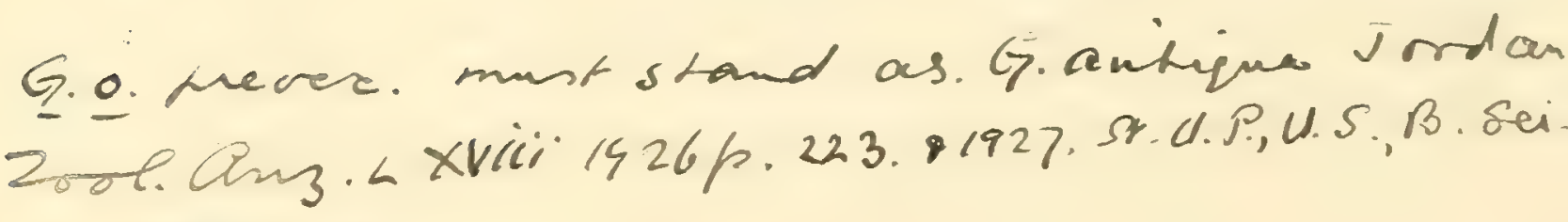
we.v $2 p .97$. 
$$
\text { . }
$$ 

Otolithur (Gobiur) rotundus, 7. Priem, Bull. So. Geol France 44$]$ vol xiv (1914), h. 273, f. 66, 6\% - Aurdijalian; Gironde.

9. Lrievesi s.n. C. Aramboung,p.193, p2. x/iii t. 3-7. Sahelian; Oran. ¿tishes?

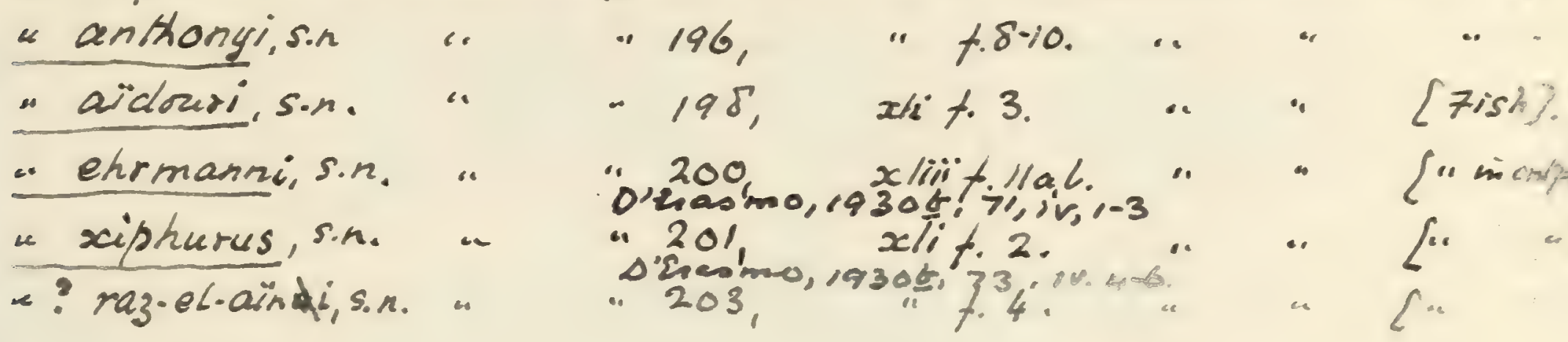

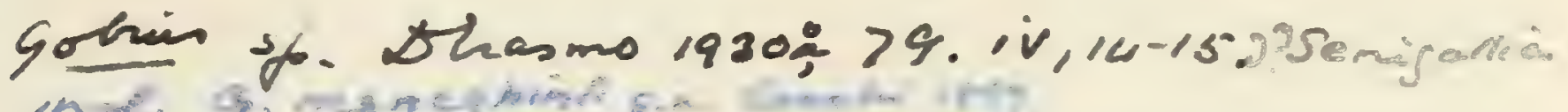

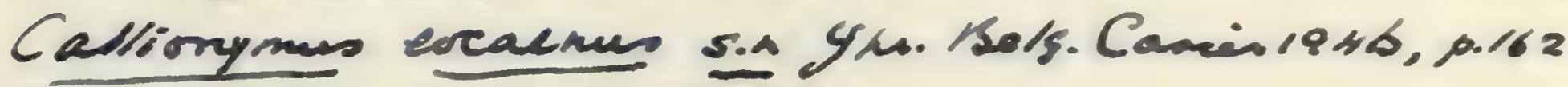

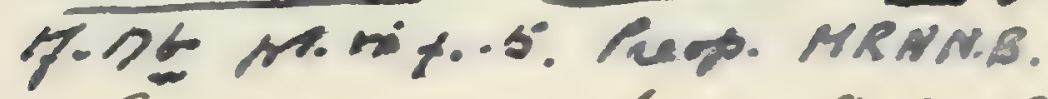

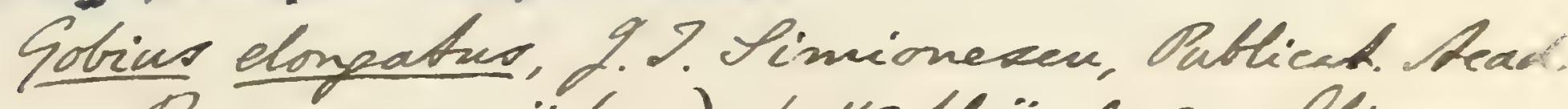

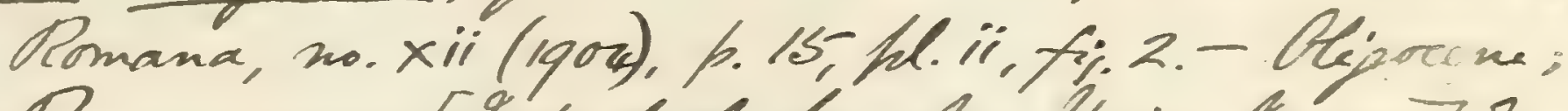

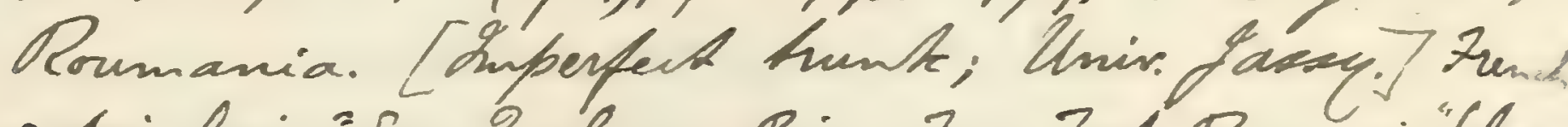

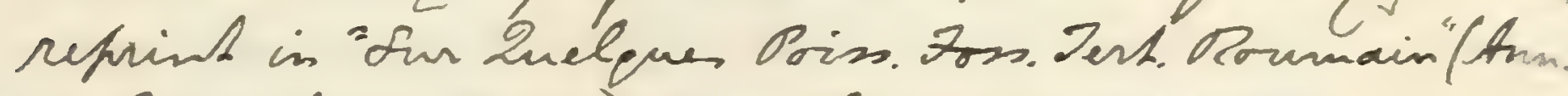
Sei. Univ. Lasy, (905), h. 15, hl. il. fip. 2. see 9.599

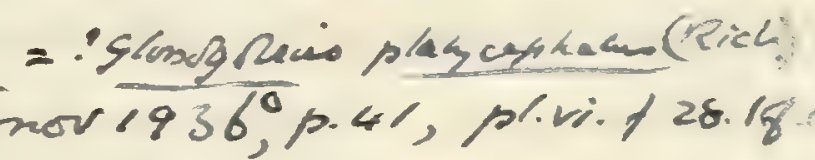

Gobius platicephames?

X.P. Smivi

Gique. N. Cancessus.

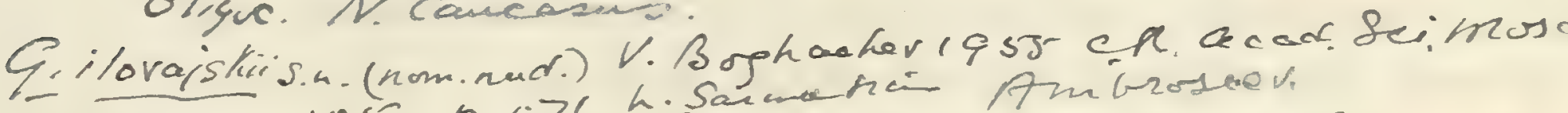

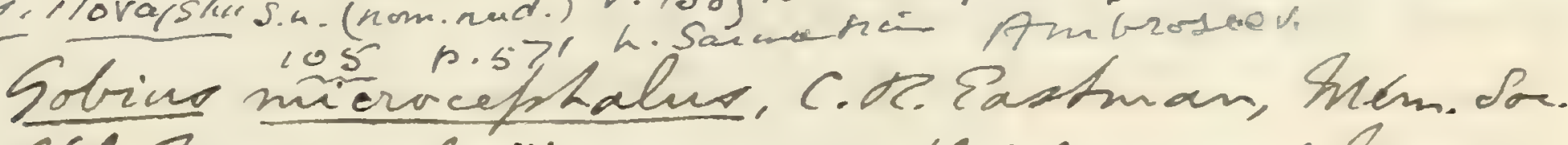
Géal. France, vol. xiii, no. 34, h. 33, hl.il. fip. 3, and Inem.

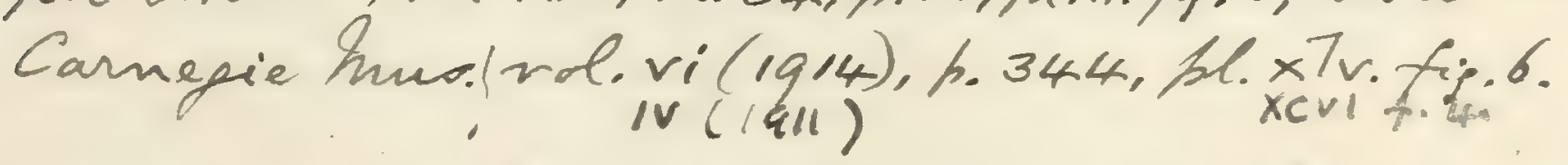

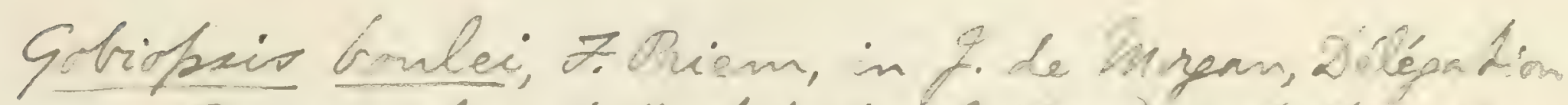

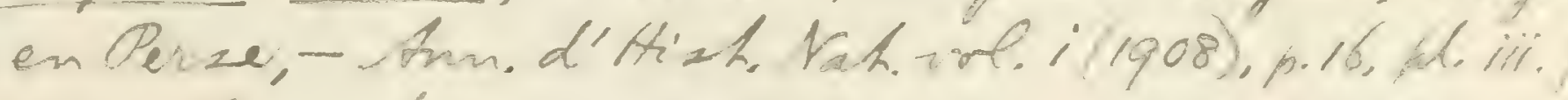
2,3. - Ul. Cretaceons: Re

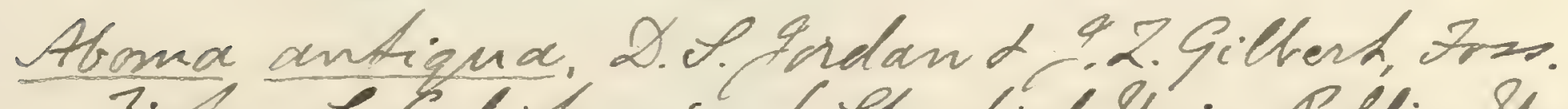

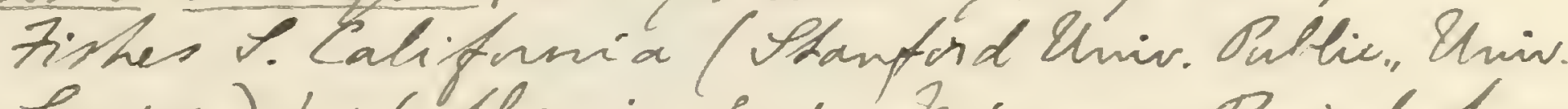
Ler.1919). 1.56. 1l. xxix. fig. 1. Iniorene; Bairdators,

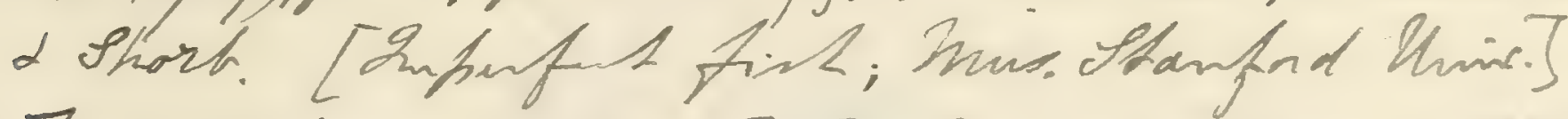

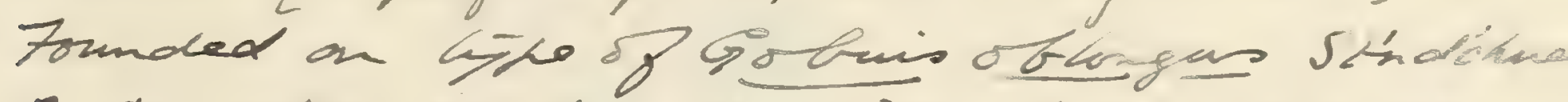
Ci. Duncker, Zovbog. unzerjer rol. Iri, 1920.p.23! 
1911. Callipheryx ppeciosus, C. D. Eastman, Mem. carnegie Mur. vol. iv. h. 384. pl. ci.fip. 1.

1920. Callipheryx Ppeciosus, 9.D'Basmo, Mendie. R. Accad. Sci. A Opoli [3] vol. Xxvi. p.12, fif. 3. CMircene; Yyracuse. Imperfect firt; Geol. Mus. Univ. Palermo.? 


\section{Family TRACHINID E.}

As Gobiidæ, but gill-opening wide, pelvic fins never united, and most of the abdominal vertebræ without transverse processes.

Small fishes living at the bottom on nearly all coasts, sometimes ranging into the deep sea. There are no extinct genera of importance.

\section{Genus CALLIPTERYX, Agassiz.}

[Poiss. Foss. vol. iv. 1838, p. 12.]

Eye apparently lateral; teeth minute and clustered. Vertebræ 10 in the abdominal, 14 in the caudal region. Dorsal fins continuous, the anterior portion comprising about 9 very short spines; anal fin less extended than posterior dorsal; caudal fin rounded. Scales very small or absent.

An extinct genus known only by two species from the marine Upper Eocene of Italy.

\section{Callipteryx speciosus, Agassiz.}

1796. Gadus merluccius, G. S. Volta, Ittiolit. Veronese, p. Ixxii. pl. xv. (errore).

1835. Callipteryx speciosus, L. Agassiz, Neues Jahrb. p. 293 (name only). 1838-42. Callipteryx speciosus, L. Agassiz, Poiss. Foss. vol. iv. pp. 12, 196, pl. xxxiii. fig. 1.

Type. Imperfect fish; Paris Museum of Natural History.

The type species, attaining a length of about $0 \cdot 7$. Maximum depth of trunk much exceeding half length of head with opercular apparatus, which is contained less than four times in the total length of the fish to the base of the caudal fin.

Form. \& Loc. Upper Eocene: Monte Bolea, near Verona.

Not represented in the Collection.

\section{Callipteryx recticaudus, Agassiz.}

1796. Trigla lyra, G. S. Volta, Ittiolit. Veronese, p. cxxxi. pl. xxx. (errore).

1835. Callipteryx recticaudus, L. Agassiz, Neues Jahrb. p. 300 (name only).

1838-42. Callipteryx recticaudus, L. Agassiz, Poiss. Foss. vol. iv. pp. 12, 198, pl. xxxiii. fig. 2.

Type. Imperfect distorted fish; Paris Museum of Natural History. A smaller and more slender species than the type, attaining a 
length of about $0: 45$. Maximum depth of trunk about half the length of the head with opercular apparatus, which is contained between three and a half and four times in the total length of the fish to the base of the caudal fin. Dorsal fin with 8 very short and stout, finely striated spines, then a more slender and slightly longer spine, then 30 articulated and divided rays, most of which are at least twice as long as the spines; anal fin with one or two feeble small spines and 20 articulated and divided rays, the fin terminating behind opposite the end of the dorsal.

Form. \& Loc. Upper Eocene: Monte Bolca.

P. 947\%. Fine specimen 0.25 in length, in counterpart, with crushed and imperfect head but otherwise displaying all the principal generic and specific characters.

History unknown.

The following extinct species have been ascribed to the existing genus Trachinus, but are not represented in the Collection :-

Trachinus dracunculus, J. J. Eeckel, Neues Jahrb. 1849, p. 500 (name only); D. G. Kramberger, Beitr. Paläont. Oesterr.Ungarns, vol. ii. (1882), p. 111, pl. xxii. figs. 3, 4.Upper Miocene; Radoboj, Croatia. [Imperfect fish; Imperial Geological Surrey, Vienna.]

Otolithus (Trachini) loevigatus, E. Koken, Zeitschr. deutsch. geol. Ges. vol. xl. (1888), p. 286, pl. xviii. figs. 13, 14.-Lower Tertiary; Jackson River, Mississippi. [Otolith.]

Qtolithus (T'rachini) mutabilis, E. Koken, loc. cit. vol. xliii.(1891), 7. Driem, B.S. S.7. [4] p. 112; Otolithus biscissus, E. Koken, loc. cit. vol. xxxvi. xiv/lg/4).h.2i4.f.68-) (1884), p. 553, pl. xi. fig. 9.-Widdle and Upper Oligocene; Gironde.

Otolithus (Trachini) seelandicus, E. Koken, Abh. phys. Cl. k. Ges. Wiss. Göttingen, vol. xxxii. (1885), p. 115, pi. v. fig. 25, and Zeitschr. deutsch. geol. Ges. vol. xliii. (1891), p. 113, figs. 8, 9.-Lower Eocene; Copenhagen. [Otolith.]

Otolithus (Trachini) verus, E. Koken, loc. cit. 1891, p. 113, pl. x. figs. 13, 14.-Upper Oligocene; Cassel. [Otolith.]

Supposed fragments of skull of the existing genus Uranoscopus, from the Lower Pliocene of Orciano, Tuscany, are named Uranoscopus peruzzii by R. Lawley, Nuovi Studi Pesci, etc., Colline Toscane (1876), p. 64 .

The following imperfectly known extinct genera and species have also been referred to the Trachinidæ, but are not represented in the Collection :- 

Trachimin ofp. Ymucs." Bels. Cancis 1946 p. 143p1.0.t.4.

(?) Trachinus dracunculus, G. OGrasmo, Hem. Carba

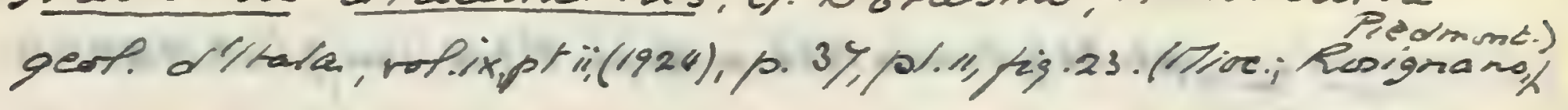

Gtolithur (rachini? bellevoyei, 7. Priem, Pois. Ins. Bassin Parizien (Outt. Amm. Oaléont. 1908), p.84, tent-fien-45,46.- Thanction; Chelons-sun-Vesle, Marme, Banes.

Otolithur (Brawhini) thevenini, 7. Priem, Bull. Sor. Géd. France $[4]$ rol. vi(1906), 1.272, fir. 30, 3/; Arm. Palient. vol, vi (qui).h.30.-U. Yhresian; Hérouval (Rize).

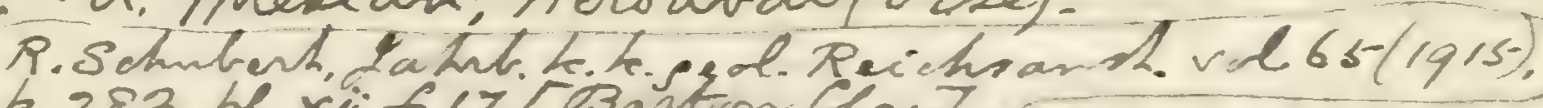

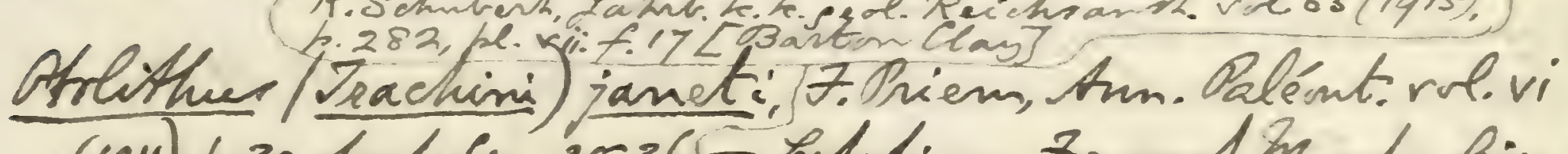

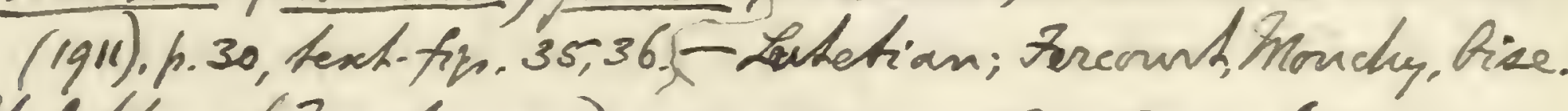
Otflithus (Jraihimo) mioednus, 9.9.Bassoli,

7. Priem, Bull. Sor. Gésl. France [4Jvol, xiv (1914),6.275, f.71,72- Burdiealian; Gironde.

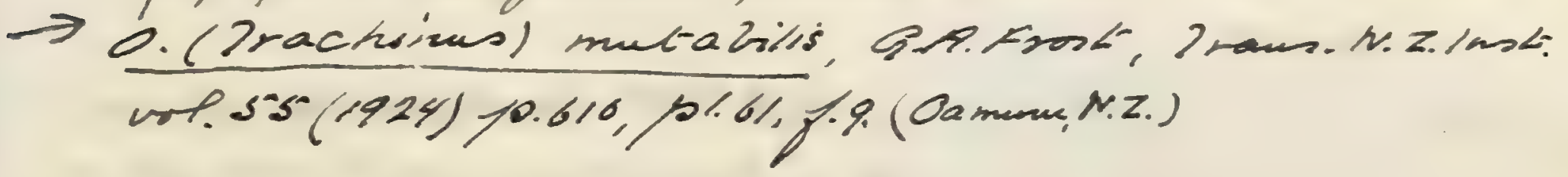



$59 / 1$

Eutricheinides orpienseis Qrambong 1952 p.267 M. $35 f 57-59$ mont. rrafuci

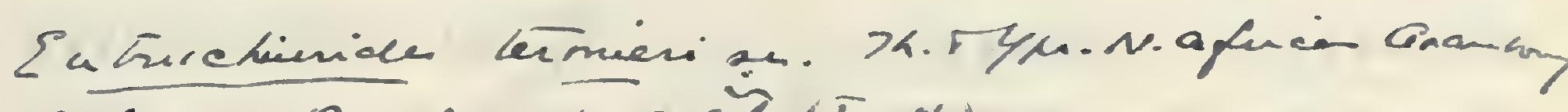

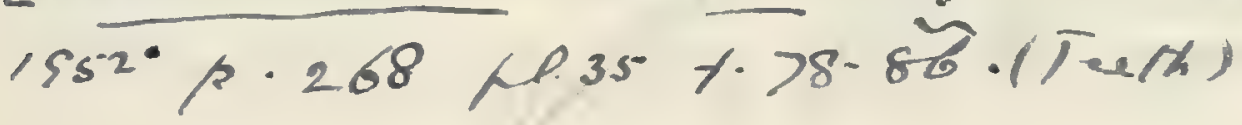

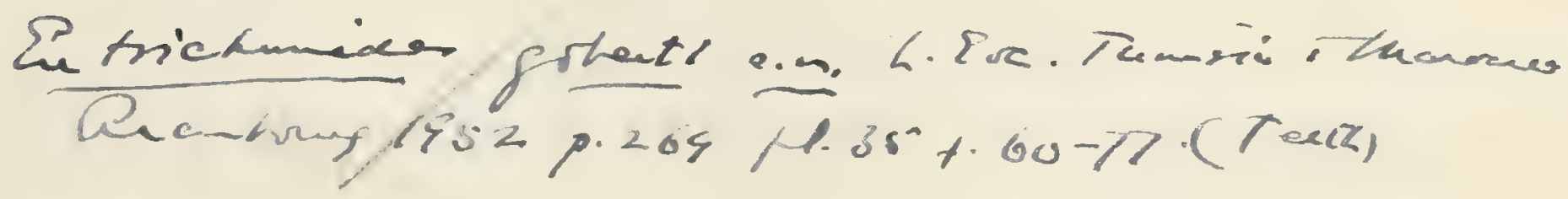


CHASMODONTIDS

Myersicus grossheini s.in. PS. Damit'clento 1910,

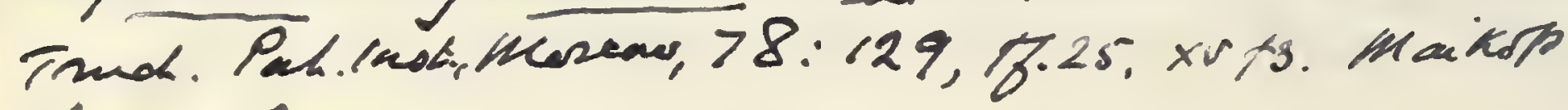
Heds, Cancesses. 
Pseudoeleginusalbyi, H. E. Sauvage, Ann. Sci. Géol. vol. iv. (1873), art. no. 1, p. 164, fig. 13.-Upper Miocene; Licata, Sicily. Sahel [Imperfect fish.]

Trachinopsis iberica, H. E. Sauvage, Bull. Soc. Géol. France [3] Zrarhincrs vol. iii. (1875), p. 641, pl. xxiv.-Lower Pliocene (?) Lorca, Murcia, Spain. [Imperfect fish.]

Pseudoeleginus intermerlius, $\$$ G. jonas, and "P. majori are merely names for undetermined fishes from the Upper Miocene of Gabbro, cribs Tuscany (de Bosniaski, Atti Soc. Tosc. Sci. Nat.-Proc.-Verb. vol. i. 1878, p. xix).

The aberrant family of LoPHIID正 seems to date back to the Eocene period, but is not represented by any fossils in the Collection. The extinct species described as follows seems to be rightly placed here:-

Lophius brachysomus, L. Agassiz, Neues Jahrb. 1835, p. 292, and Poiss. Foss. vol. v. pt. i. (1839-44), p. 114, pl. xl. Lophins piscatorius, G. S. Volta, Ittiolit. Veronese (1796), pl. xlii. tig. 3 (errore). Loricaria plecostomus, G. S. Volta, ibid. pl. xx. fig. 4 (errore).-Upper Eocene; Monte Bolca. [Imperfect fish; Prris Museum of Natural History.]

The name Lophius patagonicus has been given to undescribed teeth from the supposed Cretaceous of Patagonia (F. Ameghino, Sinops. Geol.-Paleont.-Suplem. 1899, p. 10).

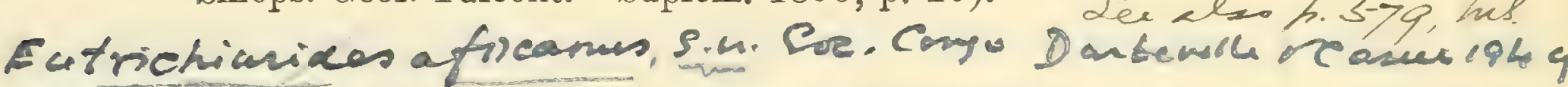
A. $24.41+x+f_{0}$, Division G. BLENNIIFORMES.

Pectoral fins with much extended base on flank; pelvic fins jugular, reduced or absent. Dorsal fin-spines numerous but usually flexible. No bony stay between circumorbital ring and preoperculum.

Synopsis of Families represented by Extinct Genera.

Bony scutes on trunk; snout produced ...... BLochind es (p. 591). No bony scutes; snout not produced ....... BLENNUD.e (p. 595).

\section{Family BLOCHIID $\approx$.}

Elongated fishes with slender caudal pedicle; snout much produced; mandibular suspensorium nearly vertical and gape very wide. Abdominal vertebræ without transverse processes, but bearing small ribs. Dorsal fin consisting only of flexible spines and occupying nearly the whole of the back; anal fin also much extended; caudal fin more or less expanded. A covering of bony scutes.

Known only by one genus of Eocene age. 


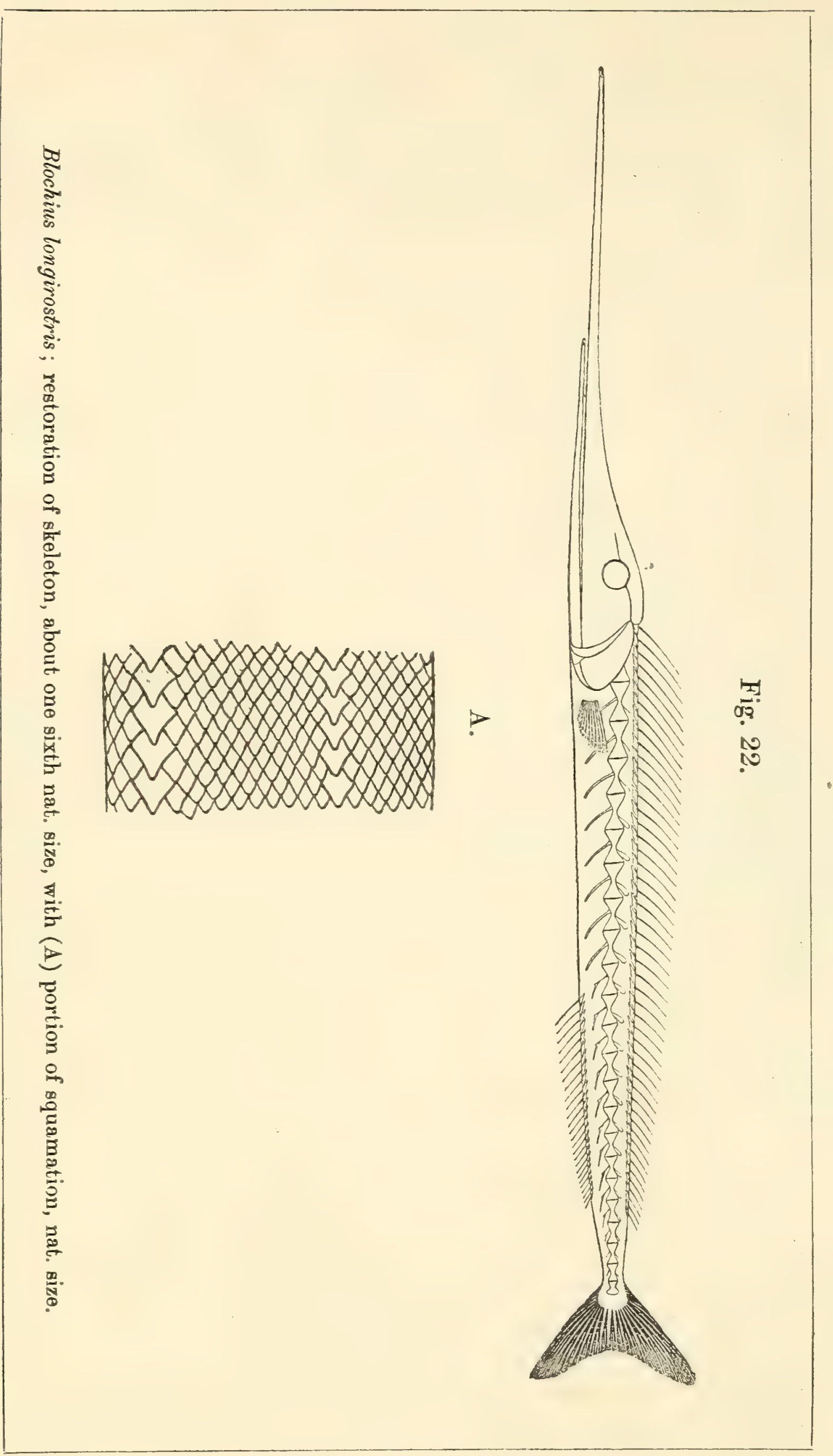



Glyptorkyneher denticulatus, Mr. Zeriche, Mém. Inue. Bon. Fist. Kath. Belp. vil. v(1910) - Poins. Oligre. Belp. h. 339, pl. xxv, fire. 3-6, heschofir. 137-1444. Glindracanthus (Glyptorhy neture) dentionlatur, Mr. Teriche, Bull. Sor. Belp. Gécl. te vol. xxii (1908), Prov. Verh. 1.381- Dipelian; Boom Belgivinaing [Mostum and verhebse; Délheid Coll.]

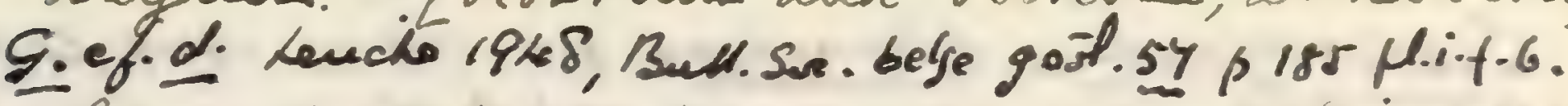
Glyptorhynchus bruxelliensis, sin. Mrheriohe.

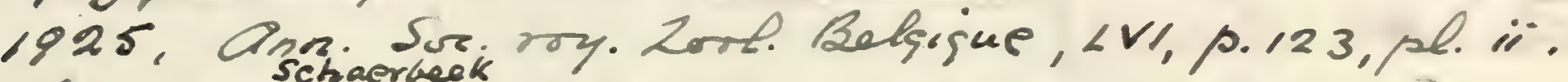
U. Bruxcelt? Brathant. [Rostrum; Thes.r. H.N. Belfigur].

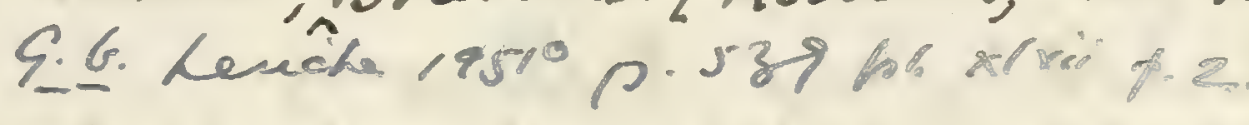
Glyptorhynches cestalies, n.5. Hench 1925 (ivid)

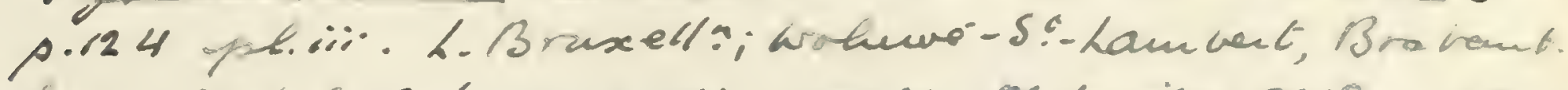

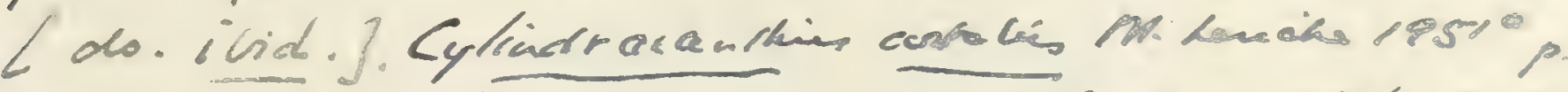

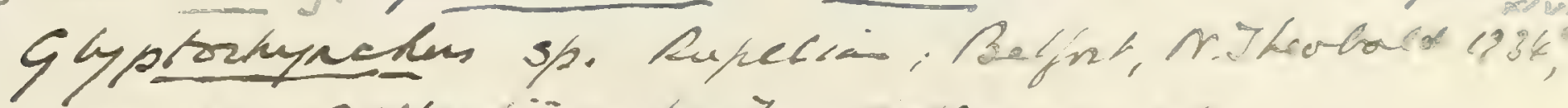

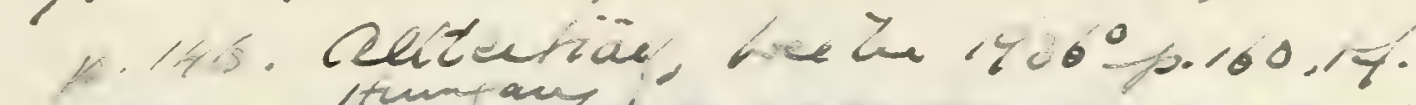

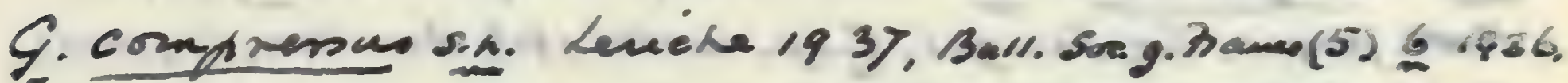

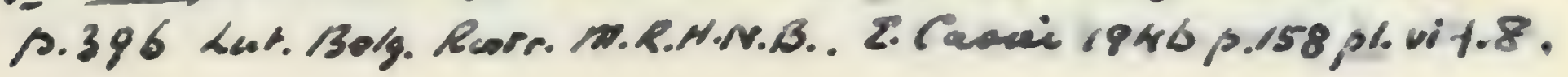

Hemirhabdorhynches gen.non deprenus sprims

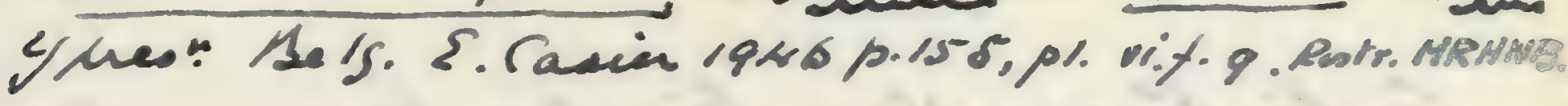

H. Yuericanes do. irid.p. $15 y$ plovit. 10. do.

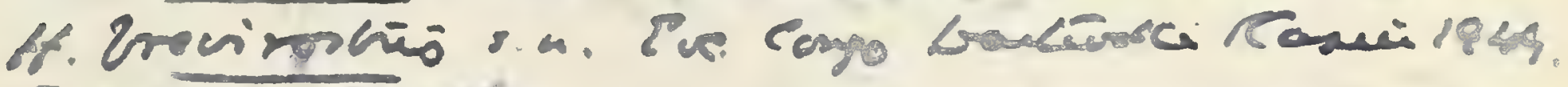

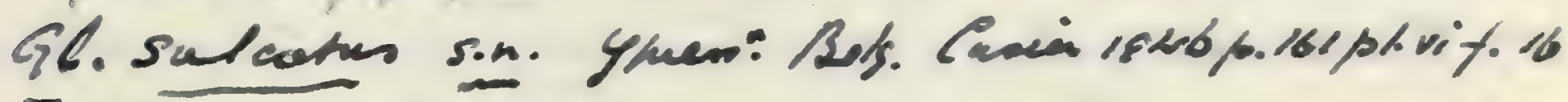
Pest. frey. mintiNes.

Congortynches häbenlabis 9.rs.4.

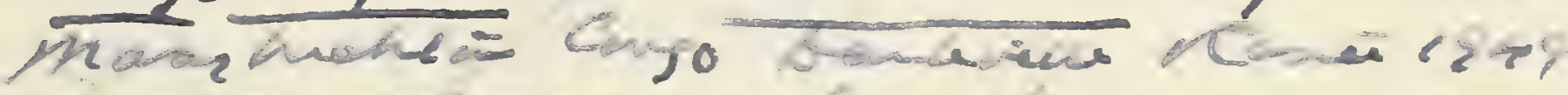

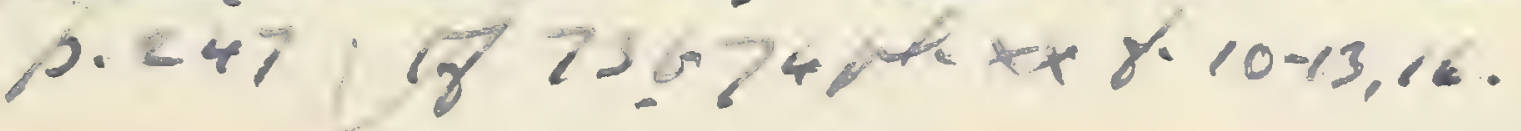




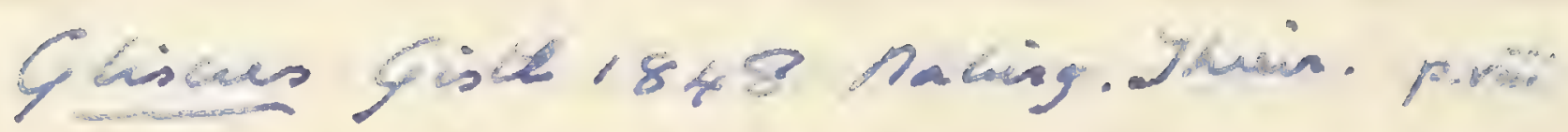

B. as ancestrod tipliex, fugens ranoms 1837 , a mor. mens. For. g52, p.23.

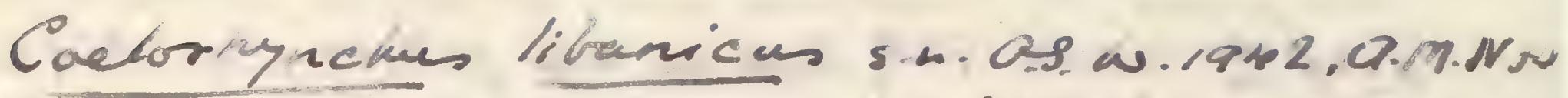

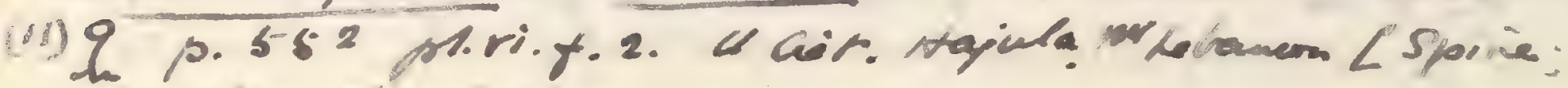
Q.w. hen paring.

Blochims emponed with young Xiphiar by C.7.Regan, Am. Masg. Kat. Hist. [8] vol. iii(1909), 1.74 .

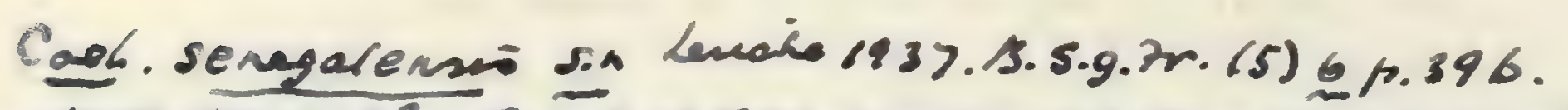

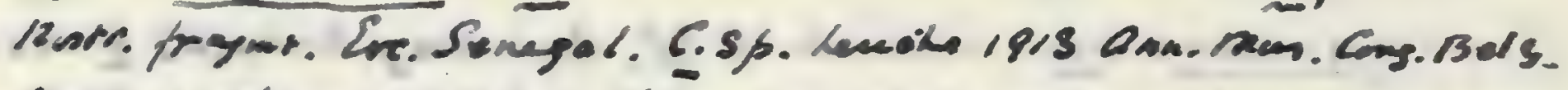
A. I11. I tane. p.894.6.

1905. Eurman; 17.30. Blochivs moorkeadi sp.ron.

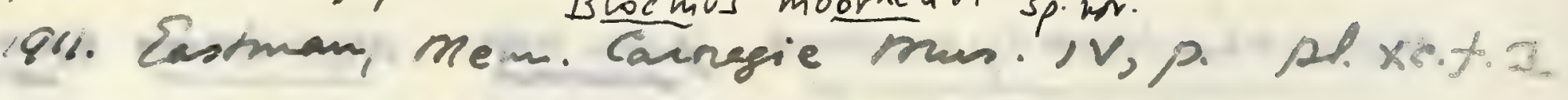

Cylisdiacandan bisulcatus 0.n. Kr. ask

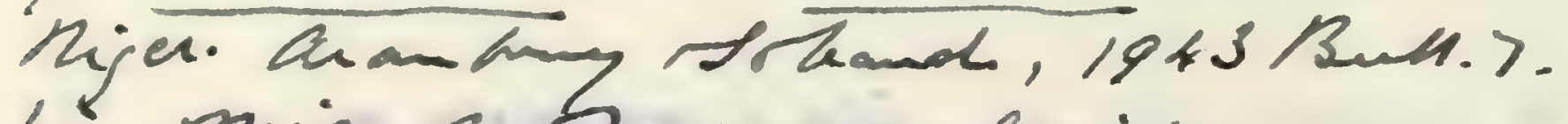

bu.mines a.tor. 10.5 2. pls.iv.v.

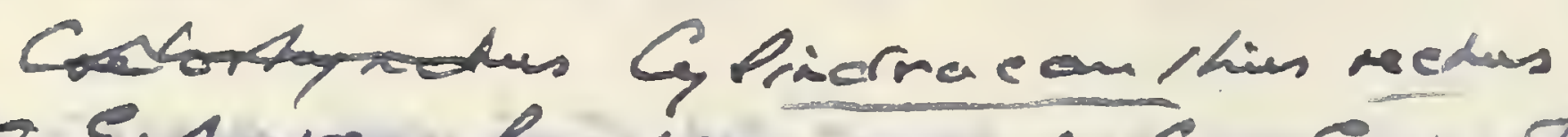

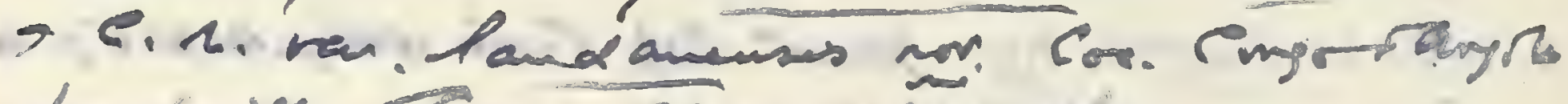

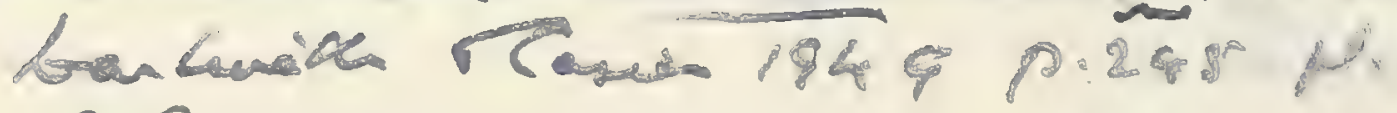

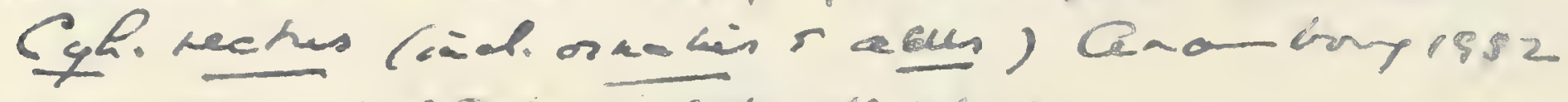

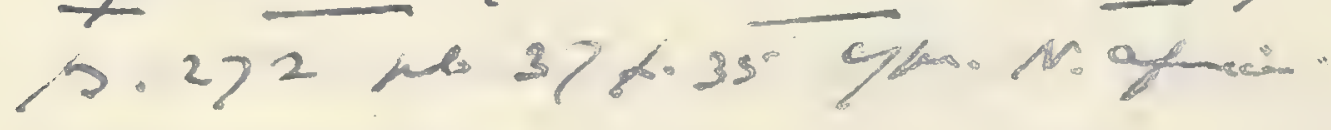



, 


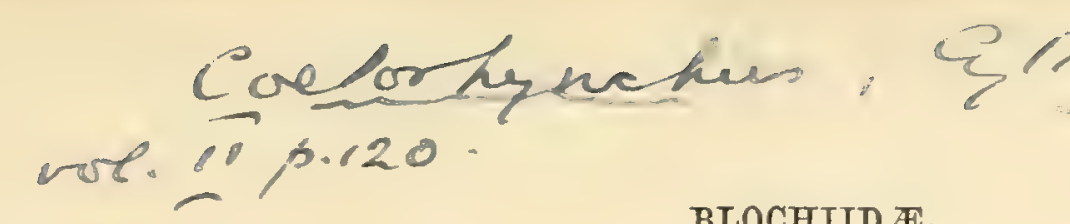

BLOCHIID无.

\section{Genus BLOCHIUS, Volta.}

[Ittiolit. Veronese, 1796, p. liii.]

Rostrum very slender, projecting far in advance of the mandible, which articulates beneath the hinder end of the cranium; rami of mandible probably fused at symphysis; teeth minute or absent. Vertebræ about 12 in the abdominal, 12 in the caudal region; the centra much elongated and constricted, imperfectly ossified. Pectoral fius small; [pelvic pair supposed to be present, but, if so, relatively small and jugular]; caudal tin slightly forked. Bony scutes diamond-shaped, slightly overlapping, completely and regularly covering the trunk and partly extending over the opercular apparatus and cheeks; two longitudinal series of scutes somewhat enlarged on each flank.

So far as can be determined from the fractured specimens in the Collection, the remarkably elongated rostrum of this genus bears much resemblance to the supposed dermal spines from the Upper Eocene named Coelorhynchus (see Part II. p. 120). When sufficiently well-preserved rostra of the typical Blochins are available for microscopical examination, it will be interesting to compare the structure with that of Coelorhynchus, and also with that of the apparently Chimæroid spines from the Cretaceous which commonly bear the same name.

\section{Blochius longirostris, Volta.}

[Text-figure 22.]

1796. Blochius longirostris, G. S. Volta, Ittiolit. Veronese, p. liii. pls. xii., lxx.

1843-44. Blochius longirostris, L. Agassiz, Poiss. Foss. vol. ii. pt. ii. p. 255 , pl. xliv.

1887. Blochius macropterus, A. de Zigno, Mem. R. Istit. Veneto, vol. xxiii. p. 25, fig. 7. [Imperfect fish with incomplete rostrum; Zigno Coll., University of Padua.]

Type. Imperfect fish; Paris Museum of Natural History.

The type species, attaining a length of about a metre. Length of head with opercular apparatus about equal to that of the vertebral column; maximum depth of trunk contained about nine times in the same measurement. Dorsal fin-spines about 50 in number, the length of the longest apparently not exceeding the maximum depth of trunk; anal fin with about 25 rays, arising slightly nearer to the caudal fin than to the pectoral pair. Dermal scutes very 
feebly crimped or smooth, the upper enlarged flank-series smaller than the lower enlarged flank-series.

Form. \& Loc. Upper Eocene: Monte Bolca, near Verona.

P. 4141. Fine specimen about 0.77 in length, deepened by distortion at the back of the head, which is figured by Agassiz, tom. cit. pl. xliv. fig. 1. The hinder part of the cranium is crushed upwards, while the mandible is displaced downwards, so that both its slender rami are seen from beneath. The mandible does not appear to have extended much further forwards than the base of the rostrum. Small scutes are seen to extend over the opercular apparatus; and the ossified sclerotic is partly preserved. The pectoral fins are displaced but both shown as indicated in Agassiz's figure; the lowermost exhibiting three of its basal bones in position. Comparatively small and delicate rays in front of the pectorals may represent pelvic fins, but it is uncertain whether these are not merely branchiostegal rays. The dorsal fin-spines have the appearance of extending forwards over the head merely in consequence of the displacement of parts just described. The depth of the abdominal region in the fossil must also be less than was actually the case during life. Enniskillen Coll.

P. 4142. More imperfect and distorted larger specimen, showing the mandible as before, and the parts of the cranium much scattered. Immediately in front of the frontals, the fractured base of the rostrum seems to consist of a pair of tubes pressed together like those of the so-called Coelorhynchus. A longitudinal series of rather large perforations penetrating the dense armour of the hinder part of the tail, appears to mark the course of the lateral line.

\section{Enniskillen Coll.}

19940. Fine small fish, distorted like the preceding specimens at the back of the head and in the abdominal region. The slender mandible is seen to extend not much further forwards than the base of the rostrum; and the delicate suspensorium is displaced between it and the cranium. Small scutes extend over the triangular operculum and perhaps over part of the cheek. The hæmal arches of most of the vertebræ are observable, and used in the accompanying restoration (fig. 22). The median fins and dermal scutes are also well preserved; the enlarged flank-scutes 
19940. Inicro. section f rratum ( = Golorhynchno) noticed by A.S. W., Imant. Goun. Geol. Sor. vol. Txxii('g'g), Phoe. h. Txxviii.

Figd J.T. Cartar 1927, Occ. Pap. Ged. Surr. Nigeric, S, pls 10,11. 


of the upper series being slightly smaller than those of the lower series.

Purchased, 1846.

P. 2089. Caudal region and other fragments of a small specimen. There are traces of scutes on the cheek. Egerton Coll.

\section{Family BLENNIIDÆ.}

Elongated fishes with stout caudal pedicle; snout not produced. Most of the abdominal vertebræ with downwardly directed transverse processes bearing the small ribs. Dorsal fin occupying nearly the whole of the back, often subdivided; anal fin also much extended; caudal fin rounded or tapering. Scales small or absent, and no bony scutes.

Marine fishes living at the bottom near almost all coasts, and a few freshwater species. Scarcely known among fossils, but represented by at least one extinct genus allied to Cristiceps, and perhaps by another (Oncolepis) of doubtful affinities.

\section{Genus PTERYGOCEPHALUS, Agassiz.}

[Poiss. Foss. vol. iv. 1839, p. 190.]

Head short and orbit very large; mouth small, with conical teeth. Vertebræ about 10 in the abdominal, 14 in the caudal region. Dorsal fin very deep, the foremost large spine displaced forwards above the head but the fin otherwise continuous. Squamation well developed and continuous, each scale with a longitudinal keel, and the keels forming regular lines along the trunk.

An Eocene genus, erroneously identified with Cristiceps ${ }^{1}$ by J. Müller, Neues Jahrb. 1853, p. 123.

\section{Pterygocephalus paradoxus, Agassiz.}

1796. Labrus malapterus, G. S. Volta, Ittiolit. Veronese, p. cexxviii. pl. lv. fig. 3 (errore).

1818. Labrus malapterus, H. D. de Blainville, Nouv. Dict. d'Hist. Nat. vol. xxvii. p. 351.

1835. Pterygocephalus paradoxus, L. Agassiz, Neues Jahrb. p. 295 (name only).

1839. Pterygocephalus paradoxus, L. Agassiz, Poiss. Foss. vol. iv. p. 191, pl. xxxii. figs. $5,6$.

1876. Cristiceps paradoxus, F. Bassani, Atti Soc. Veneto-Trent. Sci. Nat. vol. iii. p. 178.

${ }^{3}$ Cuvier \& Valenciennes, Hist. Nat. Poiss. vol. xi. (1836), p. 402. 
Type. Imperfect fish; Paris Museum of Natural History.

The type species, attaining a length of about $0 \cdot 05$. Length of head with opercular apparatus equalling maximum depth of trunk and somewhat less than one third total length of fish to base of caudal fin. Separate dorsal fin-spine about twice as long as the next, the length of which slightly exceeds depth of trunk at its insertion; continuous dorsal fin with 9 spines and 9 articulated rays; anal fin with 3 spines and 7 articulated rays.

Form. \& Loc. Upper Eocene: Monte Bolca, near Verona.

P. 653. Fine specimen 0.025 in length, noticed by Agassiz, op. cit. vol. iv. p. 192.

Egerton Coll.

P. 652, P. 3948. More imperfect larger specimen, in counterpart, showing characteristic squamation.

Egerton \& Enniskillen Colls.

As noticed by Agassiz, the following fragmentary specimens bear some resemblance to the skull of the existing genus Anarrhichas, but they exhibit too many differences to be definitely ascribed to the family Blenniidæ:-

P. 320. Imperfect occipital portion of cranium, with remains of opercular apparatus, mandibular suspensorium, and articular end of mandible, intended to be the type specimen of Laparus alticeps, Agassiz, recorded by name only in Rep. Brit. Assoc. 1844 (1845), p. 308 ; London Clay, Sheppey。 The hinder portion of the dentary bone shows the bases of a single close series of very small teeth. Egerton Coll.

P. 6479. Less incomplete head of larger fish apparently of same species; London Clay, Sheppey. The jaws are imperfect, and the dentition is not seen. The opercular apparatus is much larger than in Anarrhichas.

Beckles Coll.

P. 9478. Occipital portions of two nearly similar crania; London Clay, Sheppey.

Egerton Coll.

A tooth apparently of the existing Anarrhichas lupus, from the Coralline Crag of Gedgrave, Suffolk (Museum of Practical Geology), is described by E. T. Newton, Vert. Pliocene Dep. Britain (Mem. Geol. Surr. 1891), p. 91, pl. x. fig. 4.

The following extinct species, not represented in the Collection, have been referred to existing genera of this family :-

Blennius fossitis, D. G. Kramberger, Pad Jugoslav. Akad. vol. 


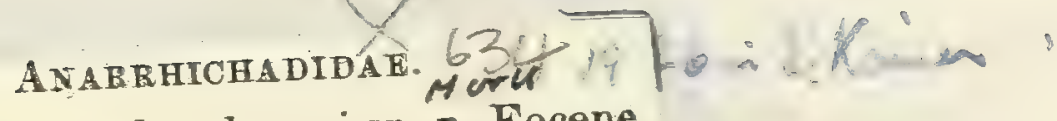
- Paranarrichas damesi sp. D. Eocene S.W. Africa, J.B̈нм Die Diamantenwüste Südwest-Afrikas 2 p. 84 fig. B. 20.

isul. leeth. Inotet. 
Ctolithus (Cepda) Eantonenzio, P. Schulent, Gahat. 4.4.ged. Peichsoust. vol. 65-(1915), 6.281, pl.vili.ti. 1s:

- Bartor Clay.

Robleming filamentozur, 7. Piem, in 9.de Mroan, Xélépation en Perse, - Im. Altidt.

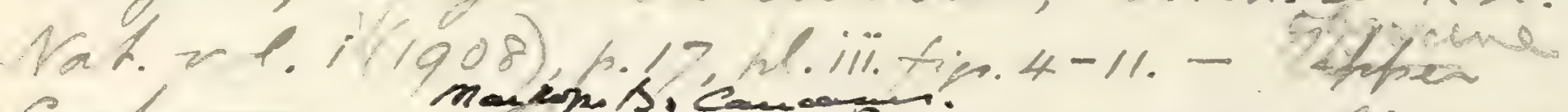

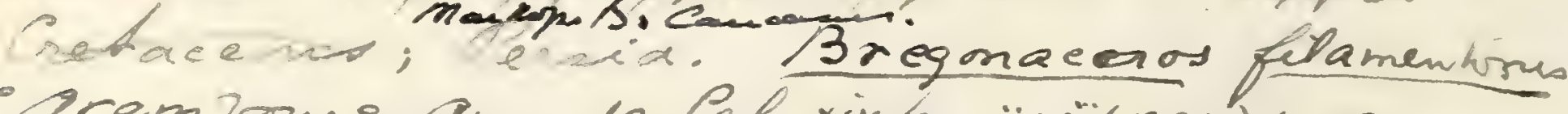

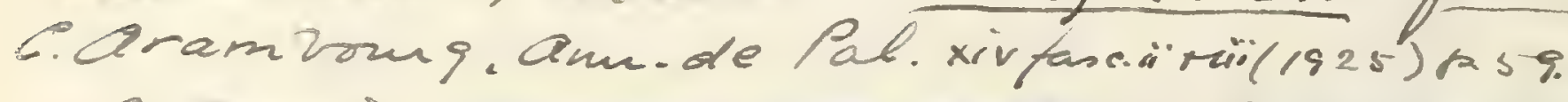

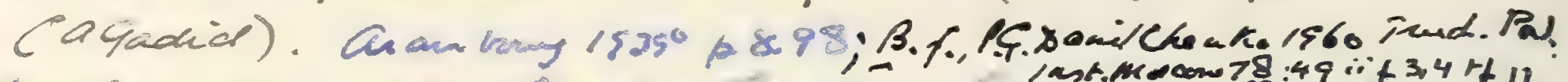

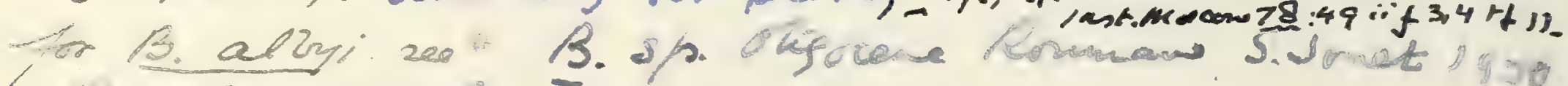

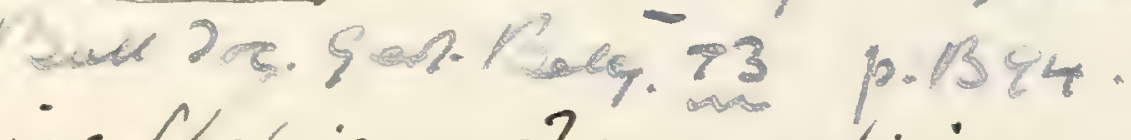

Clinus [habrisomus] pronuchipinnis, n.s., C. Qrambourg, 199\%, p.205,pl. $x$ liiiff.2.. Sahelian; Oran. [7ssh?.

Tripterygion pronasus, s.n, CQ Qrambourg, 19x7, p.207, ph xelis t.3-5, phexliit fol. Sahelian; Oran. SY Fiskes?.

LEpios COpHOL.

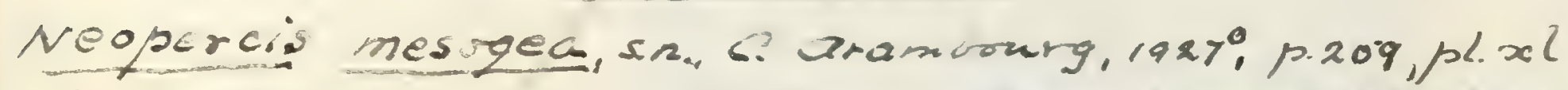

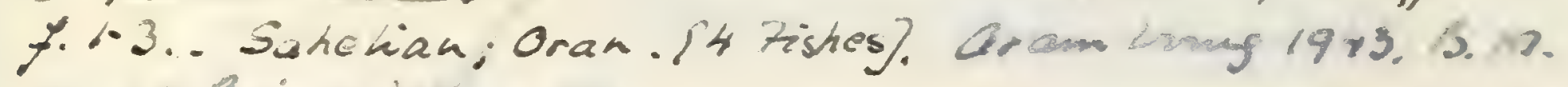
r. It R. Pain. (a)loss

BATRACTOMIDE.

Batrachoides didactyucs, Buzh-Schn.in C. Arambourg, 1927 ; p.212, ph.x/ïf.1.2. Sanelian; Oran.

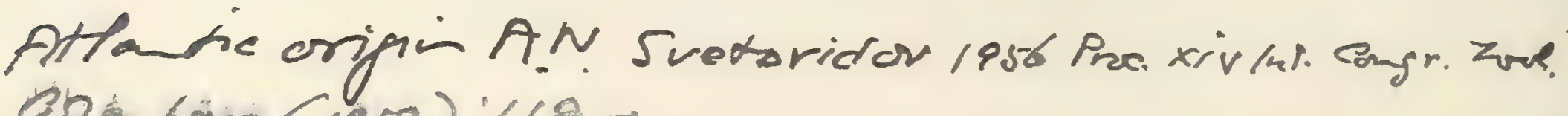

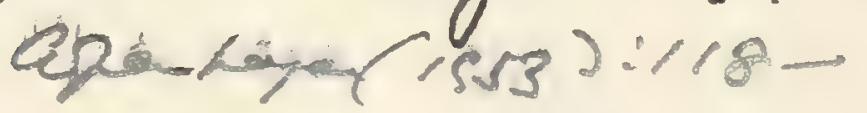



cri. (1891), p. 113, pl. iii. fig. 3.-Upper Miocene; Dolje, Croatia. [Imperfect fish; Geological Museum, University of Agram.]

Clinus grocitis, F. Steindachner, Sitzungsb. k. Akad. Wiss., math.naturw. Cl. vol. xxxvii. (1859), p. 675, pl. i. figs. 1-3.Upper Miocene; Hernals, Vienna. [Imperfect fish; Court Museum, Vienna.]

The following extinct genus and species, which is not represented in the Collection, probably belongs to the Blenniidæ, but is too imperfectly known for exact determination :-

Oncolepis isseli, F. Bassani, Palaeont. Italica, vol. iii.(1898), p. 79, pl. ix. figs. 1, 2.-Upper Eocene ; Monte Bolca. [Imperfect fish; Geological Museum, University of Genoa.]

Nothing is known of the undescribed teeth from the Pliocene of Belgium, recorded under the name of Palanarrhichas crassus, H. Le Hon, Prélim. Yém. Poiss. Tert. Belg. (1871), p. 10.

\section{Suborder X. ANACANTHINI.}

Vertebral centra always complete constricted cylinders, none coalesced. Supraoccipital extending forwards between the reduced parietals; squamosal rudimentary and fused with the large pterotic; mandible simple, each ramus consisting only of two elements (dentary and articulo-angular). No spinous fin-rays. Pectoral arch suspended from the cranium; precoracoid arch absent; infraclavicular plates absent; pectoral fin with not more than four or five basals. Pelvic fins, when present, thoracic or jugular. In the living forms:-air-bladder, when present, not connected with the œsophagus by a duct in the adult (physoclistous); optic nerves decussating; intestine without spiral valve; reproductive organs with efferent ducts.

No important extinct representatives of this suborder are known. All are normal members of the existing families, Gadidæ and Pleuronectidæ.

\section{Family GADID $\approx$.}

Trunk more or less elongate, and head bilaterally symmetrical. Mouth large and terminal; premaxilla excluding maxilla from gape; cheek-plates much reduced; gill-openings very wide. Abdominal vertebræ with transverse processes; ribs comparatively 
small. Both paired fins present, usually well-developed. Dorsal fin occupying nearly the whole of the back, simple or more or less subdivided into two or three parts; one or two anal fins; caudal fin separate, or if united with other median fins, the dorsal with a separate anterior portion. Scales small and cycloid. In the recent forms:-air-bladder and pyloric appendages usually present; pseudobranchiæ absent, or glandular and rudimentary.

This family dates back to the Upper Eocene, but only one extinct genus is recognisable. The "cod-fishes" and their allies of the present day chiefly inhabit the seas of the north temperate and arctic regions, often descending to great depths. Only one genus (Lota, Cuvier) occurs in freshwaters.

A figure of the skeleton of Lota is published by Agassiz, Poiss. Foss. vol. v. pl. H. A detailed description of the osteology of Gadus reglefinus is given by H. St. John Brooks, Proc. Roy. Dublin Soc. n. s. vol. iv. (1884), pp. 166-196, pls. v.-ix.

\section{Genus NEMOPTERYX, Agassiz.}

[Poiss. Foss. vol. v. pt. i. 1844, p. 75.]

Syn. Pulcogadus, G. vom Rath, Zeitschr. deutsch. genl. Ges. vol. xi.

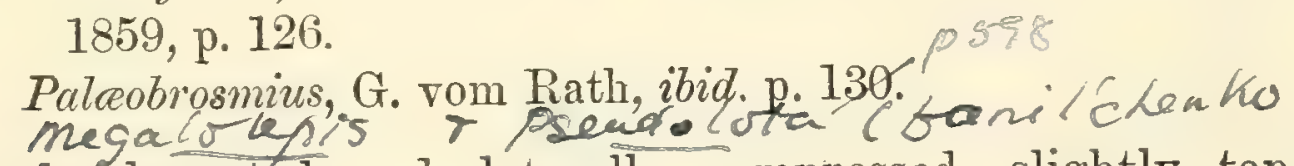

Trunk elongated and laterally compressed, slightly tapering behind. Ilargin of jaws with a single spaced series of large, recurred, pointed teeth. Pectoral fins much enlarged; pelvic fins small. Dorsal fin almost or completely subdivided into three acuminate portions, anal fin into two similar portions; caudal fin separate, truncated or rounded behind.

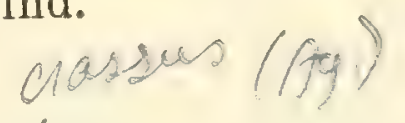

\section{Nemopteryx troscheli (vom Rath).}

1836. Cyclurus crassus, P. M. G. Egerton, Phil. Mag. vol. viii. p. 368 (name only).

1836. Cyclurus nemopteryx, P. M. G. Egerton, ibid. p. 368 (name only). 1842-43. Nemopteryx crassus, L. Agassiz, Poiss. Foss. vol. v. pt. i. pp. 6,75, pl. xxii. [Distorted fish; British Museum.]

1842-43. Nemopteryx elongatus, L. Agassiz, ibid. pp. 6, 76, pl. xxi $a$. [Distorted fish ; British Museum.]

1859. Palaogadus troschelii, G. vom Rath, Zeitschr. deutsch. geol. Ges. vol. xi. p. 126, pl. v. fig. 3.

1859. Palaobrosmius elongatus, G. vom Rath, ibid. p. 130.

1886. Nemopteryx troscheli, A. Wettstein, Fischfauna d. Tertiaer. Glarnerschief. (Denkschr. schweiz. Pal. Ges. vol. xiii.), p. 59, pl. iv. 


Palaermolva Larchanica gemiet of nor

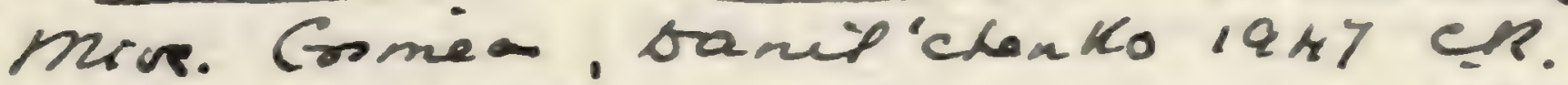
Head Sci: U RSS. NS. SS p. 2053 prge 1. (7ish).

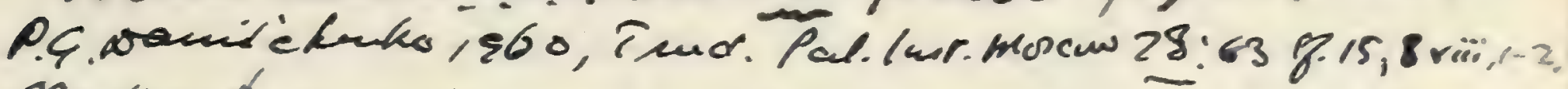
Maik op X. Eancaras.

Ruppelliances. S.9. nov.1950.

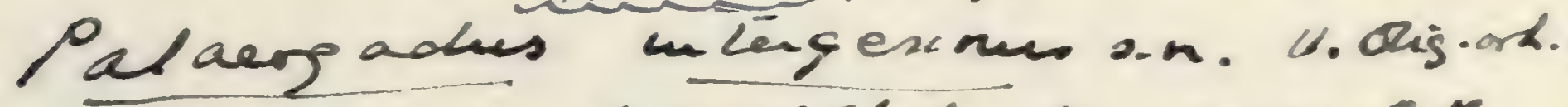

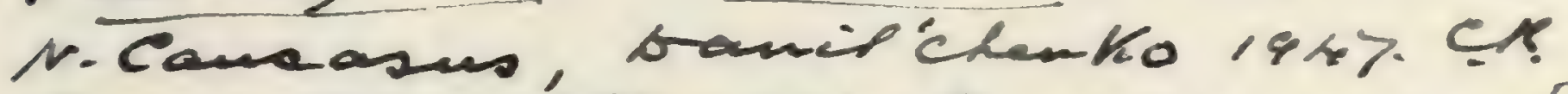
Cead. Oci: UR! SS (NS.) SS, p.660 tog. 1. Pal.

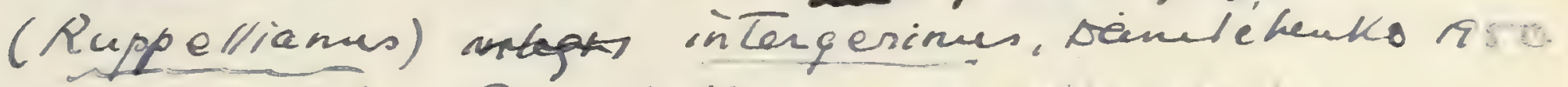
Tr. Pat inst Cead Jcillsth 25 p.13

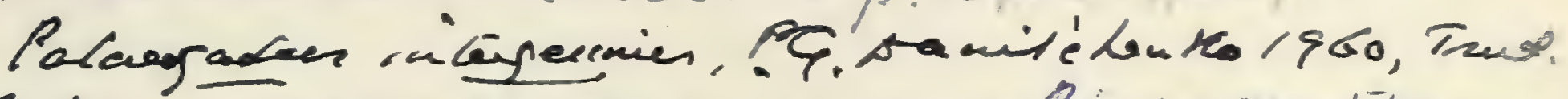

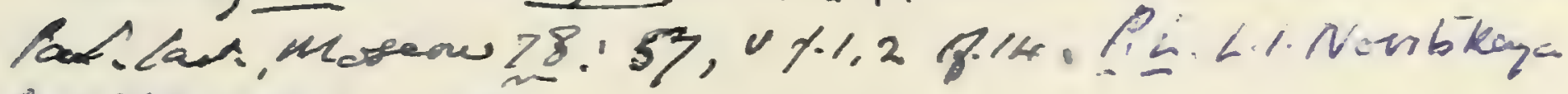
ah. 7 h. 1961.4 \&. 20

Lotimozpila s.s.now 1950.

N. athankiasui, enep.... Palargadas (totimorpha)

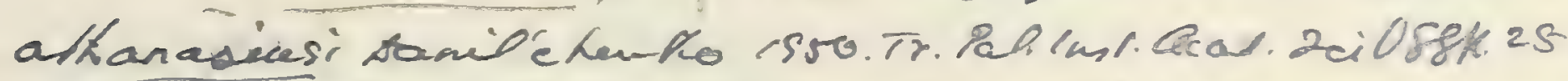

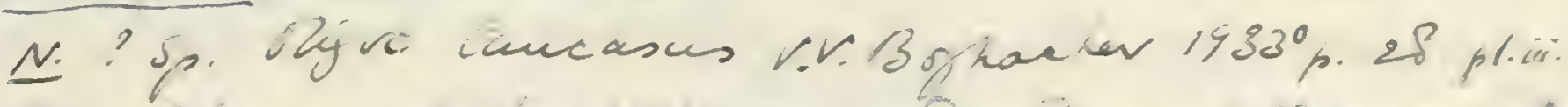

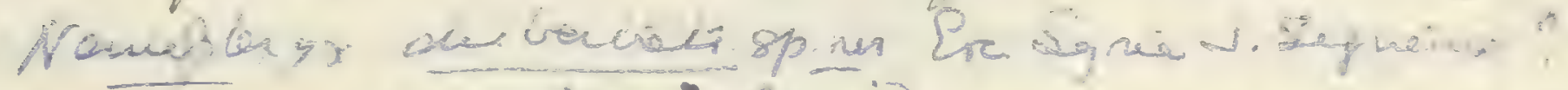
Nempleñx pectolis s-n. Ko Olyser.

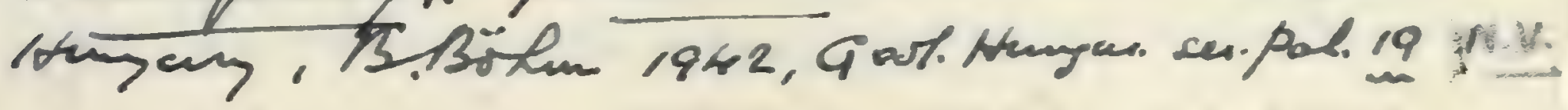

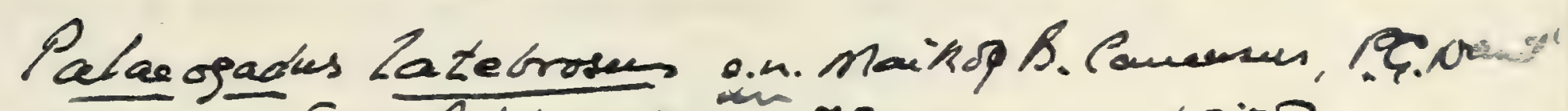

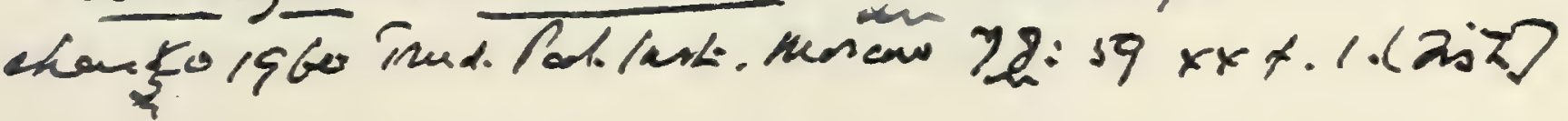

1950. Palaogpadus (Poh.) crassus, Pos. banil'chenko Trar. Pal. lust. A cad-2ci. U.SSR. $2 S^{\circ}$ p. 6.

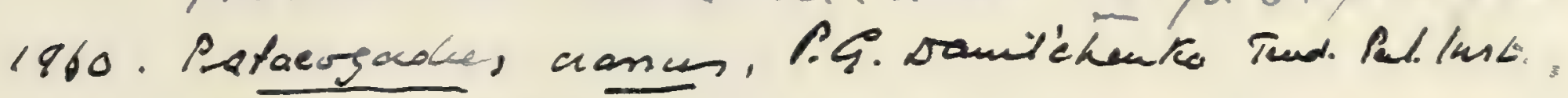
$78: 56, \times \times 4.2$.

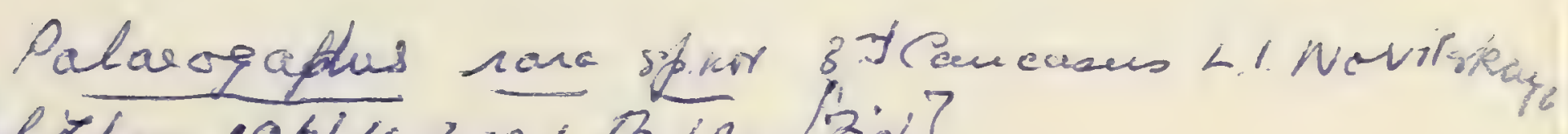

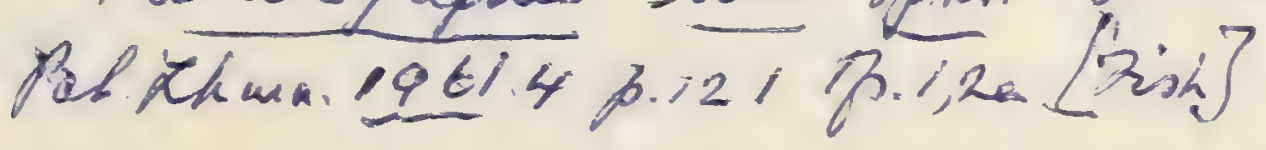

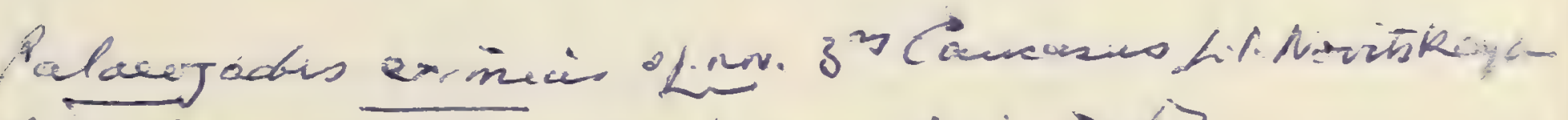

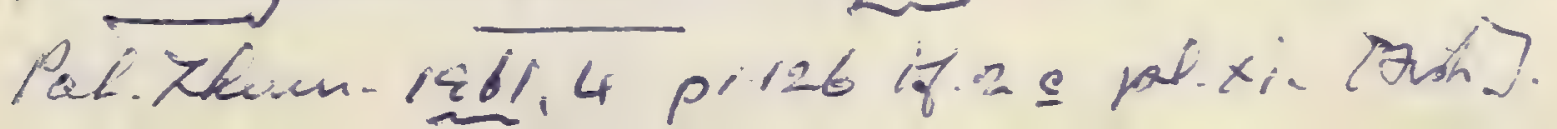


Palarupadces (Lotimngha) S imionesceri n.m. pro Gobies elongaties simionesen (p.388) non rewptrings

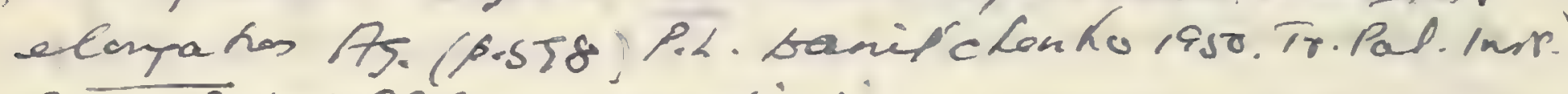
Fiad rei. USPR. 25 p.18 pliti.

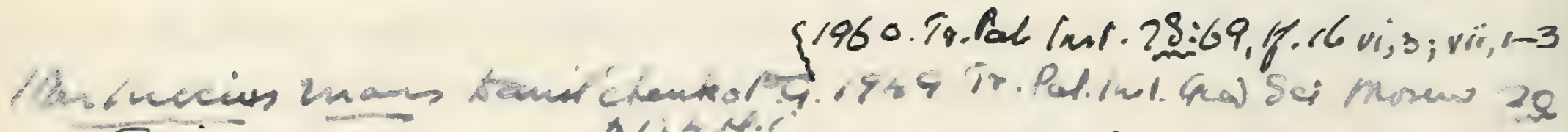

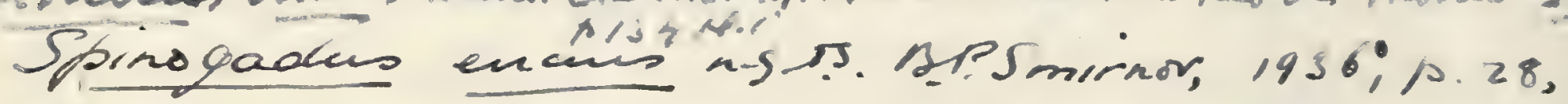

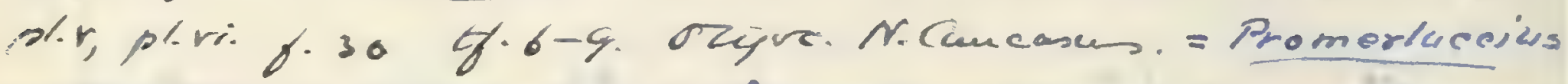
andrusuri $V$. Menner teste Boghacher $1938 \mathrm{G}$ \% wh 2not lelowor

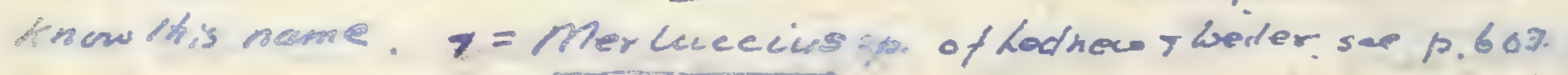

Gaches op. Pontian Rowmani, Poura" 19359, p.103

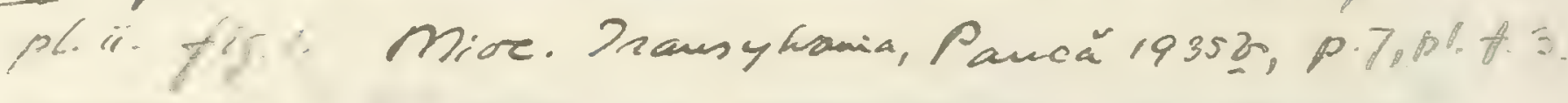


, 

Type. Slightly distorted fish; Geological Museum, University of Bonn.

The type species, attaining a length of about $0 \cdot 45$. Length of head with opercular apparatus probably exceeding twice the maximum depth of the trunk and contained about twice in the length from the pectoral arch to the base of the caudal fin. Vertebræ approximately 45 in number. Pectoral fins with about 17 rays. Anterior portion of dorsal fin with about 13 rays, the middle portion with 16 more closely arranged rays; anterior portion of anal fin with 18 rays.

Form. \& Loc. Oligocene: Glarus, Switzerland.

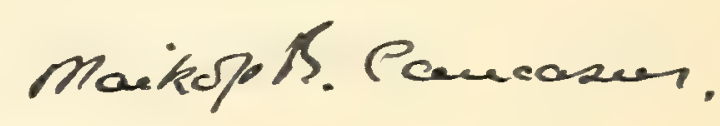

P. 457, P. 298\%. Type specimen of Nemopteryx crassus, in counterpart, described and figured by Agassiz, Toc. cit.; Engi.

Egerton \& Enniskillen Colls.

P. 458-9, P. 3989. Type specimens of Nemopteryx elongatus, one in counterpart, described and figured by Agassiz, loc. cit.: Engi. Egerton \& Enniskillen Colls.

P. 2988. Fine specimen, bent at the end of the abdominal region but not much distorted; Engi.

Enniskillen Coll.

33852-53. Imperfect elongate specimen, in counterpart; Engi. Presented by Miss Elizabeth Warne, 1859.

P. 9428. Immature fish, probably of this species, in counterpart.

History unknown.

Genus GADUS (Artedi), Linnæus.

[Syst. Nat. ed. 10, 1758, p. 251.]

Syn. Morrhua, L. Oken, Isis, 1817, p. 1182.

Trunk elongated and laterally compressed, tapering behind. Margin of jaws and vomer with small clustered teeth, not varying much in size; palatine toothless. Chin with barbel. Paired fins of moderate size. Dorsal fin completely subdivided into three portions, anal fin into two portions; caudal fin separate, truncated or slightly excavated behind. Scales very small and dense.

The following fossils belong to existing or unsatisfactorily defined species :--

P. 5255. Nodule containing very small fish; Glacial or PostGlacial Clay, Bindalen, Norway.

Presented by Henry Tryon, Esq., 1887. 
P. 8724-25. Maxilla and parasphenoid noticed by E. T. Newton, Vert. Forest Bed (Mem. Geol. Surv. 1882), p. 128 ; Forest Bed, Orerstrand and Mundesley. Savin Coll.

P. 8722-23, P. 8726. Various fragments; Forest Bed Series, wear Cromer. Savin Coll.

P. 9485. Various fragments, noticed by E. T. Newton, op. cit. p. 127; Forest Bed, Bacton.

Green Coll.

39171. Imperfect otolith of the form named Gadus pseudoeglifinus by E. T. Newton, Vert. Pliocene Dep. Brit. (Mem. Geol. Surv. 1891), p. 94, pl. x. figs. 6, 7 , the type specimen being in the Museum of Practical Geology; Red Crag, Walton-on-the-Naze, Essex. Bowerbank Coll.

403\%\%. Similar otoliths; Coralline Crag, Sudbourn, Suffolk.

Daniels Coll.

P. 5231. Imperfect similar otolith; Coralline Crag, Broom Hill, near Orford, Suffolk.

Presented by H. W. Burrows, Esq., 1898.

P. 9232. Otolith apparently of Gadus Tuscus, Linn., as described by E. T. Newton, op. cit. 1891, p. 94, pl. x. fig. 8 ; Coralline Crag, Broom Hill.

Presented by H. W. Burrows, Esq., 1898.

P. 9233. Similar otoliths; Suffolk Crag. John Brown Coll.

P. 9234. Three otoliths apparently of a variety of Gadus merlangus, Linn. (Merlangus vulgaris, Fleming), named Otolithus (Merlangus) vulgaris, var. suffolkensis by E. Koken, Zeitschr. deutsch. geol. Ges. rol. xliii. (1891), p. 90, pl. $\nabla$ fig. 5 ; Suffolk Crag.

John Brown Coll.

39171 a. Small otoliths of the form ascribed to Gadus elegans, Koken ${ }^{1}$, by E. T. Newton, op. cit. 1891, p. 96, pl. x. fig. 16; Red Crag, Nalton-on-the-Naze. Bowerbank Coll.

39171 b. Miscellaneous otoliths; Red Crag, Walton-on-the-Naze.

Bowerbank Coll.

1 This species is described as Otolithus (Gadidarum) elegans by E. Koken, Zeitschr. deutsch. geol. Ges. vol. xxrvi. (1884), p. 542, pl. xi. figs. 2, 4 (non 3), also ibid. vol. xliii. (1891), p. 93, pl. iv. figs. 1, 2, pl. v. fig. 6. It is said to range from the Middle Oligocene to the Pliocene of Western Europe. To it probably belongs the otolith wrongly described as Trigloides dejardinii by P. J. Van Beneden, Bull. Acad. Roy. Belg. [2] vol. xxxi. (1871), p. 501, pl. ii.

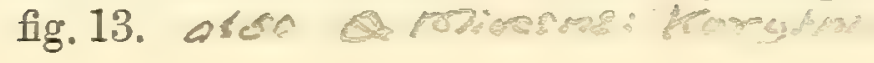



Yr.

$19+5$

$$
\text { a }
$$

.. $\quad, \quad$

$$
\begin{aligned}
& \text { and } \\
& \text { ancon }
\end{aligned}
$$


Gadus merlangus in Yoldia mart, sweden it

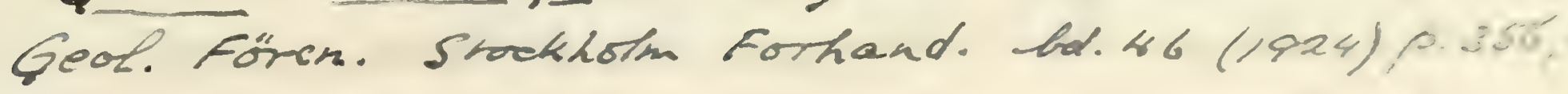

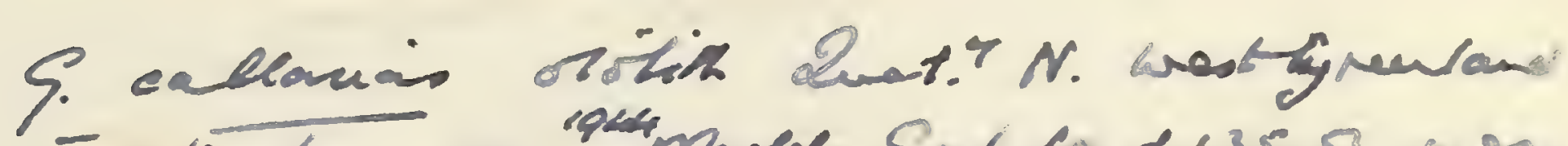

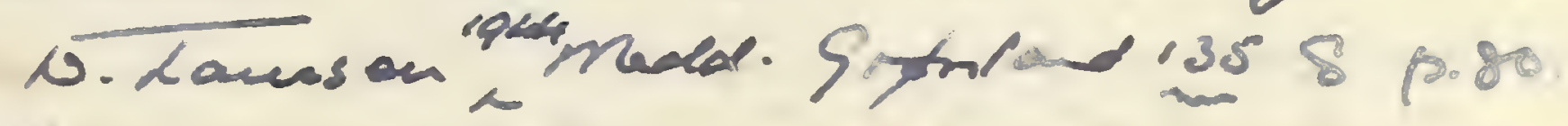

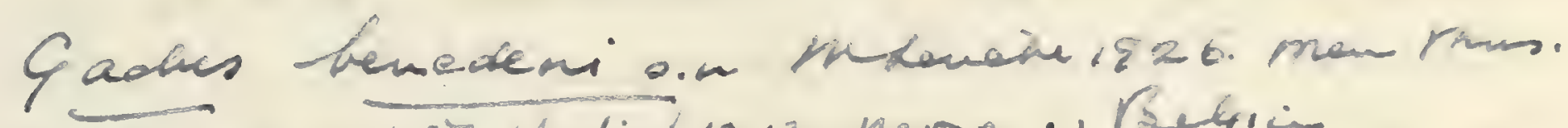

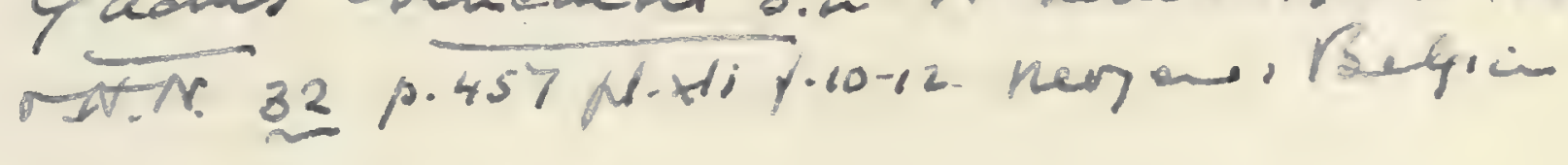

9. elogans rou.sectorakth.

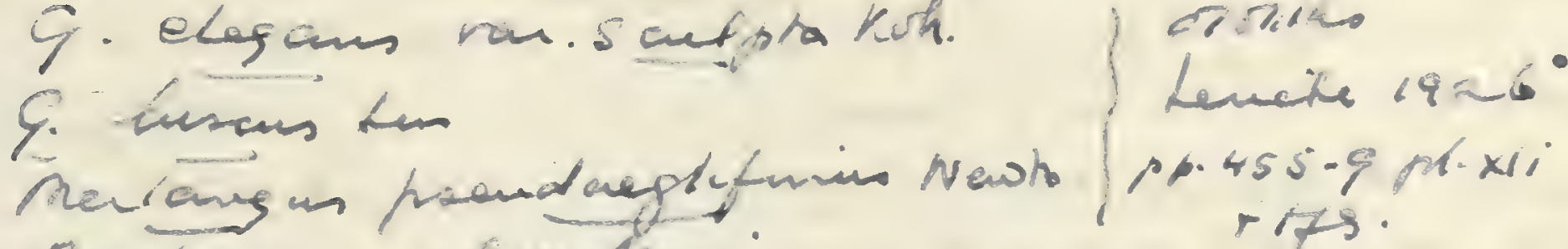

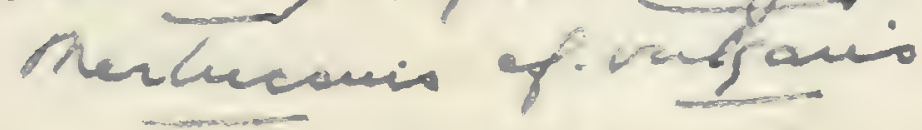
rits.

Gadus elapans, In. Leriche, Mnem. Muns. Roy. Hich. Nat

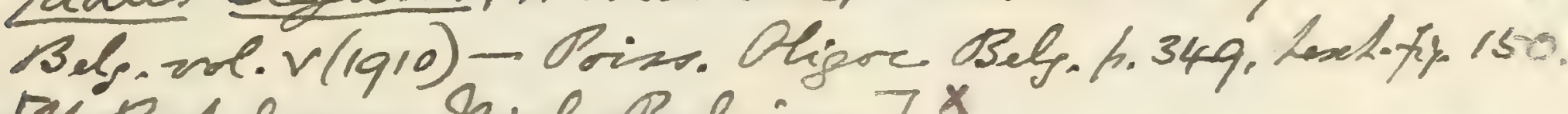
[H. Rupalian; Riel, Belpium]X

OL. (Ophidium) elegans, rars sulpta, G. A. Fiost 7raus. N.Z.Inst. v. 55 (1924) 1.610 p.61 f.7a Oamum N.Z. (ophidirdae) 


Otoliths of the existing species Gadus morrhua, Linn., G. minutus, Jinn., G. virens, Linn., and G. pollachius, Linn., are also described from the English Pliocene Crags by E. T. Newton, op. cit. 1891, pp. 93-96, pl. x. figs. 5, 9-11, 13-15.

The following imperfectly defined species all seem to belong to this genus, but are not represented in the Collection:-

Morrhua ceglefinoides, Kner \& Steindachner, Denkschr. k. Akad. Wiss., math.-naturw. Cl. vol. xxi. (1863), p. 34, pl.. fig. 2 ; D. G. Kramberger, Beitr. Paläont. Oesterr.Ungarns, vol. iii. (1883), p. 6อ̃.-Upper Miocene ; Podsused, Croatia. [Imperfect fish ; Zoological Museum, University of Vienna.]

Morrhua extensa, D. G. Kramberger, Rad Jugoslav. Akad. vol. Ixxii. (1885), p. 51, pl. v. fig. 3, and Soc. Hist. Nat. Croatica, vol. i. (1886), p. 135.-Upper Miocene; Szakadát, Siebenbürgen. [Imperfect distorted fish ; Imperial Geological Survey, Vienna.]

Morrhua lanceolata, D. G. Kramberger, Beitr. Paläont. Oesterr.Ungarns, vol. iii. (1883), p. 67, pl. xiii. fig. 5.-Upper Miocene; Podsused. [Imperfect fish; Geological Museum, University of Agram.]

Morrhua macropterygia, D. G. Kramberger, loc. cit. 1883, p. 65, pl. xiii. fig. 6.-Upper Miocene; Dolje, Croatia.

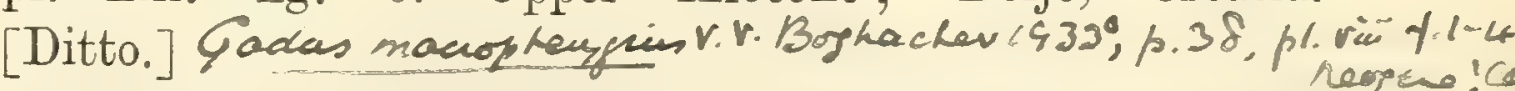
Morrhua minima, D. G. Kramberger, Rad Jugoslav. Akad. vol. 1xxii. (1885), p. 63, and ibid. vol. cri. (1891), p. 104, pl. vii. fig. 5.-Upper Miocene; Podsused. [Ditto.]

Morrhua szagadatensis, F. Steindachner, Sitzungsb. k. Akad. Wiss., math.-naturw. Cl. vol. xlvii. pt. i. (1863), p. 139, pl. ii. fig. 3.-Upper Miocene; Szakadát, Siebenbürgen. [Imperfect fish ; Court Museum, Vienna.]

Gadus latior and G. stoppanii are undefined names for fishes from the supposed Upper Miocene of Cutrò, Calabria (Bosniaski, Atti Soc. Tosc. Sci. Nat.-Proc.-Verb. vol. i. 1879, p. Ixxxii).

The so-called Gadus-polynemus (G. Fischer de Waldheim, Nouv. Mém. Soc. Imp. Nat. Moscou [2] vol. i. 1829, p. 298, pl.xxi.fig. 1) is an indeterminable fragment from limestone on the river Miasse, Govt. Orenburg, Russia.

Indeterminable teeth, and also otoliths, from the Lower Pliocene of Orciano and Siena, Tuscany, have been referred to the existing genus Merluccius, Cuvier, under the name of $M$. bosniaskii by
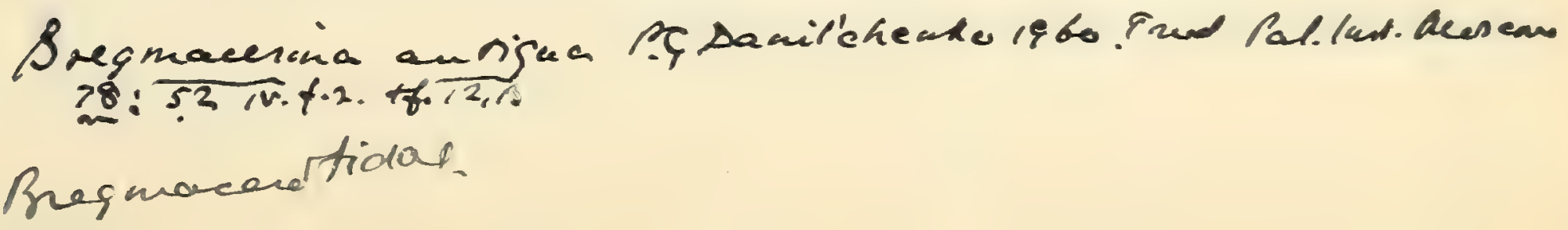
R. Lawley, Nuovi Studi Pesci, etc., Colline Toscane (1876), p. 81, pl. i. fig. 15.

The existing genera Phycis, Bloch \& Schneider, and Strinsia, Rafinesque, are not definitely known to have extinct representatives; but two fragments are provisionally ascribed to them as follows:-

Phycis suessi, F. Steindachner, Sitzungsb. k. Akad. Wiss., math.naturw. Cl. vol. xl. (1860), p. 566, pl. ii. fig. 2. Brosmius, J. J. Heckel, Jahrb. k.-k. geol. Reichsanst. vol. ii. (1851), p. 157.-Lower Pliocene; Inzersdorf, Vienna. [Caudal region; Court Museum, Vienna.]

Strinsia alata, F. Steindachner, loc. cit. vol. xxxviii. (1859), p. 771, pl. i. fig. 2.-Upper Miocene; Szakadát, Siebenbürgen. [Head, etc.; Court Museum, Vienna.]

\section{Genus BROSMIUS, Cuvier.}

[Règne Animal, ed. 2, vol. ii. 1829, p. 334.]

Trunk elongated and laterally compressed, tapering behind. Margin of jaws, vomer, and palatines with small clustered teeth, some of the vomerine and palatine teeth enlarged. Chin with barbel. Paired fins of moderate size. Dorsal and anal fins undivided; caudal fin separate, rounded behind. Scales very small.

Only one existing species in north temperate seas.

No remains of extinct species are preserved in the Collection, but the following have been described:-

Brosmius elongatus, D. G. Kramberger, Beitr. Paläont. Oesterr Ungarns, vol. iii. (1883), p. 69, pl. xiv. fig. 2, and Rad Jugoslav. Akad. vol.1xxii. (1885), p. 63.-Upper Niocene; Dolje, Croatia. [Imperfect fish; Geological Museum, University of Agram.]

Brosmins fuchsianus, D. G. Kramberger, loc. cit. 1883, p. 68, pl. xiii. fig. 4.-Upper Miocene; Podsused, Croatia. [Ditto.]

Brosmius strossmayeri, D. G. Kramberger, Toc. cit. 1883, p. 69, pl. xiv. fig. 1.-Upper Miocene (?); Beočin, Croatia. [Ditto.]

Brosmius susedanus, R. Kner, Sitzungsb. k. Akad. Wiss., math.naturw. Cl. vol. xlviii. pt. i. (1863), p. 145, pl. iii. fig. 3 ; D. G. Kramberger, loc. cit. 1883, p. 68.-Upper Miocene; Podsused. [Imperfect fish ; Court Museum, Vienna.]

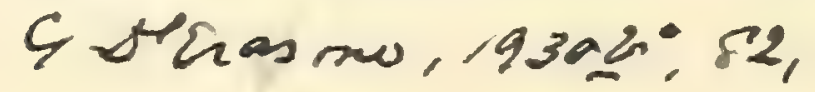



6016

merleccuie mousacthes 578 .

Mrtidas

P.

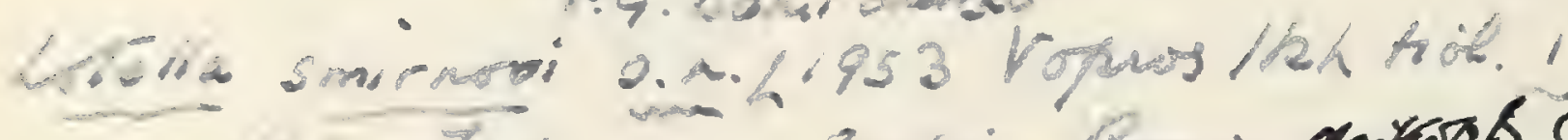

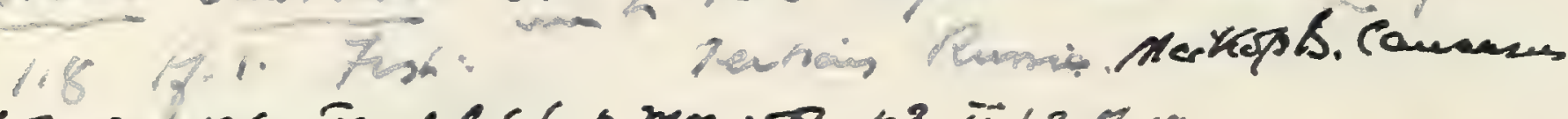

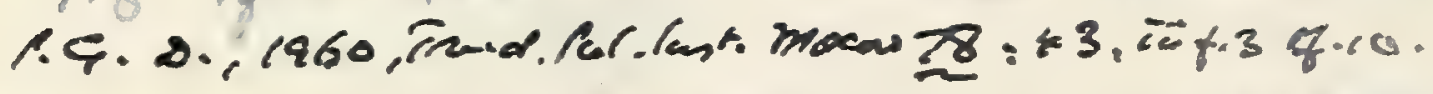

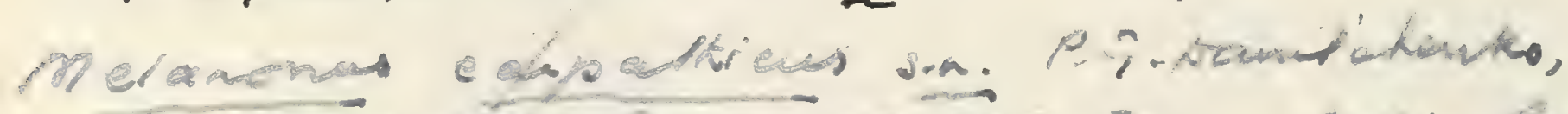

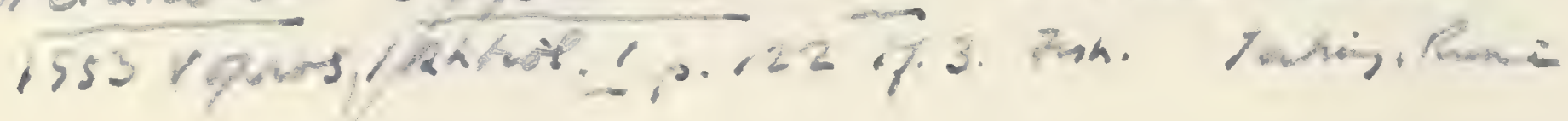

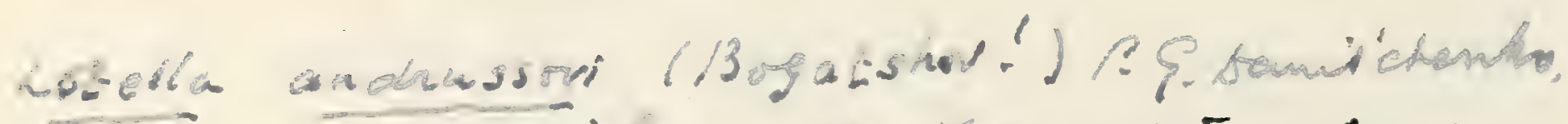

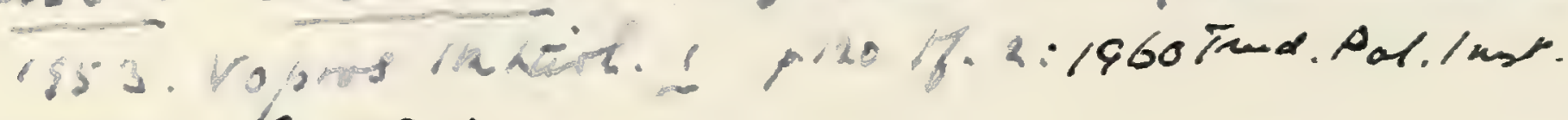
nosenc 18: 45 i. ir.t.

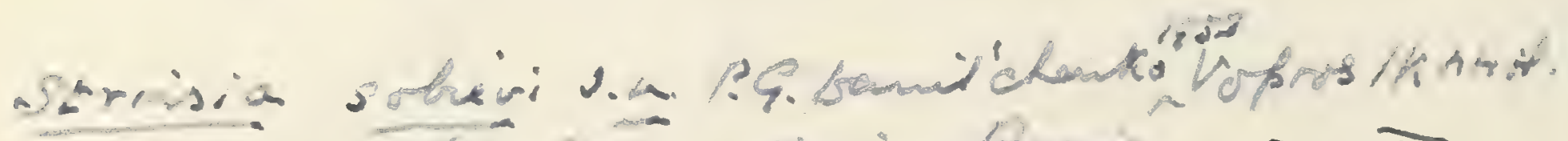

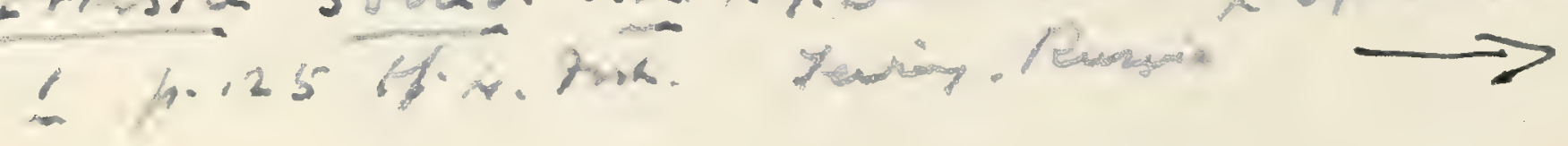




602

1tolithus (Merluccins) thepherdi, Ro Schubent, Zohkt. 4. K. ged. Peichsanst. vol. 65-(1915), p. 282, hl. vii. fipo. $25-27(228)$ - Sarton Slay.

Ot bithus (Prycio) Van Lonensir, R. Sehubent, lo. cit. 1915, h. 283, hl. vii.fip. 29. - Bartan Clay.

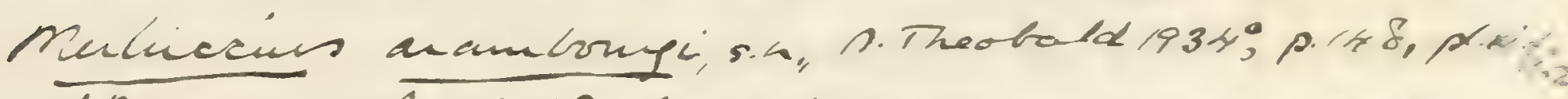

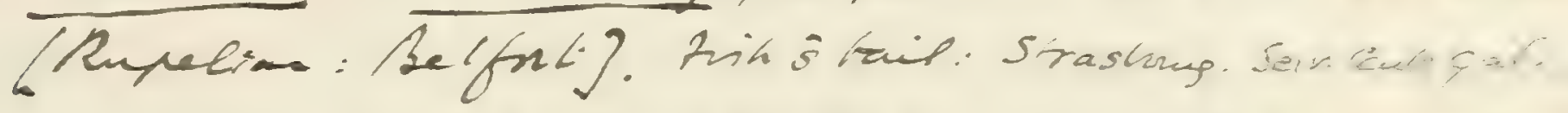

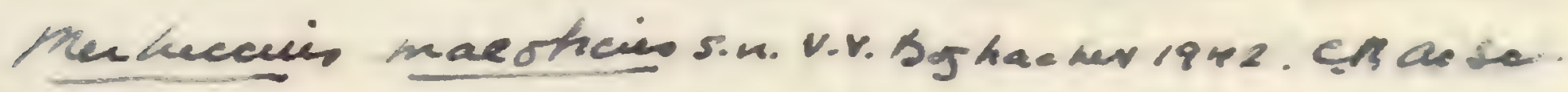

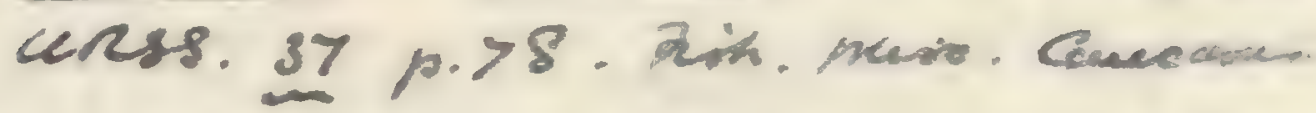

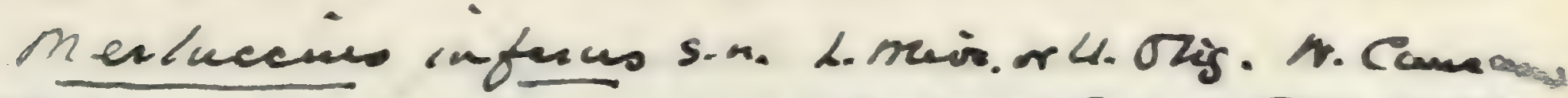

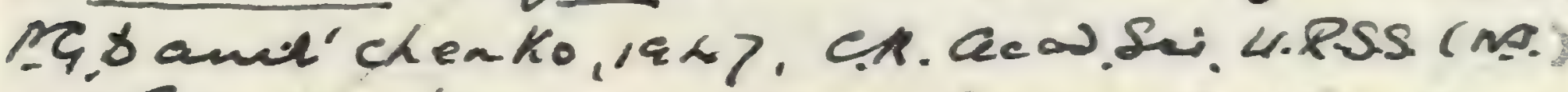

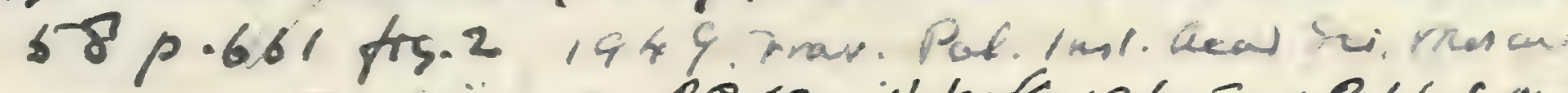

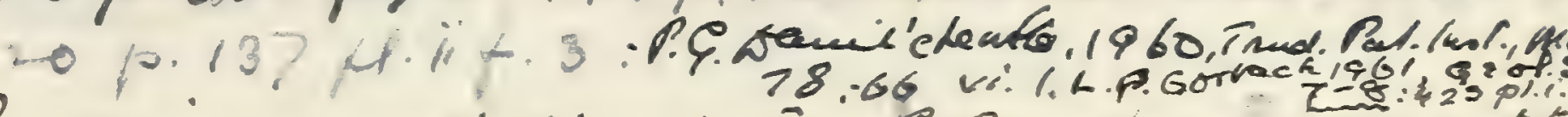
Brosmuis mudjadjens s sin, G. Aramboung, $1927,12.55$ plexif.3.- Solhelian: Oran

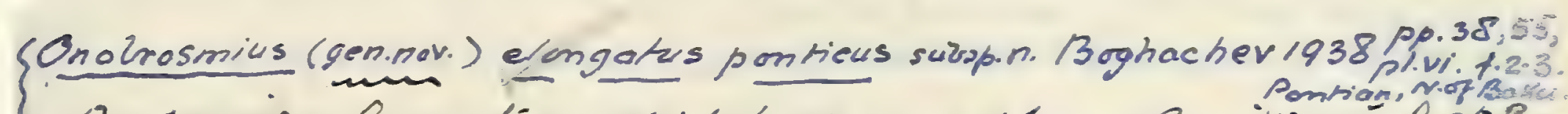

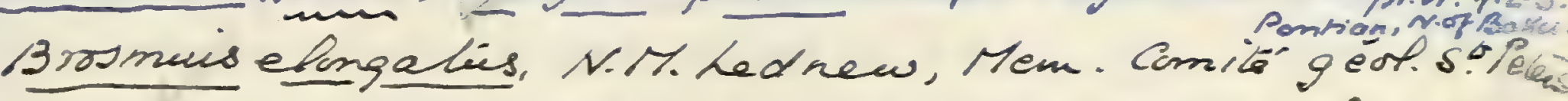

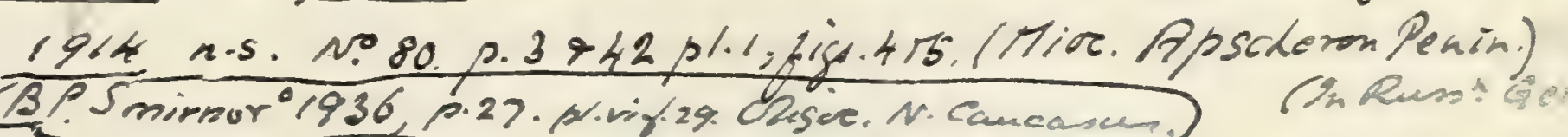

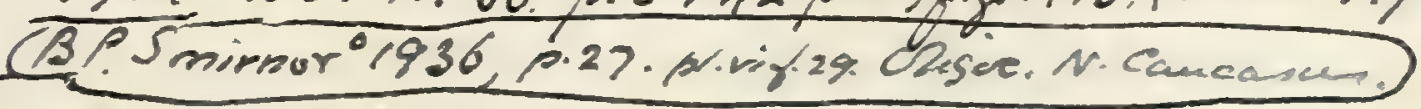

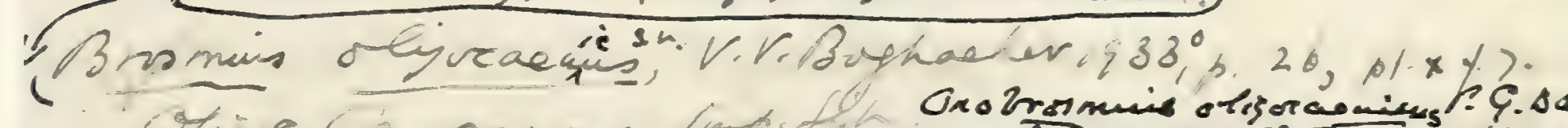

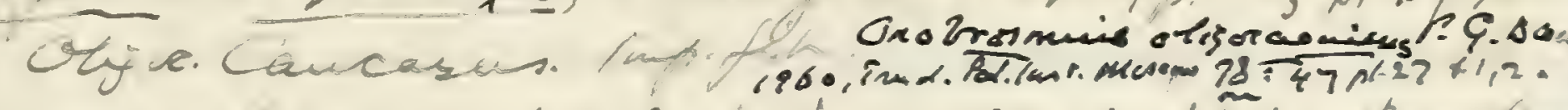

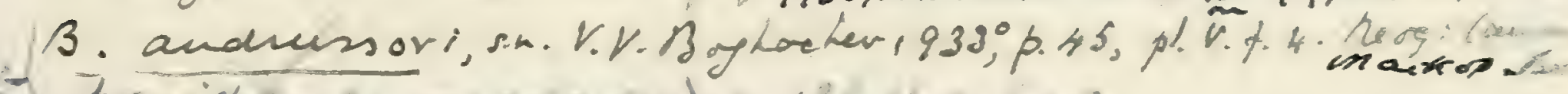

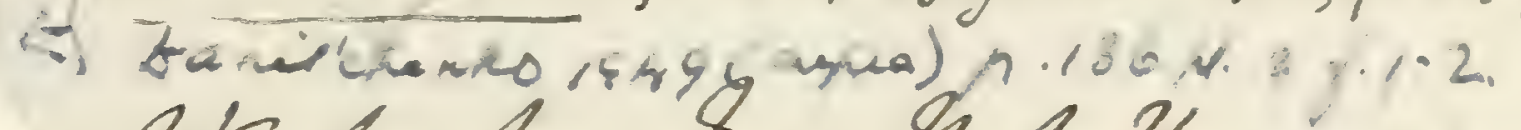

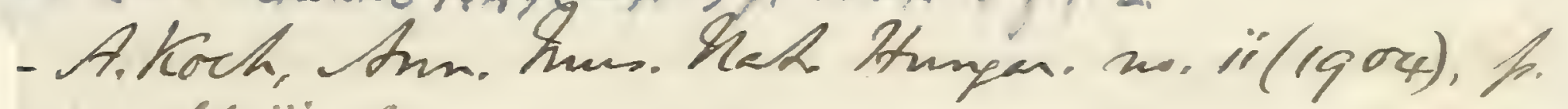
42, fl. iil, fol, 2.

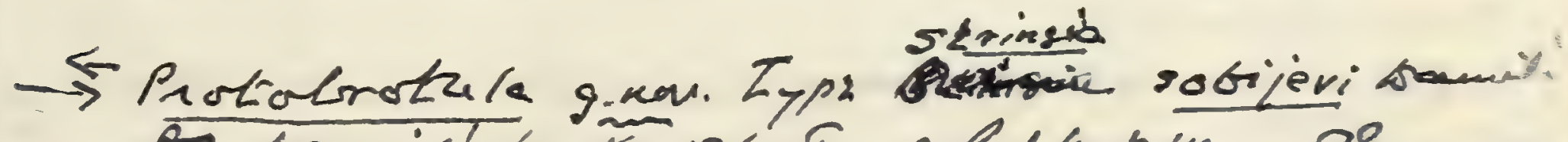

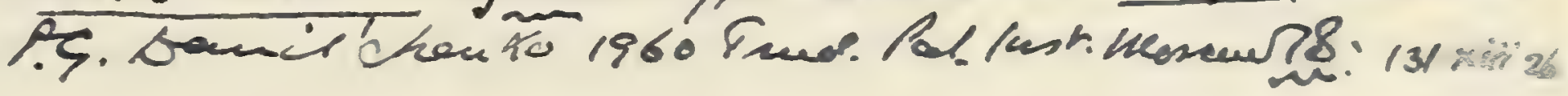




\section{.}



The following generically indeterminable fragments also seem to belong to a member of the family Gadidæ:-

P. 625. Imperfect cranium intended by Agassiz to be the type specimen of Merlinus cristatus, but not described; London Clay, Sheppey. The name is published in Rep. Brit. Assoc. 1844 (1845), p. $308 . \quad$ Egerton Coll。

P. 1738. Seven imperfect crania and associated remains, one specimen marked as intended by Agassiz to be the type of Rhinocephalus planiceps, but not described; London Clay, Sheppey. The name is published loc. cit. p. 294.

Egerton Coll.

P. 4513. Seven similar imperfect specimens; Sheppey.

Enniskillen Coll.

38909-11, 38944. Four more satisfactorily preserved similar skulls; Sheppey.

Bowerbante Coll。

43106. Small similar skull; Sheppey.

Wetherell Coll.

47985. Fine similar skull; Sheppey.

Presented by the Hon. Robert Marsham, 1877.

P. 9429. Another similar skull; Sheppey.

Purchased.

P. 4920. Fine head; Sheppey.

Dawson Coll.

P. 356 a. Small similar skull; Sheppey.

Purchased, 1881.

41723. Fragment with some anterior vertebræ; Sheppey.

Toulmin Smith Coll.

Otoliths of supposed extinct species of Gadidx have also been described as follows:-

Otolithus (Gadidarum) acutangulus, E. Koken, Zeitschr. deutsch. geol. Ges. vol. xxxvi. (1884), p. 546, pl. xi. fig. 13.-Lower Oligocene; Lattorf.

Otolithus (Gadidarum) elevatus, E. Koken, loc. cit. vol. xl. (1888), p. 290, pl. xviii. figs. 4, 5.-Lower Tertiary; Clayborne, Alabama.

Otolithus (Gadidarum) latisulcatus, E. Koken, loc. cit. 1884, p. 545 , pl. xi. fig. 5. O. (Raniceps) latisulcatus, E. Koken, loc. cit. vol. xliii. (1891), p. 86, pl. iv. fig. 4, pl. iii. fig. 2.Oligocene; Germany. Miocene; Antwerp.

Otolithus (Gadidarum) meyeri, E. Koken, loc. cit.1888, p. 289, pl. xriii. figs. 8, 9.-Lower Tertiary; Jackson River, Mississippi. 
Otolithus (Gadidarum) mucronatus, E. Koken, loc. cit. 1888, p. 290, pl. xrii. figs. 10, 11.-Lower Tertiary; Clayborne, Alabama.

COtolithus (Gadidarum) planus, E. Koken, loc. cit. 1884, p. 545, pl. xi. fig. 12.-Middle and Upper Oligocene; Söllingen, Cassel, Luithorst, and Waldböckelheim.

Otolithus (Gadidarum) ponderosus, E. Koken, Abh. phys. Cl. k. Ges. Wiss. Göttingen, vol. xxxii. (1885), p. 113, pl. จ. fig. 24, and loc. cit. 1891, p. 90, figs. 4, 5.-Lower Eocene; Copenhagen.

Otolithus (Gadus) simplex, E. Koken, loc. cit. 1891, p. 91, pl. iii. fig. 6. O. (Gadidarum) elegans, E. Koken, loc. cit. 1884, pl. xi. fig. 3 (errore).-Middle Oligocene to Pliocene; Germany and Crag of Suffolk.

Otolithus (Gadus) spectabilis, E. Koken, loc. cit. 1891, p. 94, pl. iii. figs. 3, 4.-Miocene; Holstein.

Otolithus (Gadus) tenuis, E. Koken, loc. cit. 1891, p. 92, pl. iv. figs. 3, 6. - Miocene; Bordeaux and Baden.

Otolithus (Gadi) tuberculosus, E. Koken, Zeitschr. deutsch. geol. Ges. vol. xxxvi.(1884), p. 540, pl.xi. fig. 1. O. (Raniceps) tuberculosus, E. Koken, loc. cit. vol. xliii. (1891), p. 88.Middle Oligocene; Suildorf and Magdeburg.

Otolithus (Gadus) venustus, E. Koken, loc. cit. 1891, p. 91, pl. v. figs. 2, 3.-Miocene; Holstein.

Otolithus (Merlangus) cognatus, E. Koken, loc. cit. 1891, p. 89, pl. iii. fig. 5, pl. v. fig. 1.-Ibid.

Otolithus (Merlangus) spatulatus, E. Koken, Toc. cit. 1891, p. 89, pl. ii. figs. 6, 7, 10.-Upper Oligocene; Sternberg.

Otolithus (Merluccius) attenuatus, E. Koken, Toc. cit. 1891, p. 84, pl. ii. figs. 1, 2.-Upper Oligocene; Sternberg, Freden, Cassel.

Otolithus (Merluccius) balticus, E. Koken, Toc. cit. 1885, p. 113, pl. v. figs. 22,23 , and loc. cit. 1891, p. 83, fig. 2.-Lower Eocene; Copenhagen.

Otolithus (Merluccius) emarginatus, E. Koken, loc. cit. 1884, p. 547, pl. xi. fig. 6, and loc. cit. 1891, p. 84, pl. ii. figs. 8, 9.Middle and Upper Oligocene; Germany.

Otolithus (Merluccius) miocenicus, E. Koken, loc. cit. 1891, p. 85, pl. v. fig. 4.-Miocene; Holstein.

Otolithus (Merluccius) obtusus, E. Koken, loc. cit. 1891, p. 85, pl. ii. figs. 3-5.--Upper Oligocene; Sternberg.

Otolithus (Morrhua) faba, E. Koken, Toc. cit.1891, p. 95. O. (Fadi) 


Orlither (Gadidarum) moloti, Fliniem, Poins. Fon. Bussin Darisien (Oubl. Am. Paléont. 1908), p.84, Lexh-fipr.43,44.- Thanetion; Chalom-sur-Vesle, Inarne, Arance.

Otolithur (Gadidarum) peyroti, F. Oriem, Bull. Dor.

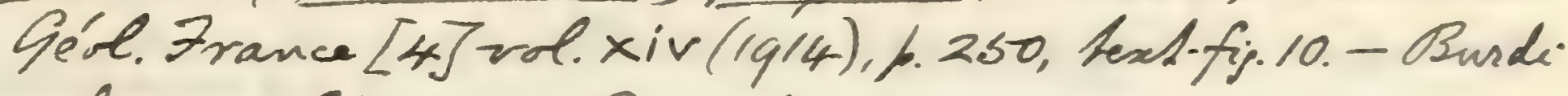
salian; Lézenan, Gironde.

raniceps planus, wheriler, abh. hess. gert.Laudesanst. vot. viphiz. $(1922), 10.73$

Q. (Gadus) elepans, van latvis, 7. Riem, Bull. Sa Géd. Arance

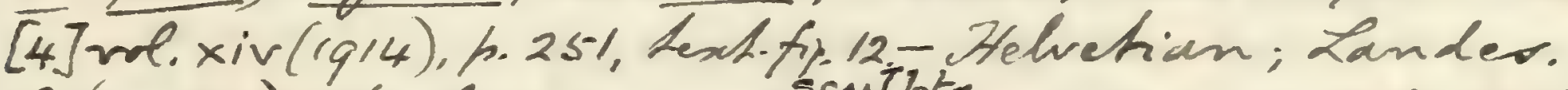

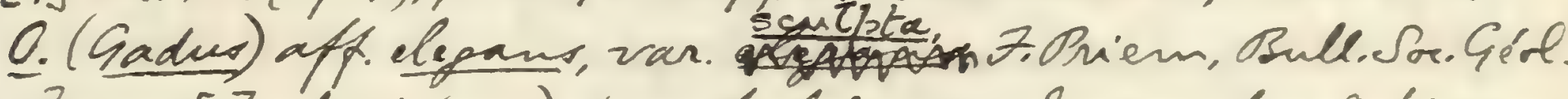

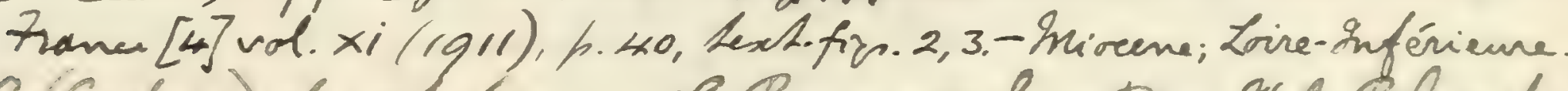
Q. (Gedur) de Ltefanii. L. Oieragrobli, tiv. Ital. Clents. 1gla,p. ipl. if. - Plicene; Iuscarys.

O. (Merluccuis) pukeusiusis, G. A. trost. Irans N.Z. Imot.

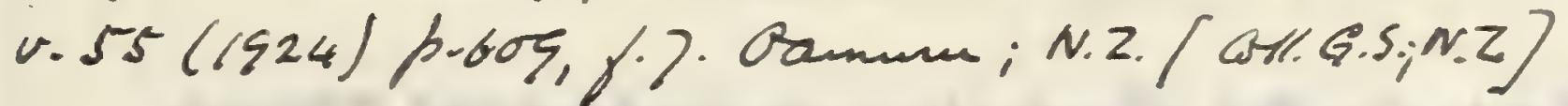

$0 .($ meelangen $)$ sin.

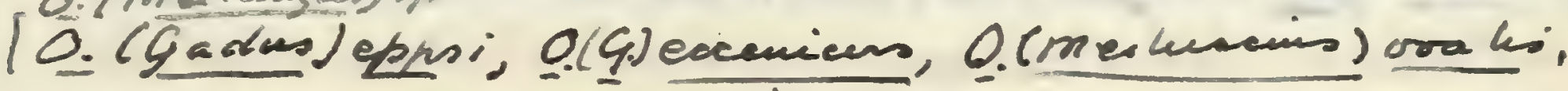

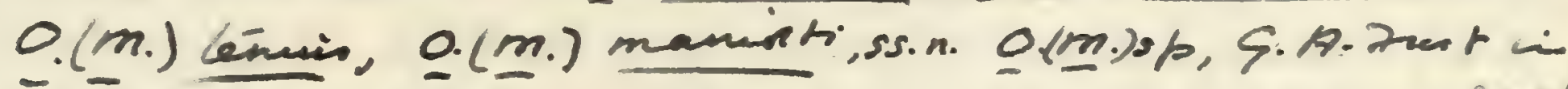

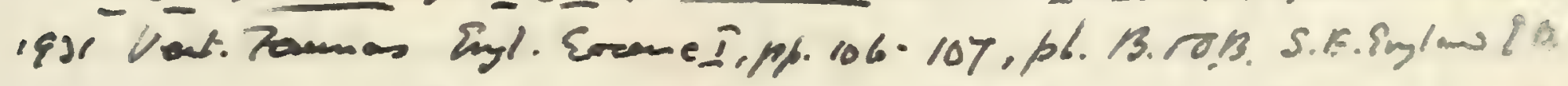

= Gadur? talticur, In. Zeriche, Ann. Sa. Gérl. Nad, vol. xxxvii(1908), h.250, hl.vi. fips.14-17 [Thanetian; harne.] Sameras Qt. (Gadid.) molsti, Thiem, ucc. to Mr. Reriche, ikilh.

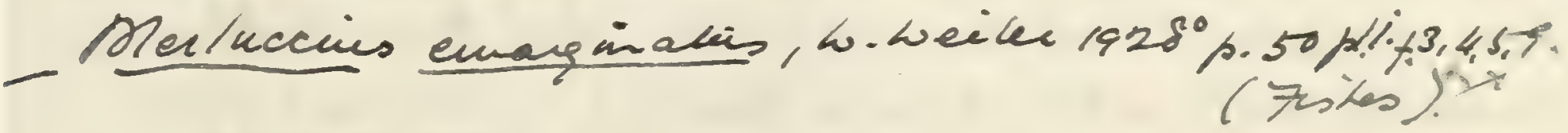

Gadus of. fata, Mn Zeriche, Mém. Mun. Don, Hich.

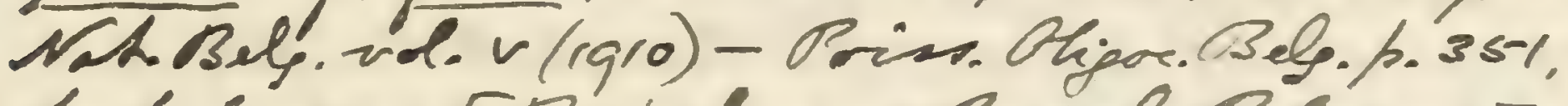
testh-fip. 151. [ORupelian; Basel, Belgiun.] 


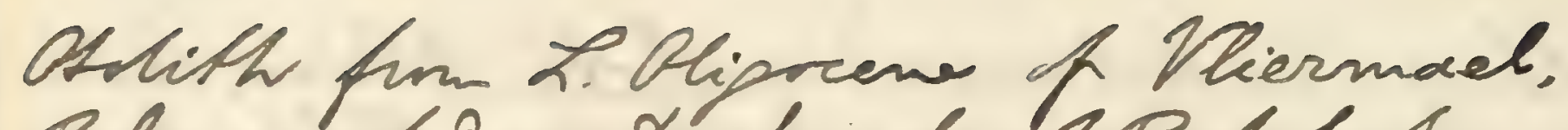

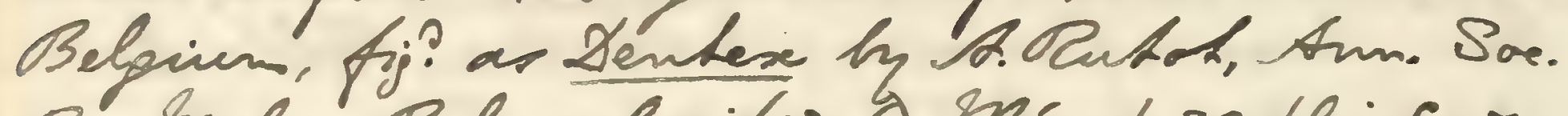

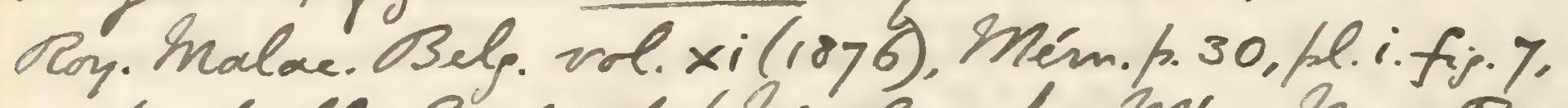
is probably Gadoid / Mn. Zeriche, Mém. Mns. Roy. Hist. Nat. Bsel, vol. v. 1910-Driss. Olipor. Belp.p.247).

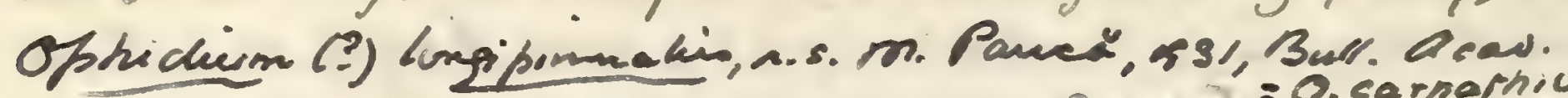
- 0. carparhicas inn"

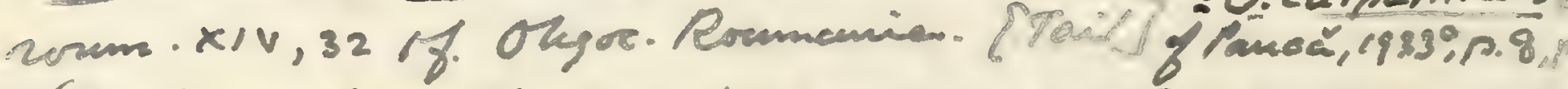

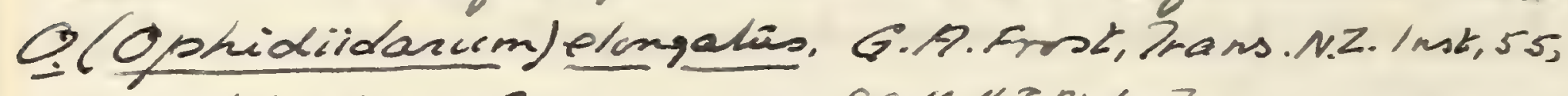
1924 p.611p1.6.

Q. (Ophiduina) pantanelli, Bassoli Schmbert. G.A. Frosti

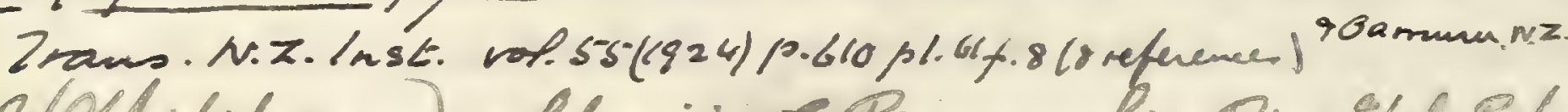

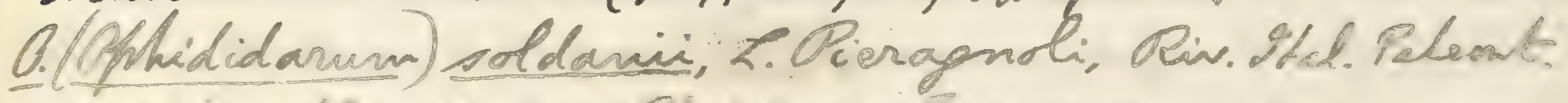

Adlithur (Othididarmm) dimidiatus, subregularis, a walt tomi, R. Schulest, Iathk. K. K.

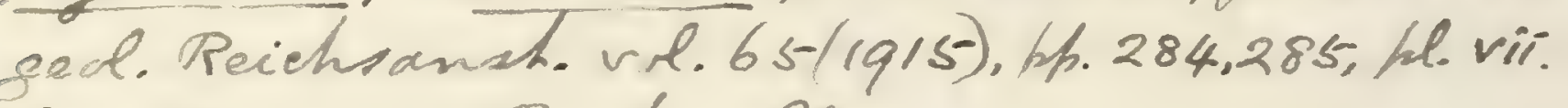
fip. 30-40. - Barton Clay.

Ptolithus (thidium) Sripnonensis, Bassol:

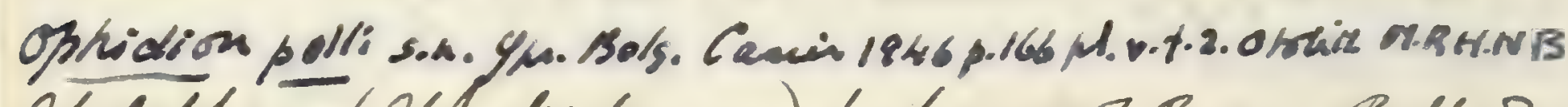
Otolithus (Ophidiidarum) Kotreni, A. Priem, Bull. Soe.

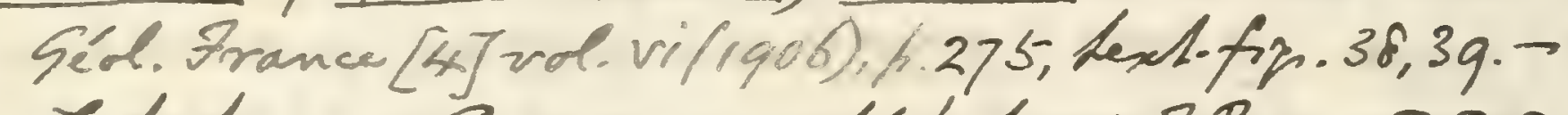
Zutetian; Grignon. afs kotemi, F. Thiem, B.S.G.F.

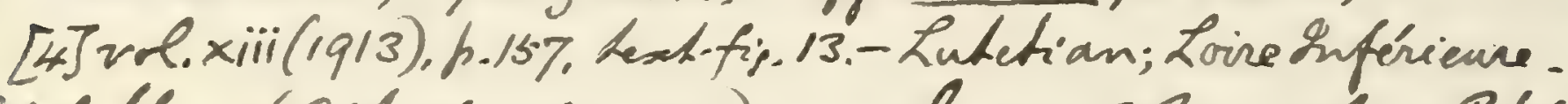
-lithns (Ophidiidarum) repulario, 7.Reiem, Amm. Palént. ve. vi (1911), h.31, fir. 37, 38. - Zwhetian; Fercont, Mouchy, $\theta_{1}$ se. $=$ Eelipes veterins seep. 520 .

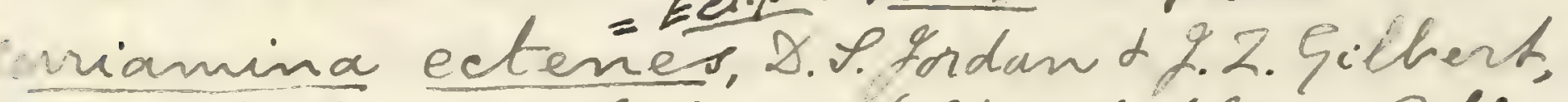
Foss. Fisher P. Califormia (Stanford Univ. Public.,

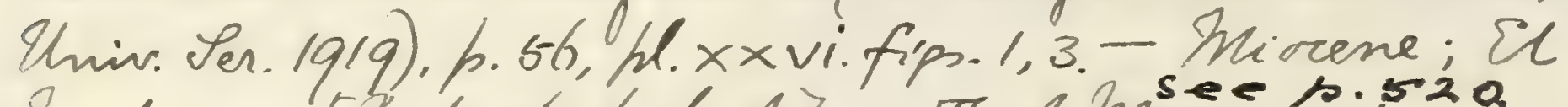

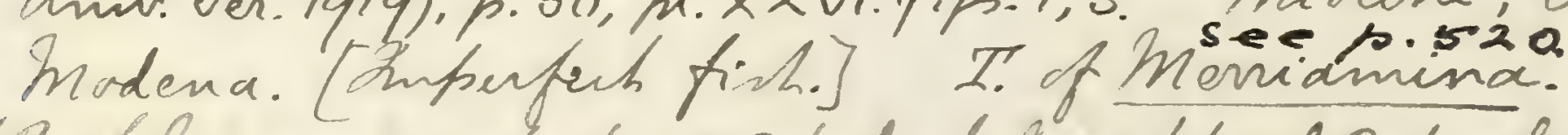

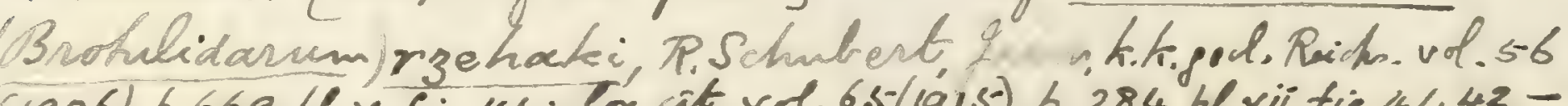

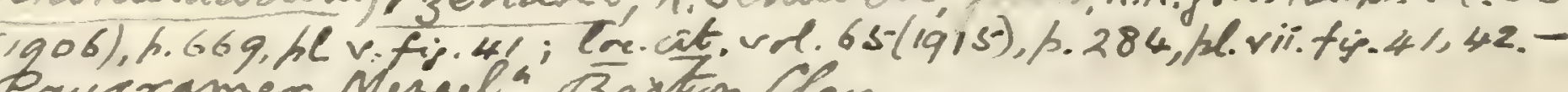

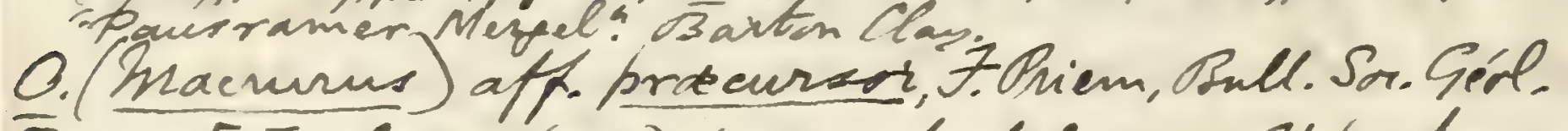

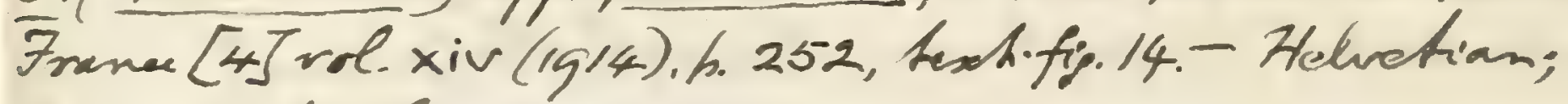
Clermont, Za dea 



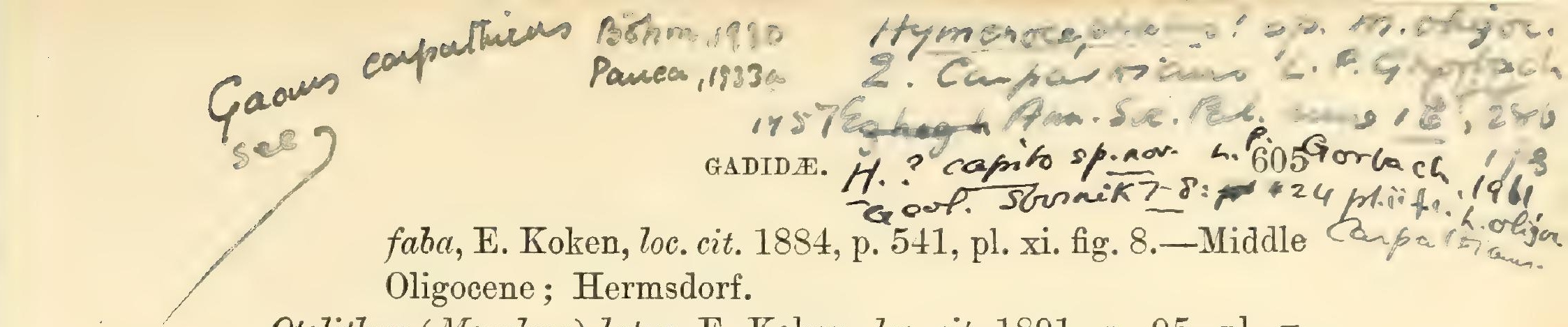

Otolithus (Morrhua) latus, E. Koken, loc. cit. 1891, p. 95, pl. x. figs. 7, 8.-Wiocene; Lüneburg.

Otolithus (Morrhua) soellingensis, E. Koken, loc. cit. 1891, p. 94, pl. iii. fig. 1.-Middle Oligocene; Söllingen.

Some of the species from Lattorf are represented in the Collection by a small series of otoliths numbered 40505-0\%. Purchased.

There are also various undetermined oteliths of Gadidæ from the Pliocene of Orciano (Tuscany) and Antibes (France).

The OpHIDIID 2 are unknown among fossils, except perhaps by one imperfect skeleton and several otoliths, which have been described as follows and are not represented in the Collection:-

Ophidium volticnum, A. B. Massalongo, Specimen Photogr. Anim. Foss. Agr. Veron. (1859), p. 39, pl. xi.-Upper Eocene; Monte Bolca.

Otolithus (Fierasfer) muntius, E. Koken, Zeitschr. deutsch. geol. Ges. vol. xliii. (1891), p. 99, pl. ri. fig. 2._Middle

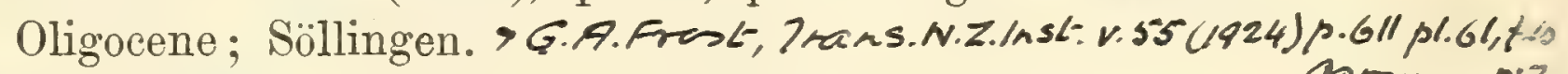

Otolithus (Fierasfer) posterus, E. Koken, ibid. p. 100, pl. vi. Oamusu, N.2. fig. 6.- Upper Oligocene; Cassel, Kl. Freden. (?) Miocene of Austria.

Otolithus (Ophidiidarum) boettgeri, difformis, hilgendorf, hybridus, marchicus, obotritus, occultus, and saxonicus, E. Koken, ibid. pp. 100-105, pl. i. figs. 5-7, pl. จ. figs. 7-9, 14, pl. vi. figs. 1, 5, pl. x. figs. 17-19.-Oligocene; Germany. The species difformis was previously named Otolithus (Gadidarum) difformis, E. Koken, loc. cit. vol. xxxvi. (1884), p. 547, pl. xi. fig. 11. Several varieties are recognised.

The specimen described as follows is too imperfect for exact determination :-

Brotula (?) longipinnata, D. G. Kramberger, Jahrb. k.-k. geol. Reichsanst. vol. xxx. (1880), p. 570, pl. viii. fig. 6.Tertiary; Nikolschitz, Moravia. [Imperfect fish; Imperial Geological Survey, Vienna.] Oshidiun / orgisinnes 60 - nes) may ho a tyon y.

The MaCrURID $x$ are also unknown among fossils, except perhaps by the otoliths. Here may be placed the following:-

7034a. Three otoliths of the form named Otolithus (Macrurus) 
prcecursor, E. Koken, Toc. cit. 1891, p. 96, fig. 6; Pliocene, Orciano, near Pisa, Tuscany.

Purchased, 1875.

Other supposed otoliths of this family, not represented in the Collection, are described as follows:-

Otolithus (Macruridarum) bavaricus, E. Koken, Palæontogr. vol. xxxviii. (1891), p. 37, fig. 1.-Upper Cretaceous; Siegsdorf, Bavaria.

Otolithus (Macruridarum) singularis, E. Koken, Zeitschr. deutsch. geol. Ges. vol. xliii. (1891), p. 98, pl. vi. fig. 9.-Lower Oligocene: Lattorf.

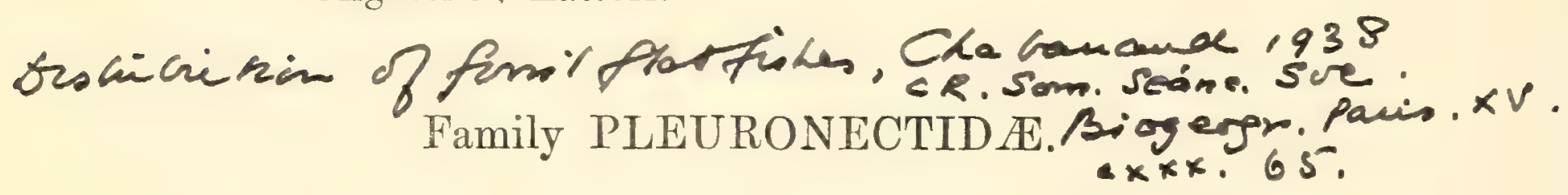

Trunk deepened, much laterally compressed and flattened, the fishes always resting on one side when adult. Skull unsymmetrically developed, and both eyes in the adult situated on the one side which is always coloured and turned upwards when at rest. Premaxilla excluding maxilla from gape. Abdominal region very short. Paired fins small, often unsymmetrically developed, and one or more sometimes absent. Dorsal and anal fins much extended, not subdivided. In the recent forms :- gills four; pseudobranchiæ well developed; air-bladder absent.

This family dates back to the Upper Eocene, but no extinct genera are recognisable. In existing seas its range is cosmopolitan, and a few forms live in freshwater.

A description of the skull of some existing Pleuronectids is published by R. H. Traquair, Trans. Linn. Soc. vol. xxv. (1866), pp. 263-296, pls. xxix.-хxxii.

\section{Genus RHOMBUS (Klein), Cuvier.}

[Règne Animal, vol. ii. 1817, p. 222.]

Mouth wide, the jaws and dentition being nearly equally developed on both sides; a narrow band of villiform teeth, without canines, on the margin of the jaws; equally small teeth also on the vomer but not on the palatines. Eyes on the left side. Gill-rakers well-developed, lanceolate; seven branchiostegal rays. Abdominal vertebræ with broad transverse processes, aud very small delicate ribs; hæmal spines at base of caudal fin somewhat expanded, not fused together. Both pairs of fins present, usually unsymmetrically developed; dorsal fin arising on the snout; caudal fin separate, rounded behind. Scales small or absent. 



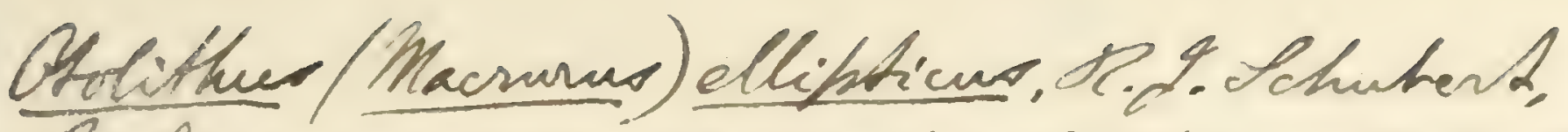

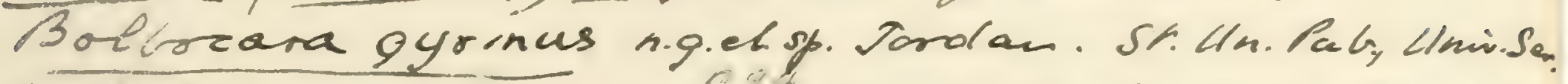

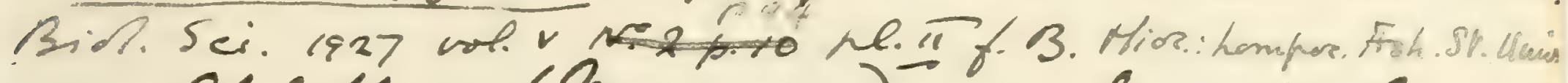

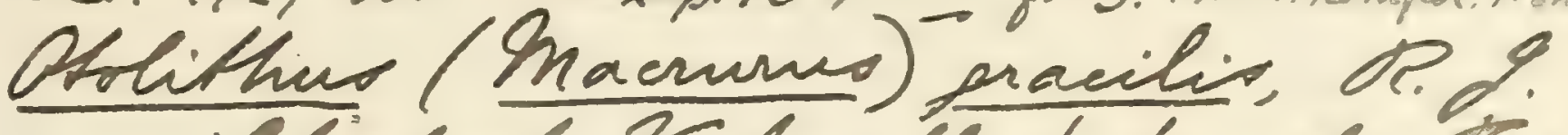

Tchickent, Derhandl. K. k. ped. deichans

1907. 15.342. - Inireene; Pardinioy

Atrlithus (hacrums) dimidiatues, YGSassoli, I

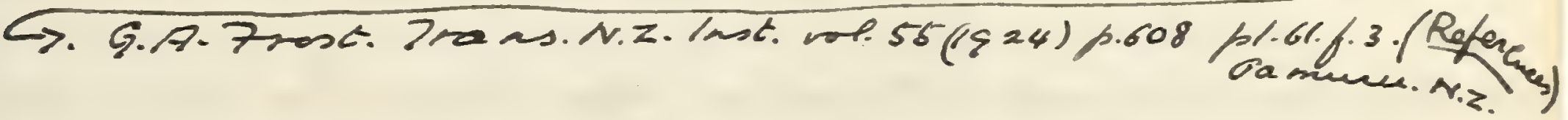

Maerurus latimleus, In. Leriche, Mém. Mns. Doy. Fist. Tat. Belf. vol. v (1910) - Bive. Dijoe. Bels. 3.352, Lesats.ti. 152. - Rupelian; Bupelmonde. [Dilkeid Coll.]

Otolithur (Hymenocephalus?) aquitanians, Friem, Bulle Soe.Géd. Brance [4] vol. xiv (1914). h.24.5, textefy, 2. - ApuiLavian; Taint-Arorillon, Gironde.

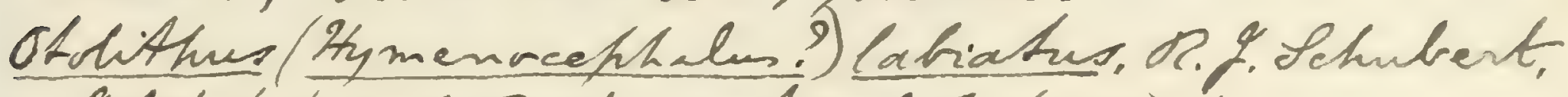
Gohnt. K. Ke.ged. Reichsanst. vol. Tr (1905), \%.

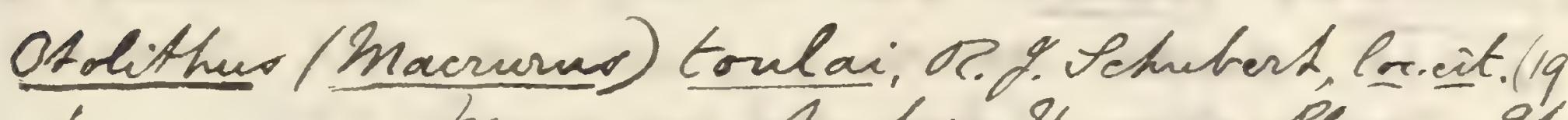
f. Hiocene; Austria-Prungary. Plicene; Itals.

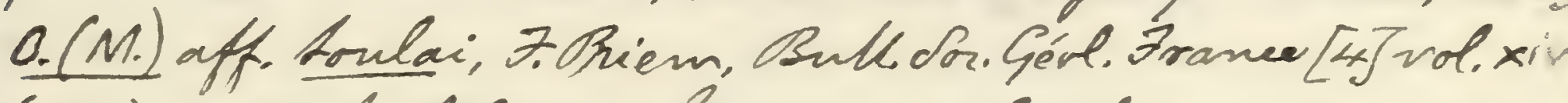
(1914), h.251, hesth.fi.13. - hicuene; Landes, ; G.A. Brost,

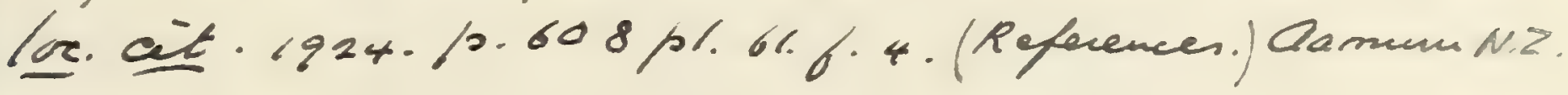

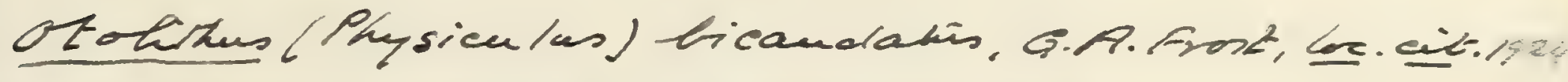
7.608 ploG J.S. Oamasu; N.Z. [G.S., N.Z.]

PSETTODOREA

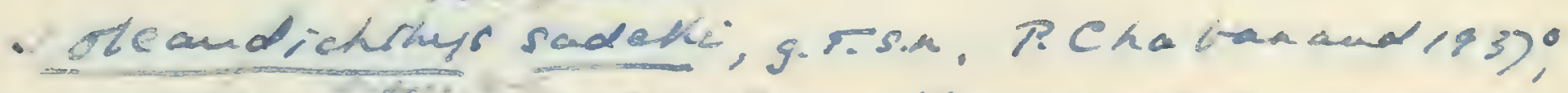

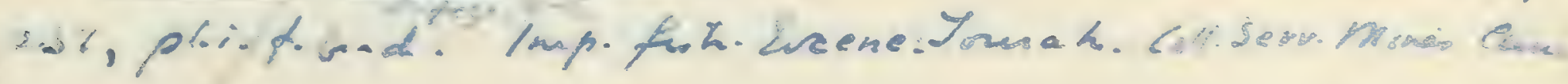


Eotothus, Pastman.

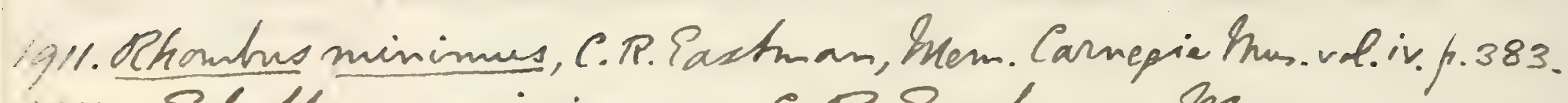
1914. Sobothue minimus, C. O. Pastman, Mem. Carnegie hus. vol. vi. 10. 328, ple xiv. fip. 1,2.

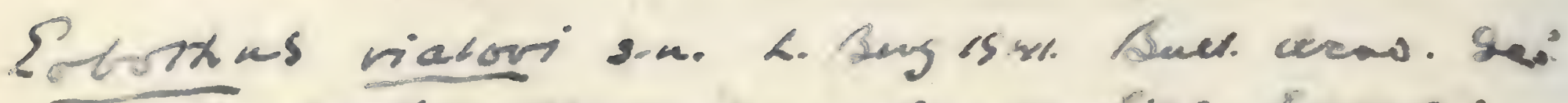
UR.28. Bosta: sw. Mo 3 p.480, 10 figs. Ereene:

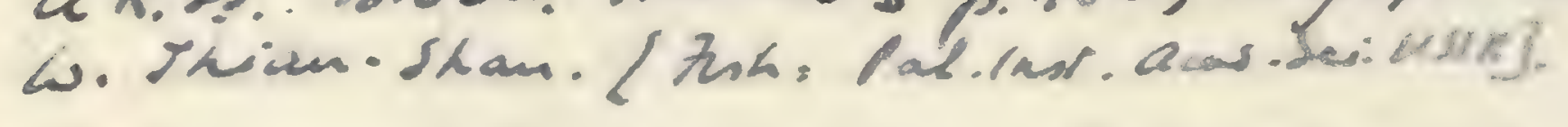

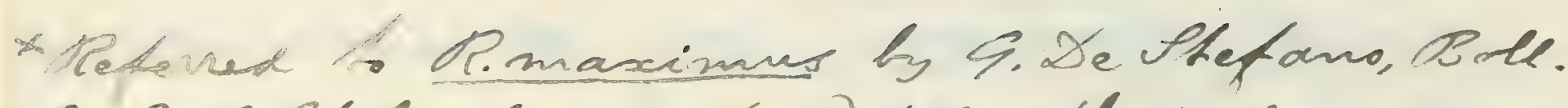

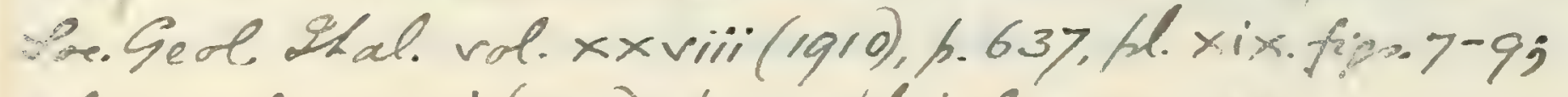
also vol. $x \times x i(1912)$, h. 70 , hli i. figs. $39-4 \%$ 


Some of these characters cannot be obserred in the fossils, which are thus only provisionally determined. The existing species inhabit the North Atlantic and Mediterranean.

\section{Rhombus minimus, Agassiz.}

1796. Pleuronectes quadratulus, G. S. Volta, Ittiolit. Veronese, p. cclx. pl. lxiii. fig. 3 (errore).

1835. Rhombus minimus, L. Agassiz, Neues Jahrb. p. 301 (name only). 1839-42. Rhombus minimus, L. Agassiz, Poiss. Foss. vol. iv. p. 289, pl. xxxiv, fig. 1.

1859. Rhombus minimus, A. B. Massalongo, Specimen Photogr. Anim. Foss. Agr. Veron. (1859), p. 3b, pl. xiii. fig. 1.

Type. Nearly complete fish; Palæontological Museum, Munich.

A very small species, attaining a length of about $0 \cdot 1$. Length of head with opercular apparatus contained two and a half times in the length from the pectoral arch to the base of the caudal fin; maximum depth of trunk about four fifths of latter measure. Vertebræ 11 or 12 in the abdominal, 20 in the caudal region. Dorsal and anal fins deepest in their middle portion, the former with about 65 , the latter with about 45 rays; both these fins terminating very close to the caudal, which comprises 17 rays. Small scales well developed, apparently cycloid.

Form. \& Loc. Upper Eocene: N. Italy.

165\%. Fine specimen, 0.06 in length, in counterpart; Monte Bolca. The head is imperfect, but the trunk and median fins are well displayed. Appearances suggest a dense squamation of small cycloid scales.

Presented by Chambers Hall, Esq.

P. 3971. Another good specimen broken and distorted in the caudal region; Monte Bolca. The dorsal fin is shown arising on the snout. The head and opercular apparatus are tolerably well preserved; and the delicate pectoral fin is seen. Some of the abdominal vertebræ exhibit their large transverse processes; and there are remains of the small, slender ribs.

Enniskillen Coll.

Dermal tubercles resembling those of the existing Rhombus maximus, Cuv., are recorded from the Lower Pliocene of Orciano, Tuscany, under the name of Rhombus gentiluomoi by R. Lawley, Nuovi Studi Pesci, etc., Colline Toscane (1876), p. 82. ${ }^{\times}$

The following small extinct species have also been referred to this genus, but are not represented in the Collection:- 
Rhombus abropteryx, H. E. Sauvage, Ann. Sci. Nat. [5] vol. xiv. (1870), art. no. 7, p. 5, and Ann. Sci. Géol. vol. iv. (1873), art. no. i. p. 104, fig. 4.--Upper Niocene; Licata, Sicily.

Rhombus bassanianus, D. G. Kramberger, Beitr. Paläont. Panca' 1938, p.130, Oesterr.-Ungarns, rol. iii. (1883), p. 71, pl. xiii. figs. 1, prosi" + 3. Mros. 2.- - Tpper Mriocene; Dolje and Vrabče, Croatia. [Geological Museum, Unisersity of Agram.]

Rhombus fitzingeri, J. J. Heckel, Neues Jahrb. 1849, p. 500 (name only).-Middle Miocene; Margarethen, Vienna. [Court Museum, Vienna.]

Rhombus hecketi, R. Kner, Denkschr. k. Akad. Wiss., math.naturw. Cl. vol. xix. (1861), p. 75, pl. x. fig. 12; F. Bassani, Atti Soc. Veneto-Trent. Sci. Nat. vol. vii. (1880), p. 89.--Ibid. [Court Museum, Vienna.]

Rhombus ligusticus, C. Pollini, Sopra Alcuni Avanzi di Pesci Fossili Terziari (Milan, 1889), p. 92, fig. 7.-Lower Oligocene; Santa Ginstina, Liguria. [Geological Museum, Unirersity of Genoa.]

Rhombus parvulus, D. G. Kramberger, loc. cit. 1883, p. 72, pl. xiii. fig. 3.- Upper Miocene; Dolje and Podsused, Croatia. [Geologieal Museum, University of Agram.]

The undefined names Rhombus minutus, $R$. nardii, $R$. vichiardii, and $R$. sauvagei are given to fishes from the Upper Yiocene of Gabbro, Tuscany, by Bosniaski, Atti Soc. Tosc. Sci. Nat.-Proc.Verb. vol. i. (1878), p. xix, and Capellini, Mem. R. Accad. Lincei [3] vol. ii. disp. i. (1878), p. 285. Rhombus caudatus and R. cutrensis are also undefined names for fishes from the supposed Upper Niocene of Cutrò, Calabria (Bosniaski, ibid. vol. i. 1879, p. 1xxxii).

An otolith of a form not represented in the Collection has been described thus:-

Otolithus (? Rhombus) thenanus, E. Koken, Zeitschr. deutsch. geol. Ges. vol. xliii. (1891), p. 107, pl. v. fig. 11.-Middle Oligocene; Waldböckelheim.

Genus PLEU RONECTES (Artedi), Linnæus.

[Syst. Nat. ed. 10, 1758, p. 268.]

Syn. Platessa, G. Cuvier, Règne Animal, vol. ii. 1817, p. 220.

Mouth small and unsymmetrical, with dentition more developed on the blind than on the coloured side; a single or double series of small teeth on the margin of the jaws, but none on the vomer or 




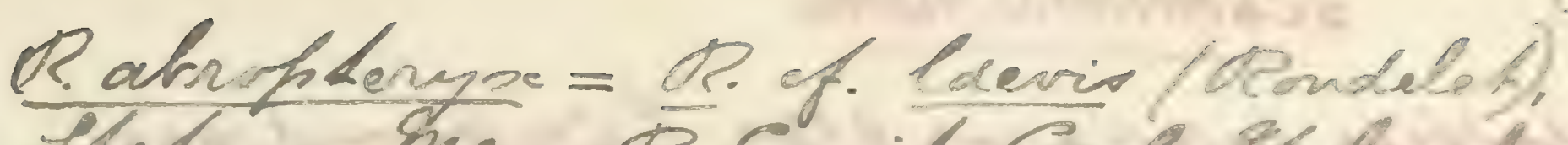

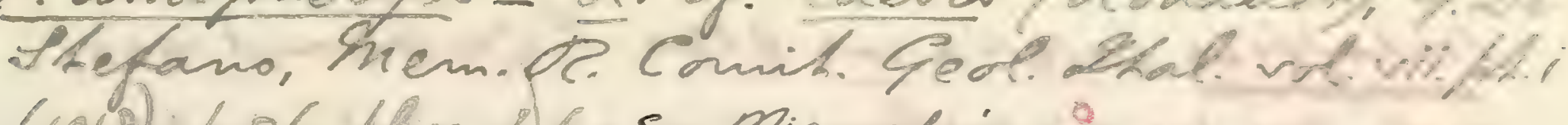

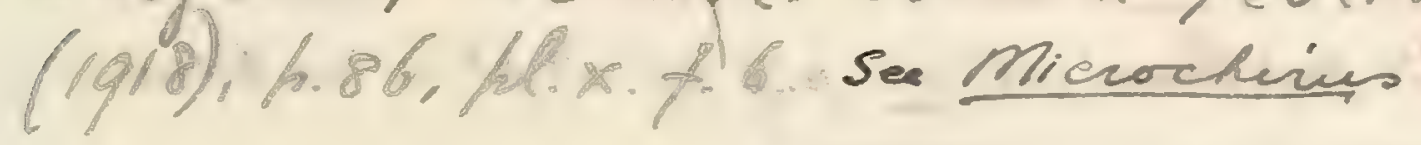

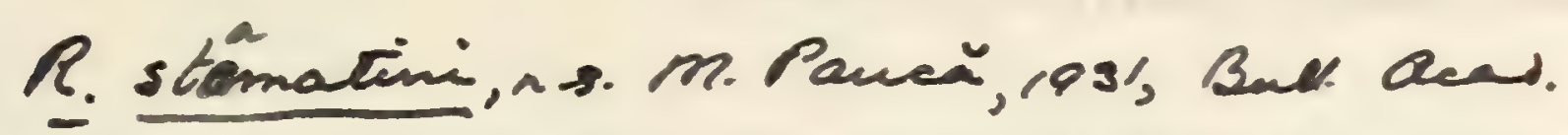

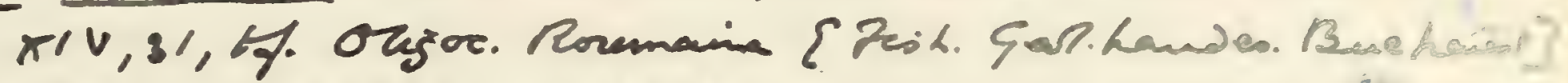

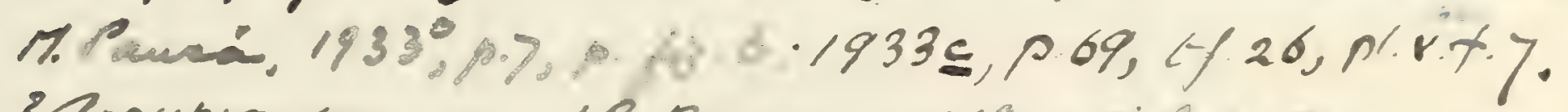

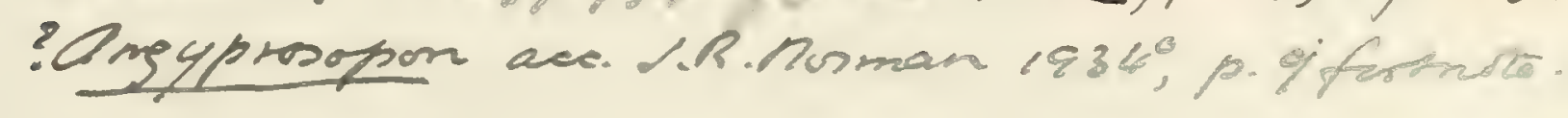

Rhomb. Ligust. R. Sankiecei, Botl. Sore gedl llat vol, Xli, p.211, plim, tis. m.

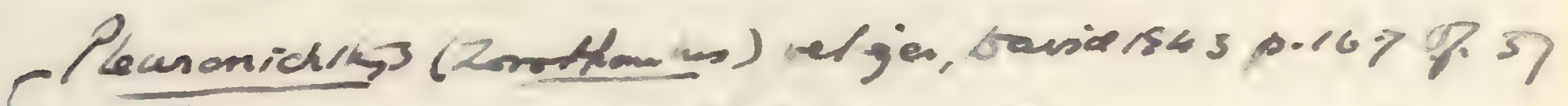
(as Zoropserra inid.p. 3 (.i- eror).

Froohombus religer, D.S. Tordan (restoration only) Naciual

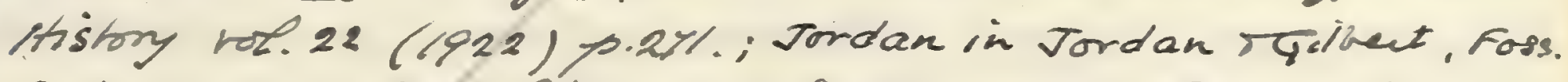

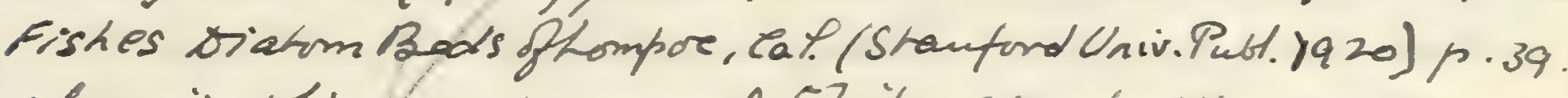
pl. xxris. Mlicene, hmpore, cal. [7ish; Stanfordllniv.] Bothus maximus, It. Imunthe, Trevis. Gerl. Undersioke, ser. C, no. 184 (1900), h. Dleistreene;

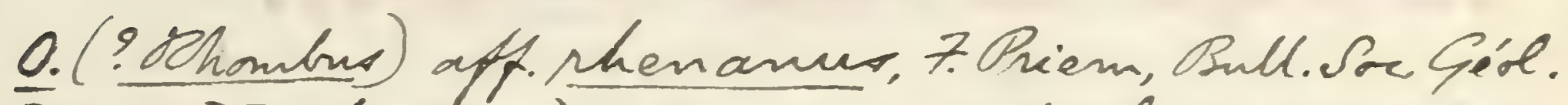
France [4] vol.xiv(1914), h.254. fic.-Aurdigalian; Girionde.

tippoglossorides maccopteia s.n. B.P. Smirnor 1936

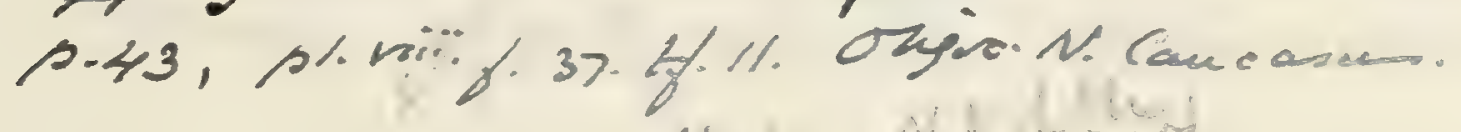

Profopselta parvila s.in. 3.P. Sminion 1936, p.44 pr.vin. 6.38 if. 12 . Orgure. N. Cancarm.

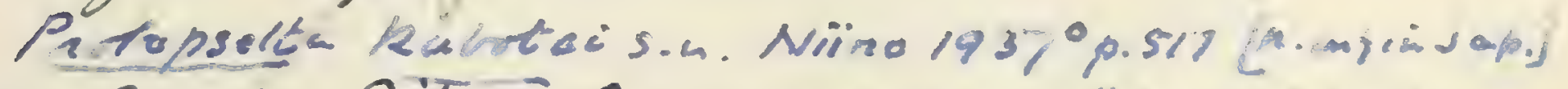

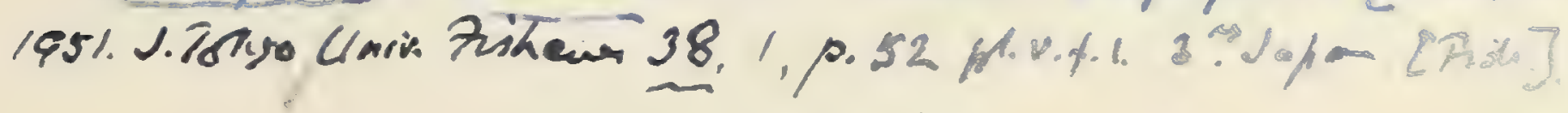


SCOPHTH ALTIDAE

Imloffius lubetians 9.rs.n. P. Civolonand 1940,

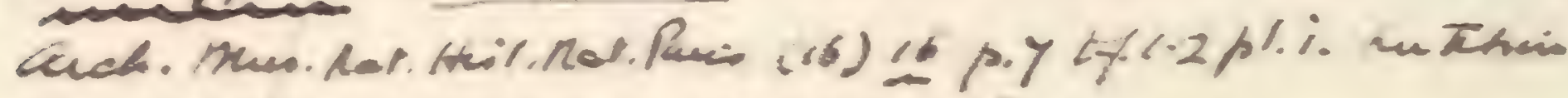

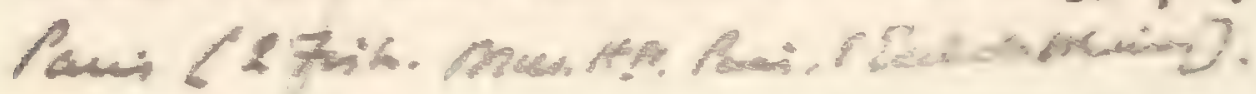

Lanysider.

Diat móeca 3atima. D.T. Fondand 2.2.9.llent, Fon.

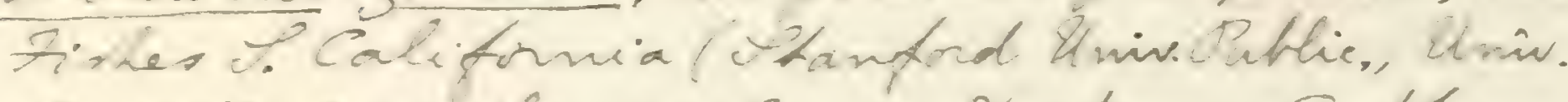

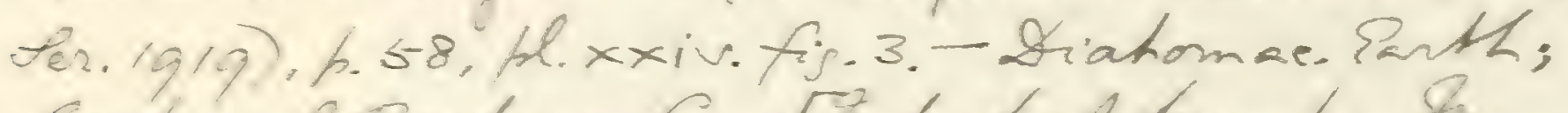

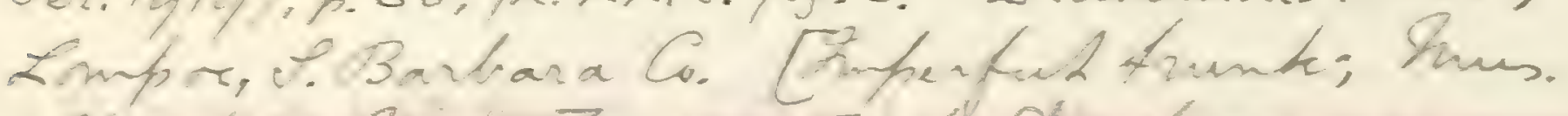
Thantria Amis. ] II. Riatomoeca.

- Lamprir 3atima, L. S. Irdam, the Scientifi Inmithly, 1920, f.472, Leakt fis. 3. .

Diatorn oeca 3 atima, Tordan TGillent, Foss Fishes Diatorn beas oflompor, Cal. (Stanford Unir. Pazkic.J1920 p.40 ptix (not a flewronectiol sypolemantay page)

Q. 3alima, tordan, 7ash 7 auna Cal. Tert' [ser pad,

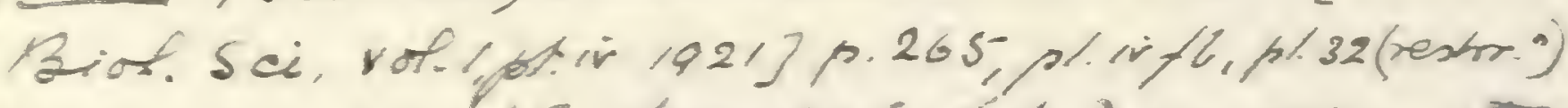

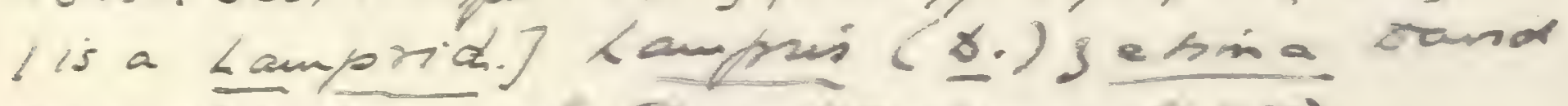

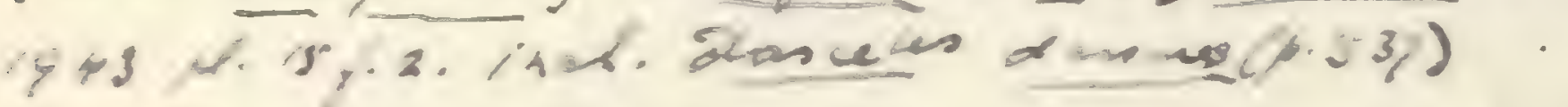

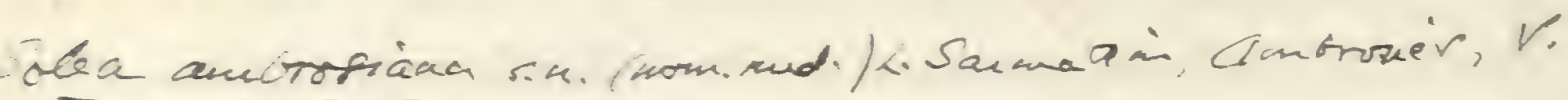

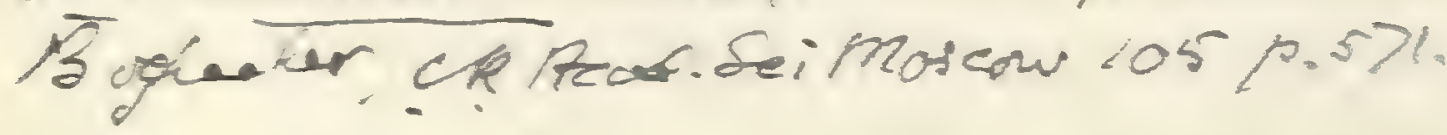

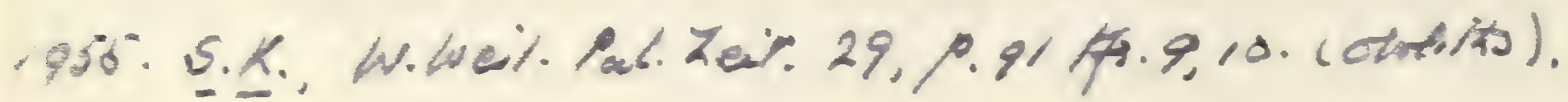




palatine. Eyes generally on the right side. Both pairs of fins present, symmetrically developed; doral fin arising above the eye: caudal fin separate, rounded behind. Scales very small $n r$ absent.

Range at present throughout the temperate and arctic seas of the northern hemisphere.

The following specimen appears to be identical with the corresponding bon of the existing Pleuronectes platessa, Linn. :-

P. 8739. Left maxilla, described as referable to Platessa sp. by E. T. Newton, Vert. Forest Bed (Mem. Geol. Surr. 1882), p. 128; Forest Bed, Overstrand, Norfolk. Savin Coll.

An otolith described as follows, probably belongs to this genus, but is not represented in the Collection:-

Otolithus (Platessa) sector, E. Koken, Zeitschr. deutsch. geol. Cres. vol. xl. (1888), p. 292, pl. xvii. figs. 14-16, and iberl. vol. xliii. (1891), p. 105, pl. i. fig. 4.-Lower Oligocene; Westeregeln and Osterweddingen, Germany. Also Lower Tertiary, Alabama.

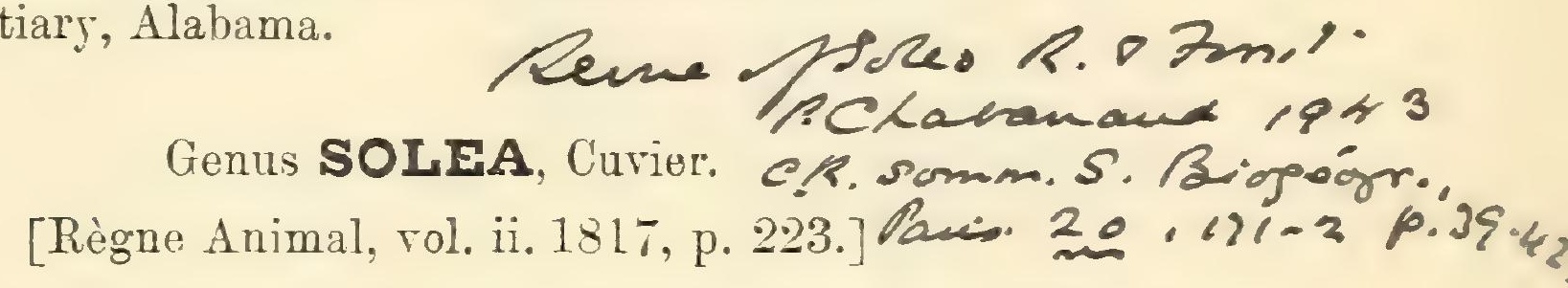

Nouth small and uns5mmetrical, twisted round to the left (blind) side; teeth minute and villiform, confined to the left margin of the jaws. Eyes on the right side, the upper being more or less in advance of the lower. Abdominal vertebræ with very small transverse processes and rudimentary ribs, but most of them with long and robust hæmapophrses. Both pairs of fins usually represented, but often unsymmetrical and one sometimes ibsent; dorsal fin arising on the snout; caudal fin separate, rounded behind. Scales very small, antero-posteriorly elongated, deeply overlapping, and ctenoid.

Existing species occur in all temperate and trofical seas, and a few inhabit freshwaters.

Solea kirchbergana, Merer.

1848. Rhombus kirchberganus, H. von Meyer, Neues Jahrb. p. 782.

1851. Solea kirchbergana, H. von Mever, Palæontogr. vol. ii. p. 102, pl. xvii. tigs. $2,3$.

1856. Solea kirchbergana, H. von Neyer, ibid. vol. vi. p. 25, pl. i. fig. 3.

1883. Rhombus kirchberganus, F. A. Quenstedt, Handb. Petrefakt. ed. 3, p. 370 , pl. xxix. figs. 2,3 .

PART IY. 
Type. Imperfect fish.

A very small species, attaining a length of about 0.08 . Length of head with opercular apparatus contained four and a half times, maximum depth of trunk two and a half times in the total length to the base of the caudal fin. Abdominal rertebræ 9, candal vertebræ 24 in number. Pectoral and pelvic fins present. Dorsal margin nearly straight in the middle, the fin comprising about 50 to 55 rays ; anal fin with about 40 rays. Squamation dense.

The otoliths of this species are described by von Meyer, loc. cit. 1856.

Form. \& Loc. Lower Viocene: Würtemberg.

33179,36578 . Fine specimen in counterpart, displaying the characters noted iu the specific diagnosis; Unterkirchberg near Ulm. The rertebral centra are broken, and the edges of the median fins are imperfect. The characteristic hæmapophyses of the abdominal vertebræ are shown, and one of the delicate pectoral fins, as also one of the small pelvic fins, is preserred. Purchased, 1861-62.

36178. More imperfect large specimen; Unterkirchberg. Purchased, 1861.

35749. Smaller specimen, with well-preserved caudal fin, which comprises 18 rays ; Unterkirchberg. Purchased, 1860.

The two undermentioned imperfect specimens represent a form essentially identical with $S$. kirchbergana, but exhibiting a more arched back and other minor differences which are considered to indicate a distinct species named $S$. antiqua by $H$. ron Meyer, Palæontogr. vol. ii. (1851), p 103, pl. xvii. figs. 4-7, and ibid. vol. vi. (1856), p. 26, pl. i. figs. 4,5 .

P. 3972. Large distorted specimen; Un'erkirchberg.

Ennishillen Coll.

35520. Imperfect specimen wanting end of tail; Unterkirchberg. One of the otoliths is seen, and both pelvic fins are preserved.

Purchased, 1850.

Otoliths, apparently of this genus, not represented in the Collection, have also been described as follows:-

Otolithus (Solect) approximatus, E. Koken, Zeitschr. deutsch. geol. Ges. vol. xliii. (1891), p. 106, pl. v. fig. 13.-Miocene; Langenfelde, Holstein.

Otolithus (Solece) glaber, E. Koken, Toc. cit. rol. xl. (1888), p. 293, 




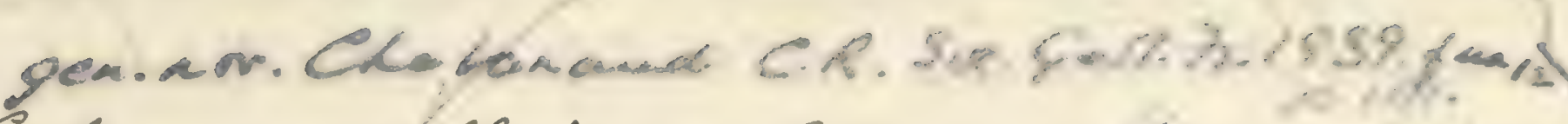
Solea proccellata s.n. Caramuromg, (92),p. 62 he

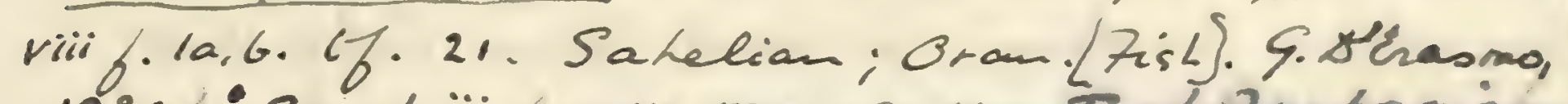

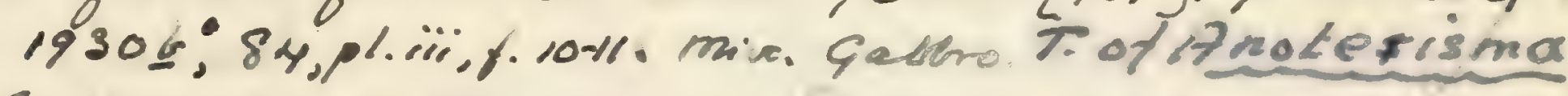

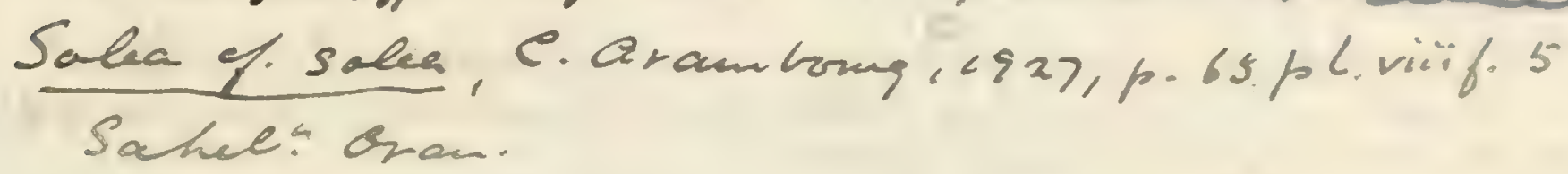

Achins medilerranens n.s. C. Anambong" $p: 6 \%$

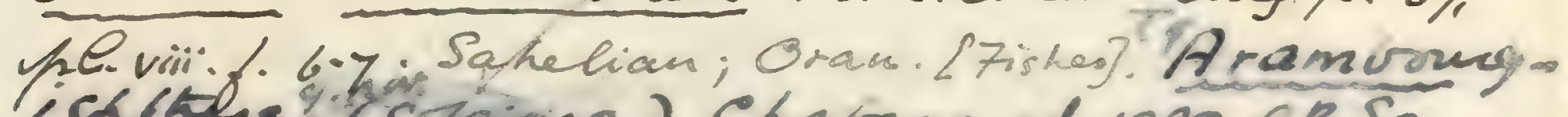
ickiths. (soteided) Chananond 1939 CR.Se. sce. geof. D. 1939 frace 18 \%.191.

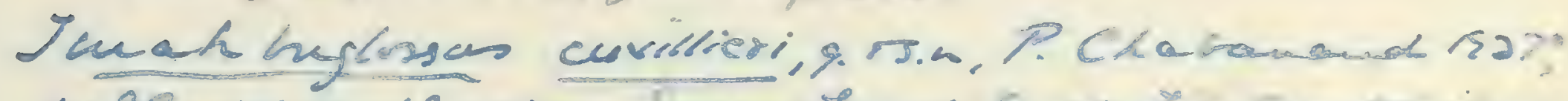

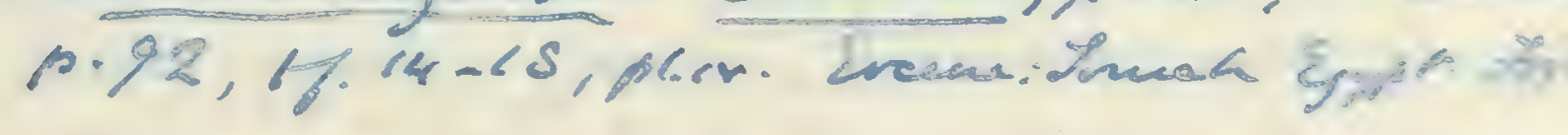

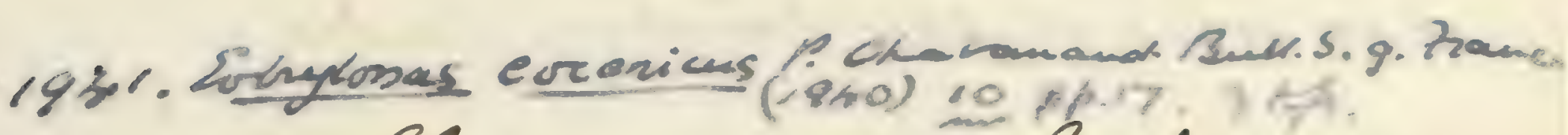
Llea ercenica, 2.S. boodw.

1910. Solea ereenica, A.S.Zoordurard, Geol. Mag. [5-] vol.vii. p.

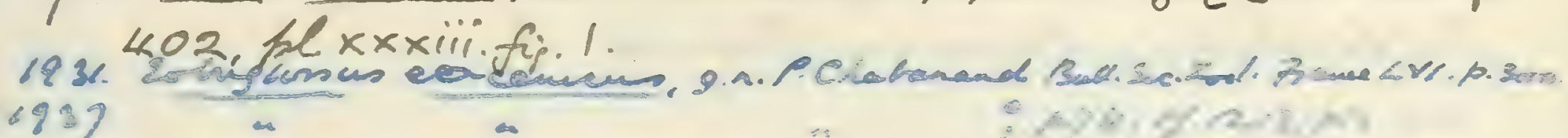
Citarichtsys oraneneis, s.n, C. Arambouig, 1927, 10 59, fh. viif. 18, tfs. 200.6. Sakelian; Oram. Imp. gish

Solea helvetica M. S., M. heriche, 1927i p.101ph.iv.f.4.- Burdigatian; Canion de triboung, Switonand./ Fish; Dusé de Fibrong?

Prolithus (Jolea) cottreani, 7Priem, Bull. Sor. Géol. Frince [4] vol. xi(1911),h.44, teathfip.8. - hiocene; Vence, Alper- maritimer.

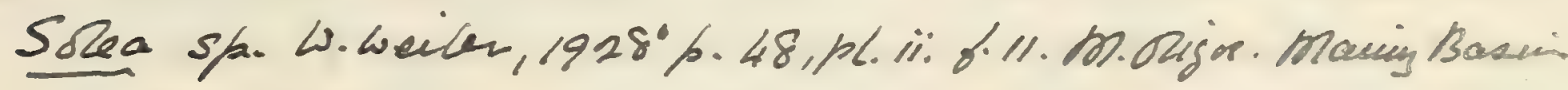




pl. xviii. fig. 3.-Lower Tertiary; Jackson River, Mississippi.

Otolithus (Solece) guestfalicus, E. Koken, loc. cit. vol. xliii. (1891), p. 106, pl. v. fig. 10.-Upper Oligocene; Bünde.

Otolithus (Solect) lenticularis, E. Koken, loc. cit. vol. хxхvi. (188t), p. 548 , pl. xi. fig. 15.-- Upper Oligocene; Cassel.

Solea sauvagei, Bosniaski (Upper Miocene, Gabbro, Tuscang) is merely a IIS. name quoted by Sauvage, Ann. Sci. Géol. vol. xi. art. no. $3(1880)$, p. 12.

Microchirus sauragel, STrasmo

The so-called Solea provincialis, H. E. Sauvage (Bull. Soc. Géol. France, [3] vol. xi. 1883, p. 488, pl. xi. fig. 3), from the Lower Oligocene of Aix-en-Provence, is not a Pleuronectid and will probably prove to be a Cyprinodont.

Another otolith supposed to belong to this family is described thus :-

Otolithus (Pleuronectidarum) acuminatus, E. Koken, loc. cit. 1891, p. 107, pl. v. fig. 12.-Middle Oligocene; Waldböckelheim.

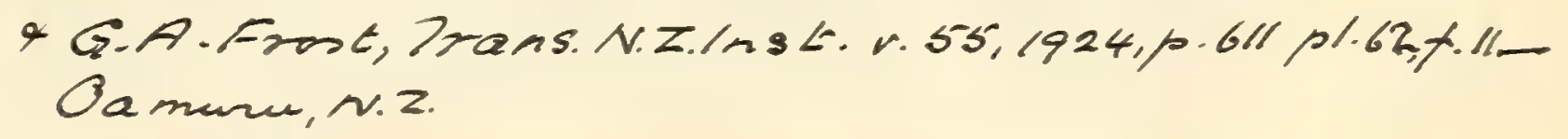

\section{INCERTæ SEDIS.}

The Collection also comprises many fragmentary fish-remains from the London Clay of Sheppey, which are at present indeterminable. Among these the following may be mentioned:-

P. 621. Imperfect cranium and fragments of jaws, marked by Agassiz and Egerton as intended to be the type specimer. of Labrophagus esocinus, named only by Agassiz, Rep. Brit. Assoc. 1844 (1845), p. 308.

Egerton Cull.

P. 631. Portion of small head and opereular apparatus, marked by Agassi\% and Egerton as intended to be the type specimen of Bothrosteus minor, named only by Agassiz, loc. cit. 1844 , p. 307 .

Egerton Coll.

P. 1764. Hinder portion of cranium labelled by Egerton as referable to Naupygus bucklandi, Agassiz (loc. cit. 1814, p. 308 , name only). 
36134. Portion of similar cranium, with vertebræ.

Purchased, 1861.

P. 619. Decaying pyritised head, marked by Egerton as intended to be the type specimen of Pachycephalus cristatus, named only by Agassiz, loc. cit. 1844, p. 308. Egerton Coll.

P. 9582. Similar head, well preserved.

Egerton Coll.

28498, 28614 a. Two similar heads, the second with part of the abdominal region.

Dixon Coll. \& Purchased, 1853.

30893. Two similar crania.

Purchased, 1856.

P. 622. Fragmentary head, marked by Agassiz and Egerton as intended to be the type specimen of Loxostomus mancus, named only by Agassiz, loc. cit. 1844, p. 308.

Egerton Coll.

Miscellaneous fish-remains of indeterminable affinities, not represented in the Collection, have also received the following names :-

Conosaurops bowmanni: Conosaurus bowmanni, R. W. Gibbes, Smithson. Contrib. vol. ii. art. no. 5 (1850), p. 10, pl. iii. figs. 1-5. Conosaurops, J. Leidy, Proc. Acad. Nat. Sci. Philad. 1868, p. 202.--Eocene: South Carolina. [Teeth.] Diplotomodon horrificus, J. Leidy, Proc. Acad. Nat. Sci. Philad. 1868, p. 202. Tomodon horrificus, J. Leidy, Smithson. Contrib. vol. xiv. art. no. 6 (1865), p. 102, pl. xx. figs. 7-9.-Cretaceous ; Mullica Hill, Gloucester Co., New Jersey. [Tooth; Academy of Natural Sciences, Philadelphia.]

=Gigantichthys pharao, W. Dames, Sitzungsb. Ges. naturf. Freunde, Onchozanoms, C.F. Berlin, 1887, p. 137. Titanichthys pharao, W. Dames, Eastman, ther. Nat. ibid.p. 70, with fig.-Upper Cretaceous; Egypt. [Tooth; sol. xxxviii (1904), p.299. Royal Museum of Natural History, Berlin.]

Hacquetic bolcensis, W. Szajnocha, Pamiet. Wydz. matem.-przyr. Akad. Umiejet. Krakow, vol. xii. (1886) p. 111, pl. iv. fig. 2.- Upper Eocene; Monte Bolca, near Verona. [Imperfect fish; University Geological Museum, Cracow.] Heterolepis, O. G. Costa, Atti R. Accad. Sci. Napoli, vol. ii. no. 22 (1865), p. 4, pl. i.-Cretaceous; Pietraroja, Province of

Benerento, Italy. [Portion of fish.]

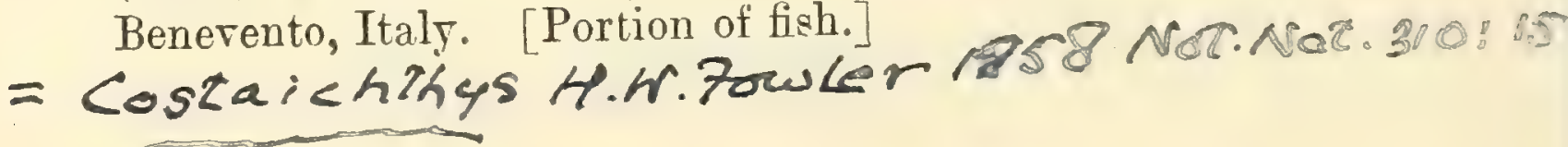





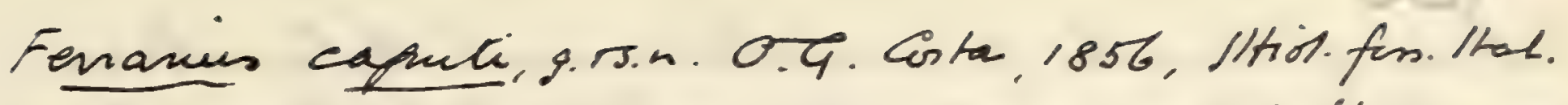

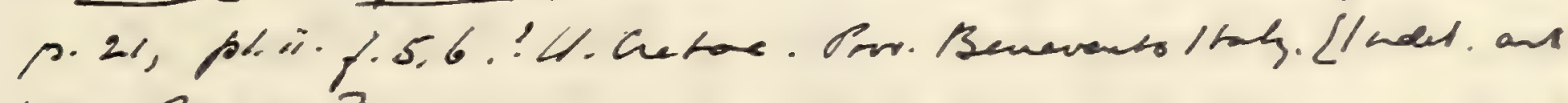
lese Pfint?

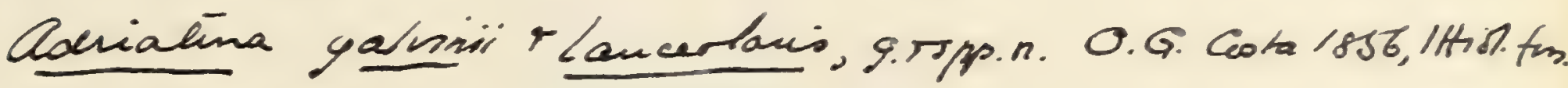

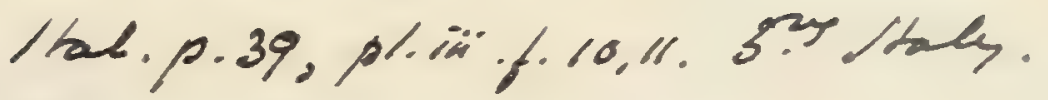

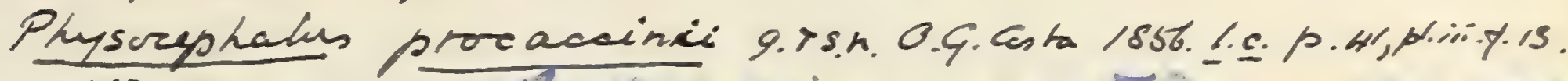

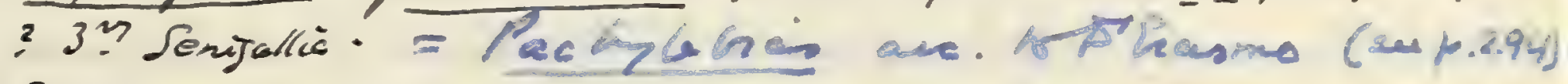

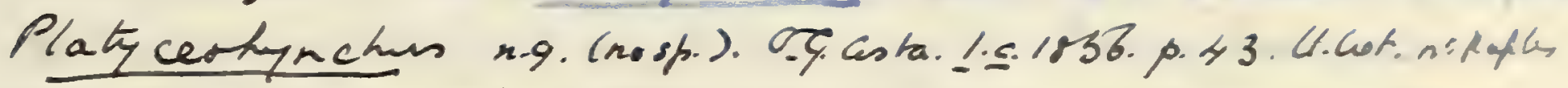

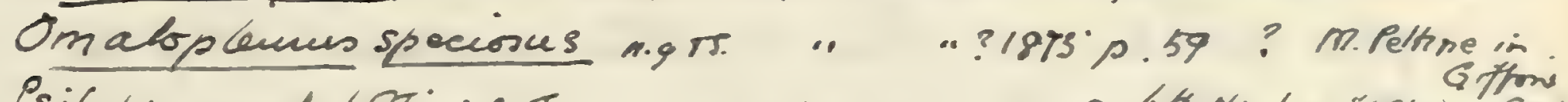
siloous mushelorai. ng. Js.

Pristidde! Seu Pris I,h.77:

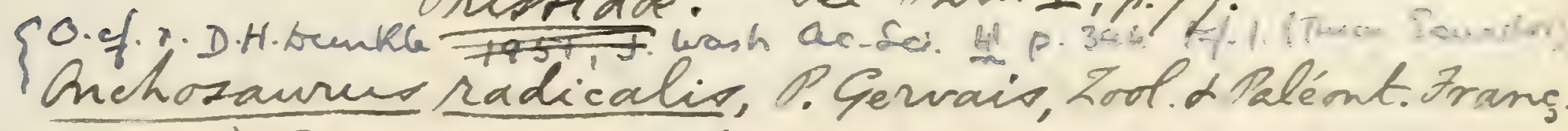

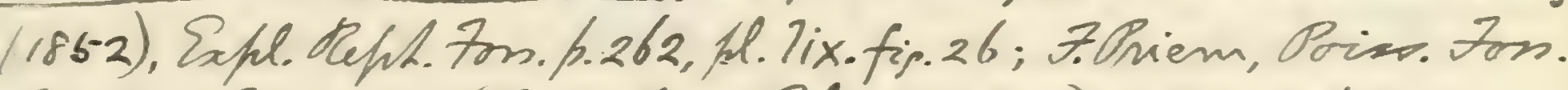
Bassin Parisien (Pabl. Anm. Paléont. 1908), f.61, texh-fi. 24. Senovian; Indre-ch-Zoire, Irance. [Joolh; hum. N.H. Pario.]

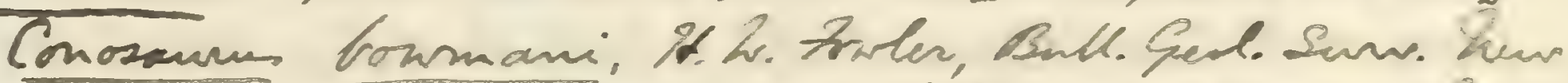

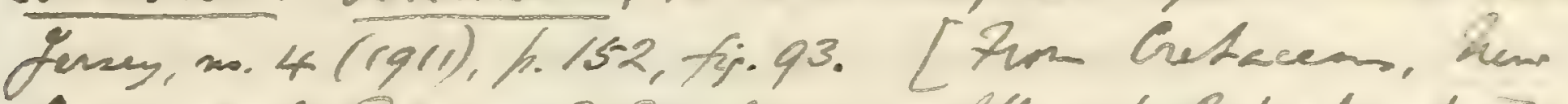

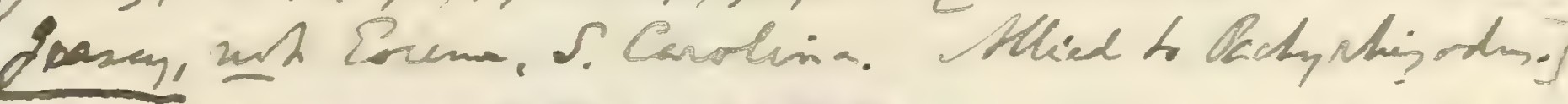

= Lomplaver ehiges p.539.

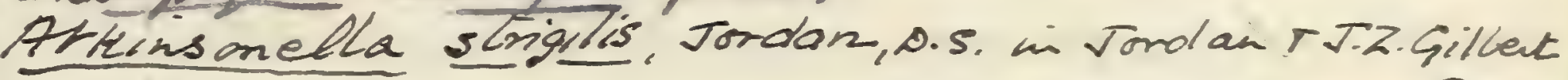

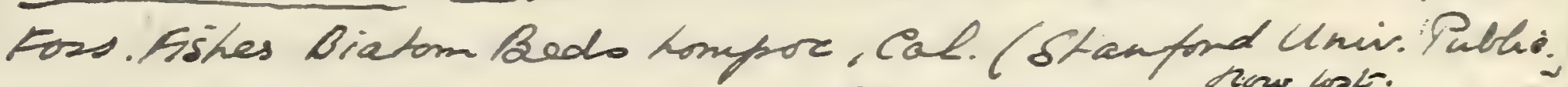

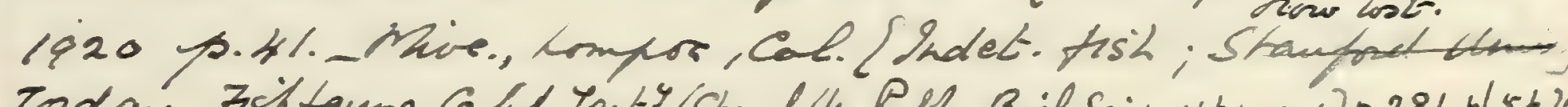

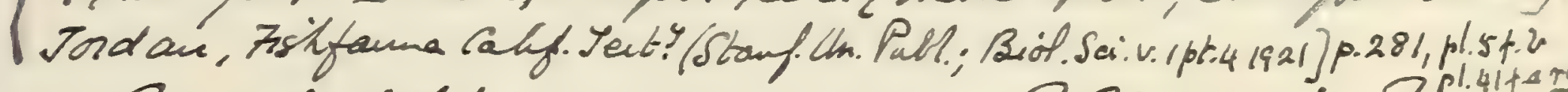
Gipantichthy munidur, R.P Haug, in Friveau, Drum. Sei. Suins. Saharienme, wollif (1gos-),

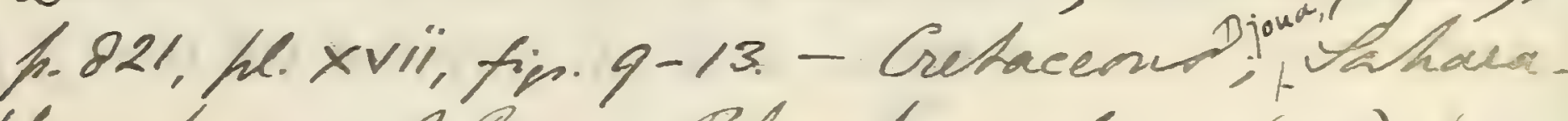

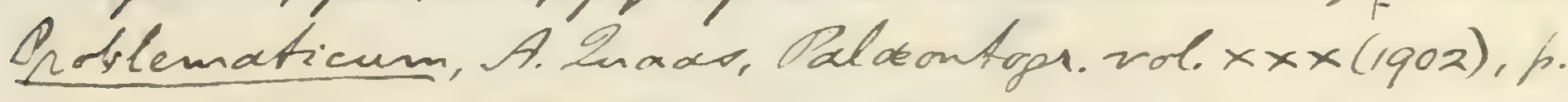
320, pl. x x viii. fi, 15 .

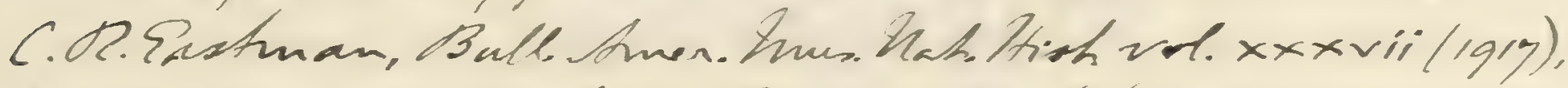
1.75.7, Sh.84-87; 9. A. Bonlenger, Comptes Rendur, wo (4) Zelolgrs), p.197. (Mnchovaumes, tre, as Characinoids) = Onchoprictir.

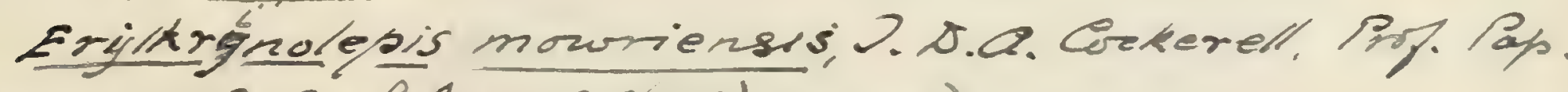

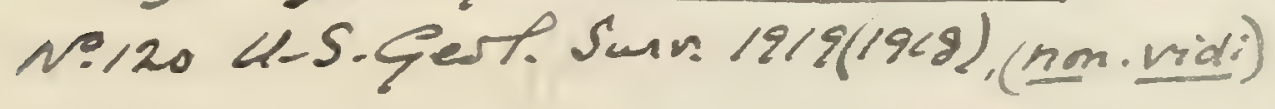


Portion of trunte of undetarmined telecostean from Meh Chang, near Chieng Mai, N. W. Siam (E.

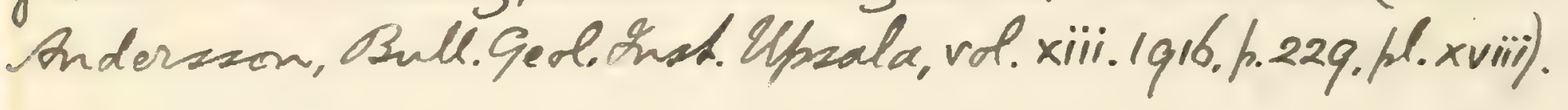

Atolithes bounholmiensio, C. Malling d R. A. Gionwell, Dancte perl. Foren. vol, iii. no. 15(1909), 1.297, pl. xi fir. 14-16. Dis $\alpha$ then somposed trlith from Lian of Bowholm.

Atolithus (incerta sedir) unbonatus, E. Koters, Zeitsech dentech. Geil. Ges. vol. xxxvi (1884), 1.557, plexii.tig.12. Mnt.rupeliensis, in. Zeriche, Mem. Mus. Dry. Hith. Nat. Beb.val.v (1910) - Brina. Olipor. Belp. 10.353, testefin. 13-3-6. (t)lithur (incertot sedir) doradir, ZPriem, Sull. Sor. Géd. France [4] vol. xiv (1914), h. 276, teach.fip. 74.Burdigalian; Lëgnan, Gironde.

Otolithuo (incertoc sedir) martillacensio, F.Priem,

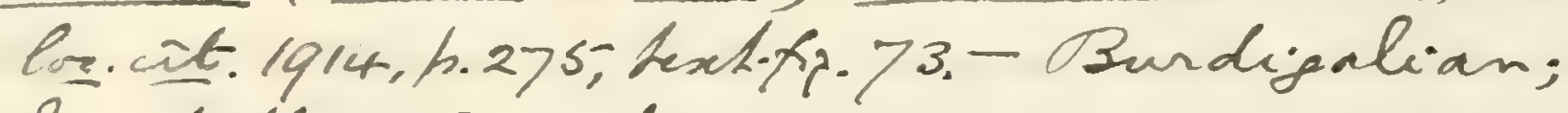
martillac, Sironde.

Beleosteus frimaerus, Volger, Offentach, Ver. Naturk.

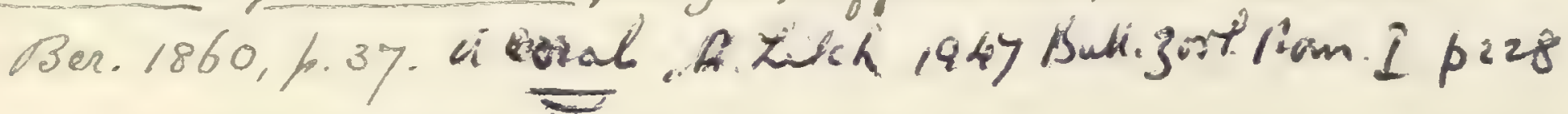

Ferrarius caputi, 0.9. Costa, Ittid. Bon 2tal.

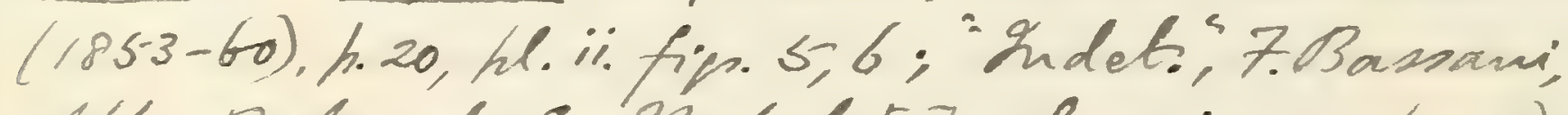

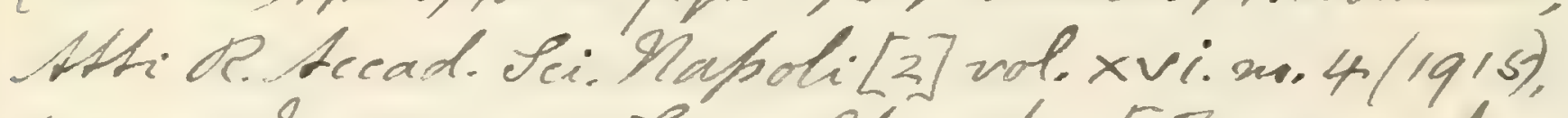
h.48.- hiocene; Zecee, Otranto. CFrement; Gerl. Mnus. Univ. Naples.] 


Platygenys rugosus, R. Owen, Catal. Foss. Rept. \& Pisces, Mus. Roy. Coll. Surg. (1854), p. 165, no.664.-London Clay; Sheppey. [Fragmentary head.]

Pygacanthus altus, R. Owen, op. cit. 1854, p. 166, no. 668.London Clay ; Sheppey. [Imperfect head.]

Toxopoma politum, R. Owen, op. cit. 1854, p. 164, no. 660.London Clay, Sheppey. [Imperfect head.]

Nothing is known of the fossil fish-remains from the London Clay of Sheppey, to which the following undefined names were applied by Agassiz, Rep. Brit. Assoc. 1844 (1845), pp. 307, 308:Bothrosieus brevifrons, Bothrosteus latus, Echenus politus, Gadopsis breviceps, Phasganus declivis, Rhipidolepis elegans, and Synophrys hopei.

$\longrightarrow$ G.A.Frost, Jrans. w.z.lnst. v.05(1924) p.613, pl.62 g.19 camumu vz.

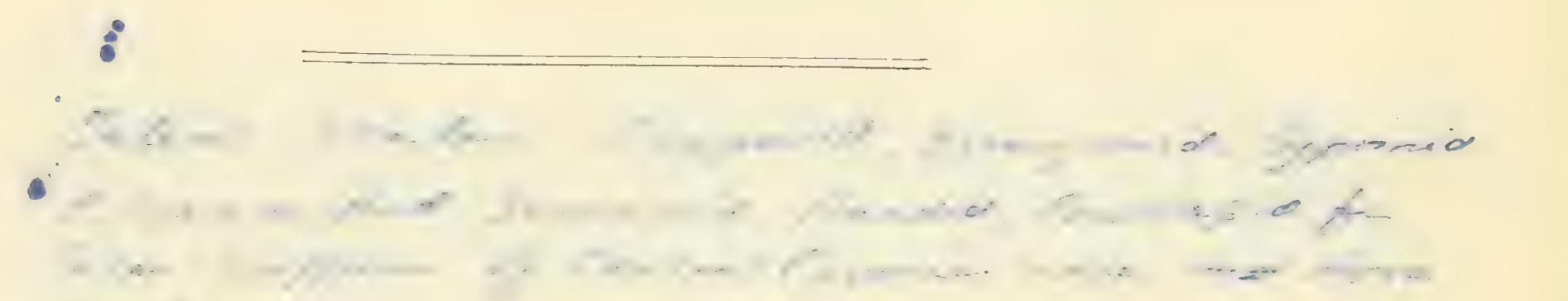




\section{ADDENDA ET CORRIGENDA.}

P. 42, \&c. Since the present volume was in type, the University Geological Survey of Kansas (vol. vi. pt. ii.) has published an important memoir on the Cretaceous Teleostean fishes of Kansas by A. Stewart. Among the additional notes on known species, may be mentioned a description and figure of the skull of Stratodus noticed above on p. 188 ; a description and figure of the imperfectly known Syllocmus latifrons (see above, p. 351), from an undetermined locality in Kansas; and a figure of the so-called Leptichthys agilis.

P. 46. The hypural bone named Ischyrhiza (?) radiata is doubtfully referred to Xiphias by C. R. Eastman, Maryland Geol. Surr.-Eocene (1901), p. 112, pl. xii. fig. 8. = Girem fis

P. 153. Line 3 for Lower Oligocene read Upper Miocene. 'See Kramberger, Verhandl. k.-k. geol. Reichsanst. 1889, p. 87.

P. 160. Add the following:-

Salmo teplitiensis, G. C. Laube, Abhandl. naturw.-med. Ver.4. vol. ii. pt. iv. (1901), p. 26, pl. iv. fig. 5.-Lower Miocehe; T'eplitz, Bohemia. [Head and anterior abdominal region ; Teplitz Museum.]

I'haumaturus deichmuelleri, G. C. Laube, loc. cit. p. 21, pl. iii. figs. 5, 6.-Lower Miocene; Kutschlin, Bohemia. [Imperfect fish; Deichmüller Coll., Dresden.]

Further notes are published by Laube (loc. cit .p. 19, pl. iii. fig. 1) on Thaumaturus furcutus. He describes Aspius elongatus as a distinct species under the name of Thawmaturus elongatus (loc. cit. p. 20, pl. iii. figs. 2-4). - The so-called Thaumaturus Tusatus is regarded as the type species of a new genus Prothymallus (loc. cit. p. 23, pl. iv. figs. 1-3); and the following new species is added:-

Prothymallus princeps, G. C. Laube, Toc. cit. p. 25, pl. iv. fig. 4. - Lower Niocene; Kundratit\%, near Leitmeritz, Bohemia. Imperfect fish ; Royal Bohemian Museum, Prague.] 


\section{.}



Tertiary otolith from Folland, 0 . Dosthumur, Verhandel. Geol. Mijin. Genoot. Nederland en Kolonièn. Gesl Ser. Deel viil(1923), ph. 105-142, with plabe.

Goreme Otototitrs fiom Singland-G.A.7rost B.M.M.W. (9) +r (1925) f. i60.ph.x. (Oypes in B.H.)

Fish orolitis fum 3. Form: of areheen

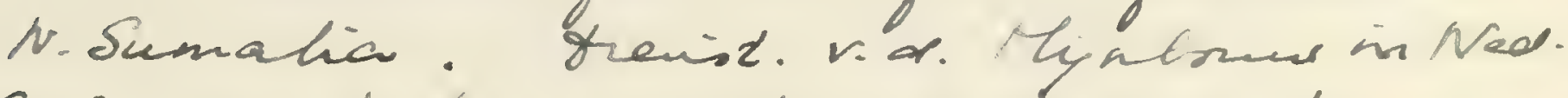
0. Indie, belonseh. Mededel., w.2. Laversdrukherij, wetievieden 1925, $285 .$, m.27,

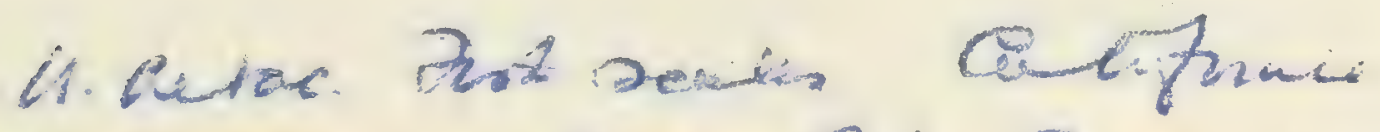

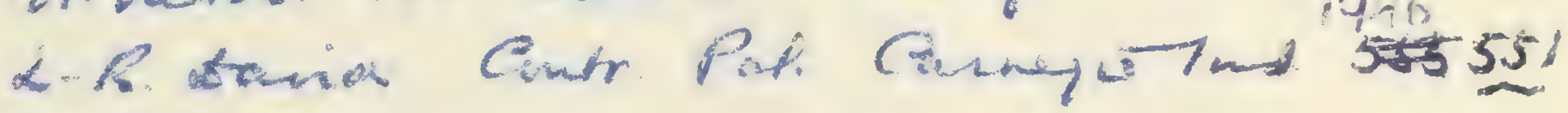
1pp. $83-112$.

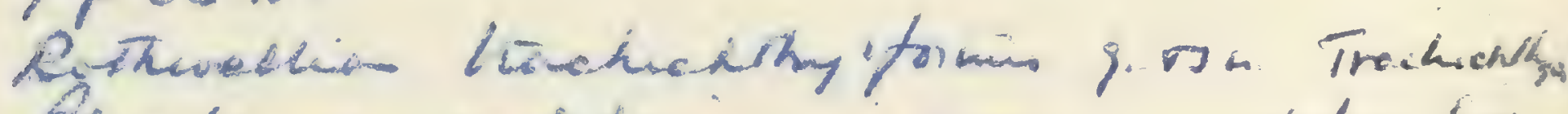

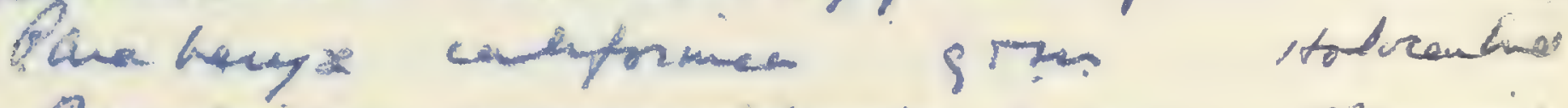

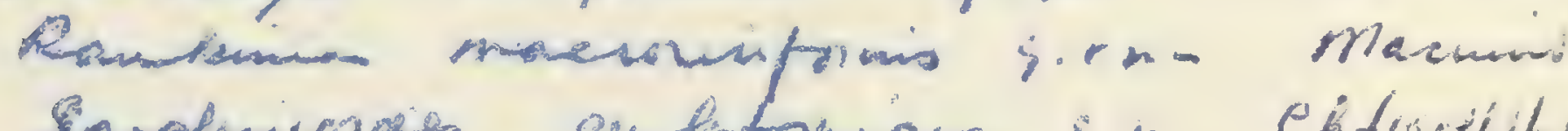

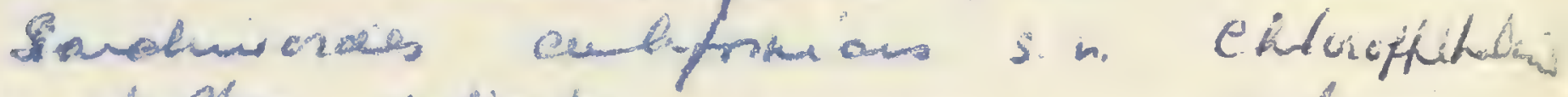

Gondkeffic detientr.

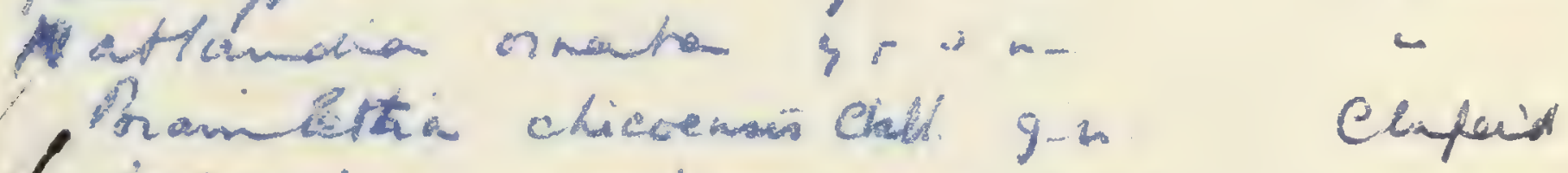

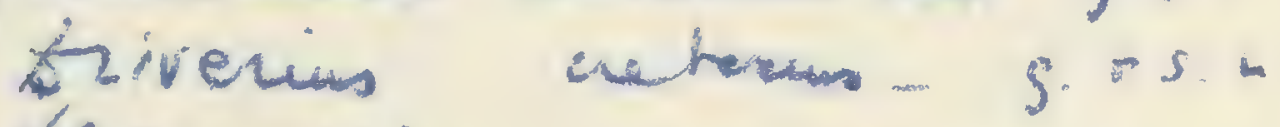
Llaimpellion moremas j.r.h. Alatid

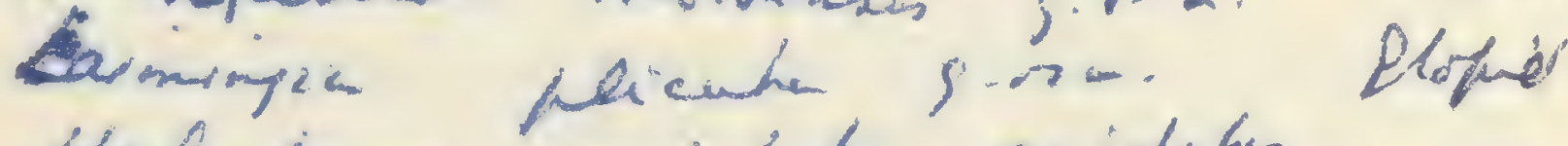

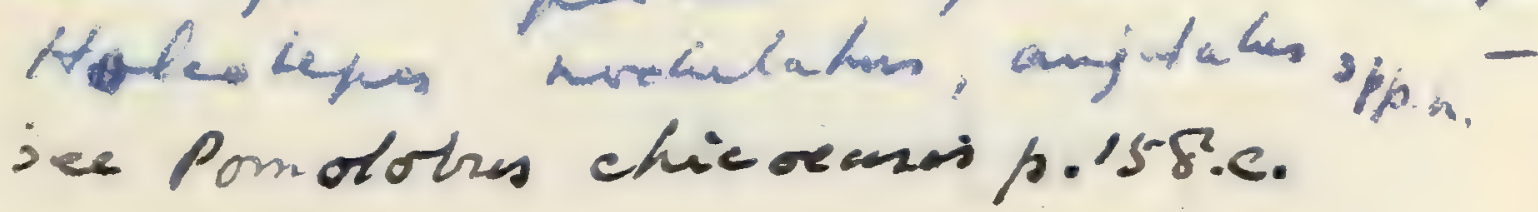

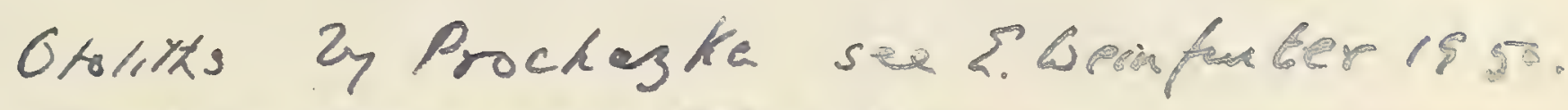

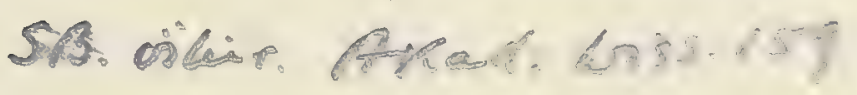


inchodus gentryi, L. Thrsate of. Bull Amen. Hum.

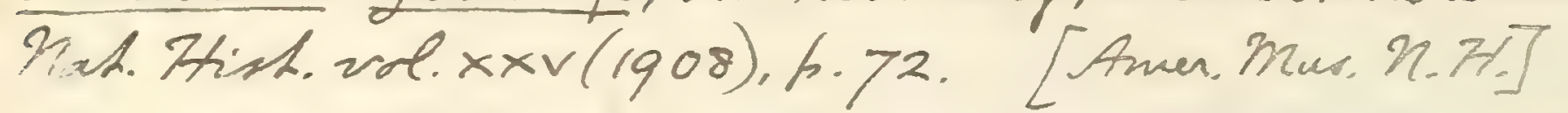


P. 190. Generically indeterminable teeth hare been referred to the so-called Phasganodus as follows:-

Phasganodus austratis, F. Ameghino, Sinopsis Geol.-Paleont.Suplem. (1899), p. 10.-Cretaceous (?); Patagonia.

Phasganodus gentryi, E. D. Cope, Proe. Amer. Phil. Soc. Fol. xir. (1875), p. 362.-Wiocene; Cumberlind Co., Tew Jersey.

P. 277. For additional notes on Totogoneus culieri, see F. Priem, Bull. Soc. Géol. France, [3] rol. xxriii. (1901), p. 847.

P. 289. Add the following:-

Esox destructus, G. C. Laube, Abhandl. naturw.-med. Ter. Lotos, vol. ii. pt. iv. (1901), p. 19, pl. ii. fig. 1.-Lom er Jiocene, Preschen, Bohemia. [Imperfect head; Geological IIuseum, German Lnirersity, Prague.]

P. 294. Add the following:-

Protebias egeranus, G. C. Laube, tbhandl, naturw.-med. Ver. Lotos, rol. ii. pt. iv. (1901), p. 28, pl. จ. figs. 1, 2.Lower Miocene; Franzensbad, Bohemia. [Imperfect fish ; Geological Museum, German [niversity, Prague,]

Prolebias pulchellus, G. C. Laube, loc. cit. p. 31, pl. ғ. figs. 3, 4.Lower Miocene; Königsberg-a.-E., Bohemia. [Ditto.]

P. 296. Nothing is known of the imperfect fish from the Upper Eocene (Gypsum) of Paris, named Poecitia Tametherii by H. D. de Blainrille, Nouv. Dict. d'Hist. Nat. vol. xxvii. (1818), p. 37t. See F. Priem, Bull. Soc. Géol. France, [3] rol. xxriii. (1901), p. 852.

Pp. 299-323. New Cyprinoids from the Lower Miocene of Bohemia are described and figured by Laube (loc. cit. pp. 33-48, pl. ii. figs. 2-5, pl. 5 . figs. 6, 7, pl. rii. figs. 1-3) under the following names:-Nemachilus tener, Tinca macropterygia, Tinca lignitica, Gobio major, Gobio vicinus, Lenciscus fritschi, and Yhondrostoma laticanda. Notes are also added on Tinca obtruncata, Leuciscus papyraceus, Leuciscus brevis, Lenciscus acrogaster, Leuciscus medius, Leuciscus colei, Chondrostome bubalus, and Chondrostome elongata. Leucisus stepheni is described as Chondrostoma stephani. 
P. 323. The imperfect fish from the Upper Eocene (Gypsum) of Paris, noticed and figured by Cuvier, Ossem. Foss. ed. 2 (1822), vol. iii. p. 348, pl. Ixxvii. fig. 14, is described under the name of Labeo? cuvieri by F. Priem, Bull. Soc. Géol. France, [3] vol. xxviii. (1901), p. 850, pl. x₹. fig. 6 . It is considered to be perhaps identical with the so-called Cyprinus minutus, H. D. de Blainville, Nouv. Dict. d'Hist Nat. vol. xxvii. (1818), p. 375.

P. 330. Some fin-spines from the Lower Eocene of Cuis, Marne, are named Siturus(?) gaudryi and Arius dutemplei by C. H. Leriche, Ann. Soc. Géol. Nord, vol. xxix. (1901), pp. 180, 181, pl. i. figs. 7-15. Sup p.334.

P. 353. The specimen numbered P. 9184 is of the same species as the fish in the Kansas University Museum regarded as the type of Leptichthys agilis by A. Stewart, Amer. Geol. vol. xxiv. (1899), p. 78.

P. 368. Add the following:-

Sphyrana tyrolensis, H. von Meyer, Palæontog'r. vol. x. (1863), p. 305, pl. l. figs. 7-11.-Lower Oligocene; Häring, Tyrol. [Dentary bone; Innsbrück Museum.]

P. 473. A generically indeterminable portion of dentary bone from the Miocene of Cumberland Co., New Jersey, is named Sphyranodus sitovianus by E. D. Cope, Proc. Amer. Phil. Soc. vol. xiv. (1875), p. 362. Sphyrcena speciosa of Leidy is also re-named Sphyrcenodus speciosus by Cope, loc. cit. p. 362 .

P. 508. Add the following:-

Smerdis isclbella, A. Gaudry, Anim. Foss. Attique (1862), p. 404, pl. 1xi. figs. 1, 2. Acanthomullus isabello, Valenciennes, Comptes Rendus, vol. lii. (1861), p. 1300.-Miocene; Koumi, Eubœea. [Imperfect fish; Paris Museum of Natural History. Type species of Acanthomullus.]

P. 509. For additional notes on Smerdis ventratis, see F. Priem, Bull. Soc. Géol. France, [3] vo]. xxviii. (1901), p. 856.

P.516. For a description of "Plectropoma uraschista," see also G. C. Laube, Abhandl. naturw.-med. Ver. Lotos, vol. ii. pt. iv. (1901), p. 48, pl. iii. figs. 7,8 . 
. 

Zareo? zho, ZRiem, Bull. Serv. Géol.

Indochine, vol. iv. fase. ii ( $(917)$, k. 2,

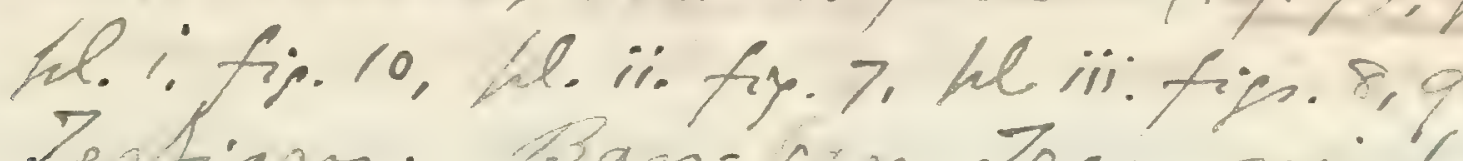

Teatians: Ban-nen, Tran-mink, Laos.

[7ish, ]

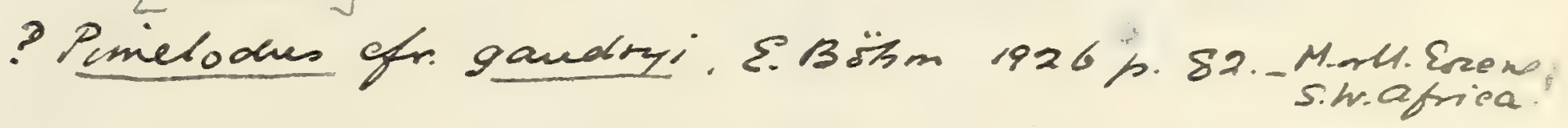

Leptichltys agilis 7.5. Ordan Bull. Unir.Kansas, xxri 1925 b6).p.231pe.xxi. CNean ho apsopelixp. 354?

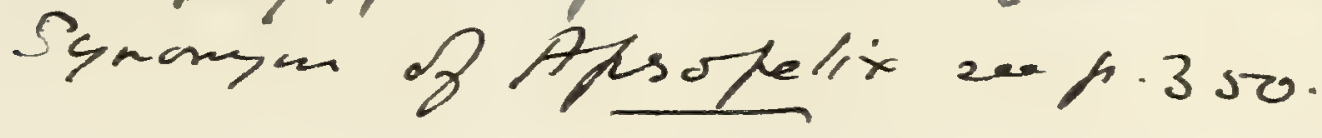

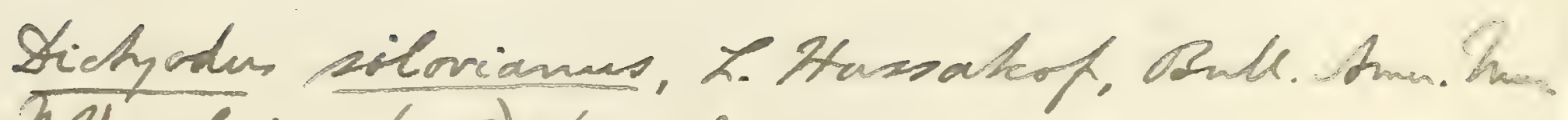
hi.1t. vale $x \times v(1900)$, h. 71, fip. $3 \%$. 
Carismibre.

ELEPHÉNORIDE.

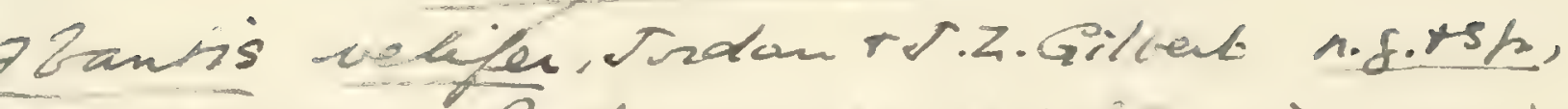
Sroan ford Chir. Publ, Unir. Sor, Biot. deci ir (1925) p.4s.

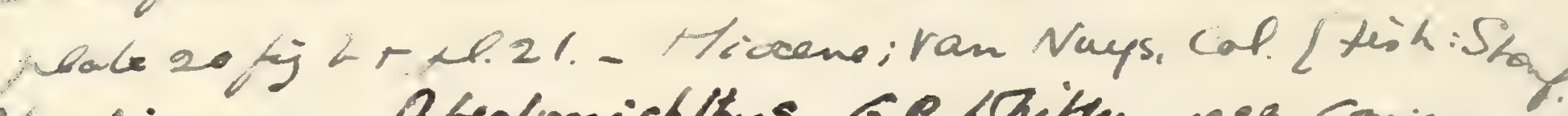

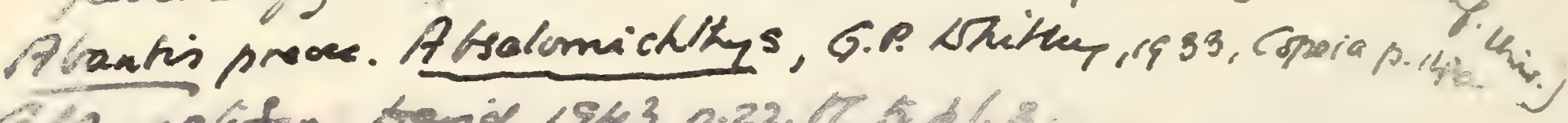

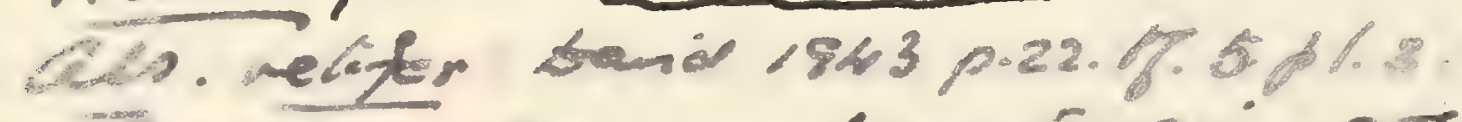

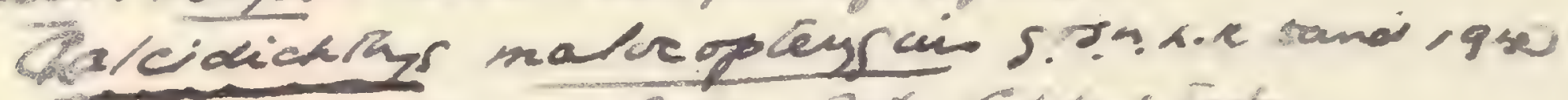

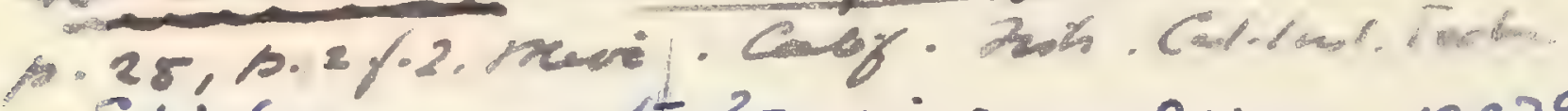
Stichacus matheracai s.u. Nii no, 1937; p.517.

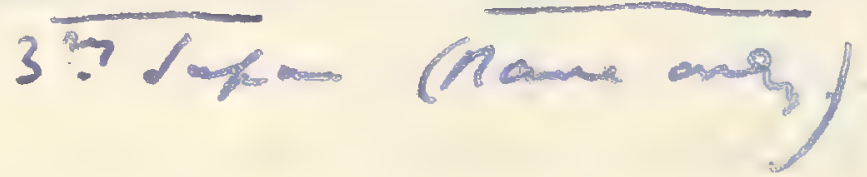

QHethus (inc. sedis) hampshirensis, R. Schubert, hab. K. K.geol. Reichsanst. wol. 65 (1915), 1.287. blviifis.23.- Baston Clay.

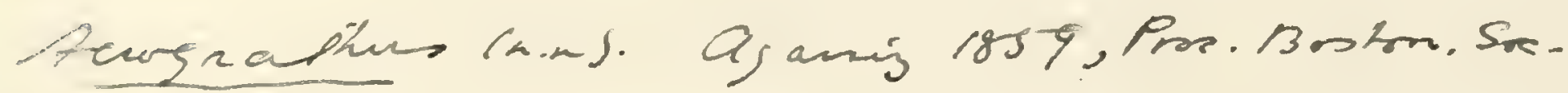
N.r. TT. Ura. 

P. 530. A new specimen in the Geological Museum of the Sorbonne, Paris, is ascribed to Sargus cuvieri by F. Priem, Bull. Soc. Géol. France, [3] vol. xxriii. (1901), p. 853, pl. xri. fig. 1.

P. 550. Add the following:-

Phyllodus hipparionyx, C. R. Eastman, Maryland Geol. Surv.Eocene (1901), p. 113. Phyllodus, J. Wyman, Amer. Journ. Sci. [2] vol. x. (1850), p. 234, fig. 9 a.-Eocene (?); Richmond, Virginia.

P. 560. The imperfectly known and indeterminable Acanthopterygian fish described as follows, has been compared with Ephippus:-

Ephippites peissenbergensis, L. von Ammon, Geogn. Jahresh. 1900 (1901), p. 59, fig. 3.-Oligocene; Peissenberg, Bavaria. [Type species. Imperfect trunk; Geological Survey Museum, Munich.]

P. 584. Add the following:-

Lepidocottus gracilis, G. C. Laube, Abhandl. naturw.-med. Ver. Lotus, vol. ii.pt. iv. (1901), p. 50, pl. v. fig. 8.- Lower Miocene; Warnsdorf, Bohemia. [Imperfect fish; Royal Bohemian Museum, Prague.]

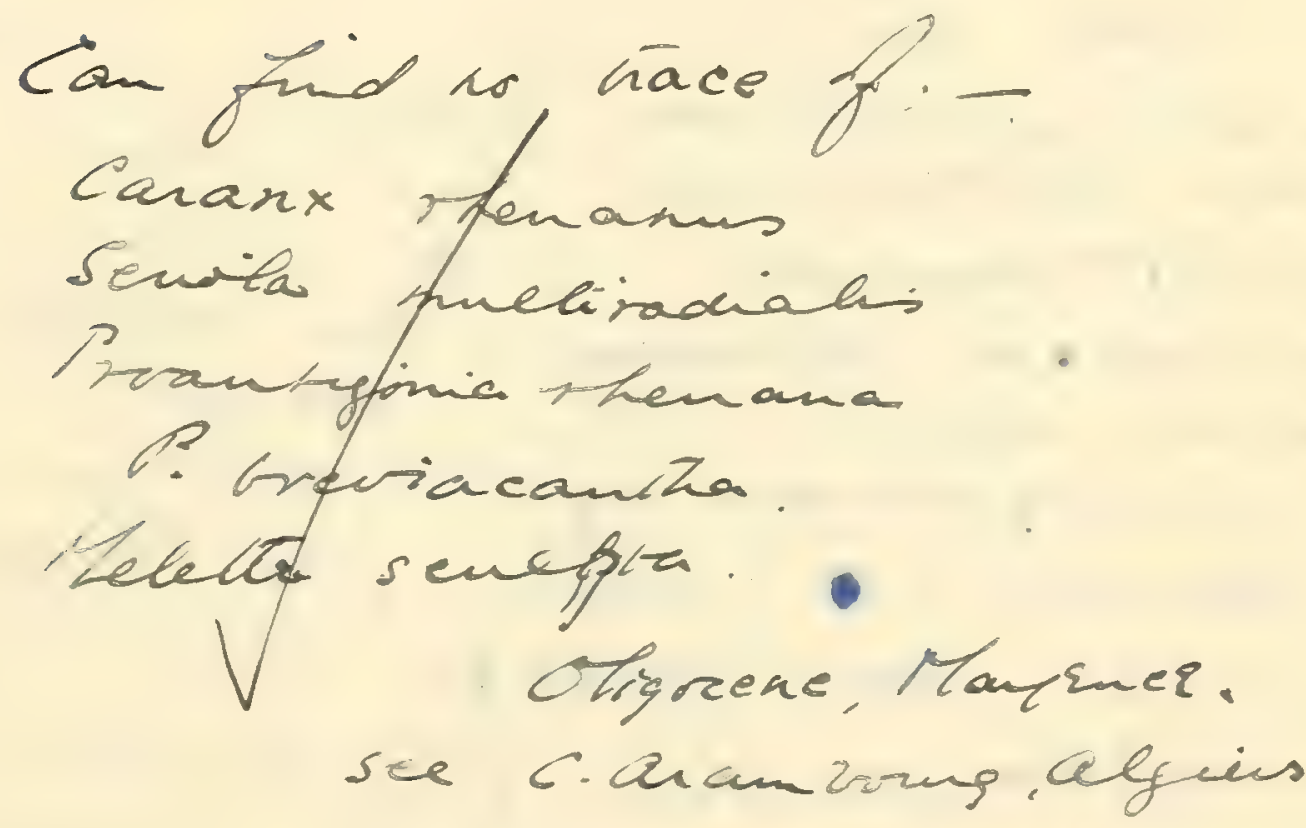


618.

- Sebastavus vertébratis, 284,51

Rixalor portêusi. $285,52$.

Setastinus inezide, $287,54$.

$\checkmark$ Phomasetus erisiger, 288,5 5.

$\checkmark$ Abma anliqua, 291,5 esth)

$\checkmark$ Araesténs prti: $291,49(6)$.

13. The Oeningen Beds occur on tort sides of the Rhire N.Bont haing in Baden, S.in Switgerland, E.end of h. Constance,

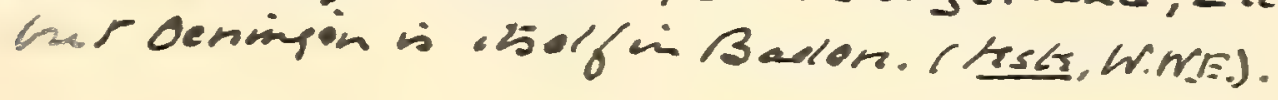

Lisias

PA.r. Tances papes 2y

Ch nuts, coteic $19.3 \% .134$.

Fik-scales fo h. nimaremis Cimert.)

Ser Rase, Puyjob, k. M Naic (.1546) Proe.

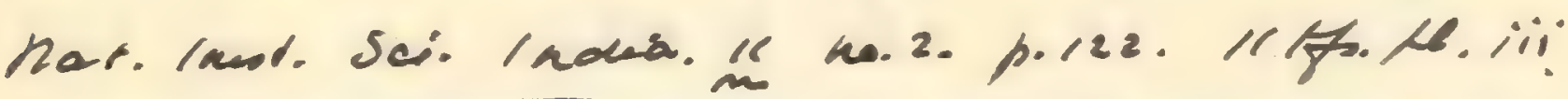

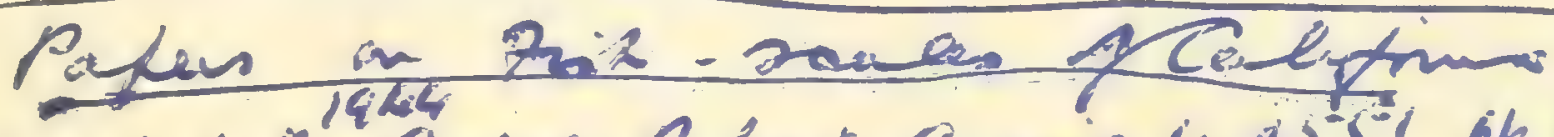

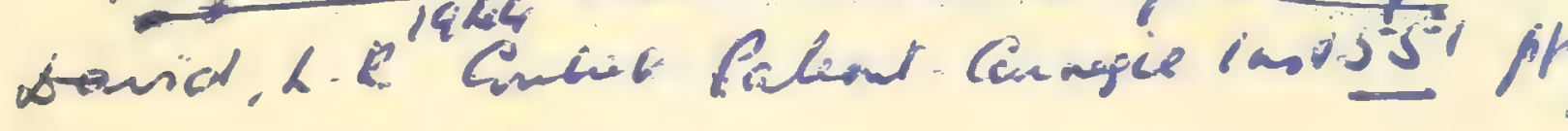

$27-43$.

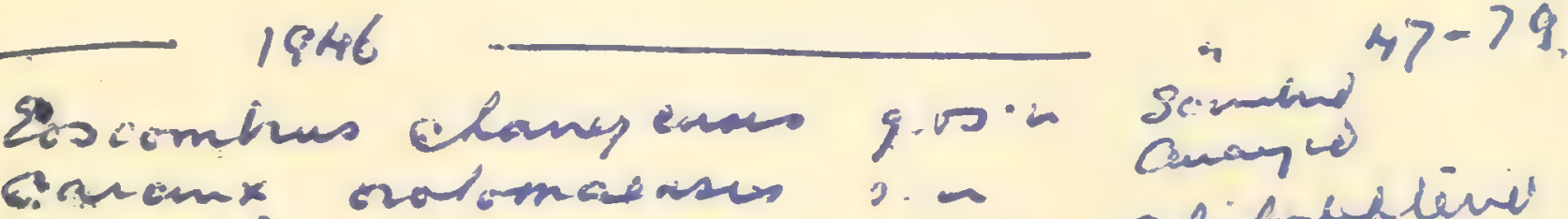

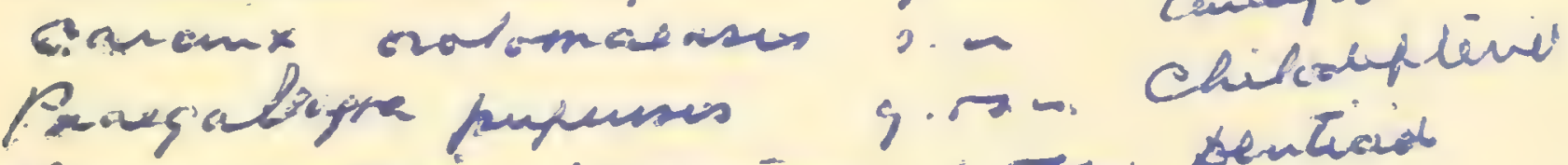

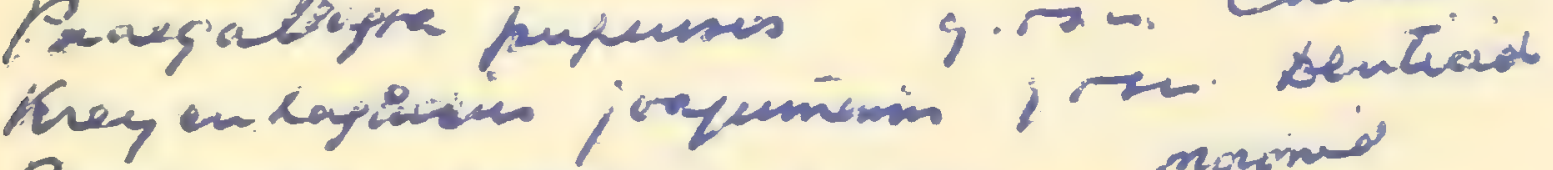

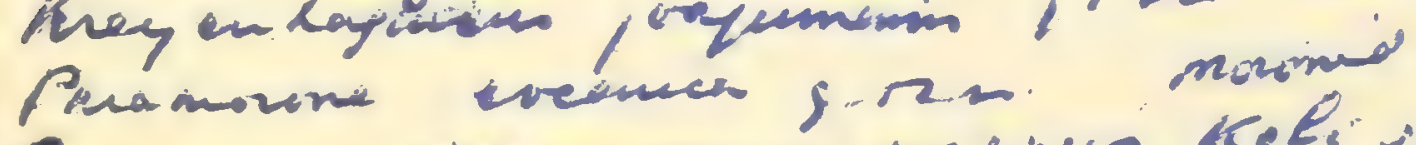

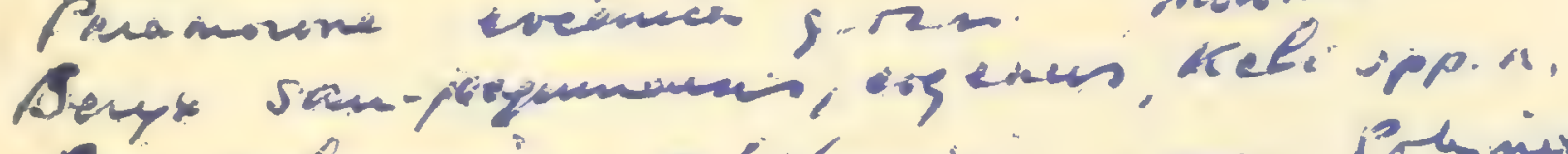

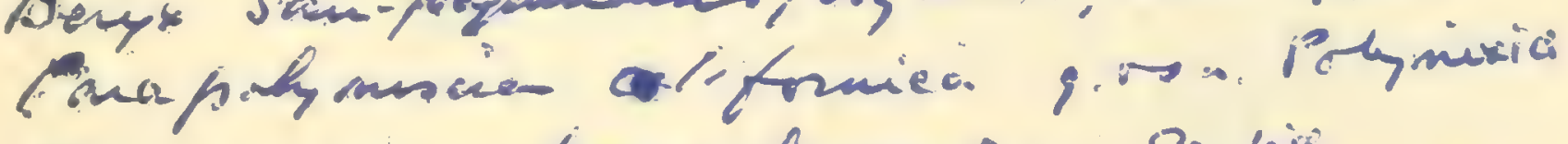

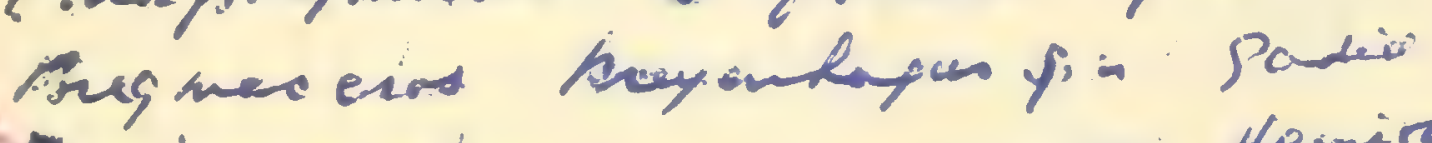

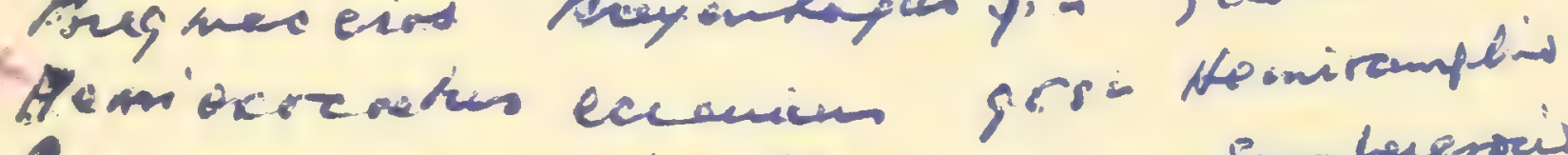

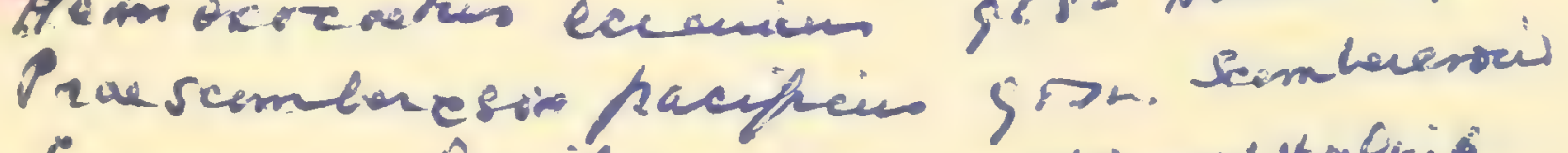

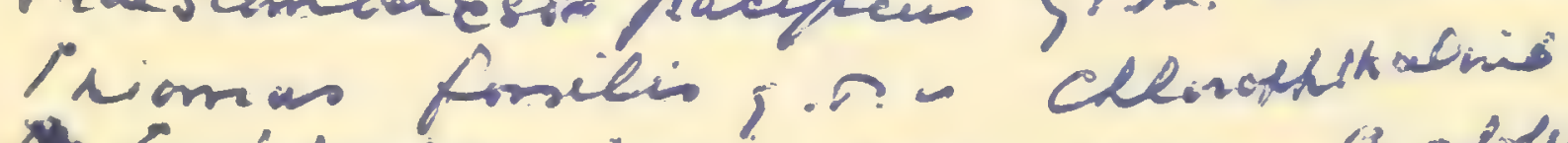

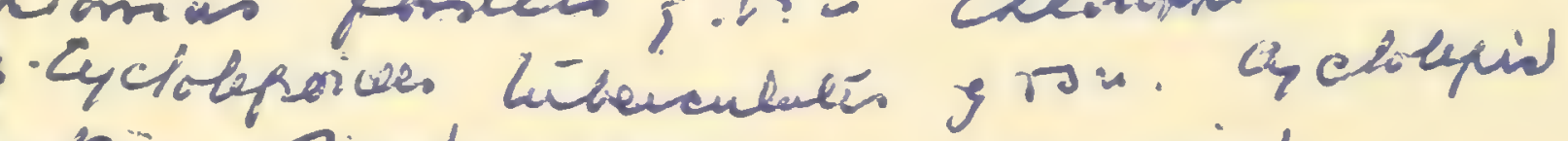

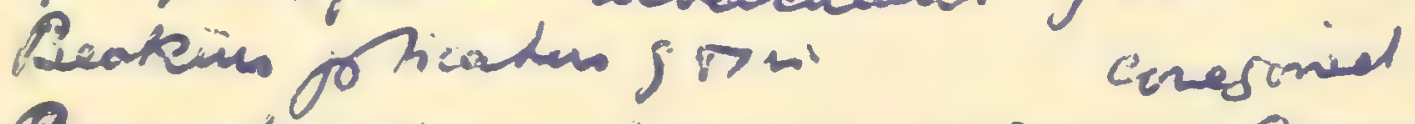

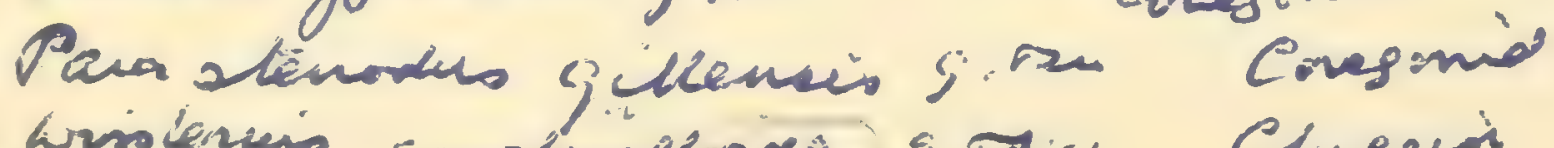

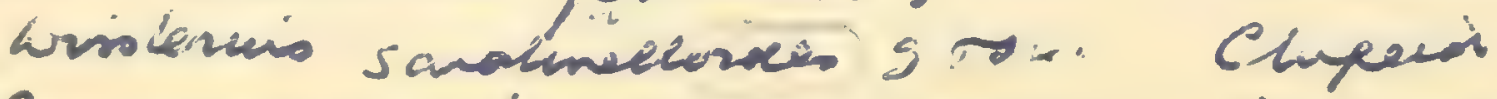

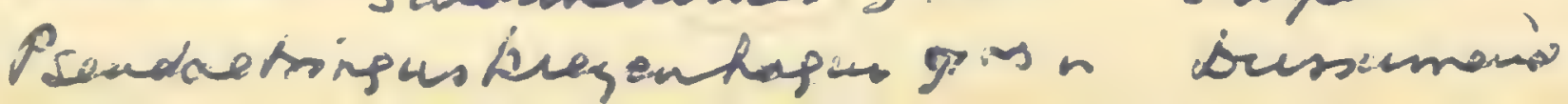




Mrocise Aoties

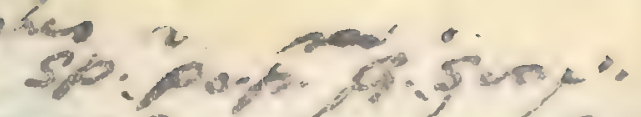

The following gistiv Law

20. fired 618

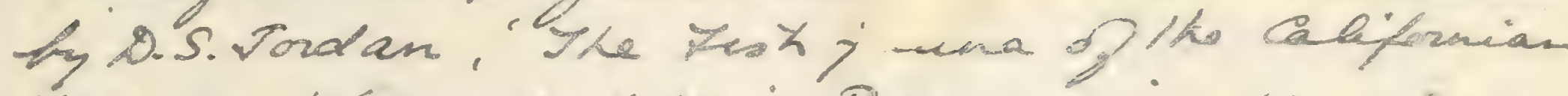

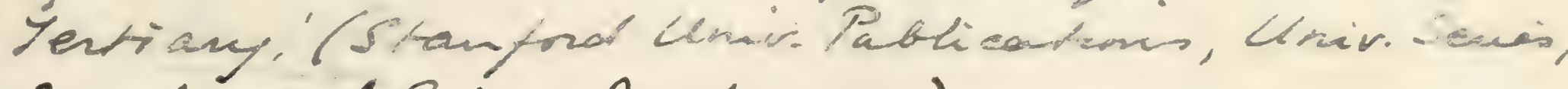
Bialagical Sci, nol. 1pt.4, 1921).

- Ganolytes cameo.p.240 plis:

$\checkmark$ Ganoëssus clepsyadra 24016.

$\checkmark$ Eetasis torriger 241 M(a)

$\checkmark$ Xyne grex

Xyoinius elmodenae

- Alisia grandis

- Quarsita quisquilia

- Smitilés elegans

- Lygisma cénax

$241 \quad 18$

- Azalois angelensis 249 23(a).

$\checkmark$ Rogenis solitudinio 253 17(t)

1 " ranclevi "2sta.

"Fofex Mpmale: $25421(b)$

$\checkmark$ Rogenites bowersi 255. 20(a)

$\checkmark$ Zelosis Ladleyi $25626(b)$.

$\checkmark$ Scomberessus acutilus $25 Y \quad 2 Y(a$.)

$\checkmark$ Syngnaltus araes $25928(6)$.

$\checkmark$ Ecepies velêrmus $2603 l(b)$.

- Amoldina inristia $26230(a)$.

$\checkmark$ Erestes jiodani 26324.

$\checkmark$ Torortioan zus veliger 264. 33.

- Zanlecteles hublsi 268. 29.

$\checkmark$ Tunita oetavia $24 r$ 39.

$\checkmark$ Zaplleger lonjurio $27138(a)$

"Turio withur. 243 3\%

- Oajstiar sagita $273.28(6)$.

1 Thysocles Eviegeri $273 \quad 36(a)$.

* Lomportitis hofkinsoni $276 \quad 41 \mathrm{~kb}$

- Neomaenis hagari 27846.

1 Rhytimias ofario $\quad 279$

- Plesinites classemi 250 "S.

Lonfroquia re liajes 28147. 
48 nowa, 588

ar, 588

Bunats. 617

Hobiomicticys.617
Frohrissa, 180

powivenas:554.

A ficenzrum 413.

Alowna. 151."

- carlogacttas, 381.

538 cominima, 15t

Retive.610

Acrommatoleprs.llt.

Adrianichltyiran, 290

Adriatina. G/2. achrestus, 580 .

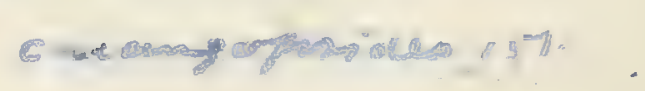

Allunvides.319 rhoncridalis, 319 .

Alburnoks,322 angurtarans, 322. Alicieta, 4ub.

Alised 158Z.

Achrestogrammus,580. grandis, 158 Z, 618

Alisodon, 304 . mirus, 304.

Alesiés.24).

iunneri, 29).

Alsisoma, 481.

Ambly gonilapidens spale

Aevix, 294.

clarsicaned .295".

orsinis. 294

pricmen. 295:

Amphinarca. 578 -

Rew iseurs. 379 . 


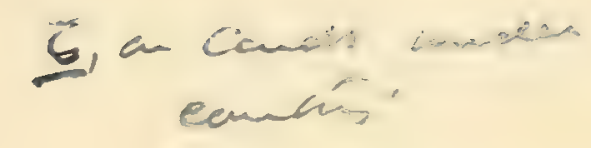

\section{ALPHABETICAL INDEX.} [Tote.-The numbers of pages on which mere incidental references occur
are printed in italics.]

Abramis, 319.

Ficerickes, 3 qubrama, 319.

Acanthias marginatus, 228.

Acanthoderma, 568. orbiculatum, 568 .

ovale, 568.

spinosum, 568.

Acanthomullus, 616. isabellæ, 616.

Acanthonemopsis, 450. capellinii, 450 .

Acanthonemus, 449 . bertrandi, 449 . filamentosus, 449 . subaureus, 449 .

Acanthonotos, 481. alatus, 481 . armatus, 481 . licatre, 482 .

Acanthophoria, 388, 391.

libanica, 390.

Acanthopleurus, 566 . brevis, 567 . serratus, 567 .

Acanthopsis, 320 . acutus, 355 . angustus, 321 .

ACANThOPTERYGII, 384.

Acanthurus, 563. canossæ, 563 . duvali, 564. gaudryi, 564 . gazolæ, 564 . haveri, 564 . ovalis, 564 . tenuis, 564 . triostegus, 563 .
Acanus, 500 æquispina, 501. arcuatus, 501 . croaticus, 563 . gracilis, 502 . longispina, 500 . minor, 500. oblongus, 501. ovalis, 500 . regleysianus, 501. spinosue, 500 . sturi, 563.

Acara, 555.

Acerina, 522.

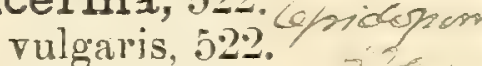

Acestrus, 494. urnatus, 494 .

Acipenser cretaceus, 234.

Acrodontosaurus, 37. gardneri, 40.

Acrogaster, 388. brevicostatus, 389 . daviesi, 390 . heckeli, 390 . minutus, 389 . parvus, 389.

Acrognathus, 243. boops, 243. '79.6\%. libanicus, 244.

Acrogrammatolepis, 58. steinlai, 58 .

Acrovuride, 562.

Acropoma, 481. alta, 481.

Agonus, 587. primas, $58 \%$.

Aipichthys, $12 \pi$. minor, 428 .
Aipichthys (cont.). nuchalis, 429. pretiosus, 427 . velifer, 427.

Alausa latissima, 156 .

Albula, 60. anlequa, 63.
brevis, 65. de zignii, 65. eppsi, 63 lata, 65 . oweni, 60.

Albulide, 59.

Alburnus, 319. miocaenicus, 319. steindachneri, 319.

Alepisaurus, 189. parand Alepocephalid 159.

Alosa, 146.

bohemica, 353 crassa, 151. elongata, 151 . numidica, 15\%. renoui, 152.

Alosina, 159. salmonea, 159

Amblypharyngodon, 304.

Amblypterus olfersi, 27 .

Amia indica, 504.

Aınia lewesiensis, 217 .

Amiurus, 328. cancellatus, 328 . maconnelli, 3IE. primac:

Ammodytes, 35t. a chertant tobianus, 361 .

AMMODTtide, 354 .

Ampheristus, 577. toliapicus, $57 \%$.

Amphiplaga, 416 . brachyptera, 416. 
Amphisile, 378.

heimrichi, 379

longirostris, 379

Amplistium, 434.

bozzianum, 435 .

dubium, 435 .

longipenne, 435 .

paradoxum, 434.

Amphodon, 474. benedeni, 474 . curvidens, 474.

Amyzon, 300 .

brevipinne, 300 .

commune, 300 .

fusiforme, 300 .

mentale, 300 .

pandatum, 300.

Anacanthini, 597.

Anapterus, 257.

albyi, $25 \%$.

elongatus, 257.

macrocephalus, 258.

megistosoma, 257.

siculus, $25 \%$.

sphekodes, 258.

toenia, 258.

Anarrhichas, 596 . lupus, 596.

Anchybopsis, 322. latus, 322 .

Ancistrodon, 570. armatus, 570.

fissuratus, 570 .

vicentinus, 570 .

Ancylostylos, 66 . gibbus, 66 .

Andreiopleura, 116. esimia, 116. vetustissima, 116.

Anædopogon, 107. tenuidens, 108.

Anenchelum, 477. brevicauda, 480 . breviceps, 478 . dorsale, 478. glarisianum, 477. heteropleurum, 478 . isopleurum, 478 . latum, 478 . longipenne, 478 . margiriatum, 228.

Anguilla, 344. branchiostegalis, 345 . brevicula, 342 . elegans, $3 \pm 5$. hakelensis, 210, 338 . interspinalis, 345 . latispina, 340 . leptoptera, 344. multiradiata, 345 . pachyura, 345 .

Anguilla (cont.). sahel-almæ, 169. ventralis, 341 . vulgaris, 344 .

Anogmasus, 71 . aratus, 72. contractus, 71 . evolutus, $72,386$. favirostris, 73 . polymicrodus, 72 .

Anormurus, 275. macrolepidotus, 277.

Anthias, 520. bassanii, 520 . stiriacus, 520 .

Apateodus, 258 glyphodus, 258 . lanceolatus, 264. striatus, 260.

Apateopholis, 229, D33

laniatus, 232.

A PHREDODERID 416.

APODES, 336.

Apogon, 521. krambergeri, 521. macrolepis, 521 . spinosus, 521 .ronsyire :

Apostasis, 563. croatica, 563. cesperimin sturi, 563.

Apsopelix, 353. sauriformis, 353.

Arapaima, 74.

Archæogadus, 212, 920. guestphalicus, 220 .

Archæoides, 442. longicostatus, 442 . longus, 443 . macrurus, 442.

Archæoteuthis, 524 . glaronensis, 524.

Archæus, 442. brevis, 443 . glarisianus, 442.

Argyreiosus, 450. minutus, 450 .

Arius, 330. baroni, 334 . bartonensis, 333 . crassus, 332. dutemplei, 616. egertoni, 331. germanicus, 33

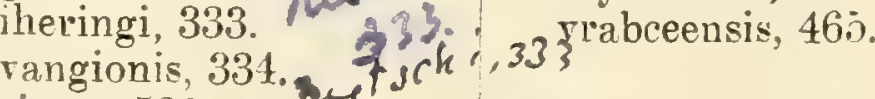

Asima, 536 . jugleri, 536 Asineoride, 416 .
Asineops, 417. pauciradiatus, $41 \%$. squainifions, 417 . viridensis, 417

Aspidolepis, 30. steinlai, 59.

Aspidopleurus, 229, 230.

cataphractus, 230.

Aspius, 318.

brongniarti, 293.

columnæ, 319.

ecnomi, 319.

elongatus, 160, 614 .

furcatus, 160 .

gracilis, 318.

minutus, 318.

vexillifer, 319 .

Astephus, 329

Atherina, 359 .

macrocephala, 359

minutissima, 361 .

sarmatica, 360 .

vardinis, 360 .

Atherinichthys, 361 .

Atieninide, 358.

Atherinoides, 361.

Atherinops, 361 .

Atherinopsis, 361 .

Auchenaspis, Bleeter, 330.

Auchenilabrus, 552.

frontalis, 552.

Auchenoglanis, 330 .

Auliscops, 372. sumatranus, 373.

Aulolepis, 126. reussi, 59. typus, $15,16,127$.

Aulorhamphus, 562. bolcensis, 562 . canossæ, 563 . capellinii, 563.

Aulorhynchide, 371.

Aulorhynchus, 372 . sumatrensis, 373.

Aulostoma, 375. bolcense, 375 .

licatæ, 376

Auxis, 457-46. de a 376 croaticus, 465 . Cauc asic a , 464 minor, $4 b 5$. propterygius, 464 . sarmaticus, 459. stiriacus, 465. thynnoides, 465

Bagarius, 335. gigas, 335.

yarrelli, 3206,335 

Ainis rmma, $6 \%$.

Inquilletides. 345

Aphanies 289 .

Anoterisma, 610.

Aloria, 32y.

Antrodonta, 536.

Hnanosmais, 71

$\frac{\text { Anthracoperca } 520}{\text { siebeipi, } 520}$

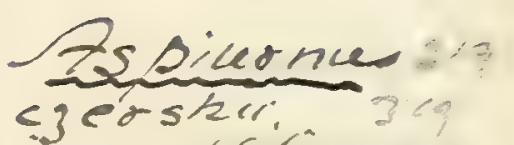

incon plekities

spinnoiaes.

mestrais.

Poryenx 49 ,

Atkinsonella,612

Apozonorides 521.

olügilis, 619. 6 th

7 hsonelix, 314, ar 6.

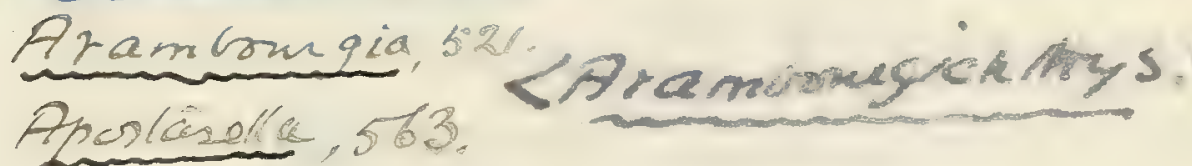

Aracana, 56\%

Kershawi, 56\%

Araeostens, s83.

volti, 585:618.

Aryyonelecus, 215 ?

lug earti, 2350

Rulucki, $235^{\text {cosmovicio }}$

Pneoscarpias, 584 .

Ardivedus, 480.

manionte, 486

Aramichlors. 40

Aristorion, nev 539. Avitolabrax, 5 emprepes, nivis9. Aurata 536.

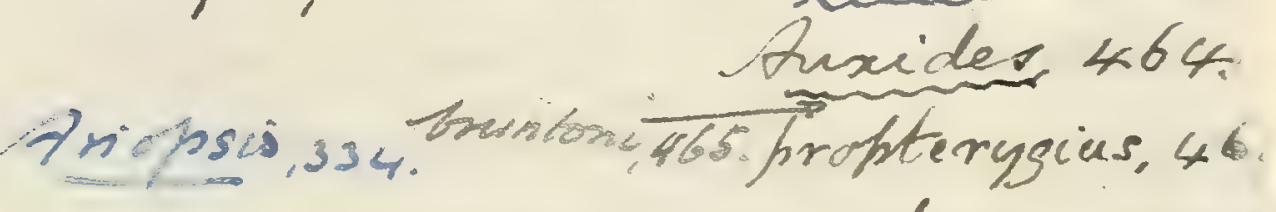

Anquiliaves, 337.

Gathshetoe, 337 .

quadrifionmin, 337 .

hackberryemisi, $33 \%$
Arnoldina, 603 .

inistia, 603.618.

Arnoldites, 603 .

Asiatoleprs, 3

onemseis, wrodicuali, eichundal: mentis. sanetde-monicte, ise dasson, 465.

Anuton, $158 \mathrm{~K}$
angelentio, $158 \mathrm{E}$

Samonariser 
Bolishmoretien, sth.

Barmanogmios, 71.

Butrachoides,597.

BARYISE 437.

Sentionas, $158 a$

Baygnid, 73

mingima, 73 .

Backius, 618

Beition, 358 .

peronides. 358 .

3 regmacenina, 607 Bulbieep; 6-87

Bregmacerotidap. 587 , raminus, 587

Bagmacera's proturam, Burtionia, 524

5\%7. Graxelliensis, 524

3 sowciar, 58 .

cylikdricers,28.

Callichthyidáe 335.

carribridus/seates
Cunsonses:

Conpualesa, 141.

Cassandra 244.

Thenamus, 442.

scirlac

Carrimellus, 296

Cearana, 85.

roch ot, 85.

resomites $99 \%$.

Cepola, 36 9.

Lancerlatin, 369.

centrarehiles, 415.

colorad inais, 415.

CENTRARCHOHE $51 \%$ $554.415,520^{\circ}$.

Carroposi: 5n.

inalicas. Syd.

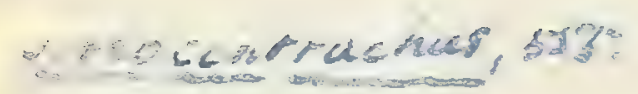

בhane,

Vicra, 323,

yedmensis,

rgasprijis2.

Botas, 608.

saxconices, 608 .

Sox, 500516 coproteofe, 42s:

Capros 418,559.

Iongirastios. 5590

radobojanus, 555 - $^{-}$

Chaenoungthes, st5\%

captorovides, 555 '.

- geingas...

Ingiepiniaturid8. Chovcidick5,617

Caprovesposus, 418. transesend, Jay.

* Cheracieghis. 297. 

Bagrus aor, 327 .

Balistes, 568. caifasii, 569 dubius, 569 .

36ZALISTIDE, 565.

revis cis

redeli, $30 \%$. inegacephalus, 302 steinheimensis, 302 . vulgaris, 302.

Basilichthys, 361 .

Bathysoma, 449. lutkeni, 449.

Bathythrissa, 67.

Belone, 356.

57 acutirostris, $357,358$. nor, flava, 357.

hasmali, tenuis, $35 \%$. Crummer laniatus, 232.

BERYCID E, 384.

Beryciformes, 384.

Berycopsis, 423. elegans, 423. lindstromi, 425.

Beryx, 385. ater, 392. dalmaticus, 386

expenus $6: 8$ dinolepidotus, 386 . germanus, 421. $\checkmark$ insculptus, 386 . lesinensis, 386. microcephalus, 124. multidentatus, 386 . niger, 392. ornatus, 397,409 . ovalis, 121. polymicrodus, 72 .

413. Tadiatus - radians, 122 sam-jure unin subovatus, 386 618.
Bothrosteus (cont.). minor, 611.

Brachygnathus, 519. tenuiceps, 519.

Brachyspondylus, 270

cretaceus, 270.

indicus, 326 .

saropterix, 323.

Brachyrhynchus, 497. Calficus 497. solidus, 497 .

teretirostris, 497 .

vanberedensis, 497."

Brosmius, 602. elongatus, 602 . fuchsianus, 602 . strossmayeri, 602. susedanus, 602.

Brotula, 605. longipinnata, 605 .

Brychætus, 76 . muelleri, 76.

Bucklandium, 330. diluvii, 330, $5 \% 0$.

Butyrinus, 60 .

Caeus, 57. leopoldi, 57.

Calamopleurus, 351. anglicus, 351.

Calamostoma, Agassiz, 383.

breviculum, 383.

Calamostoma, Steindachner, 383, 562.

bolcensis, 562 . cúnossæe, 563

Callionymus, 588. macrocephalus, 588. vestenæ, 448. K stivus 586

Callipteryx, 589. recticaudus, 589. speciosus, 589. valenciennesi, 386. vexillifer, 120. zippei, 397.

BLENNIID $2,595$.

Buennifforaes, 591.

Blennius, 596. cuneiformis, 566. fossilis, 596 . ocellaris, 566

BLOCHID. 591.

Blochius, 593. longirostris, 593. macropterus, 593 .

Boops, 537. gigas, 537.

Bothrosteus, 613. brevifrons, 613. latus, 613 .
Calopomus, 536. porosus, 536.

Cantharus, 537. ureianensis, 537.

Capito, 305.

Capitodus, 323. angustus, 536 . dubius, 537. indicus, 532. interruptus, 537. subtruncatus, 323 . truncatus, 536 .

CARANGIDE, 425 .

Carangodes, 450 . cephalus, 450.

Carangopsis, 446 . analis, 445.
Carangopsis (cont.).

brevis. 446 .

dorsalis, 447.

lanceolatus, 448.

latior, 446 .

maximus, 448.

Caranx, 441. carangopsis, 441. gracilis, 441. baueri, +11 . 9 radermae longipinnatus, 442. ovalis, 442 . rigidicaudus, 442 .

Cariniceps, 458. compressus, 458.

Catostomus, 299. cristatus, 300. shoshonensis, 300 .

Centrisciden, 377

Centriscus, 377.

aculeatus, 378. Ka ba tre ... longirostris, $37 \%$. toni, 377. velitaris, 379.

Chætodon, 560.

arcuatus, 561 .

argus, 561 .

asper, 560 .

aureus, 449.

canescens, 450.

canus, 558.

chirurgus, 559 .

hoeferi, 560 .

lineatus, 564 .

mesoleucus, 559.

nigricans, 565 .

papilio, 433.

pinnatiformis, 433.

pinnatus, 433.

pseudorhombus, 560 .

. rhomboides, 450 , 559.

rhombus, 559,560 .

saxatilis, 412.

striatus, 415 .

subarcuatus, 561 .

subaureus, 449.

substriatus, 415,560 .

subvespertilio, 433.

triostegus, 564 .

velicans, 431 .

velifer, 430 .

vespertilio, 433 .

Chetodontine, 556 .

Chetodontiformes, 556.

Chanoides, 63. Leptastea, 646. macropoina 63.

Chanos, 64. ofiata, 64

brevis, 65 .

forcipatus, 65 .

Chanopsis, 64. 
Characinide, 297.

Charitosomus, 271. formosus, 272 .

hakelensis, 274 .

lineolatus, 274 .

major, 272.

Chatoessus, 158.

brevis, 158 .

humilis, 158 .

tenuis, 158.

Chelonia radiata, 491.

Chimsera furcata, 84.

Chirocentrites, 90.

carolini, 92.

coroninii, 91.

gracilis, 91

libanicus, 105.

vexillifer, 92.

Chrrocentride, 86.

Chirocentrus, 88. polyodon, 88.

Chiromystus, 89. mawsoni, 90. wov

Chirostoma, 361.

Chirothrilid s, 279.

Chirothrix, 280.

guestfalicus, 283.

lewisi, 283.

libanicus, 280.

Chondrosteus, 115.

Chondrostoma, 316.

bubalus, 310 .

elongata, 316.

laticauda, 615 .

minutum, 318.

stephani, 615.

Chromide, 554 .

Chrysichthys, 327.

theobaldi, 327.

Chrysophrys, 534.

agassizi, 537.

N.5.54arsenaritana. 537

brusinai, 534.qN.V

cincta, 535

hennii, 537.

hertlei, 534 .

lawleyi, 534.

miocenica, 537.

seacchii, 534.

zignoi, 034.

Cimolichthys, 227.

anceps, 203.

contractus, 228.

gladiolus, 204

lewesiensis, 221.

lisbonensis, 228.

merrilli, 228.

nepæolica, 225.

semianceps, 228.

sulcatus, 22:).
Cladocyclus, 107.

gardneri, 108.

lewesiensis, 109.

occidentalis, 110 .

strehlensis, 110.

sweeti, $111_{\text {vort }}$

Clarias, 324 . anguir as is

falconeri, 324 .

Clinus, 597.

gracilis, 597.

Clupea, 146.

alta, Leidy, 145.

alta, Steindachner, 157.

antiqua, 138.

arcuata, 154.

attenuata, 19 .

beurardi, 142. tassan",

bosniaskii, 154 .

bottæ, 250 .

breviceps, 154 .

brevis, 270.

brevissima, 140.

caudata, 154.

catopygoptera, 148.

cephalus, 158.

chrysosoma, 158.

crenata, 151.

curta, 22. culus ver 150 .

cyprinoides, 63,456 .

deutex, 154.

denticiformis, 154.

doljeana, 159.

dubia, 270

ecnomi, 155 .

elongata, Davis, 55.

elongata, steindachner,

155,460 .

engrauliformis, 155 .

evolans, 133.

fontannesi, 155 .

gaudryi, 138.

gervaisi, 155 .

gigantea, 105 glyptoperma

goldfussi, 158.

gracilis, 150 .

gracillima, 155.

grandisquama, 155.

grandonii, 155 .

gregaria, 155 .

guestphalica, 237.

haidingeri, 155 .

heterocerca, 156 .

humilis, Leidy, 144.

humilis, Meyer, 150.

inflata, 156 .

intermedia, 156 .

lanceolata. 150.

larteti, 141.

lata, 19, 53 .

laticauda, 158.

latissima, 156 .
Clupea (cont.).

lawlevi, 158.

leptostea, 153.

lesinensis, 138.

lewisii, 17.

lorex, 156.

lundgreni, 156.

maceki, 156.

macrocerca. 156 .

macrophthalma, 135 .

macropoma, 63.

megaptera, 147 .

megapteryx, 156 .

melettæformis, 156 .

meneghinii, 158.

microcephala, 158 .

microsoma, 157.

minima, $245,246$.

minuta, 149.

minutissima, 158 .

mondainensis, 157.

mucronata, 157.

murænoides, 63.

numidica, 151

ombonii, 157.

ophthalmica, 158

opisthopteryx, 157.

polyachanthina, 155 .

præsardinites, 157 .

pulchra, 56.

pusilia, 144 .

sagorensis, $15+, 157$.

sardinites, 152 . C dino-shialtú 157.

sardinoides, 19 .

saulos, 157.

sauvagei, 158.

scheuchzeri, 147.

sinensis, 63 sculptate, 858 a

sphaerocephala, 154.

sprattus, 153.

styriaca, 157 .

tenuissima, 154 .

theta, 140.

thrissa, 63.

thrissoides, 63.

trinacridis, 157.

vectensis, 146.

ventricosa, 150 .

villosa, 161 .

roirouensis, 138.

vukotinovici, $15 \pi$

xenophanis, 158.

zanclea, 158. fornovi,15?

Clupeida, 128.

Clupeops, 159

insignis, 159.

Cobitis, 320 .

angustus, 321 .

bredai, 320 .

centrochir, 320.

cephalotes, $: 221$. 


Chammister, 300 O.(Cirhames),oll.

Gatruchopo, 300

Labisuleatur, GH

oregomm, 300

Chanlinetus, 128,235

delicen tritivess site.

Tinderi, 156 .

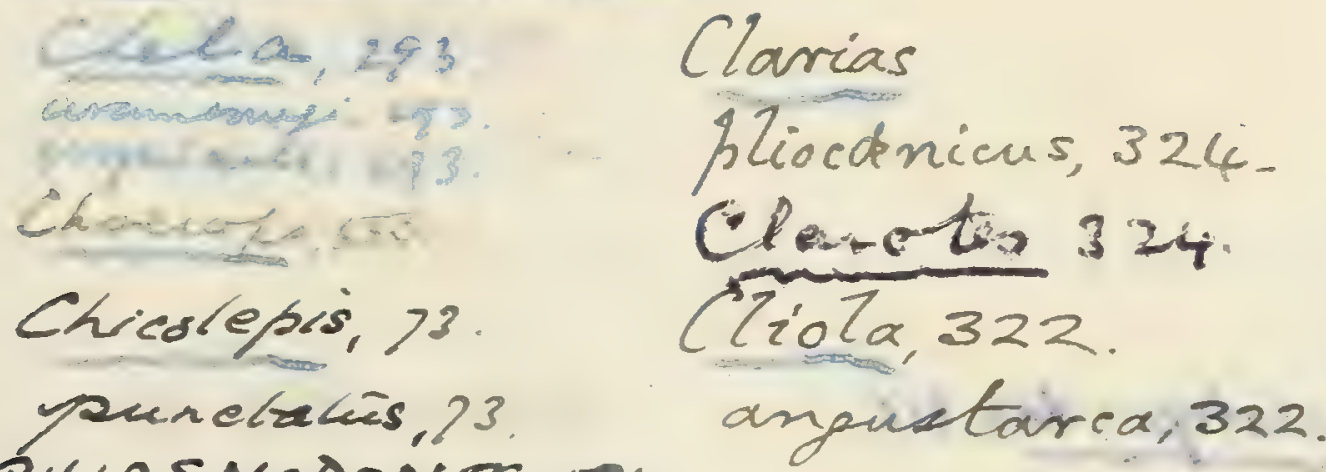

EHIASMODONTS, 5\%:

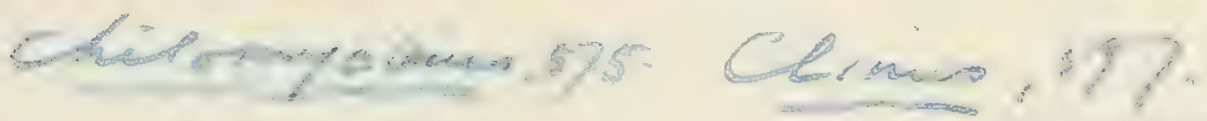

alosa.75s.

aurita, 154

hadleyri, 15-5, 618

Cichlasoma, s-ss:

wiodringi, sars?

CCCItLIDAE, 554 .

Langestiminatistic,

aitans, on.

6 verate, ress.

vexata, 73 .

Cerekerelicis; 
Eourdoti; 470

becafiain 442.

Coinolenis.

Cenger, $3 \times 2$

microchines, 342.

Copeichthys, morgani, 146 ge.

srosanus, 612. Cyeloteporides.68.

Cexisphelis 276 .

corydoras, revelaturs,

Cons astur .496

Corvehtenohsis, 73.

irevis, 73 .

Cylindracantum, 392. Batima, 609 lisulenhis,593. Diaghus 235E.311.

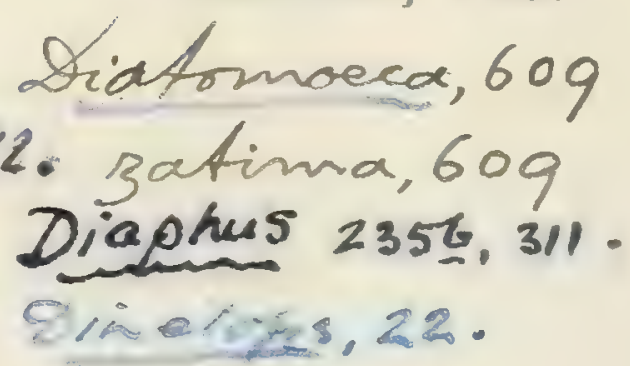

cervicormis, 585.

estaichthys.6r2.

ida vensis, 585.

verandelizi, sf.

mutros. S5 3

Ceporinoidon, 290

kyjmases, 290.

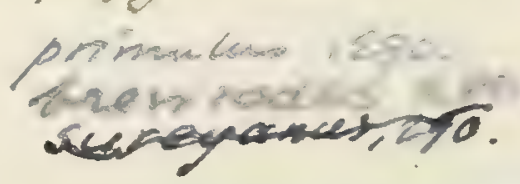

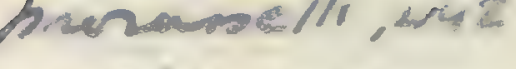
aysille, ande.

Denticopis, 71.

epoftii, 71

Deprandus, 346.

lestes, 346 .

Derrhias, 336 .

enantiors, 336.

- Dow, 570 .

Cycrontome, of 35.

Gurscein, v.V.53\%.

Dappiánielli- 343.

Dapalis, 506 .

Tristigerina, 519

ariserina

Dasceles, 537

Siverase, 160. áasument

? ir rotos, 9 ?

$=\infty$, bongeson, 27\%

tastive, 133.

Benclakes 499

erandalli, 133 .

Digfines, sto

Cenopmichturs, 579. Daunichthys, 323.

gregorionus, 323. 


Cobitis (cont.).

longiceps, 278.

teyleri, :321.

Cobitopsis, 3.) 4 .

acutus, $35 \overline{5}$.

exilis, 355.

Cœlocephaius, 457 . salmoneus, $45 \%$.

Cœlogaster, 116 . analis, 116.

Cœloperca, 519. latifrons, 519.

Cœlopoma, 470. culei, 470 . curvatum, 472 lære, 472 .

Cœlorhynchus, 593.

Conger brevior, 347.

Conosaurops, 612 . bowmanni, 612 .

Conosaurus, 612. bowmanni, 612 .

Corax fissuratus, 570 .

Coregonus, 161. lavaretus, 161.

Corvina gibberulus, 539.

Cottide, 5 SO.

Cottus, 585.

aries, 582.

breris, 582, 584 .

cryptotremus, 585.

divaricatus, 585 .

horridus, 585.

Typoceras, 585

multipinnatus. 584 .

papyraceus,

pontifex, 585.

quadricornis, 58.5.

uncinatus, 585.

Crenilabrus, $5 \pm 0$.

szajnochre, $5+1$.

wondwardi,

Crommyodus, 553 . irregularis, 553.

Cristiceps, 595. paradoxus, 595.

Crossograthide, 348 .

Crossognathus, $3 \pm 8$. sabaudianus, 349

Ctenodentex, .02\%.

lakeniensis, 522 .

Ctenopoma, 579 jemelta, $57 \%$.

Ctenothrissa, 120. microrephala, 124. radians, 122 . vexillifer, 120

Ctenothrissid.e. 119

Cybium, $465,467,469$. bartonense. 467.

bleekeri. 466 .
Cybium (cont.).

bottii, 470. 9 n.v

duinonti, 470 .

excelsitm, 467 .

lingulatum, 460

macropoinum, $\mathbf{4 6 2}$.

maculatum, 4166 .

partschi, $: 70$.

proosti, 470. unpeliensis.47

speciosum, 466 .

tenue, 470

Cycloides, 59.

incisus. 59

Cyclolepis, 59. agassizi, oystemadins

Cyclopoma, 504

gig:? s, $50 t$

micracanthum, 504 .

spinosum, 5() 1

Crclopteride, 287.

Cyclopterus, 587.

lumpus, 596, 587.

Cyclotomodon, 45 . vagrans, 45.

Cyclurus crassus, 598.

Cychrus minor, 583.

Cyclurus nemopteryz, 598.

Cypriside, 299.

Cyprinodon levatus, 416.

CYPrinodontide, 289.

Cyprinus, 300.

bipunctatus, 318.

carpio, 301.

jeses, 305 . minutus, 616 .

papyraceus, 307

priscus, 301.

squainosseus, 276.

CrtTide; 417.

Cyttoides, 417 . glarunensis, 417 .

Dactylopogon, 248 . grandis, 249 . 2ne ns 440 parvulus, 249.

Dactylopterus, 586. pliocenicus, $586^{\circ}$. rolitans, 536.

Dapedoglossus, 74 . acutus, 75 . æquipinnis, 75 . encaustus, 76 . testis, 75 .

Daptinus, 111, 112. broadheadi, 113 intermedius, 112 . phlebotoinus, 112.

Dentex, 522 breviceps, 527 . crassispinus, 522 .
Dentex (cont)

faujasi, 5.2.).

laekeniensis, 522.

leptacanthus, 52:).

microdon, $52: 3$.

muensteri, 5:3.

nobilis, 523. < pliocen, .

sardiniensis, 523 .

rentralis, 523

DERCETID.E, 171 .

Dercetis, 172 .

elongatus, 181.

limbamnensis. 173.

linguifer, $17 t$.

reussi, 173.

scutatis, 17\%.

tenuis, 181.

triqueter, 174.

Dermatoptychus, 236,243

macrophthalmus, $2+3$.

Desmichthys, 450 .

daubrei. 4.00.

Diaphyodus, $5+1,3+5$ 545.

oralis, 546.

trigonella, 546 .

Diastichus, 32:.

macrodon, 32:2.

parviclens, 32:.

strangulatus, 322

Dictyodus, 473 .

crassidens, 475 .

destructor, 474 .

priscus, 473.

rupeliensis, 473. siloriane 615

Dinopteryx, 4106

spiniosús, 407.

Diodon, 571.

acanthodes, 574 .

antiquus, 573

corsicauus, 574

erinaceus, 570 cewarem foleyi, 574 .

gigantodus, 5\%t.

heptadiodon, 5̄it.

heteronon, 575.

hilgendorfi, 575 .

incertus, 575

italicus, 575 .

meristodus, 575 .

monsegurensis, 575 .

platyodus, 575 . bulche $[$ lus, 571 ruvasendx, 57\%.

scillæ, 572 .

sigma, 573.

sienodus, 575 .

tenuispinus, 575 .

vetus, 573.

Diplomystus, 139.

altus, 14 i). 
Diplcmystus (cont.). analis, 139. birdi, 142. brevissimus, 140 . -dentalus, 139 .eduertirits. humilis, $144.900 \mathrm{ec}$, 146 longicostatus, 143. peetorosus, 140. theta, 140 . vectensis, 146.

Diplotomodon, 612. horrificus, 612.

Dipnolepis, 234. jahni, 234.

Ductor, 448. leptosomus, 448.

Dules, 521. medius, 505. temnopterus, 521 .

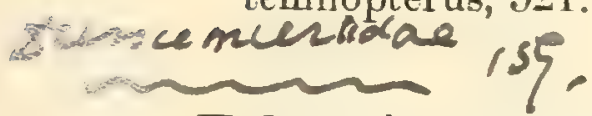

Echeneis, 451. glaronensis, 451 .

Echenus, 613. politus, 613.

\section{Echidnocephalus,} 163. tenuicaudus, 163. troscheli, 163.

Egertonia, 550 . gaultina, 73 . gosseleti, $551.9 \mathrm{~N}=\mathrm{r}$ isodonta, 551 . N N

Electrolepis, 415 . horrida, 415 .

ELOPIDE, 7.

Elopides, 23. couloni, 23.

Elopopsis, 8. crassus, 10. dentex. 205. fenzli, 9 .

haueri, 219. beckeli, 10. microdon, 9. ziegleri, 10 .

Elops, 22.

Embalorhynchus, 497.

kinnei, 497.

Empo, 221.

contracta, 228.

lisbonensis, 228. merrilli, 228.

nepaholica, 225 . sernianceps, 228. sulcata, 225.

Encheiziphius teretirostris, 497.

Enchelurus, 164. anglicus, 167.
Enchelurus (cont.). syriacus, 165 . villosus, 164 .

Enchelyopus, 343 . tigrinus, 343 .

Enchodontide, 189.

Enchodus, 190.992 amicrodus, 203. anceps, 203.

annectens, 195 . bleekeri, 466 . cirsace calliodon, 203. carinatus, 204. corneti, 204. dirus, 204. ctendo ene. dolichus, 20t. faujasi, 196.

ferox, 204.

gladiolus, 204. gracilis, 201. halocyon, 191.

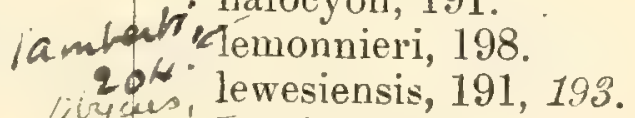
iambertrémonnieri, 198

20. lewesiensis, 191, 193. Tongidens, 199. lycodon, 204. macropterus, 202. major, 200. marchesel tii, 200 , oxytomus, 204. parvus, 204. petrosus, 205. pressidens, 205 . pulchellus, 193. recurvus, 201. semistriatus, 205. serratus, 203. shumardi, 205. subæquilateralis, 205 . tetræcus, 205. valdensis, 205.

Engraulis, 133. brevipinnis, 133. evolans, 133, 287. Iongipinnis, 133. tenuis, 230, 285.

Enneodon, 571, 5\%5. echinus, 574.

Enoplophthalmus, 323.

schlumbergeri, 323.

Enoplosus, 521. pygopterus, 521 .

Eocœlopoma, 470. colei, 470 .

curvatum, 472.

Eocottus, 580. veronensis, 581.

Eomyrus, 340 . dolloi, 340 .

latispinus, 340 . ventralis, 341 .
Eothynnus, 457.

salmoneus, 457.

Ephippites, 617. peissenbergensis, 617 .

Ephippus, 559. aster, $660-$
longipennis, 559 . nicolisi, 560 . oblongus, 560 . oweni, 570. rhombus, 559 .

Equula, 450 . scillæ, 450.

Erismatopterus, 416. endlichi, 416. levatus, 416. rickseckeri, 416 .

Esocelops, 46. cavifrons, 46.

EsOCIDE, 287.

Esox, 287.

belone, 375 .

destructus, 615 .

falcatus, 482 .

lepidotus, 288.

lewesiensis, 191.

longirostris, 375 .

lucius, $288,289,366$.

macropterus, 89 .

monasteriensis, 159.

otto, 289.

ottonis, 289.

papyraceus, 289.

robustus, 288.

saurus, 361.

sphyræna, 361, 362, 366.

spret, 362,366 .

vulpes, 153.

waltschanus, 289.

Eucynodus, 481.

hunteri, 481.

Eurygnathus, Agassiz, 46. cavifrons, 46.

Eurygnathus, Davis, 190.

ferox, 200 .

marchesettii, 200.

Eurypholis, 207.

bcissieri, $20 \%$.

freyeri, 210 .

longidens, 199.

major, 201.

sulcidens, 207.

Exocetus evolans, 133.

Exocetus exiliens, 133 .

Exocctoides, 286.

minor, 286.

tenuis, 285.

Fierasfer, 605. 
. 

Eiexcoutus, dis.

Bziveriens biti. Drings, 25 defensor $25 \%$ Dyokernignio, 87 .

Diradias. Itr6a. aratous, $146 a$. fenestralis itua.

Ectasis, 32.6
II,

Eosym: _... $5 \%$ coscombus.6is Foserramus, soro

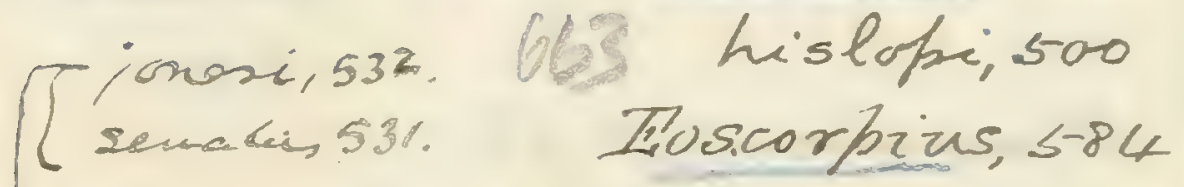
Eostomias, 18.2 primderur, 684 eximius, 128 Fritima, 415 Eolrigonodon, \$31. evides, 415

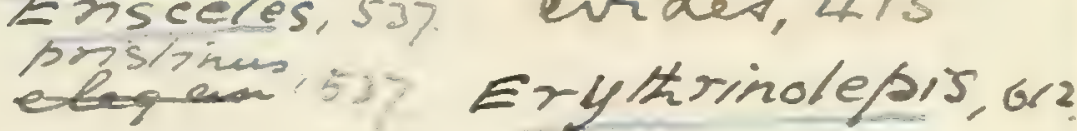

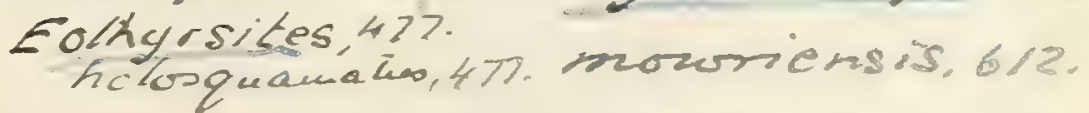

proriger, 618 gentryi, 615 .

Eodiodon, 571,5 ioñceyi. N.v.482.

Eclipes, 520,605. manni, N.605.

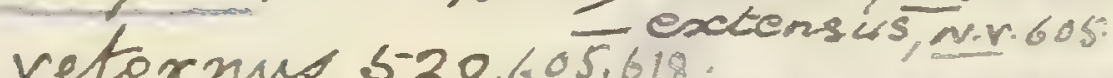
veternus, $5-20,605,618$

Shimmichther, $14 \overline{3}$ saw on inierse.

$\therefore$ Frimpens, 159 scintillarer, 159

Exipusion.5.36.

Congicostatus, 143

Eodiaphyoralus, stys. Etrumeus.

Elimma, $146_{a}$

Granneri, 146 (batbarde, $146 a$ boulec.

elmodendi, $146 \underline{\alpha}$

2Uliper, 146

Pomyctophum Eutgerhoundk

Granneri, 146

ionscieortatios, 143

Tiacertiojés $32 \leq$ Engraulites, 133 .

Eepeqeria. 334.

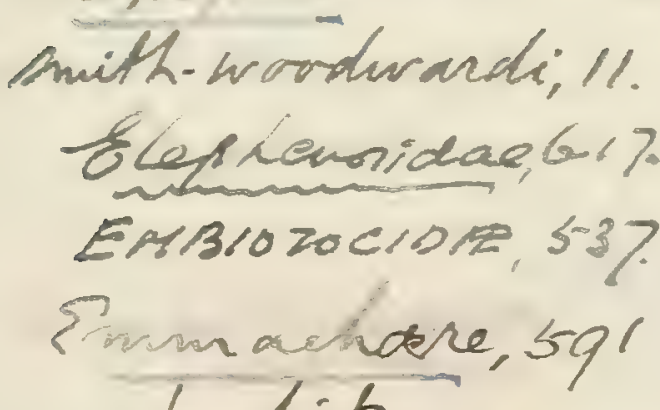

remifer, 133

Eusaphleges:

Enneles, 68. 88.

Exellia, 438

andax, 58.18

Eufrehisiores,

Ennelichthp, 58 .

Eubiócher le rhachiter, sqi

"Eucoelofaskin

Thomalea, 5 \%

dertryi; 58 .

Eargahir, 7

Emarones, 327.

Ceindbi, 76.

Eudiaphyoum

Eolinyean, 298

Eresthes

Eocynin 280

jordani, 611.6\%

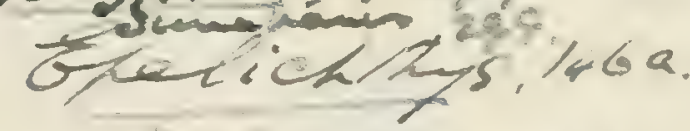

hooveri, bll.

Enchetion, 337.

Euthyunes, 4s,

montium, 337 .

Fajumia, 335

Eomyr ophes

Epinephelues 521

Felichthys, 329 .

cosobti

Ferraritus,6/3.

setcion

$\cos \theta t_{2}: 6$, 
$=327$.

188. Homirhatolomyme ane

Hincuesiokthy, 58. acumendi, 58.

Jorfex, 358

hispuralio, 358,618.

Gonidispis, 09

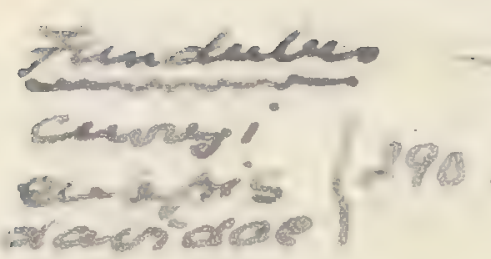

Hexagrammos, 580 achrestus, 580

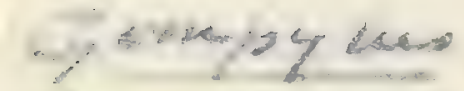

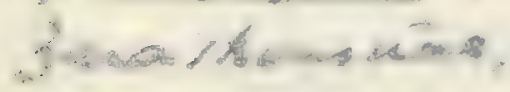

Golaxios, $235 \subseteq$.

Gastrosteops, 340 mexacanomins 370

Genhyrob-inx, 563.

Gicnoessus, 159 .

elepsyrdra, 159.618.

Gastácacanitar.437

sandyzes, 159

cameo, 159, 618

- clessyára, is

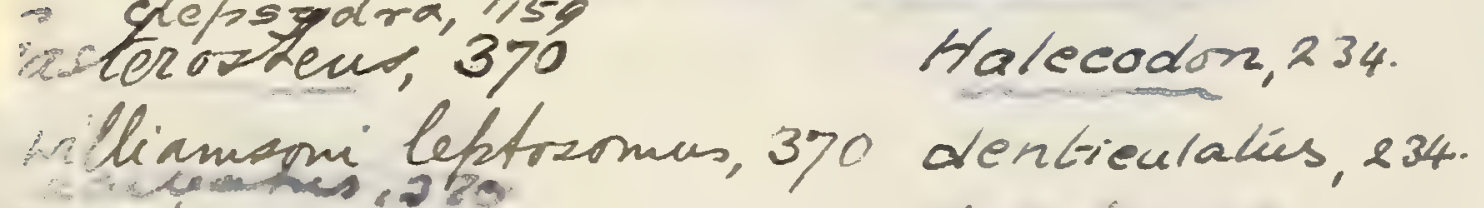

Halecodon, 234.

Gerphagas

Goylum 471

Hakrelias 150 .

Haplochives 290

Yymonsonar. $45 \%$ maciopleia, $60 \%$.

soivnyi, asi.

Halecodon,234. Hijposyngnaitus.381.

QOWOSTOMAMDZ, s5

Gearsiriellis 169.

Q0nortiynchops, 279 .

woodwarch; 279 .

Gonestoma, 158a 8551.

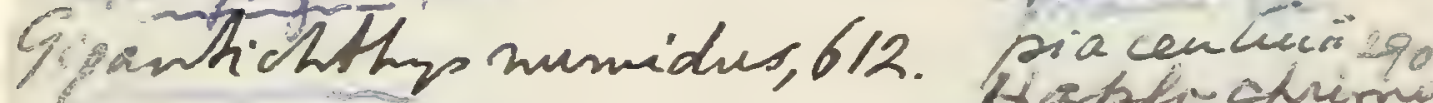

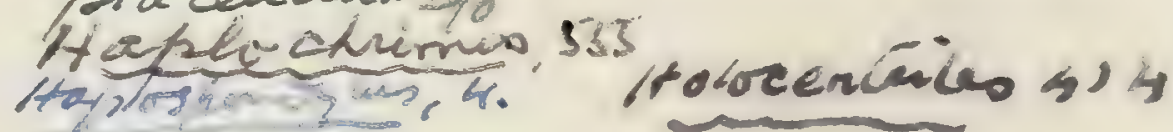

inars

Whisiona, 559.

Haycia, 584

damlica, $4-84$ tina. 158 er orals, ist

coprossoides, 559 .

Heliolenis. $11 !$

Helminitalepis, sr.

Glifforhynchus, 592. vermiculatus, sif. dentionlatus, s92.

iolseir, 588.

Trei, \$8r.

Gudkthe b14 the itwa sen $x$, titio.

Hemiex rodus 618 

Fierasfer (cont.). nuntius, 605. posterus, 605.

Fistularia, 374. bolcensis, 375 .

conternaschinensis. 375.

37 -dubia, 376. koenigi, 374. Rormomst 88 longirostris, 375 . tabacaria, 376 tenuirostris, 375 .

Fistularilde, 373.

Fundulus, 200 .

Gadide, 597.

Gadopsis, 613 . breviceps, 613 .

Gadus, 599.ciroforanaso æglefinus, 598 aspics, $60 \%$. elegans, 600. faba, 604. pespolingi, 601 latior, 601. Kenirteas, for lnseus, 600 . merlangus, 600 . merluccius, 589. minutus, 601. morrhua, 601 . pollachius, 601 . polynemus, 601 . pseudæglifinus, $600^{\circ}$. simplex, 604 . spectabilis, 604 . stoppanii, 601 s tenuis, 604. tuberculosus, 604 . venustus, 604 . virens, 601.

Gasteronemus, 437. oblongus, 440. rhombeus, 439.

Gephyrura, 296. concentrica, 296.

Gerres, 523. massalongoi, 523.

Gigantichthys, 612 . pharao, 612.

Gillicus, 99, 101. arcuatus, 101. polymicrodus, 101.

Glossodus, Cuvier, 60 heckeli, 73. Costa ins

Glyptocephalus, 570. radiatus, 570 .

GовIID

Gobitformes, 587.

Gobio, 303. analis, 304 . major, 615 . ricinus, 615.

Gobius, 588. barbatus, 581 .

PAR'T IV.
Gobius (cont.). bassanii, 588. brevis, $\overline{5} 82$. conicus, 584 . elatus, 58t.jelongatus. francofurtanus, 588 . "leptosomus, 588. $C$ : 5 E] lobini, 588. macroactus, 588 . macrurus, 581. maximus, 588 . microcephalus, 588. multipinnatus, $58 t_{\text {. }}$ s 58 oblongus, 584.pr peruzzii, 588. placicephalu smyrnensis, 448 . veronensis, 581 . vicinalis, 588 . vienuensis, 584.

Goniognathus, 577. coryphænoides, 577. maxillaris, 577.

GoxorHYNCHID 2,271

Gonorhynchus, 271. greyi, 271.

Gyunodontide, 570.

Gymnodus, 572, 5\%5. diodon, 575 .

heterodon, 575 . monsegurensis, 5,5 .

Hacquetia, 012 . bolcensis, 612 .

Halec, 212. Cassanii,220 eupterygius, 213. guestphalicus, 2:20. haueri, 219. laubei, 220 . microlepis, 218. sternbergi, 212.

Halecopsis, 133. insignis, $1 \% 4$. lævis, 134 .

HalosauRID.e, 162.

Halosaurus, 162.

Hallomi, 1.

Hemibranchit, 369.

Hemicyclus, 59 . streblensis, 59.

Hemielopcpsis, 58 . gibbus, 58 . gracilis, 58 . suessi, 58.

Hemilampronites, 59. steinlai, 59.

Hemiramphus, 358. edwardsi, 358.

Hemirhynchus, 488. colei, 488 .
Hemirhynchus (cint.). deshayesi, 488. zitteli, 487 .

Hemisaurida, 270 neocomiensis, 270.

Hemithyrsites, 481 . armatus, fol. elatus, 481. maicopicees:

Hemitrichas, 323. schisticola, 323 .

Heptadiodon, 5̄1, $5 \% 5$.

echinus, 57t.

Heterobranchus, 325.

palæindicus, 325.

Heterolepis, 612.

Heterotis, 74 .

Hexapsephus, 322 guentheri, 322.

Histialosa, 58. thiollieri, 58.

Histiocephalus, 579

bassanii, 579.

Histiophorus, 495.

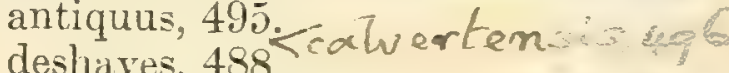
eocrenicus, 495 bomalurhamphus, 497.

parvulus, 497 .

priscus, 491

robustus, 497.

rotundus, 495 .

Histiothrissa, 131. crassapinna, 132. macrodactyla, 131.

Histiurus, 139 .

elatus, 146 . serioloides, 146 . ventricosus, 116 .

Hclacanthus, 561. microcephalus, 561 . piovenorum, 561.

Holcodon, 190. 204. lesinaeusis, 219. lycodon, 204.

Holcolepis, 11, 20. cretaceus, 20.

Holocentrum, 412 . calcarifer, 502. lanceolatum, 521 . macrocephalum, 412 . maculatum, 504 . melitense, 413. pygæum, 413. pygmæum 414. sogo, 412.

Holosteus, 270, 257.

esocinus, 270

marios 257 
Homonotus, 407.

dorsalis, 408.

rckundus, 40g. pulcher, 392.

Homorhynchus, 488. bruxelliensis, 490 .

Hoplopteryx, 396. Jrevis, 406. Tewesiensis, 397. lewisi, 404.

flundensis, 404. minor, 406. oblongus, 406. spinosus, 407. stachei, 406. superbus, 403. syriacus, 405 . zippei, 397.

Hoplostethus, 414. ingens, 414.

laciniatus, 414 . lawleyi, 414. nettelbladti, 414 , ostiolatus, 414. pisanus, 414.

Hyperlophus, 139.

Hypsodon, $37,92$. lewesiensis, $33,40,45$, $94,95,98,109$. minor, 102. oblongus, 26. toliapicus, 24 .

Hypsospondylus, 58. bassanii, 58.

Hyptius, 58. sebastiani, 58.

\section{Ichthyodectes, 99 .} acanthicus, 107 . anaides, 100. arcuatus, 101, 110. cruentus, 107. ctenodon, 100. elegans, 103. goodeanus, 107. hamatus, 107. Nibanicus, 105.

$10 \%$ minor, 102. multidentatus, 107. occidentalis, 101. perniciosus, 107. polymicrodus, 101. prognathus, 107. serridens, 101. tenuidens, 104.

Ichthyotringa, 265, 269.

tenuirnstris, 269.

Iguana (?) haueri, 564.

Imogaster, 391 . auratus, 394,419 .
Ischyrhiza, 46. antiqua, 45 cmilem 46 mira, 46 .

radiata, 46,614 .

Ischyrocephalus, 190.

cataphractus, 202.

gracilis, 201.

intermedius, 202.

macropter'us, 202.

Isodus, 190. sulcatus, 199 .

Istieus, 66 .

gracilis, 70.

grandis, 67.

lebanonensis, 71 .

macrocephalus, 67,70 .

macrocoelius, 67.

mešospondylus, 67 .

microcephalus, 67.

spottii, 71.

Istiophorus, 495.

Isurichthys, 453.

macrurus, 453.

orientalis, 453.

Isurus, Agassiz, 453. macrurus, 453 .

Julis, 541.

agassizii, 540 . muensteri, 540 . sigismundi, 541 .

Kurtus velifer, 430, 431.

Labeo cuvieri, 616 .

Labidesthes, 361 .

Labrax, 509.

bosniensis, 512.

delheidi, 512.

elongatus, 512.

heckelii, 510 .

intermedius, 512 .

latus, 512.

lepidotus, 512.

longiceps, 513.

major, 513.

mojsisovicsi, 513 .

multipinnatus, 513.

neumayri, 513 .

oeningensis, 511.

sagorensis, 513.

schizurus, 510 .

steindachneri, 513.

stiriacus, 513.

ubinoi, 510 .

LABRIDE, 539.

Iabrodon, 541 . africanus, 542 . alsinensis, 545 . bazini, 543 .
Labrodon (cont.).

belgicus, 543 .

bourgeoisi, 543 .

britannus, 543 .

canariensis, 542.

carolinensis, 543 .

chantrei, 543.

cocchii, 543.

crassus, 544 .

dilatatus, 544 .

edwardsi, 544.

gaudryi, 544.

baueri, 514.

heterodon, 544 .

multidens, 544.

pavimentatum, 544 .

polyodou, 545.

quenstedti, 545 .

rhedonum, 545 .

sacheri, 545 . ringetes, 545

sauvagei, 545 .

sellæ, $5 \pm 5$.

soldanii, 545,

superbus, 54?:

trapezoidalis, 545.

trigonella, $5+6$.

Labrophagus, 611. esocinus, 611.

Labrus, 539 .

agassizi, 540 .

bifasciatus, 464

ibbetsoni, 540 .

malapterus, 595 .

merula, 540 .

microdon, 540 .

parvulus, 540 .

priscus, 540.

punctatus, 558 .

rectifrons, 558 .

turdus, 504 .

valenciennesi, 540 .

woodwardi, 541.

Laparus, 596 .

alticeps, 596. Larimus, 518.

Lates, 502.

gibbus, 502.

gracilis, 502.

heberti, 499.

macropterus, 503.

macrurus, 503.

notæus, 502.

partschi, 503.

sagorensis, 513 .

Lebias, 290.-Lrispinasus, 503.

aymardi, 292.

cephalotes, 290.

crassicaudus, 295.

crassus, $296^{\circ}$.

eisgrabensis, 294.

furcatus, 291.

gaudryi, 294. 

Iniomi 235: Tabrodon Homernezumia (scale) inirmus, 618.

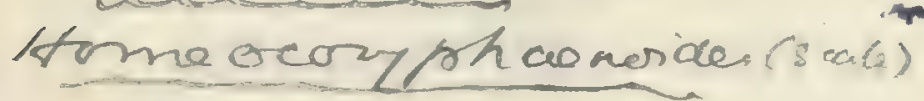

confentidens, sty 3

defressus, s-4hice

Aydreyon 207

Heserexphion, 605

3 uces, 335

nekamenai, 355

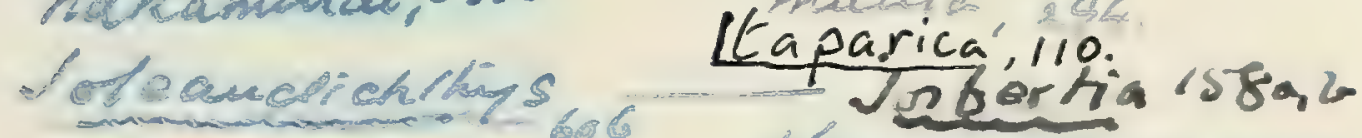

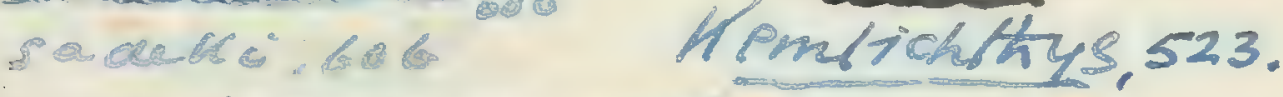

Jemelkia.579 kansamp.73.

Kadsurrorppiss." Kansius, 412

stènbergi, 412.

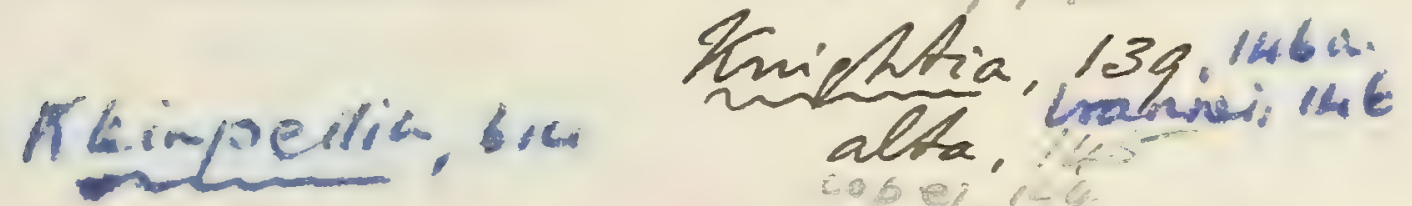

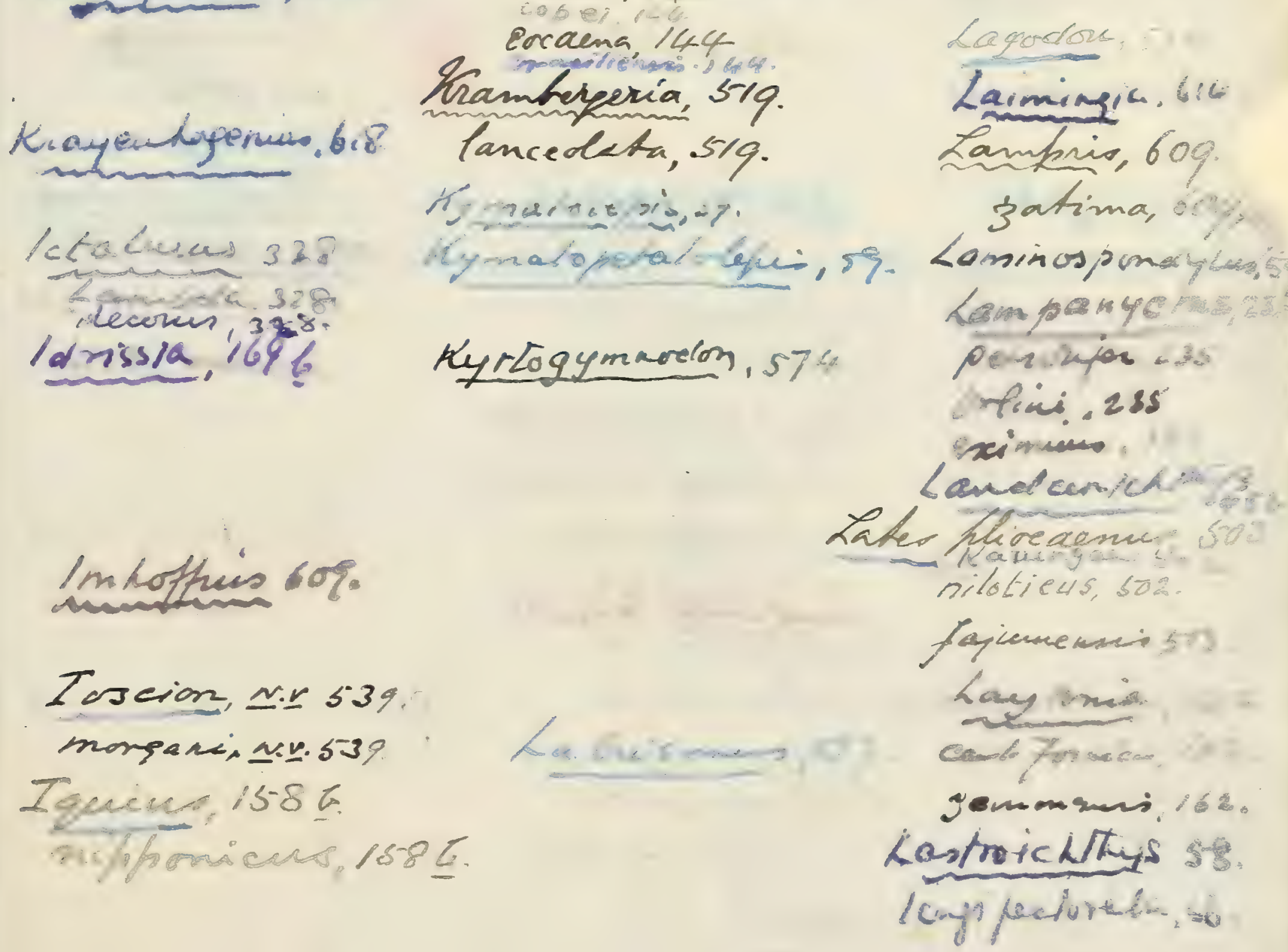


Lebonichthys 16

rednevia, kiq.

Lemisicus, 15t A

meiklejotini, 158a.

beria 520 .

silinica,

engrounius, 477

Zerichei, 479.

oswardi, 311 .

moravic as 3 .

lovisatoi, 481 .

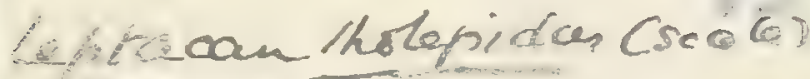

reddingi, 323.

DATOSCOPIDE: 5TY.

pachecoi, 306 .

itaik $2 \$ 610$

ocominatagiensof

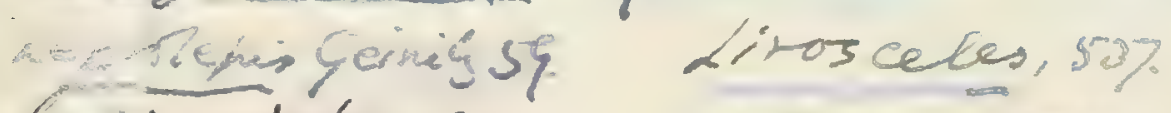

torsicephatus, 3 . elequns.

Lompochites, 스. \$35.

Lestichthys,290. Hopkinsi, wirs38.618

youcensi, 270 , Tompoguia, 539

retropes. 539.618

Lientites, 116 .

Luscichltyops, 162 . cretacens, 116 .

rimgans, 162.

Lithopecribus? $\operatorname{totan} 0.03$

hulac,603.

Lotimazpha, 598.

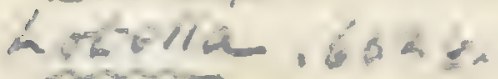

Luspia, 521 .

carotti; 521 .

Litianidat, 524

Lutiamus 524 hagari, 524

Luvarus, Nㅡ 482 .

Tiygisma, $158 \mathrm{Z}$

tenaxe, 158 L., 618

suxilión.?

Macronorides,"

astsoni,

Macropetalolepis, ils.

MacronichJhys.32\}.

Maena. 5.37

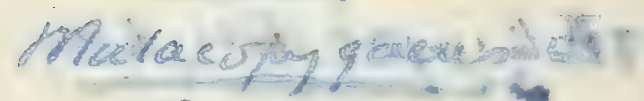

Manchurichtho,

un atokoi, 1.

Macistats stib

Mastizenences.

Marcullehella 52, 2 .

Mabarbia >52

ofumia, 458-

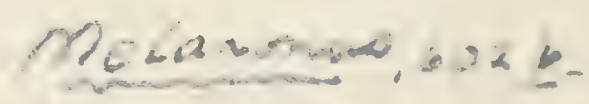

Zophar, 4so

mioedenus, 450 


$$
\text { , }
$$



Lebias (cont.). gobio, 294. meyeri, 294. minimus. 294. perpusillus, 291. tenuis, 294. zignoi, 294.

Lepidenteron, 185. longissimum, 185.

Lepidocottus, 581 . aries, 582.

brevis, 582 .

elongatus, 584 . gracilis, 617 . multipinnatus, 584 . papyraceus, 583.

Lepidopides, $47 \%$. brevispondylus, 481 . dubius, 481. leptospondylus, 481.

Lepidopus, 477. albyi, 480. 7. N. anguis, 480 .

brevicauda, 480 .

,carpathicus, 480 . dubius, 481. glarisianus, $477 . \mathrm{C}$ (permenses) leptospondylus, 481 . meneghinii, 481.

Leptecodon, 233. rectus, 233.

Leptichthys, 616. agilis, 616 .

Leptocephalus, 346 . gracilis, 346 . medius, 347 . tænia, 346.

Leptolepide, 1.

Leptosomus, 244.

arhiopicers, -crassicostatus, 246. $24 k$ c. elongatus. 245. guestphalicus, 245 . macrourus, 245 . minimus, 246.

Leptotrachelus, 173. armatus, 174. elongatus, 184. gontonii gracilis, 180. 18). hakelensis, 184 longipinnis, 187. sagittatus, 187. toiqueter, 174, 183. virgulatus, 187 .

Leuciscus, 305. acrogaster, 310. aula, 311.

bosniaskii, 310 . brevicauda, 310. brevis, 310 . bubalus, 310 . castellinensis, 311.

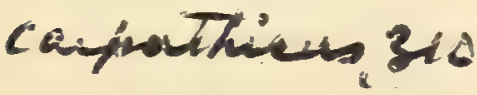

Leuciscus (cont.). cecconii, :312. cephalon, 307. cephalus, 309 . colei, 308 .

dorsalis, 311,312 . dumerili, 311,312 . eibiswalciensis, 310 . elegans, 315. erythrophthalmus, $: 309$.

eurystoinus, 311.

fritschi, 615 .

gabblensis. 311.

gibbus, 310.

gracilis, 314 . haue
hartmanni, 314.

helveticus, 305.

heterurus, 310.

krantzi, 311. kikua:

larteti, 311. 3io

latiusculus, 305 .

leptus, 309.

licatæ, 311.

macrurus, 308.

medius, 310. miccenseut

oeningensis, 305 .

papyraceus, 307.

plesiopterus, 311.

polysarcus, 311.

puellaris, 311.

pusillus, 306.

racalmuti, 311.

remotus, 311 .

rutilus, 309

sauragei, 312.

sicanus, 311,312 .

stephani, 311, 615 .

tarsiger, 315 .

turneri, 311.

vexillifer, 311. virgo. 311

Leucus, 322.

condonianus, 322 .

Jatus, 322.

Leuresthes, 361.

Lewisia, 48. ovalis, 53.

Lichia, 445 . a]ta, 446 . analis, 445 .

lata, 445 .

prisca, 444.

secunda, 446.

stoppanii, 446.

Lobodus, 537.

pedemontanus, 537.

Lobcpter us, 415. pectinatus, 415 .

LOPHID E, 591.

Lophius, 591. brachysomus, 591 . ZoZZorisq.
Lophius (cont.). patagonicus, 591 .

repiet piscatorius, 591.

Loricaria, 591 . plecostomus, 591 .

Loxostomus, 611. mancus, 611.

Lucania, 290.

Lucioperca, 521. skorpili, 521.

Lucius antedilurianus, 288.

Lutianus ephippium, 524 502,561 .

Lutodeira, 64.

Iycoptera, 1.

cherenemis coptera, 1. ferox, 3. macrorhyncha, ‥ fragit's middendorffi, 2. sinensis, 3.

Lyrilolepis, 59. okunaga. crucasicus, 59 .

Macrolepis, 415. elongatus, 415 .

Macrones, 327. aor, 327 .

Macrostcma, 561 . altum, 661 .

Macreride, 605.

Macrurus, 60อ̃. præcursor, 605.

Mallotus, 160. villosus, 161.

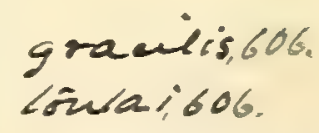

Megalodon, 37, 92. lewesiersis, 95 . sauroides, 95.

Megalolepis, 482, $5 \% 8$ - bascheaensis, 482. minuhes, 4E: latus, 482.

Megalops, 24. forcipatus, 65 . oblongus, 26. priscus, 24.

Megalurites, 571. nitidum, 572.

Megapus, 280. guestfalicus, 283.

Megistopus, 280, 284. guestfalicus, 283.

Meletta, 146. crenata, 151. doljeana, 159. gracillima, 155. grandisquama, 155. heckeli, 151. heterostoma, 152 . intermedia, 156 . longimana, 151. parisoti, 151. presardinites, $15 \pi$. sahleri, 151. 
Meletta (cont.). sardinites, 152. scheuchzeri, 147. styriaca, 157.

Melettina, 151 .

Mene, 437.

oblongus, 440 . pusilla, 441.

rhombeus, 439 .

Menidia, 361 .

Merlangus, 600. cognatus, 604. spatulatus, 604 . suffolkensis, 600 . vulgaris, 600 .

Merlinus, 603. cristatus, 603.

Merluccius, 601. Tf 0 ? attenuatus, 604 . balticus, 604 . massogeta bosniaskii, 601.588. emarginatus, 604 miocenicus, 604 . in 5 ? obtusus, 604.

Mesogaster, :61. cretaceus, 362. gracilis, 254. sphyrænoides, 362.

Metoponichthys, 558.

longirostris, 559 . octacanthus, 5.59 .

Microcoelia, 252. granulata, 252. libanica, '25:2.

Microdon nuchalis, 429.

Mìcrodon pulchellus, 421.

Mioplosus, 517. abbreviatus, 518 . beani, 518 . labracoides, 517. longus, 518. multidentatus, 518 . sauvageanus, 518 .

Monocentris, 414.

coxi, 4/3. hospes, 414. sommi4:3. integer, 414 subrotundus, 4]5.

Minopteros gigas, 89 .

Morrhua, 599 . æglefinoides, 601. extensa, 601 . faba, 604 . lanceclata. 601. lata, 605. macropterygia, 601. minima, 601. soellingensis, 605 . szagadatensis, 601 .

IIosasaurus gracilis, to.
IN DEX.

Mulleas, 5 bl.

Mugil, 363. aces, 364 brevis, 446 . freyand. cephalus, 364 . debilis, 365. chadarini 36 s. dering $360^{\circ}$ princeps, 364 .ormokis 365 radobojanus, 365 .

MUGILIDE, 363.

Muræna cæca, 347.

Muræna conger, 344 .

Muræua lewesiensis, 185.

Muræena myrus, $3+1$.

Muræna ophis, 347 .

Mcrenide, 336.

Mylocyprinus, 322. inflexus, 322.

kingi, 323 .

longidens, 323 . robustus, 322 .

Mylopharyngodon, 323.

Myripristis, 410 . homopterygius, 411 . leptacanthus, 410 toliapicus, 412 melitensis, 413 .

Myrus, 340. vulgaris, 341 .

Naseus, 564. brevirostris, 564 . nuchalis, 565 . rectifions, 564 .

Naupygus, 611. bucklandi, 611 .

Nemachilus, 320. bredai, 320 . centrochir, 320 . cephalotes, 321. tener, 615. mus teyleri, 321 ." Jumatis 320

Nematcnotus, 249. botta, 250.

Nemopteryx, 598. crassus, 598. Uthanasy elongatus, 598.kulvaes troscheli, 598. mriviris

Nettastoma, 346. bolcense, 346 .

Notacanthind, 1 li8.

Notacanthus, 169.

Nutzus agassizii, 540 .

Notelops, 27. brama, 27.

Notogoneus, 275. cuvieri, $277,615$. longiceps, 278. osculus, 275 . puiv? squamosseus, 276.

Notopiteride, 85.

Notopterus, si. primarus, s6.
Nummopalatus, 5 11 , 544.

abbas, 543 .

africanus, 542 .

bazini, 543 .

belgicus, 543

bourgeoisi, 543

britannus, 543 .

chantrei, 543.

cocchii, 543.

edwardsius, 544.

gaudryi, 544 .

halieri, 544.

heterodon, 544 .

multidens, 544 .

pavimentatus, 544 .

polyodon, 545 .

quenstedti, 545 .

rhedonum, 545 .

sacheri, 545.

sauvagei, 545 .

trapezordalis, 545 .

Odax carolinensis, 543.

Odonteus, 556 . depressus, 556 . pygmæus, 556. sparoides, 556 .

Odontostomus, 189

Oligobelus, 323. arciferus, 323.

laminatus, 323.

Oligopl archus, 519. squamipinnis, 519.

Omiodon, 270. cabassii, 270.

Ommatolampes, 490. eichwaldi, 491

Omosoma, 419. intermedium, 420 . monasteri, 421 . pulchellum, 421. sahel-alma, 419.

Omosudis, 189.

Oncolepis, 595. isseli, 597.

OpHidide, 605.

Ophidium, 605.600 barbatum, 343 , 347 / ursipin a 5 élesans, 60 voltianum, 605 .

OpHiocephalide, 369.

Ophiocephalus, $: 60$. striatus, 464.

Ophisurus acuticaudus, 347 .

Opisthomyzon, 451 .

Opisthopteryx, 253

curtus, 2:-

gracilis: 254. 
. 

morsmides , 4n

scueptatia, 158a.

Morella, bol.

inicenatas, 601

Mrazecia. 235 ?

mraj--i. 235 :

Muraene sahelienai: 3.35.

Xigerophuse: $2355^{\circ}$

Brolite wallicm, 23 or.

columnae, 315,494

ectavard 85: 3155 .

mierorna, 'sy.

yersicus, sqie.

Merriamina, 605,520 My tomyru, 343. ectenes, 605,520 frangen, 343.

Mescchpea. 128.

showchangensis, 128 .

Mus exia

glaticophala, 128 .

naciek

Myotetancelox 322 .

$120 \log 6150$ is

Microehins, Gos

Nattande- dit

apropleñy, 608

Neomaenis, 524 .

samayei, $6 m$.

Merriamella, 363 dorysa, 363

Nyctophus Nerinatio" 194

microsoma 157 ecromitisis sel

Geystias, $482,-20$.

sagitta, 482 rnus

Ofyopertesin.

ofigutalistes, sot.

Tosent 2

Onchosanares.

Onobrosmill

Nemí Athy? 347.

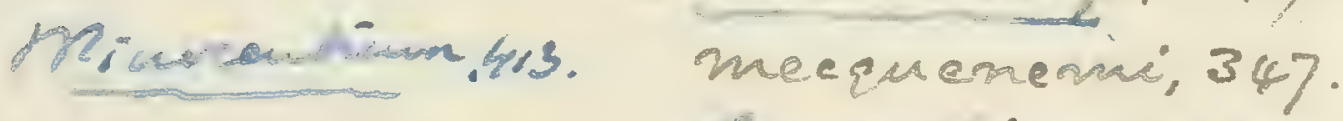

Lemachibs, 323.

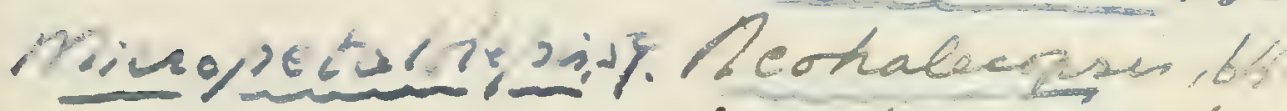

reocybium, 476 .

Niqeciean: rostratum, $47^{6}$.

gackus, NIOBRARIDRT,73.

anumare, Neopercis, $59 \%$.

portumas, 45y. Niphon, 503 .

cispiñosus,

Nowbcoplía, '

Mixogrammarelexis. Notropis, 322.

angustarans, 322.

oligodicolon

Omaloplenuer sleciosus, s.

Ophisuress Itre acurticanater

Ophiociontrats

Gehiodon rell 48

bantadiom osymandis:

Oelapis.n:

Oplegnarkías

Oplegmario.

mann;

Of is hor sisen

Nobrodectes. 99. 
bormhabmiencici, 618 .

Ophepoitrin, 523.

ingus, 242

hampstinensis, 617.

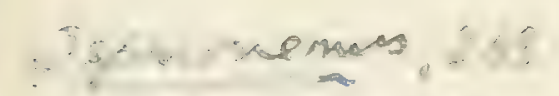

gecomply it!

Cstaciustoma,129.

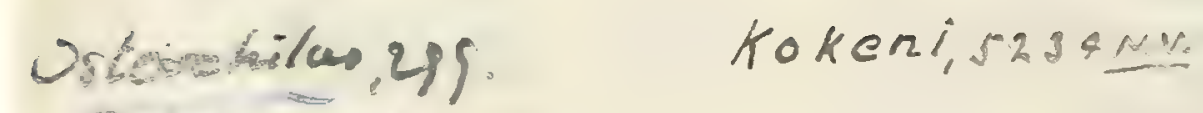

Oxysonibgidus (scale)

Osymandias, 4821me gillent: 482 rn.v. 

Orcynus, tit.

kompóschi, 456 .

lanceolatus, 456 .

latior, 456 .

medius, toti.

scaldisii, 455 ?

Oricardinus, $4 b$.

tortus, 46.

Orthagoriscus, 576 .

chelonopsis, 576.

Osmeroides, 11.

attenuatus, $1 \%$.

belgicus, 르.

brevis, 16.

crassils, 10 .

cretaceus, 20 .

diraricatus, 202.

dubius, 16.

erolutus, 72 .

glarisianus, 255 .

gracilis, 16.

granulatus, 213.

insignis, $13 \pm$.

latus, 16 .

leris, 15 .

leresiensis, 11, 13 .

lewisi, 17.

mantellii, 12.

maxinus, 18.

megapterus, 132, 239.

microcephalus, 237.

minor, 13:

monasterii, 237, 238.

pectinolepis, 22 .

polymicrodus, 72.

sardinioides, 19.

rinare: sis, 21 .

Osmerolepis, 59. reticulata, 59.

Osmerus, 162.

albyi, 162 .

cordieri, 247 .

d'achiardi, 16 ?

glarisianus, 255 .

larteti, $16 \%$.

proptersgius, 162 .

scarabellii, 162.

stilpuos, $16: 2$.

Ostariophysi, 296.

OSTEOGLOSSIDE, 73.

Osteoglossum, it. encaustum, 76.

Ostracion, $519 \%$

imperialis, 566 . dur ner.

oblongus, 569.

turritus, 569.

Otolithus, pasein seep.6/4. acuminatus, $611.86 / 4$.

acutangulus, $60 \%$.

adjunctus, 587.
Otolithus (cont.).

requalis, $5 \%, 498$.

americanus, 451 .

amplus. 539.

approximatus. 610.

attenuatus, $60 t$.

ralticus, 604.

bararicus, 606 .

biscissus, 590. Themicue

boettgeri, 605. 357

brevior, $3 \pm 7$.

claybornensis, j38 38 selus)

cognatus, $60 t$ (9copelus circurers.

cor, 587. - eottreaui, 270

crassus, 332 , 33 tume 1522.

danicus, 334 . cones torms,

(Berrcidarum) debilis, \pm 1 o.

(Mugilidarum) debilis, 365.

decipiens, 538.

difformis, 605.

dispar, 588.

distinctus, $52.2 .9 \mathrm{~N} . \mathrm{V}$.

elegaus, 600, 50 \%. Tophid

elegantulus, 532.

eleratus, 603.

ellipticus, $58 \%$.

elongatus, 539.753894 .46 og

emarginatus, 604 .

eporrectus, 538.

faba, 604. Ginlayisyl.

francofurtanus, 58?.

frequens, 52.2 .

gemma, 538 .

germanicus, $33 \mathrm{t}$.

geron, \pm 15 .

gibberulus, 539 .

glaber, 610.

gregarius, 558

guestfalions, 611.

Thilgendorfi, 605 .

holsaticus, 539 .

hospes, $41 t$.

hrbridus, 605.

ingens, 41 .

insignis, 539.

insuetus. 538.

integer, 414 .

intermedius, 538.

irregularis, 539. jaekefi

kirchbergensis, 530 . 354

>laciniatus, 414 .

lavigat us, 590.

latisulcatus, 603 laneeulata

003.587

latus, 605.

lawleyi, 41 .

lenticularis, 611 .

marchicus, 605 .

meridionalis, 533 .

mereri, 603.
Otolithus (cont.) - 0.(Elops) mioroence

miocenicus. but.

moguntinus, 522498 .

23

mucronatus, (6)t.

mutabilis, 590 .

neglectus, 415 .

nettelbladti, $t 14$.

nobilis, 5203 .

noetlingi, 522 .

nuntius, 605.

obotretus, 605.

(Merluccius) obtusus, 604.

(Scima) obtusus, 539.

oceultus, $60 \overline{\text {. }}$

ostiolatus, 414 .

oratus, 539.

parrulus, 415 -pantanelli, st.

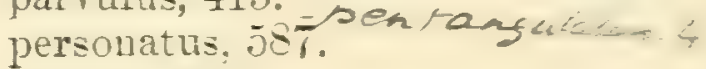

pisanus, 414 .

planus, 604.-s sicutilis.

plebejus, 522.2. 4 N.v.

ponderosus, 604 .

posterus, 605.

præcursor, 605.

primas, 587.

- pukensiensi.

Jadians, 538. Tectus, 521.

(Berycidarum) rhe-

manus, 415

(? Rhombus) rhenanus, 608.

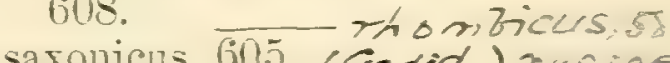

605. (Gadid.) rus ace sector, 6u9.

seelandicas, 590.

(Morrhua) soellingensis, 605

(Sparidarum) soeilingensis, 533.

similis, 238.

simples, $604.9 \%$

singularis, 606 .

spatulatus, 604 .

speciosus, 539.

spectabilis, 60t. $<$ seoporas/sa

sulcatus, 585 .

subrotundus, I1 5abnovicis,

suffolkensis, 600. (Gadid)'siz

supracretaceus, 41 .

tenuis, 604.

testis, 158.

thrnnoides, t8:- Toulario C

tubereulosus. 60t.

rangionis, 33t. -umbonatis, 6/3

rarians, 5:2.

renustus, 604 .

rerus, 590.

ricinalis, 588.

rulgaris, 600 .

Pachycephalus, 611.

cristatus, 611. 
Pachygaster, joo. polyspondylus, 520 .

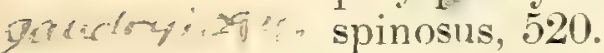
3040.294. Pachylebias, 294. rcicalmati, Jll crassicaudus, 295. 8. mow 295. Pachyrhizodus, 37.

basalis, 37 .

caninus, 44 . curvatus, 44. dibleyi, 38. gardneri, 40. glyphodus, 258. gracilis, 45.

kingii, 42.

latimentum, 42 . leptognathus, 45 . leptopsis, 45 .

marethacusis 10 frinimus, 45. sheareri, 45 . subulidens, 43 . velox, 45.

Pachystetus gregatus, 292.

Pagellus, 532. aquitanicus, 533.

-amori 533.de stefanii, 533. elegantulus, 53:. leptosteus, 533. libanicus, 390 . microdon, 533 . peruzzii, $5: 33$. stenoura, 533.

Pagrus, 533. meneghinii, 533. ondrianus, 533. pileatus, 533. priscus, 533 . torus, 534.

Palæobrosmius, 598. elongatus, 598.

Palæogadus, วั98.

troschelii, 598.

\&- Palæolycus, 211. dreginensis, 211.

Paleorhýncidde, 482.

Palæorhynchus, 483. bruxelliensis, 490 . colei, 488.

deschmanni, 487. egertoni, 488. giganteus, 487 . glarisianus, $483,48 \%$. gracilis, 486. latus, 485.

longirostris, 486 . medius, 485. microspondylus, 489 riedli, 487. zitteli, 487.

Palanarrhichas, $59 \%$. crassus, 597.
Palimphemus, 270. anceps, 270.

Palimphyes, 460 .

brevis, 460 . rerassus, 460 . elongatus, 460. glaronensis, 460 . grarilis, 460 . latus, 460 . longus, 460 .

Pantopholis, 234 . dorsalis, 234 .

Paralates, 5:0. bleicheri, 520.

Paralepis, 257.

Paraleuciscus, 312 . ecnomi, 312.

Paranguilla, 343. tigrina, 343.

Paraperca, 520. provincialis, 520 .

Paraphyllodus, 546.

Parascopelus, 256. lacertosus, 256.

Parequula, 450 . albyi, 450 .

Pegasus lesiniformis, 269.

Pegasus natans, 383.

Pelamys, 48\%. adunca, 482. robusta, 482. sard $\alpha$,

Pelargorhynchus, 188.

blochiiformis, 188. dercetiformis, 188.

Pelates, 523.

quindecimalis, 523.

Pelycorapis, 354 .

berycinus, 354.

varius, 354 .

Perca, 518.

alsheimensis, 513.

beaumonti, 515.

cyprinodon, 509 fower ' elongata, 515.

fluviatilis, 518 . forbesi, 510 . formosa, 410, ignota, lepidota, 511 . as 5 lorenti, 518. lucioperca, 511. macracantha, 518. minuta, 506 . moguntina, 512 . punctata, $366^{\circ}$ radula, 526. reboulii, 520 . uraschista, 516 .

Percesoces. 347.
Bercichthys, 51t. antiquus, 514.

beaumonti, 515 .

Percide, 498.

4 61. Perctformes, 497.

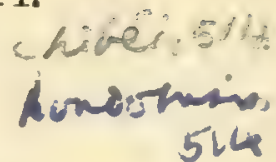

Percostoma, 519. angustum, 519.

Peristedion, 586. personatus, 587. urcianensis, 586 .

Phacodus, Cope, 553. irregularis, 553.

Phacolepis = Rhacolepis.

\% cybioides, 458.

Phareodus, 74, 76 . acutus, 76 .

sericeus, 76 .

Pharyngodopilus, 541,545

abbas, 543 .

africanus, 542. alsinensis, 544 . bourgeoisi, 543 . canariensis, 542. carolinensis, 543. crassus, 544. dilatatus, 544 . haueri, 545. multidens, 544 . polyodon, 545 . quenstedti, 545 . sellæ, 545 . soldanii, วั45. superbus, 542.

Phasganodus, 190. anceps, 203. australis, 615 . carinatus, 204. dirus, 204. gentryi, 615. gladiolus, 204. semistriatus, 205

Phasganus, 613. declivis, 613.

Pholidophorus macrorhynchus, 2.

Phycis, 602.

* suessi, 602.

Phylactocephalus, $212,218$.

microlepis, 218.

Phyllodus, 546.

bowerbanki, 549 .

culei, 549.

corsicanus, 574 .

cretaceus, 550 .

curvidens, 550 .

deborrei, 550 .

deplessus, 550 .

durali, 550 . 




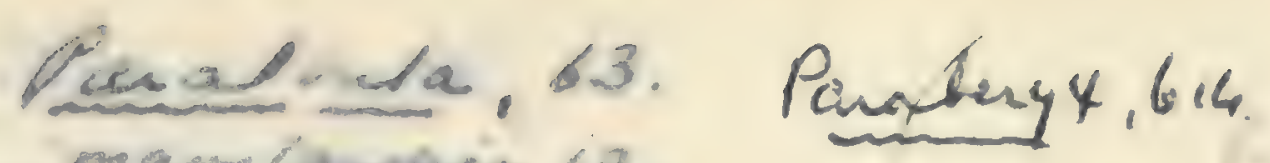

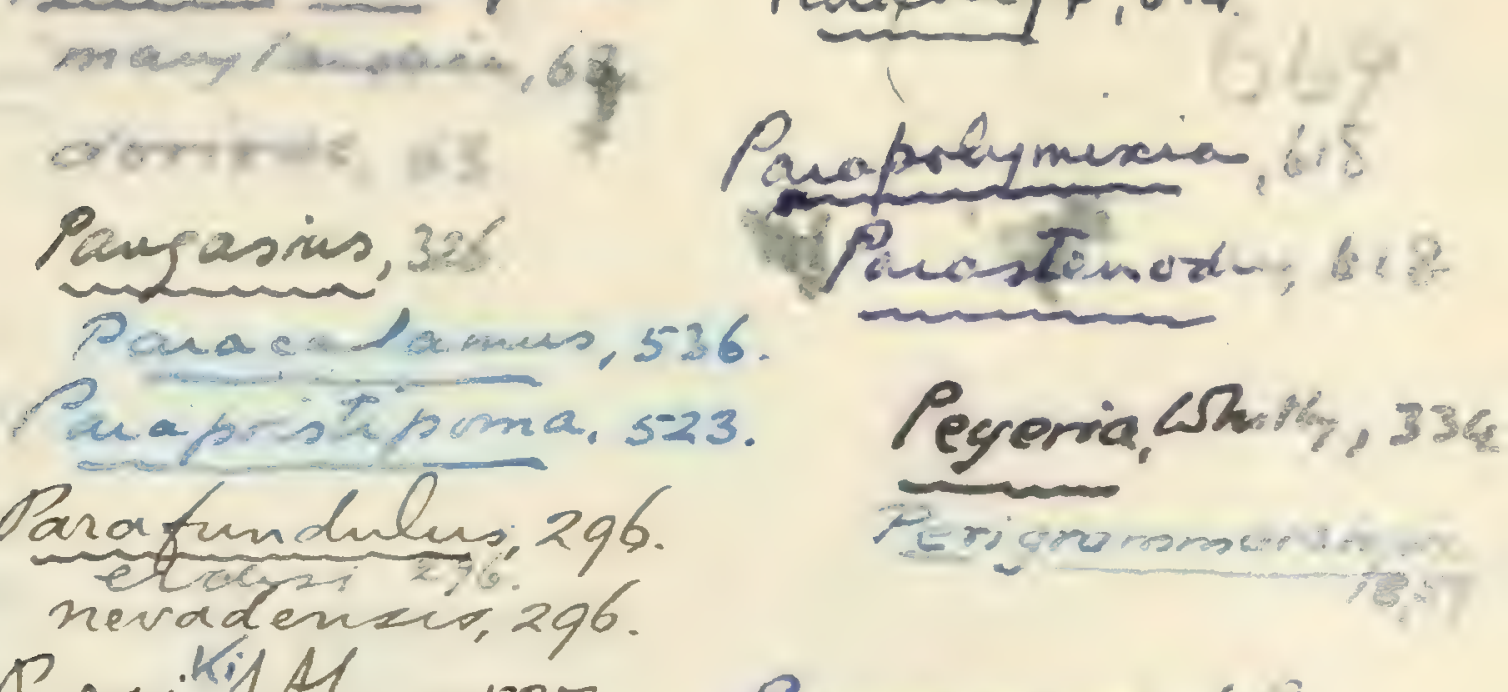

Paraicillthe, 537. Pinamorone, 6.6 ornatimimus, 537 .

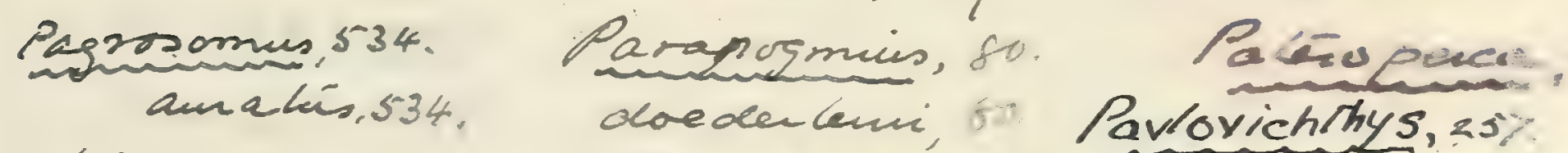

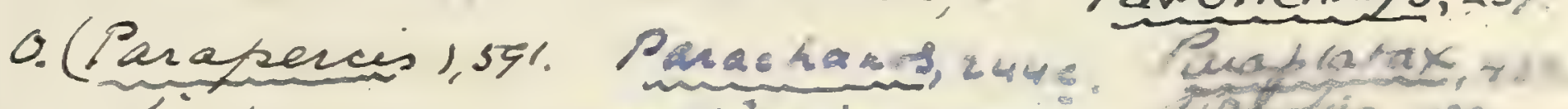

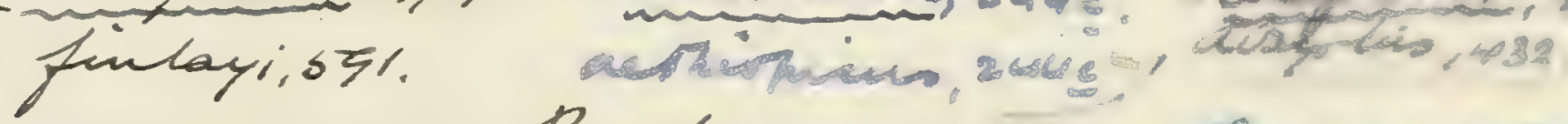
Aarakzean $5-58$

Paratichltiss, 22. polyacanthue, 5-5s Paranincigu. Parelope" ".

remensis, 533. Prazakie, "Pareomy us, 341

-siracusanus, 5-33. Pelamycytium, 402

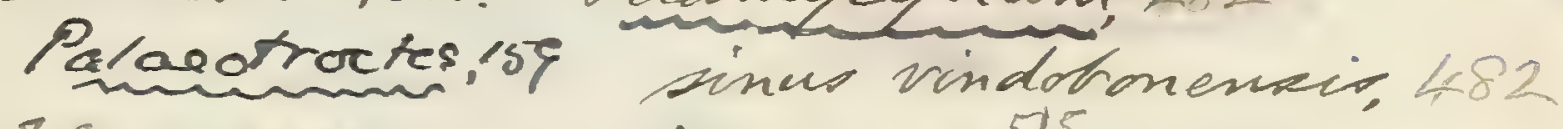
- Tepsizis3s. Pevcitia, p.515. distinctus, N.V.522. Perealatén 49 ?

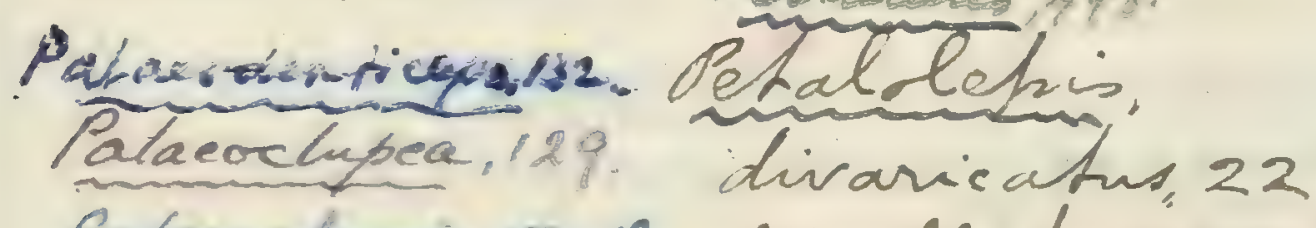

Palar thamis r5i, s: filvillitus, 22

Palaeomotra 588

Palaevelox, 28\%.

$$
\begin{aligned}
& \text { Pelecus, } 29 \text { ? } \\
& \text { Pencarina, } 499, \\
& \text { Obigrenisa, } 499 \text {. }
\end{aligned}
$$

Plopolick th

Palderescomber i45\% mavitume, 499.

spinosus, $45 \%$

Palaeorny uebreies. $35 \%$.

Palae bathy gadues (scole)

Prolumbiri, $2 \%$

Paleorantrates, 4 r\%

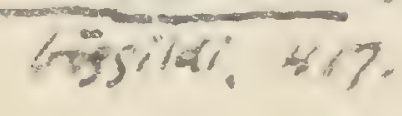


Proegabegza, bil.

Pracsermberesch, 618

PRACANTIHIDE, 4:5:5TI.

Triacenthus, 563 .

2olastus, 363 .

Plectrites. 536 .

spiñosus, 500.

classenti,536,618. Primolepis, 9einits $9 \%$

Phiserephahes, 612.

Qjsiculus, 606 .

6. licandatims, 606 .

Pitissma, 235 .

minimus, 235 .

Pirstenius 584

reveruen, 290
Provgentina. 162.

Protarkig gadurs scals

Trudiodon : 6

Prvagealues (sead) Procharax, 298.

sismmatianus,545. Problennius,597.

piosilurus, 325. filamentosus,

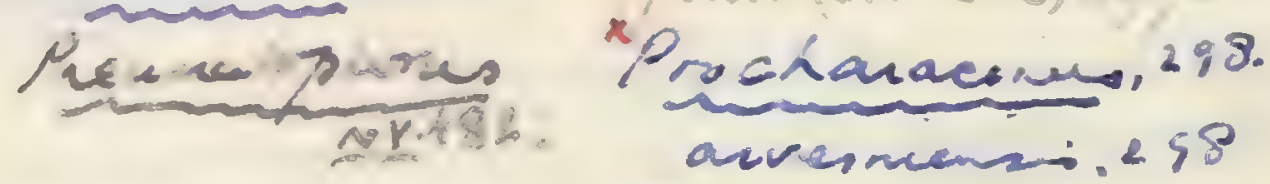

Polyipme, 235 f.

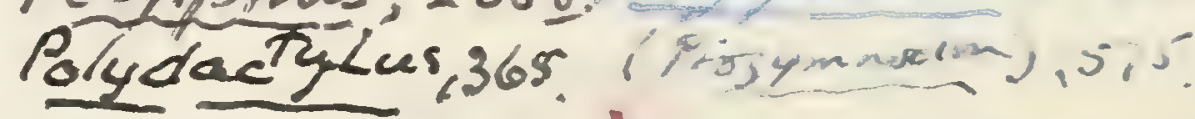

Polypserolepis."11. "Protydrven.298.

Pomadasidaes99. pelleginis. 298 .

POMATOMIDAS WIT

Pomolobec 1584.624.

Pemoxis, ssy.

Promacumes (sake)

Promerlucsius st9

ondrusoris

Promminecies Dacid (seales

Promegalops 27.

Profercanina, 499,

releli, 499 .

pierahmanmi, 49 s.

Proborthews. TS

kumanmas; ge?

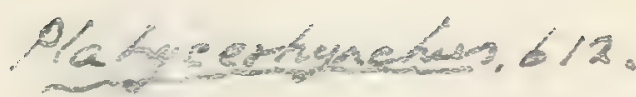




Phyllodus (cont.) elegans, 550 . gervaisi, 550 . haneri, 544 . hexagonalis, 549 . hipparionyx, 617 . incertus, 575 . inconstans, 550 . irregularis, 548 . latidens, 550 . levesquei, 550 . marginalis, 548 . medius, 548 . multidens, 544 . petiolatus, 548. planus, 547. polyodus, 547 . secundarius, 549 . speciosus, 549 . subdepressus, 544 . submedius, 549 . toliapicus, 546 . umbonatus, 550 .

Pimelodus, 328. antiquus, 329. aor, 327. sadleri, 335 .

Pisodus, 60, 61 . foucardi, 73 . oweni, 60.

Plagyodus, 189.

Planesox, 519. vorax, 519.

Platacanthus, 509. ubinoi, 510 .

Platax, 432. altissimus, 433. brevis, 429 . colchicus, 434 . costatus, 433. cuneus, 433. macropterygius, 433. minor, $42 \%, 428$. nuchalis, 429 . papilio, 433. physeteroide, 433. pileum, 433. pinnatiformis, 433. plinianus, 433. subvespertilio, 439 . woodwardi, 432.

Platessa, 608. sector, 609 .

Platinx, 89 . catullii, 89. elongatus, 89. gigas, 89.

Platops, 76. subulidens, 76 .

Platycormus, 421. germanus, 421 .
Platycormus (cont.). gibbosus, 42:3. oblongus, 422.

Platygenys, 613 . rugosus, 613 .

Platylæmus, 551. colei, 5.51.

Platylates, 520. rupeliensis, 520 .

Plectropoma uraschista, $516,61 \bar{b}$.

Pleionemus, 442. macrospondylus, 442.

Plethodus 80 . expansus, 81 .

furcatus, 84 oblongus, 83. pentagon, 83 .

Pleuracanthus serratus, 567.

Pleuronectes, 608. platessa, 434, 609 . quadratulus, 607.

Pledronectides, 606.

Plinthophorus, 221. robustus, 229.

Plioplarchus, 5ะ0. septemspinosus, 520. sexspinosus, 520 . whitei, 520.

Podocephalus, 519. nitidus, 519.

Podocys, 520. minutus, 520 .

Podopteryx, 587. albyi, 587.

bosniaski, 587 .

Poecilia lametherii, 615.

Pocilia oeningensis, 58\%.

Pœcilops, ¿966. breviceps, 296.

Pogonias multidentatus, 538.

Polynemus, 445. quinquarius, 411, 446.

Pomacanthus, 561 . subarcuatus, 561.

Pomacentrid e, 555.

Pcmaphractus, 76. egertoni, 76,80 .

Pomognathus, 212, 213.

eupterygius, 213.

Portheus, 92.

angulatus, 98.

arcuatus, 101.

australis, 97.

brachygnathus, 97.]

daviesi, 95. dunedimens. gaultinus, 95 . $8 \%$ gladius, 98.

jaxarticus. 97
Portheus (cont.)

lestrio, 97.

lowi, 97.

mantelli, 95 .

inolossus, 92.

mudgei, 97. patagonicus, 98

Prionolepis, 229. egen am

angustus, 230 .

cataphractus, 230 .

laniatus, 232.

Priscacara, 554 . clivosa, 554 .

cypha, 555. dartonxe

liops, 555.

oxyprion, 555.

pealei, 555.

serrata, 554

testudinaria, 555 .

Pristigenys, 415. macrophthalmus, 415 .

Pristipoma, 523.

furcaturn, 523.

Proantigonia, 558- Jevio s. os longirostra, 559 . coopresso : sact octacantha, 559 . radobojana, 559.- Thenens at steindachneri, 559 .

Proballostomus, 296. longulus, 296.

Prochanos, 65. rectifrons, 65 .

Progymnodon, 572, $5 \% 5$.

hilgendorfi, 575 .

Prolates, 499.

beberti, 499.

Prolebias, 290.

brongniarti, 293.

cephalotes, 290.

crassicaudus, 295.

davidi, 4.

egeranus, 615 .

furcatus, 291.

gaudryi, 294.

gobio, 294.

goreti, 293.

gregatus, 292.

meyeri, 294.

minimus, 294

oustaleti, 293.

perpusillus, 291.

pulchellus, 615 .

stenoura, 292. P

Pronotacanthus, 169.

sahel-almæ, 169. e'(forma are is)

Properca, 514.

angusta, 515 .

beaumonti, 515 .

lepidota, 511.

prisca, 516.

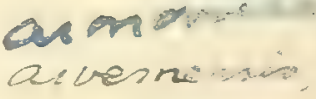

aivern.;.:. 
Protaulopsis, 371. bolcensis, 371 .

Protautoga, 553. coniclens, 553 . longidens, 553.

Protelop3, 56. anglicus, 57. geinitzi, 57.

Prothymallus, 614. lusatus, 614. princeps. 614.

Protobalistum, 566. imperiale, 566. Potśrerala, omboni, 567. e Protocatostomus, 275.

- constablei, 275.

Protosphyræna albensis, 115.

Protosphyræna inflexa, 115.

Protosyngnathus, 372.

sumatrensis, 373 .

Prymnetes, 116.

longiventer, 116.

Pseudeutropius, 326. verbeeki, 326 .

Pseudoberyx, 129. bottæ, 129, 130 . grandis, 130 . longispina, 250 . syriacus, 129.

Pseudoeleginus, 591. albyi, 591.2 intermedius, 591. jonas, 591 . majori, 591 .

Pseudolates, 499 heberti, 499.

Pseudosphrerodon, 552.

hilgendurfi, 552.

Pseudosyngnathus, 381. opisthopterus, 381.

Pseudothryptodus, 85.

intermedius, 85 .

Pseudovomer, 450 . minutus, 450 .

Ptericephalina, 146, 153. elongata, 158. macrograstrina, 158.

Pterothrissus, 67.

Pterygocephalus, 595.

paradoxus, 595.

Ptychocephalus, 487. radiatus, 487.

\section{INDEX. \\ aural us, 394}

Pycnosterinx, 391.

daviesi, 390.

discoides, 393.

dorsalis, 392, 393.

dubius, 395.

elongatus, 395.

gracilis, 394 .

heckeli, 390.

latus, 395 .

lewisi, 404.

niger, 392.

russeggeri, 392.

Pygacanthus, 613. altus, 613.

Pygæus, 557.

coleanus, 557 .

dorsalis, 558.

egertoni, 557 .

gibbus, 557 .

gigas, 558.

jemelka, 579 .

nobilis, 558 .

nuchalis, 558 .

oblongus, 558 . vatum. 558

Rndamas, 536.

jugleri, 536.

Raniceps, 603.

latisulcatus, 603. planus,604 tuberculosus, 604 .

Raphiosaurus, 37, 43 . lucius, 43.

subulidens, 43 .

Rhabdofario, 160 . lacustris, 160 .

Rhabdolepis, Marck, 11.

cretaceus, 20.

Rhacolepis, 29.

brama, 28.

buccalis, 30 effire:

latus, $3:$.

olfersii, 28.

Rhamphognathus, 361 .

paralepoides, 361 .

pompilius, 361 .

sphyræmoides, 362.

verneuili, 362 .

Rhamphornimia, 269.

rhinelloides, 269.

Rhamphosus, 377. aculeatus, 377. biserratus, 378.

Rhineastes, 329 . arcuatus, 323 . calvus, 329. grances, 32 pectinatus, 329 . peltatus, 329 .
Rhineastes (cont.).

radulus, 330.

rhæas, 329.

smithi, 330.

Rhinellus, 265, 269

curtirostris, 269. Ohicama

damoni, 268.

ferox, 267 .

furcatus, 266 .

laniatus, 232.

longirostris, 222.

nasalis, 269.

robustus, 268.

schilli, 269.

tenuirostris, 269.

Rhinocephalus, 603.

planiceps, 603.

Rhipidolepis, 613.

elegans, 613

Rhodeus, 316.

edwardsi, 317.

elongatus, 316.

exoptatus, 317.

latior, 317.

magnus, 317 .

oligactinius, 316.

Rhomuus, 606.

abropteryx, 608 .

bassanianus, 608 .

caudatus, 608.

cutrensis, 608.

fitzir geri, 608 .

gentiluomoi, 607.

heckeli, 608.

kirchberganus, 609 .

ligusticus, 608.

minimus, 607.

minutus 608.

nardii, 608.

parrulus, 608 .

rhenanus, 608.

richiardii, 608 .

sauvagei, 608 . $\mathrm{kam}$

Rhonchus, 458 .

carangoides, 458.

Rhynchorhinus, 342.

branchialis, 342 .

major, 343.

Rita, 328 .

grandiscutata, 328 .

Salmo, 159

cyprinoides, 456 . elerzhavini immigratus, 160.

lewesiensis, 11.

maræna, 63.

teplitiensis, 614 .

SAlmonide, 159.

Sandroserrus reboulii, 520. 

Poodramat 4.57

Prukacanthodes Gill, 567 .

Protarias, 520

Prosphyraena. 359

weileri,
Pfyeholopis, Gnts."

Prenoñondes, sos:

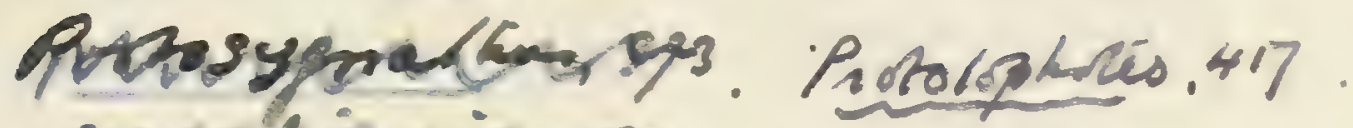

sobdeniving

Protasiganus. 524

Propstmian

Protopselta, 608 .

paunala, Ges.

Kubreai, 60 \%

Pytinobsidus seco

Pseave eserroma stso

Sendretry-s, bis

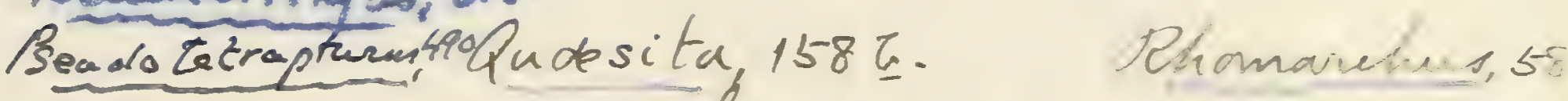
quisquilia, 158 t, 618 . ensiper, 580 , arhaminae1585 Quisque, $158 \underline{\mathrm{b}}, \mathrm{a}$ fragilis 1582 bakeri, 158 b.

quiesceus 1 tha. gilberti, $158 \mathrm{a}$

Psendolota, 603 Rasirra, 299.

Phynodonesers

abtreviatal 603. antigne, 299.

Procoloscaus 170 molvi;289.

Eorkwellia, 614

Peandotas bra,299 Rankiniablit

macurufhale, 299.

Bendoranisa 457.

Psygmolenis. 59

Psibdus, b/2.

Rhythmias. 596 .

Phomurus, 35 fulcratas, 3 .

michelutiti 612 .

Precogrammatolepis. In.

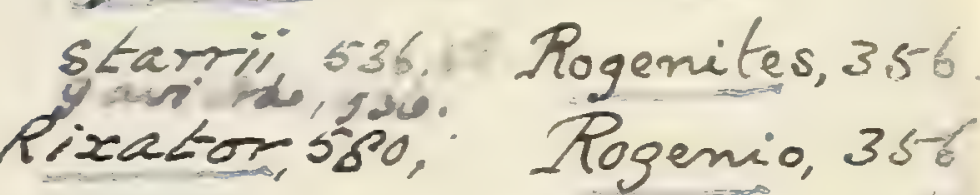

porteousi,58, 618. Lowerai, 35

inezice,s-so. solitudinis

Rupperfican, $55 \%$ Rutilus,

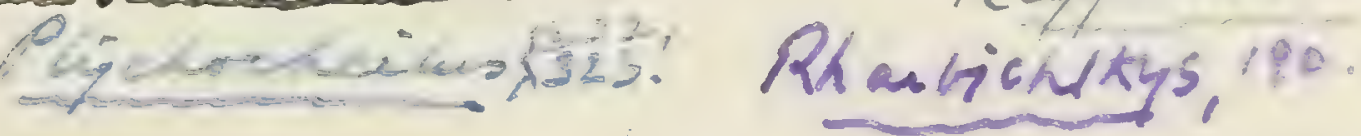

condonianus, 22

Pungituin 970

Puntics 299.

Santisia, is: unisi, e? 
Sannor pusen see My atroficane?

spmatar $=242$.
Siromberesses, 358. acutillus, 358, 618. edwardsi, 358

isoubllis, 248.

the atinarla, $158=9,155$.

Semairo ctehudsicteo, 151 .

Schizospondylus, 188.

dufius, 188 .

- Dermata, 451.

arationi, 45

Scianos 538

Telastavus, 580.

Sit. (exnus, 107

vertelralis, 580,618

Scluogogel.

$S$ elastinus, 580.

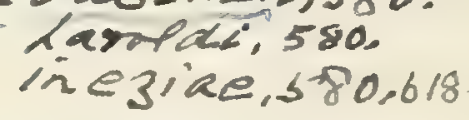

Selastoësus, 580 .

apostatios, 580 .

H.velinagus, 114.

Spolenkorslia, 252

Selotr 358 

Saurodon, 111.

affinis, 113.

broadheadi, 113.

conoideus, 113.

ferox, 113.

intermedius, 112.

lanciformis, 113.

leanus, 111, 221 .

marginatus, 229.

phlebotomus. 112.

pygmæus, 113.

xiphirostris, 113

Saurorhamphus, 207, 210.

freyeri, 210.

Sauropsidium, 58.

gracilicauda, 58 .

lævissimum, 58 .

Scardinius dumerili, 311 .

Seardinius sicanus, 311.

Scarus, 553.

baltringensis, 530, 531 .

miocenicus, 553.

oweni, 531.

suevicus, 553 .

tetrodon, 553 .

Scatophagus, 561.

affinis, 561.

capellinii, 561.

frontalis, 561 .

Sciæna, 539.

amplus, 539 .

holsaticus, 539.

irregularis, 539.

jaculatrix, 561 .

kirchbergensis, 539.

meridionalis, 539.

obtusus, 539 .

plumierii, 521 .

speciosus, 539.

undecimalis, 447.

Scienide, 538 .

Sciænurus, 524, 59\%.

bowerbanki, 527 .

brevior, 527 .

crassior, 527.

longior, 519.

Sclerognathus, 300.

Scomber, 459. alatunga, 456 .

‘cordyla, 445 . glaucus, 448 . ignobilis, 521 jeponimen 450 orcynus, 456.

pelagicus, 444 .

pelamis, 464 .

planovatus, 459 .

priscus, 459 .

rhombeus, 439 . stot

sirdi aticus, 459 .

Zrachyeétihalus, 482
Scomber (cont.).

speciosus, 466.

steindachneri, 459 .

sujedanus, 459 .

thynnus, $455,457$.

trachurus, $464,45 \%$ v o ite

Scomberodon, 465. 3ubles if dumonti, 470.

Scombramphodon, 474.

benedeni, 474

crassidens, 475 .

curvinens, 474

Sconbresocide, 3506 .

Scombresox, 357.

licatæ, 358.

obtusirostris, 357.

Scoubride, 451. $\% 365$

SCOMBRIFORJES, 418.

Scombrinus, 461 .

macropomus, 462.

nuchalis, 461 .

Scombroclupea, 135 .

gaudryi, 138 .

macrophthalma, 135 , 269.

pinuulata, 135.

Scopflid $2,235$.

Scopeloides, 254 .

glarisianus, 255.

nicolisi, 256 .
Scopelus lacertosns, 256 -circulania

Scorpæna, 577.

minima, 579.

pilari, 579 .

prior, 579.

serofa, 504 .

tessieri, 579 .

SCORPENIDE, 577.

SCORPENIFORMES, 576.

Scorpænoides, 580. poporicii, 580 .

Scorpænopterus, 580 .

siluridens, 580 .

Scyphopilori, 1.

Sebastodes, 579. = rosæ, 579. Ka m

Semiophorus, 430 .

gigas, 430. massalongianus, 431 .

438parvulus, 431.

schaerbeeki, 431.

relicans, 431.

velifer, 430.

Semotilus, 323.

bairdi, 323 .

posticus, 323.

Seriola, 444.

analis, 445 .

beaumonti, 446 .

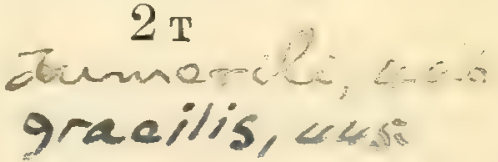


Seriola (cont.). lata, 445 .

prisca, 444.

Serranus, 521. altus, 521 .

- distinctus, 522.4 N.V.

dubius, 221 .

gracilispinis, 521 .

microstomus, 527 .

noetlingi, 522 .

occipitalis, 527.

pentacanthus, 521 .

rudis, 521.

$=$ rugosus, 522 .

stiriacus, 513, 522.

validus, 522 .

ventralis, 522, 526 .

wemmeliensis, 522.

SiluRIde, 324.

Silurus, 325.

ascita, 359.

bagres, 362 .

cataphractus, 359 .

catus, 133.

egertoni, 331 .

226 gaudryi, 616.

serdicensis, 326

Siphonostoma, 382.

albyi, 382.

castellii, 382.

Smerdis, 506 .

aduncus, 508 .

analis, 508.

budensis, 508.

elongatus, 508

formosus, 507 .

heersensis, 509.

isabellæ, 616

latior, 508 .

lorenti, 518 .

macrurus, 507.

micracanthus, 504 .

minutus, 506.

pygmæus, 505.

rhoensis, 509.

sand bergeri, 509 .

sauvagei, 509 .

sieblosensis, 509.

taramellii, 509.

Tentralis, 509, 616 .

Solea, 609.

antiqua, 610 .

approximata, 610 .

'glaber, 610.

guestfalica, 611 .

kirchbergana, 609 .

lenticularis, 611 .

provincialis, 611 .

sauvagei, 611 .

Solencdon, 190, 204 . lesinaensis, 219.
Solenodon (cont.). lobopterygius, 219. neocomiensis, 204.

Solenognathus, Pictet \& Humbert, 271, 28 年.

lineolatus, 274.

Solenorhynchus, 380 . elegans, 380 .

Solexostomatide, 379 .

Scricidens, 323. baueri, 3:3.

Spaniodon, 48. blonneli, 48.

brevis, 53.

electus, 48 .

elongatus, 51 .

hakelensis, 274.

latus, 53 .

lepturus, 54 .

sinus, 53.

SPARIDE, 524.

Sparisoma, 523.

Sparnodus, 5:4.

altivelis, 525 .

bowerbanki, 527 in rus elongatus, 526 . $^{5}{ }^{5} 5$ inflatus, 528 .

intermedius, 528 .

leth riniformis, 525 .

macrophthalmus, 525 .

micracanthus, 525 .

microstowus, 527 .gernto

moloni, 528. nesge ş30

oralis, 525.

Sparoides, 537.

molassicus, 536 .

robustus, 537.

sphæriens, 537.

tenuis, 537 .

umbonatus, 537 .

Sparosoma, 523.

ovalis, 523.

Sparus brama, 527 .

Sparus bolcanus, 558

Sparus chromis, 526.

Sparus dentex, 525 .

Sparus erythrinus, 525.

Sparus macrophthalmus, 525.

Sparus salpa, 526 .

Sparus sargus, 525.

Sparus vulgaris, 525, 527.

Spathodactylus, 98. neoromiensis, 98.

Sphærodus, 537.

aunularis, 535.

aradasii, 545.

cinctus, 534.535.

cingulatus, 535,
Sphærodus (cont.)

conicus, 537.

depressus, 536 .

discus, 536.

insignis, 537.

intermedius, 537 .

kergomardius, 535 .

lejeanianus, 530 .

lens, 536 .

oculus-serpentis, 537.

parvus, 338 .

polyodon, 545 .

pygmæus, 535

subtruncatus, 536 .

truncatus, 538.

wiechmanni, 538.

Sphagebranchus, 347. Pusilius, 347.

formosissimus, 347 .

Sphenocephalus, 387.

cataphractus, 388.

fissicaudus, 387.

Sphenolepis, Agassiz, 275.

cuvieri, 277.

squamosseus, 276 .

Sphyræna, 366.

amici, 369.

bolcensis, 366 .

carinata, 204 . Cruxeilifusus

croatica, 368.

gracilis, 366.

intermedia, 367 . lem lenws 38

maxima, 366 .

speciosa, 368,616 .

sternbergensis, 369 .

suessi, 368. onich, $36 b^{6}$

tyrolensis, 616 .

viennensis, 368 Vare na

viennensis, 368. $36 c^{2}$

SPHYREIIDE, 365.

Sphyrænodus, 473.

abcerer bottii, 470 .

524 conoideus, 476 .

crassidens, 475 .

gracilis, 469 .

lingulatus, 467 .

priseus, 473.

silovianus, 616 .

speciosus, 616.

tenuis, 469 .

Spinacanthus, 566.

blennioides, 566 .

Spinacites, 415. radiatus, 415 .

Spinax marginatus, 228.

Squalius, 323.

arciferus, 323.

bairdi, 323 . 


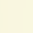



Serrotal

sanctae-bartwara, 445,

muctiriadiatis, 443.

sanatäe. eniziáe, "yst

Sertiromer, 347.

Sigmophandy:an: $3=2$

sillago, 5215

foimumasis 115,368 .

Smithites, 158 T.90.

stchurowstic, 528.

elegans, 1585.ra.,618.

Shavers anticiues, 5-30.

Socnotede, 335-

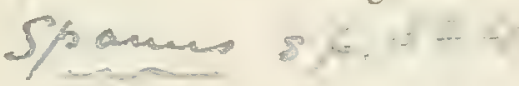

Ashquearis hexagonit: 673 leriche, iss Spinax curaformin tob. Spinscacus sys. anans, $5 \%$ \%

Spradeliviaes, is Cermaniai, $15 y$ 
Stichaen, 617,395.

makivinai sas.

Stich phorm, 2

Stainias, …482.

ischums, 스. ‥ 482 .

Starinsia, sol 2 .

Shernbesjia, 189.

waitei, 's 5.

Traskichinyoides

STERNOPT YCHIOES 235 .

sternoptwa, 258.

Irachume 4425

urisea, 255 .

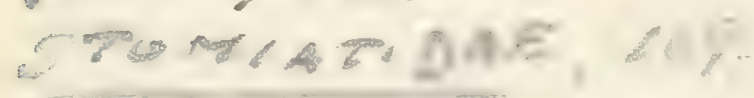

Sungarichthys, la.

$3 y$ yordes. stil

syen grantis 358

Synodus, 235 .

zudis, 258

ichedes, 258

tromin, 258.

lich nectes,

marensis, 270 .

7achysanes, 380

indomewas, 25

leostens,

al

cimarerus,

Temnodou. 449 .

isseli, 449 . minutus, st.

incomplotur, 383.

Irichiusus,

leptumes, 482.

atbui, 456.

oshrummis,

lerichei, $480^{\circ}$

huberti, 460

sliocenicus, 45b

krambergeritisy.

Thyosucles. 4al envugz

(Thy rites)

Kriegeri, 48\%,618.

escharion, N... 482.

I hysod dex, 24 ?

Tripterygion, 59:

Thyrsion, anc482.

velox, win. 482 .

Trossu/us, 270.

Tllahia, st3?"

exoletus, 270 .

fossilis, Jos

melomp plocirn, 3as. downisponas 55 


Squalius (cont). laminatus, 323. licatæ, 311. posticus, 323. readingi, 323.

Stenostoma, 423 . pulchella, 425 .

Stephanodus, 532 splendens, 532. Iibye 3 ?

Stereodus, 476. melitensis, 476 .

Stratodus, 188. anglicus, 57. apicalis, 189 oxypogon, 189.

Strinsia, 602. alata, 602 .

Stromatein e, 419.

Stylodus, 553 . lebescontei, 5503.

Sudis, 257. 25.8

Syllæmus, 350 . anglicus, 3.51 . latifrons, 351, 614 .

Sysgithide, 380 .

Syngnathus, 382. affinis, 383 .

arus, 38 z albji, 382. breviculus, 383 . heckeli, 383. helmsi, 383. opisthopterus, $38 \mathrm{~L}$. typhle, 381.

Synodontis, 324 . Synophrys, 613. hopei, 613 .

Syntegmcdus, $8 t$. altus, $8 t$.

Tachynectes, 270. brachypterjgius, 270.

longipes, 270 . macrodactylus, 270 .

Tarsichthys, 12. elegans, 315. tarsiger, 315.

Taurinichthys, 553. miocenicus, 553 . sacheri, 553.

Tautoga conidens, 553.

Telepholis, 284 . acrocephalus, 284. biantennatus, 285 . tenuis, 285.

$>$ Teratichtinys, 449 . antiquitatis, 449

Tetheodus, 190. pephredo, 205.
Tetragonopterus, 298.

arus, 298.

ligniticus, 298.

Tetrapturus, 490. minor, 116. priscus, 491.

Tetrodon, 571. hispidus, 576. honckenii, 576 . lawleyi, 571.

pygmæus, วั71. scillæ, 571 .

Teuthidid e, 523.

Teuthis, 523 .

Thaumaturus, 160. deichmuelleri, 614 . elongatus, 614 . furcatus, 160, 614 . lusatus, 160, 614.

Thrissopater, 32 . magnus, 33.

inegalups, 35. salmoneus, 33.

Thrissops gracilis, 91.

Thrissops vexillifer, 92.

Thrissopteroides, 54. elongatus, 54 .

intermedius, 55 .

latus, 54 .

$>$ pulcher, 56. tenuiceps, 55 .

Thrissopterus, 89. catullii, 89.

Thryptcdus, 82, 83, 85. rotundus, 85 . zitteli, 85.

Thynnichthys, 303. ambljostoma, 303.

Tht nnus, 454.

angustatus, 457 .

bolcensis, 457 .

Tanceolatus, 456. planovatus, 459 .

propterygius, 464. prosimus, 457. scaldisi, 455 . thynnus, 455 . toliapicus, 458. vulgaris, 455 .

Thyrsites, 481 . lovisatoi, 481.

Thyrsitocephalus, 476.

alpinus, 477 .

Tinca, 312.

francofurtana, 316 .

furcata, 312 .

leptosoma, 313. lignitica, 615 .
Tinca (cont.).

macropterygia, 615 .

magna, 312.

micropjgoptera, 314.

obtruncata, 316.

tarsiger, 315 .

valdarnensis, 315 .

vulgaris, 315 .

Titanichthys, Dames, 612.

pharao, 612.

Tomodon, 612. horrificus, 612.

Tomognathus, 116. mordax, 117.

leiodus, 117.

Toxopoma, 613. politum, 613.

Toxotes, 561 . antiquus, 561 .

Trachinide, 589 .

Trachinopsis, 591. iberica. 591.

Trachinus, 590. dracunculus, 590. lavigatus, 590. mutabilis, 590. seelandicus, 590. verus, 590.

Trachynotus, 450 . tenuiceps, 450 .

Triacanthus, 566.

Triænaspis, 173, 18\%. virgulatus, 187.

Trichiurichthys, 482. incertus, 482.

Trichiurides, 229. de l he éd marginatus, 229. or rieste $q$ miocæúus, 481.

Trichophanes, 416 .

copei, 416.

foliarum, 416.

hians, 416.

Trigla, 586.

adjuncta, 587 .

cor, 587.

elliptica, 587.

infausta, 586 .

licatæ, 586.

lyra, 589 .

nardii, $586 .<$ rhom 2icus, 5-5y. simonellii, 586.

TRIGLid E, 585.

Trigloides, 586.

alata, 586.

dejardini, 586, 600 .

insignis, 586

van benedensis, 586.

Trigonodon, 531 . Laric oweni, 531.

serratis, 531 .

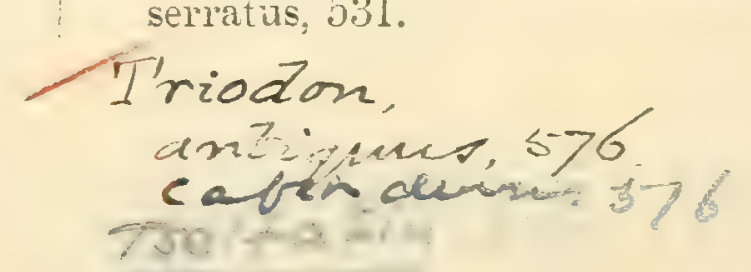


Tydeus, 257. albyi, 257.

elongatus, 257. megistosoma, 257 . sphekodes, 258.

Umbrina, 538 . pecchiolii. 538.

Uranoscəpus, 590. peruzzii, 590 . rastrum, 377.

Urenchelys, 337. anglicus, 339 . avus, 337. hakelensis, 338. 193. Uropterina, 146. platyrachis, 158.

Urosphen, 376. dubia, 376 . fistularis, 376 .

Vomer longispinus, 436.
Domer parvulus, 451.

Vomer priscus, $44 \cdot 2$.

Vomeropsis, 435 . elongatus, 437. longispinus, 436 . valenciennesi, 437.

Xiphactinus, 92. audax, 92, 98. brachygnathus, 97. lestrio, 97.

Xiphias, 490. acutirostris, 357. antiquus, 495 . delfortriei, 497. robustus, 497 .

XiPHiIde, 490.

Xiphopter'us, 482. falcatus, 482.

Xiphiorhynchus, 490.

elegans, 491.

Imparang, 496.
Xiphiorhynchus (cont.).

priseus, 491.

Suberiecius 4.54

Zanclus, 450 .

brevirostris, 450 .

eocenus, 450.

Zeus, 417.

benoisti, 417.

gallus, 449 .

hoernesi, 417.

lewesiensis, 397.

licatæ, 418.

platessa, 501 .

pliocenicus, 418.

priscus, $516^{\circ}$.

regleysianus, 501.

rhombeus, 439 .

robustus, 418 .

spinosus, 500 .

triurus, 436.

vomer, 436 . 


Iunita, 481 octaria, 481,618

Turio, r.v.482.

wilburi, wiv 482 .

culveic ON, G18.

, $N=482$

Y Yur ak Zuglonsus. 61.

domvillas, 340.

Varicer tinus, 323.

nenstiven, 323.

resatón.

antigues, bit.

Valcichthys.234.

Vrhieia,

Vinciguenía 169.

Wisslerins 6.8.

luovedaroudichlthys, sto
Xenoinissa $146 a$. Xyne, 146 Ix

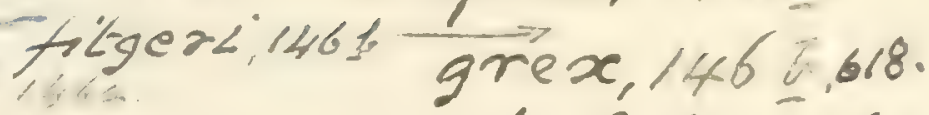

Zantechites, 362

Cestias, 465 .

hubbzi, 362,6?

iratus, 465 .

Lebraserna, 566

deane,

Zuncties, 73.

Zaphtegidae, 30 .

Zaphleges, $36 \%$

longurio. 365,

Zaprovidae, (?) nt:

Cyrimius, 553,146a Zelosis, 155

housti, 553,146a hadlegi, 155.

barbarae, $146 a$. Zororhoming, 60 . elmaxiemae. $146 a$. veliger, 608,618.

Temiagrammine. isistive, 580.

Zelutes?.

Zelotichtors:

aliaminar.

Zoropsetta. 607

Tentoges. Art 

, 



\title{
EXPLANATTON OF PLATES.
}

\author{
The specimens represented in the Plates are all preserved \\ in the Collection, and bear the register-numbers placed \\ in square brackets. Unless otherwise stated, the drawings \\ are of the natural size.
}





\section{PTATE I.}

Fig:

1. Brychcetus muelleri, sp. nor.; head, left lateral and superior $(1 a)$ aspects, one third nat. size.-London Clay; Sheppey. d. Dentary. fro Frontal. ma. Maxilla. orb. Orbit. pa. Parietal. pmx. Pre-. maxilla. s.mx. Supramaxilla. S.0.1., s.o.2. Postorbitals. 1b. Scale.

[P. 3893.]

2. Ditto; head, right lateral and supperior (2 a) aspects, one third nat. size.-Ibid. op. Operculum. p.op. Preoperculum. pet. Pectoral fin. sq. Squamosal. Other letters as above. $2 \mathrm{~b}$. Premaxillary tooth.

[P. 15\%] 78

3. Ditto; right mandibular ramus, one third nat. size.Ibid.

[43020.] 79

4. Ditto; right premaxilla, outer and oral (4a) aspects, one half nat. size.-Ibid. 


$$
678
$$


B. M. FOSS. FISHES Pt.IV.

26

$2 a \cdot \frac{1}{3}$

$4 \cdot \frac{1}{2}$
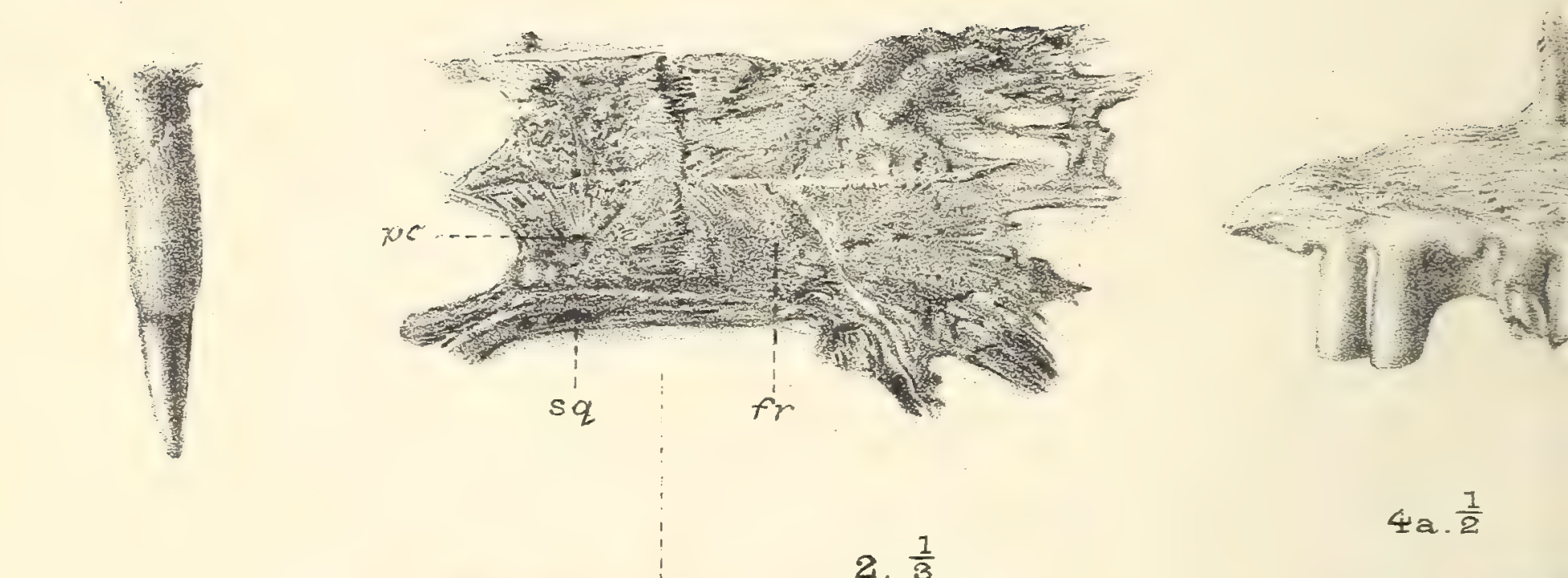

2. $\frac{1}{3}$

$4 a \cdot \frac{1}{2}$

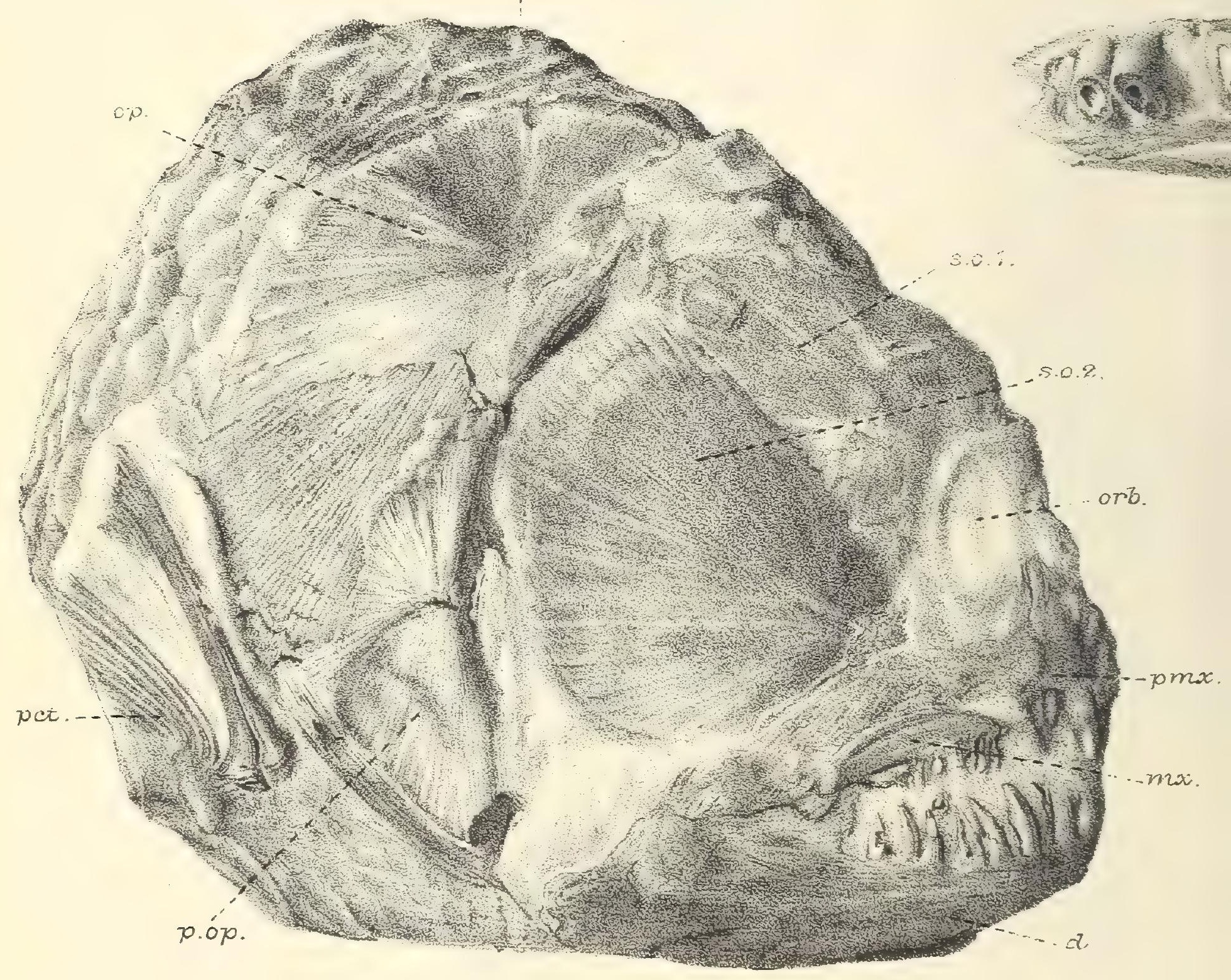

G.M Woodward del et lith 


\section{PLATE II.}

Fig.

Page

1. Osmeroides gracitis, Davis; left lateral aspect.-Upper Cretaceous: Sahel Alma, Mt. Lebanon. br. Branchiostegal rays. ch. Ceratohyal. md. Mandible. op. Operculum. qu. Quadrate. s.op. Suboperculum.

[P. 4855.] 17

2. Ditto; head, inferior aspect.-Ibid. c. Cranium. gu. Gular plate. Other letters as above. [49548.]

3. Osmeroides lewisi (Davis); left lateral aspect, two thirds nat. size.-Upper Cretaceous; Hakel, Mt. Lebanon.

[P. 6024.] 18

4. Osmeroides sarclinioides (Pictet); left lateral aspect.-

Ibid. $4 a$. Part of cranial roof of same specimen, three times nat. size. fr. Frontal. pa. Parietal. sq. Squamosal.

[P. 104.] 20 


\section{3. $\frac{2}{3}$}
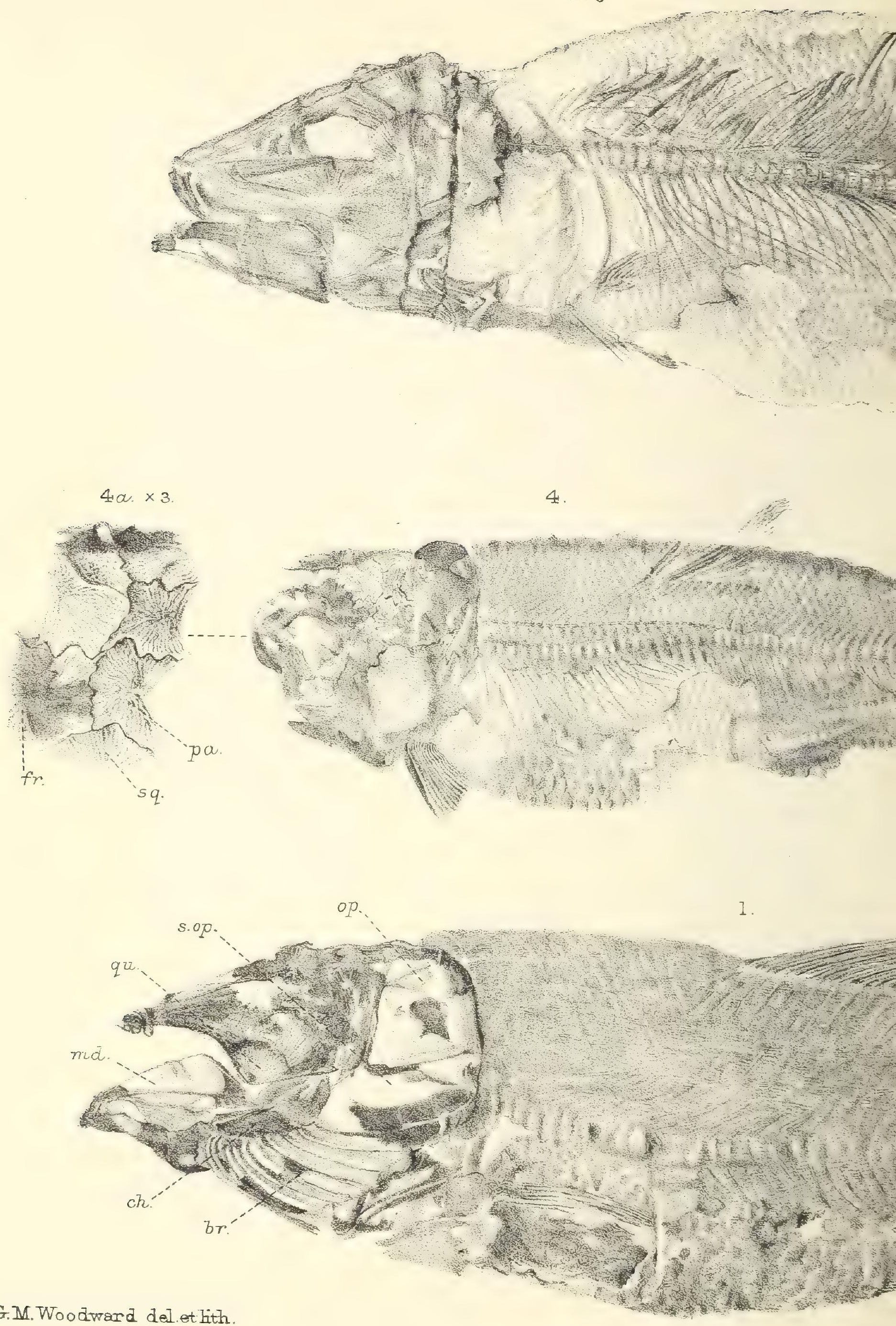

G.M.Woodward del.et lith. 


\section{PLATE III.}

Fig.

1. Esocelops cavifioms, sp. nov.; head, left lateral and inferior ( $1 a$ ) aspects, two thirds nat. size.-London Clay; Sheppey. ag. Articulo-angular. br. Branchiostegal rays. d. Dentary. ecpt. Ectopterygoid. gu. Gular. hm. Hyomandibular. mpt. Metapterygoid. op. Operculum. p. Hyomandibular process for operculum. pt.f. Postfrontal (sphenotic). qu. Quadrate. s.op. Suboperculum. sy. Ssmplectic. [P. 1749.]

2. Ditto; head, superior aspect, two thirds nat. size--Ibid. epo. Epiotic. fr. Frontal. s.o. Suborbital. s.oce. Supraoccipital.' $s q$. Squamosal. Other letters as abore.

[P. 640.]

3. Megalops priscus, sp.nov.; head, left lateral and superior (3a) aspects, one third nat. size.-Ibid. a.o. Antorbital. i.op. Interoperculum. mx. Maxilla. p.op. Preoperculum. pmx. Premaxilla. scl. Sclerotic. x. Process of maxilla. Other letters as above.

[36070.]

4. Ditto; hinder half of skull, superior aspect, two thirds nat. size.-Ibid. pa. Parietal. Other letters as above.

[P. $65 \%$.]

5. Ditto; longitudinal vertical median section of occipital portion of skull, two thirds nat. size.-Ibid. 6.occ. Basioccipital. b.sp. Basisphenoid. ex.oce. Exoccipital. Other letters as above. $5 a$. Posterior aspect of basioccipital, showing basicranial canal (b.c.). [P. 356.]

6. Ditto ; right otic region of skull, lateral aspect, two thirds nat. size.-Ibid. $f$. Facette for hyomandibular articulation. mo. Pro-otic. pt.o. Pterotic. Other letters as above.

「P. 4153. 
$3 a \cdot \frac{1}{3}$

fr.
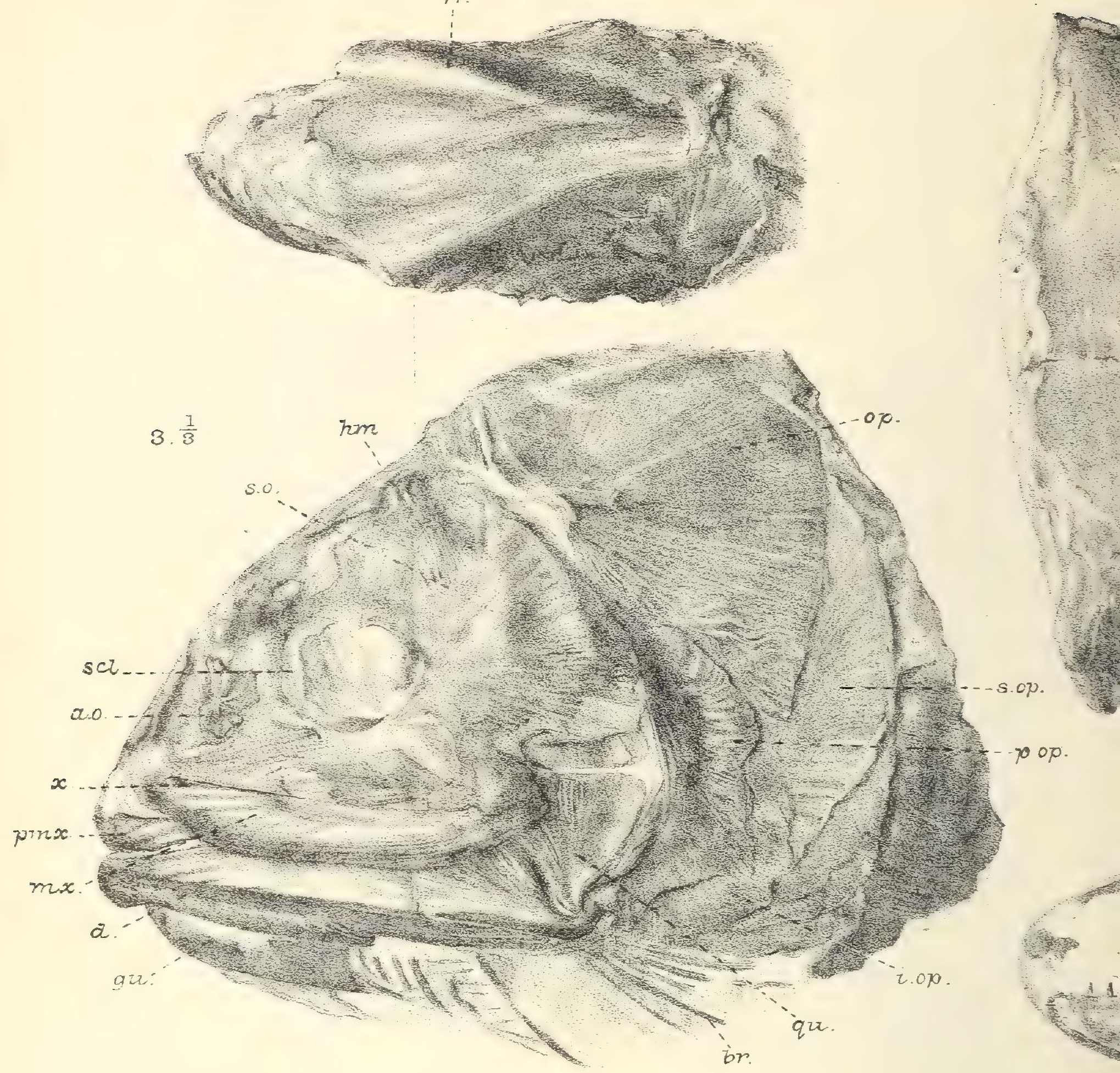

- 0 op.
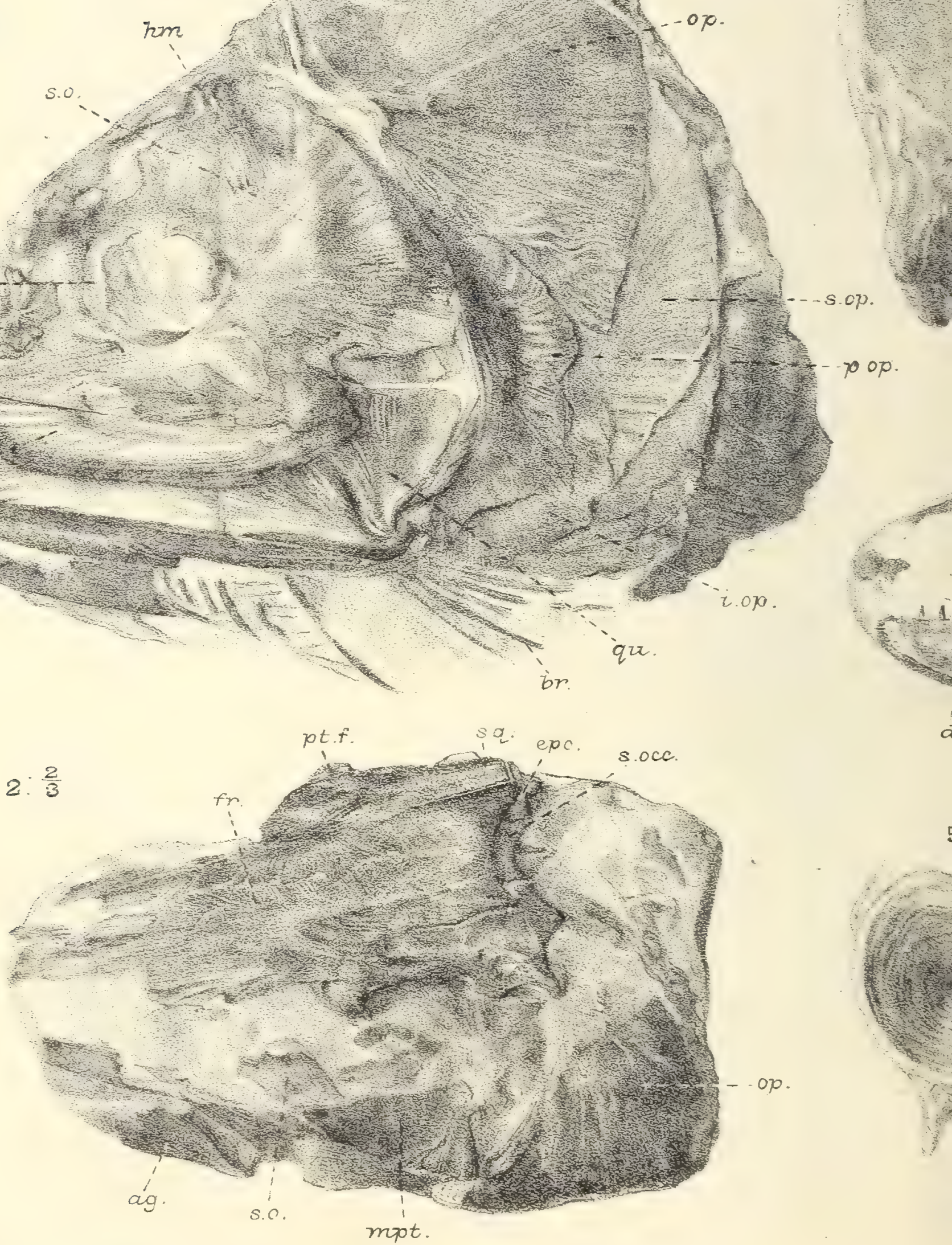

G.M. Woodwaxd del et lith. 


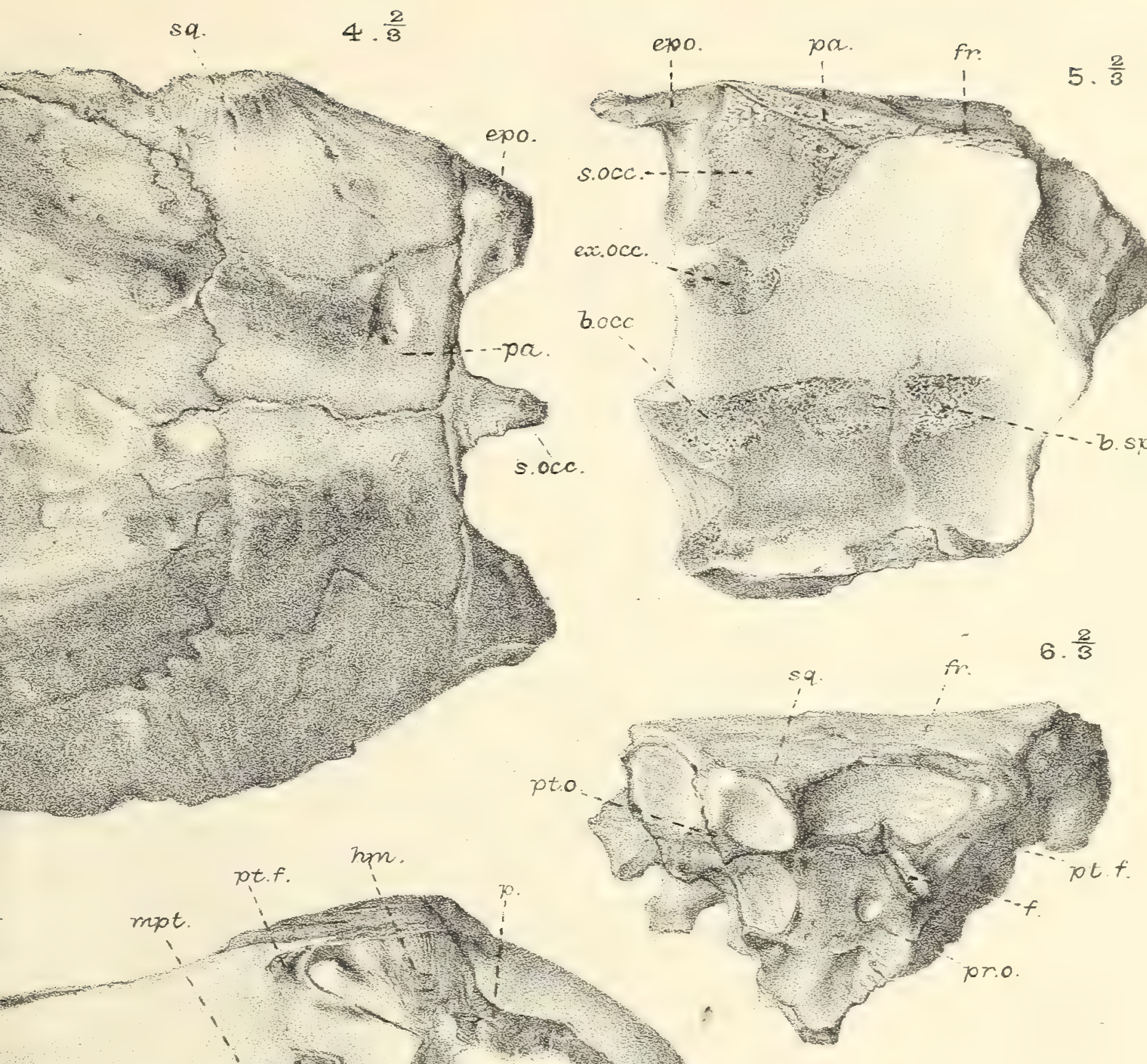

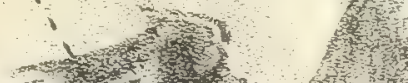

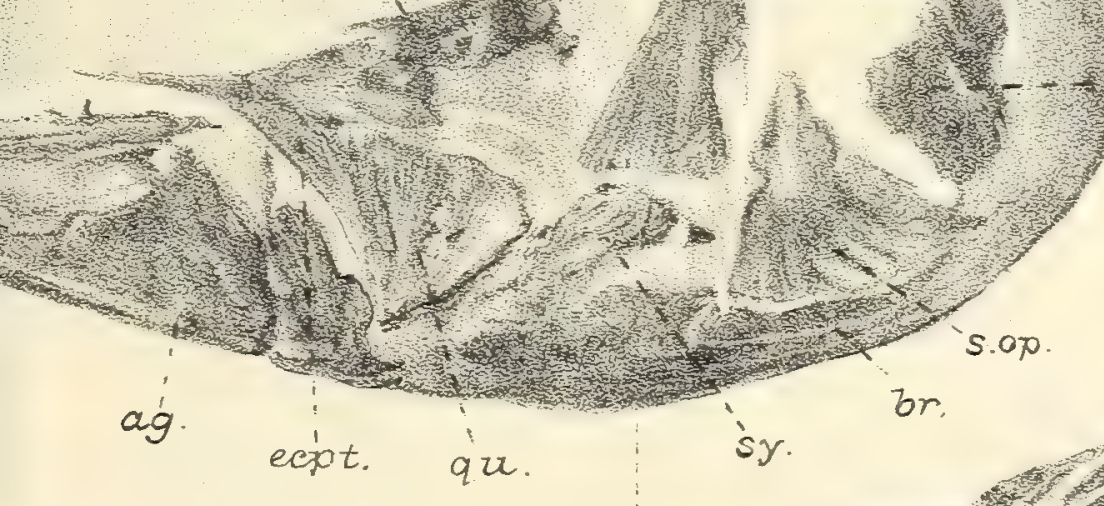

$\therefore 1 \quad$ t
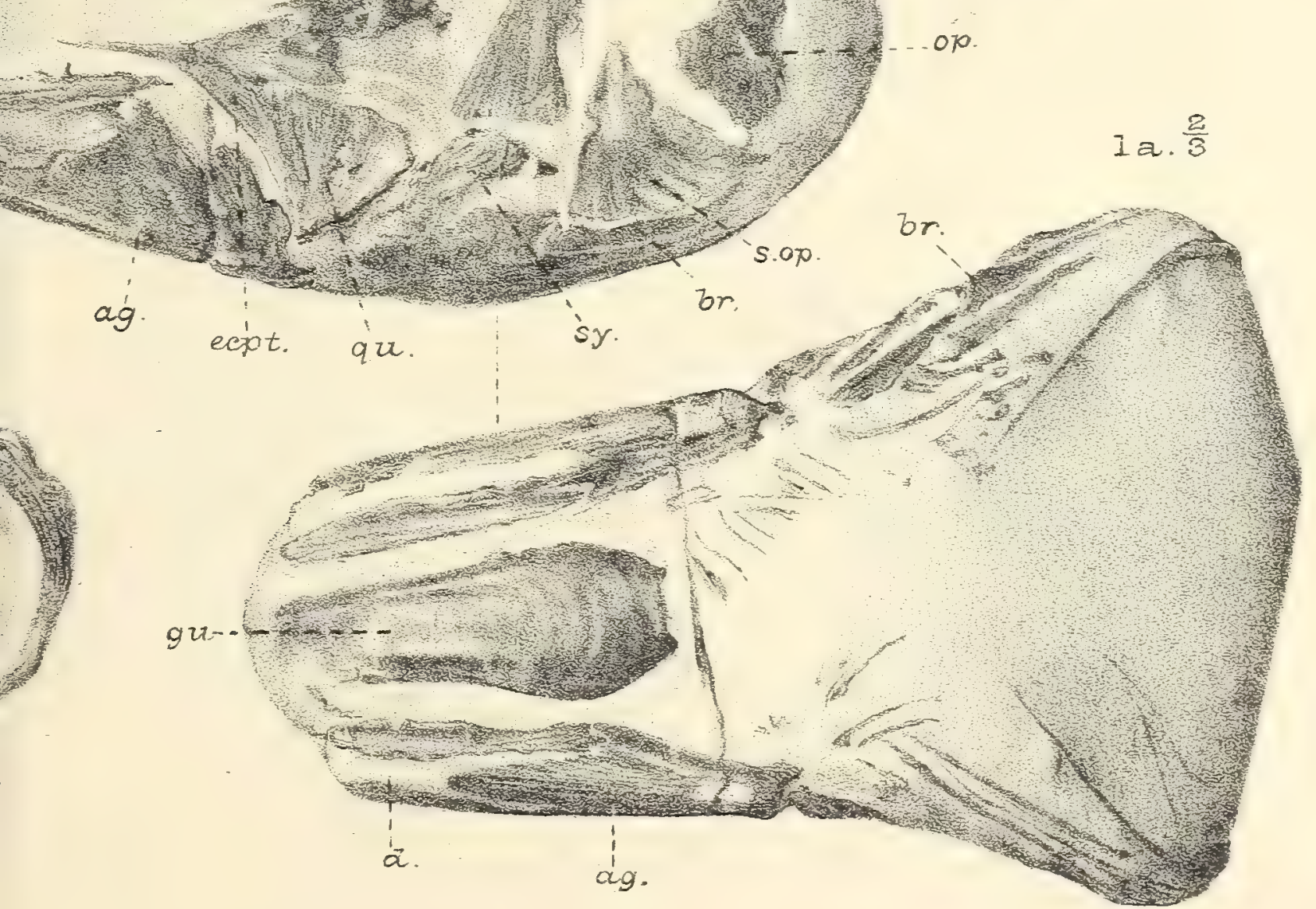



\section{PLATE IV.}

Fig.

1. Albula oweni (Owen); distorted head, right lateral and superior ( $1 \alpha$ ) aspects, one third nat. size.-Tondon Clay; Sheppey. ag. Articulo-angular. br. Branchiostegal rays. d. Dentary. ep.o. Epiotic. fr. Frontal. hm. Hyomandibular. mpt. Metapterygoid. mx. Maxilla. op. Operculum. orb. Orbit. p.op. Preoperculum. pa. Parietal. pr.f. Prefrontal. Pt.f. Postfrontal. qu. Quadrate. s.op. Suboperculum. scl. Sclerotic. $s q$. Squamosal. $x$. Inner bone bearing crushing teeth.

[P. 9158.

2. Ditto : anterior end of parasphenoid (pas.) with vomer $(v$.$) and ethmoid (eth.), oral aspect, one half nat.$ size.-Ibid.

[30528.] 


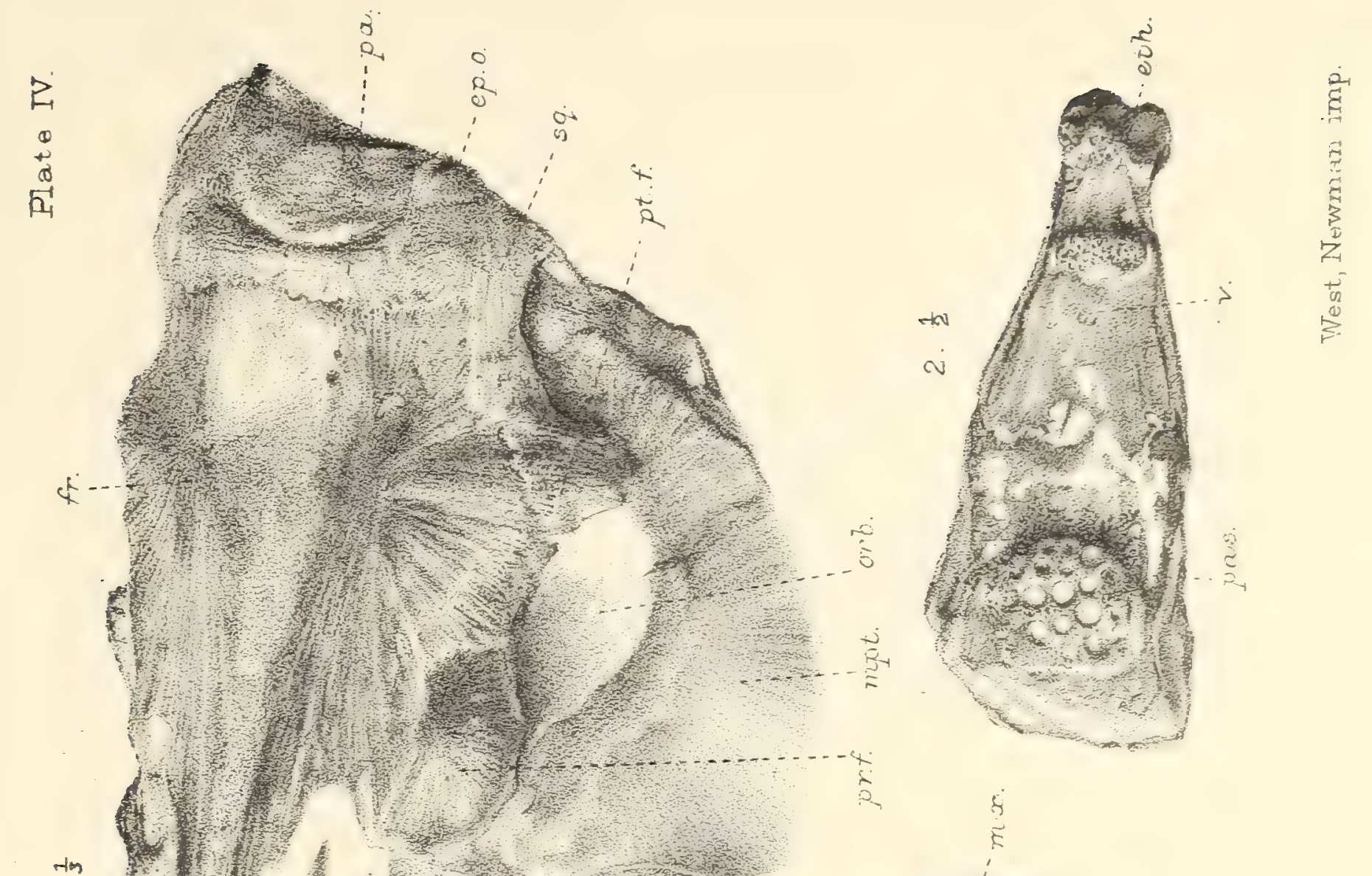

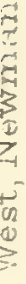
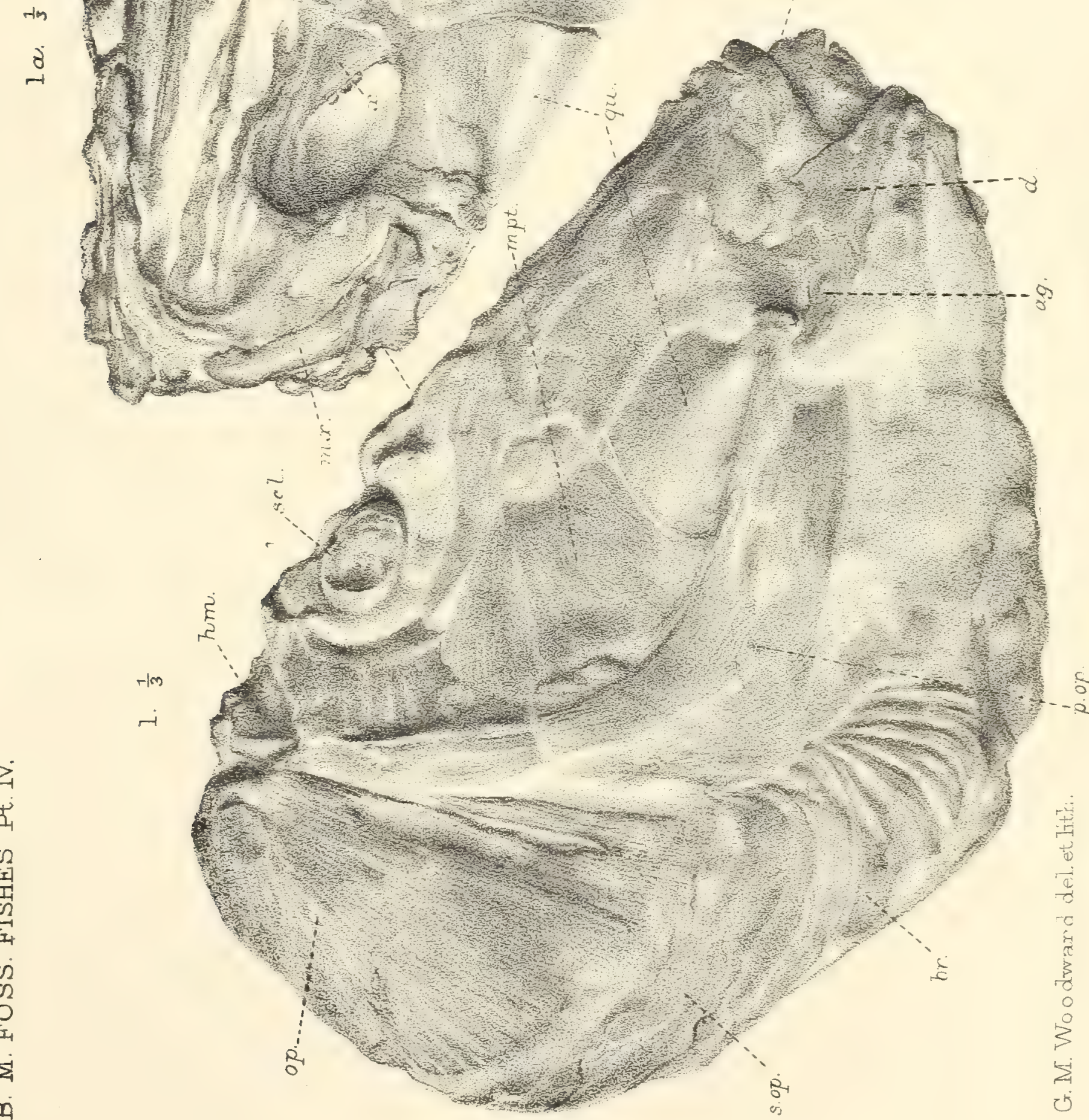

m 



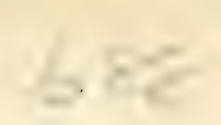




\section{PLATE V.}

Fig.

1. Thrissopater magnus, sp. nov.: distorted head, left lateral and partly superior aspect, two thirds nat. size.--Lower Chalk; Hollingbourn, Kent. a.o. Antorbital. c.o. Circumorbitals. d. Dentary. ep.o. Epiotic. eth. Ethmoid. fr. Frontal. ma. Maxilla. pa. Parietal. pmx. Premaxilla. s.mx. Supramaxilla. s.o. Suborbital. s.oce. Supraoccipital. sq. Squamosal.

[37981.] 34

2. Ditto; hinder portion of skull, superior aspect.-Lower Chalk; Kent. Letters as above. $2 a, 2 b$. Two vertebral centra of same specimen, lateral and inferior aspects. $\because$. Articulation for rib.

[490\%8.] 35 


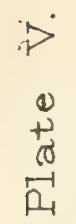

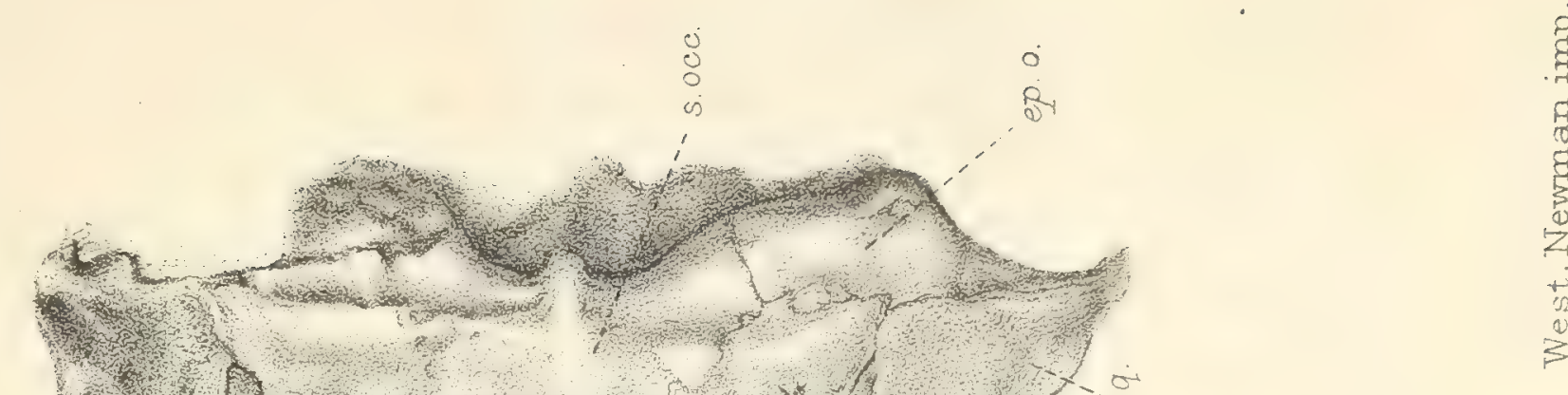

$\dot{\sim}$
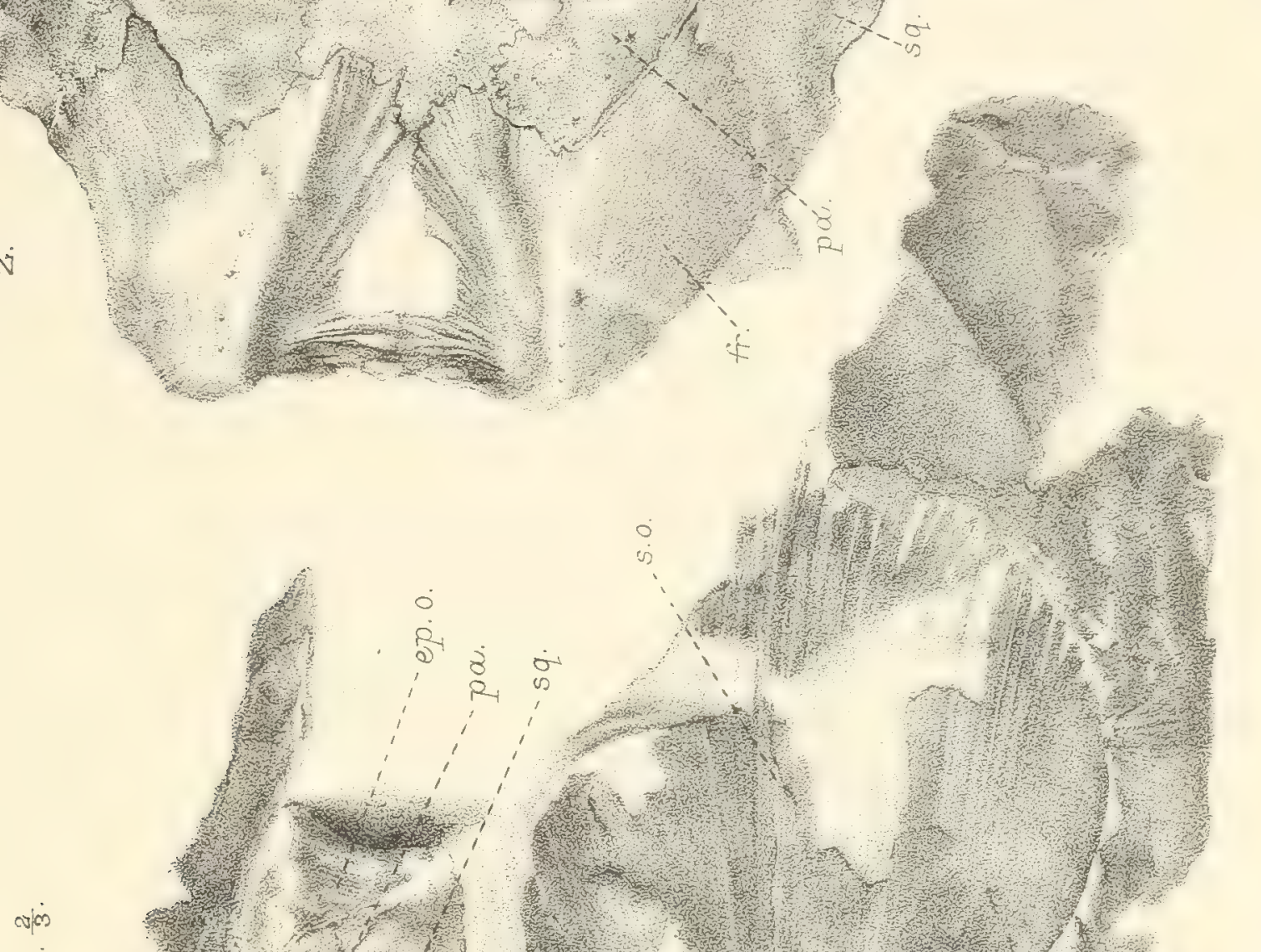

म

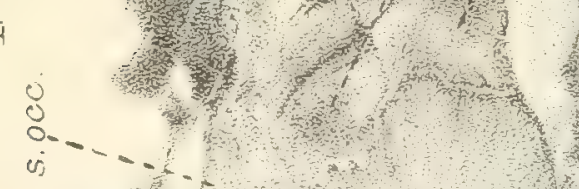

W
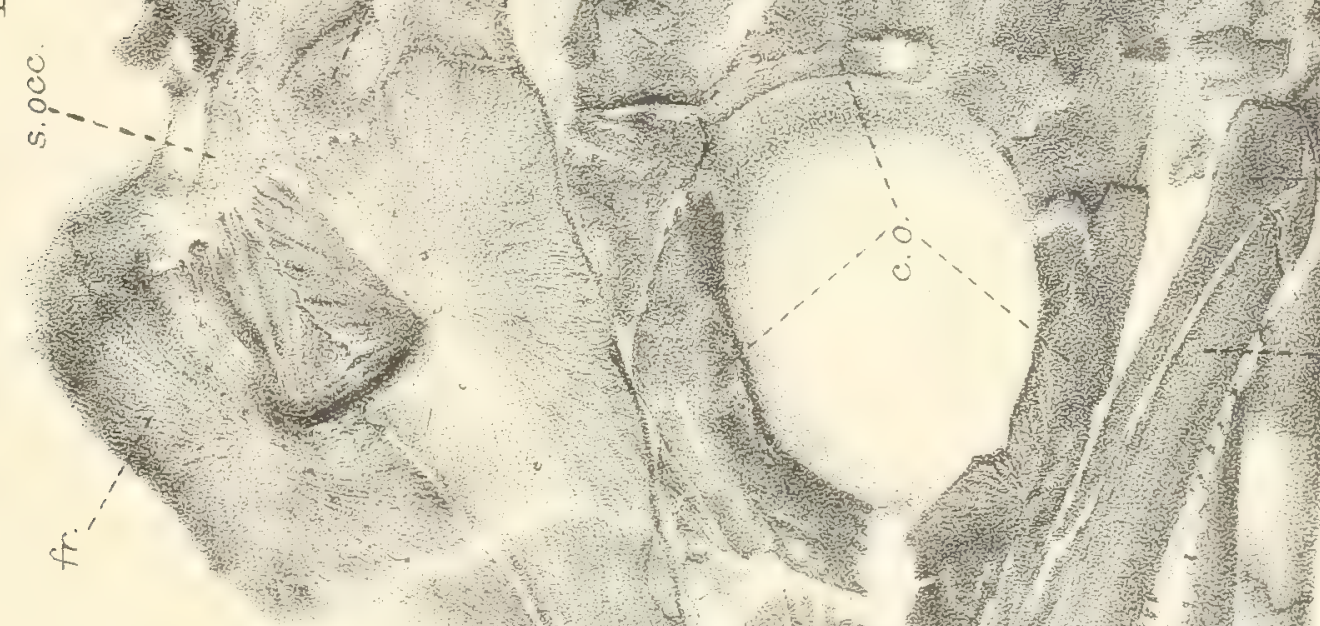

(n)

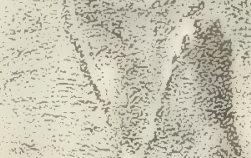

(

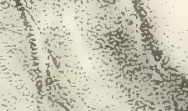

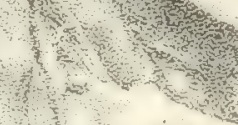

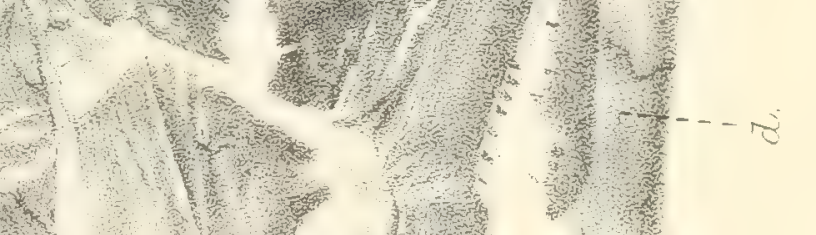

定

मि

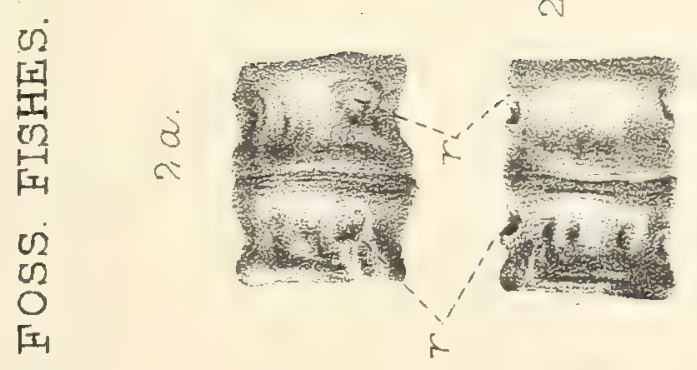

si

๓
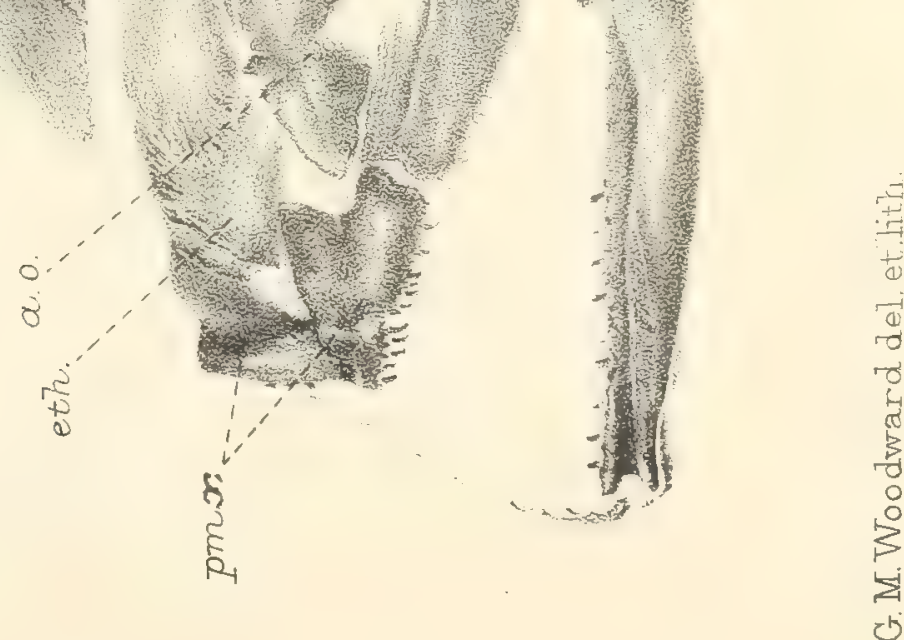

$6 \%$ 


\section{PLATE VI.}

Fig.

Page

1. Scombroclupea macrophthatma (Heckel); right lateral aspect.-Upper Cretaceous; Hakel, Mt. Lebanon. hr. Branchiostegal rays. ch. Ceratohyal. d. Dentary. $m x$. Maxilla. op. Operculum. p.op. Preoperculum. pmx. Premaxilla. qu. Quadrate. s.op. Postclavicle.

P. 4747. 136

2. Clupea catopygoptera, sp. nov.; left lateral aspect.-

Upper Eocene; Monte Bolca.

[P. 3829 a. $] \quad 148$

3. Chanoides macropoma (Agassiz); left lateral aspect.Ibid.

[P. 3829 b. $] \quad 64$ 


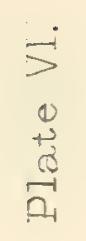

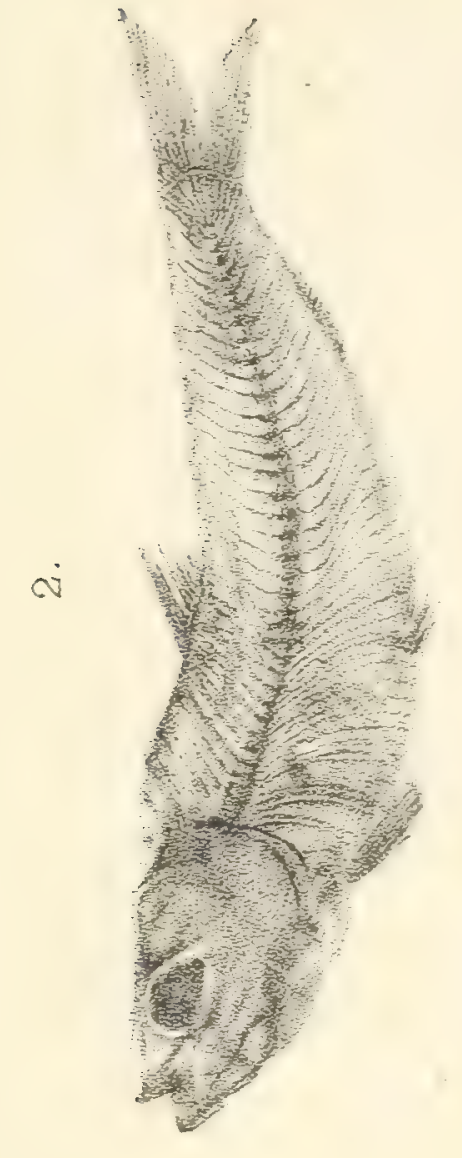

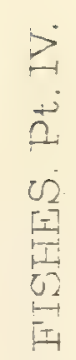

$\pi$

0

i

$m$

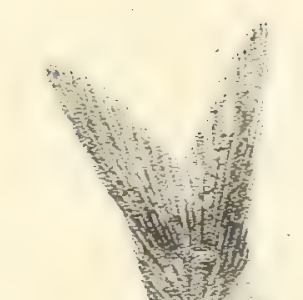

$\infty$
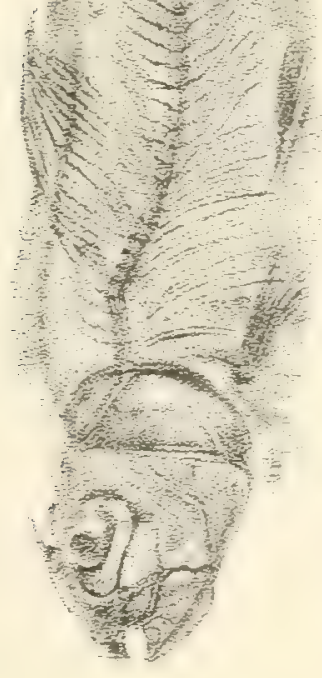

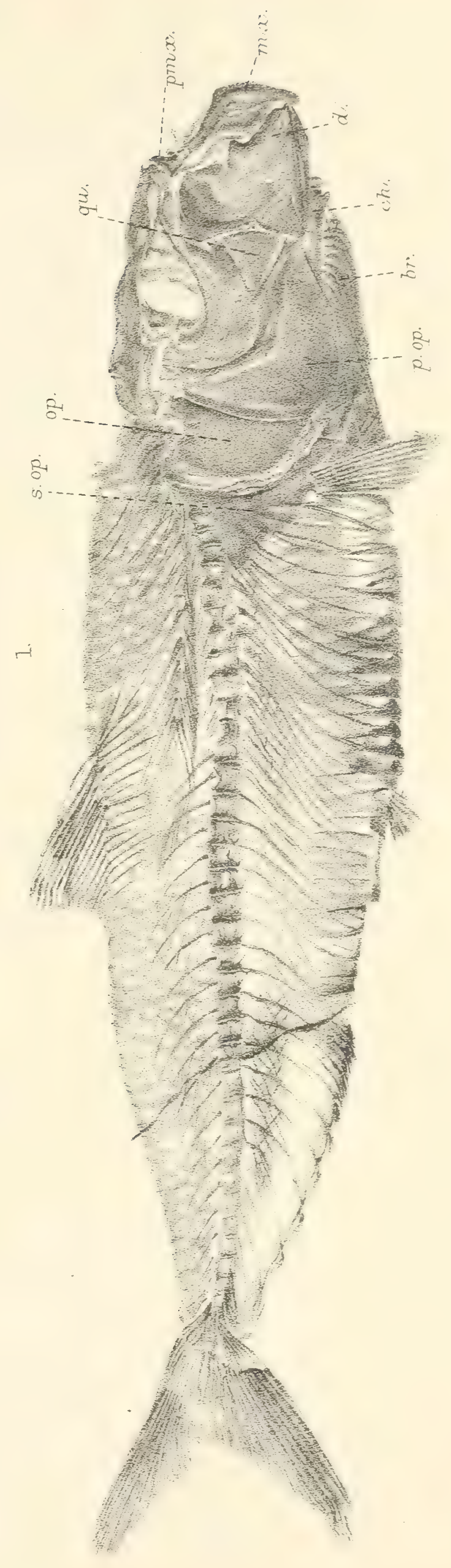





\section{PLATE VII.}

Fig.

Page

1. Pachyrhizodus subutidens (Owen); right maxilla, inner aspect.-English Chalk.

[P. 1808.]

2. Ditto; left dentary, outer aspect.-Lower Chalk; Halling. $2 a$. Portion of right dentary of same specimen, outer aspect.

3. Spaniodon elongatus, Pictet; head and anterior abdominal region, left lateral aspect.-Upper Cretaceous; Sahel Alma, Mt. Lebanon. a.o. Antorbital. br. Branchiostegal rays. d. Dentary. mx. Maxilla. p.op. Preoperculum. pet. Pectoral fin.

[48070.] 52

4. Thrissopater (?) meyalops, sp. nor.; head and pectoral arch, left lateral aspect.-Lower Chalk; Lewes. cl. Clavicle. i.o. Infraorbital. op. Operculum. p.cl. Postclavicle. p.t. Post-temporal. pmx. Premaxilla. s.o. Suborbital. s.op. Suboperculum. sct. Sclerotic. Other letters as abore. 

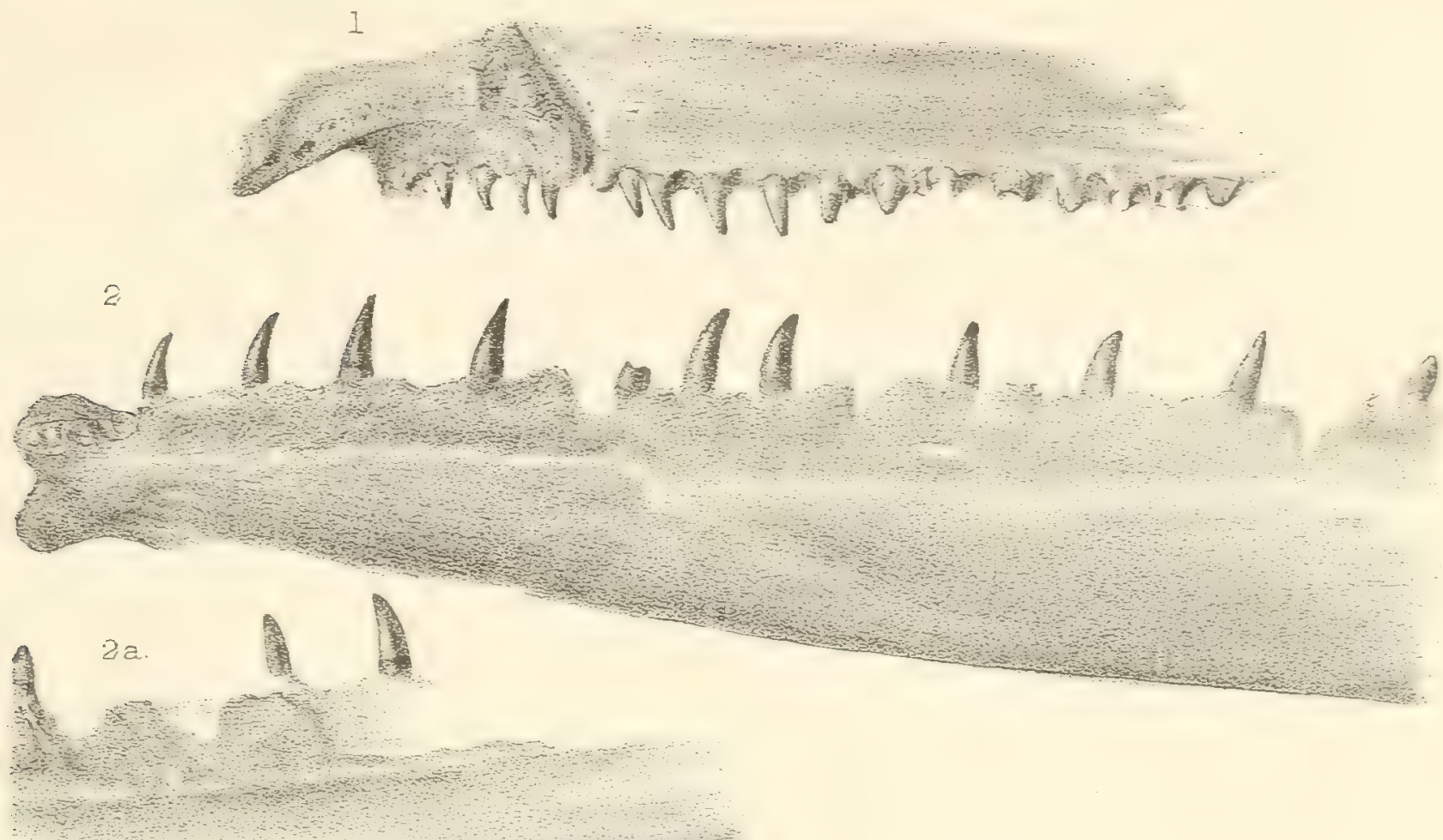

(n)
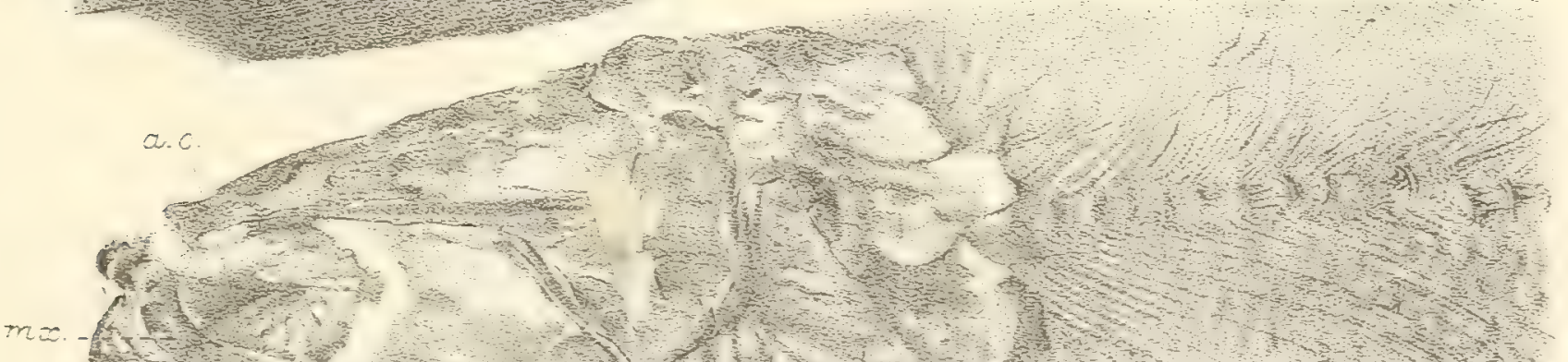

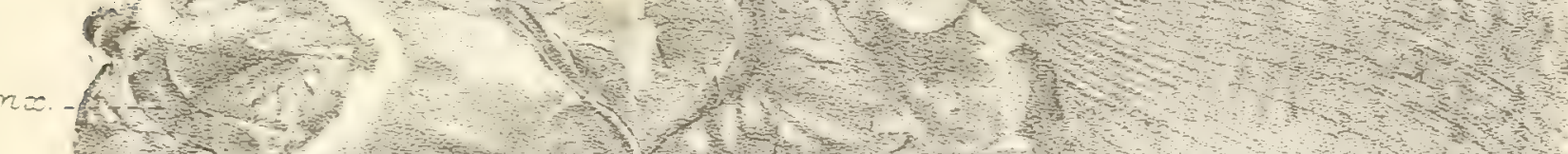

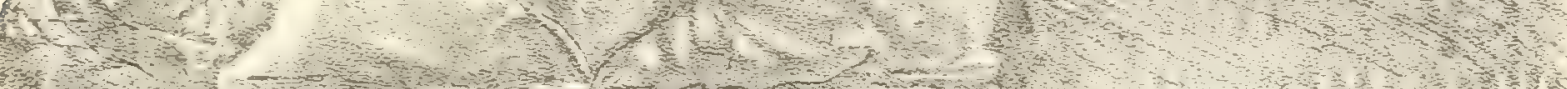

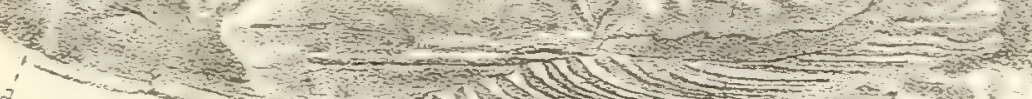

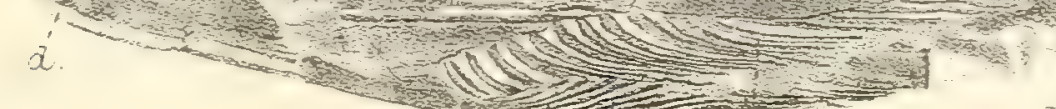

br. D. D.

D.t.
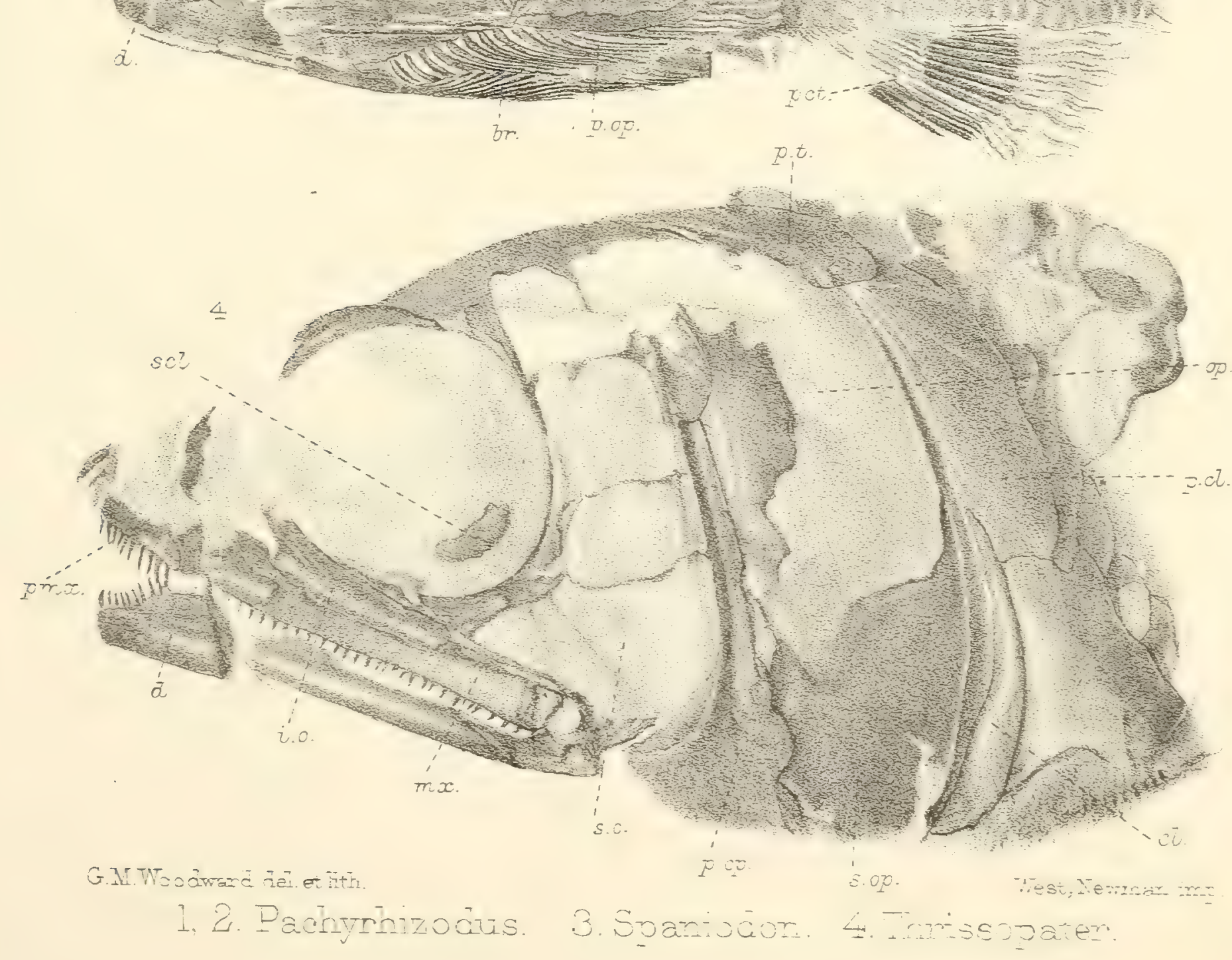



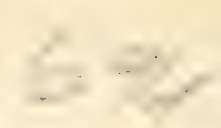




\section{PLATE VIII.}

Page

Ichthyodectes serridens, sp. nor.; head and anterior abdominal region, right lateral aspect.-Gault; Folkestone. d. Dentary. mx. Maxilla. op. Operculum. p.op. Preoperculum. pct. Pectoral fin-rays. pl. Palatine articulation. pmx. Premaxilla. pr.f. Prefrontal (ectethmoid). S.o. Suborbital. s.occ. Supra-occipital. sct. Sclerotic.

[P. 8633. $] 102$ 
占

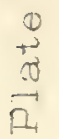

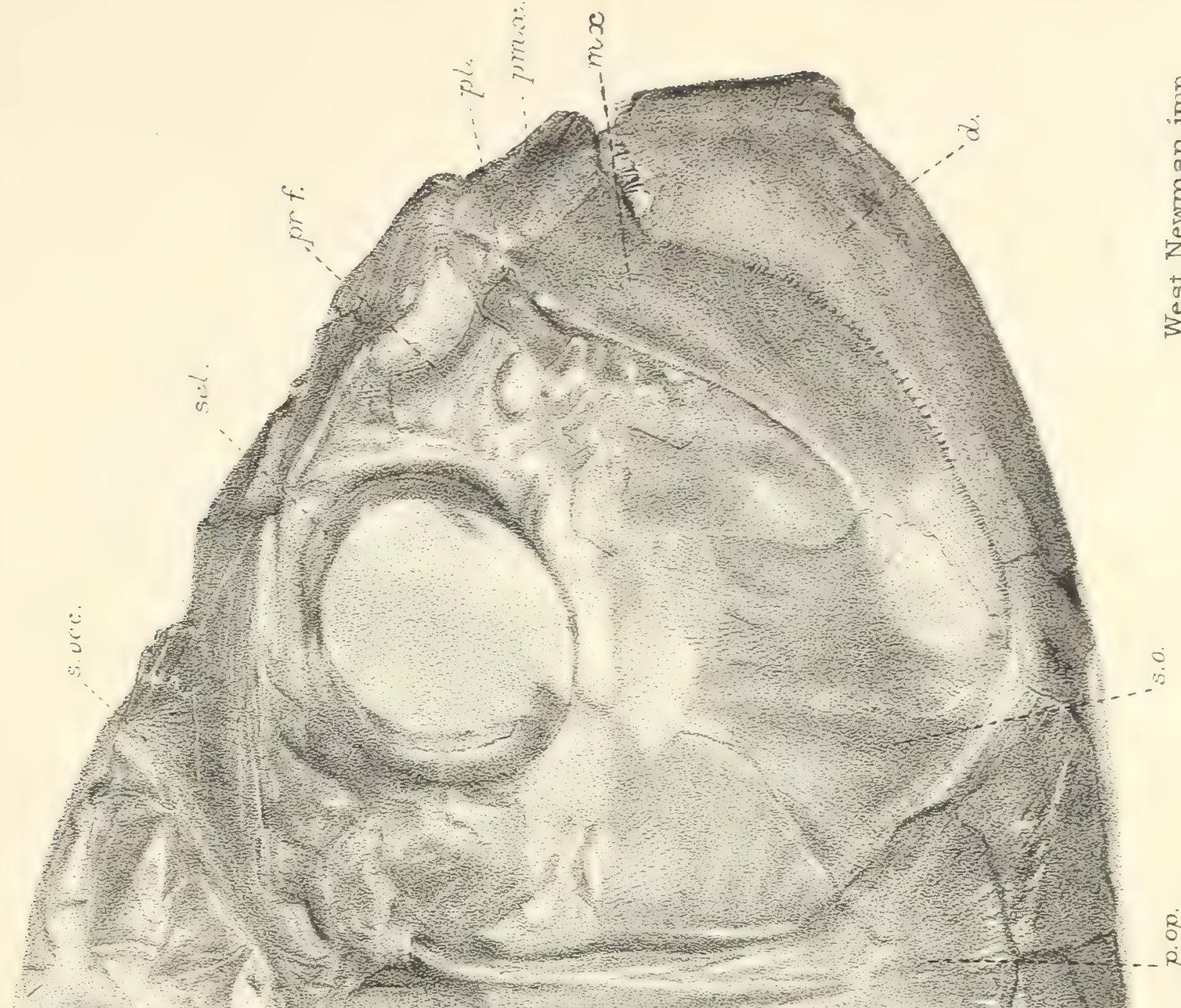

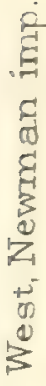

8

0
0
0
0
5
5
4
0
0
0
5
0
0
0
0

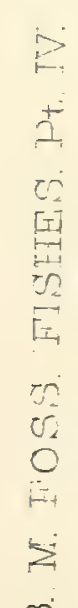

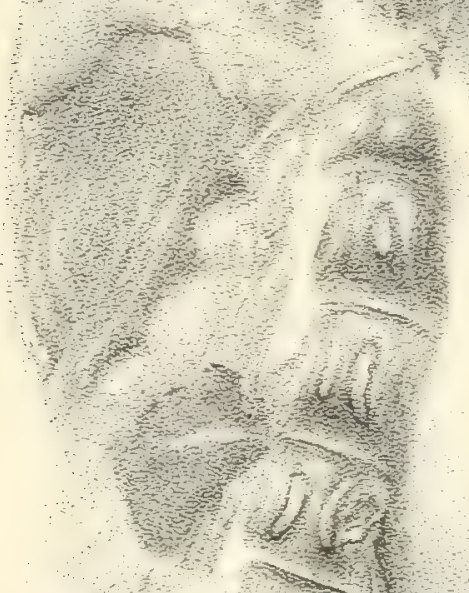

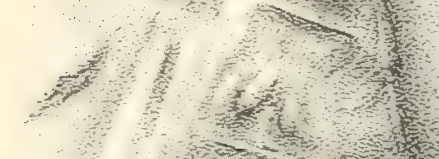

a
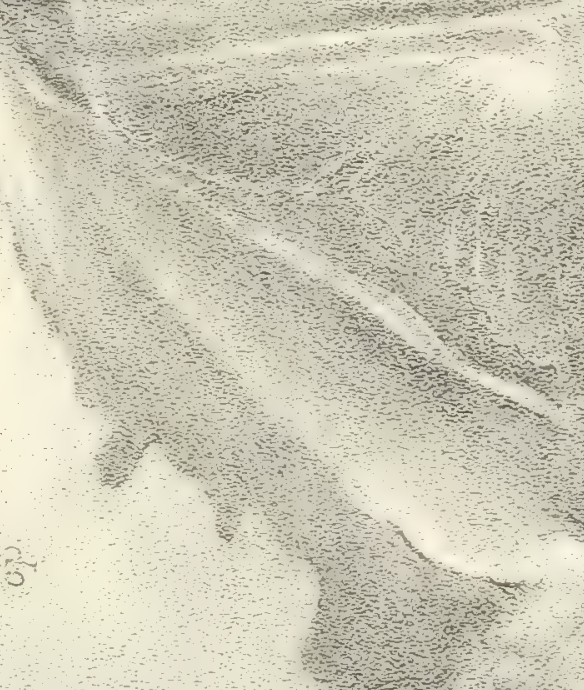

T.1.

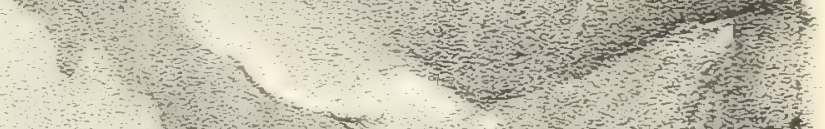

- D. W

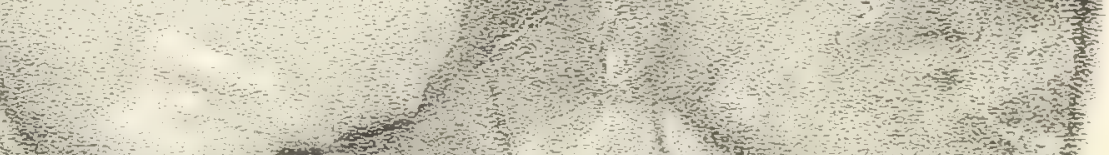

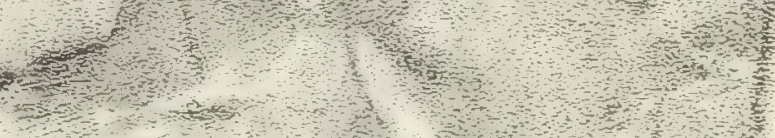
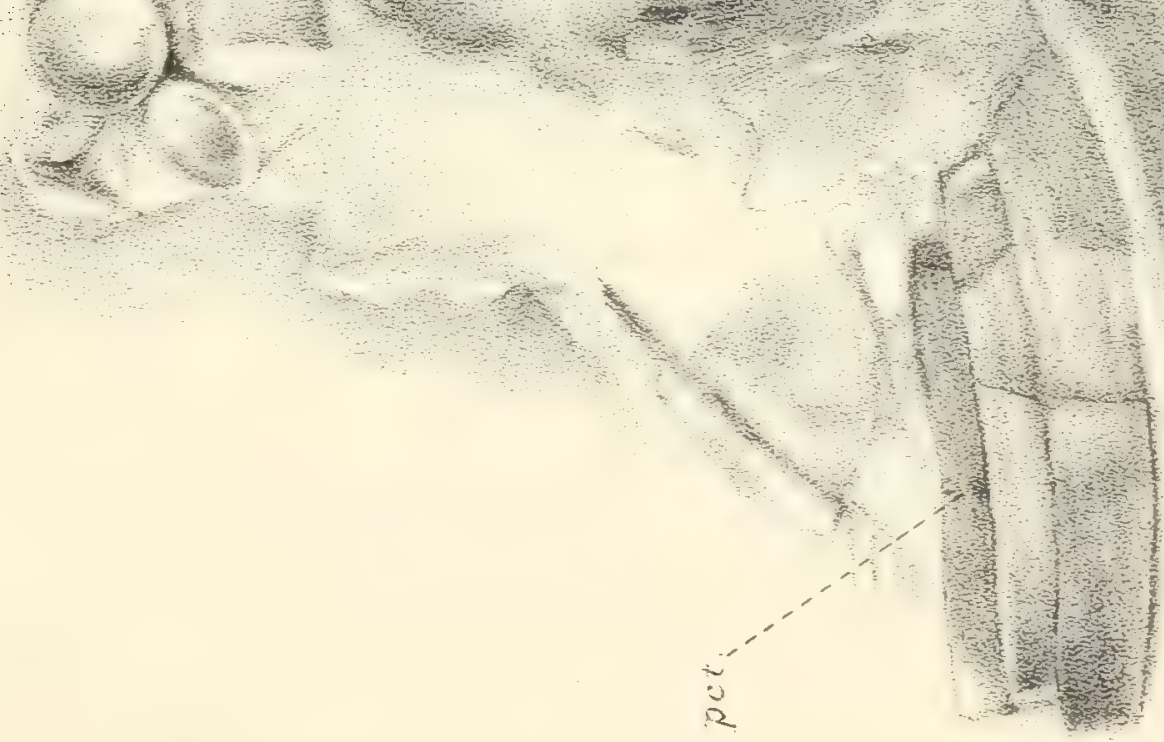

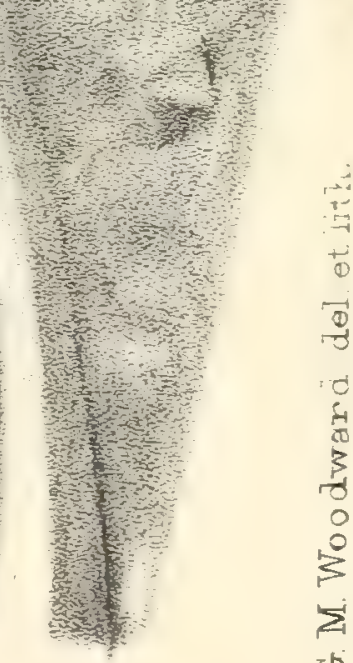





\section{PLATE IX.}

Fig.

1. Clartocyclus gardneri, Agassiz; scales, outer aspect.-

Upper Cretaceous : Ceara, Brazil.

[28901 b.] 109

2. Cladocyclus lewesiensis, Agassiz; scale, outer aspect.-

Chalk; Sussex.

[25861.] 110

3. Ditto ; scale, outer aspect.-Lower Chalk; Burham.

[41712.] 110

4. Ichthyodectes elegans, Newton ; left maxilla, outer aspect.

Lower Chalk; Upper Halling. [P. 5645.] 103

5. Ditto: left dentary, inner aspect, found with preceding

$\begin{array}{llll}\text { specimen. } & {[\text { P. 5644. }]} & 103\end{array}$

6. Ichthyodectes tenuidens, sp. nov.: head, right lateral aspect.-Lower Chalk; Burham. d. Dentary. $m x$. Maxilla. p.op. Preoperculum. pr.f. Prefrontal (ectethmoid). s.o. Suborbital. scl. Sclerotic. [49054.] 104 
4
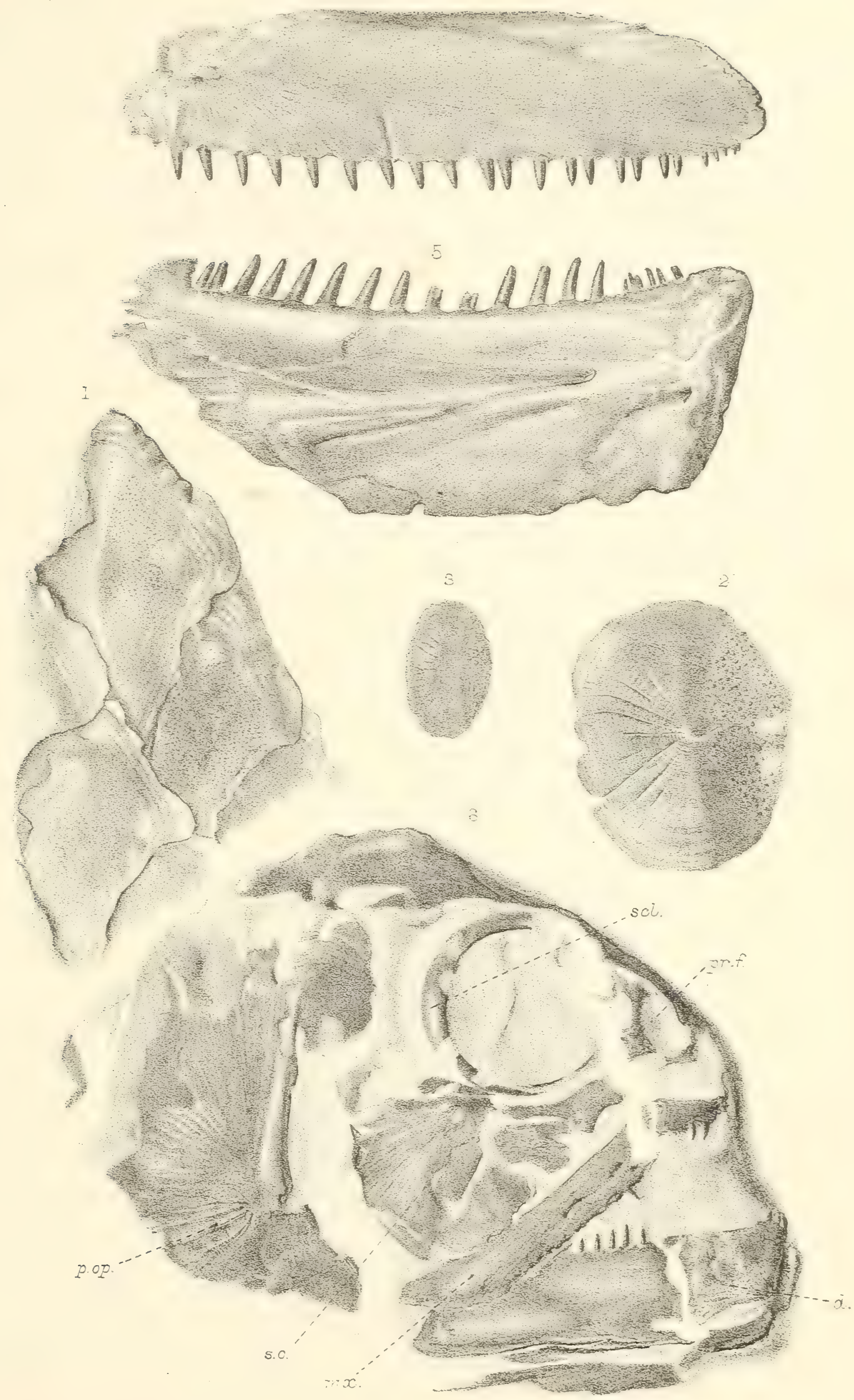



$$
698
$$


PLATE X.

Fig.

Page

1. Ctenothrissa radians (Agassiz); left lateral aspect.Lower Chalk; Burham. d. Dentary. plv. Pelvic fin.

[47911.]

123

2. Ditto; head and anterior abdominal region, right lateral aspect.-Lower Chalk; Kent. ag. Articulo-angular. $m x$. Maxilla. s.mx. Supramaxilla. Other letters as above.

[P. 4843 .

3. Ditto; head, right lateral aspect.- Ibid. i.op. Interoperculum. op. Operculum. p.op. Preoperculum. pmx. Premaxilla. s.op. Suboperculum. Other letters as above.

[P. 5699. 124

4. Ditto; restored outlines of maxillary and mandibular 122 bones. Letters as above.

5. Ctenothrissa microcephala (Agassiz); trunk, right lateral aspect.-Lower Chalk; Burham.

[P. 1946 a.] 126

6. Ditto ; imperfect fish, inferior aspect.-Ibid.

[41689.] 126 

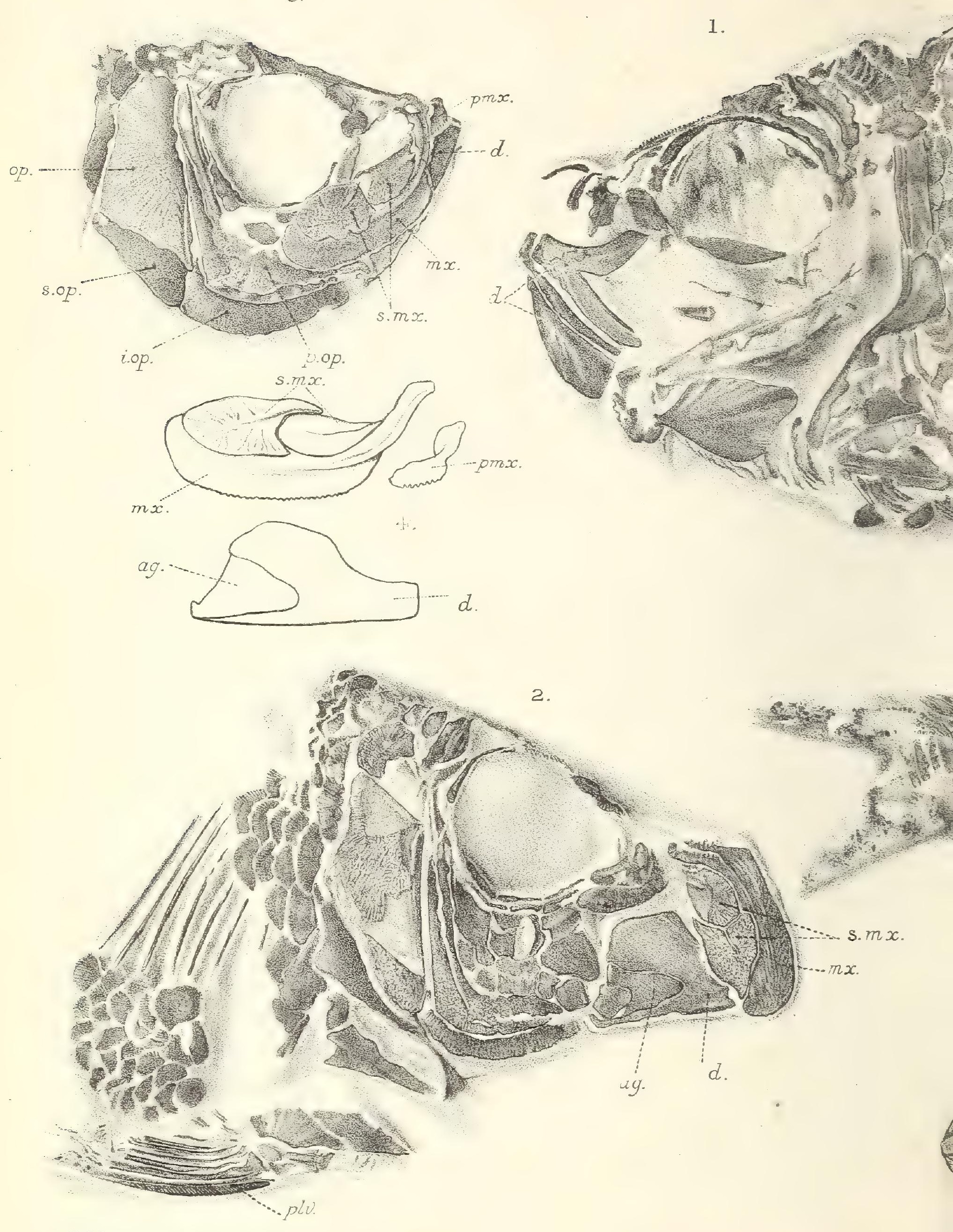

G.M.Woodward del.et.ith. 



\section{PLATE XI.}

Fig.

1. Enchodus lewesiensis (Mantell); anterior end of loft dentary, outer aspect.-Upper Chalk; Bromley.

[44578.] 193

2. Enchodus ulchellus, sp. nov.; head, left lateral aspect.Chalk: Kent. ag. Articulo-angular. d. Dentary. ecpt. Lictopterygoid. hm. Hyomandibular. op. Operculum. p.op. Preoperculum. pal. Palatine tooth. pmx. Premaxilla. s.op. Suboperculum. [P. 1703.]

3. Ditto; right premaxilla, outer aspect.-Chalk; Lewes.

[P. 5416.] 194

4. Enchodus annectens, sp. nor.; jaws of left side and right dentary ( $4 a$ ), outer aspect._English Chalk. Letters as above.

5. Ditto ; right palatine, outer aspect.-Ibid. [P. 5661.] 196

6. Enchodus faujasi, Agassiz; skull, superior aspect, and (6 a) jaws of right side, outer aspect, two thirds nat. size. ep.o. Epiotic. fr. Frontal. mx. Maxilla. pt.o. Pterotic. s.occ. Supraoccipital. $x$. Inner tooth. Other letters as above.

7. Eurypholis boissieri, Pictet: vertically crushed head and anterior abdominal region, superior aspect.-Upper Cretaceous; Hakel, Mt. Lebanon. c.o. Circumorbitals. d.s. Median dorsal scutes. o. Orbit. p.cl. Postclavicle. plu. Pelric fin. S.o. Suborbitals. Other letters as above. 

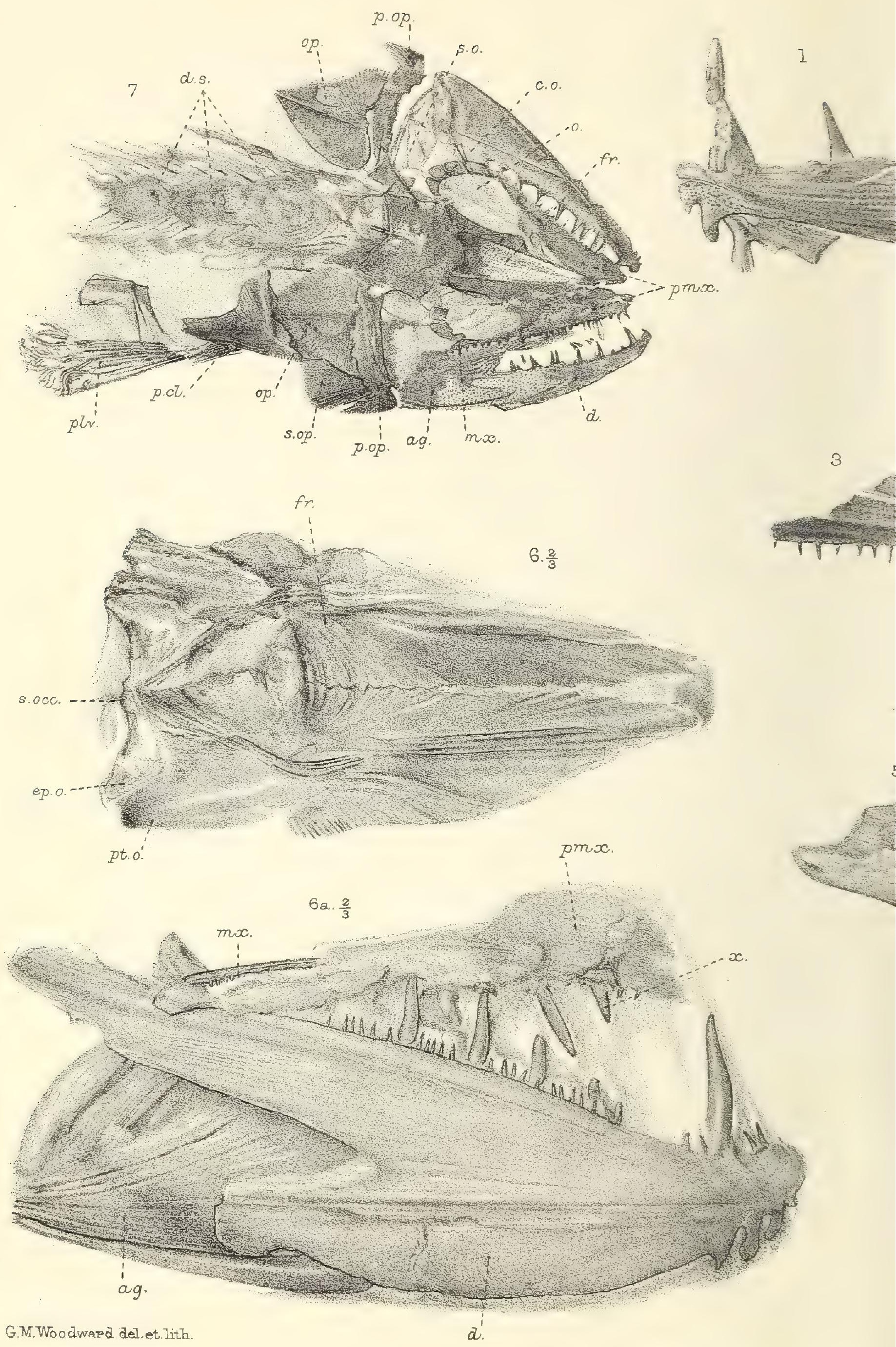

I-6. Enchodu 



\section{PLATE XII.}

Fig.

1. Enchelurus syriacus, sp. nov.; distorted fish, right lateral aspect.-Upper Cretaceous; Sahel Alma, Mt. Lebanun. br. Branchiostegal rays. pet. Pectoral tin. plv. Pelvic fins.

[P. 5998.] 165

2. Ditto; right lateral and partly superior aspect.-Ibid. op. Operculum. Other letters as above. [P. 9168.] 166

3. Enchelurus anglicus, sp. nov.; head and abdominal region, partly superior, partly left lateral aspect.Lower Chalk; Kent (?). enpt. Entopterygoid. eth. Ethmoid. fr. Frontal. md. Mandible. mx. Maxilla. pa. Parietals. sq. Squamosal. Other letters as above.

[P. 4249.] 167

4. Leptotrachelus elongatus (Agassiz); depressed head, upper aspect, and ( 4 a) part of impression of occipital region of the same.-Chalk; Lewes. orb. Orbit. p.t. Posttemporal. pmx. Premaxilla. Other letters as above.

[49793.] 185

5. Sardinioides uttenuatus, sp. nov. ; right lateral aspect, and scale $(5 a)$ enlarged three times. - Upper Cretaceous; Hakel, Mt. Lebanon. 

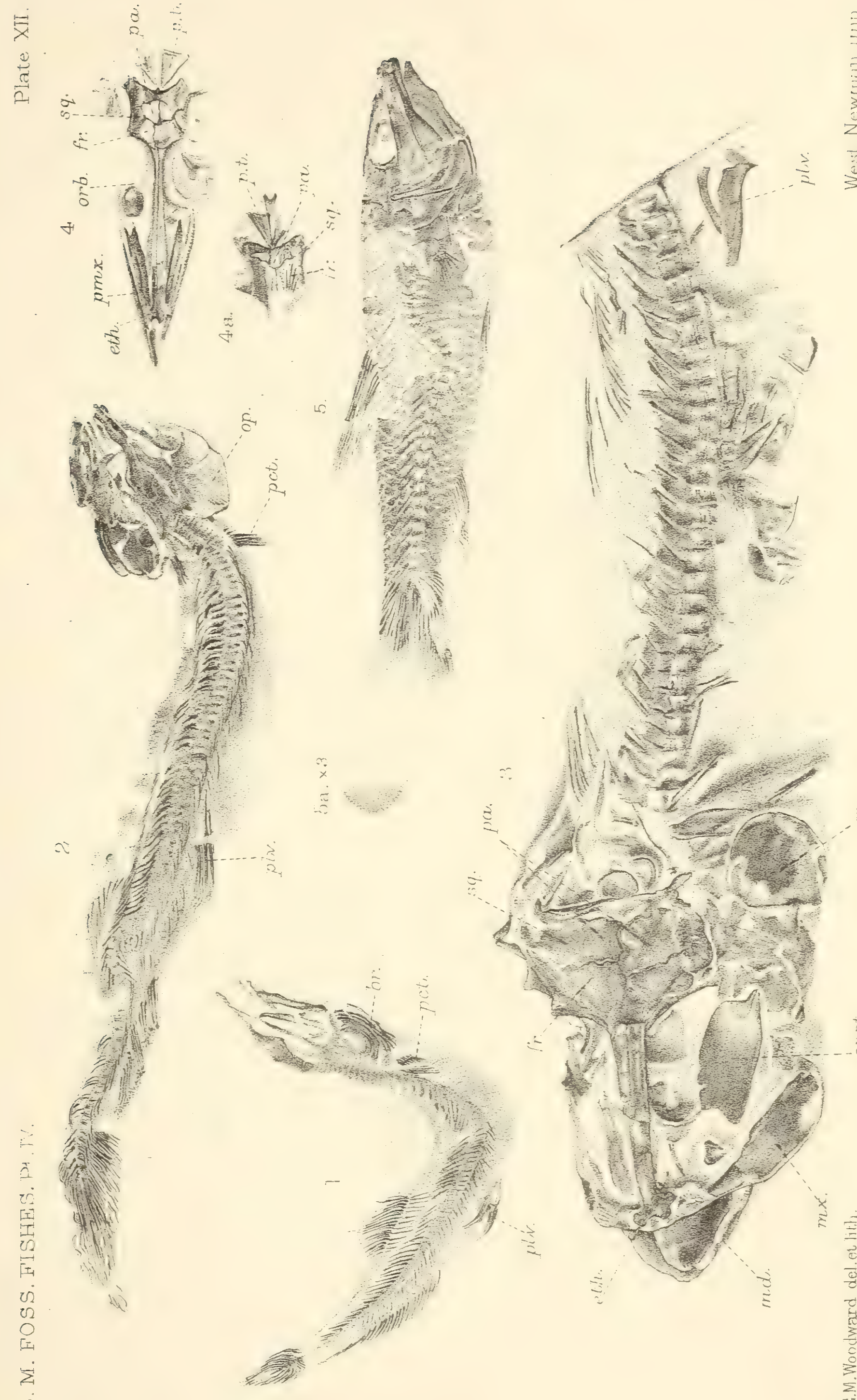

, 


\section{PLATE XIII.}

Fig.

Page

1. Rhinellus furcatus, Agassiz; left lateral aspect.-Upper

Cretaceous; Sahel Alma, Mt. Lebąnon. [P. 4762.] 266

2. Ditto; left lateral aspect.-Ibid.

[49525.] 266

3. Apateorlus glyphodus (C. C. Blake); portion of jaws, left lateral aspect.-Gault; Folkestone. d. Dentary. pmx. Fremaxilla.

[47204.] 259

4. Ditto; anterior half of right premaxilla, inner aspect. -Ibid.

5. Ditto; anterior portion of left dentary, outer aspect.Ibid.

[47204 c. $] 260$

6. Apateodus striatus, sp. nov.; anterior portion of right premaxilla, outer aspect.—Chalk; Kent. [49067.] 262

7. Apateodus lanceolatus, sp. nov.; anterior portion of right premaxilla, outer aspect.-Grey Chalk; Dover. 


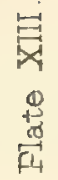

co
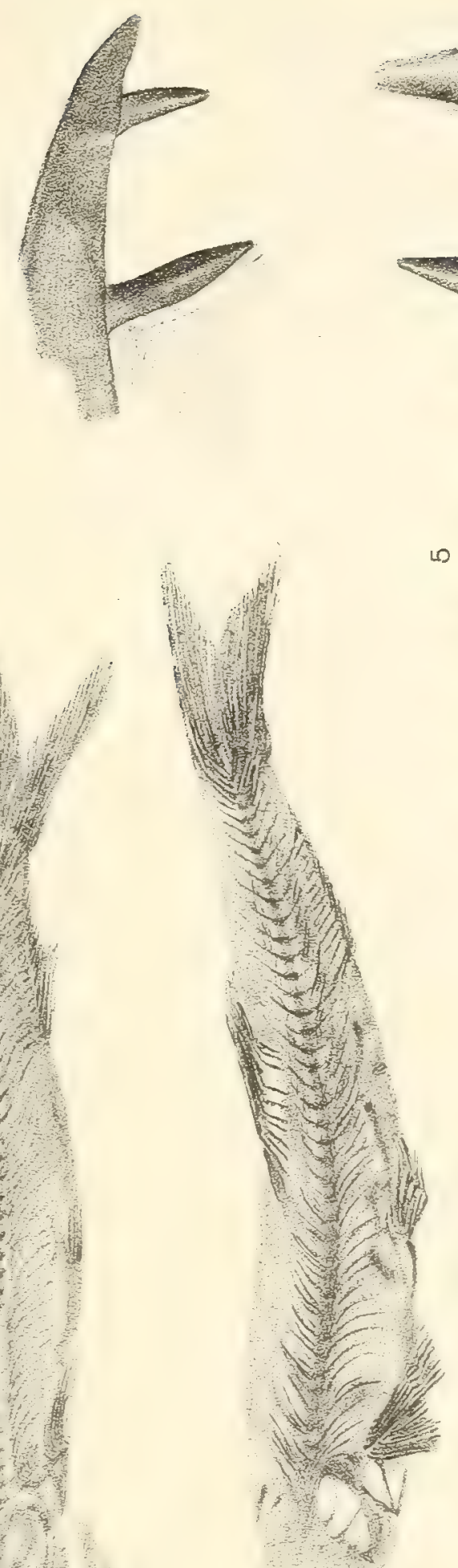

م
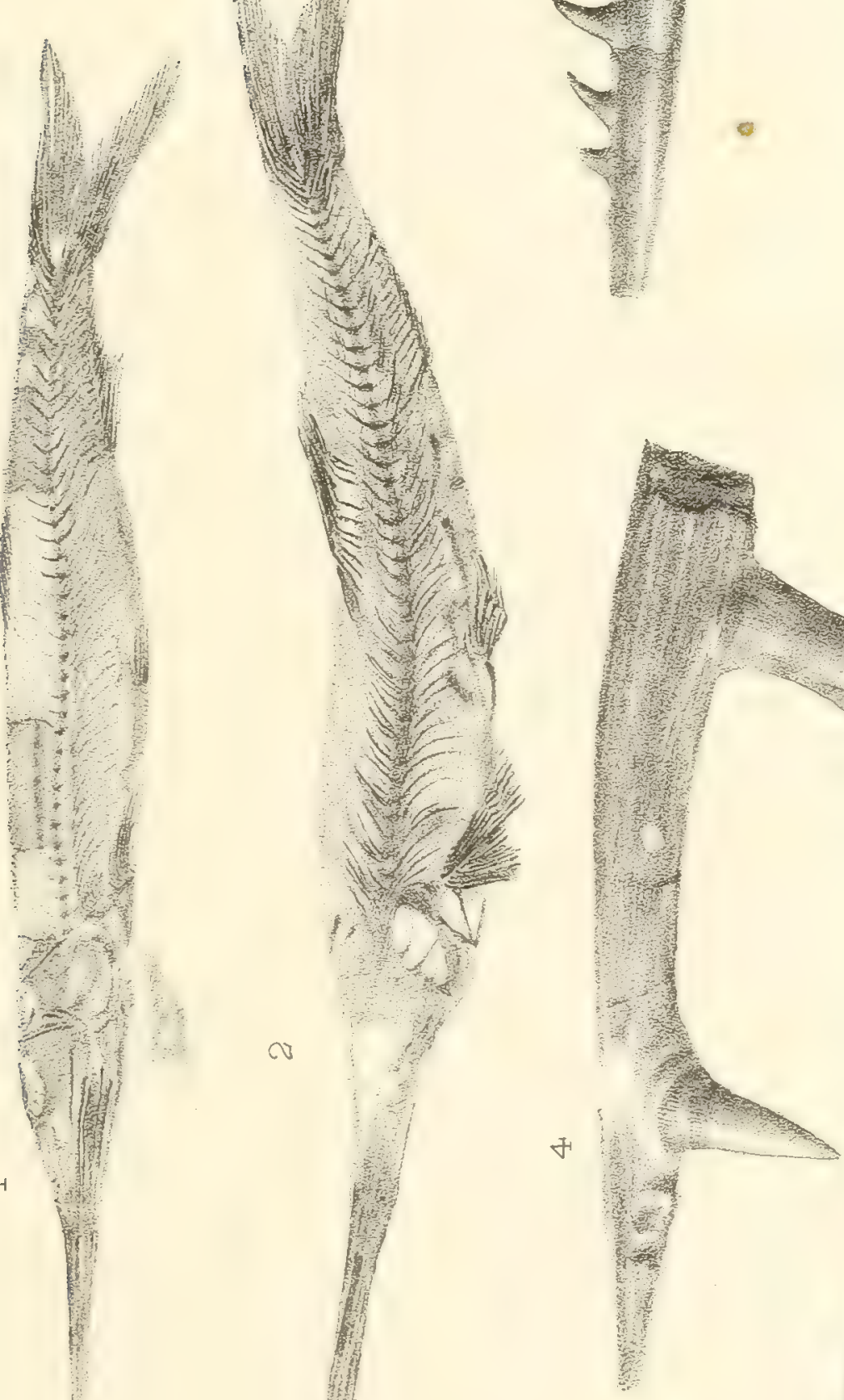

4

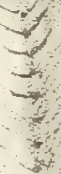

3

$+3$

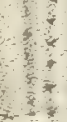

in

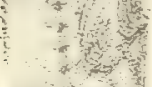

Af

$=$

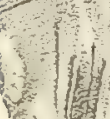

空

II

0

II

远

4

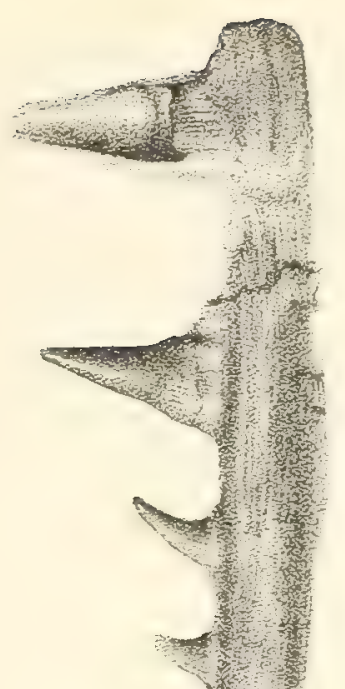

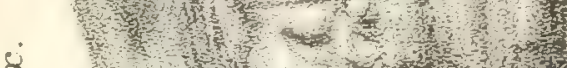
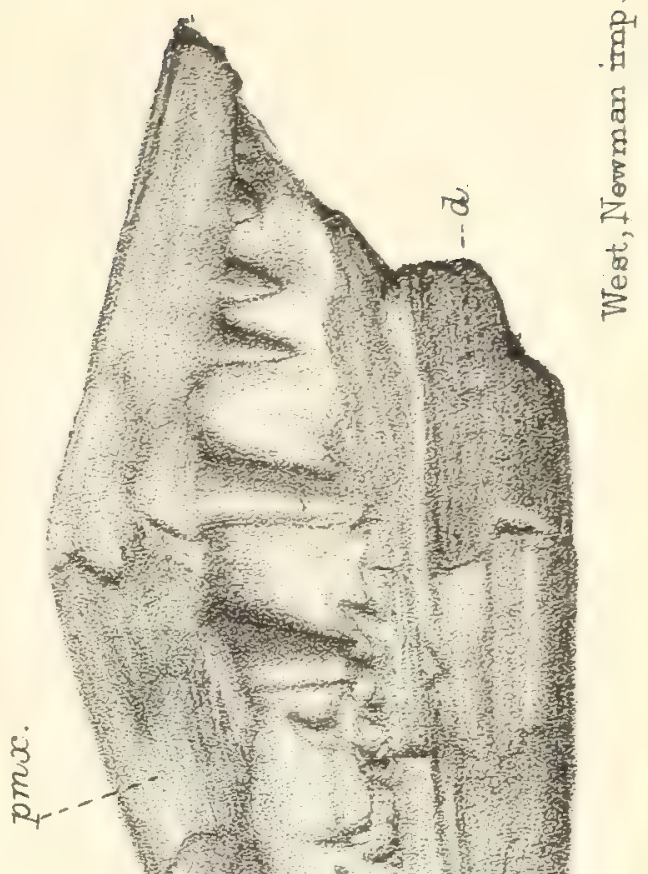

c)

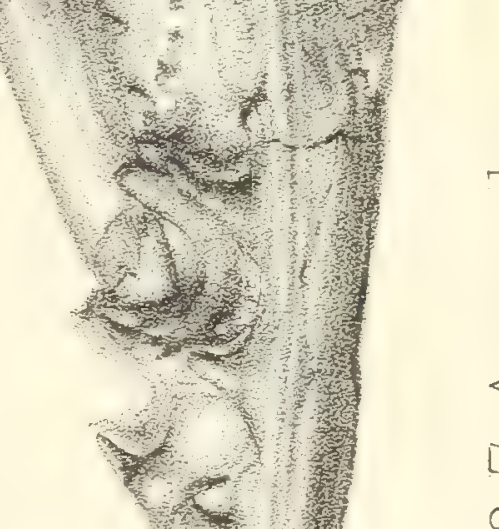

0
0
0
0
0
0
0
0
0
4
1
0
0

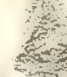

4

b

1

t.

$\sum$

7

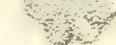

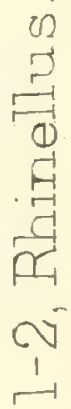

焉
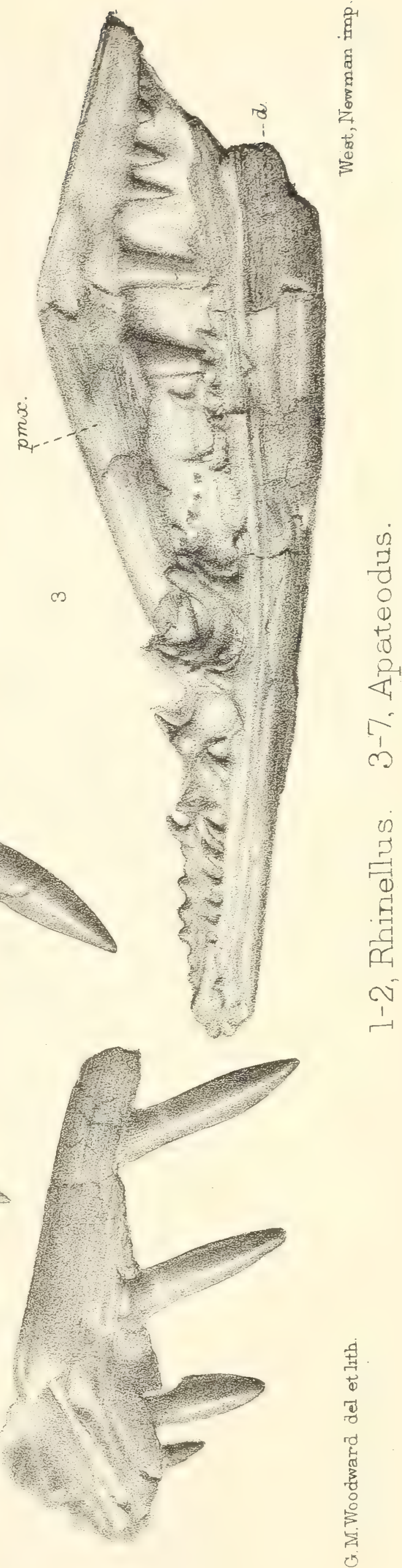


\section{PLATE XIV.}

Fig.

1. Apateodus striatus, sp. nov.: distorted head, right lateral, left lateral ( $1 a$ ), and superior (1 b) aspects.-Lower Chalk; Southeram, Lewes. ag. Articulo-angular. d. Dentary. fr. Frontal. p.op. Preoperculum. pmx. Premaxilla. qu. Quadrate. s.occ. Supraoccipital. $x$. Fragment of bone. I., II. Enlarged teeth of premaxilla.

[49821.] 261

2. Ditto ; distorted head, right lateral, left lateral $(2 \alpha)$, and superior ( $2 b$ ) aspects.-English Chalk. eth. Ethmoid. s.o. Suborbitals. Other lettering as above.

[P. 4512.] 262 


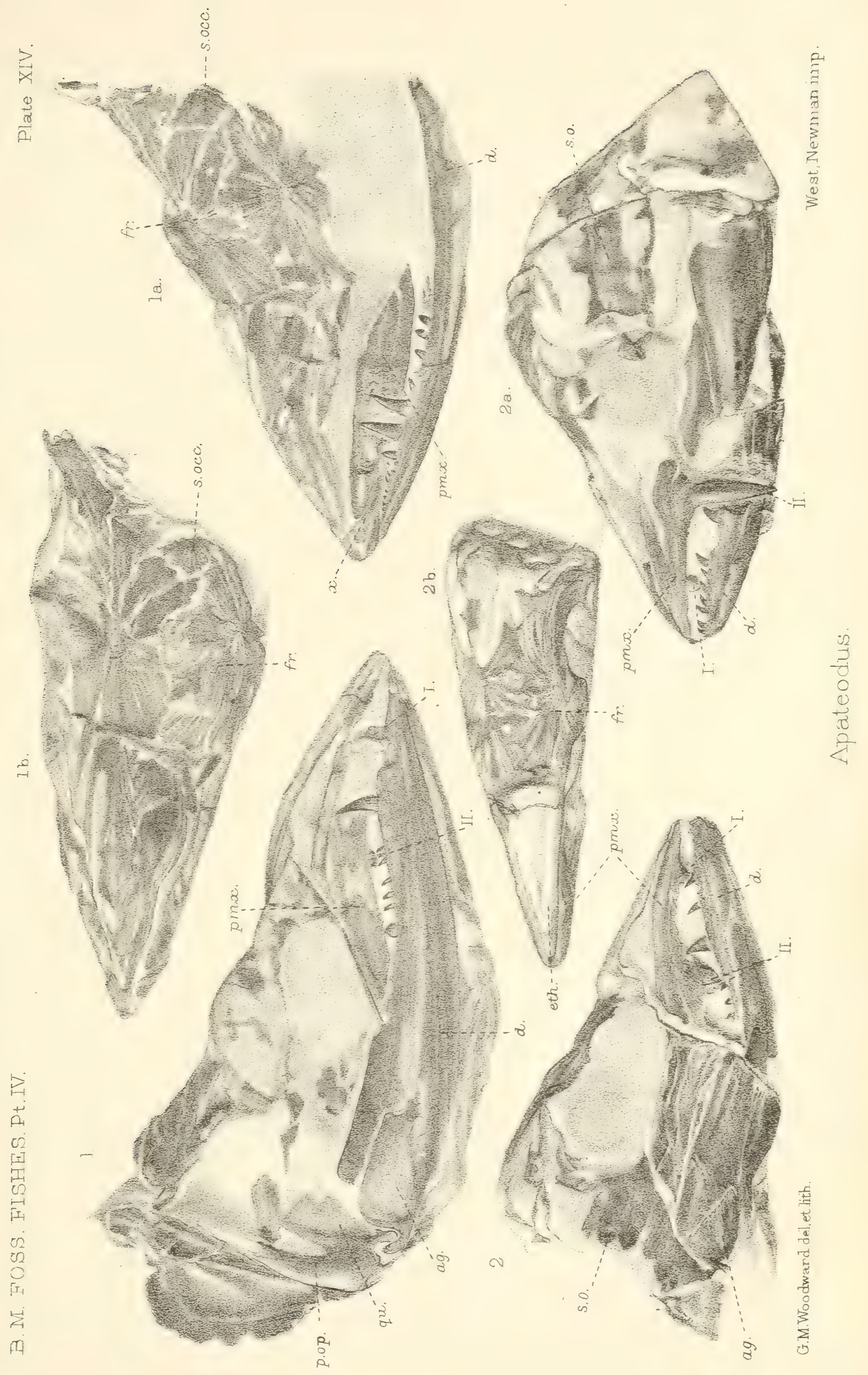





\section{PLATE $\mathrm{XV}$.}

Fig. $\quad$ Page

1. Pronotacanthus sahel-almo (Davis); left lateral aspect. Upper Cretaceous; Sahel Alma, Mt. Lebanon. plv. $\begin{array}{lll}\text { Pelvic fins. } & \text { [P. 4741.] } 169\end{array}$

2. Ditto; head and part of abdominal region, left lateral $\begin{array}{lll}\text { aspect -Ibid. } & \text { [P. 9169.] } 170\end{array}$

3. Charitosomus major, sp. nov.; right lateral aspect.Ibid. d. Dentary. $m x$. Maxilla. t. Inner teeth.

[P. 9173.] 273

4. Charitosomus lineolutus (Pictet \& Humbert); left lateral $\begin{array}{lll}\text { aspect.-Ibid. [P. 4752.] } & 274\end{array}$

5. Notogoneus longiceps (Meyer); left lateral aspect.- - Tpper

Oligocene; Mombach, Mayence.

[P. 1820.] 278 

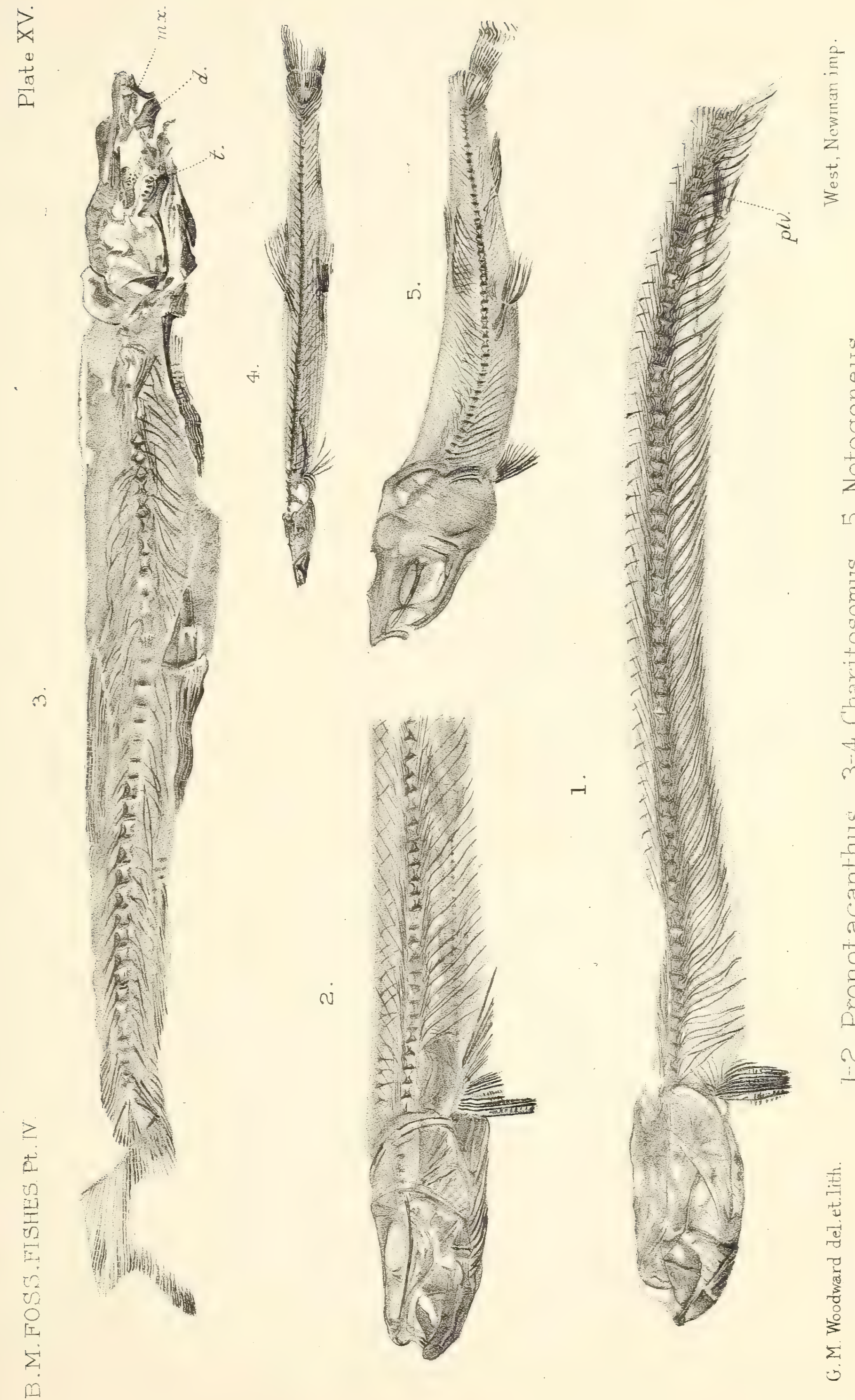

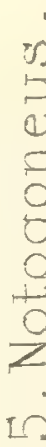





$$
7 / 2
$$




\section{PLATE XVI.}

Fig.

Page

1. Nematonotus bottce (Pictet \& Humbert); right lateral aspect.-Upper Cretaceous; Hakel, Mt. Lebanon.

[49562.] 251

2. Sardinioides pusillus, sp. nov.; left lateral as pect.-Upper

Cretaceous; Sahel Alma, Mt. Lebanon. [48123.] 240

3. Ditto; left lateral aspect.-Ibid.

[P. 4482.] 241

4. Hoplopteryx lewesiensis (Mantell); head, right lateral aspect.-Chalk; Lewes. ag. Articulo-angular. c.o. Circumorbitals. d. Dentary. i.op. Interoperculum. $m x$. Maxilla. op. Operculum. p.op. Preoperculum. pmx. Premaxilla. s.mx. Supramaxilla. s.o. Suborbitals. $s . o p$. Subonerculum.

[P. 5420.] 400 


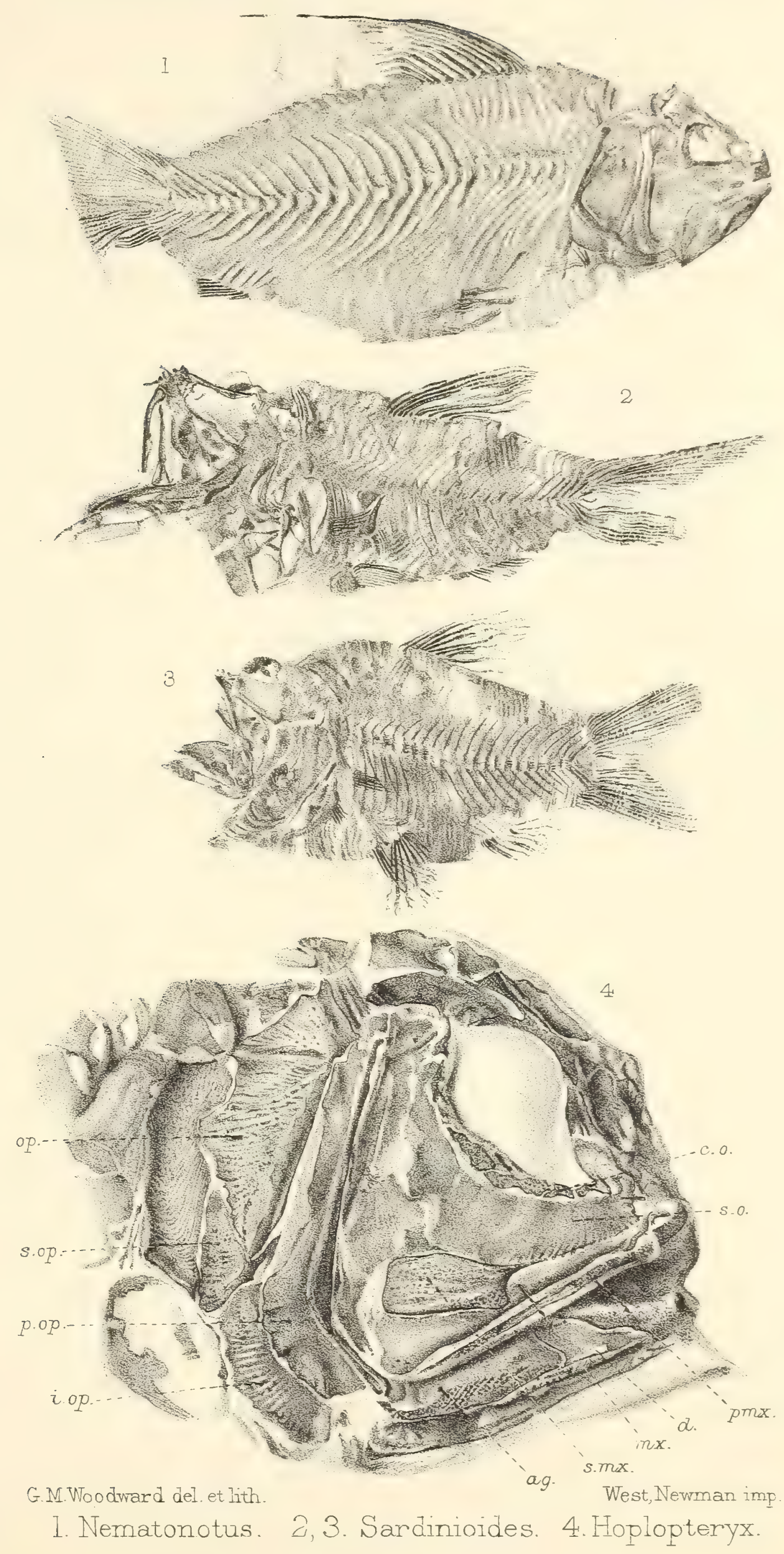



$77 \%$ 


\section{PLATE XVII.}

Fig. $\quad$ Page

1. Tetragonopterus avus, A. S. Woodw.; right lateral aspect.

-Tertiary Lignite; Taubaté, San Paulo, Brazil.

[P. 9222.] 298

2. Tetragonopterus ligniticus, A. S. Woodw.: right lateral aspect.-Ibid.

[P. 9012.] 299

3. Ditto; left lateral aspect.-Ibid.

[P. 9226.] 299

4. Arivis iheringi, A. S. Woodw.; skull, superior aspect.Ibid.

[P. 9220.] 334

5. Percichtreys antiquus, A. S. Woodw.; dorsal portion of trunk, right lateral aspect.-Ibid.

[P. 9011.] 514 

B.M. Foss. Fishes, Pt. IV.

I.

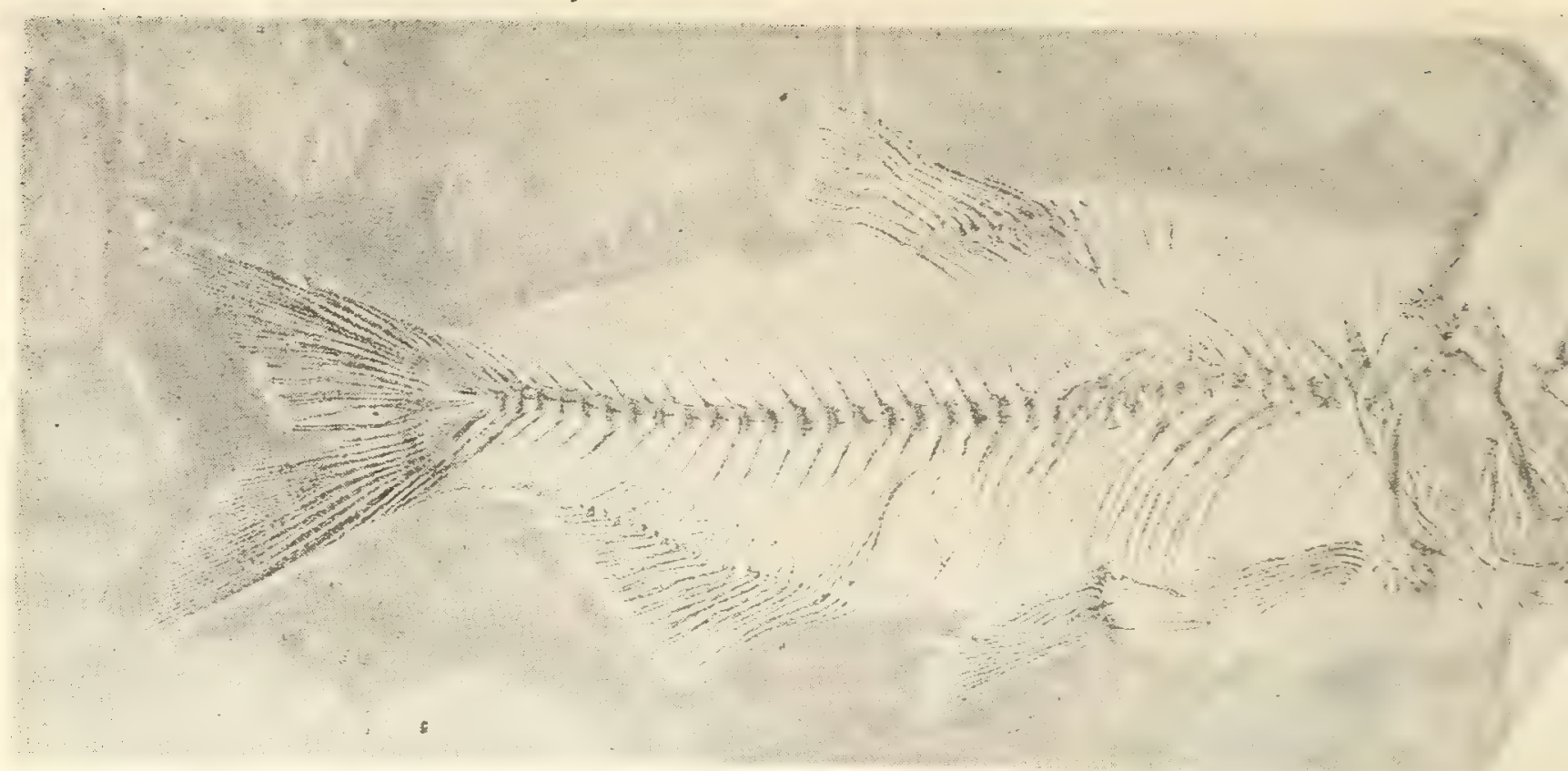

2.

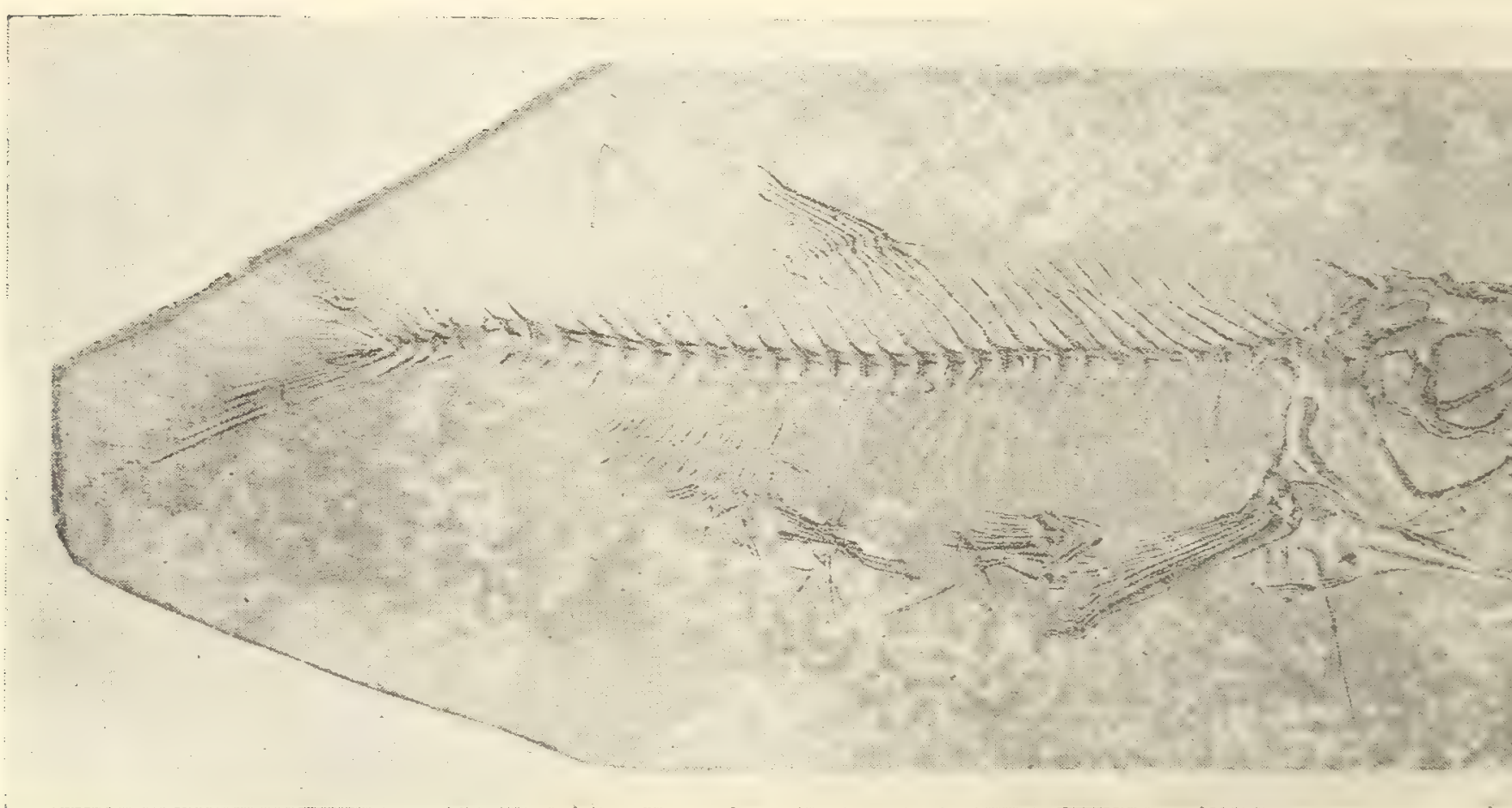

3.

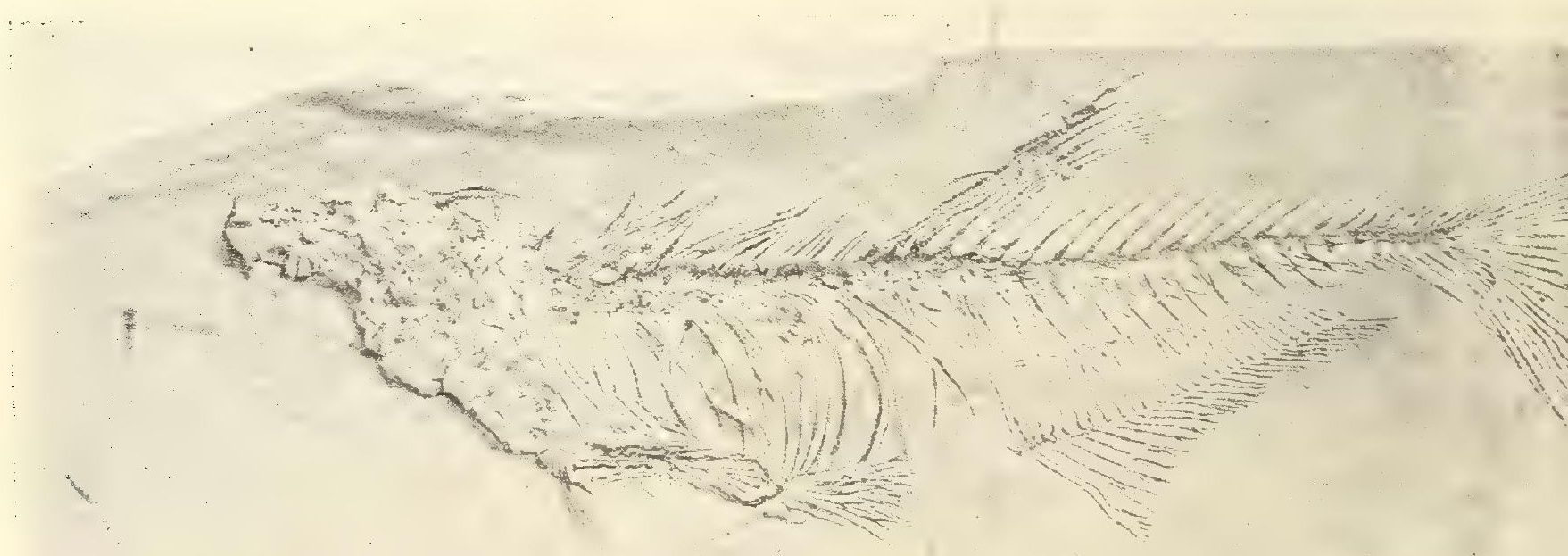

Tertiary Fis 

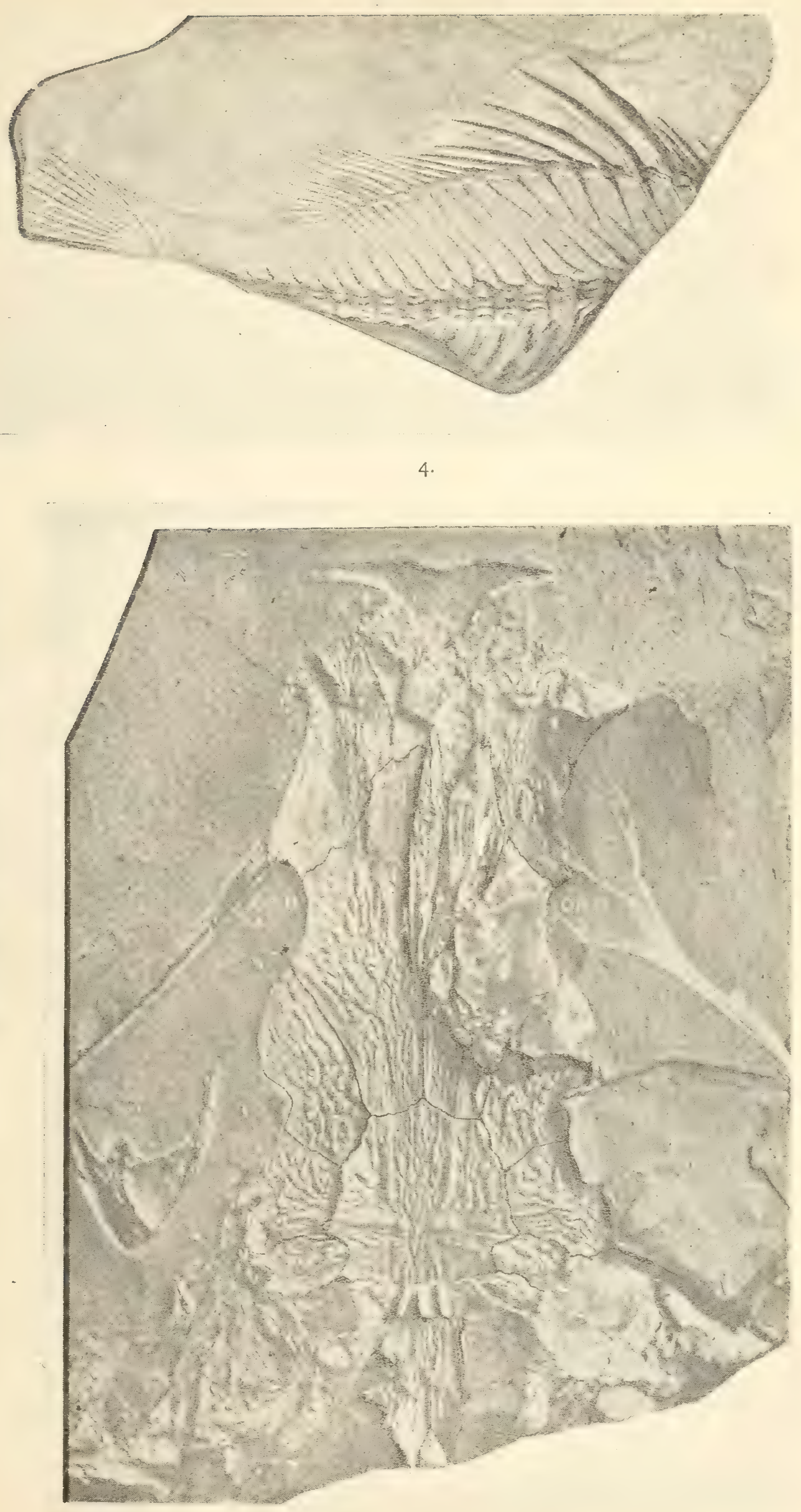

from Brazil. 




\section{PLATE XVIII.}

Fig.

1. Urenchelys avus, sp. nov.; distorted fish, right lateral aspect.-Upper Cretaceous; Sahel Alma, Mt. Lebanon.

[P. 4860.] 337

2. Ditto; head and part of abdominal region, right lateral aspect.-Ibid. $c l$. Clavicle. md. Mandible. pct.

Pectoral fin. s.occ. Sủpraoceipital.

[P. 4751.] 338

3. Urenchelys hakelensis (Davis) ; left lateral aspeet.-Upper

Cretaceous; Hakel, Mt. Lebanon.

[P. 4872.] 339

4. Rhynchorhinus branchialis, sp. nov.; head, right lateral and superior (4a) aspects.-London Clay; Sheppey. eth. Ethmoid. fr. Frontal. $h m$. Hyomandibular. md. Mandible. pa. Parietal. sq. Squamosal. $x$. Upper jaw.

[P. 163.] 


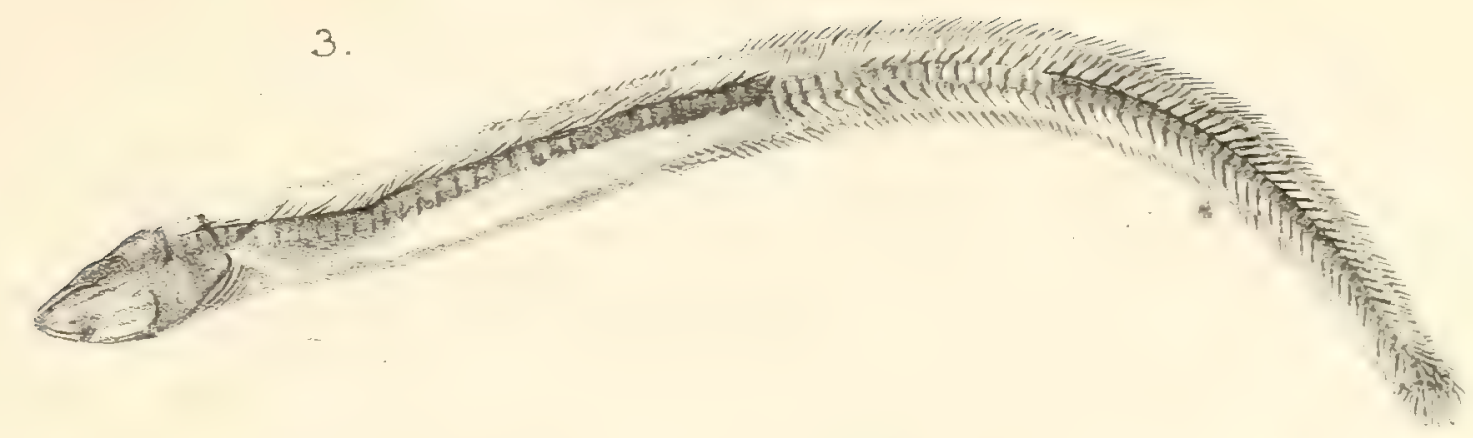

\section{S.occ}
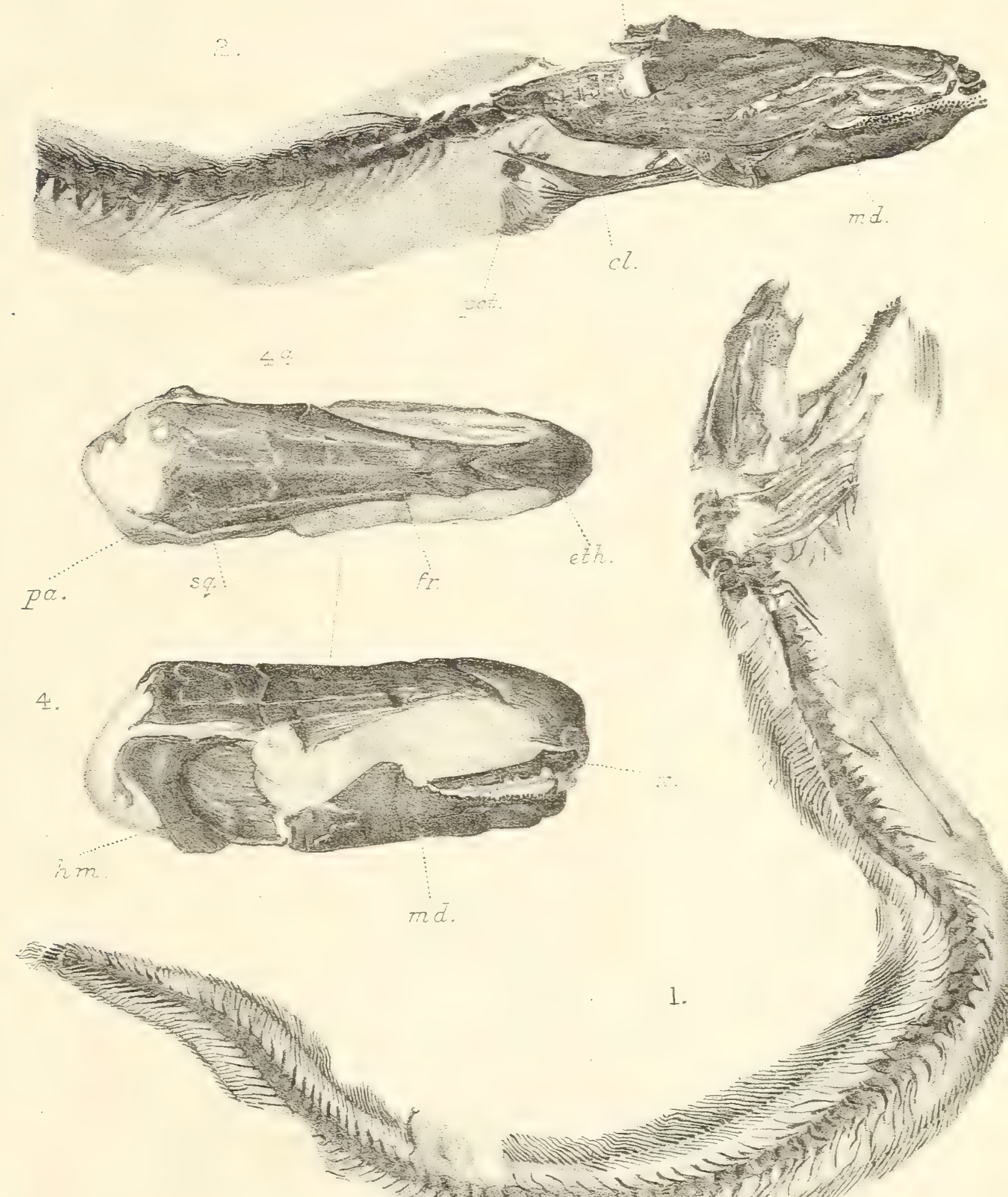

1.

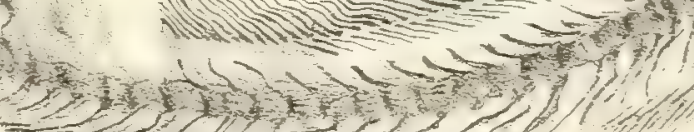

$22+120$

G.M.Voodward del eilith.

West.Newnan. imp

Apodes. 


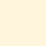





\section{PLATE XIX.}

Fig.

Page

1. Biphiorhynchus priscus (Agassiz); portion of skull, superior and left lateral ( 1 a) aspects.-London Clay; Sheppey. eth. Ethmoid. fr. Frontal. mx. Marilla. na. Nasal. pmx. Premaxilla. prf. Prefrontal (ectethmoid). sct. Sclerotic. 1b. Oral face of right premaxilla.

[28711.] 492

2. Ditto; hinder portion of skull, superior aspect.-Ibid. ep.o. Epiotic. fr. Frontal pa. Parietal. pt.f. Postfrontal (sphenotic). s.oce. Supraoccipital. sq. Squamosal.

[3238\%.] 492

3. Acestrus ornatug, sp. nov.; portion of skull, superior aspect.-Ibid. Leters as abore.

[P. 1739.] 494 
B M FOSS FISHES Pt.IV

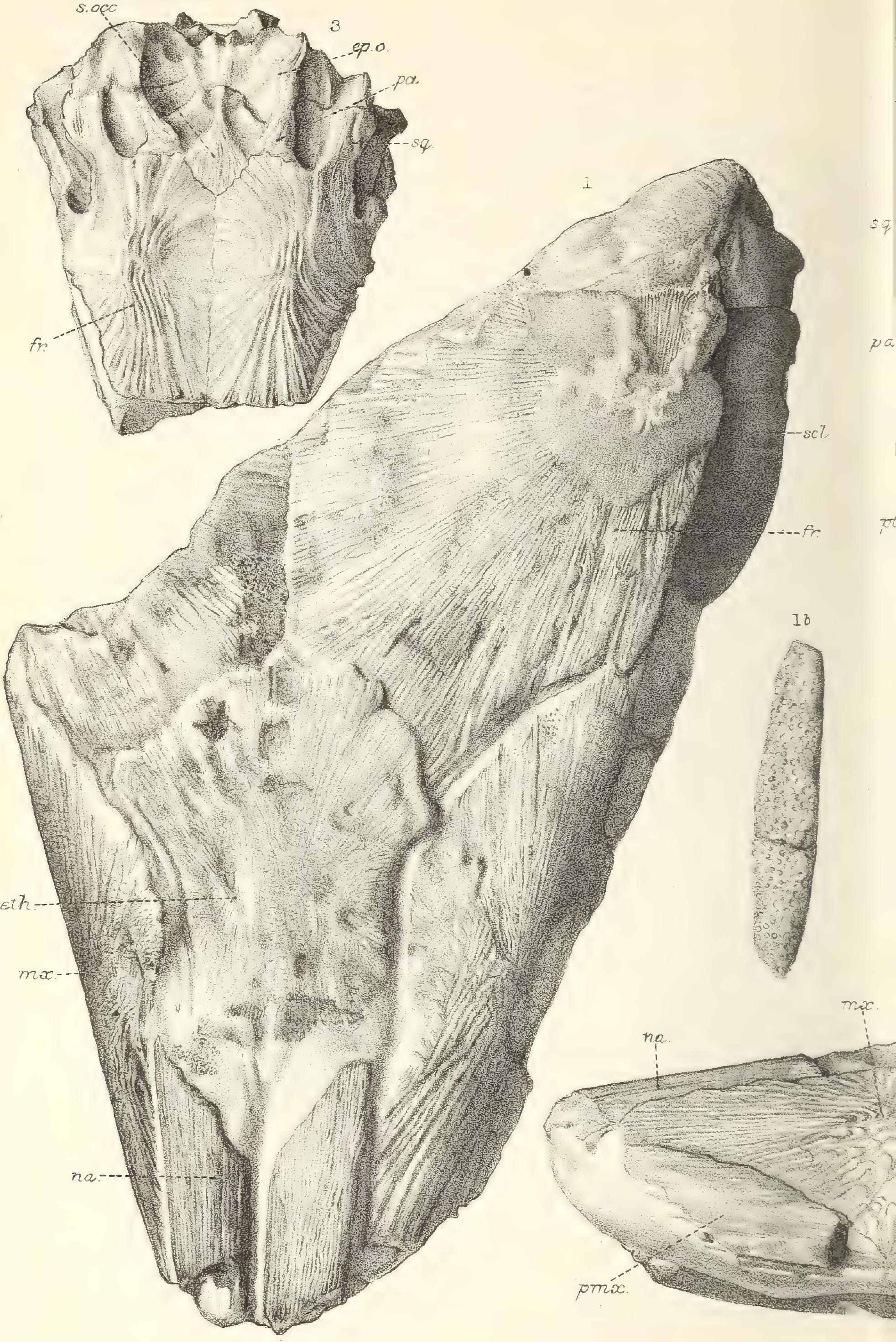

GMWoodward del et lith 

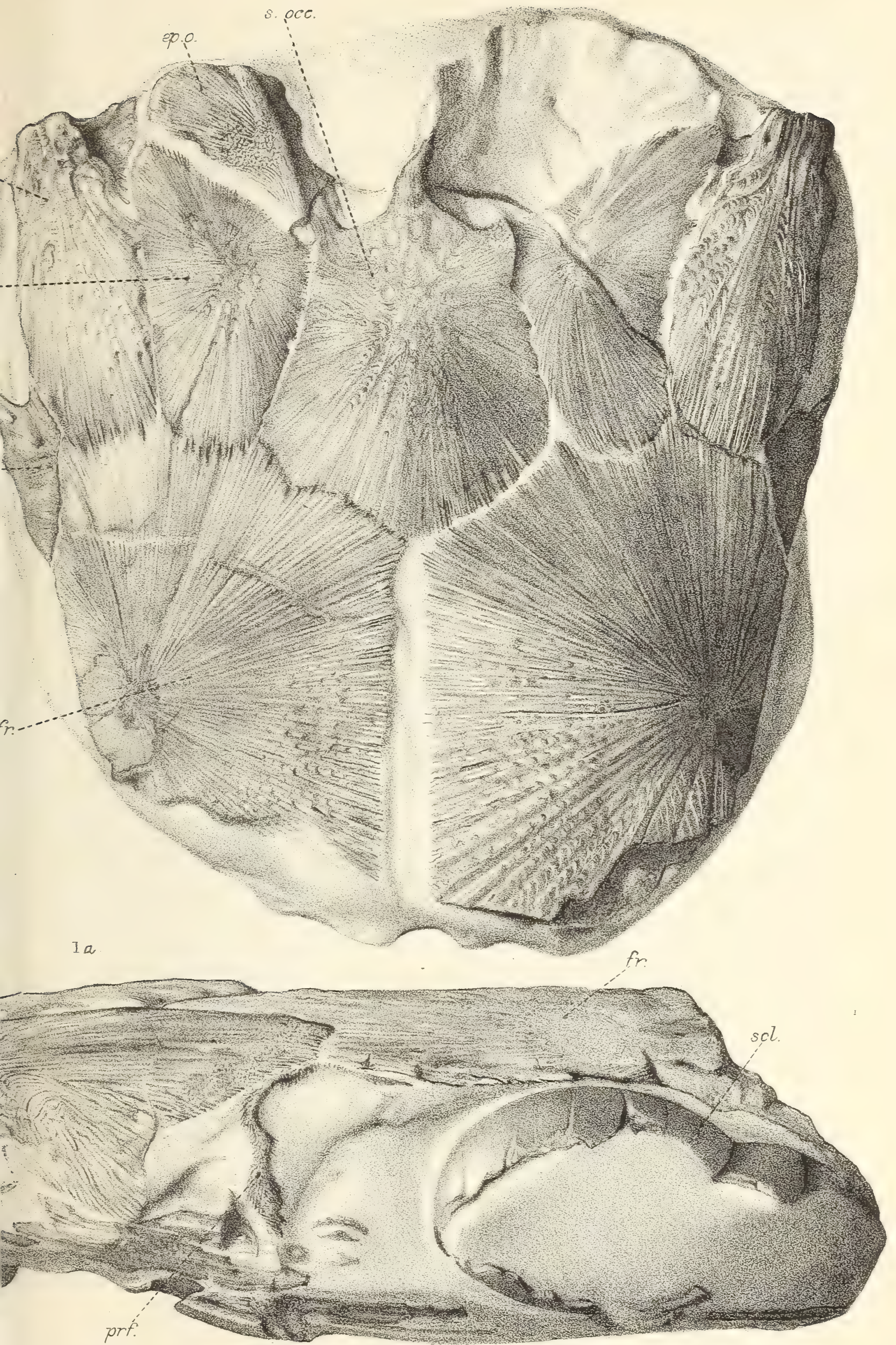

Viest, Newman ime 



\section{NATURAL HISTORY PUBLICATIONS \\ OF THE TRUSTEES OF THE BRITISH MUSEUMI,}

The following publications can be purchased through the Agency of Messrs. Longmans \& Co., 39, Paternoster Rou'; Mr. Quaritch, 15, Piccadilly; Messrs. Kegar Paul, Trench, TrÜBner \& Co., Paternoster House, Charing Cross Road; and Messrs. Dulau \& Co., 37, Soho Square; or at the Natural History Museum, Cromwell Road, London, S.W.

Catalogue of the Specimens and Drawings of Mammals, Birds, Reptiles, and Fishes of Nepal and Tibet. Presented by B. H. Hodgson, Esq., to the British Museum. 2nd edition. By John Edward Gray. Pp. xii., 90. [With an account of the Collection by Mr. Hodgson.] 186.3, 12 mo. $2 s .3 d$.

Gatalogue of the Mammalia and Birds of New Guinea in the Collection of the British Museum. [With list of Species of New Guinea Birds, and those of the neighbouring Localities.] By John Edward Gray, Ph.D., F.R.S., and George Robert Gray, F.L.S., \&c. Pp. 63. Woodcuts. 1859, 8vo. 1s. $6 d$.

Report on the Zoological Collections made in the IndoPacific Ocean during the voyage of H.M.S. "Alert," 1881-2. Pp. xх7., 684. 54 Plates. 1884, 8vo.

Summary of the Voyage $\quad .$. By Dr. R. W. Coppinger.

Mammalia $\quad \ldots \quad \ldots \quad \ldots \quad, \quad$ O. Thomas.

Aves $\quad . . \quad \ldots \quad \ldots \quad \ldots$, , R. B. Sharpe.

Reptilia, Batrachia, Pisces ... , A. Giinther.

Mollusca $\quad \ldots \quad \ldots \quad \ldots$, , E. A. Smith.

Echinodermata $\quad \ldots \quad$... , F. J. Bell.

$\begin{array}{lllll}\text { Crustacea } & \ldots & \ldots & \ldots & \text {, E. J. Miers. }\end{array}$

Coleoptera $\quad \ldots . \quad \ldots \quad$... " C. O. Waterhouse,

Lepidoptera $\quad . . \quad \ldots . \quad$.. " A. G. Butler.

Alcyonaria and Spongiida ... , S. O. Ridley.

$1 l 10 \mathrm{~s}$. 
A Monograph of Christmas Island (Indian Ocean): Physical Features and Geology by C. W. Andrews, B.A., B.Sc., F.G.S., with descriptions of the Fauna and Flora by numerous contributors. Pp. xv.,337: 22 plates (7 coloured), a map, and 27 illustrations in text. [With Index.] 1900, 8vo. $20 s$.

\section{MAMMALS.}

Catalogue of the Bones of Mammalia in the Collection of the British Museum. By Edward Gerrard. Pp. iv., 296. 1862, 8vo. 5s.

Catalogue of Monkeys, Lemurs, and Fruit-eating Bats in the Collection of the British Museum. By Dr. J. E. Gray, F.R.S., \&c. Pp. viii., 137. 21 Woodcuts. 1870, 8vo. $4 s$.

Catalogue of Carnivorous, Pachydermatous, and Edentate Mammalia in the British Museum. By John Edward Gray, F.R.S., \&c. Pp. vii., 398. 47 Woodcuts. 1869, 8vo. 6s. 6d.

Catalogue of Seals and Whales in the British Museum. By John Edward Gray, F.R.S., \&c. 2nd Edition. Pp. vii., 402. 101 Woodcuts. 1866, 8vo. $8 s$.

Supplement. By John Edward Gray, F.R.S., \&c. Pp. vi., 103. 11 Woodcuts. 1871, 8vo. 2s. 6d.

List of the Specimens of Cetacea in the Zoological Department of the British Museum. By William Henry Flower, LL.D., F.R.S., \&c. [With Systematic and Alphabetical Indexes.] Pp. iv., 36. 1885, 8vo. 1s. 6d.

Catalogue of Ruminant Mammalia (Pecora, Linnæus) in the British Museum. By John Edward Gray, F.R.S., \&c. Pp. viii., 102. 4 Plates. 1872, 8vo. 3s. $6 d$.

Catalogue of the Marsupialia and Monotremata in the Collection of the British Museum. By Oldfield Thomas. Pp. xiii., 401. 4 Coloured and 24 plain Plates. [With Systematic and Alphabetical Indexes.] 1888, 8 ro. $11.8 s$.

\section{BIRDS.}

Catalogue of the Birds in the British Museum :-

Vol. VI. Catalogue of the Passeriformes, or Perching Birds, in the Collection of the British Museum. Cichlomorphce: Part III., containing the first portion of the family Timeliidæ (Babbling Thrushes). By 
Catalogue of the Birds in the British Museum-continued.

R. Bowdler Sharpe. Pp. xiii., 420. Woodcuts and 18 coloured Plates. [With Systematic and Alphabetical Indexes.] 1881, 8vo. 17 .

Vol. VII. Catalogue of the Passeriformes, or Perching Birds, in the Collection of the British Museum. Cichlomorpha: Part IV., containing the concluding portion of the family Timeliidæ (Babbling Thrushes). By R. Bowdler Sharpe. Pp.xvi.,698. Woodcuts and 15 coloured Plates. [With Systematic and Alphabetical Indexes.] 1883, 8vo. 1l.6s.

Vol. VIII. Catalogue of the Passeriformes, or Perching Birds, in the Collection of the British Museum. Cichlomorphce: Part V., containing the families Paridæ and Laniidæ (Titmice and Shrikes); and Certhiomorphce (Creepers and Nuthatches). By Hans Gadow, M.A., Ph.D. Pp. xiii., 386. Woodcuts and 9 coloured Plates. [With Systematic and Alphabetical Indexes.] 1883, 8vo.17s.

Vol. IX. Catalogue of the Passeriformes, or Perching Birds, in the Collection of the British Museum. Cinnyrimorphce, containing the families Nectariniidæ and Meliphagidæ (Sun Birds and Honey-eaters). By Hans Gadow, M.A., Ph.D. Yp. xii., 310. Woodeuts and 7 coloured Plates. [With Systematic and Alphabetical Indexes.] 1884, 8vo. 14s.

Vol. X. Catalogue of the Passeriformes, or Perching Birds, in the Collection of the British Museum. Fringilliformes: Part I., containing the families Dicæidæ, Hirundinidæ, Ampelidæ, "Mniotiltidæ, and Motacillidæ. By R. Bowdler Sharpe. Pp. xiii., 682. Woodcuts and 12 coloured Plates. [With Systematic and Alphabetical Indexes.] 1885, 8vo. 1l.2s.

Vol. XI. Catalogue of the Passeriformes, or Perching Birds, in the Collection of the British Museum. Fringitliformes: Part II., containing the families Cœrebidæ, Tanagridæ, and Icteridæ. By Philip Lutley Sclater, M.A., F.R.S. Yp. xvii., 431. [With Systematic and Alphabetical Indexes.] Woodcuts and 18 coloured Plates. 1886, 8vo. $1 l$.

Vol. XII. Catalogue of the Passeriformes, or Perching Birds, in the Collection of the British Museum. Fringilliformes: Part III., containing the family Fringillidæ. By R. Bowdler Sharpe. Pp. xv., 871. Woodcuts and 16 coloured Plates. [With Systematic and Alphabetical Indexes.] 1888,8 vo. 1l. $8 s$. 
Catalogue of the Birds in the British Museum-continued. Vol. XIII. Catalogue of the Passeriformes, or Perching Birds, in the Collection of the British Museum. Sturniformes, containing the families Artamidæ, Sturnidæ, Ploceidæ, and Alaudidæ. Also the families Atrichiidæ and Menuridæ. By R. Bowdler Sharpe. Pp. xvi., 701. Woodcuts and 15 coloured Plates. [With Systematic and Alphabetical Indexes.] 1890, 8vo. 17. 8s.

Vol. XIV. Catalogue of the Passeriformes, or Perching Birds, in the Collection of the British Museum. Oligomyode, or the families Tyrannide, Oxyrhamphidæ, Pipridæ, Cotingidæ, Phytotomidæ, Philepittidæ, Pittidæ, Xenicidæ, and Eurylæmidæ. By Philip Lutley Sclater, M.A., F.R.S. Pp. xix., 494. Woodcuts and 26 coloured Plates. [With Systematic and Alphabetical Indexes.] 1888, 8vo. 17. 4s.

Vol. XV. Catalogue of the Passeriformes, or Perching Birds, in the Collection of the British Museum. Tracheophonw, or the families Dendrocolaptidæ, Formicariidæ, Conopophagidæ, and Pteroptochidæ. By Philip Lutley Sclater, M.A., F.R.S. Pp. xvii., 371. Woodcuts and 20 coloured Plates. [With Systematic and Alphabetical Indexes.] 1890, 8vo. 1 .

Vol. XVI. Catalogue of the Picariæ in the Collection of the British Museum. Upupa and Trochili, by Osbert Salvin. Coracice, of the families Cypselidæ, Caprimulgidæ, Podargidæ, and Steatornithidæ, by Ernst Hartert. Pp. xvi., 703. Woodcuts and 14 coloured Plates. [With Systematic and Alphabetical Indexes.] 1892, 8vo. 1l. 16s.

Vol. XVII. Catalogue of the Picariæ in the Collection of the British Museum. Coracice (contin.) and Halcyones, with the families Leptosomatidæ, Coraciidæ, Meropidæ, Alcedinidæ, Momotidæ, Totidæ and Coliidæ, by R. Bowdler Sharpe. Bucerotes and Trogones by W. R. Ogilvie Grant. Pp. xi., 522. Woodcuts and 17 coloured Plates. [With Systematic and Alphabetical Indexes.] 1892, 8vo. 1l.10s.

Vol. XVIII. Catalogue of the Picariæ in the Collection of the British Museum. Scansores, containing the family Picidæ. By Edward Hargitt. Pp. xv., 597. Woodcuts and 15 coloured Plates. [With Systematic and Alphabetical Indexes.] 1890, 8vo. 1l.6s.

Vol. XIX. Catalogue of the Picariæ in the Collection of the British Museum. Scansores and Coccyges : containing the families Rhamphastidæ, Galbulidæ, and Bucconidæ, by P. L. Sclater ; and the families Indicatoridæ, Capitonidæ, Cuculidæ, and Musophagidæ, by 
Catalogue of the Birds in the British Museum-continued.

G. E. Shelley. Pp. xii., 484: 13 coloured Plates. [With Systematic and Alphabetical Indexes.] 1891, 8vo. 1l. 5s.

Vol. XX. Catalogue of the Psittaci, or Parrots, in the Collection of the British Museum. By T. Salvadori. Pp. xvii., 658. Woodcuts and 18 coloured Plates. [With Systematic and Alphabetical Indexes.] 1891, 8vo. 1l. 10 s.

Vol. XXI. Catalogue of the Columbæ, or Pigeons, in the Collection of the British Museum. By T. Salvadori. Pp. xvii., 676. 15 coloured Plates. [With Systematic and Alphabetical Indexes.] 1893, 8vo. 1l.10s.

Vol. XXII. Catalogue of the Game Birds (Pterocletes, Gallince, Opisihocomi, Hemipodii) in the Collection of the British Museum. By W. R. Ogilvie Grant. Pp. xvi., 585. \& colomred Plates. [With Systematic and Alphabetical Indexes.] 1893, 8vo. 1l.6s.

Vol. XXIII. Catalogue of the Fulicariæ (Rallidæ and Heliornithidæ) and Alectorides (Aramidæ, Eurypygidæ, Mesitidæ, Rhinochetidæ, Gruidæ, Psophiidæ, and Otididx) in the Collection of the British Museum. By R. Bowdler Sharpe. Pp. xiii., 353. 9 coloured Plates. [With Systematic and Alphabetical Indexes.] 1894, 8vo. $20 s$.

Vol. XXIV. Catalogue of the Limicolæ in the Collection of the British Museum. By R. Bowdler Sharpe. Pp. xii., 794. Woodeuts and 7 coloured Plates. [With Systematic and Alphabetical Indexes.] 1896, 8ro. 1l. 5 s.

Vol. XXV. Catalogue of the Gaviæ and Tubinares in the Collection of the British Museum. Gaviæ (Terns, Gulls, and Skuas), by Howard Saunders. Tubinares (Petrels and Albatrosses), by Osbert Salvin. Pp. xv., 475. Woodcuts and 8 coloured Plates. [With Systematic and Alphabetical Indexes.] 1896, 8vo. 1l. 1s.

Vol. XXVI. Catalogue of the Plataleæ, Herodiones, Steganopodes, Pygopodes, Alcæ, and Impennes in the Collection of the British Museum. Plataleæ (Ibises and Spoonbills) and Herodiones (Herons and Storks), by R. Bowdler Sharpe. Steganopodes (Cormorants, Gannets, Frigate-birds, Tropic-birds, and Pelicans), Pygopodes (Divers and Grebes), Alcæ (Auks), and Impennes (Penguins), by W. R. Ogilvie-Grant. Pp. xvii., 687. Woodcuts and 14 coloured Plates. [With Systematic and Alphabetical Indexes.] 1898, 8vo. 1l.5s. 
Catalogue of the Birds in the British Museum-continued.

Vol. XXVII. Catalogue of the Chenomorphæ (Palamedeæ, Phoenicopteri, Anseres), Crypturi, and Ratitæ in the Collection of the British Museum. By $\mathrm{T}$. Salvadori. Pp. xv., 636. 19 coloured Plates. [With Systematic and Alphabetical Indexes.] 1895, 8vo. 1i. $12 s$.

A Hand-list of the Genera and Species of Birds. [Nomenclator Avium tum Fossilium tum Viventium.] By R. Bowdler Sharpe, LL.D. :-

Vol. I. Pp. xxi., 303. [With Systematic Index.] 1899, 8vo. $10 s$.

Vol. II. Pp. xv., 312. [With Systematic Index, and an Alphabetical Index to Vols. I. and II.] 1900, 8ro. 10 s.

List of the Specimens of Birds in the Collection of the British Museum. By George Robert Gray :-

Part III., Section I. Ramphastidx. Pp. 16. [With Index.] 1855, 12mo. 6d.

Part III., Section II. Psittacidæ. Pp. 110. [With Index.] 1859, 12mo. $2 s$.

Part III., Sections III. and IV. Capitonidæ and Picidæ. Pp. 137. [With Index.] 1868, 12mo. 1s. 6d.

Part IV. Columbæ. Pp. 73. [With Index.] 1856, 12mo. 1s. $9 d$.

Tart V. Gallinæ. Pp. iv., 120. [With an Alphabetical Index.] 1867, 12mo. 1 s. $6 d$.

Catalogue of the Birds of the Tropical Islands of the Pacific Ocean in the Collection of the British Museum. By George Robert Gray, F.L.S., \&c. Pp. 72. [Wi.th an Alphabetical Index.] 1859, 8vo. 1s. $6 d$.

Catalogue of the Collection of Birds' Eggs in the British Museum (Natural History) :-

Vol. I. Ratitæ. Carinatæ (Tinamiformes-Lariformes). By Eugene W. Oates. Pp. xxiii., 252. 18 Coloured Plates. [With Systematic and Alphabetical Indexes.] 1901, 8vo. 1l. 10s.

\section{REPTILES.}

Catalogue of the Tortoises, Crocodiles, and Amphisbænians in the Collection of the British Museum. By Dr. J. E. Gray, F.R.S., \&c. Pp. viii., 80. [With an Alphabetical Index.] 1844, 12mo. 1s.

Catalogue of Shield Reptiles in the Collection of the British Museum. By John Edward Gray, F.R.S., \&c.:-

Appendix. Pp.28. 1872,4to.2s.6d. 
Part II. Emydosaurians, Rhynchocephalia, and Amphisbænians. Pp. vi., 41. 25 Woodcuts. 1872, 4to. $3 s .6 d$.

Hand-List of the Specimens of Shield Reptiles in the British Museum. By Dr. J. E. Gray, F.R.S., F.L.S., \&c. Pp. iv., 124. [With an Alphabetical Index.] 1873, 8 vo. $4 s$.

Catalogue of the Chelonians, Rhynchocephalians, and Crocodiles in the British Museum (Natural History). New Edition. By George Albert Boulenger. Pp. x., 311. 73 Woodcuts and 6 Plates. [With Systematic and Alphabetical Indexes.] 1889, 8vo. 15s.

Catalogue of the Lizards in the British Museum (Natural History). Second Edition. By George Albert Boulenger :-

Vol. I. Geckonidæ, Eublepharidæ, Uroplatidæ, Pygopodidæ, Agamidæ. Pp. xii., 436. 32 Plates. [With Systematic and Alphabetical Indexes.] 1885, 8vo.20s.

Vol. II. Iguanidæ, Xenosauridæ, Zonuridæ, Anguidæ, Anniellidæ, Helodermatidæ, Varanidæ, Xantusiidæ, Teiidæ, Amphisbænidæ. Pp. xiii., 497. 24 Plates. [With Systematic and Alphabetical Indexes.] 1885. 8vo. 20s.

Vol. III. Lacertidæ, Gerrhosauridæ, Scincidæ, Anelytropidæ, Dibamidæ, Chamæleontidæ. Pp. xii., 575. 40 Plates. [With a Systematic Index and an Alphabetical Index to the three volumes.] 1887, 8vo. 17. 6s.

Catalogue of the Snakes in the British Museum (Natural History). By George Albert Boulenger, F.R.S. :-

Vol. I., containing the families Typhlopidæ, Glauconiidæ, Boidæ, Ilysiidæ, Uropeltidæ, Xenopeltidæ, and Colubridæ aglyphæ, part. Pp. xiii., 448 : 26 Woodents and 28 Plates. [With Systematic and Alphabetical Indexes.] 1893, 8vo. 1l. $1 \mathrm{~s}$.

Vol. II, containing the conclusion of the Colubridæ aglyphæ. Pp. xi., 382 : 25 Woodcuts and 20 Plates. [With Systematic and Alphabetical Indexes.] 1894. 8 vo. $17 s, 6 d$.

Vol. III., containing the Colubridæ (Opisthoglyphæ and Proteroglyphæ), Amblycephalidæ, and Viperidæ. Pp. xiv., 727 : 37 Wooderts and 25 Plates. [With Systematic Index, and Alphabetical Index to the 3 volumes.] 1896, 8ro. 1l.6s.

Catalogue of Colubrine Snakes in the Collection of the British Museum. By Dr. Albert Günther. Pp. xvi., 281. [With Geographic, Systematic, and Alphabetical Indexes.] $1858,12 \mathrm{mo} .4 \mathrm{~s}$. 


\section{BATRACHIANS.}

Catalogue of the Batrachia Salientia in the Collection of the British Museum. By Dr. Albert Günther. Pp. xvi., 160. 12 Plates. [With Systematic, Geographic, and Alphabetical Indexes.] 1858, 8vo. $6 s$.

\section{FISHES.}

Catalogue of the Fishes in the British Museum. Second edition. Vol.I. Catalogue of the Perciform Fishes in the British Museum. Vol. I. Containing the Centrarchidæ, Percidæ, and Serranidæ (part). By George Albert Boulenger, F.R.S. Pp. xix., 394. Woodcuts and 15 Plates. [With Systematic and Alphabetical Indexes.] 1895, 8vo. $15 s$.

List of the Specimens of Fish in the Collection of the British Museum. Part I. Chondropterygii. By J. E. Gray. Pp. x., 160. 2 Plates. [With Systematic and Alphabetical Indexes.] 1851, 12mo. $3 \mathrm{~s}$.

Catalogue of Fish collected and described by Laurence Theodore Gronow, now in the British Museum. Pp. vii., 196. [With a Systematic Index.] 1854, 12mo. 3s. $6 d$.

Catalogue of Apodal Fish in the Collection of the British Museum. By Dr. Kaup. Pp. viii., 163. 11 Woodeuts and 19 Plates. 185̌6, 8vo. 10s.

Catalogne of Lophobranchiate Fish in the Collection of the British Museum. By J. J. Kaup, Ph.D., \&c. Pp. iv., 80. 4 Plates. [With an Alphabetical Index.] 1856, 12mo.2s.

\section{MOLLUSCA.}

Guide to the Systematic Distribution of Mollusca in the British Museum. Part I. By John Edward Gray, Ph.D., F.R.S., \&c. Pp. xii., 230. 121 Woodcuts. 1857, 8vo. 5̌s.

'ist of the Shells of the Canaries in the Collection of the British Museum, collected by MM. Webb and Berthelot. Described and figured by Prof. Alcide D'Orbigny in the "Histoire Naturelle des Iles Canaries." Pp. 32. 1854, $12 \mathrm{mo} .1 \mathrm{~s}$.

List of the Shells of Cuba in the Collection of the British Museum collected by M. Ramon de la Sagra. Described by Prof. Alcide d'Orbigny in the "Histoire de l'Ille de Cuba." Pu. 48. 1854, 12mo. 1s.

List of the Shells of South America in the Collection of the British Museum. Collected and described by M. Alcide D'Orbigny in the "Voyage dans l'Amérique Méridionale." Pp. 89. 1854, 12mo. 2s. 
Catalogue of the Collection of Mazatlan Shells in the British Museum, collected by Frederick Reigen. Described by Philip P. Carpenter. Pp. xvi., 552. 1857, 12mo. 8s.

List of Mollusca and Shells in the Collection of the British Museum, collected and described by MM. Eydoux and Souleyet in the "Voyage autour du Monde, exécuté "pendant les années 1836 et 1837, sur la Corvette 'La "Bonite," "and in the "Histoire naturelle des Mollusques "Ptéropodes." Par MM. P. C. A. L. Rang et Souleyet. Pp. iv., 27. 1855, 12mo. 8d.

Catalogue of the Phaneropneumona, or Terrestrial Operculated Mollusca, in the Collection of the British Museum. By Dr. L. Pfeiffer. Pp. 324. [With an Alphabetical Index.] 1852, 12mo. 5 s.

Catalogue of Pulmonata, or Air Breathing Mollusca, in the Collection of the British Museum. Part I. By Dr. Louis Pfeiffer. Pp. iv., 192. Woodcuts. 1855, 12mo. 2s.6d.

Catalogue of the Auriculidæ, Proserpinidæ, and Truncatellidæ in the Cellection of the British Museum. By Dr. Louis Pfeiffer. Pp. iv., 150. Woodcuts. 1857, 12mo. 1s. 9d.

List of the Mollusca in the Collection of the British Museum. By John Edward Gray, Ph.D., F.R.S., \&c.

Part I. Volutidæ. Pp. 23. 1855, 12mo. 6d.

Part II. Olividæ. Pp.41. 1865, 12mo. $1 s$.

Catalogue of the Conchifera, or Bivalve Shells, in the Collection of the British Museum. By M. Deshayes :-

Part I. Veneridæ, Cyprinidæ, Glauconomidæ, and Petricoladæ. Pp.iv., 216. 1853, 12mo. 3s.

Part II. Petricoladæ (concluded); Corbiculadæ. Pp. 217-292. [With an Alphabetical Index to the two parts.] 1854, $12 \mathrm{mo} .6 d$.

\section{BRACHIOPODA.}

Catalogue of Brachiopoda Ancylopoda or Lamp Shells in the Collection of the British Museum. [Issued as "Catalogue of the Mollusca, Part IV." $\quad$ Pp. iv., 128. 25 Woodeuts. [With an Alphabetical Index.] 1853, 12mo. 3s.

\section{POLYZOA.}

Catalogue of Marine Polyzoa in the Collection of the British Museum. Part III. Cyclostomata. By George Busk, F.R.S. Pp. viii., 39. 38 Plates. [With a Systematic Index.] 1875, 8vo. 5s. 


\section{CRUSTACEA.}

Catalogue of the Specimens of Amphipodous Crustacea in the Collection of the British Museum. By C. Spence Bate, F.R.S., \&c. Pp. iv., 399. 58 Plates. [With an Alphabetical Index.] 1862, 8vo. 1l.5s.

\section{ARACHNIDA.}

Descriptive Catalogue of the Spiders of Burma, based upon the Collection made by Eugene W. Oates and preserved in the British Museum. By T. T.horell. Pp. xxxvi., 406. [With Systematic List and Alphabetical Index.] 1895, 8 vo. 10 s. $6 d$.

\section{MYRIOPODA.}

Catalogue of the Myriapoda in the Collection of the British Museum. By George Newport, F.R.S., P.E.S., \&c. Part I. Chilopoda. Pp. iv., 96. [With an Alphabetical Index.] 1856, 12mo. 1s. $9 d$.

\section{INSECTS.}

\section{Coleopterous Insects.}

Nomenclature of Coleopterous Insects in the Collection of the British Museum :-

Part VI. Passalidæ. By Frederick Smith. Pp. iv., 23. 1 Plate. [With Index.] 1852, 12mo. 8d.

Part VII. Longicornia, I. By Adam White. Pp. iv., 174. 4 Plates. 185\%, 12 mo. 2s. $6 d$.

Part VIII. Longicornia, II. By Adam White. Pp. 237. 6 Plates. $1855,12 \mathrm{mo} .3 \mathrm{~s} .6 \mathrm{~d}$.

Part IX. Cassididæ. By Charles H. Boheman, Professor of Natural History, Stockholm. Pp. 225. [With Index.] 1856, 12mo. $3 s$.

Illustrations of Typical Specimens of Coleoptera in the Collection of the British Museum. Part I. Lycidæ. By Charles Owen Waterhouse. Pp. x., 83. 18 Coloured Plates. [With Systematic and Alphabetical Indexes.] 1879, 8vo. 16 s. 
Catalogue of the Coleopterous Insects of Madeira in the Collection of the British Museum. By T. Vernon Wollaston, M.A., F.L.S. Pp. xvi., 234: 1 Plate. [With a Topographical Catalogue and an Alphabetical Index.] 1857, 8v0.3s.

Catalogue of the Coleopterous Insects of the Canaries in the Collection of the British Museum. By T. Vernon Wollaston, M.A., F.L.S. Pp. xiii., 648. [With Topographical and Alphabetical Indexes.] 1864, 8vo. 10s. 6d.

Catalogue of Halticidæ in the Collection of the British Museum. By the Rev. Hamlet Clark, M.A., F.L.S. Physapodes and Edipodes. Part I. Pp. xii., 301. Frontispiece and 9 Plates. 1860, 8vo. 7s.

Catalogue of Hispidæ in the Collection of the British Museum. By Joseph S. Baly, MI.E.S., \&c. Part I. Pp. x., 172. 9 Plates. [With an Alphabetical Index.] 1858, 8 vo. $6 s$.

\section{Hymenopterous Insects.}

Catalogue of Hymenopterous Insects in the Collection of the British Museum. By Frederick Smith. 12mo.:-

Part I. Andrenidæ and Apidæ. Pp. 197. 6 Plates. 1853, 2s. $6 d$.

Part II. Apidæ. Pp. 199-465. 6 Plates. [With an Alphabetical Index.] 1854. 68.

Part III. Mutillidæ and Pompilidæ. Pp.206. 6 Plates. 1855. $6 s$.

Part IV. Sphegidæ, Larridæ, and Crabronidæ. Pp. 207497. 6 Plates. [With an Alphabetical Index.] 1856. $6 s$.

Part V. Vespidæ. Pp.147. 6 Plates. [With an Alphabetical Index.] 1857. 6s.

Part VI. Formicidæ. Pp. 216. 14 Plates. [With an Alphabetical Index.] 1858. 6s.

Part VII. Dorylidæ and Thynnidæ. Pp. 76. 3 Plates. [With an Alphabetical Index.] 1859. 2s.

List of Hymenoptera, with descriptions and figures of the Typical Specimens in the British Museum. Vol. I., Tenthredinidæ and Siricidæ. By W. F. Kirby. Pp. xxviii., 450. 16 Coloured Plates. [With Systematic and Alphabetical Indexes.] 1882, 8тo. 1l. 18s. 


\section{Dipterous Insects.}

List of the Specimens of Dipterous Insects in the Collection of the British Museum. By Francis Walker, F.L.S. Part VII. Supplement III. Asilidæ. Pp. ii., 507-775. $1855,12 \mathrm{mo}$. 3s. $6 d$.

\section{Lepidopterous Insects.}

Catalogue of the Lepidoptera Phalænæ in the British Museum. By Sir George F. Hampson, Bart. :-

Vol. I. Catalogue of the Syntomidx in the Collection of the British Museum. Pp. xxi., 559 : 285 Woodcuts. [With Systematic and Alphabetical Indexes.] 1898, 8vo. $15 s$.

-Atlas of 17 Coloured Plates, 8vo. 15s.

Vol. II. Catalogue of the Arctiadæ (Nolinæ, Lithosianæ) in the Collection of the British Museum. Pp. xx., 589. 411 Woodcuts. [With Systematic and Alphabetical Indexes.] 1900, 8vo. 18s.

—Atlas of 18 Coloured Plates (xviii.-xxxv.), 8vo. $15 s$.

Illustrations of Typical Specimens of Lepidoptera Heterocera in the Collection of the British Museum :-

Part V. By Arthur Gardiner Butler. Pp. xii., 74. 78-100 Coloured Plates. [With a Systematic Index.] 1881, 4to. 2l. 10s.

Part VI. By Arthur Gardiner Butler. Pp. xv., 89. 101-120 Coloured Plates. [With a Systematic Index.] 1886, 4to. 2l. $4 s$.

Part VII. By Arthur Gardiner Butler. Pp. iv., 124. 121-138 Coloured Plates. [With a Systematic List.] 1889,4 to. $2 l$.

Part VIII. The Lepidoptera Heterocera of the Nilgiri District. By George Francis Hampson. Pp. iv., 144. 139-156 Coloured Plates. [With a Systematic List.] 1891, 4to. $2 l$.

Part IX. The Macrolepidoptera Heterocera of Ceylon. By George Francis Hampson. Pp. v., 182. 157-176 Coloured Plates. [With a General Systematic List of Species collected in, or recorded from, Ceylon.] 1893. 4to. 2l. $2 s$. 
Catalugue of Diurnal Lepidoptera described by Fabricius in the Collection of the British Museum. By Arthur Gardiner Butler, F.L.S., \&c. Pp. iv., 303. 3 Plates. 1869, 8vo. 7s.6d.

Specimen of a Catalogue of Lycænidæ in the British Museum. By W. C. Hewitson. Pp. 15. 8 Coloured Plates. 1862, 4to. $1 l .1 s$.

List of Lepidopterous Insects in the Collection of the British Museum. Part I. Papilionidæ. By G. R. Gray, F.L.S. Pp. 106. [With an Alphabetical Index.] 1856, 12mo. 2 s.

List of the Specimens of Lepidopterous Insects in the Collection of the British Museum. By Francis Walker. 12mo.:-

Part XIX. Pyralides. Pp. 799-1036. [With an Alphabetical Index to Parts XVI.-XIX.] 1859, 3s. $6 d$.

Part XX. Geometrites. Pp. 1-276. 1860, $4 s$.

Part XXI. - $\longrightarrow$ Pp. 277-498. 1860,3s.

Part XXII. - Pp. 499-755. 1861, 3s.6d.

Part XXIII. — Pp. 756-1020. 1861, 3s.6d.

Part XXIV. - — Pp. 1021-1280. 1862, 3s.6d.

Part XXV. - Pp. 1281-1477. 1862, 3s.

Part XXVI. - - Pp. 1478-1796. [With an Alphabetical Index to Parts XX.-XXVI.] 1862, $4 s .6 d$.

Part XXVII. Crambites and Tortricites. Pp. 1-286. 1863, $4 s$.

Part XXVIII. Tortricites and Tineites. Pp. 287-561. $1863,4 s$.

Part XXIX. Tineites. Pp. 562-835. 1864, 4s.

Part XXX. - Pp. 836-1096. [With an Alphabetical Index to Parts XXVII.-XXX.] 1864, 4 .

Part XXXI. Supplement. Pp. 1-321. 1864, 5s.

Part XXXII. $1865,5 s$.

Part XXXIII.

Part 2. Pp. 322-706. $1865,6 s$.

Part XXXIV. 1865, $5 \mathrm{~s} .6 \mathrm{~d}$.

Part XXXV.

Part 3. Pp. 707-1120.

[With an Alphabetical Index to Parts XXXI.XXXV.] 1866, $7 s$. 


\section{Neuropterous Insects.}

Catalogue of the Specimens of Neuropterous Insects in the Collection of the British Museum. By Francis Walker. 12mo. :-

Part I. Phryganides-Perlides. P]) iv., 192. 1852, $2 s .6 d$.

Part II. Sialidæ-Nemopterides. Pp. ii., 193-476. 1853, 3s. 6d.

Part III. Termitidæ-Ephemeridæ. Pp. ii., 477-585. 1853, 1s. $6 d$.

Catalogue of the Specimens of Neuropterous Insects in the Collection of the British Museum. By Dr. H. Hagen. Part I. Termitina. Pp. 34. 1858, 12mo. 6d.

\section{Orthopterous Insects.}

Catalogue of Orthopterous Insects in the Collection of the British Museum. Part I. Phasmidæ. By John Obadiah Westwood, F.L.S., \&c. Pp. 195. 48 Plates. [With an Alphabetical Index.] 1859, 4to. 37 .

Catalogue of the Specimens of Blattariæ in the Collection of the British Museum. By Francis Walker, F.L.S., \&c. Pp. 239. [With an Alphabetical Index.] 1868, 8vo. 5s.6d.

Catalogue of the Specimens of Dermaptera Saltatoria [Part I.] and Supplement to the Blattariæ in the Collection of the British Museum. Gryllidæ. Blattariæ. Locustidæ. By Francis Walker, F.L.S., \&c. Pp. 224. [With an Alphabetical Index.] 1869, 8vo. 5 s.

Catalogue of the Specimens of Dermaptera Saltatoria in the Collection of the British Museum. By Francis Walker, F.L.S., \&c.-

Part II. Locustidæ (continued). Pp. 225-423. [With an Alphabetical Index.] 1869, 8vo.4s.6d.

Part III. Locustidæ (continued).-Acrididæ. Pp. 425604. [With an Alphabetical Index.] 1870, 8vo. 4s.

Part IV. Acrididx (continued). Pp. 605--809. [With an Alphabetical Index.] 1870, 8vo.6s.

Part V. Tettigidæ.-Supplement to the Catalogue of Blattariæ.-Supplement to the Catalogue of Dermaptera Saltatoria (with remarks on the Geographical Distribution of Dermaptera). Pp. 811-850; 43; 116. [With Alphabetical Indexes.] 1870,8vo.6s. 


\section{Hemipterous Insects.}

Catalogue of the Specimens of Heteropterous Hemiptera in the Collection of the British Museum. By Francis Walker, F.L.S., \&c. 8vo. :-

Part I. Scutata. Pp. 240. 1867. 5s.

Part II. Scutata (continued). Pp. 241-417. 1867. 4s. Part III. Pp. 418-599. [With an Alphabetical Index to Parts I., II., III., and a Summary of Geographical Distribution of the Species mentioned.] 1868. 4s.6d. Part IV. Pp. 21.1. [With Alphabetical Index.] 1871. 6s. Part V. Pp. 202. [With Alphabetical Index.] 1872. 5s. Part VI. Pp.210. [With Alphabetical Index.] 1873. 5s. Part ViI. Pp.213. [With Alphabetical Index.] 1873. 68. Part VIII. Pp. 220. [With Alphabetical Index.] 1873.

$[6 s, 6 d$.

\section{Homopterous Insects.}

List of the Specimens of Homopterous Insects in the Collection of the British Museum. By Francis Walker. Supplement. Pp. ii., 369. [With an Alphabetical Index.] 1858, $12 \mathrm{mo}, 4 s .6 \mathrm{~d}$.

\section{VERMES.}

Catalogue of the Species of Entozoa, or Intestinal Worms, contained in the Collection of the British Museum. By Dr. Baird. Pp. iv., 132. 2 Plates. [With an Index of the Animals in which the Entozoa mentioned in the Catalogue are found, and an Index of Genera and Species.] 1853, 12mo.2s.

\section{ANTHOZOA.}

Catalogue of Sea-pens or Pennatulariidæ in the Collection of the British Museum. By J. E. Gray, F.R.S., \&c. Pp. iv., 40. 2 Woodents. 1870,8 vo. 1s. $6 d$.

Catalogue of Lithophytes or Stony Corals in the Collection of the British Museum. By J. E. Gray, F.R.S., \&c. Pp. iv., 51. 14 Woodcuts. 1870, 8vo. 3s.

Catalogue of the Madreporarian Corals in the British Museum (Natural History) :-

Vol. 'I. The Genus Madrepora. By George Brook. Pp. xi., 212. 35 Collotype Plates. [With Systematic and Alphabetical Indexes, and Explanation of the Plates.] 1893, 4to. 1l. $4 s$. 
Vol. II. The Genus Turbinaria; the Genus Astræopora. By Henry M. Bernard, M.A. Cantab., F.L.S., F.Z.S. Pp. iv., 106. 30 Collotype and 3 Lithographic Plates. [With Index of Generic and Specific Names, and Explanation of the Plates.] 1896, 4to. 18s.

Vol. III. The Genus Montipora; the Genus Anacropora. By Henry M. Bernard, M.A. Pp. vii., 192. 30 Collotype and 4 Lithographic Plates. [With Systematic Index, Index of Generic and Specific Names, and Explanation of the Plates.] 1897. 4to. 1l. 4s.

\section{BRITISH ANIMALS.}

Catalogue of British Birds in the Collection of the British Museum. By George Robert Gray, F.L.S., F.Z.S., \&c. Pp. xii., 248. [With a List of Species.] 1863, 8vo.3s.6d.

Catalogue of British Hymenoptera in the Collection of the British Museum. Second edition. Part. I. Andrenidæ and Apidæ. By Frederick Smith, M.E.S. New Issue. Pp. xi., 236. 11 Plates. [With Systematic and Alphabetical Indexes.] 1891, 8ro. $6 s$.

Catalogue of British Fossorial Hymenoptera, Formicidæ, and Vespidæ in the Collection of the British Museum. By Frederick Smith, V.P.E.S. Pp. 236. 6 Plates. [With an Alphabetical Index.] 1858, 12mo. 6s.

A Catalogue of the British Non-parasitical Worms in the Collection of the British Museum. By George Johnston, M.D., Edin., F.R.C.L., Ed., Lu.D., Marischal Coll., Aberdeen, \&c. Pp. 365. Woodcuts and 24 Plates. [With an Alphabetical Index.] 1865, 8vo. 7s.

Catalogue of the British Echinoderms in the British Museum (Natural History). By F. Jeffrey Bell, M.A. Pp.xvii., 202. Woodcuts and 16 Plates (2 Coloured). [With Table of Contents, Tables of Distribution, Alphabetical Index, Description of the Plates, \&c.] 1892, 8vo. 12s. 6d.

List of the Specimens of British Animals in the Collection of the British Museum; with Synonyma and References to figures. 12mo.:-

Part V. Lepidoptera. By J. F. Stephens. 2nd Edition. Revised by H. T. Stainton and E. Shepherd. Pp. iv., 224. 1856. 1s. $9 d$.

Part VI. Hymenoptera. By F. Smith. Pp. 134. 1851. 2s.

Part VIl. Mollusca, Acephala and Brachiopoda. By Dr. J, E, Gray. Pp. iv., 167. 1851. 3s. 6d. 
Part VIII. Fish. By Adam White. Pp. xxiii., 164. (With Index and List of Donors.) 1851. 3s.6d.

Part IX. Eggs of British Birds. By George Robert Gray. Pp. 143. 1852. 2s.6d.

Part XI. Anoplura, or Parasitic Insects. By H. Denny. Pp. iv., 51. 1852. 1s.

Part XII. Lepidoptera (continued). By James F. Stephens. Pp. iv., 54. 1852. 9d.

Part XIII. Nomenclature of Hymenoptera. By Frederick Smith. Pp.iv., 74. 185̃3, 1s. $4 d$.

Part XIV. Nomenclature of Neuroptera. By Adam White. Pp. iv., 16. 1853, 6d.

Part XV. Nomenclature of Diptera, I. By Adam White. Pp. iv., 42. 1853. $1 s$.

Part XVI. Lepidoptera (completed). By H. T. Stainton. Pp. 199. [With an Index.] 1854. 3s.

Part XVII. Nomenclature of Anoplura, Euplexoptera, and Orthoptera. By Adam White. Pp. iv., 17. 1855. $6 d$.

\section{PLANTS.}

Illustrations of the Botany of Captain Cook's Voyage Round the World in H.M.S. "Endeavour" in 1768-71. By the Right Hon. Sir Joseph Banks, Bart., K.B., P.R.S., and Dr. Daniel Solander, F.R.S. With Determinations by James Britten, F.L.S., Senior Assistant, Department of Botany, British Museum :-

Part I.-Australian Plants. 101 Copper-plates [after paintings by F. P. Nodder], with 31 pages of descriptive text. 1900, fol. $25 s$.

Part II.-Australian Plants, Pt. II. 142 Copper-plates (pls. 101-243) [after paintings by F. P. Nodder, James Miller, J. F. Miller, and John Cleveley], with 41 pages of descriptive text (pp.35-75). 1901, fol. $35 \mathrm{~s}$.

Catalogue of the African Plants collected by Dr. Friedrich Welwitsch in 1853-61:-

Vol. I. Dicotyledons. By William Philip Hiern, M.A., F.L.S., \&.e. :-

Part I. [Ranunculaceæ to Rhizophoraceæ.] Pp. xxvi., 336. [With Portrait of Dr. Welwitsch, Introduction, Bibliography, and Index of Genera.] 1896, 8vo. $7 s$. $6 d$. 
Part II. Combretaceæ to Rubiaceæ. Pp. 337-510. [With Index of Genera.] 1898, 8vo. 4s.

Part III. Dipsaceæ to Scrophulariaceæ. Pp. 511784. [With Index of Genera.] 1898, 8vo. 5s.

Part IV. Lentibulariaceæ to Ceratophylleæ. Pp. 7851035. [With Index.] 1900, 8vo. 5s.

Vol. II., Part I. Monocotyledons and Gymnosperms. By Alfred Barton Rendle, M.A., D.Sc. F.L.S., Assistant, Department of Botany. Pp. 260. [With Index of Genera.] 1899, 8vo. 6s.

Vol. II., Part II. Cryptogamia. Pp. 261-566. [With Table of Errata and General Index to the whole work.] 1901, 8vo. 6s.

\begin{tabular}{|c|c|c|c|c|c|}
\hline & \multirow{2}{*}{\multicolumn{2}{|c|}{$\begin{array}{l}. . \mathrm{By} \\
. . \quad,\end{array}$}} & \multirow{2}{*}{$\begin{array}{l}\text { William Carruthers, } \\
\text { F.R.S. } \\
\text { Antony Gepp, M.A., } \\
\text { F.L.S. }\end{array}$} \\
\hline Mosses & $\ldots$ & $\ldots$ & & & \\
\hline \multirow{3}{*}{\multicolumn{2}{|c|}{$\begin{array}{l}\text { Hepatics ... } \\
\text { Marine Algæ } \\
\text { Freshwater Algæ }\end{array}$}} & $\cdots$ & & & F. Stephani. \\
\hline & & & & & Ethel S. Barton. \\
\hline & & & & & $\begin{array}{l}\text { W. West, F.L.S., and } \\
\text { G. S. West, B.A. }\end{array}$ \\
\hline \multicolumn{2}{|c|}{ Diatomaceæ } & $\cdots$ & & & $\begin{array}{l}\text { Thomas Comber, } \\
\text { F.L.S. }\end{array}$ \\
\hline \multirow{2}{*}{$\begin{array}{l}\text { Lichenes } \\
\text { Fungi }\end{array}$} & $\cdots$ & $\ldots$ & $\ldots$ & & E. A. Wainio. \\
\hline & & & & & $\begin{array}{l}\text { Annie } \\
\text { Smith. }\end{array}$ \\
\hline \multicolumn{2}{|c|}{ Mycetozoa ... } & $\ldots$ & & & Arthur Li \\
\hline
\end{tabular}

A Monograph of Lichens found in Britain : being a Descriptive Catalogue of the Species in the Herbarium of the British Museum. By the Rev. James M. Crombie, M.A., F.L.S., F.G.S., \&c. Part I. Pp. viii., ว̌19 : 74 Woodcuts. [With Glossary, Synopsis, Tabular Conspectus, and Index.] 1894, 8vo. 16s.

A Monograph of the Mycetozoa : being a Descriptive Catalogue of the Species in the Herbarium of the British Museum. By Arthur Lister, F.L.S. Pp. 224. 78 Plates and 51 Woodcuts. [With Synopsis of Genera and List of Species, and Index.] 1894, 8vo, 15 s.

List of British Diatomaceæ in the Collection of the British Museum. By the Rev. W. Smith, F.L.S., \&c. Pp. iv., 55. $1859,12 \mathrm{mo} .1 s_{\text {. }}$ 


\section{FOSSILS.}

Catalogue of the Fossil Mammalia in the British Museum (Natural History). By Richard Lydekker, B.A., F.G.S. :-

Part I. Containing the Orders Primates, Chiroptera, Insectivora, Carnivora, and Rodentia. Pp. xxx., 268. 33 Woodcuts. [With Systematic and Alphabetical Indexes.] 1885, 8vo. 5 s.

Part II. Containing the Order Ungulata, Suborder Artiodactyla. Pp. xxii., 324. 39 Woodcuts. [With Systematic and Alphabetical Indexes.] 1885, 8vo. 6s.

Part III. Containing the Order Ungulata, Suborders Perissodactyla, Toxodontia, Condylarthra, and Amblypoda. Pp. xvi., 186. 30 Woodcuts. [With Systematic Index, and Alphabetical Index of Genera and Species, including Synonyms.] 1886, 8vo. 4s.

Part IV. Containing the Order Ungulata, Suborder Proboscidea. Pp. xxiv., 235. 32 Woodcuts. [With Systematic Index, and Alphabetical Index of Genera and Species, including Synonyms.] 1886, 8vo. 5s.

Part V. Containing the Group Tillodontia, the Orders Sirenia, Cetacea, Edentati, Marsupialia, Monotremata, and Supplement. Pp. xxxv., 345. 55 Woodcuts. [With Systematic Index, and Alphabetical Index of Genera and Species, including Synonyms.] 1887, 8vo. 6s.

Catalogue of the Fossil Birds in the British Museum (Natural History). By Richard Lydekker, B.A. Pp. xxvii., 368. 75 Woodcuts. [With Systematic Index, and Alphabetical Index of Genera and Species, including Synonyms.] 1891, 8т0. 10s. 6d.

Catalogue of the Fossil Reptilia and Amphibia in the Britiah Museum (Natural History). By Richard Lydekker, B.A., F.G.S. :-

Part I. Containing the Orders Ornithosauria, Crocodilia, Dinosauria, Squamata, Rhynchocephalia, and Proterosauria. Pp. xxviii., 309. 69 Woodcuts. [With Systematic Index, and Alphabetical Index of Genera and Species, including Synonyms.] 1888, 8vo. 7s.6d. 
Part II. Containing the Orders Ichthyopterygia and Sauropterygia. Pp.xxi., 307. 85 Woodcuts. [With Systematic Index, and Alphabetical Index of Genera and Species, including Synonyms.] 1889, 8vo. 7s.6d.

Part III. Containing the Order Chelonia. Pp. xviii., 239. 53 Woodcuts. [With Systematic Index, and Alphabetical Index of Genera and Species, including Sjnonyms.] 1889, 8vo. 7s.6d.

Part IV. Containing the Orders Anomodontia, Ecaudata, Caudata, and Labyrinthodontia; and Supplement. Pp. xxiii., 295. 66 Woodcuts. [With Systematic Index, Alphabetical Index of Genera and Species, including Synonyms, and Alphabetical Index of Genera and Species to the entire work.] 1890, 8vo. $7 s .6 d$.

Catalogue of the Fossil Fishes in the British Museum (Natural History). By Arthur Smith Woodward, F.G.S., F.Z.S. :-

Part I. Containing the Elasmobranchii. Pp. xlvii., 474. 13 Woodcuts and 17 Plates. [With Alphabetical Index, and Systematic Index of Genera and Species.] 1889, 8vo. 21s.

Part II. Containing the Elasmobranchii (Acanthodii), Holocephali, Ichthyodorulites, Ostracodermi, Dipnoi, and Teleostomi (Crossopterygii and Chondrostean Actinopterygii). Pp. xliv., 567. 58 Woodcuts and 16 Plates. [With Alphabetical Index, and Systematic Index of Genera and Species.] 1891, 8vo. 21s.

Part III. Containing the Actinopterygian Teleostomi of the Orders Chondrostei (concluded), Protospondyli, Aetheospondyli, and Isospondyli (in part). Pp. xlii., 544. 45 Woodcuts and 18 Plates. [With Alphabetical Index, and Systematic Index of Genera and Species.] 1895, 8vo. $21 s$.

Systematic List of the Edwards Collection of British Oligocene and Eocene Mollusca in the British Museum (Natural History), with references to the type-specimens from similar horizons contained in other collections belonging to the Geological Department of the Museum. By Richard Bullen Newton, F.G.S. Pp. xxviii., 365. [With table of Families and Genera, Bibliography, Correlation-table, Appendix, and Alphabetical Index.] 1891, 8vo. 6s.

Catalogue of Tertiary Mollusca in the Department of Geology, British Museum (Natural History). Part I. The AustraIasian Tertiary Mollusca. By George F. Harris, F.G.S., \&c. Pp. xxvi., 407. 8 Plates. [With Table of Families, Genera, and subGenera, and Index.] 1897, 8vo. $10 s$. 
Catalogue of the Fossil Cephalopoda in the British Museum (Natural History) :-

Part I. Containing part of the Suborder Nautiloidea, consisting of the families Orthoceratidæ, Endoceratidæ, Actinoceratidæ, Gomphoceratidæ, Ascoceratidæ, Poterioceratidæ, Cyrtoceratidæ, and Supplement. By Arthur H. Foord, F.G.S. Pp. xxxi., 344. 51 Woodcuts. [With Systematic Index, and Alphabetical Index of Genera and Species, including Synonyms.] 1888, 8vo. 10s. 6d.

Part II. Containing the remainder of the Suborder Nautiloidea, consisting of the families Lituitidæ, Trochoceratidæ, Nautilidæ, and Supplement. By Arthur H. Foord, F.G.S. Pp. xxriii., 407. 86 Woodcuts. [With Systematic Index, and Alphabetical Index of Genera and Species, including Synonyms.] 1891, 8vo. 15s.

Part III. Containing the Bactritidæ, and part of the Suborder Ammonoidea. By Arthur H. Foord, Ph.D., F.G.S., and George Charles Crick, A.R.S.M., F.G.S. Pp. xxxiii., 303. 146 Woodcuts. [With Systematic Index of Genera and Species, and Alphabetical Index.] 1897, 8vo. 12s. $6 d$.

List of theTypes and Figured Specimens of Fossil Cephalopoda in the British Museum (Natural History). By G. C. Crick, F.G.S. Pp. 103. [With Index.] 1898, 8vo. 2s.6d.

A Catalogue of British Fossil Crustacea, with their Synonyms and the Range in Time of each Genus and Order. By Henry Woodward, F.R.S. Pp. xii., 155. [With an Alphabetical Index.] 1877, 8vo. 5s.

Catalogue of the Fossil Bryozoa in the Department of Geology, British Museum (Natural History):-

The Jurassic Bryozoa. By J. W. Gregory, D.Sc., F.G.S., F.Z.S. Pp. [viii.,] 239 : 22 Woodcuts and 11 Plates. [With List of Species and Distribution, Bibliography, Index, and Explanation of Plates.] 1896, 8vo. $10 s$.

The Cretaceous Bryozoa. Vol. I. By J. W. Gregory, D.Sc., F.G.S., F.Z.S. Pp. xiv., 457 : 64 Woodcuts and 17 Plates. [With Index and Explanation of Plates.] 1899, 8vo. 16s. 
Catalogue of the Blastoidea in the Geological Department of the British Museum (Natural History), with an account of the morphology and systematic position of the group, and a revision of the genera and species. By Robert Etheridge, jun., of the Department of Geology, British Museum (Natural History), and P. Herbert Carpenter, D.Sc., F.R.S., F.L.S. (of Eton College). Pp.xv., 322. 20 Plates. [With Preface by Dr. H. Woodward, Table of Contents, General Index, Explanations of the Plates, \&c.] 1856, 4to. 25s.

The Genera and Species of Blastoidea, with a List of the Specimens in the British Museum (Natural History). By F. A. Bather, M.A., F.G.S., of the Geological Department. Pp. x., 70. 1 Woodcut. 1899, 8vo. 3s.

Catalogue of the Palæozoic Plants in the Department of Geology and Palæontology, British Museum (Natural History). By Robert Kidston, F.G.S. Pp. viii., 288. [With a list of works quoted, and an Index.] 1886, 8 vo. $5 s$.

Catalogue of the Mesozoic Plants in the Department of Geology, British Museum (Natural History). By A. C. Seward, M.A., F.R.S., F.G.S., University Lecturer in Botany and Fellow of Emanuel College, Cambridge:-

Part I. The Wealden Flora. Part I. ThallophytaPteridophyta. Pp. xxxviii., 179. 17 Woodcuts and 11 Plates. [With Preface by Dr. Woodward, Alphabetical Index, Explanations of the Plates, \&c.] 1894, 8vo. 10s.

Part II. The Wealden Flora. Part II. Gymnospermæ. Pp. viii., 259. 9 Woodcuts and 20 Plates. [With Alphabetical Index, Explanations of the Plates, \&c.] 1895, 8vo. $15 s$.

Part III. The Jurassic Flora. Part I. The Yorkshire Coast. Pp. xii., 341. 53 Woodcuts and 21 Plates. [With Preface by Dr. Woodward, Alphabetical Index, Explanations of the Plates, \&c.] 1900, 8vo. 20s.

\section{GUIDE-BOOKS.}

\section{(To be obtained only at the Museum.)}

Guide to the Galleries of Mammalia in the Department of Zoology of the British Museum (Natural History). 6th Edition. Pp. 120. 57 Woodeuts and 4 Plans. Index. 1898, 8vo. 6d. 
Guide to the Galleries of Reptiles and Fishes in the Department of Zoology of the British Museum (Natural History). 4th Edition. Pp. iv., 119. 101 Woodcuts. Index. 1898. 8vo.6d.

Guide to the Shell and Starfish Galleries (Mollusca, Polyzoa, Brachiopoda, Tunicata, Échinoderma, and Worms). Department of Zoology, British Museum (Natural History). New Edition. Pp. iv., 130. 125 Woodcuts, Plan, and Indexes. 1901, 8vo. 6d.

A Guide to the Fossil Mammals and Birds in the Department of Geology and Palæontology in the British Museum (Natural History). 7th Edition. [By Henry Woodward.] Pp. xii., 103. 116 Woodcuts. [With List of Illustrations, Table of Stratified Rocks, and Index.] 1896, 8vo. 6d.

A Guide to the Fossil Reptiles and Fishes in the Department of Geology and Palæontology in the British Museum (Natural History). [By Henry Woodward.] Pp. xiv., 129 : 165 Woodcuts. [With List of Illustrations, Table of Stratified Rocks, and Index.] 1896, 8vo. 6d.

A Guide to the Fossil Invertebrates and Plants in the Department of Geology and Palæontology in the British Museum (Natural History). [By Henry Woodward.] Pp. xvi., 158. 182 Woodcuts. [With List of Illustrations, Table of Stratified Rocks, Introduction, and Index.] 1897, 8 vo. $1 s$.

The same, in two parts :-

Part I. Mollusca to Bryozoa. Pp. xii., 64. 107 Woodcuts. [With List of Illustrations, Table of Stratified Rocks, and Introduction.] 1897, 8vo. 6d.

Part II. Insecta to Plants, \&c. Pp. ix., 64*-158. Woodcuts 108-182. [With List of Illustrations and Index to the two parts.] 1897, 8vo. 6d.

Guide to Sowerby's Models of British Fungi in the Department of Botany, British Museum (Natural History). By Worthington G. Smith, F.L.S. Pp. 82. 93 Woodcuts. With Table of Diagnostic Characters, and Index. [Second Edition.] 1898, 8vo. 4d.

Guide to the British Mycetozoa exhibited in the Department of Botany, British Museum (Natural History). By Arthur Lister, F.L.S. Pp. 42. 44 Woodcuts. Index. 1895, 8vo. 3d.

A Guide to the Mineral Gallery of the British Museum (Natural History). [By L. Fletcher, M.A., F.R.S.] Pp. 32. Plan, 1900, 8vo. 1d. 
The Student's Index to the Collection of Minerals, British Museum (Natural History). [By L. Fletcher, M.A., F.R.S.] Pp. 34. With a Plan of the Mineral Gallery. 1899, 8vo. 2d.

An Introduction to the Study of Minerals, with a Guide to the Mineral Gallery of the British Museum (Natural History). By L. Fletcher, M.A., F.R.S. Pp. 123. 41 Woodcuts. With Plan of the Mineral Gallery and Index. 1897, 8vo. 6d.

An Introduction to the Study of Rocks. By L. Fletcher, M.A., F.R.S. Pp. 118. [With plan of the Mineral Gallery, Table of Contents, and Index.] 1898, 8vo. $6 d$.

An Introduction to the Study of Meteorites, with a List of the Meteorites represented in the Collection. By $\mathrm{L}$. Fletcher, M.A., F.R.S., \&c. Pp. 95. [With a Plan of the Mineral Gallery, and an Index to the Meteorites represented in the Collection.] 1896, 8vo. $6 d$.

E. RAY LANKESTER, Director.

British Museum

(Natural History),

Cromwell Road,

London, S.W.

July 20th, 1901. 
Is cocene of mance Bolee

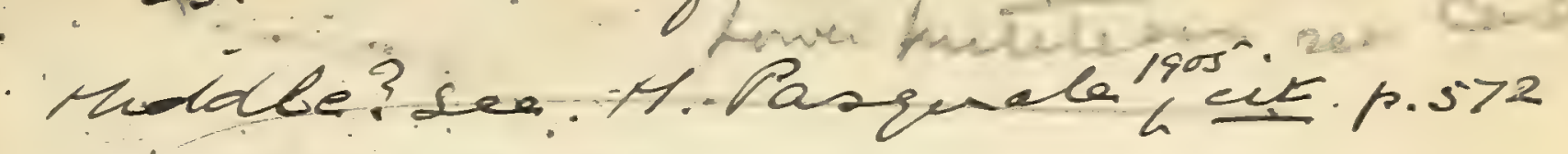
duprimation

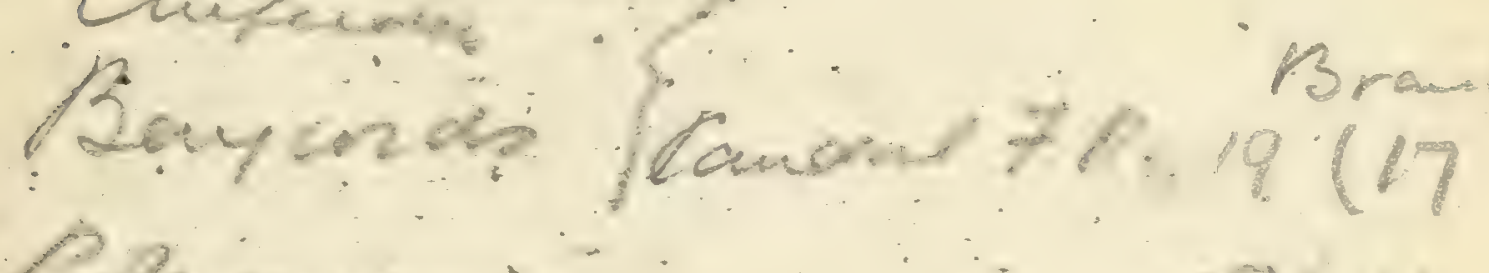

Pogmonsin

$18(16$

2)

Perand $\left.\quad \begin{array}{lll}17 & 15 & 2\end{array}\right)$ 
Mank op Beds, Carecasus, h. Oagrour.

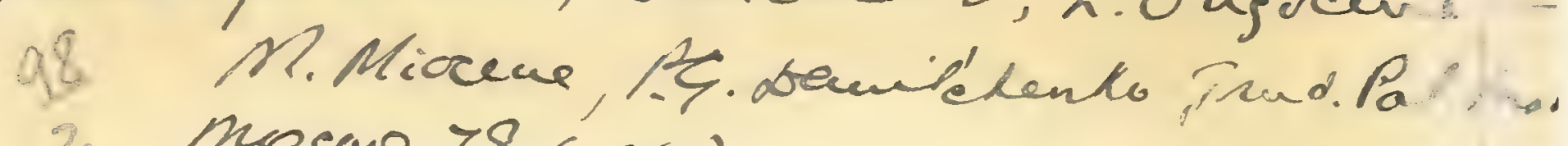
2 masear $78(1960)$. 




' 
